UNITED STATES DEPARTMENT OF THE INTERIOR

Ray Lyman Wilbur, Secretary

GEOLOGICAL SURVEY

George Otis Smith, Director

\title{
Bulletin 823
}

\section{BIBLIOGRAPHY}

OF

\section{NORTH AMERICAN GEOLOGY}

\author{
1919-1928
}

BY

JOHN M. NICKLES
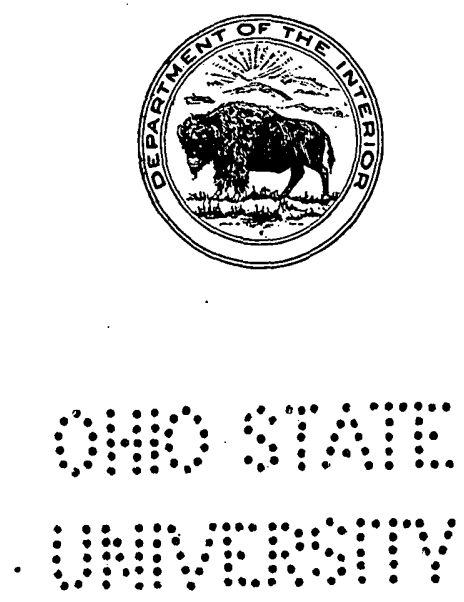

UNITED STATES

GOVERNMENT PRINTING OFFICE

WASHINGTON : 1931 


\section{$1+135$}

is

\section{CONTENTS}

Introduction

Page

Serials examined

Bibliography

Index

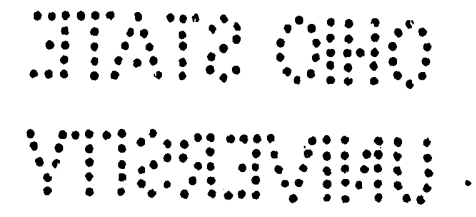




\title{
BIBLIOGRAPHY OF NORTH AMERICAN GEOLOGY 1919-1928
}

\author{
By JoHN M. NICKLES
}

\section{INTRODUCTION}

The bibliography of North American geology, including paleontology, petrology, and mineralogy, for the years 1919-1928 lists publications on the geology of the Continent of North America and adjacent islands and on Panama and the Hawaiian Islands. It includes textbooks and papers of general character by American authors, but not those by foreign authors, except papers that appear in American publications.

The papers, with full title and medium of publication, are listed under the names of their authors, which are arranged in alphabetic order. The author list is followed by an index to the literature cited.

The bibliography of North American geology to the end of 1926 is contained in the following bulletins of the United States Geological Survey: 127 (1732-1892), 188 and 189 (1892-1900), 301 (1901-1905), 372 (1906-7), 409 (1908), 444 (1909), 495 (1910), 524 (1911), 545 (1912), 584 (1913), 617 (1914), 645 (1915), 665 (1916), 684 (1917), 698 (1918), 731 (1919-20), 758 (1921-22), 784 (1923-24), and 802 (1925-26). All these bulletins are now out of print but may be consulted in the larger libraries. They have been cumulated in Bulletins 746 and 747 (1785-1918), also now out of print, and Bulletin 823 (1919-1928). The bibliography for 1927 and 1928, which is included in the present bulletin, will not be published separately.

III 


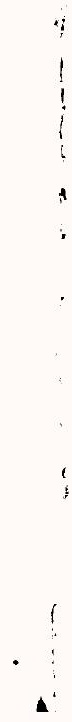




\section{SERIALS EXAMINED}

Academy of Natural Sciences of Philadelphia: Proceedings, vols. 70 (pt. 3)-79. Philadelphia, Pa.

Academy of Science of St. Louis: Transactions, vols. 23 (no. 7)-26 (no. 2). St. Louis, Mo.

Alabama Geological Survey: Bulletins 21-32, 34 ; Circulars 4, 5, 8; Museum Paper, nos. 5, 6; County Report, no. 1 (Clay County). Montgomery, Ala.

Alberta, Scientific and Industrial Research Council: Annual Report, FirstEighth; Reports 1-22. Edmonton, Alberta.

American Academy of Arts and Sciences: Proceedings, vols. 54 (no. 5)-63 (no. 11). Boston, Mass.

American Association of Petroleum Geologists : Bulletin, vols. 3-12. Tulsa, Okla.

American Institute of Mining Engineers: Bulletin, nos. 145-156; Technical Publication, nos. 1-157; Transactions, vols. 60-76. New York. See also Mining and Metallurgy.

American Journal of Science, 4th ser., vols. 47-50; 5th ser., vols. 1-16. New Haven, Conn.

American Mineralogist, vols. 4-13. Menasha, Wis.

American Museum of Natural History; Bulletin, vols. 38-55; Memoirs, new ser., vol. 3, pts. 2, 3; American Museum Novitates, nos. 1-337. New York. See also Natural History.

American Naturalist, vols. 53-62. New York.

American Philosophical Society: Proceedings, vols. 58-67; Transactions, new ser., vol. 22, pts. 4, 5. Philadelphia, Pa.

Annales de paléontologie, t. 10-17 (fasc. 1-2). Paris.

Annales des mines, $11^{\circ}$ sér., t. 6-12; $12^{\circ}$ sér., t. 1-14. Paris.

Annals and Magazine of Natural History, 9th ser., vols. 3-20; 10th ser., vols. 1, 2. London.

Appalachia, vols. 14 (no. 4)-17 (no. 1). Boston, Mass.

Arizona State Bureau of Mines: Bulletins 94, 96-99, 104-106, 113-117, 119, 122-126. Tucson, Ariz.

Association of American Geographers: Annals, vols. 9-18. Albany, N. Y.

Bernice Pauahi Bishop Musenm: Bulletin, nos. 1-57; Memoirs, vols. 5,6 (no. 1), 8-10; Occasional Papers, vols. 7, 8. Honolulu, Hawaiian Islands.

Boston Society of Natural History: Proceedings, vols. 35-39; Memoirs, vol. 6, nos. 2-4, vol. 8, no. 4; Occasional Papers, vol. 5, pp. 1-249. Boston, Mass.

Botanical Gazette, vols. 67-86. Chicago, Ill.

British Columbia, Bureau of Mines: Annual Reports of Minister of Mines, 1918-1927. Victoria, B. C.

Buffalo Society of Natural Science, vols. 12-14 (no. 1). Buffalo, New York.

Bulletins of American Paleontology, nos. 31, 33-53. Ithaca, New York.

California Academy of Sciences: Proceedings, 4th ser., vols. 9-17. San Francisco, Calif.

California State Mining Bureau: Bulletins 79, 85-101. San Francisco, Calif. 
California, University of, Department of Geology: Bulletin, vols. 12-17; Seismographic Stations; Bulletin, nos. 15-20, vol. 2, nos. 1-15; Publicacations in Gengraphy, vols. 2, 3 (no. 1). Berkeley, Calif.

Canada, Geological Survey: Summary Reports 1917-1927; Memoirs 104, 107154; Museum Bulletins 31-52. Ottawa, Ont.

Canadian Alpine Journal, vols. 10-16. Banff, Alberta.

Canadian Field Naturalist, vols. 33-42. Ottawa, Ont.

Canadian Institute of Mining and Metallurgy: Transactions, vols. 23-30; Monthly Bulletin, nos. 81-200. Montreal, Quebec.

Canadian Mining Journal, vols. 40-49. Gardenvale, Quebec.

Carnegie Institution of Washington: Yearbook, nos. 17-27. Washington, D. C. Carnegie Museum: Annals, vols. 12 (no. 2)-19 (no. 1) ; Memoirs, vol. 7 (no. 6)vol. 11 (no. 2). Pittsburgh, Pa.

Centralblatt für Mineralogie, Geologie und Paläontologie, 1919-1928. Stuttgart, Germany.

Coal Age, vols. 15-33. New York.

Colorado, University of: Studies, vols. 13 (no. 1)-16 (no. 4). Boulder, Colo.

Colorado Geological Suivey: Bulletins 11, 15, 17-19, 21-28, 30-31. Denver, Colo.

Colorado School of Mines: Magazine, vols. 9-18; Quarterly, vols. 14-23. Golden, Colo.

Connecticut Academy of Arts and Sciences: Transactions, vols. 23-26; Memoirs, vols. 6, 7. New Haven, Conn.

Connecticut State Geological and Natural History Survey: Bulletins 28-44. Hartford, Conn.

Cuba, Dirección de Montes y Minas: Boletín de Minas, nos. 5-13. Habana, Cuba.

Delaware County Institute of Science: Proceedings, vol. 8, no. 4, vol. 9, nos. 1, 2, 3. Media, Pa.

Denison University, Scientific Laboratories; Bulletin, vols. 19-23. Granville, Ohio.

Deutsche Geologische Gesellschaft: Zeitschrift, Bd. 69-80. Berlin, Germany. Economic Geology, vols. 14-23. Lancaster, Pa.

Elisha Mitchell Scientific Society: Journal, vols. 34 (no. 4)-44 (no. 1). Chapel Hill, N. C.

Engineering and Mining Journal, vols. 107-126. New York.

Engineers' Club of Philadelphia: Proceedings, vols. 36-45. Philadelphia, Pa.

Engineers' Society of Western Pennsylvania: Proceedings, vols. 35-44. Pittsburgh, $\mathrm{Pa}$.

Florida State Geological Survey: Annual Report, 12th-19th. 'Tallahassee, Fla.

Franklin Institute: Journal, vols. 187-206. Philadelphia, Pa.

Geographical Journal, vols. 53-72. London.

Geographical Review, vols. 7-18. New York.

Geographical Society of Philadelphia: Bulletin, vols. 17-26. Philadelphia, Pa.

Geological Magazine, new ser., vols. 56-65. London.

Geological Society of America: Bulletin, vols. 29-39. New York.

Geological Society of London: Quarterly Journal, vols. 73-84. London.

Geologists' Association, London: Proceedings, vols. 28-39. London.

Georgia Geological Survey: Bulletins 35-43. Atlanta, Ga.

Harvard College, Museum of Comparative Zoology: Bulletin, vols. 62-68; Memoirs, vols. 39 (nos. 3, 4), 43 (pts. 3, 4), 47-50 (nos. 1, 2), 51. Cambridge, Mass.

Hawaiian Volcano Observatory: Monthly Bulletin, vols. 7-16 (no. 10). Honolulu, Hawaii. 
Idaho, Bureau of Mines and Geology : Bulletins 1-11, 13; Pamphlets 1-9, 11-31. Moscow, Idaho.

Illinois Academy of Science: Transactions, vols. 9-20. Springfield, Ill.

Illinois State Geological Survey: Bulletins 34, 36, 38, 40-55; Press Bulletin Series, Illinois Petroleum, nos. 1-16; Cooperative Mining Series, nos. 1-20, 23-26, 28-31; Report of Investigations, nos. 1-9, 11-16; Educational Series, nos. 1, 2. Springfield, Ill.

Indiana, Department of Conservation, Division of Geology: Annual report, 1st-9th ; Publications 6, 8, 42, 55, 72, 75. Indianapolis, Ind.

Indiana Academy of Science: Proceedings, 1918-1927, vols. 28-37. Indianapolis, Inḍ.

Institution of Mining and Metallurgy: Bulletin, nos. 172-291. London.

Institution of Mining Engineers: Transactions, vols. 56-76 (pt. 3). Newcastle upon Tyne, England.

Institution of Petroleum Technologists: Journal, vols. 5-14. London.

Iowa Academy of Sciences: Proceedings, vols. 26-34. Des Moines, Iowa.

Iowa Geological Survey: vols. 27-32, Annual Reports, 1916-1926. Des Moines, Iowa.

Japan, Imperial Earthquake Investigation Committee: Bulletin, vols. 7-11. Tokyo, Japan.

Johns Hopkins University: Studies in Geology, nos. 1-8. Baltimore, Md.

Journal of Geography, vols. 18-27. Menasha, Wis.

Journal of Geology, vols. 27-36. Chicago, Ill.

Journal of Paleontology, vols. 1, 2. Chicago, Ill.

Kansas Academy of Sciences: Transactions, vols. 29, 30. Topeka, Kans.

Kansas State Geological Survey: Bulletins 5, 6 (pts. 1, 2, 5-7), 7-11, 13, 14;

Circulars 1, 2; Mineral Resources Circular 1. Lawrence, Kans.

Kansas University, Science Bulletin, vols. 11-18. Lawrence, Kans.

Kentucky Academy of Science:. Transactions, vols. 1, 2. Lexington, Ky.

Kentucky Geological Survey: Fourth Series, vol. 3, pt. 3, vol. 4, vol. 5, pt. 2;

Fifth Series, vol. 1, nos. 1-3; Sixth Series, vols. 1-30, 34; Bulletins 1-4; Pamphlets 1-14, 20, 21. Frankfort, Ky.

Lake Superior Mining Institute: Proceedings, vols. 22-26. Ishpeming, Mich.

Louisiana, Department of Conservation: Bulletins 8, 9, 11-14, 14 [15?]; Technical Paper no. 1. New Orleans, La.

Maryland Geological Survey : vols. 11, 12; Cambrian and Ordovician; Silurian; Queen Annes County; Kent County; Talbot County. Baltimore, Md.

Mazama, vols. 5 (no. 4) -7 (no. 2). Portland, Oreg.

Meddelelser om Grönland, H. 37, Bd. 23 supplement, 40, 52, 54, 58, 59, 60-70. Copenhagen, Denmark.

Mexico, Instituto Geológico: Anales, nos. 6-10, t. 2 ; Boletín, nos. 18, 33, 37-45; Folleto de Divulgación, nos. 19-30. Mexico City, D. F.

Michigan Academy of Science, Arts, and Letters: Report, 20th-22d; Papers, vols. 1-8. Ann Arbor, Mich.

Michigan Geological and Biological Survey: Publications 26-37. Lansing, Mich.

Mining and Metallurgical Society of America: Bulletin, vols. 12-21, nos. 128196. New York.

Mining and Metallurgy (American Institute of Mining and Metallurgical Engineers), nos. 157-192, vols. 4-9. New York.

Mining and Scientific Press, vols. 118-123. San Francisco, Calif.

Mining Congress Journal, vols. 5-13. Washington, D. C.

Mining Magazine, vols. 20-39. London.

Minnesota Geological Survey: Bulletins 14-21. Minneapolis, Minn. 
Mississippi State Geological Survey: Bulletins 14-22; Seventh and Eighth Biennial Reports. Jackson, Miss.

Missouri Bureau of Geology and Mines: Second Series, vols. 15-22; Biennial Reports. Jefferson City, Mo.

National Academy of Sciences: Proceedings, vols. 5-14; Memoirs, vols. 14-22. Washington, D. C.

National Geographic Magazine, vols. 35-54. Washington, D. C.

Natural History; the Journal of the American Museum of Natural History, vols. 19-28. New York.

Nature, vols. 102-122. London.

Nautilus, vols. 32-42. Philadelphia, Pa.

Neues Jahrbuch für Mineralogie, Geologie und Paläontologie, 1917-1928; Beilage-Band, 42-60.' Stuttgart, Germany.

New Jersey Geological Survey : Bulletins 19-30. Trenton, N. J.

New Mexico, State School of Mines: Bulletins 2-4. Socorro, N. Mex.

New York Academy of Sciences: Annals, vols. 28-30. New York.

New York State Museum Bulletin, nos. 203-277; Memoir 16; Handbooks 2, 3, 9. Albany, N. Y.

North Carolina Geological and Economic Survey: Biennial Reports; Bulletins 28-35; Economic Papers 49-57; Circulars 2-11, 14, 16. Raleigh, N. C.

North Dakota Geological Survey: Bulletins 1-6. Grand Forks, N. Dak.

Nova Scotia Institute of Science: Proceedings and Transactions, vols. 14-17. Halifax, Nova Scotia.

Ohio Academy of Science: Proceedings, vol. 7 , pts. 3-10, vol. 8, pts. 1-4. Columbus, Ohio.

Ohio Geological Survey: Fourth Series, Bulletins 21-27, 29-33. Columbus, Ohio.

Ohio Journal of Science, vols. 19-28. Columbus, Ohio.

Oklahoma Geological Survey: Bulletins 4, 12; 28, 31-39, 40 A-JJ, 41-43, 47; Circulars 10-12, 14, 16, 17. Norman, Okla.

Ontario Department of Mines: Reports, 27th-37th, vols. 27-37 (pt. 2). Toronto, Ontario.

Oregon Bureau of Mines and Geology: Biennial Reports; Mineral Resources of Oregon, vol. 3, nos, 1, 2. Corvallis, Oreg.

Pacific Mining News of the Engineering and Mining Journal-Press, vol. 1, nos. 1-8. San Francisco, Calif.

Paleontographica Americana, vol. 1, nos. 2-5. Ithaca, N. Y.

Paleontologische Zeitschrift, Bd. 1-10. Berlin, Germany.

Pan-American Geologist, vols. 37-50. Des Moines, Iowa.

Pennsylvania Academy of Science: Proceedings, vol. 1. Harrisburg, Pa.

Pennsylvania Geological Survey: Fourth Series; Bulletins 1-94 (mimeographed) ; Bulletins C 1, M 2-12; Topographic and Geologic Atlas, nos. $37,65,178,206$. Harrisburg, Pa.

Portland Society of Natural History: Proceedings, vol. 3, pts. 2, 3. Portland, Me.

Quebec (Province), Bureau of Mines: Reports on Mining Operations, 19181927. Quebec, Canada.

Rochester Academy of Science: Proceedings, vols. 5-6 (no. 7). Rochester, N. Y. Royal Society of Canada: Proceedings and Transactions, 3d ser., vols. 12-22. Ottawa, Ont.

Science, new ser., vols. 49-68. New York.

Scientific Monthly, vols. 8-27, New York.

Scientific Society of San Antonio: Annual Reports 15-18; Bulletin 4. San Antonio, Tex. 
Seismological Society of America: Bulletin, vols. 9-1S (no. 1). Stanford University, Calif.

Sierra Club Bulletin, vols. 10 (no. 4)-13 (no. 1). San Francisco, Calif.

Smithsonian Institution: Smithsonian Miscellaneous Collections, vols. 67 (nos. 5-9), 70-81 (nos. 1-6) ; Annual reports, 1919-1927. Washington, D. C.

Sociedad cientifica "Antonio Alzate": Memorias y Revista, t. 35 (nos. 5-12), $37-49$ (nos. 1-6). Mexico City, D. F.

Sociêté de géographie de Québec: Bulletin, vols. 13-22. Quebec, Canada.

South Dakota Geological Survey: Reports of the State Geologist, 1918-1926; Bulletins 9-12 ; Circulars 4, 6-18, 20, 22, 23, 26-29. Vermilion, S. Dak.

South Dakota School of Mines: Bulletin, nos. 13-15; Pamphlet no. 1. Rapid City, S. Dak.

Southern California Academy of Sciences: Bulletin, vols. 18-27. Los Angeles, Calif.

Staten Island Institute of Arts and Sciences: Proceedings, vols. 1-4. Staten Island, N. Y.

Tennessee Academy of Science: Journal, vols. 1-4, Nashville, Tenn.

Tennessee State Geological Survey: Resources of Tennessee, vol. 9; Bulletins 21-31, 33-36. Nashville, Tenn.

Texas, University, Bureau of Economic Geology and Technology: Bulletins $1814,1815,1817,1818,1819,1821,1822,1839,1840,1847,1849,1850$, $1852,1856,1857,1859,1860,1902,1919,1931,1932,1945,2132,2229$, $2230,2232,2234,2239,2307,2327,2330,2333,2340,2346,2383,2433$, $2509,2539,2544,2607,2609,2612,2644,2645$,' 2703, 2710, 2738, 2744, 2745, 2748, 2801, 2807, 2838. Austin, Tex.

Toronto University, Studies: Geological Series, nos. 10-27. Toronto, Ontario.

Torrey Botanical Club: Bulletin, vols. 46-55. Lancaster, Pa.

Torreya, vols. 19-28. Lancaster, $\mathrm{Pa}$.

Tufts College Studies, vols. 4, 5 (Scientific series, nos. 39-45). Tufts College, Mass.

United States Bureau of Mines: Bulletins 78, 95, 112, 117, 144, 150, 162, 165-169, 172-284, 286-289, 291-293, 295 ; Technical Papers 178, 203, 207440. Washington, D. C.

United States Geological Surrey: Annual Report, .40th-49th; Professional Papers 107, 109, 111-113, 115-122, 124-141, 142 (pts.), 143, 145-153; Bulletins $664-666,669,678,679,682,683,686-802,806$ (A) ; WaterSupply Papers 424, 429, 436, 439, 440, 442-592, 596; Geologic Atlas of the United States, folios 208-221. Washington, D. C.

United States National Museum: Bulletins 82, 100 (pts.), 102 (pts.), 103, 104, $106,108-118,121,122,124,125,131,138$; Proceedings, vols. 54-74. Washington, D. C.

Vermont Geological Survey: Reports of the State Geologist, eleventh to sixteenth. Burlington, Vt.

Virginia Geological Survey: Bulletins 11, 17, 19, 21, 22, 25, 26-31. Charlottesville, Va.

Wagner Free Institute of Science: Transactions, vols. 9-11. Philadelphia, Pa. Washington Academy of Sciences: Journal, vols. 9-18. Washington, D. C.

Washington Geological Survey: Bulletins 19, 20-23, 25-31. Olympia, Wash.

Washington, University of, Publications in Geology, vol. 1, nos. 3, 4, vol. 2. Seattle, Wash.

Western Society of Engineers: Journal, vols. 24-33. Chicago, Ill.

West Virginia Academy of Science: Proceedings (W. Va. Univ. Bull.), vols. 1, 2. Morgantown, W. Va. 
West Virginia Geological Survey: (County Reports)-Fayette County; Webster County; Nicholas County; Tucker County; Mineral and Grant Counties ; Mercer, Monroe, and Summers Counties ; Hampshire and Hardy Counties; Pendleton County. Morgantown, W. Va.

Wisconsin Academy of Science, Arts, and Letters: Transactions, vols. 19-23. Madison, Wis.

Wisconsin Geological and Natural History Survey: Biennial Reports, 11th15th; Bulletins 52-69. Madison, Wis.

Wyoming, State Geologist: Biennial Report, 11th-14th; Bulletins 18-21. Cheyenne, Wyo.

Wyoming Historical and Geological Society: Proceedings and Collections, vols. 17, 18. Wilkes-Barre, Pa.

Zeitschrift für Gletscherkunde, Bd. 10-16, Berlin, Germany.

Zeitschrift für praktische Geologie, Jg. 23-36. Berlin, Germany.

Zeitschrift für Vulkanologie, Bd. 5-11. Berlin, Germany. 


\section{BIBLIOGRAPHY}

Abbott, C. D.

1. The St. Lawrence earthquake of February 28, 1925; Seismological Soc. America, Bull., vol. 16, no. 2, pp. 133-145, 2 figs., June, 1926.

Abel, Othenio.

1. Geschichte und Methode der Rekonstruktion vorzeitlicher Wirbeltiere. viii, 327 pp., 255 figs., Jena, Gustav Fischer, 1925.

2. (and Cook, Harold J.). A preliminary study of early mammals in a new fauna from Colorado: Colorado Mus. Nat. Hist., Proc., vol. 5, no. 4, pp. 33-36, 4 figs., November 2, 1925.

3. Amerikafahrt; Eindrücke, Beobachtungen und Studien eines Naturforschers auf einer Reise nach Nordamerika und Westindien [includes various notes on the geology, physiography, and paleontology of the United States and Cuba]. 462 pp., 273 figs., Jena, Gustav Fischer, 1926.

4. Die Lebensspuren in der oberen Trias des Connecticuttales in Connecticut und Massachusetts: Zool.-Bot. Gesell. Wien, Verh., Jg. 1924-5, Bd. 74-75, pp. 145-150, 1926.

5. Die Geschichte der Equiden auf dem Boden Nordamerikas: Zool.-Bot. Gesell. Wien, Verh., Jg. 1924-5, Bd. 74-75, pp. 159-164, 1926.

6. Allognathosuchus, ein an die cheloniphage Nahrungsweise angepasster Krokodiltypus des nordamerikanischen Eozäns : Palaeont. Zeitschr., Bd. 9, H. 4, pp. 367-374, 1 fig., March, 1928.

Adams, Elliot Q. See Wherry, 1.

Adams, Frank Dawson. See also Wolff, J. E., 2.

1. Les gisements métallifères de la région nord du Canada dont l'exploitation reste à faire: Soc. géol. Belgique, Livre Jubilaire, 1874-1924, t. 1, pp. 379-384 [n. d., 1928?].

2. Origin of springs and rivers-an historical review (abstract with discussion by 0 . E. Meinzer) : Geol. Soc. America, Bull., vol. 39, no. 1, pp. 149-150, March 30, 1928; Pan-Am. Geologist, vol. 49, no. 1, pp. 65-66, February, 1928. Fennia, 50, no. 1, 16 pp., 2 pls., Helsingfors, 1928.

Adams, George Irving.

1. The formation of bauxite in sink holes: Econ. Geology, vol. 18, no. 4, pp. 410-412, June-July, 1923.

2. Geology of Alabama; The crystalline rocks: Alabama, Geol. Survey, Spec. Rept. no. 14, pp. 25-40, 1 fig., 1 pl., 1926.

3. Bauxite deposits of the southern States: Econ. Geology, vol. 22, no. 6, pp. 615-620, 1 fig., September-October, 1927.

4. The occurrence and age of certain brown iron ores in Alabama and adjacent States: Econ. Geology, vol. 23, no. 1, pp. 85-92, 1 fig., January, 1928.

5. The course of the Tennessee River and the physiography of the southern Appalachian region: Jour. Geology, vol. 36, no. 6, pp. 481-493, 4 figs., August-September, 1928. 
Adams, H. H.

1. Geological structure of Eastland and Stephens Counties, Texas: Am. Assoc. Petroleum Geologists, Bull., vol. 4, no. 2, pp. 159-167, map, 1920.

Adams, John E.

1. Carbonic flora of Butler's Landing [Johnson County, Iowa] (abstract) : Pan-Am. Geologist, vol. 46, no. 5, pp. 399-400, December, 1926.

2. Butler's Landing outlier and its fossil flora [Iowa]: Iowa. Acad. Sci., Proc., 1926, vol. 33, pp. 177-178 [1927].

Adams, Leason H. See also American Geophysical Union; Williamson, 2.

1. The nature of the interior of the earth (abstract) : Washington Acad. Sci., Jour., vol. 10, no. 17, pp. 498-499, October 19, 1920.

2. Note on the measurement of the density of minerals: Am. Mineralogist, vol. 6, no. 1, pp. 11-12, January, 1921.

3. A source of heat in volcanic activity (abstract) : Geol. Soc. America, Bull., vol. 33, no. 1, pp. 144-145, March 31, 1922.

4. A physical source of heat in springs: Jour. Geology, vol. 32, no. 3, pp. 191-194, April-May, 1924.

5. (and Washington, H. S.). The distribution of iron in meteorites and in the earth: Washington Acad. Sci., Jour., vol. 14, no. 14, pp. 333-340, 6 figs., August 19, 1924.

6. Temperatures at moderate depths within the earth: Washington Acad. Sci., Jour., vol. 14, no. 20, pp. 459-472, 2 figs., December 4, 1924.

7. (and Williamson, E. D.). The composition of the earth's interior : Smithsonian Inst., Ann. Rept., 1923, pp. 241-260, 6 figs., 1925.

8. (and Gibson, R. E.). The compressibilities of dunite and of basalt glass and their bearing on the composition of the earth: Nat. Acad. Sci., Proc., vol. 12, no. 5, pp. 275-283, May 15, 1926; Die Kompressilibilität des Dunits und des basaltischen Glases und ihre Beziehungen zur Zusammensetzung der Erde: Gerlands Beiträge zur Geophysik, Bd. 15, H. 3, pp. 241-250, 1926.

9. The earth's crust and the discontinuity beneath it: Nat. Research Council, Bull., vol. 11, pt. 2, no. 56, pp. 29-30, November, 1926 ; abstract, Am. Jour. Sci., 5th ser., vol. 12, p. 272, September, 1926.

10. The critical extent of polar ice caps: Nat. Research Council, Bull. no. 61, pp. 31-32; July, 1927.

Adams, Leverett Allen.

1. A memoir on the phylogeny of the jaw muscles in recent and fossil vertebrates: New York Acad. Sci., Annals, vol. 28, pp. 51-166, 13 pls., 5 figs., January 15, 1919.

2. The shifting of the mammalian faunas as shown by the Pleistocene remains of Illinois: Illinois State Acad. Sci., Trans., vol. 16, pp. 140-144, 1923.

3. The significance of fossil footprints: Illinois State Acad. Sci., Trans., vol. 18, pp. 172-177, 1925.

4. (and Martin, H. T.). Pliocene urodeles in western Kansas: Science, new ser., vol. 67, pp. 59-60, July 20, 1928.

Adams, Sidney F.

1. A replacement of wood by dolomite: Jour. Geology, vol. 28 , no. 4 , pp. 356365, 4 figs., May-June, 1920.

2. A microscopic study of vein quartz: Econ. Geology, vol. 15, no. 8, pp. 623664, 8 pls., December, 1920. 
Addington, Arch $\mathbf{R}$.

1. A special case of drainage adjustment near the Illinoian drift margin in southeastern Owen County, Indiana: Indiana Acad. Sci., Proc., vol. 35, pp. 125-130, 5 figs., 1926.

2. Porter's Cave and recent drainage adjustments in its vicinity: Indiana Acad. Sci., Proc., vol. 36, pp. 107-116, 6 figs., 1927.

3. A preliminary report upon the survey of Indiana caves with special reference to Marengo Cave: Indiana, Dept. Conservation, Eighth Ann. Rept., pp. 21-31, 1 fig., 1927.

4. The Litten natural bridges and closely associated phenomena, eastern Owen County, Indiana: Indiana Acad. Sci., Proc., vol. 37, pp. 143-151, 3 figs., 1928.

5. A preliminary report of investigations concerning subterranean drainage phenomena during the summer of 1927: Indiana, Dept. Conservation, Ninth Ann. Rept., pp. 9-18, 1928.

Adkins, Walter Scott. See also Lonsdale, 8 ; Winton, W. M., 1.

1. (and Winton, W. M.). Paleontological correlation of the Fredericksburg and Washita formations in north Texas: Texas, Univ., Bull. no. 1945, 128 pp., 22 pls., 6 figs., August 10, 1919 [pub. January, 1920].

2. The Weno and Pawpaw formations of the Texas Comanchean: Texas, Univ., Bull. no. 1856, pp. 1-172, 13 figs., 11 pls., October 5, 1918 [1920].

3. Geology and mineral resources of McLennan County: Texas, Univ., Bull. no. 2340, 202 pp., 10 figs., 4 pls. (incl. map), January, 1924.

4. The geology and mineral resources of the Fort Stockton quadrangle: Texas, Univ., Bull. no. 2738, 166 pp., 8 figs., 6 pls. (incl. map), October 8 , 1927.

5. Handbook of Cretaceous fossils: Texas, Univ., Bull. no. 2838, 385 pp., 37 pls., 1928.

Agar, William MacDonough.

1. The minerals of St. Lawrence, Jefferson, and Lewis counties, New York. Am. Mineralogist, vol. 6, no. 10 , pp. 148-153, no. 11, pp. 158-164, 1 fig., October and November, 1921.

2. Contact metamorphism in the western Adirondacks: Am. Philos. Soc., Proc., vol. 62, no. 3, pp. 95-174, 2 figs., 9 pls., 1923.

3. The minerals of the intermediate zone, Butte, Montana: Econ. Geology, vol. 21, no. 7, pp. 695-707, 5 figs., November, 1926.

4. The geology of Shepaug Aqueduct Tunnel, Litchfield County, Connecticut: Connecticut, State Geol. and Nat. Hist. Survey, Bull. no. 40, 38 pp., 3 figs., 8 pls., 2 maps, 1927.

Aguerrevere, Santiago E. See Schenck, 2.

Aguilar, Ángel.

1. El petróleo en nuestras costas del Pacífico: Boletín Minero, t. 7, nos. 3-4, pp. 272-275, March-April, 1919.

Aguilera, E.

1. Reseña sobre la industria minêra en la provincia de Oriente durante el año 1923 á 1924: Cuba, Dirección de montes y minas, Bol. minas, no. 8, pp. 68-70, August, 1925.

Aguilera, José Guadelupe.

1. The Sonora earthquake of 1887 : Seismol. Soc. America, Bull., vol. 10, no. 1, pp. 31-44, March, 1920. 
Albertson, Maurice Merton.

1. Isostatic adjustments on a minor scale in their relation to oil domes: Am. Inst. Min. and Met. Eng., Trans. [preprint] no. 1055, 3 pp., 1 fig., February, 1921 ; Trans., vol. 65, pp. 418-420, 1 fig., 1921. Abstract, Mining and Metallurgy, no. 170, pp. 38-39, February, 1921.

2. Possible explanation of the large initial production of some wells of the Haynesville field, Louisiana: Am. Assoc. Petroleum Geologists, Bull., vol. 7, no. 3, pp. 295-296, May-June, 1923.

Alcalá, Maximino.

1. Informe preliminar acerca de la hidrología subterranea de las cuencas de los Ríos Magdalena y Altar en el Estado de Sonora: Mexico, Inst. geol., Foll. de divulg., no. 25, 25 pp., February, 1927.

2. Hidrología subterránea de la ciudad de Zacatecas: Mexico, Inst. geol., Foll. de divulg., no. 27,15 pp., June, 1927.

Alcock, Frederick James. See also Bingay, 1.

1. Reed-File lakes area, Manitoba: Canada, Geol. Survey, Summ. Rept., 191s, pt. D, pp. 6-8, 1919.

2. Wekusko Lake area, Manitoba: Canada, Geol. Survey, Summ. Rept., 191s, pt. D, pp. 9-10, 1920.

3. The Reed-Wekusko map area, northern Manitoba: Canada, Geol. Survey, Mem. 119, 47 pp., 6 pls., 2 maps, 1920.

4. Cross-Pipestone map area, Manitoba: Canada, Geol. Survey, Summ. Rept., 1919, pt. D, pp. 11-18, 1920.

5. The Athabaska series: Am. Jour. Sci., 4th ser., vol. 50, pp. 25-32, July, 1920.

6. The origin of Lake Athabaska: Geog. Rev., vol. 10, no. 6, pp. 400-407, 8 figs., December, 1920.

7. The norite rocks of the Lake Athabasca region: Roy. Soc. Canada, Proc. and 'Trans., 3d ser., vol. 14, sec. 4, pp. 25-29, 1 fig., 1.921.

8. A local occurrence of differentiation in granite on the Churchill River, northern Manitoba, Canada: Roy. Soc. Canada, Proce and Trans., 3d ser., vol. 14, sec. 4, pp. 31-33, 1 fig., 1921.

9. Ospwagan Lake-Burntwood River area, northeln Manitoba: Canada, Geol. Survey, Summ. Rept., 1920, pt. C, pp. 1-6, map, 1921.

10. Rat River route from Threepoint Lake to southern Indian Lake, Manitoba : Canada, Geol. Survey, Summ. Rept., 1920, pt. C, pp. 6-12, map, 1921.

11. The terminal moraine of the Seal-Churchill divide [Manitoba]: Canada, Geol. Survey, Summ. Rept., 1920, pt. C, pp. 13-18, 2 figs., map, 1921.

12. The occurrence of gold at Herb Lake [Manitoba]: Canadian Inst. Min. and Met., Monthly Bull. no. 107, pp. 210-215, March, 1921.

13. (and Bruce, E. L.). Pre-Cambrian rocks of Manitoba: Geol. Soc. America, Bull., vol. 32, no. 2, pp. 267-292, 3 figs., June 30, 1921.

14. Geology of Lemieux Township, Gaspe County, Quebec: Canada, Geol. Survey, Summ. Rept., 1921, pt. D, pp. 71-96, 2 figs., 3 pls., 2 maps, 1922.

15. Flinflon map area, Manitoba and Saskatchewan: Canada, Geol. Survey, Summ. Rept., 1922, pt. C, pp. 1-36, 6 figs., 3 pls., 2 maps, 1923.

16. Copper prospects in Gaspe Peninsula, Quebec: Canada, Geol. Surrey, Summ. Rept., 1923, pt. C 2, pp. 1-12, 4 figs., 1924; Quebec, Dept. Colonization . . . Report on Mining Operations . . 1924, pp. 29-39, 2 figs., 1925. 
Alcock, Frederick James-Continued.

17. Across Gaspe: Geog. Rev., vol. 14, no. 2, pp. 197-214, 20 figs., April, 1924.

18. The Pas mineral belt [Saskatchewan-Manitoba]: Canadian Min. Jour., vol. 45, no. 30, pp. 713-715, 3 figs., July 30, 1924.

19. The mineral deposits of Gaspe [Quebec]: Canadian Min. Jour., vol. 45, no. 41, pp. 1000-1003, 4 figs., October 10, 1924.

20. Mount Albert map area, Quebec: Canada, Geol. Survey, Mem. 144, 75 pp., 5 figs., 6 pls., map, 1926.

21. Shickshock Mountains, central Gaspe, Quebec: Canada, Geol. Survey, Summ. Rept., 1924, pt. C, pp. 127-133, 2 figs., 2 pls., map, 1926.

22. Geology of Mount Serpentine, Gaspe, Quebec: Canada, Geol. Survey, Summ. Rept., 1924, pt. C, pp. 134-141, 1 fig., 1926.

23. Lead and zinc in eastern Canada: Mining and Metallurgy, vol. 7, no. 230, pp. 51-56, 4 figs., February, 1926; Canadian Min. Jour., vol. 47, no. 19, pp. 488-492, May 7, 1926.

24. Memorial of William McInnes: Geol. Soc. America, Bull., vol. 37, no. 1, pp. 96-99, 1 pl. (portr.), March 30, 1926.

25. Geology of the Great Lakes area: Canada Yearbook, 1925, p. 24, Canada, Dominion Bureau of Statistics, General Statistics Branch, Ottawa, 1926.

26. Recent developments in Gaspe Peninsula [Quebec] : Canadian Min. and Met. Bull., no. 191, pp. 367-385, 10 figs., March, 1928.

27. Rivers of Gaspe: Geol. Soc. America, Bull., vol. 39, no. 2, pp. 403-420, 8 figs., 3 pls., June, 1928; abstract, Geol. Soc. America, Bull., vol. 39, no. 1, p. 158, March 30, 1928; Pan-Am. Geologist, vol. 49, no. 1, p. 70, February, 1928.

28. Gaspe Peninsula, its geology and mineral possibilities: Quebec, Dept. Colonization, Mines and Fisheries, Report on Mining Operations, 1927, pp. 162-181, 2 figs., 3 pls., 1928.

29. Zinc-lead field of central Gaspe, Quebec: Canada, Geol. Survey, Summ. Rept., 1927, pt. C, pp. 27-46, map, 1928.

Alden, William Clinton. See also Atwood, 4; Bretz, 14; Kay, 10; Osborn, 19; Salisbury, 2; Winchester, 1.

1. Rate of movement in glaciers of Glacier National Park: Science, new ser., vol. 57, p. 268, March 2, 1923.

2. The physical features of central Massachusetts: U. S. Geol. Survey, Bull. 760, pp. 13-105, 11 figs., 17 pls., December 16, 1924.

3. Physiographic development of the northern Great Plains: Geol. Soc. America, Bull., vol. 35, no. 3, pp. 385-423, 12 pls. (incl. map), September 30, 1924; abstract, no. 1, pp. 74-75, March 30, 1924; abstract, Pan-Am. Geologist, vol. 41, no. 2, p. 140, March, 1924.

4. Pre-Wisconsin glaciation of northern Rocky Mountains (abstract) : PanAm. Geologist, vol. 43, no. 5, pp. 371-372, June, 1925.

5. Glaciation and physiography of Wind River Mountains, Wyoming (abstract) : Washington Acad. Sci., Jour., vol. 16, no. 3, p. 73, February 4, 1926.

6. The Gros Ventre landslide of June, 1925 [Wyoming] (abstract) : Washington Acad. Sci., Jour., vol. 17, no. 5, p. 123, March 4, 1927.

7. Memorial of Willis Thomas Lee: Geol. Soc. America, Bull., vol. 38, no. 1, pp. 70-93, portr., March 30, 1927.

8. Landslide and flood at Gros Ventre, Wyoming: Am. Inst. Min. and Met. Eng., Tech. Pub. no. 140, 14 pp., 11 figs., October, 1928; Trans., vol. 76, pp. 347-361, 11 figs., 1928; abstract. Mining and Metallurgy, vol. 9, no. 262, p. 465, October, 1928. 
Aiderson, Victor Clifton.

1. The oil shale industry: Colorado School of Mines, Qualt., vol. 14, no. 4, pp. 3-15, October, 1919.

2. The oil shale industry. 175 pp., 15 pls., New York, Frederick A. Stokes Company, 1920.

3. The oil shale of Kentucky: Colorado School of Mines, Quart., vol. 17, no. 4, pp. 3-15, 10 figs., October, 1922.

4. Colorado oil shale: Colorado School of Mines, Quart., vol. 20, no. 2, 53 pp., illus., April, 1925.

5. Jefferisite: Colorado School of Mines, Circular of Information, 4 pp. [n. d., 1925?].

6. Oil shale: Inst. Petroleum Technologists, Jour., vol. 12, no. 57, pp. 366-374, August, 1926.

Aldrich, H. R.

1. The dip needle in stratigraphy: Mining and Metallurgy, no. 163, p. 33, July, 1920 (abstract) ; Am. Inst. Min. and Met. Eng., Trans., vol. 66, pp. 49-63, 9 figs., 1922 (with discussion by W. O. Hotchkiss, Carl Zapffe, and Emil A. Kronquist) ; [preprint no. 998], 7 pp., 4 figs., 1920; [preprint] no. 1088, p. 12, August, 1921; discussion, no. 1038, pp. 18-24, 5 figs., January, 1921.

2. Magnetic surveying on the copper-bearing rocks of Wisconsin: Econ. Geology, vol. 18, no. 6, pp. 562-574, 2 figs., September, 1923.

Aldrich, Truman Heminway. See also Gardner, J. A., 1.

1. New Eocene species from Alabama: Bull. American Paleontology, vol. 9, no. 37, 32 pp., 3 pls., March 6, 1921.

2. Notes on the Clinton group in Alabama: Am. Inst. Min. and Met. Eng., Trans., vol. 71., pp. 304-307, 1 fig., 1925; also [preprint] no. 1375, 1924 ; abstract, Mining and Metallurgy, vol. 5, no. 215, pp. 547-548, November, 1924.

Alexander, A. Emil.

1. Devonian concretions of western and central New York: Science, new ser., vol. 68, p. 85, July 27, 1928.

Alexander, C. I.

1. Micrology of the upper Fredericksburg and lower Washita formations: Texas, Univ., Bull. no. 2544, pp. 65-67, 2 pls., 1925.

2. The stratigraphic range of the Cretaceous ostracod Bairdia subdeltoidea and its allies: Jour. Paleontology, vol. 1, no. 1, pp. 29-33, 1 pl., July, 1927.

3. The time range of the foraminiferan, Flabellammina alexanderi, in the Lower Cretaceous of north Texas: Jour. Paleontology, vol. 2, no. 1, pp. 43-44, 2 figs., March, 1928.

Alexander, W. $\mathbf{P}$.

1. Trips into the geologic past of western New York: Hobbies (Buffalo Soc. Nat. Hist.), vol. 7, no. 2, pp. 3-18, June, 1926.

Allan, John Andrew.

1. Geology of the Swan Hills in Lesser Slave Lake district, Alberta: Canada, Geol. Survey, Summ. Rept., 1918, pt. C, pp. 7-13, 1919.

2. First annual report on the mineral resources of Alberta. 103 pp., Edmonton, 1920. 
Allan, John Andrew-Continued.

3. Salt explorations at Fort McMurray [Alberta] ; Alberta, Advisory Council of Scientific and Industrial Research, First Ann. Rept., pp. 33-34, 1921.

4. Second annual report on the mineral resources of Alberta, 1920. 138, 14 pp., map, Edmonton, 1921.

5. Mineral possibilities in Alberta and adjoining territory: Canadian Inst. Min. and Met., Monthly Bull. no. 109, pp. 438-448, May, 1921; Canadian Min. Jour., vol. 42, no. 19, pp. 379-382, May 13, 1921.

6. Geological reconnaissance in Alberta during 1921: Alberta, Scientific and Industrial Research Council, 2d Ann. Rept., pp. 34-42, 1922.

7. Geology of the Drumheller coal field, Alberta, Canada: Third annual report on the mineral resources of Alberta, 1921: Alberta, Scient. and Industrial Research Council, Rept. no. 4, 72, 5 pp., 17 pls., Edmonton, 1922.

8. Geological investigations during 1922: Alberta, Scient. and Industrial Research Council, Third Ann. Rept., pp. 38-41, 1923.

9. (and Rutherford, Ralph L.). Saunders Creek and Nordegg coal basins, Alberta, Canada: Alberta, Scientific and Industrial Research Council, Rept. no. 6 (4th Ann. Rept. Mineral Resources of Alberta, pt. 1), 66 pp., 9 pls., map, 1923.

10. (and Cameron, Alan E.). An occurrence of iron on Lake Athabaska: Alberta, Scientific and Industrial Research Council, Rept. no. 7 (4th Ann. Rept. Mineral Resources of Alberta, pt. 2), 33 pp., 7 pls., 2 maps, 1923.

11. Geological investigations during 1923: Alberta, Scientific and Industrial Research Council, Fourth Ann. Rept., 1923, pp. 46-58, 1924.

12. Some problems relating to the Cretaceous and Jurassic stratigraphy in Alberta: Roy. Soc. Canada, Proc. and Trans., 3d ser., vol. 17, sec. 4, pp. 117-124, May, 1923.

13. (and Rutherford, Ralph L.). Geology along the Blackstone, Brazeau, and Pembina rivers in the foothills belt, Alberta: Alberta, Scientific and Industrial Research Council, Rept. no. 9, 53 pp., 8 pls. (incl. map), 1924.

14. Geological map of the Province of Alberta: Alberta, Scientific and Industrial Research Council, 1925. Scale, 1 inch $=25$ miles.

15. Geological investigations during 1924: Alberta, Scientific and Industrial Research Council, 5th Ann. Rept. (Rept. no. 12), pp. 32-45, 1925.

16. (and Sanderson, J. O.). An Upper Cretaceous disconformity in Alberta (abstract) : Geol. Soc. America, Bull., vol. 36, no. 1, p. 161, March 30, 1925: Pan-Am. Geologist, vol. 43, no. 2, p. 155, March 1925.

17. Geology of Alberta coal: Canadian Inst. Min. and Met., Bull., no. 156, pp. 387-405, 10 figs., April, 1925 ; Trans., vol. 28, pp. 231-251, 10 figs. [1926].

1.8. [Report of the] Geological Survey division: Alberta, Scientific and Industrial Research Council, 6th .Ann. Rept., 1925 (Rept. no. 16), pp. 32-46, 1 fig., 1926.

19. Ice crystal markings: Am. Jour. Sci., 5th ser., vol. 11, pp. 494-500, 10 figs., June, 1926.

20. (and Rutherford, Ralph L.). Paskapoo fossil plant localities of Alberta: Roy. Soc. Canada, Proc. and Trans., 3d ser., vol. 20, sec. 4, pp. 183-186, 1 pl., 1926.

4096-31—2 
Allan, John Andrew-Continued.

21. [Report of] Geological Survey division; natural gas: Alberta, Sci. and Iud. Research Council, 7th Ann. Rept., 1926, Rept. no. 20, pp. 28-37, 1927.

22. Geological Survey division [report]: Alberta, Sci. and Industrial Research Council, Eighth Ann. Rept., 1927, pp. 36-41, 1928.

Allen, Eugene Thomas. See also Day, A. L., 11, 15 ; Merwin, 5 ; Wright, F. E., 9.

1. Chemical aspects of volcanism with a collection of the analyses of volcanic gases: Franklin Inst., Jour., vol. 193, no. 1, pp. 29-80, January, 1922.

2. (and Zies, E. G.). A chemical study of the fumaroles of the Katmai region: Nat. Geog. Soc., Contributed Tech. Papers, Katmai series no. 2, pp. 75-155, illus., 1923.

3. Further evidence of the nature of hot springs (abstract) : Washington Acad. Sci., Jour., vol. 16, no. 3, p. 74, February 4, 1926.

4. (and Day, Arthur. L.). Steam wells and other activity at "The Geysers," California : Carnegie Inst. Washington, Pub. no. 378, 106 pp., 34 figs., 1 pl. (map), 1927.

5. The work of the Geophysical Laboratory on hot springs: Nat. Research Council, Bull. no. 61, pp. 255-259, July, 1927.

6. (and Day, Arthur L.). Natural steam power in California [The Geysers] : Nature, vol. 122, pp. 17-18, 27-28, July 7, 1928.

7. The classification of the hot areas in the Yellowstone Park and the causes of their development (abstract): Washington Acad. Sci., Jour., vol. 18 , no. 19 , p. 511, November $19,1928$.

Allen, Glover Morrill.

1. Bison remains from New England: Jour. Mammalogy, vol. 1, no. 4 pp. 161-164, 3 figs., August, 1920.

2. A new fossil cetacean [Archaleodelphis] : Harvard Coll., Mus. Comp. Zoology, Bull., vol. 65, no. 1, pp. 1-14, 3 figs., 1 pl., August, 1921.

3. Fossil cetaceans from the Florida phosphate beds: Jour. Mammalogy, vol. 2, no. 3, pp. 144-159, 1 fig., 4 pls., August, 1921.

4. Fossil mammals from South Carolina: Harvard Coll., Mus. Comp. Zoology, Bull., vol. 67, no. 14, pp. 447-467, 5 pls., July, 1926.

\section{Allen, Herman Camp.}

1. (and Lyder, E. E.). A chemical survey of the natural gases of Kansas and Oklahoma: Kansas, Univ., Bull., vol. 19, no. 1, Engineering Bull. no. 11, Division of State Chemical Research, Bull. no. 3, 101 pp., 10 figs., 1919.

2. The chemistry of Kansas coal : Kansas, Univ., Bull., vol. 26, no. 5, Division of Chemical Research, Bull. no. 4, pp. 127-202, 3 figs., March 1, 1925.

Allen, Maxwell W.

1. Some remarks concerning Pacific coast earthquakes: Seismological Soc. America, Bull., vol. 15, no. 2, pp. 128-139, June, 1925.

Allen, Milton Arthur. See also Butler, G. M., 1, 2.

1. (and Butler, G. M.). Barytes: Arizona, Univ., Bur. Mines, Bull. no. 99, 18 pp., 1919.

2. The southern section of the Amole mining district: Arizona, Univ., Bull. no. 106 (geol. ser. no. 2), pp. 19-25, 4 figs., May, 1920.

3. (and Butler, G. M.). Asbestos: Arizona Bur. Mines, Bull. no. 113, 31 pp., 1 fig., 1921. 
Allen, Milton Arthur-Continued.

4. (and Butler, G. M.). Fluorspar : Arizona Bur. Mines, Bull. no. 114, 19 pp., July 15, 1921.

5. (and Butler, G. M.). Vanadium: Arizona Bur. Mines, Bull. no. 115, 23 pp., September 1, 1921.

6. Arizona gold placers: Arizona Bur. Mines, Bull. no. 118, 24 pp., 1 fig., January 15, 1922.

Allen, Rolland Crater. See also Lane, 2; Tanton, 17.

1. Mineral resources of Michigan with statistical tables of production and value of mineral products for 1917 and prior years: Michigan Geol. and Biol. Survey, Pub. 27 (Geol. ser. 22), 225 pp., 2 pls. (incl. map), 1918; . . . for 1918 . . . Pub. 29 (Geol. ser. 24), 214 pp., 4 figs., 1920.

2. Correlation of formations of Huronian group in Michigan: Am. Inst. Min. and Met. Eng., Bull. no. 135, pp. 2579-2594, 1 fig., September, 1919; Trans., vol. 63, pp. 188-212, 1 fig., 1920. Discussion by W. 0. Hotchkiss, E. F. Burchard, Carl Zapffe, and E. C. Harder, Mining and Metallurgy, no. 157, sec. 12, pp. 1-6, January, 1920.

3. (and Martin, Helen M.). A brief history of the Geological and Biological Survey of Michigan; 1837 to 1872 , by R. C. Allen; 1872 to 1920, by Helen M. Martin: Michigan History Mag., vol. 6, no. 4, pp. $675-750,3$ pls. (portraits), 1922.

4. (and Martin, Helen M.). An abstract of "A history of the Michigan Geological and Biological Survey": Michigan Acad. Sci., Papers, vol. 1, pp. 224-247, 2 pls., 1923.

Allen, Victor T.

1. Anauxite from the Ione formation of California: Am. Mineralogist, vol. 13, no. 4, pp. 145-152, 1 fig., April, 1928.

2. Ione formation of: California (abstract): Pan-Am. Geologist, vol. 49, no. 4, p. 313, May, 1928.

Allende, Roque. See also Babé, 1 ; Calvache, 4.

1. Estudio técnico de los yacimientos minerales de Isla de Pinos: Cuba, Dirección de montes y minas, Bol. minas, no. 7, pp. 51-67, 5 pls., 1923.

2. Yacimientos minerales de Pinar del Río: Cuba, Dirección de montes y minas, Bol. minas, no. 7 , pp. 68-77, 1923.

3. Yacimientos metalíficos de Pinar del Río (continuación) : Cuba, Dirección de montes y minas, Bol. minas, no. 8, pp. 45-50, 1 fig., August, 1925.

4. (and Lago, Manual G.). Minas "Caridad" y "Lola" de Camagüey: Cuba, Dirección de montes y minas, Bol. minas, no. 8, pp. 51-56, August, 1925.

5. Estudio hidrológico de la cuenca del Río Almendares y su relación con los manantiales de Vento: Cuba, Dirección de montes y minas, Bol. minas, no. 9, pp. 33-73, 9 figs., 10 pls. (incl. map), 1926.

6. Yacimientos minerales de la República de Cuba; cobre: Cuba, Dirección de montes y minas, Bol. minas, año 11, no. 11, 148 pp., 50 figs., 3 pls. (incl. map), 1927.

7. Breves noticias del cobre en Cuba: Cuba, Dirección de montes y minas, Monografías geológicas (extracto), 47 pp., 1 pl. (map), 1927. 
Allende, Roque-Continued.

8. Estudio hidrológico de las cuencas de Aguada del Cura, Río de Sạ Antonio de los Baños y Laguna de Ariguanabo y sus posibles conexiones con los manantiales de Vento: Bol. minas, Habana, no. 12, pp. 4-20, 9 figs., 1 pl., 1928.

9. Informe relativo al abastecimiento de agua á la granja escuela "Juan Bautista Jiménez": Bol. minas, Habana, no. 12, pp. 21-29, 3 figs., 1928.

10. Yacimientos piritosos de la Sierra de Trinidad, Mina "Carlota": Bol. minas, Habana, no. 12, pp. 50-58, 2 figs., 1928.

11. Informe geológico sobre el acueducto de Jaruco [Cuba]: Bol. minas, Habana, no. 12, pp. 59-61, 1928.

12. Sobre un reconocimiento de terrenos graníticos en la provincia de la Habana [Cuba] : Bol. minas, Habana, no. 12, pp. 78-79, 1928.

13. Informe sobre una rápida inspección de los terrenos de Consolación del Sur [Cuba] : Bol. minas, Habana, no. 12, pp. 80-83, 1928.

14. Notas sobre los petróleos de Santa Clarita [Cuba]: Bol. minas, Habana, no. 12 , pp. $84-85,1928$.

15. Monografía del asfalto y el petróleo: Cuba, Dirección de montes y minas, Bol. minas, no. 13, 153 pp., 24 flgs., 1 pl., 1928.

Allera, Juan.

1. Campo Tecuanapa, región petrolera del Istmo [Vera Cruz, Mexico]: Bol. petróleo, vol. 25, no. 6, pp. 894-898, 5 pls., June, 1928.

Alling, Harold Lattimore. See also Kemp, 23.

1. Geology of the Lake Clear region (parts of St. Regis and Saranac quadrangles) : New York State Mus. Bull., nos. 207, 208 (March-April, 1918), pp. 111-145, 10 pls., 3 figs., 2 maps, 1919.

2. Pleistocene geology [of the Lake Placid quadrangle]: New York State Mus. Bull. nos. 211, 212, pp. 71-95, 8 pls., 7 figs., map, 1919.

3. Some problems of the Adirondack pre-Cambrian: Am. Jour. Sci., 4th ser., vol. 48, pp. 47-68, 3 figs., July, 1919. Abstract, Geol. Soc. America, Bull., vol. 30, p. 155, March 31, 1919.

4. Glacial geology [of the Mount Marcy quadrangle, Essex County, New York] : New York State Mus. Bull. nos. 229, 230, pp. 62-84, 8 figs., 3 pls., 1921.

5. The mineralography of the feldspars. Part 1: Jour. Geology, vol. 29, no. 3, pp. 193-294, 19 figs., 6 pls., April-May, 1921.

6. The origin of graphite: Econ. Geology, vol. 16, nos. 4-5, pp. 334-337, 1921.

7. Petrographic studies of some New York sediments (abstract) : Geol. Soc. America, Bull., vol. 33, no. 1, p. 107, March 31, 1922.

8. The mineralography of the feldspars; Part II: Jour. Geology, vol. 31; no. 4, pp. 282-305, 3 figs., 2 pls., May-June, no. 5, pp. 353-375, 4 figs., July-August, 1923.

9. The origin of the foliation and the naming of syntectic rocks: Am. Jour. Sci., 5th ser., vol. 8, pp. 12-32, 3 figs., July, 1924.

10. Genesis of the Adirondack magnetites: Econ. Geology, vol. 20, no. 4, pp. 335-363, June-July, 1925.

11. The potash-soda feldspars: Jour. Geology, vol. 34, no. 7, pp. 591-611, 5 figs., October-November, 1926.

12. (and Valentine, Wilbur G.). Quantitative microscopic analysis: Am. Jour. Sci., 5th ser., vol. 14, pp. 50-65, July, 1927. 
Alling, Harold Lattimore-Continued.

13. Stratigraphy of the Grenville of the eastern Adirondacks: Geol. Soc. America, Bull., vol. 38, no. 4, pp. 795-804, 4 figs., December 30, 1927 ; abstract, no. 1, pp. 121-122, March 30, 1927 ; Pan-Am. Geologist, vol. 47, no. 1, pp. 70-71, February ,1927.

14. The geology and origin of the Silurian salt of New York State: New York State Mus. Bull. no. 275, 139 pp., 20 figs., April, 1928.

Alling, Mark N.

1. Ancient river-bed deposits in California: Pacific Min. News, vol, 1, nos. 5 and 6, pp. 134-140, 161-166, 16 figs., September and October, 1922.

Allison, E. L.

1. How was placer gold formed?: Eng. and Min. Jour.-Press, vol. 117, no. 19, pp. 771-772, May 10, 1924.

Allison, Ira S.

1. The Giants Range batholith of Minnesota: Jour. Geology, vol. 33, no. 5, pp. 488-508, 5 figs., July-August, 1925.

2. Enrichment of the Mesabi iron ores: Econ. Geology, vol. 20, no. 7, pp. 693-697, November, 1925.

3. Weathered granite twice metamorphosed: Jour. Geology, vol. 34, no. 3. pp. 281-285, April-May, 1926.

4. Cretaceous rocks of northern Minnesota (abstract) : Geol. Soc. America, Bull., vol. 38, no. 1, p. 135, March 30, 1927 ; Pan.-Am. Geologist, vol. 47, no. 1, p. 78, February, 1927.

5. New erosional terms: Am. Jour. Sci., 5th ser., vol. 16, p. 360, October, 1928.

Allison, Vernon Charles.

1. The growth of stalagmites and stalactites: Jour. Geology, vol. 31, no. 2, pp. 106-125, 16 figs., February-March, 1923.

2. Quaternic and Tertic chronology': Pan-Am. Geologist, vol. 42, no. 3, pp. 199-216, 2 pls., October, 1924.

3. Climatic pattern of Cenozoic times: Pan-Am. Geologist, vol. 43, no. 3, pp. 205-216, April, 1925.

Ambronn, Richard.

1. Elements of geophysics as applied to explorations for minerals, oil, and gas. Translated by Margaret C. Cobb. xi, 372 pp., illus., New York, McGraw-Hill Book Company, 1928.

Ambrose, Arthur Warren.

1. Analysis of oil-field water problems: Mining and Metallurgy, no. 165, pp. 23-24, 1 fig., September, 1920 (abstract) ; Am. Inst. Min. and Metal. Eng., Trans. [preprint] no. 1019, 23 pp., 1920; discussion by R. A. Conkling, E. DeGolyer, and R. V. A. Mills, no. 1038, pp. 68-71, January, 1921; Trans., vol. 65, pp. 245-268, 4 figs., 1921.

2. Underground conditions in oil fields: U. S. Bur. Mines, Bull. 195, 238 pp., 43 figs., 23 pls., 1920.

American Geographical Society.

1. New York walk book: Am. Geog. Soc., Outing Series no. 2, 217 pp., illus., 1923.

Includes notes on geological features in the vicinity of New York City. 
American Geophysical Union.

1. Discussion following symposium on the constitution of the earth: Nat. Research Council, Bull. no 56 (vol 11, pt. 2), pp. 33-39, November, 1926.

American Institute of Mining and Metallurgical Engineers.

1. Discussion of the papers on geophysical prospecting presented at the New York meeting, February, 1928: Am. Inst. Min. and Met. Eng., Tech. Pub. no. 130, 31 pp., October, 1928.

Ami, Henry Marc.

1. Memorial of Robert Bell : Geol. Soc. America, Bull., vol. 38, no. 1., pp. 18-34, portr., March 30, 1927.

Aminoff, G.

1. (and Parsons, A. L.). The crystal structure of sperrylite: Toronto, Univ., Studies, Geol. ser., no. 27, pp. 5-10, 1928.

Anderegg, F. 0 .

1. (and others). Indiana limestone. 1; Efflorescence and staining: Purdue Univ., Bull., vol. 12, no. 6 (Eng. Exp. Sta., Bull. no. 33), 84 pp., 26 figs., September, 1928.

Anderson, Abram E.

1. Sand fulgurites from Nebraska, their structure and formative factors: Nebraska State Mus., Bull. 7, vol. 1, pp. 49-86, 21 figs., 1 pl., June 1925.

Anderson, Alfred $\mathrm{L}$.

1. Mica deposits of Latah County, Idaho: Idaho, Bur. Mines and Geology, Pamph. no. 14, 15 pp., 1 pl. (map) [no date, 1925?]. [Mimeographed.]

.2. Some Miocene and Pleistocene drainage changes in northern Idaho: Idaho, Bur. Mines and Geology, Pamph. no. 1.8, 29 pp., 2 pls. (maps), July, 1927. [Mimeographed.]

3. Portland cement materials near Pocatello, Idaho: Idaho, Bur. Mines and Geology, Pamph. no. 28, 15 pp. [mimeographed], 2 pls. (incl. map), June, 1928.

4. A geological reconnaissance in the St. Maries region, Idaho: Idaho, Bur. Mines and Geology, Pamph. no. 30, 22 pp., July, 1928. [Mimeographed.]

5. Genesis of the Silver Hill tin deposits [Spokane County, Washington]: Jour. Geology, vol. 36, no. 7, pp. 646-664, 6 figs., October-November, 1928.

Anderson, C. O. See Myers, 2.

Anderson, Carl B.

1. The artesian waters of northeastern Illinois: Illinois State Geol. Survey, Bull. no. 34, 326 pp., 4 pls. (incl. maps), 3 figs, 1919.

Anderson, Charles A.

1. Voitaite from Jerome, Arizona: Am. Mineralogist, vol. 12, no. 7, pp. 287-290, July, 1927; abstract, Geol. Soc. America, Bull., vol. 37, no. 1, p. 209 , March 30, 1926. 
Anderson, Frank Marion.

1. (and Hanna, G. Dallis). Fauna and stratigraphic relations of the Tejon Eocene at the type locality in Kern County, California: California Acad. Sci., Occ. Papers 11, 249 pp., 10 figs., 16 pls. (incl. map), March 18, 1925.

2. Origin of California petroleum: Geol. Soc. America, Bull., vol. 37, no. 4, pp. 585-614, December 30, 1926.

3. History of theories regarding siliceous shale and the origin of oil (abstract) : Geol. Soc. America, Bull., vol. 38, no. 1, pp. 197-199, March 30, 1927.

4. Late Cretacic fossils from Lower California: Pan-Am. Geologist, vol. 50, no. 4, pp. 283-284, 1 pl., November, 1928.

Anderson, Gustavus Edwin.

1. Experiments on the rate of wear of sand grains: Jour. Geology, vol. 34, no. 2, pp. 144-158, February-March, 1926 ; abstract, Chicago, Univ., Abstracts of Theses, Sci. Ser., vol. 3, pp. 205-208, April, 1927.

2. Geology and ore deposits of the Asientos-Tepezala district, Aguascalientes, Mexico: Am. Inst. Min. and Met. Eng., Trans. [preprint], no. 1551, 17 pp., 2 figs., February, 1926; Trans., vol. 74, pp. 238-254, 2 figs., 1926 ; abstract, Mining and Metallurgy, vol. 7, no. 230, p. 77, February, 1926.

3. The age of rounded sand grains: Oklahoma Acad. Sci., Proc., vol. 6, pt. 2, 1926 (Oklahoma, Univ., Bull., new ser. no. 348), pp. 265-267, January 1, 1927.

4. Geology of Cleveland and McClain counties: Oklahoma Geol. Survey, Bull. no. 40-N, 18 pp., 2 figs., 2 pls. (incl. maps), July, 1927.

5. On the origin of certain wide veins: Oklahoma Acad. Sci., Proc., vol. 7 (Oklahoma, Univ., Bull., new ser., no. 409), pp. 168-170 [1928].

Anderson, J. A.

1. A torsion seismometer: Optical Soc. America, Jour., vol. 8, no: 6, pp. 817-822, 1 flg., June, 1924.

2. (and Wood, H. O.). Description and theory of the torsion seismometer: Seismological Soc. America, Bull., vol. 15, no. 1, pp. 1-72, 4 figs., 4 pls., March, 1925.

Anderson, John Carter. See also Lindgren, 18.

1. Ore deposits of the Pioche district, Nevada: Eng. and Min. Jour., vol. 113, no. 7, pp. 279-285, 7 flgs., February 18, 1922.

2. Economic application of zonal theory of primary deposition of ores (with discussion by Frank L. Nason, J. E. Spurr, James F. Kemp, and others) : Am. Inst. Min. and Met. Eng., Trans., vol. 69, pp. 22-35, 5 figs., 1923 [preprint] no. 1209, 9 pp., 5 figs., January, 1923; abstract, Mining and Metallurgy, vol. 4, no. 193, p. 31, 1 fig., January, 1923.

Anderson, Robert. See also Takahashi, 1.

1. Origin of oil from marine plankton shales in California (abstract) : Geol. Soc. America, Bull., vol. 38, no. 1, pp. 199-200, March 30, 1927.

Andrews, Ernest Clayton.

1. Grove Karl Gilbert: Sierra Club Bull., vol. 11, no. 1, pp. 60-68, January, 1920.

2. Contribution to the hypothesis of mountain formation: Geol. Soc. America, Bull., vol. 34, no. 2, pp. 381-399, June 30, 1923. 
Andrews, Ernest Clayton-Continued.

3. The romance of the unknown in the preparation of geological reports: Econ. Geology, vol. 20, no. 2, pp. 189-194, March-April, 1925.

4. Structural unity of the Pacific region; evidence of the ore deposits: Econ. Geology, vol. 20, no. 8, pp. 707-722, December, 1925.

5. Igneous intrusions and ore deposits of the "zone of rock flowage": Econ. Geology, vol. 21, no. 1, pp. 81-89, January-February, 1926.

6. Hypothesis of mountain building: Geol. Soc. America, Bull., vol. 37, no. 3, pp. 439-454,.September 30, 1926; abstract, no. 1, pp. 163-164, March 30, 1926; Pan-Am. Geologist, vol. 45, no. 2, pp. 162-163, March, 1926.

Andros, Stephen 0.

1. The petroleum handbook. 206 pp., 48 figs., Chicago, The Shaw Publishing Company, 1919.

Anrep, Aleph.

1. Peat investigations [New Brunswick] : Canada, Geol. Survey, Summ. Rept., 1918, pt. F, pp. 31-32, 1919.

2. Investigations of certain peat bogs in Ontario and Quebec: Canada, Geol. Survey, Summ. Rept., 1919, pt. E, pp. 44-45, 1920.

3. Investigation of peat bogs in Ontario and Quebec: Canada, Geol. Survey, Summ. Rept., 1920, pt. D, pp. 32-34, 1921.

4. Investigation of peat bogs in Ontario: Canada, Geol. Survey, Summ. Rept., 1921, pt. D, pp. 7-11, 3 maps, 1922.

5. Synopsis of information concerning the peat situation in Canada: Canada, Geol. Survey, Summ. Rept., 1921, pt. D, pp. 12-16, 1922.

6. Investigation of peat bogs in Quebec: Canada, Geol. Survey, Summ. Rept., 1922, pt. D, pp. 13-18, 3 maps, 1923:

7. Investigation of the peat bogs in New Brunswick: Canada, Geol. Survey, Summ. Rept., 1923, pt. C 2, pp. 13-22, 1924.

8. Investigation of peat bogs in Nova Scotia: Canada, Geol. Survey, Summ. Rept., 1924, pt. C, pp. 218-239, 12 figs., 1926.

9. Investigation of peat bogs in New Brunswick: Canada, Geol. Survey, Summ. Rept., 1925, pt. C, pp. 142-153, 8 figs., 1927.

10. Investigation of peat bogs in Quebec: Canada, Geol. Survey, Summ. Rept., 1926, pt. C, pp. 73-76, 2 pls., 1927.

11. Peat bogs for the manufacture of peat litter and peat mull in southwest British Columbia: Canada, Geol. Survey, Summ. Rept., 1927, pt. A, pp. 53-61, 4 figs., 1928.

Anters, Ernst. See also Twenhofel, 22, 29.

1. The recession of the last ice sheet in New England; with a preface and contributions by J. W. Goldthwait: Am. Geog. Soc., Research series no. 11, 120 pp., 19 figs., 6 pls., New York, 1922.

2. Recession of the land ice in New England (abstract) : Geol. Soc. America, Bull., vol. 33, no. 1, pp. 86-87, March 31, 1922.

3. Cycles in glacial and postglacial deposits: Geol. Rev., vol. 13, no. 4, pp. 664-665, October, 1923.

4. Climatic changes: Science, new ser., vol. 58, pp. 420-421, November 23, 1923.

5. On the Pleistocene history of the Great Basin : Carnegie Inst., Washington, Year Book no. 22, p. 323, 1924.

6. Retreat of the last ice sheet in eastern Canada: Canada, Geol. Survey, Mem. 146, 142 pp., 37 figs., 9 pls., 1925. 
Antevs; Ernst-Continued.

7. Probable correlation between the last ice retreat in North America and in Europe (abstract) : Geol. Soc. America, Bull., vol. 36, no. 1, pp. 153-154, March 30, 1925; Pan-Am. Geologist, vol. 43, no. 2, pp. 147-148, March, 1925.

8. Pleistocene pre-Wisconsin beds in Vermont (abstract) : Geol. Soc. America, Bull., vol. 36, no. 1, pp. 154-155, March 30, 1925; Pan. Am. Geologist, vol. 43, no. 2, pp. 150-151, March, 1925.

9. Conditions of formation of the varved glacial clay (abstract) : Geol. Soc. America, Bull., vol. 36, no. 1, pp. 171-172, March 30, 1925.

10. The climatologic significance of annual rings in fossil woods: Am. Jour. Sci., 5th ser., vol. 9, pp. 296-302, April, 1925.

11. Glacial climatic conditions (abstract) : Sci. Monthly, vol. 20, no. 5, pp. 464-465, May, 1925; Pan.-Am. Geologist, vol. 43, no. 5, pp. 379-380, June, 1925.

12. On the Pleistocene history of the Great Basin: Carnegie Inst. Washington, Pub. no. 352 (Quaternary climates), pp. 51-114, 19 figs., 3 pls., July, 1925.

13. Big tree as a climate measure (abstract) : Pan-Am. Geologist, vol. 44, no. 1, pp. 74-76, August, 1925.

14. Late Quaternary changes of level in southern New England (abstract) : Geol. Soc. America, Bull., vol. 37, no. 1, pp. 181-182, March 30, 1926 ; Pan-Am. Geologist, vol. 45, no. 2, p. 170, March, 1926.

15. Sista istäckets försvinnande i Nordamerika [last ice retreat in North America]: Ymer, Stockholm (Svenska Sällskapet för Antropologi och Geografi), Årg. 1926, H. 3 o. 4, pp. 283-297, 2 figs., 1926.

16. Late Quaternary changes of level in Maine: Am. Jour. Sci., 5th ser., vol. 15, pp. 319-336, 2 figs., April; 1928; abstract, Geol. Soc. America, Bull., vol. 38, no. 1, p. 144, March 30, 1927 ; Pan-Am. Geologist, vol. 47, no. 2, pp. 151-152, March, 1927.

17. The last glaciation, with special reference to the ice retreat in northeastern North America: Am. Geog. Soc., Research ser. no. 17, 292 pp., 30 figs., 9 pls., 1928.

18. Varved sediments : Nat. Research Council, Reprint and Circ. Ser., no. 85, pp. 17-20, 1928.

Apfel, Earl T. See Wentworth, 30.

Appleford, William L. See Macelwane, 11, 13.

Applin, Esther Richards. See also Cushman, 24 ; Dumble, 6.

1. (and Ellisor, Alva E., and Kniker, Hedwig T.). Subsurface stratigraphy of the Coastal Plain of Texas and Louisiana: Am. Assoc. Petroleum Geologists, Bull., vol. 9, no. 1, pp. 79-122, 1 fig., 1 pl., January-February, 1925.

2. Memorial to Laura Lane Weinzierl: Jour. Paleontology, vol. 2, no. 4, p. 383, December, 1928.

Applin, Paul L.

1. The Stratton Ridge salt dome, Brazoria County, Texas: Am. Assoc. Petroleum Geologists, Bull., vol. 9, no. 1, pp. 1-34, 6 figs., JanuaryFebruary, 1925; Geology of salt dome oil fields, pp. 644-677, 6 figs.. 1926.

Arey, Melvin Franklin.

1. Geology of Ringgold County : Iowa Geol. Survey, vol. 27, pp. 33-64, 6 figs.. map [1920]. 
Arey, Melvin Franklin-Continued.

2. Geology of Taylor County: Iowa Geol. Survey, vol. 27, pp. 65-103, 11 figs., map [1920].

\section{Arizona Bureau of Mines.}

1. Geologic map of the State of Arizona prepared by the Arizona Bureau of Mines in cooperation with the U. S. Geological Survey by N. H. Darton and others. Scale 1:500,000. 1924.

2. The zinc resources of Arizona: Min. Jour., Phoenix, Ariz., vol. 12, no. 1, pp. 7-8, 17, May 30, 1928.

Armstrong, Lyndon K.

1. Geology of Chewelah district [Washington]. In Northwest Mines Handbook, vol. 1, pp. 149-150, published by Sidney Norman, Spokane, Washington, 1918.

Armstrong, $\mathbf{P}$.

1. A field method of reducing maps to scale: Econ. Geology, vol. 17, no. 3, pp. 219-221, 1 fig., May, 1922.

2. Zircon as criterion of igneous or sedimentary metamorphics: Am. Jour. Sci., 5th ser., vol. 4, pp. 391-395, 9 figs., November, 1922.

3. Geology and ore deposits of Elbow Lake area, northern Manitoba: Canada, Geol. Survey, Summ. Rept., 1922, pt. C, pp. 37-44, 1 fig., 1923.

Arnold, Benjamin Walworth.

1. (and Clark, Hubert Lyman). Jamaican fossil Echini; with descriptions of new species of Cainozoic Echinoidea by Herbert L. Hawkins: Harvard Coll., Mus. Comp. Zoology, Mem., vol. 50, no. 1, 84 pp., 3 figs., 22 pls., October, 1927.

Arnold, Chester A.

1. Some Devonian plant localities of central and western New York: Science, new ser., vol. 67, pp. 276-277, March 9, 1928.

Arnold, Ralph. See also Clark, B. L., 8; Laughlin, 1.

1. The recent earthquakes at Los Angeles, California: Science, new ser., vol. 52, pp. 121-122, August 6, 1920.

2. Oil geology in relation to valuation: Geol. Soc. America, Bull., vol. 31, no. 4, pp. 433-440, November 30, 1920.

3. (and Loel, Wayne). New oil fields of the Los Angeles basin, California: Am. Assoc. Petroleum Geologists, Bull., vol. 6, no. 4, pp. 303-316, 2 figs., July-August, 1922.

4. (and English, Walter A.). Canadian oil reserves: Am. Inst. Min. and Met. Eng., Traus., vol. 68, pp. 985-988, 1923; [preprint] no. 1172, 4 pp., July, 1922; abstract, Mining and Metallurgy, no. 187, pp. 40-41, July, 1922.

5. (and others). Symposium on petroleum and gas: Am. Inst. Min. and Met. Eng., Trans. [preprint], no. 1241, pp. 1-134, 12 figs., April, 1923.

6. Two decades of petroleum geology, 1903-22: Am. Assoc. Petroleum Geologists, Bull., vol. 7, no. 6, pp. 603-624, November-December, 1923.

7. Relationship of geology to development of Rocky Mountain oil fields : Nat. Petroleum News, vol. 18, no. 50, pp. 89-90, December 15, 1926.

8. Geology and development in Rocky Mountain States: Oil Weekly, vol. 44. no. 5, pp. 41-43, January 21, 1927. 
Ashley, George Hall. See also Johnson, R. H., 2, 3; Knopf, E B., 3; Miller, B. L., 9; Pennsylvania Topographic and Geologic Survey; Renick, 1. Swartz, C. K., 10; White, I. C., 9; Willis, 15; Winchester, 1.

1. A use classification of coal: Ain. Inst. Min. and Met. Eng., Bull. no. 152, pp. 1129-1141, August, 1919; (with discussion), Trans., vol. 63, pp. 782-796, 1920; Coal Age, vol. 16, pp. 918-925, 4 figs., December 25, 1919.

2. Discussion of an article by Ellis Lovejoy, entitled "Notes on fire clays of the northern Appalachian coal basin": Am. Ceramic Soc., Jour., vol. 2, no. 10, pp. 790-793, October, 1919.

3. Memorial of Albert Homer Purdue: Indiana Acad. Sci., Proc. 1918, pp. 247-257, portr., 1919.

4. The Abram Creek-Stony River coal field, northeastern West Virginia: U. S. Geol. Survey, Bull. 711, pp. 85-103, 2 pls. (incl. map), February 13, 1920. Abstract by J. D. Sears, Washington Acad. Sci., Jour., vol. 10, no. 18, p. 521, November 4, 1920.

5. The story of the Pennsylvania survey: Pennsylvania, Bur. Topog. and Geol. Survey, Misc. Papers, no. 1; 20 pp., 21 figs., Harrisburg, 1920.

6. Sulphur in coal, geological aspects: Am. Inst. Min. and Met. Eng., Bull. no. 153, pp. 2073-2079, September, 1919; Trans., vol. 63, pp. 732738, 1920. Discussion, Mining and Metallurgy, no. 157, p. 60. January, 1920.

7. How the "grand push" determined present character of Pennsylvania coal: Coal Age, vol. 17, no. 26, pp. 1307-1310, 2 figs. (maps), June 24, 1920.

8. Mineral resources of Pennsylvania : Engineers' Soc. Western Pennsylvania, Proc., vol. 37, no. 1, pp. 1-20, February, 1921.

9. (and Fettke, C. R.). Pennsylvania coals and shales greatly vary in their content of oil: Coal Age, vol. 19, no. 9, pp. 401-403, March 3, 1921.

1.0. The outlook for oil and gas in Pennsylvania: Am. Assoc. Petroleum Geologists, Bull., vol. 5, no. 1, pp. 100-101 (abstract), no. 3, pp. 357-372, May-June, 1921.

11. (and Robinson, J. F.). Oil and gas fields of Pennsylvania; Vol. I, Introduction: Pennsylvania Geol. Survey, Fourth series, 79 pp., 9 figs., 5 pls. (incl. map), 1922.

12. Proposed new nomenclature of the Appalachian coal measures (abstract with discussion): Geol, Soc. America, Bull., vol. 33, no. 1, pp 111-112, March 31, 1922.

13. The work of the Pennsylvania Geological Survey, 1919-1922: Pennsylvania, Bur. Topog. and Geologic Survey, 18 pp., 2 figs., 1923.

14. A geologic time scale: Eng. and Min. Jour.-Press, vol. 115, no. 25, pp. 1106-1109, June 23, 1923; Coal Age, vol. 24, no. 3, pp. 102-104, July 19, 1923.

15. Classification of coal . . . Coal Age, vol. 25, no. 5, pp. 167-171, January 31., 1924.

16. Proposed stratigraphic section and code (abstract, with discussion by J. J. Galloway and Charles Schuchert) : Geol. Soc. America, Bull., vol. 35, no. 1, pp. 101-103, March 30, 1924; abstract, Pan-Am. Geologist, vol. 41, no. 2, pp. 150-151, March, 1924.

17. Silurian stratigraphy at Lehigh Gap: Pennsylvania, Topog, and Geol. Survey, Bull. no. 86, 6 pp., November 23, 1925. [Mimeographed.] 
Ashley, George Hall-Continued.

18. Geology and mineral resources of the Punxsutawney quadrangle, Peunsylvania: Pennsylvania Geol. Survey, Topog. and Geol. Atlas, no. 65, Punxsutawney quadrangle, 145 pp., 26 figs., 6 pls. (maps and sections), 1926.

19. Memorial of Richard R. Hice: Geol. Soc. America, Bull., vol. 37, no. 1, pp. 94-96, 1 pl. (portr.), March 30, 1926.

20. A practical classification of coals: Pennsylvania, Topog. and Geol. Sulvey, Bull. no. 89, 16 pp., March, 1926.

21. The Pittsburgh coal bed of Pennsylvania : Am. Inst. Min. and Met. Eng., Trans., [preprint], no. 1602, 6 pp., 2 figs. (incl. map), October, 1926.

22. A stratigraphic time scale: Pennsylvania, Topog. and Geol. Survey, Bull. no. 91, 10 pp., March 30, 1927. [Mimeographed.]

23. Glacial studies of Frank Leverett outside of the Lewis and Wright glacial boundary in Pennsylvania (abstract) : Geol. Soc. America, Bull., vol. 38, no. 1, pp. 210-211, March 30, 1927; Pan-Am. Geologist, vol. 47, no. 4, pp. 313-314, April, 1927.

24. Geology and the world at large: Science, new ser., vol. 67, pp. 21-24, January 13, 1928.

25. The Canadian system: Pennsylvania, Topog. and Geol. Survey, Bull. no. 93, 10 pp., April 2, 1928. [Mimeographed.]

26. Bituminous coal fields of Pennsylvania; introductory volume, part 1, general information on coal: Pennsylvania Topog. and Geol. Survey, 4th ser., Bull. M6, pt. 1, 241 pp., 32 figs., 17 pls., 1928.

Ashmead, Dever C.

1. Anthracite losses and reserves in Pennsylvania: Pennsylvania Geol. Survey, 4th ser., Bull. M8, 71 pp., 13 figs., 1 pl. (map), 1926.

Athy, L. F. See also Ekblaw, 3.

1. Geology and mineral resources of the Herscher quadrangle: Illinois State Geol. Survey, Bull. no. 55, 120 pp., 38 figs., 2 pls. (maps), 1928; abstract, Chicago, Univ., Abstracts of Theses, Sci. Ser., vol. 3, pp. 209-215, April, 1927.

Atl, $\longrightarrow$.

1. L'attivita del Popocatepetl [Mexico] : Zeitschr. Vulkanologie, Bd. 6, H. 3, pp. 183-191, 5 pls., April, 1922.

Atwood, Alice Cary.

1. Peat; a contribution towards a bibliography of the American literature through 1925: U. S., Dept. Agr., Library, Bibliographical Contributions, no. 12, 95 pp., September, 1926. [Mimeographed.]

Atwood, Rollin Salisbury. See Atwood, 5.

Atwood, Wallace Richards. See Atwood, 6, 7.

Atwood, Wallace Walter.

1. The country around Camp Devens. [Text on back of topographic map]: Massachusetts, Camp Devens and vicinity, U. S. Geol. Survey, 1919.

2. Relation of landslides and glacial deposits to reservoir sites in the San Juan Mountains, Colorado (U. S. Geol. Survey, Bull. 685, 1918) (abstract by R. W. Stone) : Washington Acad. Sci., Jour., vol. 9, no. 11, p. 316, June 4, 1919.

3. Final stages in the physiographic evolution of the San Juan Mountains (abstract) : Geol. Soc. America, Bull., vol. 32, no. 1, pp. 70-71, March 31, 1921. 
Atwood, Wallace Walter-Continued.

4. (and Mather, Kirtley F.). Physiographic history of the San Luis Valley of Colorado and New Mexico (abstract, with discussion by William C. Alden, Andrew C. Lawson, and W. P. White) : Geol. Soc. America, Bull., vol. 35, no. 1, pp. 121-123, March 30, 1924; abstract, PanAm. Geologist, vol. 41, no. 2, pp. 157-158, March, 1924.

5. (and Atwood, Rollin Salisbury). Physiographic stages in the evolution of the San Juan Mountain region and their correlation with the physiography of the Front Ranges of Colorado (abstract): Assoc. Am. Geographers, Annals, vol. 15, no. 1, p. 31, March, 1925.

6. (and Atwood, Wallace R.). Ancient tillite near Gunnison, Colorado (abstract) : Geol. Soc. America, Bull., vol. 36, no. 1, p. 168, March 30, 1925 ; Pan-Am. Geologist, vol. 43, no. 2, p. 159, March, 1925.

7. (and Atwood, Wallace R.). Gunnison tillite of Elocene age [Colorado]: Jour. Geology, vol. 34, no. 7, pp. 612-622, 10 figs., October-November, 1926.

8. Eocene glaciation in Colorado: Third Pan-Pacific Sci. Cong., Tokyo, 1926, Proc., pp. 1826-1833, 1928.

Augur, Irving V.

1. Résumé of oil-well operations in Imperial Valley: California State Mining Bur., Summary of Operations, Califormia Oil Fields, Fifth Ann. Rept. State Oil and Gas Supervisor, vol. 5, no. 10, pp. 5-9, 1 fig., April, 1920.

Aurand, Harry A.

1. Fluorspar deposits of Colorado: Colorado Geol. Survey, Bull. 18, 94 pp., 1 pl., 10 figs., 1920.

2. Mineral deposits of the western slope: Colorado Geol. Survey, Bull. 22, 78 pp., 2 maps [1920].

Auer, Väinö.

1. Some problems of peat bog investigation in Canada: Canada, Geol. Survey, Summ. Rept., 1927, pt. 2, pp. 96-111, 1928.

Aurin, Fritz L. See also Clark, G. C., 1.

1. Pre-Pennsylvanian oil and gas horizons in Kay County, Oklahoma: Am. Assoc. Petroleum Geologists, Bull., vol. 4, no. 2, pp. 173-181, 1920.

2. (and Clark, G. C., and Trager, E. A.). Notes on the subsurface prePennsylvanian stratigraphy of the northern Mid-Continent oil fields: Am. Assoc. Petroleum Geologists, Bull., vol. 5, no. 2, pp. 117-153, 4 pls. (with discussion by M. J. Millard, C. A. Hammill, I. C. White, and W. C. Kite, pp. 324-325), March-April, 1921.

3. (and Officer, H. G., and Gould, Charles N.). The subdivision of the Enid formation: Am. Assoc. Petroleum Geologists, Bull., vol. 10, no. 8, pp. 786-799, 1 fig., August, 1926.

Aurousseau, M. See also Bowen, 14.

1. (and Washington, H. S.). The nephelite syenite and nephelite porphyry of Beemerville, New Jersey: Jour. Geology, vol. 30, no. 7, pp. 571586, 1 fig., October-November, 1922.

2. The residue from silica in rock analysis: Washington Acad. Sci., Jour., vol. 13, no. 14, pp. 330-332, August 19, 1923.

3. (and Merwin, H. E.). Olivine: I, from the Hawaiian Islands; II, pure forsterite: Am. Mineralogist, vol. 13, no. 11, pp. 559-564, November, 1928. 
Austin, George M.

1. Richmond faumal zones in Warren and Clinton counties, Ohio: U. S. Nat. Mus., Proc., vol. 70, art. 22, 18 pp., 1927.

Austin, M. M.

1. (and Parr, S. W.). Potash shales of Illinois (abstract) : Science, new ser., vol. 53, p. 240, March 11, 1921.

Ayres, Vincent $\mathrm{L}$.

1. Pyrite from Tucson, Arizona: Am. Mineralogist, vol. 9, no. 4, pp. 91-92, 2 figs., April, 1924.

Babcock, Earle Jay. See also Leonard, 7.

1. North Dakota coals and clays as factors in industrial development: North Dakota, Univ., College of Engineering, 34 pp., 1 fig., 20 pls.,[1925?].

Babe, Enrique.

1. (and Allende, Roque). Lo que es y significa la sustancia desconocida, encontrada en el pozo No. 4, a 1600 pies de profundidad en la mina de gasolina y nafta "San Juan de Motembo" [Cuba]: Bol. minas, Habana, no. 12, pp. 62-77, 3 figs., 1928.

Baddley, Elmer R. See Blackwelder, 9.

Bagg, Rufus Mather.

1. The Foraminifera of the Bonaventure cherts of Gaspé: New York State Mus. Bull. nos. 219, 220, pp. 149-204, 6 pls., 1920.

2. Fossil starfishes in the Galena limestone of Wisconsin (abstract) : Geol. Soc. America, Bull., vol. 38, no. 1, p. 227, March 30, 1927 ; Pan-Am. Geologist, vol. 47, no. 3, p. 235, April, 1927.

Bailey, Edward Battersby.

1. The ancient mountain systems of Europe and America: Scottish Geog. Mag., vol. 44, no. 6, pp. 321-334, 2 figs., November 15, 1928; Nàture, vol. 122, pp. 811-814, 2 figs., November 24 , 1928. Paleozoic mountain systems of Europe and America: Pan-Am. Geologist, vol. 50, no. 3, pp. 161-188, 2 pls., October; 1928; British Assoc. Adv. Sci., Rept. 96th Meeting, 1928, pp. 57-76, 2 figs., 1929.

2. (and Collet, L. W., and Field, R. M.). Paleozoic submarine landslips near Quebec City: Jour. Geology, vol. 36, no. 7, pp. 577-614, 9 figs., October-November, 1928.

Bailey, Gilbert Ellis.

1. Check list of the geologic formation names of California. 15 pp., University of Southern California, 1923.

2. California, a geologic wonderland. .119 pp., 1 pl., Los Angeles, The TimesMirror Press, 1924.

Bailey, I. W.

1. The problem of identifying the wood of Cretaceous and later dicotyledons; Paraphyllanthoxylon arizonense: Annals Botany, vol. 38, pp. 439451, 1 pl., July, 1924.

Bailey, J. P. See Reed, 12.

Bailey, Joseph Whitman.

1. Loring Woart Bailey; the story of a man of science. 141 pp., illus., St. John, N. B., J. \& A. McMillan, 1925. 
Bailey, Loring Woart, 1839-1925.

1. (and Mathew, G. F.). Some problems of New Brunswick geology : Roy. Soc. Canada, Trans., 3d ser., vol. 12, sec. 4, pp. 105-130, 1919.

2. The paleogeography of Acadia : Roy. Soc. Canada, Proc. and Trans., 3d ser., vol. 13, sec. 4, pp. 1-16, 1920.

Bailey, Reed W.

1. The Bear River Range fault, Utah: Am. Jour. Sci., 5th ser., vol. 13, pp. 497-502, 2 figs., June, 1927.

Bailey, Thomas Laval. See also Woodford, 4.

1. The geology and natural resources of Colorado County: Texas, Univ., Bull. no. 2333, 163 pp., 7 figs., 7 pls. (incl. map), November, 1923.

2. Extensive volcanic activity in the middle Tertiary of the south Texas Coastal Plain: Science, new ser., vol. 59, pp. 299-300, March 28, 1924.

3. The Gueydan, a new middle Tertiary formation from the southwestern Coastal Plain of Texas: Texas, Univ., Bull., no. 2645, 187 pp., 3 figs., 12 pls. (incl. map), December 1, 1926.

Bailey, Vernon.

1. Rock rivers: Natural History, vol. 20, no. 2, pp. 16-172, 5 figs., MarchApril, 1920.

Bailey, Willard F.

1. Carbonic invertebrates from a Triássic conglomerate in Arizona (abstract) : Pan-Am. Geologist, vol. 45, no. 3, p. 251, April, 1926.

Bain, George W.

1. Magnesite deposits of Grenville, Quebec: Am. Inst. Min. and Met. Eng. Trans., vol. 69, pp. 60-78, 7 figs., 1923 ; [preprint] no. 1244, 19 pp., 7 figs., May, 1923; abstract, Mining and Metallurgy, vol. 4, no. 197, p. 257, May, 1923.

2. Almandite and its significance in the contact zones of the Grenville limestone: Jour. Geology, vol. 31 , no. 8, pp. 650-668, 7 figs., November-December, 1923.

3. Alluvial fan deposits in the Upper Huronian: Am. Jour. Sci., 5th ser., vol. 8, pp. 54-60, 2 figs. (maps), July, 1924.

4. Types of magnesite deposits and their origin: Econ. Geology, vo!. 19, no. 5, pp. 412-433, August, 1924.

5. Amount of assimilation by the Sudbury norite sheet: Jour. Geology, vol. 33 , no. 5, pp. 509-525, 4 figs., pp. 509-525, 4 figs., July-August, 1925.

6. Pre-Keewatin sediments of the upper Harricana Basin, Quebec: Jour. Geology, vol. 33, no. 7, pp. 728-743, 10 figs. (incl. map), OctoberNovember, 1925.

7. Skeleton quartz crystals: Am. Mineralogist, vol, 10, no. 12, pp. 435-441, 7 figs., December, 1925.

8. Barraute area, Abitibi County, Quebec: Canada, Geol. Survey, Summ. Rept., 1924, pt. C, p. 126, map, 1926.

9. Diffusion in Agate Point vitrophyres [Lake Superior, Ontario]: Am. Jour. Sci., 5th ser., vol. 11, pp. 74-88, 7 figs., January, 1926.

10. Resorption as an agent in freeing hematite from the Grenville granite magma: Canadian Inst. Min. and Met., Bull., no. 167, pp. 379-392, 7 figs., March, 1926.

11. Agate Point rocks [Lake Superior, Ontario]: Am. Jour. Sci., 5th ser., vol. 11, p. 364, April, 1926. 
Bain, George W.--Continued.

12. Representation of three dimensional space: Canadian Min. Jour., vol. 47, no. 16, pp. 417-425, 13 figs., April 16, 1926.

13. Localization of mineral deposits of northern Ontario and Quebec: Canadian Min. Jour., vol. 47, no. 17, pp. 440-443, 3 figs., April 23, 1926.

14. Evidence of assimilation and assimilation processes: Jour. Geology, vol. 34, no. 7, pp. 657-670, 2 figs., October-November, 1926.

15. Tectonics of original Huronian of Webbwood, Ontario: Pan-Am. Geologist, vol. 44, no. 2, pp. 95-120, 1 fig., 5 pls., September, 1925.

16. Source of original Huronian sediments: Pan-Am. Geologist, vol. 44, no. 3, pp. 187-198, 2 pls., October, 1925.

17. Is the Huronic Gowganda conglomerate of glacial origin?: Pan-Am. Geologist, vol. 44, no. 5, pp. 369-386, 1 fig., 1 pl., December, 1925.

18. Killarneyan intrusives of Sudbury [Ontario] : Pan-Am. Geologist, vol. 45, no. 2, pp. 109-124, 1 pl. (map), March, 1926.

19. Chemistry of Killarneyan magma of Sudbury : Pan-Am. Geologist, vol. 45, no. 4, pp. 277-294, 4 pls., May; 1926.

20. Physiographic development of Canadian shield: Pan-Am. Geologist, vol. 46, no. 1, pp. 53-62, 2 pls., August, pp. 363-374, 2 pls., December, 1926.

21. Physiographic development of Canadian shield: Pan-Am. Geologist, vol. 47, no. 1, pp. 15-2S, 1 fig., 2 pls., February, 1927.

Geology and problems of Webbwood area, Canada, Thesis, Columbia University, 1927. Contributions from the department of geology of Columbia University, vol. 36, no. 3. Consists of titles nos. 15-21, reprints bound together.

22. The geology and mineral deposits of the Harricanaw and Bell river basins : Canadian Min. and Met. Bull., no. 178, pp. 201-247, 25 figs., 4 pls. (incl. maps), February, 1927; discussion, no. 181, pp. 594-603, May, 1927.

23. Huronian stromatoporoid-like masses: Pán-Am. Geologist, vol. 47, no. 4, pp. 281-284, 2 pls., May, 1927.

24. Geologic history of the Green Mountain front: Vermont, State Geologist, 15th Rept., 1925-26, pp. 222-241, 9 figs., 1927.

25. Contact metamorphism and related changes in composition: Vermont State Geologist, 15th Rept., 1925-26, pp. 242-263, 14 figs., 1927.

Bains, Thomas $\mathrm{H}$.

1. Location of future ores of the Southwest [discussion of Red Bed formation, Nevada, Arizona, New Mexico, Texas] : Min. Jour., Phoenix, Ariz., vol. 11, no. 9, pp. 5-7, 2 figs., September 30, 1927.

Baitsell, George Alfred.

1. (editor). The evolution of man; a series of lectures delivered before the Yale chapter of the Sigma Xi during the academic year 1921-22. 202 pp., 27 figs., New Haven, Yale University Press, 1922.

Baker, Arthur A. See also Smith, W. R., 1; Spieker, 6.

1. (and Dobbin, C. E., McKnight, E. T., and Reeside, J. B., jr.). Notes on the stratigraphy of the Moab region, Utah: Am. Assoc. Petroleum Geologists, Bull., vol. 11, no. 8, pp. 785-808, 4 figs., August, 1927.

Baker, Charles Laurence. See also Stone, 11; Udden, 5.

1. Contributions to the stratigraphy of eastern New Mexico: Am. Jour. Sci., 4th ser., vol. 49, pp. 99-126, February, 1920. 
Baker, Charles Laurence-Continued.

2. The Cretaceous of west Texas and its oil possibilities: Am. Assoc. Petroleum Geologists, Bull., vol. 5, no. 1, pp. 5-28, JanuaryFebruary, 1921.

3. General geology of Catorce mining district [San Luis Potosi, Mexico]; Am. Inst. Min. and Met. Eng., Trans. [preprint], no. 1089, 7 pp., September, 1921; vol. 66, pp. 42-48, 1922. Abstract, Mining and Metallurgy, no. 177, p. 53, September, 1921.

4. Caverns in the Guadalupe Mountain range [New. Mexico]: Science, new ser., vol. 59, p. 379, April 25, 1924.

5. Edwin Theodore Dumble: Science, new ser., vol. 65, pp. 363-364, April 15, 1927.

6. Exploratory geology of a part of southwestern trans-Pecos Texas: Texas, Univ., Bull. no. 2745, 70 pp., map. December 1, 1927.

7. Geology of the Panuco. district [Mexico] : Oil Weekly, vol. 45, no. 1, pp. $60,64,68,72,120-121$, March 25, no. 2, pp. 37-38, 46, April 1, no. 3, pp. 40-42, 59-60, April 8, no. 4, pp. 52, 54, 56, 58, April 15, 1927; [in Spanish] Bol. petróleo, vol. 24; no. 1, pp. 21-37, July, no. 2, pp. 146-159, August, 1927.

8. Panuco oil field, Mexico: Am. Assoc. Petroleum Geologists, Bull., vol. 12, no. 4, pp. 395-441, April, 1.928.

9. Possible distillation of oil from organic sediments by heat and other processes of igneous intrusions; asphalt in the Anacacho formation of Texas: Am. Assoc. Petroleum Geologists, Bull., vol. 12, no. 10, pp. 995-1003, October, 1928.

10. The date of the major diastrophism and other problems of the Marathon basin, trans-Pecos Texas: Am. Assoc. Petroleum Geologists, Bull., vol. 12, no. 11, pp. 1111-1116, November, 1928.

11. Desert range tectonics of trans-Pecos Texas: Pan.-Am. Geologist, vol. 50, no. 5, pp. 341-373, 8 pls., December, 1928.

Baker, Frank Collins.

1. The life of the Pleistocene or glacial period: Illinois, Univ., Bull., vol. 17, no. 41,476 pp., 57 pls., 3 figs., 1920.

2. A new form of Amnicola from the Ohio Pleistocene deposits with notes on a Physa from the same formation: Nautilus, vol. 33, no. 4, pp. 125-127, April, 1920.

3. Pleistocene Mollusca from Indiana and Ohio: Jour. Geology, vol. 28, no. 5, pp. 439-457, July-August, 1920.

4. Animal life in loess deposits near Alton, Illinois, with descriptions of two new varieties of land shells from the same deposits: Nautilus, vol. 34, no. 2, pp. 61-66, October, 1920.

5. The value of ecology in the interpretation of fossil faunas: School Science and Mathematics, vol. 21, pp. 323-327, April, 1921.

6. New forms of Pleistocene mollusks from Illinois: Nautilus, vol. 35, no. 1, pp. 22-24, July, 1921.

7. The importance of ecology in the interpretation of fossil faunas: Ecology, vol. 2, no. 4, pp. 277-280, October, 1921.

8. Pleistocene Mollusca from northwestern and central Illinois: Jour. Geology, vol. 30, no. 1., pp. 43-62, January-February, 1922.

9. Pleistocene. Mollusca from the vicinity of Joliet, Illinois: Illinois State Acad. Sci., Trans., vol. 15, pp. 408-420 [1923].

$4096-31-3$ 
Baker, Frank Collins-Continued.

10. Bowmanville low-water stage of glacial Lake Chicago: Science, new ser., vol: 64 , p. 249, September 10, 1926.

11. Descriptions of new forms of Pleistocene land mollusks from Illinois with remarks on other species: Nautilus, vol. 40 , no. 4 , pp. 114 1.20, April, 1927.

12. Description of new varieties of land and fresh water mollusks from the Pleistocene deposits in Illinois: Nautilus, vol. 41, no. 4, pp. 132137, April, 1928.

13. Molluscan life of the loess deposits of Illinois: Illinois State Acad. Sci., Trans., vol. 20, pp. 269-292, March, 1928.

Baker, Herbert Arthur.

1. General report of the government geologist, 1926-27: Newfoundland, Geol. Survey, Rept. of Progress for 1926, 34 pp., 1927.

2. The St. George's coal field, Newfoundland: Canadian Inst. Min. and Met., Trans., vol. 30, pp. 327-346, 3 figs. (maps) [1928] ; Second (Triennial) Empire Min. and Met. Congress, Canada, 1927, Proc., pt. 1, pp. 721-740, 3 figs. (maps), 1928.

Baker, Manley Benson.

1. Geology and minerals of the County of Leeds: Ontario Dept. Mines, 31st Ann. Rpt., vol. 31, pt. 6, 26 pp., 10 figs., 1 pl., map, 1923.

2. Metallogenesis and the pre-Cambrian of Canada: Canadian Min. Jour., vol. 45, no. 46, pp. 1121-1123, 1 fig., November 14, 1924; abstract, Pan-Am. Geologist, vol. 42, no. 1, pp. 71-72, August, 1924.

3. Metallogenesis and the pre-Cambrian of Canada (abstract) : British Assoc. Adv. Sci., Rept., 92d Meeting, p. 382, 1925.

4. Memorial of William Lawrence Uglow: Geol. Soc. America, Bull., vol. 38, no. 1, pp. 100-106, portr., March 30, 1927.

Baker, W. M. See Wallace, 17.

Baker, W. G.

1. A light-colored zone of subsoil in southern Iowa: Iowa Acad. Sci., Proc., vol. 31, pp. 347-349, 2 figs. [1926?].

Baker, William A., jr. See Swartz, C. K., 3.

Balch, Edwin Swift.

1. The Coudersport [Pennsylvania] ice mine: Am. Philos. Soc., Proc., vol. 60, no. 4, pp. 553-559, 2 figs., 1921.

Balcom, S. F.

1. The paleolithic stone age in Indiana: Indiana Acad. Sci., Proc., 38th Ann. Meeting, 1922, pp. 105-117, 6 figs., 1923.

Baldwin, Harry L., jr. See Keyte, 2.

Baldwin, s. Prentiss.

1. (and Collins, Robert F.). Descriptive geology of northeastern New Mexico (abstract) : Geol. Soc. America, Bull., vol. 39, no. 1, p. 161, March 30, 1928; Pan-Am. Geologist, vol. 49, no. 1, p. 72, February, 1928.

Bale, Hubert $\mathbf{E}$.

1. Oil and gas geology of Logan County: Oklahoma Geol. Survey, Bull. no. 40-GG, 18 pp., 2 figs., 2 pls. (incl. map), September, 1928. 
Balk, Robert. See also Cloos, 1.

1. Primary structure of granite massives (with discussion by J. F. Kemp) : Geol. Soc. America, Bull., vol. 36, no. 4, pp. 679-696, 7 figs., December 30,1925 ; abstract, no. 1, p. 169, March 30, 1925 ;.Pan-Am. Geologist, vol. 43, no. 2, p. 159, March, 1925.

2. Structure of the Cortlandt norite, New York (abstract): Geol. Soc. America, Bull., vol. 37, no. 1, p. 146, March 30, 1926; Pan-Am. Geologist, vol. 45, no. 1, p. 94, February, 1926.

3. Report on the field work done for the New York State Geological Survey in geological mapping of the Newcomb quadrangle, Essex County, N. Y. : New York State Mus. Bull. 267, pp. 30-31, 1926.

4. A contribution to the structural relations of the granitic intrusions of Bethel, Barre, and Woodbury, Vermont: Vermont, State Geologist, 15th Rept. 1925-26, pp. 39-96, 19 figs., 6 pls., 1927.

5. Die primäre Struktur des Noritmassivs con Peekskill am Hudson, nördlich New York (auch bekannt als "Cortlandt Norit"); geologische Beobachtungen zur Tektonik des Magmas und zu den Problemen der Differentiation und Palingenese: Neues Jahrb., Beilage-Bd. 57, Abt. B, pp. 249-303, 39 figs., 3 pls., 1927.

Ball, A. H. See Cockfield, 16.

Ball, John R. See also Flint, 2.

1. The intercission of Pike River near Kenosha, Wisconsin: Illinois State Acad. Sci., Trans., vol. 13, pp. 323-326 [1921].

Ball, Max Waite. See also Hintze, 1; Moore, R. C., 17.

1. The relative ages of major and minor folding and oil accumulation in Wyoming: Am. Assoc. Petroleum Geologists, Bull., vol. 5, no. 1, pp. 49-63, 5 figs., January-February, 1921.

2. Gas and oil near Fort Collins, Colorado: Colorado School of Mines, Alumni Mag., vol. 13, no. 9, pp. 10-16, January, 1924.

3. Gas near Fort Collins, Colorado: Am. Assoc. Petroleum Geologists, Bull., vol. 8, no. 1, pp. 79-87, January-February, 1924.

4. Waters from the Green River shale: Am. Assoc. Petroleum Geologists, Bull., vol. 9, no. 1, p. 171, January-February, 1925.

Ball, Sydney Hobart. See also Lindgren, 7 ; Penrose, 4 ; Wheeler, H. A., 3.

1. (and Broderick, T. M.). Magmatic iron ore in Arizona: Eng. and Min. Jour., vol. 107, pp. 353-354, 2 figs., February 22, 1919.

2. Diamonds: Eng. and Min. Jour., vol. 109, pp. 1202-1208, 5 figs., May 29, 1920.

3. Proceedings of the first annual meeting of the Society of Economic Geologists, Amherst, Massachusetts, December 28-30, 1921: Geol. Soc. America, Bull., vol. 33, no. 1, pp. 223-226, March 31, 1922.

4. The mineral resources of Greenland: Meddelelser om Groenland, Bd. 63, pp. 1-60, 23 figs., 1922.

5. The geologic and geographic occurrence of precious stones: Econ. Geology, vol. 17, no. 7, pp. 575-601, 5 figs., November, 1922.

6. Proceedings of the second annual meeting of the Society of Economic Geologists, held at Ann Arbor, Michigan, December 28-30, 1922: Geol. Soc. America, Bull., vol. 34, no. 1, pp. 143-146, March 30, 1923.

Ballard, Samuel Milroy. See also Thomson, F. A., 3.

1. The Boise Basin district in Idaho: Eng. and Min. Jour., vol. 109, pp. 881-882, 1 fig., April 10. 1920. 
Ballard, Samuel Milroy-Continued.

2. Geology and ore deposits of Alturas quadrangle, Blaine County, Idaho: Idaho, Bur. Mines and Geology, Bull. no. 5, 36 pp., 8 figs., 10 pls., 1922.

3. Geology and gold resources of Boise Basin, Boise County, Idaho: Idaho Bur. Mines and Geology, Bull. no. 9, 103 pp., 12 figs., 13 pls. (incl. map), December, 1924.

4. Geology and ore deposits of the Rocky Bar quadrangle: Idaho, Bur. Mines and Geology, Pam. no. 26, 41 pp., March, 1928. [Mimeographed.]

Balliet, Letson.

1. A study in oil deposits: Oil Age, vol. 20, no. 4, pp. 10, 12, October, 1923.

2. The genesis of petroleum: Oil Age, vol. 20 , no. 5 , pp. 10, 12, 49-50, 5 figs., November; no. 6 , pp. 10-12, 54, 3 figs., December, 1923; vol. 21, no. 1, pp. 10-11, January; no. 2, pp. 11, 26, February; no. 3, pp. 9-10, 31, March ; no. 4, pp. 18, 20, 48, April ; no. 5, pp. 16, 18, 34-35, 3 figs., May, 1924.

3. Theories as to the origin of ore deposits: Min. Jour., Phoenix, Ariz., vol. 10, no. 14, p. 7, December 15, 1926.

Ballou, W. H.

1. A question of identity; were flying reptiles merely unfeathered birds, or birds merely feathered reptiles?: Sci. Am., vol. 120, no. 22, pp. 570571, 3 figs., May 31, 1919.

Bancroft, George $\mathbf{J}$.

1. The genesis of quartz in veins: Min. and Sci. Press, vol. 119, pp. 447-448, September 27, 1919.

Bancroft, Joseph Austen.

1. (and Howard, W. V.). The essexites of Mount Royal, Montreal, P. Q.: Roy. Soc. Canada, Proc. and Trans., 3d ser., vol. 17, sec. 4, pp. 13-43, 4 pls., May, 1923.

2. Restoration of the oldest known forest [middle Devonian, Gilboa, New York] ; Science, new ser., vol. 61, pp. 507-508, May 15, 1925.

Bancroft, M. F. See also Uglow, 8.

1. Lardeau map area, British Columbia: Canada, Geol. Survey, Summ. Rept., 1918, pt. B, pp. 62-63, 1919.

2. Slocan map area, B. C.: Canada, Geol. Survey, Summ. Rept., 1919, pt. B, pp. 39-48, 1920.

3. Lardeau map-area, British Columbia: Canada, Geol. Survey, Summ. Rept., 1920, pt. A, pp. $94-102,1921$; . . . 1921, pt. A, pp. 107-112, 1 fig., 1922.

4. Discussion of paper by W. L. Uglow, Quartz veins of Barkerville, Cariboo district, British Columbia: Canadian Inst. Min. and Met., Monthly Bull., no. 129, pp. 63-64, January, 1923.

Banks, C. A.

1. The B. C. Silver Mines [Salmon River valley, British Columbia]: Min.

Mag. vol. 31, no. 3, pp. 149-152, 3 figs., September, 1924.

Barbour, Erwin Hinckley. See also Matthew, 33.

1. A preliminary report on the alkali resources of Nebraska: Nebraska Geol. Survey, vol. 4, pt. 28 , pp. 405-438, 21 figs. [1916].

2. Elephas scotti, a new primitive mammoth from Nebraska: Nebraska State Mus., Bull. 2, vol. 1, pp. 21-24, 5 figs., April, 1925. 
Barbour, Erwin Hinckley-Continued.

3. Prosthennops xiphodonticus, sp. nov., a new fossil peccary from Nebraska: Nebraska State Mus., Bull. 3, vol. 1, pp. 25-31, 2 figs., April, 1925.

4. Notes on Nebraska fulgurites: Nebraska State Mus., Bull. 6, vol. 1, pp. 45-48, 2 figs., June, 1925.

5. Hackberry conglomerate, a new Nebraska rock: Nebraska State Mus., Bull. 8, vol. 1, pp. 87-90, 5 figs., August, 1925.

6. Tetrabelodon abeli, sp. nov.: Nebraska State Mus., Bull. 9, vol. 1, pp. 91-94, 6 figs., August, 1925.

7. Skeletal parts of the Columbian mammoth Elephas maibeni, sp. nov. [Archidiskodon maibeni]: Nebraska State Mus., Bull. 10, vol. 1, pp. 95-118, 30 figs., August, 1925.

S. Archidistiodon maibeni: Nebraska State Mus., Bull. 11, vol. 1, pp. 119122, 1 fig., June, 1926.

9. Preliminary notice of a new proboscidean Amebelodon fricki gen. et sp. nov. [from Frontier County, Nebr.]: Nebraska State Mus., Bull. 13, vol. 1, pp. 131-134, 3 figs., June 15, 1927.

Bardwell, Carlos.

1. (and others). Chemical properties of Utah hydrocarbons: Utah Acad. Sci., Trans., vol. 1, pp. 78-95, February, 1918.

Barnett, Leon $\mathrm{H}$.

1. The chemistry of the earth's core: Jour. Geology, vol. 32, no. 7, pp. 615635, October-November, 1924.

Barnett, V. H. See Dobbin, 3.

Barrabe, Louis.

1. Le pétrole à la Martinique: France, Office national des combustibles liquides, Ann., $3^{\ominus}$ ann., no. 1, pp. 7-42, 5 figs., map, February, 1928.

Barrell, Joseph.

1. Grove Karl Gilbert; an appreciation: Sierra Club Bull., vol. 10, no. 4, pp. 397-399, January, 1919.

2. Sources and tendencies in American geology: Sci. Monthly, vol. 8, no. 3, pp. 193-206, March, 1919. Abstract, Geol. Soc. America, Bull., vol. 30, p. 77, March 31, 1919.

3. The place of modern languages in research, particularly geological research: Sci. Monthly, vol. 8, no. 6, pp. 481-495, June, 1919.

4. The nature and bearings of isostasy: Am. Jour. Sci., 4th ser., vol. 48, pp. 281-290, October, 1919.

5. The status of the theory of isostasy: Am. Jour. Sci., 4th ser., vol. 48, pp. 291-338, 5 figs., October, 1919.

6. (Edited by H. H. Robinson). The Piedmont terraces of the northern Appalachians: Am. Jour. Sci., 4th ser., vol. 49, pp. 227-258, 327-362, 407-428, 18 figs., 2 pls., April-June, 1920.

7. Relations of subjacent igneous invasion to regional metamorphism : Am. Jour. Sci., 5th ser., vol. 1, nos. 1-3, pp. 1-19, 174-186; 255-267, January-March, 1921.

8. The nature and environment of the Lower Cambrian sediments of the southern Appalachians: Am. Jour. Sci., 5th ser., vol. 9, pp. 1-20, 2 figs., January, 1925.

9. Marine and terrestrial conglomerates: Geol. Soc. America, Bull., vol. 36, no. 2, pp. 279-341, 6 figs., June 30, 1925. 
Barrell, Joseph-Continued.

10. Geological relations of earth condensation and resulting acceleration in rotation: Am. Jour. Sci., 5th ser., vol. 10, pp. 408-432, 499-529, November and December, 1925; vol. 11, pp. 27-41, 11 figs., January, 1926.

11. On continental fragmentation and the geologic bearing of the moon's surficial features: Am. Jour. Sci., 5th ser., vol. 13, pp. 283-314, 4 figs., April, 1927.

Barrera, Tomás.

1. Informe preliminar de las zonas mineralizadas comprendidas entre las estaciones de Magdalena, Jalisco, y Tepic, Mayarit, á uno y otro lado de la vía del Ferrocarril Sud-Pacífico: Mexico, Inst. geol., Foll. de divulg., no. 21, 27 pp., November, 1926.

2. (and Segura, David). Itinerarios geológicas en el estado de Michoacán: Mexico, Inst. geol., Bol. no. 46, pp. 3-46, 25 pls. (incl. maps), 1927.

3. Informe geológico del criadero y mina de Santa Rosa pertenecientes á la Santa Rosa Mining Co., distrito de Mazapil, estado de Zacatecas: Mexico, Inst. geol., Bol. no. 46, pp. 47-72, 19 pls. (incl. maps), 1927.

Barrett, B. H. See Gregory, J. W., 4, 5.

Barrett, Edward. See also Bennett, L. F., 2.

1. Forty first annual report of department of geology and natural resources, Indiana. 123 pp., 15 pls., 11 figs., 7 maps, Fort Wayne, Ind., 1917.

2. The dunes of northwestern Indiana : Indiana, Dept. Geology and Nat. Res., 41st Ann. Rept., pp. 11-27, 9 pls., 1917.

3. The beautiful Shades: Indiana, Dept. Geology and Nat. Res., 41st Ann. Rept., pp. 80-89, 11 figs., 1917.

4. The canyon of McCormick's Creek: Indiana, Dept. Geology and Nat. Res.; 41st Ann. Rept., pp. 90-99, 8 pls., 1917.

5. Structural geology [of oil and gas fields] : Indiana, Dept. Geology and Nat. Res., 41st Ann. Rept., pp. 100-112, map, 1917.

6. Report of department of geology and natural resources. Indiana, Year Book 1917, pp. 234-241, 1918.

7. Report of the department of geology and natural resources (forty-third annual report): Indiana, Year Book 1918, pp. 195-255, 1919.

8. (and Dove, Leonard P.). Workable coal seams of Indiana; pyrite in the coals of Indiana: Indiana, Year Book 1918, pp. 219-238, 1919.

Barrett, L. P.

1. Huronian slate areas of northeastern Baraga County [Michigan] (abstract) : Geol. Soc. America, Bull., vol. 38, no. 1, p. 117, March 30, 1927 ; Pan-Am. Geologist, vol. 47, no. 1, pp. 68-69, February, 1927.

Barrett, Nellie Okla.

1. Petroleum in Illinois in 1917 and 1918: Illinois State Geol. Survey, Bull. no. 40, pp. 9-20, 1919.

2. Mineral resources in Illinois in 1916: Illinois State Geol. Survey, Bull. no. 36, pp. 19-70, 5 figs., 1920.

3. Mineral resources in Illinois in 1917 and 1918: Illinois State Geol. Survey, Bull, no. 38, pp. 25-112, 1922.

4. Notes on Illinois bituminous shales, including results of their experimental distillation: Illinois, State Geol. Survey, Bull. no. 38, pp. 441-460, 4 figs., 1922. 
Barrett, S. A.

1. Field studies for the catlinite and quartzite groups: Milwaukee, Public Mus., Year Book, 1924, vol. 4, pp. 7-20, 13 figs., October 9, 1926.

Barringer, Daniel Moreau, 1860-1929.

1. Further notes on Meteor Crater in northern central Arizona (No. 2): Acad. Nat. Sci. Philadelphia, Proc., vol. 76, pp. 275-278, 1 pl., 1924.

2. Volcanoes or cosmic shell-holes; a discussion of the origin of the craters on the moon and of other features of her surface: Sci. Am., vol. 131, no. 1, pp. 10-11, 62-63, 3 figs., July, no. 2, pp. 102, 142-144, August, 1924.

3. Exploration at Meteor Crater [Arizona]: Eng. and Min. Jour.-Press, vol. 121, no. 2, p. 59, January 9; no. 11, pp. 450-451, March 13; no. 19, p. 771, May 8, 1926.

Barringer, Daniel Moreau, jr.

1. The most fascinating spot on earth [Meteor Crater, Arizona]: Sci. Am., vol. 137, nos. 1, 2, and 3, pp. 52-54, 144-146, 244-246, 22 figs., July, August, and September, 1927.

Barrois, Charles.

1. Notice nécrologique sur le géologue C. D. Walcott: Acad. Sci. Paris. Compt. Rend., t. 184, no. 9, pp. 489-493, February 28, 1927.

Bartle, Glenn G.

1. A change of drainage of Raccoon Creek, Parke County, Indiana: Indiana Acad. Sci., Proc. 39th Ann. Meeting, 1923, vol. 33, pp. 63-68, 1 fig., 1924.

2. Plant life as possible source of netroleum deposits: Oil Weekly, vol. 38, no. 5, pp. 46,48 , July 24,1925 .

Bartlett, Albert B.

1. Twelfth biennial report of the State geologist [of Wyoming] for the period October 1,1922 , to and including September 30, 1924. $41 \mathrm{pp}$., map, tables, Cheyenne, Wyoming, 1924.

2. Oil and gas developments of the Laramie and Medicine Bow districts: Wyoming, State Geologist, Press Bull. no. 15, 7 pp., April 1, 1924. [Mimeographed.]

3. The mineral hot springs of Wyoming: Wyoming, Geologist's Office, Bull. no. 16 [in error for 19], 15 pp., 5 figs., May 6, 1926.

4. Atlantic City-South Pass gold mining district: Wyoming, Geologist's Office, Bull. no. 20, 23 pp., 2 figs., July 15, 1926.

5. Thirteenth biennial report of the State geologist [of Wyoming] for the period October 1, 1924, to September 30, 1926. 29 pp., 1 pl., tables, Cheyenne, Wyoming [1926].

6. Mineral resources of Platte County, Wyoming: Min. Jour., Phoenix, Ariz., vol. 11, no. 21, pp. 3-4, March 30, 1928.

Bartlett, James.

1. Gravel deposits of the St. Clair River: Ontario Dept. Mines, 31st Ann. Rept., vol. 31, pt. 1, pp. 53-61, 2 figs., 1 pl., 1924.

Barton, Donald Clinton.

1. The Palangana salt dome, Duval County, Texas: Econ. Geology, vol. 15, no. 6 , pp. 497-510, 3 figs., September, 1920 .

2. The West Columbia oil field, Brazoria County, Texas: Am. Assoc. Petroleum Geologists, Bull., vol. 5, no. 1, p. 102 (abstract), no. 2, pp. 212-251, 15 figs. (with discussion by J. B. Overstreet, I. C. White, and W. E. Pratt, pp. 325-326), March-April, 1921. 
Barton, Donald Clinton-Continued.

3. Occurrence of gypsum in Gulf coast salt domes: Econ. Geology, vol. 17, no. 2, pp. 141-143, March-April, 1922.

4. The salt domes of south Texas: Am. Assoc. Petroleum Geologists, Bull., vol. 9, no. 3, pp. 536-589, 10 figs., May-June, 1925; Geology of salt dome oil fields, pp. 718-771, 10 figs., 1926.

5. (and Paxson, Roland B.). The Spindletop salt dome and oil field, Jefferson County, Texas: Am. Assoc. Petroleum Geologists, Bull., vol. 9, no. 3, pp. 594-612, 5 figs., May-June, 1925; Geology of salt dome oil fields, pp. 478-496, 5 figs., 1926.

6. Geophysical methods in the Gulf Coastal Plain: Am. Assoc. Petroleum Geologists, Bull., vol. 9, no. 3,.pp. 669-671, May-June, 1925.

7. Pine Prairie salt dome [Evangeline Parish, Louisiana] : Am. Assoc. Petroleum Geologists, Bull., vol. 9, no. 4, pp. 738-755, 5 figs., July, 1925: Geology of salt dome oil fields, pp. 419-436, 5 figs., 1926.

8. Salt-dome sulphur deposits of Texas Gulf coast: Pan-Am. Geologist, vol. 44, no. 1, pp. 59-60, August, 1925.

9. The American salt-dome problems in the light of the Rumanian and German salt domes: Am. Assoc. Petroleum Geologists, Bull., vol. 9, no. 9, pp. 1227-1268, 13 figs., 2 pls., December, 1925; Geolog. of salt dome oil fields, pp. 167-208, 13 figs., 2 pls., 1926.

10. (and Mason, S. L.). Further note on barite pisolites from the Batson and Saratoga oil fields: Am. Assoc. Petroleum Geologists, Bull., vol. 9, no. 9, pp. 1294-1295, December, 1925.

11. Notes on "paraffin dirt": Min. Mag., vol. 33, no. 6, pp. 343-347, December, 1925.

12. (and Goodrich, R. H.). The Jennings oil field, Acadia Parish, Louisiana : Am. Assoc. Petroleum Geologists, Bull., vol. 10, no. 1, pp. 7292, 6 figs., $1 \mathrm{pl}$., January, 1926; Geology of salt dome oil fields, pp. 398-418, 6 figs., 1 pl., 1926.

13. The Gulf Coast oil fields of southeast Texas and southwest Louisiana: Internationale Bergwirtschaft, Jg. 1, H. 9-10, pp. 244-253, 2 figs., June-July, 1926.

14. The indications of the fields in the Mid-Continent and Gulf Coastal Plain of the United States: Inst. Petroleum Technologists, Jour., vol. 13, no. 61, pp. 333-339, April, 1927.

15. Applied geophysical methods in America: Econ. Geology, vol. 22, no. 7, pp. 649-668, November, 1927; Queensland Gov't. Min. Jour., vol. 29, pp. 23-27, January 14, 1928.

16. The Eötvös torsion balance method of mapping geologic structure: Am. Inst. Min. and Met. Eng., Tech. ${ }^{\circ}$ Pub. no. 50, 51 pp., 13 figs., February, 1928; abstract, Mining and Metallurgy, vol. 9, no. 254, p. 83, February, 1928.

17. The economic importance of salt domes: Texas, Univ., Bull., no. 2801, pp. 7-53, 6 figs. (incl. maps), 1928.

18. Meandering in tidal streams: Jour. Geology, vol. 36, no. 7, pp. 615-629, 4 figs., October-November, 1928.

Bartram, John G.

1. (and Roark, Louis). The Healdton field, Oklahoma: Am. Assoc. Petroleum Geologists, Bull., vol. 5, no. 4, pp. 469-474, 1 fig., July-August, 1921.

2. Oil development in southern Wyoming: Mining and Metallurgy, vol. 5, no. 216, pp. 583-585, December, 1924. 
Bartram, John G.-Continuel.

3. Occurrence of black oil in Wyoming: Am. Assoc. Petroleum Geologists, Bull., vol. 10, no. 4, pp. 443-448, 1. fig., April, 1926.

Barwick, John S.

1. The Salina Basin of north-central Kansas (with discussion by Raymond C. Moore, Roy H. Hall, C. R. Thomas, John L. Rich, and Anthony Folger): Am. Assoc. Petroleum Geologists, Bull., vol. 12, no. 2,

Bascom, Florence. pp. 177-199, 5 figs. (incl. map), February, 1928.

1. The physiography of Mount Desert [Island]: Geog. Soc. Philadelphia, Bull., vol. 17, no. 4, pp. 117-130, 4 pls., map, October, 1919.

2. (and Miller, B. L.). Description of the Elkton and Wilmington quadrangles, Maryland-Delaware-New Jersey-Pennsylvania: U. S. Geol. Survey, Geol. Atlas, Elkton-Wilmington folio (no. 211) 22 pp., 4 maps, 1920.

3. The use of the two-circle contact goniometer in teaching crystallography: Am. Mineralogist, vol. 5, no. 3, pp. 45-50, 1 fig., March, 1920.

4. Cycles of erosion in the Piedmont province of Pennsylvania: Jour. Geology, vol. 29, no. 6, pp. 540-559, 25 figs., September-October, 1921.

5. The resuscitation of the term Bryn Mawr gravel; U. S. Geol. Survey, Prof. Paper 132, pp. 117-119, November 12, 1924.

6. Structural and physiographic features of the Piedmont province of Pennsylvania (abstract): Geol. Soc. America, Bull., vol. 38, no. 1, p. 211, March 30, 1927; Pan-Am. Geologist, vol. 47, no. 4, p. 319, May, 1927.

7. Fifty years of progress in petrography and petrology, 1876-1926: Johns Hopkins Univ., Studies in Geology, no. 8, pp. 33-82, 1927.

Bass, Nathan W. See also Rubey, 3.

1. Geologic structure of the Dakota sandstone in western Kansas: Am. Assoc. Petroleum Geologists, Bull., vol. 9, no. 6, pp. 1019-1023, 2 figs., September, 1925.

2. Geologic investigations in western Kansas, with special reference to oil and gas possibilities; Geology of Ellis County ; Geology of Hamilton County; Geologic structure of the Dakota sandstone; Structure and limits of the Kansas salt beds; Kansas, State Geol. Survey, Bull. 11, 95 pp., 27 figs., 9 pls. (incl. maps) [1926].

3. The origin of the asymmetrical stream valleys of Kansas (abstract) : Washington Acad. Sci., Jour., vol. 18, no. 9, p. 266, May 4, 1928.

Bassett, Charles Fernando.

1. The Devonian strata of the Alto Pass quadrangle: Illinois State Acad. Sci., Trans., vol. 18, pp. 360-368, 2 figs., 1 pl., 1925.

Bassler, Harvey. See also Reeside, 2, 4; Swartz, C. K., 1, 2.

1. A sporangiophoric lepidophyte from the Carboniferous [Cantheliophorus] : Bot. Gazette, vol. 68, no. 2, pp. 73-108, 3 pls., August, 1919.

2. (and Reeside, J. B., jr.). Oil prospects in Washington County, Utah: U. S. Geol. Survey, Bull, 726, pp. 87-107, 4 figs. (maps), August 15, 1921.

Bassler, Ray Smith. See also Canu ; Galloway, 4 ; Merrill, 48 ; Stose, 3 ; Swartz, C. K., 9 ; Twenhofel, 30 ; Ulrich, 4, 8, 9, 13; Wade, B., 3.

1. Cambrian and Ordovician: Maryland Geol. Survey, 424 pp., 58 pls. (incl. map), 27 figs. (mainly paleogeographic maps), 1919. 
Bassler, Ray Smith-Continued.

2. Proceedings of the tenth annual meeting of the Paleontological Society, held at Baltimore, Maryland, December 28, 1918: Geol. Soc. America, Bull., vol. 30, pp. 143-164, March 31, 1919.

3. Proceedings of the eleventh annual meeting of the Paleontological Society, held at Boston, Massachusetts, December 30-31, 1919: Geol. Soc. America, Bull., vol. 31, pp. 197-232, March 31, 1920.

4. Proceedings of the twelfth annual meeting of the Paleontological Society, held at Chicago, Illinois, December 28-30, 1920: Geol. Soc. America, Bull., vol. 32, no. 1, pp. 119-156, March 31, 1921.

5. Paleontological exhibits at the U. S. National Museum (abstract) : Geol. Soc. America, Bull., vol. 32, no. 1, p. 126, March 31, 1921.

6. The Bryozoa, or moss animals: Smithsonian Inst., Ann. Rept., 1920, pp. 339-380, 16 figs., 4 pls., 1922.

7. Proceedings of the thirteenth annual meeting of the Paleontological Society, held at Amherst, Massachusetts, December 28-30, 1921: Geol. Soc. America, Bull., vol. 33, no. 1, pp. 191-222, March 31, 1922.

8. Mohawkian and Cincinnatian rocks of central Tennessee (abstract) : Geol. Soc. America, Bull., vol. 33, no. 1, p. 207, March 31, 1922.

9. Proceedings of the fourteenth annual meeting of the Paleontological Society, held at Ann Arbor, Michigan, December 28-30, 1922: Geol. Soc. America, Bull., vol. 34, no. 1, pp. 121-142, March 30, 1923.

10. Embayments and overlaps in central Tennessee (abstract): Geol. Soc. America, Bull., vol. 34, no. 1, p. 132, March 30, 1923.

11. The problem of fossil multilamellar invertebrates (abstract) : Geol. Soc. America, Bull., vol. 34, no. 1, pp. 133-134, March 30, 1923.

12. Proceedings of the fifteenth annual meeting of the Paleontological Society, held at Washington, D. C., December 27-29, 1923: Geol. Soc. America, Bull., vol. 35, no. 1, pp. 169-200, March 30, 1924.

13. Geological features of the eastern highland rim of Tennessee (abstract) : Geol. Soc. America, Bull., vol. 35, no. 1, pp. 186-187, March 30, 1924.

14. Sink-hole structure in central Tennessee (abstract): Washington Acad. Sci., Jour., vol. 14, no. 15, p. 374, September 19, 1924.

15. Proceedings of the sixteenth annual meeting of the Paleontological Society, held at Ithaca, New York, December 29-31, 1924: Geol. Soc. America, Bull., vol. 36, no. 1, pp. 211-240, March 30, 1925.

16. Classification and stratigraphic use of conodonts (abstract): Geol. Soc. America, Bull., vol. 36, no. 1, pp. 218-220, March 30, 1925.

17. Early Mississippian rocks of northern Tennessee (abstract) : Geol. Soc. America, Bull., vol. 36, no. 1, p. 221, March 30, 1925.

18. The stratigraphic use of conodonts (abstract): Washington Acad. Sci., Jour., vol. 16, no. 3, pp. 72-73, February 4, 1926.

19. Proceedings of the seventeenth annual meeting of the Paleontological Society, held at New Haven, Connecticut, December 28-30, 1925 : Geol. Soc. America, Bull., vol. 37, no. 1, pp. 225-254, March 30, 1926.

20. Structural contouring in areas of unconformable formations with variable thickness (abstract) : Geol. Soc. America, Bull., vol. 37, no. 1, p. 242, March 30, 1926. 
Bassler, Ray Smith-Continued.

21. Proceedings of the eighteenth annual meeting of the Paleontological Society, held at Madison, Wisconsin, December 27-29, 1926: Geol. Soc. America, Bull., vol. 38, no. 1, pp. 219-244, March 30, 1927.

22. A new early Ordovician sponge fauna: Washington Acad. Sci., Jour., vol. 17, no. 15, pp. 390-394, September 19, 1927.

23. Proceedings of the nineteenth annual meeting of the Paleontological Society, held at Cleveland, Ohio, December 29-31, 1927 : Geol. Soc. America, Bull., vol. 39, no. 1, pp. 281-312, March 30, 1928.

24. Crinoidal affinities of Lichenocrinus (abstract) : Geol. Soc. America, Bull., vol. 39, no. 1, p. 298, March 30, 1928.

Bastin, Edson Sunderland. See also Bateman, 10 ; Knopf, E. B., 1.

1. (and Laney, F. B.). The genesis of the ores at 'Tonopah, Nevada (U. S. Geol. Survey, Prof. Paper 104, 1918) (abstract by R. W. Stone) : Washington Acad. Sci., Jour., vol. 9, no. 11, pp. 317-318, June 4, 1919.

2. Antimony in 1917 : U. S. Geol. Survey, Mineral Resources, 1917, pt. 1, pp. 653-663, 1 fig. 1 pl., May 13, 1919.

3. (and McCaskey, H. D.). The work on mineral resources done by the United States Geological Survey: Min. and Sci. Press, vol. 121, pp. 166-168, July 31, 1920.

4. Bonanza ores of the Comstock lode, Virginia City, Nevada: U. S. Geol. Survey, Bull. 735, pp. 41-63, 9 figs., March 29, 1922.

5. Silver enrichment in the San Juan Mountains, Colorado: U. S. Geol. Survey, Bull. 735, pp. 65-129, 19 figs., June 30, 1922.

6. Primary native silver ores near Wickenburg, Arizona, and their bearing on the genesis of the silver ores of Cobalt, Ontario: U. S. Geol. Survey, Bull. 735, pp. 131-155, 14 figs., Aug. 2, 1922.

7. Supergene processes at Neihart, Montana: Econ. Geology, vol. 18, no. 1, pp. 87-93, January-February, 1923.

8. Origin of certain rich silver ores near Chloride and Kingman, Arizona : U. S. Geol. Survey, Bull. 750, pp. 17-39, 12 figs., February 23, 1924.

9. Primary native silver ores of South Lorrain near Cobalt, Ontario (abstract, with discussion by T. L. Walker) : Geol. Soc. America, Bull., vol. 35, no. 1, pp. 126-127, March 30, 1924 ; abstract, Pan-Am. Geologist, vol. 41, no. 2, pp. 159-160, March, 1924.

10. Observations on the rich silver ores of Aspen, Colorado: U. S. Geol. Survey, Bull. 750, pp. 41-62, 10 figs., 1 pl., September 19, 1924.

11. Geology - a growing science : Eng. and Min. Jour.-Press, vol. 118, no. 15, pp. 578-579, October 11, 1924.

12. Primary native silver ores of South Lorrain and Cobalt, Ontario: Econ. Geology, vol. 20, no. 1, pp. 1-24, 5 figs., 7 pls., January-February, 1925.

13. (and others). The presence of sulphate reducing bacteria in oil field waters: Science, new ser., vol. 63, pp. 21-24, January 1, 1926.

14. A hypothesis of bacterial influence in the genesis of certain sulphide ores: Jour. Geology, vol. 34, no. 8, pp. 773-792, 3 figs., NovemberDecember, 1926 ; abstract, Geol. Soc. America, Bull., vol. 38, no. 1, pp. 131-132, March 30, 1927; Pan-Am. Geologist, vol. 47, no. 1, p. 76, February, 1927. 
Bastin, Edson Sunderland-Continued.

15. The problem of the natural reduction of sulphates: Am. Assoc. Petroleum Geologists, Bull., vol. 10, no. 12, pp. 1270-1299, 8 figs., December, 1926 ; abstract, Geol. Soc. America, Bull., vol. 37, no. 1, pp. 146-147, March 30, 1926; Pan-Am. Geologist, vol. 45, no. 1, pp. 94-95, February, 1926.

Bateman, Alan Mara. See also Howe, E., 1; Lindgren, 18; Wheeler, H. A., 3.

1. Military and geologic mapping-a plane-table: Geol. Soc. America, Bull., vol. 30, pp. 405-414, 5 figs., September 30, 1919.

2. Why ore is where it is: Econ. Geology, vol. 14, no. 8, pp. 640-642, December, 1919.

3. (and McLaughlin, D. H.). Geology of the ore deposits of Kennecott, Alaska: Econ. Geology, vol. 15, no. 1, pp. 1-80, 6 pls., 12 figs., January-February, 1920.

4. Geology of the ore deposits of Kennecott, Alaska (abstract) : Geol. Soc. America, Bull., vol. 31, no. 1, pp. 157-158, March 31, 1920.

5. Notes on the Kennecott Glacier, Alaska (abstract with discussion by R. T. Chamberlin and A. O. Hayes) : Geol. Soc. America, Bull., vol. 32, no. 1, pp. 52-53, March 31, 1921.

6. Economic geologists and literature: Econ. Geology, vol. 17, no. 3, pp. 214-215, May, 1922.

7. Kennecott Glacier of Alaska: Geol. Soc. America, Bull., vol. 33, no. 3, pp. 527-539, 7 figs., September 1, 1922.

8. Croppings of ore deposits: Econ. Geology, vol. 17, no. 8, pp. 703-708, December, 1922.

9. Primary chalcocite; Bristol copper mine, Connecticut: Econ. Geology, vol. 18, no. 2, pp. 122-166, 6 figs., March, 1923.

10. An Arizona asbestos deposit (with discussion by G. F. Loughlin, E. S. Bastin, H. M. Chance, J. E. Spurr, and A. C. Spencer) : Econ. Geology, vol. 18, no. 7, pp. 663-683, 3 figs., October-November, 1923.

11. The Eötvös torsion balance: Econ. Geology, vol. 19, no. 1, pp. 84-86, January-February, 1924.

12. Geology of the Beatson copper mine, Alaska: Econ. Geology, vol. 19, no. 4, pp. 338-368, 3 figs., June-July, 1924.

13. Angular inclusions and replacement deposits (with discussion by J. E. Spurr and L. C. Graton) : Econ. Geology, vol. 19, no. 6, pp. 504 520, 6 figs., September-October, 1924.

14. Notes on silver-lead deposits of Slocan district, British Columbia, Canada : Econ. Geology, vol. 20, no. 6, pp. 554-572, September-October, 1925 .

Bateman, G. C.

1. The Cobalt [Ontario] silver district: Canadian Min. Jour., vol. 45, no. 25, pp. 595-597, 3 figs., June 20, 1924.

2. Alfrerl Granville Burrows: Eng. and Min. Jour.-Press, vol. 1.20, no. 13, p. 484 , portr., September $26,1925$.

Bates, Mowry, 1875-1926. See also Lupton, 1; Semmes, 3.

1. A concrete example of the use of well logs [Red River-Crichton oil field, Louisiana] : Am. Inst. Min. and Met. Eng., Trans., vol. 61, pp. 590-597, 3 figs., 1920.

Bather, Francis Arthur.

1. A mystery crinoid; on Mysticocrinus, a new genus of Silurian Crinoidea, by Frank Springer: Geol. Mag., new ser., dec. 6, vol. 6, pp. 182-183, April, 1919. 
Bather, Francis Arthur-Continued.

2. The antiquity of parasitic disease; on the parasitism of Carboniferous crinoids: Geol. Mag., new ser., dec. 6, vol. 6, pp. 276-277, June, 1919.

3. Fossils and life; the differentia of paleontology: Science, new ser., vol. 52, pp. 257-264, September 17, 1920.

4. Fossils and life: Sci. Monthly, vol. 11, no. 5, pp. 429-435, November, 1920.

5. Growth stages of the blastoid, Orophacrinus stelliformis: Jour. Geology, vol. 30 , no. 1, pp. 73-76, January-February, 1922.

6. Habits of some North American cystids (abstract) : Pan-Am. Geologist, vol, 42 , no. 1, p. 69 , August, 1924.

7. The habits of some North American cystids (abstract): British Assoc. Adv. Sci., Rept. 92d Meeting, p. 381, 1925.

8. Dendrocystis in North America: Canada, Geol. Survey, Bull. no. 49, pp. 5-8, 1 fig., 1928.

Bauer Clyde Max. See also Clark, R. W., 1.

1. (and Reeside, J. B., jr.) Coal in the middle and eastern parts of San Juan County, New Mexico: U. S. Geol. Survey, Bull. 716, pp. 155-237, 19 pls. (including maps), February 11, 1921. Abstract, Washington Acad. Sci., Jour., vol. 11, no. 17, p. 419, October 19, 1921.

2. (and Herald, F. A.). Lignite in the western part of the Fort Berthold Indian Reservation south of Missouri River, North Dakota: U. S. Geol. Survey, Bull. 726, pp. 109-172, 17 pls., 4 figs., December 3, 1921.

3. (and Robinson, Ernest Guy). Comparative stratigraphy in Montana: Am. Assoc. Petroleum Geologists, Bull., vol. 7, no. 2, pp. 159-178, 3 figs., March-April, 1923.

4. The Ekalaka lignite field, southeastern Montana: U. S. Geol. Survey, Bull. 751, pp. 231-267, 1 fig., 5 pls. (incl. maps), December 12, 1924.

5. Lake Basin oil field [Stillwater County, Montana]: Mining and Metallurgy, vol. 6, no. 217, pp. 22-24, January, 1925.

6. Quartzite pebbles at the base of the Lance formation in Montana: Am. Assoc. Petroleum Geologists, Bull., vol. 9, no. 2, pp. 344-346, March-April, 1925.

7. Oil and gas fields of the Texas Panhandle: Am. Assoc. Petroleum Geologists, Bull., vol. 10, no. 8, pp. 733-746, 1 fig., 1 pl. (map), August, 1926.

8. Gas a big factor in the Texas Panhandle: Am. Assoc. Petroleum Geologists, Bull., vol. 12, no. 2, pp. 165-176, 4 figs., February, 1928.

Bauer, Lawson H. See also Larsen, 23 ; Lewis, 8; Palache, 23, 27, 30.

1. (and Palache, C.). Hyalophane from Franklin Furnace, New Jersey : Am. Mineralogist, vol. 11, no. 7, pp. 172-174, July, 1926.

2. (and Berman, H.). Löllingite from Franklin, New Jersey : Am. Mineralo. gist, vol. 12, no. 2, pp. 39-43, 2 figs., February, 1927.

3. (and Berman, Harry). Friedelite, schallerite, and related minerals: Am, Mineralogist vol. 13, no. 7, pp. 341-348, July, 1928.

Bayley, William Shirley. See also Ries, 5.

1. Kaolin in North Carolina, with a brief note on hydromica: Econ. Geology, vol. 15, no. 3, pp. 236-246, April-May, 1920.

2. The magnetitic ores of North Carolina-their origin: Econ. Geology, vol. 10 no. 2, pp. 142-152, 1 pl., March, 1921. 
Bayley, William Shirley-Continued.

3. Magnetites of North Carolina; their origin (abstract with discussion by T. L. Watson) : Geol. Soc. America, Bull., vol. 32, no. 1, pp. 64-65, March 31, 1921.

4. A magnetite-marble ore at Lansing, North Carolina: Elisha Mitchell Sci. Soc. Jour., vol. 37, nos. 3-4, pp. 138-152, 4 pls., March, 1922.

5. General features of the brown hematite ores of western North Carolina: U. S. Geol. Survey, Bull. 735, pp. 157-208, 10 figs., 3 pls. (incl. map), October 17, 1922.

6. General features of the magnetite ores of western North Carolina and eastern Tennessee : U. S. Geol. Survey, Bull, 735, pp. 209-270, 6 figs., December 8, 1922.

7. The magnetic iron ores of east Tennessee and western North Carolina: Tennessee, Division of Geology, Bull. 29, 252 pp., 28 figs., 23 pls., 1923.

8. Studying mines with a microscope: Illinois State Acad. Sci., Trans., vol. 16, pp. 27-28, 1923.

9. The occurrence of rutile in the titaniferous magnetites of western North Carolina and eastern Tennessee: Econ. Geology, vol. 18, no. 4, pp. 382-392, 1 pl., June-July, 1923.

10. The kaolins of North Carolina: North Carolina Geol. and Econ. Survey, Bull. no. 29, 132 pp., 14 figs., 2 pls. (incl. map), 1925.

11. Deposits of brown iron ores (brown hematite) in western North Carolina : North Carolina Geol. and Econ. Survey, Bull. no. 31, 76 pp., 11 figs., 9 pls. (incl. map), 1925.

12. Contributions of Hopkins to geology: Johns Hopkins Univ., Studies in Geology, no. 8, pp. 9-24, 1927.

13. Geology of the Tate quadrangle, Georgia ; Georgia Geol. Survey, Bull. no. 43, 170 pp., 2 figs., 22 pls., 2 maps, 1928.

Beal, Carl H.

1. The classification of undeveloped oil land for purposes of valuation: Econ. Geology, vol. 15, no. 4, pp. 315-327, 1 fig., June, 1920; Inst. Petroleum Technologists, Jour., vol. 6, no. 23, pp. 297-306, July, 1920.

Beals, Colonzo C. See also Erni, 1.

1. Soil survey of Cass County: Indiana Acad. Sci., Proc. 1918, pp. 186-204, map, 1919.

Bean, Ernest F. See also Hotchkiss, 9.

1. Economic geology and highway construction: Econ. Geology, vol. 16, no. 3, pp. 215-221, April-May, 1921.

2. Location of Wisconsin road material: Pan-Am. Geologist, vol. 37, no. 4, pp. 341-343, May, 1922.

3. Report of the director of the survey: Wisconsin, Geol. and Nat. Hist. Survey, 15th Bienn. Rept., 44 pp., 1 flg., 1926.

Beard, Donald Putnam.

1. The impact origin of the moon's craters: Popular Astronomy, vol. 25, no. 3, pp. 167-177, 1 fig., 1 pl., March, 1917.

Beaumont, A. B.

1. Soil shifting in the Connecticut Valley: Science, new ser., vol. 56, pp. 282-283, September 8, 1922. 
Becker, Clyde $\mathbf{M}$.

1. Geology of Caddo and Grady counties, Oklahoma: Oklahoma Geol. Survey, Bull. no. 40-I, 18 pp., 4 figs., and 3 pls. (incl. maps), March, 1927. Becker, George Ferdinand, 1847-1919.

1. Mechanics of the Panama Canal slides: Nat. Acad. Sci., Mem., vol. 18, pp. 67-77, 1924.

Becking, L. B.

1. (and others.) Preliminary statement regarding the diatom "epidemics" at Copalis Beach, Washington, and an analysis of diatom oil: Econ. Geology, vol. 22, no. 4, pp. 356-368, 11 figs., June-July, 1927.

Beckman, H. C.

1. Water resources of Missouri: Missouri Bur. Geology and Mines, 2d ser., vol. 20, 424 pp., 12 pls., 1927.

Beckner, Lucien.

1. Eastern Kentucky's seashore (abstract) : Science, new ser., vol. 58, p. 184, September 7, 1923; Kentucky Acad. Sci., Trans., vol. 1, p. 139, 1924.

2. Kentucky petroleum problems (abstract) : Kentucky Acad. Sci., Trans., vol. 1, p. 110, 1924.

3. Cumberland County oil horizons: Kentucky Acad. Sci., Trans., vol. 2, pp. 23-28, 1927.

Beckstrom, R. C. See also Van Tuyl, 12.

1. (and Van Tuyl, F. M.). Compaction as a cause of the migration of petroleum: Am. Assoc. Petroleum Geologists, Bull., vol. 12, no. 11, pp. 1049-1055, 2 figs., November, 1928.

Beckwith, H. T.

1. Oil and gas in Oklahoma; geology of Osage County: Oklahoma Geol. Survey, Bull. no. 40-T, 63 pp., 17 figs., 4 pls. (incl. map), February, 1928.

Beckwith, Radcliffe H.

1. Geological setting of Idaho batholith: Pan-Am. Geologist, vol. 45, no. 5, pp. 359-376, 3 pls. (inc. map), June, 1926.

2. Quartz veins of the Buffalo Hump [mining district, Idaho]: Pan-Am. Geologist, vol. 46, no. 2, pp. 111-120, 1 fig., September, 1926.

3. Ore deposition at Buffalo Hump [Idaho] : Pan-Am. Geologist, vol. 48, no. 3, pp. 191-194, 1 fig., 2 pls., October, 1927.

4. The geology and ore deposits of the Buffalo Hump district: New York Acad. Sci., Annals vol. 30, pp. 263-296, 10 figs. (incl. map), October $17,1928$.

Beede, Joshua William. See also Lee, W. T., 3.

1. Notes on the structures and oil showings in the red beds of Coke County, Texas: Am. Assoc. Petroleum Geologists, Bull., vol. 3, pp. 117-123, 1919.

2. Further notes on the structure near Robert Lee, Coke County, Texas: Texas, Univ. Bull., no. 1847, pp. 3-7, 1 pl., August 20, 1918 [1920].

3. Notes on the geology and oil possibilities of the northern Diablo Plateau in Texas: Texas, Univ., Bull. no. 1852, 40 pp., 1 flg., 7 pls. (incl. map) [1920].

4. The Wamego anticline: Kansas Acad. Sci., Trans., vol. 29, pp. 141-142, 1920. 
Beede, Joshua William-Continued.

5. Correlation of the upper Paleozoic rocks of the Hueco Mountain region of Texas (ahstract) : Science, new ser., vol. 51, p. 494, May 14, 1920.

6. (and Bentley, W. P.). The geology of Coke County: Texas, Univ., Bull. no. 1850, 82 pp., 3 figs., 17 pls. (incl. map), March, 1921.

7. Age and development of red beds and terrestrial vertebrates of the Appalachian and Kansas-Texas sections: Geol. Soc. America, Bull., vol. 33 , no. 4, pp. 671-688, November 2, 1922 ; abstract, no. 1, p. 208, March 31, 1922.

8. Report on the oil and gas possibilities of the University Block 46 in Culberson County: Texas, Univ., Bull. no. 2346, 16 pp., 2 pls., December 8, 1923 [February, 1924].

9. (and Kniker, Hedwig T.). Species of the genus Schwagerina and their stratigraphic significance: Texas, Univ., Bull. no. 2433, 96 pp., 9 pls., map [1925?].

10. (and Christner, D. D.). The San Angelo formation: Texas, Univ., Bull. no. 2607, pp. 5-17, map, June, 1926.

11. (and Christner, D. D.). The geology of Foard County: Texas, Univ., Bull. no. 2607, pp. 18-53, 5 figs., map, June, 1926.

Beeson, J. J.

1. Mining districts and their relation to structural geology: Am. Inst. Min. and Met. Eng., Trans. [preprint], no. 1500, 36 pp., 9 figs., September, 1925; discussion by Charles Keyes and Charles A. Porter, no. 1512, pp. 4-10, 2 figs., December, 1925; abstract, Mining and Metallurgy, vol. 6, no. 224, p. 438, August, 1925.

Behre, Charles Henry, jr. See also Miller, B. L., 9.

1. Native antimony from Kern County, California: Am. Jour. Sci., 5th ser.. vol. 2, pp. 330-333, December, 1921.

2. Petrological abstracts and reviews: Jour. Geology, vol. 30, no. 5, pp. 401-410, July-August, 1922.

3. Structures in the slates of northeastern Pennsylvania (abstract): Geol. Soc. America, Bull., vol. 35, no. 1, pp. 100-101, March 30, 1924; Pan-Am. Geologist, vol. 41, no. 2, pp. 149-150, March, 1924.

4. A new field for the geologist (abstract) : Geol. Soc. America, Bull., vol. 36, no. 1, pp. 147-148, March 30, 1925; Pan-Am. Geologist, vol. 43. no. 2, p. 147, March, 1925.

5. Taconic folding in the Martinsburg shales (abstract) : Geol. Soc. America, Bull., vol. 36, no. 1, pp. 157-158, March 30, 1925; Pan-Am. Geologist, vol, 43, no. 2, pp. 152-153, March, 1925.

6. Ohservations on structures in the slates of Northampton County, Pennsylvania : Jour. Geology, vol. 34, no. 6, pp. 481-506, 19 figs, August September, 1926.

7. Slate in Northampton County, Pennsylvania: Pennsylvania Geol. Survey, 4th ser., Bull. M9, 308 pp.; 49 figs., 39 pls. (incl. maps). 1927, abstract, Chicago, Univ., Abstracts of Theses, vol. 4, pp. 211-215, May, 1928.

S. Dikes and ores of the Mississippi Valley (discussion): Eng. and Min. Jour., vol. 123, no. 13, pp. 531-532, March 26, 1927. 
Behre, Charles Heñry, jr.-Continued.

9. Geologic factors in the development of the eastern Pennsylvania slate belt: Am. Inst. Min. and Met. Eng., Tech. Pub. no. 66, 17 pp., 12 figs., February, 1928; Trans., vol. 76, pp. 393-412, 12 figs., 1928; abstract, Mining and Metallurgy, vol. 9, no. 254, p. 81, February, 1928.

10. Martinsburg formation of eastern Pennsylvania (abstract): Geol. Soc. America, Bull., vol. 39, no. 1, pp. 200-201, March 30, 1928 ; Pan-Am. Geologist, vol. 49, no. 2, p. 153, March, 1928.

11. The petrography of some slates (abstract): Ohio Acad. Sci., Proc., vol. 8, pt. 4, p. 171, 1928 ; Ohio Jour. Sci., vol. 28, no. 3, p. 149, May, 1928.

Beidelman, J. C.

1. The zinc and lead deposits of Gaspesia [Quebec]: Canadian Min. Jour., vol. 41, pp. 102-105, February 6, 1920.

2. Developing zinc and lead deposits in Gaspe Peninsula: Canadian Inst. Min. and Met., Monthly Bull. no. 143, pp. 129-147, 8 figs., March, 1924 ; Trans., vol. 27, pp. 258-277, 8 figs. [1925].

Belanski, Charles Herbert, 1898-1929.

1. The Shellrock stage of the Devonian of Iowa: Am. Midland Naturalist, Notre Dame, Indiana, vol. 10, no. 10, pp. 317-370, 1 fig., July, 1927; vol. 11, no. 5, pp. 165-170, September, 1928.

2. Pentameracea of the Devonian of northern Iowa: Iowa, Univ., Studies. vol. 12, no. 7 , new ser. no. 148, 34 pp., 15 flgs., 4 pls., February 1. 1928.

3. Descriptions of some typical fossils of the Shellrock stage [of the Devonian of Iowa ]: Am. Midland Naturalist, vol. 11, no. 5, pp. 171212, 4 figs., 6 pls., September, 1928.

4. Terebratulacea of the Devonian of northern Iowa: Iowa Univ., Studies, Studies in Nat. Hist., vol. 12, no. 8, 29 pp., 15 figs., 4 pls., June 1, 1928.

Belknap, Ralph L. See Scott, I. D., 4.

Bell, Alfred Hannam. See also Clark, C. R., 1; Cockfield, 16.

1. Oil prospects in central Pike County: Illinois State Geol. Survey, Press Bull. Ser., Illinois Petroleum, no. 3, pp. 7-10, 1 fig., July 24, 1926.

2. Oil investigations in the Centralia area; preliminary report: Illinois State Geol. Survey, Press. Bull. Ser., Illinois Petroleum, no. 4, pp. 6-12, 2 figs., August 28, 1926.

3. Oil investigations in the Centralia area: Illinois State Geol. Survey, Press Bull. Ser., Illinois Petroleum, no. 5, pp. 1-10, October 16, 1926.

4. Oil possibilities of the Ayers anticline [Bond County] : Illinois State Geol. Survey, Press Bull.' Ser., Illinois Petroleum, no. 5, pp. 15-18, 1 fig., October 16, 1926.

5. The Sorento dome: Illinois State Geol. Survey, Press Bull. Ser., Illinois Petroleum, no. 6, 11 pp., 3 figs., December 4, 1926.

6. Structure of Centralia and Sandoval oil fields, Mllinois : Illinois State Geol. Survey, Illinois Petroleum, no. 10, pp. 1-12, 6 figs., July 23, 1927.

7. Recent development in the vicinity of Jacksonville: Mlinois State Geol. Survey, Press Bull. Ser., Illinois Petroleum, no. 11, 12 pp., 2 figs., September 3, 1927.

4096-31-4 
Bell, Alfred Hannam-Continued.

8. (and Workman, L. E.). The Media anticline, Henderson County, Illinois : Illinois State Geol. Survey, Press Bull. Ser., Illinois Petroleum, no. 13, 11.pp., 3 figs., January 28, 1928.

9. Recent development on the Ayers anticline [Bond County] : Illinois State Geol. Survey, Press Bull. Ser., Illinois Petroleum, no. 16, pp. 1-9, 4 flgs., June 30, 1928.

1. Recent drilling northwest of St. Francisville, Lawrence County, Illinois: Illinois State Geol. Survey, Press Bull. Ser., Illinois Petroleum, no. 16, pp. 10-18, 1 flg., June 30, 1928.

11. Oil prospecting in western Illinois on the basis of the structure of coal beds: Illinois State Acad. Sci., Trans., vol. 20, pp. 293-296, 2 figs., March, 1928.

12. The geology of Whitehorse district, Yukon Territory (abstract) : Chicago, Univ., Abstracts of Theses, Sci. Ser., vol. 4, pp. 217-222, May, 1928.

Bell, Charles N.

1. Mining methods of the Telluride district [Colorado]: Am. Inst. Min. and Met. Eng., Trans. [preprint] no. 1295, 15 pp., 2 figs., February, 1924; abstract, Mining and Mețallurgy, rol. 5, no. 206, pp. 91-93, 1 fig., February, 1924.

Bell, Harry Wesley.

1. (and Cattell, R. A.). The Monroe gas fleld, Ouachita, Morehouse, and Union parishes, Louisiana: Louisiana, Dept. Conservation, Bull. no. 9, 99 pp., 17 figs., 9 pls. (incl. maps), July, 1921.

2. (and Haury, P. S., and Kelly, R. B.). Preliminary report on the eastern part of the Smackover, Arkansas, oil and gas field. 48 pp., illus., map, published by Arkansas State Bureau of Mines . . . Little Rock, Arkansas [1923].

3. Subsurface conditions in the heavy oil producing area of Smackover, Arkansas: Am. Assoc. Petroleum Geologists, Bull., vol. 7, no. 6, pp. 672-683, 2 figs., November-December, 1923.

Bell, James Mackintosh. See also Brunton, 10.

1. The nickel-copper mines of Sudbury: Min. Mag., vol. 23, no. 2, pp. 87-94, 3 figs., August, 1920.

2. The Porcupine gold fleld, Ontario: Min. Mag., vol. 23, no. 3, pp. 139-149, 7 figs., September, 1920.

3. The occurrence of silver ores in South Lorrain, Ontario, Canada: Inst. Min. and Met., Bull. no. 209, 17 pp., 3 figs., February, 1922 ; no. 210, pp. 1-14, March, 1922 ; Trans., vol. 31, pp. 304-332, 4 figs., 1922.

4. Deep-seated oxidation and secondary enrichment at the Keeley silver mine [near Cobalt, Ontario] : Econ. Geology, vol. 18, no. 7, pp. 684-694, October-November, 1923; Min. Mag., vol. 29, no. 6, pp. 373-376, 2 figs., December, 1923 ; Canadian Min. Jour., vol. 44, no. 51, pp. 998-1000, December 21, 1923.

5. South Lorrain silver district, Ontario: Am. Inst. Min. and Met. Eng., Trans., vol. 70, pp. 1043-1052, 4 flgs., 1924; [preprint] no. 1286, 9 pp., 4 figs., January, 1924; abstract, Mining and Metallurgy, vol. 5, p. 33, January, 1924.

6. (and Thomson, Ellis). The effect of deep-seated alteration upon the mineralogical and geological features of the Keeley silver mine [Cobalt]: Toronto, Univ., Studies, Geol. ser., no. 17, pp. 18-37, 1924 ; abstract, Pan-Am. Geologist, vol. 42, no. 1, p. 72, August, 1924 ; British Assoc. Adv. Sci., Rept. 92d Meeting, pp. 382-383, 1925. 
Bell, James Mackintosh-Continued.

7. Canada's great mineral heritage: Canadian Min. Jour., vol. 45, no. 5, pp. 113-116, February 1, 1924.

8. (and Dorfman, André). Carbonaceous matter at Porcupine [Ontario]: Inst. Min. and Met., Bull. no. 236, 15 pp., May, 1924; discussion, no. 237 , pp. 1-15, June, 1924 ; Min. Mag., vol. 30 , no. 6 , pp. $377-$ 379, June, 1924.

9. (and O'Heir, H. B.). Structural control of the location of ore deposits, with especial reference to Cobalt, South Lorrain, and Porcupine: Roy. Soc. Canada, Proc: and Trans., 3d ser., vol. 20, pt. 2, sec. 4, pp. 227-236, 3 pls. 1926.

Bell, Olin G.

1. A preliminary report on the clays of Florida (exclusive of fuller's earth): Florida State Geol. Survey, 15th Ann. Rept., 1922-23, pp. 53-260, 55 figs., 1924.

Bell, Robert N.

1. Mineral resources of Idaho. In Northwest Mines Handbook, vol. 1, pp. 27-30, published by Sidney Norman, Spokane, Washington, 1918.

2. Twentieth annual report of the mining industry of Idaho for the year 1918. 135 pp., illus. [1919].

3. The I. X. L. copper prospect [Heath mining district, Adams County, Idaho] : Eng. and Min. Jour., vol. 108, pp. 400-402, 4 figs., September 6, 1919.

4. Twenty-first annual report of the mining industry of Idaho for the year 1919. 181 pp., illus. [1920].

5. Twenty-second annual report of the mining industry of Idaho for the year 1920. $24 \mathrm{pp}$. [1921].

Bell, Walter Andrew. See also Hayes, A. O., 6.

1. The Carboniferous strata of Sydney district, Cane Breton, Nova Scotia: Canada, Geol. Survey, Summ. Rept., 1920, pt. E, pp. 17-18, 1921.

2. The Mississippian formations of the Horton-Windsor district, Nova Scotia: Am. Jour. Sci., 5th ser., vol. 1, no. 2, pp. 153-173, 2 figs., February, 1921.

3. Tertiary plant remains collected by G. S. Hume in the Mackenzie River basin: Canada, Geol. Survey, Summ. Rept., 1921, pt. B, p. 76, 1922.

4. A new genus of Characeae and new Merostomata from the coal measures of Nova Scotia: Roy. Soc. Canada, Proc. and Trans., 3d ser., vol. 16, sec. 4, pp. 159-168, 1 pl., 1922.

5. Stratigraphy of Great Bras d'Or coal district, Victoria County, Cape Breton [Nova Scotia]: Canada, Geol. Survey, Mem. 133, pp. 90104, 1 fig., 1923.

6. Correlation of the Minto coal horizon [Nova Scotia]: Canada, Geol. Survey, Summ. Rept. 1923, pt. C 2, pp. 23-32, 1924.

7. Investigations of coal-bearing formations in Nova Scotia: Canada, Geol. Survey, Summ. Rept. 1923, pt. C 2, pp. 33-40, 1924.

8. The subdivision of the Carboniferous rocks of the maritime provinces: Canadian Inst. Min. and Met., Monthly Bull., vol. 152, pp. 886894, December, 1924; Trans., vol. 27, pp. 607-615 [1925]; Canadian Min. Jour., vol. 45, no. 47, pp. 1138-1141, 2 figs., November 21, 1924. 
Bell, Walter Andrew-Continued.

9. The new Glasgow conglomerate member of Pictou County, Nova Scotia: Canadian Inst. Min. and Met., Bull., no. 158, pp. 605-634, 1 fig., June, 1925 ; Trans., vol. 28, pp. 447-476, 3 figs. [1926] ; discussion, vol. 29, pp. 498-499 [1927]. In part, Canadian Min. Jour., vol. 47, no. 28, p. 694, July 9, 1926.

10. Carboniferous formations of Northumberland Strait, Nova Scotia ; Canada, Geol. Survey, Summ. Rept., 1924, pt. C, pp. 142-180, 3 figs., 4 pls., 1926.

11. Minto coal basin, New Brunswick; paleontology and correlation: Canada, Geol. Survey, Mem. 151, pp. 18-19, 1926.

12. Prospects for petroleum in Lake Ainslie district, Cape Breton Island, with notes on the occurrence of barite and granite: Canada, Geol. Survey, Summ. Rept., 1926, pt. C, pp. 100-109, 1 fig. (map), $1 \mathrm{pl} ., 1927$.

13. Outline of Carboniferous stratigraphy and geologic history of the maritime provinces of Canada: Roy. Soc. Canada, Trans., 3d ser., vol. 21, sec. 4, pp. 75-108, 2 figs., May, 1927; abstract, p. xcvi, 1927.

14. Upper Cretaceous plants from Stikine River, Cassiar district, British Columbia: Canada, Geol. Survey, Bull. no. 49, pp. 23-25, 4 pls., 1928.

15. A new Cretaceous conifer from the Belly River formation of Alberta: Canada, Geol. Survey, Bull. no. 49, p. 26, 1 pl., 1928.

16. Mesozoic plants from the Mattagami series, Ontario: Canada, Geol. Survey, Bull. no. 49, pp. 27-30, 5 pls., 1928.

Belt, Ben C.

1. Chapeño salt dome, Tamaulipas, Mexico: Am. Assoc. Petroleum Geologists, Bull., vol. 9, no. 1, pp. 134-135, January-February, 1925; Geology of salt dome oil fields, pp. 772-773, 1926.

2. Stratigraphy of the Tampico district of Mexico: Am. Assoc. Petroleum Geologists, Bull., vol. 9, no. 1, pp. 136-144, January-February, 1925.

Benedict, P. C. See Fearing, 1.

Bengston, Nels A.

1. Notes on the physiography of Honduras: Geog. Rev., vol. 16, no. 3, pp. 403-413, 8 flgs., July, 1926.

Bengzon, Ernesto.

1. Some notes and statistics on copper: Colorado School of Mines Mag., vol. 9, no. 11, pp. 299-303, 1 fig., November, 1919

Benjamin, Marcus.

1. The beginning of American geology: Science, new ser., vol. 56, pp. 480481, October 27, 1922.

Bennett, Hugh Hammond.

1. The geographical relation of soil erosion to land productivity: Geol. Rev., vol. 18, no. 4, pp. 579-605, 24 figs., October, 1928.

2. Studies on soils which bear on sedimentation: Nat. Research Council, Reprint and Circ. Ser., no. 85, pp. 80-83, 1928.

Bennett, Lee Fent.

1. Geology and the war: Indiana Acad. Sci., Proc., 1918, pp. 56-59, 1919.

2. (and Barrett, Edward). The flints and cherts of Indiana: Indiana, Year Book, pp. 212-219, 1919. 
Bensley, Benjamin Arthur.

1. A musk ox skull from Iroquois Beach deposits at Toronto; Ovibos proximus, sp. nov.: Toronto, Univ., Studies, Univ. ser., no. 23, 11 pp., 2 pls., 1923.

Benson, Allan L.

1. The. story of geology, viii, 300 pp., illus., New York, Cosmopolitan Book Corporation, 1927.

Benson, William Noel.

1. Tectonic conditions accompanying intrusion of basic and ultra-basic igneous rocks: Geol. Soc. America, Bull., vol. 31, no. 1, pp. 144-14S, March 31, 1920.

2. The tectonic conditions accompanying the intrusion of basic and ultrabasic igneous rocks: Nat. Acad. Sci., Mem., vol. 19, first mem., 90 pp., 18 figs., 1926.

Bentley, W. P. See Beede, 6.

Berg, J. E.

1. Some Coeur d'Alene geology [Idaho]: Mining and Metallurgy, vol. 8, no. 247, pp. 297-298, July, 1927.

\section{Berger, Walter $\mathbf{R}$.}

1. The extent and interpretation of the Hogshooter gas sand [Washington County, Oklahoma] : Am. Jour. Sci., 4th ser., vol. 48, pp. 189-194; 2 figs., September, 1919. Am. Assoc. Petroleum Geologists, Bull., vol. 3, pp. 212-216, 1 fig., 1919 (with discussion).

2. The relation between the structure and production in the Sallyards field, Kansas: Am. Assoc. Petroleum Geologists, Bull., vol. 5, no. 2, pp. 276-281, 3 figs., March-April, 1921.

Berkey, Charles Peter. See also Jonas, 4.

1. Introduction to the geology of Porto Rico: New York Acad. Sci., Scientific Survey of Porto Rico and the Virgin Islands, vol. 1, pt. 1, pp. 11-29, 1 pl. (map), 3 figs., 1919.

2. Engineering geology in and after the war (abstract, with discussion by O. E. Meinzer) : Geol. Soc. America, Bull., vol. 30, p. 81, March 31, 1919.

3. (and Rice, Marion). Geology of the West Point quadrangle, New York: New York State Mus. Bull, nos. 225-226, 152 pp., 56 pls., map, 1921.

4. A significant petrographic unconformity (abstract): Geol. Soc. America, Bull., vol. 32, no. 1, p. 58, March 31, 1921.

5. Rightful demesne of petrology: Pan-Am. Geologist, vol. 37, no. 5, pp. 353-356, June, 1922.

6. (and Sanborn, J. F.). Engineering geology of the Catskill water supply: Am. Soc. Civ. Eng., Proc., vol. 48, no. 7, pp. 1029-1595, 17 figs., 3 pls., September, 1922; discussion, no. 10, pp. 1889-1900, December, 1922 ; Trans., vol. 86, pp. 1-91, 17 flgs., 3 pls., 1923.

7. Proceedings of the thirty-fifth annual meeting of the Geological Society of America, held at Ann Arbor, Michigan, Thursday-Saturday, December 28-30, 1922: Geol. Soc. America, Bull., vol. 34, no. 1, pp. 1-116, 3 pls., March 30, 1923.

8. Proceedings of the thirty-sixth annual meeting of the Geological Society of America, held at Washington, D. C., Thursday-Saturday, December 27-29, 1923: Geol. Soc. America, Bull., vol. 35, no. 1, pp. 1-160, 5 pls., March 30, 1924. 
Berkey, Charles Peter-Continued.

9. The new petrology: New York State Mus. Bull. no. 251, pp. 105-11. 1924.

10. Edmund Otis Hovey (1862-1924): Science, new ser., vol. 60, pp. 559560 , December 19, 1924.

11. Proceedings of the thirty-seventh annual meeting of the Geological Society of America, held at Ithaca, New York, Monday-Wednesday, December 29-31, 1924: Geol. Soc. America, Bull., vol. 36, no. 1, pp. 1-198, 7 pls., March 30, 1925.

12. Proceedings of the thirty-eighth annual meeting of the Geological Society of America, held at New Haven, Connecticut, Monday-Wednesday, December 28-30, 1925; Geol. Soc. America, Bull., vol. 37, no. 1, pp. 1-206, March 30, 1926.

13. Early history of the earth: Nat. History (Am. Mus. Nat. Hist., Jour.), vol. 26, no. 4, pp. 375-382, 3 figs., July-August, 1926.

14. James Furman Kemp: Eng. and Min. Jour., vol. 122, no. 22, pp. 872-873, November 27, 1926; Min. and Met. Soc. America, Bull. no. 186 (vol. 19, no. 5), pp. 114-116, December, 1926; Science, new ser., vol. 64, pp. 639-642, December 31, 1926.

15. Proceedings of the thirty-ninth annual meeting of the Geological Society of America held at Madison, Wisconsin, Monday, Tuesday, and Wednesday, December 27, 28, and 29, 1926: Geol. Soc. America, Bull., vol. 38, no. 1, pp. 1-192, 7 pls., March 30, 1927.

16. Proceedings of the fortieth annual meeting of the Geological society of America, held at Cleveland, Ohio, Thursday, Friday, and Saturday, December 29, 30, and 31, 1927: Geol. Soc. America, Bull., vol. 39 , no. 1, pp. 1-260, March 30, 1928.

Berman, Harry. See also Bauer, L. H., 2 ; Foshag, 28 ; Larsen, 17, 23 ; Palache, $25,27,30$; Shannon, 65 .

1. Notes on dachiardite: Am. Mineralogist, vol. 10, no. 11, pp. 421-428, 3 figs., November, 1925.

2. The identity of "lehnerite" and ludlamite: Am. Mineralogist, vol. 10, no. 11 ; pp. $428-429$, November, 1925.

3. The optical properties of zincite from Franklin, New Jersey: Am. Mineralogist, vol. 12, no. 4, pp. 168-172, 1 fig., 1 pl., April, 1927.

Bernewitz, Max Wilhelm von. See also Osborn, H. S., 1.

1. Handbook for prospectors. ix, 319 pp., 83 figs., New York, McGraw-Hill Book Co., 1926.

Bernt, D. M., jr. See Hertel, 2.

Berry, E. Willard.

1. Upper Cretaceous Ostracoda from Maryland: Am. Jour. Sci., 5th ser., vol. 9, pp. 481-487, 1 pl., June, 1925.

2. Protoconchs of Caecum in the Miocene of Maryland: Nautilus, vol. 39, no. 2, pp. 66-67, 1 fig., October, 1925.

Berry, Edward Wilber. See also Hobbs, 16 ; Loughlin, 9.

1. The history of the linden and ash: Plant World, vol. 21, no. 7, pp. 163175, 9 figs., July, 1918.

2. Geologic history of the locust and its allies: Plant World, vol. 21, no. 11, pp. 284-298, 2 figs., November, 1918.

3. Paleogeographic significance of the Cenozoic floras of equatorial America and the adjacent regions: Geol. Soc. America, Bull., vol. 29, no. 4, pp. 631-636, December 30, 1918. 
Berry, Edward Wilber-Continued.

4. Upper Cretaceous floras of the eastern Gulf region in Tennessee, Mississippi, Alabama, and Georgia: U. S. Geol. Survey, Prof. Paper 112, 177 pp. 33 pls. (incl. map), 12 figs., 1919. Abstract by R. W. Stone, Washington Acad. Sci., Jour., vol. 9, no. 20, pp. 631-632. December 4, 1919.

5. A Cretaceous Hymenaea from Alabama: Am. Jour. Sci., 4th ser., vol. 47, pp. 65-68, 1 fig., January, 1919.

6. Pleistocene plants from Tennessee and Mississippi: Torreya, vol. 19, no. 1, pp. 8-10, January, 1919.

7. Eucalyptus never present in North America: Science, new ser., vol. 49, pp. 91-92, January 24, 1919.

8. The age of the Brandon lignite and flora: Am. Jour. Sci., 4th ser., vol. 47, pp. 211-216, March, 1919.

9. Present tendencies in paleontology: Am. Jour. Sci., 4th ser., vol. 48, pp. 1-12, July, 1919. Abstract, Washington Acad. Sci., Jour., vol. 9, no. 13, pp. 382-383, July 19, 1919.

10. The Upper Cretaceous Mississippi gulf: Scientific Monthly, vol. 9, no. 2, pp. 131-144, 6 figs., August, 1919.

11. A new Matonidium from Colorado, with remarks on the distribution of the Matoniaceae: Torrey Bot. Club, Bull., vol. 46, no. 8, pp. 285294, 2 figs., 2 pls., August, 1919.

12. An Eocene flora from trans-Pecos Texas: U. S. Geol. Survey, Prof. Paper 125, pp. 1-9, 3 pls., 2 figs., September 12, 1919; abstract by R. W. Stone, Washington Acad. Sci., Jour., vol. 10, no. 11, p. 328, June 4, 1920.

13. The geological history of the sweet gum and witch hazel : Plant World, vol. 22, no. 12, pp. 345-354, 9 figs., December, 1919.

14. Paleobotany; a sketch of the origin and evolution of floras: Smithsonian Inst., Ann. Rept., 1918, pp. 289-407, 36 figs., 6 pls., 1920.

15. The evolution of flowering plants and warm-blooded animals: Am. Jour. Sci., 4th ser., vol. 49, pp. 207-211, March, 1920:

16. The ancestors of the sequoias: Natural History, vol. 20, no. 2, pp. 153155, 3 figs., March-April, 1920.

17. Fossil plants from the late Cretaceous of Tennessee: Nat. Acad. Sci., Proc., vol. 6, no. 6, pp. 333-334, June 15, 1920.

18. The late Lower Cretaceous at Federal Hill, Maryland: Am. Jour. Sci., 4th ser., vol. 50, pp. 48-52, 5 figs., July, 1920.

19. The teaching of paleobotany: Geol. Soc., America, Bull., vol. 31, no. 3, pp. 389-392, September 30, 1920 .

20. Contributions to the Mesozoic flora of the Atlantic Coastal Plain, XIII; North Carolina: Torrey Bot. Club, Bull., vol. 47, no. 9, pp. 397-406, 2 figs. September, 1920.

21. New specific name [Inga culebrana proposed for Inga oligocaenica Berry non Engelhardt] : Torreya, vol. 20, no. 5, p. 101, September-October, 1920.

22. Concerning diastrophism: Science, new ser., vol 52, pp. 315-318, October $1,1920$.

23. The age of the Dakota flora: Am. Jour. Sci., 4th ser., vol. 50, pp. 387390, November, 1920.

24. Paleontology and pragmatism: Science, new ser., vol. 52, pp. 529-531, December 3, 1920.

25. A palm nut from the Miocene of the Canal Zone: U. S. Nat. Mus., Proc., vol. 59, pp. 21-22, 3 figs., 1921. 
Berry, Edward Wilber-Continued.

26. Tertiary fossil plants from the Dominican Republic: U. S. Nat. Mus., Proc., vol. 59, pp. 117-127, 1 pl., 1.921.

27. Tertiary fossil plants from Costa Rica: U. S. Nat. Mus., Proc., vol. 59, pp. 169-185, 6 pls., 1921.

28. Contributions to the Mesozoic flora of the Atlantic Coastal Plain, XIV; Tennessee: Torrey Bot. Club, Bull., vol. 48, no. 2, pp. 55-72, February, 1921.

29. Paleontology; its contributions to knowledge: Scientia, $2 d$ ser., vol. 29 , no. 108-4, pp. 263-274, April, 1921.

30. A Potamogeton from the Upper Cretaceous [of Henry County, Tennessee] : Am. Jour. Sc., 5th ser., vol. 1, pp. 420-423, 3 figs., May, 1921.

31. A Pseudocycas from British Columbia: Am. Jour. Sci., 5th ser., vol. 2, pp. 183-186, 1 fig., September, 1921.

32. Tertiary fossil plants from the Republic of Haiti : U. S. Nat. Mus., Proc., vol. 62, art. 14, 10 pp., 2 figs., 1 pl., 1922.

33. (and Johnston, W. A.). Pleistocene interglacial deposits in the Vancouver region, British Columbia: Roy. Soc. Canada, Proc. and Trans., 3d ser., vol. 16, sec. 4, pp. 133-140, 2 pls., 1922.

34. Additional occurrences of Pleistocene plants [Alabama and Tennessee] : Torreya, vol. 22, no. 1, pp. 10-11, January-February, 1922.

35. Northernmost extension of marine Eocene beds in Mississippi embayment: Pan-Am. Geologist, vol. 37, no. 1, pp. 75-76, February, 1922.

36. The flora of the Woodbine sand at Arthurs Bluff, Texas: U. S. Geol. Survèy, Prof. Paper 129, pp. 153-181, 1 fig., 5 pls., March 23, 1922.

37. The flora of the Cheyenne sandstone of Kansas: U. S. Geol. Survey, Prof. Paper 129, pp. 199-225, 16 pls., April 11, 1922.

38. A new genus of fossil fruit [Calatoloides, Eocene, Texas] : Am. Jour. Sci., 5th ser., vol. 3, pp. 251-253, 2 figs., April, 1922.

39. An American Spirulirostra [Isthmus of Tehuantepec, Mexico]: Am. Jour. Sci., 5th ser., vol. 3, pp. 327-334, 5 figs., May, 1922.

40. A possible explanation of upper Eocene climates: Am. Philos. Soc., Proc.; vol. 61, no. 1, pp. 1-14, 1 fig., 1922. Abstract, Science, new ser. vol. 55, p. 654, June 16, 1922.

41. Additions to the flora of the Wilcox group: U. S. Geol. Survey, Prof. Paper 131, pp. 1-21, 18 pls., July 27, 1922.

42. The geologic evidence of evolution: Sci. Monthly, vol. 15, no. 2, pp. 97-118, 5 figs., August, 1922.

43. Saccoglottis, recent and fossil : Am. Jour. Sci., 5th ser., vol. 4, pp. 127-130, 1 fig., August, 1922.

44. Environmental interpretation of fossil plants: Pan-Am. Geologist, vol. 38, no. 1, pp. 9-17, August, 1922.

45. Sagenopteris, a Mesozoic representative of the Hydropteraceae: Bot. Gazette, vol. 74, no. 3, pp. 329-331, 1 fig., November, 1922.

46. Tree ancestors; a glimpse into the past. 270 pp., 48 figs., 1 pl.; Baltimore, Williams \& Wilkins Company, 1923.

47. Pathological conditions among fossil plants. In Moodie, Roy L., Paleopathology, pp. 99-108, Urbana, 1923.

48. Miocene plants from southern Mexico: U. S. Nat. Mus., Proc., vol. 62, art. 19, 27 pp., 1 fig., 7 pls., 1923.

49. The Pennsylvanian of north-central Texas: Science, new ser., vol. 57. pp. 690-692, June 15, 1923. 
Berry, Edward Wilber-Continued.

50. The age of the supposed Lower Cretaceous of Alabama: Washington Acad. Sci., Jour., vol. 13, no. 20, pp. 433-443, 6 figs., December 4, 1923 .

51. The middle and upper Eocene floras of southeastern North America: U. S. Geol. Survey, Prof. Paper 92, 206 pp., 9 figs., 65 pls., 1924.

52. The fossil swamp deposit at the Walker Hotel site, Connecticut Avenue and De Sales Street, Washington, D. C.; organic remains other than diatoms from the excavation: Washington Acad. Sci., Jour., vol. 14, no. 1, pp. 12-25, 3 pls., January 4, 1924.

53. A cucurbitaceous fruit from the Tertiary of Texas: Torreya, vol. 24, no. 1, pp. 5-7, 2 figs., January-February, 1924.

54. A fossil flower from the Miocene of Trinidad: Am. Jour. Sci., 5th ser., vol. 7, pp. 103-108, 2 figs., February, 1924.

55. Paleobotany at the New York State Museum: Science, new ser., vol. 69, pp. 336-337, April 11, 1924.

56. An early Eocene florule from central Texas: U. S. Geol. Survey, Prof. Paper 132, pp. 87-92, 1 flg., 1 pl., April 10, 1924.

57. Ophioglossum hastatiforme Ckl. not an Ophioglossum: Torreya, vol. 24, no. 3, pp. 49-50, May-June, 1924.

58. The Mississippi Gulf in the middle and upper Eocene: Sci. Monthly, vol. 19, no. 1, pp. 30-42, 7 figs., July, 1924.

59. Fossil plants and Unios in the red beds of Wyoming: Jour. Geology, vol. 32, no. 6, pp. 488-497, 7 figs., August-September, 1924.

60. Age and area as viewed by the paleontologist: Am. Jour. Botany, vol. 11, no. 9, pp. 547-557, 16 figs., November, 1924.

61. A Sparganium from the middle Eocene of Wyoming: Bot. Gazette, vol. 78, no. 3, pp. 342-348, 7 figs., November, 1924.

62. American Tertiary terrestrial plants and their interdigitation with marine deposits: Geol. Soc. America, Bull., vol. 35, no. 4, pp. 767-784, 2 figs., December, 1924.

63. The flora of the Ripley formation: U. S. Geol. Survey, Prof. Paper 136, 94 pp., 6 figs., 23 pls., 1925.

64. The Tertiary flora of the Island of Trinidad, B. W. I. : Johns Hopkins Univ., Studies in geology, no. 6, pp. 71-160, 16 pls., 1925.

65. On correlation: Geol. Soc. America, Bull., vol. 36, no. 1, pp. 263-277, March 30, 1925.

66. Ancestry of certain monotypic, ditypic, and small genera of plants (abstract) : Geol. Soc. America, Bull., vol. 36, no. 1, p. 224, March 30, 1925.

67. A Pleistocene flora from the Island of Trinidad: U. S. Nat. Mus., Proc., vol. 66, art. 21, 9 pp., 4 pls., May 23, 1925.

68. The environment of the early vertebrates: Am. Naturalist, vol. 59, pp. 354-362, July-August, 1925.

69. Miocene Araceae related to Caladium from Trinidad: Pan-Am. Geologist, vol. 44, no. 1, pp. 38-42, 1 pl., August, 1925.

70. The age and affinities of the Tertiary flora of western Canada: Nat. Acad. Sci., Proc., vol. 11, no. 11, pp. 671-673, November 15, 1925.

71. A new Salvinia from the Eucene [Wyoming and Tennessee]: Torreya, vol. 25, no. 6, pp. 116-118, 1 fig., November-December, 1925.

72. Flora and ecology of so-called Bridger beds of Wind River Basin, Wyoming: Pan-Am. Geologist, vol. 44, no. 5, pp. 357-368, December, 1925 . 
Berry, Edward Wilber-Continued.

73. On fossil plants from the Paskapoo formation of Alberta: Roy. Soc. Canada, Proc. and Trans., 3d ser., vol. 20, pt. 2, sec. 4, pp. 189209, 1 fig., 1926.

74. The age of certain Mesozoic geological formations in western Canada: Roy. Soc. Canada, Proc. and Trans., 3d ser., vol. 20, pt. 2, sec. 4, pp. 201-206, 1926.

75. Pleistocene plants from North Carolina: U. S. Geol. Survey, Prof. Paper 140, pp. 97-119, 13 pls., February 17, 1926.

76. Terminalia in the lower Eocene of southeastern North America: Torrey Bot. Club, Bull., vol. 53, no. 2, pp. 59-65, 6 figs., February, 1926.

77. Antaeus, or the future of geology: Science, new ser., vol. 63, pp. 475-476, May 7, 1926.

78. Tertiary floras from British Columbia: Canada, Geol. Survey, Bull. no. 42, pp. 91-116, 11 pls., May 8, 1926.

79. Pre-Columbian petrified wood industry : Pan-Am. Geologist, vol. 45, no. 4, pp. 273-276, 1 pl., May, 1926.

80. The fossil seeds from the Titanotherium beds of Nebraska, their identity and significance: Am. Mus. Novitates, no. 221, 8 pp., 7 figs., June 21, 1926.

81. The term Psychozoic: Science, new ser., vol. 64, pp. 16-17, July 2, 1926.

82. Fossil leaves from Beaver County, Oklahoma: Oklahoma Geol. Survey, Bull. no. 38, pp. 34-35, 2 pls., August, 1926.

83. The romance of collecting fossil plants: Nat. History (Am. Mus. Nat. Hist., Jour.), vol. 26, no. 5, pp. 475-485, 6 figs., September-October, 1926.

84. A new type of caddis case from the lower Eocene of Tennessee: U. S. Nat. Mus., Proc., vol. 71, art. 14, 4 pp., 1 pl., 1927.

85. Frank Hall Knowlton: Science, new ser., vol. 65, pp. 7-8, January 7, 1927.

86. The term Oligocene and certain climatic considerations: Am. Jour. Sci., 5th ser., vol. 13, pp. 252-256, March, 1927.

87. Frank Hall Knowlton, 1860-1926: Am. Jour. Sci., 5th ser., vol. 13, pp. 281-282, March, 1927.

88. New plant records from the Pleistocene: Torreya, vol. 27 , no. 2, pp. 21-27, 1 pl., March-April, 1927.

89. Eocene botany of our Gulf States: Pan-Am. Geologist, vol. 47, no. 4, pp. 269-278, 1 fig., May, 1927.

90. Cycads in the Shinarump conglomerate of southern Utah: Washington Acad. Sci., Jour., vol. 17, no. 11, pp. 303-307, 5 figs., June 4, 1927.

91. Devonian floras: Am. Jour. Sci., 5th ser., vol. 14, pp. 109-120, 9 figs., August, 1927.

92. The flora of the Esmeralda formation in western Nevada: U. S. Nat. Mus., vol. 72 , art. 23,15 pp., 2 pls., 1927.

93. Links with Asia before the mountains brought aridity to the western United States: Sci. Monthly, vol. 25, no. 4, pp. 321-328, October, 1927.

94. Comments on the Wegener hypothesis. In Theory of continental drift, pp. 194-196, Am. Assoc. Petroleum Geologists, 1928.

95. Weichselia from the Lower Cretaceous of Texas: Washington Acad. Sci., Jour., vol. 18, no. 1, pp. 1-5, 1 fig., January 4, 1928.

96. Stones of Celtis in the Tertiary of the western United States: Am. Mus. Novitates, no. 298, 5 pp., 6 figs., February 3, 1928. 
Berry, Edward Wilber-Continued.

97. A caddis case of leaf pieces from the Miocene of Washington: Washington Acad. Sci., Jour., vol. 18, no. 3, pp. 60-61., 1. fig., February 4, 1928.

98. A petrified walnut from the Miocene of Nevada: Washington Acad. Sci., Jour., vol. 18, no. 6, pp. 158-160, 1 fig., March 19, 1928.

99. Cephalopod adaptations; the record and its interpretation: Quart. Rev. Biology, vol. 3, no. 1, pp. 92-108, 6 pls., March, 1928.

100. Concerning terrestrial floras in the pre-Cambrian: Am. Jour. Sci., 5th ser., vol. 15, p. 431, May, 1928.

101. Fossil nutlets of the genus Lithospermum: U. S. Nat. Mus., Proc., vol. 73, art. 13, 3 pp., 1 pl., 1928.

102. A Miocene Paliurus from the State of Washington: Am. Jour. Sci., 5th ser., vol. 16, pp. 39-44, 4 figs., July, 1928.

103. A palm fruit from the Miocene of western Panama: Washington Acad. Sci., Jour., vol. 18, no. 16, pp. 455-457, 1 fig., October 4, 1928.

104. Contributions to the Mesozoic flora of the Atlantic Coastal Plain, XV [Carroll County, Tennessee] : Torrey Bot. Club, Bull., vol. 55, no. 8, pp. 441-448, 2 pls., November, 1928.

105. The story told by fossil plants. In Creation by evolution, edited by Frances Mason, pp. 156-173, 9 figs., New York, The Macmillan Company, 1928.

Berry, Samuel Stillman.

1. Fossil chitons of western North America : California Acad. Sci., Proc., 4th ser., vol. 11, no. 18, pp. 399-526, 11 figs., 16 pls., May 16, 1922.

2. Fossil chitons from the Pleistocene of San Quintin Bay, Lower California: Am. Jour. Sci., 5th ser., vol. 12, pp. 455-456, November, 1926.

Berryman, B. A.

1. Outline of mining and smelting conditions at San Pedro, New Mexico: Utah Acad. Sci., Trans., vol. 1, pp. 122-127, February, 1918.

Best, J. Boyd.

1. Some probable relations of structure to production [of petroleum] in Kansas: Am. Assoc. Petroleum Geologists, Bull., vol. 7, no. 1, pp. 75-76, January-February, 1923.

Bevan, Arthur. See also Clapp, C. H., 2.

1. Some geologic features of the Beartooth Mountains, Montana (abstract) : Geol. Soc. America, Bull., vol. 32, no. 1, p. 29, March 31, 1921.

2. Summary of the geology of the Beartooth Mountains, Montana: Jour. Geology, vol. 31, no. 6, pp. 441-465, 12 figs. (incl. maps), September-October, 1923.

3. Outline of the geology of the Oregon quadrangle [Illinois] : Illinois State Acad. Sci., Trans., vol. 17, pp. 187-193, 1925.

4. Transition beds between the St. Peter sandstone and the Platteville limestone: Illinois State Acad. Sci., Trans., vol. 18, pp. 376-377, 1925.

5. Rocky Mountain peneplains northeast of Yellowstone Park: Jour. Geology, vol. 33, no. 6, pp. 563-587, 9 figs., August-September, 1925.

6. The Glenwood beds as a horizon marker at the base of the Platteville formation: Illinois State Geol. Survey, Rept. Investigations no. 9, 13 pp., 3 figs., 1926.

7. Glaciation of the Beartooth Mountains, Montana (abstract): Geol. Soc. America, Bull., vol. 38, no. 1., pp. 142-143, March 30, 1927 ; Pan-Am. Geologist, vol. 47, no. 2, pp. 150-151, March, 1927. 
Bevan, Arthur-Continued.

8. Rocky Mountain front in Montana (abstract) : Geol. Soc. America, Bull., vol. 39, no. 1, pp. 160-161, March 30, 1928; Pan-Am. Geologist, vol. 49, no. 1, pp. 71-72, February, 1928.

9. Cenozoic history of the Montana front ranges (abstract) : Ohio Acad. Sci., Proc., vol. 8, pt. 4, p. 177, 1928; Ohio Jour. Sci., vol. 28, no. 3, p. 155, May, 1928.

Bevier, George $M$.

1. The Damon Mound oil field, Texas: Am. Assoc. Petroleum Geologists, Bull., vol. 9, no. 3, pp. 505-535, 6 figs., 1 pl., May-June, 1925; Geology of salt dome oil fields, pp. 613-643, 6 figs., 1 pl., 1926.

2. The Barbers Hill oil field, Chambers County, Texas: Am. Assoc. Petroleum Geologists, Bull., vol. 9, no. 6, pp. 958-973, 5 figs., September, 1925; Geology of salt dome oil fields, pp. 530-545, 5 figs., 1926.

Bibbins, Arthur Barneveld.

1. A small meteor crater in Texas : Eng. and Min. Jour.-Press, vol. 121, no. 23, p. 932, 1 fig., June 5, 1926.

Bichowsky, F. Russell.

1. An unusual sulphur crystal: Washington Acad. Sci., Jour., vol. 9, no. 5, pp. 126-131, 2 figs., March 4, 1919.

Biernbaum, Morrell G.

1. Famous mineral localities of the world; the zeolite localities of Nova Scotia : Rocks and Minerals, vol. 2, no. 4, pp. 126-127, December, 1927.

2. Where and how to find minerals: Rocks and Minerals, vol. 3, no. 4, pp. 101-104, December, 1928.

Billings, Marland P.

1. On the mechanics of dike intrusion: Jour. Geology, vol. 33 , no. 2, pp. 140-150, 2 figs. (incl. map), February-March, 1925.

2. Topaz and phenacite from Baldface Mountain, Chatham, New Hampshire: Am. Mineralogist, vol. 12, no. 4, pp. 173-179, 5 figs., April, 1927.

3. Roof collapse in the late Paleozoic alkaline batholiths (abstract) : Geol. Soc. America, Bull., vol. 39, no. 1, pp. 187-188, March 30, 1928; Pan-Am. Geologist, vol. 49, no. 2, p. 143, March, 1928.

4. Relative abundance of glacial striations, crescentric fractures, and lunoid furrows (abstract) : Geol. Soc. America, Bull., vol. 39, no. 1, p. 224, March 30, 1928.

5. The petrology of the North Conway quadrangle in the White Mountains of New Hampshire: Am. Acad. Arts and Sci., Proc., vol. 63, no. 3, pp. 67-137, 11 figs., 2 pls. (incl. map), May, 1928.

6. The chemistry, optics, and genesis of the hastingsite group of amphiboles: Am. Mineralogist, vol. 13, no. 7, pp. 287-296, July, 1928.

Billingsley, Paul. See also Kemp, 8.

1. Some features of the application of geology to mining as practiced by the geological department, Anaconda Copper Mining Company [Butte, Montana]: Canadian Min. Inst., Monthly Bull, no. 97, pp. 431-435, May, 1920; Trans., vol. 23, pp. 362-367 [1921] ; Min. and Sci. Press, vol. 120, pp. 907-908, June 19, 1920. 
Bingay, T. W.

1. (and Alcock, F. J.). Lead and zinc in Canada: Canadian Min. and Met. Bull., no. 184, pp. 920-943, 13 figs., August, 1927; Canadian Inst. Min. and Met., Trans., vol. 30, pp. 225-251, 13 figs. [1928] ; Second (Triennial) Empire Min. and Met. Congress, Canada, 1927, Proc., pt. 1, pp. 633-659, 13 figs., 1928.

Binney, Edwin, jr., 1899-1928.

1. Petroleum-bearing concretions: Econ. Geology, vol. 18, no. 6, pp. 600-603, September, 1923.

2. Natural gas from beds of continental accumulation; Golden Eagle gas field, Wyoming: Econ. Geology, vol. 21, no. 7, pp. 665-694, 3 figs., November, 1926.

Birch, Stephen.

1. Geology and mining methods of Kennecott mines [Chitina district, Alaska] : Am. Inst. Min. and Met. Eng., Trans. [preprint] no. 1287, 12 pp., 2 figs., January, 1924 ; vol. 72, pp. 499-511, 2 figs., 1925; abstract, Mining and Metallurgy, vol. 5, pp. 29-30, January, 1924.

2. Geology and mining methods of Beatson mine [Prince William Sound district, Alaska] : Am. Inst. Min. and Met. Eng., Trans. [preprint] no. 1288, 7 pp., 4 figs., January, 1924; abstract, Mining and Metallurgy, vol. 5, no. 205, pp. 30-31, January, 1924.

Birdseye, Claude $\mathrm{H}$.

1. (and Moore, Raymond C.). A boat voyage through the Grand Canyon of the Colorado: Geog. Rev., vol. 14, no. 2, pp. 177-196, 18 figs., April, 1924.

Birk, Ralph A.

1. The Sayre [oil] field, Beckham County, Oklahoma: Am. Assoc. Petroleum Geologists, Bull., vol. 8, no. 3, pp. 347-349, 1 fig., May-June, 1924.

2. The extension of a portion of the Pontotoc series around the western end of the Arbuckle Mountains: Am. Assoc. Petroleum Geologists, Bull., vol. 9, no. 6, pp. 983-989, 1 fig. (map), September, 1925.

Birse, D. J.

1. Dolomitization processes in the Paleozoic horizons of Manitoba: Roy. Soc. Canada, Proc. and Trans., $3 d$ ser., vol. 22, sec. 4, pp. 215-221, 7 pls., May, 1928; abstract, vol. 21, p. xciv, 1927.

Bishop, Sherman Chauncey. See also Hartnagel, 1, 4.

1. The Temple Hill (Orange County, New York) Mastodon: Science, new ser., vol. 54, p. 170, August 26, 1921.

2. (and Clarke, Noah T.). A scientific survey of Turners Lake, Isle-auHaut, Maine ... 1922; with special examinations and notes by John M. Clarke and others. 29 pp., 22 pls., New York State Museum, Albany, N. Y., August, 1923, published privately. Also issued with New York State Museum Bulletin no. 251, 1924.

Bissell, J. L. See Kentucky Geol. Survey, 13, 17.

Bissell, Malcolm Havens.

1. On the use of the terms "denudation," "erosion," "corrosion," and "corrasion"; Science, new ser., vol. 53, pp. 412-414, April 29, 1921.

2. Postglacial history of the Connecticut River near Middletown, Connecticut (abstract) : 'Geol. Soc. America, Bull., vol. 35, no. 1, pp. 75-76, March 30, 1924. 
Bissell, Malcolm Havens-Continued.

3. Preglacial course of the Comnecticut River near Middletown, Connecticut, and its significance: Am. Jour. Sci., 5th ser., vol. 9, pp. 233240, 2 figs., March, 1925.

4. Possible cause of the semiarid climate of eastern North America in Triassic time (abstract) : Geol. Soc. America, Bull., vol. 36, no. 1, pp. 139-140, March 30, 1925.

Black, George $\mathrm{F}$.

1. Amber and its origin: Am. Mineralogist, vol. 4, nos. 7-10, pp. 83-85, 97-99, 118-120, 130-131, July-October, 1919.

2. The Belleville copper mine [North Arlington, New Jersey]: Am. Mineralogist, vol. 7, no. 9, pp. 154-158, September, 1922.

Black, R. F.

1. (and Powell, W. Carlos). Preliminary report on the underground water in Socorro and Torrance counties: New Mexico, State Eng., 8th Bienn. Rept., pp. 109-126, 2 pls. [1928].

Blackburn, Chester O. See Van Tuyl, 9, 13.

Blackwelder, Eliot. See also Twenhofel, 16, 18, 22, 29.

1. The climatic history of Alaska from a new viewpoint: Illinois Acad Sci., Trans., vol. 10, pp. 275-280 [1918].

2. The U. S. Geological Survey: Science, new ser., vol. 51, pp. 346-348, April 2, 1920.

3. The origin of the central Kansas oil domes: Am. Assoc. Petroleum Geologists, Bull., vol. 4, no. 1, pp. 89-94, 1920.

4. The trend of earth history: Science, new ser., vol. 55, pp. 83-90, 114-119, January 27 and February 3, 1922.

5. Moving underground water in the accumulation of oil and gas: Econ. Geology, vol. 17, no. 3, p. 217; May, 1922.

6. Supposed glacial formations in the pre-Cambrian terranes of the Rocky Mountains (abstract): Geol. Soc. America, Bull., vol. 35, no. 1, pp. 70-71, March 30, 1924 ; Pan-Am. Geologist, vol. 41, no. 2, p. 139, March, 1924.

7. Suggestions for the improvement of our geologic terminology (abstract) : Geol. Soc., America, Bull., vol. 35, no. 1, p. 103, March 30, 1924; Pan-Am. Geologist, vol. 41, no. 2, p. 151, March, 1924.

8. Wasatch Mountains revisited (abstract) : Geol. Soc. America, Bull., vol. 36, no. 1, pp. 132-133, March 30, 1925; Pan-Am. Geologist, vol. 43, no. 1, pp. 74-75, February, 1925.

9. (and Baddley, Elmer R.). Relations between batholiths and schistosity (abstract) : Geol. Soc. America, Bull., vol. 36, no. 1, pp. 208-209, March 30, 1925.

10. Exfoliation as a phase of rock weathering: Jour. Geology, vol. 33, no. 8, pp. 793-806, 6 figs., November-December, 1925.

- 11. Phosphate deposits of the Pacific (discussion): Econ. Geology, vol. 20, no. 7, pp. 698-699, November, 1925.

12. Photography for the field geologist: Washington Acad. Sci., Jour., vol. 16, no. 4, pp. 93-97, February 19, 1926.

13. Earthquakes in Jackson Hole, Wyoming: Seismologic Soc. America, Bull., vol. 16, no. 3, p. 196, September, 1926.

14. Pre-Cambrian geology of the Medicine Bow, Mountains: Geol. Soc. America, Bull., vol. 37, no. 4, pp. 615-658, 11 figs. (incl. maps), December 30, 1926. 
Blackwelder, Eliot-Continued.

15. Fire as an agent in rock weathering: Jour. Geology, vol. 35, no. 2, pp. 134-140, 3 figs., February-March, 1927; abstract, Geol. Soc. America, Bull., vol. 37, no. 1, pp. 142-143, March 30, 1926; Pan-Am. Geologist, vol. 45, no. .1, p. 91, February, 1926.

16. Desert weathering (abstract) : Geol. Soc. America, Bull., vol. 38 , no. 1, pp. 127-128, March 30, 1927; Pan-Am. Geologist, vol. 47, no. 1, p. 74, February, 1927.

17. Scarp at the mouth of Kern River Canyon [California] (abstract) : Geol. Soc. America, Bull., vol. 38, no. 1, p. 207, March 30, 1927.

18. Mudflow as a geologic agent in semiarid mountains (with discussion by Joseph T. Singewald, jr.) : Geol. Soc. America, Bull., vol. 39, no. 2, pp. 465-483, 7 figs., June, 1928; abstract, Pan-Am. Geologist, vol. 49, no. 2, pp. 156-157, March, 1928; Geol. Soc. America, Bull., vol. 39 , no. 1 , p. 206, March $30,1928$.

19. Origin of the desert basins of southwest United States (abstract) : Geol. Soc. America, Bull., vol. 39, no. 1, pp. 262-263, March 30, 1928.

20. Evidence of a third glacial epoch in the Sierra Nevada (abstract) : Geol. Soc. America, Bull., vol. 39, no. 1, p. 268, March 30, 1928.

21. The recognition of fault scarps: Jour. Geology, vol. 36, no. 4, pp. 289-311, 8 figs., May-June, 1928.

22. Wind abrasion in arid Southwest (abstract) : Pan-Am. Geologist, vol. 49, no. 4, p. 303, May, 1928.

23. Origin of Piedmont plains of Great Basin (abstract) : Pan.-Am. Geologist, vol. 49 , no. 4 , p. 307 , May, 1928.

24. Moraines of Convict Lake glaciers [California] (abstract): Pan-Am. Geologist, vol. 49, no. 4, p. 309, May, 1928.

25. Cavernous weatherings in arid regions (abstract): Pan-Am. Geologist, vol. 49 , no. 4 , p. 311, May, 1928.

26. Notes on sedimentary deposits in the desert: Nat. Research Council, Reprint and Circ. Ser., no. 85, pp. 78-80, 1928.

Blair, S. M. See Clark, $\dot{K}$. A., 4, 5.

Blanchard, Roland.

1. The Jervis Inlet region, British Columbia: Pacific Min. News, vol. 1, no. 3, pp. 67-69, 3 figs., July, 1922.

2. Notes on the oxidation products derived from chalcopyrite: Econ. Geology, vol. 20, no. 7, pp. 613-638, 2 figs., 2 pls., November, 1925.

3. (and Boswell, P. F.). Status of leached outcrops investigation: Eng. and Min. Jour., vol. 125 , no. 7, pp. 280-285, no. 9, pp. 373-377, 13 figs., February 18 and March 3, 1928.

Blanchard, W. O.

1. The geography of southwestern Wisconsin: Wisconsin Geol, and Nat. Hist. Survey, Bull. no. 65, 117 pp., 81 figs., 1924.

Blanchard, W. Grant, jr. See also Keyte, 2.

Blatchley, Raymond S.

1. Notes on the southwest Texas region: Oil Bull., vol. 13, no. 6, pp. 593, 595, June, 1927.

Blázquez, Luis.

1. Informe preliminar de la hidrología subterránea de las cuencas de los ríos de la Concepción y de Sonoyta, Distrito de Altar, Estado de Sonora: Mexico, Inst. geol., Foll. divulgación, no. 22, 30 pp., December, 1926. 
Blázquez, Luis-Continued.

2. Informe preliminar acerca de la hidrología subterránea de la región que comprende como pueblos principales Guadalupe, San José de la Isla, Ojocaliente, Villa García, Pinos y Villa de Arriaga, de los Estados Zacatecas y San Luis Potosí: Mexico, Inst. geol., Foll. divulgación, no. 30,17 pp., 1928.

Bliss, Eleanora F. See Knopf, Eleanora Bliss.

Bloesch, Edward.

1. Unconformities in Oklahoma and their importance in petroleum geology: Am. Assoc. Petroleum Geologists, Bull., vol. 3, pp. 253-285, 1919.

2. Remarks on subsurface contouring: Am. Assoc. Petroleum Geologists, Bull., vol. 6, no. 4, pp. 317-322, 1 fig., July-August, 1922.

3. Fort Scott-Wetumka correlation: Am. Assoc. Petroleum Geologists, Bull., vol. 10, no. 8, pp. 810-811, August, 1926.

4. Oil and gas in Oklahoma: Nowata and Craig counties: Oklahoma Geol. Survey, Bull. no. 40-EE, 30 pp., 2 figs., 1 pl., June, 1928.

Boalich, Edwin Snow.

1. (and others). The clay industry in California: California State Min. Bur., Prel. Rept. no. 7, 108 pp., 24 figs., January, 1920.

2. Notes on iron occurrences in California : California State Min. Bur., Mining in California, vol. 18, no. 3, pp. 110-113, March, 1922.

3. Bibliography of coal in California: California State Min. Bur., Mining in California, vol. 18, no. 4, pp. 152-157, April, 1922.

Bock, Peter.

1. Bericht über den Ausbruch des Vulkans Izalco, El Salvador, im November 1926: Zeitschr. Vulkanologie, Bd. 11, H. 3, pp. 190-191, July, 1928.

Böggild, Ove Balthasar.

1. Grönland. In Steinmann, G., and Wilckens, O., Handbuch der regionalen Geologie, H. 21, Bd. IV, 2a, 38 pp., 6 figs: (incl. maps), Heidelberg, 1917.

2. Dahllit von Kangerdluarsuk [Grönland]: Zeitschr. Krystallographie, Bd. 55, H. 5-6, pp. 417-425, 5 figs., 1920.

3. Leifit, ein neues Mineral von Narsarsuk, Grönland: Zeitschr. Krystallographie, Bd. 55, H. 5-6, pp. 425-429, 1920.

4 (Krönland, almindelig Oversigt; Geologi [a general account of the geology of Greenland] : Meddelelser om Grönland, Bd. 60, pp. 29-36, atlas, pl. 2 (geol. map), 1921.

5. The meteoric iron from Savik near Cape York, north Greenland: Meddelelser om Groenland, Bd. 74, pp. 9-30, 6 pls., 1927; Copenhagen, Univ., Mineralogical and Geological Museum, Contributions to Mineralogy, no. 22, 30 pp., 5 figs., 6 pls., 1927.

6. The geology of Greenland. In Greenland, published by the Commission for the direction of the geological and geographical investigations in Greenland, pp. 231-255, 6 figs. (maps), London, Humphrey Milford, Oxford University Press, 1928.

Boericke, W. F.

1. (and Garnett, T. H.). The Wisconsin zinc district: Am. Inst. Min. and Met. Eng., Bull. no. 152, pp. 1213-1235, 5 figs., August, 1919 ; Trans., vol. 63, pp. 213-243, 5 figs., 1920. Discussion by G. H. Cox and others, Mining and Metallurgy, no. 157, pp. 68-71, January, 1920. 
Böse, Emil, 1868-1927. See also Udden, 5.

1. The Permo-Carboniferous ammonoids of the Glass Mountains, west Texas, and their stratigraphical significance: Texas, Univ., Bull, no. $\mathbf{1 7 6 2 ,}$ 241 pp., 11 pls., November 5, 1917.

2. On a new Exogyra from the Del Rio clay and some observations on the evolution of Exogyra in the Texas Cretaceous: Texas, Univ., Bull. no. 1902, 22 pp., 5 pls., 1 fig., January 5, 1919.

3. On a new ammonite fauna of the Lower Turonian of Mexico: Texas Univ., Bull. no. 1856, pp. 173-252, 7 figs., 9 pls., October 5, 1918 [1920].

4. On the ammonoids from the Abo sandstone of New Mexico and the age of the beds which contain them: Am. Jour. Sci., 4th ser., vol. 49, pp. 51-60, January, 1920.

5. On the Permian of Coahuila, northern Mexico: Am. Jour. Sci., 5th ser., vol. 1, no. 2, pp. 187-194, February, 1921.

6. Algunas faunas cretácicas de Zacatecas, Durango y Guerrero: Mexico, Inst. geol., Bol., no. 42, 219 pp., 19 pls., 1923.

7. Vestiges of an ancient continent in northeast Mexico: Am. Jour. Sci., 5th ser., vol. 6, pp. 127-136, 196-214, 310-337, 4 figs., AugustOctober, 1923.

8. (and Cavins, O. A.). The Cretaceous and Tertiary of southern Texas and northern Mexico: Texas, Univ., Bull. no. 2748, pp. 7-142, 1 pl. (paleogeographic map), December, 1927.

9. Cretaceous ammonites from Texas and northern Mexico: Texas, Univ., Bull. no. 2748, pp. 143-312, 18 pls., December 22, 1927.

Boezinger, $\mathbf{H}$.

1. The minor oil fields of Kern County; Belridge and North Belridge oil fields: California State Min. Bur., Summary of Operations California Oil Fields, vol. 10, no. 1, pp. 11-18, 1 pl. (map); July, 1924.

Bole, G. A. See Stull, 2.

Bollinger, C. J.

1. A preliminary interpretation of certain peculiarities of the North and South Canadian River basins in the red beds area of Oklahoma: Oklahoma Acad. Sci., Proc., vol. 3 (Oklahoma, Univ., Bull., new ser. no. 271), pp. 117-120, October 1, 1923.

Bonazzi, Augusto,

1. Reconocimiento agro-geológico de los terrenos de las fincas Chaparra y Delicias [Cuba] : Bol. minas, Habana, no. 12, pp. 30-49, 8 figs., 1 pl., 1928.

Bond, Lewis A.

1. The registration of earthquakes at the Berkeley Station and at the Lick Observatory Station from October 1., 1919, to March 31, 1920: California, Univ., Seismographic Stations. Bull. no. 19, pp. 387-404, September 29, 1920.

2. The registration of earthquakes at the Berkeley Station and at the Lick Observatory Station from April 1, 1920, to September 30, 1920: California, Univ., Seismographic Stations, Bull., no. 20, pp. 405-422, April 29, 1921.

3. The registration of earthquakes at the Berkeley Station and at the Lick Observatory Station from October 1, 1920, to March 31, 1921: California, Univ., Pub., Seismographic Stations, Bull., vol. 2, no. 1, 15 pp., November 18, 1921.

$4096-31-5$ 
Bonillas, Ignacio S.

1. Clasificación [de rocas đel Estado de Guerrero] : Bo.. minero, t. 6, no. 4, pp. 498-504, October, 1918.

2. Descripción petrog:áfica de las rocas eruptivas y de contacto de las Sierras de Minillas, Cerro Prieto, Pichagua y Sierra de Ramírez: Mexico, Inst. geol., Bol. no. 42, pp. 47-58, 1923.

Bonine, Chesleigh Arthur. See also Twenhofel, 16, 22.

1. Underground water in migration and accumulation of oil and gas: Econ. Geology, vol. 17, no. 5, pp. 389-392, August, 1922.

2. Recent work on bentonite: Nat. Research Council, Reprint and Circ. Ser., no. 85 , pp. 12-17, 1928 .

Bonnell, Clarence.

1. The variety of physiographic material in a few counties of southern Illinois : Illinois Acad. Sci., Trans., vol. 9, pp. 203-208, 3 pls. [1917].

2. The effects of faults and dikes in the Saline County coal field (abstract) : Illinois State Acad. Sci., Trans., vol. 14, pp. 219-220 [1922].

3. Description of a boulder near the southern limit of glaciation in Illinois: Illinois State Acad. Sci., Trans., vol. 15, pp. 405-407 [1923].

Boone County Historical Society, Columbia, Missouri.

1. Dedication of Swallow memorial monument, June 5, 1928, 4 p. m., Columbia Cemetery, and facts concerning the life of George Clinton Swallow, M. D., LL. D. 50 pp., portr. [Columbia (?), 1928(?)].

Includes papers, bfographical in character, by G. C. Broadhead, Charles Keyes, James S. Williams, H. A. Buehler, and others.

Boot, David H.

1. Meteor Mountain [Arizona]: Iowa Acad. Sci., Proc:, vol. 26, pp. 379-383, 6 figs. [1920].

Bostock, Hugh S.

1. Horn silver mine, Similkameen,.British Columbia: Canada, Geol. Survey, Summ. Rept., 1927, pt. A, pp. 47-52, map, 1928.

Boswell, P. F. See also Blanchard, 3.

1. Oxidation products derived from sphalerite and galena: Econ. Geology, vol. 32, no. 5, pp. 419-453, 5 figs., August, 1927.

Bosworth, Thomas Owen, 1882-1929. See also Kindle, 9.

1. Geology of the Mid-Continent oil fields, Kansas, Oklahoma, and north Texas. xiv, 314 pp., 24 figs., 8 pls., map, New York, The Macmillan Company, 1920. Review by K. C. Heald, Econ. Geology, vol. 15, no. 7, pp. 612-617, November, 1920.

2. The Mackenzie oil field of northern Canada: Canadian Inst. Min. and Met., Monthly Bull. no. 111, pp. 629-638, July, 1921.

3. The Mackenzie oil field of northern Canada: Inst. Petroleum Technolo. gists, Jour., vol. 7, no. 28, pp. 276-291, 1 fig., 8 pls., October, 1921; Petroleum Times, vol. 5, no. 121, pp. 489-491, April 30, 1921; Canadian Min. Jour., vol. 42, no. 21, pp. 420-422, May 27, 1921 . Abstract, Geol. Mag., vol. 58, pp. 287-288, June, 1921.

4. Mackenzie oil field: Mining and Metallurgy, no. 178, pp. 47-48, October, 1921.

Boughton, Charles W. See also Moore, R. C., 6.

1. Elk City gas field, Elk and Montgomery counties, Kansas: Kansas, State Geol, Survey, Bull. 5, 31 pp., 5 pls., 6 figs. [1920].

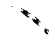


Boutwell, William D.

1. The mysterious tomb of a giant meteorite: Nat. Geog. Mag., vol. 53, no. 6, pp. 721-730, 10 figs., June, 1928.

Bowen, Charles Franklin. See also Heald, 2.

1. Anticlines in a part of the Musselshell Valley (U. S. Geol. Survey, Bull. 691, pp. 185-209, 1918) (abstract by R. W. Stone) : Washington Acad. Sci., Jour., vol. 9, no. 15, p. 442, September 19, 1919.

2. Gradations from continental to marine conditions of deposition in central Montana during the Eagle and Judith River epochs: U. S. Geol. Survey, Prof. Paper 125, pp. 11-21., 1 pl. (map), October 20, 1919.

3. (and Roundy, P. V., Ross, C. S., and Reeves, Frank). Structure and oil and gas resources of the Osage Reservation, Oklahoma: Tps. 21-23 N., Rs. 6-7 E., and Tps. 23-25 N., Rs. 3-5 E.: U. S. Geol. Survey, Bull. 686, pp. 279-301, 3 pls. (incl. maps), 1919.

Bowen, Norman Levi. See also Fairbanks, 12.

1. Crystallization differentiation in igneous magmas: Jour. Geology, vol. 27, no. 6, pp. 393-430, 5 figs., September-October, 1919.

2. Abnormal birefringence of torbenite: Am. Jour. Sci., 4 th ser., vol. 48, pp. 195-198, 2 figs., September, 1919.

3. Cacoclasite from Wakefield, Quebec: Am. Jour. Sci., 4th ser., vol. 48, pp. 440-442, December, 1919.

4. Echellite, a new mineral: Am. Mineralogist, vol. 5, no. 1, pp. 1-3, January, 1920.

5. Deformation of crystallizing magma: Jour. Geology, vol. 28, no. 3, pp. 265-267, April-May, 1920.

6. Differentiation by deformation: Nat. Acad. Sci., Proc., vol. 6, no. 4, pp. 159-162, April 15, 1920. Abstract, Geol. Soc. America, Bull., vol. 31, no. 1, p. 139, March 31, 1920.

7. Crystallization differentiation: Geol. Mag., vol. 57, pp. 238-239, May, 1320.

8. Optical properties of anthophyllite: Washington Acad. Sci., Jour., vol. 10, no. 14, pp. 411-414, 1 fig., August 19, 1920.

9. Diffusion in silicate melts: Jour. Geology, vol. 29 , no. 4, pp. 295-317, 7 figs., May-June, 1921.

10. Preliminary note on monticellite alnoite from Isle Cadieux, Quebec: Washington Acad. Sci., Jour., vol. 11, no. 12, pp. 278-281, June 19, 1921.

11. Genetic features of alnoitic rocks at Isle Cadieux, Quebec: Am. Jour. Sci., 5th ser., vol. 3, pp. 1-34, 6 figs., 1 pl., January, 1922. Abstract, Geol. Soc. America, Bull., vol. 33, no. 1, p. 130, March 31, 1922. .

12. The reaction principle in petrogenesis: Jour. Geology, vol. 30, no. 3, pp. 177-198, 5 figs., April-May, 1922.

13. The behavior of inclusions in igneous magmas: Jour. Geology, vol. 30, supplement to no. 6, pp. 513-570, August-September, 1922.

14. (and Aurousseau, M.). Fusion of sedimentary rocks in drill holes (with discussion by Sidney Powers): Geol. Soc. America, Bull., vol. 34, no. 3, pp. 431-448, 3 figs:, S:ptember $30,1923$.

15. The genesis of melilite: Washington Acad. Sci., Jour., vol. 13, no. 1, pp. 1-4, January 4, 1923.

16. Mullite, a silicate of alumina: Washington Acad. Sci., Jour., vol. 14, no. 9, pp. 183-191, May 4, 1924. 
Bowen, Norman Levi-Continued.

17. The system $\mathrm{Al}_{2} \mathrm{O}_{3}-\mathrm{SiO}_{2}$ (abstract) : Geol. Soc. America, Bull., vol. 35, no. 1, p. 123, March 30, 1924 ; Pan-Am. Geologist, vol. 41, no. 2, pp. 158159, March, 1924.

18. The mineralogical phase rule: Washington Acad. Sci., Jour., vol. 15, no. 13, pp. 280-284, July 19, 1925.

19. The amount of assimilation by the Sudbury norite sheet: Jour. Geology, vol. 33; no. 8, pp. 825-829, 2 figs., November-December, 1925.

20. Concerning "evidence of liquid immiscibility in a silicate magma, Agate Point, Ontario": Jour. Geology, vol. 34, no. 1, pp. 71-73, JanuaryFebruary, 1926.

21. (and Wyckoff, R. W. G.). A petrographic and X-ray study of the thermal dissociation of dumortierite: Washington Acad. Sci., Jour., vol. 16, no. 7, pp. 178-189, 3 figs., April 4, 1926.

22. The origin of ultrabasic and related rocks: Am. Jour. Sci., 5th ser., vol. 14, pp. 89-108, 4 figs., August, 1927.

23. The evolution of the igneous rocks. $x, 334$ pp., 82 figs., Princeton University Press, 1928.

Bowen, W. C. See Ries, 8.

Bowie, William. See also American Geophysical Union; Shepard, 8; Woodring, 8.

1. Ocean currents and isostasy: Pan-Pacific Scientific Conference, First, Proc., Bernice P. Bishop Mus., Spec. Pub. no. 7, pt. 2, p. 503, 1921.

2. The bearing of geodetic investigations on the geologic structure of the Pacific: Pan-Pacific Scientic Conference, First, Proc., Bernice P. Bishop Mus., Spec. Pub. no. 7, pt. 3, pp. 882-885, 1921.

3. Some geologic conclusions from geodetic data: Nat. Acad. Sci., Proc., vol. 7, no. 1, pp. 23-28, January, 1921.

4.. The relation of isostasy to uplift and subsidence: Am. Jour. Sci., 5th ser., vol. 2, pp. 1-20, July, 1921.

5. The yielding of the earth's crust: Smithsonian Inst., Ann. Rept., 1921, pp. 235-247, 9 figs., 1922.

6. Theory of isostasy-a geological problem: Geol. Soc. America, Bull., vol. 33 , no. 2, pp. 273-286, June 30, 1922.

7. The earth's crust and isostasy: Geog. Rev., vol. 12, no. 4, pp. 613-627, 5 figs., October, 1922.

8. The present status of the geodetic work in the United States and its value to geology: Am. Jour. Sci., 5th ser., vol. 5, pp. 378-382, May, 1923 ; abstract, Geol. Soc. America, Bull., vol. 34, no. 1, p. 74, March 30, 1924.

9. Some recent progress in isostatic investigations: Washington Acad. Sci., Jour., vol. 13, no. 13, pp. 267-270, July 19, 1923 ; abstract, Nat. Research Council, Bull., vol. 7, pt. 5, no. 41, pp. 95-96, January, 1924.

10. Earth movements in California: U. S. Coast and Geodetic Survey, Special Pub. no. 106, 22 pp., 6 figs., 1924.

11. The theory of isostasy in its relation to major earth movements: PanPacific Sci. Cong., Australia, 1923, Proc., vol. 2, pp. 1360-1366 [1924].

12. Abnormal densities in the earth's crust disclosed by analysis of geodetic data: Geog. Jour., vol. 63, no. 1, pp. 26-33, January, 1924. 
Bowie, William-Continued.

13. Earth movements in Califoruia as disclosed by triangulation (abstract, with discussion by Arthur Keith, L. C. Graton, and A. C. Lawson) : Geol. Soc. America, Bull., vol. 35, no. 1, pp. 60-62, March 30, 1924; abstract, Pan-Am. Geologist, vol. 41, no. 2, pp. 134-135, March, 1924.

14. The bearing of the theory of isostasy on some major geological problems: Franklin Inst., Jour., vol. 198, no. 2, pp. 181-200, 12 figs., August, 1924.

15. On the size of the block of the earth's crust which may be independently in isostatic equilibrium: Washington Acad. Sci., Jour., vol. 14, no. 15, pp. 355-362, September 19, 1924.

16. The causes and prediction of earthquakes: Science, new ser., vol. 61, pp. 379-380, April 10, 1925.

17. Isostasy at Madrid meeting of International Geophysical Union: PanAm. Geologist, vol. 43, no. 5, pp. 337-344, June, 1925.

18. Isostatic condition of the United States as indicated by groups of gravity stations: U. S. Coast and Geod. Survey, Serial no. 366, 11 pp., 1 pl. (map), 1926.

19. Proposed theory, in harmony with isostasy, to account for major changes in the elevation of the earth's surface: Gerlands Beiträge zur Geophysik, Bd. 15, H. 2, pp. 103-115, 4 figs., 1926.

20. Geology from the isostatic viewpoint: Sci. Monthly, vol. 22, no. 1, pp. 5-18, 11 figs., January, 1926.

21. Notes on the Airy or "roots of mountains" theory: Science, new ser., vol. 63, pp. 371-374, April 9, 1926.

22. Earthquakes from the isostatic viewpoint: Washington Acad. Sci., Jour., vol. 16 , no. 9, pp. 245-250, May 4, 1926.

23. The relation of isostasy to seismology: Am. Jour. Sci., 5th ser., vol. 12, pp. 415-418, November, 1926.

24. (and others). Discussion following Symposium on the constitution of the earth and the inferences to be drawn from it: Nat. Research Council, Bull., vol. 11, pt. 2, no. 56, pp. 33-39, November, 1926.

25. Relation of earthquakes to isostasy : Nat. Research Council, Bull., vol. 11, pt. 2, no. 56, pp. 72-73, November, 1926.

26. Isostasy: xiv, 275 pp., 39 figs., New York, E. P. Dutton \& Company, 1927.

27. The part played by isostasy in geophysics and geology: Washington Acad. Sci., Jour., vol. 17, no. 5, pp. 101-117, March 4, 1927.

28. Some phases of the vertical movement of crustal material: Am. Jour. Sci., 5th ser., vol. 14, pp. 253-258, October, 1927.

29. An early comment on isostatic compensation: Am. Jour. Sci., 5th ser., vol. 15, pp. 433-434, May, 1928.

30. Comments on the Wegener hypothesis. In Theory of continental drift, pp. 178-186, Am. Assoc. Petroleum Geologists, 1928.

31. Gravity in western Canada: Am. Jour. Sci., 5th ser., vol. 16, pp. 263-266, September, 1928.

Bowles, Oliver.

1. The technology of slate: U. S. Bur. Mines, Bull. 218, 132 pp., 41 figs.. 6 pls., 1922.

2. A plea for economic mineralogy: Am. Mineralogist, vol. 7, no. 4, pp. 67-69. April, 1922.

3. Marble quarrying industry in Tennessee: Tennessee, Dept. Education, Div. Geology, Bull. 28, pp. 163-264, 29 figs., 16 pls., 1924. 
Bowles, Oliver-Continued.

4. (and Farnsworth, Marie). Physical chemistry of the calcium sulphates, and gypsum reserves: Econ. Geology, vol. 20, no. 8, pp. 738-745, December, 1925.

Bowman, Isaiah. See Texas, Attorney General.

Bowman, W. F.

1. The South Dayton salt dome, Liberty County, Texas: Am. Assoc. Petroleum Geologists, Bull., vol. 9, no. 3, pp. 655-666, 5 figs., May-June, 1925 ; Geology of salt dome oil fields, pp. 558-559, 5 figs., 1926.

Bownocker, John Adams, 1865-1928. See also Stone, 11; White, I. C., 9.

1. Geologic map of Ohio. [Ohio, Geol. Survey], 1920. Scale, 1 to 500,000.

2. Depletion of natural gas in the Appalachian field: Natural Gas Assoc. America, Proc. 14th Ann. Meeting, pp. 253-272, 8 figs., 1920.

3. Rise and decline in production of petroleum in Ohio and Indiana: Am. Inst. Min. and Met. Eng., Trans., vol. 65, pp. 108-121, 2 figs., 1921; Mining and Metallurgy, no. 158, sec. 1, p. 34 (abstract), sec. 22, 12 pp., 2 figs., February, 1920 ; discussion by L. S. Panyity, Am. Inst. Min. and Met. Eng. [Trans., preprint no. 988], pp. 14-16, 1920.

4. Our decreasing natural gas supply (abstract) : Science, new ser., vol. 51, pp. 518-519, May 21, 1920.

5. Steel molding sand in Ohio: Ohio Jour. Science, vol. 21, no. 8, pp. 249-266, 1 fig., June, 1921.

6. Iron-molding sands in Ohio: Ohio Jour. Sci., vol. 23, no. 1, pp. 25-40, January-February, 1923.

7. Glass sands of Ohio: Ohio Jour. Sci., vol. 26, no. 1, pp. 25-41, January, 1926.

8. The Pittsburgh coal bed of Ohio: Am. Inst. Min. and Met. Eng., Trans. [preprint], no. 1605,10 pp., 1 fig. (map), October, 1926.

9. (and Stout, W.). Mineral industries of Ohio: Ohio, Geol. Survey, 4th ser., Bull. 33, 94 pp., 1928.

Boyd, H. E.

1. (and Hendricks, J. A.). Geological report of northern Nova Scotia relative to the possibilities for oil and gas: Nova Scotia, Dept. Public Works and Mines, Ann. Rept. Mines, 1927, pt. 1, pp. 185-242, 1928. Report of United States geologists on oil and gas possibilities of Nova Scotia: Canadian Min. Jour., vol. 49, no. 29, pp. 586-588, June 20, 1928.

Boyd, W. H.

1. A new method of determining the rate of recession of Niagara Falls: Roy. Soc. Canada, Proc. and Trans., 3d ser., vol. 22, sec. 4, pp. 1-12, 9 pls., March, 1928.

Boydell, H. C. See also Brunton, 10.

1. Some etching tests on pyrrhotite: Econ. Geology, vol. 17, no. 6, pp. 491-497, September, 1922.

2. The rôle of colloidal solutions in the formation of mineral deposits: Inst. Min. and Met., Bull. no. 243, 108 pp., December, 1924.

3. A physico-chemical theory of metasomatism: Econ. Geology, vol. 20, no. 4, pp. 388-391, June-July, 1925 ; (discussion), vol. 21, no. 8, pp. 806807, December, 1926.

4. Veindikes of the Engineer mine [Atlin, British Columbia] : Eng. and Min. Jour.-Press, vol. 120, no. 14, pp. 538-539, October 3, 1925. 
Boydell, H. C.-Continued.

5. Economic geology and the mining industry: Inst. Min. and Met., Bull no. 254, 12 pp., November, 1925; discussion, no. 270, pp. 27-33, March, 1927 ; ( with discussion), Trans., vol. 35, pp. 76-101, 1926.

6. Wood tin in the Tertiary rhyolites of northern Nevada (discussion) : Econ. Geology, vol. 20, no. 8, pp. 768-770, December, 1925.

7. A discussion on metasomatism and the linear "force of growing crystals": Econ. Geology, vol. 21, no. 1, pp. 1-55, 8 figs., 2 pls., JanuaryFebruary, 1926.

8. The Camp Bird compound "veindike" (discussion): Econ. Geology, vol. 21, no. 2, pp. 185-190, March-April, 1926.

9. Relations between solubility and pressure (discussion): Econ. Geology, vol. 21, no. 7, pp. 712-717, November, 1926.

10. Successive banding around rock fragments in veins (discussion): Econ. Geology, vol. 22, no. 1, pp. 94-99, January-February, 1927.

11. Operative causes in ore deposition:. Inst. Min. and Met., Bull. no. 277, 85 pp., 12 figs., October, 1927.

12. A physico-chemical theory of metasomatism (discussion): Econ. Geology, vol. 23, no. 1, pp. 105-108, January, 1928.

13. The wide dissemination of gold in northern Ontario: Canadian Min. and Met., Bull. no. 190, pp. 247-263, February, 1928; Canadian Inst. Min. and Met., Trans., vol. 31, pp. 89-114 [1929].

14. Metasomatism and the pressure of growing crystals (discussion) : Econ. Geology, vol. 23, no. 2, pp. 214-218; March-April, 1928.

Boyer, Charles Sumner.

1. List of Quaternary and Tertiary Diatomaceae from deposits of southern Canada: Canada, Victoria Memorial Mus., Mus. Bull. no. 45, 27 pp., November 9, 1926.

Boyle, J. Philip.

1. Geology of Wagoner County: Oklahoma Geol. Survey, Bull. no. 40-L, 18 pp., 6 figs., 2 pls., May, 1927.

Bradley, John H.

1. How old is the earth?: Sci. Monthly, vol. 23, no. 3, pp. 260-264, September, 1926.

Bradley, John Hodgdon, jr.

1. The Brachiopoda of the Maquoketa of Iowa: Harvard Coll., Mus. Comp. Zool., Bull., vol. 64, no. 6, pp. 503-525, 2 pls., April, 1921.

2. Geology of the Philipsburg region of Quebec, with notes on correlations within the Beekmantown: Jour. Geology, vol. 31, no. 4, pp. 314-335, 2 figs. (incl. map), May-June, 1923.

3. Trilobites of the Beekmantown in the Philipsburg region of Quebec: Canadian Field-Naturalist, vol. 39, no. 1, pp. 5-9, 1 pl., January, 1925.

4. Stratigraphy of the Kimmswick limestone of Missouri and Illinois: Jour. Geology, vol. 33, no. 1, pp. 49-74, January-February, 1925; abstract, Chicago, Univ., Abstracts of Theses, vol. 3, pp. 217-220, April, 1927.

5. The earth and its history ; a textbook of geology. 414 pp., 257 pp., Boston, Ginn and Company [1928].

Bradley, P. R.

1. Estimation of ore reserves and mining methods in Alaska Juneau mine: Am. Inst. Min. and Met. Eng., Trans. [preprint] no. 1329, 19 pp., 2 figs., March, 1924. 
Bradley, Walter Wadsworth.

1. California mineral production for 1918, with county maps: California State Min. Bur., Bull. no. 86, 212 pp., illus., 1919.

2. California mineral production for 1919, with county maps: California State Min. Bur., Bull. no. 88, 204 pp., illus., 1920.

3. California mineral production for 1920 , with county maps: California State Min. Bur., Bull. no. 90, 218 pp., illus., 1921.

4. California mineral production for 1922: California State Min. Bur., Bull. no. 93, 188 pp., 12 figs., September, 1923.

5. California mineral production for 1923: California State Min. Bur., Bull. no. 94,162 pp., 6 figs.; September, 1924.

6. Magnesite in California : California State Min. Bur., Bull. no. 79, 147 pp., 62 illus., 11 pls., 1925.

7. California mineral production for 1924: California State Min. Bur., Bull. no. 96,174 pp., 1 fig., 1925.

8. California mineral production for 1925: California State Min. Bur., Bull. no. 97,172 pp., illus., September, 1926.

9. California mineral production for 1926: California, Dept. Nat. Res., Div. Mines and Mining, Bull. no. 100, 175 pp., illus., September, 1927.

10. Biennial report of the State mineralogist: California, Div. Mines and Mining, Mining in California, vol. 24, no. 4, pp. 354-360, October, 1928.

Bradley, Wilmot H. See also Sears, 5 .

1. Fossil caddice fly cases from the Green River formation of Wyoming: Am. Jour. Sci., 5th ser., vol. 7, pp. 310-312, April, 1924.

2. An oil shale and its microorganisms from the Fuson formation of Wyoming: Am. Jour. Sci., 5th ser., vol. 8, pp. 228-234, 4 figs., September, 1924.

3. A contribution to the origin of the Green River formation and its oil shale: Am. Assoc. Petroleum Geologists, Bull., vol. 9, no: 2, pp. 247-262, 410, March-April, 1925.

4. An interpretation of the Green River formation (abstract): Washington Acad. Sci., Jour., vol. 16, no. 3, pp. 74-75, February 4, 1926.

5. Shore phases of the Green River formation in northern Sweetwater County, Wyoming: U. S. Geol. Survey, Prof. Paper 140, pp. 121131, 2 figs., 5 pls. (incl. map), February 13, 1926.

6. Fossil rhizopods of the Green River oil shale (abstract) : Geol. Soc. America, Bull., vol. 37, no. 1, p. 160, March 30, 1926; Pan-Am. Geologist, vol. 45, no. 2, p. 161, March, 1926.

7. Tertiary and Recent fresh water algae reefs (abstract) : Washington Acad. Sci., Jour., vol. 17, no. 9, pp. 232-233, May 4, 1927.

8. Zeolite beds in the Green River formation: Science, new ser., vol. 67, pp. 73-74, January 20, 1928.

Bragg, William $\mathrm{H}$.

1. Analysis of crystal structure by $X$ rays: Pan-Am. Geologist, vol. 42 , no. 3, pp. 173-198, 2 pls., October, 1924.

Brainerd, A. E.

1. (and Keyte, I. A.). Some problems of the Chugwater-Sundance contact in the Bighorn district of Wyoming: Am. Assoc. Petroleum Geologists, Bull., vol. 11, no. 7, pp. 747-752, 2 figs., July, 1927.

2. (and Keyte, I. A.). New faunal evidence from the Tensleep formation [Wyoming] : Jour. Paleontology, vol. 1, no. 2, pp. 173-174, 2 pls., August, 1927. 
Bramlette, Milton N.

1. Bentonite in the Upper Cretaceous of Louisiana: Am. Assoc. Petroleum Geologists, Bull., vol. 8, no. 3, pp. 342-344, May-June, 1924.

2. Volcanic rocks in the Cretaceous of Louisiana: Am. Assoc. Petroleum Geologists, Bull., vol. 8, no. 3, pp. 344-346, May-June, 1924.

3. A subsurface correlation of the stratigraphic units from Russell County to Marion County, Kansas: Kansas State Geol. Survey, Bull. 10, 86-93, 1925.

4. Paleozoic formations penetrated by wells in Tishomingo County, northeastern Mississippi : U. S. Geol. Survey, Bull 781, pp. 1-10, 1 pl., July, 1925.

5. Pseudo-stratification in core recoveries: Am. Assoc. Petroleum Geologists, Bull., vol. 12, no. 12, pp. 1167-1169, 1 fig., December, 1928.

Branner, George C.

1. Arkansas' mineral resources: The South's Development, Manufacturers Record, vol. 86, no. 24, pt. 2, pp. 356-361, 5 figs., December 11, 1924.

2: Arkansas Geological Survey [activities] : Pan-Am. Geologist, vol. 44, no. 4, pp. 322-323, 1 fig., November, 1925.

3. Outlines of Arkansas' mineral resources: Arkansas State Geol. Survey, 352 pp., illus., map, 1927.

4. The Arkansas coal fields: U. S., Bur. Mines, Tech. Paper 416, pp. 1-5, 1 fig., 1928.

5. Annual administrative report of the State geologist of Arkansas, Dec. 1, 1926-Dec. 1, 1927. 16 pp., Little Rock, 1928.

Branner, John Casper, 1850-1922.

1. Incidents. in the history of the Geological Survey of Arkansas, and some conclusions to be drawn therefrom. In Ferguson, Jim G., Outlines of Arkansas geology, pp. 15-20, Little Rock, 1920.

2. Road-making materials in Arkansas. In Ferguson, Jim G., Outlines of Arkansas geology, pp. 126-132, Little Rock, 1920.

Branson, Edwin Bayer.

1. A geologic section from 40 miles west of St. Louis County to Jackson County, Missouri: Am. Jour. Sci., 4th ser., vol. 49, pp. 267-278, 1 fig., April, 1920.

2. Devonian of Missouri (abstract) : Geol. Soc. America, Bull, vol. 32, no. 1, p. 35, March 31, 1921.

3. Geology of Costa Rica (abstract) : Geol. Soc. America, Bull., vol. 33, no. 1, p. 90, March $31,1922$.

4. (and Williams, James S.) Evolution of Stropheodonta demissa (Conrad) in the Snyder Creek shales of Missouri (abstract): Geol. Soc. America, Bull., vol. 34, no. 1, pp. 134-135, March 30, 1923.

5. The Devonian of Missouri: Missouri Bur. Geology and Mines, $2 d$ ser., vol. 17,279 pp., 10 figs., 79 pls., map [1924].

6. Paleozoic formation margins in Missouri: Am. Jour. Sci., 5th ser., vol. 8, pp. 317-322, 1 fig., October, 1924.

7. Course of the Gunnisor River in Colorado (abstract) : Geol. Soc. America, Bull., vol. 36, no. 1, p. 139, March 30, 1925 ; Pan-Am. Geologist, vol. 43, no. 1, p. 80, February, 1925.

8. (and Williams, J. S.) Relationship of upper Devonian and lower Mis sissippian faunas of Missouri (abstract): Geol. Soc. America Bull., vol. 36, no. 1. pp. 216-217, March 30, 1925. 
Branson, Edwin Bayer-Continued.

9. Origin and development of stream valleys (abstract) : Pan-Am. Geologist, vol. 45, no. 2, p. 173, March, 1926.

10. Mississippian series of Missouri (abstract) : Pan-Am. Geologist, vol. 45, no. 2, p. 174, March, 1926.

11. Correlation of Mississippian section of Rocky Mountain States and Mississippi Valley States (abstract) : Pan-Am. Geologist, vol, 45, no. 3, p. 248, April, 1926.

12. Old shore lines and origin of oil (abstract) : Pan-Am. Geologist, vol. 45, no. 3, p. 252, April, 1926.

13. Near shore conditions important in locating petroleum deposits: Oil and Gas Jour., vol. 24, no. 45, pp. 94, 96, April 1, 1926.

14. Red beds of Arizona, New Mexico, Colorado, Utah, and Wyoming (abstract) : Geol. Soc. America, Bull., vol. 38, no. 1, p. 137, March 30, 1927 ; Pan-Am. Geologist, vol. 47, no. 1, pp. 78-79, February, 1927.

15. Valley development (abstract) : Geol. Soc. America, Bull., vol. 38, no. 1; p. 140, March 30, 1927 ; Pan-Am. Geologist, vol. 47, no. 1, p. 80, February, 1927.

16. Devonian of Missouri, Illinois, and Iowa (abstract) : Geol. Soc. America, Bull., vol. 38, no. 1, p. 226, March 30, 1927 ; Pan-Am. Geologist, vol. 47, no. 3, p. 237, April, 1927 .

17. Triassic-Jurassic "red beds" of the Rocky Mountain region: Jour. Geology, vol. 35, no. 7, pp. 607-630, 3 figs., October-November, 1927.

18. Some observations on the geography and geology of middle-eastern Costa Rica : Missouri, Univ., Studies, vol. 3, no. 1, pp. 27-72, 30 figs., January $1,1.928$.

19. (and Mehl, M. G.). Triassic vertebrate fossils from Wyoming: Science, new ser., vol. 67, pp. 325-326, March 23, 1928.

20: (and Tarr, W. A.). New types of columnar and buttress structures: Geol. Soc. America, Bull., vol. 39, no. 4, pp. 1149-1156, 2 pls., December 30 , 1928. Columnar structures in limestone compared with buttress structures in volcanic agglomerate (abstract): Geol. Soc. America, Bull., vol. 39, no. 1, p. 225, March 30, 1928.

21. (and Mehl, M. G.). Auditory organs of some labyrinthodonts: Geol. Soc. America, Bull., vol. 39, no. 2, pp. 485-489, 2 figs., June, 1928; abstract, no. 1, p. 301, March 30, 1928.

Brantley, J. Edward.

1. Petroleum possibilities of Alabama ; Part II, Coastal Plain area : Alabama, Geol. Survey Bull. no. 22, pp. 121-220, 5 pls., 1 fig., 1920.

2. Résumé of the geology of the Gulf Coastal Plain: Am. Assoc. Petroleum Geologists, Bull., vol. 8, no. 1, pp. 21-28, January-February, 1924.

Braun, J. G.

1. Alunite in south central Texas: Eng. and Min. Jour., vol. 111, no. 5, p. 225, January 29, 1921.

Bray, Harriet G. See also Moon, 1.

1. (and Emery, Alden H.). Mineralization along the dikes of southern Vermont: Ohio Jour. Sci., vol. 23, no. 2, pp. 83-88, March-April, 1923.

Breeze, Frederick J.

1. Abandoned channels in Randolph and Delaware counties, Indiana : Indiana Acad. Sci., Proc. 38th Ann. Meeting, 1922, pp. 95-98, 1 fig., 1923. 
Breger, Carpel Leventhal.

1. Bacter.a, ores, and oil deposits : Eng. and Min. Jour.-Press, vol. 116, no. 1. pp. 4-5, July 7, 1923.

Bremer, Bernard. See Twenhofel, 32.

Bretz, J. Harlen. See also Johnston, W. A., 5.

1. The late Pleistocene submergence in the Columbia Valley of Oregon and Washington: Jour. Geology, vol. 27, no. 7, pp. 489-506, 2 figs., October-November, 1919.

2. The Juan de Fuca lobe of the Cordilleran ice sheet; Jour. Geology, vol. 28, no. 4, pp. 333-339, 1 fig., May-June, 1920.

3. Stratigraphic problems in the Columbia Valley between Snake River and Willamette River (abstract) : Geol. Soc. America, Bull., vol. 32, no. 1, pp. 36-37, March 31, 1921.

4. Geology and mineral resources of the Kings quadrangle: Illinois State Geol. Survey, Bull. no. 43, pp. 205-304, 34 figs., 3 pls. (incl. map), 1923.

5. Glacial drainage on the Columbia Plateau (with discussion by M. M. Leighton and O. E. Meinzer) ; Geol. Soc. America, Bull., vol. 34, no. 3, pp. 573-608, 12 figs., September 30, 1923.

6. The channeled scablands of the Columbia Plateau: Jour. Geology, vol. 31, no. 8, pp. 617-649,, 13 figs., 1 pl. (map), November-December, 1923.

7. The Dallas type of river channel: Jour. Geology, vol. 32, no. 2, pp. 139149, 8 figs., February-March, 1924.

8. Modern conceptions of earth history: Sci. Monthly, vol. 18, no. 3, pp. 239-256, March, 1924.

9. The age of the Spokane glaciation: Am. Jour. Sci., 5th ser., vol. 8, pp. 336-342, 1 fig., October, 1924.

10. The Spokane flood beyond the channeled scablands: Jour. Geology, vol. 33, no. 2, pp. 97-115, February-March, no. 3, pp. 236-259, 17 figs., April-May, 1925 ; abstract, Geol. Soc. America, Bull., vol. 36, no. 1, p. 144, March 30, 1925 ; Pan-Am. Geologist, vol. 43, no. 2, p. 146, March, 1925 .

11. The origin of man: Illino:s State Acad. Sci., Trans., vol. 19, pp. 61-85, 1926.

12. Geological processes and the earth's history. In The nature of the world and of man, pp. 56-84, $1 \mathrm{pl} ., 1$ insert (table of earth history), University of Chicago Press, 1926.

13. What caused the Spokane flood? (abstract) : Geol: Soc. America, Bull., vol. 38, no. 1, p. 107, March 30 , 1927 ; Pan-Am. Geologist,; vol. 47, no. 1, p. 64, February, 1927.

14. Channeled scabland and the Spokane flood (abstract with discussion by W. C. Alden, James Gilluly, E. T. McKnight, G. R. Mansfield, O. E. Meinzer, and J. T. Pardee).: Washington Acad. Sci., Jour., vol. 17, no. 8, pp. 200-211, April 19, 1927.

15. The Spokane flood; a reply [origin of physiographic features, Washington] : Jour. Geology, vol. 35, no. 5, pp. 461-468, July-August, 1927. [See also McKnight, 1.]

16. Bars of channeled scabland (abstract) : Geol. Soc. America, Bull., vol. 39, no. 1, pp. 159-160, March 30, 1928; Pan-Am. Geologist, vol. 49, n? 1, p. 71 , February, 1928. 
Bretz, J. Harlen-Continued.

17. Alternative hypotheses for channeled scabland [Washington] : Jour. Geology, vol. 36, no. 3, pp. 193-223, 6 figs., April-May, 1928; no. 4, pp. 312-341, 4 figs., May-June, 1928.

18. The channeled scabland of eastern Washington: Geog. Rev., vol. 18, no. 3, pp. 446-477, 27 figs., map, July, 1928.

19. Bars of channeled scabland [Washington] : Geol. Soc. America, Bull., vol. 39, no. 3, pp. 643-701, 16 figs., 6 pls., September 30, 1928.

Brewer, Charles, jr.

1. Genetic relationship of oil reservoirs to shore line deposits: Am. Assoc. Petroleum Geologists, Bull., vol. 12, no. 6, pp. 597-615, 6 figs., June, 1928.

Brewer, William Morten.

1. Taseko Valley iron ore deposits: British Columbia, Minister of Mines, Ann. Rept. 1919, pp. 241-251, 1920.

2. Some ore deposits of the Coast Range [British Columbia]: Canadian Inst. Min. and Met., Monthly Bull., no. 127, pp. 1176-1191, November, 1922 ; Trans., vol. 25, pp. 183-198 [1923].

3. Mineral resources tributary to the coast section of the Pacific Great Eastern Railway : Canadian Inst. Min. and Met., Bull. no. 160, pp. 798808, 1 fig., 1 pl., August, 1925; Trans., vol. 28, pp. 387-397, 1 fig. [1926].

Brewster, Edwin Tenney.

1. This puzzling planet, the earth's unfinished story; how men have read it in the past, and how the wayfarer may read it now. 328 pp., illus., Indianapolis, Bobbs-Merrill Company, c. 1928.

Bridenstine, I. J. See North, Lloyd, 1.

Bridge, Josiah. See also Drake, C. L., 10, 13.

1. (and Charles, B. E.). A Devonian outlier near the crest of the Ozark uplift: Jour. Geology, vol. 30, no. 6, pp. 450-458, 3 figs., September-October, 1922.

2. Ebb and flow springs in the Ozarks: Missouri, Univ., School of Mines and Metallurgy, Bull., pp. 17-26, 6 figs., 3 pls., November, 1923.

Bridgman, P. W.

1. The thermal conductivity and compressibility of several rocks under high pressures: Am. Jour. Sci., 5th ser., vol. 7, pp. 81-102, 4 figs., February, 1924.

Brigham, Albert Perry.

1. Cape Cod and the old colony: Geog. Rev., vol. 10, no. 1, pp. 1-22, 1 fig., July, 1920.

2. Memoir of Frederick Valentine Emerson: Assoc. Am. Geographers, Annals, vol. 10, pp. 149-152 [1921?].

3. The Appalachian Valley: Scottish Geog. Mag., vol. 40, no. 4, pp. 218-230, July 15, 1924.

4. Geology ; revised and expanded by Frederick A. Burt. 544 pp., 313 figs., New York, D. Appleton and Company, 1928.

Brinsmade, Robert Bruce.

1. Mining districts near Zimapan, Hidalgo, Mexico: Min. and Sci. Press, vol. 123, no. 9, pp. 293-297, 3 figs., August 27, 1921. 
Britton, W. E.

1. Twelfth biennial report of the Commissioners of the State Geological and Natural History Survey of Connecticut, 1925-26: Connecticut, State Geol. and Nat. Hist. Survey, Bull. no. 38, 23, pp., 1 pl., 1927.

Broadhead, G. C. See Boone County Hist. Soc.

Brock, Reginald Walter.

1. Eutsuk Lake district [British Columbia]: Canada, Geol. Survey, Summ. Rept, 1920, pt. A, pp. 81-94, 1 fig., 1921.

2. The education of a geologist: Econ. Geology, vol. 18, no. 6, pp. 595-597, September, 1923.

3. Physiography of Canada: Pan-Pacific Sci. Cong., Australia, 1923, Proc., vol, 1 , pp. $686-692,1$ fig. [1924].

4. Structure of the Pacific region of Canada: Pan-Pacific Sci. Cong., Australia, 1923, Proc., vol: 1, pp. 776-783, 1 fig. (map) [1924].

5. Ore deposits of the Pacific region of Canada: Pan-Pacific Sci. Cong., Australia, 1923, Proc., vol. 1, pp. 815-820, 1 fig. (map) [1924].

6. Petroleum provinces of Canada: Pan-Pacific Sci. Cong., Australia, 1923, Proc., vol. 2, pp. 1168-1173 [1924].

7. Conditions affecting mining in British Columbia : Canadian Inst. Min. and Met., Monthly Bull. no. 149, pp. 597-607, September, 1924.

8. Scientific ore finding: Econ. Geology, vol. 19, no. 7, pp. 674-676, November, 1924.

9. Miller, the geologist: Canadian Min. Jour., vol. 46, no. 9, February 27, 1925.

10. Success [eulogy of W. G. Miller] : Econ. Geology, vol. 20, no. 8, pp. 762765, December, 1925.

11. (and Malcolm, Wyatt). Geological formation [of Canada]: Canada Yearbook, 1925, pp. 16-23, 2 figs. (maps), Canada, Dominion Bureau of Statistics, General Statistics Branch, Ottawa, 1926.

12. W. Lawrence Uglow : Roy. Soc. Canada, Proc. and Trans., $3 d$ ser., vol. 21, pp. $\mathrm{x}-\mathrm{xl}$, portr., 1927 .

13. (and Schofield, S. J.) Geological history and metallogenetic epochs in western Cordillera of Canada: Third Pan-Pacific Sci. Cong., Tokyo, 1926, Proc., pp. 591-606, 1928.

14. Volcanoes of the Canadian Cordillera: Third Pan-Pacific Sci. Cong., Tokyo, 1926, Proc., pp. 688-710, 4 figs., 1928.

Brockway, E. R.

1. (and Owens, H. J.). Notes on the area lying between the northwestern edge of the Arbuckle Mountains and the Wildhorse sandstone: Oklahoma Acad. Sci., Proc., vol. 3 (Oklahoma, Univ., Bull., new ser. no. 271), pp. 95-96, October 1, 1923.

Broderick, Thomas Monteith. See also Ball, S. H., 1; Grout, F. F., 3, 4.

1. Some of the relations of magnetite and hematite: Econ. Geology, vol. 14, no. 5, pp. 353-366, 2 pls., 2 figs., August, 1919.

2. Detail stratigraphy of the Biwabik iron-bearing formation, east Mesabi district, Minnesota: Econ. Geology, vol. 14, no. 6, pp. 441-451. 2 pls., September-October, 1919.

3. Economic geology and stratigraphy of the Gunflint iron district, Minnesota : Econ. Geology, yol, 15, no. 5, pp. 422-452, 2 figs., JulyAugust, 1920. 
Broderick, Thomas Monteith-Continued.

4. (and Hohl, C. D.). Geophysical methods applied to exploration and geologic mapping in the Michigan copper clistrict: Econ. Geology, vol. 23 , no. 5, pp. 489-514, August, 1928.

Brodie, Walter M.

1. Coqu na, the shell rock of Florida: Min. and Sci. Press, vol. 119, pp. 193194, 2 figs., August 9, 1919.

2. Curious coal deposits in Missouri: Coal Age, vol. 16, pp. 876-881, 20 figs., December 11 and 18, 1919.

Brøgger, W. C.

1. Mindetale over Prof. Dr. Joseph Paxson Iddings: Videnskapsselskapet i Kristiania, Forh., aar 1921, pp. 45-50, 1922.

Brokaw, Albert Dudley.

1. Interpretation of so-called paraffin dirt of Gulf coast oil fields (with discussion by W. E. Wrather, E. G. Woodruff, Lee Hager, W. G. Matteson, E. W. Shaw) : Am. Inst. Min. and Met. Eng., Trans., vol. 61 , pp. $482-500,1920$.

Brooks, Alfred Hulse, 1871-1924. See also Williams, M. Y., 16.

1. The appl.cation of geology to war (abstract): Washington Acad. Sci., Jour., vol. 10, no. 11, pp. 331-333, June 4, 1920.

2. The future of Alaska mining: U. S. Geol. Survey, Bull. 714, pp. 5-57, 1 fig., 3 pls. (incl. map), 1921. Abstract, Washington Acad. Sci., Jour., vol. 11, no. 12, pp. 282-283, June 19, 1921.

3. (and Martin, G. C.). The Alaskan mining industry in 1919: U. S. Geol. Survey, Bull. 714, pp. 59-95, 1.921.

4. (and Martin, G. C.). Administrative report [mineral resuurces of Alaska, 1919] : U. S. Geol. Survey, Bull. 714, pp. 97-103, 1921.

5. (and Martin, G. C.). Gold, silver, copper, and lead in Alaska in 1919: U. S. Geol. Survey, Mineral Resources, 1919, pt. 1, pp. 227-233, April 25, 1921.

6. The geological survey of Alaska: Pan-Pacific Scientific Conference, First, Proc., Bernice P. Bishop Mus., Spec. Pub. no. 7, pt. 3, pp. 683-688, 1 fig., 1921.

7. Note on the Tertiary geology of Alaska: Pan-Pacific Scientific Conference, First, Proc., Bernice P. Bishop Mus., Spec. Pub. no. 7, pt. 3, pp. $797-800,1921$.

8. The Alaska mining industry in 1920: U. S. Geol. Survey, Bull. 722, pp. 7-67, 1921.

9. The Alaskan mining industry in 1921: U.. S. Geol. Survey, Bull. 739, pp. $1-50,1922$.

10. A petroleum seepage near Anchorage [Alaska]: U. S. Geol. Survey, Bull. 739, pp. 133-135, 1922 .

11. The scientist in $^{*}$ the Federal service: Washington Acad. Sci., Jour:, vol. 12 , no. 4 , pp. 73-115, February 19, 1922.

12. Gold, silver, copper, and lead in Alaska in 1920 ; mines report: U. S' Geol. Survey, Mineral Resources, 1920, pt. 1, pp. 441-446, April 24, 1922.

13. (and Capps, Stephen R.): The Alaska mining industry in 1922: U. S, Geol. Survey: Bull, 755 , pp. 3-49, 1923.

14. (and Capps, S. R.): Gold, silver, copper; and lead in Alaska (mines report): U. S. Geol. Survey, Mineral Resources, 1922, pt. 1, pp. $637-642,1925$. 
Brooks, Alfred Hulse-Continued.

15. Alaska's mineral resources and production, 1923: U. S. Geol. Survey, Bull. 773 , pp. 3-52, 1925.

16. Mireral resources of Alaska, 1923; Administrative report: U. S. Geol. Survey, Bull. 773, pp. 63-69, 1925.

Brooks, Betty Watt.

1. A new species of fossil hackberry (Celtis) from the "Loup Fork" Miocene of Phillips County, Kansas: Carnegie Mus., Annals, vol. 18, nos. 2-4, pp. 299-304, 1 pl. June, 1928.

Brooks, William Keith, 1848-1908.

1. Most critical episode in evolution: Pan-Am. Geologist, vol. 37, no. 2, pp. 121-130, March, 1922.

Broom, Robert.

1. On the classification of the reptiles: Am. Mus. Nat. Hist., Bull., vol. 51, pp. 39-65, 13 figs., September 17, 1924.

2. Further evidence on the structure of the Eosuchia: Am. Mus. Nat. Hist., Bull., vol. 51, pp. 67-76, 4 figs., September 17, 1924.

Brouwer, Hendrik Albertus.

1. The horizontal movement of geanticlines and the fractures near their surface: Jour. Geology, vol. 29, no. 6, pp. 560-577, 8 figs., September-October, 1921.

2. Some similarities between the geology of California and parts of the Dutch East Indies: Science, new ser., vol. 56, pp. 388-389, October $6,1922$.

3. The movement of the central Atlantic ridge: Science, new ser., vol. 57, p. 235, February 23, 1923.

4. Production of trachyte and phonolite from pyroxene andesitic magma associated with limestone: Jour. Geology, vol. 36 , no. 16, pp. 545548, August-September, 1928.

Brown, Barnum. See also Matthew, 23, 27 ; Tait, 1.

1. (and O'Connell, Marjorie). Discovery of the Oxfordian in western Cuba (abstract) : Geol. Soc. America, Bull., vol. 30, p. 152, March 31, 1919.

2. (and O'Connell, Marjorie). Correlation of the Jurassic formations of western Cuba: Geol. Soc. America, Bull., vol. 33, no. 3, pp. 639664,15 figs., September 30,1922 ; abstract with discussion by T. W. Vaughan and C. Schuchert, vol. 33, no. 1, pp. 159-160, March 31, 1922.

Brown, Charles Wilson. See also Goldthwait, 1; Wentworth, 36.

1. Field experiment in isostasy (abstract with discussion by W. M. Davis) : Geol. Soc. America, Bull., vol. 31, no. 1, p. 114, March 31, 1920.

2. Postglacial river changes in Rhode Island and continental tilt (abstract with discussion by J. B. Woodworth) : Geol. Soc. America, Bull., vol. 31, no. 1, pp. 114-115, March 31, 1920.

3. (and Gedney, Edwin K.). Problems connected with a unique occurrence of syenite in New England (abstract) : Geol. Soc. America, Bull., vol. 39, no. 1, p. 162, March 30, 1928; Pan-Am. Geologist, vol. 49, no. 1, p. 72, February, 1928.

Brown, Ernest William.

1. The age of the earth from the point of view of astronomy: Am. Philos. Šc., Proc., vol. 61, no. 4, pp. 283-285, 1922. 
Brown, Ernest William-Continued.

2. Tidal oscillations in Halemaumau, the lava pit of Kilauea: Am. Jour. Sci., 5th ser., vol. 9, pp. 7-112, 4 figs., February, 1925.

3. Tides in lava (abstract with discussion) : Washington Acad. Sci., Jour., vol. 15, no. 18, pp. 421-422, November 4, 1925; Bull. volcanologique, $2^{\mathbf{e}}$ ann., nos. 5-6, p. 333, 1925.

4. The evidences for changes in the rate of rotation of the earth and their geophysical consequences: Nat. Acad. Sci., Proc., vol. 12, no. 6, pp. 406-412, June, 1926; abstract, Science, new ser., vol. 63, p. 484, May 7, 1926.

Brown, George Granger.

1. Clays and shales of Michigan and their uses: Michigan, Geol. Survey, Pub. 36, geol. ser. 30, 444 pp., 69 figs., 41 pls. (incl. map) [1926].

Brown, G. H. See Ries, 5.

Brown, I. O. See Hager, D. S., 1.

Brown, John Stafford. See also Dake, 12 ; Woodring, 5.

1. Fault features of Salton Basin, California: Jour. Geology, vol. 30, no. 3, pp. 217-226, 1 fig., 1 pl. (map), April-May, 1922. Abstract, Washington Acad. Sci., Jour., vol. 11, no. 17, p. 423, October 19, 1921.

2. Relation of sea water to ground water along coasts: Am. Jour. Sci., 5th ser., vol. 4, pp. 274-294, 7 figs., October, 1922.

3. The Salton Sea region, California; a geographic, geologic, and hydrologic reconnaissance, with a guide to desert watering places: U. S. Geol. Survey, Water-Supply Paper 497, 292 pp., 18 figs., 19 pls. (incl. maps, 1923.

4. The hot springs of the Republic of Haiti: Jour. Geology, vol. 32, no. 5, pp. 384-399, July-August, 1924.

5. A study of coastal ground water with special reference to Connecticut: U. S. Geol. Survey, Water-Supply Paper 537, 101 pp., 20 figs., 7 pls., 1925.

6. Graphite deposits of Ashland, Alabama: Econ. Geology, vol. 20, no. 3, pp. 208-248, 2 figs. (incl. map), 2 pls., May, 1925.

7. The Nixon Fork country [Alaska] : U. S. Geol. Survey, Bull, 783, pp. 97-144, 3 figs., 2 pls. (maps), 1926.

8. Silver-lead prospects near Ruby [Alaska]: U. S. Geol. Survey, Bull. 783, pp. 145-150, 1 fig., 1926.

9. Ground water in the New Haven area, Connecticut: U. S. Geol. Survey, Water-Supply Paper 540, 206 pp., 19 figs., 15 pls., 1928.

Brown, Levi S.

1. The occurrence of leucoxene in some of the Permian Mid-Continent sediments : Am. Mineralogist, vol. 13, no. 6, pp. 233-235, June, 1928.

Brown, Ralph, $\mathrm{H}$.

1. A "Blue Ridge" in New England: Am. Jour. Sci., 5th ser., vol. 6, pp. 15-21, 2 figs., July, 1923.

Brown, Robert Wesley.

1. Origin of the folds of Osage County, Oklahoma: Am. Assoc. Petroleum Geologists, Bull., vol. 12, no. 5, pp. 501-513, 1 fig., May, 1928.

2. Occurrence of folds of the Osage type (discussion) : Am. Assoc. Petroleum Geologists, Bull., vol. 12, no. 6, pp. 675-677, June, 1928. 
Brown, Robert Wesley-Continued.

3. Exporiments relating to factors causing localization of folds: Am. Assoc. Petroleum Geologists, Bull., vol. 12, no. 6, pp. 617-623, 7 figs., June, 1928.

4. Experiments relating to the results of horizontal faulting: Am. Assoc. Petroleum Geologists, Bull., vol. 12, no. 7, pp. 715-720, July, 1928.

Brown, Samuel Boardman, 1860-1926.

1. The terraces along the Monongahela River: West Virginia Acad. Sci., Proc., vol. 1, no. 1 (W. Va. Univ. Bull., ser. no. 27 , no. 1), pp. 46-47, August, 1926.

Brown, Samuel C.

1. Notes on minerals from the Bedford, New York, Westchester County quarry: Am. Mineralogist, vol. 12, no. 9, ‥ 354, September, 1927.

Brown, Thomas Clachar.

1. Flooding of oil wells by fresh water (abstract) : Geol. Soc. America, Bull., vol. 32, no. 1, pp. 67-68, March 31, 1921.

2. Climatic conditions when coal beds were formed (abstract): Pan-Am. Geologist, vol. 49, no. 2, p. 151, March, 1928; Geol. Soc. America, Bull., vol. 39, no. 1, p. 223, March 30, 1928.

Brown, W. Horatio.

1. A probable fossil glacier: Jour. Geology, vol. 33, no. 4, pp. 464-466, 1 fig., May-June, 1925.

2. Geological section along Rio de San Lorenzo in Sinaloa, Mexico: Eng. and Min. Jour.-Press, vol. 120, no. 18, pp. 691, 779, 1 fig., October 31, 1925.

3. The mineral zones of the White Cross district and neighboring deposits in Hinsdale County, Colorado: Colorado School of Mines Mag., vol. 15, no. 11, pp. 5-15, 5 figs., March, 1926.

4. A note on the occurrence of alaskaite: Am. Mineralogist, vol. 12, no. 1, pp. 21-23, 1 fig., January, 1927.

Browning, C. P.

1. Canadian copper and its production: Canadian Min. and Met. Bull., no. 184, pp. 944-972, 12 figs., August, 1927; Canadian Inst. Min. and Met., Trans., vol. 30, pp. 194-224, 12 figs. [1928] ; Second (Triennial) Empire Min. and Met. Congress, Canada, 1927, Proc., pt. 1, pp. 601-631, 12 figs., 1928.

Browning, Iley Baker. See also Kentucky Geological Survey.

1. (and Russell, Philip G.). Coals and structure of Magoffin County, Kentucky: Kentucky Geol. Survey, Fourth Series; vol. 5, pt. 2, 552 pp., 2 maps, 1919.

Browning, W. C.

1. (and Snow, F. W.). Geology and operations of the Magma mine [Superior district, Pinal County, Arizona] : Eng. and Min. Jour.-Press, vol. 119, no. 5, pp. 197-201, 4 figs., January 31, 1925.

Bruce, Everend Lester. See also Alcock, 13.

1. Athapapuskow Lake district, Manitoba: Canada, Geol. Survey, Summ. Rept., 1918, pt. D, pp. 1-2, 1919.

2. The district lying between Reed Lake and Elbow Lake, Manitoba: Canada, Geol. Survey, Summ. Rept., 1918, pt. D, pp. 2-5, 1919.

$4096-31-6$. 
Bruce, Everend Lester-Continued.

3. Gold quartz veins and scheelite deposits in southeastern Manitoba: Canada, Geol. Survey, Summ. Rept., 1918, pt. D, pp. 11-15, 1920.

4. Knee Lake district, northeastern Manitoba: Canada, Geol. Survey, Summ. Rept., 1919, pt. D, pp. 1-11, 2 figs., 1920.

5. Chalcopyrite deposits in northern Manitoba: Econ. Geology, vol. 15, no. 5, pp. 386-397, 1 pl., 2 figs., July-August, 1920.

6. The possibility of the use of sea planes in preliminary mapping of preCambrian areas: Canadian Inst. Mir. and Met., Monthly Bull, no. 118, pp. 224-229, February, 1922.

7. The early pre-Cambrian formations of northern Ontario and northern Manitoba: Jour. Geology, vol. 30, no. 6, pp. 459-471, 1 fig., September-October, 1922.

8. Iron formation of Lake St. Joseph : Ontario Dept. Mines, 31st Ann. Rept., vol. 31 , pt. 8, pp. 1-32, 12 figs., map, 1923.

9. Eastern part of Lake St. Joseph: Ontario Dept. Mines, 31st Ann. Rept., vol. 31, pt. 8, pp. 33-38, 4 figs., map, 1923.

10. Area south of the west end of Lake St. Joseph: Ontario Dept. Mines, 31.st Ann. Rept., vol. 31, pt.' 8, pp. 39-40, 1923.

11. Geology of the upper part of the English River valley: Ontario Dept. Mines, 33d Ann. Rept., vol. 33, pt. 4, pp. 1-11, 1 fig., map, 1924.

12. Geology of the basin of Red Lake, District of Patricia: Ontario Dept. Mines, 83d Ann. Rept., vol. 33, pt. 4, pp. 12-39, 11 figs., map, 1924.

13. Mineral possibilities of northern Saskatchewan: Canadian Min. Jour.. vol. 45, no. 26, pp. 618-621, 8 figs., June 27, 1924.

14. (and Greenland, C. W.). A low iron epidote from Porcupine [Ontario] : Am. Mineralogist, vol. 9, no. 10, pp. 199-201, 1 fig., October, 1924.

15. The Coutchiching rocks of the Bear's Pass section, Rainy Lake [Ontario] : Roy. Soc. Canada, Proc. and Trans., 3d ser., vol. 19, sec. 4, pp. 43-46, 1 pl., 1925.

16. Future of the Ontario iron deposits: Canadian Min. Jour., vol. 46, no. 3, pp. 71-75, 1 fig., January 16, 1925.

17. Gold deposits of Kenora and Rainy River districts : Ontario Dept. Mines, 34th Ann. Rept., vol..34, pt. 6, pp. 1-42, illus., map, 1925; in part, Canadian Min. Jour., vol. 47, no. 8, pp. 181-185, 7 figs., February 19 ; no. 11, pp. 264-265, 1 fig., March 12, 1926.

18. Red Lake area of Patricia [Ontario]: Canadian Inst. Min. and Met., Bull., no. 166, pp. 256-269, 6 pls., February, 1926; discussion by Geo. W. Bain, R. E. Hore, W. Lindgren, J. J. O'Neill, and others, no. 169, pp. 662-670, May, 1926; (with discussion) Trans. vol. 29, pp. $196-219,7$ pls. [1927].

19. Geology of McArthur, Bartlett, Douglas, and Geikie townships (Redstone River area), District of Timiskaming: Ontario Dept. Mines, 35th Ann. Rept., vol. 35, pt. 6, pp. 37-56, 4 figs., map, 1927.

20. (and Light, Margaret). Barytocelestite from the Kingden lead mines, Galetta, Ontario : Am. Mineralogist, vol. 12, no. 11, pp. 296-398, November, 1927.

21. Coutchiching delta: Geol. Soc. America, Bull., vol. 38, no. 4, pp. 771-781, 1 fig., December 30, 1927; abstract no. 1, p. 121, March 30, 1927; Pan-Am. Geologist, vol. 47, no. 1, p. 70, February, 1927.

22. (and Hawley, J. E.). Geology of the Basin of Red Lake, District of Kenora (Patricia portion) : Ontario Dept. Mines, 36th Ann. Rept., vol. 36, pt. 3, pp. 1-72, illus., map, 1928. 
Bruce, Everend Lester-Continued.

23. Geology of the Red Lake and Woman Lake gold areas, northwestern Ontario: Am. Inst. Min. and Met. Eng., Tech. Pub. no. 107, 14 pp., 5 figs., March, 1928; Trans., vol. 76, pp. 362-377, 5 figs., 1928; abstract, Mining and Metallurgy, vol. 9, p. 148, March, 1928; extract, Min. Mag., vol. 38, no. 4, pp. 250-252, 1 fig., April, 1928.

Brucks, Ernest W.

1. The Luling field, Caldwell and Guadalupe Counties, Texas: Am. Assoc. Petroleum Geologists, Bull., vol. 9, no. 3, pp. 632-654, 7 figs., 1 pl., May-June, 1925.

2. The geology of San Marcos quadrangle, Texas: Am. Assoc. Petroleum Geologists, Bull., vol. 1.1, no. 8, pp. 825-851, 6 figs. (incl. map), August, 1927.

Brückner, Eduard.

1. Geochronologische Untersuchungen über die Dauer der Postglacialzeit in Schweden, in Finnland und in Nordamerika: Zeitschr. Gletscherkunde, Bd. 12, H. 1-2, pp. 39-57, July, 1921.

2. Forschungen über das diluviale Klima in Mexiko: Zeitschr. Gletscherkunde, Bd. 15, H. 4-5, pp. 286-289, November, 1927.

Brues, Charles Thomas.

1. Ancient insects; fossils in amber and other deposits: Sci. Monthly, vol. 17, no. 4, pp. 289-304, 13 figs., October, 1923.

Bruhl, Paul T.

1. Gold in McDuffie County, Georgia : Eng. and Min. Jour., vol. 110, no. $€$, p. 265, August 7, 1920.

Brumell, Henry Peareth $\cdot \mathrm{H}$.

1. Graphite in Quebec and Alabama; a comparison: Canadian Min. Inst., Bull. no. 88, pp. 858-860, August, 1919 ; Trans., vol. 22, pp. 378-405, 9 figs. [1920].

2. Graphite in Quebec, Canada: Eng. and Min. Jour., vol. 109, pp. 548-550, February 28, 1920.

Bruntọ, Stopford. See also Reid, J. A., 2.

1. Deroche. Hodgins, Gaudette, and Shields townships, Algoma district, Ontario: Canada, Geol. Survey, Summ. Rept., 1921, pt. D, pp. 27-33, map, 1922.

2. Jamaica, its geology and mining possibilities: Min. Mag., vol. 26, no. 4, pp. 203-208, 1 fig. (map), April, 1922.

3. The west coast of Newfoundland: Min. Mag., vol. 27, no. 5, pp. 265-273, 5 figs., November, 1922.

4. Gowganda silver district. [Ontario]: Canadian Min. Jour., vol. 45, no. 19, pp. 452-453, 4 figs., May 9, 1924.

5. Gold mining in Nova Scotia: Canadian Min. Jour., vol, 45, no. 20, pp. 475476, 1 fig., May 16, 1924.

6. Nova Scotian geology; new facts elicited by petrographical investigation: Canadian Min. Jour., vol. 45, no. 29, pp. 689-693, 15 figs. (incl. map), July 18, 1924.

7. The gold fields of northwestern Quebec: Min. Mag., vol. 31, no. 3, pp. 137-146, 8 figs., September, 1924.

8. Minerals in Jamaica: Canadian Min. Jour,, Y९l, 45, no. 51, pp. 1236-1241, 2 figs., December 19, 1924, 
Brunton, Stopford-Continued.

9. Nova Scotian geology: Mịn. Mag., vol. 31, no. 6, pp. 339-342, 1 fig. December, 1924.

10. The gold deposits of Nova Scotia; a new hypothesis concerning the structural features of the province: Inst. Min. and Met., Bull. no. 258, 18 pp. 2 figs., 5 pls. (incl. map), March, 1926; (with discussion by J. Mackintosh Bell, H. C. Boydell, and others), Trans., vol. 35, pp. 356-389, 2 figs., 5 pls. (incl. map), 1926.

11. The gold deposits of Nova Scotia; an analysis of the history and present status and a hypothesis concerning the structural features of the province in relation to the deposition of gold: Canadian Inst. Min. and Met., Bull: no. 171, pp. 781-847, 29 figs., July, 1926; discussion, no. 175 , pp. 1171-1172, November, 1926 ; (with discussion) Trans., vol. 29, pp. 424-497, 29 figs. [1927].

12. Some observations on a so-called interbedded vein at Tangier, Nova Scotia : Canadian Min. and Met., Bull. no. 194, pp. 784-803, 55 figs., 1 pl., June, 1928.

13. A survey of certain gold districts in the Province of Nova Scotia : Nova Scotia, Dept. Public Works and Mines, Ann. Rept. Mines, 1927, pt. 2, pp. 223-759, map, 1928.

Bryan, Kirk. See also Longwell, 6; Meinzer, 15; Pardee, 11, 12 ; Twenhofel, $22,29$.

1. Habits of thought of a geologist applied to military problems (abstract) : Washington Acad. Sci., Jour., vol. 9, no. 15, pp. 452-453, September $19,1919$.

2. Classification of springs: Jour. Geology, vol. 27, no. 7, pp. 522-561, 23 flgs., October-November, 1919.

3. Geology and physiography of the Papago country, Arizona (abstract) : Washington Acad. Sci., Jour., vol. 10, no. 2, pp. 52-53, January $19,1920$.

4. Mountain pediments; a discussion of the erosion of desert ranges (abstract) : Geol. Soc. America, Bull. vol. 31, no. 1, p. 152, March 31, 1920.

5. Origin of rock tanks and charcos: Am. Jour. Sci., 4th ser., vol. 50, pp. 186-206, 12 figs., september, 1920.

6. The rôle of physiography in military operations: Sci. Monthly, vol. 11, no. 5, pp. 385-403, 3 figs., November, 1920.

7. Erosion and sedimentation in the Papago country, Arizona, with a sketch of the geology: U. S. Geol. Survey, Bull. 730, pp. 19-90, 22 figs., 5 pls. (incl. map), June $8,1922$.

8. Discussion on rock-fill dam, Lees Ferry, Arizona: Am. Soc. Civil Eng., Proc., vol. 48, no. 7, pp. 1615-1627, 5 figs., September, 1922.

9. The hot-water supply of the Hot Springs, Arkansas: Jour. Geology, vol. 30, no. 6, pp. 425-449, 5 figs., September-October, 1922.

10. Geology and ground-water resources of Sacramento Valley, California: U. S. Geol. Survey, Water-Supply Paper 495, 285 pp., 10 figs., 19 pls. (incl. maps), 1923.

11. [Geological features of the Lees Ferry, Arizona, dam site]: Am. Soc. Civil Eng., Trans., vol. 86, pp. 228-240, 5 figs. (incl. map), 1923.

12. Wind erosion near Lees Ferry, Arizona: Am. Jour. Sci., 5th ser, yol, 6, pp, 291-307, 4 figs., October, 1923. 
Bryan, Kirk-Continued.

13. Pedestal rocks in the arid Southwest: U. S. Geol. Survey, Bull. 760, pp. 1-11, 5 pls., December 15, 1923.

14. The hot springs of Arkansas: Jour. Geology, vol. 32, no. 6, pp. 449-459, August-September, 1924.

15. The Papago country, Arizona; a geographic, geologic, and hydrologic reconnaissance with a guide to desert watering places: U. S. Geol. Survey, Water-Supply Paper 499, 436 pp., 41 figs., 27 pls. (incl. maps), 1925.

16. Pedestal rocks: Eng. and Min. Jour.-Press, vol. 119, no. 4, pp. 172-173, January 24, 1925.

17. Pedestal rocks in stream channels: U. S. Geol. Survey, Bull, 760, pp. 123-128, 2 pls., April, 1925.

18. Date of channel trenching (arroyo cutting) in the arid Southwest: Science, new ser., vol. 62, pp. 338-344, October 16, 1925.

19. Ground water reconnaissance in Socorro County, New Mexico: New Mexico, State Engineer, 7th Bienn. Rept., pp. 77-87 [1926].

20. Ground water reconnaissance in De Baca County, New Mexico: New Mexico, State Engineer, 7th Bienn. Rept., pp. 88-102, 2 pls. [1926].

21. Recent deposits of Chaco Canyon, New Mexico, in relation to the life of prehistoric peoples of Pueblo Bonito (abstract): Washington Acad. Sci., Jour., vol. 16, no. 3, pp. 75-76, February 4, 1926.

22. San Pedro Valley, Arizona, and the geographic cycle (abstract) : Geol. Soc. America, Bull., vol. 37, no. 1, pp. 169-170, March 30, 1926: Pan-Am. Geologist, vol. 45, no. 2, p. 166, March, 1926.

23. (and Gidley, J. W.). Vertebrate fossils and their enclosing deposits from the shore of Pleistocene Lake Cochise, Arizona: Am. Jour. Sci., 5th ser., vol. 11, pp. 477-488, 2 figs., June, 1926.

24. Pedestal rocks formed by differential erosion: U. S. Geol. Survey, Bull. 790, pp. 1-15, 1 fig., 3 pls., November 27, 1926.

25. Channel erosion of the Rio Salado, Socorro County, New Mexico: U. S. Geol. Survey, Bull. 790, pp. 17-19, November 27, 1926.

26. The "Palouse soil" problem, with an account of elephant remains in wind-borne soil on the Columbia Plateau of Washington: U. S. Geol. Survey, Bull. 790, pp. 21-45, 4 pls., January 18, 1927.

27. The "Palouse soil" problem of the Columbia Plateau, Washington (abstract) : Washington Acad. Sci., Jour., vol. 17, no. 5, pp. 120-121, March 4, 1927.

28. (and La Rue, E. C.). Persistence of features in an arid landscape; the Navajo twins, Utah: Geog. Rev., vol. 17, no. 2, pp. 251-257, 8 figs., April, 1927.

29. (and Robinson, H. F.). Erosion and sedimentation on the Zuñi watershed, New Mexico: Geol. Soc. America, Bull., vol. 39, no. 1, pp. 158-159, March 30, 1928; Pan-Am. Geologist, vol. 49, no. 1, pp. 7071, February, 1928.

30. Historic evidence on changes in the channel of Rio Puerco, a tributary of the Rio Grande in New Mexico: Jour. Geology, vol. 36, no. 3, pp. 265-282, 2 figs., April-May, 1928.

31. Glacial climate in non-glaciated regions: Am. Jour. Sci., 5th ser., vol. 16, pp. 162-164, August, 1928.

32. State of New Mexico, Middle Rio Grande Conservancy district, geology of the State line dam site: New Mexico, State Eng., 8th Bienn. Rept., pp. 253-258 [1928]. 
Bryan, Kirk-Continued.

33. Niches and other cavities in sandstone at Chaco Canyon, New Mexico; Zeitschr. Geomorphologie, Bd. 3, H. 3, pp. 125-140, 8 pls., 1928.

34. Change in plant associations by change in ground-water level: Ecology, vol. 9, no. 4, pp. 474-478, October, 1928.

Bryan, L. L. See Stearns, 6.

Bryan, P. W.

1. Some geographical facturs in the northern Appalachian coal fie!d: Scottish Geog. Mag., vol. 36, no. 4, pp. 232-244, 4 figs., October 15, 1920.

Bryant, William L. See also Hussakof, 1.

1. On the structure of Eusthenopteron: Buffalo Soc. Nat. Sci., Bull., vol. 13, no. 1, pp. 1-59, 18 pls., 8 figs., 1919.

2. The Genesee conodonts: Buffalo Soc. Nat. Sei., Bull., vol. 13, no. 2, 59 pp., 7 figs., 16 pls., 1921.

3. A new species of Bothriolepis from the upper Devonian of Canada: Buffalo Soc. Nat. Sci., Bull., vol. 13, no. 3, pp. 54-55, 2 pls., 1924.

4. On the structure of Palaeaspis and on the occurrence in the United States of fossil fishes belonging to the family Pteraspidae: Am. Philos. Soc., Proc., vol. 65, no. 4, pp. 256-271, 3 figs., 4 pls., 1926.

5. Evidence of the presence of chordates in the Cambrian (abstract): Geol. Soc. America, Bull., vol. 37, no. 1, p. 236, March 30, 1926.

-6. Evidence of the presence of chordates in the Cambrian [Eoichthys howelli, St. Albans, Vermont] : Vermont, State Geologist, 15th Rept., 192526, pp. 125-126, 1 fig., 1927.

Bryson, Herman J.

1. The mineral industry in North Carolina for 1924 and 1925: North Carolina, Dept. Conservation and Development, Econ. Paper no. 60, 64 pp., 1927.

2. The mining industry in North Carolina during 1926: North Carolina, Dept. Conservation and Development, Econ. Paper no. 62. 63 pp., 1928.

3. The story of the geologic making of North Carolina: North Carolina, Dept. Conservation and Development, Educ. ser. no. 1, 42 pp., 11 pls. (incl. map), 1928.

Buchanan, George S.

1. Early Pennsylvanian "red beds" in the Mid-Continent region: Am. Assoc. Petroleum Geologists, Bull., vol. 9, no. 4, p. 814, July, 1925.

2. The distribution and correlation of the Mississippian of Oklahoma: Am. Assoc. Petroleum Geologists, Bull., vol. 11, no. 12, pp. 1307-1320, 6 figs., December, 1927.

Bucher, Walter Herman.

1. On ripples and related sedimentary surface forms and their paleogeographic interpretation: Am. Jour. Sci., 4th ser., vol. 47, pp. 149-210, 241-269, 15 tigs., March and April, 1919.

2. The mechanical interpretation of joints: Jour. Geology, vol. 28, no. 8, pp. 707-730, 9 figs., November-December, 1920 ; vol. 29 , no. 1, pp. 1-28, 11 figs., January-February, 1921 : abstract, Science, new ser., vol. 51, pp. 519-520, May 21, 1920.

3. Cryptovolcanic structure in Ohio of the type of the Steinheim Basin (abstract): Geol. Soc. America, Bull., vol. 32, no, 1, pp. 74--75, March 31, 1921. 
Bucher, Walter Herman-Continued.

4. Probable cause of the localization of the major geosynclines (abstract): Geol. Soc. America, Bull., vol. 32, no. 1, p. 75, March 31, 1921.

5. Logan's explanation of the origin of Indiana's "kaolin": Econ. Geology, vol. 16, no. 7, pp. 481-492, November, 1921.

6. Further experiments on the fracturing of hollow brittle spheres and their bearing on major diastrophism (abstract with discussion by $\mathrm{W} . \mathrm{H}$. Hobbs) : Geol. Soc. America, Bull., vol. 34, no. 1, pp. 81-82, March $30,1923$.

7. Jeptha Knobs of Shelby County (abstract) : Science, new ser., vol. 58, p. 184, September 7, 1923; Kentucky Acad. Sci., Trans., vol. 1, p. $140,1924$.

8. The pattern of the earth's mobile belts: Jour. Geology, vol. 32 ; no. 4, pp. 265-290, 16 figs., May-June, 1924.

9. Geology of Jeptha Knob: Kentucky Geol. Survey, ser. 6, vol. 21, pp. 193237, 11 figs., map, 1925.

10. Crypto-volcanic structures of Europe and America (abstract) : Geol. Soc. America, Bull, vol. 36, no. 1, p. 149, March 30, 1925; Pan-Am. Geologist, vol. 43, no. 2, pp. 148-149, March, 1925.

11. Ueber kryptovulkanische Erscheinungen in Ohio und Kentucky: Eclogae Geol. Helvetiae, vol. 19, no. 1, pp. 141-143, March, 1925.

12. Submarine denudation (abstract): Geol. Soc. America, Bull., vol. 37, no. 1, p. 143, March 30, 1926; Pan-Am. Geologist, vol. 45, no. 1, p. 91, February, 1926.

13. Subcrustal expansion as a possible factor in earth diastrophism (abstract): Kentucky Acad. Sci., Trans., vol. 2, pp. 130-131, 1927.

14. Two test cases of conjugate joint systems (abstract) : Geol. Soc. America, Bull., vol. 39, no. 1, p. 204, March 30, 1928; Pan-Am. Geologist, vol. 49, no. 2, pp. 155-156, March, 1928.

15. Ėolian versus subaqueous cross-bedding (abstract): Ohio Acad. Sci., Proc., vol. 8 , pt. 4, p. 180, 1928 ; Ohio Jour. Sci., vol. 28, no. 3, p. 158, May, 1928.

16. Cryptovolcanic regions (abstract) : Washington Acad. Sci., Jour., vol. 18, no. 19, pp. 521-524, November 19, 1928.

Buddington, Arthur Francis. See also Ferguson, 4 ; Smyth, 2.

1. Report on the pyrite and pyrrhotite veins in Jefferson and St. Lawrence counties, New York: New York State Defense Council, Bull. no. 1, 40 pp., 4 pls., November, 1917.

2. Foliation of the gneissoid syenite-granite complex of Lewis County, New York: New York State Mus. Bull., nos. 207, 208 (March-April, 1918), pp. 101-110, 6 pls. (incl. map), 1919.

3. Pre-Cambrian rocks of southeast Newfoundland: Jour. Geology, vol. 27, no. 6, pp. 449-479, 11 figs., September-October, 1919.

4. Mineral deposits of the Wrangell district, southeastern Alaska: U. S. Geol. Survey, Bull. 739, pp. 51-75, 4 figs., 1 pl. (map), 1922.

5. On some natural and synthetic melilites: Am. Jour. Sci., 5th ser., vol. 3, pp. 35-87, 11 figs. January, 1922.

6. An association of kaolinite with miarolitic structure: Jour. Geology, vol. 31, no. 2, pp. 149-151, February-March, 1923.

7. Alaskan nickel minerals: Econ. Geology, vol. 19, no. 6, pp. 521-541, 1 pl., September-October, 1924.

8. Mineral investigations in southeastern Alaska: U. S. Geol. Survey, Bull. 773, pp. 71-139, 5 figs., 2 pls. (maps), 1925. 
Buddington, Arthur Francis-Continued

9. Mineral investigations in southeastern Alaska: U. S. Geol. Survey, Bull. 783, pp. 41-62, 1 fig., 3 pls., 1926.

10. Submarine pillow lavas of southeastern Alaska: Jour. Geology, vol. 34, no. 8, pp. 824-828, November-December, 1926.

11. Abandoned marine benches in southeastern Alaska: Am. Jour. Sci., 5 ser., vol. 13, pp. 45-52, 5 figs., January, 1927.

12. Salmon River area in southeastern Alaska : Eng. and Min. Jour., vol. 123, no. 13, pp. 525-530, 3 figs., March 26, 1927.

13. Coincident variations of types of mineralization and of Coast Range intrusives [southeastern Alaska]: Econ. Geology, vol. 22, no. 2, pp. 158-179, 1 fig., March-April, 1927.

14. Coast Range intrusives of southeastern Alaska: Jour. Geology, vol. 35, no. 3, pp. 224-246, 2 figs., April-May, 1927.

15. What draws men into geology?: Science, new ser., vol. 68, pp. 112-113, August 13, 1928.

Budelman, Herman D.

1. Tonopah, Nevada's best-known silver district; Eng. and Min. Jour.-Press, vol. 118, no. 1, pp. 5-10, 5 figs. July 5, 1924.

Budge, W. E.

1. North Dakota clays: North Dakota, Univ., Departmental Bull., vol. 11, no. 1 (College of Engineering, Division of Mines and Mining Experiments, Bull. no. 9), pp. 38-45, 3 figs., January, 1926.

Budrow, L. R. See Mishler, 2.

Buehler, Henry Andrew. See also Boone County Hist. Soc., 1.

1. Biennial report of the State geologist . . . [1917-18] : Missouri Bur. Geology and Mines, 117 pp., 4 pls., (incl. 3 maps), 1919. [Mineral resources, pp. 33-112.]

2. Biennial report of the State geologist [for 1919-20]. 85 pp., 3 pls., Missouri Bur. Geology and Mines [1921].

3. Geological map of Missouri: Missouri, Bur. Geology and Mines, 1922. Scale 1:500,000. Revised; 1926 .

4. Biennial report of the State geologist .. . [work of the Bureau of Geology and Mines for 1921 and 1922]: Missouri Bur. Geology and Mines, 133 pp., 5 pls., map [1923].

5. Mineral resources of Missouri: The South's Development, Manufacturers Record, vol. 86, no. 24, pt. 2, pp. 393-396, 6 figs., December 11, 1924.

6. Biennial report of the State geologist [for the years 1923 and 1924]: Missouri, Bur. Geology and Mines, 143 pp. [1925].

7. Missouri Bureau of Geology and Mines [activities] : Pan-Am. Geologist, vol. 44, no. 4, pp. 323-325, November, 1925.

8. Biennial report of the State geologist: Missouri, Bur. Geology and Mines, 108 pp., 2 pls. [1927].

9. Recent activities of Missouri Bureau of Geology and Mines: Pan-Am. Geologist, vol. 48, no. 1, pp. 77-80, August, 1927.

Buerger, M. J. See also Newhouse, 7.

1. Note on a method of oblique illumination: Am. Jour. Sci., 5th ser., vol. 13, pp. 262-263, March, 1927.

2. Optical notes on some of the variable contact minerals from Edenville, New York; Am. Mineralogist, vol. 12, no. 10, pp. 374-378, October, 1927. 
Buerger, M. J.-Continued.

3. The plastic deformation of ore minerals, a preliminary investigation: galena, sphalerite, chalcopyrite, pyrrhotite, and pyrite: Am. Mineralogist, vol. 13, no. 1, pp. 1-17, January, no. 2, pp. 35-51, 20 figs., February, 1928.

Buffam, B. S. W.

1. Destor area, Abitibi County, Quebec: Canada, Geol. Survey, Summ. Rept., 1925, pt. C, pp. 82-104, 1 fig., 1 pl., map, 1927.

Bullard, Fred M. See also Bybee, 3.

1. Notes on the paleontology of the Comanchean of Love County, Oklahoma: Oklahoma Acad. Sci., Proc., vol. 3 (Oklahoma, Univ.; Bull., new ser. no. 271), pp. 88-91, October 1, 1923.

2. Geology of Love County, Oklahoma : Oklahoma Geol. Survey, Bull. no. 33, 77 pp., 1 fig. 29 pls. (incl. map), January, 1925.

3. Geology of Marshall County, Oklahoma: Oklahoma Geol, Survey, Bull. no. 39, 101 pp., 5 figs., 21 pls. (incl. maps), April, 1926.

4. Lower Cretaceous of western Oklahoma; a study of the outlying areas of Lower Cretaceous in Oklahoma and adjacent States: Oklahoma Geol Survey, Bull. no. 47, 116 pp., 7 figs., 11 pls. (incl. maps), October, 1928.

Bump, James D.

1. A huge fossil fish [Portheus, from near Hot Springs, South Dakota]: Black Hills Engineer, vol. 14, no. 2, pp. 99-101, 1 fig., March, 1926.

Bunn, John R. See George, H. C., 2 ; Tomlinson, 4.

Burbank, Wilbur S. See also Woodring, 5.

1. Additional data on the properties of pumpellyite and its occurrence in the Republic of Haiti, West Indies: Am. Mineralogist, vol. 12, no. 12 , pp. 421-424, December, 1927.

2. Preliminary report on some thrust-faulting involving the Paleozoic formations in the Kerber Creek region of southern Colorado (abstract) : Geol. Soc. America, Bull., vol. 39, no. 1, pp. 172-173, March 30, 1928; Pan-Am. Geologist, vol. 49, no. 1, p. 78, February, 1928.

Burch, Albert.

1. (and Burchard, Ernest F.). Minerales de cromo y de manganeso en Cuba: Cuba, Direccion Montes y Minas, Bol. Minas no. 5, pp. 41-56, 1919.

2. (and Burchard, E. F.). Chrome and manganese ores in Cuba: Cuba, Direccion Montes y Minas, Bol. Minas no. 5, pp. 57-70, 1919.

Burchard, Ernest Francis. See also Allen, R. C., 2; Burch, 1, 2; Stone, 11.

1. Cement in 1917: U. S. Geol. Survey, Mineral Resources, 1917, pt. 2, pp. 343-380, 3 figs., February 4, 1919.

2. Iron ore, pig iron, and steel in 1917 : U. S. Geol. Survey, Mineral Resources, 1917, pt. 1, pp. 557-603, 4 figs., April 28, 1919.

3. Manganese ore deposits of Cuba (abstract) : Washington Acad. Sci., Jour., vol. 9, no. 13, pp. 385-386, July 19, 1919.

4. Chrome-ore deposits in Cuba : Am. Inst. Min. and Met. Eng., Bull. no. 153, pp. 2523-2546, 7 figs., September, 1919 ; Trans., vol. 63, pp. 150174, 8 figs., 1920. Discussion, Mining and Metallurgy, no. 157, p. 39, January, 1920. 
Burchard, Ernest Francis-Continued.

5. Fluorspar and cryolite in 1918: U. S. Geol. Survey, Mineral Resources, 1918, pt. 2, pp. 317-329, 2 figs., December 9, 1919.

6. Marble resources of southeastern Alaska; with a section on the geography and geology by Theodore Chapin: U. S. Geol. Survey, Bull. 682, 118 pp., 26 pls. (incl. maps), 6 figs., 1920.

7. Manganese ore deposits in Cuba: Am. Inst. Mìn. and Met. Eng., Trans., vol. 63, pp. 51-104, 26 figs. 1920: (abstract), Bull. no. 147, pp. 591-595, March, 1919.

8. Cement in 1918: U. S. Geol. Survey, Mineral Resources, 1918, pt. 2, pp. 565-589, 3 figs., April 9, 1920.

9. Iron ore, pig iron, and steel in 1918: U. S. Geol. Survey, Mineral Resources, 1918, pt. 1, pp. 527-584, 5 figs., April 20, 1920.

10. Chromite and chromiferous iron ore in Cuba: U. S. Geol. Survey, Mineral Resources, 1918, pt. 1, pp. 716-725, May 15, 1920.

11. Cement in 1919: U. S. Geol. Survey, Mineral Resources, 1919, pt. 2, pp. 387-404, September 21, 1921.

12. Iron ore, pig iron, and steel in 1919 : U. S. Geol. Survey, Mineral Resources, 1919, pt. 1, pp. 621-652, 1 fig., October 14, 1921.

13. (and Davis, H. W.). Iron ore, pig iron, and steel in 1920: U. S. Geol. Survey, Mineral Resources, 1920, pt. 1, pp. 365-399, 4 figs., January $23,1922$.

14. Cement in 1920: U. S. Geol. Survey, Mineral Resources, 1920, pt. 2, pp. 263-282, 2 figs., 1 pl. (map), March 7, 1922.

15. (and Davis, Hubert W.). Iron ore, pig iron, and steel in 1921: U. S. Geol. Survey, Mineral Resources, 1921, pt. 1, pp. 565-597, 4 figs., April 23, 1923.

16. (and Davis, Hubert W.). Iron ore, pig iron, and steel in 1922: U. S. Geöl. Survey, Mineral Resources, 1922, pt. 1, pp. 341-376, 4 figs., January 25, 1924.

17. Bauxite associated with siderite: Geol. Soc. America, Bull., vol. 35, no. 3 , pp. 437-448, September 30,1924 ; abstract, vol. 35 , no. 1, p. 109, March 30, 1924; Pan-Am. Geologist, vol. 41, no. 2, pp. 153-154, March, 1924.

18. Iron-ore resources of the South: The South's Development, Manufacturers Record, vol. 86, no. 24, pt. 2 pp. 283-289, 1 fig., December 11, 1924.

19. (and Bagley, B. W.). Cement in 1923: U. S. Geol. Survey, Bull. 750, Mineral Resources, 1923, pt. 2, pp. 293-325, 1 fig., 1 pl. (map), December 26, 1924.

20. Bauxite in northeastern Mississippi: U. S. Geol. Survey, Bull. 750, pp. 101-146, 3 figs., January 9, 1925.

21. (and Davis, Hubert W.). Iron ore, pig iron, and steel in 1923: U. S. Geol. Survey, Mineral Resources, 1923, pt. 1, pp. 295-329, 4 figs., January 22, 1925.

22. (and Davis, Hubert W.) Iron ore, pig iron, and steel in 1924: U. S. Bur. Mines, Mineral Resources U. S., 1924, pt. 1, pp. 297-333, 4 figs., May 14, 1926.

23. The iron-ore situation in the South: U. S. Geol. Survey [Press Notice], 10 pp., March, 1927 (mimeographed). Reprinted under title, Alabama ores equal lake supply: Iron Age, vol. 119, no. 12, pp. 847-850, March 24, 1927.

24. The western Tennessee Valley iron region: Manufacturers Record, vol. 92, no: 3, pp. 69-73, 6 figs., July 21, 1927. 
Burchard, Ernest Francis-Continued.

25. The brown iron ores of west-middle Tennessee: U. S. Geol. Survey, Bull. 795 , pp. 53-112, 4 figs., 5 pls., October $20,1927$.

26. Certain brown iron ores in Alabama (discussion): Econ. Geology, vol. 23, no. 4, pp. 454-458, June-July, 1928.

27. Iron-ore reserves and production in Tennessee River basin: U. S., 70th Cong., 1st sess., H. R. Doc. no. 185, pp. 118-119, 1928.

28. Types of manganese deposits: Am. Manganese Producers Assoc., Proc. 1st Ann. Convention, pp. 108-111., Washington, 1928.

Burckhardt, Carlos.

1. Faunas jurásicas de Symon (Zacatecas) y faunas cretácicas de Zumpango del Río (Guerrero) : Mexico, Inst. geol., Bol. no. 33, t. 1, 135 pp., 1919, t. 2 (atlas), 30 pls., 1921.

2. Faunas del Aptiano de Nazas, Durango: Mexico, Inst. geol., Bol. no. 45, 71 pp., 10 pls., 1925.

3. Cefalópodas del jurásico medio de Oaxaca y Guerrero: Mexico, Inst. geol., Bol. no. 47, 108 pp., 34 pls., 1927.

Burden, Douglas.

1. Niznaz Boko, the Great Hole in the Ground: Natural History (Am. Mus. Nat. Hist., Jour.), vol. 26, no. 6, pp. 627-634, 9 figs., NovemberDecember, 1926.

Burkhalter, Edward.

1. The variety of clays of Washington and their adaptability to ceramic industry: Am. Ceram. Soc., Bull., vol. 11, no. 8, pp. 236-239, August, 1928.

Burling, Lancaster Demorest.

1. Graptolite localities of western North America, with description of two new formation names (abstract): Geol. Soc. America, Bull., vol 32 , no. 1, pp. 127-128, March 31, 1921.

2. Cambro-Ordovician section near Mount Robson, western Canada (abstract) : Geol. Soc. Amęrica, Bull., vol. 33, no. 1, pp. 108-109, March 31, 1922.

3. The relations between the Purcell Range and the Rocky Mountains in British Columbia, Canada: Am. Jour. Sci., 5th ser., vol. 3, pp. 254-256, April, 1922.

4. A Cambro-Ordovician section in the Beaverfoot Range, near Golden, British Columbia: Geol. Mag., vol., 59, pp. 452-461, October, 1922.

5. Cambro-Ordovician section near Mount Robson, British Columbia: Geol. Soc. America, Bull., vol. 34, no. 4, pp. 721-748, December 30, 1923.

6. The origin of petroleum: Min. and Geol. Inst. India, Trans., vol. 18, pt. 3, pp. 119-167, May, vol. 19, pt. 2, pp. 171-173, November, 1924.

Burr, Freeman F.

1. Report [on the economic geology of Maine] : Maine, Public Utilities Commission, Second Ann. Rept. for 1916, pp. 17-103, 1 fig., 15 pls., Waterville, 1917.

2. Report [on mineral resources of Maine]: Maine Water Power Comm., First Ann. Rept., pp. 112-131, Augusta, Maine, 1920.

Burrard, Sidney.

1. Folding of mountain ranges-the argument from isostasy: Geol. Soc. America, Bull., vol. 33, no. 2, pp. 333-336, June 30, 1922. 
Burroughs, Elizabeth Harding.

1. Bibliography of petroleum and allied substances in $1916:$ U. S. Bur. Mines, Bull. 165, 159 pp., 1919.

2. Bibliography of petroleum and allied substances, 1917: U. S. Bur. Mines, Bull. 180, 170 pp., 1920.

3. Bibliography of petroleum and allied substances in 1918: U. S. Bur. Mines, Bull. 189, 180 pp., 1921.

4. Bibliography of petroleum and allied substances in 1919 and 1920: U. S. Bur. Mines, Bull. 216, 374 pp., 1923.

5. Bibliography of petroleum and allied substances, 1921: U. S. Bur. Mines, Bull. 220, 230 pp., 1923.

Burroughs, Reginald W.

1. Development of diatomaceous earth in Nova Scotia: Canadian Min. and Met. Bull., no. 196, pp. 973-988, 6 figs., August, 1928.

Burroughs, Wilbur Greeley.

1. A Pottsville-filled channel in the Mississippian: Kentucky Geol. Survey, ser. 6, vol. 10, pp. 115-126, 2 figs., map, 1923.

2. The geography of the western Kentucky coal field: Kentucky Geol. Survey, ser. 6, vol. 24, 211 pp., 21 figs., 50 pls., 1924 [c. 1925].

3. Activities of geological surveys in Southern States: Eng. and Min. Jour.Press, vol. 120, no. 9, p. 350, August 29, 1925.

4. The geography of the Kentucky Knobs: Kentucky Geol. Survey, ser. 6, vol. 19, 284 pp., 56 figs., 1926.

5. Geology of the Berea region: Kentucky Geol. Survey, ser. 6, vol. 26, pp. 155-208, 19 figs., 1927.

Burrows, Alfred Granville. See also Knight, C. W., 1.

1. (and Knight, C. W.). Lightning River gold area and a remarkable series series of lava flows [Ontario]: Canadian Min. Jour., vol. 40, pp. 83-86, February 12, 1919.

2. Matachewan gold area: Ontario Dept. Mines, 29th Ann. Rept., vol 29, pt. 3, pp. 53-64, 10 figs., 1920.

3. Gowganda silver area: Ontario Dêpt. Mines, 29th Ann. Rept., vol. 29, pt. 3, pp. 77-88, 4 figs., map, 1920.

4. (and Hopkins, P. E.). Kirkland Lake gold area (second report) : Ontario Dept. Mines, 29th Ann. Rept., vol. 29, pt. 4, 53 pp., illus., 2 maps, 1920.

5. Memorandum on part of the Goudreau gold area [Ontario]: Canadian Min. Jour., vol. 42, no. 31, pp. 621-622, August 5, 1921.

6. Gowganda and other silver areas: Ontario Dept. Mines, 30th Ann. Rept., vol. 30, pt. 3, 54 pp., figs. and maps, 1922.

7. Notes on the Goudreau gold area: Ontario Dept. Mines, 30th Ann. Rept., vol. 30, pt. 4, pp. 39-44, 4 figs., 1922.

8. (and Hopkins, P. E.). Boston-Skead gold area (second report) : Ontario Dept. Mines, 30th Ann. Rept., vol. 30, pt. 6, pp. 1-26, 8 figs., map, 1922.

9. (and Hopkins, P. E.). Blanche River area: Ontario Dept. Mines, 31st Ann. Rept., vol. 31, pt. 3, 22 pp., illus., map, 1922.

10. Porcupine gold deposits [Ontario]: Candian Min. Jour., vol. 44, no. 33, pp. 641-645, 5 figs., August 17, 1923.

11. The Porcupine area [Ontario]: Mining and Metallurgy, vol. 4, no. 201, pp. 474-475, September, 1923: 
Burrows, Alfred Granville-Continued.

12. (and Hopkins, P. E.). Kirkland Lake gold area : Ontario Dept. Mines, 32d Ann. Rept., vol. 32, pt. 4, pp. 1-52, illus., 1925.

13. The Porcupine gold area: Ontario Dept. Mines, 33d Ann. Rept., vol. 33. pt. 2, pp. 1-84, illus., map, 1925.

14. Recent mining developments in Ontario: Canadian Inst. Min. and Met., Bull., no. 156, pp. 351-366, 1 fig., April, 1925.

15. The Porcupine porphyry stocks [Ontario]: Canadian Min. Jour., vol. 46, no. 26, pp. 632-633, 3 figs., June 26, 1925.

16. Occurrence of gold near Beardmore, Ontario: Canadian Min. Jour., vol. 46 , no. 36 , pp. 839-840, September 4, 1925.

17. Gowganda silver area: Ontario Dept. Mines, 35th Ann. Rept., vol. 35, pt. 3, pp. 1-61, illus., map, 1926.

18. Silver deposits of Gowganda area: Canadian Min. Jour., vol. 47, no. 50, pp. 1167-1169, 8 figs., December 10, 1926.

Burt, Frederick A.

1. Soil mineralogy; a discussion of mineralogy in its application to soil studies. 82 pp., 6 figs., New York, D. Van Nostrand Company, 1927.

2. Genesis of quicksand deposits: Pan-Am. Geologist, vol. 47, no. 3, pp. 226228, April, 1927.

3. The quicksands of Brazos County, Texas: Jour. Geology, vol. 35, no. 7, pp. 663-669, 4 figs., October-November, 1927.

4. Geology in engineering training: Pan-Am. Geologist, vol. 48, no. 5, pp. 353358, December, 1927.

5. Melikaria; vein complexes resembling septaria veins in form: Jour. Geology, vol. 36, no. 6, pp. 539-544, 2 figs., August-September, 192\%

Burton, Eli Franklin.

1. Some of the physico-chemical properties of colloidal solutions and their relation to geological processes (abstract); Science, new ser., vol. 56, p. 175, August 11, 1922.

Burton, Fred R. See Dresser, 4.

Burton, George Edgar. See also Tomlinson, 4.

1. Design for logmeter: Am. Assoc. Petroleum Geologists, Bull., vol. 3, pp. 332-333, 1 fig. 1919.

2. Relation of the base of the red beds to the oil pools in a portion of southern Oklahoma: Am. Assoc. Petroleum Geologists, Bull., vol. 5, no. 2, pp. 173-177, 1 fig. (with discussion, pp. 326-327), MarchApril, 1921.

Burton, W. D.

1. Ore deposition at Premier mine, British Colombia: Econ. Geology, vol. 21, no. 6, pp. 586-604, 2 figs., September, 1926.

Burwash, Edward Moore Jackson. See also Johnston, W. A., 5.

1. A geological reconnaissance into Patricia, including part of sixth meridian line, and Wenasaga, Birch Lake, and Trout Lake rivers: On. tario Dept. Mines, 29th Ann. Rept., vol. 29, pt. 1, pp. 157-192, 11 figs., 1920.

2. Geology of the Canadian Rockies: Canadian Alpine Jour., vol. 11, pp. 97-109, 2 pls., 1920.

3. Orogenic and physiographic history of the Rocky Mountain geosynclinal: Canadian Alpine Jour., vol. 11, pp. 110-120, 1 pl., 1920. 
Burwash, Edward Moore Jackson-Continued.

4. Glacial section at Ca'gary, Alberta (abstract) : Geol. Soc. America, Bull.. vol. 32, no. 1, p. 51, March 31, 1921.

5. The pre-Cambrian of western Patricia: Jour. Geology, vol. 30, no. 5, pp. 393-400, 1 fig., July-August, 1922.

6. Geology of Ontario-Manitoba boundary; from Winnipeg River to Bloodvein River, 1921: Ontario Dept. Mines, 32d Ann. Rept., vol. 32, pt. 2, pp. 1-47, 14 figs., map, 1923.

7. Earlier glaciations of northern Manitoba (abstract) : Pan-Am. Geologist. vol. 49, no. 2, pp. 148-149, 'March, 1928; Geol. Soc. America, Bull., vol. 39 , no. 1, pp. 219-220, March $30,1928$.

8. The Fort Hope gold area [Ontario]: Canadian Min. Jour., vol. 49, no. 44, pp. 893-895, 1 fig., November 2, 1928.

Burwell, Blair.

1. Carnotite mining in southwestern Colorado: Eng. and Min. Jour., vol. 110, no. 16, pp. 755-758, 7 figs., October 16, 1920.

Bush, Reed D.

1. Geological structure and subsurface conditions: [California State Min. Bur.], Report on Oil Possibilities underlying State Land at Vel!tura School for Girls, pp. 6-8, 3 figs., 2 pis., Sacramento, 1926.

Bushnell, T. M.

1. The derelopment of soil survey: Indiana Acad. Sci., Proc. 39th Ann. Meeting, 1923, vol. 33, pp. 69-72, 1924.

2. Notes on areal geology of Jasper County, Indiana: Indiana Acad. Sci., Proc., vol. 34, pp. 133-135, 1925.

3. Some geological features of Wayne County, Indiana: Indiana Acad. Sci., Proc., vol. 35, pp. 87-90, 2 figs., 1926.

4. Physiography of the Kankakee region: Indiana Acad. Sci., Proc., vol, 37, pp. 141-142, 1928.

Bustamante, Miguel.

1. Yacimientos petrolíferos en el distrito sur de la Baja California: México, Secretaría de Industria, Comercio y Trabajo, Departamento de Petróleo, 72 pp., 6 pls., 2 maps, 1921.

2. Informe sobre la geología y la existencia de los yacimientos petrolíferos en el distrito sur de la Baja California (costa del Pacífico) : Bol. Petróleo, vol. 11, no. 6, pp. 469-543, 8 pls. (incl. maps), June, 1921.

Butler, Bert Sylvenus. See also Dunlop, 1.

1. Relation of ore deposits to thrust faults in the central Wasatch region, Utah: Econ. Geology, vol. 14, no. 2, pp. 172-175, 1 pl., 1 fig., MarchApril, 1919.

2. Ore deposits of Utah: Eng. and Min. Jour., vol. 108, pp. 605-611, 641-645, 15 figs., October 11 and 18, 1919.

3. Primary (hypogene) sulphate minerals in ore deposits: Econ. Geology, vol. 14, no. 8, pp. 581-609, 2 figs., December, 1919.

4. (and Loughlin, G. F., and others). The ore deposits of Utah: U. S. Geol. Survey, Prof. Paper 111, 672 pp., 74 figs., 57 pls. (incl. maps), 1920.

5. Copper in 1917: U. S. Geol. Survey, Mineral Resources, 1917, pt. 1, pp. 723-796, 4 figs., 1 pl., March 13, 1920.

6. Copper in 1918: U. S. Geol. Survey, Mineral Resources, 1918, pt. 1, pp. 877-935, 3 figs., September 28, 1920. 
Butler, Bert Sylvenus-Continued.

7. (and others). Discussion of the deposits of native copper (abstract): Eng. and Min. Jour.-Press, vol. 115, no. 1, pp. 27-28, January 6, 1923.

8. A suggested explanation of the high ferric oxide content of limestone contact zones: Econ. Geology, vol. 18, no. 4, pp. 398-404, 1 fig., June-July, 1923.

9. Some relations between oxygen minerals and sulphur minerals in ore deposits: Econ. Geology, vol. 22, no. 3, pp. 233-245, 1 fig., May, 1927.

Butler, Gurdon Montague. See also Allen, M. A., 1, 3-5; Wilson, E. D., 3.

1. (and Allen, M. A.). Petroleum: Arizona Bur. Mines, Bull. no. 116, 45 pp., 8 figs., October 15, 1921; Arizona Min. Jour., vol. 5, no. 21, pp. 5-7, April 1; no. 22, pp. 5, 14-16, April 15; no. 24, pp. 8, 24-27, 8 figs., May 15, 1922.

2. (and Allen, M. A.). Uranium and radium: Arizona Bur. Mines, Bull. no. 117, 26 pp., December 1, 1921.

Butts, Charles. See also Weller, S., 1.

1. Geology and oil possibilities of the northern part of Overton County, Tennessee, and of adjoining parts of Clay, Pickett, and Fentress counties: Tennessee, State Geol. Survey, Bull. 24 ,(Pt. 2-A, Ann. Rept. 1919), 45 pp., 3 pls. (incl. map), 4 tigs., 1919.

2. Geology of Barren County, Kentucky : Kentucky, Dept. Geology and Forestry, Ser. V [of Ky. Geol. Survey], Mineral and Forest Resources of Kentucky, vol. 1, no. 3, pp. 147-177, 7 figs., map., October 1, 1919.

3. The Mississippian series of eastern Kentucky; a regional interpretation of the stratigraphic relations of the Subcarboniferous group based on new and detailed field examinations: Kentucky Geol. Survey, ser. 6, vol. 7, 188 pp., 7 figs., 81 pls., sections sheet, 1922.

4. The Loyalhanna limestone of southwestern Pennsylvania especially with regard to its age and correlation: Am. Jour. Sci., 5th ser., vol. 8, pp. 249-257, 4 figs., September, 1924.

5. Geology and mineral resources of the Equality-Shawneetown area (parts of Gallatin and Saline counties) : Illinois State Geol. Survey, Bull. no. 47,76 pp., 5 figs., 3 pls. (incl. maps), 1925. Revised edition of map (pl. I), 1928.

6. (and Nelson, Wilbur A.). Geology and mineral resources of the Crossville quadrangle, Tennessee: Tennessee, Dept. Educ., Div. Geology, Bull. 33-D, 41 pp., 1 flg., 12 pls. (incl. map), 1925.

7. Coal fields of Alabama: U. S., Bur. Mines, Tech. Paper 347, pp. 1-7, 1 fig., 1925 ; Alabama Geol. Survey, Bull. 31, pp. 1-7, 3 figs., 1926.

8. Geology of Alabama: The Paleozoic rocks: Alabama, Geol. Survey, Spec. Rept. no. 14, pp. 41-230, 4 figs., 74 pls., 1926.

9. Oil and gas possibilities at Early Grove, Scott County, Virginia: Virginia Geol. Survey, Bull. 27, 18 pp., 2 figs. (incl. map), 1927.

10. Fensters in the Cumberland overthrust block in southwestern Virginia: Virginia Geol. Survey, Bull. 28, 12 pp., 2 pls. (incl. nrap), 1927.

11. The Devonian of Alabama and the unconformity at its base (abstract) : Washington Acad. Sci., Jour., vol. 17, no. 5, pp. 128-129, March 4, 1927.

12. The Devonian of Alabama: Am. Jour. Sci., 5th ser., vol. 14, pp. 365-380, 3 flgs., November, 1927. 
Butts, Charles-Continued.

13. Description of the Bessemer and Vandiver quadrangles: U. S. Geol. Survey, Geol. Atlas, Bessemer-Vandiver folio, Alabama (no. 221), 22, [2] pp., 8 maps, 2 sheets of illus., 1927.

14. Memorial of Eugene Allen Smith: Geol. Soc. America, Bull., vol, 39, no. 1, pp. 51-65, portr., March 30, 1928.

15. Variations in Appalachian stratigraphy: Washington Acad. Sci., Jour., vol. 18, no. 13, pp. 357-380, 4 figs., July 19, 1928.

Buwalda, John Peter. See also Merriam, 25; Redwood, 1; Science Service, 3.

1. Fault system at the southern end of the Sierra Nevada, California (abstract) : Geol. Soc. America, Bull., vol. 31, no. 1, p. 127, March 31. 1920.

2. Oligocene Equidae in the Marsh collection (abstract) : Geol. Soc. America, Bull., vol. 21, no. 1, p. 224, March 31, 1920.

3. Tertiary history of the lower Snake River valley, southwestern Idaho (abstract) : Geol. Soc. America, Bull., vol. 32, no. 1, p. 71, March 31, 1921.

4. Report on oil and gas possibilities of eastern Oregon: Oregon Bur. Mines and Geology, Mineral Resources of Oregon, vol: 3, no. 2, 47 pp., 3 figs., July, 1921.

5. A preliminary reconnaissance of the gas and oil possibilities of southwestern and south-central Idaho: Idaho, Bur. Mines and Geology, Pamphlet no. 5, 10 pp., July, 1923. [Mimeographed.]

6. Proceedings of the twenty-second annual meeting of the Cordilleran section of the Geological Society of America, held at Berkeley, California, March 17, 1923: Geol. Soc. America, Bull., vol. 35, no. 1, pp. 161-168, March 30, 1924.

7. Even-crested ridges as evidences of former peneplanation (abstract) : Geol. Soc. America, Bull., vol. 35, no. 1, p. 167, March 30, 1924.

8. The age of the Payette formation and the old erosion surface in Idaho: Science, new ser., vol. 60, pp. 572-573, December 19, 1924.

9. Proceedings of the twenty-third annual meeting of the Cordilleran section of the Geological Society of America, held at Stanford University, California, May 2 and 3, 1924: Geol. Soc. America, Bull., vol. 36 , no. 1, pp. 199-210, March 30, 1925.

10. Proceedings of the twenty-fourth annual meeting of the Cordilleran section of the Geological Society of America, held at Berkeley, California, February 20 and 21, 1925: Geol. Soc. America, Bull., vol. 37 , no. 1, pp. 207-224, March $30,1926$.

11. Certain inferences regarding the nature of the movements along the Hayward fault zone [California] (abstract) : Geol. Soc. America, Bull., vol. 37, no. 1, p. 212, March 30, 1926.

12. Certain events in the interesting geological history of Oregon: Oregon, Univ., Commonwealth Rev., vols. 8-9, nos. 4 and 1, pp. 121-129, October-January, 1926-7.

13. [Report on paleontological research] : Carnegie Inst. Washington, Year Book no. 25, 1925-6, pp. 4-5, December, 1926.

14. Proceedings of the twenty-fifth annual meeting of the Cordilleran section of the Geological Society of America, held at Berkeley, California, January 29 and 30, 1926: Geol. Soc. America, Bull., vol. 38, no. 1, pp. 193-208, March 30, 1927.

15. Geological features of the John Day region, eastern Oregon (abstract) : Geol. Soc. America, Bull., vol. 38, no. 1, p. 155, March 30, 1927; Pan-Am. Geologist, vol. 47, no. 2, p. 154, March, 1927. 
Buwalda, John Peter-Continued.

16. Slope of Basin range faults and scarps (abstract) : Geol. Soc. America, Bull., vol. 38, no. 1, p. 206, March 30, 1927.

17. Pleistocene and recent topographic changes in the Pacific coast States: Nat. Research Council, Bull. no. 61, pp. 39-43, July, 1927.

18. Paleontological and geological investigations in the John Day region of eastern Oregon: Science, new ser., vol. 66 , pp. 135-136, August 5, 1927.

19. (and Moore, Bernard M.). Age of the "Satsop" and the Dalles formations of Oregon and Washington: Science, new ser., vol. 66, p. 236, September 9, 1927.

20. Proceedings of the twenty-sixth annual meeting of the Cordilleran section of the Geological Society of America, held at Los Angeles, California, January 28 and 29, 1927 : Geol. Soc. America, Bull, vol. 39, no. 1, p’p. 261-270, March 30, 1928.

21. Geological features of the John Day region, eastern Oregon (abstract) : Geol. Soc. America, Bull., vol. 39, no. 1, pp. 269-270, March 30, 1928.

22. Recent geological investigations in north-central Oregon (abstract) : PanAm. Geologist, vol. 49, no. 4, p. 305, May, 1928.

23. Neocene erosion surface in central Oregon (abstract) : Pan-Am. Geologist, vol. 49, no. 4, p. 311, May, 1928.

24. (and Moore, B. N). Age of Dalles bed and "Satsop" formation and history of Columbia River gorge (abstract) : Pan-Am. Geologist, vol. 49 , no. 4 , p. 313 , May, 1928.

25. Report of investigations; John Day region: Carnegie Inst. Washington, Year Book no. 27, 1927-28, p. 235, December, 1928.

Buzzard, G. A.

1. The mineral resources of the region about La Salle: Illinois State Acad. Sci., Trans, vol. 16, pp. 367-371, 1923.

Bybee, Halbert $\mathbf{P}$.

1. Some recent notes on the Thrall oil field of Williamson County, Texas: Am. Assoc. Petroleum Geologists, Bull., vol. 5, no. 6, pp. 657-660, November-December, 1921.

2. (and Short, R. T.). The Lytton Springs oil field: Texas, Univ., Bull., no. 2539, 69 pp, 3 figs., 9 pls. (incl. maps), December, 1925.

3. (and Bullard, Fred M.). The geology of Cooke County, Texas: Texas Univ., Bull., no. 2710, pp. 5-61, 6 figs., 10 pls. (incl. map), January, 1928.

Byerly, Perry, jr. See also Macelwane, 7, 8, 14.

1. Dispersion of energy without dispersion of frequencies in transverse elastic waves in the earth: Seismol. Soc. America, Bull., vol. 14, no. 2, pp. 91-135, 11 figs., June, 1924.

2. Notes on the intensity of the Santa Barbara earthquake between Santa Barbara and San Luis Obispo [California] : Seismol. Soc: America, Bull., vol. 15, no. 4, pp. 279-281, December, 1925.

3. The depth of focus of two recent earthquakes and the depth of the surface layer of the earth in California: Seismol. Soc. America, Bull., vol. 16, no. 1, pp. 1-9, 1 pl., March, 1926.

4. Tables of earthquake waves reflected at a discontinuity at a depth of fifty kilometers: Seismol. Soc. America, Bu'l., vol. 16, no. 1, pp. 10-14, March, 1926. 
Byerly, Perry, jr.-Continued.

5. A seismological note: Science, new ser., vol. 63, p. 307, March 19, 1926.

6. (and Mitchell, George D.). The registration of earthquakes at the Berkeley Station and at the Lick Observatory Station from April 1, 1924, to September 30, 1924: California, Univ., Seismographic Stations, Bull., vol. 2, no. 8, pp. 121-140, August 24, 1926.

7. (and Mitchell, George D.). The registration of earthquakes at the Berkeley Station and at the Lick Observatory Station, October 1, 1924, to March 31, 1925: California, Univ., Seismographic Stations, Bull., vol. 2, no. 9, pp. 141-154, September 23, 1926.

8. The measurement of time on seismograms: Seismol. Soc. America, Bull., vol. 16, no. 3, pp. 194-195, 2 figs., September, 1926.

9. The Montana earthquake of June 28, 1925, G. M. C. T.: Seismol. Soc. America, Bull., vol. 16, no. 4, pp. 209-265, 1 fig., 11 pls., December, 1926.

10. The registration of earthquakes at the Berkeley Station and at the Lick Observatory Station from April 1, 1925, to September 30, 1925: California, Univ., Seismographic Stations, Bull., vol. 2, no. 10, pp. 155-180, January 18, 1927.

11. 'The registration of earthquakes at the Berkeley Station and at Lick Observatory Station from October 1, 1925, to March 31, 1926: California, Univ., Seismogiaphic Stations, Bull., vol. 2, no. 11, pp. 181-199, January 18, 1927.

12. (and Jones, Austin E.). The registration of earthquakes at the Berkeley Station and at the Lick Observatory Station from April 1, 1926, to September 30, 1926: California, Univ., Seismographic Stations, Bull., vol. 2, no. 12, pp. 210-220, March 10, 1927.

13. Southern Nevada earthquake. of August 21, 1925, and California earthquake of July 19, 1925 (abstract) : Geol. Soc. America, Bull., vol. 38 , no. 1, pp. 205-206, March 30, 1927.

14. Seismic waves and the surface layers of the earth: Nat. Research Council, Bull. no. 61, pp. 88-90, July, 1927.

15. The Evergreen, California, earthquakes of July 19, 1925, and May 28, 1927: Seismol. Soc. America, Bull., vol. 17, no. 3, pp. 137-146, 2 figs., September, 1927.

16. (and Jones, Austin E.). The registration of earthquakes at the Berkeley Station and at the Lick Observatory Station from October 1, 1926, to March 31, 1927: California, Univ., Seismographic Stations, Bull., vol. 2, no. 13, pp. 221-250, October 18, 1927.

17. The registration of earthquakes at the Berkeley Station and at the Lick Observatory Station from April 1, 1927, to September 30, 1927: California, Univ., Seismographic Stations, Bull., vol. 2, no. 14, pp. 251-272, April 4, 1928.

18. (and Dyk, Karl). The registration of earthquakes at the Berkeley Station and at the Lick Observatory Station from October 1, 1927, to March 31, 1928: California, Univ., Seismographic Stations, Bull., vol. 2, no. 15, 273-300, August 3, 1928.

19. Nature of first motion of two earthquakes (abstract) : Pan.-Am. Geologist, vol. 49, no. 4, pp. 307-308, May, 1928.

Cabeen, Charles K. See Kerr, 5; Richardson, C. H., 5.

Cable, Emmett J.

1. Relation of the Wisconsin drift to the Iowan drift as revealed in Worth County: Iowa Acad. Sci., Proc. 1918, vol. 25, pp. 539-544, 5 figs. [1919]. 
Cable, Emmett J.-Continued.

2. The Iowan-Wisconsin border: Iowa Acad. Sci., Proc., vol. 26, pp. 399-404, 3 figs. [1920].

3. The deep well at Laurens, Pocahontas County: Iowa Acad. Sci., Proc., vol. 26 , p. 405 [1920].

4. Some phases of the Pleistocene of Iowa; with special reference to the Peorian interglacial epoch. Diss., University of Iowa, 65 pp., 27 figs. [Cedar Falls, Iowa, Wolverton Bros. Printing Co., 1921.]

5. A note on a sink hole [Pocahontas County, Iowa] : Iowa Acad. Sci., Proc., vol. 27, pp. 181-183, 3 figs. [1922].

6. A note of progress on the study of the Iowan-Wisconsin borders: Iowa Acad. Sci., Proc., vol. 27, pp. 184-186, 1 fig. [1922].

7.. Extension of Dakota sandstone into Cherokee County [Iowa] (abstract) : Pan-Am. Geologist, vol. 46, no. 5, pp. 401-402, December, 1926.

8. Pleistocene bone deposits at Cherokee, Iowa (abstract) : Pan-Am. Geologist, vol. 46, no. 5, p. 402, December, 1926.

9. The bone deposit at Cherokee [Iowa]: Iowa Acad. Sci., Proc., 1926, vol. 33, pp. 179-181, 4 figs. [1927].

10. Outcrop of Cretaceous sandstone in Cherokee County: Iowa Acad. Sci., Proc., 1927, vol. 34, pp. 243-245, 2 figs. [1928].

Cadman, W. K.

1. Phantograph model: Am. Assoc. Petroleum Geologists, Bull., vol. 10, no. 12, pp. 1300-1303, 1 fig., December, 1926.

2. The Golden Lanes of Greenwood County, Kansas: Am. Assoc. Petroleum Geologists, Bull., vol. 11, no. 11, pp. 1151-1172, 10 figs., 2 pls., November, 1927.

Cady, Gilbert Haven.

1. Lateral erosion in the upper Illinois Valley by the Chicago outlet (abstract) : Illinois Acad. Sci., Trans., vol. 9. p. 210 [1917].

2. The New Richmond sandstone of northern Illinois (abstract): Illinois Acad. Sci., Trans., vol. 9, p. 210 [1917].

3. Geology and mineral resources of the Hennepin and La Salle quadrangles: Illinois State Geol. Survey, Bull. no. 37, 136 pp., 6 pls. (incl. maps), 36 figs., 1919.

4. Coal resources of District $V$ (Saline and Gallatin counties): Illinois State Geol. Survey, Cooperative Mining Series, Bull. 19, 135 pp., 9 pls. (incl. maps), 22 figs., 1919.

5. Valuable pyrite in Illinois coal beds: Coal Age, vol. 16, pp. 136-140, 9 figs., July 24, 1919.

6. The structure of the La Salle anticline: Illinois State Geol. Survey, Bull. no. 36, pp. 85-179, 9 pls. (incl. maps), 9 figs., 1920.

7. Coal resources of District IV [Illinois] : Illinois State Geol. Survey, Cooperative Mining Series, Bull. 26, 247 pp., 31 figs., 8 pls. (incl. maps), 1921.

8. The Mllinois pyrite inventory of 1918: Illinois State Geol. Survey, Bull. no. 38 , pp. 427-431, map, 1922.

9. Low-sulphur coal in Illinois: Am. Inst. Min. and Met. Eng., Bull. no. 151, pp. 1113-1115, 1 fig., July, 1919; Trans., vol. 63, pp. 641-648, 1 fig., 1920 ; Illinois, State Geol. Survey, Bull. no. 38, pp. 433-434, 1 fig., 1922; discussion, Mining and Metallurgy, no. 157, sec. 12, pp. 34-39, January, 1920.

10. The microscope and the decadence of geology: Eng. and Min. Jour.Press, vol, 118, no. 8, pp. 303-304, August 23, 1924. 
Cady, Gilbert Haven-Continued.

11. Structure of parts of northeastern Williamson and western Saline counties: Illinois State Geol. Survey, Report of Investigations no. 2, 20 pp., 2 figs., 3 pls. (incl. maps), 1925.

12. The areal geology of Saline County: Illinois State Acad. Sci., Trans., vol. 19, pp. 250-272, 5 figs. (incl. maps), 1 pl., 1926.

13. Coal stripping possibilities in southern and southwestern Illinois: Illinois, State Geol. Survey, Cooperative Mining Series, Bull. 31, 59 pp., 2 figs., 8 pls. (maps), 1927.

1i. Stratigraphic subdivisions of Pennsylvanian system of Illinois (abstract) : Pan-Am. Geologist, vol. 47, no. 5, p. 372, June, 1927.

Cahen, Edward.

1. Selenium: Mineral Foote-Notes, vol. 3, no. 5, pp. 5-16, 5 figs., SeptemierOctober, 1919.

Cairnes, Clive Elmore.

1. Coquihalla area, British Columbia: Canada, Geol. Survey, summ. Rept., 1920, pt. A, pp. 23-41, 1 fig., 1921.

2. Geological explorations in Yale and Similkameen mining divisions, southwestern British Columbia: Canada, Geol. Survey, Summ. Rept., 1922, pt. A, pp. 88-126, 1 fig., 3 maps, 1 pl., 1923.

3. Lucky Four mining property, Cheam Range, British Columbia: Canada, Geol. Survey, Summ. Rept., 1922, pt. A, pp. 127-133, 1 pl., 1923.

4. Coquihalla area, British Columbia: Canada, Geol. Survey, Mem. 139, 187 pp., 8 figs., 10 pls., map, 1924.

5. Reconnaissance of Silver Creek, Skagit and Similkameen rivers, Yale district, B. C.: Canada, Geol. Survey, Summ. Rept., 1923, pt. A, pp. 46-80, 2 figs., 3 pls., map, 1924.

6. Hillsbar gold claims, Yale district, B. C.: Canada, Geol. Survey, Summ. Rept., 1923, pt. A, pp. 81-83, 1924.

7. An occurrence of nickel ore in Yale mining division, British Columbia : Canadian Min. Jour., vol. 45, no. 48, p. 1164, November 28, 1924.

8. Pemberton area, Lillooet district, British Columbia: Canada, Geol. Survey, Summ. Rept., 1924, pt. A, pp. 76-99, 1 pl., map, 1925.

9. Nickeliferous mineral deposit, Emory Creek, Yale mining division, British Columbia: Canada, Geol. Survey, Summ. Rept., 1924, pt. A, pp. 100-105, 3 pls., 1925.

10. Preliminary report on Slocan mining area, British Columbia: Canada, Geol. Survey, Summ. Rept., 1925, pt. A, pp. 182-221, 1926.

11. Alps-Alturas group, Slocan mining division, British Columbia: Canada, Geol. Survey, Summ. Rept., 1926, pt. A, pp. 45-51, 1 pl., 1927.

12. Obsiervations on Lillooet Valley, British Columbia, with particular reference to its geology and mineral deposits: Canadian Min. Jour., vol. 48, nos. 7 and 8, pp. 140-144, 162-166, 6 figs., February 18 and 25, 1927.

13. Notes on the mining industry in Slocan district, British Columbia, with special reference to the geology and mineral deposits of the Slocan mining area: Canadian Min. and Met. Bull., no. 178, pp. 179-200, 9 figs. (incl. maps), February, 1927; Canadian Inst. Min. and Met., Trans., vol. 30, pp. 252-273, 9 figs. (incl. maps) [1928].

('alhoun, Fred Harvey Hall.

1. Memorial of Patrick Hues Mell: Geol. Soc. America, Bull., vol. 30, pp. 43-47, portr., March 31, 1919. 
Calhoun, Fred Harvey Hall-Continued.

2. Mineral resources of South Carolina: The South's Development, Manufacturers Record, vol. 86, no. 24, pt. 2, pp. 410-411, December 11, 1924.

Callahan, William H. See Gillson, 10 ; Newhouse, 6.

Calkins, F. E.

1. Principles of copper deposits: Mining and Metallurgy, vol. 4, no. 202, pp. 507-512, October, 1923.

Calkins; Frank Cathcart. See also Butler, 4; Vaughan, 16.

1. Thrust faulting in the Cottonwood district, Wasatch Mountains, Utah (abstract): Washington Acad. Sci., Jour., vol. 11, no. 17, p. 422, October 19, 1921.

Calman, W. T.

1. Dr. C. D. Walcott's researches on the appendages of trilobites: Geol. Mag., new ser., dec. 6, vol. 6, pp. 359-363, 1 fig., 1 pl., August, 1919.

Calvache Dorado, Antonio.

1. El manganeso de Buejcito: Cuba, Dirección de montes y minas, Bol. minas, no. 7 , pp. 78-84, 1923.

2. Resumen de la historia de la minería de Cuba: Cuba, Dirección de montes y minas, Bol. minas, no. 8, pp. 22-35, August, 1925.

3. Reconocimiento geológico preliminar del terreno en que se construirán las distintas secciones del acueducto difinitivo para Santiago de Cuba: Cuba Dirección de montes y minas, Bol. minas, no. 8, pp. 36-44, 9 figs., August, 1925.

4. (and Allende, Roque). Informe geológico sobre el proyecto de acueducto para la ciudad de Santiago de Cuba: Cuba, Dirección de montes y minas, Bol. minas, no. 9, pp. 7-30, 16 figs., 1926.

5. Informe sobre una formación granítica proxima á Santiago de CubaReport about a granite bed near Santiago de Cuba. 14 pp., 3 pls., Oficina de ingeniería, Santiago de Cuba, 1926.

Calvert, William $\mathbf{R}$.

1. Gas at Farnham, Utah: Am. Assoc. Petroleum Geologists, Bull., vol. 7, no. 3, pp. 293-295, May-June, 1923.

2. Geologic features of Val Verde County, Texas, and adjacent area: Oil and Gas Jour., vol. 26, no. 36, pp. 81-82, 85, 1 fig., January 26, 1928.

Camacho, Heriberto.

1. Las aguas subterráneas en Tla aalapan, Dto. de Apan, E. de Hidalgo: Mexico, Inst. geol., Anales no. 8, pp. 5-23, 3 pls. (incl. maps), 1920.

‥ Informe acerca de las aguas subterráneas del Valle de Tecamachalco 0 Valsequillo, Estado de Puebla: Mexico, Inst. geol., Anales no. 8, pp. $25-38,8$ pls., 1920.

3. Ias aguas subterráneas del valle de Morelia, Estado de Michoacán: Mexico, Inst. geol., Anales, t. 2, nos. 1-3, pp. 5-17, 11 pls. (incl. map), 1925.

4. Apuntes acerca de la actividad del Popocatepetl en relación con la sismología : Mexico, Inst. geol., Anales, t. 2, nos. 1-3, pp. 38-67, 16 pls. (incl. map), 1925.

5. A funtes para la hidrología de la región sud-oriental del Estado de Querétaro: Mexico, Inst. geol., Anales, t. 2, nos. 1-3, pp. 68-88, 13 pls., 1.925. 
Cameron, Alan Emerson. See also Allan, 10.

1. Hay and Buffalo rivers, Great Slave Lake, and adjacent country [Mackenzie] : Canada, Geol. Survey, Summ. Rept., 1921, pt. B, pp. 1-44, map, 1922.

2. Postglacial lakes in the Mackenzie River basin, Northwest Territories, Canada: Jour. Geology, vol. 30, no. 5, pp. 337-353, 14 figs., JulyAugust, 1922.

Camp, Charles L.

1. Triassic Chinle formation in Southwest (abstract): Pan-Am. Geologist, vol. 49, no. 3, pp. 304-305, May, 1928.

Camp, Samuel H. See Richardson, C. H., 2.

Campbell, A. M.

1. A new deposit of high-potash feldspar in Ontario: Eng. and Min. Jour* Press, vol. 115, no. 22, pp. 979-980, 1 fig., June 2, 1923.

Campbell, C. M.

1. The Granby mines at Phoenix [British Columbia]; Canadian Min. Inst., Trans., vol. 22, pp. 155-179, 13 figs. [1920].

2. The Similkameen district of British Columbia: Eng. and Min. Jour., vol. 111, no. 17, pp. 702-705, 7 figs., April 23, 1921.

Campbell, Donald G.

1. Palladium in Alaskan lode deposits: Min. and Sci. Press, vol. 119, pp. 520-522, 2 figs., October 11, 1919.

Campbell, E. E.

1. The Hidden Creek mine and its operations [Granby Bay, British Columbia ] : Canadian Min. Inst., Trans., vol. 22, pp. 135-154, 12 figs., [1920].

2. Mineral occurrences in the Stewart district [British Columbia] : Canadian Min. Inst., Monthly Bull., no. 95, pp. 220-224, March, 1920; Trans., vol. 23, pp. 391-395 [1921].

Campbell, Ian.

1. (and Miller, A. D.). Nepheline basalt in Richland Parish gas field, Louisiana: Am. Assoc. Petroleum Geologists, Bull., vol. 12, no. 10, pp. 985-993, 3 figs., 1 pl., October, 1928.

Campbell, J. Morrow.

1. The profession of ore hunting: Econ. Geology, vol. 17, no. 2, pp. 139-141, March-April, 1922.

2. Origin of the iron formation of the Mesabi range (discussion): Econ. Geology, vol. 18, no. 2, pp. 195-197, March, 1923.

3. Genesis of igneous ore deposits: Econ. Geology, vol. 20, no. 5, pp. 491-495, August, 1925.

Campbell, Marius Robinson. See also Eby, 5 ; LaForge, 4.

1. Character of coal in the Thomas bed near Harrison, West Virginia : U. S. Geol. Survey, Bull. 716, pp. 239-241, February 18, 1921.

2. Origin of the scenic features of the Glacier National Park [Montana]. 42 pp., 23 figs., map, National Park Service, Washington, D. C., 1921.

3. Guidebook of the western United States; Part E, The Denver \& Rio Grande Western route: U. S. Geol. Survey, Bull. 707, xi, 266 pp., 63 figs., 96 pls., 10 maps, 1922. 
Campbell, Marius Robinson-Continued.

4. Geology of the coal formations [of Kentucky]: U. S. Bureau of Mines, Technical Paper 308, pp. 7-10, 1922.

5. The Twentymile Park district of the Yampa coal field, Routt County, Colorado: U. S. Geol. Survey, Bull. 748, 82 pp., 11 figs., 13 pls., (incl. map), 1923.

6. The coal fields of Ohio: U. S., Bur. Mines, Tech. Paper 344, pp. 1-5, 2 figs., 1923.

7. (and Holden, R. J.). Broad thrust fault in the central Appalachians (abstract) : Geol. Soc. America, Bull., vol. 35, no. 1, p. 115, March 30, 1924.

8. Value of airplane photographs in geologic mapping (abstract): Washington Acad. Sci., Jour., vol. 14, no. 7, p. 163, April 4, 1924.

9. (and others). Geologic map of Wyoming: U. S. Geol. Survey, Geologic Atlas of the United States, State of Wyoming, 1925. Scale, $1: 500,000$.

10. (and others). The Valley coal fields of Virginia: Virginia Geol. Survey, Bull. no. 25, pp. 1-300, 30 figs., 27 pls. (incl. map), 1925. Extract, Metamorphism of Virginia coals : Pan-Am. Geologist, vol. 44, no. 1, pp. 62-65, August, 1925.

11. David Talbot Day: Am. Inst. Min. and Met. Eng., Trans., vol. 71, pp. 1071-1073, 1 fig. (portr.), 1925; Mining and Metallurgy, vol. 6, no. 222, pp. 302-304, 1 fig. (portr.), June, 1925.

12. The meaning of cut-off meanders in tiral streams: Washington Acad. Sci., Jour., vol. 17, no. 5, pp. 125-1.26, March 4, 1927.

13. Meaning of meanders in tidal streams: Geol. Soc. America, Bull., vol. 38, no. 3, pp. 537-555, 3 figs., September, 1927; abstract, no. 1, p. 129, March 30, 1927; Pan-Am. Geologist, vol. 47, no. 1, pp. 74-75, February, 1927.

14. Geographic terminology: Assoc. Am. Geographers, Annals, vol. 18, no. 1, pp. 25-40, March, 1928.

15. Classification of coal from the viewpoint of the geologist: Am. Inst. Min. and Met. Eng., Tech. Pub. no. 156, pp. 25-27, November, 1928.

16. Late geologic deformation of the Appalachian Piedmont as determined by river gravels (abstract): Science, new ser., vol. 68, pp. 649-650, December 28, 1928.

Campbell, R. B. See Holman, 1.

Campbell, Stewart.

1. Twenty-third annual report of the mining industry of Idaho for the year 1921. 152 pp. [1922].

2. Twenty-fourth annual report of the mining industry of Idaho for the year 1922. 209 pp. [1923].

3. Twenty-fifth annual report of the mining industry of Idaho for the year 1923. 121 pp., illus. [1924].

4. Twenty-sixth annual report of the mining industry of Idaho for the year 1924. 249 pp., illus. [1925].

5. Twenty-seventh annual report of the mining industry of Idaho for the year 1925. 270 pp., illus. [1926].

6. Twenty-eighth annual report of the mining industry of Idaho for the year 1926. $269 \mathrm{pp}$., illus. [1927].

7. Twenty-ninth annual report of the mining industry of Idaho for the year 1927. 280 pp., illus. [1.928]. 
Campbell, Stewart-Continued.

8. A geologic error regarding the Wood River district [Idaho]: Eng. and Min. Jour., vol. 126, no. 8, pp. 287-289, 3 figs. (incl. map), August 25, 1928.

Campbell, William Wallace.

1. Notes on the problem of the origin of lunar craters [including notes on Meteor Crater, Arizona] : Astronomical Soc. Pacific, Pub., vol. 32, no. 186, pp. 126-138, 2 figs., April, 1920.

Camsell, Charles.

1. (and Malcolm, Wyatt). The Mackenzie River basin: Canada, Geol. Survey, Mem. 108, 154 pp., 14 pls., 1 fig., map, 1919.

2. Mercury deposits of Kamloops Lake [British Dolumbia]: Canada, Geol. Survey, Summ. Rept., 1918, pt. B, pp. 17-22, 1919.

3. Boring operations for oil in the vicinity of Vancouver, British Columbia: Canada, Geol. Survey, Summ. Rept., 1918, pt. B, pp. 22-25, 1919.

4. Copper Mountain, Gun Creek [British Columbia]; Canada, Geol. Survey, Summ. Rept., 1918, pt. B, pp. 25-28, map, 1919.

5. Platinum investigations in British Columbia: Canada, Geol. Survey, Summ. Rept., 1918, pt. B, pp. 28-30, 1919.

6. Coquihalla map area, B. C.: Canada, Geol. Survey, Summ. Rept., 1919, pt. B, pp. 30-35, 1920.

7. Silver deposits at Stump Lake, B. C.: Canada, Geol. Survey, Summ. Rept., 1919, pt. B, pp. 35-36, 1920.

8. Geological features of the gold deposits of British Columbia: Canadian Min. Inst., Bull. no. 88, pp. 860-866, August, 1919.

9. The origin and history of the great canyon of Fraser River: Roy. Soc. Canada, Proc. and Trans., 3d ser., vol. 14, sec. 4, pp. 45-59, 1921.

Canada, Department of Mines.

1. Natural resources map of parts of Ontario and Quebec showing itinerary of American Institute of Mining and Metallurgical Engineers ... . 1923 ; scale 35 miles to 1 inch: Mining and Metallurgy, vol. 4, no. 202, October, 1923.

Canada, Department of Mines, Mines Branch.

1. Summary report of investigations made by the Mines Branch during the calendar year ending December 31, 1920, 87 pp., 7 figs., 1922.

Canada, Geological Survey.

1. [Map of] Explored routes in a belt traversed by the Canadian National Railways between Penhurst and Longlac, Algoma and Thunder Bay districts, Ontario. Scale, 4 miles to 1 inch. Canada, Geol. Survey, Pub. no. 1766, 1920.

2. Reported discovery of placer gold in Labrador: Canadian Min. Jour., vol. 44, no. 21, pp. 396-397, May 25, 1923.

3. Geological map of the Dominion of Canada and Newfoundland. Geology compiled by G. A. Young. Scale $1: 6,336,000$ or 1 inch to 100 miles. Third edition, 1924. (Pub. no. 1277.)

Canu, Ferdinand. See also Wade, B., 3.

1. (and Bassler, Ray S.). Fossil Bryozoa from the West Indies: Carnegie Inst. Washington, Pub. no. 291, pp. 73-102, 7 pls., 1919. 
Canu, Ferdinand-Continued.

2. (and Bassler, Ray S.). North American early 'Tertiary Bryozoa: U. S. Nat. Mus., Bull. 106, 879 pp., 279 figs., 162 pls., 1920.

3. (and Bassler, Ray S.). Studies on the cyclostomatous Bryozoa: U. S. Nat. Mus., Proc., vol. 61, art. 22, 160 pp., 40 figs., 28 pls., 1922.

4. (and Bassler, Ray S.). North American later Tertiary and Quaternary Bryozoa: U. S. Nat. Mus., Bull. 125, 302 pp., 38 figs., 47 pls., 1923.

5. (and Bassler, Ray S.). American and European Tertiary Bryozoa: Geol. Soc. America, Bull., vol. 35, no. 4, pp. 847-850, December 30, 1924.

6. (and Bassler, Ray S.). Studies on the cyclostomatous Bryozoa: U. S. Nat. Mus., Proc., vol. 67, art. 21, 124 pp., 46 figs., 31 pls., March $29,1926$.

7. (and Bassler, Ray S.). Class fication of the cheilostomatous Bryozoa: U. S. Nat. Mus., Proc., vol. 69, art. 14, 42 pp., 1 pl., 1927.

8. (and Bassler, Ray S.). Fossil and recent Bryozoa of the Gulf of Mexico region: U. S. Nat. Mus., Proc., vol. 72, art. 14, 199 pp., 35 figs., 34 pls., 1928.

Cape, Emily Palmer.

1. Lester F. Ward; a personal sketch. xi. 208 pp., 5 pls. (incl. portr.), New York, G. P. Putnam's Sons, 1922.

Capps, Stephen Reid. See also Brooks, 13, 14.

1. The Kantishna region, Alaska: U. S. Geol. Survey. Bull. 687, 116 pp., 17 pls. (incl. maps), 6 figs., 1919. Abstract by R. W. Stone, Washington Acad. Sci., Jour., vol. 9, no. 15, pp. 439-440, September 19, 1919.

2. Gold lode mining in the Willow Creek district [Alaska]: U. S. Geol. Survey, Bull. 692, pp. 177-186, 1919. Abstract by G. C. Martin, Washington Acad. Sci., Jour., vol. 9, no. 20, p. 633, December 4, 1919.

3. Mineral resources of the western Talkeetna Mountains [Alaska]: U. S. Geol. Survey, Bull. 692, pp. 187-205, 1 pl. (map), 1919. Abstract by G. C. Martin, Washington Acad. Sci., Jour., vol. 9, no. 20, p. 633, December 4, 1919.

4. Mineral resources of the upper Chulitna region [Alaska]: U. S. Geol. Survey, Bull. 692, pp. 207-232, 1 pl. (map), 1919. Abstract, Washington Acad. Sci., Jour., vol. 9, no. 20, p. 633, December 4, 1919.

5. The Cold Bay district [Alaska]: U. S. Geol. Survey, Bull. 739, pp. 77-116, 2 figs., 1 pl. (map), 1922.

6. Geology and mineral resources of the region traversed by the Alaska Rai.road: U. S. Geol. Survey, Bull. 755, pp. 73-150, 1 fig., 7 pls., 1924.

7. An early Tertiary placer deposit in Alaska (abstract) ; Washington Acad. Sci., Jour., vol. 14, no. 15, pp. 373-374, September 19, 1924.

8. Willow Creek district [Alaska] : U. S. Geol. Survey, Bull. 773, pp. 39-43, 1925.

9. An early Tertiary placer deposit in the Yentna district [Alaska]: U. S.

- Geol. Survey, Bull. 773, pp. 53-61, 2 figs., 1925.

10. (and Short, M. N.). A ruby silver prospect in A.aska [upper Susitna Basin] : U. S. Geol. Survey, Bull. 783, pp. 89-95, 1 fig., 1926.

11. Geology of the upper Matanuska Valley, Alaska: U. S. Geol. Survey, Bull. 791, 92 pp., 5 figs., 16 pls. (incl. maps), 1927.

12. The Toklat-Tonzona River region [Alaska]: U. S. Geol. Survey, Bull. 792, pp. 73-110, 2 pls. (maps), 1927. 
Capps, Stephen Reid-Continued.

13. Exploration in the Mount Spurr region, Alaska (abstract): Geol. Soc. America, Bull., vol. 39, no. 1, pp. 154-155, March 30, 1928; PanAm. Geologist, vol. 49, no. 1, pp. 68-69, February, 1928.

Carlson, Charles Gordon. See also Waring, 5.

1. A test of the feldspar method for the determination of the origin of metamorphic rocks: Jour. Geology, vol. 28, no. 7, pp. 632-642, 1 fig., October-Novembier, 1920.

2. Geological notes on a part of southern Trinidad, British West Indies: Econ. Geology, vol. 20, no. 2, pp. 153-167, 2 figs. (incl. map), March-April, 1925.

3. Geology of the Saginaw oil field, Michigan, and discussion of Michigan's oil prospects: Am. Assoc. Petroleum Geologists, Bull., vol: 11, no. 9, pp. 959-965, 3 figs., September, 1927.

Carman, Joel Ernest.

1. Some subsurface rock channels and cavities flled with glacial material: Ohio Jour. Sci., vol. 22, no. 5, pp. 125-128, March, 1922.

2. The Monroe division of rocks in Ohio: Jour. Geology, vol. 35, no. 6, pp. 481-506, 1 fig. (map), August-September, 1927 ; abstract, Geol. Soc. America, Bull., vol. 38, no. 1, p. 136, March 30, 1927 ; Pan-Am. Geologist, vol. 47, no. 1, p. 78, February, 1927.

3. Fossil footprints from the Pennsylvanian system in Ohio: Geol. Soc. America, Bull., vol. 38, pp. 385-395, 3 pls., June 30, 1927.

4. The rock section at the O'Shaughnessy dam [Scioto River, Delaware County, Ohio]: Ohio Jour. Sci., vol, 27, no. 6, pp. 289-294, 1 fig., December, 1927.

5. Résumé of the geology of Lucas County, Ohio (abstract) : Ohio Acad. Sci., Proc., vol. 8 , pt. 4, pp. 173-174, 1928; Ohio Jour. Sci., vol. 28, no. 3, pp. 151-152, May, 1928.

Carmichael, Ferga.

1. Oxidation of sulphides: Toronto, Univ., Studies, Geol, ser., no. 22, pp. 29-36, 1926.

2. Catalytic action in the oxidation of sulphides and arsenides: Toronto, Univ., Studies, Geol. ser. no. 24, pp. 47-53, 1927.

Carmody, $\mathbf{P}$.

1. Trinidad as a field for the study of the origin of petroleum (with discussion) : Inst. Petroleum Technologists, Jour., vol. 7, no. 28, pp. 298-325, October, 1921.

Carpenter, Everett. See also Greene, 10.

1. The Morrison field, Pawnee County, Oklahoma: Am. Assoc. Petroleum Geologists, Bull., vol. 11, no. 10, pp. 1087-1096, 7 figs., October, 1927.

2. Oil and gas in Oklahoma; geology of Washington County: Oklahoma Geol. Survey, Bull. no. 40-V, 20 pp.; 5 figs., 4 pls. (incl. map), January, 1928.

Carpenter, Ford A.

1. Early records of earthquakes in southern California: Seismol. Soc. America, Bull., vol. 11, no. 1, pp. 1-3, March, 1921.

Carpenter, Frank M.

1. Fossil insects from the lower Permian of Kansas: Harvard Coll., Mus. Comp. Zoology, Bull., vol. 67, no. 13, pp. 437-444, 3 pls., July, 1926. 
Carpenter, Frank M.-Continued.

2. A fossil insect from the lower Permian of the Grand Canyon: U. S. Nat: Mus., Proc., vol. 71, art. 23, 4 pp., 1 pl., 1927.

3. A scorpion-fly from the Green River Eocene: Carnegie Mus., Annals, vol. 18, pt. 1, pp. 241-248, 1 fig., 1 pl., March, 1928.

Carpenter, Jay A.

1. The Divide district [near Tonopah, Nevada] : Eng. and Min. Jour., vol. 107, pp. 859-861, 1 fig., May 17, 1919.

2. The Kelly silver mine at Randsburg, California: Eng. and Min. Jour. vol. 108, pp. 940-943, 3 figs., December 27, 1919.

Carpenter, Margaret.

1. Microblogy of the upper Washita: 'Texas, Univ., Bull.' no. 2544, pp. 71-74, 2 pls., 1925.

Carsey, Dorothy Ogden.

1. Foraminifera of the Cretaceous of central Texas: Texas, Univ., Bull., no. 2612, 56 pp., 8 pls., July, 1926.

Carson, Carlton $\mathbf{M}$.

1. Pliocene faunal zones in southern California : Pan-Am. Geologist, vol. 43, no. 4, pp. 265-270, May, 1925.

2. Some new species from the Pliocene of southern California, with a few changes in nomenclature: Southern California Acad. Sci., Bull., vol. 24, pt. 2, pp. 31-35, 1 pl., August 17, 1925.

Carstarphen, F. C.

1. The internal heat of the earth: Colorado School of Mines Mag., vol. 17, no. 3, pp. 5-8, 1 flg., July, 1927.

Carter, Annice.

1. (and Painter, Louise). Bell Creek-Fall Creek Valley [Delaware and Hewry counties] : Indiana Acad. Sci., Proc., vol. 36, pp. 103-105, 2 figs., 1927.

Cartwright, C. E.

1. Notes on the nonmetallic minerals of the Lillooet district [British Columbia ] : Canadian Inst. Min. and Met., Bull., no. 160, pp. 824-830, 3 figs., August, 1925; Trans., vol. 28, pp. 414-420, 3 figs. [1926].

Cartwright, Lon D., jr.

1. Lass of color of red sandstone upon deposition: Am. Assoc. Petroleum Geologists, Bull., vol. 12, no. 1, pp. 85-87, 1 fig., January, 1928.

2. Sedimentation of the Pico formation in the Ventura quadrangle, California : Am. Assoc. Petroleumr Geologissts, Bull., vol. 12, no. 3, pp. 235-369, 12 figs. (incl, map), March, 1928.

Case, Ermine Cowles.

1. Permo-Carboniferous time versus Permo-Carboniferous conditions: Michigan Acad. Sci., 20th Ann. Rept., p. 82, 1918.

2. The environment of life in the late Paleozoic in North America; a paleogeographic study. Carnegie Inst. Washington, Pub. no. 283, 273 pp., 7 flgs., paleogeographic map, 1919.

3. Study of the vertebrate fauna and paleogeography of North America in the Permian period, with especial reference to world relations: Carnegie Inst. Washington, Year Book No. 17, 1918, p. 310, February, 1919 , 
Case, Ermine Cowles-Continued.

4. Notes on a specimen of Stylemys nebrascensis Leidy: Am. Jour. Sci., 4th ser., vol. 47, pp. 435-438, 5 figs., June, 1919.

5. On a very perfect thoracic shield of a large labyrinthodont in the geological collections of the University of Michigan : Michigan, Univ., Mus. Zool., Occ. Papers no. 82, 3 pp., 1 pl., April 28, 1920.

6. Preliminary description of a new suborder of phytosaurian reptiles with a description of a new species of Phytosaurus: Jour. Geology, vol. 28, no. 6, pp. 524-535, 6 figs., September-October, 1920.

7. [Report on investigations of Permo-Carboniferous deposits]: Carnegie Inst. Washington, Year Book no. 19, p. 402, January, 1921.

8. Desmatosuchus suprensis from the Dockum Triassic beds of western Texas (abstract) : Geol. Soc. America, Bull., vol. 32, no: 1, p. 136, March 31, 1921.

9. Criteria for the determination of the climatic environment of extinct animals: Geol. Soc. America, Bull., vol. 32, no. 3, pp. 333-338, September 1, 1921.

10. Study of the vertebrate fauna and paleogeography of North America in the Permian period, with especial reference to world relations: Carnegie Inst. Washington, Year Book no. 20, 1921, pp. 443-445, February, 1922.

11. New reptiles and stegocephalians from the Upper Triassic of western Texas. 84 pp., 33 figs., 14 pls., Carnegie Institution of Washington (Pub. no. 321), October, 1922.

12. Study of the vertebrate fauna and paleogeography of North America in the Permian period, with especial reference to world relations [report of progress] : Carnegie Inst. Washington, Year Book no. 21, 1922, p. 395, 1923.

13. Study of the vertebrate fauna and paleogeography of North America in the Permian period, with special reference to world relations: Carnegie Inst. Washington, Year Book no. 22, p. 349, 1924.

14. A possible explanation of fenestration in the primitive reptilian skull. with notes on the temporal region of the genus Dimetrodon: Michigan, Univ., Mus. Geology, Contr., vol. 2, no. 1, pp. 1-12, 5 figs., July 10, 1924.

15. Environmental conditions of the Permian vertebrates: Pan-Pacific Sci. Cong., Australia, 1923, Proc., vol. 2, pp. 1047-1049 [1924].

16. Some new specimens of Triassic vertebrates in the museum of geology of the University of Michigan: Michigan Acad. Science, Arts, and Letters, Papers, vol. 4, pt. 1, pp. 419-423, 4 figs., 3 pls., February, 1925.

17. The use of bakelite in the preservation of fossil material: Science, new ser., vol. 61, pp. 543-544, May 22, 1925.

18. A specimen of Stelemys nebrascensis Leidy, with the skull prieserved: Michigan, Univ., Mus. Geology, Contr., vol. 2, no. 4, pp. 87-91, 7 figs., June 3, 1925.

19. Note on a new species of the Eocene crocodilian Allognathosuchus, A. wartheni: Michigan, Univ., Mus. Geology,. Contr., vol. 2, no. 5, pp. 93-97, 1 fig., 1 pl., June 3, 1925.

20. Environment of tetrapod life in the late Paleozoic of. regions other than North America: Carnegie Inst. Washington, Pub. no, 375, 211 pp., 23 figs., December, 1926. 
Case, Ermine Cowles-Continued.

21. Genus Coelophysis in the upper Triassic beds of western Texas (abstract): Geol. Soc. America, Bull., vol. 38, no. 1, p. 227, March 30, 1927 ; Pan-Am. Geologist, vol. 47, no. 3, pp. 235-236, April, 1927.

22. The vertebral column of Coelophysis Cope: Michigan, Univ., Mus. Geology, Contr., vol. 2, no. 10, pp. 209-222, 9 figs., 1 pl., August 3, 1927.

23. A new species of trionchid turtle, Amyda nelsoni, from the Eocene beds of southwestern Wyoming: Michigan, Univ., Mus. Geology, Contr., vol. 2, no. 11, pp. 223-226, 3 figs., 1 pl., August 3, 1927.

24. A complete phytosaur pelvis from the Triassic beds of western Texas: Michigan, Univ., Mus. Geology, Contr., vol. 2, no. 12, pp. 227-229, 1 pl., August 3, 1927.

25. The coral seas of Michigan: Natural History (Am. Mus. Nat. Hist., Jour.), vol. 27 , no. 5, pp. 420-429, 7 figs., September-October, 1927.

26. A cotylosaur from the upper Triassic of western Texas: Washington Acad. Sci., Jour., vol. 18, no. 7, pp. 177-178, 1 fig., April 4, 1928.

27. Indications of a cotylosaur and of a new form of fish from the Triassic: beds of Texas, with remarks on the Shinarump conglomerate: Michigan, Univ., Mus. Paleontology, Contr., vol. 3, no. 1, pp. 1-14, 1 pl., November 10, 1928.

Case, J. B.

1. Report on Santa Fe Springs oil field: California State Min. Bur., Summary of Operations California Oil Fields, vol. 8, no. 11, pp. 5-19, 4 pls. (incl. map), May, 1923.

2. (and Keyes, Robert L.). Report on the Long Beach oil field: California State Min. Bur., Summary of Operations California Oil Fields, vol. 9, no. 4, pp. 5-17, 3 pls., October, 1923.

3. (and Wilhelm, V. H.). Report on Huntington Beach oil field: California State Min. Bur., Summary of Operations California Oil Fields, vol. 9, no. 6, pp. 5-16, 5 pls. (incl. map), December, 1923.

Castello, Walter Owen. See also Boalich, 1.

1. The commercial minerals of California, with notes on their uses, distribution, properties, ores, field tests, and preparation for the market: California State Min. Bur., Bull. no. 87, 124 pp. January, 1920.

Cathcart, Stanley H. See also Ferguson, H. G., 6; Steidtman, 4.

1. Mining in northwestern Alaska: U. S. Geol. Survey, Bull. 712, pp. 185198, 5 figs., 1920.

2. Metalliferous lodes in southern Seward Peninsula, Alaska: U. S. Geol. Survey, Bulletin 722, pp. 163-261, 14 figs. (incl. sketch maps), 1922.

3. Mining in northwestern Alaska (U. S. Geol. Survey, Bull. 712, 1920) (abstract by R. W. Stone) : Washington Acad. Sci., Jour., vol. 11, no. 15 , p. 375 , September 19, 1921.

Catherall, A. P.

1. [Petroleum developments in] British West Indies: Inst. Petroleum 'Technologists, Jour., vol. 13, no. 63, pp. 609-611, August, 1927.

Catlin, C. N.

1. Character of the ground-water resources of Arizona: Arizona, Univ., Coll. Agr., Agr. Exp. Sta., Bull. no. 114, pp. 173-293, March 1, 1929

Cattell, R. A. See Bell, H. W., 1. 
Cave, Harold Sergius. See also Prettyman, 1.

1. Historical sketch of the Geological Survey of Georgia; bibliography and other data: Georgia, Geol. Survey, Bull. no. 39, 154 pp., 7 pls., 2 figs. (incl. map), 1922.

Cavins, O. A. See also Böse, 8.

1. [Biographical sketch of Emil Böse] : Texas, Univ., Bull, no. 2748, pp. 5-6, December 22, 1927.

Cervantes, Enrique A.

1. La industria del azufre y localización de sus criaderos en los Estados Unidos Mexicanos: Soc. cient. "Antonio Alzate," Mem. y Rev., t. 39, no. 9-12, pp. 575-582, December, 1921.

2. Industria y explotacion de la mica: Soc. cient. "Antonio Alzate," Mem. y Rev., t. 39, no. 9-12, pp. 583-595, December, 1921.

Chadbourn, Charles Henry.

1. Paragenesis of the ores of the Silver Islet mine, Thunder Bay region, Lake Superior: Econ. Geology, vol. 18, no. 1, pp. 77-82, 1 pl., January-February, 1923.

Chadwick, George Halcott. See also Galloway, 4 ; Parks, 14; Swartz, C. K., 10.

1. New species of coral [Palaeophyllum, Manitoulin Island] : Canada, Geol. Survey, Mem. 111, pp. 128-129, 1 fig. (on pl. 5), 1919.

2. A new eurypterid horizon (abstract) : Geol. Soc. America, Bull., vol. 30, pp. 152-153, March 31, 1919.

3. Portage stratigraphy in western New York (abstract) : Geol. Soc. America, Bull., vol. 30, p. 157, March 31, 191.9.

4. Remarkable persistence of thin horizons (abstract) : Geol. Soc. America, Bull., vol. 30, p. 157, March 31, 1919.

5. The Paleozoic rocks of the Canton quadrangle: New York State Mus., Bull. nos. 217, 218, 60 pp., 5 figs., 12 pls., map and sections, 1920.

6. Large fault in western New York: Geol. Soc. America, Bull., vol. 31, no. 1, pp. 117-120, 2 figs., March 31, 1920.

7. Devonian black shales of western New York (abstract) : Geol. Soc. America, Bull., vol. 32, no. 1, p. 91, March 31, 1921.

8. Chemung stratigraphy in western New York (abstract): Geol. Soc. America, Bull., vol. 34, no. 1, pp. 68-69, March 30, 1923.

9. Glacial lake problems: Geol. Soc. America, Bull., vol. 34, no. 3, pp. 499506, 1 fig., September 30, 1923.

10. The stratigraphy of the Chemung group in western New York: New York State Mus. Bull. no. 251, pp. 149-157, 1 fig., 1924.

11. (and Dunbar, E. U.). Genesee glacial lakes: Geol. Soc. America, Bull., vol. 35, no. 3, pp. 669-676, September 30, 1924.

12. Chagrin formation of Ohio (abstract): Geol. Soc. America, Bull., vol. 35, no. 1, p. 99, March 30, 1924 ; Pan-Am. Geologist, vol. 41, no. 2, pp. 148-149, March, 1924.

13. Kansas Permian unconformity (abstract) : Geol. Soc. America, Bull., vol. 35, no. 1, p. 105, March 30, 1924; Pan-Am. Geologist, vol. 41, no. 2, p. 152; March, 1924.

14. Chagrin formation of Ohio: Geol. Soc. America, Bull., vol. 36; no. 3, pp. 455-464, 2 figs., September 30, 1925.

15. New points in New York stratigraphy (abstract): Geol. Soc. America, Bull., vol. 38, no. 1, p. 160, March 30, 1927; Pan-Am. Geologist, vol. 47, no. 2, pp. 156-157, March, 1927. 
Chadiwick, George Halcott-Continued.

16. Adirondack eskers (abstract) : Pan-Am. Geologist, vol. 49, no. 2, p. 147, March, 1928; Geol. Soc. America, Bull., vol. 39, no. 1. p. 216, March 30, 1928.

17. Anorthosite outlier near Wells, New York (abstract) : Geol. Soc. America, Bull., vol. 39, no. 1, pp. 167-168, March 30, 1928; Pan.-Am. Geologist, vol. 49, no. 1, p. 76, February, 1928.

18. Ice evacuation stages at Glens Falls, New York (abstract) : Pan.-Am. Geologist, vol. 49, no. 2, p. 157, March, 1928; Geol. Soc. America, Bull., vol. 39, no. 1, pp. 207-208, March 30, 1928.

19. Glacial striae topping Catskill Mountains, New York (abstract) : PanAm. Geologist, vol. 49, no. 2, p. 147, March, 1928; Geol. Soc. America, Bull., vol. 39, no. 1, p. 216, March 30, 1928.

20. Ice evacuation stages at Glens Falls, New York : Geol. Soc. America, Bull., vol. 39, no. 4, pp. 901-922, 16 figs., December 30, 1928.

21. Adirondack eskers: Geol. Soc. America, Bull., vol. 39, no. 4, pp. 923-929, 2 figs., December 30, 1928.

Chamberlain, Charles Joseph.

1. The origin of the cycads: Science, new ser., vol. 61, pp. 73-77, January 23, 1925.

Chamberlin, Rollin Thomas. See also Bateman, 5.

1. The building of the Colorado Rockies: Jour. Geology, vol. 27, nos. 3 and 4, pp. 145-164, 225-251, 13 figs., 1919.

2. A peculiar belt of oblique faulting: Jour. Geology, vol. 27, no. 8, pp. 602613, 3 figs., November-December, 1919.

3. The American Association for the Advancement of Science; Section EGeology and geography [St. Louis meeting, December, 1919]: Science, new ser., vol. 51, pp. 491-495, 518-523, May 14 and 21, 1920.

4. Some glacier studies in Alaska (abstract): Science, new ser., vol. 51, p. 521, May 21, 1920.

5. Vulcanism and mountain making; a supplementary note: Jour. Geology, vol. 29, no. 2, pp. 166-172, Febrüary-March, 1921.

6. Tutuila, Samoa, and the coral reef problem (abstract) : Geol. Soc. America, Bull., vol. 32, no. 1, pp. 28-29, March 31, 1921.

7. Diastrophism and the formative processes; XIV, Groundwork for the study of megadiastrophism; Part II, The intimations of shell deformation: Jour. Geology, vol. 29, no. 5, pp. 416-425, 1 fig., JulyAugust, 1921.

8. On the crustal shortening of the Colorado Rockies: Am. Jour Sci., 5th ser., vol. 6, pp. 215-221, 3 figs. (incl. map), September, 1923.

9. (and Shepard, F. P.). Some experiments in folding: Jour. Geology, vol. 31, no. 6, pp. 490-512, 17 figs., September-October, 1923.

10. The significance of the framework of the continents: Jour. Geology, vol. 32, no. 7, pp. 545-574, 3 figs., October-November, 1924.

11. The wedge theory of diastrophism: Jour. Geology, vol. 33, no. 8, pp. 755792, 14 figs., November-December, 1925.

12. The origin and early stages of the earth. In The nature of the world and of man, pp. 31-55, 3 figs., University of Chicago Press, 1926.

13. Earthquakes: Kentucky Acad. Sci., Trans., vol. 2, pp. 155-164, 1927.

14. Whittling down the batholiths (abstract) : Geol. Soc. America, Bull., vol. 38, no. 1, p. 109, March 30, 1927 ; Pan-Am. Geologist, vol. 47, no. 1, p. 65, February, 1927. 
Chamberlin, Rollin Thomas-Continued.

15. Exploration of the Cariboo Mountains of British Columbia: Geog. Soc. Philadelphia, Bull., vol. 25, no. 2, pp. 59-76, 2 figs., 3 pls., April, 1927.

16. (and Link, T. A.). The theory of laterally spreading batholiths: Jour. Geology, vol. 35, no. 4, pp. 319-352, 19 figs., May-June, 1927.

17. Glacier motion as a type of rock deformation (abstract): Science, new ser., vol. 66, p. 461, November 11, 1927.

18. Instrumental work on the nature of glacier motion: Jour. Geology, vol. 36, no. 1, pp. 1-30, 16 figs., January-February, 1928.

19. The strain ellipsoid and Appalachian structures: Jour. Geology, vol. 36, no. 1, pp. 85-90, 3 figs., January-February, 1928.

20. Some of the objections to Wegener's theory. In Theory of continental drift, pp. 83-87, Am. Assoc. Petroleum Geologists, 1928.

Chamberlin, Thomas Chrowder, 1843-1928. See also Matsuyama, 1; Willis, B., 1.

1. Earth genesis: Illinois Acad. Sci., Trans., vol. 10, pp. 48-69 [1918].

2. Study of fundamental problems of geology: Carnegie Inst., Washington, Year Book no. 17, 1918, pp. 297-298, February, 1919; no. 18, 1919, pp. $343-345$, March, 1920 .

3. Investigation versus propagandism [age of Vero, Florida, deposits]: Jour. Geology, vol. 27, no. 5, pp. 305-338, July-August, 1919.

4. Diastrophism and the formative processes; $X$, The order of magnitude of the shrinkage of the earth deduced from Mars, Venus, and the moon: Jour. Geology, vol. 28, no. 1, pp. 1-17, January-February, 1920.

5. Diastrophism and the formative processes; XI, Selective segregation of material in the formation of the earth and its neighbors: Jour. Geology, vol. 28, no. 2, pp. 126-157, 2 pls., February-March, 1920.

6. The mathematics of isostasy: Am. Jour. Sci., 4th ser., vol. 49, pp. 311323, 1 fig., May, 1920.

7. Diastrophism and the formative processes; XII, The physical phases of the planetary nuclei during their formative stages: Jour. Geology, vol. 28, no. 6, pp. 473-504, September-October, 1920.

8. Diastrophism and the formative processes; XIII, The bearings of the size and rate of infall of planetesimals on the molton or solid state of the earth: Jour. Geology, vol. 28, no. 8, pp. 665-701, 1 fig., November-December, 1920.

9. [The self-compression of the earth and related problems]: Carnegie Inst. Washington Year Book no. 19, pp. 366-383, January, 1921.

10. Groundwork of the earth's diastrophism: Geol. Soc. America, Bull., vol. 32, no. 2, pp. 197-210, June 30, 1921.

11. The greater earth: Geol. Soc. America, Bull., vol. 32, no. 2 pp. 211-226, 4 figs., June 30, 1921.

12. Diastrophism and the formative processes; XIV, Groundwork for the study of megadiastrophism; Part I, Summary statement of the groundwork already laid: Jour. Geology, vol. 29, no. 5, pp. 391415, July-Augtist, 1921.

13. Diastrophism and the formative processes; $\mathrm{XV}$, the self-compression of the earth as a problem of energy: Jour. Geology, vol. 29, no. 8, pp. 679-700, November-December, 1921.

14. Study of fundamental problems of geology : Carnegie Inst. Washington. Year Book no. 20, 1921, pp. 412-425, February, 1922. 
Chamberlin, Thomas Chrowder-Continued.

15. The age of the earth from the geological viewpoint: Am. Philos. Soc., Proc., vol. 61, no. 4, pp. 247-271, 1922; Smithsonian Inst., Ann. Rept., 1922, pp. 241-261, 1924.

16. Memorial editorial; Rollin D. Salisbury, August 17, 1858-August 15, 1922 : Jour. Geology, vol. 30, no. 6, pp. 480-481, SeptemberOctober, 1922.

17. Jones's criticism of Chamberlin's Groundwork for the study of megadiastrophism: Am. Jour. Sci., 5th ser., vol. 4, pp. 253-273, October, 1922.

18. Study of fundamental problems of geology : Carnegie Inst. Washington, Year Book no. 21, 1922, pp. 359-365, January, 1923.

19. A venerable climatic fallacy: Jour. Geology, vol. 31, no. 3, pp. 179-191. April-May, 1923.

20. Significant amelionations of present Arctic climates: Jour. Geology, vol. 31, no. 5, pp. 376-406, 2 figs., July-August, 1923.

21. Review of British (Terra Nova) Antartic expedition, 1910-1913, glaciology, by C. S. Wright and R. E. Priestley, London, 1922 : Jour. Geology, vol. 31, no. 6, pp. 513-524, September-October, 1923.

22. Biographical memoir Charles Richard Van Hise, 1857-1918: Nat. Acad. Sci., Mem., vol. 17, pp. 143-151, portr., 1924.

23. Study of fundamental problems of geology : Carnegie Inst. Washington, Year Book no. 22, pp. 324-334, 1924.

24. Seventy-five years of American geology: Science, new ser., vol. 59, pp. 127-135, February 8, 1924.

25. Review of Bau und Entstehung der Alpen, by Leopold Kober: Jour. Geology, vol. 32, no. 2, pp. 168-171, February-March, 1924.

26. Review of The planetesimal hypothesis and the solar system, by Harry Fielding Reid: Jour. Geology, vol. 32, no. 3, pp. 242-262, 1 fig., April-May, 1924.

27. [Review of] The earth, its origin, history, and physical constitution, by Harold Jeffries: Jour. Geology, vol. 32, no. 8, pp. 696-716, 5 figs., November-December, 1924.

28. Study of fundamental problems of geology : Carnegie Inst. Washington, Year Book no. 23, pp. 270-282, 1 fig., December, 1924.

29. Study of fundamental problems in geology: Carnegie Inst. Washington, Year Book no. 24, pp. 344-345, December, 1925.

30. Study of fundamental problems of geology: Carnegie Inst. Washington, Year Book no. 25, 1925-26, pp. 372-387, December, 1926.

31. Certain phases of megatectonic geology: Jour. Geology, vol. 34, no. 1, pp. 1-28, January-February, 1926.

32. (and Salisbury, Rollin D.). College textbook of geology. Part I, Geologic processes and their results, rewritten and revised by Rollin T. Chamberlin and Paul MacClintock. ix, 377, xii pp., 334 figs. Part II, Historical geology. xi, 381-911, xiv pp., 274 figs. New York, Henry Holt and Company, 1927.

33. Intrageology-elastasy vs. isostasy: Jour. Geology, vol. 35, no. 1, pp. 89-94, January-February, 1927.

34. Working concepts appropriate to an earth of planetesimal origin (abstract) : Geol. Soc. America, Bull., vol. 38, no. 1, pp. 129-130, March 30, 1927 ; Pan-Am. Geologist, vol. 47, no. 1, p. 75, February, 1927.

$4096-31-8$ 
Chamberlin, Thomas Chrowder-Continued.

35. The work of Walcott: Jour. Geology, vol. 85, no. 7, p. 670, OctoberNovember, 1927.

36. The work of Weller: Jour. Geology, vol. 35, no. 8, pp. 743-744, NovemberDecember, 1927.

37. Study of fundamental problems of geology: Carnegie Inst. Washington, Year Book no. 26, pp. 338-345, December, 1927.

38. The growth of the earth: First part, The planetesimal hypothesis; Second part, The successive stages of its growth as the sources of the different peculiarities of its present adult state: Scientia, Milan, Italy, vol. 42 , nos. 9 and 10, pp. 117-127, 181-1.92 suppl. pp. 47-57, 81-91, 3 pls., 1927.

39. (and Moore, Raymond C.). Memorial of Stuart Weller: Geol. Soc. America, Bull., vol. 39, no. 1, pp. 116-126, portr., March 30, 1928.

40. Response [on receiving the Penrose medal]: Geol. Soc. America, Bull. vol. 39, no. 1, pp. 195-197, March 30, 1928.

41. The two solar families; the sun's children. 311 pp., 52 figs., Chicago, Ill., University of Chicago Press, September, 1928.

42. Certain fundamental problems of geology: Carnegie Inst. Washington, Year Book no. 27, 1927-28, pp. 362-363, December, 1928.

Chambers, A. R.

The salt deposits of Malagash, Nova Scotia: Canadian-Inst. Min. and Met., Monthly Bull. no. 145, pp. 276-285, 4 figs., May, 1924; Trans., vol. 27, pp. 248-257, 4 figs. [1925].

Champion, Milton M. See Hubbard, 7.

Chance, Henry Martyn. See also Bateman, 10.

1. (and Chance, T. M.). Low-sulphur coal in Pennsylvania: Am. Inst. Min. and Met. Eng., Bull. no. 152, pp. 1459-1468, August, 1919; Trans., vol. 63 , pp. 649-659, 1920.

Chaney, Ralph Works. See also Clements, 1, 2, 3.

1. The flora of the Eagle Creek formation [Washington and Oregon]: Chicago, Univ., Walker Museum, Contr., vol. 2, no. 5, pp. 115-181, 22 pls., 3 figs., July, 1920.

2. Further discussion of the ecological composition of the Eagle Creek flora (abstract) : Geol. Soc. America, Bull., vol. 31, no. 1, p. 222, March $31,1920$.

3. Preliminary notes on recent Tertiary collections in the west (abstract) : Geol. Soc. America, Bull., vol. 32, no. 1, p. 137, March 31, 1921.

4. A fossil flora from the Puente formation of the Monterey group: Am. Jour. Sci., 5th ser., vol. 2, pp. 90-92, August, 1921.

5. Flora of the Rancho La Brea [southern California] (abstract) : Geol. Soc. America, Bull., vol. 33, nó. 1, p. 204, March 31, 1922.

6. Notes on the flora of the Payette formation [Idaho and Oregon]: Am. Jour. Sci., 5th ser., vol. 4, pp. 214-222, September, 1922. Abstract, Geol. Soc. America, Bull., vol. 33, no. 1, pp 203-204, March 31, 1922.

7. Report of progress in paleobotanical research in the Tertiary of the West during the year 1922: Carnegie Inst. Washington, Year Book no. 21, pp. 400-401, January, 1923.

8. Paleobotanical contributions to the stratigraphy of central Oregon (abstract) : Geol. Soc. America, Bull., vol. 34, nó. 1, p. 129, March 30, 1923.

9. [Fossil floras of the John Day Basin]: Carnegie Inst. Washington, Year Book no. 22, pp. 349-350, 1824. 
Chaney, Ralph Works-Continued.

10. Preliminary report on a Tertiary flora from northwestern Nevada (abstract) : Geol. Soc. America, Bull., vol. 35, no. 1, pp. 162-163, March 30, 1924.

11. Quantitative studies of the Bridge Creek flora: Am. Jour. Sci., 5th ser., vol. 8, pp. 127-144, 2 pls., August, 1924.

12. [Studies in paleobotany of Pacific region]: Carnegie Inst. Washington, Year Book no. 23, pp. 292-393, December, 1924.

13. Notes on the occurrence of terrestrial plant fossils in association with marine deposits in the western United States: Pan-Pacific Sci. Cong., Australia, 1923, Proc., vol. 1, p. 882 [1924].

14. A note on the intercontinental relationships of a Tertiary flora: Pan. Pacific Sci. Cong., Australia, 1923, Proc., vol. 1, p. 883 [1924].

15. Tertiary forests and climates in the Great Basin and Great Plains (abstract) : Geol. Soc. America, Bull., vol. 36, no. 1, p. 218, March 30, 1925.

16. A comparative study of the Bridge Creek flora and the modern redwood forest: Carnegie Inst. Washington, Pub. no. 349 (Studies on the fossil flora and fauna of the western United States), pp. 1-22, 7 pls., August, 1925

17. The Mascall flora; its distribution and climatic relation: Carnegie Inst. Washington, Pub. no. 349 (Studies on the fossil flora and fauna of the western United States), pp. 23-48, 1 fig., 1 pl., August, 1925.

18. Notes on two fossil hackberries from the Tertiary of the western United States: Carnegie Inst. Washington, Pub. no. 349 (Studies on the fossil filora and fauna of the western United States), pp. 49-56, 1 pl., August, 1925.

19. A record of the presence of Umbellularia in the Tertiary of the western United States: Carnegie Inst. Washington, Pub. no. 349 (Studies on the fossil flora and fauna of the western United States); pp. 57-62, 1 pl., August, 1925.

20. [Studies of the Tertiary floras of the western United States] : Carnegie Inst: Washington, Year Book, no. 24, pp. 356-357, December, 1925.

21. Relationships of the marine and fresh-water Tertiary of western North America, based on recnt collections of fossil plants (abstract) : Geol. Soc. America, Bull., vol. 37, no. 1, pp. 213-214, March 30, 1926.

22. [Report on paleobotanic research]: Carnegie Inst. Washington, Year Book no. 25; 1925-6, pp. 339-402, December, 1926.

23. (and Mason, Herbert L.). Fossil plants [from asphalt deposits in Carpinteria, Santa Barbara County, California]: Science, new ser., vol. 66, pp. 156-157, August 12, 1927.

24. Geology and paleontology of the Crooked River Basin, with special reference to the Bridge Creek flora: Carnegie Inst. Washington, Pub. 346 (Contributions to Paleontology), pp. 45-138, 4 figs., 20 pls., October, 1927.

25. [Report on the investigation of fossil plants] : Carnegie Inst. Washington; Year Book no. 26, pp. 361-362, December, 1927.

26. Recent additions to the Pleistocene history of western California (abstract) : Pan-Am. Geologist, vol. 49, no. 2, pp. 149-150, March 1928; Geol. Soc. America, Bull., vol. 39, no. 1, p. 221, March 30, 1928.

27. Distribution and correlation of Tertic floras of the Great Basin (abstract) : Pan-Am. Geologist, vol. 49, no. 4, p. 314, May, 1928.

28. [Investigations in paleobotany] : Carnegie Inst. Washington, Year Book no. 27, 1927-28, pp. 382-383, December, 1928. 
Chang, M. S. See Ehlers, 10, 11.

Channing, John Parke.

1. A silverless islet [Silver Islet, Lake Superior]: Eng. and Min. Jour., vol. 108, p. 232, August 9, 1919.

Chapin, Theodore. See also Burchard, 6.

1. The structure and stratigraphy of Gravina and Revillagigedo islands, Alaska (U. S. Geol. Survey, Prof. Paper 120, pp. 83-100, 1918) (abstract by R. W. Stone) : Washington Acad. Sci., Jour., vol. 9, no. 2, p. 49, January 19, 1919.

2. The Nelchina-Susitna region, Alaska (U. S. Geol. Survey, Bull. 668, 1918) (abstract by R. W. Stone) : Washington Acad. Sci., Jour., vol. 9, no. 11, p. 320, June 4, 1919.

3. Platinum-bearing auriferous gravels of Chistochina River [Alaska]: U. S. Geol. Survey, Bull. 692, pp. 137-141, 1 fig., 1919.

4. Mining in the Fairbanks district [Alaska]: U. S. Geol. Survey, Bull. 692, pp. 321-327, 1 fig., 1919. Abstract by G. C. Martin, Washington Acad. Sci., Jour., vol. 9, no. 20, pp. 635-636, December 4, 1919.

5. A molybdenite lode on Healy River [Alaska]: U. S. Geol. Survey, Bull. 692, p. 329, 1919 . Abstract by G. C. Martin, Washington Acad. Sci., Jour., vol. 9, no. 20, p. 636, December 4, 1919.

6. Mining in the Hot Springs district [Alaska]: U. S. Geol. Survey, Bull. 692, pp. 331-335, 1919. Abstract by G. C. Martin, Washington Acad. Sci., Jour., vol. 9, no. 20, p. 636, December 4, 1919.

7. Tin deposits of the Ruby district [Alaska]: U. S. Geol. Survey, Bull. 692, p. 337, 1919.

8. Mining developments in the Matanuska coal field [Alaska]: U. S. Geol. Survey, Bull. 712, pp. 131-167, 3 pls., 4 figs., 1920.

9. Lode developments in the Willow Creek district [Alaska]: U. S. Geol. Survey, Bull. 712, pp. 169-176, 1 fig., 1920.

10. Geology in the Matanuska coal field and the Willow Creek district, Alaska (U. S. Geol. Survey, Bull. 712, 1920) (abstract by R. W. Stone): Washington Acad. Sci., Jour., vol. 11, no. 15, p. 375, September 19, 1921.

11. Mining developments in the Matanuska coal fields [Alaska]: U. S. Geol. Survey, Bull. 714, pp.. 197-199, 1921.

12. Lode developments in the Willow Creek district [Alaska]: U. S. Geol Survey, Bull. 714, pp. 201-206, 1 pl. (map), 1921.

Chapman, Lewis C.

1. The Hockley salt dome [Harris County, Texas] : Am. Assoc. Petroleum Geologists, Bull., vol. 7, no. 3, pp. 297-299, 1 fig., May-June, 1923.

Charles, B. E. See Bridge, 1.

Charles, Homer $\mathrm{H}$.

1. Oil and gas resources of Kansas; Anderson County: Kansas, State Geol. Survey, Bull. 6, pt. 7 (Kansas, Univ., Bull., vol. 28, no. 12), 95 pp., 13 figs., 9 pls. (maps and sections), June 15, 1927.

Chase, Charles A.

1. The Aztec mine, Baldy, New Mexico: Am. Inst. Min. and Met. Eng., Trans. [preprint] no. 1193, 12 pp., October, 1922. Abstract, Mining and Metallurgy, no. 190, pp. 33-35, 1 fig., October, 1922. 
Chase, R. L.

1. The oil shale industry in Colorado: Min. and Sci. Press, vol. 118, p. 82, 1 fig., January 18, 1919.

Cheney, Charles A.

1. Salt domes of northeastern Texas: Oil and Gas Jour., vol. 20, no. 32, pp. 82-83, January 6, 1922. Review by K. C. Heald, Am. Assoc. Petroleum Geologists, Bull., vol. 6, no. 1, pp. 58-59, JanuaryFebruary, 1922.

Cheney, M. G.

1. South Bend field, Young County, Texas: Am. Assoc. Petroleum Geologists, Bull., vol. 5, no. 4, pp. 503-504, July-August, 1921.

Chittenden, Russell $\mathbf{H}$.

1. Biographical memoir of Horace Lemuel Wells, 1855-1924: Nat. Acad. Sci., Biog. Mem., vol. 12, mem. 4, 15 pp., portr., 1928.

Christensen, H. P.

1. Mineral industries of Illinois [map]. Scale 1:500,000. Illinois State Geol. Survey, 1920.

2. Directory of Illinois mineral operators; to accompany mineral industries map; September 1, 1920. Illinois State Geol. Survey, 1921.

Christie, M. G.

1. Geology as an aid to air navigation: Aviation, vol. 14, no. 23, pp. 609-611, June 4, 1923.

Christner, Drue DeGarmo. See also Beede, 10, 11.

1. (and Wheeler, O. C.). The geology of Terrell County: Texas Univ., Bull. no. 1819, pp. 1-32, 8 pls. (incl. map), April 1, 1918.

Church, C. C. See also Hanna, G. D., 37.

1. A new species of Bolivinita from the lower Pliocene of California: Jour. Paleontology, vol. 1, no. 4, pp. 265-268, 1 fig., January, 1928.

Churchill, Frederick C.

1. An abandoned marine sand bar in the Cornwallis Valley, Nova Scotia: Nova Scotian Inst. Sci., Proc. and Trans., vol. 15, pt. 1, pp. 65-69; 1 fig., January 1, 1922.

2. Evidence of elevation of the sea coast as shown by fossil deltas near Wolfville, N. S. : Nova Scotian Inst. Sci., Proc. and Trans., vol. 15, pt. 3, pp. 137-140, November 1, 1923.

3. Probable change in drainage of the Black and Gaspereau rivers, Kings County, Nova Scotia; Nova Scotian Inst. Sci., Proc. and Trans., vol. 15, pt. 3, pp. 141-144, November 1, 1923.

4. The effects of glaciation in the vicinity of Wolfville; Nova Scotia: Nova Scotian Inst. Sci., Trans., vol. 15, pt. 4, pp. 161-163, November 1, 1923.

5. Recent changes in the coast line in the County of Kings, Nova Scotia: Nova Scotian Inst. Sci., Proc. and Trans., vol. 16, pp. 84-86, November 21, 1927.

Clapn, Charles Horace. See also Wilson, R. A., 5.

1. Geology of the igneous rocks of Essex County, Massachusetts: U. S. Geol. Survey, Bull. 704, 132 pp., 4 figs., 18 pls. (incl. maps), 1921. Abstract by $\mathbf{R}$. W. Stone, Waşhington Acad. Sci., Jour., vol. 11. ṇo, 19, p. 470, November 19, 1921, 
Clapp, Charles Horace-Continued.

2. (and Bevan, Arthur, and Lambert, G. S.). Geology and oil and gas prospects of central and eastetrn Montana: Montana, Univ., Bull., Bur. Mines and Met. ser., no. 4, 95 pp., 9 pls. (incl. maps), State School of Mines, June, 1921.

Clapp, Frederick Gardner.' See also Hager, 5 ; Matteson, 2.

1. Geology of Cement oil field [Caddo County, Oklahoma]: Am. Inst. Min. and Met. Eng., Trans., vol. 65, pp. 156-164, 1 fig., 1921. Abstract, Mining and Metallurgy, no. 158, pp. 34-35, February, 1920.

2. The occurrence of petroleum. In Day, David T., A handbook of the petroleum industry, vol. 1, pp. 1-166, 62 figs., 1922.

3. Oil pools in flat arches in Montana: Pan-Am. Geologist, vol. 38, no. 1, pp. 92-94, August, 1922.

4. The Teapot Dome naval reserve no. 3, Wyoming: Oil Trade Jour., vol. 15, no.' 3, pp. 31-35, 5 figs., March, no. 4, pp. 38-39, 92, 1 fig., April, no. 5 , pp. $58,60,62,84-85$, 5 figs., May, no. 6, pp. 58, 60, 62, 90 , 3 figs., June, 1924.

5. Some essentials for successful oil development: New Zealand Mining Congress, Dunedin Meeting, Proc., pp. 63-78, 1926; Eng. and Min. Jour., vol. 122, no. 15, pp. 571-576, October 9, 1926.

6. Fundamental criteria for oil occurrence: Am. Assoc. Petroleum Geologists, Bull., vol. 11, no. 7, pp. 683-703, July, 1927; Oil Weekly, vol. 45, no. 12 , pp. $35-38$, June 10 , no. 13 , pp. $43-44,94,96,98$, June 17. 1927.

7. The present stage of oil geology: Petroleum Times, vol. 18, pp. 139-140, 211-212, 285-286, July 16, 30, August 6, 1927. Estado actual de la geología petrolera : Bol. Petroleo, vol. 26, no. 2, pp. 177-180, August 1928.

Clapp, L. R.

1. Notes on Anyox [British Columbia] mining and metallurgical practice: Canadian Inst. Min. and Met., Monthly Bull., no. 140, pp. 682-700, December, $19 \approx 3$.

2. Making coppęr 600 miles:north of Vancouver [Anyox, British Columbia]: Eng. and Min. Jour.-Press, vol. 116, no. 25, pp. 1067-1075, 10 figs., December 22, 1923 .

Clark, Albert $F$.

1. (and Newton, Roy F.) Utah hydrocarbons : Utah, Univ., Bull., vol. 15, no. 2, (Eng. Exper. Sta., Bull. no. 15), pp. 33-46, Janụary, 1925.

Clark, Austin Hobart.

1. A comparative study of the most ancient and the recent marine faunas: :Wạshington Acad. Scii, Jour., vol. 14, no. 21, pp. 487-491, December $19,1924$.

Clark, Bruce Lawrence.

1. Eocene divisions of California (abstract) : Geol. Soc. America, Bull., vol. 30, no. 1, p. 154, March 31, 1919 .

2. The stratigraphic and faunal relationships of the Meganog group, middle Eacene of California : Jour. Geology, vol. 29, no. 2, pp. 125-165, 9 figs:, February-March, 1921; abstract with discussion, Geol. Soc. America, Bull., vol. 31; no, 1; pp; 192-193, March 31, 1920.

3. Paleogeography and cofpelation of the marine Tertiary deposits of the west coast (abstract) : Geol, Soc. America, Bull., vol. 32, no. $1_{1}$ p. 90, March 31, 1921. 
Clark, Bruce Lawrence-Continued.

4. Correlation of the Tertiary marine formations of the West Coast of North America: Pan-Pacific Scientific Conference, First, Proc., Bernice P. Bishop Mus., Spec. Pub. no. 7, pt. 3, pp. 801-818, 1921.

5. The marine Tertiary of the West Coast of the United States; its sequence, paleogeography, and the problems of correlation: Jour. Geology, vol. 29, no. 7, pp. 583-614, 12 figs., October-November, 1921.

6. A new family and new genus from the Tertiary of the Pacific coast: California, Univ., Pub., Dept. Geol. Sciences, Bull., vol. 14, no. 4, pp. 115-122, 2 pls., September 7, 1922.

7. Revision of the Rimella-like gastropods from the west coast of North America: California, Univ., Dept. Geol: Sci., Bull., vol. 14, no. 7, pp. 277-288, 1 pl., October 31, 1923.

8. (and Arnold, Ralph). Fauna of the Sooke formation, Vancouver Island, with description of a new coral by. T. Wavland Vaughan: California, Univ., Dept. Geol. Sci., Bull., vol. 14, no. 5, pp. 123-234, $28 \mathrm{pls}$., November $6,1923$.

9. A summary of work in progress on the Tertiary and Quaternary of western North America: Pan-Pacific Sci. Cong., Australia, 1923, Proc.. vol. 1, rp. 874-879 [1924].

10. Thrust faulting in the region of Mount Diablo [California]: Min. and Oil Bull., vol. 10, no. 11, pp. 1133, 1181, 1200, November, 1924.

11. Pelecypoda from the marine Oligocene of western North America: California, Univ., Dept. Geol. Sci., Bull., vol. 15, no. 4, pp. 69-136, 15 pls., January 5 ,: 1925.

12. Thrust faulting in the Mount Diablo region of middle California (abstract) : Geol. Soc. America, Bull., vol. 36, no. 1, p. 152, March 30, 1925 ; Pan-Am. Geologist, vol. 43, no. 2, p. 150, Marćch, 1925.

13. Preliminary report on the geology of Mount Diablo [California] (abstract): Geol. Soc. Ameriça, Bull.; vol. 36, no. 1, pp. 205-206, March 30, 1925.

14. (and Stewart, Ralph B.). Domengine horizon (middle Eocene), a newly recognized division in the Eocene of California (abstract) : Geol. Soc. America, Bull., vol. 36, no. 1; p. 227, March 30, 1925.

15. Preliminary study of geology of Mount Diablo and Byron regions, California (abstract) : Pan-Am. Geologist, vol. 43, no. 5, p. 378, June, 1925.

16. The Domengine horizon, middle Eocene of California: California, Univ., Dept. Geol. Sci., Bull., vol. 16, no. 5, pp. 99-118, 1 fig., November $4,1926$.

17. Studies in the tectonics of the coast ranges of California (abstract): Geol. Soc. America, Bull., vol.. 38, no. 1, p̀. 163, March 30, 1927; Pan-Am. Geologist, vol. 47, no. 2, p. 158, March, 1927.

18. (and Woodford, A. O.). The geology and paleontology of the type section of the Meganos formation (lower middle Eocene) of California : California, Univ. Dept. Geol. Sci., Bull.; vol. 17, no. 2, pp. 63-142, 10 pls. (incl. map), December 31, 1927.

19. Tectonics of the Valle Grande [California] (abstract) : Pan-Am. Geologist, vol. 49, no. 4, p. 304, May, 1928.

Clark, C. R.

1. (and Bell, A. H.). Oil field operations in Illinois during the first quarter of 1927: Illinois, State Geol. Survey, Press Bull. ser., Illinois Petroleum no. 8, pp. 8-12, April 16, 1927. 
Clark, Clifton Wirt.

1. Lower and Middle Cambrian formations of the Mohave Desert: California, Univ., Dept. Geol. Sci., Bull., vol. 13, no. 1, pp. 1-7, Decemter 20, 1921.

2. Geology and ore deposits of the Santa Fe district, Mineral County, Nevada : California, Univ., Dept. Geol. Sci., Bull., vol. 14, no. 1, pp. 1-74, 4 figs., 6 pls. (incl. map), September 7, 1922.

Clark, F. B. [R.?]. See Redwood, 1.

Clark, F. L.

1. Coal balls, the "finger prints" that identify" coal: Coal Age, vol. 26, no. 19, pp. 656-657, 5 figs., November 6, 1924.

Clark, Frank R. See also Redwood, 1.

1. Geology of the Last Creek coal field, Morgan County, Utah (U. S. Geol. Survey, Bull. 691, pp. 311-322, 1918) (abstract by R. W. Stone) : Washington Acad. Sci., Jour., vol. 9, no. 11, pp. 318-319, June 4, 1919.

2. The Farnham anticline, Carbon County, Utah: U. S. Geol. Survey, Bull. 711, pp. 1-13, 2 pls. (incl. map), 1 fig., July 3, 1919. Abstract by R. W. Stone, Washington Acad. Sci., Jour., vol. 9, no. 20, p. 638, December 4, 1919.

3. Notes on the Kevin-Sunburst oil field, Montana: Amr. Assoc. Petroleum Geologists, Bull., vol. 7, no. 3, pp. 263-276, 1 fig., May-June, 1923.

4. Economic geology of the Castlegate, Wellington, and Sunnyside quadrangles, Carbon County, Utah: U. S. Geol. Survey, Bull. 793, 165 pp., 3 flgs., 22 pls. (incl. map), 1928.

Clark, George Huntington.

1. Mica deposits of Alabama : Alabama, Geol. Survey, Bull. no. 24, 115 pp., 10 figs., 1921.

2. Rock asphalts of Alabama and their use in paving: Alabama, Geol. Survey, , Special Rept. no. 18, 96 pp., 14 pls., 1925.

Clark, Glenn C. See also Aurin, 2.

1. (and Aurin, F. L.). The Tonkawa [oil] field, Oklahoma: Am. Assoc. Petroleum Geologists, Bull., vol. 8, no. 3, pp. 269-283, 7 figs., 1 pl., May-June, 1924.

2. Wilcox sand production, Tonkawa field, Oklahoma: Am. Assoc. Petroleum Geologists, Bull., vol. 10, no. 9, pp. 885-891, 4 figs., 2 pls., September, 1926.

3. (and Cooper, C. L.). Oil and gas geology of Kay, Grant, Garfield, and Noble counties: Oklahoma Geol. Survey, Bull. no. 40-H, 44 pp., 11 figs. and 6 pls. (incl. maps), March, 1927.

Clark, Hubert Lyman. See Arnold, B. W., 1.

Clark, J. M. See Whorton, 1.

Clark, Karl Adolf.

1. The McMurray tar sands [northern Alberta] : Canadian Min. Jour., vol. 42, no. 48, pp. 943-944, December 2, 1921.

2. The bituminous sand and its commercial development: Alberta, Scientific and Industrial Research Council, 2d Ann. Rept., pp. 43-59, 2 figs., 1922. 
Clark, Karl Adolf-Continued.

3. 'J'he bituminous sands of northern Alberta: Alberta, Sci. and Industrial Research Council, Third Ann. Rept., pp. 42-58, 1923.

4. (and Blair, S. M.). The bituminous sands of northern Alberta: Alberta, Scientific and Industrial Research Council, 5th Ann. Rept. (Rept. no. 12 ), pp. 46-65, 3 figs., 1925.

5. (and Blair, S. M.). The bituminous sands of Alberta: Alberta, Sci. and Ind. Research Council, Rept. no. 18, 74 pp., 3 figs., 7 pls., 2 maps, 1927.

Clark, Robert Watson.

1. (and Bauer, C. Max). Notes on geology of the Okmulgee district [Oklahoma]: Am. Assoc. Petroleum Geologists, Bull., vol. 5, no. 2, pp. 282-292, 1 fig. (map), March-April, 1921.

2. Oil and gas in Oklahoma; Geology and oil and gas development in Okmulgee County, Oklahoma: Oklahoma Geol. Survey, Bull. no. 40-F, 28 pp., 6 figs., map, December, 1926.

3. Origin of folding. in Oklahoma : Am. Assoc. Petroleum Geologists, Bull., vol. 11, no. 2, p. 199, February, 1927.

4. Oil and gas in Oklahoma; geology of McIntosh County: Oklahoma Geol. Survey, Bull. no. 40-W, 14 pp., 1 fig., 4 pls., January, 1928.

Clark, Stuart K.

1. Thomas oil field, Kay County, Oklahoma: Am. Assoc. Petroleum Geologists, Bull., vol. 10, no. 7, pp. 643-655, 7 figs., July, 1926.

2. (and Daniels, James I., and Richards, J. T.). Logging rotary wells from drill cuttings: Am. Assoc. Petroleum Geologists, Bull., vol. 12, no. 1, pp. 59-76, 4 figs., January, 1928.

3. Faulting in Thomas field, Kay County, Oklahoma : Am. Assoc. Petroleum Geologists, Bull., vol. 12, no. 7, pp. 769-772, July, 1928:

Clark, Thomas Henry. See also Sayles, 14.

1. A section in the Trenton limestone at Martinsburg, New York: Harvard Coll., Mus. Comp. Zool., Bull. vol. 63, no. 1, pp. 1-18, 1 pl., May, 1919.

2. A new agelacrinitid from the Chazy of New York: Am. Jour. Sci., 4th ser., vol. 50, pp. 69-71, 1 fig., July, 1920.

3. The origin of graphite: Econ. Geology, vol. 16, no. 3, pp. 167-183, AprilMay, 1921.

4. A review of the evidence for the Taconic revolution: Boston Soc. Nat. Hist., Proc., vol. 36, no. 3, pp. 135-163, July, 1921.

5. Nature of Salterella (abstract) : Geol. Soc. America, Bull., vol. 33, no. 1, pp. 196-197, March 31, 1922.

6. Devonian limestone at St. George, Quebec (abstract) : Geol. Soc. America, Bull., vol. 33, no. 1, p. 201, March 31, 1922.

7. A new trilobite appendage: Am. Jour. Sci., 5th ser., vol. 4, pp. 245-248, 1 fig., September, 1922.

8. Geology of Levis, Quebec (abstract) : Geol. Soc. America, Bull., vol. 35, no. 1, p. 101, March 30, 1924; Pan-Am. Geologist, vol. 41, no. 2, p. 150, March, 1924.

9. The Devonian limestone at St. George, Quebec: Jour. Geology, vol. 31, no. 3, pp. 217-225, 1 fig. (paleogeographic map), April-May, 1923.

10. New fossils from the vicinity of Boston: Boston Soc. Nat. Hist., Proc., vol, 36, no. 8, pp. 473-485, 2 figs., August, 1923, 
Clark, Thomas Henry-Continued.

11. The paleontology of the Beekmantown series at Levis, Quebec: Bull. Am. Paleontology, vol. 10, no. 41, 135 pp., 9 pls., June 25, 1924.

12. On the nature of Salterella: Roy. Soc. Canada, Proc. and Trans., 3d ser., vol. 19, sec. 4 , pp. $29-41,2$ pls., 1925.

13. The structure of the Levis formation at Levis, Quebec: Roy. Soc. Canada, Proc. and Trans., 3d ser., vol. 20, pt. 2, sec. 4, pp. 169-180, 3 figs., 1 pl. (map), 1926.

14. The graptolites of the Glenogle formation [British Columbia] : Canadian Field-Naturalist, vol. 40, no. 6, pp. 136-137, September, 1926.

15. A fossil bison skull from Yukon Territory: Canadian Field-Naturalist, vol. 41 , no. 3 , pp. 45-47,.2 figs. ,March, 1927 .

16. A new cephalopod from the Trenton limestone of Montreal: Canadian Field-Naturalist, vol. 42', no. 8, pp. 187-189, 1 fig., November, 1928.

Clark, William Otterbein.

1. (and Riddell, C. W.). Exploratory drilling for water and use of ground water for irrigation in Steptoe Valley, Nevada; with an introduction by O. E. Meinzer: U. S. Geol. Survey, Water-Supply Paper 467, 70 .pp., 6 figs., 6 pls. (incl. maps), 1920; abstract, Washington Acad. Sci., Jour., vol. 11, no. 18, p. 442, November 4, 1921.

2. Ground water in Santa Clara Valley, California; U. S. Geol. Survey, Water-Supply Paper 519, 209 pp., 20 figs., 19 pls. (incl. maps), 1924.

Clarke, F. B.

1. A review of Montana [oil] developments: Oil and Gas Jour., vol. 20, no. 33 , pp. 62-64, January $13,1922$.

Clarke, Frank Wigglesworth.

1. The data of geochemistry (fourth edition): U. S. Geol. Survey, Bull. 695, 832 pp., 1920.

2. (and Wheeler, Walter Calhoun). The inorganic constituents of marine invertebrates (second edition, revised and enlarged): U. S. Geol. Survey, Prof. Paper 124, 62 pp., 1922.

3. (and Washington, H. S.). The average chemical composition of igneous rocks : Nat. Acad. Sci., Proc., vol. 8, no. 5, pp. 108-115, May, 1922.

4. (and Washington, Henry Stephens). The composition of the earth's crust: U. S. Geol. Survey, Prof. Paper 127, 117 pp., 28 tables, 1924.

5. The data of geochemistry (fifth edition): U. S. Geol. Survey, Bull. 770,841 pp., 1924.

6. The evolution and disintegration of matter: U. S. Geol. Survey, Prof. Paper 132, pp. 51-86, 1 pl., April 9, 1924.

7. The composition of the river and lake waters of the United States: U. S. Geol. Survey, Prof. Paper 135, 199 pp., 1924.

8. Mineralogical work [of Joseph Leidy]: Acad. Nat. Sci. Philadelphia, Proc., vol. 75 [Appendix], The Joseph Leidy Commemorative Meeting, pp. 49-52, 1924.

9. The internal heat of the earth: Sci. Am., vol. 134, pp. 370-371, 6 figs., June, 1926.

10. The significance of meteorites: Sci. Am., vol. 138, no. 5, pp. 430-431, 4 figs., May, 1928. 
Clarke, John Mason, 1857-1925.

1. Fourteenth report of the director of the State Museum and Science Department, including the seventy-first report of the State Museum, the thirty-seventh report of the State geolcgist, and the report of the State paleontologist for 1917: New York State Mus. Bull., nos. 207, 208 (March-April, 1918), 211 pp., illus., 1919.

2. Geological map of the Peninsula of Percé, P. Q., and its islands: New York State Mus. Bull. nos. 207, 208 (March-April, 1918), p. 147, map, 1919.

3. Biographical memoir of William Bullock Clark, 1860-1917: Nat. Acad. Sci., Biog. Mem., vol. 9, pp. 3-18, portr., May, 1919.

4. Bunaia woodwardi, a new merostome from the Silurian waterlimes of New York: Geol. Mag., new ser., dec. 6, vol. 6, pp. 531-532, 1 pl., December, 1919.

5. Fifteenth report of the director of the State Museum and Science Department, including the seventy-second report of the State $\mathrm{Mu}$ seum, the thirty-eighth report of the State geologist, and the report of the State paleontologist for 1918: New York State Mus. Bull. nos. 219, 220, 309 pp., pls., 1920.

6. Postbellum reflections on the place of paleontology among the sciences: New York State Mus. Bull. nos. 219, 220, pp. 123-128, 1920.

7. New Paleozoic crustaceans, I; Bunaia, a new merostome crustacean, from the New York Silurian waterlimes: New York State Mus. Bull. nos. 219, 220, pp. 128-134, 1 pl., 1920.

8. Armstrongia, a new genus of Devonian glass sponges: New York State Mus. Bull. nos. 219, 220, pp. 143-146, 1 pl., 1920.

9. The microscopic fauna of the Bonaventure conglomerate: New York State Mus. Bull. nos. 219, 220, pp. 147-148, 1920.

10. The great glass-sponge colonies of the Devonian; their origin, rise, and disappearance: Jour. Geology, vol. 28, no. 1, pp. 25-37, 19 figs., January-February, 1920.

11. (and Matthew, W. D.). Supposed fossil horse from the late Pleistocene found at Monroe, Orange Ccunty, New York (abstract): Geol. Soc. America, Bull., vol. 31, no. 1, p. 204, March 31, 1920.

12. A great American geologist of the last century, Professor James Hall (1811-1898) : Geol. Mag., vol. 57, pp. 483-486, portr., November, 1920.

13. James Hall, of Albany, geologist and palentclogist, 1811-1898. 565 pp., 14 pls. (incl. portr.), Albany, 1921.

14. The oldest of the forests [upper Devonian tree trunks, Schoharie Creek, Catskill Mountains, New York]: Scient. Monthly, vol. 12, no. 1, pp. 83-91, 4 pls., January, 1921.

15. (and Smyth, C. H., jr., and Ruedemann, R.). Henry Platt Cushing: Science, new ser., vol. 53, pp. 510-512, June 3, 1921.

16. Organic dependence and disease; their origin and significance: New York State Mus. Bull., nos. 221, 222, 113 pp., 105 figs., 1921 (also New Haven, Yale University Press, 1921).

17. Sixteenth report of the director of the State Museum and Science Department, including the seventy-third report of the State Museum, the thirty-ninth report of the State geologist, and the report of the State paleontologist for 1919: New York State Mus. Bull. nos. 227, 228, 146 pp., 1921. 
Clarke, John Mason-Continued.

18. Seventeenth report of the director of the State Museum and Science Department, including the seventy-fourth report of the State Museum, the fortieth report of the State geologist, and the report of the State paleontologist for 1920-21: New York State Mus., Bull. nos. 239-240, 209 pp., 12 figs., 17 pls., 1922.

19. The age of the earth from the paleontological viewpoint: Am. Philos. Soc., Proc., vol. 61, no. 4, pp. 272-282, 1922 ; Smithsonian Inst., Ann. Rept., 1922, pp. 261-269, 1924; abstract, Science, new ser., vol. 55, pp. 655-656, June 16, 1922.

20. L'île Percée, the finial of the St. Lawrence . . 203 pp., illus., New Haven, Yale University Press, 1923.

21. Boom Beach (Isle-au-Haut, Maine); a sea mill (abstract with discussion by C. K. Wentworth and C. O. Dunbar) : Geol. Soc. America, Bull., vol. 34 , no. 1 , p. 65, March $30,1923$.

22. The Burton dictyosponge (abstract) ; Restoration of the Cohoes mastodon (abstract) ; Pyorrhoea in the Cohoes mastodon (abstract) ; Temple Hill mastodon (abstract) : Geol. Soc. America, Bull., vol. 34, no. 1, pp. 127-128, March 30, 1923.

23. Eighteenth report of the director of the State Museum and Science Depart: New York State Mus. Bull. no. 251, 192 pp., illus., 1924.

24. A hemiaspidan crustacean from the New York Silurian waterlimes: New York State Mus. Bull. no. 251, pp. 119-120, 2 figs., 3 pls., 1924.

25. A colossal Devonian glass sponge: New York State Mus. Bull., no. 251, pp. 121-122, 2 pls., 1924.

26. The geological age of the Bonaventure formation: New York State Mus. Bull. no. 251, pp. 123-127, 5 figs., 1924.

27. Rosetted trails of the Paleozoic: New York State Mus. Bull. no. 251, pp. 128-130, 1 fig., 1 pl., 1924.

28. Nineteenth report of the director of the State Museum and Science Department: New York State Mus. Bull. no. 253, pp. 7-25, July, 1924.

29. D. Dana Luther, miller and geologist, 1840-1923: New York State Mus. Bull. no. 253, pp. 117-120, portr., July, 1924.

30. Twentieth report of the director of the State Museum and Science Department: New York State Mus. Bull., no. 260, pp. 7-46, illus., 1925.

31. The age of the earth: World Almanac and Book of Facts, 1926, p. 87, New York, New York World, 1926.

Clarke, Noah T. See also Bishop, 2.

1. The reconstruction of the Sterlingbush calcite cave: New York State Mus. Bull. nos. 219, 220, pp. 223-226, 1 pl., 1920.

2. Method of restoring the Cohoes mastodon: New York State Mus. Bull. no. 251, pp. 131-133, 2 pls., 1924.

Clawson, w. W., jr.

1. Oil and gas geology of Coal and Pittsburg Counties: Oklahoma Geol. Survey, Bull. 40-JJ, 16 pp., 2 figs., 2 pls. (maps), November, 1928.

Claypool, C. B.

1. (and Howard, W. V.). Method of examining calcareous well cuttings: Am. Assoc. Petroleum Geologists, Bull., vol. 12, no. 12, pp. 11471152, December, 1928.

Cleland, Herdman Fitzgerald.

1. Memorial of Henry Shaler Williams: Geol. Soc. America, Bull., vol. 30, pp. 47-65, portr., March 31, 1919. 
Cleland, Herdman Fitzgerald-Continued.

2. Practical applications of geology and physiography for use in the laboratory and class room, 69 pp., 50 figs., Excelsior Press, North Adams, Massachusetts, 1920.

3. The teaching of historical geology: Geol. Soc. America, Bull., vol. 31, no. 3, pp. 375-382, september 30, 1920.

4. The sixteenth annual New England intercollegiate geological excursion: Science, new ser., vol. 52, pp. 458-459, November 12, 1920.

5. A Pleistocene peneplain in the Coastal Plain: Jour. Geology, vol. 28, no. 8, pp. 702-706, November-December, 1920.

6. Demonstration material in geology (with discussion by W. M. Davis) : Geol. Soc. America, Bull., vol. 33, no. 1, pp. 56-85, 15 figs., March $31,1922$.

7. Weathering under constant conditions: Science, new ser., vol. 56, pp. 660-661, December 8, 1922.

8. Geology, physical and historical. 718 pp., 588 figs., New York, American Book Company [1925].

Clements, Frederic Edward.

1. (and Chaney, R. W.). Researches in sedimentation: Carnegie Inst. Washington, Year Book no. 21, 1922, p. 356, January, 1923.

2. (and Chaney, R. W.). Methods and principles in paleoecology: Carnegie Inst. Washington, Year Book no. 22, p. 319, 1924.

3. (and Chaney, R. W.). Principles and methods in paleoecology : Carnegie Inst. Washington, Year Book no. 25, 1955-26, pp. 370-371, December ,1926.

Clench, William J.

1. Description of a new species of Physa from the Pleistocene of Florida: Michigan, Univ., Mus. Zool., Occ. Papers, no. 164, 4 pp., 1 pl., August 3, 1925.

Clifton, R. L. See also Wheeler, 1.

1. Oil and gas in Oklahoma; Woods, Alfalfa, Harper, Major, Woodward, anö Ellis counties: Oklahoma Geol. Survey, Bull. no. 40-A, 24 pp., 5 pls. (incl. map), June, 1926.

2. Stratigraphy of Whitehorse sandstone; formation extends from Clarke County, Kansas, through Oklahoma aud into Panhandle area of Texas: Oil and Gas Jour., vol. 25, no. 2, pp. 70, 74, map, June 3, 1926.

3. Preliminary report on the Comanchean of northwestern Oklahoma: Oklahoma Acad. Sci., Proc., vol. 5, 1925 (Oklahoma, Univ., Bull., new ser. no. 330, Univ. Studies no. 22), pp. 128-131, April 1, 1926.

4. Correlation of the Whitehorse sandstone: Oklahoma Acad. Sci., Poc., vol, 5, 1925 (Oklahoma, Univ., Bull., new ser. no. 330, Univ. Studies no. 22), pp. 152-155, April 1, 1926.

5. Oil and gas in Oklahoma ; geology of Harmon, Greer, Jackson, and Tillman Counties: Oklahoma Geol. Survey, Bull. no. 40-Y, 24 pp., 1 fig, 1 pl. (map), January, 1928.

(Ginton, H. G. See also Foshag, 30.

I Some rare minerals from Nevada : Rockss and Minerals, vol. 2, no. 1, pp. 34 35, March, 1927. 
Cloos, Hans.

1. (and Balk, R.). Primary structure of Sierra Nevada intrusive in a crosssection from Yasemite Valley to Mono Lake, California (abstract) : Geol. Soc. America, Bull., vol. 39, no. 1, p. 185, March 30, 1928 ; Pan-Am. Geologist, vol. 49, no. 2, p. 142, March, 1928.

Cloud, W. F. See George, H. C.

Clute, Walker S.

1. Notes on the geology of Olinda field, California: Oil Bull., vol. 12, no. 9, pp. 954-955, 2 figs., September, 1926.

Cobb, Collier.

1. Physiographic processes in relation to harbor development and harbor maintenance: Elisha Mitchell Sci. Soc., Jour., vol. 38, nos. 1-2, pp. 21-23, September, 1922.

2. Permian fossils from the base of the North Carolina Newark (abstract) : Elisha Mitchell Sci. Soc., Jour., vol. 29, nos. 1-2, pp. 30-31, August, 1923.

3. The immediate ancestor of our domestic horse found fossil in Halifax County, North Carolina (abstract) : Elisha Mitchell Sci. Soc., Jour., vol. 29, nos. 1-2, pp. 31-32, August, 1923.

4. Our changing environment in North Carolina (abstract) : Elisha Mitchell Sci. Soc., Jour., vol. 43, nos. 1-2, p. 13, December, 1927.

5. A sperm whale from the Miocene(?) of Florida (abstract) : Elisha Mitchell Sci. Soc., Jour., vol. 43, nos. 1-2, pp. 23-24, December, 1927.

Cobb, Margaret Cameron. See also Ambronn, 1.

1. The origin of corundum associated with dunite in western North Carolina. Dissertation, Bryn Mawr College, 43 pp., 7 pls., map, Bryn Mawr, Pennsylvania, 1924.

2. Desilicative genesis of commercial corundum: Pan-Am. Geologist, vol. 43, no. 4, pp. 257-264, May, 1925.

Cobb, W. B.

1. Soil age and its possible signiflcance in geology (abstract) : Elisha Mitchell Sci. Soc., Jour., vol. 44, no. 1, pp. 17-18, September, 1928.

Cockburn, A. M.

1. Some geological notes on the volcanoes of Hawaii (abstract) : Geol. Mag., vol. 64, p. 187, April, 1927.

Cockerell, Theodore Dru Alison. See also Northrop, S. A., 1.

1. Some American Cretaceous fish scales; with notes on the classification and distribution of Cretaceous fishes (preface by T? W. Stanton) : U. S. Geol. Survey, Prof. Paper 120, pp. 165-202, 7 pls., 1919. Abstract by R. W. Stone, Washington Acad. Sci., Jour., vol. 9, no. 15, pp. 440-441, September 19, 1919.

2. Eocene insects from the Rocky Mountains: U. S. Nat. Mus., Proc., vol. 57, pp. 233-260, 5 pls., 11 figs., 1920.

3. The oldest mosquitoes [Culex winchesteri, western Colorado] : Nature, vol. 103, p. 44, March 20, 1919.

4. Some fossil parasitic Hymenoptera: Am. Jour. Sci., 4th ser., vol. 47, pp. 376-380, 6 figs., May, 1919.

5. Glossina and the extinction of Tertiary mammals: Nature, vol. 103, p. 265, June 5, 1919. 
Cockerell, Theodore Dru Alison-Continued.

6. Zoology [chapter 20, pp. 157-163, Florissant, Colorado, fossils]. 558 pp., illus., New York, World Book Co., 1920.

7. Biographical memoir of Alpheus Spring Packard, 1839-1905: Nat. Acad. Sci., Biog. Mem., vol. 9, pp. 181-236, portr., February, 1920.

8. Some Eocene insects from Colorado and Wyoming: U. S. Nat. Mus., Proc., vol. 59, pp. 29-39, 9 figs., 1 pl., 1921.

9. (and Sandhouse, Grace). Some Eocene insects of the family Fulgoridae: U. S. Nat. Mus., Proc., vol. 59, pp. 455-457, 1 pl., 1921.

10. The earliest bees, wasps, and ants: Science, new ser., vol. 54, pp. 154-155, August 19, 1921.

11. A fossil buttercup [Ranunculus florissantensis from Miocene of Florissant, Colorado] : Nature, vol. 109, pp. 42-43, 1 fig., January 12, 1922.

12. The fossil sawflies of Florissant, Colorado: Entomologist, vol. 55, pp. 4950, March, 1922.

13. A fossil moth from Florissant, Colorado: Am. Mus. Novitates, no. 34, 2 pp., 1 fig., March 29, 1922.

14. A new genus of fossil Liliaceae [Brachyruscus, Florissant, Colorado]: Torrey Bot. Club, Bull., vol. 49, no. 7, pp. 211-213, 1 fig., July, 1922.

15. An ancient wasp [Hoplisus archorytes, Bear Gulch, Green River formation, Colorado] : Nature, vol. 110, p. 313, September 2, 1922.

16. A fossil cichlid fish from the Republic of Haiti : U. S. Nat. Mus., Proc., vol. 63, art. 7, 2 pp., 1 pl., 1923.

17. The supposed plumage of the Eocene bird Diatryma: Am. Mus. Novitates, no. 62, 4 pp., 2 figs., March 16, 1923.

18. The scales of the fossil fish Eobrycon: Science, new ser., vol. 57, p. 418, April 6, 1923.

19. Fossil insects from the Eocene of Texas: Am. Jour. Sci., 5th ser., vol. 5, pp. 397-400, 2 figs., May, 1923.

20. The Laramie flora: Torreya, vol. 23, no. 3, pp. 52-53, May-June, 1923.

21. Fossil mammals at the Colorado Museum of Natural History: Sci. Monthly, vol. 17, no. 3, pp. 271-277, 7 figs., September, 1923.

22. A new genus of May flies from the Miocene of Florissant, Colorado [Siphlurites]: Psyche, vol. 30, no. 5, pp. 170-172, October, 1923.

23. Two fossil Hymenoptera from Florissant [Colorado] (Vespidae, Megachilidae) : Entomological News, vol. 34 , no. 9 , pp. $270-271$, November, 1923.

24. Fossil insects in the United States National Museum: U. S. Nat. Mus., Proc., vol. 64, art. 13, 15 pp., 2 figs., 2 pls., 1924.

25. A genuine fossil Ophioglossum [Tertiary, Wyoming]: Torreya, vol. 24, no. 1, pp. 10-11, 1 fig., January-February, 1924.

26. An ancestor of the Agromyzidae [Eomyza holoptera, Green River Eocene, Roan Mountains, Colorado]: Entomologist, vol. 57, pp. 199-201, September, 1924.

27. Plant and insect fossils from the Green River Eocene of Colorado: U. S. Nat. Mus., Proc., vol. 66, art 19, 13 pp., 2 pls., February 16, 1925.

28. (and Custer, Clarence). A new fossil Inocellia (Neuroptera) from Florissant: Entomologist, vol. 58, pp. 295-297, 1 fig., December, 1925.

29. The supposed fossil Ophioglossum [O. hastatiforme, Eocene, Wyoming]: Torreya, vol, 26, no. 1, pp. 10-11, January-February, 1926.

30. A fossil orthopterous insect formerly referred to Mecoptera: Entomological Soc. Washington, Proc., vol. 28, no. 6, p. 142, June, 1926. 
Cockerell, Theodore Dru Alison-Continued.

31. A Miocene Orontium (Araceae) : Torreya, vol. 26, no. 4, p. 69, 1 fig., July August, 1926.

32. Some Tertiary fossil insects: Ann. and Mag. Nat. Hist., 9th ser., vol, 1.8, pp. 313-324, 14 figs., October, 1926.

33. Hunting fossil insects : Sci. Am., vol. 135, pp. 264-265, October, 1926.

34. 'The antiquity of the Labiatae or mint family: Nature, vol. 118, p. 696, November 13, 1926.

35. An alga from the Eocene of Colorado: Torreya, vol. 26, no. 6, pp. 111-112, 1 fig., November-December, 1926.

36. Fossil insects from the Miocene of Colorado: Ann. Mag. Nat. Hist., 9th ser., vol. 19, pp. 161-166, February, 1927.

37. The Carboniferous insects of Maryland: Ann. Mag. Nat. Hist., 9th ser., vol. 19, pp. 385-416, 3 pls., April, 1927.

38. A supposed fossil catmint [from Florissant, Colorado] : Torreya, vol. 27, no. 3, p. 54, 1 fig., May-June, 1927.

39. A new oak from the Green River Eocene: Torreya, vol. 27, no. 5, pp. 9495, 1 fig., September-October, 1927.

40. Tertiary insects from eastern Oregon: Carnegie Inst. Washington, Pub. 346 (Contributions to Paleontology), pp. 64-65, 3 figs., October, 1927.

41. Fossil insects in the British Museum [some from Miocene of Florissant, Colorado] : Annals and Mag. Nat. Hist., 9th ser., vol. 20, pp. 585594, 2 figs., December, 1927.

42. A remarkable new dragon fly from the Eocene [of Colorado] (Odonata) : Entomological News, vol. 39, no. 10, pp. 297-301, 1 fig., 1 pl., December, 1928.

Cockfield, William Egbert.

1. Mayo area, Yukon: Canada, Geol. Survey, Summ. Rept., 1918, pt. B, pp. 1-15, 1919.

2. Silver-lead deposits of the Twelvemile area, Yukon: Canada, Geol. Survey, Summ. Rept., 1918, pt. B, pp. 15-17, 1919.

3. Explorations in the Ogilvie Range, Yukon: Canada, Geol. Survey, Summ. Rept., 1919, pt. B, pp. 1-3, 1920.

4. Mayo ąrea, Yukon: Canada, Geol. Survey, Summ. Rept., 1919, pt. B, pp. $3-7,1920$.

5. Sixtymile and Ladue rivers area, Yukon: Canada, Geol. Survey, Mem. 123, 60 pp., 6 pls., map, 1921.

6. Silver-lead deposits of the Keno Hill area, Mayo district, Yukon : Canada, Geol. Survey, Summ. Rept., 1920, pt. A, pp. 1-6, 1 fig., map, 1921.

7. The silver-lead ores of Mayo district, Yukon: Canadian Min. Jour., vol. 42, no: 3, pp. 44-45, January 21, 1921.

8. Silver-lead deposits of Davidson Mountains, Mayo district, Yukon : Canada, Geol. Survey, Summ. Rept., 1921, pt. A, pp. 1-6, 1 fig., 1 pl., 3 maps, 1922.

9. Explorations in southern Yukon: Canada, Geol. Survey, Summ. Rept., 1922, pt. A, pp. 1-8, 1923.

10. Recent mining developments in the Mayo district, Yukon: Canadian Min. Jour., vol. 44, no. 50, pp. 980-981, 1 fig., December 14, 1923.

11. Geology and ore deposits of Keno Hill, Mayo district, Yukon: Canada, Geol. Survey, Summ. Rept., 1923, pt. A, pp. 1-21, 4 figs., map, 1924.

12. Silver-lead deposits of Beaver River area, Yukon: Canada, Geol. Survey, Summ. Rept., 1923, pt. A, pp. 22-28, 2 figs., 1924. 
Cockfield, William Egbert-Continued.

13. The Mayo silver-lead district, Yukon: Canadian Min. Jour., vol. 45, no. 37, pp. 891-893, 1 fig., September 12, 1924 ; Min. Mag., vol. 30, no. 2, pp. 122-123, 2 figs., February, 1924.

14. The silver-lead deposits of Beaver River district, Yukon: Canadian Min. Jour., vol. 46, no. 3, pp. 65-67, 1 fig., January 16, 1925.

15. Upper Beaver River area, Mayo district, Yukon: Canada, Geol. Survey, Summ. Rept., 1924, pt. A, pp. 1-18, 2 figs., 1 pl., map, 1925.

16. (and Bell, A. H.). Whitehorse district, Yukon: Canada, Geol. Survey, Mem. 150, 63 pp., 8 pls., map, 1926.

17. Silver-lead deposit in Atlin district, British Columbia: Canada, Geol. Survey, Summ. Rept., 1925, pt. A, pp. 15-24, 2 figs., 1926.

1.8. Explorations between Atlin and Telegraph Creek, British Columbia: Canada, Geol. Survey, Summ. Rept., 1925, pt. A, pp. 25-32, map, 1926.

19. Aishihik Lake district, Yukon : Canada, Geol. Survey, Summ. Rept., 1926, pt. A, pp. 1-13, map, 1927.

20. Dezadeash Lake area, Yukon: Canada, Geol. Survey, Summ. Rept., 1927, pt. A, pp. 1-7, map, 1928.

21. Silver-lead deposits of Fifteenmile Creek, Yukon: Canada, Geol. Survey, Summ. Rept., 1927, pt. A, pp. 8-10, 1928.

22. Silver-lead deposits of Rude Creek, Yukon: Canada, Geol. Survey, Summ. Rept., 1927, pt. A, pp. 11-13, 1928.

23. Pueblo, Tamarack-Carlisle, and War Eagle-Leroi properties, Whitehorse copper belt, Yukon: Canada, Geol. Survey, .Summ. Rept., 1927, pt. A, pp. 14-18, 1928.

Coffin, Reuben Clare. See also Hess, 15.

1. (and Perini, V. C., jr., and Collins, M. J.). Some anticlines of western Colorado: Colorado Geol. Survey, Bull. 24, 61 pp., 13 figs., 2 pls. (maps), 1920.

2. An anticline in Montezuma County; Colorado Geol. Survey, Bull. 24, pp. 47-59, 1 fig., 1 pl. (map), 1920.

3. Radium, uranium, and vanadium deposits of southwestern Colorado: Colorado Geol. Survey, Bull. 16, 231 pp., 53 figs., 4 pls. (incl. maps) 1921.

4. Ground waters of parts of Elbert, El Paso, and Lincoln counties: Colorado Geol. Survey, Bull. 26, pp. 3-8, 1921.

Colburn, Frona Eunice (Wait).

1. The kingship of Mt. Lassen . . 69 pp., illus., San Francisco, Calif., Nemo Publishing Company, 1922.

Colby, Charles Carlyle.

1. Source book for the economic geography of North America. 418 pl., 11 maps, University of Chicago Press, Chicago, Illinois, 1921.

Cole, Arthur Augustus.

1. Cobalt, bonanza silver district of Ontario: Eng. and Min. Jour.-Press, vol. 118, no. 9, pp. 325-330, 7 figs., August 30, 1924.

2. The silver mining industry in Canada: Canadian Min. and Met. Bull., no. 183, pp. 807-843, 17 figs., July, 1927 ; Canadian Inst. Min. and Met., Trans., vol. 30, pp. 155-193, 17 figs. [1928]; Second (Triennial) Empire Min. and Met. Congress, Canada, 1927, Proc., pt. 1, pp. 561-599, 17 figs., 1928.

4096-31- -9 
Cole, George E.

1. Gypsum in Ontario: Ontario Dept. Mines, 34th Ann. Rept., vol. 34, pt. 2, pp. 1-34, illus., 1925.

2. Gypsum in Ontario: Canadian Inst. Min. and Met., Bull., no. 154, pp. 148162, February, 1925; Trans., vol. 28, pp. 194-208 [1926].

3. The development of gold mining in Canada:Canadian Min. and Met. Bull., no. 185, pp. 1013-1150, 50 figs., 1 pl., September, 1927; Canadian Inst. Min. and Met., Trans., vol. 30, pp. 10-154, 50 figs. [1928]; Second (Triennial) Empire Min. and Met. Congress, Canada, 1927, Proc. pt. 1, pp. 415-559, 50 figs., 1928.

Cole, Grenville Arthur James.

1. The floor of the Valley of Ten Thousand Smokes [Alaska]: Nature, vol. 112, p. 251, August 18, 1923.

Cole, Lionel Heber. See also Keele, 5.

1. Notes of a discovery of rock salt in Nova Scotia [near Malagash, Cumberland County]: Canadian Min. Jour., vol. 40, pp. 8-9, 3 figs., January 8, 1919.

2. The salt industry and the possibilities for the future development in Canada: Canadian Min. Jour., vol. 40, pp. 346-356, May 14, 1919.

3. Notes on the salt industry of Canada, with special reference to the recent discovery of rock salt in Nova Scotia; Canadian Min. Inst., Trans., vol. 22, pp. 433-443 [1920].

4. Alkali deposits of western Canada: Canadian Min. Jour., vol. 42, no. 5, pp. 92-93, February 4, 1921.

5. Silica in Canada ; its occurrence, exploitation, and uses; Part I, Eastern Canada: Canada, Dept. Mines, Mines Branch, 126 pp., 16 figs., 15 pls., 7 maps, 1923.

6. Alkali deposits of western Canada: Canada, Mines Branch, Summ. Rept., 1921, pp. 18-34, 1923.

7. Alkali deposits, western Canada: Canada, Mines Branch, Summ. Rept. 1922, pp. 9-15, 1924.

8. Volcanic ash near Waldeck, Saskatchewan: Canada, Mines Branch, Summ. Rept., 1922, pp. 15-20, 1 fig., 1924.

9. Sodium and magnesium salts of western Canada: Canadian Inst. Min. and Met., Monthly Bull., no. 143, pp. 100-128, 8 figs., March, 1924; (with discussion) Trans., vol. 27, pp. 209-247, 8 figs. [1925].

10. Sodium and magnesium salts of western Canada: Canada, Mines Branch, Investigations of Mineral Resources and the Mining Industry, 1923, pp. 47-53, 1924.

11. Sodium sulphate of western Canada; occurrence, uses and technology: Canada, Dept. Mines, Mines Branch. 160 pp., 16 figs., 15 pls., maps, 1926. [Pub. no. 646.]

12. (and Eardley-Wilmot, V. L.) Lithium-bearing minerals in Canada: Canada, Dept. Mines, Mines Branch, Investigations of mineral resources and the mining industry, 1925, pp. 69-75, 1926.

13. Silica in Canada, its occurrence, exploitation, and uses; Part II, western Canada: Canada, Dept. Mines, Mines Branch, 49 pp., 7 figs., 6 pls., 1928. [Pub. 686.]

Cole, W. Storrs.

1. A foraminiferal fauna from the Guayabal formation in Mexico: Bull. Am. Paleontology, vol. 14, no. 51, 46 pp., 5 pls., December 23, 1927.

2. A foraminiferal fauna from the Chapapote formation in Mexico: Bull. Am. Paleontology, vol. 14, no. 53, 32 pp., 4 pls., April 2, 1928. 
Coleman, Arthur Philemon. See also Daly, 12.

1. The glacial history of Prince Edward Island and the Magdalen Islands: Roy. Soc. Canada, Proc. and Trans., 3d ser., vol. 13, sec. 4, pp. 33-37, 1920.

2. Extent and thickness of the Labrador ice sheet: Geol. Soc. America, Bull., vol. 31, no. 2, pp. 319-328, 3 figs., June 30, 1920 ; abstract, no. 1, p. 128, March 31, 1920.

3. Lost placers of Ontario: Canadian Inst. Min. and Met., Monthly Bull. no. 100, pp. 655-657, August, 1920 ; Canadian Min. Inst., Trans., vol. 23, pp. 438-440 [1921].

4. Origin of the cobalt silver ores (discussion) : Econ. Geology, vol. 15, no. 6, pp. 539-541, September, 1920.

5. Norite occurrences: Canadian Min. Jour., vol. 41, p. 966, November 26, 1920.

6. Northeastern part of Labrador and New Quebec: Canada, Geol. Survey, Mem. 124, 68 pp., 10 pls., 3 maps, 1921.

7. The Gaspe Peninsula; a study of the geology of the region and its influence on the inhabitants: Roy. Soc. Canada, Proc. and Trans., 3d ser., vol. 15, pp. xxxix-lv, 1921.

8. Paleobotany and the earth's early history: Am. Jour. Sci., 5th ser., vol. 1, no. 4, pp. 315-319, April, 1921.

9. (and Parks, W. A.). Elementary geology; with special reference to Canada. 363 pp., 197 figs., London, J. M. Dent \& Sons, Ltd., 1922.

10. Physiography and glacial geology of Gaspe Peninsula, Quebec: Canada, Geol. Survey, Bull. no. 34, 52 pp., 5 figs., 7 pls., map, 1922.

11. Glacial and postglacial lakes in Ontario: Toronto, Univ., Studies, Biological series, no. 21, 76 pp., 9 figs., 6 pls., 1922.

12. Geology and the nebular theory: Nature, vol. 109, p. 775, June 17, 1922.

13. The veins of Cobalt, Ontario [pre-Cambrian glaciation]: Econ. Geology, vol. 17, no. 4, pp. 297-299, June-July, 1922.

14. The geology and surface features of the Torngat Mountains in northern Labrador (abstract): Science, new ser., vol. 56, p. 176, August 11, 1922.

15. Pleistocene and recent ice conditions in northeastern Labrador (abstract) : British Assoc. Adv. Sci., Rept. 90th meeting, p. 363, 1923.

16. Glacial features of Canada. In Handbook of Canada, pp. 375-379, Toronto, 1924.

17. Ice ages and the drift of continents: Am. Jour. Sci., 5th ser., vol. 7, pp. 398-404, May, 1924.

18. Evidences of pre-Cobalt glaciation: Canadian .Min. Jour., vol. 45, no. 18 , p. 420 , May 2, 1924.

19. The Pleistocene rocks of the Toronto region [Ontario] (abstract) : PanAm. Geologist, vol. 42, no. 1, p. 67, August, 1924; British Assoc. Adv. Sci., Rept. 92d Meeting, p. 379, 1925.

20. Raised beaches as related to the thickness of ice sheets (abstract) : PanAm. Geologist, vol. 42, no. 1, p. 74, August, 1924; British Assoc. Adv. Sci., Rept. 92d Meeting, p. 385, 1925.

21. Pre-Cambrian climates (abstract) : Pan-Am. Geologist, vol. 42, no. 4, p. 309, November, 1924; British Assoc. Adv. Sci., Rept. 92d Meeting, pp. 390-391, 1925.

22. Mining possibilities in Labrador: Canadian Min. Jour., vol. 45, no. 36, pp. 868-870, 4 figs., September 5, 1924.

23. Geology of the Sudbury nickel deposits: Econ. Geology, vol. 20, no. 6, pp. 565-576, September-October, 1924. 
Coleman, Arthur Philemon-Continued.

24. Late Paleozoic climates: Am. Jour. Sci., 5th ser., vol. 9, pp. 195-203, March, 1925.

25. The spacing of ice ages and early pre-Cambrian climates: Sci. Monthly, vol. 20, no. 5, pp. 473-475, May, 1925.

26. Ice ages, recent and ancient. xiii, 296 pp., 51 figs., 8 maps, New York, The Macmillan Company, 1926.

27. The magmatic origin of the Sudbury nickel ores: Geol. Mag., vol. 63, pp. 1.08-1.12, March, 1926.

28. The Pleistocene of Newfoundland: Jour. Geology, vol. 34, no. 3, pp. 193223, 4 figs., April-May, 1926.

29. The Sudbury ore deposits [Ontario]: Canadian Min. Jour., vol. 47, no. 46, pp. 1080-1081, November 12, 1926.

30. Glacial and interglacial periods in eastern Canada: Jour. Geology, vol. 35, no. 5, pp. 385-403, July-August, 1927.

31. Unsolved geological problems of Arctic America: Problems of Polar Research, Am. Geog. Soc., Spec. Pub. no. 7, pp. 63-72, 1928.

32. The anthraxolite of Sudbury [Ontario]: Am. Jour. Sci., 5th ser., vol. 15, pp. 25-27, January, 1928.

33. Long range correlation of varves (abstract) : Geol. Soc. America, Bull., vol. 39, no. 1, p. 150, March 30, 1928; Pan-Am. Geologist, vol. 49, no. 1, p. 66, February, 1928.

Coleman, Charles L. See Dresser, 4.

Collet, Leon W. See Bailey, E. B., 2; Twenhofel, 22, 29.

Collier, Arthur James. See also Redwood, 1; U. S. Geological Survey, 11.

1. Geology of northeastern Montana (U. S. Geol. Survey, Prof. Paper 120, pp. 17-39, 1918) (abstract by R. W. Stone) : Washington Acad. Sci., Jour., vol. 9, no. 17, p. 531, October 19, 1919.

2. The Nesson anticline, Williams County, North Dakota (U. S. Geol. Survey, Bull. 691, pp. 211-221, 1918) (abstract by R. W. Stone) : Washington Acad. Sci., Jour., vol. 9, no. 2, pp. 49-50, January 19, 1919.

3. Coal south of Mancos, Montezuma County, Colorado: U. S: Geol. Survey, Bull. 691, pp. 293-310, 6 pls. (incl. map), 2 figs., February 24, 1919. Abstract by R. W. Stone, Washington Acad. Sci., Jour., vol. 9, no. 11, p. 318, June 4, 1919.

4. Oil in the Warm Springs and Hamilton domes, near Thermopolis, Wyoming: U. S. Geol. Survey, Bull. 711, pp. 61-73, 4 pls. (incl. maps), 1 fig., January 16, 1920. Abstract, Washington Acad. Sci., Jour., vol. 10 , no. 18 , pp. 519-520, November $4,1920$.

5. Gas in the Big Sand Draw anticline, Fremont County, Wyoming: U. S. Geol. Survey, Bull. 711, pp. 75-83, 1 pl. (map), 2 figs., February 5, 1920. Abstract, Washington Acad. Sci., Jour., vol. 10, no. 18, p. 520, November 4, 1920.

6. Anticlines near Maverick Springs, Fremont County, Wyoming: U. S. Geol. Survey, Bull. 711, pp. 149-166, 3 pls. (incl. map), 1 fig., April 26, 1920.

7. The Osage oil field, Weston County, Wyoming: U. S. Geol. Survey, Bull. 736, pp. 71-110, 1 fig., 5 pls., October 16, 1922.

8. (and Cathcart, S. H.). Possibility of finding oil in laccolithic domes south of the Little Rocky Mountains, Montana: U. S. Geol. Survey, Bull. 736, pp: 171-178, 2 figs., October 31, 1922. 
Collier, Arthur James-Continued.

9. The Scobey lignite field, Valley, Daniels, and Sheridan counties, Montana: U. S. Geol. Survey, Bull. 751, pp. 157-230, 3 figs., 9 pls. (incl. map), November 17, 1924.

10. The unconformity between the Madison limestone and Eilis formation in northern Montana (abstract): Washington Acad. Sci., Jour., vol. 17, no. 5, pp. 130-131, March 4, 1927.

Collingwood, Douglas Moore.

1. Graphic method for determining the surface projection of the axis and crest traces at any depth of an asymmetrical anticline: Am. Assoc. Petroleum Geologists, Bull., vol. 5, no. 2, pp. 159-162 (with discussion by $\mathrm{K}$. C. Heald, C. W. Tomlinson, and F. H. Lahee, pp. 328-329, 1 fig., and Hugh B. Webster, pp. 497-498, 1 fig.), 2 figs., March-April, 1921.

2. Some structural and stratigraphic features affecting relative amounts of oil production in Illinois: Am. Assoc. Petroleum Geologists, Bull., vol. 5, no. 2, pp. 311-323, 3 figs., March-April, 1921.

3. Oil and gas development in the vicinity of Jacksonville: Illinois State Geol. Survey, Extract from Bull. no. 44, 30 pp., 3 figs., 1.928.

4. Oil production in Illinois: Illinois State Acad., Sci., Trans., vol. 16, pp. 372-385, 1 fig., 1923.

5. Oil developments of 1922 in Illinois: Am. Assoc. Petroleum Geologists, Bull., vol. 7, no. 1, pp. 78-82, January-February, 1923.

6. Further consideration of prospects for oil in the Decatur area: Illinois State Geol. Survey, Report of Investigations, no. 1, 44 pp., 1 fig., $1 \mathrm{pl}$. (map), 1924 .

7. Extension of Allendale oil field: Illinois State Geol. Survey, Press Bull., 4 pp., map, May 17, 1924.

8. The Lytton Springs oil field, Caldwell County, Texas: Am. Assoc. Petroleum Geologists, Bull., vol. 10, no. 10, pp. 953-975, 4 figs., 2 pls. (incl. maps), October, 1926.

Collins, George Ernest.

1. Hydrocarbon veindikes and oil shales: Eng. and Min. Jour.-Press, vol. 119, no. 19 , p. 773, May. $9,1925$.

2. Genesis of sulphide ores: Eng. and Min. Jour.-Press, vol. 121, no. 9, p. 373, February 27, 1926.

Collins, M. J. See Coffin, 1 ; Perini, 1.

Collins, Robert F. See Baldwin, 1.

Collins, R. Lee. See also Roberts, J. K., 6.

1. Travertine deposits in Virginia: Pan-Am. Geologist, vol. 41, no. 2, pp. 103106, 1 fig., March, 1924.

2. A lower Eocene termite from Tennessee: Am. Jour. Sci., 5th ser., vol. 9, pp. 406-410, 7 figs., May, 1925.

Collins, William Dennis.

1. Mineral waters in 1920 : U. S. Geol. Survey, Mineral Resources, 1920, pt. 2, pp. 161-166, October 29, 1921.

2. Mineral waters in 1921: U. S. Geol. Survey, Mineral Resources, 1921, pt. 2, pp. 229-236, February 5, 1923.

3. Mineral waters in 1922 : U. S. Geol. Survey, Mineral Resources, 1.922, pt. 2, pp. 207-220, December 20, 1923.

4. Mineral waters in 1923 : U. S. Geol. Survey, Mineral Resources, 1923, pt. 2, pp. 109-124, 1 fig., November 6, 1924. 
Collins, William Dennis-Continued.

5. (and Howard, C. S.). Index of analyses of natural waters in the United States: U. S. Geol. Survey, Water-Supply Paper 560, pp. 53-85, May, 1925.

6. (and Howard, C. S.). Chemical character of waters of Florida: U. S. Geol. Survey, Water-Supply Paper 596, pp. 177-233, 8 figs., February 17, 1928.

Collins, William Henry.

1. The ore deposits of Goudreau and Magpie-Hawk areas in Michipicoten district, Ontario : Canada, Geol. Survey, Summ. Rept., 1918, pt. E., pp. 4-30, 5 figs., 1919.

2. The Michipicoten iron ranges: Canadian Inst. Min. and Met., Monthly Bull. no. 104, pp. 930-939, 1 pl., December, 1920 ; Canadian Min. Inst., Trans., vol. $23, \mathrm{pp} .426-436,1$ pl. [1921].

3. Geological Survey [report] : Canada, Dept. Mines, Rept. for the fiscal year ending March 31, 1921, pp. 5-15, Ottawa, 1921.

4. An outline of the physiographic history of northeastern Ontario: Jour. Geology, vol. 30, no. 3, pp. 199-210, 3 figs., April-May, 1922.

5. Field work of the Geological Survey [of Canada]: Canadian Inst. Min. and Met., Bull. no. 123, pp. 743-751, July, 1922.

6. [Report of the] Geological Survey [of Canada]: Canada, Dept. Mines, Rept. for the fiscal year ending March 31, 1922, pp. 3-20, 1922.

7. The geology of Ontario's iron ores: Canadian Min. Jour., vol. 43, no. 37, pp. 625-626, September 15, 1922.

8. Geological survey [report for 1922-23] : Canada, Dept. Mines, Rept. . . . 1923, pp. 7-25, 1923.

9. Field work of the geological survey [of Canada]: Canadian Min. Jour., vol. 44, no. 28 , pp. 530-533, July 13, 1923.

10. The geology and physical geography of Canada. In Handbook of Canada, pp. 346-374, 2 figs., Toronto, 1924.

11. North shore of Lake Huron: Canada, Geol. Sürvey, Mem. 143, 160 pp., 9 figs., 17 pls., 3 maps., 1925. Extracts, with title, Ore deposits of the district north of Lake Huron, Ontario: Canadian Min. Jour., vol. 46, no. 50, pp. 1134-1136, December 11, no. 51, pp. 1154-1156, December 18, 1925, vol. 47, no. 3, pp. 54-56, January 15, no. 4, pp. 83-84, January 22, 1926.

12. [Annual report of the] Geological Survey: Canada, Dept. Mines, Report for the year ending March 31, 1924, pp. 9-33, 1925.

13. [Annual report of the] Geological Survey: Canada, Dept. Mines, Rept. for the year ending March 31, 1925, pp. 11-34, 1925.

14. Donaldson Bogart Dowling: Canadian Min. Jour., vol. 46, no. 24, pp. 581-582, portr., June 12, 1925 ; Canadian Inst. Min. and Met., Bull, no. 159, pp. 688-681, portr., July, 1925.

15. (and Quirke, T. T.). Michipicoten iron ranges: Canada, Geol. Survey, Mem. 147, pp. 1-141, 15 figs., 9 pls. (incl. maps), 1926. Extracts, with titles, The Helen iron ore deposits: Canadian Min. Jour., vol. 47, no 27, pp. 666-670, 3 figs., July 2, 1926; and Pyrite deposits of Michlpicoten district: Canadian Min. Jour., vol. 47, no. 28, pp. 685-688, July 9, 1926.

16. [Annual report of the] Geological Survey: Canada, Dept. Mines, Rept. for the year ending March 31, 1926, pp. 9-31, 1926.

17. Donaldson Bogart Dowling: Roy. Soc. Canada, Proc. and Trans., 3d ser., vol. 20, pp. iv--v, portr., 1926. 
Collins, William Henry-Continued.

18. Field work of the Geological Survey [of Canada]: Canadian Min. Jour., vol. 47 , no. 31, pp. 756-759, July 30, 1926.

19. The Nottaway sheet [northwestern Quebec]: Canadian Min. Jour., vol. 48 , no. 6 , p. 117 , February 11, 1927.

20. [Annual report of the] Geological Survey: Canada, Dept. Mines, Rept. for the year ending March 31, 1927, pp. 12-30, 1928.

21. (and James, W. F.) Mountain building in the Canadian shield (abstract) : Pan-Am. Geologist, vol. 49, no. 2, pp. 159-160, March, 1928.

22. (and James, W. F.). Orogeny of the Canadian shield (abstract) : Geol. Soc. America, Bull., vol. 39, no. 1, pp. 182-183, March 30, 1928.

23. The Keewatin iron formations: Fennia 50, no. 8, 20 pp., 5 figs., Helsingfors, 1928.

Collom, Roy Edward.

1. Notes on California oil field practice: Am. Assoc. Petroleum Geologists, Bull., vol. 7, no. 2, pp. 114-130, 3 figs., March-April, 1923.

2. Geology of the Santa Maria district [California]: Oil Bull., vol. 14, no. 4, pp. 368-369, 1 fig. (map), April, 1928.

Colony, Roy Jed. See also Fairbanks, 12 ; Lindgren, 18.

1. High-grade silica materials for glass, refractories, and abrasives: New York State Mus. Bull. nos. 203, 204, 31 pp., 15 pls., 1919.

2. A norite of the Sudbury type in Manitoba; a reconnaissance: Canadian Inst. Min. and Met., Monthly Bull. no. 13, pp. 862-872, 7 figs., November, 1920 ; Trans. vol. 24, pp. 112-123, 7 figs. [1922] ; Canadian Min. Jour., vol. 41, pp. 967-970, 7 figs., November 26, 1920.

3. The magnetite iron deposits of southeastern New York: New York State Museum Bull., nos. 249-250, 161 pp., 13 figs., 15 pls., 1923.

4. The final consolidation phenomena in the crystallization of igneous rock: Jour. Geology, vol. 31, no. 3, pp. 169-178, 12 figs., April-May, 1923.

5. An unusual quartz-diamond intergrowth: Am. Jour. Sci., 5th ser., vol. 5, pp. 400-402, 2 figs., May, 1923.

6. Field work in the Schunemunk region during 1924: New York State Mus. Bull., no. 260, pp. 22-23, 1925.

7. Some problems in the Schunemunk area: New York State Mus. Bull., no. 267 , pp. 26-29, 1926.

8. A feldspar-chalcopyrite rock-ore: Eng. and Min. Jour., vol. 123, no. 15, pp. 605-607, 5 figs., April 9, 1927.

9. (and Meyerhoff, H. A.). The copper prospect at Barrio Pasto, Porto Rico: Econ. Geology, vol. 23, no. 5, pp. 51.5-527, \& figs., August, 1928.

Colorado, State Board of Immigration.

1. Colorado, mineral, oil, and shale resources. $47 \mathrm{pp}$. [1925].

Conard, H. S.

1. Fossil plants and classification: Am. Botanist, vol. 27, no. 3, pp. 95-101, 1 fig., August, 1921.

Condit, Daniel Dale. See also Redwood, 1; Vaughan, 16.

1. Relations of late Paleozoic and early Mesozoic formations of southwestern Montana and adjacent parts of Wyoming (U. S. Geol. Survey, Prof. Paper 120, pp. 111-121, 1918) (abstract by R. W. Stone) : Washington Acad. Sci., Jour., vol. 9, no. 17, pp. 530-531, October $19,1919$. 
Condit, Daniel Dale-Continued.

2. Oil shale in western Montana, southeastern Idaho, and adjacent parts of Wyoming and Utah: U. S. Geol. Survey, Bull. 711, pp. 15-40, 1 pl. (map), 2 figs., September 27, 1919. Abstract by R. W. Stone, Washington Acad. Sci., Jour., vol. 9, no. 20, p. 638, December 4, 1919.

3. Economic geology of the Summerfield and Woodsfield quadrangles, Ohio, with descriptions of coal and other mineral resources except oil and gas: U. S. Geol. Survey, Bull. 720, 156 pp., 5 figs., 12 pls. (incl. maps), 1923.

4. Phosphate deposits in the Wind River Mountains, near Lander, Wyoming: U. S. Geol. Survey, Bull. 764, 39 pp., 1 fig., 3 pls. (incl. map), 1924.

5. (and Finch, E. H., and Pardee, J. T.). Phosphate rock in the Three ForksYellowstone Park region, Montana: U. S. Geol. Survey, Bull. 795, pp. 147-209, 1 fig., 3 pls. (incl. maps), January 9, 1928.

Condra, George Evert. See also Dunbar, 11.

1. Road materials of Nebraska; Part 2, Sand: Nebraska, Univ., Nebraska Conservation and Soil Survey, Bull. 6, 63 pp., 34 figs., Lincoln, Nebraska, 1917.

2. The stratigraphy of the Pennsylvanian system in Nebraska: Nebraska Geol. Survey, 2d ser., Bull. 1, 291 pp., 38 figs., 7 pls. (incl. maps), 1927.

Conine, W. H. See Twenhofel, 9.

Conhaim, H. J. See Grout, 14.

Conkling, R. A. See also Ambrose, 1; Washburne, 3.

1. Oil and gas in Oklahoma; geology of Pontotoc County: Oklahoma Geol: Survey, Bull. no. 40-s, 27 pp., 5 figs., map, December, 1927.

Connecticut State Geological and Natural History Survey.

1. Eighth biennial report of the commissioners . . 1917-18. Bull. no. 28, 21 pp., Hartford, 1919.

Connolly, Joseph Peter. See also O'Harra, 5 ; Ward, 13.

1. Geology and mineralogy of the Keystone district [Pennington County, South Dakota]: Black Hills Engineer, vol. 13, no. 1, pp. 11-18, January, 1925.

2. The Etta mine [Keystone district, South Dakota]: Black Hills Engineer, vol. 13, no. 1, pp. 18-23, 8 figs., January, 1925.

3. The geology class [of the South Dakota School of Mines] in the Badlands [of South Dakota]: Black Hills Engineer, vol. 14, no. 2, pp. 105111, illus., March, 1926.

4. The Tertiary mineralization of the northern Black Hills: South Dakota School of Mines, Bull. no. 15, 130 pp., 14 figs., 19 pls., September, 1927.

5. Geology of the southern Black Hills: Black Hills Engineer, vol. 16, no. 1 pp. 59-67, 2 figs., January, 1928.

Connor, M. F. See Johnston, R. A. A., 2.

Conrey, Guy Woolard.

1. Geology of Wayne County: Ohio, Geol. Survey, Fourth series, Bull. 24, 155 pp., 10 pls., 5 maps, 1921.

2. The depth of leaching of the early Wisconsin drift in Ohio (abstract) : Ohio Acad. Sci., Proc., vol. 8, pt. 4, pp. 179-180, 1928; Ohịo Jour. Sci., vol. 28, no. 3, pp. 157-158, May, 1928, 
Cook, Charles Wilford.

1. A new occurrence of ilsemannite [Gibson, Shasta County, California]: Am. Jour. Sci., 5th ser., vol. 4, pp. 50-52, July, 1922.

2. Study of capillary relationships of oil and water: Econ. Geology, vol. 18 no. 2, pp. 167-172, 1 fig., March, 1923.

3. Attempt to study the actual capillary relationships of oil and water (abstract) : Geol. Soc. America, Bull., vol. 34, no. 1, p. 100, March 30, 1923.

4. Marcasite from the Racine dolomite, Racine, Wisconsin: Am. Mineralogist,, vol. 9, no. 7, pp. 151-152, July, 1924.

5. Molybdenite deposit near New Ross, Nova Scotia: Econ. Geology, vol. 20, no. 2, pp. 185-188, March-April, 1925.

6. Fractionation of petroleum during capillary migration: Econ. Geology, vol. 20, no. 7, pp. 639-641, 1 fig., November, 1925.

7. The influence of joints in the formation of islands at the western end of Lake Erie: Michigan Acad. Sci., Papers, vol. 5, pp. 243-251, 5 figs., 1926; abstract, Pan-Am. Geologist, vol. 44, no. 2, p. 152, September, 1925.

8. (and Ehlers, George M.). A possible occurrence of the Richmond formation in the vicinity of Clayton, Idaho: Michigan Acad. Sci., Papers, vol. 7, pp. 51-53, 1927.

9. Fractionation and decomposition of petroleum during capillary migration: Econ. Geology, vol. 22, no. 3, pp. 230-232, 1 fig., May, 1927.

10. The progress of replacement and the formation of concretions: Michigan Acad. Sci., Papers, vol. 8, pp. 285-292, 1 fig. 1 pl., 1928.

Cook, Harold James. See also, Abel, 3; Gregory, W. K., 19; Hay, 41; Schramm, 2.

1. Two new bunomastodonts from Colorado: Colorado Mus. Nat. Hist., Proc., vol. 4, no. 1, 15 pp., 6 figs., February 15, 1922.

2. A Pliocene fauna from Yuma County, Colorado, with notes on the closely related Snake Creek beds, from Nebraska: Colorado Mus. Nat. Hist., Proc., vol. 4, no. 2, 29 pp., 14 pls., March 31, 1922.

3. Oldest known peccary from America: Pan-Am. Geologist, vol. 37, no. 5, pp. 357-358, 1 fig., June, 1922.

4. Basic Tertic conglomerate of Black Hills: Pan-Am. Geologist, vol, 37, no. 5, pp. 421-424, June, 1922.

5. Manganese fulgurites: Nebraska State Mus., Bull. 5, pp. 41-44, 2 figs., June, 1925.

6. Definite evidence of human artifacts in the American Pleistocene: Science, new ser., vol. 62, pp. 459-460, November 20, 1925.

7. A new genus of uintatheres from Colorado: Colorado Mus. Nat. Hist., Proc., vol. 6, no. 2, pp. 7-11, 5 pls., February 27, 1926.

8. New Eocene titanotheres from Moffat County, Colorado: Colorado Mus. Nat. Hist., Proc., vol. 6, no. 3, pp. 12-18, 11 pls., March 5, 1926.

9. A new gigantic fossil dog from Colorado: Colorado Mus. Nat. Hist., Proc., vol. 6, no. 5, pp. 29-31, 1 pl., April 16, 1926.

- 10. The antiquity of man in America; who were the first Americans? whence came they?: Sci. Am., vol. 135, no. 5, pp. 334-336, 7 figs., November, 1926.

11. A new rhinoceros of the genus Teleoceras from Colorado: Colorado Mus. Nat. Hist., Proc., vol. 7, no. 1, 2 pp., 3 pls., February 27, 1927.

12. New geological and paleontological evidence bearing on the antiquity of man in America: Natural History (Am. Mus. Nat. Hist., Jour.), vol. 27, no. 3, pp. 240-247, 9 figs., May-June, 1927. 
Cook, Harold James-Continued.

13. New trails of ancient man; remarkable finds of ancient man have recently been made in Nebraska and Oklahoma: Sci. Am., vol. 137, no. 2, pp. 114-117, 10 figs., August, 1927.

14. A new fossil bison from Texas: Colorado Mus. Nat. Hist., Proc., vol. 8, no. 3, pp. 34-36, 1 pl., March 15, 1928.

15. Further evidence concerning man's antiquity at Frederick, Oklahoma: Science, new ser., vol. 67, pp. 371-373, April 6, 1928.

16. A new longirostrine elephant from Nebraska, Trilophodon phippsi, sp. nov.: Colorado Mus. Nat. Hist., Proc., vol. 8, no. 4, pp. 37-43, 2 pls., May $1,1928$.

17. Note on an interesting juvenile lower jaw of Elephas cf. jeffersoni [Frederick, Oklahoma] ; Colorado Mus. Nat. Hist., Proc., vol. 8, no. 5, pp. 44-45, 2 figs., May 2, 1928.

Cook, John H.

1. Ablation of the eastern lobe of the Wisconsin ice sheet (abstract): Geol. Soc. America, Bull., vol. 33, no. 1, pp. 117-118, March 31, 1922.

2. The disappearance of the last glacial ice sheet from eastern New York: New York State Mus. Bull., no. 251, pp. 158-176, 1 fig., 1924:

Cook, Le Moyne.

1. A rhinoceros bone bed [Agate, Nebraska] : Black Hills Engineer, vol. 14, no. 2, pp. 95-99, 3 figs., March, 1926.

2. Annual field trip of mineralogy class [of South Dakota State School of Mines] : Black Hills Engineer, vol. 15, no. 3, pp. 164-165, May, 1927.

Cooke, Charles Wythe. See also Cushman, 10; LaForge, 4; Vaughan, 16.

1. Tertiary mollusks from the Leeward Islands and Cuba: Carnegie Inst. Washington, Pub. 291, pp. 103-156, 16 pls., 1919.

2. Stratigraphic significance of Orthaulax (abstract): Geol. Soc. America, Bull., vol. 31, no. 1, p. 206, March 31, 1920.

3. Geologic reconnaissance in Santo Domingo (abstract) : Geol. Soc. America, Bull., vol. 31, no. 1, pp. 217-219, March 31, 1920.

4. New names for West Indian Tertiary pectens: Nautilus, vol. 34, no. 4. p. 137, April, 1921.

5. Macon five million years ago: The Macon [Georgia] Magazine, vol. 1, no. 6, pp. 7-8, September, 1921.

6. Orthaulax, a Tertiary guide fossil: U. S. Geol. Survey, Prof. Paper 129, pp. 23-37, 4 pls., September 29, 1921. Abstract by Julia Gardner, Washington Acad. Sci., Jour., vol. 11, no. 19, pp. 471-472, November 19, 1921.

7. The Byram calcareous marl of Mississippi: U. S. Geol. Survey, Prof. Paper 129, pp. 79-85, March 17, 1922.

7a. The correlation of the Vicksburg group: U. S. Geol. Survey, Prof. Paper 133, pp. 1-9, 1923.

8. The relative dependableness of different kinds of fossils and some suggestions to collectors: Am. Assoc. Petroleum Geologists, Bull., vol. 7, no. 2, pp. 183-187, March-April, 1923; Oil Engineering and Finance, vol. 4, no. 84, pp. 173-174, August 18, 1923.

9. Recent contributions to the stratigraphy of the Coastal Plain of the United States: Pan-Pacific Sci. Cong., Australia, 1923, Proc., vol. 1, pp. 862-864 [1.924]. 
Cooke, Charles Wythe-Continued.

10. American and European Eocene and Oligocene mollusks: Geol. Soc. America, Bull., vol. 35, no. 4, pp. 851-856, December 30, 1924 ; abstract, no 1, p. 174, March 30, 1924.

11. Coastal terraces of Georgia (abstract): Washington Acad. Sci., Jour., vol. 15, no. 8, p. 184, April 19, 1925; Pan-Am. Geologist, vol. 43, no. 5, pp. 375-376, June, 1925.

12. Correlation of the Eocene formations in Mississippi and Alabama: U. S. Geol. Survey, Prof. Paper 140, pp. 133-136, Decemiber 29, 1925.

13. Geology of Alabama; The Cenozoic formations: Alabama, Geol. Survey, Spec. Rept. no. 14, pp. 251-297, 5 pls., 1926.

14. Correlation of the basal Cretaceous beds of the southeastern States: U. S. Geol. Survey, Prof. Paper 140, pp. 137-139, January 12, 1926.

15. New Eocene mollusks from Jackson, Mississippi: Washington Acad. Sci., Jour., vol. 16, no. 5, pp. 132-138, 1 pl., March 4, 1926.

16. Fossil man and Pleistocene vertebrates in Florida: Am. Jour. Sci., 5th ser., vol. 12, pp. 441-452, November, 1926.

17. (and Stephenson, Lloyd W.). The Eocene age of the supposed late Upper Cretaceous greensand marls of New Jersey: Jour. Geology, vol. 36, no. 2, pp. 139-148, February-March, 1928; abstract, PanAm. Geologist, vol. 49, no. 3, pp. 225-226, April, no. 4, p. 299, May, 1928.

18. New Vicksburg (Oligocene) mollusks from Mexico: U. S. Nat. Mus., Proc., vol. 73, art. 10, 11 pp., 2 pls., 1928.

19. The stratigraphy and age of the Pleistocene deposits in Florida from which human bones have been reported: Washington Acad. Sci., Jour., vol. 18, no. 15, pp. 414-421, September 19, 1928.

20. (and Stephenson, L. W.). The Eocene age of the supposed late Upper Cretaceous greensand marls of New Jersey (abstract) : Washington Acad. Sci., Jour., vol. 18, no. 9, p. 262, May 4, 1928.

Cooke, Harold Caswell.

1. Geology of Matachewan district, northern Ontario: Canada, Geol. Survey, Mem. 115, 60 pp., 5 figs., map, 1919.

2. Some stratigraphic and structural features of the pre-Cambrian of northern Quebec: Jour. Geology, vol. 27, nos. 2-5, pp. 65-78, 180-203, 263-275, 367-382, 13 figs., 1919.

3. The origin of the gold deposits of Matachewan district, northern Ontario: Econ. Geology, vol. 14, no. 4, pp. 281-301, 4 figs. (maps), June, 1919.

4. Matachewan [Ontario] gold area; the Otisse and Davidson gold deposits: Canadian Min. Jour., vol. 40, pp. 519-524, 5 figs., July 16, 1919.

5. Gabbros of East Sooke and Rocky Point [Vancouver Island, British Columbia] : Canada, Geol. Survey, Mus. Bull., no. 30, 48 pp., 1 fig., 1 map, November 15, 1919.

6. Exploration of the townships west of Kirkland Lake, Ontario: Canada, Geol. Survey, Summ. Rept., 1919, pt. E, pp. 18-19, 1920.

7. A correlation of the pre-Cambrian formations of northern Ontario and Quebec: Jour. Geology, vol. 28, no. 4, pp. 304-332, 5 figs., MayJune, 1920.

8. Kenogami, Round, and Larder Lake areas, Timiskaming district, Ontario: Canada, Geol. Survey, Mem. 131, 64 pp., 2 figs., 3 maps, 1922.

9. Geology and mineral resources of Rice Lake and Oiseau River areas, Manitoba: Canada, Geol. Survey, Summ. Rept., 1921, pt. C, 36 pp., 6 figs., 2 pls. (maps), 1922. 
Cooke, Harold Caswell-Continued.

10. Opasatika map area, Timiskaming County, Quebec: Canada, Geol. Survey, Summ. Rèpt., 1922, pt. D, pp. 19-74, 9 figs., map, 1923.

11. The Quebec gold field: Canadian Min. Jour., vol. 44, no. 15, pp. 276-278, 1 fig., April 13, 1923; Min. Mag., vol. 28, no. 6, pp. 382-383, 1 fig., June, 1923.

12. Exploration for gold in northern Quebec: Canadian Min. Jour., vol. 44, no. 21, pp. 390-392, 1 fig., May 25, 1923 ; Min. Mag., vol. 29, no. 1, pp. $49-51,1$ fig., July, 1923.

13. Character and origin of the ore deposits, Argonaut gold mine, Gauthier township, Timiskaming district, Ontario: Canada, Geol. Survey, Summ. Rept., 1923, pt. C1, pp. 42-60, 5 figs., 1924.

14. Recent gold discoveries at Larder Lake, Timiskaming district, Ontario: Canada, Geol. Survey, Summ. Rept. 1923, pt. C1, pp. 61-73, 4 figs., 1 pl., 1924.

15. Some gold deposits of western Quebec: Canada; Geol. Survey, Summ. Rept. 1923, pt. C1, pp. 76-125, 15 figs., 1924.

16. Folding and mountain-building in pre-Cambrian of northern Ontario and Quebec (abstract) : Pan-Am. Geologist, vol. 42, no. 4, pp. 308-309. November, 1924.

17. Progress of structural determinations in the Archean rocks of Ontario and Quebec: Roy. Soc. Canada, Proc. and Trans., 3d ser., vol. 19, pp. 1-19, 7 figs., 1925 .

18. Recent developments in northern Quebec: Canadian Inst. Min. and Met., Bull., no. 156, pp. 343-350, April, 1925.

19. "Between the Archean and Keweenawan is the Huronian": Roy. Soc. Canada, Proc. and Trans., 3d ser., vol. 20, sec. 4, pp. 17-37, 1 fig., 1926.

20. Recent developments in northwestern. Quebec: Canadian Inst. Min. and Met., Bull., no. 169, pp. 627-640, 2 figs., May, 1926; Trans., vol. 29, pp. 237-250, 2 figs. [1927].

21. Ore deposits of the Rouyn area, Quebec: Canadian Min. Jour., vol. 47, no. 23 , pp. 572-575, June 4, 1926.

22. Some chemical changes in rocks caused by shearing: Canada, Geol. Survey, Bull. no. 46, pp. 22-30, 3 figs., 1927. [Pub. 2125.]

23. Argonaut gold mine, Gauthier Township, Ontario: Canada, Geol. Survey, Summ. Rept., 1925, pt. C, pp: 12-16, 1927.

24. Further developments at Larder Lake, Ontario: Canada, Geol. Survey, Summ. Rept., 1925, pt. C, pp. 17-19, 1927.

25. Wright mine, Duhamel Township, Quebec: Canada, Geol. Survey, Summ. Rept., 1925, pt. C, pp. 20-27, 1 fig., 1927.

26. Gold and copper deposits of western Quebec: Canada, Geol. Survey, Summ. Rept., 1925, pt. C, pp. 28-51, 1 fig., 1927.

27. An original Keewatin surface in northern Quebec: Roy. Soc. Canada, Trans., 3d ser., vol. 21, sec .4, pp. 53-59, 2 figs., March, 1927.

28. A new era in geology ; contributed discussion on the geology and mineral deposits of the Harricanaw and Bell River basins by Geo. W. Bain : Canadian Min. and Met. Bull., no. 180, pp. 409-413, April, 1927. (See Bain, 22.)

29. On the origin of the copper ores of Rouyn district, Quebec: Canada, Geol. Survey, Summ. Rept., 1926, pt. C, pp. 48-55, map, 1927.

30. Gisements d'or et de cuivre du Quebec occidental: Soc. géographie Québec, Bull., vol. 22, nos. 1-2, pp. 120-126, January-May, no. 3, pp. 129-137, June-September, 1928. 
Cooke, Harold Caswell-Continued.

31. (and James, W. F.). A general summary of observations on the sulphide deposits of northern Quebec: Canadian Min. Jour., vol. 49, no. 34, pp. 670-674, no. 35, pp. 696-698, 7 figs., August 24 and 31, 1928 ; extract, Min. Mag., vol. 39, no. 5, pp. 316-321, November, 1928.

32. Ore relations at the Horne and Aldermac mines, Quebec: Canadian Min. and Met. Bull., no. 198, pp. 1184-1194, October, 1928; Canadian Inst. Min. and Met., Trans., vol. 31, pp. 57-82 [1929].

Cooke, M. K. See Gunter, 3.

Cooley, Mary E. See Ehlers, 12.

Cooper, Chalmer Lewis. See also Clark, G. C., 3; Shannon, 4; Woodruff, 4.

1. The Sycamore limestone: Oklahoma Geol. Survey, Circular no. 9, 26 pp., 4 figs., 4 pls., map, December, 1926.

2. Preliminary report on the Sycamore limestone: Oklahoma Acad. Sci., Proc., vol. 6, pt. 2, 1926 (Oklahoma, Univ., Bull., new ser., no. 348), pp. 254-259, January 1, 1927.

3. 'The Oklahoma coal fields: U. S. Bur. Mines, Tech. Paper 411, pp. 1-7, 2 figs., 1928.

4. The correlation of coals in Oklahoma and Kansas: Oklahoma Acad. Sci., Proc., vol. 7 (Oklahoma, Univ., Bull., new ser., no. 409), pp. 158168 [1928].

Cooper, Herschel H. See Jenkins, 5.

Copaux, H.

1. The beryllium industry: Mineral Foote-Notes, vol. 4, no. 2, pp. 3-6, March-April, 1920.

Copp, W. W.

1. (and Godde, H. A.). Report on southeastern portion of Thirty-five anticline, Sunset oil field, Kern County, California: California State Min. Bur., Summary of Operations California Oil Fields, vol. 9, no. 5, pp. 5-33, 7 pls. (incl. maps), November, 1923.

Corbett, Clifton Sherwin.

1. Method for projecting structure through an angular unconformity: Econ.

Geology, vol. 14, no. 8, pp. 610-618, 4 figs., December, 1919.

2. Leverrierite as a schist-forming mineral: Am. Jour. Sci., 5th ser., vol. 10, pp. 247-268, 1 fig., September, 1925.

3. Another Kansas meteorite?: Am. Jour. Sci., 5th ser., vol. 12, pp. 495-498, 3 figs., December, 1926.

Corbin, J: Ross. See Pennsylvania G. S., 1.

Corey, W. H.

1. Fauna and stratigraphy of Vaqueros formation in Ventura and Santa Barbara counties, California (abstract) : Pan-Am. Geologist, vol. 49, no. 4, p. 319, May, 1928.

Corless, C. V. See also Goodwin, W. L., 3 ; Mackenzie, G. C., 2.

1. Some of Canada's national problems and their physiographic cauise: Canadian Min. Jour., vol. 44, no. 17, pp. 314-317, 1 fig., no. 18, pp. 338-342, May 4, 1923.

2. The mineral wealth of Ontario (abstract) : Canadian Min. Jour., vol, 45, no. 14, pp. 332-333, April 4, 1924. 
Corless, C. V.-Continued.

3. The mineral wealth of the pre-Cambrian: Canadian Inst. Min. and Met., Monthly Bull. no. 146, pp. 366-392, June, 1924; Trans., vol. 27, pp. 174-208 [1925].

4. Mineral wealth of the pre-Cambrian in Canada: Canadian Min. Jour., vol. 45, nos. 30-33, pp. 719-721, 737-739, 773-775, 796-798, July 25, August 1, 8, and 15, 1924.

Cornwall, Ira Edmund.

1. Some notes on the Sooke formation, Vancouver Island, British Columbia : Canadian Field-Naturalist, vol. 36, no. 7, pp. 121-123, 1 fig., October, 1922.

2. Fossil Cirripedia from the upper Oligocene Sooke formation of Vancouver Island, British Columbia: California, Univ., Dept. Geol. Sci., Bull., vol. 16, no. 9, pp. 399-406, 2 pls., March 17, 1927.

Corral y Alemán, José Isaac del.

1. Informe sobre el reconocimiento de la mina de cobre "La Niña" [Pinar del Río, Cuba]: Cuba, Dirección de montes y minas, Bol. minas no. 5, pp. 71-82, 1919.

2. Reconocimiento geológico de lá mina "San José," situada en Malezas, cuartón de San Gil, término municipal de Santa Clara: Cuba, Dirección de montes y minas, Bol. minas, no. 7, pp. 42-50, 1923.

3. Investigaciones sobre el petróleo en Cuba: Cuba, Dirección de montes y minas, Bol. minas, no. 8, pp. 1-11, August, 1925.

4. Investigaciones sobre el petróleo en Cuba: Acad. Cienc. Méd., Fís. y nat. Habana, Anales, t. 62, pp. 95-113, 1925.

5. Informe sobre las canteras en la finca "La Viuda"; Cuba, Dirección de montes y minas, Bol. minas, no. 9, pp. 1-5, 1926.

Coryell, Horace Noble.

1. Parts of Pike and Adams Counties: Illinois State Geol. Survey, Bull. no. 40, pp. $69-95,6$ pls. (incl. maps), 2 figs., 1919.

2. Bryozoan faunas of the Stones River group of central Tennessee: Indiana Acad. Sci., Proc., 1919, pp. 261-340, 3 figs., 14 pls., 1921.

3. Some new Pennsylvanian Ostracoda: Jour. Paleontology, vol. 2, no. 2, pp. 87-94, 1 pl., June, 1928.

4. Some new Pennsylvanian Ostracoda: Jour. Paleontology, vol. 2, no. 4, pp. 377-381, 1 pl., December, 1928.

Coste, Eugene. See also Matteson, 2.

1. [The occurrence of oil in Alberta] (discussion): Am. Inst. Min. and Met. Eng., Bull. no. 148, pp. 718-719, April, 1919.

2. Natural gas and oil possibilities in Canada: Natural Gas, vol. 5, no. 1., pp. 24-25, 42, January, 1924.

Cottingham, Kenneth.

1. The origin of the caves at Put-in-Bay, Ohio: Ohio Jour. Sci., vol. 20, no. 2, pp. 38-42, 4 figs., December, 1919.

2. Subsurface conditions on portion of Arches Fork anticline [Roane and Calhoun counties, West Virginia] (with discussion): Am. Inst. Min. and Met. Eng., Trans., vol. 68, pp. 1138-1145, 4 figs., 1923; [preprint] no. 1115, 5 pp., 3 figs., January, 1922; [preprint] no. 1169, pp. 6-9, 1 fig., June, 1922 (discussion by David B. Reger) ; abstract., Mining and Metallurgy, no. 181, pp. 35-36, 1 fig., January, 1922. 
Cottingham, Kenneth-Continued.

3. Outline of the general geology of Ohio as disclosed by deep drill tests: Nat. Petroleum News, vol. 18, no. 32, pp. 45, 46, 48, 3 figs., August 11, 1926.

4. Structural conditions in portions of eastern Ohio: Am. Assoc. Petroleum Geologists, Bull., vol. 11, no. 9, pp. 945-958, 11 figs., September, 1927.

Cotton, Leo A.

1. Earthquake frequency, with special reference to tidal stresses in the lithosphere: Seismol. Soc. America, Bull., vol. 12, nos. 2 and 3, pp. 47-198, 11 figs., June-September, 1922.

2. Some fundamental problems of diastrophism and their geological corollaries with special reference to polar wanderings: Pan-Pacific Scientific Conference, First, Proc., Bernice P. Bishop Mus., Spec. Pub. no. 7, pt. 3, pp. 886-888, 1921; Am. Jour. Sci., 5th ser., vol. 6, pp. 453-503, December, 1923.

Couser, C. W. See Dille, 4, 6.

Cowie, George S. See MacLeod, 2.

Cox, Ben B.

1. Oil possibilities of the Payson anticline, Adams County, Illinois: Illinois, State Geol. Survey, Press Bull. Ser., Illinois Petroleum no. 7, pp. 1-4, 2 figs. (maps), February 19, 1927.

Cox, E. P.

1. A method of assigning numerical and percentage values to the degree of roundness of sand grains: Jour. Paleontology, vol. 1, no. 3, pp. 179-183, 3 figs., December, 1927.

Cox, Flemin, w.

1. Pleistocene deposits in Lawrence County: Illinois State Acad. Sci., Trans., vol. 16 , pp. $347-352,1923$.

Cox, Guy Henry, 1881-1922. See also Boericke, 1.

1. (and Dake, C. L., and Muilenburg, G. A.). Field methods in petroleum geology. 305 pp., 49 figs., 12 pls., New York, McGraw-Hill Book Company, 1921.

Crabb, E. D.

1. A fossil elephant of Oklahoma: Milwaukee, Publlc Mus., Yearbook, 1923, vol. 3, pp. 173-177, 3 figs., April 29, 1925.

2. The occurrence of Bison occidentalis in Oklahoma: Oklahoma Acad. Sci.

(Univ. Oklahoma Bull., new ser., no. 322), Proc., vol. 4, p. 124, December 1, 1925.

Craddock, W. N.

1. The Ventura (Avenue) [oil] field [Ventura County], California: Am. Assoc. Petroleum Geologists, Bull., vol. 8, no. 6, pp. 821-829, 1 fig., November-December, 1924.

Craig, Edward Hubert Cunningham.

1. Geophysical surveys as aids to the geologist: Am. Assoc. Petroleum Geologists, Bull., vol. 9, no. 1, pp. 165-167, January-February, 1925.

2. On "kerogen": Am. Assoc. Petroleum Geologists, Bull., vol. 9, no. 1, p. 180, January-February, 1925. 
Crampton, Theodore H. M.

1. Copper schist deposits of Arizona : Eng. and Min. Jour., vol. 107, p. 689, April 19, 1919.

2. The Silver Horn district, near Pioche, Nevada: Min. and Sci. Press, vol. 122, pp. 883-884, 2 figs., June 25, 1921.

Crane, Guy Walter.

1. Geological and mineralogical conditions prevailing in the Tintic district, Utah: Salt Lake Min. Rev., vol. 25, no. 10, pp. 13-14, August 30, 1923.

2. Notes on the geology of East Tintic [Utah County, Utah]: Am. Inst. Min. and Met. Eng., Trans. [preprint] no. 1491, 15 pp., 3 figs., September, 1925 ; discussion, no. 1512, pp. 11-13, December, 1925; (with discussion), Trans., vol. 74, pp. 147-162, 3 figs., 1926; abstract, Mining and Metallurgy, vol. 6, no. 227, p. 571, November, 1925 ; Min. Jour., Phoenix, Ariz., vol. 10, no. 13, pp. 3-4, 18-19, November 30, 1926.

Crane, Walter Richard. See also Hull, 1.

1. The mining and preparation of manganese ores in Tennessee: Tennes see State Geol. Survey, Resources of Tennessee, vol. 9, no. 1, pp. 32-47, 5 figs., January, 1919.

2. Red iron ore mining methods in the Birmingham district [Alabama]: Am. Inst. Min. and Met. Eng., Trans. [preprint] no. 1368, 33 pp., 20 figs., September, 1924; abstract, Mining and Metallurgy, vol. 5, no. 214, pp. 501-503, October, 1924.

3. Red iron ores and ferruginous sandstones of the Clinton formation in the Birmingham district, Alabama: U. S., Bur. Mines, Tech. Paper 377,41 pp., 23 figs., 1926.

4. Development, mining, and handling of ore in folded and faulted areas, red iron ore mines, Birmingham district, Alabama: U. S., Bur. Mines, Tech. Paper 407, 27 pp., 27 figs., 1927.

Crawford, David J. See Lonsdale, 11.

Crawford, Arthur L.

1. Euhedral oligoclase of pericline habit from Medicine Bow Mountains, Wyoming: Am. Mineralogist, vol. 11, no. 9, pp. 239-246, 5 flgs., September, 1926.

Crawford, Ralph Dixon.

1. (and Willson, K. M., and Perini, V. C.). Some anticlines of Routt County, Colorado: Colorado Geol. Survey, Bull. 23, 61 pp., 10 figs., 3 pls. (incl. map), 1920.

2. A contribution to the igneous geology of central Colorado: Am. Jour. Sci., 5th ser., vol. 7, pp. 365-388, 1 fig., May, 1924.

3. (and Gibson, Russell). Geology and ore deposits of the Red Cliff district, Colorado: Colorado Geol. Survey, Bull. 30, 89 pp., 15 figs., 3 pls. (incl. map), 1925.

Crawford, William P.

1. Weissite, a new mineral [from Colorado] : Am. Jour. Sci., 5th ser., vol. 13, pp. 345-346, April, 1927.

Cressey, George Babcock.

1. Notes on the sand dunes of northwestern Indiana: Jour. Geology, vol. 30, no. 3, pp. 248-251, April-May, 1922. 
Cressey, George Babcock-Continued.

2. The Indiana sand dunes and shore lines of the Lake Michigan Basin: Geog. Soc. Chicago, Bull. no. 8, 80 pp., 5 figs., 20 pls., May, 1928; abstract, Chicago, Univ., Abstracts of Theses, Sci. Ser., vol. 1, pp. 267-270, October, 1925.

Creveling, J. G.

1. The peridotite of Presque Isle, Michigan; a study in serpentinization : Am. Jour. Sci., 5th ser., vol. 12, pp. 515-521, December, 1926.

Crickmay, Colin Hayter. See also Hertlein, 3.

1. The discovery of the prosiphon in Cretaceous ammonites from California, with remarks upon the function of the organ: Am. Jour. Sci., 5th ser., vol. 9, pp. 229-232, 3 figs., March, 1925.

2. A note on two of Hyatt's Liassic ammonites: California Acad. Sci., Proc., 4th sèr., vol. 14, no. 3, pp. 77-81, 1 pl., July 23, 1925.

3. A Pleistocene fauna from the southwestern mainland of British Columbia : Canađian Field-Naturalist, vol. 39, no. 6, pp. 140-141, September, 1925.

4. On Beudanticeras breweri and Coloboceras stantoni: Am. Jour. Sci., 5th ser., vol. 13, pp. 503-516; 10 figs., June, 1927.

5. The geology and paleontology of the Harrison Lake district, British Columbia, together with a general review of the Jurassic faunas and stratigraphy of western North America (abstract): Stanford Univ., Abstracts of Dissertations, 1924-1926, vol. 1, pp. 131-158, June, 1927.

6. Latest Jurassic and earliest Cretaceous (abstract) : Geol. Soc. America, Bull., vol. 39, no. 1, p. 264, March 30, 1928.

7. Geology of Dead Man Island, California (abstract) : Pan-Am. Geologist, vol. 49 , no. 4 , p. 303 , May, 1928.

8. Delimitation of Jura and Trias sections in British Columbia (abstract) : Pan-Am. Geologist, vol. 49, no. 4, p. 313, May, 1928.

9. The stratigraphy of Parson Bay, British Columbia: California, Univ., Pub., Dept. Geol. Sci., Bull., vol. 18, no. 2, pp. 51-70, 3 figs., 4 pls., map, December 29, 1928.

Crider, Albert Foster. See also Weller, 17.

1. The El Dorado, Arkansas, oil field and its relation to north Louisiana structures: Am. Assoc. Petroleum Geologists, Bull., vol. 6, no. 3, pp. 193-198, May-June, 1922.

2. Relation of Upper Cretaceous to Eocene structures in Louisiana and Arkansas (with discussion): Am. Assoc. Petroleum Geologists, Bull., vol. 7, no. 4, pp. 379-383, July-August, 1923.

3. Volcanic ash in northern Louisiana: Am. Assoc. Petroleum Geologists, Bull., vol. 8, no. 4, pp. 524-525, July-August, 1924.

4. Deep Pine Island gas [northern Louisiana]: Am. Assoc. Petroleum Geologists, Bull., vol. 9, no. 1, pp. 171-172, January-February, 1925.

Crider, H. D. See Kentucky Geological Survey.

Crocker, William.

1. Association of ores and dikes: Eng. Min. Jour.-Press, vol. 117, no. 1., p. 21, January 5 ; no. 5, p. 213, February 2.1924.

$4096-31-10$ 
Croneis, Carey G. See also Hubbard, G. D., 6.

1. New cephalopods from the Fayetteville shale [of Arkansas]: Harvard Coll., Mus. Comp. Zoology, Bull., vol. 67, no. 10, pp. 341-352, 2 pls., February, 1926.

2. Notes on Cycloceras and associated genera: Am. Jour. Sci., 5th ser., vol. 12, pp. 185-192, September, 1926.

3. Unusual Carboniferous cephalopods : Science, new ser., vol. 64, pp. 622-623, December 24, 1926.

4. Sharks from Fayetteville formation: Pan-Am. Geologist, vol. 47, no. 1, pp. $41-46,1$ pl., February, 1927.

5. Oil and gas possibilities in the Arkansas Ozarks: Am. Assoc. Petroleum Geologists, vol. 11, no. 3, pp. 277-297, 2 figs., March, 1927.

Crook, Alja Robinson, 1865-1930.

1. The composition and origin of Monk's Mound [St. Clair County, Illinois] : Illinois Acad. Sci., Trans., vol. 9, pp. 82-84 [1917].

2. Guide to the mineral collections in the Illinois State Museum. 294 pp., 31 pls., 236 figs., Springfield, Illinois, 1920.

3. The origin of the Cahokia mounds: Illinois State Mus., Bull., 26 pp., 22 figs., Springfield, May, 1922.

4. Elephas primigenius boreus Hay at Golconda, Illinois: Illinois State Acad. Sci., Trans., vol. 19, pp. 288-299, 1 fig., 8 pls., 1926.

5. Elephas primigenius boreus Hay in Illinois (abtract) : Geol. Soc. America, Bull., vol. 38, no. 1, pp. 137-138, March 30, 1927; Pan-Am. Geologist, vol. 47, no. 1, p. 67, February, 1927.

Crosby, Irving Ballard. See also Crosby, w. O., 4.

1. Former courses of the Androscoggin River: Jour. Geology, vol. 30, no. 3, pp. 232-247, 5 figs., April-May, 1922 ; abstract, Geol. Soc. America, Bull., vol. 33, no. 1, p. 121, March 31, 1922.

2. The earthquake risk in Boston: Boston Soc. Civil Eng., Jour., vol. 10, no. 10 , pp. $421-430,1$ pl. (map), December, 1923.

3. The physiographic history of Pinkham Notch [White Mountains, New Hampshire] : Appalachia, vol. 15, no. 4, pp. 462-468, 1 pl., April 1924.

4. The danger of earthquakes in New England: Science, new ser., vol. 63, pp. 186-187, February 12, 1926.

5. Boston through the ages; the geological story of greater Boston. xvii, 166 pp., illus., Boston, Mass., Marshall Jones Company, 1928.

6. Potholes on Mount Jefferson [White Mountains, New Hampshire] : Appalachia, vol. 17, no. 1. (Bull. Appalachian Mountain Club, vol. 21, no. 10), pp. 44-45, June, 1898.

7. (and Leonardon, E. G.). Electrical prospecting applied to foundation problems: Am. Inst. Min. and Met. Eng., Tech. Pub. no. 131, 12 pp., 13 figs., September, 1928.

Crosby, William Otis, 1850-1925.

1. Certain aspects of glaciation in Alaska (abstract) : Geol. Soc. America, Bull., vol. 30, no. 1, p. 115, March 31, 1919.

2. Certain aspects of glacial erosion in Alaska (abstract) : Geol. Soc. America, Bull., vol. 31, no. 1, p. 132, March 31, 1920.

3. Soils of Coos County [New Hampshire] : Boston Soc. Nat. Hist., Proc., vol. 37, no. 3, pp. 54-68, 1 fig., July, 1924. 
Crosby, William Otis-Continued.

4. (and Crosby, Irving B.). Keystone faults: Geol. Soc. America, Bull., vol. 36, no. 4, pp. 623-640, 1 fig., December, 1925 ; abstract, vol. 35, no. 1, p. 94, March 30, 1924 ; Pan-Am. Geologist, vol. 41, no. 2, p. 147, March, 1924.

5. Certain aspects of glacial erosion: Geol. Soc. America, Bull., vol. 39, no. 4, pp. 1171-1181, December 30, 1928.

Cross, Julian Gifford.

1. Lake Shebandowan nickel deposit: Ontario Dept. Mines, 29th Ann. Rept., vol. 29, pt. 1, pp. 225-234, 5 figs., 1920.

2. Pre-Cambrian rocks and iron ore deposits in the Abitibi-Mattagami area: Ontario Bur. Mines, 29th Ann. Rept., vol. 29, pt. 2, pp. 1-18, 11 figs., map, 1920.

3. The Shebandowan nickel-copper deposits [Ontario]: Canadian Min. Jour., vol, 43, no. 18, pp. 270-271, May 5, 1922.

Cross, (Charles) Whitman.

1. Geology in the World War and after: Geol. Soc. America, Bull., vol. 30, no. 1, pp. 165-188, March 31, 1919.

2. Louis Valentine Pirsson: Am. Jour. Sci., 4th ser., vol. 50, pp. 173-187, portr., September, 1920 .

3. (and others). The Kilauea Volcano Observatory: Nat Acad. Sci., Proc., vol. 6 , no. 12 , pp. 706-716, December 15, 1920.

4. Are the Lance and Fort Union formations of Mesozoic time?: Science, new ser., vol. 53, pp. 304-307, April 1, 1921.

5. Tertiary aspects of Lance beds: Pan-Am. Geologist, vol. 37, no. 1, pp. 66-67, February, 1922.

6. Historical sketch of the landslides of Gaillard Cut [Panama Canal]: Nat. Acad. Sci., Mem., vol. 18, pp. 23-43, 1924.

7. (and Shannon, Earl V.). The geology, petrography, and mineralogy of the vicinity of Italian Mountain, Gunnison County, Colorado: U. S. Nat. Mus., Proc. vol. 71, art. 18, 42 pp., 15 figs. (incl. map), 2 pls., 1927.

Crouse, Charles Stevens.

1. The oil shales of Estill County, Kentucky: Eng. and Min. Jour., vol. 110, no. 1, pp. 24-27, July 3, 1920.

2. The precious metal content of the black Devonian shales of Kentucky: Kentucky Geol: Survey, ser. 6, vol. 21, pp. 49-58, 1925.

3. An economic study of the black Devonian shales of Kentucky: Kentucky Geol. Survey, ser. 6, vol. 21, pp. 59-97, 4 figs., 1925.

4. The intrastate industrial utilization of the mineral resources of Kentucky : Kentucky Geol. Survey, ser. 6, vol. 21, pp. 145-192, 1925.

5. Economic possibilities of eastern oil shales: Min. Congress Jour., vol. 12, no. 3, pp. 166-169, 5 figs., March, 1926.

Crowell \& Murray.

1. The iron ores of Lake Superior. Fourth edition, 301 pp., pls., maps, and figs., Cleveland, The Penton Press, 1920.

Crum, H. E. See Prommel, 2, 4.

Crump, Malcolm Hart, 1849-1925.

1. The Harvard summer school of geology [Cumberland Mountain, Kentucky, 1875] : Science, new ser., vol. 60, pp. 421-423, November 7, 1924. 
Cudworth, James R.

1. Report of the geology and mineral resources of the Tennessee River district in Alabama, Georgia, and Mississippi : U. S., 70th Cong., 1st sess., H. R. Doc. no. 185, pp. 159-183, 1928.

Culbertson, Glenn.

1. Some evidence indicating the importance of frost action in widening val. leys : Indiana Acad. Sci., Proc., 1920, pp. 247-248, 2 figs., 1921.

Culbertson, J. Archer.

1. Fauna of the Brassfield limestone of Jefferson County, Indiana: Indiana Acad. Sci., Proc., vol. 35, pp. 111-119, 1 pl., 1926.

2. Further observations of the erosion of Clifty and Butler Ravines, Jefferson County, Indiana: Indiana Acad. Sci., Proc., vol. 37, pp. 117-120, 2 figs., 1928.

3. Notes on some Ohio River terraces: Indiana Acad. Sci., Proc., vol. 37 pp. 120-123, 2 figs., 1928.

Culver, Harold Eugene.

1. The coal fields of southwestern Washington: Washington Geol. Survey, Bull. no. 19, 155 pp., 24 pls. (incl. maps), 12 figs., 1919.

2. Geology and mineral resources of the Morris quadrangle: Illinois State Geol. Survey, Bull. no. 43, pp. 95-204, 32 figs., 3 pls. (maps), 1923 (published as extract, 114 pp., in 1922).

3. Note on the occurrence of Fusulinas in the Pennsylvanian rocks of Illinois: Illinois State Acad. Sci., Trans., vol. 15, pp. 421-425 [1923].

4. Pennsylvanian correlation in northwestern Illinois: Geol. Soc. America, Bull., vol. 35, no. 2, pp. 321-328, 3 figs., June 30, 1924 ; abstract, no. 1, p. 116, March 30, 1924; Pan-Am. Geologist, vol. 41, no. 2, p. 157, March, 1924.

5. Preliminary report on coal-stripping possibilities in Illinois: Illinois State Geol. Survey, Cooperative Min. Ser., Bull. 28, 61 pp., 22 figs., 1925.

6. Coal resources of District III (western Illinois) : Illinois State Geol. Survey, Cooperative Min. Ser., Bull. 29, 128 pp., 14 figs., 2 maps, 1925.

7. Geology and mineral resources of the Morris quadrangle: Chicago, Univ., Abstracts of Theses, Sci. Ser., vol. 1, pp. 271-276, October, 1925.

8. Correlation of Illinois coals (abstract) : Pan-Am. Geologist, vol. 45, no. 3, pp. 253-254, April, 1926.

9. Present status of correlation of Illinois coals: Illinois, State Geol. Survey, Rept. Investigations, no. 14, 13 pp., 1927.

10. Abstract of the report [by Solon Shedd] on the geology and resources of the Pasco and Prosser quadrangles [Washington]: Washington, Dept. Conservation, Div. Geology, Reports of Investigations, no. 1, 4 pp. [mimeographed], map [1927?].

11. Mastodon remains in Washington: Science, new ser., vol. 66, pp. 540541, December 2, 1927.

12. Biennial report of the supervisor of the division of geology: Washington, Dept. Conservation and Development, Third Biennial Rept., pp. 85-92, Olympia, 1927.

13. Biennial report of the supervisor of the division of geology: Washington, Dept. Conservation and Development, Fourth Bienn. Rept., pp. 68-75, 1928.

Cumings, Edgar Roscoe.

1. Nomenclature and description of the geological formations of Indiana. In Handbook of Indiana geology (Indiana, Dept. Conservation, Pub. no. 21), pp. 403-570, 31 figs. (incl. maps), Indianapolis, 1922. 
Cumings, Edgar Roscoe-Continued.

2. The earth's framework [presidential address]: Indiana Acad. Sci., 41st Ann. Meeting, Proc., vol. 35, pp. 45-61, 1926.

3. (and Schrock, R. R.). The Silurian coral reefs of northern Indiana and their associated strata: Indiana Acad. Sci., Proc., vol. 36, pp. 71-85, 4 figs., 1927.

4. (and Shrock, Robert R.). Niagaran coral reefs of Indiana and adjacent States and their stratigraphic relations: Geol. Soc. America, Bull., vol. 39, no. 2, pp. 579-620, 12 figs., June, 1928; abstract, no. 1, p. 211, March 30, 1928; Pan-Am. Geologist, vol. 49, no. 2, pp. 145-146, March, no. 3, p. 232, April, 1928.

5. (and Shrock, Robert R.). The geology of the Silurian rocks of northern Indiana: Indiana, Division of Geology, Conservation Comm., Pub. no. 75,226 pp., 45 figs., maps and charts, 1928.

Cumming, Jorge.

1. Informe preliminar acerca de la geología y zonas petroliferas de una parte de los estados de Coahuila y Nuevo León: Mexico, Inst. Geol., Foll. Divulgación, no. 20, 15 pp., 1926.

2. Informe preliminar acerca del reconocimiento geológico-petrolero, de la parte norte del estado de Coahuila: Mexico, Inst. Geol., Foll. Divulgación, no. 29, 29 pp., map, 1928.

Cundall, Frank.

1. Description of Jamaica, pp. 26-33, 1 pl. (geologic map). In The Handbook of Jamaica for 1923; Kingston, Government Printing Office, 1923.

Cunningham, C. M.

1. (and Hardy, Norman). Notes on geology and status of development of Seal Beach and Alamitos areas, California: Am. Assoc. Petroleum Geologists, Bull., vol. 11, no. 8, pp. 870-873, August, 1927.

Cunningham, George M.

1. The Wheeler Ridge oil field [Kern County, California]; Am. Assoc. Petroleum Geologists, Bull., vol. 10, no. 5, pp. 495-501, 2 figs., May, 1926.

2. Were diatoms the chief source of California oil? (with discussion by Howard W. Kitson): Am. Assoc. Petroleum Geologists, Bull., vol. 10, no. 7, pp. 709-721, July, 1926.

Cuno, John B.

1. The mystery of a buried forest [in an excavation in Washington, D. C.] : Am. Forestry, vol. 29, pp. 105-1.06, 1. fig., February, 1923.

Currier, Louis Wade. See also Weller, s., 1.

1. Geology of northeastern Adams County: Illinois State Geol. Survey, Bull. no. 43, pp. 305-323, 4 figs., 2 pls. (mans), 1923 (published as extract, $23 \mathrm{pp}$., in 1922).

2. Fluorspar deposits of Kentucky; a description and interpretation of the geologic occurrence and industrial importance of Kentucky fluorspar: Kentucky Geol. Survey, ser. 6, vol. 13, 198 pp., 41 figs., map, 1923.

Currier \& Company.

1. New oil and geological map of Texas . . . Scale, 28 miles to 1 inch (about). Kansas City, Missouri, no date [1920?]. 
Cushing, Henry Platt, 1860-1921. See also Clarke, J. M., 15.

1. (and Newland, D. H.). Geology of the Gouverneur quadrangle: New York State Mus. Bull., no. 259, 122 pp., 16 figs., 14 pls., map, May, 1925.

Cushman, Joseph Augustine. See also Loughlin, 9.

1. Pliocene Foraminifera of the Coastal Plain of the United States (U. S. Geol. Survey, Bull. 676, 1918) (abstract by R. W. Stone) : Washington Acad. Sci., Jour., vol. 9, no. 11, pp. 328-329, June 4, 1919.

2. The age of the underlying rocks of Florida as shown by the Foraminifera of well borings: Florida State Geol. Survey, Twelfth Ann. Rept., pp. 77-103, 1 fig., 1919.

3. Fossil Foraminifera from the West Indies: Carnegie Inst. Washington, Pub. no. 291, pp. 21-71, 15 pls., 8 figs., 1919.

4. Lower Cretaceous age of the limestones underlying Florida: Washington Acad. Sci., Jour., vol. 9, no. 3, pp. 70-73, February 4, 1919.

5. Value of Foraminifera in stratigraphic correlation (abstract): Geol. Soc. America, Bull., vol. 31, no. 1, p. 205, March 31, 1920.

6. Foraminiferal fauna of the Byram marl (abstract) : Geol. Soc. America, Bull., vol. 31, no. 1, p. 215, March 31, 1920.

7. Some relationships of the foraminiferal fauna of the Byram calcareous marl [Hinds County, Mississippi] : Washington Acad. Sci., Jour., vol. 10, no. 7, pp. 198-201, April 4, 1920.

8. The American species of Orthophragmina and Lepidocyclina: U. S. Geol. Survey, Prof. Paper 125, pp. 39-105, 29 pls., 1 fig., July 26, 1920; abstract by R. W. Stone, Washington Acad. Sci., Jour., vol. 11, no. 8, p. 194, April 19, 1921.

9. Lower Miocene Foraminifera of Florida: U. S. Geol. Survey, Prof. Paper 128, pp. 67-74, 1 pl., August 12, 1920.

10. American species of Operculina and Heterostegina and their faunal relations: U. S. Geol. Survey, Prof. Paper 128, pp. 125-137, 4 pls., March 21, 1921. Abstract by C. Wythe Cooke, Washington Acad. Sci., Jour., vol. 11, no: 21, p. 511, December 19, 1921.

11. A new species of Orthophragmina [advena] from Louisiana: U. S. Geol. Survey, Prof. Paper 128, pp. 139-142, 1 pl., March 21, 1921.

12. Foraminifera from the deep wells of Florida: Florida State Geol. Survey, 13th Ann. Rept., pp. 33-70, 1 fig., 3 pls., 1921.

13. The Foraminifera of the Byram calcareous marl at Byram, Mississippi: U. S. Geol. Survey, Prof. Paper 129, pp. 87-122, 15 pls., March 17, 1922.

14. The Foraminifera of the Mint Spring calcareous marl member of the Marianna limestone: U. S. Geol. Survey, Prof. Paper 129, pp. 123152, 7 pls., March 28, 1922.

15. Use of Foraminifera in determining underground structure, especially in petroleum mining (abstract) : Geol. Soc. America, Bull., vol. 33, no. 1, pp. 145-146, March 31, 1922.

16. The Foraminifera of the Vicksburg group: U. S. Geol. Survey, Prof. Paper 133, pp. 11-67, 8 pls., 1923.

17. (and Trager, Earl A.). New formation in the Tampico Embayment region (abstract, with discussion by Joseph T. Singewald, jr.) : Geol. Soc. America, Bull., vol. 35, no. 1, p. 100, March 30, 1924; abstract, Pan-Am. Geologist, vol. 41, no. 2, p. 149, March, 1924.

18. The use of Foraminifera in geologic correlation: Am. Assoc. Petroleum . Geologists, Bull., vol. 8, no. 4, pp. 485-491, July-August, 1924. 
Cushman, Joseph Augustine-Continued.

19. A new genus of Eocene Foraminifera: U. S. Nat. Mus., Proc., vol. 66, art. 30, 4 pp.. 1 fig.. 2 pls.. January 23.1925.

20. The genera Pseudotextularia and Guembelina: Washington Acad. Sci., Jour., vol. 15, no. 6, pp. 133-134, March 19, 1925.

21. An Eocene fauna from the Moctezuma River, Mexico: Am. Assoc. Petroleum Geologists, Bull., vol. 9, no. 2, pp. 298-303, 3 pls., MarchApril, 1925.

22. Contributions from the Cushman Laboratory for Foraminiferal Research. Sharon, Massachusetts.

Vol. 1, no. 1, April, 1925.

1. A new Cretaceous Uvigerina from Louisiana, p. 1.

2. Three new species of Siphogenerina from the Miocene of California, pp. 2-3.

3. New Foraminifera from the upper Eocene of Mexicn, pp. 4-8, 1 pl.

4. A new Uvigerina from the Vienna Basin, p. 10.

5. (and Hughes, Donald D.). Some later Tertiary Cassidulinas of California, pp. 11-16, 1 pl.

6. Some new Foraminifera from the Velasco shale of Mexico, pp. 18-22, $1 \mathrm{pl}$.

7. Apertural characters in Cristellaria with descriptions of a new species, pp. 24-25, 1 pl.

Vol. 1, pt. 2, July, 1925.

8. Some Textulariidae from the Miocene of California, pp. 29-34, 1 pl.

9. Siphogenerina hughesi, a new species from California, p. 9.

10. New Species of Cassidulina from the Paciflc, pp. 36-38, 1 pl.

11. Recent Foraminifera from British Columbia, pp. 38-44, 2 pls.

12. Foraminifera as an original source of petroleum, p. 48.

Vol. 1, pt. 3, October, 1925.

13. Notes on the genus Cassidulina, pp. 51-59, 2 pls.

14. Mexican species of Marginulina, pp. 61-62.

15. Notes on the genus Tritaxilina, pp. 62--65.

16. Eocene Foraminifera from the Cocoa sand of Alabama, pp. 65-69, $1 \mathrm{pl}$.

Vol. 1, pt. 4, January, 1926.

17. The genus Chilostomella and related genera, pp. 73-79, 1 pl.

18. Some fossil Bolivinas from Mexico, pp. 81-84, 1 pl.

19. Trifarina in the American Eocene and elsewhere, pp. 86-88.

20. A peculiar Frondicularia from Mexico and Trinidad, pp. 88-89.

21. Miocene species of Nonionina from California, pp. 89-91, 1 pl.

Vol. 2, pt. 1, April, 1926.

22. Photographing Foraminifera, pp. 1-3.

23. Eouvigerina, a new genus from the Cretaceous, pp. 3-6.

24. The genus Lamarckina and its American species, pp. 7-13, $1 \mathrm{pl}$.

25. Siphogenerina plummeri, a species from the upper Cretaceous of Texas, p. 15.

26. Some Foraminifera from the Mendez shale of eastern Mexico, 16-24, 2 pls.

Vol. 2, pt. 2, July, 1926.

27. Some new Foraminifera from the upper Eocene of the southeastern Coastal Plain of the United States, pp. 29-36, 2 pls.

28. (and Stewart, Roscoe E.). A new Plectofrondicularia from the Oligocene of California, p. 39.

29. Some Pliocene Bolivinas from California, pp. 40-46, 1 pl.

Vol. 2, pt. 3, October, 1926.

30. Foraminifera of the typical Monterey of California, pp. 53-66, 3 pls.

31. The generic position of "Pulvinulina favus H. B. Brady," pp. 70-71.

32. Some phases of correlation by means of the Foraminifera, pp. 71-74. 
Cushman, Joseph Augustine-Continued.

22. Contributions from the Cushman Laboratory for Foraminiferal Research.

Sharon, Massachusetts-Continued.

Vol. 2, pt. 4, January, 1927.

33. Some new genera of the Foraminifera, pp. 77-81.

34. (and Waters, James A.). Some arenaceous Foraminifera from the upper Cretaceous of Texas, pp. 81-85.

35. American upper Cretaceous species of Bolivina and related species, pp. 85-91.

36. (and Harris, Reginald W.). The significance of relative measurements in the study of Foraminifera, pp. 92-94.

37. Sporadogenerina, a degenerate foraminiferal genus, pp. 94-95.

Vol. 3, pt. 1, March, 1927.

39. An outline of a reclassification of the Foraminifera, pp. 1-105.

Vol. 3, pt. 2, June, 1927.

40. (and Waters, James A.) Pennsylvanian Foraminifera from Michigan, pp. 107-110.

41. New and interesting Foraminifera from Mexico and Texas, pp. 111-116.

42. (and Howe, Henry V.). A species of Siphoninella in the Tertiary of America, pp. 120-121.

43. Some notes on the early formaniferal genera erected before 1808 , pp. $122-126$.

44. (and Harris, Reginald W.). Notes on the genus Pleurostomella, pp. $128-133$.

Vol. 3, pt. 3, September, 1927.

45. Notes on the collection of Defrance, pp. 141-145.

46. (and Waters, James A.). Arenaceous Palaeozoic Foraminifera from Texas, pp. 146-153.

47. Additional notes on the genus Pleurostomella, p. 156.

48. The genera Renulina and Vertebralina, pp. 158-160.

Vol. 3, pt. 4, December, 1927.

49. Trimorphism in the Foraminifera, pp. 165-167.

50. The work of Fichtel and Moll and of Montfort, pp. 168-171.

51. (and Harris, Reginald W.). Some notes on the genus Ceratobulimina, pp. 171-176.

52. Epistomina elegans (D'Orbigny) and E. partschiana (D'Orbigny), pp. $180-184$.

53. The designation of some genotypes in the Foraminifera, pp. 188-190.

Vol. 4, pt. 1, March, 1928.

54. Additional genera of the Foraminifera, pp. 1-8.

55. A new genus, Depratella, and its relation to Endothyra, pp. 9-10, by Ozawa, Yoshiaki.

56. (and Wickenden, R. T. D.). A new foraminiferal genus from the upper Cretaceous, pp. 12-13.

57. (and Ozawa, Yoshiaki). An outline of a revision of the Poly. morphinidae, pp. 13-20.

58. Apertural characters in the Lagenidae, pp. 22-25.

Vol. 4, pt. 2, June, 1928.

59. (and Waters, James A.). Some Foraminifera from the Pennsylvanian and Permian of Texas, pp. 31-55.

Vol. 4, pt. 3, September, 1928.

60. A peculiar Olavulina from the upper Cretaceous of Texas, pp. 61-62.

61. (and Waters, James A.). Additional Cisco Foraminifera from Texas, pp. 62-67.

62. The microspheric and megalospheric forms of Apterrinella grahamensis, pp. 68-69.

63. A Cretaceous Cyclammina from California, p. 70.

64. Additional Foraminifera from the upper Eocene of Alabama, pp. $73-79$.

65. On Faujasina D'Orbigny, pp. 80-81, by Hofker, J. 
Cushman, Joseph Augustine-Continued.

22. Contributions from the Cushman Laboratory for Foraminiferal Research.

Sharon, Massachusetts-Continued.

Vol. 4, pt. 4, December, 1928.

66. (and Jaris, P. W.) Cretaceous Foraminifera from Trinidad, pp. $85-103$.

67. On Rotalia beccarii (Linné), pp. 103-107.

68. Fistulose species of Gaudryina and Heterostomella, pp. 107-112.

69. (and Waters, James A.). Hyperamminoides, a new name for Hyperamminella Cushman and Waters, p. 112.

23. All introduction to the morphology and classification of the Foraminifera:

Smithsonian Misc. Coll., vol. 77, no. 4, 77 pp., î pls., July 21, 1925.

24. (and Applin, E. R.). 'Texas Jackson Foraminifera; Am. Assoc. Petroleum Geologists, Bull., vol. 10, no. 2, pp. 154-189, 6 pls., February, 1926.

25. Foraminifera of the genera Siphogenerina and Pavonina: U. S. Nat. Mus., Proc., vol. 67, art. 25, 24 pp., 6 pls., March 9, 1926.

26. The Foraminifera of the Velasco shale of the Tampico embayment [San Luis Potosi, Mexico]: Am. Assoc. Petroleum Geologists, Bull., vol. 10, no. 6, pp. 581-612, 7 pls., June, 1926.

27. Foraminifera of the genus Ehrembergina and its species: U. S. Nat. Mus., Proc., vol. 70, art. 16, 8 pp., 2 pls., 1927.

28. Some paleontologic evidence bearing on a classification of the Foraminifera : Am. Jour. Sci., 5th ser., vol. 13, pp. 53-56, January, 1.927.

29. (and Hanna, Marcus A.). Foraminifera from the Eocene near San Diego, California: San Diego Soc. Nat. Hist., Trans., vol. 5, no. 4, pp. 45-64, 3 pls., March 15, 1927.

30. Phylogenetic studies of the Foraminifera, Part I: Am. Jour. Sci., 5th ser., vol. 13, pp. 315-326, 2 figs., April, 1927.

31. The occurrence of Lituonella and Coskinolina in America: Washington Acad. Sci., Jour., vol. 17, no. S, pp. 198-200, April 19, 1927.

32. (and Hanna, G. Dallas). Foraminifera from the Eocene near Coalinga, California: California Acad. Sci., Proc., 4th ser., vol. 16, no. 8, pp. 205-228, 2 pls., April 22, 1927.

33. Some Foraminifera from the Cretaceous of Canada: Roy. Soc. Canada, Trans., 3d ser., vol. 21, sec. 4, pp. 127-132, May, 1927.

34. (and Grant, U. S., IV). Late Tertiary and Quaternary Elphidiums of the west coast of North America: San Diego Soc. Nat. Hist., Trans., vol. 5 , no. 6 , pp. 69-82, 2 pls., July $28,1927$.

35. Description of Foraminifera: Jour. Paleontology, vol. 1, no. 1, pp. 13-14, July, 1.927.

36. Sume characteristic Mexican fossil Foraminifera: Jour. Paleontology, vol. 1, no. 2, pp. 147-172, 6 pls., August, 1927.

37. Foraminifera of the genus Siphonina and related genera: U. S. Nat. Mus., Proc., vol. 72, art 20, 15 pp., 4 pls., 1927.

33. Plyylogenetic studies of the Foraminifera, Part II; Am. Jour. Sci., 5th ser., vol. 14, pp. 317-324, 1 pl., October, 1927.

39. Notes on Foraminifera in the collection of Ehrenberg: Washington Acarl. Sci., Jour., vol. 17, no. 19, pp. 487-491, November 19, 1927.

10. The American Cretaceous Foraminifera figured by Ehrenberg: Jour. Paleontology, vol. 1, no. 3, pp. 213-217, 3 pls., December, 1927.

41. Foraminifera; their classification and economic use: Cushman Laboratory for Foraminiferal Research, Spec. Pub. no. 1, 401 pp., 59 pls., sharon, Massachusetts, April, 1928. 
Cushrnan, Joseph Augustine-Continued.

42. (and Waters, James A.). The development of Climacammina and its allies in the Pennsylvanian of Texas: Jour. Paleontology, vol. 2, no. 2, pp. 119-130, 4 pls., June, 1928.

43. Fossils; what they are and their uses to man: Sci. Monthly, vol. 27, no. 4, pp. 346-348, October, 1928.

44. (and Schenck, Hubert G.). Two foraminiferal fannules from the Oregon Tertiary: California; Univ., Dept. Geol. Sci., Bull., vol. 17, no. 9, pp. 305-324, 4 pls., November 3, 1928.

45. (and Waters, James A.). Upper Paleozoic Foraminifera from Sutton County; Texas: Jour. Paleontology, vol. 2, no. 4, pp. 358-371, 3 pls., December, 1928.

Custer, Clarence. See Cockerell, 28.

Dachnowski, Alfred Paul.

1. Correlation work in peat-land problems: Bot. Gazette, vol. 70, no. 6, pp. 453-458, December, 1920.

2. Peat deposits in the United States and their classification: Soil Science, vol. 10, no. 6, pp. 453-465, December, 1920.

3. Peat deposits and their evidence of climatic changes: Bot. Gazette, vol. 72, no. 2, pp. 57-89, 12 figs., August, 1921.

4. Profiles of peatlands within limits of extinct glacial lakes Agassiz and Wisconsin: Bot. Gazette, vol. 80, no. 4, pp. 345-366, 3 figs., December, 1925 .

5. Profiles of peat deposits in New England: Ecology, vol. 7, no. 2, pp. 120135, 2 figs., April, 1926.

Dahlblom, Th.

1. The permeability of rocks: Econ. Geology, vol. 19, no. 4, pp. 389-392, JuneJuly, 1924.

Dahlgren, B. E.

1. A fossil flower [cycad] : Field Mus. Nat. Hist., Dept. Botany, Leaflet no. 5. 16 pp., 10 figs., 1924.

Dake, Charles Lawrence. See also Cox, G. H., 1.

1. The sand and gravel resources of Missouri: Missouri Bur. Geology and Mines, $2 \mathrm{~d}$ sèr., vol. 15, 274 pp., 47 pls., 2 figs., 1918.

2. Glacial features on the south side of Beartooth Plateau, Wyoming: Jour. Geology, vol. 27, no. 2, pp. 128-131, 1 fig., February-March, 1919.

3. The horizon of the marine Jurassic of Utah: Jour. Geology, vol. 27, no. 8, pp. 634-646, 10 figs. November-December, 1919.

4. The pre-Moenkopi (pre-Permian?) unconformity of the Colorado Plateau: Jour. Geology, vol. 28, no. 1, pp. 61-74, 8 figs., January-February,. 1920. Abstract, Science, new ser., vol. 51, p. 492, May 14, 1920.

5. Episodes in Rocky Mountain orogeny: Am. Jour. Sci., 5th ser., vol. 1, no. 13, pp. 245-254, March, 1921; abstract, Science, new ser., vol. 51, pp. 520-521, May 21, 1920.

6. The problem of the St. Peter sandstone; Missouri, Univ., School of Mines and Met., Bull., Tech. ser., vol. 6, no. 1, pp. 1-225, 30 pls., August, 1921.

7. Derivation of the Peter sandstone: Pan-Am. Geologist, vol. 37, no. 3, pp. 244-245, April, 1922.

8. Taxonomic significance of Peter sandstone: Pan-Am. Geologist, vol. 37, no. 4, pp. 288-300, May, 1922. 
Dake, Charles Lawrence-Continued.

9. Memorial of Guy H. Cox : Geol. Soc. America, Bull., vol. 34, no. 1, pp. 15-18, portr., March 30, 1923.

10. (and Bridge, Josiah). Subterranean stream piracy in the Ozarks: Missouri, Univ., School of Mines and Metallurgy, Bull., vol. 7, no. 1, pp. 3-14, 7 figs., 8 pls., November, 1923.

11. The scope of geologic teaching in mining engineering: Engineering Education, vol. 18, no. 8, pp. 527-536, 1923.

12. (and Brown, J. S.). Interpretation of topographic and geologic maps, with special reference to determination of structure. $\mathrm{xi}, 355 \mathrm{pp}$., 52 figs., New York, McGraw-Hill Book Company, 1925.

13. (and Bridge, Josiah). Early diastrophic events in the Ozarks (abstract) : Geol. Soc. America, Bull., vol. 38, no. 1, pp. 157-158, March 30, 1927; Pan-Am. Geologist, vol. 47, no. 2, pp. 155-156, March, 1927.

Dale, Nelson Clark.

1. Provisional report of the areal and structural geology of the western flank of the Green Mountain Range: Vermont, State Geologist, 11th Rept., pp. 194-199 [1919].

2. Postglacial manganese in Columbia County, New York: New York State Mus. Bull., nos. 207, 208 (March-April, 1918), pp. 85-100, 5 figs., 1919.

3. Notes on the areal and structural geology of a portion of the western flank of the Green Mountain Range: Vermont, State Geologist Twelfth Rept., 1919-20, pp. 43-56, 7 figs., 1 pl., 1921.

4. The box vein of Lyonsdale, Lewis County, New York: New York State Mus. Bull. no. 251, pp. 134-148, 1 fig., 4 pls., 1924.

5. Pre-Cambrian and Paleozoic geology of Fortune Bay, Newfoundland: Geol. Soc. America, Bull., vol. 38, no. 2, pp. 411-430, 8 figs., June 30, 1927 ; abstract, vol. 37 , no. 1 , p. 155, March 30, 1926; Pan-Am. Geologist, vol. 45, no. 2, p. 159, March, 1926.

Dale, Thomas Nelson.

1. Practical geology of monumental stones: Monumental News, vol. 32, no. 10 , pp. $764-765$, no. 12 , pp. $914-915$, vol. 33 , no. 1 , pp. $42-44$, no. 3, pp. 202-204, no. 4, pp. 272-273, 7 figs., October, December, 1919; January, March, April, 1920.

2. Local unconformity between the Berkshire schist and the Stockbridge limestone in Adams, Mass.: Am. Jour. Sci., 4th ser., vol. 49, pp. 369-371, May, 1920.

3. On concentric drag folding in Alabama marble: Am. Jour. Sci., 5th ser., vol. 2, pp. 319-321, 2 figs., December, 1921.

4. The commercial granites of New England: U. S. Geol. Survey, Bull. 738, 488 pp., 96 figs., 34 pls. (incl. maps), 1923.

5. The lime belt of Massachusetts and parts of eastern New York and western Connecticut: U. S. Geol. Survey, Bull. 744, 71 pp., 23 figs., 8 pls. (incl. maps), 1923.

6. Constitution and adaptation of the Holston marble of east Tennessee: Tennessee, Dept. Education, Div. Geology, Bull. 28, pp. 87-160, 10 figs., 15 pls., 1924.

Dall, William Healey, 1845-1927.

1. On some Tertiary fossils from the Pribilof Islands: Washington Acad. Sci., Jour., vol. 9, no. 1, pp. 1-3, January 4, 1919. 
Dall, William Healey-Continu'ed.

2. Pliocene and Pleistocene fossils from the Arctic coast of Alaska and the auriferous beaches of Nome, Norton Sound, Alaska: U. S. Geol. Survey, Prof. Paper 125, pp. 23-37, 2 pls., January 27, 1920. Abstract by R. W. Stone, Washington Acad. Sci., Jour., vol. 10, no. 11, p. 327, June 4, 1920.

3. Two new Pliocene pectens from Nome, Alaska: Nautilus, vol. 34, no. 3, pp. 76-77, January, 1921.

4. New fossil invertebrates from San Quentin Bay, Lower California: West American Scientist, vol. 19, no. 2, pp. 17-18, A.pril 27, 1921.

5. New shells from the Pliocene or early Pleistocene of San Quentin Bay, Lower California: West American Scientist, vol. 19, no. 3, pp. 21-23, June 15, 1921.

6. Fossils of the Olympic Peninsula [Washington]: Am. Jour. Sci., 5th ser., vol. 4, pp. 305-314, October, 1922.

7. Note on the discovery of Orygoceras in the Idaho Tertiaries: Nautilus, vol. 37 , no. 3, pp. 97-98, January, 1924.

8. Notes on molluscan nomenclature: Biol. Soc. Washington, Proc., vol. 37, pp. 87-90, February 21, 1924.

9. Report on Tertiary fossils from Brock River; Report on the Pleistocene fossils collected on the Arctic coast: Canadian Arctic Expedition, 1913-1918, Rept., vol. 11, pt. 4, pp. 27-28, 30-33, July 8, 1924.

10. Discovery of a Balkan fresh-water fauna in the Idaho formation of Snake River valley, Idaho: U. S. Geol. Survey, Prof. Paper 132, pp. 109-115, 1 pl., November 10, 1924.

11. Tertiary fossils dredged off the northeastern coast of North America: Am. Jour. Sci., 5th ser., vol. 10, pp. 213-218, September, 1925.

Daly, M. R. See Monte-Flores, 1.

Daly, Reginald Aldworth.

1. Report of the Sturgis Hooper professor of geology: Harvard Coll., Mus. Comp. Zoology, Ann. Rept. 1918-19, p. 13, 1919.

2. The coral-reef zone during and after the glacial period: Am. Jour. Sci., 4th ser., vol. 48, pp. 136-159, August, 1919.

3. Report of the Sturgis Hooper professor of geology; Report on the department of geology and geography : Harvard College, Mus. Comp. Zool., Ann. Rept., 1919-1920, pp. 15-19, 1920.

4. Changes of land and ocean levels (abstract): Washington Acad. Sci., Jour., vol. 10, no. 2, pp. 50-51, January 19, 1920.

5. The planetesimal hypothesis in relation to the earth: Sci. Montbly, vol. 10, no. 5, pp. 482-495, May, 1920.

6. A general sinking of sea level in recent time: Nat. Acad. Sci., Proc., vol. 6, no. 5, pp. 246-250, May 15, 1920.

7. Oscillations of level in the belts peripheral to the Pleistocene ice caps: Geol. Soc. America, Bull., vol. 31, no. 2, pp. 303-318, 1 pl., June 30, 1920 ; abstract, no. 1, pp. 111-112, March 31, 1920.

8. A recent world-wide sinking of ocean level: Geol. Mag., vol. 57, pp. 246-261, June, 1920. Abstract, Geol. Soc. America, Bull., vol. 31, no. 1, p. 112, March 31, 1920.

9. Report of the Sturgis Hooper professor of geology: Harvard College, Mus. Comp. Zool., Ann. Rept., 1920-1921, p. 12, 1921.

10. Postglicial changes of level in Newfoundland and Labrador (abstract) : Geol. Soc. America, Bull., vol. 32, no. 1, p: 53, March 31, 1921. 
Daly, Reginald Aldworth-Continued.

11. Postglacial warping of Newfoundland and Nova Scotia: Am. Jour. Sci., 5th ser., vol. 1, pp. 381-391, 1 fig., May, 1921.

12. Earth's crust and its evolution (abstract with discussion by W. H. Hobbs, A. P. Coleman, and J. A. Udden) : Geol. Soc. America, Bull., vol. 34, no. 1, pp. 61-62, March 30, 1923.

13. The earth's crust and its stability: Am. Jour. Sci., 5th ser., vol. 5, pp. 349-371, May. 1923.

14. Decrease of the earth's rotational velocity and its geological effects: Am. Jour. Sci., 5th ser., vol. 5, pp. 373-377, May. 1923.

15. A critical review of the Taylor-Wegener hypothesis (abstract): Washington Acad. Sci., Jour., vol. 13, no. 20, pp. 447-448, December 4, 1923.

16. Earth's elastic and non-elastic deformation, caused by the waxing and waning of ice caps (abstract) : Pan-Am. Geologist, vol. 42, no. 1, pp. 72-73, August, 1924.

17. Relation of mountain building to igneous action: Am. Philos. Soc., Proc., vol. 64 , no. 2 , pp. $283-307$, 3 figs., 1.925 ; abstract, with title Mountain chain formation: Science, new ser., vol. 61, p. x, May 1, 1925.

18. Delevelings connected with glaciation and deglaciation (abstract) : British Assoc. Adv. Sci., Rept. 92d Meeting, p. 384, 1925.

19. Pleistocene changes of level: Am. Jour. Sci., 5th ser., vol. 10, pp. 281313, October, 1925.

20. (and Palache, Charles, and Mather, Kirtley F.). Jay Backus Woodworth: Science, new ser., vol. 62, pp. 450-451., November 20, 1925.

21. Our mobile earth. 342 pp., 187 figs., New York, Charles Scribner's Sons, 1926.

22. Jay Backus Woodworth: Seismological Soc. America, Bull., vol. 16, no. 1, pp. 43-44, March, 1926.

23. Earthquakes: Boston Soc. Nat. Hist., Bull., no. 39, pp. 9-13, April, 1926.

24. The outer shells of the earth: Am. Jour. Sci., 5th ser., vol. 15, pp. 108135, February, 1928; correction, vol. 17, p. 279, March, 1929.

25. The effective moduli of elasticity in the outer earth-shells: Gerlands Beiträge zur Geophysik, Bd. 19, H. 2-3, pp. 194-209, 1928.

26. X-raying the earth: Harvard Alumni Bull., vol. 31, no. 4, pp. 99-104, October 18, 1928.

Daly, William B.

1. (and others). Mining methods in the Butte district [including an account of the geology] : Am. Inst. Min. and Met. Eng., Trans. [preprint] no. 1225, 55 pp., March, 1923 ; abstract, Mining and Metallurgy, vol. 4, no. 196, pp. 207-208, April, 1923.

Dana, Edward Salisbury.

1. Minerals and how to study them; a book for beginners in mineralogy. Second revised edition, 380 pp., 319 figs., New York, John Wiley \& Sons [1921].

2. A textbook of mineralogy, with an extended treatise on crystallography and physical mineralogy. Third edition, revised and enlarged by William E. Ford. 720 pp., 1,050 figs., New York, John Ẉiley \& Sons, 1922.

3. Biographical memoir George Jarvis Brush, 1831-1.912: Nat. Acad. Sci., Mem., vol. 17, pp. 105-112, portr., 1.924. 
Dane, Carl H. See also Dobbin, 5; U. S. Geol. Survey, 13.

1. (and Stephenson, L. W.). Notes on the Taylor and Navarro formations in east-central Texas: Am. Assoc. Petroleum Geologists, Bull., vol. 12, no. 1, pp. 41-58, 1 fig. (map), 1 pl., January, 1928.

Daneš, J. V.

1. Krasové jevy ve Spojenych Statech Amerických [karst phenomenon in the United States]: České Akad. věd a Umění Rozpr., Tř́da 2, Roč. 35, Čis. 28, 3 pp., 1926.

Daniels, James I. See also Clark, S. K., 2.

Darling, S. M.

1. Notes on lignite; its characteristics and utilization: U. S. Bur. Mines. Tech. Paper 178, 16 pp., 1919.

Dart, J. Doris. See Schuchert, 29.

Darton, Nelson Horatio. See also Arizona Bur. Mines; Redwood, 1; Stone, 11.

1. Description of the Newell quadrangle, South Dakota: U. S. Geol. Survey, Geol. Atlas, Newell folio, no. 209, 7 pp., 6 figs., 3 maps, illus. sheet, 1919.

2. Description of the Syracuse and Lakin quadrangles, Kansas: U. S. Geol. Survey, Geol. Atlas, Syracuse-Lakin folio (no. 212), 10 pp., 7 figs., 6 maps, illus. sheet, 1920.

3. The Grand Canyon as an object lesson in geology: Wyoming Hist. and Geol. Soc., Proc. and Coll., vol. 17, pp. 1-20, 6 figs., 10 pls., 1920.

4. Geysers of Yellowstone National Park: Geologische Charakterbilder (K. Andrée), Heft 23 [8 pp.], 1 fig., 6 pls., Berlin, 1920.

5. Artesian waters in the vicinity of the Black Hills, South Dakota (U. S. Geol. Survey, Water-Supply Paper 428, 1918) (abstract) : Washington Acad. Sci., Jour., vol. 10, no. 7, p. 209, April 4, 1920.

6. Geothermal data of the United States, including many original determinations of underground temperature: U. S. Geol. Survey, Bull. 701, 97 pp., 3 figs., 1 pl. (map), 1920. Abstract by M. I. Goldman, Washington Acad. Sci., Jour., vol. 10, no. 18, p. 519, November 4, 1920.

7. Structure of some mountains in New Mexico (abstract) : Geol. Soc. America, Bull., vol. 31, no. 1, p. 116, March 31, 1920.

8. Permian salt deposits of the south-central United States: U. S. Geol. Survey, Bull. 715, pp. 205-223, 10 figs., 4 pls. (incl. map), April 28, 1921. Abstract by M. I. Goldman; Washington Acad. Sci., Jour., vol. 11, no. 19, pp. 470-471, November 19, 1921.

9. Badlands of South Dakota and Nebraska: Geologische Charakterbilder (K. Andrée), Heft 25 [7 pp.], 2 figs., 6 pls., Berlin, 1921.

10. Geologic reconnaissance in Baja California: Jour. Geology, vol. 29, no. 8, pp. 720-748, 22 figs., November-December, 1921.

11. Geologic structure of parts of New Mexico: U. S. Geol. Survey, Bull. 726, pp. 173-275, 33 figs., 21 pls. (incl. maps), March 31, 1922.

12. Grand Canyon of the Colorado River: Geologische Charackterbilder (K. Andrée) Heft 30 [16 pp.], 3 figs., 10 pls., Berlin, 1924.

13. (and others). Geologic map of the State of Arizona, prepared by the Arizona Bureau of Mines in cooperation with the U. S. Geological Survey. Scale-1: 500,000. 1924. 
Darton, Nelson Horatio-Continued.

14. (and Paige, Sidney). Description of the central Black Hills [with contributions by J. D. Irving] : U. S. Geol. Survey, Geol. Atlas U. S., Central Black Hills folio (no. 219), 34 pp., 40 figs., 7 maps, section and 2 illustrations sheets, 1925.

15. Structural features of New Mexico and Arizona (abstract) : Geol. Soc. America, Bull., vol. 36, no. 1, p. 163, March 30, 1925; Pan-Am. Geologist, vol. 43, no. 2, p. 156, March, 1925.

16. Topographic and geologic maps of Arizona and New Mexico (abstract) : Pan-Am. Geologist, vol. 43, no. 5, p. 364, June, 1925.

17. A résumé of Arizona geology: Arizona, Univ., Arizona Bur. Mines, Bull. no. 119 (geol. ser. no, 3), 298 pp., 105 figs. (incl. maps), 128 pls. (incl. maps), October 15, 1925.

18. Geology of the Guantanamo Basin, Cuba: Washington Acad. Sci., Jour., vol. 16, no. 12, pp. 324-333, 5 figs. (incl. map), June 19, 1926.

19. (and Reeside, J. B., jr.). Guadalupe group: Geol. Soc. America, Bull., vol. 37, no. 3, pp. 413-428, 4 figs., 6 pls. (incl. map), September 30, 1926 ; abstract, no. 1, pp. 155-156, March 30, 1926; Pan-Am. Geologist, vol. 45, no. 2, p. 159, March, 1926.

20. The Permian of Arizona and New Mexico: Am. Assoc. Petroleum Geologists, Bull., vol 10, no. 9, pp. 819-852, 10 figs., September, 1926.

21. The red sandstones of New Mexico: U. S., 70th Cong. 1st sess., Sen. Doc. no. 18 (New Mexico State memorial stone), pp. 22-23, 1928.

'22. Memorial of William Libbey: Geol. Soc. America, Bull., vol. 39, no. 1, pp. 35-40, portr., March 30, 1928.

23. Memorial of Charles Doolittle Walcott: Geol. Soc. America, Bull., vol. 39, no. 1, pp. 80-116, portr., March 30, 1928.

24. Tectonics of Arizona and New Mexico (abstract) : Geol. Soc. America, Bull., vol. 39, no. 1, p. 182, March 30, 1928 ; Pan-Am. Geologist, vol. 49 , no. 2 , p. 141 , March, 1928.

25. Geologic map of New Mexico: U. S. Geol. Survey, 1928. Scale 1:500,000.

26. "Red Beds" and associated formations in New Mexico; with an outline of the geology of the State: U. S. Geol. Survey, Bull. 794, 356 pp., 173 figs., 62 pls. (incl. maps), 1928.

Davenport, Frank B.

1. Virginia anthracite [Pulaski, Wythe, Montgomery, and Roanoke counties] : Mining and Metallurgy, vol. 4, no. 203, p. 554, November, 1923.

Davey, Wheeler P. See Fairbanks, 12.

Davidson, Pirie.

1. A cestraciont spine from the middle Triassic of Nevada: California, Univ., Dept. Geology, Bull., vol. 11, no. 4, pp. 433-435, 2 figs., May 9, 1919.

2. Alticamelus alexandrae, a new camel from the Barstow upper Miocene of the Mohave Desert: California, Univ., Dept. Geol. Sci., Bull., vol. 14, no. 12. pp. 397-408, 16 figs., November 20, 1923.

Davidson, 3 . C. See also Graton, 1.

1. The hiddenite occurrence in North Carolina: Am. Mineralogist, vol. 12, no. 8, pp. 305-307, August, 1927.

Davies, D. James.

1. Mining and metallurgy in Newfoundland: Inst. Min. and Met., Bull., no. 243, 8 pp., December, 1924. 
Davies, Stanley J.

1. Western Canada [petroleum in 1924] : Inst. Petroleum 'Technologists, Jour., vol. 11, no. 51, pp. 417-419, August, 1925.

Davis, Angus W.

1. The Dolly Varden mine, Alice Arm, British Columbia: Canadian Min. Inst., Monthly Bull. no. 94, pp. 159-161, February, 1920.

2. British Columbia mineral survey district no. 3 and the Pacific Great Eaștern Railway: Canadian Inst. Min. and Met., Bull., no. 160, pp. 809-811, August, 1925; Trans., vol. 28, pp. 398-400 [1926].

Davis, Charles Wesley. See also Lind, 1.

1. The composition and age of uranium minerals from Katanga, South Dakota, and Utah: Am. Jour. Sci., 5th ser., vol. 11, pp. 201-217, March, 1926.

2. (and Vacher, H. C.). Bentonite, its properties, mining, preparation, and utilization: U. S., Bur. Mines, Tech. Paper 439, 51 pp., 1 fig., 1928.

Davis, Darrell Haug.

1. The geography of the Jackson Purchase: Kentucky Geol. Survey, ser. 6, vol, 9,185 pp., 32 figs., 68 pls., 1923.

2. The geography of the mountains of eastern Kentucky: Kentucky Geol. Survey, ser. 6, vol. 18, 180 pp., 21 figs., 58 pls., 1924.

3. The geography of the Blue Grass region of Kentucky: Kentucky Geol. Survey, ser. 6, vol. 23, 215 pp., 7 figs., 57 pls., 1927.

Davis, Elmer Fred.

1. The registration of earthquakes at the Berkeley Station and at the Lick Observatory Station from October 1, 1917, to March 31, 1918: California, Univ., Seismographic Stations, Bull no. 15, pp. 325-338, August 7, 1919.

2. The registration of earthquakes at the Berkeley Station and at the Lick Observatory Station from April 1. 1918, to September 30, 1918: California, Univ., Seismographic Stations, Bull. no. 16, pp. 339-355, April 10, 1920.

3. The registration of earthquakes at the Berkeley Station and at the Lick Observatory Station from October 1, 1918, to March 31, 1919: California, Univ., Seismographic Stations, Bull., no. 17, pp. 357-370, April 21, 1920.

4. The registration of earthquakes at the Berkeley Station and at the Lick Observatory. Station from April 1, 1919, to September 30, 1919: California, Univ., Seismographic Stations, Bull., no. 18, pp. 371-385, April 21, 1920.

Davis, H. R.

1. The new Romney [Ontario] oil well: Canadian Inst. Min. and Met, Monthly Bull. ṇo. 145, pp. 286-298, 1 fig.. May, 1924.

Davis, Hubert W. See Burchard, 13, 15, 16, 21, 22.

Davis, N. B.

1. Feldspar in the Ottawa district: Canadian Inst. Min. and Met., Monthly Bull. no. 118, pp. 229-235, 4 figs., February, 1922.

Davis, R. N.

1. An ancient tree [vertical tree trunk in coal near Scranton, Pennsylvania]: Nature Mag., vol. 10, no. 5, p. 299, November, 1927.

Davis, R. O. E. See Twenhofel, 16, 18, 22, 29. 
Davis, Watson.

1. The story of copper. 385 pp., illus., New York, The Century Co. [1924].

2. Notes on the Santa Barbara earthquake: Science, new ser., vol. 62, pp. $\mathrm{x}$, xii, July 10, 1925.

3. Science Service and the location of earthquake epicenters: Seismol. Soc. America, Bull., vol. 16, no. 1, pp. 41-42, March, 1926; Science, new ser., vol. 63, p. 426, April 23, 1926.

4. (and Stockley, James). Seismology, the public, and Science Service (abstract) : Seismol. Soc. America, Bull., vol. 16, no. 2, pp. 155-157, June, 1926.

Davis, William Morris. See also Brown, C. W., 1; Cleland, 6; Foye, 5; - $\quad$ Meinzer, 5; Osborn, 19; Schuchert, 20; Woodworth, 1.

1. The geological aspects of the coral-reef problem: Science Progress, vol. 13, no. 51, pp. 420-444, 3 figs., January, 1919.

2. The framework of the earth: Am. Jour. Sci., 4th ser., vol. 48, pp. 225-241, September, 1919; (abstract), Geol. Soc. America, Bull., vol. 31, no. 1, p. 110, March 31, 1920.

3. Features of glacial origin in Montana and Idaho: Assoc. Am. Geographers, Annals, vol. 10, 16 figs., pp. 75-147 [1921?].

4. Lower California and its natural resources; a review: Geog. Rev., vol. 11, no. 4, pp. 551-562, October, 1921.

5. Faults, underdrag, and landslides of the Great Basin ranges: Geol. Soc. America, Bull., vol. 33, no. 1, pp. 92-96, 2 figs., March 31, 1922.

6. Deflection of streams by earth rotation: Science, new ser., vol. 55, pp. 478-479, May 5, 1922.

7. Geological overthrusts and underdrags (abstract): Science, new ser., vol. 55, p. 493, May 5, 1922.

8. Peneplains and the geographical cycle: Geol. Soc. America., Bull., vol. 33, no. 3, pp. 587-598, September 30, 1922.

9. Topographical maps of the United States: Sci. Monthly, vol. 15, no. 6, pp. 557-560, December, 1922.

10. Memoir of Frederic Putnam Gulliver: Assoc. Am. Geographers, Annals, vol. 11, pp. 112-116 [1922?].

11. The cycle of erosion and the summit level of the Alps: Jour. Geology, vol. 31, no. 1, pp. 1-41, January-February, 1923.

12. Drowned coral reefs south of Japan: Nat. Acad. Sci., Proc., vol. 9, no. 2, pp. 58-62, February, 1923.

13. The marginal belts of the coral seas: Nat. Acad. Sci., Proc., vol. 9, no. 8, pp. 292-296, August, 1923.

14. The depth of coral-reef lagoons: Nat. Acad. Sci., Proc., vol. 9, no. 8, pp. 296-301, August, 1923.

15. The marginal belts of the coral seas: Am. Jour. Sci., 5th ser., vol. 6, pp. 181-195, September, 1923.

16. The island of Oahu: Jour. Geography, vol. 22 , no. 9, pp. 354-357, 3 figs., December, 1923.

17. Notes on coral reefs: Pan-Pacific Sci. Cong., Australia, 1923, Proc., vol. 2, pp. 1161-1163 [1924].

18. The formation of the Lesser Antilles: Nat. Acad. Sci., Proc., vol. 10, no. 6, pp. 205-211, June 15, 1924.

19. A tilted-up, beveled-off atoll : Science, new ser., vol. 60 , pp. 51-56, 2 figs., July 18, 1924; abstract, vol. 59, p. 544, May 16, 1924; Pan-Am. Geologist, vol. 42, no. 1, p. 74, August, 1924; British Assoc. Adv. Sci., Rept. 92d Meeting, p. 385, 1925. 
Davis, William Morris-Continued.

20. Modification of Darwin's theory of coral reefs by the gracial-control theory (abstract) : Pan-Am. Geologist, vol. 42, no. 1, pp. 73-74, August, 1924; British Assoc. Adv. Sci., Rept. 92d Meeting, pp. $384-385,1925$.

21. Gilbert's theory of laccoliths (abstract) : Washington Acad. Sci., Jour., vol. 14, no. 15, p. 375, September 19, 1924.

22. Shaded topographic maps: Science, new ser., vol. 60 , pp. 325-327, October 10, 1924.

23. Classification of oceanic islands (abstract) : Pan-Am. Geologist, vol. 42, no. 4, p. 319, November, 1924; Geol. Soc. America, Bull., vol. 37, no. 1, pp. 216-217, March $30,1926$.

24. The progress of geography in the United States: Assoc. Am. Geographers, Annals, vol. 14, no. 4, pp. 159-215, December, 1924.

25. A Roxen lake in Canada [Lake Timiskaming]: Scottish Geog. Mag., vol. 41, no. 2, pp. 65-74, 2 figs., March 16, 1925.

26. The Basin Range problem: Nat. Acad. Sci., Proc., vol. 11, no. 7, pp. 387392, 2 figs., July 15, 1925.

27. Laccoliths and sills (abstract with discussion): Washington Acad. Sci., Jour., vol. 15 , no. 18, pp. 414-415, November 4, 1925 ; Bull. volcanologique, $2^{e}$ ann., nos. 5-6, pp. 323-324, 1925.

28. Biographical memoir of Grove Karl Gilbert, 1843-1918; Nat. Acad. Sci., Mem., vol. 21, 5th mem., 303 pp. 18 figs. and pls. (incl. portraits). 1926.

29. The Lesser Antilles: Am. Geog. Soc., Map of Hispanic America, Pub. no. 2, 207 pp. 66 figs., 16 pls., 1926.

30. Subsidence rate of reef-encircled islands: Nat. Acad. Sci., Proc., vol. 12. no. 2, pp. 99-105, 2 figs., February, 1926.

31. Origin of the Lesser Antilles (abstract): Geol. Soc. America, Bull., vol. 37 , no. 1, pp. 220-221, March 30, 1926.

32. The value of outrageous geological hypotheses: Science, new ser., vol. 63 , pp. 463-468, May 7, 1926.

33. The rifts of southern California: Am. Jour. Sci., 5th ser., vol. 13, pp. 5772, 6 figs., January, 1927.

34. Channels, valleys, and intermont plains: Science, new ser., vol. 66, pp. 272-274, September 23, 1927.

35. The coral-reef problem: Am. Geog. Soc., Spec. Pub. no. 9, 596 pp., 227 figs. and pls., New York, 1928.

36. The formation of coral reefs: Sci. Monthly, vol. 27, no. 4, pp. 289-300, 6 figs., October, 1928.

37. Die Entstehung von Korallenriffen: Gesell. Erdkunde Berlin, Zeitschr. 1928, no. 9-10, pp. 359-391, 13 figs., 1928.

Davis, William T.

1. (and Leng, Charles W.). Cretaceous fossils from Staten Island [New York] : Staten Island Inst. Arts and Sci., Proc., vol. 4, pts. 1-3, pp. 47-50, 2 pls., August 18, 1927.

Davison, Charles.

1. On scales of seismic intensity and on the construction and use of isoseismal lines: Seismol. Soc. America, Bull., vol. 11, no. 2, pp. 95-129, 3 figs., June, 1921.

2. Notes on some seismological terms: Seismol. Soc. America, Bull., vol. 14, no. 1, pp. 26-37, March, 1924.

3. Twin earthquakes: Jour. Geology, vol. 35, no. 6, pp. 507-526, 7 figs., August-September, 1927. 
Davy, William Myron. See also Lindgren, 11.

1. (and Farnham, C. Mason). Microscopic examination of ore minerals. 154 pp., New York, McGraw-Hill Book Co., 1920. Review by H. E. Merwin, Econ. Geology, vol. 15, no. 7, pp. 618-619, November, 1920. Review by E. T. Wherry, Am. Mineralogist, vol. 5, no. 8, pp. 152-154, August, 1920.

2. A reflecting microscope for the mining engineer: Mining and Metallurgy, no. 163, pp. 30-31, 1 fig., July, 1920 (abstract) ; Am. Inst. Min. and Met. Eng., Trans. [preprint no 996], 7 pp., 2 figs., 1920.

Dawson, C. B.

1. Lead-zinc deposits near Great Slave Lake, Northwest Territory: Canadian Min. Jour., vol. 43, no. 23, p. 358, June 9, 1922.

Dawson, J. Chesley.

1. Oil shales: Canadian Inst. Min. and Met., Bull., no. 153, pp. 26-59, 4 figs., January, 1925.

Dawson, J. M.

1. (and Hanna, Marcus, and Kirby, Grady). Igneous dikes in Bandera County, Texas: Econ. Geology, vol. 22, no. 6, pp. 621-624, 1 fig., September-October, 1927.

Day, Arthur Louis. See also Allen, E. T., 4.

1. Geophysical laboratory [report of the director]: Carnegie Inst. Washington, Year Book no. 17, pp. 127-138, February, 1919; no. 19, pp. 159-177, January, 1921; no. 20, 1921, pp. 157-174, February, 1922; no. 21 , 1922 , pp. 127-150, January, 1923 ; no. 22 , pp. 127-147, February, 1924 ; no. 23 , pp. 53-65, December, 1924 ; no. 24 , pp. 51-69, December, 1925 ; no. 25 , 1925-6, pp. 61-86, December, 1926 ; no. 26 , 1926-7, pp. 63-79, December, 1927 ; no. 27, 1927-8, pp. 71-87, December, 1928.

2. George Ferdinand Becker: Am. Jour. Sci., 4th ser., vol. 48, pp. 242-245, September, 1919.

3. Memorial of George Ferdinand Becker: Geol. Soc. America, Bull., vol. 31, no. 1, pp. 14-25, port., March 31, 1920.

4. Cooperative studies of California earth movements (abstract): Science, new ser., vol. 55, pp. 492-493, May 5, 1922.

5. Possible causes of the volcanic activity at Lassen Peak [California]: Seismol. Soc. America, Bull., vol. 12, nos. 2 and 3, pp. 35-46, 2 pls., June-September, 1922 ; Franklin Inst., Jour., vol. 194, no. 5, pp. 569582, 1 fig., November, 1922.

6. (and others). Preliminary report of advisory committee in seismology: Carnegie Inst. Washington, Year Book no. 20, 1921, pp. 175-178, February, 1922.

7. (and others). Seismology; report of the advisory committee: Carnegie Inst. Washington, Year Book no. 21, 1922, pp. 390-394, January, 1923. Seismol. Soc. America, Bull., vol. 12, no. 4, pp. 231-237, December, 1922.

8. (and others). Report of the advisory committee on seismology of the Carnegie Institution of Washington: Seismol. Soc. America, Bull., vol. 13, no. 4, pp. 159-169, December, 1923 ; Carnegie Inst. Washington, Year Book no. 22, pp. 362-368, 1924.

9. The year's progress in volcanology: Nat. Research Council, Bull., vol. 7, pt. 5, no. 41, pp. 71-73, January, 1924.

10. The volcano Kilauea in action (abstract) : Kentucky Acad. Sci., Trans. vol. 1, pp. 51-56, 2 pls., 1924. 
Day, Arthur Louis-Continued.

11. (and Allen, E. T.). The sources of the heat and the source of water in the hot springs of the Lassen National Park: Jour. Geology, vol. 32, no. 3, pp. 178-190, April-May, 1924.

12. Hot springs and fumaroles of "The Geysers" region, California: Jour. Geology, vol. 32, no. 6, pp. 459-460, August-September, 1924.

13. (and Willis, Bailey). Cooperation in seismology: Science, new ser., vol. 60, pp. 217-218, September 5, 1924.

14. (and others). Report of the advisory committee on seismology of the Carnegie Institution of Washington: Seismol..Soc. America, Bull., vol. 14, no. 3, pp. 201-212, September, 1924; Carnegie Inst. Washington, Year Book, no. 23, pp. 306-313, December, 1924.

15. (and Allen, E. T.). The volcanic activity and hot springs of Lassen Peak [California]. 190 pp., 81 figs., 13 pls., Carnegie Inst. Washington, Pub. no. 360, April, 1925.

16. The study of earth movements in California: Science, new ser., vol. 61, pp. 323-328, March 27, 1925.

17. Some causes of volcanic activity : Bull. volcanologique, $2^{\circ}$ ann., nos. 5-6, pp. 216-233, 1925; Smithsonian Inst., Ann. Rept., 1925, pp. 257270,3 pls., 1926.

18. Gases in volcanic activity (abstract with discussion): Washington Acad. Sci. Jour., vol. 15, no. 18, pp. 415-416, November 4, 1925 ; Bull. volcanologique, $2^{\circ}$ ann., nos. 5-6, pp. 325-327, 1925.

19. (and others). Seismology; report of the advisory committee: Carnegie Inst. Washington, Year Book no. 24, pp. 370-380, December, 1925; Seismol. Soc. America, Bull., vol. 16, no. 1, pp. 45-60, March, 1926.

20. Santa Barbara earthquake (abstract) : Geol. Soc. America, Bull., vol. 37, no. 1, p. 143, March 30, 1926 ; Pan-Am. Geologist, vol. 45, no. 1, p. 91, February, 1926.

21. Difficulties in the study of local earth movements: Washington Acal. Sci., Jour., vol. 16, no. 9, pp. 250-254, 1 fig., May 4, 1926.

22. (and others). Seismology; report of the advisory committee: Carnegie Inst. Washington, Year Book no. 25, 1925-6, pp. 415-435, December, 1926; Seismol. Soc. America, Bull., vol. 17, no. 1, pp. 25-48, March, 1927.

23. Reports of progress in seismological work in the United States; A, Carnegie Institution of Washington: Nat. Research Council, Bull. no 61, pp. 72-74, July, 1927.

24. (and others). Seismology; report of the advisory committee: Carnegie Inst. Washington, Yearbook no. 26, pp. 385-389, December, 1927 ; no. 27, pp. 410-421, December, 1928.

25. The year's volcanological publications (abstract) : Washington Acad. Sci., Jour., vol. 18, no. 19, pp. 510-511, November 19, 1928.

26. Further study of voicano gases (abstract) : Third Pan-Pacific Sci. Cong., Tokyo, 1926, Proc., p. 710, 1928.

Day, David Talbot, 1859-1925.

1. A handbook of the petroleum industry. Vol. 1, $964 \mathrm{pp}$., vol. 2, $1006 \mathrm{pp}$., illus., New York, John Wiley \& Sons, 1922.

Dean, Bashford.

1. Charles Rochester Eastman: Science, new ser., vol. 49, pp. 139-141, February 7, 1919.

2. Memoir of Charles Rochester Eastman: Geol. Soc. America, Bull., vol. 30, pp. 27-36, portr., March 31, 191.9. 
Dean, Bashford-Continued.

3. Dr. Moodie's opisthotonos: Science, new ser., vol. 49, p. 357, April '11, 1919.

Dean, David. See Snow, 1.

Deatrick, E. P.

1. Principles of soil ciassification: West Virginia Acad. Sci., Proc., vol.' 1, no. 1 (W. Va. Univ. Bull., ser. no. 27, no. 1), pp. 48-51., August, 1926.

De Beque, G. Robert.

1. Oil shales of DeBeque, Colorado: Eng. and Min. Jour., vol. 109, pp. 348353, 3 figs. January 31, 1920.

Decker, Charles Elijah. See also Gould, C. N., 9.

1. Studies in minor folds. 89 pp., 44 figs., 3 pls., University of Chicago Press, Chicago, Illinois, September, 1920.

2. Preliminary notes on a new geologic map of the Arbuckle Mountains of Oklahoma : Oklahoma Acad. Sci., Proc., vol. 3 (Oklahoma, Univ., Bull., new ser. no. 271), pp. 91-94, October 1, 1923.

3. A preliminary list giving the distribution of Proboscidea in Oklahoma: Oklahoma Acad. Sci. (Univ. Oklahoma Bull., new ser., no 322), Proc., vol. 4, pp. 123-124, December 1, 1925.

4. Transverse structural features of Arbuckle Mountains [Oklahoma] (abstract) : Pan-Am. Geologist, vol. 45, no. 3, pp. 254-255, April 1926.

5. Transverse structures in Arbuckle Mountains of Oklahoma: Pan-Am. Geologist, vol. 46, no. 3, pp. 189-192, October, 1926.

6. Some new fossil algal horizons in the Arbuckle Mountains: Oklahoma Acad. Sci., Proc., vol. 6, pt. 2, 1926 (Oklahoma, Univ., Bull., new ser. no. 348), pp. 260-262, 2 figs., January 1, 1927.

7. Stuart Weller: Am. Assoc. Petroleum Geologists, Bull., vol. 11, no. 12, pp. 1347-1348, December, 1927.

8. (and Merritt, Clifford A.). Physical characteristics of the Arbuckle limestone: Oklahoma Geol. Survey, Circ. no. 15, 56 pp., 1 fig., 5 pls., January, 1928.

9. The correlation of rocks by means of microscopic fossils: Oklahoma Acad. Sci., Proc., vol. 7 (Oklahoma, Univ., Bull., new ser., no 409), pp. 171-176 [1928].

Decker, LaVerne.

1. Structural trends in southern Oklahoma: Oklahoma Geol. Survey, Bull. no. 40-P, 13 pp., 1 pl. (map), July, 1927; Bull. 40, vol. 1, pp. 69-77, July, 1928.

Deeds, John F.

1. (and White, Walter N.). Water power and irrigation in the Madison River basin Montana: U. S. Geol. Survey, Water-Supply Paper 560, pp. 1-30, 2 figs., January 26, 1925.

2. (and White, Walter N.). Water power and irrigation in the Jefferson River basin, Montana: U. S. Geol. Survey, Water-Supply Paper 580, pp. 41-113, map, December 14, 1926.

De Ford, Ronald $\mathrm{K}$.

1. Areal geology of Cimarron County, Oklahoma: Am. Asoc. Petroleum Geologists, Bull., vol. 11.; no. 7, pp. 753-755. July, 1927. 
De Geer, Gerard.

1. On the determination of geochronology by a study of laminated deposits: Science, new ser., vol. 52, pp. 502-503, November 26, 1920.

2. Correlation of late glacial clay varves in North America with the Swedish time scale: Geol. Fören. i Stockholm, Förhandl., Bd. 43, H. 1-2, pp. 70-73, 1 fig., January-February, 1921.

3. Om Nordamerikas Kvartärgeologi belyst av dem svenska tidsskalen [American glacial deposits referred to Swedish time scale] : Geol. Fören, i Stockholm, Förhandl., Bd. 43, H. 5, pp. 497-499, May, 1921.

4. On the solar curve as dating the ice age, the New York moraine, and Niagara Falls through the Swedish time scale: Geografiska Annaler, Arg. 8, H. 4 (Stockholms Högskolas Geokronol. Inst., Data 9), pp. 253-284, 3 pls., 1926. Translation by G. Steinmann, Schwankungen der Sonnenstrahlung seit 18,000 Jahren: Geol. Rundschau, Bd. 18, H. 6, pp. 417-454, 1 fig., January, 1928.

5. Om New York-moränens verkliga ålder och betydelse [on the actual age and significance of the New York moraine] : Geol. Fören. i Stockholm, Förh., Bd. 48, H. 2, pp. 143-148, March-April, 1926.

6. Geochronology as based on solar radiation: Science, new ser., vol. 66, pp. $458-460$, November 11,1927 ; corrections, vol. 67 , p. 240 , March 2, 1928.

DeGolyer, Everette Lee. See also Ambrose, 1; Matteson, 2; Ordóñez, 2; Washburne, 3.

1. The West Point, Texas, salt dome, Freestone County: Jour. Geology, vol. 27, no. 8, pp 647-663, 2 figs., November-December, 1919.

2. Theory of volcanic origin of salt domes (with discussion by J. A. Udden and E. T. Dumble) : Am. Inst. Min. and Met. Eng., Trans., vol. 61, pp. $456-477,1920$.

3. Zacamixtle [oil] pool, Mexico: Am. Assoc. Petroleum Geologists, Bull., vol. 5, no. 1, p. 85, January-February, 1921.

4. Debt of geology to the petroleum industry: Am. Assoc. Petroleum Geologists, Bull., vol. 5, no. 3, pp. 394-398, May-June, 1921.

5. On the estimating of petroleum reserves: Econ. Geology, vol. 17, no. 1, pp. 40-45, January-February, 1922.

6. Cooperation in geology: Econ. Geology, vol. 18, no. 1, pp. 83-86, January-February, 1923.

7. Notes on the salt domes of North America (abstract) : Geol. Soc. America, Bull., vol. 34, no. 1, p. 66, March 30, 1923.

8. What is an economic geologist?: Econ. Geology, vol. 19, no. 4, pp. 473474, August, 1924.

9. The occurrence of vanadium and nickel in petroleum (with discussion by G. Steiger, E. T. Erickson, F. L. Nason, and D. F. Hewett) : Econ. Geology, vol. 19, no. 6, pp 550-558, September-October, 1924.

10. The geologist and the petroleum industry: Am. Petroleum Inst. Bull., vol. 5, no. 75, pp. 24-27, December 31, 1924.

11. The geologist and the petroleum industry: Nat: Petroleum News, vol. 16, no. 51, pp. 45, 46, 48, December 17, 1924; Oil Engineering and Finance, vol. 6, no. 105, pp. 24-26, January, 1925.

12. Discovery by geophysical methods of a new salt dome in the Gulf coast (abstract) : Geol. Soc. America, Bull., vol. 36, no. 1, p. 161, March 30, 1925; Pan.-Am. Geologist, vol. 43, no. 2, March, 1925.

13. State geological surveys and economic geology: Econ. Geology, vol. 20, no. 4, pp. 376-381, June-July, 1925. 
DeGolyer, Everette Lee-Continued.

14. Discovery of potash salts and fossil algae in Texas salt dome [Markham, Texas]: Am. Assoc. Petroleum Geologists, Bull., vol. 9, no. 2, pp. 348-349, March-April, 1925; Geology of salt dome oil fields, pp. 781-782, 1926.

15. Origin of North American salt domes: Am. Assoc. Petroleum Geologists, Bull., vol. 9, no. 5, pp. 831-874, August, 1925; Geology of salt dome oil fields, pp. 1-44, 1926.

16. Geophysical methods in economic geology: Econ. Geology, vol. 21, no. 3, pp. 294-298, May, 1926.

17. (and others). Geology of salt dome oil fields; a symposium on the origin, structure, and general geology of salt domes, with special reference to oil production and treating chiefly. the salt domes of North America. 797 pp. illus., published by American Association of Petroleum Geologists, 1926. [Reprint in book form of papers in volume 9 of the Bulletin.]

18. The seductive influence of the closed contour: Econ. Geology, vol. 23, no. 6, pp. 681-682, September-October, 1928.

De Iongh, W. H. D.

1. Enkele geologische en mineralogische mededeelingen over Mexico in het algemeen en over de mijndistricten Zacatecas, Pachuca, en Real del Monte in het bijzonder [general geology of Mexico and ore deposits of Zacatecas and other districts, particularly the silver ores] : De Ingenieur, Den Haag, Jaarg. 35, no. 1, pp. 4-9, 2 figs., January 3, 1920.

Deiss, Charles F., jr.

1. Anisotrypa waynensis, a new bryozoan from the Warsaw formation of Kentucky: Michigan, Univ., Mus. Geology, Contr., vol. 2, no. 14. pp. 237-239, 2 pls., August 3, 1927.

DeKalb, H. Leonard.

1. A guide to the geology of Fergus County, Montana. 48 pp., 10 figs., Lewiston, Mont., Argus Printing \& Supply Co. [1923?].

De Landero, Carlos F. See Landero, Carlos F. de.

Delavan, Fred.

1. Some recent finds of remains of the extinct ground sloth in southwest Iowa: Iowa Acad. Sci., Proc., 1926, vol. 33, pp. 203-205 [1927].

Dellenbaugh, Frederick Samuel.

1. Memorial to John Wesley Powell: Am. Anthropologist, vol. 20, no. 4, pp. 432-436, 2 pls., October-December, 1918.

DeLury, Justin Sarsfield.

1. Mineral prospects in southeastern Manitoba; Rice Lake, Maskwa River, and Boundary districts. 55 pp., illus., Manitoba Bulletins, Office of Commissioner of northern Manitoba, The Pas, Manitoba [1920].

2. Some economic aspects of the Falcon Lake district, Manitoba: Canadian Min. Inst., Trans., vol. 22, pp. 320-328 [1920].

3. An occurrence of tin near the Ontario-Manitoba boundary: Canadian Min. Jour., vol. 41, pp. 520-521, 2 figs., June 25, 1920.

4. Mineral prospects in southeastern Manitoba: Rice Lake, Maskwa River, and Boundary districts: Manitoba Bulletins, Commissioner of Northern Manitoba, 55 pp., illus., map [1921]. 
DeLury, Justin Sarsfield-Continued.

5. An application of the theory of metallogenesis to the prospecting areas of Manitoba: Canadian Inst. Min. and Met., Bull., no. 162, pp. 931940, October, 1925 ; Trans., vol. 28 , pp. $358-370,1$ pl. [1926].

6. Wapawekka and Deschambault lakes area, Saskatchewan: Canada, Geol. Survey, Summ. Rept., 1924, pt. B, pp. 23-50, map (in two sheets), 1926.

7. Experiments with model glaciers: Jour. Geology, yol. 34, no. 3, pp. 266274, 3 figs., April-May, 1926.

8. Pegmatites of southeastern Manitoba: Canadian Min. Jour., vol. 47, no. 28, pp. 695-697, July 9, 1926.

Denis, Theophile Constant.

1. Report on mining operations in the Province of Quebec during the year 1918: Quebec (Province), Department of Colonization, Mines, and Fisheries, 158 pp., map, Quebec, 1919.

2. Report on mining operations in the Province of Quebec during the year 1919: Quebec (Province), Department of Colonization, Mines, and Fisheries, 160 pp., pls., map, Quebec, 1920.

3. Report on mining operations in the Province of Quebec during the year 1920: Quebec (Province), Department of Colonization, Mines, and Fisheries, 140 pp., illus., Quebec, 1921.

4. Report on mining operations in the Province of Quebec during the year 1921: Quebec (Province), Department of Colonization, Mines, and Fisheries, 156 p’., illus., Quebec, 1922.

5. Report on mining operations in the Province of Quebec during the year 1922: Quebec (Province), Dept. of Colonization, Mines, and Fisheries, 138 pp., 1923.

6. Prospects for gold in northwestern Quebec: Eng. and Min. Jour.-Press, vol. 115, no. 15, pp. 674-675, April 14, 1923.

7. Report on mining operations in the Province of Quebec during the year 1923: Quebec (Province), Department of Colonization, Mines, and Fisheries, 124 pp., illus., 1924.

8. Report on mining operations in the Province of Quebec during the year 1924: Quebec (Province), Dept. Colonization, Mines and Fisheries. 170 pp., illus., 1925.

9. Report on mining operations in the Province of Quebec during the year: 1925: Quebec (Province), Department of Colonization, Mines, and Fisheries, 198 pp., illus., 1926.

10. Report on mining operations in the Province of Quebec during the year 1926: Quebec (Province), Department of Colonization, Mines, and Fisheries, 191 pp., illus., 1927.

11. Mining operations in the Province of Quebec during the year 1927: Quebec (Province), Department of Colonization, Mines, and Fisheries, Bur. Mines, 246 pp., illus., 1928.

Denison, A. R.

1. The Robberson field, Garvin County, Oklahoma: Am. Assoc. Petroleum Geologists, Bull., vol. 7, no. 6, pp. 625-644, 9 figs., November-December, 1923.

2. Early Pennsylvanian sediments west of the Nemaha granite ridge, Kansas: Am. Assoc. Petroleum Geologists, Bull., vol 10, no. 6, p. 636. June, 1926. 
Denison, F. Napier.

1. The British Columbia earthquake of December 6, 1918: Seismol. Soc. America, Bull., vol. 9, no. 1, pp. 20-23, March, 1919.

De Quervain, F. See Hirschi, 4.

De Silva, Luis.

1. El mineral de Mezquital del oro en el Estado de Zacatecas: Bol. minero, t. 20, no. 4, pp. 155-169, October, 1925.

Deussen, Alexander.

1. Salt domes of Texas and Louisiana: Oil Weekly, vol. 24, no. 4, pp. 11, 16, 18, January 21, 1922.

2. (and Lane, Laura Lee). Hockley salt dome, Harris County, Texas: Am. Assoc. Petroleum Geologists, Bull., vol. 9, no. 7, pp. 1031-1060, 6 figs., 1 pl., October, 1925 ; Geology of salt dome oil fields, pp. 570599, 6 figs., 1 pl., 1926.

DeWolf, Frank Walbridge. See also Richardson, G. B., 1.

1. The outlook for geology and geography: School Science and Mathematics, vol. 19, no. 5, pp. 391-397, May, 1919; Illinois State Acad. Sci., Trans., vol. 12, pp. 47-54 [1920].

2. Administrative report from July 1, 1916, to June 30, 1917: Illinois State Geol. Survey, Bull. no. 36, pp. 9-18, 1920.

3. Gravel and limestone in Illinois: Illinois Soc. Engineers, 35th Ann. Rept., pp. 72-73, 1920.

4. (and Mylius, L. A.). A new Trenton field in Illinois: Am. Assoc. Petroleum Geologists, Bull., vol. 4, no. 1, pp. 43-46, 1 fig., 1920.

5. Administrative report from July 1, 1917, to June 30, 1919; Illinois, State Geol. Survey, Bull. no. 38, pp. 10-23, 1922.

6. Relation of topographic and geologic mapping of Illinois to professional engineering: Western Soc. Eng., Jour., vol. 28, no. 1, pp. 18-26, 4 figs. (maps), January, 1923.

7. (and Seashore, Paul T.). Diamond drilling near Kerens, Navarro County, Texas: Am. Assoc. Petroleum Geologists, Bull., vol. 10, no. 7, pp. 703-708, 1 pl., July, 1926.

Diamond, Benjamin T.

1. An introduction to fossils: Rocks and Minerals, vol. 1, no. 2, pp. 37-39, December, 1926 ; vol. 2 , no. 1 , pp. 16-18, March ; no. 2 , pp. 58-60, June ; no. 3, pp. 102-103, September ; no. 4, pp. 142-143, December, 1927 ; vol. 3 , no. 1, pp. 18-19, March ; no. 2, pp. 40-41, June; vol. 3, no. 3, pp. 86-87, September, 1928.

Diaz Lozano, Enrique.

1. Dépositos diatomiferos en el Valle de Toxi, Ixtlahuaca, Estado de México: Mexico, Inst. Geol., Anales, no. 9, pp. 1-19, 5 pls., 1920.

2. Manantiales en el pueblo de Tepexi de Rodríguez, Estado de Puebla: Mexico, Inst. Geol., Anales, no. 9, pp. 21-29, 9 pls., 1920.

3. Sierra del Novillo o Trinchera, Distrito Sur, Baja California: Mexico, Inst. Geol., Bol. no. 39, pp. 71-92, 31 pls. (incl. maps), 1922.

4. Los restos fósiles de "Elephas" encontrados en terrenos de la hacienda de Tepexpan, Estado de México: Mexico, Inst. Geol., Anales, t. 2, nos. 6-10, pp. 201-202, 1927.

5. Corte geológico entre Cárdenas, San Luis Potosí, 'y Tampico, Tampico, en la línea del ferrocarril de San Luis á Tampico: Bol. Petróleo, vol. 23, no. 3, np. 162-171, 7 pls., map, March, 1927. 
Diaz Lozano, Enrique-Continued.

6. Los microorganismos fósiles y la geología del petróleo: Bol. Petróleo, vol. 26, nos. 4-5, pp. 397-400, October and November, 1928.

Dice, Lee Raymond.

1. Rodents and lagomorphs of the Rancho La Brea deposits [California]: Carnegie Inst. Washington, Pub. no. 349, pp. 119-130, 17 figs., August, 1925.

Dickerson, Roy Ernest.

1. A criticism of the "Faunal relationships of the Meganos group" by Bruce L. Clark: Jour. Geology, vol. 30, no. 4, pp. 295-302, 1 fig., MayJune, 1922.

2. Tertiary and Quaternary history of the Petaluma, Point Reyes, and Santa Rosa quadrangles [California]: California Acad. Sci., Proc., 4th ser., vol. 11, no. 19, pp. 527-601, 25 pls., (incl. maps), July 10, 1922.

Dickey, J. B. R. See Pennsylvania Topographic and Geologic Survey.

Diener, Carl.

1. Major features of earth's surface: Pan-Am. Geologist, vol. 37, no. 3, pp. 177-197, April, 1922.

2. A critical phase in the history of ammonites: Am. Jour. Sci., 5th ser., vol. 4, pp. 120-126, August, 1922.

Dietrich, Waldemar Fenn.

1. The clay resources and the ceramic industry of California: California State Min. Bur., Bull. no. 99, 383 pp., 70 figs., 12 pls., January, 1928.

2. Clay prospecting and mining in California: Am. Inst. Min. and Met. Eng., Trans., vol. 76, pp. 413-429, 1928.

Dille, Glenn S.

1. Notes on the occurrence of a black bituminous shale near Palo, Linn County, Iowa: Iowa Acad. Sci., Proc., vol. 30, pp. 441-443 [1924].

2. Anticlines of the State of Iowa: Iowa Acad. Sci., Proc., 1926, vol. 33, pp. 183-198 [1927].

3. Nature of Devonic oolite from Linn County (abstract) : Pan-Am. Geologist, vol. 48 , no. 2 , p. 158, September, 1927.

4. (and Couser, C. W.). Ancient glacial lakelet near. Cedar Rapids [Iowa] (abstract) : Pan-Am. Geologist, vol. 48, no. 5, p. 376, December, 1927.

5. Notes on the occurrence of oolitic limestone in the Otis beds of the Devonian, Kenwood, Iowa: Iowa Acad. Sci., Proc., 1927, vol. 34, pp. 231-233, 4 pls. [1928].

6. (and Couser, C. W.). An extinct glacial pond near Cedar Rapids, Linn County, Iowa: Iowa Acad. Sci., Proc., 1927, vol. 34, p. 239, 2 figs. [1928].

Diller, Joseph Silas, 1850-1928.

1. Recent studies of domestic chromite deposits: Am. Inst. Min. and Met. Eng., Bull. no. 153, pp. 1995-2040, 29 figs., September, 1919; Trans., vol. 63, pp. 105-149, 26 figs., 1920.

2. Chromite in 1918: U. S. Geol. Survey, Mineral Resources, 1918, pt. 1, pp. 657-679, 1 fig., May 15, 1920.

3. Asbestos in 1918: U. S. Geol. Survey, Mineral Resources, 1918, pt. 2, pp. 545-556, March 20, 1.920. 
I)iller, Joseph Silas-Continued.

4. Talc and soapstone in 1918. U. S. Geol. Survey, Mineral Resources, 1918, pt. 2, pp. 557-563, March 29, 1920.

5. (and Fairchild, J. G., and Larsen, E. S.). High-grade talc for gas burners : Econ. Geology, vol. 15, no. 8, pp. 665-673, December, 1920.

6. Chromite in 1919: U. S. Geol. Survey, Mineral Resources, 1919, pt. 1, pp. 87-91, February 4, 1921.

7. Talc and soapstone in 1919: U. S. Geol. Survey, Mineral Resources, 1919, pt. 2, pp. 265-268, April 14, 1921 .

8. Asbestos in 1919: U. S. Geol. Survey, Mineral Resources, 1919, pt. 2, pp. 299-307, 1 fig., May 14, 1921.

9. Chromite in the Klamath Mountains, California and Oregon: U. S. Geol. Survey, Bull. 725, pp. 1-35, 6 figs., 5 pls., August 3, 1921. Abstract, Washington Acad. Sci., Jour., vol. 12, no. 3, p. 72, February 4, 1922.

10. Surface fusion of lava: Geol. Soc. America, Bull., vol. 33, no. 1, pp. 142144, 2 figs., March 31, 1922.

11. Did Crater Lake, Oregon, originate by a volcanic subsidence or an explosive eruption?: Jour. Geology, vol. 31, no. 3, pp. 226-227, 1 fig., April-May, 1923.

12. (and Kay, G. F.). Description of the Riddle quadrangle [Oregon]: U. S. Geol. Survey, Geol. Atlas U. S., Riddle folio, Oregon (no. 218), 8 pp., 8 figs., 3 maps, 1924.

Dixon, Dorothy Elizabeth.

1. Bibliography of the geology of Oregon: Oregon, Univ., Pub., Geology ser., vol. 1, no. 1, 125 pp., June, 1926.

Doak, Samuel E.

1. The Oriskany iron ores of Virginia: Eng. and Min. Jour., vol. 111, no. 9, pp. 386-387, February 26, 1921.

Dobbel, Lillian M.

1. Magnesite crystals from Orangedale, Nova Scotia: Am. Mineralogist, vol. 8 , no. 12, pp: 223-228, 3 figs., December, 1923.

Dobbin, Carroll Edward. See also Baker, A. A., 1; Thom, 3, 7, 8, 16; Wegemann, 1.

1. Geology of the Wiles area, Ranger district, Texas: U. S. Geol. Survey, Bull. 736, pp. 55-69, 5 figs., 2 pls. (incl. map), June 28, 1922.

2. (and Reeside, J. B., jr.). The Lance-Fox Hills contact an eastern Montana and the Dakotas (abstract) : Washington Acad. Sci., Jour., vol. 14, no. 7, pp. 165-166, April 4, 1924.

3. (and Barnett, V. H.). The Gillette coal field, northeastern Wyoming: U. S. Geol. Survey, Bull. 796, pp. 1-50, 3 figs. (incl. maps), 11 pls., August 8, 1927.

4. (and Reeside, J. B., jr.). Problems of the Chugwater-Sundance contact (discussion) : Am. Assoc. Petroleum Geologists, Bull., vol. 11, no. 11, pp. 1235-1236, November, 1927.

5. (and Hoots, H. W., and Dane, C. H.). Geology and oil and gas possibilities of the Bell Springs district, Carbon County, Wyoming: U. S. Geol. Survey, Bull. 796, pp. 171-197, 2 figs. 5 pls. (incl. map), January 19, 1928.

Dodd, Harold v.

1. Some preliminary experiments on the migration of oil up low-angle dips: Econ. Geology, vol. 17, no. 4, pp. 274-291, 2 figs., June-July, 1922. 
Dodd, Harold V.-Continued.

2. Dominguez oil field: California State Min. Bur., Summary of Operations California Oil Fields, vol. 12, no. 4, pp. 7-20, 4 figs., 2 pls., October, 1926.

Dodge, W. E.

1. Notes to inventor geologists [recording machines]: Am. Assoc. Petroleum Geologists, Bull., vol. 6, no. 1, pp. 50-53, 1 pl., January-February, 1922.

Dolan, E. P.

1. The contact-metamorphic zone of Mount Royal, Montreal, P. Q.: Roy. Soc. Canada, Proc. and Trans., 3d ser., vol. 17, sec. 4, pp. 127-151, May, 1923.

Doll, Charles G. See also Fisher, L. W., 4.

Dolmage, Victor.

1. Quatsino Sound and certain mineral deposits of the west coast of Van. couver Island, British Columbia: Canada, Geol. Survey, Summ. Rept., 1918, pt. B, pp. 30-38, 1 fig., 1919.

2. Barkley Sound, Vancouver Island, British Columbia: Canada, Geol. Survey, Summ. Rept., 1919, pt. B, pp. 12-20, 1920.

3. Sunloch copper district [Vancouver Island], British Columbia: Canada, Geol. Survey, Summ. Rept., 1919, pt. B, pp. 20-30, 2 figs. (incl. map), 1920.

4. The high-grade silver ores of the Stewart district, British Columbia: Canadian Min. Jour., vol. 41, pp. 454-458, 10 figs., June 4, 1920.

5. West coast of Vancouver Island between Barkley and Quatsino sounds [British Columbia]: Canada, Geol. Survey, Summ. Rept., 1920, pt. A, pp. 12-22, 1921.

6. Geological mapping in the Canadian Cordillera: Pan-Pacific Scientific Conference, First, Proc., Bernice P. Bishop Mus., Spec. Pub. no. 7, pt. 3, pp. 689-695, 1 fig., 1921.

7. The Marble Bay mine, Texada Island, British Columbia: Econ. Geology, vol. 16, no. 6, pp. 372-392, 2 pls., September-October, 1921.

8. Coast and islands of British Columbia between Burke and Douglas channels: Canada, Geol. Survey, Summ. Rept., 1921, pt. A, pp. 22-49, 2 figs., 2 maps, 1922.

9. Coast and islands of British Columbia between Douglas Channel and the Alaskan boundary: Canada, Geol. Survey, Summ. Rept., 1922, pt. A, pp. 9-34, 2 maps, 1923.

10. Post-Pleistocene volcanics of the British Columbia coast: Jour. Geology, vol. 32, no. 1, pp. 36-48, 9 figs., January-February, 1924.

11. The work of the Geological Survey [of Canada] in British Columbia: Canadian Min. Jour., vol. 45, no. 9, pp. 211-212, 1 fig., February 29, 1924.

12. Prospecting: Canadian Min. Jour., vol. 45, no. 17, pp. 391-396, April 25, 1924.

13. The western mineral belt of British Columbia: Canadian Min. Jour., vol. 45, no. 26, pp. 614-617, June 27, 1924.

14. The B. C. silver mine [Stewart district, British Columbia]: Canadian Min. Jour., vol, 45, no. 30, pp. 711-712, 3 figs., July 25, 1924 ; Min. Mag., vol. 31, no, 3, p. 188, September, 1924. 
Dolmage, Victor-Continued.

15. Chilko Lake and vicinity, British Columbia : Canada, Geol. Survey, Summ. Rept., 1924, pt. A, pp. 59-75, 1 fig., 2 pls., map, 1925.

16. Tatla-Bella Coola area, Coast district, British Columbia: Canada, Geol. Survey, Summ. Rept., 1925, pt. A, pp. 155-163, map, 1926.

17. Finlay River district, British Columbia: Canada, Geol. Survey, Summ. Rept., 1927, pt. A, pp. 19-41, 2 pls. (maps), 1928.

Dolman, C. D.

1. Magnesite; its geology, products, and their uses: Am. Inst. Min. and Met. Eng., Bull. no. 152, pp. 1193-1202, 2 figs., August, 1919; (with discussion), Trans., vol. 63, pp. 175-187, 2 figs., 1920.

Donnay, Joseph D. H.

1. Cleavage vs. parajointing (abstract) : Pan-Am. Geologist, vol. 49, no. 4, p. 308, May, 1928.

Donoghue, David.

1. Absence of metamorphosed sedimentary rocks in the Texas Panhandle: Am. Assoc. Petroleum Geologists, Bull., vol. 8, no. 2, pp. 241-242, March-April, 1924.

2. The Bayou Bouillon salt dome, St. Martin Parish, Louisiana: Am. Assoc. Petroleum Geologists, Bull., vol. 9, no. 9, pp. 1283-1289, 1 fig., December, 1925; Geology of salt dome oil fields, pp. 345-351, 1 fig., 1926.

3. Section 28 salt dome, St. Martin Parish, Louisiana: Am. Assoc. Petroleum Geologists, Bull., vol. 9, no. 9, pp. 1290-1293, 1 fig., December, 1925 ; Geology of salt dome oil fields, pp. 352-355, 1 fig., 1926.

4. Thirteenth annual meeting of the American Association of Petroleum Geologists, San Francisco and Los Angeles, California, March 2125, 1928: Am. Assoc. Petroleum Geologists, Bull., vol. 12, no. 5, pp. 570-591, May, 1928.

Dorfman, Andre. See Bell, J. M., 9.

Dorsey, George Edwin.

1. Stratigraphy and structure of the Newark system in Maryland and its relation to the Newark system of eastern North America (abstract) : Geol. Soc. America, Bull., vol. 30, pp. 155-157, March 31, 1919.

2. The origin of color of red beds: Jour. Geology, vol. 34, no. 2, pp. 131-143, February-March, 1926.

3. The present status of the carbon-ratio theory (with discussion by Russell S. 'Tarr) : Am. Assoc. Petroleum Geologists, Bull., vol. 11, no. 5, pp. 455-465, May, 1927.

Dott, Robert H.

1. Notes on Pennsylvanian paleogeography, with special reference to southcentral Oklahoma: Oklahoma Geol. Survey, Bull. no. 40-J, 22 pp., 11 figs. (incl. maps), March, 1927 ; Bull. 40, vol. 1, pp. 51-69, 11 figs. (incl. maps), July, 1928.

2. Geology of Garvin County: Oklahoma Geol. Survey, Bull. no. 40-K, pp. 7-31, 3 figs., 3 pls. (incl. map), May, 1927.

3. Geology of Garvin County, Oklahoma, and the Robberson field: Am. Assoc. Petroleum Geologists, Bull., vol. 11, no. 8, p. 889, August, 1927. 
I ougherty, Ellsworth Y.

1. The gold quartz lodes of Porcupine, Ontario: Min. and Sci. Press, vol. 118, pp. 532-536, 10 figs., April 19, 1919.

2. Relation of regional deformations to the distribution of ore in the preCambrian: Min. and Sci. Press, vol. 119, pp. 227-230, 1 fig., August 16, 1919.

3. Mode of formation of the Porcupine quartz veins: Econ. Geology, vol. 20, no. 7, pp. 660-670, 2 pls., November, 1925.

4. Formation of Porcupine quartz veins (discussion) : Econ. Geology, vol. 21, no. 6, pp. 612-619, September, 1926.

5. Replacement of aluminous rocks: Eng. and Min. Jour., vol. 122, no. 10. pp. 380-381, September 4, 1926.

6. Magnetite deposits of Madera County, California: Eng. and Min. Jour., vol. 123, no. 19, pp. 765-770, 7 figs., May 7, 1927; vol. 124, no. 8, p. 301, August 20, 1927.

7. The opening as a reason for ore: Econ. Geology, vol. 23, no. 5, pp. 569-578. August, 1928.

Douglas, A. Vibert. See Douglas, G. Vibert, 5.

Douglas, C. B. E.

1. Banding around rock fragments: Eng: and Min. Jour., vol. 122, no. 18, p. 700, October 30, 1926.

Douglas, G. Vibert.

1. Spectroscopy applied to mineral determination: Econ. Geology, vol. 19, no. 8, pp. 766-768, December, 1924.

2. The Whiskey Lake area, District of Algoma: Ontario Dept. Mines, 34th Ann. Rept., vol. 34, pt. 4, pp. 34-49, illus., map, 1926.

3. La Cloche area, District of Sudbury : Ontario Dept. Mines, 34th Ann. Rept., vol. 34, pt. 4, pp. 50-51, map, 1926.

4. Reconnaissance from Red Lake to Favourable Lake, District of Patricia : Ontario Dept. Mines, 35th Ann. Rept., vol. 35, pt. 4, 1925, 28 pp., 21 figs., 2 maps, 1926.

5. (and Douglas, A. Vibert). A solution of fault problems: Canadian Min. and Met. Bull., no. 198, pp. 1228-1232, 3 figs., October, 1928; Canadian Inst. Min. and Met., Trans., vol. 31, pp. 12-16, 3 figs. [1929].

Douglas, George Mellis.

1. Copper deposits of Arctic Canada: Eng. and Min. Jour.-Press, vol. 118, no. 3, pp. 85-89, 5 figs., July 19, 1924 ; Min. Mag., vol. 31, no. 3, pp. 178-180, 1 fig., September, 1924.

Douglas, J. M. See Hintze, 1.

Douglass, Earl.

1. The oil problem in the Uinta Basin, Utah: Salt Lake Min. Rev., vol. 23. no. 16 , pp. 12-13, November 30,1921 ; no. 17, pp. 14-15, December 15, no. 18, pp. 9-11, December 30 , 1921; no. 20, pp. 13-14, January 30,1922 ; no. 22, pp. 9-11, February 28 ; no. 23, pp. 11-14, March 15 ; vol. 24 , no. 1 , pp. $17-18$, April 15 ; no. 2 , pp. 9-11, April 30 ; no. 5, pp. 11-13, June 15; no. 7, pp. 9-11, July 15; no. 10, pp. 11-14. 21 figs., August 30, 1922.

2. Oil problems in the Uinta Basin, Utah: Salt Lake Min. Rev., vol. 24, no. 21 , pp. 17-18, February 15, 1923; vol. 25, no. 3, pp. 18-20, May 15, 1923. 
Douvillé, Henri.

1. Les orbitoïdes en Amérique: Soc. géol. France, Compt. Rend. Somm., nos. 10-11, pp. 106-107, 1923.

2. Les orbitoïdes et leur évolution en Amérique: Soc. géol. France, Bull., $4^{\text {e }}$ sér., t. 23 , nos. 7-8, pp. 369-376, 4 figs., 1 pl., 1924.

3. Revision des lépidocyclines: Soc. géol. France, Mém., new ser., t. 1, mém. no. 2, 49 pp., 47 figs., 2 pls., 1924.

Dove, Leonard P. See also Barrett, 8; Leonard, 7.

1. Sphalerite in coal pyrite [Bicknell, Indiana] : Am. Mineralogist, vol. 6, no. 3, p. 61, March, 1921.

2. The problem of prospecting. for coal in glaciated areas: North Dakota, Univ., Quart. Jour., vol. 11, no. 3, pp. 215-222, 5 figs., April, 1921.

3. The geology and structure of the east side of the Nesson anticline: North Dakota, Univ., Quart. Jour., vol. 12, no. 3, pp. 240-249, 4 figs., 2 pls., April, 1922.

4. Clinkertill, a new metamorphic rock: Science, new ser., vol. 56, p. 338, September 22, 1922.

5. The prospecting and evaluation of lignite lands in North Dakota: North Dakota, Univ., Quart. Jour., vol. 14, no. 1, pp. 60-69, November, 1923.

6. Dakalite: North Dakota, Univ., Departmental Bull., vol. 11, no. 1 (College of Engineering, Division of Mines and Mining Experiments, Bull. no. 9), pp. 33-37, January, 1926.

Dow, Charles Mason.

1. Anthology and bibliography of Niagara Falls (chapter 7, Science, geology, and physics). 2 vols., 1423 pp., illus., published by the State of New York, Albany, 1921.

Dowell, Norah E. See Stearns, Norah Dowell.

Dowling, Donaldson Bogart, 1858-1925. See also Hume, 28.

1. (and Slipper, S. E., and McLearn, F. H.). Investigations in the gas and oil fields of Alberta, Saskatchewan, and Manitoba: Canada, Geol. Survey, Mem. 116, 89 pp., 14 pls. (incl. maps), 1919.

2. The structure and correlation of the formations underlying Alberta, Saskatchewan, and Manitoba: Canada, Geol. Survey, Mem. 116, pp. 1-9, 1919.

3. Records of selected wells arranged in east-west order [Manitoba, Saskatchewan, and Alberta]: Canada, Geol. Survey, Mem. 116, pp. 34-84, map, 1919.

4. Gasoline in natural gas; experiments on Alberta gas: Canada, Geol. Survey, Summ. Rept., 1918, pt. C, pp. 17-42, 1 fig., 1919.

5. Oil possibilities and developments in the Great Plains: Canada, Geol. Survey, Summ. Rept., 1919, pt. C, pp. 20-24, 1 map, 1920.

6. [The occurrence of oil in Alberta] (discussion): Am. Inst. Min. and Met. Eng., Bull. no. 149, p. 854, May, 1919.

-. The rocks of the plains. In Oil and gas in western Canada, compiled under the direction of the Superintendent Natural Resources Intelligence Branch, Dept. Interior, Canada, pp. 10-15, 2 figs., 1920.

8 The possibilities of the oil resources of Canada: Canadian Min. Jour., vol. 41, pp. 287-292, 2 figs., April 9, 1920.

9. The oil possibilities of western Canada: Canadian Min. Inst., Monthly Bull. no. 98, pp. 469-477, 2 figs., June, 1920 ; Trans., vol. 23, pp. 351-359 [1921]. 
Dowling, Donaldson Bogart-Continued.

10. Review of prospecting for oil on the Great Plains: Canada, Geol. Survey, Summ. Rept., 1920, pt. B, pp. 11-25, 7 figs., 1921.

11. Underlying seams of the Souris coal field, southeastern Saskatchewan: Canada, Geol. Survey, Summ. Rept., 1920, pt. B, pp. 26-29, 1921.

12. The Turtle Mountain coal measures [Manitoba]: Roy. Soc. Canada, Proc. and Trans., 3d ser. vol. 14, sec. 4, pp. 35-43, 2 figs., 1921.

13. The possibilities of the oil resources of Canada: Roy. Canadian Inst., no. 29, vol. 13, pt. 1, pp. 39-47, 2 figs., February, 1921.

14. History of discovery of western coal fields: Canadian Min. Jour., vol. 42 , no. 41 , pp. 819-821, October 14, 1921.

15. Geological structure of the Mackenzie River region: Canada, Geol. Survey, Summ. Rept., 1921, pt. B, pp. 79-90, 3 figs., 2 pls., 1922.

16. The eastern belt of the Canadian Cordilleras; an inquiry into the age of the deformation: Roy. Soc. Canada, Proc. and Trans., 3d ser., vol. 16, sec. 4, pp. 175-186, 2 figs., 2 pls., 1922.

17. The Mackenzie River basin (abstract): Science, new ser., vol. 56, pp. 175-176, August 11, 1922.

18. Red Lake district of Patricia [Ontario] : Canadian Min. Jour., vol, 43, no. 40, pp. 676-678, 1 fig., October 6, 1922.

19. Investigation of artesian water, coal, petroleum, and natural gas: Canada, Geol. Survey, Summ. Rept., 1922, pt. B, pp. 101-126, 2 pls., map, 1923.

20. Bow River coal basin within the Rocky Mountains, Alberta: Canada, Geol. Survey, Summ. Rept., 1923, pt. B, pp. 63-85, 4 figs., 1924.

Downing, Eliot Rowland.

1. A naturalist in the Great Lakes region. 328 pp., 452 figs., Chicago, University of Chicago Press, 1922.

Doxsee, W. W.

1. The location of epicenters, 1921: Canada, Dominion Observatory, Ottawa, Pub., vol. 7, no. 2, pp. 61-78, 1925.

2. The location of epicenters, 1922: Canada, Dominion Observatory, Ottawa, Pub., vol. 7, no. 3, pp. 81-102, 1926.

Drane, Brent $\mathbf{S}$.

1. North Carolina's mineral resources and their development: The South's Development, Manufacturers Record, vol. 86, no. 24, pt. 2, pp. 398-401, December 11, 1924.

2. Biennial report of the State geologist and director, 1923-1924: North Carolina Geol. and Econ. Survey, 65 pp., 1925.

3. (and Stuckey, Jasper L.). The mineral industry in North Carolina from 1918-1923 (inclusive) : North Carolina Geol. and Econ. Survey, Econ. Paper no. 55, 104 pp., 1925.

Draper, L. L.

1. Genesis of sulphide ores: Eng. and Min. Jour.-Press, vol. 121, no. 11, pp. 449-450, March 13, 1926.

Dreher, Otto.

1. The files of the oil geologist: Am. Assoc. Petroleum Geologists, Bull., vol. 9, no. 2, pp. 331-339, 6 figs., March-April, 1925.

2. Symbols for dip and strike: Am. Assoc. Petroleum Geologists, Bull., vol. 11, no. 8, pp. 868-870, 4 figs., August, 1927. 
Dresser, John Alexander.

1. Granitic segregations in the serpentine series of Quebec: Roy. Soc. Canada, Proc. and Trans., 3d ser., vol. 14, sec. 4, pp. 7-13, 1921.

2. Mining in Quebec: Canadian Min. Jour., vol. 44, no. 33, pp. 645-647, 1 fig., August 17, 1923.

3. The Magog conglomerate; a horizon mark in the "Quebec group"; Roy. Soc. Canada, Proc. and Trans., 3d ser., vol. 19, sec. 4, pp. 115-121, 1925 .

4. (and others). Geological traverses in the counties of Maskinonge, SaintMaurice, Champlain, Portneuf, Quebec, Montmorency: Quebec, Dept. Colonization, Mines, and Fisheries, Mines Branch, 11 pp. [French text, pp. 13-22], 6 maps, 1928.

5. Copper in the eastern townships [of Quebec]: Canadian Min. and Met. Bull., no. 191, pp. 341-346, March, 1928; Canadian Inst. Min. and Met., Trans., vol. 31, pp. 83-88 [1929].

Driver, Herschel L.

1. An aid in disintegrating samples for micro-organic study: Jour. Paleontology, vol. 1, no. 4, pp. 253-254, January, 1928.

2. Foraminiferal section along Adams Canyon, Ventura County, California : Am. Assoc. Petroleum Geologists, Bull., vol. 12, no. 7, pp. 753-756, 1 pl., July, 1928.

Drummond, Robert.

1. Minerals and mining, Nova Scotia. 368 pp., Mining Record Office, Stellarton, N. S., 1918.

Drury, Charles William.

1. Cobalt; its occurrence, metallurgy, uses, and alloys: Ontario Bur. Mines. Rept. 1918, vol. 27, pt. 3, sec. 1, 133 pp., map, 27 figs., 1919.

Duane, William.

1. The radioactive point of view [of the age of the earth] : Am. Philos. Soc. Proc., vol. 61, no. 4, pp. 286-288, 1922.

2. The age of the earth (abstract) : Science, new ser., vol. 55, p. 656, June 16. 1922.

Dub, George David.

1. (and Moses, Frederick G.). Mining and preparing domestic graphite for crucible use: U. S. Bur. Mines. Bull. 112, 80 pp., 5 pls., 20 figs., 1920.

Dubendorff, H. H. See Schwennesen, 2.

Duce, J. F. See White, D, 1.

Duce, James Terry.

1. Geology of parts of Las Animas, Otero, and Bent counties: Colorado Geol. Survey, Bull. 27, pt. 3, pp. 73-102, 2 figs., map, 1924.

2. Carbon dioxide from wells in Colorado: Am. Assoc. Petroleum Geologists, Bull., vol. 8, no. 6, p. 831, November-December, 1924.

Dufresne, A. 0 .

1. An occurrence of native gold in calcite [Dorchester County, Quebec] : Canadian Inst. Min. and Met., Monthly Bull., no. 128, pp. 1227-1228, December, 1922. 
Dufresne, A. O.-Continued.

2. An occurrence of native gold in calcite [Dorchester County, Quebec]: Canadian Inst. Min. and Met., Monthly Bull., no. 128, pp. 1227-1228, December, 1922 ; Min. Mag. vol. 28, no. 1, pp. 59-60, January, 1923. Descubrimiento de oro nativo en calcite: Cuba, Dirección de Montes y Minas, Bol. Minas, no. 7, pp. 87-88, 1923.

3. Gold in northwestern Quebec: Canadian Min. Jour., vol. 44, no. 33, pp. 647649, 3 figs., August 17, 1923.

4. Notes on some of the gold deposits in Temiscamingue and Abitibi counties: Quebec, Dept. Colonization ... Report on Mining Operations ... 1924, pp. 42-78, 3 pls., 3 figs. (maps), 1925.

5. Mineral deposits of western Quebec and their development in 1925 : Quebec, Dept. Colonization . . . Report on Mining Operations . . 1925, pp. 99-153, 1926.

6. Recent mineral discoveries in western Quebec: Canadian Inst. Min. and Met., Bull., no. 169, pp. 610-626, 1 fig., map, May, 1926: Canadian Min. Jour., vol. 47, no. 23, pp. 569-571, 1 flg., June 4, 1926.

7. Copper and zinc deposits of western Quebec: Canadian Min. Jour., vol. 47, no. 33, pp. 793-798, 4 figs., August 13, 1926.

8. Report on mining operations in the Province of Quebec during the year 1927: Quebec (Province), Department of Colonization, Mines, and Fisheries, Bur. Mines, 246 pp., illus., 1928.

9. (and Taschereau, R. H.). Progress in the development of the mineral deposits of western Quebec in 1927: Quebec, Dept. Colonization, Mines, and Fisheries, Bur. Mines, Rept. on Mining Operations, 1927, pp. 77-161, 15 figs., 7 pls., 1928.

10. Mining developments in western Quebec during 1926 and 1927: Canadian Min. and Met. Bull., no. 198, pp. 1171-1183, October, 1928.

Dumble, Edwin Theodore, 1852-1927. See also DeGolyer, 2.

1. The geology of east Texas: Texas, Univ., Bull. no. 1869, 388 pp., 12 pls. (incl. map), December 10, 1918 [published February, 1920].

2. Foraminiferal guides to Texas coast deposits: Pan-Am. Geologist, vol, 39, no. 1, pp. 61-63, February, 1923.

3. Oil well stratigraphy on Gulf coastal plains: Pan-Am. Geologist, vol. 39, no. 2, pp. 95-100, March, 1923.

4. Marine Wilcox in Mexico: Science, new ser., vol. 57, p. 31, July 13, 1923.

5. Memorial of Anthony Wayne Vogdes: Geol. Soc. America, Bull., vol. 35, no. 1, pp. 37-42, portr., March 30, 1924.

6. (and Applin, E. R.). Subsurface geology of Idolo Island, Vera Cruz, Mexico: Pan-Am. Geologist, vol. 41, no. 5, pp. 335-346, June, 1924.

7. A revision of the Texas Tertiary section with special reference to the oilwell geology of the coast region: Am. Assoc. Petroleum Geologists, Bull., vol. 8, no. 4, pp. 424-444, July-August, 1924.

Dunbar, Carl Owen. See also Chadwick, 11; Clarke, J. M., 21; Schuchert, 16.

1. Stratigraphy and correlation of the Devonian of western Tennessee: Tennessee State Geol. Survey, Bull. 21, 127 pp., 3 pls., 11 figs. 1919.

2. New species of Devonian fossils from western Tennessee: Connecticut Acad. Arts and Sci., Trans., vol. 23, pp. 109-158, 5 pls., February, 1920.

3. Kansas Permian insects, Part 2; Paleolimulus, a new genus of Paleozoic Xiphosura, with notes on other genera: Am. Jour. Sci., 5th ser., vol. 5, pp. 443-454, 8 figs.; June, 1923. 
Dunbar, Carl Owen-Continued.

4. Kansas Permian insects, Part 1, The geologic occurrence and the environment of the insects: Am. Jour. Sci., 5th ser., vol. 7, pp. 171-209, 3 figs., March, 1924.

5. Phases of cephalopod adaptation. In Organic adaptation to environment, pp. 187-223, 4 figs., New Haven, Yale University Press, 1924.

6. Memorial of Thomas A. Bostwick: Geol. Soc. America, Bull., vol. 35, no. 1, p. 181, March 30, 1924.

7. Was there Pennsylvanian-Permian glaciation in the Arbuckle and Wichita Mountains of Oklahoma?: Am. Jour. Sci., 5th ser., vol. 8, pp. 241-248, September, 1924.

8. Olenellus with antennules (abstract): Geol. Soc. America, Bull., vol. 36, no. 1, p. 229, March $30,1925$.

9. Antennae in Olemellus getzi n. sp.: Am. Jour. Sci., 5th ser., vol. 9, pp. 303-308, 2 figs., April, 1925.

10. Pseudopercula in the tabulate coral Favosites: Am. Jour. Sci., 5th ser., vol. 13, pp. 101-114, 9 figs., February, 1927; abstract: Pan-Am. Geologist, vol. 47, no. 3, p. 240, April, 1927.

11. (and Condra, G. E.). The Fusulinidae of the Pennsylvanian system in Nebraska: Nebraska Geol. Survey, 2d ser., Bull. 2, 135 pp., 1.3 figs., 15 pls., December, 1927.

12. Fusulinidae as an aid in zoning the American upper Carboniferous strata (abstract) : Geol. Soc. America, Bull., vol. 39, no. 1, pp. 290-291, March 30, 1928; Pan-Am. Geologist, vol. 49, no. 3, p. 226, April, 1928.

13. On an ammonite shell investing commensal Bryozoa: Am. Jour. Sci., 5th ser., vol. 16, pp. 164-165, August, 1928.

Dunkin, D. D.

1. Mining and preparation of St. Peter sandstone in Arkansas: Am. Inst. Min. and Met. Eng., Tech. Pub. no. 55, 10 pp., 8 figs., February, 1928 ; Trans., vol. 76, pp. 430-441, 8 figs., 1928; abstract, Mining and Metallurgy, vol. 9, no. 254, p. 79, February, 1928.

Dunlop, John P.

1. (and Butler, B. S:). Silver, copper, lead, and zinc in the Central States in 1918: U. S. Geol. Survey, Mineral Resources, 1918, pt. 1, pp. 59-125, October 31, 1919.

2. Gold and silver in 1918: U. S. Geol. Survey, Mineral Resources, 1918, pt. 1, pp. 727-781, 1 fig., 1 pl., July 15, 1920.

3. Gold, silver, copper, lead, and zinc in the Eastern States in 1919 ; U. S. Geol. Survey, Mineral Resources, 1919, pt. 1, pp. 41-50, November $8,1920$.

4. Silver, copper, lead, and zinc in the Central States in 1919: U. S. Geol. Survey, Mineral Resources, 1919, pt. 1, pp. 235-285, May 25, 1921.

5. Gold and silver in 1919: U. S. Geol. Survey, Mineral Resources, 1919, pt. 1, pp. 665-709, 1 fig., 1 pl., October 31, 1921.

6. (and Begeman, F.). Silver, copper, lead, and zine in the Central States in 1920: U. S. Geol. Survey, Mineral Resources, 1920, pt. 1, pp. 113-150, November 11, 1921.

7. Gold, silver, copper, lead, and zinc in the Eastern States in 1921 ; mines report: U. S. Geol. Survey, Mineral Resources, 1921, pt. 1, pp. 7-13, May 12, 1922.

8. Gold and silver in 1920 (general report) : U. S. Geol. Survey, Mineral Resources, 1920, pt. 1, pp. 511-548, 1 fig., 1 pl., June 23, 1922. 
Dunlop, John P.-Continued.

9. (and Begeman, F.). Silver, copper, lead, and zinc in the Central States in 1921 ; mines report: U. S. Geol. Survey, Mineral Resources, 1921, pt. 1, pp. 75-105, August 15, 1922.

10. Gold and silver in 1921 (general report) : U. S. Geol. Survey, Mineral Resources, 1921, pt. 1, pp. 429-466, January 26, 1923.

11. Gold, silver, copper, lead, and zinc in the Eastern States in 1922 (mines report) : U. S. Geol. Survey, Mineral Resources, 1922, pt. 1, pp. 7-14, June 12, 1923.

12. (and Begeman, F.). Silver, copper, lead, and zinc in the Central States in 1922:- U. S. Geol. Survey, Mineral Resources, 1922, pt. 1, pp. 137-168, October 10, 1923.

13. Secondary metals in 1922: U. S. Geol. Survey, Mineral Resources, 1922, pt. 1, pp. 173-191, November 7, 1923.

14. Gold and silver in 1922 (general report) : U. S. Geol. Survey, Mineral Resources, 1922, pt. 1, pp. 595-635, 1 fig., 1 pl., June 4, 1924.

1.5. Gold, silv́er, copper, lead, and zinc in the Eastern States in 1923; (mines report) : U. S. Geol. Survey, Mineral Resources, 1923, pt. 1, pp. 1-7, July 7, 1924.

16. (and Begeman, F.). Silver, copper, lead, and zinc in the Central States in 1923 (mines report) : U. S. Geol. Survey, Mineral Resources, 1923, pt. 1, pp. 47-78, September 30, 1924.

17. Gold and silver in 1923 (general report) : U. S. Geol. Survey, Mineral Resources, 1923, pt. 1, pp. 549-585, 1 fig., 1 pl., April 6, 1925.

18. Gold, silver, copper, lead and zine in the Eastern States in 1924 (mine report) : U. S. Geol. Survey, Mineral Resources, 1924, pt. 1, pp. 1-6, June, 1925.

Dunn, J. A.

1. Origin of metallic concentrations by magmation: Econ. Geology, vol. 19, no. 6, pp. 577-582, September-October, 1924.

Dunn, Paul Heaney.

1. Map of the areal and structural geology of Bourbon County, Kentucky:

Kentucky Geol. Survey, ser. 6, 1928. Scale 1 inch=1 mile.

Dunn, Robert.

1. Geological mapping of Canadian Cordillera: Canadian Min. Jour., vol. 42, no. 36, pp. 726-727, September 9, 1921.

2. Discovery of bauxite in British Columbia: Canadian Min. Jour., vol. 44, no. 48 , pp. 947-948, November $30,1923$.

Duparc, Louis.

1. Sur les gisements platinifères du Wyoming: Soc. phys. et d'hist. nat. de Genève, Compt. rend. des séances, vol. 41, no. 2, pp. 102-104, AprilJuly, 1924.

Du Rietz, T. A.

1. The deformation of the pre-Cambrian peneplain of North America: Geol. Fören. Stockholm, Förh., Bd. 47, H. 2, pp. 250-257, map, MarchApril, 1925.

Du Toit, Alex L.

1. The origin of corundum aplite: Econ. Geology, vol. 23, no. 7, pp. 806-809, November, 1928. 
Dutton, Clarence Edward, 1841-1912.

1. On some of the greater problems of physical geology: Washington Acad. Sci., Jour., vol. 15, no. 15, pp. 359-369, August 19, 1925. (Reprinted from Philos. Soc. Washington, Bull., vol. 11, pp. 51-64, 1889.).

Dwyer, J. L.

1. Seminole area subsurface formations [Oklahoma]: Oil and Gas Jour., vol. 26, no. 37, pp. 70, 148, February 2, 1928.

Dyer, William Spafford. See alsc Hume, 28 ; Parks, 8.

1. On Conularia rugosa from the Lockport limestone at Hamilton, Ontario: Roy. Soc. Canada, Proc. and Trans., 3d ser., vol. 15, sec. 4, pp. 65-68, 2 pls., 1921.

2. The Minto coal basin of New Brunswick: Canadian Inst. Min. and Met., Monthly Bull. no. 145, pp. 251-275, 8 figs., May, 1924; Trans., vol. 27, pp. 385-409, 8 figs. [1925] ; Canadian Min. Jour., vol. 45, no. 45, pp. 1091-1096, 4 figs., November 7, 1924.

3. The paleontology of the Credit River section. [Ontario]; Ontario Dept. Mines, 32d Aun. Rept., vol. 32, pt. 7, pp. 47-88, 7 pls., 1925.

4. The stratigraphy and paleontology of Toronto and vicinity, Part VI; Stratigraphy and correlation of the Credit River section: Ontario Dept. Mines, 32d Ann. Rept., vol. 32, pt. 7, pp. 117-134, 2 figs., 1925.

5. Geology of the gypsum deposits of southwestern Ontario: Ontario Dept. Mines, 34th Ann. Rept., vol. 34, pt. 2, pp. 35-58, 6 figs., 1925.

6. Bore hole records and their use in determination of favorable structure for natural gas accumulation: Intercolonial Gas Jour. of Canada, vol. 18, no. 2, pp. 64-66, 5 figs., February, 1925.

7. Oil and gas horizons in Ontario: Canadian Min. Jour., vol. 46, no. 20, pp. 494-496, May $15,1925$.

8. Minto coal basin, New Brunswick: Canada, Geol. Survey, Mem. 151, 42 pp., 3 figs., 2 maps, 1926.

9. Geological structure in the western end of Cypress Hills, Alberta: Canada, Geol. Survey, Summ. Rept., 1926, pt. B, pp. 15-29, 2 figs., 1927.

10. Oil and gas prospects in southern Saskatchewan: Canada, Geol. Survey, Summ. Rept., 1926, pt. B, pp. 30-38, 1 fig., 1927.

11. The Mesozoic clay deposits of the Mattagami and Missinaibi rivers, northern Ontario: Canadian Min. and Met. Bull., no. 196, pp. 989-1001, 2 pls. (incl. map), August, 1928.

Dyk, Karl. See Byerly, 18.

Eakin, Henry Miner.

1. The Porcupine gold placer district, Alaska: U. S. Geol. Survey, Bull. 699, 29 pp., 8 pls. (incl. maps), 1919. Abstract by R. W. Stone, Washington Acad. Sci., Jour., vol. 9, no. 11, p. 326, June 4, 1920.

Eakle, Arthur Starr.

1. New and rare minerals formed in limestone by' contact metamorphism (abstract) : Geol. Soc. America, Bull., vol. 31, no. 1, pp. 162-163, March 31, 1920.

2. Vonsenite; a preliminary note on a new mineral [from Riverside, California ] : Am. Mineralogist, vol. 5, no. 8, pp. 141-143, August, 1920.

3. Jurupaite, a new mineral [Crestmore, near Riverside, California]: Am. Mineralogist, vol. 6, no. 7, pp. 107-109, July, 1921. 
Wakle, Arthur Starr-Continued.

4. Massive troilite from Del Norte County, California: Am. Mineralogist, vol. 7, no. 5, pp. 77-80, May, 1922.

5. Minerals of California : California State Min. Bur., Bull. no. 91, 328 pp., 1923.

6. Foshagite, a new silicate from Crestmore, California: Am. Mineralogist, vol. 10, no. 4, pp. 97-99, April, 1925.

7. Camsellite from California: Am. Mineralogist, vol. 10, no. 4, pp. 100-102, April, 1925.

8. Needed extension in mineralogic instruction: Am. Mineralogist, vol. 11, no. 3, pp. 45-52, March, 1926.

9. Famous mineral localities: Crestmore, Riverside County, California: Am. Mineralogist, vol. 12, no. 8, pp. 319-321, August, 1927.

10. Mineral names: Am. Mineralogist, vol. 13, no. 11, pp. 533-536, November, 1928.

Eardley-Wilmot, Vere Levinge. See also Cole, L. H., 12.

1. Graphite; recent developments in the Buckingham district [Quebec]: Canadian Inst. Min. and Met. Bull. no. 110, pp. 539-555, June, 1921 ; Trans., vol. 24, pp. 124-142 [1922].

2. Canadian feldspar in 1922; fluorspar in 1922; graphite in Canada, 1922; talc and soapstone in Canada, 1922; the molybdenum situation in Canada in 1922 : Canada, Mines Branch, Summ. Rept. 1922, pp. 2144, 1924.

3. Natural abrasive materials in Canada: Canada, Mines Branch, Investigations of Mineral Resources and the Mining Industry, 1923, pp. 12-15, 1924.

4. Molybdenum and its future prospects in Canada: Canadian Min. Jour., vol. 45, no. 33, pp. 787-788, August 15, 1924.

5. The origin and uses of diatomaceous earth: Canadian Min. Jour., vol. 45 , no. 38, pp. 918-920, September 19, 1924.

6. Molybdenum; metallurgy and uses and the occurrence, mining, and concentration of its ores: Canada, Dept. Mines, Mines Branch, 202 pp., 55 figs., 11 pls., maps, 1925. [Pub. no. 592.]

7. Abrasives; Part II, Corundum and diamond: Canada, Dept. Mines, Mines Branch, 51 pp., 6 figs., 5 pls., 1927. [Pub. no. 675.]

8. Abrasives ; Part III, Garnet: Canada, Dept. Mines, Mines Branch, 69 pp., 17 figs., 4 pls. 1927. [Pub. no. 677.]

9. Diatomite, its occurrence, preparation, and uses: Canada, Dept. Mines, Mines Branch, 182 pp., 31 figs., 15 pls. map, 1928. [Pub. no. 691.]

Earle, Kenneth Wilsọn.

1. Report on the geology of Antigua. $28 \mathrm{pp}$., Government Printing Office, Antigua, Leeward Island, 1923.

2. Geological survey of the Windward and Leeward Islands: The geology of St. Lucia. 4 pp., Castries, Ste. Lucie, 1923. [Not seen.]

3. Preliminary report on geology of Windward and Leeward islands (abstract) : Pan-Am. Geologist, vol. 40, no. 4, p. 320, November, 1923 ; British Assoc. Adv. Sci., Rept. 91st Meeting, Liverpool, 1923, p. 446, 1924.

4. The geology of St. Lucia: Saint Lucia Gazette, vol. 93, no. 16, pp. 107-111, May 10, 1924.

5. The geology of the British Virgin Islands: Geol. Mag., vol. 61, no. 8, pp. 339-351, 1 fig., 1 pl. (maps), August, 1924. 
Earle, Kenneth Wilson-Continued.

6. Reports on the geology of St. Kitts-Nevis, British West Indies, and the geology of Anguilla, British West Indies. $50 \mathrm{pp}$., published by the Crown Agents for the Colonies, London [n. d., 1924?].

7. Geological survey of the Windward and Leeward Islands; The geology of St. Vincent and the neighboring Grenadines, 8 pp., Kingston, 1924. [This and an earlier edition, Castries, 1923, not seen.]

8. Geological survey of Grenada and the (Grenada) Grenadines. 9 pp., St. George, 1924.

9. The geology of the West Indies [reply to T. Wayland Vaughan's criticisms] : Geol. Mag., vol. 64, pp. 191-192, April, 1927.

10. Report on the geology of Saint Vincent and the neighboring Grenadines. Geological Survey of the Windward and Leeward Islands. $8 \mathrm{pp}$, Kingston, Government Printing Office, 1928. [Original edition, 1924, not seen.]

11. Geological notes on the Island of Dominica, B. W. I.: Geol. Mag., vol. 65, pp. 169-187, 2 figs., April, 1928.

Easton, H. D.

1. Is Mississippi to be an oil State?: Oil Weekly, vol. 23, no. 5, pp. 12, 26, 28, 2 figs., October, 1922.

2. Oil and gas possibilities in the Trinity sand in the Louisiana-Arkansas area : Oil Weekly, vol. 38, no. 2, pp. 27-28, 66-69, 2 figs., July 3, 1925, vol. 46, no. 3, pp. 39-41, 1 fig., July 8, 1927.

Eaton, Arthur. See Lee, W. T., 3.

Eaton, Frederick $\mathrm{S}$.

1. Mineral localities of Connecticut: Rocks and Minerals, vol. 2, no. 4, pp. 141142, December, 1927.

Eaton, George F.

1. John Day Felidae in the Marsh collection: Am. Jour. Sci., 5th ser., vol. 4, pp. 425-452, 12 figs., December, 1922.

2. Vertebrate fossils from the Mina Erupción [Chihuahua, Mexico]: Am. Jour. Sci., 5th ser., vol. 6, pp. 229-238, 9 figs., September, 1923.

Eaton, Harry Nelson. See also Miller, B. L., 9.

1. Some subordinate ridges of Pennsylvania: Jour. Geology, vol. 27, no. 2, pp. 121-127, 1919.

2. Notes on certain conglomeratic structures in limestones in central Pennsylvania: Science, new ser., vol. 49, p. 474, May 16, 1919.

3. The Oriskany sandstone faunule at Oriskany Falls, New York (abstract) : Science, new ser., vol. 51, p. 493, May 14, 1920; Am. Jour. Sci., 5th ser., vol. 1, pp. 427-430, May, 1921.

4. The present status of the Medina problem in southeastern Pennsylvania (abstract) : Science, new ser., vol. 56, p. 175, August 11, 1922.

5. A Vernon shale (Silurian) fauna in central New York: New York State Mus. Bull., no. 253, pp. 111-118, 1 pl., July, 1924.

6. Structural relations of the igneous rocks of the Wamsutta red beds, Massachusetts (abstract): Geol. Soc. America, Bull., vol. 36, no. 1, pp. 165-166, March 30, 1925; Pan-Am. Geologist, vol. 43, no. 2, p. 157, March, 1925.

7. Geological excursion of New York State colleges : Science, new ser., vol. 62. pp. 431-432, November 13, 1925. 
Eaton, J. E.

1. Structure of Los Angeles Basin and environs: Oil Age, Los Angeles, California, vol. 20 , no. 6 , pp. 8-9, 52, 2 figs., December, 1923 ; vol. 21 , no. 1, pp. 16-18, 52, 54, 3 figs., January, 1924.

2. The Ventura oil field, California; a brief review of its stratigraphy and structure: Oil Bull., vol. 12, no. 5, pp. 521-524, 2 figs., May, 1926.

3. A contribution to the geology of Los Angeles Basin, California: Am. Assoc. Petroleum Geologists, Bull., vol. 10, no. 8, pp. 753-767, 2 figs. (map and sections), August, 1926; Oil Bull., vol. 12, no. 9, pp. 970-977, 1037, 2 figs., September, 1926:

4. Geology and oil fields of Ventura Basin, Ventura County, California : Oil Age, vol. 23, no. 11, pp. 16-18, map, November, 1926.

5. The Potrero oil field [California] : Oil Bull., vol. 13, no. 11, pp. 1154, 1215, November, 1927.

6. Divisions and duration of the Pleistocene in southern California: Am. Assoc. Petroleum Geologists, Bull., vol. 12, no. 2, pp. 111-141, 3 figs., February, 1928.

7. Pleistocene of southern California: Am, Assoc. Petroleum Geologists, Bull., - vol. 12, no. 5, pp. 559-560, May, 1928.

8. San Clemente well proves new high-gravity oil field in west part of Los Angeles Basin [California]; Petroleum World, Los Angeles, Calif., vol. 13, no. 8, pp. 52-53, 2 figs., August, 1928.

9. How California has conserved oil: Oil Bull., vol. 14, no. 10, pp. 1030-1032, 1037, 2 figs., October, 1928.

10. Notes on the principle and theory of isostasy: Am. Assoc. Petroleum Geologists, Bull. vol. 12, no. 12, pp. 1163-1166, December, 1928.

Ebert, Fred Charles.

1. Records of water levels in wells in southern California: U. S. Geol. Survey, Water-Supply Paper 468, 156 pp., 1 fig., 4 pls. (incl. map), 1921.

Eby, George.

1. Earth disturbances at Dixie, Washington, September 14, 1921: Seismol. Soc. America, Bull., vol 11, nos. 3-4, pp. 195-196, SeptemberDecember, 1921.

Eby, James Brian.

1 (with chapters by M. R. Campbell and G. W. Stose). The geology and mineral resources of Wise County and the coal-bearing portion of Scott County, Virginia : Virginia Geol. Survey, Bull, no. 24, 617 pp., 55 figs., 45 pls. (incl. maps), 1923.

2. The possibilities of oil and gas in southwest Virginia as inferred from isocarbs: Am. Assoc. Petroleum Geologists, Bull., vol. 7, no. 4, pp. 421-426, 1 fig., July-August, 1923.

3. The carbonization of some Colorado coals by igneous intrusion (abstract) : Washington Acad. Sci., Jour., vol. 14, no. 15, p. 376, September $19,1924$.

4. Contact metamorphism of some Colorado coals: Am. Inst. Min. and Met. Eng., Trans. [preprint], no. 1401, 5 pp., 2 figs., January, 1925; Trans., vol. 71, pp. 246-252, 1925; abstract, Mining and Metallurgy, vol. 6, no. 328, p. 620, December, 1925.

5 (and Campbell, M. R.). The Virginia coal fieIds: U. S. Bur. Mines, Tech. Paper 365, pp. 1-5, 1926.

6. Geology of coal formation [of West Virginia]: U. S., Bur. Mines, Tech. Paper 405, pp. 1-5, 1928. 
Eby, John H.

1. Bottom in ore deposits of Coeur d'Alene [region, Idaho] : Pan-Ain. Geologist, vol. 49, no. 3, pp. 179-182, April, 1928.

Eckel, Edwin Clarence.

1. Cements, limes, and plasters; their materials, manufacture, and properties. 2d edition, 655 pp., 158 figs., New York, John Wiley \& Sons, 1922.

2. Cements, limes, and plasters; their materials, manufacture, and properties. 3d edition, 699 pp., 161 figs., New York, John Wiley \& Sons, 1928.

\section{Eckes, Charles R.}

1. Description of cuttings from the Duffer wells, Ranger field [Texas] (with discussion): Am. Assoc. Petroleum Geologists, Bull., vol. 3, pp. 39-43, 1919 .

Eckis, Rollin.

1. Alluvial fans of the Cucamonga district, southern California : Jour. Geology, vol. 36, no. 3, pp. 225-247, 8 figs., April-May, 1928.

Eddingfield, F. T. See Harder, 4.

Eddington, Arthur Stanley.

1. The borderland of astronomy and geology: Smithsonian Inst., Ann. Rept. 1923, pp. 195-202, 1925.

Ede, J. A.

1. Mineral resources of the La Salle district [Illinois]: Am. Inst. Min. and Met. Eng., Bull. no. 153, pp. 2609-2630, 8 figs., September, 1919; Trans., vol. 63, pp. 244-265, 8 figs., 1920.

Edsoll, Fanny Carter.

1. Notes on the Simpson formation, Oklahoma (with discussion): Am. Assoc. Petroleum Geologists, Bull., vol. 7, no. 5, pp. 558-564, 3 figs., September-October, 1923.

2. Criteria for the recognition of heavy minerals occurring in the MidContinent field: Oklahoma Geol. Survey, Bull. no. 31, 32 pp., 2 pls., December, 1925.

3. Ordovician correlations in Oklahoma: Am. Assoc. Petroleum Geologists, Bull., vol. 11, no. 9, pp. 967-975, September, 1927.

Edwards, E. M. See Kindle, 28.

Edwards, Everett C. See also Twenhofel, 8, 11.

1 (and Orynski, Leonard W.). Westbrook field, Mitchell County, Texas: Am. Assoc. Petroleum Geologists, Bull., vol. 11, no. 5, pp. 467-476, 3 figs. May, 1927.

2. Stratigraphic position of the Big Lime of west Texas: Am. Assoc. Petroleum Geologists, Bull.; vol. 11, no. 7, pp. 721-728, 1 fig., 1 pl., July, 1927; Oil Weekly, vol. 46, no. 9, pp. 146-148, 150, 152, 2 figs., August 19, 1927.

Edwards, Ira.

1. A visit to the petrified forests of Arizona: Milwaukee, Public Mus., Yearbook, 1923, vol. 3, pp. 164-170, 5 figs., April 29, 1925.

2. The sea caves of Devil's Island: Milwaukee, Public Mus., Yearbook, 1.924, vol. 4, pp. 94-98, 4 figs., October 9, 1926.

3. The new geological groups [in the Public Museum of the City of Milwaukee] : Milwaukee, Public Mus., Yearbook, 1924, vol. 4, pp. 122-129, 5 figs., October 9, 1926. 
Edwards, Ira-Continued.

4. Underground geology at the Endless Caverns, New Market, Virginia : Milwaukee, Public Mus., Yearbook, 1925, vol. 5, pp. 82-104, 11 figs., March 10, 1927.

5. A geological expedition to Rainbow Natural Bridge, Utah: Milwaukee, Public Mus., Yearbook, 1925, vol. 5, pp. 104-121, 9 figs., March 10, 1927.

Edwards, W. N.

1. Origin of certain filamentous forms from Eocene beds: Nature, vol. 112, p. 9, July 7, 1923.

2. On the cuticular structure of the Devonian plant Psilophyton: Linnean Soc., Jour., Botany vol. 46, no. 310, pp. 377-385, 5 figs., 1 pl., April 16, 1924.

Eggleston, Julius Wooster.

1. Eruptive rocks at Cuttingsville, Vermont: Vermont, State Geologist, 11th Rept., pp. 167-193, 2 pls. (incl. map) [1919].

Ehlers, George Marion. See also Cook, C. W., 8; Ruedemann, 15.

1. An interesting illustration of a process of destruction of a glaciated surface: Michigan Acad. Sci., 20th Ann. Rept., pp. 59-63, 2 pls., 2 figs., 1918.

2. Heterolasma foerstei, a new genus and species of Tetracoralla from the Niagaran of Michigan: Am. Jour. Sci., 4th ser., vol. 48, pp. 461-467, 3 figs., December, 1919.

3. Notes on the stratigraphy of the Racine formation of the northern peninsula of Michigan: Michigan Acad. Sci., 21st Ann. Rept., pp. 87-90, 1920.

4. Niagaran rocks of the northern peninsula of Michigan (abstract) : Geol. Soc. America, Bull., vol. 32, no. 1, pp. 129-130, March 31, 1921.

5. (and Hussey, R. C.). A new gastropod and a new cephalopod from the Devonian of Michigan: Michigan Acad. Sci., Papers, vol. 1, pp. 248-252, 2 pls., 1923.

6. (and Leighly, J. B.). Lipsanocystis traversensis, a new cystid from the Devonian of Michigan: Michigan Acad. Sci., Papers, vol. 2, pp. 155-158, 3 figs., 1923.

7. The presence of Cataract strata in Michigan supported by fossil evidence: Michigan Acad. Sci., Papers, vol. 3, pp. 281-283, 1924.

8. An Ordovician reef on Sulphur Island, Lake Huron: Michigan Acad. Sci., Arts and Letters, Papers, vol. 4, pt. 1, pp. 425-429, 1 fig., 3 pls., February, 1925.

9. Two new crinoids from the Devonian of Michigan: Michigan, Univ., Mus. Geology, Contr., vol. 2, no. 6, pp. 99-104, 1 pl., June 3, 1925; abstract, Pan-Am. Geologist, vol. 44, no. 2, p. 160, September, 1925.

10. (and Chang, M. S.). New brachiopods from Mississippian rocks of Kentucky (abstract) : Pan-Am. Geologist, vol. 44, no. 2, p. 160, September, 1925.

11. (and Chang, M. S.). New brachiopods from the Warsaw formation of Wayne County, Kentucky: Michigan, Univ., Mus. Geology, Contr., vol. 2, no. 7, pp. 105-110, 1 pl., July 15, 1926.

12. (and Cooley, Mary E.). Discovery of a Hamilton fauna in southeastern Michigan: Michigan, Univ., Mus. Geology, Contr., vol. 2, no. 13, pp. 231-236, August 3, 1927. 
Ehrenberg, Kurt.

1. The crinoid occurrence at Crawfordsville, Indiana: Am. Mus. Novitates, no. 204, 12 pp., 2 figs., December 24, 1925.

2. Zur Frage der biologischen Deutung der (Camerocrinus-) Wurzeln (Lobolithen) von Scyphoorinus: Palaeont. Zeitschr., Bd. 8, H. 3, pp. 199-220, 4 figs., October 9, 1926.

Eichelberger, O. H. See Thompson, S. A., 1.

Eichler, A.

1. (and others). Linneit von Littfeld in Westfalen und zinkhaltiger Kupferglanz von Sinaloa in Mexiko: Centralbl. Mineralogie, no. 8, pp. 225-227, April 15, 1922.

Ekblaw, George E.

1. Paleozoic karst topography: Illinois State Acad. Sci., Trans., vol. 17, pp. 208-212, 1925.

2. Post-Chester, pre-Pennsylvanian faulting in the Alto Pass area: Illinois State Acad. Sci., Trans., vol. 18, pp. 378-382, 1 fig., 1925.

3. (and Athy, L. F.). Glacial Kankakee torrent in northeastern Illinois: Geol. Soc. America, Bull., vol. 36, no. 2, pp. 417-427, 4 figs., June 30, 1925; abstract, no. 1, p. 155, March 30, 1925 ; Pan-Am. Geologist, vol. 43, no. 2, p. 151, March, 1925.

Ekblaw, W. Elmer.

1. Economic geology : Am. Year Book, 1927, pp. 597-599, 1928.

Eldridge, W. J. See Robinson, W. I., 4.

Elledge, Emmett R. See also Moore, R. C., 5.

1. The economic geology of the Arkansas City district: Kansas, State Geol. Survey, Bull. 8, pp. 5-37, 2 figs., 11 pls. (incl. map), 1921.

Elles, Gertrude L.

1. Evolutional paleontology in relation to the lower Paleozoic rocks: PanAm. Geologist, vol. 40, no. 4, pp. 259-288, November, 1923; British Assoc. Adv. Sci., Rept. 91st Meeting, 1923, pp. 83-107, 5 figs., 1924.

Ellis, Arthur Jackson, 1885-1920.

1. (and Lee, Charles H.). Geology and ground waters of the western part of San Diego County, California: U. S. Geol. Survey, Water-Supply Paper 446, 321 pp., 47 pls. (incl. maps), 18 figs., 1919; abstract, Washington Acad. Sci., Jour., vol. 11, no. 10; pp. 235-236, May 19, 1921.

2. Mineral waters in 1917: U. S. Geol. Survey, Mineral Resources, 1917 pt. 2, pp. 483-520, April 21, 1919.

3. Mineral waters in 1918: U. S. Geological Survey, Mineral Resources, 1918, pt. 2, pp. 495-531, 1 pl. (map), March 19, 1920.

4. Mineral waters in 1919: U. S. Geol. Survey, Mineral Resources, 1919, pt. 2, pp. 115-149, January 21, 1921.

5. (and Meinzer, O. E.). Ground water in Musselshell and Golden Valley counties, Montana: U. S. Geol. Survey, Water-Supply Paper 518, 92 pp., 11 figs., 5 pls. (incl. map), 1924.

Ellis, Edwin E.

1. Occurrence of commercial zinc and lead ore bodies in the Tri-State district: Eng. and Min. Jour.-Press, vol. 121, no. 5, pp. 209-210, January 30, 1826. 
Ellis, Ernest W. See Kirkham, 7.

Ellis, Robert Walpole.

1. The oil situation in New Mexico: New Mexico, State Univ., Bull. 101 (Geol. Series 3), 48 pp., map, December, 1920.

2. Geology of the Sandia Mountains: New Mexico, State Univ., Bull, no. 4, (Geol. ser. 3), 45 pp., 2 figs., 4 pls., map, September, 1922.

3. Oil and gas in New Mexico in 1923: New Mexico, State Univ., Bull. no. 112, Geol. ser. 3, 29 pp., May, 1923.

4. Tables for determining common minerals and rocks: New Mexico, State Univ., Bull., Geol. ser., vol. 3, no. 6, 46 pp., September, 1923.

5. Geologic map of the State of New Mexico. Scale, 1 inch $=12$ miles. State University of New Mexico, Albuquerque, 1925.

Ellison, Robert S.

1. What the oil company expects of the geologist: Am. Assoc. Petroleum Geologists, Bull., vol. 6, no. 6, pp. 516-522; November-December, 1922.

Ellisor, Alva Christine. See also Applin, E. R., 1.

1. Species of Turritella from the Buda and Georgetown limetones of Texas: Texas, Univ., Bull. no. 1840, 26 pp., 4 pls., July 15, 1918.

2. The age and correlation of the chalk at White Cliffs, Arkansas, with notes on the subsurface correlations of northeast Texas: Am. Assoc. Petroleum Geologists, Bull., vol. 9, no. 8, pp. 1152-1164, 2 pls.; November, 1925 .

3. Coral reefs in the Oligocene of Texas: Am. Assoc. Petroleum Geologists, Bull., vol. 10, pp. 976-985, 4 figs., October, 1926.

Ells, Sydney Clarke.

1. The bituminous sands of northern Alberta (abstract): Geol. Mag., new ser., dec. 6, vol. 6, p. 142, March, 1919.

2. Cretaceous shales of Manitoba and Saskatchewan as a possible source of crude petroleum: Canada, Mines Branch, Summ. Rept., 1921, pp. 34-41, 2 maps, 1923.

3. Oil shales of Canada: Canada, Mines Branch, Summ. Rept., 1921, pp. 41-55, 1923.

4. Bituminous sands of northern Alberta: Canada, Mines Branch, Summ. Rept., 1922, pp. 44-46, 1924:

5. Bituminous sands of northern Alberta: Canada, Mines Branch, Investigations of Mineral Resources and the Mining Industry, 1923, pp. 4-11, 1924.

6. Bituminous sands of northern Alberta: Canadian Min. Jour., vol. 45, nos. 13 and 17, pp. 298-304, 400-403, 6 figs., March 28 and April 25, 1924 ; Inst. Petroleum Technologists, Jour., vol. 10, no. 43, pp. 358359, June; no. 45, pp. 710-717, 2 pls., September, 1924.

7. Oil shales of Canada. In McKee, Ralph H., Shale oil., pp. 43-60, New York, 1925.

8. Bituminous sands of northern Alberta; occurrence and economic possibilities; report on investigations to the end of 1924 : Canada, Dept. Mines, Mines Branch, 244 pp., 47 figs., 43 pls., 12 maps and sections, 1926. [Pub. no. 632.]

9. Bituminous sands of northern Alberta; their character and economic importance: Canadian Inst. Min. and Met., Trans., vol. 30, pp. 646670, 7 figs. [1928]; Second (Triennial) Empire Min. and Met. Congress, Canada, 1927, Proc., pt. 3, pp. 130-154, 7 figs., 1928. 
Ellsworth, H. V. See also Johnston, R. A. A., 1; Palache, 31; Poitevin, 5, 7.

1. (and Poitevin, E.). Camsellite, a new borate mineral from British Columbia, Canada: Roy. Soc. Canada, Proc. and Trans., 3d ser., vol. 15 , sec. 4 , pp. 1-8, 3 pls., 1921.

2. Radium-bearing pegmatites of Ontario: Canada, Geol. Survey, Summ. Rept., 1921, pt. D, pp. 51-70, 2 figs., 2 pls., 1922.

3. Recent discoveries of radioactive minerals in Ontario: Canada, Geol. Survey, Summ. Rept., 1923, pt. C 1, pp. 6-20, 2 figs., 5 pls., 1924.

4. The blue corundum of the Bancroft area [Hastings County, Ontario]: Canadian Min. Jour., vol. 45, no. 41, pp. 1009-1010, 1 fig., October $10,1924$.

5. Atomic disintegration as a measure of geologic time: Pan-Am. Geologist, vol. 42 , no. 4, pp. 273-280, November, 1924.

6. Radioactive minerals as geological age indicators: Am. Jour. Sci., 5th ser., vol. 9, pp. 127-144, February, 1925; abstract, British Assoc. Adv. Sci., Rept. 92d Meeting, p. 390, 1925; Pan-Am. Geologist, vol. 42, no. 4, p. 320, November, 1924.

7. Canadian pegmatites and their minerals: Canadian Min. Jour., vol. 46, no. 9, pp. 224-226, February 27, 1925.

8. Duration of pre-Cambrian time: Pan-Am. Geologist, vol. 43, no. 2, pp. 99-104, March, 1925.

9. Chemistry of the potash-bearing horizon of the Malagash salt deposit, Nova Scotia: Canada, Geol. Survey, Summ. Rept., 1924, pt. C. pp. 181-198, 1926.

10. (and Walker, John F.). Knopite and magnetite occurrence, southeastern British Columbia: Canada, Geol. Survey, Summ. Rept., 1925, pt. A, pp. 230-232, 1926.

11. Euxenite-polycrase from Mattawan township, Nipissing district, Ontario: Am. Mineralogist, vol. 11, no. 12, pp. 329-331, December, 1926.

12. Toddite, a new uranium mineral from Sudbury district, Ontario: Am. Mineralogist, vol. 11, no. 12, pp. 332-334, December, 1926.

13. Ellsworthite crystals from Haliburton County, Ontario : Am. Mineralogist, vol. 12, no. 2, pp. 48-53, 1 fig., February, 1927.

14. Lyndochite, a new mineral of the euxenite-polycrase group from Lyndoch township, Renfrew County, Ontario: Am. Mineralogist, vol. 12, no. 5, pp. 212-218, 2 figs., May, 1927.

15. A new analysis of the Maberly, Ontario, euxenite: Am. Mineralogist, vol. 12 , no. 10 , pp. 365-367, October, 1927.

16. I, Uranothorite from the MacDonald mine, Hybla, Ontario ; II, Alpha and beta hyblite, new sulphatic alteration products of the Hybla thorite: Am. Mineralogist, vol. 12, no. 10, pp. 368-372, 1 fig., October, 1927.

17. A mineral related to a samarskite from the Woodcox mine, Hybla, Ontario :. Am. Mineralogist, vol. 13, no. 2, pp. 63-65, February, 1928.

18. A mineral related to samarskite from Parry Sound, Ontario: Am. Mineralogist, vol. 13, no. 2, pp. 66-68, February, 1928.

19. I, Thucholite, a remarkable primary carbon mineral from the vicinity of Parry Sound, Ontario (with contribution, The volatiles in thucolite, by E. S. Shepherd) ; II, Cyrtolite intergrowth associated with the Parry Sound thucholite: Am. Mineralogist, vol. 13, no. 8, pp. 409-441, 3 figs., August, 1928.

20. Thucholite and uraninite from the Wallingford mine near Buckingham, Quebec: Am. Mineralogist, vol. 13, no. 8, pp. 442-448, 2 figs., August, 1928. 
Ellsworth, H. V.-Continued.

21. Euxenite from Sabine Township, Nipissing district, Ontario: Am. Mineralogist, vol. 13, no. 9, pp. 484-487, 1 fig., September, 1928.

Elmore, Clarence Jerome.

1. The diatoms (Bacillarioideae) of Nebraska: Nebraska Geol. Survey, vol. 8,214 pp., 23 pls. [no date, 1926 ?].

Elsing, Morris Jesup.

1. The Bisbee mining district [Arizona] : Eng. and Min. Jour.-Press, vol. 115, no. 4, pp. 177-184, 5 figs., January 27, 1923.

Elworthy, Reginald Thomas.

1. Natural gas in Alberta: Canada, Mines Branch, Investigations of Mineral Resources and the Mining Industry, 1923, pp. 16-46, 1924.

2. Helium in Canada: Canadian Min. Jour., vol. 45, no. 51, pp. 1233-1235, December 19, 1924.

3. New development in the Turner Valley oil field, Alberta : Inst. Petroleum Technologists, Jour., vol. 11, no. 49, pp. 200-201, April, 1925.

4. Natural gas and petroleum in northern Alberta: Canada, Dept. Mines, Mines Branch, Investigations of Mineral Resources . . . 1924, pp. 103-115, 1926.

5. Helium in Canada: Canada, Dept. Mines, Mines Branch, 64 pp., 2 pls., 2 maps, 1926. [Pub. no. 679.]

6. Hot springs in western Canada ; their radioactive and chemical properties: Canada, Dept. Mines, Mines Branch, Investigations of mineral resources and the mining industry, 1925, pp. 1-33, 1926.

7. Natural gas in New Brunswick: Canada, Dept. Mines, Mines Branch, Investigations of mineral resources and the mining industry, 1925, pp. 34-38, 1926.

8. Natural gas in Canada: Canadian Inst. Min. and Met., Trans., vol. 30, pp. 680-686 [1928] ; Second (Triennial) Empire Min. and Met. Congress, Canada, 1927; Proc., pt. 3, pp. 164-170, 1928.

Ely, Fred B.

1. Concerning theories [respecting occurrence, etc., of petroleum] : Am. Assoc.

Petroleum Geologists, Bull., vol. 8, no. 1, pp. 94-96, JanuaryFebruary, 1924.

Emerson, Benjamin Kendall. See also Foye, 6.

1. William Bullock Clark (1860-1917) : Am. Acad. Arts, Proc., vol. 54, no. 6, pp. $412-415$, September, 1919.

Emerson, Frederick Valentine, 1871-1919.

1. Some Port Hudson outcrops in Louisiana: Science, new ser., vol. 50, p. 460, November 14, 1919.

2. Agricultural geology. 319 pp., 270 figs., New York, John Wiley \& Sons, 1920.

3. Agricultural geology ; revised by John E. Smith. 377 pp., 271 figs., New York, John Wiley \& Sons, 1928.

Emerson, O. H. See also Finch, 6.

1. The formation of a and pahoehoe: Am. Jour. Sci., 5th ser., vol. 12, Ill. 109-114, August, 1926.

Einery, Alden H. See Bray, 1.

Emery, W. B. See Redwood, 1. 
Emig, William Harrison.

1. Mosses as rock builders: Oklahoma, Univ., Bull. (Proc. Oklahoma Acad. Sci., 1910-1920), new ser. no. 220, pp. 38-40, July 15, 1921.

Emmens, Newton W.

1. The Wainwright oil and gas field [Alberta]: Canadian Min. Jour., vol. 46 , no. 5 , pp. $120-124$, no. 6 , wp. 145-150, 10 figs., January 30 , and February 6, 1925.

2. Mineral resources of the Lardeau and Iront Lake mining divisions of British Columbia: Canadian Min. Jour., vol. 47, no. 1, pp. 5-8, 3 figs., January 1, no. 2, pp. 36-38, 2 tigs., January 8, 1926.

Emmet, W. L. R.

1. Formation of the earth and moon. 15 pp., 2 figs. [priv. pub., 1927(?). No particulars given as to time or place of publication].

2. Formation of the moon and earth: Sci. Monthly, vol. 24, no. 1, pp. 15-24, 3 figs., January, 1928.

Emmons, Richard Conrad. See also Winchell, A. N., 18.

1. Concerning inclusions in igneous magmas: Jour. Geology, vol. 34, no. 5, pp. 422-428, July-August, 1926.

2. (and Stockwell, C. H., and Jones, R H. B.). Argentite and acanthite: Am. Mineralogist, vol. 11, no. 12, pp. 326-328, 1 fig., December, 1926.

3. Wakomata Lake map area, Algoma district, Ontario: Canada, Geol. Survey, Summ. Rept., 1926, pt. C, pp. 1-15, 1 fig., map, 1927.

4. Diabase differentiation: Am. Jour. Sci., 5th ser., vol. 13 pp. 73-82, 3 figs., January, 1927.

5. A diabase chert breccia: Jour. Geology, vol. 36, no. 6, pp. 569-572, August-September, 1928.

6. The double dispersion method of mineral determination: Am. Mineralogist, vol. 13, no. 10, pp. 504-515, 5 figs., October, 1928.

7. Studies in mineral separation in a finely divided state: Am. Jour. Sci., 5th ser., vol. 16, pp. 423-445, 8 figs., November, 1928.

8. Notes on the precipitation of calcium carbonate: Jour. Geology, vol. 36, no. 8, pp. 735-742, 5 figs., November-December, 1928.

Enmmons, Samuel Franklin.

1. (and Irving, J. D., and Loughlin, G. F.). Geology and ore deposits of the Leadville mining district, Colorado: U. S. Geol. Survey, Prof. Paper 148, 368 pp., 111 figs., 70 pls., 1927.

Emmons, William Harvey, See also Lindgren, 18; Udden; Johan A., 2.

1. Experiments on accumulation of oil in sands (abstract): Am. Assoc. Hetroleum Geologists, Bull., vol. 5, no. 1, pp. 103-104, January-February, 1921.

2. Geology of petroleum. 610 pp., 254 figs., New York, McGraw-Hill Book Company, 1921.

3. General economic geology; a textbook. ‘516 pp., 257 figs., New York, McGraw-Hill Book Company, 1922.

4. (and Larsen, Esper S.). Geology and ore deposits of the Creede district, Colorado: U. S. Geol. Survey, Bull. 718, 198 pp., 32 figs., 12 pls. (incl. maps), 1923.

5. Geology of prospecting: Eng. and Min. Jour.-Press, vol. 115, no. 3, pp. 122-1.23, January 20, 1923. 
Emmons, William Harvey-Continued.

6. Primary downward changes in ore deposits (with discussion by J. E. Spurr) : Am. Inst. Min. and Met. Eng., Trans., vol. 70, pp. 964 997, 13 figs., 1924 ; [preprint] no. 1319, 29 pp., 13 figs., March, 1924; abstract, Mining and Metallurgy, vol. 5, no. 207, pp. 140-141, March, 1924 ; no. 209, pp. 245-246, May, 1924.

7. The major hinge zone of Tertiary deformation and some of its precious metal deposits: International Geol. Cong., 13th Sess., Belgium, 1922, fasc. 3, pp. 1521-1532, 1925.

S. (and Laney, F. B.). Geology and ore deposits of the Ducktown mining district, Tennessee (with the active collaboration of Arthur Keith) : U. S. Geol. Survey, Prof. Paper 139, 114 pp., 15 figs., 42 pls. (incl. map), 1926.

9. Relations of metalliferous lode systems to igneous intrusives: Am. Inst. Min. and Met. Eng., Pam. no. 1571, 42 pp., 23 figs., June, 1926; Trans., vol. 74, pp. 29-70, 23 figs., 1926; abstract, Mining and Metallurgy, vol. 7, no. 234, p. 263, June, 1926.

10. Zonal arrangement of metalliferous lodes (abstract) : Pan-Am. Geologist, vol. 47, no. 1, pp. 75-76; February, 1927.

11. Relations of the disseminated copper ores in porphyry to igneous intrusives (with discussion) : Am. Inst. Min. and Met. Eng., Trans., vol. 75, pp. 797-815, 5 figs., 1927; [preprint] no. 1638, 13 pp., 5 figs., February, 1927; abstract, Mining and Metallurgy, vol. 8, no. 242, p. 88, February, 1927.

12. The state and density of solutions depositing metalliferous veins: Am. Inst. Min. and Met. Eng., Tech. Pub. no. 71, 13 pp., 6 figs., February, 1928; Trans., vol. 76, pp. 308-320, 6 figs., 1928 ; abstract, Mining and Metallurgy, vol. 9, no. 254, pp. 82-83, February, 1928.

Emory, Lloyd T.

1. Bauxite, its supply and manner of formation: Eng. and Min. Jour., vol. 123, no. 19, p. 771, May 7, 1927.

Engel, Rene.

1. Preliminary notes on the geology of the Elsinore Valley (abstract): Geol. Soc. America, Bull., vol. 39, no. 1, p. 267, March 30, 1928.

Engineering and Mining Journal.

1. The origin of iron ores: Eng. and Min. Jour., vol. 109, p. 1053, May 8, 1920.

2. Applications of the zonal theory: Eng. and Min. Jour.-Press, vol. 117, no. 10, p. 393, March 8, 1924.

3. The microscope and the decadence of geology: Eng. and Min. Jour.-Press, vol. 118 , no. 3, pp. 82-83, July 19, 1924.

4. Development of the ore magma theory : Eng. and Min. Jour.-Press, vol. 119, no. 22 , pp. $874-875$, May 30,1925 .

5. The ghost of the molten magma: Eng. and Min. Jour.-Press, vol, 120, no. 9, p. 322, August.29, 1925.

6. The natural history of the pegmatites: Eng. and Min. Jour.-Press, vol. 120, no. 11, pp. 402-403, September 12, 1925.

7. Mining for shooting stars [Meteor Crater, Arizona] : Eng. and Min. Jour.Press. vol. 120, no. 26, pp. 1001-1002, December 26, 1925.

8. Ore deposition or ore injection: Eng. and Min. Jour.-Press, vol. 121, no. 12, p. 475, March 20, 1926.

9. Essentials of the ore magma theory: Eng. and Min. Jour.-Press, vol. 121, no. 16, pp. 634-635, April 17, 1926. 
Engineering and Mining Journal-Continued.

10. Ore deposition in the Tri-State district: Eng. and Min. Jour.-Press, vol. 121, no. 23, p. 913, June 5, 1926.

11. Dikes and ores of the Mississippi Valley: Eng. and Min. Jour., vol. 123, no. 3, p. 82, January 15, 1927.

English, George Letchworth.

1. The scientific valuation of minerals: Am. Mineralogist, vol. 12, no. 5, pp. 197-209, May, 1927.

English, Leon.

1. Robberson oil field, Garvin County, Oklahoma: Oklahoma Acad. Sci., Proc., vol. 2 (Oklahoma, Univ., Bull., new ser. no. 247), pp. 85-86, October $1,1922$.

English, Walter Atheling. See also Arnold, 4.

1. Geology and petroleum resources of northwestern Kern County, California : U. S. Geol. Survey, Bull. 721, 48 pp., 2 figs., 2 pls. (incl. map), 1921.

2. Some plane-table methods (with discussion) : Am. Assoc. Petroleum Geologists, Bull., vol. 8, no. 1, pp. 47-54, 3 figs., January-February, 1924.

3. Geology and oil resources of the Puente Hills region, southern California : U. S. Geol. Survey, Bull. 768, 110 pp., 3 figs., 14 pls. (incl. maps), 1926.

4. Notes on the McKittrick, California, oil field: Am. Assoc. Petroleum Geologists, Bull., vol. 11, no. 6, pp. 617-620, 1 fig., June, 1927.

5. Outline of the geology of the San Joaquin Valley oil fields [California]: Oil Bull., vol. 14, no. 4, pp. 362-367, April, 1928.

Erickson, E. Theodore. See also DeGolyer, 9.

1. Tschermigite (ammonium alum) from Wyoming: Washington Acad. Sci., Jour., vol. 12, no. 3, pp. 49-54, February 4, 1922.

Erlenborn, W.

1. Report on the feldspar deposits of Quetachou Manicouagan Bay: Quebec, Dept. Colonization . . ., Report on Mining Operations . . . 1924, pp. 93-111, 2 pls. (incl. map), 1925.

Erni, Chester Pralle.

1. (and Beals, C. C.). Soil survey of Carroll County :Indiana, Dept. Geology and Nat. Res., 41st Ann. Rept., pp. 45-66, map, 1917.

Ernst, Walter S.

1. Statistics of the mineral production of Alabama for 1922: Alabama Geol. Survey Bull. no. 27, 139 pp., 1924.

Esarey, Ralph E.

1. Notes on the relation of the Mt. Carmel and Heltonville faults to the Dennison anticline [Lawrence County] : Indiana Acad. Sci., Proc., vol. 34, pp. 135-139, 1925.

2. The Tri-County oil field of southwestern Indiana : Am. Assoc. Petroleum Geologists, Bull., vol. 11, no. 6, pp. 601-610, 6 figs., June, 1927.

3. The oil shales of Indiana: Min. Cong. Jour., vol. 14, no. 1, pp. 5-7, 11, 7 figs., January, 1928.

$4096-31-13$ 
Escher, Berend George.

1. On the hot "lahar" (mud flow) of the Valley of Ten Thousand Smokes, Alaska: K. Akad. Wetensch. Amsterdam, Proc. Sec. Sci., vol. 24,

Eskola, Pentti. pp. 282-293, 3 figs., March, 1922.

1. On contact phenomena between gneiss and limestone in western Massachusetts: Jour. Geology, vol. 30, no. 4, pp. 265-294, 3 figs., MayJune, 1922.

Estabrook, Edward L.

1. Faulting in Wyoming oil fields: Am. Assoc. Petroleum Geologists, Bull., vol. 7, no. 2, pp. 95-102, 1 fig., March-April, 1923.

2. Occurrences of oil and gas in Wyoming: Am. Assoc. Petroleum Geologists, Bull., vol. 8, no. 4, p. 515, July August, 1924.

3. Analyses of Wyoming oil field waters: Am. Assoc. Petroleum Geologists, Bull., vol. 9. no. 2, pp. 235-246, 3 figs., March-April, 1925.

4. (and Rader, Clarence M.). History of production of Salt Creek oil field, Wyoming: Am. Inst. Min. and Met. Eng., Trans. [preprint], no. 1503, 51 pp., 8 figs., September, 1925; (with discussion), [preprint], no. 1570 (Petroleum development and technology in 1925), pp. 199-254, 8 figs., April, 1926.

Estlin, E. S.

1. Natural gas in Ontario: Canadian Inst. Min. and Met., Monthly Bull. no. 105, pp. 57-62, January, 1921 ; Trans., vol. 24, pp. 81-85 [1922].

2. Natural gas in 1920 [in Ontario]; Oil field operations, 1920: Ontario Dept. Mines, 30th Ann. Rept., vol. 30, pt. 5, 62 pp., illus., 1922.

Etherington, Thomas J.

1. Tertic rocks of part of Chehalis Valley, Washington (abstract) : Pan-Am. Geologist, vol. 49, no. 4, p. 314, May, 1928.

Ettlinger, I. A. See also Short, 1.

1. Ore deposits support hypothesis of a central Arizona batholith: Am. Inst. Min. and Met. Eng., Tech. Pub. no. 63, 23 pp., 6 figs. (incl. map), February, 1928; abstract, Mining and Metallurgy, vol. 9, no. 254, p. 77, February, 1928.

Evans, C. S. See also Walker, 3.

1. Placer gold and lead-zinc deposits, Dogtooth Range, Kootenay district, British Columbia: Canada, Geol. Survey, Summ. Rept., 1926, pt. A, pp. 52-55, 1927.

Evans, George Watkin.

1. Preliminary report on the Horseshoe district of the Teton coal basin, southeastern Idaho: U. S. Bur. Mines, Bull., 166, pp. 90-103, 1 pl. (map), 3 figs., 1919.

2. Alaskan coal fields: Am. Inst. Min. and Met. Eng., Trans. [preprint] no. 1047, 10 pp., February, 1921 ; vol. 66, pp. 286-298, 1922. Abstract, Mining and Metallurgy, no. 170, pp. 34-35, February, 1921.

3. Coal mining in the State of Washington during 1923: Washington, Division of Geology, Bull. no. 30, pp. 184-215, 1924.

4. Report on the Horseshoe Basin area of the Teton coal field in southeastern Idaho: Idaho, Bur. Mines and Geology, Pam. no. 10, 15 pp., April, 1924. [Mimeographed.] 
Evans, Isabel P. See also Merrill, 45 ; Ransome, 8, 14 ; Ross, C. P., 4.

1. Bibliography of quicksilver in North America: U. S. Geol. Survey, Mineral Resources, 1917, pt. 1, pp. 425-455, March 18, 1919.

2. Recent publications on quicksilver in North America: U. S. Geol. Survey, Mineral Resources, 1918, pt. 1, pp. 179-182, October 31, 1919; 1919, pt. 1, pp. 177-180, April 5, 1921; 1920, pt. 1, pp. 437-439, March 27, 1922 ; 1921, pt. 1 , pp. $117-120$, August 7,$1922 ; 1922$, pt. 1, pp. 121124, September 18, 1923.

Evans, John R. C.

1. The Richmond fauna of northeasern Illinois (abstract): Chicago, Univ., Abstracts of Theses, Sci. Ser., vol. 2, pp. 199-205, September, 1926.

Evans, John William.

1. Isostasy and geological structure (abstract): Pan-American Geologist, vol. 44, no. 4, pp. 329-330, November, 1925.

2. Continental drift (abstract) : Pan-Am. Geologist, vol. 44, no. 4, pp. 332333, November, 1925.

Evans, Noel.

1. Stratigraphy of Weatherford area, Oklahoma (with discussion by Henry F. Schweer): Am. Assoc. Petroleum Geologists, Bull., vol. 12, no. 7, pp. 705-714, 2 figs., July, 1928.

Evans, Oren F.

1. Some observations on erosion and transportation in the Wichita Mountain area: Oklahoma Acad. Sci., Proc., vol. 2 (Oklahoma, Univ., Bull., new ser. no. 247), pp. 77-79, October 1, 1922.

2. A study of some conglomerates near the eastern limits of the red beds of Oklahoma : Oklahoma Acad. Sci., Proc., vol. 3 (Oklahoma, Univ., Bull., new ser. no. 271), pp. 94-95, October 1, 1923.

3. Some observations on the South Canadian River near Norman: Oklahoma Acad. Sci., Proc., vol. 3 (Oklahoma, Univ., Bull., new ser. no. 271), pp. 120-123, October 1, 1923.

4. Some processes in the formation of the stream valleys of the interior plains region of the United States (abstract): Oklahoma Acad. Sci., Proc., vol. 5, 1925 (Oklahoma, Univ., Bull., new ser. no. 330, Univ. Studies no. 22), p. 150, April 1, 1926.

5. A stream valley type of Oklahoma: Oklahoma Acad. Sci., Proc., vol. 6, pt. 2, 1926 (Oklahoma, Univ., Bull., new ser. no. 348), pp. 229-231, January 1, 1927.

6. Origin of certain stream valleys of the interior plains regions of the United States: Am. Jour. Sci., 5th ser., vol. 13, pp. 257-259, March, 1927.

7. Preliminary report on road materials of western Oklahoma: Oklahoma Geol. Survey, Circular no. 17, 19 pp., 1 fig., 1 pl. (map), August, 1928.

8. Physiography in relation to past climates: Oklahoma Acad. Sci., Proc., vol. 7 (Oklahoma, Univ., BuH., new ser., no. 409), pp. 149-151 [1928].

9. Some reasons for the parallel courses of streams in Oklahoma: Oklahoma Acad. Sci., Proc., vol. 7 (Oklahoma, Univ., Bull., new ser., no. 409), pp. 152-154 [1928].

Eve, A. S.

1. (and Keyes, D. A.). Geophysical methods of prospecting: U. S., Bur. Mines Tech. Paper 420, 26 pp., 27 figs., 1927; Min. Rev., Salt Lake City, Utah, vol. 29, no. 22, pp. 7-15, 18, February 29, 1928. 
Everit, R. S.

1. Hot spring water from Clifton, Arizona: Econ. Geology, vol. 20, no. 3, pp. 291-292, May, 1925.

Eyl, W. C. See also Kentucky G. S., 23, 36, 41.

1. (and Hudnall, J. S.). Map of the areal and structural geology of Jackson County, Kentucky: Kentucky Geol. Survey, Ser. 6, 1927. Scale 1 inch $=1$ mile.

2. Map of the areal and structural geology of Lee County, Kentucky : Kentucky Geol. Survey, Ser. 6, 1927. Scale 1 inch $=1$ mile.

Faessler, Carl. See Dresser, 4.

Fairbanks, Ernest E.

1. Notes on mineragraphic technique: Econ. Geology, vol. 19, no. 2, pp. 213214, March, 1924.

2. The identification of manganese minerals: Econ. Geology, vol. 19, no. 8, pp. 769-770, December, 1924.

3. Angular inclusions and replacement deposits : Econ. Geology, vol. 20, no. 3, pp. 293-295, May, 1925.

4. A modification of Lemberg's staining method: Am. Mineralogist, vol. 10, no. 5, pp. 126-127, May, 1925.

5. The form of replacement crystals: Am. Mineralogist, vol. 10, no. 7, pp. 163-166, July, 1925.

6. The mechanism of replacement and recrystallization: Econ. Geology, vol. 20, no. 5, pp. 470-484, 1 fig., August, 1925.

7. Dumortierite from Nevada: Am. Mineralogist, vol. 11, no. 4, pp. 93-96, April, p. 135, May, 1926.

8. Electrical conductivity of ore minerals (discussion): Econ. Geology, vol. 21, no. 4, pp. 399-401, June-July, 1926.

9. Zeophyllite from Idaho, with note on the determination of Mallard's constant: Am. Mineralogist, vol. 11, no. 9, pp. 249-252, September, 1926.

10, A geological reconnaissance of the Dracut norite stock of Massachusetts: Boston Soc. Nat. Hist., Proc., vol. 38, no. 8, pp. 397-412, 1 fig., September, 1927.

11. The importance of pollucite: Am. Mineralogist, vol. 13, no. 1, pp. 21-25, January, 1928.

12. (editor). The laboratory investigation of ores; a symposium. ix, 262 pp., New York, McGraw-Hill Book Company, 1928.

Includes the following papers:

Lindgren, Waldemar. Historical review of the study of polished sections of opaque minerals, pp. 1-6.

7-34.

Davey, Wheeler $P$. Crystal analysis by means of $X$ ray, pp. 35-85. Loveland, R. P. and Trivelli, A. P. H. Practical photomicrography, pp. 86-102.

Fairbanks, Ernest E. Dielectric methods, pp. 103-111.

Lane, Alfred C. Genetic significance of grain, pp. 112-131.

Colony, R. J. Ore-mineral sequence, pp. 132-146.

Newhouse, W. H. The microscopic criteria of replacement in the opaque ore minerals, pp. 147-161.

Thiel, G. A. The textural relationships of the opaque manganese minerals, pp. 162-171.

Bowen, N. L. Geologic thermometry, pp. 172-199.

Guild, F. N. The enrichment of silver ores, 200-239.

Fairbanks, Ernest E. Zonal distribution, pp. 240-242.

Schwartz, G. M. Ore-dressing microscopy, pp. 243-255. 
Fairchild, Herman Leroy. See also Diller, 5 ; Stoller, 1.

1. Pleistocene marine submergence of the Hudson, Champlain, and St. Lawrence valleys: New York State Mus., Bull., nos. 209, 210, 76 pp., 25 pls. (incl. maps), 1919.

2. Postglacial sea-level waters in eastern Vermont: Vermont, State Geologist, 11th Rept., pp. 52-75, 1 pl., 2 figs. [1919].

3. Henry Augustus Ward: Rochester Acad. Sci., Proc., vol. 5, pp. 241-251, portr., May, 1919.

4. Grove Karl Gilbert: Rochester Acad. Sci., Proc., vol. 5, pp. 251-259, portr., May, 1919.

5. Edwin Eugene Howell: Rochester Acad. Sci., Proc., vol. 5, pp. 259-261, May, 1919.

6. The Rochester Canyon and the Genesee River base-levels: Rochester Acad. Sci., Proc., vol. 6, pp. 1-55, 14 pls.; 13 tigs., October, 1919.

7. Postglacial uplift of southern New England: Geo. Soc. America, Bull., vol. 30 , no. 4, pp. 597-636, 3 figs., December 31 , 1919 ; abstract, no. 1, pp. 89-90, March 31, 1919.

8. Musical sands: Science, new ser., vol. 51, pp. 62-64, January 16, 1920.

9. A nature drama [Pleistocene, New York State]: Sci. Monthly, vol. 10, no. 4, pp. 405-417, 13 figs., April, 1920.

10. The latest glacial features in the United States (abstract): Science, new ser., vol. 51, p. 493, May 14, 1920.

11. Pleistocene clays as a chronometer: Science, new ser., vol. 52, pp. 284 286 , September 24, 1920 .

12. [Review of] Text-book of geology, by Amadeus W. Grabau: Science, new ser., vol. 54, pp. 494-497, November 18, 1921 . [Includes notes on American textbooks of geology.]

13. The Pinnacle Hills or the Rochester kame moraine: Rochester Acad. Sci., Proc., vol. 6, no. 5, pp. 141-194, 5 figs., 54 pls., November, 1923.

14. The development of geologic science: Sci. Montlily, rol. 19, no. 1, pp. 77-101, July, 1924.

15. Geologic history of the Genesee country. In History of the Genesee country (western New York), edited by Lockwood R. Doty, vol. 1, pp. 15-110, 37 pls., Chicago, The S. J. Clarke Publishing Company, 1925. Another edition with title, Geology of western New York, 62 pp., 37 pls., Published by the author, Rochester, New York, November, $192 \tilde{\text {. }}$

16. The Susquehanna River in New York and evolution of western New York drainage: New York State Mus. Bull., no. 256, 99 pp., 10 figs., 39 pls., 1925.

17. Changing levels of the Great Lakes: Sci. Monthly, vol. 22, no. 3, pp. 193-199, March, 1926.

18. Pleistocene features of southern New England: Science, new ser., vol. 63, pp. 260-262, March 5, 1926.

19. The Mendon kame area: Rochester Acad. Sci., Proc., vol. 6, no. 6, pp. 195-215, 8 figs., 4 pls., August, 1926.

20. Geologic romance of the Finger Lakes: Sci. Monthly, vol. 23, no. 2, pp. 161-173, 10 figs., August, 1926; Smithsonian Inst., Ann. Rept., 1927, pp. 289-298, 4 figs., 6 pls., 1928.

21. The Dansville Valley and drainage history of western New York: Rochester Acad. Sci., Proc., vol. 6 no. 7, pp. 217-242, 9 figs., 8 pls., October, 1926.

22. Our world in the making: Science, new ser., vol. 64, pp. 365-371, October $15,1926$. 
Fairchild, Herman Leroy-Continued.

23. Memoir of Israel C. White: Geol. Soc. America, Bull., vol. 39, no. 1, pp. 126-145, portr., March 30, 1928.

24. Geologic story of the Genesee Valley and western New York. 215 pp., 193 pp., illus., Rochester, N. Y., published by the author, 1928.

25. Thomas Chrowder Chamberlin--teacher, administrator, geologist, philosopher: Science, new ser., vol. 68, pp. 610-612, December 21, 1928.

Fairchild, J. G. See also Miser, 2.

1. Notes on the analysis of mineral sulphide water: Washington Acad. Sci., Jour., vol. 10, no. 20, pp. 559-565, December 4, 1920.

Fansett, George Richard.

1. Field tests for the common metals; $3 d$ ed., revised: Arizona, Bur. Mines, Bull. no. 105 (Min. Tech. Ser. no. 23), 29 pp., 1920.

Faribault, Eugene Rođolphe. See also McKenzie, N.

1. Investigations in western Nova Scotia : Canada, Geol. Survey, Summ. Rept., 1917, pt. F, pp. 17-20, 1918.

2. Investigations in western Nova Scotia : Canada, Geol. Survey, Summ. Rept., 1918, pt. F, pp. 1-4, 1919.

3. Investigations in southwestern Nova Scotia: Canada, Geol. Survey, Summ. Rept., 1919, pt. F, pp. 2-20, 4 maps, 1920.

4. Geological mapping of Berwick and Lakeview map areas, Kings and Annapolis counties, Nova Scotia: Canada, Geol. Survey, Summ. Rept., 1920, pt. E, pp. 6-16, 1921.

Farnham, C: Mason. See Davy, 1.

Farnsworth, H. R.

1. The sedimentation of the Sunset oil field and the extension of the Thirtyfive anticline [Kern County, California]: Oil Bull., vol. 13, no. 11, pp. 1133-1139, 6 figs., November, 1927.

2. Geological features of Sunset field [Kern County, California] : Oil and Gas Jour., vol. 26, no. 47, pp. 72, 88, 90, 94, 96, 99, 100, 6 figs., April 12, 1928.

Farnsworth, Marie. See Bowles, 4.

Farnum, Dwight.

1. Carnotite in the Gateway district of Colorado and Utah: Min. and Sci. Press, vol. 119, pp. 127-128, 1 fig., July 26, 1919.

Farrington, Oliver Cummings.

1. Etching iron meteorites: Am. Mineralogist, vol. 5, no. 3, pp. 57-59, March, 1920.

2. Agate, physical properties and origin: Field Mus. Nat. Hist., Dept. Geology, Leaflet no. 8, pp. 1-19, 1 fig., 10 pls., 1927.

Fath, Arthur Earl. See also Redwood, 1.

1. The origin of the faults, anticlines, and buried "granite ridge" of the northern part of the Mid-Continent oil and gas field: U. S. Geol. Survey, Prof. Paper 128, pp. 75-84, 3 pls., 3 figs., August 13, 1920; (abstract by M. I. Goldman), Washington Acad. Sci., Jour., vol. 11, no. 10, pp. 236-237, May 19, 1921.

2. Geology of the Eldorado oil and gas fleld, Butler County, Kansas; Kansas, State Geol. Survey, Bull. 7, 187 pp., 9 figs., 19 pls. (incl. maps) [1921]. 
Fath, Arthur Earl-Continued.

3. The age of the domes and anticlines in the Lost Soldier-Ferris district, Wyoming: Jour. Geology, vol. 30, no. 4, pp. 303-310, 1 pl. (map), May-June, 1922.

4. Is the Stapleton pay of the El Dorado field, Butler County, Kansas, Ordovician or Mississippian in age?: Am. Assoc. Petroleum Geologists, Bull., vol. 6, no. 4, pp. 374-376, July-August, 1922.

5. (and Moulton, G. F.). Oil and gas fields of the Lost Soldier-Ferris district, Wyoming: U. S. Geol. Survey, Bull. 756, 57 pp., 2 figs., 8 pls. (incl. map), 1924.

6. Geology of the Bristow quadrangle, Creek County, Oklahoma, with reference to petroleum and natural gas: U. S. Geol. Survey, Bull. 759, 63 pp., 3 figs., 13 pls. (incl. maps), 1925.

Fay, Albert Hill.

1. A glossary of the mining and mineral industry: U. S. Bur. Mines, Bull. 95, 754 pp., 1920.

2. The Illinois-Kentucky fluorspar industry: Eng. and Min. Jour., vol. 122, no. 5, pp. 165-169, 10 figs., July 31, 1926.

Fearing, Frederick C.

1. Alaska tip deposits: Eng. and Min. Jour., vol. 110, no. 4, pp. 154-158, 3 figs., July 24, 1920.

2. Manganese deposits of Lunenburg County, Nova Scotia: Eng. and Min. Jour.-Press, vol. 115, no. 1, pp. 11-15, 8 figs., January 6, 1923; no. 11, pp. $482-483$, March 17,1923 ; no. 23 , pp. 1008-1009, June 9, 1923 .

Fearing, J. L., jr.

1. (and Benedict, P. C.). Geology of the Verde Central mine [Jerome district, Arizona] : Eng. and Min. Jour.-Press, vol. 119, no. 15, pp. 609-611, 4 figs., April 11, 1925.

2. Some notes on the geology of the Jerome district, Arizona: Econ. Geology, vol. 21, no. 8, pp. 757-773, 5 figs., December, 1926.

Feilding, Rowland C.

1. Notes on the geology and ore occurrences of thè Porcupine gold field [Ontario]: Inst. Min. and Met., Buil.' no. 231,10 pp., December, 1923 ; no. 232 (discussion), pp. 9-20, January, 1924; discussion by H. H. Knox, Min. Mag., vol. 30, no. 2, 'pp. 120-122, 2 figs., February, 1924. Extracts, Canadian Min. Jour., vol. 45, no. 3, pp. 75-76, January 18, 1924, no. 16, pp. 372-373, April 18, 1924.

Feiss, J. W.

1. Casting invertebrate fossils in sealing wax and type metal (abstract): Geol. Soc. America, Bull., vol. 37, no. 1, p. 235, March 30, 1926.

Feliciano, José María.

1. The relation of concretions to coal seams: Jour. Geology, vol. 32, no. 3, pp. 230-239, April-May, 1924; abstract, Chicago, Univ., Abstracts of Theses, Sci. Ser., vol. 2, pp. 207-216, September, 1926.

Fellman, Carl M.

1. The mining of fluorspar and its uses: Lake Superior Min. Inst., Proc., vol. 25, pp. 197-211, 8 figs., 1926. 
Fenneman, Nevin Melanchthon.

1. Functions of the division of geology and geography of the National Research Council: Science, new ser., vol. 56, pp. 620-624, December 1, 1922.

2. Physiographic provinces and sections in western Oklahoma and adjacent parts of Texas: U. S. Geol. Survey, Bull. 730, pp. 115-134, 2 figs., 3 pls., December 20, 1922.

3. Recent work in paleobotany : Science, new ser., vol. 57, pp. 44-45, January $12,1923$.

4. A classification of natural resources: Science, new ser., vol. 61, pp. 191-197, February 20, 1925.

5. Resource survey of the Commercial Club of Cincinnati; abstract of results : Cincinnati, Univ., Inst. Sci. Research, ser. 2, no. 1, 86 pp., 14 figs., June, 1927.

6. Physiographic divisions of the United States; third edition, revised and enlarged: Assoc. Am. Geographers, Annals, vol. 18, no. 4, pp. 261353, map, December, 1928.

Fenner, Clarence Norman.

1. Geology of the Katmai region, Alaska, and the great eruption of 1912 (abstract) : Geol. Soc. America, Bull., vol. 31, no. 1, p. 140, March $31,1920$.

2. The Katmai region, Alaska, and the great eruption of 1912 : Jour. Geology, vol. 28 , no. 7 , pp. 569-606, 17 figs., October-November, 1920.

3. The Katmai region, Alaska, and the great eruption of 1912 (Jour. Geology, vol. 28, pp. 569-606, 1920) (abstract): Washington Acad. Sci., Jour., vol. 11, no. 16, p. 394, October 4, 1921.

4. Evidences of assimilation during the Katmai eruption of 1912 (abstract) : Geol. Soc. America, Bull., vol. 33, no. 1, p. 129, March 31, 1922.

5. The origin and mode of emplacement of the great tuff deposit in the Valley of 'Ten Thousand Smokes: Nat. Geog. Soc., Contributed Technical Papers, Katmai series, no. 1, 74 pp., illus., 1923 ; abstract, Science, new ser., vol. 57, pp. 446-447, April 13, 1923.

6. Moving pictures of the Valley of Ten Thousand Smokes, Alaska (abstract) : Geol. Soc. America, Bull., vol. 35, no. 1, p. 112, March 30, 1924; Pan-Am. Geologist, vol. 41, no. 2, p. 156, March, 1924.

7. Earth movements accompanying the Katmai eruption: Jour. Geology, vol. 33, no. 2, pp. 116-139, February-March, no. 3, pp. 193-233, 18 figs., April-May, 1925.

8. The Katmai magmatic province: Jour. Geology, vol. 35, no: 7, pt. 2, pp. 673772, 15 figs., October-November, 1926.

9. An unusual occurrence of albite [Paterson, New Jersey]: Am. Mineralogist, vol. 11, no. 10, pp. 255-259, 1 fig., October, 1926.

10. Magmatic problems of the Aleutians: Nat. Research Council, Bull. no. 56 (vol. 11, pt. 2), pp. 124-127, November, 1926.

11. The analytical determination of uranium, thorium, and lead as a basis for age calculations: Am. Jour. Sci., 5th ser., vol. 16, pp. 369-381, November, 1928.

If enton, Carroll Lane. See also Fenton, Mildred Adams, 3.

1. Some new brachiopods and gastropods from the Devonian of Iowa: Am. Midland Naturalist, vol. 5, no. 11, pp. 213-224, 2 pls., September, 1918. 
Fenton, Carroll Lane-Continued.

2. The Hackberry stage of the upper Devonian of Iowa: Am. Jour. Sci., 4th ser., vol. 48, pp. 355-376, 5 figs. (incl. map), November, 1919.

3. The Hackberry stage of the upper Devonian: Am. Midland Naturalist, vol. 6, no. 9, pp. 179-200, 1 pl., 1 fig., May, 1920.

4. (and Fenton, Mildred Adams). The stratigraphy and fauna of the Hackberry stage of the Upper Devonian: Michigan, Univ., Contr., Mus. Geology, vol. 1, 260 pp., 9 figs., map, 45 pls., 1924.

5. (and Fenton, Mildred Adams). Some Black River brachiopods from the Mississippi Valley: Iowa Acad. Sci., Proc. 1922, vol. 29, pp. 67-77, 2 pls. [1924?].

6. (and Fenton, Mildred Adams). Ecologic interpretations of some biostratigraphic terms: Am. Midland Naturalist, Notre Dame, Indiana, vol. 11, no. 1, pp. 1-23, January, 1928.

7. Apparent orthogenesis in the genus Spirifer (abstract) : Ohio Acad. Sci., Proc., vol. 8, pt. 4, p. 171, 1928 ; Ohio Jour. Sci., vol. 28, no. 3, p. 149, May, 1928.

8. The stratigraphy and larger fossils of the Plattin formation in Ste. Genevieve County, Misouri: Am. Midland Naturalist, Notre Dame, Indiana, vol. 11, no. 2, pp. 86-96, March, nos. 3, 4, pp. 125-143, 7 pls., May-July, 1928.

9. Forms of Strophomena from Black River and Richmond formations: Am. Midland Naturalist, vol. 11, nos. 3, 4, pp. 144-159, 3 pls., May-July, 1928.

10. The Spirifer orestes phylum; its evolution and ecology (abstract) : Chicago, Univ., Abstracts of Theses, Sci. Ser., vol. 4, pp. 223-226, May, 1928.

Fenton, Mildred Adams. See also Fenton, Carroll Lane, 4, 6.

1. New species of Aulopora from the Devonian of Iowa: Am. Midiand Naturalist, Notre Damre, Indiana, vol. 10, nos. 11-12, pp. 373-384, 2 pls., September-November, 1927.

2. The nature and relationships of the genus Aulopora (abstract): Ohio Acad. Sci., Proc., vol. 8, pt. 4, p. 172, 1928; Ohio Jour. Sci., vol. 28, no. 3, p. 150, May, 1928.

3. (and Fenton, Carroll Lane). A new species of Schizophoria from the Devonian of Iowa : Am. Midland Naturalist, vol. 11, nos. 3, 4, pp. 160161, 1 pl., May-July, 1928.

Ferguson, Henry Gardiner. See also Scott, D. B., 1.

1. Graphite in 1918: U. S. Geol. Survey, Mineral Resources, 1918, pt. 2, pp. 223-265, 4 figs., 1 pl., October, 1919.

2. The limestone ores of Manhattan, Nevada: Econ. Geology, vol. 16, no. 1. pp. 1-36, 6 figs. (incl. maps), January, 1921.

3. The Mogollon district, New Mexico: U. S. Geol. Survey, Bull. 715, pp. 171-204, 2 figs., 6 pls. (incl. maps), February 8, 1921. Abstract by R. W. Stone, Washington Acad. Sci., Jour., vol, 11, no. 15, pp. 375-376, September 19, 1921.

4. The Round Mountain district, Nevada: U. S. Geol. Survey, Bull. 725, pp. 383-406, 6 figs., November 21, 1921.

5. Geology and ore deposits of the Manhattan district, Nevada: U. S. Geol. Survey, Bull. 723, 163 pp., 15 figs., 18 pls. (incl. maps), 1924.

6. (and Cathcart, S. H.). Major structural features of some western Nevada ranges (abstract): Washington Acad. Sci., Jour., vol. 14, no. 15, pp. 376-379, September 19, 1924. 
Ferguson, Henry Gardiner-Continued.

7. Late Tertiary and Pleistocene faulting in western Nevada (abstract): Geol. Soc. America, Bull., vol. 37, no. 1, p. 164, March 30, 1926; Pan-Am. Geologist, vol. 45, no. 2, pp. 163-164, March, 1926.

8. Geology and ore deposits of the Mogollon mining district, New Mexico: U. S. Geol. Survey, Bull. 787, 100 pp., 5 figs., 25 pls. (incl. maps), 1927.

9. Regional relations of Nevada ore deposits (abstract): Washington Acad. Sci., Jour., vol. 17, no. 5, pp. 121-122, March 4, 1927.

10. The Gilbert district, Nevada: U. S. Geol. Survey, Bull. 795, pp. 125-145, 2 figs. (maps), November 4, 1927.

Ferguson, Jim G.

1. Outlines of the geology, soils, and minerals of the State of Arkansas [cover title, Outlines of Arkansas geology]. 192 pp., illus., published by the [Arkansas] State Bureau of Mines, Manufactures and Agriculture, Little Rock, 1920.

2. Minerals in Arkansas. 160 pp., illus., Little Rock, Ark., 1922.

Ferguson, John Bright.

1. (and Merwin, H. E.). The ternary system $\mathrm{CaO}-\mathrm{MgO}_{\mathrm{S}} \mathrm{SiO}_{2}$ : Am. Jour. Sci., 4th ser., vol. 48, pp. 81-123, 17 figs., August, 1919.

2. (and Merwin, H. E.). Wollastonite $\left(\mathrm{CaO}-\mathrm{SiO}_{2}\right)$ and related solid solutions in the ternary system-lime-magnesia-silica: Am. Jour. Sci., 4th ser., vol. 48, pp. 165-189, 8 figs., September, 1919.

3. The oxidation of lava by steam: Washington Acad. Sci., Jour., vol. 9, no. 18, pp. 539-546, November 4, 1919.

4. (and Buddington, A. F.): The binary system åkermanite-gehlenite: Am. Jour. Sci., 4th ser., vol. 50, pp. 131-140, 4 figs., August, 1920.

Ferguson, R. N.

1. The oil and gas prospects in the vicinity of Buttonwillow, Kern County, California : California State Min. Bur., Summary of Operations California Oil Fields, Monthly Chapter, Seventh Ann. Rept. State Oil and Gas Supervisor, vol. 7, no. 3, pp. 7-13, 1 fig., September, 1921. Abstract by K. C. Heald, Am. Assoc. Petroleum Geologists, Bull., vol. 6, no. 1, pp. 57-58, January-February, 1922.

:. (and Willis, C. G.). Dynamics of oil-field structure in southern California: Am. Assoc. Petroleum Geologists, Bull., vol. 8, no. 5, pp. 576-583, 2 figs., September-October, 1924.

Fermor, L. L.

1. The pitch of rock folds: Econ. Geology, vol. 19, no. 6, pp. 559-562, September-October, 1924.

Fernández Peralta, Ricardo. See Tristán, 2.

Ferrier, Walter Frederick.

1. (assisted by Ferrier, Dorothy J.). Annotated catalogue of and guide to the publications of the Geological Survey, Canada, 1845-1917. 544 pp., Canada, Geol. Survey, 1920.

2. (and Graham, R. P. D.). Pseudomorphs of corundum after spinel from Bathurst Township, Lanark County, Ontario; with a note on the identification of the original locality of the spinel: Roy. Soc. Canada, Proc. and Trans., 3d ser., vol. 22, sec. 4, pp. 31-38, 2 pls. March, 1928. 
Fettke, Charles Reinhard. See also Ashley, 9; Pennsylvania Geol. Survey.

1. Glass manufacture and the glass sand industry of Pennsylvania: Pennsylvania Topog. and Geol. Survey, Rept. no. 12, 278 pp., 108 pls., 1918 [1919 on cover-title].

2. (and Hubbard, Bela). Limonite deposits of Mayaguez Mesa, Porto Rico: Am. Inst. Min. and Met. Eng., Trans., vol. 61, pp. 97-112, 8 figs., 1920.

3. Oil resources in coal and carbonaceous shales of Pennsylvania: Pennsylvania Geol. Survey, 4th ser., 119 pp., 16 figs., 6 pls., 1923.

4. Cannel coal and carbonaceous shale deposits of Pennsylvania (with discussion) : Am. Inst. Min. and Met. Eng., Trans., vol. 69, pp. 11671181, 7 figs., 1923 [preprint], no. 1233, 15 pp., 7 figs., February, 1923; abstract, Mining and Metallurgy, vol. 4, no. 194, p. 93, February, 1923.

5. The geology of the Humacao district, Porto Rico: New York Acad. Sci., Scientific Survey of Porto Rico and the Virgin Islands, vol. 2, pt. 2, pp. 117-197, 53 figs., map, 1924.

6. Magnetite deposits of eastern Porto Rico (with discussion by S. Harbert Hamilton and A. K. Knickerbocker) : Am. Inst. Min. and Met. Eng., Trans., vol. 70, pp. 1024-1042, 6 figs., 1924 [preprint], no. 1294, 15 pp., 6 figs., February, 1924; abstract, Mining and Metallurgy, vol. 5, no. 208, pp. 195-196, April, 1924.

7. (and Hill, E. G.). Vanport limestone of Butler and southern Venango counties: Pennsylvania Geol. Survey, 4th ser., Bull. M7, pp. 282$292,1925$.

8. Note on a calcified log from the Pittsburgh coal near Morgantown, West Virginia: Am. Mineralogist, vol. 10, no. 5, pp. 109-112, 3 figs., May, 1925.

9. Preliminary note on a calcified log from the Pittsburgh coal near Morgantown, West Virginia: Pennsylvania Acad. Sci. Proc., vol. 1, pp. 66-68, 2 pls., 1926.

Fiedler, Albert G.

1. Report on investigations of the Roswell artesian basin, Chaves and Eddy counties, New Mexico: New Mexico, State Engineer, 7th Bienn. Rept., pp. 21-60, 10 pls. [1926].

2. (and Nye, S. Spencer). Ground-water investigation of the Roswell artesian basin, New Mexico: New Mexico, State Eng., 8th Bienn. Rept., pp. 81-107, 5 pls. (incl. maps) [1928].

3. Report on a reconnaisance of the ground-water area of the Mimbres Valley, Luna County, New Mexico: New Mexico, State Eng., 8th Bienn. Rept., pp. 159-171 [1928].

Field, John. See Becking, 1.

Field, Richard Montgomery. See also Bailey, E. B., 2.

1. The middle Ordovician of central and south central Pennsylvania: Am. Jour. Sci., 4th ser., vol. 48, pp. 403-428, 3 figs., December, 1919.

2. Origin of the "beach rock" (coquina) at Loggerhead Key, Tortugas (abstract) : Geol. Sci. America, Bull., vol. 31, no. 1, p. 215, March 31, 1920.

3. The use of the term fossil: Science, new ser., vol. 51, pp. 634-635, June $25,1920$.

4. Further remarks on "the use of the term fossil": Science, new ser., vol. 59 pp. 117-118, February 4, 1921. 
Field, Richard Montgomery-Continued.

5. A natural classification of sedimentary rocks (abstract): Science, new ser., vol. 56, pp. 174-175, August 11, 1922.

6. Geology manual, an instruction and laboratory manual for beginners; Part I, Physical geology. 149 pp., 18 pls., Princeton, Princeton University Press, 1.927.

7. Summer school of geology and natural resources: Science, new ser., vol. 65, pp. 229-231, March 4, 1927.

8. Suggestions as to the study of marine sediments: Canadian Field Nat., vol. 42, no. 5, pp. 119-121, 1 fig., May, 1928.

9. The great Bahama Bank; studies in marine carbonate sediments: Am. Jour. Sci., 5th ser., vol. 16, pp. 239-246, 1 fig., September, 1928.

Field, V. W.

1. A Utah feldspar locality: Am. Mineralogist, vol. 6, no. 6, pp. 103-104, June, 1921.

Fieldner, Arno Carl.

1. (and others). Analyses of Ohio coals: U. S., Bur. Mines, Tech. Paper 344, 40 pp., 1923.

2. (and others). Analyses of mine samples [of Pennsylvania coals] : Pennsylvania Geol. Survey, 4th ser., Bull. M6, pt. 4, pp. 13-256, 1925.

3. (and others). Analyses of Alabama coals: U. S., Bur. Mines, Tech. Paper 347 , pp. 12-107, 1925.

4. (and others). Analyses of mine samples [of coals in Utah]: U. S., Bur. Mines, Tech. Paper 345, pp. 23-85, 1925.

5. (and others). Analyses of mine samples [of Tennessee coals]: U. S., Bur. Mines, Tech. Paper 356, 94 pp., 1926.

6. (and others). Analyses of Virginia coals: U. S., Bur. Mines, Tech. Paper 365, pp. 8-69, 1926.

7. (and others). Analyses of Missouri coals: U. S., Bur. Mines., Tech. Paper 366, pp. 8-37, 1926.

8. (and others). Analyses of West Virginia coals: U. S., Bur. Mines, Tech. Paper 405, 343 pp., 1928.

9. (and others). Analyses of Oklahoma coals: U. S., Bur. Mines, Tech. Paper 411, 62 pp., 1928.

10. (and others). Analyses of Arkansas coals: U. S., Bur. Mines, Tech. Paper 416, 26 pp., 1928.

Figgins, J. D.

1. The antiquity of man in America: Natural History (Am. Mus. Nat. Hist., Jour.), vol. 27, no. 3, pp. 229-239, 8 figs., May-June, 1927.

Fillman, Louise.

1. Classification of lenses (abstract): Iowa Acad. Sci., Proc., 1922, vol. 29, p. 128 [1924?].

2. Origin of limestone conglomerates (abstract) : Iowa Acad. Sci., Proc. 1922, vol. 29 , p. 128 [1924?].

3. Cenozoic history of the northern Black Hills of South Dakota (abstract) : Geol. Soc. America, Bull., vol. 37, no. 1, p. 172, March 30, 1926; Pan-Am. Geologist, vol. 45, no. 2, pp. 167-168, March, 1926.

Filmer, Edwin Alfred.

1. An accurate method of taking readings on exceedingly low rock dips: Science, new ser., vol. 68, p. 459, November $9,1928$.

Finch, E. H. See Condit, 5. 
Finch, John Wellington.

1. Platinum discoveries in Wyoming [Encampment district] : Eng. and Min. Jour.-Press, vol. 120, no. 3, pp. 95-96, 1 fig., July 18, 1925.

2. Sedimentary metalliferous deposits of the red beds: Am. Inst. Min. and Met. Eng., Tech. Pub. no. 51, 7 pp., February, 1928; Trans., vol. 76, pp. 378-392, 1928; abstract, Mining and Metallurgy, vol. 9, no. 254, p. 84, February, 1928.

Finch, Ruy Herbert. See also Jaggar, 9.

1. [Observations on Halemaumau]: Hawaiian Volcano Observatory, Monthly Bull., vol. 8, nos. 3-5, pls., 1920.

2. On the prediction of tidal waves: Pan-Pacific Sci. Cong., Australia, 1923, Proc., vol. 2, pp. 1366-1368 [1924].

3. Seismic sequences of the explosive eruption of Kilauea in May, 1924: Seismol. Soc. America, Bull., vol. 14, no. 4, pp. 217-222, 1 fig., 3 pls., December, 1924.

4. An earthquake prediction at Hawaiian Volcano Observatory: Science, new ser., vol. 61, pp. 42-43, January 9, 1925.

5. The earthquakes at Kapoho; Island of Hawaii, April, 1924: Seismological Soc. America, Bull., vol. 15, no. 2, pp. 122-127, 2 figs., June, 1925.

6. (and Emerson, O. H.). Sulphate deposits in lava tubes: Am. Jour. Sci., 5th ser., vol. 10, pp. 39-40, July, 1925.

7. Expedition to the southwest rift of Mauna Loa: Hawaiian Volcano Observatory, Monthly Bull., vol. 13, no. 12, pp. 89-91, December, 1925.

8. New York City an aseismic area: Science, new ser., vol. 64, p. 183, August $20,1926$.

9. An observatory for the study of Lassen Peak [Californa]: Seismological Soc. America, Bull., vol. 18, no. 1, pp. 5-8, 1 fig., 1 pl., March, 1928.

Finger, Charles J.

1. The ice age. Ten cent pocket series no. 327, edited by E. Haldeman-Julius. 63 pp., Girard, Kansas, Haldeman-Julius Company, 1922.

Finlay, James Ralph.

1. The geology and economics of coal : Eng. and Min. Jour., vol. 107, pp. 945950, May 31, 1919.

2. The Permian revolution in North America: Eng. and Min. Jour., vol. 112, no. 27, pp. 1058-1059, December 31, 1921.

3. Report of appraisal of mining properties of New Mexico. 154 pp. [New Mexico, State Tax Commission, 1922].

Finley, F. L.

1. Kamiskotia gold area, District of Cochrane: Ontario Dept. Minès, 34th Ann. Rept., vol. 34, pt. 6, pp. 43-64, illus., map, 1925.

2. Wasapika section, West Shiningtree gold area, District of Sudbury: Ontario Dept. Mines, 35th Ann. Rept., vol. 35, pt. 6, pp. 83-96, 7 figs.. 1927.

Fippin, Elmer 0.

1. More on singing sands: Science, new ser., vol. 51, p. 64, January 16, 1920.

Fischer, Arthur Homer.

1. A summary of mining in the State of Washington: Washington, Univ., Engineering Exper. Șta. Series, Bull. no, 4, 124 pp., map, Noṿember, 1918. 
Fisher, Cassius Asa. 1872-1930.

1. Salt Creek oil field, Wyoming: Mining and Metallurgy, vol. 6, no. 222, pp. 279-284, 5 figs., June, 1925.

2. (and Lloyd, E. Russell). The northern Cordilleran geosyncline and its relation to petroleum accumulation: Am. Assoc. Petroleum Geologists, Bull., vol. 11, no. 1, pp. 19-29, 1 figs., January, 1927.

Fisher, Daniel Jerome.

1. The teaching of crystallography: Jour. Geology, vol. 32, no. 6, pp. 529-542, 5 figs., August-September, 1924.

2. Geology and mineral resources of the Joliet quadrangle: Illinois State Geol. Survey, Bull. no. 51, 160 pp., 47 figs., 6 pls. (incl. maps), 1925.

3. Structure of Herrin (No. 6) coal seam near Duquoin: Illinois State Geol. Survey, Rept. of Investigations no. 5, 34 pp. 15 figs., 2 pls., 1925.

4. Cretaceous rocks of the Book Cliffs in eastern Utah (abstract) : Geol. Soc. America, Bull., vol. 38, no. 1, pp. 134-135, March 30, 1927; Pan-Am. Geologist, vol. 47 , no. 1, p. 78, February, 1927.

5. Notes regarding the coalification process: Jour. Geology, vol. 35, no. 7, pp. 639-646, 3 figs., October-November, 1927.

6. Geology of the Joliet district [Illinois] : Illinois State Acad. Sci., Trans., vol. 20, pp. 30-37, 3 figs., March, 1928.

Fisher, Lloyd W.

1. (and Simons, F. L.). Applications of colloid chemistry to mineralogy; Part I, Preliminary report: Am. Mineralogist, vol. 11, no. 5, pp. 124-130, 4 figs., May, 1926.

2. (and Gedney, Edwin K.). Notes on the mineral localities of Rhode Island; I, Providence County: Am. Mineralogist, vol. 11, no. 12, pp. 334-340, December, 1926.

3. Quartz from Iowa Canyon, Nevada: Am. Mineralogist, vol. 12, no. 5, pp. 225-226, 2 figs., May, 1927.

4. (and Doll, Charles G.). Notes on the mineral localities of Rhode Island; Part II, Remaining counties: Am. Mineralogist, vol. 12, no. 12, pp. 427-436, December, 1927.

Fisher, Norman B.

1. The Quebec asbestos industry: Canadian Min. Jour., vol. 44, no. 33, pp. 649-655, 9 figs., August 17, 1923.

Fiske, L. E.

1. The relation of structure to production in five oil and gas fields of the Kentucky eastern coal field: Am. Assoc. Petroleum Geologists, Bull., vol. 11, no. 5, pp. 477-492, 10 figs., May, 1927.

Fitch, A. A.

1. The origin of the zinc deposits of Franklin Furnace, New Jersey: Min. Mag., vol. 39, no. 2, pp. 82-\$4, 2 figs., August, 1928.

Fitch, William Edward.

1. Mineral waters of the United States and American spas. 799 pp., 37 figs., Philadelphia, Lea \& Febiger, 1927.

Fletcher, A. R.

1. The dynamics of the Mexican Cordillera: Min. Jour., Arizona, vol. 12, no. 6, pp. 7-8, 35, 1 fig., August 15, 1928. 
Flint, George $\mathrm{M}$.

1. Famous mineral localities; Beryl Hill, Grafton, New Hampshire: Am. Mineralogist, vol. 4, no. 3, pp. 21-22, 1 pl., March, 1919.

Flint, Richard Foster.

1. A brief view of Rocky Mountain structure: Jour. Geology, vol. 32, no. 5, pp. 410-431, 9 figs., July-August, 1924.

2. (and Ball, John R.). Revision of the Silurian of southeastern Missouri : Jour. Geology, vol. 34, no. 3, pp. 248-256, April-May, 1926; abstract, Geol. Soc. America, Bull., vol. 37, no. 1, p. 243, March 30, 1926.

3. Thrust faults in southeastern Missouri: Am. Jour. Sci., 5th ser., vol. 12, pp. 37-40, 2 figs., July, 1926.

4. The geology of parts of Perry and Cape Girardeau counties, Missouri (abstract) : Chicago, Univ., Abstracts of Theses, Sci. Ser., vol. 3, pp. 221-224, April, 1927.

5. Pleistocene terraces of lower Connecticut Valley (abstract): Pan-Am. Geologist, vol. 49, no. 2, pp. 147-148, March, 1928; Geol. Soc. America, Bull., vol. 39, no. 1, pp. 216-217, March 30, 1928.

6. Eskers and crevasse fillings: Am. Jour. Sci., 5th ser., vol. 15, pp. 410-416, 3 figs., May, 1928.

7. Natural boundaries in the Interior I.ow Plateau physiographic province: Jour. Geology, vol. 36, no. 5, pp. 451-457, 2 figs., July-August, 1928.

8. Pleistocene terraces of the lower Connecticut Valley: Geol. Soc. America, Bull., vol. 39, no. 4, pp. 955-984, 9 figs., December 30, 1928.

Flores, Teodoro.

1. Estudio geológico-minero de los distritos de El Oro $\mathrm{y}$ Tlalpujahua: México, Inst. geol., Bol. no. 37, 85 pp., 20 pls. (incl. maps), 1920.

2. Informes preliminares de algunas de las zonas mineras situadas al este y oeste del ferrocarril Sud-Pacífico de México en el Estado de Sonora $\mathbf{y}$ de las minas de grafito en el región de Moradillas del mismo estado: Mexico, Departamento de exploraciones y estudios geológicos, Folleto de divulgaciôn, no. 13, 20 pp., map., September, 1925.

3. Estudio geologico de la zona minera comprendida entre los minerales de Atotonilco el Chico y Zimapán, en el Estado de Hidalgo: Mexico, Inst. geol., Bol. 43, 159 pp., 35 pls., 1924 [1926?].

4. Informe preliminar acerca de algunas zonas mineralizadas vecinas á la vía del Sud-Pacífico de México, entre las estaciones Carbó y Santa Ana en el Estado de Sonora: Mexico, Departamento de exploraciones y estudios geológicos, Folleto de divulgación, no. 19, September, 1926.

5. Informe preliminar acerca de la geólogía general y zonas mineralizadas vecinas a la vía del Ferrocarril Sud-Pácífico de México, entre las estaciones Santa Ana $\mathbf{y}$ Nogales, en el Estado de Sonora: Mexico, Inst. geol., Folleto de divulgación, no. 28, 33 pp., August, 1927.

Foerste, August. Frederick. See also Miller, A. M., 1; .Slocom, 1; Ulrich, 6; Twenhofel, 30.

1. Echinodermata of the Brassfield (Silurian) formation of Ohio: Denison Univ., Sci. Lab., Bull., vol. 19, pp. 3-32, 7 pls., 1 fig., April, 1919. 
Foerste, August Frederick-Continued.

2. Silurian fossils from Ohio, with notes on related species from other horizons: Ohio Jour. Sci., vol. 19, no. 7, pp. 367-404, 2 figs., 4 pls., May, 1919.

3. Notes on Isotelus, Acrolichas, Calymene, and Encrinurus: Denison Univ., Sci. Lab., Bull., vol. 19, pp. 65-82, 6 pls., September, 1919.

4. New species of brachiopod [Rhynchotreta williamsi, Manitoulin Island]: Canada, Geol. Survey, Mem. 111, p. 126, 2 figs. on pl. 7, 1919.

5. The generic relations of the American Ordovician Lichadidae: Am. Jour. Sci., 4th ser., vol. 49, pp. 26-50, 2 figs., 4 pls., January, 1920.

6. Presence of upper Silurian sandstone in Essex County, northeastern Massachusetts (abstract) : Geol. Soc. America, Bull., vol. 31, no. 1, pp. 206-207, March 31, 1920.

7. Intercalation of thecal plates in Holocystites in connection with the criteria upon which species can be distinguished (abstract): Geol. Soc. America, Bull., vol. 31, no. 1, pp. 207-208, March 31, 1920.

8. Method of appearance of additional arms on increasing age in Caryocrinites (abstract) : Geol. Soc.' America, Bull., vol. 31, no. 1, pp. 220-221, March 31, 1920.

9. The Kimmswick and Plattin limestones of northeastern Missouri : Denison Univ. Bull., Sci. Lab., Jour., vol. 19, pp. 175-224, 3 pls., May, 1920.

10. Racine and Cedarville cystids and blastoids, with notes on other echinoderms: Ohio Jour. Sci., vol. 21, no. 2, pp. 33-78, 4 figs., 4 pls., December, 1920.

11. Notes on Arctic Ordovician and Silurian cephalopods: Denison Univ. Bull., Scientific Laboratories, Jour., vol. 19, pp. 247-306, 1 flg., 9 pls., September, 1921.

12. Unattached simple Paleozoic corals (abstract) : Geol. Soc. America, Bull., vol. 33, no. 1, p. 201, March 31, 1922.

13. The distribution of the Ottawa Trenton echinoderm faunas: Canadian Field-Naturalist, vol. 36, no. 5, pp. 84-86, May, 1922.

714. Notes on Medinan, Niagaran, and Chester fossils: Denison Univ., Sci. Lab., Jour., vol. 20, pp. 37-120, 13 pls., June, 1923.

15. Upper Ordovician faunas of Ontario and Quebec: Canada, Geol. Survey, Mem. 138, 255 pp., 14 figs., 46 pls., 1924.

16. Silurian cephalopods of northern Michigan: Michigan, Univ., Mus. Geology, Contr., vol. 2, no. 3, pp. 19-120, 2 figs., 17 pls., July 10, 1924.

17. Notes on American Paleozoic cephalopods: Denison Univ., Sci. Lab., Jour., vol. 20, pp. 193-267, 22 pls., December, 1924.

18. Cephalopoda of Lake Timiskaming area and certain related species: Canada, Geol. Survey, Mem. 145, pp. 64-93, 2 figs., 7 pls., 1925.

19. Notes on cephalopod genera ; chiefly coiled Silurian forms : Denison Univ., Sci. Lab., Jour., vol. 21, pp. 1-69, 34 pls., March, 1925.

20. Cephalopoda from the Ordovician and Sillurian of Great Slave Lake: Canada, Geol. Survey, Bull., no. 44, pp. 65-72, 1 pl., 1926.

21. Actinosiphonate, trochoceroid, and other cephalopods: Denison Univ. Bull., vol. 26, no. 6, Sci. Lab. Jour., vol. 21, pp. 285-383, 22 pls., September, 1926.

22. Ordovician and Silurian cephalopods of the Hudson Bay area: Denison Univ. Bull., vol. 27, no. 3, Sci. Lab., Jour., vol. 22, pp. 1-107, I fig., 24 pls., March, 1927.

23. Devonian cephalopods from Alpena in Michigan: Michigan, Univ., Mus. Geology, Contr., vol. 2, no. 9, pp. 189-208, 5 pls., August 3, 1927. 
Foerste, August Frederick-Continued.

24. American Arctic and related cephalopods: Denison Univ. Bull., vol. 28, no. 2, Sci. Lab., Jour., vol. 23, pp. 1-110, 29 pls., January, 1928.

25. Memorial of Charles Joseph Norwood: Geol. Soc. America, Bull., vol. 39, no. 1, pp. 40-47, portr., March 30, 1928.

26. Some hitherto unflgured Ordovician cephalopods from Anticosti Island: Roy. Soc. Canada, Proc. and Trans., 3d ser., vol. 22, sec. 4, pp. 223-234, 11 pls., May, 1928.

27. New Devonian Cephalopoda from Nova Scotia: Canada, Geol. Survey, Bull. no. 49, pp. 9-13, 1 fig., 1928.

28. A restudy of some of the Ordovician and Silurian cephalopods described by Hall: Denison Univ. Bull., vol. 38, no. 8, Sci. Lab., Jour., vol. 23, pp. 173-230, 8 pls., July, 1928.

29. Contributions to the geology of Foxe Land, Baffin Island; Part II, The cephalopods of Putnam Highland: Michigan, Univ., Mus. Paleontology, Contr., vol. 3, no. 3, pp. 25-70, 11 pls., November 10, 1928.

30. A restudy of American orthoconic Silurian cephalopods: Denison Univ. Bull., vol. 28, no. 10, Sci. Lab., Jour., vol. 23, pp. 236-320, 28 pls., December 31, 1928.

Fohs, F. Julius.

1. (and Robinson, Heath M.). Structural study of a part of northeast Texas with some stratigraphic sections (abstract): Geol. Soc. America, Bull., vol. 34, no. 1, pp. 70-71, March 30, 1923.

2. Structural and stratigraphic data of northeast Texas petroleum area: Econ. Geology, vol. 18, no. 8, pp. 709-731, 1 fig., 3 pls. (incl. map); December, 1923.

Foley, Lyndon L.

1. The origin of the faults in Creek and Osage counties, Oklahoma (with discussion by F. H. Lahee, W. T. Thom, jr., W. A. J. M. van der Gracht, W. W. Rubey, and others) : Am. Assoc. Petroleum Geologists, Bull., vol, 10, no. 3, pp. 293-303, 5 figs., March, 1926.

2. Mechanics of the Balcones and Mexia faulting: Am. Assoc. Petroleum Geologists, Bull., vol. 10, no. 12, pp. 1261-1269, 7 figs., December, 1926.

3. Origin of folding in Oklahoma: Am. Assoc. Petroleum Geologists, Bull., vol. 11, no. 6, pp. 639-640, June, 1927.

4. Review of Isostasy by William Bowie: Am. Assoc. Petroleum Geologists, Bull., vol. 12, no. 2, pp. 218-223, 2 figs., February, 1928.

Folger, Anthony. See also Barwick, 1.

1. The Missouri-Iowa field conference: Am. Assoc. Petroleum Geologists, Bull. vol. 12, no. 2, pp. 201-211, February, 1928.

Foran, W. T. See Paige, 5; Smith, P. S., 7.

Forbes, C. R. See McQueen, 1.

Forbes, J. J.

1. Coal losses of Tennessee: Tennessee, Dept. Educ., Div. Geology, Bull. 33-E, 36 pp., 2 figs., 1925.

Ford, William Ebenzer.

1. New mineral names: Am. Jour. Sci., 4th ser., vol. 47 , pp. 446-448, June, 1919 ; vol. 49, pp. 452-453, June, 1920 ; 5th ser., vol. 1, pp. 516-518, June, 1921.

4096-31-14 
Ford, William Ebenzer-Continued.

2. A textbook of mineralogy, with an extended treatise on crystallography and physical mineralogy, by Edward Salisbury Dana. Third edition, revised and enlarged by William E. Ford. 720 pp., 1,050 figs., New York, John Wiley \&.Sons, 1922.

Forrester, Glenn C.

1. Origin of the buried Whirlpool-St. Davids gorge: Am. Jour. Sci., 5th ser., vol. 12, pp. 244-248, 2 figs., September, 1926.

2. The Falls of Niagara. 155 pp., 27 figs., 15 pls., New York, D. Van Nostrand Company, 1928.

Forrester, J. B.

1. A short comment on Bulletin 371 [Richardson, G. B., Reconnaissance of the Book Cliffs coal field (1909)] of the U. S. Geological Survey : Utah Acad. Sci., Trans., vol. 1, pp. 24-31, February, 1918.

2. A general survey of the Jurassic in southeastern Utah: Utah Acad. Sci., Trans., vol. 1, pp. 33-43, February, 1918.

Foshag, William Frederick. See also Hess, 30 ; Larsen, 7, 19.

1. Famous mineral localities; Yuma County, Arizona: Am. Mineralogist, vol. 4, no. 12, pp. 149-150, December, 1919.

2. The chemical composition of hydrotalcite and the hydrotalcite group of minerals: U: S. Nat. Mus., Proc., vol. 58, pp. 147-153, 1920.

3. Some recent accessions to the mineral collections of the United Stater National Museum: U. S. Nat. Mus., Proc., vol. 58, pp. 303-305, 3 pls., 1920.

4. Sulphohalite from Searles Lake, California: Am. Jour. Sci., 4th ser., vol. 49, pp. 76-77, January, 1920.

5. Thaumasite (and spurrite) from Crestmore, California: Am. Mineralogist, vol. 5, no. 4, pp. 80-81, April,.1920.

6. Apthitalite (glaserite) from Searles Lake, California: Am. Jour. Sci., 4th ser., vol. 49, pp. 367-368, May, 1920.

7. Illustration of the hexagonal system; hematite from New Mexico: Am. Mineralogist, vol. 5, no. 8, pp. 149-150, 2 figs., August; 1920.

8. Plazolite, a new mineral [from Riverside, California] : Am. Mineralogist, vol. 5, no. 11, pp. 183-185, November, 1920.

9. The crystallography and chemical composition of creedite: U. S. Nat. Mus., Proc., vol. 59, pp. 419-424, 3 figs., 1921.

10. The origin of the colemanite deposits of California: Econ. Geology, vol. 16, no. 3, pp. 199-214, April-May, 1921.

11. The isomorphic relations of the sulpho-salts of lead and copper: Am. Jour. Sci., 5th ser., vol. 1, pp. 444-446, May, 1921.

12. New minerals: Am. Mineralogist, vol. 6 , no. 8 , p. 132, August, 1921 ; no. 9, pp. 140-141, September, 1921.

13. (and Larsen, E. S.). Eakleite from Isle Royale, Michigan: Am. Minera'ogist, vol. 7, no. 2, pp. 23-24, February, 1922.

14. (and Wherry, E. T.). Notes on the composition of talc: Am. Mineralogist, vol. 7, no. 10, pp. 167-171, October, 1922.

15. Calico Hills, San Bernardino County, California: Am. Mineralogist, vol. 7, no. 12, pp. 208-209, December, 1922.

16. Catapleiite from Magnet Cove, Arkansas: Am. Mineralogist, vol. 8, no. 4, pp. 70-72, April, 1923.

17. Famous mineral localities: Furnace Creek, Death Valley [California]: Am. Mineralogist, vol. 9, no. 1, pp. 8-10, January, 1924. 
Foshag, William Frederick-Continued.

18. Priceite from Furnace Creek, Inyo County, California: Am. Mineralogist, vol. 9, no. 1, pj. 11-13, January, 1924.

19. Centrallasite from Crestmore, California: Am. Mineralogist, vol. 9, no. 4, pp. 88-90, April, 1924.

20. The world's biggest borax deposits [California and Nevada] : Eng. and Min. Jour.-Press, vol. 118, no. 11, pp. 419-421, 6 figs., September 13, 1924.

21. (and Gage, R. B.). Chlorophoenicite, a new mineral from Franklin Furnace, New Jersey; Washington Acad. Sci., Jour., vol. 14, no. 15, pp. 362-363, September 19, 1924.

22. Hedyphane from Franklin Furnace, New Jersey: Am. Mineralogist, vol. 10, no. 10, pp. 351-353, October, 1925.

23. The minerals of Obsidian Cliff, Yellowstone National Park, and their origin: U. S. Nat. Mus., Proc., vol. 68 , art. 17, 18 pp., 5 figs., 5 pls., 1926.

24. Saline lakes of the Mohave Desert region: Econ. Geology, vol. 21, no. 1, pp. 56-64, January-February, 1926.

25. The identity of newtonite with alunite: Am. Mineralogist, yol. 11, no. 2, pp. 33-35, February, 1926.

26. Radiated chrysotille from Franklin Furnace, New Jersey : Am. Mineralogist, vol. 11, no. 2, pp. 38-39, February, 1926.

27. Processes in contact metamorphism (discussion) : Econ. Geology, vol. 21, no. 2, pp. 194-197, March-April, 1926.

28. (and Berman, Harry M., and Gage, Robert B.). The occurrence and properties of chlorophoenicite, a new arsenate from Franklin, New Jersey: U. S. Nat. Mus., Proc., vol. 70, art. 20, 6 pp., 2 figs., 1927.

29. The selenite caves of Naica, Mexico: Am. Mineralogist, vol. 12, no. 6, pp. 252-256, 2 figs., June, 1927.

30. (and Clinton, H. G.). An occurrence of pitticite in Nevada: Am. Mineralogist, vol. 12 , no. 7 , pp. 290-292, July, 1927 .

31. (and Hess, Frank L.). Rossite and metarossite, two new vanadates from Colorado: U. S. Nat. Mus., Proc., vol. 72, no. 11, 12 pp., 2 figs., 1927:

32. Quicksilver deposits of the Pilot Mountains, Mineral County, Nevada: U. S. Geol. Survey, Bull. 795, pp. 113-123, 2 figs., 1 pl. (map), October 27, 1927; Min. Jour. Phoenix, Ariz., vol. 11, no. 22, pp. 5-6, 12-14, 1 fig. (map), April 15, 1928.

33. The minerals of Mexico: Smithsonian Inst., Explorations and Field Work in 1927, pp. 21-26, 6 figs., 1928. (Pub. 2957.)

Foster, E. D. See Riddell, 1.

Foulk, Charles William.

1. Industrial water supplies of Ohio: Ohio, Geol. Survey, 4th ser., Bull. no. 29,406 pp., 1925.

Fowke, Gerard.

1. The genesis of the Ohio River: Indiana Acad. Sci., Proc., vol. 34, pp. 81102, 3 figs., 1925.

2. Note on the preglacial drainage of the Tradewater River, Kentucky: Indiana Acad. Sci., Proc., vol. 35, pp. 109-110, 1 fig., 1926. 
Fox, James P.

1. Geomorphogeny of the Berkeley Hills between the city of Berkeley and San Pablo Bay (abstract) : Geol. Soc. America, Bull., vol. 37, no. 1, p. 211, March 30, 1926.

Fox, Leo S.

1. Some structural features of the east side of the San Joaquin Valley, California : Oil Bull., vol. 14, no. 6, pp. 587-588, 654, June, 1928.

Foye, Wilbur Garland.

1. A report of the geological work within the Rochester, Vermont, quadrangle: Vermont, State Geologist, 11th Rept., pp. 76-98, 1 pl., 5 figs. [1919].

2. A new occurrence of rhodonite: Am. Mineralogist, vol. 4 , no. 10, pp. 124 125, October, 1919 ; [correction] vol. 5, no. 6, p. 120, June, 1920.

3. "Denudation," "elosion," "corrosion," and "corrasion": Science, new ser., vol. 54, p. 130, August 12, 1921.

4. Mineral localities in the vicinity of Middletown, Connecticut: Am. Mineralogist, vol. 7, no. 1, pp. 4-12, 1 fig., January, 1922.

5. Structure of the Connecticut basin during the Newark epoch (abstract with discussion by W. J. Miller, J. B. Woodworth, W. M. Davis, C. E. Gordon, C. R. Longtvell, H. B. Kümmel, W. N. Rice, and L. S. Westgate) : Geol. Soc. America, Bull., vol. 33, no. 1, pp. 87-89, March 31, 1922.

6. Geology of the Guilford, Connecticut, quadrangle (abstract with discussion by B. K. Emerson): Geol. Soc. America, Bull., vol. 33, no. 1, p. 147, March 31, 1922.

7. Origin of the Triassic trough of Connecticut: Jour. Geology, vol. 30, no. 8, pp. 690-699, 7 figs., November-December, 1922.

8. The New England intercollegiate geological excursion: Science, new ser., vol. 58, pp. 344-345, November $2,1923$.

9. Abnormal dips near the eastern boundary fault of the Connecticut Triassic: Science, new ser., vol. 60, p. 240, March 7, 1924.

10. Anterior range of Connecticut (abstract, with discussion by A. C. Lawson ) : Geol. Soc. America, Bull., vol. 35, no. 1, p. 87, March 30, 1924; abstract, Pan-Am. Geologist, vol. 41, no. 2, p. 143, March, 1924.

11. Pillow structure in the Triassic basalts of Connecticut: Geol. Soc. America, Bull., vol. 35, no. 2, pp. 329-346, 12 figs., June 30, 1924.

12. The New England intercollegiate geologic excursion: Science, new ser., vol. 60 , p. 378 , October $24,1924$.

13. Geology and structure of the eastern highland of Connecticut (abstract) : Geol. Soc. America, Bull., vol. 36, no. 1, p. 166, March 30, 1925; Pan-Am. Geologist, vol. 43, no. 2, p. 157, March, 1925.

14. Correlation of the metamorphic rocks of northeastern Connecticut with those of adjacent portions of Massachusetts (abstract): Geol. Soc. America, Bull., vol. 37, no. 1, p. 156, March 30, 1926 ; Pan-Am. Geologist, vol. 45, no. 2, p. 159, March, 1926.

15. The occurrence of thulite at Haddam, Connecticut: Am. Mineralogist, vol. 11, no. 8, pp. 210-213, 3 figs., August, 1926.

16. Fall excursion of the New England intercollegiate geologists: Science, new ser., vol. 64, p. 421, October 29, 1926.

17. The New England intercollegiate geological excursion: Science, new ser., vol. 66, p. 419, November 4 , 1927 .

18. The New England intercollegiate geological excursion: Science, new ser., vol. 68 , pp. $486-487$, November 16, 1928. 
Foyles, Edward J.

1. The geology about Mills Springs, Monticello quadrangle, Kentucky: Am. Mus. Novitates, no. 11, 10 pp., 4 figs., June 17, 1921.

2. Preliminary report on the Ordovician formations of Vermont: Vermont, State Geologist, Thirteenth Rept., 1921-1922, pp. 71-86, 3 figs., 4 pls., 1923.

The geology of Shoreham, Bridport, and Fort Cassin, Vermont: Vermont, State Geologist, Fourteenth Rept.; 1923-1924, pp. 204-217, 3 pls., 1924.

4. The stratigraphy of the townships of Addison, Panton, and southwestern Ferrisburg, Vermont: Vermont, State Geologist, 15th Rept., 1925-26, pp. 111-120, 1 pl. (map), 1927.

-5. Locality list of Vermont invertebrate fossils: Vermont, State Geologist, 15th Rept., 1925-26, pp. 163-190, 1927.

Fralich, Charles D. See Torrey, 1.

Frame, James.

1. Further notes on the gold deposits of the southern Appalachians: Eng. and Min. Jour., vol. 111, no. 1, p. 4, January 1 ,1921.

Frankenfield, John S. See Hawkins, 8.

Franks, Arthur J.

1. (and Goodier, B. D.). Preliminary study of the organic matter of Colorado oil shales: Colorado School of Mines, Quart., vol. 17, no. 4, Supplement A, 16 pp., October, 1922.

Fraser, F. J.

1. A simple apparatus for heavy mineral separation: Econ. Geology, vol. 23, no. 1, pp. 99-100, January, 1928.

2. Eastend area, Cypress Hills, Saskatchewan; petrography of the sediments, mechanical analysis: Canada, Geol. Survey, Summ. Rept., 1927, pt. B, pp. 44-53, 1928.

Fraser, H. J.

1. Experimental studies in the formation of varves (abstract): Roy. Soc. Canadla, Proc. and Trans., 3d ser., vol. 21, p. xciii, 1927.

Fréchette, Howells.

1. Iron oxide pigments in Ontario: Canada, Mines Branch, Summ: Rept., 1921, pp. 9-12, 1923.

2. Mineral pigments: Canada, Mines Branch, Summ. Rept., 1922, pp. 7-9, 1924.

Freeman, Horace.

1. The genesis of sulphide ores: Eng. and Min. Jour.-Press, vol. 120, no. 25, pp. 973-975, December 19, 1925; Bol. minero, t. 21, no. 1, pp. 8-12, January, 1926.

2. Genesis of sulphide ores: Eng. and Min. Jour.-Press, vol. 121, no. 14, pp. 571-572, April 3, 1926.

3. Genesis of sulphide ores: Eng. and Min. Jour., vol. 122, no. 9, pp. 340341, August 28, 1926.

Freeman, John R.

1. Tilting of the earth in the Great Lakes region, pp. 149-171B in his Regulation of the Great Lakes ... ; a report to the Chicago Sanitary District, 1926. 


\section{Freeman, Lawrence.}

1. Features common to the Appalachian zinc deposits (abstract): Ohio Acad. Sci., Proc., vol. 8 , pt. 4, p. 176, 1928; Ohio Jour. Sci., vol. 28 , no. 3 , p. 154, May, 1928.

Freeman, Otis W.

1. Geography and geology of Fergus County [Montana]. Fergus County High School Bulletin 2, 71 pp., illus., Lewistown, Montana, 1919.

2. Oil in the Quadrant formation in Montana: Eng. and Min. Jour.-Press, vol. 113, no. 19, pp. 825-827, May 13, 1922.

3. New occurrence of the Belt terrane in Montana: Science, new ser., vol. 57, p. 418, April 6, 1923.

4. The origin of Swimming Woman Canyon, Big Snowy Mountains, Montana, an example of a pseudo-cirque formed by landslide sapping: Jour. Geology, vol. 33, no. 1, pp. 75-79, 2 figs., JanuaryFebruary, 1925.

5. Scabland mounds of eastern Washington: Science, new ser., vol, 64, pp. 450-451, November 5, 1926.

6. Mammoth found in loess of Washington: Science, new ser., vol. 64, p. 477, November 12, 1926.

Fretz, $\Lambda$. Henry.

1. Memorial of F. B. Peck: Am. Mineralogist, vol. 11, no. 3, pp. 55-56, March, 1926.

Freudenberg, Wilhelm.

1. Geologie von Mexiko; dargestellt nach der Literatur und nach eigenen Forschungen. 232 pp., 28 figs., 2 pls., Berlin, Gebrüder Borntraeger, 1921.

2. Die Säugetierfauna des Pliocäns und Postpliocäns von Mexiko; II Teil, Mastodonten und Elefanten: Geologische und Palaeontologische Abhandlungen (Pompeckj und Von Huene), Bd. 18 (N. F., Bd. 14), H. 3, 76 pp., 28 figs., 9 pls., Jena, 1922.

Frick, Childs.

1. Extinct vertebrate faunas of the badlands of Bautista Creek and San Timoteo Cañon, southern California: California, Univ., Dept. Geology, Bull., vol. 12, no. 5, pp. 277-424, 165 figs., 8 pls., December 28, 1921.

2. Prehistoric evidence: Natural History (Am. Mus. Nat. Hist., Jour.), vol. 26, no. 5, pp. 440-448, 3 figs., September-October, 1926.

Friedlaender, Immanuel.

1. Vulkanische Nachrichten über den Ausbruch in San Salvador: Zeitschr. Vulkanologie, Bd. 4, H. 4, p. 308, 1 pl., Derember, 1918.

2. Notizen über die Bogosloff-Inseln: Zeitschr. Vulkanologie, Bd. 5, H. 1, pp. 51-55, 1 fig., June, 1919.

3. Vulkanische Ereignisse in Mexiko; Erdbeben und Ausbruch (?) am Orizaba: Zeitschr. Vulkanologie, Bd. 6, H. 2, pp. 80-85, 1 fig., June, 1921.

4. Vulkanische Ereignisse in Mexiko; Ausbruch des Popocatepetl: Zeitschr. Vulkanologie, Bd. 6, H. 2, pp. 85-88, 2 pls., June, 1921.

5. La erupción del Popocateptl [México] : Soc. cient. "Antonio Alzate," Mem. y Rev., t. 40, nos. 2-6, 3 pls., 1922.

6. Die Insel Kaula in der Hawaii Gruppe: Zeitschr. Vulkanologie, Bd. 7, H. 2, pp. 107-108, 1 fig., 2 pls., July, 1923. 
Friedlaender, Immanuel-Continued.

7. (and Sonder, Richard A.). Ueber das Vulkangebiet von San Martin Tuxtla in Mexiko: Zeitschr. Vulkanologie, Bd. 7, H. 3, pp. 162187, 3 figs., 8 pls. (incl. map), November, 1923.

8. Bemerkungen zu den Abbildungen vom Kilauea-Ausbruch im Mai, 1924: Zeitschr. Vulkanologie, Bd. 10, H. 1, p. 47, 2 pls., September, 1926.

9. Ausbruch des Mauna Loa, Hawaii, im April, 1926: Zeitschr. Vulkanologie, Bd. 10, H. 1, pp. 48-49, 1 fig., September, 1926.

Fritel, P. H.

1. Note sur les aralias des flores crétaciques de l'Amérique du Nord et du Groenland: Soc. géol. France, Bull., $4^{\mathrm{e}}$ sér., t. 14, pp. 1-22, 13 figs., 1914.

Fritz, Madeleine. See also Parks, 9.

1. The stratigraphy and paleontology of Toronto and vicinity, Part IV; Hydrozoa, Echinodermata, Trilobita, markings: Ontario Dept. Mines, 32d Ann. Rept., vol. 32, pt. 7, pp. 1-34, 5 figs., 3 pis., 1925.

2. The stratigraphy and paleontology of the Workman's Creek section of the Cincinnatian series of Ontario: Roy. Soc. Canada, Proc. and Trans., 3d ser., vol. 20, sec. 4, pp. 77-107, 1 fig., 1 table, 4 pls., 1926.

Frost, Frederick H.

1. Statistical identification; $I$, as applied to Parapavo: California, Univ., Dept. Geol: Sci., Bull., vol. 17, no. 1, pp. 57-62, September 30, 1927.

2. The Pleistocene flora of Rancho La Brea: California, Univ., Pub. in Botany, vol. 14, no. 3, pp. 73-98, 5 pls., November 30, 1927.

Fryxell, F. M. See also Romer, 14.

1. The physiography of the region of Chicago. 55 pp., 17 figs. (incl. maps), 5 pls. (maps), University of Chicago Press, Chicago, Illinois, April, 1927.

Fuller, Margaret Bradley.

1. The physiographic development of the Big Thompson River Valley in Colorado: Jour. Geology, vol. 31, no. 2, pp. 126-137, 7 figs., FebruaryMarch, 1923.

2. General features of pre-Cambrian structure along the Big Thompson River in Colorado: Jour. Geology, vol. 32, no. 1, pp. 49-63, 11 figs., January-February, 1924.

3. An occurrence of witherite in the Altyn limestone at Many Glacier, Montana : Am. Mineralogist, vol. 9, no. 7, p. 154, July, 1924.

4. Early Quaternic drainage diversions around Mount. Olympus, Colorado: Pan-Am. Geologist, vol. 43, no. 1, pp. 51-54, 2 figs., February, 1925.

5. The bearing of some remarkable potholes on the early Pleistocene glaciation of the Front Range, Colorado: Jour. Geology, vol. 33, no. 3, pp. 224-235, 11 figs., April-May, 1925.

6. Contact metamorphism in the Big Thompson schist of north central Colorado: Am. Jour. Sci., 5th ser., vol. 11, pp. 194-200, 1 fig., March, 1926.

7. Pre-Cambrian sedimentation in northern Colorado (abstract) : Geol. Soc. America, Bull., vol. 37, no. 1, p. 161, March 30, 1926 ; Pan-Am. Geologist, vol. 45, no. 2, pp. 161-162, March, 1926.

8. The geology of the Big Thompson River Valley in Colorado from the Continental Divide to the foothills area (abstract): Chicago, Univ., Abstracts of Theses, Sci. Ser., vol. 2, pp. 217-222, September, 1926. 
Fuller, Margaret Bradley-Continued.

9. Stratigraphic boundaries in Glacier National Park, Montana (abstract) : Geol. Soc. America, Bull., vol. 38, no. 1, p. 153, March, 1927 ; PanAm. Geologist, vol. 47, no. 2, p. 154, March, 1927.

10. Multiple-level cirques: Illinois State Acad. Sci., Trans., vol. 20, pp. 297303, 6 figs., 2 pls., March, 1928.

Fuller, Myron Leslie.

1. (and others). Water problems of the Bend series [Texas]; general discussion: Am. Assoc. Petroleum Geologists, Bull., vol. 3, pp. 151$162,1919$.

2. Quick method of reconnaissance mapping: Econ. Geology, vol. 14, no. 5, pp. 411-423, August, 1919.

3. Relation of oil to carbon ratios of Pennsylvanian coals in north Texas: Econ. Geology, vol. 14, no. 7, pp. 536-542, 1 fig., November, 1919.

4. Carbon ratios in Carboniferous coals of Oklahoma, and their relation to petroleum : Econ. Geology, vol. 15, no. 3, pp. 225-235, 1 fig., AprilMay, 1920.

Fuller, Richard E. See also Peacock, 1.

1. The mode of origin of the color of certain varicolored obsidians [southcentral Oregon]: Jour. Geology, vol. 35, no. 6, pp. 570-573, 4 figs., August-September, 1927.

2. The closing phase of a fissure eruption: Am. Jour. Sci., 5th ser., vol. 14, pp. 228-230, 2 figs., September, 1927.

3. The Asotin craters of the Columbia River basalt: Jour. Geology, vol. 36, no. 1, pp. 56-74, 7 flgs., January-February, 1928.

Funkhouser, William Delbert.

1. (and Webb, W. S.). Ancient life in Kentucky: Kentucky Geol. Survey, ser. 6, vol. 34, 349 pp., 176 illus., 1928.

Furcron, A. S.

1. An unusual oolite near Hayfield, Frederick County, Virginia (abstract) : Iowa Acad. Sci., Proc., 1925, vol. 32, p. 360 [1926].

Furlong, Eustace Leopold. See also Stock, 9, 16, 19, 21, 22.

1. Notes on the occurrence of mammalian remains in the Pleistocene of Mexico, with a description of a new species, Capromeryx mexicana: California, Univ., Dept. Geol. Sci., Bull., vol. 15, no. 5, pp. 137152, 11 figs., 1925.

2. The occurrence and phylogenetic status of Merycodus from the Mohave Desert Tertiary : California, Univ., Dept. Geol. Sci., Bull., vol. 17, no. 4, pp. 145-186, 28 figs., 5 pls., Norember 22, 1927.

G.

1. James Furman Kemp: Canadian Min. and Met. Bull., no. 177, pp. 22-25, portr., January, 1927.

Gaby, Walter E.

1. The Yerington district, Nevada : Min. and Sci. Press, vol. 118, pp. 625-626, May 10, 1919.

2. Combination dip chart and protractor: Min. and Sci. Press, vol. 123, no. 6, p. 201, 2 figs., August 6, 1921.

3. A slide-rule dip chart: Mining and Metallurgy, no. 189, pp. 48-50, 2 figs., September, 1922. 
Gaertner, H. R. v.

1. (and Machatschki, Felix). Der Thomsonit aus dem Basalt von Disko, Grönland : Centralbl. Mineralogie, Abt. A, no. 11, pp. 365-366, 1927.

Gage, Robert B. See also Foshag, 21, 28.

1. (and Larsen, Esper S., and Vassar, Helen E.). Schallerite, a new arsenosilicate mineral from Franklin Furnace, New Jersey: Am. Mineralogist, vol. 10, no. 1, pp. '9-11, January, 1925.

Gale, Hoyt R.

1. Summary of west coast subgenus Trophoscycon (abstract) : Pan-Am. Geologist, vol. 49, no. 4, pp. 315-316, May, 1928.

Gale, Hoyt Stoddard.

1. (and Hicks, W. B.). Potash in 1917: U. S. Geol. Survey, Mineral Resources, 1917, pt. 2, pp. 397-481, 1 fig., March 13, 1919.

2. Saltpeter in Guatemala : Eng. and Min. Jour., vol. 107, pp. 1025-1031, 6 figs., June 14, 1919.

3. The Callville Wash colemanite depost [Clark County, Nevada] : Eng. and Min. Jour., vol. 112, no. 14, pp. 524-530, 5 figs., October 1, 1921.

4. Priceite, the borate mineral in Curry County, Oregon: Min. and Sci. Press, vol. 123, no. 26, pp. 895-898, 2 figs., December 24, 1921.

5. Borate deposits near Kramer, California: Am. Inst. Min. and Met. Eng., Trans. [preprint], no. 1553, 15 pp., 1 fig., February, 1926; vol. 73, pp. 449-463, 1 fig., 1926; abstract, Mining and Metallurgy, vol. 7, no. 233, p. 227, May, 1926.

6. A new borate mineral [kernite, California] : Eng. and Min. Jour., vol. 123, no. 1, p. 10, January 1, 1927.

Gale, Henry G. See Michelson, 1.

Galloway, Jesse James. See Ashley, 16; Ulrich, 6.

1. Geology and natural resources of Rutherford County, Tennessee: Tennessee State Geol. Survey, Bull. 22, 81 pp., pls., map, 1919.

2. The rounding of grains of sand by solution: Am. Jour. Sci., 4th ser., vol. 47, pp. 270-280, 5 figs., April, 1919.

3. Value of the physical characters of sand grains in the interpretation of the origin of sandstones (abstract): Geol. Soc. America, Bull., vol. 33, no. 1, pp. 104-105, March 31, 1922.

4. Red limestones and their geologic significance (abstract with discussion by I. C. White, G. H. Chadwick, T. W. Stanton, and R. S. Bassler) : Geol. Soc. America, Bull., vol. 33, no. 1, pp. 105-107, March 31, 1922.

5. Nature of Taonurus and its use in estimating geologic time (abstract): Geol. Soc. America, Bull., vol. 33, no. 1, p. 199, March 31, 1922.

6. Revision of the classification and nomenclature of Foraminifera (abstract) : Geol. Soc. America, Bull., vol. 37, no. 1, pp. 235-236, March 30, 1926.

7. Methods of correlation by means of Foraminifera: Am. Assoc. Petroleum Geologists, Bull., vol. 10, no. 6, pp. 562-567, June, 1926.

8. (and Wissler, Stanley G.). Pleistocene Foraminifera from the Lomita quarry, Palos Verdes Hills, California: Jour. Paleontology, vol., no. 1, pp. 35-87, 6 pls., July, 1927; correction of names, no. 3, p. 193, December, 1927.

9. Notes on the genus Polylepidina and a new species: Jour. Paleontology, vol. 1, no. 4, pp. 299-303, 3 figs., 1 pl., January, 1928. 


\section{Galloway, Jesse James-Continued.}

10. A revision of the family Orbitoididae: Jour. Paleontology, vol. 2, no. 1, pp. 45-69, 4 figs., March, 1928 .

11. Structure and phylogeny of orbitoid Foraminifera (abstract) : Pan-Am. Geologist, vol. 49, no. 3, pp. 230-231, April, 1928; Geol. Soc. America, Bull., vol. 39, no. 1, pp. 296, March 30, 1928.

12. The change in ideas about Foraminifera: Jour. Paleontology, vol. 2, no. 3, pp. 216-228, September, 1928.

13. (and Harlton, Bruce H.). Some Pennsylvania Foraminifera of Oklahoma, with special reference to the genus Orobias: Jour. Paleontology, vol. 2, no. 4, pp. 338-357, 2 pls., December, 1928.

Galloway, John D.

1. Annual report of the minister of mines [of British Columbia] for the year ended 31st December, $1924 \ldots 388$ pp., figs., pls., maps, Victoria, B. C., 1925.

2. Notes on the Cariboo district of British Columbia: Canadian Inst. Min. and Met., Bull. no. 160, pp. 812-823, 3 figs., August, 1925; Trans., vol. 28 , pp. 401-413, 4 figs. [1926].

3. Annual report of the minister of mines [of British Columbia] for the year ended 31st. December, 1925 . . 466 pp., figs., pls., maps, Victoria, B. C., 1926.

4. Annual report of the minister of mines [of British Columbia] for the year ended 31st December, 1926 . . 468. pp., figs., pls., maps, Victoria. B. C., 1927.

5. Annual report of the minister of mines [of British Columbia] for the year ended 31st December, 1927 . . 501 pp., figs., pls., maps, Victoria, B. C., 1928.

Galpin, Sidney Longman.

1. The Rockford geodes (abstract): Iowa Acad. Sci., Proc. 1922, vol. 29, pp. 128-129 [1924?].

2. The geology of the more refractory clays and shales of Iowa: Iowa Geol. Survey, vol. 31, pp. 53-89, 7 figs., 2 pls., [1926?].

Gálvez, Vicente.

1. Apuntes sobre el mineral de Puerto de Nieto, Estado de Guanajuato: Mexico, Inst. geol., Anales, no. 6, pp. 1-9, 1 pl. (map), 1919.

2. Exploración en la Península de Baja California por la Comisión Exploradora del Pacífico: Mexico, Inst. geol., Bol. no. 39, 108 pp., 67 pls., 1922.

3. Informe preliminar acerca de las aguas subterráneas de la parte del Valle de San Luis Potosí comprendida entre la ciudad de este mismo nombre y Jarral de Berrio: Mexico, Departamento de exploraciones $\mathrm{y}$ estudios geológicos, Folleto de divulgación, no. 12, pp. 3-20, map, August, 1925.

4. Informe preliminar acerca de la hidrología subterránea de la cuenca entre San Luis Potosí y Alaquines, Estado de San Luis Potosí: Mexico, Departamento de exploraciones y estudios geológicos, Folleto de divulgación, no. 17, pp. 3-19, June, 1926.

5. (and Hernández, Apolinar). Informe preliminar sobre la hidrología subterránea de la cuenca entre Pendencia y Ranchito, Estado de San Luis Potosí: Mexico, Departamento de exploraciones y estudios geológicos, Folleto de divulgacion, no. 17, pp. 31-42, June, 1926. 
Gálvez, Vicente-Continued.

6. Los pueblos de Villa de Ålvarez, Coquimatlán, Ixtlahuacán, Tecomán y Minatitlán, del Estado de Colima, considerados en sus recursos en aguas subterráneas: Mexico, Inst. geol., Anales, t. 2, no. 4, pp. 91-127, 45 figs., 1926.

7. Algunas exploraciones en el distrito sur de la Peninsula de Baja Cali: fornia: Mexico, Inst. geol., Anales t. 2, nos. 6-10, pp. 157-194, 25 pls., map, 1927.

8. Apuntes sobre algunos recursos de agua de la Colonia Lourdes en las proximidades de Saltillo, Estado de Coahuila : Mexico, Inst. geol., Anales, t. 2, nos. 6-10, pp. 198-201, 1927.

Gannett, R. W.

1. Experiments relating to the enrichment of tungsten ores: Econ. Geology, vol. 14, no. 1, pp. 68-78, January-February, 1919.

Garbrecht, Louis.

1. New mining fields in eastern Nicaragua: Eng. and Min. Jour., vol. 109, pp. 791-797, 5 figs., April 3, 1920.

García, José Aurelio. See also Paredes, 3.

1. Monografía del grafito: Bol. minero, t. 21, no. 2, pp. 64-75, 1 pl. February, 1926.

2. Monografía del estaño: Bol. minero, t. 22 , no. 1 , pp. 6-29, 1 pl. (map), July, 1926.

Gardescu, Ionel I. See also Ruedemann, P., 1.

1. (and Johnson, R. H.). The effect of stratigraphic variation on folding: Am. Assoc. Petroleum Geologists, Bull., vol. 5, no. 4, pp. 481-483, $1 \mathrm{pl}$., July-August, 1921.

Gardner, E. D. See Lausen, 3.

Gardner, H. F.

1. The calcite cave in the New York State Museum: Am. Mineralogist, vol. 5, no. 1, pp. 3-5, January, 1920.

Gardner, James Henry.

1. Rock distortion on local structures in the oil fields of Oklahoma (with discussion) : Am. Assoc. Petroleum Geologists, Bull., vol. 6, no. 3, pp. 228-243, 7 figs., May-June, 1922.

2. Volcanic ash in North Canadian Valley, Oklahoma: Am. Assoc. Petroleum Geologists, Bull., vol. 7, no. 5, pp. 576-578, September-October, 1923.

3. Some factors influencing Kentucky as an oil State (abstract) : Kentucky Acad. Sci., Trans., vol. 1, pp. 48-50, 1924.

4. Map of the geology of the Hartford quadrangle, Ohio, Butler, and Muhlenberg counties, Kentucky, by James H. Gardner: Kentucky Geol. Survey, Ser. 6, 1925 . Scale, $1: 62,500$.

5. The Elm Lick coal bed [Ohio County]: Kentucky Geol. Survey, Ser. 6, vol. 26, pp. 129-154, 1927.

6. "Samplograph" recommended for subsurface correlation: Oil Weekly, vol. 46, no. 2, p. 34, July 1, 1927.

7. The samplograph : Am. Assoc. Petroleum Geologists, Bull., vol. 11, no. 8, pp. 867-868, August, 1927. 
Gardner, Julia Anna. See also Cooke, C. W., 6.

1. (and Aldrich, T. H.). Mollusca from the upper Miocene of South Carolina with descriptions of new species: Acad. Nat. Sci. Philadelphia, Proc., vol. 71, pt. 1, pp. 17-53, 4 pls., 1919.

2. New species of Mollusca from the Eocene deposits of southwestern Texas: U. S. Geol. Survey, Prof. Paper 131, pp. 109-115, 5 pls., February 12, 1923.

3. Fossiliferous marine Wilcox in Texas: Am. Jour. Sci., 5th ser., vol. 7 , pp. 141-145, February, 1924.

4. Coastal Plain and European Miocene and Pliocene mollusks: Geol. Soc. America, Bull., vol. 35, no. 4, pp. 857-866, December 30, 1924 ; abstract, no. 1, p. 175, March 30, 1924.

5. The detection of the Chipola fauna in the Marks Head marl: Washington Acad. Sci., Jour., vol. 15, no. 12, pp. 264-268, June 19, 1925.

6. A new Midway brachiopod, Butler salt dome, Texas: Am. Jour. Sci., 5th ser., vol. 10, pp. 134-138, 1 pl., August, 1925.

7. The molluscan fauna of the Alum Bluff group of Florida: U. S. Geol. Survey, Prof. Paper 142, pp. 1-184, 28 pls., 1926; pp. 185-249, $8 \mathrm{pls.}$, June 5, 1928.

8. The nomenclature of the superspecific groups of Corbula in the lower Miocene of Florida: Nautilus, vol. 40, no. 2, pp. 41-47, October, 1926.

9. On Scott's new correlation of the Texas Midway: Am. Jour. Sci., 5th ser., vol. 12 , pp. 452-455, November, 1926.

10. The restoration of Ostrea multilirata Conrad 1857: Washington Acad. Sci., Jour., vol. 16, no. 19, pp. 513-514, November 18, 1926.

11. New species of mollusks from the Eocene of Texas: Washington Acad. Sci., Jour., vol. 17, no. 14, pp. 362-383, 4 pls., August 19, 1927.

12. The correlation of the marine Yegua of the type sections [Texas] : Jour. Paleontology, vol. 1, no. 3, pp. 245-251, December, 1927.

13. Tertiary formations of Texas (abstract) : Pan-Am. Geologist, vol. 49, no. 4, pp. 295-296; May, 1928; Geol. Soc. America, Bull., vol. 39, no. 1, p. 277, March 30, 1928.

14. A new gastropod [Turritella pilsbryi] from the Miocene of Virginia: Washington Acad. Sci., Jour., vol. 18, no. 20, pp. 561-563, 1 fig., December. 4, 1928.

Gardner, Nathaniel Lyon.

1. Two new fossil algae from the Miocene: Acad. Nat. Sci. Philadelphia, Proc., vol. 75, pp. 361-363, 1 fig., 1 pl., 1924.

Garfias, Valentin Richard. See also Orđōñez, 2.

1. Petroleum resources of the world. 243 pp., maps, New York, John Wiley \& Sons, 1923.

Garnett, T. H. See Boericke, 1.

Garrett, Dan L.

1. Stratigraphy and structure of northeastern New Mexico: Am. Assoc. Petroleum Geologists, Bull., vol. 4, no. 1, pp. 73-82, 2 figs., 1920.

Garrison, R. H. See Vickery, 7.

Gauthier, Henri.

1. Road material surveys in the city and district of Montreal, Quebec: Canada, Geol. Survey, Mem. 114, 52 pp., 4 pls., 1 fig., 1 map, 1919. 
Gavin, Martin Joseph.

1. Oil shale, an historical, technical, and economic study: U. S. Bur. Mines, Bull. 210, 201 pp., 4 figs., 18 pls., Denver, 1922.

Gaylord, Earl Graham. See also Hanna, 12.

1. (and Taff, J. A.). Geological organization of an oil company: Am. Assoc. Petroleum Geologists, Bull., vol. 8, no. 5, pp. 651-661, SeptemberOctober, 1924.

2. (and Hanna, G. D.). Correlation of organic shales in the southern end of the San Joaquin Valley, California: Am. Assoc. Petroleum Geologists, Bull., vol. 9, no. 2, pp. 228-234, 2 pls., March-April, 1925.

Gedney, Edwin K. See Brown, C. W., 3 ; Fisher, L. W., 2.

Geijer, Per.

1. Replacement and folding: Econ. Geology, vol. 19, no. 3, pp. 281-285, AprilMay, 1924.

2. Processes in contact metamorphism : Econ. Geology, vol. 20, no. 7, pp. 689 690, November, 1925.

3. The publishing of geological information : Econ. Geology, vol. 21, no. 6, pp. 605-609, September, 1926.

4. James Furman Kemp : Geol. Fören. Stockholm, Förh., Bd. 48, H. 4, p. 593, November-December, 1926.

5. Facts and theory in mining geology: Econ. Geology, vol. 22, no. 3, pp. 300-303, May, 1927.

6. A fault surface (editorial) : Econ. Geology, vol. 23, no. 7, pp. 804-805, November, 1928.

Geis, W. H.

1. The origin of light oils in the Rocky Mountain region (with discussion) :

Am. Assoc. Petroleum Geologists, Bull., vol. 7, no. 5, pp. 488-506, 1 fig., September-October, 1923.

Gentry, Bruce.

1. The Texas lignite industry: Coal Age, vol. 16, pp. 59-60, 1 fig. (map), July 10, 1919.

George, Harold Coulter.

1. The Alaska oil fields: Eng. and Min. Jour.-Press, vol. 114, no. 27, pp. 1163-1167, 4 figs., December 30, 1922.

2. (and Bunn, John R.). Petroleum engineering in the Fox and Graham oil and gas fields, Carter County, Oklahoma: 81 pp., 4 figs., U. S., Bur. Mines, in cooperation with Office of Indian Affairs, The State of Oklahoma, and Ardmore Chamber of Commerce, 1924. [Mimeographed.]

3. Some stalactitic forms of marcasite [lead and zinc district, Wisconsin and Illinois] : Oklahoma Acad. Sci., Proc., vol. 5, 1925 (Oklahoma, Univ., Bull., new ser., no. 330, Univ. Studies no. 22), pp. 125-127, 1 fig., April 1, 1926.

4. Some features of ore bodies formed in synclines by meteoric waters: Oklahoma Acad. Sci., Proc., vol. 6, pt. 2, 1926 (Oklahoma, Univ.. Bull., new ser. no. 348), pp. 279-285, 2 figs., January 1, 1927.

5. (and Cloud, W. F.). Oil sands and production relations: Oklahoma Geol. Survey, Bull. no. 43, 142 pp., 19 figs., August, 1927. 
George, P. W.

1. Experiments with Eötrös torsion balance in the Tri-State zinc and lead district: Am. Inst. Min. and Met. Eng., Tech. Pub. no. 65, 9 pp., 6 figs., February, 1928.

George, Russell D. See also Stone, 11.

1. (and others). Mineral waters of Colorado: Colorado Geol. Survey, Bull. 11, 474, pp., 40 figs., 2 pls., 1920.

2. Oil shales of Colorado: Colorado Geol. Survey, Bull. 25, 78 pp., 10 figs., 2 maps, 1921.

3. Notes on the geology of the line of the proposed Moffat tunnel: Colorado Geol. Survey, 11 pp., July, 1922.

4. Memorial of Richard Charles Hills: Geol. Soc. America, Bull, vol. 35, no. 1, pp. 43-46, portr., March 30, 1924.

5. Origin of oil shales; geology and distribution of oil shales. In McKee, Ralph H., Shale oil, pp. 27-36, 37-43, 60-73, 2 figs., New York, 1925.

6. Geology and natural resources of Colorado. 228 pp., figs., pls, maps, published by the University of Colorado, Boulder, Colorado, 1927. .

7. Geological outlook for Colorado ores: Pan-Am. Geologist, vol. 49, no. 2, pp. 111-116, March, 1928.

George, William 0.

1. The relation of the physical properties of natural glasses to their chemical composition: Jour. Geology, vol. 32, no. 5, pp. 353-372, 5 figs., July-August, 1924.

Gerrie, William. See also Walker, 55.

1. Molydenite in Lacorne and Malartic townships, Quebec: Toronto, Univ., Studies, Geol. ser. no. 24, pp. 37-40, 1927.

Gerry, C. N.

1. Gold, silver, copper, lead, and zine in Idaho and Washington in 1917 : U. S. Geological Survey, Mineral Resources, 1917, pt. 1, pp. 457-507, April 3, 1919.

2. Gold, silver, copper, lead, and zinc in Montana in 1918: U. S. Geol. Survey, Mineral Resources, 1918, pt. 1, pp. 265-302, February 26, 1920.

3. Gold, silver, copper, lead, and zinc in Idaho and Washington in 1918: U. S. Geol. Survey, Mineral Resources, 1918, pt. 1, pp. 461-511, February 27, 1920.

4. Gold, silver, copper, lead, and zine in Montana in 1920: U. S. Geol. Survey, Mineral Resources, 1920, pt. 1, pp. 195-219, December 17, 1921.

5. Gold, silver, copper, lead, and zinc in Idaho in 1920: U. S. Geol. Survey, Mineral Resources, 1920, pt. 1, pp. 239-259, December 27, 1921.

6. Gold, silver, copper, lead, and zinc in Washington in 1920: U. S. Geol. Survey, Mineral Resources, 1920, pt. 1, pp. 261-269, December 27, 1921.

7. Gold, silver, copper, lead, and zinc in Montana in 1921; mines report: U. S. Geol. Survey, Mineral Resources, 1921, pt. 1, pp. 283-309, November 17, 1922.

8. Gold, silver, copper, lead, and zinc in Idaho (mines report) : U. S. Geol. Survey, Mineral Resources, 1921, pt. 1, pp. 399-420, February 12, 1923.

9. Gold, silver, copper, lead, and zinc in Washington (mines report) : U. S. Geol. Survey, Mineral Resources, 1921, pt. 1, pp. 421-428, February 12, 1923. 
Gerry, C. N.-Continued.

10. Gold, silver, copper, lead, and zinc in Idaho in 1922 (mines report) : U. S. Geol. Survey, Mineral Resources, 1922, pt. 1, pp. 217-244, December 18, 1923.

11. Gold, silver, copper, lead, and zinc in Washington in 1922 (mines report) : U. S. Geol. Survey, Mineral Resources, 1922, pt. 1, pp. 245-256, December 18, 1923.

12. Gold, silver, copper, lead, and zinc in Montana in 1922 (mines report) :

U. S. Geol. Survey, Mineral Resources, 1922, pt. 1, pp. 453-488, March 12, 1924.

13. Gold, silver, copper, lead, and zinc in Idaho (mine report): U. S. Geol. Survey, Mineral Resources, 1923, pt. 1, pp. 375-404, February 12, 1925.

14. Gold, silver, copper, lead, and zinc in Washington (mine report) : U. S. Geol. Survey, Mineral Resources, 1923, pt. 1, pp. 405-416, February $12,1925$.

15. Gold, silver, copper, lead, and zinc in Montana in 1923 (mine report) :

U. S. Geol. Survey, Mineral Resources, 1923, pt. 1; pp. 447-479, March 18, 1925.

Gester, G. C.

1. Olsservations relating to the origin and accumulation of oil in California : Am. Assoc. Petroleum Geologists, Bull., vol. 10, no. 9, pp. 892-900, September, 1926.

2. Origin and accumulation of oil in California (abstract) : Geol. Soc. America, Bull., vol. 38, no. 1, pp. 200-202, March 30, 1927.

Gester, S. H.

1. Huntington Beach oil field, Orange County, California: Am. Assoc. Petroleum Geologists, Bull., vol. 8, no. 1, pp. 41-46, 2 figs., JanuaryFebruary, 1924.

Gianella, Vincent $\mathbf{P}$.

1. Minerals of Sespe formation, California, and their bearing on its origin: Am. Assoc. Petroleum Geologists, Bull., vol. 12, no. 7, pp. 747752, July, 1928.

Gibson, R. E. See Adams, L. H., 8.

Gibson, Russell. ' See Crawford, R. D., 3.

Gibson, Thomas $\mathrm{W}$.

1. Statistical review of the mineral industry of Ontario for 1918. Ontario Bur. Mines, 28th Ann. Rept., 1919, pp. 1-95, illus., Toronto, 1919.

2. The alleged coal beds at Sudbury [Ontario]: Canadian Min. Jour., vol. 43, no. 33, pp. 554-555, August 18, 1922.

Gidley, James Williams. See also Bryan, 23 ; Miller, G. S., 1; Wade, B., 3.

1. Significance of divergence of the first digit in the primitive mammalian foot: Washington Acad. Sci., Jour., vol. 9, no. 10, pp. 273-280, May 19, 1919.

2. New species of claenodonts from the Fort Union (basal Eocene) of Montana: Am. Mus. Nat. Hist., Bull., vol. 41, pp. 541-556, 10 figs., 1 pl., December 8, 1919.

3. A Pleistocene cave deposit of western Maryland: Smithsonian Inst., Ann. Rept., 1918, pp. 281-287, 6 pls., 1920.

4. Pleistocene peccaries from the Cumberland cave deposit: U. S. Nat. Mus., Proc,, vol. 57, pp. 651-678, 2 pls., 13 figss., 1920. 
Gidley, James Williams-Continued.

5. Preliminary report on fossil vertebrates of the San Pedro Valley, Arizona, with descriptions of new species of Rodentia and Lagomorpha: U. S. Geol. Survey, Prof. Paper 131, pp. 119-131, 2 pls., December 26, 1922.

6. Paleocene primates of the Fort Union, with discussion of relationships of Eocene primates: U. S. Nat. Mus., Proc., vol. 63, art. 1, 38 pp., 4 figs., 5 pls., 1923.

7. Fossil Proboscidea and Edentata of the San Pedro Valley, Arizona: U. S. Geol. Survey, Prof. Paper 140, pp. 83-95, 13 pls., February 8, 1926.

8. Fossil man in Florida (abstract) : Geol. Soc. America, Bull., vol. 37, no. 1, pp. 239-240, March 30, 1926.

9. (and Loomis, Frederic B.). Fossil man in Florida: Am. Jour. Sci., 5th ser., vol. 12, pp. 254-264, September, 1926.

10. American wild horses: Sci. Monthly, vol. 25, no. 3, pp. 265-271, 7 figs., September, 1927.

11. Continuing the elephant hunt: Smithsonian Inst., Explorations and Field Work in 1927, pp. 11-16, 7 figs.; 1928. (Pub. 2957.)

12. A new species of bear from the Pleistocene of Florida: Washington Acad. Sci., Jour., vol. 18, no. 15, pp. 430-433, September 19, 1928.

Gilbert, Chester Garfield.

1. (and Pogue, Joseph E.). The mineral resources of the United States; the energy resources of the United States, a field for reconstruction: U. S. Nat. Mus., Bull. 102, vol. 1, 165 pp., 8 pls., 15 figs., 1919.

Gilbert, Geoffrey.

1. Oxidation and enrichment at Ducktown, Tennessee (with discussion): Am. Inst. Min. and Met. Eng., Trans., vol. 70, pp. 998-1023, .12 figs., 1924; [preprint] no. 1318, 23 pp., 2 figs., March, 1924; abstract, Mining and Metallurgy, vol. 5, no. 212, pp. 393-394, August, 1924.

2. The relation of hardness to the sequence of the ore minerals: Econ. Geology, vol. 19, no. 7, pp. 668-673, November, 1924.

3. The antipathy of bornite and pyrrhotite: Econ. Geology, vol. 20, no. 4, pp. 364-370, June-July, 1925.

4. Some magnetite-hematite relations: Econ. Geology, vol. 20, no. 6, pp. 587-596, 1 fig., September-October, 1925.

5. The significance of hematite in certain ore deposits: Econ. Geology, vol. 21, no. 6, pp. 560-577, 1 fig., September, 1926.

6. Changes in the oxidation of iron in magnetite (discussion) : Econ. Geology, vol. 22, no. 3, pp. 308-310, May, 1927.

7. Gammon River area and Rickaby Lake schist belt, District of Kenora (Patricia portion) : Ontario Dept. Mines, 36th Ann. Rept., vol. 36, pt. 3, pp. 73-84, 1 fig., map, 1928.

Gilbert, Grove Karl, 1843-1918.

1. Studies of Basin Range structure: U. S. Geol. Survey, Prof. Paper 153, 92 pp., 57 figs., 40 pls., 1928.

Gilbert, James Zacchaeus. See also Jordan, D. S., 2.

1. Family Muraenidae, Deprandus lestes Jordan and Gilbert, new genus and species: Southern California Acad. Sci., Bull., vol, 20, pt. 1, pp. 2930, 1 fig., April, 1921. 
Gilbert, James Zacchaeus-Continued.

2. The bone drift of the tar beds of Rancho La Brea [Los Angeles, California] : Southern California Acad. Sci., Bull., vol. 26, pt. 3, pp. 59-66, 8 figs., September-December, 1927.

Giles, Albert William.

1. Brecciation in the Niagara limestone at Rochester, New York: Am. Jour. Sci., 4th ser., vol. 47, pp. 349-354, 2 figs., May, 1919.

2. Minerals in the Niagara limestone of western New York: Rochester Acad. Sci., Proc., vol. 6, no. 2, pp. 57-72, December, 1920.

3. The geology and coal resources of Dickenson County, Virginia: Virginia Geol. Survey, Bull. no. 21, 224 pp., 21 figs., 18 pls. (incl. maps), 1921.

4. The geology and coal resources of the coal-bearing portion of Lee County, Virginia: Virginia Geol. Survey, Bull. no. 26, pp. 1-177, 11 figs., 21 pls. (incl. maps), 1925.

5. Thomas Leonard Watson: Science, new ser., vol. 61, pp. 225-226, February $27,1925$.

6. The geology and coal resources of the coal-bearing portion of Lee County, Virginia (abstract) : Chicago Univ., Abstracts of Theses, Sci. Ser., vol. 1, pp. 277-283, October, 1925.

7. Virginia Geological Survey [activities] : Pan-Am. Geologist, vol. 44, no. 4, pp. 325-326, November, 1925.

8. The geology of Little North Mountaiı in northern Virginia and West Virginia: Jour. Geology, vol. 35, no. 1, pp. 32-57, 5 figs., JanuaryFebruary, 1927.

9. An oil seep in the folded Appalachians [Powell Valley, Lee County, Virginia] : Am. Assoc. Petroleum Geologists, Bull, vol. 11, no. 7, pp. 757-763, 1 fig. (map), July, 1927.

10. The origin and occurrence in Rockbridge County, Virginia, of so-called "bentonite": Jour. Geology, vol. 35, no. 6, pp. 527-541, AugustSeptember, 1927.

11. Oil and gas possibilities of Virginia: Econ. Geology, vol. 22, no. 8, pp. 791-825, 7 figs., December, 1927.

Gịll, Adam Capen.

1. Preliminary report on the chromite of Kenai Peninsula, Alaska: U. S. Geol. Survey, Bull. 712, pp. 99-129, 3 pls. (maps), 1919. Abstract by J. D. Sears, Washington Acad. Sci., Jour., vol. 10, no. 18, p. 522, November 4, 1920.

2. Chromite of Kenai Peninsula, Alaska: U. S. Geol. Survey, Bull. 742,52 pp., 4 pls. (incl. maps), 1922.

Gill, J. E.

1. Gunflint iron-bearing formation, Ontario: Canada, Geol. Survey, Summ. Rept., 1924, pt. C, pp. 28-88, 1 fig., 4 pls. (incl. maps), 1926.

2. Origin of the Gunflint iron-bearing formation: Econ. Geology, vol. 22, no. 7, pp. 687-728, 6 figs., November, 1927.

Gilliatt, J. B.

1. Folding and faulting of the Wabana ore deposits: Canadian Inst. Min. and Met., Monthly Bull., no. 152, pp. 895-913, 10 figs., 3 pls., December, 1924; Trans., vol. 27, pp. 616-634 [1925].

$4096-31-15$ 
Gillson, Joseph L.

1. (and Shannon, Earl V.). Szaibelyite from Lincoln County, Nevada: Am. Mineralogist, vol. 10, no. 6, pp. 137-139, June, 1925.

2. Zircon, a contact-metamorphic mineral in the Pend Oreille district, Idaho: Am. Mineralogist, vol. 10, no. 8, pp. 187-194, August, 1925.

3. Conichalcite from the Bristol mine, Lincoln County, Nevada: Am. Mineralogist, vol. 11, no. 5, pp. 109-114, May, 1926.

4. Optical notes on some minerals from the Mahopac iron mine, Brewster, New York: Am. Mineralogist, vol. 11, no. 10, pp. 281-286, October, 1926.

5. Pigeonite from the Triassic traps of the Connecticut Valley: Am. Minerälogist, vol. 11, no. 11, pp. 317-319, November, 1926.

6. Granodiorites in the Pend Oreille district of northern Idaho: Jour. Geology, vol. 35, no. 1, pp. 1-31, 3 figs., 3 pls., January-February, 1927.

7. Origin of the Vermont talc deposits, with a discussion on the formation of talc in general: Econ. Geology, vol. 22, no. 3, pp. 246-287, 7 figs., May, 1927.

8. The granite of Conway, New Hampshire, and its druse minerals: Am. Mineralogist, vol. 12, no. 8, pp. 307-319, 3 figs., August, 1927.

9. Biaxial calcite: Am. Mineralogist, vol. 12, no. 10, pp. 357-360, October, 1927.

10. (and Calahan, William H., and Millar, William B.). Adirondack studies; the age of certain Adirondack gabbros, and the origin of the reaction rims and peculiar border phases found in them: Jour. Geology, vol. 36, no. 2, pp. 149-163, 6 figs., February-March, 1928.

11. Horizontal versus vertical forces in crustal movements of the earth [report of address by Bailey Willis]: Science, new ser., vol. 67, pp. 608-610, June 15, 1928.

12. On the origin of the alkaline rocks: Jour. Geology, vol. 36, no. 5, pp. 471-474, July-August, 1928.

Gilluly, James. See also Bretz, 14; Mather, 12 ; Paige, 5.

1. (and Heald, K. C.). Stratigraphy of the El Dorado oil field, Arkansas, as determined by drill cuttings: U. S. Geol. Survey, Bull. 736, pp. 241-248, 1 pl., February 9, 1923.

2. (and Reeside, John B., jr.). Jurassic formations of eastern Utah (abstract): Geol. Soc. America, Bull., vol. 37, no. 1, pp. 158-159, March 30, 1926; Pan-Am. Geologist, vol. 45, no 2 pp. 160-161, March, 1926.

3. Analcite diabase and related alkaline syenite from Utah: Am. Jour. Sci., 5th ser., vol. 14, pp. 199-211, 1 fig., September, 1927.

4. (and Reeside, John B., jr.). Sedimentary rocks of the San Rafael Swell and some adjacent areas in eastern Utah: U. S. Geol. Survey, Prof. Paper 150, pp. 61-110, 1 fig., 7 pls., February 15, 1928.

5. Basin Range faults in the Oquirrh Range, Utah (abstract): Geol. Soc. America, Bull., vol. 39, no. 1, p. 183, March 30, 1928; Pan-Am. Geologist, vol. 49, no. 2, pp. 140-141, March, 1928.

6. Isostasy as a factor in Basin Range faulting in the Oquirrh Range, Utah (abstract) : Washington Acad. Sci., Jour., vol. 18, no. 9, pp. 263264, May 4, 1928.

7. Basin range faulting along the Oquirrh Range, Utah: Geol. Soc. America, Bull., vol. 39, no. 4, pp. 1103-1130, 6 figs., 2 pls., December 30, 1928. 
Gilmore, Charles Whitney. See also Merriam, 27 ; Wade, B., 3.

1. A new restoration of Triceratops, with notes on the osteology of the genus:

U. S. Nat. Mus., Proc., vol. 55, pp. 97-112, 7 pls., 6 figs., 1919.

2. New fossil turtles, with notes on two described species: U. S. Nat. Mus., Proc., vol. 56, pp. 113-132, 9 pls., 8 figs., 1919.

3. A mounted skeleton of Dimetrodon gigas in the United States National Museum with notes on the skeletal anatomy: U. S. Nat. Mus., Proc., vol. 56, pp. 525-539, 4 pls., 8 figs., 1919.

4. Reptilian faunas of the Torrejon, Puerco, and underlying Upper Cretaceous formations of San Juan County, New Mexico; U. S. Geol. Survey, Prof. Paper 119, 71 pp., 26 pls., 33 figs., 1919. Abstract by R. W. Stone, Washington Acad. Sci., Jour., vol. 10, no. 11, pp. 327-328, June 4, 1920.

5. An ornithomimid dinosaur in the Potomac of Maryland: Science, new ser., vol. 50, pp. 394-395, October 24, 1919.

6. Reptile reconstructions in the United States National Museum: Smithsonian Inst., Ann. Rept., 1918, pp. 271-280, 6 pls., 1920.

7. Osteology of the carnivorous Dinosauria in the United States National Museum, with special reference to the genera Antrodemus (Allosaurus) and Ceratosauris: U. S. Nat. Mus., Bull. 110, 159 pp., 36 pls., 79 figs., 1920.

8. The fauna of the Arundel formation of Maryland: U. S. Nat. Mus., Proc., vol. 59, pp. อ81-594, 5 pls., 1921.

9. A new horned dinosaur from Canada; the Styracosaurus albertensis, with a 6-foot skull bristling with horns: Sci. Am. Monthly, vol. 3, no. 1, pp. 7-8, 2 figs., January, 1921.

10. Remarks on some additions to the fossil vertebrate exhibition in the National Museum (abstract): Washington Acad. Sci., Jour., vol. 11, no. 3, p. 66, February 4, 1921.

11. An extinct sea lizard from western Kansas [Tylosaurus proriger]: Sci. Am., vol. 124, no. 14, pp. 273, 280, 3 figs., April 2, 1921.

12. Discovery of sauropod dinosaur remains in the Upper Cretaceous of New Mexico: Science, new ser., vol. 54, p. 274, September 23, 1921.

13. A new description of Saniwa ensidens Leidy, an extinct varanid lizard from Wyoming: U. S. Nat. Mus., Proc., vol. 60, art. 23, 28 pp., 22 figs., 3 pls., 1922.

14. The smallest known horned dinosaur, Brachyceratops: U. S. Nat. Mus., Proc. vol. 61, art. 3, 4 pp., 4 pls., 1922.

15. A new fossil turtle, Kinosternon arizonense, from Arizona: U. S. Nat. Mus., Proc., vol. 62, art. 5, 8 pp., 7 figs., 5 pls., 1922.

16. The horned dinosaurs: Smithsonian Inst., Ann. Rept., 1920, pp. 381-387, 8 pls., 1922.

17. A new sauropod dinosaur from the Ojo Alamo formation of New Mexico: Smithsonian Misc. Coll., vol. 72, no. 14, 9 pp., 2 pls., January 31, 1922.

18. A new species of Corythosaurus with notes on other Belly River Dinosauria : Canadian Field- Naturalist, vol. 37, no. 3, pp. 46-52, 1 fig., 5 pls., March, 1923.

19. A new species of Aspideretes from the Belly River Cretaceous of Alberta, Canada: Roy. Soc. Canada, Proc. and Trans., 3d ser., vol. 17, sec. 4, pp. 1-11, 5 pls., May, 1923.

20: A new species of Laosaurus, an ornithischian dinosaur from the Cretaceous of Alberta: Roy. Soc. Canada, Proc. and Trans., 3d ser., vol. 18. sec. 4, pp. 1-7, 2 pls., May, 1924. 
Gilmore, Charles Whitney-Continued.

21. Contributions to vertebrate paleontology: A new coelurid dinosaur from the Beily River Cretaceous of Alberta; A new species of hadrosaurian dinosaur from the Edmonton formation (Cretaceous) of Alberta; On the genus Stephanosaurus, with a description of the type specimen of Lambeosaurus lornbei Parks; On the skull and skeleton of Hypacrosaurus, a helmet-crested dinosaur from the Edmonton Cretaceous of Alberta: Canada, Geol. Survey, Bull. no. 38, 89 pp., 17 figs., 12 pls., March 6, 1924.

22. On Troodon validus, an orthopodous dinosaur from the Belly River Cretaceous of Alberta, Canada: Alberta, Univ., Dept. Geology, Bull. no. 1, 43 pp., 3 flgs., 15 pls., March 29, 1924.

23. The Dinosaur National Monument and its fossils (abstract) : Washington Acad. Sci., Jour., vol. 19, no. 15, p. 381, September 19, 1924.

24. A nearly complete articulated skeleton of Camarasaurus, a saurischian dinosaur from the Dinosaur National Monument, Utah: Carnegie Mus., Mem., vol. 10, no. 3, pp. 347-384, 5 figs, 5 pls., July 10, 1925.

25. Osteology of ornithopodous dinosaurs from the Dinosaur National Monument, Utah : Carnegie Mus., Mem., vol. 10, no. 4, pp. 385-410, 8 figs., 1 pl., July 10, 1925.

26. Fossil foootprints from the Grand Canyon: Smithsonian Misc. Coll., vol. 77, no. 9, 41 pp., 23 figs., 12 pls., January 30, 1926.

27. Fossil footprints from the Grand Canyon (abstract) : Geol. Soc. America, Bull., vol. 37, no. 1, pp. 240-241, March 30, 1926.

28. A new aetosaurian reptile from the Morrison formation of Utah: Carnegie Mus., Annals., vol. 16, no. 2, pp. 325-348, 4 figs., 3 pls., March, 1926.

29. On a nearly complete lizard skull from the Oligocene of Nebraska: Kansas, Univ., Sci. Bull., vol. 16, no. 6, pp. 229-231, 1 pl., March, 1926.

30. On fossil turtles from the Pleistocene of Florida: U. S. Nat. Mus., Proc., vol. 71 , art. 15,10 pp., 4 figs., 5 pls., 1927.

31. Footprints of unknown vertebrate animals in the Carboniferous and Permian of the Grand Canyon (abstract) : Science, new ser., vol. 65, pp. 479-480, May 13, 1927.

32. Fossil footprints in the Grand Canyon (abstract) : Washington Acad. Sci., Jour., vol. 7, no. 10, p. 272, May 19, 1927.

33. Fossil footprints from the Grand Canyon; second contribution: Smithsonian Misc. Coll., vol. 80, no. 3, 78 pp., 37 figs., 21 pls., July 30, 1927.

34. Note on a second occurrence of the mosasaurian reptile Globidens: Science, new ser., vol. 66, p. 452, November, 1927.

35. Fossil footprints from the Grand Canyon; third contribution: Smithsonian Misc. Coll., vol. 80, no. 8, 16 pp., 7 figs., 5 pls., January 28, 1928.

36. Fossil footprints in the Grand Canyon of the Colorado, Arizona: Smithsonian Inst., Explorations and Field Work in 1927, pp. 7-10, 3 figs., 1928. (Pub. 2957.)

37. (and Sturdevant, Glenn E.). Discovery of fossil tracks on the north rim of the Grand Canyon: Science, new ser., vol. 67, p. 216, February $24,1928$.

38. Fossil lizards of North America: Nat. Acad. Sci., Mem., vol. 22, 3d mem., 201 pp., 106 figs., 27 pls., 1928.

39. A new fossil reptile from the Triassic of New Jersey: U. S. Nat. Mus., Proc., vol. 73, art. 7, 8 pp., 3 figs., 3 pls., 1928. 
Gilmore, Charles Whitney-Continued.

40. A new pterosaurian reptile from the marine Cretaceous of Oregon: U. S. Nat. Mus., Proc., vol. 73, art. 24, 5 pp., 2 figs., 1928.

41. Fossil footprints from the Fort Union (Paleocene) of Montana: U. S. Nat. Mus., Proc., vol. 74, art. 5, 4 pp., 3 pls., 1928.

Girty, George Herbert.

1. The Bend formation and its correlation (with discussion): Am. Assoc. Petroleum Geologists, Bull., vol. 3, pp. 71-81, 1919.

2. (and Moore, Raymond C.). Age of the Bend series [Texas]: Am. Assoc. Petroleum Geologists, Bull., vol. 3, pp. 418-420, 1919.

3. Carboniferous and Triassic faunas [of Utah]: U. S. Geol. Survey, Prof. Paper 111, pp. 641-648, 6 pls., 1920.

4. Observations on the faunas of the Greenbrier limestone and adjacent rocks : West Virginia Geol. Survey, Tucker County, pp. 450-488, 1923.

5. (and Roundy, P. V.). Notes on the Glenn formation of Oklahoma with consideration of new paleontologic evidence (with discussion by W. L. Goldston, jr.) : Am. Assoc. Petroleum Geologists, Bull., vol. 7, no. 4, pp. 331-349, July-August, 1923.

6. On the genera Cladochomus and Monilipora: Jour. Geology, vol. 33, no. 1, pp. 19-27, January-February, 1925.

7. Mississippian formations of San Saba County, Texas: Geologic age and correlation; The macro-fauna of the limestone of Boone age: U. S. Geol. Survey, Prof. Paper 146, pp. 3-4, 24-43, 2 pls.; 1926.

8. Faunas of the Pennsylvanian and Mississippian periods: West Virginia Geol. Survey, Mercer, Monroe, and Summers counties, pp. 847-860, 1926.

9. A new area of Carboniferous rocks in Mexico: Science, new ser., vol. 63, pp. 286-287, March 12, 1926.

10. Descriptions of new species of Carboniferous and Triassic fossils [from southeastern Idaho]: U. S. Geol. Survey, Prof. Paper 152, pp. 411-446, 7 pls., 1927.

11. The generic characters of Astartella Hall: Washington Acar. Sci., Jour., vol. 17, no. 16, pp. 417-423, 1 pl., October 4, 1927.

12. The Pocono fauna of the Broad Top coal field, Pennsylvania: U. S. Geol. Survey, Prof. Paper 150, pp. 111-127, 2 pls., February 17, 1928.

13. The generic name Orbiculoidea D'Orbigny and its application: Washington Acad. Sci., Jour., vol. 18, no. 5, pp. 128-142, March 4, 1928.

14. Characters of the brachiopod genus Lingulidiscina Whitfield: Washington Acad. Sci., Jour., vol. 18, no. 9, pp. 241-249, May 4, 1928.

Girvin, H. H.

1. Geology of the Onaman gold area [Ontario] : Canadian Min. Jour., vol. 45, no. 37, pp. 899-900; 1 fig., September 12, 1924.

Gleason, H. A.

1. The measurement of postglacial time: Science, new ser., vol. 52, p. 340, October 8, 1920.

Gledhill, Thomas Lloyd.

1. Iridosmine crystals from Ruby Creek, Atlin district, British Columbia: Toronto, Univ., Studies, Geol. Series, no. 12, pp. 40-42, 1 fig., 1921.

2. Geology along an eastward continuation of Niven's 4th base line: Ontario Dept. Mines, 33d Ann. Rept., vol. 33, pt. 6, pp. 18-39, 13 figs. (incl. map), 1925. 
Gledhill, Thomas Lloyd-Continued.

3. Tashota-Onaman gold area, District of Thunder Bay: Ontario Dept. Mines, 34th Ann. Rept., vol. 34, pt. 6, pp. 65-85, illus., map, 1925; Canadian Min. Jour., vol. 46, no. 38, pp. 884-885, September 18, 1925.

4. Lightning River gold area, District of Cochrane: Ontario Dept. Mines, 34th Ann. Rept., vol. 34, pt. 6, pp. 86-98, illus., map, 1925 ; Canadian Min. Jour., vol. 47, no. 9, pp. 226-228, 1 fig., February 26, 1926.

5. Grassy River area, District of Sudbury: Ontario Dept. Mines, 35th Ann. Rept., vol. 35, pt. 6, pp. 57-76, 11 figs., map, 1927.

6. Notes on the south part of the Grassy River area: Ontario Dept. Mines, 35th Ann. Rept., vol. 35, pt. 6, pp. 77-82, 5 figs., 1927.

7. Michipicoten gold area, District of Algoma: Ontario Dept. Mines, 36th Ann. Rept., vol. 36, pt. 2, pp. 1-49, illus., maps, 1927.

8. Goudreau-Lochalsh gold area, District of Algoma: Ontario Dept. Mines, 36th Ann. Rept., vol. 36, pt. 2, pp. 51-86, illus., map, 1927.

Glenk, Robert.

1. Louisiana lignite: Louisiana, Dept. Conservation, Bull. no. 8, 65 pp., illus., map, March, 1921.

Glenn, I.eonidas Chalmers. See also Texas, Attorney General.

1. Oil fields of Kentucky and Tennessee: Am. Inst. Min. anā Met. Eng., Trans., vol. 65, pp. 122-139, 1921; Mining and Metallurgy, no. 157, sec. 1, p. 51 (abstract), sec. 5,12 pp., January, 1920; discussion, no. 1.59 , sec. 2 , pp. 18-19, March, 1920; discussion by Wilbur A. Nelson and Stuart St. Clair, Am. Inst. Min. and Met. Eng. [Trans., preprint no. 988], pp. 9-14, 1920.

2. Some paleontological evidence on the age of the oil-bearing horizon at Burkburnett, Texas : Am. Assoc. Petrolenm Geologists, Bull., vol. 5, no. 2, pp. 154-158 (with discussion by R. C. Moore, p. 324), MarchApril, 1921.

3. Oil development and prospects in Tennessee: Am. Assoc. Petroleum Geologists, Bull., vol. 5, no. 1, p. 100 (abstract), no. 2, pp. 168-172, March-April, 1921.

4. The geology and coals of Webster County: Kentucky Geol. Survey, Series Six, vol. 5, 249 pp., 31 figs., 1922.

5. The geology and coals of Webster Ccunty ... : Kentucky Geol. Survey, ser. 6, vol. 5, 249 pp., 31 figs., map, 1922.

6. The northern Tennessee coal field, included in Ancerson, Campbell, Claiborne, Fentress, Morgan, Overton, Pickett, Roane, and Scott counties: Tennessee, Dept. Education, Division of Geology (State Geol. Survey), Bull. 33-B, 478 pp., 28 figs., 13 pls., 1925.

7. A new meteorite from Baldwyn, Mississippi: Am. Jour. Sci., 5th ser., vol. 9 , p. 488, June, 1925.

8. Geology and physiography of the Red River boundary between Texas and Oklahoma: Pan-Am. Geologist, vol. 43, no. 5, p. 365, June, 1925.

9. The geology of the proposed Great Smoky Mountains National Park: Tennessee Acad. Sci., Jour., vol. 1, no. 2, pp. 15-15, April, 1926.

10. (and Lee, Wallace). Preliminary map of the areal and structural geology of Union County, Kentucky; areal geology in reconnaissance by L. C. Glenn, structural geology by Wallace I.ee: Kentucky Geol. Survey, Ser. 6, 1928. Scale 1:62,500. 
Glenı, Leonidas Chalmers-Continued.

11. (and McFarlan, A. C.). Geological map of Butler County, Kentucky; Pennsylvanian by L. C. Glenn, Mississippian by A. C. McFarlan. Scale 1: 62,500. Kentucky Geol. Survey, ser. 6, 1928.

Glenn, M. L. See Larsen, 4.

Glock, Waldo S. See also Trowbridge, 4.

1. The use of the terms flint and chert: Iowa Acad. Sci., Proc., vol. 27, pp. 167-173 [1922].

2. Deficiency of atmospheric dust in coal: Science, new ser., vol. 56, pp. 484-485, October 27, 1922.

3. Algae as limestone makers and climatic indicators: Am. Jour. Sci., 5th ser., vol. 6, pp. 377-408, November, 1923.

4. Has not geology a message for everybody?: Pan-1m. Geologist, vol. 43, no. 5, pp. 345-348, June, 1925.

5. The significance of red color in sediments: Am: Jour. Sci.; 5th ser., vol. 14, pp. 155-156, August, 1927.

6. An analysis of erosional terms: Am. Jour. Sci., 5th ser., vol. 15, pp. 471483, June, 1928.

Glover, Sheldon L. See also Patty, 2.

1. Geology of the clays of Washington: Washington, Univ., Bull., Eng. Exper. Sta., ser., Bull. no. 18, pp. 22-28, October, 1923.

Goddard, Pliny E.

1. The antiquity of man in America: Natural History (Am. Mus. Nat. Hist., Jour.), vol. 26, no. 3, pp. 257-259, May-June, 1926.

Godde, H. A. See also Copp, 1.

1. Oil fields of Ventura County: California State Min. Bur., Summary of Operations California Oil Fields., vol. 10, no. 5, pp. 5-24, 4 pls. (maps), November, 1924.

2. (and Keyes, R. L.). Report on the northeastern flank of the Buena Vista Hills, Midway oil field, Kern County, California : California State Min. Bur., Summary of Operations California Oil Fields, vol. 12, no. 1, pp. 5-12, 1 fig. 3 pls., July, 1926.

3. (and Musser, E. H.). Development of the Maricopa shale production in the southeastern portion of Thirty-five anticline, Sunset oil field, Kern County, California: California State Min. Bur., Summary of Operations California Oil Fields, vol. 12, no. 11, pp. 5-16, 4 pls., May, 1927.

4. Miocene formations in the east side fields of Kern County: California, Dept. Nat. Res., Div. Mines and Mining, Summary of Operations California Oil Fields, vol. 14, no. 1, pp. 5-15, 1 pl., July, 1928.

Goldman, Marcus Isaac. See also Darton, 6, 8; Fath, 1; Hancock, 3, 4, 6; Howe, M. A., 4; Johnson, R. H., 5; Schultz, 1; Shaw, E. W., 6; Winchester, 3.

1. General character, mode of occurrence, and origin of glauconite (abstract) : Washington Acad. Sci., Jour., vol. 9, no. 16, pp. 501-502, October 4, 1919.

2. Structure and oil and gas resources of the Osage Reservation, Oklahoma; T. 29 N., Rs. 11 and 12 E.: U. S. Geol. Survey, Bull. 686, pp. 329-352, 1 pl. (map), 3 figs., 1920. 
Goldman, Marcus Isaac-Continued.

3. Structure and oil and gas resources of the Osage Reservation, Oklahoma; T. 20, R. 10 E.: U. S. Geol. Survey, Bull. 686, pp. 353-358, 1 pl. (map), 1920.

4. (and Robinson, Heath M.). Structure and oil and gas resources of the Osage Reservation, Oklahoma, T. 28 N., Rs. 11 and 12 E.: U. S. Geol. Survey, Bull. 686, pp. 359-394, 4 pls. (incl. maps), 2 figs., 1920.

5. Lithologic subsurface correlation in the "Bend" series of north-central Texas: U. S. Geol. Survey, Prof. Paper 129, pp. 1-22, 1 fig., 1 pl., 1921. Abstract, Am. Assoc. Petroleum Geologists, Bull., vol. 5, no. 1, p. 199, 1921.

6. Field description of sediments (abstract) : Geol. Soc. America, Bull., vol. 32, no. 1, p. 24, March 31, 1921.

7. Association of glauconite with unconformities (abstract): Geol. Soc. America, Bull., vol. 32, no. 1, p. 25, March 31, 1921.

8. Lithology of the "Bend series" and contiguous formations of north-central Texas (abstract): Washington Acad. Sci., Jour., vol. 11, no. 17, pp. 425-426, October 19, 1921.

9. A schedule for the field description of sedimentary rocks: Am. Assoc. Petroleum Geologists, Bull., vol. 6, no. 3, pp. 254-259, May-June, 1922.

10. Basal glauconite and phosphate beds: Science, new ser., vol. 56, pp. 171-173, August 11, 1922.

11. "Black shale" formation in and about Chesapeake Bay: Am. Assoc. Petroleum Geologists, Bull., vol. 8, no. 2, pp. 195-201, March-April, 1924.

12. Petrography of salt dome cap rock: Am. Assoc. Petroleum Geologists, Bull., vol. 9, no. 1, pp. 42-78, 33 figs., January-February, 1925; Geology of salt dome oil fields, pp. 50-86, 33 figs., 1926.

13. Testing and adjusting the binocular microscope and suggestions on the use of microscopes in general: Am. Assoc. Petroleum Geologists, Bull., vol. 9, no. 1, pp. 175-179, 1 fig., January-February, 1925.

14. Petrography of Ordovician and Mississippian limestones at their contact in Texas (abstract): Pan-Am. Geologist, vol. 44, no. 1, p. 79, August, 1925.

15. (and Merwin, H. E.). Color chart of the committee on sedimentation of the National Research Council: Am. Assoc. Petroleum Geologists, Bull., vol. 9, no. 6, pp. 1018-1019, September, 1925.

16. Petrology of the contact of the Ordovician Ellenburger limestone and the Mississippian limestone of Boone age in San Saba County, Texas: U. S. Geol. Survey, Prof. Paper 146, pp. 44-59, 27 pls., 1926.

17. Proportions of detrital organic calcareous constituents and their chemical alteration in a reef sand from the Bahamas: Carnegie Inst. Washington, Pub. no. 344 (Papers from the Department of Marine Biology of the Carnegie Institution of Washington, vol. 23), pp. 37-66, 1 fig., February, 1926.

Goldring, Winifred.

1. Decreasing salinity of the Pleistocene Champlain sea going southward, as shown by the character of the fauna, with a brief discussion of the Pleistocene fauna of the Hudson Valley and its significance (abstract) : Geol. Soc. America, Bull., vol. 32, no. 1, pp. 132-133, March 31, 1921. 
Goldring, Winifred-Continued.

2. Annual rings of growth in Carboniferous wood: Bot. Gazette, vol. 72, no. 5, pp. 326-330, 1 pl., November, 1921.

3. The Champlain sea; evidence of its decreasing salinity southward as shown by the character of the fauna: New York State Mus. Bull., nos. 239-240, pp. 153-194, 2 figs., 5 pls., 1922.

4. The Devonian crinoids of the State of New York: New York State Mus., Memoir 16, 670 pp., 63 figs., 60 pls., 1923.

5. The Upper Devonian forest of seed ferns in eastern New York: New York State Mus. Bull. no. 251, pp. 50-92, 7 figs., 11 pls., 1924.

6. New museum exhibits: The fossil forests of Gilboa; What is a fossil? What is a geological formation?: New York State Mus. Bull., no. 267, pp. 81-84, 1 pl., 1926.

7. New Upper Devonian plant material [Gilboa, New York] : New York State Mus. Bull., no. 267, pp. 85-87, 5 pls., 1926.

S. New species of Hamilton crinoids [Hamilton, New York]: New York State Mus. Bull., no. 267, pp. 89-92, 1 fig., 2 pls., 1926.

9. The oldest known pertrified forest [Gilboa, Schoharie County, New York] : Sci. Monthly, vol. 24, no. 6, pp. 515-529, 14 figs., June, 1927.

Goldschmidt, Victor.

1. (and Gordon, Samuel G.) Crystallographic tables for the determination of minerals: Acad. Nat. Sci. Philadelphia, Spec. Pub. no. 2, 70 pp., 4 figs., 1928.

Goldschmidt, Victor Moritz.

1. On the metasomatic processes in silicate rocks: Econ. Geology, vol. 17, no. 2, pp. 105-123, March-April, 1922.

2. Metasomatic processes in fissure veins (discussion): Econ. Geology, vol. 21, no. 1, pp. 91-94, January-February, 1926.

3. A physico-chemical theory of metasomatism (discussion) : Econ. Geology, vol. 22, no. 5, pp. 521-523, August, 1927.

Goldston, W. L., jr. See also Girty, 5.

1. Differentiation of the Glenn formation in the U. S. G. S. Ardmore quadrangle. 3 sheets, maps and sections, Oklahoma Geol. Survey [1922].

2. Differentiation and structure of the Glenn formation: Am. Assoc. Petroleum Geologists, Bull., vol. 5, no. 1, p. 105, January-February, 1921 (abstract), vol. 6, no. 1, pp. 5-23, 1 fig., 5 pls. (incl. maps), January-February, 1922.

3. Structure of the Glenn formation, Oklahoma: Oil Engineering and Finance, vol. 1, no. 15, pp. 481-483, April, 1922.

Goldthwait, James Walter. See also Anters, 1.

1. Submergence and postglacial uplift in New Hampshire (abstract, with discussion by C. W. Brown) : Geol. Soc. America, Bull., vol. 31, no. 1, pp. 112-113, March 31, 1920.

2. Dispersion of stones in the drift in New Hampshire (abstract): Geol. Soc. America, Bull., vol. 31, no. 1, pp. 130-131, March 31, 1920.

3. Survey of road materials in New Hampshire (abstract): Geol. Soc. America, Bull., vol. 31, no. 1, pp. 154-155, March 31, 1920.

4. Glaciation of New Hampshire (abstract) : Geol. Soc. America, Bull., vol. 33 , no. 1, p. 86, March 31, 1922.

5. Physiography of Nova Scotia: Canada, Geol. Survey, Mem. 140, 179 pp., 18 figs., 28 pls. (incl. map), 1924. 
Goldthwait, James Walter-Continued.

6. The geology of New Hampshire: New Hampshire Acad. Sci., Handbook no. 1, 86 pp., 22 figs., 27 pls., 2 maps, Concord, N. H., Rumford Press, 1925.

7. Late glacial oscillations of level in the St. Lawrence-Ottawa Valley (abstract) : Geol. Soc. America, Bull., vol. 37, no. 1, pp. 173-174, March 30, 1926 ; Pan-Am. Geologist, vol. 45, no. 2, p. 168, March, 1926.

Gonyer, Forest A. See Hewett, 21; Ross, C. S., 25; Shannon, 75, 76.

Goodier, B. D. See Franks, 1.

Goodrich, Harold Beach.

1. Petroleum geology - the past and the future: Am. Assoc. Petroleum Geologists, Bull., vol. 5, no. 4, pp. 450-457, July-August, 1921.

2. Anthony F. Lucas; biographical notice: Am. Inst. Min. and Met. Eng., Trans., vol. 65, pp. 421-423, portr., 1921.

Goodrich, R. H. See Barton, 12.

Goodspeed, G. E.

1. Effects of inclusions in small porphyry dikes at Cornucopia, Oregon: Jour. Geology, vol. 35, no. 7, pp. 653-662, 4 figs., October-November, 1927.

2. (and Weymouth, A. A.). Mineral constituents and origin of a certain kaolin deposit near Spokane, Washington: Am. Ceramic Soc., Jour., vol. 11, no. 9, pp. 687-695, 4 figs., September, 1928.

Goodwin, L. H.

1. West Shiningtree gold district, Ontario: Eng. and Min. Jour., vol. 108, pp. 261-264, 4 figs., August 16, 1919.

2. The East Tintic district, Utah: Eng. and Min. Jour., vol. 109, pp. 79-81, 3 figs., January 10, 1920.

Goodwin, Ralph Talbot.

1. The organic content of oil shales: Colorado School of Mines, Quart., vol. 18, no. 1, Supplement A, 41 pp., 13 figs., January, 1923.

Goodwin, W. L.

1. Titaniferous iron ores in Canada: Canadian Min. Inst., Trans., vol. 22, pp. 86-99 [1920].

2. The outliers of Porcupine; a study of the eastward extension of the Porcupine gold field [Ontario]: Canadian Min. Jour., vol. 45, no. 14, pp. 324-326, 1 fig., April 4, 1924; Min. Mag., vol. 30, no. 5, pp. 310-312, 1 fig., May, 1924.

3. (and Corless, C. V.). Willet Green Miller: Canadian Min. Jour., vol. 46, no. 7, pp. 165-166, portr., February 13, 1925.

Goodwin, W. M.

1. Lake Fortune gold [northwestern Quebec] : Canadian Min. Jour., vol. 44, no. 40, pp. 776-779, 5 figs., October 5, 1923; Min. Mag., vol. 29, no. 5, pp. 303-305, 1 fig., November, 1923.

2. Developments in the Quebec gold belt: Canadian Inst. Min. and Met., Monthly Bull., no. 143, pp. 188-198, 3 figs., March, 1924.

Goranson, Roy W.

1. A correlation of the Mesozoic formations of the Pacific coast of North America : Am. Jour. Sci., 5th ser., vol. 8, pp. 61-78, July, pp. 159182, August, 1924. 
Goranson, Roy W.-Continued.

2. The determination of plagioclase feldspars: Am. Mineralogist, vol. 11, no. 6, pp. 139-154, 4 figs., June, 1926.

3. Calumet Island, Pontiac County, Quebec: Canada, Geol. Survey, Summ. Rept., 1925, pt. C, pp. 105-124, 1 fig., map, 1927.

4. Aegirite from Libby, Montana : Am. Mineralogist, vol. 12, no. 1, pp. 37-39, January, 1927.

5. The density of the island of Hawaii, and density distribution in the earth's crust: Am. Jour. Sci., 5th ser., vol. 16, pp. 89-120, 1 fig., August, 1928.

Gordon, C. C.

1. The Virgin Valley, Nevada, opal deposits: Min. Rev., Salt Lake City, Utah, rol. 30 , no. 6 , pp. $7-8$, June $30,1928$.

Gordon, Charles Henry.

1. Barite deposits in upper east Tennessee: Tennessee State Geol. Survey, Bull. 23 (Pt. 1, Ann. Rept. 1919), pp. 65-70, 1920.

2. Notes on the geology of the cove areas of east Tennessee (abstract) : Science, new ser., vol. 51, pp. 492-493, May 14, 1920.

3. History, occurrence, and distribution of the marbles of east Tennessee: Tennessee, Dept. Education, Div. Geology, Bull. 28, pp. 15-86, 13 figs., 10 pls. (incl. maps), 1924.

4. Mica-peridotite dike in Union County, Tennessee (abstract): Geol. Soc. America, Bull., vol. 38, no. 1, pp. 125-126, March 30, 1927 ; Pan-Am. Geologist, vol. 47, no. 1, p. 73, February, 1927.

Gordon, Clarence E. See also Foye, 5 ; Keith, 1.

1. Ancient rock deformations and their present expressions in western Ver. mont (abstract) : Geol. Soc. America, Bull., vol. 32, no. 1, pp. 88-89, March 31, 1921.

2. Studies in the geology of western Vermont: Velmont, Stâte Geologist, Twelfth Rept., 1919-20, pp. 114-279, 13 figs., 17 pls., 1921.

3. The geology of western Vermont: Science, new ser., vol. 55, p. 208, February 24, 1922.

4. Studies in the geology of western Vermont (second paper) : Vermont, State Geologist, Thirteenth Rept., 1921-22, pp. 143-285, 7 pls., 1923.

5. Studies in the geology of western Vermont (third paper) : Vermont, State Geologist, Fourteenth Rept., 1923-24, pp. 218-259, 1924.

6. Notes on the geology of the townships of Bristol, Lincoln, and Warren: Vermont, State Geologist, 15th Rept., 1925-26, pp. 272-318, 1927.

Gordon, J. P.

1. The probabilities of a stable gold production from northern Manitoba: Canadian Inst. Min. and Met., Monthly Bull. no. 118, pp. 168-173, February, 1922.

Gordon, Samuel G. See also Goldschmidt, V., 1 ; Merwin, 6.

1. Two American occurrences of epidesmine: Am. Mineralogist, vol. 5, no. 9, p. 167, September, 1920.

2. The dufrenite locality at Midvale, Rockbridge County, Virginia: Am. Mineralogist, vol. 5, no. 12, pp. 197-198, December, 1920.

3. Ordovician basalts and quartz diabases in Lebanon County, Pennsylvania : Acad. Nat. Sci. Philadelphia, Proc., vol. 72, pt. 3, pp. 354-357, 5 figs., 1921.

4. Desilicated granitic pegmatites: Acad. Nat. Sci. Philadelphia, Proc., vol. 73, pt. 1, pp. 169-192, 13 figs., 1921. 
Gordon, Samuel G.-Continued.

5. Texas, Lancaster County, Pennsylvania: Am. Mineralogist, vol. 6, no. 7, pp. 113-117, July, 1921.

6. The mineralogy of Pennsylvania: Acad. Nat. Sci. Philadelphia, Special Pub. no. 1, 255 pp., 110 figs., 1 pl., 1922.

7. The chromite deposits of the State line serpentines [Pennsylvania-Maryland] : Acad. Nat. Sci. Philadelphia, Proc., vol. 73, pt. 3, pp. 449454, 4 figs., 1922.

8. Corundum Hill (Franklin), Macon County, North Carolina : Am. Mineralogist, vol. 7, no. 11, pp. 189-190, November, 1922.

9. Crystallographic notes on glaucochroite, willemite, celestite, and calcite from Franklin, New Jersey: Acad. Nat. Sci. Philadelphia, Proc., vol. 74, pp. 105-112, 7 figs., 1923.

10. Crystallographic notes on wavellite from Bolivia, Pennsylvania, Arkansas, and Bohemia: Acad. Nat. Sci. Philadelphia, Proc., vol. 74, pp. 113-119, 4 figs., 1923.

11. A correction : recently described crystals of glaucochroite from Franklin, New Jersey, are tephroite: Am. Mineralogist, vol. 8, no. 2, pp. 33-34, February, 1923.

12. Recently described "bisbeeite" from the Grand Canyon is cyanotrichite: Am. Mineralogist, vol. 8, no. 5, pp. 92-93, May, 1923.

13. Optical notes on thomsonite: Am. Mineralogist, vol. 8, no. 7, pp. 125-127, July, 1923.

14. Crystallographic notes on hodgkinsonite, datolite, and calciothomsonite from Franklin, New Jersey: Acad. Nat. Sci. Philadelphia, Proc., vol. 75, pp. 271-274, 2 figs., 1924.

15. The composition of thomsonite: Acad. Nat. Sci. Philadelphia, Proc., vol. 76, pp. 103-107, 1 fig., 1924.

16. Minerals obtained in Greenland on the second Academy-Vaux expedition, 1923 : Acad. Nat. Sci. Philadelphia, Proc., vol. 76, pp. 249-268, 3 figs, 2 pls., 1924.

17. Mineralogical notes, 1-10: Acad. Nat. Sci. Philadelphia, Proc., vol. 77, pp. 1-13, 5 figs., 1926.

18. Penroseite and trudellite; two new minerals : Acad. Nat. Sci. Philadelphia, Proc., vol. 77, pp. 317-324, 1926.

19. Mining cryolite in Greenland: Eng. and Min. Jour.-Press, vol. 121, no. 6, pp. 236-240, 3 figs., February 6, 1926.

20. On arfvedsonite, riebeckite, and crocidolite from Greenland: Acad. Nat. Sci. Philadelphia, Proc., vol. 79, pp. 193-205, 4 figs., 1928.

21. The probable identity of gageite with tephroite: Acad. Nat. Sci. Philadelphia, Proc., vol. 79, pp. 207-208, 1928.

22. Memorial of George Vaux, jr. : Am. Mineralogist, vol. 13, no. 3, pp. 97-101. portr., March, 1928.

23. Calcite from the French Creek iron mines, Chester County, Pennsylvania: Festschrift Victor Goldschmidt, pp. 108-116, 5 figs., Heidelberg; Carl Winters Universitätsbuchhandlung, 1928.

Gore, F. D.

1. Oil shale in Santa Barbara County, California: California State Min. Bur., Mining in California, vol. 19, no. 4, pp. 211-224, 5 figs., 2 pls. (maps), September, 1923.

2. Oil shale in Santa Barbara County, California: Am. Assoc. Petroleum Geologists, Bull., vol. 8, no. 4, pp. 459-472, 5 figs., July-August, 1924. 
Gossner, B.

1. The crystal form of boleite: Am. Mineralogist, vol. 13 , no. 12, pp. 580-582, December, 1928.

Goudge, M. F.

1. Magnesium sulphate in British Columbia: Canada, Dept. Mines, Mines Branch, Investigations of Mineral Resources . . 1924, pp. 62-80, 1 fig., 1926.

2. Sodium carbonate in British Columbia: Canada, Dept. Mines, Mines Branch, Investigations of Mineral Resources . . 1924, pp. 81-102, 1 flg., 3 pls., 1926.

3. Preliminary report on the limestones of Quebec and Ontario: Canada, Dept. Mines, Mines Branch, 75 pp., 3 figs., 16 pls., 1927. (Pub. no. 682.)

Goudkoff, Paul P.

1. Correlative value of the microlithology and micropaleontology of the oilbearing formations in the Sunset-Midway and Kern River oil fields: Am. Assoc. Petroleum Geologists, Bull., vol. 10, no. 5, pp. 482-494, 4 figs., May, 1926.

Gouin, Frank.

1. Oil and gas in Oklahoma the geology of the oil and gas fields of Stephens County, Oklahoma: Oklahoma Geol. Survey, Bull. no. 40-E, 52 pp., 1 fig., 6 pls. (incl. map), October, 1926.

2. Geology of Beckham County: Oklahoma Geol. Survey, Bull. no. 40-M, 17 pp., 2 figs., 2 pls. (incl. maps), May, 1927.

3. Oil and gas in Oklahoma; geology of Comanche County: Oklahoma Geol. Survey, Bul. no. 40-DD, 25 pp., 1 fig., 2 pls., June, 1928.

Gould, Charles Newton. See also Aurin, 3.

1. Preliminary notes on the geology and structure of the Amarillo region [Texas] : Am. Assoc. Petroleum Geologists, Bull., vol. 4, no. 3, pp. 269-275, 1920.

2. Platamus occidentalis: Oklahoma, Univ., Bull. (Proc. Oklahoma Acad. Sci., 1910-1920), new ser. no. 220, pp. 40-43, July 15, 1921.

3. Crystalline rocks of the plains (with discussion by R. S. Knappen) : Geol. Soc. America, Bull., vol. 34, no. 3, pp. 541-560, 3 figs., September 30, 1923.

4. Buried mountain ranges in Oklahoma: Oklahoma Acad. Sci., Proc., vol. 3 (Oklahoma, Univ., Bull., new ser. no. 271), pp. 123-125, October $1,1923$.

5. A new classification of the Permian red beds of southwestern Oklahoma: Am. Assoc. Petroleum Geologists, Bull., vol. 8, no. 3, pp. 322-341, 1 fig. (map), May-June, 1924.

6. Oklahoma's hidden treasures: The South's Development, Manufacturers Record, vol. 86, no. 24, pt. 2, pp. 403-407, 7 figs., December 11, 1924.

7. Geology in Mid-Continent operations [oil fields of Oklahoma]: Oil and Gas Jour., vol. 23, no. 36, pp. 192, 224, January 29, 1925.

8. Recent studies on the Permian of the Plains (abstract) : Pan-Am. Geologist, vol. 45, no. 3, pp. 247-248, April, 1925.

9. Index to the stratigraphy of Oklahoma; with lists of characteristic fossils by Charles E. Decker: Oklahoma Geol. Survey, Bull. no. 35, 115 pp., chart, September, 1925. 
Gould, Charles Newton-Continued.

10. The correlation of the Permian of Kansas, Okiahoma, and northern Texas: Am. Assoc. Petroleum Geologists, Eull., vol. 10, no. 2, pp. 144-153, 1 fig. (map), February, 1926.

11. (and Lonsdale, John T.). Geology of Texas County, Oklahoma: Oklahoma Geol. Survey, Bull. no. 37, 62 pp., 6 figs., 9 pls., map, April, 1926.

12. Carboniferous rocks of Oklahoma (abstract) : Pan-Am. Geologist, vol. 45, no. 3, pp. 248-249, April, 1926.

13. Carbonic rocks of north central Texas (abstract) : Pan-Am. Geologist, vol. 45 , no. 3, pp. 250-251, April, 1926.

14. Our present knowledge of the Permian of the Great Plains: Jour. Geology, vol. 34, no. 5, pp. 415-421, July-August, 1926.

15. (and Lonsdale, John T.). Geology of Beaver County, Oklahoma: Oklahoma Geol. Survey, Bull. no: 38, 71 pp., 17 figs., map, August, 1926.

16. (and Lewis, Frank E.). The Permian of western Oklahoma and the Panhandle of Texas: Oklahoma Geol. Survey, Circular no. 13, 29 pp., 2 pls. (maps), December, 1926.

17. Oklahoma Survey, seventh field conference: Am. Assoc. Petroleuni Geologists, Bull., vol. 10, no. 12, pp. 1306-1308, December, 1926.

18. Oklahoma Geological Survey; eighth field conference, November 9-17, 1926: Am. Assoc. Petroleum Geologists, Bull., vol. 11, no. 1, pp. 90-91, January, 1927.

19. The upper Paleozoic rocks of Oklahoma; stratigraphy and areal geology: Oklahoma Geol. Sụrvey, Bull. no. 41, pp. 5-21, map, January, 1927.

20. Unsolved geological problems in Oklahoma in 1925: Oklahoma Acad. Sci., Proc., vol. 5, 1925 (Oklahoma, Univ., Bull., new ser., no. 330, Univ. Studies no. 22), pp. 136-140, April 1, 1926.

21. Geology and oil fields of the Mid-Continent area: Oklahoma Acad. Sci., Proc., vol. 5, 1925 (Oklahoma, Univ., Bull., new ser., no. 330, Univ. Studies no. 22), pp. 142-145, April 1, 1926.

22. Celestite, a new mineral for Oklahoma: Oklahoma Acad. Sci., Prcc., vol. 5, 1925 (Oklahoma, Univ., Bull., new ser., no. 330, Univ. Studies no. 22), pp. 145-147, April 1, 1926.

23. Notes on the extension of the Blaine gypsum in Oklahoma, Kansas, and Texas (abstract) : Oklahoma Acad. Sci., Proc., vol. 5, 1925 (Oklahoma, Univ., Bull., new ser., no. 330, Univ. Studies no. 22), 151152, April 1, 1926.

24. Dead ones, or obsolete formation names in Oklahoma: Oklahoma Acad. Sci., Proc., vol. 6,.pt. 2, 1926 (Oklahoma, Univ., Bull., new ser., no. 348), pp. 234-238, January 1, 1927.

25. Radiate structure of sand barite crystal masses: Oklahoma Acad. Sci., Proc., vol. 6, pt. 2, 1926 (Oklahoma, Univ., Bull., new ser., no. 348), pp. 239-242, January 1, 1927.

26. New leaf fossils from the Permian of central Oklahoma: Oklahoma Acad. Sci., Proc., vol. 6, pt. 2, 1926 (Oklahoma, Univ., Bull., new ser., no. 348), pp. 263-264, January 1, 1927.

17. (and Willis, Robin). Tentative correlation of the Permian formations of the southern Great Plains: Geol. Soc. America, Bull., vol. 38, no. 3 , pp. 431-442, 2 figs., September 30,1927 ; abstract, no. 1 , p. 139, March 30, 1927 : Pan-Am. Geologist, vol. 47, no. 1, pp. 79-80, February, 1927. 
Gould, Charles Newton-Continued.

28. Fossil footprints near Abilene, Texas: Am. Assoc. Petroleum Geologists, Bull., vol. 11, no. 6, pp. 633-634, June, 1927.

29. Gypsum and salt: My Oklahoma, vol. 1, no. 8, pp. 22, 50, 55, November, 1927.

30. My friend Glyptodon and his pals: My Oklahoma, vol. 1, no. 8, pp. 32-33, 36, 52, 5 figs., November, 1927.

31. Oklahoma, the geologists' laboratory: Oklahoma Geol. Survey, Circ. no. 16, 16 pp., 6 figs., December, 1927.

32. Deep-well temperatures in Oklahoma: Am. Assoc. Petroleum Geologists, Bull., vol. 12, no. 7, pp. 765-766, July, 1928.

33. Humanizing geology: Sci. Monthly, vol. 27, no. 5, pp. 416-428, 10 figs., November, 1928.

Gould, Laurence McKinley.

1. Petrography of some Sierra la "Sal dikes [eastern Utah] (abstract) : Pan-Am. Geologist, vol. 44, no. 2, p. 158, September, 1925.

2. The rôle of orogenic stresses in laccolithic intrusions: Am. Jour. Sci., 5th ser., vol. 12, pp. 119-129, 4 figs., August, 1926.

3. A "laccolite in the air" [La Sal Mountains, Utah]: Michigan Acad. Sci., Papers, vol. 5, pp. 253-256, 1 fig., 1926; abstract, Pan-Am. Geologist, vol. 44, no. 2, p. 160, September, 1925.

4. The geology of La Sal Mountains of Utah: Michigan Acad. Sci., Papers, vol. 7, pp. 55-106, 7 figs., 8 pls., 1927.

5. Terraces of the Holstensborg district, Greenland (abstract) : Geol. Soc. American, Bull., vol. 38, no. 1, pp. 139-140, March 30, 1927; Pan-Am. Geologist, vol. 47, no. 1, p. 80; February, 1927.

6. The Putnam Baffin Island expedition; report on the physical geography: Geog. Rev., vol. 18, no. 1, pp. 27-40, map (of Foxe Land), January, 1928.

7. Geological results of Putnam Baffin Island expedition (abstract) : PanAm. Geologist, vol. 49, no. 2, p. 149, March, 1928; Geol. Soc. America, Bull., vol. 39, no. 1, p. 220, March 30, 1928.

8. Contributions to the geology of Foxe Land, Baffin Island; Part I. The rocks and their distribution: Michigan, Univ., Mus. Paleontology, Contr., vol. 3, no. 3, pp. 19-24, 2 figs., 2 pls., November 10, 1928.

Gow, James Ellis.

1. (and Tilton, John L.). Geology of Adair County: Iowa Geol. Survey, vol. 27, pp. 277-344, 3 figs., 1 pl., map [1920].

Grabau, Amadeus William.

1. Migration of geosynclines (abstract): Geol. Soc. America, Bull., vol. 30, p. 87, March 31, 1919.

2. Conditions of deposition of some Tertiary petroliferous sediments (abstract): Geol. Soc. America, Bull., vol. 30, pp. 103-104, March 31, 1919.

3. Prevailing stratigraphic relationships of the bedded phosphate deposits of Europe, north Africa, and North America (abstract) : Geol. Soc. America, Bull., vol. 30, p. 104, March 31, 1919.

4. Relation of the Holochoanites and the Orthochoanites to the Protochoanites and the significance of the Bactritidae (abstract, with discussion) : Geol. Soc. American, Bull., vol. 30, pp. 148-149, March 31, 1919. 
Grabau, Amadeus William-Continued.

5. Inclusion of the Pleistocenic period in the Psychozoic era (abstract, with discussion): Geol. Soc. America, Bull., vol. 30, pp. 149-150, March 31, 1919.

6. Significance of the Sherburne sandstone in upper Devonic stratigraphy: Geol. Soc. America, Bull., vol. 30, no. 4, pp. 423-470, 2 figs., December 31, 1919.

7. Significance of the middle Siluric in American and European geology (abstract) : Geol. Soc. America, Bull., vol. 31, no. 1, p. 138, March $31,1920$.

8. Unicline; a term proposed for monoclinal ridges of erosion (abstract) : Geol. Soc. America, Bull., vol. 31, no. 1, p. 153, March 31, 1920.

9. Geology of the nonmetallic mineral deposits other than silicates; vol. I, Principles of salt deposition. 435 pp., 125 figs., New York, McGraw Hill Book Company, 1920.

10. Sixty years of Darwinism: Natural History, vol. 20, no. 1, pp. 59-72, 6 figs. January-February 1920.

11. The Niagara cuesta from a new viewpoint: Geog. Rev. vol. 9 no. 4, pp. 264-276, 17 figs., April-June, 1920.

12. A textbook of geology. [2 vols.] Part I, General geology ; Part II, Historical geology. 864, 976 pp., 1980 figs., Boston, D. C. Heath \& Co., 1920-21.

13. Principles of stratigraphy. $2 d$ ed., 1185 pp., 264 figs., New York, A. G. Seiler, 1924.

14. Use of the term "Sinian" (abstract) : Geol. Soc. America, Bull., vol. 36, no. 1, p. 175, March 30, 1925.

Gradenwitz, Alfred.

1. Searching the interior of the earth's crust: Eng. and Min. Jour.-Press, vol. 118, no. 2, pp. 54-56, 3 figs., July 12, 1924.

Graeber, Charles K. See Honess, 3, 4.

Graham, Hoyt.

1. Effect of electrolytes and hydrogenian concentration of sedimentation of Pleistocene clays (abstract) : Pan-Am. Geologist, vol. 48, no. 5, pp. 377-378, December, 1927.

Graham, Richard Percival Devereux. See also Ferrier, 2.

1. On ferrierite, a new zeolitic mineral from British Columbia; with notes on some other Canadian minerals: Roy. Soc. Canada, Trans., 3d ser., vol. 12, sec. 4, pp. 185-201, 1 pl., 5 figs., 1919.

2. Mines and mineral deposits of Canada: Canadian Inst. Min. and Met., Monthly Bull. no. 151, pp. 715-830,.2 pls. (maps), November, 1924; Trans., vol. 27, pp. 19-134, 2 pls. (maps), [1925] ; Canadian Min. Jour., vol. 45, nos. 35 and 36, pp. 845-849, 878-881, 3 figs., August 29 and September 5, 1924.

3. Mines and mineral deposits of Canada: Inst. Min. and Met. Bull. no. 248, 98 pp., 2 pls. (maps), May, 1925; discussion, no. 249, pp. 21-28, June, 1925; Trans., vol. 34, pt. 2, pp. 251-355, 2 pls. (maps), 1925.

4. Pseudomorphs after spinel from Bathurst, Lanark County, Ontario (abstract) : Roy. Soc. Canada, Proc. and Trans., 3d ser., vol. 21, p. $\mathrm{xCV}, 1927$.

Graham, William A. P.

1. Experiments on the origin of phosphate deposits: Econ. Geology, vol. 20, no. 4, pp. 319-334, 1 fig., June-July, 1925. 
Graham, William A. P.-Continued.

2. Notes on hornblende; variations in the chemical composition of hornblende from different types of igneous rocks: Am. Mineralogist, vol. 11, no. 5, pp. 118-123, 3 figs., May, 1926.

Granger, Walter. See also Matthew, 16.

1. (and Simpson, George Gaylord). Multituberculates in the Wasatch formation: Am. Mus. Novitates, no. 312, 4 pp., 2 figs., May. 14, 1928.

Grant, Ulysses Sherman. See also Miller, B. L., 9.

1. Possible horizons for oil and gas in northeastern Illinois: Illinois State Acad. Sci., Trans., vol. 15, pp. 389-392 [1923].

2. The age of the earth: Jour. Geography, vol. 24, no. 7, pp. 276-279, October, 1925.

Grant, U. S., IV. See Cushman, 34.

Grant, Wilbur H.

1. Résumé of' geology of United Comstock Mines [Sierra Nevada, Washoe mining district, Storey County, Nevada] : Mining and Metallurgy, no. 191, pp. 39-41, November, 1922.

Grant, William M. See Hanna, 27.

Graser, F. A.

1. Recent developments in the Huntington Beach oil field: California State Min. Bur., Summary of Operations Cailfornia Oil Fields, vol. 12, no. 12, pp. 5-16, 7 pls., June, 1927.

Grasty, John Sharshall, 1880-1930.

1. Types of deposits of manganese-bearing material in Virginia: Am. Manganese Producers Assoc., Proc. 1st Ann. Convention, pp. 97-107, Washington, 1928.

Graton, Louis Caryl. See also Bateman, 13; Bowie, 13 ; Hewett, 11.

1. (and Davidson, S. C.). Microscopical interpretation of folded structures: Econ. Geology, vol. 23, no. 2, pp. 158-184, 3 figs., March-April, 1928.

2. Underground photography without flash light: Econ. Geology, vol. 22, no. 4, pp. 388-399, June-July, 1927.

Grawe, Oliver Rudolph.

1. Septaria from the Pennsylvania shale [St. Louis, Mo.] : Washington Univ. Studies, vol. 11, no. 1, pp. 65-69, 1 pl., July, 1923.

2. Some breccias of the St. Louis formation in the St. Louis, Missouri, region: Washington Univ. Studies, vol. 13, Sci. ser., no. 1, pp. 45-62, 6 pls., 1925.

3. Quantitative determination of rock color: Science, new ser., vol. 66, pp. 61-62, July 15, 1927.

4. A table for the identification of Nevada's common minerals, with notes on their occurrence and use: Nevada, Univ., Bull., vol. 22, no. 1, 13 pp., table, February 15, 1928.

5. The mineralogy of dumortierite; megascopic mineralogy; bibliography: Nevada, Univ., Bull., vol. 22, no. 2 (Mackay School of Mines, Bull. on Dumortierite), pp. 7-21, 27-30, 45-47, March 15, 1928.

Gray, Francis William.

1. Coast erosion of the coal measures in the Sydney coal field, Cape Breton:

Canadian Min. Jour., vol. 41, pp. 433-437, 9 figs., May 28, 1920.

$4096-31-16$ 
Gray, Francis William-Continued.

2. Canada's coal supply: Canadian Min. Inst., Monthly Bull. no. 97, pp. 406415, May, 1920 ; Trans., vol. 23, pp. 297-307 [1921].

3. Mining coal under the sea in Nova Scotia, with notes on comparable undersea coal-mining operations elsewhere: Canadian Min. and Met., Bull. no. 182, pp. 638-758, 18 figs. (incl. maps), June, no. 188, pp. 1433-1494, December, 1927; Canadian Inst. Min. and Met., Trans., vol. 30, pp. 986-1176, 18 figs. (incl. maps) [1928] ; Second (Triennial) Empire Min. and Met. Congress, Canada, 1927, Proc., pt. 2, pp. 1-191, 18 figs. (incl. maps), 1928.

Gray, John P.

1. (and others). Horace Vaughan Winchell: Mining and Metallurgy, vol. 4, no. 201, pp. 463-464, portr., September, 1923.

Green, Frederick E.

1. Vicissitudes of silver mining at Newburyport, Massachusetts: Eng. and Min. Jour.-Press, vol. 115, no. 11, pp. 483-484, March 17, 1923.

Green, W. F.

1. Geology of base line running west from near mile 19, western boundary of the Nipigon forest reserve: Ontario Dept. Mines, 32d Ann. Rept., vol. 32, pt. 3, 1923, pp. 1-7, 4 pls., 1924.

Greene, Frank Cook. See also Sawyer, 1; White, L. H., 1.

1. Oklahoma's stratigraphic problem: Oil and Gas Jour., vol. 18, no. 49, pp. 54 and 56, May 7, 1920.

2. Preliminary sketch of the history of the lower Missouri: Geol. Soc. America, Bull., vol. 32, no. 1, pp. 83-87, March 31, 1921.

3. Origin of oil in northern Mid-Continent [field]: Oil and Gas Jour., vol 21, no. 51 , pp. $18,111,112$, May $17,1923$.

4. Are there " red beds" of Chester age in the Mid-Continent region?: Am. Assoc. Petroleum Geologists, Bull., vol. 7, no. 6, pp. 696-697, November-December, 1923.

5. Granite wells in the northern Mid-Continent region: Am. Assoc. Petroleum Geologists, Bull., vol. 9, no. 2, pp. 351-354, March-April, 1925.

6. Geology of the Stonewall quadrangle, Oklahoma; Am. Assoc. Petroleum Geologists, Bull., vol. 9, no. 2, p. 355, March-April, 1925.

7. Various types of granite form largest group in Mid-Continent: Oil and Gas Jour., vol. 24, no. 22, pp. 69, 133, October 22, 1925.

8. (and Pond, W. F.). The geology of Vernon County: Missouri Bur. Geology and Mines, $2 d$ ser., vol. 19, 152 pp., 14 figs., 14 pls. (incl. map), 1926.

9. Oil and gas in Oklahoma; Subsurface stratigraphy of western Oklahoma: Oklahoma Geol. Survey, Bull. 40-D, 14 pp., 1 fig., map, September, 1926 ; Bull. 40, vol. 1, pp. 41-50, 1 fig., map, July, 1928.

10. Oil and gas in Oklahoma; geology of Pawnee County [the Morrison field, Pawnee County, Oklahoma, pp. 21-28, by Everett Carpenter]: Oklahoma Geol. Survey, Bull. no. 40-CC, 28 pp., 8 figs., 3 pls., February, 1928.

Greenland, Cyril Walter. See also Bruce, 14.

1. Note on the optical fluorite from Madoc, Ontario: Am. Mineralogist, vol. 5, no. 12, p. 211, December, 1920.

Greer, L. See Wallace, 18. 


\section{Greger, Darling K.}

1. The Devonian of central Missouri (II) : Am. Jour. Sci., 4th ser., vol. 49, pp. 265-266, April, 1920.

2. The Devonian of central Missouri (III) ; the Cooper limestone: Am. Jour. Sci., 4th ser., vol. 50, pp. 20-24, 1 fig., July, 1920.

3. North American species of the brachipod Etheridgina: Geol. Mag., vol. 57, pp. 535-538, 1 pl., December, 1920.

Gregory, Herbert Ernest.

1. Professor [Henry Shaler] Williams at Yale: Science, new ser., vol. 49 pp. 63-65, January 17, 1919.

2. Co-operation in advanced geologic instruction: Am. Jour. Sci., 4th ser. vol. 47, pp. 281-286, April, 1919. Abstract, Geol. Soc. America, Bull., vol. 31, p. 94, March 31, 1919.

3. Geology in the Students' Army Training Corps (abstract): Geol. Soc America, Bull., vol. 30, pp. 81-82, March 31, 1919.

4. Teaching of geology as related to research: Geol. Soc. America, Bull., vol. 31, no. 3, pp. 357-361, September 30, 1920.

5. Ninth biennial report of the Geological and Natural History Survey of Con necticut: Connecticut State Geol. and Nat. Hist. Survey, Bull. no. 32,18 pp., 1920.

6. History of geology : Sci. Monthly, vol. 12, no. 2, pp. 97-126, February, 1921.

7. Geology. In The development of the sciences, edited by L. L. Woodruff, pp. 169-213, 5 pls. (portraits), New Haven, Yale University Press, 1923.

8. Geologic relations [of the granites of Connecticut]: U. S. Geol. Survey, Bull. 738, pp. 355-361, 1 pl. (map), 1923.

9. (and Noble, Levi F.). Notes on a geological traverse from Mohave, California, to the mouth of San Juan River, Utah: Am. Jour. Sci., 5th ser., vol. 5, 229-238, March, 1923.

10. Memorial of Joseph Barrell: Geol. Soc. America, Bull., vol. 34, no. 1, pp. 18-28, portr., March 30, 1923.

11. Glaciation of Mauna Kea (abstract) : Third Pan-Pacific Sci. Cong., Tokyo, 1926, Proc., p. 1833, 1928.

Gregory, John Walter.

1. Magmatic ores: Canadian Min. Jour., vol. 46, no. 28, pp. 665-668, July 10, 1925 ; Faraday Soc., Trans., vol. 20, no. 60, pp. 449-458, April, 1925.

2. Movements of the continents (abstract) : Pan-Am. Geologist, vol. 44, no. 4, pp. 333-334, November, 1925.

3. The Sudbury nickel ores: Geol. Mag., vol. 63, pp. 190-192, April, 1926.

4. (and Barrett, B. H.). The stratigraphical position of the Keewatin: Jour. Geology, vol. 35, no. 2, pp. 141-149, February-March, 1927.

5. (and Barrett, B. H.). The major terms of the pre-Paleozoic: Jour. Geology, vol. 35, no. 8, pp. 734-742, November-December, 1927.

6. Wegener's hypothesis. In Theory of continental drift, pp. 93-96, Am. Assoc. Petroleum Geologists, 1928.

т. Present Scottish usage of term drift: Pan-Am. Geologist, vol. 50, no. 5, pp. 375-376, December, 1928.

Gregory, William King. See also Williston, 1.

1. The evolution of the human face: Natural History, vol. 19, nos. 4-5, pp. 421-425, 9 figs., April-May, 1919.

2. On the structure and relationships of Notharctus, an American Eocene primate: Am. Mus. Nat. Hist., Mem., new ser., vol. 3, pt. 2, pp. 49-243, 84 figs., 37 pls., September, 1920. 


\section{Gregory, William King-Continued.}

3. Studies in comparative myology and osteology, No. IV; A review of the evolution of the lachrymal bone of vertebrates with special reference to that of mammals: Am. Mus., Nat. Hist., Bull., vol. 42, pp. 95-263, 194 figs., 1 pl., 1920.

4. Studies in comparative myology and osteology, No. V; On the anatomy of the preorbital fossæ of Equidæ and other ungulates: Am. Mus. Nat. Hist., Bull., vol. 42, pp. 265-283, 25 figs., 1 pl., 1920.

5. Restoration of Camarasaurus and life model: Nat. Acad. Sci., Proc., vol. 6 , no. 1, pp. 16-17, January 15, 1920.

6. The origin and evolution of the human dentition. 548 pp., 353 figs., Baltimore, Williams \& Wilkins Company, 1922.

7. (and Hellman, Milo). Notes on the type of Hesperopithecus haroldcookii Osborn: Am. Mus. Novitates, no. 53, 16 pp., 6 figs., January 6, 1923.

8. A Jurassic fish fauna from western Cuba, with an arrangement of the families of holostean ganoid fishes: Am. Mus. Nat. Hist., Bull., vol. 48, pp. 223-242, 5 figs., 1 pl., 1923.

9. (and Miner, R. W., and Noble, G. K.). The carpus of Eryops and the structure of the primitive chiropterygium: Am. Mus. Nat. Hist., Bull., vol. 48, pp. 279-288, 4 figs., 1923.

10. Further notes on the molars of Hesperopithecus and Pithecanthropus: Am. Mus. Nat. Hist., Bull., vol. 48, pp. 509-526, 13 figs., 1923.

11. A fossil ganoid fish (Lepidotus ( 9 ) lacotanus, new species) from the Lower Cretaceous of South Dakota: Am. Mus. Novitates, no. 134, 8 pp., 2 figs., October 10, 1924.

12. (and Hellman, Milo). Dentition of Dryopithecus and the origin of man (abstract) : Pan-Am. Geologist, vol. 42, no. 4, pp. 307-308, November, 1924.

13. The family tree of man: Am. Mus. Nat. Hist., Guide Leaflet series no. 52, pp. 36-48, illus., May, 1925.

14. (and Hellman, Milo). The dentition of Dryopithecus and the origin of man: Am. Mus. Nat. Hist., Anthropolngical Papers, vol. 28, pt. 1, pp. 1-123, 32 figs., 25 pls., 1926.

15. Paleontology of the human dentition; structural stages in the evolution of the cheek teeth: Am. Jour. Phys. Anthropology, vol. 9, no 4, pp. 401-426, 8 figs., October-December, 1926.

16. The origin of man from the anthropoid stem-when and where?: Am. Philos. Soc., Proc., vol. 66, pp. 439-463, 5 figs., 1 pl., 1927.

17. Two views of the origin of man: Science, new ser., vol. 65, pp. 601-605, June 24, 1927.

18. Hesperopithecus apparently not an ape nor a man: Science, new ser., vol. 66, pp. 579-581, December 16, 1927.

19. (and Cook, Harold, J.). New material for the study of evolution; a series of primitive rhinoceros skulls (Trigonias) from the lower Oligocene of Colorado: Colorado Mus. Nat. Hist., Proc., vol. 8, no. 1 pp. 1-32, 5 figs., 6 pls., February 1, 1928; abstract, Geol. Soc. America, Bull., vol. 38, no. 1, p. 235, March 30, 1927 ; Pan-Am. Geologist, vol. 47, no. 3, pp. 239-240, April, 1927.

20. Did man originate in central Asia?: Sci. Monthly, vol. 24, no. 5, pp. 385-401, 14 figs., May, 1927.

21. (and Kellogg, Remington). A fossil porpoise from California: Am. Mus. Novitates, no. 269, 7 pp., 3 figs., May 20, 1927.

22. Were the ancestors of man primitive brachiators?: Am. Philos. Soc., Proc., vol. 77, no. 2, pp. 129-150, 5 figs., 4 pls., 1928. 
Gregory, William King-Continued.

23. Dawn-man or ape? was our ancestor a dawn-man, or did we descend directly from an anthropoid ape of an ancient geologic epoch?: Sci. Am., vol. 137, no. 3, pp. 230-232, 8 figs., September, 1927.

24. The upright posture of man; a review of its origin and evolution: $\dot{m}$. Philos. Soc., Proc., vol. 67, no. 4, pp. 339-374, 15 figs., 2 pls., 1928.

25. The lineage of man. In Creation by evolution, edited by Frances Mason, pp. 270-292, New York, The Macmillan Company, 1928.

Gregory, Winifred.

1. Supplement to the bibliography of Minnesota mining and geology : Minnesota, Univ., School of Mines Exp. Station, Bull. no. 8, 43 pp., November 24, 1920.

Greig, J. W.

1. Immiscibility in silicate melts (abstract): Geol. Soc. America, Bull., vol. 35, no. 1, p. 124, March 30, 1924; Pan-Am. Geologist, vol. 41; no. 2, p. 158, March, 1924.

2. Woman and Narrow lakes area, District of Kenora (Patricia portion) : Ontario Dept. Mines, 36th Ann. Rept., vol. 36, pt. 3, pp. 85-110, 6 figs., map, 1928.

3. On the evidence which has been presented for liquid silicate immiscibility in the laboratory and in the rocks of Agate Point, Ontario: Am. Jour. Sci., 5th ser., vol. 15, pp. 375-402, 10 figs., May, 1928.

Gress, E. M.

1. An annotated list of fossil plants of the Dakota formation (Cretaceous) in the collections at the Carnegie Museum, including descriptions of three new species: Carnegie Mus., Annals, vol. 13, nos. 3-4, pp. 274-332, 2 pls., March, 1922.

Grider, Richard L.

1. Determining dip and strike graphically: Eing. and Min. Jour., vol. 123, no. 24, pp. 969-970, 2 figs., June 11, 1927.

Grier, Norman McDowell.

1. New forms of Calamites [from East Bellevue, Pennsylvania] : Am. Midland Naturalist, vol. 5, no. 6, pp. 147-150, 3 pls., November, 1917.

2. The fossil flora of the vicinity of Cold Spring Harbor [Long Island, New York] : Am. Midland Naturalist, vol. 9, no. 10, pp. 513-527, July, 1925.

3. The geology of Long Island with especial reference to the Cold Spring Harbor region and its flora: Am. Midland Naturalist, vol. 9, no. 11, pp. 531-563, 1 fig., September, 1925.

4. The Hitchcock lecture upon ichnology, and the Dartmouth college ichnological collection: Am. Midland Naturalist, Notre Dame, Indiana, vol. 10, no. 7, pp. 161-197, January, 1927; abstract, Geol. Soc. America, Bull., vol. 38, no. 1, pp. 234-235, March 30, 1927; PanAm. Geologist, vol. 47, no. 3, p. .239, April, 1927.

Griffin, Judson R. See Savage, 18.

Griggs, Robert Fiske.

1. The character of the eruption [of Katmai] as indicated by its effects on nearby vegetation: Ohio Jour. Sci., vol. 19, no. 3, pp. 173-209, 19 figs., January, 1919.

2. The Katmai National Monument and the Valley of Ten Thousand Smokes: Science, new ser., vol. 49, pp. 236-237, March 7, 1919. 
Griggs, Robert Fiske-Continued.

3. The great Mageik landslide [Katmai district, Alaska] : Ohio Jour. Sci., vol. 20 , no. 8, pp. 325-354, 17 figs., June, 1920.

4. A program for the study of the volcanoes of the Aleutian region: PanPacific Scientific Conference, First, Proc., Bernice P. Bishop Mus., Spec. Pub. no. 7, pt. 2, pp. 356-358, 1921.

5. Our greatest national monument [Katmai National Monument, Alaska]: Nat. Geog. Mag., vol. 40, no. 3, pp. 219-292, illus., September, 1921.

6. The Valley of Ten Thousand Smokes [Alaska]. 340 pp., 16 pls., 217 figs., 9 maps, Washington, The National Geographic Society, 1922.

7. Observations on the incandescent sand flow of the Valley of Ten Thousand Smckes: K. Akad. Wetensch. Amsterdam, Proc. Sec. Sci., vol. 25, pp. 42-50, 5 figs., March, 1923.

8. The cause of earthquakes: Nat. Geog. Mag., vol. 44, no. 4, pp. 443-452. 1 fig., 2 pls., October, 1923.

Grim, Ralph E.

1. Recent oil and gas prospecting in Mississippi with a brief study of subsurface geology: Mississippi State Geol. Survey, Bull. no. 21, 98 pp., 4 figs., 1928.

2. Preliminary report on bentonite in Mississippi : Mississippi Geol. Survey, Bull. no. 22, 14 pp., 5 figs., January, 1928. [mimeoglaphed].

Grimes, John Alden.

1. Some suggestions concerning ore genesis: Mining and Metallurgy, vol, 9, pp. 532-536, December, 1928.

Grimm, M. W.

1. (and Howe, Henry V.). New Waskom gas field of Louisiana and Texais: Pan-Am. Geologist, vol. 43, no. 5, pp. 333-335, 1 pl. (map), June, 1925.

Grinnell, George Bird.

1. An old-time bone hunt; an account of the expedition undertaken by Prof. O. C. Marsh in $\mathbf{1 8 7 0}$ to the then wild West: Natural History, vol. 23, no. 4, pp. 329-336, 2 figs., July-August, 1923.

Griswold, W. R.

1. Chemistry of ore solutions: Eng. and Min. Jour., vol. 122, no. 6, p. 224. August 7, 1926.

Grizzle, M. A.

1. Geochemical relationship of waters encountered in the Huntington Beach field : California State Min. Bur., Summary of Operations California Oil Felds, vol. 9, no. 6, pp. 17-28, December, 1923.

Grout, Frank Fitch. See also Tanton, 17.

1. Clays and shales of Minnesota; with contributions by E. K. Soper: U. S. Geol. Survey, Bull. 678, 259 pp., 16 pls., 38 figs., 1919. Abstract by R. W. Stone, Washington Acad. Sci., Jour., vol. 9, no. 19, p. 600 , November 19, 1919.

2. (and Soper, E. K.). Geology of Minnesota: U. S. Geol. Survey, Bull. 678, pp. 70-105, 2 pls. (incl. map), 3 figs., 1919.

3. (and Broderick, T. M.). The magnetite deposits of the eastern Mesabi range, Minnesota: Minnesota Geol. Survey, Bull. no. 17, 58 pp., 18 pls. (incl. maps), 9 flgs., 1919. 
Grout, Frank Fitch-Continued.

4. (and Broderick, T. M.). Organic structures in the Biwabik iron-bearing formation of the Huronian in Minnesota: Am. Jour. Sci., 4th ser., vol. 48, pp. 199-205, 4 figs., September, 1919.

5. The nature and origin of the Biwabik iron-bearing formation of the Mesabi range, Minnesota : Econ. Geology, vol. 14, no. 6, pp. 452464, 2 pls., 1 fig., September-October, 1919.

6. Movements in crystallizing magna : Jour. Geology, vol. 28, no. 3, pp. 255264, April-May, 1920.

7. Origin of east Mesabi magnetic ores: Pan-Am. Geologist, vol. 37, no. 4, pp. 337-339, May, 1922.

8. Graphic study of igneous rock series: Geol. Soc. America, Bull., vol. 33, no. 3, pp. 617-638, 4 figs., September 30, 1922.

9. Magnetite pegmatites of northern Minnesota (with discussion by $\mathrm{W}$. J. Miller) : Econ. Geology, vol. 18, no. 3, pp. 253-269, 4 figs., AprilMay, 1923.

10. Occurrences of ladder veins in Minnesota: Econ. Geology, vol. 18, no. 5, pp. 494-505, 1 fig., August, 1923.

11. The relation of texture and composition of clays: Am. Ceramic Soc., Jour., vol. 7, no. 2, pp. 122-140, February, 1924.

12. Notes on biotite: Am. Mineralogist, vol. 9, no. 8, pp. 159-165, 1 fig., August, 1924.

13. (and Thiel, George A.). Notes on stilpnomelane: Am. Mineralogist, vol. 9, no. 11, pp. 228-231, 1 fig., November, 1924.

14. (and Conhaim, H. J.). The rate of secondary enrichment by acid waters: Econ. Geology, vol. 20, no. 3, pp. 289-291, May, 1925.

15. Coutchiching problem (with discussion by Andrew C. Lawson) : Geol. Soc. America, Bull., vol. 36, no. 2, pp. 351-364, 9 figs., June 30, 1925 ; abstract, no. 1, p. 160, March 30, 1925 ; Pan-Am. Geologist, vol. 43, no. 2, pp. 153-154, March, 1925.

16. Relation of texture and composition of clays: Geol. Soc. America, Bull., vol. 36 , no. 2 pp. $393-415,2$ figs., June $30,1925$.

17. A peculiar shonkinite related to granite: Am. Jour. Sci., 5th ser., vol. 9, pp. 472-480, 5 figs., June, 1925.

18. The Vermilion batholith of Minnesota: Jour. Geology, vol. 33, no. 5, pp. 467-487, 11 figs., July-August, 1925.

19. A magnetite segregation in banded syenite in Minnesota: Econ. Geology, vol. 20, no. 5, pp. 424-430, 4 figs., August, 1925.

20. The geology and magnetite deposits of northern St. Louis County, Minnesota: Minnesota Geol. Survey, Bull. no. 21, 220 pp., 16 figs., 12 pls., maps, 1926.

21. The use of calculations in petrology; a study for students: Jour. Geology, vol. 34, no. 6, pp. 512-558, 11 figs., August-September, 1926.

22. (and Schwartz, G. M.). Changes in the geologic map of northeastern Minnesota (abstract) : Geol. Soc. America, Bull., vol. 38, no, 1, p. 115, March 30, 1927; Pan-Am. Geologist, vol. 47, no. 1, דp. 67-68, February, 1927.

23. (and Schwartz, G. M.). Rove slate area in Minnesota (abstract) : Geol. Soc. America, Bull., vol. 38, no. 1, p. 115, March 30, 1927 ; Pan-Am. Geologist, vol. 47, no. 1, p. 68, February, 1927.

24. Fundamental problems of the batholiths and methods for their attack: Jour. Geology, vol. 35, no. 4, pp. 311-318, 1 flg., May-June, 1927. 


\section{Grout, Frank Fitch-Continued.}

25. (and Schwartz, G. M.). An alunitic gold ore in the Black Hills [South Dakota] : Econ. Geology, vol. 22, no. 4, pp. 369-373, 3 figs., JuneJuly, 1927.

26. Anorthosite and granite as differentiates of a diabase sill on Pigeon Point, Minnesota (abstract) : Geol. Soc. America, Bull., vol. 39, no. 1, p. 167, March 30, 1928; Pan-Am. Geologist, vol. 49, no. 1, pp. 75-76, February, 1928.

27. Anorthosite and granite as differentiates of a diabase sill on Pigeon Point, Minnesota: Geol. Soc. America, Bull., vol. 39, no. 2, pp. 555-577, June, 1928.

Groves, James.

1. Fossil charophyte fruits from Texas: Am. Jour. Sci., 5th ser., vol. 10, pp. 12-14, 3 figs., July, 1925.

Gruner, John Walter.

1. Geologic reconnaissance of the southern part of the Taos Range, New Mexico: Jour. Geology, vol. 28, no. 8, pp. 731-742, 1 pl. (map), 4 figs., November-December, 1920.

2. Paragenesis of the martite ore bodies and magnetites of the Mesabi range [Minnesota]: Econ. Geology, vol. 17, no. 1, pp. 1-14, 3 figs., 2 pls., January-February, 1922.

3. Organic matter and the origin of the Biwabik iron-bearing formation of the Mesabi range: Econ. Geology, vol. 17, no. 6, pp. 407-460, 5 figs., 3 pls., September, 1922.

4. Algae, believed to be Archean: Jour. Geology, vol. 31, no. 2, pp. 146-148, 3 figs., February-March, 1923.

5. Contributions to the geology of the Mesabi range, with special reference to the magnetites of the iron-bearing formation west of Mesaba [Minnesota]: Minnesota Geol. Survey, Bull. 19, 71 pp., 17 figs., 13 pls., 1924.

6. Discovery of life in the Archean: Jour. Geology, vol. 33, no. 2, pp. 151152, 3 figs., February-March, 1925.

7. Silicification of erosion surfaces (discussion): Econ. Geology, vol. 21, no. 1, pp. 97-98, January-February, 1926.

8. Magnetite-martite-hematite: Econ. Geology, vol. 21, no. 4, pp. 375-393, 3 figs., 1 pl., June-July, 1926.

9. The Soudan formation and a new suggestion as to the origin of the Vermilion iron ores: Eicon. Geology, vol. 21, no. 7, pp. 629-644, 6 figs., November, 1926.

10. Changes in the oxidation of iron in magnetite; two kinds of magnetite? (discussion) : Econ. Geology, vol. 22, no. 7, pp. 744-749, November, 1927.

11. The oscillation method of X-ray analysis of crystals: Am. Mineralogist, vol. 13, no. 4, pp. 123-141, 12 figs., April, 1928.

12. The use of the oscillation method in determining the structure of analcite: Am. Mineralogist, vol. 13, no. 5, pp. 174-194, 11 figs., May, 1928.

13. The chemical formula of boracite: Am. Mineralogist, vol. 13, no. 9, pp. 481-483, September, 1928.

Grunsky, C. E.

1. A contribution to the climatology of the ice age: California Acad. Sci., Proc., 4th ser., vol. 16, no. 2, pp. 53-85, 4 figs., 1 pl., January 31, 1927. 
Guck, Homer.

1. Geology of the Michigan copper district: Eng. and Min. Jour., vol. 108, pp. 948-949, December 27, 1919.

Guerard, Albert.

1. Fric Knight Jordan: Science, new ser., vol. 63, p. 327, March 26, 1926.

Guernsey, T. D

1. Quartz sand and clay deposits, Melford, Cape Breton: Canada, Geol. Sur. vey, Summ. Rept., 1926, pt. C, pp. 110-124, 2 figs., 1927.

2. The geology of North Mountain, Cape Breton [Nova Scotia]: Canada, Geol. Survey, Summ. Rept., 1927, pt. C, pp. 47-82, map, 1928.

Guild, J'rank Nelson. See also Fairbanks, 12.

1. Flagstaffite, a new mineral from Arizona: Am. Mineralogist, vol. 5, no. 10, pp. 169-172, 2 figs., October, 1920.

2. The identity of flagstaffite and terpin hydrate: Am. Mineralogist, vol. 6, no. 9 , pp. 133-135, September, 1921.

3. Wulfenite from Lavic, California: Am. Mineralogist, vol. 6, no. 12, pp. 167-168, 2 figs., December, 1921.

4. Flagstaffite, a new Arizona mineral and its identity with terpin hydrate (abstract) : Science, new ser., vol. 55, p. 543, May 19, 1922.

5. Bornite as a furnace product: Am. Mineralogist, vol. 9, no. 10, pp. 201-205, October, 1924.

6. Some microscopic features of the silver minerals: Festschrift victor Goldschmidt, pp. 135-142, 8 figs., Heidelberg, Carl Winters Universitätsbuchhandlung, 1928.

Gunning, H. C.

1. Syenite porphyry of Boischatel Township, Quebec: Canada, Survey, Bull. no. 46 , pp. $31-41,3$ pls., 1927. [Pub. 2125.]

Gunter, Herman. See also Sellards, 12.

1. Administrative report; statistics of mineral production in Florida during 1918: Florida State Geol. Survey, 13th Ann. Rept., pp. 5-24, $25-32,1921$.

2. Administrative report; mineral production in Florida during 1919 ; statistics on mineral production in Florida during 1920; Florida State Geol. Survey, 14th Ann. Rept., 1921-22, pp. 5-32, 1922.

3. (and Cooke, M. K.). Geology of Florida and a résumé of the drilling for oil: National Petroleum News, vol. 14, no. 21, pp. .67-68, 71-72, 2 figs. (incl. map), May 22, 1922.

4. Comanchan backbone of Florida: Pan-Am. Geologist, vol. 39, no. 1, pp. 66-67, February, 1923.

5. Administrative report; statistics on mineral production in Florida during 1921 and 1922: Florida State Geol. Survey, 15th Ann. Rept., 1922-1923, pp. 5-23, 1924.

6. Mineral resources of Florida: The South's Development, Manufacturers Record, vol. 86, no. 24, pt. 2, pp. 363-366, 9 figs., December 11, 1924.

7. Administrative report; statistics of mineral production in Florida during 1923 : Florida State Geol. Survey, 16th Ann. Rept., pp. 7-25, 1 pl., 1925.

8. Statistics of mineral production in Florida during 1924: Florida State Geol. Survey, 17th Ann. Rept., pp. 11-19, 1926.

9. Administrative report; statistics of mineral production in Florida during 1925: Florida State Geol. Survey, 18th Ann. Rept., pp. 5-25, 1927. 
Gunter, Herman-Continued.

10. Administrative report; statistics of mineral production in Florida during; 1926: Florida State Geol. Survey, 19th Ann. Rept., pp. 13-31, 1928.

11. (and Martens, J. H. C.). Geology of Florida (abstract) : Geol. Soc. America, Bull., vol. 39, no. 1, pp. 272-273, March 30, 1928; PanAm. Geologist, vol. 49, no. 3, p. 234, April, 1928.

12. Basement rocks encountered in a well in Florida: Am. Assoc. Petroleum Geologists, Bull., vol. 12, no. 11, pp. 1107-1108, November, 1928.

Guppy, Henry Brougham.

1. Fossil botany in the western world; an appreciation: Am. Jour. Sci., 4th ser., vol. 49, pp. 372-374, May, 1920.

2. America's contribution to the study of the plant world: Jour. Ecology, vol. 9, no. 1, pp. 90-94, September 30, 1921.

Gurwitsch, Leo.

1. The chemical and the geological question of the origin of petroleum: Oil Field Engineering, vol. 2, no. 5, pp. 59-63, September, 1927.

Haack, Wilhelm.

1. Ueber eine marine Permfauna aus Nordmexiko nebst Bemerkungen über Devon daselbst: Deutsche geol. Gesell., Zeitschr., Bd. 66, H. 4, pp. 482-504, 2 figs., 2 pls., 1914.

Haanel, Benjamin F.

1. Facts about peat: Canada, Mines Branch, 48 pp., 1924.

2. Final report of the peat committee. . . ; peat, its manufacture and uses: Canada, Dept. Mines, Mines Branch, no. 641, 298 pp., 46 figs., 58 pls., 1926.

Haanel, Eugene, 1841-1927.

1. Summary report of the Mines Branch of the Department of Mines [of Canada] for the calendar year ending December 31, 1918. 225 pp., 6 figs., Ottawa, 1920.

2. Summary report of the Mines Branch of the Department of Mines [of Canada] for the calendar year ending December 31, 1919. 182 pp., 2 figs., Ottawa, 1920.

Haas, William $\mathrm{H}$.

1. Erosion features of the Mesa Verde [Colorado] : Illinois Acad. Sci., Trans., vol. 9, pp 211-219 [1917].

2. Formation of clay balls: Jour. Geology, vol. 35, no. 2, pp. 150-157, 5 figs., February-March, 1927.

Haase, Leo G.

1. Little geological studies in southern California (author's illustrated notes on geological formations in southern California). 24 pp., illus., Long Beach, California, 1926.

Habermeyer, George Conrad.

1. Public ground-water supplies in Illinois: Illinois State Water Survey, Bull. no. 21, 710 pp., 11 figs. and pls., 1925.

Hackford, J. E.

1. Nature of coal: Mining and Metallurgy, no. 163, pp. 35-36, July, 1920 (abstract) ; Am. Inst. Min. and Met. Eng., Trans vol. 65, pp. 217228, 1921 [preprint no. 1001], 6 pp., 1920; discussion by W. $\mathrm{x}$. Pratt, David White, E. De Golyer, Reinhardt Thiessen, and C. E. Waters [preprint] no. 1038, pp. 63-68, January, 1921. 
Hafer, Claude.

1. Placer gold in Indiana: Eng. and Min. Jour., vol. 111, no. 25, p. 1023, June 18, 1921.

Hagens, Graddus $\mathbf{R}$.

1. Mineral resources of Natrona County, Wyoming: Min. Jour., Phoenix. Ariz., vol. 11, no. 15, pp. 3-6, 52-53, December 30, 1927.

Hager, Dilworth S.

1. (and Brown, I. O.). The Minerva oil field, Milam County, Texas: Am. Assoc. Petroleum Geologists, Bull., vol. 8, no. 5, pp. 632-640, 3 figs., September-October, 1924.

2. (and Stiles, S.). The Blue Ridge salt dome, Fort Bend County, Texas: Am. Assoc. Petroleum Geologists, 'Bull., vol: 9, no. 2, pp. 304-316, 4 figs., March-April, 1925; Geology of salt dome oil fields, pp. 600612, 4 figs., 1926.

3. Factors affecting the color of sedimentary rocks: Am. Assoc. Petroleum Geologists, Bull., vol. 12, no. 9, pp. 901-938, September, 1928.

Hager, Dorsey.

1. Practical oil geology; the application of geology to oil field problems. Third edition, 253 pp., 126 figs., New York, McGraw-Hill Book Company, 1919.

2. Geology of oil fields of north central Texas (with discussion by W. E. Pratt) : Am. Inst. Min. and Met. Eng., Trans., vol. 61, pp. 520-531, 8 figs., 1920.

3. Oil possibilities of the Holbrook area in northeast Arizona. 31 pp., 8 figs. [private publication, copyright 2921]. Mining and Oil Bulletin, vol. 8 , no. 1 , pp. $23-26,33-34$; no. 2 , pp. $71-74,81,94$; no. 3 , pp 135-140, 12 figs., January, February, and March, 1922.

4. The Holbrook area, Arizona: Min. and Oil Bull., vol. 8, no. 9, p. 523, September, 1922.

5. Sunburst oil and gas field, Montana (with discussion by F. G. Clapp) : Am. Inst. Min. and Met. Eng. ,Trans., vol. 69, pp. 1101-1120, 5 figs., 1923 ; [preprint], no. 1218, 19 pp., 5 figs., February, 1923; abstract. Mining and Metallurgy, vol. 4, no. 194, pp. 84-85, 1 fig., February. 1923.

6. Stratigraphy, northeast Arizona, southeast Utah: Min. and Oil Bull., vol. 10, no. 2, pp. 135, 137, 139, 167, 1 fig., February, no. 4, pp. 383, 385, 423, 439, 2 figs., April, 1924.

7. Oil possibilities in western Washington: Oil and Gas Jour., vol. 23, no. 13-A, pp. 32, 112-113, 2 figs., August 21, 1924.

8. Practical oil geology ... Fourth edition, 309. pp., 161 figs., New York, McGraw-Hill Book Company, 1926.

9. Meteor Crater [Arizona] : Eng. and Min. Jour.-Press, vol. 121, no. 9, p. 374, February 27, 1926 .

Hager, Lee. See Brokaw, 1.

Haggen, E. A.

. 1. Geology of the Pend Oreille formations [Pend Oreille district, northeastern Washington]: Min. and Industrial Record (Vancouver, British Columbia), vol. 31, no. 4, pp. 82-83, April, 1928; Min. Mag., vol. 38 , no. 6, pp. 384-385, June, 1928. 
Hake, Benjämin F.

1. Occurrence of Pholadomya in the Miocene of California (abstract): Geol. Soc. America, Bull., vol. 37, no. 1, p. 214, March 30, 1926.

2. Scarps of the southwestern Sierra Nevada, California: Geol. Soc. America, Bull., vol. 39, no. 4, pp. 1017-1030, 1 fig., 1 pl., December 30, 1928; abstract, Geol. Soc. America, Bull., vol. 38, no. 1, p. 164, March 30, 1927 ; Pan-Am. Geologist, vol. 47, no. 2, p. 158, March, 1927.

Haley, Charles Scott.

1. Dry placers of southern California: California State Min. Bur., Mining in California, vol. 18, no. 7, pp. 321-324, July, 1922; Pacific Min. News, vol. 1, no. 8, pp. 235-236, December, 1922.

2. Tertiary sluice robbers: California State Min. Bur., Mining in California, vol. 18, no. 10, pp. 550-553, October, 1922.

3. Gold placers of California: California State Min. Bur., Bull. 92, 167 pp., 36 figs., 7 pls., June, 1923.

4. Primary and secondary gold concentrations: California State Min. Bur., Mining in California, vol. 19, no. 1, pp. 38-40, January, 1923: Mining and Metallurgy, vol. 4, no. 203, p. 564, November, 1923.

Haley, D. F.

1. Molybdenite operations at Climax, Colorado; Am. Inst. Min. and Met. Eng., Trans., vol. 61, pp. 71-76, 1920.

Haliburton, E. D.

1. Newfoundland's coal areas: Canadian Min. Jour., vol. 40, no. 50, pp. 946947, 1 fig., December 17, 1919.

Hall, C. W.

1. Geology of the Yoquivo, Chihuahua, mining district [Mexico]; Am. Inst. Min. and Met. Eng., Trans. [preprint], no. 1530, 15 pp., 5 figs., February, 1926 ; Trans., vol. 74, pp. 223-237, 5 figs., 1926 ; abstract, Mining and Metallurgy, vol. 7, no. 230, p. 77, February, 1926.

Hall, D. A. See Locke, 4.

Hall, George M. See also Swartz, C. K., 5.

1. Species of the mammalian subfamily Bassariscinae: California, Univ., Dept. Geol. Sci., Bull., vol. 16, no. 11, pp. 435-448, 2 figs., 1 pl., March 17, 1927.

Hall, George M. See also Swartz, C. K., 5.

1. Extinction of the Tetracoralla: Pan-Am. Geologist, vol. 37, no. 4, pp. 322-327, May, 1922.

2. Description of fire clay localities [in Maryland] : Maryland Geol. Survey, vol. 11, pp. 349-375, 1922.

3. Ground water in the Ordovician rocks near Woodstock, Virginia: U. S. Geol. Survey, Water-Supply Paper 596, pp. 45-66, 4 figs., 2 pls., August 22, 1927.

4. Note on an ebb and flow spring near Rogersville, Tennessee: Tennessee Acad. Sci., Jour., vol. 3, pp. 3-9, 3 figs., July, 1928.

Hall, Roy H. See Barwick, 1.

Hallimond, A. F.

1. Studies in the mica group (a discussion): Am. Mineralogist, vol. 12, no. 11, pp. 413-414, November, 1927.

2. Studies in the mica group (discussion) : Am. Mineralogist, vol. 13, no. 8, pp. 451-452, August, 1928. 
Hallimond, A. F.-Continued.

3. The formula of glauconite: Am. Mineralogist, vol. 13, no. 12, pp. 589-590, December, 1928.

Hamilton, Fletcher.

1. Report XVII of the State mineralogist; mining in California during 1920. 562 pp., 62 figs., 9 pls., California State Min. Bur., 1921.

2. California's mineral resources and the State Mining Bureau: California State Min. Bur., Mining in California, vol. 18, no. 11, pp. 618-627, November, 1922.

Hamilton, George $\mathrm{H}$.

1. Continent formation and legend of Atlantis: Pan-Am. Geologist, vol. 50, no. 1, pp. 23-28, August, 1928.

Hamilton, S. Harbert. See Fettke, 6.

Hamilton, Walter Raleigh.

1. Development of petroleum geology in California: Am. Assoc. Petroleum Geologists, Bull., vol. 5, no. 4, pp. 457-460, July-August, 1921.

Hamlin, Homer.

1. Report on geological examination of Iron Canyon dam and reservoir site. In Report on Iron Canyon Project, California, by Homer J. Gault and W. F. McClure: U. S. Reclamation Service in cooperation with the State of California and the Iron Canyon Project Association, pp. 41-59, 9 pls., Washington, Government Printing Office, 1921.

Hammer, A. A.

1. (and Lloyd, A. M.). A study of some Upper Cretaceous sedimentation and diastrophism in Montana: Am. Assoc. Petroleum Geologists, Bull., vol. 9, no. 5, pp. 886-903, 1 fig., 2 pls., August, 1925.

2. (and Lloyd, A. M.). Notes on the Quadrant formation of east-central Montana: Am. Assoc. Petroleum Geologists, Bull., vol. 10, no 10, pp. 986-996, 2 pls. (incl. maps), October, 1926.

Hammill, Chester A. See also Aurin, 2.

1. The Cretaceous of northwestern Louisiana: Am. Assoc. Petroleum Geologists, Bull., vol. 5, no. 2, pp. 298-310, 3 figs., March-April, 1921.

Hance, James Harold.

1. Work of the Illinois State Geological Survey: Illinois State Acad. Sci., Trans., vol. 14, pp. 207-212 [1922].

2. Some questions in general and petroleum geology which are suggested by oil occurrences in Crawford County, Pennsylvanian beds; Illinois State Acad. Sci., Trans., vol. 17, pp. 199-203, 1925.

3. Geology and mineral resources of the Wellsville quadràngle, Ohio (abstract) : Chicago, Univ., Abstracts of Theses, Sci. Ser., vol. 1, pp. 285-288, October, 1925.

Hancock, Eugene Thomas. See also Redwood, 1.

1. Geology and oil and gas prospects of the Lake Basin field, Montana (U. S. Geol. Survey, Bull. 691, pp. 101-147, 1918) (abstract by R. W. Stone) : Washington Acad. Sci., Jour., vol. 9, no. 2, p. 50, January 19, 1919.

2. Geology and oil and gas prospects of the Huntley field, Montana: U. S. Geol. Survey, Bull. 711, pp. 105-148, 5 pls. (incl. map), 2 figs., 1920. Abstract by J. D. Sears, Washington Acad. Sci., Jour., vol. 10 , no. 18 , p. 521, November 4, 1920. 
Hancock, Eugene Thomas-Continued.

3. The Upton-Thornton oil field, Wyoming: U. S. Geol. Survey, Bull. 716, pp. 17-34, 1 pl. (map), 1 fig., 1920. Abstract by M. I. Goldman, Washington Acad. Sci., Jour., vol. 10, no. 18, pp. 522-523, November 4, 1920.

4. The Mule Creek oil field, Wyoming: U. S. Geol. Survey, Bull. 716, pp. 35-53, 1 fig., 1 pl. (map), July 27, 1920. Abstract by M. I. Goldman, Washington Acad. Sci., Jour., vol. 10, no. 21, p. 598, December $19,1920$.

5. The Lance Creek oil and gas field, Niobrara County, Wyoming: U. S. Geol. Survey, Bull. 716, pp. 91-122, 4 pls. (incl. map), December 13, 1920 ; abstract by M. I. Goldman, Washington Acad. Sci., Jour., vol. 11 , no. 10 , p. 237 , May $19,1921$.

6. The New Salem lignite field, Morton County, North Dakota: U. S. Geol. Survey, Bull. 726, pp. 1-39, 4 figs., 5 pls. (incl. map), May 6, 1921. Abstract by M. I. Goldman, Washington Acad. Sci., Jour., vol. 12, no. 1, p. 19, January $4,1922$.

7. Geology and coal resources of the Axial and Monument Butte quadrangles, Moffat County, Colorado: U. S. Geol. Survey, Bull. 757, 134 pp., 6 figs., 19 pls., 1925.

Handlirsch, Anton.

1. Revision der paläozoischen Insekten: Akad. Wissensch. Wien, Math.naturw. Klasse, Denkschr., Band 96, pp. 511-592, 91 figs., 1919.

Handy, F. M.

1. Stevens County magnesite [Washington]. In Northwest Mines Handbook, vol. 1, pp. 315-318, 1 fig., published by Sidney Norman, Spokane, Washington, 1918.

Haney, James A.

1. The Kantishna mining district, Alaska: Min. and Sci. Press, vol. 122, pp. 881-882, 1 fig., June 25, 1921.

Haney, Marshall.

1. The tin deposits of Virginia, U. S. A. : Canadian Min. Jour., vol. 41, p. 801, October 1, 1920.

2. The mining of paint; yellow ocher deposits of the Cartersville district, Georgia : Eng. and Min. Jour., vol. 110, no. 18, pp. 859-860, 2 figs., October 30, 1920.

3. Petroleum: Sci. Monthly, vol. 17, no. 6, pp. 548-562, December, 1923.

4. The tin deposits of the Carolinas: Eng. and Min. Jour., vol. 126, no. 26, pp. 1023-1024, December 29, 1928.

Hanna, G. Dallas. See also Anderson, F. M., 1; Gaylord, 2; Taff, 4, 6 ; Takahashi, 1; Weaver, 3.

1. Geological notes on the Pribilof Islands, Alaska, with an account of the fossil diatoms: Am. Jour. Sci., 4th ser., vol. 48, pp. 216-224, September, 1919.

2. Fossil mollusks from the John Day Basin in Oregon: Oregon, Univ., Pub., vol. 1, no. 6,8 pp., 1 pl., August, 1920.

3. [Report of] Department of Invertebrate. Paleontology: California Acad. Sci., Proc., 4th ser., vol. 9, nos. 14 and 15, pp. 387-389, 1920.

4. Miocene land shells from Oregon: Kansas Univ. Sci. Bull., vol. 13, no. 1, pp. 3-11, 1 pl., May, 1920.

5. Pleistocene mollusks from Wallace County, Kansas: Kansas Univ. Sci. Bull., vol. 13, no. 2, pp. 17-19, May, 1920. 
Hanna, G. Dallas-Continued.

6. Fossil fresh-water mollusks from Oregon: Oregon, Univ., Pub., vol. 1, no. 12, 22 pp., 4 pls., August, 1922.

7. Upper Miocene lacustrine mollusks from Sonoma County, California: California Acad. Sci., Proc., 4th ser., vol. 12, no. 3, pp. 31-41, 3 pls., January 2, 1923.

8. Results of preliminary examination of seven samples of sediments from near Lomita [California]: Southern California Acad. Sci., Bull., vol. 22, pt. 2, pp. 64-65, July, 1923.

9. Pleistocene fresh-water mollusks from north-central Texas: Nautilus, vol. 37, no. 1, pp. 25-26, July, 1923.

10. Some Eocene Foraminifera near Vacaville, California: California, Univ., Dept. Geol. Sci., Bull., vol. 14, no. 9, pp. 319-328, 2 pls., October 31, 1923.

11. Succinea avara Say from the tar pits of California; Nautilus, vol. 37, no. 3, p. 106, January, 1924.

12. (and Gaylord, E. G.). Description of a new genus and species of freshwater gastropod mollusk (Scalez petrolia) from the Etchegoin Pliocene of California: California Acad. Sci., Proc., 4th ser., vol. 13, no. 9, pp. 147-149, 2 figs., March 18, 1924.

13. Rectifications of nomenclature: California Acad. Sci., Proc., 4th ser., vol. 13, no. 10, pp. 151-186, March 18, 1924.

14. Smaller Foraminifera for stratigraphy: Am. Assoc. Petroleum Geologists, Bull., vol. 8, no. 2, pp. 246-250, March-April, 1924.

15. (and McLellan, Mary E.). A new species of whale from the type locality of the Monterey group: California Acad. Sci., Proc., 4th ser., vol. 14, pp. 237-241, 5 pls., June 14, 1924.

16. Insects in the California tar traps: Science, new ser., vol. 59, p. 555, June 20, 1924.

17. (and Driver, H. L.). The study of subsurface formations in California oil field development: California State Min. Bur., Summary of Operations California Oil Fields, vol. 10, no. 3, np. 5-26, 10 figs., September, 1924.

18. (and Hanna, Marcus A.). Foraminifera from the Eocene of Cowlitz River, Lewis County, Washington: Washington, Univ., Pub. in Geology, vol. 1, no. 4, pp. 57-62, 1 pl., October, 1924.

19. Gigantic amphibian from Kansas coal measures: Pan-Am. Geologist, vol. 42, no. 3, pp. 235-236, October, 1924.

20. Miocene marine vertebrates in Kern County, California: Science, new ser., vol. 61, pp. 71-72, January 16, 1925.

21. The extraction of fossils from refractory rocks: Jour. Geology, vol. 33, no. 5, pp. 545-547, July-August, 1925.

22. The age and correlation of the Kreyenhagen shale in California: Am. Assoc. Petroleum Geologists, Bull., vol. 9, no. 6, pp. 990-999, September, 1925.

23. 'Tertic expanse of North American continent in Pacific Ocean: Pan-Am. Geologist, vol. 44, no. 2, p. 147, September, 1925.

24. Was there a Pacific continent?: Science, new ser., vol. 62 , pp. 491-492, November 27, 1925.

25. Paleontology of Coyote Mountain, Imperial County, California: California Acad. Sci., Proc., 4th ser., vol. 14, no. 18, pp. 427-502, 1 fig., 10 pls., March 23, 1926.

26. Microscopical research in California petroleum field: Oil and Gas Jour., vol, 24, no. 45, p. 96, April 1, 1926. 
Hanna, G. Dallas-Continued.

27. (and Grant, William M.). Miocene marine diatoms from Maria Madre Island, Mexico: California Acad. Sci., Proc., 4th ser., vol. 15, no. 2, pp. 115-192, 1 fig., 11 pls., April 16, 1926.

28. Further notes on Scalez petrolia: Nautilus, vol. 40, no. 1, pp. 14-16, July, 1926.

29. (and Hertlein, Leo George). Expedition of the California Academy of Sciences to the Gulf of California in 1921; Geology and paleontology : California Acad. Sci., Proc., 4th ser., vol. 16, no. 6, pp. 137156, 1 pl., April 22, 1927.

30. A note on the geology of St. Matthew Island, Bering Sea: Am. Jour. Sci., 5th ser., vol. 13, p. 450, May, 1927.

31. The lowest known Tertiary diatoms in California: Jour. Paleontology, vol. 1, no. 2, pp. 103-127, 5 pls., August, 1927.

32. Geology of the west Mexican islands: Pan-Am. Geologist, vol. 48, no. 1, pp. 1-24, 3 figs., 8 pls., August, 1927.

33. Cretaceous diatoms from California: California Acad. Sci., Occ. Papers 13, 48 pp., 5 pls., September 17, 1927.

34. (and Hertlein, Leo George). Notes on Ostrea californica Marcou [California] : Nautilus, vol. 41, no. 2, pp. 45-47, October, 1927.

35. Silicoflagellata from Cretaceous of California: Jour. Paleontology, vol, 1, no. 4, pp. 259-263, 1 pl., January, 1928.

36. An early reference to the theory that diatoms are the source of bitumi. nous substances: Am. Assoc. Petroleum Geologists, Bull., vol. 12. no. 5, pp. 555-556, May, 1928.

37. (and Church, C. C.). Freezing and thawing to disintegrate shales: Jour. Paleontology, vol. 2, no. 2, p. 131, June, 1928.

38. The Monterey shale of California at its type locality, with a summary of its fauna and flora: Am. Assoc. Petroleum Geologists, vol. 12, no. 10, pp. 969-983, 4 pls., October, 1928.

39. The age of the diatom-bearing shales at Malaga Cove, Los Angeles County, California: Am. Assoc. Petroleum Geologists, Bull., vol. 12, no. 11, pp. 1109-1111, November, 1928.

Hanna, Marcus Albert. See also Cushman, 29, 32 ; Dawson, 1 ; Hanna, G. D., 18.

1. Notes on the genus Venericardia from the Eocene of the West Coast of America : California, Univ., Dept. Geol. Sci., Bull., vol. 15, no. 8, pp. 281-306, 9 pls., May 21, 1925.

2. An interesting volcanic ash from Calcasieu Parish, Louisiana: Am. Assoc. Petroleum Geologists, Bull., vol. 10, no. 1, pp. 93-95, 1 pl., January, 1926.

3. Geology of the La Jolla quadrangle, California : California, Univ., Dept. Geol. Sci., Bull., vol: 16, no. 7, pp. 187-246, 7 pls., map, November $20,1926$.

4. Separation of fossils and other light materials by means of heavy liquids : Econ. Geology, vol. 22, no. 1, pp. 14-17, January-February, 1927.

5. An Eocene invertebrate fauna from the La Jolla quadrangle, California: California, Univ., Dept. Geol. Sci., Bull., vol. 16, no. 8, pp. 247298, 34 pls., March 25, 1927.

6. Society of Economic Paleontologists and Mineralogists: Jour. Paleontology, vol. 1, no. 1, pp. 3-9, July, 1927.

7. Clarification of oil-discolored bromoform: Jour, Paleontology, vol. 1, no. 2, p. 145, August, 1927, 
Hanna, Marcus Albert-Continued.

8. The Journal of Paleontology: Science, new ser., vol. 66, p. 295, September $30,1927$.

9. A simple thin-section lap: Jour. Paleontology, vol. 1, no. 3, p. 219, 1 pl., December, 1927.

10. Report of the secretary-treasurer [of the Society of Economic Paleontologists and Mineralogists]: Jour. Paleontology, vol. 2, no. 2, pp. 167-172, June, 1928.

Hannibal, Harold. See also Jordan, 11.

1. Notes on Tertiary sirenians of the genus Desmostylus: Jour. Mammalogy, vol. 3, no. 4, pp. 238-240, 2 pls., November, 1922.

Hansen, George $\mathrm{H}$.

1. Hairy mammoth skeleton in Utah: Science, new ser., vol. 68, p. 621 , December 21, 1928.

Hanson, George. See also Schofield, 7, 11, 14.

1. Some Canadian occurrences of pyritic deposits in metamorphic rocks: Econ. Geology, vol. 15, no. 7, pp. 574-609, 2 pls., 3 figs., November, 1920.

2. Upper Kitzault Valley, British Columbia: Canada, Geol. Survey, Summ. Rept., 1921, pt. A, pp. 7-21, 3 figs., map, 1922.

3. Reconnaissance between Kitsult River and Skeena River, British Columbia : Canada, Geol. Survey, Summ. Rept., 1922, pt. A, pp. 35-50, 2 flgs (maps), 1923.

4. The Dolly Varden mine [Nass River mining division, British Columbia] : Canadian Inst. Min. and Met., Monthly Bull., no. 124, pp. 887-895, 1 flg., August, 1922 ; Trans., vol. 25, pp. 212-220, 1 fig. [1923].

5. The Premier mine [northwestern British Columbia]: Canadian Inst. Min. and Met., Trans., vol. 25, pp. 225-232 [1923].

6. Reconnaissance between Skeena River and Stewart, British Columbia: Canada, Geol. Survey, Summ. Rept., 1923, pt. A, pp. 29-45, 3 figs. (maps), 1924.

7. Mining activity in the area between Portland Canal and Skeena River [British Columbia]: Canadian Min. Jour., vol. 45, no. 9, pp. 198-199, 2 figs., February 29, 1924.

S. Northwestern British Columbia: Canadian Min. Jour., vol. 45, no. 22, pp. 521-524, 5 figs., May 30, 1924.

9. Driftwood Creek map area, Babine Mountains, British Columbia : Canada Geol. Survey, Summ. Rept., 1924, pt. A, pp. 19-37, 1 fig., map, 1925.

10. Prince Rupert to. Burns Lake, British Columbia: Canada Geol. Survey, Summ. Rept., 1924, pt. A, pp. 38-46, 1925.

11. Reconnaissance in Zymoetz River area, Coast district, British Columbia: Canada Geol Survey, Summ. Rept., 1925, pt. A, pp. 100-119, map, 1926.

12. Zoning of mineral deposits in British Columbia : Roy. Soc. Canada, Trans., 3d ser., vol. 21, sec. 4, pp. 119-126, May, 1927; abstract, p. xcvi, 1927.

Hard, Herbert A. See Meinzer, 13.

Harder, Edmund Cecil. See also Allen, R. C., 2.

1. Iron-depositing bacteria and their geologic relations: U. S. Geol. Survey, Prof. Paper 113, 89 pp., 12 pls., 14 figs., 1919 ; abstract, Washington Acad. Sci., Jour., vol. 11, no. 3, pp. 56-57, February 4, 1921. 
Harder, Edmund Cecil-Continued.

2. (and Hewett, D. F.). Recent studies of domestic manganese deposits: Am. Inst. Min. and Met. Eng., Trans., vol. 63, pp. 3-50, 1920; (abstract), Bull. no. 149, pp. 895-901, May, 1919.

3. Bacteria and iron deposition: Pahasapa Quart., vol. 9, no. 3, pp. 105-112, 2 figs., April, 1920.

4. (and Eddingfield, F. T.). The iron ores of the World: Eng. and Min. Jour., vol. 109, pp. 1060-1064, May 8, 1920.

Harding, S. T.

1 Ground-water resources of the southern San Joaquin Valley: California, Dept. Public Works, Div. Eng. and Irrig., and Water Rights, Bull. no. 11, 146 pp., 29 figs., 3 maps, 1927.

Hardy, Allison.

1. The A B C of geology. 137 pp., New York, Vanguard Press, 1927.

Hardy, Norman. See Cunningham, 1.

Hares, C. J.

1. Tertiary glaciation in Wyoming, Colorado, and Utah: Science, new ser., vol. 62, p. 308, October 2, 1925.

2. Glacial origin of the Bishop conglomerate of Wyoming, Colorado, and Utah (abstract) : Geol. Soc: America, Bull., vol. 37, no. 1, pp. 174-175, March 30, 1926; Pan-Am. Geologist, vol. 45, no. 2, p. 168, March, 1926.

3. What is the Denver formation? (abstract) : Geol. Soc. America, Bull., vol. 37, no. 1, p. 175, March 30, 1926 ; Pan-Am. Geologist, vol. 45, no. 2, p. 168, March, 1926.

4. Post-Miocene-pre-Eocene glaciation in the Rocky Mountains (abstract) : Geol. Soc. America, Bull., vol. 37, no. 1, pp. 175-176, March 30, 1926; Pan-Am. Geologist, vol. 45, no. 2, pp. 168-169, March, 1926.

5. Geology and lignite resources of the Marmarth field southwestern North Dakota: U. S. Geol. Survey, Bull. 775, 110 pp., 1 fig., 14 pls., (incl. map), 1928.

Harker, Alfred.

1. The Sudbury laccolite: Geol. Mag., vol. 63, p. 192, April, 1926.

Harkness, R. B.

1. Oil and gas in Ontario: Canadian Inst. Min. and Met., Monthly Bull., no. 143, pp. 148-156, 1 fig., March, 1924 ; (with discussion), Trans., vol. 27 pp. 374-384, 1 fig. [1925].

2. Natural gas in 1922 and petroleum in 1922: Ontario Dept. Mines, 32d Ann. Rept., vol. 32, pt. 5, 99 pp., illus., 1924.

3. Natural gas in 1923 and petroleum in 1923: Ontario Dept. Mines, 33d Ann. Rept., vol. 33, pt. 5, 1924, 112 pp., illus., 1925.

4. Natural gas in 1924 and petroleum in 1924: Ontario Dept. Mines, 34th Ann. Rept., vol. 35, pt. 5, 74 pp., 3 figs., 1926.

5. Natural gas in 1925 and petroleum in 1925: Ontario Dept. Mines, 35th Ann. Rept., vol. 35, pt. 5, 69 pp., 5 figs , map, 1927.

6. Natural gas in 1926 and petroleum in 1926 : Ontario Dept. Mines, 36th Ann. Rept., vol. 36, pt. 4, 40 pp., 3 figs., 1928.

7. The oil and gas fields of Ontario: Canadian Inst. Min. and Met., Trans., vol. 30, pp. 597-611, map [1.928] ; Second (Triennial) Empire Min. and Met. Congress, Canada, 1927, Proc., pt. 3, 81-95, map, 1928. 
Harlton, Bruce H. See also Galloway, 13 ; Tomlinson, 4.

1. Some Pennsylvanian Ostracoda of the Glenn and Hoxbar formations of southern Oklahoma and of the upper part of the Cisco formation of northern Texas: Jour. Paleontology, vol. 1, no. 3, pp. 203-212, 2 pls., December, 1927.

2. Some Pennsylvanian Foraminifera of the Glenn formation of southern Oklahoma: Jour. Paleontology, vol. 1, no. 1, pp. 15-27, 5 pls., July, 1927.

3. Pennsylvanian Foraminifera of Oklahoma and Texas: Jour. Paleontology, vol. 1, no. 4, pp. 305-310, 2 pls., January, 1928.

4. Pennsylvanian ostracods of Oklahoma and Texas: Jour. Paleontology, vol. 2, no. 2, pp. 132-141, 1 pl., June, 1928.

Harnsberger, Thomas $\mathrm{K}$.

1. The geology and coal resources of the coal-bearing portion of Tazewell County, Virginia : Virginia Geol. Survey, Bull. no. 19, 195 pp., 14 pls. (incl. maps), 17 figs., 1919.

\section{Harper, Roland McMillan.}

1. Resources of southern Alabama: Alabama Geol. Survey, Special Rept. no. 11, 152 pp., 28 fig., July, 1920.

2. Geography of central Florida: Florida State Geol. Survey, Thirteenth Ann. Rept., pp. 71-288, 42 figs., 1921.

3. Natural resources of southern Florida: Florida State Geol. Survey, Eighteenth Ann. Rept., pp. 27-206, 58 figs., 1927.

\section{Harrington, George Leavitt.}

1. The Anvik-Andreafski region, Alaska (including the Marshall district) : U. S. Geol. Survey, Bull. 683, 70 pp., 7 pls. (incl. maps), 1918. Abstract by R. W. Stone, Washington Acad. Sci., Jour., vol. 9, no. 19, pp. 600-601, November 19, 1919.

2. The gold and platinum placers of the Tolstoi district [Alaska]: U. S. Geol. Survey, Bull. 692, pp. 339-351, 1 pl. (map), 1919. Abstract by G: C. Martin, Washington Acad. Sci., Jour., vol. 9, no. 20, p. 636, December 4, 1919.

3. Tin mining in Seward Peninsula: U. S. Geol. Survey, Bull. 692, pp. 353-363, 1919. Abstract by G. C. Martin, Washington Acad. Sci., Jour., vol. 9, no. 20, p. 636, December 4, 1919.

4. Graphite mining in Seward Peninsula: U. S. Geol. Survey, Bull. 692, pp. 363-367, 1919. Abstract by G. C. Martin, Washington Acad. Sci., Jour., vol. 9, no. 20 , p. 636, December 4, 1919.

5. The gold and platinum placers of the Kiwalik-Koyuk region [Alaska]: U. S. Geol. Survey, Bull. 692. pp. 369-400, 1 pl. (map), 1919. Abstract by G. C. Martin, Washington Acad. Sci., Jour., vol. 9, no. 20, p. 636, December 4, 1919.

6. Mineral resources of the Goodnews Bay region, Alaska: U. S. Geol. Survey, Bull. 714, pp. 207-228, map, 1921. Abstract by R. W. Stone, Washington Acad. Sci., Jour., vol. 11, no. 15, p. 376, September 19, 1921.

7. Mining on Seward Peninsula, Alaska: U. S. Geol. Survey, Bull. 714, pp. 229-237, 1921.

Harris, Gilbert Dennison. See also Van Winkle, 1.

1. Pelecypoda of the St. Maurice and Claiborne stages: Bull. Am. Paleontology, vol. 6, no. 31, 260 pp., 59 pls., June 30, 1919. 
Harris, Gilbert Dennison-Continued.

2. The genera Lutetia and Alveinus, especially as developed in America: Palaeontographica Americana, vol. 1, no. 2, pp. 105-118, 1 pl., 8 figs., Ithaca, Harris Company, 1920.

3. A reprint of the more inaccessible paleontological writings of Robert John

Lechmere Guppy: Bull. Am. Paleontology, vol. 8, no. 35, 198 pp.

1 fig., 11 pls. (incl. portr.), March 15, 1921

4. (and Hodson, Floyd). The rudistids of Trinidad: Palaeontographica Americana, vol. 1., no. 3, pp. 119-162, 11 pls., November 25, 1922.

5. Notes on the paleontology [of the Island of Trinidad]: Johns Hopkins Univ., Studies in Geology, no. 7, pp. 87-112, 5 pls., 1926.

Harrị, T. F. See Woodford, 5, 7.

Harris, T. M.

1. The Rhaetic flora of Scoresby Sound, east Greenland: Meddelelser om Groenland, Bd. 68, pp. 43-148, 34 figs., 13 pls., 1926.

Harrison, John Burchmore.

1. Notes on the extraneous minerals in the coral limestones of Barbados (abstract) : Geol. Mag., new ser., dec. 6, vol. 6, p. 382, August, 1919.

2. The genesis of a fertile soil [Barbados] : West Indian Bull., vol. 18, no. 3, pp. 77-98 [1920].

3. Note on the occurrence of rhyolitic pebbles in Antigua: West Indian Bull,, vol. 18 no. 3, pp. 99-101 [1920].

\section{Harrison, Thomas S.}

1. Porphyry at Amarillo [Texas] : Am. Assoc. Petroleum Geologists, Bull., vol. 7, no. 4, pp. 434-439, July-August, 1923.

2. Some ideas regarding oil accumulation in the Rocky Mountain region (with discussion) : Am. Assoc. Petroleum Geologists, Bull., vol. 7, no. 6, pp. 661-671, November-December, 1923.

3. Colorado-Utah salt domes: Am. Assoc. Petroleum Geologists, Bull., vol. 11, no. 2, pp. 111-133, 15 figs., 1 pl., February, 1927.

Harrison \& Eaton [firm].

1. Report on investigation of oil and gas possibilities of western Oregon: Oregon Bur. Mines and Geology, Min. Res. Oregon, vol. 3, no. 1, pp. 3-37, 5 pls. (relief maps and sections), March, 1920.

Harshberger, John William.

1. The origin of columnar holes in wandering dunes: Science, new ser., vol. 57, pp. 727-728, June 22, 1923.

Harstad, A. J.

1. Montana sapphires: Rocks and Minerals, vol. 1, no. 2, pp. 21-22, December, 1926.

2. The agate: Rocks and Minerals, vol. 2, no. 1, pp. 3-5, March, 1927.

Hart, Gilbert.

1. Geological hammers: Am. Mineralogist, vol. 12, no. 9, p. 354, 1 fig., September, 1927.

2. The nomenclature of silica: Am. Mineralogist, vol. 12, no. 11, pp. 383-395, November, 1927.

Harter, R. F. H.

1. Some notes on the Butte, Montana, district: Rocks and Minerals, vol. 3, no. 3, pp. 78-82, September, 1928. 
Hartley, Burton.

1. The petroleum geologist in Mexico: Am. Assoc. Petroleum Geologists, Bull., vol. 5, no. 4, pp. 463-466, July-August, 1921.

2. 'The oil fields of Mexico: Am. Assoc. Petroleum Geologists, Bull., vol. 5, no. 4, pp. 504-507, 1 fig., July-August, 1921.

3. Certain relations between production and structure in northeastern Osage County, Oklahoma: Am. Assoc. Petroleum Geologists, Bull., vol. 6, no. 5, pp. 464-471, 3 figs., September-October, 1922.

Hartnagel, Chris Andrew. See also Newland, 8.

1. (and Bishop, S. C.). The mastodons, mammoths, and other Pleistocene mammals of New York State: New York State Mus. Bull., nos. 241-242, 110 pp., 25 pls., 1922.

2. Industral geology [of New York]: New York State Mus. Bull. no. 260, pp. 18-21, 1925.

3. The oil.fields of New York State. Am. Assoc. Petroleum Geologists, Bull., vol. 9, no. 4, pp. 798-802, July, 1925.

4. (and Bishop, Sherman C.). Additional records of Pleistocene mammals [in New York]: New York State Mus. Bull., no. 267, pp. 22-25, 1926.

5. Industrial geology [of New York] : New York State Mus. Bull. no. 267, pp. 34-37, 1926.

6. The mining and quarry industries of New York from 1919 to 1924 : New York State Mus. Bull., no. 273, 102 pp., 1927.

7. Stark's Knob [Saratoga County, New York] : Rocks and Minerals, vol. 3, no. 3, pp. 84-85, September, 1928.

Hartsook, Arthur J.

1. Chemistry and the petroleum industry : Rice Inst. Pam., vol. 11, no. 1, pp. 74-94, January, 1924.

Hartzell, W. F.

1. Natural solidified petroleum; its mining, treatment, and uses: Eng. and Min. Jour., vol. 125, no. 6, pp. 253-254, 2 figs., February 11, 1928.

Harvey, Roger $\mathbf{D}$.

1. Electrical conductivity and polished mineral surfaces: Econ. Geology, vol. 23, no. 7, pp. 778-803, 7 figs., November, 1928.

\section{Harvey, Ruth Sawyer.}

1. Drainage modifications and glaciation in the Danbury region, Connecticut: Connecticut, State Geol. and Nat. Hist. Survey, Bull. no. 30, 59 pp., 5 pls., 10 figs., 1920.

Harvie, Robert.

1. Asbestos, Weir Township, Bonaventure County, Quebec: Canada, Geol. Survey, Summ. Rept., 1920, pt. D, p. 84, 1921.

2. Notes on the allanite deposit at Lac a Baude, Champlain County, Quebec: Can. Min. Jour., vol. 42, no. 29, p. 575, July 22, 1921.

3. Dufresnoy map area, Abitibi district, Quebec: Canada, Geol. Survey, Summ. Rept., 1923, pp. 145-150, 1924.

4. Dufresnoy Lake map area ; report on part of the gold belt of northwestern Quebec: Canadian Min. Jour., vol. 45, no. 16, pp. 364-366, 2 figs., April 18, 1924.

Hasebrink, A.

1. Das Eisenerzvorkommen von Wabana (Neufundland): Glückauf, Jg. 62, no. 18, pp. 553-561, 16 figs., May 1, 1926. 
IIaseltine, Raymond Holden.

1. Iron ore depasits of Georgia: Georgia, Geol. Survey, Bull. no. 41, 222 pp., 7 flgs., 10 pls., 1.924.

Haseman, J. D.

1. The humic-acid origin of asphalt: Am. Assoc. Petroleum Geologists, Bull., vol. 5, no. 1, pp. 75-79, January-February, 1921.

Hashimoto, Tadaichi. See Becking, 1.

Hassan, A. A.

1. The geological importance of the Marathon fold [Brewster County, Texas] : Oil Trade, vol. 17, no. 2, pp. 32-34, 67-69, 1 fig., February, 1926.

Hastings, John B.

1. Mount Wheeler and Lehman Cave, White Pine County, Nevada (abstract) : Geol. Soc. America, Bull., vol. 32, no. 1, p. 69, March 31, 1921.

Haury, P. S. See Bell, H. W., 2.

Havenor, H. E.

1. Mining camps of North America ; Tintic, Utah: Jing. and Min. Jour.-Press, vol. 11.7, no. 9, pp. 355-361, 10 figs., March 1, 1924.

Hawaiian Volcano Observatory.

1. Weekly (after no. 1, Monthly) Bulletin, vols. 7-16, Honolulu, Hawaii, 1919-28.

Hawkins, Alfred C.

1. Two new forms on quartz from Pikes Peak [Colorado]: Am. Mineralogist, vol. 6 , no. 12, p. 169, December, 1921.

2. Crystallography of three minerals irom Rhode Island: Am. Mineralogist, vol. 7, no. 2, pp. 27-29, 2 figs., February, 1922.

3. (and Shannon, Earl V.). Canbyite, a new mineral [Wilmington, Delaware] : Am. Mineralogist, vol. 9, no. 1, pp. 1-5, January, 1924.

4. Alternative interpretations of some crystalline schists in southeastern Pennsylvania: Am. Jour. Sci., 5th ser., vol. 7, pp. 355-364, 1 fig., May, 1924.

5. Fluorite from Rochester, New York: Am. Mineralogist, vol. 10, no. 2, pp. 34-36, February, 1925.

6. Directional factors in radio crystal detectors: Am. Mineralogist, vol. 11 , no. 6 ; pp. 164-165, June, 1926.

7. Notes on pyrite and celestite from Rochester, New York: Am. Mineralogist, vol. 11, no. 6, p. 165, June, 1926.

8. (and Frankenfield, John S.). Pyrite from Cornwall, Pennsylvania: Am. Mineralogist, vol. 11, no. 9, pp. 252-253, 1 ig., September, 1926.

9. Halite and glauberite cavities and included minerals from central New Jersey: Am. Mineralogist, vol. 13, no. 6, pp. 238-239, June, 1928.

10. Casts and pseudomorphs of halite and glauberite from the Triassic of New Jersey (abstract): Geol. Soc. America, Bull., vol. 39, no. 1, p. 167, March 30, 1928; Pan-Am. Geologist, vol. 49, no. 1, p. 75, February, 1928.

11. Halite and glauberite cavities in the Triassic rocks of central New Jersey: Am. Jour. Sci., 5th ser., vol. 16, pp. 361-362, October, 1928.

12. Structure favors oil and gas production in New Jersey: Oil Weekly, vol. 50, no. 9, pp. 54, 56, 3 figs., August 17, 1928.

Hawkins, Herbert Leader. See also Arnold, B. W., 1.

1. Some Cretacenus Echinoidea from Jamaica: Geol. Mag., vol. 60, no. 5, pp. 199-216, 1 pl., May, 1923. 
Hawkins, Herbert Leader-Continued.

2. Notes on a new collection of fossil Echinoidea from Jamaica: Geol. Mag., vol. 61 , no. 7, pp. 312-324, 1 pl., July, 1924.

3. The Cretaceous shales of Jamaica: Geol. Mag., vol. 64, p. 142, March, 1927.

Hawley, Gladys Willetta.

1. Analyses of Illinois coals: Illinois State Geol. Survey, Cooperative Mining Series, Bull. no. 27, extract A, 68 pp., 1 fig., 1923.

Hawley, J. E. See also Bruce, 22.

1. Geology and economic possibilities of Sutton Lake area, District of Patricia: Ontario Dept. Mines, 34th Ann. Rept., vol. 34, pt. 7, 56 pp., illus. (incl map), 1926.

2. An evaluation of the evidence of life in the Archean: Jour. Geology, vol. 34, no. 5, pp. 441-461, 7 figs., July-August, 1926.

3. Geology of Ogden, Bristol, and Carscallen townships, Cochrane district: Ontario Dept. Mines, 35th Ann. Rept., vol. 35, pt. 6, pp. 1-36, 17 figs., map, 1927.

Haworth, Erasmus. See Stone, 11.

Hawtof, E. M.

1. Petroleum developments [in Cooke County]: Texas, Univ., Bull., no. 2710, pp. 63-149, January, 1928.

Hawxhurst, Robert, jr.

1. The Piz Piz gold district, Nicaragua: Min. and Sci. Press, vol. 122, pp. 353-360, 5 figs., March 12, 1921.

Hay, Oliver Perry, 1846-1930.

1. Descriptions of some mammalian and fish remains from Florida of probably Pleistocene age: U. S. Nat. Mus., Proc., vol. 56, pp. 103112, 3 pls., 1919.

2. [On Pleistocene geology and vertebrate paleontology of the Atlantic Coastal Plain]: Carnegie Inst. Washington, Year Book no. 17, 1918, pp. 311-312, February, 1919.

3. On some proboscideans of the State of New York: Science, new ser., vol. 49, pp. 377-379, April 18, 1919.

4. On the relative ages of certain Pleistocene deposits: Am. Jour. Sci., 4th ser., vol. 47, pp. 361-375, May, 1919.

5. Anthropologic Scraps. No. 1, pp. 1-4, September 10, 1919 [issued Oct. 20, 1919] ; no. 2, pp. 5-8, December 3, 1919 ; no. 3, pp. 9-12, March 29, 1920. Washington, D. C. [Private publication.]

6. Descriptions of some Pleistocene vertebrates found in the United States: U. S. Nat. Mus., Proc., vol. 58, pp. 83-146, 9 pls., 4 figs., 1920.

7. [On Pleistocene vertebrates and Pleistocene geology]: Carnegie Inst. Washington, Year Book no. 18, 1919, pp. 361-362, March, 1920.

8. [Report of investigations on Pleistocene vertebrates]: Carnegie Inst. Washington, Year Book No. 19, pp. 402-404, January, 1921.

9. Descriptions of species of Pleistocene Vertebrata types or specimens of most of which are preserved in the United States National Museum: U. S. Nat. Mus., Proc., vol. 59, pp. 599-642, 9 pls., 1921.

10. Report on work done on the Pleistocene epoch and its vertebrate fossils: Carnegie Inst. Washington, Year Book no. 20, 1921, pp. 445-446, February, 1922.

11. Description of a new fossil sea cow from Florida, Metaxytherium floridanum: U. S. Nat. Mus., Proc., vol. 61, art. 17, 4 pp., 1 pl., 1922. 
Hay, Oliver Perry-Continued.

12. Discussion of the Pleistocene and its vertebrate faunas (abstract): Geol. Soc. America, Bull., vol. 33, no. 1, p. 156, March 31, 1922.

13. Observations on some extinct elephants. 19 pp., 10 figs., 4 pls., June 12, 1922 [private print].

14. Further observations on some extinct elephants: Biol. Soc. Washington, Proc., vol. 35, pp. 97-101, September 30; 1922.

15. Report on work done on the Pleistocene epoch and its vertebrate fossils: Carnegie Inst. Washington, Year Book no. 21, 1922, p. 395, January, 1923.

16. The Pleistocene of North America and its vertebrated animals from the States east of the Mississippi River and from the Canadian provinces east of longitude $95^{\circ} .499$ pp., 25 figs., 41 pls., Carnegie Inst. Washington, Pub. no. 322, February, 1923.

17. Description of remains of Bison occidentalis from central Minnesota: U. S. Nat. Mus., Proc., vol. 63, art. 5, 8 pp., 2 pls., 1923.

18. Characteristics of sundry fossil vertebrates: Pan-Am. Geologist, vol. 39, no. 2, pp. 101-120, 2 figs., 3 pls.; March, 1923.

19. Oligocene sea turtles of South Carolina: Pan-Am. Geologist, vol. 40, no. 1, pp. 29-31, 2 pls., August, 1923.

20. Description of some fossil vertebrates from the upper Miocene of Texas: Biol. Soc. Washington, Proc., vol. 37, pp. 1-19, 2 figs., 6 pls., January 29, 1924.

21. Notes on the osteology and dentition of the genera Desmostylus and Cornwallius: U. S. Nat. Mus., Proc., vol 65, art 8, 8 pp., 2 figs., 2 pls., 1924.

22. On the geological age of the Walker Hotel swamp deposit, in Washington, D. C., and on the origin and the ages of the Coastal Plain terraces in general: Washington Acad. Sci., Jour., vol. 14, no. 12, pp. 255-264, June 19, 1924.

23. The Pleistocene of the middle region of North America and its vertebrated animals. 385 pp., 5 figs., 29 maps, Carnegie Inst. Wash. ington [Publication no. 322A], October, 1924.

24. a revision of the Pleistocene period in North America, based especially on glacial geology and vertebrate palentology: Washington Acad. Sci., Jour., vol. 15, no. 6, pp. 126-133, March 19, 1925.

25. On remains of mastodons found in Texas, Anancus brazosius and Gomphotherium cimarronis: U. S. Nat. Mus., Proc., vol. 66, art. 35, 15 pp., 9 figs., 4 pls., April 25, 1925.

26. A further and detailed description of the type of Elephas roosevelti Hay and descriptions of three recently referred specimens: U. S. Nat. Mus., Proc., vol. 66, art. 34, 6 pp., 1 fig., 4 pls., May 22, 1925.

27. On the correlation of certain Pleistocene deposits and their fossils: Washington Acad. Sci., Jour., vol. 15, no. 11, pp. 239-246, June 4, 1925.

28. Vicissitudes of Pleistocene vertebrates (abstract): Pan-Am. Geologist vol. 43, no. 5, pp. 365-367, June, 1925.

29. Extinct proboscideans of Mexico: Pan-Am. Geologist, vol. 44, no. 1, pp. 21-37, 2 pls., August, 1925.

30. Review of Dr. Günther Schlesinger's paper on mastodons: Washington Acad. Sci., Jour., vol. 15, no. 16, pp. 381-387, October 4, 1925.

31. Report on the progress of the investigation on the Pleistocene of North America and its vertebrate animals: Carnegie Inst. Washington, Year Book no. 24, p. 357, December, 1925. 
Hay, Oliver Perry-Continued.

32. Two new Pleistocene mastodons: Washington Acad. Sci., Jour., vol. 16, no. 2, pp. 35-41, 2 pls., January 19, 1926.

33. A collection of Pleistocene vertebrates from southwestern Texas: U. S. Nat. Mus., Proc., vol. 68, art. 24, 18 pp., 2 figs., 8 pls., 1926.

34. Description of remains of an elephant found at Port Williams, Washington: Washington Acad. Sci., Jour., vol. 16, no. 6, pp. 154-159, $1 \mathrm{pl}$, March 19, 1926.

35. The geological age of Tuolumne Table Mountain, California : Washington Acad. Sci., Jour., vol. 16, no. 13, pp. 358-361, July 9, 1926.

36. On the geological age of Pleistocene vertebrates found at Vero and Mel. bourne, Florida: Washington Acad. Sci., Jour., vol. 16, no. 14, pp. 387-392, August 19, 1926.

37. Professor Osborn on the mammals and the birds of the California tar pools : Science, new ser., vol. 64, pp. 426-427, October 29, 1926.

38. On the type skull of Equus laurentius Hay: Washington Acad. Sci., Jour., vol. 17, no. 1, pp. 5-7, January 3, 1927.

39. The Pleistocene of the western region of North America and its vertebrated animals. 346 pp., 21 maps, 12 pls., Carnegie Inst., Washington, Pub. no. 322B, July, 1927.

40. A review of recent reports on investigations made in Florida on Pleistocene geology and paleontology: Washington Acad. Sci., Jour., vol. 17, no. 11, pp. 277-283, June 4, 1927.

41. (and Cook, Harold J.). Preliminary descriptions of fossil mammals recently discovered in Oklahoma, Texas, and New Mexico: Colorado Mus. Nat. Hist., Proc., vol. 8, no. 2, pt. 1, p. 33, February 2, 1928.

42. Correlation on the basis of fossil vertebrates (abstract) : Pan.-Am. Geologist, vol. 49, no. 4, pp. 297-298, May, 1928; Geol. Soc. America, Bull., vol. 39, no. 1, pp. 278-279, March 30, 1928.

43. On the antiquity of relics of man at Frederick, Oklahoma: Science, new ser., vol. 67, pp. 442-444, April 27, 1928.

44. Again on Pleistocene man at Vero, Florida: Washington Acad. Sci., Jour., vol. 18, no. 9, pp. 233-241, May 4, 1928.

45. Characteristic mammals of the early Pleistocene: Washington Acad. Sci., Jour., vol. 18, no. 15, pp. 421-430, September 19, 1928.

46. Further consideration of the shell of Chelys and of the constitution of the armor of turtles in general: U. S. Nat. Mus., Proc., vol. 73, art. 3, 12 pp., 2 pls., 1928.

47. An extinct camel from Utah: Science, new ser., vol. 68, pp. 299-300, September 28, 1928.

Hayes, Albert Orion. See also Bateman, 5.

1. Investigations in Nova Scotia and New Brunswick: Canada, Geol, Survey, Summ. Rept., 1918, pt. F, pp. 5-31, 3 figs., 1919.

2. The Malagash salt deposit, Cumberland County, Nova Scotia: Canada, Geol. Survey, Mem. 121, 24 pp., 1 fig., 2 maps, 1920.

3. Investigations in Nova Scotia and New Brunswick: Canada, Geol. Survey, Summ., Rept., 1919, pt. F, pp. 20-22, 1920.

4. Nova Scotian oolitic iron deposits of sedimentary origin: Canadian Min. Inst., Trans., vol. 22, pp. 112-122 [1920].

5. Carboniferous salt and potash deposits of eastern Canada (abstract) : Geol. Soc. America, Bull., vol. 31, no. 1, p. 155, March 31, 1920. 
Hayes, Albert Orion-Continued.

6. (and Bell, W. A.). 'The southern part of the Sydney coal field, Nova Scotia : Canada, Geol. Survey, Mem. 133, pp. 1-89, 2 figs., map, 1923.

7. Bituminous shale and other mineral occurrences in the vicinity of Sussex, New Brunswick: Canada, Geol. Survey, Summ. Rept., 1925, pt. C, pp. 125-131, map, 1927.

8. William S. Valiant: Science, new ser., vol. 65, p. 415, April 29, 1927.

9. Wabana iron mines and deposits, Newfoundland: Mining and Metall., vol. 9, no. 260, pp. 361-366, 8 figs., August, 1928.

Hayes, Charles Willard, 1859-1916.

1. Handbook for field geologists. Third edition, revised and rearranged by Sidney Paige. 166 pp., 20 figs., 3 pls., New York, John Wiley \& Sons, 1921.

Hayes, Ellen.

1. River-bank movements due to the earth's rotation: Science, new ser., vol. 55, p. 567, May 26, 1922.

Hayes, Murray 0.

1. (and Eaton, Harry N.). An extinct hot spring basin in western Utah: Science, new ser., vol. 68, pp. 230-231, September 7, 1928.

Hayford, John Fillmore, 1868-1925.

1. Isostasy: Nat. Research Council, Bull., vol. 3, pt. 2, no. 17, pp. 11-16, March, 1922.

2. The establishment of isostasy: Western Soc. Eng., Jour., vol. 29, no. 9, pp. 350-362, 2 figs., September, 1924.

3. Determining the figure of the earth by triangulation: Am. Jour. Sci., 5th ser., vol. 16, pp. 121-128, August, 1928.

Haynes, Winthrop C. See Moore, R. C., 7.

Hazlitt, Henry $\mathbf{S}$.

1. Origin of ore deposits: Eng. and Min. Jour.-Press, vol. 117, no. 10, p. 413, March 8, 1924.

Headden, William Parker.

1. Alkalis in Colorado (including nitrates) : Colorado Agr. Coll., Agr. Exper. Sta., no. 239, 58 pp., May, 1918.

2. A contribution to the hydrology of the San Luis Valley, Colorado: Colorado Sci. Soc., Proc., vol 11, pp. 223-238, June, 1919.

3. A tantalate and some columbites from Custer County, South Dakota: Am. Jour. Sci., 5th ser., vol. 3, pp. 293-299, April, 1922.

4. Phosphorescence and luminescence in calcites: Am. Jour. Sci., 5th ser., vol. 5, pp. 314-328, April, 1923.

5. Deportment of calcites toward radium radiations: Am. Jour. Sci., 5th ser., vol. 6, pp. 247-264; 8 figs., September, 1923.

6. The relation of composition, color, and radiation to luminescence in calcites: Colorado Sci. Soc., Proc., vol. 11, pp. 399-434, December, 1923.

7. Luminescence in the Ingleside calcites affected by acids: Am. Jour. Sci., 5th ser., vol. 8, pp. 509-517, December, 1924.

Headstrom, Birger $\mathbf{R}$.

1. The origin of man. 100 pp., Princeton University Press, 1921. 
Heald, Kenneth Conrad. See also Bosworth, 1; Cheney, 1; Collingwood, 1; Ferguson, R. N., 1; Gilluly, 1 ; Mills, R. V. A., 5 ; Powers, 16 ; Richardson, G. B., 4 ; Roundy, 1.

1. Structure and oil and gas resources of the Osage Reservation, Oklahoma; T. 25 N., R. 9 E.: U. S. Geol. Survey, Bull, 686, pp. 27-41, 5 figs., 1 pl. (map), 1918.

2. (and Bowen, C. F., and others). Structure and oil and gas resources of the Osage Reservation, Oklahoma; T. 24 N., R. 9 E.: U. S. Geol. Survey, Bull. 686, pp. 193-212, 2 pls. (incl. map), 3 figs., 1919.

3. Structure and oil and gas resources of the Osage Reservation, Oklahoma; T. 27 N., R. 8 E.: U. S. Geol. Survey, Bull. 686, pp. 213-222, 2 pls. (incl. map), 5 figs., 1919.

4 (and Mather, Kirtley F.). Structure and oil and gas resources of the Osage Reservation, Oklahoma: T. 26 N., R. 8 E.: U. S. Geol. Survey, Bull. 686, pp. 223-236, 1 pl. (map), 2 figs., 1919.

5. The oil-bearing horizons of Wyoming: Am. Assoc. Petroleum Geologists, Bull., vol. 5, no. 2, pp. 186-211, March-April, 1921.

6. Discussion on The relative ages of major and minor folding and oii accumulation in Wyoming: Am. Assoc. Petroleum Geologists, Bull., vol. 5, no. 3, pp. 408-410, May-June, 1921.

7. Methods of detecting small quantities of petroleum: Am. Assoc. Petroleum Geologists, Bull., vol. 5, no. 5, pp. 620-621, September-October, 1921.

8. (and Rubey, W. W.). El Dorado oil field in Arkansas not on an anticline: Am. Assoc. Petroleum Geologists, Bull., vol. 6, no. 4, pp. 358-367, 1 fig., July-August, 1922.

9. Oil in middle Ordovician in Indiana: Am. Assoc. Petroleum Geologists, Bull., vol. 6, no. 4, p. 374, July-August, 1922.

10. Oil in Idaho?: Am. Assoc. Petroleum Geologists, Bull., vol. 6, no. 5, pp. 472-473, September-October, 1922.

11. The National Research Council and oil geology: Am. Assoc. Petroleum Geologists, Bull., vol. 7, no. 5, pp. 467-472, September-October, 1923.

12. Contribution to stratigraphy of western Kansas: Am. Assoc. Petroleum Geologists, Bull., vol. 8, no. 2, pp. 242-243; March-April, 1924.

13. Oil geology and science: Am. Assoc. Petroleum Geologists, Bull., vol. 8, no. 4, pp. 473-484, July-August, 1924.

14. Sandstone inclusion in salt in mine on Avery's Island: Am. Assoc. Petroleum Geologists, Bull., vol. 8, no. 5, pp. 674-676, SeptemberOctober, 1924.

15. Meeting of the Geological Society of America: Am. Assoc. Petroleum Geologists, Bull., vol. 10, no. 1, p. 100, January, 1926.

16. The Kevin-Sunburst oil field, Montana: Am. Assoc. Petroleum Geologists, Bull., vol. 10, no. 2, p. 197, February, 1926.

17. Annual meeting of the Cordilleran branch of the Geological Society of America: Am. Assoc. Petroleum Geologists, Bull., vol. 10, no. 4, pp. 449-450, April, 1926.

18. The geology of the Ingomar anticline, Treasure and Rosebud counties, Montana: U. S. - Geol. Survey, Bull. 786, pp. 1-37, 5 figs., 2 pls. (incl. map), October 18, 1926.

19. Research and the American Association of Petroleum Geologists: Am. Assoc. Petroleum Geologists, Bull., vol. 12, no. 9, pp. 939-948, September, 1928. 
Heath, Fred T. See Wilson, H., 1.

Heck, Nicholas Hunter.

1. A deep off the coast of Mexico and Central America: Seismol. Soc. America, Bull., vol. 14, no. 3, p. 200, September, 1924.

2. Earthquakes of 1925: Seismological Soc. America, Bull., vol. 15, no. 2, pp. 106-113, 3 figs., June, 1925.

3. Seismological work of the Coast and Geodetic Survey: Nat. Research Council, Bull. no. 53 (vol. 10, pt. 3), pp. 49-50, July, 1925.

4. Earthquakes: Sci. Monthly, vol. 22, no. 2, pp. 139-142, February, 1926.

5. Evidences of great submarine changes in configuration accompanied by earthquakes (abstract) : Pan-Am. Geologist, vol. 45, no. 3, pp. 255256, April, 1926.

6. How earthquakes are located: Sci. Monthly, vol. 22, no. 5, pp. 455-458, May, 1926.

7. Outstanding problems in seismology: Washington Acad. Sci., Jour., vol. 16, no. 9, pp. 240-244, May 4, 1926.

8. Earthquake epicenters in the north Pacific: Seismological Soc. America, Bull., vol. 16, no. 3, pp. 182-186, 2 figs., September, 1926.

9. Progress of seismological investigations in the United States, January 1, 1925, to June 30, 1927: U. S. Coast and Geodetic Survey, Spec. Pub. no. 132,12 pp., 2 figs., 1927.

10. Some unusual submarine features in the north Pacific Ocean (abstract) : Washington Acad. Sci., Jour., vol. 17, no. 5, pp. 127-128, March 4, 1927.

11. Reports of progress in seismological work in the United States; C, Seismological work of the U. S. Coast and Geodetic Survey: Nat. Research Council, Bull. no. 61, pp. 77-79, July, 1927.

12. Earthquake history of the United States, exclusive of the Pacific region: U. S. Coast and Geodetic Survey, Spec. Pub. no. 149, 61 pp., map, 1928.

Hedberg, Hollis D.

1. The effect of gravitational compaction on the structure of sedimentary rocks : Am. Assoc. Petroleum Geologists, Bull., vol. 10, no. 11, pp. 1035-1072, 3 figs., November, 1926.

2. The effect of gravitational compaction on the structure of sedimentary rocks; a reply to a discussion by W. W. Rubey: Am. Assoc. Petroleum Geologists, Bull., vol. 11, no. 8, pp. 875-886, August, 1927.

Heikes, Victor C.

1. (and Loughlin, G. F.). Arsenic in 1922: U. S. Geol. Survey, Mineral Resources, 1922, pt. 1, pp. 53-76, 2 figs., September 17, 1923.

2. (and Loughlin, G .F.). Arsenic in 1923: U. S. Geol. Survey, Mineral Resources, 1923, pt. 1, pp. 159-181, 2 figs., November 13, 1924.

3. (and Loughlin, G. F.). Arsenic deposits in the United States: U. S., 68th Cong., 1st Sess., Sen. Doc. no 27, 7 pp., 1924.

Heiland, C. A.

1. Construction, theory, and application of magnetic field balances: Am. Assoc. Petroleum Geologists, Bull., vol. 10, no. 12, pp. 1189-1200, 7 figs., December, 1926.

2. Schweydar-Bamberg types of Eötvös torsion balance: Am. Assoc. Petroleum Geologists, Bull., vol. 10, no. 12, pp. 1201-1209, 3 figs., December, 1926.

3. Modern instruments and methods of seismic prospecting: Am. Inst. Min. and Met. Eng., Tech. Pub. no. 149, 19 pp., 13 figs., October, 1928. 
Heim, Arnold.

1. Vulkane in der Umgebung der Oase La Purisima auf der Halbinsel NiederKalifornien: Zeitschr. Vulkanologie, Bd. 6, H. 1, pp. 15-21, 7 figs., 4 pls. (incl. map), April, 1921.

2. The Tertiary of southern Lower California: Geol. Mag., vol. 59, pp. 529547, 7 figs., 2 pls., December, 1922.

3. Notes on the Jurassic of Tamazunchale, Sierra Madre Oriental, Mexico: Eclogae Geologicae Helvetiae, vol. 20, no. 1, pp. 84-87, 2 figs., October, 1926.

4. (and others). Vulkanische Ereignisse; Berichte über die jüngste vulkanische Tätigkeit in Mittelamerika: Zeitschr. Vulkanologie, Bd. 10, H. 2, pp. 114-119, December, 1926.

Heist, H. D.

1. Geological position of test wells drilled in eastern Utah oil fields: Salt Lake Min. Reṿ., vol. 24, no. 1, p. 19, 1 fig., April 15, 1922.

Heller, A. H.

1. California oil field development, with special reference to wildcatting: Oil Bull., vol. 13, no. 5, pp. 513-515, 517-519, 521, 4 figs., May, 1927.

Hellman, Milo. See also Gregory, 7, 12, 14.

1. Racial characters in human dentition; Part I, A racial distribution of the Dryopithecus pattern and its modifications in the lower molar teeth of man: Am. Philos. Soc., Proc., vol. 77, no. 2, pp. 157174, 7 figs., 1928.

Henbest, Lloyd G.

1. Fusulinellas from the Stonefort limestone member of the Tradewater formation [Illinois] : Jour. Paleontology, vol. 2, no. 1, pp. 70-85, 2 figs., 3 pls., March, 1928; abstract, Geol. Soc. America, Bull., vol. 39, no. 1, p. 291, March 30, 1928; Pan-Am. Geologist, vol. 49, no. 3, pp. 226-227, April, 1928.

2. Pre-Pennsylvanian surface west of the Duquoin anticline: Illinois State Acad. Sci., Trans., vol. 20, pp. 265-268, 3 figs., March, 1928.

Henderson, Charles William.

1. Mining in Colorado; a history of discovery, development, and production: U. S. Geol. Survey, Prof. Paper 138, 263 pp., 20 figs., 1 pl. (map), 1926.

Henderson, E. P. See Ross, C. S., 13 ; Schaller, 9 ; Short, 3.

Henderson, George G.

1. The geology of Tom Green County: Texas Univ., Bull., no. 2807, 116 pp., 2 figs., 8 pls. (incl. map), February 15, 1928.

Henderson, Junius.

1. The Cretaceous formations of the northeastern Colorado plains: Coloracto Geol. Survey, Bull. 19, pp. 7-57, 1920.

2. The foothills formations of north central Colorado: Colorado Geol. Survey, Bull, 19, pp. 58-96, 11 figs., 1 pl. (map), 1920.

3. The nomenclature and systematic positions of some North American fossils and recent mollusks: Nautilus, vol, 33, no. 4, pp. 118-122. April, 1920.

4. The glacial geology of Grand Mesa, Colorado: Jour Geology, vol. 31, no. 8, pp. 676-678, November-December, 1923. 
Henderson, Junius-Continued.

5. Footprints in Pennsylvanian sandstones of Colorado: Jour. Geology, vol. 32, no. 3, pp. 226-229, 3 figs., April-May, 1924.

6. The origin of the Green River formation: Am. Assoc. Petroleum Geologists, Bull., vol. 8, no. 5, pp. 662-668, December-October, 1.924.

7. Geology in its relation to landscape. vii, 152 pp., illus., Boston, Massachusetts, The Stratford Company, 1925.

8. Sources of material from which petroleum may have been derived: California Acad. Sci., Proc., 4th ser., vol. 15, no. 10, pp. 269-278, April, 26, 1926.

9. A Pleistocene fossil locality on Big Hope Island, Puget Sound [Washington]: Colorado, Univ., Studies, vol. 16, no. 1., pp. 1-3, June, 1927.

Hendricks, J. A. See also Boyd, H. I.

Hendricks, Robert.

1. (and Knight, Nicholas). Some Iowa sandstone: Iowa Acad. Sci., Proc,, 1927, vol. 34, pp. 247-248 [1928].

Hendrickson, A. B.

1. Report on the Kern front area of the Kern River oil field: California State Min. Bur., Summary of Operations California Oil Fields, vol. 13, no. 7, pp. 5-18, 5 pls., January, 1928.

Hendrickson, Victor J.

1. The Kevin-Sunbur'st oil field, Montana: Oil Bull., vol. 13, no. 9, pp. 929, 931, 933, 990, September, 1927.

Henley, A. S.

1. The Big Hill salt dome, Jefferson County, Texas: Am. Assoc. Petroleum Geologists, Bull., vol. 9, no. 3, pp. 590-593, 2 figs., May-June, 1925 ; Geology of salt dome oil fields, pp. 497-500, 2 figs., 1926.

Hennen, Ray Vernon.

1. Fayette County. West Virginia Geol. Sulvey, 1002 pp., 24 pls. 23 figs., 2 maps in atlas, 1919.

2. Israel Charles White: Am. Assoc. Petroleum Geologists, Bull., vol. 12, no. 3, pp. 339-351, portr., March, 1928.

Henniger, W. F.

1. Occurrence of sulphur waters in the Gulf coast of Texas and Louisi ana, and their significance in locating new domes: Am. Assoc. Petroleum Geologists, Bull., vol. 9, no. 1, pp. 35-37, JanuaryFebruary, 1925; Geology of salt dome oil fields, pp. 774-776, 1926.

Henning, John L.

1. Sulphur mining (with discussion) : Am. Assoc. Petroleum Geologists, Bull., vol. 3 , pp. 242-252, 1919.

Henny, Gerard.

1. Some notes on the geology of the south Joaquin Valley, California: Am. Assoc. Petroleum Geologists, Bull., vol. 11, no. 6, pp. 611-615, 1 fig., June, 927.

Heuriksen, Kai L.

1. Critical notes upon some Cambrian arthropods described by Charles $\mathbf{D}$. Walcott: Dansk Naturl. Foren., Vidensk. Medd., Bd. 86 (separate, 20 pp.), 1928; Muséum de minéralogie et de géologie de l'Université de Copenhague, Communications paléontologiques, no. 28. 
Henry, Earl C.

1. Mining methods in the Mineville, New York, district: Am. Inst. Min. and Met. Eng., Trans. [preprint] no. 1192, 7 pp., October, 1922.

Herald, Frank A. See Bauer, C. M., 2.

Hereza y Ortuño, Juan.

1. Synopsis of a theory of metallogeny: Eng. and Min. Jour.-Press, vol. 119, no. 4, pp. 160-162, January 24, 1925.

Hernández, Apolinar. See also Gálvez, 5.

1. Informe preliminar acerca de las aguas subterráneas de San Luis Potosí a Catorce: Mexico, Departamento de exploraciones y estudios geológicos, Folleto de divulgaciôn, no. 12, pp. 21-30, August, 1925.

2. Informe preliminar de las aguas subterráneas de las zonas de Cedral, Matehuala, Vallejo y Ciudad del Maíz, en el Estado de San Luis Potosí: Mexico, Departamento de exploraciones y estudios geológicos, Folleto de divulgación, no. 17, pp. 20-30, June, 1926.

Herold, Stanley C.

1. Jamin action-what it is and how it affects production of oil and gas: Am. Assoc. Petroleum Geologists, Bull., vol. 12, no. 6, pp. 659670, 9 figs., June, 1928.

Heroy, William B.

1. Rock pressure: Am. Assoc. Petroleum Geologists, Bull., vol. 12, no. 4, pp. 355-384, 4 figs., April, 1928.

Herrera, Alfonso L.

1. Mineralogía y geología. 471 pp., illus., Mexico, Herrero Hermanos, Sucesores, 1925.

Hertel, F. W.

1. Ventura is one of California's greatest [oil] fields: Oil Weekly, vol. 44, no. 11, pp. 47-50, 52, 54, 56, 58, 10 figs., March 4, 1927.

2. (and Bernt, D. M. jr., and Pieper, H. K.). Oil fields of Ventura County and Newhall district [California]: Oil Bull., vol. 14, no. 4, pp. 370374, 1 fig., (map), April, 1928.

3. Ventura Avenue oil field, Ventura County, California: Am. Assoc. Petroleum Geologists, Bull., vol. 12, no. 7, pp. 721-742, 7 figs., July, 1928.

Hertlein, Leo George. See also Hanna, G. D., 29, 34 ; Jordan, E. K., $2,4$.

1. Pectens from the Tertiary of Lower California: California Acad. Sci., Proc., 4th ser., vol. 14, no. 1, pp. 1-35, 6 pls., July 21, 1925.

2. New species of marine fossil Mollusca from western North America: Southern California Acad. Sci., Bull., vol. 24, pt. 2, pp. 39-44, 2 pls., August 17, 1925.

3. (and Crickmay, Colin H.). A summary of the nomenclature and stratigraphy of the marine Tertiary of Oregon and Washington: Am. Philos. Soc., Proc., vol. 64, no. 2, pp. 224-282, 1925.

4. (and Jordan, Eric Knight). Paleontology of the Miocene of Lower California: California Acad. Sci., Proc., 4th ser., vol. 16, no. 19, pp. 605-646, 5 pls., September 2, 1927.

5. Pecten (Patinopectin) lohri, new name for Pecten oweni Arnold, a Pliocene species from California: Nautilus, vol. 41, no. 3, pp. 93-94, January, 1928.

6. Preliminary report on the paleontology of the Channel Islands, California : Jour. Paleontology, vol. 2, no. 2, pp. 142-157, 4 pls., June, 1928. 
Hess, Frank L. See also Foshag, 31; Larsen, 18; Stone, 11.

1. Tactite, the product of contact metamorphism: Am. Jour. Sci., 4th ser., vol. 48, pp. 377-378, November, 1918.

2. Cobalt, molybdenum, nickel, titanium, tungsten, radium, uranium, and vanadium in 1916: U. S. Geol. Survey, Mineral Resources, 1916, pt. 1, pp. 775-807, February 25, 1919.

3. The tungsten resources of the world: Eng. and Min. Jour., vol. 108, pp. 715-722, 1 fig., November 1, 1919.

4. Phenocrysts in granitic intrusions (abstract): Washington Acad. Sci. Jour., vol. 9, no. 10, pp. 294-295, May 19, 1919.

5. [Note on cobalt-bearing veins, Lemhi County, Idaho] (abstract) : Washington Acad. Sci., Jour., vol. 9, no. 16, p. 501, October 4, 1919.

6. (and Wells, Roger C.). Brannerite, a new uranium mineral [Stanley Basin, central Idaho] : Franklin Inst., Jour., vol. 189, no. 2, pp. 225-237, 2 figs., February, 1920; no. 6, pp. 779-780, June, 1920.

7. Cobalt, molybdenum, tantalum, titanium, radium, uranium, and vanadium in 1918: U. S. Geol. Survey, Mineral Resources, 1918, pt. 1, pp. 791-817, 1 fig., June 29, 1920.

8. Cobalt, molybdenum, nickel, titanium, tungsten, radium, uranium, and vanadium in 1917: U. S. Geol. Survey, Mineral Resources, 1917, pt. 1, pp. 899-959, August 31, 1920.

9. Nickel in 1918: U. S. Geol. Survey, Mineral Resources, 1918, pt. 1, pp. 783790, June 29, 1920.

10. Tungsten in 1918: U. S. Geol. Survey, Mineral Resources, 1918, pt. 1, pp. 973-1026, March 21, 1921.

11. (and Larsen, E. S.). Contact-metamorphic tungsten deposits of the United States: U. S. Geol. Survey, Bull. 725, pp. 245-309, 10 figs., 4 pls. (incl. map), August 9, 1920. Abstract by R. W. Stone, Washington Acad: Sci., Jour., vol. 11, no. 20, p. 494, December 4, 1921.

12. Cobalt, molybdenum, nickel, tantalum, titanium, tungsten, radium, uranium, and vanadium in 1919: U: S. Geol. Survey, Mineral Resources, 1919, pt. 1, pp. 711-729, November 10, 1921.

13. Cobalt, molybdenum, nickel, tantalum, titanium, tungsten, radium, uranium, and vanadium in 1920: U. S. Geel. Survey, Mineral Resources, 1920, pt. 1, pp. 401-417, February 20, 1922.

14. Uranium-bearing asphaltite sediments of Utah: Eng. and Min. Jour.Press, vol. 114, no. 7, pp. 272-276, 4 figs., August 12, 1922.

15. Review of Radium, uranium, and vanadium deposits of southwestern Colorado, by R. C. Coffin and others (Colorado Geol. Survey, Bull. 16, 1921) : Econ. Geology, vol. 17, no. 6, pp. 506-511, September, 1922.

16. Cobalt, molybdenum, nickel, tantalum, titanium, tungsten, radium, uranium, and vanadium in 1921: U. S. Geol. Survey, Mineral Resources, 1921, pt. 1, pp. 207-233, October 23, 1922.

17. Ilsemannite at Ouray, Utah: U. S. Geol. Survey, Bull. 750, pp. 1-16, 1 fig., 2 pls., June 28, 1923.

18. Molybdenum deposits-a short review: U. S. Geol. Survey, Bull. 761, 35 pp., 4 figs., 10 pls., 1924.

19. Cobalt, molybdenum, nickel, tantalum, titanium, tungsten, radium, uranium, and vanadium in 1922: U. S. Geol. Survey, Mineral Resources, 1922, pt. 1, pp. 557-583, March 14, 1924. 
Hess, Frank L.-Continued.

20. New and known minerals from the Utah-Colorado carnotite region: U. S. Geol. Survey, Bull. 750, pp. 63-78, 8 pls., October 14, 1924.

21. Rare metals; cobalt, molybdenum, nickel, tantalum, titanium, tungsten, radium, uranium, and vanadium in 1923: U. S. Geol. Survey, Mineral Resources, 1923, pt. 1, pp. 235-258, November 29, 1924.

22. The age of the earth: Sci. Monthly, vol. 20, no. 6, pp. 597-602, June, 1925.

23. The natural history of the pegmatites: Eng. and Min. Jour.-Press, vol. 120, no. 8, pp. 289-298, 17 figs., August 22, 1925.

24. Platinum near Centennial, Wyoming: U. S. Geol. Survey, Bull. 780, pp. 127-135, 1 fig., January 13, 1926.

25. Oolites (abstract) : Washington Acad. Sci., Jour., vol. 16, no. 3, pp. 76-77, February 4, 1926.

26. Potash and the South: Min. Congress Jour., vol. 12, no. 5, pp. 344-346, 398, 3 flgs., May, 1926.

27. Rare metals; cobalt, molybdenum, nickel, tantalum, titanium, tungsten, radium, uranium, and vanadium in 1924: U. S., Bur. Mines, Mineral Resources U. S., 1924, pt. 1, pp. 451-476, June 7, 1926.

28. The sources and use of cesium (abstract) : Washington Acad. Sci., Jour., vol. 17, no. 5, pp. 124-125, March 4, 1927.

29. Notes on Florida phosphate deposits (abstract): Washington Acad. Sci., Jour., vol. 17, no. 12, p. 321, June 19, 1927.

30. (and Foshag, William F.). Crystalline carnotite from Utah: U. S. Nat. Mus., Proc., vol. 72, art. 12, 6 pp., 1927.

31. [Occurrence of pollucite near Hebron, Maine] (abstract): Washington Acad. Sci., Jour., vol. 18, no. 9, p. 262, May 4, 1928.

Hewett, Donnel Foster. See also DeGolyer, 9 ; Harder, 2; Stose, 1.

1. Manganese ore as a war mineral (abstract): Geol. Soc. America, Bull., vol. 30, pp. 97-98, March 31, 1919.

2. [Manganese deposits] (abstract) : Washington Acad. Sci., Jour., vol. 9, no. 13, pp. 386-387, July 19, 1919.

3. Manganese and manganiferous ores in 1917: U. S. Geol. Survey, Mineral Resources, 1917, pt. 1, pp. 665-696, 1 fig., October 31, 1919.

4. The Heart Mountain overthrust, Wyoming: Jour. Geology, vol. 28, no. 6, pp. 536-557, 4 figs. (incl. map), September-October, 1920. Abstract, Washington Acad. Sci., Jour., vol. 10, no. 2, p. 51, January 19, 1920; Geol. Soc. America. Bull., vol. 31, no. 1, p. 122, March 31, 1920.

5. Manganese and manganiferous ores in 1918: U. S. Geol. Survey, Mineral Resources, 1918, pt. 1, pp. 607-656, 1 fig. 1 pl., April 10, 1920.

6. Measurements of folded beds: Econ. Geology, vol. 15, no. 5, pp. 367-385, 6 figs., July-August, 1920.

7. (and Shannon, E. V.). Orientite, a new hydrous silicate of manganese and calcium from Cuba: Am. Jour. Sci., 5th ser., vol. 1, pp. 491506, 5 figs., June, 1921.

8. Manganese deposits near Bromide, Oklahoma: U. S. Geol. Survey, Bull. 725, pp. 311-329, 4 figs., July 26, 1921.

9. Carnotite in southern Nevada : Eng. and Min. Jour.-Press, vol. 115, no. 5, pp. 232-235, 4 figs., February 3, 1923.

10. Structure of the Spring Mountain Range, southern Nevada (abstract) : Geol. Soc. America, Bull., vol. 34, no. 1, pp. 89-90, March 30, 1923.

$4096-31-18$ 
Hewett, Donnel Foster-Continued.

11. Dolomitization in southern Nevada (abstract, with discussion by James F. Kemp, R. B. Sosman, and L. C. Graton) : Geol. Soc. America, Bull., vol. 35, no. 1, pp. 124-125, March 30, 1924 ; abstract, PanAm. Geologist, vol. 41, no. 2, p. 159, March, 1924.

12. Dolomitization near Goodsprings, Nevada (abstract) : Washington Acad. Sci., Jour., vol. 14, no. 7, pp. 164-165, April 4, 1924.

13. Deposits of magnesia alum near Fallon, Nevada: U. S. Geol. Survey, Bull. 750, pp. 79-86, 2 figs., October 23, 1924.

14. (and Schaller, W. T.). Hisingerite from Blaine County, Idaho: Am. Jour. Sci., 5th ser., vol. 10, pp. 29-38, 1 fig., July, 1925.

15. Carnotite discovered near Aguila, Arizona: Eng. and Min. Jour.-Press, vol. 120, no. 1, p. 19, July 4, 1925.

16. Geology and oil and coal resources of the Oregon Basin, Meeteetse, and Grass Creek Basin quadrangles, Wyoming: U. S. Geol. Survey, Prof. Paper 145, 111 pp., 10 figs., 32 pls. (incl. maps), 1926.

17. Progress in the survey of the Ivanpah quadrangle, Nevada-California (abstract) : Geol. Soc. America, Bull., vol. 37, no. 1, pp. 164-165, March 30, 1926; Pan-Am. Geologist, vol. 45, no. 2, p. 164, March, 1926.

18. Late Tertiary thrust faults in the Mojave Desert, California: Nat. Acad. Sci., Proc., vol. 14, no. 1, pp. 7-12, 2 figs., January, 1928; abstract, Science, new ser., vol. 65, p. 480, May 13, 1927.

19. A manganese deposit of Pleistocene age in Bannock County, Idaho: U. S. Geol. Survey, Bull. 795, pp. 211-218, 1 fig., January 16, 1928.

20. Two Tertiary epochs of thrust-faulting in the Mojave Desert, California (abstract) : Geol. Soc. America, Bull., vol. 39, no. 1, pp. 178-179, March 30, 1928; Pan-Am. Geologist, vol. 49, no. 2, p. 140, March, 1928.

21. (and Shannon, Earl V., and Gonyer, Forest A.) Zeolites from Ritter Hot Spring, Grant County, Oregon: U. S. Nat. Mus., Proc., vol. 73, art. 16, 18 pp., 2 pls., 1928.

22. Dolomitization and ore deposition: Econ. Geology, vol. 23, no. 8, pp. 821-863, 8 figs., December, 1928 .

Hewitt, E. A.

1. Exploration methods in the Park City, Utah, district: Min. Congress Jour., vol. 12, no. 1, pp. 54-55, 2 figs., January, 1928.

Heyl, Paul Renno.

1. The density of the earth and the inferences to be drawn from it: Nat. Research Council, Bull., vol. 11, pt. 2, no. 56, pp. 25-26, November, 1926; abstract, Am. Jour. Sci., 5th ser., vol. 12, p. 271, September, 1926.

Hibbard, F. N.

1. A new seismograph at Chicago: Seismol. Soc. America, Bull., vol. 9, no. 2, pp. 42-44, 2 figs., June, 1919.

Hibbard, Raymond R.

1. Conodonts from the Portage group of western New York: Am. Jour. Sci.. 5th ser., vol. 13, pp. 189-208, 4 pls., March, 1927.

2. Western New York conodonts: Rocks and Minerals, vol. 3, no. 4, pp. 117119, 1 pl., December, 1928.

Hibbs, G. Gillingham.

1. Boulder County [Colorado] fluorspar: Eng. and Min. Jour., vol. 109, pp. 494-495, February 21, 1920. 
Hice, Richard Roberts.

1. The white clay possibilities of Pennsylvania: Am. Ceramic Soc., Jour., vol. 2, no. 9, pp. 685-694, 1 pl., September, 1919.

Hicks, Clifford. See Patton, L. T., 4.

Hicks, W. B. See also Gale, 1 ; Pennsylvania Topographic and Geologic Survey.

1. Potash in 1918: U. S. Geol. Survey, Mineral Resources, 1918, pt. 2, pp. 385-445, March 31, 1920.

2. (and Nourse, M. R.). Potash in 1919: U. S. Geol. Survey, Mineral Resources, 1919, pt. 2, pp. 77-94, December 8, 1920.

3. Potash resources of Nebraska: U. S. Geol. Survey, Bull. 715, pp. 125-139, 1 fig., February 8, 1921. Abstract by R. W. Stone, Washington Acad. Sci., Jour. vol. 11, no. 15, p. 376, September 19, 1921.

Higgins, Daniel Franklin. See also Leith, 10.

1. Determination of dip and strike from any two components, and the inverse problem: Econ. Geology, vol. 18, no. 1, pp. 26-52, 16 figs., 2 pls., January-February, 1923.

2. "Epi-anticlinal" faults (discussion) : Am. Assoc. Petroleum Geologists, Bull., vol. 11, no. 11, pp. 1233-1234, November, 1927.

Hill, B. F. See Stone, 11.

Hill, E. G. See Fettke, 7.

Hill, Edward Allison.

1. Geological notes on oil structures. 85 pp., 6 pls., San Francisco, HallGutstadt Company, 1922.

2. Notes on Florida oil possibilities, historical and geological: Oil Age, vol. 24, no. 10, pp. 38-54, 2 figs., November, 1927.

Hill, H. B.

1. (and Sutton, Chase E.). Production and development problems in the Powell oil field, Navarro County, Texas: U. S. Bur. Mines, Bull. 284, 122 pp., 35 figs., 1928.

Hill, James Madison.

1. The platinum situation: Eng. and Min. Jour., vol. 108, pp. 131-137, 4 figs., July 26, 1919.

2. Tin; its political and commercial control : Eng. and Min. Jour., vol. 109, pp. 1011-1020, 2 figs., May 1, 1920.

3. The Taylor Creek tin deposits, New Mexico: U. S. Geol. Survey, Bull. 725, pp. 347-359, 1 fig., November 18, 1921.

4. The Los Burros district, Monterey County, California: U. S. Geol. Survey, Bull. 735, pp. 323-329, 1923.

5. California gold production, 1849-1923: Econ. Geology, vol. 21, no. 2, pp. 172-179, 1 fig., March-April, 1926.

Hill, James H.

1. Clay deposits of the Alberhill Coal and Clay Company: California State Min. Bur., Mining in California, vol. 19, no. 4, pp. 185-210, 19 figs., September, 1923.

Hill, Robert Thomas. See also Sellards, 18; Texas, Attorney General, 1.

1. The Gulf coast salt domes: Econ. Geology, vol. 14, no. 8, pp. 643-644, December, 1919.

2. The rifts of southern California: Seismol. Soc. America, Bull., vol. 10, no. 3, pp. 146-149, September, 1920. 
Hill, Robert Thomas-Continued.

3. Two limestone formations of the Cretaceous of Texas which transgress time diagonally: Science, new ser., vol. 53, pp. 190-191, February 25, 1921.

4. Data on the geographic nomenclature of the southern California and Texas regions (abstract) : Geol. Soc. America, Bull., vol. 34, no. 1, p. 67, March 30, 1923.

5. Further contributions to the knowledge of the Cretaceous of Texas and northern Mexico (abstract): Geol. Soc. America, Bull., vol. 34, no. 1, pp. 72-73, March 30, 1923.

6. Sand rivers of Texas and California and some of their accompanying phenomena (abstract) : Geol. Soc. America, Bull., vol. 34, no. 1, p. 95, March $30,1923$.

7. Summary of physiographic investigations made in connection with the Oklahoma-Texas boundary suit: Texas, Univ., Bull., no. 2327, pp. 157-172, August, 1923.

8. Southern California geology and Los Angeles efarthquakes; with an introduction to the physical geography of the region. 232 pp., 38 figs., 4 pls. (maps), published by the Southern California Academy of Sciences, Los Angeles, California, 1928.

9. Earthquake conditions in southern California (abstract): Geol. Soc. America, Bull., vol. 39, no. 1, pp. 188-189, March 30, 1928.

10. Three great upholding formations in the physiography of the Southwest (abstract) : Geol. Soc. America, Bull., vol. 39, no. 1, p. 264, March 30, 1928.

11. Transcontinental structural digression (abstract): Geol. Soc. America, Bull., vol. 39, no. 1, p. 265, March 30, 1928.

Hillebrand, William Francis.

1. The analysis of silicate and carbonate rocks (a revised and enlarged edition of Bull. 422) : U. S. Geol. Survey, Bull. 700, 285 pp., 23 figs., 1919.

2. Carnotite and tyuyamunite and their ores in Colorado and Utah: Am. Jour. Sci., 5th ser., vol. 8, pp. 201-216, September, 1924; abstract, Science, new ser., vol. 59, p. 444, May 16, 1924.

Hills, Thomas M.

1. Some estimates of the thickness of the sedimentary rocks of Ohio: Jour. Geology, vol. 28, no. 1, pp. 84-86, January-February, 1920.

2. Glaciation of the Upper Kern Canyon and its tributaries: Sierra Club Bull., vol. 13, no. 1, pp. 17-19, February, 1928.

Hills, Victor Gardiner.

1. Petrified wood carrying silver at Creede, Colorado: Eng. and Min. Jour.Press, vol. 117, no. 16, p. 647, April 19, 1924.

2. Magmas, dikes, and veins: Mining and metallurgy, vol. 8, no. 244, pp. 189-190, April, 1927.

Hill-Tout, Charles.

1. The phylogeny of man from a new angle: Roy. Soc. Canada, Proc. and Trans., 3d ser., vol. 15, sec. 2, pp. 47-82, 6 pls., 1921.

2. Man closer to ancestral type than anthropoid apes (abstract) : Pan-Am. Geologist, vol. 42, no. 3, p. 236, October, 1924. 
Hinds, Henry.

1. Description of the Colchester and Macomb quadrangles, Illinois: U. S. Geol. Survey, Geol. Atlas, Colchester-Macomb folio, no. 208, 14 pp., 14 figs., 4 maps, 1919.

2. Unconformities in the Pennsylvanian: Am. Assoc. Petroleum Geologists, Bull., vol. 10, no. 12, pp. 1303-1304, December, 1926.

Hinds, Norman Ethan Allen.

1. An alkali gneiss from the pre-Cambrian of New Jersey: Am. Jour. Sci., 5th ser., vol. 1, no. 4, pp. 355-364, April, 1921.

2. Geology of Kauai, Hawaiian Islands (abstract) : Geol. Soc. America, Bull., vol. 33, no. 1, p. 125, March 31, 1922.

3. Geological observations on the Island of Maui, Hawaii : Science, new ser., vol. 61, pp. 316-318, March 20, 1925.

4. Geology of the Island of Maui, Hawaii (abstract) : Geol. Soc. America, Bull., vol. 36, no. 1, pp. 173-174, March 30, 1925.

5. The Green River formation: Science, new ser., vol. 62, p. 34, July 10, 1925.

6. Melilite and nephelite basalt in Hawaii: Jour. Geology, vol. 33, no. 5, pp. 526-539, July-August, 1925.

7. Maui and the Maui group, Hawaii: Geog. Soc. Philadelphia, Bull., vol. 23, no. 4, pp. 147-165, 3 figs., 2 pls., October, 1925.

8. Amphitheater valley heads: Jour. Geology, vol. 33, no. 8, pp. 816-818, 1 fig. November-December, 1925.

9. Fault topography in Hawaii (abstract) : Geol. Soc. America, Bull., vol. 37, no. 1, p. 210, March 30, 1926.

10. Geomorphology of the Island of Maui, Hawaii (abstract) : Geol. Soc. America, Bull., vol. 37, no. 1, pp. 215-216, March 30, 1926.

11. Intrusive rocks in Klamath Mountains, California (abstract).: Pan-Am. Geologist, vol. 49, no. 4, pp. 308-309, May, 1928.

12. Maui Volcano, Hawaii (abstract) : Pan-Am. Geologist, vol. 49, no. 4, pp. 311-312, May, 1928.

Hintze, Ferdinand Friis.

1. Oil accumulation in relation to periods of folding (with discussion by J. M. Douglas, Max Ball, and Glen Ruby) : Am. Assoc. Petroleum Geologists, Bull., vol. 7, no. 1, pp. 58-66, January-February, 1923.

Hippard, C. W.

1. Résumé of the theory of the origin of coal : Coal Age, vol. 16, pp. 104-107, July 17, 1919.

Hirschi, H.

1. Radioaktivität zweier Eruptivgesteine and ihre genetische Beziehung zur Pechblende von Central City, Colorado: Schweizerische Mineralogische und Petrographische Mitteilungen, Bd. 3, H. 3-4, pp. 240$252,1923$.

2. Beiträge zur Petrographie $v$ von Baja California, Mexiko: Schweizerische Min. und Petrog. Mitt., Bd. 6, H. 2, pp. 346-350, map, 1926.

3. Dumortierit-Andalusitgesteine des Rochester Districts (Nevada) : Schweizerische Min. und Petrog. Mitt., Bd. 7, H. 1, pp. 45-53, 1927.

4. (and De Quervain, F.). Beiträge zur Petrographie von Baja California (Mexiko) : Schweizerische Min. und Petrog. Mitt., Bd. 7, H. 1, pp. 142-164, 1927 ; Bd. 8, H. 2, pp. 323-356, 1928. 


\section{Hisazumi, Hisakichi.}

1. Informe preliminar acerca de la geología petrolera de la zona comprendida entre los ríos 'Tecolutla y Misantla, en los estados de Veracruz y Puebla: Mexico, Inst. geol., Foll. divulgación, no. 23, 20 pp., 1926.

Hitchcock, Charles Henry, 1836-1919. See also Grier, 4.

1. The great fault of the Sudbury nickel district [Ontario]: Canadian Min Jour., vol. 42, no. 11, p. 215, 1 fig., March 18, 1921.

Hite, M. P.

1. Some observations of storm effects on ocean inlets [Atlantic coast, Maryland, North Carolina] : Am. Jour. Sci., 5th ser., vol. 7, pp. 319-326, 4 figs., April, 1924.

Hixon, Hiram W. See also Johnson, R. H., 2; Matteson, 2; White, D., 1; Willis, 4.

1. The inorganic origin of petroleum: Eng. and Min. Jour., vol. 112, no. 16, pp. 622-623, October 15, 1921.

2. Is coal a mineralized peat bog or has it been formed from woody deposits of great river deltas?: Coal Age, vol. 21, no. 1, pp. 8-9, January $5,1922$.

3. Origin of petroleum: Eng. and Min. Jour.-Press, vol. 117, no. 9, pp. 370371, March 1, 1924.

4. Deep-seated ore chemistry: Eng. and Min. Jour.-Press, vol. 118, no. 7, p. 263, August 16, 1924.

5. Magma : Eng. and Min. Jour.-Press, vol. 118, no. 24, pp. 942-943, December 13, 1924.

6. Hydrocarbon veindikes and oil shales: Eng. and Min. Jour.-Press, vol. 119, no. 16, p. 653, April 18, 1925.

7. Chlorine as a magmatic solvent for metals: Eng. and Min. Jour.-Press, vol. 121, no. 6, p. 249, February 6, 1926.

8. Ore deposits and allied phenomena (discussion) : Eng. and Min. Jour., vol. 123, no. 13, p. 533, March 26, 1927.

9. Magmas, dikes, and veins: Mining and Metallurgy, vol. 8, no. 245, p. 232, May, 1927 ; no. 249, pp. 391-392, September, 1927.

Hoadley, Charles W.

1. Some mineral localities in Orange County, New York: Rocks and Minerals, vol. 3, no. 2, pp. 33-34, June, 1928.

Hobbs, William Herbert. See also Bucher, 6 ; Daly, 12 ; Loomis, 4 ; Louderback, 4 ; Shepard, 8 ; Stose, 21 ; Taber, 6 ; Visher, 4 ; Woodring, 8 ; Woodworth, 1.

1. The peculiar weathering process of desert regions with illustrations from Egypt and the Soudan: Michigan Acad. Sci., 20th Ann. Rept., pp. 93-99, 8 pls., 1918.

2. Calcination volcanoes (abstract): Geol. Soc. Anrerica, Bull., vol. 31, no. 1, p. 115, March 31, 1920.

3. Extremes of mountain-glacier erosion (abstract) : Geol. Soc. America, Bull., vol. 31, no. 1, p. 130, March 31, 1920.

4. The mechanics of the glacial anticyclone illustrated by experiment: Nature, vol. 105, pp. 644-645, 2 figs., July 22, 1920.

5. Earth evolution and its facial expression. 178 pp., 84 figs., New York, The Macmillan Company, 1921.

6. The fixed glacial anticyclone compared to the migrating anticyclone: Am. Philos. Soc., Proc., vol. 60, no. 1, pp. 34-42, 1921. 
Hobbs, William Herbert-Continued.

7. Evolution of arcuate mountains (abstract with discussion by A. C. Lawson, B. Willis, and S. Taber) : Geol. Soc. America, Bull., vol. 32, no. 1, pp. 30-31, Macrh 31, 1921.

8. Doctrine of the zone of flow challenged (abstract) : Geol. Soc. America, Bull., vol. 32, no. 1, p. 32, March 31, 1921.

9. Clustal deformation in the Pacific and Atlantic regions (abstract): Geol. Soc. America, Bull., vol. 32, no. 1, pp. 32-33, 1921.

10. Postglacial faulting in the French River district of Ontario: Anr. Jour. Sci., 5th ser., vol. 1, pp. 507-509, 2 figs., June, 1921.

11. Studies of the cycle of glaciation: Jour. Geology, vol. 29, no. 4, pp. 370386, 15 figs., May-June, 1921.

12. Les glaciers du monde actuel. Trans. from English by A. Allix and J. Blache. Extrait de la Revue de géographie alpine (Université de Grenoble), vol. 10, 99 pp., 20 figs., 9 pls., 1922.

13. A significant contrast between the Atlantic and Paciflc coastal regions (abstract) : Assoc. Am. Geographers, Annals, vol. 11, pp. 124-125 [1922?].

14. The southwestern Michigan meteor of November 26, 1919: Michigan Acad. Sci., Papers, vol. 1, pp. 253-268, 3 figs., 1923.

15. The rate of movement in vertical earth adjustments connected with the growth of mountains: Am. Philos. Soc., Proc., vol. 62, no. 2, pp. 63-73, 2 figs., 1923.

16. Correspondence between the Gondwana system of Hindustan and the Newark system of the eastern United States (abstract with discussion by E. W. Berry, C. K. Wentworth, Sidney Powers, George C. Martin, and David White): Geol. Soc. Amerfea, Bull,, vol. 34, no. 1, pp. 82-85, March 30, 1923.

17. The Asiatic arcs: Geol. Soc. America, Bull., vol. 34, no. 2, pp. 243-252, 3 figs., June 30, 1923.

18. The growing mountain ranges of the Pacific region: Pan-Paciflc Sci. Cong., Australia, 1923, Proc., vol. 1, pp. 746-757 [1924].

19. Contrasted lava types in the Pacific region: Pan-Pacific Sci. Cong., Australia, 1923, Proc., vol. 1, pp. 838-842 [1924].

20. Reef formations as an index of mountain-building processes: Pan-Pacific Sci. Cong., Australia, 1923, Proc., vol. 2, pp. 1120-1128, 2 figs [1924].

21. De Montessus de Ballore: Seismol. Soc. America, Bull., vol. 14, no. 3, pp. 177-180, September, 1924.

22. The unstable middle section of the island ares: Geologisch-Minjbouwkundig Genootschap voor Nederland en Kolonien, Verh., Geol. ser., D. 8 (Gedenkboek . . D Dr. R. D. M. Verbeek), pp. 219-261, 19 flgs., 4 pls., 1925.

23. The trough-deeps of the island ares: International Geol. Cong., 13th Sess., Belgium, 1922, fasc. 2, pp. 725-730, 5 figs., 1925.

24. [Review of] Movement of continental masses under action of tidal forces, by F. B. Taylor: Jour. Geology, vol. 33, no. 7, pp. 751-752, OctoberNovember, 1925.

25. The glacial anticyclones; the poles of the atmospheric circulation: Michigan, Univ., Studies, Sci. ser., vol. 4, 198 pp., 53 figs., 3 pls., New York, The Macmillan Company, 1926.

26. The cause of earthquakes; especially those of eastern United States: Michigan Acad. Sci., Papers, vol. 5, pp. 257-282, 5 figs., 1926 ; Smithsonian Inst., Ann. Rept., 1926, pp. 257-277, 5 figs., 1927; abstract, Pan-Am. Geologist, vol. 44, no. 2, p. 160, September, 1925. 
Hobbs, William Herbert-Continued.

27. Plans of the University of Michigan expedition to Greenland in 1926-27 (abstract) : Geol. Soc. America, Bull., vol. 37, no. 1, p. 144, March 30, 1926 ; Pan-Am. Geologist, vol. 45, no. 1, p. 92, February, 1926.

28. James Hutton, the pioneer of modern geology : Science, new ser., vol. 64, pp. 261-265, September 17, 1926.

29. The first Greenland expedition of the University of Michigan: Geog. Rev., vol. 17, no. 1, pp. 1-35, 33 figs., January, 1927.

30. Two glaciations within the land-ribbon surrounding the inland ice of Greenland (abstract) : Geol. Soc. America, Bull., vol. 38, no. 1, p. 212, March 30, 1927: Pan-Am. Geologist, vol. 47, no. 4, pp. 314-315, April, 1927.

31. Glacial history of southwestern Greenland (abstract) : Pan-Am. Geologist, vol. 49, no. 2, p. 149, March, 1928; Geol. Soc. America, Bull., vol. 39, no. 1 , pp. 220-221, March $30,1928$.

32. The poles of the atmospheric circulation (abstract): Washington Acad. Sci., Jour., vol. 18, no. 10, pp. 283-284, May 19, 1928.

Hobson, G. V.

1. Mica and its international relationships: Second (Triennial) Empire Min. and Met. Congress, Canada, 1927, Proc., pt. 1, pp. 140-187 11 figs., 1 pl. (map), 1928.

Hodge, Edwin Thomas.

1. The geology of the Coamo-Guayama district, Porto Rico: Scientific Survey of Porto Rico and the Virgin Islands, vol. 1, pt. 2, pp. 111-228, 50 figs., map, New York Acad. Sci., 1920.

2. Proposed quantitative and mineralogical classification of igneous rocks (abstract) : Geol. Soc. America, Bull., vol. 35, no. 1, pp. 164-165, March 30, 1924.

3. A proposed classification of igneous rocks: Oregon, Univ., Pub., vol. 2, no. 7, 72 pp., 16 figs., November, 1924.

4. Quantitative mineralogical and chemical classification of igneous rocks (abstract) : Pan-Am. Geologist, vol. 43, no. 5, pp. 374-375, June, 1925.

5. Mount Multnomah, ancient ancestor of the Three Sisters: Oregon, Univ., Pub., vol. 3, no. 2 [vol. 2, no. 10], 160 pp., 94 figs., map, August 1, 1925.

6. Geology of Mount Jefferson [Oregon]: Mazama, Ann. Ser., vol. 7, no. 2, pp. 25-58, 5 figs., map, December, 1925.

7. Practical classification of igneous rocks: Pan-Am. Geologist, vol. 46, no. 1, pp. 25-48, 5 figs., 1 pl., August, 1926.

8. Composition and structure of the Cascade Mountains in central Oregon (abstract) : Geol. Soc. America, Bull., vol. 38, no. 1, pp. 162-163, March 30, 1927 ; Pan-Am. Geologist, vol. 47, no. 2, p. 157, March, 1927.

9. Mineralogic and chemical classification of igneous rocks (abstract) : Geol. Soc. America, Bull., vol. 38, no. 1, p. 204, March 30, 1927.

10. Geology of the Oregon Cascades (abstract) : Geol. Soc. America, Bull., vol. 38, no. 1, pp. 204-205, March 30, 1927.

11. A quantitative mineralogical and chemical classification of igneous rocks: Oregon, Univ., Pub., Geology ser., vol. 1, no. 2, pp. 133-200, 8 figs., March, 1927.

12. Native asphalts in Oregon: Am. Assoc. Petroleum Geologists, Bull., vol. 11., no. 4, pp. 395-406, April, 1927. 
Hodge, Edwin Thomas-Continued.

13. Structural features in John Day and Deschutes River canyons (abstract) : Pan-Am. Geoologist, vol. 49, no. 4, pp. 305-306, May, 1928.

14. Framework of Cascade Mountains in Oregon: Pan-Am. Geologist, vol. 49. no. 5, pp. 341-356, 2 pls., June, 1928.

Hodge, James Michael.

1. Coals of Middle Fork of Kentucky River in Leslie and Harlan counties: Kentucky Geol. Survey, 166 pp., 1918.

2. Coals of the north fork of Kentucky River in Perry and portions of Breathitt and Knott counties [Kentucky] : Kentucky Geol. Survey, Fourth ser., vol. 3, pt. 3, 418 pp., 5 maps, 1918.

3. The coals of Goose Creek and its tributaries [Clay County]: Kentucky Geol. Survey, Fourth series, vol. 4, pt. 3, pp. 1-183, 1918.

\section{Hodgson, Ernest A.}

1. Location of epicenters [of earthquakes], 1917-18: Canada, Dept. Interior, Dominion Observatory, Ottawa, Pub., vol. 5, no. 4, pp. 89-124, 1921.

2. Variable velocity of $\mathrm{L}$ waves: Seismol. Soc. America, Bull., vol. 11, no. 1, pp. 58-62, 2 figs., March, 1921.

3. Three remarkable earthquakes in 1918: Seismol. Soc. America, Bull., vol. 11, no. 2, pp. 131-133, 1 pl., June, 1921.

4. Temperature control of the vertical seismograph at the Dominion Observatory, Ottawa: Seismol. Soc. America, Bull., vol. 11, no. 2, pp. 134-135, June, 1921.

5. A proposed research into the possibilities of earthquake prediction: Seismol. Soc. America, Bull., vol. 13, no. 3, pp. 100-104, September, 1923.

6. System for recording seismologic data at the Dominion Observatory, Ottawa, Canada: Seismol. Soc. America, Bull., vol. 14, no. 4, pp. 265-273, 1 fig., 2 pls., December, 1924.

7. The recording of seismologic data at the Dominion Observatory, Ottawa, Canada: Union géodesique et géophysique internationale, Section de séismologie, Ser. A, fasc. no. 2, pp. 89-120, Paris, 1925.

8. The St. Lawrence earthquake, February 28, 1925: Seismological Soc. America, Bull., vol. 15, no. 2, pp. 84-90, 16 figs., June, 1925.

9. The rotation effects of the St. Lawrence earthquake of February 28, 1925 : Royal Astronomical Soc. Canada, Jour., vol. 19, no. 6, pp. 169-178, 1 fig., October, 1925.

10. Hypothesis correlating data collected with reference to St. Lawrence earthquake of February 28, 1925 (abstract) : Pan-Am. Geologist, vol. 45, no. 2, pp. 172-173, March, 1926.

11. Seismology in Canada (abstract) : Seismological Soc. America, Bull., vol. 16, no. 2, pp. 153-154, June, 1926.

12. Minute cooling effects revealed by the seismograph: Nat. Research Council, Bull., no. 56 (vol. 11, pt. 2), pp. 64-65, November, 1926.

13. Seismology in Canada: Canada Yearbook, 1925, pp. 30-31, Canada, Do. minion Bureau of Statistics, General Statistics Branch, Ottawa, 1926.

14. The St. Lawrence earthquake, February 28, 1925: Roy. Soc. Canada, Trans., 3d ser., vol. 21, sec. 4, pp. 145-152, May, 1927; abstract, p. xcv, 1927. 
Hodyson, Ermest A.-Continued.

15. Report of progress in seismological work in Canada; the seismological work of the Dominion Observatory, Ottawa: Nat. Research Council, Bull. no. 61, pp. 79-88, July, 1927.

16. Bibliography of seismology: Seismological Soc. America, Bull., vol. 17, no. 3, pp. 149-182, September; no. 4, pp. 218-248, December, 1927; vol. 18 , no. 1 , pp. 16-63, March, 1928.

Hodson, Floyd.

1. (and Hodson, Helen K.). Short cuts in picking out and sectioning Foraminifera: Am. Assoc. Petroleum Geologists, Bull., vol. 10, no. 11, pp. 1173-1174, November, 1926.

2. The origin of bedded Pennsylvanian fire clays in the United States: Am. Ceramic Soc., Jour., vol. 10, no. 9, pp. 721-746, 1 fig., September, 1927.

Hodson, Helen K. See also Hodson, Floyd, 1.

1. Names for the stellate "Orthophragmina": Am. Jour. Sci., 5th ser., vol. 12, pp. 353-354, October, 1926.

2. Foraminifera from Venezuela and Trinidad: Bull. Am. Paleontology, vol. 12, no. 47, 46 pp., 8 pls., December 24, 1926.

Hoffman, Frederick L.

1. Earthquake hazards and insurance. 169 pp., New York, The Spectator Company, 1928.

Hoffman, Malvin G.

1. Volcanic tuffs in central Oklahoma: Am. Assoc. Petroleum Geologists, Bull., vol. 9, no. 2, p. 344, March-April, 1925.

2. Veining along faults in the Pennsylvanian sandstones in Oklahoma: Jour. Geology, vol. 34, no. 1, pp. 83-84, January-February, 1926.

Hoffman, Ralph.

1. The finding of Pleistocene material in an asphalt pit at Carpinteria, California : Science, new ser., vol. 66, p. 155, August 12, 1927.

Hoffman, Robert. See Wandke, 4.

Hoffman, W.

1. Die Braunkohlenlager der Vereinigten Staaten von Nordamerika und der Stand ihrer Ausnutzung: Braunkohle, Jahrg. 26, H. 32, pp. 729733, H. 33, pp. 760-766, 6 figs., November 5 and 12, 1927.

Hoffmeister, John Edward. See Vaughan, 36, 37; Wentworth, 33.

Hohl, C. D. See Broderick, 4.

Holbrook, Elmer Allen.

1. (and Nelson, Wilbur A.). The coal pyrite resources of Tennessee and tests on their availability : Tennessee State Geol. Survey, Resources of Tennessee, vol. 9, no. 1, pp. 60-70, January, 1919. Coal Age, vol. 15, pp. 1077-1079, June 12, 1919.

Holden, Edward Fuller, 1901-1925. See also Kraus; 5.

1. Limonite pseudomorphous after pyrite from York County, Peunsylvania: Am. Mineralogist, vol. 4, no. 6, pp. 68-69, June, 1919.

2. An American occurrence of sarcopside [Deering, New Hampshire]: Am. Mineralogist, vol. 5, no. 5, pp. 99-102, May, 1920.

3. A calcium phosphate with ratios between those of triplite and sarcopside: Am. Mineralogist, vol. 5, no. 9, p. 166, September, 1920. 
Holden, Edward Fuller-Continued.

4. Specific gravity and composition in iron-rutile: $\Lambda \mathrm{m}$. Mineralogist, vol. 6 , no. 6, pp. 1.00-103, 1 fig., June, 1921.

5. A study of the constitution of thaumasite: Am. Mineralogist, vol. 7 , no. 1 , pp. 12-14, January, 1922.

6. Ceruleofibrite, a new mineral [Bisbee, Arizona]: Am. Mineralogist, vol. 7, no. 5, pp. 80-83, 1 fig., May, 1922.

7. The color of three varieties of quartz: Am. Mineralogist, vol. 8 , no. 7, pp. 117-121, July, 1923.

8. "Ceruleofibrite" is connellite: Am. Mineralogist, vol. 9, no. 3, pp. 55-56, March, 1924.

9. The cause of color in rose quartz: Am. Mineralogist, vol, 9, no. 4, pp. 75-88, April, no. 5, pp. 101-108, May, 1924.

10. Further note on sarcopside: Am. Mineralogist, vol. 9, no. 10, pp. 205-207, October, 1924.

11. The transmission of light by citrine: Am. Mineralogist, vol. 10, no. 5, pp. 127-128, 1 fig., May, 1925.

12. The cause of color in smoky quartz and amethyst: Am. Mineralogist, vol. 10, no. 9 , pp. 203-252, 5 figs., September, 1925.

13. Pigments of amethyst and smoky quartz (abstract) : Pan-Am. Geologist, vol. 44, no. 2, pp. 158-159, September, 1925.

14. Hematite inclusions in the Lake Superior amethyst: Michigan Acad. Sci., Papers, vol. 5, pp. 283-285, 1 fig., 1926.

Holden, Roy Jay. See also Campbell, M. R., 6 ; Merwin, 6.

1. Notes on the Oriskany and Helderberg in Virginia (abstract): Geol. Soc. America, Bull., vol. 31, no. 1., p. 137, March 31, 1920.

2. Origin of Clinton hematite ores: Econ. Geology, vol. 20, no. 1, pp. 101-103, January-February, 1925.

Hole, Allen David.

1. Preliminary report on the molding sands of Indiana: Indiana, Year Book 1918, pp. 196-207, 1919.

2. Notes on the paleontology of certain Chester formations in southern Indiana : Indiana Acad. Sci., Proc. 1918, pp. 183-1.85, 1.91 .9$.

Holland, L. F. S.

1. Meteor Mountain crater, Arizona: Eng. and Min. Jour.-Press, vol. 119, no. 6, pp. 253-254, February 7, 1925.

Holland, William Jacob.

1. Charles Rochester Eastman: Carnegie Mus., Annals, vol. 12, nos. 2-4, pp. 346-352, portr., October, 1919.

2. Description of the type of Uintasaurus douglassi Holland: Carnegie Mus., Annals, vol. 15, nos. 2 and 3, pp. 119-138, 7 figs., 5 pls., July, 1924.

3. The skull of Diplodocus: Carnegie Mus., Mem., vol. 9, no. 3, pp. 379-403, 11 figs., 4 pls., November, 1924.

4. Obituary, Jacob L. Wortman : Carnegie Mus., Annals, vol. 17, no. 2, pp. 199 201, May, 1927.

Hollick, Arthur. See also Howe, 3 ; Science Service, 1.

1. Some botanical problems that paleobotany has helped to solve: Brooklyn Botanic Garden, Mem., vol. 1, pp. 187-190, July 6, 1918.

2. The taxonomic and morphologic status of Ophioglossum alleni Lesquereux: Torrey Bot. Club, Bull., vol. 50, no. 6, pp. 207-213, 3 pls., June, 1923.

3. Cycads, living and extinct: New York Bot. Garden, Jour., vol. 24, no. 283, pp. 135-140, 1 fig., July, $1 \overline{9} 23$. 
Hollick, Arthur-Continued.

4. A review of the fossil flora of the West Indies, with descriptions of new species: New York Bot. Garden, Bull., vol. 12, no. 45, pp. 259-323, 1 fig., 15.pls., September 13, 1924.

5. A new fossil species of Hydrangea [Tertiary, Alaska Peninsula]: Torrey Bot. Club, Bull., vol. 52, no. 1, pp. 21-22, 1 pl., January, 1925.

6. Paleobotanical exploration in Porto Rico: New York Bot. Garden, Jour., vol. 27, no. 317, pp. 102-104, May, 1926.

7. Report on a tree trunk and associated lignitic debris excavated in Manhattan Island [New York]: Am. Mus. Novitates, no. 213, 6 pp., 2 figs., May 6, 1926.

8. Fossil walnuts and lignite from Porto Rico: New York Bot. Garden, Jour., vol. 27, no. 322, pp. 223-227, 1 fig., October, 1926.

9. Records of glaciation in the New York Botanical Garden: New York Bot. Garden, Jour., vol. 27, no. 324, pp. 269-278, 7 figs., December, 1926.

10. The flora of the St. Eugene silts, Kootenay Valley, British Columbia: New York Bot. Garden, Mem., vol. 7, pp. 389-464, 1 fig., 19 pls., March 1, 1927.

11. Report of the paleobotanist: New York Bot. Garden, Bull., vol. 13, no. 48, pp. 217-218, June 8, 1927.

12. Paleobotany of Porto Rico: New York Acad. Sci., Scientific Survey of Porto Rico and the Virgin Islands, vol. 7, pt. 3, pp. 173-393, 38 pls., October 31, 1928.

13. The story of the redwoods: New York Bot. Garden, Jour., vol. 29, no. 347, pp. 281-282, November, 1928.

Holman, E.

1. (and Campbell, R. B.). The Bellevue oil field, Louisiana: Am. Assoc. Petroleum Geologists, Bull., vol. 7, no. 6, pp. 645-652, 1 fig., November-December, 1923.

Holmes, Arthur.

1. The basaltic rocks of the Arctic region: Mineral. Mag., vol. 18, pp. 180223, 2 pls., August, 1918.

2. (and Lawson, Robert W.). Factors involved in the calculation of radioactive minerals: Am. Jour. Sci., 5th ser., vol. 13, pp. 327-244, April, 1927.

Holmes, Grace B.

1. A bibliography of the conodonts with descriptions of early Mississippian species: U. S. Nat. Mus., Proc., vol. 72, art. 5, 38 pp., 11 pls., 1928.

Holmes, William Henry.

1. The antiquity phantom in American archeology [antiquity of artifacts from Melbourne, Florida] : Science, new ser., vol. 62, pp. 256-258, September 18, 1925.

Holtedahl, Olaf.

1. Summary of geological results. Second Norwegian. Arctic Expedition in the Fram, 1898-1902, Rept. No. 36, 27 pp., 6 pls., 4 figs., map, Videnskabs-Selskabet i Kristiania, 1917.

2. Paleogeography and diastrophism in the Atlantic-Arctic region during Paleozoic time: Am. Jour. Sci., 4th ser., vol. 49, pp. 1-25, 12 figs., January, 1920. 
Holtedahl, Olaf-Continued.

3. On the rock formations of Novaya Zemlya, with notes on the Paleozoic stratigraphy of other Arctic lands: Report of the scientific results of the Norwegian Expedition to Novaya Zemlya 1921, no. 22, 183 pp., 44 pls., Videnskapsselskapet i Kristiania, 1924.

4. Some points of structural resemblance between Spitsbergen and Great Britain, and between Europe and North America: Norske Videnskaps-Akademi i Oslo, Avhandl., Mat.-Nat. Kl., 1925, no. 4, 20 pp., 5 figs., 1925.

5. Tectonics of Arctic regions: Pan-Am. Geologist, vol. 46, no, 4, pp. 257272, 3 figs., 2 pls., November, 1926.

Holtz, H. C. See Howe, J. L., 1.

Holway, Ruliff Stephen.

1. Stream and ocean terraces in relation to recent earth movements (abstract) : Assoc. Am. Geographers, Annals, vol. 11, pp. 125-126 [1922?].

Holzwasser, Florrie.

1. Geology of Newburgh and vicinity: New York State Mus. Bul. no. 270, 95 pp., 12 figs., 39 pls., map and section sheet, 1926.

Honess, Arthur Pharaoh.

1. The etching figures of topaz: Am. Mineralogist, vol. 6, no. 4, pp. 71-77, 1 fig., 1 pl., April, 1921.

2. Some interesting chalcedony pseudomorphs from Big Badlands, South Dakota: Am. Jour. Sci., 5th ser., vol. 5, pp. 173-174, February, 1923.

3. (and Graeber, C. K.). A new occurrence of an igneous dike in southwestern Pennsylvania: Am. Jour. Sci., 5th ser., vol. 7, pp. 313-315, April, 1924.

4. (and Graeber, C. K.). Petrography of the mica peridotite dike at Dixonville, Pennsylvania: Am. Jour. Sci., 5th ser., vol. 12, pp. 484-494, 6 figs., December, 1926.

5. The nature, origin, and interpretation of the etch figures on crystals. xiii, 171 pp., 95 figs., New York, John Wiley \& Sons, 1927.

Honess, Charles William. See also Miser, 29.

1. Structural features of the southern Ouachita Mountains, Oklahoma (abstract with discussion by H. D. Miser) : Geol. Soc. America, Bull., vol. 31, no. 1, pp. 121-122, March 31, 1920.

2. The Stanley shale of Oklahoma: Am. Jour. Sci., 5th ser., vol. 1, no. 1, pp. 63-80, 1 fig., January, 1921.

3. Field work in the Ouachita Mountains: Am. Assoc. Petroleum Geologists, Bull., vol. 5, no. 6, p. 679, November-December, 1921.

4. Geology of the southern Ouachita Mountains of Oklahoma ; Part I, Stratigraphy, structure, and physiographic history, 278 pp., 6 figs., 92 pls. (incl. map) ; Part II, Geography and economic geology, 76 pp., 3 figs., 28 pls.: Oklahoma Geol. Survey, Bull. 32, Norman, April, 1923.

5. Geology of southern Leflore and northwestern McCurtain counties, Oklahoma: Bureau of Geology, Norman, Oklahoma, Circular no. 3, 23 pp., 2 figs., 5 pls. (incl. map), Norman, January, 1924.

6. Oil and gas in Oklahoma; geology of Atoka, Pushmataha, McCurtain, Bryan, and Choctaw counties: Oklahoma Geol. Survey, Bull., no. 40-R, 32 pp., 3 figs., November, 1927. 
Honigmann, Ernesto.

1. La región minera al norte-oriente del mineral de La Colorada, Sonor: [México] : Bol. ninero, t. 14, no. 1, pp. 15-24, July, 1922.

2. Las minas abandonadas "El Promontorio" y "La Cueva," Hermosillo, Sonora [México] : Bol. minero, t. 14, no. 1, pp. 24-28, 3 pls., July, 1922.

3. La mina de "La Turquesa," San José de Guaymas, Sonora [México]: Bol. minero, t. 14, no. 1, pp. 28-34, July, 1922.

4. La industria del grafito en el Estado de Sonora: Bol. minero, t. 20, no. 2, pp. 49-60, August, 1925.

5. La Cía. minera San José, S. A., municipalidad de La Colorada, distrito de Hermosillo, Sonora: Bol. minero, t. 20, no. 2, pp. 60-67, August, 1925.

6. Las minas del Cerro Colorado, municipalidad de San Marcial, distrito de Guaymas, Sonora: Bol. minero, t. 20, no. 2, pp. 67-73, August, 1925.

Hood, O. P. See Odell, 1.

Hoots, Harold William. See also Dobbin, 5.

1. Geology of a part of western Texas and southeastern New Mexico, with special reference to salt and potash (preface by J. A. Udden) : U. S. Geol. Survey, Bull. 780, pp. 33-126, 1 fig., 15 pls. (incl. maps), 1925.

2. Geologic features of the southern end of the San Joaquin Valley, California (abstract) : Washington Acad. Sci., Jour., vol. 17, no. 5, pp. 123-124, March 4, 1927.

3. Heavy-mineral data at the southern end of San Joaquin Valley [California ] Am. A.ssoc. Petroleum Geologists, Bull., vol. 11, no. 4, pp. 369-372, April, 1927.

4. Oil possibilities at Comanche Point and near Wheeler Ridge, California: Oil Age, vol. 24, no. 4, p. 19, April, 1927 ; Petroleum World, Los Angeles, vol. 12, no. 4, p. 98, April, 1927.

5. Geology of the Wheeler Ridge area, Kern County, California (abstract) : Stanford Univ., Abstracts of Dissertations, 1924-1926, vol. 1, pp. 135-137, June, 1927.

6. Oil possibilities and survey of oil and gas exploration in southwestern Humboldt County, California: Oil Age, vol. 25, no. 3, pp. 29-31, 79, 1 fig., March, 1928.

7. Oil and gas exploration in southwestern Humboldt County, California. [U. S.], Department of the Interior, Memorandum for the Press, release date March 5, 1928. 9 pp. (mimeographed), 1 pl. (geol. map and sections).

Hoover, Herbert Clark.

1. Some notes on crossings [North Star mine, Grass Valley, California] : Min. and Sci. Press, vol. 120, pp. 743-744, 5 figs., May 22, 1920 (reprinted from vol. 72, pp. 166-167, February 29, 1896).

Hopkins, Oliver Baker. See also Power's, 12; Redwood, 1.

1. (and Powers, Sidney). Structure and oil and gas resources of the Osage Reservation, Oklahoma; T. 24 N., R. 11 and 12 E.: U. S. Geol. Survey, Bull. 686, pl). 237-253, 4 pls. (incl. map), 1919.

2. (and Powers, Sidney, and Robinson, H. M.). The structure of the MadillDenison area, Oklahoma and Texas, with notes on oil and gas development: U. S. Geol. Survey, Bull. 736, pp. 1-33, 6 pls. (incl. maps), June 6, 1922. 
Hopkins, Oliver Baker-Continued.

3. Some structural features of the plains area of Alberta caused by Pleistocene glaciation: Geol. Soc. America, Bull., vol. 34, no. 3, pp. 419-430, 10 figs., September 30, 1923.

4. Oil and gas development in the foothills belt of Alberta and British Columbia: Canadian Inst. Min. and Met., Trans., vol. 30, pp. 626-640, 3 figs. [1928]; Second (Triennial) Empire Min. and Met. Congress, Canada, 1927, Proc., pt. 3, pp. 110-124, 3 figs., 1928.

Hopkins, Percy Eugene. See also Burrows, 4, 8, 9, 12 ; Knight, C. W., 1.

1. Larder Lake gold area: Ontario Bur. Mines, 28th Ann. Rept., vol. 28, pt. 2, pp. 71-77, 3 figs., 1919. Canadian Min. Jour., vol. 40, pp. 68-71, 3 figs., February 5, 1919.

2. West Shiningtree gold area: Ontario Dept. Mines, 29th Ann. Rept., vol. 29, pt. 3, pp. 28-52, 16 figs., map, 1920. Reprinted as Bull. 39, 26 pp., 1920.

3. Ontario gold deposits; their character, distribution, and productiveness: Ontario Dept. Mines, 30th Ann. Rept., vol. 30, pt. 2, 73 pp., figs., and pls. (including maps), 1922.

4. Ontario gold deposits; their character, distribution, and productiveness: Canadian Inst. Min. and Met., Monthly Bul., no. 118, pp. 173-188, February, 1922 ; Trans., vol. 25, pp. 32-47, 1 flg. [1923].

5. Schreiber-Duck Lake area [Ontario]: Ontario Dept. Mines, 30th Ann. Rept., vol. 30, pt. 4, pp. 1-26, illus., 1922.

6. The Kirkland Lake gold area, Ontario: Mining and Metallurgy, vol. 4, no. 200, pp. 392-394, 2 figs., August, 1923.

7. Lebel and Gauthier townships (area between Kirkland and Larder lakes) : Ontario Dept. Mines, 32d Ann. Rept., vol. 32, pt. 4, pp. $53-88$, illus., map, 1925.

8. Larder Lake gold area: Ontario Dept. Mines, 33d Ann. Rept., pt. 3, pp. 1-26, 14 figs., 1 pl., map, 1925.

9. Night Hawk Lake gold area: Ontario Dept. Mines, 33d Ann. Rept., vol. 33, pt. 3, pp. 27-36, 5 figs., map, 1925.

10. Notes on gold in McNeil and other townships: Ontario Dept. Mines, 33d Ann. Rept., vol. 33, pt. 3, pp. 37-40, 3 figs., 2 pls. (maps), 1925.

11. The Costello gold deposit at Pancake Lake [Ontario]: Canadian Min. Jour., vol. 46, no. 25, pp. 601-604, 3 figs., June 19, 1925.

Hopwood, Arthur T.

1. A fossil rice-rat from the Pleistocene of Barbuda [West Indies] : Ann. and Mag. Nat. Hist., 9th ser., vol. 17, pp. 328-330, 1. pl., March, 1926.

Hore, Reginald Edwin. See also Bruce, 18; Tyrrell, 7, 9.

1. The Wasapika gold area [Sudbury district, Ontario]: Canadian Min. Jour. vol. 40, pp. 490-501, 30 figs., July 9, 1919.

2. The Huntingdon copper mine [Eastman], Quebec: Canadian Min. Jour., vol. 40, pp. 582-584, 4 figs., August 6, 1919.

3. Recent developments in Wasapika gold area [Sudbury district, Ontario] : Canadian Min. Jour., vol. 40, pp. 677-678, September 10, 1919.

4. Some notes on ores and rocks of Wasapika gold area [Sudbury district, Ontario] : Canadian Min. Jour., vol. 40, pp. 749-750, October 7, 1919.

5. A new gold field in Ontario [Wasapika area, Sudbury mining division]: Min. and Sci. Press, vol. 119, pp. 595-596, 1 fig., October 25, 1919. 
Hore, Reginald Edwin-Continued.

6. The pitchblende deposit in Butte township, Nipissing district, Ontario: Canadian Min. Jour., vol. 40, pp. 830-831, 4 figs., November 5, 1919.

7. Country rocks of Elliott pitchblende deposits [Butte township, Ontario] : Canadian Min. Jour., vol. 40, no. 50, p. 948, December 17, 1919.

8. Porcupine, premier gold district of northern Ontario: Eng. and Min. Jour.-Press, vol. 115, no. 8, pp. 359-363, 8 figs., February 24, 1923.

9. The Rouyn-Boischatel gold area, Temiskaming County, QQuebec: Canadian Min. Jour., vol. 45, no. 31, pp. 745-748, 5 figs., August 1; 1924.

10. Willet G. Miller: Mining and Metallurgy, vol. 6, no. 219, pp. 160-161, March, 1925.

Hoskin, Arthur Joseph.

1. The winning of oil from rocks: Min. and Sci. Press, vol. 118, pp. 701-707, 10 figs., May 24, 1919.

Hoskins, J. Hobart.

1. A Paleozoic angiosperm from an American coal ball : Bot. Gazette, vol. 75, no. 4, pp. 390-399, 7 figs., 1 pl., June, 1923.

2. Structure of Pennsylvanian plants from Illinois: Bot. Gazette, vol. 82, no. 4, pp. 427-437, 2 pIs., December, 1926.

3. Notes on the structure of Pennsylvanian plants from Illinois, II : Bot. Gazette, vol. 85, no. 1, pp. 74-82, 7 figs., 1 pl., March, 1928.

4. Structure of some Carboniferous plants from Illinois: Indiana Acad. Sci., Proc., vol. 37, pp. 373-376, 1928.

Hosted, Joseph O. See also Wright, L. B., 1.

1. (and Wright, L. B.). Geology of the Homestake ore bodies and the Lead area of South Dakota : Eng. and Min. Jour.-Press, vol. 115, nos. 18 and 19, pp. 783-799, 836-843, 21 figs., May 5 and 12, 1923.

Hosterman, J. F.

1. The Tonkawa oil and gas field, Oklahoma: Am. Assoc. Petroleum Geologists, Bull., vol. 8, no. 3, pp. '284-300, 3 flgs., May-June, 1924.

Hostetter, J. C. See Merwin, 2.

Hotchkiss, William Otis. See also Allen, R. C., 2.

1. Geology of the Gogebic Range and its relation to recent mining developments : Eng. and Min. Jour., vol. 108, pp. 443-452, 501-507, 537541, 577-582, 35 figs., September 13, 20, and 27 and October 4, 1919.

2. Report of the director of the survey: Twelfth biennial report of the Commissioners of the Geological and Natural History Survey, covering the period from July 1, 1918, to June 30, 1920. 37 pp., 2 figs., Madison, Wisconsin, 1920.

3. Exploration methods on the Gogebic range: Am. Inst. Min. and Met. Eng., Trans., vol. 68, pp. 287-293, 1923 ; [preprint] no. 995, 7 pp., 1920 ; abstract, Mining and Metallurgy, no. 163, pp. 29-30, July, 1910.

4. Report of the director of the survey: Wisconsin, Geol. and Nat. Hist. Survey, 13th Bienn. Rept. of the Commissioners, 37 pp., 3 figs., 1922.

5. Magnetic methods for exploration and geologic work: Am. Inst. Min. and Met. Eng., Trans., vol. 69, pp. 36-47, 3 figs., 1923; [preprint] no. 1232, 12 pp., 3 figs., February, 1923; abstract, Mining and Metallurgy, vol. 4, no. 194, pp. 94-95, 1 fig., February, 1923. 
Hotchkiss, William Otis-Continued.

6. Geology of the Baraboo ganister deposits: Am. Ceramic Soc., Jour., vol. 6, no. 11, pp. 1160-1166, 4 figs., November, 1923.

7. Recent developments in the geology of the Gogebic range (with discussion by A. C. Lane) : Lake Superior Min. Inst., 23d Ann. Meeting, Proc., vol. 23, pp. 47-55, 1923.

8. The Lake Superior geosyncline: Geol. Soc. America, Bull., vol. 34, no. 4, pp. 669-678, December 30, 1923.

9. The Lake Superior geosyncline: Lake Superior Min. Inst., Proc., 24th Ann. Meeting, vol. 24, pp. 140-148, 1925. (Reprinted from Geol. Soc. America, Bull., vol. 34, 1923.

10. (and Bean, E. F.). A brief outline of the geology, physical geography, geography, and industries of Wisconsin: Wisconsin Geol. and Nat. Hist. Survey, Bull. no. 67, 60 pp.., 27 flgs., 5 pls., 1925.

Hough, George A.

1. Notes on an unlisted mineral [cocinerite, Ramos, San Luis Potosi, Mexico] : Am. Jour. Sci., 4th ser., vol. 48, p. 206, September, 1919.

Houghton, Douglas.

1. Geological reports of Douglas Houghton, first State geologist of Michigan 1837-1845, ed. by George N. Fuller. 700 pp., 7 pls. (incl. portr. and maps), Lansing, The Michigan Historical Commission, 1928.

Hovey, Edmund Otis, 1862-1924. See also Reeds, 5.

1. Proceedings of the thirty-first annual meeting of the Geological Society .of America, held at Baltimore, Maryland, December 27 and 28, 1918: Geol. Soc. America, Bull., vol. 30, pp. 1-142, 6 pls., March $31,1919$.

2. Proceedings of the thirty-second annual meeting of the Geological Society of America, held at Boston, Massachusetts, December 29-31, 1919: Geol. Soc. America, Bull., vol. 31, pp. 1-176, 7 pls., March 31, 1920.

3. Proceedings of the thirty-third annual meeting of the Geological Society of America, held at Chicago, Illinois, December 28-30, 1920: Geol. Soc. America, Bull., vol. 32, no. 1, pp. 1-118, 1 pl., March 31, 1921.

4. Proceedings of the thirty-fourth annual meeting of the Geological society of America, held at Amherst, Massachusetts, Wednesday-Friday, December 28-30, 1921: Geol. Soc. America, Bull., vol. 33, no. 1, pp. 1-186, 3 pls., March 31, 1922.

5. A tree fern of middle Devonian time [Psaronius, Schoharie County, New York] : Natural History (Jour. Am. Mus. Nat. Hist.), vol. 22, no. 5, pp. 458-460, 3 figs., September-October, 1922.

6. Aerolite from Rose City, Michigan: Am. Mus. Novitates, no. 52, 7 pp., 3 figs., November 23, 1922.

7. A new meteorite from Michigan: Natural History, vol. 23, no. 1, pp. 87-88, January-February, 1923.

8. Aerolite from Rose City, Michigan (abstract) : Geol. Soc. America, Bull., vol. 34, no. 1, p. 97, March 30, 1923.

9. Earthquakes: Natural History, vol. 23, no. 5, pp. 457-461, SeptemberOctober, 1923.

10. The volcanic Caribbees: Pan-Pacific Sci. Cong., Australia, 1923, Proc., vol. 1, pp. 836-837 [1924].

11. Geology of northwest Greenland and its relation to the flora, fauna, and people of the region: Am. Jour. Sci., 5th ser., vol. 8, pp. 189200, September, 1924.

$4096-31-19$ 
Hovey, Edmund Otis-Continued.

12. A new meteoric stone from Johnstown, Weld County, Colorado; with supplemental notes by George P. Merrill and Earl V. Shannon: Am. Mus. Novitates, no. 203, 13 pp., 6 figs., November 30, 1925.

Howard, C. S. See Collins, 5.

Howard, Hildegarde.

1. A review of the fossil bird Parapavo californicus (Miller), from the Pleistocene asphalt beds of Rancho La Brea: California, Univ., Dept. Geol. Sci., Bull., vol. 17, no. 1, pp. 1-30, 13 pls., September 30, 1927.

Howard, L. O.

1. The Chewelah and Colville districts of northeastern Washington: Mining and Metallurgy, vol. 6, no. 222, pp. 271-278, 8 figs., June, 1925.

Howard, Waldorf Vivian. See also Bancroft, J. A., 1; Claypool, 1.

1. Some outliers of the Monteregian Hills [Quebec]: Roy. Soc. Canada, Proc. and Trans., 3d ser., vol. 16, sec. 4, pp. 47-95, 1 pl., 1922.

2. Devonian volcanic rocks near Dalhousie, New Brunswick: Geol. Soc. America, Bull., vol. 37, no. 3, pp. 475-496, 2 figs., September 30, 1926 ; abstract, no. 1, p. 152, March 30, 1926; Pan-Am. Geologist, vol. 45, no. 2, pp. 158-159, March, 1926.

3. A classification of limestone reservoirs; Am. Assoc. Petroleum Geologists, Bull., vol. 12, no. 12, pp. 1153-1161, December, 1928.

Howe, Ernest.

1. The gold ores of Grass Valley, California (with discussion by A. M. Bateman, Waldemar Lindgren, J. E. Spurr, and the author) : Econ. Geology, vol. 19, no. 7, pp. 595-622, 2 pls., November, 1924.

Howe, Henry Van Wagenen. See also Grimm, 1.

1. Correlation of the Empire formation, Oregon (abstract): Geol. Soc. America, Bull., vol. 32, no. 1, p. 147, March 31, 1921.

2. Faunal and stratigraphic relationships of the Empire formation, Coos Bay, Oregon: California, Univ., Dept. Geol. Sciences, Bull., vol. 14, no. 3, pp. 85-114, 6 pls., September 8, 1922.

3. The Arkadelphia formation; historical summary: Louisiana State Univ., Univ. Bull., new ser., vol. 16, no. 5, pt. 1, 10 pp., June, 1924.

4. The Arkadelphia formation, stratigraphy: Louisiana State Univ., Univ. Bull., new ser., vol. 16, no. 5, pt. 2, 17 pp., June, 1924.

5. The Nacatoch formation: Louisiana State Univ., Univ. Bull., new ser., vol. 16, no. 5, pt. 3, 25 pp., June, 1924.

6. Louisiana's mineral resources, past and present: The South's Development, Manufacturers Record, vol. 86, no. 24, pt. 2, pp. 378-381, December 11, 1924.

7. "The Many salt dome," Sabine Parish, Louisiana: Am. Assoc. Petroleum Geologists, Bull., vol. 9, no. 1, pp. 170-171, January-February, 1925.

8. Extension of Midway formation into Louisiana: Pan-Am. Geologist, vol. 43 , no. 4, p. 309, May, 1925.

9. Astoria, mid-Tertic type of Pacific coast: Pan-Am. Geologist, vol. 45, no. 4, pp. 295-306, 1 pl. (map), May, 1926.

10. An observation on the range of the genus Hantkenina: Jour. Paleontology, vol. 2, no. 1, pp. 13-14, 2 figs., March, 1928. 
Howe, Henry Van Wagenen-Continued.

11. Additions to the list of species occurring in the type Red Bluft clay, Hiwannee, Mississippi : Jour. Paleontology, vol. 2, no. 3, pp. 173-176, September, 1928.

Howe, James Lewis.

1. (and Holtz, H. C.). Bibliography of the metals of the platinum group; platinum, palladium, iridium, rhodium, osmium, ruthenium, 17481917 : U. S. Geol. Survey, Bull. 694, 558 pp., 1919. Abstract by R. W. Stone, Washington Acad. Sci., Jour., vol. 10, no. 10; p. 301, May 19, 1920.

Howe, Marshall Avery.

1. Tertiary calcareous Algae from the islands of St. Bartholomew, Antigua, and Anguilla: Carnegie Inst. Washington, Pub. no. 291, pp. 9-19, 6 pls., 1919.

2. Two new Lithothamineae, calcareous algae, from the lower Miocene of Trinidad, British West Indies: U. S. Nat. Mus., Proc., vol. 62, art. 7, 3 pp., 4 pls., 1922.

3. (and Hollick, Arthur). A new American fossil hepatic [Jungermanniopsis from Florissant, Colorado] : Torrey Bot. Club., Bull., vol. 49, no. 7, pp. 207-209, 1 fig., July, 1922.

4. (and Goldman, Marcus I.). Lithothamnium (?) ellisianum, sp. nov., from the Jurassic Ellis formation of Montana: Am. Jour. Sci., 5th ser., vol. 10, pp. 314-324, 11 figs., October, 1925.

Howell, Benjamin Franklin.

1. Correlation of the middle Cambrian of Newfoundland and Great Britain (abstract) : Geol. Soc. America, Bull., vol. 31, no. 1, p. 214, March 31, 1920.

2. Oldhamia in the Lower Cambrian of Massachusetts (abstract) : Geol. Soc. America, Bull., vol. 33, no. 1, pp. 198-199, March 31, 1922.

3. Gilbert Van Ingen (1869-1925): Science, new ser., vol. 62, pp. 101-103, July 31, 1925.

4. The faunas of the Cambrian Paradoxides beds at Manuels, Newfoundland: Bulletins of American Paleontology, vol. 11, no. 43, 140 pp., 3 pls., 7 tables, November 11, 1925.

5. The Cambrian-Ordovician stratigraphic column of southeastern Newfoundland: Canadian Field-Naturalist, vol. 40, nọ. 3, pp. 52-57, March, 1926.

6. Problematical fossil, possibly a fish plate, from the Cambrian Paradoxides beds of northwestern Vermont (abstract) : Geol. Soc. America, Bull., vol 37, no. 1, p. 236, March 30, 1926.

7. Cambrian Paradoxides beds in northwestern Vermont (abstract): Geol. Soc. America, Bull., vol. 37, no. 1, pp. 242-243, March 30, 1926.

8. Discovery of two additional Cambrian faunas in New Brunswick (abstract) : Geol. Soc. America, Bull., vol. 38, no. 1, p. 228, March 30, 1927 ; Pan-Am. Geologist, vol. 47, no. 3, p. 236, April, 1927.

9. The finding of the St. Albans Cambrian "fish-plate": Vermont, State Geologist, 15th Rept., 1925-26, pp. 121-124, 1927.

10. [Marking of type specimens] : Geol. Soc. America, Bull., vol. 39, no. 1, pp. 287-288, March 30, 1928.

Howell, Jesse V.

1. Twin Lakes district of Colorado [Lake and Pitkin counties]: Colorado Geol. Survey, Bull. 17, 108 pp., 27 figs., 2 pls. (maps), 1919. 
H.owell, Jesse V.-Continued.

2. Some structural factors in the accumulation of oil in southwestern Oklahoma: Econ. Geology, vol. 17, no. 1, pp. 15-33, 4 figs., JanuaryFebruary, 1922.

3. Notes on the pre-Permian Paleozoics of the Wichita Mountain area: Am. Assoc. Petroleum Geologists, Bull., vol. 6, no. 5, pp. 413-425, 2 pls., September-October, 1922.

4. Petroleum and natural gas in Iowa: Iowa Geol. Survey, vol. 29, pp. 1-48, 4 pls. (incl. map) [1924].

Howell, R. W. See Wegemann, 1.

Howley, James Patrick.

1. Geological map of Newfoundland ... Scale 1 inch $=17$ miles (about). Reprinted 1925.

Hoyt, Mary E.

1. Petroleum; a selected bibliography: Colorado School of Mines, Quart., vol. 22, no. 2, 25 pp., April, 1927.

Hrdlička, Aleš.

1. Recent discoveries attributed to early man in America: Bur. Am. Ethnology, Bull. 66, 67 pp., 14 pls., 8 figs., 1918. [Includes an account of the Vero, Fla., remains.]

2. Antiquity of man in America in light of recent discoveries (abstract) : Pan-Am. Geologist, vol. 42, no. 4, p. 319, November, 1924.

3. The peopling of the earth: Am. Philos. Soc., Proc., vol. 65, no. 3, pp. 150$156,1926$.

4. The evidence bearing on man's evolution: Smithsonian Inst., Ann. Rept., 1927, pp. 417-433, 1928.

Hubbard, Bela. See also Fettke, 2.

1. Tertiary Mollusca from the Lares district, Porto Rico: New York Acad. Sci., Scientific Survey of Porto Rico and the Virgin Islands, vol. 3, pt. 2, pp. 79-164, 16 pls. 1920.

2. The Tertiary formations of Porto Rico: Science, new ser., vol. 51, pp. 395-396, April 16, 1920. Abstract, Geol. Soc. America, Bull., vol. 31, no. 1, p. 135, March 31, 1920.

3. The geology of the Lares district, Porto Rico: New York Acad. Sci., Scientific Survey of Porto Rico and the Virgin Islands, vol. 2, pt. 1, pp. 1-115, 42 figs., 4 pls., map, 1923.

Hubbard, George" David. See also Jones, 0. C., 1:

1. Concretions in lake deposits at Elyria, Ohio: Ohio Jour. Sci., vol. 22, no. 3, pp. 97-98, January, 1922.

2. Colloids in geologic problems: Am. Jour. Sci., 5th ser., vol. 4, pp. 95-110, August, 1922; Chemical News, vol. 125, pp. 390-395, December 29, 1922 ; vol. 126, pp. 6-9, January 5, 1923.

3. Biographical sketch of George Frederick Wright: Ohio Acad. Sci., Proc., vol. 7, pt. 7, pp. 243-247, March 1, 1923.

4. Geology of a small tract in south central Vermont [Whitingham area]: Vermont, State Geologist, Fourteenth Rept., 1923-1924, pp. 260343, 6 figs., 8 plis. (incl. maps), 1924.

5. Dimensions of the Cincinnati anticline: Ohio Jour. Science, vol. 24, no. 3, pp. 161-166, 2 pls., May, 1924.

6. (and Croneis, Carey G.). Notes on the geology of Giles County, Virginia : Denison Univ. Bull., vol. 24, no. 5, Sci. Lab., Jour., vol. 20, pp. 307377, 1 pl. (map), December, 1924. 
Hubbard, George David-Continued.

7. (and Champion, Milton M.). Physiographic history of five river valleys in northel'n Ohio: Ohio Jour. Sci., vol. 25, no. 2, pp. 51-84, March, 1925.

8. Sink-holes and springs near Bellevue, Ohio (abstract) : Geol. Soc. America, Bull., vol. 39, no. 1, p. 226, March 30, 1928.

9. Quantitative vs. qualitative studies in geology (abstract) : Ohio Acad. Sci., Proc., vol. 8, pt. 4, p. 170, 1928; Ohio Jour. Sci., vol. 28, no. 3, p. 148, May, 1928.

10. Quantitative vs. qualitative studies in geology : Science, new ser., vol. 68, pp. 171-174, August 24, 1928.

11. A plea for more quantitative studies in geology : Eng. and Min. Jour., vol. 126, no. 14, pp. 537-539, October 6, 1928; Queensland Govt. Min. Jour., vol. 29, pp. 528-529, December 15, 1928.

Hubbard, W. E.

1. (and Thompson, W. C.). The geology and oil fields of Archer County, Texas: Am. Assoc. Petroleum Geologists, Bull., vol. 10, no. 5, pp. 457-481, 6 figs., 1 pl., May, 1926.

Hubbard, Wyant D.

1. The Black Lake asbestos area [Quebec]: Eng. and Min. Jour., vol. 112, no. 10, pp. 365-368, 6 figs., September 3, 1921.

Hubbert, $M$. King.

1. A suggestion for the simplification of fault descriptions: Jour. Geology, vol. 35, no. 3, pp. 264-269, 6 figs., April-May, 1927.

2. The direction of the stresses producing given geologic strains: Jour. Geology, vol. 36, no. 1, pp. 75-84, 4 figs., January-February, 1928.

3. (and Melton, Frank A.). Gravity anomalies and petroleum exploration by the gravitational pendulum: Am. Assoc. Petroleum Geologists, Bull., vol. 12, no. 9, pp. 889-899, 6 figs., September, 1928.

Hubbs, Carl L.

1. Recent contributions to our knowledge of the fossil fishes of California: Science, new ser., vol. 60, pp. 177-179, August 22, 1924.

Hudnall, James S. See also Eyl, 1; Kentucky Geol. Survey, 5, 8, 9, 10, $11,12,15,16,18,21,22$.

1. The Elkhorn coal field: Kentucky Geol. Survey ser. 6, vol. 27, pp. 131133, map, 1925.

2. Coals of Martin County: Kentucky Geol. Survey, ser. 6, vol. 26, pp. 209228,1 pl., 1927.

3 Marine invasions in eastern Kentucky in Pennsylvanian times: Kentucky Acad. Sci., Trans., vol, 2, pp. 44-46, 1927.

Hudson, Frank Samuel.

1. Geology of the Cuyamaca region of California, with special reference to the origin of the nickeliferous pyrrhotite: California, Univ., Dept. Geol. Sciences, Bull., vol. 13, no. 6, pp. 175-252, 7 fgs, 6 pls., map, June 29, 1922.

2. The South Mountain oil field [Ventura County, California]: Am. Assoc. Petroleum Geologists, Bull., vol. 8, no. 6, pp. 810-820, 1 fig., November-December, 1924.

3. (and Taliaferro, N. L.). Calcium chloride waters from certain oil fields in Ventura County, California: Am. Assoc. Petroleum Geologists, Bull., vol. 9, no. 7, pp. 1071-1088, October, 1925. 
Hudson, Frank Samuel-Continued.

4. (and Taliaferro, N. L.). An interesting example of a deep bore hole: Am. Assoc. Petroleum Geologists, Bull., vol. 10, no. 8, pp. 775-785, 2 figs., August, 1926.

5. Occurrence of oil in basalt in southwestern Washington: Am. Assoc. Petroleum Geologists, Bull., vol. 11, no. 1, pp. 87-88, January, 1927

Hudson, George Henry.

1. A preliminary paper concerning the fault systems of the northern Champlain Valley: Vermont, State Geologist, Thirteenth Rept., 19211922 , pp. 87-92, 5 pls. (incl. maps), 1923.

2. The need of improved technique in illustration: Jour. Geology, vol. 33, no. 6, pp. 642-657, 1 fig., 4 pls., August-September, 1925.

3. The surface characteristics of Astrocystites (Steganoblasus) ottawaensis: Vermont, State Geologist, 15th Rept., 1925-26, pp. 97-110, 5 pls., 1927.

Huene, Friedrich von.

1. Reptilian and stegocephalian remains from the Triassic of Pennsylvania in the Cope collection: Am. Mus. Nat. Hist., Bull., vol. 44, pp. 561574, 20 flgs., December 27, 1921.

2. The Triassic reptilian order Thecodontia: Am. Jour. Sci., 5th ser., vol. 4, pp. 22-26, July, 1922.

3. Notes on the age of the continental Triassic beds in North America, with remarks on some fossil vertebrates: U. S. Nat. Mus., Proc., vol. 69, art. 18, 10 pp., 8 figs., 1926.

Huerta, Santiago de la. See Ortega, 1.

Huggins, Maurice $\mathbf{L}$.

1. Crystal cleavage and crystal structure: Am. Jour. Sci., 5th ser., vol. 5, pp. 303-313, 7 figs., April, 1923.

Hughes, Richard.

1. Granite wells in central Oklahoma: Am. Assoc. Petroleum Geologists, Bull., vol. 5, no. 3, p. 421, May-June, 1921.

Huguenin, Emile. See also Boalich, 1.

1. The minor oil fields of Kern County; Devils Den field: California State Min. Bur., Summary of Operations California Oil Fields, vol. 9, no. 12, pp. 5-11, 1 pl. (map), June, 1924.

2. Inglewood oil field: California State Min. Bur., Summary of Operations California Oil Fields, vol. 11, no. 12, pp. 5-15, 5 flgs., 2 pls., June, 1926.

Hulin, Carlton D.

1. Mineralization in the vicinity of Randsburg, California: Eng. and Min. Jour.-Press, vol. 119, no. 10, pp. 407-411, 6 figs., March 7, 1925.

2. Mineralization in the Randsburg quadrangle, California (abstract): Geol. Soc. America, Bull., vol. 36, no. 1, p. 208, March 30, 1925.

3. Geology and ore deposits of the Randsburg quadrangle, California: California State Min. Burr., Bull. 95, 152 pp., 8 figs., 31 pls. (incl. map), 1925. Review by J. E. Spurr, Eng. and Min. Jour.-Press, vol. 121, no. 11, pp. 463-464, 2 figs., March 13, 1926.

4. Geology and mineralization at Pachuca, Mexico (abstract) : Pan-Am. Geologist, vol. 49, no. 4, pp. 310-311, May, 1928. 
Hull, Joseph Poyer Deyo.

1. (and LaForge, Laurence, and Crane, W. R.). Report on the rnanganese deposits of Georgia: Georgia Geol. Survey, Bull. no. 35, 295 pp., 11 pls., 26 figs., 2 maps, Atlanta, 1919.

2. (and Teas, L. P.). A preliminary report on the oil prospect near Scotland, Telfair County, Georgia: Georgia Geol. Survey, 23 pp., 4 figs., map, 1919.

3. Report on the barytes deposits of Georgia: Georgia Geol. Survey, Bull. no. 36, 146 pp., 11 pls., 17 flgs., 4 maps, 1920.

4. The Haynesville pool [Louisiana]: Am. Assoc. Petroleum Geologists, Bull., vol. 5, no. 5, pp. 629-633, September-October, 1921.

5. (and Spooner, W. C.). A review of oil and gas pools in north Louisiana territory: Am. Assoc. Petroleum Geologists, Bull., vol. 6, no. 3, pp. 179-192, 259 (note by Wallace E. Pratt), May-June, 1922.

6. The Bellevue [oil] pool, Louisiana: Am. Assoc. Petroleum Geologists, Bull., vol. 6, no. 3, pp. 247-250, May-June, 1922.

7. Webster Parish gas fields, Louisiana: Am. Assoc. Petroleum Geologists, Bull., vol. 6, no. 3, pp. 251-252, May-June, 1922.

8. Wildcat wells in south-central Arkansas stop short of deep oil sands: Am. Assoc. Petroleum Geologists, Bull., vol. 6, no. 5, pp. 477-478. September-October, 1922.

0. El Dorado oil field in Arkansas not on an anticline: Am. Assoc. Petroleum Geologists, Bull., vol. 6, no. 5, pp. 479-480, September-October, 1922.

10. Notes on the stratigraphy of producing sands in northern Louisiana and southern Arkansas (with discussion): Am. Assoc. Petroleum Geologists, Bull., vol. 7, no. 4, pp. 362-369, July-August, 1923.

11. Plans for compilation of Louisiana-Arkansas geology: Am. Assoc. Petroleum Geologists, Bull., vol. 8, no. 3, pp. 350-351, MayJune, 1924.

12. Guide notes on the Midway in southwestern Arkansas: Am. Assoc. Petroleum Geologists, Bull., vol. 9, no. 1, pp. 167-170, January-February, 1925.

13. Prothro salt dome, Bienville Parish, Louisiana: Am. Assoc. Petroleum Geologists, Bull., vol. 9, no. 5, pp. 904-906, August, 1925.

14. Discovery of Nigger Creek oil pool, Limestone County, Texas: Am. Assoc. Petroleum Geologists, Bull., vol. 10, no. 10, pp. 997-998, October, 1926.

15. The Denver meeting [of the American Association of Petroleum Geologists] : Am. Assoc. Petroleum Geologists, Bull., vol. 10, no. 11, pp. 1178-1181, November, 1926.

Hume, George Sherwood. See also McLearn, 14.

1. The stratigraphy and geologic relations of the Paleozoic outlier of Lake Timiskaming: Am. Jour. Sci., 4th ser., vol. 50, pp. 293-309, 2 figs., (incl. map), October, 1920.

2. Great Slave Lake area [Mackenzie] : Canada, Geol. Survey, Summ. Rept., 1920 , pt. B, pp. 30-36, 1921.

3. North Nahanni and Root rivers area and Caribou Island, Mackenzie River district: Canada, Geol. Survey, Summ. Rept., 1921, pt. B, pp. 67-78, 2 pls., 1922.

4. Norman oil fields, Mackenzie River area: Canadian Min. Jour., vol. 43, no. 48, pp. 816-817, December 1, 1922. 
Hume, George Sherwood-Continued.

5. Geology of the Norman oil fields and a reconnaissance of a part of Jiard River : Canada, Geol. Survey, Summ. Rept., 1922, pt. B, pp. 47-64, 2 pls., map, 1923.

6. A Kinderhook fauna from the Liard River, N. W. T., Canada: Am. Jour. Sci., 5th ser., vol. 6, pp. 48-52, 1 fig. (map), July, 1923.

7. Recent developments in the Fort Norman oil area [Mackenzie River]: Canadian Min. Jour., vol. 44, no. 48, pp. 939-940, 1 fig., November 30, 1923.

8. Mackenzie River area, district of Mackenzie, Northwest Territories: Canada, Geol. Survey, Summ. Rept., 1923, pt. B, pp. 1-15, 1 fig., 1 pl., map, 1924.

9. Clay deposits on Athabasca River, Alberta: Canada, Geol. Survey, Summ. Rept., 1923, pt. B, pp. 16-20, 1924.

10. The Wainwright oil and gas area, Alberta: Inst. Petroleum Technologists, Jour., vol. 10, no. 41, pp. 83-84, February, 1924; Canadian Chem. and Metal.. vol. 8. no. 1, p. 21. January, 1924.

11. The oil situation and prospects in Canada: Inst. Petroleum Technologists, Jour., vol, 10, no. 41, pp. 84-86, February, 1924.

12. Liquid fuels in Canada (abstract): Pan-Am. Geologist, vol. 42, no. 1, pp. 75-76, August, 1924.

13. The Wainwright-Irma oil and gas area, Alberta: Canadian Min. Jour., vol. 45, no. 52, pp. 1259-1264, 4 figs., December 26, 1924.

14. The Paleozoic outlier of Lake Timiskaming, Ontario and Quebec: Canada, Geol. Survey, Mem. 145, 129 pp., 7 figs., 16 pls., 1925.

15. Oil developments and prospects in Canada, 1924: Canadian Inst. Min. and Met., Bull., no. 154, pp. 163-169, 1 fig. (map), February, 1925 : Trans., vol. 28, pp. 222-230, 1 fig. [1926] ; Inst. Petroleum Technologists, Jour., vol. 11, no. 51, pp. 411-417, August, 1925.

16. The Wainwright-Irma oil and gas area, Alberta: Inst. Petroleum Technologists, Jour., vol. 11, no. 49, pp. 201-202, April, 1925.

17. The search for oil in Alberta: Canadian Min. Jour., vol. 46, no. 52, pp. 1180-1182, 1 fig., December 25, 1925.

18. Ordovician and Silurian fossils from Great Slave Lake [Northwest Territories, Canada]: Canada, Geol. Survey, Bull. no. 44, pp. 59-64, 2 pls., 1926.

19. Oil and gas prospects of the Wainwright-Vermilion area, Alberta: Canada, Geol. Survey, Summ. Rept., 1924, pt. B, pp. 1-22, map, 1926.

20. Oil prospects in the vicinity of Battle River at the Alberta-Saskatchewan boundary: Canada, Geol. Survey, Summ. Rept. 1925, pt. B, pp. 1-13, map, 1926 ; Canadian Min. Jour., vol. 47, no. 15, pp. 393-395, 1 fig., April 9, 1926.

21. Notes on developments during 1925 in the Wainwright field, Alberta: Canada, Geol. Survey, Summ. Rept., 1925, pt. B, pp. 14-15, 1926.

22. Turner Valley oil area, Alberta : Canada, Geol. Survey, Summ. Rept., 1926, pt. B, pp. 1-14, map, 1927.

23. Oil and gas developments in Canada: Inst. Petroleum Technologists, Jour., vol. 13, no. 63, pp. 607-609, August, 1927.

24. Carbon ratios of coal as an index of oil and gas prospects in western Canada: Canadian Min. and Met. Bull., no. 179, pp. 325-345, March, 1927; Canadian Inst. Min. and Met., Trans., vol. 30, pp. 499-520, 1 fig. [1928]. 
Hume, George Sherwood-Continued.

25. Oil and gas prospects of the Great Plains of western Canada: Canadian Inst. Min. and Met., Trans., vol. 30, pp. 612-625, 1 fig. [1928] : Second (Triennial) Empire Min. and Met. Congress, Canada, 1927, Proc., pt. 3, p. 96-109, 1 fig., 1928.

26. Oil prospects of British Columbia : Canadian Inst. Min. and Met., Trans., vol. 30, pp. 641-645 [1928] ; Second (Triennial) Empire Min. and Met. Congress, Canada, 1927, Proc., pt. 3, pp. 125-129, 1928.

27. The Mackenzie River area: Canadian Inst. Min. and Met. Trans., vol. 30, pp. 671-679, 2 figs. [1928] ; Second (Triennial) Empire Min. and Met. Congress, Canada, 1927, Proc., pt. 3, pp. 155-163, 2 figs., 1928.

28. Oil and gas in western Canada: Canada, Geol. Survey, Econ. Geol. ser., no. 5, 152 pp., 14 figs. (incl. maps), 1928. Extract, with title Physiography and stratigraphical geology of the Great Plains: Canadian Min. Jour., vol. 49, no. 43, pp. 875-877, 3 figs., October 26, 1928.

Includes sections contributed by M. Y. Williams, W. S. Dyer, and D. B. Dowling.

29. Developments of petroleum and natural gas in Canada: Inst. Petroleum Tech., Jour., vol. 14, no. 69, pp. 669-676, August, 1928.

30. Oil prospects near Bragg Creek, Alberta: Canada, Geol. Survey, Summ. Rept., 1927, pt. B, pp. 1-20, 3 figs., 1928.

Hummel, $\mathbf{K}$.

1. Neuere amerikanische Ansichten über Erdöllagerstätten: Geol. Rundschau, Bd. 15, H. 1, pp. 52-75, May 20, 1924.

2. Development of ore deposit theories in Europe: Econ. Geology, vol. 20, no. 5, pp. 495-499, August, 1925.

3. Tourmaline-bearing cinnabar veins of the Mazatzal Mountains, Arizona: Econ. Geology, vol. 22, no. 4, pp. 407-408, June-July, 1927.

Humphreys, William Jackson.

1. Seismological reports [monthly]; Monthly Weather Review, vol. 47, 1919; vol. $48,1920$.

2. Earthquakes felt in the United States during 1919: Monthly Weather Review, vol. 47, p. 911, December, 1919.

3. Status and needs of seismology : Nat. Research Council, Bull., vol. 7, pt. 5, no. 41, pp. 52-54, January, 1924.

4. Some factors of climatic control (abstract) : Pan-Am. Geologist, vol. 43, no. 5, pp. 378-379, June, 1925.

5. The origin of the ocean and the atmosphere: Nat. Research Council, Bull., vol. 11, pt. 2, no. 56, pp. 32-33, November, 1926 ; abstract, Am. Jour. Sci., 5th ser., vol. 12, pp. 272-273, September, 1926.

Hunt, Herbert A.

1. Agricultural aspects of rock weathering: Pan-Am. Geologist, vol, 42, no. 4, pp. 245-258, November, 1924.

Hunt, Richard N.

1. The ores in the limestones at Bingham, Utah: Am. Inst. Min. and Met. Eng., Trans., vol. 70, pp. 856-883, 9 figs., 1924 ; [preprint] no. 1323, 28 pp., 9 figs., March, 1924; abstract, Mining and Metallurgy, vol. 5, no. 212, pp. 392-393, August, 1924. 
Hunt, S. Frank.

1. Cambrian rocks, structures, and ore deposits in Tintic mining district [Utah] : Min. Rev. (Salt Lake City, Utah), vol. 29, no. 21, pp. 1315, February 15, 1928.

Hunt, Walter Fred. See also Kraus, 2, 8.

1. (editor). American Mineralogist; Journal of the Mineralogical Society of America. Vol. 7, nos. 1-12, January-December, 1922.

2. Assaying with the blowpipe; lead, copper, and silver ores: Am. Mineralogist, vol. 9 , no. 7, pp. 145-150, July, 1924.

3. An improved Wentworth recording micrometer: Am. Mineralogist, vol. 9, no. 9, pp. 190-193, 2 figs., September, 1924.

Hunter, C. D. See Kentucky Geological Survey, 29.

Hunter, John Frederick, 1888-1917.

1. Pre-Cambrian rocks of Gunnison River, Colorado: U. S. Geol. Survey, Bull., 777, 94 pp., 5 figs., 15 pls. (incl. map), 1925.

Huntington, Ellsworth.

1. (and Visher, S. S.). Climatic changes, their nature and causes. 329 pp., 13 figs., New Haven, Yale University Press, 1922.

2. Earth and sun; an hypothesis of weather and sun spots'. xxv, $296 \mathrm{pp}$., 53 figs., New Haven, Yale University Press, 1923.

3. Solar cyclonic explanation of glaciation: Pan-Am. Geologist, vol. 39 no. 1, pp. 25-42, February, 1923.

4. Problem of mild geological climates (abstract) : Geol. Soc. America, Bull., vol. 34 , no. 1, p. 81, March $30,1923$.

5. Environment and racial character. In Organic adaptation to environment, pp. 281-299, New Haven, Yale University Press, 1924.

\section{Huntley, Louis Grow.}

1. (and Huntley, Stirling). Mexican oil fields: Mining and Metallurgy, no. 177, pp. 27-32, 3 figs., September, 1921.

2. A graphic model of the Tepetate-Chinampa pool in the Mexican [oil] fields: Am. Assoc. Petroleum Geologists, Bull., vol. 5, no. 6, pp. 677-679, 1 pl., November-December, 1921.

3. The Sabine uplift [Arkansas-Louisiana]: Am. Assoc. Petroleum Geologists, Bull., vol. 7, no. 2, pp. 179-181, 2 figs., March-April, 1923.

4. Geological features illustrated by models : Am. Assoc. Petroleum Geologists, Bull., vol. 8, no. 1, pp. 89-93, 3 figs., January-February, 1924.

5. Geological and archeological records of the Yucatan Peninsula: Science, new ser., vol. 68, pp. 264-265, September 21, 1928.

Huntley, Charles Stirling, 1895-1926. See also Johnson, R. H., 3.

1. Oil development on the Isthmus of Tehuantepec: Am. Inst. Min. and Met. Eng., Trans., vol. 69, pp. 1150-1166, 5 figs., 1923 ; [preprint] no. 1227, 17 pp., 5 figs., February, 1923; abstract, Mining and Metallurgy, vol. 4, no. 194, pp. 90-91, February, 1923.

Huntoon, Louis D.

1. Porcupine ore deposits [northern Ontario] (with discussion): Am. Inst. Min. and Met. Eng., Trans., vol. 69, pp. 48-59, 1923; [preprint] no. 1272, 6 pp., August, 1923; abstract, Mining and Metallurgy, vol. 4, no. 201, p. 480, September, 1923. 
Hurst, Macleod Ewart.

1. Supergene processes at Neihart, Mountana: Econ. Geology, vol. 17, no. 5, pp. 383-388, 2 pls., August, 1922.

2. Rock alteration and ore depositions at Telluride, Colorado: Econ. Geology, vol. 17, no. 8, pp. 675-702, 7 figs. December, 1922.

3. Tungsten deposits near Hazelton, British Columbia: Canada, Geol. Sur. vey, Summ. Rept., 1924, pt. A, pp. 44-46, 1925.

4. Arsenic-bearing deposits in Canada : Canada, Geol. Survey, Econ. Geology Ser., no. 4, 181 pp., 21 figs., 1927. [Pub. no 2131].

5. The favourable Lake area [District of Patricia, Ontario] : Canadian Min. Jour., vol. 49, no. 40, pp. 800-801, 1 fig. (map), October 5, 1928.

Eussakof, Louis.

1. (and Bryant, W. L.). Catalog of the fossil fishes in the museum of the Buffalo Society of Natural Sciences: Buffalo Soc. Nat. Sci., Bull., vol. 12, 346 pp., 70 pls., 64 figs., 1918.

2. Structure of the head and dorsal armor of Dinichthys pustulosus Eastman: Geol. Soc. America, Bull., vol. 37, no. 1, p. 245, March 30, 1926.

Hussey, Russell Cladius. See also Ehlers, 5.

1. The Richmond formation of Michigan: Michigan, Univ., Mus. Geology, Contr., vol. 2, no. 8, pp. 113-187, 1 fig., 11 pls., July 15, 1926.

2. Contributions to the geology of Foxe Land, Baffin Island; Part III, Corals, brachiopods, gastropods, and ostracods from Putnam Highland: Michigan, Univ., Mus. Paleontology, Contr., vol. 3, no. 3, pp. 71-76, 4 pls., November 10, 1928.

3. Cystoids from the Trenton rocks of Michigan: Michigan, Univ., Mus. Paleontology, Contr., vol. 3, no. 4, pp. 77-79, 1 pl., November 10, 1928.

Hutton; J. G. See also Stone, 11.

Hyde, Jesse Earl.

1. Geology of Camp Sherman quadrangle: Ohio, Geol. Survey, Fourth serfes, Bull. 23, 190 pp., 18 figs., 20 pls., map, 1921.

2. Collecting fossil fishes from the Cleveland shale: Natural History (AmMus. Nat. Hist., Jour.), vol. 26, no. 5, pp. 497-504, 10 figs, September-October, 1926.

3. The Mississippian system [of Vinton County]: Ohio, Geol. Survey, 4th ser., Bull. 31, pp. 43-64, 1927.

4. Fossil fishing in Cleveland shale: Cleveland Mus. Nat. Hist., Pop. Pub., vol. 1, no. 1, 12 pp., 12 figs., November, 1928.

Hylander, C. J.

1. A mid-Devonian Callixylon [Eighteenmile Creek, New York] : Am. Jour. Sci., 5th ser., vol. 4, pp. 315-321, 6 figs., October, 1922. Notice by G. R. Wieland, Torreya, vol. 23, no. 2, pp. 32-33, March-April, 1923.

Ickes, E. L.

1. Similar, parallel, and neutral surface types of folding: Econ. Geology, vol. 18, no. 6, pp. 575-591, 9 figs., September, 1923.

2. The determination of formation thicknesses by the method of graphical integration: Am. Assoc. Petroleum Geologists, Bull., vol. 9, no. 3, pp. 451-463, 3 figs., May-June, 1925. 
Ickes, E. L.-Continued.

3. Origin of the faults in Creek and Osage counties, Oklahoma: Am. Assoc. Petroleum Geologists, Bull., vol. 10, no. 7, pp. 727-729, 1 flg., July, 1926.

Iddings, Joseph Paxson, 1857-1920.

1. Biographical memoir of Arnold Hague, 1840-1917: Nat. Acad. Sci., Biog. Mem., vol. 9, pp. 21-38, portr., May, 1919.

2. Igneous rocks; composition, texture and classification, description and occurrence. In two volumes. Vol. 1 (second edition, revised), 465 pp., 3 pls., 22 figs., New York, John Wiley \& Sons, 1920.

3. Relative densities of igneous rocks calculated from their norms: Am. Jour. Sci. 4th ser., vol. 49, pp. 363-366, May, 1920.

4. Louis Valentine Pirsson: Science, new ser,, vol. 51, pp. 530-532, May, 28, 1920.

Iglesias, Carlos A.

1. Ensayo para determinar la extensión total probable del área que se puede considerar como petrolifera en la República, así como de las porciones ya exploradas [petroleum areas of Mexico] : Bol. Petroleo, vol. 5, no. 4, pp. 333-335, map, April, 1918.

Ihering, Hermann von.

1. Die Geschichte des Atlantischen Ozeans. vii, 237 pp., 9 pls., Jena, Gustav Fischer, 1927.

Illing, Vincent Charles.

1. Geology of the Naparima region of Trinidad, British West Indies: Geol.

Soc. London, Quart. Jour., vol. 84, pt. 1, pp. 1-56, 5 figs., 2 pls. (incl. map), April 30, 1928; abstract, Abstracts of Proc., no. 1161, p. 50, February 10, 1927.

Illinois State Geological Survey.

1. Geologic map of Illinois. Scale 1: 500,000 or 8 miles to 1 inch. 1917 .

2. List of publications on the geology of Illinois, with appended index:

Illinois State Geol. Survey, 44 pp., August 1, 1926.

3. [Map of the] Mineral industries of Illinois . . . 1927. Scale 1:500,000.

Imbeaux, Edouard.

1. Les grands bassins artésiens des Litats-Unis: Acad. Sci. Paris, Compt. Rend., t. 179, pp. 726-729, 1 fig., October 20, pp. 799-802, October 27, 1924.

Ingall, Elfric Drew.

1. Deep borings in British Columbia and the Yukon: Canada, Geol. Survey, Surnm. Rept., 1924, pt. A. pp. 145-148, 1925.

2. Deep borings in the prairie provinces and northwest territolies: Canada, Geol. Survey, Summ. Rept., 1924, pt. B, pp. 105-116, 1926.

3. Deep borings in Ontario, Quebec, and maritime provinces: Canada, Geol. Survey, Summ. Rept., 1924, pt. C, pp. 240-246, 1926.

4. Deep borings in British Columbia and the Yukon: Canada, Geol. Survey, Summ. Rept., 1925, pt. A, p. 233, 1926.

5. Deep horings in the prairie provinces and northwest territories: Canada, Geol. Survey, Summ. Rept., 1925, pt. B, pp. 31-42, 1926.

6. Deep borings in Ontario, Quebec, and the maritime provinces: Canada, Geol. Survey, Summ. Rept., 1925, pt. C, pp. 154-161, 1927.

7. Deep borings in the prairie provinces and northwest territories: Canada, Geol. Survey, Summ. Rept., 1926, pt. B, pp. 43-52, 1927. 
Ingall, Elfric Drew-Continued.

8. Deep borings in Ontario and maritime provinces: Canada, Geol. Survey, Summ. Rept., 1926, pt. C, pp. 125-132, 1927.

9. Deep borings in the prairie provinces and northwest territories: Canada, Geol. Survey, Summ. Rept., 1927, pt. B, pp. 81-91, 1928.

10. Deep borings in Ontario and maritime provinces: Canada, Geol. Survey, Summ. Rept., 1927, pt. C, pp. 112-115, 1928.

Ingalls, Albert G.

1. Out of doors with the earth: Sci. Am., vol. 132, pp. 365-367, 9 figs., June, 1925.

2. Are the continents drifting?: Sci. Am., vol. 134, pp. 8-9, 6 figs., January, 1926.

3. Little-known ice ages of great antiquity: Sci. Am., vol. 135, pp. 272-273, October, 1926.

4. Mastodon or mammoth?: Sci. Am., vol. 135, pp: 289-290, 292, 8 figs., October, 1926.

Ingalls, Walter Renton.

1. Rossiter W. Raymond: Eng. and Min. Jour., vol. 107, pp. 135-142, 4 figs. (incl. portr.), January 18, 1919.

Inman, 0. L.

1. Iron-depositing bacteria: Science, new ser., vol. 57, p. 13, July 6, 1923.

Insley, Herbert.

1. The gabbros and associated intrusive rocks of Harford County, Maryland: Maryland Geol. Survey, vol. 12, pp. 289-322, 1928.

Institute for Government Research.

1. Service monographs of the United States Government, No. 1. The U. S. Geological Survey; its history, activities, and organization. 163 pp., 2 maps, New York, D. Appleton and Company, 1918.

Ireland, $\mathrm{H}$. Andrew.

1. Spirifer horizons of the Ohio mid-Devonian: Oklahoma Acad. Sci., Proc., vol. 6, pt. 2, 1926 (Oklahoma, Univ., Bull., new ser. no. 348), pp. 246-250, January 1, 1927.

Irion, V. K.

1. A brief survey of the natural resources of Louisiana: Louisiana, Dept. Conservation, Bull. 13, 48 pp., illus., January, 1926.

Irving, John Duer. See Darton, 14; Emmons, S. F., 1.

I'win, J. S.

1. Oil and gas possibilities of eastern Alberta: Am. Assoc. Petroleum Geologists, Bull., vol. 7, no. 2, pp. 147-158, 1 fig., March-April, 1923.

2. Faulting in the Rocky Mountain region: Am. Assoc. Petroleum Geologists, Bull., vol. 10, no. 2, pp. 105-129, 7 figs., February, 1926.

Israelsky, Merle Cathcart.

1. Some new forms of west coast fossil Echinoidea: California, Univ., Dept. Geol. Sci., Bull., vol. 14, no. 11, pp. 377-396, 6 pls., November $7,1923$.

2. Notes on some echinoids from the San Rafael and Tuxpam beds of the Tampico region, Mexico: California Acad. Sci., Proc., 4th ser., vol 13, no. 8, pp. 137-145, 3 pls., March 18, 1924. 
Jackson, Robert Tracy.

1. Value and use of stages in development in teaching paleontology: Geol. Soc. America, Bull., vol. 31, no. 3, pp. 395-399, September 30, 1920.

2. Fossil Echini of the West Indies: Carnegie Inst. Washington, Pub. no. 306, pp. 1-103, 6 figs., 18 pls., 1922.

Jacobs, Elbridge Churchill.

1. The lime industry in Vermont: Vermont, State Geologist, 11th Rept., pp. 158-164 [1919].

2. Progress in talc production: Vermont, State Geologist, Twelfth Rept, 1919-20, pp. 101-113, 1921.

3. The geology of Lake Willoughby: Vermont, State Geologist, Twelfth Rept., 1919-20, pp. 280-298, 3 figs., 6 pls., 1921.

4. The geology of Westmore, Brownington, and Charleston [Orleans County] : Vermont, State Geologist, Thirteenth Rept., 1921-1922, pp. 93-108, 8 pls. (incl. maps), 1923.

5. The clay deposits and clay industries of Vermont: Vermont, State Geologist, 15th Rept., 1925-26, pp. 191-221, 6 figs., 1927.

6. Flood erosion at Cavendish, Vermont: Science, new ser., vol. 66, pp. 653654, December 30, 1927.

Jaeger, Fritz.

1. Untersuchungen über das diluviale Klima in Mexiko: Gesell. Erdkunde Berlin, Zeitschr., no. 9-10, pp. 366-373, 1925.

2. Forschungen über das diluviale Klima in Mexiko: Petermanns Mitteilungen, Ergänzungsheft no. 190, 64 pp., 13 pls. (incl. maps), Gotha, Justus Perthes, 1926.

Jaekel, Otto.

1. Phylogenie und System der Pelmatozoen: Palaeontologische Zeitschr., Bd. 3, H. 1, pp. 1-128, 114 figs., October, 1918.

Jaggar, Thomas Augustus, jr. See also Science Service, 2.

1. [Observations on Hawaiian volcanoes, chiefly on Halemaumau]: Hawaiian Volcano Observatory, Monthly Bull., vols. 7-16, 1919-1928.

2. Seismometric investigation of the Hawaiian lava column: Seismol. Soc. America, Bull., vol. 10, no. 4, pp. 155-275, 11 pls., December, 1920.

3. The program of experimental volcanology: Pan-Pacific Scientific Conference, First, Proc., Bernice P. Bishop Mus., Spec. Pub. no. 7, pt. 2, pp. 309-324, 1921.

4. Experiences in a volcano observatory [at Hawaii]: Natural History, Jour. Am. Mus. Nat. Hist., vol. 21, no. 4, pp. 337-342, 2 figs., JulyAugust, 1921.

5. A plea for geophysical and geochemical laboratories: Washington Acad. Sci., Jour., vol. 12, no. 15, pp. 343-353, September 19, 1922.

6. (and Thurston, L. A.). The Hawaiian Volcano Research Association: Pan-Pacific Sci. Cong., Australia, 1923, vol. 1, pp. 847-850 [1924].

7. The lava tide, seasonal tilt, and the volcanic cycle: Pan-Pacific Sci. Cong., Australia, 1923, Proc., vol. 2, pp. 1369-1375, 4 figs. [1924].

8. Activity of Kilauea Volcano: Science, new ser., vol. 60, supplement, pp. $\mathrm{x}$, xii, September 5, 1924.

9. (and Finch, R. H.). The explosive eruption of Kilauea in Hawaii, 1924: Am. Jour. Sci., 5th ser., vol. 8, pp. 353-374, 14 figs., November, 1924. 
Jaggar, Thomas Augustus, jr.-Continued.

10. The Hawaiian volcanoes (abstract): Washington Acad. Sci., Jour., vol. 15, no. 13, p. 304, July 19, 1925.

11. Geological notes on Mauna Kea: Hawaiian Volcano Observatory, Monthly Bull., vol. 13, no. 10, pp. 75-77, 6 pls., October, 1925.

12. Earthquake insurance: Matériaux pour l'étude des calamités, ann. 2, no. 7, pp. 191-217, October-December, 1925.

13. Plus and minus volcanicity (abstract): Washington Acad. Sci., Jour., vol. 15, no. 18, pp. 416-417, November 4, 1925 ; Bull. volcanologique; $2^{\circ}$ ann., nos. 5-6, pp. 327-328, 1925.

14. Progress of volcanology during 1924: Washington Acad. Sci., Jour., vol. 15 , no. 18 , pp. $424-425$, November, 1925 ; Bull. volcanologique, $2^{\circ}$ ann., nos. 5-6, pp. 336-337, 1925.

15. So-called volcanic earthquakes: Science, new ser., vol. 63, pp. 414-415, April 23, 1926.

16. The section of volcanology of the U. S. Geological Survey: Science, new ser., vol. 64, pp. 242-243, September 10, 1926.

17. Engulfment in volcanism (abstract): Washington Acad. Sci., Jour., vol. 17, no. 1, pp. 23-24, January 3, 1927.

18. Temperatures of volcano borings: Hawaiian Volcano Observatory, Monthly Bull., vol. 15, no. 3, pp. 15-17, March, 1927.

19. The opportunity for scientific research in the national parks of America: Hawaiian Volcano Observatory, Monthly Bull., vol. 15, no. 4, pp. 23-28, April, 1927.

20. Volcano research of the United States Geological Survey: Washington Acad. Sci. Jour., vol. 18, no. 19, pp. 512-515, November, 1928.

21. Volcanic relations of great Pacific earthquakes (abstract) : Third PanPacific Sci. Cong., Tokyo, 1926, Proc., p. 370, 1928.

22. (and Finch, R. H.). Tilting and level changes at Pacific volcanoes: Third Pan-Pacific Sci. Cong., Tokyo, 1926, Proc., pp. 672-686, 3 figs., 1928.

23. (and Finch, R. H.). Temperatures of volcano borings (abstract) : Third Pan-Pacific Sci. Cong., Tokyo, 1926, Proc., p. 687, 1928.

24. Engulfment during Pacific explosive eruptions (abstract) : Third PanPacific Sci. Cong., Tokyo, 1926, Proc., pp. 687-688, 1928.

Jakosky, J. J.

1. The inductive method of geophysical prospecting: Canadian Min. Jour., vol. 49 , nos. 14,15 , and 16 , pp. $286-289,311-313,327-329,16$ figs., April 6, 13, and 21, 1928.

2. Operating principles of inductive geophysical processes: Am. Inst. Min. and Met. Eng., Tech. Pub. no. 134, 39 pp., 27 figs., October, 1928.

James, Albert V. G.

1. Factors producing columnar structure in lavas and its occurrence near Melbourne, Australia: Jour. Geology, vol. 28, no. 5, pp. 458-469, 16 figs. July-August, 1920.

Tames, W. F. See also Collins, W. H., 21, 22 ; Cooke, H. C., 31.

1. Duparquet map area, Quebec: Canada, Geol. Survey, Summ. Rept., 1922, pt. D, pp. 75-96, map, 1923.

2. Rouyn map area, Timiskaming County, Quebec: Canada, Geol. Survey, Summ. Rept., 1923, pt. C 1, pp. 126-144, 1 fig., 1 map, 1924.

3. The Rouyn map area; report on part of the Quebec gold belt: Canadian Min. Jour., vol. 45, no. 18, pp. 421-425, 4 figs., May 2, 1924. 
James, W. F.-Continued.

4. (and Mawdsley, J. B.). Cléricy and Kinojevis map areas, Témiscamingue and Abitibi counties, Quebec: Canada, Geol. Survey, Summ. Rept., 1924, pt. C, pp. 99-125, 2 maps, 1926; in part, Canadian Min. Jour., vol. 46, no. 10, pp. 243-246, 3 figs., March 6, 1925.

5. (and Mawdsley, J. B.). La Motte and Fournière map area, Abitibi County, Quebec: Canada, Geol. Survey, Summ. Rept., 1925, pt. C, pp. 52-77, 2 maps, 1927.

6. (and Mawdsley, J. B.). Certain mineral deposits in Desmeloizes and Trécesson townships, Quebec: Canada, Geol. Survey, 1925, pt. C, pp. 78-81, 1927.

7. (and Mawdsley, J. B.). Fiedmont and Dubuisson map areas. Abitibi County, Quebec: Canada, Geol. Survey, Summ. Rept., 1926, pt. C, pp. 56-72, 2 figs. (maps), 1927.

8. Developments in the western part of Rouyn district [Quebec] : Canadian Min. and Met. Bull., no. 198, pp. 1195-1212, 3 flgs., October, 1928.

Jandorf, Morton Lehmayer.

1. Unusual minerals in limestone near York, Pennsylvania: Am. Mineralogist, vol. 5, no. 11, p. 196, November, 1920.

Janensch, W.

1. Dinosaurier-Reste aus Mexiko: Centralbl. Mineralogie, Abt. B, 1926, no. 6 pp. 192-197, 2 figs., 1926.

Jaques, H. E.

1. Some proboscidean remains found in Henry County: Iowa Acad. Sci., Proc. 1921, vol. 28, pp. 65-68, 4 figs. [1923].

Jarvis, Gerald.

1. Lacustrine littoral forms referable to ice pressure: Canadian Field-Nat, vol. 42, no. 2, pp. 29-32, February, 1928.

Jarvis, Royal P.

1. Magmas, dikes, and veins: Mining and Metallurgy, vol. 8, no. 241, pp 28-31, January, 1927 ; no. 247, pp. 321-322, July, 1927.

Jeannet, Alph.

1. Contribution a l'étude des échinides tertiaires de la Trinité et du Vénézuéla: Soc. paléont. suisse, Mém., vol. 48,49 pp., 12 figs., 6 pls. 1928.

Jeffrey, Edward Charles.

1. Genus Sequoia in the Mesozoic (abstract): Geol. Soc. America, Bull., vol. 32, no. 1, p. 134, March 31, 1921.

2. Genus Araucarioxylon in the American Cretaceous (abstract): Geol. Soc. America, Bull., vol. 32, no. 1, p. 135, March 31, 1921.

3. Cupressinoxyla of the Mesozoic (abstract): Geol. Soc. America, Bull., vol. 32, no. 1, p. 135, March 31, 1921.

4. Transitional coals and their bearing on hypotheses of the origin of coals (abstract) : Geol. Soc. America, Bull., vol. 33, no. 1, pp. 148-149, March 31, 1922.

5. Organization of Pennsylvania anthracite and the peat hypotheses of the origin of coal (abstract) : Geol. Soc. America, Bull., vol. 33, no. 1, p. 149, March 31, 1922.

6. Pines of the Mesozoic and their relationship to older and more modern types (abstract) : Geol. Soc. America, Bull., vol. 33, no. 1, pp. 204205, March 31, 1922. 
Jeftrey, Edward Charles-Continued.

7. Occurrence of the parichnos of Bertrand in certain gymnosperms (abstract) : Geol. Soc. America, Bull., vol. 33, no. 1, p. 208, March 31, 1922.

8. The structure and origin of coking coals: Science, new, ser., vol. 58, pp. 285-286, October 12, 1923.

9. The origin and organization of coal: Am. Acad. Arts and Sci., Mem., vol. 15, no. 1, 52 pp., 13 pls., November 10, 1924.

10. Coal and civilization. 178 pp., 44 figs., 1 pl., New York, The Macmillan Company, 1925.

11. Coal in relation to coke: Am. Inst. Min. and Met. Eng., Trans. [preprint], no. 1399, 10 pp., 12 figs., January, 1925; with discussion, Trans., vol. 71 , pp. 149-164, 13 figs., 1925 ; abstract, Mining and Metallurgy, vol. 64, no. 228, p. 614, December, 1925.

12. Conifers and the coal question: Science, new ser., vol. 65, pp. 356-357, April 8, 1927.

Jeffreys, Harold.

1. Origin of the solar system; a reply to "T. C. C.": Am. Jour. Sci., 5th ser., vol. 9, pp. 395-405, May, 1925.

Jelliff, Fred R.

1. Fishing with a hammer [occurrence of fossils in coal-measure shales near Galesburg, Illinois] : Illinois State Acad. Sci., Trans., vol. 16, pp. 335-341, 1 fig., 6 pls., 1923.

2. A prolific coal field [Knox County]: Illinois State Acad. Sci., Trans., vol. 18, pp. 383-393, 4 figs., 1925.

3. Life in a coal-measure mud rock: Illinois State Acad. Sci., Trans., vol. 19, pp. 306-307, 1 pl., 1926.

Jenkins, Olaf Pitt.

1. Geologic map of Tennessee. Second edition. Tennessee State Geol. Survey, 1919. Scale, 1:500,000.

2. (and Wilson, Eldred D.). List of United States Geological Survey publications relating to Arizona: Arizona, Univ., Bull. no. 104 (geol. ser. no. 1), 40 pp., 1920.

3. (and Wilson, Eldred D.). A geological reconnaissance of the Tucson and Amole Mountains: Arizona, Univ., Bull. no. 106 (geol. ser., no. 2), pp. 5-18, 7 figs., 3 pls., May, 1920.

4. Underground water supply of the region about White Bluffs and Hanford: Washington, Dept. Conservation and Development, Division of Geology, Bull. no. 26, (geol. ser.), 41 pp., 4 pls. (incl. map), 1922.

5. (and Cooper, H. H.). A study of the iron ores of Washington: Washington, Dept. Conservation, Division of Geology, Bull. no. 27 (geol. ser.), pp. 11-115, 11 flgs., 1 pl. (map), 1922.

6. Verde River lake beds near Clarkdale, Arizona: Am. Jour. Sci., 5th ser., vol. 5, pp. 65-81, 7 figs. (incl. map), January, 1923.

7. Geological investigation of the coal flelds of western Whatcom County, Washington: Washington, Dept. Conservation, Div. Geology, Bull. no. 28, 135 pp., 2 figs., 4 pls. (incl. map), 1923.

8. Geological investigation of the coal fields of Skagit County, Washington: Washington, Dept. Conservation, Division of Geology, Bull. no 29, 63 pp., 5 figs., 7 pls. (incl. map), 1924.

$4096-31-20$. 
Jenkins, Olaf Pitt-Continued.

9. Lead deposits of Pend Oreille and Stevens counties, Washington: Washington, Dept, Conservation, Div. Geology, Bull. no. 31, 153 pp., 15 figs., 3 pls., 1924.

10. Unconformity between the Ringold and Ellensburg formations, Washington: California, Univ., Dept. Geol. Sci., Bull., vol. 15, no. 2, pp. 45-47, 1 fig., 1 pl., September 17, 1924.

11. Clastic dikes of southeastern Washington (abstract) : Geol. Soc. America, Bull., vol. 36, no. 1, p. 202, March 30, 1925.

12. Genetic types of Washington lead ores: Pan-Am. Geologist, vol. 43, no. 5, pp. 349-356, 1 pl. (map), June, 1925.

13. Mechanics of clastic dike intrusion: Eng. and Min. Jour.-Press, vol. 120, no. 1, p. 12, 2 figs., July 4, 1925.

14. Clastic dikes of eastern Washington and their geologic significance: Am. Jour. Sci., 5th ser., vol. 10, pp. 234-246, 2 figs., September, 1925.

15. The Spokane flood; a discussion: Jour. Geology, vol. 33, no. 7, pp. 747748, October-November, 1925.

16. Extensive preglacial oxidation of lead deposits in northeastern Washington (abstract) : Geol. Soc. America, Bull., vol. 37, no. 1, p. 209, March 30, 1926.

Jennings, Otto Emery.

1. Fossil plants from the beds of volcanic ash near Missoula, western Montana : Carnegie Mus., Mem., vol. 8, no. 2, pp. 385-450, 1 flg., 12 pls., September, 1920.

2. Have the streams of Long Island been deflected by the earth's rotation?: Science, new ser., vol. 55, p. 291, March 17, 1922.

Jennison, William Franklyn.

1. Manganese deposits in Nova Scotia: Eng. and Min. Jour.-Press, vol. 115, no. 17, p. 746, April 28, 1923.

Jensen, Joseph.

1. (and Robertson, Glenn D.). Development in southern California since 1923 : Am. Assoc. Petroleum Geologists, Bull., vol. 12, no. 6, pp. 625-650, 13 figs. (incl. maps), June, 1928.

Jensen, J. B.

1. The aspect of the petro-shales of the western slope [Colorado, Utah, and Wyoming] : Am. Mining Cong., 23d Ann. Convention, Rept. of Proc., pp. 532-550, 1921.

Jepsen, Glenn L. See also Sinclair, 10.

1. Fossil collecting in the badlands [South Dakota]: Black Hills Engineer, vol. 14, no. 2, pp. 77-86, 12 figs., March, 1926.

2. The oldest known cat, Hoplophoneus oharrai [from badlands, South Dakota] : Black Hills Engineer, vol. 14, no. 2, pp. 87-92; 2 figs., March, 1926.

Jewell, W. B.

1. Mineral deposits of the Hyder district, southeastern Alaska : Econ. Geology, vol. 22, no. 5, pp. 494-517, 6 figs., August, 1927.

Jillson, Willard Rouse. See also Kentucky Geol. Survey; Randolph, 1.

1. Geologic map of Kentucky and the adjoining States showing the surficial distribution of oil and gas producing formations in the Appalachian and adjacent fields. Lexington, Ky., 1918. Scale 1: 5,000,000. 
Jillson, Willard Rouse-Continued.

2. The oil and gas resources of Kentucky: Kentucky, Dept. Geology and Forestry, Series 5, Bull. 1, 630 pp., illus. (incl. maps), 1919. 2 d. ed., 1920.

3. The geology and coals of Stinking Creek, Knox County, Kentucky: Kentucky, Dept. Geology and Forestry, Series 5, Bull. 3, 89 pp., map, illus., 1919.

4. Sketch of the development of the oil and gas industry in Kentucky during the past century (1819-1919) : Kentucky, Dept. Geology and Forestry, Mineral and Forest Resources of Kentucky, vol. 1, no. 1, pp. 3-28, 12 figs., April, 1919.

5. The used and unused natural gas fields of eastern Kentucky and their relation to present and future public service demands: Kentucky, Dept. Geology and Forestry, Mineral and Forest Resources of Kentucky, vol. 1, no. 1, pp. 29-36, 2 figs., April, 1919.

6. A bibliography of Kentucky petroleum, natural gas, asphalt, and oil shale: Kentucky, Dept. Geology and Forestry, Mineral and Forest Resources of Kentucky, vol. 1, no. 1, pp. 37-43, April, 1919.

7. Structural deformation and its relation to proven oil and gas accumulation in eastern Kentucky: Kentucky, Dept. Geology and Forestry, Ser. V. [of Ky. Geol. Survey], Mineral and Forest Resources of Kentucky, vol. 1, no. 2, pp. 47-57, 7 figs., July 1, 1919.

8. The status of the Mauch Chunk in sontheastern Kentucky as a producer of petroleum and natural gas: Kentucky, Dept. Geology and Forestry, Ser. V [of Ky. Geol. Survey], Mineral and Forest Resources of Kentucky, vol. 1, no. 2, pp. 85-93, July 1, 1919.

9. The Kendrick shale; a new calcareous fosssil horizon in the coal measures of eastern: Kentucky: Kentucky, Dept. Geology and Forestry, Ser. V [of Ky. Geol Survey], Mineral and Forest Resources of Kentucky, vol. 1, no. 2, pp. 96-104, 2 figs., July 1, 1919.

10. The migration of the headwaters divide of Right Middle Creek, Floyd County, Kentucky: Kentucky, Dept. Geology and Forestry, Ser. V [of Ky. Geol. Survey], Mineral and Forest Resources of Kentucky, vol. 1, no. 2, pp. 105-109, 1 fig., July 1, 1919. Am. Jour. Sci., 4th ser., vol. 47, pp. 60-64, 1 fig., January, 1919.

11. The low-sulphur coals of Kentucky: Kentucky, Dept. Geology and Forestry, Ser. V [of Ky. Geol. Survey], Mineral and Forest Resources of Kentucky, vol. 1, no. 2, pp. 115-119, 1 fig., July 1; 1919. Am. Inst. Min. and Met. Eng., Bull. no. 153, pp. 1675-1679, 1 fig., September, 1919 ; Trans., vol. 63, pp. 723-726, 1920.

1.2. The new oil and gas pools of Allen County: Kentucky, Dept. Geology and Forestry, Ser. V [of Ky. Geol. Survey], Mineral and Forest Resources of Kentucky, vol. 1, no. 2, pp. 120-143, 3 figs., July 1, 1919.

13. The oil and gas geology of Breathitt and Knott counties: Kentucky, Dept. Geology and Forestry, Ser. V [of Ky. Geol. Survey], Mineral and Forest Resources of Kentucky, vol. 1, no. 3, pp. 178-219, 6 figs., 2 maps, October 1, 1919 ; also in Ser. V, Bull. 4, pp. 98-139, 1920.

14. A bibliography of the coals of Kentucky : Kentucky, Dept. Geology and Forestry, Ser. V [of Ky. Geol. Survey], Mineral and Forest Resources of Kentucky, vol. 1, no. 3, pp. 285-301, October 1, 1919. 
Jillson, Willard Rouse-Continued.

15. The production of coal in Kentucky : Kentucky, Dept. Geology and Forestry, Ser. V [of Ky. Geol. Survey], Mineral and Forest Resources of Kentucky, vol. 1, no. 3, pp. 302-320, 10 figs., October 1, 1919.

16. The Wier sand-a newly recognized oil horizon in eastern Kentucky: Kentucky, Dept. Geology and Forestry, Ser. V [of Ky. Geol. Sur. vey], Mineral and Forest Resources of Kentucky, vol. 1, no. 3, pp. 321-333, 2 figs., October 1, 1919.

17. The pay oil sands of eastern Kentucky: Kentucky, Dept. Geology and Forestry, Ser. V [of Ky. Geol. Survey], Mineral and Forest Resources of Kentucky, vol. 1, no. 3, pp. 334-366, 10 figs., October 1. 1919.

18. The new oil and gas pools of Warren County, Kentucky: Kentucky, Dept. Geology and Forestry, Ser. V [of Ky. Geol. Survey], Mineral and Forest Resources of Kentucky, vol. 1, no. 3, pp. 368-396, 7 figs., map, Óctober 1, 1919 ; also in Ser. V, Bull. 4, pp. 223-251, 1920.

19. New fossil invertebrates from a new fossil horizon in the coal measures of eastern Kentucky (abstract) : Science, new ser., vol. 50, p. 95, July 25, 1919.

20. Geologic map of Kentucky showing oil and gas pools and pipe lines and the eastern and western coal fields: Kentucky Geol. Survey, Series 6, 1920. Scale, 1 inch=10 miles. Another edition, 1923.

21. Contributions to Kentucky geology; an indexed collection of all the shorter papers and reports of the State geologist written during the year 1919 on the mineral resources of the commonwealth [chiefly petroleum, natural gas, and coal] ; Kentucky, Dept. Geology and Forestry, Ser. 5, Bull. 4, 266 pp., 65 figs., 1920.

22. A bibliography of the several books, reports, papers, and maps relating to geology written and prepared by Willard Rouse Jillson: Kentucky Geol. Survey, Ser. no. VI (Pamphlet no. 1), 7 pp., Frankfort, Ky., 1920.

23. Geological problems in the recovery of oil and gas in Kentucky: Am. Assoc. Petroleum Geologists, Bull., vol. 4, no. 3, pp. 303-312, 1 fig., 1920 ; Kentucky Geol. Survey, Ser. 6, vol. 2, pp. 59-70, 1921.

24. A Mauch Chunk island in the Mississippian seas of eastern Kentucky (abstract) : Science, new ser., vol. 51, p. 492, May 14, 1920.

25. Economic papers on Kentucky geology ; an indexed collection of thirteen short papers and reports on the geology and special occurrence of oil and gas, oil shale, asphalt, rock, and fluorspar within the commonwealth: Kentucky Geol. Survey, ser. 6, vol. 2, 304 pp., illus., 1921.

26. An administrative report (years of 1920 and 1921): Kentucky Geol. Survey, ser. 6, vol. 6, pp. 1-34, 2 pls., 1921.

27. Geology and coals of the Middle Fork of the Kentucky River near Buckhorn in Perry and Breathitt counties: Kentucky Geol. Survey, ser. 6, vol. 6, pp. 53-101, 28 figs., 1921.

28. Oil and gas possibilities of the "Jackson Purchase" region: Kentucky Geol. Survey, ser. 6, vol. 6, pp. 191-220, 11 figs., 1921.

29. Recent mineral production in Kentucky: Kentucky Geol. Survey, ser. 6, vol. 6 , pp. $261-267,1921$.

30. The region about Frankfort: Kentucky Geol. Survey, ser. 6, vol. 6, pp. 269-282, 8 figs., 1 pl. (map), 1921. 
Jillson, Willard Rouse-Continued.

31. A bibliography of the several books, reports, papers, and maps principally relating to geology written and prepared by Willard Rouse Jillson: Kentucky Geol. Survey, ser. 6, Pamphlet no. 2, 11 pp., 1921.

32. The production of eastern Kentucky crude oils. . . . 99 pp., 1 fig., prepared for and published by the Cumberland Pipe Line Co., Winchester, Ky., 1921.

33. Physiographic effects of the volcanism of Mt. St. Helens [Washington] : Geog. Rev., vol. 11, no. 3, pp. 398-405, 6 figs., July, 1921.

34. A history of the Kentucky Geological Survey (1838-1921) : Kentucky State Historical Soc., Register, vol. 19, no. 57, pp. 90-112, 2 pls. (portraits), September, 1921.

35. Oil-field stratigraphy of Kentucky : Kentucky Geol. Survey, ser. 6, vol. 3, 738 pp., 35 figs., 1922.

36. A bibliography of the several books, reports, papers, and maps, principally relating to geology, written and prepared by Willard Rouse Jillson : Kentucky Geol. Survey, ser. 6, Pamphlet no. 3, 14 pp., Frankfort, Ky., 1922.

37. The coal industry in Kentucky; an historical sketch; 87 pp., Frankfort, The State Journal Company, 1922.

38. The conservation of natural gas in Kentucky. 152 pp., 43 figs., Louisville, Kentucky, John P. Morton \& Company, 1922.

39. A bibliography of the geology and paleontology of the John Day region, Oregon. 7 pp., Frankfort, Kentucky, 1923 [private publication].

40. Administrative report for the (Sixth) Kentucky Geological Survey (years 1922 and 1923), 30 pp., 2 pls., (incl. map), 1923.

41. A bibliography of the Mammoth Cave of Kentucky: Kentucky Geol. Survey, ser. 6, vol. 10, pp. 149-156, 1923.

42. Geological research in Kentucky; a summary account of the several geological surveys of Kentucky, including a complete list of their publications and a general bibliography of 806 titles pertaining to Kentucky geology: Kentucky Geol. Survey, ser. 6, vol. 15, 228 pp., 10 pls. (maps and portraits), 1923.

43. Emory River overthrust of east Tennessee: Pan-Am. Geologist, vol. 39, no. 5, pp. 373-378, 2 pls. (incl. map), June, 1923.

44. The Haddix-Coalburg geosyncline (abstract): Science, new ser., vol. 58, p. 184, September 7, 1923 ; Kentucky Acad. Sci., Trans., vol. 1, pp. 144-145, 1924.

45. Land of ten thousand sinks (abstract): Science, new sèr., vol. 58, pp. 184-185, September 7, 1923 ; Kentucky Acad. Sci., Trans., vol. 1, pp. 143-144, 1924.

46. A gigantic slate slide [Burdine, Letcher County, Kentucky] (abstract) : Science, new ser., vol. 58, p. 185, September 7, 1923; Kentucky Acad. Sci., Trans., vol. 1, p. 146, 1924.

47. New Tennessee oil pool: Pan-Am. Geologist, vol. 40, no. 3, pp. 197-202, 2 pls., October, 1923.

48. An isothrustic hypothesis: Pan-Am. Geologist, vol. 40, no. 4, pp. 251-258, $1 \mathrm{pl} .$, November, 1923.

49. Unique Devonic sandbar [Cheatham County, Tennessee] : Pan-Am. Geologist, vol. 40, no. 5, pp. 333-337, 1 pl., December, 1923.

50. Kentucky State parks; a brief presentation of the geology and topog. raphy of some proposed State park areas based upon original field investigation. 92 pp., 32 pls. and figs., Kentucky Geol. Survey, Frankfort, Ky., 1924. 
Jillson, Willard Rouse-Continued.

51. A bibliography of the several books, reports, papers, and maps principally relating to geology written and prepared by Willard Rouse Jillson: Kentucky Geol. Survey, ser. 6, Pamphlet no. 4, 17 pp., 1924.

52. The coal industry in Kentucky: Kentucky Geol. Survey, ser. 6, vol. 20, 164 pp., 42 figs. and pls., map, 1924.

53. New fossil invertebrates from a new fossil horizon in the coal measures of eastern Kentucky (abstract) : Kentucky Acad. Sci., Trans., vol. 1, p. 68, 1924.

54. A mica deposit in eastern Kentucky (abstract): Kentucky Acad. Sci.. Trans., vol. 1, p. 71, 1924.

55. Asphalt coal : Kentucky Acad. Sci., Trans., vol. 1, pp. 78-81, 1924.

56. The occurrence of Cretaceous sediments between the Cumberland and Tennessee rivers in western Kentucky: Kentucky Acad. Sci., Trans., vol. 1, pp. 81-83, 1924.

57. Depletion of Kentucky crude oils: Kentucky Acad. Sci., Trans., vol. 1, pp. 122-127, 1924.

58. Early mineral explorations in the Mississippi Valley (1540-1840) : Illinois State Hist. Library, Pub. no. 31 (Illinois State Hist. Soc., Trans. 1924), pp. 41-57, 1924.

59. Geology of Harpeth River, Tennessee, area: Oil and Gas Jour., vol. 23, no. 6, pp. 58, 70, 1 fig. (map), January 10, 1924.

60. Fault pattern of Kentucky: Pan-Am. Geologist, vol. 41, no. 1, pp. 31-32, February, 1924.

61. New relief map of Kentucky : Pan-Am. Geologist, vol. 41, no. 1, pp. 75-76, February, 1924.

62. Kentucky cannel coals: Pan-Am. Geologist, vol. 41, no. 2, pp. 97-98, March, 1924.

63. Primeval tracts in Kentucky: Pan-Am. Geologist, vol. 41, no. 3, pp. 169175, 1 pl., April, 1924.

64. Kentucky rock asphalt: Pan-Am. Geologist, vol. 41, no. 4, pp. 251-258, 3 pls., May, 1924; Kentucky Geol. Survey, ser. 6, vol. 30, pp. 95103, 7 figs., 1927 [c. 1928] ; Eng. and Min. Jour., vol. 125, no. 25, pp. 1011-1012, 2 figs., June 23, 1928.

65. Glacial pebbles in eastern Kentucky: Science, new ser., vol. 60, pp. 101102, August 1, 1924; Kentucky Acad. Sci., Trans., vol. 2, pp. 73$76,1927$.

66. American karst country: Pan-Am. Geologist, vol. 42, no. 1, pp. 37-44, 4 pls., August, 1924.

67. Glaciation in eastern Kentucky: Pan-Am. Geologist, vol. 42, no. 2, pp. 125-132, 3 pls., September, 1924.

68. Outlook for mineral development in Kentucky : The South's Development, Manufacturers Record, vol. 86, no. 24, pt. 2, pp. 374-375, December 11, 1924.

69. Administrative report for the (Sixth) Kentucky Geological Survey, years 1924 and 1925: Kentucky Geol. Survey, ser. 6, Pam. 5, 54 pp., 7 pls., 1925.

70. Geologic map of Kentucky showing oil, gas, coal, asphalt, and fluorspar fields: Kentucky Geol. Survey, ser. 6, 1925. Scale: 1 inch=30 miles.

71. Early glaciation in Kentucky: Pan-Anr. Geologist, vol: 44, no. 1, pp. 1720, 1 pl., August, 1925; abstract, Kentucky Acad. Sci., Trans., vol. 2, p. 137, 1927. 
Jillson, Willard Rouse-Continued.

72. Agricultural perspective of Kentucky geology: Pun-Am. Geologist, vol. 44, no. 4, pp. 295-308, 387-396, 5 pls., map, November and December, 1925.

73. New oil pools of Kentucky : Kentucky Geol. Survey, ser. 6, vol. 12, 394 pp., 103 illus. (incl. maps), 1926.

74. Résumé of Kentucky's mineral resources: Kentucky Geol. Survey, ser. 6, Pam. 7, 11 pp., illus., 1926.

75. Fire clays of northeastern Kentucky: Kentucky Geol. Survey, ser. 6, Pam. 8, 9 pp., 3 figs., 1926.

76. The clays of Kentucky: The Ceramist, vol. 7, no. 5, pp. 281-285, 3 figs., February, 1926; Kentucky Geol. Survey, ser. 6, Pam. 9, 15 pp., 6 figs., 1926.

77. A bibliography of the several books, reports, papers, and maps principally relating to geology written and prepared by Willard Rouse Jillson: Kentucky Geol. Survey, ser. 6, Pam. no. 11, 22 pp., 1926.

78. Recent geological investigations in Kentucky: The Kentucky Outlook, vol. 2, no. 2, p. 6, January 9, 1926.

79. Natural resources of Kentucky : The Kentucky Outlook, vol. 2, no. 7, pp. 4-5, February 13, 1926.

80. Major drainage modiffcations of Big Sandy River: Pan-Am. Geologist, vol. 46, no. 1, pp. 49-51, 1 fig., 1 pl., August, 1926.

81. Oil domes of Ashland [Boyd County, Kentucky] : Pan-Am. Geologist, vol. 46, no. 2, pp. 121-122, 1 pl., September, 1926.

82. Kentucky State parks; a brief presentation of geology and topography of some proposed State park areas based upon original field investigations. vii, 92 pp., 35 illus., Kentucky Geological Survey, Frankfort, Ky., 1927.

83. Geology of the oil shales of the eastern United States: Kentucky Geol. Survey, ser. 6, pam. 10, 18 pp., 10 figs., 1927.

84. Geology of the Island Creek oil pool: Kentucky Geol. Survey, ser. 6, pam. 12, 55, 20 figs. and pls., 1927.

85. Kentucky's mineral resources: Kentucky Geol. Survey, ser. 6, pam. 13. 45 pp., 37 figs. (incl. mineral index maps), 1927.

86. Geologic map of Kentucky showing oil and gas pools and pipelines, fluorspar and rock asphalt deposits, and the eastern and western coal fields . . . by Willard Rouse Jillson. Scale 1 inch $=10$ miles, Kentucky Geol. Survey, ser. 6, 1927.

87. Geologic map of Kentucky showing oil, gas, coal, asphalt, and fluorspar fields, by Willard Rouse Jillson, $2 d$ ed., revised. Scale 1 inch $=30$ miles. Kentucky Geol. Survey, ser. 6, 1927.

88. Geological map of Ohio County, Kentucky: Kentucky Geol. Survey, ser. 6, 1927. Scale 1 inch $=1$ mile.

89. Shading of contoured topographic maps: Pan-Am. Geologist, vol. 47, no. 1, pp. 11-14, 3 pls., February, 1927.

90. Valley-filled areas of western Kentucky coal field (abstract) : Pan-Aut. Geologist, vol. 47, no. 4, pp. 315-316, May, 1927.

91. Recent activities of Kentucky Geological Survey: Pan-Am. Geologist, vol. 48, no. 3, pp. 235-240, October, 1927.

92. Geology of the Carter caves (abstract): Kentucky Acad. Sci., Trans., vol. 2, p. 77, 1927. 
Jillson, Willard Rouse-Continued.

93. Major drainage modifications of the Big Sandy River (abstract) : Kentucky Acad. Sci., Trans., vol. 2, pp. 137-139, 1927.

94. Exploration for oil and gas in Boyd County, Kentucky (abstract) : Kentucky Acad. Sci., Trans., vol. 2, pp. 139-141, 1927.

95. Geology of the oil shales of the eastern United States (abstract) : Kentucky Acad. Sci., Trans., vol. 2, pp. 226-227, 1927.

96. Geology of oil shales of eastern United States: Pan-Am. Geologist, vol. 48, no. 4 , pp. 262-272, 4 pls., November, 1927.

97. Administrative report for the (sixth) Kentucky Geological Survey, years 1926 and 1927: Kentucky Geol. Survey, ser. 6, Pam. 20, 96 pp., 30 illus., index map, 1927.

98. The topography of Kentucky; a systematic study and classification of the prominent physical features of Kentucky coupled with an indexed collection of twenty-four separate papers on the geology and mineral resources of the Commonwealth: Kentucky Geol. Survey, Ser. 6, vol. 30, 291 pp., 131 illus., 1927 [c. 1928].

99. Geology of Amory, Mississippi, gas field: Oil and Gas Jour., vol. 26, no. 36 , pp. 58, 126, 128, 4 figs., January 26, 1928.

100. Recently abandoned entrenched meander [western Kentucky] : Pan-Am. Geologist, vol. 50, no. 1, pp. 5-6, August, 1928; abstract, Ohio Acad. Sci., Proc., vol. 8, pt. 4, pp. 177-178, 1928; Ohio Jour. Sci., vol. 28, no. 3, pp. 155-156, May, 1928.

101. Pre-Pennsylvanian deformation in western Kentucky (abstract) : Ohio Acad. Sci., Proc., vol. 8, pt. 4, pp. 174-175, 1928; Ohio Jour. Sci., vol. 28, no. 3, pp. 152-153, May, 1928.

102. Early Carbonic deformation in western Kentucky: Pan-Am. Geologist, vol. 49, no. 5, pp. 357-358, 1 pl., June, 1928.

103. Oil and gas map of Butler County, Kentucky. Scale 1:62,500. Kentucky Geol. Survey, ser. 6, 1928.

104. Reconnaissance geological map of Ohio County, Kentucky Geol. Survey, ser. 6, 1928. Scale 1 inch $=1$ mile.

105. Sketches in geology; a group of twenty-two separate papers on American geology [reprinted from earlier publications]. 150 pp., 43 illus., Louisville, Kentucky, C. T. Dearing Printing Co., 1928.

106. Geology in the service of a new National Park: Pan-Am. Geologist, vol. 50, no. 4, pp. 268-270, 1 pl., November, 1928.

107. Peneplanes in Kentucky : Pan-Am. Geologist, vol. 50, no. 5, pp. 333-338, 2 pls., December, 1928.

108. A correlation of the coals of western Kentucky, southeastern Illinois, and southwestern Indiana: Min. Cong. Jour., vol. 14, no. 12, pp. 914-916, December, 1928.

Johannsen, Albert.

1. (and Stephenson, E. A.). On the accuracy of the Rosiwal method for the determination of the minerals in a rock: Jour. Geology, vol. 27, no. 3, pp. 212-220, April-May, 1919.

2. A planimeter method for the determination of the percentage compositions of rocks: Jour. Geology, vol. 27, no. 4, pp. 276-285, 6 figs., May-June, 1919.

3. A quantitative mineralogical classification of igneous rocks-revised: Jour. Geology, vol. 28, nos. 1-3, pp. 38-60, 158-177, 210-232, 7 figs., 1920. 
Johannsen, Albert-Continued.

4. Petrological abstracts and reviews: Jour. Geology, vol. 30, no. 2, pp. 170174, February-March; no. 3, pp. 252-256, April-May; no. 4, pp. 319-324, May-June; no. 6, pp. 482-500, September-October; no. 7, pp. 632-645, October-November; no. 8, pp. 703-716, NovemberDecember, 1922 ; vol. 31, no. 1, pp. 80-85, January-February, 1923 ; vol. 32 , no. 4 , pp. 337-343, May-June, no. 5, pp. 443-446, JulyAugust, 1924; vol. 34, no. 5, pp. 475-478, July-August; no. 6, pp. 559-571, August-September; no. 8, pp. 840-842, November-December, 1926 ; vol. 35, no. 4, pp. 378-384, May-June, 1927.

5. On the representation of igneous rocks in triangular diagrams: Jour. Geology, vol. 30, no. 2, pp. 167-169, 1 fig., February-March, 1922.

6. Essentials for the microscopical determination of rock-forming minerals and rocks in thin sections. 53 pp., 24 figs., University of Chicago Press, 1922.

7. (and Phemister, T. C.). A new method for measuring the optic angle of minerals: Jour. Geology, vol. 24, no. 1, pp. 81-84, 1 fig., JanuaryFebruary, 1924.

8. (and Phemister, T. C.). A note on the elasticity of some minerals and its measurement: Jour. Geology, vol. 33, no. 3, pp. 268-271, 1 fig., April-May, 1925.

9. A revised field classification of igneous rocks: Jour. Geology, vol, 34, no. 2, pp. 181-182, February-March, 1926.

10. (and Merritt, C. A.). Comparative losses in crushing and sifting rock minerals: Jour. Geology, vol. 34, no. 3, pp. 275-280, April-May, 1926.

11. The recognition of minerals and the determination of their properties in crushed rocks: Jour. Geology, vol. 34, no. 5, pp. 462-465, JulyAugust, 1926.

12. On the use of the terms "diabase" and "dolerite": Jour. Geology, vol. 35, no. 3, pp. 270-275, April-May, 1927.

13. Comparative color ratios of American and European rocks : Jour. Geology, vol. 36, no. 3, pp. 283-286, April-May, 1928.

14. The serpentines of Harford County, Maryland: Maryland Geol. Survey, vol. 12, pp. 195-287, 2 figs., 2 pls., 1928.

Johnson, Bertrand Leroy. See also Knopf, A., 6.

1. Mining on Prince William Sound: U. S. Geol. Survey, Bull. 692, pp. 143151, 1919.

2. Mineral resources of Jack Bay district and vicinity, Prince William Sound: U. S. Geol. Survey, Bull. 692, pp. 153-173, 1 pl., 1 fig. (maps), 1919.

3. Mining in central and northern Kenai Peninsula [Alaska]: U. S. Geol. Survey, Bull. 692, pp. 175-176, 1919.

4. Tin in 1920 : U. S. Geol. Survey, Mineral Resources, 1920, pt. 1, pp. 505509, April 27, 1922.

5. Tin in 1921: U. S. Geol. Survey, Mineral Resources, 1921, pt. 1, pp. 71-73, August 1, 1922.

6. Coal resources of the Pan-Pacific region: Mid-Pacific Mag., vol. 25, no. 6, pp. 519-536, illus., June, 1923.

7. Tin in 1922: U. S. Geol. Survey, Mineral Resources, 1922, pt. 1, pp. 169172, October 11, 1923.

8. Tin in 1923: U. S. Geol. Survey, Mineral Resources, 1923, pt. 1, pp. 101103, September 26. 1924. 
Johnson, Bertrand Leroy-Continued.

9. Tin in 1924: U. S. Geol. Survey, Mineral Resources, 1924, pt. 1, pp. 31-33, August 7, 1925.

Johnson, Charles Willison.

1. Fossil shells from the St. Lucie Canal, Florida: Nautilus, vol. 36, no. 1, pp. 10-11, July, 1922.

Johnson, Columban A.

1. Coal, oil, gas, and electricity; our natural resources. 107 pp., illus., Pittsburgh, Charles W. Swope, 1921.

Johnson, Douglas Wilson. See also Gardescu, 1; Johnson, R. H., 6; Pratt, 10, 13 ; White, D.; 1.

1. Shore processes and shore line development. 584 pp., 73 pls., 148 figs., New York, John Wiley \& Sons, 1919.

2. Retrograding of offshore bars (abstract) : Geol. Soc. America, Bull., vol. 33, no. 1., pp. 121-122, March 31, 1922.

3. The scenery of American rivers: Geog. Soc. Philadelphia, Bull., vol. 20, nos. 3-4, pp. 22-27, April-July, 1922.

4. Rectilinear shore lines of the New England-Acadian region (abstract) : Geol. Soc. America, Bull., vol. 34, no. 1, p. 57, March 30, 1923.

5. Some analogous shore lines of partially submerged Triassic lowlands (abstract) : Assoc. Am. Geographers, Annals, vol. 13, no. 4, p. 211, December, 1923.

6. (and Stolfus, M. A.). The submerged coastal plain and oldland of New England: Science, new ser., vol. 59, pp. 291-293, March 28, 1924.

7. La morphologie sous-marine du golfe du Maine: Annales de Géographie, ann. 33; no. 184, pp. 313-328, 4 figs., July 15, 1924.

8. The New England-Acadian shore line. $x x, 608$ pp., 273 figs., New York, John Wiley \& Sons, 1925.

9. Blue book of the geological field excursion from New York to Gettysburg. 29 pp., 8 figs., New York, Columbia University Press, 1926.

10. Subaqueous terraces of the Great Lakes and the Saint Lawrence embayment (abstract) : Geol. Soc. America, Bull., vol. 36, no. 1, p. 136, March 30, 1925 ; Pan-Am. Geologist, vol. 43, no. 1, p. 77, February, 1925.

11. Submarine physiography of the Gulf of Maine (abstract): Geol. Soc. America, Bull., vol. 36, no. 1, pp. 148-149, March 30, 1925; Pan-Am. Geologist, vol. 43, no. 2, p. 148, March, 1925.

12. William Otis Crosby: Science, new ser., vol. 63, pp. 609-610, June 18, 1926.

13. Field trips in geology: Science, new series, vol. 64, pp. 396-397, October $22,1926$.

14. (and Winter, Elizabeth). Sea-level surfaces and the problem of coastal subsidence: Am. Philos. Soc., Proc., vol. 66, pp. 465-496, 12 figs., 1927 ; abstract, Science, new ser., vol. 65, p. 480, May 13, 1927.

15. Shore-line investigations on the Atlantic coast: Science, new ser., vol. 65, pp. 4-7, January 7, 1927; Recherches sur les lignes de rivage de l'océan Atlantique: Annales Géog., ann. 36, pp. 176-180, March 15, 1927. 
Johnson, Douglas Wilson-Continued.

16. (and Pratt, Wallace E.). A local subsidence of the Gulf coast of 'Texas [Goose Creek oil field]: Geog. Jour., vol. 69, no. 1, pp. 61-65, January, 1927; Un affaissement local de la côte du golfe du Mexique au Texas: Annales Géog., ann. 36, pp. 81-85, January 15, 1927.

17. Mean sea level as affected by shore line changes: Science, new ser., vol. 66, pp. 60-61, July 15, 1927.

18. Physiography of Atlantic coast of North America (abstract): Pan-Am. Geologist, vol. 50, no. 4, pp. 311-312, November, 1928.

Johnson, George F.

1. The Mayo silver area, Yukon Territory: Canadian Min. Jour., vol. 41, pp. 990-991, December 3, 1920.

Johnson, H. H.

1. The Kirkland Lake gold field [northern Ontario]: Min. Mag., vol. 21, no. 1, pp. 29-30, 2 figs., July, 1919.

Johnson, Harry R.

1. (and Warren, Van Court). Geological and structural conditions of the San Gabriel Valley region: California, Dept. Public Works, Div. Water Rights, Bull. no. 5, pp. 73-100, 1927.

Johnson, Jesse Harlan.

1. An interesting occurrence of isomorphous siderite and calcite: Pahasapa Quart, vol. 9, no. 1, p. 20, December, 1919.

2. Water pool calcite, an interesting cave mineral: Pahasapa Quart. [vol. 9, no. 2], pp. 61-64, 3 figs., February, 1920.

3. (and Snyder, J. P.). The caves of the Black Hills: Pahasapa Quart., vol. 9, no. 4, pp. 175-187, 9 figs., June, 1920.

4. Bibliography of the geology of the Denver Basin of Colorado: Colorado School of Mines, Circular of Information, 7 pp. [1923].

5. Tertiary man; a partial summary of present opinion and knowledge on the subject: Colorado School of Mines, Alumni Mag., vol. 13, no. 7, pp. 8-10, November, 1923.

6. Pleistocene man: Colorado School of Mines, Alumni Mag., vol. 13, no. 11, pp. 8-13, March, 1924.

7. Bibliography of the geology of northwestern Colorado: Colorado School of Mines, Circular of Information, $7 \mathrm{pp}$. [1924].

8. Bibliography of the geology of southwestern Colorado: Colorado School of Mines, Circular of Information, 7 pp., September, 1924.

9. (and Waldschmidt, W. A.). Mining districts in Colorado: Colorado School of Mines, Circular of Information, 4 pp., Golden, Colo., November, 1924.

10. Bibliography of the geology of northeastern Colorado: Colorado School of Mines, 12 pp., January, 1925.

11. What a geologist means when he says "evolution": Colorado School of Mines, Alumni Mag., vol. 14, no. 9, pp. 8-10, January, 1925.

12. (and Waldschmidt, W. A.). Famous Colorado mineral localities; Table Mountain and its zeolites: Am. Mineralogist, vol. 10, no. 5, pp. 118-120, May, 1925:

13. The geology of the Golden area, Colorado: Colorado School of Mines, Quart., vol. 20, no. 3, 25 pp., 3 figs., 3 pls., July, 1925. 
Johnson, Jesse Harlan-Continued.

14. Bibliography of the geology of southeastern Colorado: Colorado Scliool of Mines, Circular of Information, 11 pp., August, 1925.

15. Bibliography of Colorado maps published by the State and Federal governments: Colorado School of Mines, Quart., vol. 20, no. 4, 40 pp., October, 1925.

16. Some present tendencies in geology; closer study of earth reveals that earlier periods are much more remote than previously believed; science is constantly changing: Colorado School of Mines Mag., vol. 15, no. 7, pp. 11-12, November, 1925.

17. Bibliography of geophysical principles, apparatus, and methods applied to prospecting: Colorado School of Mines Mag., vol. 15, no. 10, pp. 11-16, 21, February, 1926. [Also reprint, 7 pp.]

18. Bibliography of the geology and related subjects of northwestern Colorado (revised to June 1, 1926) : Colorado School of Mines, Quart., vol. 21, no. 3, 52 pp., July, 1926.

19. Biliography of the geology of north-central Colorado: Colorado School of Mines, Quart., vol. 22, no. 4, 38 pp., October, 1927.

20. A new locality for Fox Hills fossils in Colorado: Washington Acad. Sci., Jour., vol. 18, no. 11, pp. 305-306, June 4, 1928.

21. Bibliography of the geology of south-central Colorado: Colorado School of Mines, Quart., vol. 23, no. 4, 30 pp., October, 1928.

Johnson, J. P.

1. Meridian and base lines south of Lake St. Joseph, District of Thunder Bay : Ontario Dept. Mines, 33d Ann. Rept., vol. 33, pt. 6, pp. 40-48, illus., 1925.

Johnson, Meredith E. See Pennsylvania, 1.

1. Mineral resources of the Greensburg quadrangle, Westmoreland County, Pennsylvania: Pennsylvania Geol. Survey, 4th ser., Topog. and Geol. Atlas, no. 37, Greensburg quadrangle, 162 pp., 25 figs. (incl. maps), 9 pls., 4 maps, 1925.

Johnson, Roswell Hill. See also White, D., 1.

1. Variation in decline curves of various oil pools: Mining and Metallurgy, no. 157 , sec. 1 , p. 48 (abstract), sec. 8,5 pp., January, 1920; Am. Inst. Min. and Met. Eng., Trans., vol. 65, pp. 365-373, 1921.

2. Water displacement. in oil and gas sands: Mining and Metallurgy, no. 157, sec. 1, p. 50 (abstract), sec. 7, 4 pp., January, 1920. Eng. and Min. Jour., vol. 109, pp. 516-517, February 21, 1900 . Discus. sion by David White, G. H. Ashley, E. W. Shaw, and H W. Hixon, Am. Inst. Min. and Met. Eng., Trans., [preprint] no. 994, pp. 5-9, 1920, vol. 65, pp. 498-504, 1921.

3. (and Huntley, Stirling). A résumé of the Pennsylvania-New York oil field: Mining and Metallurgy, no. 158, sec. 1, p. 32 (abstract), sec. 23, 4 pp., February, 1920. Discussion by G. H. Ashley, Am. Inst. Min. and Metal. Eng. Trans., [preprint] no. 994, p. 3, 1920. Am. Inst. Min. and Met. Eng., Trans., vol. 65, pp. 151-155, 1921.

4. The cementation process in sandstone: Am. Assoc. Petroleum Geologists, Bull., vol. 4, no. 1, pp. 33-35, 1920. Eng. and Min. Jour., vol. 110, no. 3, pp. 125-126, July 17, 1920.

5. The time factor in the accumulation of oil and gas: Am. Assoc. Petroleum Geologists, Bull., vol. 5, no. 4, pp. 475-480 (with discussion by M. I. Goldman, p. 498), July-August, 1921. 
Johnson, Roswell Hill-Continued.

6. Rôle of cross-waves in the formation of tomboloes and points (abstract with discussion by D. W. Johnson) : Geol. Soc. America, Bull., vol. 33, no. 1, p. 1.22, March 31, 1922.

7. A series of six radio talks on oil and gas: Pittsburgh, Univ., Radio Pub. no. 19, 44 pp., 1926.

Johnston, C. Stuart.

1. Polygonal weathering in igneous and sedimentary rocks: Am. Jour. Sci., 5th ser., vol. 13, pp. 440-444, 2 figs., May, 1927.

Johnston, Ivan Murray.

1. Expedition of the California Academy of Sciences to the Gulf of California in 1921; the botany [geology, pp. 952-957] : California Acad. Sci., Proc., 4th ser., vol. 12, no. 30, pp. 951-1218, May 31, 1924.

Johnston, Robert Angus Allister.

1. (and Ellsworth, H. V.). The Annaheim meteorite [Saskatchewan]: Roy. Soc. Canada, Proc. and Trans., 3d ser., vol. 15, sec. 4, pp. 69-92, 3 figs., 14 pls., 1921.

2. (and Connor, M. F.). The Blithfield meteorite [Renfrew County, Ontario] : Roy. Soc. Canada, Proc. and Trans., 3d ser., vol. 16, sec. 4, pp. 187-194, 2 pls., 1922.

Johnston, William Alfred. See also Berry, 32 ; Twenhofel, 16 ; Uglow, 10.

1. Superficial deposits and soils of Winnipegosis area, Manitoba: Canada, Geol. Survey, Summ. Rept., 1918, pt. D, p. 11, 1920.

2. Late Pleistocene changes of level in northern Manitoba, Canada (abtract) : Geol. Soc. America, Bull., vol. 31, no. 1, p. 131, March 31, 1920.

3. Winnipegosis and upper Whitemouth River areas, Manitoba; Pleistocene and Recent deposits: Canada, Geol. Survey, Mem. 128, 42 pp., 2 figs., 2 maps, 1921.

4. Pleistocene oscillations of sea level in the Vancouver region, British Columbia: Roy. Soc. Canada, Proc. and Trans., 3d ser., vol. 15, sec. 4, pp. 9-19, 1921.

5. A late Pleistocene readvance of the ice sheets in the Vancouver region, British Columbia (abstract with discussion by J. H. Bretz and E. M. Burwash) : Geol. Soc. America, Bull., vol. 32, no. 1, pp. 5152, March 31, 1921.

6. The occurrence of calcareous sandstone in the recent delta of Fraser River, British Columbia: Am. Jour. Sci., 5th ser., vol. 1, pp. 447449, May, 1921.

7. The age of the recent delta of Fraser River, British Columbia: Am. Jour. Sci., 5th ser., vol. 1, pp. 450-453, May, 1921.

8. Sedimentation of the Fraser River delta: Canada, Geol. Survey, Mem. 125, 46 pp., 9 pls. (incl. maps), 1921.

9. Sedimentation in the recent delta of Fraser River, British Columbia, Canada (abstract) : Geol. Soc. America, Bull., vol. 32, no. 1, p. 52 . March 31, 1921.

10. Placer mining in Barkerville area, British Columbia: Canada, Geol. Survey, Summ. Rept., 1921, pt. A, pp. 57-71, 1 flg., 1 pl., 2 maps, 1922.

11. Gold-dredging possibilities in the Barkerville area, British Columbia: Canadian Inst. Min. and Met., Monthly Bull., no. 118, pp. 151-167, February, 1922 ; Trans., vol. 25, pp. 165-182 [1923]. 
Johnston, William Alfred-Continued.

12. The character of the stratification of the sediments in the recent delta of Fraser River, British Columbia, Canada: Jour. Geology, vol. 30, no. 2, pp. 115-129, 2 figs., February-March, 1922.

13. Notes on prospecting in the Cariboo, British Columbia: Canadian Min. Jour., vol. 43, no. 22, pp. 338-339, June 2, 1922.

14. Placer deposits of Cedar Creek area, Cariboo district, British Columbia : Canadian Min. Jour., vol. 43, no. 45, pp. 762-765, 2 figs., November 10,1922 .

15. Sedimentation in Lake Louise, Alberta, Canada: Am. Jour. Sci., 5th ser., vol. 4, pp. 376-386, 1 fig., November, 1922. Abstract, Science, new ser., vol. 56, p. 174, August 11, 1922.

16. Imbricated structure in river gravels: Am. Jour. Sci., 5th ser., vol. 4, pp. 387-390, 2 figs., November, 1922.

17. Geology of Fraser River Delta map area [British Columbia]: Canada. Geol. Survey, Mem. 135, 87 pp., 6 pls., map, 1923.

18. Placer mining in Cedar Creek area, British Columbia: Canada, Geol. Survey, Summ. Rept., 1922, pt. A, pp. 68-81, 2 figs., 1 pl., 1923.

19. Placers in Cobalt conglomerate: Canadian Min. Jour., vol. 45, no. 2, p. 56, January 11, 1924.

20. Cedar Creek placers [Cariboo district, British Columbia] : Canadian Min. Jour., vol. 46, no. 5, pp. 117-119, 2 figs., January 30, 1925.

21. Gold dredging on Fraser River [British Columbia]: Canadian Min. Jour., vol. 46, no. 9, pp. 229-232, 1 fig., February 27, 1925.

22. (and Uglow, W. L.). Placer and vein gold deposits of Barkerville, Cariboo district, British Columbia: Canada, Geol. Survey, Mem. 149, 246 pp., 33 figs., 15 pls., map, 1926.

23. Gold placers of Dease Lake area, Cassiar district, British Columbia: Canada, Geol. Survey, Summ, Rept., 1925, pt. A, pp. 33-74, 5 figs., 3 pls., 1926.

24. The Pleistocene of Cariboo and Cássiar districts, British .Columbia, Canada : Roy. Soc. Canada, Proc. and Trans., 3d ser., vol. 20, pt. 2, sec. 4, pp. 137-147, 1926.

25. Lack of evidence on the Pacific coast of Canada for a recent sinking of ocean level : Am. Jour. Sci., 5th ser., vol. 12, pp. 249-253, September, 1926.

26. The age of the Upper Great Gorge of Niagara River: Roy. Soc. Canada, Proc. and Trans., 3d ser., vol. 22, sec. 4, pp. 13-29, 3 figs., March, 1928.

Johnston, William Drumm, jr.

1. Fossil hunting in the White River badlands: Sci. Monthly, vol. 22, no. 3, pp. 200-214, 9 figs., March, 1926.

2. Marcasite inclusions in fluorite from the central Kentucky barite-flouritecalcite veins: Am. Mineralogist, vol. 11, no. 7, pp. 174-180, 4 figs., July, 1926; abstract, Geol. Soc. America, Bull., vol. 36, no. 1, p. 171, March 30, 1925; Pan-Am. Geologist, vol. 43, no. 2, p. 158, March, 1925.

3. Ants as prospectors: Science, new ser., vol. 68, p. 157, August 17, 1928.

4. Fluorspar in New Mexico: New Mexico School of Mines, State Bur. Mines and Min. Res., Bull. no. 4, 128 pp., 40 figs., map, 1928.

Joly, John.

1. The age of the earth: Sci. Monthly, vol. 16, no. 2, pp. 205-216, 2 figs., February, 1923. 
Joly, John-Continued.

2. Continental movement. In Theory of continental drift, pp. 88-89, Am. Assoc. Petroleum Geologists, 1928.

Jonas, Anna Isabel. See also Knopf, E. B., 3; Stose, 15, 18, 21, 26, 27, 28.

1. (and Knopf, E. B.). Stratigraphy of the metamorphic rocks of southeastern Pennyslvania and Maryland (abstract): Washington Acad. Sci., Jour., vol. 11, no. 18, pp. 446-447, November 4, 1921.

2. Rocks of the McCalls Ferry quadrangle, Pennsylvania: Pennsylvania, Bur. Topographic and Geol. Survey, Bull. no. 62, 6 pp., map, February 3, 1923 [mimeographed].

3. Rocks of the Quarryville quadrangle, Pennsylvania: Pennsylvania, Bur. Topographic and Geol. Survey, Bull. no. 75, 9 pp., map, April 25, 1923.

4. Pre-Cambrian rocks of the western Piedmont of Maryland: Geol. Soc. America, Bull., vol. 35, no. 2, pp. 355-363, 1 fig., June 30, 1924; abstract, with discussion by C. P. Berkey and Arthur Keith, vol. 35, no. 1, pp. 90-91, March 1924; Pan-Am. Geologist, vol. 41, no. 2, p. 145, March, 1924.

5. (and Stose, George W.). Geology and mineral resources of the New Holland quadrangle, Pennsylvania: Pennsylvania Geol. Survey, 4th ser., Topog. and Geol. Atlas, no. 178, New Holland quadrangle, 40 pp., 5 pls., 2 maps, 1926.

6. (and Knopf, E. B.). Summary of the pre-Cambrian geology of Pennsylvania and Maryland (abstract): Geol. Soc. America, Bull., vol. 38, no. 1, pp. 111-112, March 30, 1927.

7. Summary of the pre-Cambrian geology of Virginia to the James River (abstract) : Geol. Soc. America, Bull., vol. 38, no. 1, pp. 112-113, March 30, 1927.

8. Geologic reconnaissance in the Piedmont of Virginia : Geol. Soc. America, Bull., vol. 38, no. 4, pp. 837-846, 1 fig. (map)., December 30, 1927; abstract, no. 1, pp. 118-119, March 30, 1927 ; Pan. Am. Geologist, vol. 47, no. 1, pp. 69-70, February, 1927.

Jones, Arthur Taber.

1. The temperatures of meteorites: Science, new ser., vol. 56, pp. 169-170, August 11, 1922.

2. The temperature of a black spherical meteorite: Am. Jour. Sci., 5th ser., vol. 5, pp 247-255, March, 1923.

Jones, Austin E. See Byerly, 12, 16.

Jones, Edward Leroy, jr. See also Pardee, 4 ; Umpleby, 3.

1. A reconnaissance of the Pine Creek district, Idaho: U. S. Geol. Suryey, Bull. 710, pp. 1-36, 1 pl. (map), August 27, 1919. Abstract by R. W. Stone, Washington Acad. Sci., Jour., vol. 9, no. 20, p. 637, December 4, 1919.

2. Deposits of manganese ore in New Mexico: U. S. Geol. Survey, Bull. 710, pp. 37-60, 1 fig. (map), October 21, 1919.

3. (and Ransome, F. L.). Deposits of manganese ore in Arizona: U. S. Geol. Survey, Bull. 710, pp. 93-184, 6 pls. (incl. maps), 8 figs., January 29, 1920.

4. Deposits of manganese ore in southeastern California: U. S. Geol. Survey, Bull. 710, pp. 185-208, 1 pl. (map), December 30, 1919. Abstract by $\mathbf{R}$. W. Stone, Washington Acad. Sci., Jour., vol. 10, no. 16, pp. 470-471, October 4, 1920. 
Jones, Edward Leroy, jr.-Continued.

5. A deposit of manganese ore in Wyoming: U. S. Geol. Survey, Bull. 715, pp. 57-59, September 18, 1920. Abstract by J. D. Sears, Wash. ington Acad. Sci., Jour., vol. 11, no. 16, p. 392, October 4, 1921.

6. Some deposits of manganese ore in Colorado: U. S. Geol. Survey, Bull. 715, pp. 61-72, September 17, 1920 ; abstract by J. D. Sears, Washington Acad. Sci., Jour., vol. 11, no. 16, p. 393, October 4, 1921.

7. Manganese deposits of the Colorado River desert region (abstract): Washington Acad. Sci., Jour., vol. 9, no. 13, pp. 384-385, July 19, 1919.

Jones, Ernest Lester.

1. Earthquake investigation in the United States: U. S. Coast and Geodetic Survey, serial no. 304, 27 pp., 8 figs., 1925.

2. Seismological work of the U. S. Coast and Geodetic Survey: Seismological Soc. America, Bull., vol. 15, no 2, pp. 79-83, June, 1925.

3. Science and the earthquake peril: Franklin Inst., Jour., vol. 201, no. 5, pp. 563-596, 19 figs., May, 1926.

4. The seismological work of the United States Coast and Geodetic Survey (abstract) : Seismological Soc. America, Bull., vol. 16, no. 2, pp. 154-155, June, 1926.

Jones, Grove B.

1. (and Brill, J. Bayard). Soil survey of Benton County, Indiana : Indiana, Dept. Geology and Nat. Res., 41st Ann. Rept., pp. 28-44, map, 1917.

Jones, I. W.

1. Carbon ratios as an index of oil and gas in western Canada: Econ Geology, vol. 23, no. 4, pp. 353-380, 2 figs., June-July, 1928.

Jones, J. Claude. See also Stone, 11.

1. Suggestive evidence on the origin of petroleum and oil shale: Am. Assoc. Petroleum Geologists, Bull., vol. 7, no. 1, pp. 67-72, JanuaryFebruary, 1923.

2. The geologic history of Lake Lahontan: Carnegie Inst. Washington, Pub. no. 352 (Quaternary climates), pp. 1-50, 8 figs., 6 pls., July, 1925; abstract, Chicago, Univ., Abstracts of Theses, Sci. Ser., vol. 1, pp. 289-296, October, 1925.

3. The geology of the deposit of dumortierite in Humboldt Queen Canyon, Pershing County, Nevada; petrography; origin of the deposit: Nevada, Univ., Bull., vol. 22, no. 2 (Mackay School of Mines, Bull. on Dumortierite), pp. 23-26, 31-32, 33-34, March 15, 1928.

4. Age of Lake Lahontan (abstract) : Pan-Am. Geologist, vol. 49, no. 4, pp. 306-307, May, 1928.

Jones, 0. C.

1. (and Hubbard, G. D.). Dynamics of the lithosphere: Ohio Jour. Sci., vol. 22, no. 7, pp. 193-208, May, 1922.

Jones, Owen Thomas.

1. The Ordovician-Silurian boundary in Britain and North America: Jour. Geology, vol. 33, no. 4, pp. 371-388, May-June, 1925; abstract, British Assoc. Adv. Sci., Rept. 92d Meeting, pp. 393-394, 1925; Pan-Am. Geologist, vol. 42, no. 4, p. 316, November, 1924.

2. Notes on the Silurian rocks of Arisaig, Nova Scotia: Am. Jour. Sci., 5th ser., vol. 11, pp. 119-1.25, February, 1926. 
Jones, Philip M.

1. The origin of the prairie: Sclence, new ser., vol. 68, pp. 329-330, October 7, 1927.

Jones, R. H. B. See also Emmons, R. C., 2.

1. Geology and ore deposits of Hudson Bay Mountain, Coast district, :British Columbia: Canada, Geol. Survey, Summ. Rept., 1925, pt. A, pp. 120-143, 1 pl., map, 1926.

Jones, Richard A.

1. The relation of the Reynosa Escarpment to the oil and gas flelds of Webb and Zapata counties, Texas (with discussion) : Am. Assoc. Petroleum Geologists, Bull., vol. 7, no. 5, pp. 532-545, 1 fig., September-October, 1923

2. Large gas well in Jim Hogg County, Texas: Am. Assoc. Petroleum Geologists, Bull., vol. 8, no. 5, pp. 676-677, September-October, 1924.

3. A reconnaissance study of the Salado arch, Nuevo Leon and Tamaullpas, Mexico: Am. Assoc. Petroleum Geologists, Bull., vol. 9, no, 1, pp. 123-133, 1 fig., January-February, 1925.

4. An outcrop of surface oil sand in the Permian "red beds" of Coke County, west Texas: Am. Assoc. Petroleum Geologists, Bull., vol. 9, no. 8, pp. 1215-1216, 1 fig., November, 1925.

5. Practical application of paleontology to the oil industry: Oil Weekly, vol. 39, no. 13, pp. 37, 40, 76-77, December 18, 1925.

6. Discoveries renew interest in salt domes of southwest Texas: Oil Weekly, vol. 40, no. 3, pp. 32-34, 36, 2 figs., January 8, 1926.

7. Subsurface Cretaceous section of southwest Bexar County, Texas: Am. Assoc. Petroleum Geologists, Bull., vol. 10, no, 8, pp. 768-774, August, 1926.

8. Life of ocean competent original source of oil: Oil Weekly, vol. 45, no. 11, pp. 29-30, 42, 2 figs., June 3, 1927.

9. Complex oceanic chemistry initial factor in oil formation: Oil Weekly, vol. 46, no. 4, pp. 39-41, 88, 90, 92, 96, July 15, 1927.

10. Dissemination almost universal-accumulations rare; migration and concentration of oil deposits still one of the greatest scientific problems: Oil Weekly, vol. 46 , no. 12, pp. 33-36, 3 figs., September 9, 1927.

11. Evidence for recent uplift on Gulf [of Mexico coast, Texas] : Oil and Gas Jour., vol. 26 , no. 46, pp. 82, 115-116, 118, 121-122, 125-126, 129, 5 figs., April 5, 1928.

Jones, Robert W.

1. The geology of the Catskill Portland-cement region [New York]: Am. Ceramic Soc., Jour., vol. 2, no. 11, pp. 870-882, 11 figs., 2 pls. (maps), November, 1919.

2. Limestone for Portland cement in Greene County, New York: Eng. and Min. Jour.-Press, vol. 121, no. 20, pp. 805-806, 4 figs., May 15, 1926.

Jones, Walter Bryan.

1. Statistics of the mineral production of Alabama for 1917: Alabama Geol. Survey, Bull. no. 21, 128 pp., 1920.

2. Statistics of the mineral production of Alabama for 1923: Alabama, Geol. Survey, Bull. no. 29, 106 pp., 1925.

3. Supplemental list of economic minerals and rocks of Alabama: Alabama Geol. Survey, Bull. no. 30, 15 pp., May 1, 1925.

$4096-31-21$ 
Jones, Walter Bryan-Continued.

4. Index to the mineral resources of Alabama: Alabama Geol. Survey, Bull. no. 28,250 pp., 15 figs. (maps), 42 pls., 1926.

5. Statisties of the mineral production of Alabama for 1924: Alabama, Geol. Survey, Bull. no. 32, 123 pp., 1926.

6. Bauxite in Alabama, with a special discussion of the Margerum district: Econ. Geology, vol. 21, no. 8, pp. 792-802, 2 figs., December, 1926.

7. Petroleum products in shallow wells in Alabama: Alabama, Geol. Survey, Circ. 4, 33 pp., 5 figs., 4 pls., July, 1927.

8. Eugene Allen Smith: Eng. and Min. Jour., vol. 124, no. 25, p. 993, December $17,1927$.

9. Eugene Allen Smith: Science, new ser., vol. 67, pp. 7-9, January 6, 1928.

10. Geology of the Coastal Plain of Alabama (abstract) : Geol. Soc. America, Bull., vol. 39, no. 1, p. 273, March 30, 1928; Pan-Am. Geologist, vol. 49 , no. 3 , pp. $235-237$, April, 1928.

11. Statistics of the mineral production of Alabama for 1925: Alabama, Geol. Survey, Bull. no. 34, 185 pp., 1928.

12. Summary of the distribution and occurrence of the rock-asphalt deposits of Alabama: Alabama, Geol. Survey, Circ. 5, 19 pp., 7 pls., June, 1928.

13. Outlines of Alabama geology: Pan-Am. Geologist, vol. 50, no. 1, pp. 7-22, 2 figs., August, 1928.

Jones, Wellington Downing.

1. (and Whittlesey, Derwent S.). An introduction to economic geography ; Volume I, Natural environment as related to economic life. $375 \mathrm{pp}$., 366 figs. Chicago, Illinois, The University of Chicago Press [c. $1925]$.

Jones, William $\mathbf{F}$.

1. The relation of oil pools to ancient shore lines: Econ. Geology, vol. 15, no. 1, pp. 81-87, 1 fig., January-February, 1920.

2. A critical review of Chamberlin's Groundwork for the study of megadiastrophism: Am. Jour. Sci., 5th ser., vol. 3, pp. 393-413, June, 1922.

3. Aspectos geológicos generales de la región de Tabasca en su relación con la existencia de petróleo: Bol. Petróleo, Mexico, vol. 17, no. 5, pp. 349-352, May, 1924.

4. Replacement or displacement by dikes [Medford area, eastern Massachusetts] : Eng. and Min. Jour.-Press, vol. 121, no. 6, p. 250, February $6,1926$.

Jones, William Richard.

1. The recent discovery of cassiterite in British Honduras: Min. Mag., vol. 31, no. 4, pp. 206-208, 3 flgs. (incl. map), October, 1924.

Joralemon, Ira $\mathbf{B}$.

1. The microscope and the decadence of geology: Eng. and Min. Jour.-Press, vol. 118, no. 8, p. 304, August 23, 1924.

Jordan, David Starr.

1. Fossil fishes of southern California; I, Fossil fishes of the Soledad deposits, by David Starr Jordan; II, Fossil flshes of the Miocene (Monterey) formations, by David Starr Jordan and James Zaccheus Gilbert; III, Fossil fishes of the Pliocene formations, by David Starr Jordan and James Zaccheus Gilbert: Leland Stanford Junlor University Pub., Univ. ser., 98 pp., 31 pls., 1919. 
Jordan, David Starr-Continued.

2. (and Gilbert, James Zaccheus). Fossil fishes of diatom beds of Lompoc, California : Leland Stanford Junior University Pub., Unlv. ser., 44 pp., 29 pls., February, 1920.

3. A Miocene catastrophe [fossil Hsh, Santa Barbara County, California] : Natural History, vol. 20, no. 1, pp. 18-22, 5 figs., January-February, 1920.

4. An ancient moonfish [Lampris zatima, Lompoc, California]: Scl. Monthly, vol. 11, no. 5, pp. 470-473, 3 figs., November, 1920.

5. The fish fauna of the California Tertiary: Stanford Univ. Pub., Univ. ser., Biological Sciences, vol. 1, no. 4, 300 pp., 57 pls., 1821.

6. The Miocene shore fishes of California: Sci. Monthly, vol. 13, no. 5, pp. 460-464, 4 figs., November, 1921.

7. John Casper Branner: Science, new ser., vol. 55, pp. 340-341, March 31, 1922.

8. Description of a new species of fossil herring, Quisque bakeri, from the Texas Miocene: Am. Jour. Sci., 5th ser., vol. 3, pp. 249-250, 1. fig., April, 1922.

9. Some sharks' teeth from the California Pliocene: Am. Jour. Scl., 5th ser., vol. 3, pp. 338-342, 9 flgs., May, 1922.

10. A classification of fishes including families and genera as far as known: Stanford Univ. Pub., Univ: ser., Biological Sciences, vol. 3, no. 2, 243, x pp., 1923.

11. (and Hannibal, Harold). Fossil sharks and rays of the Paciflc slope of North America: Southern California Acad. Sci., Bull., vol. 22, pt. 2, pp. 27-68, 5 flgs., 10 pls., July, 1923.

12. Description of Miocene fishes from southern California: Southern California Acad. Sci., Bull., vol. 23, pt. 2, pp. 42-50, 8 flgs., MarchApril, 1924.

13. Description of a recently discovered fossil sculpin from Nevada regarded as Cottus beldingi: U. S. Nat. Mus., Proc., vol. 65, art. 6, 2 pp., 1 pl., September 12, 1924.

14. A collection of fossil fishes in the University of Kansas from the Niobrara formation of the Cretaceous: Kansas Univ. Scl. Bull, vol. 15, no. 6, pp. 219-245, 11 pls., December, 1924.

15. The fossil fishes of the Miocene of southern California: Stanford Univ. Pub., Univ. ser., Biol. Sciences, vol. 4, no. 1, 51 pp., 21 pls., 1925.

16. New sharks from the Temblor group in Kern County, California: Callfornia Acad. Sci., Proc., 4th ser., vol. 15, no. 8, pp. 257-261, 1 pl., April 26, 1926.

17. The fossil fishes of the Miocene of southern California ; contribution no. 9 : Stanford Uniy. Pub., Biol. Sci., vol. 5, no. 2, pp. 89-99, 4 pls., 1927.

18. Kindleia, a new genus of cichlid fishes from the Upper Cretaceous of Alberta: Canadian Field-Nat., vol. 41, no. 7, pp. 145-147, 14 flgs., October, 1927.

19. Note on Kindleia and Stylomyleodon (fossil fish from Cretaceous deposits of Alberta) : Canadian Field Nat., vol. 42, no. 2, p. 47, February, 1928 .

Jordan, Eric Knight. See also Hertlein, 4.

1. Quaternary and recent molluscan faunas of the west coast of Lower California: Southern California Acad. Sci., Bull., vol. 23, pt. 5, pp. 145-156, October 25, 1924. 
Jordan, Eric Knight-Continued.

2. (and Hertlein, Leo George). A Pliocene fauna from Maria Madre Island, Mexico; California Acad. Scl., Proc., 4th. ser., vol. 15, no. 4, pp. 209-216, 1 pl., April 26, 1926.

3. Mollusean fauna of the Pleistocene of San Quintin Bay, Lower California : California Acad. Scl., Proc., 4th ser., vol. 15, no. 7, pp. 241-254, 1 fig., 1 pl., April 26, 1926.

4. (and Hertlein, Leo George). Contribution to the geology and paleontology of the Tertiary of Cedros Island and adjacent parts of Lower California: California Acad. Sci., Proc., 4th ser., vol. 15, no. 14, pp. 409-464, 1 fig., 8 pls., July 22, 1926.

Juárez, J. Vicente.

1. En que forma se encuentra el petróleo en el subsuelo?: Bol. Petróleo, vol. 24, no. 2, pp. 141-145, 2 pls., August, 1927.

Juday, Chancey. See also Twenhofel, 29.

Kaiser, C. L.

1. The minor oil fields of Kern County; Wheeler Ridge fleld: California State Min. Bur., Summary of Operations California Oil Fields, vol. 9, no. 12, pp. 25-29, 2 pls., June, 1924.

2. The minor oil fields of Kern County; Poso Creek fleld: California State Min. Bur., Summary of Operations California Oil Fields, vol. 10, no. 1, pp. 19-22, 1 pl. (map), July, 1924.

Kalb, Georg.

1. Erzmikroskopische Untersuchung des Castillit: Centralbl. Mineralogie, no. 18, pp. 545-547, 3 figs., September 15, 1923 . Examen microscópico de la castillita: Soc. cient. "Antonio Alzate," Mem. y rev., t. 44, nos. 3-8, pp. 351-354, 3 figs., 1925.

Kato, Takeo.

1. The problem of the cupriferous pyritic deposits: Econ. Geology, vol. 20, no. 1, pp. 97-100, January-February, 1925.

2. Replacement copper ore deposits in quartzite: Econ. Geology, vol. 21, no. 4, pp. 394-396, June-July, 1926.

Katz, Frank James. See also Stose, 1.

1. Garnet in North Carolina and the market for abrasive garnet: Eng. and Min. Jour., vol. 107, pp. 903-906, 1 fig., May 24, 1919.

Kauenhowen, w.

1. Geologie und Technik der nordamerikanischen Helium-Vorkommen: Petroleum, Zeitschr. . ... , Berlin-Wien,·Bd. 20, no. 1, pp. 3-6, 1 fig., January 1, 1924.

Kay, George Frederick. See also Diller, 12; Stone, 11.

1. Twenty-fifth annual report of the State geologist; administrative report: Iowa Geol. Survey, vol. 27, pp. 1-11 [1920].

2. Mineral production in Iowa for 1916: Iowa Geol. Survey, vol. 27, pp. 13-32 [1920].

3. Some large boulders in the Kansan drift of southern Iowa: Iowa Geol. Survey, vol. 27, pp. 345-353, 5 figs. [1920].

4. (and Pearce, J. Newton). The origin of gumbotil: Jour. Geology, vol, 28, no. 2, pp. 89-125, 1 fig. (map), February-March, 1920. 
Kay, George Frederick-Continued.

5. Further discussion of the Aftonian gravels and their relation to the drift sheets in the region about Afton Junction and Thayer, Iowa (abstract) : Geol. Soc. Ameriea, Bull., vol. 31, no. 1, p.p. 132-133, March 31, 1920.

6. Significance of the relation of proboscidean remains to the surface of Nebraskan gumbotil, near Osceola, Clarke County, Iowa (with discussion by James H. Lees) : Geol. Soc. America, Bull., vol, 32, no. 1, pp. 80-83, March 31, 1921.

7. The glacial period; its record in Iowa (abstract): Science, new ser., vol. 56, p. 174, August 11, 1922.

8. Comparative study of the Nebraskan and Kansan tills in Iowa (abstract) : Geol. Soc. America, Bull., vol. 33, no. 1, p. 115, March 31, 1922.

9. Twenty-eighth and twenty-ninth annual reports of the State geologist: Iowa Geol. Survey, vol. 29, pp. iii-xx [1924].

10. Recent studies of the Pleistocene in western Iowa (abstract, with discussion by W. C. Alden) : Geol. Soc. America, Bull., vol. 35, no. 1, pp. 71-74, March 30, 1924; Pan-Am. Geologist, vol. 41, no. 2, pp. 139-140, March, 1924.

11. Some recent interpretations of glacial deposits in Iowa (abstract) : PanAm. Geologist, vol. 42, no. 1, p. 68, August, 1924; British Assoc. Adv. Sci., Rept. 92d Meeting, p. 381, 1925.

12. Some recent Pleistocene studies in Iowa [particularly the Iowan till] (abstract) : Pan-Am. Geologist, vol. 46, no. 5, p. 404, December, 1926.

13. Rock resources of Iowa: Iowa Geol. Survey, vol. 32 , pp. 51-65, 13 figs. (incl. map), 1927.

14. Loveland loess; post-Illinoian, pre-Iowan in age: Science, new ser., vol. 68, pp. 482-483, November 16, 1928.

15. The relative ages of the Iowan and Illinoian drift sheets: Am. Jour. Sci., 5th ser., vol. 16, pp. 497-518, 6 figs., December, 1928.

16. History of the investigations and classifications of the Pleistocene deposits of Iowa : Iowa Geol. Survey, vol. 34, 67 pp., 2 figs., 1928 (preprint).

Kay, George Marshall.

1. Stratigraphy and paleontology of the Decorah formation in northeastern Iowa (abstract) : Geol. Soc. America, Bull, vol. 38, no. 1, p. 225, March 30, 1927 ; Pan-Am. Geologist, vol. 47, no. 3, p. 236, April, 1927.

2. Divisions of the Decorah formation [in northeastern Iowa] : Science, new ser., vol. 67, p. 16, January $6,1928$.

Keele, Joseph.

1. Mesozoic clays in northern Ontario: Canada, Geol. Survey, Summ. Rept., 1919, pt. G, pp. 13-19, 1920.

2. Clay and shale deposits of the Abitbi and Mattagami rivers: Ontario Bur. Mines, 29th Ann. Rept., vol. 29, pt. 2, pp. 31-55, 1 fig., 1920.

3. Mesozoic clays and sands in northern Ontario: Canada, Geol. Survey, Summ. Rept., 1920, pt. D, pp. 35-39, 1 fig., 1921.

4. Mesozoic clays and sands in northern Ontario: Roy. Soc. Canada, Proc. and Trans., 3d ser., vol. 15, sec. 4, pp. 25-46, 1 fig., 1921.

5. (and Cole, L. H.). Report on structural materials along the St. Lawrence River between Prescott, Ontario, and Lachine, Quebec: Canada, Dept. Mines, Mines Branch, 119 pp., 5 figs., 30 pls., 3 maps, 1922. 
Keele, Joseph-Continued.

6. Notes on clays of the Missinaibi River: Ontario Dept. Mines, 30th Ann. Rept., vol. 30, pt. 1, pp. 171-175, 4 figs., 1922.

7. Notes on clays of the Missinaibi River: Ontario Dept. Mines, 31st Ann. Rept., vol. 31, pt. 10, pp. 95-96, 1923.

8. Preliminary report on the clay and shale deposits of Ontario: Canada, Geol. Survey, Mem. 142, 176 pp., 11 figs., 9 pls., 1924.

Keeley, Frank J.

1. Additional notes on the Deal [Monmouth County, New Jersey] meteorite: Acad. Nat. Sci. Philadelphia, Proc., vol. 72, pt. 3, pp. 358-359, 1821.

2. Additional notes on igneous rocks of Ogunquit, Maine: Acad. Nat. Sci. Philadelphia, Proc., vol. 75, pp. 105-109, 1924.

Keeney, Robert M.

1. Uranium and vanadium in 1918: Colorado School of Mines Mag., vol. 9, no. 10, pp. 273-278, October, 1919.

Keith, Arthur. See also Bowie, 13 ; Jonas, 4 ; LaForge, 4 ; Willis, B., 1.

1. Cambrian succession of northwestern Vermont (abstract with discussion by E. C. Gordon) : Geol. Soc. America, Bull., vol. 33, no. 1, pp. 123-124, March 31, 1922.

2. Cambrian succession of northwestern Vermont: Am. Jour. Sci., 5th ser., vol. 5, pp. 97-139, 1 fig. (map), February, 1923; Vermont, State Geologist, Fourteenth Rept., 1923-24, pp. 105-136, 1924.

3. Outlines of Appalachian structure: Geol. Soc. America, Bull., vol. 34, no. 2, pp. 309-380, 1 pl. (map), June 30, 1923.

4. Memorial of Jay Backus Woodworth: Geol. Soc. America, Bull., vol. 37, no. 1, pp. 134-141, 1 pl. (portr.), March 30, 1926.

5. The geology of the St. Lawrence earthquake of February 28, 1925 (abstract) : Seismological Soc. America, Bull., vol. 16, no. 2, p. 158, June, 1926.

6. Great Smoky overthrust (abstract) : Geol. Soc. America, Bull., vol. 38, no. 1, pp. 154-155, March 30, 1927.

7. Recent series of New England earthquakes (abstract): Seismological Soc America, Bull., vol. 17, no. 3, pp. 191-192, September, 1927.

8. Recently determined overthrusts in the Appalachians (abstract) : Geol. Soc. America, Bull., vol. 39, no. 1, p. 178, March 30, 1928; Pan-Am. Geologist, vol. 49, no. 2, pp. 139-140, March, 1928.

9. Structural symmetry in North America: Geol. Soc. America, Bull., vol. 39, no. 1, pp. 321-385, 22 figs., March 30, 1928.

Kelley, P. K.

1. The Sulphur salt dome, Louisiana: Am. Assoc. Petroleum Geologists, Bull., vol. 9, no. 3, pp. 479-496, 7 figs., 1 pl., May-June, 1925; Geology of salt dome oil fields, pp. 452-469, 7 figs., 1 pl., 1926.

Kellogg, A. E.

1. Cinnabar ore in Jackson County, Oregon: Eng. and Min. Jour., vol. 107, p. 787, 2 figs., May 3, 1919.

2. Placer mining in Oregon [Waldo district, Josephine County]: Eng. and Min. Jour., vol. 108, pp. 90-91, July 19, 1919.

3. Oil developments in Rogue River valley, Oregon: Eng. and Min. Jour., vol. 111, no. 22, pp. 913-914, 1 fig., May 28, 1921.

4. Cobalt in Jackson County, Oregon: Eng. and Min. Jour., vol. 112, no. 17, p. 650 , October $22,1921$. 
Kellogg, A. E.-Continued.

5. Platinum in the quartz veins of southwest Oregon: Eng. and Min. Jour.Press, vol. 113, no. 23, p. 1000, June 10, 1922.

6. Quicksilver in the Gold Hill, Oregon, District: Min. Jour., Phoenix, Ariz., vol. 11, no. 8, pp. 7, 14-15, September 15, 1927.

7. Origin of manganese in southwestern Oregon: Min. Jour., Phoenix, Ariz., vol. 11 , no. 13 , pp. 7,13 , November 30,1927 .

8. Auriferous gravels of southwest Oregon: Min. Jour., Phoenix, Ariz., vol. 11, no. 20, pp. 3-6, 54-55, 3 figs., March 15, 1928.

9. Origin of copper in southwestern Oregon: Min. Jour., Phoenix, Ariz., vol. 12, no. 2, pp. 9-10, June 15, 1928.

10. Llano de Oro placers, Waldo district, Oregon: Min. Jour., Arizona, vol. 12, no. 4, pp. 9-11, July 15, 1928.

Kellogg, Remington. See also Gregory, W. K., 21 ; Merriam, 25.

1. A new pinniped [Pliopedia pacifica] from the upper Pliocene of California: Jour. Mammalogy, vol. 2, no. 4, pp. 212-226, 13 figs., November, 1921.

2. Pinnipeds from Miocene and Pleistocene deposits of California : California, Univ., Dept. Geology, Bull., vol. 13, no. 4, pp. 23-132, 6 figs., April 14, 1922.

3. Description of the skull of Megaptera miocaena, a fossil humpback whale from the Miocene diatomaceous earth of Lompoc, California: U. S. Nat. Mus., Proc., vol. 61, art. 14, pp. 1-18, 4 pls., 10 figs., 1922.

4. Description of two squalodonts recently discovered in the Calvert Cliffs, Maryland; and notes on the shark-toothed cetaceans: U. S. Nat. Mus., Proc., vol. 62, art. 16, 69 pp., 3 figs., 20 pls., 1923.

5. Description of an apparently new toothed cetacean from South Carolina: Smithsonian Misc. Coll., vol. 76, no. 7, 7 pp., 2 pls., July 25, 1923.

6. A fossil porpoise from the Calvert formation of Maryland: U. S. Nat. Mus., Proc., vol. 63, art. 14, 39 pp., 18 pls., 1924.

7. Description of a new genus and species of whalebone whale from the Calvert Cliffs, Maryland: U. S. Nat. Mus., Proc., vol. 63, art. 15, 14 pp., 6 pls., 1924.

8. Tertlary pelagic mammals of eastern North America: Geol. Soc. America, Bull., vol. 35, no. 4, pp. 755-766, December, 1924.

9. A fossil physeteroid cetacean from Santa Barbara County, California: U. S. Nat. Mus., Proc., vol. 66, art. 27, 8 pp., 2 pls., February 28, 1925.

10. Additions to the Tertiary history of the pelagic mammals on the Pacific coast of North America : Carnegie Inst. Washington, Pub. no. 348, 120 pp., 29 figs., 13 pls., April, 1925.

11. On the occurrence of remains of fossil porpoises of the genus Eurhinodolphis in North America: U. S. Nat. Mus., Proc., vol. 66, art. 26, 40 pp., 1 fig., 17 pls., May 23, 1925.

12. Supplementary observations on the skull of the fossil porpoise Zarhachis flagellator Cope: U. S. Nat. Mus., Proc., vol. 67, art. 28, 18 pp., 5 pls., February 24, 1926.

13. [Paleontological research on cetaceans]: Carnegie Inst. Washington, Year Book no. 25, 1925-6, pp. 405-407, December, 1926.

14. Kentriodon pernix, a Miocene porpoise from Maryland: U. S. Nat Mus., Proc., vol. 68, art. 19, 55 pp., 20 flgs., 14 pls., 1927. 
Kellogg, Remington-Continued.

15. Study of the skull of a fossil sperm whale from the Temblor Mocene of southern California: Carnegie Inst. Washington, Pub. 346 (Contributions to paleontology), pp. 1-24, 9 pls., October, 1927.

16. Fossil pinnipeds from California : Carnegie Inst. Washington, Pub. 346 (Contributions to paleontology), pp. 25-37, 8 figs., October, 1927.

Kellum, Lewis Burnett.

1. The age of the Trent marl in North Carolina: Jour. Geology, vol. 33, no. 2 pp. 183-187, February-March, 1925.

2. Paleontology and stratigraphy of the Castle Hayne and Trent marls in North Carolina: U. S. Geol Survey, Prof. Paper 143, 56 pp. 1 flg., 11 pls., 1926.

Kelly, R. B. See Bell, H. W., 2.

Kelly, Sherwin F. See also Leouardon, 1, 2.

1. Electrical prospecting in Canada: Canadian Inst. Min. and Met., Monthly Bull., no. 143, pp. 166-187, 14 figs., March, 1924.

2. The microstructure of anthracite and anthraxolite: Toronto, Univ., Studias, Geol. ser., no. 22, pp. 44-47, 1 pl., 1926.

Kelly, William A.

1. The Carboniferous fauna of Grand Ledge: Michigan Acad. Sci., Papers, vol. 8, pp. 293-295, 1928.

Kemnitzer, L. E.

1. The Salinas earthquake of December 27, 1924 [California]: Seismol. Soc. America, Bull., vol. 14, no. 4, pp. 230-232, 1 fig., December, 1924.

Kemnitzer, William.

1. The Chittenden earthquake of July 24, 1921 [California] : Seismol. Soc. America, Bull., vol. 11, nos. 3-4, pp. 189-190, 1 pl., September-December, 1921.

2. The Eagle Lake [Lassen County, California] earthquake of July 21, 1921: Seismol. Soc. America, Bull., vol. 11, nos. 3-4, pp. 192-183, 1 pl., September-December, 1921.

Kemp, James Furman, 1859-1926. See also Anderson, J. C., 2 ; Balk, 1; Hewett, 11; Lindgren, 18; Miller, B. L., 8; Mitchell, G. J., 5; Spurr, 20 ; Wheeler, H. A., 3.

1. Memorial of John Duer Irving: Geol. Soc. America, Bull., vol. 30, no. 1, pp. 37-42, portr., March 31, 1919.

2. Observations on a Florida sea beach with reference to oil geology: Econ. Geology, vol. 14, no. 4, pp. 302-323, 4 pls., June, 1919.

3. Stractural and petrographic geology: Geol. Soc. America, Bull., vol. 31, no. 3, pp. 351-356, September 30, 1920.

4. Geology in the law: Econ. Geology, vol. 15, no. 3, pp. 259-265, April-May, 1920.

5. Memorial of Alexis Anastay Julien : Geol. Soc. America, Bull., vol. 31, n๑.1, pp. 81-88, portr., March 31, 1920.

6. Memorial of Gaillard Sherburne Rogers: Geol. Soc. America, Bull., vol. 31, no. 1, pp. 97-100, portr., March 31, 1920.

7. Geology of the Mount Marcy quadrangle, Essex County, New York: New York State Mus. Bull., nos. 229-230, 86 pp., 14 figs., 25 pis., map, 1921. 
Kemp, James Furman-Cantinued.

8. (and Billingsley, Paul). Sweet Grass Hills, Montana : Geol. Soc. America, Bull., จol. 32 , no. 4 , pp. $437-478,14$ figs. (incl. maps), 6 pls., December 1, 1921; abstract, vol. 31 , no. 1, pp. 158-159, March 31 . 1920.

9. The zonal distribution of ores: Econ. Geology, vol. 17 , no. 1 , pp. $46-48$, January-February, 1922.

10. New features in structural geology of the anthracite basins [Wilkes-Barre region, Pennsylvania] : Am. Inst. Min. and Met. Eng., Trans. [preprint] no. 1112, 15 pp., 15 figs., January, 1922 ; vol. 66, pp. 303-317, 15 flgs., 1922 ; abstract, Mining and Metallurgy, no. 181, pp. 29-30, January, 1922.

11. Memorial of Henry Platt Cushing: Geol. Soc. America, Bull., vol. 33, no. 1, pp. 44-55, portr., March 31, 1922.

12. After-effects of igneous intrusion: Geol. Soc. America, Bull., vol. 33, no. 1, pp. 231-254, March 31, 1922; abstract, Eng. and Min. Jour.-Press, vol. 113, no. 8, pp. 338-339, February 25, 1922.

13. Isostasy and applied geology: Geol. Soc. America, Bull., vol. 33, no. 2, pp. 327-331, June $30,1922$.

14. Memorial of Levi Holbrook: Geol. Soc. America, Bull., vol. 34, no. 1, pp. 51-52, March 30, 1923.

15. On veins from intrusive magmas with contrasted contents of metals: Econ. Geology, vol. 18, no. 8, pp. 772-774, December, 1923.

16. Albert Reid Ledoux: Am. Inst. Min. and Met. Eng., Trans., vol. 70, pp. 1207-1212, portr., 1924.

17. Memorial of Horace Vaughn Winchell: Geol. Soc. America, Bull., vol. 35, no. 1 , pp. 46-56, portr., March 30, 1.924.

18. Edmund Otis Hovey, 1862-1924: Natural History (Am. Mus. Nat. Hist., Jour.), vol. 24, no. 6, pp : 705-709, portr., November-December, 1924.

19. The pegmatites: Econ. Geology, vol. 19, no. 8, pp. 697-723, December, 1924.

20. Memorial of Edmund Otis Hovey: Geol. Soc. America, Bull., vol. 36, no. 1, pp. 85-100, portr., March 30, 1925.

21. (and Knight, S. H.). Pre-Cambrian geology north of Laramie, Wyoming (abstract) : Geol. Soc. America, Bull., vol. 36, no. 1, pp. 159160, March 30, 1925; Pan-Am. Geologist, vol. 43, no. 2, p. 153, March, 1925.

22. First award of the Penrose medal [to T. C. Chamberlin] : Science, new ser., vol. 61, pp. 381-382, April, 10, 1925.

23. (and Alling, Harold L.). Geology of the Ausable quadrangle: New York State Mus. Bull., no. 261, 126 pp., 24 figs., 12 pls., map, June, 1925.

24. New methods for the study of granitic intrusives: Econ. Geology, vol. 20, no. 6, pp. 597-601, September-October, 1925.

25. Recent physiographic observations in the Laramie Range, Wyoming (abstract) : Science, new ser., vol. 62, p. 520, December 4, 1925.

26. General geological relations of platinum: Eng. and Min. Jour.-Press, vol. 121, no. 18, pp. 717-719, May 1, 1926.

27. The international geological congresses: Econ. Geology, vol. 21, no. 7, pp. 708-711, November, 1926.

28. Introduction and review of the literature on the geology of the Virgin Islands: New York Acad: Sci., Scientific Survey of Porto Rico and the Virgin Islands, vol. 4, pt. 1, pp. 3-69, 1926.

Kendall, J. D.

1. The formation of ore bodies; Canadian Min. Inst.., Trans., vol, 21, np 298-421, 64 flgs. [1919]. 
Kendall, J. D.-Continued.

2. The formation of coal: Canadian Min. Inst., Monthly Bull., no. 86, pp. 600 606 ; no. 87 , pp. $761-778$; no. 88 , pp. 877-882, 19 figs., June-August, 1919 ; Trans., vol. 22, pp. 250-283, 19 figs. [1920].

Kennedy, William.

1. The Bryan Heights salt dome, Brazoria County, Texas: Am. Assoc. Petroleum Geologists, Bull., vol. 9, no. 3, pp. 613-625, 6 figs., MayJune, 1925; Geology of salt dome oil fields, pp. 678-690, 6 figs., 1926.

Kentucky Geological Survey. See also Dunn, P. H., 1; Eyl, 1, 2; Gardner, J. H., 4; Glenn, 10 ; Jillson, 88, 104 ; Mcfarlan, 1; Miller, A. M., 20, 21 ; Perry, E. S., 1 ; Robinson, L. C., 1; Sutton, 1, 2 ; Weller, 17.

1. Map of the structural geology of Breathitt County, Kentucky: Kentucky, Dept. Geology and Forestry, 1919. Scale 1:62,500.

2. Map of the structural geology of Knott County, by I. B. Browning : Kentucky, Dept. Geology and Forestry, 1919. Scale 1: 62,500.

3. Map of the structural geology of Johnson County . . . by I. B. Browning: Kentucky Geol. Survey, Ser. 6, 1921. Scale 1:62,500.

4. Map of the structural geology of Magoffin County . . . by I. B. Browning : Kentucky Geol. Survey, Ser. 6, 1921. Scale, 1:62,500.

5. Map of the structural geology of Floyd County, Kentucky; structural geology by J. S. Hudnall: Kentucky Geol. Survey, Ser. 6, 1922. Scale $1: 62,500$.

6. Map of the structural geology! of Martin County, Kentucky; structural geology by J. S. Hudnall: Kentucky Geol. Survey, Ser. 6, 1923. Scale, 1: 62,500 .

7. Map of Monroe County, Kentucky, by G. W. Pirtle [oil and gas data]; Kentucky Geol. Survey, Ser. 6, 1923. Scale, 1 inch=1 mile.

S. Map of the structural geology of Pike County, Kentucky; structural geology by J. S. Hudnall: Kentucky Geol. Survey, Ser. 6, 1923. Scale, 1:62,500.

9. Map of the Rockcastle River uplift in Laurel and Clay counties, Kentucky, by W. R. Jillson and J. S. Hudnall: Kentucky Geol. Survey, Ser. 6, 1923. Scale 1:62,500.

10. Map of the Williamsburg anticline in Whitley County, Kentucky, by W. R. Jillson and J. S. Hudnall [incl. geologic data] : Kentucky Geol. Survey, Ser. 6, 1923. Scale 1:62,500.

11. Map of the structural geology of Boyd County Kentucky; structural geology by J. S. Hudnall: Kentucky Geol. Survey, Ser. 6, 1924. Scale $1: 62,500$.

12. Map of the structural geology of parts of Cumberland, Monroe, and Clinton counties, Kentucky; structural geology by J. S. Hudnall and G. W. Pirtle: Kentucky Geol. Survey, Ser. 6, 1924. Scale 1 inch $=1$ mile.

13. Oil and gas map of Hancock County, Kentucky, by J. L. Bissell : Kentucky Geol. Survey, Ser. 6, 1924. Scale, $1: 62,500$.

14. Map of the structural geology of the region south of Irvine and Berea in Estill, Jackson, Lee, Madison, and Rockcastle counties, Kentucky: Kentucky Geol. Survey, Ser. 6, 1924. Scale, 1 inch=1 mile.

15. Structural map Isonville oil pool, Elliott County, Kentucky, by J. S. Hudnall and A. E. Williams: Kentucky Geol. Surrey, Ser. 6, 1924. Scale, 1 inch $=1 / 2$ mile. 
Kentucky Geological Survey-Continued.

16. Map of the structural geology of Leslie County, Kentucky . . . by J. S. Hudnall and others. Kentucky Geol. Survey, Ser. 6, 1924. Scale, $1: 62,500$.

17. Economic map of McLean County, Kentucky, by J. L. Bissell : Kentucky Geol. Survey, Ser. 6, 1924. Scale, 1:62,500.

18. Map of the subsurface structural geology of Martin County, Kentucky; structural geology by J. S. Hudnall: Kentucky Geol. Survey, Ser. 6, 1924. Scale, $1: 62,500$.

10. Map of Metcalfe County, Kentucky, by H. D. Crider [oil and gas data] : Kentucky Geol. Survey, Ser. 6, 1924. Scale, 1 inch $=1$ mile.

20. Topographic map of Muhlenberg County, Kentucky [incl. geologic data] : Kentucky Geol. Survey, Ser. 6, 1924. Scale, 1:62,500.

21. Map of the structural geology of the Paint Creek uplift in Floyd, Johnson, Magoffin, Morgan, Lawrence, and Elliott counties, Kentucky ; structural geology by J. S. Hudnall and I. B. Browning: Kentucky Geol. Survey, Ser. 6, 1924. Scale, 1:62,500.

22. Map of the structural geology of Perry County, Kentucky; structural geology by J. S. Hudnall: Kentucky Geol. Survey, Ser. 6, 1924. Scale, $1: 62,500$.

23. Oil and gas map of Barren County, Kentucky, by W. C. Eyl: Kentucky Geol. Survey, Ser. 6,1925 . Scale, 1 inch $=1$ mile.

24. Map of the subsurface structural geology of Boyd County, by W. R. Jillson: Kentucky Geol. Survey, Ser. 6, 1925. Scale 1:62,500.

25. Oil and gas map of Boyd County, Kentucky, by W. R. Jillson: Kentucky Geol. Survey, Ser. 6, 1925. Scale 1:62,500.

26. Structural map of Carter County, Kentucky: Kentucky Geol. Survey, Ser. 6, 1925. Scale, 1 inch $=1$ mile.

27. Oil and gas map of Elliott County, Kentucky, by A. B. Williams: Kentucky Geol. Survey, Ser. 6, 1925. Scale, 1 inch=1 mile.

28. Reconnaissance map of the structural geology of Knox County, Kentucky; structural geology by C. V. Theis: Kentucky Geol. Survey, Ser. 6, 1925. Scale, 1:62,500.

29. Oil and gas map of Taylor County, Kentucky, by C. D. Hunter: Kentucky Geol. Survey, Ser. 6, 1925. Scale, 1 inch $=1$ mile.

30. Oil and gas map of Bracken County, Kentucky, by Evans McGraw and Earl Sherwood: Kentucky Geol. Survey, Ser. 6, 1926. Scale 1 inch $=1$ mile.

31. Map of Edmonson County, Kentucky [showing geologic data]: Kentucky Geol. Survey, Ser. 6, 1926. Scale, 1:62,500.

32. Map of Grayson County, Kentucky [showing geologic data]: Kentucky Geol. Survey, Ser. 6, 1926. Scale, 1 inch $=1$ mile.

33. Reconnaissance structural oil and gas map of Greenup County, Kentucky ; Kentucky Geol. Survey, Ser. 6, 1926. Scale, 1 inch=1 mile.

34. Structural map of Lawrence County, Kentucky: Kentucky Geol. Survey, Ser. 6, 1926. Scale, 1 inch $=1$ mile.

35. Oil and gas map of Bath County, Kentucky, by Earl Sherwood: Kentucky Geol. Survey, Ser. 6, 1927. Scale $1 \mathrm{Inch}=1 \mathrm{mile}$.

38. Map of the subsurface structural geology of the Bells Run anticline, Ohio County, Kentucky, by W. C. Eyl : Kentucky Geol. Survey, Ser. 6, 1927. Scale 1 inch $=1$ mile.

37. Structural geological oil and gas map of Breathitt County, Kentucky, by I. B. Browning; second edition revised by W. R. Jillson: Kentucky Geol. Survey, Ser. 6, 1927. Scale 1 inch=1 mile. 
Kentucky Geological Survey-Continued.

38. Reconnaissance map of the struetural geology of Clay County, Kentucky, by C. V. Theis and others: Kentucky Geol. Survey, Ser. 6,1927 . Scale 1 inch $=1$ mile.

39. Map of the structural geology of Harlan County, Kentucky, by R. Milfer and S. Withers: Kentucky Geol. Survey, Ser. 6, 1927. Scale $1: 62,500$.

40. Structural geological map of Henderson County, Kentucky, by C. V. Theis : Kentucky Geol. Survey, Ser. 6, 1927. Scale 1 inch=1 mile.

41. Map of the areal and structural geology of Lee County, Kentucky, by W. C. Eyl : Kentucky Geol. Survey, Ser. 6, 1927. Scale 1 inch $=1$ nrile.

42. Map of the structural geology, fault pattern, of Lincoln County, Ken. tucky; geology by A. C. McFarlan and H. T. Richardson: Kentucky Geol. Survey, Ser. 6, 1927. Scale 1 inch $=1$ mile.

43. Structural geological oil and gas map of Owsley County, Kentucky; geology by E. S. Perry: Kentucky Geol. Survey, Ser. 6, 1927. Scale 1 inch $=1$ mile.

44. Oil and gas map of Powell County, Kentucky, by Evans C. McGraw: Kentucky Geol. Survey, Ser. 6, 1927. Scale 1 inch $=1$ mile.

45. Oil and gas map of Wayne County, Kentucky, by F. H. Douglas: Kentucky Geol. Survey, Ser. 6, 1927. Scale 1 inch $=1$ mile.

46. Map of the structural geology of Bell County, Kentucky . . . by D. Chisholm, R. Miller, and S. Withers: Kentucky Geological Survey, Ser. 6, 1928. Scale 1: 62,500.

47. Map of Calloway County, Kentucky, by W. E..Bach: Kentucky Geol. Survey, Ser. 6, 1928. Scale 1 inch $=1$ mile.

48. Map of Carlisle County, Kentucky, by R. O. Bishop and A. Montgomery. Kentucky Geol. Survey, Ser. 6, 1928. Scale 1 inch $=1$ mile.

49. Map of the subsurface structural geology of Floyd County, Kentucky ; structural geology by Raymond Miller and Spencer Withers: Kentucky Geol. Survey, Ser. 6, 1928. Scale $1: 62,500$.

50. Oil and gas map of Green County, Kentucky, by Evans C. McGraw : Kentucky Geological Survey, Ser. 6, 1928 . Scale 1 inch $=1$ mile.

51. Map of Marshall County, Kentucky, by W. E. Bách and T. G. Strunk: Kentucky Geol. Survey, Ser. 6, 1928. Scale 1 inch=1 mile.

52. Map of lower Miller Creek, Estill County, Kentucky, showing available cement materials : Kentucky Geol. Survey, Ser. 6, 1988. Scale, 1 inch $=\mathbf{1 5 0 0}$ feet.

53. Map [and generalized stratigraphic section] of Nelson County, Kentucky, by S. Withèrs, R. Miller, and G. Briggs. Kentucky Geol. Survey, Ser. 6, 1928. Scale, 1 inch $=1$ mile.

54. Oil and gas map of Warren County, Kentucky, by W. C. Eyl : Kentucky Geol. Survey, Ser. 6, 1928. Scale, 1:62,500.

Kerr, Forrest A.

1. Dease Lake area, Cassiar district, British Columbia: Canada, Geol. Survey, Summ. Rept., 1925, pt. A, pp. 75-99, 1 fig., 1 pl., map, 1926.

2. Preliminary report on Stikine River area, British Columbia: Canada, Geol. Survey, Summ. Report, 1926, pt. A, pp. 14-84, 1 fig. (map), 1927.

3. The eastern contact zone of the coast range batholith on the Stikine River [British Columbia] : Canadian Min: and Met. Buil., no. 189; pr. 179-183, January, 1928. 
Kerr, Paul F.

1. The determination of opaque ore minerals by X-ray diffraction patterns: Econ. Geology, vol. 19, no. 1, pp. 1-34, 6 figs., 2 pls., JanuaryFebruary, 1924.

2. A magmatic sulphide ore, Chichagof Island, Alaska: Econ. Geology, vol. 19, no. 4, pp. 369-376, 2 figs., June-July, 1924.

3. A simple rotation apparatus [for measuring axial angles] : Am. Mineralogist, rol. 9, no. 8, pp. 169-171, 1 fig., August, 1924.

4. (and Schenck, Hubert G.):- Active thrust faults in San Benito County, California: Geol. Soc. America, Bull., vol. 36, no. 3, pp. 465-494, 13 flgs., September 30, 1925; abstract, no. 1, p. 157, March 30, 1925 ; Pan-Am. Geologist, vol. 43, no. 2, p. 152, March, 1925.

5. (and Cabeen, Charles K.). Electrical conductivity of ore minerals: Econ. Geology, vol. 20, no. 8, pp. 729-737, December, 1925.

6. The signficance of strain structure in quartz from Ducktown, Tennessee: Am. Mineralogist, vol. 11, no. 8, pp. 206-209; 2 figs., August, 1926.

7. (and Schenck, Hubert G.). Significance of the Matilija overturn [Santa Ynez Mountains, California]: Geol. Soc. America, Bull., vol. 39, no. 4, pp. 1087-1102, 4 figs., December 30, 1928; abstract, no. 1, p. 187, March 30, 1928; Pan.-Am. Geologist, vol. 49, no. 1, p. 77, February, 1928.

Kerr-Lawson, D. E.

1. The crystallography of potassium fluozirconate: Toronto, Univ., Studies, Geol. ser., no. 20 , pp. 63-67, 3 figs., 1925.

2. Pleochroic haloes in biotite from near Murray Bay, Province of Quebec: Toronto, Univ., Studies, Geol. ser. no. 24, pp. 54-70, 4 figs., 4 pls., 1827.

3. Pleochroic haloes in biotite: Toronto, Univ., Studies, Geol. ser., no. 27, pp. 15-27, 9 figs., 2 pls., 1928.

Kesler, L. W.

1. Oil and gas resources of Kansas in 1927 : Kansas State Geol. Survey, Min. Res. Circ. 1 (Kansas, Univ., Bull., vol. 29, no. 11), 60 pp., 6 figs., June 1, 1928

Kew, William Stephen Webster. See also Laughlin, 1.

1. Structure and oil resources of the Simi Valley, southern California: U. S. Geol. Survey Bull. 691, pp. 323-347, 4 pls. (incl map), 1 fig., April 9, 1919. Abstract by $R$. W. Stone, Washington Acad. Sci., Jour., vol. 9, no. 15, pp. 441-442, September 19, 1919.

2. Geology of a part of the Santa Ynez River district, Santa Barbara County, California: California, Univ., Dept. Geology, Bull., vol. 12, no. 1, pp. 1-21, 2 pls. (incl. map), 2 figs., November 20, 1919.

3. Cretaceous and Cenozoic Echinoidea of the Pacific coast of North America : California, Univ., Dept. Geology, Bull. vol. 12, no. 2, pp. 23-236, 40 pls., 5 figs., September 28, 1920.

4. Geologic formations of a part of southern California and their correlation: Am. Assoc. Petroleum Geologists, Bull., vol. 7, no. 4, pp. 411-420, July-August, 1923.

5. Geologic evidence bearing on the Inglewood earthquake of June 21, 1920. Seismol. Soc. America, Bull., vol. 13, no. 4, pp. 155-158, 1 fig., December, 1923.

6. Geology and oil resources of a part of Los Angeles and Ventura counties, California : U. S. Geol. Survey, Bull. 753, 202 pp., 7 flgs., 17 pls. (incl. maps), 1024. 
Kew, William Stephen Webster-Continued.

7. Faulting in the western part of San Gabriel Mountains (abstract) : Geol. Soc. America, Bull, vol. 35, no. 1, pp. 165-166, March 30, 1924.

8. A geologic summary of California oil flelds: Oil Bull., vol. 12, no. 1, pp. 33-35, 39, 41, 43, 1 pl., January, 1926.

8. Geologic and physiographic features in the San Pedro Hills. Los Angeles County, California : Oil Bull., vol. 12, no. 5, pp. 513-518, 590, 3 figs., May, 1926.

10. Geologic sketch of Santa Rosa Island, Santa Barbara County, California : Geol. Soc. America, Bull., vol. 38, no. 4, pp. 645-653, 1 pl. (map), December, 1927.

11. Geologic sketch of Santa Rosa Island, Ventura County, California (abstract) : Geol. Soc. America, Bull., vol. 39, no. 1, p. 267, March 30, 1928.

Keyes, Charles Rollin. See also Beeson, 1; Boone County Hist. Soc., 1.

1. Tectonic adjustment of a rotating straticulate spheroid: Am. Jour. Sci., 4th ser., vol. 47, pp. 108-112, 5 figs, February, 1919.

2. Provincial unity of continental interior coal fields: Iowa Acad. Sci., Proc. 1918, vol. 25, pp. 545-550 [1919].

3. Preglacial Moingona River : Iowa Acad. Sci., Proc. 1918, vol. 25, pp. 551-559, 7 figs. [1919].

4. Alpine structures of Jasper Park [northwestern Alberta] (abstract) : Iowa Acad. Sci., Proc. 1918, vol. 25, pp. 561-568, 2 pls. [1919].

5. Memorial of Garland Carr Broadhead: Geol. Soc. America, Bull., vol. 30, pp. 13-27, port., March 31, 1919.

6. Geotectonic adaption through retardation of the earth's rotation (abstract) : Geol. Soc. America, Bull., vol. 30, pp. 87-88, March 31, 1919.

7. Tectonic form of the continents: Science, new ser., vol. 49, pp. 612-613, June 27, 1919.

8. Louisian vs. Mississippian as a periodic title (abstract): Science, new ser., vol. 50, p. 74, July 18, 1919.

9. Tertiary gravels of northern Utah (abstract) : Science, new ser., vol. 50, p. 74, July 18, 1919.

10. Orogenics of the Great Basin: Science, new ser., vol. 50, p. 413, October 31, 1919.

11. Paleozolc diastrophics of the northern Mexican tableland: Jour. Geology, vol. 28, no. 1, pp. 75-83, 3 flgs., January-February, 1920.

12. Earth's radius of molar repose (abstract) : Geol. Soc. America, Bull., vol. 31, no. 1, p. 111, March 31, 1920.

13. Frosive clews to the high plateaus of Utah (abstract) : Geol. Soc. America, Bull., vol. 31, no. 1, pp. 151-152, March 31, 1920.

14. Geological setting of New Mexico: Jour. Geology, vol. 28, no. 3, pp. 233-254, 6 flgs., April-May, 1920.

15. Telluric relations of dislocative fissure veins: Eng. and Min. Jour., vol. 109, pp. 965-966, April 24, 1920.

16. Isostatic measure of the Rocky Mountains: Geol. Mag., vol. 57, pp. 262266, June, 1920.

17. Span of the great ice age: Annals of Iowa, 3d ser., vol. 12, no. 5, pp. 369-373, 1 pl., July, 1920.

18. A century of Iowa geology : Iowa Acad. Sci., Proc., vol. 26, pp. 407-440, 13 pls. (portr.) [1920].

18. Southward extenslon of the Bozeman Tertiaries into Utah (abstract) : Iowa Acad. Bcl., Proc., vol. 26, pp. 467-469 [1820]. 
Keyes, Charles Rollin-Continued.

20. Stratigraphic delimitation of St. Louis formation: Iowa Acad. Sci, Proc., vol. 26, pp. 471-475 [1920].

21. When Hopkins geology was in flower: Johns Hopkins Alumnl Mag., vol. 9, no. 3, pp. 204-212, March, 1921.

22. An origin of crystalline schists (abstract) : Geol. Soc. America, Bull., vol. 32, no. 1, p. 34, March 31, 1921.

23. Peneplainal affinities of high plateaus of Utah (abstract): Geol. Soc. America, Bull., vol. 32, no. 1, p. 56, March 31, 1921.

24. Crazing of mountain massifs (abstract): Science, new ser., vol. 54, p. 308, September 30, 1921.

25. Erosion of high plateaux (abstract): Science, new ser., vol. 54, p. 308, September 30, 1921.

26. Interglacial volcanic ash (abstract) : Science, new ser., vol. 54, p. 308, September 30, 1921.

27. (editor). Pan-American Geologist, vols. 37-50, 1922-28. Continues volume numbering of the American Geologist.

28. Three grand discoveries of life: Pan-Am. Geologist, vol. 37. no. 1, pp. 1-14, pls., February, 1922.

29. Blister hypothesis of laccolithic mountains: Pan-Am. Geologist, vol. 37, no. 1, pp. 25-34, 4 figs., February, 1922.

30. Emerson geological loving cup: Pan-Am. Geologist, vol. 37, no. 1, pp. $41-48,3$ pls. (incl. portr.), February, 1922.

31. Stratigraphy of the Black Hills Tertiaries: Pan-Am. Geologist, vol. 37, no. 1, pp. 63-64, 1 fig., February, 1922.

32. Physiographic setting of earliest Tertiary : Pan-Am. Geologist, vol. 37, no. 1 , pp. 69-70, February, 1922.

33. Basal Tertiary in Rocky Mountain region; Orotaxial relationships of Lance series of Montana; Biotic significance of Cannonball fauna; Ancient salt lake Cànnonball: Pan-Am. Geologist, vol. 37, no. 1, pp. 70-75, February, 1922.

34. Minimum span of isostatic effect: Pan-Am. Geologist, vol. 37, no. 1, pp. 79-81, February, 1922.

35. Changing sphericity of our earth: Pan-Am. Geologist, vol. 37, no. 1., pp. 81-84, February, 1922.

36. Discovery of Gilbert's star [origin of Coon Butte, Arizona]: Pan-Am. Geologist, vol. 37, no. 1, pp. 86-87, February, 1922.

37. Major telluric stresses initiated by diminishing rate of earth's rotation: Pan-Am. Geologist, vol. 37, no. 1, pp. 87-88, February, 1922.

38. Continental dynamies: Pan-Am. Geologist, vol. 37, no. 1, pp. 88-90, February, 1922.

39. Geological directrix of isostasy; Geotectonic economy of thrust faulting; Erosional agencies under variant climatic stimuli : Pan-Am. Geologist, vol. 37, no. 1, pp. 90-96, February, 1922.

40. Isostatic theory and applied geology: Pan-Au. Geolugist, vol. 37, no. 2, pp. 97-106, March, 1922.

41. New Mexican laccolithic structures: Pan-Am. Geologist, vol. 37, no. 2, pp. 109-120, 5 figs., 1 pl., March, 1922.

42. (and Rowley, R. R.). Serial affinities of Siluric formations in northeastern Missouri : Pan-Am. Geologist, vol. 37, no. 2, pp. 1.31-138, March, 1922.

43. Geological work of R. Ellsworth Call : Pan-Am. Geologist, vol. 37, no. 2, pp. 151-160, portr., March, 1822. 
Ireyes, Charles Rollin-Continued.

44. Glant bay bar of ancient Bonneville Lake; Thrust at Crow's Nest; Biplanation of earth's straticulate crust: Flexures in Canadian - front ranges of Rockies; Some prairie tectonics; Tectonic setting of Utah's high plateaus: Pan-Am. Geologist, vol. 37, no. 2, pp. 167176, 2 figs., 2 pls., March, 1922.

45. Memorial of Orestes Hawley Saint John: Geol Soc. America, Bull., vol. 33, no. 1, pp. 31-44, portr., March 31, 1922.

46. Life eras before the Cambrian (abstract) : Geol. Soc. America, Bull., vol. 33, no. 1, pp. 107-108, March 31, 1922.

47. Tectonic setting of laccolithic genesis: Pan-Am. Geologist, vol. 37, no. 3, pp. 203-212, 2 figs., April, 1922.

48. Ore deposition in trunk channels of circulatory ground waters: PanAm. Geologist, vol. 37, no. 3, pp. 226-230, April, 1922.

49. Passing of Murchison's Siluria; Yorkic period of stratigraphy: PanAm. Geologist, vol. 37, no. 3, pp. 233-235, 243-244, April, 1922.

50. Complexity of Peter sandstone: Pan-Am. Geologist, vol. 37, no. 3, pp. 245-246, April, 1922.

51. Muscogee shales of western interior coal fleld: Pan-Am. Geologist, vol. 37, no. 3, pp. 248-249, April, 1922.

52. Galena limestone as a terranal title: Pan-Am. Geologist, vol. 37, no. 3, pp. 252-255, 1 fig., April, 1922.

53. Dakotan sandstone in Missouri : Pan-Am. Geologist, vol. 37, no. 3, p. 256, April, 1922.

54. John Casper Branner: Pan-Am. Geologist, vol. 37, no. 4, pp. 257-266, portr., May, 1922.

55. Climatic influences in vadose ore deposition: Pan-Am. Geologist, vol. 37, no. 4, pp. 275-287, May, 1922.

56. Eral affiliations of Grassy black shale: Pan-Am. Geologist, vol. 37, no. 4, pp. 307-310, Мay, 1922.

57. Judicial attitude in geological criticism: Pan-Am. Geologist, vol. 37, no. 4, pp. 311-320, May, 1922.

58. Lowering of life's record into the abyss of time: Pan-Am. Geologist, vol. 37, no. 4, pp. 327-328, May, 1922.

59. America's mountain of gold: Pan-Am. Geologist, vol. 37, no. 4, pp. 335-337, May, 1922.

60. First mention of the ores [of] zinc in America: Pan-Am. Geologist, vol. 37, no. 4, pp. 340-341, May, 1922.

61. New borate field in Nevada: Pan-Am. Geologist, vol. 37, no. 4, pp. 343-344, May, 1922.

62. Circulatory cycles of ore-bearing waters: Pan-Am. Geologist, vol. 37, no. 4, pp. 347-350, 1 fig., May, 1922.

63. World's oil reserves: Pan-Am. Geologist, vol. 37, no. 4, pp. 350-352, May, 1922.

64. Verity of the pipe vein: Pan-Am. Geologist, vol. 37, no. 4, p. 352, May, 1922.

65. Summit plane of the Colorado Rockies: Pan-Am. Geologist, vol. 37, no. 5, pp. 359-362, 1 fig., June, 1922.

66. Nature of vadose ore deposition: Pan-Am. Geologist, vol. 37, no. 5, pp. 379-392, June, 1822.

67. [Formation of boraciferous beds] : Pan-Am. Geologist, vol. 37, no. 5, pp. 399-416, June, 1922. 
Keyes, Charles Rollin-Comtinued.

68. Limitation of Cretacic formations in southwestern Iowa: Rio Grande Carbonic province: Pan-Am. Geologist, vol. 37, no. 5, pp. 424-425, 1 llg., 425-426, June, 1922.

69. Vein nature of commercial borates : novel characteristics of the colemanite deposits of California and Nevada: Eng. and Min. Jour.-Press, vol. 113, no. 25, p. 1082, June 24, 1922.

70. Introduction of modern geology into America [geological work of Thomas Nuttall] : Pan-Am. Geologist, vol. 38, no. 1, pp. 1-8, 1 pī. (portr.), August, 1922.

71. Orogenic consequence of a diminishing rate of earth's rotation: Pan-Am. Geologist, vol. 38, no. 1, pp. 51-80, 5 figs., August, 1922.

72. Antiquity of Chupadera Mesa iron deposits: Pan-Am. Geologist, vol. 38, no. 1, pp. 89-92, 1 fig., August, 1922.

73. Antimony deposits in Okanogan Valley, Washington: Pan-Am. Geologist, vol. 38, no. 1, pp. 94-96, 1 fig., 1 pl., August, 1922.

74. Rollin D. Salisbury : Pan-Am. Geologist, vol. 38, no. 2, pp. 97-104, portr., September, 1922.

75. Peneplanal affinities of high plateaux of Utah: Pan-Am. Genlogist, vol. 38, no. 2, pp. 119-140, 1 fig., September, 1922.

76. Discovery of Paleozoic formations in New Mexico; Faulting of Bonneville Lake deltas: Pan-Am. Geologist, vol. 38, no. 2, pp. 141-145, September, 1922.

77. Permian rocks of Grand Canyon: Pan-Am. Geologist, vol. 38, no. 2, pp. 147-149, September, 1922.

78. Use of Chester as terranal title: Pan-Am. Geologist, vol. 38, no. 2, pp. 149-150, September, 1922.

79. Absence of Laramian beds in southern Colorado: Pan-Am. Geologist, vol. 38, no. 2, pp. 150-153, September, 1922.

80. Pennsylvanian in time span: Pan-Am. Geologist, vol. 38, no. 2, pp. 153154, September, 1922.

81. Superior Paleozoics of Rio Grande: Pan-Am. Geologist, vol. 38, no. 2, pp. 154-160, September, 1922.

82. Physiographic paradox of the desert; Measure of eolic depletion of Great Plains; Desert-soil sorting by winds; Elutriation of diamonds by the winds; Significance of girdled mountains; Multiplanary relief of American deserts; Basinal sand drifting on arid piedmonts: Pan-Am. Geologist, vol. 38, no. 2, pp. 161-176, 1 fig., September, 1922.

83. Framework of Arizona geology: Pan-Am. Geologist, vol. 38, no. 3, pp. 231-252, 1 pl., October, 1922.

84. Overthrusts in Great Basin ranges: Pan-Am. Geologist, vol. 38, no. 3, pp. 253-260, October, 1922.

85. Antiquity of Lingula: Pan-Am. Geologist, vol. 38, no. 3, pp. 261-262, October, 1922.

86. Late Paleozoic fossils on summit of Ozarks: Pan-Am. Geologist, vol. 38, no. 3, pp. 263-265, October, 1922.

87. Devonic outliers on the Missouri Highlands: Pan-Am. Geologist, vol. 38, no. 3, pp. 271-272, October, 1922.

88. Pioneer geological explorations of Edwin James: Pan-Am. Geologist, vol. 38, no. 4, pp. 273-282, portr., November, 1922.

89. Terranal differentiation of Iowa Cambric succession: Pan-Am. Geolngist, vol. 38, no. 4, nn. 313-326, November, 1922.

$4096-31-22$ 
Keyes, Charles Rollin-Continued.

90. Delimitations of sundry Arizona terranes: Pan-Am. Geologist, vol. 38, no. 4, pp. 335-339, November, 1922.

91. Diastrophic aspect of Aux Vases sandstone: Pan-Am. Geologist, vol. 38, no. 4, pp. 339-348, November, 1922.

92. Bridging the ages of ice [glacial deposits at Des Moines, Iowa] : Pan-Am. Geologist, vol. 38, no. 5, pp. 349-358, 2 pls., December, 1922.

93. Ceramics of gumbo soils: Pan-Am. Geologist, vol. 38, no. 5, pp. 403-408, - December, 1922.

94. Grand Canyon's palatial section: Pan-Am. Geologist, vol. 38, no. 5, pp. 409-412, December, 1922.

95. Volcanic ash in glacial till; Original of McGee's complex drift sections: Pan-Am. Geologist, vol. 38, no. 5, pp. 413-420, 1 pl., December, 1922.

96. Climatic index of Bonneville Lake beds : Pan-Am. Geologist, vol. 38, no. 5, pp. 422-424, December, 1922.

97. Geological conquest of the air: Scientia (Bologna, Italy), vol. 30, no. 116, pp. 439-446, supplement (French translation) 59-66, December 1, 1921; abstract by author, Revue de Géologie, ann. 4, no. 1, pp. 59-60, January, 1923.

98. The mechanics of laccolithic intrusion (presented before the Geological Society of America, St. Louis meeting). 36 pp., 14 figs., Washington, 1922. Abstract by author in Revue de Géologie, ann. 4, no. 1, pp. 39-40, January, 1923.

99. Discovery of volcanic ash in Iowa: Iowa Acad. Sci., Proc. 1921, vol. 28, pp. 49-53, 3 figs. [1923].

100. Geological age of the terrepleins of Utah's plateaux: Iowa Acad. Sci., Proc. 1921, vol. 28, pp. 54.56, I fig. [1923].

101. Batholithic veinings of the Sierra de las Cucaras in Baja California (abstract) : Iowa Acad. Sci., Proc. 1921, vol. 28, pp. 57-58, 1 tig. [1923].

102. Glacial work of James Edward Todd: Pan-Am. Geologist, vol. 39, no. 1, pp. 1-14, portr., February, 1923.

103. Contraposed criteria of geological classification: Pan-Am. Geologist, rol. 39, no. 1, pp. 51-54, February, 1923.

104. Biotic resolution of Red Wall limestone of Grand Canyon: Fean-Am. Geologist, vol. 39, no. 1, pp. 57-61, February, 1923.

105. Belt of maximum epirotic deposition; Eolian sands as interglacial deposits : Pan-Am. Geologist, vol. 39, no. 1, pp. 63-65, 65-66, 1 fig., February, 1923.

106. Mid-Ordovicic nomenclature in Missouri ; Devonic unconformity in Arizona; Reconstruction of Iowa's geology: Pan-Am. Geologist, vol. 39, no. 1, pp. 67-70, 70-72, 72, February, 1923.

107. Brass ore in nature; Dialytic rôle of selvages; Rare metals from New Mexico: Pan-Am. Geologist, vol. 39, no. 1, pp. 75-76, 77-79, 79-80, February, 1923.

108. Transplantation of English terranal classification to America by Davia Dale Owen: Pan-Am. Geologist, vol. 39, no. 2, pp. 81-94, 1 pl. (portr.), March, 1923.

109. Taxonomic differentiation of American pre-Cambrian rocks: Pan-Am. Geologist, vol. 39, no. 2, pp. 125-140, 2 pls., March, 1923.

110. Creative productivity of our geological surveys: Pan-Am. Geologist, vol. 39, no. 2, pp. 141-148, March, 1923. 
Keyes, Charles Rollin-Continued.

111. Cosmical derivation ' of metals; Midget coal fleld of America [O'Mara district, New Mexico]; Localization of ore values in gouge materials; Tres Amigos gold veins of Arizona: Pan-Am. Geologist, vol. 39, no. 2, pp. 152-154, 154-156, 1 fig., 156-159, 159-160, 1 fig., March, 1923.

112. Orogenic exigencies of a rotary earth (abstract) : Geol. Soc. America, Bull., vol. 34, no. 1, p. 62, March 30, 1923.

113. Extension of the New York system through the West, by James Hall: Pan-Am. Geologist, vol. 39, no. 3, pp. 161-168, 1 pl. (portr.), April, 1923.

114. Metallic content of rocks: Pan Am. Geologist, vol. 39, no. 3, pp. 201238, April, 1923.

115. Uniformity in geological classitications: Pan-Am. Geologist, vol. 39, no. 3, pp. 239-246, April, 1923.

11.6. Low rim point of Bonneville Lake basin; Withdrawal of marginal drainage in desert development; Climatic changes of lator geological times; Lake ancestry in arid lands; Pan-Am. Geologist, vol. 39, no. 3, pp. 247-248, 249-251, 1pl., 251-252, 252-254, 254-256, April, 1923.

117. Microscopical petrography in the interpretation of rock metamorphosis as introduced into America by George Huntington Williams: PanAm. Geologist, vol. 39, no. 4, pp. 257-272, 1 pl. (portr.), May, 1923.

118. Circumstate correlations of Iowa's geological formations: Pan-Am. Geologist, vol. 39, no. 4, pp. 317-326, May, 1923.

119. Current digest of geological literature; Some unusual aspects of Green River coals: Pan-Am. Geologist, vol. 39, no. 4, pp. 327-332, May, 1923.

120. Incorporation of meteoritic metals in terrestrial ores; Depths of metallic contact mineralization: Pan Am. Geologist, vol. 39, no. 4, pp. 333-336, May, 1923.

121. Gustavus Detlef Hinrichs, mineralogist, meteorologist, and physical chemist: Pan-Am. Geologist, vol 39, no. 5, pp. 337-352, 1 pl. (portr.), June, 1923.

122. Evolution of through-flowing rivers in arid regions: Pan-Am. Geologist, vol, 39, no. 5 pp. 379-386, June, 1923.

123. Taxonomy of the Mississippian section; Earliest geographic title for the early Carbonic section of Mississippi Valley; Four-group arrangement of early Carbonic terranes: Pan-Am. Geologist, vol. 39, no. 5, pp. 387-390, 390-395, 395-398, June, 1923.

124. Water table of the loess (abstract): Science, new ser., vol. 57, p. 148, August 24, 1923.

125. Stratigraphic position of Sweetland black shales (abtsract) : Science, new ser., vol. 57, p. 148, August 24, 1923.

126. Numerical limitations to glacial epochs (abstract): Science, new ser., vol. 57, pp. 147-148, August 24, 1923.

127. Foundation of American stratigraphy by Ebenezer Emmons: Pan-Am. Geologist, vol. 40, no. 1, pp. 1-14, 1 pl. (portr.), August, 1923.

128. Geology of Nevada: Pan-Am. Geologist, vol. 40, no. 1, pp. 35-64, 4 pls., August, 1923.

129. Taconic question fifty years after: Pan-Am. Geologist, vol. 40, no. 1 , pp. 65-68, August, 1823. 
Keyes, Charles Rollin-Continued.

130. Genetic classification of American early Carbonic terranes; Invalidity of Madison limestone as terranal title; Type localities for sundry Nevada terranes: Pan-Am. Geologist, vol. 40, no. 1, pp. 69-75, 1 pl., 75-77, 77-80, August, 1923.

131. Thomas Crowder Chamberlin at fourscore: Pan-Am. Geologist, vol. 40, no. 2, pp. 81-94, 2 pls. (portraits), September, 1923.

132. Isostatic aspects of southern Rocky Mountains: Pan-Am. Geologist, vol. 40, no. 2, pp. 139-150, 1 pl., September, 1023.

133. Taxonomy of the periods in geology: Pan-Am. Geologist, vol. 40, no. 2, pp. 151-156, September, 1923.

134. Primary origin of metallic content of ores: Pan-Am. Geologist, vol. 40, no. 2, pp. 157-158, September, 1923.

135. American copper mining in the stone age: Pan-Am. Geologist, vol. 40 , no. 2, pp. 158-160, September, 1923.

136. Horace Vaughan Winchell, mining geologist: Pan-Am. Geologist, vol. 40, no. 3, pp. 161-180, portr., October, 1923.

137. Structure of Dodge gypsum basin [Iowa] : Pan-Am. Geologist, vol. 40, no. 3, pp. 215-234, 4 flgs., 3 pls., October, 1923.

138. Field geology as a necessary adjunct to rock oil discovery: Pan-Am. Geologist, vol. 40, no. 3, pp. 238-240, October, 1923.

- 139.:Raphael Pumpelly, premier explorer: Pan-Am. Geologist, vol. 40, no. 4, pp. 241-250, 1 pl. (portr.), November, 1923.

140. Phenomenal deposition of desert gypsum: Pan-Am. Geologist, vol. 40, no. 4, pp. 289-298, 1 fig., 3 pls., November, 1923.

141. Geology by proxy [abstracting geologic literature] : Pan-Am. Geologist, vol. 40, no. 4, pp. 299-302, November, 1923.

142. Prediction of earthquakes in the premises: Pan-Am. Geologist, vol. 40, no. 4, pp. 302-304, November, 1923.

143. Geological pioneering of Jules Marcou: Pan-Am. Geologist, vol. 40, no. 5, pp. 321-332, December, 1923.

144. Cubist method of geological correlation: Pan-Am. Geologist, vol. 40, no. 5, pp. 357-374, 3 pls., December, 1923.

145. Preparation in geological communication: Pan-Am. Geologist, vol. 40, no. 5, pp. 375-379, December, 1923.

146. Black Mesa iron deposits of Plumosa district of Arizona: Pan-Am. Geologist, vol. 40, no. 5, pp. 383-384, December, 1923.

147. Laramian hiatus around the southern Rockies: Iowa Acad. Sci., Proc. 1922, vol. 29, pp. 101-103 [1924?].

148. Horizontal movement in oblique faulting of inclined strata : Iowa Acad. Sci... Proc. 1922, vol. 29, p. 104 [1824?].

149. Taxonomic rank of Pennsylvanian groupings: Iowa Acad. Sci., Proc. 1922, vol. 29, pp. 105-106 [1924?].

150. James Edward Todd and Iowa geology: Iowa Acad. Sci., Proc., vol. 30 , pp. 35-42, portr. [1924].

151. The crystallographic work of Gustavus Hinrichs: Am. Mineralogist, vol. 9, no. 1, pp. 5-8, January, 1824.

152. Grand staircase of Utah: Pan-Am. Geologist, vol. 41, no. 1, pp. 33-68, 6 . flgs., 9 pls., February, 1924.

153. Latter day trend in geologic paleontology; Formative conditions of ore deposition; Porphyry coppers of Palomas Range of western Arizona; Delimitation of sundry rock terranes of Nevada ; Zacatecas copper deposits associated with acidic eruptives: Pan-Am. Geologist, vol. 41, no. 1, pp. 69-72, 73-75, 76-78, 78-79, 79-80, February, 1924. 
Keyes, Charles Rollin-Continued.

164. Last of geological pioneers: Ferdinand Vandiveer Hayden: Pan-Am. Geologist, vol. 41, no. 2, pp. 81-06, portr., March, 1924.

155. Genetie significance of desert range: Pan-Am. Geologist, vol. 41, no. 2, pp. 131-132, March, 1924.

156. Cubist school in terranal classification (abstract): Geol. Soc. America, Bull., vol. 35, no. 1, pp. 77-78, March 30, 1924 ; Pan-Am. Geologist, vol. 41, no. 2, pp. 141-142, March, 1924.

157. Rarest stone lilies [notice of Frank Springer's Crinoidea Flexibilia and some account of his life]: Annals of Iowa, $3 \mathrm{~d}$ ser., vol, 14, no. 4, pp. 273-280, 2 pls. (incl. portr.), April, 1924.

158. Anthony Wayne Vogdes: Pan-Am. Geologist, vol. 41, no. 3, pp. 161-168, portr., April, 1924.

159. Denudation of the desert: Pan-Am. Geologist, vol. 41, no. 3, pp. 205-218, April, 1924.

160. Basin range structure in the Great Basin: Pan-Am. Geologist, vol. 41, no. 3, pp. 210-224, April, 1924.

161. Ore deposits of New Mexico: Pan-Am. Geologist, vol. 41, no. 3, pp. 227-233, April, 1924.

162. Razing of ancestral Rockies: Pan-Am. Geologist, vol. 41, no. 4, pp. 277-314, 1 fig., 3 pls., May, 1924.

163. Merging of Devonic and Siluric periods: Pan-Am. Geologist, vol. 41, no. 4, pp. 315-316, May, 1924.

164. Global concurrence on geological periods of time: Pan-Am. Geologist, vol, 4, no. 4, pp. 317-320, May, 1924.

165. Mastery of winds in land sculpture: Pan-Am. Geologist, vol. 41, no. 5, pp. 321-334, 2 pls., June, 1924.

166. Recency of Iowa gypsum deposition: Pan-Am. Geologist, vol. 41, no. 5, pp. 367-380, 1 pl., June, 1924.

167. Simplicity in geological classification: Pan-Am. Geologist, vol. 41, no. 5, pp. 381-384, June, 1924.

168. Recessional streams of arid regions: Pan Am. Geologist, vol. 42, no. 1, pp. 30-36, August, 1924.

169. Toronto meeting of British Association for Advancement of Science: Pan-Am. Geologist, vol. 42, no. 1, pp. 63-66, August, 1924.

170. Soil transport through the air and the deposition of loess: Pan-Am. Geologist, vol. 42, no. 2, 133-148, September, 1924.

171. Solar initlation of glaciation?: Pan-Am. Geologist, vol. 42, no. 2, pp. 149-150, September, 1924.

172. Is geology in the doldrums?: Eng. and Min. Jour.-Press, vol. 118, no. 14, pp. 541-642, October 4, 1924.

173. Exploratory coal stratigraphy of John James Stevenson: Pan-Am. Geologist, vol. 42, no. 3, pp. 161-172, October, 1924.

174. End of deflation: Pan-Am. Geologist, vol. 42, no. 3, pp. 219-228, October, 1924.

175. Genetic basis of geological classification: Pan Am. Geologist, vol. 42, no. 3, pp. 229-232, October, 1924.

176. Saint John and the fishes: Pan-Am. Geologist, vol. 42, no. 3, pp. 233235, October, 1924.

177. Dumble silver plaque: Pan-Am. Geologist, vol. 42, no. 4, pp. 241-244, 2 pls. (incl. portr.), November, 1924.

178. Working plans in geological field operations: Pan-Am. Geologist, vol. 42, no. 4, pp. 281-296, November, 1924. 
Keyes, Charles Rollin-Continued.

179. Trend in university instruction; Geological science in its decadence?: Pan-Am. Geologist, vol. 4, no. 2, pp. 297-301, 301-305, November, 1924.

180. Shifting of the continental masses: Pan-Am. Geologist, vol. 42, no. 4, pp. 305-306, November, 1924.

181. Edmund Otis Hovey: Pan-Am. Geologist, vol. 42, no. 5, pp. 321-330, 2 pls., December, 1924.

182. What is our American Permian?: Pan Am. Geologist, vol. 42, no. 5, pp. 357-370, 2 pls., December, 1924.

183. Physiography of Missouri: Pan-Am. Geologist, vol. 42, no. 5, pp. 371-372, December, 1924.

184. Inapplicability of term Pennsylvanian to Iowa coal measures (abstract) : Pan-Am. Geologist, vol. 42, no. 5, p. 379, December, 1924.

185. Easternmost extension of western deserts (abstract): Pan-Am. Geologist, vol. 42, no. 5, p. 380, December, 1924.

186. Recent light on significance of early Devonic hiatus in Iowa (abstract) : Pan-Am. Geologist, vol. 42, no. 5, pp. 379-380, December, 1924.

187. The crystule, a unit measure of matter: Am. Mineralogist, vol. 10, no. 1, pp. 15-17, January, 1925. Crystule; the ultimate unit of crystal form: Pan-Am. Geologist, vol. 43, no. 1, pp. 69-71, February, 1925.

188. Iron streak in the loess: Pan-Am. Geologist, vol: 43, no. 1, pp. 71-72, February, 1925.

189. Thomas Leonard Watson: Pan-Am. Geologist, vol. 43, no. 2, pp. 81-84, portr., March, 1925.

190. Shagreened terrene of Wyoming: Pan-Am. Geologist, vol. 43, no. 2, pp. 105-138, 2 figs., 3 pls., March, 1925.

191. Bibliography of isostasy: Pan-Am. Geologist, vol. 43, no. 2, pp. 139-143, March, 1925.

192. Our missing Permian (abstract): Geol. Soc. America, Bull., vol. 36, no. 1, p. 162, March 30, 1925: Pan-Am. Geologist, vol. 43, no. 2, pp. 155-156, March, 1925.

193. Alfred Hulse Brooks, Alaskan pioneer: Pan-Am. Geologist, vol. 43, no. 3, pp. 161-174, portr., 1 pl., April; 1925.

194. Homonymy-identity of geological relations: Pan-Am. Geologist, vol. 43, no. 3, pp. 217-224, April, 1925.

195. Revise Eocene classification of the Cordillera: Pan-Am. Geologist, vol. 43, no. 3, pp. 225-230, April, 1925.

196. Evolutional stages in geologic classification; Devonic crinoids of New York; Iowa and its wealth of crinoids; Note on synonymy of Onychopus; Basis of species: Pan-Am. Geologist, vol. 43, no. 3, pp. 231-233, 234-235, 237-238, 239, 239-240, April, 1925.

197. Willet Green Miller, Canadian pre-Cambrianist: Pan-Am. Geologist, vol. 43, no. 4, pp. 241-256, portr., May, 1925.

198. Mid-Cretacic deposition of epicontinental seas: Pan-Am. Geologist, vol. 43, no. 4, pp. 287-302, 3 pls., May, 1925.

199. Proper designation of Iowa coal measures ; Basal quartzites of Cordilleran massif; Title of Fernando formation of California; Porvincial afflnities of Sweetland black shales of Iowa : Pan-Am. Geologist, vol. 43 , no. 4, pp. 309-311, 313-315, 315-316, 317-318, 1 pl. May, 1825. 
Keyes, Charles Rollin-Continued.

200. Early geological explorations of Joseph Nicholas Nicollet in the Mississippi Valley: Pan-Am. Geologist, vol. 43, no. 5, pp. 321-332, portr., June, 1925.

201. John Mason Clarke, paleontologist: Pan-Am. Geologist, vol. 44, no. 1, pp. 1-16, portr., August, 1925.

202. Regional plantations about the Mesozoic-Cenozoic boundary: Pan-Am. Geologist, vol. 44, no. 1, pp. 43-52, 2 figs., August, 1925.

203. Out on the Cretaceo-'Tertic border: Pan-Am. Geologist, vol, 44, no. 1, pp. 53-56, August, 1925.

204. Gashed veins on the Queen of Sheba [Arizona]; Vanadinite deposits of the Elephant Butte [New Mexico]: Pan-Am. Geologist, vol. 44, no. 1, pp. 60-62, 67-68, August, 1925.

205. William Maclure, father of modern geology : Pan-Am. Geologist, vol. 44, no. 2, pp. 81-94, portr., September, 1925.

206. Periodicity of glaciation: Pan-Am. Geologist, vol. 44, no. 2, pp. 139-142, 1 fig., September, 1925.

207. Isostasy versus tumefaction: Pan-Am. Geologist, vol. 44, no. 2, pp. 143146, September, 1925.

208. Earliest geographic designation for Iowa chalk; Nicollet's title for Spergen limestone: Pan-Am. Geologist, vol. 44, no. 2, pp. 147-149, 149-151, September, 1925.

209. Oldest unmetamorphosed rocks are around Pacific Basin: Pan-Am. Geologist vol. 44, no. 3, pp. 207-224, 3 pls., October, 1925.

210. Secular wasting of glacial till sheets; Standardization of American terranal classification; Origin of the continents: Pan-Am. Geologist, vol. 44, no. 3, pp. 225-227, 227-232, 232-234, October, 1925.

211. Louis Agassiz and glacial hypothesis: Pan-Am. Geologist, vol. 44, no. 4, pp. 241-242, portr., November, 1925.

212. Isostatic quest of the Holy Grail: Pan-Am. Geologist, vol. 44, no. 4, pp. 313-316, November, 1925.

213. Norton bronze tablet: Pan-Am. Geologist, vol. 44, no. 5, pp. 337-344, 3 pls. (incl. portr.), December, 1925.

214. Astronomical theory of great ice ages; and Newcombian criticism : PanAm. Geologist, vol. 44, no. 5, pp. 397-406, 1 pl., December, 1925.

215. Early Devonic planation in continental interior (abstract) : Iowa Acad. Sci., Proc., vol. 31, pp. 331-332 [1926?].

216. Beginnings of desert in Iowa (abstract) : Iowa Acad. Sci., Proc., vol. 31, pp. 332-333 [1926?].

217. Pennsylvanian as a periodic title for Iowa coal measures: Iowa Acad. Sci., Proc., vol. 31, pp. 351-352 [1926?].

218. Rogers of the folded mountains: Pan-Am. Geologist, vol. 45, no. 1, pp. 1-14, portri., February, 1926.

219. Glacial control ; and recalculated values of earth's orbital excentricity: Pan-Am. Geologist, vol. 45, no. 1, pp. 49-74, 1 fig., 3 pls., February, 1926.

220. Controlling cause of periodic glaciation (abstract) : Geol. Soc. America, Bull., vol. 37, no. 1, pp. 177-178, March 30, 1926 ; Pan-Am. Geologist, vol. 45, no. 1, pp. 93-94, February, 1926.

221. Present status of astronomical theory of glacial epochs: Pan-Am. Geologist, vol. 45, no. 2, pp. 141-148, March, 1926.

222. How shall we classify our glacial till sheets?: Pan-Am. Geologist, vol. 45, no. 2, pp. 149-152, March, 1926. 
Keyes, Charles Rollin-Continued.

223. New geological map of Kentucky; Expansion of seismological interest; Motion picture in geography and geology: Pan-Am. Geologist, vol. 45, no. 2, pp. 152-154, 154-155, 155-156, March, 1926.

224. Estival epoch; the contrasted analogue of an ice age: Pan-Am. Goologist, vol. 45, no. 3, pp. 225-236, April, 1926.

225. Westward extension of the Uintah arch; Geological mapping of Arizona : Pan-Am. Geologist, vol. 45, no. 3, pp. 243-245, 245-246, April, 1926.

226. Crollian composition of climate and time: Pan-Am. Geologist, vol. 45, no. 4, pp. 307-318, May, 1926.

227. Geological message of the jaundiced snow : Pan-Am. Geologist, vol. 45, no. 4, pp. 319-320, May, 1926.

228. Geological date of Red Oak faulting; Tectonic significance of transverse horizontal faulting in desert ranges; Tectonic framework of desert ranges: Pan-Am. Geologist, vol. 45, no. 4, pp. 321-324, 324-326, 326-328, May, 1926.

229. Forgotten geological map of Minnesota and its belated tectonic significance: Pan-Am. Geologist, vol. 45, no. 4, pp. 328-334, 1 fig., 2 pls. (maps), May, 1926.

230. Complications of the glacial cycle: Pan-Am. Geologist, vol. 45, no. 5, pp. 337-348, 1 fig., June, 1926.

231. Regional creep of earth's crust and prediction of earthquakes : Pan-Am. Geologist, vol. 46, no. 1, pp. 63-66, August, 1926.

232. Mechanism of glacial recessional moraines: Pan-Am. Geologist, vol. 46, no. 2, pp. 123-136, 2 figs., 2 pls., September, 1926.

233. Stability in geological nomenclature: Pan-Am. Geologist, vol. 46, no. 2, pp. 137-144, September, 1926.

234. Ancient rock column of Montana : Pan-Am. Geologist, vol. 46, no. 3, pp. 195-232, 3 figs., 4 pls., October, 1926.

235. Desmesne of economic geology: Pan-Am. Geologist, vol. 46, no. 3, pp. 233-238, October, 1926.

236. Astronomical measure of geologic time (abstract) : Pan-Am. Geologist, vol. 46 , no. 3 , pp. 250-251, October, 1926.

237. Our first genetic classification of rocks: Pan-Am. Geologist, vol. 46, no. 4, pp. 315-316, November, 1926.

238. Why a Glacial prial? [number of glacial stages] : Pan-Am. Geologist, vol. 46 , no. 5, pp. 393-398, December, 1926.

239. Taxonomy of Iowa's glacial deposits (abstract): Pan-Am. Geologist, vol. 46 , no. 5, p. 400 , December, 1926.

240. Terranal affinities of Iowa chalks (abstract) : Pan-Am. Geologist, vol. 46 , no. 5 , pp. 400-401, December, 1926.

241. Water table of the loess (abstract) : Pan-Am. Geologist, vol. 46, no. 5, p. 401; December, 1926.

242. Translocation of 'Iowa's Siouan Mountains (abstract) : Iowa Acad. Sci., Proc., 1925, vol. 32, p. 361 [1926].

243. New method of precise geological correlation; stratigraphic value of volcanic ash (abstract) : Iowa Acad. Sci., Proc., 1925, vol. 32, p. $362[1926]$.

244. Water table of the loess (abstract) : Iowa Acad. Sci., Proc., 1926, rol. 33 , p. 219 [1927].

245. Terranal affinities of Iowa chalks (abstract) : Iowa Acad. Scl., Proc., 1.926, vol. 33, po. 219-220 [1927]. 
Keyes, Charles Rollin-Continued.

246. Tasonomy of Iowa's glacial deposits (abstract) : Iowa Acad. Sci., Proc., 1926, vol. 33, p. 220 [1927].

247. Centenary commemoration of William Smith: Pan-Am. Geologist, vol. 47, no. 1, pp. 1-10, portr., February, 1927.

248. Under side of earth's straticulate crust: Pan-Am. Geologist, vol. 47, no. 1, pp. 59-62, February, 1927.

249. Charles Joseph Norwood: Mining and Metallurgy, vol. 8, no. 243, p. 154, March, 1927.

250. James Furman Kemp, economic geologist: Pan-Am. Geologist, vol. 47, no. 2, pp. 81-92, portr., March, 1927.

251. Correlation of original Permian succession: Pan-Am. Geologist, vol. 47, no. 2, pp. 137-142, March, 1927.

252. Stratigraphic affinities of so-called Trenton limestone of Iowa: Pan-Am. Geologist, vol. 47, no. 2, pp. 144-148, 2 figs., March, 1927.

253. [Obituaries], Charles Rochester Eastman: Orestes Hawley St. John; Andrew Gordon Wilson: Annals of Iowa, 3d ser., vol. 15, no. 8, pp. 633-636, April, 1927.

254. Charles Doolittle Walcott: Pan-Am. Geologist, vol. 47, no. 3, pp. 161-170, portr., April, 1927.

255. Taxonomy of geological periods: Pan-Am. Geologist, vol. 47, no. 4, pp. 285-304, inset (table), May, 1927.

256. Stockwellia, a basic unit of geological time: Pan-Am. Geologist, vol. 47, no. 4, pp. 305-310, May, 1927.

257. Taxonomy of our glacial till sheets; Canons of geological nomenclature: Pan-Am. Geologist, vol. 47, no. 5, pp. 351-366, 367-368, June, 1927.

258. What is the original Belt terrane: Pan-Am. Geologist, vol. 47, no. 5, pp. 372-375, June, 1927.

259. Desert ranges of Arizona : Pan-Am. Geologist, vol. 47, no. 5, pp. 376378, June, 1927.

260. Taconic question restated: Pan-Am. Geologist, vol. 48, no. 1, pp. 55-70, August, 1927.

261. Creative productivity in American geology: Pan-Am. Geologist, vol. 48, no. 1, pp. 71-76, August, 1927.

262. Mississippian series; its synonymy and taxonomy: Pan-Am. Geologist, vol. 48, no. 2, pp. 135-150, 2 pls., September, 1927.

263. Retreat of Des Moines glacial lobe (abstract) : Pan-Am. Geologist, vol. 48, no. 2, pp. 155-156, September, 1927.

264. Jurassic events in Iowa (abstract) : Pan-Am. Geologist, vol. 48, no. 2, p. 160 , September, 1927.

265. Standardization of geological terminology : Pan-Am. Geologist, vol. 48, no. 3, pp. 213-217, October, 1927.

266. Ice flutings on interglacial deposits: Pan-Am. Geologist, vol. 48, no. 3, pp. 217-218, October, 1927.

267. Concentration of rare earth minerals for geologic age determinations: Pan-Am. Geologist, vol. 48, no. 4, pp. 299-306, November, 1927; abstract, no. 2, p. 160, September, 1927.

268. Passing of Murchison's Permian?; Littlest piece of ice: the crystule: Pan-Am. Geologist, vol. 48, no. 4, pp. 307-313, 313-314, November, 1927.

269. Springer of the crinoids: Pan-Am. Geologist, vol. 48, no. 5, pp. 321-334, 2 pls. (inel. portr.), December, 1927. 
Keyes, Charles Rollin-Continued.

270. Rules of nominal priority in geology; Tectonic framework of Desert ranges: Pan-Am. Geologist, vol. 48, no. 5, pp. 359-363, 363-364, December, 1927.

271. Israel C. White, petroleumist: Pan-Am. Geologist, vol. 49, no. 1, pp. 1-10, portr., February, 1928.

272. Moving the mountains: Pan-Am. Geologist, vol. 49, no. 1, pp. 53-56, February, 1928.

273. Crinoidal bibliography of Frank Springer: Pan-Am. Geologist, vol. 49, no. 1, pp. 60-63, February, 1928.

274. Pioneer geology of George Clinton Swallow: Pan-Am. Geologist, vol. 49, no. 2, pp. 81-94, 2 pls. (incl. portr.), March, 1928.

275. Homogeny in American carbonic stratigraphy: Pan-Am. Geologist, vol. 49, no. 2, pp. 117-134, 151-152 (abstract), 4 figs., 1 pl., March, 1928; abstract, Geol. Soc. America, Bull., vol. 39, no. 1, p. 198, March 30, 1928.

276. Trend in paleontological geology: Pan-Am. Geologist, vol. 49, no. 2, pp. 135-138, March, 1928.

277. Geological causes of glacial epochs: Pan-Am. Geologist, vol. 49, no. 3, pp. 195-216, 2 figs., 1 pl., April, 1928.

278. How designate pre-Paleozoic time units: Pan-Am. Geologist, vol. 49, no. 3, pp. 217-224, April, 1928.

279. Swallowian foundations of Kansas stratigraphy: Pan-Am. Geologist, vol. 49, no. 4, pp. 275-290, 1 fig., 2 pls., May, 1928.

280. What is a four stage glacial cycle: Pan-Am. Geologist, vol. 49, no. 4, pp. 291-294, 1 fig., May, 1928.

281. Appalachian Paleozoics in world science: Pan-Am. Geologist, vol. 49, no. 5, pp. 321-340, 1 pl., June, 1928.

282. Glacial tills and iceberg drifts: Pan-Am. Geologist, vol. 49, no. 5, pp. 369-372, June, 1928.

283. Discordance of Missourian series upon Des Moines coal measures (abstract) : Pan-Am. Geologist, vol. 49, no. 5, pp. 374-375, June, 1928.

284. Triassic age of Iowa's major syncline (abstract): Pan-Am. Geologist, vol. 49 , no. 5 , pp. $375-376$, June, 1928.

285. America's great potash reserves: Pan-Am. Geologist, vol. 50, no. 1, pp. 39-56, 4 figs., 3 pls., August, 1928.

286. Terranal limitation in geographic designation: Pan-Am. Geologist, vol. 50, no. 1, pp. 57-60, August, 1928.

287. Meek's original Plattesmouth terrane; Validity of Marais des Cygnes as terranal title; Lexington formation in Missouri; Synonymy of Broadhead's Atchison shales: Pan-Am. Geologist, vol. 50, no. 1, pp. 62-66, 67-69, 70-71, 72-74, August, 1928.

288. Theory of multiple glaciations: Pan-Am. Geologist, vol. 50, no. 2, pp. 131-144, September, 1928.

289. Urgent need of international stratigraphical lexicon: Pan-Am. Geologist, vol. 50, no. 2, pp. 145-148, September, 1928.

290. Lateral expanse of Rocky Mountain geosyncline; Bolson substructure of trans-Pecos Texas: Pan-Am. Geologist, vol. 50, no. 2, pp. 154158, 158-160, September, 1928.

291. Irreducible residuum of Siluria: Pan-Am. Geologist, vol. 50, no. 3, pp. 215-224, October, 1928.

292. College research in geology: Pan-Am. Geologist, vol. 50, no. 3, pp. 225226, October, 1928. 
Keyes, Charles Rollin-Continued.

293. Fantasy of buoyant hypothesis : Pan-Am. Geologist, vol. 50, no. 4, pp. 307310, November, 1928.

294. Prodromus of Steno: Pan-Am. Geologist, vol. 50, no. 5, pp. 377-380, December, 1928.

Keyes, Mary G. See also Washington, 33, 36, 37.

1. Making thin sections of rocks: Am. Jour. Sci., 5th ser., vol. 10, pp. 538-550, 1 fig., December, 1925.

Keyes, Robert L. See Case, J. B., 2; Godde, 2.

Keys, D. A. See Eve, 1.

Keyte, I. A. See also Brainerd, 1, 2.

1. Pennsylvanian crinoids from western Colorado (abstract): Geol. Soc. America, Bull., vol. 36, no. 1, p. 227, March 30, 1925.

2. (and Blanchard, W. Grant, jr., and Baldwin, Harry L., jr.). GaptankWolfcamp problem of the Glass Mountains, Texas: Jour. Paleontology, vol. 1, no. 2, pp. 175-178, 1 pl., August, 1927.

Kidder, S. J.

1. Mining methods in Mogollon district, New Mexico: Am. Inst. Min. and Met. Eng., Trans. [preprint] no. 1314, 21 pp., 8 figs., March, 1924 ; abstract, Mining and Metallurgy, vol. 5, no. 207, pp. 142-143, March, 1924:

Kimball, James Putnam.

1. Relaciones geológicas y génesis de las minas de hierro especular de Santiago de Cuba: Cuba, Direccion montes y minas, Bol. minas no. 5, pp. 83-95, 1919.

Kindle, Edward Martin. See also Twenhofel, 16, 18, 22, 29.

1. Obituary, Lawrence M. Lambe, 1863-1919: Canadian Min. Inst. Monthly Bull., no. 85, pp. 544-545, May, 1919 . Canadian Field-Naturalist, vol. 34, no. 3, pp. 56-57, March, 1920.

2. A neglected factor in the rounding of sand grains: Am. Jour. Sci., 4th ser., vol. 47, pp. 431-434, June, 1919.

3. Inequalities of sedimentation: Jour. Geology, vol. 27, no. 5, pp. 339366, July-August, 1919.

4. The discovery of a Portage fauna in the Mackenzie River valley: Canada, Geol. Survey, Mus. Bull., no. 29, pp. 1-8, 2 pls., October 18, 1919.

5. The climatic interpretation of two early Ordovician mud-crack horizons: Canadian Field-Naturalist, vol. 33, no. 5, p. 96, November, 1919.

6. Notes on the iron ores of Mackenzie River valley: Canada, Geol. Survey, Summ. Rept., 1919, pt. C, pp. 1-2, 1920.

7. Memorial of Lawrence M. Lambe: Geol. Soc. America, Bull., vol. 31, no. 1, pp. 88-97, portr., March. 31, 1920.

8. Obituary, Walter R. Billings: Canadian Field-Naturalist, vol. 34, no. 3, pp. 57-58, March, 1920. Geol. Mag., vol. 57, pp. 287-288, June, 1920.

9. (and Bosworth, T. O.). Oil-bearing rocks of lower Mackenzie River valley : Canada, Geol. Survey, Summ. Rept., 1920, pt. B, pp. 37-63, 2 figs., 5 pls., 2 maps, 1921. In part, Canadian Min. Jour., vol. 42. no. 32, pp. 635-647, 11 figs., August 12, 1921. 
Kindle, Edward Martin-Continued.

10. Distribution of Stringocephahes burtoni in Canada [Devonian]: Roy. Soc. Canada, Proc. and Trans., 3d ser., vol. 15, sec. 4, pp. 21-24, 1921.

11. Shore-line migration and recent coordinate changes in bottom topography at Point Pelee, Lake Erie (abstract): Geol. Soc. Aumerica, Bull,, vol. 32, no. 1, p. 57, March 31, 1921.

12. Suggestions to oil prospectors in the Mackenzie River Valley: Canadian Min. Jour., vol. 42, no. 18, pp. 356-361, 10 figs., May, 6, 1921.

13. An example of gravity deformation in a limestone slab: Canadian FieldNaturalist, vol. 35, no 6, pp. 115-116, 1 fig., September, 1921.

14. A tree three million years old [Red Deer Valley, Alberta]: Illustrated Canadian Forestry Mag., vol. 17, no. 7, pp. 381-382, 408-409, 2 figs., September, 1921.

15. The Mackenzie River oil region: Canadian Inst. Min. and Met., Monthly Bull. no. 108, pp. 306-311, April, 1921; Trans., vol. 24, pp. 75-80 [1922].

16. Lilley and Devonic fishes: Pan-Am. Geologist, vol. 37, no. 4, pp. 330331, May, 1922.

17. Notes on post-glacial terraces on the eastern and western shores of the Gulf of St. Lawrence: Canadian Field-Naturalist, $\nabla 01.36$, no. 6, pp. 111-113, September, 1922.

18. Canadian streams with some unusual features: Canadian Field-Naturalist, vol. 37, no. 2, pp. 21-22, February, 1923.

19. Unusual type of sand bar: Pan-Am. Geologist, vol. 39, no. 1, pp. 15-16, 1 pl., February, 1923.

20. Notes on mud crack and ripple mark in recent calcareous sediments: Jour. Geology, vol. 31, no. 2, pp. 138-145, 4 figs., 1923.

21. A note on mud crack and associated joint structure: Am. Jour. Sci., 5th ser., vol. 5, pp. 329-330, 1 fig., April, 1923.

22. The physical and biological characterictics of certain types of marlite balls from Manitoba and Michigan: Roy. Soc. Canada, Proc. and Trans., 3d ser., vol. 17, sec. 4, pp. 105-114, 3 pls., May, 1823.

23. Nomenclature and genetic relations of certain calcareous rocks: PanAm. Geologist, vol. 39, no. 5, pp. 365-372, 5 pls., June, 1923.

24. Range and distribution of certain types of Canadian Pleistocene concretions (with discussion by T. T. Quirke): Geol. Soe. Amevica, Bull., vol. 34, no. 3, pp. 609-648, 4 figs., 8 pls., September 30, 1928 ; abstract, no. 1, pp. 64-65, March 30, 1923.

25. Geography and geology of Lake Melville district, Labrador Peninsula : Canada, Geol. Survey, Mem. 141, 105 pp., 10 figs., 17 pls., 1924.

26. Geology of a portion of the northern part of Moose River basin, Ontario : Canada, Geol. Survey, Summ. Rept. 1923, pt. C 1, pp. 21-41, 3 pls., 1924. .

27. Observations on ice-borne sediments by the Canadian and other Aretic expeditions: Am. Jour. Sci., 5th ser., vol. 7, pp. 251-286, 2 flgs., April, 1924.

28. (and Edwards, E. M.). Literature of ripple mark: Pan-Am. Geologist, vol. 41, no. 3, pp. 191-203, April, 1924.

29. Note on a mammoth tusk from the Arctic Archipelago: Am. Jour. Sei., 5th ser., vol. 8, pp. 183-185, 3 figs., August, 1924.

30. Standard Paleozoic section of Rocky Mountains near Banff, Alberta: Pan-Am. Geologist, vol. 42, no. 2, pp. 11:3-124, 2 pls., September, 1924. 
Kindle, Edward Martin-Continued.

31. The terraces of the Lake Melville district, Labrador: Geog. Rev., vol. 14, no. 4, pp. 597-602, 3 flgs., October, 1924.

32. Three new Devonic fossils from Alberta: Pan-Am. Geologist, vol. 42, no. 8, pp. 217-218, 1 pl., October, 1924.

33. Edward J. Whittaker [obituary notice] : Canadian Inst. Min. and Met., Monthly Bull. no. 151, pp. 256-258, portr., November, 1924.

34. Certain types of sedimentation now in progress on or near the Atlantic coast of North America (abstract) : Pan-Am. Geologist, vol. 42, no. 4, p. 311, November, 1924; British Assoc. Adv. Sci., Rept. 92d Meeting, p. 301, 1925.

35. The bottom deposits of Lake Ontario: Roy. Soc. Canada, Proc. and Trans., 3d ser., vol. 19, sec. 4, pp. 47-102, 1 fig., 3 pls., 3 maps, 1925.

36. A note on rhizocretions: Jour. Geology, vol. 33, no. 7, pp. 744-746, 1 fig., October-November, 1925.

37. Contrasted types of mud cracks: Roy. Soc. Canada, Proc. and Trans., 3 d ser., vol. 20 , sec. 4 , pp. $71-75,5$ pls., 1926.

38. The occurrence of the genus Leptodus in the anthracolithic fauna. of British Columbia: Roy. Soc. Canada, Proc. and Trans., 3d ser., vol. 20, sec. 4, pp. 109-111, 1 flg., 1926.

39. A comparison of recent and late Champlain stages of McKay Lake as diatom habitats: Canadian Field-Naturalist, vol. 40, no. 4, pp. 83-84, April, 1926.

40. Some fossils in the Dominion National Museum: Canadian Min. Jour., vol. 47 , no. 18 , pp. 465-466, 3 figs., April 30, 1926.

41. The story of the stones in the Dominion Parliament Building: Canadian Min. Jour., vol. 47, no. 28, pp. 689-691, 3 figs., July 9, 1926 ; Sci. Monthly, vol. 23, no. 6, pp. 539-544, 4 figs., December, 1926.

42. Notes on the tidal phenomena of Bay of Fundy rivers: Jour. Geology, vol. 34, no. 7, pp. 642-652, 3 figs., October-November, 1926.

43. The romance of fossil hunting; a review: Canadian Min. Jour., vol. 48, p. 9, January 7, 1927.

44. Scale of hardness and cohesion for sedimentary rocks: Am. Assoc. Petroleum Geologists, Bull., vol. 11, no. 2, p. 199, February, 1927.

45. The rôle of thermal stratification in lacustrine sedimentation: Roy. Soc. Canada, Trans., 3d ser., vol. 21, sec. 4, pp. 1-35, 5 figs., 3 pls., March, 1927 ; abstract, Geol. Soc. America, Bull., vol. 38, no. 1, p. 150, March 30, 1927 ; Pan-Am. Geologist, vol. 47, no. 2, p. 153, March, 1927.

46. Conodont fauna from the lower Mackenzie River valley (abstract) : Geol. Soc. America, Bull., vol. 38, no. 1, p. 234, March 30, 1927; PanAm. Geologist, vol. 47, no. 3, p. 236, April, 1927.

47. The occurrence and correlation of a Devonian fauna from Peace River, Alberta : Canada, Geol. Survey, Bull. no. 49, pp. 14-18, 3 pls., 1928.

48. A crustacean new to the Pleistocene fauna of Canada: Canadian FieldNaturalist, vol. 42, no. 9, pp. 211-212, 1 fig., December, 1928.

King, Philip B.

1. Physiography of southwestern South Dakota (abstract): Pan-Am. Geolo. gist, vol. 42, no. 5, pp. 378-379, December, 1924.

2. The geologic structure of a portion of the Glass Mountains of west Texas: Am. Assoc. Petroleum Geologists, Bull., vol. 10, no. 9, pp. 877-884, 2 figs., 1 pl. (næap), September, 1926. 
King, Phillp B.-Continued.

3. Notes on the physiography of southwestern North Dakota (abstract) : Iowa Acad. Sci., Proc., vol. 31, p. 333 [1926?].

4. The Bissett formation, a new stratigraphic unit in the Permian of west Texas: Am. Jour. Sci., 5th ser., vol. 14, pp. 212-221, 3 figs. (incl. map), September, 1927.

5. Corrosion and corrasion on Barton Creek, Austin, Texas: Jour. Geology, vol. 35, no. 7, pp. 631-638, 7 flgs., October-November, 1927.

6. (and King, Robert E.). The Pennsylvanian and Permian stratigraphy of the Glass Mountains: Texas, Univ., Bull. no. 2801, pp. 109-145, 2 figs., 3 pls. (map and sections), 1928.

King, Robert E. See King, Philip B., 6.

KIrby, Grady. See Dawson, 1.

Kirk, Charles Townsend.

1. Notes on Sequoyah County, Oklahoma: Am. Assoc. Petroleum Geologists, Bull., vol. 5, no. 4, p. 503, July-August, 1921.

2. (and Weirich, T. E.). Steep subsurface folds versus faults: Geol. Soc. America, Bull., vol. 38, no. 4, pp. 577-589, 7 figs., December 30, 1927 ; abstract, no. 1, p. 152, March 30, 1927 ; Pan-Am. Geologist, vol. 47, no. 2, pp. 153-154, March, 1927.

Kirk, Edwin. See also Slocum, 1; Wilson, A. E., 4.

1. Paleozoic glaciation in southeastern Alaska (abstract): Washington Acad. Sci., Jour., vol. 9, no. 4, pp. 107-108, February 19, 1919.

2. Brooksina, a new pentameroid genus from the Upper Silurian of southeastern Alaska: U. S. Nat. Mus., Proc., vol. 60, art. 19, 8 pp., 1 pl., 1922.

3. Harpidium, a new pentameroid brachiopod genus from southeastern Alaska : U. S. Nat. Mus., Proc., vol. 66, art. 32, 7 pp., 2 pls., April 11, 1925.

4. Notes on an early collection of Paleozoic fossils from Ellesmereland: Am. Jour. Sci., 5th ser., vol. 10, pp. 445-447, November, 1925.

5. Cymbidium, a new genus of Silurian pentameroid brachiopods from Alaska: U. S. Nat. Mus., Proc., vol. 69, art. 23, 5 pp., 1 pl., 1926.

6. Pycnodesma, a new molluscan genus from the Silurian of Alaska: U. S. Nat. Mus., Proc., vol. 71, art. 20, 9 pp., 2 pls., 1927.

7. New American occurrence of Stringocephalus: Am. Jour. Sci., 5th ser., vol. 13, pp. 219-222, March, 1927:

8. Macluritella, a new gastropod genus from the lower Ordovician of Coloradio: Am. Jour. Sci., 5th ser., vol. 14, pp. 288-292, 1 pl., October 1927.

9. Pycinodesma, new name for Pycnodesma Kirk not Schrammen: Washington Acad. Sci., Jour., vol. 17, no. 21, p. 543, December 19, 1927.

10. Fossil marine faunas as indicators of climatic conditions: Smithsonian Inst., Ann. Rept., 1927, pp. 299-307, 1928.

11. Bathmopterus, a new fossil gastropod genus from the Silurian of Alaska: U. S. Nat. Mus., Proc., vol. 74, art'. 18, 4 pp., 1 pl., 1928.

Kirk, Stuart Raeburn.

1. Ostracoda from the Trenton limestone of Nashville, Tennessee: Am. Jour. Sci., 5th ser., vol. 16, pp. 410-422, 1 fig., November, 1928. 
Kïirkbride, W. H.

1. The earthquake at Santa Barbara, California, June 29, 1925, as it affected the railroad of the Southern Pacific Company: Seismological Soc. America, Bull., vol. 17, nọ. 1, pp. 1-7, 7 pls., March, 1927.

Lirkham, Virgil Raymond Drexel. See also Laney, 1 ; Piper, 5.

1. Petroleum possibilities of certain anticlines in southeastern Idaho: Idaho. Bur. Mines and Geology, Bull. no. 4, 36 pp., 9 pls. (maps), 1922.

2. Notes on the geology of eastern Bear Lake County, Idaho, with reference to oil possibilities: Idaho, Bur. Mines and Geology, Pamphlet no. 7, 6 pp., November, 1923. [Mimeographed.]

3. Geology and oil possibilities of Bingham, Bonneville, and Caribou counties, Idaho: Idaho, Bur. Mines and Geology, Bull. no. 8, 116 pp., 8 pls. (maps), September, 1924.

4. Phosphate deposits of Idaho and their relation to the world supply: Am. Inst. Min. and Met. Eng., Trans. [preprint], no. 1405, 28 pp., 16 figs., January, 1925; (with discussion), Trans., vol. 71, pp. 308-338, 16 figs., 1925; abstract, Mining and Metallurgy, vol. 6, no. 221, pp. 247-248, May, 1925.

5. Oil possibilities of southeastern Idaho: Mining and Metallurgy, vol. 6, no. 218, pp. 71-74, 5 figs., February, 1925.

6. Some adverse influences of glaciation on mining: Eng. and Min. Jour.Press, vol. 121, no. 26, pp. 1046-1049, 9 figs., June 26, 1926.

7. (and Ellis, Ernest W.). Geology and ore deposits of Boundary County, Idaho: Idaho Bur. Mines and Geology, Bull. no. 10, 78 pp., 13 pls. (inc. maps), November, 1926.

8. Ground water for municipal supply at St. Maries, Idaho: Idaho, Bur. Mines and Geology, Pam. no. 17, 11 pp., 1 pl. (map), November, 1926. [Mimeographed.]

9. A geologic reconnaissance of Clark and Jefferson and parts of Butte, Custer, Fremont, Lemhi, and Madison counties, Idaho: Idaho, Bur. Mines and Geology, Pam. no. 19, 47 pp., 4 pls. (incl. map), January, 1927. [Mimeographed.]

10. Ground water for municipal supply at Potlatch, Idaho: Idaho, Bur. Mines and Geology, Pam. no. 23, 12 pp., 2 pls. (incl. map), June, 1927. [Mimeographed text.]

11. Underground water resources in the vicinity of Orofino, Idaho, and Lapwai, Idaho: Idaho, Bur. Mines and Geology, Pam. no. 24, 17 pp., 3 pls. (incl. maps), July, 1927. [Mimeographed.]

12. Brief papers on geologic field work in Idaho during 1927: Idaho, Bur. Mines and Geology, Pam. no. 29, 15 pp., June, 1928. [Mimeographed.]

Kirkpatrick, Paul.

1. Seismic measurements by the overthrow of columns: Selsmological Soc. America, Bull., vol. 17, no. 2, pp. 95-109, 7 figs., June, 1927.

2. Simple apparatus for seismic measurements: Nat. Research Council, Bul. no. 61 , pp. 91-96, 2 figs., July, 1927.

Kirkpatrick, R. Z.

1. Earthquakes in Panama up to January 1, 1920: Seismol. Soc. America, Bull., vol, 10, no. 3, pp. 121-128, September, 1920.

Kitchin, Finlay Lorimer.

1. The so-called Malone Jurassic formation in Texas: Geol. Mag., vol. 63, pp. 454-469, October, 1926. 
Kite, W. C. See also Aurin, 2.

1. Geology of Kingfisher and Canadian counties: Oklahoma Geol. Survey, Bull. no. 40-0, 13 pp., 2 flgs. and 1 pl. (inel. maps); July, 1927.

Kithil, Karl L.

1. Prospecting by the earth-wave travel method: Eng. and Min. Jour., vol. 122, no. 24, pp. 931-936, 7 figs., December 11, 1926.

Kitson, Howard W. See also Cunningham, 2.

1. Experiments in shear-zone folding (abstract): Geol. Soc. America, Bull., vol. 39, no. 1, pp. 268-269, March 30, 1928.

2. Origin of the folds of Osage County, Oklahoma: Am. Assoc. Petroleum Geologists, Bull., vol. 12, no. 10, pp. 1026-1028, October, 1928.

Kitto, Franklin Hugo.

1. New oil fields of northern Canada: Canada, Dept. of the Interior, Natural Resources Intelligence Branch, 8 pp., map, 1921.

Klem, Mary J.

1. Hambach of the blastolds: Pan-Am. Geologist, vol. 40, no. 1, pp. 32-34, August, 1923.

Klotz, Otto Julius.

1. The present status of the seismological work in the Pacific: Seismol. Soc. America, Bull., vol. 10, no. 4, pp. 300-309, December, 1920.

2. Analysis of earthquake waves: Roy. Soc. Canada, Proc. and Trans., 3d ser., vol. 14, sec. 3 , pp. $47-53,1921$.

3. Status of the seismological work in the Pacific: Pan-Pacific Scientiflc Conference, First, Proc., Bernice P. Bishop Mus., Spec. Pub. no. 7, pt. 2, pp. 397-408, 1921.

Knapp, Arthur.

1. Rock classification from the oil driller's standpoint: Am. Inst. Min. and Met. Eng., Trans., vol. 65, pp. 424-429, 1921 ; Eng. and Min. Jour., vol. 109, pp. 514-516, February, 1920; Boletín del Petróleo, vol. 9, no. 6, pp. 519-533, June, 1820.

2. Technical papers and their presentation: Am. Assoc. Petroleum Geologists, Bull., vol. 12, no. 1, pp. 77-83, January, 1928.

Knapp, George N.

1. The foundry sands of Minnesota: Minnesota Geol. Survey, Bull. no. 18, 105 pp., 13 figs., 1923.

Knappen, Russell Stafford. See also Gould, C. N., 3.

1. Geology and mineral resources of the Dixon quadrangle: Illinois State Geol. Survey, Bull. no. 49, 141 pp., 20 figs., 5 pls. (incl. maps), 1926.

2. James Furman Kemp: Am. Assoc. Petroleum Geologists, Bull., vol. 11, no. 2, pp. 221-222, February, 1927.

Knickerbocker, A. K. See Fettke, 6.

Knight, Cyril Workman. See also Burrows, 1 ; Miller, W. G., 2, 3.

1. (and Burrows, A. G., Hopkins, P. E., and Parsons, A. L.). Abitibi-Night Hawk gold area, District of Timiskaming: Ontario Bur. Mines, 28th Ann. Rept., vol. 28, pt. 2, pp. 1-70, 50 flgs., map, 1919.

2. Occurrence of elaterite, or elastic bitumen, in a fluorite vein at Madoc, Ontario: Canadian Min. Jour. vol. 40, pp. 399-400, June 4, 1918.

3. A new discovery of pitchblende [Butt township, Ontario]: Canadian Min. Jour., vol. 40, p. 772, October 14, 1919. 
Knight, Cyril Workman-Continued.

4. Windy Lake and other nickel areas [Ontario]: Ontario Dept. Mines, 29th Ann. Rept., vol. 29, pt. 1, pp. 193-224, 14 figs., map, 1920.

5. Ben Nevis gold area: Ontario Dept. Mines, 29th Ann. Rept., vol. 29, pt. 3, pp. 1-27, 13 figs., map, 1920.

6. Argónaut gold mine: Ontario Dept. Mines, 29th Ann. Rept., vol. 29, pt. 3, pp. 65-76, 5 figs., map, 1920.

7. Cobalt [Ontario]-its past and future: Eng. and Min. Jour.-Press, vol, 113, no. 18, pp. 761-768, 4 figs., May 6, 1922.

8. The geology of Ontario's iron ores: Canadian Min. Jour., vol. 43, no. 37, p. 625, September 15, 1922. Iron and Steel of Canada, vol. 5, no. 9, pp. 158-159, September, 1922.

9. Lightning River gold area [Ontario]: Canadian Min. Jour., vol. 43, no 41, pp. 695-699, October 13, 1922.

10. The chemical composition of the norite micropegmatite, Sudbury, Ontario, Cänada : Econ. Geology, vol. 18, no. 6, pp. 592-594, September, 1923.

11. Geology of the mine workings of Cobalt and South Lorrain silver areas: Ontario Dept. Mines, 31st Ann. Rept., vol. 31, pt. 2, pp. x-xiv, 1-238, 321-358, 56 figs., and maps, plans, and sections, 1924. [Pp. 189-237 also issued as Bull. no. 48, 1923.]

12. Lightning River gold area: Ontario Dept. Mines, 33d Ann. Rept., vol. 33, pt. 3 , pp. 41-49, 1 pl., 1925.

13. Reminiscences of Willet G. Miller: Canadian Inst. Min. and Met., Bull. no. 157, pp. 534-559, 11 pls. (portr.), May, 1925; Trans., vol. 28, pp. 19-44, 11 pls. (portr.) [1926].

Knight, J. Brōokes.

1. Some Pennsylvanian ostracods from the Henrietta formation of eastern Missouri: Jour. Paleontology, vol. 2, no. 3, pp. 229-267, 5 pls., September, 1928.

2. Some Pennsylvanian ostracods from the Henrietta formation of eastern Missouri : Jour. Paleontology, vol. 2, no. 4, pp. 318-337, 2 pls., December, 1928.

Knight, -Nicholas. . See also Hendricks 1; Reed, 1.

1. A chemical study of-dolomites: Iowa Acad. Sci., Proc. 1921, vol. 28, pp. 37-45. [1923].

2. Iowa glass sand (abstract) : Pan-Am. Geologist, vol. 46, no. 5, pp. 402-403, December, 1926.

3. Towa glass sands: Pan-Am. Geologist, vol. 47, no. 4, pp. 279-280, May, 1927.

Knight, Samuel Howell. See also Kemp, 21.

1. Eolian abrasion of quartz grains (abstract) : Geol. Soc. America, Bull., vol. 35, no. 1, pp. 107-108, March 30, 1924; Pan-Am. Geologist, vol. 41 , no. 2 , p. 153, March, 1924.

2. A short study in geology: Midwest Review, vol. 9, no. 1, pp. 3-4, 29, January, 1928.

Kniker, Hedwig Thusnelda. See also Applin, E. R., 1; Beede, 9.

1. Comanchean and Cretaceous Pectinidae of Texas: Texas, Univ., Bull., no. 1817, 56 pp., 10 pls., March 20, 1918.

$4096-31 \div 23$ 
Kinopf, Adolph.

1. Tin in 1918: U. S. Geol. Survey, Mineral Resources, 1918, pt. 1, pp. 23-31, September 9, 1919.

2. Present tendencies in geology; metalliferous deposits: Econ. Geology, vol. 14, no. 7, pp. 543-554, November, 1919 . Abstract, Washington Acad. Sci., Jour., vol. 9, no. 15, p. 543, September 19, 1919.

3. The Divide silver district, Nevada: U. S. Geol. Survey, Bull. 715, pp. 147170, 1 fig., 1 pl. (map), February 12, 1921. Abstract, Washington Acad. Sci., Jour., vol. 11, no. 18 pp. 441-442, November 4, 1921.

4. Ore deposits of Cedar Mountain, Mineral County, Nevada: U. S. Geol. Survey, Bull. 725, pp. 361-382, 5 figs., November 19, 1921.

5. The Candelaria silver district Nevada: U. S. Geol. Survey, Bull. 735, pp. 1-22, 2 figs., January 20, 1922.

6. (and Johnson, B. L.). Tin in 1919: U. S. Geol. Survey, Mineral Resources, 1919, pt. 1, pp. 747-750, January 26, 1922.

7. Geology and ore deposits of the Rochester district, Nevada: U. S. Geol. Survey, Bull. 762, 78 pp., 5 figs., 4 pls. (incl. map), 1924.

8. Bibliography of isostasy. $39 \mathrm{pp}$., issued in mimeographed form by the Division of Geology and Geography, National Research Council, Washington, D. C., 1924.

9. Discovery of andalusite in California: Eng. and Min. Jour.-Press, vol. 120, no. 20 , p. 778 , November $14,1925$.

10. Recent developments in the Aspen district, Colorado: U. S. Geol. Survey, Bull. 785, pp. 1-28, 6 figs., 1 pl. (map), March 30, 1926.

Knopf, Eleanora Bliss. See also Jonas, 1, 6.

1. Some problems of international readjustment of mineral supplies as indicated in recent foreign literature: Econ. Geology, vol. 14, no. 2, pp. 147-171, 5 figs., March-April, 1919. Abstract, with discussion by E. S. Bastin, Geol. Soc. America, Bull., vol. 30, pp. 101-102, March 31, 1919.

2. Chrome ores of southeastern Pennsylvania and Maryland: U. S. Geol. Survey, Bull 725, pp. 85-99, 1 fig., August 4, 1921. Abstract by R. W. Stone, Washington Acad. Sci., Jour., vol .11, no. 20, p. 494, December 4, 1921.

3. (and Jonas, Anna I.). Stratigraphy of the crystalline schists of Pennsylvania and Maryland: Am. Jour. Sci., 5th ser., vol. 5, pp. 40-62, 3 figs., January, 1923 ; abstract, with discussion by Florence Bascom and G. H. Ashley : Geol. Soc. Am., Bull., vol. 33, no. 1, pp. 110-111, March 31, 1922.

4. Relation of former drainage channels to the topography of eastern Pennsylvania and Maryland (abstract) : Geol. Soc. America, Bull., vol. 35, no. 1, p. 77, March 30, 1924; Pan-Am. Geologist, vol. 41, no. 2. p. 141, March, 1924.

5. Correlation of residual erosion surfaces in the eastern Appalachian high. lands: Geol. Soc. America, Bull., vol. 35, no. 3, pp. 633-668, 15 figs. September 30, 1924.

6. Some results of recent work in the southern Taconic area: Am. Jour. Scl. 5th ser., vol. 14, pp. 429-458, 7 figs., December, 1927.

Knowiton, Frank Hall, 1860-1926. See also Manson, 2.

1. Relations between the Mesozoic floras of North and South America: Geol. Soc. America, Bull., vol. 29, no. 4, pp. 607-614, December 30, 1918.

2. A catalogue of the Mesozoic and Cenozoic plants of North America: U. S. Geol. Survey, Bull. 696, 815 pp., 1919. 
Knowlton, Frank Hall-Continued.

3. Evolution of geologic climates: Geol. Soc. America, Bull., vol. 30, no. 4, pp. 499-566, December 30, 1919; abstract, with title, Climates of the past, vol. 30, no. 1, p. 151, March 31, 1919.

4. A dicotyledonous flora in the type section of the Morrison formation: Am. Jour. Sci., 4th ser., vol. 49, pp. 189-194, March, 1920.

5. Are the Lance and Fort Union formations of Mesozoic time?: Science, new ser., vol. 53, pp. 307-308, April 1, 1921.

6. Criteria for determination of climate by means of fossil plants: Geol. Soc. America, Bull., vol. 32, no. 3, pp. 353-358, September 1, 1921.

7. Further remarks on the evolution of geologic climates: Am. Jour. Sci., 5th ser., vol. 2, pp. 187-196, October, 1921.

8. The Laramie flora of the Denver Basin; with a review of the Laramie problem: U. S. Geol. Survey, Prof. Paper 130, 175 pp., 1 fig., 38 pls., 1922.

9. Floral continuity in Lance and Union sections: Pan-Am. Geologist, vol, 37, no. 1, pp. 67-68, February, 1922.

10. A fossil dogwood flower [Cornus speciosissima, Converse County, Wyoming] : Am. Jour. Sci., 5th ser., vol. 4, pp. 136-138, 2 figs., August, 1922.

11. Revision of the flora of the Green River formation with descriptions of new species: U. S. Geol. Survey, Prof. Paper 131, pp. 133-182, 5 pls., March 30, 1923.

12. Fossil plants from the Tertiary lake beds of south-central Colorado: U. S. Geol. Survey, Prof. Paper 131, pp. 183-197, 4 pls., March 31, 1923.

13. Flora of the Animas formation: U. S. Geol. Survey, Prof. Paper 134, pp. 71-98, 13 pls., 1924.

14. The possible origin of the angiosperms: Science, new ser., vol. 61, pp. 568-570, May 29, 1925.

15. Evidence of fossil plants to climatic zoning in Mesozoic times (abstract) : Pan-Am. Geologist, vol. 44, no. 1, pp. 69-70, August, 1925.

16. Flora of the Latah formation of Spokane, Washington, and Coeur d'Alene, Idaho: U. S. Geol. Survey, Prof. Paper 140, pp. 17-81, 24 pls., February 19, 1926.

17. Plants of the past; a popular account of fossil plants. xix, 275 pp., 90 figs., Princeton, Princeton University Press, 1927.

18. The fossil forests of the Yellowstone National Park: U. S., Nat. Park Service, 29 pp., 15 figs., 1928.

Knox, Henry H. See also Feilding, 1.

1. An effect of climatic change on the superficial alteration of ore deposits: Econ. Geology, vol. 17, no. 8, pp. 654-661, December, 1922.

Knox, John Knox.

1. Geology of the serpentine belt, Coleraine sheet, Thetford-Blake Lake mining district, Quebec. 67 pp., 3 pls., map, Thesis, University of Chicago, 1918.

2. Geology of New Mexico as an index to probable oil resources: Am. Assoc. Petroleum Geologists, Bull., vol. 4, no. 1, pp. 95-112, 1920.

3. Probable oil resources of New Mexico: Eng. and Min. Jour., vol. 110, no. 2, pp. 69-74, July 10, 1920 .

Koch, Lauge.

1. Stratigraphy of northwest Greenland: Dansk geol. Foren., Meddel., Bd. 5, no. 17, 78 pp., 12 figs., 1 pl., map, 1920. 
Koch, Lauge-Continued.

2. Some new features in the physiography and geology of Greenland: Jour. Geology, vol. 31, no. 1, pp. 42-65, 8.figs., January-February, 1923.

3. Preliminary report upon the geology of Peary Land, Arctic Greenland: Am. Jour. Sci., 5th ser., vol. 5, pp. 189-199, 2 figs. (maps), March, 1923.

4. The geology of north Greenland: Am. Jour. Sci., 5th ser., vol. 9, pp. 271286, 5 figs., April, 1925.

5. Ice cap and sea ice in north Greenland: Geog. Rev., vol. 16, no. 1, pp. 98-107, 2 figs., January, 1926.

6. A new fault zone in northwest Greenland: Am. Jour. Sci., 5th ser., vol. 12, pp. 301-310, 2 figs., October, 1926.

7. Two recent journeys on the coast of eastern Greenland, with appendix Note on the geology of eastern Greenland: Geog. Jour., vol. 71 no. 1, pp. 1-15, 8 pls., January, 1928.

8. Preliminary statement of the stratigraphy of east Greenland: Am. Jour. Sci., 5th ser., vol. 15, pp. 346-349, April, 1928.

9. Contributions to the glaciology of north Greenland: Meddel. om Groenland, Bd. 65, pp. 181-464, 140 figs., 6 pls., 1928.

Kock, W. See also Zuschlag, 1.

Koenigsberger, J. G.

1. Field observations of electrical resistivity and their practical application:

Am. Inst. Min. and Met. Eng., Tech. Pub. no. 129, 17 pp., 5 figs., November, 1928.

Koschmann, A. H.

1. Oil and gas in Oklahoma: geology of Payne County: Oklahoma Geol. Survey, Bull. no. 40-X, 13 pp., 4 -figs., 1 pl., January, 1928.

Kotick, A. F.

1. The Rincon oil field [California] : Oil Bull., vol. 14, no. 10, pp. 1033-1037, 7 figs., October, 1928.

Kovarik, A. F.

1. (and McKeehan, L. W.). Radioactivity [VII, Radioactivity in geology and cosmology, pp. 135-152] : Nat. Research Council, Bull., vol. 10, pt. 1, no. 51, 203 pp., 1925.

Lirampert, E. W.

1. The oil fields of the Rawlins-Lost. Soldier district, Wyoming: Am. Assoc. Petroleum Geologists, Bull., vol. 7, no. 2, pp. 131-146, 4 figs., MarchApril, 1923.

2. Reported oil strikes in Hanna Basin and Red Desert, Wyoming: Am. Assoc. Petroleum Geologists, Bull., vol. 7, no. 5, pp. 575-576, September-October, 1923.

Kratzert, J. See also Wittich, 14, 15, 20, 22, 26.

1. Einige neue Mineralvorkommen im Granit von Guadalcazar, Mexiko: Centralbl. Mineralogie, no. 18, pp. 561-564, September 15, 1922. Algunos nuevos hallazgos de minerales en el granito de Guadalcazar, S. L. P.: Soc. cient. "Ant. Alz." Mem. y Rev., t. 46, nos. 1-2, pp. 89-94, February, 1926.

Kraus, Edward Henry.

1. The new mineralogical laboratory at the University of Michigan: Am. Mineraloglst, vol. 4, no. 5, pp. 45-56, 4 figs., 2 pls., May, 1919. 
Kraus, Edward Henry-Continued.

2. (and.Hunt, Walter Fred). Mineralogy; an introduction to the study of minerals and crystals. xiv, 561 pp., 696 figs., New York, McGrawHill Book Company, 1920.

3. The future of mineralogy in America: Am. Mineralogist, vol. 6, no. 2, pp. 23-34, February, 1921. Science, new ser., vol. 53, pp. 219-226, March 11, 1921.

4. Some unusual speciments of "float" copper [from Michigan]: Am. Mineralogist, vol. 9, no. 2, pp. 23-26, 6 figs., February, 1924.

5. (and Holden, Edward Fuller). Gems and gem materials. vii, 222 pp., 256 figs., New York, McGraw-Hill Book Company, 1925.

6. Edward Fuller Holden: Science, new ser., vol. 63, pp. 84-85, January 22, 1926.

7. Memorial of Edward Fuller Holden: Am. Mineralogist, vol. 11, no. 3 pp. 57-59, portr., March, 1926.

8. (and Hunt, Walter Fred). Mineralogy; an introduction to the study of minerals and crystals. .2d ed., 604 pp., 766 .figs., New York, McGraw-Hill Book Company, 1928.

Krejci, Milo W.

1. Ancient man in Nevada: Eng. and Min. Jour., vol. 122, no. 3, p. 103. July $17,1926$.

Krey, Frank.

1. Geology, distribution, and occurrence of the potash-bearing shale of Union County : Illinois, Univ., Agr. Exper. Sta., Bull. no. 232, pp. 237-243, 1 fig., March, 1921.

2. Structural reconnaissance of the Mississippi Valley area from Old Monroe, Missouri, to Nauroo, Illinois: Illinois State Geol. Survey, Bull. no. 45, 86 pp., 18 pls. (incl. map), 1924; Missouri Bur. Geology and Mines, 2d ser., vol. 18, 86 pp., 18 pls. (incl. map), 1924.

3. (and Lampar, J. E.). Limestone resources of Illinois: Illinois State Geol. Survey, Bull. no. 46, 392 pp., 70 figs., 1925.

Krueger, Hans.

1. Die Hessische Grönland expedition, 1925; geologische Ergebnisse: Peter manns Mitt., Jg. 72, II. 5-6, pp. 108-110, 1926.

Kümmel, Henry Barnard. See also Foye, 5 ; Miller, B. L., 9.

1. Report of the State geologist: New Jersey, Dept. Conservation and Development, Ann. Rept., 1918, pp. 29-62, 2 pls., 1919.

2. Report of the State geologist: New Jersey, Dept. Conservation and Development, Ann. Rept., 1919, pp. 31-53, 1919.

3. Report of the State geologist: New Jersey, Dept. Conservation and Development, Ann. Rept., 1920, pp. 33-78, Trenton, N. J., 1920.

4. Report of the State geologist: New Jersey, Dept. Conservation, Ann. Rept., 1921, pp. 27-52, 2 pls., Trenton, 1921.

5. Report of the State geologist [1921-23]: New Jersey, Dept. Conservation, Ann. Rept. 1922-23, pp. 21-36, 3 pls., 1923.

6. Memorial of John Conover Smock: Geol. Soc. America, Bull., vol. 38, no. 1, pp. 93-100, portr., March 30, 1927.

7. State geological surveys: Sci. Monthly, vol. 25, no. 5, pp. 445-450, November, 1927.

8. Memorial of Mayville W. Twitchell: Geol. Soc. America, Buli., vol. 39. no. 1, pp. 47-51, portr., March 30, 1928. 
Kuhn, Olin R.

1. How much coal is left in Pennsylvania?: Coal Age, vol. 27, no. 6, pp. 209214, 6 figs., February 5, 1925.

2. Iron ore deposits of Cuba : Eng. and Min. Jour.-Press, vol. 121, no. 15, pp. 607-610, 5 figs., April 10, 1926.

Kunz, George Frederick.

1. Reminiscences of William E. Hidden: Am. Mineralogist, vol. 4, nos. 8, 10, 11, pp. 100,128-129, 142-145, August, October, and November, 1919.

2. Alfred Joseph Moses; a biographical sketch: Mining and Metallurgy, no. 162, pp. 20-21, portr., June, 1920.

Kupferbiirger, w.

1. Danburite from La Sirena, near Zimapan, Mexico: Am. Mineralogist, vol. 10, no. 1, pp. 14-15, January, 1925.

Labbe, Charles.

1. The placers of the Johnnie district, Nevada: Eng. and Min. Jour., vol. 112, no. 23, pp. 895-896, December 3, 1921.

Lacroix, A.

1. Les caractéristiques lithologiques des Petites Antilles: Soc. Géol. Belgique, Livre Jubilaire, 1874-1924, t. 1., pp. 385-405 [n. d., 1928?].

Ladd, George E.

1. Landslides and their relation to highways; a report of observations made in West Virginia and Ohio to determine the cause of slides and devise means of control : Public Roads, vol. 8, no. 2, pp. 21-31, 35, April, 1927.

Ladd, Harry S. See also Stainbrook, 2, 3 ; Thomas, A: O., 22; Wentworth, 33. 1. Maquoketa shales in Jackson County (abstract) : Pan-Am. Geologist, vol. 42, no. 5, pp. 377-378, December, 1924.

2. Depauperate fauna of the Maquoketa (abstract): Geol. Soc. America, Bull., vol. 36, no. 1, p. 228, March 30, 1925.

3. Notes on the geology of Jackson County, Iowa: Iowa Acad. Sci., Proc., vol. 31, pp. 341-345 [1926?].

4. Maquoketa faunas (abstract) : Pan-Am. Geologist, vol. 49, no. 3, p. 227, April, 1928; Geol. Soc. America, Bull, vol. 39, no. 1, pp. 291-292, March 30, 1928.

Ladoo, Raymond Bardeen.

1. Bauxite; occurrence, mining, and uses: Eng. and Min. Jour.-Press, vol. 114, no. 19, pp. 805-809, 1 fig., November 4, 1922.

2. Talc and soapstone; their mining, milling, products, and uses: U. S., Bureau of Mines, Bull. 213, 133 pp., 23 figs., 15 pls., 1923.

3. Barytes; occurrence, mining, uses: Eng. and Min. Jour.-Press, vol. 115, no. 7, pp. 319-324, 8 figs., February 17, 1923.

4. Nonmetallic minerals; occurrence, preparation, utilization. 686 pp., 51 figs., McGraw-Hill Book Company, New York, 1925.

5. Fluorspar, its mining, milling, and utilization, with a chapter on cryolite: U. S. Bur. Mines, Bull. 244, 185 pp., 26 figs., 1927.

LaForge, Laurence. See also Hull, 1.

1. [The Fall Line] : Min. Congress Jour., vol. 5, no. 8, p. 272, August, 1919.

2. [The use of the words talus and shingle] (abstract): Washington Acad. Sci., Jour., vol. 9, no. 16, pp. 500-501, October 4, 1919. 
LaForge, Laurence-Continued.

3. The fossil swamp deposit at the Walker Hotel site, Connecticut Avenue and De Sales Street, Washington; D. C.; the geographic and historical evidence: Washington Acad. Sci., Jour., vol. 14, no. 1, pp. 33-41, 2 figs., January 4, 1924.

4. (and Cooke, Wythe, Keith, Arthur, and Campbell, Marius). Physical geography of Georgia; with an introduction by S. W. McCallie: Georgia Geol. Survey, Bull. no. 42, 189 pp., 6 figs., 43 pls., 1925.

Lagler, Carl. See Staub, Walther, 1.

Lago, Manuel García. See also Allende, 4.

1. Minas de "Asiento Viejo"; estudio del yacimiento de la mina "Celia Gregoria": Cuba, Dirección de montes y minas, Bol. minas, no. 8, pp. 57-60, August, 1925.

I a Gorce, John Oliver.

1. Pirate rivers and their prizes: Nat. Geog. Mag., vol. 50, no. 1, pp. 87-132, 44 figs., July, 1926.

Lahee, Frederic Henry. See also Collingwood, 1; Foley, 1; Lupton, 1; Mills,

R. V. A., 5 ; Pratt, W. E., $7,9$.

1. Graphic determination of dip components where dips are measured in feet per mile: Econ. Geology, vol. 14, no. 2, pp. 176-178, 1 fig., MarchApril, 1919 ; no. 3, pp. 262-263, May, 1919.

2. Geologic factors in oil prospecting: Econ. Geology, vol. 14, no. 6, pp. 480 490, 5 figs., September-October, 1919.

3. The barometric method of geologic surveying for petroleum mapping: Econ. Geology, vol. 15, no. 2, pp. 150-169, 8 figs., March, 1920.

4. Relation of oil pools to ancient shore lines (discussion) : Econ Geology, vol. 15, no. 4, pp. 350-354, June, 1920.

5. Use of the terms "erosion," "denudation," "corrasion," and "corrosion": Science, new ser., vol. 54, p. 13, July 1, 1921.

6. Field methods in petroleum geology. In Day, David T., A handbook of the petroleum industry, vol. 1, pp. 167-201, 30 figs., 1922.

7. Temperature of fluids in wells: Am. Assoc. Petroleum Geologists, Bull., vol. 6, no. 6, pp. 547-548, November-December, 1922.

8. Field geology. Second edition, 649 pp., 457 figs., 1 pl., New York, McGrawHill Book Company, 1923.

9. The Currie field, Navarro County, Texas: Am. Assoc. Petroleum Geologists, Bull., vol. 7, no. 1, pp. 25-36, 8 figs., January-February, 1923.

10. Sericitization and dolomitization compared with the fixed carbon ratio of coal as indices of metamorphism in oil-bearing formations: Am. Assoc. Petroleum Geologists, Bull., vol. 7, no. 3, pp. 291-293, MayJune, 1923.

11. The New Richland [oil] field, Navarro County, Texas: Mining and Metallurgy, vol. 5, no. 212, pp. 379-380, August, 1924.

12. Note on the origin of petroleum: Am. Assoc. Petroleum Geologists, Bull., vol. 8, no. 5, pp. 669-671, 2 figs., September-October, 1924.

13. Structural and stratigraphic data of northeast Texas: Econ. Geology, vol. 19, no. 6, pp. 563-565, September-October, 1924.

14. The education of the geologist: Econ. Geology, vol. 19, no. 7, pp. 684-686, November, 1924.

15. The permeability of rocks: Econ. Geology, vol. 19, no. 8, pp. 768-769, December, 1924. 
Lahee, Frederic Henry-Continued.

16. The Wortham and Lake Richland faults .[Texas]: Am. Assoc. Petroleum Geologists, Bull., vol. 9 , no. 1, pp. 172-175, 2 figs., January-February, 1925.

17. Comparative study of well logs on the Mexia type of structure: Am. Inst. Min. and Met. Eng., Trans. [preprint], no. 1396, 21 pp., 16 figs., February, 1925; (with discussion), Trans., vol. 71, pp. 1329-1350, 16 figs., 1925 ; abstract, Mining and Metallurgy, vol. 6, no. 220, pp. 203-205, 1 fig., April, 1925.

18. The rate of solution of gypsum : Jour. Geology, vol. 33, no. 5, pp. 548-549, July-August, 1925.

19. Further notes on the origin and nature of the Currie structure, Navarro County, Texas: Am. Assoc. Petroleum Geologists, Bull., vol. 10, no. 1, pp. 61-71, 6 figs., January, 1926.

20. Clay Creek dome, Washington County, Texas: Am. Assoc. Petroleum Geologists, Bull., vol. 12, no. 12, pp. 1166-1167, December, 1928.

Laird, George A.

1. Wildcat drilling in Warren County, Kentucky: Eng. and Min. Jour., vol. 109, p. 1031, May 1, 1921.

Laizure, C. McK.

1. Bibliography of limestone deposits in California : California State Min. Bur., Mining in California, vol. 18, no. 12, pp. 751-754, December, 1922.

Lajous, Luis $\mathbf{F}$.

1. Informe sobre los terrenos petroliferos de la región Tabasco-Chiapas, en las zonas de Pichucalco, Macuspana, El Salto, La Trinidad, San Pedro Sabana, Palenque, Montecristo y Tenosique: Bol. Petróleo, Mexico, vol. 16, no. 5, pp. 305-324, 1 pl. (map), November, 1923.

2. Condiciones geológicas necesarias para la formación y conservación del petróleo: Bol. Petróleo, Mexico, vol. 6, pp. 357-368, December, 1923.

3. La formaciōn de los domos salinos en la costa del golfo: Bol. Petróleo, vol. 26, no. 3, pp. 278-288, September, 1928.

Lake, Francis Wilbur. See Phelps, 1.

Lakes, Arthur.

1. The Hahn's Peak mining region, Routt County, Colorado: Mountain States Mineral Age, vol. 12, no. 7, pp. 10-14, 6 figs., July 1927. Reprinted from Mining Science, vol. 60, pp. 292-296, September 30, 1909.

Lamar, John Everts. See, also Krey, 3.

1. Notes on the Waterloo anticline: Illinois Acad. Sci., Trans., vol. 15, pp. 398-404 [1923].

2. The use of the microscope in the study of subsurface stratigraphy: Illinois State Acad. Sci., Trans., vol. 16, pp. 353-358, 1923.

3. Geology and mineral resources of the Carbondale quadrangle: Illinois State Geol. Survey, Bull. no. 4S, 172 pp. 28 figs., 5 pls. (incl. maps), 1925.

4. Glacial phenomena in the vicinity of Carbondale: Illinois State Acad. Sci., Trans., vol. 17, pp. 181-186, 1925.

5. The oolite of the Ste. Genevieve formation: Illinois State Acad. Sci., Trans., vol. 18, pp. 409-413, 5 pls., 1925. 
I.amar, John Everts-Continued.

6. Preliminary report on the economic mineral resources of Calhoun County: Illinois State Geol Survey, Rept. Investigations no. 8, 21 pp., 1 fig., 1926.

7. Sedimentary analysis of the limestones of the Chester series: Econ. Geology, vol. 21, no. 6, pp. 578-585, 3 figs., September, 1926.

8. New facts concerning the St. Peter sandstone of Illinois : Geol. Soc. America, Bull., vol. 38, no. 3.; pp. 459-468, 7 figs.; September, 1927 ; abstract, no. 1, p. 147, March 30, 1927 ; Pan-Am. Geologist, vol. 47, no. 2, p. 152, March, 1927.

9. Geology and economic resources of the St. Peter sandstone of Illinois; Inlinois State Geol. Survey, Bull. no. 53, 175 pp., 43 figs., 3 pls. (map), 1928.

10. Preliminary report on the fuller's earth deposits of Pulaski County : Illinois State Geol. Survey Rept. of Investigations no. 15, 31 pp., 8 figs. (incl. map), 1928 .

11. Cretaceous, Tertiary and Quaternary formations of extreme southern Illinois (abstract): Geol. Soc: America, Bull., . vol. 39, no. 1, pp. 203-204, March 30, 1928; Pan-Am. Geologist, vol. 49, no. 2, p. 155, March, 1928.

12. Karst topography and sanitary engineering at Alton, Illinois: Illinois State Acad. Sci., Trans., vol. 20, pp. 261-264, 1 fig., March, 1928.

13. A study of the core of the Yanaway well no. 33 in the Siggins pool: Illinois State Geol. Survey, Press Bull. Ser., Illinois Petroleum, no. 15, pp. 1-8, 1 fig., May 12, 1928.

Lamb, Horace.

1. The constitution of the earth: Science, new ser., vol. 62, pp. 229-236, September 11, 1925.

2. Physical constitution of the earth: Pan-Am. Geologist, vol. 44, no. 5, pp. 345-356 December, 1925.

Lambart, H. F. J.

1. Notes on the Klutlan Glacier and glacier's of the Pacific coast ranges through Canada and Alaska: Canadian Alpine Jour., vol. 11, pp. 147-155, 3 pls., 1920.

Lambe, Lawrence Morris, 1863-1919.

1. The hadrosaur Edmontosaurus from the Upper Cretaceous of Alberta: Canada, Geol. Survey, Mem. 120, 79 pp. 39 figs., 1920.

2. Description of a new genus and species (Panoplosaurus mirus) of an armored dinosaur from the Belly River beds of Alberta: Roy. Soc. Canada, Proc. and Trans., 3d ser., vol. 13 sec. 4, pp. 39-50, 12 pls., 1920.

Lambert, G. S. See Clapp, C. H., 2 ; Wilson, R. A., 5.

Lämbert, Jules.

1. Nouvelles observations sur quelques échinides néogènes de l'île d'Anguilla : Annals and Mag. Nat. Hist., 9th ser., vol. 9, pp. 587-596, 1 pl., May, 1922.

2. Note sur quelques échinides recueillis par Mr. Walther Staub dans lè Néogène de l'est du Mexique: Eclogae geologicae Helvetiae, vol. 21, 10. 1; pp. 272-283, $\theta$ flgs., 1 pl., 1928.

Lambert, Walter Davis.

1. The internal constitution of the earth: Washington Acad. Sci., Jour., vol. 10, no. 5, pp. 122-143, March 4, 1920. 
Lambert, Walter Davis-Continued.

2. Elastic yielding of the earth's crust under a load of sedimentary deposits: Geol. Soc. America, Bull., vol. 34, no. 2, pp. 305-308, June 30, 1923.

3. The mechanics of the Taylor-Wegener hypothesis of continental migration (abstract): Washington Acad. Sci., Jour., vol. 13, no. 20, pp. 448-450, December 4, 1923.

4. Forces tending to cause movements in the earth's crust (abstract) : Nat Research Council, Bull., vol. 7, pt. 5, no. 41, p. 93, January, 1924.

Lamborn, Raymond E. See also Stout, 5.

1. The Olentangy shale in southern Ohio: Jour. Geology, vol. 35, no. 8, pp. 708-722, 1 fig. (map), November-December, 1927.

Land, Alfred C. See Fairbanks, 12.

Landell-Mills, Thomas.

1. (and others). The Carboniferous rocks of the Deer Lake district of Newfoundland (abstract with discussion): Geol. Soc. London, Abstr. Proc., no. 1083, pp. 53-54, March 2, 1922.

Landero, Carlos F. de.

1. Correlación de las formaciones diatomíferas y los yacimientos de petróleo de Alta California: Soc. cient. "Antonio Alzate," Mem. y Rev., t. 43, nos. 1-2, pp. 95-101, January-February, 1924. Bol. petróleo, Mexico, vol. 16, no. 3, pp. 158-161, September, 1923; vol. 19, no. 3, pp. 139-142, March, 1925.

Landes, Henry.

1. History of geology in the State of Washington: Washington Hist. Quart., vol. 19, no. 4, pp. 243-249, October, 1928.

Landes, Kenneth K. See also Moore, R. C., 37.

1. The paragenesis of the granite pegmatites of central Maine: Am. Mineralogist, vol. 10, no. 11, pp. 355-411, 5 figs., 7 pls., November, 1925.

2. Geology of the Knik-Matanuska district, Alaska: U. S. Geol. Survey, Bull. 792, pp. 51-72, 1 pl. (map), 1927.

3. A petrographic study of the pre-Cambrian of Kansas: Am. Assoc. Petroleum Geologists, Bull., vol. 11, no. 8, pp. 821-824, August, 1927.

4. Volcanic ash in Kansas: Geol. Soc. America, Bull., vol. 39, no. 4, pp. 931940, 3 figs., December, 1928; abstract, no. 1, p. 166, March 30, 1928; Pan-Am. Geologist, vol. 49, no. 1, p. 75, February, 1928.

5. Volcanic-ash resources of Kansas: Kansas State Geol. Survey, Bull. 14, 58 pp., 1 fig., 5 .pls., April 15, 1928.

6. Sequence of mineralization in the Keystone, South Dakota, pegmatites: Am. Mineralogist, vol. 13, no. 10 , pp. 519-530, no. 11, pp. 537-558, 5 figs., October and November, 1928.

7. Lithium, caesium, and rubidium : Foote-Prints, vol. 1, no. 3, pp. 5-17, 1928.

Landon, Robert E.

1. Roemerite from California: Am. Mineralogist, vol. 12, no. 7, pp. 279-283, 2 figs., July, 1927.

Lane, Alfred Church. See also Hotchkiss, 7 ; Rogers, A. F., 7; Stauffer, 9; White, I. C., 2.

1. Table for determining common rocks: Lefax, Philadelphia, January, 1919.

2. Tables [I-XIX] for the recognition of minerals: Lefax, Philadelphia; 1919-22 (?). [Only part seen.] 
Lane, Alfred Church-Continued.

3. Geological column; France, Britain, Germany, United States: Lefax, Philadelphia, October, 1919.

4. Correlation of formations of Huronian group in Michigan (discussion of paper by R. C. Allen) : Am. Inst. Min. and Met. Eng., Bull. no. 156, pp. 3113-3115, December, 1919.

5. Till argillites (pellodites), pre-Cambrian, Permian, and Pleistocene (abstract) : Geol. Soc. America, Bull., vol. 31, no. 1, p. 125, March $31,1920$.

6. Accordant levels in the White Mountains (abstract): Geol. Soc. America, Bull., vol. 32, no. 1, p. 53, March 31, 1921.

7. White Mountain physiography: Am. Jour. Sci., 5th ser., vol. 1, no. 4, pp. 349-354, April, 1921.

8. Segregation granites: Jour. Geology, vol. 30, no. 2, pp. 162-166, FebruaryMarch, 1922.

9. Is the present the first of a new chapter? (abstract) : Geol. Soc. America, Bull., vol. 33, no. 1, p. 141, March 31, 1922.

10. Weight of sedimentary rocks per unit volume: Geol. Soc. America, Bull., vol. 33, no. 2, pp. 353-369, 1 fig., June 30, 1922.

11. Keweenaw geothermal gradients and the ice age (abstract): Geol. Soc. America, Bull., vol. 34, no. 1, p. 86, March 30, $\mathbf{9 2 3 .}$

12. Solvents and precipitants in the Michigan copper lodes (abstract) : Geol. Soc. America, Bull., vol. 34, no. 1, p. 100, March 30, 1923.

13. [Terms for shapes of valleys] : Jour. Geology; vol. 31, no. 4, p. 348, MayJune, 1923.

14. The temperature of mines: Science, new ser., vol. 57, p. 142, August 24, 1923.

15. Geotherms of Lake Superior copper country: Geol. Soc. America, Bull,, vol. 34, no. 4, pp. 703-720, 1 pl., December 30, 1923.

16. The importance of water analyses: Am. Assoc. Petroleum Geologists, Bull., vol. 8, no. 1, pp. 87-88, January-February, 1924.

17. Memorial of Marshman E. Wadsworth: Geol. Soc. America, Bull., vol. 35, no. 1, pp. 15-25, portr., March 30, 1924.

18. Native silver in an iron mine (abstract): Geol. Soc. America, Bull., vol. 35 , no. 1 , pp. 127-128, March 30, 1924; Pan-Am. Geologist, vol. 41 , no. 2 , p. 160 , March, 1924.

19. The geologic time scale: Eng. and Min. Jour.-Press, vol. 118, no. 20, p. 778 , Nevember $15,1924$.

20. Measurement of geological age by atomic disintegration: Lake Superior Min. Inst., Proc. 24th Ann. Meeting, vol. 24, pp. 106-116, 1925; abstract, Pan-Am. Geologist, vol. 45, no. 2, pp. 157-158, March, 1926.

21. Laurentian problems and atomic disintegration: Canadian Inst. Min. and Met., Bull. no. 157, pp. 484-508, May, 1925 ; Trans., vol. 28, pp. 102129 [1926].

22. On the relative ages of pre-Cambrian rocks: Canadian Min. Jour., vol. 46, no. 24, pp. 579-581, June 12, 1925.

23. The age of the earth and the oceans (abstract) : Washington Acad. Sci., Jour., vol. 15, no. 13, pp. 304-305, July 19, 1925.

24. Graphs of rock analyses (abstract) : Geol. Soc. America, Bull., vol. 37, no. 1, p. 148, March 30, 1926 ; Pan-Am. Geologist, vol. 45, no. 1, p. 96, February, 1926.

25. Geologic age calculations: Science, new ser., vol. 64, p. 119, July 30, 1928. 
Lane, Alfred Church-Continued.

26. Nathaniel Southgate Shaler (1841-1906): Am. Acad. Arts and Sci., Proc., vol. 61, pp. 557-561, November, 1926.

27. Calcium chloride waters, connate and diagenetic: Am. Assoc. Petroleum Geologists, Bull., vol. 11, no. 12, pp. 1283-1305, December, 1927.

28. Calcium chloride waters (abstract) : Geol. Soc. America, Bull., vol. 38, no. 1, p. 123, March 30, 1927; Pan-Am. Geologist, vol. 47, no. 1. pp. 71-72, February, 1927.

29. Till on overthrust gravels (abstract) : Geol. Soc. America, Bull., vol. 39, no. 1, p. 151, March 30,1928 ; Pan-Am. Geologist, vol. 49, no. 1, p. 67, February, 1928.

30. Geologic age by lead uranium ratios: Science, new ser., vol. 67, p. 631, June 22, 1928.

Lane, H. H.

1. A new rhinoceros from Kansas [Paraphelops rooksensis n. sp.]: Kansas, Univ., Bull., vol. 28, no. 18, Sci. Bull., vol. 17; no. 2, pp. 297-307, 4 pls., September, 1927.

Lane, Laura Lee. See Deussen, 2.

Laney, Francis Baker. See also Bastin, 1; Emmons, W. H., 8; Livingston, 3 ; Piper, 6.

1. (and Kirkham, V. R. D., and Piper, A. M.). Ground water supply at Moscow, Idaho: Idaho, Bur. Mines and Geology, Pamph. no. 8, 13 pp., 2 pls., : Deceinber, 1923. : [Mimeographed.]

Lang, S. S.

1. Porphyry intrusions of the Michigan copper district: Eng. and Min. Jour., vol. 107, p. 452, March 8, 1919.

2. Copper deposits of Lake Superior: Min. and Sci. Press, vol, 121, pp. 407408, September 18, 1920.

Lang, Walter $\mathbf{B}$.

1. Terms of the geologic column; their origin and significance. In The development of the sciences, edited by L. L. Woodruff, pp. 312314, New Haven, Yale University Press, 1923.

2. Potash investigations in 1924: U. S. Geol. Survey, Bull. 785, pp. 29-43, 2 figs., 1 pl., May 20, 1926.

3. Unusual natural gases: Am. Assoc. Petroleum Geologists, Bull., vol. 10, no. 11, pp. 1176-1177, November, 1926.

4. A correction for well logs: Am. Assoc. Petroleum Geologists, Bull., vol. 11, no. 10, pp. 1116-1117, October, 1927.

Langford, George $B$.

1. Shiningtree silver area, District of Timiskaming: Ontario Dept. Mines, 36th Ann. Rept.; vol. 36, pt. 2, pp. 87-99, illus., map, 1927.

2. Wasapika section, West Shiningtree gold area, District of Sudbury: Ontario Dept. Mines, 36th Ann. Rept., vol. 36, pt. 2, pp. 100-104, map, 1927.

Langley, A. G.

1. Mining in the Kootenays: Canadian Min. Jour., vol. 44, no. 25, pp. 472474, June 22, 1923.

Launing, J.

1. The gypsum deposits of Moose River [northern Ontario] : Canadian Mín. Jour., vol. 47, no. 50, pp. 1172-1174, 4 figs., December 10, 1926. 
Lapham, Macy H.

1. Fossil remains in the loess of eastern Washington: Sclence, new ser., vol. 65, pp. 446-447, May 6, 1927.

Larde, Jorge.

1. El terremoto del 6 de septiembre de $1915 \mathrm{y}$ los demas-terremotos de El Salvador. 71 pp., Observatorio Meterológico y Sísmológico de El. Salvador, San Salvador, C. A., Imprenta Nacional [1916].

2. El volcân de Izalco. 120 pp., illus., San Salvador, C. A., Imprenta Nacional, 1923.

3. Geología general de Centro América y especial de El Salvador. 82 pp., San Salvador, Imprenta Nacional [1924].

4. El volcân de Izalco en El Salvador, America Central, de 1922 a 1925 : Bull. volcanologique, $2^{\circ}$ ann., nos. 5-6, pp. 209-211, 1925.

Large, Thomas.

1. The glaciation of the Cordilleran region: Science, new ser., vol. 56, pp. 335-336, September 22, 1922.

2. Glacial border of Spokane [Washington]: Pan-Am. Geologist, vol. 38, no. 5, pp. 359-366, December, 1922.

3. Drainage changes in northeastern Washington and northern Idaho since extrarasation of Columbia basalts: Pan-Am. Geologist, vol. 41, no. 4, pp. 259-270, 4 pls., May, 1924.

Iarsen, Esper Signius. See also Diller, 5; Enmons, W. H., 4; H'oshag, 13; Gáge, 1; Hess, 1.1 ; Pardee, 5; Shannon, 53, 63.

1. The occurrence of cinnabar near Black Pine, Idaho: Idaho, Univ., School of Mines, vol. 14, Bull. no. 2, pp. 65-67, January, 1919.

2. (and Shannon, Earl V.). Boussingaultite from South Mountain near Santa Paula, California : Am. Mineralogist, vol. 5, no. 7, pp. 127129, July, 1920.

3. (and Livingston, D. C.). Geology of the Yellow Pine cinnabar-mining district, Idaho: U. S: Geol. Survey, Bull. 715, pp. 73-83, 2 figs. (incl. map), September 15, 1920; abstract, Washington Acad. Sci., Jour., vol. 11, no. 8, pp. 192-193, April 19, 1921.

4. (and Glenn, M. L.): Some minerals of the melanterite and chalcanthite groups with optical data on the hydrous sulphates of manganese and cobalt: Am. Jour. Sci., 4th ser., vol. 50, pp. 225-233, September; 1920:

5. (and Ross, Clarence $S$.). The $R$ and $S$ molybdenum mine, Taos County, New Mexico: Econ. Geology, vol. 15, no. 7, pp. 567-573, November, 1920.

6. The microscopic determination of nonopaque minerals: U. S. Geol. Survey, Bull., 679, 294 pp., 14 figs., 1 pl., 1921.

7. (and Foshag, W. F.). Merwinite, a new calcium-magnesium orthosilicate from Crestmore, California: Am. Mineralogist, vol. 6, no. 10, pp. 143-148, 1. fig., October, 1821.

8. Supplementary report on the geology of the areas covered by the Wagon Wheel Gap experiment stations, Rio Grande National Forest. Colorado: Monthly Weather Review, Supplement no. 17, pp. 3-4, 1922.

9. (and Shannon, E. V.). Bustamite from Franklin Furnace, New Jersey: Am. Mineralogist, vol. 7, no. 6, pp. 95-100; June, 1922.

10. (and Shannon, E. V.): Notes on some new rhodonite specimens from Franklin Furnace, New Jersey: Am. Mineralogist, vol. 7, no. 9, pp. 149-152, September, 1922. 
Larsen, Esper Signius-Continued.

11. The identity of eakleite and xonotlite: Am. Mineralogist, vol, 8, no. 10, pp. 181-182, September, 1823.

12. (and Shannon, Earl V.). Ganophyllite from Franklin Furnace, New Jersey: Am. Mineralogist, vol. 9, no. 12, pp. 238-240, December, 1924.

13. (and Schaller, Waldemar T.). The identity of variscite and peganite and the dimorphous form, metavariscite: Am. Mineralogist, vol. 10, no. 2, pp. 23-28, February, 1925.

14. (and Vassar, Helen E.). Chalcoalumite, a new mineral from Bisbee, Arizona : Am. Mineralogist, vol. 10, no. 4, pp. 79-83, April, 1925.

15. The identity of ectropite and bementite: Am. Mineralogist, vol. 10, no. 11, pp. 418-421, November, 1925.

16. (and Wherry, Edgar T.). Beidellite, a new mineral name: Washington Acad. Sci., Jour., vol. 15, no. 21, pp. 465-466, December 19, 1925.

17. (and Berman, Harry). The identity of gilpinite and johannite: Am. Mineralogist, vol. 11, no. 1, pp. 1-5, 2 figs., January, 1926.

18. (and Hess, F. L., and Schaller, W. T.). Uranium minerals from Lusk, Wyoming: Am. Mineralogist, vol 11, no. 6, pp. 155-164, June, 1926.

19. (and Foshag, William F.). Cancrinite as a high-temperature mineral from Colorado: Am. Mineralogist, vol. 11, no. 11, pp. 300-303, November, 1926.

20. (and Steiger, George). Dehydration and optical studies of alunogen, nontronite, and griffithite: Am. Jour. Sci., 5th ser., 15, pp. 1-19, 3 figs., January, 1928.

21. A hydrothermal origin of corundum and albitite bodies: Econ. Geology, vol. 23, no. 4, pp. 398-433, 4 figs., June-July, 1928.

22. Origin of the albitite bodies of Pennsylvania and elsewhere (abstract) : Geol. Soc. America, Bull., vol. 39, no. 1, pp. 162-163, March 30, 1928; Pan-Am. Geologist, vol. 49, no. 1, pp. 72-73, February, 1928.

23. (and Bauer, L. H., and Berman, H.). Norbergite from Franklin, New Jersey : Am. Mineralogist, vol. 13, no. 7, pp. 349-353, 1 fig., July, 1928.

24. The optical properties of the humite group: Am. Mineralogist, vol. 13, no. 7, pp. 354-359, July, 1928.

Larsen, J. A.

1. Soil shifting and deposits : Science, new ser., vol. 55, p. 457, April 28, 1922.

La Rue, E. C. See Bryan, 28.

Lasky, Samuel G.

1. Transverse faults at Kennecott [Alaska], and their relation to the main fault systems : Am. Inst. Min. and Met. Eng., Tech. Pub. no. 152, 17 pp., 10 flgs., November, 1928.

Laughlin, Homer.

1. (and Arnold, Ralph, and Kew, William S. W.). Southern California earthquake of July 22, 1923: Seismol. Soc. America, Bull., vol. 13, no. 3, pp. 105-106, 1 pl., September, 1923.

Lausen, Carl.

1. (and Wilson, E. D.). Gold and copper deposits near Payson, Arizona : Arizona, Univ., Arizona Bur. Mines, Bull. no. 120, 44 pp., 3 fl zs., 5 pls., December 1, 1925; Min. Jour., Phoenix, Ariz., vol. 10, no. 18, pp. 5-7, 12-14, February 28, 1827. 
Lausen, Carl-Continued.

2. Tourmaline-bearing cinnabar veins of the Mazatzal Mountains, Arizona: Econ. Geology, vol. 21, no. 8, pp. 7\$2-791, 2 figs., December, 1926.

3. (and Gardner, E. D.). Quicksilver (mercury) resources of Arizona : Arizona, Bur. Mines, Bull. no. 122, 112 pp., 23 figs., 15 pls., June 1, 1927.

4. Piedmontite from the Sulphur Spring Valley, Arizona: Am. Mineralogist, vol. 12, no. 7, pp. 283-287, 1 fig., July, 1927.

5. The occurrence of olivine bombs near Globe, Arizona: Am. Jour. Sci., 5th ser., vol. 14, pp. 293-306, 4 figs., October, 1927.

6. Hydrous sulphates formed under fumerolic conditions at the United Verde mine [Jerome, Arizona] : Am. Mineralogist, vol. 13, no. 6, pp. 203229, 7 flgs., June, 1928.

Lavington, Charles. S.

1. An oil seep in north central Nevada: Am. Assoc. Petroleum Geologists Bull., vol. 11, no. 10, pp. 1117-111s, October, 1927.

Lawler, T. B.

1. On the occurrence of sandstone dikes and chalcedony veins in the White River Oligocene: Am. Jour. Sci., 5th ser., vol. 5, pp. 160-172, 5 figs. February, 1923.

Lawson, Andrew Cowper. See also Atwood, W. W., 4; Bowie, 13 ; Foye, 10 ; Grout, 15; Hobbs, 7; Quirke, 11; Stose, 21; Udden, 11; Woodring, 8.

1. The mobility of the coast ranges of California; an exploitation of the elastic rebound theory: California, Univ., Pub., Dept. Geology, Bull. vol. 12, no. 7, pp. 431-473, 19 figs., January 11, 1921; abstract, Geol. Soc. America, Bull., vol. 32, no. 1, p. 45, March 31, 1921.

2. Isostatic compensation considered as a cause of thrusting: Geol. Soc. America, Bull., vol, 33, no. 2, pp. 337-351, 9 tigs., June 30, 1922.

3. Report on geology of Iron Canyon [Sacramento River, California]. In Report on Iron Canyon Project, California, by Homer J. Gault and W. F. McClure: U. S. Reclamation Service in cooperation with the State of California and the Iron Canyon Project Association, pp. 71-76, Washington, Government Printing Office, 1921.

4. The prediction of earthquakes: Univ. California Chronicle, vol. 24, no. 3, pp. 315-336, 9 figs., July, 1922.

5. Work of the division of geology and geography of the National Research Council : Geol. Soc. America, Bull., vol. 35, no. 1, pp. 80-83, March $30,1924$.

6. The continental shelf off the coast of California: Nat. Research Council, Bull., vol. 8, pt. 2, no. 44, 23 pp., 1 tig., April, 1.924.

7. The geological implications of the doctrine of isostasy: Nat. Research Council, Bull., vol. 8, pt. 4, no. 46, 22 pp., June, 1924.

8. The Cypress Plain: California, Univ. [Dept. Geol. Sci., Bull.], Pub. in Geol. Sci., vol. 15, no. 6, pp. 153-158, 1 fig., March 16, 1925.

9. Folded mountains and isostasy: Geol. Soc. America, Bull., vol. 38, no. 1, pp. 253-273, March 30, 1927.

10. The Cordilleran shield: Third Pan Pacific sci. Cong., Tokyo, 1026, Proc., pp. 371-388, 1 fig., 1928.

Lawson, C. C. See Schairer, 1, 2.

Iawson, Robert W. Sec Holnes, 2. 
Leavitt, David H. See Reynolds, 1.

Ledoux, A.

1. Sand and gravel in Ontario: Ontario Bur. Mines, Rept. 1918; vol. 27, pt. 2, 138 pp., 45 figs., map, 1918.

Ledoux, Albert Reid, 1852-1923.

1. Singing sands: Science, new ser., vol. 51, pp. 462-464, May 7, 1920.

Lee, Charles H. See Ellis, A. J., 1.

Lee, Howard S.

1. Pyrite deposits of Leadville, Colorado: Am. Inst. Min. and Met. Eng., Trans., vol. 61 , pp. $66-70, .1920$.

Lee, O. Ivan.

1. (and Wherry, Edgar T.). Manganotantalite from Amelia, Virginia: Am. Mineralogist, vol. 4, no. 7, pp. 80-83, 2 figs., July, 191.9.

2. Notes and news of minerals of the rarer elements: Rocks and Minerals, vol. 1 , no. 2 , pp. $24-25$, December, 1926 ; vol. 2 , no. 1 , pp. 6-8, March ; no. 2, pp. 62-64, June; no. 3, pp. 100-101., September ; no. 4 , pp. 140-141, December, 1927 ; vol. 3 , no. 1 , pp. 16-17, March, 1928.

Lee, R. J.

1. The lignites of Saskatchewan: Canadian Inst. Min. and Met., Monthly Bull no. 131, Trans. pp. 62-74, 7 figs., March, 1923; Trans., vol. 26, pp. 192-205, 7 figs. [1924].

I.ee, Wallace. See also Glenn, 10; Lupton, 1, 2 ; Rogers, G. S., 8.

1. Description of the Gillespie and Mount Olive quadrangles: U. S. Geol. Survey, Geol. Atlas U. S., Gillespie-Mount Olive folio, Illinois (no. 220), 14 pp., 16 figs., 4 maps, 1926.

Lee, Willis Thomas, 1864-1926. See also Vaughan, 7.

1. Type section of the Morrison formation: Am. Jour. Sci., 4 th ser., vol. 49 , pp. 183-188, March, 1920. Abstract, with discussion by W. H. Twenhofel, Geol. Soc. America, Bull., vol. 31, no. 1, pp. 135-136, March 31, 1920.

2. Notes on the Manzano group, New Mexico: Am. Jour. Sci., 4th ser., vol. 49, pp. 323-326, May, 1920.

3. Concerning granite in wells in eastern New Mexico: Am. Assoc. Petroleum Geologists, Bull., vol. 5, no. 2, pp. 163-167 (with discussion by John Rich, W. E. Pratt, R. C. Moore, J. W. Beede, and Arthur Eaton, pp. 329-331), March-April, 1921.

4. The Raton mesas of New Mexico and Colorado: Geog. Rev., vol. 11, no. 3, pp. 384-397, 13 figs., July, 1891.

5. The face of the earth as seen from the air; a study in the application of: airplane photography to geograplyy: Am. Geog. Soc., Special Pub. no. 4,110 pp., 82 figs., 1922 .

6. Description of the Raton, Brilliant, and Koehler quadrangles: U. S. Geol. Survey, Geol. Atlas U. S., Raton-Brilliant-Koehler folio, New Mexico-Colorado (no. 214), 17 pp., 21 figs., 10 maps, section and illustrations sheet, 1922.

7. Peneplains of the Front Range and Rocky: Mountain National Park Colorado: U. S. Geol. Survey, Bull., 730, pp. 1-17, 3 figs., 8 pls., April 4, 1922.

S. Continuity of some oil-bearing sands of Colorado and Wyomiug: U. S. Geol. Survey, Bull. 751, un. 1-22, 3 figs., 6 pls., April 24, 1923. 
Lee, Willis Thomas-Continued.

9. Building of the southern Rocky Mountains: Geol. Soc. America, Bull., vol. 34, no. 2, pp. 285-300, 4 figs., June 30, 1923.

10. Coal resources of the Raton coal field, Cofax County, New Mexico: U. S. Geol. Survey, Bull. 752, 254 pp., 18 figs., 22 pls., 1924.

11. Geography, geology, and physiography of the Great Salt Lake basin: U. S. Geol. Survey, Water-Supply Paper 517, pp. 3-9, 1924.

12. A visit to Carlsbad Cavern [Guadalupe Mountains, New Mexico]: Nat. Geog. Mag., vol. 45, no. 1, pp. 1-40, 42 figs., January, 1924.

13. Erosion and fill (abstract, with discussion by I. C. White) : Geol. Soc. America, Bull., vol. 35, no. 1, p. 99, March 30, 1924; abstract, Pan-Am. Geologist, vol. 41, no. 2, p. 149, March, 1924.

14. Erosion by solution and fill [Pecos Valley, New Mexico]: U. S. Geol. Survey, Bull, 760, pp. 107-121, 5 figs., 8 pls., April 4, 1925.

15. Carlsbad Caveln [New Mexico]: Sci. Monthly, vol. 21, no. 2, pp. 186190, August, 1925.

16. New discoveries in Carlsbad Cavern [New Mexico]: Nat. Geog. Mag., vol. 48, no. 3, pp. 301-319, 20 figs., September, 1925.

17. Stories in stone . . . xii, 226 pp., 3 figs., 49 pls., New York, D. Van Nostrand Company, 1926.

18. An ice cave in New Mexico: Geog. Rev., vol. 16, no. 1, pp. 55-59, 3 figs., January, 1926.

19. Correlation of geologic formations between east-central Colorado, central Wyoming, and southern Montana: U. S. Geol. Survey, Prof.'Paper 149, 80 pp., 5 figs., 35 pls., 1927.

Lees, James Henry. See also Kay, 6; Miller, W. J., 17.

1. A description of the region about Camp Dodge: Iowa Geol. Survey, 60 pp., 22 figs., map, 1918.

2. Park sites along Des Moines valley: Iowa Acad. Sci., Proc. 1918, vol. 25, pp. 569-585, 2 pls., 13 figs. [1919].

3. Some features of the Fort Dodge gypsum: Iowa Acad. Sci., Proc. 1918, vol. 25, pp. 587-597, 11 figs. [1919].

4. (and Thomas, A. O.). The Ste. Genevieve marls near Fort Dodge and their fauna: Iowa Acad. Sci., Proc. 1918, vol. 25, pp. 599-616, 1 pl. [1919].

5. 'The history of Boyer Valley: Iowa Acad. Sci., Proc., vol. 26, pp. 493-500, 2 figs. [1820].

6. Valley gravels of northeastern Iowa (abstract) : Geol. Soc. America, Bull., vol. 32, no. 1, pp. 49-50, March 31, 1921.

7. The conservation of underground waters: Iowa Acad. Sci., Proc., vol. 27, pp. 187-196 [1922].

8. Mineral production in Iowa for 1917 and 1918: Iowa Geol. Survey, vol. 28, pp. 3-46 [1923].

9. Some Pleistocene exposures in Des Moines: Iowa Acad. Sci., Proc.; 1921, vol. 28 , pp. 59-63 [1923].

10. An unusual well record in northwestern Iowa: Iowa Acad. Sci., Proc., vol. 30, pp. 445-450, 1 fig. [1924] ; abstract, Science, new ser., vol. 57, p. 147, August 24, 1923.

11. Mineral production in Iowa in 1919 and 1920: Iowa Geol. Survey, vol. 29, pp. xxi-xlviii [1924].

12. The structure of the Fort Dodge beds: Iowa Acad. Sci., Proc., 1922, vol. 29, pp. 113-120, 4 figs., [1.924?].

$4096-31-24$ 
Lees, James Henry-Continued.

13. Mineral production in Iowa in 1921 and 1922 : Iowa Geol. Survey, vol. 30, pp. 7-32 [1925].

14. Mineral production in Iowa in 1923 and 1924 : Iowa Geol. Survey, vol. 31, pp. 9-52 [1926?].

15. Stone axes from Adel [Iowa]: Iowa Acad. Sci., Proc., 1925, vol, 32, pp. 331-334, 2 pls. [1926].

16. Mineral production in Iowa in 1925 and in 1926 : Iowa Geol. Survey, vol. 32, pp. 9-50, 1927.

17. Iowa coal areas and characteristics of Iowa coal: Iowa Geol. Survey, vol. 32 , pp. $65-81,1927$.

18. Geology of Crawford County: Iowa Geol. Survey, vol. 32, pp. 239-362, 29 figs., map, 1927.

Leffingwell, Ernest de Koven.

1. The Canning River region, northern Alaska: U. S. Geol. Survey, Prof. Paper 109, 251 pp., 35 pls. (incl. maps), 33 figs., 1919. Abstract by J. T. Pardee, Washington Acad. Sci., Jour., vol. 9, no. 13, pp. 375-376, July 19, 1919.

Leggette, Max.

1. The preparation of thin sections of friable rock: Jour. Geology, vol. 36, no. 6, pp. 549-557, August-September, 1928.

Legrave, Michel.

1. Note sur un cas de solifluxion observé dans les Coast Ranges de Californie: Soc. géol. Belgique, Ann., t. 46, 1. 2, pp. B150-152, 1 fig., 1923.

2. Note sur les gisements de pétrole de Californie: Revue Universelle des Mines, ser. 7, t. 4, no. 3, pp. 149-155, November, 1924.

Leighly, J. B. See Ehlers, 6.

Leighton, Henry. See also Pennsylvania, 1; Stone, 11.

1. (and Somers, Ransom E.). An outline and bibliography on the framework of the world: Pittsburgh, Univ., Radio Pub. no. 13, 10 pp., 1925.

2. The geology of Pittsburgh and its environs; a popular account of the general geologic features of the region: Carnegie Mus., Annals, vol. 17 , no. 1 , pp. $91-162,8$ figs. (incl. maps), 7 pls. (incl. map). June-November, 1926.

3. (and Somers, Ransom E.). A series of eight radio talks on man and the earth, with a select bibliography. Pittsburgh, Univ., Radio Pub. no. 32, 82 pp., 1927.

Leighton, Morris Morgan. See also Bretz, 5 ; Twenhofel, 22, 29.

1. The road-building sands and gravels of Washington: Washington Geol. Survey, Bull. no. 22, 307 pp., 9 pis. (incl. maps), 36 figs. (outline county mays), 1919.

2. Gravel deposits of Illinois: Illinois Soc. Engineers, 35th Ann. Rept., pp. 73-74, 1920.

3. The present status of the Pleistocene in Illinois (abstract) : Science, new ser., vol. 51, p. 521, May 21, 1920.

4. Post-Illinoian drift in northern Illinois west of the mapped Wisconsin moraine (abstract) : Geol. Soc. America, Bull., vol. 32, no. 1, pp. 8687, March 31, 1921.

5. The Pleistocene succession near Alton, Illinois, and the age of the mammalian fossil fauna: Jour. Geology, vol. 29, no. 6, mp. 505-514, Soptember-Octoher, 1921. 
Leighton, Morris Morgan-Continued.

6. Further data on the differentiation of the glacial drift sheets of northern Illinois (abstract with discussion by Frank Leverett): Geol. Soc. America, Bull., vol. 33, no. 1, pp. 116-117, March 31, 1922.

7. The glacial history of the Sangamon River valley at Decatur and its bearing on the reservoir project: Illinois State Acad. Sci., Trans., vol. 14, pp. 213-218, 1 pl. [1922].

8. The origin of the Cahokia mounds (abstract): Illinois State Acad. Sci., Trans., vol. 16, p. 327, 1923.

9. Pleistocene of northwestern Illinois: a graphic presentation of some of the chief lines of evidence (abstract); Fossiliferous loess beneath tilted Galena dolomite at the border of the Belvidere lobe in northwestern Illinois (abstract) : Geol. Soc. America, Bull., vol. 34, no. 1, p. 90, March 30, 1923.

10. The differentiation of the drift sheets in northwestern Illinois: Jour. Geology, vol. 31, no. 4, pp. 265-281, 4 figs., May-June, 1923.

11. Geology and the Decatur [Illinois] dam and reservoir project: Eng. NewsRecord, vol. 91, no. 7, pp. 264-266, 2 figs., August 16, 1923.

12. The geological aspects of some of the Cahokia (Illinois) mounds: Illinois, Univ., Bull., vol. 21, no. 6, pp. 57-97, 8 figs., October 8, 1923.

13. Modern geology and its contribution to engineering: Western Soc. Eng., Jour., vol. 28, no. 11, pp. 491-506, 5 figs., November, 1923.

14. The glacial history of the Elgin region: Illinois State Acad. Sci., Trans., vol. 17, pp. 65-71, 1925.

15. Memorial to Dr. Thomas L. Watson: Science, new ser., vol. 61, pp. 255256, March 6, 1925.

16. Field meeting of the Association of American State Geologists: Science, new ser., vol. 62, pp. 452-453, November 20, 1925.

17. A notable type Pleistocene section; the Farm Creek exposure near Peoria, Illinois: Jour. Geology, vol. 34, no. 2, pp. 167-174, 1 fig., FebruaryMarch, 1926; Illinois State Geol. Survey, Rept. Investigations, no. 11, pp. 3-9, 1 fig., 1926; Illinois State Acad. Sci., Trans., vol. 18, pp. 167-174, 1 fig., 1925.

18. Glacial geology and engineering in Illinois: Illinois State Acad. Sci., Trans., vol. 19, pp. 246-249, 1926.

19. State geological surveys: Am. Year Book, 1927, pp. 158-162, 1928.

20. Lake Illinois and the question of post-early Wisconsin deformation in northern Illinois (abstract): Geol. Soc. America, Bull., vol. 39, no. 1 , p. 215 , March 30,1928 ; Pan-Am. Geologist, vol. 49, no. 2, p. 147, March, 1928.

21. Exposure showing late Sangamon loess and early Peorian loess, with their soil zones [Illinois] (abstract) : Geol. Soc. America, Bull., vol. 39, no. 1, p. 215, March 30, 1928; Pan-Am. Geologist, vol. 49, no. 2, p. 147, March, 1928.

22. Studies of glacial sediments in 1927 : Nat. Research Council, Reprint and Circ. Ser., no. 85, pp. 43-60, 1928.

Leith, Charles Kenneth. See also Tanton, 17.

1. International control of minerals: Min. and Sci. Press. vol. 118, pp. 357361, March 15, 1919.

2. Internationalization of mineral resources (abstract): Geol. Soc. America, Bull., vol. 30, pp. 107-108, March 31, 1919.

3. Memorial of Charles Richard Van Hise: Geol. Soc. America, Bhll., vol. 31, no. 1, pp. 100-110, portr., March 31, 1920. 
Leith, Charles Kenneth-Continued.

4. Geologists as witnesses in mining litigation: Econ. Geology, vol. 15, no. 8, pp. 674-680, December, 1920.

5. The economic aspects of geology. $457 \mathrm{pp} .13$ figs., New York, Henry Holt and Company, 1921.

6. The structural failure of the lithosphere: Science, new ser., vol. 53, pp. 195-207, March 4, 1921.

7. International mineral problems: Econ. Geology, vol. 16 , no. 3 , pp. 222226, April-May, 1921.

8. Composite nature of rock mass movement: Pan-Am. Geologist, vol. 37, no. 1, pp. 84-86, February, 1922.

9. Structural geology ; revised edition. 390 pp., 103 figs., New York, Henry Holt and Company, 1923.

10. A layman's view of the theory of isostasy (abstract with discussion by D. F. Higgins and T. P. Shepard) : Geol. Soc. America, Bull., vol. 34 , no. 1, p. 57, March 30, 1923.

11. Field versus laboratory evidence in the identification of metamorphic rocks : Econ. Geology, vol. 18, no. 3, pp. 288-290, April-May, 1923.

12. Oscar Rohn: Am. Inst. Min. and Met. Eng., 'Trans., vol. 70, p. 1232, portr., 1924.

13. A sedimentary problem [formation of iron deposits] : Econ. Geology, vol. 19, no. 4, pp. 382-385, June-July, 1924.

14. Silicification of erosion surfaces: Econ. Geology, vol. 20, no. 6, pp. 513523, September-October, 1925.

15. Some political aspects of the world manganese situation (with discussion) : Am. Inst. Min. and Met. Eng., Trans., vol. 75, pp. 260-271, 1927.

16. Lake Superior pre-Cambrian: Geol. Soc. America, Bull., vol. 38, no. 4, pp. 749-752, December 30, 1927 ; abstract, no. 1, pp. 110-111, March 30, 1927 ; Pan-Am. Geologist, vol. 47, no. 1, p. 66, February, 1927.

17. What is the job of the economic geologist?: Econ. Geology, vol. 23, no. 4, pp. 451-453, June-July, 1928.

Leng, Charles W. See Davis, W. T., 1.

Lenher, Victor.

1. Occurrence, chemistry, and uses of selenium and tellurium (with discussion) : Am. Inst. Min. and Met. Eng., Trans., vol. 69, pp. 1035-1057, 1923 ; [preprint] no. 1198, 20 pp., January, 1923.

Leonard, Arthur Gray.

1. The geology of North Dakota: Jour. Geology, vol. 27, no. 1, pp. 1-27, 2 figs. (incl. map), January-February, 1919.

2. The surface features of North Dakota and their origin: North Dakota Univ., Quart. Jour., vol. 9, no. 3, pp. 209-219, 2 pls., map, April, 1919.

3. Possibilities of oil and gas in North Dakota: North Dakota Geol. Survey, Bull. no. 1, 9 pp., 1920.

4. The White River formation in North Dakota: North Dakota, Univ., Quart. Jour., vol. 12, no. 3, pp. 218-228, 3 pls. (incl. map), April, 1922.

5. Gravel deposits of North Dakota suitable for road surfacing and construction work: North Dakota, Univ., Quart. Jour., vol. 14, no. 4, pp. 383-393, June, 1924.

6. The : contest between land and sea near San Diego [California]: North Dakota, Univ., Quart. Jour., vol. 15, no. 2, pp. 135-140, 2 figs., 2 pls., January, 1925. 
Leonard, Arthur Gray-Continued.

7. (and Babcock; Earle J., and Dove, Leonard P.). The lignite deposits of North Dakota: North Dakota Geol. Survey, Bull. no. 4, 240 pp., 21 pls. (incl. maps), 1925.

8. The geology of North Dakota; the surface features of North Dakota and their origin; the lignite deposits of North Dakota: North Dakota, Univ., Departmental Bull., vol. 11, no. 1 (College of Engineering, Division of Mines and Mining Experiments, Bull. no. 9), pp. 4-25, 2 figs., January, 1926.

9. Lignitic coals of North Dakota : Pan-Am. Geologist, vol. 45, no. 2, pp. 135140, 3 pls., March, 1926.

10. The State geological survey during the past twenty-five years [North Dakota]: North Dakota, Univ., Quart. Jour., vol. 18, no. 2, pp. 122-127, 1 pl. (portr.), January, 1928.

Leonard, R. J. See also Schwartz, 15.

1. The hydrothermal alteration of certain silicate minerals: Econ. Geology, vol. 22, no. 1, pp. 18-43, 2 figs., January-February, 1927.

2. Pedestal rocks resulting from disintegration [Texas Canyon, Arizona] : Jour. Geology, vol. 35, no. 5, pp. 469-474, 2 figs., July-August, 1927.

3. An occurrence of schistose galena [Camou, Sonora, Mexico]: Econ. Geology, vol. 23, no. 5, pp. 578-581, 2 figs., August, 1928.

Leonard, William Clement.

1. Facts concerning the Kentucky oil fields ... 10 pp. [New York, 1919].

Leonardon, E. G. See also Crosby, 7.

1. (and Kelly, Sherwin F.). Exploration for ore by potential methods: Canadian Min. and Met. Bull., no. 189, pp. 157-178, 15 figs., January, 1928; Eng. and Min. Jour., vol. 125, no. 2, pp. 46-49, no. 4, pp. 163-166, 15 figs., January 14 and 28, 1928.

2. (and Kelly, Sherwin F.). Some applications of potential methods to structural studies: Am. Inst. Min. and Met: Eng., Tech. Pub. no. 115, 18 pp., 13 figs., April, 1928; Canadian Min. and Met., Bull. no. 193, pp. 706-725, 13 figs., May, 1928; Canadian Inst. Min. and Met., Trans., vol. 31, pp. 222-241, 13 figs. [1929] ; abstract, Mining and Metallurgy, vol. 9, no. 256, p. 193, April, 1928.

Lesher, Carl E.

1. [Maps of] coal fields and producing districts, Pennsylvania, Ohio, Indiana, Illinois, Kentucky, Tennessee, West Virginia, and part of Maryland, Virginia, Alabama and part of Georgia. Scale 1:1,000,000. U. S. Geological Survey, 1919.

LeVene, Clara M. See Schuchert, 32.

Levensaler, Lewis A.

1. The Fairhaven silver-lead district, Alaska: Min. and Sci. Press, vol. 122, pp. 195-196, 1 fig., February 5, 1921.

Leverett, Frank. See also Leighton, M. M., 6 ; Osborn, 19.

1. Features of the country around Camp Custer [near Battle Creek, Michigan] (abstract) : Michigan Acad. Sci., 20th Ann. Rept., pp. $53-54,1918$.

2. Drainage features and uplift of shore lines in Elsie and Perrinton quadrangles :[Michigan] (abstract): Michigan Acad. Sci., 20th Ann. Rept., p. 55, 1918. 
Leverett, Frank-Continued.

3. Pleistocene epoch [in Minnesota]: U. S. Geol. Survey, Bull. 678, pp. 76-78, 1919.

4. (and Sardeson, Frederick W.). Surface formations and agricultura] conditions of the south half of Minnesota: Minnesota Geol. Survey, Bull. no. 14, 147 pp., 9 pls. (incl. map), 15 figs., 1919. Abstract, Washington Acad. Sci., Jour., vol. 10, no. 16, pp. 471-472, October 4, 1920.

5. Glacial and glacial lake features in the vicinity of Kalamazoo: Michigan Acad. Sci., 21st Ann. Rept., pp. 91-92, 1920.

6. Studies on the shore lines of the Saginaw basin [Michigan] (abstract) : Michigan Acad. Sci., 22d Ann. Rept., p. 89, 1921.

7. Results of glacial studies in the northern peninsula of Michigan in 1919 (abstract) : Michigan Acad. Sci., 22đ Ann. Rept., pp. 89-90, 1921.

8. Outline of the Pleistocene history of Mississippi Valley: Jour. Geology, vol. 29, no. 7, pp. 615-626, 2 figs., October-November, 1921.

9. Glacial formations on the Coteau des Prairies (abstract): Geol. Soc. America, Bull., vol. 33, no. 1, pp. 101-102, March 31, 1922.

10. What constitutes the Altamont moraine? (abstract) : Geol. Soc. America, Bull., vol. 33, no. 1, pp. 102-103, 1 fig., March 31, 1922.

11. Old glaciation in the Cordilleran region: Science, new ser., vol. 56, p. 388 , October $6,1922$.

12. Memorial of James E. Todd: Geol. Soc. America, Bull., vol. 34, no. 1, pp. 44-51, portr., March 30, 1923.

13. Glacial deposits of Missouri and adjacent districts (abstract) : Geol. Soc. America, Bull., vol. 34, no. 1, pp. 91-92, March 30, 1923.

14. Map of the surface formations of the southern peninsula of Michigan: Michigan, Geol. Survey Division, 1924. Scale, 1: 750,000.

15. Oldest (Nebraskan?) drift in western Illionis and southeastern Missouri in relation to "Lafayette gravel" and drainage and development (abstract) : Geol. Soc. America, Bull., vol. 35, no. 1, p. 69, March 30, 1924; Pan-Am. Geologist, vol. 41, no. 2, p. 138, March, 1924.

16. Factors that determine direction of ice movement (abstract): Pan-Am. Geologist, vol. 44, no. 2, pp. 152-153, September, 1925.

17. The Pleistocene glacial stages; were there more than four?: Am. Philos. Soc., Proc., vol. 65, no. 2, pp. 105-118, 1926.

18. Status of Iowa drift problem (abstract): Pan-Am. Geologist, vol. 45, no. 2, pp. 171-172, March, 1926.

19. Studies of Pleistocene phenomena of Ohio River Basin (abstract) : Science, new ser., vol. 63, pp. 484-485. May 7. 1926.

20. Results of glacial investigations in Pennsylvania and New Jersey in 1926 and 1927 (abstract) : Geol. Soc. America, Bull., vol. 39, no. 1, p. 151, March 30, 1928; Pan-Am. Geologist, vol. 49, no. 1, pp. 66-67, February, 1928.

Levison, Wallace Goold.

1. Developing crystallized mineral specimens: Am. Mineralogist, vol. 4, no. 2, pp. 14-15, February, 1919.

Levorsen, A. I.

1. Convergence studies in the Mid-Continent region: Am. Assoc. Petroleum Geologists, Bull., vol 11, no. 7, pp. 657-682, 18 figs., July, 1927.

2. Oil and gas in Oklahoma; geology of Seminole County: Oklahoma Geol. Survey, Bull. no. 40-BB, 70 pp., 15 flgs., March, 1928. 


\section{Lewis, Alfred Strong}

1. Ore deposits of Cave Creek district in Arizona: Eng. and Min. Jour., vol. 110, no. 15, pp. 713-716, 3 figs. (incl. map), October 9, 1920.

Lewis, F. Park.

1. Fossil eggs in Bermuda: Hobbies (Buffalo Soc. Nat. Hist.), vol. 8, no. 11, pp. 19-23, 2 figs., May, 1928.

\section{Lewis, Fratk.}

1. Mining quicksilver [Terlingua district, Texas] : Colorado School of Mines Mag., vol. 16, no. 12, pp. 4-6, April, 1927.

Lewis, Frank E. See Gould, C. N., 10.

Lewis, Joseph Volney. See also Spurr, 17; Twenhofel, 16, 18; Wilder, 1.

1. Magnetic and non-magnetic chrome: Econ. Geology, vol. 14, no. 6, pp. 491494, September-October, 1919.

2. The magmatic origin of barite deposits: Econ. Geology, vol. 14, no. 7, pp. 568-570, November, 1919.

3. Chrome-ore deposits in North Carolina: Eng. and Min. Jour., vol. 109, pp. 1112-1114, 3 figs., May 15, 1920.

4. A manual of determinative mineralogy, with tables for the determination of minerals by means of, I, their physical characters, II, blowpipe and chemical characters. Third edition, 298 pp., 81 figs., New York, John Wiley \& Sons, 1921.

5. Proceedings of the first annual meeting of the Society of Economic Geologists, held at Chicago, Illinois, December 28-29, 1920: Geol. Soc. America, Bull., vol. 32, no. 1, pp. 157-162, March 31, 1921.

6. Deposits of chrome ore in North Carolina: U. S. Geol. Survey, Bull. 725, pp. 101-139, 2 figs., 1 pl. (map), August 4, 1921. Abstract by R. W. Stone, Washington Acad. Sci., Jour., vol. 11, no. 20, pp. 494495, December 4, 1921.

7. Geology and mining of mica: Eng. and Min. Jour.-Press, vol. 113, no. 20, pp. 856-864, 4 figs., May 20, 1922.

8. (and Bauer, L. H.). Cyprine and associated minerals from the zinc mine at Franklin, New Jersey: Am. Jour. Sci., 5th ser., vol. 4, pp. 249251, September, 1922.

9. Fissility of shale and its relations to petroleum: Geol. Soc. America, Bull., vol. 35, no. 3; pp. 557-590, September 30, 1924; abstract, Geol. Soc. America, Bull., vol. 34, no. 1, pp. 63-64, March 30, 1923.

10. The ghost of the "molten magma": Eng. and Min. Jour.-Press, vol. 118, no. 7, p. 250, August 16, 1924.

11. Mining geology [review of progress in] : Eng. and Min. Jour.-Press, vol. 119, no. 3, pp. 102-104, January 17, 1925.

12. Possible inorganic petroleum: Eng. and Min. Jour.-Press, vol. 120, no. 4, pp. 137-139, July 25, 1925.

13. Progress in mining geology: Eng. and Min. Jour.-Press, vol. 121, no. 3, pp. 103-105, January 16, 1926.

14. Magmatic carbons and hydrocarbons (abstract): Geol. Soc. America, Bull., vol. 37, no. 1, pp. 148-149, March 30, 1926; Pan-Am. Geologist, vol. 45, no. 1, p. 96 , February, 1926.

15. Geology advances theory of ore deposits: Eng. and Min. Jour., vol. 123, no. 4, pp. 143-145, January 22, 1927.

16. Mining geology : Eng. and Min. Jour., vol. 125, no. 3, pp. 114-115, January 21, 1928.

Lewis, Lyman W. See Palache, 24. 
Lewis, Robert Strong.

1. (and Varley, Thomas). The mineral industry of .Utah: Utah, Univ., Bull., vol. 10, no. 11 (Utah Engineering Station, Department of Metallurgical Research, Bull. no. 12), 201 pp., map (mining districts), December, 1919.

Lewis, Samuel J.

1. The ore deposits of Mexico: Min. and Sci. Press, vol. 120, pp. 412-420, 2 figs. (maps), March 20, 1920 ; pp. 443-450, 7 figs., March 27, 1920; pp. $933-939$, 6 figs., June 26 , 1920 ; vol. 121 , pp. 16-20, 5 figs.; July 3, 1920 ; pp. 375-382, 5 figs., September 11, 1920 ; pp. 521-528, 5 figs., October $9,1920$.

Ley, Henry A.

1. The relation of quality ô̂ oil to structure at El Dorado, Arkansas (with (liscussion) : Am. Assoc. Petroleum Geologists, Bull., vol. 7, no. 4, pp. 350-361, 1 fig., July-August, 1923.

2. Subsurface observations in southeast Kansits: Am. Assoc. Petroleum Geologists, Bull., vol. 8, no. 4, pp. 445-453, July-A ưgust, 1924:

3. The Kirk gas sand in the Graham district, Oklahoma: Am. Assoc. Petroleum Geologists, Bull., vol. 9, no. 6, p. 1024, September,-1925.

4. The granite ridge of Kansas: Am. Assoc. Petroleum Geologists, Bull., vol. 10, no. 1, pp. 95-96, January, 1926.

5. Mississippi lime west of the granite ridge in Kansas: Am. Assoc. Petroleum Geologists, Bull., vol. 10, no. 1, pp. 96-97, January, 1926.

6. The Sheridan test, Ellsworth County, Kansas: Am. Assoc. Petroleum Geologists, Bull., vol. 10, no. 2, p. 109, February, 1926.

7. Age of producing horizon, Rice County, Kansas: Am. Asssoc. Petroleum Geologists, Bull., vol. 10, no. 2, pp. 197-198, February, 1926.

Liddle, Ralph Alexander.

1. The Marathon fold and its influence on petroleum accumulation: Texas, Univ., Bull., no. 1847, pp. 9-16, 1 pl., August 20, 1918 [1920].

2. (and Prettyman, T. M.). Geology and mineral resources of Crockett County with notes on the stratigraphy, structure, and oil prospects of the central Pecos Valley: Texas, Univ., Bull. no. 1857, 97 pp., 4 pls. (incl. maps), 6 figs., October 10, 1918 [1920].

3. The geology and mineral resources of Medina County: Texas, Univ., Bull. no. 1860 (October 25, 1918), 177 pp., 9 figs., 9 pls. (incl. map), March, 1921.

4. The geology of Venezuela and Trinidad. 552 pp., 22 figs. (incl. maps), 83 pls., Fort Worth, Texas, J. P. MacGowan [1928].

Light, Margaret. See Bruce, 20.

Lilley, Ernest Raymond.

1. Petroleum provinces of the United States: Eing. and Min. Jour.-Press, vol. 116, no. 6, pp. 243-245, 1 fig. (map), August 11, 1923:

2. Coal as an aid in oil exploration: Eng. and Min. Jour.-Press, vol. 117, no. 25, pp. 1009-1012, 3 figs., June 21. 1924.

3. The oil industry; production, transportation, resources, refining, and marketing. x, 548 pp., 181 figs., New York, D, Nan Nostrand Company, 1925.

4. The geology of petroleum and naturai gas. 524 pp., 173 figs., New York, D. Van Nostrand Company, 1928: 
Lillibridge, H. E.

1.: Foraker - limestone in Lincoln County (abstract): Oklahoma Acad. Sci., Proc., vol. 2 (Okla, Ưniv., Bull., new ser. no. 247), p. 89, October 1, 1922.

Lincoln, Francis Church.

1. Mining districts and mineral resources of Nevada. $295 \mathrm{pp}$., map, Reno, Nevada Newsletter Publishing Company, 1923.

2. Half a century of mining in the Black Hills: Eng. and Min. Jour., vol. 122, no. 6, pp. 205-214, August 7, 1926.

3. Pegmatite mining in the Black Hills [South Dakota]: Eng. and Mill. Jour., vol, 123, no. 25, pp. 1003-1006, 4 figs., June 18, 1927.

4. The Etta mine; a unique lithia producer in the Black Hills [South Dakota] : Eng. and Min. Jour., vol. 124, no. 6, pp. 213-214, 2 figs., August 6, 1927.

Lind, Samuel Coville.

1. (and Davis, C. W.). A new deposit of uranium ore [Lusk, Wyoming]: Science, new ser., vol. 49, pp. 441-443, May 9, 1919.

Iindgren, Waldemar. See also Bruce, 18;- Fairbanks, 12; Howe, E., 1; Shimer, 8; Wheeler, H. A., 3.

1. Mineral deposits. 2d ed., 957 pp., 284 figs., New York, McGraw-Hill Book Company, 1919.

2. (and Loughlin, G. F.). Geology and ore deposits of the Tintic mining district, Utah: U. S. Geol. Survey, Prof. Paper 107, 282 pp., 39 pls. (incl. maps), 49 figs., 1919. Abstract, Washington Acad. Sci., Jour., vol. 9, no. 11, pp. 316-317, June 4, 1919.

3. Economic geology as a profession (editorial) : Econ. Geology, vol. 14, no. 1, pp. 79-86, January-February, 1919.

4. Regarding magmatic nickel deposits: Econ. Geology, vol. 15, no. 6, pp. 535-538, September, 1920.

5. Present tendencies in the study of mineral deposits: Min. and Met. Soc. America, Bull. no. 145 (vol. 14, no. 2), pp. 42-49, January, 1921.

6. A suggestion for the terminology of certain mineral deposits: Econ. Geology, vol. 17, no. 4, pp. 292-294, June-July, 1922.

7. (and Ball, Sydney H.). Summary of proceedings of the Society of Economic Geologists, 1921-22. 24 pp. [n. d., 1923?].

8. The elucation of the geologist: Econ. Geology, vol. 18, no. 4, pp. 405-409, June-July, 1923.

9. Goncentration and circulation of the elements from the standpoint of economic geology : Econ. Geology, vol. 18, no. 5, pp. 419-442, August, 1.923.

10. The colloid chemistry of minerals and ore deposits. In Bogue, Robert Herman (editor), The theory and application of colloidal behavior: chapter 18, vol. 2, pp. 445-465, New York, McGrnw-Hill Book Company, 1.924.

11. (and Davy, W. Myron). Nickel ores from Key West mine, Nevada: Econ. Geology, vol. 19, no. 4, pp. 309-319, 2 pls., June-July, 1924.

12. Contact metamorphism at Bingham, Utah: Geol. Soc. America, Bull, vol. 35, no. 3, pp. 507-534, 1 fig., September 30, 1924.

13. Microchemical reactions: Econ. Geology, vol. 19, no. 8, pp. 762-764, December, 1924.

14. The cordierite-anthophyllite mineralization at Blue Hill, Maine, and its relation to similar occurrences: Nat. Acad. Sci., Proc., rol. 11, no. 1. pp. 1-4, January 15, 1925. 
Lindgren, Waldemar-Continued,

15. Gel replacement, a new aspect of metasomatism: Nat. Acad. Sci., Proc., vol. 11, no. 1, pp. 5-11, January 15, 1925.

16. Metasomatism: Geol. Soc. America, Bull., vol. 36, no. 1, pp. 247-261, March 30, 1925.

17. Ore deposits of the Jerome and Bradshaw Mountains quadrangles, Arizona: U. S. Geol. Survey, Bull. 782, 192 pp., 10 figs., 23 pls. (incl. maps), 1926.

18. Magmas, dikes, and veins (with discussion by J. T. Singewald, W. H. Emmons, J. C. Anderson, J. F. Kemp, R. J. Colony, A. M. Bateman, J. E. Spurr, C. A. Porter, and Blamey Stevens) : Am. Inst. Min. and Met. Eng., Trans., vol. 74, pp. 71-126, 4 figs., 1926; Pam. no. 1575, 47 pp., June, 1926 ; Eng. and Min. Jour., vol. 122, no. 4, pp. 125-133, July 24, 1926; abstract, Mining and Metallurgy, vol. 7, no. 235, pp. 305-306, July, 1926. Extract, Canadian Min. Jour., vol. 47, no. 34, pp. 821-828, August 20, 1926.

19. World lead deposits: Mining and Metallurgy, vol. 7, no. 234, pp. 244-245, June, 1926; Canadian Min. Jour., vol. 47, no. 38, pp. 908-909, September 17, 1926.

20. James Furman Kemp; to his memory: Econ. Geology, vol. 22, no. 1, pp. 84-90, January-February, 1927.

21. Hot Springs and magmatic emanations: Econ. Geology, vol. 22, no. 2, pp. 189-192, March-April, 1927.

22. Paragenesis of minerals in the Butte veins (discussion) : Econ. Geology, vol. 22, no. 3, pp. 304-307, May, 1927.

23. Mineral deposits. 3d ed., 1049 pp., 317 figs., New York, McGraw-Hill Book Company, 1928.

24. Research in processes of ore deposition: Am. Inst. Min. and Met. Eng., Tech. Pub. no. 78, 14 pp., February, 1928; Trans., vol. 76, pp. 290-307, 1928; abstract, Mining and Metallurgy, vol. 9, no. 254, p. 79, February, 1928.

25. Bibliographies, annotated bibliographies, and geological abstracts: Econ. Geology, vol. 23, no. 5, pp. 564-568, August, 1928.

26. Report of the committee on processes of ore deposition: Econ. Geology, vol. 23, no. 6, pp. 591-611, September, 1928.

Lindly, John M.

1. Pyrite in coal: Iowa Acad. Sci., Proc. 1922, vol. 29, pp. 107-109, 3 figs. [1924?].

2. Winfield's deep well: Iowa Acad. Sci., Proc. 1922, vol. 29, pp. 110-112 [1924?].

3. Deep well at Brighton (abstract) : Pan-Am. Geologist, vol. 42, no. 5, p. 380, December, 1924.

4. The deep water well at Brighton: Iowa Acad. Sci., Proc., 1924, vol. 31, pp. 365-367 [1926?].

5. Deep well at Morning Sun [Iowa] : Iowa Acad. Sci., Proc., 1925, vol. 32, pp. 343-344 [1926].

6. Davenport's deep well: Iowa Acad. Sci., Proc., 1927, vol. 34, p. 247 [1928].

I.ink, Theodore A. See also Chamberlin, R. T., 16.

1. The origin and significance of "epi-anticlinal" faults as revealed by experiments: Am. Assoc. Petroleum Geologists, Bull., vol. 11, no. 8, pp. 853-866, 9 figs., August, 1927.

2. Epi-anticlinal faults in geologic structures: Oil Engineering and Technology, vol. 8, no. 9, pp. 325-328, 4 figs., September, 1927. 
Link, Theodore A.-Continued.

3. The oil geology of Alberta: Imperial Oil Review, vol. 12, no. 2, pp. 1-4, April, no. 3, pp. 1-5, June, 1928.

4. Relationship between over- and under-thrusting as revealed by experiments: Am. Assoc. Petroleum Geologists; Bull., vol. 12, no. 8, pp. 825-854, 952, 36 figs., August, 1928.

5. En échelon folds and arcuate mountains: Jour. Geology, vol. 6, no. 6, pp. 526-538, 12 figs., August-September, 1928.

6. A new species of Fistulipora [Canyon formation, Eastland County, Texas] : . Jour. Paleontology, vol. 2, no. 3, pp. 87-94, 1 pl., September, 1928.

Linker, S. See also Rae, 1.

1. The relation of peat to oil shale: Am. Peat. Soc., Jour., vol. 18, no. 2, pp. 45-49, April, 1925.

Linton, Robert.

1. Tertiary clays of southern California: Am. Ceramic Soc., Jour., vol. 11, no. 10, pp. 771-781, 4 figs., October, 1928.

Lipman, Charles B.

1. The discovery of living microorganisms in ancient rocks: Science, new ser., vol. 68, pp. 272-273, September 21, 1928.

Little, George, 1837-1923.

1. Memoirs of George Little. $125 \mathrm{pp}$., Tuscaloosa [Alabama], Weatherforl Printing Company, 1924.

Little, Homer Payson. See also Mathews, 3.

1. A flowing artesian well at Winslow, Maine: Science, new ser., vol. 49, pp. 24-25, January 3, 1919.

2. Geology as a profession: Science, new ser., vol. 54, pp. 619-622, December 23, 1921.

3. List of manuscript bibliographies in geology and geography : National Research Council, Reprint and Circular Series, no. 27, 17 pp., 1922.

4. Erosional cycles in the Front Range of Colorado and their correlation (with discussion): Geol. Soc. America, Bull., vol. 36, no. 3, pp. 495-512, 11 figs., September 30, 1925; abstract, no. 1, p. 138, March 30, 1925 ; Pan-Am. Geologist, vol. 43, no. 1, p. 79, February, 1925.

Little, James M.

1. Bisbee [Arizona] geology (discussion): Eng. and Min. Jour., vol. 123, no. 24, p. 970, June 11, 1927.

Littlefield, Max Sylvan.

1. Lake Huron winter beach forms: Iowa Acad. Sci., Proc., vol. 30, pp. 451453, 2 figs. [1924].

2. Preliminary report on an investigation of the molding sand resources of Illinois: Illinois State Geol. Survey, Rept. Investigations no. 3, 37 pp., 1925.

3. Natural-bonded molding sand resources of Illinois: Illinois State Geol. Survey, Bull. no. 50, 183 pp., 49 flgs., 1925.

4. Mississippi River gravels below the mouth of the Arkansas River (abstract) : Geol. Soc. America, Bull., vol. 38, no. 1, p. 147, March 30, 1927 ; Pan-Am. Geologist, vol. 47, no. 2, p. 152, March, 1927.

Livingston, Douglas Clermont. See also Larsen, 3 ; Umpleby, 2 ; Varley, 1.

1. Geology of Idaho. In Northwest Mines Handbook, vol. 1, pp. 21-26, pub lished by Sidney Norman, Spokane, Washington, 1918. 
Livingston, Douglas Clermont-Continued.

2. Tungsten, cinnabar, manganese, molybdenum, and tin deposits of Idaho: Idaho, Univ., School of Mines, vol. 14, Bull. no. 2, $67 \mathrm{pp}, 7$ pls., January, 1919.

3. (and Laney, F. B.). The copper deposits of the Seven Devils and adjacent districts (including Heath, Hornet Creek, Hoodoo, and Deer Creek) : Idaho, Bur. Mines and Geology, Bull. no. 1, 105 pp., 13 pls., 11 maps, 1920.

4. A geologic reconnaissance of the Mineral and Cuddy Mountain urining district, Washington and Adams counties, Idaho: Idaho, Bur. Mines and Geology, Pamphlet no. 13, 24 pp., 3 maps [1925?] (mimeographed).

5. Certain topographic features of northeastern Oregon and their relation to faulting: Jour. Geology, vol. 36, no. 8, pp. 694-708, 4 figs., November-December, 1928.

Livingstone, Jennie.

1. Organic constituents of oil shales and related rocks: Colorado, Univ., Studies, vol. 16, no. 2, pp. 149-170, 3 pls., April, 1928:

Lloyd, A. M. See Hammer, 1, 2.

Lloyd, E. Russell. See also Fisher, C. A., 2 ; Willis, 27.

1. Petroleum in 1918: U. S. Geol. Survey, Mineral Resources, 1918, pt. 2, pp. 969-1169, 10 figs., September 20, 1920.

2. Igneous rocks [of the Hot Springs district, Arkansas] : U. S. Geol. Survey, Geol. Atlas U. S., Hot Springs folio, Arkansas (no. 215), pp. 7-8, 1923.

Lloyd, Stewart J.

1. Relation of oil to carbon ratios (discussion): Econ. Geology, vol. 15, no. 1, pp. 94-96, January-February, 1920.

2. Oil prospecting in Alabama: Alabama Geol. Survey, Leaflet no. 2, 3 pp., map, February, 1920.

Lobeck, Armin Kohl.

1. Block diagrams: Jour. Geography, vol. 19, no. 1, pp. 24-32, 15 figs., January, 1920.

2. A physiographic diagram [map] of the United States. Scale, $1: 3,000,000$. A. J. Nystrom \& Co., Chicago, 1921.

3. Physiographic diagram of the United States (abstract) : Geol. Soc. America, Bull., vol. 32, no. 1, p. 71, March 31, 1921.

4. Physiographic diagram of the United States. Small-scale edition. $8 \mathrm{pp}$, map, 1922.

5. The physiography of Porto Rico: Scientific Survey of Porto Rico and the Virgin Islands, vol. 1, pt. 4, pp. 301-379, 41 figs., map, New York Academy of Sciences, 1922.

6. Block diagrams and other graphic methods used in geology and geography. 206 pp., 287 figs., New York, John Wiley and Sons, 1924.

7. Panorama of physiographic types. 4 pp., 2 charts, Madison, Wisconsin, Wisconsin Geographical Press, 1926.

8. A popular guide to the geology and physiography of Allegany State Park: New York State Mus. Handbook 1, 288 pp., 131 figs., 3 pls. (maps), 1927.

9. Glacial phenomena in and near Allegany State Park, New York (abstract) : Geol. Soc. America, Bull., vol. 38, no. 1, p. 141, March 30. 1927 ; Pan-Am. Geologist, vol. 47, no. 2, p. 150, March, 1927. 
Loweck, Armin Kohl-Continued.

10. The geology and physiography of the Mammoth Cave National Park: Kentucky Geol. Survey, ser. 6, Pam. 21, 69 pp., 37 figs., 1 pl., 1928.

Locke, Augustus. See also Merwin, 6; Morse, H. W., 1.

1. The profession of ore hunting: Econ. Geology, vol. 16, nos. 4-5, pp. 243-278, 1921.

2. Experiment in ore-hunting geology: Mining and Metallurgy, no. 184, pp. 27-29, 1 fig., April, 1922.

3. Present tendencies in exploration for new mines (with discussion) : Am. Inst. Min. and Met. Eng., Trans., vol. 69, pp. 3-21, 10 figs., 1923.

4. (and Hall, D. A., and Short, M. N.). Rôle of secondary enrichment in genesis of Butte chalcocite (with discussion by G. M. Schwartz) : Am. Inst. Min. and Met. Eng., Trans., vol. 70, pp. 933-963, 17 figs., 1924 ; [preprint] no. 1308, 30 pp., 17 figs., March, 1924; abstract, Mining and Metallurgy, vol. 5, no. 210, pp. 292-293, June, 1924.

5. Geology as a guide to ore: Econ. Geology, vol. 20, no. 7, pp. 691-692, November, 1925.

6. Leached outcrops as guides to copper ore. 175 pp., 18 figs., 24 pis., Baltimore, The Williams and Wilkins Company, 1926.

7. The formation of certain ore bodies by mineralization stoping: Econ. Geology, vol. 21, no. 5, pp. 431-453, 15 figs., August, 1926.

8. Ore finding: Mining and Metallurgy, vol. 7, no. 240, pp. 520 523, December, 1926.

9. Primary conceptions in ore geology : Econ. Geology, vol. 22, no. 1, pp. 80-84 January-February. 1927.

10. The geologist's place in the finding of ore: Min. Jour., Phoenix, Ariz., vol. 10, no. 16, pp. 5-6, 60-61, January 15, 1927.

11. The opening as a reason for ore: Econ. Geology, vol. 23, no. 1, pp. 93-98, January, 1928.

Lockett, J. R.

1. Notes on Clinton sandstone in Ohio: Nat. Petroleulu News, vol, 16, nc. 44 pp. 73, 75, 76, 79, 81, 83, October, $29,1924$.

2. General structure of the producing sands in eastern Ohio: Am. Assoc. Petroleum Geologists, Bull., vol. 11, no. 10, pp. 1023-1033, 1 fig., October, 1927.

Lockwood, C. D.

1. Oil may exist in southeast Oklahoma: Oil and Gas Jour:, vol. 24 , no. 30, pp. 51, 104, December 17, 1925.

2. Geology of Panhandle [Texas] : Oil and Gas Jour., vol. 24, no. 43, pp. 30, 152, map, March 18, 1926.

Lodochnikow, W. N.

1. A discussion of N. L: Bowen's paper, "The problem of the anorthosites": Jour. Geology, vol. 33, no. 2, pp. 153-172, 1925.

Leol, Wayne. See Arnold, 3.

Loewinson-Lessing, $\mathbf{F}$.

1. The problem of the anorthosites and other mono-mineral igneous rocks: Jour. Geology, vol. 31, no. 2, pp. 89-105, February-March, 1923.

Logan, Clarence August. See also Boalich, 1.

1. PIatinum and allied metals in California: California State Min. Bur., no. 85,120 pp., 4 pls. (incl. maps), 10 figs., 191.9. 
Logan, Clarence August-Continued.

2. Notes on the West Point district, Calaveras County: California State Min. Bur., Mining in California, vol. 18, no. 1, pp. 15-21, January, 1922.

3. Copper mining in California : Min. Congress Jour., vol. 12, no. 9, pp. 631, 632, 639, September, 1926.

Logan, William Newton. See also Ries, 5 ; Moulton, 8.

1. The occurrence of coal in Monroe County: Indiana Acad. Sci., Proc. 1918, pp. 172-176, 2 pls., 1919.

2. Note on occurrence of indianaite in Monroe County, Indiana: Indiana Acad. Sci., Proc. 1918, pp. 177-182, 3 pls., 1919.

3. A bio-chemical theory of the origin of indianaite: Science, new ser., vol. 49 , p. 197, February 21, 1919.

4. Kaolin of Indiana: Indiana, Dept. of Conservation, Division of Geology, Pub. no. 6, 131 pp., 43 pls., (incl. maps), 1919.

5. Petroleum and natural gas in Indiana; a preliminary report: Indiana, Dept. Conservation, Pub. no. 8, 279 pp., 63 pls. and figs. (incl. maps), 1920.

6. Report of the division of geology : Indiana, Dept. Conservation, 1st Ann. Rept. (reprinted from Year Book), pp. 9-39 [1920].

7. Report of the division of geology : Indiana, Dept. Conservation, $2 \mathrm{~d}$ Ann. Rept: (reprinted from Year Book), pp. 251-257, 1921.

8. The building stones of Indiana: Indiana, Dept. Conservation, $2 d$ Ann. Rept. (reprinted from Year Book), pp. 257-263, 1921.

9. Cement materials and industries: Indiana, Dept. Conservation, $2 d$ Ann. Rept. (reprinted from Year Book), pp. 263-272, 1921.

10. Economic geology of Indiana. In Handbook of Indiana geology (Indiana, Dept. Conservation, Pub. no. 21), pp. 571-1058, 161 figs. (incl. maps), Indianapolis, 1922.

11. Vanishing of eastern coal seams in Indiana: Pan-Am. Geologist, vol. 37, no. 2, p. 167, March, 1922.

12. Peat deposits of Indiana: Am. Peat Soc., Jour., vol. 16, no. 1, pp. 22-29, January, 1923; Indiana, Dept. Conservation, 4th Ann. Rept., pp. 21-26, 1923.

13. Report of the division of geology : Indiana, Dept. Conservation, 4th Ann. Rept., pp. 8-18, 1923.

14. The geology of McCormick's Creek Canyon: Indiana, Dept. of Conservation, Division of Lands. and Waters, Pub. no. 38, pp. 17-19, 1923.

15. Outlines of Indiana geology : Pan-Am. Geologist, vol. 40, no. 2, pp. 111138, 1 fig., 5 pls. (maps), September, 1923.

16. Report of the division of geology : Indiana, Dept. Conservation, 5th Ann. Rept., pp. 10-17, 1924.

17. Petroleum conservation: Indiana, Dept. Conservation, 5th Ann. Rept. pp. 17-25, 1924.

18. Geological conditions in the oil fields of southwestern Indiana: Indiana, Dept. Conservation, Pub. no. 42, 125 pp., 6 figs., 1924.

19. Refractory clays and shales of Indiana: Am. Ceramic Soc., Jour., vol. 7, no. 3, pp. 201-206, March, 1924.

20. Report of the division of geology: Indiana, Dept. Conservation, 6th Ann. Rept., pp. 10-19, 1925.

21. The conservation of natural gas: Indiana, Dept. Conservation, 6th Ann. Rept., pp. 19-21, 1925.

22. Indiana petroleum conditions in 1924: Am. Inst. Min. and Met. Eng., no. 1447, pp. 112-119, 1 fig., April, 1925. 
rogan, William Newton-Continued.

23. The sub-Trenton formations of Indiana: Indiana Acad. Sci., Proc., vol. 34, p. 75-79, 1925.

24. The geology of the deep wells of Indiana: Indiana, Dept. Conservation, Div. Geology, Pub. no. 55, 540 pp., 1926.

25. Stratigraphy of Pennsylvanian and upper Mississippian formations of southwestern Indiana (abstract) : Pan-Am. Geologist, vol. 45, no. 2, pp. 175-176, March, 1926.

26. Report of the division of geology: Indiana, Dept. Conservation, 7th Ann. Rept., pp. 9-16, 1926.

27. Some features of the Cincinnati arch as shown by geological conditions in an Indiana gas field: Indiana Acad. Sci., Proc., vol. 36, pp. 65-70, 2 figs., 1927.

28. Report of the division of geology: Indiana, Dept. Conservation, 8th Ann. Rept., pp. 13-21, 1927.

29. Report of the division of geology: Indiana, Dept. Conservation, 9th Ann. Rept., pp. 9-18, 1928.

Lombard, R. H. See Merwin, 5.

Long, Eleanor Tatum.

1. Minor faulting in the Cayuga Lake region: Am. Jour. Sci., 5th ser., vol. 3, pp. 229-248, 10 figs., April, 1922.

2. The mouth of preglacial Salmon Creek, New York: Am. Jour. Sci., 5th ser., vol. 12, pp. 510-514, 1 fig., December, 1926.

Longfellow, Dwight $\mathrm{W}$.

1. Symmetric disposition of Tertic mountain systems: Pan-Am. Geologist, vol. 50, no. 2, pp. 103-106, 1 fig., September, 1928.

Longwell, Chester Ray. See also Foye, 5 ; Stille, 1.

1. Geology of the Muddy Mountains, Nevada, with a section to the Grand Wash Cliffs in western Arizona: Am. Jour. Sci., 5th ser., vol. 1, no. 1, pp. 39-62, 5 figs., January, 1921.

2. (and Waters, E. O.). A practical method for determining dip and strike: Econ. Geology, vol. 16, no. 6, pp. 405-409, 2 figs., September-October, 1921.

3. The Muddy Mountain overthrust in southeastern Nevada: Jour. Geology, vol. 30, no. 1, pp. 63-72, 7 figs., January-February, 1922.

4. (and others). Geology of the Colorado River in southeastern Utah (abstract with discussion by David White): Geol. Soc. America, Bull., vol. 33, no. 1, pp. 122-123, March 31, 1922.

5. Notes on the structure of the Triassic rocks in southern Connecticut: Am. Jour. Sci., 5th ser., vol. 4, pp. 223-236, 2 figs., September, 1922.

6. (and Miser, H. D., Moore, R. C., Bryan, Kirk, and Paige, Sidney). Rock formations in the Colorado Plateau of southeastern Utah and northern Arizona: U. S. Geol. Survey, Prof. Paper 132, pp. 1-23, 1 flg., 10 pls., July 27, 1923.

7. Kober's theory of orogeny: Geol. Soc. America, Bull., vol. 34, no. 2, pp. 231-241, 9 figs., June 30, 1923.

8. Thrust faults and faults [in error for flaws] in southern Nevada (abstract) : Geol. Soc. America, Bull., vol. 35, no. 1, pp. 64-65, March 30, 1924 ; Pan-Am. Geologist, vol. 41, no. 2, p. 136, March, 1924.

9. Geological significance of isostasy and gravity measurements; a review: Geog. Rev., vol. 15, pp. 123-129, January, 1925. 
Longwell, Chester Ray-Continued.

10. Complex structure in the Spring Mountains, Nevada (abstract): Geol. Soc. America, Bull., vol. 36, no. 1, p. 150, March 30, 1925; Pan-Am. Geologist, vol. $4 \xi$, no. 2 , p. 149 , March, 1925.

11. The pre-Triassic unconformity in southeru Nevada: Am. Jour. Sci., 5th ser., vol. 10, pp. 93-106, 5 figs., August, 1925.

12. Structural studies in southern Nevada and western Arizona: Geol. Soc. America, Bull., vol. 37, no. 4, pp. 551-583, 7 figs., 4 pls., December 30, 1926 ; abstract, no. 1, p. 165, March 30,1926 ; Pan-Am. Geologist, vol. 45 , no. 2 , p. 164 , March, 1926.

13. Geophysical problems of: general interest; a survey of recent literature: Geog. Rev., vol. 17, no. 3, pp. 467-475, July, 1927.

14. Three common types of desert mud cracks: Am. Jour. Sci., 5th ser., vol. 15, pp. 136-145, 9 figs., February, 1928.

15. Geology of the Muddy Mountains, Nevada, with a section through the Virgin Range to the Grand Wash Cliffs, Arizona: U. S. Geol. Survey, Bull. 798, 152 pp., 9 figs., 17 pls. (incl. map), 1928.

16. Some physical tests of the displacement hypothesis. In Theory of continental drift, pp. 145-157, 5 figs., Am. Assoc. Petroleum Geologists, 1928.

17. Lessons from the St. Francis dam [California] : Science, new ser., vol. 67, pp. 36-37, July 13, 1928.

18. The Triassic of Connecticut: Am. Jour. Sci., 5th ser., vol. 16, pp. 259-263, 4 figs., September, 1928.

19. Herschel's view of isostatic adjustment: Am. Jour. Sci., 5th ser., vol. 16, pp. 451-453, 1 fig., November, 1928.

Lonsdale, John Tipton. See also Gould, C. N., 11, 15 ; Palache, 20.

1. Some effects of heat on the properties of minerals: Am. Mineralogist, vol. 8, no. 8, pp. 141-14:7, August, 1923.

2. Post-Cincinnatian granites of northeastern Piedmont Virginia: Jour. Geology, vol. 34, no. 2. pp, 159-166, 3 figs. (maps), February-March, 1926.

3. A Piedmont Virginia maguatic complex: Am. Jour. Sci., 5th ser., vol. 11, pp. 505-513, 2 figs., June, 1926.

4. Niter and soda niter from Brewster County, Texas: Am. Mineralogist, vol. 11, no. 7, pp. 189-190, July, 1926.

5. The occurrence of caliche in Oklahoma (abstract) : Iowa Acad. Sci., Proc., 1925, vol. 32 , p. 357 [1926].

6. The occurrence of caliche in Oklahoma: Oklahoma Acad. Sci., Proc., vol. 5, 1925 (Oklahoma, Cniv., Bull., new ser. no. 330, Univ. Studies no. 22), pp. 132-136, April 1, 1926.

7. Geology of the gold-pyrite belt of the northeastern Piedmont, Virginia: Virginia Geol. Survey, Bull. 30, 110 pp., 11 figs., 9 pls., 1927.

8. (and Adkins, W. S.). Eukedral orthoclase crystals from Sierra Blanca, Texas: Am. Mineralogist, vol. 12, no. 6, pp. 256-259, 1 fig., June, 1927.

9. The Florence meteorite of Williamson County, Texas: Am. Mineralogist, vol. 12, no. 11, pp. 398-404, 2 pls., November, 1927.

10. Igneous rocks of the Balcones fault region of Texas: Texas, Univ., Bull. no. 2744,178 pp., 20 figs., 9 pls. (incl. map), November 22; 1927.

11. (and Crawford, David J.). Pseudo-igneous rock and baked shale from the burning of lignite, Freestone County, Texas: Texas, Univ., Bull. no. 2801., pp. 147-158, 1 fig., 3 pls., 1928. 
Lonsdale, John Tipton-Continued.

12. Analcite from Brewster County, Texas: Am. Mineralogist, vol. 13, no. 8, pp. 449-450, August, 1928.

Loomis, Bénjamin Franklin.

1. Pictorial history of the Lassen Volcano [California]. 135 pp., 84 figs., map, Anderson, Calif., Anderson Valley News Press [1926].

Loomis, Frederic Brewster. See also Gidley, 9.

1. An amphibian from the Eocene: Am. Jour. Sci., 4th ser., vol. 47, pp. 217219, 1 fig., March, 1919.

2. Pawnee Creek beds of Colorado (abstract) : Geol. Soc. America, Bull., vol. 21, no. 1, p. 224, March 31, 1920.

3. On Ticholeptus rusticus and the genera of Oreodontidae: Am. Jour. Sci., 4th ser., vol. 50, pp. 281-292, 4 figs., October, 1920.

4. Postglacial faulting about Mount Toby, Massachusetts (with discussion by W. H. Hobbs) : Geol. Soc. America, Bull., vol. 32, no. 1, pp. 75-80, 3 figs., March 31, 1921.

5. Origin of South American faunas [including relations to North American faunas] : Geol. Soc. America, Bull., vol. 32, no. 1, pp. 187-196, March 31, 1921.

6. Lower Miocene at Van Tassel, Wyoming (abstract) : Geol. Soc. America, Bull., vol. 33, no. 1, p. 211, March 31, 1922 .

7. Upper Pawnee Creek beds (abstract): Geol. Soc. America, Bull., vol. 33 , no. 1, p. 211, March 31, 1922.

8. Field book of common rocks and minerals; for identifying the rocks and minerals for the United States and interpreting their origins and meanings. xviii, 278 pp., 73 pls., New York, G. P. Putman's Sons, 1923.

9. Oreodons of the lower Harrison beds: Am. Jour. Sci., 5th ser., vol. 6, pp. 222-228, 5 figs., September, 1923.

10. The oreodonts of the lower Oligocene: Carnegie Mus., Annals, vol. 15, nos. 2 and 3, pp. 369-378, 3 figs., 3 pls., July, 1924.

11. Miocene oreodonts in the American Museum: Am. Mus. Nat. Hist., Bull., vol. 51, pp. 1-37, 26 figs., July 10, 1924.

12. Artifacts associated with the remains of a Columbian elephant at Melbourne, Florida: Am. Jour. Sci., 5th ser., vol. 8, pp. 503-508, 2 figs., December, 1924.

13. Leptauchenia and Cyclopidius: Am. Jour. Sci., 5th ser., vol. 9, pp. 241249, 4 figs., March, 1925.

14. Dentition of artiodactyls: Geol. Soc. America, Bull., vol. 36, no. 4, pp. 583-604, 20 figs., December 30, 1925; abstract, no. 1, p. 226, March 30, 1925.

15. The evolution of the horse. xvi, 233 pp., 41 figs., 25 pls., Boston, Marshall Jones Company, 1926:

16. Early man in Florida: Natural History (Am. Mus. Nat. Hist., Jour.), vol. 26, no. 3, pp. 260-262, 2 figs., May-June, 1926.

17. A giant tortoise from Florida: Am. Jour. Sci., 5th ser., vol. 13, pp. 435439, 2 figs., May, 1927.

18. Poebrotherium: Am. Jour. Sci., 5th ser., vol. 16, pp. 137-142, 3 figs., August, 1928.

19. Phylogeny of the deer: Am. Jour. Sci., 5th ser., vol. 16, pp. 531-542, 10 figs., December, 1928.

$4096-31-25$ 
Loomis, Frederic Brewster-Continued.

20. The evolution of the horse and the elephant. In Creation by evolution, edited by Frances Mason, pp. 225-241, 4 figs., New York, the Macmillan Company, 1928.

Loomis, Harve.

1. Occurrence of limestone in northeastern Garvin County, Oklahoma: Am. Assoc. Petroleum Geologists, Bull., vol. 6, no. 1, pp. 54-55, JanuaryFebruary, 1922.

2. The Burket-Seeley pool, Greenwood County, Kansas: Am. Assoc. Petroleum Geologists, Bull., vol. 7, no. 5, pp. 482-487, 3 figs., SeptemberOctober, 1923.

Lord, Richard C.

1. Origin of the brines of eastern Ohio (abstract): Ohio Acad. Sci.,. Proc., vol. 8, pt. 4, pp. 175-176, 1928 ; Ohio Jour. Sci., vol. 8, no. 3, pp. pp. 153-154, May, 1928.

Lorenzana, Louís García.

1. Informe geológico de unos terrenos de los que se han encontrado muestras de amianto: Cuba, Dirección de montes y minas, Bol. minas, no. 8, pp. 61-63, 1 fig., August, 1925.

Louderback, George Davis. See also Twenhofel, 16.

1. Preliminary results of a study of the San Francisco Bay sediments (abstract with discussion by E. W. Shaw) : Geol. Soc. America, Bull., vol. 31, no. 1, pp. 123-125, March 31, 1920.

2. Age of the scarp-producing faults of the Great Basin (abstract) : Geol. Soc. America, Bull., vol. 31, no. 1, p. 127, March 31, 1920.

3. Proceedings of the nineteenth annual meeting of the Cordilleran section, held at Pasadena, California, June 19-22, 1919; Geol. Soc. America, Bull., vol. 31, pp. 191-196, March 31, 1920.

4. Certain marked differential movements in the San Francisco Bay region (abstract with discussion by W. H. Hobbs) : Geol. Soc. America, Bull., vol. 32, no. 1, p. 45, March 31, 1921.

5. Basin range structure in the Great Basin: California, Univ., Dept. Geol. Sci., Bull., vol. 14, no. 10, pp. 329-376, 2 figs., 9 pls., November 8 , 1923.

6. Geologic section across the Coast Ranges of California (abstract, with discussion by Robin Willis) : Geol. Soc. America, Bull., vol. 35, no. 1, p. 95, March 30, 1924; abstract, Pan-Am. Geologist, vol. 41, no. 2 , p. 147 , March, 1924.

7. Period of scarp production in the Great Basin: California, Univ., Dept. Geol. Sci., Bull., vol. 15, no. 1, pp. 1-44, 3 figs., 3 pls., May 22, 1924.

8. Morphologic features of the Basin Range displacements in the Great Basin: California, Univ., Dept. Geol. Sciences, Bull., vol. 16, no. 1, pp. 1-42, 9 figs., $\theta$ pls., January 9, 1926.

9. Geologic conditions at the [St. Francis] dam site: Report of the Commission to investigate the causes leading to the failure of the St. Francis dam near Saugus, California, pp. 10-13, California State Printing Office, Sacramento, 1928.

10. Geologic features of Kennett dam site [Sacramento River]: California, Dept. Public Works, Div. Engineering and Irrigation, Bull. no. 13, pp. 56-59, 2 pls., California State Printing Office, Sacramento, 1928.

11. The geology of the St. Francis dam site: Am. Soc. Civil Eng., San Francisco section, [Proc.], vol. 24, no. 3, pp. 9-10, June 19, 1928, 
Loughlin, Gerald Francis. See also Bateman, 10 ; Butler, 4 ; Emmons, S. F., 1: Heikes, 1; Lindgren, 2; Smith, G. O., 3.

1. Two lamprophyre dikes near Santaquin and Mount Nebo, Utah (U. S. Geol. Survey, Prof. Paper 120, pp. 101-109, 1918) (abstract by R. W. Stone) : Washington Acad. Sci., Jour., vol. 9, no. 8, p. 228, April 19, 1919.

2. Oxidized zinc ores of Leadville, Colorado (U. S. Geol. Survey, Bull. 681, 1918) (abstract): Washington Acad. Sci., Jour., vol. 9, no. 17, p. 529, October 19, 1919.

3. Rock products and the war (abstract) : Geol. Soc. America, Bull., vol. 30, p. 97; March 31, 1919.

4. Lime in 1917: U. S. Geol. Survey, Mineral Resources, 1917, pt. 2, pp. 583613, May 13, 1919.

5. (and Coons, A. T.). Stone in 1917: U. S. Geol. Survey, Mineral Resources, 1917, pt. 2, pp. 615-682, June 20, 1919.

6. (and Coons, A. T.). Slate in 1918: U. S. Geol. Survey, Mineral Resources, 1918, pt. 2, pp. 267-282, 1 fig., October 23, 1919.

7. (and Insley, Herbert). Lime in 1918: U. S. Geol. Survey, Mineral Resources, 1918, pt. 2, pp. 815-S56, 3 figs., 3 pls., June 7, 1920.

8. (and Coons, A. T.). Stone in 1918: U. S. Geol. Survey, Mineral Resources, 1918, pt. 2, pp. 1189-1313, 8 figs., 7 pls., October 11, 1920.

9. (and Berry, E. W., and Cushman, J. A.). Limestones and marls of North Carolina: North Carolina Geol. and Econ. Survey, Bull. no. 28, 211 pp., 3 figs., 17 pls. (incl. maps), 1921.

10. (and Coons, A. T.). Slate in $1919:$ U. S. Geol. Survey, Mineral Resources, 1919, pt. 2, pp. 369-375, July 29, 1921.

11. (and Coons, A. T.). Lime in 1919: U. S. Geol. Survey, Mineral Resources, 1919, pt. 2, pp. 405-41.8, October 6, 1921.

12. (and Coons, A. T.). Stone in 1919: U. S. Geol. Survey, Mineral Resources, 1919, pt. 2, pp. 419-455, October 18, 1921.

13. (and Coons, A. T.). Slate in 1920 : U. S. Geol. Survey, Mineral Resources, 1920, pt. 2, pp. 135-143, October 12, 1921.

14. (and Coons, A. T.). . Lime in 1920: U. S. Geol. Survey, Mineral Resourcés, 1920, pt. 2, pp. 178-188, November 3, 1921.

15. (and Coons, A. T.). Stone in 1920 : U. S. Geol. Survey, Mineral Resources, 1920, pt. 2, pp. 225-262, March 6, 1922.

16. Magnesium in 1921: U. S. Geol. Survey, Mineral Resources, 1921, pt. it, pp. 19-20, June 14, 1922.

17. (and Coons, A. T.). Slate in 1921: U. S. Geol. Survey, Mineral Resources, 1921, pt. 2, pp. 23-30, June 29, 1922.

18. (and Coons, A. T.). Lime in 1921: U. S. Geol. Survey, Mineral Resources, 1921, pt. 2, pp. 155-168, November 29, 1922.

19. (and Coons, A. T.). Stone in 1921: U. S. Geol. Survey, Mineral Resour'ces, 1921, pt. 2, pp. 175-213, January 22, 1923.

20. (and Clark, Martha B.). Mineral resources of the United States in 1922 (preliminary summary) : U. S. Geol. Survey, Mineral Resources, 1922, pp. 1A-124A, August 15, 1923.

21. (and Coons, A. T.). Slate in 1922: U. S. Geol. Survey, Mineral Resources, pt. 2, pp. 165-175. November 6, 1923.

22. Notes on ground waters: Econ. Geology, vol. 19, no. 1, pp. 62-71, 2 figs., January-February, 1924.

23. (and Coons, A. T.). Stone in 1922 : U. S. Geol. Survey, Mineral Resources. 1922, pt. 2, pp. 261-344, 3 figs., April 10, 1924. 
Loughlin, Gerald Francis-Continued.

24. An interesting case of dangerous aggregate; the altered feldspar and causes of its disintegration: Am. Concrete Inst., Proc., vol. 19, pp. 150-153, 1923; Concrete, vol. 22, no. 4, pp. 146-147, April, 1923.

25. (and Coons, A. T.). Slate in $1923:$ U. S. Geol. Survey, Mineral Resources, 1923, pt. 2, pp. 49-61, 3 figs., September 25, 1924.

26. (and Coons, A. T.). Stone in 1923: U. S. Geol. Survey, Mineral Resources, 1923, pt. 2, pp. 205-234, December 18, 1924.

27. (and Coons, A. T.). Lime in 1923: U. S. Geol. Survey, Mineral Resources, 1923, pt. 2, pp. 275-284, December 19, 1924.

28. The mineral resources of the United States in 1922: U. S. Geol. Survey, Mineral Resources, 1922, pt. 1, pp. 1A-124A, 1925.

29. (and Coons, A. T.). Slate in 1924: U. S., Bur. Mines, Mineral Resources U. S., 1924, pt. 2, pp. 151-160, December 16, 1925.

30. (and Coons, A. T.). Lime in 1924: U. S., Bur. Mines, Mineral Resources U. S., 1924, pt. 2, pp. 193-230, May 22, 1926.

31. Guides to ore in the Leadville district, Colorado: U. S. Geol. Survey, Bull. 779, 37 pp., 4 figs., 7 pls. (incl. map), 1926.

32. Ore at deep levels in the Cripple Creek district, Colorado: Am. Inst. Min. and Met. Eng., Tech. Pub. no. 13, 32 pp., 12 figs., August, 1927; Trans., vol. 75, pp. 42-73, 12 figs., 1927; abstract, Washington Acad. Sci., Jour., vol. 17, no. 12, pp. 321-322, June 19, 1927; Mining and Metallurgy, vol. 8, no. 248, p. 357, August, 1927.

33. Qualifications of different kinds of natural stone for concrete aggregate: Am. Concrete Inst., Proc., vol. 23, pp. 319-351, 19 figs., 1927.

34. Usefulness of petrology in the selection of limestone: Rock Products, vol. 31, no. 6, pp. 50-59, 15 figs., March 17, 1928.

Louis, Herbert.

1. Die Verbreitung von Glacialformen im Westen der Vereinigten Staaten: Zeitschr. Geomorphologie, Bd. 2, H. 4, pp. 221-235, Leipzig, 1927.

Lovejoy, Ellis.

1. Notes on fire clays of the northern Appalachian coal basin (with discussion) : Am. Ceramic Soc., Jour., vol. 2, no. 5, pp. 374-390, May, 1919.

Loveland, R. P. See Fairbanks, 12.

Lovering, Thomas S.

1. The leaching of iron protores; solution and precipitation of silica in cold water: Econ. Geology, vol. 18, no. 6, pp. 523-540, 1 fig., September, 1923.

2. Magmatic chalcopyrite, Park County, Montana: Econ. Geology, vol. 19, no. 7, pp. 636-640, November, 1924.

3. Metasomatism and linear "force of growing crystals" (discussion) : Econ. Geology, vol. 21, no. 5, pp. 507-511, August, 1926.

4. Relations between stress, strain, and rupture in structural geology (abstract) : Geol. Soc. America, Bull., vol. 38, no. 1, pp. 151-152, March 30, 1927.

5. Organic precipitation of metallic copper: U. S. Geol. Survey, Bull. 795, pp. 45-52, June 18, 1927.

6. Williams thrust fault (abstract) : Geol. Soc. America, Bull., vol. 39, no. 1, pp. 173-174, March 30, 1928. 
Lovering, Thomas S.-Continued.

7. Geology of the Moffat Tunnel, Colorado: Am. Inst. Min. and Met. Eng., Trans., vol. 76, pp. 337-346, 1928; abstract, Washington Acad. Sci., Jour., vol. 18, no. 9, p. 264, May 4, 1928.

8. The fracturing of incompetent beds: Jour. Geology, vol, 36, no. 8, pp. 709717, 3 figs., November-December, 1928.

Low, A. P.

1. The east coast of Hudson Bay: Canadian Min. Jour., vol. 49, no. 36, pp. 712-727, no. 37, pp. 736-739, 5 figs., map, September 7 and 14, 1928.

Lowe, Ephraim Noble. See also Ries, 5.

1. Sixth biennial report, 1916-1917, of the director of the [Mississippi] State Geological Survey ... 12 pp. [1918].

2. Mississippi, its geology, geography, soil, and mineral resources (a revision, with additions, of Bulletin no. 12) : Mississippi State Geol. Survey, Bull. no. 14, 346 pp., 20 figs., map, 1919.

3. Oil and gas prospecting in Mississippi: Mississippi State Geol. Survey, Bull. no. 15, 80 pp., 1 pl., 1 fig., 1 map, 1919.

4. Road-making materials of Mississippi: Mississippi State Geol. Survey, Bull. no. 16, 139 pp., 1 fig., March, 1920.

5. Seventh biennial report, 1918-1919, of the director of the State geological survey to the Mississippi legislature. $12 \mathrm{pp}$., Jackson, Miss. [1920?].

6. Eighth biennial report, 1920-1921, of the director of the State geological survey to the Mississippi legislature. $48 \mathrm{pp}$. [1921?].

7. Present status of oil and gas prospects in Mississippi: Am. Assoc. Petroleum Geologists, Bull., vol. 5, no. 4, pp. 490-496, July-August, 1921.

8. Ninth biennial report, 1921-1923, of the director of the State Geological Survey to the Mississippi Legislature, pp. 3-14 [1923].

9. (and others). Petroleum prospecting in Mississippi: Ninth Biennial Report, 1921-1923, of the director of the State Geological Survey to the Mississippi Legislature, pp. 15-190, 1 fig. (sketch map) [1923].

10. A questionnaire on the mineral resources of Mississippi and the work of the State Geological Survey: Mississippi State Geol. Survey, Bull. no. 18, 32 pp., March, 1923.

11. Mineral resources of Mississippi: The South's Development, Manufacturers Record, vol. 86, no. 24, pt. 2, pp. 389-390, December 11, 1924.

12. Geology and mineral resources of Mississippi: Mississippi State Geol. Survey, Bull. no. 20, 140 pp., 10 figs., 1925.

13. Stratigraphy of Mississippi (abstract) : Pan-Am. Geologist, vol. 49, no. 3, pp. 237-238, April, 1928; Geol. Soc. America, Bull., vol. 39, no. 1, p. 274, March 30, 1928.

Lucas, Anthony Francis, 1855-1921.

1. Possible existence of deep-seated oil deposits on Gulf coast (with discussion by G. S. Rogers) : Am. Inst. Min. and Met. Eng., Trans., vol. 61, pp. 501-519, 5 figs., 1920.

2. Urgency for deeper drilling on the Gulf coast: Mining and Metallurgy, no. 164, pp. 26-27, August, 1920 (abstract) ; Am. Inst. Min. and Met. Eng., Trans. [preprint no. 1004], 5 pp., 1 fig., 1920; discussion, no. 1038 , pp. 44-48, January, 1921.

Lucas, Frederic Augustus, 1852-1929.

1. Animals of the past; an account of some of the creatures of the ancient world. Sixth and revised edition, 207 pp., illus., Am. Mus. Nat. Hist., Handbook series no. 4, New York, 1922. 
Lucke, P. K.

1. The relation of sulphides to water level in Mexico: Am. Inst. Min. and Met. Eng., Trans., vol. 61, pp. 143-146, 3 flgs., 1920.

Ludlum, Albert Claude, 1867-1928.

1. Chester Wells Purington: Mining and Metallurgy, vol. 4, no. 203, pp. 578579, portr., November, 1923 ; Am. Inst. Min. and Met. Eng., Trans., vol. 70 , pp. 1235-1237, portr., 1924.

Lütgens, Rudolf.

1. Geographische und geologische Beobachtungen in Nordwest-Haiti: Geog. Gesell. in Hamburg, Mitt., Bd. 32, pp. 41-90, 10 figs., 4 pls. (incl. map), 1919.

Lugn, Alvin Leonard.

1. A theory of origin of some limestone masses and septaria: Iowa, Univ., Studies, new ser., no. 104, Studies in Natural History, vol. 11, no. 8, pp. 19-22, 3 figs., March 1, 1926.

2. Methods of collecting sediment samples from the Mississippi River: Iowa. Univ.; Studies, new ser., no. 104, Studies in Natural History, vol. 11, no. 8, pp. 23-31, 2 pls., March 1, 1926.

3. Some large glacial boulder's in Des Moines County, Iowa: Iowa Acad. Sci., Proc., vol. 32, pp. 345-350, 7 figs. [1926].

4. The Mississippian-Pennsylvanian and Pennsylvanian-Pleistocene unconformities in Lucas County, Iowa: Iowa Acad. Sci., Proc., 1925, vol. 32, pp. 351-356, 2 figs. [1926].

5. Observed origin of some mud pebbles (abstract) : Pan-Am. Geologist, vol. 46, no. 5, pp. 403-404, December, 1926.

6. Geology of Lucas County: Iowa Geol. Survey, vol, 32, pp. 101-237, 33 flgs., 2 pls., map, 1927.

7. Sedimentation in the Mississippi River between Davenport, Iowa, and Cairo, Illinois: Augustana Library Pub., no. 11, 104 pp., 2 figs., 24 pls., 1927.

8. Some observations on undertow: Iowa Acad. Sci., Proc., 1926, vol. 33, pp. 199-201 [1927].

9. An observed origin of some mud pebbles: Iowa Acad. Sci., Proc., 1927, vol. 34, pp. 249-251, 3 figs. [1928].

10. Discussion of a sample of cobble gravel from the Mississippi River: Iowa Acad. Sci., Proc., 1927, pp. 253-256, 2 figs. [1928].

Lull, Richard Swann.

1. Samuel Wendell Williston: Am. Jour. Sci., 4th ser., vol. 47, pp. 220-224, March, 1919.

2. The sauropod dinosaur Barosaurus Marsh; redescription of the type specimens in the Peabody Museum, Yale University: Connecticut Acad. Arts and Sci., Mem., vol. 6, 42 pp., 7 pls., 10 figs., December, 1919.

3. Tertiary artiodactyls from the Marsh collection (abstract): Geol. Soc. America, Bull., vol. 21, no. 1, p. 224, March 31, 1920.

4. New Tertiary artiodactyls: Am. Jour. Sci., 4th ser., vol. 50, pp. 83-130, 25 flgs., 1 pl., August, 1920.

5. An upper Carboniferous footprint from Attleboro, Massachusetts: Am. Jour. Sci., 4th ser., vol. 50, pp. 234-236, 1 fig., September, 1920.

6. The Cretaceous armored dinosaur, Nodosaurus textilis Marsh: Am. Jour. Sci., 5th ser., vol. 1, no. 2, pp. 97-126, 7 figs., 4 pls., February, 1921. 
Lull, Richard Swann-Continued.

7. New camels in the Marsh collection: Am. Jour. Sci., 5th ser., vol. 1, pp. 392-404, 5 figs., May, 1921.

8. Fauna of the Dallas sand pits [Texas] : Am. Jour. Sci., 5th ser., vol. '2, pp. 159-176, 5 figs., September, 1921.

9. The antiquity of man. In The evolution of man, edited by G. A. Baitsell, pp. 1-38, 10 figs., New Haven, 1922.

10. Restoration of Blastomeryx marshi: Am. Jour. Sci., 5th ser., vol. 3, pp. 159-161, 2 figs., March, 1922. Abstract, Geol. Soc. America, Bull., vol. 33, no. 1, p. 211, March 31, 1922.

11. Supposed labyrinthodont footprints from the Maryland Carboniferous (abstract): Geol. Soc. America, Bull., vol, 33, no. 1, p. 211, March 31, 1922.

12. Primitive Pecora in Yale Museum: Am. Jour. Sci., 5th ser., vol. 4, pp. 111-119, ${ }^{\circ} 1$ fig., August, 1922.

13. Variations or specific distinctions; which?: Geol. Soc. America, Bull., vol. 33, no. 3, pp. 599-604, September 30, 1922.

14. Biographical memoir Samuel Wendell Williston, 1852-1918: Nat. Acad. Sci.; Mem., vol. 17, pp. 113-141, portr., 1924.

15. Dinosaurian climatic response. In Organic adaptation to environment, pp. 225-279, 13 figs., 1 pl., New Haven, Yale University Press, 1924.

16. Probable reptilian footprints from the Maryland Carboniferous: West Virginia Geol. Survey, Mineral and Grant counties, pp. 731-734: 6 pls., 1924.

17. The ways of life. 365 pp.. 24 figs., New York, Harper \& Brothers, 1925.

18. Early fossil hunting in the Rocky Mountains: Natural History (Am. Mus. Nat. Hist., Jour.), vol. 26, no. 5, pp. 455-462, 5 figs., September-October, 1926.

19. A new footprint locality [North Branford, Connecticut]: Am. Jour. Sci., 5th ser., vol. 14, pp. 48-49, 1 fig., July, 1927.

20. Ancient man. 152 pp., 7 figs., New York, Doubleday, Doran \& Company, 1928.

21. Connecting and missing links in the ascent to man. In Creation by evolution, edited by Frances Mason, pp. 255-269, New York, The Macmillan Company, 1928.

Lunt, Horace Fletcher.

1. (and others). The oil shales of northwestern Colorado: Colorado, Bur. Mines, Bull. no. 8, 59 pp., 3 pls., 5 figs., 1919.

2. Ore deposition at Creede, Colorado: Eng. and Min Jour.-Press, vol. 117, no. 24, p. 973, June 14, 1924.

Lupton, Charles T. See also Stone, 11.

1. (and Lee, Wallace). Geology of the Cat Creek oil fields, Fergus and Garfield counties, Montana : Am. Assoc. Petroleum Geologists, Bull., vol. 5, no. 2, pp. 252-275, 2 figs., 1 pl. (with discussion by F. H. Lahee and Mowry Bates, pp. 327-328), March-April, 1921.

2. (and Lee, Wallace, and Van Burgh, L. R.). Oil possibilities of western Kansas (with discussion) : Am. Assoc. Petroleum Geologists, Bull., vol. 6, no. 2, pp. 69-90, 5 figs., 1 pl., March-April, 1922.

3. Geologic section in western Kansas [boring, Gove County]: Am. Assoc. Petroleum Geologists, Bull., vol. 6, no. 6; pp. 549-551, NovemberDecember, 1922. 
Lupton, Charles T.-Continued.

4. Results and prospects of deeper drilling in the Rocky Mountain fields: Am. Assoc. Petroleum Geologists, Bull., vol. 7, no. 4, pp. 400-410, July-August, 1923.

5. (and Marks, E. M.). Oil possibilities in South Dakota west of the Missouri River: Oil and Gas Jour., vol. 23, no. 5, pp. 78, 80, 82, S4, June 26, 1924.

6. Areal and structural geologic map of Otero County, Colorado. Scale $1 / 2$ inch $=1$ mile. 1926. Engraved and printed by the Clason Map Co., Denver.

\section{Luquer, Lea McIlvaine.}

1. Alfred J. Moses: Am. Mineralogist, vol. 5, no. 6, pp. 109-112, June, 1920.

Lusk, Ralph Gordon, 1897-1927. See also Mather, 9, 12.

1. A pre-Chattanooga sink hole [Gainsboro quadrangle, Tennessee] : Science, new ser., vol. 65, pp. 579-580, June 10, 1927.

2. The significance of structure in the accumulation of oil in Tennessee: Am. Assoc. Petroleum Geologists, Bull., vol. 11, no. 9, pp. 905-917, 3 figs., September, 1927.

3. Gravel on the Highland Rim Plateau, and terraces in the valley of Cumberland River: Jour. Geology, vol. 36, no. 2, pp. 164-170, 1 fig., February-March, 1928.

Lyder, E. E. See Allen, H. C., 1.

Lyman, Frank.

1. Benjamin Smith Lyman: Mining and Metallurgy, no. 170, pp. 23-24, February, 1921.

Lynch, F. C. C.

1. Asbestos, a Canadian specialty: Min. and Sci. Press, vol. 120, pp. 531-533, 4 figs., April 10, 1920.

Lyon, Marcus Ward, jr.

1. Goniobasis livescens Menke, a Pleistocene shell in Furnessville Blowout, dunes of Porter County: Indiana Acad. Sci., Proc. 38th Ann. Meeting, 1922, pp. 123-124, 1 fig., 1923.

Mabery, Charles Frederic, 1850-1927.

1. The genesis of petroleum as shown by its nitrogen constituents (abstract) : Science, new ser., vol. 49, pp. 549-550, June 6, 1919.

McArthur, D. C.

1. Nonmetallic mineral deposits of Manitoba: Canadian Inst. Min. and Met., Monthly Bull. no. 105, pp. 15-16, January, 1921.

Macaulay, R. M.

1. The source of placer platinum in the Tulameen district of British Columbia: Eng. and Min. Jour., vol. 107, pp. 303-306, 1 fig., February 15, 1919.

McBeth, Reid Sayers.

1. Pioneering the Gulf coast; a story of the life and accomplishments of Capt. Anthony F. Lucas. 80 pp., illus. [New York, 1918].

2. Oil, the new monarch of motion . . 210 pp., illus., New York, Markets . Publishing Corp., 1919. 
Mac Boyle, Errol.

1. Mines and mineral resources of Nevada County: Chapters of State Mineralogist's Report, Biennial Period 1917-18, 270 pp., 4 pls., 32 figs., California State Min. Bur., 1919.

2. Mines and mineral resources of Plumas County: Chapters of State Mineralogist's Report, Biennial Period 1917-18, 188 pp., 1 pl., 11 flgs., California State Min. Bur., 1920.

3. Mines and mineral resources of Sierra County: Chapters of State Mineralogist's Report, Biennial Period 1917-18, 144 pp., 3 pls., 18 flgs., California State Min. Bur., 1920.

McBride, Russell Smith.

1. (and Sievers, E. G.). Natural gas in 1919-1921: U. S. Geol. Survey, Mineral Resources, 1921, pt. 2, pp. 335-369, 13 figs., May 22, 1923.

Macbride, Thomas Huston.

1. Section of late Tertiary and Quaternary marls near DeLand, Florida (abstract) : Pan-Am. Geologist, vol. 42, no. 5, p. 382, December, 1924; Iowa Acad. Sci., Proc., vol. 31, p. 334 [1926?].

McCabe, Joseph.

1. Ice ages; the story of the earth's revolutions. 134 pp., 4 pls., New York., G. P. Putnam's Sons, 1922.

McCabe, R. E.

1. The minor oil fields of Kern County; Lost Hills oil field: California State Min. Bur., Summary of Operations California Oil Fields, vol. 10, no. 1, pp. 5-10, 2 pls. (incl. map), July, 1924.

McCallie, Samuel Washington. See also LaForge, 4.

1. Notes on the geology of Georgia: Jour. Geology, vol. 27, no. 3, pp. 165-179, 4 figs. (incl. map), April-May, 1919.

2. Notes on the geology of Georgia: Georgia, Geol. Survey, Bull. no. 39, pp. 72-85, 1 fig. (map), 1922.

3. The Pitts meteorite [Wilcox County, Georgia]: Am. Jour. Sci., 5th ser., vol. 3, pp. 211-215, 1 fig., March, 1922. Georgia, Geol. Survey, Bull. no. 39, pp. 141-149, 1 pl., 1 fig., 1922.

4. The mineral resources of Georgia: The South's Development, Manufacturers Record, vol. 86, no. 24, pt. 2, pp. 369-373, 3 figs., December 11, 1924.

5. A preliminary report on the mineral resources of Georgia ; revised edition: Georgia, Geol. Survey, Bull. no. 23, 164 pp., 1 fig., 22 pls. (incl. map), 1926.

6. Notes on the Social Circle meteorite [Georgia]: Am. Jour. Sci., 5th ser., vol. 13, p. 360, April, 1927.

7. Georgian coastal plains terranes: Pan-Am. Geologist, vol. 49, no. 3, pp. 167-178, April, 1928.

8. Mesozoic and Cenozoic formations of Georgia (abstract) : Pan-Am. Geologist, vol. 49, no. 3, p. 235, April, 1928.

McCann, William Sidney.

1. The Maskwà River copyer-nickel deposit, southeastern Manitoba: Canada, Geol. Survey, Summ. Rept., 1920, pt. C, pp. 19-29, 3 figs., map, 1921.

2. Possibilities of finding oil or natural gas at Edmunston, New Brunswick: Canada, Geol. Survey, Summ. Rept., 1921, pt. D, pp. 97-99, 1921.

3. Geology and mineral deposits of the Bridge River map area, British Columbia: Canada, Geol. Survey, Mem. 130, 115 pp., 11 figs., 11 pls., 2 maps, 1922. 
McCann, William Sidney-Continued.

4. The gold quartz veins of Bridge River district, British Columbia, and their relationship to similar ore deposits in the western Cordilleras : Econ. Geology, vol. 17, no. 5, pp. 350-369, 4 figs., August, 1922.

MacCarthy, Gerald R:

1. Mud cracks on steeply inclined surfaces: Jour. Geology, vol. 30, no. 8, p. 702, November-December, 1922.

2. Some facts and theories concerning laccoliths: Jour. Geology, vol. 33, no. 1, pp. 1-18, 7 figs., January-February, 1925.

3. Iron coloration in rocks and minerals: Elisha Mitchell Sci. Soc., Jour., vol. 41, nos. 1-2, pp. 135-137, September, 1925.

4. Iron-stained sands and clays: Jour. Geology, vol. 34, no. 4, pp. 352-360, May-June, 1926.

5. Colors produced by iron in minerals and the sediments: Am. Jour. Sci., 5th ser., vol. 12, pp. 17-36, July, 1926.

6. The green color of certain ferrous minerals: Am. Mineralogist, vol. 11, no. 12, pp. 321-325, December, 1926.

7. Experiments in underthrusting: Am. Jour. Sci., 5th ser., vol. 16, pp. 51-67, 9 figs., July, 1928; abstract, Geol. Soc. America, Bull., vol. 39, no. 1, p. 172, March 30, 1928; Pan-Am. Geologist, vol. 49, no. 1, p. 77, February, 1928.

8. The origin of folded mountains (abstract): Elisha Mitchell Sci. Soc., Jour., vol. 44, no. 1, pp. 14-15, September, 1928.

McCartney, G. C. See Wallace, 23.

McCaskey, Hiram Dryer. See also Bastin, 3.

1. (and others). Our mineral supplies: U. S. Geol. Survey, Bull. 666, 278 pp., 6 figs., 1 pl., 1919.

MacCaughey, Vaughan.

1. Activity of Kilauea Volcano [Hawaii]: Science, new ser., vol. 49, pp. 188-189, February 21, 1919.

McCaughey, William John.

1. Note on the Becke reaction: Am. Mineralogist, vol. 5, no. 7, p. 134, July, 1920.

2. Mineralogical examination of coal formation clays: Ohio Geol. Survey, 4th ser., Bull. 26, pp. 516-522, 1923.

McClellan, H. W.

1. Laumontite from southern Oregon: Am. Mineralogist, vol. 11, no. 10, pp. 287-288, October, 1926.

MacClintock, Paul.

1. The Pleistocene history of the lower Wisconsin River: Jour. Geology, vol. 30, no. 8, pp. 673-689, 5 figs., November-December, 1922.

2. The breaking of waves in shallow water: Jour. Geology, vol. 32, no. 5, pp. 407-409, 3 figs., July-August, 1924.

3. Pre-Illinoian till in southern Illinois: Jour. Geology, vol. 34, no. 2, pp. 175-180, 4 figs., February-March, 1926; Illinois State Geol. Survey, Rept. Investigations, no. 11, pp. 10-15, 4 figs., 1926.

McClung, C. E.

1. Martinichthys, a new genus of Cretaceous fish from Kansas, with descriptions of six new species: Am. Philos. Soc., Proc., vol. 65, no. 5, suppl., pp. 20-26, 2 pls., 1926. 
McCollom, C. R. See Templeton, 1.

McComb, H. E.

1. An investigation of the Milne-Shaw seismograph: Seismol. Soc. America, Bull., vol. 12, no. 4, pp. 220-226, 1 fig., December, 1922.

McConnell, R. G.

1. Sault Ste. Marie area, District of Algoma: Ontario Dept. Mines, 35th Ann. Rept., vol. 35, pt. 2, pp. 1-52, 9 figs., map, 1927.

McCormack, John T. See also Romer, 10.

1. Experiments on the dehydration of gypsum: Jour. Geology, vol. 34, no. 5, pp. 429-433, July-August, 1926.

\section{McCornack, Ellen Condon.}

1. Contributions to the Pleistocene history of Oregon, Univ., Leaflet series, Geology Bull., vol. 6, no. 3, pt. 2, 23 pp., 2 figs., October, 1920.

2. Thomas Condon, pioneer geologist of Oregon (with Foreword by Henry Fairfield Osborn). xv, 355 pp., illus.; Eugene, Oregon, University Press, 1928.

McCoy, Alexander Watts. See also Washburne, 2.

1. Notes on principles of oil accumulation: Jour. Geology, vol. 27, no. 4, pp. 252-262, 6 figs., May-June, 1919.

2. Reply to discussion by C. W. Washburne on "Notes on principles of oil accumulation"; Jour. Geology, vol. 28, no. 4, pp. 371-373, MayJune, 1920.

3. Experimental studies of subsurface relations in oil and gas fields (discussion) : Econ. Geology, vol. 15, no. 8, pp. 680-682, December, 1920.

4. Experimental petroleum geology: Am. Assoc. Petroleum Geologists, Bull., vol. 5, no. 4, pp. 466-468, July-August, 1921.

5. A short sketch of the paleogeography and historical geology of the MidContinent oil district and its importance to petroleum geology: Am. Assoc. Petroleum Geologists, Bull., vol. 5, no. 1, pp. 102-103 (abstract), no. 5, pp. 541-584, 1 fig., 10 pls., September-October, 1921.

6. Soluble material in oil shale: Am. Assoc. Petroleum Geologists, Bull., vol. 9 , no. 6 , p. 1025 , September, 1925 .

7. A brief outline of some oil-accumulation problems: Am. Assoc. Petroleum Geologists, Bull., vol. 10, no. 11, pp. 1015-1034, 1 fig., November, 1926.

McCrea, Charles.

1. Willet Green Miller: Canadian Min. Jour., vol. 47, no. 47, pp. 1107-1110, 2 figs., November 19, 1926.

MacCurdy, George Grant.

1. Human origins; a manual of prehistory; volume $I$, the old stone age and the dawn of man and his arts. 440 pp., 254 figs., New York, D. Appleton and Company, 1924.

MacCurdy, H. M.

1. Mastodon remains found in Gratiot County, Michigan: Michigan Acad. Sci., 21st. Ann. Rept., pp. 109-110, 1920.

McDermid, A. J.

1. Ore deposits of Gold Hill mine, at Quartzburg, Idaho: Eng. and Min. Jour.-Press, vol. 114, no. 13, pp. 537-540, 6 figs., September 23 , 1922. 
- MacDonald, Donald Francis.

1. Contributions to the geology and paleontology of the Canal Zone, Panama, and geologically related areas in Central America and the West Indies; the sedimentary formation of the Panama Canal Zone, with special reference to the stratigraphic relations of the fossiliferous beds: U. S. Nat. Mus., Bull. 103, pp. 525-545, 2 pls. (maps), 2 figs., 1919.

2. (and others). Notes on the stratigraphy of Panama and Costa Rica: Am. Assoc. Petroleum Geologists, Bull., vol. 3, pp. 363-366, 1919.

3. Some factors of Central American geology that may have a bearing on the origin of petroleum: Am. Assoc. Petroleum Geologists, Bull., vol. 4, no. 3, pp. 263-268, 2 figs., 1920.

4. (and others). Informe final geológico y geográfico de Costa Rica : Revista de Costa Rica (San Jose, Costa Rica), año 2, no. 1, pp. 28-32, September; no. 2, pp. 50-57, October; no. 4, pp. 106-111, December, 1927 ; no. 5, pp. 139-148, January, 1921.

5. The geology of the Panama Canal with special reference to the slides: Nat. Acad. Sci., Mem., vol. 18, pp. 45-67, 1924.

McDonald, O. G. See Merritt, 4.

McDonald, Worth W.

1. The Cotton Valley, Louisiana, oil field: Am. Assoc. Petroleum Geologists, Bull., vol, 9, no. 5, pp. 875-885, 1 fig., August, 1925.

Macelwane, James B. See also American Geophysical Union, 1; Bowie, 24; Rogers, A. F., 23.

1. Some seismological evidence that is not evident: Science, new ser., vol. 56 , pp. 478-480, October 27, 1922.

2. The registration of earthquakes at the Berkeley Station and at the Lick Observatory Station from April 1, 1921, to September 30, 1921: California, Univ., Pub., Seismographic Stations, Bull., vol. 2, no. 2 , pp. 17-27, November 8, 1922.

3. A study of the relation between the periods of elastic waves and the distance traveled by them, based upon the seismographic records of the California earthquake, January 31, 1922: Seismol. Soc. America, Bull., vol. 13, no. 2, pp. 14-69, 6 figs., 1 pl., June, 1923.

4. The Corralitos [California] earthquake, September 19, 1923: Seismol. Soc. America, Bull., vol. 13, no. 3, pp. 109-112, 1 pl., September, 1923.

5. Eureka earthquake, January 31, 1922 (abstract): Geol. Soc. America, Bull., vol. 35 no. 1, p. 165, March 30, 1924.

6. The interior of the earth: Seismol. Soc. America, Bull., vol. 14, no. 2, pp. 81-89, 2 figs., June, 1924.

7. (and Byerly, Perry, jr.). The registration of earthquakes at the Berkeley Station and at the Lick Observatory Station from October 1, 1921, to March 31, 1922: California, Univ., Seismographic Stations, Bull., vol. 2, no. 3, pp. 29-54, March 15. 1924.

8. (and Byerly, Perry, jr.). The registration of earthquakes at the Berkeley Station and at the Lick Observatory Station from April 1, 1922, to September 30, 1922: California, Univ., Seismographic Stations, Bull., vol. 2, no. 4, pp. 55-56, October 13, 1924.

9. Recent seismic activity in central California (abstract with discussion by Warren D. Smith) : Geol. Soc. America, Bull vol. 36, no. 1, pp. 203-204, March 30, 1925. 
Macelwane, James B.-Continued.

10. New evidence for a sharply bounded and very rigid core in the earth (abstract) : Physical Rev., 2d ser., vol. 25, no. 5, p. 721, May, 1925.

11. (and Appleford, William L.). The registration of earthquakes at the Berkeley Station and at the Lick Observatory Station from October 1, 1922, to March 31, 1923: California, Univ., Seismographic Stations, Bull., vol. 2, no. 5, pp. 67-87, July 30, 1925.

12. The earthquake of January 22, 1923 [western North America]: California, Univ., Seismographic Stations, Bull., vol. 2, no. 5, pp. 88-90, July 30, 1925.

13. (and Appleford, William L.). The registration of earthquakes at the Berkeley Station and at the Lick Observatory Station from April 1, 1923, to September 30, 1923: California, Univ., Seismographic Stations, Bull., vol. 2, no. 6, pp. 91-105, December 31, 1925.

14. (and Byerly, Perry). The registration of earthquakes at the Berkeley Station and at the Lick Observatory Station from October 1, 1923, to March 31, 1924: California, Univ., Seismographic Stations, Bull., vol. 2, no. 7, pp. 107-119, December 31, 1925.

15. Are important earthquakes ever caused by impact?: Seismological Soc. America, Bull., vol. 16, no. 1, pp. 15-18, March, 1926; abstract, Pan-Am. Geologist, vol. 45, no. 3, p. 253, April, 1926.

16. Evidence furnished by the earthquake of June 26, 1924, for a sharply bounded and very rigid core in the earth (abstract) : Geol. Soc. America, Bull., vol. 37, no. 1, pp. 209-210, March 30, 1926.

17. The Jesuit seismographic stations in the United States and Canada-a retrospect: Seismological. Soc. America, Bull., vol. 16, no. 3, pp. 187-193, September, 1926.

1. New seismological tables: Nat. Research Council, Bull., no. 56 (vol, 11, pt. 2), pp. 65-69, November, 1926.

19. (and Repetti, William C.). The Crystal Springs, California, earthquake of February 10, 1925: Seismological Soc. America, Bull., vol. 17, no. 1, pp: 15-19, 1 fig., March, 1927 ; abstract, Pan-Am. Geologist, vol. 47, no. 4, p. 316, May, 1927.

20. (and Repetti, William C.). The Calaveras Valley, California, earthquake of April 3, 1924: Seismological Śoc. America, Bull.; vol. 17, no. 1, pp. 20-24, 1 fig., March, 1927 ; abstract, Pan-Am. Geologist, vol. 47, no. 4, p. 316, May, 1927.

21. Reports of progress in seismological work in the United States; B, Jesuit Seismological Association: Nat. Research Council, Bull. no. 61, pp. 74-77, July, 1927.

22. Some new wave groups observed on the records of the south Pacific earthquake of June 26, 1924: Nat. Research Council, Bull. 61, pp. 90-91, July, 1927.

McEvoy, James.

1. Smoky River coal field; examination and comparison with the Kananaskis area: Canada, Dominion Fuel Board [Pub.] no. 7, Geol. Survey [Pub.] no. 2055, 15 pp., 3 figs., 5 pls. [1925].

McEwan, Eula Davis.

1. A study of the brachiopod genus Platystrophia: U. S. Nat. Mus., Proc., vol. 56, pp. 383-448, 11 pls., 1919. Review by F. A. Bather, Geol. Mag., vol. 57, pp. 88-90, February, 1920.

2. The Ordovician of Madison, Indiana: Am. Jour. Sci., 4th ser., vol. 50, pp. 154-158, August, 1920. 
McFarlan, Arthur Crane. See also Glenn, 11 ; Kentucky G. S., 42.

1. The bryozoan faunas of the Chester series of Illinois and Kentucky (abstract) : Chicago Univ., Abstracts of Theses, Sci. Ser., vol. 2, pp. 223-227, September, 1926.

2. (and others). Map of the areal and structural geology of Garrard County, Kentucky: Kentucky Geol. Survey, Ser. 1927. Scale 1 inch $=1$ mile.

3. The West Hickman fault zone of Jessamine and Fayette counties, Kentucky (abstract) : Kentucky Acad. Sci., Trans., vol. 2, pp. 214216, 2 figs., 1927.

4. The base of the "Big Lime" as a key horizon for structural work in northeastern Kentucky (abstract) : Kentucky Acad. Sci., Trans., vol. 2, pp. 216-217, 1927.

McFarland, R. S.

1. Stroud oil field, Oklahoma: Mining and Metallurgy, vol. 5, no. 211, pp. 334-335, 1 fig., July, 1924.

Macfarlane, John Muirhead.

1. The evolution and distribution of fishes. 564 pp., 72 figs., New York, The Macmillan Company, 1923.

2. Fishes the sources of petroleum. 451 pp., 51 figs., New York, The Macmillan Company, 1923.

McGill, William M.

1. Gold and silver mining in Ontario : Colorado School of Mines, Alumni Mag., vol. 14, no. 5, pp. 10-16, September, no. 6, pp. 12-18, October, 1924.

McGonigle, Fritz. See Thomson, F. A., 6.

McGraw, Evans. See Kentucky G. S., 28, 44, 50.

Macgregor, Alexander Miers.

1. The origin of sedimentary iron ores: Econ. Geology, vol. 20, no. 2, pp. 195-197, March-April, 1925.

MacGregor, J. G.

1. Structural features of certain Rouyn ore-bodies: Canadian Min. Jour., vol. 49, no. 23, pp. 456-460, 8 figs., June 8, 1928; Min. Mag., vol. 39, no. 2, pp. 117-120, 4 figs., August, 1928.

McGuigan, F. H. See also Melton, 7.

Machamer, G. W. See Van Tuyl, 5.

Machatschki, Felix. See also Gaertner, 1.

1. Enstatit-Hornblendit von Grönland: Centralbl. Mineralogie, Abt. A, no. 5, pp. 172-175, 1 fig., 1927.

McInnes, William, 1858-1925.

1. Report of the directing geologist: Canada, Geol. Survey, Summ. Rept., 1917, pt. A, pp. 1-14, 1919.

2. Report of the directing geologist: Canada, Geol. Survey, Summ. Rept., 1918, pt. A, pp. 1-14, 1919.

3. Report of the director: Canada, Geol. Survey, Summ. Rept., 1919, pt. A, pp. 1-15, 1921.

McIntosh, D. S.

1. Notes on an esker in the interior of Digby County, Nova Scotia: Nova Scotian Inst. Sci., Proc. and Trans., vol. 16, pp. 139-141, November 21, 1927. 
MacKay, Bertram Reid. See also Wilson, M. E., 2.

1. Cariboo gold fields, British Columbia: Canada, Geol. Survey, Summ. Rept., 1918, pt. B, pp. 39-56, 3 figs., 1 pl., 1919.

2. Placer operations in Cariboo area of British Columbia: Eng. and Min. Jour., vol. 107, pp. 1035-1041, 1 fig., June 14, 1919.

3. Cariboo district, B. C.: Canada, Geol. Survey, Summ. Rept., 1919, pt. B, pp. 36-37, 1920.

4. Beaucevilie map-area, Quebec: Canada, Geol. Survey, Mem. 127, 105 pp., 7 figs., 13 pls., 2 maps, 1921.

5. Hat Creek coal deposit, Kamloops district, British Columbia: Canada, Geol. Survey, Summ. Rept., 1925, pt. A, pp. 164-181, 3 figs., 1926.

McKay, Guy R.

1. Park City, a lead-silver district in Utah: Eng. and Min. Jour.-Press, vol. 116, no. 1, pp. 7-14, 8 figs., July 7, 1923.

McKee, J. P. See also Tomlinson, 4.

McKee, Ralph Harper.

1. (and others). Shale oil. 326 pp., 35 figs., American Chemical Society Monograph series, New York, The Chemical Catalog Company, 1925.

McKeehan, L. W. See Kovarik, 1501.

McKelvey, Samuel Robert.

1. The Dinosauria. 20 pp., 7 figs., Denver, The Research Company, 1920.

Mackenzie, George Cleghorn.

1. An investigation of certain Canadian platinum and manganese resources: Canadian Min. Inst., Trans., vol. 22, pp. 305-319, 3 figs. [1920].

2. (and Corless, C. V.). Willet G. Miller: Canadian Inst. Min. and Met., Bull., no. 155, pp. 178-181, portr., March, 1925.

MacKenzie, John David, 1888-1922.

1. The limonite deposits in Taseko Valley, British Columbia: Canada, Geol. Survey, Summ. Rept., 1920, pt. A, pp. 42-70, 2 figs., 8 maps, 1921.

2. A reconnaissance between Taseko Lake and Fraser River, British Columbia : Canada, Geol. Survey, Summ. Rept., 1920, pt. A, pp. 70-81, 2 figs., map, 1921.

3. Copper deposits on Lasqueti Istand, British Columbia: Canada, Geol. Survey, Summ. Rept., 1921, pt. A, pp. 50-58, 2 figs., 1922.

4. The historical and structural geology of the southernmost Rocky Mountains of Canada: Roy. Soc. Canada, Proc. and Trans., 3d ser., vol. 16, sec. 4, pp. 97-132, 3 figs., 1922.

5. The coal measures of Cumberland and vicinity, Vancouver Island: Canadian Inst. Min. and Met., Monthly Bull. no. 122, pp. 667-693, 13 figs., June, 1922 ; Trans., vol. 25, pp. 382-411, 13 figs., [1923].

6. Description of clastic sediments (discussion) : Econ. Geology, vol. 18, no. 2, pp. 194-195, March, 1923.

7. Alberni area, Vancouver Island, British Columbia: Canada, Geol. Survey, Summ. Rept., 1922, pt. A, pp. 61-67, map, 1923.

McKenzie, Norman.

1. Annual report on the mines, 1926: Nova Scotia, Dept. Public Works and Mines, 424 pp., Halifax, N. S., 1927. Includes reports on gold fields of Nova Scotia by T. A. Rickard, J. C. Murray, and E. R. Faribault. 
McKenzie, Norman-Continued.

2. Report on the mines of Nova Scotia, 1927: Nova Scotia, Dept. Public Works and Mines, 2 pts., 756 pp., Halifax, 1928.

McKinstry, Hugh E. See also Warren, C. H., 2.

1. The Poorhouse quarry, Chester County, Pennsylvania: Am. Mineralogist, vol. 5, no. 6, pp. 121-122, June, 1920.

2. The minerals of Rockport, Massachusetts: Am. Mineralogist, vol. 6, no. 3, pp. 56-60, March, 1921.

3. The Unionville, Pennsylvania, corundum mines: Am. Mineralogist, vol. 6, no. 9, pp. 135-137, September, 1921.

4. A protractor for plotting dips on inclined sections: Econ. Geology, vol. 18, no. 4, pp. 393-397, 4 figs., June-July, 1923.

5. Magnetic, electrochemical, and photochemical tests in the identification of opaque minerals: Econ. Geology, vol. 22, no. 7, pp. 669-677, 2 figs., November, 1927.

6. Microchemical tests in the identification of opaque minerals: Econ. Geology, vol. 22 , no. 8 , pp. 830-843, December, 1927.

7. Silver-lead-zinc veins at Atlin, British Columbia: Eng. and Min. Jour., vol. 125, no. 12, pp. 495-497, 2 figs., March 24, 1928.

8. Silver mineralization at Beaverdell, British Columbia: Econ. Geology, vol. 23, no. 4, pp. 434-441, June-July, 1928.

McKnight, Edwin T. See also Baker, A. A., 1; Bretz, 14.

1. The Spokane flood; a discussion [origin of physiographic features, Washington] : Jour. Geology, vol. 35, no. 5, pp. 453-460, July-August, 1927. [See also Bretz, 15].

MacLachlan, Donald C.

1. Geologic structure of a small area in Wayne, Pulaski, and Russell counties, Kentucky : Michigan Acad. Sci., Papers, vol. 8, pp. 297-307, 3 pls., 1928.

McLaughlin, D. H. See also Bateman, 3.

1. Copper sulphides in syenite and pegmatite dikes: Econ. Geology, vol. 14, no. 5, pp. 403-410, August, 1919.

2. Ore deposition and enrichment at the Evergreen mine, Gilpin County, Colorado : Econ. Geology, vol. 14, no. 6, pp. 465-479, 2 pls. SeptemberOctober, 1919.

McLaughlin, R. P.

1. Conservation of oil and gas resources in California: Am. Assoc. Petroleum Geologists, Bull., vol. 4, pp. 17-26, 1920.

2. "Structure" [proper usage of the term] : Am. Assoc. Petroleum Geologists, Bull., 5, no. 1, p. 98, January-February, 1921.

3. Regularity of decline of oil wells in California: Am. Assoc. Petroleum Geologists, Bull., vol. 5, no. 2, pp. 178-185, 10 figs., March-April, 1921.

4. California oil felds: Am. Assoc. Petroleum Geologists, Bull., vol. 5, no. 5, pp. 623-625, September-October, 1921.

MacLean, A.

1. Lignite in Saskatchewan: Canadian Inst. Min. and Met., Monthly Bull. no. 101, pp. 685-699, 5 figs., September, 1920: Canadian Min. Inst., Trans., vol. 23, pp. 308-323 [1921]. 
McLearn, Frank Harris. See also Dowling, 1.

1. Cretaceous, lower Smoky River, Alberta: Canada, Geol. Survey, Summ. Rept., 1918, pt. C, pp. 1-7, 1919.

3. The Cretaceous of Peace and Athabaska valleys [Alberta]: Canada, Geol. Survey, Mem: 116, pp. 25-33, 1919.

3. New species of pelecypods from the Cretaceous of northern Alberta: Canada, Geol. Survey, Mus. Bull. no. 29, pp. 9-12, 3 pls., October 18, 1919.

4. Little Smoky River, Alberta: Canada, Geol. Survey, Summ. Rept., 1919, pt. C, pp. 13-14, 1920.

5. Three new pelecypods from the Coloradoan of the Peace and Smoky valleys, Alberta : Canadian Field-Naturalist, vol. 34, no. 3, pp. 53-56, 1 pl., March, 1920.

6. Mesozoic of upper Peace River, British Columbia: Canada, Geol. Survey, Summ. Rept., 1920, pt. B, pp. 1-6, 1 fig., 1921.

7. Peace River Canyon coal area, British Columbia: Canada, Geol. Survey, Summ. Rept., 1922, pt. B, pp. 1-46, 2 figs. (incl. map), 1 pl., 1923.

8. Paleontology of the Silurian rocks of Arisaig, Nova Scotia: Canada, Geol. Survey, Mem. 137, 179 pp., 1 fig. (map), 30 pls., 1924.

9. New pelecypods from the Fernie formation of the Alberta Jurassic: Roy. Soc. Canada, Proc. and Trans., $3 d$ ser., vol. 18, sec. 4, pp. 39-61, 9 pls., 1924.

10 New species from the Coloradoan of lower Smoky and lower Peace rivers, Alberta: Canada, Geol. Survey, Bull. no. 42, pp. 117-126, 4 pls., May 8, 1926.

11. New Jurassic species from the Hazleton group of British Columbia: Canada, Geol. Survey, Bull. no. 44, pp. 89-99, 7 pls., 1926.

12. The Mesozoic and Pleistocene deposits of the lower Misșinaibi, Opazatika, and Mattagami rivers, Ontario: Canada, Geol. Survey, Summ. Rept., 1926, pt. C, pp. 16-44, 5 figs., 1927.

13. Some Canadian Jurassic faunas: Roy. Soc. Canada, Trans., $3 d$ ser., vol. 21, sec. 4, pp. 61-73, 1 pl., March, 1927.

14. (and Hume, G. S.). The stratigraphy and oil prospects of Alberta, Canada: Am. Assoc. Petroleum Geologists, Bull., vol. 11, no. 3, pp. 237-260, 4 figs. (incl. map), March, 1927; discussion, no. 5, p. 515, May, 1927.

15. New Jurassic Ammonoidea from the Fernie formation, Alberta: Canada, Geol. Survey, Bull. no. 49, pp. 19-22, 5 pls., 1928.

16. Stratigraphy, structure, and clay deposits of Eastend area, Cypress Hills, Saskatchewan: Canada, Geol. Survey, Summ. Rept., 1927, pt. B, pp. 21-53, map, 1928.

McLeish, John.

1. Summary report of investigations made by the Mines Branch during the calendar year ending December 31, 1920: Canada, Department of Mines, Mines Branch, 87 pp., 7 figs., 1922.

2. [Report of the] Mines Branch: Canada, Dept. Mines, Rept., 1924, pp. 49-60, 1925.

McLellan, Mary E. See Hanna, 15.

McLellan, Roy Daridson.

1. The Devonian Orcas group of Washington: Am. Jour. Sci., 5th ser., vol. 8, pp. 217-222, September, 1924.

$4096-31-26$ 
McLellan, Roy Davidson-Continued.

2. The geology of the San Juan Islands: Washington, Univ., Pub. in Geology, vol. 2, 185 pp., 10 figs., 22 pls., map, November, 1927.

McLennan, J. C.

1. Report on some sources of helium in the Britisk Empire: Canada, Dept. Mines, Mines Branch, Bull. no. 31, 72 pp., 1 pl., 20 figs., 4 maps, 1920.

MacLeod, C. W.

1. The Goudreau gold area [District of Algoma, Ontario]: Canadian Min. Jour., vol. 44, no. 16, pp. 295-297, 1 fig., April 30, 1923.

2. The Goudreau gold area [Ontario] : Canadian Inst. Min. and Met., Bull., no. 167 , pp. 393-401, 2 figs., March, 1926; Trans., vol. 29, pp. 183195, 2 figs. [1927].

MacMacken, Joseph G.

1. Eolative soils of Washington wheat lands: Pan-Am. Geologist, vol. 43, no. 3, pp. 177-184, April, 1925.

2. Lake Lewis and flood waters of Okanogan ice sheet: Pan-Am. Geologist, vol. 48, no. 2, pp. 101-108, September, 1927.

MacMillan, William D.

1. The mathematics of isostasy. Am. Jour. Sci., 4th ser., vol. 49, pp. 318-323, May, 1920.

McMillin, H. C. See Becking, 1.

McNairn, William Harvey.

1. The birth of a science [geology] : Natural History, vol. 20, no. 3, pp. 247252, May-June, 1920.

MacNaughton, Lewis $\mathrm{W}$.

1. Notes on the undescribed meteorites in the collection of the American Museum of Natural History: Am. Mus. Novitates, no. 207, 2 pp., February 16, 1926.

McNutt, V. H.

1. Obituary, Guy Henry Cox: Am. Assoc. Petroleum Geologists, Bull., vol. 6, no. 6, pp. 566-569, portr., November-December, 1922.

McQueen, H. S.

1. (and Forbes, C. R.). Mining of diaspore and flint fire clays in Missouri : Mining and Metallurgy, vol. 9, pp. 271-275, 10 figs., June, 1928.

Macready, George A.

1. Petroleum industry of Trinidad: Mining and Metallurgy, no. 165, pp. 2122, September, 1920 (abstract) ; Am. Inst. Min. and Met. Eng., Trans. [preprint no. 1017], 10 pp., 1 fig. 1920; Trans., vol. 65, pp. 58-68, 1 fig., 1921.

MacVicar, John.

1. Coal areas northwest of Brule Lake, Alberta: Canada, Geol. Survey, Summ. Rept., 1919, pt. C, pp. 8-13, 1 fig., 1920.

2. Preliminary investigation of coal deposits on Smoky, Hay, and Berland rivers, Alberta: Canada, Geol. Survey, Summ. Rept., 1923, pt. B, pp. 21-62, 7 figs. (incl. maps), 4 pls., 1924. 
MacVichie, Duncan.

1. Iron fields of the Iron Springs and Pinto mining districts, Iron County, Utah: Am. Inst. Min. and Met. Eng., Trans. [preprint] no. 1468, 11 pp., 9 figs., July, 1925 ; Trans., vol. 74, pp. 163-173, 9 figs., 1926 ; abstract, Mining and Metallurgy, vol. 6, no. 224, p. 441, August, 1925.

Maddren, Alfred Geddes.

1. Sulphur on Unalaska and Akun islands and near Stepovak Bay, Alaska: U. S. Geol. Survey, Bull. 692, pp. 283-298, 1 pl. (map), 6 figs.; 1919. Abstract by R. W. Stone, Washington Acad. Sci., Jour., vol. 9, no. 20, pp. 634-635, December 4, 1919.

2. The beach placers of the west coast of Kodiak Island, Alaska: U. S, Geol. Survey, Bull. 692, pp. 299-319, 1 pl. (map), 1919. Abstract by R. W. Stone, Washington Acad. Sci., Jour., vol. 19, no. 20, p. 635 , December 4, 1919.

Mahon, Sadie.

1. The micrology of the middle Washita formations: Texas, Univ., Bull., no. 2544, pp. 67-71, 3 pls., 1925.

Mailhiot, Adhémar.

1. Geology of a portion of the projected township of Lemieux, County of Gaspe, Province of Quebec: Quebec (Province), Department of Colonization, Mines, and Fisheries, Rept. on Mining Operations, 1918, pp. 134-145, map, 1919.

2. Geology of Mount Albert, County of Gaspe, Province of Quebec: Quebec (Province), Department of Colonization, Mines, and Fisheries, Rept. on Mining Operations, 1918, pp. 146-151, 1919.

3. The upper Harricana River gold area [Timiskaming County, Quebec] : Canadian Min. Jour., vol. 40, pp. 765-770, 12 figs., October 14, 1919.

4. Gold deposits at Lake Demontigny, Abitibi, P. Q.: Quebec (Province). Dept. Colonization .... Rept. on Mining Operations, 1919, 11). 125-158, 3 pls., 5 figs., map, 1920.

5. The new zinc and lead fields of Gaspé Peninsula [Quebec]: Canadian Min. Inst., Trans., vol. 22, pp. 368-377, 1 fig. [1920].

6. Molybdenite deposits of Lacorne Township, Abitibi, P. Q.: Canadian Min. Jour., vol. 41, pp. 135-138, 4 figs., February 18, 1920.

Majorelle, Jean.

1. Les champs de pétrole de l'est des Etats-Unis: Revue de l'Industrie Minérale, no. 55, pp. 177-196, 15 figs., April 1, 1923.

Makemson, Maud Worcester.

1. Locating the epicenter of an earthquake: Seismological Soc. America, Bull., vol. 17, no. 1, pp. 8-14, 1 fig., March, 1927.

Malcolm, Wyatt. See also Brock, 11; Camsell, 1.

1. Contributions to the economic geology of Canada, 1922: Canadian Min. Jour., vol. 44, no. 1, pp. 27-29, January 5, 1923.

2. Joseph Keele; an appreciation: Canadian Min. Jour., vol. 44, no. 25, p. 475, June 22, 1923.

3. Contributions to the economic geology of Canada: Canadian Min. Jour., vol. 45, no. 1, pp. 15-18, January 4, 1924.

4. The mineral industry of Canada. In Handbook of Canada, pp. 384-396, 5 figs., Toronto, 1924. 
Malcolm, Wyatt-Continued.

5. William McInnes; an appreciation: Canadian Min. Jour., vol. 46, no. 13, pp. 317-318, portr., March 27, 1925.

6. Limestone on Abitibi and Mattagami rivers, Ontario: Canada, Geol. Survey, Summ. Rept., 1924, pt. C, pp. 96-98, 1 fig., 1926.

7. Economic geology of Canada, 1923 and 1924: Canada Yearbook, 1925, pp. 25-30, Canada, Dominion Bureau of Statistics, General Statistics Branch, Ottawa, 1926.

8. (and Robinson, A. H. A.). Canada; geology, mines, and metallurgical industries. 214 pp., 40 pls., 16 maps, Canada, Department of mines, 1927. Prepared for the Second (Triennial) Empire Mining and Metallurgical Congress, 1927.

Malott, Clyde Arnett.

1. The "American Bottom" region of eastern Greene County, Indiana-a type unit in southern Indiana physiography: Indiana Univ. Studies, vol. 6, Study no. 40, 61 pp., 10 figs., 2 maps, March, 1919.

2. (and Thompson, J. D., jr.). The stratigraphy of the Chester series of southern Indiana (abstract) : Science, new ser., vol. 51, pp. 521522, May 21, 1920.

3. A notable case of successive stream piracy in southern Indiana (abstract) : Science, new ser., vol. 51, p. 523, May 21, 1920.

4. Some special physiographic features of Knobstone cuesta region of southern Indiana ; an example of explanatory physiography : Indiana Acad. Sci. Proc., 1919, pp. 361-383, 7 figs., 2 maps, 1921.

5. Planation stream piracy: Indiana Acad. Sci., Proc., 1920, pp. 249-260, 5 figs., $1 \mathrm{pl}, 1921$.

6. The physiography of Indiana. In Handbook of Indiana geology (Indiana, Dept. Conservation, Pub. no. 21), pp. 59-256, 51 figs., 3 pls. (incl. maps), Indianapolis, 1922.

7. A subterranean cut-off and other subterranean phonomena along Indian Creek, Lawrence County, Indiana: Indiana Acad. Sci., Proc. 1921, pp. 203-210, 5 figs., 1922.

8. The upper Chester of Indiana: Indiana Acad. Sci., Proc., vol. 34, pp. 103132, 11 figs., 1925.

9. The glacial boundary in Indiana: Indiana Acad. Sci., Proc., vol. 35, pp. 93-107, 6 figs., 1926.

10. An analysis of erosion: Indiana Acad. Sci., Proc., vol. 37, pp. 153-163, 1928.

11. The valley form and its development: Indiana Univ. Studies, vol. 15, Studies, no. 81, 82, pp. 3-34, December, 1928.

12. Base-level and its varieties: Indiana Univ. Studies, vol. 15, Studies no. 81, 82, pp. 35-59, December, 1928.

Manchester, James G.

1. The minerals of the Bergen archways [New Jersey]: Am. Mineralogist, vol. 4, no. 9. pp. 107-116, 4 pls., 5 figs., September, 1919.

Mann, Albert.

1. Suggestions for collecting and preparing diatoms: U. S. Nat. Mus., Proc., vol. 60, art. 15,8 pp., 1922.

2. The fossil swamp deposit at the Walker Hotel site, Connecticut Avenue and De Sales Street, Washington, D. C.; diatom deposit found in the excavation: Washington Acad. Sci., Jour., vol. 14, no. 1, pp. 26-32, 1 pl., January 4, 1924. 
Mannhardt, L. Alfred. See Wood, H. E., 1.

Manning, Paul De Vries.

1. The genesis of oil shale and its relation to petroleum and other fuels. Dissertation . . . Columbia University, 73 pp., 13 figs., New York, N. Y., 1927.

Mansfield, George Rogers. See also Bretz, 14; Noble, 4 ; Willis, B., 1.

1. Preliminary report on potash exploration in New Jersey greensands: New Jersey, Dept. Conservation and Development, Ann. Rept. for 1919, pp. 99-104, 1919.

2. General features of the New Jersey glauconite beds: Econ. Geology, vol. 14, no. 7, pp. 555-567, November, 1919.

3. Geography, geology, and mineral resources of the Fort Hall Indian reservation, Idaho: U. S. Geol. Survey, Bull. 713, 152 pp., 4 figs.. 12 pls. (incl. maps), 1920.

4. Types of Rocky Mountain structure in southeastern Idaho (abstract with discussion by G. W. Stose): Geol. Soc. America, Bull., vol. 31, no. 1.pp. 126-127, March 31, 1920.

5. The Wasatch and Salt Lake formations of southeastern Idaho: Am. Jour. Sci., 4th ser., vol. 49, pp. 399-406, 1 fig., June, 1920.

6. Triassic and Jurassic in southeastern Idaho and neighboring regions: Am. Jour. Sci., 4th ser., vol. 50, pp. 53-64, 3 figs., July, 1920.

7. The physical and chemical character of New Jersey greensand: Econ. Geology, vol. 15,, no. 7, pp. 547-566, 1 pl., November, 1920.

8. Coal in eastern Idaho: U. S. Geol. Survey, Bull. 716, pp. 123-153, 2 pls. (maps), 3 figs., December 14, 1920; abstract, Washington Acad. Sci., Jour., vol. 11, no. 8, p. 193, April 19, 1921.

9. Potash in New Jersey greensands (abstract) : Mining and Metallurgy, no. 169 , pp. 28-29, January, 1921.

10. Igneous geology of southeastern Idaho: Geol. Soc. America, Bull,, vol. 32 , no. 2, pp. 249-266, 3 figs. (incl. map), June 30, 1921.

11. Types of Rocky Mountain structure in southeastern Idaho: Jour. Geology, vol. 29, no. 5, pp. 444-468, 15 figs., July-August, 1921.

12. Potash in the greensands of New Jersey: U. S. Geol. Survey, Bull. 727, 146 pp., 6 figs., 10 pls. (incl. maps), 1922; (reprint) New Jersey, Dept. Conservation and Development, Div. Geology and Waters, Bull. 23, February, 1923.

13. The geography of part of southeastern Idaho (abstract): Assoc. Am. Geographers, Annals, vol. 11, pp. 128-129 [1922?]

14. The potash field in western Texas: Industrial and Eng. Chemistry, vol. 15, no. 5, pp. 494-497, map, May, 1923.

15. Structure of the Rocky. Mountains in Idaho and Montana: Geol. Soc. America, Bull., vol, 34, no. 2, pp. 263-284, 3 figs., June 30, 1923.

16. Nitrates in 1922: U. S. Geol. Survey, Mineral Resources, 1922, pt. 2, pp. 39-40, August 24, 1923.

17. Potash in 1922: U. S. Geol. Survey, Mineral Resources, 1922, pt. 2, pp. 87-107, October 12, 1923.

18. Phosphate rock in 1922: U. S. Geol Survey, Mineral Resources, 1922, pt. 2, pp. 109-132, October 16, 1923.

19. Tertiary planation in Idaho: Jour. Geology, vol. 32 , no. 6, pp. 472-487, 5 figs., August-September, 1924 ; abstract, Assoc. Am. Geographers. Annals, vol. 14, no. 1, p. 43, March, 1924.

20. (and Boardman, Leona). Potash in 1923: U. S. Geol. Survey, Mineral Resources, 1923, pt. 2, pp, 167-204, 1 fig., 2 pls., December 12, 1924. 
Mansfield, George Rogers-Continued.

21. Phosphate rock in 1923: U. S. Geol. Survey, Mineral Resources, 1923, pt. 2, pp. 239-273, December 20, 1924.

22. Physiography of southeastern Idaho (abstract) : Washington Acad. Sci., Jour., vol. 15, no. 8, pp. 182-183, April 19, 1925.

23. Geography of southeastern Idaho: Assoc. Am. Geographers, Annals, vol. 15, no. 2, pp. 51-64, 3 figs., June, 1925.

24. (and Boardman, Leona). Potash in 1924: U. S. Bur. Mines, Mineral Resources U. S., 1924, pt. 2, pp. 27-61, October 24, 1925.

25. Phosphate rock in 1924: U. S. Bur. Mines, Mineral Resources U. S., 1924, pt. 2, pp. 77-112, November 7, 1925.

26. Section E (Geology and geography) [Kansas City session, American Association for the Advancement of Science]: Science, new ser., vol. 63, pp. 126-127, January 29, 1926.

27. The story of the northern Rockies: Sci. Monthly, vol. 23, no. 5, pp. 447450, November, 1926.

28. Phosphate reserves ample for 2,000 years: Eng. and Min. Jour., vol. 122, no. 21, pp. 810-814, 3 figs., November 20, 1926.

29. Geography, geology, and mineral resources of part of southeastern Idaho: U. S. Geol. Survey, Prof. Paper 152, pp. 1-409, 46 figs., 63 pls., 1927.

30. Summary of the geology of southeastern Idaho with notes on recent work (abstract): Washington Acad. Sci., Jour., vol. 17, no. 5, pp. 129-130, March 4, 1927.

31. New potash fields of the United States [California, Utah, Texas-New Mexico] : Min. Congress Jour., vol. 13, no. 3, pp. 187-188, March, 1927.

32. Proceedings of section $\mathrm{E}$ of the American Association for the Advancement of Science [Philadelphia, December, 1926]: Geol. Soc. America, Bull., vol. 38, no. 1, pp. 209-217, March 30, 1927.

33. Structural features of southeastern Idaho (abstract) : Geol. Soc. America, Bull., vol. 38, no. 1, p. 212, March 30, 1927; Pan-Am. Geologist, vol. 47 , no. 4, p. 320, May, 1927.

34. How the fertilizer minerals of commerce are distributed: Eng. and Min. Jour., vol. 123, no. 14, pp. 567-570, April 2, 1927.

35. The Idaho phosphate field: Mining and Metallurgy, vol. 9, no. 253, pp. 19-20, 2 figs., January, 1928.

36. Geography, geology and mineral resources of part of southeastern Idahoa summary (abstract): Geol. Soc. America, Bull., vol. 39, no. 1, p. 191, March 30, 1928; Pan-Am. Geologist, vol. 49, no. 2, p. 144, March, no. 4, pp. 299-300, May, 1928.

37. Proceedings of section $\mathrm{E}$ of the American Association for the Advancement of Science: Geol. Soc. America, Bull., vol. 39, no. 1, pp. 272-280, March 30, 1928.

38. American potash: Tech. Eng. News (Mass. Inst. Technology), vol. 9, no. 3, pp. 94-95, 120, 122, 124, April, 1928.

Mansfield, Wendell C. See also Woodring, 7.

1. A contribution to the late Tertiary and Quaternary paleontology of northeastern Florida: Florida State Geol. Survey, 15th Ann. Rept., 19221923, pp. 25-51, 2 pls., 1924.

2. Miocene gastropods and scaphopods from Trinidad, British West Indies: U. S. Nat. Mus., Proc., vol. 66, art. 22, 65 pp., 10 pls., September 18, 1925. 
Mansfield, Wendell C.-Continued.

3. Note on the occurrence of the Choptank formation in the Nomini Cliffs, Virginia: Washington Acad. Sci., Jour., vol. 16, no. 7, pp. 175-177, April 4, 1926.

4. Some peculiar fossil forms from Maryland: U. S. Nat. Mus., Proc., vol. 71, art. 16, 9 pp., 5 pls., 1927.

5. Oil-prospecting well near Havelock, North Carolina: North Carolina, Dept. Conservation, Econ. Paper no. 58, 19 pp., 1927.

6. Notes on the Pleistocene faunas from Maryland and Virginia and Pliocene and Pleistocene faunas from North Carolina: U. S. Geol. Survey, Prof. Paper 150, pp. 129-140, 1 fig., 2 pls., February 20, 1928.

7. New fossil mollusks from the Miocene of Virginia and North Carolina, with a brief outline of the divisions of the Chesapeake group: U. S. Nat. Mus., Proc., vol. 74, art. 14, 11 pp., 5 pls., 1928.

Manson, Marsden.

1. Secular changes of geological climates: Pan.-Am. Geologist, vol. 37, no, 4, pp. 301-306, May, 1922.

2. The evolution of climates. 66 pp., 1 fig., copyright by Marsden Manson, 1922. Review by F. H. Knowlton, Science, new ser., vol. 56, pp. 254-255, September 1, 1922.

3. The evolution of climates-a rejoinder: Science, new ser., vol. 56, pp. 571-573, November 17, 1922.

4. The unsatisfactory status of the glacial controversy: Science, new ser., vol. 62, pp. 212-214, September 4, 1925.

Marble, Charles F.

1. Gems found in Maine: Rocks and Minerals, vol. 1, no. 2, pp. 22-23, December, 1926.

2. Mineral localities of Maine; the Greenwood mine: Rocks and Minerals, vol. 2, no. 3, p. 88, September, 1927.

3. Mineral localities of Maine; the Rumford tin mine: Rocks and Minerals, vol. 2 , no. 4 , p. 125, December, 1927.

4. Mineral localities of Maine; the Hartford chrysoberyl prospect: Rocks and Minerals, vol. 3, no. 1, p. 21, March, 1928.

5. Petalite at Peru, Maine: Rocks and Minerals, vol. 3, no. 4, p. 125, December, 1928.

Margerie, Emmanuel de.

1. Une mission d'enseignement géologique aux États-Unis: Soc. gêol. Belgique, Livre jubilaire, 1874-1924, t. 1, fasc. 1, pp. 213-226 [n. d., 1925?].

2. Commentaire de l'atlas of Colorado (1877): France, Comité des travaux historiques et scientifiques, Bulletin de la Section de geographie, t. 39, ann. 1924, pp. 1-80, 8 figs., 4 pls. (portr.), 7 maps, 1924 [1925].

Marks, E. M. See Lupton, 5.

Marks, J. E.

1. The iron ranges of northwestern Ontario: Lake Superior Min. Inst., Proc. 24th Ann. Meeting, vol. 24, pp. 200-208, 1 fig. (map), 1925.

Marland Oil Co. of Mexico.

1. Informe sobre la exploración geologica de la Baja California : Bol. petróleo, vol. 17 , no. 6 , pp. $417-453$, June, vol. 18 , no. 1, pp. 14-53, 60 pls., map, July, 1924. 
Marr, J. E.

1. Obituary, Charles Doolittle Walcott, LL. D., Sc. D., Ph. D. : Geol. Mag., vol. Marshall, J. R. 64, pp. 189-190, April, 1927.

1. Upper Elk River valley, British Columbia: Canada, Geol. Survey, Summ. Rept., 1920, pt. B, pp. 7-10, 1921.

2. Kananaskis Lakes-Palliser River map area: Canada, Geol. Survey, Summ. Rept., 1921, pt. B, pp. 91-94, 1922.

3. Whitesail-Tahtsa lakes area, British Columbia: Canada, Geol. Survey, Summ. Rept., 1924, pt. A, pp. 47-58, map, 1925.

4. Eutsuk Lake area, Coast district, British Columbia : Canada, Geol. Survey, Summ. Rept., 1925, pt. A, pp. 144-154, map, 1926.

5. Lakelse Lake map area, coast district, British Columbia: Canada, Geol. Survey, Summ. Rept., 1926, pt. A, pp. 35-44, 1 fig. (map), 1927.

6. Clearwater Lake map area, British Columbia: Canada, Geol. Survey, Summ. Rept., 1927, pt. A, pp. 42-46, 1928.

Marshall, William Blanchard.

1. New fossil fresh-water mollusks from Florida: U. S. Nat. Mus., Proc., vol. 68, art. 11, 4 pp., 1 pl., 1926.

Martens, James Hart Curry. See also Gunter, 11.

1. Study of the igneous rocks of Ithaca, New York, and vicinity (abstract) : Geol. Soc. America, Bull., vol. 34, no. 1, p. 99, March 30, 1923.

2. Scorodite from Putnam County, New York: Am. Mineralogist, vol. 9, no. 2, pp. 27-28, February, 1924.

3. Igneous rocks of Ithaca, New York, and vicinity: Geol. Soc. America, Bull., vol. 35, no. 2, pp. 305-320, 1 fig., June 30, 1924.

4. Glacial boulders in eastern, central, and northern New York: New York State. Mus. Bull., no. 260, pp. 81-116, 4 figs., 1925.

5. Barite and associated minerals in concretions in the Genesee shale [central New York] : Am. Mineralogist, vol. 10, no. 4, pp. 102-104, April, 1925.

6. Sulphate minerals from weathering of shale near Ithaca, New York: Am. Mineralogist, vol. 10, no. 7, pp. 175-176, July, 1925.

7. Some pre-Cambrian rocks in northern Quebec: Canadian Min. and Met. Bull., no. 177, pp. 99-126, 14 figs. (incl. map), January, 1927; Canadian Inst. Min. and Met., Trans., vol. 30, pp. 274-301, 14 figs. (incl. map) [1928].

8. Sand and gravel deposits of Florida: Florida State Geol. Survey, 19th Ann. Rept., pp. 33-123, 25 figs., 1 pl. (map), 1928.

9. Beach deposits of ilmenite, zircon, and rutile in Florida: Florida State Geol. Survey, 19th Ann. Rept., pp. 124-154, 11 figs., 1928.

Martin, Gail.

1. Geological conditions at Bingham, Utah: Min. Jour. (Phoenix, Ariz.), vol. 11, no. 8, pp. 7, 14-15, February 15, 1928.

Martin, George Curtis. See also Brooks, 3, 4, 5; Capps, 2, 3, 4; Chapin, 4, 5, 6; Harrington, 2, 3, 4, 5; Hobbs, 16 ; Mertie, 2, 3.

1. The Nenana coal field, Alaska: U. S. Geol. Survey, Bull. 664, 54 pp., 11 pls. (maps), 1919. Abstract by R. W. Stone, Washington Acad. Sci., Jour., vol. 9, no. 11, pp. 320-321, June 4, 1919.

2. The Alaskan mining industry in 1917: U. S. Geol. Survey, Bull. 692, pp. 11-42, 1919. 
Martin, George Curtis-Continued.

3. Geologic problems at the Matanuska coal mines [Alaska]: U. S. Geol. Survey, Bull. 692, pp. 269-282, 3 figs., 1919. Abstract, Washington Acad. Sci., Jour., vol. 9, no. 20, p. 634, December 4, 1919.

4. Gold, silver, copper, and lead in Alaska in 1918: U. S. Geol. Survey, Mineral Resources, 1918, pt. 1, pp. 127-142, October 30, 1919.

5. (and others). Mineral resources of Alaska; report on progress of investigations in 1918: U. S. Geol. Survey. Bull. 712, 204, xv pp., 6 pls. (incl. maps), 10 figs., 1920.

6. Mineral resources of Alaska; preface; administrative report: $U$. S. Geol. Survey, Bull. 712, pp. 1-10, 1919.

7. The Alaskan mining industry in 1918: U. S. Geol. Survey, Bull. 712, pp. 11-52, 1919.

8. Preliminary report on petroleum in Alaska: U. S. Geol. Survey, Bull. 719, 83 pp., 6 figs., 11 pls. (incl. maps), 1921.

9. Gold lodes in the upper Kuskokwim region, Alaska: U. S. Geol. Survey, Bull. 722, pp. 149-161, 1 pl., 2 figs. (maps), 1921.

10. A supposed petroleum seepage in the Nenana coal field [Alaska]: U;. S. Geol. Survey, Bull. 739, pp. 137-147, 2 figs., 1922.

11. Natural coal tar mistaken for oil residue: Am. Assoc. Petroleum Geologists, Bull., vol. 6, no. 4, pp. 293-302, 1 fig., July-August, 1922.

12. Petroleum in Alaska: Pan-Pacific Sci. Cong., Australia, 1923, Proc., vol. 2, pp. 1173-1180, 1 fig. [1924].

13. Correlation and paleogeography of the Cretaceous of Alaska: PanPacific Sci. Cong., Australia, 1923, Proc., vol. 2, pp. 1345-1359 [1924].

14. The outlook for petroleum near Chignik [Alaska]: U. S. Geol. Survey, Bull. 773, pp. 209-213, map, 1925.

15. The Mesozoic stratigraphy of Alaska: U. S. Geol. Survey, Bull. 776, 493 pp., 13 figs., 1926.

Martin, Handel T. See also Adams, L. A., 4.

1. Anguillavus hackberryensis; a new species and a new genus of fish from the Niobrara Cretaceous of Kansas: Kansas Univ. Sci. Bull., vol. 13, no. 7, pp. 95-98, 1 pl., May, 1920.

2. Discovery of gigantic footprints in the coal measures of Kansas: Science, new ser., vol. 55, pp. 99-100, January 27, 1922.

3. Huge amphibian from the upper coal measures of Kansas (abstract) Geol. Soc. America, Bull., vol. 33, no. 1, p. 212, March 31, 1922.

4. Indications of a gigantic amphibian in the coal measures of Kansas: Kansas Univ. Sci. Bull., vol. 13, no. 12, pp. 101-113, 3 pls., July, 1922.

5. A new bison from the Pleistocene of Kansas, with notice of new locality for Bison occidentalis: Kansas Univ. Sci. Bull., vol. 15, no. 6, pp. 273-278, December, 1924.

6. On the occurrence of Bison latifrons in Comanche County, Kansas: Kansas, Univ., Bull., vol. 28, no. 18, Sci. Bull., vol. 17, no. 7, pp. 397407, 2 pls., September, 1927.

Martin, Helen M. See Allen, R. C., 3, 4; Smith, R. A., 2.

Martin, Laura Hatch.

1. The geology of the Stonington region, Connecticut: Connecticut State Geol. and Nat. Hist. Survey, Bull. no. 33, 70 pp., 9 figs., 8 pls., map, 1925. 
Martin, Lawrence.

1. A Pennsylvanian's discovery of the Driftless Area: Geog. Soc. Philadelphia, Bull., vol. 31, no. 4, pp. 32-39 (140-147), 1 fig., October, 1923.

2. (and Williams, Frank E.). An ice-eroded fiord; the mode of origin of Lynn Canal, Alaska: Geog. Rev., vol. 14, no. 4, pp. 576-596, 22 figs., October, 1924 .

Martínez, Juan. See Wandke, 8.

Martínez Quintero, Rodolfo.

1. Estudio microscópico de las arenas volcánicas del Popocatepetl: Mexico, Inst. geol., Anales, t. 2, nos. 1-3, pp. 61-63, 1925.

Marvin, Charles Frederick.

1. Earthquake and volcano investigations of the United States Weather Bureau: Pan-Pacific Scientific Conference, First, Proc., Bernice P. Bishop Mus., Spec. Pub. no. 7, pt. 2, p. 424, 1921.

Marzel, John G.

1. Fourteenth biennial report of the State geologist of the State of Wyoming, October 1, 1926-September 30, 1928. 110+22 pp., table, Cheyenne, Wyoming [1928?].

Mason, Herbert L. See also Chaney, 23.

1. Fossil records of some west American conifers: Carnegie Inst. Washington, Pub. 346 (Contributions to Paleontology), pp. 139-158, 5 pls., October, 1927.

Mason, Max Sylvan.

1. Physical exploration for ores: Min. and Met. Soc. America, Bull. no. 191 (vol. 20, no. 5), pp. 98-133, 21 figs., November, 1927; (with discussion), Am. Inst. Min. and Met. Eng., Tech. Pub. no. 45, 32 pp., 21 figs., December, 1927.

Mason, Shirley L. See Barton, 10.

1. A statistical investigation of the effects of structure upon oil and gas production in the Osage [Nation, Oklahoma]: Am. Assoc. Petroleum Geologists, Bull., vol. 3, pp. 407-417, 6 figs., 1919.

Mather, Kirtley Fletcher. See also Atwood, W. W., 4; Daly, 20; Heald, 4; Schuchert, 20 ; Shaw, E. W., 1; Trask, 6.

1. The manipulation of the telescopic alidade in geologic mapping: Denison Univ., Sci. Lab., Bull., vol. 19, pp. 97-142, 13 figs., September 1919.

2. (and Mehl, Maurice G.) The importance of drainage area in estimating the possibilities of petroleum production from an anticlinal structure: Denison Univ., Sci. Lab., Bull., vol. 19, pp. 143-146, 1 pl., September, 1919.

3. Oil and gas resources of the northeastern part of Sumner County, Tennessee: Tennessee, State Geol. Survey, Bull. 24 (Pt. 2-B, Ann. Rept., 1919), 39 pp., 1 pl. (map), 1 fig., 1920.

4. Revolution VS. evolution; the paleontologist renders his verdict: Denison Univ., Scientific Laboratories, Jour., vol. 19, pp. 307-323, September, 1921.

5. The underground migration of oil and gas: Denison Univ., Sci. Lab., Jour., vol. 20, pp. 155-185, 1 fig., June, 1923. 
Mather, Kirtley Fletcher-Continued.

6. Geologic factors in organic evolution: Ohio Jour. Sci., vol. 24, no. 3, pp. 117-145, May, 1924.

7. Mineral resources of the Kamishak Bay region [Alaska]: U. S. Geol. Survey, Bull. 773, fp. 159-181, map, 1925.

8. Physiographic surfaces in the Front Range of northern Colorado and their equivalents on the Great Plains (abstract) : Geol. Soc. America, Bull., vol. 36, no. 1, pp. 134-135, March 30, 1925; Pan-Am. Geologist, vol. 43, no. 1, pp. 76-77, February, 1925.

9. (and Lusk, Ralph G.). A laboratory manual of dynamic and structural geology. 103 pp., Cambridge, Harvard University Press, 1926.

10. Glacial geology of Cape Breton Island, Nova Scotia (abstract) : Geol. Soc. America, Bull., vol. 37, no. 1, pp. 178-180, March 30, 1926; Pan-Am. Geologist, vol, 45, no. 2, p. 169, March, 1926.

11. Ralph Gordon Lusk: Science, new ser., vol. 66, pp. 292-293, September 30, 1927.

12. (and Gilluly, James, and Lusk, Ralph G.). Geology and oil and gas prospects of northeastern Colorado: U. S. Geol. Survey, Bull., 796, pp. 65-124, 5 figs., 5 pls. (incl. map), January 17, 1928.

13. Old Mother Earth. 177 pp., 61 figs., Cambridge, Harvard University Press, 1928.

14. Dynamical and structural geology. Am. Year Book, 1927, pp. 594-596, 1928.

Mathews, Edward Bennett. See also Swartz; C. K., 3.

1. Relative efficiency of normative and modal classifications of igneous rocks. (abstract) : Geol. Soc. American, Bull., vol. 30, pp. 91-92, March 31, 1919.

2. Relation of student and teacher: Geol. Soc. America, Bull., vol. 31, no. 3, pp. 393-394, September 30, 1920.

3. (and Little, H. P.). Geology and geography in the United States: Geol. Soc. America, Bull., vol. 32, no. 2, pp. 227-248, 4 figs., June 30 , 1921; National Research Council, Reprint and Circular Series, no. 17, 22 pp., 1921. Abstract, Geol. Soc. America, Bull., vol. 32, no. 1, p. 44, March 31, 1921.

4. Origin, distribution, and uses of clay with special reference to the fire clays of western Maryland: Maryland Geol. Survey, vol. 11, pp. 291-336, 1922.

5. Catalogue of published bibliographies in geology, 1896-1920: Nat. 'Research Council, Bull., vol. 6, pt. 5, no. 36, October, 1923.

6. Maryland [mineral resources]: The South's Development, Manufacturers Record, vol. 86, no. 24, pt. 2, pp. 384-386, December 11, 1924.

7. (Editor). Fifty years' progress in geology, 1876-1926; papers presented at the geological conference during the fiftieth anniversary of the Johns Hopkins University, October, 1926: Johns Hopkins Univ., Studies in Geology, no. 8, 161 pp., Baltimore, 1927.

8. Progress in structural geology: Johns Hopkins Univ., Studies in Geology, no. 8, pp. 137-161, 1927.

Mathias, Henry Edwin.

1. Syngenetic origin of pyrite concretions in the Pennsylvanian shales of north-central Missouri: Jour. Geology, vol. 36, no. 5, pp. 440-450, July-August, 1928. 
Matley, Charles Alfred.

1. Report on the work of the Government geologist and on the progress of the geological surveys in Jamaica for economic purposes: Supplement to the Jamaica Gazette, vol. 46, no. 9, pp. 225-231, July 4, 1923 ; Jamaica, Ann. Gen. Rept. for 1922, pp. 77-83, 1924.

2. Some recent contributions to the geology of Jamaica, with a bibliography. In Cundall, Frank, The Handbook of Jamaica for 1923, pp. 676688, Kingston, Government Printing Office, 1923. Excerpt 16 pp., 1923.

3. Report on the hydrology of the Liguanea plain and on the possibilities of irrigating it. 5 pp. [issued with (?) The Jamaica Gazette, Extraordinary, no. 45, August 10, 1923].

4. Report by the Government geologist on the progress of the geological surveys in Jamaica in connection with its water resources for the period June, 1923, to April, 1924: Supplement to the Jamaica Gazette, vol. 47, no. 7, pp. 45-48, May 23, 1924 ; Jamaica, Ann. Gen. Rept. for 1923, pp. 18-21, 1925.

5. Report by the government geologist on the progress of the geological surveys in Jamaica for economic purposes (except as regards water resources) for the period June, 1923, to April, 1924: Jamaica Gazette, Supplement, vol. 47, no. 12, pp. 128-130, July, 1924.

6. Recent geological work in Jamaica (abstract) : Pan-Am. Geologist, vol. 42, no. 4, pp. 311-313, November, 1924.

7. Reconnaissance geological survey of Cayman Islands, British West Indies (abstract) : Pan-Am. Geologist, vol. 42, no. 4, pp. 313-315, November, 1924.

8. Report of a reconnaissance geological survey of the Cayman Islands: Jamaica, Ann. Gen. Rept. for 1923, pp. 41-45, 1925.

9. Report by the government geologist on the progress of the geological surveys in Jamaica for economic purposes (except as regards water resources) for the period June, 1923, to April, 1924: Jamaica, Ann. Gen. Rept. for 1923, pp. 100-102, 1925.

10. Report on a mineral spring at Windsor, St. Ann, and on the probability of the occurrence of petroleum in its neighborhood: Jamaica, Ann. Gen. Rept. for 1923, pp. 306-308, 1925.

11. Report on the strata in the valley of St. Ann's Great River, Parish of St. Ann, Jamaica: Supplement to the Jamaica Gazette, vol. 48, no. 3, pp. 13-15, January 15, 1925.

12. Recent geological work in Jamaica (abstract) : British Assoc. Adv. Sci. Rept. 92d Meeting, pp. 391-392, 1925.

13. A reconnaissance geological survey of the Cayman Islands, British West Indies (abstract) : British Assoc. Adv. Sci., Rept. 92d Meeting, pp. 392-393, 1925.

14. The geology of the Cayman Islands, British West Indies, and their relations to the Bartlett trough: Geol. Soc. London, Quart. Jour., vol. 82, pt. 3, pp. 352-387, 13 figs., October 19, 1926 ; abstract, with discussion, Geol. Soc. London, Abstracts of Proc., no. 1150, pp. 7476, April 29, 1926.

Matsumoto, Hikoshichirô.

1. Revision of Palaeomastodon and Moeritherium; Palaeomastodon intermedius and Phiomia osborni, new species (with note by H. F. Osborn) : Am. Mus., Novitates, no. 51, 6 pp., 3 figs., November 21, 1922. 
Matsuyama, Motonori.

1. On some physical properties of ice (with introductory note by T. C. Chamberlin): Jour. Geology, vol. 28, no. 7, pp. 607-631, 13 figs., October-November, 1920.

Matteson, W. G. See also Brokaw, 1.

1. A review of the development in the new central Texas oil fields during 1918: Am. Assoc. Petroleum Geologists, Bull., vol. 3, pp. 163-211, 5 figs., 1919. Econ. Geology, vol. 14, no. 2, pp. 95-146, 1 pl., 3 figs., March-April, 1919.

2. Secondary intrusive origin of Gulf Coastal Plain salt domes: Am. Inst. Min. and Met. Eng., Trans. [preprint] no. 1048, 28 pp., February, 1921; abstract, Mining and Metallurgy, no. 170, p. 37, February, 1921; discussion, by Eugene Coste, E. W. Shaw, J. I. Fogue, F. C. Clapp, E. DeGolyer, W. G. Matteson, H. W. Hixon, R. V. A. Mills, Am. Inst. Min. and Met. Eng., Trans. [preprint] no. 1073, pp. 2332, May, 1921; [preprint] no. 1088, pp. 21-24, August, 1921; Trans. vol. 65, pp. 295-334, 1921.

Matthes, François Emile.

1. Relief shading of topographic maps (abstract): Washington Acad. Sci., Jour., vol. 9, no. 10, p. 293, May 19, 1919.

2. Cockscomb Crest [Sierra Nevada] : Sierra Club Bull., vol. 11, no. 1, pp. 2128, 5 pls., January, 1920.

3. The story of Yosemite Valley: U. S., National Park Service, Making of American Scenery, no. 1, 4 pp. [1922].

4. Evidences of two glacial stages in the Sierra Nevada (abstract): Geol. Soc. America, Bull., vol. 35, no. 1, pp. 69-70, March 30, 1924; PanAm. Geologist, vol, 41, no. 2, pp. 138-139, March, 1924.

5. Hanging side valleys of the Yosemite and the San Joaquin Canyon (abstract) : Washington Acad. Sci., Jour., vol. 14, no. 15, pp. 379-380, September 19, 1924.

6. Erolution Basin [Sierra Nevada, California] (abstract): Assoc. Am. Geographers, Annals, vol. 15, no. 1, p. 41, March, 1925.

7. Evidences of recurrent glaciation in the Sierra Nevada of California (abstract) : Science, new ser., vol. 61, pp. 550-551, May 22, 1925.

8. Devil's Post-pile in the Sierra Nevada (abstract) : Pan-Am. Geologist, vol. 43 , no. 5, p. 372, June, 1925.

9. Kings River Canyon and Yosemite Valley: Sierra Club Bull., vol. 12, no. 3, pp. 224-236, 5 pls., 1926.

10. Influence of subsidiary dislocations in the strata of the Grand Canyon on the development of its topography (abstract) : Geol. Soc. America, Bull., vol. 38, no. 1, p. 213, March 30, 1927 ; Pan-Am. Geologist, vol. 47 , no. 4 , p. 318 , May, 1927.

11. Influence of secondary faults on the development of the Grand Canyon topography (abstract) : Washington Acad. Sci., Jour., vol. 17, no. 9, pp. 233-234, May 4, 1927.

12. Evidence of three glaciations in the Yosemite region (abstract): Washington Acad. Sci., Jour., vol. 18, no. 9, p. 260, May 4, 1928.

13. The boundary between the Pleistocene and the Recent in the Sierra Nevada of California: Third Pan-Pacific Sci. Cong., Tokyo, 1926, Proc., pp. 1766-1767, 1928.

Matthes, Gerard H.

1. Aerial photography as an aid in geological studies: Am. Inst. Min. and Met. Eng., Trans., vol. 76, pp. 321-336, 4 figs., 1928. 
Mattues, 0 .

1. (and Oberföll, L). Epidot von Alaska: Festschrift Victor Goldschmidt, pp. 175-178, Heidelberg, Carl Winters Universitätsbuchhandlung, 1928.

Matthew, George Frederick, 1837-1923. See also Bailey, L. W., 1.

1. The delta of the Iittle River group and some of its peculiarities: Roy: Soc. Canada, Proc. and Trans., 3d ser., vol. 13, sec. 4, pp. 17-21, 1920.

2. A Devonian glacier [St. John area, new Brunswick]; Roy Soc. Canada, Proc. and Trans., 3d ser., vol. 14, sec. 4, pp. 1-6, 1921.

3. On the Mispec group (Devonian) [near St. John, New Brunswick]: Roy. Soc. Canada, Proc. and Trans., 3d ser., vol. 15, sec. 4. np. 105-109, 1921.

Matthew, William Diller, 1871-1930. See also Clarke, J. M., 11; Sinclair, 7.

1. Affinities and origin of the Antillean mammals: Geol. Soc. America, Bull.. vol. 29 , no. 4 , pp. 657-666, December $30,1918$.

2. Contributions to the Snake Creek fauna; with notes upon the Pleistocene of western Nebraska: Am. Mus. Nat. Hist., Bull., vol. 38, pp. 183229, 7 pls., 20 figs., 1918.

3. (and Granger, Walter). A revision of the lower Eocene Wasatch and Wind River faunas; Part V, Insectivora (continued), Glires, Edentata : Am. Mus. Nat. Hist., Bull., vol. 38, pp. 565-657, 68 figs., 1918.

4. [Evolution of the dinosaurs.] : Natural History, vol. 19, nos. 4-5, pp. 491493, April-May, 1919.

5. Recent discoveries of fossil vertebrates in the West Indies and their bearing on the origin of the Antillean fauna: Am. Philos. Soc., Proc., vol. 58, no. 3, pp. 161-181, 1919. Abstract, Science, new ser., vol. 49 , pp. 546-547, June 6, 1919.

6. Plato's Atlantis in paleogeography: Nat. Acad. Sci., Proc., vol. 6, no. 1, pp. 17-18, January 15, 1920.

7. Flying reptiles: Natural History, vol. 20, no. 1, pp. 73-81, 4 figs., JanuaryFebruary, 1920.

8. Status and limits of the Paleocene (abstract) : Geol. Soc. America, Bull., vol. 31, no. 1, p. 221, March 31, 1920.

9. New specimen of the Pleistocene bear Arctotherium from Texas (abstract) : Geol. Soc. America, Bull., vol. 21, no. 1, pp. 224-225, March 31, 1920.

10. John Campbell Merriam: new president of the Carnegie Institution: Natural History, vol. 20, no. 3, pp. 253-254, portr., May-June, 1920.

11. A new genus of rodents [Reithroparamys] from the middle Eocene: Jour. Mammalogy, vol. 1, no. 4, pp. 168-169, August, 1920.

12. Social evolution; a paleontologist's viewpoint: Natural History, vol. 20, no. 4, pp. 374-377, September-October, 1920.

13. Canadian dinosaurs: Natural History, vol. 20, no. 5, pp. 539-544, 4 figs., November-December, 1920.

14. The proofs of the evolution of man: Natural History, vol. 20, no. 5, pp. 574-575, November-December, 1920.

15. The Cannonball Lance formation: Science, new ser., vol. 54, pp. 27-29, July 8, 1921.

16. (and Granger, Walter). New genera of Paleocene mammals: Am. Mus. Novitates, no. 13, 7 pp., September 6, 1921. 
Matthew, William Diller-Continued.

17. Stehlinius, a new Eocene insectivore: Am. Mus. Novitates, no. 14, 5 pp., 2 figs., September 7, 1921.

18. Fossil vertebrates and the Cretaceous-Tertiary problem: Am. Jour. Sci., 5th ser., vol. 2, pp. 209-227, October, 1921.

19. Why paleontology?: Natural History (Am. Mus. Nat. Hist., Jour.), vol. 21, no. 6, pp. 639-641, 1 fig., November-December, 1921.

20. Phyletic relations of Lance vertebrates: Pan-Am. Geologist, vol. 37, no. 1, pp. 68-69, February, 1922.

21. New light on the phylogeny of the Canidae (abstract) : Geol. Soc. America, Bull., vol. 33, no. 1, p. 214, March 31, 1922.

22. A superdreadnaught of the animal world-the armored dinosaur Palaeoscincus: Natural History (Jour. Am. Mus. Nat. Hist.), vol. 22, no. 4, pp. 333-342, 5 figs., July-August, 1922.

23. (and Brown, Barnum). The family Deinodontidae with notice of a new genus from the Cretaceous of Alberta: Am. Mus. Nat. Hist., Bull., vol. 46, pp. 367-385, 1 fig., 1922.

24. Stratigraphy of the Snake Creek fossil quarries and the correlation of the faunas (abstract): Geol. Soc. America, Bull., vol. 34, no. 1, p. 131, March 30, 1923.

25. Fossil bones in the rock; the fossil quarry near Agate, Sioux County, Nebraska: Natural History, vol. 23, no. 4, pp. 359-369, 11 figs., July-August, 1923.

26. Recent progress and trends in vertebrate paleontology (presidential address): Geol. Soc. America, Bull., vol. 34 , no. 3, pp. 401-418, September 30, 1923; Smithsonian Inst., Ann. Rept., 1923, pp. 273$289,1925$.

27. (and Brown, Barnum). Preliminary notices of skeletons and skulls of Deinodontidae from the Cretaceous of Alberta: Am. Mus. Novitates, no. 89, 10 pp., 5 figs., October 11, 1923.

28. Memorial of George F. Matthew: Geol. Soc. America, Bull., vol. 35, no. 1, pp. 181-182, March 30, 1924.

29. A new link in the ancestry of the horse [Plesippus] : Am. Mus. Novitates, no. 131, 2 pp., September 23, 1924; abstract, British Assoc. Adv. Sci., Rept. 92d Meeting, pp. 380-381, 1925.

30. Blanco and associated formations of northern Texas (abstract) : Geol. Soc. America, Bull., vol. 36, no. 1, pp. 221-222, March 30, 1925.

31. Fossil mammal faunas of Florida (abstract) : Geol. Soc. America, Bull., vol. 36 , no. 1, p. 225, March 30, 1925.

32. The value of paleontology: Natural History (Jour. Am. Mus. Nat. Hist.), rol. 25, no. 2, pp. 166-168, March-April, 1925.

33. (and Barbour, E. H.). An American fossil giraffe, Giraffa nebrascensis, sp. nov.: Nebraska State Mus., Bull. 4, vol. 1, pp. 33-40, 7 figs., April, 1925.

34. The evolution of the horse; a record and its interpretation: Quart. Rev. Biology, vol. 1, no. 2, pp. 139-185, 27 figs., 1 pl., April, 1926.

35. On a new primitive deer and two traguloid genera from the lower Miocene of Nebraska: Am. Mus. Novitates, no. 215, 8 pp., 3 figs., May 10, 1926.

36. Farly days of fossil hunting in the High Plains: Natural History (Am. Mus. Nat. Hist., Jour.), vol. 26, no. 5, pp. 449-454, 5 figs., September-October, 1926. 
Matthew, William Dillel-Continued.

37. (and Siegfriedt, J. C. F.). New fossil mammals from the Fort Union of Montana (abstract) : Geol. Soc. America, Bull., vol. 39, no. 1, p. 300, March 30, 1928.

38. Affinities of some new Paleocene mammals from Fort Union beds (abstract) : Pan-Am. Geologist, vol. 49, no. 4, p. 319, May, 1928.

39. Outline and general principles of the history of life: California, Univ., Syllabus ser., Syllabus no. 213, 253 pp., 21 figs., 1928. [Not seen.]

Matthews, Asa A. L.

1. Marine lower Triassic beds of Utah (abstract): Geol. Soc. America, Bull., vol. 36, no. 1, p. 200, March 30, 1925.

Maury, Carlotta Joaquina.

1. On the correlation of Porto Rican Tertiary formations with other Antillean and mainland horizons: Am. Jour. Sci., 4th ser., vol. 48, pp. 209215, September, 1919.

2. A proposal of two new Miocene formational names: Science, new ser., vol. 50, p. 591, December 26, 1919.

3. Tertiary Mollusca from Porto Rico and their zonal relations: Scientific Survey of Porto Rico and the Virgin Islands, vol. 3, pt. 1, pp. 1-77, 9 pls., New York Acad. Sci., 1920.

4. Recent mollusks of the Gulf of Mexico and Pleistocene and Pliocene species. from the Gulf States; Part I, Pelecypoda: Bull. Am. Paleontology. vol. 8, no. 34, 115 pp., 1 pl., December 15, 1920.

5. Recent Mollusca of the Gulf of Mexico and Pleistocene and Pliocene species from the Gulf States; Part 2, Scaphopoda, Gastropoda, Amphineura, Cephalopoda: Bull. Am. Paleontology, vol. 9, no. 38, 142 pp.. January 31, 1922.

6. The recent Arcas of the Panamic province: Palaeontographica Americana, vol. 1, no. 4, pp. 163-208, 3 pls., December 25, 1922.

7. A new formational name [Soldado formation, Trinidad region]: Science. new ser., vol. 61, p. 43, January 9, 1925.

8. A further contribution to the paleontology of Trinidad (Miocene horizons) : Bull. Am. Paleontology, vol. 10, no. 42, 250 pp., 43 pls., March 27, 1925.

9. Trinitasia, a new molluscan genus from South America: Science, new ser., vol. 67, p. 318, March 23, 1928.

10. The Brasso fossiliferous Miocene of Trinidad, West Indies: Science, new ser., vol. 67, p. 348, March 30, 1928.

Mawdsley, J. B. See also James, W. F., 4, 5, 6, 7.

1. St. Urbain area, Charlevoix district, Quebec: Canada, Geol. Survey, Mem. 152, 58 pp., 9 figs., 2 pls., map, 1927.

2. The Chibougamau district, Quebec: Quebec, Dept. Colonization, Mines and Fisheries, Report on Mining operations, 1927, pp. 182-198, 1928; Canadian Min. Jour., vol. 49, no. 46, pp. 942-945, 2 figs., November 16, 1928.

3. Eagle River area, Abitibi territory, Quebec: Quebec, Dept. Colonization, Mines and Fisheries, Report on the Mining Operations, 1927, pp. 199-204, 1928.

4. Recent geological investigations in Chibougamau district, Quebec: Canadian Min. and Met. Bull., no. 198, pp. 1213-1227, October, 1928; abstract, Min. Mag., vol, 39, no. 5, pp. 323-324, November, 1928. 
Mawdsley, J. B.-Continued.

5. Lake Darid area, Chibougamau district, Quebec: Canada, Geol. Survey, Summ. Rept., 1927, pt. C, pp. 1-22, map, 1928.

6. Eagle River area, Abitibi territory, Quebec: Canada. Geol. Survey, Summ. Rept., 1927, pt. C, pp. 23-26, 1928.

Maxson, John H.

1. Merychippus isonesus (Cope) from the later Tertiary of the Crooked River basin, Oregon: Carnegie Inst. Washington, Contributions to Palaeontology, Pub. no. 393, pp. 55-58, 1 fig., September, 1928 ; abstract, Pan-Am. Geologist, vol. 49, no. 4, p. 319, May, 1928.

Maynard, J. E. See also Moore, 21; Wallace, 11.

1. The clays of the Lake Agassiz Basin: Roy. Soc. Canada, Proc. and Trans., 3d ser., vol. 19, sec. 4, pp. 103-114, 1925.

Maynard, Thomas Poole.

1. Cartersville potash slates; their economic relation to chemical and industrial post-war development (abstract) : Geol. Soc. America, Bull., vol. 30, p. 112, March 31, 1919.

2. (and others). Directory of commercial minerals in Georgia and Alabama along the Central of Georgia Railway. 154 pp., illus., issued by Industrial Department, Central of Georgia Railway, Savannah, Georgia, n. d. [1923?].

Mayor, Alfred Goldsborough.

1. Bibliographical memoir Samuel Hubbard Scudder, 1837-1911; Nat. Acad. Sci., Mem., vol. 17, pp. 79-104, portr., 1924.

Mead, Warren Judson.

1. Notes on the mechanics of geologic structures: Jour. Geology, vol. 28, no. 6, pp. 505-523, 12 figs., September-October, 1920.

2. Determination of attitude of concealed bedded formations by diamond drilling: Econ. Geology, vol. 16, no. 1., pp. 37-47, 7 figs., January, 1921.

3. (and Swanson, C. O.). X-ray determination of minerals: Econ. Geology, vol. 19, no. 5, pp. 486-489, August, 1924.

4. The geologic rôle of dilatancy: Jour. Geology, vol. 33, no. 7, pp. 685-698, 9 figs., October-November, 1925.

Meek, Charles E.

1. Notes on the stratigraphy and Pleistocene fauna from Peard Bay, Arctic Alaska: California, Univ., Dept. Geol. Sci., Bull., vol. 14, no. 13, pp. 409-422, 1 fig., 5 pls., November 23, 1923.

2. Genesis of a sandstone dike as indicated by heavy minerals: Am. Assoc. Petroleum Geologists, Bull., vol. 12, no. 3, pp. 271-277, 1 fig., March, 1928.

Megathlin, G. R.

1. Spodumene and autunite from Alstead, New Hampshire: Am. Mineralogist, vol. 13, no. 12, pp. 578-579, December, 1928.

Megraw, Herbert Ashton.

1. Gold mining in the Southern States: Eng. and Min. Jour., vol. 110, no. 20, pp. 938-940, 1 fig., November, 1920.

Mehl, Maurice Goldsmith. See also Branson, 19, 21; Mather, 2.

1. The use of outline charts in teaching vertebrate paleontology: Deaison Univ., Sci. Lab., Bull., vol. 19, pp. 47-53, 4 pls., 1 fig., April, 1919. $4096-31-27$ 
Mehl, Maurice Goldsmith-Continued.

2. Some factors in the geographic distribution of petroleum: Denison Univ., Sci. Lab., Bull., vol. 19, pp. 55-63, 2 pls. (maps), April, 1919.

3 . The use of models in the interpretation of data for determining the structure of bedded rocks: Dension Univ. Bull., Scientific Laboratories, Jour., vol. 19, pp. 157-167, 1 pl., 6 figs., May, 1920.

4. Some suggestions for indicating drilling operations: Denison Univ. Bull., Scientific Laboratories, Jour., vol. 19, pp. 169-174, 3 figs., May, 1920.

5. The influence of the differential compression of sediments on the attitude of bedded rocks (abstract) : Science, new ser., vol. 51, p. 520, May 21, 1920.

6. "Petroliferous provinces": Science, new ser., vol. 51, pp. 541-543, May $28,1920$.

7. A new form of Diplocaulus: Jour. Geology, vol. 29, no. 1, pp. 48-56, 2 figs., January-February, 1921.

8. Some suggestions for photgraphing fossils: Science, new ser., vol. 54, p. 358, October 14, 1921.

9. A new phytosaur from the Trias of Arizona: Jour. Geology, vol. 30, no. 2, pp. 144-157, 3 figs., February-March, 1922.

10. Wind-faceted stones from Wyoming (abstract): Geol. Soc. America, Bull., vol. 36, no. 1, pp. 137-138, March 30, 1925; Pan-Am. Geologist, vol. 43, no. 1, pp 78-79, February, 1925.

11. Brain of the phytosaurs (abstract) : Geol. Soc. America, Bull., vol. 36, no. 1, p. 225, March 30, 1925.

12. Development of a secondary palate in the Phytosauria (abstract) : Geol. Soc. America, Bull., vol. 36, no. 1, p. 227, March, 30, 1925.

13. Use of the vertebrate fossils in correlation of Triassic beds of the western interior region (abstract) : Pan-Am. Geologist, vol. 45, no. 2, p. 174, March, 1926.

14. Amphibian remains from Permian beds of Oklahoma (abstract) : PanAm. Geologist, vol. 45, no. 3, pp. 252-253, April, 1926.

15. Trematops thomasi, a new amphibian species from the Permian of Oklahoma : Jour. Geology, vol. 34, no. 5, pp. 466-474, 5 figs., JulyAugust, 1926.

16. Our world in the making: Science, new ser. vol. 64 , pp. 577-578, December 10, 1926. [See Fairchild, 22.]

17. Apatodonosaurus, a new genus of ichthyosaurs from the Jurassic of Wyoming: Denison Univ., Bull., vol. 28, no. 2, Sci. Lab., Jour., vol. 23, pp. 111-126, 2 figs., 6 pls., January, 1928; abstract, Geol. Soc. America, Bull., vol. 38, no. 1, pp. 233-234, March 30, 1927.

18. Pseudopalatus pristinus, a new genus and species of phytosaurs from Arizona: Missouri, Univ. Studies, vol. 3, no. 1, pp. 3-22, 6 figs., 3 pls., Jnuary 1, 1928.

19. The Phytosauria of the Wyoming Triassic: Denison Univ. Bull., vol. 38, no. 8, Sci. Lab., Jour., vol. 23, pp. 141-172, 9 figs., 3 pls., July, 1928.

Meigs, C. C.

1. (and others). Report on Texas alkali lakes: Texas, Univ., Bull., no. 2234, 60 pp., 9 figs., 9 pls., September 8, 1922 [1923]. 
Meinzer, Oscar Edward. See also Berkey, 2; Bretz, 5, 14; Clark, W. 0. 1; Ellis, A. J., 5 ; Renick, 10 ; Twenhofel, 22, 29.

1. Quantitative methods of estimating ground-water supplies: Geol. Soc. America, Bull., vol. 31, no. 2, pp. 329_338, June 30, 1920. Abstract, Geol. Soc. America, Bull., vol. 31, no. 1, p. 156, March 31, 1920 ; Washington Acad. Sci., Jour., vol. 9, no. 10, pp. 293-294, May 19, 1919.

2. Hidrología subterránea: Ingeniería Internacional, New York, t. 5, no. 4, pp. 195-202, 10 figs., April, 1921; Bol. Minero, t. 11, no. 6, pp. 837-849, 3 fig.., June, 1921.

3. Ground-water problems in the Hawaiian Island (abstract): Washington Acad. Sci., Jour., vol. 11, no. 17, pp. 424-425, October 19, 1921.

4. Recent volcanic events on the Island of Hawaii (abstract) : Washington Acad. Sci., Jour., vol. 11, no. 17, p. 427, October 19, 1921.

5. Map of the Pleistocene lakes of the Basin-and-Range province and its significance: Geol. Soc. America, Bull., vol. 33, no. 3, pp. 541-552, 4 figs., September 1, 1922; abstract, with discussion by W. M. Davis, vol. 33, no. 1, pp. 118-120, March 31, 1922.

6. The occurrence of ground water in the United States, with a discussion of principles: U. S. Geol. Survey, Water-Supply Paper 489, 321 pp., 110 figs., 31 pls. (incl. maps), 1923.

7. Outline of ground-water hydrology, with definitions: U. S. Geol. Survey, Water-Supply Paper, 494, 71 pp., 35 figs., 1923.

8. Ground water in Pahsimeroi Valley, Idaho, Bur. Mines and Geology, Pamphlet no. 9, 35 pp., 5 figs., 3 pls., February, 1924 [mimeographed].

9. (and Dowell, Norah E.). New hydrologic laboratory in the United States Geological Survey (abstract): Geol. Soc. America, Bull., vol. 35, no. 1, pp. 106-107, March 30, 1924; Pan-Am. Geologist, vol. 41, no. 2, p. 152, March, 1924.

10. Origin of the thermal springs of Nevada, Utah, and southern Idaho: Jour. Geology, vol. 32, no. 4, pp. 295-303, 4 figs., May-June, 1924.

11. Structure of the rocks and its meaning to drillers: Howell Drillers News, vol. 3, no. 6, pp. 1-2, 6, 3 figs., June, no. 7, pp. 1, 3, 9, July, 1924.

12. Investigations of ground water in the western part of the United States: Pan-Pacific Sci. Cong., Australia, 1923, vol. 2, pp. 1284-1290 [1924].

13. [A course of lectures on ground water]: Howell Drillers News, vol. 3, nos. 4-11, April-November, 1924.

14. (and Hard, Herbert A.). The artesian-water supply of the Dakota sandstone in North Dakota with special reference to the Edgeley quadrangle: U. S. Geol. Survey, Water-Supply Paper 520, pp. 7395, 2 figs., 2 pls., January 24, 1925.

15. Artesian water supply of Dakota sandstone (abstract) : Pan-Am. Geologist, vol. 43, no. 5, pp. 377-378, June, 1925.

16. (and Renick, B. Coleman, and Bryan, Kirk). Geology of No. 3 reservoir site of the Carlsbad irrigation project, New Mexico, with reference to water-tightness: U. S. Geol. Survey, Water-Supply Paper 580, pp. 1-39, 2 figs., 2 pls. (incl. map), September 3, 1926.

17. Large springs in the United States: U. S. Geol. Survey, Water-Supply Paper 557, 94 pp., 23 figs., 17 pls., 1927.

18. Plants as indicators of ground water: U. S. Geol. Survey, Water-Supply Paper 577, 95 pp., 15 figs., 12 pls., 1927. 
Meinzer, Oscar Edward-Continued.

19. Geology of large springs (abstract) : Geol. Soc. America, Bull., vol. 38, no. 1, pp. 213-216, March 30, 1927.

20. Compressibility and elasticity of artesian aquifers: Econ. Geology, vol. 23, no. 3, pp. 263-291, 8 figs., May, 1928; abstract, Geol. Soc. America, Bull., vol. 39, no. 1, p. 222, March 30, 1928; Pan-Am. Geologist, vol. 49, no. 2, p. 150, March, 1928.

Meisel, Max.

1. A bibliography of American natural history; the pioneer century, 17691865, vol. 2, 741 pp., Brooklyn, New York, The Premier Publishing Co., 1926.

Meland, Norman. See Reed, R. D., 3.

Melcher, Arles Francis.

1. Determination of pore space of oil and gas sands: Mining and Metallurgy, no. 160, pp. 31-32 (abstract), sec. 5, 22 pp., 3 figs., April, 1920 ; discussion by R. V. A. Mills and C. W. Washburne, Am. Inst. Min. and Metal Eng., Trans. [preprint) no. 1038, pp. 51-59, January, 1921; vol. 65, pp. 469-497, 4 figs., 1921.

2. Investigations on permeability and absorption of "sands" for oil, water, and gas, with reference to their normal and possible yield: Am. Assoc. Petroleum Geologists, Bull., vol. 6, no. 2, p. 143, MarchApril, 1922.

3. Texture of oil sands with relation to the production of oil: Am. Assoc. Petroleum Geologists, Bull., vol. 8, no. 6, pp. 716-774, 13 figs., November-December, 1924.

4. Apparatus for determining the absorption and the permeability of oil and gas sands for certain liquids and gases under pressure: Am. Assoc. Petroleum Geologists, Bull., vol. 9, no. 3, pp. 442-450, 5 figs., May-June, 1925.

Melhase, John.

1. Andalusite in California [Inyo Range]: Eng. and Min. Jour.-Press, vol. 120, no. 3, pp. 91-94, 7 figs., July 18, 1925.

2. Asbestos deposits of Arizona: Eng. and Min. Jour-Press., vol. 120, no. 21, pp. 805-810, 5 figs., November 21, 1925.

3. Mining bentonite in California: Eng. and Min. Jour.-Press, vol. 121, no. 21, pp. 837-842, 4 figs., May 22, 1926.

4. Constructing geologic sections with unequal scales: Am. Assoc. Petroleum Geologists, Bull., vol. 11, no. 7, pp. 755-757, 2 figs., July, 1927.

Melton, Frank Armon. See also Hubbert, 3.

1. The ancestral Rocky Mountains of Colorado and New Mexico: Jour. Geology, vol. 33, no. 1, pp. 84-89, 1 fig., January-February, 1925.

2. Interpretation of the isostatic anomaly: Am. Jour. Sci., 5th ser., vol. 10, pp. 166-174, 1 fig., August, 1925.

3. Correlation of Permo-Carboniferous red beds in southwestern Colorado and northern New Mexico: Jour. Geology, vol. 33, no. 8, pp. 807815, 1 fig., November-December, 1925.

4. Structural and stratigraphic studies in the Sangre de Cristo Range of Colorado (abstract) : Chicago, Univ., Abstracts of Theses, Sci. Ser., vol. 3, pp. 225-229, April, 1927.

5. Jurassic-Cretaceous peneplane in Aikansas, Oklahoma, and Kansas (abstract) : Geol. Soc. America, Bull., vol. 39, no. 1, p. 205, March 30, 1928; Pan-Am. Geologist, vol. 49, no. 2, p. 156, March, 1928. 
Melton, Frank Armon-Continued.

6. Unusual aerial photographs from southwestern Arkansas (abstract): Pan-Am. Geologist, vol. 49, no. 2, p. 156, March, 1928; Geol. Soc. America, Bull., vol. 39, no. 1, p. 205, March, 1928.

7. Geology from the air (abstract) : Pan-Am. Geologist, vol. 49, no. 2, p. 156, March, 1928; Geol. Soc. America, Bull., vol. 39, no. 1, p. 206, March $30,1928$.

8. (and McGuigan, F. H.). The depth of the base of the Trinity sandstone and the present attitude of the Jurassic peneplain in southern Oklahoma and southwestern Arkansas: Am. Assoc. Petroleum Geologists, Bull., vol. 12, no. 10, pp. 1005-1014, 3 figs., October, 1928.

Mendenhall, Thomas Corwin.

1. The beginnings of American geology [geological survey of Ohio]: Science, new ser., vol. 56, pp. 661-663, December 8, 1922.

Mendenhall, Walter Curran.

1. Memorial of Grove Karl Gilbert: Geol. Soc. America, Bull., vol. 31, no. 1, pp. 26-64, portr., March 31, 1920.

2. Trends in American geology [notice by T. C.] : Nature, vol. 117, pp. 489491, April 3, 1926; abstract, Pan-Am. Geologist, vol. 45, no. 2, p. 171, March, 1926.

3. Cooperative geologic surveys in Colorado: Mining and Metallurgy, vol. 7, no. 239, pp. 476-478, November, 1926.

4. Oil possibilities of an area northeast of Petaluma, Sonoma County, California: Am. Assoc. Petroleum Geologists, Bull., vol. 11, no. 4, p. 425, April, 1927 .

5. Volcano stations of the U. S. Geological Survey: Nat. Research Council, Bull. no. 61, pp. 269-271, July, 1927.

Merriam, Clinton Hart.

1. Grove Karl Gilbert, the man: Sierra Club Bull, vol. 10, no. 4, pp. 391-396, portr., January, 1919.

2. William Healey Dall: Science, new ser., vol. 65, pp. 345-347, April 8, 1927 ; Smithsonian Inst., Ann. Rept., 1927, pp. 563-566, portr., 1928.

Merriam, John Campbell.

1. Tertiary mammalian faunas of the Mohave Desert: California, Univ., Dept. Geology, Bull., vol. 11., no. 5, pp. 437 a-e, 438-585, 253 figs., August 30, 1919.

2. The beginnings of human history read from the geological record; the emergence of man: Sci. Monthly, vol. 9, no. 3, pp. 193-209, 8 tigs., September, 1919 ; vol. 10, no. 4, pp. 321-342, 18 figs., April, 1920 ; no. 5, pp. 425-437, 11 figs., May, 1920.

3. Earth sciences as the background of history: Geol. Soc. America, Bull., vol. 31, no. 1, pp. 233-246, March 31, 1920.

4. The teaching of historical geology as a factor conditioning research: Geol. Soc. America, Bull., vol. 31, no. 3, pp. 339-349, September $30,1920$.

5. The earth sciences as the background of history: Sci. Monthly, vol. 12, no. 1, pp. 5-17, January, 1921.

6. Origin and history of the bear family in the Western Hemisphere, with particular reference to the relation of this question to problems of geographical history: Nat. Acad. Sci., Proc., vol. 7, no. 7, pp. 183-185, July, 1921. 
Merriam, John Campbell-Continued.

7. An outline of progress in paleontological research on the Pacific coast: California, Univ., Dept. Geology, Bull., vol. 12, no. 3, pp. 237-266, August 6, 1921.

8. (and Stock, Chester). Notes on the peccary remains from Rancho La Brea : California, Univ., Dept. Geol. Sci., Bull., vol. 13, no. 2, pp. 9-17, 10 figs., December 22, 1921.

9. (and Stock, Chester). Occurrence of Pleistocene vertebrates in an asphalt deposit near McKittrick, California: Science, new ser., vol. 54, pp. 566-567, December 9, 1921.

10. (and associates). [Report on] continuation of paleontological researches: Carnegie Inst. Washington, Year Book no. 20, 1921, pp. 447-451, February, 1922.

11. Fauna of the Pleistocene asphalt deposits of McKittrick, California (abstract) : Science, new ser., vol. 55, pp. 493-494, May 5, 1922.

12. (and others). [Report on] continuation of paleontological researches: Carnegie Inst. Washington, Year Book no. 21, pp. 398-400, January, 1923.

13. The cats of Rancho La Brea [California] (abstract) : Washington Acad. Sci., Jour., vol. 13, no. 11, p. 238, June 4, 1923.

14. (and others). [Studies of the John Day region]: Carnegie Inst. Washington, Year Book no. 22, pp. 351-353, 1924.

15. Present status of investigations concerning antiquity of man in California: Science, new ser., vol. 60, pp. 1-2, July 4, 1924.

16. (and others). [Paleontological researches in the Pacific region]: Carnegie Inst. Washington, Year Book no. 23, pp. 293-296, December, 1924.

17. (and Stock, Chester). Relationships and structure of the short-faced bear, Arctotherium, from the Pleistocene of California: Carnegie Inst. Washington, Pub. no. 347 (Papers concerning the paleontology of the Pleistocene of California and the Tertiary of Oregon), pp. 1-35, 5 figs., 10 pls., October 8, 1925.

18. (and Stock, Chester). A llama from the Pleistocene of McKittrick, California: Carnegie Inst. Washington, Pub. no. 347 (Papers conceriing the paleontology of the Pleistocene of California and the Tertiary of Oregon), pp. 37-42, 4 figs., October 8, 1925.

10. (and Stock, Chester, and Moody, C. L.). The Pliocene Rattlesnake formation and fauna of eastern Oregon, with notes on the geology of the Rattlesnake and Mascall deposits: Carnegie Inst. Washington, Pub. no. 347 (Papers concerning the paleontology of the Pleistocene of California and the Tertiary of Oregon), pp. 43-92, 45 figs., October 8, 1925.

20. (and others). Continuation of paleontological researches: Carnegie Inst. Washington, Year Book no. 24, pp. 258-360, December, 1925.

21. Problem of the Pliocene in the Pacific coast and Great Basin regions (abstract) : Geol. Soc. America, Bull., vol. 37, no. 1, p. 156, March 30, 1926 ; Pan-Am. Geologist, vol. 45, no. 2, pp. 159-160, March, 1926.

22. (and Stock, Chester). A Pliocene bear from Oregon (abstract): Science, new ser., vol. 64, p. 508, November 19, 1926.

23. The cave of the magic pool [Samwel Cave, Shasta County, California]: Scribner's, vol. 82, no. 3, pp. 264-272, 7 figs., September, 1927.

24. (and Stock, Chester). A hyaenarctid bear from the later Tertiary of the John Day Basin of Oregon: Carnegie Inst. Washington, Pub. 346 (Contributions to Paleontology), pp. 39-44, 1 pl., October, 1927. 
Merriam, John Campbell-Continued.

25. (and associates). Continuation of paleontological researches [chiefly investigations on the geology and paleontology of eastern Oregon] : Carnegie Inst. Washington, Yearbook no. 26, pp. 363-366, December, 1927.

26. Doctor Walcott as a paleontologist, and his relations with the Carnegie Institution of Washington: Smithsonian Misc. Coll., vol. 80, no. 12, pp. 5-9, May 12, 1928.

27. (and Gilmore, Charles W.). An ichthyosaurian reptile from marine Cretaceous of Oregon: Carnegie Inst. Washington, Contributions to Palaeontology, Pub. no. 393, pp. 1-4, 1 fig., September, 1928.

28. (and Stock, Chester). A further contribution to the mammalian fauna of the Thousand Creek Pliocene, northwestern Nevada: Carnegie Inst. Washington, Contributions to Palaeontology, Pub. no. 393, pp. 5-21, 14 figs., 3 pls., September, 1928.

29. (and others). Continuation of paleontological researches: Carnegie Inst. Washington, Yearbook no. 27, 1927-28, pp. 384-389, December, 1928.

Merrill, George Perkins, 1854-1929. See also Hovey, 12.

1. The composition and structure of meteorites compared with that of terrestrial rocks: Smithsonian Inst., Ann. Rept., 1917, pp. 175-188, 9 pls., 4 figs., 1919.

2. The percentage number of meteorite falls and finds considered with reference to their varying basicity: Nat. Acad. Sci., Proc., vol. 5, no. 2, pp. 37-39, February, 15, 1919.

3. A heretofore undescribed meteoric stone from Kansas City, Missouri: U. S. Nat. Mus., Proc., vol. 55, pp. 95-96, 2 pls., 1919.

4. Second report on researches on the chemical and mineralogical composition of meteorites: Nat. Acad. Sci., Mem., vol. 14, 4th mem., 15 pp., 5 pls., 4 figs., 1919.

5. The Cumberland Falls meteorite: Science, new ser., vol. 50, p. 90, July $25,1919$.

6. Contributions to a history of American State geological and natural history surveys: U. S. Nat. Mus., Bull. 109, 549 pp., 37 pls. (portraits), 1920.

7. Report on the department of geology: U. S. Nat. Mus., Ann. Rept. 1920, pp. 101-115, 1 pl. 1920.

8. The Cumberland Falls, Whitley County, Kentucky, meteorite: U. S. Nat. Mus., Proc., vol. 57, pp. 97-105, 5 pls., 1 fig. 1920. Abstract, Geol. Soc. America, Bull., vol. 31, no. 1, p. 160, March 31, 1920

9. Notes on the meteorite of Estherville, Iowa, with special reference to its included "peckhamite" and probable metamorphic nature: U. S.

Nat. Mus., Proc., vol. 58, pp. 363-370, 3 pls., 1920.

10. On chondrules and chondritic structure in meteorites: Nat. Acad. Sci., Proc., vol. 6, no. 8, pp. 449-472, 17 figs., 1 pl., August 15, 1920.

11. Obituary, Joseph Paxson Iddings: Am. Jour. Sci., 4th ser., vol. 50, p. 316, October, 1920.

12. A retrospective view of the origin of Meteor Crater, Arizona: Astronomical Soc. Pacific, Pub., vol. 32, no. 189, pp. 259-264, 1 fig. October, 1920.

13. The Cumberland Falls, Whitley County, Kentucky, meteorite: U. S. Nat. Mus., Proc., vol. 57, pp. 97-105, 1 fig., 5 pls., 1920; Kentucky Geol. Survey, ser. 6, vol. 6, pp. 35-51, 8 figs., 1921. Abstract, Geol. Soc. America, Bull., vol. 31, no. 1, p. 160, March 31, 1920. 
Merrill, George Perkins-Continued.

14. Report on the department of geology: U. S. Nat. Mus., Ann. Rept., 1921, pp. 81-95, 1 pl., 1921.

15. On the mineral composition and structure of the Troup [Texas] meteorite: U. S. Nat. Mus., Proc., vol. 59, pp. 477-478, 1 pl., 1921.

16. On metamorphism in meteorites: Geol. Soc. America, Bulll., vol. 32, no. 4, pp. $395-414,5$ pls., December 1, 1921 ; abstract, no. 1, pp. 62-63, March 31, 1921.

17. A meteoric iron from Owens Valley, California: Nat. Acad. Sci., Mem., vol. 19, 4th mem., 7 pp., 2 pls., 1922.

18. (assisted by Moodey, M. W., and Wherry, E. T.). Handbook and descriptive catalogue of the collections of gems and precious stones in the United States National Museum: U. S. Nat. Mus., Bull. 118, 225 pp., 26 figs., 14 pls., 1922.

19. On meteoric irons from Alpine, Brewster County, Texas, and Signal Mountain, Lower California, and a pallasite from Cold Bay, Alaska: U. S. Nat. Mus., Proc., vol. 61, art. 4, 4 pp., 2 pls., 1922.

20. New meteorites [Cold Bay. Alaska; Navajo, Arizona]: Am. Jour. Sci., 5th ser., vol. 3, pp. 153-154, February, 1922.

21. A new meteoric iron [Owens Valley, California]: Am. Jour. Sci., 5th ser., vol. 3, p. 225, March, 1922.

22. Meteoric iron from Odessa, Ector County, Texas: Am.' Jour. Sci., 5th ser., vol. 3, pp. 335-337, 1 fig., May, 1922.

23. A new meteoric iron [Nickelsville, Scott County, Virginia]: Am. Jour. Sci., 5th ser., vol. 3, p. 386, May, 1922.

24. Observations of falling meteorites: Science, new ser., vol. 55, pp. 675676, June 23, 1922.

¿5. Report on the department of geology: U. S. Nat. Mus., Report on the Progress and Condition of the United States National Museum for the year ending June 30, 1922, pp. 75-90, 1922.

26. The department of geology of the U. S. National Museum: Smithsonian Inst., Ann. Rept., 1921, pp. 261-302, 1 fig., 20 pls., 1922.

27. Report on the department of geology: U. S. Nat. Mus., Report on the Progress and Condition of the United States National Museum for the year ending June 30, 1923, pp. 81-96, 1923.

28. A meteoric metabolite from Dungannon, Virginia: U. S. Nat. Mus., Proc., vol. 62, art. 18, 2 pp., 2 pls., 1923.

29. Recently found meteoric irons from Mesa Verde Park, Colorado, and Savannah, Tennessee: U. S. Nat. Mus., Proc., vol. 63, art. 18, 4 pp., 3 pls., 1923.

30. On a recently found meteoric iron from Glasgow, Barren County, Kentucky : Am. Jour. Sci., 5th ser., vol. 5, pp. 63-64, January, 1923.

31. New meteoric irons: Am. Jour. Sci., 5th ser., vol. 5, p. 92, January, 1923.

32. A newly found iron meteorite from Somerset County, Pennsylvania: Am. Jour. Sci., 5th ser., vol. 5, pp. 175-176, February, 1923.

33. The St. John paleontological collection: Am. Jour. Sci., 5th ser., vol. 5, pp. 438-439, May, 1923.

34. A new meteoric iron [McDowell County, North Carolina] : Am. Jour. Sci., 5th ser., vol. 5, p. 519, June, 1923.

35. Report of the department of geology: U. S. Nat. Mus., Report on the Progress and Condition of the United States National Museum for the year ended June 30, 1924, pp. 73-88, 1924.

36. The first one hundred years of American geology. 773 pp., 130 figs., 36 pls., New Haven, Yale University Press, 1924. 
Merrill, George Perkins-Continued.

37. Quartz in meteoric stones: Am. Mineralogist, vol. 9, no. 5, pp. 112-113, 1 fig., 1924.

38. On a stony meteorite from Anthony, Harper County, Kansas, and a recently found meteoric iron from Mejillones, Chile: Nat. Acad. Sci., Proc., vol. 10, no. 7, pp. 306-312, 5 figs., July, 1924.

39. On a meteoric iron from Four Corners, San Juan County, New Mexico: Nat. Acad. Sci., Proc., vol. 10, no. 7, pp. 312-318, 5 figs., July, 1924.

40. An unrecorded meteorite from Mississippi [Palahatchie, Rankin County] : Am. Jour. Sci., 5th ser., vol. 9, p. 436, May, 1925.

41. A new meteoric stone from Baldwyn, Mississippi: U. S. Nat. Mus., Proc., vol. 67, art. 6, 2 pp., 1 pl., May 22, 1925.

42. Notes on the meteoric stone of Colby, Wisconsin: U. S. Nat. Mus., Proc., vol. 67, art. 2, 3 pp., 1 pl., May 23, 1925.

43. Meteors: Sci. Monthly, vol. 21, no. 5, pp. 456-461, November, 1925.

44. Report on the department of geology: U. S. Nat. Mus., Report on the Progress and Condition of the United States National Museum. for the year ended June 30, 1925, pp. 73-90, 1926.

45. Biographical memoir George Ferdinand Becker, 1847-1919; bibliography compiled by Isabel P. Evans: Nat. Acad. Sci., Mem., vol. 21, 2d mem., 19 pp., portr., 1926.

46. The present condition of knowledge on the composition of meteorites: Am. Philos. Soc., Proc., vol. 65, no. 2, pp. 119-130, 1926.

47. New meteorites [Oakley, Idaho; Forksville, Virginia]: Am. Jour. Sci., 5th ser., vol. 12, p. 532, December, 1926.

48. Report on the department of geology (prepared by R. S. Bassler) : U. S. Nat. Mus., Report on the Progress and Condition of the United States National Museum for the year ended June 30, 1926, pp. 8197, 1927.

49. A meteoric iron from Owens Valley, California: Nat. Acad. Sci., Mem., vol. 19, 4th mem., 7 pp., 2 pls., 1927.

50. A stony meteorite from Forksville, Mecklenburg County, Virginia: U. S. Nat. Mus., Proc., vol. 70, art. 21, 4 pp., 3 pls., 1927.

51. Report on the department of geology: U. S. Nat. Mus., Report on the progress and condition of the United States National Museum for the year ended June 30, 1927, pp. 85-97, 1927.

52. A recently found iron meteorite from Oakley, Idaho: U. S. Nat. Mus., Proc., vol. 71, art. 21, 3 pp., 2 pls., 1927.

53. Heretofore undescribed meteoric irons from (1) Bolivia, South America, (2) western Arkansas, and (3) Seneca Township, Michigan: U. S. Nat. Mus., Proc., vol. 72, art. 4.4 pp., 2 pls., 1927.

54. On newly discovered meteoric irons from the Wallapai (Hualapai) Indian Reservation, Arizona: U. S. Nat. Mus., Proc., vol. 72, art. 22, 4 pp., 3 pls., 1927.

55. Two noted mineral collections: Sci. Monthly, vol. 25, no. 4, pp. 314-320, 7 figs.; October, 1927.

56. Concerning the metal in meteorites (abstract): Science, new ser., vol. 66, p. 461, November 11, 1927.

57. Concerning the origin of the metal in meteorites: U. S. Nat. Mus., Proc., vol. 73, art. 21,7 pp., 3 pls., 1928.

58. Report on the department of geology: U. S. Nat. Mus., Report on the Progress and Condition of the United States National Museum for the year ended June 30, 1928, pp. 87-99, 1928. 
Merritt, Clifford A. See also Decker, 8; Johannsen, 10.

1. The function of colloids in pegmatitic growths: Roy. Soc. Canada, Proc. and Trans., 3d ser., vol. 17, sec. 4, pp. 61-68, May, 1923.

2. The function of gels in the formation of quartz and carbonate veins: Roy. Soc. Canada, Proc. and Trans., 3d ser., vol. 18, sec. 4, pp. 85-90, 2 figs., 1924.

3. Angular inclusions in ore deposits: Econ. Geology, vol. 20, no. 6, pp. 602604, September-October, 1925.

4. Bigstone and Fox Rivers area, northern Manitoba: Canada, Geol. Survey, Summ. Rept., 1925, pt. B, pp. 27-30, map, 1926.

Merritt, John Wesley.

1. Pennsylvanian sedimentation around Healdton Island [Healdton, Oklahoma] : Am. Assoc. Petroleum Geologists, Bull., vol. 4, no. 1, pp. 47-52, 4 figs., 1920.

2. Structures of western Chaves County, New Mexico: Am. Assoc. Petroleum Geologists, Bull., vol. 4, no. 1, pp. 53-57, 5 figs., 1920.

3. Structural and metamorphic geology of the Hanover district of New Hampshire: Vermont, State Geologist, Twelfth Rept., 1919-20, pp. 1-36, 1 fig., 13 pls., 1921.

4. (and McDonald, O. G.). Oil and gas in Oklahoma: Oil and gas in Creek County, Oklahoma: Oklahoma Geol. Survey, Bull. no. 40-C, 47 pp., 8 figs., 7 pls. (incl. map), August, 1926.

Mertie, John Beaver, jr. See also Smith, P. S., 7.

1. Repeated stream piracy in the Tolovana and Hess River basins, Alaska (abstract) : Washington Acad. Sci., Jour., vol. 9, no. 4, pp. 109-110, F'ebruary 19, 1919.

2. Platinum-bearing gold placers of the Kahiltna Valley [Alaska] : U. S. Geol. Survey, Bull. 692, pp. 233-264, 1 pl. (map), 1919. Abstract by G. C. Martin, Washington Acad. Sci., Jour., vol. 9, no. 20, p. 633, December 4, 1919.

3. Chromite deposits in Alaska: U. S. Geol. Survey, Bull. 692, pp. 265-267, 1 fig., 1919. Abstract by G. C. Martin, Washington Acad. Sci., Jour., vol. 9, no. 20, pp. 633-634, December 4, 1919.

4. The Salt Chuck palladium-copper mine [Prince of Wales Island, Alaska] : Eng. and Min. Jour., vol. 110, no. 1, pp. 17-20, 6 figs., July 3, 1920.

5. Lode mining in the Juneau and Ketchikan districts [Alaska]: U. S. Geol. Survey, Bull. 714, pp. 105-128, 1 pl., 1921.

6. Notes on the Salmon-Unuk River region [Alaska]: U. S. Geol. Survey, Bull. 714, pp. 129-142, 1 pl. (map), 1921.

7. The occurrence of metalliferous deposits in the Yukon and Kuskokwim regions, Alaska: U. S. Geol. Survey, Bull. 739, pp. 149-165, 1922.

8. Graphic and mechanical computation of thickness of strata and distance to a stratum: U. S. Geol. Survey, Prof. Paper 129, pp. 39-52, 8 figs., 3 pls., March 14, 1922.

9. Igneous rocks [of the Raton, Brilliant, and Koehler quadrangles]: U. S. Geol. Survey, Geol. Atlas U. S., Raton-Brilliant-Koehler folio, New Mexico-Colorado (no. 214), pp. 9-12, 1922.

10. Analysis of structure below an unconformity: Econ. Geology, vol. 17, no. 7, pp. 572-574, 2 figs., November, 1922.

11. (and Harrington, G. L.). The Ruby-Kuskokwim region, Alaska: U. S. Geol. Survey, Bull. 754, 129 pp., 2 figs., 5 pls. (incl. maps), 1924.

12. Geology and gold placers of the Chandalar district [Alaska]: U. S. Geol. Survey, Bull. 773, pp. 215-263, 4 figs., 1 pl., 1925. 
Mertie, John Beaver, jr.-Continued.

13. The Paleozoic geology of interior Alaska (abstract): Washington Acad. Sci., Jour., vol. 16, no. 3, pp. 78-79, February 4, 1926.

14. Igneous rocks of the upper Matanuska Valley: U. S. Geol. Survey, Bull. 791, pp. 55-72, 1927.

15. Paleozoic and pre-Cambrian geology of upper Yukon Valley (abstract) : Geol. Soc. America, Bull., vol. 38, no. 1, p. 137, March 30, 1927 ; Pan-Am. Geologist, vol. 47, no. 1, p. 79, February, 1927.

16. Preliminary report of the Sheenjek River district, Alaska: U. S. Geol. Survey, Bull. 797, pp. 99-123, 1 fig., map, 1928.

Merwin, Herbert E. See also Aurousseau, 3; Davy, 1; Ferguson, J. B., 1, 2; Goldman, 15; Posnjak, 1; Shepherd, 5; Washington, 11, 19, 26, 28, 35 ; Wyckoff, 5 , 6.

1. (and Posnjak, E.). The iron hydroxide minerals (abstract) : Washington Acad. Sci., Jour., vol. 9, no. 4, pp. 108-109, February 19, 1919.

2. (and Hostetter, J. C.). Hematite and rutile formed by the action of chlorine at high temperatures: Am. Mineralogist, vol. 4, no. 10, pp. 126-127, 1 fig., October, 1919.

3. Some features of stream development and of glaciation in the Catskil Mountains (abstract): Geol. Soc. America, Bull., vol. 31, no. 1, p. 152, March 31, 1920.

4. Chemical researches on sediments: Geol. Soc. America, Bull., vol. 31, no. 4, pp. 419-423, November 30, 1920 ; abstract, Washington Acad. Sci., Jour., vol. 11, no. 17, p. 419, October 19, 1921.

5. (and Lombard, R. H., and Allen, E. T.). Cubanite, identity with chalmersite; magnetic properties: Am. Mineralogist, vol. 8, no. 8, pp. 135138, August, 1923.

6. (and Locke, Augustus, and Posnjak, E.). Sulphate minerals formed by oxidation of pyritic ore at Bisbee, Arizona (abstract, with discussion by R. C. Wells, Samuel G. Gordon, and R. J. Holden) : Geol. Soc. America, Bull., vol. 35, no. 1, pp. 125-126, March 30, 1924 ; abstract, Pan-Am. Geologist, vol. 41, no. 2, p. 159, March, 1924.

7. Note on the hydrated sulphates of magnesia in hot springs (abstract): Washington Acad. Sci., Jour., vol. 14, no. 15, p. 382, September 19, 1924.

Meserve, Philip W.

1. Note on the depth of the Champlain submergence along the Maine coast: Am. Jour. Sci., 4th ser., vol. 48, pp. 207-208, 1 fig., September, 1919.

Mesler, R. D. See Ulrich, 14.

Metcalf, R. J.

1. Discovery of the Yates pool, Pecos County, Texas: Am. Assoc. Petroleum Geologists, Bull., vol. 11, no. 6, p. 635, June, 1927.

Metcalf, Woodbridge.

1. An ancient pine cone [Oakland, California] : Am. Forestry, vol. 29, p. 172, 1 fig., March, 1923.

Meunier, Stanislas.

1. Observations sur deux météorites tombées aux Etats-Unis: Soc. géol. France, Compte réndu Séances, ann. 1921, pp. 145-146", 1921.

Mexico, Departamento del Petrôleo.

1. Bibliografía del petróleo en México. Monografías bibliograficicas mexicanas, no. 8, 169 pp., Mexico, 1927. 
Mexico, Instituto Geológico.

1. Cátálogo sistemático de especies minerales de México y sus aplicaciones industriales: Mexico, Inst. Geol., Bol. 40, 290 pp., 1923.

2. Catálogo geográfico de las especies minerales de México: Mexico, Inst. Geol., Bol. no. 41, 152 pp., 1923.

Mexico. Secretaría de Agricultura y Fomento.

1. Atlas geográfico de la República Mexicana construido y editado en la Dirección de Estudios geográficos y climatológicos con la cooperación del Instituto Geológico de México, 1919-1921. Atlas geográfico $y$ geologico. 32 sheets and additional unnumbered sheets including geologic maps of the Republic on the scale $1: 6,500,000$ and of the individual States on various scales. Other editions omit geologic maps of the individual states.

Meyer, A. M. See 'Tomlinson, 4.

Meyer, H. C.

1. Zirconia, its occurrence and application: Mineral Foote-Notes, vol. 3, no. 2, pp. 2-12, March-April, 1919.

Meyerhoff, Howard A. See also Colony, 9.

1. The physiography of the Virgin Islands, Culebra, and Vieques: New York Acad. Sci., Scientific Survey of Porto Rico and the Virgin Islands, vol. 4, pts., 1 and 2, pp. 71-219, 55 figs., 4 pls. (incl. maps). 1926-27.

2. Tertiary physiographic development of Porto Rico and the Virgin Islands: Geol. Soc. America, Bull., vol. 38, no. 4, pp. 557-575, 7 figs., December 30,1927 ; abstract, no. 1, pp. 141-142, March 30, 1927 ; PanAm. Geologist, vol. 47, no. 2, p. 150, March, 1927.

Michelson, Albert Abraham.

1. (and Gale, Henry G.). The rigidity of the earth: Jour. Geology, vol. 27, no. 8, pp. 585-601, 8 figs., 1 pl., November-December, 1919.

Michigan Geological and Biological Survey.

1. Catalog and table of contents of the publications of the Geological and Biological Survey division of the Michigan Department of Conservation, with a list of publications of the United States Geological Survey, relating to Michigan; 1838-1922. $36 \mathrm{pp} ., 1 \mathrm{pl}$. [1923].

Mijares, Carlos G.

1. Las publicaciones del Instituto geológico de México: Mexico, Inst. Geol., Anales, no. 10, 19 pp., 1923.

Millar, William B. See Gillson, 10.

Millard, M. J. See Aurin, 2.

Miller, A. H.

1. Gravity results in the Mackenzie Basin: Am. Jour. Sci., 5th ser., vol. 7, pp. 411-412, May, 1924.

2. Gravity in western Canada: Roy. Soc. Canada, Trans., 3d ser., vol. 21, sec. 4, pp. 175-187, 2 figs., May, 1927 ; abstract, p. xcv, 1927.

3. Gravitational methods of geophysical prospecting: Canadian Min. Jour., vol. 49, no. 24, pp. 476-481, 11 figs., June 15, 1928.

Miller, A. K.

1. A new echinoid from the Sundance of west-central Wyoming: Am. Jour. Sci., 5th ser., vol. 16, pp. 143-146, 4 figs., August, 1928. 
Miller, Arthur McQuiston, 1861-1929.

1. The geology of Kentucky ... [with introduction by August F. Foerste] : Kentucky, Dept. Geology and Forestry, Series 5, Bull. 2, xxix, 392 pp., 114 illus. (incl. maps), Frankfort, 1919.

2. The Cumberland Falls meteorite: Science, new ser., vol. 49, pp. 541-542, June 6, 1919.

3. The Cumberland Falls meteorite: Kentucky, Dept. Geology and Forestry. Ser. V [of Ky. Geol. Survey], Mineral and Forest Resources of Kentucky, vol. 1, no. 2, pp. 110-114, 2 figs., July 1, 1919.

4. The McCreary County [Kentucky] aerolite (abstract) : Science, new ser., vol. 50, p. 96, July 25, 1919.

5. Geology of Allen County: Kentucky, Dept. Geology and Forestry, Ser. V. [of Ky. Geol. Survey], Mineral and Forest Resources of Kentucky, vol. 1, no. 3, pp. 220-242, \& figs., map, October 1., 1919.

6. Cumberland Falls, Kentucky, meteorite (abstract): Geol. Soc. America, Bull., vol. 31, no. 1 pp. 159-160, March 31, 1920.

7. Professor Field's use of the term fossil: Science, new ser., vol. 52, p. 408 , October 29, 1920.

8. Fossils-are they merely "prehistoric," or must they also be "geologic"? Science, new ser., vol. 53, pp. 258-259, March 18, 1921.

9. Nicholasville, Kentucky, well (abstract) : Geol. Soc. America, Bull., vol. 32 , no. 1, pp. 35-36, March 31, 1921.

10. Glacial man in America?: Pan-Am. Geologist, vol. 37, no. 2, pp. 107-108, March, 1922.

11. Licks and caves of the lower Ohio Valley as repositories of mammalian remains, including those of man: Geol. Soc. America, Bull., vol: 33, no. 1, pp. 156-159, March 31, 1922.

12. Meteorite hunting: Science, new ser., vol. 56, pp. 249-251, September 1, 1922.

13. Recent cave explorations in Kentucky for animal and human remains: Kentucky Geol. Survey, ser. 6, vol. 10, pp. 107-113, 2 figs., 1923.

14. Meteorites: Sci. Monthly, vol. 17 , no. 5, pp. 435-448, 7 figs., November, 1923.

15. Faulting in north-central Kentucky (abstract): Kentucky Acad. Sci., Trans., vol. 1, pp. 29-30, 1924.

16. Some historic fish remains (abstract): Kentucky Acad. Sci., Trans., vol. 1, pp. 37-38, 1924.

17. History and present status of opinions in regard to the origin and antiquity of man (abstract) : Kentucky Acad. Sci., Trans., vol. 1, pp. 44-46, 1924.

18. The geologic structure which explains the accumulation of oil in.the Irvine field (abstract) : Kentucky Acad. Sci., Trans., vol. 1, p. 47, 1924 .

19. The McCreary County aerolite (abstract) : Kentucky Acad. Sci., Trans., vol. 1, p. $71,1924$.

20. Map of the geology of Adair County, Kentucky, by A. M. Miller: Kentucky Geol. Survey, ser. 6, 1924. Scale, 1:62,500.

21. Map of the geology of Woodford County, Kentucky, by A. M. Miller: Kentucky Geol. Survey, ser. 6, 1924. Scale 1:62,500.

22. Geology of Woodford County: Kentucky Geol. Survey, ser. 6, vol. 21, pp. 119-144, 5 figs., 1925.

23. Origin of the prairie: Science, new ser., vol. 66 , pp. 655-656, December 30, 1927. 
Miller, Benjamin LeRoy. See also Bascom, 2; Pennsylvania, 1.

1. Graphite industry of the United States and Canada: Eng. and Min. Jour., vol. 112, no. 6, pp. 207-213, 3 figs., August 6, 1921.

2. Coal resources of the Americas. 24 pp., 14 pls. (incl. map), The Pan American Union, Washington, Government Printing Office, 1923.

3. Lead and zinc ores of Pennsylvania: Pennsylvania Geol. Survey, 4th ser., Bull. M5, 91 pp., 7 figs. (maps), 5 pls., 1924.

4. Limestones of Pennsylvania: Pennsylvania Geol. Survey, 4th ser., Bull. M7, 368 pp., 7 figs., 15 pls. (incl. map), 1925.

5. Mineral resources of the Allentown quadrangle, Pennsylvania: Pennsylvania Geol. Survey, 4th ser., Topog. and Geol. Atlas, no. 206, Allentown quadrangle, 195 pp., 2 figs., 11 pls., 4 maps, 1925.

6. The physiography, geology, and mineral resources of Kent County: Maryland Geol. Survey, Kent County, pp. 25-109, 3 maps, 1926.

7. The physiography, geology, and mineral resources of Queen Annes County; Maryland Geol. Survey, Queen Annes County, pp. 25-91, 2 maps, 1926.

8. The physiography, geology, and mineral resources of Talbot County: Maryland Geol. Survey, Talbot County, pp. 23-96, 5 pls., map, 1926.

9. Taconic folding in Pennsylvania (with discussion by Henry B. Kümmel, I. C. White, George H. Ashley, James F. Kemp, H. N. Eaton, Bradford Willard, Charles H. Behre, jr., and U. S. Grant) : Geol. Soc. America, Bull., vol. 37, no. 3, pp. 497-511, September 30, 1926, abstract, vol. 36, no. 1, p. 157, March 30, 1925 ; Pan-Am. Geologist, vol. 43 , no. 2 , p. 152 , March, 1925.

10. An unusual case of limestone decomposition (abstract): Pennsylvania Acad. Sci., Proc., vol. 1, pp. 77-78, 1926.

11. The origin and utilization of the Cambro-Ordovician limestones of Pennsylvania: Pennsylvania Acad. Sci., Proc., vol. 1, pp. 89-99, 1 pl. (map), 1926.

12. Progress in ore genesis studies, 1876-1926: Johns Hopkins Univ., Studies in Geology, no. 8, pp. 121-135, 1927.

13. Origin and utilization of the limestones: West Virginia Acad. Sci., Proc., vol. 2 (W. Va. Univ. Bull., ser. no. 29, no. 1), pp. 102-106, August, 1928.

Miller, Eric R. See Winchell, A. N., 1, 4.

Miller, Gerrit Smith, jr.

1. (and Gidley, J. W.). A new fossil rodent [Ischromys] from the oligocene of South Dakota: Jour. Mammalogy, vol. 1, no. 2, pp. 73-74, February, 1920.

2. Notes on the casts of the Pithecanthropus molars: Am. Mus. Nat. Hist., Bull., vol. 48, pp. 527-530, 2 figs., 1923.

Miller, Loye Holmes.

1. Asphalt beds of Rancho La Brea [California] (abstract): Washington Acad. Sci., Jour., vol. 11, pp. 262-263, June 4, 1921.

2. The birds of Rancho La Brea [California]: Carnegie Inst. Washington, Pub. no. 349 (Studies on the fossil flora and fauna of the western United States), pp. 63-106, 20 figs., 6 pls., August, 1925.

3. Avian remains from the Miocene of Lompoc, California: Carnegie Inst. Washington, Pub. no. 349 (Studies on the fossil flora and fauna of the western United States), pp. 107-117, 1 fig., 9 pls., August, 1925.

4. Bird remains [from asphalt pit, Carpinteria, Santa Barbara County, California]: Science, new ser., vol. 66, p. 156, August 12, 1927. 
Miller, Raymond. See Kentucky G. S., 49 ; Murphy, 1.

Miller, Thomas I.

1. Memorial of Joseph Parker Wintringham: Am. Mineralogist, vol. 12, no. 3, pp. 70-71, 1 fig. (portr.), March, 1927.

Miller, Wendell $\mathbf{z}$.

1. The Burbank field, Osage County, Oklahoma: Am. Assoc. Petroleum Geologists, Bull., vol. 5, no. 4, p. 502, July-August, 1921.

Miller, Willet Green, 1866-1925.

1. The pre-Cambrian of central Canada (abstract): Geol. Mag., new ser., dec. 6, vol. 6, pp. 524-526, November, 1919.

2. (and Knight, Cyril W.). Certain post-Timiskaming igneous rocks of Ontario for which the name Haileyburian is proposed: Canadian Min. Jour., vol. 41, p. 653, August 13, 1920 .

3. (and Knight, Cyril W.). Haileyburian intrusive rocks: Ontario Dept. Mines, 29th Ann. Rept., vol. 29, pt. 1, pp. 235-236, 1920.

4. The pre-Cambrian of central Canada (abstract) : British Assoc. Adv. Sci., Rept. 87th meeting, pp. 192-194, 1920.

5. Geology's debt to the mineral industry: Science, new ser., vol. 57, pp. 247-252, March 2, 1923; Min. Mag., vol. 28, no. 5, pp. 311-314, May, 1923.

6. The Matachewan series and its pre-Cambrian relations [northeastern Ontario] : Canadian Min. Jour., vol. 44, no. 16, pp. 298-299, April $20,1923$.

7. Ontario's triumvirate of great mining areas; a remarkable triangle: Canadian Min. Jour., vol. 44, no. 25, pp. 470-471, 1 fig., June 22, 1923.

8. Geology of northeastern Ontario: Canadian Min. Jour., vol. 44, no. 33, pp. 622-625, 4 figs., August 17, 1923.

9. Discovery and development of Cobalt [Ontario]: Mining and Metallurgy, vol. 4, no. 201, pp. 475-477, September, 1923.

10. The Sudbury-Cobalt-Porcupine area [Ontario]: Mining and Metallurgy, vol. 4 , no. 202 , pp. 523-525, October, 1923.

11. Uranium minerals in Haliburton district, Ontario: Canadian Min. Jour., vol. 45 , no. 2, p. 44, January 11, 1924.

12. Pre-Cambrian rocks of Canada (abstract) : Pan-Am. Geologist, vol. 42, no. 1, pp. 76-78, August, 1924; British Assoc. Adv. Sci., Rept. 92d Meeting, pp. 386-387, 1925.

Miller, William John. See also Foye, 5 ; Grout, 9.

1. Geology of the Lake Placid quadrangle: New York State Mus., Bull. nos. 211, 212, 106 pp., 30 pls., 8 figs., map, 1919.

2. Geology of the Schroon Lake quadrangle: New York State Mus., Bull. no. 213, 214, 102 pp., 14 pls., 9 figs., map, 1919.

3. Pegmatite, silexite, and aplite of northern New York: Jour. Geology, vol. 27, no. 1, pp. 28-54, 11 figs., January-February, 1919. Abstract, Geol. Soc. America, Bull., vol. 30, p. 93, March 31, 1919.

4. Silexite, a new rock name: Science, new ser., vol. 49 , p. 149, February 7 , 1919.

5. Magnetic iron ore deposits of Clinton County, New York (abstract) : Geol. Soc. America, Bull., vol. 30, pp. 93-94, March 31, 1919.

6. Significance of the gorge at Little Falls, New York: Jour. Geography, vol. 18, no. 4, pp. 156-158, April, 1919.

7. Magnetic iron ores of Clinton County, New York: Econ. Geology, vol. 14, no. 7, pp. 509-535, 2 pls., 1 fig., November, 1919. 
Miller, William John-Continued.

8. How the Adirondacks were made: The Conservationist, Albany, N. Y., vol. 3, no. 3, pp. 35-38, 4 figs., March, 1920.

9. Anorthosite gabbro in northern New York (abstract) : Geol. Soc. America, Bull., vol. 31, no. 1, pp. 140-141, March 31, 1920.

10. The geological history of the Connecticut Valley of Massachusetts; a nopular account of its rocks and origin. 74 pp., 27 figs., map, [Northampton, Mass., The Hampshire Bookshop, 1921].

11. Features of a body of anorthosite gabbro in northern New York: Jour. Geology, vol. 29, no. 1, pp. 29-47, 7 figs., January-February, 1921.

12. Some crystal localities in St. Lawrence County, New York: Am. Mineralogist, vol. 6, no. 4, pp. 77-79, April, 1921.

13. Origin of Adirondack magnetite deposits: Econ. Geology, vol. 16, no. 3, pp. 227-233, April-May, 1921. Abstract, Geol. Soc. America, Bull., vol. 32, no. 1, pp. 63-64, March 31, 1921.

14. Wilmington Notch [Adirondacks, New York]: The Conservationist (published by Conservation Commission, State of New York), vol. 4, no. 7, pp. 99-101, 3 figs., July, 1921.

15. Geology, the science of the earth's crust. Popular Science Library, vol. 3, 384 pp., 80 figs., 20 pls., New York, P. F. Collier \& Son Company, 1922.

16. Sillimanite-schist inclusions in granite (abstract) : Geol. Soc. America, Bull., vol. 33, no. 1, pp. 130-183, 1 fig., March 31, 1922.

17. Intraformational corrugated rocks: Jour. Geology, vol. 30, no. 7, pp. 587-610, 10 figs., October-November, 1922; abstract with discussion by James H. Lees: Geol. Soc. America, Bull., vol. 33, no. 1, p. 98, March 31, 1922.

18. Discussion of paper by F. L. Nason on The sedimentary phases of the Adirondack magnetic iron ores: Econ. Geology, vol. 17, no. 8, pp. 709-713, 1922.

19. Geology of the Luzerne quadrangle: New York State Mus. Bull., nos. 245, 246, 66 pp., 14 figs., 11 pls., 1923.

20. Zion Canyon National Park, Utah: Jour. Geography, vol. 22, no. 5, pp. 161-171, 7 figs., May, 1923.

21. Pre-Cambrian folding in North America: Geol. Soc. America, Bull., vol. 34, no. 4, pp. 679-702, December 30, 1923.

22. An introduction to physical geology with special reference to North America. 435 pp., 351 figs., 1924.

23. The geological history of New York State [second edition]: New York State Mus. Bull., no. 255, 148 pp., 39 figs. (incl. map), 52 pls., 1924.

24. An introduction to geology (physical and historical) : Part I, An introduction to physical geology, 435 pp., 351 figs. ; Part II, An introduction to historical geology, 399 pp., 238 figs., New York, D. Van Nostrand Company, 1925.

25. Remarkable Adirondack glacial lake: Geol. Soc. America, Bull., vol. 36, no. 3, pp. 513-520, 1 fig., September 30, 1925; abstract, no. 1, p. 162, March 30, 1925; Pan-Am. Geologist, vol. 43, no. 2, p. 155, March, 1925.

26. Geology of the Lyon Mountain quadrangle: New York State Mus. Bull., no. 271, 101 pp., 9 figs., 13 pls., map, 1926.

27. Origin of pyrite deposits of St. Lawrence County, New York: Econ. Geology, vol. 21, no. 1, pp. 65-67, January-February, 1926. 
Miller, William John-Continued.

28. Glaciation in the San Gabriel Mountains, Callifornia: Jour. Geology, vol. 34, no. 1, pp. 74-82, 5 figs., January-February, 1926; abstract, Geol. Soc. America, Bull., vol. 37, no. 1, p. 180, March 30, 1926; Pan-Am. Geologist, vol. 45, no. 2, p. 169, March, 1926.

29. Crystalline rocks of the middle-southern San Gabriel Mountains, California (abstract) : Geol. Soc. America, Bull., vol. 37, no. 1, p. 149, March 30, 1926 ; Pan-Am. Geologist, vol. 45, no. 1, p. 96, February, 1926.

30. Present status of the pre-Cambrian geology of northern New York (abstract): Geol. Soc. America, Bull., vol. 37, no. 1, pp. 219-220, March 30, 1926.

31. Red Rock Canyon, California: Jour. Geography, vol. 25, no. 9, pp. 330336, 7 figs., December, 1926.

32. An introduction to physical geology, with special reference to North America. 2d ed., 435 pp., 351 illus., New York, D. Van Nostrand Company, 1927 .

33. Geomorphology of the southwestern San Gabriel Mountains of California : California, Univ., Dept. Geol. Sci., Bull., vol. 17, no. 6, pp. 193240, 2 figs., 7 pls., April 21, 1928 ; abstract, Geol. Soc. America, Bull., vol. 39, no. 1, p. 269, March 30, 1928.

34. Anorthosite in Los Angeles County, California (abstract) : Geol. Soc. America, Bull., vol. 39, no. 1, pp. 164-165, March 30, 1928; Pan-Am. Geologist, vol. 49, no. 1, pp. 73-74, February, 1928.

35. Geology of Deep Spring Valley, California : Jour. Geology, vol. 36, no. 6, pp. 510-525, 8 figs. (incl. map), August-September, 1928 ; abstract, Geol. Soc. America, Bull., vol. 39, no. 1, p. 190, March 30, 1928; Pan-Am. Geologist, vol. 49, no. 2, p. 144, March, 1928.

Millikan, C. V.

1. Inter-relations of the folds of Osage County, Oklahoma: Am. Assoc. Petroleum Geologists, Bull., vol. 4, no. 2, pp. 151-158, 6 figs., 1920.

Millis, John.

1. The drumlins (abstract) : Science, new ser., vol. 56, p. 174, August 11, 1922.

2. Surface features of the moon, the earth, and Mars: Popular Astronomy, vol. 31, no. 1, pp. 1-11, 5 figs., 3 pls., January, 1923.

3. The constructional history of the solar system and of our earth-a speculation. 12 pp., December, 1925. [Priv. pub.]

4. Dualistic hypothesis of earth genesis: Pan-Am. Geologist, vol. 45, no. 4, pp. 257-271, May, 1926.

Mills, Enos Abijah.

$\circ$

1. Romance of geology; being adventures with glaciers, rivers, and wind, fossil hunting, trailing ancient seashores, and following mirages of the desert. xii, 245 pp., illus., Garden City, New York, Doubleday, Page \& Company, 1926.

Mills, Ronald Van Auken. See also Ambrose, 1; Matteson, 2; Neal, 1; Robinson, H. M., 1; Washburne, 3.

1. (and Wells, Roger C.). The evaporation and concentration of waters associated with petroleum and natural gas: U. S. Geol. Survey, Bull. 693, 104 pp., 4 pls., 5 figs., 1919. Abstract, Washington Acad. Sci., Jour., vol. 9, no. 17, pp. 529-530, October 19, 1919.

$4096-31-28$ 
Mills, Ronald Van Auken-Continued.

2. Experimental studies of subsurface relationships in oil and gas fields: Econ. Geology, vol. 15, no. 5, pp. 398-421, 4 pls., 1 fig., July-August, 1920.

3. Experimental studies of subsurface relationships in oil and gas fields (discussion) : Econ. Geology, vol. 16, no. 1, pp. 52-60, January, 1921.

4. Relations of texture and bedding to the movements of oil and water through sands: Econ. Geology, vol. 16, no. 2, pp. 124-141, 2 figs., 4 pls., March, 1921.

5. Natural gas as a factor in oil migration and accumulation in the vicinity of faults (with discussion by Leon J. Pepperberg, F. H. Lahee, and K. C. Heald) : Am. Assoc. Petroleum Geologists, Bull., vol. 7, no. 1, pp. 14-24, January-February; 1923.

.Mills-Bullard, Bess.

1. A summary of oil production in Oklahoma by years: Okláhoma Acad. Sci. (Univ. Oklahoma Bull., new ser., no. 322), Proc., vol. 4, pp. 121-123, 1 pl., December 1, 1925.

2. Oil and gas in Oklahoma; digest of Oklahoma oil and gas fields: Oklahoma Geol. Survey, Bull. no. 40-Q, 187 pp., map, June, 1928; Bull. 40, vol. 1, pp. 101-276, map, July, 1928.

Milner, Henry B.

1. Trinidad; a review of its geology and oil resources: Min. Mag., vol. 25, nos. 3 and 4, pp. 139-148, 205-213, 7 figs., September and October, 1921.

2. Petroleum in Central America and the West Indies: Min. Mag., vol. 27, no. 1, pp. 9-18, 5 figs., July, 1922.

3. The study and correlation of sediments by petrographic methods: Min. Mag., vol. 28, no. 2, pp. 80-92, 2 figs., 2 pls., February, 1923.

4. The oil fields of the Los Angeles Basin, southern California : Min. Mag., vol. 29, no. 6, pp. 329-336, 5 figs., December, 1923, vol. 30 , no. 1 , pp. 9-16, 5 figs., January, 1924.

5. Report of research on sedimentary rocks by British petrologists for the year 1927: Nat. Research Council, Reprint and Circ. Ser., no. 85, pp. 9-12, 1928.

Minor, H. E.

1. Chemical relation of salt dome waters: Am. Assoc. Petroleum Geologists, Bull., vol. 9, no. 1, pp. 38-41, 1 fig., 2 pls., January-February, 1925; Geology of salt dome oil fields, pp. 777-780, 1 fig., 2 pls., 1926.

2. Goose Creele oil field, Harris County, Texas: Am. Assoc. Petroleum Geologists, Bull., vol. 9, no. 2, pp. 286-297, 4 figs., March-April, 1925 ; Geology of salt dome oil fields, pp. 546-557, 4 figs., 1926.

3. The Edgerly oil field, Louisiana: Am. Assoc. Petroleum Geologists, Bull., vol. 9, no. 3, pp. 497-504, 4 figs. May-June, 1925 ; Geology of salt dome oil fields, pp. 470-477, 4 figs., 1926.

Minor, Roy Waldo. See also Gregory, W. K., 9.

1. The pectoral limb of Eryops and other primitive tetrapods: Am. Mus. Nat. Hist., Bull., vol. 51, pp. 145-312, 104 figs., January 16, 1925.

2. A fossil myriapod of the genus Parajulus from Florissant, Colorado: Am. Mus. Novitates, no. 219, 5 pp., 5 figs., June 18, 1926. 
Miser, Hugh Dinsmore. See also Longwell, 6; Moulton, 8; Purdue, 1; Redwood, 1; Stone, 11; Stose, 1, 16; U. S. Geol. Survey, 14.

1. Manganese deposits of the Batesville district, Arkansas (abstract) : Washington Acad. Sci., Jour., vol. 9, no. 13, p. 384, July 19, 1919.

2. (and Fairchild, J. G.). Hausmannite in the Batesville district, Arkansas: Washington Acad. Sci., Jour., vol. 10, no. 1, pp. 1-8, January 4, 1920.

3. Mississippian tuff in the Ouachita Mountain region (abstract with discussion by Sidney Powers): Geol. Soc. America, Bull., vol. 31, no. 1, pp. 125-126, March 31, 1920.

4. Geology and general topographic features of Arkansas. In Ferguson, Jim G., Outlines of Arkansas geology, pp. 21-42, Little Rock, 1920.

5. Preliminary report on the deposits of manganese ore in the Batesville district, Arkansas: U. S. Geol. Survey, Bull. 715, pp. 93-124, 3 pis. (incl. map), 4 figs., November 15, 1920 ; abstract, Washington Acad. Sci., Jour., vol. 11, no. 8, p. 194, April 19, 1921.

6. Mineral resources of the Waynesboro quadrangle, Tennessee: Tennessee State Geol. Survey, Bull. 26, 171 pp., 7 figs., 16 pls. (incl, map), 1921.

7. Llanoria; the Paleozoic land area in Louisiana and eastern Texas: Am. Jour. Sci., 5th ser., vol. 2, pp. 61-89, 1 fig. (map), August, 1921. Abstract, Geol. Soc. America, Bull., vol. 32, no. 1, pp. 40-41, March 31, 1921; Washington Acad. Sci., Jour., vol. 11, no. 18, pp. 444-445, November 4, 1921.

8. Deposits of manganese ore in the Batesville district, Arkansas: U. S. Geol. Survey, Bull. 734, 273 pp., 26 figs., 17 pls. (incl. maps), 1922.

9. (and Ross, C. S.). Peridotite dikes in Scott County, Arkansas: U. S. Geol. Survey, Bull. 735, pp. 271-278, 2 figs., 1 pl., December 22, 1922.

10. (and Ross, C. S.). Diamond-bearing peridotite in Pike County, Arkansas: Econ. Geology, vol. 17, no. 8, pp. 662-674, 3 figs., 1 pl., December, 1922.

11. Geology and general topographic features of Arkansas. In Ferguson, Jim G., Minerals in Arkansas, pp. 11-34, Little Rock, Ark., 1922.

1.2. (and Ross, Clarence S.). Diamond-bearing peridotite in Pike County, Arkansas: U. S. Geol. Survey, Bull. 735, pp. 279-322, 3 figs., 8 pls. (incl. maps), 1923.

13. (and Trimble, K. W., and Paige, Sidney). The Rainbow Bridge, Utah: Geog. Rev., vol. 13, no. 4, pp. 518-531, 12 figs., October, 1923.

14. The San Juan Canyon, southeastern Utah: a geographic and hydrographic reconnaissance: U. S. Geol. Survey, Water-Supply Paper 538, 80 pp., 3 figs., 22 pls. (incl. map), 1924.

15. Temperature of Oklahoma's deepest well: Am. Assoc. Petroleum Geologists, Bull., vol. 8, no. 4, pp. 525-526, July-August, 1924.

16. A new areal geologic map of Oklahoma (abstract): Washington Acad. Sci., Jour., vol. 14, no. 15, p. 382, September 19, 1924.

17. Geologic structure of San Juan Canyon and adjacent country, Utah: U. S. Geol. Survey, Bull. 751, pp. 115-155, 1 fig., 6 pls. (incl. map), December 10, 1924.

18. (and Ross, Clarence S.). Diamond-bearing peridotite in Pike County, Arkansas: Smithsonian Inst., Ann. Rept., 1923, pp. 261-272, 3 pls., 1925.

19. (and Ross, Clarence S.). Volcanic rocks in the Upper Cretaceous of southwestern Arkansas and southeastern Oklahoma: Am. Jour. Sci., 5th ser., vol. 9, no. 2, pp. 113_126, February, 1925. 
Miser, Hugh Dinsmore-Continued.

20. Erosion in San Juan Canyon, Utah: Geol. Soc. America, Bull., vol. 36. no. 2 , pp. $365-377,2$ figs., 2 pls., June 30,1925 ; abstract, no. 1 , pp. 138-139, March 30, 1925; Pan-Am. Geologist, vol. 43, no. 1, p. 79, February, 1925.

21. Notes on Paleozoic rocks encountered in a well near Florence, Alabama: U. S. Geol. Survey, Bull. 781, pp. 11-12, July, 1925.

22. (and Ross, Clarence S.). Pre-Cambrian rhyolite discovered in well in northwestern Arkansas: Am. Assoc. Petroleum Geologists, Bull., vol. 9 , no. 7 , p. 1115 , October, 1925.

23. Tennessee Geological Survey [activities]: Pan-Am. Geologist, vol. 44, no. 4, pp. 320-321, November, 1925.

24. Geologic map of Oklahoma: U. S. Geol. Survey, Geologic Atlas of the United States, State of Oklahoma, 1926. Scale, 1:500,000.

25. Erosion in the San Juan Canyon, Utah (abstract): Washington Acad. Sci., Jour., vol. 16, no. 3, pp. 68-69, February 4, 1926.

26. Erosion in the San Juan Canyon, Utah (abstract): Washington Acad. Sci., Jour., vol. 17, no. 4, pp. 98-99, February 19, 1927.

27. Lower Cretaceous (Comanche) rocks of southeastern Oklahoma and southwestern Arkansas: Am. Assoc. Petroleum Geologists; Bull., vol. 11, no. 5. pp. $443-453.2$ figs. May. 1927.

28. Shapes of stream pebbles in San Juan County, Utah (abstract) : Washington Acad., Sci., Jour., vol. 17, no. 10, 270-271, May 19, 1927.

29. (and Honess, C. W.). Age relations of the Carboniferous rocks of the Ouachita Mountains of Oklahoma and Arkansas: Oklahoma Geol. Survey, Bull. no. 44, 48 pp., 2 figs., November, 1927.

30. Structure of the Ouachita Mountains of Arkansas and Oklahoma (abstract) : Geol. Soc. America, Bull., vol. 39, no. 1, pp. 180-181, March 30, 1928; Pan-Am. Geologist, vol. 49, no. 2, p. 141, March, 1928.

31. Structure of the Ouachita Mountains of Oklahoma and Arkansas (abstract) : Washington Acad. Sci., Jour., vol. 18, no. 9, pp. 266-267, May 4, 1928.

Mishler, R. T.

1. Geology of the El Tigre district, Mexico: Min. and Sci. Press, vol. 121, pp. 583-591, 6 figs., October 23, 1920.

2. (and Budrow, L. R.). Methods of mining and ore estimation at Lucky Tiger mine [El Tigre, Sonora, Mexico]: Am. Inst. Min. and Met. Eng., Trans. [preprint] no. 1413, 16 pp., 2 figs., February, 1925.

Mitchell, George D. See Byerly, 6, 7.

Mitchell, Graham John.

1. Ore deposition in the Warren district, Arizona: Eng. and Min. Jour., vol. 109, pp. 874-875, 1 fig., April 10, 1920.

2. Vertical extent of copper ore minerals in the Junction mine, Warren district, Arizona : Eng. and Min. Jour., vol. 109, pp. 1411-1412, 2 figs., June 26, 1920.

3. Effect of erosion on mineralized areas in northern Sonora: Eng. and Min. Jour., vol. 110, no. 23, pp. 1081-1082, December 4, 1920.

4. Replacement copper deposits in the Warren district [Bisbee, Arizona]: Eng. and Min. Jour., vol. 112, no. 7, pp. 246-250, 3 figs., August 13, 1921. 
Mitchell, Graham John-Continued.

5. Rate of formation of copper sulphate stalactites: Mining and Metallurgy, no. 170, p. 33, February, 1921; discussion by J. F. Kemp, Am. Inst. Min. and Met. Eng., Trans. [preprint], no. 1073, pp. 46-47, May, 1921 ; Trans., vol. 66, pp. 64-65, 1922.

6. Antimony in southwestern Arkansas: Eng. and Min. Jour.-Press, vol. 114, no. 11, pp. 455-456, 3 figs., September 9, 1922.

7. Geology of the Ponce district, Porto Rico: New York Acad. Sci., Scientific Survey of Porto Rico and the Virgin Islands, vol. 1, pt. 3, pp. 229300, 9 figs., 4 pls. (incl. map), 1922.

8. Diamond deposits in Arkansas: Eng. and Min. Jour.-Press, vol. 116, no. 7, pp. 285-287, 5 figs., August 18, 1923.

9. Capping as a guide to copper deposits : Eng. and Min. Jour.-Press, vol. 116, no. 21, pp. 891-893, 5 figs., November $24,1923$.

10. Primary chalcocite at Cananea, Mexico: Eng. and Min. Jour.-Press, vol. 117 , no. 22, pp. 880-882, 10 figs., May 31, 1924.

11. Ore injection at the Cananea-Duluth mine [Cananea, Sonora, Mexico] : Eng. and Min. Jour.-Press, vol. 119, no. 2, pp. 45-48, 11. figs, January 10, 1925.

12. The geology of Sonora [Carboniferous deposit]: Science, new ser., vol. 67, p. 373, April 6, 1928.

Mitchell, Guy Elliott.

1. The standing stone forests of Wyoming: Sci. Am., vol. 134, pp. 98-99, 7 figs., February, 1926.

Mitchell, W. G.

1. Certain ore deposits of the Southwest (discussion): Am. Inst. Min. and Met. Eng., Bull. no. 148, p. 735, April, 1919.

Moberg, M. Wilcox.

1. New species of Coskinolina and Dictyoconus? from Florida: Florida State Geol. Survey, 19th Ann., Rept., pp. 166-170, 3 pls., 1928.

Moffatt, John.

1. The Malagash [Nova Scotia] salt deposits: Canadian Min. Jour., vol. 43, no. 32, p. 530, August 11, 1922.

Moffit, Fred Howard.

1. Mining in Chitina Valley, Alaska: U. S. Geol. Survey, Bull. 714, pp. 189196, 1921.

2. Geology of the vicinity of Tuxedni Bay, Cook Inlet, Alaska: U. S. Geol. Survey, Bull. 722, pp. 141-147, 1 pl. (map), 1921. Abstract, Washington Acad. Sci., Jour., vol. 12, no. 3, p. 72, February 4, 1922.

3. The Iniskin Bay district [Alaska]: U. S. Geol. Survey, Bull. 739, pp. 117-132, 1 pl. (map), 1922.

4. (and Mertie, J. B., jr.). The Kotsina-Kuskulana district, Alaska: U. S. Geol. Survey, Bull. 745, 149 pp., 8 figs., 19 pls. (incl. maps), 1923.

5. The metalliferous deposits of Chitina Valley, Alaska: U. S. Geol. Survey, Bull. 755, pp. 57-72, 1923.

6. The occurrence of copper on Prince William Sound, Alaska: U. S. Geol. Survey, Bull. 773, pp. 141-158, 1925.

7. The Iniskin-Chinitna Peninsula and the Snug Harbor district, Alaska: U. S. Geol. Survey, Bull. 789, 71 pp., 1 flg., 11 pls. (incl. maps), 1927. 
Moffit, Fred Howard-Continued.

8. Mineral industry of Alaska in 1925 and administrative report: U. S. Genl. Survey, Bull. 792, pp. 1-49, 1 fig., 1927.

Mohoroviěice, A.

1. A critical review of the seismic instruments used to-day and of the organizations of seismic service: Seismol. Soc. America, Bull., vol. 14, no. 1, pp. 38-59, 1 fig., March, 1924.

Molengraaff, G. A. F.

1. Wegener's continental drift. In Theory of continental drift, pp. 90-92, Am. Assoc. Petroleum Geologists, 1928.

Monahan, Joseph W.

1. Minerals in eastern exposures of the Lockport in New York State: Am. Mineralogist, vol. 13, no. 2, pp. 70-71, February, 1928.

Monnett, Victor E.

1. Topographic criteria of oil-field structure: Am. Assoc. Petroleum Geologists, Bull., vol. 6, no. 1, pp. 37-41, 1 pl., January-February, 1922.

2. Possible origin of some of the structures of the Mid-Continent oil field: Econ. Geology, vol. 17, no. 3, pp. 194-200, 4 figs., May. 1922.

3. The Finger Lakes of central New York: Am. Jour. Sci., 5th ser., vol. 8, pp. 33-53, 6 figs. (incl. maps), July, 1924.

4. Pre-Paleozoic topography of Oklahoma (abstract) : Oklahoma Acad. Sci. (Univ. Oklahoma Bull., new ser., no. 322), Proc., vol. 4, p. 119, Dec. 1, 1925.

5. Detailed geology of the northern part of Murray County, Oklahoma : Oklahoma Acad. Sci., Proc., vol. 6, pt. 2, 1926 (Oklahoma, Univ., Bull., new ser., no. 348), pp. 243-245, January 1, 1927.

6. The "buried hills" as a structural agency: Oklahoma Acad. Sci., Proc., vol. 6, pt. 2, 1926 (Oklahoma, Univ., Bull., new ser., no. 348), pp 268-272, January 1, 1927.

Monte-Flores, Maximo Macambyra.

1. Rôle of bedrock in the distribution of the hydro-carbons: Mining and Metallurgy, no. 157, sec. 1, p. 47 (abstract), sec. 6, 3 pp., 2 figs., January, 1920. Discussion by M. R. Daly, Am. Inst., Min. and Met. Eng. [Trans., preprint no. 988], pp. 16-18, 1920.

Montessus de Ballore, Fernand de.

1. Basis of the geologic theory of earthquakes: Seismol. Soc. America, Bull., vol. 9, no. 1, pp. 8-19, March, 1919.

Montijo, Fernando, jr.

1. The Las Chipas mine [near Arizpe] in Sonora, Mexico: Min. and Sci. Press, vol. 121, pp. 58-60, 1 fig., July 10, 1920.

Montoulieu, Enrique J.

1. Informe técnico sobre un reconocimiento practicado en tierras de la hacienda "Motembo," Coralillo, Provinçia de Santa Clara, en relación con informes recibidos por el Gobierno de la República sobre el hallazgo de extensos yacimientos de potasa [potash deposits, Santa Clara province, Cuba]: Cuba, Dirección Montes y Minas, Boletin de Minas, no. 6, pp. 17-23, 1920.

2. Génesis de las corrientes subterraneas de la meseta central de Cuba: Acad. cienc. méd. Habana, Anales, t. 63 , pp, 41-71, 1 pl. (map), May-June, 1926. 
Moodey, Margaret W. See Merrill, 18.

Moodie, Roy Lee.

1. Bacteriologic and pathologic evidences in past geologic ages: Chicago Pathological Soc., Trans., vol. 10, no. 3, pp. 84-88, October 1, 1916.

2. The influence of disease in the extinction of races: Science, new ser., vol. 45 , pp. 63-64, January 19, 1917.

3. Studies in paleopathology ; general consideration of the evidence of pathological conditions found among fossil animals: Annals of Medical History, vol. 1, no. 4, pp. 374-393, 20 figs., New York, December, 1917.

4. Pathologic lesions among extinct animals; a study of the evidences of disease millions of years ago: Surgical Clinics of Chicago, vol. 2, no. 2, pp. 318-331, 10 figs., April, 1918.

5. On the parasitism of Carboniferous crinoids: Jour. Parasitology, vol. 4, no. 4, pp. 174-175, June, 1918. Abstract, Am. Soc. Zoologists, Proc., p. 34, December 27, 1917 (not seen) ; Anatomical Record, Philadelphia, vol. 14, no. 1, pp. 102-103, January 20, 1918.

6. Studies in paleopathology; opisthotonos and allied phenomena among fossil vertebrates: Am. Naturalist, vol. 52, pp. 384-394, 8 figs., August-September, 1918.

7. Studies in paleopathology; pathological evidences of disease among ancient races of man and extinct animigls: Surgery, Gynecology, and Obstetrics, vol. 27, no. 5, pp. 498-510, 45 figs., Chicago, November, 1918.

8. Paleopathology : Southern Medical Jour., vol. 12, no. 4, pp. 182-184, April, 1919.

9. Opisthotonos: Science, new ser., vol. 50, pp. 275-276, September 19, 1919.

10. Thread moulds and bacteria in the Devonian: Science, new ser., vol. 51, pp. 14-15, January 2, 1920.

11. Ancient bacteria and the beginnings of disease: Sci. Monthly, vol. 11, no. 4, pp. 362-364, October, 1920.

12. Evolution's most romantic moment: Sci. Monthly, vol. 11, no. 5, pp. 464-469, 5 figs., November, 1920.

13. Stone age man's cure for headache: Sci. Monthly, vol, 12, no. 2, pp. 161162, 1 fig., February, 1921.

14. Osteomyelitis in the Permian: Science, new ser., vol. 53, p. 333, April 8, 1921.

15. Status of our knowledge of Mesozoic pathology: Geol. Soc. America, Bull., vol. 32, no. 3, pp. 321-325, September 1, 1921.

16. Bacteria in the American Permian: Science, new ser., vol. 54, pp. 194195, September 2, 1921.

17. Historical sketch of paleopathology (abstract) : Geol. Soc. America, Bull., vol. 33, no. 1, pp. 197-198, March 31, 1922.

1.8. Disease and injury among fossil men and the beginnings of surgery: Sci. Monthly, vol. 14, no. 4, pp. 391-394, 3 figs., April, 1922.

19. 'J'he paleopathology of the parasuchians: Science, new ser., vol. 56, p. 417, October 13, 1922.

20. The antiquity of disease. 148 pp., 36 figs., Chicago, Illinois, University of Chicago Press, 1923.

21. Paleopathology; an introduction to the study of ancient evidences of disease. 567 pp., 117 figs., and pls., University of Illinois Press, Urbana, Illinois, 1923. 
Moodie, Roy Lee-Continued.

22. The paleopathology of the fossil invertebrates: Science, new ser., vol. 57, p. 85, January 19, 1923.

23. An unusual form of Pliocene pathology: Am. Jour. Sci., 5th ser., vol. 5, pp. 334-336, 1 fig., April, 1923.

24. Pachyostosis: Science, new ser., vol. 58, p. 351, November 2, 1923.

25. A Cretaceous fish spine: Am. Naturalist, vol. 60, pp. 290-293, 1 pl., MayJune, 1926.

26. Tumors in the Lower Carboniferous: Science, new ser., vol. 66, p. 540, December 2, 1927.

27. The ichnology of Texas: Science, new ser., vol. 67, pp. 215-216, February 24, 1928.

28. The histological nature of ossified tendons found in dinosaurs: Am. Mus. Novitates, no. 311, 2 pp., 6 pls., April 25, 1928.

Moody, C. L. See Merriam, 19.

Mook, Charles Craig. See also Osborn, H. F., 6, 8, 10.

1. Skull characters and affinities of the extinct Florida gavial, Gavialosuchus americana (Sellards) : Am. Mus. Nat. Hist., Bull., vol. 44, pp. 3341, 5 pls., April 8, 1921.

2. Allognathosichus, a new genus of Eocene crocodilians: Am. Mus. Nat. Hist., Bull., vol. 44, pp. 105-110, 1 pl., April 13, 1921.

3. Description of a skull of a Bridger crocodilian : Am. Mus. Nat. Hist., Bull., vol. 44, pp. 111-116, 2 pls., April 13, 1921.

4. The skull of Crocodilus acer Cope: Am. Mus. Nat. Hist., Bull., vol. 44, pp. 117-121, 2 pls., April 13, 1921.

5. A new species of alligator from the Snake Creek beds [Agate, Nebraska] : Am. Mus. Novitates, no. 73, 13 pp., 5 figs., May 8, 1923:

6. A new crocodilian from the Wasatch beds [of Wyoming] : Am. Mus. Novitates, no. 137, 4 pp., 2 figs., October 16, 1924.

7. Further notes on the skull characters of Gavialosuchus americana (Sellards) : Am. Mus. Novitates, no. 155, 2 pp., 1 fig., December 30, 1924.

8. A revision of the Mesozoic Crocodilia of North America: Am. Mus. Nat. Hist., Bull., vol. 51, pp. 319-432, 63 flgs., 2 pls., April 30, 1925.

9. Note on the occurrence of thrust faulting in western Newfoundland: Geol. Mag., vol. 63, pp. 348-350, 2 figs., August, 1926.

Moon, E. A.

1. (and Bray, H. G.). Differential tilting of the continental shelf off the Atlantic coast of North America: Science, new ser., vol. 61, pp. 237-238, February 27, 1925.

Moore, Bernard M. See Buwalda, 19, 24.

Moore; Dudley W.

1. Unusual geological trend in new Kansas oil pool [Woodson County, Kansas] : Oil Trade, vol. 16, no. 5, pp. 35-36, 1 fig., May, 1925.

Moore, Elwood S. See also Pennsylvania, 1; Ries, 5; Wheeler, H. A., 3.

1. Iron deposits on the Belcher Islands, Hudson Bay: Canadian Min. Inst., Bull. no. 82, pp. 196-206, 4 figs., February, 1919: Trans., vol. 22, pp. 100-111, 4 figs. [1920].

2. Ore deposits of Arctic Canada: Eng. and Min. Jour., vol. 110, no. 9, pp. 396-400, 8 figs., August 28, 1920. 
Moore, Elwood S.-Continued.

3. Studies of selimentation in the universities of the eastern part of the United States (abstract) : Geol. Soc. America, Bull., vol. 32, no. 1, p. 19, March 31, 1921.

4. Coal ; its properties, analysis, classiflcation, geology, extraction, uses, and distribution. 462 pp., 20 pls., 142 figs., New York, John Wiley \& Sons, 1922.

5. [American Association for the Advancement of Science; proceedings of] Section E (Geology and geography): Science, new ser., vol. 57, pp. 112-113, January 26, 1923.

6. (and Taylor, T. G.). The silica refractories of Pennsylvania: Pennsylvania Geol. Survey, 4th ser., Bull. M3, 100 pp., 10 figs. (incl. maps), 16 pls., 1924.

7. American Association for the Advancement of Science [Report of nreeting of] Section E (Geology and geography): Science, new ser., vol. 59 , pp. 89-90, January 25, 1924.

8. The American Association for the Advancement of Science; the section of geology: Science, new ser., vol. 60, p. 250, September 12, 1924.

9. [Proceedings of the American Association for the Advancement of Science], Section $\mathbf{E}$ (Geology and geography): Science, new ser., vol. 61, p. 148, February 6, 1925.

10. Gold in quartzite in the Goudreau district, Ontario: Canadian Min. Jour., vol. 46, no. 6, p. 142, February 6, 1925.

11. Some geological conditions controlling the formation of iron deposits in Canada: Canadian Inst. Min. and Met., Bull. no. 155, pp. 209-219, March, 1925; Trans., vol. 28, pp. 132-140 [1926].

12. Sources of carbon in the pre-Cambrian formations: Roy. Soc. Canada, Proc. and Trans., 3d ser., vol. 19, sec. 4, pp. 21-26, 3 pls, 1925.

13. Why coal has cleat and the way in which it runs: Coal Age, vol. 27, no. 16, pp. 576-578, 3 figs., April 16, 1925.

14. The geological age of the Homestake ore bodies: Econ. Geology, vol. 20 , no. 6, pp. 604-605, September-October, 1925.

15. Mississagi Reserve and Goulais River iron ranges, District of Algoma: Ontario Dept. Mines, 34th Ann. Rept., vol. 34, pt. 4, pp. 1-33, illus., map, 1926.

16. A lead and zinc deposit in Keewatin iron formation [Sudbury mining division, Ontario] : Canadian Inst. Min. and Met., Bull. no. 167, pp. 371-378, 3 figs., March, 1926.

17. Origin of a Keweenawan boulder conglomerate (abstract): Geol. Soc. America, Bull., vol. 37, no. 1, p. 157, March 30, 1926; Pan-Am. Geologist, vol. 45, no. 2, p. 160, March, 1926.

18. The Keweenawan series at the eastern end of Lake Superior (abstract) : British Assoc. Adv. Sci., Rept. 94th meeting, p. 346, 1926; Jour. Sci. Trans., Oxford, p. 14, 1926; Pan-Am. Geologist, vol. 46, no. 4, p. 320, November, 1926.

19. Batchawana area, District of Algoma: Ontario Dept. Mines, 35th Ann. Rept., vol. 35, pt. 2, pp. 53-85, 17 figs., map, 1927.

20. Sahkatawich (Rush) Lake section, Woman River iron range, District of Sudbury: Ontario Dept. Mines, 35th Ann. Rept., vol. 35, pt. 2, pp. 86-96, 2 figs., map, 1927.

21. (and Maynard, J. E.). Origin of the pre-Cambrian banded iron formations (abstract) : Geol. Soc. America, Bull., vol, 39, no. 1, p. 225. March 30, 1928. 
Moore, Hastings.

1. (and Snider, L. B.). Stratigraphy of the Weatherford area, Oklahoma: Am. Assoc. Petroleum Geologists, Bull., vol. 12, no. 10, pp. 1024 1026, October, 1928.

Moore, John Irwin.

1. A review of the present knowledge of fossil scorpions with the description of a new species from the Pottsville formation of Clay County, Indiana: Indiana Acad. Sci., Proc. 38th Ann. Meeting, 1922, pp. 125-134, 2 pls., 1923.

Moore, Raymond Cecil. See also Barwick, 1 ; Birdseye, 1 ; Chamberlin, T. C. 38; Girty, 2; Glenn, 2; Lee, W. T., 3; Longwell, 6; Panyity, 1; Plummer, 4; Van Tuyl, 2.

1. The stratigraphy of the Kinderhook group in western Illinois and Mis. souri (abstract) : Illinois Acad. Sci., Trans., vol. 9, p. 211 [1917].

2. The Bend series of central Texas (with discussion): Am. Assoc. Petroleum Geologists, Bull., vol. 3, pp. 217-241, 1919.

3. Oil and gas resources of Kansas; Part I, General geology of oil and gas: Kansas, State Geol. Survey, Bull. 6 [pt. 1], 83 pp., 8 pls., 9 figs. [1920].

4. Oil and gas resources of Kansas; Part 2, Geology of Kansas: Kansas, State Geol. Survey, Bull. 6 [pt. 2], 98 pp., 17 pls. (incl. maps), 12 figs., 1920.

5. (and Elledge, Emmett R.). The oil and gas resources of Allen and Neosho counties, Kansas : Kansas State Geol. Survey, Bull. 6, pt. 5, 22 pp., 2 figs., 4 pls. (incl. map) [1920?].

6. (and Boughton, Charles W.). Oil and gas resources of Wilson and Montgomery counties, Kansas: Kansas State Geol. Survey, Bull. 6, pt. 6, 32 pp., 3 figs., 4 pls. (incl. map) [1920?].

7. (and Haynes, Winthrop P.). An outcrop of basic igneous rock in Kansas: Am. Assoc. Petroleum Geologists, Bull., vol. 4, no. 2, pp. 183-187 1920.

8. The relation of the buried granite in Kansas to oil production: Am. Assoc. Petroleum Geologists, Bull., vol. 4, no.. 3, pp. 255-261, 5 figs., 1920.

9. Petrolẹum resources of Kansas: Mining and Metallurgy, no. 158, sec. 1 , p. 43 (abstract), sec. 29, 11 pp., 1 fig., February, 1920; Am. Inst. Min. and Met. Eng., Trans., vol. 65, pp. 97-107, 1 fig., 1921.

10. The relation of mountain folding to the oil and gas fields of southern Oklahoma: Am. Assoc. Petroleum Geologists, Bull., vol. 5, no. 1, pp. 32-48, 4 figs., January-February, 1921.

11. Hercynian orogenic movements in southern Oklahoma (abstract) : Geol. Soc. America, Bull., vol. 32, no. 1, p. 48, March 31, 1921.

12. On the stratigraphy of northeastern Arizona: Am. Assoc. Petroleum Geologists, Bull., vol. 6, no. 1, pp. 47-49, January-February, 1922 ; Min. and Oil Bull., vol. 8, no. 6, pp. 322-323, 326, June, 1922.

13. (and Plummer, F. B.). Pennsylvanian stratigraphy of north central Texas: Jour. Geology, vol. 30 , no. 1, pp. 18-42, 4 figs. (incl. maps), January-February, 1922.

14. Buried granite in Kansas (abstract) : Geol. Soc. America, Bull., vol. 33, no. 1, pp. 96-98, March 31, 1922.

15. Pennsylvanian faunas of north Texas and their correlation (abstract) : Geol. Soc. America, Bull., vol. 33, no. 1, pp. 199-200, March 31, 1922 . 
Moore, Raymond Cecil-Continued.

16. Age of the Barnett (lower Bend) shale of central Texas: Am. Assoc. Petroleum Geologists, Bull., vol. 6, no. 2, pp. 150-153, MarchApril, 1922.

17. Stratigraphy of a part of southern Utah (with discussion by E. G. Woodruff, J. L. Rich, M. W. Ball, C. W. Tomlinson, Charles Schuchert, and the author): Am. Assoc. Petroleum Geologists, Bull., vol. 6, no. 3, pp. 199-227, 5 figs., 2 pls., May-June, 1922.

18. Possible oil in southern Utah: Am. Assoc. Petroleum Geologists, Bull., vol. 6, no. 3, pp. 244-247, 1 fig., May-June, 1922.

19. Stratigraphy of northeastern Arizona: Min. and Oil Bull., vol, 8, no. 6, pp. 322-323, 1 fig., June, 1922.

20. Quantitative criteria in paleogeography (abstract with discussion by C. Schuchert) : Geol. Soc. America, Bull., vol. 34, no. 1, pp. 85-86, March 30, 1923.

21. Structural features of the Colorado Plateau and their origin (abstract) : Geol. Soc. America, Bull., vol. 34, no. 1, pp. 88-89, March 30, 1923.

22. Physiography of the Paria River valley, southern Utah (abstract) : Geol. Soc. America, Bull., vol. 34, no. 1, p. 94, March 30, 1923.

23. Early Mississippian formations of the type region along Mississippi River, in Iowa, Illinois, and Missouri (abstract): Geol. Soc. America, Bull., vol. 34, no. 1, pp. 128-129, March 30, 1923.

24. The Shreveport meeting [of the American Association of Petroleum Geologists, March, 1923] : Am. Assoc. Petroleum Geologists, Bull., vol. 7, no. 2, pp. 202-209, March-April, 1923.

25. Geological observations on a traverse through the Grand Canyon of the Colorado (abstract) : Geol. Soc. America, Bull., vol. 35, no. 1. pp. 85-87, March 30, 1924; Pan-Am. Geologist, vol. 41, no. 2, p. 143, March, 1924.

26. Geologic report on the inner gorge of the Grand Canyon of Colorado River: U. S. Geol. Survey, Water-Supply Paper 556, pp. 125-171, 1 fig., 5 pls., 1925.

27. Fossils from wells in central Kansas: Kansas State Geol. Survey, Bull. 10, pp. 94-104, 1925.

28. The Wichita meeting of the American Association of Petroleum Geologists, March 26, 27, 28, 1925: Am. Assoc. Petroleum Geologists, Bull., vol. 9, no. 3, pp. 678-704, May-June, 1925.

29. Memorial, Glenn Beckley Morgan : Am. Assoc. Petroleum Geologists, Bull., vol. 9 , no. 8 , pp. 1220-1221, portr., November, 1925.

30. Origin of enclosed meanders on streams of the Colorado Plateau: Jour. Geology, vol. 34, no. 1, pp. 29-57, 11 figs., January-February, 1926.

31. Significance of inclosed meanders in the physiographic history of the Colorado Plateau country: Jour. Geology, vol. 34, no. 2, pp. 97-130, 11 figs., February-March, 1926.

32. Early Pennsylvanian deposits west of the Nemaha granite ridge, Kansas: Am. Assoc. Petroleum Geologists, Bull., vol. 10, no. 3, pp. 205-216, 2 figs., $1 \mathrm{pl}$., March, 1926.

33. The subsidence near Sharon Springs, Kansas: Science, new ser., vol. 64, pp. 130-131, August 6, 1926.

34. Note on subsidence near Sharon Springs, Wallace County, Kansas: Kansas, State Geol. Survey, Bull. 11, pp. 95-96 [1926].

35. Problems in the history of the Grand Canyon region (abstract) : Washington Acad. Sci., Jour., vol. 17, no. 10, pp. 272-274, May 19, 1927. 
Moore, Raymond Cecil-Continued.

36. Mississippian corals from a central Kansas well : Am. Assoc. Petroleum Geologists, Bull., vol. 11, no. 12, pp. 1239-1331, December, 1927.

37. (and Landes, Kenneth K.). Underground resources of Kansas: Kansas State Geol. Survey, Bull. 13 (Kansas State Board of Agriculture, Rept. for the quarter ending December, 1926), 154 pp., 115 figs., 1927.

38. Framework of southeastern North America (abstract): Geol. Soc. America, Bull., vol. 39, no. 1, pp. 181-182, March, 1928; Pan-Am: Geologist, vol. 49, no. 2, p. 141, March, 1928.

39. Pennsylvanian micro-faunas from Oklahoma and Texas (abstract) : Geol. Soc. America, Bull., vol. 39, no. 1, p. 292, March 30, 1928 ; Pan-Am. Geologist, vol. 49, no. 3, pp. 227-228, April, 1928.

40. Paleogeographic significance of graptolite beds of eastern United States (abstract) : Pan-Am. Geologist, vol. 49, no. 3, p. 228, April, 1928; Geol. Soc. America, Bull., vol. 39, no. 1, pp. 292-293, March 30, 1928.

41. Early Mississippian formations in Missouri: Missouri Bur. Geology and Mines, second ser., vol. 21, 283 pp., 2 figs., 13 pls., 1928.

Moore, Richard B.

1. Helium, a natural asset: Am. Inst. Min. and Met. Eng., Trans., vol. 69, pp. 110-122, 1923.

2. Measurement of geologic time by atomic disintegration: Mining and Metallurgy, vol. 5, no. 210, p. 263, June, 1924.

Moran, Robert B.

1. The rôle of the geologist in the development of the California oil fields: Am. Assoc. Petroleum Geologists, Bull., vol. 8, no. 1, pp. 73-78, January-February, 1924.

MLoreman, W. L.

1. Micrology of the Woodbine, Eagle Ford, and Austin chalk: Texas, Univ., Bull. no. 2544, pp. 74-78, 4 pls., 1925.

2. Fossil zones of the Eagle Ford of north Texas: Jour. Paleontology, vol. 1, no. 1, pp. 89-101, 1 fig., 4 pls., July, 1927.

Morey, George W.

1. The development of pressure in magmas as. a result of crystallization: Washington Acad. Sci., Jour., vol. 12, no. 9, pp. 219-230, 1 fig., May 4, 1922.

2. Relation of crystallization to the water content and vapor pressure of water in a cooling magma: Jour. Geology vol. 32, no. 4, pp. 291295, May-June, 1924.

Morgan, G. B.

1. Areal geology of Wyoming [correlation table and production data]. On reverse of geological map of Wyoming. Published by G. B. Morgan, State Geologist, and C. S. Hill, Commissioner of Immigration, Cheyenne, Wyo. [1919].

2. Activities of the Wyoming Geological Survey and its relationship to the growing mineral industries: Am. Mining Cong., 23d Ann. Convention, Rept. of Proc., pp. 471-476, 1921.

3. Wyoming oil shales: Am. Mining Cong., 23d Ann. Convention, Rept. of Proc., pp. 529-531, 1921.

4. Eleventh biennial report of the State geologist [of Wyoming] for the period Octóber 1,1920 , to and including September 30, 1922.34 pp., map [Sheridan, Wyo., 1922]. 
Morgan, George Dillon.

1. A Siluro-Devonian oil horizon in southern Oklahoma: Oklahoma Geol. Survey, Circular no. 10, 13 pp., March, 1922.

2. Arkose of the northern Arbuckle area: Oklahoma Geol. Survey, Circular no. 11, 7 pp., March, 1922.

3. Arkose of the northern Arbuckle area: Oklahoma Acad. Sci., Proc., vol. 2, pp. 87-88 (Oklahoma Univ., Bull. new ser. no. 247), pp. 87-88, October 1, 1922.

4. A Siluro-Devonian oil horizon in southern Oklahoma (abstract): Oklahoma Acad. Sci., Proc., vol. 2 (Oklahoma, Univ., Bull., new ser. no. 247), pp. 88-89, October $1,1922$.

5. Geology of the Stonewall quadrangle, Oklahoma: Bureau of Geology, Bull. no 2, 248 pp., 1 fig., 53 pls. (incl. map), January, 1924.

6. Boggy unconformity and overlap in southern Oklahoma: Bureau of Geology, Norman, Oklahoma, Circular no. 2,8 pp., 2 pls. (maps), Norman, January, 1924.

7. Stratigraphic position of the Franks and Seminole formations of Oklahoma: Oklahoma Geol. Survey, Circular no. 12, 17 pp., 1 pl., March, 1923.

Morgan, Percy Gates.

1. The so-called "psendomorphous" quartz of Tertiary gold-silver veins:

Econ. Geology, vol. 20, no. 3, pp. 203-207, 1 fig., May, 1925.

Morize, $\mathrm{H}$

1. A seismograph constructed on a new principle: Seismol. Soc. America, Bull., vol. 11, nos. 3-4, pp. 183-188, 2 figs., September-December, 1921.

Morningstar, Helen.

1. Pottsville fauna of Ohio: Ohio Geol. Survey, 4th ser., Bull. 25, 312 pp., 1 fig., 16 pls., 1922.

2. Catalogue of type fossils in the geological museum at the Ohio State University: Ohio Jour. Sci., vol. 24, no. 1, pp. 31-64, January, 1924.

Morse, Edward Sylvester.

1. On certain fossil shells in the boulder clay of Boston Basin: Am. Jour. Sci., 4th ser., vol. 49, pp. 157-165, 3 figs., March, 1920.

Morse, $\mathrm{H}$. W.

1. (and Locke, Augustus). Recent progress with leached ore capping (with discussion by G. F. Loughlin and H. W. Morse) ; Econ. Geology, vol. 19, no. 3, pp. 249-258, April-May, 1924.

Morse, Jared Kirtland.

1. Bibliography of crystal structure. xix, 164 pp., illus., Chicago, Ill., University of Chicago Press, c. 1928.

Morse, Paul Franklin, 1897-1929.

1. The bauxite deposits of Mississippi: Mississippi State Geol. Survey, Bull. no. 19, 208 pp., 14 maps, December, 1923.

2. Petroleum prospecting in Mississippi : Am. Assoc. Petroleum Geologists, Bull., vol. 7, no. 6, pp. 684-695, November-December, 1923.

Morse, Roy $\mathbf{R}$.

1. Oil possibilities along the southern margin of the Black Hills, South Dakota (abstract) : Geol. Soc. America, Bull. vol. 31, no. 1, p. 195, March 31, 1920. 
Morse, Roy R.-Continued.

2. A note on jointage and the application of the strain ellipsoid: Jour. Geology, vol. 31, no. 8, pp. 669-675, 4 figs., November-December, 1923.

3. Meeting of the Pacific section [of the American Association of Petroleum Geologists, San Francisco, 1925] : Am. Assoc. Petroleum Geologists, Bull., vol. 10, no. 1, pp. 100-102, January, 1926.

Morse, William Clifford.

1. Appalachian field trip: Science, new ser., vol. 57, pp. 142-143, February 2, 1923.

2. A geological field trip: Science, new ser., vol. 59, pp. 523-524, June 13, 1924.

3. Field trips in geology: Science, new ser., vol. 63, p. 617, June 18, 1926.

4. Paleozoic rocks of Mississippi : Jour. Geology, vol. 36, no. 1, pp. 31-43, 1 fig., January-February, 1928.

Mortimore, Morris E. See Trowbridge, 1.

Morton, Dudley J.

1. Notes on the footprint of Thinopus antiquus: Am. Jour. Sci., 5th ser., vol. 12, pp. 409-414, 6 figs., November, 1926.

Moscheles, J.

1. Der Lake Bonneville und das eiszeitliche Klima : Zeitschr. Gletscherkunde, Bd. 12, H. 3-4, pp. 166-167, May, 1922.

Moses, Frederick G. See Dub. 1.

Mosier, Jeremiah George.

1. (and others). De Kalb County soils : Illinois, Univ., Agr. Exper. Sta., Soil Rept. no. 23, 51 pp., map, June, 1922.

Moss, Frank A.

1. Geology of Carson Hill [California] : Eng. and Min. Jour., vol. 124, no. 26, pp. 1010-1012, December 24, 1927.

Mossom, Stuart.

1. A preliminary report on the limestones and marls of Florida: Florida State Geol. Survey, 16th Ann. Rept., pp. 27-203, 7 figs., 52 pls. (incl. map), 1925.

2. A review of the structure and stratigraphy of Florida, with special reference to the petroleum possibilities: Florida State Geol. Survey. 17th Ann. Rept., pp. 169-275, 1 fig. (map), 1926.

Moulton, F. R.

1. The planetesimal hypothesis: Science, new ser., vol. 68, pp. 549-559, December 7, 1928.

Moulton, Gail Francis. See also Fath, 5; Thom, 1; Ward, 14.

1. Oil and gas prospects in southern Perkins County: South Dakota Geol. and Nat. Hist. Survey, Circular 14, 12 pp., 2 figs., December, 1923.

2. Faulting south of Billings, Montana: Jour. Geology, vol. 32, no. 6, pp. 511523, 7 figs., August-September, 1924.

3. Petroleum development in Illinois during 1924: Am. Inst. Min. and Met. Eng., Trans. [preprint] no. 1441, 7 pp., March, 1925.

4. Carbon ratios and petroleum in Illinois: Illinois State Geol. Survey, Rept. of Investigations no. 4, 18 pp., 5 figs., 1925.

5. Proper testing for oil structure in Illinois and some areas deserving such testing: Illinois State Geol. Survey, Rept. of Investigations no. 6, 22 pp., 9 figs., 1925. 
Moulton, Gail Francis-Continued.

6. Further contributions to the geology of the Allendale oil field, with a revised structure map: Illinois State Geol. Survey, Report of Investigations no. 7, 27 pp., 12 figs., 4 pls. (incl. map), 1925.

7. Some features of red bed bleaching: Am. Assoc. Petroleum Geologists, Bull., vol. 10, no. 3, pp. 304-311, 3 figs., March, 1926.

8. (and Miser, Hugh D., and Logan, W. N.). Petroleum developments in the Mississippi Valley region during 1925: Am. Inst. Min. and Met. Eng., no. 1570 (Petroleum development and technology in 1925), pp. 643-652, April, 1926; abstract, Mining and Metallurgy, vol. 7, no. 231, p. 137, March, 1926.

9. Oil and gas possibilities near Sparta: Illinois State Geol. Survey, Press Bull. Ser., Illinois Petroleum, no. 1, pp. 2-7, map, April 17, 1926.

10. Petroleum developments during 1925 [in Illinois]: Illinois State Geol. Survey, Press Bull. Ser., Illinois Petroleum, no. 1, pp. 7-8, April 17, 1926.

11. (and Weller, J. Marvin). Prospecting for Hoing sand oil pools : Illinois State Geol. Survey, Press Bull. Ser., Illinois Petroleum, no: 2, pp. 3-4, May 29, 1926.

12. Recent petroleum developments in Illinois: Illinois State Geol. Survey, Press Bull. Ser., Illinois Petroleum, no. 2, pp. 5-6, May 29, 1926.

13. The bearing of the structural relations between the Pennsylvanian and older formations on petroleum prospecting in western Illinois: Illinois State Geol. Survey, Press Bull. Ser., Illinois Petroleum, no. 3, pp. 1-7, 4 figs., July 24, 1926.

14. Current oil field operations in Illinois: Illinois State Geol. Survey, Press Bull: Ser., Illinois Petroleum, no. 3, pp. 10-14, July 24, 1926.

15. Areas for further prospecting near the Martinsville pool, Clark County: Illinois State Geol. Survey, Press Bull. Ser., Illinois Petroleum, no. 4, pp. 1-5, 1 fig., August 28, 1926.

16. Oil field water investigations-Waterloo field: Illinois State Geol. Survey, Press Bull. Ser., Illinois Petroleum, no. 5, pp. 11-15, 2 figs., October 16, 1926.

17. Petroleum in Illinois during 1926: Illinois State Geol. Survey, Illinois Petroleum, Press Bull. Ser., no. 7, pp. 5-12, February 19, 1927.

18. Plane-table survey underground: Am. Assoc. Petroleum Geologists, Bull., vol. 11, no. 4, pp. 425-426, April, 1927.

19. New producing horizon in Wabash County: Illinois State Geol. Survey, Illinois Petroleum, Press Bull. Ser., no. 10, p. 12, July 23, 1927 ; Am. Assoc. Petroleum Geologists, Bull., vol. 11, no. 9, p. 991, September, 1927.

20. Important new developments in southwestern Indiana: Am. Assoc. Petroleum Geologists, Bull., vol. 11, no. 9, pp. 991-992, September, 1927.

21. Deeper production in the Allendale oil field: Illinois State Geol. Survey, Illinois Petroleum, Press Bull. Ser., no. 12,.2 figs., September 24, 1927.

22. (and Young, Jackson). Structure and prospects of eastern Clark County : Illinois State Geol. Survey, Press Bull. Ser., Illinois Petroleum, no. 14, 12 pp., 3 figs., March 17, 1928.

23. Loss of red color of rocks: Am. Assoc. Petroleum Geologists, Bull., vol. 12, no. 7, pp. 767-769, July, 1928.

24. The Baker, Montana, gas field: Black Hills Engineer, vol. 16, no. 4, pp. 254-259, 3 figs., November, 1928. 
Moyer, W. Irwin.

1. The natural gas fields of eastein United States and their probable future life (with discussion by I. C. White and others) : Natural Gas Assoc. America, Proc. 15th Ann. Meeting, 1920, pp. 44-59, 2 flgs., 1921.

Müllerried, Friedrich K. G.

1. (and Scheuble, Hugo). Ueber die Tätigkeit des Popocatepetl (Mexiko) vom November 1923 bis März 1924: Zeitschr. Vulkanologie, Bd. 9, H. 1, pp. 52-55, 2 pls., August, 1925.

2. Informe preliminar acerca de la geologia y zonas petrolíferas de una parte de la región carbonífera de Coahuila y Nuevo León: Mexico, Inst. Geol., Foll. Divulgación, no. 26, 21 pp., 1927.

Muilenburg, Garrett A. See also Cox, G. H., 1.

1. Manganese deposits of Colorado: Colorado Geol. Survey, Bull. 15, 76 pp., 1 pl. (map), 1919.

2. Geology of the Tarryall district, Park County, Colorado: Colorado Geol. Survey, Bull. 31, 64 pp., 10 pls. (incl. map), May, 1925.

Muir, John, 1838-1914.

1. Studies in the Sierra; no. 5, Postglacial denudation: Overland Monthly vol. 13, pp. 393-402 (1874) : Sierra Club Bull., vol. 10, no. 4, pp. 414-428, 4 pls., 3 figs., January, 1919.

2. Studies in the Sierra; no. 6, Formation of soils (reprinted from Overland Monthly of December, 1874) : Sierra Club Bull. vol. 11, no. 1, pp. 69-85, 5 figs., January, 1920.

3. Studies in the Sierra; no. 7, Mountain building (reprinted from the Overland Monthly of January, 1875) : Sierra Club Bull., vol. 11, no. 2, pp. 181-193, 7 figs., January, 1921.

Mulholland, William.

1. The earthquake problem in southern California: Seisnrol. Soc. America, Bull., vol. 10, no. 4, pp. 289-297, December, 1920.

Muller, Siemon.

1. Mesozoic stratigraphy of Great Basin region (abstract) : Pan-Am. Geologist, vol. 49, no. 4, p. 317, May, 1928.

Muñoz Lumbier, Manuel.

1. Descripción histórica de la Red Seismológica Nacional: México, Inst. Geol., Bol. no. 18, 69 pp., illus., 1919.

2. Algunos datos sobre las islas mexicanas para contribuir al estudio de sus recursos naturales: México, Inst. Geol., Anales no. 7, 56 pp., 9 pls., 1919.

3. Los temblores de Guatemala: Boletín minero, t. 7, 1-2; México, Departamento de exploraciones y estudios geológicos, Folleto de divulgación no. 1, 4 pp., 1 pl., January-February, 1919.

4. Breves apuntes sobre los fenómenos volcánicos: Bol. Minero, t. 11, no. 1, pp. 35-41, 2 pls., January, 1921.

5. Los temblores de tierra: Bol. Minero, t. 13, no. 3, pp. 320-328, 1 pl., March, 1922.

6. Glosario de voces de geología y geografía física: México, Departamento de exploraciones $\boldsymbol{y}$ estudios geológicos, Folleto de divulgación, no, 11, 61 pp., January, 1924. 
Murphy, R. E.

1. (and Miller, R.). Reconnaissance map of the structural and areal geology of McCready County, Kentucky: Kentucky Geological Survey, ser. 6, 1928. Scale 1 inch $=1$ mile.

Murray, J. C. See also McKenzie, N.

1. Joseph Burr Tyrrell: Eng. and Min. Jour.-Press, vol. 115, no. 6, p. 277, portr., February 10, 1923.

2. Charles Camsell: Eng. and Min. Jour.-Press, vol. 115, no. 10, p. 455, portr., March 10, 1923.

Musser, E. H.

1. Report on the Torrance oil field: California State Min. Bur., Summary of Operations California Oil Fields, vol. 11, no. 3, pp. 5-17, 3 figs., 2 pls., September, 1925.

2. The Rosecrans oil field: California State Min. Bur., Summary of Operations California Oil Fields, vol. 11, no. 5, pp. 5-21, 3 figs, November, 1925.

3. The Richfield oil field: California State Min. Bur., Summary of Operations California Oil Fields, vol. 12, no. 6, pp. 5-18, 2 figs., 3 pls. (incl. map), December, 1926.

Musset, René.

1. La production de la bauxite aux États-Unis: Soc. géol. minér. Bretagne, Bull., t. 2, fasc. 2, pp. 264-273, January, 1922.

Myers, William Marsh.

1. Advantages of oblique illumination in mineragraphy: Am. Mineralogist, vol. 9, no. 9, pp. 177-188, 10 figs., September, 1924.

2. (and Anderson, C. O.). Garnet; its mining, milling, and utilization: U. S., Bur. Mines, Bull. 256, 54 pp., 3 figs., 3 pls., 1925.

3. (and Peck, Albert B.). A fulgurite from South Amboy, New Jersey: Am. Mineralogist, vol. 10, no. 6, pp. 152-155, June, 1925; abstract, Pan.-Am. Geologist, vol. 44, no. 2, pp. 159-160, September, 1925.

4. The mineralogy of some commercial garnets: Am. Jour. Sci., 5th ser., vol. 12, pp. 115-118, August, 1926.

Mylius, Louis Aubrey. See also DeWolf, 4.

1. Oil and gas prospecting in parts of Clark, Coles, Edgar, Douglas, Vermilion, and Champaign counties: Illinois State Geol. Survey, Press Bulletin, 7 pp., 1 fig. (map), July 10, 1920.

2. A restudy of the Staunton gas pool: Illinois State Geol. Survey, Extract from Bull. no. 44, 23 pp., 3 pls. (incl. maps), 1 fig., 1919.

3. Oil and gas in Monroe County, Illinois: Am. Assoc. Petroleum Geologists, Bull., vol. 5, no. 1, pp. 87-88, January-February, 1921.

4. Oil possibilities of the Posten School structure, Monroe County, Ininois: Illinois State Geol. Survey, Press Bulletin, November 19, 1921, 3 pp., map.

5. Stratigraphy of the southern half of the La Salle anticline: Illinois State Acad. Sci., Trans., vol. 14, pp. 221-228 [1922].

6. Oil and gas development and possibilities in parts of eastern Illinois: Illinois State Geol. Survey, Extract from Bull. 44, 64 pp., 3 figs., 7 pls. (incl. map), 1923.

7. Oil and gas development and possibilities in east-central Illinois (Clark, Coles, Douglas, Edgar, and parts of adjoining counties: Illinois State Geol. Survey, Bull. no. 54, 205 pp., 13 figs., 31 pls. (incl. maps), 16 tables, 1927.

$4096-31-29$ 
Naething. Foster $\mathbf{S}$.

1. The Black Range tin district of New Mexico: Min. and Sci. Press, vol. 122, pp. 557-558, 1 fig., April 23, 1921.

2. The Oklahoma-Kansas-Missouri zinc-lead field: Eng. and Min. Jour., vol. 122 , no. 16 , pp. 604-608, October 16, 1926.

3. Ores of the Joplin region (discussion) : Eng. and Min. Jour., vol. 123, no. 14, p. 575, April 2, 1927.

Nakashima, Kinzo.

1. A new method for measuring refractive indices under the microscope: Jour. Geology, vol. 34, no. 3, pp. 235-247, 6 figs., April-May, 1926.

Nash, James Philip.

1. (and others). Road-building materials in Texas: Texas, Univ., Bull. no. 1839, 159 pp., 10 pls., July 10, 1918 [1920?].

Nason, Frank Lewis, 1856-1928. See also Anderson, J. C., 2; DeGolyer, 9; Miller, W. J., 18; Wheeler, H. A., 3.

1. Sedimentary phases of the Adirondack magnetic iron ores: Econ. Geology, vol. 17, no. 8, pp. 633-654, December, 1922.

2. Sedimentary phases of Adirondack magnetites: Econ. Geology, vol. 19, no. 3, pp. 288-295, April-May, 1924.

National Academy of Sciences.

1. Report of the commitee of the National Academy of Sciences on Panama Canal slides: Nat. Acad. Sci., Mem., vol. 18, 84 pp., 51 pls., 19 figs., 1924.

National Research Council.

1. Transactions of the American Geophysical Union, fourth annual meeting, April, 1923, Washington, D. C. : Nat. Research Council, Bull., vol. 7, pt. 5, no. 41, 150 pp., January, 1924.

Nattress, Thomas.

1. On the manner of occurrence of potassium nitrate in Oregon: Michigan Acad. Sci., 20th Ann. Rept., pp. 57-58, 1918.

Navarro, Daniel V.

1. Reseña minera del Estado de Jalisco: Bol. minel'o, t. 22, no. 4, pp. 166-259, 12 pls. (incl. maps), October, 1926.

Neal, Roy O.

1. Petroleum hydrology applied to Mid-Continent field (with discussion by G. S. Rogers and R. Van A. Mills) : Am. Inst. Min. Eng., Bull. no. 145, pp. 1-8, January, 1919 ; Bull. no. 147, pp. 603-606, March, 1919 : Trans., vol. 61, pp. 565-579, 1920.

Nebel, Merle Louis. See also Savage, 8.

1. Brown County: Illinois State Geol. Survey, Bull. no. 40, pp. 21-50, 1 pl. (map), 13 figs., 1919.

2. Goodhope and La Harpe quadrangles: Illinois State Geol. Survey, Bull. no. 40, pp. 51-67, 2 pls. (maps), 1 fig., 1919.

3. The basal phases of the Duluth gabbro near Gabamichigami Lake, Minnesota, and its contact effects: Econ. Geology, vol. 14, no. 5, pp. 367402, 4 pls., 3 figs., August, 1919.

Needham, C. E.

1. Ripley greensands of Mississippi : Pan-Am. Geologist, vol. 50, no. 2, pp. 117-120, September, 1928. 
Nelson, Edward William.

1. Lower California and its natural resources: Nat. Acad. Sci., Mem., vol. 16, mem. 1, 194 pp., 35 pls., 1921.

Nelson, N. C.

1. Pseudo-artifacts from the Pliocene of Nebraska: Science, new ser., vol. 67, pp. 316-317, March 23, 1928.

Nelson, Richard Newman. See also Packard, 2.

1. Geology of the hydrographic basin of the upper Santa Ynez River, California: California, Univ., Dept. Geol. Sci., Bull., vol. 15, no. 10, pp. 327-396, 13 figs., 4 pls., May 27, 1925; abstract, Geol. Soc. America, Bull., vol. 35, no. 1, pp. 166-167, March 30, 1924.

2. A contribution to the paleontology of the Martinez Eocene of California : California, Univ., Dept. Geol. Sci., Bull., vol. 15, no. 11, pp. 397-466, 13 pls. (incl. map), September 24, 1925.

3. (and Schenck, Hubert G.). Calcareous Algae in Paciflc coast limestones (abstract) : Geol. Soc. America, Bull., vol. 39, no. 1, p. 266, March 30, 1928.

Nelson, Wilbur Armistead. See also Butts, 6; Holbrook, 1; Twenhofel, 29.

1. Administrative report of State geologist, 1918: Tennessee State Geol. Survey, Resources of Tennessee, vol. 9, no. 1, pp. 3-22, January, 1919.

2. Administrative report of the State Geologist, 1919: Tennessee State Geol. Survey, Bull. 23 (Pt. 1, Ann. Rept. 1919), pp. 7-29, 1920.

3. Press bulletins for 1919: Probable oil structures in west Tennessee: Probable structure and geology in Reelfoot Lake district, Tennessee, and possibilities for finding oil and gas; Oil possibilities and structure in the western valley of Tennessee; Explorations for oil in Sumner County, Tenn.; Tennessee State Geol. Survey, Bull. 23 (Pt. 1, Ann. Rept. 1919), pp. 30-43, 1920.

4. Notes on the Kentucky-Tennessee oil fields: Tennessee State Geol. Survey, Bull. 23 (Pt. 1, Ann. Rept. 1919), pp. 44-47, 1920.

5. Administrative report of the State geologist, 1920: Tennessee, State Geol. Survey, Bull. 25, pp. 7-45, 1921.

6. Report on the geology and structural features of Benton County as they affect oil and gas possibilities: Tennessee, State Geol. Survey, Bull. 25, pp. 41-45, 1921.

7. Notes on a volcanic ash bed in the Ordovician of middle Tennessee: Tennessee, State Geol. Survey, Bull. 25, pp. 46-48, 1921.

8. Description of oil ant gas areas in Tennessee and conditions affecting new areas: Am. Assoc. Petroleum Geologists, Bull., vol. 5, no. 1, p. 99 (abstract), no. 6, pp. 645-656, map, November-December, 1921; Tennessee State Geol. Survey, Bull. 25, pp. 49-66, 1921.

9. Mid-Ordovicic volcanic ash in Tennessee: Pan-Am. Geologist, vol. 37, no. 3, pp. 251-252, April, 1922.

10. Volcanic ash bed in the Ordovician of Tennessee, Kentucky, and Alabama: Geol. Soc. Amrerica, Bull., vol. 33, no. 3, pp. 605-615, Sep. tember 30, 1922. Abstract, with discussion by Charles Shuchert and others, vol. 33, no. 1, p. 152, March 31, 1922.

11. Administrative report of the State geologist, 1921-22, 45 pp., Nashville Tennessee, 1923.

12. Geologic map of Tennessee. Third edition. Tennessee State Geol. Survey, 1923. Scale 1:500,000.

13. Appalachian bauxite deposits: Geol. Soc. America, Bull., vol, 34, no. 3, pp. 525-539, 4 figs., September 30, 1923. 
Nelson, Wilbur Armistead-Continued.

14. Reelfoot-an earthquake lake [western Tennessee]: Nat. Geog. Mag., vol. 45, no. 1, pp. 95-114, 20 figs., January, 1924.

15. Oil developments along the Kentucky-Tennessee line during 1923: Am. Assoc. Petroleum Geologists, Bull., vol. 8, no. 4, pp. 454-458, JulyAugust, 1924.

16. The oil horizons of Kentucky, northeastern Mississippi, and Tennessee: Am. Assoc. Petroleum Geologists, Bull., vol. 8, no. 5, pp. 621-631; September-October, 1924.

17. Mascot, Tennessee, zinc area: Mining and Metallurgy, vol. 5, no. 214, pp. 469-471, October, 1924 ; Am. Inst. Min. and Met. Eng., Trans., vol. 71, pp. 289-298; also [preprint] no. 1379, 1924.

18. Ducktown, Tennessee, copper district: Am. Inst. Min. and Met. Eng., Trans. [preprint] no. 1378, 5 pp., October, 1924; vol. 71, pp. 299$303,1925$.

19. What are Tennessee's mineral resources?: The South's Development, Manufacturers Record, vol. 86, no. 24, pt. 2, pp. 414-418, 5 figs., December 11, 1924.

20. The southern Tennessee coal field included in Bledsoe, Cumberland, Franklin, Grundy, Hamilton, Marion, Putnam, Rhea, Sequatchie, Van Buren, Warren, and White counties: Tennessee, Dept. Educ., Div. Geology, Bull. 33-A, 239 pp., 12 figs. (maps), 8 pls., 1925.

21. The coals and geology of the Herbert Domain: Tennessee, Dept. Educ., Div. Geology, Bull. 33-C, 54 pp., 4 pls. (incl. map), 1925.

22. Administrative report of the State geologist, 1923-1924: Tennessee, Division of Geology, Bull. 35, 50 pp., 1925.

23. Two new voleanic-ash horizons in the Stones River group of the Ordovician of Tennessee (abstract) : Geol. Soc. America, Bull., vol. 36, no. 1 , p. 159, March 30,1925 ; Pan-Am. Geologist, vol. 43, no. 2, p. 153, March, 1925.

24. Observations on different periods of igneous activity at Bauxite, Arkansas (abstract) : Geol. Soc. America, Bull., vol. 36, no. 1, p. 167, March 30, 1925 ; Pan-Am. Geologist, vol. 43, no. 2, p. 158, March, 1925.

25. Geology and evolution: Sci. Monthly, vol. 21, no. 3, pp. 312-316, September, 1925.

26. Topography and geology of the coal field [of Tennessee]: U. S., Bur. Mines, Tech. Paper 356, pp. 1-4, 1 fig., 1926.

27. Volcanic ash deposit in the Ordovician of Virginia (abstract): Geol. Soc. America, Bull., vol. 37, no. 1, pp. 149-150, March 30, 1926; Pan-Am. Geologist, vol. 45, no. 1, p. 96, February, 1926.

28. Practical economic value of the service of a State geological survey: Eng. and Min. Jour., vol. 123, no. 16, pp. 640-642, April 16, 1927.

29. Geologic map of Virginia: Virginia Geol. Survey, 1928. Scale 1: 500,000. Nelson, Willard B.

1. Brief physiography. 186 pp., illus., New York, Globe Book Company, 1927. Ness, John.

1. The search for oil in the west [Alberta and Saskatchewan]: Canadian Inst. Min. and Met., Monthly Bull. no. 108, pp. 278-306, 20 figs., April, 1921. Canadian Min. Jour., vol. 42, no 16, pp. 313-323, 20 figs, April 22, 1921.

2. Canada's northern oil fields: Oildom, vol. 13, no. 3, pp. 43-51, illus., March. 1922. 
Netzeband, W. F.

1. Relation of fracture zones to ore bodies in the Tri-State district: Mining and Metallurgy, vol. 9, no. 262, pp. 446-447, October, 1928.

Neumann, Emm. Ma. S.-Navarro.

1. The Berchmans seismograph: Seismol. Soc. America, Bull. vol. 12, no. 1, pp. 24-27, 1 pl., March, 1922.

Neumann, Frank.

1. Some remarks on certain earthquakes of 1925; the problem of determining epicenters: Seismological Soc. America, Bull., vol. 15, no. 2, pp. 114-121, June, 1925.

2. Earthquakes of 1925 ; the problem of determining epicenters (abstract) : Washington Acad. Sci., Jour., vol. 15, no. 13, p. 308, July 19, 1925.

3. The Texas earthquake of July 30,1925 (abstract): Seismological Soc. America, Bull., vol. 16, no. 2, p. 158, June, 1926.

4. Seismological report, January, February, March, 1925: U. S. Coast and Geod. Survey, Serial no. 328, 48 pp. 1926.

5. (and Service, Jerry H.). Seismological report, April, May, June, 1925: U. S. Coast and Geod. Survey, Serial no. 337, 46 pp., 1926.

6. Seismological report, July, August, September, 1925: U. S. Coast and Geodetic Survey, Serial no. 363, 64 pp., 1926.

7. The need for seismological observatories in the Aleutian Islands: Nat. Research Council, Bull. no. 56 (vol. 11, pt. 2), pp. 127-130, November, 1926.

8. Surface wave velocities in North America (abstract) : Pan-Am. Geologist, vol. 47, no. 4, pp. 316-317, May, 1927.

9. Seismological report, October, November, December, 1925, and supplement for 1924: U. S. Coast and Geod. Survey, Serial no. 388, 119 pp., 2 pls. (maps), 1927.

10. (and Service, Jerry H.). Seismological report, January, February, March, 1926: U. S. Coast and Geod. Survey, Serial no. 395, 52 pp., 1927; April, May, June, 1926, Serial no. 406, 60 pp., 1928.

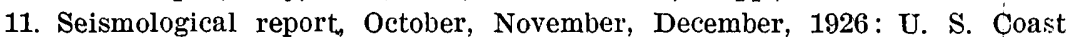
and Geodetic Survey, Serial no. 431, S9 pp., 1 fig., 1928.

Neumann, Fred Robert.

1. The southern Appalachian earthquake of October 20, 1924: Seismol. Soc. America, Bull., vol. 14, no. 4, pp. 223-229, 1 fig., December, 1924.

2. Origin of the Cretaceous white clays of South Carolina: Econ. Geology, vol. 22, no. 4, pp. 374-387, 4 figs.; June-July, 1927.

Neumann, L. Murray. See 'Twenhofel, 18, 22.

Nevin, Charles Merrick.

1. Albany molding sands of the Hudson Valley: New York State Mus. Bull., no. 263,81 pp., 26 figs.; 1925.

2. (and Trainer, D. W., jr.). Laboratory study in delta building: Geol. soc. America, Bull., vol. 38 , no. 3 , pp. 451-458, 6 figs., September 30 , 1927 ; abstract, no. 1, p. 165, March 30 , 1927 ; Pan-Am. Geologist, vol. 47, no. 2, pp. 158-159, March, 1927.

Newcombe, R. B. See also Poindexter, 1.

1. Oil and gas development in Michigan: Michigan Geol. Survey, Pub. 37, pp. 141-299, 1928. 
Newhouse, W. H. See also Fairbanks, 12.

1. Paragenesis of marcasite: Econ. Geology, vol, 20, no. 1, pp. 54-66, 3 figs., January-February, 1925.

2. An examination as to the intergrowth of certain minerals: Econ. Geology, vol. 21, no. 1, pp. 68-69, January-February, 1926.

3. Some forms of iron sulphide occurring in coal and other sedimentary rocks : Jour. Geology, vol. 35, no. 1, pp. 73-83, January-February, 1927.

4. The equilibrium diagram of pyrrhotite and pentlandite and their relations in natural occurrences: Econ. Geology, vol. 22, no. 3, pp. 288-299, 2 figs., May, 1927.

5. Intimate intergrowths and mutual boundaries as proof of contemporaneous deposition: Econ. Geology, vol. 22, no. 4, pp. 403-407, June-July, 1927.

6. (and Callahan, W. H.). Two kinds of magnetite? Econ. Geology, vol. 22, no. 6, pp. 629-632, September-October, 1927.

7. (and Buerger, M. J.). Observations on wood tin nodules: Econ. Geology, vol. 23, no. 2, pp. 185-192, March-April, 1928.

8. The time sequence of hypogene ore mineral deposition: Econ. Geology, vol. 23, no. 6, p. 647-659, September-October, 1928.

Newland, David Hale. See also Cushing, 1; Stone, 11.

1. Magnetic iron ores of Clinton County, New York: Econ. Geology, vol. 15, no. 2, pp. 177-180, March, 1920.

2. The mineral resources of the State of New York: New York State Mus., Bull., nos. 223, 224, 315 pp:, figs., pls. (maps), 1921.

3. Geology of gypsum and anhydrite: Econ. Geology, vol. 16, no. 6, pp. 393404, September-October, 1921.

4. Relation of gypsum supplies to mining: Am. Inst. Min. and Met. Eng., Trans. [preprint], no. 1094, 10 pp., September, 1921; vol. 66, pp. 89-98, 1922; abstract, Mining and Metallurgy, no. 177, pp. 51-53, September, 1921.

5. Source of the suplhates in the Salina beds (abstract) : Geol. Soc. America, Bull., vol. 33, no. 1, p. 150, March 31, 1922.

6. Paragenesis of martite and magnetite (discussion): Econ. Geology, vol. 17, no. 4, pp. 299-302, June-July, 1922 .

7. Sedimentary phases of Adirondack magnetites (discussion): Econ. Geology, vol. 18, no. 3, pp. 291-296, April-May, 1923.

8. (and Hartnagel, C. A.). The mining and quarry industries of New York for 1925 and 1926: New York State Mus., Bull. no. 277, 126 pp., September, 1928.

9. Recent progress in the study of the Salina formation : Nat. Research Council, Reprint and Circ. Ser., no. 85, pp. 36-43, 1928.

Newman, M. A.

1. Nonmetallic minerals of southern California; gypsum: California State Min. Bur., Mining in California, vol. 18, no. 5, pp. 230-234, May, 1922.

Newton, Roy F. See Clark, A. F., 1.

Nicholls, William M.

1. Geologic section across the middle Salinas Valley of California from the San Antonio River to San Lorenzo Creek (abstract): Geol. Soc. America, Bull., vol. 36, no. 1, p. 201, March 30, 1925. 
Nichols, D. A.

1. Landslides in Canada: Canadiau Field-Naturalist, vol. 42, no. 9, pp. 212216, 4 pls., December, 1928.

Nichols, H. G.

1. (and Uglow, W. L.). British Columbia as a mining province: Min. Mag., vol. 29, no. 2, pp. 73-81, 1 fig., August, 1923.

Nickles, John M.

1. Bibliography of North American geology for 1919-20: U. S. Geol. Survey, Bull. 731, 282 pp., 1922.

2. Geologic literature on North America, 1785-1918; Part I, Bibliography: U. S. Geol. Survey, Bull. 746, 1,167 pp., 1923 [March, 1924] ; Part II, Index, Bull. 747, 658 pp., 1924.

3. Bibliography of North American geology for 1921-22: U. S. Geol. Survey, Bull. 758, 273 pp., 1924.

4. Bibliography of North American geology for 1923-1924: U. S. Geol. Survey, Bull. 784, 280 pp., 1927.

5. Bibliography of North American geology for 1925 and 1926: U. S. Geol. Survey, Bull. 802, 286 pp., 1928.

Nicol, John M.

1. Magmas and ore magmas: Eng. and Min. Jour., vol. 122, no. 20, pp. 778779, November 13, 1926.

Nicolas, Frank J.

1. General index of the reports of the Ontario Bureau of Mines, volumes I to $\mathrm{XXV}$ (1891-1916) : [Ontario, Dept. Mines], 871 pp., 2 maps, Toronto, 1921.

2. Index to separate reports 1906-1910 and summary reports 1905-1916: Canada, Geol. Survey, 305 pp., 5 maps, 1923.

3. Index to paleontology (geological publications [of the Geological Survey of Canada], 1847-1916) : Canada, Geol. Survey, 383 pp., 1925. [Pub. no. 2034.]

Nicolescu, C. $\mathbf{P}$.

1. Wichtige Erdölgebiete der Welt und ihr petrographischer, mineralogischer und paleontologischer Charakter: Internationale Zeitschr. Bohrtechnik, Erdölbergbau, und Geologie, Jg. 35, no. 12, pp. 108-109, June 15, 1927.

Niemi, Signa.

1. Mesabi iron range of Minnesota; a bibliography. 18 pp., Library School, University of Wisconsin, June, 1920.

Nishio, Keijiro.

1. Native copper and silver in the Nonesuch formation, Michigan: Econ. Geol., vol. 14, no. 4, pp. 324-334, 1 pl., 1 fig., June, 1919.

Noble, Levi F. See also Gregory, H. E., 9.

1. Geologic history of the Bright Angel quadrangle, Arizona. Text and 1 fig. on back of topographic sheet, Bright Angel quadrangle, Arizona (Coconino County), U. S. Geol. Survey, 1918.

2. Colemanite in Clark County, Nevada: U. S. Geol. Survey, Bull. 735, ipp. 23-39, 2 figs., 3 pls., February 23, 1922.

3. A section of the Paleozoic formations of the Grand Canyon at the Bass trail: U. S. Geol. Survey, Prof. Paper 131, pp. 23-73, 4 figs., 7 pls., August 19, 1922. 
Noble, Levi F.-Continued.

4. (and Mansfield, G. R., and others). Nitrate deposits in the Amargosa region, southeastern California: U. S. Geol. Survey, Bull. 724, 99 pp., 7 figs., 35 pls. (incl. maps), 1922.

5. Borate deposits in the Kramer district, Kern County, California: U. \$. Geol. Survey, Bull. 785, pp. 45-61, 5 figs., October 5, 1926.

6. Note on a colemanite deposit near Shoshone, California, with a sketch of the geology of a part of Amargosa Valley: U. S. Geol. Survey, Bull, 785, pp. 63-73, 1 fig., October 13, 1926.

7. The San Andreas rift and some other active faults in the desert region of southeastern California: Carnegie Inst. Washington, Year Book no. 25, 1925-26, pp. 415-428, December, 1926; Seismological Society America, Bull., vol. 17, no. 1, pp. 25-39, March, 1927.

8. A section of the Kaibab limestone in Kaibab Gulch, Utah: U. S. Geol. Survey, Prof. Paper 150, pp. 41-60, 1 fig., 3 pls., January 14, 1928.

9. The San Andreas rift in a part of southern California: Third Pan-Pacific Sci. Cong., Tokyo, 1926, Proc., pp. 394-400, 1928.

Noble, G. K. See Gregory, W. K., 9.

Noé, Adolph Charles.

1. Cycad-like leaves from the Permian of Texas (abstract): Geol. Soc. America, Bull., vol. 32, no. 1, p. 134, March 31, 1921

2. Fossil flora of Braidwood, Illinois: Illinois State Acad. Sci., Trans., vol. 15, pp. 396-397 [1923].

3. The flora of the western Kentucky coal field: Kentucky. Geol. Survey, ser. 6, vol. 10, pp. 127-148, 24 figs., 1923.

4. Coal balls: Science, new ser., vol. 57, p. 385, March 30, 1923.

5. A Paleozoic angiosperm: Jour. Geology, vol, 31, no. 4, pp. 344-347, 2 rigs., May-June, 1923.

6. Pennsylvanian flora of northern Illinois: Illinois State Geol. Survey, Bull. 52,113 pp., 45 pls., 1925.

7. Coal balls here and abroad: Illinois State Acad. Sci., Trans., vol. 17, pp. $179-180,1925$.

8. The fossil flora of northern Illinois: Illinois State Acad. Sci., Trans., vol. 18 , pp. 206-207, 1925.

9. Dakota sandstone plants from Cimarron County, Oklahoma: Oklahoma Geol. Survey, Bull. no. 34, pp. 93-107, 7 pls., October, 1925.

10. American coal balls (abstract): Science, new ser., vol. 62, p. 524, December 4, 1925.

11. The fossil flora of Harrisburg, Illinois: Illinois State Acad. Sci., Trans., vol. 19 , pp. $283-285,1926$.

12. Coal ball studies (abstract): Geol. Soc. America, Bull., vol. 37, no. 1, p. 241, March 30, 1926.

13. Pennsylvanian system of Iowa (abstract) : Pan-Am. Geologist, vol. 47, no. 5, pp. 375-376, June, 1927.

Nolan, Thomas B.

1. Potash brines underlying Great Salt Lake Desert, Utah (abstract) : Washington Acad. Sci., Jour., vol. 17, no. 10, pp. 274-275, May 19, 1927.

2. Potash brines in the Great Salt Lake Desert, Utah: U. S. Geol. Survey, Bull. 795, pp. 25-44, June 16, 1927.

3. Stratigraphy and structure, Gold Hill quadrangle, Utah (abstract) : Geol. Soc. America, Bull., vol. 39, no. 1, pp. 183-184, March 30, 1928, Pan-Ạm. Geologist, vol. 49, nก. 2, p. 142, March, 1928 . 
Nolan, Thomas B.-Continued.

4. A late Paleozoic positive area in Nevada: Am. Jour. Sci., 5th ser., vol. 16, pp. 153-161, 3 figs., August, 1928.

Nopesa, Francis.

1. On the probable habits of the dinosaur Struthiomimus: Annals and Mag. Nat. Hist., 9th ser., vol. 10, pp. 152-155, 1 fig., July, 1922.

Nordenskjöld, Otto.

1. Die nordatlantischen Polarinseln: Handbuch d. regionalen Geologie (Steinman u. Wilckens), Bd. 4, Abt. 2b, H. 24, 31 pp., 10 figs., 1 pl. (map), Heidelberg, 1921.

2. Polar nature, a general characterization (especially chapter 3 , The causes and natural conditions of the Ice Age as illustrated by polar nature to-day, pp. 39-51). In The geography of the polar regions: Am. Geog. Soc., Spec. Pub. no. 8, New York, 1928.

Nordstrom, Allan. See also Sundberg, 1.

North, Frederick John.

1. On Syringothyris Winchell and certain Carboniferous Brachiopoda referred to Spiriferina D'Orbigny: Geol. Soc. London, Quart. Jour., vol. 76, pt. 2, pp. 162-227, 3 pls., 6 figs., November 30, 1920.

North, Lloyd.

1. (and Bridenstine, I. J.). Some notes on iron-depositing bacteria: Econ. Geology, vol. 17, no. 5, pp. 393-394, August, 1922.

Northrop, John D.

1. The petroleum resources of the world: Eng. and Min. Jour., vol. 108, pp. 953-955, 1 fig., December 27, 1919; vol. 109, pp. 34-38, 1 fig., January 3, 1920.

Northrop, Stuart Alvord.

1. Beetles from the Fox Hills Cretaceous strata of South Dakota; with an appendix by T. D. A. Cockerell: Am. Jour. Sci., 5th ser., vol. 15, pp. 28-38, 1 pl., January, 1928.

Norton, E. A.

1. The inter-relation of soils and geology (abstract): Illinois State Acad. Sci., Trans., vol. 19, p. 245, 1926.

Norton, William Harmon.

1. Wapsipinicon breccias of Iowa: Iowa Geol. Survey, vol. 27, pp. 355-547, 48 figs., 10 pls. [1920].

2. The elements of geology. 464 pp., 376 figs., Boston, Ginn and Company [copyright 1.905, 1921].

3. Calcareous nodules of Wapsipinicon terrane (abstract) : Pan-Am. Geologist, vol. 46, no. 5, p. 405, December, 1926.

4. A reconsideration of the age of certain outliers in Linn and Jackson counties: Iowa Acad. Sci., Proc., 1926, vol. 33, pp. 207-211 [1927].

5. New stratigraphic data from Iowa deep wells (abstract) : Pan-Am. Geologist, vol. 48, no. 2, pp. 156-157, September, 1927.

Nowels, Kenneth B.

1. Preliminary report on water conditions in the First Wall Creek sand, Salt Creek oil field, Wyoming: Am. Assoc. Petroleum Geologists, Bull., vol. 8, no. 4, pp. 492-504, 3 figs.. July-August. 1924. 
Nuttall, Winfred Laurence Falkiner.

1. Tertiary Foraminifera from the Naparima region of Trinidad, British West Indies: Geol. Soc. London, Quart. Jour., vol. 84, pt. 1, pp. 57-116, 13 figs., 6 pls., April 30, 1928; abstract, Abstracts of Proc., no. 1161, pp. 50-51, February 10, 1927.

2. Notes on the Tertiary Foraminifera of southern Mexico: Jour. Paleontology, vol. 2, no. 4, pp. 372-376, 1 pl., December, 1928.

\section{Nutting, Perley Gilman.}

1. Geochemical relations between petroleum, silica, and water: Econ. Geology, vol. 21, no. 3, pp. 234-242, May, 1926.

2. Pressures in planetary atmospheres: Washington Acad. Sci., Jour., vol. 16, no. 9, pp. 254-258, May 4, 1926.

3. Nature of petroleum filtering earths: Oil and Gas Jour., vol. 27, no. 6, pp. 138, 139, June 28, 1928.

4. Petroleum and the filtering earths: Washington Acad. Sci., Jour., vol. 18, no. 15 , pp. 409-414, September 19, 1928.

5. Some geological consequences of the selective adsorption of water and hydrocarbons by silica and silicates: Econ. Geology, vol. 23, no. 7, pp. 773-777, November, 1928.

Nye, S. Spencer. See also Fiedler, 2.

1. Geology of the Cactus Flat reservoir site for the Hope community, New Mexico: New Mexico, State Eng., 8th Bienn. Rept., pp. 179-192, 1 fig. [1928].

Oakes, M. C.

1. Building materials of Oklahoma: Oklahoma Acad. Sci., Proc. vol. 3 (Oklahoma, Univ., Bull., new ser., no. 271), pp. 113-117, October 1, 1923.

Oberföll, L. See Matthes, 1.

Obregón, Máriano B.

1. Carbón y petróleo en los Estados Unidos Mexicanos; sus yacimientos, origen, distribucion y manera de utilizarlos: Soc. cient. "Antonio Alzate," Mem. y Rev., t. 43, pp. 157-299, 1924.

Ockerman, John W.

1. Fauna of the Galena limestone near Appleton [Wisconsin]: Wisconsin Acad. Sci., Arts, and Letters, Trans., vol. 22, pp. 99-142, 3 pls., 1926.

O'Connell, Marjorie. See also Brown, B., 1, 2.

1. The Schrammen collection of Cretaceous Silicispongiae in the American Museum of Natural History: Am. Mus. Nat. Hist., Bull., vol. 41, pp. 1-261, 5 figs., 14 pls., map, August 1, 1919.

2. Orthogenetic development of the costae in the Perisphinctinae: Am. Jour. Sci., 4th ser., vol. 48, pp. 450-460, 2 figs., December, 1919. Abstract, Geol. Soc. America, Bull., vol. 30, no. 1, p. 152, March 31, 1919.

3. The Jurassic ammonite fauna of Cuba: Am. Mus. Nat. Hist., Bull., vol. 42, pp. 643-692, 8 figs., 5 pls., 1920.

4. Further studies on the Jurassic of Cuba (abstract) : Geol. Soc. America, Bull., vol. 31, no. 1, p. 136, March 31, 1920.

5. New species of ammonite opercula from the Mesozoic rocks of Cuba: Am. Mus. Novitates, no. 28, 15 pp., 18 figs., December 29, 1921.

f. Phylogeny of the ammonite genus Ochetoceras: Am. Mus. Nat. Hist., Bull., vol. 46, pp. 387-411, 1922. 
O'Connor, J. J.

1. The latent iron-ore resources in Canada lying north of Lake Superior: Canadian Min. Jour., vol. 40, no. 50, pp. 952-953, December 17, 1919.

Odell, William Wallace.

1. (and Hood, O. P.). Possibilities for the commercial utilization of peat: U. S., Bur. Mines, Bull. 253, 160 pp., 23 figs., 6 pls., 1926.

Officer, H. G. See Aurin, 3.

o'Harra, Cleophas Cisney.

1. Lignite coals and their utilization: Pahasapa Quart., vol. 8, no. 2, pp. 1635, illus., February, 1919.

2. The Badlands: Pahasapa Quart., vol. 9, no. 4, pp. 207-213, 7 figs., June, 1920.

3. The White River Badlands: South Dakota School of Mines, Bull. no. 13, 181 pp., 75 figs., 96 pls. (incl. map), November, 1920.

4. Materials used in the making of Portland cement: Black Hills Engineer, vol. 12, no. 2, pp. 59-64, 1 pl., March, 1924.

5. (and Connolly, Joseph P.). The geology, mineralogy, and scenic features of Custer State Park, South Dakota: South Dakota School of Mines, Bull. no. 14, 123 pp., 5 figs., 60 pls. (incl. maps), January, 1926.

O'Heir, H. B. See Bell, J. M., 9.

Ohern, Daniel Webster.

1. Fifty years of petroleum geology: Johns Hopkins Univ., Studies in Geology, no. 8, pp. 83-120, 1927.

Ohrenschall, Robert D. See Wentworth, 38.

Oklahoma Geological Survey.

1. Map showing distribution of mineral resources. 1921: [Scale: 30 miles to 1 inch, about.]

2. Robberson oil and gas field, Garvin County, Oklahoma; Oklahoma Geol. Survey, Press Bulletin no. 10, text and map [1922].

Oldham, Richard Dixon.

1. The depth and twofold character of earthquake origins: Jour. Geology, vol. 34, no. 5, pp. 385-398, July-August, 1926.

Oldroyd, Ida Shepard.

1. Description of a new fossil species of a clam of the genus Crassatellites [Pleistocene, near Lomita, Los Angeles County, California] : Southern California Acad. Sci., Bull., vol. 23, pt. 1, p. 10, 1 fig., January-February, 1924.

Oldroẏd, Thomas Shaw.

1. New Pleistocene mollusks from California: Nautilus, vol. 34, no. 4, pp. 114 116, 1 pl., April, 1921.

2. Some varieties of western Olivellas: Nautilus, vol. 34, no. 4, pp. 117-119, 1 pl., April, 1921.

3. The fossils of the lower San Pedro fauna of Nob Hill cut, San Pedro, California: U. S. Nat. Mus., Proc., vol. 65, art. 22, 39 pp., 2 pls., 1924.

Olmstead, Seymour G.

1. Economic geology of the Ophir mining district [Utah]: Econ. Geology, vol. 16, no. 7, pp. 433-456, 1 fig., November, 1921. 
Olsson, A. A.

1. The Miocene of northern Costa Rica; with notes on its general stratigraphic relations: Bull. Am. Paleontology, vol. 9, no. 39, Part I, pp. 1-167, April 21, 1922; Part II, Class Pelecypoda, pp. 169-309, 32 pls., June 21, 1922.

Omori, Fusakichi, 1868-1923.

1. Earthquake zones of the Pacific: Pan-Pacific Scientific Conference, First, Proc., Bernice P. Bishop Mus., Spec. Pub. no. 7, pt. 2, pp. 369 377, 3 figs., 1921.

O'Neill, John Johnston. See also Bruce, 18.

1. Preliminary report on the economic geology of Hazleton district, British Columbia: Canada, Geol. Survey, Mem. 110, 51 pp., 10 pls., 5 figs., 3 maps, 1919.

2. The platinum situation in Canada, 1918: Canada, Geol. Survey, Summ. Rept., 1918, pt. G, pp. 1-15, map, 1919.

3. Deposits of native copper in Arctic Canada: Canadian Min. Inst., Trans., vol. 22, pp. 406-416, 3 figs. [1920] ; Min. and Sci. Press, vol. 118, pp. 807-811, 5 figs., June 14, 1919.

4. Salmon River district, Portland Canal mining division, B. C.: Canada, Geol. Survey, Summ. Rept., 1919, pt. B, pp. 7-12, 1920.

5. The geology of the Arctic coast of Canada west of the Kent Peninsula : Canadian Arctic Expedition 1913-18, Rept., vol. 11, pt. A, 107 pp., 6 figs., 35 pls., 3 maps, July 8, 1924.

Ontario Department of Mines.

1. Ontario's mines and mineral resources. 87 pp., illus., Ontario Department of Mines, Toronto, Canada, 1924.

2. General index to the reports of the Ontario Department of Mines, volumes XXVI to XXXV (1917-1927), 668 pp., 1928.

Ontario Iron Ore Committee.

1. Report of the Ontario iron ore committee, with appendix, 1923: Ontario, Dept. Mines, 306 pp., 52 figs., Toronto, 1924.

Orcutt, Charles Russell.

1. Pleistocene beds of San Quentin Bay, Lower California: West American Scientist, vol. 19, no. 3, pp. 23-24, June 15, 1921.

Orcutt, W. W.

1. Early oil development in California: Am. Assoc. Petroleum Geologists, Bull., vol. 8, no. 1, pp. 61-72, January-February, 1924.

Ordoñez, Ezequiel.

1. Petróleo en el sur de Tamaulipas: Soc. cient. "Antonio Alzate," Mem. y Rev., t. 38, nos. 5-8, pp. 257-269, June 1919.

2. Oil in southern Tamaulipas, Mexico (with discussion by V. R. Garfias and E. DeGolyer ) : Am. Inst. Min. and Met. Eng., Trans., vol, 61, pp. 532-543, 1920.

Orser, Edward $\mathrm{H}$.

1. Kirkland Lake, Ontario's second gold district: Eng. and Min. Jour.-Press, vol. 121, no. 8, pp. 317-323, 3 figs., February 20, 1926.

Ortega, Gustavo.

1. Los recursos petroliferos mexicanos y su actual explotación: Mexico, Secretaría de Industria, Comercio y Trabajo, Dept. de Petróleo, 49. pp., 36 pls., Mexico, 1925. 
Ortega, Pablo.

1. (and Huerta, Santiago de la). El carbón de piedra, el petróleo, el asfalto, los betunes, y et gas natural de Cuba: Cuba, Dirección de Montes y Minas, Bol. Bibliog. no. 1, 23 pp., La Habana, 1919.

Orynski, Leonard D. See Edwards, 1.

Osbon, Clarence C. See also Soper, 2.

1. Peat in the Dismal Swamp, Virginia and North Carolina: U. S. Geol. Survey, Bull. 711, pp. 41-59, 3 pls. (incl. map), October 29, 1919. Abstract, Washington Acad. Sci., Jour., vol. 10, no. 20, p. 574, December 4, 1920.

2. Classification and formation of peat and related deposits: Am. Peat Soc., Jour., vol. 14, no. 1, pp. 37-44, 2 pls., January, 1921.

Osborn, Chase Salmon.

1. The earth upsets (another terrestrial motion). 216 pp., Baltimore, Waverly Press, 1927.

Osborn, Henry Fairfield. See also McCornack, 2; Matsumoto, 1.

1. Samuel Wendell Williston: Science, new ser.; vol. 49, pp. 274-278, March 21, 1919.

2. Memorial of Samuel Wendell Williston: Geol. Soc. America, Bull., vol. 30, no. 1, pp. 66-76, portr., March 31, 1919.

3. Seventeen skeletons of Moropus; probable habits of the animal: Nat. Acad. Sci., Proc., vol. 5, no. 7, pp. 250-252, 1 fig., July 15, 1919.

4. Paleomustodon, the ancestor of the long-jawed mastodons only: Nat. Acad. Sci., Proc., vol. 5, no. 7, pp. 265-266, 1 fig., July 15, 1919.

5. Camarasaurus, Amphicoelias, and other sauropods of Cope: Geol. Soc. America, Bull., vol. 30, pp. 379-388, September 30, 1919.

6. (and Mook, Charles Craig). Characters and restoration of the sauropod genus Camarasaurus Cope: Am. Philos. Soc., Proc., vol. 58, no. 6, pp. 386-396, 1 pl., 3 figs., 1919.

7. New titanotheres of the Huerfano: Am. Mus. Nat. Hist., Bull., vol. 41, pp. 557-569, 7 figs., December 10, 1919.

8. (and Mook, Charles Craig). Reconstruction of the skeleton of the sauropod dinosaur Camarasaurus Cope (Morosaurus Marsh): Nat. Acad. Sci., Proc., vol. 6, no. 1, p. 15, January 15, 1920.

9. The hall of the age of man in the American Museum: Natural History, vol. 20, no. 3, pp. 229-246, 14 figs., May-June, 1920.

10. (and Mook, C. C.). Camarasaurus, Amphicoelias, and other sauropods of Cope: Am. Mus. Nat. Hist., Mem., new ser., vol. 3, pt. 3, pp. 251387, 127 figs., 26 pls., January, 1921.

11. The evolution, phylogeny, and classification of the Proboscidea: Am. Mus. Novitates, no. 1, 15 pp., 4 figs., January 31, 1921.

12. The hall of the age of man in the American Museum: Nature, vol. 107, pp. 236-240, 4 figs., April 21, 1921.

13. Resemblances and contrasts between zoologic and paleontologic research in mammalogy; desirability of uniform standards and systems in classification, in description, in measurement, in reasoning: Jour. Mammalogy, vol. 2, no. 1, pp. 1-11, February, 1921.

14. First appearance of the true mastodon in America: Am. Mus. Novitates no. 10, 6 pp., 2 pls., June 15, 1921. Science, new ser., vol. 54, p. 108, August 5, 1921.

15. Adaptive radiation and classification of the Proboscidea: Nat. Acad. Sci., Proc., vol. 7, no. 8, pp. 231-234, 1 fig., August, 1921. 
Osborn, Henry Fairfield-Continued.

16. Evolution, phylogeny, and classification of the Mastodontoidea: Geol. Soc. America, Bull., vol. 32, no. 3, pp. 327-332, September 1, 1921.

17. Orthogenesis as observed from paleontological evidence beginning in the year 1889: Am. Naturalist, vol. 56, no. 643, pp. 134-143, MarchApril, 1922.

18. Hesperopithecus, the first anthropoid primate found in America: Am. Mus. Novitates, no. 37, 5 pp., 3 figs., April 25, 1922.

19. (and Reeds, C. A.). Old and new standards of Pleistocene division in relation to the prehistory of man in Europe (with discussion by Frank Leverett, W. C. Alden, and W. M. Davis) : Geol. Soc. America, Bull., vol. 33, no. 3, pp. 411-490, 14 figs., July 3, 1922.

20. Species of American Pleistocene mammoths; Elephas jeffersonii, new species: Am. Mus. Novitates, no. 41, 16 pp., 12 flgs., July 8, 1922.

21. Hesperopithecus, the first anthropoid primate found in America: Science, new ser., vol. 55, pp. 463-465, May 5, 1922 ; Nat. Acad. Sci., Proc., vol. 8, no. 8, pp. 245-246, August, 1922.

22. Hesperopithecus, the anthropoid primate of western Nebraska: Nature, vol. 110, pp. 281-283, 2 figs., August 26, 1922.

23. (and Reeds, C. A.). Recent discoveries on the antiquity of man: Nat. Acad. Sci., Proc., vol. 8, no. 8, pp. 246-247, August, 1922; Science, new ser., vol. 56, p. 256, September 1, 1922.

24. Migrations and affinities of the fossil proboscideans of Eurasia, North and South America, and Africa: Am. Naturalist, vol. 56, no. 646, pp. 448-455, 1 fig., September-October, 1922.

25. Dibielodon edensis (Frick) of southern California; Miomastodon of the middle Miocene, new genus: Am. Mus. Novitates, no. 49,4 pp., 3 figs., October 23, 1922.

26. Close of the age of mammals: Jour. Mammalogy, vol, 3, no. 4, pp. 219237, 6 figs., November, 1922. Abstract, Science, new ser., vol. 55, p. 627, June 9, 1922.

27. Mastodons of the Hudson Highlands: Natural History, vol. 23, no. 1, pp. 3-24, 14 figs., January-February, 1923.

28. A new genus and species of Ceratopsia from New Mexico, Pentaceratops sternbergii: Am. Mus. Novitates, no. 93, 3 pp., 1 fig., October 18, 1923.

29. New subfamily, generic, and specific stages in the evolution of the Proboscidea: Am. Mus. Novitates, no. 99, 4 pp., December 27, 1923.

30. Joseph Leidy, founder of vertebrate paleontology in America: Science, new ser., vol. 59, pp. 173-176, February 22, 1924.

31. Joseph Leidy, founder of vertebrate paleontology in America: Acad. Nat. Sci. Philadelphia, Proc., vol. 75 [Appendix] The Joseph Leidy Commemorative Meeting, pp. 54-61, 1924.

32. Parelephas in relation to phyla and genera of the family Elephantidae: Am. Mus. Novitates, no. 152, 7 pp., 2 figs., December 20, 1924.

33. Additional generic and specific stages in the evolution of the Proboscidea: Am. Mus. Novitates, no. 154, 5 pp., 2 figs., December 24, 1924.

34. Final conclusions on the evolution, phylogeny, and classification of the Proboscidea: Am. Philos. Soc., Proc., vol. 64, no. 1, pp. 17-35, 3 figs., 1925.

35. The elephants and mastodons arrive in America: Natural History (Am. Mus. Nat. Hist., Jour.), vol. 25, no. 1, pp. 3-23, 17 figs., 1 pl., January-February, 1925. 
Osborn, Henry Fairfield-Continued.

36. The hall of the age of man: Am. Mus. Nat. Hist., Guide Leaflet series no. 52, 48 pp., 32 figs., May, 1925.

37. The origin of species as revealed by vertebrate paleontology; a rejoinder to William Bateson (abstract) : Science, new ser., vol. 61, pp. 523-524, May 15, 1925.

38. The origin of species as revealed by vertebrate paleontology: Nature, vol. 115, pp. 925-926, 961-963, June 13, and 20, 1925.

39. The origin of species, II ; Distinctions between rectigradations and allometrons: Nat. Acad. Sci., Proc., vol. 11, no. 12, pp. 749-752, December 15, 1925.

40. The evolution of human races: Natural History (Am. Mus. Nat. Hist,, Jour.), vol. 26, no. 1, pp. 3-13, 4 figs., January-February, 1926.

41. The origin of species, 1859-1935; Yale Univ., Peabody Mus. Nat. Hist,, Bull. 1, no. 1, pp. 25-38, 1926; Sci. Monthly, vol. 22, no. 3, pp. 185-192, March, 1926.

42. The problem of the origin of species as it appeared to Darwin in 1859 and as it appears to us to-day: Nature, vol. 118, pp. 270-273, August 21, 1926 [and correction], p. 591, October 23, 1926; Science, new ser., vol. 64, pp. 337-341, October 8, 1926; abstract, Pan-Am. Geologist, vol. 46, no. 4, pp. 335-336, November, 1926.

43. J. L. Wortman; a biographical sketch: Natural History (Am. Mus. Nat. Hist., Jour.), vol. 26, no. 6, pp. 652-653, portr., November-December, 1926.

44. Additional new genera and species of the mastodontoid Proboscidea : Am. Mus. Novitates, no. 238, 16 pp., 12 figs., November 30, 1926.

45. Mastodons and mammoths of North America : Am. Mus. Nat. Hist., Guide Leaflet no. 62, 46 pp., illus., 1926. (Reprinted from Nat. Hist., vol. 23, pp. 3-24 and vol. 25, pp. 3-23, 1923 and 1925.)

46. The origin of species, V; Speciation and mutation: Am. Naturalist, vol. 61, pp. 5-42, 6 figs., January-February, 1927.

47. Man rises to Parnassus; critical epochs in the pre-history of man. 217 pp., 83 figs., Princeton, New Jersey, Princeton University Press, 1927.

48. Recent discoveries relating to the origin and antiquity of man: Science, new ser., vol. 65, pp. 481-488, 2 figs., May 20, 1927, p. 597, June 17, 1927 ; Am. Philos. Soc., Proc.; vol. 66, pp. 373-389, 2 figs., 1927; Palaeobiologica, Jg. 1, Bd. 1, pp. 189-202, 3 figs., 1928.

49. Present status of the problem of human ancestry: Am. Philos. Soc., Proc., vol. 77 , no. 2, pp. 151-155, 1928.

50. The plateau habitat of the pro-dawn man: Science, new ser., vol. 67, pp. 570-571, June 8, 1928.

Osborn, Henry Stafford, 1823-1894.

1. Prospector's field book and guide in the search for and the easy determination of ores and other useful minerals. 9th ed., revised by M. W. von Bernewitz, 364 pp., 56 figs., New York, Henry Carey Baird \& Co., 1920.

Osborn, W. G.

1. Oil possibilities of the St. Peter sandstone in Iowa, 12 pp., Keosauqua, Iowa, May, 1926. [Private publication.] 
Osborne, Clarence B.

1. A theory to account for occurrence of oil in the vesicular cavities of igneous intrusions: Am. Assoc. Petroleum Geologists, Bull., vol. 7, no. 3, pp. 288-290, May-June, 1923.

2. Ewart Gladstone Sinclair: Am. Assoc. Petroleum Geologists, Bull., vol. 11, no. 12, pp. 1348-1349, December, 1927.

Osborne, Freleigh Fitz. See also Uglow, 15.

1. Antipathy of bornite and pyrrhotite (discussion): Econ. Geology, vol, 22, no. 1, pp. 99-101, January-February, 1927.

2. Technique of the investigation of iron ores: Econ. Geology, vol. 23, no. 4, pp. 442-450, 4 figs., June-July, 1928.

3. Certain magmatic titaniferous iron ores and their origin: Econ. Geology, vol. 23 , no. 7 , pp. 724-761, no. 8, pp. 895-922, 13 figs., November and December, 1928.

Ostergaard, Jens Mathias.

1. Fossil marine mollusks of Oahu: Bernice P. Bishop Mus., Bull. 51; 32 pp., 1 fig., 2 pls., 1928.

Over, Edwin, jr.

1. Mineral localities of Colorado: Rocks and Minerals, vol. 3, no. 4, pn. 110111, December, 1928.

Overbeck, Robert Milton. See also Schwennesen, 2.

1. Geology and mineral resources of the west coast of Chichagof Island [southeastern Alaska]: U. S. Geol. Survey, Bull. 692, pp. 91-136, map. 1919. Abstract by R. W. Stone, Washington Acad. Sci., Jour., vol. 9 , no. 20 , p. 632 , December $4,1919$.

2. Nickel deposits in the lower Copper River valley, Alaska: U. S. Geol. Survey, Bull. 712, pp. 91-98, 1 fig. (map), 1919. Abstract by R. W. Stone, Washington Acad. Sci., Jour., vol. 10, no. 16, p. 472 , October 4, 1920.

3. Placer mining in the Tolovana district, Alaska: U. S. Geol. Survey, Bull. 712, pp. 177-184, 1920. Abstract by J. D. Sears, Washington Acad. Sci., Jour., vol. 10, no. 18, p. 522, November 4, 1920.

Overstreet, J. B. See Barton, 2.

Owen, Luella Agnes.

1. Later studies on the loess: Pan-Am. Geologist, vol. 45, no. 5, pp. 377-382, June, 1926 ; abstract, no. 2, pp. 173-174, March, 1926.

Owen, W. T.

1. Southwest Texas oil fields: Eng. and Min. Jour.-Press, vol. 114, no. 12, pp. 506-510, 4 figs., September 16, 1922.

Owens, H. J. See Brockway, 1.

Ower, Leslie $\mathrm{H}$.

1. The geology of British Honduras. 24 pp., (map) [Colonial Secretary's Office], Belize, British Honduras, July, 1928.

2. Geology of British Honduras: Jour. Geology, vol. 36, no. 6, pp. 494-509, 3 figs., August-September, 1928.

3. The silica lines of British Honduras: Geol. Mag., vol. 65, pp. 507-510, 1 fig. (map), November, 1928. 
Pabst, Adolf.

1. Observations on inclusions in the granitic rocks of the Sierra Nevada: California, Univ., Dept. Geol. Sci., Bull., vol. 17, no. 10, pp. 325386, 10 figs., 9 pls., October 24, 1928.

Pace, Lula.

1. Geology of McLennan County, Texas: Baylor Bull. (Baylor Univ., Waco, Tex.), vol. 24, no. 1, 25 pp., 12 figs., 2 maps, January, 1921.

Pack, Frederick James.

1. Wonders of Utah geology: Utah, Univ., Bull. vol. 10, no. 12, 24 pp., illus., 1919.

2. Geology of Weber County [Utah]: Utah Univ., Bull., vol. 11, no 19, pp. 5-23, 12 figs., June, 1921.

3. The Elsinore earthquakes in central Utah: Seismol. Soc., America, Bull., vol. 11, nos. $3-4$, pp. 155-165, 3 pls., September-December, 1921.

4. Natural bridging in the High Plateaus [Utah] : Pan-Am. Geologist, vol. 37, no. 3, pp. 213-225, 3 figs., 5 pls., April, 1922.

5. Outstanding geological features of Colorado River basin: Pan-Am. Geologist, vol. 38, no. 4, pp. 289-298, 10 pls., November, 1922.

6. Torrential potential of desert waters [Utah]: Pan-Am. Geologist, vol. 40, no. 5, pp. 349-356, 5 pls., December, 1923.

7. New discoveries relating to the Wasatch fault: Am. Jour. Sci., 5th ser., vol. 11, pp. 399-410, 6 figs., May, 1926; abstract, Geo. Soc. America, Bull., vol. 37, no. 1, p. 182, Mareh 30, 1926; Pan-Am. Geologist, vol. 45, no. 2, p. 170, March, 1926.

8. Structure of thermal springs on the Wasatch fault: Am. Jour. Sci., 5th ser, vol. 14, pp. 408-41.8, 4 figs., Novenber, 1927; abstract, Geol. Soc. America, Bull., vol. 38, no. 1, p. 161, March 30, 1927 ; Pan-An. Geologist, vol. 47 , no. 2 , p. 157 , March, 1927.

Pack, Robert Wallace.

1. The Sunset-Midway oil field, California ; Part I, Geology and oil resources ; U. S. Geol. Survey, Prof. Paper 116, 179 pp., 45 pls. (incl. maps), 15 figs., 1920; abstract by J. D. Sears, Washington Acad. Sc.., Jour., vol, 11, no. 3, p. 58, February 4, 1921.

Packard, Earl Leroy. See also Merriam, 25 ; Smith, W. D., 1.

1. An addition to the marine mammalian fauna of Newport, Oregon (abstract) : Geol. Soc. America, Bull., vol. 32, no. 1., p. 148, March 21, 1921.

2. (and Nelson, R. N.). Geologic occurrence of the Hardgrave Jurassic fauna of Burns, Oregon (abstract) : Geol. Soc. America, Bull., vol. 32, no. 1, p. 148, March 31, 1921.

3. The Trigoniae from the Pacific coast of North America: Oregon; Univ., Pub., vol. 1, no. 9, 58 pp., 11 pls., May, 1921.

4. New species from the Cretaceous of the Santa Ana Mountains, California : California, Univ., Dept. Geol. Sci., Bull., vol. 13, no. 10, pp. 413-462, 15 pls., June $30,1922$.

5. An aberrant oyster from the Oregon Eocene: Oregon, Univ., Pub., vol. 2, no. 4, 6 pp., 4 pls., December, 1923.

6. A new section of Paleozoic and Mesozoic rocks in central Oregon: Am. Jour. Sci., 5th ser., vol. 15, pp. 221-224, March, 1928.

7. Cretacic rocks of central Oregon (abstract) : Pan-Am. Geologist, vol. 49, no. 4, p. 305 , May, 1928.

$4096-31-30$ 
Packard, Earl Leroy-Continued.

8. Discovery of Baird Mississippian fauna of central Oregon (abstract) : Pan-Am. Geologist, vol. 49, no. 4, p. 315, May, 1928.

Pagliuchi, F. D.

1. A mining reconnaissance from Mazatlan [Sinaloa, Mexico]: Eng. and Min. Jour.-Press, vol. 115, no. 12, pp. 542-546, 9 figs., March 24, 1923.

Paige, Sidney. See also Darton, 14; Hayes, C. W., 1; Longwell, 6; Miser, 13.

1. United States Geological Survey as a civic institution during the war (abstract) : Geol. Soc. America, Bull., vol. 30, pp. 78-79, March 31, 1919.

2. Copper deposits of the Tyrone district, New Mexich: U. S. Geol. Survey, Prof. Paper 122, 53 pp., 29 figs., 10 pls. (incl. maps), 1922.

3. The geology of the Homestake mine [Lead, South Dakota] : Econ. Geology, vol. 18 , no. 3, pp. 205-237, 13 figs. (incl. map), April-May, 1923.

4. Geology of the region around Lead, South Dakota, and its bearing on the Homestake ore body: U. S. Geol. Survey, Bull. 765, 58 pp., 19 figs., 11 pls., 1924.

5. (and Foran, W. T., and Gilluly, James). A reconnaissance of the Point Barrow region, Alaska: U. S. Geol. Survey, Bull. 772, 33 pp., 4 figs., 9 pls. (incl. map), 1925.

6. Earthquakes: Sci. Monthly, vol. 20, no. 6, pp. 611-616, June, 1925.

7. La Plata formation in the plateau country (abstract) : Pan-Am. Geologist, vol. 44, no. 1, pp. 76-77, August, 1925.

Painter, Louise. See Carter, 1.

Palache, Charles. See also Bauer, L. H., 1; Daly, 20.

1. The two-circle goniometer: Am. Mineralogist, vol. 5, no. 2, pp. 23-33, 3 figs., February, 1920.

2. The gnomonic projection: Am. Mineralogist, vol. 5, no. 4, pp. 67-80, 17 figs., April, 1920.

3. Further notes on crystal drawing: Am. Mineralogist, vol. 5, no. 5, pp. 96-99, 2 figs., May, 1920.

4. The Goldschmidt two-circle method; calculations in the isometric system: Am. Mineralogist, vol. 5, no. 6, pp. 112-116, 1 fig., June, 1920.

5. The Goldschmidt two-circle method; calculations in the tetragonal system: Am. Mineralogist, vol. 5, no. 7, pp. 129-132, 3 figs., July, 1920.

6. The Goldschmidt two-circle method; calculations in the hexagonal system: Am. Mineralogist, vol. 5, no. 8, pp. 143-149, 4 figs., August, 1920.

7. (and Shannon, Earl V.). Higginsite, a new mineral of the olivenite gioup [Bisbee, Arizona] : Am. Mineralogist, vol. 5, no. 9, pp. 155-15i, 2 figs., September, 1920.

8. The Goldschmidt two-circle method; calculations in the orthorhombic system : Am. Mineralogist, vol. 5, no. 9, pp. 158-159, 1 fig., September, 1920.

9. Illustration of the orthorhombic system; measurements and calculations on higginsite: Am. Mineralogist, vol. 5, no. 9, pp. 159-164, 2 figs., September, 1920.

10. The Goldschmidt two-circle method; calculations in the monoclinic system, illustrated by monazite from Weymouth, Massachusetts: Am. Mineralogist, vol. 5, no. 10, pp. 173-181, 5 figs., October, 1920.

11. The Goldschmidt two-circle method; introduction to the triclinic system: Am. Mineralogist, vol. 5, no. 11, pp. 185-190, 4 figs., November, 1920.

12. A new mode of occurrence of struvite: Am. Mineralogist, vol. 8, no. 4, pp. 72-73, 1 fig., April, 1923. 
Palache, Charles-Continued.

13. (and Pinger, A. W.). The scapolite deposit of Bolton, Massachusetts: Am. Mineralogist, vol. 8, no. 9, pp. 153-157, September, 1923.

14. The chrysoberyl pegmatite of Hartford, Maine: Am. Mineralogist, vol. 9, no. 11, pp. 217-221, 1 fig., November, 1924.

15. (and Vassar, Helen E.). Some minerals of the Keweenawan copper deposits; pumpellyite, a new mineral; sericite; saponite: Am. Mineralogist, vol. 10, no. 11, pp. 412-418, November, 1925.

16. Catalogue of the collection of meteorites in the mineralogical museum of Harvard University: Am. Acad. Arts and Sci., vol. 61, no. 6, pp. 151-159, May, 1926.

17. Notes on new or incompletely described meteorites in the mineralogical museum of Harvard University: Am. Jour. Sci., 5th ser., vol. 12, pp. 136-150, August, 1926.

18. (and Vassar, Helen E.). A note on cyanotrichite: Am. Mineralogist, vol. 11, no. 8, pp. 213-214, August, 1926.

19. Memorial of Frederick Alexander Canfield: Am. Mineralogist, vol. 12, no. 3, pp. 67-70, 1 fig. (portr.), March, 1927.

20. (and Lonsdale, John T.). The Tulia meteorite, Swisher County, Texas: Am. Jour. Sci., 5th ser., vol. 13, pp. 353-359, 6 figs., April, 1927.

21. Crystallography of azurite from Tsumeb, southwest Africa, and the axial ratio of azurite: Am. Mineralogist, vol. 12, no. 4, pp. 99-143, 39 figs., 8 pls., April, 1927.

22. (and Shannon, E. V.). Holdenite, a new arsenate of manganese and zinc, from Franklin, New Jersey : Am. Mineralogist, vol. 12, no. 4, pp. 144-148, 1 fig., April, 1927.

23. (and Bauer, L. H.). Cahnite, a new boro-arsenate of calcium from Franklin, New Jersey: Am. Mineralogist, vol. 12, no. 4, pp. 149153, 1 fig., 1 pl., April, 1927.

24. (and Lewis, Lyman W.). A saw attachment adapting Goldschmidt's model cutting machine to the sawing of wooden models: Am. Mineralogist, vol. 12, no. 4, pp. 154-156, 2 pls., April, 1927.

25. (and Berman, Harry). Crystallographic notes; 1, Phosphophyllite; 2, Hematite; 3, Willemite ; 4, Hedyphane: Am. Mineralogist, vol. 12, no. 4, pp. 180-187, 7 figs., April, 1927.

26. (and Bauer, L. H.). McGovernite, a new mineral from Sterling Hill, New Jersey: Am. Mineralogist, vol. 12, no. 10, pp. 373-374, October, 1927.

27. (and Bauer, L. H., and Berman, H.). Larsenite and calcium-larsenite, new members of the chrysolite group, from Franklin, New Jersey : Am. Mineralogist, vol. 13, no. 4, pp. 142-144, April, 1928.

28. Mineralogical notes on Franklin and Sterling Hill, New Jersey: Am. Mineralogist, vol. 13, no. 7, pp. 297-329, 7 pls., July, 1928.

29. The phosphorescence and fluorescence of Franklin minerals : Am. Mineralogist, vol. 13, no. 7, pp. 330-333, 1 fig., July, 1928.

30. (and Bauer, L. H., and Berman, H.). Larsenite, calcium-larsenite, and the associated minerals at Franklin, New Jersey: Am. Mineralogist, vol. 13, no. 7, pp. 334-340, July, 1928.

31. (and Ellsworth, H. V.). Zircon from North Burgess, Ontario: Am. Mineralogist, vol. 13, no. 7, pp. 384-391, 1 fig., 1 pl., July, 1928.

32. (and Shannon, Earl V.). Beryllonite and other phosphates from Newry, Maine: Am. Mineralogist, vol. 13, no. 7, pp. 392-396, July, 1928.

33. Seligmannite from Bingham, Utah: Am. Mineralogist, vol. 13, no. 7, pp. 402-405, 1 fig, July, 1928. 
Palache, Charles-Continued.

34. (and Shannon, Earl V.). A new meteorite from Washington County, Colorado: Am. Mineralogost, vol. 13, no. 7, pp. 406-409, 1 pl., July, 1928.

Palmer, Andrew Henry.

1. California earthquakes during 1918: Seismol. Soc. America, Bull., vol. 9, no. 1, pp. 1-7, 1 pl., March, 1919.

2. California earthquakes during 1919: Seismol. Soc. America, Bull., vol. 10, no. 1, pp. 1-8, 1 pl., March, 1920.

3. Recent California earthquakes: Sci. Monthly, vol. 10, no. 6, pp. 529-552, 17 figs., June, 1920.

4. California earthquakes during 1920: Seismol. Soc. America, Bull., vol. 11, no. 1, pp. 7-14, March, 1921.

5. California earthquakes during 1921: Seismol. Soc. America, Bull, vol. 12, no. 1, pp. 20-23, 1 pl., March, 1922.

Palmer, Chase.

1. Phosphorus in California petroleum: Econ. Geology, vol, 17, no. 2, pp. 100-104, March-April, 1922.

2. California oil-field waters: Econ. Geology, vol. 19, no. 7 , pp. 623-635, November, 1924.

Palmer, Dorothy Bryant Kemper.

1. A fauna from the middle Eocene shales near Vacaville, California: California, Univ., Dept. Geol. Sci., Bull., vol. 14, no. 8, pp. 289-318, 6 pls., November 3, 1923.

Palmer, E. Laurence.

1. Rock stories: Cornell Rural School Leaflet, vol. 19, no. 3, 50 pp., January, 1926.

2. Rocks and minerals: Cornell Rural School leaflet, vol. 21, no. 3, 48 pp., illus., January, 1928.

Palmer, Elra C.

1. The geology of the District of Columbia: Rocks and Minerals, vol. 1, no. 2, p. 27, December, 1926; vol. 2, no. 1, pp. 10-11, March, 1927.

Palmer, Harold Shjöth. See also Wentworth, 21.

1. New graphic method for determining the depth and thickness of strata and the projection of dip (U. S. Geol. Survey, Prof. Paper 120, pp. 123-128, 1918) (abstract) : Washington Acad. Sci., Jour., vol. 9, no. 8, p. 228, April 19, 1919.

2. Graphic determination of dip components where dips are measured in feet per mile: Econ. Geology, vol. 14, no. 4, pp. 346-348, 1 fig., June, 1919.

3. Radian measures in plane-table mapping: Econ. Geology, vol. 15, no. 3, pp. 266-267, April-May, 1920.

4. Ground water in the Norwalk, Suffield, and Glastonbury areas, Connecticut: U. S. Geol. Survey, Water-Supply Paper 470, 171 pp., 12 pls. (incl. maps), 18 figs., 1920; abstract, Washington Acad. Sci., Jour., vol. 11, no. 21, p. 510, December 19, 1921.

5. Ground water in the Southington-Granby area, Connecticut: U. S. Geol. Survey, Water-Supply Paper 466, 219 pp., 30 figs., 7 pls. (incl. maps), 1921. Abstract, Washington Acad. Sci., Joụr., vol. 12, nọ, 1, pp. 19-20, January 4, 1922. 
Palmer, Harold Shjöth-Continued.

6. Structure of the South Mountain laccolith, Fergus County, Montana: Am. Jour. Sci., 5th ser., vol. 10, pp. 119-133, 4 figs., August, 1925.

7. The Honolulu type of artesian structure: Hawaiian Planters' Record, vol. 30, no. 4, pp. 422-433, 10 figs., October, 1926.

8. The geology of the Honolulu artesian system. $68 \mathrm{pp}$., 21 figs., map, Supplement to the report of the Honolulu Sewer and Water Commission to the Legislature of the Territory of Hawaii, 14th regular session, 1927.

9. Geology of Kaula, Nihoa, Necker, and Gardner islands, and French Frigates Shoal [Hawaiian Islands]: Bernice P. Bishop Mus., Bull. 35, 35 pp., 12 figs., 3 pls., 1927.

10. A study of the viscosity of lava: Hawaiian Volcano Observatory, Monthly Bull., vol. 15, no. 1, pp. 1-4, January, 1927.

11. Das artesische Gebiet von Honolulu [Hawaii] : Geol. Gesell. Wien, Mitt., Bd. 19, H. 1, pp. 19-36, 7 figs., 1927.

12. Karrenbildung in den Basaltgesteinen der Hawaiischen Inseln: Geog. Gesell. Wien, Mitt., Bd. 70, Nr. 4-6, pp. 89-94, 1 pl., 1927.

13. Lapiés in Hawaiian basalts: Geog. Rev., vol 17, no. 4, pp. 627-631, 3 figs., October, 1927.

\section{Palmer, Howard.}

1. Observations on the Freshfield Glacier, Canadian Rockies: Jour. Geology, vol. 32, no. 5, pp. 432-441, 8 figs., July-August, 1924.

2. The Freshfield Glacier, Canadian Rockies: Smithsonian Misc. Coll., vol. 76, no. 11, 16 pp., 1 fig., 9 pls., August 2, 1924.

Palmer, Katherine Van Winkle. See also Price, W. A., 12; Weaver, 3.

1. (and Harris, G. D.). New or otherwise interesting Tertiary molluscan species from the east coast of America: Bull. Am. Paleontology, vol. 8 , no. 33, pp. 1-32, 3 pls., March 6, 1919.

2. Illustrations and descriptions of fossil Mollusca contained in the paleontological collections at Cornell University: Bull. Am. Paleontology, vol. 8, no. 36, 12 pp., 1 pl., March 1, 1921.

3. Marine Pleistocene fossils from New York City: Science, new ser., vol. 57, pp. 585-586, May 18, 1923.

4. Foraminifera and a small molluscan fauna from Costa Rica: Bull. Am. Paleontology, vol. 10, no. 40, 18 pp., 2 pls., June 13, 1923.

5. The Veneridae of eastern America; Cenozoic and recent: Palaeontographica Americana, vol. 1, no. 5, pp. 209-428, 35 figs., 45 pls., 1926 [text published March, 1927; pls., February, 1929].

Palmer, Leroy A.

1. The Cold Bay oil field [Alaska Peninsula]: Pacific Min. News, vol. 1, no. 6, pp. 171-172, 3 figs., October, 1922.

2. The eastern portion of the Mohave Desert, a region of diversified mineral possibilities: Pacific Min. News, vol. 1, no. 8, pp. 234-235, December, 1922.

3. Magnesite mining in California : Am. Inst. Min. and Met. Eng. [preprint] no. 1629, 13 pp., 8 figs., February, 1927.

4. Magnesite mining in California (with discussion): Am. Inst. Min. and Met. Eng., Trans., vol. 75, pp. 743-756, 8 figs., 1927.

5. Kernite or rasorite?: Eng. and Min. Jour., vol. 123, no. 12, p. 494, March 19, 1927. 


\section{Palmer, Robert Hastings.}

1. Tectonic setting of Lago de Chapala [Mexico]: Pan-Am. Geologist, vol. 45, no. 2, pp. 125-134, 2 pls., March, 1926.

2. Upper Pleistocene occurrence along the Oaxaca coast of Mexico: Science, new ser., vol. 63, p. 476, May 7, 1926.

3. The Hoh formation of Washington: Jour. Geology, vol. 35, no. 3, pp. 276278, April-May, 1927.

4. Geology of eastern Hidalgo and adjacent parts of Vera Cruz, Mexico: Am. Assoc. Petroleum Geologists, Bull., vol. 11, no. 11, pp. 11731220, 11 figs., November, 1927.

5. Geology and petroleum possibilities of the Olympic Peninsula, Washington: Am. Assoc. Petroleum Geologists, Bull., vol. 11, no. 12, pp. 13211328, 3 figs., December, 1927.

6. Sand holes of the strand: Jour. Geology, vol. 36, no. 2, pp. 176-180, February-March, 1928.

7. The rudistids of southern Mexico: Cálifornia Acad. Sci., Occ. Papers 14, 137 pp., 8 figs., 18 pls., February 29, 1928.

8. Fossil and recent corals and coral reefs of western Mexico; three new species: Am. Philos. Soc., Proc., vol. 67, no. 1, pp. 21-31, 3 pls., 1928.

9. Geology of southern Oaxaca, Mexico: Jour. Geology, vol. 36, no. 8, pp. 718734, 8 figs., November-December, 1928.

Pan-American Geologist. See Keyes, 27.

Panyity, L. S. See also Bownocker, 3.

1. Prospecting for oil and gas. 249 pp., 128 figs., 28 tables, New York, John Wiley \& Sons, 1920. Review by Raymond C. Moore, Econ. Geology, vol. 15, no. 4, pp. 356-359, June, 1920.

2. Lithology of Berea sand in southeastern Ohio and its effect on production: Am. Inst. Min. and Met. Eng., Trans., vol. 61, pp. 478-481, 2 figs., 1920.

3. Oil and gas bearing horizons of the Ordovician system in Ohio: Am. Assoc. Petroleum Geologists, Bull., vol. 5, no. 1, p. 104 (abstract), no. 5, pp. 609-619, 3 figs., September-October, 1921.

Papish, Jacob.

1. Sulphur dioxide as a source of volcanic sulphur: Indiana Acad. Sci., Proc., 1918, pp. 170-171, 1919.

2. New occurrences of germanium : Econ. Geology, vol. 23, no. 6, pp. 660-670, September-October, 1928.

Pardee, F. G.

1. Mineral resources of Michigan; Part I, Metallic minerals: Michigan, Geol. Survey, Pub. 37, pp. 5-58, 3 figs., 1928.

Pardee, Joseph Thomas. See also Bretz, 14; Condit, 5 ; Leffingwell, 1 ; Richards, R. W., 2.

1. Geology and mineral deposits of the Colville Indian Reservation, Washington (U. S. Geol. Survey, Bull. 677, 1918) (abstract) : Washington Acad. Sci., Jour., vol. 9, no. 11, p. 315, June 4, 1919.

2. Some manganese deposits in Madison County, Montana (U. S. Geol. Survey; Bull. 690, pp. 131-143, 1918) (abstract by R. W. Stone) : Washington Acad. Sci. Jour., vol. 9, no. 2, pp. 48-49, January 19, 1919.

3. Manganese deposits of the Northwestern States (abstract): Washington Acad. Sci., Jour., vol. 9, no. 13, p. 385, July 19, 1919. 
Pardee, Joseph Thomas-Continued.

4. (and Jones, E. L., jr.). Deposits of manganese ore in Nevada: U. S. Geol. Survey, Bull. 710, pp. 209-248, 1 pl. (map), 2 figs., March 15, 1920. Abstract, Washington Acad. Sci., Jour., vol. 10, no. 20, p. 573, December 4, 1920.

5. (and Larsen, E. S., jr., and Steiger, George). Bementite and neotocite from western Washington, with conclusions as to the identity of bementite and caryopilite: Washington Acad. Sci., Jour., vol. 11, no. 2, pp. 25-32, January 19, 1921.

6. Phosphate rock near Maxville, Granite County, Montana: U. S. Geol. Survey, Bull. 715, pp. 141-145, 1 fig., 1 pl. (map), February 7, 1921. Abstract, Washington Acad. Sci., Jour., vol. 11, no. 16, pp. 393-394, October 4, 1921.

7. Chromite ores in Washington: U. S. Geol. Survey, Bull. 725, pp. 61-65, 1 fig., August 3, 1921.

8. Deposits of manganese ore in Montana, Utah, Oregon, and Washington: U. S. Geol. Survey, Bull. 725, pp. 141-243, 11 figs., 4 pls. (incl. map), August 8, 1921. Abstract, Washington Acad. Sci., Jour., vol. 12, no. 3, pp. 71-72, February 4, 1922.

9. Glaciation in the Cordilleran region [Spokane area, Washington]: Science, new ser., vol. 56, pp. 686-687, December 15, 1922.

10. Geology and ground-water resources of Townsend Valley, Montana: U. S. Geol. Survey, Water-Supply Paper 5்39, 61 pp., 7 figs. (incl. map), 2 pls., 1925.

11. (and Bryan, Kirk). Origin of fossiliferous Latah clays and associated basalts near Spokane [Washington] (abstract): Pan-Am. Geologist, vol. 43, no. 5, pp. 369-370, June, 1925.

12. (and Bryan, Kirk). Geology of the Latah formation in relation to the lavas of Columbia Plateau near Spokane, Washington: U. S. Geol. Survey, Prof. Paper 140, pp: 1-16, 3 figs., 7 pls. (incl. map), Feb. ruary 19, 1926.

13. The Montana earthquake in relation to the geology of the region (abstract) : Seismological Soc. America, Bull., vol. 16, no. 2, p.: 157, June, 1926.

14. The Montana earthquake of June 27, 1925: U. S. Geol. Survey, Prof. Paper 147, pp. 7-23, 11 pls. (incl. maps), September 20, 1926.

1.5. Manganese-bearing deposits near Lake Crescent and Humptulips, Washington: U. S. Geol. Survey, Bull. 795, pp. 1-24, 2 figs., 2 pls. (incl. map), 1927.

16. Changes in elevation of the Rocky Mountains in Pleistocene time as possible climatic factors: Nat. Research Council, Bull. no. 61, pp. 33-35, July, 1927.

17. Earthquake in the Bighorn Mountains, Wyoming, November 17, 1925: Seismological Soc. America, Bull., vol. 17, no. 3, pp. 129-136, 1 fig., September, 1927.

Paredes, Trinidad.

1. Exploración geológica de una parte del Estado de Guerrero [México]: Bol. Minero, t. 6, no. 4, pp. 481-498, October, 1918.

2. Algunos criaderos de fierro en el Estado de Hidalgo: Boletín Minero, t. 8, no. 3-4, pp. 338-351, map, September-October, 1919.

3. (and García, J. Aurelio). Estudio de la Laguna de Cuyutlán, Estado de Colima [México] : Boletín Minero, t. S, nos. 5-6, pp. 584-597, map, November-December, 1919. 
Paredes, Trinidad-Continued.

4. Memoria relativa al objeto, historia y desarrollo del Instituto Geológico Nacional: Soc. cient. "Antonio Alzate," Mem., t. 35, nos. 1-2, pp. 21-50, 12 pls., March, 1920.

5. El petróleo en algunas islas del Golfo de California: Boletín del Petróleo, vol. 9, no. 5, pp. 403-415, 5 pls. (incl. maps), May, 1920.

6. El carbộn y la grafita del Estado de Sonora: Boletín Minero, t. 9, nos. 5-6, pp. 608-613, 1 pl., May-June, 1920.

7. La circulación de las aguas en la falda occidental del Ixtaccihuatl: Soc. cient. "Antonio Alzate," Mem. y Rev., t. 40, no. 1, pp. 1-40, 10 pls., October, 1921.

8. La cuenca artesiana de Zavala, Hacienda de Gorgorrón, San Luis Potosí: Soc. cient. "Antonio Alzate," Mem. y Rev., t. 41, no. 4, pp. 161-183, February, 1923.

9. Circulación de las aguas subterráneas en la falda occidental del Iztaccihuatl : Mexico, Inst. geol., Anales, t. 2, nos. 1-3, pp. 18-37, 1925.

10. Algunos criaderos de fierro en los estados de Guanajuato, Jalisco y Michoacắn : Bol. minero, t. 20, no. 1, pp. 9-27, 1 pl. (map), July, 1925.

11. "La Ferrería" de valle de Bravo, Estado de.México: Bol. minero, t. 22, no. 1, pp. 29-40, 1 pl. (map), July, 1926.

Park, James.

1. Sudbury ore deposits: Econ. Geology, vol. 20, no. 5, pp. 500-504, August, 1925.

Park, John Furness.

1. Mining methods of Jarbidge district [Nevada]: Am. Inst. Min. and Met. Eng., Trans. [preprint] no. 1400, 11 pp., 3 figs., January, 1925.

Parker, Edward Wheeler.

1. Notes on the anthracite region [Pennsylvania]: Mining and Metallurgy, no. 178, pp. 25-26, 3 figs., October, 1921.

Parker, G. H.

1. William Healey Dall (1845-1927) : Am. Acad. Arts and Sci., Proc., vol. 62, no. 9, pp. 251-253, May, 1.928.

Parkins, Almon Ernest.

1. The sand dunes of Lake Michigan: Tennessee Acad. Sci., Jour., vol. 1, no. 3, pp. 12, 15, July, 1926.

Parkinson, John.

1. A note on the petrographical characters of some rocks from the Northern Range of Trinidad: Geol. Mag., vol. 62, pp. 133-136, 1 fig., March, 1925.

2. The Central Range of Trinidad: Geol. Mag., vol. 63, pp. 383-384, August, 1926.

Parks, Emerson M.

1. Migration of oil and water, a further discussion: Am. Assoc. Petroleun Geologists, Bull., vol. 8, no. 6, pp. 697-715, November-December, 1924.

2. Water analyses in oil production and some analyses from Poison Spider, Wyoming: Am. Assoc. Petroleum Geologists, Bull., vol. 9, no. 6, pp. 927-946, 3 figs., September, 1925. 
Parks, Henry Martin.

1. Biennial report of the Oregon Bureau of Mines and Geology for 1917-18. $30 \mathrm{pp}$. [December, 1918].

2. Biennial report of the Oregon Bureau of Mines and Geology for 1919-20. 26 pp. [December, 1920].

Parks, William Arthur. See also Coleman, 9.

1. The great fossil reptiles of Alberta: Hamilton Assoc., Jour. and Proc., no. 29, pp. 131-140, 1919.

2. Preliminary description of a new species of trachodont dinosaur of the genus Kritosaurus: Roy. Soc. Canada, Proc. and Trans., 3d ser,, vol. 13, sec. 4, pp. 51-59, 4 pls., 1920.

3. The osteology of the trachodont dinosaur Kritosaurus incurvimanus: Toronto, Univ., Studies, Geol. Series no. 11, 76 pp., 22 figs., 7 pls., 1920.

4. On Triarthrus canadensis, Triarthrus glaber, and Triarthrus spinosus: Roy. Soc. Canada, Proc. and Trans., 3d ser., vol. 15, sec. 4, pp. 47$52,1 \mathrm{pl}, 1921$.

5. The head and fore limb of a specimen of Centrosaurus apertus: Roy. Soc, Canada, Proc. and Trans., $3 d$ ser., vol. 15, sec. 4, pp. 53-63, 4 pls., 1921.

6. The development of stratigraphic geology and paleontology in Canada: Roy. Soc. Canada, Proc. and Trans., $3 d$ ser., vol. 16, sec. 4, pp. 146, 1922.

7. Paraisaurolophus valkeri, a new genus and species of crested trachodont dinosaur: Toronto, Univ., Studies, Geol. ser. no. 13, 32 pp., 9 pls., 1922.

8. (and Dyer, W. S.). The stratigraphy and paleontology of Toronto and vicinity ; Part 2, The Molluscoidea : Ontario Dept. Mines, 30th Ann. Rept., vol. 30, pt. 7, 43 pp., 7 pls., 1922.

9. (assisted by Madeleine Fritz). The stratigraphy and paleontology of Toronto and vicinity; Part III, Gastropoda, Cephalopoda, and Vermes: Ontario Dept. Mines, 31st Ann. Rept., vol. 31, pt. 9, 45 pp., 6 pls., 1923.

10. Corythosaurus intermedius, a new species of trachodont dinosaur [from the Belly River formation of Red Deer River valley, Alberta]: Toronto, Univ., Studies, Geol. ser., no. 15, 57 pp., 13 figs., 6 pls., 1923.

11. New species of crested trachodont dinosaur (abstract) : Geol. Soc. America, Bull., vol. 34, no. 1, p. 130, March 30, 1923.

12. Dyoplosaurus acutosquameus, a new genus and species of armoured dinosaur; and notes on a skeleton of Prosaurotophus maximus: Toronto, Univ., Studies, Geol. ser., no. 18, 35 pp., 2 figs., 5 pls., 1924.

13. The dinosaurs of Alberta. In Handbook of Canada, pp. 380-383, 1 fig., Toronto, 1924.

14. Upper Ordovician at Toronto, Ontario (abstract, with discussion by George H. Chadwick) : Geol. Soc. America, Bull., vol. 35, no. 1. pp. 103-104, March 30, 1924; abstract, Pan-Am. Geologist, vol. 41, no. 2, pp. 151-152, March, 1924.

15. Paleozoic strata at Toronto (abstract) : Pan-Am. Geologist, vol. 42, no. 1, pp. 67-68, August 1924 ; British Assoc. Adv. Sci., Rept. 92d Meeting. p. $379,1925$. 
Parks, William Arthur-Continued.

16. Dinosaurs of Alberta (abstract) : Pan-Am. Geologist, vol. 42, no. 1, pp. 68-69, August, 1924.

17. The stratigraphy and paleontology of Toronto and vicinity, Part VI; Stratigraphy and correlation of the Dundas formation: Ontario Dept. Mines, 32d Ann. Rept., vol. 32, pt. 7, pp. 89-116, 2 figs., 1925.

18. The stratigraphy and paleontology of Toronto and vicinity: addenda et corrigenda : Ontario Dept. Mines, 32d Ann. Rept., vol. 32, pt. 7, pp. 35-38, 1 pl., 1925.

19. Struthiomimus brevetertius, a new species of dinosaur from the Edmonton formation of Alberta: Roy. Soc. Canada, Proc. and Trans., 3d ser., vol. 20, sec. 4, pp. 65-70, 1 fig., 1 pl., 1926.

20. Arrhinoceratops brachyops, a new genus and species of Ceratopsia from the Edmonton formation of Alberta : Toronto, Univ., Studies, Geol. ser., no. 19, 15 pp., 2 pls., 1925.

21. New genus and species of horned dinosaur from the Cretaceous of Alberta (abstract) : Geol. Soc. America, Bull., vol. 36, no. 1, p. 226, March 30, 1925.

22. Buried Indian workshop with remains of an extinct mammal [in Saskatchewan]: Geol. Soc. America, Bull., vol. 36, no. 2, pp. 429-434, 1 pl., June 30, 1925; abstract, no. 1, pp. 225-226, March 30, 1925.

23. Cultural aspects in geology: Nature, vol. 116, pp. 432-435, September 19, abstract, p. 340, August 29, 1925 ; Pan-Am. Geologist, vol. 44, no. 3, pp. 161-186, October, 1925; British Assoc. Adv. Sci., Rept. 93d Meeting, pp. 55-74, 1926.

24. The dinosaurs of Alberta (abstract) : British Assoc. Adv. Sci., Rept. 92d Meeting, p. 381, 1925.

25. Time and life: Roy. Soc. Canada, Proc. and Trans., $3 d$ ser., vol. 20, pp. lxv-lxxxv, 1926.

26. Thescelosaurus warreni, a new species of orthopodous dinosaur from the Edmonton formation of Alberta: Toronto, Univ., Studies, Geol. ser., no. 21, 42 pp., 18 figs., 2 pls., 1926.

27. Canada's resources in building stone: Canadian Inst. Min. and Met., Bull. no. 156, pp. 367-386, 3 figs., April, 1925; Trans., vol. 28, pp. 141-160, 3 figs. [1926].

28. Trenton-Collingwood-Utica relationships in western Ontario (abstract) : J Geol. Soc. America, Bull., vol. 38, no. 1, p. 229, March 30, 1927 ; PanAm. Geologist, vol. 47, no. 3, p. 238, April, 1927.

29. Champsosaurus albertensis, a new species of rhynchocephalian from the Edmonton formation of Alberta : Toronto, Univ., Studies, Geol. ser., no. 23,48 pp., 25 figs., 2 pls., 1927.

30. Albertosarus arctungus, a new species of therapodous dinosaur from the Edmonton formation of Alberta: Toronto, Univ., Studies, Geol. ser., no. 25, 42 pp., 20 figs., 1 pl., 1928.

31. Some reflections on paleontology : Geol. Soc. America, Bull., vol. 39, no. 1, pp. 387-402, March 30, 1928.

32. Faunas and stratigraphy of the Ordovician black shales and related rocks in southern Ontario: Roy. Soc. Canada, Proc. and Trans., 3d ser., vol. 22, sec. 4, pp. 39-92, 28 figs., 1 pl., March, 1928.

33. Struthiomimus samueli, a new species of Ornithomimidae from the Belly River formation of Alberta: Toronto, Univ., Studies, Geol. ser., no. 26, 24 pp., 5 pls., 1928. 
Parmelee, Cullen Warren.

1. (and Schroyer, C. R.). Further investigations of Illinois fire clays: Illinois, State Geol. Survey, Bull. no. 38, pp. 273-417, 14 figs., 1922. Extract, 149 pp., 14 figs., 1921.

2. Refractory clays of Illinois: Am. Ceramic Soc., Jour., vol. 5, no. 10, pp. 685-692, October, 1922.

Parr. S. W. See Austin, M. M., 1.

Parry, John.

1. Minerals deposited by bacteria in mine water: Eng. and Min. Jour.-Press, vol. 115, no. 23, pp. 1011-1016, 6 figs.; June 9, 1923.

Parsons, Arthur B.

1. Operations of the Mesabi Iron Co.: Eng. and Min. Jour.-Press, vol. 117, no. 4, pp. 157-167, 12 figs., January 26, 1924.

2. The Tintic Standard mine [Tintic district, Utah] : Eng. and Min. Jour.Press, vol. 120, no. 17, pp. 645-652, 7 figs., October 24, 1925.

Parsons, Arthur Leonard. See also Aminoff, 1 ; Knight, C. W., 1; Walker, T. L., $7,11,16,17,18,24,25,26,27,28,32,33,36,39,40,41,42,43,45,46$, $47,48,49,50,51,52,53,54,55$.

1. Calculation in the triclinic system, illustrated by anorthite: Am. Mineralogist, vol. 5, nos. 11 and 12, pp. 190-194, 198-207, 3 figs., November and December, 1920.

2. (and Thomson, E.). Animikite and macfarlanite from Silver Islet, Thunder Bay, Lake Superior: Toronto, Univ., Studies, Geol. ser., nọ. 12, pp. 23-26, 1 pl., 1921.

3. Calcite from Shangoinah Island, near Thunder Cape, Lake Superior: Toronto, Univ., Studies, Geol. ser., no. 12, pp. 51-53, 1 pl., 1921.

4. A third type of proustite from Cobalt, Ontario: Toronto, Univ., Studies, Geol. ser., no. 14, pp. 89-90, 1 fig., 1922.

5. Economic deposits in Thunder Bay district: Ontario Dept. Mines, 30th Ann. Rept., vol. 30, pt. 4, pp. 27-28, 4 figs., 1922.

6. The preservation of mineral specimens: Am. Mineralogist, vol. 7, no. 4, pp. 59-63, April, 1922.

7. The formation of kaolin at moderate depths: Am. Mineralogist, vol. 8, no. 9, pp. 157-162, September, 1923.

8. Xanthoconite from Cobalt, Ontario: Toronto, Univ., Studies, Geol. ser., no. 17, pp. 11-12, 1924.

9. Pectolite and apophyllite from Thetford mines, Quebec: Toronto, Univ., Studies, Geol. ser., no. 17, pp. 55-57, 1924.

10. The Royal Ontario Museum of Mineralogy : Canadian Min. Jour., vol. 45, no. 23, pp. 554-555, 2 figs., June 6, 1924.

11. Albertite in gypsum from Hillsboro, New Brunswick: Toronto, Univ., Studies, Geol. ser., no. 20, pp. 33-34, 1925.

12. Additional data concerning the preservation of minerals: Am. Mineralogist, vol. 11, no. 4, pp: 79-82, April, 1926.

13. The dehydration of gypsum: Toronto, Univ., Studies, Geol. ser., no. 24, pp. 24-27, 1927.

Parsons, C. S.

1. Bathurst iron mine [New Brunswick]: Canadian Min. Jour., vol. 45, no. 49, pp. 1193-11.94, December 5, 1924. 
Pastor Giraud, Antonio.

1. Exploración geologica en la región de La Purísima: Mexico, Inst. Geol.. Bol. no. 39, pp. 93-108, 6 pls. (incl. maps and sections), 1922.

Patterson, J. W. See Stock, 22.

Patton, Horace Bushnell, 1858-1929.

1. Geology and ore deposits of the Platoro-Summitville mining district, Colorado: Colorado Geol. Survey, Bull. 13, 122 pp., 40 pls. (incl. maps), 2 figs., 1917 [1918].

2. Merging of Carlile shale and Timpas limestone formations in southeastern Colorado: Geol. Soc. America, Bull., vol. 34, no. 3, pp. 495-498, 2 figs., September 30, 1923.

3. Underground water possibilities for stock and domestic purposes in the La Junta area, Colorado: Colorado Geol. Survey, Bull. 27, pt. 1. pp. 1-72, 4 figs., 2 pls. (incl. map), 1924.

Patton, Leroy T. See also Sellards, 21.

1. In support of Gardner's theory of the origin of certain concretions: Jour. Geology, vol. 30, no. 8, pp. 700-701, 1 fig., November-December, 1922.

2. The geology of Potter County: 'Texas, Univ., Bull., no. 2330, 184 pp., 4 figs., 9 pls. (incl. map), November, 1923.

3. Geology and the location of dams in west Texas: Econ. Geology, vol. 19, no. 8, pp. 756-761, December, 1924.

4. (and Hicks, Cliftord). Notes on the occurrence of glacial material beyond the border of the drift in Muskingum County, Ohio: Ohio Jour. Sci., vol. 25, no. 2, pp. 97-98, March, 1925.

5. The sandstone dikes around Rockwall, Texas: Holland's Mag., Dallas, Texas, vol. 44, no. 6, pp. 5, \$6, 4 figs., June, 1925.

6. Geology and the location of dams on the Canadian River, Texas: Econ. Geology, vol. 20, no. 5, pp. 464-469, August, 1925.

7. The stratigraphy of western Oklahoma and adjacent parts of Texas: Am. Jour. Sci., 5th ser., vol. 12, pp. 193-197, 1. fig., September, 1926.

Patton, Milton John.

1. The coal resources of Canada: Econ. Geography, vol. 1, no. 1, pp. 73-88, 18 figs., March, 1925. Reprint, Queen's Univ., Kingston, Ontario, Bull. Dept. History . . . no. 50, 19 pp., February, 1925.

Patton, Raymond Stanton.

1. Coast erosion (abstract): Geol. Soc. America, Bull., vol, 35, no. 1, pp. 7677, March 30, 1924 ; Pan-Am. Geologist, vol. 41, no. 2, p. 141, March, 1924.

Patty, Ernest N. See also Whitwell, 1.

1. Dominant features controlling ore deposits of Washington: Eng. and Min. Jour., vol. 110, no. 10, pp. 467-470, 3 figs., September 4, 1920.

2. (and Glover, S. L.). The mineral resources of Washington, with statistics for 1919.: Washington Geol. Survey, Bull. no. 21, 155 pp., 3 figs., 13 pls. (incl. map), 1921.

3. The metal mines of Washington: Washington Geol. Survey, Bull. no. 23, 366 pp., 27 figs., 36 pls. (incl. maps), 1921.

Pautsch, E.

1. Methods of applied geophysics: Am. Assoc. Petroleum Geologists, Bull., vol. 12, no. 8, pp. 863-865, August, 1928.

Paxson, Roland B. See Barton, 5. 
Payne, Henry Mace.

1. The undeveloped mineral resources of the South. 368 pp., American Mining Congress, Washington, D. C., 1928.

Peabody Museum of Natural History, Yale University.

1. General guide to the exhibition halls of the Peabody Museum of Natural History, Yale University. 54 pp., illus., New Haven, 1927.

Peacock, Martin A.

1. (and Fuller, Richard E.). Chlorophaeite, sideromelane, and palagonite from the Columbia River Plateau: Am. Mineralogist, vol. 13, no. 7, pp. 360-383, 1 pl., July, 1928.

Pearce, J. Newton. See Kay, G. F., 4.

Pearce, N. C.

1. Oil in the western provinces [of Canada]: Canadian Min. Jour., vol. 40, pp. 673-676, 3 figs., September 10, 1919.

2. Larder Lake district, northern Ontario: Canadian Min. Jour., vol., 40, pp. 693-695, 2 figs., September 17, 1919.

Pearson, Helga $\mathbf{S}$.

1. Some skulls of Perchoerus (Thinohyus) from the White River and John Day formations: Am. Mus. Nat. Hist., Bull., vol. 48, pp. 61-96, 17 figs., 1923.

Pearson, Peter Henry.

1. Surface marks of oil deposits. 74 pp., 1 fig., published by P. H. Pearson, Washington, D. C., copyright 1920.

Peattie, Roderick.

1. Geography of Ohio: Ohio Geol. Survey, 4th ser., vol. 27, 137 pp., 28 figs.. 8 pls., 1923.

Peck, Albert B. See also Myers, 3.

1. Note on andalusite from California; a new use and some thermal properties: Am.. Mineralogist, vol. 9, no. 6, pp. 123-129, 1 fig., June, 1924; California State Min. Bur., Mining in California, vol. 20, no. 2, pp. 149-154, 1 fig., April, 1924.

2. Changes in the constitution and microstructure of andalusite, cyanite, and sillimanite at high temperatures and their significance in industrial practice: Am. Mineralogist, vol. 10, no. 9, pp. 253-280, 11 figs., September, 1925 ; Am. Ceramic Soc., Jour., vol. 8, no. 7, pp. 407-429. 11 figs., July, 1925.

3. The time factor in the formation of some artificial minerals: Jour. Geology. vol. 34, no. 1, pp. 65-70, 1 fig., January-February, 1926.

4. Dumortierite as a commercial mineral: Am. Mineralogist, vol. 11, no. 4. pp. 96-101, April, 1926.

Peck, Charles Harvey.

1. Our world; a sketch of origins according to science. 215 pp., New York. The Franklaye Press, 1921.

Peck, Frederick Burritt, 1860-1925. See also Pennsylvania, 1; Ries, 5.

1. Occurrence and origin of white clays at Saylorsburg, Monroe County, Pennsylvania (abstract) : Geol. Soc. America, Bull., vol. 30, no. 1. p. 96, March 31, 1919.

2. Vanport limestone of Lawrence County: Pennsylvania Geol. Survey, 4th ser., Bull. M7, pp. 292-304, 1 fig., 1 pl., 1925. 


\section{Pedersen, Alwin.}

1. Einiges über Gletscher und glaziologische Bescheinungen an der Ostküste Grönlands, insbesondere im Bereich des Scoresbysund: Zeitschr. Gletscherkunde, Bd. 15, H. 4-5, pp. 253-260, 6 figs., November, 1927.

Peele, Robert.

1. James Furman Kemp: Eng. and Min. Jour., vol. 122, no. 22, p. 872, portr., November, 27, 1926.

Pegau, A. A. See also Wentworth, 22.

1. Rutherford mines, Amelia County, Virginia : Am. Mineralogist, vol. 13, no. 12, pp. 583-588, December, 1928.

Penck, Albrecht.

1. Geography among the earth sciences: Am. Philos. Soc., Proc., vol. 66, pp. 621-644, 1927.

Pennsylvania, Bureau of Topographic and Geological Survey.

1. Bulletin, nos. 1-94 [mimeographed] :

1. Effect of the war on the price of coal in Pennsylvania, by George H. Ashley. September 24, 1919.

2. Oil and gas in southeast Pennsylvania, by George H. Ashley, October, 1919.

3. Development and probable life of gas pool at McKeesport, Pennsylvania, by George H. Ashley. November 28, 1919.

4. Decline of McKeesport gas pool, by George $\mathrm{H}$ Asbley. December $26,1919$.

5. The McKeesport gas pool, Allegheny County, Pennsylvania, by George H. Ashley. January 12, 1920.

6. River and creek coal in eastern Pennsylvania, by C. W. Webbert. January 16, 1920.

7. A high-grade building stone in Greene County, by George H. Ashley. May 28, 1920.

8. The origin of Pennsylvania coal, by George H. Ashley. May 30, 1920.

9. Future use of raw coal, by George H. Ashley. June, 1920.

10. The possibility of oil and gas from deeper drilling in western Pennsylvania, by George H. Ashley. June 4, 1920.

11. Gas wells on Nine Mile Run, Pittsburgh, Penna., by J. French Robinson. June 26, 1920.

12. Gas wells on Pollock Run, Westmoreland County, Pennsylvania, by J. French Robinson. July 1, 1920.

13. Natural-gas situation in Pennsylvania, by George H. Ashley. October, 1920.

14. Future sources of power, by George H. Ashley. November 24. 1920.

15. Mineral resources of Pennsylvania, by George H. Ashley. December 1, 1920.

16. Geology of oil and gas in relation to coal, by George H. Ashley. December 1, 1920.

17. Future of natural gas in Pennsylvania, by George H. Ashley. December 18, 1920.

18. Oil from Pennsylvania shales and coals; preliminary report of work of Chas. R. Fettke. January 1, 1921.

19. Production of the McKeesport gas pool, by J. French Robinson. January 24, 1921.

20. Pennsylvania iron ores, by J. Ross Corbin. April, 1921.

21. Feldspar in Pennsylvania, by George H. Ashley. September 20, 1921.

22. The coal deposits of southern Somerset County, by J. D. Sisler. [No. date.]

23. Coal beds in Cambria County, Pennsylvania, by J. D. Sisler. January 16,1922 . 
Pennsylvania, Bureau of Topographic and Geological Survey-Continued.

1. Bulletin-Continued.

24. Coal beds in Greene County, Pennsylvania, by J. D. Sisler. January $28,1922$.

25. Coal reserves in Greene County, Pennsylvania, by John F. Reesc. January 31, 1922.

26. Coal beds in Washington County, Pennsylvania, by J. D. Sisler. March 10, 1922.

27. Coal reserves in Washington County, Pennsylvania, by John F.

Reese. March 10, 1922.

28. Magnesite in Pennsylvania, by R. W. Stone. February 10, 1922.

29. Geologic structure of the Greensburg quadrangle, Penna., by M. E. Johnson. February 25, 1922.

30. Coal beds in Allegheny County, Pennsylvania, by J. D. Sisler. April 18, 1922.

31. Coal reserves in Allegheny County, Pennsylvania, by John F. Reese. April 18, 1922 .

32. Coal beds in Fayette County, Pennsylvania, by J. D. Sisler. March 15, 1922.

33. Coal reserves in Fayette County, Pennsylvania, by John F. Reese. March 15, 1922.

34. Coal beds in Westmoreland County, by J. D. Sisler. March 25, 1922.

35. Coal reserves in Westmoreland County, Pennsylvania, by John F.

Reese. March 25, 1922.

36. Coal beds in Indiana County, Pennsylvania, by J. D. Sisler. April $27,1922$.

37. Coal reserves in Indiana County, Pennsylvania, by John E. Reese. April 29, 1922.

38. Coal beds in Armstrong County, Pennsylvania, by J. D. Sisler. May 10, 1922.

39. Coal reserves in Armstrong County, Pennsylvania, by John F. Reese. May 20, 1922.

40. White clay deposits at Saylorsburg, Monroe County, Pennsylvania, by Frederick B. Peck. June 3, 1922.

41. Coal beds in Elk County, Pennsylvania, by J. D. Sisler. June 24, 1922.

42. Coal beds in Jefterson County, Pennsylvania, by J. D. Sisler. May 25, 1922.

43. Coal reserves in Somerset County, Pennsylvania, by John F. Reese. June 15, 1922.

44. Coal reserves in Cambria County, Pennsylvania, by John F. Reese. June 20, 1922

45. White clay deposits in central Pennsylvania, by E. S. Moore. July 5, 1922.

46. Coal beds in Butler County, Penusylvania, by J. D. Sisler. June 21, 1922.

47. Manganese occurrences in eastern Pennsylvania, by Benjamin $L$. Miller, July 15, 1922.

48. Pyrite from bituminous coal mines in Pennsylvania, by Henry Leighton. July 26, 1922.

49. Coal beds in Clarion County, Pennsylvania, by J. D. Sisler.' September 10, 1922.

50. Coal beds in Center, Cameron, Clinton, and Lycoming counties, Pennsylvania, by J. D. Sisler. September 12, 1922.

51. New oil pool at Tidioute and gas pools near Corry and Meadville, Penna., by M. E. Johnson. July 28, 1922.

52. Coal beds in Mercer, Crawford, Venango, Forest, Warren, McKean, Potter, Tioga, and Bradford counties, Pennsylvania, by J. D. Sisler. September 15, 1922.

53. Coal reserves in Clearfield County, Pennsylvania, by John F. Reese. August 22, 1922.

54. Bituminous coal reserves in Pennsylvania, by John F. Reese. August 1, 1922.

55. Coal beds in Lawrence County, Pennsylvania, by J. D. Sisler. September 25. 1922. 
Pennsylvania, Bureau of Topograph:c and Geological Survey-Continued.

1. Bulletin-Continued.

56. Oil fields rejuvenated, by Robert B. Bossler. September 1, 1922.

57. Coal beds in Beaver County, Pennsylvania, by J. D. Sisler. Octobel: $30,1922$.

58. Potash fiasco in Tioga County, Pennsylvania, by R. W. Stone, and Simple tests for potash, by W. B. Hicks. October 31, 1922.

59. Bog-iron ore, by J. Ross Corbin. December 12, 1922.

60. Geologic structure of the Pittsburgh quadrangle, Pa., by M. E. Johnson. January 15, 1923.

61. Magnetite in Pennsylvania, by $J$. Ross Corbin. January 22, 1923.

62. Rocks of the McCalls Ferry quadrangle, Penna., by Anna I. Jonas. February 3, 1923.

63. Brown iron ores in Pennsylvania, by J. Ross Corbin. February $15,1923$.

64. Coal beds in southern Somelset County, Pennsylvania, by James D. Sisler. February 20, 1923.

65. Lead and zinc ores in Blair County, Penna., by Benjamin LeRoy Miller. March 5, 1923.

66. Oil and gas development in Pennsylvania in 1922 , by M. E. Johnson. March 6, 1923.

67. Lead and zinc ores near Phoenixville, Chester County, Pennsylvania, by Benjamin LeRoy Miller. March 19, 1923.

68. Lead and zinc ores in Lancaster County, Pennsylvania, by Benjamin LeRoy Miller. March 17, 1923.

69. Lead and zinc ores in Bucks County, Pennsylvania, by Benjamin LeRoy Miller. March 15, 1923.

70. Zinc ores at Friedensville, Lehigh County, Penna., by Benjamin LeRoy Miller. March 20, 1923.

71. Copper ores in Pennsylvania, by J. Ross Corbin. April 2, 1923.

72. Flagstone industry in northeastern Pennsylvania, by $\mathbf{R}$. W. Stone. April 5, 1923.

73. Oll and gas sands in the north half of the Pittsburgh quadrangle, Penna., by M. E. Johuson. April 20, 1923.

74. Chromite in Pennsylvania, by. J. Ross Corbin. April 20, 1923.

75. Rocks of the Quarryville quadrangle, Penna., by Anna I. Jonas.

April 25, 1923.

76. Calcareous marl in Pennsylvania south of the terminal moraine by J. B. R. Dickey. May 3, 1923.

77. Gold in Pennsylvania, by J. Ross Corbin. May 5, 1923.

78. Gas in Leidy Township, Clinton County, Penna., by Meredith E. Johnson. June 12, 1923.

79. Tidioute oil pool, Warren County, Pa., by Meredith E. Johnson. July 17, 1923.

80. Coal beds in northern Somerset County, Pennsylvania, by James

D. Sisler. September 15, .1923.

81. Volatile matter in Pennsylvania coals, by James D. Sisler. November 1, 1923.

82. Roofing granules industry in southeastern Pennsylvania, by

R. W. Stone. November 10, 1.923.

83. The living earth, by Geo. H. Ashley. Tanuary 10, 1924.

84. Coal reserves in Clarion County, Pennsylvania, by James D.

Sisler. March 10, 1924.

85. Coal reserves in Jefferson County, Pennsylvania, by James $\mathrm{D}$.

Sisler. March 20, 1924.

86. The age and origin of the earth, by George H. Ashley, 8 pp., June 10, 1924.

87. Molding sands in Pennsylvania, by R. W. Stone, 20 pp., August $8,1925$.

88. Silurian stratigraphy at Lehigh Gap, by George H. Ashley, 6 pp., November $23,1925$.

89. A practical classification of coals, by George H. Ashley, 16 pp., March, 1926.

90. Pennsylvania, the makings of a world power, by George $\mathrm{H}$. Ashley, 23 pp., August 25, 1926. 
Pennsylvania, Bureau of 'Topographic and Geological Survey-Continued.

1. Bulletin-Continued.

91. A stratigraphic time scale, by George H. Ashley, 10 pp., March 30,1927 .

92. Anthracite culm and silt, by James D. Sisler, 9 pp., January $23,1928$.

93. The Canadian system, by George H. Asbley, 10 pp., April 2, 1928.

94. High spots in Pennsylvania, by George H. Ashley, 8 pp., May 5, 1928.

2. [Report] : Pennsylvania, Dept. Forests and Water's, Rept. June 1, 1924, to May 31, 1926, pp. 26-31 [1927].

Penrose, Richard Alexander Fullerton, jr.

1. Radium and uranium; their ores and occurrence in nature: New York State Mus. Bull., nos. 207, 208, pp. 199-208, 1919.

2. The relation of economic geology to the general principles of geology: Econ. Geology, vol. 16, no. 1, pp. 48-51, January, 1921. Abstract, Eng. and Min. Jour., vol. 111, no. 2, pp. 65-66, January 8, 1921.

3. The Society of Economic Geologists; its sphere and its future: Econ. Geology, vol. 17, no. 2, pp. 124-127, March-April, 1922.

4. (and Ball, S. H.). Summary of proceedings of the Society of Economic Geologists, 1920-21. A publication of the Society of Economic Geologists. 16 pp. [1922].

5. Memorial to John Casper Branner: Geol. Soc. America, Bull., vol. 36, no. 1, pp. 15-44, portr., March 30, 1925.

6. Biographical memoir John Casper Branner, 1850-1922: Nat. Acad. Sci., Mem., vol. 21, 3d mem., 20 pp., portr., 1926.

Pentland, A. See also Wallace, 21.

1. A method of measuring the angularity of sands (abstract): Roy. Soc. Canada, Proc. and Trans., 3d ser., vol. 21, sec. 4, p. xciii, 1927.

Pepperberg, Leon J. See also Mills, R. V. A., 5.

1. Thermal currents as a factor in oil accumulation: Am. Assoc. Petroleum Geologists, Bull., vol. 7, no. 4, pp. 429-431, July-August, 1923.

Perini, V. C., jr. See also Coffin, 1 ; Crawford, R. D., 1.

1. (and Collins, M. J.). Anticlines in Routt and Moffat counties: Colorado Geol. Survey, Bull. 24, pp. 7-46, 10 figs., 1 pl. (map), 1920.

Perkins, Edward H.

1. The origin of the Dighton conglomerate of the Narragansett basin of Massachusetts and Rhode Island: Am. Jour. Sci., 4th ser., vol. 49, pp. 61-75, 1 fig., January, 1920.

2. A new graptolite locality in central Maine; with notes on the graptolites by Rudolf Ruedemann : Am. Jour. Sci., 5th ser., vol. 8, pp. 223-227, September, 1924.

3. (and Smith, Edward S. C.). Contributions to the geology of Maine, No. 1; A geological section from the Kennebec River to Penobscot Bay: Am. Jour. Sci., 5th ser., vol. 9, pp. 204-228, 7 figs. (incl. maps), March, 1925.

4. Contributions to the geology of Maine, No. 2; Part 1, The Moose River sandstone and its associated formations: Am. Jour. Sci., 5th ser., vol. 10, pp. 368-375, 1 fig. (map), October, 1925.

$4096-31-31$ 
Perkins, Edward H.-Continued.

5. Contributions to the geology of Maine, No. 3; The evolution of the drainage of the Waterville region: Am. Jour. Sci., 5th ser., vol. 14, pp. 352-364, 3 figs., November, 1927.

Perkins, George Henry.

1. Report of the State geologist on the mineral industries and geology of Vermont, 1917-18: Eleventh of this series. 247 pp., 18 pls., 10 figs. [1919].

2. Physiography of Vermont: Vermont, State Geologist, 11th Rept., pp. 1-44 [1919].

3. The physiography of Vermont: Science, new ser., vol. 49, pp. 77-81, January 24, 1919.

4. The geology of Mill Stone Hill [Barre, Vermont] : Vermont Soc. Engineers, Proc., pp. 6-10, October 8, 1920.

5. A detailed study of the Trenton beds of Grand Isle: Vermont, State Geologist, Twelfth Rept., 1919-20, pp. 77-89, 4 pls., 1921.

6. Mineral resources: Vermont, State Geologist, Twelfth Rept., 1919-20, pp. 299-326, 5 pls., 1921.

7. History and summary of geological work in Vermont, 1810-1923: Vermont, State Geologist, Thirteenth Rept., 1921-22, pp. 1-70, 1923.

8. Mineral resources: Vermont, State Geologist, Thirteenth Rept., 1921-22, pp. 329-338, 1923.

9. The geology of Grand Isle County: Vermont, State Geologist, Fourteenth Rept., 1923-24, pp. 63-71, 1924.

10. Mineral resources: Vermont, State Geologist, Fourteenth Rept., 1923-24, pp. 344-351, 1924.

11. Report of the State geologist on the mineral industries and geology of Vermont, 1925-26, fifteenth of this series, 322 pp., 46 pls., Burlington, Vt., 1927.

12. The present state of our knowledge of peat: Vermont, State Geologist, Fifteenth Rept., 1925-26, pp. 1-38, 1927.

13. Mineral resources, 1926-27: Vermont, State Geologist, Fifteenth Rept., 1925-26, pp. 264-271, 1927.

Perkins, T. A.

1. As to the filling of veins: Eng. and Min. Jour.-Press, vol. 116, no. 23, p. 991, December 8, 1.923.

Perrine, Irving. See Woodruff, 1.

Perry, E. L.

1. Summary report on the geology of Plymouth and Bridgewater, Vermont: Vermont, State Geologist, Fifteenth Rept., 1925-26, pp. 160-162, 1927.

Perry, Eugene S. See also Kentucky G. S., 43.

1. Geological map of Lewis County, Kentucky: Kentucky Geol. Survey, Ser, 6, 1925. Scale, 1 inch $=1$ mile.

2. The Kevin-Sunburst and other oil and gas fields of Sweetgrass arch:. Montana, State Bur. Mines and Met., Mem. no. 1, 41 pp. and 3 figs (mimeographed), 8 pls., December, 1928.

Perry, Gene.

1. Subsurface structure of eastern Kentucky: Am. Assoc. Petroleum Geologists, Bull., vol. 8, no. 2, pp. 152-157, 4 figs., March-April, 1924. 
Peterson, Eunice.

1. Block faulting in the St. Croix Valley [Minnesota] : Jour. Geology', vol. 35, no. 4, pp. 368-374, 4 figs., (incl. map), May-June, 1927.

Peterson, Olof August.

1. Report upon the material discovered in the upper Eocene of the Uinta Basin by Earl Douglass in the years 1908-9, and by O. A. Peterson in 1912 : Carnegie Mus., Annals, vol. 12, nos. 2-4, pp. 40-168, 14 pls., 19 figs., October, 1919.

2. The American diceratheres : Carnegie Mus., Mem., vol. 7, no. 6, pp. 399-476, 10 pls., 37 figs., July, 1920.

3. A fossil-bearing slab of sandstone from the Agate Spring quarries of western Nebraska exhibited in the Carnegie Museum: Carnegie Mus., Annals, vol. 15, no. 1, pp. 91-93, 1 fig., 1 pl., March, 1923.

4. The hyoid arch of the Miocene camel Stenomylus: Carnegie Mus., Annals, vol. 15, no. 1, pp. 94-95, 1 pl., March, 1923.

5. Restoration of Merychyus elegans subsp. minimus Peterson: Carnegie Mus., Annals, vol. 15, no. 1, pp. 96-103, 10 figs., 2 pls., March, 1923.

6. Discovery of fossil mammals in the Brown's Park formation of Moffat County, Colorado: Carnegie Mus., Annals, vol. 15, nos. 2 and 3, pp. 299-304, 3 figs., July, 1924.

7. Osteology of Dolichorhinus longiceps Douglass, with a review of the species of Dolichorhinus in the order of their publication: Carnegie Mus., Mem., vol. 9, no. 4, pp. 405-472, 18 figs., 14 pls., November, 1924.

8. The Brown's Park formation: Science, new ser., vol. 63, p. 231; February $26,1926$.

9. The fossils of the Frankstown cave, Blair County, Pennsylvania: Carnegie Mus., Annals, vol. 16, no. 2, pp. 249-314, 10 figs., 9 pls., March, 1926.

10. The inferior dentition of a young mastodon: Carnegie Mus., Annals, vol. 17, no. 2, pp. 255-257, 2 figs., May, 1927.

11. The Brown's Park formation: Carnegie Mus., Mem., vol. 11, no. 2, pp. 87-121, 24 figs., 7 pls., April 8, 1928.

Peterson, Orrin P.

1. Some geological features and court decisions of the Utah Apex-Utah Consolidated controversy, Bingham district [Utah] : Am. Inst. Min. and Met. Eng., Trans., vol. 70, pp. 904-932, 13 figs., 1924; [preprint] no. 1341, 29 pp., 13 figs., June, 1924; abstract, Mining and Metallurgy, vol. 5, no. 216, pp. 597-598, December, 1924.

Peterson, P. P.

1. Rate and mode of soil deposition in the Palouse area of Washington and Idaho: Science, new ser., vol. 55, pp. 102-103, January 27, 1922.

Peterson, William.

1. Dinosaur tracks in the roofs of coal mines; a strange phenomenon noted in Utah and Colorado: Natural. History (Am. Mus. Nat. Hist., Jour.), vol. 24, no. 3, pp. 38s-391, 4 figs., May-June, 1924.

Petrascheck, Wilhelm.

1. Kristalliner Magnesit in Amerika: Montanistische Rundschau, Jg. 14, no. 1.2, pp. 262-263, June 16, 1922.

2. Metallogenetic zones: Econ. Geology, vol. 18, no. 8, pp. 777-778, December, 1923.

Petrunkevitch, Alexander.

1. Tertiary spiders and opilionids of North America : Connecticut Acad. Arts and Sci., Trans., vol. 25, pp. 211-279, 30 figs., March, 1922. 
Petry, Loren C. .

1. Fossil plants showing structure from late Devonic rocks of New York (abstract) : Pan-Am. Geologist, vol. 44, no. 1, p. 76, August, 1925.

Pettijohn, Francis J.

1. Intraformational phosphate pebbles of the Twin City Ordovician: Jour. Geology, vol. 34, no. 4, pp. 361-373, 2 figs., May-June, 1926.

Phalen, William Clifton.

1. Salt resources of the United States: U. S. Geol. Survey, Bull. 669, 284 pp., 17 pls. (incl. maps), 16 figs., 1919. Abstract by R. W. Stone, Washington Acad. Sci., Jour., vol. 9, no. 19, p. 600, November 19, 1919.

2. The magnesite industry in the United States: Min. and Sci. Press, vol. 119, pp. 295-298, 5 figs., August 30, 1919.

Phelps, Robert William.

1. (and Lake, Francis Wilbur). Petroleum engineering. 574 pp., 107 figs., Houston, Texas, Gulf Publishing Company, 1924.

Phemister, Thomas Crawford. See also Johannsen, 7, 8; Williams, M. Y., 17.

1. The determination of $2 \mathrm{~V}$ in sections perpendicular to an optic axis: Jour. Geology, vol. 32, no. 5, pp. 400-406, 7 figs., July-August, 1924.

2. A note on the Lancaster Gap mine, Pennsylvania: Jour. Geology, vol. 32, no. 6, pp. 498-510, 8 figs., August-September, 1924.

3. A criticism of the application of the theory of assimilation to the Sudbury sheet: Jour. Geology, vol. 33, no. 8, pp. 819-824, November-December, 1925.

4. Igneous rocks of Sudbury and their relation to the ore deposits: Ontario Dept. Mines, 34th Ann. Rept., vol. 34, pt. 8, 61 pp., illus., 1926.

5. Evidence of assimilation and assimilation processes: Jour. Geology, vol. 34 , no. 7 , pp. 653-656, October-November, 1926.

6. A comparison of the Keweenawan sill rocks of Sudbury and Cobalt, Ontario: Roy. Soc. Canada, Proc. and Trans., 3d ser., vol. 22, sec. 4, pp. 121-197, 7 figs., 4 pls., May, 1928.

Phillips, Alexander Hamilton.

1. Thomsonite from Peekskill, New York: Am. Mineralogist, vol. 9, no. 12, pp. 240-241, December, 1924.

2. Memorial of Washington A. Roebling: Am. Mineralogist, vol. 12, no. 3, pp. 64-67, 1 fig. (portr.), March, 1927.

Picher, Rodolphe Hector.

1. Road materials in a portion of Vaudreuil County, Quebec, and along the St. Lawrence River from the Quebec boundary to Cardinal, Ontario: Canada, Geol. Survey, Mem. 106, 12 pp., 1918.

2. Report on road materials along the St. Lawrence River, from the Quebec Boundary line to Cardinal, Ontario: Canada, Mines Branch, Bull. no. 32, 65 pls., map, 1920.

3. Investigations of road materials in New Brunswick and Nova Scotia: Canada, Mines Branch, Investigations in Ceramics and Road. Materials, 1924, pp. 18-45, 1925 .

4. Road materials in eastern Ontario: Canada, Dept. Mines, Mines Branch, Investigations in Ceramics and Road Materials, pp. 23-29, 1926.

Pieper, H. K. See Hertel, 2. 
Piers, Harry.

1. Obituary notice of Walter Henry Prest, geologist, 1856-1920: Nova Scotian Inst. Sci., Trans., vol. 15, pt. 4, pp. xli-xliii, November 1, 1923.

2. On a new tungsten (scheelite) deposit at Lower Sackville, Halifax County, Nova Scotia: Nova Scotian Inst. Sci., Proc. and Trans., vol. 16, pp. 38-45, November 21, 1927.

Piggot, Charles Snowden.

1. Lead isotopes and the problem of geologic time: Washington Acad. Sci., Jour., vol. 18, no. 10, pp. 269-273, May 19, 1928.

2. The radium content of Stone Mountain granite: Washington Acad. Sci., Jour., vol. 18, no. 11, pp. 313-316, June 4, 1928.

Pike, F. H.

1. On the difficulties encountered in the evolution of air-breathing vertebrates: Science, new ser., vol. 59, pp. 402-403, May 2, 1924.

Pike, R. W.

1. Geological studies in the San Antonio and Nacimiento River valleys, Monterey County, California (abstract) : Geol. Soc. America, Bull., vol. 37, no. 1, p. 213, March 30, 1926.

Pilsbry, Henry Augustus.

1. Revision of W. M. Gabb's Tertiary Mollusca of Santo Domingo: Acad. Nat. Sci. Philadelphia, Proc., vol. 73, pt. 2, pp. 305-428, 48 figs., 32 pls., 1922.

2. Recent and fossil Bermudan snails of the genus Poecilozonites: Acad. Nat. Sci. Philadelphia, Proc., vol. 76, pp. 1-9, 6 figs., 1924.

3. Miocene and Pleistocene Cirripedia from Haiti: U. S. Nat. Mus. Proc., vol. 65, art. 2, 3 pp., 1 pl., 1924.

4. William Healey Dall: Nautilus, vol. 41, no. 1, pp. 1-6, July, 1927.

Pinger, A. W. See Palache, 13.

Pinkley, George R.

1. (and Roth, Robert). An altered volcanic ash from the Cretaceous of western Kansas: Am. Assoc. Petroleum Geologists, Bull., vol. 12, no. 10, pp. 1015-1022; 3 figs., October, 1928.

Piper, Arthur M. See also Laney, 1.

1. Geology and water resources of the Goose Creek basin, Cassia County, Idaho: Idaho, Bur. Mines and Geology, Bull. no. 6, 78 pp., 6 pls. (incl. map), 1923.

2. Geology and water resources of the Bruneau River basin, Owyhee County, Idaho: Idaho, Bur. Mines and Geology, Pamphlet no. 11, 56 pp., maps (n. d., 1924?) [mimeographed].

3. Possibilities of petroleum in Power and Oneida counties, Idaho: Idaho, Bur. Mines and Geology, Pamphlet no. 12, 24 pp., 1 fig., 4 pls. (maps), December, 1924 [mimeographed].

4. Ground water for irrigation on Camas Prairie, Camas and Elmore counties, Idaho: Idaho, Bur. Mines and Geology, Pam. 15, 46 pp., 6 figs., 1 pl. (map) [1926] [mimeographed].

5. (and Kirkham, Virgil R. D.). Ground water for municipal supply at Idaho Falls, Idaho: Idaho, Bur. Mines and Geology, Pam. no. 16, 13 pp. [1926] [mimeographed]. 
Piper, Arthur M.-Continued.

6. (and Laney, Francis B.). Geology and metalliferous resources of the region about Silver City, Idaho: Idaho Bur. Mines and Geology, Bull. no. 11, 165 pp., 6 figs., 13 pls. (incl. maps), December, 1926.

7. Metalliferous resources of Silver City, Idaho (abstract): Washington Acad. Sci., Jour., vol. 17, no. 9, pp. 237-238, May 4, 1927.

8. The origin of artesian pressure: Econ. Geology, vol, 23, no. 6, pp. 683-696, September-October, 1928.

Pirsson, Louis Valentine, $1860-1919$.

1. Rock classification for engineering: Econ. Geology, vol. 14, no. 3, pp. 264266, 1 fig., May, 1.919.

2. A textbook of geology . . Part I, Physical geology. 2d ed., 470 pp., 319 figs., map, New York, John Wiley \& Sons, 1920.

3. Biographical memoir of James Dwight Dana, 1813-1895: Nat. Acad. Sci., Biog. Mem., vol. 9, pp. 41-92, portr., December, 1919.

4. The classification of igneous rocks; a study for students: Am. Jour. Sci., 5th ser., vol. 2, pp. 265-284, November, 1921.

5. (and Schuchert, Charles). Introductory geology for use in universities, colleges, schools of science, etc., and for the general reader. Part I, Physical geology, by Louis V. Pirsson; Part II, Outlines of historical geology, by Charles Schuchert, x, 693 pp., illus., mạp, New York, J. Wiley \& Sons, 1924.

6. Rocks and rock minerals; a manual of the elements of petrology without the use of the microscope. Second edition, revised by Adolph Knopf. 426 pp., 74 figs., 36 pls., New York, John Wiley \& Sons, 1926.

Pirtle, G. W. See Kentucky G. S., 7, 12.

Platts, John B.

1. Replacement by ores: Eng. and Min. Jour.-Press, vol. 121, no. 6, pp. 249250, February 6, 1.926.

Plummer, Frederick Byron. See also Moore, R. C., 13.

1. Preliminary paper on the stratigraphy of the Pennsylvanian formations of north-central Texas (with discussion) : Am. Assoc. Petroleum Geologists, Bull., vol. 3, pp. 132-150, 3 figs., 1919.

2. Progress in petroleum geology: Am. Assoc. Petroleum Geologists, Bull., vol. 5; no. 3, pp. 413-416, May-June, 1921.

3. A new compass for geologists: Am. Assoc. Petroleum Geologists, Bull., vol. 5, no. 4, pp. 511-512, 1 fig., July-August, 1921.

4. (and Moore, R. C.). Stratigraphy of the Pennsylvanian formations of north central Texas: Texas, Univ., Bull. no. 2132, 237 pp., 19 figs., 27 pls. (incl. map) [1922].

5. (and Plummer, H. J.). Midway correlations on the basis of Foraminifera (abstract) : Pan-Am. Geologist, vol. 49, no. 4, p. 297, May, 1928; Geol. Soc. America, Bull., vol. 39, no. 1, p. 278, March 30, 1928.

Plummer, Helen Jeanne. See also Plummer, F. B., 5.

1. Foraminifera of the Midway formation in Texas: Texas, Univ., Bull. no. 2644, 206 pp., 15 pls. (incl.. map), November 22, 1926.

Plyler, E. K.

1. The growth of ice crystals: Jour. Geology, vol. 34, no. 1, pp. 58-64, 2 figs.. January-February, 1926. 
Pogue, Joseph Ezekiel. See also Gilbert, C. G., 1 ; Matteson, 2.

1. Geology as a basis of citizenship (abstract) : Geol. Soc. America, Bull., vol. 30, p. 77, March 31, 1919.

2. The economics of petroleum. 375 pp., 150 figs., New York, John Wiley \& Sons, 1921.

3. Optical fluorite in southern Illinois: Illinois, State Geol. Survey, Bull. no. 38 , pp. 419-425, 1 fig., 1922.

Pohl, Erwin R.

1. Geological explorations in Michigan: Smithsonian Inst., Explorations and Field Work in 1927, pp. 27-32, 6 figs., 1928. (Pub. 2957.)

Poindexter, O. F.

1. (and Newcombe, R. B.). Mineral resources of Michigan; Part II, Nonmetallic minerals: Michigan, Geol. Survey, Pub. 37, pp. 59-139, 7 figs., 1928.

Poitevin, Eugene. See also Ellsworth, 1.

1. Crystallography of some Canadian minerals; albite, titanite, scapolite, and polycrase: Am. Mineralogist, vol. 4, no. 2, pp. 11-13, 2 figs., February, 1919.

2. Crystallography of some Canadian minerals; stephanite, epidote, and calamine: Am. Mineralogist, vol. 4, no. 3, pp. 22-25, 3 figs., March, 1919.

3. Crystallography of some Canadian minerals; axinite: Am. Mineralogist, vol. 4, no. 4, pp. 32-36, 5 figs., April, 1919.

4. Crystallography of some Canadian minerals; cerusite: Am. Mineralogist, vol. 4, no. 5, pp. 56-58, 8 figs., May, 1919.

5. (and Ellsworth, H. V.). Inyoite from New Brunswick: Canada, Geol. Survey, Bull. no. 32, 18 pp., 10 figs., 3 pls., May, 1921.

6. Platiniferous rocks from Tulameen map area, Yale district, British Columbia, and Ural Mountains, Russia : Canada, Geol. Survey, Summ. Rept., 1923, pt. A., pp. 84-101, 5 figs. (incl. maps), 2 pls., 1924.

7. (and Ellsworth, H. V.). New optical data for analyzed sussexite: Am. Mineralogist, vol. 9, no. 9, pp. 188-190, September, 1924.

8. A new occurrence of lansfordite from Atlin, British Columbia: Am. Mineralogist, vol. 9, no. 11, pp. 225-228, 2 figs., November, 1924.

9. Mineralogy at Ottawa: Canadian Min. Jour., vol. 46, no. 9, pp. 227-228, February, 1925.

10. Contributions to Canadian mineralogy, 1926: Canada, Geol. Survey, Bull. no. 46, pp. 1-21, 7 figs., 1927. [Pub. 2125.]

Pollock, James B.

1. The amount of the geologically recent negative shift of strand line on Oahu: Washington Acad. Sci., Jour., vol. 18, no. 3, pp. 53-59, February 4, 1.928.

2. A study of the fringing and fossil coral reefs on Oahu, one of the Hawaian Islands (summary): Third Pan-Pacific Sci. Cong., Tokyo, 1926, Proc., pp. 1834-1836, 1928.

3. Fringing and fossil coral reefs of Oahu : Bernice P. Bishọp Mus., Bull. 55, 56 pp., 3 figs., 6 pls., 1928.

Pompeckj, Josef Felix.

1. Is the earth growing old?: Smithsonian Inst., Ann. Rept., 1927, pp. 255-270, 1928.

Pond, W. F. See Greene, 8. 
Ponton, Gerald M.

1. (and Whitehurst, John W.). The Spring Hill-Sarepta gas field, Webster and Bossier parishes, Louisiana: Am. Assoc. Petroleum Geologists, Bull., vol. 7, no. 5, pp. 546-554, 1 fig., September-October, 1923.

Poor, Russell Spurgeon.

1. The character and significance of the basal conglomerate of the Pennsylvanian system in southern Illinois : Illinois State Acad. Sci., Trans., vol. 18, pp. 369-375, 1 fig. (map), 1925.

2. Oil possibilities of the Galesburg quadrangle, Knox and Warren counties, Illinois: Illinois, State Geol. Survey, Illinois Petroleum, Press Bull. ser., no. 9, 8 pp., 2 figs., June 18, 1927.

Porter, Charles A. See also Beeson, 1 ; Lindgren, 18.

1. The economic aspect of economic geology : Min. and Sci. Press, vol. 122, pp. 161-162, January 29, 1921.

2. Minor crustal movements and ore deposits : Eng. and Min. Jour.-Press, vol. 118, no. 20, pp. 781-782, 1 fig., November 15, 1924.

3. Intersecting fracture zones and mineral districts: Eng. and Min. Jour.Press, vol. 118, no. 17, pp. 650-652, 2 figs., October 25, 1924.

Porter, Mary W.

1. Practical crystal drawing: Am. Mineralogist, vol. 5, no. 5, pp. 89-95, 4 figs., May, 1920.

Porter, William W., II.

1. The New England earthquake of January 7, 1925: Seismol. Soc. America, Bull., vol. 14, no. 4, pp. 233-239, 1 fig., December, 1924 [1925].

Posnjak, Eugen. See also Merwin, 1, 6; Sosman, 10.

1. (and Merwin, H. E.). The hydrated ferric oxides: Am. Jour. Sci., 4th ser., vol. 47, pp. 311-348, 5 figs., May, 1919.

2. (and Tunell, George). Studies of weathering and sedimentation: Carnegie Inst. Washington, Year Book no. 27, 1927-28, pp. 71-76, 2 figs., December, 1928.

Poulsen, Chr.

1. The Cambrian, Ozarkian, and Canadian faunas of northwest Greenland: Meddelelser om Grønland, Bd. 70, pp. 233-343, 10 figs., 8 pls., 1927; also issued as Communications paléntologiques, no. 24, Muséum de Minéralogie et de géologie de l'Université de Copenhague.

Powell, W. Carlos. See also Black, R. F., 1.

1. (and Staley, C. G.) Report on investigation of the geology and water resources of the Tularosa basin: New Mexico, State Eng., 8th Bienn. Rept., pp. 193-206, map [1928].

Powers, Sidney. See also Bowen, N. L., 14; Hobbs, 16 ; Hopkins, O. B., 1, 2 ; Miser, 3 ; Tomlinson, 4.

1. Intrusive bodies at Kilauea: Zeitschr. Vulkanologie, Bd. 3, H. 1, pp. 28-35, October, 1916.

2. The Sabine uplift, Louisiana: Am. Assoc. Petroleum Geologists, Bull., vol. 4, no. 2, pp. 117-136, 2 figs., 1920.

3. The Butler salt dome, Freestone County, Texas: Am. Jour. Sci., 4th ser., vol. 49, pp. 127-142, 2 figs., February, 1920.

4. A lava tube at Kilauea: Hawaiian Volcano Observatory, Monthly Bull., vol. 8, no. 3, pp. 46-49, March, 1920. 
Powers, Sidney-Continued.

5. Notes on Hawaiian petrology : Am. Jour. Sci., 4th ser., vol. 50, pp. 256-280, 3 figs., October, 1920.

6. Strand markings in the Pennsylvanian sandstones of Osage County, Oklahoma : Jour. Geology, vol. 29, no. 1, pp. 66-80, 7 figs., JanuaryFebruary, 1921.

7. Petroleum geology-its past and its future: Am. Assoc. Petroleum Geologists, Bull., vol. 5, no. 4, pp. 445-446, July-August, 1921.

8. The number of American geologists : Am. Assoc. Petroleum Geologists, Bull., vol. 5, no. 4, pp. 499-500, July-August, 1921.

9. Solitario uplift, Presidio-Brewster counties, Texas: Geol. Soc. America, Bull., vol. 32, no. 4, pp. 417-428, 4 figs., December 1, 1921; abstract, no. 1, pp. 46-47, March 31, 1921.

10. Gastropod trails in Pennsylvanian sandstones in Texas: Am. Jour. Sci., 5th ser., vol. 3, pp. 101-107, 3 figs., February, 1922.

11. Reflected buried hills and their importance in petroleum geology: Econ. Geology, vol. 17, no. 4, pp. 233-259, 2 figs., June-July, 1922.

12. (and Hopkins, O. B.). The Brooks, Steen, and Grand Saline salt domes. Smith and Van Zandt counties, Texas: U. S. Geol. Survey, Bull., 736, pp. 179-239, 2 figs., 4 pls., December 23, 1922.

13. New geological map of Oklahoma: Am. Assoc. Petroleum Geologists, Bull., vol. 8, no. 2, p. 240, March-April, 1924.

14. Cotton Valley oil and gas field, Webster Parish, Louisiana: Am. Assoc. Petroleum Geologists, Bull., vol. 8, no. 2, pp. 244-246, 1 fig., MarchApril, 1924.

15. Stroud oil field, Oklahoma: Mining and Metallurgy, vol. 5, no. 208, pp. 184-185, 1 fig., April, 1924.

16. Structural geology of the Mid-Continent region: a field for research (with discussion by K. C. Heald) : Geol. Soc. America, Bull., vol. 36, no. 2, pp. 379-392, June 30, 1925 ; abstract, no. 1, p. 156, March 30, 1925 ; Pan-Am. Geologist, vol. 43, no. 2, p. 151, March, 1925.

17. Interior salt domes of Texas: Am. Assoc. Petroleum Geologists, Bull., vol. 10, no. 1, pp. 1-60, 14 figs., 1 pl., January, 1926; Geology of salt dome oil fields, pp. 209-268, 14 figs., 1 pl., 1926.

18. Effect of salt and gypsum on the formation of Paradox and other valleys of southwestern Colorado (abstract) : Geol. Soc. America, Bull., vol. 37, no. 1, p. 168, March 30, 1926; Pan-Am. Geologist, vol. 45, no. 2, p. 166, March, 1926.

19. The function of State geological surveys: Econ. Geology, vol. 21, no. 6, pp. 610-612, September, 1926.

20. Oil and gas in Oklahoma; petroleum geology in Oklahoma: Oklahoma Geol. Survey, Bull. no. 40-G, 24 pp., December, 1926 ; Bull. no. 40, vol. 1, pp. 1-20, July, 1928.

21. Age of folding of the Wichita, Arbuckle, and Ouachita mountains, Oklahoma (abstract) : Geol. Soc. America, Bull., vol. 38, no. 1, p. 150, March 30, 1927 ; Pan-Am. Geologist, vol. 47, no. 2, p. 155, March, 1927.

z2. Crinerville oil field, Carter County, Oklahoma: Am. Assoc. Petroleum Geologists, Bull., vol. 11, no. 10, pp. 1067-1085, 6 figs., October, 1927.

23. The Seminole uplift, Oklahoma: Am. Assoc. Petroleum Geologists, Bull., vol. 11, no. 10, pp. 1097-1108, 4 figs., October, 1927. 
Powers, Sidney-Continued.

24. Buried ridges in west Texas: Am. Assoc. Petroleum Geologists, Bull., vol. 11, no. 10, pp. 1109-1115, 2 figs., October, 1927.

25. Plains type of folding (abstract) : Pan-Am. Geologist, vol. 49, no. 2, pp. 157-158, March, 1928; Geol. Soc. America, Bull., vol. 39, no. 1, p. 208, March 30, 1928.

26. Age of the folding of the Oklahoma Mountains-the Ouachita, Arbuckle, and Wichita Mountains of Oklahoma and the Llano-Burnet and Marathon uplifts of Texas: Geol. Soc. America, Bull., vol. 39, no. 4, pp. 1031-1072, 11 figs., December 30, 1928.

Prather, Harold $P$.

1. Manitoba, a potential Canadian mining area: Eng. and Min. Jour., vol. 122, no. 23, pp. 887-893, 4 figs., December 4,1926 .

Pratt, Joseph Hyde.

1. Biennial report of the State geologist, 1917-1918: North Carolina Geol. and Econ. Survey, 110 pp., Raleigh, 1919.

2. (and Berry, Miss H. M.). The mining industry in North Carolina during 1913-17, inclusive: North Carolina Geol. and Econ. Survey, Econ. Paper no. 49, 170 pp., 1 pl., 1919.

3. Biennial report of the State geologist, 1919-1920. 74 pp., North Carolina Geol. and Econ. Survey, Raleigh, 1921.

4. The work of the State Geological Survey and mining conditions in North Carolina : Am. Mining Cong., 23d Ann. Convention, Rept. of Proc., pp. 488-491, 1921.

5. Extension of Triassic coal field of North Carolina: Pan-Am. Geologist, vol. 37, no. 3, pp. 246-24S, April, 1922.

6. Recovery of low-grade magnetitic ores in North Carolina: Pan-Am. Geologist, vol. 37, no. 4, pp. 345-347, May, 1922.

7. Biennial report of the State geologist and director, 1921-1922: North Carolina Geol. and Econ. Survey, 104 pp., Raleigh; 1923.

Pratt, Wallace Everett. See also Barton, 2 ; Hackford, 1 ; Hager, D., 2 ; Hull, 5 , Johnson, D. W., 16 ; Lee, W. T., 3 ; Washburne, 3.

1. Geologic structure and producing areas in north Texas petroleum fields (with discussion) : Am. Assoc. Petroleum Geologists, Bull., vol. 3, pp. 44-70, 1919.

2. The present excitement [petroleum] at Fort Stockton, Texas: Am. Assoc. Petroleum Geologists, Bull., vol. 5, no. 1, pp. 88-89, JanuaryFebruary, 1911.

3. The recent discovery [of oil and gas] at El Dorado, Arkansas: Am. Assoc. Petroleum Geologists, Bull., vol. 5, no. 1, pp. 90-91, JanuaryFebruary, 1921.

4. A note on supposed evidence of the volcanic origin of Gulf coast salt domes: Am. Assoc. Petroleum Geologists, Bull., yol. 5, no. 1, pp. 91-94, January-February, 1921.

5. A new Gulf coast salt dome [Fort Bend County, Texas]: Am. Assoc. Petroleum Geolgoists, Bull., vol. 6, no. 3, pp. 252-254, May-June, 1922.

6. Oil at Luling, Caldwell County, Texas: Am. Assoc. Petroleum Geologists, Bull., vol. 7, no. 2, pp. 182-183, March-April, 1923.

7. (and Lahee, F. H.). Faulting and petroleum accumulation at Mexia, Texas (with discussion) : Am. Assoc. Petroleum Geologists, Bull.. vol. 7, no. 3, pp. 226-236, 3 figs., 1 pl., May-June, 1923. 
Pratt, Wallace Everett-Continued.

8. Oil and gas in the Texas Panhandle (with discussion): Am. Assoc. Petroleum Geologists, Bull., vol. 7, no. 3, pp. 237-249, 3 figs., May-June; 1923.

9. (and Lahee, F. H.). Faulting and petroleum accumulation at Mexia, Texas: Oil, Engineering and Finance, vol. 4, no. 82, pp. 119-1.22, 4 figs., August 4, 1923.

10. (and Johnson, Douglas W.). Recent local subsidence of the Gulf coast of Texas (abstract) : Geol. Soc. America, Bull., vol. 37, no. 1, p. 169, March 30, 1926; Pan-Am. Geologist, vol. 45, no. 2, pp. 166167, March, 1926.

11. (and Sellards, E. H.). Depression of Goose Creek oil field, Texas (abstract) : Pan-Am. Geologist, vol. 45, no. 3, p. 254, April, 1926.

12. An earthquake in the Panhandle of Texas [July 30, 1925] : Seismological Soc. America, Bull., vol. 16, no. 2, pp. 146-149, 1 pl., June, 1926.

13. (and Johnson, Douglas W.). Local subsidence of the Goose Creek oil field [Texas]: Jour. Geology, vol. 34, no. 7, pp. 577-590, 6 figs., Octobèr-November, 1926.

14. Two new salt domes in: Texas [Moss Bluff and Boggy Creek domes] : Am. Assoc. Petroleum Geologists, Bull., vol. 10, no. 11, pp. 11711172, November, 1926.

15. Some questions on the cause of the subsidence of the surface in the Goose Creek field, Texas: Am. Assoc. Petroleum Geologists. Bull., vol. 11. no. 8, pp. 887-889, August,; 1927.

16. Diatoms seen as probable source of petroleum: Oil Weekly, vol. 47, no. 3, pp. 33-34, 44, 3 figs., October 7, 1.927; [in Spanish], Bol. Petroleo, vol. 25, no. 1, pp. 19-23, January, 1928.

Prescott, Basil. See also Shaw, S. F., 1.

1. The underlying principles of the limestones replacement deposits of the Mexican province: Eng. and Min. Jour., vol. 122, no. 7, pp. 246253, no. 8, pp. 289-296, 11 figs., August 14 and 21, 1926.

Pressler, Edward $D$.

1. Upper faunal horizons of San Fernando section in Ventura County, California (abstract) : Pan-Am. Geologist, vol. 49, no. 4, p. 318, May, 1928 .

Prest, Walter Henry, 1856-1920.

1. On the nature and origin of the eskers of Nova Scotia: Nova Scotian Inst. Sci., Proc. and Trans., vol. 14, part 4, pp. 371-393, 1919.

2. Esker excavation in Novia Scotia [at Middlefield, Queens County] : Nova Scotian Inst. Sci., Proc. and Trans., vol. 15, pt. 1, pp. 33-45, 2 figs., January 1, 1922.

Prettyman, Thomas Mann. See also Liddle, 2.

1. (and Cave; H. S.). Petroleum and natural gas possibilities in Georgia: Georgia Geol. Survey, Bull. no. 40, 167 pp., 13 figs., 8 pls., map, 1923.

Price, George McCready.

1. Geology. In Geography and geology, Modern American education, vol. 3, pp. 417-524, 37 figs., American Educational Institute, Philadelphia, 1920. 
Price, George McCready-Continued.

2. The fossils as age markers in geology: Princeton Theological Review, vol. 20, no. 4, pp. 585-615, October, 1922.

3. The new geology; a textbook for colleges, normal schools, and training schools; and for the general reader. 726 pp., 452 figs., Pacific Publishing Association, Mountain View, California [1923].

4. Geology and its relation to scripture revelation: Victoria Inst., Jour. of Trans., vol. 56, pp. 97-123, 1924.

5. Evolutionary geology and the new catastrophism. 352 pp., 91 figs., Pacific Press Publishing Association, Mountain View, California, 1926.

6. Facts and theories in geology: Science, new ser., vol. 65, pp. 373-374, April 15, 1927.

Price, Paul Holland. See also Reger, 9; Tilton, 12, 13.

1. The coprolite limestone horizon of the Conemaugh series in and around Morgantown, West Virginia: Carnegie Mus., Annals, vol. 17, no. 2, pp. 211-254, 10 figs., 12 pls., May, 1927.

2. Marble of Pocahontas County, West Virginia: West Virginia Acad. Sci., Proc., vol. 2 (West Virginia Univ. Bull., ser. no. 29, no. 1), pp. 107-117, 7 figs., August, 1928.

Price, William Armstrong. See also Swartz, C. K., 2.

1. Notes on the paleontology of Webster County; Invertebrate fossils from the Pottsville series: West Virginia Geol. Survey, Webster County, pp. 544-615, 2 figs., 2 pls., 1920.

2. A Pocono brachiopod fauna: Science, new ser., vol. 51., pp. 146-147, February $6,1920$.

3. Hydrozoan affinities of Serpulites Sowerby (abstract): Geol. Soc. America, Bull., vol. 31, no. 1, p. 210, March 31, 1920.

4. Carbon ratios in Carboniferous coals of Oklahoma and their relation to petroleum (discussion) : Econ. Geology, vol. 15, no. 7, pp. 61.0-611, November, 1920.

5. Shell regeneration in a Pennsylvanian brachiopod: Washington Acad. Sci., Jour., vol. 11, no. 2, pp. 32-36, 1 fig., January 19, 1921.

6. Chert deposits of West Virginia: West Virginia Geol. Survey, Nicholas County; pp. 221-240, 2 pls., 1 fig., 1921.

7. Notes on the paleontology of Nicholas County; Invertebrate fossils from the Pottsville series: West Virginia Geol. Survey, Nicholas County, pp. 751-788, 2 pls., 1 fig., 1921.

8. General formulae for the determination of thickness and depth of strata: Econ. Geology, vol. 17, no. 5, pp. 370-381, 1 fig., August, 1922.

9. Description of members, Chemung series: general account, Portage series: West Virginia, Tucker County, pp. 245-257, 1923.

10. Caliche and pseudo-anticlines: Am. Assoc. Petroleum Geologists, Bull., vol. 9, no. 6, pp. 1009-1017, 2 figs., September, 1925.

11. Gas and oil near Edna, Jackson County, Texas: Am. Assoc. Petroleum Geologists, Bull., vol. 10, no. 9, p. 905, September, 1926.

12. (and Palmer, Katherine Van Winkle). A new fauna from the Cook Mountain Eocene near Smithville, Bastrop County, Texas: Jour. Paleontology, vol. 2, no. 1, pp. 20-31, 1 fig., 2 pls., March, 1928.

Primmer, George $\mathrm{H}$.

1. The Sudbury nickel region [Ontario]: Geog. Soc. Philadelphia, Bull., vol. 25, no. 1, pp. 33-42, 5 figs., January, 1927. 
Prior, Charles E.

1. Notes on the Salmon River mining district [northwestern British Columbia] : Min. and Sci. Press, vol. 121, pp. 518-520, 3 figs., October 9, 1920.

Prior, George Thurland.

1. On the chemical composition of the meteorites Amana (=Homestead) and Eagle Station [Iowa and Kentucky] : Mineral. Mag., vol. 18, pp. 173-179, August, 1918.

Prister, Augusto.

1. Notas preliminares sobre vestigios glaciales en el Estado de Hidalgo y en el Valle de México: Soc. cient. "Ant. Alz.," Mem. y Rev., t. 48, nos. 1-6, pp. 1-13, 9 pls., 1927.

Prommel, H. W. C.

1. Geology and structure of portions of Grand and San Juan counties, Utah: Am. Assoc. Petroleum Geologists, Bull., vol. 7, no. 4, pp. 384-399, 2 figs., 1 pl., July-August, 1923.

2. (and Crum, H. E.). Salt domes of Permian and Pennsylvanian age in southeastern Utah and their influence on oil accumulation: Am. Assoc. Petroleum Geologists, Bull., vol. 11, no. 4, pp. 373-393, 11 figs., April, 1927.

3. Salt domes, fractures, and test wells in southeast Utah: Oil Weekly, vol. 45 , no. 11 , pp. 41,45 , June 3,1927 .

4. (and Crum, H. E.). Structural history of parts of southeastern Utah from interpretation of geologic sections: Am. Assoc. Petroleum Geologists, Bull., vol. 11, no. 8, pp. 809-820, 2 figs., August, 1927; Oil Weekly, vol, 46, no. 7, pp. 31-34, 42, August 5, 1927.

5. Anticlines on Nequoia arch, Green River Desert, Utah: Oil Weekly, vol. 47, no. 11, pp. 310, 318, December 2, 1927.

Prout, F. S.

1. Schist east of Santa Rosa, New Mexico: Am. Assoc. Petroleum Geologists, Bull,, vol. 11, no. 1, p. 88, January, 1927.

Prouty, William Frederick. See also Swartz, C. K., 9; Tilton, 12, 13.

1. Further evidence of the age of the crystalline and semicrystalline rocks in Alabama (abstract): Geol. Soc. America, Bull., vol. 30, pp. 113-114, March 19, 1919.

2. Crystalline graphite denosits of Alabama (abstract): Geol. Soc. America, Bull., vol. 30, pp. 112-113, March 31, 1919.

3. Notes on the geology of a portion of Clay County, Alabama (abstract) : Elisha Mitchell Sci. Soc., Jour., vol. 36, nos. 1-2, p. 4, September, 1920.

4. Age of Talladega phyllite [Carboniferous] (abstract) : Geol. Soc. America, Bull., vol. 33, no. 1, p. 151, March 31, 1922.

5. Age of Talladega slates of Alabama: Pan-Am. Geologist, vol. 34, no. 5, pp. 363-366, 1 fig., 1 pl., June, 1922.

6. The age of the Ocoee and associated rocks of Clay County, Alabama (abstract) : Elisha Mitchell Sci. Soc., Jour., vol. 38, nos. 1-2, pp. 16-17, September, 1922.

7. The rejuvenated Ocoee (abstract) : Elisha Mitchell Sci. Soc., Jour., vol. 38, nos. 1-2, p. 33, September, 1922.

8. Geology of the Muscle Shoals area, Alabama: Elisha Mitchell Sci. Soc., Jour., vol. 38, nos. 1-2, pp. 88-89, September, 19:2. 
Prouty, William Frederick-Continued.

9. (and Swartz, C. K.). Sections of the Rose Hill and McKenzie formations : Maryland Geol. Survey, Silurian, pp. 53-104, 3 pls., 1923.

10. Geology and mineral resources of Clay County, with special reference to the graphite industry: Alabama Geol. Survey, County Rept. no. 1, 190 pp., 53 figs., 26 pls., map (in separate cover), 1923.

11. Structural conditions in west central Appalachians (abstract): Elisha Mitchell Sci. Soc., Jour., vol. 41, nos. 1-2, pp. 23-24, September, 1925.

12. Triassic basin west of Raleigh (abstract) : Elisha Mitchell Sci. Soc., Jour., vol. 41, nos. 1-2, pp. 24-26, September, 1925.

13. Relation of rock character and structure to topography in the central belt of the folded Appalachians (abstract) : Elisha Mitchell Sci. Soc., Jour., vol. 41, nos. 1-2, pp. 44-46, September, 1925.

14. Faunas of the Devonian, Silurian, and Ordovician periods: West Virginia Geol. Survey, Mercer, Monroe, and Summers counties, pp. $860-867,1926$.

15. The Triassic of the Durham Basin (abstract): Elisha Mitchell Sci. Soc., Jour., vol. 42, nos. 1-2, pp. 22-24, October, 1926.

16. Triassic deposits of Durham, North Carolina, and structural relations to other Triassic basins of eastern North America (abstract) : Geol. Soc. America, Bull., vol. 39, no. 1, pp. 210-211, March 30, 1928; Pan-Am. Geologist, vol. 49, no. 2, p. 145, March, no. 3, p. 231, April, 1928.

17. Typical structures of central Appalachian area and their relation to topography (abstract) : Elisha Mitchell Sci. Soc., Jour., vol. 44, no. 1, p. 14, September, 1928.

Prutzman, Paul W.

1. Chemical characteristics of California petroleums: Am. Assoc. Petroleum Geologists, Bull., vol. 8, no. 5, pp. 560-575, SeptemberOctober, 1924.

Purdue, Albert Homer, 1861-1918.

1. (and Miser, H. D.). Description of the Hot Springs district: U. S. Geol. Survey, Geol. Atlas U. S., Hot Springs folio, Arkansas (no. 215), 12 pp., 8 figs., 3 maps, section and illustration sheets, 1923.

Purdy, Wesley.

1. A summary of the Canadian foothills belt: Am. Assoc. Petroleum Geologists, Bull., vol. 4, no. 3, pp. 249-254, 1920.

Putnam, George Palmer.

1. The Putnam Baffin Island expedition: Geog. Rev., vol. 18, no. 1, pp. 1-40, 37 figs., map, January, 1928.

Putnam, George Rockwell.

1. Condition of the earth's crust and the earlier American gravity observations: Geol. Soc. America, Bull., vol. 33, no. 2, pp. 287-302, 1 fig.. June 30, 1922.

2. The equilibrium theory of the earth's crust: Washington Acad. Sci., Jour., vol. 16, no. 11, pp. 285-291, June 4, 1926.

3. Notes and reflections on isostasy: Science, new ser., vol. 65, pp. 245-248, March 11, 1927.

4. Regional isostatic reduction of gravity determination: Nat. Acad. Sci., Proc., vol. 14, no. 5, pp. 407-418, 1 fig., May, 1928. 
Putnam, George Rockwell-Continued.

5. Proof of isostasy by a simple gravity reduction method: Nat. Acad. Sci., Proc., vol. 14, no. 5, pp. 418-427, 1 fig. May, 1928.

Putnam, Palmer Cosslet.

1. A chart showing the chemical relationships in the mineral kingdom. 31 pp., chart, New York, John Wiley \& Sons, 1925.

2. The existence of a once homogeneous magma-mass underlying Central America: Jour. Geology, vol. 34, no. 8, pp. 807-823, 6 figs., November-December, 1926.

3. (and Roberts, E. J., and Selchow, D. H.). Contributions to determinative mineralogy: Am. Jour. Sci., 5th ser., vol. 15, pp. 89-102, 253261, 423-430, 455-460, 10 figs., 1 pl., February, March, May, and June, 1928.

Pycraft, W. P.

1. The Nebraska tooth [Hesperopithecus haroldcookii]: Nature, vol. 11.0, pp. 707-708, November 25, 1922.

Q., H. M.

1. Obituary, W. L. Uglow: Canadian Min. Jour., vol. 47, no. 37, p. 885, September 10, 1926.

Quervain, F.. See Herschi, 4.

Quinn, R. F. See Wallace, 21.

Quirke, Terence Thomas. See also Collins, W. H., 15; Kindle, 24.

1. The Richardton [North Dakota] meteorite: Science, new ser., vol. 49, pp. 92-93, January 24, 1919.

2. The Richardton [North Dakota] meteorite: Jour. Geology, vol. 27, no. 6, pp. 431-448, 2 figs., September-October, 1919.

3. Metallic copper in a meteorite vein: Econ. Geology, vol. 14, no. 8, pp. 619-624, 1 pl., December, 1919.

4. An analysis of the process of thrust faulting (abstract): Science, new ser., vol. 51, p. 519, May 21, 1920.

5. Concerning the process of thrust faulting: Jour. Geology, vol. 28, no. 5, pp. 417-438, 7 figs., July-August, 1920.

6. Discussion of "Summaries of pre-Cambrian literature of: North America,". by Edward Steidtmann: Jour. Geology, vol. 29, no. 5, pp. 469-474, July-August, 1921.

7. Geneva map area, Sudbury district, Ontario: Canada, Geol. Survey, Summ. Rept., 1920, pt. D. pp. 7-18, map, 1921.

8. Wanapitei Lake map area [Sudbury district, Ontario]: Canada, Geol. Survey, Summ. Rept., 1921, pt. D, pp. 34-50, map, 1922.

9. Parallel folds and boudinage (abstract): Geol. Soc. America, Bull., vol. 34, no. 1, pp. 59-60, March 30, 1923.

10. Boudinage, an unusual structural phenomenon: Geol. Soc. America, Bull., vol. 34, no. 4, pp. 649-660, 9 flgs., December, 30, 1923.

11. Huronian complex near Killarney, Ontario (abstract, with discussion by A. C. Lawson) : Geol. Soc. America, Bull., vol. 35, no. 1, pp. 89-90, March 30, 1924 ; abstract, Pan-Am. Geologist, vol. 41, no. 2, pp. 144-145, March, 1924.

12. Correlation of Huronian and Grenville rocks: Jour. Geology, vol. 32, no. 4, pp. 316-335, 8 figs., May-June, 1924.

13. Correlation of Huronian and Grenville rocks of southeastern Ontario (abstract) : Pan-Am. Geologist, vol. 42, no. 4,-p. 308, November, 1924 ; British Assoc. Adv. Sci., Rept. 92d Meeting, p. 390, 1925. 
Quirke, Terence Thomas-Continued.

14. Elements of geology. 414 p., 147 figs., New York, Henry Holt and Company, 1925.

15. Potholes and certain features of glacial abrasion: Illinois State Acad, Sci., Trans., vol. 17, pp. 194-198, 4 pls., 1925.

16. Some features of continental glaciation: Illinois State Acad. Sci., Trans., vol. 18, pp. 394-400, 3 figs., 1 pl., 1925.

17. Origin of sedimentary iron ores (discussion): Econ. Geology, vol. 20, no. 8, pp. 770-771, December, 1925.

18. Huronian-Grenville relations: Am. Jour. Sci., 5th ser., vol. 11, pp. 165-173, February, 1926.

19. Mineral deposits of Rutter map area, Sudbury district, Ontario: Canada, Geol. Survey, Summ. Rept., 1924, pt. C, pp. 89-95, 1 fig., 1926.

20. Are some intrusions replacement deposits? (abstract) : Geol. Soc. America, Bull., vol. 38, no. 1, pp. 119-121, March 30, 1927 ; Pan-Am. Geologist, vol. 47, no. 1, p. 70, February, 1927.

21. Evidence of assimilation and assimilation processes: Jour. Geology, vol. 35, no. 2, pp. 180-182, February-March, 1927.

22. Killarney gneisses and migmatites: Geol. Soc. America, vol. 38, no. 4, pp. 753-770, 2 figs., 5 pls., December 30, 1927.

23. Structure of the Killarnean terrane (abstract): Geol. Soc. America, Bull., vol. 39, no. 1, pp. 189-190, March 30, 1928; Pan-Am. Geologist, vol. 49, no. 2, pp. 143-144, March, 1928.

24. Larger earth deformations: Pan-Am. Geologist, vol. 49, no. 4, pp. 241258, 3 figs., 1 pl., May, 1928.

Raasch, Gilbert 0 .

1. Fossil collecting in Michigan and Ontario: Milwaukee, Public Mus., Yearbook 1927, vol. 7, pp. 81-90, 6 figs., June 1, 1928.

2. The Appel collection of lead region minerals [Wisconsin]: Milwaukee, Public Mus., Yearbook 1927, vol. 7, pp. 185-192, 3 pls., June 1., 1928.

Rader, Clarence M. See Estabrook, 4.

Rae, Colin C. See also Washburne, 5 .

1. A possible origin of oil: Am. Inst. Min. and Met. Eng., Trans., vol. 68, pp. 1112-1120, 1923; [preprint] no. 1132, 4 pp., February, 1922 ; (discussion) [preprint] no. 1169, pp. 2-6, June, 1922; abstract, Mining and Metallurgy, no. 182, pp. 64-65, February, 1922.

2. Organic material of carbonaceous shales: Am. Assoc. Petroleum Geologists, Bull., vol. 6, no. 4, pp. 333-341, July-August, 1922.

3. Big Sand Draw field, Fremont County, Wyoming: Am. Assoc. Petroleum Geologists, Bull., vol. 12, no. 12, pp. 1137-1146, 2 figs., December, 1928.

Ragotzy, Federico. See Wittich, 16.

Ramsay, Wilhelm.

1. The probable solution of the climate problem in geology: Smithsonian Inst., Am. Rept., 1924, pp. 237-248, 1 fig., 1925.

Ramsdell, Lewis S.

1. The crystal structure of some metallic sulphides: Am. Mineralogist, vol. 10, no. 9, pp. 281-304, 1 fig., September, 1925.

2. Crystal structure of the pyrite group (abstract): Pan-Am. Geologist, vol. 44, no. 2, p. 152, September, 1925. 
Ramsdell, Lewis S.-Continued.

3. The crystal structure of silver sulphide: Am. Mineralogist, vol. 12, no 2, pp. 25-26, February, 1927.

Randolph, Helen Fitz.

1. Mammoth Cave and the cave region of Kentucky; with bibliography of Mammoth Cave by Willard Rouse Jillson. 153 pp., illus., Louisville, Ky., The Standard Printing Company, 1924.

Rangel, Manuel.

1. (and Terrones, Alberto). Mineral resources of Durango: Eng. and Min. Jour., vol. 112, no. 5, pp. 168-174, 6 figs., July 30, 1921.

Ransome, Frederick Leslie. See also Jones, E. L , jr., 3.

1. The copper deposits of Ray and Miami, Arizona: U. S. Geol. Survey, Prof. Paper 115, 192 pp., 54 pls. (incl. maps), 29 figs., 1919; abstract, Washington Acad. Sci., Jour., vol. 11, no. 3, pp. 57-58, February 4, 1921.

2. Quicksilver in 1917: U. S. Geol. Survey, Mineral Resources, 1917, pt. 1, pp. 367-424, 2 pls. (maps), March 18, 1919.

3. Quicksilver in 1918: U. S. Geol. Survey, Mineral Resources, 1918, pt. 1, pp. 143-178. 1 fig.. October 31. 1919.

4. The functions and ideals of a national geological survey: Science, new ser., vol. 51, pp. 173-180, 201-207, February 20 and 27, 1920. Washington Acad. Sci., Jour., vol. 10, no. 4, pp. 85-109, February 19, 1920. Smithsonian Institution, Ann. Rept., 1919, pp. 261-280, 1921. Abstract, Eng. and Min. Jour., vol. 109, pp. 279-280, January 24, 1920.

5. Geologists as expert witnesses: Econ. Geology, vol. 15, no. 4, pp. 339-349, June, 1920.

6. Geology and metal mining, with particular reference to the work of the U. S. Geological Survey: Am. Mining Cong., 23rd Ann. Convention, Rept. of Proc., pp. 407-411, 1921.

7. Quicksilver in 1919: U. S. Geol. Survey, Mineral Resources, 1919. pt. 1, pp. 149-180, 1 fig., April 5, 1921.

8. Quicksilver in 1920: U. S. Geol. Survey, Mineral Resources, 1920, pt. 1, pp. 419-439, March 27, 1922.

9. Ore deposits of the Sierrita Mountains, Pima County, Arizona: U. S. Geol. Survey, Bull. 725, pp. 407-428, 4 figs., 4 pls., March 30, 1922.

1.0. Quicksilver in 1921: U. S. Geol. Survey, Mineral Resources, 1921, pt. 1, pp. 107-117, 1 fig., August 7, 1922.

11. Description of the Ray quadrangle [Arizona]: U. S. Geol. Survey, Geol. Atlas U. S., Ray folio, Arizona (no. 217), 24 pp., 13 figs., 4 maps, illustration sheet, 1923.

12. Geology of the Oatman gold district, Arizona ; a preliminary report; U. S.

- Geol. Survey, Bull. 743, 58 pp., 7 figs , 12 pls. (incl. map), 1923.

13. Ancient high-level potholes near the Colorado River (abstract) : Science, new ser., vol. 57, p. 593, May 18, 1923.

14. Quicksilver in 1922; with a supplementary bibliography by Isabel $P$. Evans: U. S. Geol. Survey, Mineral Resources, 1922, pt. 1, pp. 113124, September 18, 1923.

15. Basin Range structure at Jerome, Arizona: Science, new ser., vol. 61, pp. 659-660, 1 fig., June 26, 1925.

16. Some possible lines of research on ore deposits: Econ. Geology, vol. 20, no. 5, pp. 485-490, August, 1825.

$4096-31-32$ 
kansome, Frederick Leslie-Continued.

17. On teaching economic geology : Econ. Geology, vol. 21, no. 5, pp. 498-501., August, 1926.

18. Directions of progress in economic geology: Econ. Geology, vol. 23, no. 2, pp. 119-131, March-April, 1928.

19. Geology of the St. Francis dam site: Econ. Geology, vol. 23, no. 5, pp. 553-563, 8 figs.; August, 1928.

20. Geology as related to high dams: Eng. News-Record, vol. 101, no. 18, pp. 657-659, November 1, 1928.

Rastall, Robert Heron.

1. Theoretical considerations of the genesis of ore deposits: Jour. Geology, vol. 29, no. 6, pp. 487-501, 1 fig., September-October, 1921.

2. Metallogenetic zones: Econ. Geology, vol. 18, no. 2, pp. 105-121, 3 figs. March, 1923.

Rathbun, Mary Jane. See also Wade, B., 3.

1. West Indian Tertiary decapod crustaceans: Carnegie Inst. Washington, Pub. 291, pp. 157-184, 9 pls., 1919.

2. Additions to West Indian Tertiary decapod crustaceans: U. S. Nat. Mus., Proc., vol. 58, pp. 381-384, 1 pl., 1920.

3. Decapod crustacean $\mathcal{S}$ from the Upper Cretaceous of North Carolina : North Carolina Geol. Survey, vol. 5, pt. 1, pp. 403-408, 2 pls., 1923.

4. Fossil crabs from the Republic of Haiti: U. S. Nat. Mus., Proc., vol. 63, art. 9, 6 pp., 2 pls., 1923.

5. The fossil stalk-eyed Crustacea of the Pacific slope of North America: U. S. Nat. Mus., Bull. 138, 155 pp., 6 figs. 39 pls., 1926.

6. 'Two new crabs from the Eocene of Texas: U. S. Nat. Mus., Proc., vol. 73, art. 6,6 pp., 3 pls., 1.928.

Raw, Frank.

1. The ontogenies of trilobites and their significance: Am. Jour. Sci., 5th ser., vol. 14, pp. 7-35, 131-149, 240, 27 figs., July, August, and September, 1927.

Rayburn, J. M.

1. The deposit of double-thick Upper Freeport coal situated in the valley of Allegheny River in Allegheny, Butler, and Westmoreland counties, Pennsylvania: Engineers' Soc. Western Pennsylvania, Proc., vol. 40, no. 1, pp. 27-44, 6 figs., February, 1924.

Rayleigh, (Lord), Robert John Strutt.

1. (and others). The age of the earth: Smithsonian Inst., Ann. Rept., 1921, pp. 249-260, 1922.

Raymond, Percy Edward.

1. Report on invertebrate paleontology: Harvard Coll., Mus. Comp. Zool., Ann. Rept., 1919-1920, pp. 30-31, 1920.

2. The pygidium of the trilobite: Geol. Mag., vol. 57, pp. 22-25, January, 1920.

3. Middle Ordovician of Virginia and Tennessee (abstract): Geol. Soc. America, Bull., vol. 31, no. 1, p. 137, March 31, 1920.

4. Paleontological collections in the vicinity of Boston (abstract) : Geol. Soc. America, Bull., vol. 31, no. 1, p. 205, March 31, 1920.

5. Trilobites as ancestors (abstract): Geol. Soc. America, Bull., vol. 31, no. 1, pp. 214-215, March 31, 1920.

6. Some new Ordovician trilobites: Harvard Coll., Mus. Comp. Zool., Bull., vol. 64 , no. 2 , pp. $273-296$, .Tuly, 1920. 
Raymond, Percy Edward-Continued.

7. Phylogeny of the Arthropoda with especial reference to the trilobites: Am. Naturalist, vol. 54, pp. 398-413, September-October, 1920.

8. The appendages, anatomy, and relationships of trilobites: Connecticut Acad. Arts and Sci., Mem., vol. 7, 169 pp., 11 pls., 46 figs., December, 1920. [Foreword by Charles Schuchert.]

9. Report on invertebrate paleontology : Harvard College, Mus. Comp. Zool., Ann. Rept. 1920-1921, pp. 27-28, 1921.

10. A contribution to the description of the fauna of the Trenton group: Canada, Geol. Survey, Museum Bull. no. 31., 64 pp., 11 pls., February $17,1921$.

11. A new fossil startish from New England: Boston Soc. Nat. Hist., Proc., vol. 36, no. 4, pp. $165-170,1$ pl., August, 1921.

12. Critelia for species, phylogenies, and faunas of trilobites: Geol. Soc. America, Bull., vol. 32, no. 3, pp. 349-352, September 1, 1921.

13. The history of corals and the "limeless" oceans: Am. Jour. Sci., 5th ser., vol. 2, pp. 343-347, 3 figs., December, 1921.

14. Report on invertebrate paleontology : Harvard Coll., Mus. Comp. Koology, Ann. Rept., 1921-1922, pp. 19--20, 1.922.

15. Seaside notes [formation of trails]: Am. Jour. Sci., 5th ser., vol. 3, pp. 108-114, February, 1922.

16. The Ceratopyge fauna in western North America: Am. Jour., Sci., 5th ser., vol. 3, pp. 204-210, March, 1922.

17. Possible habits of cephalopods and trilobites (abstract): Geol. Soc. America, Bull., vol. 33, no. 1, p. 197, March 31, 1922.

18. Trenton of central Tennessee and Kentucky: Geol. Soc. America, Bull. vol. 33 , no. 3 , pp. 571-585, Sentember 30,1922 ; abstract, no. 1. p. 109, March 31, 1922.

19. A trilobite containing color markings [Cambrian, Cherokee County, Alabama ] : Am. Jour. Sci., 5th ser., vol. 4, pp. 461-464, 1 fig., December, 1922.

20. Report on invertebrate paleontology : Harvard Coll., Mus. Comp. Zoology, Ann. Rept. for 1922-1923, pp. 21-22; 1923.

21. New fossils from the Chapman sandstone: Boston Soc. Nat. Hist., Proc., vol. 36 , no. 7, pp. 467-472, 1 pl., June, 1923.

22. Report on invertebrate paleontology: Harvard College, Mus. Comp. Zoology, Ann. Rept. for 1923-1924, pp. 22-23, 1924.

23. New Upper Cambrian and lower Ordovician trilobites from Vermont: Boston Soc. Nat. Hist., Proc., vol. 37, no. 4, pp. 389-406, 3 pls., July, 1924 ; Vermont, State Geologist, Fourteenth Rept., 1923-1924, pp. 137-203, 3 pls., 1924.

24. The oldest coral reef: Vermont, State Geologist, Fourteenth Rept., 19231924, pp. 72-76, 1924.

25. Report on invertebrate paleontology : Harvard Coll., Mus. Comp. Zoology, Ann. Rept. Director, 1924-25, pp. 21-22, 1925.

26. A possible factor in the formation of dolomite (abstract): Geol. Soc. America, Bull., vol. 36 , no. 1, p. 168, March 30, 1925 ; Pan-Am. Geologist, vol. 43 , no. 2, p. 158, March $30,1.925$.

27. Mechanical factors in the evolution of the tetrabranchiate cephalopods (abstract) : Geol. Soc. America, Bull., vol. 36, no. 1, pp. 228-239, March 30, 1925.

28. Some trilobites of the lower middle Ordovician of eastern North America: Harvard Coll., Mus. Comp. Zoology, Bull., vol. 67, no. 1, pp. 1-180, 10 pls., April, 1925. 
Raymond, Percy Edward-Continued.

29. The Anaspida and the problem of the origin of the vertebrates: Am. Jour. Sci., 5th ser., vol. 10, pp. 433-436, November, 1925.

30. Two new fossil fishes from Alberta: Am. Jour. Sci., 5th ser., vol. 10, pp. 551-555, 2 figs., December, 1925.

31. A new oyster from the Cretaceous of Cuba: Boston Soc. Nat. Hist., Occ. Papers, vol. 5, pp. 183-185, 1 pl., December, 1925.

32. Report on invertebrate paleontology : Harvard Coll., Mus. Comp. Zoology, Ann. Rept. Director, 1925-26, pp. 21-22, 1926.

33. Report on invertebrate paleontology : Harvard Coll., Mus. Comp. Zoology, Ann. Rept. Director, 1926-27, pp. 20-21, 1927.

34. The significance of red color in sediments: Am. Jour. Sci., 5th ser., vol. 13, pp. 234-251, March, 1927; vol. 14, pp. 157-158, August, 1927.

35. The ontogenies of trilobites and their significance (discussion): Am. Jour. Sci., 5th ser., vol. 15, pp. 168-170, February, 1928.

36. Two new Cambrian trilobites: Am. Jour. Sci., 5th ser., vol. 15, pp. 309313, April, 1928.

37. The brachipods of the Lenoir and Athens formations of Tennessee and Virginia : Harvard Coll., Mus. Comp. Zool., Bull., vol. 68, no. 6, pp. 293-309, 3 pls., May, 1928.

38. Report on invertebrate paleontology: Harvard Coll., Mus. Comp. Zoology, Ann. Rept. Director, 1927-28, p. 15, 1928.

Read, L. C.

1. The Cordilleran ice sheet: Natural History, Jour. Am. Mus. Nat. Hist., vol. 21, no. 3, pp. 251-254, May-June, 1921.

Reagan, Albert $B$.

1. Correlation of the formations described in the Fort Apache region in Arizona with similar formations in other parts of the State:

Kansas Acad. Sci., Trans., vol. 29, pp. 178-180, 1920.

2. The Mine Centre mining district, Ontario, and adjacent territory in the United States: Kansas Acad. Sci., Trans., vol. 29, pp. 181-183, 1920.

3. Glacial deposits in Pine River valley, Colorado: Indiana Acad. Sci., Proc., 1919, pp. 353-354, 1921.

4. Probable Eocene glacial deposits in the Fort Apache region, Arizona : Indiana Acad. Sci., Proc., 1919, pp. 355-358, 1921.

5. Probable Eocene glacial deposits in the Fort Apache region, Arizona: Kansas Acad. Sci., Trans., vol. 30, pp. 126-129, 1922.

6. Glacial deposits in Pine River valley, Colorado: Kansas Acad. Sci., Trans., vol. 30, pp. 129-130, 1922.

7. Cretacic Mollusca of Pacific slope: Pan-Am. Geologist, vol. 41, no. 3, pp. 179-189, 4 pls., April, 1924.

8. Stratigraphy of the Hopi Buttes volcanic field, Arizona: Pan-Am. Geologist, vol. 41, no. 5, pp. 355-366, 1 fig. (map), June, 1924.

9. Recent changes in the plateau region: Science, new ser., vol. $60, \mathrm{pp}$. 283-285, September 26, 1924.

10. Stream aggradation through irrigation: Pan-Am. Geologist, vol. 42, no. 5, pp. 335-344, December, 1924.

11. Geology of Fort Apache region, Arizona (abstract) : Pan-Am. Geologist, vol. 42 , no. 5 , p. 375 , December, 1924.

12. Identification of two fossil leaves from Iowa, one from Arizona, and a "tree trunk" from Kansas: Indiana Acad. Sci., Proc., vol, 34, pp: 141-142, 1 fig., 1925. 
Reagan, Albert B.--Continued.

13. Petrified forest of Ganado [Arizona]: Pan-Am. Geologist, vol. 43, no. 2, pp. 97-98, March, 1925.

14. Life and mythology of Ganado petrified forest: Pan-Am. Geologist, vol. 43, no. 3, pp. 238-239, April, 1925.

15. Late Cretacic formations of Black Mesa, Arizona: Pan-Am. Geologist, vol. 44, no. 4, pp. 285-294, 1 pl., November, 1925.

16. Description of some fossil plants from the Stanford paleontological collection: Indiana Acad. Sci., Proc., vol. 35, pp. 121-123, 7 figs., 1926.

17. Fossil plants from St. John collection (abstract) : Pan-Am. Geologist, vol. 45, no. 3, p. 251, April, 1926.

1.8. Extension of Cretacic Laramie formation into Arizona: Pan-Am. Geologist, vol. 46, no. 3, pp. 193-194, 1 pl., October, 1926.

19. Fossils from the Mancos-Dakota-Tununk formation in the vicinity of Steamboat, Arizona : Indiana Acad. Sci., Proc., vol. 36, pp. 11.9-127, 26 figs., 1927.

20. Contributions to the geology of the Navajo country, Arizona, with notes on the archeology (abstract) : Stanford Univ., Abstracts of Dissertations, 1924-1926, vol. 1, pp. 138-150, 1 pl., June, 1927.

21. Garnets in the Navajo country: Am. Mineralogist, vol. 12, no. 11, pp. 414-415, November, 1927.

22. Mineral resources of the Navajo country [northeastern Arizona]: Min. Jour. (Phoenix, Ariz.), vol. 11, no. 18, pp. 3-4, 15, February 15, 1928.

23. Origin of small prairies on Olympic Peninsula : Pan-Am. Geologist, vol. 49, no. 4, pp. 259-262, May, 1928.

24. Dakotan fossils incorporated in Recent deposits: Pan-Am. Geologist, vol. 50, no. 1, pp. 69-70, August, 1928.

Reber, Louis Ehrhart, jr.

1. Geology and ore deposits of the Jerome district [Yavapai County, Arizona] : Am. Inst. Min. and Met. Eng., Trans. [preprint no. 984], 24 pp., 1 fig. (map), 1 pl. [1920] ; vol. 66, pp. 3-26, 1 fig. (map), 1922. Abstract, Mining and Metallurgy, no. 161, sec. 1, pp. 25-27, May, 1920: Eng. and Min. Jour., vol. 110, no. 12, p. 566, September $18,1920$.

Redfield, Arthur Huber.

1. The Isthmian oil fields of Mexico: Eng. and Min. Jour., vol. 111, no. 12, pp. 510-514, 1 fig., March 19, 1921; Bol. Petróleo, vol. 11, no. 4, pp. 293-303, map, April, 1921.

2. Petroleum in the Canadian Northwest: Eng. and Min. Jour., vol. 111, no. 21, pp. 871-875, 1 fig., May 21, 1921.

3. The petroleum possibilities of Guatemala: Eng. and Min. Jour., vol. 112, no. 14, pp. 540-544, 2 figs., October $1,1921$.

4. Petroleum reserves of the West Indies (with discussion) : Am. Inst. Min. and Met. Eng., Trans., vol. 68, pp. 1082-1090, 1923; [preprint] no. 1166, 6 pp., June, 1922 ; abstract, Mining and Metallurgy, no. 186, p. 39, June, 1922.

5, Petroleum reserves of Central America: Am. Inst. Min. and Met. Eng., Trans., vol. 68 , pp. 1004-1013, 1923; [preprint] no. 1178, 10 pp., July, 1922 ; abstract, Mining and Metallurgy, no. 187, pp. 35-36, July, 1922. 
Redfield, Arthur Huber-Continued.

6. Graphite in 1922: U. S. Geol. Survey, Mineral Resources, 1922, pt. 2, pp. 63-68, September 11, 1923.

7. The petroleum possibilities of Costa Rica: Econ. Geology, vol. 18, no. 4, pp. 354-381, 2 figs., June-July, 1923; Revista Económica, San Salvador, año 11, no. 3, pp. 117-118, January, no. 4, pp. 174-178, 1 pl., February, no. 5, pp. 230-236, March, 1924.

8. The petroleum possibilities of Honduras: Econ. Geology, vol. 18, no. 5, pp. 474-493, 1 fig., August, 1923 ; Revista Económica, año 11, no. 7, pp. 341-346, May; no. 8, pp. 397-401, 1 fig., June ; no. 9, pp. 453-455, July, 1924.

9. The petroliferous systems of South America, Central America, and the West Indies: Pau-Pacific Sci. Cong., Australia, 1923, Proc., vol. 2, pp. 1207-1244 [1924].

10. The petroliferous provinces of the United States (abstract) : Washington Acad. Sci., Jour., vol. 17, no. 9, pp. 235-237, May 4, 1927.

Redfield, John S.

1. Mineral resources in Oklahoma: Oklahoma Geol. Survey, Bull. no. 42, 130 pp., 8 figs., 34 pls. (incl. map), May, 1927.

2. Oklahoma's mineral production in 1925: Oklahoma Acad. Sci., Proc., vol. 7 (Oklahoma, Univ., Bull., new ser., no. 409), pp. 155-1.57 [1.928].

Redmon, H. E. See Ruedemann, P., 2.

Redwood, Boverton:

1. Petroleum; a treatise on the geographical distribution and geological occurrence of petroleum and natural gas . . 4th edition, 3 vols. London, Charles Griffin \& Company, 1922. [The part dealing with the United States was contributed by various members of the United States Geological Survey.]

Reed, Burleigh $\mathbf{B}$.

1. (and Knight, Nicholas). Some American dolomites: Iowa Acad. Sci., Proc., vol. 26, pp. 377-378 [1920].

Reed, Fredda Doris.

1. Flora of an Illinois coal ball : Bot. Gazette, vol. 81, no. 4, pp. 460-469, 1 fig., 1 pl., June, 1926; abstract, Chicago, Univ., Abstracts of Theses, Sci., Ser., vol. 3, pp. 299-302, April, 1927.

Reed, Lyman C.

1. The Welsh, Louisiana, oil field: Am. Assoc. Petroleum Geologists, Bull., vol. 9, no. 3, pp. 464-478, 6 figs., May-June, 1925; Geology of salt dome oil fields, pp. 437-451, 6 figs., 1926.

2. Possible evidence of Pleistocene ice action in southeast Texas: Am. Jour. Sci., 5th ser., vol. 15, pp. 520-521, June, 1928.

Reed, R. D. See also Rogers, A. F., 25; Twenhofel, 29.

1. Subsurface studies: Oklahoma Acad. Sci., Proc., vol. 2 (Oklahoma, Univ., Bull., new ser. no. 247), pp. 80-85, October 1, 1922.

2. Some suggestions in regard to Pennsylvania paleogeography in the Henryetta district,. Oklahoma: Am. Assoc. Petroleum Geologists, Bull., vol. 7, no. 1, pp. 50-57, 2 figs., January-February, 1923 :

3. (and Meland, Norman). The Verden sandstone [Oklahoma]: Jour. Geology, vol. 32, no. 2, pp. 150-167, 4 figs., February-March, 1924.

4. Some methods for heavy mineral investigations: Econ, Geology, vol. 19, no. 4, pp. 320-337, 1 fig., June-July, 1924, 
Reed, R. D.-Continued.

5. Rôle of heavy minerals in the Coalinga Tertiary formations: Econ. Geology, vol. 19, no. 8, pp. 730-749, 2 figs., December, 1924.

6. The post-Monterey disturbance in the Salinas Valley, California: Jour. Geology, vol. 33, no. 6, pp. 588-607, 3 figs., August-September, 1925.

7. Miocene paleogeography in the central Coast Ranges [California]: Am. Assoc. Petroleum Geologists, Bull., vol. 10, no. 2, pp. 130-137, 1 fig., February, 1926.

8. Effect of the wind in San Joaquin and Salinas valleys (abstract) : Geol. Soc. America, Bull., vol. 37, no. 1, pp. 214-215, March 30, 1926.

9. Aragonite concretions from the Kettleman Mills, California: Jour: Geology, vol. 34, no. pp. 820-833, 2 figs., November-December, 1926.

10. Wind and soil in the Gabilan Mesa [in central Coast Ranges, California] : Jour: Geology, vol. 35, no. 1, pp. 84-88, 1 fig., January-February, 1927.

11. Phosphate beds in the Monterey shales (abstract): Geol. Soc. America, Bull., vol. 38, no. 1, pp. 195-196, March 30, 1927.

12. (and Bailey, J. P.). Subsurface correlation by means of heavy minerals: Am. Assoc. Petroleum Geologists, Bull., vol. 11, no. 4, pp. 359-368, 4 figs., April, 1927.

13. A siliceous shale formation from southern California: Jour. Geology, vol. 36, no. 4, pp. 342-361, 4 figs., May-June, 1928.

14. The ocurrence of feldspar in California sandstones: Am. Assoc. Petroleum Geologists, Bull.; vol. 12, no. 10, pp. 1023-1024, October, 1.928.

Reeder \& Company.

1. The Appalachian oil field. 21 pp., New York, 1920.

Reeds, Chester Albert. See also Osborn, 19, 23 ; Sayles, 11; Science Service, 8. 1. Recent movements of Swiss and Alaskan glaciers: Natural History (Jour. Am. Mus. Nat. Hist.), vol. 21, no. 3, pp. 269-271, May-June, 1921.

2. Geology of New York City and its vicinity: Natural History (Jour. Am. Mus. Nat. Hist.), vol. 22, no. 5, pp. 431-445, 11 figs., SeptemberOctober, 1922; Am. Mus. Nat. Hist., Guide Leaftet series no. 56, 15 pp., 13 figs., March, 1925.

3. Banded postglacial clay near New York City (abstract) : Geol. Soc. America, Bull., vol. 34, no. 1, pp. 92-93, March 30, 1923.

4. Seasonal records of geologic time as noted in annual rings of trees, banded glacial clays, and certain deposits made during periods of arid climate: Natural History, vol. 23, no. 4, pp. 371-380, 8 figs., JulyAugust, 1923.

5. Postglacial clays at Little Gerry, New Jersey (abstract, with discussion by E. O. Hovey) : Geol. Soc. America, Bull., vol. 35, no. 1, pp. 66-67, March 30, 1924; abstract, Pan-Am. Geologist, vol. 41, no. 2, pp. 136-137, March, 1924.

6. Glacial Lake Hackensack and adjacent lakes (abstract) : Geol. Soc. America, Bull., vol. 36, no. 1, p. 155, March 30, 1925; Pan-Am. Geologist, vol. 43, no. 2, p. 151, March 30, 1925.

7. The varved clays at Little Ferry, New Jersey: Am. Mus. Novitates, no. 209, 16 pp., 10 figs., February 17, 1926.

8. Subterranean streams of the "Endless Caverns," Virginia (abstract): Geol. Soc. America, Bull., vol. 37, no. 1, p. 171, March 30, 1926; Pan-Am. Geologist, vol. 45, no. 2, p. 167, March 30, 1925. 
Reeds, Chester Albert--Continued.

9. Varved clays at Haverstraw, New York (abstract) : Geol. Soc. America, Bull., vol. 37, no. 1, pp. 180-181, March 30, 1926; Pan-Am. Geologist, vol. 45, no. 2, pp. 169-170, March 30, 1926.

10. New York City as a field for earthquake study: Science, new ser., vol. 63, pp. 415-418, April 23, 1926.

11. The Arbuckle Mountains, Oklahoma: Natural History (Am. Mus. Nat. Hist., Jour.), vol. 26, no. 5, pp. 463-474, 11 figs. (incl. map), September-October, 1926; Oklahoma Geol. Survey, Circular no. 14, 15 pp., 11 figs., March, 1.927.

12. Glacial lakes and clays near New York City : Natural History (Ann. Mus. Nat. Hist., Jour.), vol. 27, no. 1, pp. 55-64, 12 figs., JanuaryFebruary, 1927.

13. James Furman Kemp, 1859-1926 : Natural History (Am. Mus. Nat. Hist., Jour.), vol. 27, no. 1, pp. 105-107, portr., January-February, 1927.

14. Desert landscapes of northwestern Nevada: Natural History (Am. Mus. Nat. Hist., Jour.), vol. 27, no. 5, pp. 449-461, 22 figs., SeptemberOctober, 1927.

15. Varved glacial clays at Haverstraw, New York (abstract) : Pan-Am. Geologist, vol. 49, no. 2, p. 148, March, 1928; Geol. Soc. America, Bull., vol. 39, no. 1, pp. 217-218, March 30, 1928.

16. Rivers that flow underground: Natural History (Am. Mus. Nat. Hist., Jour.), vol. 28, no. 2, pp. 131-146, 17 figs., March-April, 1928.

17. Volcanoes in action: Natural History (Am. Mus. Nat. Hist., Jour.), vol. 28, no. 3, pp..302-317, 12 figs., May-June, 1928.

18. Living glaciers: Natural History (Am. Mus. Nat. Hist., Jour.), vol. 28, no. 4, pp. 379-393, 16 figs., July-August, 1928.

Reese, John F. See also Pennsylvania T. G. S., 1.

1. (and Sisler, James D.). Bituminous coal fields of Pennsylvania; introductory volume, part 3, Coal resources: Pennsylvania Geol. Survey, Fourth ser., Bull. M6 pt. 3, 153 pp., 4 pls.; 1928.

Reeside, John Bernard, jr. See also Baker, A. A., 1; Bassler, H., 2 ; Bauer, C. M., 1; Darton, 19 ; Dobbin, 2, 4; Gilluly, 2, 4; Spieker, 3, 5.

1. Some American Jurassic ammonites of the general Quenstedticeras, Cardioceras, and Amoeboceras, family Cardioceratidæ: U. S. Geol. Survey, Prof. Paper 118, 64 pp., 24 pls., 1 fig., 1919.

2. (and Bassler, Harvey). Phases of the Carboniferous and Triassic of southwestern Utah (abstract) : Washington Acad. Sci., Jour., vol. 11, no. 18, pp. 445-446, November 4, 1921.

3. Note on the stratigraphy of San Juan County, New Mexico, with special reference to the occurrence of dinosaurs: Smithsonian Misc. Coll., vol. 72, no. 14, pp. 4-6, January 31, 1922.

4. (and Bassler, Harvey). Stratigraphic section in southwestern Utah and northwestern Arizona: U. S. Geol. Survey, Prof. Paper 129, pp. 5377, 1 fig., 5 pls., March, 1922.

5. The fauna of the so-called Dakota formation of northern central Colorado and its equivalent in southeastern Wyoming: U. S. Geol. Survey, Prof. Paper 131, pp. 199-207, 6 pls., April 23, 1923.

6. A new fauna from the Colorado group of southern Montana: U. S. Geol. Survey, Prof. Paper 132, pp. 25-33, 11 pls., November 5, 1923. 
Reeside, John Bernard, jr.-Continued.

7. Notes on the geology of Green River valley between Green River, Wyoming; and Green River, Utah : U. S. Geol. Survey, Prof. Paper 132, pp. 3550, 6 figs., November 30, 1923.

8. Upper Cretaceous and Tertiary formations of the western part of the San Juan Basin of Colorado and New Mexico: U. S. Geol. Survey, Prof. Paper 134, pp. 1-70, 5 figs., 4 pls. (incl. map), 1924.

9. A new nautiloid cephalopod, Eutrephoceras sloani, from the Eocene of South Carolina: U. S. Nat. Mus., Proc., vol. 65, art. 5, 4 pp., 2 pls., 1924.

10. A rare Cretaceous sea urchin, Scutellaster cretaceus Cragin: U. S. Nat. Mus., Proc., vol. 66, art. 20, 4 pp., 2 figs., 1 pl., 1924.

11. A comparison of the genera Metaplacenticeras Spath and Placenticeras Meek: U. S. Geol. Survey, Prof. Paper 147, pp. 1-5, 2 pls., August $25,1926$.

12. The cephalopods of the Eagle sandstone and related formations in the western interior of the United States: U. S. Geol. Survey, Prof. Paper 151, 87 pp., 1 fig., 45 pls., 1927.

13. Cephalopods from the lower part of the Cody shale of Oregon Basin, Wyoming: U. S. Geol. Survey, Prof. Paper 150, pp. 1-19, 8 pls., October 6, 1927.

14. The scaphites, an Upper Cretaceous ammonite group: U. S. Geol. Survey, Prof. Paper 150, pp. 21-40, 3 pls., October 8, 1927.

15. An Acanthoceras rhotomagense fauna in the Cretaceous of the Western Interior: Washington Acad. Sci., Jour., vol. 17, no. 17, pp. 453-454, October 19, 1927.

16. Two new unionid pelecypods from the upper Triassic: Washington Acad. Sci., Jour., vol. 17, no. 19, pp. 476-478, 1 fig., November 4, 1927.

17. New Cretaceous mollusks from Colorado and Utah: Washington Acad. Sci., Jour., vol. 18, no. 11, pp. 306-313, 2 pls., June 4, 1928.

Reeves, Frank.

1. Geology of the Cement oil field, Caddo County, Oklahoma: U. S. Geol. Survey, Bull. 726, pp. 41-85, 4 figs., 7 pls. (incl. maps), August 10, 1921 ; abstract by R. W. Stone, Washington Acad. Sci., Jour., vol. 11, no. 21, p. 510, December 19, 1921.

2. Geology of the Ranger oil field, Texas: U. S. Geol. Survey, Bull. 736, pp. 111-170, 2 figs., 17 pls., 1922.

3. Oil fields of central Montana: [U. S. Geol. Survey], [Press Notice], 6 pp., map [1921?]. [Mimeographed.]

4. Oil fields of central Montana: U. S. Geol. Survey, [Press Notice], 4 pp., April 22, 1921. [Mimeographed.]

5. Oil fields of central Montana: U. S. Geol. Survey, [Press Notice], 3 pp., map, May 16, 1921. [Mimeographed.]

6. Geology of northern Fergus County, Montana: U. S. Geol. Survey, Press Notice, 7 pp., map [1922?]. [Mimeographed.]

7. The structure of the Bearpaw Mountains, Montana: Am. Jour. Sci., 5th ser., vol. 8, pp. 296-311, 5 figs. (incl. maps), October, 1924 ; abstract, Geol. Soc. America, Bull., vol. 35, no. 1, p. 93, March 30, 1924 ; Pan-Am. Geologist, vol, 41, no. 2, p. 146, March, 1924.

8. Geology and possible oil and gas resources of the faulted area south of the Bearpaw Mountains, Montana: U. S. Geol. Survey, Bull. 751. pp. 71-114, 5 figs., 5 pls. (incl. map), October 13, 1924. 
Reeves, Frank-Continued.

9. Shallow folding and faulting around the Bearpaiw Mountains: Am. Jour. Sci., 5th ser., vol. 10, pp. 187-200, 6 figs., September, 1925; abstract, Pan-Am. Geologist, vol. 44, no. 1, pp. 78-79, August, 1925.

10. Geology of the Cat Creek and Devils Basin oil fields and adjacent areas in Montana: U. S. Geol. Survey, Bull. 786, pp. 39-95, 6 figs., 3 pls. (incl. maps), 1927.

11. The landslide origin of the thrust faults around Bearpaw Mountains (abstract) : Washington Acad. Sci., Jour., vol. 17, no. 5, p. 127, March 4, 1927.

12. Thrust faulting adjacent to the Highwood Mountains, Montana (abstract): Washington Acad. Sci., Jour., vol. 17, no. 9, p. 232, May 4, 1927.

13. The present status of the carbon-ratio theory: Am. Assoc. Petroleum Geologists, Bull., vol. 11, no. 6, p. 637, June, 1927.

14. The carbon-ratio theory in the light of Hilt's law: Am. Assoc. Petroleum Geologists, Bull., vol. 12, no. 8, pp. 795-823, 5 figs., August, 1928.

Reeves, John R.

1. The Anderson esker [Indiana]: Am. Jour. Sci., 4th ser., vol. 50, pp. 65-68, 1 fig., July, 1920.

2. Oil shales of Indiana : Eng. and Min. Jour., vol. 110, no. 20, pp. 954-955, November 13, 1920.

3. Preliminary report on the oil shales of Indiana. In Handbook of Indiana geology (Indiana, Dept. Conservation, Pub. no. 21), pp. 10591105, 16 figs., Indianapolis, 1922.

4. New Albany oil shale of Indiana: Eng. and Min. Jour.-Press, vol. 114, no. 13 , p. 554, September $23,1922$.

5. Oil shales of Indiana: Indiana University, Department of Geology, 92 pp., June, 1923. [Mimeographed.]

6. A section through the New Albany shale: Indiana, Dept. Conservation, 4th Ann. Rept., pp. 18-21, 1 fig., 1923.

7. The production of oil in Indiana : Am. Assoc. Petroleum Geologists, Bull.. vol. 9, no. 2, pp. 317-325, 1 fig. (map), March-April, 1925.

8. The value of relief models and a simple method for their construction: Am. Assoc. Petroleum Geologists, Bull., vol. 9, no. 2, pp. 340-341, March-April, 1925.

9. An inclusion of petroleum in a fossil cast [Bloomington, Indiana]: Am. Assoc. Petroleum Geologists, Bull., vol. 9, no. 3, p. 667, May-June, 1925.

10. Concerning the accumulation of oil: Am. Assoc. Petroleum Geologists, Bull., vol. 9, no. 6, pp. 1023-1024, September, 1925.

Reger, David Bright. See also Cottingham, 2; White, D., 1; Willis, B., 4.

1. Webster County and portion of Mingo district, Randolph County, south of Valley Fork of Elk River: West Virginia Geol. Survey [County reports], 682 pp., 24 figs., 35 pls., 2 maps, 1920.

2. Recent oil and gas developments in West Virginia: Am. Assoc. Petroleum Geologists, Bull., vol. 4, no. 1, pp. 27-31, 1920.

3. Nicholas County: West Virginia Geol. Survey [County Reports], 847 pp., 2 maps, 34 pls., 2 figs., 1921.

4. Oil and gas development in West Virginia for the year 1920: Am. Assoc. Petroleum Geologists, Bull., vol. 5, no. 1, pp. 80-84, JanuaryFebruary, 1921. 
Reger, David Bright-Continued.

5. Carbon ratios of coals in West Virginia oil fields: Am. Inst. Min. and Met. Eng., Trans. [preprint] no. 1056, 5 pp., 1 fig., February, 1921; abstract, Mining and Metallurgy, no. 170, p. 39, 1 fig., February, 1921 ; discussion by J. T. Singewald, Am. Inst. Min. and Met. Eng.. Trans. [preprint] no. 1073, pp. 33-34, May, 1921; Trans., vol. 65, pp. 522-527, 1 fig., 1921.

6. Tucker County: West Virginia Geol. Survey, 542 pp., 11 figs., 16 pls., 2 maps, 1923.

7. Mineral and Grant counties: West Virginia Geol. Survey, 866 pp., 31. figs., 43 pls., 4 maps (in atlas), $\cdot 1924$.

8. First test of the Clinton oil sand in West Virginia: Am. Inst. Min. and Met. Eng., Trans. [preprint], no. 1447, pp. 72-77, 1 fig., April, 1925.

9. (assisted by Paul H. Price). Mercer, Monroe, and Summers counties: West Virginia Geol. Survey, 963 pp., 30 figs., 34 pls., 6 maps (in atlas), 1926.

10. Paleobotany and paleontology ; introduction [and list of fossil localities] : West Virginia Geol. Survey, Mercer, Monroe, and Summers counties, pp. 799-836, 844-846, 1926.

11. Smokeless coals of West Virginia: Coal Age, vol. 29, no. 18, pp. 633-637, 7 figs., May 6, 1926.

12. Conglomerate rocks of West Virginia: West Virginia Acad. Sci., Proc., vol. 1, no. 1 (W. Va. Univ. Bull., ser. no. 27, no. 1), pp. 57-64, August, 1926.

13. Pocono stratigraphy in the Broadtop Basin of Pennsylvania: Geol. Soc. America, Bull., vol. 38, no. 2, pp. 397-410, June 30, 1927 ; abstract, no. 1, pp. 156-157, March 30, 1927 ; Pan-Am. Geologist, vol. 47, no. 2, p. 155, March, 1927.

14. The Copley oil pool of West Virginia: Am. Assoc. Petroleum Geologists, Bull., vol. 11, no. 6, pp. 581-599, 5 figs., June, 1927.

15. The Tygart Valley Devonian trees of West Virginia: Am. Jour. Sci., 5th ser., vol. 15, pp. 49-57, January, 1928.

16. The Cheat Mountain coal field of Randolph County, West Virginia : West Virginia Geol. Survey, Bull. 3, 34 pp., map, 1928.

17. The Cheat Mountain coal field of Randolph County, West Virginia : West Virginia Acad. Sci., Proc., vol. 2 (West Virginia Univ. Bull., ser. no. 29, no. 1), pp. 118-131, August, 1928.

Reid, Harry Fielding. See also Am. Geophysical Union, 1; Bowie, $24 . \quad$ •

1. (and Taber, Stephen). Recent earthquakes of Porto Rico (abstract) : Geol. Soc. America, Bull., vol. 30, no. 1, pp. 83-84, March 31, 1919.

2. (and Taber, Stephen). The Porto Rico earthquake of 1918, with descriptions of earlier earthquakes: U. S., 66th Cong., 1st Sess., H. R. Doc. no. 269,74 pp., 8 pls., 1919.

3. (and Taber, Stephen). The Porto Rico earthquake of October-November, 1918: Seismol. Soc. America, Bull., vol. 9, no. 4, pp. 95-127, 8 pls., December, 1919.

4. (and Taber, Stephen). The Virgin Islands earthquakes of 1867-1868: Seismol. Soc. America, Bull., vol. 10, no. 1, pp. 9-30, 3 flgs., March, 1920.

5. The distribution of land and water on the earth: Am. Philos. Soc.. Proc.. vol. 59, no. 4, pp. 313-324, 3 figs., 1920. 
Reid, Harry Fielding-Continued.

6. The problems of seismology: Nat. Acad. Sci., Proc., vol. 6, no. 10, pp. 555561, October 15, 1920. Nat. Research Council, Reprint and Circular Ser., no. 11, pp. 555-561, 1920.

7. Orogenic forces (abstract) : Geol. Soc. America, Bull., vol. 32, no. 1, p. 33, March 31, 1921.

8. Some astronomical tests of the planetesimal hypothesis (abstract): Geol. Soc. America, Bull., vol. 33, no. 1, p. 140, March 31, 1922.

9. Isostasy and earth movements: Geol. Soc. America, Bull., vol. 33, no. 2, pp. 317-326, June 30, 1922.

10. Note on the record of surface waves: Seismol. Soc. America, Bull., vol. 13, no. 3, pp. 107-108, September, 1923.

11. The movement in the slides [Panama Canal Zone]: Nat. Acad. Sci., Mem., vol. 18, pp. 77-84, 1924.

12. The planetesimal hypothesis and the solar system: Am. Jour. Sci., 5th ser., vol. 7, pp. 37-64, 4 figs., January, 1924.

13. The seismograph and friction (abstract): Nat. Research Council, Bull., vol. 7, pt. 5, no. 41, pp. 97-98, January, 1924.

14. The interpretation of the seismogram: Nat. Research Council, Bull., no. 53 (vol. 10, pt. 3), pp. 50-51, July, 1925.

15. The influence of friction on seismographs: Seismological Soc. America, Bull., vol. 15, no. 3, pp. 222-241, 2 figs., September, 1925.

16. Earthquakes and the weather: Geog. Rev., vol. 16, no. 1, pp. 152-153, January, 1926.

17. Dynamics of faulting (abstract) : Geol. Soc. America, Bull., vol. 37, no. 1, p. 166, March 30, 1926; Pan-Am. Geologist, vol. 45, no. 2, pp. 164-165, March, 1926.

18. Note on the influence of the moon on earthquakes: Nat. Research Council, Bull., no. 56 (vol. 11, pt. 2), pp. 73-74, November, 1926.

19. The fundamentals of isostasy (abstract): Science, new ser., vol. 65, p. 480, May 13, 1927.

Reid, John Allen.

1. Origin of manganese deposits of Lunenburg County, Nova Scotia: Eng. and Min. Jour.-Press, vol. 115, no. 7, pp. 307-308, February 17, 1923.

2. Discussion on "The gold deposits of Nova Scotia," by Sir Stopford Brunton: Canadian Inst. Min. and Met., Bull., no. 173, pp. 10391044, September, 1926.

3. A feldspar-chalcopyrite rock-ore (discussion): Eng. and Min. Jour., vol. 123, no. 19, p. 771, May 7, 1927.

Reid, John T.

1. Hanging rocks and earthquakes: Eng. and Min. Jour.-Press, vol. 118, no. 8, p. 305, August 23, 1924.

Reid, W. Spencer. See Varley, 2.

Reinecke, Leopold.

1. Road materials in the vicinity of Regina, Saskatchewan: Canada, Geol. Survey, Mem. 107 (geol. ser. 90), 28 pp.. 2 pls., 3 figs., map, 1919.

2. Undeveloped mineral resources of the Clinton district, B. C.: Canadian Min. Inst., Bull. no. 88, pp. 871-876, 1 fig., August, 1919; no. 89, pp. $940-950$, 3 figs., September, 1919 ; no. 90, pp. 1039-1049, October, 1919; Trans., vol. 22, pp. 341-367, 6 figs. [1920]. 
Reinecke, Leopold-Continued.

3. Mineral deposits between Lillooet and Prince George, British Columbia: Canada, Geol. Survey, Mem. 118, 129 pp., 18 figs., 17 pls., 1920.

Reinhard, Max.

1. Interprétation tectonique de la région pétrolifère de la vallée de Santa Clara en Californie et considérations théoriques sur les gîtes de pétrole: Arch. sci. phys. nat., 5th ser., vol. 1, pp. 63-78, 2 pls. (incl. map), January-February, 1919.

Reinhart, Philip W.

1. Origin of the Sespe formation of South Mountain, California: Am. Assoc. Petroleum Geologists, Bull., vol. 12, no. 7, pp. 743-746, July, 1928.

Reinholt, Oscar Halvorsen.

1. Oildom; its treasures and tragedies. . . Part one, 128 pp., illus., copyright, 1924 ; Part two, pp. 129-384 + [13 pp., index], Philadelphia, David McKay Co., copyright, 1927.

Reiter, A. F.

1. Present status of copper mining in Garfield County: Oklahoma, Univ., Bull. (Proc. Oklahoma Acad. Sci., 1910-1920), new ser. no. 220, p. 67, July 15, 1921.

2. Manganese deposits in Custer County: Oklahoma, Univ., Bull. (Proc. Oklahoma Acad. Sci., 1910-1920), new ser. no. 220, p. 68, July 15, 1921.

3. Anticlinal folds in central Custer County: Oklahoma, Univ., Bull. (Proc. Oklahoma Acad. Sci., 1910-1920), new ser. no. 220, pp. 68-69, July 15, 1921.

Renick, B. Coleman. See also Meinzer, 15.

1. Correlation of the Pottsville and lower Allgheny formations in western Pennsylvania (abstract with discussion by G. H. Ashley) : Geol. Soc. America, Bull., vol. 34, no. 1, pp. 68-69, March 30, 1923.

2. The correlation of the lower Allegheny-Pottsville section in western Pennsylvania: Jour. Geology, vol, 32 , no. 1, pp. 64-80, 4 figs., January-February, 1924; abstract, Chicago, Univ., Abstracts of Theses, Sci. ser., vol. 1, pp. 297-304, 1 fig., October, 1925.

3. Base exchange in ground water by silicates as illustrated in Montana: U. S. Geol. Survey, Water-Supply Paper 520, pp. 53-72, 1 fig., 3 pls., 1924.

4. Additional ground-water supplies for the city of Enid, Oklahoma: U. S. Geol. Survey, Water-Supply Paper 520, pp. 15-26, 3 figs. (incl. map), 1924.

5. Some geochemical relations of ground water and associated natural gas in the Lance formation, Montana: Jour. Geology, vol. 32, no. $\$$, pp. 668-684, 3 figs., November-December, 1924.

6. Ground water in Sandoval County, New. Mexico: [U. S. Geol. Survey], (Press Notice), 2 pp., December 26, 1924. [Mimeographed.]

7. Airplanes for geologic explorations in inaccessible regions: Am. Assoc. Petroleum Geologists, Bull., vol. 9, no. 6, pp. 947-957, 4 pls., September, 1.925.

8. California oil field waters (discussion) : Econ. Geology, vol. 20, no. 7, pp. 697-698, November, 1925. 
Renick, B. Coleman-Continued.

9. The geology and artesian water prospects in the San Jose-Rio Puerco valley, in Sandoval County, New Mexico: New Mexico, State Engineer, 7th Bienn. Rept., pp. 61-75, 1 fig. [1926].

10. Geology and ground water resources of the drainage basin of the Rio Penasco above Hope, New Mexico. (with an introduction by 0 . E. Meinzer) : New Mexico, State Engineer, 7th Bienn. Rept., pp. 103138, 4 figs., 1 pl. [1926].

11. Petrology of a portion of Malheur County, Oregon (abstract) : Geol. Soc. America, Bull., vol. 37, no. 1, pp. 151-152, March 30, 1926; PanAm. Geologist, vol. 45, no. 2, p. 158, March, 1926.

12. Recently discovered salt domes in east Texas: Am. Assoc. Petroleum Geologists, Bull., vol. 12, no. 5, pp. 527-547, 1 pl., May, 1928.

Renner, George T., jr.

1. The physiographic interpretation of the Fall Line: Geog. Rev., vol. 17, no. 2, pp. 278-286, 13 figs., April, 1927.

2. The fall line of the eastern United States: Science, new ser., vol. 66, pp. $356-357$, October 14, 1927.

Repetti, William C. See Macelwane, 19, 20.

Resser, Charles E.

1. Bibliographic studies of the Cambrian (abstract): Geol. Soc. America, Bull., vol. 31, no. 1, p. 213, March 31, 1920.

2. Memorial of Anthony W. Vogdes: Geol. Soc. America, Bull., vol. 35, no. 1, p. 184, March 30, 1924.

3. Subdivisions of the Cambrian (abstract) : Geol. Soc. America, Bull., vol.' 35 , no. 1, pp. 185-186, March 30, 1924 . -

4. The Cambrian in the Rocky Mountains (abstract): Washington Acad. Sci., Jour., vol. 17, no. 5, p. 130, March 4, 1927.

5. Cambrian geology of the Rocky Mountains: Smithsonian Inst., Explorations and Field Work in 1927, pp. 17-20, 3 figs., 1928. (Pub. 2957.)

6. Cambrian fossils from the Mohave Desert: Smithsonian Misc. Coll., vol. 81, no. 2, 14 pp., 3 pls., July 5, 1928.

Rettger, R. E.

1. The bauxite deposits of southeastern Alabama: Econ. Geology, vol. 20, no. 7, pp. 671-686, 3 figs., November, 1925.

Reyes, Alicia E.

1. Ejemplar número 21.3 del museo paleontológico del Instituto Geológico de México: Mexico, Inst. Geol., Anales, t. 2, nos. 6-10, 2 pls., $192 \pi$.

Reynolds, Donald D.

1. (and Leavitt, David H.) A scree of Triassic age [Connecticut Valley, Massachusetts]: Am. Jour. Sci., 5th ser., vol. 13, pp. 161-171, February, 1927.

Rhodes, E. O.

1. The Paint Creek uplift: Kentucky, Dept. Geology and Forestry, Ser. V [of Ky. Geol. Survey], Mineral and Forest Resources of Kentucky, vol. 1, no. 3, pp. 243-250, map, October 1, 1919.

Rice, E. M. See Thomas, N. L., 3.

Rice, George S.

1. (and others). Analyses of Iowa coals. U. S. Bur. Mines, Tech. Paper 269, 26 pp., 1921. 
Rice, George S.-Continued.

2. Some problems in ground movement and subsidence: Am. Inst. Min. and Met. Eng., Trans., vol. 69, pp. 374-398, 14 figs., 1923; [preprint] no 1271, pp. 1-20, 14 figs., Sentember, 1923.

Rice, Marion. See also Berkey, 3.

1. Petrographic notes on the ore deposits of Jerome, Arizona: Am. Inst. Min. and Met. Eng., Trans., vol. 61, pp. 60-65, 9 figs., 1920.

Rice, William North, 1845-1928. See also Foye, 5.

1. (and Foye, Wilbur Garland). Guide to the geology of Middletown, Connecticut, and viçinity: Connecticut, State Geol. and Nat. Hist. Survey, Bull., no. 41,137 pp., 33 figs., (incl. maps), 3 pls., 1927.

Rich, Arthur.

1. Geology of southeastern New Mexico: Oil and Gas Jour., vol. 25, no. 8, pp. 130-131, map, July 15, 1926.

Rich, John Lyon. See also Barwick, 1; Lee, W. T., 3 ; Moore, R. C., 17.

1. A graphical method of determining the average inclination of a land surface from a contour map: Illinois Acad. Sci., Trans., vol. 9, pp. 195-199 [1917].

2. A probable buried mountain range of early Permian age east of the present Rocky Mountains in New Mexico and Colorado: Am. Assoc. Petroleum Geologists, Bull., vol. 5, no. 5, pp. 605-608, SeptemberOctober, 1921.

3. Moving underground water as a primary cause of the migration and accumulation of oil and gas: Econ. Geology, vol. 16, no. 6, pp. 347-371, September-October, 1921.

4. A convenient loose-leaf system for field maps and notes: Econ. Geology, vol. 16, no. 7, pp. 479-481, November, 1921.

5. The stratigraphy of eastern New Mexico-a correction: Am. Jour. Sci., 5th ser., vol. 2, pp. 295-298, November, 1921.

6. Shoestring sands of eastern Kansas: Am. Assoc. Petroleum Geologists, Bull., vol. 7, no. 2, pp. 103-113, 6 figs., March-April, 1923.

7. Further notes on the hydraulic theory of oil migration and accumulation: Am. Assoc. Petroleum Geologists, Bull., vol. 7, no. 3, pp. 213-225; 1 fig., May-June, 1923; Nat. Petroleum News, vol. 15, no. 28, pp. 75-76, 1 fig., July 11, 1923.

8. Buried Pennsylvanian channels and sand bars of eastern Kansas (abstract) : Geol. Soc. America, Bull., vol. 37, no. 1, p. 159, March 30 , 1926 ; Pan-Am. Geologist, vol. 45, no. 2, p. 161, March, 1926.

9. Further observations on shoestring oil pools of eastern Kansas: Am. Assoc. Petroleum Geologists, Bull., vol. 10, no. 6, pp. 568-580, 3 figs., June, 1926; Oil and Gas Jour., vol. 25, no. 1, pp. 62, 65, 68, 70, 3 figs., May 27, 1926.

10. Geological notes: Am. Assoc. Petroleum Geologists, Bull., vol. 11, no. 9, pp. 1008-1010, September, 1927.

11. Generation of oil by geologic distillation during mountain building: Am. Assoc. Petroleum Geologists, Bull., vol. 11, no. 11, pp. 1139-1149, 1 fig., November, 1927.

12. A theory of petroleum origin: Oil Eng. and Tech., vol. 9, no. 1, pp. 5-8, 1 fig., January, 1928.

13. Geology of Glenn pool of Oklahoma (discussion) : Am. Assoc. Petroleum Geologists, Bull., vol. 12, no. 2, pp. 213-215, February, 1928. 
Rich, John Lyon-Continued.

14. Generation of petroleum as an accompaniment of mountain building (abstract) : Geol. Soc. America, Bull., vol. 39, no. 1, pp. 191-192, March 30, 1928; Pan-Am. Geologist, vol. 49, no. 2, pp. 144-145, March, 1928.

15. Jointing in limestones as seen from the air: Am. Assoc. Petroleum Geologists, Bull., vol. 12, no. 8, pp. 861-862, August, 1928.

Richards, Esther E. See Vaughan, 23.

Richards, Gragg.

1. Veins with fibrous quartz and chlorite from the vicinity of Providence, Rhode Island: Am. Mineralogist, vol. 10, no. 11, pp. 429-433, November, 1925.

Richards, J. T. See Clark, S. K., 2.

Richards, Ralph Webster.

1. Commercial oil geology east of the Mississippi: Am. Assoc. Petroleum Geologists, Bull., vol. 5, no. 4, pp. 460-463, July-August, 1921.

2. (and Pardee, J. T.). The Melrose phosphate field, Montana: U. S. Geol. Survey, Bull. 780, pp. 1-32, 2 figs. 2 pls., (maps), April 13, 1925.

Richardson, Charles Henry.

$\checkmark 1$. The Ordovician terranes of central Vermont: Vermont, State Geologist, 11th Rept., pp. 45-51, 3 pls. [1919].

2 (and Camp, Samuel H.). The terranes of Northfield, Vermont: Vermont State Geologist, 11th Rept., pp. 99-119, 6 pls. (incl. map), [1919].

3. The terranes of Roxbury, Vermont: Vermont, State Geologist, 11th Rept., pp. 120-140, 4 pls., 1 fig. [1919].

4. The glass sands of Kentucky: Kentucky Geol. Survey, Ser. 6, vol. 1, 149 pp., 23 figs., 1920.

5. (and Cabeen, C. K.). The geology and mineralogy of Braintree, Vermont: Vermont, State Geologist, Twelfth Rept., 1919-20, pp. 57-76, 1 pl., 1921.

6. The building stones of Kentucky: Kentucky Geol. Survey, ser. 6, vol. 11, 355 pp., 85 figs., 1923.

7. (and Cabeen, Charles K.). The geology and petrography of Randolph, Vermont: Vermont, State Geologist, Thirteenth Rept., 1921-1922, pp. 109-142, 1 pl. (map), 1923.

8. The terranes of Bethel, Vermont: Vermont, State Geologist, Fourteenth Rept., 1923-1924, pp. 77-103, 10 pls. (incl. map), 1924.

9. The road materials of Kentucky: Kentucky Geol. Survey, ser. 6, vol. 22, 209 pp., 48 figs. and pls., 1924.

10. The mineralogy of Kentucky; a description of the physical and chemical properties of minerals native to Kentucky: Kentucky Geol. Survey, ser. 6, vol. 27 , pp. 1-127, 1925.

11. The geology and petrography of Barnard, Pomfret, and Woodstock, Vermont: Vermont, State Geologist, 15th Rept., 1925-26, pp. 127159, 7 pls. (incl. map), 1927.

12. The molding sands of Kentucky : Kentucky Geol. Survey, ser. 6, vol. 29, pp. 1-64, 20 figs., 1927.

13. Cement materials of Kentucky: Kentucky Geol. Survey, ser. 6, vol. 29, pp. 65-154, 33 figs., 1 pl., 1927.

14. Irasburg conglomerate [Vermont] (abstract): Pan-Am. Geologist, vol. 49. no. 2, p. 146, March, no. 3, p. 232, April, 1928; Geol. Soc. America, Bull., vol. 39, no. 1, pp. 212-213, March 30, 1928. 
Richardson, George Burr. See also Butler, B. S., 4; Redwood, 1; Roundy, 1.

1. (and DeWolf, F. W.). [Map of the] Oil and gas fields of the State of 'Illinois. Scale, 1:500,000. U. S. Geol. Survey, 1921.

2. [Map of the] Oil and gas fields of the State of Louisiana. Scale, 1 inch $=12$ miles. U. S. Geol. Survey, 1921.

3. [Map of the] Oil and gas fields of Pennsylvania. Scale, 1: 500,000. U. S. Geol. Survey, 1921.

4. (and Heald, K. C.). [Map of the] Oil and gas fields of the State of Wyoming. Scale, 1: 500,000. U. S. Geol. Survey, 1921.

5. Petroleum in 1919-1921: U. S. Geol. Survey, Mineral Resources, 1921, pt. 2, pp. 253-333, 6 figs., May 26, 1923.

6. Natural gas in 1922: U. S. Geol. Survey, Mineral Resources, 1922, pt. 2, pp. 353-358, April 26, 1924.

7. Petroleum in 1922: U. S. Geol. Survey, Mineral Resources, 1922, pt. 2, pp. 359-438, 7 figs., 2 pls., July 15, 1924.

8. Natural gas in 1923: U. S. Geol. Survey, Mineral Resources, 1923, pt. 2, pp. 351-358, March 3, 1925.

9. Petroleum in 1923: U. S. Geol. Survey, Mineral Resources of the United States, 1923, pt. 2, pp. 365-420, 6 figs., 2 pls., August 27, 1925.

10. (and Coons, A. B.). Petroleum in 1924: U. S. Bur. Mines, Mineral Resources of the United States, 1924, pt. 2, pp. 385-458, 4 figs., October 2, 1926.

11. The Upper Cretaceous section in the Colob Plateau, southwest Utah: Washington Acad. Sci., Jour., vol. 17, no. 18, pp. 464-475, 1 fig., November 4, 1927.

12. Structure of the Pittsburgh Basin (abstract) : Geol. Soc. America, Bull., vol. 39, no. 1, p. 188, March 30, 1928; Pan-Am. Geologist, vol. 49, no. 2, p. 143, March, 1928.

13. Structure-contour maps of the Pittsburgh-Huntington basin: Geol. Soc. America, Bull., vol. 39, no. 2, pp. 543-553, 2 figs., 2 pls., June, 1928.

Richardson, H. T. See Kentucky G. S., 42.

Richardson, W. D.

1. The singing sands of Lake Michigan: Science, new ser., vol. 50, pp. 493-495, November 28, 1919.

Richarz, Stephen.

1. Eine tertiäre Vergletscherung Alaskas und die Polwanderung: Deutsche geol. Gesell., Zeitschr., Bd. 74, Monatsber., no. 5-7, pp. 180-190, 1922.

2. Some inclusions in basalt: Jour. Geology, vol. 32, no. 8, pp. 685-689, November-December, 1924.

3. Alfred Wegener's theory of origin of the continents: Pan-Am. Geologist, vol. 43, no. 2, pp. 85-96, March, 1925.

4. Climates of the geologic past: Pan-Am. Geologist, vol. 45, no. 2, pp. 97-108, March, 1926.

5. Quartz keratophyre from the Porcupine gold area, Ontario: Am. Jour. Sci., 5th ser., vol. 11, pp. 441-442, May, 1926.

6. Biotic basis of stratigraphy : Pan-Am. Geologist, vol. 46, no. 2, pp. 101110, September, 1926.

7. The amphibole grünerite of the Lake Superior region: Am. Jour. Sci., 5th ser., vol. 14, pp. 150-154, August, 1927.

8. The relation of French and American grünerites to similar ferromanganese amphiboles of Sweden: Am. Mineralogist, vol. 12, no. 9, pp. 351353, 1 fig., September, 1927.

$4096-31-33$ 
Richarz, Stephen-Continued.

9. Grünerite rocks of the Lake Superior region and their origin: Jour. Geology, vol. 35, no. 8, pp. 690-707, November-December, 1927.

10. Problems of the Equator: Pan-Am. Geologist, vol, 49, no. 1, pp. 21-34, 2 figs., February, 1928.

11. Metamorphism of the Lake Superior iron formations (abstract) : Geol. Soc. America, Bull., vol. 39, no. 1, pp. 164-165, March 30, 1928; Pan-Am. Geologist, vol. 49, no. 1, pp. 74-75, February, 1928.

12. Carl Diener and modern paleontology : Pan-Am. Geologist, vol. 50, no. 1, pp. 1-4, 1. pl. (portr.), August, 1928.

Rickaby, H. C.

1. Geology of Ontario-Manitoba boundary: from Bloodvein River to Twelfth base line, 1922: Ontario Dept. Mines, 32d Ann. Rept., vol. 32, pt. 2, pp. 49-59, 8 figs., map, 1923.

2. The mineral association of the salt deposits at Malagash, Nova Scotia: Toronto, Univ., Studies, Geol. ser., no. 16, pp. 46-52, 1 fig., 1923.

Rickard, Thomas Arthur. See also McKenzie, N., 1.

1. Horace V. Winchell, mining geologist: Min. and Sci. Press, vol. 118, pp. 211-219, 9 figs., February 15, 1919.

2. Willet G. Miller, Canadian geologist: Min. and Sci. Press, vol. 118, pp. 779-786, June 7, 1919.

3. The Bunker Hill enterprise, V; the geology and mineralogy of the lode [Coeur d'Alene district, Idaho] : Min. and Sci. Press, vol. 120, pp. 261-268, 5 figs., February 21, 1920.

4. (Editor). Rossiter Worthington Raymond; a memorial published by the American Institute of Mining and Metallurgical Engineers. 95 pp., New York, 1920.

5. Applied geology at Butte [Montana]: Min. and Sci. Press, vol. 123, nn. 13, pp. 427-431, 4 figs., September 24, 1921.

6. The forecasting of earthquakes: Eng. and Min. Jour.-Press, vol. 113, no. 23, p. 992, June 10, 1922.

7. Petroleum geologists meet at Los Angeles: Eng. and Min. Jour.-Press, vol. 116, no. 15, pp. 643-644, October 13, 1923.

8. The Chino enterprise, III; geology of Santa Rita [New Mexico] : Eng. and Min. Jour.-Press, vol. 116, no. 23, pp. 981-985, 1 fig. (map), December 8, 1923.

9. A great mining adventure [Jerome district, Yavapai County, Arizona] : Eng. and Min. Jour-Press, vol. 117, no. 24, pp. 959-963, 2 figs., June 14, 1924.

10. The Ahumada lead mine and the ore deposits of the Los Lamentos Range $_{,}$in Mexico: Eng. and Min. Jour.-Press, vol. 118, no. 10, pp. 365-374, 9 figs., September 6, 1924.

11. The geologic distribution of gold: Eng. and Min. Jour.-Press, vol. 119, no. 12, pp. 486-487, March 21, 1925.

12. James Furman Kemp; in memoriam: Eng. and Min. Jour., vol. 123, no. 1, pp. 32-33, portr., January 1, 1927.

Riddell, C. W. See Clark, W. O., 1.

Riddell, Guy C.

1. (and Foster, E. D.). Geology and ores of the Shadow Mountains [San Bernardino County, California] : Min. Jour. (Phoenix, Ariz.), vol. 11, no. 12, pp. 3-6, 33-34, November 15, 1927. 
Ries, Heinrich.

1. The occurrence of high-grade American clays and the possibility of their further development: Am. Ceramic Soc., Jour., vol. 1, no. 7, pp. 446-467, 16 figs., July, 1918.

2. High-grade clays of the United States (abstract): Geol. Soc. America, Bull., vol: 30, pp. 95-96, March 31, 1919.

3. (and Somers, R. E.). The clays and shales of Virginia west of the Blue Ridge: Virginia Geol. Survey, Bull. no. 20, 118 pp., 8 figs. (incl. maps), 14 pls. (incl. map), 1920.

4. (and Watson, T. L.). Elements of engineering geology. 365 pp., 252 figs., New York, John Wiley \& Sons, Inc., 1921.

5. (and Bayley, W. S., and others). High-grade clays of the eastern United States, with notes on some western clays: U. S. Geol. Survey; Bull. 708, 314 pp., 38 figs., 30 pls., 1922.

6. The clay deposits of Kentucky: Kentucky Geol. Survey, Ser. 6, vol. 8, 241 pp., 62 figs., 1922.

7. Fire clays of the eastern coal field of Kentucky: Am. Ceramic Soc., Jour., vol. 5, no. 7, pp. 397-408, 6 figs., July, 1922.

8. (and Bowen, W. C.). Origin of the zinc ores of Sussex County, New Jersey: Econ. Geology, vol. 17, no. 7, pp. 517-571, 2 figs., 5 pls., November, 1922.

9. Zirconium; history and chemistry: Mineral Foote-Notes, vol. 3, no. 6, pp. 3-7, November-December, 1919.

10. Economic geology. 5th ed., 843 pp., 291 figs., New York, John Wiley \& Sons, 1925.

11. (and Watson, Thomas L.). Engineering geology. 3d ed., 708 pp., 253 figs., 88 pls., New York, John Wiley \& Sons, 1925.

12. Memorial of Thomas L. Watson: Geol. Soc. America, Bull., vol. 36, no. 1, pp. 116-128, portr., March 30, 1925.

13. Memorial of Thomas L. Watson: Am. Mineralogist, vol. 10, no. 3, pp. 54-57, portr., March, 1925.

14. Bibliography of clay deposits: Am. Ceramic Soc., Bull., vol. 4, no. 9, pp. 428-510, September, 1925.

15. Clays; their occurrence, properties, and uses, with special reference to those of the United States and Canada. 3d ed., 613 pp., 173 figs., New York, John Wiley \& Sons, 1927.

16. Geology [contributions to engineering and industry]: Sci: Monthly, vol. 24, no. 4, pp. 302-308, April, 1927.

17. A needed line of research [on clay] : Econ. Geology, vol. 22, no. 6, pp. 625-628, September-October, 1927.

Riffenburg, H. B.

1. Chemical character of ground waters of the northern Great Plains: U. $\mathbf{S}$. Geol. Survey, Water-Supply Paper 560, pp. 31-52, 4 figs., April 21, 1925.

Rigaud, F.

1. Les gisements de pétrole d'Ámérique; les Htats-Unis et le Canada: La Nature, ann. 51, no. 2547, pp. 51-54, 2 figs., January 27, 1923.

Ring, A. E.

1. Silver-bearing petrified wood [Creede, Colorado]: Eng. and Min. Jour.Press, vol. 117, no. 22, pp. 891-892, May 31, 1924. 
Roark, Louis. See also Bartram, 1.

1. The Hewitt oil field, Carter County, Oklahoma : Indiana Acad. Sci., Proc., 1921, pp. 211-220, 1 pl., 1922.

2. Geology of the Papoose oil field, Okfuskee and Hughes Counties, Oklahoma : Oklahoma Geol. Survey, Bull. no. 36, pp. 7-18, 1 flg. (map), February, 1926.

Roberts, D. C.

1. Methods of identifying subsurface strata for correlative purposes [in California oil fields] : California State Min. Bur., Summary of Operations California Oil Fields, vol. 11, no. 7, pp. 5-26, 3 figs., January, 1926.

2. Fossil markers of Midway-Sunset-Elk Hills region in Kern County, California : California State Min. Bur., Summary of Operations California Oil Fields, vol. 12, no. 10, pp. 5-10, 4 pls., April, 1927; extract, Oil Bull., vol. 14, no. 1, pp. 24-26, 4 pls., January, 1928.

Roberts, E. J. See Putnam, P. C., 3.

Roberts, Hugh M. See also Zapffe, 2.

1. Gold veins of central Idaho: Eng. and Min. Jour.-Press, vol. 118, no. 19, pp. 741-742, November 8, 1924.

2. Discussion of papers on Sudbury ore deposits: Econ. Geology, vol. 20, no. 4, pp. 382-388, June-July, 1925.

Roberts, John.

1. Low-temperature origin of anthracite: Pan-Am. Geologist, vol. 48, no. 1, pp. 39-54, 3 figs., August, 1927.

Roberts, John R.

1. The North Texas oil fields: Eng. and Min. Jour., vol. 109, pp. 964-965, April 24, 1920.

Roberts, Joseph Kent.

1. New Terebratula from Eocene terranes of Maryland: Pan-Am. Geologist, vol. 38, no. 1, pp. 19-28, 1 pl., August, 1922.

2. Triassic basins of northern Virginia: Pan-Am. Geologist, vol. 39, no. 3, pp. 185-200, 1 pl., April, 1923.

3. Jurassic (?) intrusives of Piedmont Virginia : Pan-Am. Geologist, vol. 39, no. 4, pp. 289-296, 2 pls., May, 1923.

4. Petrographic analysis of Triassic sandstones: Pan-Am. Geologist, vol. 41, no. 1, pp. 22-30, 1 pl., February, 1924.

5. Reconnaissance geological map of Lyon County, Kentucky, by J. K. Roberts, Stuart Weller, and others: Kentucky Geol. Survey, Ser. 6, 1926. Scale, 1 inch $=1$ mile.

6. (and Collins, R. Lee). The Tertiary of west Tennessee: Am. Jour. Sci., 5th ser., vol. 12, pp. 235-243, 1 fig. (map), September, 1926.

7. The Tuscaloosa formation in Kentucky: Am. Jour. Sci., 5th ser., vol. 14, pp. 465-472, 1 fig., December, 1927.

8. The geology of the Virginia Triassic: Virginia Geol. Survey, Bull. 29, 205 pp., 19 figs., 23 pls. (incl. maps), 1928.

9. Tertiary stratigraphy of west Tennessee: Geol. Soc. America, Bull., vol. 39, no. 2, pp. 435-446, June, 1928; abstract, Geol. Soc America, Bull., vol. 39, no. 1, pp. 192-193, March 30, 1928; Pan-Am. Geologist, vol. 49, no. 2, p. 145, March; no. 3, pp. 231-232, April, 1928. 
Ruberts, Milnor.

1. The gouging of valleys by glaciers as an aid to prospecting: Pacific Min. News, vol. 1, no. 7, pp. 202-204, November, 1922.

Robertson, Glenn D. See Jensen, 1.

Robertson, William Fleet, 1859-1929.

1. Annual report of the minister of mines [of British Columbia] for the year ending 31st December, 1918. . . . 510 pp., pls., maps, Victoria, B. C., 1919.

2. Annual report of the minister of mines [of British Columbia] for the year ending 31st December, 1919. . . . 393 pp., pls., figs., maps. Victoria, B. C., 1920.

3. Annual report of the minister of mines [of British Columbia] for the year ending 31st December, 1920. . . . 377 pp., pls., figs., maps, Victoria, B. C., 1921.

4. Arnual report of the minister of mines [of British Columbia] for the year ending 31st December, $1921 \ldots 365$ pp., figs., pls., maps, Victoria, B. C., 1922.

5. Annual report of the minister of mines [of British Columbia] for the year ending 31st December, 1922. . . . 373 pp., illus., map, Victoria, B. C., 1923.

6. Annual report of the minister of mines [of British Columbia] for the year ending 31st December, 1923. . . . 309 pp., illus., map, Victoria, B. C., 1924.

Robie, E. H.

1. The Meteor Crater project [Arizona]: Eng. and Min. Jour., vol. 125, no. 21, pp. 850-852, 3 figs., May 26, 1928.

Robinsou, Arthur Herbert Ashburner. See also Malcolm, 8; Timm, 1.

1. Titanium: Canada, Dept. Mines, Mines Branch, 127 pp., 5 figs., maps, 1922.

2. Current activities in zinc-lead mining in British Columbia: Canada, Mines Branch, Investigations of Mineral Resources and the Mining Industry, 1923, pp. 54-68, 1924.

3. Titaniferous magnetic deposits of Bourget Township, Chicoutimi district, Quebec: Canada, Mines Branch, Investigations of mineral resources and the mining industry, 1924, pp. 42-54, 1 fig., 1926 ; Quebec, Dept. Colonization . . ., Report on Mining Operations . . . 1925, pp. 4664, 1 fig., 1926.

4. Notes on zinc and lead in eastern Canada: Canada, Dept. Mines, Mines Brauch, Investigations of mineral resources and the mining industry, 1925, pp. 60-68, 1926.

Robinson, Ernest Guy. See also Bauer, C. M., 3.

1. Some notes on the Upper Cretaceous paleogeography of Montana; Am. Assoc. Petroleum Geologists, Bull., vol. 8, no. 5, pp. 554-559, 4 figs., September-October, 1924.

Robinson, H. F. See Bryan, 29.

Robinson, Heath M. See also Fohs, 1; Goldman, 4; Hopkins, O. B., 2.

1. (and Mills, R. V. A.). Structure and oil and gas resources of the Osage Reservation, Oklahoma; T. 27 N., R. 11 E. : U. S. Geol. Survey Bull. 686, pp. 255-277, 2 pls. (incl. map), 3 figs., 1919.

2. (and Mills, R. V. A.). Structure and oil and gas resources of the Osage Reservation, Oklahoma: T. 27 N., R. 10 E. : U. S. Geol. Survey, Bull. 686, pp. 303-327, 3 pls. (incl. map), 2 figs., 1919. 
Robinson, Heath M.-Continued.

3. Geologic structure and oil and gas prospects of a part of Jefferson County, Oklahoma : U. S. Geol. Survey, Bull. 726, pp. 277-302, 2 pls. (maps), 1 flg., December 20, 1921.

4. The origin of the structure [of northeast Texas petroleum area]; Econ. Geology, vol. 18, no. 8, pp. 722-731, December, 1923.

Robinson, Henry Hollister, 1873-1925. See also Barrell, 6.

1. Tenth and eleventh biennial reports of the Commissioners of the State Geological and Natural History Survey of Connecticut, 1921-1924: Connecticut, State Geol. and Nat. Hist. Survey, Bull. no. 35, 17 pp., 1924.

Robinson, H. S.

1. Geology of the Pearl Lake area, Porcupine district, Ontario : Econ. Geology, vol. 18, no. 8, pp. 753-771, 5 figs., December, 1923.

Robinson, J. French. See Ashley, 11 ; Pennsylvania T. G. S., 1.

Robinson, Lewis Cass.

1. Map of the areal and structural geology of Morgan County, Kentucky; areal geology by L. C. Robinson: Kentucky Geol. Survey, Ser. 6, 1925. Scale, 1 inch $=1$ mile.

2. Geology of Morgan County, Kentucky: Kentucky Geol. Survey, Ser. 6, vol. 26 , pp. 229-259, 1927.

Robinson, W. I.

1. Folds resulting from vertically acting forces: Jour. Geology, vol. 31, no. 4, pp. 336-343, 2 figs., May-June, 1923.

2. Some remarks on the care of well samples: Am. Assoc. Petroleum Geologists, Bull., vol. 7 , no. 4, pp. 432-434, July-August, 1923.

3. The ancestry of the Hexacoralla: Am. Jour. Sci., 5th ser., vol. 6, pp. 424426, November, 1923.

4. (and Eldridge, W. J.). A method for correlating gumbos: Am. Assoc. Petroleum Geologists, Bull., vol. 9, no. 5, pp. 906-910, August, 1925.

Rockwell, F. G. See Shannon, 1.

Roddy, H. Justin.

1. Problems of calcareous concretions in streams (abstract): Pennsylvania Acad. Sci., Proc., vol. 1, p. 76, 1926.

Rode, Carl.

1. Structures in vicinity of Santa Cruz [California] (abstract): Pan-Am. Geologist, vol. 49, no. 4, pp. 309-310, May, 1928.

Roeschlaub, H. M.

1. Possibilities of the oil-shale industry: Eng. and Min. Jour., vol. 108, pp. 572-576, 3 figs., October 4, 1919.

Roesler, Max.

1. Some garnet reaction rims in anorthosite: New York State Mus., Bull. nos. 229-230, pp. 39-46, 4 pls., 1921.

Roger, John.

1. A probable origin of petroleum: Science, new ser., vol. 66, p. 152, August $12,1927$.

Rogers, Allen H.

1. Geophysics and the mining engineer: Am. Inst. Min. and Met. Eng., Tech. Pub. no. 135, 7 pp., September, 1928. 
Rogers, Austin Flint.

1. Colemanite pseudomorphous after inyoite from Death Valley, California: Am. Mineralogist, vol. 4, no. 11, pp. 135-139, 2 figs , 1 pl., November, 1919.

2. An interesting occurrence of manganese minerals near San Jose, California: Am. Jour. Sci., 4th ser., vol. 48, pp. 443-449, December, 1919.

3. Organization meeting of the Mineralogical Society of America: Am Mineralogist, vol. 5, no. 1, pp. 10-11, January, 1920.

4. Contact-metamorphic deposit at the Mountain Lake mine near Salt Lake City, Utah (abstract) : Geol. Soc. America, Bull., vol. 31, no. 1, p. 162, March 31, 1920.

5. Introduction to the study of minerals and rocks; a combined textbook and pocket manual. Second edition, 527 pp., 578 figs., New York, McGraw-Hill Book Company, 1921.

6. Cristobalite in the spherulitic obsidian from Yellowstone National Park: Am. Mineralogist, vol. 6, no. 1, pp. 4-6, January, 1921; Supplementary note on cristobalite, no. 3, p. 60, March, 1.921.

7. Tridymite-orthoclase rock, a new metamorphic rock type from Imperial County, California (abstract with discussion by A. C. Lane) : Geol. Soc. America, Bull., vol. 33, no. 1, p. 129, March 31, 1922.

8. Proceedings of the twentieth annual meeting of the Cordilleran section of the Geological Society of America held at Berkeley, California, March 26, 1921: Geol. Soc. America, Bull., vol. 33, no. 1, pp. 187190, March 31, 1922.

9. Collophane, a much neglected mineral: Am. Jour. Sci., 5th ser., vol. 3, pp. 269-276, April, 1922.

10. A new occurrence of cristobalite in California: Jour. Geology, vol. 30, no. 3, pp. 211-216, 1 fig., April-May, 1922.

11. Delafossite from Ḱimberly, Nevada: Am. Mineralogist, vol. 7, no. 6, pp. 102-103, June, 1922.

12. The optical properties and morphology of bisbeeite [Grand Canyon, Arizona ] : Am. Mineralogist, vol. 7, no. 9, pp. 153-154, 1 fig., September; 1922.

13. The use of plans and elevations in the study of geometrical crystallography : Am. Mineralogist, vol. 8, no. 2, pp. 19-31, 7 figs., February, 1923.

14. Proceedings of the twenty-first annual meeting of the Cordilleran section of the Geological Society of America, held at Stanford University, California, April 29, 1922: Geol. Soc. America, Bull., vol. 34, no. 1, pp. 117-120, March 30, 1923.

15. The crystallography of hydromagnesite: $\Lambda \mathrm{m}$. Jour. Sci., 5th ser., vol. 6 , pp. 37-47, 10 figs., July, 1923.

16. Euhedral magnesite crystals from San Tose, California: $\Lambda$ nn. Minerlogist, vol. 8, no: S, pp. 138-140, 2 figs., August, 1923.

17. The crystallography of searlesite: Am. Jour. Sci., 5th ser. vol. 7, pp. 498-502, 4 figs., June, 1924.

18. Kempite, a new manganese mineral from California: Am. Jour. Sci., 5th ser., vol. 8, pp. 145-150, 3 figs., August, 1924.

19. Mineralogy and petrography of fossil bone: Geol. Soc. America, Bull., vol. 35 , no. 3 , pp. 535-556, 3 figs., 4 pls., September 30 , 1924: abstract, no. 1, p. 108, March 30, 1924; Pan-Am. Geologist, vol. 41, no. 2, p. 153, March, 1924. 
Rogers, Austin Flint-Continued.

20. Clinozoisite from Lower California : Am. Mineralogist, vol. 9, no. 11, pp. 221-224, 1 fig., November, 1924.

21. Origin of the dolomitic limestone at Argentine, Kansas (abstract) : Geol.

Soc. America, Bull., vol. 36, no. 1, pp. 170-171, March 30, 1925;

Pan-Am. Geologist, vol. 43, no. 2, p. 160, March, 1925.

22. Kempite, a new manganese mineral from Santa Clara County, California (abstract) : Geol. Soc. America, Bull., vol. 36, no. 1, p. 206, March $30,1925$.

23. Crystal symmetry (abstract with discussion by James B. Macelwane) :

Geol. Soc. America, Bull., vol. 36, no. 1, pp. 207-208, March 30, 1925.

24. Friedel's law of rational symmetric intercepts: Am. Mineralogist, vol. 10, no. 8, pp. 181-187, 2 figs., August, 1925.

25. (and Reed, R. D.). Sand-calcite crystals from Monterey County, California : Am. Mineralogist, vol. 11, no. 2, pp. 23-28, 2 figs., February, 1926.

26. Geology of Cormorant Island, Salton Sea, Imperial County, California (abstract) : Geol. Soc. America, Bull., vol. 37, no. 1, p. 219, March 30, 1926 ; Pan.-Am. Geologist, vol. 45, no. 3, pp. 249-250, April, 1926.

27: A mathematical study of crystal symmetry: Am. Acad. Arts and Sci., Proc., vol. 61, no. 7, pp. 161-203, 48 figs., June, 1926.

28. The addition and subtraction rule in geometrical crystallography: Am. Mineralogist, vol. 11, no. 11, pp. 303-315, 6 figs., November, 1926.

29. Nature and origin of the "brown rock" phosphorites of Tennessee (abstract) : Geol. Soc. America, Bull., vol. 38, no. 1, pp. 122-123, 203, March 30, 1927 ; Pan-Am. Geologist, vol. 47, no. 1, p. 71, February, 1927.

30. Natural history of the silica minerals: Am. Mineralogist, vol. 13, no. 3, pp. 73-92, 20 figs., March, 1928.

31. Nature and origin of "brown rock" phosphorites of Tennessee (abstract) : Pan-Am. Geologist, vol. 49, no. 4, pp. 298-299, May, 1928; Geol. Soc. America, Bull., vol. 39, no. 1, pp. 279-280, March 30, 1928.

32. A tabulation of the 32 crystal classes: Am. Mineralogist, vol. 13, no. 12, pp. 571-577, December, 1928.

Rogers, Gaillard Sherburne, 1889-1919. See also Lucas, A. F., 1; Neal, 1.

1. The Sunset-Midway oil field, California; Part II, Geochemical relations of the oil, gas, and water: U. S. Geol. Survey, Prof. Paper 117, 103 pp., 2 pls., 8 figs., 1919. Abstract by J. D. Sears, Washington Acad. Sci., Jour., vol. 10, no. 18, p. 523, November 4, 1920.

2. Petroleum hydrology applied to Mid-Continent field (discussion) [oil field waters of California and Mid-Continent fields] : Am. Inst. Min. Eng., Bull. no. 147, pp. 603-606, March, 1919.

3. Intrusive origin of the Gulf coast salt domes: Econ. Geology, vol. 14, no. 2, pp. 178-180, March-April, 1919.

4. Origin of the salt domes of the Gulf coast (abstract) : Washington Acad. Sci., Jour., vol. 9, no. 10, pp. 291-292, May 19, 1919.

5. Helium, the new balloon gas: Nat Geog. Mag., vol. 35, no. 5, pp. 441-456, illus., May, 1919.

6. Some oil-field waters of the Gulf coast: Am. Assoc. Petroleum Geologists, Bull., vol. 3, pp. 310-331, 2 figs., 1919.

7. Helium-bearing natural gas: U. S. Geol. Survey, Prof. Paper 121, 113 pp., 16 figs., 4 pls. (incl. maps), 1921. 
liogers, Gaillard Sherburne-Continued.

8. (and Lee, Wallace). Geology of the Tullock Creek coal fleld, Rosebud and Big Horn counties, Montana: U. S. Geol. Survey, Bull. 749. 181 pp., 5 figs., 16 pls., 1923.

Rogers, J. K.

1. Observations on some Cincinnati landslides (abstract): Ohio Acad. Sci., Proc., vol. 8, pt. 4, p. 179, 1928; Ohio Jour. Sci., vol. 28, no. 3, p. 157, May, 1928.

Rogers, R. G.

1. The minor oil fields of Kern County; Sunset Extension field: California State Min. Bur., Summary of Operations California Oil Fields, vol. 9, no. 12, pp. 18-24, 3 pls. (incl. map), June, 1924.

2. Notes on the topography and structure of Alamitos Heights [California]: Oil Bull., vol. 13, no. 7, pp. 715, 717, 719, 3 figs., July, 1927.

Rogers, William Ross.

1. Statistical review of the mining industry of Ontario for 1919: Ontario Dept. Mines, 29th Ann. Rept., 1920, pt. 1, pp. 1-60, 1919.

2. Statistical review of Ontario's mineral industry in 1920: Ontario Dept. Mines, 30th Ann. Rept., vol. 30, pt. 1, pp. 1-54, Toronto, 1922.

3. Statistical review of Ontario's mineral industry in 1922: Ontario Dept. Mines, 32d Ann. Rept., vol. 32, pt. 1, 66 pp., 1925.

4. Statistical review of Ontario's mineral industry in 1923: Ontario, Dept. Mines, 33d Ann. Rept., vol. 33, pt. 1, 63 pp., 1925.

5. (and Young, A. $C_{j}$ ). Statistical review of Ontario's mineral industry in 1924: Ontario Dept. Mines, 34th Ann. Rept., vol. 34, pt. 1, 60 pp., 1926.

6. District of Patricia, Red Lake, and adjacent areas: Ontario, Dept. Mines, Bull. no. 56, 11 pp., 2 figs., 1 pl. (maps), 1926.

7. (and Young, A. C.). Statistical review of Ontario's mineral industry in 1925: Ontario Dept. Mines, 35th Ann. Rept., vol. 35, pt. 1., pp. 1-63, figs., 1927.

Rohlfing, D. P.

1. Iron-ore deposits of southern Utah: Eng. and Min. Jour.-Press, vol. 115, no. 16, pp. 716-719, 7 figs., April 21, 1923.

Romberg, Arnold.

1. A practical long-period seismograph : Science, nẹw ser., vol. 50, pp. 141-142. 1 fig., August 8, 1919.

2. Theory of a nontilt seismograph: Seismol. Soc. America, Bull., vol. 9, no. 4, pp. 135-139, 2 figs., December, 1919.

Romer, Alfred Sherwood.

1. The ilium in dinosaurs and birds: Am. Mus. Nat. Hist., Bull., vol. 48, pp. 141-145, 2 figs., 1923.

2. The pelvic musculature of saurischian dinosaurs: Am. Mus. Nat. Hist., Bull., vol. 48, pp. 605-617, 8 figs., 1923.

3. A radial exostosis in the fossil canid Daphoenus: Am. Jour. Sci., 5th ser., vol. 8, pp. 235-240, 1 fig., September, 1924.

4. An ophiacodont reptile from the Permian of Kansas: Jour. Geology, vol: 33, no. 2, pp. 173-182, 3 figs., February-March, 1925.

5. Permian amphibian and reptilian remains described as Stephanospondylus: Jour. Geology, vol. 33, no. 4, pp. 447-463, 5 figs., May-June, 1925. 
Romer, Alfred Sherwood-Continued.

6. A lower Miocene horse, Anchitherium agatense (Osborn) : Am. Jour. Sci, 5th ser., vol. 12, pp. 325-335, 4 figs., October, 1926.

7. Vertebrate faunal horizons in the Texas red beds (abstract): Geol. Soc. America, Bull., vol. 38, no. 1, pp. 232-233, March 30, 1927 ; PanAm. Geologist, vol. 47, no. 3, p. 239, April, 1927.

8. Notes on the Permo-Carboniferous reptile Dimetrodon: Jour. Geology, vol. 35, no. 8, pp. 673-689, 9 figs., November-December, 1927.

9. (and Sutton, A. H.). A new arctoid carnivore from the lower Miocene [Wyoming]: Am. Jour. Sci., 5th ser., vol. 14, pp. 459-464, 2 figs., December, 1927.

10. (and McCormack, J. T.). A large Palaeocastor from the lower Miocene: Am. Jour. Sci., 5th ser., vol. 15, pp. 58-60, 1 fig., January, 1928.

11. A skeletal model of the primitive reptile Seymouria, and the phylogenetic position of that type: Jour. Geology, vol. 36, no. 3, pp. 248-260, 4 figs., April-May, 1928.

12. The notochord in fossil vertebrates: Am. Jour. Sci., 5th ser., vol. 15, pp. 432-433, May, 1928.

13. Vertebrate faunal horizons in the Texas Permo-Carboniferous red beds: Texas, Univ., Bull., no. 2801, pp. 67-108, 1 fig., 1928.

14. A "fossil" camel recently living in Utah: Science, new ser., vol. 68, pp. 19-20, July 6, 1928.

15. (and Fryxell, F. M.). Paramiatus gurleyi, a deep-bodied amiid fish from the Eocene of Wyoming: Am. Jour. Sci., 5th ser., vol. 16, pp. 519-527, 3 figs., December, 1928.

Roos, Alford.

1. Mining lepidolite in New Mexico [near Embudo]: Eng. and Min. Jour:Press; vol. 121, no. 26, pp. 1037-1042, 3 figs., June 26, 1926.

Root, Towner B.

1. The oil and gas resources of the Ava-Campbell Hill area: Illinois State Geol. Survey, Rept. Investigations no. 16, 27 pp., 4 figs., 3 pls. (incl. maps), 1928.

Ropes, Leverett $\mathbf{S}$.

1. Oil possibilities in Montana: Eng. and Min. Jour., vol. 111, no. 18, pp. 754-755, April 30, 1921.

Rose, Bruce.

1. Northern part of Crowsnest coal field, Alberta: Canada, Geol. Survey, Summ. Rept., 1918, pt. C, pp. 13-16, 1919.

2. Highwood coal area, Alberta: Canada, Geol. Survey, Summ. Rept. 1919. pt. C, pp. 14-20, 1 fig., 1920.

3. Structure in the Crowsnest coal area, Alberta: Canadian Inst. Min. and Met., Monthly Bull., no. 150, pp. 609-619, 1 pl., October, 1924; Trans., vol. 27, pp. 484-494, 1 pl. [1925].

4. Murphy, Hoyle, and Matheson townships, Porcupine gold area: Ontario Dept. Mines, 33d Ann. Rept., vol. 33, pt. 3, pp. 50-54, map, 1925.

Ross, A. J. M.

1. Mining methods at the Homestake [Lead, South Dakota]: Am. Inst. Min. and Met. Eng., Trans. [preprint] no. 1408, 22 pp., 21 figs., February, 1925. 
Ross, Charles C.

1. Petroleum and natural gas development in Alberta: Canadian Inst. Min. and Met., Bull., no. 168, pp. 466-495, 10 figs., April, 1926; Trans., vol. 29, pp. 317-346, 10 figs. [1927].

Ross, Clarence Samuel. See also Larsen, 5; Miser, 9, 10, 12, 18, 19, 22.

1. The chloritic material in the ores of southeastern Missouri (abstract) : Illinois Acad. Sci., Trans., vol. 9, p. 209 [1917].

2. Structure and oil and gas resources of the Osage Reservation, Oklahoma, Tps. 21 and 22 N., R. 11 E.: U. S. Geol. Survey Bull. 686, pp. 179191., 3 pls. (incl. maps), 1 fig., 1919.

3. The Lacasa area, Ranger district, north-central Texas: U. S. Geol. Survey, Bull. 726, pp. 303-314, 3 figs., 2 pls., December 23, 1921.

4. A method of distinguishing fused cores [in drillings]: Am. Assoc. Petroleum Geologists, Bull., vol. 6, no. 4, pp. 372-374, July-August, 1922.

5. Leverrierite and related minerals: U. S. Geol. Survey, Water-Supply Paper 520, pp. 60-61, 1924.

6. (and Shannon, Earl V.). Mordenite and associated minerals from near Challis, Custer County, Idaho: U. S. Nat. Mus., Proc., vol. 64, art. 19,19 pp., 3 pls., 1924.

7. A method of preparing thin sections of friable rock: Am. Jour. Sci., 5th ser. vol. 7, pp. 483-485, June, 1924.

8. Evidences of slumping previous to consolidation in the Pennsylvanian of Oklahoma: Am. Assoc. Petroleum Geologists, Bull., vol. 8, no. 4, pp. 505-510, 2 figs., July-August, 1924.

9. Nephelite-hauynite alnoite from Winnett, Montana: Am. Jour. Sci., 5th ser., vol. 11, pp. 218-227, March, 1926.

10. Beds of volcanic material as key horizons: Am. Assoc. Petroleum Geologists, Bull., vol. 9, no. 2, pp. 341-343, March-April, 1925.

11. (and Shannon, Earl V.). The origin, occurrence, composition, and physical properties of the mineral iddingsite: U. S. Nat. Mus., Proc., vol. 67, art. 7, 19 pp., 2 pls., May 15, 1925.

12. (and Shannon, E. V.). Nature of bentonite and related clays (abstract) : Pan-Am. Geologist, vol. 43, no. 5, pp. 364-365, June, 1925.

13. (and Henderson, E. P.). Topaz and associated minerals from the Einstein silver mine, Madison County, Missouri: Am. Mineralogist, vol. 10, no. 12, pp. 441-443, December, 1925.

14. (and Shannon, Earl V.). The so-called genthite from Webster, North Carolina: Am. Mineralogist, vol. 10, no. 12, pp. 444-445, December, 1925.

1.5. (and Shannon, Earl V.) The minerals of bentonite and related clays and their physical properties: Am. Ceramic Soc., Jour., vol. 9, no. 2, pp. 77-96, 4 figs., February, 1926.

16. (and Shannon, Earl V.). Nickeliferous vermiculite and serpentine from Webster, North Carolina: Am. Mineralogist, vol. 11, no. 4, pp. 90-93, April, 1926.

17. The optical properties and chemical composition of glauconite: U. S. Nat. Mus., Proc., vol. 69, art. 2, 15 pp., 2 figs., May 29, 1926.

18. Methods of preparation of sedimentary materials for study: Econ. Geology, vol. 21, no. 5, pp. 454-468, 1 fig., August, 1926.

19. A Colorado lamprophyr of the verite type: Am. Jour. Sci., 5th ser., vol. 12, pp. 217-229, September, 1926.

20. (and Shannon, Earl V.). The chemical composition and optical properties of beidellite: Washington Acad. Sci., Jour., vol. 15, no. 21, pp. $467-468$, December $19,1925$. 
Ross, Clarence Samuel-Continued.

21. Altered Paleozoic volcanic materials and their recognition: Am. Assoc. Petroleum Geologists, Bull., vol. 12, no. 2, pp. 143-164, 8 figs., February, 1928.

22. Sedimentary analcite: Am. Mineralogist, vol. 13, no. 5, pp. 195-197, May, 1928.

23. Preparation of sedimentary materials for study (discussion) : Econ. Geology, vol. 23, no. 3, p. 334, May, 1928.

24. Report on the studies of clays (abstract) : Washington Acad. Sci., Jour., vol. 18, no. 9, p. 265, May 4, 1928.

25. (and Shannon, Earl V., and Gonyer, Forest A.). The origin of nickel silicates at Webster, North Carolina : Econ. Geology, vol. 23, no. 5, pp. 528-552, 6 figs., August, 1928.

26. Physico-chemical factors controlling magnatic differentiation and vein formation: Econ. Geology, vol. 23, no. 8, pp. 864-886, December, 1928.

27. The mineralogy of clays: First International Congress of Soil Science, June 13-22, 1927, Washington, D. C., U. S. A., Proc. and Papers, Commission V, pp. 555-561, Washington, 1928.

Ross, Clyde Polhemus. See also Schrader, 10; Vaughan, 16.

1. Geology of the lower Gila region, Arizona: U. S. Geol. Survey, Prof. Paper 129, pp. 183-197, 5 pls., March 29, 1922; abstract, Washington Acad. Sci., Jour., vol. 10, no. 2, pp. 51-52, January 19, 1920.

2. The geology of a part of the Ammonoosuc mining district, New Hampshire: Am. Jour. Sci., 5th ser., vol. 5, pp. 267-302, 3 figs. (incl. maps), April, 1923.

3. A new copper district near Salmon, Idaho: Eng. and Min. Jour.-Press, vol. 118, no. 6, pp. 205-208, 5 figs., August 9, 1924.

4. Quicksilver in 1923; with supplementary bibliography by Isabel P. Evans: U. S. Geol. Survey, Mineral Resources, 1923, pt. 1, pp. 35-46, September 29, 1924.

5. Geology and ore deposits of the Aravaipa and Stanley mining districts, Graham County, Arizona: U. S. Geol. Survey. Bull. 763, 120 pp., 8 figs., 13 pls. (incl. maps), 1925.

6. Ore deposits of the Saddle Mountain and Banner mining districts, Arizona : U. S.. Geol. Survey, Bull. 771, 72 pp., 6 figs., 17 pls. (incl. maps), 1925.

7. The copper deposits near Salmon, Idaho: U. S. Geol. Survey, Bull. 774, 44 pp., 7 figs., 5 pls. (incl. map), 1925.

8. Tertiary planation in eastern Oregon and central Idaho (abstract): Pan.-Am. Geologist, vol. 43, no. 5, p. 367, June, 1925.

9. Quicksilver in 1924: U. S. Geol. Survey, Mineral Resources U. S., 1924, pt. 1, pp. 13-19, July 30, 1925.

10. A disseminated lead prospect in northern Boise County, Idaho: Idaho, Bur. Mines and Geology, Pam. no. 20, 7 pp., December, 1926. [Mimeographed.]

11. Some features of the Paleozoic stratigraphy of Idaho (abstract) : Washington Acad. Sci., Jour., vol. 17, no. 5, p. 125, March 4, 1927.

12. The Vienna district, Blaine County, Idaho: Idaho, Bur. Mines and Geology, Pam. no. 21, 17 pp., 3 pls. (incl. map), April, 1927.

13. Ore deposits in Tertiary lava in the Salmon River Mountains, Idaho: Idaho, Bur. Mines and Geology, Pam. no. 25, 21 pp., 1 pl. (map), August, 1927. [Mimeographed.] 
Ross, Clyde Polhemus-Continued.

14. Deposits of Saddle Mountain and Banner districts [Arizona] : Min. Jour., Phoenix, Ariz., vol. 10, no. 24, pp. 3-5, 12-13, 1 fig., May 15; vol. 11, no. 1 , pp. $6-7,20$, May 30 ; no. 3 , pp. $5-6$, June 30 ; no. 6 , pp. 7 , 54-56, August 15 ; no. 8, p. 6, September 15 ; no. 9, p. 8, September $30,1927$.

15. Salient features of geology of south-central Idaho (abstract) : Washington Acad. Sci., Jour., vol. 18, no. 9, pp. 267-268, May 4, 1928.

16. Mesozoic and Tertiary granite rocks in Idaho: Jour. Geology, vol. 36, no. 8, pp. 673-693, 1 fig. (map), November-December, 1928.

Ross, J. S.

1. (and Swedenborg, E. A.) Analyses of waters of the Salt Creek field applied to underground problems: Am. Inst. Min. and Met. Eng., Tech. Pub. no. 157, 17 pp., 3 figs., December, 1928; abstract, Mining and Metallurgy, vol. 9, no. 264, p. 556, December, 1928.

Ross, James G.

1. Occurrences of chrome iron ore: Canadian Min. Inst., Bull., no. 92, pp. 1204-1207, December, 1919; Trans., vol. 22, pp. 130-134 [1920].

Roth, Robert. See also Pinkley, 1.

1. The Robberson field, Garvin County, Oklahoma: Oklahoma Geol. Survey, Bull. no. 40-K, pp. 32-52, 4 figs., May, 1927.

2. Correlation of a well core with outcrop sandstone [Carter County, Oklahoma ] : Econ. Geology, vol. 23, no. 1, pp. 45-54, 2. figs. (incl. map), January, 1928.

3. Monoceratina, a new genus of Ostracoda from the Pennsylvanian of Oklahoma : Jour. Paleontology, vol. 2, no. 1, pp. 15-19, 1 fig., March, 1928.

Rothpletz, August.

1. Ueber die systematische Deutung und die stratigraphische Stellung der ältesten Versteinerungen Europas und Nordamerikas mit besonderer Berüksichtigung der Crytozoen and Oolithe; I. Teil, Die Fauna der Beltformation bel Helena in Montana: Kön. Bayerische Akad. Wiss., mat-phys. Kl., Abh., Bd. 28, 1. Abh., 46 pp., 3 pls., 1915.

2. Ueber die systematische und die stratigraphische Stellung der ältesten Versteinerungen Europas and Nordamerikas mit besonderer Berücksichtigung der Cryptozoen und Oolithe; II. Teil, Ueber Crypotozoon, Eozoon, und Atikokania: Kön. Bayerische Akad. Wiss., mat.-phys. Kl., Abh., Bd. 28, 4, Abh., 92 pp., 8 pls., 8 figs., 1916.

Rothrock, Edgar Paul. See also Ward, 13.

1. Sand and gravel deposits in eastern South Dakota: South Dakota Geol. and Nat. Hist. Survey, Circular 15 (South Dakota, Univ., Bull., ser. 24, no. 4), 31 pp. 5 figs. (incl. map), February, 1924.

2. On the force of crystallization of calcite: Jour. Geology, vol. 33, no. 1, pp. 80-83, January-February, 1925.

3. Sand and gravel deposits of Yankton County [South Dakota] : South Dakota Geol. and Nat. Hist. Survey, Circular 21, 57 pp., 2 figs., map, May, 1925.

4. Geology of Cimarron County, Oklahoma: Oklahoma Geol. Survey, Bull. no. 34, pp. 7-92, 18 figs., 3 pls. (incl. map), October, 1925; abstract; Chicago Univ., Abstracts of Theses, Sci. Ser., vol. 1, pp. 305-309, October, 1925. 
Rothrock, Edgar Paul-Continued.

5. Sand and gravel deposits of Minnehaha; geology: South Dakota Geol. and Nat. Hist. Survey, Circular 26, pp. 7-35, 6 figs. (incl. map), May, 1926.

6. Records of some deep wells in South Dakota: South Dakota Geol. and Nat. Hist. Survey, Pam. 1, 10 pp., 1 pl., December, 1926. [Mimeographed]

Round, Eda M.

1. A Crossotheca from the Rhode Island Carboniferous: Am. Jour. Sci., 5th ser., vol. 4, pp. 131-135, 3 figs., August, 1922.

2. A modern plant fossil: Torrey Bot. Club, Bull., vol. 49, no. 3, pp. 63-64, 1 fig., March, 1922.

3. Annularia with Paleostachya fruit: Bot. Gazette, vol. 73, no. 4, pp. 326328, 1 fig., April, 1922.

4. Correlation of fossil floras of Rhode Island and New Brunswick: Bot. Gazette, vol. 78, no. 1, pp. 116-118, 4 figs., September, 1924.

5. Correlation of coal floras in Henry County, Missouri, and the Narragansett Basin : Bot. Gazette, vol. 83, no. 1, pp. 61-69, 3 figs., March, 1927.

Roundy, Paul Vere. See also Girty, 5; Woodring, 19.

1. (and Heald, K. C., and Richardson, G. B.). Structure and oil and gas resources of the Osage Reservation, Oklahoma ; Tps. 26 and 27 N., R. 12 E.: U. S. Geol. Survey, Bull. 686, pp. 395-420, 1 fig., 6 pls. (incl. maps), 1922.

2. Bibliography of conodont and Paleozoic annelid jaw literature: Nat. Research Council, Division of Geology and Geography, 4 pp., Washington, D. C., March 16, 1925 [mimeographed].

3. Mississippian formations of San Saba County, Texas; Introduction; The micro-fauna: U. S. Geol. Survey, Prof. Paper 146, pp. 1-2, 5-23, 4 pls., 1926.

4. Description of ostracodes: Jour. Paleontology, vol. 1, no. 1, pp. 11-12, July, 1927.

Rowe, E. P.

1. Oil and gas possibilities in Ontario: Intercolonial Gas Jour. of Canada, vol. 18, no. 2, pp. 66-68, February, 1925.

Rowe, Jesse Perry.

1. Possibility of oil and gas in Montana: Am. Assoc. Petroleum Geologists, Bull., vol. 4, no. 3, pp. 313-315, 1920.

2. Oil and gas in Montana: Eng. and Min. Jour., vol. 110, no. 9, pp. 412-417, 1 fig., August 28, 1920.

3. Petroleum and natural gas in Montana: Eng. and Min. Jour.-Press, vol. 121, no. 14, pp. 563-568, 3 figs., April 3, 1926.

4. Montana's coal exceeds that of any other State: Coal Age, vol. 30, no. 13, pp. 429-431, 3 figs., September 23, 1926.

5. Minor metals and nonmetallic minerals of Montana: Eng. and Min. Jour., rol. 125, no. 20, pp. 816-818, May 19, 1928.

Rowe, R. C.

1. The Buckingham district, Province of Quebec: Eng. and Min. Jour., vol. 124, no. 23, pp. 893-895, 4 figs., December 3, 1927.

Rowley, A. B.

1. Recent study of geological conditions in northwestern South Dakota : Oil Weekly, vol. 26, no. 11, pp. 10-11, 1 fig., September 9, 1922. 
Rowley, R. R. See Keyes, 42.

Royce, Stephen.

1. Certain advances in geological information relative to the Lake Superior iron deposits: Lake Superior Min. Inst., Proc. 24th Ann. Meeting, vol. 24, pp. 149-181, 1925.

Rubey, William W. See also Foley, 1; Heald, 8; U. S. Geol. Survey, 12.

1. Wildcat exploration in south central Arkansas: Am. Assoc. Petroleum Geologists, Bull., vol. 6, no. 4, pp. 350-358, 1 fig., July-August. 1922.

2. Progress report on a subsurface study of the Pershing oil and gas field, Osage County, Oklahoma : U. S. Geol. Survey, Bull. 751, pp. 23-70, 9 figs., 3 pls. (incl. map), July 18, 1923.

3. (and Bass, N. W.). The geology of Russell County, Kansas, with special reference to oil and gas resources: Kansas State Geol. Survey, Bull. 10, pp. 1-86, 11 figs., 7 pls. (incl. maps), 1925.

4. Determination and use of thicknesses of.incompetent beds in oil field mapping and general structural studies: Econ: Geology, vol. 21, no. 4, pp. 333-351, 4 figs., June-July, 1926.

5. Oil possibilities of the Black Hills region: Am. Assoc. Petroleum Geologists, Bull., vol. 10, no. 11, p. 1177, Nomember, 1926.

6. Stream piracy in northeastern Wyoming (abstract) : Washington Acad. Sci., Jour., vol. 17, no. 5, p. 120, March 4, 1927.

7. The origin of the Mowry shale (abstract) : Washington Acad. Sci., Jour., vol. 17, no. 9, p. 235, May 4, 1927.

8. The effect of gravitational compaction on the structure of sedimentary rocks ; a discussion: Am. Assoc. Petroleum Geologists, Bull., vol. 11, no. 6, pp. 621-632, 1 fig., June, 1927 ; no. 12, pp. 1333-1336, December, 1927.

9. Gullies in the Great Plains formed by sinking of the ground: Am. Jour. Sci., 5th ser., vol. 15, pp. 417-422, May, 1928.

10. Possible varves in marine Cretaceous shale in Wyoming (abstract): Washington Acad. Sci., Jour., vol. 18, no. 9, pp. 260-262, May 4, 1928.

Ruby, Glen M. See also Hintze, 1 .

1. Reflected buried hills and petroleum geology : Econ. Geology, vol. 18, no. 1, pp. 93-96, January-February, 1923.

2. Peculiar, phases of oil saturation in certain sandstones: Am. Assoc. Petroleum Geologists, Bull., vol. 7, no. 5, pp. 473-481, 2 figs., September-October, 1923.

Rude, G. T.

1. Shore changes at Cape Hatteras: Assoc. Am. Geographers, Annals, vol. 12, pp. 87-95, 2 figs. [1923?].

Ruedemann, Paul.

1. (and Gardescu, Ionel). Estimation of reserves of natural gas wells by relationship of production to closed pressure: Am. Assoc. Petroleum Geologists, Bull., vol. 6, no. 5, pp. 444-463, 6 figs., SeptemberOctober, 1922.

2. (and Redmon, H. E.): The Turkey Mountain lime pools, Oklahoma : Am. Assoc. Petroleum Geologists, Bull:, vol. 11, no. 9, pp. 933-944, 8 figs., September, 1927. 
Ruedemann, Rudolf. See also Clarke, J. M., 15 ; Perkins, E. H., 2 ; Schuchert, 28 ; Uirich, 4.

1. On some fundamentals of pre-Cambrian paleogeography: Nat. Acad. Sti., Proc., vol. 5, no. 1, pp. 1-6, 1 fig., January 15, 1919.

2. A recurrent Pittsford (Salina) fauna: New York State Mus. Bull., nos. 219,220 , pp. 205-222, 3 pls., 1920.

3. Paleontologic contributions from the New York State Museum: New York State Mus. Bull., nos. 227, 228, pp. 63-130, 61 tigs., 1921.

4. Observations on the mode of life of primitive cephalopods: Geol. Soc. America, Bull., vol. 32, no. 3, pp. 315-320, 9 figs., September 1, 1921.

5. Report on fossils from the so-called Trenton and Utica beds of Grand Isle, Vermont: Vermont, State Geologist, Twelfth Rept., 1919-20, pp. 90-100, 1 pl., 1921.

6. Additional studies in arrested evolution: Nat. Acad. Sci., Proc., vol. 8, no. 3, pp. 54-55, March, 1922.

7. New forms of life from the Silurian: Nat. Acad. Sci., Proc., vol. 8, no. 3, pp. 55-56, March, 1922.

8. On the occurrence of an Amus in the Permian of Oklahoma: Jour. Geology, vol. 30, no. 4; pp. 311-318, 5 figs., May-June, 1922.

9. Further notes on the paleontology of arrested evolution: Am. Naturalist, vol. 56, no. 644, pp. 256-272, May-June, 1922.

10. Positions of the ancient continents: Pan-Am. Geologist, vol. 38, no. 5, pp. 367-377, December, 1922.

11. The existence and configuration of pre-Cambrian continents: New York State Mus. Bull., nos. 239-240, pp. 65-152, 9 figs., 1922.

12. Fundamental lines of North American geologic structure: Am. Jour. Sci., 5th ser., vol. 6. pp. 1-10, 4 figs., July, 1923; New York State Mus. Bull., no. 260, pp. 71-80, 4 figs., 1925.

13. An ancestral acorn barnacle: New York State Mus. Bull., no. 251, pp. 93-104, 1 fig., 2 pls., 1924.

14. Recent publications on the origin and habitat of the Eurypterida: Am. Jour. Sci., 5th ser., vol. 7, pp. 227-232, March, 1924.

15. (and Ehlers, G. M.). Occurrence of the Collingwood formation in Michigan : Michigan Univ., Mus. Geology, Contr., vol. 2, no. 2, pp. 13-18, July 10, 1924; abstract, Geol. Soc. America, Bull., vol. 35, no. 1, p. 186, March 30, 1924.

16. The Utica and Lorraine formations of New York; Part 1, Stratigraphy : New York State Mus. Bull., no. 258, 175 pp., 10 figs., 7 pls. (incl. maps), 1925.

17. The Utica and Lorraine formations of New York; Part 2, Systematic paleontology ; No. 1, Plants, sponges, corals, graptolites, crinoids, worms, bryozoans, brachiopods: New York State Mus. Bull., no. 262, 171 pp., 75 tigs., 13 pls., June, 1925.

18. The Utica and Lorraine formations of New York; Part 2, Systematic paleontology ; No. 2, Mollusks, crustaceans, and eurypterids : New York State Mus. Bull., no. 272, 227 pp., 26 figs., 28 pls., August, 1926.

19. Some Silurian (Ontarian) faunas of New York: New York State Mus. Bull., no. 265, 134 pp., 40 figs., 24 pls., 1925.

20. Siluric faunal facies in juxtaposition: Pan-Am. Geologist, vol. 44, no. 4, pp. 309-312, 1 fig., November, 1925.

21. [Report on] paleontology and paleobotany: New York State Mus. Bull., no. 267 , pp. 32-33, 1926. 
Ruedemann, Rudolf-Continued.

22. Faunal facies differences of the Utica and Lorraine shales: New York State Mus. Bull., no. 267, pp. 61-77, 5 figs., 1926.

23. A Devonian starfish from Gaspé: New York State Mus. Bull., no. 267, p. 79, 1 pl., 1926.

24. Neuere amerikanische Theorien über die Entstehung der Kontinente und Ozeane: Geol. Rundschau, Bd. 17a (Festschrift, Gustav Steinmann), pp. 49-61, 7 figs., 1926.

25. Hunting fossil marine faunas in New York State: Natural History (Am. Mus. Nat. Hist., Jour.), vol. 26, no. 5, pp. 505-514, 7 figs., September-October, 1926.

26. Fossil evidence of the existence of a Pacific ocean in early Ordovician time (abstract) : Geol. Soc. America, Bull., vol. 39, no. 1, pp. 299300, March 30, 1928.

27. Geology of the Capitol district [Albany, New York] (abstract) : Science, new ser., vol. 68, p. 649, December 28, 1928.

Rukeyser, Walter A.

1. Asbestos mining and milling in Quebec: Eng. and Min. Jour.-Press, vol. 113, no. 15, pp. 617-625, 11 figs., April 25, 1922.

Runner, Joseph James.

1. The origin of coal : Pahasapa Quart., vol. 8, no. 2, pp. 74-83, February, 1919.

2. Some problems of Black Hills pre-Cambrian geology : Pahasapa Quart., vol. 10, no. 1, pp. 17-26, December, 1920.

3. Evidences of an unconformity within the pre-Cambrian of the Black Hills of South Dakota (abstract): Geol. Soc. America, Bull., vol. 32, no. 1, pp. 37-38, March 31, 1921.

4. Origin and history of Lake Chelan (abstract) : Geol. Soc. America, Bull., vol. 32, no. 1, pp. 87-88, March 31, 1921.

5. Notes on the gold-quartz veins of the Atlantic City-South Pass district, Wyoming: Wyoming, Geologist's Office, Bull. no. 20, pp. 18-23. July 15, 1926.

6. The pre-Cambrian geology of the Nemo district, Black Hills, South Dakota, with special reference to a pre-Cambrian unconformity (abstract) : Chicago, Univ., Abstracts of Theses, Sci. Ser., vol. 2, pp. 229-234, September, 1926.

7. Intrusion mechanics of the Harney Peak batholithic granite (abstract) : Geol. Soc. America, Bull., vol. 39, no. 1, p. 186, March 30, 1928; Pan-Am. Geologist, vol. 49, no. 2, p. 142, March, 1928.

8. Older pre-Cambrian of the Medicine Bow Mountains [Wyoming] (abstract) : Geol. Soc. America, Bull., vol. 39, no. 1, p. 202, March 30, 1928 ; Pan-Am. Geologist, vol. 49, no. 2, p. 154, March, 1928.

9. (and Thomas, L. C.). Stratigraphic relations of the Cherry Creek group in the Madison Valley, Montana (abstract) : Geol. Soc. America, Bull., vol. 39, no. 1, pp. 202-203, March 30, 1928; Pan-Am. Geologist, vol. 49, no. 2, pp. 154-155, March, 1928.

Russell, J. W.

1. Evidences of quite recent extinction of American mastodon (abstract) : Pan-Am. Geologist, vol. 42, no. 1, pp. 74-75, August; no. 3, p. 235, October, 1924 ; British Assoc. Adv. Sci., Rept. 92d Meeting, p. 385, 1925. 
Russell, Jeanne.

1. Glaciation in the Bitterroot Mountains of Montana (abstract): Geol. Soc. America, Bull., vol. 37, no. 1, p. 218, March 30, 1926.

Russell, Loris S. See also Rutherford, 7.

1. Mollusca of the Paskapoo formation in Alberta: Roy. Soc. Canada, Proc. and Trans., 3d ser., vol. 20, sec. 4, pp. 207-220, 3 pls., 1926.

2. A new species of the genus Catopsalis Cope from the Paskapoo formation of Alberta: Am. Jour. Sci., 5th ser., vol. 12, pp. 230-234, 1 fig., September, 1926.

3. A new fossil fish from the Paskapoo beds of Alberta : Am. Jour. Sci., 5th ser., vol. 15, pp. 103-107, 4 figs., February, 1928.

4. The genera Kindleia and Stytomyleodon: Am. Jour. Sci., 5th ser., vol. 15, p. 264, March, 1928.

Russell, Philip G. See also Browning, 1.

1. The coals of Sexton Creek ... [Clay County, Kentucky]: Kentucky Geol. Survey, Fourth series, vol. 4, pt. 3, pp. 185-260, 1918.

Russell, Richard Joel.

1. Preliminary statement on the geology of the Warner Range in northeastern California (abstract) : Geol. Soc. America, Bull., vol. 37, no. 1, p. 222. March $30,1926$.

2. Recent horizontal offsets along the Haywards fault: Jour. Geology, vol. 34, no. 6, pp. 507-511, 2 figs., August-September, 1926; abstract, Geol. Soc. America, Bull., vol. 37, no. 1, pp. 211-212, March 30, 1926.

3. Surprise Valley fault [California] (abstract) : Geol. Soc. America, Bull., vol. 38, no. 1, pp. 167-168, March 30, 1927.

4. Landslide lakes of the northwestern Great Basin: California, Univ., Pub. in Geography, vol. 2, no. 7, pp. 231-254, 4 figs., May 12, 1927.

5. The land forms of Surprise Valley, northwestern Great Basin: California, Univ., Pub. in Geography, vol. 2, no. 11, pp. 323-358, 12 figs., October $22,1927$.

6. Basin Range structure and stratigraphy of the Warner Range, northeastern California : California, Univ., Dept. Geol. Sci., Bull., vol. 17, no. 11, pp. 387-496, 32 figs., map, November 8, 1928.

Russell, William L.

1. The structural and stratigraphic relations of the great Triassic fault of southern Connecticut: Am. Jour. Sci., 5th ser., vol. 4, pp. 483-497, 6 figs., December, 1922.

2. The camptonite dikes in the Connecticut Triassic: Am. Jour. Sci., 5th ser., vol. 5, pp. 409-416, 3 figs., May, 1923.

3. Some experiments on capillarity and oil migration: Econ. Geology, vol. 19, no. 1, pp. 35-61, January-February, 1924.

4. The possibilities of oil in western Ziebach County: South Dakota Geol. and Nat. Hist. Survey, Circular 20, 25 pp., 4 figs., 1 pl., February, 1925.

5. Relation between isocarbs and oil and gas production in Kentucky: Econ. Geology, vol. 20, no. 3; pp. 249-260, 2 figs., May, 1925.

6. Well $\log$ in northern Ziebach County: South Dakota Geol, and Nat. Hist. Survey, Circular 18, pp. 3-7, September, 1925.

7. The possibilities of oil-in western Corson County: South Dakota Geol. and Nat. Hist. Survey, Circular 27, 18 pp., 5 figs., March, 1926.

8. Structures in western Haakon and eastern Pennington counties: South Dakota Geol. and Nat. Hist. Survey, Circular 28, 24 pp., 5 figs., April, 1926. 
Russell, William L.-Continued.

9. Oil and gas accumulation in the Clinton sand of Ohio: Econ. Geology, vol. 21, no. 6, pp. 538-559, 2 figs., September, 1926.

10. A quick method for determining porosity: Am. Assoc. Petroleum Geologists, Bull., vol. 10, no. 10, pp. 931-938, 1 fig., October, 1926.

11. Porosity and crushing strength as indices of regional alteration: Am. Assoc. Petroleum Geologists, Bull., vol. 10, no. 10, pp. 939-952, 1 fig., October, 1926.

12. The proofs of the carbon-ratio theory: Am. Assoc. Petroleum Geologists, Bull., vol. 11, no. 9, pp. 977-989, September, 1927.

13. The origin of the sandstone dikes of the Black Hills region: Am. Jour. Sci., 5th ser., vol. 14, pp. 402-408, 3 figs., November, 1927.

14. A fossil desert in western South Dakota: Am. Jour. Sci., 5th ser., vol. 15, pp. 146-150, February, 1928.

15. The origin of artesian pressure: Econ. Geology, vol. 23, no. 2, pp. 132-157, 2 figs., March-April, 1928.

Rutherford, Ralph L. See also Allan, 9, 20, 24; Warren, 8.

1. Corrosion by saline waters: Roy. Soc. Canada, Proc. and Trans., 3d ser., vol. 18, sec. 4, pp. 31-37, 1 pl., 1924.

2. A convenient method for checking the index of a liquid: Am. Mineralogist, vol. 9, no. 10, pp. 207-208, October, 1924.

3. Some coal-seam correlation problems in Alberta : Canadian Inst. Min. and Met., Monthly Bull., no. 152, pp. 942-951, 3 figs., December, 1924; Trans., vol. 27, pp. 550-559, 3 figs. [1925].

4. Geology of the foothills belt between McLeod and Athabasca rivers, Alberta: Alberta, Scientific and Industrial Research Council, Rept. no. 11, 82 pp., 8 pls., map, 1925.

5. Geology of the area between Athabasca and Embarras rivers, Alberta: Alberta, Scientific and Industrial Research Council, Geol. Survey Div., Rept. no. 15, 29 pp., 3 pls., map, 1926.

6. Geology along the Bow River between Cochrane and Kananaskis, Alberta : Alberta, Scientific and Industrial Research Council, Geol. Survey Div., Rept. no. 17, 46, v pp., 7 pls., map, 1927.

7. (and Russell, Loris S.). Mammal tracks from the Paskapoo beds of Alberta : Am. Jour. Sci., 5th ser., vol. 15, pp. 262-264, 1 fig., March, 1928.

8. Geology of the area between North Saskatchewan and McLeod Rivers, Albert: Alberta, Sci. and Ind. Research Council, Rept. no. 19, 41 pp., 2 pls. (incl. map), 1928.

9. Two interesting boulders in the glacial deposits of Alberta: Jour. Geology, vol. 36, no. 6, pp. 558-563, August-September, 1928.

10. Anthraxolite from the Northwest Territories of Canada: Am. Mineralogist, vol. 13, no. 10, pp. 516-518, October, 1928.

Rutledge, John Joseph.

1. Peace River oil [Alberta] : Canadian Min. Jour., vol., 40, pp. 401-402, June 4, 1919.

Rutten, $\mathbf{L}$.

1. Cuba, de Antillen en de zuidelijke Molukken: K. Akad. Wetens, Amsterdam, Versl. Afd. Natuurk, D. 31, pp. 213-225, 1 pi., 1923; Cuba, the Antilles, and the southern Moluccas: K. Akad. Wetens. Amsterdam, Proc. Sec. Sciences, vol. 25, pp. 263-274, 1 pl., March, 1923 , 
Rybár, Stephen.

1. The Eötvös torsion balance and its application to the finding of mineral deposits: Econ. Geology, vol, 18, no. 7, pp. 639-662, 15 flgs., October-November, 1923.

St. Clair, Stuart. See also Glenn, 1.

1. Irvine oil district, Kentucky : Am. Inst. Min. and Met. Eng., Trans., vol. 65, pp. 165-175, 1 fig., 1921; Bull. no. 151, pp. 1079-1089, 1 fig, July, 1919; Kentucky, Dept. Geology and Forestry, ser. 5 [of Ky. Geol. Survey], Mineral and Forest Resources of Kentucky, vol. 1, no. 2, pp. 58-76, 9 figs., July 1, 1919.

2. Clay deposits near Mountain Glen, Union County, Illinois: Illinois State Geol. Survey, Bull., no. 36, pp. 71-83, 2 figs., 1920.

3. The oil pools of Warren County, Kentucky: Kentucky Geol. Survey, ser. 6, vol. 6, pp. 103-148, 15 figs., 1921.

4. Oil geology of Warren County, Kentucky: Am. Assoc. Petroleum Geologists, Bull., vol. 5, no. 1, p. 100, January-February, 1921 (abstract) ; vol. 6, no. 1, pp. 24-36, January-February, 1922.

St. John, Ruth N.

1. Replacement vs. impregnation in petrified wood: Econ. Geology, vol. 22, no. 7, pp. 729-739, 2 figs., November, 1927.

Salazar Salinas, Leopoldo.

1. Informe sobre mapas geológicos de México: Pan-Pacific Scientific Conference, First, Proc., Bernice P. Bishop Mus., Spec. Pub. no. 7, pt. 3, pp. 706-711, 1921.

2. (and others). Memoria relativa al terremoto mexicano del 3 de enero de 1920: Mexico, Inst., Geol., Bol. no. 38, 107 pp., 66 pls., 1922.

3. (and others). El Cerro de Mercado, Durango: Mexico, Inst. Geol, Bol. no. 44, 90 pp., 20 pls., 1923.

4. Algunas observaciones sobre el origen del criadero de fierro de Durango, llamado Cerro de Mercado: Soc. cient. "Antonio Alzate," Mem. y Rev., t. 43, no. 9-12, pp. 621-638, September-December, 1924.

5. Fenómenos geologicos en el valle de México y su influjo sobre la producción de tolvaneras . . . : Soc. cient. Ant. Alz., Mem., t. 46, no. 3-6, pp. 237-277, March-June, 1926.

Salisbury, Rollin D., 1858-1922. See also Chamberlin, T. C., 32 ; Weller, 1.

1. Physiography. 3d ed., revised, 676 pp., 608 flgs., New York, Henry Holt and Company, 1919.

2. (and Alden, William C.). The geography of Chicago and its environs (revised edition) : Geog. Soc. Chicago, Bull. no. 1, 63 pp., 29 figs., 2 pls., May, 1920.

Salton, G. H.

1. Mining practice at Sterling Hill mine [Franklin Furnace district], New Jersey Zinc Company : Canadian Inst. Min. and Met., Monthly Bull., no. 137, pp. 567-593, 22 figs., September, 1923.

Sampson, Edward. See also Wilson, R. A., 5.

1. Talc and soapstone in 1920: U. S. Geol. Survey, Mineral Resources, 1920, pt. 2, pp. 201-213, 3 figs., January 20, 1922.

2. Asbestos in 1920. U. S. Geol. Survey, Mineral Resources, 1920, pt. 2, pp. 309-322, 1 fig., July 7, 1922.

3. Chromite in 1921: U. S. Geol. Survey, Mineral Resources, 1921, pt. 1, pp. 15-17, May 15, 1922. 
Sampson, Edward-Continued.

4. Talc and soapstone in 1921: U. S. Geol. Survey, Mineral Resources, 1921, pt. 2, pp. 97-103, 2 figs., August 4, 1922.

5. Asbestos in 1921: U. S. Geol. Survey, Mineral Resources, 1921, pt. 2, pp. 135-142, 1 fig., September 19, 1922.

6. Chromite in 1922: U. S. Geol. Survey, Mineral Resources, 1922, pt. 1, pp. 107-112, 1 fig., August 27, 1923.

7. Asbestos in 1922: U. S. Geol. Survey, Mineral Resources, 1922, pt. 2, pp. 31-37, 1 fig., August 29, 1923.

8. The ferruginous chert formations of Notre Dame Bay, Newfoundland: Jour. Geology, vol. 31, no. 7, pp. 571-598, 4 figs., October-November, 1923.

9. Talc and soapstone in 1922 : U. S. Geol. Survey, Mineral Resources, 1922, pt. 2, pp. 81-86, October 11, 1923.

10. Note on the determination of anisotropism in metallic minerals : Econ. Geology, vol. 18, no. 8, pp. 775-777, December, 1923.

11. Arizona asbestos deposits: Econ. Geology, vol. 19, no. 4, pp. 386-388, 1 fig., June-July, 1924.

12. (and Meyer, H. M.). Chromite in 1923: U. S. Geol. Survey, Mineral Resources, 1923, pt. 1, pp. 113-117, October 29, 1924.

13. Asbestos in 1923. U. S. Geol. Survey, Mineral Resources, 1923, pt. 2, pp. 339-350, 1 fig., February 9, 1925.

14. Geologic mapping with airplane photographs in Arizona (abstract) : Geol. Soc. America, Bull., vol. 36, no. 1, p. 135, March 30, 1925; Pan Am. Geologist, vol. 43, no. 1, p. 77, February, 1925.

15. Belt sedimentation and correlation (abstract) : Geol. .Soc. America, Bull., vol. 38, no. 1, pp. 111-112, March 30, 1927; Pan-Am. Geologist, vol. 47, no. 1, p. 66, February, 1927.

16. Geology and silver ore deposits of the Pend Oreille district, Idaho: Idaho, Bur. Mines and Geology, Pam. no. 31, 25 pp. (mimeographed), 5 pls., December, 1928.

Sampson, Ernest H. S.

1. Some tin placer deposits of Mexico: Eng. and Min. Jour. vol. 124, no. 4, pp. 137-139, 4 figs., July 23, 1927.

Sanborn, Ethel I.

1. Notes on Goshen flora (abstract): Pan-Am. Geologist, vol. 49, no. 4, p. 318, May, 1928.

Sanborn, James F. See Berkey, 6.

Sánchez Roig, Mario.

1. Una excursión a Viñales [Jurassic fossils]: Revista de Agricultura, Comercio, y Trabajo, año 2, no. 12, pp. 588-591, 9 figs., Habana, December, 1919.

2. La fauna jurásica de Viñales: Cuba, Secretaría de Agr., Bol. Especial, 61 pp., 23 pls., 1920.

3. Escualidos del Mioceno y Plioceno de la Habana: Cuba, Dirección de montes y minas, Boletín de minas, no. 6, pp. 1-16, 12 pls., 1920.

4. Revision de los equínidos fosiles cubanos: Soc. cubana hist. nat. "Felipe Poey," Mem., vol. 6, nos. 1-2, pp. 6-92, 14 pls., 1924; also separate, 68 pp., 14 pls., Habana, G. Lopez Salas, 1924.

5. La fauna cretacica de la región central de Cuba: Soc. cubana hist. nat. "Felipe Poey," Mem., vol. 7, nos. 1-2, pp. 83-102, 10 pls., 1926.

6. Los equinodermos fosiles de Cuba: Cuba, Direccion de montes y minas, Bol. minas no. 10, pp. 1-143, 43 pls., December, 1926. 
Sanderson, J. O. G. See also Allan, 16.

1. Criteria for the determination of sandstones of Upper Cretaceous age in Alberta (abstract) : Roy. Soc. Canada, Proc. and Trans., 3d ser., vol. 17, sec. 4, pp. 124-125, May, 1923.

Sandhouse, Grace. See Cockerell, 9.

Sandidge, John R.

1. The recurrent brachiopods of the Lower Cretaceous of northern Texas: Am. Jour. Sci., 5th ser., vol. 15, pp. 314-318, 1 fig., April, 1928.

Sands, J. Melville.

1. Burbank field, Osage County, Oklahoma: Am. Assoc. Petroleum Geologists, Bull., vol. 8, no. 5, pp. 584-592, 2 figs., September-October, 1924.

2. Burbank field, Osage County, Oklahoma: Am. Assoc. Petroleum Geologists, Bull., vol. 11, no. 10, pp. 1.045-1054, 5 figs., October, 1.927.

Sansom, C. A.

1. The history and geology of the oil fields of Mexico: Inst. Petroleum Technologists, Jour., vol. 10, no. 43, pp. 306-310, June, 1.924.

Santillan, Manuel.

1. Informe preliminar de variaś zonas mineralizadas de la parte central del Estado de Guerrero: Mexico, Departamento de exploraciones y estudios geológicos, Folleto de divulgación, no. 15, 27 pp., map, October, 1925.

2. Informe preliminar de varias zonas mineralizadas de la parte norte y noroeste del Estado de Guerrero: Mexico, Departamento de exploraciones y estudios geologicos, Folleto de divulgación, no. 1.8, 17 pp., May, 1926.

3. Estudio preliminar de las zonas mineralizadas que se encuentran á uno y otro lado de la carretera en proyecto entre Durango, Durango, y Mazatlán, Sinaloa: Mexico, Departamento de exploraciones y estudios geológicos, Folleto de divulgación, no. 24, 28 pp., February, 1927.

Sapper, Karl.

1. Alte und neue Bilder des Masaya und Momotombo [volcanoes, Nicaragua] : Zeitschr. Vulkanologie, Bd. 2, H. 4, pp. 226-231, June, 1916.

2. Ueber Hornitos und verwandte Gebilde: Zeitschr. Vulkanologie, Bd. 5, H. 1, pp. 1-39, 9 pls., 5 figs., June, 1919.

3. Los volcanes de la América Central. 116 pp., 5 pls. Halle (Saale), Max Niemeyer, 1925. (Estudios sobre América y España, Extraserie.)

4. El infierno de Masayo; documentos históricos publicados con una introducción: Estudios sobre América y España; Serie geografica (publicaciones del Instituto americanista de la Universidad de Wuerzburgo), no. 2, 65 pp., 3 pls., Halle (Saale), Max Niemeyer, 1925.

5. Die vulkanische Tätigkeit in Mittelamerika im 20. Jahrhundert: Zeitschr. Vulkanologie, Bd. 9, H. 4 and 5, pp. 156-203, 231-270, 17 figs., 12 pls., February and July, 1926.

6. Reise in Mittelamerika 1923-24: Deutsch. Geographentag, Breslau, Verh., Bd. 21, pp. 30-49, 1925 [not seen] ; abstract, Geol. Zentralblatt, Bd. 34, no. 5, p. 219, December 1, 1926.

7. Ein Beitrag zur Paläogeographie Mittelamerikas: Gesell. Erdkunde Berlin, Zeitschr., Sonderband zur Hundertjahrfeier, pp. 57-67, 1928. 
Sardeson, Frederick William. See also Leverett, 4.

1. Uescription of the Herman, Barrett, Chokio, and Morris quadrangles, Minnesota: U. S. Geol. Survey, Geol. Atlas, Herman-Morris folio (no. 210), 10 pp., 12 figs., 8 maps, 1919.

2. Employment of geologists: Pan-Am. Geologist, vol. 38, no. 3, pp. 268-271, October, 1922.

3. Glacial drift sheets in Minnesota: Pan-Am. Geologist, vol. 38, no. 5, pp. 383-402, 3 pls., December, 1922.

4. Cone domes of Sunburst oil field: Pan-Am. Geologist, vol. 39, no. 1, pp. 17-22, 2 figs., 1 pl., February, 1923.

5. Portland cement materials in Minnesota : Pan-Am. Geologist, vol. 39, no. 2, pp. 121-124, March, 1923.

6. Geology of the name Minnesota : Pan-Am. Geologist, vol. 39, no. 4, pp. 273281, 1 pl., May, 1923.

7. Crude aspects of the petroleum genesis problem: Pan-Am. Geologist, vol. 40, no. 1, pp. 19-28, August, 1923.

8. Minnesota eskers and sundry kames: Pan-Am. Geologist, vol. 40, no. 2, pp. 95-101, 1 fig., September, 1923.

9. History of Mille Lacs, Minnesota: Pan-Am. Geologist, vol. 40, no. 3, pp. 181-196, 3 pls., October, 1923.

10. Glacial origin of the Buffalo Plains of Minnesota : Pan-Am. Geologist, vol. 40, no. 5, pp. 339-348, 1 pl. (map), December, 1923.

11. Tetradium and coral evolution: Pan-Am. Geologist, vol. 41, no. 1, pp. 1-16, 1.pl., February, 1924.

12. Type outcrops of Minnesota River valley: Pan-Am. Geologist, vol. 41, no. 2, pp. 107-122, 1 pl. (map), March, 1924.

13. Volcanic ash in Ordovicic rocks of Minnesota: Pan-Am. Geologist, vol. 42, no. 1, pp. 45-52, August, 1924.

14. Selective teaching in geology : Pan-Am. Geologist, vol. 42, no. 4, pp. 263272, November, 1924.

15. Habit of an Ordovicic pelecypod: Pan-Am. Geologist, vol. 42, no. 5, pp. 345-356, 1 pl., December, 1924.

16. Ordovicic Crinoidea [Minnesota] : Pan-Am. Geologist, vol. 43, no. 1, pp. 55-68, 1 pl., February, 1925.

17. Primitive cephalopods from Minnesota: Pan-Am. Geologist, vol. 43, no. 3, pp. 185-204, 2 pls., April, 1925.

18. Ordovicic kelp, sponges, and sea worms in Minnesota : Pan-Am. Geologist, vol. 43, no. 4, pp. 271-286, 1 pl., May, 1925.

19. Geology in open forum: Pan-Am. Geologist, vol. 44, no. 3, pp. 199-206, October, 1925.

20. Shakopee dolomite and its cone-domes: Pan-Am. Geologist, vol. 45, no. 1, pp. 29-48, February, 1926.

21. Peter sandstone and its buttes: Pan-Am. Geologist, vol. 45, no. 3, pp. 211-224, April, 1926.

22. Beloit formation and bentonite: Pan-Am. Geologist, vol. 45, no. 5, pp. 383-392, 1 pl., June, 1926; vol. 46, no. 1, pp. 11-24, 1 fig., August, 1926.

23. Four-stage glacial epoch : Pan-Am. Geologist, vol. 46, no. 3, pp. 175-188, October, 1926.

24. Pioneer repopulation of devasted sea bottoms: Pan-Am. Geologist, vol. 46, no. 4, pp. 273-288, November, 1926.

25. Oldest Pleistocene till: Pan-Am. Geologist, vol. 47, no. 3, pp. 179-196, 3 pls., April, 1927. 
Sardeson, Frederick William-Continued.

26. Pathologic ornamentation on Strophomena incurvata Shepherd (abstract) : Geol. Soc. America, Bull., vol. 38, no. 1, p. 226, March 30, 1927 ; Pan-Am. Geologist, vol. 47, no. 3, p. 237, April, 1927.

27. Shore line of Galena seas: Pan-Am. Geologist, vol. 47, no. 5, pp. 331342, June, 1927.

28. Block faulting on the grand prairies?: Pan-Am. Geologist, vol. 48, no. 2, pp. 127-134, September, 1927.

29. Nomenclature of glacial formations: Pan-Am. Geologist, vol. .48, no. 4, 287-298, November, 1927.

30. Ordovicic bentonite in the Northwest [southeastern Minnesota]: Pan. Am. Geologist, vol. 48, no. 5, pp. 347-354, December, 1927.

31. Derivation of the Calceocrinidae: Pan-Am. Geologist, vol. 49, no. 1, pp. 35-46, 1 pl., February, 1928.

32. Most primitive of starfishes: Pan-Am. Geologist, vol. 49, no. 1, pp. 5859, February, 1928.

33. Starfish beginnings and Protopalaeaster: Pan-Am. Geologist, vol. 49, no. 2, pp. 99-110, 1 pl., March, 1928.

34. Recent extensions of our glacial tills: Pan-Am. Geologist, vol. 49, no. 4, pp. 263-270, 1. pl., May, 1928.

35. Heliokleptic earth: Pan-Am. Geologist, vol. 50, no. 1, pp. 29-38, August, 1928.

36. Bentonite seams in stratigraphic correlation: Pan-Am. Geologist, vol. 50, no. 2, pp. 107-116, September, 1928.

Sarle, Clifton J.

1. Sketch of the geology of the Dos Cabezas Mountains of southwestern Arizona (abstract) : Science, new ser., vol. 55, p. 544, May 19, 1922.

Sauer, Carl Ortwin.

1. The geography of the Ozark Highland of Missouri: Geographic Society of Chicago, Bull., no. 7, 245 pp. 44 figs., 26 pis., January, 1920 .

2. The morphology of landscape: California, Univ., Pub. in Geography, vol. 2, no. 2, pp. 19-53, October 12, 1925.

3. (assisted by others). Geography of the Pennyroyal [region, Kentucky] : Kentucky Geol. Survey, Ser. 6, vol. 25, 303 pp., 125 figs. and pls. (incl. maps), 1927.

Saunders, L. W. See also Wilhelm, 3 .

1. The minor oil fields of Kern County; Hovey Hills field: California State Min. Bur., Summary of Operations California Oil Fields, vol. 9, no. 12, pp. 11-18, 2 pls. (incl. map), June, 1924.

Savage, Thomas Edmund. See also Tough, 1.

1. The Thebes sandstone and Orchard Creek shale and their faunas in Illinois: Illinois Acad. Sci., Trans., vol. 10, pp. 261-275, 2 pls. [1918].

2. (and Van Tuyl, Francis M.). Geology and stratigraphy of the area of Paleozoic rocks in the vicinity of Hudson and James bays: Geol.. Soc. America, Bull., vol. 30, pp. 339-378, 3 pls., 4 figs. (paleogeographic maps), September 30, 1919.

3. The Devonian formations of Illinois: Am. Jour. Sci., 4th ser., vol. 49, pp. 169-182, 3 figs., March, 1920.

4. The Devonian rocks of southwestern Illinois (abstract): Science, new ser., vol. 51, pp. 494-495, May 14, 1920. 
Savage, Thomas Edmund-Continued.

5. (and Udden, J. A.). The geology and mineral resources of the Edgington and Milan quadrangles: Illinois, State Geol. Survey, Bull. no. 38, pp. 115-208, 20 figs., map, 1922 ; Extract, 96 pp., 1921.

6. Geology and mineral resources of the Avon and Canton quadrangles: Illinois, State Geol. Survey, Bull. no. 38, pp. 209-271, 8 figs., map, 1922 ; Extract, 67 pp., 1921.

7. New species of Devonian fossils from western Illinois: Illinois State Acad. Sci., Trans, vol. 14, pp. 197-206, 4 pls. [1922].

8. (and Nebel, M. I.). Geology and mineral resources of the La Harpe and and Good Hope quadrangles: Illinois State Geol. Survey, Bull. no. 43, pp. 9-93, 11 figs., map, 1923 (published as extract in 1921).

9. The paleontologist's view of evolution: Illinois State Acad. Sci., Trans., vol. 16, pp. 39-42, 1923.

10. Oriskany limestone in Illinois (abstract): Geol. Soc. America, Bull., vol. 35, no. 1, p. 106, March 30, 1924.

11. Marine invertebrate fossils as horizon markers in the Pennsylvanian rocks of Illinois: Jour. Geology, vol. 32, no. 7, pp. 575-582, October-November, 1924.

12. Richmond rocks of Iowa and Illinois: Am. Jour. Sci., 5th ser., vol. 8, pp. 411-427, November, 1924.

13. The correlation of the Maquoketa and Richmond rocks of Iowa and Illinois: Illinois State Acad. Sci., Trans., vol. 17, pp. 233-247, 1925.

14. Comparison of the Devonian rocks of Illinois and Missouri: Jour. Geology, vol. 33, no. 5, pp. 550-558, July-August, 1925 ; abstract, Illinois State Acad. Sci., Trans., vol. 18, p. 408, 1925.

15. Oriskany rocks in Illinois: Am. Jour. Sci., 5th ser., vol. 10, pp. 139-144, 2 . figs., August, 1925.

16. Silurian rocks of Illinois: Geol. Soc. America, Bull., vol. 37, no. 4, pp. 513-533, 1 fig., December 30,1926 ; abstract, no. 1 , pp. 159-160, March 30, 1926; Pan-Am. Geologist, vol. 45, no. 2, p. 161, March, 1926 ; Illinois State Acad. Sci., Trans., vol. 19, pp. 286-287, 1926.

17. Significant breaks and overlaps in the Pennsylvanian rocks of Illinois: Am. Jour. Sci., 5th ser., vol. 14, pp. 307-316, October, 1927; abstract, Geol. Soc. America, Bull., vol. 38, no. 1, pp. 135-136, March 30, 1927; Pan-Am. Geologist, vol. 47, no. 1, p. 78, February, 1927.

18. (and Griffin, Judson R.). Significance of crystalline boulders in Pennsylvanian limestone in Illinois: Geol. Soc. America, Bull., vol. 39, no. 2, pp. 421-428, 2 figs., June, 1928; abstract, no. 1, p. 212, March, 1928; Pan-Am. Geologist, vol. 49, no. 2, p. 146, March, no. 3, p. 232, April, 1928.

Sawtelle, George.

1. The Batson oil field, Hardin County, Texas: Am. Assoc. Petroleum Geologists, Bull., vol. 9, no. 9, pp. 1277-1282, 2 figs., 1 pl., December, 1925 ; Geology of salt dome oil fields, pp. 524-529, 1 pl., 1926.

Sawyer, Roger W.

1. Areal geology of a part of southwestern Oklahoma (with discussion by F. C. Greene and others) : Am. Assoc. Petroleum Geologists, Bull., vol. 8, no. 3, pp. 312-321, 2 figs. (maps), May-June, 1924.

Sayles, Robert Wilcox. See also Twenhofel, 16, 18.

1. Seasonal deposition in aqueoglacial sediments: Harvard Coll., Mus. Comp. Zool., Mem., vol. 47, no. 1, 67 pp., 16 pls., 2 figs., February, 1919. 
Sayles, Robert Wilcox-Continued.

2. Report on the geological collections: Harvard Coll., Mus. Comp. Zool., Ann. Rept., 1919-1920, p. 32, 1920.

3. Report on the geological collections: Harvard Coll., Mus. Comp. Zool., . Ann. Rept., 1920-1921, p. 29, 1921.

4. Microscopic sections of till and stratified clay: Geol. Soc. America, Bull., vol. 32, no. 1, pp. 59-62, 4 figs., March 31, 1921.

5. Report on the geological collections: Harvard Coll., Mus. Comp. Zoology, Ann. Rept., 1921-1922, p. 21, 1922 .

6. Possible tillite at Levis, Quebec (abstract): Geol. Soc: America, Bull., vol. 33, no. 1, pp. 90-100, March 31, 1922.

7. Preliminary notes on some regularly banded argillites which suggest seasonal deposition ( abstract) : Geol. Soc. America, Bull.; vol. 33, no. 1, p. 133, March 31, 1922.

8. The dilemma of the paleoclimatologists: Am. Jour. Sci., 5th ser., vol. 3, pp. 456-473, June, 1922.

9. Report on the geological collections: Harvard College, Mus. Comp. Zoology, Ann. Rept. for 1922-1923, pp. 23-24, 1923.

10. Report on the geological collections: Harvard Coll., Mus. Comp. Zoology, Ann. Rept. for 1923-1924, pp. 22-23, 1924.

11. Variability of summer deposition in glacial varves (abstract, with discussion by C. A. Reeds) : Geol. Soc. America, Bull., vol. 35, no. 1, pp. 67-68, March 30, 1924; abstract, Pan-Am. Geologist, vol. 41, no. 2, p. 137, March, 1924.

12. Are some fossil soils in Bermuda recorders of interglacial episodes? (abstract) : Geol. Soc. America, Bull., vol. 35, no. 1, pp. 68-69, March 30, 1924 ; Pan-Am. Geologist, vol. 41, no. 2, pp. 137-138, March, 1924.

13. Report on the geological collections: Harvard Coll., Mus. Comp. Zoology, Ann. Rept. Director, 1924-5, p. 23, 1925.

14. (and Clark, Thomas H.). Pleistocene Bermuda (abstract) : Geol. Soc. America, Bull., vol. 36, no. 1, pp. 141-142, March 30, 1925; Pan-Am. Geologist, vol. 43, no. 2, pp. 145-146, March, 1925.

15. Superficial factors in earthquakes: Science, new ser., vol. 62, pp. 299-301, October 2, 1925 ; Royal Astronomical Soc. Canada, Jour., vol. 19, no. 6, pp. 179-182, October, 1925.

16. Report on the geological collections: Harvard Coll., Mus. Comp. Zoology, Ann. Rept. Director, 1925-26, p. 23, 1926.

17. George Carroll Curtis: Geog. Rev., vol. 16, no. 2, pp. 332-333, April, 1926.

18. Report on the geological collections: Harvard Coll., Mus. Comp. Zoology, Ann. Rept. Director, 1926-27, p. 22, 1927.

19. Three Pleistocene tills in southern Maine (abstract) : Geol. Soc. America, Bull., vol. 38, no. 1, pp. 142-143, March 30, 1927 ; Pan-Am. Geologist, vol. 47 , no. 2, p. 150, March, 1927.

20. Is there any effect of superficial factors in seismic and volcanic activity? (abstract) : Seismological Soc. America, Bull., vol. 17, no. 3, pp. 189-191., September, 1927.

Sayre, Robert $\mathrm{H}$.

1. Arsenical ore deposits in the United States: Eng. and Min. Jour.-Press, vol. 118, no. 24, pp. 929-932, 6 figs., December 13, 1924.

Schaffer, Franz Xaver.

1. Major earth features and their transformation: Pan-Am. Geologist, vol. 50, no. 2, pp. 121-130, September, 1928. 
Schagen van Soelen, J. C.

1. Angular inclusions and banded and "orbicular" structure in ore veins: Eng. and Min. Jour., vol. 122, no. 20, pp. 777-778, 1 fig., November 13, 1926.

Schairer, J. F.

1. (and Lawson, C. C.). Copiapite from the Santa Maria Mountains, eastern Riverside County, California: Am. Mineralogist, vol. 9, no. 1.2, pp. 242-244, December, 1924.

2. (and Lawson, C. C.). On pickeringite from Portland, Conneticut: Am. Jour. Sci., 5th ser., vol. 11, pp. 301-304, 1 fig., April, 1926.

3. Lithiophilite and other rare phosphates from Portland, Connecticut: Am. Mineralogist, vol. 11, no. 4, pp. 101-104, April, 1926.

Schaller, Waldemar Theodore. See also Hewett, 14 ; Larsen, 13, 18.

1. Plancheite and shattuckite, copper silicates, are not the same mineral: Washington Acad. Sci., Jour., vol. 9, no. 5, pp. 131-134, March 4, 1919.

2. Gems and precious stones in 1918: U. S. Geol. Survey, Mineral Resources, pt. 2, pp. 7-14, July 16, 1919.

3. Mica in 1918: U. S. Geol. Survey, Mineral Resources, 1918, pt. 2, pp. 629694, May 24, 1920.

4. Thorium, zirconium, and rare-earth minerals in 1919: U. S. Geol. Survey, Mineral Resources, 1919, pt. 2, pp. 1-32, September 1, 1920.

5. Gillespite, a new mineral. [Alaska] : Washington Acad. Sci., Jour., vol. 12, no. 1, pp. 7-8, January 4, 1922.

6. Argentojarosite, a new silver mineral [from Dividend, Utah]: Washington Acad. Sci., Jour., vol. 13, no. 11, p. 233, June 4, 1923.

7. The genesis of lithium pegmatites: Am. Jour. Sci., 5th ser., vol. 10, pp. 269-279, 1 fig., September, 1925.

8. Index of refraction of hisingerite-a correction: Am. Jour. Sci., 5th ser., vol. 11, p. 376, April, 1926.

9. (and Henderson, Edward P.). Purple muscovite from New Mexico: Am. Mineralogist, vol. 11, no. 1, pp. 5-16, January, 1926.

10. How pegmatites form (abstract) : Am. Mineralogist, vol. 11, no. 2, pp. 41-42, February, 1926.

11. Genesis of lithium pegmatites (abstract) : Washington Acad. Sci., Jour., vol. 16 , no. 3 , p. 76 , February $4,1926$.

12. Kernite, a new sodium borate: Am. Mineralogist, vol. 12, no. 1, pp. 24-25, January, 1927.

13. Mineral replacements in pegmatites: Am. Mineralogist, vol. 12, no. 3, pp. 59-63, March, 1927.

14. The mineralogy of the Tintic Standard mine, Utah (abstract): Washington Acad. Sci., Jour., vol. 17, no. 5, p. 121, March 4, 1927.

15. The probable identity of camsellite with szaibelyite: Am. Mineralogist, vol. 13, no. 6, pp. 230-232, June, 1928.

16. Hydroboracite from California: Festschrift Victor Goldschmidt, pp. 256262, 1 fig., Heildelberg, Carl Winter's Universitaitsbuchhandlung, 1928.

Schander, Johannes.

1. Der Unterglund der Texas-Golfkuiste and seine Schwereverhältnisse: Zeitschr. prakt. Geologie, Jg. 35, H. 10, pp. 152-157, 5 figs., October, 1927. 
Scheffel, Earl R.

1. "Slides" in the Conemaugh formation near Morgantown, West Virginia : Jour. Geology, vol. 28, no. 4, pp. 340-355, 5 figs., May-June, 1920.

2. "Soot" in coal: Science, new ser., vol. 59,-pp. 212-213, February 29, 1924.

3. Some problems of the ofl and gas industry: West Virginia Acad. Sci., Proc., vol: 1 , no. 1 (W. Va. Univ. Bull., ser. no. 27, no. 1), pp. 65-70, August, 1926.

4. A phase of coal conservation: West Virginia Acad. Sci., Proc., vol. 1, no. 1 (W. Va. Univ. Bull., ser no. 27, no. 1), pp. 71-73, August, 1926.

Schempp, C. A.

1. Argento-jarosite, a new silver mineral [from Utah]: Am. Jour. Sci., 5th ser., vol. 6, pp. 73-75, July, 1923.

Schenck, Hubert Gregory. See also Cushman, 44 ; Kerr, P. F., 4, 7.

1. Physiography of the Eugene quadrangle, Oregon (abstract with discussion by Warren D. Smith) : Geol. Soc. America, Bull., vol. 36, no. 1, p. 203, March 30, 1925.

2. (and Aguerrevere, Santiago E.). Morphologic nomenclature of orbitoidal Foraminifera: Am. Jour. Sci., 5th ser., vol. 11, pp. 251-256, 3 figs., March, 1926.

3. Cassididae of western America : California, Univ., Dept. Geol. Sci., Bull., vol. 16, no. 4, pp. 69-98, 1 fig., 4 pls., May 4, 1926.

4. Should new fossil species be described from weils?: Science, new ser., vol. 64, pp. 65-66, July 16, 1926.

5. Marine Oligocene of Oregon: California, Univ., Dept. Geol. Sci., Bull, vol. 16, no. 12, pp. 449-460, 1 fig., March 19, 1927; abstract, Geol. Soc. America, Bull., vol. 38, no. 1, p. 202, March 30, 1927.

6. Diatomaceous shale interbedded with arkose (abstract): Geol. Soc. America, Bull., vol. 38, no. 1, p. 196, March 30, 1927.

7. Diatoms in western Oregon shales: Econ. Geology, vol. 22, no. 6, pp. 565568, 2 figs., September-October, 1927.

8. A new echinoid from the California Eocene: San Diego Soc. Nat. Hist., Trans., vol. 5, no. 12, pp. 195-201, 1 pl., April 28, 1928.

9. Pittsburg Bluff fauna of Oregon Oligocene (abstract) : Pan-Am. Géologist, vol. 49, no. 4, pp. 302-303, May, 1928.

10. Discocyclina in California (abstract) : Pan-Am. Geologist, vol. 49, no. 4, pp. 316-317, May, 1928.

11. The biostratigraphic aspect of micropaleontology: Jour. Paleontology, vol. 2, no. 2, pp. 158-165, 1 pl., June, 1928.

12. Stratigraphic relations of western Oregon Oligocene formations: California. Univ., Dept. Geol. Sci., Bull., vol. 18, no. 1, pp. 1-50, 18 figs., November $30,1928$.

s'cheuble, Hugo. See Müllerried, 1.

schilling, Karl H. See Wagner, C. M., 1.

Nichlossmacher, $\mathbf{K}$.

1. Mikroskopische Untersuchungsbeiträge zur Kenntniss der kanadischen Kobalt-Nickel-Silberformation [T'emiskaming, Ontario]: Zeitschr. prakt. Geologie, Jg. 29, H. 9, pp. 131-134, 8 figs., September, 1921.

Schmidt, M. M.

1. The common rocks and gem stones of Kansas and how to recognize them:

Kansas Acad. Sci., Trans., vol. 29, pp. 85-88, 1920. 
Schmitt, Harrison Ashley.

1. Possible potash production from Minnesota shale: Econ. Geology, vol. 19, no. 1, pp. 72-83, 1 fig., January-February, 1924.

2. Geologic notes on the Santa Barbara area in the Parral district of Chihuahua, Mexico: Eng. and Min. Jour., vol. 126, no. 11, pp. 407-411, 4 figs, September 11, 1928.

Schneider, Henry G.

1. Smackover oil field, Ouachita and Union Counties, Arkansas: Am. Inst. Min. and Met. Eng., Trans:, vol. 70, pp. 1076-1099, 3 figs., 1924; [preprint] no. 1326, 24 pp., 3 figs., March, 1924.

2. Names of producing sands in the Smackover, Arkansas, fleld: Am. Assoc. Petroleum Geologists, Bull., vol. 9, no. 7, pp. 1116-1117, October, 1925.

Schneider, Hyrum.

1. General geology of Utah: Utah, Univ., Bull., vol. 10, no. 11 (Engineering Station, Department of Metallurgical Research, Bull., no. 12), pp. 3-33, December, 1919.

2. A discussion of certain geologic features of the Wasatch Mountains: Jour. Geology, vol. 33, no. 1, pp. 2\&-48, 5 figs., January-February, 1925.

3. A study of glauconite: Jour. Geology, vol. 35, no, 4, pp. 289-310, 2 figs., May-June, 1927

Schneiderhöhn, H.

1. Argentite and acanthite: Am. Mineralogist, vol. 12, no. 5, pp. 210-211, May, 1927.

Schoch, Eugene Paul. See also Sellards, 25, 26.

1. Chemical analyses of Texas rocks and minerals: Texas, Univ., Bull., no. 1814, 256 pp., March 5, 1918 [1920?].

Schönberg, J. W.

1. Bericht über die jüngsten Ereignisse und Arbeiten am Masaya, Nicaragua : Zeitschr. Vulkanologie, Bd. 11, H. 2, pp. 128-134, 4 pls., December, 1927.

Schoewe, Walter Henry.

1. The interpretation of certain leached gravel deposits in Louisa and Washington counties, Iowa: Iowa Acad. Sci., Proc., vol. 26, pp. 393398 [1920].

2. Southernmost extension of Kansas tills : Pan-Am. Geologist, vol, 38, no. 5, pp. 378-382, 1 fig., December, 1922.

3. Origin and history of extinct Lake Calvin (abstract) : Geol. Soc. America, Bull., vol. 34, no. 1, pp. 93-94, March 30, 1923.

4. The temporary Mississippi River: Jour. Geology, vol. 31, no. 5, pp. 420-432, 1 fig. (map), July-August, 1923.

5. Glacial geology of Kansas: Pan-Am. Geologist, vol. 40, no. 2, pp. 102-110, $1 \mathrm{pl}$ (map), September, 1923.

6. The origin and hstory of extinct Lake Calvin: Iowa Geol. Survey, vol. 29, pp. 49-222, 32 figs., 14 pls. (incl. maps) [1924].

7. Till-like deposits south of Kansas River in Douglas County, Kansas: Iowa Acad. Sci., Proc. 1922, vol. 29, pp. 61-65, 1 fig. [1924?].

Schofield, Stuart James. See also Brock, 13.

1. Britannia map area [British Columbia]: Canada, Geol. Survey, Summ. Rept., 1918, pt. B, pp. 56-59, 1919. 
Schofield, Stuart James-Continued.

2. Ainsworth mining district, British Columbia : Canada, Geol. Survey, Summ. Rept., 1918, pt. B, pp. 60-62, 1919.

3. The Mesozoic period of mineralization in British Columbia: Canadian Min. Inst., Trans., vol. 21, pp. 422-427, 1 pl. (map) [1919].

4. Geology and ore deposits of Ainsworth mining eamp, British Columbia: Canada, Geol. Survey, Mem. 117, 73 pp., 3 pls., 6 figs., 12 maps, 1920.

5. The discovery of fossils in the Mesozoic rocks of Hedley, B. C.: Canada, Geol. Survey, Summ. Rept., 1919, pt. B, pp. 38-39, 1920.

6. The origin of the Purcell Trench, British Columbia (Kootenay Lake valley) : Roy. Soc. Canada, Proc. and Trans., 3d ser., vol. 13, sec. 4, pp. 23-31, 3 figs. (maps), 1920.

7. (and Hanson, George). Salmon River district, British Columbia: Canada, Geol. Survey, Summ. Rept., 1920, pt. A, pp. 6-12, 1 fig., 1921.

8. The origin of the Rocky Mountain trench, British Columbia: Roy. Soc. Canada, Proc. and Trans., 3d ser., vol. 14, sec. 4, pp. 61-97, 5 figs., 1921.

9. The ore deposits of British Columbia: Canadian Inst. Min. and Met., Monthly Bull. no. 112, pp. 703-714, August, 1921; Trans., vol. 24, pp. 86-98 [1922].

10. The discovery of Olenellus fauna in southeastern British Columbia: Science, new ser., vol. 54, pp. 666-667, December 30, 1921.

11. (and Hanson, G.). Geology and ore deposits of Salmon River district, British Columbia: Canada, Geol. Survey, Mem. 132, 81 pp., 6 figs., 4 pls., map, 1922.

12. Relationship of the pre-Cambrian (Beltian) terrain to the Lower Cambrian strata of southeastern British Columbia: Canada, Geol. Survey, Bull. no. 35 (Geol. ser. no. 42), 15 pp., 2 figs., October 30, 1922.

13. The geological record of the Cordillera in Canada: Roy. Soc. Canada, Proc. and Trans, 3d ser., vol. 17, sec. 4, pp. 79-103, May, 1923.

14. (and Hanson, George). The Salmon River district, British Columbia: Min. Mag., vol. 28, no. 4, pp. 203-214, 9 figs., April, 1923.

15. Geological record in British Columbia (abstract): Geol. Soc. America, Bull., vol. 35, no. 1, p. 164, March 30, 1924.

16. The fissure systems of British Columbia: Canadian Inst. Min. and Met, Bull., no. 159, pp. 759-764, 1 fig., July, 1925 ; Trans., vol. 28, pp. 428-433, 1 fig. [1926].

17. The Britannia mines, British Columbia: Econ. Geology, vol. 21, no. 3, pp. 271-284, 3 figs., May, 1926.

Schrader, Frank Charles. See also Stose, 17.

1. Pyrite at the Haile mine, Kershaw, South Carolina, with a note on pyritization at the Brewer mine, near Jefferson: U. S. Geol. Survey, Bull. 725, pp. 331-345, 1 pl., October 21, 1921.

2. Antimony in 1919: U. S. Geol. Survey, Mineral Resources, 1919, pt. 1, pp. 287-311, 2 figs., 2 pls., June 6, 1921.

3. Antimony in 1920: U. S. Geol. Survey, Mineral Resources, 1920, pt. 1, pp. 73-84, 2 figs., 1 pl., October 27, 1921.

4. Antimony in 1921: U. S. Geol. Survey, Mineral Resources, 1921, pt. 1, pp. 121-128, September 18, 1922.

5. The Jarbidge mining district, Nevada, with a note on the Charleston district: U. S. Geol. Survey, Bull. 741, 86 pp., 19 figs., 20 pls. (incl. maps), 1923. 
Schrader, Frank Charles-Continued.

6. Antimony in 1922: U. S. Geol. Survey, Mineral Resources, 1922 pt. 1, pp. 97-105, August 7, 1923.

7. Molybdenite in the Rocky Bar district, Idaho: U. S. Geol. Survey, Bull. 750, pp. 87-99, 3 figs., 1 pl., October 25, 1924.

8. Antimony in 1923: U. S. Geol. Survey, Mineral Resources, 1923, pt. 1, pp. 277-293, 2 figs., January 21, 1925.

9. Antimony in 1924: U. S. Bur. Mines, Mineral Resources, 1924, pt. 1, pp: 105-118, 1 fig., March 13, 1926.

10. (and Ross, Clyde P.). Antimony and quicksilver deposits in the Yellow Pine district, Idaho: U. S. Geol..Survey, Bull. 780, pp. 137-164, 4 figs., 2 pls. (incl. map), March 12, 1926.

Schramm, Eck Frank.

1. Notes on the oil shales of southwestern Wyoming: Am. Assoc. Petroleum Geologists, Bull., vol. 4, no. 2, pp. 195-208, 7 figs., 1920.

2. (and Cook, H. J.). The Agate anticline, Sioux County, Nebraska : Kanoka Petroleum Company, Geol Dept., Bull. A, 38 pp., 3 figs., 8 pls., Lincoln, Nebraska, July, 1921.

Schroeder, Rolf A.

1. Ball clays of west Tennessee: Tennessee State Geol. Survey, Resources of Tennessee, vol. 2, no. 2, pp. 81-180, 13 figs., April, 1919.

2. Curious erosion feature in west Tennessee clays: Jour. Geology, vol. 27, no. 6 , pp. 480-481, 1 fig., September-October, 1919.

3. A contribution to the geology of Essex County, Vermont: Vermont, State Geologist, Twelfth Rept., 1919-20, pp. 37-42, 1 fig., 1921.

Schroyer, Charles Ross. See also Parmelee, 1; Stauffer, 1.

1. Notes on potash possibilities in Illinois: Illinois, State Geol. Survey, Bull. no. 38, pp. $435-440,1922$.

Schuchert, Charles. See also Ashley, 16 ; Brown, B., 2 ; Moore, R. C., 17, 20 ; Nelson, W. A., 10; Pirsson, 5; Raymond, 8 ; Spieker, 3 ; Twenhofel, 30 ; Woodring, 8.

1. The Taconic system resurrected: Am. Jour. Sci., 4th ser., vol. 47, pp. 113-116, February, 1919.

2. The proper name for the fossil hydroid Beatricea: Am. Jour. Sci., 4th ser., vol. 47, pp. 293-296, 1 fig., April, 1919.

3. A Lower Cambrian edrioasterid, Stomatocystites walcotti: Smithsonian Misc. Coll., vol. 70, no. 1, 8 pp., 1 pl., 1 fig., 1919.

4. The relations of stratigraphy and paleogeography to petroleum geology: Am. Assoc. Petroleum Geologists, Bull., vol. 3, pp. 286-298, 1919.

5. Joseph Barrell: Science, new ser., vol. 49, pp. 605-607, June 27, 1919.

6. Joseph Barrell: Sci. Monthly, vol. 9, no. 1, pp. 93-96, portr., July, 1919.

7. Joseph Barrell (1869-1919) : Am. Jour. Sci., 4th ser., vol. 48, pp. 251-280, portr., October, 1919.

8. Petroliferous provinces (discussion of paper by E. G. Woodruff): Am. Inst. Min. and Met. Eng., Trans., vol. 65, pp. 204-216, 1921; Bull. no. 155, pp. 3058-3070, November, 1919.

9. A paleontologic revival at Yale University: Science, new ser., vol. 51, pp. 80-81, January 23, 1920.

10. American paleontologists and the immediate future of paleontology: Geol. Soc. America, Bull., vol. 31, no. 3, pp. 363-373, September 30, 1920. 
Schuchert, Charles-Continued.

11. The boundary between the Silurian and Devonian in Shropshire and France: Science, new ser., vol. 52, pp. 339-340, October 8, 1920.

12. Diagenesis in sedimentation (with discussion) : Geol. Soc. America, Bull., vol. 31 , no. 4 , pp. $425-432$, November $30,1920$.

13. The nature of Paleozoic crustal instability in eastern North America: Am. Jour: Sci., 4th șer., vol. 50, pp. 399-414, 6 figs., December, 1920.

14. The evolution of primitive plants from the geologist's viewpoint: New Phytologist, vol. 19, no. 9-10, pp. 272-275, November-December, 1920.

15. Are the Lance and Fort Union formations of Mesozoic time?: Science, new ser., vol. 53, pp. 45-47, January 14, 1921.

16. (and Dunbar, C. O.). Stratigraphy and diastrophism of western Newfoundland (abstract) : Geol. Soc. America, Bull., vol. 32, no. 1, pp. 38-39, March 31, 1921.

17. Evolution of geologic climates: Am. Jour. Sci., 5th ser., vol. 1, no. 4, pp. 320-324, April, 1921.

18. Methods of determining the relationships of marine invertebrate fossil faunas: Geol. Soc. America, Bull., vol. 32, no. 3, pp. 339-348, September 1, 1921.

19. Lance and Union formations are Mesozoic in age: Pan-Am. Geologist, vol. 37, no. 1, pp. 65-66, February, 1922.

20. The Andean geosyncline (abstract with discussion by F. P. Shepard, W. M. Davis, K. F. Mather, and T. W. Vaughan): Geol. Soc. America, Bull., vol. 33. no. 1, pp. 90-91, March 31, 1922.

21. Devonian of Oklahoma, with special reference to the Oriskany and Camden formations: Geol. Soc. America, Bull., vol. 33, no. 4, pp. 665-670, November 2, 1922.

22. Sites and nature of the North American geosynclines (presidential address) : Geol. Soc. America, Bull., vol. 34, no. 2, pp. 151-229, 17 figs. (paleogeographic maps), June 30, 1923.

23. A textbook of geology for use in universities, colleges, schools of science, etc., and for the general reader, Part II, second, revised edition. 724 pp., 237 flgs., 47 pls., map, 1924. Review by Arthur Holmes, Nature, vol. 114, pp. 376-377, September 13, 1924.

24. The value of micro-fossils in petroleum exploration: Am. Assoc. Petroleum Geologists, Bull., vol. 8, no. 5, pp. 539-553, SeptemberOctober, 1924.

25. The paleogeography of Permian time in relation to the geography of earlier and later periods: Pan-Pacific Sci. Cong., Australia, 1923. Proc., vol. 2, pp. 1079-1091, 6 figs. (paleogeographic maps) [1924].

26. Significance of Taconic orogeny: Geol. Soc. America, Bull., vol. 36, no. 2, pp. 343-350, June 30, 1925.

27. John Mason Clarke, 1857-1925: Am. Jour. Sci., 5th ser., vol. 10, p. 92, July, 1925.

28. (and Ruedemann, Rudolf). John Mason Clarke (1857-1925) : Science, new ser., vol. 62, pp. 117-121, August 7, 1925.

29. (and Dart, J. Doris). Stratigraphy of the Port Daniel-Gascons area of southeastern Quebec: Canada, Geol. Survey, Bull. no. 44, pp. 35-58, 4 pls. (incl. map), 1926.

30. Memorial of John Mason Clarke: Geol. Soc. America, Bull., vol. 37, no. 1, pp. 49-93, 1 pl. (portr.), March 30, 1926. 
Schuchert, Charles-Continued.

31. Stille's analysis and synthesis of the mountain structures of the earth: Am. Jour. Sci., 5th ser., vol. 12, pp. 277-292, 2 figs., October, 1926.

32. (and LeVene, Clara M.). The earth and its rhythms. 410 pp., illus., New York, D. Appleton and Company, 1927.

33. James Furman Kemp, 1859-1926: Am. Jour. Sci., 5th ser., vol, 13, pp. 99-100, January, 1927.

34. Winters in the Upper Devonian of New York and Acadia: Am." Jour. Sci., 5th ser., vol. 13, pp. 123-131, February, p. 159, August, 1927.

35. Unconformities as seen in disconformities and diastems: Am. Jour. Scl., 5th ser., vol. 13, pp. 260-262, March, 1927.

36. Charles Doolittle Walcott, paleontologist, 1850-1927: Science, new ser., vol. 65, pp. 455-456, May 13, 1927.

37. William Healey Dall, 1845-1927: Am. Jour. Sci., 5th ser., vol. 14, p. 88 , July, 1927.

38. Stuart Weller, 1870-1927 : Am. Jour Sci., 5th ser., vol, 14, p. 332, October, 1927.

39. The Pennsylvanian-Permiän systems of western Texas: Am. Jour. Sci., 5th ser., vol. 14, pp. 381-401, November, 1927.

40. Biological classification, past and present: Am. Jour. Sci., 5th ser., vol. 14, pp. 419-420, November, 1927.

41. Eugene Allen Smith: Am. Jour. Sci., 5th ser., vol. 14, p. 428, November, 1927.

42. Frank Springer, 1848-1927 : Am. Jour. Sci., 5th ser., vol. 14, pp. 507-508, December, 1927.

43. Biographical memoir of Joseph Barrell, 1869-1919 : Nat. Acad. Sci., Biog. Mem., vol. 12, mem. 1; 40 pp.; portr., 1927.

44. Emil Böse, 1868-1927: Am. Jour. Sci., 5th ser., vol. 15, p. 88, January, 1928.

45. Israel Charles White, 1848-1927 : Am. Jour. Sci., 5th ser., vol. 15, p. 188 , February, 1928.

46. Memorial of Frank Springer: Geol. Soc. America, Bull., vol. 39, no. 1, pp. 65-80, portr., March 30, 1928.

47. Middle Permian age of the late Paleozoic glaciation (abstract) : Pan-Am. Geologist, vol. 49, no. 2, pp. 158-159, March, 1928; Geol. Soc. America, vol. 39, no. 1, pp. 208-209, March 30, 1928.

48. Paleogeography of North America during Triassic and Jurassic times (abstract) : Pan-Am. Geologist, vol. 49, no. 3, p. 240, April, 1928; Geol. Soc. America, Bull.; vol. 39, no. 1, p. 275, March. 30, 1928.

49. Charles Doolittle Walcott (1850-1927) : Am. Acad. Arts and Sci., Proc., vol. 62, no. 9, pp. 276-285, May, 1928.

50. The hypothesis of continental displacement. In Theory of continental drift, pp. 104-144, 9 figs., Am. Assoc. Petroleum Geologists, 1928.

51. 'The continental displacement hypothesis as viewed hy Du Toit: Am. Jour. Sci., 5th ser., vol. 16, pp. 266-274, September, 1928 .

52. Review of the late Paleozoic formations and faunas, with special reference to the ice age of middle Permian time: Geoi. Soc. America, Bull., vol. 39, no. 3, pp. 769-886, 6 figs., tables, September 30, 1928.

58. Biográphical memoir of John Mason Clarke: Nat. Acad. Sci, Biog. Mem., vol. 12, mem. 8, pp. 183-244, portr., 1928.

$4096-31-35$ 
Schultz, Alfred Reginald.

1. Oil possibilities in and around Baxter Basin, in the Rock Springs uplift, Sweetwater County, Wyoming: U. S. Geol. Survey, Bull. 702, 107 pp., 9 figs., 17 pls. (incl. maps), 1920; abstract by M. I. Goldman, Washington Acad. Sci., Jour., vol. 11, no. 17, pp. 418-419, October 19, 1921.

Schürmann, H. M. E.

1. Beitrag zur Petrographie der Hollywood Hills (Santa Monica-Gebirge) bei Los Angeles, Süd-Kalifornien: Centralbl. Mineralogie, Abt. A, no. 1, pp. 7-13, 1 fig., 1928.

Schwartz, George Melvin. See also Fairbanks, 12; Grout, 22, 23, 25.

1. Notes on textures and relationships in the Globe copper ores [Arizona] : Econ. Geology, vol. 16, nos. 4-5, pp. 322-329, 1 pl., 1 fig., 1921.

2. Chalersite at Fierro, New Mexico, with a note on its occurrence at Parry Sound, Ontario: Econ. Geology, vol. 18, no. 3, pp. 270-277, 2 figs., 1 pl., April-May, 1923.

3. Solving metallurgical problems with the reflecting microscope: Eng. and Min. Jour.-Press, vol. 116, no. 6, pp. 237-238, 4 figs., August 11, 1923.

4. New ore of the east Mesabi range: Eng. and Min. Jour.-Press, vol, 116, no. 10, pp. 409-412, 9 figs., September 8, 1923.

5. Stannite, its associated minerals and their paragenesis: Am. Mineralogist, vol. 8, no. 9, pp. 162-164, 2. figs., September, 1923.

6. An occurrence of xonotlite in Minnesota: Am. Mineralogist, vol. 9, no. 2, pp. 32-33, 2 figs., February, 1924.

7. The contrast in the effect of granite and gabbro intrusions on the Ely greenstone: Jour. Geology, vol. 32, no. 2, pp. 89-138, 11 figs., February-March, 1924.

8. Primary relationships and unusual chalcopyrite in copper deposits at Parry Sound, Ontario: Econ. Geology, vol. 19, no. 2, pp. 209-213, 2 figs., March, 1924.

9. On the nature and origin of hisingerite from Parry Sound, Ontario: Am. Mineralogist, vol. 9, no. 7, pp. 141-144, 2 figs., July, 1924.

10. Contact effects of gabbro and granite on ore deposition: Econ. Geology, vol. 1.9 , no. 7 , pp. 681-684, November, 1924.

11. Xonotlite and pectolite in a diabase pegmatite from Minnesota: Am. Mineralogist, vol. 10, no. 4, pp. 83-88, 2 figs., April, 1925.

12. A sulphide diabase from Cook County, Minnesota: Econ. Geology, vol, 20, no. 3, pp. 261-265, 1 pl., May, 1925.

13. Geology of the Etta spodumene mine, Black Hills, South Dakota: Econ. Geology, vol. 20, no. 7, pp. 646-659, 2 figs., November, 1925.

14. Geode concretions from the Black Hills, South Dakota: Am. Mineralogist, vol. 11, no. 2, pp. 30-33, 1 fig., February, 1926.

15. (and Leonard, R. J.) Alteration of spodumene in the Etta mine, Black Hills, South Dakota: Am. Jour. Sci., 5th ser., vol. 11, pp. 257-264, 2 figs., March, 1926.

16. Contact action of pegmatite on schist (abstract) : Geol. Soc. America, Bull., vol. 37, no. 1, p. 150, March 30, 1926 ; Pan-Am. Geologist, vol. 45, no. 2, p. 158, March, 1926.

17. Intergrowths of chalcopyrite and cubanite; experimental proof of the origin of intergrowths and their bearing on the geologic thermometer: Econ. Geology, vol. 22, no. 1, pp. 44-61, 9 figs., JanuaryFebruary, 1927. 
Schwartz, George Melvin-Continued.

18. Significance of intergrowths of chalcopyrite and cubanite (abstract): Geol. Soc. America, Bull., vol. 38, no. 1, pp. 123-124, March 30, 1927 ; Pan-Am. Geologist, vol. 47, no. 1, p. 72 , February, 1927.

19. Preparation of polished sections of ores: Econ. Geology, vol. 22, no. 2, pp. 193-195, March-April, 1927.

20. Iron sulphide pseudomorphs of plant structures in coal: Jour. Geology, vol. 35, no. 4, pp. 375-377, 3 figs., May-June, 1927.

21. Microscopic replacement versus injection in ores: Am. Mineralogist, vol. 12, no. 8, pp. 297-304, 12 figs., August, 1927.

22. (and Leonard, R. J.). Contact action of pegmatite on schist: Geol. Soc. America, Bull., vol. 38, no. 4, pp. 655-664, 1 fig., 1 pl., December 30, 1927.

23. The Black Hills mineral region: Am. Mineralogist, vol. 13, no. 2, p. 56-63, February, 1928.

24. Experiments bearing on bornite-chalcocite intergrowths: Econ. Geology, vol. 23, no. 4, pp. 381-397, 2 pls., June-July, 1928; abstract, Geol. Soc. America, Bull., vol. 39, no. 1., pp. 163-166, March 30,1928 ; Pan-Am. Geologist, vol. 49, no. 1, p. 73, February, 1928.

25. Dyscrasite and the silver-antimony constitution diagram: Am. Mineralogist, vol. 13, no. 10, pl. 495-503, 4 figs., October, 1928.

26. Copper veins on Susie Island, Lake Superior: Econ. Geology, vol. 23, no. 7, pp. 762-772, 9 figs., Noviember, 1928.

Schwarz, E. H. L.

1. Terrestrial and lunar faults compared: Jour. Geology, vol. 36, no. 2, pp. 97-112, 8 figs., February-March, 1928.

Schwarzenbek, F. X. See Swigart, 1.

Schwenneson, Alvin Theodore.

1. Geology and water resources of the Gila and San Carlos valleys in the San Carlos Indian Reservation, Arizona: U. S. Geol. Survey, Water-Supply Paper 450, pp. 1-27, 4 pls. (maps), 2 figs., November 10, 1919 ; abstract by J. D. Sears, Washington Acad. Sci., Jour., vol. 11 , no. 3 , pp. 58-59, February $4,1921$.

2. (and Overbeck, R. M., and Dubendorf, H. H.). The Long Beach oil field [Californ:a] and its problems: Am. Assoc. Petroleum Geologists, Bull., vol. 8, no. 4, pp. 403-423, 6 figs., 1 pl., July-August, 1924.

Schwerin, Martin.

1. The Illinois-Kentucky fluorspar district: Eng. and Min. Jour., vol. 122, no. 16, p. 623, October 16, 1926.

2. Än unusual fluorspar deposit [Elizabethtown, Illinois]: Eng. and Min. Jour., vol. 126, no. 9, pp. 335-339, 2 figs., September 1, 1928.

Science Service.

1. [Evolution of modern plants and of modern climates] : Science, new ser., vol. 65 , p. xii, January $7,1927$.

2. The heat of Kilauea: Science, new ser., vol. 65, p. x, March 4, 1927.

3. Research on earthquakes: Science, new ser., vol. 65, p. x; April 1, 1927.

4. Fossil implements in Pliocene deposits [in western Nebraska]: Science, new ser., vol. 65, p. x, May $6,1927$.

5. The antiquity of man in America: Sci. Monthly, vol. 24, no. 5, pp. 477, 479, May, 1927.

6. The sinking of land as a cause for the Mississippi floods: Science, new ser., vol. 65, p. $x$, Juñe $3,1927$. 


\section{Science Service-Continued.}

7. The eruption of Kilauea: Science, new ser., vol. 66, p. x, July 15, 1927.

8. Clay layers in New Jersey and the ice sheet: Science, new ser., vol. 66, p. x, July 15, 1927.

9. Evidences of early man in America: Science, new ser., vol. 66, p. $x$, September $23,1927$.

10. Ancient inhabitants of America: Science, new ser., vol. 66, pp. xii, xiv, November 11, 1927.

Scott, David B.

1. Ore deposits of the Mogollon district [New Mexico]: Mining and Metallurgy, no. 158, sec. 1, p. 33, 1 fig. (abstract), sec. 33, 22 pp., 5 figs., February, 1920; (with discussion by $H$. G. Ferguson), Am. Inst. Min. and Met. Eng., Trans., vol. 63, pp. 289-310, 5 figs., 1920.

Scott, Flora Murray.

1. Notes on the flora of the Miocene of the Tesla region, California: Torrey Bot. Club, Bull., vol. 53, no. 6, pp. 403-410, 1 pl., June, 1926.

Scott, Gayle. See also Winton, H., 1; Winton, W. M., 2.

1. Some gerontic ammonites of the Duck Creek formation: Texas Christian Univ. Quart., vol. 1, no. 1, 31 pp., 9 pls., April, 1924.

2. Études stratigraphiques et paléontologiques sur les terrains crétacés du Texas. Thesis, Université de Grenoble, 218 pp., 1 fig., 3 pls., Grenoble, 1926; Grenoble, Univ., Annales, n. s., sec. sci., t. 3, pp. 93-210 (1926).

3. The Woodbine sand of Texas interpreted as a regressive phenomenon: Am. Assoc. Petroleum Geologists, Bull., vol. 10, no. 6, pp. 613-634, 2 figs., 1 pl., June, 1.926.

4. On a new correlation of the Texas Cretaceous: Am. Jour. Sci., 5th ser., vol. 12, pp. 157-161, August, 1926.

5. Ammonites of the genus.Dipoloceras, and a new Hamites from the Texas Cretaceous: Jour. Paleontology, vol. 2, no. 2, pp. 108-118, 1 fig., 2 pls., June, 1928.

6. (and Moore, Marcus H.). Ammonites of enormous size from the Texas Cretaceous: Jour. Paleontology, vol. 2, no. 4, pp. 273-278, 2 pls., December, 1928.

Scott, Irving Day.

1. Inland lakes of Michigan : Michigan Geol. Survey, Pub. 30( Geol. Ser. 25), 383 pp., 93 figs., 20 pls., 1921.

2. Physiography of some Michigan dunes (abstract): Geol. Soc. America, Bull., vol. 38, no. 1, pp. 140-141, March 30, 1927; Pan-Am. Geologist, vol. 47, no. 2, pp. 149-150, March, 1927.

3. Ice push on lakes: Michigan Acad. Sci., Papers, vol. 7, pp. 107-123, 2 figs., 3 pls., 1927.

4. (and Belknap, Ralph L.). The Creelsboro natural bridge [Russell County, Kentucky] : Michigan Acad. Sci., Papers, vol. 7, pp. 125-133, 4 figs., 1927.

Scott, Walter W.

1. (and Stroud, B. K.). The Haynesville oil field, Claiborne Parish, Louisiana: Louisiana, Dept. Conservation, Bull. no. 11, 26 pl., map, January, 1922.

2. Preliminary report on underground conditions in the Haynesville oil tield, Louisiana: Am. Assoc. Petroleum Geologists, Bull., vol. 6, no. 2, p. 142, March-April, 1922. . 
Scott, William Berryman.

1. Physiography, the science of the abode of man. 384 pp., illus., New York, P. F. Collier \& Son Company, 1922.

2. Leidy's paleontological and geological work: Sci. Monthly, vol. 18, no. 4, pp. 433-439, April, 1924.

3. Paleontological and geological work [of Joseph Leidy]: Acad. Nat. Sci. Philadelphia, Proc., vol. 75 [Appendix] The Joseph Leidy Commemorative Meeting, pp. 36-43, 1924.

4. Geological climates: Geol.-Soc. America,. Bull., vol. 37, no. 1, pp. 261-278, March 30, 1926.

5. Development of American paleontology : Am. Philos. Soc., Proc., vol. 66, pp. $409-429,1927$.

6. The origin of the mammalian faunas of North and South America: Palaeobiologica, Jg. 1, Bd. 1, pp. 253-262, 1928.

7. Some applications of paleontology: Science, new ser., vol. 67 , pp. 327-333, March 30, 1928.

8. Geological climates: Smithsonian Inst., Ann. Rept., 1927, pp. 271-287, 1928.

Seagle, B. F., jr.

1. Home of the world's largest deposit of cyanite [Yancy County, North Carolina] : Rocks and Minerals, vol. 2, no. 1, pp. 19-22, 4 figs., March, 1927.

Searight, Waiter v.

1. Fossil annelid jaws from the Iowa Devonian: Iowa Acad. Sci., Proc., vol. 30 , pp. 433-436, 1 pl. [1924].

2. Global distribution of Fusulina (abstract) : Pan-Amer. Geologist, vol. 46, no. 5, p. 406, December, 1926.

Sears, Julian Ducker. See also Ashley, 4; Gill, A. C., 1 ; Hancock, 2 ; Jones, E. L., 5 , 6 ; Overbeck, 3 ;.Pack, R. W.; 1; Rogers; G. S., 1; Westgate; 1 .

1. Deposits of manganese ore in Costa Rica: U. S. Geol. Survey, Bull. 710, pp. 61-83, 1 pl. (map), 26 figs., . December. 30, 1919.

2. Deposits of manganese ore near Boqueron River, Panama: U. S. Geol. Survey, Bull. 710, pp. 85-91, 3 figs., December 30, 1919. Abtract, Washington Acad. Sci., Jour., vol. 10, no. 20, pp. 573-574, December 4, 1920.

3. Geology and oil and gas prospects of part of Moffat County, Colorado, and southern Sweetwater County, Wyoming: U. S. Geol. Survey, Bull. 751, pp. 269-319, 3 figs., 3 pls. (incl. map), December 13, 1924.

4. Relations of the Browns Park formation and the Bishop conglomerate and their rôle in the origin of Green and Yampa rivers: Geol. Soc. America, Bull., vol. 35, no. 2, pp. 279-304, 11 figs., 1 pl., June 30, 1924 ; abstract, no. 1, p. 93, March 30, 1924 ; Pan-Am. Geologist. vol. 41 , no: 2, p. 146, March, 1924.

5. (and Bradley, W. H.). Relations of the Wasatch and Green River formations in northwestern Colorado and southern Wyoming: U. S. Geol. Survey, Prof. Paper 132, pp. 93-107, 2 figs., 2 pls. (incl. map): November 6, 1924.

6. Geology and coal resources of the Gallup-Zuni Basin, New Mexico: U. S. Geol. Survey, Bull. 767, 52 pp., 4 figs., 17 pls. (incl. maps), 1925.

7. Geology of the Baxter Basin gas field, Sweetwater County, Wyoming: U. S. Geol. Survey, Bull. 781, pp. 13-27, 1 fig:, 5 pls. (incl: map), February 4, 1926. 
Seashore, Paul T. See DeWolf, 7 .

Seashore, Robert H.

1. Geology about Belton in northwestern Montana (abstract): Pạn-Am. Geologist, vol. 42, no. 5, p. 374, December, 1924; Iowa Acad. Sci., Proc., vol. 31, pp. 334-335 [1926?].

Secrist, Mark Howard.

1. Zinc deposits of east Tennessee: Tennessee, Dept. Education, Div. Geology, Bull. 31, 165 pp., 14 figs., 24 pls. (incl. map), 1924.

Segsworth, Walter E. See Wright, D. G. H., 3.

Segura, David. See also Barrera, 2.

1. El mercurio en México: Bol. Minero, t. 26, no. 1, pp. 16-49, 1 pl. (map), July, 1928.

Seismological Society of America.

1. The bibliographical bulletin of the eastern section of the Seismological Society of America; vol. 1, no. 1, 1926-vol. 3, no. 5, 1928. [Mimeographed.]

Selchow, D. H. See Putnam, P. C., 3.

Sellards, Elias Howard. See also Pratt, W. E., 11; Texas, Attorney General, 1.

1. Administrative report: Florida State Geol. Survey, Twelfth Ann. Rept., pp. vii-viii, 1919.

2. Literature relating to liuman remains and artifacts at Vero, Florida: Am. Jour. Sci., 4th ser., vol. 47, pp. 358-360, May, 1919. Florida State Geol. Survey, Twelfth Ann. Rept., pp. 1-4, 1919.

3. Geologic sections across the everglades of Florida: Florida State Geol. Survey, Twelfth Ann. rept., pp. 67-76, 1 fig., 1919.

4. Review of the geology of Florida, with special reference to structural conditions : Florida State Geol. Survey, Twelfth Ann. Rept., pp. 105141, 2 pls. (maps), 1 fig., 1919.

5. Geology of Florida : Jour. Geology, vol. 27, no. 4, pp. 286-302, 1 pl. (map), 2 figs., May-June, 1919.

6. Comanchean formations underlying Florida: Am. Jour. Sci., 4th ser., vol 48, pp. 13-16, 1 fig., July, 1919.

7. Structural conditions in the oil fields of Bexar County, Texas: Am. Assoc. Petroleum Geologists, Bull., vol. 3, pp. 299-309, 1919.

8. Some characteristics of the Balcones fault zone (abstract) : Science, new ser., vol. 51, p. 519, May 21, 1920.

9. The underground position of the Ellenburger formation in north central Texas: Am. Assoc. Petroleum Geologists, Bull., vol. 4, no. 3, pp. 283-298, map, 1920.

10. The geology and mineral resources of Bexar County: Texas, Univ., Bull., no. 1932, 202 pp., 1 pl., 6 figs., map, March, 1920.

11. On the underground position of the Ellenburger formation in north central Texas; with a preliminary countour map: Texas, Univ., Bull. no. 1849, 32 pp., map, July, 1920.

12. (and Gunter, Herman). On the petroleum possibilities of Florida: Florida State Geol. Survey, Fourteenth Ann. Rept., 1921-22, np. 33-135, 10 figs., map, 1922.

13. Notes on the oil and gas fields of Webb and Zapata counties: Texas, Univ., Bull., no. 2230, pp. 5-29, 1 fig., September, 1922. 
Sellards, Elias Howard-Continued.

14. The underground position of the Austin formation in the San Antonio oil fields: Texas, Univ., Bull., no. 2230, pp. 30-40, 1 fig., September, 1922.

15. Well records in Panola County, including structural contour map: Texas, Univ., Bull., no. 2232, 33 pp., 2 pls., 1922.

16. The producing horizon in the Rios well in Caldwell County: Texas, Univ., Bull., no. 2239, 40 pp., November, 1922.

17. The Oklahoma-Texas boundary suit: Science, new ser., vol. 57, pp. 346349, March 23, 1923.

18. (and Tharp, B. C., and Hill, R. T.). Investigation on the Red River made in connection with the Oklahoma-Texas boundary suit: Texas, Univ., Bull., no. 2327, 174 pp., 2 figs., 9 pls., 6 maps, August, 1923.

19. The Luling oil field in Caldwell County, Texas: Am. Assoc. Petroleum Geologists, Bull., vol. 8, no. 6, pp. 775-788, 2 figs., NovemberDecember, 1924.

20. Mineral resources of Texas: The South's Development, Manufacturers Record, vol. 86, no. 24, pt. 2, pp. 421-423, December 11, 1924.

21. (and Patton, Leroy T.). The subsurface geology of the Big Lake oil field: Am. Assoc. Petroleum Geologists, Bull., vol. 10, no. 4, pp. 365-381, 9 figs., April, 1926.

22. Geographic distribution of geologists in the United States: Am. Assoc. Petroleum Geologists, Bull., vol. 11, no. 3, pp. 305-306, March, 1927.

23. Unusual structural feature in the plains region of Texas (abstract) : Geol. Soc. America, Bull., vol. 38, no. 1, p. 149, March 30, 1927; Pan.-Am. Geologist, vol. 47, no. 2, pp. 152-153, March, 1927.

24. The Florida phosphate deposits: Intern. Geol. Cong., XIV, Compt. rend., fasc. 1, pp. 297-305, 1 fig. (map), 1927; Pan-Am. Geologist, vol. 49, no. 3, pp. 183-194, April, 1928.

25. (and Schoch, E. P.). Minable deposits of potash in Midland County, Texas: Commercial Fertilizer, vol. 35, no. 5, pp. 49-51, November, 1927.

26. (and Schoch, E. P.). Core drill tests for potash in Midland County, Texas: Texas, Univ., Bull., no. 2801, pp. 158-201, 2 figs., 1928.

27. Fossil cycad localities in Texas (abstract) : Pan-Am. Geologist, vol. 49, no. 3, p. 228, April, 1928.

28. Texas Bureau of Economic Geology: Pan-Am. Geologist, vol. 50, no. 1, pp. 75-80, August, 1928.

Semmes, Douglas Ramsay.

1. The geology of the San Juan district, Porto Rico: New York Acad. Sci., Scientific Survey of Porto Rico and the Virgin Islands, vol. 1, pt. 1, pp. 33-110, 4 pls., map, 26 figs., 1919.

2. Petroleum possibilities of Alabama : Part I, Northern Alabama: Alabama, Geol. Survey, Bull., no. 22, p. 9-120, 1 pl., 20 figs., 1920.

3. Oil possibilities in northern Alabama: Mining and Metallurgy, no. 159, sec. 1, p. 51. (abstract), sec. 5, 10 pp., 1. fig. (map), March, 1920; discussion by David White and Mowry Bates, Am. Inst. Min. and Met. Eng., Trans., [preprint] no. 1038, p. 60, January, 1921; vol. 65, pp. 140-150, 1 fig. (map), 1921.

4. Notes on the Tertiary intrusives of the lower Pecos Valley, New Mexico: Am. Jour. Sci., 4th ser., vol. 50, pp. 415-430, 7 figs., December, 1920. 
Semmes, Douglas Ramsay-Continued.

5. Petroliferous formations of the Tampico Embayment, Mexico (abstract) : Am. Assoc. Petroleum Geologists, Bull., vol. 5, no. 1, p. 101, January-February, 1921.

Sen, Janshi.

1. Genetic classification of röcks: Pan-Am. Geologist, vol, 41, no. 3, pp. 176-178, April, 1924.

2. Natural arrangement in crystal symmetry: Pan-Am. Geologist, vol. 42, no. 5, pp. 331-334, December, 1924:

Senécal, Clovis Omer.

1. Color printing of geological maps; Canada, Geol. Survey, Bull. no. 44, 4 pp., 4 pls., March 14, 1925.

Service, Jerry H. See also Neumann, F., 5, 10.

1. Seismic wave velocity and densities of crustal materials.: Science, new ser., vol. 63, pp. 616-61.7, June 18, 1926.

Seward, Albert Charles.

1. A supposed Paleozoic angiosperm [from the coal measures of Illinois]: Bot. Gazette, vol. 76, no. 2, p. 215, October, 1923.

2. On a new species of Tempskya from Montana, Tempsikya knowltoni, sp. nov.: Annals of Botany, vol. 38, pp. 485-507, 3 flgs., 2 pls., July, 1924.

3. Notes sur la flore crétacique du Groenlanḋ: Soc. géol. Belgique, Livre jubilaire, 1874-1924, t. 1, fasc. 1, pp. 227-263, 6 figs., 3 pls. [n. d., 1925?].

4. The Cretaceous plant-bearing rocks of western Greenland: Roy. Soc. London, Philos. Traṇs., ser. B, vol 215, pp. 57-175, 37 figs., 9 pls., August 9, 1926.

Seyler, Clarence A.

1. The microstructure of coal: Am. Inst. Min. and Met. Eng., Trans., vol. 71, pp. 117-126, 18 figs., 1925 ; [preprint], no. 1428, 10 pp., 18 figs., March, 1925; abstract, Mining and Metallurgy, vol. 6, no. 227, p. 571, November, 1925.

Shannon, Charles William.

1. (and Rockwell, F. G.). New oil and gas development in Oklahoma: Am. Assoc. Petroleum Geologists, Bull., vol. 4, no. 3, pp: 277-281, 1920.

2. An Oklahoma meteorite: Oklahoma, Univ., Bull. (Proc. Oklahoma Acad. Sci., 1910-1920), new ser. no. 220, pp. 66-67, July: 15, 1921.

3. Physiographic features and surface èlevations [of Oklahoma]: Bureau Monthly, published by Bureau of Geology, Norman, Okla., vol. 1, no: 1, pp. 6-9, 1 fig. (map); April, 1925.

4. (and others). Coal in Oklahoma (revised and edited by C, L. Cooper) : Oklahoma Geol.; Survey; Bull, no. 4, 110 pp:, 12 figs., 23 pls. (incl. maps), July, 1926.

Shannon, Earl Victor. See also Cross, 7 ; Gillson, 1 ; Hewett, 21; Hawkins, 3 ; Hovey 12 ; Larson, $2,9,10,12$; Palache, $7,22,32,34 ;$; Ross, C. S., $6,11,12,14,15,16,20,25$; Wherry, 18.

1. Famous mineral localities; the datolite locality near Westfield, Massachusetts: Am. Mineralogist, vol. 4, no. 1, pp. 5-6, January, 1919.

2. Anglesite from the Coeur d'Alene district, Idaho: Am. Jour. Sci., 4th ser., vol. 47, pp. 287-292, 7 figs., April, 1919. 
Shannon, Earl Victor-Continued.

3. Famous mineral localities; the Pelham asbestos mine, Massachusetts: Am. Mineralogist, vol. 4, no. 4, pp. 37-39, April, 1919.

4. Famous mineral localities; the Chester emery mine [Massachusetts]: Am. Mineralogist, vol, 4, no. 6, pp. 69-72, June, 1919.

5. Linarite and leadhillite from Idaho: Am. Mineralogist, vol. 4, no. 8, pp. 93-94, August, 1919.

6. On coarse gabbroid diabase in Westfield, Massachusetts: Jour. Geology, vol. 27, no. 7, pp. 579-581, October-November, 1919.

7. The occurrence of bindheimite as an ore mineral : Econ. Geology, vol. 15, no. 1, pp. 88-93, January-February, 1920.

8. A new description of amesite: Am. Jour. Sci., 4th ser., vol. 49, pp. 96-98, February, 1920.

9. The trap quarry at Meriden, Connecticut: Am. Mineralogist, vol. 5, no. 2, p. 34, February, 1920.

10. Bismutoplagionite, a new mineral: Am. Jour. Sci., 4th ser., vol. 49, pp. 166-168, March, 1920.

11. Strickland's quarry, Portland, Connecticut: Am. Mineralogist, vol. 5, no. 3, pp. 51-54, March, 1920.

12. The old lithia mine in. Chatham, Connecticut: Am. Mineralogist, vol 5, no. 4, pp. 82-84, April, 1920.

13. Diabantite, stilpnomelane, and chalcodite of the trap quarries of Westfield, Massachusetts: U. S. Nat. Mus., Proc., vol. 57, pp. 397-403, 1920.

14. Petrography of some lamprophyric dike rocks of the Coeur d'Alene mining district, Idaho: U. S. Nat. Mus., Proc., vol. 57, pp. 475-495, 3 pls., 4 figs., 1920.

15. Recent accessions in the division of applied geology: U. S. Nat. Mus., Proc., vol. 58, pp. 323-326, 1920.

16. Analyses and optical properties of amesite and corundophilite from Chester, Massachusetts, and of chromium-bearing chlorites from California and W.yoming: U. S. Nat. Mus., Proc., vol. 58, pp. 371$379,1920$.

17. Notes on anglesite, anthophyllite, calcite, datolite, sillimanite, stilpnomelane, tetrahedrite, and triplite: U. S. Nat. Mus., Proc., vol. 58, pp. 437-453, 13 figs., 1920.

18. Some minerals from the old tungsten mine at Long Hill in Trumbull, Connecticut: U. S. Nat. Mus., Proc., vol. 58, pp. 469-482, 1 fig., 1920.

19. Boulangerite, bismutoplagionite, naumannite, and a silver-bearing variety of jamesonite: U. S. Nat. Mus., Proc., vol. 58, pp. 589-607, 1920.

20. An occurrence of naumannite in Idaho: Am. Jour. Sci., 4th ser., vol. 50, pp. 390-391, November, 1920.

21. Description of ferroanthophyllite, an orthorhombic iron amphibole from Idaho, with a note on the nomenclature of the anthophyllite group : U. S. Nat. Mus., Proc., vol. 59, pp. 397-401, 1921.

22. Description of vivianite encrusting a fossil tusk from gold placers of Clearwater County, Idaho: U. S. Nat. Mus., Proc., vol. 59, pp. 415-417; 1 fig., 1 pl., 1921،

23. A crystallographic study of the datolite from Westfield, Massachusetts: U. S. Nat. Mus., Proc., vol. 59, pp. 479-539, 24 figs., 4 pls., 1921.

24. Ludwigites from Idaho and Korea: U. S. Nat. Mus., Proc., vol. 59; pp. 667-676, 1921. 
Shannon, Earl Victor-Continued.

25. Mineralogy of some black sands from Idaho, with a description of the methods used for their study: U. S. Nat. Mus., Proc., vol. 60, art. 3, 33 pp., 28 figs., 1921.

26. Massive laumonite from Montana: Am. Mineralogist, vol. 6, no. 1, pp. 6-7, January, 1921.

27. Owyheeite [Owyhee County, Idaho]: Am. Mineralogist, vol. 6, no. 4, pp. 82-83, April, 1921.

28. Additional notes on crystallography and composition of boulangerite: Am. Jour, Sci., 5th ser., vol. 1, pp. 423-426, May, 1921.

29. The old cobalt mine in Chatham, Connecticut: Am. Mineralogist, vol. 6, no. 5, pp. 88-90, May, 1921.

30. On galenobismutite from a gold-quartz vein in Boise County, Idaho: Washington Acad. Sci., Jour., vol. 11, no. 13, pp. 298-300, July 19, 1921.

31. The old tungsten mine in Trumbull, Connecticut: Am. Mineralogist, vol. 6 . no. 8, pp. 126-128, August, 1921.

32. Notes on an andorite-bearing silver ore from Nevada: U. S. Nat. Mus., Proc., vol. 60, art. 16, 5 .pp., 1922.

33. Velardeñite from a new locality in Tulare County, California: U. S. Nat. Mus., Proc., vol. 60, art. 22, 4 pp., 1922.

34. Mineralogic notes on pucherite, pyrite, trichalcite, and wavellite: U. S. Nat. Mus., Proc., vol. 62, art. 9, 10 pp., 10 figs., 1922.

35. Notes on the mineralogy of three gouge clays from precious-metal veins: U. S. Nat. Mus., Proc., vol. 62, art. 15, 11 pp., 1922.

36. Cristobalite from the Columbia River basalt of Spokane, Washington: Washington Acad. Sci., Jour., vol. 12, no. 8, pp. 195-196, April 19, 1922.

37. (and Wherry, E. T.) Notes on white chlorites: Washington Acad. Sci., Jour., vol. 12, no. 10, pp. 239-241, May 19, 1922.

38. Note on the cyprine from Franklin Furnace, New Jersey: Am. Mineralogist, vol. 7, no. 8, pp. 140-142, August, 1922.

39. Note on a garnet from a pegmatite in Idaho: Am. Mineralogist, vol. 7, no. 10, pp. 171-173, Octoher, 1922.

40. On siderite and associated minerals from the Columbia River basalt at Spokane, Washington: U. S. Nat. Mus., Proc., vol. 62, art. 12, pp. 1-19, 14 figs., 3 pls., 1923.

41. Crystallographic notes on stephanite in a silver ore from Mexico: U. S. Nat. Mus., Proc., vol. 63, art. 11, 6 pp., 4 figs., 1923.

42. Note on leuchtenbergite from Philipsburg, Montana: Am. Mineralogist, vol. 8, no. 1, pp. 8-10, January, 1923.

43. Note on cobaltiferous gahnite from Maryland: Am. Mineralogist, vol. 8, no. 8, pp. 147-148, August, 1923.

44. Barrandite from Manhattan, Nevada: Am. Mineralogist, vol. 8, no. 10, pp. 182-184, October, 1893.

45. Benjaminite, a new sulphosalt mineral of the klaprotholite group: U. S. Nat. Mus., Proc., vol. 65, art. 24, 9 pp., 3 figs., 1924.

46. The mineralogy and petrology of intrusive diabase at Goose Creek, Loudoun County, Virginia : U. S. Nat. Mus., Proc., vol. 66, art. 2, 86, pp., 32 flgs., 9 pls., 1924.

47. An occurrence of iron-cobalt-bearing gersdorffite in Idaho: Washington Acad. Sci., Jour., vol. 14, no. 13, pp. 275-277, July 19, 1924.

48. Chromium-colored margarite from Montgomery County, Maryland: Am., Mineralogist, vol. 9, no. 9, pp. 194-195, September, 1924. 
Shannon, Earl Victor-Continued.

49. An iron anrphibole similar to hudsonite from Custer County, Idaho: Am. Jour. Sci., 5th ser., vol. 8, pp. 323-324, October, 1924.

50. The present status of the mineral remingtonite: Am. Mineralogist, vol. 9, no. 10, pp. 208-209, October, 1924.

51. An occurrence of xonotlite at Leesburg, Virginia: Am. Mineralogist, vol. 10, no. 1, pp. 12-13, January, 1925.

52. A re-examination of beaumontite from Baltimore [Maryland]: Aur. Mineralogist, vol. 10, no. 2, pp. 31-34, February, 1925.

53. (and Larsen, Esper S.). Merrillite and chloraptite from stony meteorites: Am. Jour. Sci., 5th ser., vol. 9, pp. 250-260, March, 1925.

54. Boulangerite from the Cleveland mine, Stevens County, Washington: Washington Acad. Sci., Jour., vol. 15, no. 9, pp. 195-197, May 4, 1925.

55. Mineralogy and petrography of Triassic limestone conglonrerate metamorphosed by intrusive diabase at Leesburg, Virginia: U. S. Nat. Mus., Proc., vol. 66, art. 28, 31 pp., 8 figs., 3 pls., May 22, 1925.

56. The so-called halloysite of Jones Falls, Maryland: Am. Mineralogist, vol. 10, no. 7, pp. 159-161, July, 1925.

57. Jamesonite from Slate Creek, Custer County, Idaho: Am. Mineralogist, vol. 10, no. 8, pp. 194-197, August, 1925.

58. Tetradymite from the Hailey quadrangle, Idaho: Am. Mineralogist, vol. 10, no. 8, pp. 198-199, August, 1925.

59. Petzite from the Last Chance mine, Colnucopia district, Oregon: Washington Acad. Sci., Jour., vol. 15, no. 14, pp. 342-344, August 19, 1925.

60. Magnesite and kammerite from Low's mine'(Line Pit), Cecil County, Maryland: Washington Acad. Sci., Jour., vol. 15, no. 19, pp. 434438, November 19, 1925.

61. The minerals of Idaho: U. S. Nat. Mus., Bull. 131, 483 pp., 170 figs., $19 \mathrm{pls} ., 1926$.

62. Mineralogy of the chrome ore from Etchison, Montgomery County, Maryland: Am. Mineralogist, vol. 11, no. 1, pp. 16-20, January, 1926.

63. (and Larsen, Esper S.). A peculiar manganiferous serpentine from Franklin Furnace [New Jersey]: Am. Mineralogist, vol. 11, no. 2, pp. 28-30, February, 1926.

64. Some minerals from the Kensington mica mine, Montgomery County: Maryland: Am. Mineralogist, vol. 11, no. 2, pp. 35-37, February, 1926.

65. (and Bernran, H.). Barysilite from Franklin Furnace, New Jersey: Am. Mineralogist, vol. 11, no. 5, pp. 130-132, May, 1926.

66. The identity of carrolite with linnaeite: Am. Jour. Sci., 5th ser., vol. 11 pp. 489-493, June, 1926.

67. The serpentine locality of Montville, New Jersey: Am. Mineralogist, vol. 12; no. 2, pp. 53-55, February, 1927.

68. The oxidation of meteoric irons with comparative descriptions of two new examples of magnetic iron oxides from terrestrial sources: U. S. Nat. Mus., Proc., vol. 72, art. 21, 15 pp., 1927.

69. Calcite oolites with pentagonal dodecahedral form: Washington Acad. Sci., Jour., vol. 17, no. 16, pp. 409-417, October 4, 1927.

70. "Blythite" and the manganese garnet from Amelia, Virginia: Washington. Acad. Sci., Jour., vol. 17, no. 17, pp. $444-452$, October 19, 1927. 
Shannon, Earl Victor-Continued.

71. Apatite crystals from Wiant's quarry, near Pilot, Maryland: Am. Mineralogist, vol. 12, no. 11, pp. 408-410, 2 figs., November, 1927.

72. On the determination of alkalies in rocks and minerals: Am. Mineralogist, vol. 12, no. 11, pp. 411-413, November, 1927.

73. A lead ore consisting of native lead, leadhillite, and lithargite [Hailey, Idaho] : Econ. Geology, vol. 22, no. 8, pp. 826-829, December, 1927.

74. Ammoniojarosite, a new mineral of the jarosite group from Utah: Am. Mineralogist, vol. 12, no. 12, pp. 424-426, December, 1927.

75. (and Gonyer, Forest A.). Almandite-spessartite garnet from Gwynn? Falls, Baltimore: Washington Acad. Sci., Jour., vol. 17, no. 21, pp. 534-536, December 19, 1927.

76. (and Gonyer, Forest A.). Natrojarosite from Kingınan, Arizona: Washington Acad. Sci., Jour., vol. 17, no. 21, pp. 536-537, December 19, 1927.

77. Vermiculite from the Bare Hills near Baltimore, Maryland: Am. Jour. Sci., 5th ser., vol. 15, pp. 20-24, January, 1928.

78. Miargyrite and tetrahedrite from the Flint district, Idaho: Am. Mineralogist, vol. 13, no. 1, pp. 18-21, 2 figs., January, 1928.

79. Xanthonconite and associated minerals from the General Petite mine, Atlanta district, Idaho: Am. Mineralogist, vol. 13, no. 9, pp. 469-475, September, 1928.

Shapley, Harlow.

1. Note on a possible factor in changes of geological climate: Jour. Geology, vol. 29, no. 6, pp. 502-504, September-October, 1921.

Shaw, Edmund.

1. The sand and gravel resources of the Trinity River district, Texas: Rock Products, vol. 31, no. 6, pp. 66-71, 20 figs., March 17, 1928.

Shaw, Eugene Wesley. See also Brokaw, 1; Johnson, R. H., 2 ; Louderback, 1 ; Matteson, 2; Redwood, 1; Weller, 19 ; Willis, 4.

1. (and Mather, Kirtley F.). The oil fields of Allen County, Kentucky, with notes on the oil geology of adjoining counties: U. S. Geol. Survey, Bull. 688, 126 pp., 10 pls. (incl. maps); 10 figs., 1919. Abstract by R. W. Stone, Washington Acad. Sci., Jour., vol. 9, no. 15, p. 439, September 19, 1919.

2. An interpretation of the so-called paraffin dirt of the Gulf Coast oil fields (discussion) : Am. Inst. Min. Eng., Bull. no. 145, pp. 98101, January, 1919.

3. Mexican petroleum and the war (abstract): Geol. Soc. America, Bull., vol. 30, pp. 109-110, March 31, 1919.

4. Stratigraphy of the Gulf Coastal Plain as related to salt domes (abstract): Washington Acad. Sci., Jour., vol. 9, no. 10, pp. 289291, May 19, 1919.

5. Present tendencies in geology; sedimentation: Washington Acad. Sci., Jour., vol. 9, no. 17, pp. 513-521, October 19, 1919.

6. (and Ports, P. L.). Natural gas resources available to Dallas and other cities of central north Texas: U. S. Geol. Survey, Bull. 716, pp. 55-89, 2 pls. (maps), 10 figs., 1920 ; abstract by M. I. Goldman, Washington Acad. Sci., Jour., vol. 11, no. 8, pp. 193-194, April 19, 1921.

7. Physical and geographic criteria in the study of sedimentary deposits: Geol. Soc. America, Bull., vol. 31, no. 4, pp. 411-418, November $30,1920$. 
Shaw, Eugene Wesley-Continued.

8. Description of the New Athens and Okawville quadrangles: U. S. Geol. Survey, Geol. Atlas U. S., New Athens-Okawville folio, Illinois (no. 213), 12 pp., 6 figs., 4 maps, 1921.

9. Description of the Carlyle and Centralia quadrangles [Illinois]: U. S. Geol. Survey, Geol. Atlas U. S., Carlyle-Centralia folio, Illinois (no. 216), 10 pp., 5 figs., 4 maps, 1923.

10. Memorial of Joseph William Winthrop Spencer: Geol. Soc. America, Bull., vol. 35, no. 1, pp. 25-37, portr., March 30, 1924.

Shaw, G. R.

1. The chemistry of platinum at high temperatures and pressures: Econ. Geology, vol. 16, no. 8, pp. 524-548, December, 1921.

Shaw, $\mathrm{H}$

1. New method of radio-aeronautic prospecting: Econ. Geology, vol. 20, no. 4, pp. 391-395, June-July, 1925.

Shaw, J.' B.

1. Fire clays of Pennsylvania: Pennsylvania Geol. "Survey, 4th ser., Bull. M 10, 69 pp., 9 figs., 1928.

Shaw, John W.

1. Ore horizons at Cobalt: Eng. and Min. Jour.-Press, vol. 115, no. 18, p. 791, May 5, 1923.

Shaw, S. F.

1. The ore deposits of Sierra Mojada, Coahuila, Mexico (with discussion) : Am. Inst. Min. and Met. Eng., Trans., vol. 68, pp. 556-586, 3 figs., 1923 ; [preprint] no. 1182, 17 pp., 3 figs., August, 1922; abstract, Mining and Metallurgy, no. 188, pp. 33-34, 2 figs., August, 1922.

Shea, E. F.

1. Water conditions in the Urschel pool, Marion County, Kansas : Am. Assoc. Petroleum Geologists, Bull., vol. 6, no. 5, pp. '426-443, 10 figs., September-October, 1922.

Shead, Arthur Curtis.

1. An Oklahoma meteorite: Oklahoma Acad. Sci., Proc., vol. 2 (Oklahoma, Univ., Bull., new ser. no. 247), p. 79, October 1; 1922.

2. Phosphate rocks in Oklahoma: Oklahoma Acad. Sci., Proc., vol. 3 (Oklahoma, Univ., Bull., new ser. no. 271), pp. 97-102, 3 figs., October $1,1923$.

3. Notes on barite in Oklahoma with chemical analyses of sand barite rosettes: Oklahoma Acad. Sci., proc., vol. 3 (Oklahoma, Univ., Bul!,, new ser. no. 271), pp. 102-106, October 1, 1923.

4. "Drillite" and its significance to the geologist: Oklahoma Acad. Sci., Proc., vol. 3 (Oklahoma, Univ., Bull., new ser. no. 271), pp. 107108, October 1, 1923.

5. Notes on the Black Mesa basalt: Oklahoma Acad. Sci., Proc., vol. 3 (Oklahoma, Univ., Bull., new ser. no. 271), pp. 108-113, 2 figs., October 1, 1923.

6. Notes on permanent labels for thin rock sections mounted on glass slides: Oklahoma Acad. Sci. (Univ. Oklahoma Bull., new sẹr. no. 322), Proc., vol. 4, p. 120, December 1, 1925.

7. Notes on a possible explanation for the circular white spots found in the red shales of the Permian red beds: Oklahoma Acad. Sci., Proc., vol. 5, 1925 (Oklahoma, Univ., Bull., new ser. no. 33̣0, Univ. Studies no. 22), pp. 127-128, April 1, 1926. 
Shead, Arthur Curtis-Continued.

8. (and Williams, Guy Yandell, and others). Chemical analyses of Oklahoma mineral raw materials: Oklahoma, Univ., Bull., new ser. 423, 138 pp., December, 1928.

Shedd, Solon.

1. Mineral resources of Washington. In Northwest Mines Handbook, vol. 1, pp. 146-149, published by Sidney Norman, Spokane, Washington, 1918.

2. Coke and limestone of Washington: Washington, Dept. Conservation, Division of Geology, Bull. no. 27, pp. 117-146, 1922.

3. Topography and geology of the Okanogan Highlands and Columbia Platean of Washington (abstract) : Geol. Soc. America, Bull., vol. 34, no. 1, 1). 75 , March 30, 1923.

4. The mineral resources of Washington: Washington, Division of Geology, Bull. no. 30, pṕ. 1-183, 3 figs., 1924.

5. Report of the supervisor of geology from October 1, 1922, to September 30, 1924; Washington, Dept. Conservation and Development; 12 pp., map, Olympia, 1924.

6. Washington Geological Survey [activities]: Pan-Am. Geologist, vol. 44, no. 4, pp. 326-327, November, 1925.

Sheldon, Pearl G.

1. A new dike near Ithaca, New York: Science, new ser., vol. 53, pp. 20-21, January 7, 1921.

2. Significant characteristics of glacial erosion as illustrated by an erosion channel: Jour: Geology, vol. 34, no. 3, pp. 257-265, 2 figs., AprilMay, 1926.

3. On the association of faulting with dike intrusion: Jour. Geology, vol. 35, no. 4, pp. 353-367, 6 figs., May-June, 1927.

4. Note on the angle of fracture cleavage: Jour. Geology, vol. 36, no. 2, pp. 171-175, 1 fig., February-March, 1928.

5. Some sedimentation conditions in middle Portage rocks: Am. Jour. Sci., 5th ser., vol. 15, pp. 243-252, 3 figs., March, 1928.

Shenon, P. J.

1. Gold at Bannack, Montana : Eng. and Min. Jour., vol. 123, no. 8, p. 326, 3 figs., February 19, 1927.

2. Geology and ore deposits of the Birch Creek district, Idaho: Idaho, Bur. Mines and Geology, Pam. no. 27, 25 pp., 5 pls. (incl. maps), Apṛil. 1928 [mimeographed].

Shepard, Francis Parker. See also Chamberlin, R. T., 9; Leith, 10; Schuchert, 20.

1. Possible Silurian tillite in southeastern British Columbia: Jour. Geology, vol. 30, no. 1, pp. 77-81, 2 figs., January-February, 1922.

2. The structural relation of the Purcell Range and the Rocky Mountains of Canada: Jour. Geology, vol. 30, no. 2, pp. 130-139, 7 figs., February-March, 1922. Abstract, Geol. Soc. America, Bull., vol. 33. no. 1, pp. 91-93, March 31, 1922.

3. Problems in stratigraphy along the Rocky Mountain trench : Jour. Geology, vol. 30, no. 5, pp. 361-376, 4 figs., July-August, 1922.

4. Isostasy as a result of earth shrinkage: Jour. Geology; vol. 31, no. 3, pp. 208-216, 4 figs., April-May, 1923; abstract; Geol. Soc. America, Bull., vol. 34, no. 1, pp. 62-63;-March 30; 1923.

5. Indications of important horizontal compression in the Colorado Rockies: Am. Jour. 'Sci., 5th ser., vol. 5, pp. 403-408, 5 figs., May, 1923. 
Shepard, Francis Parker-Continued.

6. To question the theory of periodic diastrophism: Jour. Geology, vol. 31, no. 7, pp. 599-613, 2 figs., October-November, 1923.

7. The bearing of normal faults on the hypothesis of a shrinking earth: Am. Jour. Sci., 5th ser., vol. 7, pp. 146-154, 5 figs., February, 1924.

8. Mountain building without loss of isostatic equilibrium (abstract, with discussion by William Bowie and W. H. Hobbs): Geol. Soc. America, Bull., vol. 35, no. 1, pp. 62-63, March 30, 1924; abstract, Pan-Am. Geologist, vol. 41, no. 2, p. 135, March, 1924.

9. Lantern slide examinations in geology: Illinois State Acad. Sci., Trans., vol. 18, pp. 414-417, 1 fig., 3 pls., 1925.

10. Some transverse faults along the Rocky Mountain trench (abstract): Geol. Soc. America, Bull., vol. 36, no. 1, p. 156, March 30, 1925; Pan-Am. Geologist, vol. 43, no. 2, pp. 151-152, March, 1925.

11. Further investigations of the Rocky Mountain trench [British Columbia]: Jour. Geology, vol. 34, no. 7, pp. 623-641, 13 figs. (incl. map), October-November, 1926.

12. Influence of oscillating sea level on the development of the continental shelf (abstract) : Science, new ser., vol. 66, p. 462, November 11, 1927.

13. Significance of submerged deltas in the interpretation of the continental shelves: Geol. Soc. America, Bull., vol. 39, no. 4, pp. 1157-1170, 8 figs., December 30, 1928; abstract, Geol. Soc. America, Bull., vol. 39, no. 1, pp. 157-158, March 30, 1928; Pan-Am. Geologist, vol. 49, no. 1, p. 70, February, 1928.

Shepard, T. P. See Leith, 10.

Shepherd, Ernest Stanley. See also Ellsworth, 19.

1. The composition of the gases of Kilauea: Hawaiian Volcano Observatory, Bull., vol. 7, no. 7, pp. 94-97, July, 1919. Abstract, Washington Acad. Sci., Jour., vol. 10, no. 1, pp. 23-24, January 4, 1920.

2. Two gas collections from Mauna Loa: Hawaiian Volcano Observatory, Monthly Bull., vol. 8, no. 5, pp. 65-67, May, 1920; abstract, Washington Acad. Sci., Jour. vol. 11, no. 17, pp. 420-421, October 19, 1921.

3. The analysis of gases obtained from volcanoes and from rocks: Jour. Geology, vol. 33, no. 3, suppl., pp. 289-370, 28 figs., April-May, 1925.

4. Note on the chemical significance of engulfment at Kilauea (with discussion): Washington Acad. Sci., Jour., vol. 15, no. 18, November 4, 1925 ; Bull. Volcanologique, $2^{e}$ ann., nos. 5-6, pp. 328-332, 1925.

5. (and Merwin, H. E.). Gases of the Mont Pelée lavas of 1902: Jour. Geology, vol. 35, no. 2, pp. 97-116, February-March, 1927.

6. The present status of the volcano gas problem: Nat. Research Council, Bull. no. 61, pp. 259-263, July, 1927.

Sheppard, George.

1. Recent development work relating to petroleum in western Canada [A]berta and Saskatchewan]: Canadian Inst. Min. and Met., Monthly Bull., no. 113, pp. 802-818, September, 1921; Trans., vol. 24, pp. 60-74, 10 figs. [1922].

Sherman, R. W.

1. The West Goleta district [California]; a summary of the geology of the Edwards anticline: Oil Bull., vol. 13, no. 11. pp. 1144, 1165, November, 1927. 
Sherwood, Earl. See Kentucky G. S., 28, 35.

Sherzer, William Hittell.

1. Explosive eruptions of Kilauea: Science, new ser., vol. 57, pp. 459-461, April 20, 1923.

2. A new find of the woolly elephant in Michigan: Science, new ser., vol. 65, p. 616, June 24, 1927.

Shideler, William H.

1. Some faunal correlations of the Richmond (abstract) : Geol. Soc. America, Bull., vol. 34, no. 1, p. 130, March 30, 1923.

2. The basal Richmond of the Cincinnati province (abstract): Geol. Soc. America, Bull., vol. 34, no. 1, p. 132 March 30, 1923.

3. Recurrent faunas in the Cincinnatian (abstract) : Ohio Acad. Sci., Proc., vol. 8, pt. 4, p. 173, 1928; Ohio Jour. Sci., vol. 28, no. 3, p. 151, May, 1928.

4. A re-study of the Hamburg, Indiana, section (abstract) : Ohio Acad. Sci., Proc., vol. 8, pt. 4, p. 173, 1928; Ohio Jour. Sci., vol. 28, no. 3, p. 151, May, 1928.

Shiltz, John H.

1. Soil survey of Whitley County : Indiana, Dept. Geology and Nat. Res., 41st Ann. Rept., pp. 67-78, 1917.

Shimek, Bohumil.

1. Further notes on Helicina occulta Say: Iowa Acad. Sci., Proc., vol. 26, pp. 385-390 [1920].

2. The prairies again: Science, new ser., vol. 68, pp. 321-323, October 5, 1928.

Shimer, Hervey Woodburn.

1. Samuel Wendell Williston (1852-1918) : Am. Acad. Arts, Proc., vol. 54, no. 6. pp. 421-423, September, 1919.

2. Permo-Triassic of northwestern Arizona : Geol. Soc. America, Bull., vol. 30. no. 4, pp. 471-497, 1 fig., December 31 , 1919 ; abstract, no. 1, p. 155, March 31, 1919.

3. Some forces in man's social evolution: Science, new ser., vol. 60, pp. 199203, February 29, 1924.

4. An introduction to earth history. viii, 411 pp., 141 figs., Boston, Ginn and Company, c. 1925 .

5. Memorial of Frederick Burritt Peck: Geol. Soc. America, Bull., vol. 37, no. 1, pp. 111-114, 1 pl. (portr.), March 30, 1926.

6. Upper Paleozoic faunas of the Lake Minnewanka section, near Banff:, Alberta : Canada, Geol. Survey, Bull. no. 42, pp. 1-84, 1 fig. 8 pls., May 8, 1926.

7. A Triassic coral reef fauna in British Columbia: Canada, Geol. Survey, Bull. no. 42, pp. 85-89, May 8, 1926.

8. (and Lindgren, Waldemar). Memorial of William Otis Crosby: Geol. Soc. America, Bull., vol. 38, no. 1, pp. 34-45, portr., March 30, 1927.

Shipley, John Wesley.

1. The Valley of Ten Thousand Smokes: Science, new ser., vol. 49, pp. 589-591, June 20, 1919.

2. Some chemical observations on the volcanic emanations and incrustations in the Valley of Ten Thousand Smokes, Katmai, Alaska: Am. Jour. Sci., 4th ser., vol. 50, pp. 141-153, 1 fig., August, 1920. 
Shipton, Washburne Denning.

1. A new exposure of Mississippian strata near Saint Louis, Missouri : Washington Univ. Studies, vol. 11., no. 1, pp. 59-63, 2 pls., July, 1923.

2. The occurence of Nebraskan drift in northern Missouri: Washington Univ. Studies, vol. 12, Scientific ser., no. 1, pp. 53-71, 1924.

Short, Maxiwell Naylor. See also Capps, 10 ; Locke, 4.

1. (and Ettlinger, I. A.). Ore deposition and enrichment at the Magma mine, Superior, Arizona: Am. Inst. Min. and Met. Eng., Trans. [preprint], no. 1552, 54 pp., 29 figs. (incl. map), February, 1926; (with discussion), Trans. vol. 74, pp. 174-222, 29 figs. (incl. map), 1926; abstract, Mining and Metallurg甲, vol. 7, no. 232, pp. 175-176, 1 fig., April, 1926.

2. The preparation of polished sections of ores: Econ. Geology, vol. 21, no. 7, pp. 648-664, 2 figs., 1926.

3. (and Henderson, E. P.). Tetradymite from Hachita, New Mexico: Am. Mineralogist, vol. 11, no. 11, pp. 316-317, November, 1926.

Short, R. T. See Bybee, 2.

Shrock, Robert $R$. See also Cumings, 3, 4, 5.

1. Some interesting physiographic features of the upper Wabash drainage basin in Indiana: Indiana Acad. Sci., Proc., vol. 37, pp. 125-139, 4 figs., 1928.

2. A new graptolite fauna from the Niagaran of northern Indiana: Am. Jour. Sci., 5th ser., vol. 16, pp. 1-38, 10 figs., 5 pls., July, 1928.

Schufeldt, Robert Wilson.

1. A comparative study of some subfossil remains of birds from Bermuda, including the "cahow": Carnegie Mus., Annals. vol. 13, nos. 3-4, pp. 333-418, 16 pls., March, 1922.

Shuler, Ellis William.

1. The geology of Dalias County : Texas, Univ., Bull. no. 1818, 54 pp., 21 pls. (incl. map), March 25, 1918.

2. Occurrence of human remains with Pleistocene fossils, Lagow sand pit, Dallas, Texas: Science, new ser., vol. 57, pp. 333-334, March 16. 1923.

Siebenthal, Claude Ellsworth, 1869-1930.

1. Cadmium in 1918: U. S. Geol. Survey, Mineral Resources, 1918, pt. 1, pp. 1-12, May 8, 1919.

2. Zinc and cadmium in 1916: U. S. Geol. Survey, Mineral Resources, 1916, pt. 1, pp. 809-835, 1 pl., June 9, 1919.

3. Lead in 1916: U. S. Geol. Survey, Mineral Resources; 1916, pt. 1, pp. 837854, 1 pl., June 10, 1919.

4. Zinc in 1917: U. S. Geol. Survey, Mineral Resources, 1917, pt. 1, pp. 855879, April 6, 1920.

5. Lead in 1917: U. S. Geol. Survey, Mineral Resources, 1917, pt.' 1, p]). 881-897, 1 pl., 1920.

6. Cadmium in 1919: U. S. Geol. Survey, Mineral Resources, 1919, pt. 1, pp. 1-8, June 18, 1920.

7. Lead in 1918: U. S. Geol. Survey, Mineral Resources, 1918, pt: 1, pp. 937-971, 1 pl., January 6, 1921.

8. Zinc in 1918: U. S. Geol. Survey, Mineral Resources, 1918, pt. 1, pp. 1027-1074, 2 figs., 1 pl., April 29, 1921.

$4096-31-36$ 
Siebenthal, Claude Ellsworth-Continued.

9. (and Stoll, A.). Cadmium in 1920: U. S. Geol. Survey, Mineral Resources, 1920, pt. 1, pp. 1-6, May 12, 1921.

10. (and Stoll, A.). Lead in 1919 (general report) : U. S. Geol. Surves, Mineral Resources, 1919, pt. 1, pp. 313-330, 1 pl., October 6, 1921.

11. (and Stoll, A.). Zinc in 1919: U. S. Geol. Survey, Mineral Resources, 1919, pt. 1, pp. 653-664, 1 pl., October 13, 1921.

12. (and Stoll, A.). Lead in 1920 (general report): U. S. Geol. Survey, Mineral Resources, 1920, pt. 1, pp. 85-95, 1 fig., October 14, 1921.

13. (and Stoll, A.). Zinc in 1920: U. S. Geol. Survey, Mineral Resources, 1920, pt. 1, pp. 221-237, December 19, 1921.

14. (and Stoll, A.). Cadmium in 1921: U. S. Geol. Survey, Mineral Resources, 1921, pt. 1, pp. 1-5, April 10, 1922.

15. (and Stoll, A.). Zinc in 1921: U. S. Geol. Survey, Mineral Resources, 1921, pt. 1, pp. 21-33, June 17, 1922.

16. (and Stoll, A.). Lead in 1921 (general report) : U. S. Geol. Survey, Mineral Resources, 1921, pt. 1, pp. 35-43, July 3, 1922.

17. (and Stoll, A.). Lead and zinc pigments and salts in 1921: U. S. Geol. Survey, Mineral Resources, 1921, pt. 1, pp. 55-62, 1 fig., July 10, 1922.

18. (and Stoll, A.). Cadmium in 1922: U. S. Geol. Survey, Mineral Resources, 1922, pt. 1, pp. 1-5, May 22, 1923.

19. (and Stoll, A.). Lead in 1922 (general report) : U. S. Geol. Survey, Mineral Resources, 1922, pt. 1, pp. 27-36, 1 fig., July 17, 1923.

20. (and Stoll, A.). Zinc in 1922: U. S. Geol. Survey, Mineral Resources, 1922, pt. 1, pp. 37-52, 2 figs., July 18, 1923.

21. (and Stoll, A.). Lead and zinc pigments and salts in 1922: U. S. Geol. Survey, Mineral Resources, 1922, pt. 1, pp. 77-85, 2 figs., July 25, 1923.

22. (and Stoll, A.). Zinc in 1923 (smelter report) : U. S. Geol. Survey, Mineral Resources, 1923, pt. 1, pp. 79-99, 2 figs., October 10, 1924.

23. (and Phillips, E. R.). Barytes and barium products in 1923: U. S. Geol. Survey, Mineral Resources, 1923, pt. 2, pp. 79-88, 1 fig., October 16, 1924.

24. (and Stoll, A.). Lead and zinc pigments and salts in 1923: U. S. Geol. Survey, Mineral Resources, 1923, pt. 1, pp. 119-128, 2 figs., November $3,1924$.

25. (and Stoll, A.). Lead in 1923 (smelter report): U. S. Geol. Survey, Mineral Resources, 1923, pt. 1, pp. 129-144, 1. fig., November 4, 1924.

26. (and Stoll, A.). Cadmium in 1923-1924: U. S. Geol. Survey, Mineral Resources, 1924, pt. 1, pp. 7-11, 1925.

27. Balance sheets for mine and smelter production of domestic copper, lead, and zinc: Econ. Geology, vol. 20, no. 1, pp. 83-96, January-February, 1925.

28. Contour map of the surface of the beds underlying the Cherokee shale in a portion of the Picher district, Oklahoma, showing relations of ore bodies to the surface contoured: [U. S. Geol. Survey], 4 pp. [mimeographed] and map, April 20, 1925.

20. (and Stoll, A.). Zinc in 1924 (smelter report) : U. S., Bur. Mines, Mineral Resources U. S., 1924, pt. 1, pp. 235-254, 2 figs., April 13, 1926.

Siegfriedt, J. C. F. See Matthew, 37. 
Siegfus, Stanley $\mathbf{S}$.

1. A reconnaissance of the Promontory Point mining district, Utah: Utah, Univ., Bull., vol. 15, no. 2 (Eng: Exper. Sta., Bull. no. 15), pp. 57-72, 5 figs., January, 1925.

2. Some geological features of the Washington magnesite deposits: Eng. and Min. Jour., vol. 124, no. 22, pp. 853-857, 6 figs., November 26, 1927.

Sill, Rush T.

1. Chemistry of enrichment of silver deposits: Mining and Metallurgy, no. 189, pp. 21-23, September, 1922.

simmersbach, $B$.

1. Die bergbauliche Entwicklung Kanadas mit besonderer Berücksichtigung der Nickelgewinnung: Zeitschr. prakt. Geologie, Jg. 25, H. 7, pp. 111-116, July, 1917.

2. Prehnit vom Adams Sund, Admiralty Inlet, Baffinsinsel, Franklin: Zeitschr. prakt. Geologie, Jg. 25, H. 8, pp. 139-141, August, 1917.

Simons, F. L. See Fisher, L. W., 1.

simonds, Frederic William.

1. Memorial of Edwin Theodore Dumble: Geol. Soc. America, Bull., vol. 39, no. 1, pp. 18-29, portr., March 30, 1928.

Simpson, George Gaylord. See also Granger, 1.

1. Mesozoic Mammalia, I; American triconodonts: Am. Jour. Sci., 5th ser., vol. 10, pp. 145-165, 334-358, 21 figs., August and October, 1925; abstract, Geol. Soc. America, Bull., vol. 36, no. 1, p. 229, March 30, 1925.

2. Mesozoic Mammalia, II ; T'inodon and its allies: Am. Jour. Sci., 5th ser., vol. 10, pp. $451-470,9$ figs., November, 1925.

3. Meso\%oic Mammalia, III; Preliminary comparison of Jurassic mammals except multituberculates: Am. Jour. Sci., 5th ser., vol. 10, pp. 559-569, 3 tigs., December, 1925.

4. Mesozoic Mammalia, IV; The multituberculates as living animals: Am. Jour. Sci., 5th ser., vol. 11, pp. 228-250, 8 tigs., March, 1926.

5. Mesozoic Mammalia, V; Dromatherium and Microconodon: Am. Jour. Sci., 5th ser., vol. 12, pp. 87-108, 4 tigs., August, 1926.

6. Reconnaissance of part of the Santa Fe formation (abstract) : Geol. Soc. America, Bull., vol. 36, no. 1, p. 230, March 30, 1925.

7. The age of the Morrison formation: Am. Jour. Sci., 5th ser., vol. 12, pp. 198-216, September, 1926.

8. New reconstruction of Lasanius (abstract) : Geol. Soc. America, Bull., vol. 37, no. 1, p. 237, March 30, 1926.

9. Pre-Cretaceous evolution of mammalian lower molars (abstract): Geol. Soc. America, Bull., vol. 37, no. 1, p. 238, March 30, 1926.

10. Are Dromatherium and Microconodon mammals? [from Triassic of North Carolina] : Science, new ser., vol. 63, pp. 548-549, May 28, 1926.

11. The fauna of Quarry 9.[Morrison formation, Como Bluff, Wyoming]: Am. Jour. Sci., 5th ser., vol. 12, pp. 1-1.1, 1 fig., July, 1926.

12. American terrestrial Rhynchocephalia: Am. Jour. Sci., 5th ser., vol. 12, pp. 12-16, 2 figs., July, 1926.

13. Mammalian fauna of the Hell Creek formation of Montana: Am. Mus. Novitates, no. $267 ; 7$ pp., 6 figs., April 30, 1927.

14. Mammalian fauna and correlation of the Paskapoo formation of Alberta : A.m.-Mus. Novitates, no. 268, 10 pp., ? figs., April 30, 1927. 
Simpson, George Gaylord-Continued.

15. A North American Oligocene edentate: Carnegie Mus., Annals, vol. 17, $\because \quad$. no. 2 , pp. $283-298,1 \cdot \mathrm{pl}$; May; 1927.

16. Mesozoic Mammalia, VI; Genera of Morrison pantotheres: Am. Jour. Sci., ... ... 5. 5th ser., vol. 13, pp. 409-416, May, 1927.

17. Mesozoic Mammalia, VII; Taxonomy of Morrison multituberculates: Am. Jour. Sci., 5th ser., vol. 14, pp. 36-38, July, 1927.

18. Tathiodon, new genus, to replace Tanaodon Simpson non Kirk; a correction: Am. Jour. Sci., 5th ser., vol. 14, p. 71, July, 1927.

19. Mesozoic Mammalia, VIII; Genera of Lance mammals other than multituberculates: Am. Jour. Sci., 5th ser., vol. 14, pp. 121-130, August, 1927.

20. Mesozoic Mammalia, IX; The brain of Jurassic mammals : Am. Jour. Sci., 5th ser., vol. 14, pp. 259-268, 4 figs., October, 1927.

.21. A new mammalian fauna from the Fort Union of soathern Montana : Am. Mus. Novitates, no. 297, 15 pp., 14 figs., February 2, 1928; abstract, Geol. Soc. America, Bull., vol. 39, no. 1, pp. 300-301, March 30, 1928.

22. Mesozoic mammals, $X$; Some Triassic mammals: Am. Jour. Sci., 5th ser., vol. 15, pp. 154-167, 3 figs., February, 1928.

23. Mesozoic Mammalia, XI; Brancatherulum tendagurense Dietrich: Am. Jour. Sci., 5th ser., vol. 15, pp. 303-308, 2 figs., April, 1928.

24. American Eocene didelphids: Am Mus. Novitates, no. 307; 7. pp., 5 figs., April 14, 1928.

25. Mesozoic Mammalia, XII; The internal mandibular groove of Jurassic mammals: Am. Jour. Sci., 5th ser., vol. 15, pp. 461-470, 7 figs., June, 1928.

26. Pleistocene mammals from a cave in Citrus County, Florida: Am. Mus. Novitates, no. 328, 16 pp., 11 figs., October 26, 1928.

27. (and Elftman, Herbert Oliver.). Hind limb musculature and habits of a Paleocene multituberculate: Am. Mus. Novitates, no. 333, $19 \mathrm{pr}$., 6 figs., November 1, 1928.

Simpson, Howard Edwin.

1. Artesian-water conditons in North Dakota: North Dakota Geol. Survey, Bull. no. 2, 7 pp., Grand Forks, 1923.

2. The principles of conservation as applied to artesian waters [North Dakota] : North Dakota, Univ., Quart. Jour., vol. 15, no. 4, pp. 287.-297, May, 1925.

3. The badlands of the Little Missouri [North Dakota]: North Dakota, Univ., Quart. Jour., vol. 16, no. 2, p. 148, 4 pls., Januacy, 1926.

4. The conservation of artesian water: North Dakota Geol. Survey, Bull. no. 5, 22 pp., 1 fig., 1926.

5. The water supply of Harvey, North Dakota; a method of water prospecting: North Dakota Geol. Survey, Bull. no. 6, pp. 3-8, 1 pl., 1927.

6. The third biennial report of the State water geologist: North Dakota Geol. Survey, Bull. no. 6, pp. 9-16, 1927.

Simpson, Louis.

1. Oil-yielding shales in the province of New Brunswick: Canadian Min. Inst., Monthly Bull., no. 1, pp. 42-47, January, 1919.

Sinclair, Ewart Gladstone, 1884-1927.

1. Oil possibilities of the Black Hills region: Ain. Assoc. Petroleum Geologists, Bull., vol. 10, no. 8, pp. 800-809, August, 1926. 
Sinclair, William John.

1. New mounts in the Princeton geological museum (abstract): Geol. Soc. America, Bull., vol. 31, no. 1, p. 223, March 31, 1920.

2. A new Hoplophoneus from the Titanotherium beds [South Dakota]: Am. Philos. Soc., Proc., vol. 60, no. 2, pp. 96-98, 1 fig., 1921.

3. The "turtle-Oreodon layer" or "red layer," a contribution to the stratigraphy of the White River Oligocene (results of the Princeton University 1920 expedition to South Dakota) : Am. Philos. Soc., Proc., vol. 60, no. 3, pp. 457-466, 1 pl., 1921.

4. Entelodonts from the Big Badlands of South Dakota in the geological museum of Princeton University : Am. Philos. Soc., Proc., vol. 60, no. 4, pp. 467-495, 22 figs., 1921.

5. The small entelodonts of the White River Oligocene: Am. F'hilos. Soc., Proc., vol. 61, no. 1, pp. 53-64, 5 figs., 1922.

6. Hyracodons from the Big Badlands of South Dakota: Am. Philos. Soc. Proc., vol. 61, no. 1, pp. 65-79, 8 figs., 1922. Abstract, Geol. Soc. America, Bull., vol. 33, no. 1, pp. 209-210, March 31, 1922 ; Science, new ser., vol. 55, p. 654, June 16, 1922.

7. Stratigraphy of the lower Oreodon beds of the South Dakota Big Badlands (abstract with discussion by W. D. Matthew) : Geol. Soc. America, Bull., vol. 33, no. 1, pp. 155-156, March 31, 1922.

8. The faunas of the concretionary zones of the Oreodon beds, White River Oligocene: Am. Philos. Soc., Proc., vol. 63, no. 1, pp. 94-133, 10 figs., 1 pl., 1924.

9. The mounted skeleton of a new Mesohippus from the Protoceras beds: Am. Philos. Soc., Proc., vol. 64, no. 1, pp. 55-63, 1 pl., 1925.

10. (and Jepson, G. L.). The skull of Eusmilus: Am. Philos. Soc., Proc., vol. 66, pp. 391-407, 8 figs., 1927.

11. Omorhamphus, a new flightless bird from the lower Eocene of Wyoming: Am. Philos. Soc., Proc., vol. 67, no. 1, pp. 51-65, 3 figs., 2 pls., 1928.

Sine, F. L.

1. Antozonite from Monteagle Township, Hastings County, Ontario: Toronto, Univ., Studies, Geol. ser., no. 20, pp. 22-24, 1925.

2. Fetid feldspar from Loughboro Township, Frontenac County, Ontario: Toronto, Univ., Studies, Geol. ser., no. 20, pp. 25-27, 1925.

3. The pegmatite dikes of southeastern Ontario: Canadian Min. Jour., vol. 47 , no. 7 , pp. 169-171, February 12 , no. 10 , pp. 237-243, 2 figs., March 5, no. 11, pp. 257-262, 1 fig., March 12, 1926.

Singewald, Joseph T., jr. See also Cushman, 17; Lindgren, 18; Reger, 5.

1. Sand chrome deposits of Maryland (abstract) : Geol. Soc. America, Bull., vol. 30, p. 111, March 31, 1919.

2. Maryland sand chrome ore: Econ. Geology, vol. 14, no. 3, pp. 189-197, 5 figs., May, 1919.

3. A genetic comparison of the Michigan and Bolivian copper deposits: Econ. Geology, vol. 23, no. 1, pp. 55-61, January, 1928.

4. Discussion of Wegener theory. In Theory of continental drift, pp. 189-193, Am. Assoc. Petroleum Geologists, 1928.

5. Notes on feldspar, quartz, chrome, and manganese in Maryland: Maryland Geol. Survey, vol. 12, pp. 91-194, 6 figs., 13 pls. (incl. maps), 1928.

Singewald, Quentin Dreyer.

1. Origin and distribution of rock oil: Pan-Am. Geologist, vol. 39, no. 4, pp. 282-288, May, 1923. 
Sisler, James Donaldson. See also Pennslyvania T. G. S., 1; Reese, 1.

1. Bituminous-coal losses and mining methods in Pennsylvania, including thickness, character, and reserves of coal: Pennsylvania Geol. Survey, 4th ser. [Bull. M4], 216 pp., 29 figs. [1924].

2. Geology of Pennsylvania bituminous coals: Pennsylvania Geol. Survey, 4th ser., Bull. M6, pt. 4, pp. 2-6, 1925.

3. Bituminous coal fields of Pennsylvania; Part II, Detailed description of coal fields: Pennsyivan:a, Topog. and Geol. Survey, Bull. M6, pt. 2, 511 pp., 152 figs., 14 pls. (incl. maps), 1926.

Sizer, Frank L.

1. The Divide district [Tonopah, Nevada]: Min. and Sci. Press, vol. 118, pp. 631-633, 4 figs., May 10, 1919.

Skeels, Frank H.

1. A preliminary report on the clays of Idaho: Idaho, Bur. Mines and Geology, Bull. no. 2, 74 pp., 9 figs., 1920.

Skirvin, Orren W.

1. Experimental study of the invasion of oil into a water-wet sand: Econ. Geology, vol. 17, no. 6, pp. 461-469, September, 1922.

Slate, Frederick.

1. Bibliographical memoir of Eugene Woldemar Hilgard, 1833-1916: Nat. Acad. Sci., Biog. Mem., vol. 9, pp. 95-155, portr., November, 1919.

Slater, George.

1. A "new section" in the upper drift deposits of Toronto, 1924: Roy. Soc. Canada, Trans., 3d ser., vol. 21, sec. 4, pp. 37-46, 5 figs., March, 1927:

2. Structure of the Mud Buttes and Tit Hills in Alberta: Geol. Soc. America, Bull., vol. 38, no. 4, pp. 721-730, 6 figs., 2 pls., December 30, 1927; abstract, no. 1, pp. 161-162, March 30, 1927; Pan-Am. Geologist, vol. 47, no. 2, p. 157 , March, no. 3, pp. 223-224, October, 1927 ; British Ascoc. Adv. Sci., Rept. 95th Meeting, pp. 321-322, 1927.

3. Structure of drumlins on southern shore of lake Ontario, New York State, 1924 (abstract) : Pan-Am. Geologist, vol. 50, no. 3, p. 232, October, 1928.

Slavik, F.

1. Note on zaratite from Bohemia, Pennsylvania, and Tasmania: Am. Mineralogist, vol. 11, no. 10, pp. 279-280, October, 1926.

Slawson, Chester B.

1. A new method of crystal drawing: Am. Mineralogist, vol. 6, no. 11, pp. 155-158, 3 figs., November, 1921.

2. The thermo-optical properties of heulandite: Am. Mineralogist, vol. 10, no. 9, pp. 305-331, 4 figs., 3 pls., September, 1925.

Slipper, Stanley Eades. See also Dowling, 1.

1. Sketch of the geology of southern and central Alberta: Canada, Geol. Survey, Mem. 116, pp. 11-24, 1919.

2. Sheep River gas and oil field, Alberta: Canada, Geol. Survey, Mem. 122, 46 pp., 4 figs., 8 pls., 3 maps, 1921.

Slocom, Arthur Ware.

1. (and Foerste, August F.). New echinoderms from the Maquoketa beds of Fayette County, Iowa [with description of Pleurocystites multistriatus by E. O. Ulrich and Edwin Kirk] : Iowa Geol, Survey, vol. 29 , pp. 315-382, 5 figs.. 6 pls. [1924]. 
Smith, A. F.

1. The mineral resources of the Tennessee River basin in Tennessee, Kentucky, and Virginia: U. S., 70th Cong., 1st sess., H. R. Doc. no. 185 , pp. 120-158, 1928 .

2. Investigation of possibilities of pig-iron production in east Tennessee: U. S., 70th Cong., 1st sess., H. R. Doc. no. 185, pp. 183-192, 1928.

Smith, Arthur H. De Witt.

1. Mining methods of Verde mining district [Arizona]: Am. Inst. Min. and Met. Eng., Trans. [preprint], no. 1309, 43 pp., 12 figs., March, 1924.

Smith, Edward S. C. See also Perkins, E. H., 3.

1. Geology of the Pawtuckaway Mountains [New Hampshire] (abstract); Geol. Soc. America, Bull., vol. 33, no. 1, p. 128, March 31, 1922.

2. The Rangeley conglomerate [Maine]: Am. Jour. Sci., 5th ser., vol. 5, pp. 147-154, 1 fig., February, 1923.

3. Contributions to the geology of Maine, No. 2; Part II, The igneous rock of Mt. Kineo and vicinity: Am. Jour. Sci., 5th ser., vol. 10, pp. 437-444, 1 fig., November, 1925.

4. A possible tillite from northern Maine: Am. Jour. Sci., 5th ser., vol. 15, pp. 61-65, 1 fig., January, 1928.

5. The Cambrian in northern Maine: Am. Jour. Sci., 5th ser., vol. 15, pp. 484-486, 1 fig., June, 1928.

6. The Cambrian in northern Maine (abstract): Science, new ser., vol. 68, pp. 648-649, December 28, 1928.

Smith, Ernest Rice.

1. The Pleistocene locality at Wailes Bluff [St. Marys County], Maryland, and its molluscan fauna: Michigan Acad. Sci., 22d Ann. Rept., pp. 85-88, 1921.

2. Three new brackish-water Pliocene Mollusca from Louisiana: Indiana Acad. Sci,. Proc., 38th Ann. Meeting., 1922, pp. 135-136, 5 figs., 1923.

3. A case of stream piracy near Greencastle, Indiana: Indiana Acad. Sci., Proc., 39th Ann. Meeting, vol. 33, pp. 73-75, 3 figs., 1924.

Smith, Eugene Allen, 1841-1927.

1. Report of progress for the fiscal years 1914-1918: Alabama, Geol. Survey, 14 pp. [1919].

2. A geological map of Alabama: Alabama, Geol. Survey, Bull. 22, frontispiece, 1920.

3. Report of progress for the fiscal years 1918-1922: Alabama, Geol. Survey, 16 pp. [1922].

4. Mineral industries of Alabama: The South's Development, Manufacturers Record, vol. 86, no. 24, pt. 2, pp. 350-354; December 11, 1924. Reprint, 14 pp.

5. (and others). Geologic map of Alabama ... Scale, 1:500,000. Alabama Geol. Survey, 1926. Accompanies Special report no. 14.

6. Report of progress for the fiscal years 1923-1926: Alabama Geol. Survey, 16 pp., 1926.

7. Recent activities of Alabama Geological Survey : Pan-Am. Geologist, vol. 48, no. 3, pp. 229-234, 2 figs., October, 1927.

Smith, George L.

1. Contributions to the geology of southwestern Iowa : Iowa Acad. Sci., Proc., 1918, vol. 25, pp. 521-537, 1 fig. [1919]. 
Smith, George Otis.

1. Fortleth annual report of the Director of the Dnited States Geological Survey to the Secretary of the Interior for the fiscal year ended June 30, 1919.200 pp., 2 pls. (maps), 1 fig., Washington, 1919.

2. (Editor). The strategy of minerals .. 372 pp. 17 figs., New York, $D$. Appleton \& Company, 1919.

3. Economic limits to domestic independence in minerals (abstract, with discussion by G. F. Loughlin and F. E. Wright) : Geol. Soc. America, Bull., vól. 30, pp. 98-99, March 31, 1919.

4. Military contribution of civilian engineers: Geol. Soc. America, Bull., vol. 30, no. 3, pp. 399-404, September 30, 1919; abstract, no. 1, p. 79, March 31, 1919.

5. Geological Survey reports: Eng. and Min. Jour., vol. 108, p. 740, November 1, 1919.

6. Forty-first annual report of the Director of the United States Geological . Survey to the Secretary of the Interior for the fiscal year ended June 30, 1920. 180 pp, 3 pls. (maps), Washingon, 1920.

7. The public service opportunity of the oil geologist: Am. Assoc. Petroleum Geologists, Bull., vol. 4, no, 1, pp. 5-15, 1920.

8. Our industry's part: Am. Mining Congress; Rept. of the Proceedings of the Twenty-Second Annual Convention - [vol. 23], pp. 317-325 [1920].

9. Forty-second annual report of the Director of the United States Geological Survey to the Secretary of the Interior, for the fiscal year ended June 30, 1921. 108 pp., 1 pl. (map), Washington, 1921.

10. Scientific by-products of applied geology: Eng. and Min. Jour., vol. 111, no. 2, pp. 66-67, January 8, 1921; Washington Acad. Sci., Jour., vol. 11, no. 9, pp. 203-207, May 4, 1921.

11. Geology in partnership with American industry: Franklin Inst., Jour., vol. 192, no. 5, pp. 623-635, November, 1921.

12. War problems in minerals, V; United States Geological Survey, 19141918: Eng. and Min. Jour., vol. 112, no. 23, pp. 892-894, December $3,1921$.

13. Forty-third annual report of the Director of the United States Geological Survey to the Secretary of the Interior, for the fiscal year ended June 30, 1922. 80 pp., 1 pl. (map), Washington, 1922.

14. Plain geology: Econ. Geology, vol. 17, no. 1, pp. 34-39, January-February, 1922.

15. The occurrence of granite in Maine: U. S. Geol. Survey, Bull. 738, pp. 205-209, 1 pl. (map), 1923.

16. Forty-fourth annual report of the Director of the United States Geological Survey to the Secretary of the Interior for the fiscal year ended June 30, $1923.89 \mathrm{pp}$., 1 pl. (map), Washington, 1923.

17. Forty-fifth annual report of the Director of the United States Geological Survey to the Secretary of the Interior for the fiscal year ended June 30, 1924. 83 pp., 1 pl. (map), Washington, 1924.

18. Alfred Hulse Brooks: Science, new ser., vol. 61, pp. 80-81, January 23, 1925.

19. Alfred Hulse Brooks: Mining and Metallurgy, vol. 6, no. 218, pp. 98-99, February, 1925.

20. Topographic and geologic maps: Military Engineer, vol. 17, no. 95, pp. 381-395, 19 figs., 8 pls., September-October, 1925. 
Smith, George Otis-Continued.

21. Forty-sixth annual report of the Director of the Geological Survey to the Secretary of the Interior for the fiscal year ended June 30, 1925. 91 pp., 1 pl. (map), Washington, 1925.

22. Forty-seventh annual report of the Director of the Geological Survey to the Secretary of the Interior for the fiscal year ended June 30 , 1926. $96 \mathrm{pp}$., Washington, 1926.

23. Forty-eighth annual report of the Director of the Geological Survey to the Secretary of the Interior for the fiscal year ended June 30, 1927. 77 pp., Washington;. United States Government Printing Office, 1927.

24. Geology at work: Johns Hopkins Univ., Studies in Geology, no. 8, pp. 25-32, 1927.

25. Charles Doolittle Walcott: Am. Jour. Scl., 5th ser., vol. 14, pp. 1-6, portr., July, 1927.

26. Charles D. Walcott and the United States Geological Survey: Smithsonian Misc. Coll., vol. 80, no. 12, pp. 17-18, May 12, 1928.

27. Federal surveys and maps: Am. Year.Book; 1927, pp. 156-158, 1928.

28. Forty-ninth annual report of the Director of the Geological Survey to the Secretary of the Interior, 1928. 77 pp., Washington, .United States Government Printing Office, 1928.

29. Charles Doolittle Walcott: Smithsonian Inst., Ann. Rept., 1927, pp. 555561, 2 pls. (portr.), 1928.

30. Joseph Silas Diller-an appreciation: Eng. and Min. Jour., vol. 126, no. 23, p. 913, December 8, 1928.

Smith, Isabel F.

1. A columbite crystal from Boothwyn, Pennsylvania: Am. Mineralogist, vol. 4, no. 10, pp. 121-123, 1 pl., October, 1919.

2. Genesis of anorthosites of Piedmont Pennsylvania: Pan-Am. Geologist, vol. 38, no. 1, pp. 29-50, 3 figs., 1 pl., August, 1922.

3. Anorthosite in the Piedmont province of Pennsylvania. Dissertation, Bryn Mawr College, 40 pp., 5 figs., Bryn Mawr., Pennsylvania, 1923.

Smith, James Perrin.

1. Climatic relations of the Tertiary and Quaternary faunas of the California region: California Acad. Sci., Proc., 4th ser., vol. 9, no. 4, pp. 123-173, 1 pl., July 12, 1919.

2. John Casper Branner: Jour. Geology, vol. 32, no. 3, pp, 240-241, AprilMay, 1924.

3. Upper Triassic marine invertebrate faunas of North America : U. S. Geol. Survey, Prof. Paper 141; 262 pp., 121 pls., 1927.

Smith, John Eliphalet.

1. Deposits of volcanic ash (abstract) : Elisha Mitchell :Scl. Soc., Jour., vol. 35, no. 1-2, pp: 7-8, October; 1919.

2. Agricultural geology: Science, new. ser., vol. 52, pp. 139-142, August 13, 1920; Iowa Acad. Scl., Proci; vol. 27; pp. 175-179 [1922]:

3. Eolian deposits in Webster County, Iowa (abstract): Science, new ser., vol. 54, p. 307, 'September 30, 1921.

4. Three glacial tills at Ames, Iowa (abstract) : Science; new ser., vol. 54, p. 307, September 30, 1921; Iowa Acad. Sci., Proc. 1921, vol. 28, pp. 47-48, 1 fig. [1923].

5. A field of eskers in central Iowa (abstract) : Iowa Acad. Sci., Proc., vol. 27, p. 180 [1922]. 
Smith, John Eliphalet-Continued.

6. Geology in rural welfare: Pan-Am. Geologist, vol. 38, no. 4, pp. 283-288, November, 1922.

7. Algona recessional stages of Wisconsin glaciation in Iowa (abstract): Pan-Am. Geologist, vol. 42, no. 5, p. 376, December, 1924; Iowa Acad. Sci., Proc., vol. 31, p. 339 [1926?].

8. Fort Dodge stages of retreating glaciers (abstract) : Pan-Am. Geologist, vol. 42, no. 5, pp. 376-377, December, 1924; Iowa Acad. Sci., Proc., vol. 31, p. 335 [1926?].

9. Theoretical stage in retreat of Iowa glaciers (abstract) : Pan-Am. Geologist, vol. 42, no. 5, p. 377, December, 1924; Iowa Acad. Sci., Proc., vol. 31 , p. 335 [1926?].

10. Preliminary State map of Wisconsin glacial till [in Iowa] (abstract) : Pan-Am. Geologist, vol. 42, no. 5, p. 377, December, 1924.

11. The fertilizer materials of Iowa : Iowa Geol. Survey, vol. 31, pp. 91-151, 13 figs., 7 pls., (incl. maps) [1926?].

12. The Algona recessional stages of the Wisconsin glaciation in Iowa (abstract) : Iowa Acad. Sci., Proc., vol. 31, pp. 335-337, 1 fig. [1926?].

13. A preliminary map of the Wisconsin till in Iowa (abstract): Iowa Acad. Sci., Proc., vol. 31, pp. 337-338 [1926?].

14. The Humboldt stages of the Wisconsin glaciation in Iowa (abstract) : Iowa Acad. Sci., Proc., vol. 31, pp. 338-339 [1926?].

15. Molding sand in eastern Iowa (abstract) : Iowa Acad. Sci., Proc., 1925, vol. 32, pp. 357-358 [1926].

16. Glacial geology of Story County (abstract) : Iowa Acad. Sci., Proc., 1925, vol. 32, pp. 358-359 [1926].

17. Recessional moraines in central Iowa (abstract) : Pan-Am. Geologist. vol. 48 , no. 2 , p. 155 , September, 1927.

Smith, Louis $\mathbf{H}$.

1. Diffusion in ore genesis: Econ. Geology, vol. 23, no. 8, pp. 928-929, December, 1928.

Smith, Philip Sidney.

1. Sulphur and pyrites in 1.918: U. S. Geol. Survey, Mineral Resources, 1918, pt. 2, pp. 357-377, 3 figs., December 11, 1919.

2. Sulphur and pyrites in 1919: U. S. Geol. Survey, Mineral Resources, 1919, pt. 2, pp. 535-546, April 29, 1922.

3. Sulphur, pyrites, and sulphuric acid in 1920: U. S. Geol. Survey, Mineral Resources, 1920, pt. 2, pp. 301-308, June 16, 1922.

4. Notes on activities of the Geological Survey of United States of America: Pan-Pacific Sci. Cong., Australia, 1923, Proc., vol. 2, pp. 1296-1303 [1924].

5. Alfred Hulse Brooks: Assoc. Am. Geographers, Annals, vol. 15, no. 4, pp. 159-161, December, 1925.

6. Mineral industry of Alaska in 1924 and administrative report: U. S. Geol. Survey, Bull. 783, pp. 1-39, 1926.

7. (and Mertie, J. B., jr., and Foran, W. T.). Summary of recent surveys in northern Alaska: U. S. Geol. Survey, Bull. 783, pp. 151-166, 1 fig., 1 pl. (map), 1926.

8. Fields for future Alaskan studies (abstract): Washington Acad. Sci., Jour., vol. 16, no. 3, p. 79, February. 4, 1926. 
Smith, Philip Sidney-Continued.

9. Memorial of Alfred Hulse Brooks: Geol. Soc. America, Bull., vol. 37, no. 1, pp. 15-48, 1 pl. (portr.), March 30, 1926.

10. Oil developments in Alaska: Am. Inst. Min. and Met. Eng., no. 1570 (Petroleum development and technology - in 1925), pp. 653-656, April, 1926; abstract, Mining and Metallurgy, vol. 7, no. 232, p. 177, April, 1926.

11. Geologic investigations in northern Alaska: U. S. Geol. Survey, Bull. 792, pp. 111-120, 1 pl. (map), 1927.

12. Mineral industry of Alaska in 1926 and administrative report: U. S. Geol. Survey, Bull. 797, pp. 1-66, 1927.

13. Some post-Tertiary changes in Alaska of climatic significance: Nat. Research Council, Bull. no. 61, pp. 35-39, 1 fig., July, 1927.

Smith, Richard A. See also Stone, 11.

. 1. Mineral resources of Michigan . . . : Michigan, Geol. Survey, Pub. 32 (Geol. ser. 26), 145 pp. [1922].

2. (and Martin, Helen M.). Mineral resources of Michigan . . . : Michigan, Dept. Conservation, Geol. Survey Div., 138 pp. [1923?].

3. Oil development in Michigan and the anticline at Seul Choix Point: Michigan Acad. Sci., Papers, vol. 1, pp. 269-272, 1923.

4. Mineral resources of Michigan with statistical tables of production and value for 1922 and prior years: Michigan Geol. Survey, Pub. 34 (geol. ser. 28), 146 pp. [1924].

5. Mineral resources of Michigan, with statistical tables of production and value of mineral products for 1923 and prior years: Michigan, Geol. Survey, Pub. 35 (Geol. ser. 29), 115 pp. [n. d., 1925 ;].

Smith, Richard W.

1. Mining and washing phosphate rock in Tennessee: Eng. and Min. Jour.Press, vol. 115, no. 5, pp. 221-236, 8 figs., February 3, 1923.

2. Geology and utilization of Tennessee phosphate rock: Am. Inst. Min. and Met. Eng., Trans., vol. 74, pp. 127-146, 5 figs., 1926 ; [preprint] no. 1373, September, 1.924.

Smith, Stanley.

1. Memorial of Sir John Burchmore Harrison: Geol. Soc. America, Bull., vol. 38, no. 1, pp. 45-52, portr., March $30,1927$.

Smith, Walter R.

1. (and Baker, A. A.). The Cold Bay-Chignik district, Alaska: U. S. Geol. Survey, Bull. 755, pp. 151-218, 1 fig., 5 pls. (maps), 1924.

2. Aniakchak Crater, Alaska Peninsula: U. S. Geol. Survey; Prof. I'aper 132, pp. 139-145, 1 fig, 4 pls., May 15, 1925.

3. The Cold Bay-Katmai district [Alaska]: U. S. Geol. Survey, Bull. 773, pp. 183-207, map, 1925.

4. Geology and oil development of the Cold Bay district: U. S. Geol. Survey, Bull. 783, pp. 63-88, 1 fig., 1 pl. (map), 1926.

Smith, Warren Du Pré. See also Macelwane, 9; Schenck, 1; Takahashi, 1.

1. (and Packard, Earl L.). The salient features of the geology of Oregon: Jour. Geology, vol. 27, no. 2, pp. 79-120, 3 figs., 1 pl., 1919. Oregon, Univ., Bull, vol 16, no 7, pp. 79-120, 3 figs., 1 pl., July, 1919.

2. Rock classification for engineering: Econ. Geology, vol. 14, no. 2, pp. 180-183, March-April, 1919. 
Smith, Walter Du Pré-Continued.

3. Geology as a synthetic science (abstract) : Geol. Soc. America, Bull., vol. 30, pp. 77-78, March 31, 1919.

4. War work by the department of geology at the University of Oregon (abstract) : Geol. Soc. America, Bull., vol. 30, p. 83, March 31, 1919.

5. Earthquakes in Oregon: Seismol. Soc. America, Bull., vol. 9, no. 3, pp. 59-71, 2 figs., September, 1919. Also issued as Oregon, Univ., Pub., vol. 1, no. 3, February, 1920.

6. Physical and economic geography of Oregon (abstract) : Geol. Soc. America, Bull., vol. 32, no. 1, p. 146, March 31, 1921.

7. Geology and our civilization: Sci. Monthly, vol. 18, no. 2, pp. 168-180, February, 1924.

8. Petroleum possibilities of western Oregon: Econ. Geology, vol. 19, no. 5, pp. 455-465, August, 1924.

9. Physical and economic geography of Oregon: Oregon, Univ., Commonwealth Review, new ser., vol. 6, nos. 2 and 3, pp. 21-31, AprilJuly, no. 4, pp. 56-89, 6 figs. (incl. map), 4 pls., December, 1924.

10. Geology of Steens and Pueblo Mountains, southeastern Oregon (abstract) : Geol. Soc. America, Bull., vol. 36, no. 1, p. 202, March 30, 1925.

11. Physical and economic geography of Oregon; the Willamette Valley: Oregon, Univ., Commonwealth Review, vol. 7, no. 4, pp. 137-195, 10 figs., 2 pls., October; 1925.

12. Physical and economic geology of Oregon; the southeastern lake province: Oregon, Univ., Commonwealth Review, vol. 8, nos. 2-3, pp. 199-253, 5 figs., 2 pls., April-July, 1926.

13. Physical and economic geography of Oregon; the Coast Range province: Oregon, Univ., Commonwealth Review, vol. 8, nos. 2-3, pp. 254297, 15 figs., 3 pls., April-July, 1926.

14. Contribution to the geology of southeastern Oregon (Steens and Pueblo Mountains): Jour. Geology, vol. 35, no. 5, pp. 421-440, 10 figs., July-August, 1927.

15. Geological suite from eastern Oregon (abstract) : Geol. Soc. America, Bull., vol. 39, no. 1, pp. 168-169, March 30, 1928; Pan-Am. Geologist, vol. 49 , no. 1 , pp. 76-77, February, 1928.

16. Owyhee project of Oregon (abstract) : Pan-Am. Geologist, vol. 49, no. 4, p. 306, May, 1928.

17. Diatomaceous deposits of eastern Oregon (abstract) : Pan-Am. Geologist, vol. 49 , no. 4 , p. 306, May, 1928.

18. Features of Wallowa Mountains, Oregon (abstract) : Pan-Am. Geologist, vol. 49, no. 4, p. 314, May, 1928.

Smith, William Sydney Tangier.

1. Jasperoid of the Joplin district, Missouri, Kansas, and Oklahoma (abstract): Geol. Soc. America, Bull., vol. 33, no. 1, pp. 147-148, March 31, 1922.

2. The determination of dip and strike: Econ. Geology, vol. 17, no. 3, pp. 207213, 5 figs., May, 1922.

3. An apparent-dip protractor: Econ. Geology, vol. 20, no, 2, pp. 181-184, 1 fig., March-April, 1925; abstract, Geol. Soc. America, Bull., vol. 36, no. 1, p. 206, Murch 30, 1925. 
Smitheringale, W. V.

1. Antimony; an outline of the geology of the world's antimony deposits and a proposed classification; with notes on the properties and uses of antimony and its compounds: Canadian Min. and Met. Bull., no. 180, pp. 414-468, April, 1927.

2. Mineral association at the George gold-copper mine, Stewart; British Columbia: Econ. Geology, vol. 23, no. 2, pp. 193-208, 2 figs.. March-April, 1928.

Smithsonian Institution.

1. Explorations and field work of the Smithsonian Institution in 1918: Smithsonian Misc. Coll., vol. 70, no. 2, 122 pp. [geological and paleontological, pp. 3-27], 127 figs., 1919; in 1919, vol. 72, no. 1. 80 pp., 77 figs., 1920 ; in 1920 , vol. 72 , no. 6, 126 pp., 138 figs., 1921 ; in 1921, vol. 72, no. 15,128 pp., 132 figs., 1922; in 1922, vol. 74 , no. 5,153 pp., 145 figs., 1923 ; in 1923 , vol. 76 , no. 10 ; 128 pp., 123 figs., 1924 ; in 1924, vol. 77 , no. 2,136 pp., 138 figs., 1925 ; in 1925 , vol. 78 , no. 1,132 pp., 128 flgs., 1926 ; in 1926 , vol. 78 , no. 7,259 pp., 247 figs., 1927.

Smyth, Charles Henry, jr. See also Clarke, J. M., 15.

1. On the genetic significance of ferrous silicate associated with the Clinton iron ores: New York State Mus. Bull., nos. 207-209, pp. 175-198, 6 pls., 1919.

2. (and Buddington, A. F.). Geology of the Lake Bonaparte quadrangle: New York State Mus. Bull., no. 269, 106 pp., 24 pls., map, 1926.

3. The genesis of alkaline rocks: Am. Philos. Soc., Proc., vol. 66, pp. 535$580,1927$.

Smythe, D. D.

1. Arsenopyrite twins from New Mexico: Am. Mineralogist, vol, 6, no. 5, pp. 85-86, 1 fig., May; 1921 .

2. A contact-metamorphic iron-ore deposit near Fairview, New Mexico: Econ. Geology, vol. 16, no. 6, pp. 410-418, 2 pls., 1 fig., SeptemberOctober, 1921.

Snelgrove, A. K.

1. Mineral exploration in Newfoundland : during the decade 1917-1927: Canadian Inst. Min. and Met., Trans., vol. 30, pp. 302-326, 13 figs., map [1928] ; Second (Triennial) Empire Min. and Met. Congress. Canada, 1927, Proc., pt. 1, pp. 695-719, 13 figs, 1928.

2. The geology of the central mineral belt of Newfoundland: Canadian Min. and Met. Bull., no. 197, pp. 1057-1127, 8 figs., 2 pls. (maps), September, 1928.

Snider, L. B. See Moore, H.; 1.

Snider, Luther Crocker. See also Stone, 11.

1. Oll and gas in the Mid-Continent fields. 393 pp., 97 figs. (incl maps), Oklahoma City, Okla., Harlow Publishing Co., 1920.

2. A suggested explanation for the surface subsidence in the Goose Creek oil and gas field, Texas: Am. Assoc. Petroleum Geölogists, Bull., vol. 11, no. 7, pp. 729-745, July, 1927.

Snow, D. R.

1. (and Dean, David). Rainbow Bend fleld, Cowley County, Kansas: Am. Assoc. Petroleum Geologists, Bull., vol. 9, no. 6, pp. 974-982, 2 figs., September, 1925. 
Snow, F. W. See Browning, 1.

Snowden Piggot, Charles.

1. Radium and geology: Am. Chem. Soc., Jour., vol. 50, no. 11, pp. 29102916, November, 1928.

Snyder, J. P. See Johnson, J. H., 3.

Sohon, F. W.

1. A graphical determination of the actual amplitude of the earth's motion from seismographical data: Seismol. Soc. America, Bull., vol. 14, no. 3, pp. 185-196, 5 figs., September, 1924.

Soley, John Codman.

1. Sources of volcanic energy. 247 pp., illus., New York, G. P. Putnam's Sons, 1924.

Somers, Ransome Evarts. See also leighton, H., 1, 3; Ries, 3, 5.

1. Microscopic examination of clays: Washington Acad. Sci., Jour., vol. 9, no. 5, pp. 113-126, March 4, 1919.

2. Origin, migration, and accumulation of petroleum: Eng. and Min. Jour. Press, vol. 115, no. 2, pp. 66-69, 5 figs., January 13, 1923.

3. Petrographic criteria of structure in the Cromwell oil field, Oklahoma: Econ. Geology, vol. 23, no. 3, pp. 31.7-322, May, 1928.

Sommermeier, Leopold.

1. Ueber einen Fossilfund aus der Unteren Kreide von Trinidad [Didymotis trinidadensis, Lowel Cretaceous] : Centralbl. Mineralogie, 1918, no. 7-8, pp. 131-136, 2 figs., April, 1918.

Sonder, Richard A. See Friedlaender, 7.

Soper, Edgar Kirke. See also Grout, 1, 2 ; Varley, 1.

1. The peat deposits of Minnesota: Minnesota Geol. Survey, Bull. no. 16, $261 \mathrm{pp} ., 21 \mathrm{pls}$. (incl. maps), 10 figs., 1919.

2. (and Osbon, C. C.). The occurrence and uses of peat in the United .States: U. S. Geol. Survey, Bull. 728, 207 pp., 32 figs., 18 pls., 1922.

Sorenson, Robert li.

1. The geology and ore deposits of the South Mountain mining district, Owyhee County, Idaho: Idaho, Bur. Mines and Geology, Pam. no. 22, 47 pp., 5 pls. (incl. maps), May, 1927. (Mimeographed.)

Sosman, Robert Browning. See also Am. Geophysical Union, 1; Bowie, 24; Hewett, 11.

1. The temperature inversions in the fumaroles of the Valley of 'Ten Thousand Smokes, Alaska Peninsula (abstract): Washington Acad. Sci., Jour., vol. 9, no. 10, pp. 292-293, May 19, 1919.

2. Note on volcanic explosions (abstract): Washington Acad. Sci., Jour., vol. 9, no. 10, pp. 296-297, May 19, 1919.

3. [Report of investigations of the] Geophysical laboratory: Carnegie Inst. Washington, Year Book no. 18, 1919, pp. 153-174, March, 1920.

4. An outline of geophysical-chemical problems : Nat. Acad. Sci., Proc., vol. 6, no. 10, pp. 592-601, October 15, 1920. Nat. Research Council, Reprint and Circular ser., no. 11, pp. 592-601, 1920.

5. An outline of geophysical-chemical problems : Smithsonian Inst., Ann. Rept., 1921, pp. 225-234, 1922.

6. Status and problems of geophysical chemistry: Nat. Research Council, Bull., vol. 7, pt. 5, no. 41, pp. 74-77, January, 1924. 
Sosman, Robert Browning-Continued.

7. Symposium on hot springs (abstract) : Nat. Research Council, Bull., vol. 7, vt. 5, no. 41, pp. 149-150, January, 1924.

S. Notes on the papers presented in the symposium on hot springs; General summary of the symposium on hot springs: Jour. Geology, vol. 32, no. 6, pp. 464-471, August-September, 1924.

9. Section of volcanology, summary of reports of committees : Nat. Research Council, Bull., vol. 10, pt. 3, no. 53, p. 80, July, 1925.

10. (and Posnjak, E.). Ferromagnetic ferric oxide, artificial and natural: Washington Acad. Sci., Jour., vol. 15, no. 14, pp. 329-342, 3 figs., August 19, 1925.

11. Scientific papers and discussions at the 1925 meeting of the section of volcanology, American Geophysical Union: Washington Acad. Sci., Jour., vol. 15, no. 18, pp. 413-425, November 4, 1925.

12. Oxygen and volcanism (abstract with discussion) : Washington Acad. Sci., Jour., vol. 15, no. 18 , pp. 422-423, November 4, 1925 ; Bull. volcanologique, $2^{\mathrm{e}}$ ann., nos. 5-6, pp. 334-335, 1925.

13. Seismic waves and what we learn from them as to the interior of the earth: Nat. Research Council, Bull., vol. 11, pt. 2, no. 56, pp. 26-28, November, 1926; abstract, Am. Jour. Sci., 5th ser., vol. 12, pp. 271-272, September, 1926.

Soyster, Hale B.

1. (and Taylor, Thos. G.). Oil and gas in Oklahoma; oil and gas geology of Muskogee County: Oklahoma Geol. Survey, Bull. no. 40-FF, 28 pp., 3 figs., 4 pls. (incl. map), September, 1928.

Spath, L. F.

1. Eotriassic ammonites from east Greenland: Geol. Mag., vol. 64, pp. 474475, October, 1927.

Spearman, Charles.

1. The graphite industry: Canadian Min. Jour., vol. 40, pp. 87-88, February $12,1919$.

2. Gold in an altered basic dike [Dubuisson Township, northwestern Quebec] : Canadian Min. Jour., vol. 45, no. 4, p. 87, January 25, 1924.

3. The significance of the middle Eozoic sediments of Ontario and Quebe: : Canadian Min. Jour., vol. 45, no. 8, pp. 169-170, February 22, 1924.

4. The Kirkland Lake ore bodies [Ontario] : Canadian Min. Jour., vol. 45, nos. 28 and 29 , pp. 668-669, 694-695, 7 figs., July 11 and 1s, 1924.

5. Variable velocity hypothesis; and earth's physiognomy: Pạn-Am. Geologist, vol. 47, no. 4, pp. 241-254, May, 1927.

Speckman, W. N.

1. Marengo Cave, Marengo, Indiana: Illinois State Acad. Sci., Trans., vol. 16, pp. 393-395, 2 pls., 1923.

2. Lake Abram, Berea, Ohio: Illinois State Acad. Sci., Trans., vol. 16, pp. 396-398, 1923.

Spence, Hugh Swaine.

1. Graphite: Canada, Dept. Mines, Mines Branch, 202 pp., 56 pls., 43 figs., 6 maps, 1920.

2. Phosphate in Canada: Canada, Mines Branch, 156 pp., 12 figs., 32 pls., maps, 1920.

3. The origin of graphite (discussion): Econ. Geology, vol, 16, no. 8, pp. 561-563, December, 1921. 
Spence, Hugh Swaine-Continued.

4. Barium and strontium in Canada: Canada, Mines Branch, 100 pp., 18 figs., 15 pls., 1922.

5. Talc and soapstone in Canada: Canada, Dept. Mines, Mines Branch, 85 pp., 15 figs., 2 pls., map, 1922.

6. Le graphite au Canada: Soc. géographie. Québec, Bull., vol. 16, no. 1, pp. 17-28, 5 figs., January-February, 1922.

7. Investigation of miscellaneous nonmetallic minerals: Canada, Mines Branch, Summ. Rept., 1921, pp. 12-18, 1923.

8. Bentonite; Feldspar: Canada; Mines Branch, Investigations of Mineral Resources and the Mining Industry, 1923, pp. 1-3, 1924.

9. An addition to the mineral resources of western Canada: bentonite or colloidal clay: Inst. Petroleum Technologists, Jour., vol. 10, no. 45. pp. 707-709, September, 1924.

10. Canadia's barytes resources: Canadian Min. Jour., vol. 45, no. 46, pp. 1116-1118, 2 figs., November 14, 1924.

Spencer, Arthur Coe. See also Bateman, 10 ; Stose, 21.

1. Metasomatism and linear "force of growing crystals" (discussion) : Econ. Geology, vol. 21, no. 5, pp. 504-507, August, 1926.

Spencer, Joseph William Winthrop.

1. Preglacial slope and crest of the Niagara escarpment: Geol. Soc. America, Bull., vol. 32, no. 1, pp. 54-56, 3 figs., March 31, 1921.

Spencer, Leonard James.

1. Mineralogical characters of turite (=turgite) and some other iron ores from Nova Scotia: Mineralogical Mag., vol. 18, pp. 339-348, 4 figs., May, 1919.

Spieker, Edmund Maute.

1. The petroleum geology of a part of the western Peace River district, British Columbia: Am. Assoc. Petroleum Geologists, Bull., vol. 6. no. 2, pp. 112-138, 1 fig., March-April, 1922.

2. Geology of the coal fields [of Utah]: U. S., Bur. Mines, Tech. Paper 345, pp. 13-22, 1 fig., 1925.

3. (and Reeside, John B., jr.). Cretaceous and Tertiary formations of the Wasatch Plateau, Utah (with discussion by Charles Schuchert) : Geol. Soc. America, Bull., vol. 36, no. 3, pp. 435-454, 3 figs., September 30,1925 : abstract, no. 1, pp. 150-151, March 30, 1925; Pan-Am. Geologist, vol. 43, no. 2, p. 149, March, 1925.

4. Post-Cretaceous orogeny in central Utah (abstract) : Geol. Soc. America, Bull., vol. 37, no. 1, p. 166, March 30, 1926 ; Pan-Am. Geologist, vol. 45 , no. 2 , p. 165 , March, 1926.

5. (and Reeside, John B., jr.). Upper Cretaceous shore line in Utah: Geol. Soc. America, Bull.; vol. 37, no. 3, pp. 429-438, 3 figs., September 30, 1926 ; abstract, no. 1, p. 160, March 30,1926 ; Pan-Am. Geologist, vol. 45, no. 2, p.' 161, March, 1926.

$\checkmark$ 6. (and Baker, Arthur A.). Geology and coal resources of the Salina Canyon district, Sevier County, Utah: U. S. Geol. Survey, Bull. 796, pp. 125-170, 2 figs. '(maps), 4 pls. (incl. map), January 18, 1928.

Spier, Leslie.

1. Concerning man's antiquity at Frederick, Oklahoma: Science, new ser., vol. 67 , pp. 160-161, February 10, 1928.

2. A note on reputed ancient artifacts from Frederick, Oklahoma: Science, new ser., vol. 68 , p. 184, August 24, 1928. 
Spock, L. E., jr.

1. Geological reconnaissance of parts of Grand, Jackson, and Larimer counties, Colorado: New York Acad. Sci., Annals, vol. 30, np. 177-261, 46 figs., 1 pl. (map), October 22, 1928.

Spooner, W. C. See also Hull, 5.

1. The Monrue gas field; geology : Louisiana, Dept. Conservation, Bull. no. 12, pp. 4-6, 1 pl. [1926].

2. Interior salt domes of Louisiana: Am. Assoc. Petroleum Geologists, Bull., vol. 10, no. 3, pp. 217-292, 25 figs., 1 pl., March, 1926; Geology of salt dome oil fields, pp. 269-344, 25 figs., 1 pl., 1926.

3. Geology of Gulf Coastal Plain of Arkansas and Louisiana (abstract) : Pan-Am. Geologist, vol. 49, no. 3, pp. 238-239, April, 1928; Geol. Soc. America, Bull., vol. 39, no. 1, pp. 274-275, March 30, 1928.

4. Rainbow City field, Union County, Arkansas: Am. Assoc. Petroleum Geologists, Bull., vol. 12, no. 7, pp. 763-764, July, 1928.

5. Production in East Carroll Parish, Louisiana: Am. Assoc. Petroleum Geologists, Bull., vol. 12, no. 7, p. 765, July, 1928.

Spoor, H. C., jr.

1. Current oil field operations in Illinois: Illinois State Geol. Survey, Press Bull. Ser., Illinois Petroleum, no. 5, pp. 18-24, October 16, 1926.

Springer, Frank, 1848-1927.

1. New species of crinoid [Eucheirocrinus ontario]: Canada, Geol. Survey, Mem. 111, p. 127, 1 fig., 1919.

2. The Crinoidea Flexibilia. $486 \mathrm{pp}$., 51 figs., and atlas of 79 pls., The Smithsonian Institution, 1920.

3. The fossil crinoid genus Dolatocrinus and its allies: U. S. Nat. Mus., Bull. 115, 78 pp., 6 figs., 16 pls., 1921.

4. New species of Devonian Crinoidea from northern Canada: Canada, Geol. Survey, Bull. no. 33, pp. 15-18, 1 pl., September 14, 1921.

5. Crinoids from the upper Cretaceous of Tamaulipas, Mexico: U. S. Nat. Mus., Proc., vol. 61, art. 5, pp. 1-4, 1 pl., 1922.

6. Balanocrinus in America: Pan-Am. Geologist, vol. 38, no. 3, pp. 262-263, October, 1922.

7. On the fossil crinoid family Catillocrinidae: Smithsonian Misc. Coll., vol. 76, no. 3, 41 pp., 5 pls., August 3, 1923.

8. A Tertiary crinoid from the West Indies: U. S. Nat. Mus., Proc., vol. 65, art. $3,8 \mathrm{pp} ., 1 \mathrm{pl}$, 1924 .

9. A remarkable fossil echinoderm fauna in the East Indies: Am Jour. Sci., 5th ser., vol. 8, pp: 325-335, October, 1924.

Includes notes on the distribution of Crinoidea in America.

10. Occurrence of the crinoid genus Apiocrinus in America: U. S. Nat. Mus., Proc., vol. 67, art. 18, 5 pp., 1 pl., April 8, 1925.

11. The genus Pentacrinus in Alaska: U. S. Nat. Mus., Proc., vol. 67, art. 5, 7 pp., 1 pl., May 22, 1925.

12. American Silurian crinoids: Smithsonian Inst., 239 pp., 33 pls., 1926.

13. Unusual forms of fossil crinoids: U. S. Nat. Mus., Proc., vol. 67, art. 9, 137 pp., 26 pls., February 15, 1926.

14. Upper Devonian crinoids from Mackenzie River valley: Canada, Geol. Survey, Bull. no. 42, pp. 127-132, 1 pl., May 8, 1926.

$4096-31-37$ 
Spurr, Josiah Edward. See also Anderson, J. C., 2 ; Bateman, 10, 13 ; Emmons, W. H., 6 ; Gray, J. P., 1; Howe, E., 1; Hulin, 3 ; Lindgren, 18; Engineering and Mining Journal-Press.

1. Commercial control of the mineral resources of the world (abstract): Geol. Soc. America, Bull., vol. 30, pp. 108-109, March 31, 1919.

2. (Editor). Political and commercial geology and the world's mineral resources. 562 pp., 23 figs. New York, McGraw-Hill Book Company, 1920.

3. The copper ores of Lake Superior: Eng. and Min. Jour., vol. 110, no. 8, pp. 355-357, 1 fig., August 21, 1920.

4. Origin of desert ranges of Mexico: Pan-Am. Geologist, vol. 37, no. 1, p. 79, February, 1922.

5. The zonal theory of ore deposition : Eng. and Min. Jour.-Press, vol. 113, no. 12, p. 489, March 25, 1922.

6. The ore magmas; a series of essays on ore deposition. 2 vols., 915 pp., 175 figs., New York, McGraw-Hill Book Company, 1923.

7. The flling of fissure veins: Eng. and Min. Jour.-Press, vol. 116, no. 8, pp. 329-330, 2 figs., August 25, 1923.

8. The gold ores of Porcupine [Ontario] : Eng. and Min. Jour.-Press, vol. 116, no. 15, pp. 633-638, 6 figs., October 13, 1923.

9. The pre-Cambrian veins of Kirkland Lake, Ontario: Eng. and Min. Jour.Press, vol. 116, no. 16, pp. 671-672, 1 fig., October 20, 1923.

10. The origin of metallic concentrations by magmation: Econ. Geology, vol. 18, no. 7, pp. 617-638, October-November, 1923.

11. The content of metals in intrusive magmas: Econ. Geology, vol. 19, no. 1, pp. 89-92, January-February, 1924.

12. Upper Mississippi lead and zinc ores: Eng. and Min. Jour.-Press, vol. 117, nos. 6 and 7, pp. 246-250, 287-292, 16 figs., February 9 and 16, 1924.

13. Ore injection at Edwards, New York: Eng. and Min. Jour.-Press, vol. 117, no. 17, pp. 684-689, 7 figs., April 26, 1924.

14. Ore deposition at the Creighton nickel mine, Sudbury, Ontario: Econ. Geology, vol. 19, no. 3, pp. 275-280, 1 fig., April-May, 1924.

15. Ore magmas (abstract) : Canadian Min. Jour., vol. 45, no. 45, p. 1099, November 7, 1924.

16. Alfred Hulse Brooks: Eng. and Min. Jour.-Press, vol. 118, no. 22, p. 871, portr., November 29, 1924.

17. (and Lewis, J. Volney). Ore deposition at Franklin Furnace, New Jersey: Eng. and Min. Jour.-Press, vol. 119, no. 8, pp. 317-328, 21 figs., February 21, 1925.

18. The Camp Bird [Colorado] compound veindike: Econ. Geology, vol. 20, no. 2, pp. 115-152, 10 figs., March-April, 1925 ; Eng. and Min. Jour.Press, vol. 119, no. 13, pp. 517-529, 12 figs., March 28, 1925.

19. Ore magmas versus magmatic waters: Eng. and Min. Jour.-Press, vol. 119, no. 22, p. 890 , May $30,1925$.

20. Basic dike injections in magmatic vein sequences (with discussion by J. F. Kemp) : Geol. Soc. America, Bull., vol. 36, no. 3, pp. 545-582, 4 figs., September 30, 1925; abstract, no. 1, p. 167, March 30, 1925 ; Pan-Am. Geologist, vol. 43, no. 2, p. 145, March, 1927.

21. What is a magma?: Eng. and Min. Jour.-Press, vol. 120, no. 15, p. 562, October 10, 1925.

22. Angular inclusions in ore deposits (discussion): Econ: Geology, vol. 20, no. 8, pp. 766-767, December, 1925. 
Spurr, Josiah Edward-Continued.

23. Alkaline sulphides as collectors of metals : Eng. and Min. Jour.-Press, vol. 120, no. 25 , pp. $975-977$, December 19, 1925 ; Bol. minero, t. 21, no. 1, pp. 12-16, January, 1926.

24. Geology applied to mining; a first book of general geology and metallology. 361 pp., 124 figs., New York, McGraw-Hill Book Company, 1926.

25. Formation of Porcupine quartz veins (discussion) : Econ. Geology, vol. 21. no. 1, pp. 95-96, January-February, 1926.

26. Magmas, dikes, and veins: Eng. and Min. Jour., vol. 122, no. 4, pp. 134-140, July 24, 1926.

27. Lead-zinc chimneys in limestone: Eng. and Min. Jour., vol. 122, no. 8, pp. 296-298, August 21, 1926.

28. Successive banding around rock fragments in veins: Econ. Geology, vol. 21, no. 6, pp. 519-537, 16 figs., September, 1926; Eng. and Min. Jour., vol. 122, no. 13, pp. 491-498, 18 figs., September 25, 1926.

29. Crystallization temperature of veins near the surface (discussion): Econ. Geology, vol. 21, no. 6, pp. 619-621, September, 1926.

30. The Kentucky-Illinois ore magmatic district: Eng. and Min. Jour., vol. 122, no. 18 , pp. $695-699$, no. $19^{\circ}$, pp. $731-738,13$ figs., October 30 aud November 6, 1926.

31. The southeast Missouri ore magmatic district: Eng. and Min. Jour., vol. 122, no. 25, pp. 968-975, 8 figs., December 18, 1926.

32. Ores of the Joplin region (Picher district [Oklahoma]) : Eng. and Min. Jour., vol. 123, no. 5, pp. 199-209, 10 figs., January 29, 1927.

33. Iron ores of Iron Mountain and Pilot Knob: Eng. and Min. Jour., vol. 123, no. 9, pp. 363-366, 4 figs., February 26, 1927.

34. A feldspar-chalcopyrite rock-ore from Sonora: Eng. and Min. Jour., vol. 123, no. 15, pp. 604-605, April 9, 1927.

Stabler, Herman.

1. (and others). oWater power of the world; Part II of World atlas of: commercial geology: U. S. Geol. Survey, 39 pp., 10 pls. (maps), 1921.

Stadnichenko, Taisia. See also White, D., 11, 19.

1. (and White, David). Microthermal observations on some carbonaccous rocks: Oil and Gas Jour., vol. 24, no. 46, p. 120, April 8, 1926.

2. (and White, David). Microthermal observations of some oil shales and other carbonaceous rocks: Am. Assoc. Petroleum Geologists, Bull., vol. 10, no. 9, pp. 860-876, September, 1926.

Stadnichenko, Maria M.

1. The Foraminifera and Ostracoda of the marine Yegua of the type sections: Jour. Paleontology, vol. 1, no. 3, pp. 221-243, 2 pls., December, 1927.

Stainbrook, Merrill A. See also 'Thomas, A. O., 14.

1. Apparent fossil fruits from the Fort Union beds of North Dakota: Iowa Acad. Sci., Proc., vol. 30, pp. 455-458, 2 figs. [1924].

2. (and Ladd, H, S.). Fauna of State beds (abstract) : Pan-Am. Geologist, vol. 42 , no. 5, p. 382, December, 1924.

3. (and Ladd, H. S.). The fauna of the State Quarry beds: Iowa Acad. Sci., Proc., vol. 31, pp. 353-366, 1 pl. [1926?]. 
Stalder, Walter.

1. The Ciervo anticlinal-bow oil field of [Fresno County] California: Eng. and Min. Jour., vol. 113, no. 10, pp. 409-413, 6 figs, March 11, 1922.

2. A section of the Monterey (Salinas) shales in Pine Canyon, Monterey County, California: Am. Assoc. Petroleum Geologists, Bull., vol. 8, no. 1, pp. 55-60; 1 fig., January-February, 1924.

Staley, C. G. See Powell, 1.

Stansfield, Edgar.

1. (and others). Analyses of Alberta coal: Alberta, Sci. and Indus. Research Council, Rept. no. 14, 63 pp., 20 figs., 1925.

Stansfield, John.

1. Surface deposits of southeastern Saskatchewan: Canada, Geol. Survey, Summ. Rept., 1918, pt. C, pp. 42-48, 1919.

2. Hornblendite at Vavasour mine, Cantley, Quebec: Geol. Mag., vol. 57, p. 307, July, 1920.

3. Banded precipitates of vivianite in a Saskatchewan fire clay: Geol. Mag., vol. 59, no. 8, pp. 356-358, 1 pl., August, 1922.

4. Extensions of the Monteregian petrographical province to the west and northwest [Quebec]: Geol. Mag., vol. 60, no. 10, pp. 433-453, 2 figs., October, 1923.

5. Nomenclature and relations of the lamprophyres: Geol. Mag., vol. 60, no. 12, pp. 550-554, December, 1923.

6. Ohemical characters of okaite: Am. Jour. Sci., 5th ser., vol. 11, pp. 396398, May, 1926.

7. Assimilation and petrogenesis; separation of ores from magmas. $197 \mathrm{pp}$., 30 pls., Urbana, Ill., Valley Publishing Co., 1928.

Stanton, Timothy William. See also Cockerell, 1; Galloway, 4.

1. Mesozoic history of Mexico, Central America, and the West Indies: Geol. Soc. America, Bull., vol. 29, no. 4, pp. 601-606, December 30, 1918.

2. [Correlation of western Upper Cretaceous formations]: U. S. Geol. Survey, Prof. Paper 120, pp. 165-167, 1919.

3. The fauna of the Cannonball marine member of the Lance formation: U. S. Geol. Survey, Prof. Paper 128, pp. 1-60, 9 pls., 3 figs., August 11, 1920 ; abstract by R. W. Stone, Washington Acad. Sci., Jour., vol. 11, no. 6, p. 138, March 19, 1921.

4. A new Cretaceous rudistid from the San Felipe formation of Mexico: U. S. Nat. Mus., Proc., vol. 59, pp. 453-454, September 14, 1921.

5. Some problems connected with the Dakota sandstone: Geol. Soc. America, Bull., vol. 33, no. 1, pp. 255-272, 2 pls., March 31, 1922.

6. Affinities of the Cannonball fauna: Pan-Am. Geologist, vol. 37, no. 1, pp. 64-65, February, 1922.

7. Biotic taxonomy of.Comanche succession : Pan-Am. Geologist, vol. 38, no. 3, pp. 266-268, October, 1922.

8. [Review of] The geology and invertebrate paleontology of the Comanchean and "Dakota" formations of Kansas, by W. H. Twenhofel: Am. Jour. Sci., 5th ser., vol. 9, pp. 340-341, April, 1925.

9. Evidence of invertebrates on the question of climatic zones during Mesozoic time: Sci. Monthly, vol. 20, no. 5, pp. 459-463, May, 1925.

10. Climatic zones of Mesozoic times (abstract) : Pan-Am. Geologist, vol. 44, no. 1, pp. 70-71, August, 1925. 
Stanton, Timothy William-Continued.

11. Well $\log$ in northern Ziebach County; the fossil content: South Dakota Geol. and Nat. Hist. Survey, Circular 18, pp. 8-14, September, 1925.

12. Two new faunas in the marine upper Triassic of Nevada (abstract): Science, new ser., vol. 63, p. 485, May 7, 1926.

13. The Cretaceous of Texas: Am. Jour. Sci., 5th ser., vol. 13, pn. 517-522, June, 1927.

14. The Lower Cretaceous or Comanche series: Am. Jour. Sci., 5th Ser., vol. 16, pp. 399-409, 1 fig., November, 1928; (abstract), Geol. Soc. America, Bull., vol. 39, no. 1, p. 276, March 30, 1928; Pan-Am. Geologist, vol. 49, no. 3, p. 240, April, 1928.

Stark, J. T.

1. The primary structure of the Kekequabic granite [northeasteru Minnesota ] : Jour. Geology, vol. 35, no. S, pp. 723-733, 3 figs., NovemberDecember, 1927.

Staub, Walther.

1. (and Lagler, Carl). Ueber eine erluschene vulkanische Tätigkeit in der Golfregion des nordösțlichen Mexiko: Zeitschr. Vulkanologie, Bd. 6, H. 3, pp. 103-113, 3 pls., April, 1922 .

2. Beiträge zur Landeskunde des nordöstlichen Mexico: Gesell. Erdkunde Berlin, Zeitschr., 1923, no. 5-7, pp. 187-212, 3 figs., 1923.

3. Zur Kenntniss der Anordnung der Gebirgsketten in Ostmexiko: Geol. Rundschau, Bd. 16, H, 3, pp. 161-166, 1 fig., June 30, 1925.

4. Der Unterbau des Erdölgebietes von nordost Mexiko: Zeitschr. prakt. Geologie, Jg. 34, H. 8, pp. 120-125, August, 1926.

Stauffer, Clinton Raymond.

1. (and Schroyer, C. R.). The Dunkard series of Ohio: Ohio Geol. Survey, Fourth series, Bull. 22, 167 pp., 14 pls. (incl. map), 1920.

2. Devonian of Minnesota (abstract): Geol. Soc. America, Bull., vol. 32, no. 1, pp. 34-35, March 31, 1921.

3. The Minnesota Devonian and its relationship to the general Devonian problem of North America: Am. Jour. Sci., 5th ser., vol. 4, pp. 396-412, 1 fig., November, 1922.

4. The fossil elephants of Minnesota: Science, new ser., vol. 60 , pp. $40-41$, July 11, 1924.

5. The Jordan sandstone [Minnesota]: Jour. Geology, vol. 33, no. 7, pp. 699-713, 1 fig., October-November, 1925.

6. Mineralization of the Platteville-Decorah contact zone in the Twin City region: Geol. Soc. America, Bull., vol. 36, no. 4, pp. 615-622, December 30, 1925; abstract, no. 1, p. 169, March 30, 1925; Pan-Am. Geologist, vol. 43, no. 2, pp. 158-159, March, 1925.

7. Minnesota's oil and gas possibilities: Am. Assoc. Petroleum Geologists, Bull., vol. 10, no. 2, pp. 190-196, 1 fig. (map), February, 1926.

8. Devonian section in the Santa Rita Mountains of Arizona (abstract) : Geol. Soc. America, Bull., vol. 38, no. 1, p. 133, March 30, 1927; Pan-Am. Geologist, vol. 47, no. 1, p. 77, February, 1927.

9. Age of the Red Clastic series of Minnesota (with discussion by Alfred C. Lane) : Geol. Soc. America, Bull., vol. 38, no. 3, pp. 469-477, 1 fig., September, 1927 ; abstract, no. 1, p. 122, March 30, 1927 ; Pan-Am. Geologist, vol. 47, no. 2, p. 154, March, 1927.

10. New and little known fossils from Ordovicic of Minnesota (abstract): Pan-Am. Geologist, vol. 49, no. 3, p. 228, April, 1928. 
Stauffer, Clinton Raymond-Continued.

11. The Devonian section on Pinal Creek, Arizona: Ohio Jour. Sci., vol. 28, no. 3, p. 152, May (abstract), no. 5, pp. 253-260, September, 1928; abstract, Ohio Acad. Sci., Proc., vol. 8, pt. 4, p. 174, 1928.

12. Devonian of the Santa Rita mountains, Arizona: Geol. Soc. America, Bull., vol. 39, no. 2, pp. 439-433, June, 1928.

Staunton, W. F.

1. Ore possibilities at the Congress mine [Yavapai County, Arizona]: Eng. and Min. Jour., vol. 122, no. 20, pp. 769-771, 2 figs., November 13, 1926.

Stearn, Noel H.

1. A background for the application of geomagnetics to exploration: Am. Inst. Min. and Met. Eng., Tech. Pub. no. 150, 28 pp., October, 1928.

2. The dip needle as a geological instrument: Am. Inst. Min and Met. Eng., Tech. Pub. no. 151, 19 pp., 7 figs., October, 1928.

Stearns, Harold T.

1. Note on the first discovery of vanadinite in Idaho: Am. Mineralogist, vol. 8, no. 7, pp. 127-128, July, 1923.

2. The origin of a niter deposit near Dubois, Idaho: Am. Mineralogist, vol. 9, no. 6, pp. 135-137, June, 1924.

3. Craters of the Moon National Monument [Idaho]: Geog. Rev., vol. 14, no. 3, pp. 362-372, 9 figs., July, 1924.

4. Igneous geology of the Mud Lake Basin, Idaho (abstract) : Washington Acad. Sci., Jour., vol. 19, no. 15, pp. 380-381, September 19, 1924.

5. The 1924 eruption of the Hawaiian volcano: Sci. Am., vol. 132, pp. 242243, 6 figs., April, 1925.

6. (and Bryan, L. L.). Preliminary report on the geology and water resources of the Mud Lake Basin, Idaho: U. S. Geol. Survey, WaterSupply Paper 560, pp. 87-132, 2 figs., 2 pls. (maps), October 20, 1925.

7. The explosive phase of Kilauea Volcano, Hawaii, in 1924: Bull. volcanologique, $2^{\circ}$ ann., nos. 5-6, pp. 193-208, 13 pls., 1925; abstract, Zeitschr. Vulkanologie, Bd. 10, H. 1, pp. 46-47, September, 1926.

S. Origin of the volcanoes of Mauna Loa and Kilauea (abstract) : Geol. Soc. America, Bull., vol. 37, no. 1, pp. 150-151, March 30, 1926; Pan-Am. Geologist, vol. 45, no. 2, p. 158, March, 1926.

9. Volcanism in the Mud Lake area, Idaho: Am. Jour. Sci., 5th ser. vol. 11, pp. 353-363, 7 figs., April, 1926.

10. The Keaiwa or 1823 lava flow from Kilauea Volcano, Hawaii: Jour. Geology, vol. 34, no. 4, pp. 336-351, 7 figs., May-June, 1926.

11. The great explosions of Kilauea Volcano in 1924 (abstract) : Washington Acad. Sci., Jour., vol. 16, no. 18, pp. 502-503, November 3, 1926.

12. The "Craters of the Moon" in Idaho: Geog. Jour., vol. 71, no. 1, pp. 4349, 1 fig., 2 pls., January, 1928.

13. Record of earthquake made by automatic recorders on wells in California : Seismological Soc. America, Bull., vol. 18, no. 1, pp. 9-15, 3 figs., March, 1928.

14. Craters of the Moon National Monument, Idaho: Idaho Bur. Mines and Geology, Bull. no. 13, 57 pp., 21 pls., July, 1928.

15. Lava Beds National Monument, California : Geog. Soc. Philadelphia, Bull., vol. 26, no. 4, pp. 239-253, 12 figs., October, 1928.

Stearns, Norah Dowell. See also Meinzer, 9.

1. Laboratory tests of water-bearing materials (abstract): Pan-Am. Geologist, vol. 44, no. 1, pp. 77-78, August, 1925. 
Stearns, Norah Dowell--Continued.

2. Report on the geology and ground-water hydrology of the experimentul aren of the United States Public Health Service at Fort Caswell, North Carolina: U. S., Hygienic Laboratory, Bull. no. 147, pp. 137-168, 8 figs., 2 pls., 1927.

3. Exploring the Craters of the Moon, Idaho: Geog. Soc. Philadelphia, Bull., vol. 26, no. 4, pp. 279-290, 5 figs., October, 1928.

Steele, L. L.

1. Notes on two fossil coal resins: Am. Jour. Sci., 5th ser., vol. 7, pp. 389392, May, 1924.

Stefanini, Giuseppe.

1. Relations between American and European Tertiary echinoid faunas: Geol. Soc. America, Bull., vol. 35, no. 4, pp. 827-846, 4 figs., December $30,1924$.

Stefansson, Vilhjalmur.

1. Polar temperatures and coal measures: Nature, vol. 112, p. 162, August 4, 1923.

Steidtmann, Edward.

1. Feldspars as indicators of sedimentary or igneous origin of gneisses and schists: Geol. Soc. America, Bull., vol. 31, no. 1, pp. 141-144, March 31, 1920.

2. Summaries of pre-Cambrian literature of North America: Jour. Geology, vol. 28 , no. 6 , pp. 558-568, no. 7 , pp. 643-658, no. 8, pp. 743-751, 1920.

3. Summaries of pre-Cambrian literature of North America: Jour. Geology, vol. 29 , no. 1, pp. 81-86, January-February; no. 2, pp. 173-187, February-March, 1921.

4. (and Catheart, S. H.). Geology of the York tin deposits, Alaska: U. S. Geol. Survey, Bull. 733, 130 pp., 23 figs., 12 pls. (incl. maps), 1922.

5. Limestones and marls of Wisconsin: Wisconsin Geol. and Nat Hist. Survey, Bull. no. 66, 208 pp., 19 figs., 6 pls. (incl. map), 1924.

6. Faceted sandstone pebbles of the North River, Virginia: Jour. Geology, vol. 34, no. 8, pp. 836-839, 1 fig., November-December, 1926.

Steiger, George. See also DeGolyer, 9 ; Larsen, 20; Pardee, 5; Stone, 11 ; Twenhofel, 18, 22, 29.

1. [List of] chemical studies which bear on sedimentation: Nat. Research Council, Reprint and Circ. Ser., no. 85, pp. 20-23, 1928.

Steiner, George.

1. Torsion-balance principles as applied by the original Eötvös torsion balance: Am. Assoc. Petroleum Geologists, Bull., vol. 10, no. 12, pp. 1210-1226, 12 figs., December, 1926.

Steinmayer, R. A.

1. "Surface indicators of oil" in Louisiana: Louisiana Eng. Soc., Proc., vol. 10, no. 6, pp. 257-268, 2 figs., December, 1924.

2. A geological survey of the subaqueous strata of Lake Pontchartrain, New Orleans, Louisiana: Louisiana Eng. Soc., Proc., vol. 13, no. 2, pp. 68-87, 1 fig., 4 pls. (incl. maps), April, 1927.

Stensiö, Erik Andersson.

1. On the head of the macropetalichthyids, with certain remarks on the head of the other arthrodires: Field Mus. Nat. Hist., Geol. Ser., vol. 4, no. 4, pp. 87-1.97, 26 figs., 13 pls., October, 1925. 
Stephenson, C. D.

1. Observations on the Verdeu sundstone of southwestern Oklahoma: $\Delta \mathbf{m}$. Assoc. Petroleum Geologists, Bull., vol. 9, no. 3, pp. 626-631, 1 fig., May-June, 1925.

Stephenson, E. A. See Johannsen, 1.

Stephenson, Lloyd William. See also Cooke, C. W., 17, 20; Dane, 1.

1. Some Upper Cretaceous shells of the rudistid group from Tamaulipas, Mexico: U. S. Nat. Mus., Proc., vol. 61, art. 1, 28 pp., 15 pls., 1922.

2. Age of the producing sand, Eldorado field, Arkansas: Am. Assoc. Petroleum Geologists, Bull., vol. 6, no. 1, p. 54, January-February, 1922.

3. A chance of more oil in southwestern Texas: Am. Assoc. Petroleum Geologists, Bull., vol. 6, no. 5, pp. 475-476, September-October, 1922.

4. The Cretaceous formations of North Carolina ; Part I, Invertebrate fossils of the Upper Cretaceous formations: North Carolina Geol.. Survey, vol. 5, pt. 1, 604 pp., 102 pls. (incl. map), 1923.

5. Geology of Alabama; The Mesozoic rocks: Alabama, Geol. Survey, Spec. Rept. no. 14, pp. 231-250, 15 pls., 1926.

6. Major features in the geology of the Atlantic and Gulf Coastal Plain: Washington Acad. Sci., Jour., vol. 16, no. 17, pp. 460-480, 1 pl. (map), October 18, 1926.

7. On the origin of the "rock wall" at Rockwall, Texas: Washington Acad. Sci., Jour., vol. 17, no. 1, pp. 1-5, 2 figs., January 3, 1927.

8. Notes on the stratigraphy of the Upper Cretaceous formations of Texas and Arkansas: Am. Assoc. Petroleum Geologists, Bull., vol. 11, no. 1, pp. 1-17, 1 pl., January, 1927 ; and [note of correction] no. 3, pp. 308-309, March, 1927.

9. Additions to the Upper Cretaceous invertebrate faunas of the Carolinas: U. S. Nat. Mus., Proc., vol. 72, art. 10, 25 pp., 9 pls., 1927.

10. The ground-water resources of Mississippi: U. S. Geol. Survey, WaterSupply Paper 576, 515 pp., 3 figs., 12 pls. (incl. map), 1928.

11. Structural features of the Atlantic and Gulf Coastal Plain (abstract) : Geol. Soc. America, Bull., vol. 39, no. 1, p. 179, March 30, 1928; Pan-Am. Geologist, vol. 49, no. 2, pp. 140-141, March, 1928.

12. Major marine transgressions and regressions, and structural features of Gulf Coastal Plain (abstract) : Pan-Am. Geologist, vol. 49, no. 4, pp. 301-302, May, 1928; Geol. Soc. America, Bull., vol. 39, no. 1, pp. 275-276, March 30, 1.928.

13. Upper Cretaceous or Gulf series (abstract) : Geol. Soc. America, Bull., vol. 39, no. 1, p. 276, March 30, 1928; Pan-Am. Geologist, vol. 49, no. 4, p. 295, May, 1928.

14. Major marine transgressions and regressions and structural features of the Gulf Coastal Plain: Am. Jour. Sci., 5th ser., vol. 16, pp. 281298, 12 figs. (maps), October, 1928.

15. Correlation of the Upper Cretaceous or Gulf series of the Gulf Coastal Plain: Am. Jour. Sci., 5th ser., vol. 16, pp. 485-496, 1. pl. (chart), December, 1928.

16. Structural features of the Atlantic and Gulf Coastal Plain: Geol. Soc. America, Bull., vol. 39, no. 4, pp. 887-899, 1 fig., December 30, 1928.

Sterki, v.

1. Marl deposits in Ohio and their fossil Mollusca: Ohio Jour. Sci., vol. 20, no. 6, pp. 173-184, April, 1920. 
Steruberg, Charles Hazelius.

1. Hunting dinosaurs in the badlands of the Red Deer River, Alberta, Canada; a sequel to the life of a fossil hunter. $232 \mathrm{pp}$., $52 \mathrm{pls}$, Lawrence, Kansas, 1917.

2. Sternberg's expedition to the Red Deer River, Alberta, 1917: Kansas Acad. Sci., 'Trans., vol. 29, pp. 88-91, 1920.

3. Explorations of the Permian of Texas and the chalk of Kansas, 1918: Kansas Acad. Sci., Trans., vol. 30, pp. 119-120, 1922.

4. Field work in Kansas and Texas: Kansas Acad. Sci., Trans., vol. 30, pp. 339-341, 1922.

Sternberg, Charles M.

1. A supplementary study of Panoptosuurus mirus [Belly River beds, Alberta]: Roy. Soc. Canada, Proc. and Trans., $3 d$ ser., vol. 15, sec. 4, pp. 93-104, 2 pls., 1921.

2. A popular description of dinosaurs: Camadian Field Naturalist, vol. 35, no. 4, pp. 61-66, April, 1921.

3. Notes on the Lance formation of southern Saskatchewan: Canadian Field-Naturalist, vol. 38, no. 4 pp. 66-70, April, 1924.

4. Integument of Chasmosaurus belli: Canadian Field-Naturalist, vol. 39, no. 5, pp. 108-110, 1 pl., May, 1925.

5. A new species of Thespesius from the Lance formation of Saskatchewan: Canada, Geol. Survey, Bull. no. 44, pp. 73-84, 1 fig., 3 pls., 1926.

6. Dinosaur tracks from the Edmonton formation of Alberta: Canada, Geol. Survey, Bull. no. 44, pp. 85-87, 1 fig., 1 pl., 1926.

7. Notes on the Edmonton formation of Alberta: Canadian Field-Naturalist, vol. 40, no. 5, pp. 102-104, May, 1926.

8. Horned-dinosaur group in the National Museum of Canada: Canadian Field-Naturalist, vol. 41, no. 4, pp. 67-73, 2 figs., April, 1927.

9. Homologies of certain bones of the ceratopsian skull: Roy. Soc. Canada, Trans., 3d ser., vol. 21, sec. 4, pp. 135-143, 3 pls., May, 1927.

10. A new armored dinosaur [Edmontonia longiceps] from the Edmonton formation of Alberta: Roy. Soc. Canada, Proc. and Trans., 3d ser., vol. 22, sec. 4, pp. 93-107, 3 pls., March, 1928.

Sterns, F. H.

1. The Pleistocene man of Vero, Florida: Sci. Am. Suppl., vol. 87, pp. 118-119, February 22, 1919.

Sterrett, Douglas Bovard.

1. Mica deposits of the United States: U. S. Geol. Survey, Bull. 740,342 pp., 96 figs., 29 pls. (incl. maps), 1923.

Stetson, Henry C.

1. Lasanius and the problem of vertebrate origin: Jour. Geology, vol. 35, no. 3, pp. 247-263, April-May, 1927.

2. The distribution and relationships of the Trinucleidae: Harvard College, Mus. Comp. Zoology, Bull., vol. 68, no. 2, pp. 87-104, 1 pl., July, 1927.

3. Report on vertebrate paleontology: Harvard Coll., Mus. Comp. Zoology, Ann. Rept. Director, 1927-28, p. 15, 1928.

4. A new American Thelodus: Am. Jour. Sci., 5th ser., vol. 16, pp. 221-231. 6 figs., September, 1928. 
Stevens, John B:

1. A comparative study of the San Joaquin Valley oil fields: Am. Assoc. Petroleum Geologists, Bull., vol. 8, no. 1, pp. 29-40, 3 figs., JanuaryFebruary, 1924.

Stevens, Neil E.

1. Two petrified palms from interior North America [Palmoxylon from South Dakota and from Colorado]: Am. Jour. Sci., 5th ser., vol. 1, pp. 431-443, 16 figs., May, 1921.

Stevenson, John James, 1841-1924.

1. Interrelation of the fossil fuels, IV : Am. Philos. Soc., Proc., vol. 59, no. 6, pp. 405-511, 1920.

2. Interrelations of the fossil fuels. [Combined from papers appearing in] Proceedings of the American Philosophical Society, vol. 55, 1916; vol. 56, 1917; vol. 57, 1918; vol. 59, 1920. Press of the New Era Printing Company, Lancaster, Pa., 1916-1921.

3. Geologic age characteristics of the coals: Pan-Am. Geologist, vol. 37, no. 2, pp. 139-150, March, 1922.

Stewart, Beatrice Helen.

1. The stratigraphy and paleontology of 'Toronto and vicinity; Part I, The Pelecypoda: Ontario Dept. Mines, 29th Ann. Rept., vol, 29, pt. 6, 58 pp., 5 pls., 1920.

Stewart, Grace Anne.

1. The fauna of the Little Saline limestone in Ste. Genevieve County: Missouri Bur. Geology and Mines, 2d ser., vol. 17, pp. 213-269, 15 pls. [1924].

2. Fauna of the Silica shale of Lucas County: Ohio, Geol. Survey, 4th ser., Bull. 32,76 pp., 1 fig., 5 pls., 1927.

3. Fauna of the Silica shale of Lucas County, Ohio (abstract) : Geol. Soc. America, Bull., vol. 39, no. 1, p. 297, March 30, 1928.

Stewart, James Smith.

1. Geology of the disturbed belt of southwestern Alberta: Canada, Geol. Survey, Mem. 112, 71 pp., 5 pls., map, 1919.

2. Oil and gas possibilities in northeastern British Columbia: Canada, Geol. Survey, Summ. Rept., 1919, pt. C, pp. 3-7, 1 fig., 1920.

Stewart, Ralph B. See also Clark, B. L., 14.

1. Gabb's California fossil type gastropods: Acad. Nat. Sci. Philadelphia, Proc., vol. 78, 1926, pp. 287-447, 13 pls., 1927.

Stiles, E. See Hager, D. S., 2.

Stille, Hans.

1. The shrinkage of the earth (abstract by Chester R. Longwell of an address entitled "Die Schrumpfung der Erde . . ."): Am. Jour. Sci., 5th ser., vol. 6, pp. 168-172, August, 1923.

Stillman, F. B.

1. $\Lambda$ reconnaissance of the Wasatch front between Alpine and American Fork canyons, Utah: Jour. Geology, vol. 36, no. 1, pp. 44-55, 5 figs., January-February, 1928. 
Stillwell, Frank Leslie:

1. A Bendigo problem and its bearing on force of crystallization: Econ. Geology, vol. 18, no. 5, pp. 506-510, 2 figs., August, 1923.

2. Origin of asbestos veins: Econ. Geology, vol. 20, no. 1, pp. 104-105, January-February, 1925.

Stipp, Thomas F.

1. The relation of Foraminifera to the origin of California petroleum: California Acad. Sci., Proc., 4th ser., vol. 15, no. 9, pp. 263-268, April 26, 1926 ; Am. Assoc. Petroleum Geologists, Bull., vol. 10, no. 7, pp. 697-702, July, 1926.

Stock, Chester. See also Merriam, 8, 9, 17, 22, 24, 25, 28.

1. Cenozoic history of the ground sloth group (abstract) : Geol. Soc. America, Bull., vol. 31, no. 1, pp. 194, 322, March 31, 1920.

2. Minutes of the ninth annual meeting of the Pacific coast section of the Paleontological Society: Geol. Soc. America, Bull., vol. 31, no. 1, pp. 231-232, March 31, 1920.

3. An early Tertiary vertebrate fauna from the southern coast ranges of California : California, Univ., Dept. Geology, Bull., vol. 12, no. 4, pp. 267-276, 6 figs., April 8, 1920.

4. Origin of the supposed human footprints of Carson City, Nevada: Science, new ser., vol. 51, p. 514, May 21, 1920.

5. A mounted skeleton of Mylodon harlani: California, Univ., Pub., Dept. Geology, Bull., vol. 12, no. 6, pp. 425-430, 1 pl. November 22, 1920.

6. Minutes of the tenth annual meeting of the Pacific coast section of the Paleontological Society: Geol. Soc. America, Bull.; vol. 32, no. 1, pp. 145-149, March 31, 1921.

7. Later Cenozoic mammalian remains from the Meadow Valley region, southeastern Nevada: Am. Jour. Sci., 5th ser., vol. 2, pp. 250-264, 12 figs., November, 1921; Abstract, Geol. Soc. America, Bull., .vol. 32, no. 1, pp. 146-147, March 31, 1921.

8. Note on an Hipparion tooth from the Siestan deposits of the Berkeley Hills, California : California, Univ., Dept. Geol. Sci., Bull., vol. 13, no. 3, pp. 19-21, 1 fig., December 22, 1921.

9. (and Furlong, E. L.). A marsupial from the John Day Oligocene of Logan Butte, eastern Oregon: California, Univ., Dept. Geol. Sci., Bull., vol. 13, no. 8, pp. 311-317, 5 figs., May 11, 1922.

10. Mammalian forms occurring in association with marine invertebrates in western North America : Pan-Pacific Sci. Cong., Australia, 1923, Proc., vol. 1, pp. 880-881 [1924].

11. Some mammalian forms common to the Pliocene of America and Asia: Pan-Pacific Sci. Cong., Australia, 1923, Proc., vol. 1, p. 881 [1924].

12. A recent discovery of human remains in Los Angeles, California: Science. new ser., vol. 60, pp. 2-5, July 4, 1924.

13. Cenozoic gravigrade edentates of western North America, with special reference to the Pleistocene Megalonychinae and Mylodontidae of Rancho La Brea [California]. 206 pp., 120 figs., 47 pls., published by the Carnegie Institution of Washington [Pub. no. 331], Washington, January, 1925.

14. Discovery of mammalian remains in Sespe beds near Santa Paula, California (abstract) : Geol. Soc. America, Bull., vol. 36, no. 1, p. 201, March 30, 1925. 
Sitock, Chester-Contimued.

15. Recent discovery of human remains in Los Angeles, California (abstract) : Geol. Soc. America, Bull., vol. 36, no. 1, p. 201, March $30,1925$.

16. (and Furlong, E. L.). New canid and rhinocerotid remains from the Ricardo Pliocene of the Mohave Desert, California: California, Univ., Dept. Geol. Sci., Bull., vol. 16, no. 2, pp. 43-60, 4 pls., March 16, 1926.

17. Anchitheriine horses from Fish Lake valley region, Nevada: California, Univ., Dept. Geol. Sci., Bull., vol. 16, no. 3, pp. 61-68, 1 fig., 1 pl., April 10, 1926.

18. [Report on paleontological research] : Carnegie Inst. Washington, Year Book no. 25, 1925-6, pp. 404-405, December, 1926.

1.9. (and Furlong, E. L.). Skull and skeletal remains of a ruminant of the Preptoceras-Euceratherium group from the McKittrick Pleistocene, California : California, Univ., Dept. Geol. Sci., Bull., vol. 16, no. 10, pp. 409-434, 5 figs., 4 pls., January 25, 1927.

20. Pleistocene fauna and flora [from asphalt deposits in Carpinteria, Santa Barbara County, California]: Science, new ser., vol. 66, pp. 155156, August 12, 1927.

21. (and Furlong, E. L.). Occurrence of Pleistocene elephant on Santa Rosa Island, California (abstract) : Pan-Am. Geologist, vol. 49, no. 4, p. 315, May, 1928.

22. (and Patterson, J. W., and Furlong, E. L.). Tertic mammalian fauna from Kern River bed, California (abstract) : Pan-Am. Geologist, vol. 49, no. 4, p. 318, May, 1928.

23. A peccary from the McKittrick Pleistocene, California: Carnegie Inst. Washington, Contributions to Paleontology, Pub. no. 393, pp. 23-27, 7 figs., September, 1928.

24. Tanupolama, a new genus of llama from the Pleistocene of California: Carnegie Inst. Washington, Contributions to Paleontology, Pub. no. 393, pp. 29-37, 6 pls., September, 1928.

25. Canid and proboscidean remains from the Ricardo deposits, Mohave Desert, California : Carnegie Inst. Washington, Contributions to Paleontology, Pub. no. 393, 39-47, 1 fig., 4 pls., September, 1928.

26. A tooth of Hipparion mohavense from the Puente formation, California : Carnegie Inst. Washington, Contributions to Paleontology, Pub. no. 393, pp. 49-53, 1 fig., September, 1928.

Stockdale, Paris Buell.

1. Stylolites; their nature and origin: Indiana Univ. Studies, vol. 9, Study no. 55, 97 pp., 36 figs., December, 1922.

2. Solutive genesis of stylolitic structures: Pan-Am. Geologist, vol. 39, no. 5, pp. 353-364, 3 figs., 3 pls., June, 1923.

3. The stratigraphic significance of solution in rocks: Jour. Geology, vol. 34, no. 5, pp. 399-414, 7 figs., July-August, 1926.

4. Some features of the Borden (Knobstone) rocks of southern Indiana (abstract) : Ohio Acad. Sci., Proc., vol. 8, pt. 4, pp. 176-177, 1928; Ohio Jour. Sci., vol. 28, no. 3, pp. 154-155, May, 1928.

Stockley, G. M.

1. Final report of the government geological department [of Jamaica]: Supplement to the Jamaica Gazette, vol. 48, no. 5, pp. 23-35, March 27, 1925. 
Stockwell, C. H. See also Emmons; R. C., 2.

1. Galena Hill, Mayo district, Yukon: Canada, Geol. Survey, Summ. Rent., 1925, pt. A, pp. 1-14, map, 1926.

2. An X-ray study of the garnet group: Am. Mineralogist, vol. 12, no. 9, pp. 327-344, September, 1927.

Stoess, P. C.

1. Arsenic deposits near Seattle, Washington: Eng. and Min. Jour.-Press, vol. 118, no. 21, pp. 821-822, November 22, 1924.

Stolfus, M. A. See Johnson, D. W., 6.

Stoller, James Hough.

1. Topographic features of the Hudson valley and the question of postglacial marine waters in the Hudson-Champlain valley: Geol. Soc. America, Bull., vol. 30, pp. 415-422, 2 figs., September 30, 1919; abstract, with discussion by H. L. Fairchild, pp. 90-91, March 31, 1919.

2. Glacial geology of the Cohoes quadrangle: New York State Mus. Bull. nos. 215, 216, 49 pp., 11 figs., 2 pls., map, 1920.

3. Late Pleistocene history of the lower Mohawk and middle Hudson region: Geol. Soc. America, Bull., vol. 33, no. 3, pp. 515-526, 1 fig., September 1, 1922; abstract, vol. 33, no. 1, p. 117, March 31, 1922.

Stone, John B.

1. The products and structure of Kilauea: Bernice P. Bishop Mus., Bull. 33, 59 pp., 7 figs., 2 pls., 1926.

2. The Keaiwa flow of 1923, Hawaii: Am. Jour. Sci., 5th ser., vol. 11, pp. 434-440, 3 figs., May, 1926.

Stone, Ralph Walter. See also Atwood, W. W., 2; Bastin, 1; Berry, 4, 11; Bowen, C. F., 1; Capps, 1; Cathcart, 3 ; Chapin, 1, 2, 10 ; Clapp, C. H., 1; Clark, F. R., 1, 2; Cockerell, 1; Collier, 1, 2, 3; Condit, 1, 2 ; Cushman, 1, 8; Dall, 2; Eakin, 1; Ferguson, H. G., 3 ; Gilmore, 4 ; Grout, 1; Hancock, 1; Harrington, 1, 6; Hess, 11; Hicks, 3; Howe, J. L., 1; Jones, E. L. 1, 4; Kew, 1; Knopf, E. B., 2 ; Lewis, J. V., 6 ; Loughlin, 1 ; Maddren, 1, 2 ; Martin, G. C., 1; Overbeck, 1, 2 ; Pardee, 2 ; Pennsylvania, 1; Phalen, 1; Reeves, F., 1; Shaw, E. W., 1.

1. Phosphate rock an economic army (abstract): Geol. Soc. America, Bull., vol. 30, p. 104, March 31, 1919.

2. Magnesite industry (abstract) : Geol. Soc. America, Bull., vol. 30, p. 115, March 31, 1919.

3. Sand and gravel in 1917: U. S. Geol. Survey, Mineral Resources, 1917, pt. 2, pp. 381-396, February 21, 1919.

4. Magnesium in 1918: U. S. Geol. Survey, Mineral Resources, 1918, pt. 1, pp. 13-21, July 28, 1919.

5. Salt, bromine, and calcium chloride in 1918: U. S. Geol. Survey, Mineral Resources, 1918, pt. 2, pp. 117-134, August 16, 1919.

6. Phosphate rock in 1918: U. S. Geol. Survey, Mineral Resources, 1918, pt. 2, pp. 199-222, October 4, 1919.

7. Sand and gravel in 1918: U. S. Geol. Survey, Mineral Resources, 1918, pt. 2, pp. 299-315, October 31, 1919.

8. Gypsum in 1918: U. S. Geol. Survey, Mineral Resources, 1918, pt. 2, pp. 282-298, November 6, 1919.

9. Magnesium in 1919: U. S. Geol. Survey, Mineral Resources, 1919, pt. 1, pp. 29-32, August 11, 1920. 
Stone, Ralph Walter-Continued.

10. Gypsum in 1919: U. S. Geol. Survey, Mineral Resources, 1919, pt. 2, pp. 99-113, December 28, 1920.

11. (and others). Gypsum deposits of the United States: U. S. Geol. Survey, Bull. 697,326 pp., 37 pls., 57 figs., 1920 . Includes contributions by George Steiger, E. F. Burchard, H. D. Miser, F. L. Hess, R. D. George, G. F. Kay, Erasmus Haworth, R. A. Smith, J. C. Jones, N. H. Darton, D. H. Newland and Henry Leighton, J. A. Bownocker, L. C. Snider, J. G. Hutton, W. E. Wrather, C. L. Baker, B. F. Hill, C. T. Lupton, and G. W. Stose.

12. Sand and gravel in 1919: U. S. Geol. Survey, Mineral Resources, 1919, pt. 2, pp. 151-164, January 5, 1921.

13. Phosphate rock in 1919: U. S. Geol. Survey, Mineral Resources, 1919, pt. 2, pp. 211-225, February 25, 1921.

14. Salt, bromine, and calcium chloride in 1920 : U. S. Geol. Survey, Mineral Resources, 1920, pt. 2, pp. 17-25, August 5, 1921; revised ed., February 21, 1922.

15. Phosphate rock in 1920: U. S. Geol. Survey, Mineral Resources, 1920, pt. 2, pp. 27-35, 1 fig., August 11, 1921.

16. Meteorites found in Pennsylvania (abstract) : Geol. Soc. America, Bull., vol. 35, no. 1, p. 107, March 30, 1924; Pan-Am. Geologist, vol. 41, no. 2, pp. 152-153, March, 1924.

17. Black granite of northern Bucks County, Pennsylvania (abstract) : Pennsylvania Acad. Sci., Proc., vol. 1, p. 63, 1926.

18. Fossil ivory (abstract) : Pennsylvania Acad. Sci., Proc., vol. 1, p. 81. 1926.

19. Pennsylvania building stone (abstract) : Pennsylvania Acad. Sci., Proc., vol. 1, p. 100, 1926.

20. Molding sands of Pennsylvania: Pennsylvania Geol. Survey, 4th ser., Bull. M 11, 94 pp., 10 figs., 21 pls., 1928.

Stopes, Marie Carmichael.

1. The constitution of coal: Canadian Min. Jour., vol. 43, no. 31, pp. 505506, August 4, 1922.

Storm, Willis. See also Tomlinson, 1.

1. The "2-4" shallow oil and gas field, Stephens County, Oklahoma: Am. Assoc. Petroleum Geologists, Bull., vol. 5, no. 5, pp. 626-627, September-October, 1921.

2. The Velma oil and gas field, Stephens County, Oklahoma: Am. Assoc. Petroleum Geologists, Bull., vol. 5, no. 5, pp. 627-629, SeptemberOctober, 1921.

3. The Fox oil and gas field, Carter County, Oklahoma: Am. Assoc. Petroleum Geologists, Bull., vol. 6, no. 4, pp. 367-369, July-August, 1922.

4. The carbon ratio: Am. Assoc. Petroleum Geologists, Bull., vol. 7, no. 3, p. 291, May-June, 1923.

5. Carbon ratios of Cretaceous coals in New Mexico in their possible relation to oil: Am. Assoc. Petroleum Geologists, Bull., vol. 8, no. 4, pp. 519-524, 1 fig., July-August, 1924.

Stose, George Willis. See also Eby, J. B., 1; Jonas, 5 ; Mansfield, G. R., 4; Stone, 11 ; Willis, B., 1.

1. (and others). Manganese deposits of the west foot of the Blue Ridge, Virginia : Virginia Geol. Survey, Bull. no. 17, $166 \mathrm{pp}$., 22 pls. (incl. maps), 16 figs., 1919. 
Stose, George Willis-Continued.

2. Glauberite crystal cavities in the Triassic rocks in the vicinity of Gettysburg, Pa.: Am. Mineralogist, vol. 4, no. 1, pp. 1-4, 1 fig., 1 pl., January, 1919.

3. Travertine from Rock Creek Park, District of Columbia (abstract, with discussion by R. S. Bassler) : Washington Acad. Sci., Jour., vol. 9, no. 10, p. 292, May 19, 1919.

4. Manganese deposits of the Appalachian Valley of Virginia and Tennessee (abstract): Washington Acad. Sci., Jour., vol. 9, no. 13, pp. 382-384, July 19, 1.919.

5. Strontium in 1918: U. S. Geol. Survey, Mineral Resources, 1918, pt. 2, pp. 541-544, March 30, 1920.

6. Barytes and barium products in 1918: U. S. Geol. Survey, Mineral Resources, 1918, pt. 2, pp. 951-967, June 28, 1920.

7. Manganese ores of the Southern States: Eng. and Min. Jour., vol. 110, no. 6, pp. 256-262, 7 figs., August 7, 1920.

8. Strontium in 1919: U. S. Geol. Survey, Mineral Resources, 1919, pt. 2, pp. 95-98, December 9, 1920.

9. Barytes and barium products in 1919: U. S. Geol. Survey, Mineral Resources, 1919, pt. 2, pp. 335-347, July 28, 1921.

10. Strontium in 1920: U. S. Geol. Survey, Mineral Resources, 1920, pt. 2, pp. 93-95, September 17, 1921.

11. Barytes and barium products in 1920: U. S. Geol. Survey, Mineral Resources, 1920, pt. 2, pp. 189-199, December 6, 1921.

12. Structure of the pre-Pennsylvanian rocks of the Big Stone Gap area, Wise County, Virginia (abstract) : Geol. Soc. America, Bull., vol. 33, no. 1, pp. 98-99, March 31, 1922.

13. Strontium in 1921: U. S. Geol. Survey, Mineral Resources, 1921, pt. 2, pp. 31-32, July 5, 1922.

14. Barytes and barium products in 1921: U. S. Geol. Survey, Mineral Resources, 1921, pt. 2, pp. 125-134, September 11, 1922.

15. (and Jonas, A. I.). The lower Paleozoic section of southeastern Pennsylvania: Washington Acad. Sci., Jour., vol. 12, no. 15, pp. 358-366, September 19, 1922.

16. (and Miser, H. D.). Manganese deposits of western Virginia: Virginia Geol. Survey, Bull. no. 23, 206 pp., 39 figs., 31 pls. (incl. maps), 1922.

17. (and Schrader, F. C.). Manganese deposits of east Tennessee: U. S. Geol. Survey, Bull. 737, 154 pp., 45 figs., 34 pls. (incl. maps), 1923.

18. (and Jonas, Anna I.). Ordovician overlap in the Piedmont province of Pennsylvania and Maryland: Geol. Soc. America, Bull., vol. 34, no. 3,.pp. 507-524, 17 figs. (incl. maps), September 30, 1923.

19. Strontium in 1922: U. S. Geol. Survey, Mineral Resources, 1922, pt. 2, pp. 59-61, September 12, 1923.

20. Barytes and barium products in 1922: U. S. Gecl. survey, Mineral Resources, 1922, pt. 2, pp., 141-152, November 3, 1923.

21. New type of structure in the Appalachians: Geol. Soc. America, Bull., vol. 35, no. 3, pp. 465-480, 8 figs., September 30, 1924; abstract (with discussion by W. H. Hobbs, E. T. Wherry, A. C. Lawson, A. I. Jonas, and A. C. Spencer), no. 1, pp. 63-64, March 30, 1924; abstract, Pan-Am. Geologist, vol. 41, no. 2, pp. 135-136, March, 1924.

22. The black shale of southwestern Virginia: Jour. Geology, vol. 32, no. 4, pp. 311-315, 1 fig., May-June, 1924. 
Stose, George Willis-Continued.

23. Strontium in 1923: U. S. Geol. Survey, Mineral Resources, 1923, pt. 2, pp. 23-26, July $19 ; 1924$.

24. Notes on the origin of Clinton hematite ores: Econ. Geology, vol. 19, no. 5, pp. 405-411, 2 figs., August, 1924.

25. Mineral resources of Adams County, Pennsylvania: Pennsylvania Geol. Survey, 4th ser., Bull. C. 1, pt. 2, 64 pp., 1 fig., 11 pls. (incl. map), 1925.

26. (.nd Jonas, Anna I.). Triassic sedimentary rocks and basaltic flow northwest of Lebanon, Pennsylvania (abstract) : Geol. Soc. America, Bull., vol. 36, no. 1, pp. 160-161, March 30, 1925; Pan-Am. Geologist, vol. 43, no. 2, p. 154, March 30, 1925.

27. (and Jonas, Anna I.). Triassic rocks northwest of Lebanon, Pennsylvania (abstract) : Pan-Am. Geologist, vol. 43, no. 5, pp. 368-369, June, 1925.

28. (and Jonas, Anna I.). Ordovician shale and associated lava in south eastern Pennsylvania (abstract): Washington Acad. Sci., Jour., vol. 17 , no. 9 , p. 240 , May $4,1927$.

29. (and Jonas, Anna I.). Ordovician shale and associated lava in southeastern Pennsylvania: Geol. Soc. America, Bull., vol. 38, no. 3, pp. 505-536, 10 figs., September, 1927; abstract, no. 1, pp. 138-139, March 30, 1927 ; Pan-Am. Geologist, vol. 47, no. 1, p. 79, February, 1927.

30. Progress on a tectonic map of Pennsylvania (abstract) : Geol. Soc. America, Bull., vol. 38, no. 1, p. 216, March 30, 1927; Pan-Am. Geologist, vol. 47, no. 4, pp. 319-320, May, 1927.

31. Possible post-Cretaceous faulting in the Appalachians : Geol. Soc. America, Bull., vol. 38, no. 3, pp. 493-503, 7 figs., table, September, 1927 ; abstract, no. 1, pp. 216-217, March 30, 1927 ; Pan-Am. Geologist, vol. 47, no. 4, p. 320, May, 1927.

32. Possible post-Cretaceous faulting in the Appalachians (abstract) : Washington Acad. Sci., Jour., vol. 17, no. 9, p. 235, May 4, 1927.

33. High gravels of Susquehanna River above Columbia, Pennsylvania: Geol. Soc. America, Bull., vol. 39, no. 4, pp. 1073-1086, 7 figs., 1 pl., December 30, 1928; abstract, no. 1, p. 224, March 30, 1928.

Stout, Wilber. See also Bownocker, 9 ; Ries, 5.

1. Geology of Muskingum County: Ohio, Geol. Survey, Fourth series, Bull. 21, 351 pp., 13 pls. (incl. maps), 1 fig., Columbus, 1918.

2. Coals of Ohio and their limitations for by-product coke: Coal Age, vol. 16, pp. 674-677, 707-711, 1 fig., October 23 and 30, 1919.

3. (and others). Coal-formation clays of Ohio: Ohio Geol. Survey, 4th ser., Bull. 26, 588 pp., 5 figs., 15 pls., map, 1923.

4. Origin of coal-formation clays: Ohio Geol. Survey, 4th ser., Bull. 26, pp. 532-568, 1923.

5. (and Lamborn, R. E.). Geology of Columbiana County: Ohio Geol. Survey, 4th ser., Bull. 28, 408 pp., 3 figs., 6 pls. (incl. maps) 1924.

6. Geology of Vinton County : Ohio, Geol. Survey, 4th ser., Bull. 31, 402 pp., 1 fig., 2 pls., 5 maps, 1927.

7. Some features of the Monongahela series (abstract): Ohio Acad. Sci., Proc., vol. 8, pt. 4, p. 175, 1928; Ohio Jour. Sci., vol. 28. no. 3, p. 158, May, 1928. 
Stow, Marcellus $\mathrm{H}$.

1. An occurrence of Oriskany sandstone with celestite cement: Am. Jour. Sci., 5th ser., vol. 16, pp. 446-450, November, 1928.

Stoyanow, A. A.

1. Notes on recent stratigraphic work in Arizona: Am. Jour. Sci., 5th ser., vol. 12, pp. 311-324, 1 fig., October, 1926.

Strachan, Robert.

1. The Crowsnest Pass coal field [British Columbia]: Canadian Inst. Min. and Met., Monthly Bull., no. 102, pp. 776-778, October, 1920; Canadian Min. Inst., Trans., vol. 23, pp. 276-290 [1921.].

Strahorn, A. T.

1. Geology at site of proposed diversion works [at Headgate Rock, near Parker, Arizona]. In Report by C. A. Engle, Proposed irrigation project, Colorado River Indian Reservation, pp. 15-17, Hearings before Conmittee on Irrigation of Arid Lands, House of Representatives, 67th Cong., $2 d$ sess., on H. R. 11449 . . . , 1922.

Straub, Charles E.

1. Effect of gravitational compaction on the structure of sedimentary rocks: Am. Assoc. Petroleum Geologists, Bull., vol. 11., no. 8, pp. 889 891, August, 1927.

Strauss, H. A.

1. To help lay the ghost of the "molten magma": Eng. and Min. Jour.-Press, vol. 118, no. 11, p. 422, September 13, 1924.

Stromborg, Oscar.

1. Discussion of the question, "Where does petroleum come from?": Oil Age, vol. 23, no. 1, pp. 59, 61, January, no. 2 , pp. 41, 43, 4 figs., February, 1926.

Stroud, Benjamin Kendrick. See also Scott; W. W., 1.

1. The Monroe gas field, Louisiana: Am. Assoc. Petroleum Geologists Bull., vol. 7, no. 5, pp. 565-574, September-October, 1923.

Stryker, W. L. See also Twenhofel, 20.

1. Subsurface geology of Wilson County, Kansas: Am. Assoc. Petroleum Geologists, Bull., vol. 9, no. 8, pp. 1207-1214, 3 pls., November, 1925.

Stuart, Murray.

1. The natural gas associated with oil deposits: Econ. Geology, vol. 22, no. 3, pp. 310-311, May, 1927.

Stuckey, Jasper L. See also Drane, 3.

1. The pyrophyllite deposits of the Deep River region of North Carolina: Econ. Geology, vol. 20, no. 5, pp. 442-463, 2 figs. (incl. map), 2 pls., August, 1925.

2. Chloritoid from the Deep River region, North Carolina: Am. Mineralogist, vol. 11, no. 7, pp. 186-188, July, 1926.

3. The pyrophyllite deposits of Moore and Chatham counties, North Carolina (abstract) : Elisha Mitchell Sci. Soc., Jour., vol. 43, nos. 1-2, p. 12, December, 1927.

4. A Cretaceous sandstone quarry near Kinston, North Carolina (abstract) : Elisha Mitchell Sri. Soc., Jour., vol. 44, no. 1, mp. 22-23, September, 1928 .

4096-31-38 
Stuckey, Jasper L.-Continued.

5. The pyrophyllite deposits of North Carolina, with a more detailed account of the geology of the Deep River region: North Carolina, Dept. Conservation and Development, Bull. no. 37, 62 pp., 1 fig., 1 pl. (maps), 1928.

Stull, Ray Thomas.

1. Distribution of kaolin and bauxite of the Coastal Plain of Georgia: Am. Ceramic Soc., Jour., vol. 7, no. 7, pp. 513-522, 2 figs., July, 1924.

2. (and Bole, G. A.). Beneficiation and utilization of Georgia clays: U. S. Bur. Mines, Bull. 252, 72 pp., 23 figs., 1926.

Sturdevant, Glenn E. See Gilmore, 37.

Suárez Murias, Eduardo R.

1. Visita de inspeción á la Isla de Pinos: Cuba, Dirección Montes y Minas, Boletín de Minas, ṇo 6, pp. 24-28, 1 fig., 1920.

2. Reconocimiento de la zona minera comprendida entre Bahía Honda y La Palma, provincia de Pinar del Río: Cuba, Dirección Montes y Minas, Boletín de Minas, no. 6, pp. 29-32, 1 fig., 1920.

3. Visita de inspección á las minas de cromo de San Miguel de los Baños: Cuba, Dirección Montes y Minas, Boletín de Minas, no. 6, pp. 3940, 1920.

4. Mineral resources of Cuba: Eng. and Min. Jour.-Press, vol. 114, no. 5, pp. 197-198, July 29, 1922.

Sudbury, Louise.

1. What is the first fossil collected by man?: Science, new ser., vol. $68, \mathrm{p}$. 135, August 10, 1928.

Sulzer, Elmer G.

1. Erosional freaks of the Saluda limestone: Indiana Acad. Sci., Proc. 1918, p. 309, 1919.

2. Remnant monument near Madison: Indiana Acad. Sci., Proc. 1918, pp. 310-311, 3 figs., 1919.

Suman, John $R$.

1. The Saratoga oil field, Hardin County, Texas: Am. Assoc. Petroleum Geologists, Bull., vol. 9, no. 2, pp. 263-285, 5 figs., March-April, 1925; Geology of salt dome oil fields, pp. 501-523, 5 figs., 1926.

2. Edwin Theodore Dumble: Am. Assoc. Petroleum Geologists, Bull., vol. 11, no. 4, pp. 439-440, April, 1927.

Sundberg, Karl.

1. (and Nordstrom, Allan). Electrical prospecting for molybdenite at Questa, New Mexico: Am. Inst. Min. and Met. Eng., Tech. Pub. no. 122, 13 pp., 10 figs., August, 1928.

Sur, Forest John Swears.

1. Condition of the Spindletop oil field [Beaumont, Texas]: Eng. and Min. Jour., vol. 111, no. 6, p. 273, 2 figs., February 5, 1921.

2. Two oil tests which may prove Utah to be a great oil producing State: Oil Age, vol. 25, no. 2, p. 28, February, 1928.

Sutton, A. H. See also Romer, 9 ; Weller, 17.

1. Map of the geology of the Dawson Springs quadrangle, Caldwell, Hopkins, and Christian counties, Kentucky: Kentucky Geol. Survey, Ser. 6, 1927. Scale 1:62,500.

2. Preliminary map of the areal and structural geology of Christian County, Kentucky: Kentucky Geol. Survey, ser. 6, 1928. Scale 1:62,500. 
Sutton, Chase E. See Hill, H. B., 1.

Swanson, Clarence Otto. See also Mead, W. J., 3.

1. The origin, distribution, and composition of laterite: Am. Ceramic Soc., Jour., vol. 6, no. 12, pp. 1248-1260, 1 fig., December, 1923.

2. The genesis of the Texada Island magnetite deposits: Canada, Geol. Survey, Summ. Rept., 1924, pt. A, pp. 106-144, 5 figs., 1925.

3. Notes on stress, strain, and joints: Jour. Geology, vol. 35, no. 3, pp. 193223, 15 figs., April-May, 1927.

4. Isostasy and mountain building: Jour. Geology, vol. 36, no. 5, pp. 411433, 2 figs., July-August, 1928.

Swanson, W. L.

1. Geology of certain base and meridian lines west of Lake Nipigon: Ontario Dept. Mines, 32d Ann. Rept., vol. 32, pt. 3, 1923, pp. 8-22, 3 pls., 1924.

2. The mineral association of the wolframite deposits at Burnt Hill Brook, York County, New Brunswick: Toronto, Univ., Studies, Geol. ser. no. 20, pp. 28-32, 1925.

Swartley, Arthur M.

1. Mineral resources of Oregon: Northwest Mines Handbook, vol. 1, pp. 294-299, Spokane, Washington, Sidney Norman, 1918.

Swartz, Charles Kephart. See also Prouty, 9.

1. (and Bassler, Harvey). Typical section of the Allegheny formation (abstract): Geol. Soc. America, Bull., vol. 30, no. 1, pp. 153-154, March 31, 1919.

2. (and Price, W. Armstrong, and Bassler, Harvey). Coal measures of Maryland: Geol. Soc. America, Bull., vol. 30, no. 4, pp. 567-596, 2 pls., 1 fig., December 31, 1919; abstract, no. 1, p. 154, March 31, 1919.

3. (and Baker, Wm. A., jr.). The coal formations and mines of Maryland, with introduction by Edward Bennett Mathews: Maryland Geol. Survey, vol. 11, pp. 27-288, 10 figs., 7 pls. (incl. map), 1922.

4. Distribution and stratigraphy of the coal measures of Maryland; Correlation of the coal measures of Maryland; The coal basins of Maryland: Maryland Geol. Survey, vol. 11, pp. 35-126, 1922.

5. (and Hall, George M.). Stratigraphy of the Carboniferous of Maryland: Maryland Geol. Survey, vol. 11, pp. 337-348, 1922.

6. Geologic relations and geographic distribution of the Silurian strata of Maryland; Stratigraphic and paleontologic relations of the Silurian strata of Maryland: Maryland Geol. Survey, Silurian, pp. 1923, 25-51, 1 fig., 4 pls., 1923.

7. Sections of the Wills Creek and Tonoloway formations: Maryland Geol. Survey, Silurian, pp: 105-181, 1 pl., 1923.

8. Correlation of the Silurian formations of Maryland with those of other areas: Maryland Geol. Survey, Silurian, pp. 183-232, 1923.

9. (and others). Systematic paleontology; Silurian (Coelenterata, Mollusca, Trilobita, by C. K. Swartz and W. F. Prouty; Vermes and Brachiopoda, by W. F. Prouty and C. K. Swartz; Bryozoa, by R. S. Bassler; Ostracoda, by E. O. Ulrich and R. S. Bassler; Merostomata, by C. K. Swartz) : Maryland Geol. Survey, Silurian, pp. 393-778, 59 pls., 1923. 
Swartz, Charles Kephart-Continued.

10. Earlier Silurian formations of Pennsylvania (abstract, with discussion by George H. Ashley and George H. Chadwick) : Geol. Soc. America, Bull., vol. 35, pp. 104-105, March 30, 1924; abstract, PanAm. Geologist, vol. 41, no. 2, p. 152, March, 1924.

Swartz, Joel Howard.

1. The age of the Chattanooga shale of Tennessee: Am. Jour. Sci., 5th ser., vol. 7, pp. 24-30, January, 1924.

2. Brief notice of a new radioactive method of determining the age of the earth (abstract) : Elisha Mitchell Sci. Soc., Jour., vol. 41, nos. 1-2, pp. 21-22, September, 1925.

3. Brief notice of two new methods of stratigraphic correlation, with special reference to the Chattanooga black shale (abstract): Elisha Mitchell Sci. Soc., Jour., vol. 41, nos. 1-2, pp. 22-23, September, 1925.

4. The Big Stone Gap shale of southwestern Virginia: Science, new ser., vol. 64, p. 226, September 3, 1926.

5. A self-correcting formula for the calculation of rock thickness (abstract) : Elisha Mitchell Sci. Soc., Jour., vol. 42, nos. 1-2, pp. 11-12, October, 1926.

6. The Chattanooga shale of southwestern Virginia (abstract) : Elisha Mitchell Sci. Soc., Jour., vol. 42, nos. 1-2, p. 13, October, 1926.

7. The age of the Big Stone Gap shale of southwestern Virginia: Am. Jour. Sci., 5th ser., vol. 12, pp. 512-531, 3 figs., December, 1926.

8. Subaerial sun cracks: Am. Jour. Sci., 5th ser., vol. 14, pp. 69-70, July, 1927.

9. The Chattanoogan age of the Big Stone Gap shale of southwestern Virginia : Science, new ser., vol. 66, pp. 36-37, July 8, 1927.

10. The Chattanoogan age of the Big Stone Gap shale: Am. Jour. Sci., 5th ser., vol. 14, pp. 485-499, 2 figs., December, 1927.

11. Chattanooga . shale in eastern Tennessee and Virginia (abstract): Geol. Soc. America, Bull., vol. 39, no. 1, p. 201, March 30, 1928; Pan-Am. Geologist, vol. 49, no. 2, pp. 153-154, March, no. 4, pp. 300-301, May, 1929.

12. The Devono-Mississippian black shales of Virginia and Tennessee (abstract) : Elisha Mitchell Sci. Soc., Jour., vol. 44, no. 1, pp. 20-21, September, 1928.

13. Some X-ray studies of fossils (abstract) : Elisha Mitchell Sci. Soc., Jour., vol. 44, no. 1, p. 22, September, 1928.

Swedenborg, E. A. See Ross, J. S., 1.

Sweet, P. W. K. See Wright, A., jr., 1.

Swift, T. T.

1. Date of channel trenching in the Southwest: Science, new ser., vol. 63, pp. 70-71, January 15, 1926.

Swigart, Theodore Earl.

1. (and Schwarzenbek, F. X.). Petroleum engineering in the Hewitt oil field, Oklahoma: U. S. Bur. Mines in cooperation with the State of Oklahoma and the Ardmore. [Oklahoma] Chamber of Commerce, 135 pp., 41 figs., January, 1921.

Swinnerton, Allyn C.

1. A method of estimating postglacial time: Science, new ser., vol. 62, p. 566, December 18, 1925. 
Swinnerton, Allyn C.-Continued.

2. Observation on some details of wave erosion; wave furrows and shore potholes: Jour. Geology, vol. 35, no. 2, pp. 171-179, 6 figs., February-Mar'ch, 1927.

3. Ohio geologists' field trip: Science, new ser., vol. 65, p. 610, June 24, 1927.

4. Varied signiflcance of term geosyncline: Pan-Am. Geologist, vol. 48, no. 3, pp. 195-200, October, 1927; abstract, vol. 47, no. 4, pp. 317$318,1927$.

Sykes, Godfrey.

1. The delta and estuary of the Colorado River: Geog. Rev., vol. 16, no. 2, pp. 232-255, 16 figs., 1 pl. (map), Aprll, 1926.

Symons, Henry $\mathrm{H}$.

1. California mineral production for 1927: California, Dept. Nat. Res. Div. Mines and Mining, Bull. no. 101, 311 pp., September, 1928.

Taber, Stephen. See also Hobbs, 7 ; Reid, H. F., 1, 2, 3, 4.

1. The mechanics of vein formation (with discussion) : Am. Inst. Min. and Met. Eng., Trans., vol, 61, pp. 3-41, 5 figs., 1920.

2. Jamaica earthquakes and the Bartlett trough: Seismol. Soc. America, Bull., vol. 10, no. 2, pp. 55-89, 1 pl., June, 1920.

3. The Inglewood earthquake in southern California, June 21, 1920: Seismol. Soc. America, Bull., vol. 10, no. 3, pp. 129-145, 1 fig., 7 pls., September, 1920.

4. The earthquake problem in southern California: Seismol. Soc. America, Bull., vol. 10, no. 4, pp. 276-289, December, 1920.

5. The Los Angeles earthquakes of July, 1920: Seismol. Soc. America, Bull. vol. 11, no. 1, pp. 63-79, 1 fig., March, 1921.

6. The great fault troughs of the Antilles: Jour. Geology, vol. 30, no. 2, pp. 89-114, 1 fig., 1 pl., February-March, 1922 ; abstract with discussion by W. H. Hobbs, Geol. Soc. America, Bull., vol. 32, no. 1, p. 47, March 31, 1921.

7. The seismic belt of the Greater Antilles: Seismol. Soc. America, Bull, vol. 12, no. 4, pp. 199-219, 1 pl., December, 1922.

8. Some criteria used in recognizing active faults: Geol. Soc. America, Bull,, vol. 34, no. 4, pp. 661-668, 1 fig., December 30, 1923.

9. The origin of veins of flbrous minerals: Econ. Geologist, vol. 19, no. 5, pp. 475-486, 5 flgs., August, 1924.

10. The Inglewood fault zone [California]: Seismol. Soc. America, Bull., vol. 14, no. 3, pp. 197-199, September, 1924.

11. The active fault zones of the Greater Antilles: International Geol. Cong., 13th Sess., Belgium, 1922, fasc. 2, pp. 731-736, 1 fig., 1925.

12. Evidence on Basin Range structure: Science, new ser., vol. 62, pp. 436437, November 13, 1925.

13. Metasomatism and the pressure of growing crystals (discussion) : Econ. Geology, vol. 21, no. 7, pp. 717-727, 1 fig., November, 1926.

14. The origin of veins: Eng. and Min. Jour:; vol. 122, no. 22, pp. 858-859, November 27, 1926.

15. Fault troughs: Jour. Geology, vol. 35, no. 7, pp. 577-606, 7 figs., OctoberNovember, 1927.

16. The linear force of growing crystals (discussion): Econ. Geology, vol. 23, no. 3, pp. 335-336, May, 1928.

17. Effect of earthquakes on artesian waters: Econ. Genlogy, vol. 23, no. 6 , pp. 696-697, Septemher-Octoher, 1928. 
Taff, Joseph Alexander. See also Gaylord, 1.

1. Proceedings of the fifteenth summer meeting, held in conjunction with the sixteenth annual meeting of the Cordilleran section, University of California and Stanford University, August 3, 4, and 5, 1915: Geol. Soc. America, Bull., vol. 31, pp. 177-184, March 31, 1920.

2. Proceedings of the seventeenth annual meeting of the Cordilleran section, held at San Diego, California, August 10, 1916: Geol. Soc. America, Bull., vol. 31, pp. 185-186, March 31, 1920.

3. Proceedings of the eighteenth annual meeting of the Cordilleran section, held at Stanford University, California, April 6 and 7, 1917: Geol. Soc. America, Bull., vol. 31, pp. 187-190, March 31, 1920.

4. (and Hanna, G. D.). Notes on the age and correlation of the Moreno shale [California] : Am. Assoc. Petroleum Geologists, Bull., vol. 10, no. 8, pp. 812-814, August, 1926.

5. Edward T. Dumble: Mining and Metallurgy, vol. 8, no. 243, p. 154, March, 1927.

6. (and Hanna, G. D.). A geologic section in the center of the San Joaquin Valley, California Acad. Sci., Proc., 4th ser., vol. 16, no. 16, pp. 509-515, April 27, 1927.

7. Preliminary report on the geology of the Arbuckle and Wichita Mountains in Indian Territory and Oklahoma: Oklahoma Geol. Survey, Bull. no. 12, 95 pp., 1 fig., 8 pls. (incl. maps), January, 1928. (Republication of U. S. Geol. Survey, Prof. Paper 31, pp. 11-81, 1904.)

Taft, H. H.

1. The Sierra Madre of northwestern Mexico: Eng. and Min. Jour., vol. 113, no. 2, pp. 48-50, January 14, 1922.

Tait, John.

1. (and Brown, Barnum). How the Ceratopsia carried and used their head: Roy. Soc. Canada, Proc. and Trans., 3d ser., vol. 22, sec. 5, pp. 13-23, 1 fig., 1 pl., 1928.

Takahashi, Jun-ichi R.

1. Diatom theory of origin of petroleum in California (abstract with discussion by Dallas Hanna, Warren D. Smith, and Robert Anderson) : Geol. Soc. America, Bull., vol. 36, no. 1, pp. 206-207, March 30, 1925.

2. Preliminary report on the origin of California petroleum: Econ. Geology, vol. 22 , no. 2 , pp. 133-157, March-April, 1927.

3. On the diatom theory of the origin of petroleum in California (abstract) : Third Pan-Pacific Sci. Cong., Tokyo, 1926, Proc., pp. 1613-1614, 1928.

Talbot, H. W.

1. The origin of peat: Pahasapa Quart., vol. 8, no. 2, pp. 69-72, February, 1919.

Taliaferro, Nicholas Lloyd. See also Hudson, 3, 4.

1. Notes on the geology of Ventura County, California: Am. Assoc. Petroleum Geologists, Bull., vol. 8, no. 6, pp. 789-810, 1 fig., 1 pl., NovemberDecember, 1924.

Talmage, Sterling $\mathbf{B}$.

1. The diagnostic value of color in polished sections: Econ. Geology, vol. 20, no. 2, pp. 168-180, 1 fig., March-April, 1925.

2. Quantitative standards for hardness of the ore minerals: Econ. Geology, vol. 20, no. 6, pp. 531-553, September-October, 1925. 
Tams, E.

1. Erdbeben und Ausbruch des Katmai: Zeitschr. Vulkanologie, Bd. S, H. 3, pp. 137-149, 1 pl. (map), October, 1924.

Tanner, Vasco Myron.

1. Notes on the collection of fossil fishes contained in the University of Utah, with the description of one new species: Utah, Univ., Bull., vol. 15, no, 6 (Geol. Bull.), 16 pp., 3 pls., May, 1925.

Tansey, Vivian Ouray.

1. The fauna and the correlation of the Bailey limestone in the Little Saline Creek area of Ste. Genevieve County, Missouri: Missouri Bur. Geology and Mines, 2d ser., vol. 17, pp. 166-212, 17 pls. [1924.]

'Tauton, Thomas Leslie.

1. The Harricanaw-I'Lrgeon basin, northern Quebec: Canada, Geol. Survey, Mem. 109, 84 pp., 9 pls. (incl. map), 2 figs., 1919.

2. The Canadian National Railways between Longuelac and Oba, northern Ontario: Canada, Geol. Survey, Summ. Rept., 1918, pt. E. pp. 1-3, 1919.

3. Shore of Lake Superior between Port Arthur and Nipigon: Canada, Geol. Survey, Summ. Rept., 1919, pt. E, pp. 1-7, map, 1920.

4. Silver Islet and vicinity, Thunder Bay district, Ontario: Canadian Min. Inst., Monthly Bull. no. 97, pp. 415-430, 5 figs., May, 1920 ; Trans., vol. 23, pp. 402-418, 5 figs. [1921].

5. Thunder Bay district, Ontario: Canada, Geol. Survey, Summ. Rept., 1920, pt. D, pp. 1-2, 1921.

6. Nipigon-Schreiber district, Ontario: Canada, Geol. Survey, Summ. Rept., 1920 , pt. D, pp. $2-7,1921$.

7. Geology [on map of] Explored routes in a belt traversed by the Canadian National Railways between Longlac and Nipigon, Thunder: Bay district, Ontario. Scale, 4 miles to 1 inch. Canada, Geol. Survey, Pub. no. 1836, 1921.

S. An exploration north of Thunder Bay, Ontario: Canada, Geol. Survey, Summ. Rept., 1921, pt. D, pp. 1-6, 1922.

9. Palladium-bearing nickel deposit at Shebandowan Lake, Thunder Bay district, Ontario: Canada, Geol. Survey, Summ. Rept., 1922, pt. D, pp. 1-8, 2 figs., 1923.

10. Gold occurrence at Makwa, Sudbury district, Ontario: Canada, Geol. Survey, Summ. Rept., 1922, pt. D, pp. 9-12, 1 fig., 1923.

11. The effect of glaciation on prospecting for mineral deposits in the Laurentian Plateau: Geog. Rev., vol. 13, no. 1, pp. 107-111, 1 fig., January, 1923.

12. Iron formation at Gravel Lake, Thunder Bay district, Ontario: Canada, Geol. Survey, Summ. Rept. 1923, pt. C1, pp. 1-5, 1924.

13. Evidence of liquid immiscibility in a silicate magma, Agate Point, Ontario: Jour. Geology, vol. 33, no. 6, pp. 629-641, 4 figs., AugustSeptember, 1925.

14. Recognition of the Coutchiching near Steeprock Lake, Ontario: Roy. Soc. Canada, Proc. and Trans., 3d ser., vol. 20, sec. 4, pp. 39-49, 4 figs., 1926.

15. Erastern part of Matawin iron range, Thunder Bay district, Ontario: Canada, Geol. Survey, Summ. Rept., 1924, pt. C, pp. 1-27, 1 fig., map, 1926.

16. Mineral deposits of Steeprock Lake map area, Ontario: Canada, Geol. Survey, Summ. Rept., 1925, pt. C, pp. 1-11, 1927. 
Tanton, Thomas Leslie-Continued.

17. Stratigraphy of the northern subprovince of the Lake Superior region (with discussion by F. F. Grout, T. L. Tanton, R. C. Allen, and C. K. Leith) : Geol. Soc. America, Bull., vol. 38, no. 4, pp. 731-748, 11 figs., December 30, 1927 ; abstract, no. 1, pp. 114-115, March 30, 1927 ; Pan-Am. Geologist, vol. 47, no. 1, p. 67, February, 1927.

18. Emulsions of silicates: Am. Jour. Sci., 5th ser., vol. 15, pp. 66-6S, January, 1928.

Tarr, Ralph Stockton, 1864-1912.

1. (and von Engeln, O. D.). New Physical geography. xii, 689 pp., 543 figs., 8 pls., New York, The Macmillan Company, 1926.

Tarr, Russell S.

1. The red beds near the base of the Cherokee shales: Am. Assoc. Petroleum Geologists, Bull., vol. 9, no. 2, pp. 350-351, March-April, 1925.

Trarr, William Arthur. See also Branson, 20; Twenhofel, 16, 18, 22, 29.

1. The barite deposits of Missouri: Econ. Geology, vol. 14, no. 1, pp. 4667, 2 figs., January-February, 1919.

2. Contribution to the origin of dolomite (abstract): Geol. Soc. America, Bull., vol. 30, p. 114, March 31, 1919.

3. The origin of glauconite (abstract) : Science, new ser., vol. 51, pp. 491-492, May 14, 1920.

4. The possibility of a relationship between crystal types and the mode of occurrence of minerals (abstract): Science, new ser., vol. 51, p. 519, May. 21, 1920.

5. Notes on concretions (abstract) : Science, new ser., vol. 51, p. 520, May $21,1920$.

6. A possible factor in the origin of dolomite (abstract): Science, new ser., vol. 51, May 21, 1920.

7. Tables for the determination of the common minerals and rocks. Revised and enlarged, 1921. 32 pp., Columbia, Missouri, The Missouri Book Company, 1921.

8. The minerals of Madison County, Missouri: Am. Mineralogist, vol. 6, no. 1, pp. 7-10, January, 1921.

9. Cobalt-nickel-copper-lead deposits of Fredericktown, Missouri (abstract) : Geol. Soc. America, Bull., vol. 32, no. 1, p. 66, March 31, 1921.

10. Syngenetic origin of concretions in shale: Geol. Soc. America, Bull., vol. 32, no. 4, pp. 373-384, 2 figs., December 1, 1921; abstract with discussion, no. 1, pp. 26-27, March 31, 1921.

11. Cone-in-cone: Am. Jour. Sci., 5th ser., vol. 4, pp. 199-213, 11 figs., September, 1922.

12. A high-temperature vein in Madison County, Missouri (abstract): Geol. Soc. America, Bull., vol. 34, no. 1, p. 99, March 30, 1923.

13. Intrenched and incised meanders of some streams on the northern slope of the Ozark Plateau in Missouri: Jour. Geology, vol. 32, no. 7, pp. 583-600, 8 figs., October-November, 1924.

14. Is the Chalk a chemical deposit?: Geol. Mag., vol. 62, pp. 252-264, June, 1925.

15. The origin of cheret and flint: Univ. Missouri Studies, vol. 1, no. 2, 46 pp., 3 figs., 8 pls., April 1, 1926.

16. Silicification of erosion surfaces (discussion): Econ. Geolngy, vol. 21, no. 5, pp. 511-51., August, 1926. 
'Tar'r, William Arthur-Continued.

17. Origin of chert and flint (abstract) : Geol. Soc. America, Bull., vol. 38, no. 1, p. 124, March 30, 1927 ; Pan-Am. Geologist, vol. 47, no. 1, p. 73, February, 1927.

18. Alternating deposition of pyrite, marcasite, and possibly melnikovite: All. Mineralogist, vol. 12, no. 12, pp. 417-421, December, 1927.

19. Syngenetic pyritization in local reducing areas of Pennsylvanian shales in Missouri: Jour. Geology, vol. 36, no. 5, pp. 434-439, July-August, 1928 ; abstract, Geol. Soc. America, Bull., vol. 39, no. 1, p. 163, March 30, 1928; Pan-Am. Geologist, vol. 49, no. 1, p. 73, February, 1928.

20. Cone-in-cone on concretions from the Devonian of New York: Science, new ser., vol. 68, p. 403, October 26, 1928.

Taschereau, R. H. See Dufresne, 9.

Tatum, J. L.

1. Cretaceous and Tertiary of southern Texas and northern Mexico: Am. Assoc. Petroleum Geologists, Bull., vol. 12, no. 9, pp. 949-950, September, 1928.

Taylor, Frank B.

1. One-man surveys for the oil geologist: Colorado School of Mines Mag., vol. 9, no. 10, pp. 269-272, 1 pl., October, 1919.

Taylor, Frank Bursley.

1. Some points in the mechanics of arcuate and lobate mountain structures (abstract) : Geol. Soc. America, Bull., vol. 32, no. 1, pp. 31-32, March 31, 1921.

2. An objection to the contraction hypothesis as accounting for mountains (abstract) : Geol. Soc. America, Bull., vol. 32, no. 1, pp. 33-34, March 31, 1921.

3. The lateral migration of land masses (abstract): Washington Acad. Sci., Jour., vol. 13, no. 20, pp. 445-447, December 4, 1923.

4. Moraines of the St. Lawrence Valley: Jour. Geology, vol. 32, no. 8, pp. 641-667, 12 figs., 1 pl. (map), November--December, 1924.

5. Movement of continental masses under action of tidal forces: Pan-Am. Geologist, vol. 43, no. 1, pp. 15-50, 2 figs., 2 pls., February, 1925.

6. Reconnaissance of the recessional moraines of the Finger Lakes region (abstract) : Geol. Soc. America, Bull., vol. 36, no. 1, p. 142, March $30,1925$.

7. Moraines of recession between Indiana and New England (abstract) : Geol. Soc. America, Bull., vol. 36, no. 1, pp. 172-173, March 30, 1925.

8. Relation of recessional moraines to Niagara Falls (abstract) : Pan-Am. Geologist, vol. 44, no. 2, pp. 153-154, September, 1925.

9. Greater Asia and isostasy (abstract) : Pan-Am. Geologist, vol. 44, no. 2, pp. 156-157, September, 1925.

10. Tidal forces in the making of continents and mountains (abstract) : Geol. Soc. America, Bull., vol. 37, no. 1, pp. 167-168, March 30, 1926 ; Pan-Am. Geologist, vol. 45, no. 2, p. 162, March, 1926.

11. Evidence of recurrent depression and resilience in the region of the Great Lakes: Michigan-Acad. Scl., Papers, vol. 7, pp. 135-143, 1 fig., 1927.

12. The present and recent rate of land tilting in the region of the Great Lakes : Michigan Acad. Sci., Papers, vol. 7, pp. 145-157, 3 figs., 1927 
Taylor, Frank Bursley-Continued.

13. Salient points in Tertiary epeirogeny (abstract): Geol. Soc. America, Bull., vol. 38, no. 1, pp. 107-109, March 30, 1927; Pan-Am. Geologist, vol. 47 , no. 1, p. 65. February, 1927.

14. Relation of Lake Erie to recent and present land tilting (abstract) : Geol. Soc. America, Bull., vol. 38, no. 1, p. 128, March 30, 1927 ; Pan-Am. Geologist, vol. 47, no. 1, p. 74, February, 1927.

15. Asia and North America-a comparison in Tertiary diastrophism (abstract): Geol. Soc. America, Bull., vol. 39, no. 1, pp. 153-154, March 30, 1928; Pan-Am. Geologist, vol. 49, no. 1, p. 68, February, 1928.

16. Bearing of distribution of earthquakes and volcanoes on their origin (abstract) : Geol. Soc. America, Bull., vol. 39, no. 1, p. 174, March 30, 1928; Pan-Am. Geologist, vol. 49, no. 1, p. 78, February, 1928.

17. Sliding continents and tidal and rotational forces. In Theory of continental drift, pp. 158-177, 4 figs., Am. Assoc. Petroleum Geologists, 1928.

18. North America and Asia; a comparison in Tertiary diastrophism: Geol. Soc. America, Bull., vol. 39, no. 4, pp. 985-1000, 4 figs., December $30,1928$.

19. Bearing of distribution of earthquakes and volcanoes on their origin: Geol. Soc. America, Bull., vol. 39, no. 4, pp. 1001-1016, December $30,1928$.

Taylor, Thomas Garrett. See Moore, E. S., 6; Soyster, 1.

Teas, Livington Pierson. See also Hull, 2.

1. Preliminary report on the sand and gravel deposits of Georgia: Georgia Geol. Survey, Bull. no. 37, 392 pp., 13 figs., 20 pls., map, 1921.

2. Haynesville field, Louisiana: Am. Assoc. Petroleum Geologists, Bull., vol. 6, no. 1, pp. 53-54, January-February, 1922.

3. The Haynesville, Louisiana [oil] field: Am. Assoc. Petroleum Geologists, Bull., vol. 6, no. 4, pp. 371-372, July-August, 1922.

4. New producing depths at El Dorado, Arkansas: Am. Assoc. Petroleum Geologists, Bull., vol. 6, no. 5, pp. 473-474, September-October, 1922.

5. Differential compacting the cause of certain Claiborne dips [in the north Louisiana-south Arkansas district] (with discussion): Am. Assoc. Petroleum Geologists, Bull., vol. 7, no. 4, pp. 370-378, 6 figs., JulyAugust, 1923.

Teetor, Paul.

1. Clay and shale resources in the vicinity of Arkansas City, Kansas: Kansas, State Geol. Survey, Bull. 8, pp. 38-47, 2 figs., 1921.

Tegland, Nellie M.

1. Genus Thyasira in Tertic rocks of North America (abstract): Pan-Am. Geologist, vol. 49, no. 4, p. 317, May, 1928.

Teller, Mrs. Edgar E.

1. Memorial of Edgar E. Teller: Geol. Soc. America, Bull., vol. 35, no. 1, pp. 182-184, March 30, 1924.

Tello, Rafael M.

1. Informe sobre las perforaciones practicados en el rancho "La Candelaria," del Estado de Coahuila : Mexico, Inst. Geol., Anales, t. 2, nos. 6-10, pp. 195-197, 1 pl., 1927. 
Templeton, R. R.

1. (and McCollom, C. R.). Santa Fe Springs field, California (with discussion) : Am. Assoc. Petroleum Geologists, Bull., vol. 8, no. 2, pp. 178-194, 1 fig., 1 pl., March-April, 1924.

Tenney, J. $\mathbf{B}$.

1. The mineral industries of Arizona: Arizona Bur. Mines, Bull., no. 125, 135 pp., February 15, 1928.

Termer, Franz.

1. Mitteilungen über die Vulkantätigkeit in Guatemala im Jahre 1927: Zeitschr. Vulkanologie, Bd. 11, H. 3, pp. 188-190, 1 pl., July, 1928.

Termier, Pierre.

1. Une visite au Grand Cañon du Colorado: Revue Univ., t. 19, no. 17, pp. 553-569, December, 1924.

2. The drifting of the continents: Smithsonian Inst., Aun. Rept., 1924, pp. 219-236, 1925.

Terrones Benitez, Alberto.

1. The camp of Guanacevi [Durango, Mexico]: Eng. and Min. Jour.-Press, vol. 114, no. 4, pp. 139-144, 7 figs., July 22, 1922.

Tester, A. C. See also Twenhofel, 22, 24.

1. Cone-in-cone in stratigraphic correlation (abstract): Pan-Am. Geologist, vol. 46, no. 5, p. 406, December, 1926.

2. The use of cone-in-cone structure for the purposes of correlation: Iowa Acad. Sci., Proc., 1926, vol. 33, p. 218 [1927].

3. Comanchean fossils from the glacial drift of Iowa (abstract) : Geol. Soc. America, Bull., vol. 38, no. 1, p. 233, March 30, 1927.

Texas, Attolney General.

1. (and others). [Suit to ascertain the boundary line between the state of Oklahoma and the State of Texas along Red River.] In the Supreme Court of the United States, October term, 1921. In Equity, Original No. 20. The State of Oklahoma, Complainant, $v$. the State of Texas, Defendant. Brief for Defendant . . April 24, 1922. Part I, Statement of case and argument, 472 pp. ; Part II, Abstract of the evidence, 766 pp. [Expert testimony by Robert T. Hill, pp. 255-343; by E. H. Sellards, pp. 353434 ; by L. C. Glenn, pp. 577-641; by Isaiah Bowman, pp. 642662 .

Contains various data regarding the behavior of rivers, particularly the Red River, and the geologic and physiographic features of the Red River and its banks, more especially in the Big Bend region.

Thacker, Richard B.

1. Do all Gulf salt domes have vents?: Eng. and Min. Jour.-Press, vol. 121, no. 17, pp. 684-686, 4 figs., April 24, 1926.

Tharp, B. C. See Sellards, 18.

Tharp, William Edgar.

1. Notes on the areal geology of Hancock County: Indiana Acad. Sci., Proc., vol. 35, pp. 91-92, 1926.

2. Notes on the areal geology of Miami County, Indiana: Indiana Acad Sci., Proc., vol. 36, pp. 117-118, 1927.

'Theis, Charles Vernon. See also Kentucky G. S., 28, 38, 40.

1. Geological map of Hopkins County, Kentucky: Kentucky Geol. Survey, Ser. 6, 1924. Scale, 1: 62,500 . 
Theis, Charles Vernon-Continued.

2. The filled valleys of western Kentucky (abstract): Ohio Acad. Sci., Proc., vol. 8, pt. 4, pp. 178-179, 1928; Ohio Jour. Sci., vol. 28, no. 3, pp. 156-157, May, 1928.

Thiel, George A. See also Fairbanks, 12 ; Grout, 13.

1. Gas an important factor in oil accumulation: Eng. and Min. Jour., vol. 109, pp. 888-889, 3 figs., April 10, 1920.

2. The manganese minerals; their identification and paragenesis: Econ. Geology, vol. 19, no. 2, pp. 107-145, 3 figs., 2 pls., March, 1924.

3. The precipitation of manganese from meteoric solutions: Am. Jour. Sci., 5th ser., vol. 7, pp. 457-472, June, 1924.

4. High-temperature manganese veins of the Cuyuna range [Minnesota]: Econ. Geology, vol. 19, no. 4, pp. 377-381, June-July, 1924.

5. Iron sulphides in magnetic belts near the Cuyuna range: Econ. Geology, vol. 19, no. 5, pp. 466-472, 1 fig., August, 1924.

6. Study of polished surfaces: Econ. Geology, vol. 19, no. 6, pp. 582-584, September-October, 1924.

7. Commercial possibilities of the magnetite slates of the Cuyuna range [Minnesota] : Eng. and Min. Jour.-Press, vol. 118, no. 19, pp. 735738, 7 figs., November 8, 1924.

8. Manganese precipitated by micro-organisms: Econ. Geology, vol. 20, no. 4, pp. 301-310, 2 pls., June-July, 1925.

9. Phosphorus iron ores in the Cuyuna Range [Minnesota]: Eng. and Min. Jour.-Press, vol. 121, no. 17, pp. 687-690, 4 figs., April 24, 1926.

1.0. The enrichment of bauxite deposits through the activity of microorganisms: Econ. Geology, vol. 22, no. 5, pp. 480-493, 2 figs., August, 1927.

11. The relative effectiveness of bacteria as agents of chemical denudation: Jour. Geology, vol. 35, no. 7, pp. 647-652, 2 figs., October-November, 1927.

12. Geology of the Cuyuna range: Geol. Soc. America, Bull., vol. 38, no. 4, pp. 783-793, 5 figs., December 30, 1927; abstract, no. 1, p. 116, March 30, 1927 ; Pan-Am. Geologist, vol. 47, no. 1, p. 68, February, 1927.

13. A summary of the activity of bacterial agencies in sedimentation: Nat. Research Council, Reprint and Circ. Ser., no. 85, pp. 61-77, 1928.

Thiessen, Reinhardt. See also Hackford, 1.

1. Occurrence and origin of finely disseminated sulphur compounds in coal: Am. Inst. Min. and Met. Eng., Bull. no. 153, pp. 2431-2444, 10 figs., September, 1919; Trans., vol. 63, pp. 913-931, 10 figs., 1920; discussion, Mining and Metallurgy, no. 157, sec. 12, pp. 40-44, January, 1920 ; Coal Age, vol. 16, pp. 668-673, 10 figs., October 23, 1919.

2. Structure in Paleozoic bituminous coals: U. S. Bur. Mines, Bull. 117, 296 pp., 160 pls., 1920.

3. Compilation and composition of bituminous coals: Jour. Geology, vol. 28, no. 3, pp. 185-209, 9 pls., April-May, 1920.

4. The correlation of coal seams by means of spore exines (abstract) : Science, new ser., vol. 51, p. 522, May 21, 1920.

5. Under the microscope coal has already lost much of its former mystery: Coal Age, vol. 18, nos. 24-26, pp. 1183-1189, 1223-1226, 1275-1279, 30 figs., December 9,16 , and 23,1920 ; vol. 19, no. 1, pp. 12-15, 5 figs., January 6, 1921. 
Thiessen, Reinhardt-Continued.

6. Recent developments in the microscopic study of coal: Canadian Min. Jour., vol. 42 , no. 4 , pp. $64-68$, no. 5 , pp. $86-91$, no. 6, pp. 109-113, no. 7, pp. 124-218, 31 figs., January 28-February 18, 1921.

7. Origin and composition of certain oil shales: Econ. Geology, vol. 16, nos. 4-5, pp. 289-300, 2 pls., 1921; abstract, with discussion by F. R. Van Horn, Geol. Soc. America, Bull., vol. 32, no. 1, pp. 72-74, March 31, 1921.

8. The origin and constitution of coal: Wyoming Hist. and Geol. Soc., Proc. and Coll., vol. 19, preprifít 44 pp. 21 pls., Wilkes-Barre, Pa., 1924.

9. (and Wilson, Ford E.). Correlation of coal beds of the Allegheny formation of western Pennsylvania and eastern Ohio: Coal-mining Investigations, Bull. 10, 56 pp., 6 figs., 23 pls., Carnegie Institute of Technology, Pittsburgh, Pennsylvania, 1924.

10. Microscopic examination of Kentucky oil shales: Kentucky Geol. Survey, ser. 6, vol. 21, pp. 1-47, 37 pls., 1925.

11. The microscopical constitution of coal: Am. Inst. Min. and Met. Eng., Trans. [preprint], no. 1438, 50 pp., March, 1925; with discussion, Trans., vol. 71, pp. 35-116, 30 figs., 1925.

12. Origin of the boghead coals: U. S. Geol. Survey, Prof. Paper 132, pp. 121-135, 14 pls., May 14, 1925.

13. Classification of coal from the viewpoint of the paleobotanist (with discussion) : Am. Inst. Min. and Met. Eng., Tech. Pub. no. 156, pp. 28-46, November, 1928.

Thom, William Taylor, jr. See also Foley, 1.

1. (and Moulton, G. F.). The Soap Creek oil field, Crow Indian Reservation, Montana: U. S. Geol. Survey, 15 pp., map, December 5, 1921. [Press Bulletin mimeograph.]

2. Relation of deep-seated faults to surface structure in the region northeast of the Yellowstone Park plateau (abstract): Geol. Soc. America, Bull., vol. 33, no. 1, p. 99, March 31, 1922.

3. (and Dobbin, C. E.). Oil and gas prospects in Garfleld County, Montana : Am. Assoc. Petroleum Geologists, Bull., vol. 6, no. 2, pp. 144-150, 1 fig., March-April, 1922.

4. Oil and gas prospects in and near the Crow Indian Reservation, Montana: U. S. Geol. Survey, Bull. 736, pp. 35-53, 1 pl. (map), July 6, 1922.

5. Oil possibilities of South Dakota: Am. Assoc. Petroleum Geologists, Bull., vol. 6, no. 6, pp. 551-553, November-December, 1922.

6. The relation of deep-seated faults to the surface structural features of central Montana: Am. Assoc. Petroleum Geologists, Bull., vol. 7, no. 1, pp. 1-13, 2 figs., 1 pl., January-February, 1923.

7. (and Dobbin, C. E.). Correlation of the Lebo member of the Fort Union with Cannonball member of the Lance (abstract): Washington Acad. Sci., Jour., vol. 14, no. 7, p. 165, April 4, 1924.

8. (and Dobbin, C. E.). Stratigraphy of Cretaceous-Eocene transition beds in eastern Montana and the Dakotas: Geol. Soc. America, Bull., vol. 35, no. 3, pp. 481-505, 4 figs., 3 pls., September 30, 1924; abstract, no. 1, p. 98, March 30, 1924 ; Pan-Am. Geologist, vol. 41, no. 2, p. 148, March, 1924.

9. "Direct synthesis of higher from lower hydrocarbons": Am. Assoc. Petroleum Geologists, Bull., vol. 8, no. 6, pp. 830-831, NovemberDecember, 1924. 
Thom, William Taylor, jr.-Continued.

10. Production and potentialities of the South's coal fields: The South's Development, Manufacturer's Record, vol. 86, no. 24, pt. 2, pp. 297-303, December 11, 1924.

11. (and others). Structure map of northeastern Oklahoma, prepared by the Oklahoma Geological Survey in cooperation with the U. S. Geological Survey, 1925. Scale 1:500,000.

12. Moisture as a component of the volatile matter of coal: Am. Inst. Min. and Met. Eng., Trans. [preprint] no. 1451, 4 pp., May, 1925; with discussion, Trans., vol. 71, pp: 282-288, 1 fig., 1925; abstract, Mining and Metallurgy, vol. 7, no. 229, p. 26, January, 1926.

13. Relation of earth temperatures to buried hills and anticlinal folds: Econ. Geology, vol. 20, no. 6, pp. 524-530, 2 figs., September-October, 1925.

14. Topography and geology of the coal areas [of Missouri]: U. S., Bur. Mines, Tech. Paper 366, pp. 1-4, 1 fig., 1926.

15. Need for petroleum geology research: Oil and Gas Jour., vol. 24, no. 37, pp. 21, 143-144, February 4, 1926.

16. (and Dobbin, C. E.). Origin of the structural features of eastern Montana (abstract) : Geol. Soc. America, Bull., vol. 37, no. 1, p. 168, March 30, 1926.

17. Earth temperatures, buried hills, and anticlinal folds (discussion) : Econ. Geology, vol. 22, no. 1, pp. 91-94, January-February, 1927.

18. Subsidence and earth movements caused by oil extraction or by drilling oil and gas wells (with discussion) : Am. Inst. Min. and Met. Eng., Trans., vol. 75, pp. 734-742, 1927.

19. The Minturn district and the northwestern part of the Gillette field [Wyoming] : U. S. Geol. Survey, Bull. 796, pp. 50-64, 2 pls. (maps), August 8, 1927.

20. Synclinal oil occurrence and regional uplift: Am. Assoc. Petroleum Geologists, Bull., vol. 12, no. 5, pp. 554-555, May, 1928.

21. Classification of coal from proximate analysis and calorific value (with discussion) : Am. Inst. Min. and Met. Eng., Tech. Pub. no. 156, pp. 15-19, November, 1928.

'Thomas, Abram Owen. See also Lees, 4.

1. Notes on the geology of Antigua: Iowa Univ., Studies, vol. 8, no. 3, pp. 213-219, May, 1919.

2. Echinoderms of the Iowa Devonian (abstract) : Geol. Soc. America, Bull., vol. 31, no. 1, pp. 211-212, March 31, 1920.

3. An illustration of the wedge work of roots: Iowa Acad. Sci., Proc., vol. 26, pp. $477-480,1$ fig. [1920].

4. A Herpetocrinus from the Silurian of Iowa: Iowa Acad. Sci., Proc. vol. 26, pp. 481-482, 1 fig. [1920].

5. The Independence shale near Brandon, Iowa: Iowa Acad. Sci., Proc., vol. 26 , pp. 485-491 [1.920].

6. A cephalopod from the coal measures at Mystic, Iowa (abstract) : Science, new ser., vol. 54, pp. 308-309, September 30, 1921.

7. Note on a beaver tooth from the Pleistocene at Des Moines, Iowa (abstract) : Science, new ser., vol. 54, p. 309, September 30, 1921.

3. Some Oligocene brachiopods from the Island of Antigua, British West Indies (abstract) : Science, new ser., vol. 54, p. 309, September 30, 1921. 
Thomas, Abram Owen-Continued.

9. Small fossils from the Lime Creek shales (abstract) : Geol. Soc. America, Bull., vol. 32, no. 1, pp. 1.30-131, March 31, 1921.

10. The geographic distribution of Iowa Devonian echinoderms (abstract) : Science, new ser., vol. 57, p. 147, August 24, 1923.

11. Some giant Stromatopora from near Iowa City, Iowa (abstract) : Science, new ser., vol. 57, p. 147, August 24, 1923.

12. Echinoderms of the Iowa Devonian: Iowa Geol. Survey, vol. 29, pp. 385550, 21 figs., 20 pls. [1924].

13. Some new Paleozoic glass sponges from Iowa: Iowa Acad. Sci., Proc. 1922, vol. 29, pp. 85-90, 1 pl. [1924?].

14. (and Stainbrook, M. A.). Status of certain rhynchonellid brachiopods from the Devonian of Iowa: Iowa Acad. Sci., Proc. 1922, vol. 29, pp. 93-98, 2 figs., 1 pl. [1924?] ; abstract, Science, new ser., vol. 54, p. 308, September 30, 1921.

15. Notes on some mammalian remains reported in Iowa during the past year (abstract) : Iowa Acad. Sci., Proc. 1922, vol. 29, p. 129 [1924?].

16. The geographic distribution of Iowa Devonian echinoderms: Iowa Acad. Sci., Proc., vol. 30, pp. 463-465 [1924].

17. Some large colonies of Stromatopora found near Iowa City, Iowa: Iowa Acad. Sci., Proc., vol. 30, pp. 467-470, 1 fig. [1924].

18. Some fossils from an outcrop in Des Moines: Iowa Acad. Sci., Proc., vol. 30 , pp. 471-479, 2 pls. [1924].

19. Some Goniatites from the Paleozoics of Iowa (abstract) : Pan-Am. Geologist, vol. 42, no. 5, p. 381, December, 1924; Iowa Acad. Sci., Proc., vol. 31, p. 340 [1926?].

20. Pleistocene mammalian remains recently found in Iowa (abstract) : Pan-Aw. Geologist, vol. 42, no. 5, pp. 381-382, December, 1924; Iowa Acad. Sci. Proc., vol. 31, p. 340 [1926?].

21. Fossil pine cone from drift of northern Iowa (abstract): Pan-Am. Geologist, vol. 42, no. 5, p. 382, December, 1924; Iowa Acad. Sci., Proc., vol. 31, pp. 339-340 [1926?].

22. (and Ladd, H. S.). Additional cystoids and crinoids from the Maquoketa shale of Iowa: Iowa, Univ., Studies, new ser., no. 104, Studies in Natural History, vol. 11, no. 8, pp. 5-18, 6 pls., March 1, 1926.

23. Echinoderms of the Iowa Devonian (abstract) : Chicago, Univ., Abstracts of Theses, Sci. Ser., vol. 2, pp. 235-238, September, 1926.

24. A horntail trilobite from McGregor, Iowa: Iowa Acad. Sci., Proc., 1926, vol. 33, pp. 213-218, 1 pl. [1927].

25. The occurrence of the brachiopod Bilobites bilobus in the Silurian of Iowa: Iowa Acad. Sci., Proc., 1926, vol. 33, pp. 221-222, 1 flg. [1927].

26. Proboscidean remains from Red Oak and Ottumwa, Iowa (abstract) : Iowa Acad. Sci., Proc., 1926, vol. 33, pp. 222-223 [1927].

Thomas, C. S.

1. Oil, whence and whither?: Oil Bull., vol. 14, no. 4, pp. 382-383, April, 1928.

Thomas, Chester Reams. See also Barwick, 1.

1. Origin of anticline in Benton shale area of western Kansas: Oil and Gas Jour., vol. 23, no. 47, pp. 128-129, April 16, 1925.

2. Flank production of the Nemaha Mountains (granite ridge), Kansas: Am. Assoc. Petroleum Geologists, Bull., vol. 11, no. 9, pp. 919-931, 5 figs., September, 1927. 
'Thomas, Chester Reams-Continued.

3. Permian fossils found in drill samples purported to be below the Welch chert from well in Dickinson County, Kansas: Am. Assoc. Petroleum Geologists, Bull., vol. 11, no. 10, p. 1118-1120, October, 1927.

Thomas, E. T.

1. Craterlets in east central Arkansas probably due to the New Madrid earthquake: Science, new ser., vol. 56, pp. 21-22, July 7, 1922.

2. The effect of pressure on the migration of oil: Am. Assoc. Petroleum Geologists, Bull., vol. 8, no. 4, pp. 527-528, July-August, 1924.

3. An aid to the study of Foraminifera: Am. Assoc. Petroleum Geologists, Bull., vol. 9, no. 3, pp. 667-669, May-June, 1925.

Thomas, Kirby.

1. Coal and oil in Rhode Island: Coal Age, vol. 15, p. 748, April 24, 1919.

Thomas, Norman L.

1. Brachiopods from the St. Clair limestone, Arkansas: Denison Univ. Bull vol. 26, no. 6, Sci. Lab., Jour., vol. 21, pp. 385-401, 1 pl., September, 1926.

2. The use of evolutionary changes in geologic correlation: Jour. Paleontology, vol. 1, no. 2, pp. 135-139, August, 1927.

3. (and Rice, E. M.). Changing characters in some Texas species of Guembelina: Jour. Paleontology, vol. 1, no. 2, pp. 141-144, 1 fig., August, 1927.

4. Some brachiopods from the St. Clair limestone, Arkansas: Denison Univ., Bull., vol. 38, no. 8, Sci. Lab., Jour., vol. 23, pp. 127-140, 1 pl., July, 1928.

Thompson, Arthur Perry.

1. Mineral deposition and the circle of fire: Min. Jour., Phoenix, Ariz., vol. 10, no. 16, pp. 3-4, 18-21, January 15, 1927.

Thompson, David Grosh.

1. Ground water in Lanfair Valley, California: U. S. Geol. Survey, WaterSupply Paper 450, pp. 29-50, 2 pls. (maps), 1 fig., January 15, 1920.

2. Ground water for irrigation near Gage, Ellis County, Oklahoma: U. S. Geol. Survey, Water-Supply Paper 500, pp. 33-53, 3 figs., 1 pl., 1921, Abstract, Washington Acad. Sci., Jour., vol. 12, no. 1, p. 20, January 4, 1922.

3. Pleistocene lakes along Mohave River, California (abstract) : Washington Acad. Sci., Jour., vol. 11, no. 17, pp. 423-424, October 19, 1921.

4. Memorandum on investigation of quantities of ground water available for public and industrial supplies in New Jersey; New Jersey, Report of the Water Policy Commission, Part 2, pp. (A) 29-40, February $27,1926$.

5. Ground-water problems on the barrier beaches of New Jersey: Geol. Soc. America, Bull., vol. 37, no. 3, pp. $463-474,5$ figs., 1 pl., September 30, 1926; abstract, no. 1, pp. 161-162, March 30, 1926; Pan-Am. Geologist, vol. 45 , no. 2, p. 162, March, 1926.

6. Ground-water supplies of the Atlantic City region: New Jersey, Dept. Conserv. and Devel., Bull. 30, 138 pp., 23 figs., 7 pls., 1928.

Thompson, J. D., jr. See Mạlott, 2. 
Thompsou, Phillips.

1. The Mackenzie River basin: Eng. and Min. Jour., vol. 108, pj. 866-868, 1 fig., December 6, 1919.

Thompson, s. A.

1. (and Eichelberger, O. H.). Vinton salt dome, Calcasieu Parish, Louisiana : Am. Assoc. Petroleum Geologists, Bull., vol. 12, no. 4, pp. 385394, 2 figs., 2 pls., April, 1928.

Thompson, Wallace C. See also Hubbard, W. E., 1.

1. The Millway limestone of northeast Texas: Am. Assoc. Petroleum Geolo. gists, Bull., vol. 6, no. 4, pp. 323-332, 2 figs., July-August, 1922.

Thompson, William.

1. Theory of vein formation: Mining and Metall., vol. 9, no. 262, p. 467, October, 1928.

Thomson, Ellis. See also Bell, J. M., 6 ; Parsons, A. L., 2 ; Walker, T. L., 5.

1. A mineralographic study of the pyrite group: 'Toronto, Univ., Studies, Geol. ser., no. 12, pp. 32-39, 1 pl., 1921.

2. Mineralography: Canadian Min. Jour., vol. 43, no. 6, pp. 78-80, February $10,1922$.

3. The occurrence of tellurides in Ontario: Toronto, Univ., Studies, Geol. ser., no. 14, pp. 91-98, 1 pl., 1922.

4. Goudreau gold area, Michipicoten district, Ontario: Canada, Geol. Survey, Summ. Rept., 1921, pt. D, pp. 17-26, 3 figs., 1922.

5. Mineralography as an aid to millìng: Am. Mineralogist, vol. 8, no. 6, pp. 99-104, 8 figs., June, 1923.

6. Ores of the Silver Islet mine [Lake Superior]: Econ. Geology, vol. 18, no. 5, pp. 516-517, August, 1923.

7. A mineralographic study of germanite: Toronto, Univ., Studies, Geol. ser., no. 17 , pp. 62-65, 1924.

S. The tellurides: Canadian Min. Jour., vol. 45, no. 49, pp. 1187-1190, 4 figs., December 5, 1924.

9. A reexamination of keweenawite: Toronto, Univ., Studies, Geol. ser., no. 20, pp. 35-38, 1925.

10. Mineralographic notes on certain arsenides and sulpharsenides of cobalt, nickel, and iron: Toronto, Univ., Studies, Geol. ser., no. 20, pp. $54-58,1925$.

11. Missinaibi map area [Michipicoten iron ranges, Ontario]: Canada, Geol. Survey, Mem. 147, pp. 143-161, 1926.

12. A mineralographic examination of cohenite from Ovifak, Greenland: Toronto, Univ., Studies, Geol. ser., no. 24, pp. 41-43, 1927.

13. Canadian localities for chalmersite: Toronto, Univ., Studies, Geol. ser., no. 24, pp. 44-46, 1927.

14. A new telluride occurrence in Quebec: Toronto, Univ., Studies, Geol. ser., no. 27, pp. 11-14, 2 pls., 1928.

Thomson, Francis Andrew.

1. Notes on the antimony deposits [of Idaho] : Idaho, Univ., School of Mines, vol. 14, Bull. no. 2, pp. 45-53, January, 191.9.

2. First annual report of the secretary of the State Bureau of Mines and Geology for the period April 20th to December 31st, 1919. 16 pp., Moscow, Idaho, 1920.

$4096-31-39$ 
Thomson, Francis Andrew-Continued.

3. (and Ballard, Samuel M.). Geology and gold resources of north central Idaho: Idaho Bur. Mines and Geology, Bull. no. 7, 127 pp., 15 figs., 27 pls. (incl. maps), 1924.

4. Gold veins of sundry areas in the Idaho batholith: Eng. and Min. Jour.Press, vol. 118, no. 14, pp. 533-540, 10 figs., October 4, 1924.

5. Six years' work of the Idaho Bureau of Mines and Geology, 1919-1924: Idaho, Bur. Mines and Geology, Press Bull. no. 11, 8 pp., map, December, 1924.

6. (and McGonigle, Fritz). Zonal distribution of gold, silver, lead, and copper ores in Idaho: Eng. and Min. Jour.-Press, vol. 120, no. 6, pp. 216-218, 1 fig., August 8, 1925.

Thoreau, J.

1. Camp Bird compound veindike (discussion) : Econ. Geology, vol. 21, no. 1, pp. 90-91, January-February, 1926.

Thorington, J. Monroe.

1. The Lyell and Freshfield glaciers, Canadian Rocky Mountains, 1926: Smithsonian Misc. Coll., vol. 78, no. 6, 8 pp., 12 pls., February 5 , 1927.

Thornberry, Martin Harmon.

1. A treatise on Missouri clays, including production, occurrence, types, analyses, and softening points, with addenda: Missouri, Univ., School of Mines and Metallurgy, Bull., Technical ser., 69 pp., illus., February, 1925.

Thornbury, Delmar L.

1. California's redwood wonderland, Humboldt County [geology, chapter 7, pp. 43-50]. 167 pp., illus. [San Francisco, California, June, 1923].

Thorpe, Malcolm Rutherford.

1. Structural features of the Abajo Mountains, Utah: Am. Jour. Sci., 4th ser., vol. 48, pp. 379-389, 4 figs., November, 1919.

2. New species of Oligocene (White River) Felidae: Am. Jour. Sci., 4th ser., vol. 50, pp. 207-224, 10 figs., September, 1920.

3. John Day Promerycochoeri, with descriptions of five new species and one new subgenus: Am. Jour. Sci., 5th ser., vol. 1, no. 3, pp. 215-244, 6 figs., March, 1921 .

4. Leptauchenia Leidy and Cyclopidius (Pithecistus) Cope, with descriptions of new and little known forms in the Marsh collection: Am. Jour. Sci., 5th ser., vol. 1, pp. 405-419, 6 figs., May, 1921.

5. Two new fossil Carnivora: Am. Jour. Sci., 5th ser., vol. 1, pp. 477-483, 5 figs., June, 1921.

6. John Day Eporeodons, with description of new genera and species: Am. Jour. Sci., 5th ser., vol. 2, pp. 93-111, 16 figs., August, 1921.

7. Two new forms of Agriochoerus: Am. Jour. Sci., 5th ser., vol. 2, pp. 111119, 4 figs., August, 1921.

8. A newly mounted Eporeodon [from Scott's Bluff, Nebraska]: Am. Jour. Sci., 5th ser., vol. 2, pp. 309-312, 4 figs., December, 1921.

9. A new Merycoidodon: Am. Jour. Sci., 5th ser., vol. 2, pp. 334-342, 2 figs., December, 1921.

10. A new generic name for Pliocyon marshi [Araeocyon marshi] : Am. Jour. Sci., 5th ser., vol. 3, p. 97, January, 1922.

11. Oregon Tertiary Canidae, with descriptions of new forms: Am. Jour. Sci., 5th ser., vol. 3, pp. 162-176, 5 figs., March, 1922. 
Thorpe, Malcolm Rutherford-Continued.

12. A new genus of Oligocene Hyaenodontidae [Neohyaenodon]: Am. Jour. Sci., 5th ser., vol. 3, pp. 277-287, 2 figs., April, 1922.

13. Araeocyon, a probable Old World migrant: Am. Jour. Sci., 5th ser., vol. 3, pp. 371-377, May, 1922. Abstract, Geol. Soc. America, Bull., vol. 33, no. 1, pp. 214-215, March 31, 1922.

14. Some Tertiary Carnivora in the Marsh collection, with descriptions of new forms: Am. Jour. Sci., 5th ser., vol. 3, pp. 423-455, 13 figs., June, 1922.

15. Primitive and carnivore-like characters of the Merycoidodontidae (abstract) : Geol. Soc. America, Bull., vol. 33, no. 1, pp. 212-213, March 31, 1922.

16. Restoration of Eporeodon socialis Marsh (abstract) : Geol. Soc. America, Bull., vol. 33, no. 1, pp. 213-214, March 31, 1922.

17. Notes on the Bridger (Eocene) Carnivora: Am. Jour. Sci., 5th ser., vol. 5, pp. 23-39, January, 1923.

18. New species of Uinta Carnivora from White River, Utah: Am. Jour. Sci., 5th ser., vol. 5, pp. 218-224, 4 figs., March, 1923.

19. The hyoid apparatus of Merycoidedon: Am. Jour. Sci., 5th ser., vol. 5, pp. 225-228, 1 fig., March, 1923.

20. New reconstructions in the Yale Peabody Museum: Am. Jour. Sci., 5th ser., vol. 6, pp. 91-99, 6 pls., August, 1923.

21. The primitive and carnivore-like characters of the Merycoidodontidae: Am. Jour. Sci., 5th ser., vol. 6, pp. 239-246, September, 1923.

22. The generic distinctions between Merycochoerus Leidy and Promerycochoerus Douglass: Am. Jour. Sci., 5th ser., vol. 7, pp. 121-131, February, 1924.

23. White River (Oligocene). Eporeodons: Am. Jour. Sci., 5th ser., vol. 7, pp. 219-226, March, 1924.

24. Additional notes on Oreodontoides oregonensis Thorpe: Am. Jour. Sci., 5th ser., vol. 7, pp. 316-318, 3 figs., April; 1924.

25. A new species of extinct peccary from Oregon: Am. Jour. Sci., 5th ser., vol. 7, pp. 393-397, 4 figs., May, 1924.

26. The geological history of the Oreodonts: Jour. Mammalogy, vol. 6, no. 2, pp. 69-82, 5 figs., 2 pls., May, 1925.

Thurmond, F. LeRoi.

1. Is there a Canyon Diablo meteorite? : Eng. and Milı. Jour., vol. 122, no. 21, pp. 817-81.8, 3 figs., November 20, 1926.

Thurston, A. W.

1. Correlations of well drillings in northern Illinois with outcroppings of early Paleozoic beds in Wisconsin: Illinois State Acad. Sci., Trans., vol. 16, pp. 342-346, 1923.

Thurston, L. A. See Jaggar, 6.

Thwaites, Fredrik Turville. See also Twenhofel, 4.

1. A glacial gravel seam in limestone at Ripon, Wisconsin: Jour. Geology, vol. 29, no. 1, pp. 57-65, 7 figs., January-February, 1921.

2. (and Twenhofel, W. H.). Windrow formation; an upland gravel formation of the driftless and adjacent areas of the upper Mississippi Valley: Geol. Soc. America, Bull., rol. 32, no. 2, pp. 293-314, 1 fis., June 30, 1921 ; abstract, vol. 31, no. 1, p. 133, March 31, 1920. 
Thwaites, Fredrik Turville-Continued.

3. The Paleozoic rocks found in deep wells in Wisconsin and northern Illinois: Jour. Geology, vol. 31, no. 7, pp. 529-555, 2 figs., OctoberNovember, 1923 ; abstract, Geol. Soc. America, Bull., vol. 34, no. 1, p. 73, March 30, 1923.

4. Development of the theory of multiple glaciation in North America (abstract) : Geol. Soc. America, Bull., vol. 37, no. 1, pp. 182-183, March 30, 1926.

5. The origin and significance of pitted outwash: Jour. Geology, vol. 34, no. 4, pp. 308-319, 3 figs., May-June, 1926.

6. The development of the theory of multiple glaciation in North America: Wisconsin Acad. Sci., Trans., vol. 23, pp. 41-164, 1927.

7. Stratigraphy and geologic structure of northern Illinois with special reference to underground water supplies: Illinois State Geol. Survey, Rept. of Investigations no. 13, 49 pp., 2 figs. (incl. map.), 2 pls., 1927.

S. Pre-Wisconsin terraces of the Driftless Area of Wisconsin: Geol. Soc. America, Bull., vol. 39, no. 2, pp. 621-641, 6 figs., June, 1928; abstract, no. 1, p. 219, March 30, 1928; Pan-Am. Geologist, vol. 49, no. 2, p. 148, March, 1928.

Tickell, F. C.

1. The correlative value of the heavy minerals: Am. Assoc. Petroleum Geologists, Bull., vol. 8, no. 2, pp. 158-168, 12 figs., March-April, 1924.

Tideswell, F. V.

1. (and Wheeler, R. V.). The constitution of coal: Am. Inst. Min. and Met. Eng., Trans. [preprint] no. 1429, 7 pp., March, 1925; with discussion, Trans., vol. 71, pp. 176-183, 1925.

Tieje, Arthur Jerrold.

1. Underground waters of parts of Lincoln and Crowley counties: Colorado Geol. Survey, Bull. 26, pp. 9-15, 1921.

2. Suggestions as to the description and naming of sedimentary rocks: Jour. Geology, vol. 29, no. 7, pp. 650-666, October-November, 1921.

3. The red beds of the Front Range in Colorado; a study in sedimentation: Jour. Geology, vol. 31, no. 3, pp. 192-207, April-May, 1923.

4. New earliest known vertebrates (abstract) : Geol. Soc. America, Bull., vol. 35, no. 1, p. 162, March 30, 1924.

5. The Pliocene and Pleistocene history of Baldwin Hills [California] : Min. and Oil Bull., vol. 10, no. 11, p. 1132, 2 figs., November, 1924.

6. The Pliocene and Pleistocene history of the Baldwin Hills, Los Angeles County, California: Am. Assoc. Petroleum Geologists, Bull., vol. 10, no. 5, pp. 502-512, May, 1926.

7. Microfauna of the uppermost Pliocene or lowermost Pleistocene in the Los Angeles Basin, California (abstract): Geol. Soc. America, Bull., vol. 38, no. 1, p. 234, March, 1927 ; Pan-Am. Geologist, vol. 47, no. 3, pp. 237-238, April, 1927.

Tilley, Cecil E.

1. A publication for geological abstracts: Econ. Geology, vol. 14, no. 7, pp. 570-572, November, 1919.

Tillyard, Robin John.

1. The lower Permian insects of Kansas; preliminars announcement: Fntomological Nerss, vol. 34, pp. 292-295, December, 1923. 
Tillyard, Robin John-Continued.

2. Description of a. new paleodictyopterid [from Permian of Kansas]: Am. Jour. Sci., 5th ser., vol. 7, pp. 203-207, 1 fig., 2 pls., March, 1924.

3. Kansas Permian insects; Part 3, The new order Protohymenoptera: Am. Jour. Sci., 5th ser., vol. 8, pp. 113-122, 5 figs., 1 pl., August, 1924.

4. Kansas Permian insects; Part 4, The order Paleodictyoptera: Am. Jour. Sci., 5th ser., vol. 9, pp. 328-335, 3 flgs., April, 1925.

5. Kansas Permian insects; Part 5, The orders Protodonata and Odonuta: Am. Jour. Sci., 5th ser., vol. 10, pp. 41-73, 14 figs., July, 1925.

6. Kansas Permian insects; Part 6, Additions to the orders Protohymenoptera and Odonata: Am. Jour. Sci., 5th ser., vol. 11, pp. 58-73, 9 figs., January, 1926.

7. Kansas Permian insects; Part 7, The order Mecoptera: Am. Jour. Sci., 5th ser., vol. 11, pp. 133-164, 19 figs., February, 1926.

8. Kansas Permian insects; Part 8, The order Copeognatha: Am. Jour. Sci., 5th ser., vol. 11, pp. 315-349, 19 figs., April, 1826.

9. Kansas Permian insects; Part 9, The order Hemiptera: Am. Jour. Sci., 5th ser., vol. 11, pp. 381-395, 7 figs., May, 1926.

10. Kansas Permian insects; Part 10, The new order Protoperlaria; a study of the typical genus Lemmatophora Sellards; Part 11, Order Protoperlaria ; family Lemmatophoridae: Am. Jour. Sci., 5th ser., vol. 16, pp. 185-220, 19 figs., September, pp. 313-348; 22 figs., October, 1928.

11. Kansas Permian insects, Part 12, The family Delopteridæ, with a discussion of its ordinal position: Am. Jour. Sci., 5th ser., vol. 16, pp. 469-484, 11 figs., December, 1928.

Tilton, John Littlefield, 1863-1930. See also Gow, 1.

1. The Thurman-Wilson fault through southwestern Iowa, and its bearings: Jour. Geology, vol. 27, no. 5, pp. 383-390, 4 figs., July-August, 1919.

2. Geology of Clarke County : Iowa Geol. Survey, vol. 27, pp. 105-169, 4 figs., map [1920].

3. Geology of Cass County Iowa Geol. Survey, vol. 27, pp. 171-176, 15 figs., 1 pl., map [1920].

4. Note on conditions at the head of flood plains: Iowa Acad. Sci., Proc., vol. 26, p. 391 [1920].

5. Strata near Stuart, Iowa: Geol. Soc. America, Bull., vol. 33, no. 4, pp. 689-702, 3 figs., November 2, 1922; abstract, no. 1, p. 153, March 31, 1922.

6. Observations on coal swamps in northern West Virginia where Permian conditions prevail (abstract): Geol. Soc. America, Bull., vol. 34, no. 1, p. 72, March 30, 1923.

7. The Missouri series of the Pennsylvanian system in southwestern Iowa: Iowa Geol. Survey, vol. 29, pp. 223-313, 17 figs., 9 pls. (incl. maps) [1924].

8. Cross section of the Permian in West Virginia (abstract) : Geol. Soc. America, Bull., vol. 36, no. 1, p. 220, March 30, 1925.

9. The definition of loess: Science, new ser., vol. 62 , p. 83, July 24, 1925.

10. Permian vertebrates from West Virginia: Geol. Soc. America, Bull., vol. 37, no. 2, pp. 385-395, 2 figs., 1 pl., June 30, 1926 ; abstract, no. 1, p. 238, March 30, 1926.

11. Local conditions at a Mississippian disconformity: West Virginia Acad. Sci., Proc., vol. 1, no. 1 (W. Va. Univ. Bull., ser. no. 27, no. 1), pp. 74-80, 7 figs., August, 1926. 
Tilton, John Littlefield-Continued.

12. The Permian of West Virginia as a field of research (abstract). West Virginia Acad. Sci., Proc., vol. 1, no. 1 (W. Va. Univ. Bull., ser. no. 27 , no. 1, p. 128 , August, 1926.

13. Structure and scenery in West Virginia (abstract) : Geol. Soc. America, Bull., vol. 38, no. 1, p. 217, March 30, 1927; Pan-Am. Geologist, vol. 47, no. 4, pp. 318-319, April, 1927.

14. (and Prouty, William F., and Price, Paul H.). Pendleton County: West Virginia Geol. Survey, [County reports], 384 pp., 25 figs., 80 pls., 2 maps (in atlas), 1927.

15. (and Prouty, William F., Tucker, R. C., and Price, Paul H.). Hampshire and Hardy counties: West Virginia Geol. Survey, [County reports], 624 pp., 19 figs., 78 pls., 4 maps (in atlas), 1927.

16. History of the development of the department of geology at West Virginia University (abstract) : West Virginia Acad. Sci., Proc., vol. 2 (W. Va. Univ. Bull., ser. no. 29, no. 1), pp. 137-139, August, 1928.

17. Scenic geology in West Virginia: West Virginia Acad. Sci., Proc., vol. 2 (W. Va. Univ. Bull., ser. no. 29, no. 1), pp. 140-144, August, 1928.

18. Two illustrations of wind action in West Virginia: West Virginia Acad. Sci., Proc., vol. 2 (W. Va. Univ. Bull., ser. no. 29, no. 1), pp. 145150, 3 figs., August, 1928.

Timm, W. B.

1. (and Robinson, A. H. A.). The gold fields of western Quebec: Canada, Mines Branch, Investigations of mineral resources and the mining industry, 1924, pp. 55-61, 1926. The gold ores of northwestern Quebec: Canadian Min. Jour., vol. 46, no. S, pp. 194-197, February 20, 1925.

'ingley, Richard Hoadley.

1. Alunite and its products: Eng. and Min. Jour.-Press, vol. 115, no. 11., pp. 494-497, 5 figs., March 17, 1923.

Todd, E. W.

1. The estimation of niobium, tantalum, and titanium in minerals: Toronto, Univ., Studies, Geol. ser., no. 16, pp. 40-45, 1923.

2. The quartz spectrograph in mineral analysis: Toronto, Univ., Studies, Geol. ser., no. 17, pp. 66-68, 1 pl., 1924.

3. Kenogamissi Lake area including townships of Denton and Keefer: Ontario Dept. Mines, 32d Ann. Rept., vol. 32, pt. 3, pp. 23-35, 2 figs., 2 pls., map, 1924.

4. Groundhog River area: Ontario Dept. Mines, 33d Ann. Rept., vol. 33, pt. 6, pp. 1-17, illus., 1925.

5. The Matabitchuan area, districts of Timiskaming and Nipissing: Ontario Dept. Mines, 34th Ann. Rept., vol. 34, pt. 3, 38 pp., illus., map, 1925 ; extract, Canadian Min. Jour., vol. 47, no. 6, pp. 139-142, 1 fig., February 5, 1926.

6. Gowganda vein minerals: Ontario Dept. Mines, 35th Ann. Rept., vol. 35, pt. 3, pp. 62-78, 11 figs., 1926.

7. Anima-Nipissing Lake area: Ontario Dept. Mines, 35th Ann., Rept., vol. 35, pt. 3, pp. 79-104, 7 figs., map, 1926.

8. Kirkland Lake gold area: Ontario Dept. Mines, 37th Ann. Rept., vol. 37, pt. 2, 176 pp., illus. (incl. maps), 1928. 
'Told, James Edward, 1846-1922.

1. Certain diverse interpretations of Pleistocene in the Dakotas (abstract) : Geol. Soc. America, Bull.; vol. 31, no. 1, pp. 134-135, March 31, 1920.

2. Aqueous loess (abstract): Kansas Acad. Sci., Trans., vol. 29, pp. 115116, 1920.

3. Lacustrine beds near Atchison (abstract) : Kansas Acad. Sci., Trans., vol. 29, pp. 116-117, 1920.

4. More evidence that Platte River, Nebraska, formerly connected with Grand River, Missouri: Kansas Acad. Sci., Trans., vol. 30, pp. 179-182, 1922.

5. Is the channel of the Missouri River through North Dakota of Tertiary origin?: Geol. Soc. America, Bull., vol. 34, no. 3, pp. 469-493, 6 figs., September 30, 1923; abstract, vol. 33, no. 1, pp. 120-121, March 31, 1922.

6. Glacial diversion of the Missouri River: Pan-Am. Geologist, vol. 39, no. 3, pp. 169-184, April, 1923.

Toepelman, Walter Carl.

1. Paleontology of the [Badlands] area: South Dakota Geol. and Nat. Hist. Survey, Bull. 11, pp. 61-73, August, 1922.

2. The possibilities of oil in eastern Harding County: South Dakota Geol. and Nat. Hist. Survey, Circular 12, 12 pp., 3 figs., March, 1923.

3. Underground water resources of parts of Crowley and Otero counties: Colorado Geol. Survey, Bull. 27, pt. 2, pp. 59-72, map, 1924.

4. Notes on the Laramie formation in central Weld County, Colorado: Jour. Geology, vol. 34, no. 8, pp. 834-835, November-December, 1926.

5. The geology of a portion of the Slim Buttes region of northwestern South Dakota, with special reference to unusual structural features due to slumping (abstract) : Chicago, Univ., Abstracts of Theses, Sci., Ser., vol. 4, pp. 227-234, May, 1.928.

Tolmachoff, Innokenti Pavlovich.

1. Note on the Devonian fauna of Ellesmere Land: Am. Jour. Sci., 5th ser., vol. 11, pp. 47-55, January, 1926.

2. On the fossil faunas from Per Schei's Series D from Ellesmere Land with exception of brachiopods, corals, and cephalopods: Second Norwegian Arctic Expedition in the Fram 1898-1902, Report (published by Norske Videnskaps-Akademi i Oslo), no. 38,106 pp., 8 pls., 1926.

3. Note on the extinction of the mammoth in Siberia: Am. Jour. Sci., 5th ser., vol. 14, pp. 66-69, July, 1927.

4. Note on the discovery of the Champlain fauna on Lake St. John, Quebec, Canada: Canadian Field-Naturalist, vol. 41, no. 6, pp. 123-125, 4 figs., September, 1927.

5. Extinction and extermination: Geol. Soc. America, Bull., vol. 39, no. 4, pp. 1131-1148, December 30, 1928; abstract, no. 1, pp. 293-294, March 30, 1928; Pan-Am. Geologist, vol. 49, no. 3, p. 229, April, 1928.

Tolman, C. F. See also Becking, 1.

1. Summary of progress in the microscopic study of the siliceous shales (abstract) : Geol. Soc. America, Bull., vol. 38, no. 1, pp. 196-197, March 30, 1927.

2. Biogenesis of hydrocarbons by diatoms: Econ. Geology, vol. 22, no. 5, pp. 454-474, 1 fig., 5 pls., August, 1927. 
Tomlinson, Charles Weldon. See also Collingwood, 1; Moore, R. C., 17.

1. (and Storm, Willis). The Graham field, Oklahoma: Am. Assoc. Petroleum Geologists, Bull., vol. 8; no. 5, pp. 593-620, 10 figs., September-October, 1924.

2. Buried hills near Mannsville, Oklahoma: Am. Assoc. Petroleum Geologists, Bull., vol. 10, no. 2, pp. 138-143; 3 figs., February, 1926.

3. Pennsylvanian system in the Ardmore Basin [Oklahoma] (abstract) : Geol. Soc. America, Bull., vol. 38, no. 1, p. 156, March 30, 1927; Pan-Am. Geologist, vol. 47, no. 2, pp. 154-155, March, 1927.

4. Oil and gas geology of Carter County: Oklahoma Geol. Survey, Bull. no. 40-Z, 78 pp., 15 figs., 3 pls. (incl. map), September, 1928.

Includes contributions by John R. Bunn, Sam H. Woods and J. P. McKee, Geo. E. Burton, A. M. Meyer, Bruce Harlton, and Sidney Powers.

Tondorff, Francis Anthony, 1870-1930.

1. The registration of earthquakes at the Georgetown University [District of Columbia] Station ... January 1, 1916, to January 1, 1917 : Georgetown Univ., Seismographic Station, Bull. no. 1, 23 pp., January 1, 1917.

2. The registration of earthquakes at the Georgetown University [District of Columbia] Station . . . January 1, 1917, to January 1, 1918:

Georgetown Univ., Seismographic Station, Bull. no. 2, 30 pp., January 1, 1918.

3. The registration of earthquakes at the Georgetown University [District of Columbia] Station . . . January 1, 1918, to January 1, 1919: Georgetown Univ., Seismographic Station, Bull. no. 3, 31 pp., January 1, 1919.

4. The registration of earthquakes at the Georgetown University [District of Columbia] Station . . J January 1, 1919, to January 1, 1920: Georgetown Univ., Seismographic Station, Bull. no. 4, 25 pp., January 1, 1920.

5. The registration of earthquakes at the Georgetown University [District of Columbia] Station . . . January 1, 1920, to January 1, 1921: Georgetown Univ., Seimographic Station, Bull. no. 5, 25 pp., April 1, 1921.

6. The registration of earthquakes and press dispatches on earthquakes from January 1, 1921, to January 1, 1922 : Georgetown [District of Columbia] Uniy. Pub., 18th ser., no. 3, 24 pp., Washington, D. C., March, 1922.

7. How the earth telegraphed its Tokyo quake to Washington: Nat. Geog. Mag., vol. 44, no. 4, pp. 453-454, 1 pl., October, 1923.

8. Enhancing the value of the seismogram: Nat. Research Council, Bull, no. 53 (vol. 10, pt. 3), pp. 46-48, July, 1925.

9. Seismology, a retrospect: Washington Acad. Sci., Jour., vol. 16, no. 9, pp. 233-240, 2 figs., May 4, 1926.

Torres, Lidio A.

1. Configuración hipotética de la región petrolifera del Pánuco en el horizonte de las calizas Tamasopo: Bol. petróleo, vol. 22, no. 2, pp. 83-104, 3 pls., August, 1926.

2. Breve discusion sobre las teorias del origen del petróleo: Bol. petróleo, vol. 24, no. 6, pp. 649-654, December, 1927. 
Torrey, Paul D.

1. (and Fralich, Charles D.). An experimental study of the origin of salt domes : Jour. Geology, vol. 34, no. 3, pp. 224-234, 10 figs., AprilMay, 1926.

2. Oil-field waters of the Bradford pool [Pennsylvania]: Am. Inst. Min. and Met. Eng., Tech. Pub. no. 38, 15 pp., 4 figs., December, 1927; Oil and Gas Jour., vol. 26, no. 40, pp. 155, 157-158, 161-162, 3 figs., February 23, 1928.

3. Some factors influencing production of oil by flooding in the Bradford and Allegany fields [Pennsylvania] : Am. Inst. Min. and Met. Eng., Tech. Pub. no. 39, 24 pp., 11 figs., December, 1927.

4. Geologic factors in water flooding: Oil and Gas Jour., vol. 26, no. 52, pp. 66, 111-112, 115-116, May 17, 1928.

5. Some geological factors influencing the recovery of oil by flooding. Am. Petroleum Inst., Devel. and Prod. Eng. Bull. no. 202, pp. 144-148, September, 1928.

Torrey, Ray Ethan.

1. The comparative anatomy and phylogeny of the Coniferales; part 3, Mesozoic and Tertiary coniferous woods: Boston Soc. Nat. Hist., Mem., vol. 6, no. 2, pp. 39-106, 1 fig., 8 pls., April, 1923.

Tough, Frederick $B$.

1. (and Williston, Samuel H., and Savage, T. F.). Experiments in water control in the Flat Rock pool, Crawford County: Illinois State Geol. Survey, Bull. no. 40, pp. 97-140, 3 pls. (maps), 18 figs., 1919.

Tovote, William L., 1872-1919.

1. The copper industry of the Southwest: Min. Mag., vol. 20, no. 5, pp. 267275, 339-350, 6 figs., May and June, 1919.

2. Certain ore deposits of the Southwest (with discussion) : Am. Inst. Min. and Met Eng., Trans., vol. 61, pp. 42-59, 1920.

Townley, Sidney $\mathrm{D}$.

1. Earthquakes on the Pacific coast of North America: Seismol. Soc. America, Bull., vol. 9, no. 3, pp. 72-85, September, 1919.

2. John Casper Branner : Seismol. Soc. America, Bull., vol: 12, no. 1, pp. 1-11, portr., March, 1922.

Trager, Earl A. See also Aurin, 2; Cushman, 16.

1. A laboratory method for the examination of well cuttings: Econ. Geology, vol. 15, no. 2, pp. 170-176, 1 fig., March, 1920.

2. A résumé of the oil-shale industry, with an outline of methods of distillation: Am. Assoc. Petroleum Geologists, Bull., vol. 4; no. 1, pp. 59-71, 6 figs., 1920.

3. Underground stratigraphic characteristics of eastern Oklahoma : Am. Jour. Sci., 5th ser., vol. 5, pp. 140-146, February, 1923.

4. Kerogen and its relation to the origin of oil: Am. Assoc. Petroleum Geologists, Bull., vol. 8, no. 3, pp. 301-311, 4 figs., 3 pls., May-June, 1924.

5. 'The geologic history of the Panuco River valley and its relation to the origin and accumulation of oil in Mexico: Am. Assoc. Petroleum Geologists, Bull., vol. 10, no. 7, pp. 667-696; 7 figs., 3 pls., July, 1926 ; [in Spanish], Bol. petroleo, vol. 22, no. 4, pp. 243-260, 9 pls., Octoher, 1.926. 
Trainer, David W., jr. See also Nevin, 2.

1. The geology of molding sand deposits: Am. Foundrymen's Assoc., Trans., vol. 33 , pp. 797-807, 1926; also Reprint no. 428.

2. The molding sands of Maryland: Maryland Geol, Survey, vol. 12, pp. 27-89, 1 fig., 1928.

3. Molding sands of Wisconsin : Wisconsin Geol. and Nat. Hist. Survey, Bull. no. 69,103 pp., 15 figs., 5 tables, 1928.

Trask, Parker Davies.

1. A study of the fauna and stratigraphy of the Briones formation of middle California (abstract) : Geol. Soc. America, Bull., vol. 32, no. 1, pp. 145-146, March 31, 1921.

2. The Briones formation of middle California: California, Univ., Dept. Geol. Sci., Bull., vol. 13, no. 5, pp. 133-174, 8 pls., May 10, 1922.

3. Unique garnet sand forming along the beach at the mouth of the Sur River, Monterey County, California (abstract) : Geol. Soc. America, Bull., vol. 35, no. 1, p. 165, March 30, 1924.

4. Origin of the Santa Lucia coast range, California (abstract) : Geol. Soc. America, Bull., vol. 36, no. 1, p. 151, March 30, 1925; Pan-Am. Geologist, vol. 43, no. 2, pp. 149-150, March, 1925.

5. Geology of Point Sur quadrangle, California : California, Univ., Dept. Geol. Sci., Bull., vol. 16, no. 6, pp. 119-186, 2 figs., 1 pl., map, November 10, 1926.

6. (and Mather, Kirtley F.). Stratigraphy of the Lake Ainslie region, Cape Breton Island, Nova Scotia (abstract): Washington Acad. Sci., Jour., vol. 17, no. 12, pp.. 322-324, June 19, 1927.

7. Oceanography and oil deposits: Nat. Research Council, Bull. no. 61, pp. 235-240, 2 figs., July, 1927.

8. Results of distillation and other studies of the organic nature of some modern sediments: Am. Assoc. Petroleum Geologists, Bull., vol. 11, no. 11, pp. 1221-1230, November, 1927.

9. Limestones as a source of oil: Am. Assoc. Petroleum Geologists, Bull., vol. 12, no. 5, pp. 556-557, May, 1928.

10. The potential value of several recent American coastal and inland deposits as future source beds of petroleum: Am. Assoc. Petroleum Geologists, Bull., vol. 12, no. 11, pp. 1057-1068, November, 1928.

Treasher, Ray C.

1. Origin of the loess of the Palouse region, Washington: Science, new ser., vol. 61, p. 469, May 1, 1925.

2. A binocular magnifier for the determination of opaque minerals: Science, new ser., vol. 64, pp. 332-333, October 1, 1926.

3. Stratigraphic aspects of loess of Palouse region: Pan-Am. Geologist, vol. 46, no. 4, pp. 305-314, 2 pls., November, 1926.

Trechmann, C. T.

1. The Cretaceous and Tertiary question in Jamaica: Geol. Mag., vol. 59, pp. 422-431, 3 figs., September, 1922.

2. The Barrettia beds of Jamaica: Geol. Mag., vol. 59, pp. 501-514, 1 fig., 3 pls., November, 1922.

3. The Yellow limestone of Jamaica and its Mollusca: Geol. Mag., vol. 60, no. 710, pp. 337-367, 5 pls., August, 1923.

4. The carbonaceous shale or Richmond formation of Jamaica: Geol. Mag., vol. 61, no. 1, pp. 2-19, 2 pls., January. 1924.

5. The Cretaceous limestones of Jamaica and their Mollusca: Geol. Mag., vol. 61, no. 9, pp. 385-410, 1 fig., 4 pls., September, 1924. 
Trechmann, C. T.-Continued.

6. The Scotland beds of Barbados: Geol. Mag., vol. 62, pp. 481-504, 4 pls., November, 1925.

7. The Northern Range of Trinidad: Geol. Mag., vol. 62, pp. 544-551, 1 pl., December, 1925.

8. The Cretaceous shales of Jamaica: Geol. Mag., vol. 64, pp. 27-41, 49-65, 3 figs., 4 pls., January and February, 1927.

Trelease, William.

1. Bearing of the distribution of the existing flora of Central America and the Antilles on former land connections: Geol. Soc. America, Bull., vol. 29, no. 4, pp. 649-656, December 30, 1918.

2. The American oaks: Nat. Acad. Sci., Mem., vol. 20, 255 pp., 7 figs., 420 pls., 1924.

Includes sections on the geologic history and evolution of the oaks.

Trimble, K. W. See Miser, 13.

Trischka, Carl.

1. Asbestos and the Arizona industry: Eng. and Min. Jour., vol. 124, no. 9, pp. 337-340, 5 figs., August 27, 1927.

2. The silica outcrops of the Warren mining district, Arizona: Eng. and Min. Jour., vol. 125, no. 26, pp. 1045-1050, 7 figs., June 30, 1928.

Tristán, J. Fidel.

1. Recent eruptions of Poás Volcano in Costa Rica: Zeitschr. Vulkanologie, Bd. 2, H. 3, pp. 140-146, 7 pls., January, 1916.

2. (and Fernández Peralta, Ricardo). Informe presentado al Señor Ministro de Instrucción Pública sobre la actividad del volcán Irazú. Colegio de Señoritas, Publicaciones, Serie A, no. 1, 1917 [not seen]. La Gaceta,. Diario Oficial, año 39, no. 130, pp. 662-664, 6 figs., San José, Costa Rica, December 4, 1917.

3. The activity of the volcano Irazú in Costa Rica: Zeitschr. Vulkanologie, Bd. 7, H. 2, pp. 93-104, 1 fig., 9 pls., July, 1923.

Trivelli, A. P. H. See Fairbanks, 12.

Troedsson, Gustaf T.

1. Modern ideas on American stratigraphy and paleogeography: New York State Mus. Bull., no 260, pp. 117-126, 1925.

2. On the middle and upper Ordovician faunas of northern Greenland; I, Cephalopods: Jubilaeumsekspeditionen Nord om Groenland, 192023, Nr. 1 (Saertryk af Meddelelser om Groenland, LXXI), 157 pp., 17 figs., 65 pls., 1926. Also issued as Communications paléontologiques no. 25 of the Muséum de mineralogie et de géologie de l'Université de Copenhague, 1926.

3. Charles D. Walcott: Geol. Fören. Stockholm, Förh., Bd. 49, H. 2, pp. 290292, portr., March-April, 1927.

Trowbridge, Arthur Carleton. See also Twenhofel, 16, 18.

1. The erosional history of the Driftless Area: Iowa, Univ., Studies, 1st ser., no. 40, Studies in Natural History, vol. 9, no. 3, 127 pp., 35 figs., January 1, 1921.

2. The existing stage of erosion in the United States (abstract): Science, new ser., vol. 54, p. 307, September 30, 1921.

3. (and Lonsdale, J. T.). Some north-south topographic profiles in the United States (abstract) : Science, new ser., vol. 54, pp. 307-308, September $30,1921$. 
Trowbridge, Arthur Carleton-Continued.

4. (and Glock, W. S.). Quantitative study of the derivation of North American Algonkian sediments (abstract): Geol. Soc. America, Bull., vol. 33, no. 1, p. 108, March 31, 1922.

5. A geologic reconnaissance in the Gulf Coastal Plain of Texas near the Rio Grande: U. S. Geol. Survey, Prof. Paper 131, pp. 85-107, 1 pl. (map), February 12, 1923.

6. Tertiary stratigraphy in the lower Rio Grande region (abstract): Geol. Soc. America, Bull., vol. 34, no. 1, p. 75, March 30, 1923.

7. Sedimentation at the mouths of the Mississippi River-preliminary report (abstract) : Geol. Soc. America, Bull., vol. 34, no. 1, p. 95, March $30,1923$.

8. The status of sedimentation in Iowa (abstract) : Iowa Acad. Sci., Proc. 1922, vol. 29, p. 127 [1924].

9. Reynosa formation in southwest Texas (abstract): Geol. Soc. America, Bull., vol. 36, no. 1, pp. 164-165, March 30, 1925; Pan-Am. Geologist, vol. 43, no. 2, pp. 154-155, March; 1925.

10. (and Mortimore, Morris E.). Correlation of oil sands by sedimenetary, analysis : Econ. Geology, vol. 20, no. 5, pp. 409-423, 10 figs., 2 pls., August, 1925.

11. Reynosa formation in lower Rio Grande region, Texas: Geol. Soc. America, Bull., vol. 37, no. 3, pp. 455-462, 3 figs., September 30, 1926.

12. Disposal of sediments carried to the Gulf of Mexico by Southwest Pass, Mississippi River (abstract) : Geol. Soc. America, Bull., vol. 38, no. 1, 148, March 30, 1927 ; Pan-Am. Geologist, vol. 47, no. 2, p. 152, March, 1927.

Troxell, Edward Leffingwell.

1. Study of the entelodonts (abstract): Geol. Soc. America, Bull., vol. 31, no. 1, p. 223, March $31,1920$.

2. A tiny Oligocene artiodactyl Hypisodus alacer sp. nov.: Am. Jour. Sci., 4th ser., vol. 49, pp. 391-398, 4 figs., June, 1920.

3. Entelodonts in the Marsh collection: Am. Jour. Sci., 4th ser., vol. 50, pp. 243-255, 361-386, 431-445, 20 figs., 1 pl., October-December, 1920.

4. The American bothriodonts: Am. Jour. Sci., 5th ser., vol. 1, no. 4, pp. 325-339, 7 figs., April, 1921.

5. Palaeologus, an extinct hare: Am. Jour. Sci., 5th ser., vol. 1, no. 4, pp. 340-348, 20 figs., April, 1921.

6. The nature of a species in paleontology and a new kind of type specimen: Jour. Geology, vol. 29, no. 5, pp. 475-479, July-August, 1921.

7. New amynodonts in the Marsh collection: Am. Jour. Sci., 5th ser., vol. 2, pp. 21-34, 7 figs., July, 1921.

8. New species of Hyracodon: Am. Jour. Sci., 5th ser., vol. 2, pp. $34-40,5$ figs., July, 1921.

9. Caenopus, the ancesetral rhinoceros: Am. Jour. Sci., 5th ser., vol. 2, pp. 41-51, 6 figs., July, 1921.

10. A study of Diceratherium and the diceratheres: Am. Jour. Sci., 5th ser., vol. 2, pp. 197-208, 8 figs., October, 1921.

11. Oligocene rodents of the genus Ischyromys: Am. Jour. Sci., 5th ser., vol. 3, pp. 123-130, 7 figs., February, 1922.

12. Fossils of the Connecticut Valley (abstract): Geol. Soc. America, Bull., vol, 33, no. 1, p. 209, March 31, 1922.

13. Relationship of the Great Basin and Great Plains fauna (abstract) : Geol. Soc. America, Bull., vol. 33, no. 1, p. 210, March 31, 1922. 
Troxell, Edward Leffingwell-Continued.

14. The status of Homogalax, with two new species: Am. Jour. Sci., 5th ser., vol. 3, pp. 288-292, 4 figs., April, 1922.

15. Helaletes redefined: Am. Jour. Sci., 5th ser., vol. 3, pp. 365-370, 3 figs., May, 1922.

16. Horned Eocene ungulates: Am. Jour. Sci., 5th ser., vol. 4, pp. 31-37, 5 figs., July, 1922.

17. The genus Hyrachynus and its subgroups: Am. Jour. Sci., 5th ser., vol. 4, pp. 38-49, 5 figs., 1 pl., July, 1922.

1. Pauromys perditus, a small rodent [Bridger formation, Wyoming] : Am. Jour. Sci., 5th ser., vol. 5, pp. 155-156, 1 fig., February, 1923.

19. Diplolophus, a new genus of rodents: Am. Jour. Sci., 5th ser., vol. 5, pp. 157-159, 5 figs., February, 1923.

20. American rhinoceroses and the evolution of Diceratheriam (abstract) : Geol. Soc. America, Bull., vol. 34, no. 1, p. 134, March 30, 1923.

21. The Eocene rodents Sciuravus and Tillomys: Am. Jour. Sci., 5th ser., vol. 5, pp. 383-396, 23 figs., May, 1923.

22. The Apatemyidae: Am. Jour. Sci., 5th ser., vol. 5, pp. 503-506, 6 figs., June, 1923.

23. A new marsupial [Herpetotherium marsupium, Bridger Basin, Wyoming] : Am. Jour. Sci., 5th ser., vol. 5, pp. 507-510, 4 figs., June, 1923.

24. Geological features of city parks: Science, new ser., vol. 60, pp. 308-309, October 3, 1924.

25. Mechanics of crocodile vertebrae: Geol. Soc. America, Bull., vol. 36, no. 4, pp. 605-614, 6 figs., December 30, 1924.

26. The Bridger crocodiles: Am. Jour. Sci., 5th ser., vol. 9, pp. 29-72, 22 figs., Januar'y, 1925.

27. Hyposaurus, a marine crocodilian: Am. Jour. Sci., 5th ser., vol. 8, pp. 489514, 15 figs., June, 1925.

28. Thoracosaurus, a Cretaceous crocodile: Am. Jour. Sci., 5th ser., vol. 10, pp. 219-233, 6 figs., September, 1925.

29. Fossil logs and nuts of hickory: Sci. Monthly, vol. 21, no. 6, pp. 570-572, 3 figs., December, 1925.

30. Smiladectes or Notharctus: Am. Jour. Sci., 5th ser., vol. 11, pp. 423-428, 3 figs., May, 1926.

Trueman, Arthur Elijah.

1. Aspects of ontogeny in the study of ammonite evolution: Jour. Geology, vol. 30, no. 2, pp. 140-143, 1 fig., February-March, 1922.

Tucker, R. C. See Tilton, 13.

Tucker, William Burling. See also Boalich, 1.

1. Economic minerals of the Avawatz Mountains: California State Min. Bur., Mining in California, vol. 18, no. 3, pp. 114-117, March, 1922.

2. Gold lodes of the East Fork mining district, Trinity County: California State Min. Bur., Mining in California, vol. 18, no. 6, pp. 270-273, June, 1922.

3. Silver lodes of the South Fork mining district, Shasta County: California State Min. Bur., Mining in California, vol. 18, no. 7, pp. 313-321, 2 figs., July, 1922.

4. Copper resources of Shasta County: California State Min. Bur., Mining in California, vol. 20, no. 4, pp. 41.9-447, 13 figs., 1 pl. (map), October, 1924. 
Tucker, William Motier.

1. Pyrite deposits in Ohio coal : Econ. Geology, vol. 14, no. 3, pp. 198-219, 3 figs. (maps), May, 1919.

2. A zone of large concretions in the Knobstone [Monroe County, Indiana] : Indiana Acad. Sci., Proc., 1921, pp. 221-222, 2 figs., 1922.

3. History of the lakes near La Porte, Indiana: Indiana Acad. Sci., Proc. 38th Ann. Meeting, 1922, pp. 83-94, 5 figs., 1923.

Tunell, George. See Posnjak, 2.

Turner, Henry Ward.

1. The magmatic origin of the chalcopyrite and bornite at Engels [Plumas County, California] : Min. and Sci. Press, vol. 123, no. 10, pp. 333334, September 3, 1921.

2. Platinum in quartz veins: Eng. and Min. Jour., vol. 113, no. 12, pp. 4SS489, March 25, 1922.

3. Origin of Wilshire gold ore [California] : Eng. and Min. Jour.-Press, vol. 11.8, no. 5, p. 172, August 2, 1924.

4. Magnesite deposits and their origin: Econ. Geology, vol. 20, no. 2, pp. 197198, March-April, 1925.

5. Metal content in magmas (discussion) : Econ. Geology, vol. 20, no. 6, pp. 607-608, September-October, 1925.

Turner, Homer Griffield.

1. Laboratory determinations of dip and strike: Science, new ser., vol. 55, pp. 53-54, 1 fig., January 13, 1922.

2. (and Randall, H. R.). A preliminary report on the microscopy of anthracite coal: Jour. Geology, vol. 31, no. 4, pp. 306-313, 11 figs., May-June, 1923.

3. Microscopical structure of anthracite: Am. Inst. Min. and Met. Eng., Trans. [preprint] no. 1409, 21 pp., 21 figs., February, 1925; with discussion, Trans., vol. 71, pp. 127-148, 21 figs., 1925; abstract, Mining and Metallurgy, vol. 7, no. 229, p. 26, January, 1926.

Twenhofel, Lillian $\mathrm{H}$.

1. Changes in the oxidation of iron in magnetite: Econ. Geology, vol. 22, no. 2, pp. 180-188, March-April, 1927.

Twenhofel, William Henry. See also Lee, W. T., 1; Stanton, 8; Thwaites, 2.

1. The chert of the Wreford and Foraker limestones along the State line of Kansas and Oklahoma: Am. Jour. Sci., 4th ser., vol. 47, pp. 407-429, 1 fig., June, 1919.

2. Additional facts relating to the granite boulders of southeastern Kansas: Am. Jour. Sci., 4th ser., vol. 48, pp. 132-135, August, 1919.

3. Pre-Cambrian and Carboniferous algal deposits: Am. Jour. Sci., 4th ser., vol. 48, pp. 339-352, 5 figs., November, 1919.

4. (and Thwaites, F. T.). The Paleozoic section of the Tomah and Sparta quadrangles, Wisconsin: Jour. Geology, vol. 27, no. 8, pp. 614-633, 2 figs., November-December, 1919.

5. [The Cretaceous sediments of Kansas (discussion)] : Geol. Soc. America, Bull., vol. 31, no. 1, pp. 135-136, March 31, 1920.

6. The Comanchean and Dakota strata of Kansas: Am. Jour. Sci., 4th ser., vol. 49, pp. 281-297, 1 fig., April, 1920.

7. Revision of the Anticosti section (abstract) : Geol. Soc. America, Bull., vol. 31, no. 1, p. 209, March 31, 1920. 
'Twenhofel, William Henry-Continued.

8. (and Edwards, E. C.). The metamorphic rocks of Woodsou County, Kansas: Am. Assoc. Petroleum Geologists, Bull., vol. 5, no. 1, pp. 64-74, 1 fig., 1 pl., January-February, 1921.

9. (and Conine, W. H.). The postglacial terraces of Anticosti Island: Am. Jour. Sci., 5th ser., vol. 1, pp. 268-27S, 2 figs., March, 1921.

10. Studies of sedimentation in the universities of the central part of the United States (abstract) : Geol. Soc. America, Bull., vol. 32, no. 1, p. 20, March 31, 1921.

11. (and Edwards, E. C.). Occurrence of basal conglomerates (abstract) : Geol. Soc. America, Bull., vol. 32, no. 1, p. 40, March 31, 1921.

12. Faunal and sediment variations in the Anticosti sequence: Canada, Geol. Survey, Bull. no. 33, pp. 1-14, September 14, 1921.

13. Impressions made by bubbles, raindrops, and other agencies: Geol. Soc. America, Bull., vol. 32, no. 4, pp. 359-371, 7 figs., December 1, 1921.

14. Development of shrinkage cracks in sediments without exposure to the atmosphere (abstract) : Geol. Soc. America, Bull., vol. 34, no. 1, p. 64, March 30, 1923.

15. The negligible oil possibilities of Wisconsin : Am. Assoc. Petroleum Geologists, Bull., vol. 7, no. 6, pp. 653-660, 1 fig. (map), NovemberDecember, 1923.

16. (and others). Report of the committee on sedimentation. $65 \mathrm{pp}$. Issued in mimeograph form by the National Research Council, Washington, D. C., 1924.

17. The geology and invertebrate paleontology of the Comanchean and "Dakota" formations of Kansas: Kansas, State Geol. Survey, Bull. 9, 135 pp., 23 pls. (incl. maps), 1924.

18. (and others). Researches in sedimentation in 1924; report of the committee on sedimentation. $78 \mathrm{pp}$., issued in mimeographed form by the National Research Council, Washington, D. C., 1925. Includes contributions by E. M. Kindle, J. Volney Lewis, A. C. Trowbridge, Eliot Blackwelder, J. A. Udden, L. Murray Neumann, W. A. Tarr, Robert W. Sayles, R. O. E. Davis, George Steiger; C. E. Van Orstrand, and W. H. Twenhofel.

19. Significance of some of the surface structures of central and westeru Kansas: Am. Assoc. Petroleum Geologists, Bull., vol. 9, no. 7, pp. 1061-1070, October, 1925.

20. (and Stryker, W. L.). The subsurface distribution of the Comanchean in western Kansas: Am. Assoc. Petroleum Geologists, Bull., vol. 9, no. 7 , October, 1925 .

21. Treatise on sedimentation. 661 pp., 61 figs., Baltimore, The Williams \& Wilkins Company, 1926.

22. (and others). Researches in sedimentation in 1925-1926; report of the committee on sedimentation. $98 \mathrm{pp}$., issued in mimeographed form by the National Research Council, Washington, D. C., 1926. Includes contributions by C. A. Bonine, A. C. Tester, Eliot Blackwelder, R. C. Wallace, L. W. Collet, L. Murray Neumann, Kirk Bryan, George Steiger, C. E. Van Ostrand, O. E. Meinzer, R. O. E. Davis, E. M. Kindle, T. Wayland Vaughan, M. M. Leighton, Ernst Anters, W. H. Twenhofel, and W. A. Tarr. 
Twenhofel, William Henry-Continued.

23. Intrusive granite of the Rose dome, Woodson County, Kansas: Geol. Suc. America, Bull., vol. 37, no. 2, pp. 403-412, 2 figs., June 30, 1926: abstract, vol. 36, no. 1, pp. 166-167, March 30, 1925; Pan-Am. Geologist, vol. 43, no. 2, p. 157, March 30, 1925.

24. (and Tester, A. C.). New data on the Comanchean strata of central Kansas: Am. Assoc. Petroleum Geologists, Bull., vol. 10, no. 6, pp. 553-561, June, 1926.

25. Hunting fossils on Anticosti Island: Natural History (Am. Mus. Nat. Hist., Jour.), vol. 26, no. 5, pp. 515-524, 9 figs., September-October, 1926.

26. Geology of the Mingan Islands: Geol. Soc. America, Bull., vol. 37, no. 4, pp. 535-550, 1 fig., December 30,1926 ; abstract, no. 1, pp. 172-173, March 30, 1926; Pan-Am. Geologist, vol. 45, no. 2, pp. 165-166, 1926.

27. Ordovician strata in deep wells of western central Kansas: Am. Assoc. Petroleum Geologists, Bull., vol. 11, no. 1, pp. 49-53, January, 1927.

28. Research in sedimentation: Jour. Geology, vol. 35, no. 2, pp. 183-190, February-March, 1927.

29. (and others). Researches in sedimentation in 1926-1927; report of the committee on sedimentation. 78 pp., 1 fig. Issued in mimeographed form by the National Research Council, Washington, D. C., 1927. Includes contributions by E. M. Kindle, Kirk Bryan, Leon W. Collet, W. A. Nelson, George Steiger, R. O. E. Davis, O. E. Meinzer, Chancey Juday, M. M. Leighton, Ernst Antersi, Thomas Wayland Vaughan, R. C. Wallace, Eliot Blackwelder, W. A. Tarr, and $\mathbf{R}$. D. Reed.

30. Geology of Anticosti Island [descriptions of Bryozoa and Ostracoda by R. S. Bassler and of Cephalopoda by A. F. Foerste] ; Canada, Geol. Survey, Mem. 154, 481 pp., 1 fig. (map), 60 pls., 1.927. Review by Charles Schuchert, Am. Jour. Sci., 5th ser., vol. 17, pp. 93-96, January, 1929.

31. Inquiry into the magnitude of the deep-sea deposits (abstract) : Pan-Am. Geologist, vol. 49, no. 2, p. 151, March, 1928; Geol. Soc. America, Bull., vol. 39, no. 1, pp. 222-223, March 30, 1928.

32. (and Bremer, Bernard). An extension of the Rose dome intrusives, Kansas: Am. Assoc. Petroleum Geologists, Bull., vol. 12, no. 7, pp. 757-762, July, 1928.

33. Oölites of artificial origin: Jour. Geology, vol. 36, no. 6, pp. 564-568, August-September, 1928.

34. Report of the committee on sedimentation, 1927-1928: Nat. Research Council, Reprint and Circ. Ser., no. 85, 83 pp., 1928.

Twitchell, George $B$.

1. Affinities of the true stromatoporids (abstract) : Ohio Acad. Sci., Proc., vol. 8, pt. 4, p. 172, 1928; Ohio Jour. Sci., vol. 28, no. 3, p. 150, May, 1928.

Twitchell, Mayville William, 1868-1927.

1. Our mineral industry in 1918: New Jersey, Dept. Conservation and Development, Ann. Rept. for 1919, pp. 105-115, 1919.

2. The mineral industries of New Jersey in 1921 and 1922: New Jersey, Dept. Conservation and Development, Ann. Rept. 1922 and 1923, 1.). $37-45,1.923$.

3. The mineral industry of Now Jersey for 1923: New Jersey, Dept. Conservation and Development, Geol, ser., Bull. 26, 15 plp., 1925. 
'Twitchell, Mayville William-Continued.

4. The mineral industry of New Jersey for 1924: New Jersey, Dept. Conservation and Development, Geol. ser., Bull. 27, 14 pp., 1925.

5. Important ground water horizons in New Jersey: New Jersey, Report of the Water Policy Commission, Part 2, pp. (A) 41-53, February 27, 1926.

6. The mineral industry of New Jersey for 1925: New Jersey, Dept. Conservation and Development, Bull. 29, 16 pp., 1927.

Tyrrell, Juseph Burr.

1. Was there a "Cordiller:an glacier" in British Columbia?: Jour. Geology, vol. 27, no. 1, pp. 55-60, January-February, 1919.

2. Notes on the placer mines of Cariboo, British Columbia: Econ. Geology, vol. 14, no. 4, pp. 335-345, 1 fig., 1 pl., June, 1919.

3. The veins of Cobalt [Ontario] (discussion): Econ. Geology, vol. 15, no. 5 , pp. 453-454, July-August, 1920.

4. Mining in Canada: Science, new ser., vol. 57, pp. 31-38, January 12, 1923.

5. Preglacial oxidation in northern Ontario (discussion) : Econ. Geology, vol. 18, no. 3, pp. 296-297, April-May, 1923.

6. Dinosaurs and coal in the Red Deer country, Alberta: Science, new ser., vol. 57, pp. 457-459, April 20, 1923.

7. (and Hore, R. E.). The Kirkland Lake fault: Roy. Soc. Canada, Proc. and Trans., 3d ser., vol. 20, sec. 4, pp. 51-63, 4 figs., 1926 ; Canadian Min. Jour., vol. 46, no. 23, pp. 561-564, June 5, 1925.

S. Memorial of Willet Green Miller: Geol. Soc. America, Bull., vol. 37, no. 1, pp. 99-110, 1 pl. (portr.), March 30, 1926; Canadian Min. Jour., vol. 47 , no. 41 , pp. $973-976$, October $8,1926$.

9. (and Hore, R. E.). Geology of the Kirkland Lake gold mine [Ontario] : Mining and Metallurgy, vol. 7, no. 231, pp. 118-121, 2 figs., March, 1926.

Udden, Johan August. See also Daly, 12; DeGolyer, 2; Hoots, 1; Savage, 5; Twenhofel, 16, 18; Waite, 1.

1. Fossil ice crystals; an instance of the practical value of "pure science": Texas, Univ., Bull. no. 1821., 8 pp., 10 pls., April 10, 1918.

2. The anticlinal theory as applied to some quicksilver deposits: Texas, Univ., Bull. no. 1822, 30 pp., 16 figs., April 15, 1918. Review by W. H. Emmons, Eng. and Min. Jour., vol. 107, pp. 916-917, 2 figs., May 24, 1919.

3. Aids to identification of geological formations: Texas, Univ., Bur. Econ. Geology and Technology, Handbook series no. 1, 69 pp. [n. d., 1919?].

4. (and Waite, V. V.). Microscopic characteristics of the Bend and the Ellenburger limestones. [Texas, Univ., Bur. Econ. Geology, Austin, 1919.] (Mimeographed, 25 pp., 10 photographs, edition limited.)

5. (and Baker, C. L., and Böse, Emil). Review of the geology of Texas, 3d ed., revised 1919: Texạs, Univ., Bull. 1916, no. 44, 178 pp., 12 figs., map [1919].

6. Anticlinal theory as applied to some quicksilver deposits (abstract) : Geol. Soc. America, Bull., vol. 30, p. 112, March 31, 1919.

7. Oil-bearing formations in Texas: Am. Assoc. Petroleum Geologists. Bull., vol. 3, pp. S2-9S, 1919.

$4096(--31--40$ 
Udden, Johan August-Continued.

8. Observations on two deep borings near the Balcones faults [Texas] (with discussion) : Am. Assoc. Petroleum Geologists, Bull., vol. 3, pp. 124$131,1919$.

9. Suggestions of a new method of making underground observations: Am. Assoc. Petroleum Geologists, Bull., vol. 4, no. 1, pp. 83-85, 1 fig., 1920.

10. The Troup, Texas, meteorite: U. S. Nat. Mus., Proc., vol. 59, pp. 471-476, 2 figs., 2 pls., 1921.

11. Chronology in geology (with discussion by A. C. Lawson): Geol. Soc. America, Bull., vol. 32, no. 1, pp. 21-23, March 31, 1921.

12. Characteristics of some Texas sedimentary rocks as seen in well samples: Am. Assoc. Petroleum Geologists, Bull., vol. 5, no. 3, pp. 373-385, May-June, 1921.

13. Some cavern deposits in the Permian in west Texas: Geol. Soc. America, Bull., vol. 33, no. 1, pp. 153-155, March 31, 1922.

14. Wide extent of Texas potash formations: Pan-Am. Geologist, vol. 37, no. 3, pp. 149-251, April, 1922.

15. Potash wells in western Texas: Pan-Am. Geologist, vol. 37 , no. 4, pp. 344345, May, 1922.

16. The "rim rock" of the High Plains: Am. Assoc. Petroleum Geologists, Bull., vol. 7, no. 1, pp. 72-74, January-February, 1923.

17. Laminated structure of anhydrite beds: Pan-Am. Geologist, vol. 41 , no. 3 , p. 227, April, 1924.

18. Laminated anhydrite in Texas: Geol. Soc. America, Bull., vol. 35, no. 2, pp. 347-354, 4 pls., June 30, 1924; abstract, no. 1, p. 114, March $30,1924$.

19. Study of the laminated structure of certain drill cores obtained from the Permian rocks of Texas, with particular reference to the bearing of the stratigraphic sequence upon problems of climatic variation: Carnegie Inst. Washington, Year Book no. 24, p. 345, December, 1925.

20. Etched potholes: Texas, Univ., Bull. no. 2509, 9 pp., 2 figs., 6 pls., December, 1925.

21. Texas Bureau of Economic Geology [activities] : Pan-Am. Geologist, vol. 44, no. 4, pp. 327-328, November, 1925.

22. The Southwest earthquake of July 30, 1925: Texas, Univ., Bull. no. 2609, 32 pp., 1 pl. (map), June, 1926.

23. (and Waite, V. V.). Some microscopic characteristics of the Bend and Ellenburger limestones: Texas Univ., Bull. no. 2703, 8 pp., 9 pls., February, 1927.

24. Fossils from the Word formation of west Texas (abstract) : Geol. Soc. America, Bull., vol. 38, no. 1, p. 159, March 30, 1927; Pan-Am. Geologist, vol. 47 , no. 2 , p. 156, March, 1927.

25. A neglected field in stratigraphy : Texas, Univ., Bull., no. 2801, pp. 55-66, 1928.

26. Potash in Texas: Intern. Bergwirthschaft, Jg. 3, H. 4-5, pp. 80-81, April-May, 1928.

27. Study of the laminated structure of certain drill cores obtained from Permian rocks of Texas: Carnegie Inst. Washington, Year Book no. 27 , p. 363 , December, 1928. 
Udden, Ton Andreas.

1. Subsurface geology of the oil districts of north central 'Texas: Am. Assoc. Petroleum Geologists, Bull., vol. 3, pp. 34-38, 1919.

2. Occurrence of Ordovician sediments in western Kansas: Am. Assoc. Petroleum Geologists, Bull., vol. 10, no. 6, pp. 634-635, June, 1926.

3. Can we classify the methods by which oil fields have been discovered?: Oklahoma Acad. Sci., Proc., vol. 6, pt. 2, 1926 (Oklahoma, Univ., Bull., new ser. no. 348), pp. 273-278, January 1, 1927.

Uglow, William Lawrence, 1884-1926. See also Bancroft, M. F., 4; Johnston, W. A., 22; Nichols, 1; Young, G. A., 6.

1. Geology of platinum deposits: Eng. and Min. Jour., vol. 108, pp. 352-355; 390-393, August 30 and September 6, 1919.

2. Possibilities for platinum in western Canada: Canadian Min. Inst., Monthly Bull. no. 95, pp. 207-220, March, 1920; Trans., vol. 23, pp. 374-389 [1921].

3. Geology of the North Thompson Valley map area, British Columbia: Canada, Geol. Survey, Summ. Rept., 1921, pt. A, pp. 72-106, 12 figs., 2 pls., map, 1922.

4. A so-called bornite-chalcopyrite intergrowth from Legate Creek, Pacific British Columbia: Am. Mineralogist, vol. 7, no. 1, pp. 1-4, 4 figs., January, 1922.

5. The Eocene coal basin at Chu Chua, British Columbia: Canadian Inst. Min. and Met., Monthly Bull., no. 124, pp. 896-907, August, 1922.

6. Quartz veins of Barkerville, Cariboo district, British Columbia: Canadian Inst. Min. and Met., Monthly Bull., no. 127, pp. 1165-1175, November, 1922.

7. The Eocene coal basin at Chu Chua, British Columbia (with discussion) : Canadian Inst. Min. and Met., Monthly Bull., no. 124, pp. 896907, August, 1922 ; Trans., vol. 25, pp. 370-381 [1923].

8. Quartz veins of Barkerville, Cariboo district, British Columbia (with discussion by M. F. Bancroft) : Canadian Inst. Min. and Met. Monthly Bull., no. 127, pp. 1165-1175, November, 1922; Trans., vol. 25, pp. 152-164 [1923].

9. Bedrocks and quartz veins of Barkerville map area, Cariboo district, British Columbia: Canada, Geol. Survey, Summ. Rept., 1922, pt. A, pp. 82-87, 1923.

10. (and Johnston, W. A.). Origin of the placer gold of the Barkerville area, Cariboo district, British Columbia, Canada: Econ. Geology, vol. 1.8, no. 6, pp. 541-561, 3 figs., September, 1923.

11. Cretaceous age and early Eocene uplift of a peneplain in southern British Columbia: Geol. Soc. America, Bull., vol. 34, no. 3, pp. 561-572, 4 figs., September 30, 1923.

12. The Windpass gold mine, Chu Chua, British Columbia: Canadian Min. Jour., vol. 45, no. 2, pp. 47-49, 4 figs., January 11, 1924.

13. Ore problems and the microscope: Canadian Inst. Min. and Met., Monthly Bull., no. 147, pp. 495-502, July, 1924.

14. Undiscovered mines of British Columbia: Canadian Inst. Min. and Met., Monthly Bull., no. 138, pp. 595-613, October, 1923; Trans., vol. 26, pp. 300-318 [1.924].

15. (and Osborne, F. F.). A gold-cobaltite-lodestone deposit, British Columbia, with notes on the occurrence of cobaltite: Econ. Geology, vol. 21, no. 3, pp. 285-298, May, 1926. 
Uglow, William Lawrence-Continued.

16. Genesis of the magnetite deposits near the west coast of Vancouver Island: Econ. Geology, vol. 21, no. 4, pp. 352-363, June-July, 1926.

17. L'Etang limestone deposit, Charlotte County, New Brunswick: Canada, Geol. Survey, Summ. Rept., 1925, pt. C, pp. 132-135, 1 fig., 1927.

Uhrlaub, Rudolph.

1. Butler County, Kansas [petroleum fields]: Am. Assoc. Petroleum Geologists, vol. 5, no. 3, pp. 421-424, May-June, 1921.

Ulrich, Edward Oscar. See also Slocom, 1; Swartz, C. K., 9 ; Winchester, 1.

1. Ostracoda [from the Chapman sandstone of Maine]: U. S. Geol. Survey, Prof. Paper 89, pp. 289-293, 1 pl., 1916.

2. Newly discovered instances of early Paleozoic oscillations (abstract) : Washington Acad. Sci., Jour., vol. 9, no. 10, pp. 297-298, May 19, 1919.

3. Major causes of land and sea oscillations: Washington Acad. Sci., Jour., vol. 10 , no. 3, pp. 57-78, 4 figs., February 4, 1920. Smithsonian Inst., Ann. Rept., 1920, pp. 321-337, 4 figs., 1922.

4. (and Ruedemann, Rudolf, and Bassler, R. S.). Notes on the ventral appendages of Neolenus serratus: Smithsonian Misc. Coll., vol. 67, no. 7, pp. 366-368, December 20, 1921.

5. Some new facts bearing on correlations of Chester formations: Geol. Soc. America, Bull., vol. 33, no. 4, pp. 805-852, 2 figs., November 2, 1922.

6. Revision of the Paleozoic systems; Part II, The Ordovician system (abstract with discussion by J. J. Galloway and A. F. Foerste) : Geol. Soc. America, Bull., vol. 33, no. 1, p. 112, March 31, 1922.

7. Ordovician "hypoparian" genera of trilobites (abstract): Geol. Soc. America, Bull., vol. 33, no. 1, pp. 205-206, March 31, 1922.

8. (and Bassler, R. S.). American Silurian formations: Maryland Geol. Survey, Silurian, pp. 233-270, 8 figs., 1923.

9. (and Bassler, R. S.). Paleozoic Ostracoda ; their morphology, classification, and occurrence: Maryland Geol. Survey, Silurian, pp. 271391, 18 figs., 1923.

10. New classification of the "Heterocrinidae": Canada, Geol. Survey, Mem. 138, pp. 82-101, 11 figs., 1924.

11. Modiodesma n. gen. Ulrich, and the genotype of Modiolopsis Hall: Canada, Geol. Survey, Mem. 138, pp. 183-190, 1924.

12. Notes on new names in table of formations and on physical evidence of breaks between Paleozoic systems in Wisconsin: Wisconsin Acad. Sci. Trans., vol. 21, pp. 71-107, 1924.

13. (and Bassler, Ray S.). A classification of the toothlike fossils, conodonts, with descriptions of American Devonian and Mississippian species: U. S. Nat. Mus., Proc., vol. 68, art. 12, 63 pp., 5 figs., 11 pls., 1926.

14. (and Mesler, R. D.). Fauna and stratigraphy of the Saint Clair limestone of Arkansas and Oklahoma (abstract) : Geol. Soc. America, Bull., vol. 37, no. 1, pp. 243-244, March 30, 1926.

15. Relative values of criteria used in drawing the Ordovician-Silurian boundary: Geol. Soc. America, Bull., vol. 37, no. 2, pp. 279-348, June 30, 1926.

16. Organic and physical criteria in stratigraphic correlation (abstract): Pan-Am. Geologist, vol. 46, no. 1, p. 73, August, 1926. 
Ulrich, Edward Osear-Continued.

17. Comparison of European and American Paleozoic sections (abstract): Pan-Am. Geologist, vol. 46, no. 1, pp. 73-74, August, 1926.

18. Fossiliferous boulders in the Ouachita "Caney" shale and the age of the shale containing them: Oklahoma Geol. Survey, Bull. no. 45, 48 pp., 3 figs., 6 pls., November, 1927.

Umpleby, Joseph Bertram.

1. World view of mineral wealth (abstract): Geol. Soc. America, Bull., vol. 30, p. 107, March 31, 1919.

2. (and Livingston, D. C.). A reconnaissance in south central Idaho embracing the Thunder Mountain, Big Creek, Stanley Basin, Sheep Mountain, and Seafoam districts: Idaho, Bur. Mines and Geology, Bull. no. 3, 23 pp., map. 5 pls., 1920.

3. (and Jones, E. L., jr.). Geology and ore deposits of Shoshone County, Idaho: U. S. Geol. Survey, Bull., 732, 156 pp., 8 figs., 16 pls. (incl. maps), 1923.

4. Some structural features of northern Idaho (abstract) : Geol. Soc. America, Bull., vol. 34, no. 1, p. 66, March 30, 1923.

5. The Osburn fault, Idaho: Jour. Geology, vol. 32, no. 7, pp. 601-614, 4 figs., October-November, 1924.

6. Increasing the extraction of oil by water flooding: Am. Inst. Min. and Met. Eng., no. 1570 (Petroleum development and technology in 1925), pp. 112-129, 16 figs., April, 1926.

United States Geological Survey.

1. [Map of] State of West Virginia and part of Maryland ; coal fields and producing districts, compiled by C. E. Lesher. Scale 1: 1,000,000. 1919. [Similar maps of Virginia, Kentucky, Tennessee, Alabama and part of Georgia, Pennsylvania, Ohio, Indiana, Illinois.]

2. [Map showing] oil and gas fields of the State of Kansas. Scale: 1 inch $=12$ miles. 1920.

3. World atlas of commercial geology ; Part I, Distribution of mineral production: U. S. Geol. Survey, 72 pp., 72 pls. (maps), 1921.

4. World atlas of commercial geology; Part II, Water power of the world: U. S. Geol. Survey, 39 pp., 10 pls. (maps), 1921.

5. [Map showing] oil and gas fields of the State of Louisiana. Scale: 1 inch $=12$ miles. 1921.

6. [Map showing] oil and gas fields of the State of Oklahoma. Scale: 1 inch $=12$ miles. 1921.

7. The El Dorado, Arkansas, oil and gas field; geological outline: Arkansas, Bureau of Mines ..., pp. 71-86, 2 pls., Little Rock, Arkansas, 1922.

8. The oil supply of the United States: Am. Assoc. Petroleum Geologists, Bull., vol. 6, no. 1, pp. 42-46, January-February, 1922.

9. Relief map, State of Ohio. Scale, 1:380,160. 1922.

10. Relief map, State of Idaho. Scale, 1 inch=12 miles. 1926. Relief shading by R. W. Berry.

Memoranda for the press [mimeographed]:

11. Kevin-Sunburst oil field, Montana. 4 pp., map, January 12, 1926. (4655)

12. Possibility of finding oil in anticline near Edgemont, South Dakota. 2 pp., map, August 19, $1926 . \quad$ (8580)

13. Oil-bearing formations of southwestern Arkansas. $7 \mathrm{pp} ., 1 \mathrm{pl}$. (sections), September 10, 1926. (8823) 


\section{United States Geological Survey-Continued.}

14. Lead and zinc ores of Sharp and Lawrence counties, Arkansas. $2 \mathrm{pp}$. November 17, $1926 . \quad$ (10707)

15. Result of core-drilling test in New Mexico. $2 \mathrm{pp} ., 1 \mathrm{pl}$ ( $\log$ of boring), December 8, $1926 . \quad$ (10994)

16. Geology and oil in southeastern Utah. 8 pp., July 29, $1927 . \quad$ (16318)

17. Oil possibilities at Comanche Point and near Wheeler Ridge, California. 2 pp., March 28, 1927. (13338)

18. Relief map, State of Tennessee. 1927. Scale 1:500,000.

19. Geologic map of southwestern Humboldt County [California] : Oil Bull., vol. 14, no. 4, p. 376, April, 1928.

U. S. Senate, Committee on Agriculture and Forestry.

1. Investigation of potash deposits. Hearing before the Committee on Agriculture and Forestry, United States Senate, 68th Cong., 1st sess. on S. 1925. 47 pp. Washington, Government Printing Office, 1924.

Upham, Warren.

1. Memorial of Charles Henry Hitchcock: Geol. Soc. America, Bull., vol. 31, no. 1, pp. 64-80, portr., March 31, 1920.

2. Drumlins at Lake Placid [New York] (abstract): Geol. Soc. America, Bull., vol. 31, no. 1, pp. 128-130, March 31, 1.920.

3. Memorial of George Frederick Wright: Geol. Soc. America, Bull., vol. 33, no. 1, pp. 15-30, portr., March 31, 1922.

4. Stages of the ice age: Geol. Soc. America, Bull., vol. 33, no. 3, pp. 491-514. September 1, 1922 ; abstract, vol. 33, no. 1, pp. 100-101, March 31, 1922.

Urbina, Fernando. See also Waitz, 1.

1. Los yacimientos petrolíferos submarinos: Bol. petróleo, vol. 5 , no. 4, pp. 337-377, 15 pls., 3 maps, April, 1918; vol. 25, no. 5, pp. 693-732, 15 pls. (incl. maps), May, 1928.

Uren, Lester Charles.

1. The elements of the oil-well-spacing problem: Am. Assoc. Petroleum Geologists, Bull., vol. 9, no. 2, pp. 193-216, 6 figs., March-April, 1925.

Urrutia, Claudio.

1. Determination of the azimuth in violent and local earthquakes: Seismol. Soc. America, Bull., vol. 9, no. 2, pp. 3s-41, June, 1919.

Vacher, H. C. See Davis, C. W., 2.

Valentine, Wilbur G. See Alling, 12.

Van Burgh, L. R. See Lupton, 2.

Van Couvering, Martin.

1. An outline of petroleum geology and its importance to the natural gasoline industry: Petroleum World, Los Angeles, vol, 12, no. 11, pp. 114-116, 128-130, November, 1927.

Van Deloo, Jacob.

1. Twenty-first report of the director of the State Museum and science department, including the seventy-eighth report of the State Museum, the forty-fourth report of the State geologist, and report of the State paleontologist for 1925: New York State Mus. Bull., no. 267, 107 pp., illus., 1926. 
Van de Putte, J.

1. Phénomènes séismiques et volcaniques au Guatémala. 143 pp., Bruxelles, 1924. [Not seen.] Abstract, Rev. Géologie, 5th ann., no. 4, p. 238, April, 1924.

Van der Gracht, W. A. J. M. van Waterschoot. See also Foley, 1; Willis, 27.

1. (and others). Theory of continental drift; a symposium on the origin and movement of land masses both intercontinental and intracontinental, as proposed by Alfred Wegener. x, 240 pp., 29 figs., published by the American Association of Petroleum Geologists, Tulsa, Oklahoma, 1928.

2. The problem of continental drift. In Theory of continental drift, pp. 1-75, 12 figs., Am. Assoc. Petroleum Geologists, 1928.

3. Remarks regarding the papers offered by the other contributors to the symposium. In Theory of continental drift, pp. 197-226, Am. Assoc. Petroleum Geologists, 1928.

Vander Leck, Lawrence.

1. Petroleum resources of California with special reference to unproved areas: California State Min. Bur., Bull., no. 89, 186 pp., 12 figs., 12 pls. (incl. maps), July, 1921.

2. Memoranda on asphalt and bituminous sand deposits of California: California State Min. Bur., Mining in California, vol. 18, no. 5, pp. 228-230, May, 1922.

Vanderpool, Harold $\mathrm{C}$.

1. Producing sands in the Garber oil field: Oklahoma Acad. Sci., Proc., vol. 6, pt. 2, 1926 (Oklahoma, Univ., Bull., new ser. no. 348), pp. 286289, January 1, 1927.

2. Fossils from the Trinity group (Lower Comanchean) : Jour. Paleontology, vol. 2, no. 2, pp. 95-107, 3 pls., June, 1928.

3. A preliminary study of the Trinity group in southwestern Arkansas, southeastern Oklahoma, and northern Texas: Am. Assoc. Petroleum Geologists, Bull., vol. 12, no. 11, pp. 1069-1094, 5 figs., November, 1928.

Vanderwilt, John W.

1. A drill core section of the Salina below the salt bed of the Detroit Rock Salt Company mine: Michigan Acad. Sci., Papers, vol. 3, pp. 285287,1 pl. 1924.

2. Improvements in the polishing of oies: Econ. Geology, vol. 23, no. 3, pp. 292-316, 8 figs., May, 1928.

Van Horn, Frank Robertson. See also Thiessen, 7.

1. Third annual meeting of the Mineralogical Society of America [Ann Arbor, December 29, 1922] : Am. Mineralogist, vol. 8, no. 3, pp. 46-55, March, 1923.

2. Proceedings of the third annual meeting of the Mineralogical Society of America, held at Ann Arbor, Michigan, December 29, 1922: Geol. Soc. America, Bull., vol. 34, no. 1, pp. 147-150, March 30, 1923.

3. Fourth annual meeting of the Mineralogical Society of America [Washington, D. C., December, 1923] : Am. Mineralogist, vol. 9, no. 3, pp. 56-71, March, 1924.

4. Proceedings of the fifth annual meeting of the Mineralogical Society of America [Ithaca, New York, December 31, 1924]: Am. Mineralogist, vol. 10, no. 3, pp. 61-6s, March, 1925. 
Van Horn, Frank Robertson-Continuea.

5. Proceedings of the fifth annual meeting of the Mineralogical Society of America, held at Cornell University, Ithaca, New York, December 31, 1924: Geol. Soc. America, Bull., vol. 36, no. 1, pp. 241-246. March 30, 1925.

6. The occurrence of a large iron-tourmaline in Alabama pegmatite: Am. Mineralogist, vol. 10, no. 10, pp. 348-350, 2 figs., October, 1925.

7. Suggestions concerning the use of species names in the garnet, amphibole, pyrozene, and tourmaline groups (abstract): Am. Mineralogist, vol. 11, no. 3, pp. 52-54, March, 1926.

S. Proceedings of the sixth annual meeting of the Mineralogical Society of America : Am. Mineralogist, vol. 11, no. 3, pp. 59-68, March, 1926.

9. Proceedings of the sixth annual meeting of the Mineralogical Society of America, held at New Haven, Connecticut, December 28, 29, 30, 1925: Geol. Soc. America, Bull., vol. 37, no. 1, pp. 255-260, March $30,1926$.

10. Proceedings of the seventh annual meeting of the Mineralogical Society of America : Am. Mineralogist, vol. 12; no. 3, pp. 71-91, Mareh, 1927.

11. Proceedings of the seventh annual meeting of the Mineralogical Society of America, held at Madison, Wisconsin, December 27, 28, 29, 1926: Geol. Soc. America, Bull., vol. 38, no. 1, pp. 245-252, March $30,1927$.

12. Proceedings of the eighth annual meeting of the Mineralogical Society of America [Cleveland, December, 1927]: Am. Mineralogist, vol. 13, no. 3, pp. 105-117, March, 1928.

13. Proceedings of the eighth annual meeting of the Mineralogical Society of America, held at Cleveland, Ohio, December 29, 30, and 31, 1927: Geol. Soc. America, Bull., vol. 39, no. 1, pp. 313-320, March $30,1928$.

14. Large magnetite and franklinite crystals from Franklin Furnace, New Jersey : Am. Mineralogist, vol. 13, no. 5, pp. 171-173, 2 figs., May, 1928.

Van Leckwyck, W.

1. Le Canada et ses ressources minérales: Rev. univ. Mines, Liége, $7^{\text {me }}$ sér., t. 18, no. 5, pp. 208-225, June 1, 1928.

Van Lennep, David.

1. Great Green River coal deposits: Pan-Am. Geologist, vol. 39, no. 4, pp. 297-316, May, 1923.

Van Name; Willard G.

1. The supposed Paleozoic bamacle Protobalınus and its bearing on the origin and phylogeny of the barnacles: Am. Mus. Novitates, no. 197, 8 pp., 3 figs., November 21, 1925.

2. A new specimen of Protobalanus, supposed Paleozoic barnacle: Am. Mus. Novitates, no. 227, 6 pp., 2 figs., October 11, 1926.

Van Orstrand, Charles Edwin. See also Twenhofel, 18, 22.

1. Temperatures in some deep wells in the United States (abstract): Washington Acad. Sci., Jour., vol. 9, no. 13, p. 382, July 19, 1919.

2. Deep-earth temperatures in the United States (abstract): Washington Acad. Sci., Jour., vol. 13, no. 4, p. 65, February 19, 1923.

3. Notes on isostasy: Geol. Soc. America, Bull., vol. 34, no. 2, pp. 300-305, 2 ligs., Jume 30, 1928. 
Van Orstrand, Charles Edwin-Continued.

4. Some phases of the resistance of the earth's material to changes (ab. stract): Nat. Research Council, Bull., vol. 7, pt. 5, no. 41, pp. 94-95, January, 1924.

5. Apparatus for the measurement of temperatures in deep wells by means of maximum thermometers: Econ. Geology, vol. 19, no. 3, pp. 228 248, 11 flgs., April-May, 1924.

6. Temperatures in some springs and geysers in Yellowstone National Park: Jour. Geology, vol. 32, no. 3, pp. 194-225, 5 figs., April-May, 1924.

7. Some evidence on the variation of temperature with geologic structure in California and Wyoming oil districts: Econ. Geology, vol. 21. no. 2, pp. 145-165, 11 figs., March-April, 1926.

S. A possible dependence of deep-earth temperatures on geologic structure (abstract) : Washington Acad. Sci., Jour., vol. 16, no. 18, p. 503, November 3, 1926.

9. Temperature of world's deepest wells: Oil and Gas Jour., vol. 26, no. 48, pp. 39, 152-153, 9 figs., April 19, 1928.

10. On the nature of isogeothermal surfaces: Am. Jour. Sci., 5th ser., vol. 15, pp. 495-519, 9 figs., June, 1928; abstract, Mining and Metallurgy, vol. 9, pp. 461, 462, 1 fig., October, 1928.

Van Tuyl, Francis Maurice. See also Beckstrom, 1; Savage, 2.

1. The physical history of the upper Mississippi Valley during the late Paleozoic (abstract) : Illinois Acad. Sci., Trans., vol. 10, p. 280 [1918].

2. (and Moore, Raymond C.). Late Mississippian orogenic movements in North America (abstract): Geol. Soc. America, Bull., vol. 30, pp. 88-89, March 31, 1919.

3. The Cripple Creek district of Colorado, a re-survey; geology and ore deposits: Colorado School of Mines, Quart., vol. 14, no. 3, pp. 5-10, 1 fig., July, 1919.

4. The future of the petroleum industry in the United States: Colorado School of Mines Mag., vol. 10, no. 12, pp. 215-219, December, 1920.

5. (and Machamer, G. W.). Physical history of the Colorado Front Range (abstract) : Geol. Soc. America, Bull., vol. 34, no. 1, pp. 87-88, March 30, 1923.

0. Elements of petroleum geology. 275 pp., 34 figs., Denver, Colorado, The Petroleum Publishing Co. of Colorado [c. 1924].

7. Notes on the origin of petroleum: Colorado School of Mines, Alumni Mag., vol. 14, no. 1, pp. 8-12, Mas, 1924.

8. The stratigraphy of the Mississippian formations of Iowa: Iowa Geol. Survey, vol. 30, pp. 33-349, 16 figs., 6 pls. (incl. map) [1925].

9. (and Blackburn, Chester O.). The effect of rock flowage on the kerogen of oil shale: Am. Assoc. Petroleum Geologists, Bull., vol. 9, no. 1, pp. 158-164, 1 fig., January-February, 1925.

10. The occurrence of dolomite: Colorado School of Mines Mag., vol. 1.4, no. 11, pp. 14-17, March, 1925.

11. The future oil supply: Colorado School of Mines Mag., vol. 15, no. 2, pp. 6-9, June, 1925.

12. (and Beckstrom, R. C.). Pressure effect on migration and accumulation of petroleum: Oil and Gas Jour., vol. 24, no. 6, pp. 70, 74, 78, 92, July 2, 1925.

13. (and Blackburn, Chester O.). The relation of oil shale to petroleum: Am. Assoc. Petroleum Geologists, Bull., vol. 9, no. 8, November, 1925. 
Van Tuyl, Francis Maurice-Continued.

14. The effect of pressure on the migration and accumulation of petrolenm: Am. Assoc. Petroleum Geologists, Bull., vol. 10, no. 10, pp. 917930, 4 figs., October, 1926.

Van Winkle, Katherine. See Palmer, Katherine Van Winkle.

Varley, Thomas. See also Lewis, 1.

1. (and others). A preliminary report on the mining districts of Idaho: U. S. Bur. Mines, Bull. 166, pp. 1-\$9, 2 pls. (maps), 1919.

2. (and Reid, W. S.). The extraction of potash from low-grade alunite from Marysvale district, Utah: Utah, Univ., Bull., vol. 11, no. 15, 31 pp., December, 1920.

Vassar, Helen E. See also Gage, 1; Larsen, 14; Palache, 15, 18.

1. Clerici solution for mineral separation by gravity: Am. Mineralogist, vol. 10, no. 5, pp. 123-125, 1 fig., May, 1925.

Vaughan, Francis Edward.

1. Geology of the San Bernardino Mountains north of San Gorgonio Pass: California, Univ., Pub., Dept. Geol. Sci., Bull., vol. 13, no. 9, pp. 319-411, 12 figs., 7 pls., map, December 30, 1922.

2. The Five Islands, Louisiana: Am. Assoc. Petroleum Geologists, Bull., vol. 9, no. 4, pp. 756-797, 12 figs., July, 1925; Geology of salt dome oil fields, pp. 356-397, 12 figs., 1926.

Vaughan, Thomas Wayland. See also Brown, B., 2 ; Clark, B. L., 8 ; Schuchert, 20; Twenhofel, $16.22,29$.

1. (and others). Contributions to the geology and paleontology of the West Indies: Carnegie Inst. Washington, Pub. no. 291, 184 pp., pls., 1919.

2. Contributions to the geology and paleontology of the Canal Zone, Panama, and geologically related areas in Central America and the West Indies; Fossil corals from Central America, Cuba, and Porto Rico, with an account of the American Tertiary, Pleistocene, and recent coral reefs: U. S. Nat. Mus., Bull. 103, pp. 189-524, 85 pls., 21 figs., 1919.

3. Contributions to the geology and paleontology of the Canal Zone, Panama, and geologically related areas in Central America and the West Indies; the biologic character and geologic correlation of the sedimentary formations of Panama in their relation to the geologic history of Central America and the West Indies: U. S. Nat. Mus., Bull. 103, pp. 547-612, 191.9.

4. Corals and the formation of coral reefs: Smithsonian Inst., Ann. Rept., 1917, pp. 189-276, 37 pls., 16 figs., 1919.

5. Presentation of geologic information for engineering purposes (abstract) : Geol. Soc. America, Bull., vol. 30, pp. 79-80, March 31, 1919.

6. [Report on] study of the stratigraphic geology and of the fossil corals and associated organisms in several of the smaller West Indian islands: Carnegie Inst. Washington, Year Book no. 18, 1919, pp. 345-346, March, 1920.

7. Features of the shifts of land and sea-level in the Atlantic and Gulf Coastal Plain during Pleistocene and post-Pleistocene time (abstract, with discussion by W. T. Lee): Geol. Soc. America, Bull. vol. 31., no. 1, p. 113, March 31, 1920. 
Vaughan, Thomas Wayland-Continued.

8. Stratiggaphy of the Virgin Islands of the United States and of Culebra and Vieques islands (abstract) : Geol. Soc. America, Bull., vol. 31, no. 1, pp. 216-217, March 31, 1920.

9. Corals from the Cannonball marine member of the Lance formation: U. S. Geol. Survey, Prof. Paper 128, pp. 61-66, 1 pl., August 11, 1920.

10. Researches on sedimentation: Geol. Soc. America, Bull., vol. 31, no. 4, pp. 401-410, November 30, 1920.

11. Some features of the Virgin Islands of the United States; the relations of the Virgin Islands to the principal Caribbean ridges and deeps; islands of, the Virgin Bank; St. Croix (abstract): Assoc. Am. Geographers, Annals, vol. 9, pp. 78-82 [1920?].

12. Geological mapping in the western part of the United States, Central America, and the West Indies: Pan-Pacific Scientific Conference, First, Proc., Bernice P. Bishop Mus., Spec. Pub. no. 7, pt. 3, pp. 696-705, 1 fig., 1921.

13. Correlation of the Tertiary formations of Central America and the West Indies: Pan-Pacific Scientific Conference, First, Proc., Bernice P. Bishop Mus., Spec. Pub. no. 7, pt. 3, pp. 819-844, 1921.

14. The basis of the correlation of post-Cretaceous formations of the Pacific region: Pan-Pacific Scientific Conference, First, Proc., Bernice P. Bishop Mus., Spec. Pub. no, 7, pt. 3, pp. 866-873, 1921.

15. General statement on the work of the committee on sedimentation, division of geology and geography, National Research Councii (abstract) : Geol. Soc. America, Bull., vol. 32, no. 1, p. 19, March 31, 1921.

16. (and Cooke, Wythe, Condit, D. D., Ross, C. P., Woodring, W. P., and Calkins, F. C.). A geological reconnaissance of the Dominican Republic: Dominican Republic, Geol. Survey, Mem., vol. 1, 268 pp., 23 pls. (incl. maps), Washington, 1921. Spanish edition, 302 pp., Washington, 1922.

17. Stratigraphic significance of the species of West Indian fossil Echini: Carnegie Inst., Washington, Pub. no. 306, pp. 105-122, 1922.

18. The study of the earth sciences, its purpose and its interrelations with medicine: U. S. Naval Medical Bull., vol. 18, no. 1, pp. 3-16, 1923.

19. Studies of fossils from Walu Bay, Fiji; corals and bottom samples from the Bahamas and Florida: Carnegie Inst., Washington, Year Book no. 21, pp. 187-190, January, 1923.

20. The work of Joseph Barrell on problems in sedimentation: Geol. Soc. America, Bull., vol. 34, no. 1, pp. 28-44, March 30, 1923.

21. Studies of the larger Tertiary Foraminifera from tropical and subtropical America: Nat. Acad. Sci., Proc., vol. 9, no. 7, pp. 253-257, July, 1923.

22. Stratigraphy of the Virgin Islands of the United States and of Culebra and Vieques islands, and notes on eastern Porto Rico: Washington Acad. Sci., Jour., vol. 13, no. 14, pp. 303-317, August 19, 1923.

23. On the relative value of species of smaller Foraminifera for the recognition of stratigraphic zones. (with discussion by Esther E. Richards) : Am. Assoc. Petroleum Geologists, Bull., vol. 7, no. 5, pp. 517-531, September-October, 1923.

24. Sediments and climate: Geog. Rev., vol. 13, no. 4, p. 665, October, 1923. 
Vaughan, Thomas Wayland-Continued.

25. Report of the committee on sedimentation and marine deposits: Nat. Research Council, Bull., vol. 7, pt. 5, no. 41, pp. 136-138, January, 1924.

26. Recent progress in the study of the tectonic features of the West Indies and Central America: Pan-Pacific Sci. Cong., Australia, 1923, Proc., vol. 1, pp. 735-741 [1924].

27. A sketch of the history of igneous activity in the northern and northeastern West Indies: Pan-Pacific Sci. Cong., Australia, 1928, Proc., vol. 1, pp. 851-855 [1924].

28. Correlation of the Cainozoic formations in the Pacific region; introduction to the symposium: Pan-Pacific Sci. Cong., Australia, 1923, Proc., vol. 1, pp. 860-862 [1924].

29. Recent additions to knowledge of the correlation of the Tertiary geologic formations of northeastern Mexico, Central America, the West Indies, northern South America, and Lower California: PanPacific Sci. Cong., Australia, 1923, Proc., vol. 1, pp. 864-870 [1924].

30. The embryonic and meridional chambers of American species of lepidocycline Foraminifera: Pan-Pacific Șci. Cong., Australia, 1923, Proc., vol. 1, pp. 871-873 [1924].

31. The ecology and growth rate of corals: Pan-Pacific Sci. Cong., Australia, 1923, Proc., vol. 2, pp. 1092-1101 [1924].

32. Coral reefs and submerged platforms: Pan-Pacific Sci. Cong., Australia, 1923, Proc., vol. 2, pp. 1128-1134 [1924].

33. Oceanography in its relations to other earth sciences: Washington Acad. Sci., Jour., vol. 14, no. 14, pp. 307-333, 2 pls., August 19, 1924.

34. Criteria and status of correlation and classification of Tertiary deposits : Geol. Soc. America, Bull., vol. 35, no. 4, pp. 677-742, 3 pls. (correlation tables, December, 1924 ; abstract, no. 1, pp. 171-172, March 30, 1924.

35. American and European Tertiary larger Foraminifera: Geol. Soc. America, Bull., vol. 35, no. 4, pp. 785-822, 6 figs., 7 pls., December, 1924; abstract, no. 1, pp. 173-174, March 30, 1924.

36. American and European Tertiary corals: Geol. Soc. America, Bull., vol. 35, no. 4, pp. 823-825, December 30, 1924.

37. (and Hoffmeister, John Edward). New species of fossil corals from the Dominican Republic: Harvard Coll., Mus. Comp. Zoology, Bull., vol. 67, no. 8, pp. 315-326, 4 pls., November, 1925.

38. (and Hoffmeister, John Edward). Miocene corals from Trinidad: Carnegie Inst. Washington, Pub. no. 344 (Papers from the Department of Marine Biology of the Carnegie Institution of Washington, vol. 33), pp. 105-134, 1 fig., 7 pls., February, 1926.

39. Application of the generic name Phyllocoenia Milne Edwards and Haime and the International code of zoological nomenclature: Science, new. ser., vol. 63, pp. 338-339, March 26, 1926.

40. Notes on the igneous rocks of the northeast West Indies and on the geology of the Island of Anguilla : Washington Acad. Sci., Jour., vol. 16, no. 13, pp. 345-358, July 19, 1926.

41. The stratigraphic horizon of the beds containing Lepidocyclina chaperi on Haut Chagres, Panama: Nat. Acad. Sci., Proc., vol. 12, no. 8, pp. 519-522, August, 1926.

42. Species of Lepidocyclina and Carpenteria from the Cayman Islands and their geological significance: Geol. Soc. London, Quart. Jour., vol. 82, pt. 3, pp. 388-400, 3 pls., October 19, 1926. 
Vaughan, Thomas Wayland-Continued.

43. Seismological investigations and oceanography: Nat. Research Council, Bull., no. 56 (vol. 11, pt. 2), pp. 69-72, November, 1926.

44. Larger Foraninifera of the genus Lepidocyolina related to Lepidocyclina mantelli: U. S. Nat. Mus., Proc., vol. 71, art. 8, 5 pp., 4 pls., 1927.

45. A new species of Eocene coral, Archohelia clarki, from California [from Meganos formation]: California, Univ. Dept. Geol. Sci., vol. 17, no. 3, pp. 143-144, 1 pl., December 31, 1927.

46. Species of large arenaceous and orbitoidal Foraminifera from the Tertiary deposits of Jamaica: Jour. Paleontology, vol. 1, no. 4, pp. 277-298, 8 pls., January, 1928.

47. Yaberinella jamaicensis, a new genus and species of arenaceous Foraminifera : Jour. Paleontology, vol. 2, no. 1, pp. 7-12, 2 pls., March, 1928.

48. Notes on the types of Lepidocyclina mantelli (Morton) Gümbel and on topotypes of Nummulites floridamus Conrad: Acad. Nat. Sci. Philadelphia, Proc., vol. 79, pp. 299-303, 1 pl., 1928.

49. New species of Operculina and Discocyclina from the Ocala limestone: Florida State Geol. Survey, 19th Ann. Rept., pp. 155-165, 2 pls., 1928.

50. Family 45, Orbitoididae. In Cushman, Joseph A., Foraminifera, their classification and economic use, pp. 336-356, Sharon, Massachusetts, 1928.

51. Results of recent investigations of American Tertiary larger Foraminifera : Third Pan-Pacific Sci. Cong., Tokyo, 1926, Proc., pp. 1850-1857, 1928.

Vaux, George, jr.

1. Some unusual quartz pseudomorphs from the Hopewell mine, Warwick Township, Chester County, Pennsylvania: Acad. Nat. Sci., Philadelphia, Proc., vol. 78, 1926, pp. 17-19, 3 figs., 1927.

2. The mines at Falls of French Creek, Chester County, Pennsylvania: Am. Mineralogist, vol. 13, no. 1, pp. 25-29, January, 1928.

Veatch, Arthur Clifford.

1. Estimation of petroleum reserves: Econ. Geology, vol. 17, no. 2, pp. 132139, March-April, 1922.

Veatch, Jethro Otto.

1. Geology as a factor in soil classification: Michigan Acad. Sci., Papers, vol. 5, pp. 285-296, 1925; abstract, Pan.-Am. Geologist, vol. 44, no. 2, pp. 157-158, September, 1925.

Versluys, J.

1. An investigation of the problem of the estimation of gas reserves: Am. Assoc. Petroleum Geologists, Bull., vol. 12, no. 11, pp. 1095-1105, November, 1928.

VerWiebe, Walter A.

1. The stratigraphy of the petroliferous area of eastern Mexico: Am. Jour. Soc., 5th ser., vol. 8, pp. 277-295, 385-394, 481-502, OctoberDecember, 1924.

2. Geology of southern Mexico oil fields: Pan-Am. Geologist, vol. 44, no. 2, pp. 121-138, 2 pls. (incl. map), September, 1925.

3. Oil fields of southern Mexico (abstract) : Pan-Am. Geologist, vol. 44, no. 2, p. 151, September, 1925.

4. Geology and oil fields of State of Tabasco [Mexico] : Pan-Am. Geologist, vol. 44, no. 4, pp. 273-284, 1 pl., November, 1925. 
VerWiebe, Walter A.-Continued.

5. Tectonics of the Tehuantepec Isthmus: Pan-Am. Geologist, vol. 45, no. 1, pp. 15-28, 1 pl. (map), February, 1926.

6. Oil fields of Isthmus of Tehuantepec [Mexico]: Pan-Am. Geologist, vol. 45, no. 3, pp. 189-200, 1 fig., 1 pl., April, 1926.

7. Salt domes of Isthmus of Tehuantepec: Pan-Am. Geologist, vol. 45, no. 5, pp. 349-358, June, 1926.

8. Geology of Roscommon County, Michigan: Michigan Acad. Sci., Papers, vol. 7, pp. 159-166, 1 fig. (map), 1927.

9. Surface geology of Menominee County, Michigan: Michigan Acad. Sci., Papers, vol. 7, pp. 167-179, 1 pl., 1927.

10. The stratigraphy of Alpena County, Michigan: Michigan Acad. Sci., Papers, vol. 7, pp. 181-192, 1 fig. (map), 1927.

11. Stratigraphy of Chippewa County, Michigan: Michigan Acad. Sci., Papers, vol. 9, pp. 309-331, 3 figs. (incl. map), 1928.

Vestal, Arthur G.

1. The Colorado mountain front; subdivisions north of the front range (abstract) : Assoc. Am. Geographers, Annals, vol. 10, pp. 155-156 [1921?].

Vickery, Frederick Paul.

1. The San Jose [California] earthquake: Seismol. Soc. America, Bull., vol. 10, no. 4, pp. 311-315, 2 figs., 1 pl., December, 1920.

2. The apparent intensity of earthquake shock in alluvial areas: Seismol. Soc. America, Bull., vol. 11, no. 1, pp. 80-82, March, 1921.

3. The structural dynamics of the Livermore region: Jour. Geology, vol. 33, no. 6, pp. 608-628, 8 figs., August-September, 1925.

4. Piracy and persistence of antecedent streams on the Los Angeles coastal belt (abstract) : Geol. Soc. America, Bull., vol. 38, no. 1, p. 207, March 30, 1927.

5. The interpretation of the physiography of the Los Angeles coastal belt [California]: Am. Assoc. Petroleum Geologists, Bull., vol. 11, no. 4, pp. 417-424, 2 figs., April, 1927.

6. Notes on geology of Goleta district, California: Oil Bull., vol. 13, no. 4, pp. 350-352, 2 figs., April, 1927.

7. Structural dynamics of the Livermore region [California] (abstract): Stanford Univ., Abstracts of Dissertations, 1924-1926, vol. 1, pp. 151-156, June, 1927.

8. The Goleta oil field [California] : something about its geology, its development, and its future: Oil Bull., vol. 13, no. 7, pp. 691, 764, July, 1927.

9. (and Garrison, R. H.). The Goleta field [petroleum, southern California] : Mining and Metallurgy, vol. 8, no. 250, pp. 428-433,.4 figs., October. 1927.

10. Structural features of coastal southern California (abstract) : Geol. Soc. America, Bull., vol. 39, no. 1, p. 267, March 30, 1928.

11. Geology of the Los Angeles Basin: Oil Bull., vol. 14, no. 4, pp. 355-361, 1 fig (map), April, 1928.

12. Consequent streams: Am. Assoc. Petroleum Geologists, Bull., vol. 12, no. 5, pp. 515-526, 5 figs., Mar, 1928.

Vilbrandt, Frank C.

1. An oil-bearing shale of North Carolina: Elisha Mitchell Sci. Soc., Jour., vol. 41, nos. 1-2, pp. 108-114, September, 1925. 
Vilbrandt, Frank C.-Continued.

2. Oil-bearing shales of Deep River valley : North Carolina, Dept. Conservation, Econ. Paper no. 59, 23 pp., 1927.

Villafaña, Andrés.

1. Reseña geológico-minera de la región de El Oro, México, y Tlalpujahua, Michoacán: Soc. cient. "Antonio Alzate," Mem. y Rev., t. 41, no. 1, pp. 27-47, July, 1922.

Villafaña, Edmundo.

1. El distrito minero Tepezalá-Asientos, Aguascalientes: Bol. minero, t. 15, no. 4, pp. 465-470, 5 pls., April, 1923.

Villatoro, J. A.

1. Algunas consideraciones sobre exploraciones geológicas de petróleo: Bol. Petróleo, vol. 26, no. 1, pp. 9-11, July, 1928.

Visher, Stephen Sargent. See also Huntington, 1.

1. The geography of South Dakota: South Dakota State Geol. and Nat. Hist. Survey, Bull. \&, pp. 1-177, 52 figs., July, 1918.

2. Geology of the Sullivan County, Indiana, oil field (abstract) : Science, new ser., vol. 51, p. 493, May 14, 1920.

3. Climate and geology (abstract) : Science, new ser., vol. 51, pp. 522-523, May 21, 1920.

4. Structural features of Indiana (abstract with discussion by W. H. Hobbs on glacial anticyclones): Geol. Soc. America, Bull., vol. 32, no. 1, pp. 27-28, March 31, 1921.

5. Increased oceanic salinity as one cause of increased climatic contrasts, Geol. Soc. America, Bull., vol. 32, no. 4, pp. 429-436, December 1: 1921.

6. The time of glacial loess accumulation in its relation to the climatic implications of the great loess deposits; did they chiefly accumulate during glacial retreat?: Jour. Geology, vol. 30, no. 6, pp. 472-479, September-October, 1922.

7. Special physiographic features in South Dakota: Pan-Am. Geologist, vol. 41, no. 5, pp. 347-354, June, 1924.

S. The solar-cyclonic hypothesis and the glacial period: Sci. Monthly, vol. 20 , no. 5, pp. 475-478, May, 1925.

9. Glacial periods and solar-cyclonic hypothesis (abstract) : Pan-Am. Geologist, vol. 44, no. 1, p. 74, August, 1925.

Vivar, Gonzalo.

1. Conclusiones principales del informe que acerca de algunos terrenos de los estados de Chiapas y Tabasco . . . : Bol. Petróleo, Mexico, vol. 17, no. 4, pp. 291-295, April, 1924.

2. Informe preliminar acerca de la geología y zonas petrolíferas de la parte norte de los Estados de Tamaulipas y Nuevo León: Mexico Departamento de exploraciones y estudios geológicos, Folleto de divulgación, no. 14, 12 pp., map, October, 1925.

3. Informe preliminar sobre el estudio geológico-petrolero de la regiôn de Ojinaga, Estado de Chihuahua: Mexico, Departamento de exploraciones y estudios geologicos, Folleto de divulgación, no. 16, 12 pp., October, 1925.

4. Bosquejo geológico de una parte del Estado de Colima: Mexico, Inst. geol., Anales, t. 2, no. 5, pp. 131-154, 5 pls., map, 1926. 
Vogdes, Anthony Wayne, 1843-1924.

1. Paleozoic Crustacea; Part I, A bibliography of Paleozoic Crustacea ; Part II, A list of the genera and subgenera of the Trilobita; Part III, A summary of the Ordovician genus Cybele Lovén: San Diego Soc. Nat. Hist., Trans., vol. 4, 154 pp., 2 pls., June 22, 1925.

Vogt, Johan Herman Lie.

1. The physical chemistry of the crystallization and magmatic differentiation of igneous rocks: Jour. Geology, vol. 29, no. 4, pp. 318-350, 5 figs., May-June; no. 5, pp. 426-443, 11 figs., July-August; no. 6, np. 515-539, 10 figs., September-October; no. 7, pp. 627-649, 23 figs., October-November ; no. 8, pp. 659-672, 2 figs., November-December, 1921 ; vol. 30, no. 7, pp. 611-630, 2 figs., October-November; no. 8, pp. 659-672, 2 figs., November-December, 1922.

2. Nickel in igneous rocks: Econ. Geology, vol. 18, no. 4, pp. 307-353, JuneJuly, 1923.

3. The physical chemistry of the crystallization and magmatic differentiation of igneous rocks: Jour. Geology, vol. 31, no. 3, pp. 233-252, 3 figs., April-May, no. 5, pp. 407-419, July-August, 1923.

4. Mrgmas and igneous ore deposits: Econ. Geology, vol. 21, no. 3, pp. 207233, no. 4, pp. 309-332, no. 5, pp. 469-497, 6 figs., May-August, 1926.

5. On ore magmas: Eng. and Min. Jour., vol. 123, nos. 16 and 17, pp. 645650, 682-684, April 16 and 23, 1927.

6. Geology of the platinum metals : Econ. Geology, vol. 22, no. 4, pp. 321-355, 1 fig., June-July, 1927.

Von Engeln, Oscar Diedrich. See also Tarr, R. S., 1.

1. The Tully glacial series: New York State Mus., Bull. nos. 227, 228, pp. 39-62, 1 fig., 20 pls., map, 1921.

2. The geography of the Ithaca, New York, region: Assoc. Am. Geographer's, Annals, vol. 16, no. 3, pp. 124-150, 2 figs., September; 1926.

Von Schlichten, Otto $\mathrm{C}$.

1. The newer aspect of crystallography (abstract) : Ohio Acad. Sci., Proc., vol. 8, pt. 4, p. 170, 1928; Ohio Jour. Sci., vol. 28, no. 3, p. 148, May, 1928.

Voskuil, W. H.

1. Phosphate industry and resources of the United States: Intern. Bergwirtschaft, Jg. 3, H. 6; pp. 97-120, 1 fig., June, 1928.

Wade, Arthur.

1. Two shallow oil fields in Texas-a detailed study (with discussion): Inst. Petroleum Technologists, Jour., vol. 13, no. 61, pp. 181-206, 6 figs., 2 pls., April, 1927.

Wade, Bruce.

1. Recent studies of the Upper Cretaceous of Tennessee: Jour. Geology: vol. 28, no. 5, pp. 377-394, 2 figs., July-August, 1920 . Tennessee State Geol. Survey, Bull. 23 (Pt. 1, Ann. Rept. 1919), pp. 51-64, 2 figs., 4 pls. (incl. map), 1920.

2. The fossil annelid genus Hamulus Morton, an operculate Serpula: U. S. Nat. Mus., Proc., vol. 59, pp. 41-46, 2 pls., 1921.

3. The fauna of the Ripley formation on Coon Creek, Tennessee (Bryozoa, by Ferdinand Canu and R. S. Bassler, pp. 32-39; Crustacea, by Mary J. Rathbun, pp. 184-191; Reptilla, by C. W. Gilmore, pp. 191192 ; Pisces, by J. W. Gidley, p. 192) : U. S. Geol. Survey. Prof. Paper 137, 272 pp., 2 figs., 72 pls., 1926. 
Wade, William hogers.

1. (and Wandke, Alfred). Geology and mining methods at Pilares mine [Los Pilares de Nacozari, Sonora, Mexico]: Am. Inst. Min. and Met. Eng., Bull., no. 152, pp. 1143-1169, 14 figs., August, 1919; Trans., vol. 63 , pp. $382-407$, 14 figs., 1920.

2. (and Wandke, Alfred). A big zinc mine in New York State at Edwards, St. Lawrence County: Eng. and Min. Jour.-Press, vol. 116, no. 3, pp. 95-99, 5 figs., July 21, 1923.

Wade, Verdi Valentine. See Udden, 4.

\section{Wagner, Carroll Marshall.}

1. (and Schilling, Karl H.) The San Lorenzo group of the San Emigdio region, California : California, Univ., Dept. Geol. Sci., Bull., vol. 14, no. 6, pp. 235-276, 8 pls., November 3, 1923.

Wagner, Emanuel.

1. Prospecting with the Eötvös balance: Eng. and Min. Jour.-Press, vol. 116, no. 14, pp. 583-589, 6 figs., October 6, 1923.

Wagner, Percy Albert.

1. The danger of generalizations: Econ. Geology, vol. 20, no. 3, pp. 282-285, May, 1925.

2. Wood tin-gel replacement of cassiterite (discussion); Econ. Geology, vol. 21, no. 7, pp. 727-731, November, 1926.

3. The microscope and ore geology : Econ. Geology, vol. 21, no. 8, pp. 803805, December, 1926.

4. The pipe form of ore deposit: Econ. Geology, vol. 22, no. 7, pp. 740-741, November, 1927.

5. Changes in the oxidation of iron in magnetite (discussion): Econ. Geology, vol. 22 , no. 8 , pp. 845-846, December, 1927.

6. Origin of the magmatic sulphide ores: Econ. Geology, vol. 23, no. 8, pp. 923-927, December, 1928.

Waibel, Ieo.

1. Die Inselberglandschaft von Arizona und Sonora: Gesell. Erdkunde Berlin; Zeitschr., Sonderband zur Hundertjahrfeier, pp. 68-91, 1928.

Waite, V. V. See also Udden, 23.

1. (and Udden, J. A.). Observations on the Bend [series] in Bough No. 1 in Brown County, Texas: Am. Assoc. Petroleum Geologists, Bull., vol. 3, pp. 334-344, 1 fig., 1919.

Waitz, Paul.

1. (and Urbina, Fernando). Los temblores de Guadalajara en 1912: México, Inst. geol., Bol. no. 19, 83 pp., 32 pls., 1919.

2. Descripción petrográfica de unas rocas de Zumpango del Río (Guerrero)

[México]: México, Inst. geol., Bol. no. 33, t. 1, pp. 85-89, 1919.

3. "Nubes ardentes" observadas en las erupciones del Jorullo (1759), del Ceboruco (1870), y del volcín de Colima (1913); El volcán del Jorullo; La nueva actividad y el estado actual del volcan Popocatepetl : Soc. cient. "Antonio Alzate," Mem. y Rev., t. 37, nos. 4-6, pp. 267-313, 12 pls., December, 1920.

4. Popocatepetl again in activity: Am. Jour. Sci., 5th ser., vol. 1, no. 1, pp. 81-87, 2 figs., January, 1.921.

5. Ascensión al cráter del volcán de Sta. María, Guatemala, en Agosto de 1922 : Soc. cient. "Antonio Alzate," Mem. y Rev., t. 41, nos. 7-9, pp. 343-351, 13 pls., October, 1923.

$4096-31-41$ 
Waitz, Paul-Continued.

6. Erupciones rhyolîticas ligadas con fracturas tectónicas entre Aguascalientes y San Luis Potosî: Soc. cient. "Antonio Alzate," Mem., t. 46, no. 3-6, pp. 201-212, March-June, 1926.

Walcott, Albert J.

1. Some factors influencing crystal habit: Am. Mineralogist, vol. 11, no. 9, pp. 221-239, September, no. 10, pp. 259-278, November, 1926 .

Walcott, Charles Doolittle, 1850-1927.

1. Cambrian geology and paleontology, IV; No. 5, Middle Canfbrian Algae: Smithsonian Misc. Coll., vol. 67, no. 5, pp. 217-260, 17 pls., December, 26, 1919.

2. Cambrian geology and paleontology, IV ; No. 6, Middle Cambrian Spongiae: Smithsonian Misc. Coll., vol. 67, no. 6, pp. 261-364, 31 pls., 1920.

3. Glacier Lake section, Alberta: Smithsonian Misc. Coll., vol. 72, no. 1, p. $15,1920$.

4. Cambrian geology and paleontology, IV; No. 7, Notes on structure of Neolenus: Smithsonian Misc. Coll., vol. 67, no. 7, pp. 365-456, 23 figs., 15 pls., December 20, 1921.

5. Occurrence of the oldest known trilobites [Silver Peak district, Nevada]: Pan-Am. Geologist, vol. 37, no. 4, p. 329, May, 1922.

6. Anatomy of early trilobites: Pan-Am. Geologist, vol. 37, no. 4, pp. 321322, 2 pls., May, 1922.

7. Cambrian geology and paleontology, IV; No. 8, Nomenclature of some. post-Cambrian and Cambrian Cordilleran formations (2): Smithsonian Misc. Coll., vol. 67, no. 8, pp. 457-476, March 5, 1923.

8. Cambrian geology and paleontology, IV; No. 9, Cambrian and Ozarkian Brachiopoda, Ozarkian Cephalopoda and Notostraca: Smithsonian Misc. Coll., vol. 67, no. 9, pp. 477-554, 21 pls., June 3, 1924.

9. Cambrian geology and paleontology, V; No. 1, Geological formations of Beaverfoot-Brisco-Stanford Range, British Columbia, Canada: Smithsonian Misc. Coll., rol. 75, no. 1., pp. 1-51, 11 figs., 8 pls., June 28, 1924.

10. Cambrian geology and paleontology, V; No. 2, Cambrian and lower Ozarkian trilobites: Surithsonian Misc. Coll., vol. 75, no. 2, pp. 53-60, 6 pls., July 19, 1924.

11. La discordance de stratification et la lacune stratigraphique pré-déyonienne dans les provinces Cordillères d'Alberta et de Colombie Britannique, Canada: Soc. Géol. Belgique, Livre Jubilaire, pp. 119-123, 1 fig., 2 pls., 1924.

12. Science and service: Science, new ser., vol. 61, pp. 1-5, January 2, 1925.

13. The geological record and the American continent (abstract): Science, new ser., vol. 61, pp. $x$, xii, January 9, 1925.

14. Geological explorations in the Canadian Rockies (abstract): Science, new ser., vol. 61, p. 129, February 6, 1925.

15. Cambrian geology and paletontology, V, No. 3, Cambrian and Ozarkian trilobites: Smithsonian Misc. Coll., vol. 75, no. 3, pp. 59-146, 2 figs., 10 pls., June 1, 1925.

16. John Mason Clarke: Science, new ser., vol. 62, p. 558, December 18, 1925.

17. Cambrian geology and paletontology, V; No. 4, Pre-Devonian sedimentation in southern Canadian Rocky Mountains: Smithsonian Misc. Coll,, vol. 75, no. 4, pp. 147-173, 10 figs., 1 pl. (map), April 2, 1927. 
Walcott, Charles Doolittle-Continued.

18. Cambrian geology and paleontology, V; No. 5, Pre-Devonian Paleozoic formations of the Cordilleran provinces of Canada: Smithsonian Misc. Coll., vol. 75, no. 5, pp. 175-368, 12 figs., 108 pls., September 14, 1928.

Waldorf, Creighton 0 .

1. The subsidence of the Colorado River delta: Eng. and Min. Jour., vol. 125, no. 25, pp. 1021-1022, June 23, 1928.

Waldschmidt, William A. See also Johnson, J. H., 9, 12.

1. The largest known beryl crystal: Pahasapa Quart., vol. 9, no. 1, pp. 11-16, 3 pls., 1 fig., December, 1919.

2. Columbite crystals from the Black Hills: Pahasapa Quart., pp. 67-71, 2 pls., 4 figs., February, 1920.

3. A peculiar occurrence of epsomite in the Black Hills: Pahasapa Quart., vol. 9, no. 3, pp. 138-140, 1 fig., April, 1920.

4. The geology and mineralogy of the Custer State Park [Black Hills, South Dakota] : Pahasapa Quart., pp. 199-207, 5 figs., map, June, 1921.

5. Phosgenite from the Terrible mine, near Ilse, Custer County, Colorado: Am. Mineralogist, vol. 8, no. 2, pp. 31-33, February, 1923.

6. Titanium-bearing jefferisite from Westcliffe, Custer County, Colorado: Am. Mineralogist, vol. 9, no. 5, pp. 113-116, May, 1924.

7. The microscope in mining, metallurgy, and geology: Colorado School of Mines, Alumni Mag., vol. 14, no. 8, pp. 8-9, December, 1924.

8. Deformation in ores, Coeur d'Alene district, Idaho: Econ. Geology, vol. 20, no. 6, pp. 573-586, 2 pls., September-October, 1925.

Walker, John Fortune. See also Ellsworth, 10.

1. Geology and mineral deposits of Windermere map area, British Columbia: Canada, Geol. Survey, Mem. 148, 69 pp., 3 figs., 8 pls., map, 1926.

2. Reconnaissance in the Purcell Range west of Brisco, Kootenay district, British Columbia: Canada, Geol. Survey, Summ. Rept., 1925, pt. A, pp. 222-229, map, 1926.

3. (and Evans, C. S.). The geology of the Rocky Mountain trench (abstract) : Roy. Soc. Canada, Proc. and Trans., 3d ser., vol. 21, p. $\mathrm{xcv}, 1927$.

Walker, R. T.

1. A glacially transported mine: Eng. and Min. Jour.-Press, vol. 118, no. 8, pp. 295-296, 1 fig., August 23, 1924.

2. Deposition of ore in preexisting limestone caves: Am. Inst. Min. and Met. Eng., Tech. Pub. no. 154, 43 pp., 22 figs., 1928.

3. Mineralized volcanic explosion pipes: Eng. and Min. Jour., vol. 126, nos. 23, 24, and 25, pp. 895-898, 939-942, 976-984, 19 figs., December 8, 15 , and 22, 1928.

Walker, Thomas Leonard. See also Bastin, 9.

1. Mineralogy of the H. B. mine, Salmo, B. C.: Toronto, Univ., Studies, Geol. ser., no. 10, 25 pp., 10 figs., 1918.

2. Stalactitic barite from Madoc, Ontario: Am. Mineralogist, vol. 4, no. 7, pp. 79-80, 1 pl., July, 1919.

3. Fluorite from Madoc, Ontario: Am. Mineralogist, vol. 4, no. 8, pp. 95-96, 1 fig., August, 1919.

4. Cosalite from Ontario: Toronto, Univ., Studies, Geol. ser., no. 12, pp. 5-10, 1 fig., 1921. 
Walker, Thomas Leonard-Continued.

5. (and Thomson, E.). An examination of lillianite and galenobismutite: Toronto, Univ., Studies, Geol. ser., no. 12, pp. 11-15, 1921.

6. Dyscrasite from Cobalt, Ontario: Toronto, Univ., Studies, Geol. ser., no. 12. pp. 20-22, 1921.

7. (and Parsons, A. L.). Rammelsbergite from Cobalt, Ontario: Toronto, Univ., Studies, Geol. ser., no. 12, pp. 27-31, 1 pl, 1921.

8. Epsomite lakes near Ashcroft, British Columbia: Toronto, Univ., Studies, Geol. ser., no. 12 , pp. $43-45,1921$.

9. Orthoclase from Penticton, British Columbia: Toronto, Univ., Studies, Geol. ser., no. 12 , pp. $46-50$, 5 figs., 1921.

10. Ulexite from the maritime provinces: Toronto, Univ., Studies, Geol. ser.. no. 12, pp. 54-57, 1 fig., 1921.

11. (and Parsons, A. L.). The dehydration of spencerite: Toronto, Univ., Studies, Geol. ser., no. 12, pp. 58-62, 5 figs., 1921.

12. A chemical study of conglomerates: Toronto, Univ., Studies, Geol. ser., no. 12 , pp. $63-68,1921$.

13. Cleavable bornite from Usk, British Columbia : Am. Mineralogist, vol. 6 , no. 1, pp. 3-4, January, 1921.

14. Skutterudite from Cobalt, Ontario: Am. Mineralogist, vol. 6, no. 3, pp. 54-56, 1 fig., March, 1921.

15. "Allemontite" from Atlin, British Columbia: Am. Mineralogist, vol. 6, no. 6, pp. 97-99, 1 pl., June, 1921.

16. (and Parsons, A. L.). Tubular amygdaloid from Nova Scotia: Toronto, Univ., Studies, Geol. ser., no. 14, pp. 5-12, 3 pls., 1922. Abstract, Geol. Soc. America, Bull., vol. 33, no. 1, p. 126, March 31, 1922.

17. (and Parsons, A. L.). The zeolites of Nova Scotia: Toronto, Univ., Studies, Geol. ser., no. 14, pp. 13-73, 8 figs., 1922.

18. (and Parsons, A. L.). Notes on some Canadian diopsides: Toronto, Univ., Studies, Geol. ser., no. 14, pp. 74-79, 5 figs., 1922.

19. Dumortierite from Ashby Township, Addington County, Ontario : Toronto, Univ., Studies, Geol. ser., no. 14, pp. 80-83, 1 fig., 1922.

20. Copiapite from Liard Post, British Columbia: Toronto, Univ., Studies, Geol. ser., no. 14, pp. 84-86, 1 fig., 1922.

21. Fibroferrite from Quatsino, British Columbia: Toronto, Univ., Studies, Geol. ser., no. 14, pp. 87-88, 1922.

22. Alteration of silicates, by Sonstadt's solution: Am. Mineralogist, vol. 7, no. 6, pp. 100-102, June, 1922.

23. The development of mineralogical methods: Am. Mineralogist, vol. 8, no. 3, pp. 41-46, March, 1923.

24. (and Parsons, A. L.). The North Mountain basalt of Nova Scotia; glaciation, tubular amygdaloid, mordenite, and louisite: 'Toronto, Univ., Studies, Geol. ser., no. 16, pp. 5-12, 3 pls., 1923.

25. (and Parsons, A. L.). Ellsworthite and associated minerals from Hybla, Ontario: Toronto, Uiv., Studies, Geol. ser., no. 16, pp. 13-20, 1 fig., 1923.

26. (and Parsons, A. L.). Hatchettolite and associated minerals from Hybla, Ontario: Toronto, Univ., Studies, Geol. ser., no. 16, pp. 21-24, 1923.

27. (and Parsons, A. L.). Shattering of minerals and rocks about inclusions: Toronto, Univ., Studies, Geol. ser., no. 16, pp. 25-28, 1923.

28. (and Parsons, A. L.). Notes on Canadian minerals-allanite, axinite, columbite, and sillimanite: Toronto, Univ., Studies, Geol. ser., no. 16, pp. 29-37, 1923. 
Walker, Thomas Leonard-Continued.

29. Trevorite, a distinct mineral species: Toronto, Univ., Studies, Geol. ser., no. 16 , pp. 53-54, 1923.

30. Huronite from Gowganda, Ontario: Toronto, Univ., Studies, Geol. ser., no. 16 , pp. 55-57, 1 pl., 1923.

31. Chapmanite, a new hydrous ferrous silicoantimonate, from South Lorrain, Ontario: 'Toronto, Univ., Studies, Geol. ser., no. 17, pp. 5-8, 1924.

32. (and Parsons, A. L.). Skutterudite and loellingite from the La Rose mine, Cobalt, Oontario: Toronto, Univ., Studies, Geol. ser., no. 17, pp. 9-10, 3 pls., 1924.

33. (and Parsons, A. L.). The arsenates of cobalt, nickel, and iron observed in the silver-bearing veins at Cobalt, Ontario: Toronto, Univ., Studies, Geol. ser., no. 17, pp. 13-17, 1924.

34. Chemical and microscopic examination of ferric and ferrous vein materials, and of chert from the Keeley mine [Cobalt district, Ontario] : Toronto, Univ., Studies, Geol. ser., no. 17, pp. 38-41, 1924.

35. Uraninite from Cardiff Township, Ontario: Toronto, Univ., Studies, Geol. ser., no. 17, pp. 42-45, 1924.

36. (and Parsons, A. L.). Pegmatite minerals from New Ross, Nova Scotia: Toronto, Univ., Studies, Geol. ser., no. 17, pp. 46-50, 1924.

37. The age of some Canadian pegmatites: Toronto, Univ., Studies, Geol. ser., no. 17, pp. 51-54, 1924.

38. Hastingsite from Dungannon Township, Hastings County, Ontario: Toronto, Univ., Studies, Geol. ser., no. 17, pp. 58-61, 1924.

39. (and Parsons, A. L.). Evanescent pink sodalite and associated minerals from Dungannon Township, Ontario: Toronto, Univ:, Studies, Geol. ser., no. 20, pp. 5-13, 1925.

40. (and Parsons, A. L.). The characteristics of primary calcite: Toronto, Univ., Studies, Geol. ser., no. 20, pp. 14-17, 1 pl., 1925.

41. (and Parsons, A. L.). Zonal plechroic twinned phlogopite: Toronto, Univ., Studies, Geol. ser., no. 20, pp. 18-19, 1 pl., 1925.

42. (and Parsons, A. L.). Petzite from the Hollinger mine, Timmins, Ontario: Toronto, Univ., Studies, Geol. ser., no. 20, pp. 39-40, 1925.

43. (and Parsons, A. L.). The rate of oxidation of arsenides of iron, cobalt, and nickel: 'Toronto, Univ., Studies, Geol. ser., no. 20, pp. 41-48, 1925.

44. Arsenides from the silver veins of South Lorrain, Ontario: Toronto, Univ., Studies, Geol. ser., no. 20, pp. 49-53, 2 pls., 1925.

45. (and Parsons, A. L.). A comparison of the Port Arthur, Cobalt, South Lorrain, and Gowganda silver vein minerals: Toronto, Univ., Studies, Geol. ser., no. 20, pp. 59-62, 1925.

46. (and Parsons, A. L.). New localities for Canadian minerals: Toronto, Univ., Studies, Geol. ser., no. 20, pp. 68-71, 1925.

47. (and Parsons, A. L.). Minerals from the new nepheline syenite area, French River, Ontario: Toronto, Univ., Studies, Geol. ser., no. 22, pp. 5-14, 3 figs., 1 pl., 1926.

48. (and Parsons, A. L.). Zeolites and related minerals from Lake Nipigon, Ontario: Toronto, Univ., Studies, Geol. ser., no. 22, pp. 15-19, 1926.

49 (and Parsons, A. L.). Apatite, lepidomelane, and associated minerals from Faraday Township, Hastings County, Ontario: Toronto, Univ., Studies, Geol. ser., no. 22, pp. 20-25, 4 figs., 1 pl., 1926. 
Walker, Thomas Leonard-Continued.

50. (and Parsons, A. L.). Changes in water level and flotation as forces of erosion: Toronto, Univ, Studies, Geol. ser., no. 22, pp. 26-28, 1 fig., 1 pl., 1926.

51. (and Parsons, A. L.). A re-examination of bytownite and huronite: Toronto, Univ., Studies, Geol. ser. no. 24, pp. 5-11, 1927.

52. (and Parsons, A. L.). Beryl and associated minerals from Lyndoch township, Renfrew County, Ontario: Toronto, Univ., Studies, Geol. ser. no. 24, pp. 12-14, 1 fig., 1927.

53. (and Parsons, A. L.). Notes on Canadian minerals, tremolite, clinohumite, stromeyerite, natron, and hexahydrite: Toronto, Univ., Studies, Geol. ser. no. 24, pp. 15-23, 1 fig., 1927.

54. (and Parsons, A. L.). The contact phenomena of the nepheline syenites of Port Coldwell, Ontario: Toronto, Univ., Studies, Geol. ser. no. 24, pp. 28-32, 1927.

55. (and Gerrie, William). Influence of hot natural brines on dolomitization: Toronto, Univ., Studies, Geol. ser. no. 24, pp. 33-36, 1927.

56. Geological hammers: Am. Mineralogist, vol. 12, no. 5, pp. 226-227,1 fig., May, 1927.

57. On the nature of louisite: Nova Scotian Inst. Sci., Proc. and Trans., vol. 16; pp. 35-37, 1 fig., November 21, 1927.

Wallace, Robert Charles. See also Twenhofel, 22, 29.

1. Mining development in northern Manitoba: Canadian Min. Inst., Monthly Bull., no. 83, pp. 287-296, March, 1919; Trans., vol. 22, pp. 329340 [1920].

2. The northern Manitoba field: Canadian Min. Jour., vol. 40, pp. 549-550, Jüly 23, 1919.

3. The gold discovery at Copper Lake, northern Manitoba: Canadian Min. Jour., vol. 40, pp. 731-733, October 1, 1919.

4. Progress in the northern Manitoba mineral belt: Canadian Min. Jour., vol. 40, pp. 843-846, 1 fig., November 12, 1919.

5. The Flinflon ore body [Manitoba-Saskatchewan] : Canadian Inst. Min. and Met. Monthly Bull. no. 106, pp. 106-118, 6 figs., February, 1921; Trans., vol. 24, pp. 99-111, 6 figs. [1922] ; Canadian Min. Jour., vol. 42, no. 9, pp. 170-174, 6 figs., March 4, 1921. Reissued with addendum by Industrial Development Board of Manitoba, 15 pp., 6 figs., August, 1927.

6. The search for oil in the Pasquia Hills: Canadian Min. Jour., vol. 42, no. 27, pp. 540-542, July 8, 1921 ; Canadian Inst. Min. and Met., . Monthly Bull. no. 113, pp. 791-795, September, 1921.

7. The gold discovery at Elbow Lake, Manitoba: Canadian Min. Jour., vol. 42, no. 36, p. 720, September 9, 1921.

8. Secondary processes in some pre-Cambrian ore bodies: Roy. Soc. Canada, Proc. and Trans., 3d ser., vol. 16, sec. 4, pp. 169-174, 1922.

Y. The distribution of the colloidal products of weathering: Roy. Soc. Canada, Proc. and Trans., 3d ser., vol. 17, sec. 4, pp. 69-77, May, 1923.

10. Manitoba's contribution to Canada's mining opportunities: Canadian Inst. Min. and Met., Monthly Bull., no. 143, pp. 90-99, 2 figs. (maps), March, 1924.

11. (and Maynārd, J. E.). The clays of the Lake Agassiz basin: Roy. Soc. Canada, Proc. and Trans., $3 d$ ser., vol. 18 , sec. $4,{ }^{\circ}$ pp. 9-30, 7 figs., $1 \mathrm{pl} .$, May, 1924. 
Wallace, Robert Charles-Continued.

12. An unusual occurrence of cyanite [Reed-Wekusko map-area, northern. Manitoba]: Am. Mineralogist, vol. 9, no. 6, pp. 129-135, 2 figs., June, 1924

13. The mineral resources of Manitoba: Manitoba, Industrial Development Board, 48 pp., illus., map, Winnipeg, 1925.

14. The geological formations of Manitoba. $58 \mathrm{pp}$., pls., map, published by the Natural History Society of Manitoba, 1925.

15. Relationships in mineral deposits in northwestern Manitoba: Econ. Geology, vol. 20, no. 5, pp. 431-441, 1. fig., August, 1925.

16. Mineral deposits of Hudson Bay territory (with discussion) : Canadian Inst. Min. and Met., Bull., no. 164, pp. 1165-1176, 3 figs., December, 1925 ; Trans., vol. 28 , pp. 301-310 [1926].

17. (and Baker, W. F., and Ward, G.). The Red River as an erosive agent: Roy. Soc. Canada, Proc. and Trans., $3 d$ ser., vol. 20 , pt. 2 , sec. 4 , pp. 149-167, 3 figs., 1926.

18. (and Greer, L.). The nonmetallic mineral resources of Manitoba. 93 pp., 9 figs., 5 pls., Industrial Development Board of Manitoba, 1927.

19. The mineral resources of Manitoba (second edition): Manitoba, Industrial Development Board, 58 pp., 12 pls. (incl. maps), Winnipeg, 1927.

20. Varve materials and banded rocks: Roy. Soc. Canada, Trans., 3d ser., vol. 21, sec. 4, pp. 109-118, 1 fig., 2 pls., May, 1927; abstract, p. xciii, 1927.

21. (and Pentland, A., and Quinn, R. F.). Paleozoic, Mesozoic, and Pleistocene sands in Manitoba (abstract) : Roy. Soc. Canada, Proc. and Trans., 3d ser., vol. 21, p. xciv, 1927.

22. Copper-zinc and gold mineralization in Manitoba: Canadian Min. and Met. Bull., no. 190, pp. 264-273, 7 figs., February, 1928; Canadian Inst. Min. and Met., Trans., vol. 31, pp. 42-56, 7 figs. [1929]; Canadian Min. Jour., vol. 49, no. 8, pp. 170-172, 3 figs., February 24, 1928.

23. (and McCartney, G. C.). Heavy minerals in sand horizons in Manitoba and eastern Saskatchewan: Roy. Soc. Canada, Proc. and Trans., 3d ser., vol. 22, sec. 4, pp. 199-214, 1 fig., 4 pls., May, 1928.

Walter, Otto Theodore.

1. Upper Cambrian trilobites [of Iowa] (abstract) : Geol. Soc. America, Bull., vol. 32 , no. 1, p. 128, March 31, 1921.

2. An Iowa Cambrian eurypterid (abstract) : Iowa Acad. Sci., Proc. 1922, vol. 29 , pp. 126-127 [1924?].

3. Trilobites of Iowa and some related Paleozoic forms: Iowa Geol. Survey, vol. 31 , pp. 167-388, 6 figs., 18 pls. [1926?].

Walton, John.

1. On the structure of a Middle Cambrian Alga from British Columbia (Marpolia spissa Walcott) : Cambridge Philos. Soc., Proc., Biol. Sci., vol. 1, no. 1, pp. 59-62, 1 fig., 1 pl., August, 1923.

Wandke, Alfred. See also Wade, W. R., 1, 2.

1. Geology of the Portsmouth basin, Maine and New Hampshire (abstract) : Geol. Soc. America, Bull., vol. 31, no. 1, p. 138, March 31, 1920.

2. Intrusive rocks of the Portsmouth Basin, Maine and New Hampshire: Am. Jour. Sci., 5th ser., vol. 4, pp. 139-158, 1 fiig., August, 1922.

3. A petrologic study of the Cape Neddick gabbro [York County, Maine]: Am. Jour. Sci., 5th ser., vol. 4, pp. 295-304, 1 fig., October, 1922. 
Wandke, Alfred-Continued.

4. (and Hoffman, Robert). A study of the Sudbury [Ontario] ore deposits: Econ. Geology, vol. 19, no. 2, pp. 169-204, 3 figs., 2 pls., March, 1924.

5. The Caridad mine, Sonora, Mexico: Econ. Geology, vol. 20, no. 4, pp. 311318, June-July, 1925.

6. Shattering by replacement: Econ. Geology, vol. 20, no. 6, pp. 605-607, 1 fig., September-October, 1925.

7. Molecular migration and mineral transformation: Econ. Geology, vol. 21, no. 2, pp. 166-171, March-April, 1926.

S. (and Martínez, Juan). The Guanajuato mining district, Guanajuato, Mexico: Econ. Geology, vol. 23, no. 1, pp. 1-44, 5 figs., January, 1928.

Wanless, Harold Rollin.

1. Lithology of the White River sediments: Am. Philos. Soc., Proc., vol. 61, no. 3, pp. 184-203, 1 fig., 2 pls., 1922. Abstract, Science, new ser., vol. 55, p. 654, June 16, 1922.

2. Notes on sand calcite from South Dakota: Am. Mineralogist, vol. 7 , no. 5, pp. 83-86, 2 figs., May, 1922.

3. The stratigraphy of the White River beds of South Dakota: Am. Philos. Soc., Proc., vol. 62, no. 4, pp. 190-269, 10 figs., 9 pls., 1923.

4. Physiographic significance of post-Miocene gravels of western South Dakota (abstract) : Geol. Soc. America, Bull., vol. 36, no. 1, p. 140, March 30, 1925 ; Pan-Am. Geologist, vol. 43, no. 1, p. 80, February, 1925.

5. Stratigraphy and paleontology of the Pennsylvanian of northwestern Illinois (abstract) : Geol. Soc. America, Bull., vol. 38, no. 1, pp. 133134, March 30, 1927; Pan-Am. Geologist, vol. 47, no. 1, p. 77, February, 1927.

6. Oil possibilities of the Alexis quadrangle, Mercer and Warren counties, Illinois: Illinois, State Geol. Survey, Press Bull. ser., Illinois Petroleum no. 8, pp. 1-7, 3 figs., April 16, 1927.

7. Pleistocene and recent history of Alexis quadrangle [Illinois]: Illnois State Acad. Sci., Trans., vol. 20, pp. 254-260, March, 1928.

Wanner, Henry E.

1. Some faunal remains from the Trias of York County, Pennsylvania: Acad. Nat. Sci. Philadelphia, Proc., vol. 73, pt. 1, pp. 25-37, 6 figs. 3 pls., 1921.

2. Some additional faunal remains from the Trias of York County, Pennsylvania: Acad. Nat. Sci. Philadelphia, Proc., vol. 78, 1926, pp. 21-28, 4 figs., $1 \mathrm{pl}$., 1927.

Ward, Freeman. See also Wilson, R. A., 3.

1. Biennial report of the State geologist, 1916-1918: South Dakota State Geol. and Nat. Hist. Survey, Bull. 8, pp. 179-189, July, 1918.

2. The possibilities of oil and gas in Harding County: South Dakota Geol. and Nat. Hist. Survey, Circular no. 4, 8 pp., October, 1918.

3. Chalk: South Dakota Geol. and Nat. Hist. Survey, Circular 6, 4 pp., November, 1919.

4. Report of the State geologist [of South Dakota], 1918-1920. 1.5 pp., Daily Leader, Madison, S. D. [1920].

5. The Quaternary geology of the New Haven region; Connecticut: Connecticut State Geol. and Nat. Hist. Survey, Bull. no. 29, 78 pp., 9 pls. (incl. maps), 17 figs., 1920. 
Ward, Freeman-Continued.

6. The possibilities of oil in eastern Pennington County: South Dakota Geol. and Nat. Hist. Survey, Circular 8 (South Dakota Univ., Bull., ser. 21, no. 7), 11 pp., 2 figs., October, 1921.

7. Annual report of the State geologist, State of South Dakota, 1920-1922. 32 pp., Pierre, S. D., 1922.

8. The geology of a portion of the Badlands: South Dakota Geol. and Natural Hist. Survey, Bull. 11, pp. 1-59, 11 figs., 17 pls. (incl. map), August, 1922.

9. (and Wilson, R. A.). The possibilities of oil in western Dewey County: South Dakota Geol. and Nat. Hist. Survey, Circular 9, 10 pp., 4 figs., September, 1922.

10. Dome structures in South Dakota: Pan-Am. Geologist, vol. 39, no. 2, pp. 149-151, 2 pls., March 30, 1923.

11. Note on mud cracks: Am. Jour. Sci., 5th ser., vol. 6, pp. 308-309, 1 fig., October, 1923.

12. The Lance problem in South Dakota: Am. Jour. Sci., 5th ser., vol. 7, pp. 65-68, January, 1924; abstract, Geol. Soc. America, Bull., vol. 30 , no. 1, p. 71 , March, 1923.

13. (and others). The natural resources of South Dakota: South Dakota Geol. and Nat. Hist. Survey, Circular 16, 28 pp., April, 1924.

14. (and Moulton, Gail F.). Field conditions in southern Haakon County: South Dakota Geol, and Nat. Hist. Survey, Circular 17, 4 pp., May, 1924.

15. The biennial report of the State geologist, 1922-1924: South Dakota Geol. and Nat. Hist. Survey, 24 pp. [1925].

16. Structures in northern Haakon County: South Dakota Geol. and Nat. Hist. Survey, Circular 22, 15 pp., 3 figs., March, 1925.

17. The structure of western. South Dakota: South Dakota Geol. and Nat. Hist. Survey, Circular 25, 7 pp., map, October, 1925.

18. The biennial report of the State geologist, 1924-1926: South Dakota Geol. and Nat. Hist. Survey, 22 pp. [1926?].

19. The position of the Interior formation [South Dakota]: Am. Jour. Sci., 5th ser., vol. 11, pp. 350-352, 1 fig., April, 1926.

Ward, G. See Wallace, 17.

Waring, Gerald Ashley.

1. Ground water in the San Jacinto and Temecula basins, California: U. S. Geol. Survey, Water-Supply Paper 429, 113 pp., 14 pls. (incl. maps), 15 figs., 1919. Abstract, Washington Acad. Sci., Jour., vol. 10, no. 16, pp. 472-473, October 4, 1920.

2. Ground water in the Meriden area, Connecticut: U. S. Geol. Survey, WaterSupply Paper 449, 83 pp., 10 figs., 7 pls. (incl. maps), 1920.

3. Ground water in Pahrump, Mesquite, and Ivanpah valleys, Nevada and California: U. S. Geol. Survey, Water-Supply Paper 540, pp. 51-81, 5 pls., (incl. maps), 2 figs., 1920.

4. Use of the sketching case in geologic work: Am. Assoc. Petroleum Geologists, Bull., vol. 8, no. 5, pp. 672-674, 1 fig., September-October, 1924.

5. (and Carlson, C. G.). Geology and oil resources of Trinidad, British West Indies: Am. Assoc. Petroleum Geologists, Bull., vol. 9, no. 6, pp. 1000-1008, 1 fig., 1 pl., September, 1925.

6. The geology of the Island of Trinidad, British West Indies : Johns Hopkins Univ., Studies in Geology, no. 7, 180 p.., 1 fig., 20 pls.. 1926. 
Warner, Charles Albert.

1. Field mapping for the oil geologist. 145 pp., 40 figs., New York, John Wiley \& Sons, Inc., 1921.

Warner, Thor.

1. An anticlinorium on the southern California coast: Oil Age, Los Angeles, California, vol. 19, no. 26, pp. 12-14, 3 figs., June 27, 1923.

2. Lindero anticline, Ventura County, California: Min. and Oil Bull., vol. 10, no. 6, pp. 589, 591, 652, June, 1924.

Warren, Charles Hyde.

1. A manual of determinative mineralogy. 163 pp., New York, McGraw-Hill Book Company, 1921.

2. (and McKinstry, Hugh E.). The granites and pegmatites of Cape Ann. Massachusetts: Am. Acad. Arts and Sci., Proc., vol. 59, no. 14, pp. 315-357, 5 pls., September, 1924.

Warren, Helen Ann.

1. Survey of the life of Louis Agassiz; the centenary of the glacial theory: Sci. Monthly, vol. 27, no. 4, pp. 355-366, October, 1928.

Warren, Percival S.

1. A Kinderhook fauna from Nordegg, Alberta: Am. Jour: Sci., 5th ser., vol. 10 , pp. 448-450, November, 1925.

2. The invertebrate fauna of the upper part of the Edmonton formation on the Red Deer River, Alberta: Roy. Soc. Canada, Proc. and Trans., 3d ser., vol. 20 , pt. 1, sec. 4, pp. 1-7, 1 pl., 1926.

3. A marine fauna in the Birch Lake sandstone, Alberta: Roy. Soc. Canada, Proc. and Trans., 3 d ser., vol. 20, pt. 1. ses. 4, pp. 9-14, 1 pl., 1926.

4. Banff area, Alberta: Canada, Geol. Survey, Mem. 153, 94 pp., 7 pls., map, 1927. [No. 2121]

5. Geology and oil prospects in the vicinity of Riverhurst, Saskatchewan: Canada, Geol. Survey, Summ. Rept., 1926, pt. B, pp. 39-42, 1927.

6. A new cycad from the Kootenay coal measures of Alberta: Roy. Soc. Canada, Trans., 3d ser., vol. 21, sec. 4, pp. 47-50, 2 pls., March, 1927.

7. The Palaeozoics of the Crowsnest Pass, Alberta: Roy. Soc. Canada, Proc. and Trans., 3d ser., vol. 22, sec. 4, pp. 109-120, 1 pl., March, 1928.

8. (and Rutherford, R. L.). Fossil zones in the Colorado shale of Alberta: Am. Jour. Sci., 5th ser., vol. 16, pp. 129-136, August, 1928.

Warren, Van Court. See Johnson, H. R., 1.

Warthin, Aldred Scott, jr.

1. Fossil fishes from the Triassic of Texas: Michigan, Univ., Mus. Paleontology, Contr., vol. 3, no. 2, pp. 15-18, 1 pl., November 10, 1928.

Washburne, Chester Wesley. See also Melcher, 1 ; Woodruff, 1.

1. Some physical principles of the origin of petroleums: Am. Assoc. Petroleum Geologists, Bull., vol. 3, pp. 345-362, 1919.

2. A discussion of "Notes on principles of oil accumulation" by A. W. McCoy: Jour. Geology, vol. 28, no. 4, pp. 366-370, May-June, 1920.

3. Oil field brines: Mining and Metallurgy, no. 164, p. 27, August, 1920 (abstract) ; Am. Inst. Min. and Met. Eng., Trans. [preprint no. 1010], 13 pp., 1920 ; discussion by R. V. A. Mills, E. DeGolyer, W. E. Pratt, R. A. Conkling, and C. W. Washburne [preprint] no. 1038, pp. 71-84, January, 1921. 
Washburne, Chester Wesley-Continued.

4. Oil-field brines: Am. Inst. Min. and Met. Eng., Trans., vol. 65, pp. 269$294,1921$.

5. Colin C. Rae's "Organic material of carbonaceous shales": Am. Assoc. Petroleum Geologists, vol. 7, no. 4, pp. 440-442, July-August, 1923.

6. Capillary relationships of oil and water: Econ. Geology, vol. 18, no. 6, pp. 598-600, September, 1923.

7. California oil field waters (discussion) : Econ. Geology, vol. 20, no. 4, pp. 395-396, June-July, 1925.

8. Relation of earth temperatures to buried hills and anticlinal folds (discussion) : Econ. Geologig, vol. 21, no. 4, pp. 397-399, June-July, 1926.

9. Intersection of faults (abstract) : Geol. Soc. America, Bull., vol. 39, no. 1, p. 175, March 30, 1928; Pan-Am. Geologist, vol. 49, no. 1, pp. 78-79, February, 1928.

10. Relation of faults to folds (abstract) : Geol. Soc. America, Bull., vol. 39, no. 1, pp. 175-176, March, 1928; Pan-Am. Geologist, vol. 49, no. 1, p. 79, February, 1928.

11. Epianticlinal faults of Elk Basin, Wyoming (abstract) : Geol. Soc. America, Bull., vol. 39, no. 1, p. 176, March 30, 1928; Pan-Am. Geologist, vol. 49 , no. 1 , pp. $79-80$, February, 1928.

12. Curvature of faults (abstract) : Geol. Soc. America, Bull., vol. 39, no. 1, pp. 176-177, March 30, 1928; Pan-Am. Geologist, vol. 49, no. 1, p. 80, February, 1928.

13. Velocity of slipping on normal faults (abstract): Geol. Soc. America, Bull., vol. 39, no. 1, p. 177, March 30, 1928; Pan-Am. Geologist, vol. 49 , no. 2, p. 139, March, 1928.

14. Origin of normal faults (abstract) : Geol. Soc. America, Bull., vol. 39, no. 1, pp. 263-264, March 30, 1928.

15. The origin of normal faults (abstract): Washington Acad. Sci., Jour., vol. 18, no. 12, pp. 346-350, June 19, 1928.

Washington, Henry Stephens. See also Adams, L. H., 4; Am. Geophysical Union, 1; Aurousseau, 1; Bowie, 2, 4; Clarke, F. W., 3, 4; Wyckoff, 5 .

1. Manual of the chemical analysis of rocks. Third edition, 271 pp., New York, John Wiley \& Sons, 1919.

2. Italite, a new leucite rock: Am. Jour. Sci., 4th ser., vol. 50, pp. 33-47, July, 1920.

3. The problems of volcanology: Nat. Acad. Sci., Proc., vol. 6, no. 10, pp. 583-592, October 15, 1920. Nat. Research Council, Reprint and Circular Ser., no. 11, pp. 583-592, 1920.

4. The chemistry of the earth's crust: Franklin Inst., Jour., vol. 190, no. 6, pp. 757-815, 6 figs., December, 1920. Smithsonian Inst., Ann. Rept., 1920, pp. 269-319, 6 figs., 1922. Abstract, Washington Acad. Sci., Jour., vol. 11, no. 17, p. 420, October 19, 1921.

5. The lavas of the Hawaiian volcanoes: Papers from the Geophysical Laboratory, Carnegie Institution of Washington, no. 434, $12 \mathrm{pp}$. [reprint from], Hawaiian Annual for 1922, 1921.

6. The chemistry of the Pacific volcanoes; the limitations of our knowledge: Pan-Pacific Scientific Conference, First, Proc., Bernice P. Bishop Mus., Spec. Pub. no. 7, pt. 2, pp. 325-345, 1921.

7. Remarks on volcanoes: Pan-Pacific Scientific Conference, First, Proc., Bernice P. Bishop Mus., Spec. Pub. no. 7, pt. 2, pp. 361-368, 1921. 
Washington, Henry Stephens-Continued.

๖. Ocean currents and geological change: Pan-Pacific Scientific Conference, First, Proc., Bernice P. Bishop Mus., Spec. Pub. no. 7, pt. 2, p. 504, 1921.

9. Rocks of Kohala and Kea, Hawaii (abstract) : Geol. Soc. America, Bull., vol. 3, no. 1., p. 58, March 31, 1921.

10. Volcanology of the Fawaiian Islands (abstract): Geol. Soc. America, Bull., vol. 32, no. 1, p. 72, March 31, 1921.

11. (and Merwin, H. E.). Aphthitalite from Kilauea: Am. Mineralogist, vol. 6, no. 8, pp. 121-125, August, 1921.

12. The granites of Washington, D. C.: Washington Acad. Sci., Jour., vol. 11, no. 19, pp. 459-470, 1 fig., November 19, 1921.

1.3. Obsidian from Copan [Honduras] and Chichen Itza [Yucatan]: Washington Acad Sci., Jour., vol. 11, no. 20, pp. 481-487, 1 fig., December $4,1921$.

14. Augite of Haleakala, Maui, Hawaiian Islands: Am. Jour. Sci., 5th ser., vol. 3, pp. 117-122, February, 1922.

15. Isostasy and rock density: Geol. Soc. America, Bull., vol. 33, no. 2, pp. 375-410, 2 figs., June 30, 1922.

16. A worked jade pebble from Copan [Honduras]: Washington Acad. Sci., Jour., vol. 12, no. 17, pp. 387-391, 1 fig., October 19, 1922.

17. Deccan traps and other plateau basalts: Geol. Soc. America, Bull., vol. 33, no. 4, pp. 765-804, 2 figs., November 2, 1922 ; abstract, no. 1, p. 146, March 31, 1922.

18. The jades of middle America: Nat. Acad. Sci., Proc., vol. 8, no. 11, pp. 319-326, 1 fig., November, 1922.

19. (and Merwin, H. E.). Note on enstatite, hypersthene, and actinolite: Am. Mineralogist, vol. 8, no. 4, pp. 63-67, April, 1923.

20. Petrology of the Hawaiian Islands; I, Kohala and Mauna Kea, Hawaii : Am. Jour. Sci., 5th ser., vol. 5, pp. 465-502, 1 fig., June, 1923.

21. Petrology of the Hawaiian Islands; II, Hualalai and Mauna Loa: Am. Jour. Sci., 5th ser., vol. 6, pp. 100-126, August, 1923.

22. Petrology of the Hawaiian Islands; III, Kilauea and general petrology of Hawaii: Am. Jour. Sci., 5th ser., vol. 6, pp. 338-367, October, 1923.

23. Petrology of the Hawaiian Islands; IV, 'The formation of aa and pahoehoe: Am. Jour. Sci., 5th ser., vol. 6, pp. 409-423, 3 figs, November, 1923.

24. Comagmatic regions and the Wegener hypothesis: Washington Acad. Sci., Jour., vol. 13, no. 15, pp. 339-347, September 19, 1923.

25. The density of the earth as calculated from the densities of Mauna Kea and Haleakala: Washington Acad. Sci., Jour., vol. 13, no. 21, pp. 453-456, December 19, 1923.

26. (and Merwin, H. E.). On babingtonite: Am. Mineralogist, vol. 8, no. 12, pp. 215-223, 1 fig., December, 1923.

27. The densities of deep-seated material of the earth's crust, as determined by chemical analysis, and the bearing of such densities on the theory of isostasy (abstract): Nat. Research Council, Bull., vol. 7, pt. 5, no. 41, p. 92, January, 1924.

28. (and Merwin, H. E.). Acmite and aegirite (abstract) : Geol. Soc. America, Bull., vol. 35, no. 1, pp. 109-110, March 30, 1924; Pan-Am. Geologist, vol. 41, no. 2, p. 154, March, 1924.

29. The radial distribution of certain elements in the earth: Washington Acad Sci., Jour., vol. 14, no. 19, pp. 435-442, November 19, 1924. 
Washington, Henry Stephens--Continued.

30. The modern study of minerals: Am. Mineralogist, vol. 10, no. 3, pp. 45-52, March, 1925.

31. The chemical composition of the earth: Am. Jour. Sci., 5th ser., vol. 9, pp. 351-378, 2 tigs., May, 1925.

32. What the earth is madle of: Sci. Am., vol. 133, pp. 10-11., 3 figs., July, 1925.

33. (and Keyes, Mary G.). Petrology of the Hawaiiarf Islands, V; The Leeward Islands: Am. Jour. Sci., 5th ser., vol. 12, pp. 336-352, October, 1926.

34. The chemical composition of the earth, of meteorites, and of the sun's atmosphere: Nat. Research Council, Bull., vol. 11, pt. 2, no. 56, pp. 30-32, November, 1926; abstract, Am. Jour. Sci., 5th ser., vol. 12, p. 272, September, 1926.

35. (and Merwin, H. E.). The acmitic pyroxenes: Am. Mineralogist, vol. 12, no. 6, pp. 233-252, June, 1927.

36. (and Keyes, Mary G.). Rocks of the Galapagos Islands [and of Hawaii] : Washington Acal. Sci., Jour., vol. 17, no. 21, pp. 538-543, December 19, 1927.

37. (and Keyes, Mary G.). Petrology of: the Hawaiian Islands, VI; Maui : Am. Jour. Sci., 5th ser., vol. 15, pp. 199-220, March, 1928.

38. Present volcanic activity over the earth (abstract): Washington Acad. Sci., Jour., vol. 18, no. 19, pp. 509-510, November 19, 1928.

Washington, Geological Survey.

1. The biennial report of the Board of Geological Survey of the State of Washington for the term 1917-1919, 26 pp., 2 pls. (maps), Olympia, Wash., 1919.

2. The biennial report of the Board of Geological Survey of the State of Washington for the term 1919-1921, 29 pp., Olympia, 1921.

Wasson, Isabel B. See Wasson, Theron, 2 .

Wasson, Theron.

1. Lost Lake salt dome, Texas: Am. Assoc. Petroleum Geologists, Bull., vol. 11, no. 6, p. 633, June, 1927.

2. (and Wasson, Isabel B.). Cabin Creek field, West Virginia: Am. Assoc. Petroleum Geologists, Bull., vol. 11, no. 7, pp. 705-719, 5 figs., 1 pl., July, 1927.

Watanabé, Manjirô.

1. Zonal precipitation of ores from a mixed solution: Econ. Geology, vol. 19, no. 6, pp. 497-503, 1. tig., September-October, 1924.

Waterman, Charles.

1. An analytical examination of South Dakota Cretaceous shales: Black Engineer, vol. 15, no. 3, pp. 166-171, May, 1927.

Waters, Aaron.

1. Concerning the differentiation of a lamprophyric magna at Corbaley Canyon, Washington: Jour. Geology, vol. 35, no. 2, pp. 158-170, 3 figs., February-March, 1927.

2. A structural and petrographic study of the Glass Buttes, Lake County, Oregon: Jour. Geology, vol. 35, no. 5, pp. 441-452, 1 fig., JulyAugust, 1927.

Waters, Everett O. See Longwell, 2. 
Waters, James A. See also Cushman, 42, 45.

1. A group of Foraminifera from the Dornick Hills formation of the Ardmore Basin [Carter County, Oklahoma] : Jour. Paleontology, vol. 1, no. 2, pp. 129-133, 1 pl., August, 1927.

2. A group of Foraminifera from the Canyon division of the Pennsylvanian formation in Texas: Jour. Paleontology, vol. 1, no. 4, pp. 271275, 1 pl., January, 1928.

Watson, E. H.

1. San Juan area seems to afford most promising opportunity for oil exploration in Utah: Petroleum World, Los Angeles, vol. 12, no. 5, pp. 62-63, 68, 1 fig., May, 1927.

Watson, John Wilbur.

1. Abstraction of potassium during sedimentation. Diss., Univ. Virginia, 30 pp. [no date, 1913?].

Watson, Thomas Leonard, 1871-1924. See also Bayley, 3; Ries, 4, 11.

1. Administrative report of the State geologist for the biennial period 19161917 : Virginia Geol. Survey, 36 pp., Charlottesville, 1918.

2. Cerium, its occurrence and application: Mineral Foote-Notes, vol. 3, no. 3, pp. 4-10, May-June, 1919.

3. Glass-sand resources of Virginia: Am. Ceramic Soc., Jour., vol. 2, no. 10, pp. 794-803, October, 1919.

4. Earthquake in Warren and Rappahannock counties, Virginia, September 5, 1919: Seismol. Soc. America, Bull., vol. 9, no. 4, pp. 128-134, 4 figs., December, 1919.

5. Alabama meeting of the Association of American State Geologists: Science, new ser., vol. 51, pp. 19-20, January 2, 1920.

6. Note on the composition of allanite: Am. Mineralogist, vol. 5, no. 1, pp. 6-7, January, 1920.

7. Bearing of experimental data on the formation of smithsonite (abstract) : Geol. Soc. America, Bull., vol. 31, no. 1, pp. 161-162, March 31, 1920.

8. Administrative report of the State geologist for the biennial period 19181919. 31 pp., map, Virginia Geol. Survey, 1920.

9. Petrography of a lamprophyre dike cutting. a pyrite body in Boyd Smith mine, Louisa County, Virginia: Washington Acad. Sci., Jour., vol. 11, no. 14, pp. 341-345, August 19, 1921.

10. Lazulite of Graves Mountain, Georgia, with notes on other occurrences in the United States: Washington Acad. Sci., Jour., vol. 11, no. 16, pp. 386-391, October 4, 1921.

11. Rutile-ilmenite intergrowths: Am. Mineralogist, vol. 7, no. 11, pp. 185188, November, 1922.

12. Geology of a vein occurrence of rutile-ilmenite in a new locality [Amelia County, Virginia] : Washington Acad. Sci., Jour., vol. 12, no. 20, pp. 447-454, December 4, 1922.

13. A contribution to the geology of the Virginia emery deposits: Econ. Geology, vol. 18, no. 1, pp. 53-76, 5 figs. (incl. map), 1 pl., January-February, 1923.

14. The Sharps meteorite, Richmond County, Virginia: U. S. Nat. Mus., Proc., vol. 64, art. 2, 4 pp., 2 pls., 1923.

15. Native copper deposits of the south Atlantic States compared with those of Michigan: Econ. Geology, vol. 18, no. 8, pp. 732-752, 1 fig. (map), December, 1923. 
Watson, Thomas Leonard-Continued.

16. Thermal springs of the southeast Atlantic States: Jour. Geology, vol. 32, no. 5, pp. 373-384, 2 figs., July-August, 1924.

17. The mineral resources of Virginia: The South's Development, Manufacturers Record, vol. 86 , no. 24, pt. 2, pp. 426-428, December 11, 1924.

18. Hoegbomite from Virginia: Am. Mineralogist, vol. 10, no. 1, pp. 1-9, 3 figs., January, 1925.

Watts, Arthur S.

1. (and others). The fire clays of Maryland: Maryland Geol. Survey, vol. 11, pp. 289-539, 107 figs., 4 pls., 1922.

Watts, William L.

1. Geological structures favorable to the accumulation of petroleum: Southern California Acad. Sci., Bull., vol. 19, pt. 1., pp. 13-20, 7 figs., January, 1920.

Watts, William Whitehead.

1. Geology in the service of man : Canadian Min. Jour., vol. 45, no. 33, pp. 792795, August 15, 1924 ; Pan-Am. Gèologist, vol. 42, no. 1, pp. 1-29, August, 1924; British Assoc. Adv. Sci., Rept. 92d Meeting, pp. 89108, 1925; Smithsonian Inst., Ann. Rept., 1925, pp. 271-296, 1926.

Weaver, Charles Edwin.

1. Geological history of Washington. In Northwest Mines Handbook, vol. 1, pp. 143-145, published by Sidney Norman, Spokane, Washington, 1918.

2. The mineral resources of Stevens County: Washington Geol. Survey, Bull., no. 20, 350 pp., 20 pls. (incl. map), 14 figs., 1920.

3. (and Palmer, Katherine Van Winkle). Fauna from the Eocene of Washington: Washington, Univ., Pub. in Geology, vol. 1, no. 3, 55 pp., 5 pls., June, 1922. Critical notes on the paper, by G. Dallas Hanna, Nautilus, vol. 36, no. 4, pp. 141-142, April, 1923.

Webb, Arthur Lovat.

1. The future of Canada as a gold producer: Min. Mag., vol. 28, no. 3, pp. 150-155, 3 figs., March, 1923.

Webb, W. S. See Funkhouser, 1.

Webbert, C. W. See Pennsylvania, 1.

Webster, Hugh B. See Collingwood, 1.

Weed, Walter Harvey.

1. West Shining Tree gold prospects [Ontario]: Eng. and Min. Jour.-Press, vol. 116, no. 2, pp. 68-69, 1 fig., July 14, 1923.

2. Superficial copper deposits: Eng. and Min. Jour.-Press, vol. 119, no. 15 p. 605, April 11, 1925.

3. Veindikes of the Engineer mine, near Atlin, British Columbia: Eng. and Min. Jour.-Press, vol. 119, no. 26, pp. 1037-1040, 7 figs., June 27, 1925.

Weeks, Albert W.

1. Some experimental work testing the hydraulic theory of oil migration and accumulation by means of the downward circulation of water: Am. Assoc. Petroleum Geologists, Bull., vol. 9, no. 8, pp. 1143-1151, 1 fig., November, 1925.

2. Methods of plotting well logs: Econ. Geology, vol. 20, no. 7, pp. 693, November, 1925. 
Weeks, Fred Boughton.

1. Possibilities of the Calico mining district [San Bernardino County, California]: Eng. and Min. Jour.-Press, vol. 119, no. 19, pp. 757-763, 3 figs., May 9, 1925.

Weeks, Herbert J.

1. Oil and water possibilities of parts of. Delta and Mesa counties, Colorado: Colorado Geol. Survey, Bull. 28, 46 pp., 7 figs., 2 pls. (maps), 1925.

Weeks, Ludlow J.

1. Geology and ore deposits of Stirling area, Richmond County, Nova Scotia : Canada, Geol. Survey, Summ. Rept., 1924, pp. 199-217, 2 figs., $1 \mathrm{pl} ., 1926$.

2. The geology of parts of eastern Arctic Canada: Canada, Geol. Survey, Summ. Rept., 1925, pt. C, pp. 136-141, 2 pls., 1927.

3. Cumberland Sound Area, Baffin Island: Canada, Geol. Survey, Summ. Rept., 1927, pt. C, pp. 83-95, 2 pls., map, 1928.

Wegeman, Carroll Harvey.

1. Notes on the oil fields of Wyoming: Am. Assoc. Petroleum Geologists, Bull., vol. 4, no. 1, pp. 37-42, 1920. Eng. and Min. Jour., vol. 109, pp. 1417-1419, June 26, 1920.

2. (and Howell, R. W., and Dobbin, C. E.). The Pumpkin Buttes coal field, Wyoming: U. S. Geol. Survey, Bull. 806, pp. 1-14, 1 fig., 5 pls., October 8, 1928.

Wegener, Alfred.

1. The origin of continents and oceans. Translated from the third German edition by J. G. A. Skerl. 212 pp., 44 figs., New York, E. P. Dutton and Company, n. d. [1923?].

2. Two notes concerning my theory of continental drift. In Theory of continental drift, pp. 97-103, Am. Assoc. Petroleum Geologists, 1928.

Weidman, Samuel.

1. Probability of Pennsylvanian glaciation of the Arbuckle and Wichita mountain regions (abstract): Geol. Soc. America, Bull., vol. 32, no. 1, p. 91, March 31, 1921.

2. Evidence of glaciation in the Arbuckle region: Oklahoma Acad. Sci., Proc., vol. 2 (Oklahoma, Univ., Bull., new ser. no. 247), pp. 73-74, October 1, 1922.

3. Physiographic history of the Arbuckle Mountains: Oklahoma Acad. Sci., Proc., vol 2 (Oklahoma, Univ., Bull., new ser: no. 247), pp. 74-77, October 1, 1922.

4. Was there Pennsylvanian-Permian glaciation in the Arbuckle and Wichita mountains of Oklahoma?: Jour. Geology, vol. 31, no. 6, pp. 466-489, 16 figs., September-October, 1923.

5. Tri-State lead and zinc district: Bureau Monthly, published by Bureau of Geology. Norman, Okla., vol. 1, no. 1, p. 19, 2 figs., April, 1925.

6. Lichens as: weathering agents of limestone: Oklahoma Acad. Sci., Proc., vol. 5, 1925 (Oklahoma, Univ., Bull., new ser. no. 330, Univ. Studies no. 22), pp. 147-150, April 1, 1926.

Weigel, William Melvin.

1. Mining ocher at Cartersville, in Georgia: Eng. and Min. Jour.-Press, vol. 116, no. 20, pp. 854-856, 2 figs., November 17, 1923.

2. Technology and uses of silica and sand: U. S., Bur. Mines, Bull. 266, 204 pp., 50 figs., 1927. 
Weinig, A. J.

1. Angular fragments in veins: Eng. and Min. Jour., vol. 122, no. 26, pp. 1020-1021, 1 fig., December 25, 1926.

Weirich, T. E. See Kirk, 2.

Weitzberg, Fritz.

1. El ventísquero del Popocatepetl: Soc. cient. "Antonio Alzate," Mem. y Rev., t. 41 , no. 2-3, pp. 65-90, 9 pls., November-December, 1922.

Weld, Christopher Minot.

1. [Iron-ore resources of] Cuba: Am. Inst. Min. and Met. Eng., Trans., vol. 61, pp. 124-130, 1920.

Weller, James Marvin. See also Moulton, 11.

1. The geology of Edmonson County: Kentucky Geol. Survey, Ser. 6, vol. 28, 246 pp., 56 figs. and pls., 1927.

Weller, Stuart, 1871-1927. See also Roberts, 5.

1.. (with the collaboration of Charles Butts, L. W. Currier, and R. D. Salisbury). The geology of Hardin County and the adjoining part of Pope County: Illinois State Geol. Survey, Bull. no. 41,416 pp., 30 figs., 11 pls., 1920.

2. The Chester series in Illinois: Jour. Geology, vol. 28, nos. 4 and 5, pp. 281303, 395-416, 1 fig., 1920 ; abstract, Science, new ser., vol. 51., p. 494, May 14, 1920.

3. Fossils as aids in teaching stratigraphy, or applied paleontology: Geol. Soc. America, Bull., vol. 31, no. 3, pp. 383-388, September 30, 1920.

4. Geology of the Golconda quadrangle; a detailed report on the stratigraphy and structure of that portion of the Golconda quadrangle lying in Kentucky: Kentucky Geol. Survey, Ser. 6, vol. 4, 148 pp., 1 fig., 1921.

5. Oil and gas possibilities in Caldwell County, Kentucky: Kentucky Geol. Survey, series 6, vol. 6, pp. 221-231, 2 figs., 1921.

6. Some events in the geological history of southern Illinois: Illinois State Acad. Sci., Trans., vol. 14, pp. 21-35 [1922].

7. Geology of the Princeton quadrangle: Kentucky Geol. Survey, Ser. 6, vol. 10 pp. 1-105, 12 figs., section and map, 1923.

8. Problematic fossil from the Silurian of Illinois (abstract): Geol. Soc. America, Bull., vol. 36, no. 1, p. 217, March 30, 1925.

9. A new type of Silurian worm: Jour. Geology, vol. 33, no. 5, pp. 540-544, 1 fig., July-August, 1925.

10. Map of the structural geology (fault pattern) of the Golconda and Cave in Rock quadrangles in Kentucky: Kentucky Geol. Survey, ser. 6, 1925. Scale $1=62,500$.

11. The making of southern Illinois: Illinois State Acad. Sci., Trans., vol. 19 , pp. $27-49,1926$.

12. Faunal zones in the standard Mississippian section: Jour. Geology, vol. 34, no, 4, pp. 320-335, May-June, 1926.

13. Fossil collecting in the Mississippian formations of the Mississippi Valley: Natural History (Am. Mus. Nat. Hist., Jour.), vol. 26, no. 5, pp. 487-495, 12 figs., September-October, 1926.

14. Map of the areal and structural geology (fault pattern) of Livingston County, Kentucky, by Stuart Weller and others: Kentucky Geol. Survey, Ser. 6, 1926 . Scale, 1 inch $=1$ mile.

15. The story of the geologic making of southern Illinois: Illinois State Geol. Survey, Educ. Ser. no. 1, 41 pp., 11 figs., 1927.

$4096-31-42$ 
Weller, Stuart-Continued.

16. Geology of the Cave in Rock quadrangle: Kentucky Geol. Survey, Ser. 0 , vol. 26, pp. 1-128, 9 figs. (incl. map), 1927.

17. (and Sutton, A. H., and Crider, A. F.). Map of the areal and structural geology (fault pattern) of Caldwell County, Kentucky: Kentucky Geol. Survey, Ser. 6, 1927. Scale 1 inch=1 mile.

18. Paleontology and human relations: Geol. Soc. America, Bull., vol. 38, no. 1, pp. 275-285, March 30, 1927; Smithsonian Inst., Ann. Rept., 1927, pp. 309-319, 1928.

19. (and St. Clair, Stuart). Geology of Ste. Genevieve County, Missouri : Missouri Bur. Geology and Mines, second ser., vol. 22, 352 pp., ; figs., 25 pls., 2 maps, 1928 . (Description of Quaternary deposits by E. W. Shaw, pp. 251-255.)

Wells, Edgar Herbert.

1. Manganese in New Mexico: New Mexico State School of Mines, Bull. no. 2, Mineral Resources Survey, 85 pp., map, 1918.

2. Oil and gas possibilities of the Puertecito district, Socorro and Valencia counties, New Mexico: New Mexico State School of Mines, Bull. no. 3, Mineral Resources Survey, 47 pp., map, Socorro, N. M., 191\%.

3. The geology of the El Vado dam site and reservoir, Rio Arriba County, New Mexico: New Mexico, State Lng., 8th Bienn. Rept., pp. 239251 [1928].

Wells, Roger Clark. See also Hess, 6; Merwin, 6; Mills, 1.

1. Sodium salts in 1917: U. S. Geol. Survey, Mineral Resources, 1917, pt. 2, pp. 305-341, January 27, 1919.

2. Sodium and sodium compounds in 1918: U. S. Geol. Survey, Mineral Resources, 1918, pt. 2, pp. 159-198, October 24, 1919.

3. Sodium compounds in 1919: U. S. Geol. Survey, Mineral Resources, 1919, pt. 2, pp. 47-76, 1920.

4. An unusual deposit of aragonite from sea water: Washington Acad. Sci. Jour., vol. 10, no. 9, pp. 249-254, May 4, 1920.

5. Some effects produced by common changes in natural waters: Pan-Pacific Scientific Conference, First, Proc., Bernice P. Bishop Mus., Spec. Pub. no. 7 , pt. 2 , pp. $630-634,1921$.

6. Chemical and physical researches on sedimentation (abstract) : Geol. Soc. America, Bull., vol. 32, no. 1, pp. 23-24, March 31, 1921.

7. Sodium compounds in 1920: U. S. Geol. Survey, Mineral Resources, 1920, pt. 2, pp. 123-134, September 30, 1921.

8. Sodium sulphate; its sources and uses: U. S. Geol. Survey, Bull. 717, 43 pp., 13 figs., 1923.

9. Chemical suggestions concerning the origin of Lake Superior copper ores (abstract) : Geol. Soc. America, Bull., vol. 34, no. 1, p. 100, March 30, 1923.

10. Reaction between ferrous and cuprous salts: Am. Jour. Sci., 5th ser., vol. 8, pp. 428-433, November, 1924.

11. Chemistry of deposition of native copper from ascending solutions: U. S. Geol. Survey, Bull. 778, 71 pp., 2 figs., 1925.

12. Observations on the minor constituents of petroleum: Econ. Geology, vol. 20, no. 3, pp. 286-288, May, 1925.

Wentworth, Chester Keeler. See also Clarke, J. M., 21; Hobbs, 16.

1. A laboratory and field study of cobble abrasion: Jour. Geology, vol. 27, no. 7, pp. 507-521, 28 figs., October-November, 1919. 
Wentworth, Chester Keeler-Continued.

2. Field study of the shapes of river pebbles (abstract) : Geol. Soc. America, Bull., vol. 32 , no. 1, pp. 89-90, March 31, 1921.

3. Russell Fork fault of southwest Virginia: Jour. Geology, vol. 29, no. 4, pp. 351-369, 8 figs., May-June, 1921.

4. Pebbles and history: The Iowa Alumnus, vol. 19, no. 3, pp. 86-87, December, 1921.

5. A note on the wedge work of pebbles: Am. Jour. Sci., 5th ser., vol. 2, pp. 313-318, 3 figs., December, 1921.

6. The geology and coal resources of Russell County, Virginia: Virginia Geol. Survey, Bull. no. 22, 179 pp., 16 figs., 28 pls., 1922.

7. Adapting a short-bellows roll-film Kodak for detail work in the field: Jour. Geology, vol. 30, no. 2, pp. 158-161, 2 figs., February-March, 1922.

8. A method of measuring and plotting the shapes of pebbles: U. S. Geol. Survey, Bull. 730, 91-114, 17 figs., 2 pls., June 26, 1922. Abstract Geol. Soc. America, Bull., vol. 32, no. 1, p. 89, March 31, 1921.

9. A scale of grade and class terms for clastic sediments: Jour. Geology, vol. 30 , no. 5, pp. 377-392, 3 figs., July-August, 1922.

10. The shapes of beach pebbles: U. S. Geol. Survey, Prof. Paper 131, pp. 75-83, 8 figs., 2 pls., December 20, 1922.

11. Late Tertiary and Pleistocene terrace plains of the middle Atlantic Coastal Plain (abstract) : Geol. Soc. America, Bull., vol. 34, no. 1, p. 91, March 30, 1923.

12. An improved recording micrometer for rock analysis: Jour. Geology, vol. 31, no. 3, pp. 228-232, 2 figs., April-May, 1923.

13. The fossil swamp deposit at the Walker Hotel site, Connecticut Avenue and De Sales Street, Washington, D. C.; formations exposed in the excavation: Washington Acad. Sci., Jour., vol. 14, no. 1, pp. 1-11, 7 figs., January 4, 1924.

14. Note on a cobble of peculiar shape: Jour. Geology, vol. 32, no. 6, pp. 524-528, 2 figs., August-September, 1924.

15. The geology of Lanai [Hawaiian Islands] : Bernice P. Bishop Mus., Bull. 24, 72 pp., 13 figs., 7 pls., 1925.

16. Photographic practice for field geologists: Iowa, Univ., Studies, new ser., no. 89, Studies in Natural History, vol. 11, no. 4, pp. 17-41, 5 pls., March 15, 1925.

17. The desert strip of west Molokai [Hawaiian Islands]: Iowa, Univ., Studies, new ser., no. 89, Studies in Natural History, vol. 11, no. 4, pp. 41-56, 4 figs., 3 pls., March 15, 1925.

18. A tropical peat bog [Washington Island, North Pacific] (abstract) : Geol. Soc. America, Bull., vol. 36, no. 1, p. 137, March 30, 1925; Pan-Am. Geologist, vol. 43, no. 1, p. 78, February, 1925.

19. Tuff craters of Oahu (abstract) : Geol. Soc. America, Bull., vol. 36, no. 1, pp. 151-152, March 30, 1925; Pan-Am. Geologist, vol. 43, no. 2, p. 150, March, 1925.

20. Chink-faceting; a new process of pebble-shaping: Jour. Geology, vol. 33, no. 3, pp. 260-267, 5 figs., April-May, 1.925.

21. Eustatic bench of islands of the north Pacific: Geol. Soc. America, Bull., vol. 36, no. 3, pp. 521-544, 14 figs., September 30, 1925; abstract (by Chester K. Wentworth and H. S. Palmer), no. 1, pp. 136-1.37, March 30, 1925; Pan-Am. Geologist, vol. 43, no. 1, pp. 77-78, February, 1925. 
Wentworth, Chester Keeler-Continued.

22. Pyroclastic geology of Oahu (with the collaboration of A. A. Pegau in petrology) : Bernice P. Bishop Mus., Bull. 30, 121 pp., 28 figs., 22 pls., 1926.

23. Physical features of the Hawaiian Islands (abstract) : Iowa Acad. Sci., Proc., 1925, vol. 32, pp. 359-360 [1926].

24. Sedimentary processes on volcanic islands (abstract) : Iowa Acad. Sci., Proc., 1925, vol. 32, pp. 360-361 [1926].

25. Graphic computation of volumes of contoured solids: Am. Jour. Sci., 5th ser., vol. 11, pp. 305-311, 3 figs., April, 1926.

26. Principles of erosion in Hawaii (abstract) : Geol. Șoc. America, Bull., vol. 37, no. 1, pp. 171-172, March 30, 1926; Pan-Am. Geologist, vol. 45, no. 2, p. 167, March, 1926.

27. Methods of mechanical anaylsis of sediments: Iowa, Univ., Studies in Natural History, vol. 11, no. 11, 52 pp., 9 figs., October 15, 1926.

28. The geology and coal resources of the Middlesboro Basin in Kentucky: Kentucky Geol. Survey, Ser. 6, vol. 29, pp. 155-235, 30 figs., 1 pl., 1927.

29. Estimates of marine and fluvial erosion in Hawaii: Jour. Geology, vol. 35, no. 2, pp: 117-133, February-March, 1927.

30. (and Apfel, Earl T.). The composition of geological publication in the biennium 1921-1922: Science, new ser., vol. 65, pp. 231-232, March 4,1927 .

31. Striated boulders on the southern coastal plain of Virginia (abstract) : Geol. Soc. America, Bull., vol. 38, no. 1, pp. 150-151, March 30, 1927 ; Pan-Am. Geologist, vol. 47, no. 2, p. 153, March, 1927.

32. The accuracy of mechanical anaylsis: Am. Jour. Sci., 5th ser., vol. 13, pp. 399-408, 5 figs., May, 1927.

33. (and Hoffmeister, J. E., and Ladd, H. S.). Unusual types of sediments from Pacific Islands (abstract): Washington Acad. Sci., Jour., vol. 17, no. 10, pp. 275-276, May 19, 1927.

34. Underground photography-a depth of focus chart: Econ. Geology, vol. 23, no. 1, pp. 100-105, 2 figs., January, 1928.

35. Examination of dam sites in the Tennessee River basin (abstract) : Geol. Soc. America, Bull., vol. 39, no. 1, pp. 204-205, March 30, 1928; Pan-Am. Geologist, vol. 49, no. 2, p. 156, March, 1928.

36. Striated cobbles in southern States (abstract with discussion by Charles W. Brown) : Geol. Soc. America, Bull., vol. 39, no. 1, pp. 218-219, March 30, 1928; Pan-Am. Geologist, vol. 49, no. 2, p. 148, March, 1928.

37. Principles of stream erosion in Hawaii : Jour. Geology, vol. 36, no. 5, pp. 385-410, 20 figs., July-August, 1928.

38. (and Ohrenschall, Robert D., and Wolford, John J.). Summary of geologic reports on dam sites [of Tennessee River]: U. S., 70th Cong., 1st sess., H. R. Doc. no. 185, pp. 197-210, 1928.

39. The geology of the Cove Creek reservoir [Tennessee]: U. S., 70th Cong., 1st sess., H. R. Doc. no. 185, pp. 210-232, 1928.

40. Studies of coarse sediments, 1923-1927: Nat. Research Council, Reprint and Circ. Ser., no. 85, pp. 23-35, 1928.

41. Striated cobbles in Southern States: Geol. Soc. America, Bull., vol. 39, no. 4, pp. 941-953, 1 fig., 3 pls., December 30, 1928. 
Westcott, Henry Palmer.

1. Handbook of natural gas. 3d ed., 725 pp., 255 tigs., Erie, Pennsylvania, Metric Metal Works, 1920.

Westgate, Lewis Gardner. See also Foye, 5.

1. Deposits of iron ore near Stanford, Montana: U. S. Geol. Survey, Bull. 715, pp. 85-92, 4 figs. (incl. maps), September 16, 1920.

2. Deposits of iron ore near Stanford, Montana (U. S. Geol. Survey, Bull. 715,1920 ) (abstract by J. D. Sears) : Washington Acad. Sci., Jour., vol. 11, no. 16, p. 393, October: 4, 1921.

3. Ore deposits of the Salmon River district, Portland Canal region, Alaska: U. S. Geol. Survey., Bull. 722, pp. 117-140, 3 figs., 1921.

4. Deposits of chromite in eastern Oregon: U. S. Geol. Survey, Bull. 725, pp. 37-60, 11 figs., August 3, 1921.

5. Deposits of chromite in Stillwater and Sweet Grass counties, Montana: U. S. Geol. Survey, Bull 725, pp. 67-84, 5 figs., August 3, 1921.

6. Geology of Delaware County: Ohio, Geol. Survey, 4th ser., Bull. 30, 147 pp., 28 figs:, 12 pls., 2 maps, 1926.

7. (and Knopf, Adolph). Geology of Pioche, Nevada, and vicinity: Am. Inst. Min. and Met. Eng., Trans., vol. 75, pp. 816-836, 4 figs., 1927; [preprint], no. 1647, 21 pp., 4 figs., March, 1927 ; abstract, Mining and Metallurgy, vol. 8, no. 243, p. 150, March, 1927.

Weston-Dunn, J. A.

1. Some relations between metal content, lode filling, and country rock: Econ. Geology, vol. 18, no. 5, pp. 443-473, 1 fig., August, 1923.

Wetmore, Alexander.

1. Five new species of birds from cave deposits in Porto Rico: Biol. Soc. Washington, Proc., vol. 33, pp. 77-81, 2 pls., December 30, 1920.

2. A fossil owl from the Bridger Eocene: Acad. Nat. Sci. Philadelphia, Proc., vol. 73 , pt. 3 , pp. $455-458,2$ figs., 1922.

3. Bird remains from the caves of Porto Rico: Am. Mus. Nat. Hist., Bull., vol. 46, pp. 297-333, 25 figs., 1922.

4. Avian fossils from the Miocene and Pliocene of Nebraska: Am. Mus. Nat. Hist., Bull., vol. 48, pp. 483-507, 20 figs., 1923.

5. Fossil birds from southeastern Arizona: U. S. Nat. Mus., Proc., vol. 64, art. 5, 18 pp., 9 figs., 1924 .

6. The systematic position of Palaeospriza bella Allen, with observations on other fossil birds: Harvard College, Mus. Comp. Zoology, Bull., vol. 67 , no. 2, pp. 183-193, 4 figs., 4 pls., May, 1925.

7. Descriptions of additional fossil birds from the Miocene of Nebraska: Am. Mus. Novitates, no. 211, 5 pp., 6 figs., March 11, 1926.

8. Fossil birds from the Green River deposits of eastern Utah: Carnegie Mus., Annals, vol. 16, nos. 3-4, pp. 391-399, 2 pls., April, 1926.

9. Description of a fossil hawk from the Miocene of Nebraska: Carnegie Mus., Annals, vol. 16, nos. 3-4, pp. 403-406, 1 pl., April, 1926.

10. The fossil birds of North America: Natural History (Am. Mus. Nat. Hist., Jour.), vol. 26, no. 5, pp. 525-526, September-October, 1926.

11. An additional record for the fossil hawk, Urubitinga enecta [Sioux County, Nebraska] : Am. Mus. Novitates, no. 241, 3 pp., 3 figs., December 31, 1926.

12. Fossil birds from the Oligocene of Colorado: Colorado Mus. Nat. Hist., Proc., vol. 7, no. 2, 11 pp., 23 figs., July 15, 1927. 
Wetmore, Alexander-Continued.

13. Additional specimens of fossil birds from the upper Tertiary deposits of Nebraska: Am. Mus. Novitates, no. 302, 5 pp., 2 figs., February 29, 1928.

14. Prehistoric ornithology in North America: Washington Acad. Sci., Jour., vol. 18, no. 6, pp. 145-158, March 19, 1928.

15. The systematic position of the fossil bird Cyphornis magnus: Canada, Geol. Survey, Bull. no. 49, pp. 1-4, 1928.

Weymouth, A. Allen. See also Goodspeed, 2.

1. Simple methods for making thin sections: Econ. Geology, vol. 23, no. 3, pp. 323-330, May, 1928.

2. The occurrence of tridymite and cristobalite in a granite xenolith: Am. Jour. Sci., 5th ser., vol. 16, pp. 237-238, September, 1928.

Wheeler, Arthur 0.

1. Notes on the glaciers of the main and Selkirk ranges of the Canadian Rocky Mountains: Canadian Alpine Jour., vol. 11, pp. 121-146, 7 pls., 1920.

2. Motion of the Yoho Glacier, 1917, 1918, and 1919: Canadian Alpine Jour., vol. 11, pp. 182-185, 1 pl, 1920 .

3. Motion of the Robson Glacier [British Columbia]: Canadian Alpine Jour., vol. 13, pp. 158-159, 1923.

Wheeler, E. P., II.

1. Olivine from Monhegan Island, Maine: Am. Mineralogist, vol. 12, no. 6, pp. 259-261, June, 1927.

2. Stellerite from near Juneau, Alaska: Am. Mineralogist, vol. 12, no. 10, pp. 360-364, October; 1927.

Wheeler, H. C.

1. (and Clifton, R. L.). Age and correlation of Garber sands [Garber oil field, Oklahoma]: Oil and Gas Jour., vol. 24, no. 27, pp. 34, 92, 101, 104, 3 figs., November 26, 1925.

Wheeler, Harold Leslie.

1. Bibliography of the occurrence, geology, and mining of manganese with some references on its metallurgy and uses: Econ. Geology, vol. 14, no. 3, pp. 245-261, May, 1919.

Wheeler, Herbert Allen.

1. North Texas oil fields: Eng. and Min. Jour., vol. 109, pp. 741-747, 2 figs., March 27, 1920.

2. The North Texas oil fields: Eng. and Min. Jour., vol. 109, pp. 1317-1319, June 12, 1920.

3. Rapid formation of lead ore: Mining and Metallurgy, no. 158, sec. 1, p. 35, 1 fig. (abstract), sec. 25, 4 pp., 1 fig., February, 1920 ; (with discussion by Frank L. Nason, James F. Kemp, H. V. Winchell, W. Lindgren, S. H. Ball, Alan M. Bateman, and E. S. Moore), Am. Inst. Min. and Met. Eng., Trans., vol. 63, pp. 311-323, 1 fig., 1920.

4. The influence of faulting in the Illinois oil fields: Eng. and Min. Jour., vol. 111, no. 1, pp. 22-24, January 1, 1921.

5. The new Wamac oil pool [Marion County] in Illinois: Eng. and Min. Jour., vol. 113, no. 5, pp. 213-214, February 4, 1922.

6. Some facts about Teapot dome [Wyoming]: Eng. and Min. Jour.-Press, vol. 117, no. 12, pp. 480-482, 1 fig., March 22, 1924.

7. The oil resurrection of Colorado: Eng. and Min. Jour.-Press, vol. 119, no. 2, pp. 51-54, January 10, 1925. 
Wheeler, Richard Vernon. See Tideswell, 1.

Wheeler, Walter Calhoun. See Clarke, F. W., 2.

Wherry, Edgar Theodore. See also Davy, 1; Foshag, 14; Larsen, 16; Lee, O. I., 1; Merrill, 18; Shannon, 37 ; Stose, 21.

1. (and Adams, Elliot Q.). The classification of mimetic crystals: Washington Acad. Sci., Jour., vol. 9, no. 6, pp. 153-157, March 19, 1919.

2. Chalcopyrite crystals from the Bergen archways [New Jersey]: Am. Mineralogist, vol. 4, no. 9, pp. 116-118, 2 figs., September, 1919.

3. Monazite from Boothwyn, Pennsylvania: Am. Mineralogist, vol. 4, no. 10, pp. 123-124, 1 pl., October, 1919.

4. Phenol red indicator as an aid to the geologist (abstract): Geol. Soc. American, Bull., vol. 31, no. 1, p. 161, March.31, 1920.

5. Illustration of the isometric system; pyrite from Falls of French Creek, Pennsylvania: Am. Mineralogist, vol. 5, no. 6, pp. 116-117, June, 1920.

6. Lists of the isometric minerals included in Goldschmidt's Winkeltabellen : Am. Mineralogist, vol. 5, no. 6, pp. 117-119, June, 1920.

7. Lists of the tetragonal minerals included in Goldschmidt's Winkeltabell'n: Am. Mineralogist, vol. 5, no. 7, pp. 132-133, July, 1920.

8. Lists of the hexagonal and trigonal minerals included in Goldschmidt's Winkeltabellen: Am. Mineralogist, vol. 5, no. 8, pp. 150-152, August, 1920.

9. Lists of the orthorhombic minerals included in Goldschmidt's Winkeltabellen: Am. Mineralogist, vol. 5, no. 9, pp. 164-166, September; 1920.

10. Lists of the monoclinic minerals included in Goldschmidt's Winkeltabellen: Am. Mineralogist, vol. 5, no. 10, pp. 181-182, October, 1920.

11. The nomenclature and classification of sulphide minerals: Washington Acad. Sci., Jour., vol. 10, no. 17, pp. 487-496, October 19, 1920.

12. List of triclinic minerals included in Goldschmidt's Winkeltabellen: Am. Mineralogist, vol. 5, no. 12, p. 208, December, 1920.

13. (and Foshag, W. F.). A new classification of the sulpho-salt minerals: Washington Acad. Sci., Jour., vol. 11, no. 1, pp. 1-8, January 4, 1921.

14. New mineral species described during 1916-1920: Am. Mineralogist, vol. 6, no. 1, pp. 12-17, January, 1921.

15. The Florence Pilkington Manchester memorial collection [of minerals at Fall River, Massachusetts] : Am. Mineralogist, vol. 6, no. 3, p. 53, 1 pl., March, 1921.

16. New minerals: Am. Mineralogist, vol. 6, no. 3, pp. 63-68, March, 1921; no. 5, pp. 92-95, May, 1921 ; no. 6 , p. 105 , June, 1921 ; no. 7 , pp. 118-119, July, 1921 ; no. 9 , p. 140, September, 1921 ; no. 11, pp. $165-$ 166, November, 1921.

17. Review of the optical-crystallographic properties of calcium oxalate monohydrate [whewellite]: Washington Acad. Sci.; Jour., vol. 12, no. 8, pp. 196-200, 1 fig., April 19, 1922.

18. (and Shannon, E. V.). Crocidolite from eastern Pennsylvania: Washington Acad. Sci., Jour., vol. 12, no. 10, pp. 242-244, May 19, 1922.

19. The plagioclase feldspars as a case of atomic isomorphism: Am. Mineralogist, vol. 7, no. 7, pp. 113-121, July, 1922.

20. Volume isomorphism in the silicates: Am. Mineralogist, vol. 8, no. 1, pp. 1-8, January, 1923. 
Wherry, Edgar Theodore-Continued.

21. Note on the composition of thomsonite: Am. Mineralogist, vol. 8, no. 7, pp. 121-125, 1 fig., July, 1923.

22. Classified list of minerals described or discredited during 1921: Am. Mineralogist, vol. 9, no. 2, p. 34, February, 1924.

23. At the surface of a crystal: Am. Mineralogist, vol. 9, no. 3, pp. 45-54, 12 figs., March, 1924.

24. Surface of a crystal: Pan-Am. Geologist, vol. 41, no. 4, pp. 241-250, 1 fig., $1 \mathrm{pl} .$, May, 1924.

25. Further notes on atomic volume isomorphism: Am. Mineralogist, vol. 9, no. 8, pp. 165-169, August, 1924.

26. Radio-detector minerals: Am. Nineralogist, vol. 10, no. 2, pp. 28-31, February, 1925.

27. Bentonite as a one-dimensional colloid: Am. Mineralogist, vol. 10, no. 5, pp. 120-123, May, 1925.

28. A tabulation of the aluminium silicate minerals: Am. Mineralogist, vol. 10, no. 6, pp. 140-145, 1 fig., June, 1925.

29. Pseudo-isomorphism as illustrated in thomsonite: Am. Mineralogist, vol. 10, no. 10, pp. 342-347, October, 1925.

30. A visit to the locality of newtonite [Newton County, Arkansas]: Am. Mineralogist, vol. 10, no. 10, pp. 350-351, October, 1925.

31. Names for the symmetry classes based on axes: Am. Mineralogist, vol. 12, no. 5, pp. 218-224, May, 1927.

32. The status of keeleyite: Am. Mineralogist, vol. 13, no. 1, pp. 29-30, January, 1928.

33. Arrangement of the symmetry classes: Am. Mineralogist, vol. 13, no. 5, pp. 198-199, May, 1928.

Whitbeck, Ray Hughes.

1. The geography and economic development of southeastern Wisconsin: Wisconsin Geol. and Nat. Hist. Survey, Bull. no. 58, 252 pp., 93 figs., 1921.

White, Charles Henry.

1. The need of quantitative methods in applied geology: Min. and Sci. Press, vol. 122, pp. 601-605, April 30, 1921.

2. Desert varnish : Am. Jour. Sci., 5th ser., vol. 7, pp. 413-420, May, 1924.

3. Supergene enrichment of copper below a lean pyritic zone [at Cananea, Mexico] : Econ. Geology, vol. 19, no. 8, pp. 724-729, December, 1924.

White, (Charles) David. See also Hackford, 1 ; Hobbs, 16 ; Johnson, R. H., 2 ; Longwell, 4 ; Science Service, 6 ; Semmes, 3 ; Stadnichenko, T., 1, 2 ; Willis, B., 4 ; Winchester, 1.

1. Genetic problems affecting search for new oil regions: Am. Inst. Min. and Met. Eng., Trans., vol. 65, pp. 176-198, 1921; Mining and Metallurgy, no. 158 , sec. 1 , p. 32 (abstract), sec. 21,20 pp., February, 1920; abstract, Eng. and Min. Jour., vol. 109, pp. 512-514, February 21, 1920 ; discussion by R. H. Johnson, H. W. Hixon, David Reger, and J. F. Duce, Am. Inst. Min. and Met. Eng., Trans. [preprint], no. 994, pp. 9-12, 1920.

2. The petroleum resources of the world: Am. Acad. Political and Social Science, Annals, vol. 89, no. 178, pp. 111-134, pls. (maps), May, 1920.

3. The unmined supply of petroleum in the United States. In Redwood, Boverton, Petroleum, 4th ed., vol. 1, pp. 92-96, 1 fig., London, 1922. 
White, (Charles) David-Continued.

4. [Oil shales of the United States]: Am. Mining Cong., 23rd Ann. Convention, Rept. of Proc., pp. 151-153, 1921.

5. Federal cooperation: Am. Mining Cong., 23d Ann. Convention, Rept. of Proc., pp. 456-470, 1921.

6. Our future oil supply : Eng. and Min. Jour., vol. 111, no. 21, pp. 951-955, June 4, 1921.

7. Potash reserves in west Texas: Mining and Metallurgy, no. 184, pp. 19-25, 2 figs., April, 1922.

8. Oil reserves of the United States: Am. Inst. Min. and Met. Eng., Trans., vol. 68 , pp. 953-958, 1923 ; [preprint] no. 1165,6 pp., June, 1922; abstract, Mining and Metallurgy, no. 186, pp. 37-38, June, 1922.

9. The oil supply of the world: Mechanical Engineering, vol. 44, no. 9, pp. 567-569, September, 1922. Abstract, Eng. and Min. Jour., vol. 113, no. 11, pp. 455-456, March 18, 1922.

10. Problems in oil geology and their advancement through cooperative research: Am. Assoc. Petroleum Geologists, Bull., vol. 6, no. 6, pp. 509-515, November-December, 1922.

11. (and Stadnichenko, T.). Some mother plants of petroleum in the Devonian black shales: Econ. Geology, vol. 18, no. 3, pp. 238-252, 5 pls., April-May, 1923.

12. Radioactivity and oil-field location: Am. Assoc. Petroleum Geologists, Bull., vol. 7, no. 3, pp. 290-291, May-June, 1923.

13. Some needed peat investigations: Am. Peat Soc., Jour., vol. 17, no. 2, pp. 45-56, April, 1924.

14. Gravity observations from the standpoint of the local geology: Geol. Soc. America, Bull., vol. 35, no. 2, pp. 207-277, 1 pl., June 30, 1924.

15. Researches in geology of finding and recovery of oil: Nat. Petroleum News, vol. 16, no. 43 , pp. 85, 87, October $22,1924$.

16. Proposed oceanographic research by the navy: Jour. Geology, vol. 32, no. 8 , pp. 690-695, November-December, 1924.

17. Permian of western America from the paleobotanical standpoint: PanPacific Sci. Cong., Australia, 1923, Proc., vol. 2, pp. 1050-107 [1924].

18. Researches in geology of finding oil: Oil and Gas Jour., vol. 23, no. 20-A, pp. 64-A, 196-H, October 9, 1924.

19. (and Stadnichenko, T.). Some mother plants of petroleum in the Devonian black shales: Kentucky Geol. Survey, Ser. 6, vol. 21, pp. 99-11.7, 5 pls., 1925.

20. Quelques relations entre les charbons de différentes espèces et la composition des dépôts sédimentaires originels: Soc. géol. Belgique, Livre jubilaire, 1874-1924, t. 1, pp. 365-378, 1 pl., 1925.

21. Public geology and national mineral wealth: International Geol. Cong., 13th Sess., Belgium, 1922, fasc. 3, pp. 1711-1718, 1925.

22. Plant fossils [indications of ancient climate] (abstract) : Science, new ser., vol. 61, p. xii, January 9, 1925.

23. Environmental conditions of deposition of coal: Am. Inst. Min. and Met. Eng., trans. [preprint], no. 1402, 21 pp., January, 1925; (with discussion), Trans., vol. 71, pp. 3-34, 1925; abstract, Mining and Metallurgy, vol. 6, no. 222, p. 298, June, 1925.

24. Progressive regional carbonization of coals : Am. Inst. Min. and Met. Eng., Eng., Trans. [preprint], no. 1414, 27 pp., February, 1925; (with discussion), Trans., vol. 71, pp. 253-281, 3 figs., 1925 ; abstract, Mining and Metallurgy, vol. 6, no. 222, jp. 300-301, June, 1925. 
White, (Charles) David-Continued.

25. Projected oceanographic investigations (abstract): Geol. Soc. America, Bull., vol. 36, no. 1, p. 147, March 30, 1925; Pan-Am. Geologist, vol. 43, no. 2, pp. 146-147, March, 1925.

26. Upper Paleozoic climate as indicated by fossil plants: Sci. Monthly, vol. 20, no. 5, pp. 465-473, May, 1925.

27. Coal : Sci. Monthly, vol. 21, no. 2, pp. 177-181, August, 1925.

28. Late Paleozoic climates as indicated by fossil plants (abstract) : PanAm. Geologist, vol. 44, no. 1, p. 73, August, 1925.

29. General features of the Mississippian floras of the Appalachian trough: West Virginia Geol. Survey, Mercer, Monroe, and Summers counties, pp. 837-843, 1926.

30. Geologic factors affecting and possibly controlling Pleistocene ice sheet development in North America (abstract) : Washington Acad. Sci., Jour., vol. 16, no. 3, pp. 69-72, February 4, 1926.

31. Some cold waves of geologic history: Sci. Monthly, vol. 22, no. 4, pp. 359-363, April, 1926.

32. Memorial of Frank Hall Knowlton: Geol. Soc. America, Bull., vol. 38, no. 1, pp. 52-70, portr., March 30, 1927.

33. The flora of the Hermit shale in the Grand Canyon, Arizona: Nat. Acad. Sci., Proc., vol. 13, no. 8, pp. 574-575, August, 1927.

34. Study of the fossil floras in the Grand Canyon, Arizona: Carnegie Inst. Washington, Year Book no. 26, pp. 366-369, December, 1927.

35. Discussion of floating continents. In Theory of continental drift, pp. 187188, Am. Assoc. Petroleum Geologists, 1928.

36. Some' factors in rock metamorphism: Nat. Acad. Sci., Proc. vol. 14, no. 1, pp. 5-7, January, 1928.

37. A spiral graph of geologic time: Washington Acad. Sci., Jour., vol. 18, no. 8, pp. 201-203, 1 fig., April 19, 1928.

38. The promotion of knowledge of pre-Cambrian life: Science, new ser., vol. 67, pp. 620-621, June 22, 1928.

39. Algal deposits of Unkar Proterozoic age in the Grand Canyon, Arizona: Nat. Acad. Sci., Proc., vol. 14, no. 7, pp. 597-600, July, 1928.

40. Encouragement of pre-Cambrian paleontology: Jour. Geology, vol. 36, no. 8, pp. 743-744, November-December, 1928.

41. Study of the fossil floras in the Grand Canyon, Arizona: Carnegie Inst. Washington, Year Book no. 27, 1927-28, pp. 389-390, December, 1928.

White, George W.

1. The limestone caves and caverns of Ohio: Ohio Jour. Sci., vol. 26, no. 2, pp. 73-116, 16 figs., March, 1926.

White, Israel Charles, 1848-1927. See also Aurin, 2; Barton, 2; Galloway, J. J., 4 ; Lee, W. T., 13; Miller, B. L., 9 ; Moyer, 1.

1. West Virginia's second deepest well of the world, the I. H. Lake No. 1, No. 4304 of the Hope Natural Gas Company's West Virginia series: Ohio Gas and Oil Men's Jour.; vol. 1, no. 2, pp. 17-22, Septmeber, 1919.

2. Some results of deep drilling in the Appalachian oil and gas fields (abstract with discussion by A. C. Lane) : Geol. Soc. America, Bull., vol. 31, no. 1, p. 157, March 31, 1920.

3. Geographic distribution of sulphur in West Virginia coal beds: Am. Inst. Min. and Met. Eng., Bull. no. 153, pp. 2197-2206, 8 figs., September, 1919 ; Trans., vol. 63 , pp. 932-944, 8 figs., 1920. Discussion, Mining and Metallurgy, no. 157, pp. 51-53, January, 1920. 
White, Israel Charles-Continued.

4. Important epochs in the history of petroleum and natural gas: Geol. Soc. America, Bull., vol. 32, no. 1, pp. 171-186, March 31, 1921.

5. Map of West Virginia showing coal, oil, gas, iron ore, and limestone areas. Scale, 8 miles to 1 inch. West Virginia Geological Survey, 1921.

6. The natural resources of West Virginia: The South's Development, Manufacturers Record, vol. 86, no. 24, pt. 2, pp. 432-434, December 11, 1924.

7. Memorial of John James Stevenson: Geol. Soc. America, Bull., vol. 36, no. 1, pp. 100-115, portr., March 30, 1925.

8. Greatest coal field in the world [West Virginia] : Pan-Am. Geologist, vol. 44, no. 1, pp. 65-67, August, 1925.

9. (and Ashley, G. H., and Bownocker, J. A.). The Pittsburgh coal bed (with discussion) : Am. Inst. Min. and Met. Eng., Trans., vol. 74, pp. 481-506, 7 figs. (incl. maps), 1926.

10. World's greatest oil discovery: Pan-Am. Geologist, vol. 49, no. 1, pp. 4752, February, 1928.

White, James.

1. Coal resources of western Canada: Coal Age, vol. 15, pp. 744-748, 858-862, 4 figs., 1919.

White, Luther $\mathbf{H}$.

1. (and Greene, F. C.). Correlation of the "Wilcox" sand in the Okmulgee district with the Osage, Oklahoma: Am. Assoc. Petroleum Geologists, Bull., vol. 5, no. 3, pp. 399-407, 2 pls., May-June, 1921.

2. Oklahoma's deep horizons correlated [pre-Chattanooga formations] : Oil and Gas Jour., vol. 24, no. 45; pp. 60, 110, 112, 114, 116, map (opp. p. 17), April 1, 1926.

3. Oil and gas in Oklahoma; subsurface distribution and correlation of the pre-Chattanooga ("Wilcox" sand) series of northeastern Oklahoma : Oklahoma Geol. Survey, Bull. no. 40-B, 23 pp., 2 pls. (incl. map), June, 1926 ; Bull. no. 40, vol. 1, pp. 21-40, 2 pls. (incl. map), July, 1929.

White, Maynard Pressley.

1. Some index Foraminifera of the Tampico Embayment area of Mexico: Jour. Paleontology, vol. 2, no. 3, pp. 177-215, no. 4, pp. 280-316, 6 figs., 4 pls., September and December, 1928.

White, W. P. See also Atwood, W. W., 4 ; Wyckoff, 5.

1. Quartz inversion in chalcedony (abstract): Geol. Soc. America, Bull., vol. 35, no. 1, p. 112, March 30, 1924 ; Pan-Am. Geologist, vol. 41, no. 2, pp. 155-156, March, 1924.

White, Walter N. See also Deeds, 1, 2.

1. Recent work on the discharge method of estimating ground water supplies (abstract) : Washington Acad. Sci., Jour., vol. 17, no. 9, pp. 238240, May 4, 1927.

Whitehead, Walter Lucius.

1. The veins of Cobalt, Ontario: Econ. Geology, vol. 15, no. 2, pp. 103-135, 2 pls., 5 figs., March, 1920.

Whitehurst, John W. See Ponton, 1. 


\section{Whitlock, Herbert Percy.}

1. Réné Just Hauy and his influence: New York State Mus. Bull., nos. 207, 208, pp. 149-155, 1 pl. (portr.), 1919.

2. Crystallographic studies of barite: New York State Mus. Bull., nos. 207, 208, pp. 157-164, 7 figs., 1919.

3. Pyrite crystals from Broadway and 207th Street, New York City: Am. Mineralogist, vol. 4, no. 4, pp. 31-32, 1 pl., April, 1919.

4. Pyrite crystals from Bald Mountain, Colorado: Am. Mineralogist, vol. 4, no. 6, pp. 67-68, 2 figs., June, 1919.

5. The Mineralogical Society of America: Science, new ser., vol. 51, pp. 219220, February 27, 1920.

6. Wood turned to opal: Natural History, vol. 20, no. 1, p. 82, JanuaryFebruary, 1920.

7. A model for demonstrating crystal structure: Am. Jour. Sci., 4th ser., vol. 49, pp. 259-264, 13 figs., April, 1920.

8. Alfred J. Moses, 1859-1920: Science, new ser., vol. 51, pp. 429-430, April $30,1920$.

9. Obituary, Alfred J. Moses, 1859-1920: Am. Jour. Sci., 4th ser., vol. 49, p. 389, May, 1920.

10. The Morgenthau collection [of minerals in New York City]: Am. Mineralogist, vol. 6, no. 1, pp. 1-2, 1 pl., January, 1921.

11. Proceedings of the first annual meeting of the Mineralogical Society of America, held at Chicago, Illinois, December 29, 1920: Geol. Soc. America, Bull., vol. 32, no. 1, pp. 163-170, March 31, 1921.

12. Proceedings of the second annual meeting of the Mineralogical Society of 'America, held at Amherst, Massachusetts, December 29, 1921: Geol. Soc. America, Bull., vol. 33, no. 1, pp. 227-230, March 21, 1922.

13. The Morgan memorial hall of minerals and gems: Natural History (Jour. Am. Mus. Nat. Hist.), vol. 22, no. 5, pp. 447-451, 4 pls., SeptemberOctober, 1922.

14. A list of new crystal forms of minerals: Am. Mus. Nat. Hist., Bull. vol. 46 , pp. 89-278, 1922.

15. Crystallographic studies of pyrite: Am. Mus. Novitates, no. 112, 8 pp., 7 figs., May 28, 1924.

16. The story of the minerals: Am. Mus. Nat. Hist., Handbook series no. 12, 144 pp., illus., New York, 1925.

17. Memorial of Edmund Otis Hovey: Am. Mineralogist, vol. 10, no. 3, pp. 58-60, portr., March, 1925.

18. The mimicry of minerals: Natural History (Am. Mus. Nat. Hist., Jour.), vol. 25, no. 2, pp. 156-161, 8 figs., March-April, 1925.

19. Crystallographic studies of apatite: Am. Mus. Novitates, no. 190, 4 pp., 1 fig., October 7, 1925.

20. Mineralogy and petrography: Am. Year Book, 1927, pp. 599-600, 1928.

Whitman, Alfred Russell.

1. Diffusion in vein genesis at Cobalt [Ontario]: Econ. Geology, vol. 15, no. 2, pp. 136-149, March, 1920.

2. The veins of Cobalt, Ontario (discussion) [glacial conditions in Ontario]: Econ. Geology, vol. 16, no. 8, pp. 558-561, December, 1921.

3. Genesis of the ores of the Cobalt district, Ontario, Canada: California, Univ., Pub., Dept. Geol. Sciences, Bull., vol. 13, no. 7. pp. 253-310. 3 figs., 2 pls., May 31, 1922. 
Whitman, Alfred Russell-Continued.

4. A synthetic porphyry at Porcupine [Ontario]: Jour. Geology, vol. 35, no. 5, pp. 404-420, 10 figs., July-August, 1927.

5. Diffusion in ore genesis: Econ. Geology, vol, 23 , no. 5, pp. 473-488, 5 flgs., August, 1928.

Whitney, Francis Luther.

1. Bibliography and index of North American Mesozoic Invertebrata: Bull. Am. Paleontology, vol. 12, no. 48, 448 pp., June 29, 1928.

Whitney, Milton, 1860-1927.

1. The depletion of soils by chemical denudation: Science, new ser., vol. 56. pp. 216-218, August 25, 1922.

Whitney, Ray $\mathrm{H}$,

1. [Geology of the Mexia oil field, Texas] : Oil and Gas. Jour., vol. 20, no. 42, pp. 92-93, 96-97, 100-101, March 17, 1922.

Whitson, Andrew Robeson.

1. (and others). Soil survey of Dane County, Wisconsin: Wisconsin Geol. Nat. Hist. Survey, Bull. no. 53-A (soil ser. no. 20), 86 pp., map, 1917.

2. (and others). Soil survey of Buffalo County, Wisconsin: Wisconsin Geol. Nat. Hist. Survey, Bull. no. 54-A (soil ser. no. 23), 76 pp., map, 1917.

3. (and others). Reconnaissance soil survey of south part of north central Wisconsin: Wisconsin Geol. and Nat. Hist. Survey, Bull. no. 52-A (soil ser. no. 16), 108 pp., map, 4 pls., 3 figs., 1918.

4. (and others). Soil survey of Wood County, Wisconsin: Wisconsin Geol. Nat. Hist. Survey, Bull. no. 52-B (soil ser. no. 17), 86 pp., map, 1918.

5. (and others). Soil survey of Portage County, Wisconsin: Wisconsin Geol. Nat. Hist. Survey, Bull. no. 52-C (soil ser. no. 18), 79 pp., map, 1918.

6. (and others). Soil survey of Door County, Wisconsin: Wisconsin Geol. and Nat. Hist. Survey, Bull. no. 52-D (soil ser. no. 19), 72 pp., 3 figs., map, 1919.

7. (and others). Soil survey of Milwaukee County, Wisconsin: Wisconsin Geol. and Nat. Hist. Survey, Bull. no. 56-A (soil ser. no. 28), 63 pp., 3 figs., map, 1919.

8. (and others). Soil survey of Waupaca County, Wisconsin: Wisconsin Geol. Nat. Hist. Survey, Bull. no. 54-C ( soil ser. no. 25), 84 pp., map, 1921.

9. (and others). Soil survey of Outagamie County, Wisconsin: Wisconsin Geol. and Nat. Hist. Survey, Bull. no. 54-D (soil ser. no. 26), 78 pp., 2 figs., 2 pls., map, 1921.

10. (and others). Soil survey of northern Wisconsin: Wisconsin Geol. and Nat. Hist. Survey, Bull. no. 55 ( soil ser. no. 27), 46 pp., 6 figs., map, 1921.

11. (and others). Soil survey of Rock County, Wisconsin: Wisconsin Geol. and Nat. Hist. Survey, Bull. no. 53-B, 80 pp., 5 pls., map, 1.922.

12. (and others). Soil survey of Jackson County, Wisconsin: Wisconsin Geol. and Nat. Hist. Survey, Bull. no. 54-B (soil ser. no. 24), 85 pp., 2 figs. 5 pls., map, 1923. 
Whitson, Andrew Robeson-Continued.

13. (and others). Soil survey of Adams County, Wisconsin: Wisconsin Geol. and Nat. Hist. Survey, Bull. no. 41-D (soil ser. no. 42), 83 pp., 3 figs., 6 pls., map, 1924.

14. Soils of Wisconsin: Wisconsin Geol. and Nat. Hist. Survey, Bull. no. 68; 270 pp., 20 figs., 32 pls., map, 1927.

Whittaker, Edward J., 1891-1924.

1. The fossil molluscan faunas of the marl deposits of the Ottawa district: Canada, Geol. Survey, Bull. no. 33, pp. 59-77, 4 pls., September 14, 1921.

2. Mackenzie River district between Great Slave Lake and Simpson: Canada, Geol. Survey, Summ. Rept., 1921, pt. B, pp. 45-57, 2 pls., map, 1922.

3. Pleistocene and recent fossils of the St. Lawrence Valley from Prescott to Beauharnois: Report on structural materials along the St. Lawrence River (Keele and Cole), pp. 103-108, Canada, Mines Branch. 1922.

4. Bottom deposits of McKay Lake, Ottawa [Ontario]: Roy. Soc. Canada, Proc. and Trans., 3d ser., vol. 16, sec. 4, pp. 141-157, 1 fig., 2 pls.. 1922.

5. Mackenzie River district between Providence and Simpson, Northwest Territories: Canada, Geol. Survey, Summ. Rept., 1922, pt. B, pp. 88-100, 2 figs., 2 pls. 1923.

Whittemore, C. R.

1. Geology and metallurgical treatment of the Sullivan zine ore [Trail, East Kootenay district, British Columbia]: Canadian Inst. Min. and Met., Monthly Bull., no. 136, pp. 509-545, August, 1923; Trans., vol. 26, pp. 441-477 [1924].

Whittemore, J. W.

1. The clays of Louisiana; Shreveport area: Louisiana, Dept. Conservation, Bull. 14, 84 pp., illus., May, 1927.

2. Clays and clay development of Louisiana: Am. Ceramic Soc., Jour., vol. 11, no. 10, pp. 782-784, October, 1928.

Whittlesey, Derwent S. See Jones, W. D., 1.

Whitwell, George E.

1. (and Patty, E. N.). The magnesite deposits of Washington; their occurrence and technology: Washington Geol. Survey, Bull. no. 25, 194 pp., 5 flgs., 13 pls., 1921.

Whorton, Chester.

1. (and Clark, J. M.). Mineola dome of northeast Missouri (abstra?t) : Pan-Am. Geologist, vol. 45, no. 3, p. 250, April, 1926.

Wi.chman, F. M.

1. The Ophir mining district, Utah: Eng. and Min. Jour., vol. 110, no. 12, pp. 560-563, 3 figs., September 18, 1920.

Wickham, Henry Frederick.

1. Fossil beetles from Vero, Florida: Am. Jour. Sci., 4th ser., vol. 47, pp. 355-357, May, 1919. Florida State Geol. Survey, Twelfth Ann. Rept., pp. 5-7, 1919. 
Wiedey, Lionel William.

1. Notes on the Vaqueros and Temblor formations of the California Miocene with descriptions of new species: San Diego Soc. Nat. Hist., vol. 5, no. 10, pp. 95-182, 13 pls., March 31, 1928.

2. Revision of Turritellas of Vaqueros and Temblor Miocene of California (abstract) : Pan-Am. Geologist, vol. 49, no. 4, pp. 318-319, May, 1928.

Wieland, George Reber. See also Hylander, 1.

1. Classification of the Cycadophyta: Am. Jour. Sci., 4th ser., vol. 47, pp. 392-406, 3 figs., June, 1919.

2. [Paleobotanical studies]: Carnegie Inst. Washington, Year Book no. 17, 1918, pp. 312-314, February, $1919 ;$ no. 18, 1919, pp. 362-363, March, 1920.

3. Distribution and relationship of the cycadeoids: Am. Jour. Botany, vol. 7, no. 4, pp. 125-145, 5 figs., 1 pl., April, 1920.

4. The Tetracentron-Drimys question: Am. Jour. Sci., 4th ser., vol. 49, pp. 382-383, May, 1920.

5. The long-necked sauropod Barosaurus: Science, new ser., vol. 51, pp. 528530, May 28, 1920.

6. Recedent lake shores of the Cretaceous: Science, new ser., vol. $52 \mathrm{pp}$. 537-538, Decenrber 3, 1920.

7. [Report on investigations of Cycadeoidea]: Carnegie Inst. Washington, Year Book no. 19, pp. 404-405, January, 1921.

8. Monocarpy and pseudomonocarpy in the cycadeoids: Am. Jour. Botany, vol. 8, no. 4, pp. 218-230, 1 fig., 4 pls., April, 1921.

9. Paleobotany as viewed by two geologists: Science, new ser., vol. 53, pp. 437-439, May 6, 1921.

10. Two new North American cycadeoids: Canada, Geol. Survey, Bull. no. 33, pp. 79-85, 1 fig., 2 pls., September 14, 1921.

11. [Progress of cycadophyte investigation] : Carnegie Inst. Washington, Year Book no. 20, pp. 452-457, February, 1922.

12. Devonian plants: Science, new ser., vol. 55, pp. 427-428, April 21, 1922.

13. [Report on investigations of cycadeoids]: Carnegie Inst. Washington, Year Book no. 21, pp. 396-397, January, 1923.

14. Fossil plants as evidence for resistance to environment. In Organic adaptation to environment, pp. 149-185, 3 pls., New Haven, Yale University Press, 1924.

15. Progress in study of cycadeoids: Carnegie Inst. Washington, Year Book no. 22 , pp. $353-354,1924$.

16. Recent achievements in paleobotany: Science, new ser., vol. 60, pp. 233-235, September 12, 1924.

17. [Studies on fossil cycads]: Carnegie Inst. Washington, Year Book no. 23, pp. 296-298, December, 1924.

18. Dinosaur feed: Science, new ser., vol. 61, pp. 601-603, June 12, 1925.

19. Triaso-Jurassic plant evolution and climate: Am. Naturalist, vol. 59, pp. 452-474, September-October, 1925; abstract, Pan-Am. Geologist, vol. 44, no. 1, p. 80, August, 1925.

20. Dinosaur extinction: Am. Naturalist, vol. 59, pp. 557-565, NovemberDecember, 1925.

21. [Report on investigations of cycadeoids]: Carnegie Inst. Washington, Year Book no. 24, pp. 360-362, December, 1925.

22. The El Consuelo cycadeoids [southern Oaxaca, Mexico]: Bot. Gazette, vol. 81, no. 1, pp. 72-86, 1 fig., March, 1926. 
Wieland, George Reber-Continued.

23. [Research on cycadeoids] : Carnegie Inst. Washington, Year Book no. 25, pp. $407-408$, December, 1926.

24. [Cycadeoid investigations] : Carnegie Inst. Washington, Year book no. 26, pp. 370-372, December, 1927.

25. Certain fossil plants erroneously refelred to cycadeoids: Bot. Gazette, vol. 86 , no. 1, pp. 32-49, 14 figs., September, 1928.

26. [Report of investigations on the cycadeoids] : Carnegie Inst. Washington, Year Book no. 27, pp. 390-391, December, 1928.

Wilcox, Walter D.

1. Dr. Charles D. Walcott: Canadian Alpine Jour., vol. 16, pp. 231-234, portr., 1928.

Wilder, Frank Alonzo.

1. Some conclusions in regard to the origin of gypsum: Geol. Soc. America, Bull., vol. 32, no. 4, pp. 385-394, December 1, 1921; (abstract, with discussion by J. V. Lewis), vol. 32, no. 1, p. 67, March 31, 1921.

2. Gypsum ; its occurrence, origin, technology, and uses, with special chapters devoted to gypsum in Iowa: Iowa Geol. Survey, vol. 28, pp. 47537 [1923].

3. Gypsum and the gypsum industry: Min. Congress Jour., vol. 12, no. 3, pp. 156, 173, March, 1926.

4. Gypsum and anhydrite: Am. Mineralogist, vol. 13, no. 9, pp. 476-480, 3 figs., September, 1928.

Wilhelm, Victor H. See also Case, J. B., 3.

1. The geology of the Portland Canal district [British Columbia]: Min. and Sci. Press, vol. 122, pp. 95-96, 1 fig., January 15, 1921.

2. Baja California and oil possibilities: Min. and Sci. Press, vol. 123, no. 4, pp. 125-127, 1 fig., July 23, 1921.

3. (and Saunders, L. W.). Report on the Mt. Poso oil field: California State Min. Bur., Summary of Operations California Oil Fields, vol. 12, no. 7, pp. 5-12, 2 pls., January, 1927.

4. The possibility of deeper production in the Coalinga field, California: Oil Bull., vol. 13, no. 7, pp. 695-699, 3 figs., July, 1927.

Wilkerson, Albert S.

1. Possible sources of some boulders in the glacial drift of Missouri: Science, new ser., vol. 65, p. 404, April 22, 1927.

Wilkes, W. N.

1. Minerals of Arkansas: Arkansas, Bur. Mines, Manufactures, and Agriculture, 127 pp., illus., 1925.

Wilkins, T. Russell.

1. Actino-uranium and enlarged ancient halos (abstract) : Geol. Soc. America, Bull., vol. 38, no. 1, p. 124, March 30, 1927 ; Pan-Am. Geologist,. vol. 47, no. 1, pp. 72-73, February, 1927.

Willard, Bradford. See also Miller, B. L., 9.

1. Mud cracks forming over water [Badlands, South Dakota] : Jour. Geology, vol. 33, no. 3, pp. 286-287, 1 fig., April-May, 1925.

2. A six-rayed Devonaster eucharis (Hall) : Jour. Geology, vol. 34, no. 1, pp. 85-87, 1 fig., January-February, 1926.

3. The age and origin of the Shawangunk formation: Jour. Paleontology, vol. 1, no. 4, pp. 255-258, 1 pl., January, 1928. 
Willard, Bradford-Continued.

4. Teaching vertebrate paleontolugy: Jour. Geology, vol. 36, no. 3, pp. 261-264, 2 figs., April-May, 1928.

5. The brachiopods of the Ottosee and Holston formations of Tennessee and Virginia : Harvard Coll., Mus. Comp. Zool., Bull., vol. 68, no. 6, pp. 255-292, 3 pls., May, 1928.

Willard, Daniel Everett.

1. The story of the North Star State [Minntsota]. 395 pp., 156 figs., St. Paul, Minn., Webb Publishing Company, 1922.

2. The story of the prairies, or the landscape geology of North Dakota. Tenth edition, revised, 375 pp., 170 figs., Saiit Paul, Minn., Webb Publishling Company, 1923.

Willey, Arthur.

1. Origin of land vertebrates (abstract) : Pan-Am. Geologist, vol. 43, no. 3, pp. 233-234, April, 1925.

Williams, A. E. See Kentucky Geol. Surveỳ, 15, 27.

Williams, Charles Francis.

1. The Mayo district in Yukon Territory : Eng. and Min. Jour.-Press, vol. 113, no. 24, pp. 1039-1046, 11 figs., June 17, 1922.

2. Ore deposition in the Tri-State district: Eng. and Min. Jour.-Press, vol. 121. no. 22, p. 893, May 29, 1926.

Williams, D. W:

1. Correlation of producing sands in southeasterm Kansas anil northeastern Oklahoma: Am. Assoc. Petroleum Geologists, Bull., vol. 5, no. 2, pp. 293-297, 2 figs., March-April, 1921.

2. Oil and gas in Marion, Chase, Dickinson, Morris, and Geary counties, Kansas: Am. Assoc. Petroleum Geologists, Bull., vol. 5, no. 4, pp. 507-511, July-August, 1921.

Williams, Edward Higginson, jr.

1. The deep Kansan pondings in Pennsylvania and the deposits therein: Am. Philos. Soc., Proc., vol. 59, no. 1, pp. 49-84, 15 figs., 1920.

Williams, Frank E. See Martin, L., 2.

Williams, George 0 .

1. Radium-bearing silts of southeastern Utah: Fng. and Min. Jour., vol. 119, no. 5, pp. 201-202, January 31, 1925.

Williams, Guy Yandell. See Shead, 8.

Williams, Henry Shaler, 1847-1918.

1. Upper Paleozoic faunas of Missouri: Pan-Am. Geologist, vol. 37, no. 1, pp. 35-40, February, 1922.

Williams, Howel.

1. A recent volcanic eruption near Lassen Peak, California: California, Univ., Dept. Geol. Sci., Bull., vol. 17, no. 7, pp. 241-263, 10 figs., May 19, 1928.

2. Geology of Marysville Buttes, California (abstract): Pan-Am. Geologist, vol. 49 , no. 4, p. 312, May, 1928.

Williams, Ira Abraham.

1. The Oregon cares; remarkable "marble halls" of Josephine County: Natural History, vol. 20, no. 4, pp. 397-405, 10 figs., SeptemberOctober, 1920.

$4096-31-43$ 
Williauns, Ira Abraham-Continued.

2. Underground waters in arid valleys of Oregon: Pan-Am. Geologist, vol. 39, no. 1, pp. 76-77, February, 1923.

3. The lava river tunnel [Deschutes County, Oregon]: Natural History. vol. 23, no. 2, pp. 162-171, 7 figs., March-April, 1923.

Williams, James S. See also Boone County Hist. Soc.; Branson, 4.

1. Louisiana limestone of northeastern Missouri (abstract) : Pan-Am. Geologist, vol. 45, no. 3, p. 252, April, 1926.

Williams, Merton Yarwood. See also Hume, 28.

1. The Silurian geology and faunas of Ontario Peninsula and Manitoulin and adjacent islands: Canada, Geol. Survey, Mem. 111, $195 \mathrm{pp}$. 34 pls., 6 figs., 2 maps, 1919.

2. Oil fields of southwestern Ontario: Canada, Geol. Survey, Summ. Rept., 1918, pt. E, pp. 30-41, 2 figs., map, 1919.

3. The geology of Ontario as it affects gas and oil production: Canadian Min. Jour., vol. 40, p. 655, September 3, 1919.

4. The oil fields of Elgin, Essex, and the southern part of Kent counties, Ontario: Canada, Geol. Survey, Summ. Rept., 1919, pt. E, pp. 7-16, 1920.

5. Oil occurrence in a syncline in the Trenton formation of Kent County: Canada, Geol. Survey, Summ. Rept., 1919, pt. E, pp. 16-18, 3 pls., 1920.

6. Paleozoic rocks of Mattagami and Abitibi rivers, Ontario: Canada, Geol. Survey, Summ. Rept., 1919, pt. G, pp. 1-12, 2 figs., 1920.

7. Paleozoic geology of the Mattagami and Abitibi rivers : Ontario Bur. Mines, 29th Ann. Rept. vol. 29, pt. 2, pp. 19-30, 1 fig., 1920.

8. Paleozoic sections south of James Bay (abstract) : Geol. Soc. America, Bull., vol. 31, no. 1, pp. 138-139, March 31, 1920.

9. Future prospects for oil and gas production in Ontario: Canadian Min. Inst., Monthly Bull., no. 96, pp. 320-325, April, 1920; Canadian Min. Inst., Trans., vol. 23, pp. 341-347 [1921].

10. Paleozoic stratigraphy of Pagwachuan, lower Kenogami and lower Albany rivers: Canada, Geol. Survey, Summ. Rept., 1920, pt. D, pp. 18-25, 1 fig., 1921.

11. Oil possibilities of Manitoulin Island: Canada, Geol. Survey, Summ. Rept., 1920, pt. D, pp. 26-32, 2 figs., 1921.

12. Stratigraphy of the Moose and Albany rivers of northern Ontario (abstract) : Geol. Soc. America, Bull., vol. 32, no. 1, p. 39, March 31, 1921.

13. Exploration east of Mackenzie River between Simpson and Wrigley: Canada, Geol. Survey, Summ. Rept., 1921, pt. B, pp. 56-66, map, 1922.

14. Reconnaissance across northeastern British Columbia and the geology of the northern extension of Franklin Mountains, Northwest Territories: Canada, Geol. Survey, Summ. Rept., 1922, pt. B, pp. 65-87, 1923.

15. Oil prospects in southern Alberta: Canadian Min. Jour., vol. 44, no. 48, pp. 949-950, November 30, 1923.

16. Franklin Mountains [Mackenzie]: Geol. Soc. America, Bull., vol. 35, no. 3, pp. 449-464, 3 figs., September 30, 1924; abstract, with discussion by Alfred H. Brooks, no. 1, pp. 96-98, March 30, 1924; abstract, Pan-Am. Geologist, vol. 41, no. 2, pp. 147-148, March, 1924. 
Williams, Merton Yarwood-Continued.

17. Sandstone dikes in southeastern Alberta (petrography of the dikes, by T. C. Phemister, pp. 157-162) : Roy. Soc. Canada, Trans., 3d ser., vol. 21, sec. 4, pp. 153-174, 4 pls., May, 1927 ; abstract, p. xciv, 1927.

18. Memorial of William Lawrence Uglow: Am. Mineralogist, vol. 12, no. 5, pp. 191-197, 1 fig. (portr.), May, 1927.

Williams, T. B.

1. Identification of coals: Econ. Geology, vol. 21, no. 4, pp. 364-374, 7 figs., June-July, 1926.

Williamson, E. D. See also Adams, L. H., 7.

1. Earthquakes and the elastic properties of the earth (abstract): Washington Acad. Sci., Jour., vol. 10, no. 17, p. 498, October 19, 1920.

2. (and Adams, L. H.). Density distribution in the earth: Washington Acad. Sci., Jour., vol. 13, no. 19, pp. 413-431, 5 figs., November 19, 1923.

Willis, Bailey. See also Am. Geophysical Union, 1; Bowie; 24; Day, 13; Gillson, 11; Hobbs, 7.

1. Structure of the Pacific ranges, California (abstract, with discussion by R. T. Chamberlin, A. Keith, G. R. Mansfield, and G. W. Stose) : Geol. Soc. America, Bull., vol. 30, pp. 84-86, March 31, 1919.

2. Discoidal structure of the lithosphere: Nat. Acad. Sci., Proc., vol. 5, no. 9, pp. 377-383, September 15, 1919.

3. Joseph Barrell and his work: Jour. Geology, vol. 27, no. \& pp. 664-672, November-December, 1919.

4. Geologic distillation of petroleum: Mining and Metallurgy, no. 157, sec. 1, p. 49 (abstract), sec. 10, 7 pp., January, 1920; Am. Inst. Min and Met. Eng., Trans. [preprint], no. 1088, pp. 18-20, August, 1921. Oil and Gas Jour., vol. 18, no. 43, pp. 54-55, March 26, 1920. Discussion by David Reger, David White, H. W. Hixon, and E. W. Shaw [Am. Inst. Min. and Met. Eng., Trans. preprint no. 994, pp. 12-19, 19201 .

5. Structure of the coast ranges of California (abstract with discussion) : Geol. Soc. America, Bull., vol. 31, no. 1, p. 193, March 31, 1920.

6. Discoidal structure of the lithosphere: Geol. Soc. America, Bull., vol. 31., no. 2, pp. 247-302, 6 pls., 2 figs., June 30, 1920.

7. Aerial observation of earthquake rifts: Seismol. Soc. America, Bull., vol. 11, no. 2, pp. 136-139, June, 1921; Science, new ser., vol. 54, pp. 266-268, September 23, 1921.

S. Rôle of isostatic stress: Geol. Soc. America, Bull., vol. 33, no. 2, pp. 371374, June 30, 1922.

9. Geology of the Colorado River basin with reference to engineering problems: Science, new ser., vol. 56, pp. 177-182, August 1S, 1922.

1.0. (and Wood, H. O.). Fault map of the State of California compiled from data assembled by the Seismological Society of America ... Compilation of faults by Bailey Willis and H. O. Wood. Scale. 1. 506,880 . 1922 .

11. Geologic structures. 295 pp., 121 figs., 10 pls., New York, McGraw-Hill Book Company, 1923.

12. Earthquakes: Science, new ser., vol. 57, pp. xii, xiv, January 19, 1923.

13. A fault map of California: Seismol. Soc. America, Bull., vol. 13, no. 1, pp. 1-12, map, March, 1923.

14. Dynamics of faulting and folding (abstract) : Geol. Soc. America, Bull., vol. 34, no. 1, p. 58, March $30,1923$. 
Willis, Bailey-Continued.

15. Fault map of California ; Faults of the Coast Ranges of California (abstract with discussion by G. H. Ashley and the author): Geol. Soc. America, Bull., vol. 34, no. 1, pp. 58-59, March 30, 1923.

16. Memorial tribute to Raphael Pumpelly: Geol. Soc. America, Bull., vol. 35, no. 1, pp. 42-43, March 30, 1924.

17. (and Wood, H. O.). A fault map of California: Science, new ser., vol. 59, pp. 310-311, April 4, 1924.

18. Warthquake risk in California: Seismol. Soc. America, Bull., vol. 13, no. 3 , pp. 89-99, 5 figs., September, 1923 ; no. 4, pp. 147-154, 1 fig., 1 pl., December, 1923 ; vol. 14, no. 1, pp. 9-25, 1 fig., 4 pls., March, 1924 ; no. 2, pp. 150-164, 2 figs., June, 1924 ; no. 4, pp. 256264, December, 1924.

19. Memorial of Raphael Pumpelly: Geol. Soc. America, Bull., vol. 36, no. 1, pp. 45-\$4, portr., March 30, 1925.

20. Rocky Mountain structure: Jour. Geology, vol. 33, no. 3, pp. 272-277, 1 fig., April-May, 1925.

21. The Santa Barbara earthquake: Science, new ser., vol. 62 , p. $\mathrm{x}$, July $10,1925$.

22. A study of the Santa Barbara earthquake of June 29, 1925: Seismological Soc. America, Bull., vol. 15, no. 4, pp. 255-278, 1 fig., 2 pls., December, 1925.

23. Essays on earthquakes: Seismological Soc. America, Bull., vol. 16, no. 1, pp. 27-40, March, 1926.

24. The Californian orogenic period (abstract): Science, new ser., vol. 63, p. 484, May 7, 1926.

25. The work of the Seismological Society of America (abstract): Seismological Soc. America, Bull., vol. 16, no. 2, pp. 150-153, June, 1926.

26. Some geological features of the Washington magnesite deposits (discussion) : Eng. and Min. Jour., vol. 124, no. 22, p. 858, November. 1926.

27. Folding or shearing, which? (with discussion by E. Russell Lloyd and W. A. J. M. van Waterschoot van der Gracht) : Am. Assoc. Petroleum Geologists, Bull., vol. 11, no. 1, pp. 31-47, January, 1927.

28. Normal faulting on upthrust arches (abstract) : Geol. Soc. America, Bull., vol. 38, no. 1, pp. 203-204, March 30, 1927.

29. Report on comparative seismology: Carnegie Inst. Washington, Year Book no. 26, pp. 390-392, December, 1927.

30. La force sismique en Californie: Soc. géol. Belgique, Livle jubilaire, $1874-1924$, t. 1, pp. 407-460, 9 figs., 7 jls. [n. d., 1928?].

31. Continental drift. In Theory of continental drift, pp. 76-\$2, Am. Assoc. Petroleum Geologists, 1928.

32. Prof. T. C. Chamberlin: Nature, vol. 122, pp. 930-931, December 15, 1928.

33. Geotectonics of the Pacific: Third Pan-Pacific Sci. Cong., Tokyo, 1926, Proc., vol. 1, pp. 358-369, 1928.

34. Seismicity of Chile and California: Third Pan-Pacific Sci. Cong., 'Tokyo, 1926, Proc., vol. 1, pp. 389-394, 1928.

Willis, C. G. See Ferguson, R. N., 2.

Willis, Robin. See also Gould, 27 ; Louderback, 6.

1. Topography of active faulting in California (abstract) : Geol. Soc. America, Bull., vol. 36, no. 1, pp. 143-144, March 30, 1925. 
Willis, Robin-Continued:

2. Physiography of the California Coast Ranges: Geol. Soc. America, Bull., vol. 36, no. 4, pp. 641-678, 23 figs., December, 1925; abstract, no. 1, p. 143, March 30, 1925; Pan-Am. Geologist, vol. 43, no. 2, p. 146, March, 1925.

Williston, Samuel H. See Tough, 1.

Williston, Samuel Wendell, 1852-1918.

1. The osteology of the reptile; arranged and edited by William King Gregory. 300 pp., 191 figs., Cambridge, Harvard University Press, 1925.

Willson, Fred F.

1. The Montana earthquake of June 27, 1925; damage in Gallatin County: Seismological Soc. America, Bull., vol. 16, no. 3, pp. 165-169, 6 pls., September, 1926.

Willson, K. M. See Crawford, R. D., 1.

Willmarth, Mary Grace.

1. Geologic time classification of United States Geological Survey compared with other classifications: U. S. Geol. Survey, Bull. 769, plate I, 1924 [issued separately].

2. The geologic time classification of the United States Geological Survey compared with other classifications, accompanied by the original definitions of era, period, and epoch terms: U. S. Geol. Survey, Bull. 769, 138 pp., 1925.

Wilmore, A. N.

1. Barbados, a key to the physical history of the West Indies and Caribbean regions: Geographical Teacher, London, no. 69, vol. 12, pt. 5, pp. 357-363, summer, 1924.

Wilson, Alfred William Gunning.

1. Coalmont amber [British Columbia]: Canada, Mines Branch, Summ. Rept., 1921, pp. 1-2, 1923.

2. Precious metals in Canada: In Handbook of Canada, pp. 397-407, 1 fig., Toronto, 1924; Canadian Min. Jour., vol. 45, nos. 20 and 21, pp. 471-474, 495-498, 7 figs., May 16 and 23, 1924.

Wilson, Alice E.

1. The range of certain lower Ordovician faunas of the Ottawa Valley, with descriptions of some new species: Canada, Geol. Survey, Bull. 110. 33, pp. 19-57, 7 figs., 3 pls., September 14, 1921.

2. Ordovician fossils from St. Lawrence Canal system localities, Ontario and Quebec: Report on structural materials along the St. Lawrence River (Keele and Cole), pp. 109-111, Canada, Mines Branch, 1922

3. A new genus and a new species of gastropod from the upper Ordovician of British Columbia: Canadian Field-Naturalist, vol. 38, no. 8 , pp. 150-151, 2 fig., 2 pls., October, 1924.

4. An upper Ordovician fauna from the Rocky Mountains, British Columbia: Canada, Geol. Survey, Bull. no. 44, pp. 1-34, 2 figs., 8 pls., 1926. Review by Edwin Kirk, Jour. Geology, vol. 35, no. 3. pp. 287288, April-May, 1927. 
Wilson, Benjamin $\mathrm{H}$.

1. Deductions from the occurrence and character of two large quartzose conglomerate boulders of unknown origin found in the Kansas drift sheet at Centerville, Iowa: Iowa Acad. Sci., Proc. 1922, vol. 29, pp. 121-126, 2 figs., [1924?].

2. An excellent example of high clay bank erosion in Lee County, Iowa : Iowa Acad. Sci., Proc., vol. 30, pp. 425-431, 5 figs. [1924.]

3. Physiographic evolution of Lake Cooper (abstract) : Pan-Am. Geologist, vol. 46, no. 5, p. 403, December, 1926.

4. Notes on the progress of the physiographic evolution of Lake Cooper (abstract) : Iowa Acad. Sci., Proc., 1926, vol. 33, p. 221 [1927].

Wilson, Eldred Dewey. See also Jenkins, 2,3 ; Lausen, 1.

1. Proterozoic Mazatzal quartzite of central Arizona: Pan-Am. Geologist, vol. 38, no. 4, pp. 299-312, 3 pls., November, 1922.

2. Geology and ore deposits of the Courtland-Gleeson region, Arizona: Arizona: Arizona Bur. Mines, Bull. no. 123 (geol. ser. no. 5), 79 pp., 17 figs., 3 pls. (incl. map), June 1, 1927.

3. Arizona gold placers ( second edition, revised) : Arizona Bur. Mines, Bull. no. 124, 60 pp., 12 figs. (incl. maps), August 15, 1927.

4. Asbestos deposits of Arizona; with an introduction on asbestos minerals by G. M. Butler : Arizona Bur. Mines, Bull. no. 126, 100 pp., 7 figs., 8 pls., October 15, 1928.

Wilson, Ernest H.

1. Barite from Great Notch, New Jersey: Am. Mineralogist, vol. 4, no. 1, p. 4, January, 1919.

Wilson, Ford E. See Thiessen, 9.

Wilson, Hewitt.

1. (and Bennett, A. Lee, and Heath, Fred T.). Preliminary report on the residual kaolin and feldspar in the Pacific Northwest: Am. Ceramic Soc., Jour., vol. 6, no. 3, pp. 475-490, 9 figs., March, 1923.

2. The clays and shales of Washington; their technology and uses: Washington, Univ., Bull., Eng. Exper. Sta. ser., Bull. no. 18, 224 pp., October, 1923.

Wilson, John Howard.

1. An occurrence of carnotite near Denver: Eng. and Min. Jour.-Press, vol. 116, no. 6, pp. 239-240, 1 fig., August 11, 1923.

2. Microscopic subsurface work in the Rocky Mountain region: Mining and Metallurgy, vol. 5, no. 216, p. 582, December, 1924.

3. Lithologic character of shale as an index of metamorphism: Am. Assoc. Petroleum Geologists, Bull., vol. 10, no. 6, pp. 625-633, June, 1926.

Wilson, Malcolm Earl.

1. The occurrence of oil and gas in Missouri: Missouri Bur. Geology and Mines, 2d ser., vol. 16, 284 pp., 11 pls. (incl. maps), 1922.

Wilson, Morley Evans.

1. Geology and mineral deposits of a part of Amherst township, Quebec: Canada, Geol. Survey, Mem. 113, 54 pp., 7 pls., 3 figs., map, 1919.

2. (and MacKay, B. R.) Landslide adjacent to Riviere Blanche, St. Thuribe, Parish of St. Casimir, Portneuf County, Province of Quebec: Quebec (Province), Rept. on Mining Operations, 1918, pp. 152-156, 2 pls.. 1919. 
Wilson, Morley Evans-Continued.

3. Mineral deposits in the Ottawa Valley: Canada, Geol. Survey, Summ. Rept., 1919, pt. E., pp. 19-44, 10 figs.; 3 maps, 1920.

4. Molybdenite in the lower Ottawa Valley: Canadian Inst. Min. and Met., Monthly Bull., no. 102, pp. 749-754, 3 figs., October, 1920; Canadian Min. Inst., Trans., vol. 23, pp. 419-425, 3 figs. [1921].

5. Madoc district, Ontario: Canada, Geol. Survey, Summ. Rept., 1920, pt. D, pp. $39-40,1921$.

6. The fluorspar deposits of Madoc district, Ontario: Canada, Geol. Survey, Summ. Rept., 1920, pt. D, pp. 41-78, 9 figs., 1921. Canadian Min. Jour., vol. 42, no. 45, pp. 887-892, November 11, 1921.

7. The relationships of the Paleozoic to the pre-Cambrian along the southern border of the Laurentian highlands in southeastern Ontario and the adjacent portions of Quebec: Roy. Soc. Canada, Proc. and Trans., 3d ser., vol. 14, sec. 4, pp. 15-24, 1 fig., 1921.

8. Talc in Canada: Canadian Min. Jour., vol, 43, no. 23, p. 356, June 9, 1922.

9. The fluorspar deposits of the Madoc district, Ontario (abstract): Science, new ser., vol. 56, p. 176, August 11, 1922.

10. Arnprior-Quyon and Maniwaki areas, Ontario and Quebec: Canada, Geol. Survey, Mem. 136, 152 pp., 17 pls., 4 maps, 1924.

11. A discovery of copper-bearing minerals in Petite Nation seigniory, Papineau County, Quebec: Canada, Geol. Survey, Summ. Rept. 1923, pt. C1, pp. 74-75, 1924.

12. Ontario's lead mine [Kingdon lead mine, Galetta, Ontario]: Canadian Min. Jour., vol. 45, nos. 20 and 21, pp. 477-478, 501-502, May 16 and $23,1924$.

13. Grenville pre-Cambrain subprovince (abstract) : Pan-Am. Geologist, vol. 42, no. 1, pp. 79-80, August, 1924.

14. A discovery of copper-bearing minerals in Petite Nation Seigniory, Papineau County, Quebec: Quebec, Dept. Colonization . . ., Report on Mining Operations . . . 1924, pp. 39-42, 1925.

15. The Grenville pre-Cambrian subprovince: Jour. Geology, vol. 33, no. 4, pp. 389-407, 3 figs., May-June, 1925; abstract, British Assoc. Adv. Sci., Rept. 92d Meeting, pp. 388-389, 1925.

16. Talc deposits of Canada: Canada, Geol. Survey, Econ. Geology ser., no. 2, 149 pp., 19 figs., 14 pls., 1926.

17. Mineral deposits in Nova Scotia and New Brunswick: Canada, Geol. Survey, Summ. Rept., 1926, pt. C, pp. 77-99, 8 figs., 1927.

18. Some problems of classification in the Canadian pre-Cambrian shield: Geol. Mag., vol. 64, pp. 1-7, January, 1927.

19. Hastings series (abstract) : Geol. Soc. America, Bull., vol. 38 , no. 1, p. 118, March 30, 1927; Pan-Am. Geologist, vol. 47, no. 1, p. 69, February, 1927.

Wilson, Philip D.

1. Notes on certain ore deposits of the Southwest (discussion) : Am. Inst. Min. Eng., Bull. no. 146, pp. 445-447, February, 1919.

2. The British Columbia batholith and related ore deposits: Am. Inst. Min. and Met. Eng., Trans., vol. 68, pp. 536-551, 1 fig., 1923 ; [pre-print] no. 1183, 16 pp., 1 fig., August, 1922; abstract, Mining and Metallurgy, no. 188, pp. 34-37, 1 fig., August, 1922.

3. Veposition of copper carbonate from mine water: Am. Inst. Min. and Met. Eng., Trans., vol. 68, pp. 552-555, 1923; abstract, Mining and Metallurgy, no. 188, p. 37, August, 1922. 
Wilson, Philip D.-Continued.

4. Methods of mine sampling, recording underground geological data and estimation of ore reserves (committee report) : Am. Min. Congress, 27th Ann. Convention, Rept. of Proc., pp. 332-351, 1925 ; Arizona Min. Jour., vol. 8, no. 11, pp. 11-13, 25-26, November 1, 1924.

Wilson, Roy Arthur. See also Ward, 9.

1. The possibilities of oil in South Dakota; a preliminary discussion: South Dakota Geol. and Nat. Hist. Survey, Bull. 10 (South Dakota, Univ., Bull., ser. 22, no. 3), 97 pp., 18 figs., map, March, 1922.

2. The possibilities of oil in northern Dewey County: South Dakota Geol. and Nat. Hist. Survey, Circular 10, 9 pp., 3 figs., December, 1922.

3. (and Ward, Freeman). The possibilities of oil in northern Ziebach County: South Dakota Geol. and Nat. Hist. Survey, Circular 13, 11 pp., 4 figs, April, 1923.

4. The bearing of geologic features in South Dakota upon oil possibilities: Am. Assoc. Petroleum Geologists, Bull., vol. 7, no. 5, pp. 507-516. 1 fig., September-October, 1923.

5. (and Lambert, J. S., and Capp, C. H.). Belt series in Montana (abstract, with discussion by Edward Sampson) : Geol. Soc. America, Bull., vol. 35, no. 1, pp. 91-92, March 30, 1924; abstract, Pan-Am. Geologist, vol. 41, no. 2, pp. 145-146, March, 1924.

6. Oil and gas possibilities in northeastern Meade County: South Dakota Geol. and Nat. Hist. Survey, Circular 23, 14 pp., 3 figs., April, 1925.

7. The Ragged Butte structure [in southwestern Dewey County, South Dakota] : South Dakota Geol. and Nat. Hist. Survey, Circular 24, 7 pp., 2 figs., 1 pl., April, 1925.

8. The upper Paleozoic rocks of Oklahoma; paleogeography: Oklahoma Geol. Survey, Bull. no. 41, pp. 22-66, 30 figs., January, 1927.

9. The Pennsylvanian of Oklahoma and its problems. Oklahoma Acad. Sci., Proc., vol. 6, pt. 2, 1926 (Oklahọma, Univ., Bull., new ser., no. 348), p. 251, January 1, 1927.

10. Problems of stratigraphy in Oklahoma (abstract) : Oklahoma Acad. Sci., Proc., vol. 6, pt. 2, 1926 (Ok'ahoma, Univ., Bull., new ser., no. 348), pp. 252-253, January 1. 1927.

Wilson, Roy M.

1. Summary of the July, 1927, eruption of Kilauea: Hawaiian Volcano Observatory, Monthly Bull., vol. 15, no. 7, pp. 52-54, July, 1927.

Wilson, W. B.

1. Geology of Glenn pool of Oklahoma: Am. Assoc. Petroleum Geologists, Bull., vol. 11, no. 10, pp. 1055-1065, 5 figs., October, 1927.

Wilson, William James, 1851-1920.

1. Notes on some fossil plants from New Brunswick: Canada Geol. Survey, Summ. Rept., 1917, pt. F, pp. 15-17, 1918.

Wiman, Carl.

1. Some reptiles from the Niobrara group in Kansas: Upsala, Univ., Geol. Inst., Bull., vol. 18, pp. 9-18, 9 figs., 3 pls., 1920.

Winchell, Alexander Newton. See also Winchell, N. H., 2.

1. (and Miller, E. R.). Further notes on the dust fall of March 9, 1918: Am. Jour. Sci., 4th ser., vol. 47, pp. 133-134, February, 1919. 
Winchell, Alexander Newton-Continued.

2. (and others). Handbook of mining in the Lake Superior region. Prepared for the Lake Superior meeting of the American Institute of Mining and Metallurgical Engineers, held in August, 1920. 260 pp., illus. (incl. maps) [Minneapolis, 1920].

3. The origin of graphite: Econ. Geology, vol. 16, no. 7, pp. 492-500, November, 1921.

4. (and Miller, E. R.). The great dust fall of March 19, 1920: Am. Jour. Sci., 5th ser., vol. 3, pp. 349-364, May, 1922.

5. Studies in the pyroxene group: Am. Jour. Sci., 5th ser., vol. 6, pp. 504-520, 7 figs., December, 1923.

6. Studies in the amphibole group: Am. Jour. Sci., 5th ser., vol. 7, pp. 287-310, 4 figs., April, 1924.

7. The properties of scapolite: Am. Mineralogist, vol. 9, no. 5, pp. 108112, 1 fig., May, 1924.

8. Petrographic studies of limestone alterations at Bingham [Utah] (with discussion) : Am. Inst. Min. and Met. Eng., Trans., vol. 70, pp. 884903, 9 figs., 1924 ; [preprint] no. 1322, 16 pp., 9 figs., March, 1924 ; abstract, Mining and Metallurgy, vol. 5, no. 211, p. 350, July, 1924.

9. The composition of melilite: Am. Jour. Sci., 5th ser., vol. 8, pp. 375-384, November, 1924.

10. Isotropic quartz: Am. Mineralogist, vol. 9 , no. 12, pp. 235-237, 2 figs., December, 1924.

11. Studies in the mica group: Am. Jour. Sci., 5th ser., vol. 9, pp. 309-327, 415-430, 5 figs., April, 1925; abstract, Am. Mineralogist, vol. 10, no. 3, pp. 52-54, March, 1925.

12. A new theory of the composition of the zeolites: Am. Mineralogist, vol. 10, nos. 4-7, pp. 88-97, 112-117, 145-152, 166-174, 6 figs., AprilJuly, 1925.

13. The $\mathrm{FeSiO}_{3}-\mathrm{CaSiO}_{3}-\mathrm{MgSiO}_{3}-\mathrm{NaFeSi}_{2} \mathrm{O}_{6}$ system of monoclinic amphibo'es: Am. Mineralogist, vol. 10, no. 10, pp. 335-341, 2 figs., October, 1925.

14. Studies in the feldspar group: Jour. Geology, vol. 33, no. 7, pp. 714-727, 6 figs., October-November, 1925.

15. A new kind of metamorphism and its application to the theory of ore deposits : Econ. Geology, vol. 20, no. 7, pp. 642-645, November, 1925.

16. Chlorite as a polycomponent system: Am. Jour. Sci., 5th ser., vol. 11, pp. 283-300, 4 figs., April, 1926.

17. Doubtful mineral species as illustrated by "faroelite": Am. Mineralogist, vol. 11, no. 4, pp. 82-89, April, 1926.

18. (and Emmons, R. C.). Some methods for determining refractive indices: Am. Mineralogist, vol. 11, no. 5, pp. 115-118, 2 figs., May, 1926.

19. The chemical constitution of the tetrahedrite-tennantite system: Am. Mineralogist, vol. 11, no. 7, pp. 181-185, July, 1926.

20. Relations between properties and composition in the amblygonite-montebrasite series: Am. Mineralogist, vol. 11, no. 9, pp. 246-249, 1 fig., September, 1926.

21. Notes on the triclinic pyroxenes: Am. Mineralogist, vol. 12, no. 1, pp. 10-14, January, 1927.

22. "Finger prints" of minerals: Science, new ser., vol. 65, p. 499, May 20, 1927.

23. "Finger prints" of minerals : Am. Mineralogist, vol. 12, no. 6, pp. 261262, June, 1927. 
Winchell, Alexander Newton-Continued.

24. Further studies in the mica group: Am. Mineralogist, vol. 12, no. 7, pp. 267-279, 2 figs., July, 1927.

25. Isomorphous relations of $\mathrm{MgSiO}_{3}$ and $\mathrm{AlAlO}_{3}$ in silicates: Am. Mineralo. gist, vol. 13, no. 2, pp. 52-56, 2 figs., February, 1928.

26. Additional notes on chlorite: Am. Mineralogist, vol. 13, no. 5, pp. 161170, 3 figs., May, 1928.

27. The composition of muscovite (further discussion): Am. Mineralogist, vol. 13, no. 11, pp. 567-569, November, 1928.

Winchell, Horace Vaughan, 1865-1923. See also Wheeler, 3.

1. Geology of Pachuca and El Oro, Mexico: Am. Inst. Min. and Met. Eng., Trans. [preprint], no: 1074, 14 pp., 1 fig.; June, 1921; vol. 66; pp. 27-41, 1 fig., 1922. Abstract, Mining and Metallurgy, no. 174, pp. 34-35, June, 1921.

Winchell, Newton Horace, 1839-1914.

1. (and Winchell, A. N.). Elements of optical mineralogy; an introduction to microscopic petrography. Second edition. Part 1, Principles and methods, 216 pp., 251 figs., New York, John Wiley \& Sons, 1922.

2. (and Winchell, A. N.). Elements of optical mineralogy, an introduction to mocroscopic petrography; entirely rewritten and much enlarged by Alexander $\mathrm{N}$. Winchell. $2 \mathrm{~d}$ ed., pt. 2, Descriptions of minerals, with special reference to their optic and microscopic characters. 424 pp., 333 figs., New York, John Wiley \& Sons, 1927.

Winchester, Dean Eddy.

1. Contorted bituminous shale of Green River formation in northwestern Colorado (abstract with discussion by E. O. Ulrich, David White, W. C. Alden, and G. H. Ashley) : Washington Acad. Sci., Jour., vol. 9, no. 10, pp. 295-296, May 19, 1919.

2. Oil shales: Franklin Inst., Jour., vol. 187, no. 6, pp. 689-703, June, 1919.

3. Geology of Alamosa Creek valley, Socorro County, New Mexico, with special reference to the occurrence of oil and gas: U. S. Geol. Survey, Bull. 716, pp. 1-15, 5 pls. (incl. map), 1920 ; abstract by M. I. Goldman, Washington Acad. Sci., Jour., vol. 11, no. 11, p. 260, June 4, 1921.

4. Distribution and importance of the oil-shale deposits of the United States: Coloradu School of Mines, Quart., vol. 17, no. 4, Supplement B, pp. 51-52, October, 1922; American Min. Congress, Twenty-fifth Ann. Convention, Rept. of Proc., pp. 756-758, 1922.

5. Oil shale of the Rocky Mountain region: U. S. Geol. Survey, Bull. 729, 204 pp., 4 figs., 18 pls. (incl. maps), 1923.

Wing, Monta Eldo.

1. The Silurian Gastropoda of northeastern Illinois (abstract): Chicago, Univ., Abstracts of Theses, Sci. Ser., vol. 1, pp. 311-317, October. 1925.

Wingard, J. H.

1. Statistics of the mineral production of Alabama for 1918: Alabama, Geol. Survey, Bull. no. 23, 155 pp., 1921.

2. Statistics of the mineral production of Alabama for 1919 and 1920: Alabama, Geol. Survey, Bull. no. 25, 146 pp., 1922.

3. Statistics of the mineral production of Alabama for 1921: Alabama Geol. Survey, Bull. no. 26, 111 pp., 1923. 
Winters, Elizabeth. See Johnson, D. W., 14.

Winton, Hortense.

1. (and Winton, W. M., and Scott, Gayle). Fossils; Natural history manual of the T. C. U. [Texas Christian University], vicinity [Tarrant County, Texas] (fourth edition): Texas Christian Univ. Bull., vol. 20, no. 2, pp. 47-58, 1 pl., March, 1924.

Winton, Will McClain. See also Adkins, 7 ; Winton, H., 1.

1. (and Adkins, W. S.). The geology of Tarrant County: Texas, Univ., Bull. no. 1931, 123 pp., 6 pls., 6 figs., 2 maps, 1920.

2. (and Scott, Gayle). The geology of Johnson County: Texas, Univ., Bull. no. 2229, 68 pp., 4 figs., 4 pls., map, 1922.

3. The geology of Denton County: Texas, Univ., Bull. no. 2544, 86 pp., 8 figs., 21 pls., map, November 22,1925 .

4. Report of the Fort Worth section meeting: Jour. Paleontology, vol. 1, no. 4, pp. 311-312, January, 1928.

Wisconsin Geological Survey.

1. Fourteenth biennial report of the Commissioners of the Geological and Natural History Survey covering the period from July 1, 1922, to June 30, 1924. 44 pp., Madison, Wisconsin, 1924.

Wisser, Edward.

1. Oxidation subsidence at Bisbee, Arizona: Econ. Geology, vol. 22, no. 8, pp. 761-790, 20 figs., December, 1927.

Wissler, Stanley G. See Galloway, 8.

Withers, Spencer. See Kentucky G. S., 49.

Withers, Thomas Henry.

1.. On a new brachyurous crustacean from the Upper Cretaceous of Jamaica. Annals and Mag. Nat. Hist., 9th ser., vol. 10, pp. 534-511, 2 pls., November, 1922.

2. Some Cretaceous and Tertiary decapod crustaceans from Jamaica: Annals and Mag. Nat. Hist., 9th ser., vol. 13, pp. 81-93, 3 pls., January, 1924.

3. Some decapod crustaceans (Callianassa and Ranina) from the oligocene of. Washington State, U. S. A.: Annals and Mag. Nat. Hist., 9th ser., vol. 14, pp. 121-127, 1 pl., July, 1924.

4. Decapod crustaceans from the Oligocene of Anguilla: Annals and Mag. Nat. Hist., 9th ser., vol. 14, pp. 225-233, 1 pl., August, 1924.

5. A new cirripede from the Niobrara Cretaceous of Kansas: Annals and Mag. Nat. Hist., 9th ser., vol. 17, pp. 7-11, 1 fig., January, 1926.

6. Decapod crustaceans (Callianassa) from the Scotland beds of Barbados: Geol. Mag., vol. 63, pp. 104-108, 1 pl., March, 1926.

7. Scalpellum sanchezi, sp. n., a cirripede from the lower Miocene of Cuba: Ann. and Mag. Nat. Hist., 9th ser., vol. 18, pp. 616-621, 1 fig., 1 pl., December, 1926.

8. Ranina trechmanni, a new Cretaceous crab from Jamaica: Geol. Mag., vol. 64, pp. 176-180, 1 fig., 1 pl., April, 1927.

Wittich, Ernesto.

1. Ueber Lavahöhlen im Pedregal von San Angel bei Mexiko: Neues Jahrb., 1916, Bd. 1, H. 3, pp. 126-133, 4 pls., July 29, 1916... 
Wittich, Ernesto-Continued.

2. Fenómenos desérticos en los alrededores de San Luis Potosí : Soc. cient: “Antonio Alzate," Mem. y Rev., t. 37, no. 2, pp. 65-70, 3 pls., January, 1919.

3. Apuntes preliminares acerca de la zona minera de Guadalcázar, S. L. P. “Antonio Alzate," Mem. y Rev., t. 38, no. 3-4, pp. 101-120, 8 pls., March, 1919.

4. Apuntes preliminares acerca de la zona minera de Guadalcázar, S. L. P. [San Luis Potosí, México]: Petróleo, vol. 13, no. 196, pp. 5-6, April 10, 1920.

5. La fluorita en los criaderos de contacto y de cinabrio de Guadalcizar. S. L. P. [San Luis Potosí, México] : Petróleo, vol. 13, no. 197, p. 10, April 17, 1920.

6. Apuntes acerca del azufre con betán de las minas de Huascamá, Cerritos, S. L. P. [San Luis Potosi, México] : Boletín Minero, t. 9, nos. 5-6, pp. 614-616, May-June, 1920.

7. Observaciones acerca de placeres de cinabrio $\mathbf{y}$ oro, encontrados en el distrito de Guadalcázar, S. L. P. [San Luis Potosí, México] : Boletín Minero, t. 10, nos. 3-4, pp. 253-256, September-October, 1920.

8. La emersión moderna de la costa occidental de la Baja California: Soc. cient. "Antonio Alzate," Mem., t. 35, nos. 3-4, pp. 121-144, 10 pls., 1 fig., August, 1920.

9. Estudios geológicos sobre el mineral de El Chico, Hidalgo: Soc. cient. "Antonio Alzate," Mem., t. 38, nos. 9-10, pp. 321-349, 6 pls., July, 1920.

10. Contribución a la geología de Atotonilco el Grande, Hidalgo: Soc. cient. "Antonio Alzate," Mem. y. Rev., t. 38, nos. 11-12, pp. 407-427, 4 pls., 3 figs., January, 1921.

11. Ueber das Vorkommen von Quecksiber-Sulfiden in Sanden der Goldseifen bei Guadalcázar, San Luis Potosi, Mexiko: Zeitschr. prakt. Geologie, Jg. 29. H. 6, pp. 91-93, June, 1921.

12. Observaciones geológicas en la altiplanicie de San Juan de los Llauos, Puebla: Soc. cient. "Antonio Alzate," Mem. y. Rev., t. 39, no. 9-12, pp. 597-613, December, 1921; Bol. Minero, t. 12, no. 3, pp. 306314, September, 1921.

13. La fluorita en la República Mexicana: Bol. Minero, t. 12, no. 4, pp. 430 433, October, 1921.

14. (and Kratzert, J.). Ueber ein neues Vorkommen von Dumortierit im Granit bei Guadalcázar, Nordmexiko: Centralbl. Mineralogie, no. 21, pp. 648-650, November 1, 1921.

15. (and Kratzert, J.). Contribuciones á la mineralogía mexicana: Suc. cient. "Antonio Alzate," Mem. y Rev., t. 39, no. 9-12, pp. 651-661, December, 1921.

16. (and Ragotzy, Federico). La geologia de lá regiớn minera de Guadalcázar, San Luis Potosí : Bol. Minero, t. 12, no. 6, pp. 661-667, 12 pls., December, 1921; Soc. cient. "Antonio Alzate," Mem. y Rev., t. 40, nos. 2-6, pp. 145-178, 1 pl., 1922.

17. El descubrimiento del vanadio: Bol. Minero, t. 13, no. 1, pp. 4-15, January, 1922.

18. Observaciones acerca de la baritina en México: Bol. Minero, t. 13, no. 3, pp. 312-318, March, 1922.

19. Las calizas coraligenas del Tajo de Andonegui, Tampico, México: Bol. Minero, t. 13, no. 3, pp. 318-320, March, 1922. 
Wittich, Ernesto-Continued.

20. (and Kratzert, J.). Ueber vulkanische Quarz- und Glasaschen aus den Schuttkegeln von Guadalcázar, San Luis Potosí, Mexiko: Centralbl. Mineralogie, no. 9, pp. 258-261, May 1, 1922.

21. Los levantamientos de las costas mexicanas, en relación con las teorías sobre los movimientos de los continentes: Bol. Minero, t. 14, no. 1, pp. 7-15, July, 1922.

22. (and Kratzert, J.). Contribuciones a la mineralogía mexicana, IV : Soc. cient. "Antonio Alzate," Mem. y Rev., t. 40, no. 7-9, pp. 423-433, July-September, 1922.

23. Geologie und Nutzmineralien. In Mexiko; kurzer Bericht über die wirtschaftlichen Fortschritte im letzten Jahrzehnt mit statistischen Angaben, graphischen Darstellungen, und Karten. Consulado general de México en Alemania, Hamburgo, 1923.

24. Beitrag zur Geologie der Golfregion von Mexiko: Naturh.-medizin. Ver. Heidelberg, Verh., N. F., Bd. 15, Beilageheft 2, pp. 1-4, 1923.

25. Los minerales de Huautla, Morelos, y Chiautla, Puebla: Bol. Minero, t. 15, no. 3, pp. 320-345, 8 pls. (incl. map), March, 1923.

26. (and Kratzert, J.). Contribuciones a la mineralogía mexicana: Bol. Minero, t. 15, no. 4, pp. 475-479, April, 1923.

27. Skizze del: Geologie und der Minerallagerstätten von Mexiko: Freiberger geol. Gesellschaft, X. Bericht, pp. 13-18, April, 1925 [not seen]; abstract, Geol. Zentralblatt, Bd. 32, no. 7, pp. 327-328, October 15, 1925.

28. Los depósitos de Tecal (ónix-mármol) y las salinas de la región de Chila y Tulcingo, Estado de Puebla: Soc. cient. "Antonio Alzate," Mem. y rev., t. 45 , nos. 1-6, pp. 115-128, 1926.

Wolf, Albert G.

1. Gulf coast salt domes: Colorado School of Mines Mag., vol. 10, no. 9, pp. 171-177, 3 figs., September, 1920.

2. Relation of topography to the oil fields of the Texas Gulf Coastal region: Eng. and Min. Jour., vol. 111, no. 11, pp. 474-475, March 12, 1921.

3. The White Point gas field [San Patricio County, Texas] : Eng. and Min. Jour., vol. 113, no. 4, pp. 174-175, 4 figs., January 28, 1922.

4. The origin of salt domes: Eng. and Min. Jour.-Press, vol. 115, no. 9, pp. 412-414, March 3, 1923.

5. Big Hill salt dome, Matagorda County, Texas: Am. Assoc. Petroleum Geologists, Bull., vol. 9, no. 4, pp. 711-737, 3 figs., July, 1925; Geology of salt dome oil fields, pp. 691-717, 3 figs., 1926.

6. Hauerite in a salt-dome cap rock [Matagorda County, Texas] : Am. Assoc. Petroleum Geologists, Bull., vol. 10, no. 5, pp. 531-532, 1 fig. May, 1926.

Wolff, John Eliot.

1. Charles Richard Van Hise (1857-1918) : Am. Acad. Arts and Sci., Proc, vol. 55, no. 10, pp. 511-512, November, 1920.

2. Mount Monadnock, Vermont, a Monteregian Hill (abstract with discussion by F. D. Adams and others): Geol. Soc. America, Bull., vol. 33. no. 1, pp. 127-128, March 31, 1922.

3. Cloudburst on San Gabriel Peak, Los Angeles County, California: Geol Soc. America, Bull., vol. 38, no. 3, pp. $443-450,7$ figs., September' 1927 : abstract, vol. 39, no. 1, p. 266, March 30, 1928. 
Wolff, Julius Frederic.

1. Recent geologic development on the Mesabi iron range, Minnesota (discussion) : Am. Inst. Min. and Met. Eng., Trans., vol. 61, pp. 113$115,1920$.

Wolford, John J. See Wentworth, 38.

Wood, Casey A.

1. The fossil eggs of Bermudan birds: Ibis, 11th ser., vol. 5, no. 2, pp. 193-207, 3 pls., April, 1923.

Wood, George McLane.

1. The geology of Mount Desert: Text on back of topographic sheet, Maine (Hancock County), Lafayette National Park, U. S. Geol. Survey, 1922.

Wood, Harry Oscar. See also Anderson, J. A., 2; W.illis, 10, 17.

1. The tectonic aspect of volcanic eruption in Hawaii: Pan-Pacific Scientific Conference, First, Proc., Bernice P. Bishop Mus., Spec. Pub. no. 7 , pt. 2, pp. 346-353, 1921.

2. "Regional" versus "world" seismology in relation to the Pacific basin: Pan-Pacific Scientific Conference, First, Proc., Bernice P. Bishop Mus., Spec. Pub. no. 7, pt. 2, pp. 387-391, 1921.

3. On a piezo-electrical accelerograph: Seismol. Soc. America, Bull., vol. 11, no. 1, pp. 15-57, 9 figs., 2 pls., March, 1921.

4. Some considerations touching on isostasy: Geol. Soc. America, Bull., vol. 33, no. 2, pp. 303-316, 1 fig., June 30, 1922.

5. Earthquake reports: Seismol. Soc. America, Bull., vol. 14, no. 1, pp. 60-64, March, 1924.

Wood, Horace Elmer, 2 d.

1. The problem of the Uintatherium molars: Am. Mus. Nat. Hist., Bull., vol. 48, pp. 599-604, 4 figs., 1923.

2. The position of the "sparassodonts"; with notes on the relationships and history of the Marsupialia: Am. Mus. Nat. Hist., Bull., vol. 51, pp. 77-101, 57 figs., 2 tables, September 19, 1.924.

3. (and Mannhardt, L. Alfred). Oligocene section in Battle Creek Canyon, Washington County, South Dakota (abstract) : Geol. Soc. America. Bull. vol. 36, no. 1, pp. 222-223, March 30, 1925.

4. Hyracodon petersoni, a new cursorial rhinoceros from the lower Oligocene: Carnegie Mus., Annals, vol. 16, no. 2, pp. 315-318, 1 fig., 1 pl.. March, 1926.

5. Some early Tertiary rhinoceroses and hyracodonts (abstract): Geol. Soc. America, Bull., vol. 37, no. 1, pp. 238-239, March 30, 1926.

6. Some early Tertiary rhinoceroses and hyracodonts: Bull. Am. Paleont, vol. 13, no. 50, 104 pp., 7 pls., December 3, 1927.

Woodard, John.

1. Origin of prairies in Illinois: Illinois State Acad. Sci., Trans., vol. 16, pp. 259-263, 1923.

Woodbridge, Dwight Edwards.

1. Iron-ore deposits on the Belcher Islands [Hudson Bay]: Eng. and Min. Jour., vol. 112, no. 7, pp. 251-254, 4 figs., August 13, 1921.

Woodford, Alfred Oswald. See also Clark, B. L., 18.

1. The Catalina metamorphic facies of the Franciscan series: California, Univ., Dept. Geol. Sci., Bull., vol. 15, no. 3, pp. 49-68, 2 figs., 3 pls., September 19, 1924. 
Woodford, Alfred Oswald-Continued.

2. Methods for heavy mineral investigations: Econ. Geology, vol. 20, no. 1, pp. 108-104, January-February, 1925.

3. The San Onofre breccia; its nature and origin: California, Univ., Dept. Geol. Sciences, Bull., vol. 15, no. 7, pp. 159-280, 11 figs., 13 pls. (incl. maps), May 20, 1925.

4. (and Bailey, T. L.). Northwestern continuation of the San Onofre breccia: California, Univ., Dept. Geol. Sci., Bull., vol. 17, no. 5, pp. 187-191, 1 fig., March 9, 1928.

5. (and Harris, T. F.). Geology of Blackhawk Canyon, San Bernardino Mountains, California (abstract): Geol. Soc. America Bull., vol. 39 , no. 1, p. 268, March 30, 1928.

6. The San Quintin volcanic field, Lower California: Am. Jour Sci., 5th ser., vol. 15, pp. 337-345, 3 figs., April, 1928.

7. (and Harriss, T. F.). Geology of Blackhawk Canyon, San Bernardino Mountains, California : California, Univ., Dept. Geol. Sci., Bull., vol. 17, no. 8, pp. 265-304, 4 figs., 6 pls., June 20, 1928.

Woodring, Wendell Phillips. See also Vaughan, 16.

1. Stratigraphy, structure, and possible oil resources of the Miocene rocks of the central plain: Haiti, Geol. Survey, 19. pp., map, Washington, 1922.

2. Middle Eocene Foraminifera of the genus Dictyoconus from the Republic of Haiti : Washington Acad. Sci., Jour., vol. 12, no. 10, pp. 244-247, May 19, 1922.

3. Tertiary mollusks of the genus Orthanlax from the Republic of Haiti, Porto Rico, and Cuba: U. S. Nat. Mus., Proc., vol. 64, art. 1, 12 pp., 1 pl., 1923.

4. An outline of the results of a geological reconnaissance of the Republic of Haiti : Washington Acad. Sci., Jour., vol. 13, no. 7, pp. 117-129, April 4, 1923.

5. (and Brown, John S., and Burbank, Wilbur S.). Geology of the Republic of Haiti. 631 pp. (French edition, 710 pp.), 37 figs., 40 pls. (incl. maps), Republic of Haiti, Department of Public Works, Port-auPrince, 1924.

6. Some new Eocene Foraminifera of the genus Dictyoconus: Geology of the Republic of Haiti, pp. 608-610, illus., 1924.

7. (and Mansfield, Wendell C.). Some new middle Eocene and lower Miocene mollusks: Geology of the Republic of Haiti, pp. 611-613, illus., 1924.

8. Tertiary history of the north Atlantic Ocean: Geol. Soc. America, Bull., vol. 35 , no. 3 , pp. $425-435$, September 30,1924 ; abstract, with discussion by Charles Schuchert, A. C. Lawson, W. M. Bowie, ant W. H. Hobbs, no. 1, pp. 84-85, March 30, 1924; abstract, Pan-Am. Geologist, vol. 41, no. 2, pp. 142-143, March, 1924.

9. West Indian, Central American, and European Miocene and Pliocene mollusks: Geol. Soc. America, Bull., vol. 35, no. 4, pp. 867-886, 4 figs., December 30, 1924; abstract, no. 1, pp. 175-176, March 30, 1924.

10. Mincene mollusks from Bowden, Jamaica; pelecypods and scaphopods: Carnegie Inst. Washington, Pub. no. 366, 222 pp., 28 pls., May, 1925.

11. Quaternary leef caps of Republic of Haiti (abstract) : Pan-Am. Geologist, vol. 43, no. 5, pp. 376-377, June, 1925.

12. Arca patricia Sowerby, a Miocene fossil from the Dominican Republic: Science, new ser., vol. 62, pp. 518-519, December 4, 1925. 
Woodring, Wendell Phillips-Continued.

13. Miocene climate of tropical America (abstract) : Washington Acad. Sci., Jour., vol. 16, no. 3, p. 77, February 4, 1926.

14. Pliocene Viviparus-like opercula from California: Nautilus, vol. 39, no. 4, pp. 109-111, April, 1926.

15. Fossil Viviparus-like calcareous opercula: Nautilus, vol. 40, no. 1, pp. 12-14, July, 1926.

16. How fossils got into the rocks: Sci. Monthly, vol. 23, no. 4, pp. 337-345, 6 figs., October, 1926.

17. American Tertiary mollusks of the genus Clementia: U. S. Geol. Survey, Prof. Paper 147, pp. 25-42, 1 fig., 4 pls., November 22, 1926.

18. Geologic history and paleobiologic significance of the genus Clementia (abstract) : Washington Acad. Sci., Jour., vol. 17, no. 5, p. 128, March 4, 1927.

19. (and Roundy, P. V.). Geology and oil development of the Elk Hills, California (abstract) : Washington Acad. Sci., Jour., vol. 17, no. 10, pp. 271-272, May 19, 1927.

20. Distribution in tropical America of turritellas of phylum of Turritella ocoyana (abstract) : Pan-Am. Geologist, vol. 49, no. 4, pp. 314-31.5, May, 1928.

21. Ecology of mollusks of Bowden formation, Jamaica (abstract) : Pan-Am. Geologist, vol. 49, no. 14, pp. 317-318, May, 1928.

22. Miocene mollusks from Bowden, Jamaica; Part II, Gastropods and discussion of results: Carnegie Inst. Washington, Pub. no. 385, 564 pp., 3 figs., 40 pls., November 28, 1928.

23. Tectonic features of the Caribbean region: Third Pan-Pacific Sci. Cong., Tokyo, 1926, Proc., pp. 401-43i, 1 fig., 1928.

Woodruff, Elmer Grant. See also Brokaw, 1; Moore, R. C., 17; Schuchert, 8 .

1. Petroliferous provinces: Am. Inst. Min. and Met. Eng., Bull., no. 150, pp. 907-912, 1 fig., June, 1919, discussion by Irving Perrine and C. W. Washburne, Bull. no. 156, pp. 3146-3147, December, 1919 ; Trans., vol. 65, pp. 199-216, 1 fig., 1921.

2. Notebook form and symbols for petroleum geologists: Econ. Geology, vol. 14, no. 5, pp. 424-426, 2 figs., August, 1919.

3. The science of petroleum geology : Am. Assoc. Petroleum Geologists, Bull,, vol. 5, no. 4, pp. 446-450, July-August, 1921.

4. (and Cooper, C. L.). Oil and gas in Oklahoma; geology of Rogers County : Oklahoma Geol. Survey, Bull. no. 40-U, 24 pp., 3 figs., 2 pls (incl. map), March, 1928.

Woods, Sam H. See Tomlinson, 4.

Woods, Thomas S.

1. The porphyry intrusions of the Michigan copper district: Eng. and Min. Jour., vol. 107, pp. 299-302, 3 figs., February 15, 1919.

Woodward, Arthur Smith.

1. A supposed ancestral man in North America [Hesperopithecus haroldcookii] : Nature, vol. 109, p. 750, June 10, 1922.

2. Dr. John M. Clarke: Nature, vol. 116, p. 368, September 5, 1925.

3. Dr. C. D. Walcott: Nature, vol. 119, pp. 325-326, February 26, 1927.

Woodward, Robert Simpson, 1849-1924.

1. The compressibility of the earth (abstract) : Washington Acad Sci., Jour., vol. 13, no. 3, pp. 44-45, February 4, 1923. 
Woodworth, Jay Backus, 1865-1925. See also Brown C. W., 2 ; Foye, 4.

1. Relations of fault-block mountains to folded chains (abstract with discussion by W. H. Hobbs and W. M. Davis) : Geol. Soc. America, Bull., vol. 31, no. 1, pp. 115-116, March 31, 1920.

2. Report on the department of geology and geography: Harvard College, Mus. Comp. Zool., Ann. Rept., 1920-21, pp. 13-16, 1921.

3. Cross section of the Appalachians in southern New England: Geol. Soc. America, Bull., vol. 34, no. 2, pp. 253-261, June 30, 1923.

Woolard, Edgar W.

1. The Virginia earthquake of September 5, 1919: Monthly Weather Re. view, vol. 47, p. 839 , November, 1919.

Woolnough, W. G.

1. Carbon ratios as an index of oil and gas: Econ. Geology, vol. 23, no. 7, pp. 809-810, November, 1928.

2. Origin of white clays and bauxite, and chemical criteria of peneplanation: Econ. Geology, vol. 23, no. 8, pp. 887-894, December, 1928.

Woolsey, W. J.

1. Asbestos in California: Pacific Min. News, vol. 1, no. 4, pp. 104-106, 4 figs., August, 1922.

Wooster, Lyman Child.

1. Glacial moraines in the vicinity of Estes Park, Colorado: Kansas Acad. Sci., Trans., vol. 29, pp. 91-94, 1920.

2. The geology of Kansas. 43 pp., 6 figs. [Emporia, Kansas], 1928. [Pri vate publication.]

Worcester, Philip George.

1. The geology of the Ward region, Boulder County, Colorado: Colorado Geol. Survey, Bull. 21, 74 pp., 2 maps [1921].

2. The physiography of Colorado (abstract) : Chicago, Univ., Abstracts of Theses, Sci. Ser., vol. 2, pp. 239-247, September, 1926.

Wordie, J. M.

1. The Cambridge expedition to east Greenland in 1926 ; geology : Geog. Jour., vol. 70, no. 3, pp. 252-253, September, 1927.

Workman, L. E. See also Bell, A. H., 8.

1. The geological columnar section at Monmouth, Illinois, as revealed by the new deep wells: Illinois State Acad. Sci., Trans., vol. 19, pp. 300-305, 1926.

Wortman, Jacob Lawson, 1856-1926.

1. On some hitherto unrecognized reptilian characters in the skull of the Insectivora and other mammals: U. S. Nat. Mus., Proc., vol. 57, pp. 1-52, 16 figs., 1920.

Wrather, William Embry. See also Brokaw, 1; Stone, 11.

1. The Vinton, Louisiana, oil field: Am. Assoc. Petroleum Geologists, Bull., vol. 5, no. 2, pp. 339-340, March-April, 1921.

2. The Mexia [oil] pool, Mexia, Texas: Am. Assoc. Petroleum Geologists, Bull., vol. 5, no. 3, pp. 419-421, May-June, 1921.

3. Supposed igneous rock from Wichita County, Texas, wells: Am. Assoc. Petroleum Geologists, Bull., vol. 5, no. 4, pp. 512-515, 1 pl., JulyAugust, 1921.

4096-31- - 44 
Wrather, William Embry-Continued.

4. The Mirando Oil Company well, Zapata County, Texas: Am. Assoc. Petroleum Geologists, Bull., vol. 5, no. 5, pp. 625-626, SeptemberOctober, 1921.

5. Dinosaur tracks in Hamilton County, Texas: Jour. Geology, vol, 30, no. 5, pp. 354-360, 5 figs., July-August, 1922.

6. Obituary, Rollin D. Salisbury: Am. Assoc: Petroleum Geologists, Bull., vol. 6, no. 6, pp. 563-566, 2 figs. (portr.), November-December, 1922.

7. Memorial of William Kennedy: Geol. Soc. America, Bull., vol. 39, no. 1, pp. 29-34, portr., March 30, 1928.

8. What of our future oil supply? : Econ. Geology, vol. 23, no. 3, pp. 331-333, May. 1928.

Wright, Albert, jr.

1. (and Sweet, P. W. K.). The Jurassic as a source of oil in western Cuba: Am. Assoc. Petroleum Geologists, Bull., vol. 8, no. 4, pp. 516-519, July-August, 1924.

Wright, Clarence A. See Varley, 1.

Wright, Douglas G. H.

1. The Black River area: Ontario Dept. Mines, 30th Ann. Rept., vol. 30, pt. 6, pp. 27-62, 18 figs., map, 1922.

2. Geology of the Watabeag area, district of Timiskaming and Cochrane: Ontario Dept. Mines, 31st Ann. Rept., vol. 31, pt. 7, 33 pp., 15 figs., map, 1922.

3. (and Segsworth, Walter E.). Extension of the Porcupine gold belt into Quebec: Eng.and Min. Jour.-Press, vol. 117, no. 19, pp 763-764, 1 fig., May 10, 1924.

4. The Red Lake gold area [District of Patricia, Ontario] : Eng. and Min. Jour., vol. 122, no. 1, pp. 15-20, 1 fig. (map), July 3, 1926.

Wright, Floyd E.

1. Oil and gas [in Indiana]: Indiana, Dept. Geology and Nat. Res., 41.st Ann. Rept., pp. 114-121, 2 maps, 1917.

2. Report of the State supervisor of natural gas: Indiana, Year Book 1918, pp. 207-212, 1919.

Wright, Frank James.

1. The physiography of the upper James River basin in Virginia: Virginia Geol. Survey, Bull. no. 11, 67 pp., 7 figs., 13 pls., 1925.

2. The Blue Ridge of Southern Virginia and western North Carolina: Denison Univ. Bull., Sci. Lab., Jour., vol. 22, pp. 116-132, 4 figs., 2 pls., March, 1927.

3. Gravels on the Blue Ridge: Denison Univ. Bull., Sci. Lab., Jour., vol. 22, pp. 133-135, 1 fig., March, 1927.

4. The erosional history of the Blue Ridge (abstract) : Ohio Acad. Sci., Proc., vol. 8 , pt. 4, p. 180, 1928 ; Ohio Jour. Sci., vol. 28, no. 3, p. 158, May, 1928.

5. The erosional history of the Blue Ridge: Denison Univ., Bull., vol. 28, no. 10, Sci. Lab., Jour., vol. 23, pp. 321-344, 6 pls., December 31, 1928.

Wright, Frederick Eugene. See also Am. Geophysical Union, 1; Bowie, 24 ; Smith, G. O., 31.

1. Polarized light in the study of ores and metals: Am. Philos. Soc., Pruc., vol. 58, no. 7, pp. 401-447, 12 figs., 191.9. 
Wright, Frederick Eugene-Continued.

2. Examination of ores and metals in polarized light: Mining and Metallurgy, no. 158, sec. 1 pp. 44-45 (abstract), sec. 9, 12 pp., 3 figs., February, 1920; Am. Inst. Min. and Met. Eng., Trans., vol. 63, pp. 370381, 3 figs., 1920.

3. Experimental studies of the formation of jointing planes (abstract): Geol. Soc. Ameriea, Bull., vol. 31, no. 1, p. 120, March 31, 1920.

4. Experiments illustrating development of igneous rock textures (abstract) : Geol. Soc. America, Bull., vol. 31, no. 1, p. 141, March 31, 1920.

5. Methods for distinguishing natural from cultivated pearls: Washington Acad. Sci., Jour., vol. 13, no. 13, pp. 282-287, 2 figs., July 19, 1923.

6. Stereoscopic photography in geological field work: Washington Acad. Sci., Jour., vol. 14, no. 3, pp. 63-72, 2 figs., February 4, 1924 ; abstract, Geol. Soc. America, Bull., vol. 35, no. 1, p. 113, March 30, 1924 ; Pan-Am. Geologist, vol. 41, no. 2, p. 156, March, 1924.

7. Gravity and underground lava (abstract with discussion): Washington Acad. Sci., Jour., vol. 15, no. 18, p. 421, November 4, 1925; Bull. volcanologique, $2^{\mathrm{e}}$ ann., nos. 5-6, pp. 332-333, 1925.

8. Memorial of Robert Simpson Woodward: Geol. Soc. America, Bull., vol. 37, no. 1, pp. 115-134, 1 pl. (portr.), March 30, 1926.

9. (and Allen, E. T.). Curtisite, a new organic mineral from Skaggs Springs, Sonoma County, Califörnia (abstract) : Am. Mineralogist, vol. 11., no. 3, p. 67, March, 1926.

10. Gravity on the earth and on the moon: Sci. Monthly, vol. 24, no. 5, pp. 448-462, May, 1927.

11. Factors bearing on the formation of craters on the moon: Nat. Research Council, Bull. no. 61, pp. 266-269, July, 1927.

Wright, George Frederick, 1838-1921.

1. Charles Conrad Abbott and Ernest Volk [human remains in Trenton, New Jersey, gravels] : Science, new ser., vol. 50, pp. 451-453, November 14, 1919.

2. The ice age in North America. Sixth enlarged edition, supplementary chapter [preface]. 24 pp., 1 fig., Bibliotheca Sacra Company, Oberlin, Ohio [1920?].

3 The preglacial outlet of Lake Erie: Science, new ser., vol. 53, pp. 286-287, March 25, 1921.

4. Origin and distribution of the loess (abstract) : Geol. Soc. America, Bull., vol. 32, no. 1, pp. 48-49, March 31, 1921.

Wright, John Frank.

1. Brockville-Malloryton map area, Ontario: Canada, Geol. Survey, Summ. Rept., 1920, pt. D, pp. 78-84, 1 fig., 1921.

2. Brockville-Mallorytown map area, Ontario: Canada, Geol. Survey, Mem. 134, 63 pp., 2 figs., 4 pls., map, 1923.

3. Rice Lake map area, southeastern Manitoba: Canada, Geol. Survey, Summ. Rept., 1922, pt. C, pp. 45-82, 5 figs., 3 pls., map, 1923.

4. Geology and mineral prospects of the northern part of Beresford Lake map area, southeast Manitoba: Canada, Geol. Survey, Summ. Rept., 1923, pt. B, pp. 86-104, 1 fig., map, 1924.

5. Wabigoon and Trap Lake soapstone deposits, Ontario: Canadian Min. Jour., vol. 45, no. 36, pp. 871-872, September 5, 1924.

6. The central Manitoba gold field; some geological notes on the east certral Manitoba (Rice Lake) gold area: Canadian Min. Jour., vol. 46, no. 4, pp. 91-95, 5 figs. (incl. map), January 23, 1925. 
Wright, John Frank-Continued.

7. Oiseau and Maskwa copper and copper-nickel deposits, southeastern Manitoba: Canadian Inst. Min. and Met., Bull. no. 155, pp. 220-231, 1 fig. (map), March, 1925; Trans., vol. 28, pp. 161-173, 1 fig. (map) [1926].

8. The geology of the Brockville-Mallorytown map area [Ontario] (abstract): Chicago Univ., Abstracts of Theses, Sci. Ser., vol. 1, pp. 319-323, October, 1925.

9. Geology and mineral deposits of the east central Manitoba mining district (with discussion) : Canadian Inst. Min. and Met., Bull. no. 164, pp. 1146-1164, 9 figs., December, 1925; Trans., vol. 28, pp. 311-329, 9 figs. [1926].

10. Geology and mineral deposits of Oiseau River map area, Manitoba; Canada, Geol, Survey, Summ. Rept., 1924, pt. B, pp. 51-104, 1 . fig., 4 pls., 2 maps, 1926.

11. Oxford and Knee lakes area, northern Manitoba: Canada, Geol. Survey, Summ. Rept., 1925, pt. 3, pp. 16-26, map, 1926.

12. Island Lake area, Manitoba: Canada, Geol. Survey, Summ. Rept., 1927, pt. B, pp. 54-80, 2 pls. (maps), 1928.

Wright, Lawrence $B$. See also Hosted, 1.

1. (and Hosted, J. O.). Geological methods of the Homestake Mining Co., Lead, South Dakota: Eng. and Min. Jour-, vol. 112, no. 23, pp. 886-889, 6 flgs., December 3, 1921.

2. Porphyries of the Porcupine area [Ontario]: Eng. and Min. Jour.-Press, vol. 119, no. 11, pp. 446-447, March 14, 1925 .

3. The relation of the Tertiary rhyolites to mineralization in the Homrestake mine: Black Hills Engineer, vol. 14, no. 3, pp. 163-166, 1 fig., May, 1926.

Wright, William Josiah.

1. Investigations in New Brunswick and Nova Scotia: Canada, Geol. Survey, Summ. Rept., 1919, pt. F, pp. 1-2, 1920.

2. Geology of the Moncton map-area [New Brunswick]: Canada, Geol. Survey, Mem. 129, 69 pp., 3 figs., 7 pls., 4 maps, 1922.

Wuensch, C. Erb.

1. Statistical treatise on gold and silver: Colorado School of Mines Mag., vol. 9, no. 5, pp. 109-113, May, 1919.

2. Seconciary enrichment at Eagle mine, Bonanza, Colorado: Am. Inst. Min. and Met. Eng., Trans., vol. 69, pp. 96-109, 1 fig., 1923 ; [preprint] no. 1251, 14 pp., 1 fig., June, 1923; abstract, Mining and Metallurgy, vol. 4, no. 198, pp. 307-308, 1 fig., June, 1923.

Wyckoff, Dorothy.

1. Maps without culture; a new aid in the teaching of physiography: Jour. Geography, vol. 25, no. 8, pp. 307-309, November, 1926.

Wyckoff, Ralph Walter Graystone. See also Bowen, 21.

1. The crystal structures of some carbonates of the calcite group: Am. Jour. Sci., 4th ser., vol. 50, p. 317-360, 18 flgs., November, 1920.

2. The determination of the structure of crystals: Franklin Inst., Jour., vol. 191, no. 2, pp. 199-230, 26 figs., February, 1921.

3. The crystal structure of alabandite (MnS) [Puebla, Mexico]: Am. Jour. Sci., 5th ser., vol. 2, pp. 239-249, 4 figs., November, 1921. 
Wyckoff, Ralph Walter Graystone-Continued.

4. A survey of existing crystal structure data: Franklin Inst., Jour., vol. 195 , no. 2 , pp. $183-210$, no. 3 , pp. 349-365, no. 4 , pp. 531-552, 20 figs., February, March, and April, 1923.

5. (and Merwin, H. E., and Washington, H. S.). X-ray diffraction patterns of the pyroxenes (abstract, with discussion by W. P. White): Geol. Soc. America, Bull., vol. 35, no. 1, pp. 110-111, March 30, 1924 ; abstract, Pan-Am. Geologist, vol. 41, no. 2, pp. 154-155, March, 1924.

6. (and Merwin, Herbert E.). The crystal structure of dolomite: Am Jour. Sci., 5th ser., vol. 8, pp. 447-461, 8 figs., December, 1924; abstract, Geol. Soc. America, Bull., vol. 35, no. 1, p. 111, March 30, 1924; Pan-Am. Geologist, vol. 41, no. 2, p. 155, March, 1924.

Wylie, Charles Clayton.

1. The Tilden meteor, an Illinois daylight fall: Science, new ser., vol. 66, p. 451, November $11,1927$.

Wyman, L. E.

1. Notes on the Pleistocene fossils obtained from Rancho La Brea asphalt pits: Los Angeles County Museum of History, Science, and Art, Dept. Natural Sciences, Misc. Pub. no. 2, 35 pp., 22 figs., May, 1918.

Wysor, D. C.

1. Diaspore clay of Arkansas and Missouri: Am. Ceramic Soc., Jour., vol. 6, no. 3, pp. 501-505, 1 fig., March, 1923.

Yabe, Hisakatsu.

1. (and Shimizu, Saburo). A note on the genus Mortoniceras: Japanese Jour. Geology and Geography, vol. 2, no. 2, pp. 27-30, Tokyo, 1923.

Yates, Arthur B.

1. The occurrence of quartz in the Homestake mine [Lead, South Dakota]: Black Hills Engineer, vol. 14, no. 3, pp. 167-171, 2 figs., May, 1926.

Yeo, Herbert W.

1. Report on the Canadian River investigation: New Mexico, State Eng., 8th Bienn. Rept., pp. 259-297 [1928].

Yermoloff, Nicholas.

1. The diatomaceous earth of Lompoc, Santa Barbara County, California: Geol. Mag., vol. 57, pp. 271-277, June, 1920.

Young, A. C. See Rogers, W. R., 5, 7.

Young, Clinton Mason:

1. Kansas coal; occurrence and production : Kansas, Univ., Bull., vol. 26, no. 5. Eng. Bull. no. 13, pp. 13-123, 29 figs., March 1, 1925.

Young, George Albert. See also Canada G. S., 3.

1. Burnthill Brook map area, New Brunswick: Canada Geol. Survey, Summ. Rept., 1917, pt. F, pp. 1-1.5, 1 pl., 1 fig. (maps), 1918.

2. Coal seams of Gloucester County, New Brunswick: Canada, Geol. Survey, Summ. Rept., 1920, pt. E, pp. 1-5, 1921.

3. Iron-bearing rocks of Belcher Islands, Hudson Bay : Canada, Geol. Survey, Summ. Rept., 1921, pt. E, 61 pp., 3 figs. (maps), 1922.

4. Proposals regarding a time scale for the pre-Cambrian: Roy. Soc. Canada, Proc. and Trans., 3d ser., vol. 17, sec. 4, pp. 45-59, May, 1923. 
Young, George Albert-Continued.

5. Geology and economic minerals of Canada: Canada, Geol. Survey, Econ. Geology ser., no. 1, 187, 57 pp., 1 fig., 38 pls., 2 maps, 1926. [Pub. no. 2065.]

6. (and Uglow, W. L.). The iron ores of Canada; Volume 1, British CoIumbia and Yukon: Canada, Geol. Survey, Econ. Geology ser., no. 3, 253 pp., 44 figs., 1926.

Young, George Joseph.

1. Divide silver-gold district of Nevada: Eng. and Min. Jour., vol. 109, pp. 62-66, 7 figs., January 10, 1920.

2. Collapse of mountain summits: Sierra Club Bull., vol. 11, no. 3, pp. 290$291,1922$.

3. The Salmon River district of British Columbia and contiguous Alaska: Pacific Min. News, vol. 1, no. 8, pp. 225-230, 6 figs., December, 1922.

Young, Jackson. See also Moulton, 22.

Young, Jacob W.

1. The halogen salts of silver at Wonder, Nevada: Econ. Geology, vol. 14, no. 5, pp. 427-430, August, 1919.

2. The formation of the Sevier Valley in Utah: Eng. and Min. Jour., vol. 110 , no. 17 , p. 803 , October $23,1920$.

3. The flling of fissure veins: Eng. and Min. Jour.-Press, vol. 116, no. 15, pp. 639-640, October 13, 1923.

4. The Sudbury [Ontario] ore deposits: Econ. Geology, vol. 19, no. 7, pp. 677-681, November, 1924.

5. Origin of certain carbonaceous materials : Eng. and Min. Jour.-Press, vol. 118, no. 25, pp. 982-983, December 20, 1924.

6. On the inorganic origin of the hydrocarbons: Canadian Inst. Min. and Met., Bull. no. 162, pp. 952-966, October, 1925.

7. Angular inclusions in ore deposits (discussion) : Econ. Geology, vol. 21. no. 4, pp. 402-403, June-July, 1926.

Zambonini, Ferrucio.

1. The isomorphism of albite and anorthite (abstract by H. S. Washington) : Am. Mineralogist, vol. 8, no. 5, pp. 81-92, May, 1923.

Zapffe, Carl. See also Allen, R. C., 2.

1. Manganiferous iron ores of Cuyuna district, Minnesota: Am. Inst. Min. and Met. Eng., Trans., vol. 71, pp. 372-385, 1925 (with discussion) ; also [preprint], no. 1390, 1924; abstract, Mining and Metallurgy, vol. 6, no. 227 , pp. 573-574, November, 1925.

2. Stratigraphy and correlation of the Cuyuna iron ore district, Minnesota (with discussion by Hugh M. Roberts) : Lake Superior Min. Inst., Proc. 24th Ann. Meeting, vol. 24, pp. 89-105, pl. (map), 1925.

3. Further data on the correlation of the Cuyuna iron-bearing member [Minnesota] : Lake Superior Min. Inst., Proc., vol. 25, pp. 219-227, 2 figs., 1926.

4. Reserves of Lake Superior maganiferous iron ores: Am. Inst. Min. and Met. Eng., Trans., vol. 75, pp. 346-371, 3 figs., 1927.

5. Geologic structure of the Cuyuna iron district, Minnesota: Econ. Geology, vol. 23, no. 6, pp. 612-646, 11 figs., September-October, 1928.

Zavaritsky, A. N.

1. Classification of magmatic ore deposits: Econ. Geology, vol, 22, no, 7 , pp. 678-686, November, 1927. 
Ziegler, Victor.

1. Popular oil geology. 2d ed., 171 pp., 62 tigs., New York, John Wiley \& Sons, 1920.

2. Geologic and economic features of oil structures : Econ. Geology, vol. 15, no. 3, pp. 247-258, April-May, 1920.

Zies, Emanuel George. See also Allen, E. T., 2.

1. The fumarolic incrustations in the Valley of Ten Thousand Smokes: Nat. Geog. Soc., Contributed Technical Papers, Katmai ser., vol. 1., no. 1, pp. 157-179, 2 figs., 1924.

2. Fumarolic incrustations of the Katmai region (abstract): Geol. Soc. America, Bull., vol. 35, no. 1, p. 123, March 30, 1924; Pan-Am. Geologist, vol. 41, no. 2, p. 158, March, 1924.

3. Hot springs of the Valley of Ten Thousand Smokes: Jour. Geology, vol. 32 , no. 4, pp. 303-310, 1 fig., May-June, 1924.

4. The concentration of metallic constituents by volcanic emanations: Nat. Research Council, Bull. no. 61, pp. 263-265, July, 1927.

5. The acid gases contributed to the sea during volcanic activity (abstract) : Washington Acad. Sci., Jour., vol. 18, no. 19, pp. 511-512, November $19,1928$.

Zodac, Peter.

1. Rocks and Minerals, published quarterly at Peekskill, New York, vol. 1, no. 1, September, 1926-vol. 3, no. 4, December, 1928.

Zubiría y Campa, Luis.

1. La minería en el Estado de Durango [México]: Soc. cient. "Antonio Alzate," Mem. y Rev., t. 38, no. 3-4, pp. 177-198, map, March, 1919.

Zuschlag, T. H.

1. (and Kock, W.) The results of an electro-magnetic survey at Ducktown, Tennessee: Canadian Min. Jour., vol. 49, no. 32, pp. 636-638, 5 figs., August 10, 1928.

Anonymous.

1. Manganese ore in Georgia: Science, new ser., vol. 48 , pp. $360-362$, Octobel: 11, 1918.

2. Eminent living geologists; Charles Doolittle Walcott: Geol. Mag., new ser., dec. 6, vol. 6, pp. 1-10, portr., January, 1919.

3. Mining copper at Kennecott, Alaska: Min. and Sci. P'ress, vol. 118, pp. 5356, 3 figs., January 11, 1919.

4. Geology of Montreal River district of northern Ontario: Eng. and Min. Jour., vol. 107, pp. 575-576, March 29, 1919.

5. The deepest well: Min. and Sci. Pres. vol. 119, pp. 341-342, September 6, 1919.

6. Thirty million years ago; newly discovered pre-Cambrian sea wherein earth's first creatures were born: Sci. Am., vol. 120, pp. 682-683, 698, 6 figs., June 28, 1919.

7. The Knee Lake district in northern Manitoba: Min. and Sci. Press, vol. 121, pp. 306-307, 1 fig., August 28, 1920.

8. Notes on Canadian minerals: Toronto, Univ., Studies, Geol. ser. no. 12, pp. $69-72,1921$.

9. Society of Economic Geologists holds meeting in Chicago [December 28-30, 1920] : Eng. and Min. Jour., vol. 111, no. 2, pp. 65-67, January $8,1921$.

10 The oil fields in the Northwest Territory: Canadian Inst. Min. and Met., Monthly Bull. no. 105, pp. 15-16, January, 1921. 
Anonymous-Continued.

11. Important oil fields in northern Canada: Am. Assoc. Petroleum Genlogists, Bull., vol. 5, no. 1, pp. 85-87, January-February, 1921.

12. An eminent living American geologist and paleontologist-Professor John M. Clarke: Geol. Mag., vol. 58, pp. 292-294, portr., July, 1921.

13. Frederick Leslie Ransome: Eng. and Min. Jour., vol. 112, no. 3, pp. 99, portr., July 16, 1921.

14. Frank L. Hess: Eng. and Min. Jour-Press, vol. 113, no. 2, p. 57, portr., January 14, 1922.

15. James Furman Kemp: Eng. and Min. Jour-Press, vol. 113, no. 9, p. 367, portr., March 4, 1922.

16. Second annual meeting of the Mineralogical Society of America: Am. Mineralogist, vol. 7, no. 3, pp. 45-50, March, 1922.

17. Restorations figuring Miocene fishes: Natural History (Jour. Am. Mus. Nat. Hist.), vol. 22, no. 3, pp. 271-274, 10 figs., May-June, 1922.

18. Horace V. Winchell: Eng. and Min. Jour.-Press, vol. 113, no. 21, p. 926, portr., May 27, 1922.

19. An American anthropoid primate [Hesperopithecus haroldcookii, Nebraska]: Sci. Monthly, vol. 14, no. 6, pp. 588-590, 2 figs., June, 1922.

20. Magnesite in southern Nevada: Science, new ser., vol. 56, p. 69, July 21, 1922.

21. The Shenandoah Caverns, Virginia: Science, new ser., vol. 56, pp. 240-241, September 1, 1922.

22. The New England intercollegiate geological excursion: Science, new ser., vol. 56, pp. 442-443, October 20, 1922.

23. A forest under the City of Washington: Science, new ser., vol. 56, pp. 529-530, November 10, 1922.

24. Benjamin Leroy Miller: Eng. and Min. Jour.-Press, vol. 114, no. 25, p. 1060, portr., December 16, 1922.

25. Charles D. Walcott, president of the American Association for the Advancement of Science for the year 1923: Science, new ser., vol. 57, pp. 120-121, January 26, 1923.

26. The late Dr. J. D. Mackenzie, M. C.: Canadian Inst. Min. and Met., Monthly Bull., no. 129, pp. 65-67, portr., January, 1923.

27. Economic geologists meet at Ann Arbor [December, 1922]: Eng. and Min. Jour.-Press, vol. 115, no. 1, pp. 27-28, January 6, 1923.

28. Economic geologists hold annual technical meeting [in New York City, May 18 and 19, 1923] : Eng. and Min. Jour.-Press, vol. 115, no. 21, pp. 942-944, May 26, 1923.

29. Horace V. Winchell [obituary notice] : Eng. and Min. Jour.-Press, vol. 116, no. 5, p. 203, portr., August 4, 1923.

30. Petroleum possibilities in deep sands near Osage field, Wyoming: Eng. and Min. Jour.-Press, vol. 116, no. 9, p. 376, September 1, 1923.

31. Obituary, Professor Raphael Pumpelly: Am. Jour. Sci., 5th ser., vol. 6, pp. 375-376, October, 1923.

32. A prominent Canadian geologist, Willet G. Miller: Eng. and Min. Jour.Press, vol. 116, no. 10, p. 664, portr., October 20, 1923.

33. Smoky River coal field [northwestern Alberta]: Canadian Min. Jour., vol. 45, no. 13, pp. 308-310, 2 figs., March 28, 1924.

34. Nova Scotia's mineral resources: Canadian Min. Jour., vol. 45, no. 14, pp. 328-331, April 4; 1924. 
Anonymous-Continued.

35. Production of petroleum in 1923: Am. Inst. Min. and Met. Eng., no. 1335, 264 pp., April, 1924.

36. Dr. Frank Dawson Adams: Canadian Min. Jour., vol. 45, no. 21, pp. 493494, portr., May 23, 1924.

37. Earthquake in northern California, January 22, 1923: Seismol. Soc. America, Bull., vol. 14, no. 2, pp. 165-168, June; 1924.

38. Geologists of note: Hoyt Stoddard Gale: Eng. and Min. Jour.-Press, vol. 118, no. 16 , p. 604, portr., October 18, 1924.

39. Oil and gas in northeastern Colorado: Oil and Gas Jour., vol. 23, no. 23-A, pp. 46, 110-111, 1 fig., October 30, 1924.

40. Obituary, Edmund Otis Hovey: Am. Jour. Sci., 5th ser., vol. 8, p. 445, November, 1924.

41. Oil and gas in northeastern Colorado; prospects of developing new fields: Colorado School of Mines, Alumni Mag., vol. 14, no. 7, pp. 13-18, November, 1924.

42. Willet G. Miller: Am. Inst. Min, and Met. Eng., Trans., vol, 71, pp. 1376$1377,1925$.

43. Investigators gradually unfold origin and present nature of coal: Coal Age, vol. 27, no. 9, pp. 31.9-323, 2 figs., February 26, 1925.

44. What makes coal coke?: Coal Age, vol. 27, no. 10, pp. 364-366, 1 fig, March 5, 1925.

45. Production of petroleum in 1924: Am. Inst. Min. and Met. Eng., no 1447, 247 pp., April, 1925.

46. Sierra Nevada earthquakes of March 20, 1925: Seismological Soc. America, Bull, vol. 15, no. 2, pp. 140-142, June, 1925.

47. Jay Backus Woodworth: Science, new ser., vol. 62, p. 150, August 14, 1925.

48. Washington meeting of American Association for Advancement of Science Pan-Am. Geologist, vol. 43, no. 5, pp. 363-380, June, vol. 44, no. 1, pp. 69-80, August, 1925.

49. Professor Jay Backus Woodworth: Am. Jour. Sci., 5th ser., vol, 10, pp. 381--382, October, 1925.

50. Geological conference in western Texas: Science, new ser., vol. 62, p. 413, November 6, 1925.

51. Dinosaurs leave footprints in Utah coal mines: Coal Age, vol. 28, no. 22, 2 figs., November 26, 1925.

52. In memoriam, John Mason Clarke, 1857-1925: New York State Mus Bull., no. 267, pp. 7-11, 1926.

53. The South Dakota badlands : Black Hills Engineer, vol. 14, no. 2, pp. 65-76, 13 figs., March, 1926.

54. Kansas City meeting [of Section E] of American Association [for the Advancement of Science]: Pan-Am. Geologist, vol. 45, no. 2, pp. 170-176, no. 3, pp. 247-256, March and April, 1926.

55. Petroleum development and technology in 1925: Am. Inst. Min. and Met. Eng., no. 1570, 784 pp., April, 1926.

56. The first meeting of the eastern section of the Seismological Society of America: Science, new ser., vol. 63, p. 449, April 30, 1926.

57. Eleventh annual meeting of the American Association of Petroleum Geologists, Dallas, Texas, March 25-27, 1926: Am. Assoc. Petroleum Geologists, Bull., vol. 10, no. 5, pp. 538-549, May, 1926.

58. Geologic map of a portion of western Texas and southeastern New Mexico: Oil and Gas Jour., vol. 24, no. 52, p. 182, May 20, 1926. 
Anonymous-Continued.

59. Eastern section of the Seismological Society of America: Seismological Soc. America, Bull., vol. 16, no. 2, pp. 150-159, June, 1926.

60. The St. Lawrence earthquake: Canadian Min. Jour., vol. 47, no. 33, pp. 801-802, August 13, 1926.

61. James Furman Kemp: Mining and Metallurg̀y, vol. 7, no. 239, p. 546, portr., December, 1926.

62. Henry Hollister Robinson, Ph. D. : Connecticut, State Geol. and Nat. Hist. Survey, Bull. no. 38, pp. 7-8, 1 pl. (portr.), 1927.

63. Charles D. Walcott: Mining and Metallurgy, vol. 8, no. 243, pp. 153-154, portr., March, 1927.

64. Twelfth annual meeting of the American Association of Petroleum Geologists, Tulsa, Oklahoma, March 24, 25, and 26, 1927: Am. Assoc. Petroleum Geologists, Bull., vol. 11, no. 5, pp. 524-551, May, 1927.

65. Geologists of note; Arthur Philemon Coleman : Eng. and Min. Jour., vol. 123 , no. 21, p. 836 , portr., May $31,1927$.

66. Projects in petroleum research: Am. Assoc. Petroleum Geologists, Bull., vol. 11, no. 9, pp. 1003-1008, September, 1927.

67. The Kansas geological field conference: Science, new ser., vol. 66, pp. 275276, September 23, 1927.

68. Fossils of Baffin Land: Science, new ser., vol. 66, pp. 473-474, November 18, 1927.

69. Climates of geologic past: Pan-Am. Geologist, vol. 49, no. 2, pp. 95-98, March, 1928.

70. Bibliography of published writings of Charles D. Walcott: Smithsonian Misc. Coll., vol. 80, no. 12, pp. 23-37, May 12, 1928.

71. The antiquity of man in America: Sci. Monthly, vol. 24, no. 5, pp. 477-479, May, 1927.

72. Gold deposits in Helena district, Montana [based on work by J. T. Pardee] : Min. Jour., Phoenix, Ariz., vol. 12, no. 2, pp. 13, 56-58, June 15, 1928.

73. Memorial of Alpheus Hyatt: Science, new ser., vol. 68, pp. 291-292, September 28, 1928. 


\section{N D E X}

(The numbers refer to entries in the bibliography)

Aa and pahoeboe, formation: Emerson. o. H., 1.

Abajo Mountains, Utah, structural features : Thorpe, 1.

Abitibi-Night Hawk gold area, Timiskaming district, Ontario : Knight, C. W., 1.

Abrasive materials.

Canada : Eardley-Wilmot, 3.

Corundum : Eardley-Wilmot, 7.

Diamond: Eardley-Wilmot, 7.

Garnet: Eardley-Wilmot, 8.

North Carolina: Katz, 1.

Abstracting geologic literature: Keyes, 141. Abstraction of potassium during sedimentation: Watson, J. W., 1.

Acadia, paleogeography : Bailey, L. W., 2. Adirondacks : Alling, H. L., 1.

Addresses.

Ancient mountain systems of Europe and America: Balley, E. B., 1.

Appalachian stratigraphy, variations in : Butts, 15.

Applied geology, scientific by-products : Smith, G. O., 10.

At the surface of a crystal: Wherry, 23.

Borderland of astronomy and geology : Eddington, 1.

Change in ideas about Foraminifera : Galloway, J. J., 12.

Classification of natural resources: Fenneman, 4.

Constitution of earth: Lamb, 1.

Colrelation: Berry, 65.

Cultural aspects in geology : Parks, 23.

Cycads, origin: Chamberlain, 1.

Dakota sandstone problems: Stanton, 5.

Development of stratigraphic geology and paleontology in Canada: Parks, 6.

Development of American paleontology: Scott, W. B., 5.

Direction of progress in economic geology : Ransome, 18.

Earth genesis: Chamberlin, T. C., 1.

Earth sciences as the background of history: Merriam, J. C., 3.

Earth movements in California: Day, 16.

Earth's framework: Cumings, 2.

Earth sciences as the background of history: Merriam, 5 .

Economic geology, relation to the general principles of geology: Penrose. 1479 .
Addresses-Continued.

Evolutional paleontology in relation to the lower Paleozoic rocks: Elles, 1.

Forces in man's social evolution: Shimer, 3.

Folded mountains and isostasy: Lawson, 9.

Fossils and life : Bather, 4.

Geography among the earth sciences: Penck, 1.

Geologic factors in evolution: Mather, 6. Geologist and petroleum industry: DeGolyer, 10.

Geological climates: Scott, W. B., 4.

Geology and the world at large: Ashley, 24.

Geology at work: Smith, G. O., 24.

Geology in partnership with American industry: Smith, G. O., 11.

Geology in the petroleum industry : DeGolyer, 11.

Geology in the service of man: Watts, W. W., 1.

Geology in the world war and after: Cross, C. W., 1.

Geology's debt to the mineral industry: Miller, W. G., 5.

Great fossil reptiles of Alberta : Parks, W. A., 1.

Igneous intrusion, after-effects : Kemp, 12.

James Hutton, pioneer of modern geology : Hobbs, 28.

Land and sea oscillations, major causes: Ulrich, 3.

Metasomatism : Lindgren, 16.

Military contribution of civilian engineers: Smith, G. O., 4.

Mineral deposits, present tendencies in the study of : Lindgren, 5 .

Mineralogy, future in America : Kraus, $:$.

Mineralogic instruction, needed extension : Eakle, 8.

Mineral replacements in pegmatites: Schaller, 13.

Modern study of mineralogy : Washington, 30 .

National geological survey, functions and ideals: Ransome, 4.

North American geosyncline : Schuchert, 22.

Oceanography in its relation to other earth sciences: Vaughan, 33. 
Addresses-Continued.

Oklahoma, the geologists' laboratory : Gould, C. N., 31.

Opportunity for scientific research in the national parks: Jagger, 19.

Origin and antiquity of man: Miller, A. M., 17.

Origin of species: Osborn, 41.

Outrageous geological hypotheses: Davis, 32.

Paleontology, applications: Scott, W. B., 7 .

Paleontology and human relations: Weller, 18.

Paleozoic mountain systems of Europe and America: Bailey, E. B., 1.

Petroleum and natural gas, epochs in the history of: White, I. C., 4.

Place of paleontology among the sciences : Clarke, J. M., 353.

Plain geology : Smith, G. O., 14.

Prehistoric ornithology: Wetmore, 14.

Present tendencies in paleontology: Berry, 9.

Progress and trends in vertebrate paleontology : Matthew, 26.

Réne Just Hauy: Whitlock, 1.

Science and service: Walcott, 12.

Scientific by-products of applied geology : Smith, G. O., 10.

Scientist in the Federal service: Brooks, 11.

Seventy-five years of American geology : Chamberlin, T. C., 24

Society of Economic Geologists; its sphere and its future: Penrose, 3.

Some reflections on paleontology : Parks, 31.

Sources and tendencies in American geology : Barrell, 2.

South American faunas, origin : Loomis, F. B., 5 .

Structural failure of the lithosphere: Leith, 6.

Structural symmetry, North America: Keith, 8.

Studying mines with a microscope: Bayley, 8.

Trend of earth history : Blackwelder, 4. Trends in American geology : Mendenhall, W. C., 2.

Aerial observation, use in geology : Willis, 7 . Agate: Farrington, 2 ; Harstad, 2.

Age of the earth. See Earth, age.

Agricultural aspects of rock weathering: Hunt, H. A., 1.

Agricultural geology: Emerson, F. V., 3 ; Smith, J. E., 2.

Ainsworth district, British Columbia : Schofleld, 4.

Airplane mapping, Arizona: Sampson, 14.

Airplanes for geologic exploration : Renick, 7 .

Aishihik Lake area, Yukon: Cockfield, 19.
Alabama.

Geological Survey, recent activitles:

Smith, E. A., 7.

reports : Smith, E. A., 1, 3, 6 .

Areas described.

Bessemer-Vandiver quadrangle: Butts, 13.

Clay County: Prouty, 10.

Economic geology.

Bauxite deposits: Adams, G. I., 3; Jones, W. B., 6.

formation in sink holes: Adams, G. I., 1.

Margerum district, Jones, W. B., 6. southeastern Alabama: Rettger, 1.

Brown iron ores: Burchard, 26.

age and occurrence: Adams, G. 1., 4.

Clay County: Prouty, 3.

Coal, analyses : Fieldner, 3.

Coal fields : Butts, 7.

Graphite: Brummell, 1 ; Prouty, 2. Ashland area: Brown, J. S., 6.

Economic minerals and rocks: Jones, W. B., 3.

Iron ores, Clinton formation, Birmingham district: Aldrich, T. H., 2; Crane, W. R., 3.

Clinton ore, Birmingham district: Crane, W. R., 2.

Kaolin : Clark, G. H., 1.

Mica deposits: Clark, G. H., 1.

Mineral production, Jones, W. B., 1 ; 2, 5, 11: Wingard, 1, 2.

Mineral resources: Ernst, 1; Jones, W. B., 4 ; Maynard, T. P., 2 ; Smith, E. A., 4 ; Wingard, 3.

Oil possibilities, northern Alabama: Semmes, 3.

Oil prospecting: Lloyd, S. J., 2.

Oil to carbon ratio: Lloyd, S. J., 1.

Petroleum possibilities, Coastal Plain area: Brantley, 1; northern Alabama: Semmes, 2, 3.

Petroleum products in shallow wells: Jones, W. B., 7.

Red iron ore, Birmingham district: Crane, W. R., 4.

Resources, souther'n Alabama: Harper, 1.

Rock-asphalt deposits : Clalk, G. H., 2 ; Jones, W. B., 12.

Historical geology.

Ashland graphite area: Brown, J. S., 3.

Bentonite in Ordovician : Nelson, 22.

Boring near Florence: Miser, 21.

Cenozoic: Cooke, C. W., 13.

Chester series: Ulrich, 5 .

Clay County: Prouty, 3.

Clinton formation: Aldrich, T. H., 2.

Coastal Plain : Brantley, 1 ; Jones, W B., 10.

Cretaceous : Berry, 4.

eastern Alabama : Berry, 50.

Crystalline rocks: Adams, G. I., 2.

Crystalline and semicrystalline rocks, age : Prouty, 1. 
Alabama-Continued.

Historical geology-Continued.

Eocene formations, correlation: Cooke, C. W., 12.

Devonian: Butts, 11, 12.

General : Jones, W. B., 13.

Geologic map : Smith, E. A., 2, 5.

Mesozoic: Stephenson, 5.

Muscle Shoals area : Prouty, 8.

Northern Alabama: Semmes, 2, 3.

Ocoee rocks, Clay County, age: Prouty, $6,7$.

Paleozoic: Butts, 8.

Talladega phyllite, Clay County, age: Prouty, 4.

Talladega slates: Prouty, 5.

Mineralogy.

Iron-tourmaline in pegmatite: Van Horn, 6.

Paleontology.

Cretaceous floras: Belry, 4.

Eocene Mollusca : Aldrich, T. H., 1.

Foraminifera, Vicksburg group : Cushman, 16.

$\mathrm{H}$ a $\mathrm{nt} \mathrm{k}$ e $\mathrm{ina}$, Eocene foraminifer: Cushman, 17, 19.

Hymenaea, Fayette County : Berry, 5. Mississippian conodonts: Holmes, G. B., 1.

Pleistocene plants: Berry, $\mathbf{3 4}$.

Petrology.

Bentonite: Ross, C. S., 21.

Physical geology.

Drag-folding in marble: Dale, T. N., 3.

Physiographic geology.

Pleistocene peneplain in Coastal Plain : Cleland, 5.

Alamosa Creek valley, Socorro County, New Mexico: Winchester, 3.

Alaska.

General : Smith, P. S., 8.

Geological survey: Brooks, 6.

Northern Alaska: Smith, P. S., 11.

St. Matthew Island, Bering Sea : Hanna, G. D., 30.

Surveys and investigations, administrative report: Brooks, 4.

Areas described.

Alaska Railroad region: Capps, 6.

Canning River region, northern Alaska : Leffingwell, 1.

Chichagof Island, west coast: Overbeck, 1 .

Chandalar district: Mertie, 12.

Chignik region: Martin, G. C., 14.

Chitina Valley: Moffit, 5.

Chulitna region: Capps, 4 .

Cold Bay district: Capps, 5; Smith, W. R., 4.

Cold Bay-Chignik district: Smith, W. R., 1.

Cold Bay-Katmai district: Smith, W. R., 3.

Iniskin Bay district: Moffit, 3.

Iniskin-Chinitna Peninsula: Mofft, 7.

Jack Bay district, Prince William Sound: Johnson, B. L., 2.
Alaska-Continued.

Areas described-Continued.

Kahiltna Valley: Mertie, 2.

Kamishak Bay region: Mather, 7.

Kantishna region: Capps, 1.

Kiwalik-Koyuk region: Harrington, 1.

Knik-Matanuska district: Landes, K. K., 2.

Kodiak Island: Maddren, 2.

Kotsina-Kuskulana district: Moftt, 4.

Kuskokwim region: Martin, G. C., 9.

Matanuska Valley, upper : Capps, 11.

Mt. Spurr region: Capps, 13.

Nixon Fork country : Brown, J. S., 7.

Northwestern Arctic Alaska: Smith, P. S., 7.

Point Barrow region: Paige, 5.

Porcupine district: Eakin, 1.

Ruby-Kuskokwim region: Mertie, 11.

Salmon River district, Portland Canal region: Westgate, 2.

Seward Peninsula: Cathcart, 2.

Sheenjek River district: Mertie, 16.

Snug Harbor district: Moffit, 7 .

Talkeetna Mountains, western : Capps, 3.

Toklat-Tonzona River region: Capps, 12.

Tolstoi district: Harrington, 2.

Tuxedni Bay vicinity, Cook Inlet: Moffit, 2.

Valley of Ten Thousand Smokes: Griggs, 6.

Wrangell district, southeastern Alaska: Buddington, 4.

York region: Steidtman, 4.

Economic geology.

Anvik-Andreafski region : Harrington, 2.

Beatson copper mine: Bateman, 12.

Beatson mine, Prince William Sound district: Birch, 2.

Bituminous deposit, Nenana coal fleld : Martin, G. C., 11.

Chichagof Island, west coast: Orerbeck, 1.

Chistochina region: Chapin, 3.

Chitina Valley: Moffit, 1, 5.

Chromite deposits: Diller, 1 ; Mertie, 3.

Kenai Peninsula : Gill, A. C., 1, 2.

Chulitna region: Capps, 4.

Coal fields: Evans, G. W., 2.

Coal, Matanuska field: Chapin, 8.

Nenana field: Martin, G. C., 1.

Cold Bay oil field: Palmer, L. A., 1.

Copper, Kennecott: Bateman, 3; Anon., 3.

Prince William Sound: Moffit, 6.

Early Tertiary placer deposit: Capps, 7.

Fairbanks district: Chapin, 4.

Fairhaven silver-lead district: Leven. saler, 1.

Future of Alaska mining: Brooks. 2.

Gold, Anvik-Andreafski region: Harrington, 1.

Chichagof Island: Overbeck, 1.

Porcupine district: Eakin, 1. 
Alaska-Continued.

Economic geology-Continued.

Gold, silver, copper, and lead : Martin, G. C., 4 .

Tolovana district: Overbeck, 3.

Juneau and Ketchikan districts : Mèrtie, 5.

Willow Creek district: Chapin, 12.

Gold, silver, copper, and lead: Brooks, $5,12,14$.

Gold lodes, Kuskokwim reglon: Martin, G. C., 9.

Goodnews Bay region: Harrington, 6.

Gypsum: Stone, 11.

Hot Springs district: Chapin, 6 .

Hyder district, southeastern Alaska : Jewell, 1.

Jack Bay district, Prlnce William Sound: Johnson, B. L., 2.

Juneau district: Bradley, P. R., 1 ; Mertie, 5.

Kahiltna Valley: Mertie, 2.

Kantishna region: Capps, 1; Hadey, J. A., 1.

Kenai Peninsula: Johnson, $\$$.

Kennecott copper deposits: Bateman, $3,4$.

Kennecott mines, Chitina district: Birch, 1.

Ketchikan district: Mertie, o.

Kiwalik-Koyuk region, gold and platinum placers: Harrington, 5 .

Kodiak Island, beach placers: Maddren, 2.

Magmatic sulphide ore, Chichagof Island: Kerr, P. F. 2.

Marble resources, southeastern Alaska : Burchard, 6.

Matanuska coal flelds: Chapin, 11; Martin, G. C., 3.

Metalliferous deposits, Yukon and Kuskokwim regions: Mertie, $\boldsymbol{7}$.

Mineral deposits, southeastern Alaska : Buddington, 8, 13.

Mineral industry: Brooks, 15; Smith, P. S., 6, 12.

Mineral resources : Broks, A. H., 2, 3, 16 : Moffit, 8.

Mining industry: Brooks, 8, 8, 13 ; Martin, G. C., 2, 7.

Molybdenite, Healy River: Chapin, 5.

Nenana coal field : Martin, G. C., 1, 10.

Nickel, Copper River valley: Overbeck, 2.

Nickel minerals : Buddington, 7 .

Northwestern Alaska : Cathcart, 1.

Oil developments, Cold Bay district: Smith, W. R., 4.

Oil flelds : George, H. C., 1.

Palladium, Prince of Wales Island : Campbell, D. G., 1.

Petroleum : Martin, G. C., 8, 12 ; Smith, P. S., 10.

Iniskin Bay district: Mofft, 3.

Petroleum seepage, Anchorage : Brooks, 10.
Alaska-Continued.

Economic geology-Continued.

Porcupine district: Eakin, 1.

Prince William Sound: Johnson, B. L., 1.

Ruby district, tin : Chapin, 7.

Ruby silver prospect, Susitna Basin : Capps, 10.

Salmon River area, southeastern Alaska : Buddington, 12.

Portland Canal region: Westgate, 2. Salmon-Unuk River region: Mertie, 6.

Salt-Chuck palladium-copper mine,

Prince of Wales Island : Mertie, 4.

Seward Peninsula : Harrington, 7.

graphite: Harrington, 4.

metalliferous lodes: Cathcart, 2.

tin : Harrington, 3.

Silver-lead prospects near Ruby : Brown, J. S., 8.

Southeastern Alaska: Buddington, 9.

Talkeetna Mountains, western : Capps, 3.

Tin, Lost River district: Fearlng, 1.

York region: Steidtman, 4.

Tolstoi district: Harrington, 2.

Unalaska and Akun islands, sulphur: Maddren, 1.

Willow Creek district: Capps, 8; Chapin, 12.

gold lode, mining: Capps, 2 ; Chapin, 9.

Wrangell district, southeastern Alaska : Buddington, 4.

Yentna gold placer district: Capps, ?. Historical geology.

Anvik-Andreafski region : Harrington, 1.

Canning River region, northern Alaska: Leffingwell, 1.

Chistochina region: Chapin, 3.

Glaciation, P a 1 e o z o $1 \mathrm{c}$, southeastern Alaska: Kirk, E., 1.

Coast Range intrusives: Buddington, 14.

Cretaceous: Martin, G. C., 13.

Goodnews Bay region: Harrington, 6.

Kahiltna Valley: Mertie, 2.

Kantishna region: Capps, 1.

Kenai Peninsula, southwestern part: Gill, A. C., 2.

Kennecott: Bateman, 10.

Kiwalik-Koyuk region: Harrington, 5.

Kodiak Island: Maddren, 2.

Matanuska coal fields: Martin, G. C., 3.

Mesozolc formations: Goranson, 1.

Mesozoic stratigraphy: Martin, G. C., 15.

Paleoclimatology : Blackwelder, 1.

Paleozoic, interior Alaska: Mertie, 13.

Peard Bay region: Meek, 1.

Pliocene: Dall, 2.

Porcupine district: Eakin, 1.

Pribilof Islands: Hanna, G. D., 1.

Prince William Sound : Mofft, 6.

Salmon-Unuk River region: Mertle, 6.

Tertiary: Brooks, 7.

Tolstoi district: Harrington, 2. 
Alaska-Continued.

Historical geology-Continued.

'Tuxedni Bay vicinity, Cook Inlet: Mofflt, 2.

Upper Yukon Valley: Mertie, 15.

Mineralogy.

Epidote: Matthes, O., 1.

Gillespite, Dry Delta : Schaller, 5.

Meteorite, Cold Bay: Merrill, 19, 20.

Nickel minerals : Buddington, 7.

Stellerite, Juneau: Wheeler, E. P., 2.

laleontology.

Bathmopterus, Silurian : Kirk, 11.

Brooksina : Kirk, 2.

Crustacea, stalk-eyed : Rathbun, 5.

Cymbidium, pentameroid brachiopod: Kirk, 5.

Harpidium, pentamerold brachlopod, southeastern Alaska: Kirk, 3.

Hydrangea, Tertiary sandstone: Hollick, 5.

Ientacrinus: Springer, 11.

l'eard Bay region, Pleistocene: Meek, 1.

Pliocene and Pleistocene: Dall, 2.

Pliocene pectens, Nome: Dall, 3 .

Pribilof Islands: Hanna, G. D., 1.

Pycnodesma, Silurian: Kirk, E., 6.

Tertiary, Pribilof Islands : Dall, 1.

Upper Triassic: Smith, J. P., 3.

petrology.

Assimilation, during the Katmai eruption of 1912 : Fenner, 4.

Coast Range intrusives: Buddington, 14.

Katmai magmatic province: Fenner, 8.

Magmatic problems of Aleutians: Fenner, 10.

Matanuska Valley, upper: Mertie, 14. Submarine pillow lavas, southeastern Alaska: Buddington, 10.

Physical geology.

Bogoslof Islands : Friedlaender, 2.

Earth movements accompanying Katmai eruption: Fenner, 7.

Faulting, Kennecott: Lasky, 1.

Glacial erosion: Crosby, W. O., 2, 5.

Glacier studies: Chamberlin, T. C., 15.

Glaciers: Crosby, w. O., 5.

Kennecott Glacier: Bateman, 5, 7.

Klutlan Glacier : Lambart, 1.

movement: Reeds, 1 .

Kaolinite associated with miarolitlc structure: Buddington, 6.

Katmai, earthquakes and eruption, 1912 : Tams, 1.

eruption: Griggs, 6.

Valley of Ten Thousand Smokes: Griggs, 5.

Katmai region: Fenner, 1.

fumaroles, chemical study: Allen, E. T., 25.

fumarolic incrustations: Zies, 1, 2. tuff deposits, Valley of Ten Thousand Smokes: Escher, 1 ; Fenner. 5 ; Griggs, 7.
Alaska-Continued.

Physical geology-Continued.

Valley of Ten Thousand Smokes: Shipley, 1 ; floor : Cole, G. A. J., 1 ; temperature inversions in fumaroles: Sosman, 1.

hot springs : Zies, 3.

moving pictures: Fenner, 6.

Katmai Volcano: Griggs, 2 ; eluption : Fenner, 2; Griggs, 1.

Mageik landslide, Katmai district: Griggs, 3.

Volcanic emanations and incrustations: Shipley, 2.

Volcanoes, Aleutian region: Griggs, 4. Physiographio geology.

Aniakchak Crater, Alaska Peninsula: Smith, W. R., 2.

Canning River Region, northern Alaska : Leffingwell, 1.

Glaciation, Tertiary: Richarz, 1.

Katmai region: Fenner, 2.

Lynn Canal region: Martin, L., 2.

Marine benches, southeastern Alaska: Buddington, 11.

Post-Tertiary changes: Smith, P. S., 13.

Stream piracy, Tolovana and Hess River basins: Mertie, 1.

Alberta.

Geological reconnaissance: Allan, 6 .

Red Deer region: Tyrrell, 6.

Report of geological investigations, 1922 : Allan, 8.

Report of geological survey: Allan, 18, $21,22$.

Smoky, Hay, and Berland rivers : MacVicar, 2.

Areas described.

Area between Athabasca and Embarras rivers: Rutherford, 5.

Banff area: Warren, P. S., 4.

Blackstone, Brazeau, and Pembina rivers, foothills belt: Allan, 13.

Bow River between Cochrane and Kananaskis : Rutberford, 6.

Bragg Creek area: Hume, 30.

Cypress Hills, western end: Dyer, 9.

Drumbeller district: Allan, 7 .

Foothills belt between McLeod and Athabasca rivers: Rutherford, 4.

Kananaskis Lakes-Palliser River area : Marshall, J. R., 2.

Little Smoky River: McLearn, 4.

North Saskatchewan and McLeod rivers : Rutherford, 8.

Saunders Creek and Nordegg coal basins : Allan, 9.

Turner Valley oil area : Hume, 22.

Economio geology.

Bituminous sands, northern Alberta: Clark, K. A., 2, 3, 4, 5; Ells, 1,4 $5,6,8,9$.

Bow River coal basin: Dowling, 20.

Carbon ratios: Jones, I. W., 1.

Clay, Athabasca River: Hume, 9. 
Alberta-Continued.

Economic geology-Continued.

Coal : Allan, 17.

analyses: Stansfield, E., 1.

Brule Lake region: MacVicar, 1.

Crowsnest area: Rose, 3.

Drumheller district: Allan, 7.

Highwood area : Rose, 2.

Red Deer region: Tyrrell, 6.

Smoky, Hay, and Berland rivers: MacVicar, 2

Coal-seam correlation: Rutherford, 3.

Crowsnest coal area: Rose, 3.

Gas and oil fields: Dowling, 2.

General : Allan, 11, 15, 18.

McMurray tar sands: Clark, K. A., 1.

Mineral resources : Allan, 2, 4, 5, 6 .

Natural gas: Allan, 21; Dowling, 4 ; Elworthy, 1, 4.

Oll and gas: Hume, 28 ; possibilities, eastern Alberta: Irwin, 1.

Oll and gas development, foothills belt: Hopkins, O. B., 4.

Oil possibilities, Great Plains: Dowling, 5.

Oil prospecting: Dowling, 10 ; Ness, 1.

Oil prospects: McLearn, 14

Battle River: Hume, 20.

Bragg Creek : Hume, 30.

southern Alberta : Williams, M. Y., 15.

Peace River oil: Rutledge, 1.

Petroleum : Hume, 15, 17, 23 ; Link, 3. and natural gas: Ross, C. C., 1. occurrence: Coste, 1; Dowllng, 6 ; Purdy, 1.

Turner Valley: Davies, S. J., 1.

Sheep River gas and oil fleld: Slipper, 2.

Smoky River coal field, McAvoy, 1; Anon, 33.

Turner Valley oil field: Elworthy, 3.

Wainwright oil field: Emmens, 1; Hume, 21.

Wainwright oil and gas area : Hume, 10.

Wainwright-Irma oil and gas area: Hume, 13, 16.

Wainwright-Vermilion area : Hume, 19.

Historical geology.

Banff section: Keyes, 178.

Battle River: Hume, 20.

Borings : Dowling, 3.

Fort McMurray: Allan, 3.

Brule Lake region: MacVicar, 1.

Central Alberta: Sheppard, 1.

Cordillera: Burwash, 2.

Cordilleran formations, nomenclature: Walcott, 7 .

Correlation: Dowling, 2.

Cretaceous and Jurassic stratigraphy: Allan, 12.

Cretaceous formations: Berry, 74 . lower Smoky River: McLearn, 1. Peace and Athabaska valleys: McLearn, 2.

Crowsnest Pass, Paleozoic: Warren, P. S., 7 .
Alberta-Continued.

Historical geology-Continued.

Crowsnest coal field, northern part: Rose, 1.

Cypress Hills, western end, borings : Dyer, 9.

Devonian, central basin : Dowling, 5 .

Edmonton formation, Red Deer River: Sternberg, C. M., 7.

Edmonton-P a s k a o o disconformity ; Allan, 16.

Fossil zones of Colorado shale: Warren, P. S., 8.

General: Allan, 18; Dowling, 10.

Geologic map: Allan, 14.

Glacier Lake section: Walcott, 3.

Highwood coal area: Rose, 2.

Jasper Park region: Keyes, 37.

Lake Minnewanka section near Banff: Shimer, 6.

Mud Buttes : Slater, 2.

Northern Cordilleran geosyncline: Fisher, C. A., 2.

Ozarkian system: Walcott, 7.

Paskapoo formation: Allan, 20 ; Russell, L. S., 1 ; Simpson, G. G., 14.

Pre-Devonian deposits: Walcott, 11.

Pre-Devonian sedimentation, southern Rocky Mountains: Walcott, 17, 18.

Red Deer River: Sternberg, C. H., 1.

Rocky Mountains : MacKenzle, J. D., 4.

Sheep River gas and oil field: Slipper, 2.

Southern Alberta: Dowling, 19.

Stratigraphy : McLearn, 14.

Southern and central Alberta: Slipper, 1 .

Southwestern Alberta : Stewart, J. S., 1.

Swan Hills, Lesser Slave Lake district: Allan, 1.

Wainwright-Vermilion area : Hume, 19.

Western Alberta: Purdy, 1.

Paleontology.

Albertosaurus arctungus, Edmonton formation: Parks, 30.

Arrhinoceratops, Edmonton : Parks, 20.

Aspideretes, Belly River Cretaceous: Gilmore, 19.

Banff area : Warren, P. S., 4.

Birch Lake sandstone, marine fauna: Warren, P. S., 3.

Cambrian trilobites: Raymond, 36.

Catopsalis, Paskapoo formation: Russell, L. S., 2.

Centrosaurus apertus, Belly River beds : Parks, 5.

Champsosaurus albertensis, Edmonton formation: Parks, 29.

Coloradoan, lower Smoky and lower Peace rivers: McLearn, 10.

Corythosaurus, Red Deer River: Gilmore, 18 ; Parks, 10.

Cretaceous conifer, Belly River formation : Bell, W. A., 15.

Cretaceous plants: Berry, 74 .

Cycad from Kootenay coal measures: Warren, P. S.. 6. 
Alberta--Continued.

Palcontology-Continued.

Cycadeoid, Belly River beis: Wieland, 1.0.

Deinodontidae, Cretaceous: Matthew, $23,27$.

Devonian: Kindle, 32.

Peace River: Kindle, 47.

Dinosaur tracks, Edmonton formation : Sternberg, C. M., 6.

Dinosaurs : Matthew, 13 ; Parks, 13, 16.

Belly River beds: Lambe, 2 ; Parks, W. A., 2.

Belly River formation: Gilmore, 18, 21.

Edmonton Cretaceous: Gilmore, 21 ; Parks, 21, 24 ; Sternberg, C. M., 10.

Red Deer River: Sternberg, C. H., 1. byoplosaurus acutosquameus, armored dinosaur: Parks, 12.

Edmonton formation, Red Deer River : Sternberg, C. M., 7 ; Invertebrata: Warren, P. S., 2.

Edmontosaurus: Lambe, 1.

Fishes. Raymond, 30.

Fossil zones of Colorado shale: Warren, P. S., 8.

Jurassic Ammonoidea, Fernie formation: McLearn, $\mathbf{1 5 .}$

Jurassic faunas: McLearn, 13.

Kinderhook fauna, Nordegg: Warren, P. S., 1.

Kindleia, cichlid fish, Cretaceous: Jordan, D. S., 18.

Kritosaurus, Belly River formation : Tarks, 3.

Lake Minnewanka section near Banff: Shimer, 6.

Laosaurus, Cretaceous: Gilmore, 20.

Mammal tracks, Paskapoo beds: Rutherford, 7 .

Mammalia, Paskapoo formation : Simpson, G. G., 14.

f.alaeoscincus: Matthew, 22.

I'anoplosaurus milus, Belly River beds: Sternberg, C. M., 1.

Parasaurolophus, Red Deer River: Parks, 7.

Paskapoo formation, Mollusca : Rus- sell, L. S., 1.

plants: Berry, 73.

lelecypoda, Cretaceous : McLearn, 8, 5. liernie formation: McLearn, 9.

Prosaurolophus maximus: Parks, 12.

Red Deer River fossil beds: Steruberg, C. H., 2.

Reptilia: Parks, W. A., 1.

Stephanosaurus, crested dinosaur: Parks, 11.

Struthiomimus brevetertius, Edmonton formation: Parks, 19.

samueli, Belly River formation: Parks, 33.

stylomyleodon lacus, Paskapoo beds: Russell, L. S. 3 .
Alberta-Continued.

Palcontology-Continued.

Styracosaurus, Red Deer River: Gilmore, 9.

Thescelosaurus warreni, Edmonton formation: Parks, 26.

Tree, Red Deer Valley : Kindle, 14.

Troodon validus, Belly River formamation: Gilmore, 22.

\section{petrology.}

Sandstone dikes, southeastern Alberta: Williams, M. Y., 17.

Sandstones, criteria for age determination: Sanderson, 1.

\section{Physical geology.}

Corrosion by saline waters, Sult Prairie: Rutherford, 1.

Crowsnest coal area, structure : Rose, 3. thrusting: Keyes, 44.

Freshfield Glacier: Palmer, H., 1, 2.

Lyell and Freshfield glaciers: Thorington, 1.

Mud Buttes, structure: Slater, 2.

Sandstone dikes, southeastern Alberta : Williams, M. Y., 17.

Sedimentation in Lake Louise: Johnston, W. A., 15.

Southwestern Alberta: Stewart, J. S., 1.

Structural features produced by Tleistocene glaciation: Hopkins, O. B., 3.

Physiographic geology.

Cypress plain: Lawson, 8.

Boulders in glacial deposits: Rutherford, 9 .

Glacial section at Calgary: Burwash, 4.

Lake Athabasca, origin: Alcock, 6.

Mud Buttes, structure: Slater, 2.

Fostglacial lakes, Mackenzie River ba sin : Cameron, 2.

Southwestern Alberta: Stewart, J. S., 1.

Underground water.

Southern Alberta, artesian area : Dowling, 19.

Aleutian Islands, magmatic problems: Fen. ner, 10.

Algal reefs in Green River formation : Bradley, W. H., 7.

Algae.

Archean : Gruner, 4, 6.

California, Los Angeles, Miocene: Gardner, N. L., 1.

Lithothamnium, Ellis formation, Mon tana: Howe, M. A., 4.

Middle Cambrian: Walcott, C. D., 1.

Pre-Cambrian and Carboniferous: Twenhofel, 3.

Trinidad, Miocene : Howe, M. A., 2.

West Indies Tertiary calcareous : Howe, M. A., 1.

Wyoming, Fuson oil shale: Bradley, W. H., 2.

Algae as limestone makers and climatic indicators : Glock, 3 . 
Algonkian. See Pre-Cambrian.

Algonkian sediments, quantitative study: Trowbridge, 4.

Alidade, telescopic, manipulation : Matber, 1. Alkali deposits.

Canada, western : Cole, L. H., 4, 6, 7, 9.

Colorado: Headden, 1.

Nebraska : Barbour, 1.

Texas, western : Meigs, 1.

Allanite, Quebec, Champlain County, Lac a Baude: Harvie, 2.

Allegany State Park, New York: Lobeck, 8. Allendale oil field, Illinois: Moulton, 6.

Alluvial fan deposits in Upper Huronian : Bain, 3.

Alluvial fans, California, San Bernardino Mountains: Vaughan, F. E., 1.

Cucamonga district, California: Eckis, 1.

Almandite and its significance in the cantact zones of the Grenville limestone: Bain, 2.

Alpine structures, Jasper Park, Alberta : Keyes, 4.

Altamont moraine: Leverett, 10.

Alturas quadrangle, Blaine County, Idaho: Ballard, 2.

Alum.

Nerada, Fallon, magnesia alum : Hewett, 13 .

Alunite. See also Potash.

Texas, south central: Braun, 1.

Utah, Marysvale: Tingley, 1. Amber.

British Columbia, Coalmont: Wilson, A. W. G., 1.

origin: Black, G. F., 1.

American Mineralogist: Hunt, W. F., 1.

Ammonites. See Cephalopoda.

Ammonoosuc mining district, New Hampshire : Ross, C. P., 2.

Amphibia.

Colorado, Pennsylvanian sandstones, footprints: Henderson, 5.

Desmatosuchia, Triassic: Case, 10.

Diplocaulus primigenius, Baylor County, Texas: Mehl, 5.

Environmental conditions of Permian vertebrates: Case, 15.

Elyops, carpus: Gregory, W. K., 9. pectoral limb: Miner, 1.

Kansas, coal measures: Martin, H. T., 3.

Onychopus: Martin, H. 'T., 4.

footprints : Hanna, 19.

Labyrinthodont footprints, Carboniferous, Maryland: Lull, 11.

Labyrinthodont thoracic shield : Case, 5.

Labyrinthodonts, auditory organ : Branson, 21.

Ohio, Pennsylranian, footprints : Carman, 3.

Permian: Mehl, 14

Tetrapods, primitive : Miner, 1.

Texas, Triassic: Case, 16.

western, Upper 'Triassic : Case, 11.
Amphibia-Continued.

Trematops thomasi, Permian, Oklaboma : Mehl, 15.

Urodeles, Pliocene, western Kansas: Adams, L. A., 4.

West Virginia, footprints : Lull, 16.

Wyoming, Lysite beds, Ototriton: Loomis, F. B., 1.

Triassic: Branson, 19.

Amphicoelias : Osborn, 5.

Amygdaloid, tubular, Nova Scotia : Walker, 16.

Analyses of natural waters, index: Collins, W. D., 5.

Anaspida and origin of vertebrates: Raymond, 29.

Andalusite.

California: Melhase, 1.

Anguilla, geology : Earle, 6; Vaughan, 40.

Paleontology.

Decapod crustacenns, Oligocene: Withers, 4.

Echinoids, Neogene: Lambert, J., 1.

Tertiary calcareous Algae: Howe, M. A., 1.

Angular fragments in veins: Weinig, 1.

Anhydrite, geology : Newland, 3.

Aniakchak Crater, Alaska Peninsula: Smith, W. R., 2.

Annelida.

Hamulus, Cretaceous, Tennessee : Wade, B., 2.

Iowa, Devonian : Searight, 1.

Anorthosites, formation : Loewinson, 1.

Anthozoa.

British Columbia, Triassic coral reef fauna: Shimer, 7.

Archohelia clarki, Meganos formation, California: Vaughan, 45.

Aulopora, Devonian, Iowa: Fenton, M. A., 1.

Cannonball fauna: Vaughan, 9.

Cladochonus and Monilipora: Girty, 6. Dominican Republic: Vaughan, 37.

Ecology and growth rate of corals: Vaughan, 31.

Favosites, pseudopercula: Dunbar, 10

Heterolasma, Silurian, Michigan : Ehlers, 2.

Hexacoralla, ancestry: Robinson, W. I., 3.

History : Raymond, 13.

Paleozoic corals, attachment: Foerste, 12.

Mexico, western : Palmer, R. H., 8.

Michigan : Case, 25.

New York, Utica, and Lorraine formations: Ruedemann, 17.

Nomenclature: Vaughan, 39.

Pseudopercula in Favosites: Dunbar, 10.

Tertiary : Vaughan, 36.

Tetracoralla, extinction, cause: Hall, G. M., 1.

Tetradium and coral evolution: Sarde. son, 11. 
Anthozoa-Continued.

Trinidad, Miocene: Vaughan, 38.

Vermont, Chazyan coral reef: Raymonid, 24.

West Indies: Vaughan, T. W., 2.

Anthracite.

Microstructure : Kelly, S. F., 2 ; Turner, H. G., 3.

Origin : Jeffrey, 5.

Low-temperature origin : Roberts, J., 1.

Pennsylvania : Asbmead, 1.

Anthraxolite, microstructure: Kelly, S. F., 2.

Sudbury, Ontario: Coleman, 32.

Anticosti Island: Twenhofel, 30.

Antigua.

Geology : Earle, 1 ; Thomas, A. 0., 1.

Paleontology.

Lepidocyclina, Oligocene: Vaughan, 44.

Oligocene brachiopods: Thomas, A. 0., 8.

Tertlary calcareous Algae: Howe, $M$. A., 872.

\section{Petrology.}

Rhyolitic pebbles: Harrison, J. B., 3.

Antillean fauna, origin: Matthew, 5.

Antilles. See West Indies.

Antimony: Bastin, 2; Schrader, 2-4, 6, 8, 9 ; Smitheringale, 1.

Alaska, Alaska Railroad region: Capps, 6.

Arkansas, Sevier County: Mitchell, 6 .

Idaho: Thomson, F. A., 1; Pine Creek district: Jones, Ed. L., 1.

Salmon River Mountains: Ross, C. P., 13.

Washington, Okanogan Valley : Keyes, 73.

Anvik-Andreafski region, Alaska : Harring: ton, 1.

Apatite.

Quebec, Buckingham district ; Rowe, R. C., 1 .

Appalachian field trip, Morse, W. C., 1.

Appalachian oil and gas fields, geology: Mills, R. V. A., 1.

Appalachian oil field: Reeder \& Company, 1 . Appalachians.

Cross section in southern New England: Woodworth, 3.

New structural type in: Stose, 21.

Structure: Keith, 2.

Apparatus.

Torsion seismometer : Anderson, J. A., 2. Application of geology to mining: Billingsley, 1.

Arachnida.

Eurypterid horizon, New York: Chadwick, 2.

Paleolimulus, Permian xiphosuran, Kansas: Dunbar, 3.

Tertiary : Petrunkevitch, 1.

Aragonite deposited from sea water: Wells, R. C., 4.

Aravaipa mining district, Arizona: Ross, C. S., 5 .

Arbuckle Mountains, Oklahoma: Reeds, 11. Ar'chean, evidence of life in evaluated Hawley, J. E., 2.
Irchean. Sec Pre-Cambrian.

Aretic regrions.

Arctic coast of Canada: O'Neill, 5.

Baffin Island: Gould, L. M., 7.

Canada, eastern: Weeks, L. J., 2.

Cumberland Sound area, Baffln Island:

Weeks, L. J., 3.

Geological problems: Coleman, 31.

Areas described.

Foxe Land: Gould, L. M., 6.

North Atlantic polar islands: Nordenskjöld, 1.

\section{Historical geology.}

Baffin Land, Frobisher Bay : Anon., 68.

Ellesmere Land: Holtedahl, 1.

Foxe. Land: Gould, L. M., 8.

General : Coleman, 31 ; Holtedahl, 3.

Western Greenland: Seward, 4.

Paleontology.

Baffin Island, corals, brachiopods, gas tropods, and ostracodes : Hussey, 2. cephalopods : Foerste, 29.

Frobisher Bay: Anon, 68.

Cephalopoda : Foerste, 24, 29.

Ordovician and Silurian : Foerste, 11. northern Greenland : Troedsson, 2.

Cretaceous plants, western Greenland: Seward, 4

Devonian fauna, Ellesmere Land: Tolmachoff, 1.

Ellesmere Land, Devonian : Tolmachoff, 2.

Mammoth tusk, Banks Island: Kindle, 29.

Paleozoic, Ellesmere Land: Kirk, 4.

Pleistocene, Arctic coast: Dall, 9.

Tertiary fossils, Brock River: Dall, 9. Petrology.

Basaltic rocks: Holmes, A., 1.

Physical geology.

Ice, characteristics: Kindle, 27.

Sediments, distribution by Arctic ice: Kindle, 27.

Tectonics: Holtedahl, 5.

Physiographio geology.

Baffin Island: Gould, I. M., 6.

Argillites suggesting seasonal deposition: Sayles, 7.

Argonaut gold mine, Ontario: Knight, C. w., 6.

Arizona.

Alrplane mapping: Sampson, 14

Outline of geology: Keyes, 83.

Petrified forests: Edwards, I., 1.

United States Geological Survey publications relating to Arizona: Jenkins, 2.

Areas described.

Aravaipa and Stanley mining districts, Graham County : Ross, C. P., 5.

Courtland-Gleeson region: Wilson, E. D., 2.

Jerome district, Yavapai County : Reber, 1.

Navajo country: Reagan, 20.

Oatman district: Ransome, 12.

Papago country: Bryan, 7, 25. 
Arizona-Continued.

Areas described-Continued.

Payson district: Lausen, 1.

Ray-Miami region: Ransome, 1.

Saddle Mountain and Banner mining districts: Ross, C. P., 6.

San Carlos Indian Reservation : Schwennesen, 1.

Sierrita Mountains, Pima County: Ransome, 9.

Economic geology.

Amole district: Allen, M. A., 2.

Aravaipa and Stanley mining districts, Graham County: Ross, C. P., 5.

Asbestos: Allen, M. A., 3 ; Melhase, 2 ; Sampson, 11; Trischka, 1; Wilson, E. D., 4.

Sierra Ancha: Bateman, 3.

Barytes: Allen, M. A., 1.

Bisbee district: Elsing, 1; Little, J. M., 1.

Black Mesa iron deposits, Plumosa district: Keyes, 146.

Carnotite, Aguila: Hewett, 15.

Cave Creek district: Lewis, A. S., 1, Central Arizona: Ettlinger, 1.

Copper: : Tovote, 1.

Globe district: Schwartz, 1.

Jerome district: Mitchell, W. G., 1; Rice, M., 1.

Ray-Miami region: Ransome, 1.

Warren district: Mitchell, 4.

Copper ore minerals, vertical distribution in Junction mine, Warren district: Mitchell, 2.

Copper schist deposits: Crampton, 1.

Courtland-Gleeson region, copper-lead deposits: Wilson, E. D., 2.

Deposition of copper carbonate from mine water: Wilson, P. D., 3.

Field tests for common metals: Fansett, 1.

Fluorspar: Allen, M. A., 4.

Gashed veins, Queen of Sheba: Keyes, 204.

Globe district: Schwartz, 1.

Gold, Oatman district: Ransome, 12.

Gold and copper, Payson district : Lausen, 1.

Gold placers : Allen, M. A., 6 ; Wilson, E. D., 3 .

Gypsum : Stone, 11.

Iron ore, magmatic, Eureka district: Ball, S. H., 1.

Jerome district, Yavapai County: Re ber, 1; Fearing, J. L., 2; Rickard, 9.

Jerome and Bradshaw Mountains quadrangles : Lindgren, 17.

Magma mine, Superior district, Pinal County: Browning, W. C., 1.

Manganese: Jones, Ed. L., 3 ; Colorado River desert region: Jones, Ed. L., 7.

Mazatzal Mountains, tourmaline-bearing cinnabar veins: Lausen, 2.
Arizona-Continued.

Economic geology-Continued.

Mineral resources: Rowe, J. P., 5; Tenney, 1.

Navajo country: Reagan, 22.

Oil possibilities: Butler, G. M., 1.

Holbrook area, northeastern Arizona: Hager, D., 3.

Ore deposits: Tovote, 2 ; age and classification: Wilson, P. D., 1.

Porphyry coppers, Palomas Range: Keyes, 153.

Quicksilver resources: Lausen, 3.

Ray quadrangle: Ransome, 11.

Red Bed ores: Bains, 1.

Saddle Mountain and Banner districts, Pinal and Gila Counties: Ross, C. P., 6, 14 .

Salt deposits: Phalen, 1.

Sierrita Mountains, Pima County : Ransome, 9.

Silver ores, Chloride and Kingman, origin : Bastin, 1.

Wickenburg: Bastin, 6.

Superior dis t r i c t, M a $\mathrm{g}$ ma mine: Short, 1.

Tourmaline-bearing cinnabar veins, Mazatzal Mountains: Hummel, 3.

Tres Amigos gold veins: Keyes, 111.

Tucson and Amole Mountains: Jenkins, 3 .

Uranium and vanadium: Butler, $G$. M., 2.

Vanadium: Allen, M. A., 5.

Verde Central mine, Jerome district: Fearing, J. L., 1.

Verde mining district: Smith, A. H. D., 1.

Warren district: Mitchell, G. J., 1. silica outcrops: Trischka, 2.

Yavapai County, Congress mine: Staunton, 1.

Zinc: Ariz. Bur. Mines, 2.

Historical geology.

Black Mesa: Reagan, 15.

Bright Angel quadrangle, geologic history : Noble, 1.

Carboniferous fossils in Triassic conglomerate: Bailey, W. F., 1.

Cave Creek district: Lewis, A. S., 1.

Central Arizona: Ettlinger, 1.

Colorado Plateau: Longwell, 6.

Colorado River basin; Pack, F. J., 5.

Correlation of Fort Apache formations : Reagan, 1.

Dakota fossils in Recent deposits: Reagan, 24.

Devonian: Keyes, 106 ; and Carboniferous: Stoyanow, 1.

Santa Rita Mountains: Stauffer, 12. section, Pinal Creek: Stauffer, 11.

Dos Cabezas Mountains, southwestern Arizona: Sarle, 1.

Fort Apache region: Reagan, 4, 11.

Eocene glacial deposits: Reagan, 5.

General : Keyes, 83, 144. 
Arizona-Continued.

Historical geology-Continued.

Geologic map: Ariz. Bur. Mines, 1; Darton, 13.

Geologic traverse, Mohave to San Juan River: Gregory, H. E., 9.

Gila region : Ross, C. P., 1.

Globe district: Schwartz, 1.

Grand Canyon region: Moore, R. C., 35 ; White, D., 39.

Frand Canyon of Colorado River: Darton, 12 ; Moore, R. C., 25, 26.

Grand Canyon section : Keyes, 94.

Holbrook area, northeastern Arizona: Hager, D., 3, 4.

IIeadgate Rock, lower Colorudo River: Strahorn, 1.

Hopi Buttes volcanic field: Reagan, 8. Terome and Bradshaw Mountains quadrangles: Lindgren, 17.

Jerome district, Yavapai County: Fearing, J. L., 2; Reber, 1. Smith, A. H. D., 1.

Lake Cochise area: Bryan, 23.

Laramie formation: Reagan, 18.

Lees Ferry region: Bryan, 8, 11.

Lower Gila region: Ross, C. P., 1.

Mazatzal quartzite, central Arizona: Wilson, E. D., 1.

Mohave County: Reeside, 4.

Nomenclature of formations: Keyes, 90 .

Northeastern Arizona: Hager, D., 6; Moore, R. C., 12, 19.

Northwestern Arizona: Longwell, 12.

I'aleozoic, Grand Canyon: Noble, 3.

Palomas Range: Keyes, 153.

Papago country, soutliwestern Arizona: Bryan, 3.

Permian : Darton, 20.

I'ermo-Triassic, northwestern Arizona: Shimer, 2.

Pre-Moenkopi unconformity, Colorado Plateau: Drake, 4.

Ray-Miami region: Ransome, 1.

Redwall limestone: Keyes, 104.

Résume of geology: Darton, 17.

St. Clair limestone: Ulrich, 14.

San Pedro Valley: Gidley, 7.

Santa Rita limestone, Devonian: Stauffer, 8.

Superior district: Short, 1.

Tucson and Amole Mountains: Jenkins, 3.

Verde River lake beds: Jenkins, 6 .

Warren district: Mitchell, G. J., 1.

Mineralogy.

Analcite, sedimentary, Yavapai County : Ross, C. S., 22.

Bisbeette, Grand Canyon: Rogers, A. F., 12.

Ceruleofibrite, Bisbee: Holden, 6.

Chalcoalumite, Bisbee: Larsen, 14.

Cyanotrichite, Grand Canyon : Gordon, S. G., 12 ; Palache, 18.

Dumortierite, Clip: Bowen, 21.
Arizona--Continued

Minerulogy-Continued.

Flagstaffite: Guild, 1, 4; identily with terpin hydrate: Guild, 2 .

Garnets, Navajo country: Reagan, 21. Globe district: Schwartz, 1.

Higginsite, Bisbee: Palache, 7.

Hydrous sulphates, United Verdo mine: Lausen, 6.

Meteorite, Gun Creek, Gila County : Palache, 17.

Navajo: Merrill, 20.

Wallapai Indian Reservation: Merrill, 54.

Natrofarosite, Kingman: Shannon, 76.

Piedmontite, Sulphur Spring Valley: Lausen, 4.

Pylite, Tucson: Ayres, 1.

Ray-Miami region: Ransome, 1.

Sulphate minerals, Bisbee: Merwin, 6. Yuma County: Foshag, 1.

Voltaite, Jerome: Anderson, C. A., 1. Paleontology.

Algal remains, Unker group, Grand Canyon: White, D., 39.

Arthrodira, Devonian: Stoyanow, 1.

Bird remains, Benson: Wetmore, 5.

Brachiopods, St. Clair li mest on e: Thomas, N. L., 1.

Devonian section, Pinal Creek: Stauffer, 11.

Footprints, Grand Canyon: Gilmole, $26,27,31,32,33,35,36,37$.

Fossil floras, Grand Canyon: White, D., 34, 35.

Fossil wood, Navajo country: Reagan, 16.

Ganado petrified forest: Reagan, 13, 14.

Hermit shale flora, Grand Canyon: White, D., 33.

Insect, 'Iypus gilmorei, Grand Canyon : Carpenter, F. M., 2.

Mancos-Dakota-Tununk f or m a t i o n, Steamboat: Reagan, 19.

Nilsonia, Steamboat: Reagan, 12.

Paraphyllanthoxylon arizonense: Balley, I. W., 1.

Pleistocene Vertebrata, Anita, Coconino County: Hay, 9.

Phytosaur, Pseudopalatus pristinus: Mehl, 18.

Proboscidea and Edentata, San Pedro Valley : Gidley, 7.

Unionid pelecypod, Shinarump conglomerate: Reeside, 16

Vertebrata, Lake Cochise area: Bryan, 23.

San Pedro Valley: Gidley, 5.

Turtle, Kinosternon arizonense: Gilmore, 15.

\section{Petrology.}

Jerome ores: Rice, M., 1.

Olivine bombs near Globe: Lausen, 5.

Physical geology.

Basin Range structure at Jerome : Ransome, 15. 
Arizona-Continued.

Plyysical goology-Continued.

Chatunel trenching in Southwest: Swift, 1.

Colorado Plateau, structural features: Moore, R.C., 21.

Frosion and sedimentation, Papago country: Bryan, 7.

Gashed veins, Queen of Sheba: Keyes, 204.

Northwestern Arizona: Longwell, 12.

Oxidation subsidence at Bisbec: Wisser, 1.

Pedestal rocks: Bryan, 13.

Texas Canyon, southeastern Arizona : Leonard, R. J., 2.

San Pedro Valley: Bryan, 22.

Stream aggradation through irrigation: Reagan, 10.

Wind erosion: Bryan, 12.

Physiographic geology.

Channels, valleys, and intermont plains : Davis, W. M., 34 .

Colorado River basin : Pack, 5.

Coon Butte, origin: Keyes, 36.

Desert ranges: Keyes, 259.

Grand Canyon region: Burden, 1; Moore, R. C., 35 ; Noble, 1.

Grand Canyon of the Colorado: Birdseye, 1 ; Darton, 3, 12; 'I'ermier, 1.

development influenced by secondary faults: Matthes, 11.

Giand Canyon topography : Matthes, 10. Island mountain topography : Waibel, 1. Meteor Crater : Barringer, 1, 2; Boutwell, 1 ; Campbell, W. W., 1 ; Eng. M. J., 7 ; Hager, D., 9 ; Holland, L. F. S., 1 ; Robie, 1 ; Thurmond, 1.

origin; Merrill, 8.

Papago country, southwestern Arizona : Bryan, 3, 7, 15.

Rock tanks and charcos, origin: Bryan, 5.

San Carlos Indian Reservation: Schwennesen, 1.

San Pedro Valley: Bryan, $2 \dot{2}$.

Underground water.

Ground-water resources: Catlin, 1.

Hot spring water, Clifton : Everit, 1.

Papago country: Bryan, 15.

San Carlos Indian Reservation: Schwenuesen, 1.

Arkadelphia formation, stratigraphy : Howe, H. V. W., 4.

Arkansas.

Geological Survey activities: Branner, G. C., 2.

Geological surveys : Branner, J. C., 1. State geologist's report, 1927: Branner, 5 .

Areas described.

Batesville distlict: Miser, 8 .

Hot Springs district: Purdue, 1.

Economic geology.

Antimony, Sevier County: Mitchell, 6.

Coal analyses: Fieldner, 10.
Arkansas-Continued.

Economic geology-Continued.

Coal fields: Br:auner, G. C., 4.

Diamoud deposits: Mitchell, 8.

Diamond-bearing peridotite area, Pike County: Miser, 10, 12.

Diaspore clay: Wysor, 1.

El Dorado oil field: Crider, 432; Heald, 8; Hull, 5, 9; Ley, 1; Pratt, W. E., 3 ; 'Teas, 4; U. S. G. S., 7.

age of producing sand; Stephenson, 2.

General: Ferguson, J. G., 1.

Gypsum: Stone, 11.

Lead and zinc ores, Sharpe and Lawrence counties: U. S. G. S., 14.

Manganese: Stose, 7.

Batesville district: Miser, 1, 5, 8.

Mineral resources: Branner, G. C., 1, 3; Ferguson, J. G., 1, 2.

Oil-producing sands in southern Arkansas : Hull, 10.

Ozark region, oil and gas possibilities: Croneis, 5.

Petroleum-bearing concretions, Newton County : Binney, 1.

Rainbow City field, Union County : Spooner, 4.

Road-making materials : Branner, J. C., 2.

St. Peter sandstone: Dunkin, 1.

Smackover oil and gas field, Ouachita and Union counties: Bell, H. W., 2,3 ; Schneider, H. G., 1.

Structural features of oil fields, southern Arkansas: Crider, 2.

Trinity sand, oil and gas possibilities: Easton, 2.

Wildcat wells, south-central Arkansas: Hull, 8.

Fistorical geoloyy.

Arkadelphia formation : Howe, H. V. W., 3,4 .

Boring, Union County: U. S. G. S., 7.

Coastal Plain: Spooner, 3.

Diamond-bearing peridotite area, Pike County: Miser, 12.

El Dorado oil and gas field: Gilluly, 1. U. S. G. S., 7.

General : Ferguson, J. G., 1 ; Miser, 4, 11.

Hot Springs area: Bryan, 9.

Igneous action at Bauxite: Nelson, 24.

Lower Cretaceous, southwestern Arkansas: Miser, 27.

Midway formation: Howe, 8. southwestern Alkansas: Hull, 12.

Mississippian tuff, Ouachita Mountains: Miser, 3.

Nacatoch formation: Howe, H. V. W., 5.

Ozark region: Croneis, 5.

Paleozoic: Miser, 7.

Pre-Cambrian rhyolite in well in northwestern Arkansas: Miser. 22.

Sabine uplift: Huntley, L. G., 3.

St. Peter sandstone: Dake, 6 . 
Arkansas-Continued.

Historical geology-Continued.

Smackover oil field sands: Schneider, H. G., 2.

South central Arkansas: Rubey, 1.

Southwestern Arkansas: U. S. G. S., 13.

Stratigraphy of oil-producing sands in southern Arkansas: Hull, 10.

Trinity group: Vanderpool, 3 :

Trinity sandstone, depth of base: Melton, 8.

Upper Cretaceous: Stephenson, 8.

Volcanic rocks, Cretaceous: Miser, 19.

White Cliffs chalk, age and correlation: Ellisor, 2.

\section{Mineralogy.}

Catapleiite, Magnet Cove: Foshag, 16.

Hausmannite, Batesville district: Miser, 2.

Meteorite, western Arkansas: Merrill, 53.

Minerals : Wilkes, 1.

Newtonite, Newton County: Wherry, 30.

identity with alunite: Foshag, 25.

Pyrite and wavellite: Shannon, 34.

Paleontology.

Brachiopoda, St. Clair limestone: Thomas, N. L., 4.

Cephalopoda, Fayetteville: Croneis, 3. Rayonnoceras, Fayetteville: Croneis, 1.

Sharks, Fayetteville formation: Croneis, 4.

Trilobite, St. Clair limestone: Fuerste, 14.

Trinity fauna: Vanderpool, 2.

Petrology.

Hot Springs district, igneous rocks: Lloyd, E. R., 2.

Volcanic rocks, Cretaceous: Miser, 19.

Wavellite, Montgomely County: Gordon, S. G., 10.

Pliysical geology.

Craterlets, east central Arkansas: Thomas, E. T., 1.

Differential compacting the cause of certain Claiborne dips: Teas, 5.

Granite in wells: Gould, C. N., 3.

Ouachita Mountains: Miser, 31.

structure: Miser, 30.

Peridotite dikes, Scott County : Miser, 9.

Structural features of oil fields, southern Arkansas: Crider, 2.

Underground water.

Gage, Ellis County : Thompson, D. G., 2.

Hot Springs : Bryan, 9, 14.

Arsenic.

Nerada Toquima Range: Fergusón, H. G., 2.

Canada: Hurst, 4 .

General : Heikes, 1, 2.

United States: Heikes, 3 ; Sayre, 1.

Washington, Seattle district: Stoess, 1. Artesian pressure, origin : Russell, W. L., 15. Artesian waters and wells. See Underground water.

Artiodactyls, dentition : Loomis, 14.
Arthropoda.

Balanus, Haiti : Pilsbry, 3.

Cambrian : Henriksen, 1.

Crabs, Eocene, Texas : Rathbun, 6.

Eurypterida: Ruedemann, 3.

Phylogeny: Raymond, 7.

Scorpions: Moore, J. I., 1.

Articulata. See Arthropoda.

Arundel fauna, Maryland: Gilmore, 8.

A sbestos.

Arizona: Allen, M. A., 3; Melbase, 2; Sampson, 11 ; 'Trischka, 1 ; Wilson, E. D., 4.

Sierra Ancha: Bateman, 10.

California : Woolsey, 1.

General: Diller, 3; Sampson, 2, 5, 7, 13; Trischka, 1.

Quebec: Fisher, N. B., 1; Lynch, 1. $\mathrm{Ru}$ Keyser, 1.

Black Lake: Hubbard, W. D., 1.

Bonarenture County, Weir Township : Harvie, 1.

Asbestos veins, origin: Stillwell, 2 .

Asotin craters of Columbia River basalt: Fuller, R. E., 3.

Aspen district, Pitkin County, Colorado: Knopf, A., 10

Asphalt. See also Bituminous rocks and sands.

Alabama : Jones, W. B., 12.

California: Vander Leck, 2.

Cuba : Allende, 15.

Humic acid origin : Haseman, 1.

Kentucky : Jillson, 25.

Edmonson County, rock asphalt : Jillson, 64 ; Weller, J. M., 1.

Oklahoma, Love County: Bullard, 2. southeastern : Honess, C. W., 6.

Oregon: Hodge, E. T., 12.

Trinidad: Hartzell, 1; Milner, 1; Waring, 6.

Asphaltic rock.

Alabama : Clark, G. H., 2.

Aspidella-like markings, Cambridge slate: Clark, T. H., 10.

Associations, meetings.

American Association for the Advancement of Science, Section E, proceedings :

Boston meeting, December, 1922: Moore, E. S., 5.

Cincinnati, 1923-24 : Moore, E. S., 8 ; geology : Moore, E. S., 7.

Kansas City, December, 1925 : Mans. field, G. R., 26 ; Anon., 54.

Nashville, December, 1927: Marisfield, G. R., 37.

Philadelphia, December, 1926 : Mansfield, G. R., 32.

St. Louis, 1919 : Chamberlin, T. C., 17.

Wasbington, 1924-25 : Moore, I. S., 9 ; Anon., 48.

American Association of Petroleum Geologists, proceedings :

Dallas, Texas, 1926, eleventh annual meeting: Anon., 57. 
Associations, meetings-Continued American Association of Petroleum Geologists, proceedings-Continued. Denver, 1926 : Hull, 15.

Los Angeles meeting: Rickard, 7.

San Francisco, thirteenth annual meeting; Donoghue, 4.

Shreveport, eighth annual meeting: Moore, R. C., 24.

Tulsa meeting, 1927 : Anon., 64.

Wichita meeting, 1925 : Moore, R. C., 28.

Fort Worth section meeting: Winton, W. M., 4.

Pacific section, San Francisco, 1925 : Morse, R. R., 3.

Association of American State Geologists, Alabama meeting: Watson, I. L., 5.

meeting in October, 1925, in eastern Pennsylvania : Leighton, 16.

British Association for the Advancement of Science, Toronto meeting : Keyes, 169.

Cordilleran section of the Geological Society of America, proceedings : fifteenth to eighteenth meetings : Taff, 1, 2, 3.

nineteenth meeting, Pasadena: Lou. derback, 3.

twentieth, Berkeley : Rogers, A. F., 8. twenty-first, 'Stanford University : Rogers, A. F., 14.

twenty-second, Berkeley : Buwalda, 6. twenty-third, Stanford University : Buwalda, 9.

twenty-fourth, Berkeley : Buwalda, 10. twenty-fifth, Berkeley: Buwalda, 14 twenty-sixth, Los Angeles, January, 1927 : Buwalda, 20.

Geological Society of America, proceedings :

Amherst, 34th meeting, 1921: Hovey, 4.

Ann Arbor, 35th, 1922: Berkey, 5.

Baltimore, 31st, 1918: Hovey, 1.

Boston, 32d, 1919 : Hovey, 2.

Chicago, 33d, 1920 : Hovey, 3.

Cleveland, 40th, 1927 : Berkey, 16.

Ithaca, 37th, 1924 : Berkey, 11.

Madison, 39th, 1926 : Berkey, 15.

New Haven, 38th, 1925: Berkey, 12 ; Heald, 15.

Washington, 36th, 1923 : Berkey, 8.

Kansas geological field conference: Anon., 67.

Mineralogical Society of America, organization: Rogers, A. F., 3; Whitlock, 5.

first annual meeting, Chlcago, 1920 : Whitlock, 11.

second annual meeting, Amherst, 1921 : Whitlock, 12 ; Anon., 16.

third annual meeting, Ann Arbor: Van Horn, 1, 2.
Associations, meetings-Continued

Mineralogical Society of AmericaContinued.

fourth annual meeting, Washington, 1923 : Van Horn, 3.

fifth annual meeting, Ithaca, New York: Van Horn, 4, 5.

sixth annual meeting, New Haven, December, 1925 : Van Horn, 8, 9. seventh annual meeting, Madison, December, 1926 : Van Horn, 10, 11.

eighth annual meeting, Cleveland, December, 1927 : Van Horn, 12, 13.

Pacific coast section of the Paleontological Society, ninth annual meeting: Stock, 2.

tenth annual meeting: Stock, 6 .

Paleontological Society, proceedings :

tenth annual meeting, Baltimore, 1918 : Bassler, 2.

eleventh, Boston, 1919 : Bassler, 3.

twelfth, Chicago, 1920 : Bassler, 4.

thirteenth, Amberst, 1921: Bassler, 7 .

fourteenth, Ann Arbor, 1922: Bassler, 9.

fifteenth, Washington, 1923: Bassler, 12.

sixteenth, Ithaca, 1924 : Bassler, 15. seventeenth, New Haven, 1925 : Bassler, 19.

eighteenth, Madison, 1926 : Bassler, 21.

nineteenth, Cleveland, 1927 : Bassler, 23.

Seismological Society of America, eastern section : Anon., 59.

Society of Economic Geologists, Proceedings, 1920-21: Penrose, 4.

fil'st annual meeting, Amherst, 1921 : Ball, S. H., 3.

first [organization] annual meeting, Chicago, 1920: Lewis, 5.

Chicago meeting, December, 1920: Anon., 9.

proceedings, 1921-22: Lindgren, 7.

Ann Arbor meeting: Anon., 27.

New York City, May, 1923: Anon., 28.

second annual meeting, Ann Arbor, 1922 : Ball, S. H., 6.

Society of Economic Faleontologists and Mineralogists: Hanna, M. A., $6,10$.

Asteroidea.

Devonaster eucharis (Hall), six-rayed : Willard, B., 2.

Hudsonaster, Minnesota: Sardeson, 33.

Hudsonasteridae: Raymond, 11.

Macroporaster nylanderi, Silurian, Maine : Raymond, 11.

Starfishes, Decorah shale, Minnesota : Sardeson, 32.

Gaspe, Quebec : Ruedemann, 23.

Athabaska series: Alcock, 5.

Athapapuskow Lake district, Manitoba : Bruce, 1. 
Atikokania: Rothpletz, 2

Atlantic and Gulf Coastal Plain, major geological features: Stephenson, 6.

Atlantic ridge, central, movement: Brouwer, 3.

Atlas of Colorado: Margerie, 2.

Ausable quadrangle, New York: Kemp, 23.

Attitude of concealed bedded formations, determination of: Mead, 2.

Aulacera: Schuchert, 2.

Aux Vases sandstone, diastrophic aspects: Keyes, 91.

Aves: Ballou, 1.

Arizona, Benson : Wetmore, 5.

Bermuda : Shufeldt, 1.

California, Carpinteria asphalt pit: Miller, L. H., 4.

Miocene, Lompoc: Miller, I, H., 3.

Rancho La·Brea: Miller, L. H., 1, 2.

Colorado, Oligocene: Wetmore, 12.

Cyphornis magnus: Wetmore, 15.

Diatryma, plumage: Cockerell, 17. supposed plumage : Edwards, W. N., 1.

Fossil eggs, Bermuda: Lewis, F. P., 1 ; Wood, C. A., 1.

General: Wetmore, 10.

Ilium in dinosaurs and birds : Romer, 1.

Minerva saurodosis, Bridger formation, Wyoming: Wetmore, 2.

Nebraska, Miocene: Wetmore, 7.

Agate Springs, Miocene hawk : Wetmore, 9,11

Miocene and Pliocene: Wetmore, 4.

Sioux County: Wetmore, 13.

Omol'hamphus, Eocene, Wyoming : Sinclair, 11.

Palaeospiza be 11 a, Florissant: Wetmore, 6.

Parapavo callfornicus, Rancho La Brea asphalt beds: Howard, H., 1.

Porto Rico, cave deposits: Wetmore, $1,3$.

Prehistoric ornithology: Wetmore, 14.

Utah, Green River beds: Wetmore, 8 .

Axial and Monument Butte quadrangles, Moffat C o u n t y, Colorado: Hancock, 7 .

Aztec mine, Baldy, New Mexico: Chase, C. A., 1.

Bacteria, ancient: Moodle, 11, 16.

Bacteria as agents of chemical denudation : Thiel, 11.

Bacteria, iron-depositing : : Harder, 1.

Bahamas.

Physical geology.

Detrital constituents in a reef sand: Goldman, 17.

Bakelite for cementing sections: Ross, C. S., 7 .

Ba la nocrinus, Tamaulipas, Mexico: Springer, 5.

Banded clays: Sayles, 1.

Barbados.

Iristorical geology.

General: Wilmore, 1.

Scotland beds: Trechmann, 6 .
Barbados-Continued.

Paleontology.

Scotland beds: Trechmann, 6; Callianassal: Withers, 6.

Pctrology.

Coral limestones, minerals in: Harrison, J. B., 1.

Physical geology.

Soils, genesis : Harrison, J. B., 2.

Rarbers Hill oll field, Chambers County, Texas: Bevier, 2.

Barite : Allen, M. A., 1 ; Stose, 6.

Arizona : Allen, M. A., 1.

Canada:. Spence, 4, 10.

General: Ladoo, 3; Slebenthal, 23 ; Stose, 9, 11, 14.

Georgia : Hull, 3.

Magmatic origin: Lewis, J. V., 2.

Mexico: Wittich, 18.

Missouri : Tarr, W. A., 1.

Nova Scotia, Inverness County, Lake Ainslie district: Bell, W. A., 12.

Ontario, Groundhog River area : Todd, E. W., 4.

Tennessee, eastern : Gordon, C. H., 1. Barite pisolites, Batson and Saratoga oil fields: Barton, 10.

Barium : Stose, 20.

Barkerville area, Cariboo district, British Columbia : Johnston, 22.

Barkley Sound, Vancouver Island, British Columbia: Dolmage, 2.

Barometric surveying in petroleum mapping: Lahee, 3.

Barosaurus: Lull, 2.

Barrell's work on sedimentation : Vaughan, 20.

Barytes. See Barite.

Base level : Malott, 12.

Basin Range structure: Gilbert, G. K., 1 ; Keyes, 160 ; Louderback, 5; Russell, R. J., 6.

Basin Ranges, origin : Davis, 26.

Batchawana area, District of Algoma, Ontario : Moore, E. S., 19.

Batesville district, Arkansas : Miser, 5.

Batholiths. See also Intrusions.

Colorado, central : Crawford, R. D., 2.

Arizona, central : Ettlinger, 1.

General: Barrell, 4; Chamberlin, R. T., 14.

Idaho: Beckwith, R. H., 1.

Laterally spreading theory: Chamberlin, R. T., 16.

Minnesota, Giants Range: Allison, I. S., 1.

Vermilion : Grout, 18.

Orogenic batholiths: Barrell, 4.

Problems of : Grout, 24.

Batholiths and schistosity, relations: Blackwelder, 9.

Batrachia. See Amphibia.

Batson oil fleld, Hardin County, Texas : Sawtelle, 1.

Bauxite.

Alabama : Jones, W. B., 6.

southeastern: Rettger, 1. 
Bauxite-Continued.

Appalachian bauxite deposits: Nelson, 13.

Association with siderite: Burchard, 1.7.

British Columbia: Dunn, R., 2.

Enrichment: Thiel, 10

Formation: Emory, 1 ; in sink holes : Adams, G. I., 1.

General : Ladoo, 1 ; Morse, P. F., 1.

Georgia, Coastal Plain: Stull, 1, 2.

Mississippi, northeastern: Burchard, 17, 20 ; Morse, P. F., 1.

Origin: Nelson, 10, 13.

Southern States: Adams, G. I., 3.

United States: Morse, P. F., 1; Musset, 1.

Baxter Basin gas field, Sweetwater County, Wyoming: Sears, 7.

Bayou Bouillon salt dome, St: Martin Parish, Louisiana: Donoghue, 2.

Beaches. See also Shore lines; Terraces.

Alaska: Dall, 2 ; southeastern, marine benches: Buddington, 11.

Ininois, Chicago area: Salisbury, 2.

Manitoba, Upper Whitemouth area: Tohnston, W. A., 3.

Winnipegosis area: Johnston, W. A., 3. Beartooth Mountains, Montana : Bevan, 2. Beatricea: Schuchert, 2.

Beauceville area, Quebec: MacKay, B. R., 4. Belcher Islands, Hudson Bay, iron deposits : Moore, E. S., 1.

Bell Springs district, Cảrbon County, Wyoming: Dobbin, 5.

Bellevue oil field, Louisiana : Holman, 1.

Beloit formation and bentonite: Sardeson, 22.

Belt fauna: Rothpletz, 1.

Belt formation, Helena, Montana: Rothpletz, 1.

Bemis moraine: Leverett, 10.

Bend formation, Texas: Girty, 1.

Ben Nevis gold area, Ontario: Knight, C. W., 5 .

Bentonite. See also Volcanic ash.

California: Melbase, 3.

Canada: Spence, 8 ; western : Spence, 9.

General : Bonine, 2; Davis, C. W., 2; Ross, C. S., 12 ; in correlation: Sardeson, 36.

Kansas, Logan County: Pinkley, 1.

Louisiana, Upper Cretaceous: Bramlette, 1.

Mineralogy: Ross, C. S., 15.

Minnesota, southeastern: Sardeson, 30.

Mississippi : Grim, 2.

Occurrence and origin: Giles, 10.

Ordovician, Tennessee, Kentucky, and Alabama: Nelson, 10.

Paleozoic: Ross, C. S., 21.

Tennessee: Nelson, 9.

Wyoming, Shoshone River : Hewett, 16.

Bermudas.

Fossil soils: Sayles, 12, 16.

Paleontology.

Avian remains : Shufeldt, 1.
Bermudas-Continued.

Paleontology-Continued.

Fossil eggs: Lewis, F. P., 1; Wood, C. A., 1.

Poecilozonites: Pilsbry, 2.

Physical geology.

Changes of level: Sayles, 14.

Beryl crystal, Black Hills: Waldschmidt, 1. Beryllium : Copaux, 1.

Bessemer-Vandiver folio, Alabama (no. 221) : Butts, 13.

Bibliography.

Alaska, petroleum : Martin, G. C., 8.

Ammonite opercula : O'Connell, 5.

Anguilla : Earle, 6.

Antigua : Earle, 1.

Arizona : Jenkins, 2.

Ray-Miami region: Ransome, 1.

Arkansas, diamond deposits : Mitchell, G. J., 8.

Hot Springs district: Purdue, 1. Arthrodires: Stensio, 1.

Asphalts, native: Hodge, E. T., 12.

Bailey, L. W., writings : Bailey, J. W., 1.

Barrell, Joseph, writings: Gregory, H. E., 10; Schuchert, 7, 43.

Becker, G. F., writings : Day, 3; (Evans), Merrill, 45.

Bell, Robert, writings: Ami, 1.

Black Hills region : O'Harra, 3.

Branner, J. C., writings : Penrose, 5, 6.

Broadhead, G. C., writings : Keyes, 5.

Brooks, A. H., writings : Smith, P. S., 9.

Brush, G. J., writings : Dana, 3.

California, coal : Boalich, 3.

limestone deposits: Laizure, 1. southeastern: Brown, J. S., 3.

Canada, Geological Survey publications: Ferrier, 1.

Catalogue of bibliographies in geology, 1896-1920: Mathews, 5.

Cement materials : Burchard, 19 ; Richardson, C. H., 13.

Central America and West Indies: Vaughan, 13.

Clark, W. B., writings : Clarke, J. M., 3.

Clarke, J. M., writings : Schuchert, 30, 53.

Chert and flint: Tarr, 15.

Coal, Kentucky: Jillson, 14.

Coarse sediments: Wentworth, 40.

Clay deposits: Ries, 14.

Colorado, Denver Basin: Johnson, J. H., 4.

Golden area: Johnson, J. H., 13.

Leadville mining district: Emmons, S. F., 1.

maps, Johnson, J. H., 15.

north-central: Johnson, J. H., 19 ; foothills formation: Henderson, J., 2.

northeastern: Johnson, J. H., 10; Cretạceous: Henderson, J., 1.

northwestern : Johnson, J. H., 7, 18. south-central : Johnson, J. H., 21. southeastern: Johnson, J. H., 14. 
Bibliography-Continued.

Colorado-Continued.

southwestern: Johnson, J. H., 8. western, mineral deposits ; Aurand, 2.

Concretions : Kindle, 24.

Cone-in-cone : Tarr, 11.

Conodont and annelid jaw literature: Roundy, 2.

Conodonts: Holmes, G. B., 1.

Contact metamorphisms of basic igneous rocks: Schwartz, 7.

Copper, Canada: Browning, C. P., 1.

Coral Reefs: Davis, W. M., 35.

Corundum : Cobb, M. C., 1.

Costa Rica: Redfield, 7 .

Cox, G. H., writings : Dake, 9.

Cretaceous-Eocene transition beas: Thom, 8.

Crinoidea: Keyes, 273.

Devonian, New York: Goldring, 4.

Flexibilia: Springer, 2.

Crosby, W. O., writings: Shimer, 8.

Crustacea, Paleozoic: Vogdes, 1.

Cryolite: Ladoo, 5.

Crystal structure: Morse, J. K., 1.

Cuba, carbonaceous materials: Ortega, P., 1.

Cushing, H. P., writings: Kemp, 11.

Daimonhelix: Mansfield, W. C., 4.

Dana, J. D., writings: Pirsson, 3.

Dikes, clastic: Williams, M. Y., 17.

Dominican Republic: Vaughan, 16.

Dumble, E. T., writings : Simonds, 1.

Dumortierite: Grawe, 5.

Eastman, C. R., writings : Dean, 2.

Emerson, B. K., writings : Keyes, 30.

Emerson, F. V., writings : Brigham, 2.

Fire clay : Shaw, J. B., 1.

Florida: Sellards, 6 ; human remains : Sellards, 2.

Fluorspar deposits: Aurand, 1; Ladoo, 5 .

Foraminifera : Cushman, 22, 41 ; Plummer, H. J., 1.

General: Meisel, 1.

Geologic literature on North America, 1785-1918: Nickles, 2.

Geophysical methods: Barton, 15.

Geophysical principles applied to prospecting: Johnson, J. H., 17:

Georgia : Cave, 1.

Gilbert, G. K., writings : Mendenhall, W. C., 1.

Glacial period divisions: Osborn, 19

Glass sands : Richardson, C. H., 4.

Grand Canyon of the Colorado: Darton, 3 .

Great Basin, Pleistocene, history: Anters, 12

Greenland : Böggild, 1, 6; Koch, 2; fossil plants: Seward, 4.

Gulliver, F. F., writings : Davis, 10.

Guppy, R. J. L., writings : Harris, G. D., 3 .

Gypsum : Stone, 11 ; Wilder, 2.

Fague, Arnold, writings: Iddings, 1.

Haiti : Woodring, 5.
Bibliography-Continued.

Harrison, J. B., writings : Smith, S., 1.

Hice, R. R., writings : Ashley, 19.

Hilgard, E. W., writings : Slate, 1.

Hills, R. C., writings : George, R. D., 4.

Hitchcock; C. H., writings : Upham, 1.

Holden, E. F., writings : Kraus, 7.

Honduras : Redfield, 8.

Horse, evolution: Matthew, 34.

Hovey, E. O., writings : Kemp, 20.

Fuman remains, Vero, Florida: Scllards, 2.

Idaho: Campbell, S., 1, 2; phospliate reserve: Mansfield, G. R., 29.

Igneous rocks: Benson, W. N., 2.

Illinois: Ill. G. S., 2.

Indiana, stratigraphy and paleontology : Cumings, 1.

Iowa, Pleistocene: Cable, 4.

Iron depositing bacteria: Harder, $\mathrm{J}$.

Irving, J. D., writings : Kemp, 1.

Isostasy : Knopf, 8.

Jamaica : Matley, 2 .

Jillson, W. R., writings: Jillson, 22, $31,36,51,77$.

Julien, A. A., writings : Kemp, 5.

Kansas, Cretaceous: Twenhofel, 17.

Permian: Dunbar, 4.

Kentucky : Jillson, 7, 15, 21, 42 ; Miller, A. M., 1; western coal field : Burroughs, W. G., 2 .

Kennedy, William, writings: Wrather, 7.

Knowlton, F. H., writings : White, D., 32.

Labrador: Kindle, 25.

Laccoliths: Gould, L. M., 2 ; MacCarthy, 2.

Lambe, L. M., writings: Kindle, 7.

Lee, W. T., writings : Alden, 7.

Libbey, William, writings: Darton, 22.

Lizards, North America: Gilmore, 38.

Louisiana, Five Islands: Vaughan, F. E., 2

McInnes, William, writings : Alcock, 24.

Magñesite: Whitwell, 1.

Mammoth Cave: Jillson, 41.

Manganese : Harder, 2 ; Hewett, 3 ; Muilenburg, 1 ; Wheeler, H. L., 1 .

Manitoba: Wallace, 14.

Manuscript bibllographies, list: Little, H. P., 3 .

Maryland, Cambrian and Ordovician : Bassler, R. S., 1.

Kent County : Miller, B. L., 6.

Queen Annes County : Miller, B. L., 7.

Talbot County: Miller, B. L., 8.

Mell, P. H., writings : Calhoun, 1.

Mesozoic and Cenozoic plants, catalog: Knowlton, 2.

Mesozoic Invertebrata: Whitney, F. L., 1.

Mid-Continent oil fields: Merritt, J. W., 4.

Miller, W. G., writings : Tyrrell, 8. 
Bibliography-Continued.

Mineral supplies, United States: McCaskey, 1.

Minnesota : Gregory, W., 1 .

Mesabi iron range: Niemi, 1.

Mississippi River, drainage problem: Schoewe, 6.

Missouri, Devonian: Branson, 5.

Molding sands : Richardson, C. H., 12.

Montana, phosphate deposits : Condit, 5.

Moses, A. J., writings : Luquer, 1.

Newfoundland, central mineral belt: Snelgrove, 2.

southeastern, Cambrian-Ordovician : Howell, 5.

New Hampshire: Goldthwait, 6.

New York, Allegany Strite Park: Lobeck, 8.

Salt deposits: Alling, 14.

Silurian faunas: Ruedemann, 19.

Utica and Lorraine formations: Ruedemann, 16.

Niagara Falls: Dow, 1.

Niagaran coral reefs: Cumings, 4.

North American geology: Nickles, 1-5.

Norwood, C. J., writings: Foerste, 25.

Oil shales: Alderson, 2 ; George, R. D., 2 ; Jillson, 25 ; Reeves, J. R., 5 ; Winchester, 5.

Oregon: Dixon, 1 ; Smith, W. D., 1.

John Day region: Jillson, 39.

Packard, A. S., writings : Cockerell, 7.

Paleontology, Paciflc coast : Merriam, 7.

Peat: Atwood, A. C., 1 ; Haanel, B. F., 1.

Peck, F. B., writings: Shimer, 5.

Pennsylvania, mineralogy: Gordon, S. G., 6.

Piedmont region: Smith, I. F., 3.

Fermian: Schuchert, 52.

Great Plains: Gould, C. N., 14.

Petroleum: Burroughs, 1-5; Hoyt, 1.

Mexico: Mexico, Dept. Petrol., 1.

Phosphates: Mansfield, G. R., 21, 25.

Platinum group of metals: Howe, J. L., 1.

Pleistocene life: Baker, F. C., 1.

Porto Rico, Lares district: Hubbald, B., 3.

Ponce district: Mitchell, 7.

Potash : Gale, 631 ; Hicks, 1, 2 ; Mansfield, G. R., 17, 20, 24.

Postglacial uplift of southern New England: Fairchild, 7 .

Pre-Cambrian, northern Quebec: Cooke, H. C., 2 .

Pre-Cambrian literature: Steidtmann, $2,3$.

Prest, W. H., writings : Piers, 1.

Pumpelly, Raphael, writings : Willis, 19.

Purdue, A. H., writings: Ashley, 3.

Quebec: Clark, T. H., 11.

Mount Albert area : Alcock, 20.

Quickșilver: Evans, I. P., 1, 2; Ross, C. P., 4 .

Mexico: Segura, 1.

Ripple marks: Bucher, 1 ; Kindle, 28.

Robinsun, H. H., writings : Anon., 62.
Bibliography-Continued.

Rogers, G. S., writings : Kemp, $\boldsymbol{6}$.

Rudistids : Palmer, R. H., 7.

St. John, 0. H., writings : Keyes, 45.

St. Kitts-Nevis : Earle, 6.

Salt: Phalen, 1.

Scudder, S. H., writings : Mayor, 1.

Seismology: Hodgson, 16; Seism. Soc. Am., 1.

Mexico: Muñoz Lumbier, 1.

Shale oil : McKee, 1.

Silurian, Indiana: Cummings, 5.

Smith, E. A., writings : Butts, 14.

Smock, J. C., writings : Kümmel, 6.

South Dakota, central Black Hills: Darton, 14

Spencer, J. W. W., writings: Shaw, E. W., 10.

Springer, Frank, writings: Schuchert, 46 ; Springer, 12.

Stevenson, J. J., writings: White, I. C., 7.

Stylolites, nature and origin: Stockdale, 1.

Tennessee, Ducktown district: Emmons, W. H., 8.

Tertiary, Oregon and Washington: Hertlein, 3.

Texas, Fredericksburg and Washita formations: Adkins, 1.

McLennan County: Adkins, 2.

north central : Beede, 11.

northeastern : Fohs, 2.

Weno and Pawpaw formations: Adkins, 2.

Todd, J. E., writings: Keyes, 102 ; Leverett, 12.

Triassic: Roberts, J. K., 8; Smith, J. P., 3.

Triconodonts : Simpson, G. G., 1.

Trilobites: Raymond, 8.

Iowa: Walter, 3.

Trinucleidae : Stetson, 2.

Tungsten, United States : Hess, 2.

Twitchell, M. W., writings : Kümmel, 8 .

Uglow, W. L., writings : Baker, M. B., 4 ; Williams, M. Y., 18.

U. S. Geological Survey: Inst. Govt. Research, 1.

Utah, hydrocarbons: Clark, A. F. 1. ore deposits: Butler, 4.

Van Hise, C. R.; writings : Chamberlin, T. C., 6 ; Leith, 3.

Virgin Islands: Meyerhoff, 1.

Vogdes, A. W., writings: Dumble, 5; Keyes, 158.

Wadsworth, M. E., writings: Lane, 17.

Walcott, C. D., writings: Darton, $2 \ddot{3}$; Anon., 2, 70 .

Washington, mineral resources: Fischer, 1.

Stevens County : Weaver, 2.

San Juan Islands: McLellan, 2.

Watson, T. L., writings : Ries, 12.

Weller, Stuart, writings: Chamberlin, 'T. C., 39.

Wells, H. L., writings : Chittenden, 1. 
Bibliography-Continued.

White, I. C., writings : Fairchild, 23 ; Hennen, 2.

Williams, H. S., writings : Cleland, 1.

Williston, S. W., writings : Lull, 14.

Winchell, II. V., writings: Kemp, 17 ; Keyes, 136.

Woodward, R. S., writings: Wright, F. E., 8.

Woodworth, J. B., writings: Keith, 3.

Wright, G. F., writings : Upham, 3.

Big Hill salt dome, Jefferson County, Texas: Henley, 1.

Big Hill salt dome, Matagorda County, Texas : Wolf, 5.

Big Lake oil field, Reagan County, Texas: Sellards, 21.

Big Thompson River valley, Colorado, physlographic development: Fuller, M. B., 1.

Bindheimite as an ore mineral: Shannon, 7. Biography.

Adams, F. D. : Anon., 36.

Agassiz, Louis: Keyes, 211; Warren, H. A., 1.

Bailey, L. W. : Bailey, J. W., 1.

Barrell, Joseph : Gregory, H. E., 10 ; Vaughan, 20; Schuchert, 5, 6, 7, 43 ; Willis, 3.

Becker, G. F.: Day, A. L., 2, 3 ; Merrill, 45 .

Bell, Robert: Ami, 1.

Billings, W. R. : Kindle, 8.

Böse, Emil : Cavins, 1; Schuchert, 44.

Bostwick, T. A.: Dunbar, 6.

Branner, J. C. : Jordan, 7 ; Keyes, 54 ; Penrose, 5, 6; Smith, J. P., 2; Townley, 2.

Broadhead, G. C. : Keyes, 5.

Brooks, A. H. : Keyes, 193; Smith, G. O., 18, 19 ; Smith, P. S., 5, 9 ; Spurr, 16.

Brush, G. T.: Dana, 3.

Burrows, A. G.: Bateman, G. C., 2.

Call, R. E. : Keyes, 43.

Canfleld, F. A.: Palache, 19.

Camsell, Charles : Murray, 2.

Chamberlin, T. C.: Fairchild, 25; Kemp, 22 ; Keyes, 131; Willis, ¿2.

Clark, W. B. : Clarke, J. M., 3 ; Emerson, B. K., 1.

Clarke, J. M. : Keyes, 201 ; Schuchert, $27,28,30,53$; Walcott, 16 ; Woodward, A. S., 2 ; Anon., 12, 52.

Coleman, A. P.: Anon., 65.

Condon, Thomas : McCormack, 2.

Cox, G. H. : Dake, 9 ; McNutt, 1.

Crosby, W. O.: Johnson, D. W., 12 ; Shimer, 8.

Curtis, G. C.: Sayles, 17.

Cushing, H. P.: Clarke, J. M., .15 ; Kemp, 11.

Dall, W. H.: Merriam, C. H., 2 ; Parker, G. H., 1 ; Pllsbry, 4 ; Schuchert, 37.

Dana, J. D.: Pirsson, 3.

Day, D. T. : Campbell, M. R., 11.
Biography-Continued.

De Montessus de Ballole: Hobbs, 21.

Diener, Carl: Richarz, 12.

Diller, J. S. : Smith, G. O., 30.

Dowling; D. B. : Collins, W. H., 14, 17.

Dumble, E. T. : Baker, C. L., 5 ; Keyes, 177 ; Simonds, 1 ; Suman, 2 ; Taff, 5.

Eastman, C. R.: Dean, 1, 2 ; Holland, W. J., 1 ; Keyes, 253.

Emerson, B. K. : Keyes, 30.

Emerson, F. V.: Brigham, 2.

Emmons, Ebenezer: Keyes, 127.

Gale, H. S. : Anon., 38.

Gilbert, G. K.: Andrews, 1; Barrell, 1; Davis, 28; Fairchild, 4 ; Mendenhall, W. C., 1 ; Merriam, C. H., 1.

Gulliver, F. P.: Davis, 10.

Guppy, R. J. L. : Harris, G. D., 3.

Hall, James: Clarke, J. M., 12, 13.

Hague, Arnold: Iddings, 1.

Hambach, Gustav : Klem, 1.

Harrison, J. B. : Smith, S., 1.

Haïy, R. J.: Whitlock, 1.

Hayden, F. V.: Keyes, 154.

Hess, F. L. : Anon., 14.

Hice, R. R. : Ashley, 19.

Hidden, W. E.: Kunz, 1.

Hilgard, E. W.: Slate, 1.

Hills R. C. : George, R. D., 4.

Hinrtchs, G. D.: Keyes, 121, 151.

Hitchcock, C. H. : Upham, 1.

Holbrook, Levi : Kemp, 14.

Holden, E. F.: Kraus, 1503, 1504.

Hovey, E. O.: Berkey, 10 ; Kemp, 6 ; Keyes, 181 ; Kemp, 6, 18 ; Whitlock, 17 ; Anon., 40.

Howell, E. E. : Fairchild, 5.

Hyatt, Alpheus: Anon., 73.

Iddings, J. P.: Brøgger, 1 ; Merrill, 11.

Irving, J. D. : Kemp, 1.

James, Edwin : Keyes, 88.

Jordan, E. K. : Guerard, 1.

Julien, A. A. : Kemp, 5.

Keele, Joseph : Malcolm, 2.

Kemp, J. F. : Berkey, 14 ; G., 1 ; Geijer, 4 ; Keyes, 250 ; Knappen, 2 ; Iindgren, 20 ; Peele, 1; Reeds, 13; Rickard, 12 ; Schuchert, 33 ; Anon., 15,61 .

Kennedy, William: Wrather, 7.

Knowlton, F. H. : Berry, 85, 87 ; White, D., 32.

Lambe, L. M. : Kindle, 1, 7.

Ledoux, A. R. : Kemp, 16.

Lee, W. T. : Alden, 7.

Leidy, Joseph: Clarke, F. W., 3 ; Osborn, 30, 31 ; Scott, W. B., 2, 3.

Libbey, William : Darton, 22.

Lilley, A. T. : Kindle, 16.

Little, George: Little, G., 1.

Lucas, A. F.: Goodrich, 2 ; McBeth, 1.

Lusk, R. G. : Mather, 11.

Luther, D. D. : Clarke, J. M., 29.

Lyman, B. S. : Lyman, 1.

McInnes, William: Alcock, 24 ; Malcolm, 5. 
Biography-Continued.

Maclure, William : Keyes, 205.

Mackenzie, J. D. : Anon., 26.

Marcou, Jules : Keyes, 143.

Matthew, G. F.: Matthew, 28.

Mell, P. H.: Calhoun, 1.

Merriam, J. C. : Matthew, 10.

Miller, B. I.. : Anon., 24.

Miller, W. G.: Brock, 9. 10 ; Goodwin, W. L., 3 ; Hore, 10 ; Keyes, 197 ; Knight, C. W., 13; McCrea, 1; Mackenzie, G. C., 2; Rickard, 2; Tyrrell, 8; Anon., 32, 42.

Moses, A. J.: Kunz, 2; Luquer 1; Whitlock, 8, 9.

Morgan, G. B. : Moore, R. C., 29.

Nicollet, J. N.: Keyes, 200.

Norton, W. H. : Keyes, 213.

Norwood, C. J.: Foerste, 25; Jillson, 97 ; Keyes, 249.

Nuttall, Thomas: Keyes, 70.

Owen, D. D.: Kieyes, 108.

Packard, A. S.: Cockerell, 7.

Peck, F. B. : Fretz, 1; Shimer, 5.

l'irsson, L. V.: Cross, C. W., 2 ; Iddings, 4.

Powell, T. W., memorial : Dellenbaugh, 1.

Prest, W. H.: Piers, 1.

Pumpelly, Raphacl : Keyes, 139 ; Willis, 16, 19 ; Anon., 31.

Purdue, A. H.: Ashley, 3.

l'urington, C. W.: Ludlum, 1.

Ransome, F. I. : Anon., 13.

Raymond, R. W.: Ingalls, W. R., 1: Rickard, 4.

Robinson, H. H. : Auon., 6z.

lRoebling, W. A.: Phillips, 2.

Rogers, (r. S. : Kemp, 6.

Roger's, H. D. : Keyes, 218.

Rohn, Oscar: Leith, 12.

St. John, O. H. : Keyes, 45, $25 \dot{ }$.

Salisbury, R. D. : Chamberlin, 'T. C., 1 ; Keyes, 74 ; Wrather, 6.

Scudder, S. H.: Mayor, 1.

Shaler, N. S.: Lane, 26.

Sinclair, E. G. : Osborne, 2.

Smith, E. A. : Butts, 14 ; Jones, W. B., 8,9 ; Schuchert, 41.

Smith, William : Keyes, 247.

Smock, J. C. : Kümmel, 6.

Spencer, J. W. W. : Shaw, 10.

Springer, Frank: Keyes, 157, 269 ; Schuchert, 42, 46 ; Springer, 12.

Stevenson, J. J.: Keyes, 173; White, I. C., $T$.

Swallow, G. C.: Boone Co. Hist. Soc., 1. Keyes, 274.

Teller, E. E. : Teller, 1.

Todd, J. E. : Keyes, 102, 145 ; Leverett, 12.

Twitchell, M. W. : Kümmel, 8.

Tyrrell, J. B. : Murray, 1.

Uglow, W. L. : Baker, M. B., 4 ; Brock, 12 ; Q., 1 ; Williams, M. Y., 18.

Valiant, W. S. : Hayes, A. O., 8.
Biography-Continued.

Van Hise, C. R. : Chamberlin, 'J. C., 6 ; Leith, 3 ; Wolff, I. E., 1.

Van Ingen, Gilbert: Howell, B. F., 3.

Vaux, George, jr. : Gordon, S. G., 22.

Vogdes, A. W. : Dumble, 5 ; Keyes, 158 ; Resser, 2.

Wadsworth, M. E. : Lane, 17.

Walcott, C. D.: Barrois, 1 ; Chamberlin, T. C., 35 ; Darton, 23 ; Keyes, 254 ; Marr, 1 ; Merriam, 26 ; Schuchert, 36; 49 ; Smith, G. 0., 25, 26, 29 ; Troedsson, 3 ; Woodward, A. S., 3 ; Wilcox, 1 ; Anon., 2, 25, 6.3.

Ward, H. A. : Fairchild, 558.

Ward, I. F. : Cape, 1.

Watson, T. I.: Giles, 5 ; Keyes, 189 ; Leighton, 15 ; Ries, 1.2, 13.

Weinzierl, I.. L. : Applin, 2.

Weller, Stuart: Chamberlin, 'T'. (.., :36, 39 ; Decker, 7 ; .Jillson, 97 ; Schuchert, 38 .

Wel]s, I.T. I.. : Chittenden, 1.

White, I. C. : Fairchild, 23 ; Itennen, 2 ; Keyes, 271 ; Schuchert, 45.

Whittaker, E. .T.: Kindle, 3:3.

Williams, G. H. : Keyes, 117.

Williams, H. S. : Cleland, 1 ; Gregory, H. E., 1.

Williston, S. W. : Lull, 1, 14; Osborn, H. I., 1, 2 ; Shimer, 1.

Wilson, A. G.: Kieyes, 253.

Winchell, H. V. : Gray, J. P., 1 ; Kenı, 17 ; Keyes, 136 ; Rickard, 1; Anon., 18, 29.

Wintringham, J. P: : Miller, 'T. 1., 1.

Woodward, R. S. : Wright, F. E., 8.

Woodworth, J. B.: Daly, 20, 22 ; Keith, 3 ; Anon., 47, 49.

Wortman, J. L. : rolland, W. T., 5; Osborn, 43.

Wright, G. F.: Hubbard, G. D., 3; Upham, 3.

Biplanation of earth's crust: Keyes, 44.

Birds. See Aves.

Bishop conglomerate, glacial origin: Hares, 2.

Bissett formation, Texas: King. 4 .

Bituminous rocks and sands. See also Oll shale.

Alberta, northern : Clark, K. A., 1-4 ; Ells, 1, 4-8, 9.

California: Vander Ireck, 2.

Illinois: Barrett, N. O., 4.

Iowa, Linn County : Dille, 1.

Kentucky, western coal ficld: Burroughs, W. G., 2.

Black sands, Idaho: Shannon, 25.

Black shales, origin and composition: Thiessen, 7 .

Blastoidea.

Astrocystites: Hudson, G. H., 2.

Astrocystites. (Steganoblastus) ottawaensis: Hudson, G. H., 3.

Chester fauna: Weller, S., 1.

Orophocrinus stelliformis, growth stages: Bather, 5. 
Block diagrams: Lobeck, 6 .

Blue Ridge salt dome, Fort Bend County, Texas: Hager, D. S., 2.

Boghead coals, origin: Thiessen, 12.

Bonaventure formation, geological age: Clarke, 26.

Bone, fossil, mineralogy and petrography: Rogers, A. F., 19.

Boraciferous beds, formation: Keyes, 67.

Borate deposits, California and Nevada, vein nature: Keyes, 69.

Borax.

California: Foshag, 20.

Kramer : Gale, 5 ; Noble, 5.

colemanite, near Shoshone: Noble, 6.

Origin: Foshag, 10.

Nevada: Foshag, 20 ; Keyes, 61.

Clark County: Noble, 2.

Callville Wash: Gale, 3.

Borings.

Alabama, Coastal Plain: Brantley, 1.

Florence: Miser, 21.

northern: Semmes, 2, 3.

Alberta: Allan, 4.

Cypress Hills: Dyer, 9.

Fort McMurray : Allan, 3.

Wainwright-Vermilion area: Hume, 19.

Waterways : Allan, 11.

Apparatus for measurement of temperatures in deep wells: Van Orstrand, $\mathbf{5}$.

Arizona, Camp Verde: Jenkins, 6.

Arkansas, Batesville district: Miser, 8 . Ozark region: Croneis, 5. south central: Rubey, 1.

Union County: U. S. Geol. Survey, 7.

British Columbia: Ingall, 1.

Fraser River Delta: Johnston, W. A., 17.

California, San Diego County : Ellis, A. J., 1.

San Joaquin Valley: Taff, 6.

Ventura County: Hudson, 4

Canada: Ingall, 6, 10.

eastern: Ingall, 8.

prairie provinces: Dowling, 3 ; Ingall, 2, 5; and Northwest Terrltories: Ingall, 7 .

Colorado: Colorado, 1.

Fort Collins: Ball, M. W., 2, 3.

La Junta area: Patton, H. B., 3. northeastern: Mather, 12.

Deep wells : Anon., 5.

Deepest wells: Van Orstrand, 10.

Examination of well cuttings: Trager, 1.

Florida: Sellards, 12.

Fused cores: Ross, C. S., 4.

Fused sedimentary rocks in drill cores: Bowen, 14.

Georgia, Coastal Plain: Prettyman, 1.

Illinois : Krey, 2.

Allendale oil field, Wabash County : Moulton, 21.

Carlyle-Centralla district: Shaw, 9. Clark County: Moulton, 22.
Borings-Continued.

Illinois-Continued.

Colchester and Macomb quadrangles:

Hinds, H., 1.

Decatur area : Collingwood, 6.

District IV : Cady, 7.

east-central : Mylius, 7 .

Edgington-Milan area: Savage, 5.

Goodhope and La Harpe quadrangles: Nebel, 2.

Jacksonville area: Bell, A. H., 7 ; Collingwood, 3.

Joliet quadrangle : Fisher, D. J., 2.

Lawrence County, St. Francisville area : Bell, A. H., 10.

Monmouth : Workman, 1.

New Athens-Okawville area: Shaw, E. W., 8.

northeastern : Anderson, C. B:, 1.

Indiana: Logan, 5, 24.

southwestern: Logan, 18.

Iowa, Atlantic: Tilton, 3.

Brighton: Lindly, 4.

Crawford County: Lees, 18.

Davenport : Lindly, 6 .

Ida County : Lees, 10.

Lucas County : Lugn, 6.

Morning Sun: Lindly, 5.

Pocahontas County, L a ure ns: Cable, 3.

Winfield : Lindly, 2.

Kansas, Gove County: Lupton, 3.

Rose dome, Woodson County: 'Twenhofel, 32.

Syracuse and Lakin quadrangles: Darton, 2.

western : Twenhofel, 20.

Wilson County: Stryker, 1.

Kentucky : Jillson, 2, 21, 25, 35, 73.

Shaw, E. W., 1.

Allen County : Jillson, 12.

Bowling Green : Nelson, 16.

Breathitt and Knox Counties: Jillson, 13.

Caldwell County : Weller, 5.

Edmonson County : Weller, J. M., 1.

eastern: Jillson, 16, 17.

Island Creek oil pool, Owsley County: Jillson, 83, 84.

Jackson Purchase region: Jillson, 28.

Nicholasville: Miller, 9.

Princeton quadrangle: Weller, 7.

southeastern: Jillson, 8.

Stinking Creek region: Jillson, 3.

Warren County: Jillson, 18; Laird, 1 ; St. Clair, 3.

Webster County: Glenn, 4, 5.

Logging rotary-drilled wells: Clark, S. K., 2.

Logmeter : Burton, G. E., 1.

Louisiana, northern: Spooner, 2. northwestern : Hammill, 1.

Richland Parish : Campbell, I., 1.

Sulphur salt dome: Kelley, 1.

Webster Parish : Ponton; 1.

Welsh oil fleld : Reed, L. C., 1. 
Borings-Continued.

Metamorphosed core material: Wrather, 3.

Mexico, Isthmus of Tehuantepec: Huntley, s., 1.

Vera Cruz, Idolo Island: Dumble, $\boldsymbol{~}$.

Michigan, Detroit: Vanderwilt, 1.

Mississippi : Grim, 1 ; Lowe, 3, 9.

Tishomingo County: Bramlette, 4.

Missouri : Krey, 2 ; Wilson, Mal. E., 1.

Vernon County: Greene, 8.

Montana, faulted area south of Bearpaw Mountains: Reeves, F., 8.

Glendive: Bowen, C. F., 2.

Vananda: Bowen, C. F., 2.

Nebraska : Schramm, 2.

Pennsylvanian : Condra, 2.

Nevada, Steptoe Valley: Clark, W. O., 1.

New Mexico: Darton, 10 ; Ellis, R. W., 1.

North Carolina, Havelock: Mansfield, W. C., 5.

North Dakota, Ellendale: Meinzer; 14.

Nova Scotia, Sydney coal field: Hayes, 6.

Ohio: Panyity, 3.

Vinton County : Stout, 6.

Oklahoma : Bloesch, 1 ; Shaw, E. W., 6.

Beaver County: Gould, C. N., 15.

Caddo County, Cement field : Reeves, F', 1.

Carter County: Roth, 2; Tomlinson, 4.

central : Hughes, 1.

Cimarron County: Rothrock, 4.

Harmon, Greer, Jackson, and Tillman counties: Clifton, 5.

Jefferson County: Robinson, H. M., 3.

Kingflsher and Canadian counties: Kite, 1.

Love County: Bullard, 2.

Marshall County : Bullard, 3.

Fapoose oil field: Roark, 2.

southern: Hopkins, O. B., 2; Morgan, G. D., 1.

Stonewall quadrangle: Morgan, G. D., 5 .

Ontario: Estlin, 2 ; Harkness, 3, 5, 6 ; Ingall, 3.

Romney : Davis, H. R., 1.

southwestern: Williams, M. Y., 4.

Pennsylvania, Greensburg quadrangle: Johnson, M. E., 1.

Plotting well logs: Weeks, A. W., 2.

Prairie provinces and Northwest Territories: Ingall, 9.

Pseudo-stratiflcation in cores: Bramlette, 5 .

Samplegraph : Gardner, J. H., 5, 6.

South Dakota: Rothrock, 6.

Ziebach County: Russell, w. L., 6.

Tennessee, northern: Glenn, 6.

Sumner County: Mather, 3.

Wayneshoro quadrangle: Miser, 6.

Borings-Continued.

Texas, Amarillo region: Gould, C. N., 1. ; Harrison, 'L. S., 1.

Bexar County : Sellards, 10.

Brown County : Waite, 1.

central: Matteson, 1.

Caldwell County: Sellards, 16.

Colorado County: Bailey, T. L., 1.

Damon Mound oil field: Bevier, 1.

Denton County: Winton, W. M., 3.

Foard County: Beede, 11.

Fort Stockton quadrangle: Adkins, 4.

Lytton Springs oil field: Bybee, 2.

McLennan County : Adkins, 3 ; Pace, 1.

Medina County : Liddle, 3.

Mexia oil field: Lahee, 17.

Minerva fleld, Milam County : Hager, D. S., 1.

Midland County : Sellards, 26.

north central: Goldman, 5.

northeastern (part) : Hopkins, O. B., 2.

Panola County : Sellards, 15.

Potter County: Patton, L. T., 2.

Ranger oil field : Reeves, F., 2.

salt domes: Powers, 12.

Tarrant County: Winton, W. M., 1.

Webb and Zapata counties : Sellards, 1.3.

westel'n: Mansfield, G. R., 14.

West Point salt dome: De Golyer, 1.

United States: Phalen, 1.

Utah, San Juan field: Miser, 17.

southeastern : Prommel, 2.

Virginia, Tazewell County : Harnsberger, 1.

Well logs, correction : Lang, W. B., 4.

Well samples, care of : Robinson, W. I., 2.

West Vil'ginia, Cabell County : Reger, 8.

Cheat Mountain coal field, Randolph County: Reger, 15; 16.

Grant County : $\bar{\tau}$.

Marion County, deepest well : White, I. C., 1.

Mercer, Monroe, and Summers counties: Reger, 9.

Wisconsin: Thwaites, 3.

Wyoming, Big Horn Basin : Hewett, 1.6.

Cambria: Hancock, 4.

Lance Creek field: Hancock, 5.

Rock Springs area, Sweetwater County: Schultz, 1.

- Upton-Thornton oil field: Hancock, 3.

Botany, fossil. See Paleobotany.

Boudinage: Quirke, 10.

Boulders.

Glacial, New York: Martens, 4.

Kentucky: Jillson, 71.

Iowa, Kansas drift: Kay, 3.

Kansas, southeastern, granite boulders : Twenhofel, 2.

Kentucky, glacial boulders : Jillson, 67. Row River between Cochrane and Kananaskis, Alberta : Rutherford, 6 . 
Royer Valley, Iowa : Lees, 5.

Brachiopoda.

Alberta, Devonian : Kindle, 32.

Peace River, Devonian : Kindle, 47.

Arkansas, St. Clair limestone: 'Thomas, N. L., 1, 2, 4

Beloit formation: Sardeson, 24.

Bilobites bilobus, Iowa: Thomas, A. O., 25.

Brooksina, Alaska : Kirk, E., 2.

Cambrian: Walcott, 8.

Cymbidium, Alaska : Kirk, 5.

Derbya: Price, W. A., 1.

Derbya crassa, abnormal sculpture: Price, 5.

Etheridgina : Greger, 3.

Harpidium, pentameroid brachlopod, southeastern Alaska: Kirk, 3.

Iowa, Devonian Pentameracea : Belanski, 2.

Hackberry stage : Fenton, C. L., 1.

Maquoketa shale : Bradley, W. H., 2.

Kentucky, Mississippian: Ehlers, 10.

Wayne County, Warsaw formation: Eblers, 11.

Lenoir and Athens formations, Tennessee and Virginia : Raymond, 37.

Leptodus, British Columbia : Kindle, 38.

Lingula, antiquity : Keyes, 85.

Lingulidiscina: Girty, 14.

New York, Utica and Lorraine formations: Ruedemann, 17.

Oligocene, Antigua: Thomas, 8.

Ontario, Toronto area : Parks, W. A., 8.

Ozarkian: Walcott, 8.

Orbiculoidea : Girty, 13.

Ottosee and Holston formations, Tennessee and Virginia: Willard, B., 5.

Platystrophia: McEwan, 1.

Pocono fauna: Price, W, A., 2.

Pugnoldes, Devonian, Iowa: Thomas, 14

Rbynchotrema and Zygospira, Black River: Fenton, 5.

Recurrent brachiopods, Lower Cretaceous, northern Texas: Sandidge, 1 .

Schizophoria, Devonian, Iowa : Fenton, M. A., 3.

Spilifer: Butts, 3.

orthogenesis: Fenton, C. L., 7.

Spirifer orestes phylum: Fenton, C. L., 10.

Stringocephalus, distribution: Kir'k, E., 7.

Stringocephalus burtoni, distribution : Kindle, 10.

Stropheodonta demissa, evolution in Snyder Creek shales: Branson, 4.

Strophomena, Black River and Richmond: Fenton, C. L., 9.

Stroplomena incurvata, pathologic ornamentation: Sardeson, 26.

Syringothyris : North, F. J., 1.

'Terebratula, Eocene, Maryland: Roherts, J. K., 1.

$4096-31-46$
Brachiopoda-Continued.

Terebratulacea, Deronian, Iowa: $\mathrm{Be}$ lanski, 4.

'I'cxas, Butler salt dome, Midway formation: Gardner, J. A., 6.

San Saba County, Míssissippian Girty, 7.

Brass ore in nature: Keyes, 107.

Breccia.

Iowa, Wapsipinicon breccias: Norton W. H., 1.

New York, Rochester: Giles, 1.

Breccias of St. Louis formation: Grawe, 2. Bridge Creek flora, Oregon: Chaney, 16.

Bridge River district, British Columbia: McCann, 3, 4.

Bristow quadrangle, Creek County, Okla homa: Fath, 6.

British Columbia.

Coal resin, Coalmont: Steele, 1.

General: Dolmage, 11.

Clearwater, Lake area: Marshall, J. R., 6.

Finlay River district: Dolmage, 17.

Reconnaissance, Skeena Rjver to Stew art: Hanson, 6.

Areas described.

Ainsworth district: Schofleld, 4.

Alberni area, Vancouver Island: Mac Kenzie, J. D., 7.

Atlin-Telegraph Creek : Cockfleld, 18.

Barkerville area, Cariboo district: Johnston, W. A., 10, 22.

Barkley Sound, Vancouver Island: Dolmage, 2.

Bridge River area: McCann, 3, 4.

Britannia area : Schofleld, 1.

Cariboo district: Mackay, B. R., 3; Uglow, $\boldsymbol{\theta}$.

Eedar Creek area: Johnston, W. A., 18.

Cheam Range: Cairnes, 3.

Chilko Lake area: Dolmage, 15.

Coast and islands between Burke and Douglas channels : Dolmage, 8 ; between Douglas Channel and the Alaskan boundary : Dolmage, 9 .

Coquihalla area: Cairnes, 4; Camsell, 6.

Copper Mountain, Gun Creek: Camsell, 4.

Dease Lake area, Cassiar district: Johnston, W. A., 23; Kerr, F. A., 1.

Dewdney Trail : Cairnes, 2.

Driftwood Creek area, Babine Moun. tains : Hanson, 9.

Eutsuk Lake district: Brock, 1 ; Marshall, J. R., 4.

Fraser River Delta map area; Johnston, W. A., 17.

Farrison Lake district: Crickmay, 5.

Hat Creek coal area, Kamloops district: MacKay, B. R., 5.

Hazleton district: O'Nelll, 1.

Tervis Inlet region: Blanchard, R., 1.

Kettle Valley : Cairnes, 2. 
British Columbia-Continued.

Areas described-Continued.

Kitsault River to Skeena River : Hanson, 3.

-Kitsault Valley; Hanson, 2.

Lakelse Lake area, coast district: Marshall, J. R., 5.

Lardeau area: Bancroft, M. F., 3.

Lasqueti Island: MacKenzie, J. D., 3.

Lillooet Valley : Cairnes, 12.

Lillooet-Prince George region : Reinecke, 3.

North Thompson Valley, Kamloops district: Uglow, 3.

Peace River district: Spieker, 1.

Peace River canyon coal a!ea; McLearn, 7.

Pemberton area, Lillooet d is trict : Cairnes, 8.

Prince Rupert to Burns Lake : Hanson, 10.

Purcell Range west of Brisco, Kootenay district: Walker, J. F., 2.

Quatsino Sound district, Vancouver Island: Dolmage, 1.

Salmon River district: O'Neill, 3; Schofield, 11; Young, G. J., 3.

Slocan area: Bancroft, M. F., 2.

Stikine River area: Kerr, F. A., 2, 3.

Sunloch copper district, Vancouver Island: Dolmage, 3.

Tatla-Bella Coola area, Coast district: Dolmage, 16.

Whitesail-Tahtsa lakes area: Marshall, J. R., 3.

Windermere area, Kootenay district: Walker, J. F., 1.

Yale district, Silver Creek, Skagit and Similkameen rivers: Cairnes, 5.

Zymoetz River area, Coast district: Hanson, 11.

Economic geology.

Alberni area, Vancouver Island: MacKenzie, J. D., 7.

Alice Arm district: Davis, A. W., 1.

Alps-Alturas group, Slocan mining division: Cairnes, 11.

Anyox copper deposits: Clapp, L. R., $1,2$.

B. C. silver mine, Stewart district: Dolmage, 14.

Bauxite: Dunn, R., 2.

Bornite and pyrrhotite in Jeune ores, Vancouver Island: Osborne, F. F.,1.

Britannia mines, copper: Schofield, 17.

Cariboo district: Galloway, J. D., 2; Johnston, W. A., 13.

Barkerville area: Uglow, 9.

Cariboo gold fields: MacKay, B. R., $1,2$.

Cheam Range, Lucky Four ore deposits : Cairnes, 3 .

Clearwater Lake area: Marshall, J. R., 6.

Clinton district: Reinecke, 2.

Coal, Vancouver Island: MacKenzie, J. D., 5.
1

British Columbia-Continued.

Economic geology-Continued.

Coalmont amber: Wilson, A. W. G., 1.

Coast and islands between Douglas Channel and the Alaskan boundary : Dolmage, 9.

Coast Range ore deposits: Brewer, W. M., 2.

Copper, Lasqueti Island: MacKenzie, J. D., 3.

Hidden Creek mine: Campbell, E. E., 1.

Copper sulphides, La Fleur Mountain : McLaughlin, D. H., 1.

Coquihalla area: Cairnes, 1.

Cordillera, metallogenetic epochs : Brock, 13.

Crowsnest Pass coal field: Strachan, 1.

Dolly Varden mine, Kitsault River district: Hanson, 4.

Elk River valley: Marshall, J. R., 1. Engineer mine, Atlln: Weed, 3.

Epsomite, Ashcroft: Walker, 8.

Finlay River district: Dolmage, 17.

Fissure systems: Schofleld, 16.

General: Brock, 7 ; Galloway, J. D., 1-4; Nichols, H. G., 1 ; Robertson, $3-6$.

Gold : Camsell, 8.

Barkerville ar'ea: Johnston, W. A., 10, 11.

Bridge River area: McCann, 3, 4.

Cedar Creek area: Johnston, W. A., 18.

coast and islands between Burke and Douglas channels: Dolmage, 8.

Coquiballa area: Camsell, 6.

Dease Lake area, Cassiar district: Johnston, W. A., 23.

Fraser River: Johnston, W. A., 21.

Placer gold, Barkerville area, Cariboo district, origin; Uglow, 10.

Gold-cobaltite-lodestone deposit, North Thompson Valley: Uglow, 15.

Granby mines, Phoenix: Campbell, E. E., 2.

Hat Creek coal area, Kamloops district: MacKay, B. R., 5.

Hazleton district: O'Neill, 1.

Hidden Creek mine, Granby Bay: Campbell, E. E., 1.

Kamloops Lake, mercury deposits: Camsell, 2.

Iron ores: Young, G. A., 6.

Kootenay region: Langley, 1.

Lardeau district: Bancroft, M. F., 1, 4.

Lardeau and Trout Lake mining divisions: Emmrens, 2.

Lillooet district : Cartwright, C. E., 1.

Lillooet-Prince George region : Reinecke, 3.

Limonite, Taseko Valley: MacKenzie, J. D., 1.

Magnesium sulphate: Goudge, 1.

Magnetic deposit, Vancouver Island, genesis: Uglow, 16. 
British Columbia-Continued.

Éoonomic geology-Continued.

Marble Bay mine, T'exada Island: Dolmage, 7 .

Mesozoic mineralization: Schofield, 3

Mineral deposits: Wilson, P. D., 2.

Mineral resources, Pacific Great Eastern Railway: Blewer, W. M., 3 ; Davis, A. W., 2.

Mineralization, George gold-copper mine, Stewart: Smitheringale, 2.

Mining industry : Galloway, J. D., 1-5 ; Robertson, 1-6.

Nickel ore, Yale district: Cairnes, 7,0

Northwestern British Columbia: Hanson, 8.

Oil and gas development, foothills belt: Hopkins, O. B., 4.

Oil and gas possibilities, northeastern British Columbia: Stewart, J. S., 2 .

Oil possibilities, Vancouver region: Camsell, 3

Peace River district: Spieker, 1.

Oil prospects: Hume, 27.

Ore deposits: Schofield, 9, 11.

prospecting: Uglow, 14.

Peace River canyon coal area: McLearn, 7 .

I'eat, southwestern British Columbia: Anrep, 11.

Placer gold and lead-zinc deposits, Dogtooth Range, Kootenay district: Evans, C. S., 1.

Placers, Cariboo district: Johnston, W. A., 13, 14 ; Tyrrell, 2 .

Cedar Creek: Johnston, W. A., 20.

Platiniferous rocks, Tulameen area, Yale district: Poitevin, 6.

Platinum : Camsell, 5 ; Uglow, 2 ; Tulameen district: Macaulay, 1.

Portland Canal district: Hanson, 7 ; Wilhelm, 1.

Premier mine: Burton, W. D., 1; Hanson, 5.

Quartz veins, Barkerville, Cariboo district: Uglow, $6,8$.

Quatsino Sound district, Vancouver Island: Dolmage, 1.

Salmon River district: Banks, 1 ; Prior, C. E., 1 ; Schofield, 7, 14.

Silver, Stump Lake: Camsell, 7 .

Silver mineralization, Beaverdell: McKinstry, 8.

Silver-lead deposits, Ainsworth district: Schofield, 4.

Atlin district: Cockfield, 17 .

Slocan district: Bateman, 14.

Silver-lead-zinc veins, Atlin : McKinstry, 7 .

Similkameen district: Campbell, C. M., 2.

Horn silver mine: Bostock, 1.

Slocan district: Cairnes, 10, 13.

Sodium carbonate: Goudge, 2.
British Columbia-Continued.

Eoonomic geology-Continued.

Southwestern British Columbia, Yale, and Similkameen mining divisions : Cairnes, 2.

Stewart district : Campbell, E. E., 1, 2. silver ores: Dolmage, 4.

Sunloch copper district, Vancouver Island : Dolmage, 3.

'Taseko Valley iron deposits: Brewer, W. M., 1.

Texada Island magnetites: Swanson, C. $0 ., 2$.

Tungsten near Hazelton: Hurst, 3.

Vancouver Island, west coast: Dolmage, 5.

Western mineral belts: Dolmage, 13.

Windpass gold mine, Chu Chua : Uglow, 12.

Yale district, Hillsbar gold claims: Cairnes, 6.

Zinc, East Kootenay district: Whittemore, C. R., 1.

Zinc and lead: Robinson, A. H. A., 2.

Zoning of mineral deposits: Hanson, 12.

Historical geology.

Ainsworth district: Sçhofield, 2.

Barkerville district: Uglow, 6 .

Cariboo district: Uglow, 8.

Beaverfoot - Brisco - Stanford Range : Walcott, 9

Borings : Ingall, 1, 4.

Bow River section, Banff: Kindle, 30.

Bridge River district: McCann, 4.

Cambro-Ordovician section, Beaverfoot Range: Burling, 4; Mount Robson area : Burling, 2, 5 .

Copper Mountain, Gun Creek : Camsell, 4.

Coquihalla area : Cairnes, 1.

Cordillera: Burwash, 2

geological record: Schofield, 13.

Cordilleran formations, nomenclature: Walcott, 7 .

Elk River valley : Marshall, J. R., 1.

Eocene coal basin, Chu Chua: Uglow, 7.

Fraser River canyon: Camsell, 9

Geologic history: Brock, 4, 13.

Geologic mapping: Dolmage, 6.

Geologic record: Schofield, 15.

Igneous activity: Brock, 14.

Jurassic and 'Triassic, relations: Crickmay, 8.

Iower Cambrian, southeasteln British Columbia: Schofield, 10.

Mesozoic formations: Goranson, 1 ; Schofield, 3; Hedley : Schofield, 5.

Northeastern British Columbia: Stewart, J. S., 2.

North Thompson Valley : Uglow, 11, 15

Parson Bay: Crickmay, 9.

Pleistocene, Vancouver Island: Berry. 33. 
British Columbia-Continued.

Historical geology-Continued.

Pre-Cambrian and Cambrian, southeastern British Columbia: Schofield, 12.

Pre-Devonian deposits : Walcott, 11, 17, 18.

Purcell Range and Rocky Mountains, relations: Burling, 3 .

Rocky Mountain region: Schofield, 8 .

Rocky Mountain trench: Shepard, 3, 11.

St. Eugene silts, Kootenay Valley : Hollick, 10.

Salmon River district: Schofield, 7.

Silurian tillite: Shepard, 1.

Sooke formation, Vancouver Island: Clark, B. I.., 8 ; Cornwall, 1.

Southwestern British Columbia, Yale and Similkameen mining divisions: Cairnes, 2.

Taseko Lake-French Bar Creek: MacKenzie, J. D., 2.

Taseko Valley: MacKenzie, J. D., 1.

Tulameen district: Macaulay, 1.

Upper Peace River region: McLearn, 6.

Vancouver Island, coal measures: MacKenzie, .J. D., 5 .

west coast: Dolmage, 5 .

Vancouver region: Camsell, 3; Schofield, 17.

\section{Mineralogy.}

"Allemontite," Atlin: Walker, 15.

Axinite, Nickel Plate Mountain : Poitevin, 3.

Bornite, cleavable, Usk: Walker, 13.

Bornite-chalcopyrite intergrowth, Legate Creek: Uglow, 4

Calamine, Ainsworth: Poitevin, 2.

Camsellite, Douglas Lake : Ellsworth, 1.

Cerusite, Moyie: Poitevin, 4.

Copiapite, Liard Post: Walker, 20.

Ferrierite, Kamloops Lake: Graham, R. P. D., 1.

Fibroferrite, Quatsino: Walker, 21.

H. B. mine, Salmo: Walker, 'T. L., 1.

Ilidosmine crystals, Ruby Cleek, Atlin district: Gledhill, 1.

Knopite and magnetite occurrence, Moose Creek : Ellsworth, 10.

Lansfordite, Atlin: Poitevin, 8.

Marble Bay mine, Texada Island: Dolmage, 7.

Orthoclase, Penticton: Walker, 9.

Sundry minerals: Poitevin, 10.

Paleontology.

Algae, Middle Cambrian: Walcott, 1.

Cambrian: Walcott, 8.

Ceratopyge fauna:- Raymond, 16.

Cirripedia, Sooke formation, Vancouver Island: Cornwall, 2.

Cretaceous Mollusca: Reagan, 7.

Cretaceous plants, Stikine River, Cassiar district: Bell, W. A., 14.

Crustacea, stalk-eyed: Rathbun, 5.

Cyphornis magnus, Vancouver Island: Wetmore, 15.
British Columbia-Continued.

P'aleontology - Continued.

Diatomaceae: Boyer, 1.

Foraminifera: Cushman, 22.

Graptolites, Glenogle formation : Clar'k, T. H., 14.

Jurassic, Hazelton group : McLearn, 11.

Leptodus: Kindle, 38.

Marpolia, Cambrian Alga: Walton, 1.

Myadesma, Vancouver Island: Clark, B. L., 6 .

Ordovician, Rocky Mountains: Wilson, A. E., 4.

Palliseria, upper Ordovician: Wilson, A. E., 3.

Pleistocene, southwestern British Columbia: Crickmay, 3.

Pseudocycas, Dunvegan sandstone, Moberly Lake: Berly, $\mathbf{3 1 .}$

Sooke formation, Vancouver Island: Clark, B. L., 8; Cornwall, 1.

Saint Eugene silts, flora: Hollick, 10.

Spongiae, Middle Cambrian : Walcott, 2.

Tertiary floras: Berry, 78.

Triassic coral reef fauna: Shimer, 7 .

Upper Triassic: Smith; J. P., 3.

Petrology.

Gabbros, East Sooke and Rocky Point, Vancouver Island: Cooke, H. C., 5.

Post-Pleistocene volcanics, Milbank Sound region: Dolmage, 10.

Physical geology.

Bromley Glacier: Hayes in Bateman, 5.

Concretions: Kindle, 24.

Earthquake, December 6, 1918: Denison, F. N., 1 .

Igneous activity : Brock, 14.

Frazer River delta, sedimentation: Johnston, W. A., 8, 9.

sandstone in delta, formation: Johnston, W. A., 6.

stratification: Johnston, W..A., 12.

Robson Glacier, motion: Wheeler, A. $0 ., 3$.

Physiographic geology.

Cordilleran ice sheet: Read, 1.

Cariboo Mountains: Chamberlin, R. 'I., 15.

Cretaceous peneplain, southern British Columbia: Uglow, 11.

Fraser River canyon: Camsell, 9.

Fraser River delta: Johnston, W. A., $7,8$.

Glacial deposits, Vancouver region: Jolunston, W. A., 5.

Glaciation: Tyrrell, 1.

Llewellyn Glacier : Read, 1.

Pleistocene, Cariboo and Cassiar districts: Johnston, W. A., 24.

Pleistocene oscillations of sea level, Vancouver region: Johnston, W. A., 4.

Purcell trench : Schofield, 6.

Purcell Range and Rocky Mountains, structural relation: Shepard, 2. 
British Columbia-Continued.

Physiographic geology-Continued.

Rocky Mountain trench: Shepárd, 2, 11 ; origin: Schofield, 8.

Yoho Glacier, movement, 1917-19: Wheeler, A. O., 2.

Underground water.

Hot Springs: Elworthy, 6.

British Honduras.

General : Ower, 1.

Economio geology.

Cassiterite: Jones, W. R., 1.

Historical geology.

General: Ower, 2.

Silica lines: Ower, 3.

British Virgin Islands, geology : Earle, 5.

Brockville-Mallory area, Ontario : Wright, J. F., 1, 2.

Bromine: Stone, R. W., 5, 14.

Brown's Park formation: Peterson, 8.

Bryan Heights salt dome, Brazoria County, Texas : Kennedy, 1.

Bryozoa.

Anisotrypa waynensis, Warsaw formation, Kentucky : Deiss, 1.

Aulopora, nature and relationships: Fenton, M. A., 2.

Carboniferous, Oklahoma: Morgan, G. D., 5.

Cheilostomata, classiflcation : Canu, 7.

Chester series, Illinois and Kentucky: McFarlan, 1.

Cyclostomata: Canu, 3, 6.

Fistulipora, Canyon formation, Texas: Link, 6.

General : Bassler, 6.

Gulf of Mexico region: Canu, 8.

New York, Utica and Lorraine formations : Ruedemann, 17.

North American later Tertiary and Quaternary : Canu, 4.

Ontario, Toronto area : Parks, 8.

Workman's Creek section, Cincinnatian series : Fritz, 2.

Stones River group: Coryell, 2.

'Tennessee, Ripley fauna: Wade, B., 3.

Tertiary: Canu, 2, 5.

West Indies: Canu, 1.

Bubble impressions: Twenhofel, 13.

Buffalo Hump mining district, Idabo : Beckwith, R. H., 2.

Building stone. See also Granite; Limestone; Sandstone; Stone.

Canada: Parks, 27.

General : Richardson, C. H., 6.

Indiana: Logan, 8, 10.

Kentucky : Richardson, C. H., 6.

Oklaboma : Oakes, 1.

Pennsylvania: Stone, 19.

Burbank field, Osage County, Oklahoma: Sands, 1, 2.

Burket-Seeley oil pool, Greenwood County, Kansas: Loomis, H., 2.

Burnthill Brook area, New Brunswick: Young, G. A., 1.

Butler salt dome, Texas: Powers, 3.
Buttress structure: Branson, 20.

Byram marl, Mississippi : Cooke, C. W., 7.

Cadmium: Siebenthal, 1, 2, 6, 9, 14, 18, 26.

Caesium: Landes, K. K., 7.

Cahokia Mounds, Illinois, geological aspects : Leighton, 12 ; origin: Leighton, 8.

Calcination volcanoes: Hobbs, 10.

Calcites, behavior to radium radiations: Headden, 5 .

luminescence: Headden, 6.

Calcium carbonate, precipitation: IEnmons, R. C. 8 .

Calcium chloride: Stone, 5, 14.

Caliche: Udden, 16.

formation: Wanless, 3.

Oklahoma: Lonsdale, 5 .

origin : Lonsdale, 6.

Caliche and pseudo-anticlines: Price, W. A., 10.

California.

Cormorant Island, Salton Sea, Imperial County: Rogers, A. F., 26.

Geologic conditions at St. Francis dam site, San Francisquito Canyon: Louderback, 9.

Geologic features: Bailey, C. I., 2.

Kennett dam site, Sacramento River: Louderback, 10.

St. Francis dam site: Louderback, 9, 11 ; Ransome, 19.

State mineralogist's report: Bradley. W. W., 10.

Areas described.

Cuyamaca region: Fudson, F. S., 1.

Humboldt County : Thornbury, 1.

Iron Canyon, Sacramento River: Hamlin, 1 ; Lawson, 3.

Ivanpah quadrangle: Fewett, 1.7.

La Jolla quadrangle: Hanna, M. A., 3.

Lanfair Valley, San Bernardino County: Thompson, D. G., 1.

Los Angeles County : Kew, 6.

Mohave Desert, eastern part: I'almer, L. A., 2.

Petaluma, Point Rcyes, and Santa Rosa quadrangles: Dickerson, 2.

Point Sur quadrangle: Trask, 5.

Randsburg quadrangle: Hulin, 3 .

Sacramento Valley: Bryan, 10.

Salton Sea region: Brown, J. S., 3.

San Bernardino Mountains: Vaúghan, F. E., 1.

San Gabriel Valley region: Johnsou, H. R., 1.

San Diego County, western part: Ellis, A. J., 1.

Santa Rosa Island, Santa Barbara County : Kew, 10.

Santa Ynez River district, Santa Barbara County: Kew, 2.

Simi Valley, southern California: Kew, 1.

Sunset-Midway oil field: Pack, R. W., 1.

Upper Santa Ynez River basin : Nelson: R. N., 1 .

Ventura County: Kew, 6. 
California-Continued.

A reas described-Continued.

Warner Range, northeastern California : Russell, R. .T., 1.

Wheeler Ridge area, Kern County : Hoots, 5 .

Economic geology.

Ancient river-bed deposits : Alling, M. N., 1.

Asbestos: Woolsey, 1.

Alamitos and Seal Beach oil fields: Cunningham, C. M., 1.

Andalusite: Knopf, A., 9; Melhase, 1.

Asphalt and bituminous sand deposits: Vander Leck, 2.

Avawatz Mountains: Tucker, W. B., 1. IBelridge and North Belridge oil fields, Kern County : Boezinger, 1.

Bentonite : Melhase, 3.

Borate deposits, Kramer: Gale, 5.

Borax : Foshag, 20.

Buena Vista Hills, Midway oil field, Kern County: Godde, 2

Calaveras County, West Point district: Logan, C. A., 2.

Calico mining district, San Bernardino County : Weeks, F. B., 1.

Carson Hill : Moss, 1.

Chromite, Klamath Mountaius : Diller, 4.

Chromite deposits : Diller, 1.

Cierro oil fleld: Stalder, 1.

Clay : Boalich, 1 ; Dietrich, 1, 2.

Alberhill, Riverside County: Hill, J. H., 1.

Coal, bibliography: Boalich, 3 .

Coalinga field: Wilhelm, 4.

Colemanite deposits, origin : Foshag, 10 Colemanite near Shoshone: Noble, 6 .

Copper: Jogan, C. A., 3.

Engels, Plumas County, origin : Turner, H. W., 1.

Shasta County : Tucker, W. B., 4.

Development of oil fields: Moran, 3. Devils Den oil field, Kern County: Huguenin, 1.

Diatomiferous horizons and petroleum deposits : Landero, 1.

Dominguez oil field: Dodd, 2.

Dry placers, southern California : Haley, C. S., 1.

Economic minerals: Castello, 1.

Early oil development: Orcutt, W. W., 1.

Gold, Wilshire district: Turner, H. W., 3.

Gold lodes, East Fork district, Trinity County: Tucker, W. B., 2.

Gold ores, Grass Valley: Howe, E., 1.

Gold placers: Haley, 3.

Gold production 1849-1923 : Hill, J. M., 5.

Goleta district: Vickery, 6, 8, 9.

Gypsum: Stone, 11.

southern California: Newman, 1.

Hovey Hills oil field, Kern County : Saunders, 1.
California-Continued.

Eoonomio geology-Continued.

Fumboldt County, oil and gas exploration: Hoots, 6,7 .

Huntington Beach oil field, O r a n g e County: Case, J. B., 3 ; Gester, S. H., 1 ; Graser, 1.

Iron ore: Boalich, 2.

Identifying subsurface strata : Roberts, D. $\mathrm{C}, \mathrm{1}$.

Inglewood oil field: Huguenin, 2.

Kelly silver mine, Randsburg, Kern County: Carpenter, J. A., 2.

Fern County, northwestern: English, W. A., 1.

Sunset oil field, Thirty-five anticline: Godde, 3.

Kern River oil field, Kern Front area: Hendrickson, 1.

Kramer borate deposits, Kern County : Noble, 5 .

Lindero anticline, Ventura County: War'ner:, T., 2.

Limestone deposits, bibliography : Ialzure, 1.

Long Beach oil field: Case, J. B., 2; Schwennesen, 2.

Los Angeles basin, oil fields: Arnold, 3 ; Milner, 4; Vickery, 11.

structure: Eaton, J. E., 1.

Los Burros district, Monterey County : Hill, J. M., 4.

Lost Fills oil field, Kern County : McCabe, R. E., 1.

McKittrick. oil field, structure: Inglish, W. A., 4.

Magnesite: Bradley, W. W., 6; Palmer, L. A., 3 ; Phalen, 2.

Sonoma County: 'Iurner, H. W., 4.

Magnetite, Madera County : Dougherty, 6.

Manganese, southeastern California: Jones, Ed. L., 4.

Mineral production: Bradley, W. W., 1-5, 7-9.

1927 : Symons, 1.

Mineral resources: Hamilton, F., 1, 2 .

Mineralization, Randsburg: Hulin, 1.

Mt. Poso oil field: Wilhelm, 3.

Nevada County: Mac Boyle, 3.

Nitrate deposits, Amargosa region, southeastern California: Noble, 4.

Oil and gas prospects, Buttonwillow, Kern County : Ferguson, R. N., 1.

Oil, gas, and water, relations in Sunset-Midway field : Rogers, G. S., 1.

Oil-fleld waters : Palmer, C., 2 ; Roger's, G. S., 2.

Oil flelds: Collom, 1; Heller, 1; Kew, 8; McLaughlin, R. P., 2; Tolman, 2.

Los Angeles Basin: Arnold, 3 ; Milner, 4 ; Vickery, 11.

San Joaquin Valley: English, W. A., 5 ; Stevens, J. B., 1.

Santa Maria district: Collom, 2. 
California-Continued.

Economic geology-Continued.

Oil fields-Continued.

Ventura County: Godde, 1 ; Taliaferro, 1; and Newhall district: Hertel, 2.

Oil possibilities, Comanche Point and Wheeler Ridge: U. S. G. S., 17.

near Petaluma, Sonoma County : Mendenhall, 4.

Oil shale, Santa Barbara County : Gore, $1,2$.

Oil structures: Hill, E. A., 1.

Olinda oil field: Clute, 1.

Petroleum : Landero, 1; Legraye, 2; Vander Leck, 1.

diatom origin: Takahashi, 3.

Elk Hills: Woodring, 19.

Kern County : English, W. A., 1.

Los Angeles and Ventura counties: Kew, 6.

origin : Anderson, F. M., 2, 3; Ander'son, R., 1 ; Cunningham, G. M., 2 ; McLaughlin, R. P., 1 ; Stipp, 1 ; Takahashi, 2 ; and accumulation : Gester, G.. C., .1, 2.

production decline: McLaughlin, R. P., 2.

Randsburg quadrangle: Hulin, 1, 2. Richfield oil field: Musser, 3.

Santa Clara Valley : Reinhard, 1.

Simi Valley: Kew, 1.

southern California : Eaton, J. E., 9 ; Jensen, 1.

Sunset-Midway oil field : Pack, R. W., 1. Petroleum geology, development : Hamilton, W. R., 1.

Petroleums, chemical characteristics: Prutzman, 1.

Phosphorus in California petroleum : Palmer, C., 1.

Placers: Haley, 2.

Platinum and allied metals: Logan, C. A., 1.

Plumas County: Mac Boyle, 2.

Poso Creek oil fleld, Keln County : Kaiser, 2.

Potrero oil fleld: Eaton, J. E., 5.

Primary and secondary gold concentrations: Haley, 4.

Rincon oil field: Kotick, 1.

Rosecrans oil field: Musser, 2.

Salt deposits: Phalen, 1.

San Joaquin Valley oil flelds: Stevens, J. B., 1.

structural features: Hoots, 4.

Santa Fe Springs oil field: Case, J. B., 1 ; Templeton, 1.

Shadow Mountains, San Bernadino County : Riddell, 1.

Sierra County: Mac Boyle, 3.

Silver lodes, South Fork district, Shasta County : Tucker, W. B., 3.

South Mountain oil fleld, Ventura County: Hudson, F. S., 2.

Sunset Extension oil field, Kern County: Rogers, R. G., 1.
California-Continued.

Economic geology-Continued.

Sunset oil field: Farnsworth, 2.

Sunset-Midway oil field : Pack, R. W., 1.

Tertiary clays: Linton, 1.

Thirty-five anticline, Sunset oil field, Kern County : Copp, 1.

Torrance oil field: Musser, 1.

Tungsten ores: Hess, 11.

Vein crossing, Grass Valley : Hoover, 1. Ventura Arenue oil field: Hertel, 3.

Ventura Basin, Ventura County: Eaton, J. E., 4.

Ventura County oil fields: Godde, 1.

Ventura oil fleld, Ventura County: Craddock, 1; Bush, 1; Eaton, J. E., 2; Hertel, 1.

West Goleta district: Sherman, 1.

Wheeler Ridge oil field, Kern County: Cunningham, G. M., 1; Kaiser, 1.

Historical geology.

Alamitos Heights : Rogers, R. G., 2.

Amargosa Valley: Noble, 6.

Baldwin Hills, Los Angeles County, Pliocene and Pleistocene history: Tieje, 5, 6.

Bautista Creek Pleistocene: Frick, 1. Blackhawk Canyon, San Bernardino Mountains : Woodford, 7.

Boring, Ventura County: Hudson, F. S., 4.

Briones formation: Trask, 1, 2.

Cambrian, Mohave Desert: Clark, C. W., 1.

- Bristol Mountain: Resser, 6.

Carson Hill : Moss, 1.

Catalina metamorphic facies of Franciscan series: Woodford, 1.

Coalinga, Tertiary formations: Reed, 5.

Coalinga field: Wilhelm, 4.

Coyote (Carrizo) Mountain, Imperial County ; Hanna, 25.

Dead Man Island: Crickmay, 7.

Deep Spring Valley : Miller, W. J., 35.

Diatomaceous shale interbedded with arkose: Schenck, 6.

Domengine horizon, Eocene: Clark, $B$. L., 14, 16.

Elk Hills: Woodring, 19.

Eocene, La Jolla quadrangle: Hanna, M. A., 5.

Eocene divisions: Clark, B. L., 1.

Fernando formation, nomenclature : Keyes, 199.

Foraminiferal section, Adams Canyon, Ventura County: Driver, 2.

Geologic formation names, check list: Balley, G. E., 1.

Geological traverse, Mohave to San Juan River: Gregory, H. E., 8.

Goleta district: Vickery, 6.

Human remains, Los Angeles: Stock, 15.

Humboldt County : Hoots, 6, 7.

southwestern, geologic map: U. S. G. S., 18. 
California-Continued.

Historical geology-Continued.

fluntington Beach oil field: Graser, 1.

Identifying subsurface strata: Roberts, D. C., 1.

Imperial Valley: Augur, 1.

Ione formation: Allen, V. T., 2.

Kern County, northwestern: English, W. A., 1.

Kreyenhagen shale, age and correlation : Hanna, 22.

Livermore region, structural dynamics : Vickery, 7.

Lomita beds, constitution and fossils: Hanna, G. D., 8.

Los Angeles Basin: Arnold, 3 ; Eaton, J. E., 3, 8; Vickery, 11.

Malaga Cove diatom-bearing shales, age : Hanna, G. D., 39.

Martinez Eocene, Ventura County : Nelson, R. N., 2.

Marysville Buttes: Williams, H., 2.

Matilija overturn, Ventura County: Kerr, 7.

Meganos group: Clark, B. L., 2, 18; Dickerson, 1.

Mesozoic formations: Goranson, 1.

Microlithology and micropaleontology of oil-bearing formations in Sunset-Midway and Kern River oil fields: Goudkoff, 1.

Midway-Sunset-Elk Hills region, Kern County: Roberts, D. C., 2.

Miocene, Kern County: Godde, 4.

Santa Barbara County: Jordan, D. S., 3.

Miocene paleogeography, central Coast Ranges: Reed, 7.

Mohave Desert: Merriam, J. C. 1.

Monterey County, San Antonio and Nacimiento valleys: Pike, R. W., 1.

Monterey shale: Hanna, G. D., 38.

Monterey (Salinas) shales, Pine Canyon, Monterey. County: Stalder, 2.

Moreno shale, age and correlation: Taff, 4.

Mount Diablo: Clark, B. L., 13; and Byron regions: Clark, B. L., 15.

Mount Poso oil field: Wilhelm, 3.

Nevada County: Mac Boyle, 1.

Olinda oil field : Clute, 1.

Qil fields: Kew, 8.

Orange County, Newport Beach : Meek, 2.

Organic shales, San Joaquin Valley: Gaylord, 2.

Phosphate beds in Monterey shales: Reed, R. D., 11.

Pico formation, sedimentation : Cartwright, L. D., 2.

Pleistocene, divisions and duration, southern California: Eaton, J. E., 6.

southern California : Eaton, J. E., 7.

Pleistocene-Recent boundary: Matthes, 13.
California-Continued

Historical geology-Continued.

Pliocene, southern California: Carson, 1.

Plumas County: Mac Boyle, 1.

Puente formation: Chaney, 4.

Puente Hills region: English, W. A., 3.

San Benito County : Kerr, P. F., 4.

San Gabriel Mountains : Miller, W. J., 29.

San Joaquin Valley: English, W. A., 5 ; Stevens, J. B., 1.

geologic section: Taff, 6 .

Lazard area : Reed, R. D., 12.

southern part: Henny, 1 ; Hoots, $2,3$.

San Lorenzo group, San Emigdio region: Wagner, C. M., 1.

San Onofre breccia: Woodford, 3, 4.

San Pedro Hills, Los Angeles County: Kew, 9.

Santa Clara Valley: Reinhard, 1.

Santa Maria district: Collom, 2.

Santa Rosa Island: Kew, 11.

Santa Ynez River Basin: Nelson, 12.

Santa Ynez River district, Santa Barbara County: Kew, 2.

San Timoteo Pliocene : Frick, 1.

Section in Salinas Valley: Nicholls, 1.

Sierra County: Mac Boyle, 3.

Southern California: Hill, R. T., 8; Kew, 4.

Sunset oil field, Kern County : Farnsworth, 1 .

Sunset-Midway oil field : Pack, R. W., 1.

Tejon group: Anderson, F. M., 1.

Tertiary : Clark, B. L., 9. correlation: Clark, B. L., 4.

marine : Clark, B. L., 5.

Tertiary and Cretaceous: Stewart, R. B., 1.

Three glacial epochs in Sierra Nevada : Blackwelder, 20.

Tuolumne Table Mountain, age : Hay, 35.

Vaqueros and Temblor formations; Wiedey, 1.

Vaqueros formation, Ventura and Santa Barbara counties: Corey, 1.

Ventura Basin, Ventura County : Eaton, J. E., 4.

Ventura County: Taliaferro, 1.

Ventura oil field: Eaton, J. E., 2.

Ventura quadrangle: Cartwright, $L$. D., 2.

Warner Range: Russell, R. J., 6.

West Goleta district: Sherman, 1.

Wheeler Ridge oil field: Cunningham, G. M., 1.

Mineralogy.

Andalusite, Mono County: Peck, A. B., 1.

Anauxite, Ione formation: Allen, V. T., 1.

Antimony, native, Kern County : Behre, 1.

Apthitalite, Searles Lake: Foshag, 6. 
California-Continued.

Mineralogy-Continued.

Boussingaultite, South Mountain, Santa Paula: Larsen, 2.

Calico Hills, San Bernardino County: Foshag, 15.

Camsellite, Marin County: Eakle, 7. Centrallasite, Crestmore: Foshag, 19. Chlorite, chromiferous: Shannon, 16.

Coalinga Tertiary formation, rôle of heavy minerals: Reed, 5.

Colemanite pseudomorphous after inyoite, Death Valley: Rogers, A. F., 1.

Coplapite, Santa Maria Mountains, eastern $R$ iverside County: Schairer, 1.

Crestmore, Riverside County: Eakle, 9.

Cristobalite: Rogers, A. F., 10.

Curtisite, Sonoma County: Wright, F. E., 9.

Economic minerals: Castello, 1.

Foshagite, Crestmore: Eakle, 6.

Furnace Creek, Death Valley: Foshag, 17.

Hydroboracite, Inyo County: Schaller, 16.

Hydromagnesite, crystallography : Rogers, A. F., 15.

Ilsemannite, Shasta County: Cook, C. W., 1.

Jurupaite, Crestmole : Eakle, 3.

Kempite, Santa Clara County : Rogers, A. F., 18, 22.

Magnesite, San Jose: Rogers, A. F., 16.

Kernite, Kern County : Gale, H. S., 6 ; Schaller, 12.

Manganese minerals, San Jose : Rogers, A. F., 2.

Merwinite, Crestmore : Larsen, 7.

Meteorite, Owens Valley: Merrill, 17, $21,49$.

Minerals : Eakle, 5.

Minerals in limestone formed by contact metamorphism, Crestmore, Riverside County: Eakle, 1.

Ilazolite, Rirerside : Foshag, 8.

I'riceite, Furnace Creek, Inyo County: Foshag, 18.

Roemerite, Trinity County : Landon, 1.

Sand-calcite crystals, Monterey County : Rogers, A. F., 25.

Sespe formation, Ojai Valley : Gianella, 1.

Sulphohalite, Searles Lake: Foshag, 4. 'Talc, Porterville: Foshag, 14.

Thaumasite and spurrite, Crestmore: Foshag, 5.

'Tourmaline field, San Diego County: Schaller, 7 .

Troilite, Del Norte County: Eakle, 4. Volardeñite, Tulare County: Shannon, 33.

Vunsenite, Riverside : Eakle, 2.
California-Continued.

Mincralogy-Continued.

Wulfenite, Lavic: Guild, 3.

Xonotlite: Larsen, 11.

Paleontology.

Algae, Miocene, Los Angeles: Gardner, N. L., 1.

Alticamelus, San Bernardino County: Davidson, P., 2.

Archohelia clarki, Meganos formation : Vaughan, 45.

Arctotherium, Pleistocene: Merriam, 17.

Asphalt pits near Los Angeles: Hay, 37.

Bassariscinae: Hall, E. R., 1.

Beudanticeras breweri and Coloboceras stantoni : Crickmay, 4.

Bird remains, Carpinterid asphalt pit: Miller, B. L., 4.

Miocene, Lompoc: Miller, L. H., 3.

Rancho La Brea: Miller, L. H., 2.

Bolivinita, Pliocene, Los Angeles Basin : Church, 1.

Briones fauna: Trask, 2.

Cambrian, Bristol Mountain : Resser, 6.

Canid and proboscidean remains, Mo. have Desert: Stock, 25.

Canid and rhinocerotid remains, R:cardo Pliocene, Mohave Desert: Stock, 16.

Cassididae : Schenck, 3.

Cats, Rancho La Brea: Merriam, 13.

Cetotheres: Kellogg, R., 1.0.

Channel Islands: Hertlein, 6.

Chitons: Berry, S. S., 1.

Conifers: Mason, H. L., 1.

Coyote (Carrizo) Mountain, Imperial County : Hanna, 25.

Crassatellites, Pleistocene, Los Angeles County : Oldroyd, I. S., 1.

Cretaceous diatoms: Hanna, G. D., 33. Mollusca : Reagan, 7.

Santa Ana Mountains : Packard, 4.

Crustacea, stalk-eyed : Rathbun, 5.

Deprandus lestes: Gilbert, J. Z., 1.

Desmostylus, San Jose: Hannibal, 1.

Diabelodon edensis : Osborn, 25.

Diatomaceae, Lompoc, Santa Barbara County: Yermoloff, 1.

Discocyclina: Schenck, 10.

Echinoidea : Kew, 3. west coast : Israelsky, 1.

Elephant, Fleistocene, Santa -Rosa Island : Stock, 21.

Elphidiums, Tertiary and Quaternary : Cushman, 34.

Eocene echinoid: Schenck, 8. invertebrates, La Jolla quadrangle: Hanna, M. A., 5.

Vacaville: Palmer, D. B. K., 1.

Foraminifera: Cushman, 22.

Eocene, Coalinga: Cushman, 32.

San Diego: Cushman, 29.

Vacaville: Hanna, G. D., 10.

Foraminiferal section, Adams Canyon, Ventura County: Driver, 2. 
California-Continued.

l'alcontology-Continued.

1 ossil fishes : Hubbs, 1.

Miocene : Jordan, 5.

Lompoc: Jordan, D. S., 2, 12.

southern California : Jordan, D. S., 1.

tossil sharks and rays: Jordan, 11.

Gastropod, Etchegoin Pliocene : Hanna, G. D., 12.

Gastropoda, Gabb's types: Stewart, R. B., 1.

Hipparion, Siestan, Berkeley Hills : Stock, 8.

Hipparion mohavense, Puente formation: Stock, 26.

Human remains, Los Angeles, Stock, 12.

Insects in tar traps: Hanna, G. D., 16. Lampris 'zatima, Lompoc: Jordan, D. S., 4.

Llama, Pleistocene, McKittrick : Merriam, 18.

Lomita beds, constitution and fossils: Hanna, G. D., 8.

Mammalia, associated with marine forms: Stock, 10.

Sespe beds, Santa Paula: Stock, 1.4.

Kern River bed: Stock, 22.

Martínez Eocene: Nelson, R. N., 2.

Meganos fauna: Clark, B. L., 2, 18.

Megaptera, Lompoc: Kellogg, R., 3.

Miocene fishes: Jordan, 6.

Merycodus, Mohave Desert: Furlong, 2.

Microfauna, Los Angeles Basin: Tieje, 7.

Midway-Sunset-Elk Hills region, Kern County, fossil markers: Roberts, D. C., 2.

Miocene fishes, southern California : Jordan, D. S., 15, 17.

flora, Tesla region: Scott, F. M., 1. lacustrine mollusks, Sonoma County :

Hanna, G. D., 7.

marine vertebrates, Kern County : Hanna, G. D., 20.

Mohave Desert: Merriam, J. C., 1.

Mollusca, Pleistocene: Oldroyd, T. S., 1 ; Santa Barbara: Palmer, K. V. W., 2.

Mylodon harlani, mounted skeleton : Stock, 4.

Olivella ; Oldroyd, 2.

Organic shales, San Joaquin Valley: Gaylord, 2.

Ostrea californica Marcou: Hanna, G. D., 34 .

Parapavo californicus, Rancho La Brea asphalt beds : Howard, H., 1.

Pecten lohri, Pliocene : Hertlein, 5.

Peccary, McKittrick Pleistocene : Stock, 23.

Rancho La Brea: Merriam, 8.

Pelecypoda, marine Oligocene: Clark, B. I., 11.

Pholadomya in Miocene. deposits : Hake, 1.
California-Continued.

Paleontology-Continued.

Physeteroid cetacean, Santa Barbara County : Kellogg, R., 9.

Physeteroid whales: Kellogg, R., 10

Pine cone, Oakland: Metcalf, W., 1.

Pinnipeds : Kellogg, R., 16.

Miocene, Lompoc: Kellogg, R., 1.0.

Miocene and Pliocene: Kellogg, R., 2.

Plants, Carpinteria asphalt pit : Chaney, 23.

Pleistocene fossils, Carpinteria asphalt pit: Hoffman, R., 1; Stock, 20.

Pleistocene flora, Rancho La Brea : Frost, 2.

southern California: Chaney, 26.

Pleistocene Foraminifera, Palos Verdes Hills : Galloway, J. J., 8.

Pleistocene Megalonychinae and Mylodontidae, Rancho La Brea : Stock, 13.

Pleistocene Vertebrata, Bautista Creek: Frick, 1.

McKittrick asphalt deposit : Merriam, $9,11$.

Pliocene, southern California: Carson, 1; Gastropoda: Carson, 2.

Vertebrata, San Timoteo: Frick, 1.

Viviparus-like opercula: Woodring, 14.

Pliopedia, Pliocene : Kellogg, R., 1.

Porpoise, San Diego: Gregoly, W. K., 21.

Prosiphon in Cretaceous ammonites: Crickmay, 1.

Puente flora, Chaney, 4.

Rancho La Brea asphalt beds: Miller, L. H., 1 ; Wyman, 1; flora : Chaney, 5.

Ricardo fauna: Stock, 25.

Rimella-like gastropods : Clark, B. L., 7.

Rodents and lagomorphs, Rancho la Brea : Dice, 1.

Ruminant, McKittrick Pleistocene : Stock, 19.

San Lorenzo group, San Fmigdio region : Wagner, C. M., 1.

San Pedro fauna, Nob Hill cut, San Pedro: Oldroyd, T. S., 3.

Scalez petrolia: Hanna, 28.

Sharks, Temblor group, Kern County : Jordan, D. S., 16.

Sharks' teeth, Pliocene: Jordan, 9.

Siliciflagellata, Cretaceous : Hanna, G. D., 35.

Sperm whale, Temblor Miocene: Kellogg, R., 15.

Succinea avara, asphalt pit, Rancho Ia Brea: Hanna, G. D., 11..

Tanupolama, Pleistocene: Stock, 24.

Tejon fauna, Kern County : Anderson, F. M., 1.

Terrestrial plants in marine deposits: Chaney, 13.

Tertiary and Quaternary faunas: Smith, J. P., 1. 
California-Continued.

Paleontology-Continued.

Tertiary diatoms: Hanna, G. D., 31.

Mollusca : Hertlein, 2.

Vertebrate fauna, southern coast ranges: Stock, 3.

Trigoniae : Packard, 3.

Turritellas, Miocene: Wiedey, 2.

Upper Triassic: Smith, J. P., 3.

Vaqueros and Temblor formations : Wiedey, 1.

Venericardia, Eocene: Hanna, M. A., 1.

Whale, Monterey group: Hanna, G. D., 15.

Xyne grex, Santa Barbara County: Petrology. Jordan, D. S., 3.

Anorthosite, Los Angeles County : Miller, W. J., 34.

Cuyamaca region: Hudson, F. S., 1.

Feldspar in sandstones: Reed, R. D., 14.

Hollywood Hills, near Los Angeles: Schürmann, 1.

Inclusions in granitic rocks, Sierra Nevada: Pabst, 1.

Siliceous shale formation: Reed, R. D., 13 ; Tolman, 1.

Tridymite-orthoclase rock, Imperial County: Rogers, A. F., 7.

Physical geology.

Anticlinorium, southern coast: Warner, T., 1.

Aragonite concretions, Kettleman Hills : Reed, 9.

Basin Range structure in the Great Basin : Louderback, 5.

Berkeley Hills, geomorphogeny : lox, 1.

Blackhawk Canyon, San Bernardino Mountains: Woodford, 5, 7.

Calaveras Valley earthquake, April 13, 1924: Macelwane, 20.

Cloudburst on San Gabriel Peak, Los Angeles County: Wolff, J. E., 3.

Coast erosion, San Diego region : Leonard, 6.

Coast Ranges : Clark, B. L., 17. Willis, 20.

mobility : Lawson, 1; structure, Willis, 5.

Coastal southern California, structural features: Vickery, 10.

Correlative value of heavy minerals: Tickell, 1.

Crustal movements: Day, 4.

Crystal Springs earthquake, February 10, 1925: Macelwane, 19.

Deep Spring Valley: Miller, W. J., 35.

Differential movements, San Francisco Bay region: Louderback, 4.

Earth movements: Bowie, 10, 13 ; Day, 16.

Earthquake conditions, southern Callfornia : Hill, R. T., 9.

Farthquake records made by well recorders: Stearns, H. T., 13.
California-Continued.

Pliysical geology-Continued.

Barthquake rifts, acrial observition : Willis, 7.

Earthquakes: Townley, 1; Willis, 18.

Calaveras Valley, April 3, 1924: Macelwane, 20.

Chittenden: Kemnitzer, W., 1.

Corralitos, September 19, 1923: Macelwane, 4.

Crystal Springs, February 10, 1.925: Macelwane, 19.

Eagle Lake, Lassen County: Kemnitzer, W., 2.

Evergreen, July 19, 1925 and May 28, 1927: Byerly, 15.

Inglewood, June 21, 1920 : Taber, 3 ; geologic evidence: Kew, 5.

January 31, 1922: Macelwane, 3.

Los Angeles, July, 1920: Taber, 5.

Los Angeles region: Arnold, R., 1.

northern Callfornia, January 22 , 1923: Anon., 37.

recent: Palmer, A. H., 3; Macelwane, 9 ; depth of focus: Byerly, 3.

registration: Bond, 1-3; Byerly, 6, 7, 10-12, 16-18; Davis, E. F., 1-3; Macelwane 2, 7, 8, 11, 13, 14.

Salinas, December 27, 1924: Kemnitzer, L. E., 1.

San Jose: Vickery, 1.

Santa Barbara, June 29, 1925 : Kirkbride, 1.

Sierra Nevada, March 30, 1925: Anon., 46.

southern California: Mulholland, 1; Taber, 4 ; early records: Carpenter, F. A., 1; July 22, 1923: Laughlin, 1.

1918, 1919, 1920; 1921: Palmer, A. H., 1, 2, 4, 5.

Erosion, Los Angeles County : Wolff, J. E., 3.

Fault map: Willis, 10, 13, 17.

Fault system at southern end of Sierra Nevada: Buwalda, 1.

Faulting: Willis, 27.

San Gabriel Mountains : Kew, 7.

Coast Ranges: Willis, 15.

Fused sedimentary rocks in drill cores : Bowen, N. L., 1.

Gabilan Mesa, soil deposition: Reel, R. D., 10.

Garnet sand on beach, Monterey County: Trask, 3.

Geologic section across the Coast Ranges: Louderback, 6.

Hayward fault zone movements: Buwalda, 11.

Inglewood fault zone: Taber, 10.

Jointing, Merced Canyon: Morse, F. F., 2.

Intrusive rocks, Klamath Mountains: Hinds, N. E. A., 11.

Kettlemran Hills, aragonite: Reed, 9. 
California-Continued.

Physical geology-Continued.

Landslides: Nichols, D. A., 1.

Lassen Peak : Loomis, B. F., 1. recent eruption: Williams, H., 1. volcanic activity: Day, 15; cause: Day, 5.

Lassen Peak Observatöry: Finch, R. H., 9.

Livermore region, structural dynumics : Vickery, 3,7 .

Los Angeles Basin, oil-field structure: Ferguson, R. N., 2.

McKittrick oil field, structure : English, W. A., 4.

Matilija overturv, Ventura County : Kerr, 7.

Mobility of coast ranges: Lawson, 1 .

Monterey County, San Antonio and Nacimiento valleys: Pike, R. W., 1 .

Mount Diablo: Clark, B. L., 13.

Mount Lassen : Colburn, 1.

Offsets along Haywards fault: Russell, R. J., 2.

Orogenic period: Willis, 24.

Permian revolution: Finlay, 2.

Pico formation, sedimentation: Cart. wright, L. D., 2.

Post-Monterey disturbance, Salinas Valley : Reed, 6.

Puente Hills region: English, W. A., 3.

Rancho La Brea tar beds, mode of accumulation: Gilbert, J. Z., 2.

Rifts of southern California: Davis, W. M., 33 ; Hill, R. T., 2.

Samwel Cave, Shasta County, Merriam, 23.

San Andreas rift, soutbern California : Noble, 7, 9 ; Willis, 7.

Salton Basin, fault features: Brown, J. S., 1.

San Francisco Bay sediments: Louderback, 1.

San Joaquin Valley, east side, structural features: Fox, 1.

southern part: Henny, 1 ; Hoots, 2.

Sandstone dike, Orange County, genesis: Meek, 2.

Santa Barbara earthquake: Davis, $D$. H., 2; Willis, 21, 22.

intensity : Byerly, 2.

Santa Cruz area: Rode, 1

Santa Lucia Coast Range, origin : Trask, 4.

Scarps, southwestern Sierra Nevada: Hake, 2.

Seismic force: Willis, 30 .

Seismicity: Willis, 34

Seismological investigation: Day, 8.

Sespe formation, Ojai Valley, origin: Gianella, 1.

South Mountain, origin : Reinhart, 1. Sierra Nevada, postglacial denudation: Muir, 1.

southwestern: Hake, 2.
California-Continued.

Physical geology-Continued.

Solifuxion, Coast Ranges: Legraye, 1.

Southeru California: Haase, 1; Hill, R. 'T., 8 .

Surprise Valley fault: Russell, R. J., 3.

"The Geysers," Sonoma County : Allen, E. T., 4,6 .

Thrust faulting in Mojave Desert: Hewett, 18, 20.

Mount Diablo region: Clark, B. L. $10,12$.

San Benito County : Kerr, P. F., 4.

Valle Grande : Clark, B. L., 19.

Variation of temperature with geologic structure in oil districts: Van Orstrand, 1.

Warner Range : Russell, R. J., 6.

Wind action in San Joaquin and Salinas valleys: Reed, 8.

Physiographic geology.

Alluvial fans, Cucamonga district: Eckis, 1.

Bakersfield fault scarp : Gilbert, G. K., 1.

Classification and nomenclature of physiographic features: Hill, $R$. T., 4.

Coast ranges: Willis, 2.

Cockscomb C'rest, Yosemite : Matthes, 2.

Consequent streams: Vickery, 12.

Continental shelf off the coast: Lawson, 6.

Deep Spring Valley: Miller, W. J., 35.

Evolution Basin, Sierra Nevada: Matthes, 9.

Glacial stages, Sierra Nevada: Matthes, 4.

Glaciation, San Gabriel Mountains : Miller, W. J., 28.

Hanging side valleys, Yosemite Valley, and San Joaquin Canyon: Matthes, 5.

Kern Canyon, glaciation: Hills, $T$. M.; 2.

Kings River Canyon and Yosemite Valley: Matthes, 9.

Lake Mono: Anters, 12.

Landslide lakes : Russell, R. J., 4.

Lassen Peak region: Loomis, B. F., 1; Williams, H., 1.

Lava Beds National Monument: Stearns, H. T., 15.

Los Angeles coastal belt: Vickery, 5 .

Moraines of Convict Lake glaciers: Blackwelder, 24.

Offsets along Haywards fault: Russell, R. J., 2.

Piracy and persistence of antecedent streams on Los Angeles coástal belt: Vickery, 4.

Pleistocene lakes along Mohave River: Thompson, D. G., 3.

Recurrent glaciation in Sierra Nevada: Matthes, 7.

Red Rock Canyon: Miller, W. J., 31 . 
California-Continued.

Physiographic geology-Continued.

Rifts of southern California: Hill, R. T., 2.

Saline lakes, Mohave Desert: Foshag, 24.

Salton Basin: Brown, J. S., 1.

Sand rivers: Hill, R. T., 6.

San Gabriel Mountains, southwestern, geamorphology : Miller, W. J., 33.

San Pedro Hills, Los Angeles County: Iiew, 9.

Santa Clara Valley: Clark, W. O., 2.

Scarp at mouth of Kern River Canyon : Blackwelder, 17.

Scarp production in Great Basin : Louderback, 7.

Scarps, southwestern Sierra Nevada: Hake, 2.

Sierra Nevada: Muir, 3.

Devil's Post-pile: Matthes, 8.

Souther'n California: Hill, R. T., 8.

Surprise Valley, northwestern Grent Basin : Russell, R. J., 5.

Topography of active faulting: Willis, R., 1.

Yosemite region, three glaciations: Matthes, 12.

Yosemite Valley : Matthes, 3.

Underground water.

Calcium chloride waters, Ventura County: Fudson, F. S., 3.

Hot springs, Lassen National Park, source of heat and water: Day, 11.

Sonoma County: Day, 12.

Huntington Beach oil field: Grizzle, 1.

Lanfair Valley, San Ber nardino County : Thompson, D. G., 1.

Lassen National Park, hot springs: Day, 15.

Oil-field waters: Palmer, C., 2 ; Rogers, G. S., 2.

Pahrump, Mesquite, and Ivanpah Valleys: Waring, 3.

Sacramento Valley: Bryan, 10.

Salton Sea region: Brown, J. S., 3.

San Diego County, western part: Ellis, A. J., 1.

San Jacinto and Temecula basins: Waring, 1.

San Joaquin Valley: Harding, 1.

Santa Clara Valley: Clark, W. O., 2.

The Geysers, Sonoma County: Allen, E. T., 3, 4.

Water levels, southern California : Ebert, 1.

Camarasaurus: Osborn, 5, 6.

Cambrian. See also Paleontology, Cambrian.

Acarlia : Bailey, L. W., 2.

Alabama: Butts, 8 ; Jones, W. B., 13.

Bessemer-Vandiver qu a drangle: Butts, 13.

Alberta, Banff area: Warren, P. S., 4. Glacier Lake section: Walcott, 3. pre-Devonian Paleozoic: Walcott, 18.
Cambrian-Continued.

Arctic regions, Ellesmere Land: Holtedahl, 1.

Appalachians, southern, Lower Cambrian : Barrell, 8.

Arbuckle limestone, Oklahoma : Decker, 8.

Arizona: Darton, 17 ; Keyes, 83.

Aravaipa-Stanley region: Ross, C. P., 6.

central : Ettlinger, 1.

Courtland-Gleeson region: Wilson, E. D., 2.

Grand Canyon: Noble, 3.

Grand Canyon district: Moore, $\mathbf{R}$. C., 26.

northeastern, Holbrook area : Hager, D., 3.

Ray-Miami region: Ransome, 1.

Tucson and Amole Mountains: Jenkins, 3.

Ray quadrangle: Ransome, 11.

Arkansas: Misel, 4, 11.

Belt formation, Helena, Montana : Rothpletz, 1 .

Bibliographic studies: Resser, 1.

British Columbia, Beaverfoot Range: Burling, 4.

Beaverfoot-Brisco-Stanford $\mathrm{R}$ a $\mathbf{n} \mathrm{g}$ e: Walcott, 9 .

Bow River section, Banff : Kindle, 30.

Kamloops district, North Thompson valley: Uglow, 3.

Mount Robson area: Burling, 2; Cambro-Ordovician section: Burling, 5.

pre-Devonian Paleozoic: Walcott, 18. Rocky Mountain region: Schofield, 8. Rocky Mountain trench: Shepard, 3. southeastern: Schofleld, 10, 12.

Windermere area, Kootenay district: Walker, J. F., 1.

California, Deep Spring Valley : Miller, W. J., 35.

Mohave Desert: Clark, C. W., 1.

San Bernardinó Mountains: Vaughan, F. E., 1.

Canadian Rockles: Burwash, 2.

Colorado: Keyes, 162.

Red Cliff district: Crawford, R. D., 3.

Cordilleran formation, nomenclature: Walcott, 7.

General : Keyes, 234 ; Resser, 4.

Georgia : McCallie, 1.

Tate quadrangle: Bayley, 13.

Greenland: Böggild, 1.

norther'n: Koch, 4.

northwestern: Koch, 1 ; Poulsen, 1. Peary Land: Koch, 3.

Idaho, Fort Hall Indian. Reservation: Mansfield, G. R., 3.

Pend Oreille district: Sampson, 16. southeastern : Mansfield, 29. 
Cambrian-Continued.

Illinois: Thwaites, 3.

Kings quadrangle: B1'etz, 4 .

northern: Thwaites, 7.

Indiana, sub-Trenton formations: Logan, 23.

Iowa: Keyes, 89.

Ida County : Lees, 10.

Mackenzie, Franklin Mountains: Williams, M. Y., 14.

Mackenzie River district: Williams, M. Y., 13.

Mackenzie River between Norman and Beaver River: Hume, 5.

Maine, northern : Smith, E. S. C., 5, 6. Maryland : Bassler, R. S., 1.

Massachusetts, Essex County: Clapp, C. H., 1 .

Minnesota: Grout, 2.

Jordan sandstone: Stauffer, 5.

Red Clastic series: Stauffer, 9.

Missouri: Wilson, Mal, E., 1.

Ste. Genevieve County : Weller, 19.

Montana: Keyes, 234.

Beartooth Mountains : Bevan, 2.

Fergus County: Freeman, 0. W., 1.

Helena region: Rothpletz, 1.

Nevada: Keyes, 128. Nolan, 4.

Manhattan district: Ferguson, H. G., $2,5$.

Muddy Mountains : Longwell, 15.

Pioche district: Westgate, 6.

New Brunswick: Bailey, L. W., 1.

Newfoundland: Howell, B. F., 1.

Fortune Bay : Dale, N. C., 5.

southeastern: Howell, 5.

western: Schuchert, 16.

New Hampshire, Ammonoosuc district: Ross, C. P., 2.

New Jersey, Sussex County : Ries, 8.

New Mexico: Darton, 26 ; Keyes, 14. eastern: Baker, C. L., 1.

New York, Canton quadrangle: Chadwick, 5.

Lake Clear region: Alling, H. L., 1. Gouverneur quadrangle: Cushing, 1. Lake Bonaparte quadrangle: Smyth, 2.

Luzerne quadrangle: Miller, W. J., 19.

West Point quadrangle: Berkey, 3.

Oklahoma : Gould, 9.

Arbuckle Mountains : 'Taff, 7.

Carter County: Tomlinson, 4.

Comanche County: Gouin, 3.

southern Ouachita Mountains: Honess, C. W., 4.

Stonewall quadrangle: Morgan, G. D., 5.

Wichita Mountains: Taff, 7.

Ontario, Brockville-Mallorytown area: Wright, J. F., 2.

Pennsylvania: Miller, B. L., 4.

Allentown quadrangle: Miller, B. L., 5.

McCalls Ferry quadrangle: Jonas, 2.

New Holland quadrangle: Jonas, 5.
Cambrian-Continued.

Pennsylvania-Continued.

Northampton County, slate belt: Behre, 7 .

Piedmont Plateau: Knopf, E. B., 3. Quarryville quadrangle: Jonas, 3.

southeastern: Hawkins, A. C., 4 : Stose, 15, 21.

Pennsylvania and Maryland, Piedmont province: Stose, 18.

Pre-Devonian sedimentation, Canadian Rocky Mountains: Walcott, 17.

Quebec, Beauceville area: MacKay, B. R., 4.

Coleraine area: Knox, J. K., 1 .

Rocky Mountains: Resser, 5.

South Dakota, central Black Hills: Darton, 14.

Subdivisions: Resser 3

Taconic area, southern: Knopf, E. B., 6.

Taconic system resurrected: Schuchert, 1.

Tennessee, Ducktown district: ' Emmous, W. H., 7.

east: Secrist, 1.

Texas: Udden, J. A., 3, 13.

Utah: Butler, 4; Keyes, 156. Ophir district: Olmstead, 1.

Tintic district: Lindgren, 2.

Vermont, Addison, Panton, and Ferrisburg townships: Foyles, 4.

Barnard, Pomfret, and Woodstock townships : Richardson, C. H. 11.

Bethel Township: Richardson, C. H., 8.

Braintree: Richardson, C. H., 5.

Green Mountains, western flank : Dale, N. C., 1.

Northfleld : Richardson, C. ..., 2.

northwestern: Keith, 1; Raymond, 23 ; Paradoxides beds: Howell, 7.

Orange County, Randolph Township : Richardson, C. H., 7.

Plymouth and Bridgewater townships: Perry, E. L., 1.

Roxbury : Richardson, C. H., 3.

Shoreham and Bridport: Foyles, 3.

western: Gordon, C. E., 2, 4.

Virginia: Giles, 11.

Blue Ridge, west foot: Stose, 1.

Giles County: Hubbard, G. D., 6.

Little North Mountain: Giles, 8.

Piedmont: Jonas, 8.

southwestern: Butts, 10.

Valley coal flelds: Campbell, M. R., 9. western : Stose, 16.

West Virginia, conglomerate rocks: Reger, 12.

Wisconsin: Thwaites, 3; Ulrich, 12.

Tomah-Sparta quadrangles: Twenhofel, 4.

Wyoming, Bell Springs district, Carbon County: Dobbin, 5.

Wind River Mountains: Condit, 4. :amp Bird compound veindike: Spurr, 18 
Cump Devens area, Massachusetts: Atwood, W. W., 1.

Lamp Dodge region, Iowa: Lees, 1.

'anada (general). See also names of Provinces.

Borings : Ingall, 10.

eastern Canada: Ingall, 8.

prairie provinces and Northwest territories: Ingall, 2, 5, 7, 9 .

Carbon in pre-Cambrian formations: Moore, E. S., 12.

Central Arctic coast; O'Neill, 5.

Eastern Arctlo Canada: Weeks, L. J., 2.

Elementary geology : Coleman, 9.

Field work of Geological Survey : Collins : W. H., 5.

Field work of Survey: Collins, 9, 18.

Geological mapping of Cordillera: Dunn, R., 1.

Geological Survey, publications, cata$\log$ : Ferrier, 1.

Geological Survey, reports : Collins, W. H., $3,6,8,12,13,16,20$; McInnes, 1-3.

Glaciation, effect on prospecting for mineral deposits; Tanton, 11.

Gravity observations, western Canada : Miller, A. H., 2.

Great Lakes area: Alcock, 25.

Hudson May, east coast: Low, 1.

Index to reports of Canada Geological Survey : Nicolas, 2.

Mackenzie River basin: Camsell, 1.

Mapping pre-Cambrian areas : Bruce, 6.

Mines Branch, reports: Haanol, E., 1, 2 ; McLeish, 1, 2.

Pacific region, structure: Brock, 3 .

Pre-Cambrian time, duration: Ellsworth, 9.

Seismology in Canada: Hodgson, 11.

Areas described.

Belcher Islands, Hudson Bay: Young, G. A., 3.

Economic geology.

Abrasive materials : Eardley-Wilmot, 3.

Alkali deposits, western Canada: Cole. L. H., 4, 6, 7 .

Apatite: Spence, 2.

Arsenic-bearing deposits : Hurst, 4.

Barytes: Spence, 4, 10.

Belcher Islands, Hudson Bay, iron deposits : Moore, E. S., 1.

Bentonite: Spence, 8, 9.

Building stone: Parks, 27.

Carbon ratios of coal as an index of oil and gas prospects in western Canada: Hume, 24.

Coal: Gray, F. W., 2 ; western Canada : White, J., 1.

Coal fields, western, history of discovery: Dowling, 14.

Coal resources: Patton, M. J., 1.

Copper : Browning, C. P., 1.

Arctic Canada; Douglas, G. M., 1 ; O'Neill, 3.
Canada (general)-Continued.

Economic geology-Continued.

Diatomaceous earth: Eardley-Wilmot, 5.

Diatomite : Eardley-Wilmot, 9.

Feldspar: Eardley-Wilmot, 2 ; Spence, 8.

Fluorspar : Eardley-Wilmot, 2.

General: Bell, J. M., 7 ; Corless, 1 ; Malcolm, 1, 3; Young, G. A. 5.

Gold : Cole, G. E., 3 ; Webb, 1.

Graphite: Eárdley-Wilmot, 2 ; Spence, 1.

Helium : Elworthy, 1, 5; McLennan, 1.

Hudson Bay region: Wallace, 16.

Iron deposits : Moore, E. S., 11.

Belcher Islands : Woodbridge, 1 ; Young, G. A., 3.

Lead and zinc: Bingay, 1; eastern Canada: Alcock, 23.

I.iquid fuels : Hume, 12.

Mackenzie River basin: Camsell, 1; Hume, 27.

Manganese: Mackenzie, G. C., 1.

Metallogenesis a nd pre-Cambrian : Baker, M. B., 2.

Mineral deposits: Graham, R. P. D., 3 ; undeveloped: Adams, F. D., 1.

Mineral pigments : Frechette, 2.

Mineral resources: Graham, R. P. D., 3 ; Malcolm, 4, 7, 8; Van Leckwyck, 1 ; Young, G. A., 5.

Mineral wealth of the pre-Cambrian : Corless, 3, 4.

Mining in Canada : Tyrrell, 4.

Molybdenum : Eardley-Wilmot, 1, 2, 4.

Natural gas: Elworthy, 8.

Nonmetallic minerals: Spence, 7 .

Oil and gas, western Canada: Hume, 28 ; Pearce, 1.

Oil and gas prospects, Great Plains, western Canada: Hume, 25.

Oil possibilities, western Canada : Dowling, 9.

Oil reserves: Arnold, 4.

Oil resources: Dowling, 8, 13.

Oil shales: Ells, 4, 7 .

Oil situation and prospects: Hume, 1.1.

Ore bodies, occurrence in pre-Cambrian: Dougherty, 2.

Ore deposits, occurrence: Kelly, S. F., 1 ; of Arctic Canada: Moore, E. S., 2 .

Pacific region: Brock, 4.

Peat: Anrep, 5 ; Haanel, B. F., 2.

Peat bogs: Auer, 1.

Pegmatites and their minerals: Ellsworth, 7 .

Petroleum: Hume, 15; and natural gas: Hume, 29.

Petroleum prorinces: Brock, 6.

Phosphate: Spence, 2.

Platinum: Mackenzie, G. C., 1 ; O'Neill, 2.

Pre-Cambrian and ore deposition : Baker, M. B., 3. 
Canada (general)-Continued.

Economic geology--Continued.

Pre-Cambrian iron formation, origin: Moore, E. S., 21.

Precious metals: Wilson, A. W.. G., 2.

Prospecting : Dolmage, 12.

Salt: Cole, L. H., 2, 3.

Silica, eastern Canada: Cole, L. H., 5. western Canada: Cole, L. H., 13.

Silver : Cole, A. A., 2.

Sodium and magnesium salts, westem Canada: Cole, L. H., 9.

Sodium sulphate: Cole, L. H., 11.

Strontium: Spence, 4.

I'alc and soapstone: Eardley-Wilmot, 2 ; Spence, 5 .

Titanium: Robinson, A. H. A., 2.

Talc deposits: Wilson, M. E., 16.

litaniferous iron ores: Goodwin, W. L., 1.

Zinc and lead, eastern Canada: Robinson, A. H. A., 3.

Historical geology.

Canadian shield, orogeny: Collins, if. H., 22.

Climate, pre-Cambrian : Coleman, 21.

General : Brock, 11 ; Collins, 10 ; Malcolm, 8 ; Young, G. A., 5 .

Geological map: Can. G. S.. 3.

Grenville subprovince: Wilson, M. I., 12.

Keewatin, stratigraphic position: Gregory, J. W., 4

Laurentian problems and atomic dis. integrations: Lane, 21.

Northern Coldilleran geosyncline: Fisher, C. A., 2.

Plains formations : Dowling, 7.

Pre-Cambrian : Cooke, H. C., 19 ; Miller, W. G., 4, 12.

l're-Cambrian classification: Wilson, M. E., 18.

Pre-Cambrian time scale: Young, G. A., 4.

Pre-Cambrian and ore deposition: Baker, M. B., 3 .

Retreat of last ice sheet in eastern Canada: Anters, 6.

\section{Mineralogy.}

Lithium-bearing minerals: Cole, L. H., 12.

Mineralogy at ottawa : Poitevin, 9.

Pegmatites, age: Walker, 37.

Sundry minerals: Poitevin, 10 ; Anon., 8.

\section{Paleontology.}

Diatomaceae: Boyer, 1.

Diatoms: Eardley-Wilmot, 9.

Dinosaur group, National Museum of Canada : Sternberg, C. M., 8.

Eocene floras, western Canada: Berry, 70.

Index to paleontology, 1847-1916: Nicolas, 3.

Sagenopteris: Berry, 45.

Stringocephalus burtoni, distribution : Kindle, 10.
Canada (generai)-Continued.

Petrology.

Pegmatites and their minerals: Ellsworth, 7 .

Physical geology.

Concretions: Kindle, 24.

St. Lawrence earthquake, February 28, 1925 : Hodgson, 14.

Seismology: Hodgson, 13.

Physiographic geology.

Cordilleran ice sheet: Reed, 1.

Cordilleras: Dowling, 16.

General : Brock, 3 ; Collins, 10 ; Corless, 1 ; Young, G. A., 5.

Glacial features: Coleman, 16.

Glacial periods, eastern Canada: Coleman, 30 .

Glaciers, Rocky Mountains: Wheeler, A. O., 1.

Mountain bulding in the Canadian shield : Collins, W. H., 21.

Recent sinking of ocean level, lack of evidence of, in western Canada: Johnston, W. A., 25.

Relief map of prairie provinces: Dowling, 1 .

Retreat of last ice sheet in eastern Canada: Antevs, 6.

Rocky Mountain gosynclinal : Burwash, 3.

Canadian shield, physiographic development: Bain, 20, 21.

Canadian system: Ashley, 25.

Canal Zone. See Panama.

Candelaria silver district, Nevada: Knopf, A.. 5.

Cannel coal.

I'ennsylvania: Fettke, 4.

Canning River region, northern Alaska : Leffingwell, 1.

Cannonball fauna: Stanton, 3; corals : Vaughan, 9.

Cape Breton Island. See Nova Scotia.

Capillary relationships of oil and water: Cook, C. W., 2.

Carbon dioxide from wells in Colorado: Duce, 2.

Carbon in pre-Cambrian formations: Moore, E. S., 12.

Carbon ratios: Woolnough, 1.

Carbon-ratio theory, present status: Norsey, 3 ; Reeves, F., 14 ; proofs : Russell, W. L., 12.

Carbonaceous material, origin: Young, J. W., 5.

Carbonaceous rocks, microthermal study: Stadnichenko, 1.

Carbonaceous shales, organic material: Rae, 2 ; Washburne, 5 .

Carbondale quadrangle, Illinois: Lamar, 3.

Carboniferous. See also Paleontology, Carboniferous.

Acadia : Bailey, L. W., 2.

Alàbama: Butts, 8 ; Jones, W. B., 13 ; Prouty, 1.

Bessemer-Vandiver q u a d ra $\mathrm{n} g \mathrm{le}$ : Butts, 13. 
Carboniferous-Continued.

Alabama-Continued.

Muscle Shoals area: Prouty, 8.

northern: Semmes, 2.

Ocoee rocks: Prouty, $6,7$.

Alaska, Anvik-Andreafski region : Halrington, 1

Canning River region: Leffingwell, 1. Chistochina region: Chapin, 3.

Chitina Valley: Moffit, 5.

Kotsina-Kuskulana district : Moffit, 4. interior : Mertie, 13.

Nixon Folk country : Brown, J. S., 7.

Porcupine district: Eakin, 1.

Sheenjek River district: Mertie, 16.

Alberta, Banff area: Warren, P. S., 4. Crowsnest Pass: Warren, P. S., 7.

Lake Minnewanka section: Shimer, 6.

Saunders Creek and Nordegg coal basins : Allan, 9.

Allegheny formation, typical section: Swartz, C. K., 1.

Appalachian coal measures, nomenclature: Ashley, 12.

Arctic regions, wllesmere Land: Holtedahl, 1.

Arizona : Darton, 17 ; Keyes, 83 ; Stoyanow, 1.

Aravaipa-Stanley region; Ross; C. P., 5.

central : Ettlinger, 1.

Courtland-Gleeson region: Wilson, I. D., 2.

Grand Canyon district : Moore, R. C., 26 ; Noble, 3.

Grand Canyon section : Keyes, 94.

Holbrook area : Hager, D., 3.

Hopi Buttes volcanic field: Rengan, 8.

Lees Ferry region: Bryan, 8.

Narajo country : Reagan, 20.

northeastern: Moore, R. C., 12, 19.

northwestern : Reeside, 4 ; Shimer, 2.

Papago country: Bryan, 7, 15.

Payson district: Lausen, 1.

Permian: Darton, 19.

Ray quadrangle: Ransome, 1, 11.

Ray-MiamL region: Ransome, 11.

Saddle Mountain and Banner mining districts: Ross, C. P., 6.

Arkansas: Miser, 4, 7, 11.

Batesville district: Miser, 8.

Hot Springs district: Purdue, 1.

Atchison shales: Keyes, 287.

Aux Vases sandstone, diastrophic aspects: Keyes, 91.

Barnett shale, central Texas; Moore, R. C., 16.

Big Stone Gap shale, Chattanoogan age : Swartz, J. H., 10.

Borden (Knobstone) rocks, southern Indiana: Stockdale, 4.

British Columbia, Ainsworth district: Schofield, 2, 4.

Bow River section, Banff: Kindle, 30 .

$4096-31-47$
Carboniferous-Continued.

British Columbia, Ainsworth districtContinued.

Bridge River area: McCann, 3.

Cariboo district, Barkerville area : Johnston, W. A., 22 ; Uglow, 9.

Coquihalla area: Caimes, $1,3$.

Lillooet-Prince George reglon: Reinecke, 3

Selkirk Range : Schofield, 6.

Slocan area: Bancroft, M. F'., 2.

southwestern: Cairnes, 2.

'Taseko Lake-French Bar Creek: MacKenzie, J. D., 2.

Yale district: Cuirnes, $\mathbf{5}$.

British Honduras: Ower, 2.

Buried Permian mountain range, New Mexico and Colorado: Rich, J. L., 2.

California, Blnckhawk Canyou, San Bernardino Mountains: Woodford, 7.

Mohave Desert: Clark, C. W., 1.

Canada, maritime provinces: Bell, W. A., 13.

Cape Breton, Great Bras d'Or coal district: Bell, W. A., 5.

Chester formations, correlation : Ulich, 5.

Chester series : Keyes, 78, 91 ; Weller, 2.

Colorado: Keyes, 162.

enst-central : Lee, W. 'I., 19.

Golden area: Johnson, J. H., 13.

Leadville district: Einmons, S. F., 1.

Moffat County : Sears, 3.

Montezuma County, McElmo anticline: Coffin, 2.

north central, foothills formations: Henderson, 2.

Pitkin County, Aspen a is trict : Knopf, A., 10.

red beds of firont Range : 'lieje, 3.

Red Cliff district: Craw ford, R. D: 3.

Routt and Moffat counties: Perini, 1.

Sangre de Cristo Range: Melton, 4.

southern, and New Mexico, northern, colrelation : Melton, 3.

southwestern: Coffin, 3.

'Lar'ryall district: Muilenburg, 2.

Correlation, Iexas-Kansas: Beede, 3.

Dighton conglomerate, origin : Perkins, G. H., 1.

Devono-Mississippian black shales, Virginia and Tennessee: Swartz J. H., 12.

Enid formation : Aurin, 3.

General: Keyes, 144, 198.

Georgia: McCallie, 1.

Glenn formation, north central Texas:

Goldston, 2; southern Oklahoma: Goldston, 2.

Grassy black shales: Keyes, 56 .

Greenland : Böggild, 1.

northern: Koch, 4.

Peary Land: Koch, 3.

Guadalupe group: Darton, 19.

Homogeny in classiflcation: Keyes, 275. 
Carboniferous-Continued.

Jdaho, Bingham, Bonneville, and Caribou counties: Kirkham, 3.

Fort Hall Indian Reservation : Mansfield, G. R., 3.

Mud Lake basin: Stearns, 6 .

southeastern : Kirkham, 1 ; Mansfield, 29.

11linois : Culver, 2.

Adams County, northeastern: Currier, 1.

Allendale oil field: Moulton, 7 .

Ava-Campbell Hill area: Root, 1.

Avon-Canton area: Savage, 6 .

basal Pennsylvanian conglomerate: Poor, 1.

Brown County : Nebel, 1.

Calhoun County: Lamar, 6.

Carbondale quadrangle: Lamar, 3.

Carlyle-Centralia district: Shaw, 9.

Chester series: Weller, 2.

Colchester and Macomb quadrangles :

Hinds, H., 1.

coal beds, correlation: Culver, 9.

District IV : Cady, 7.

east-central: Mylius, 7.

Edgington-Milan area: Savage, $\mathbf{5}$.

Equality-Shawneetown area: Butts, 5.

Gillespie and Mount Olive quadrangles : Lee, W., 1.

Good Hope and La Harpe quadrangles: Nebel, 2.

Hardin County : Weller, S., 1.

Henderson County : Bell, A. H., 8.

Hennepin quadrangle: Cady, 3.

Herscher quadrangle: Athy, 1.

Jacksonville area: Collinwood, 3.

Knox County : Jelliff, 2.

La Harpe and Good Hope quadrangles: Savage, 8.

La Salle quadrangle: Cady, 3, 6.

Mississippi Valley: Krey, 2.

Morris quadrangle: Culver, 2.

New Athens-Okawville area: Shaw, 8.

northwestern, Pennsylvanian : Culver, 4; Wanless, 5.

Pennsylvanian: Savage, 17 ; subdivisions: Cady, 14.

Pennsylvanian marine faunas: Savage, 11.

Pennsylvanian unconformities: Savage, 17.

Pike and Adams counties: Coryell, 1.

Ste. Genevieve formation: Lamar, 4.

Saline County : Cady, 12.

Saline and Gallatin counties: Cady, 4.

southern : Henbest, 2 ; Weller, 6.

Waterloo anticline: Lamar, 1.

western : Culver, 6.

Williamson and Saline counties (parts): Cady, 11.
Carboniferous-Continued.

Indiana: Cummings, 1 ; Logan, 1.5.

Greene County, eastern: Malott, 1. Lawrence County : Esarey, 1.

Mississippian: Stockdale, 1.

Orange County, Chester formations :

Hole, 2.

southern, Chester series: Malott, 2.

southwestern: Logan, 18, 25.

upper Chester: Malott, 8.

Interior coal fields: Keyes, 2.

Iowa : Howell, J. V., 4.

Adair County : Gow, 1.

Butler's Landing outlier: Adams, J. E., 2.

Cass County : Tilton, 3.

Clarke County: Tilton, 2.

Fort Dodge, Ste. Genevieve marls : Lees, 4.

Lake Calvin region: Schoewe, 6.

Linn and Jackson counties, outliers :

Norton, W. H., 4.

Lucas County: Lugn, 4, 6.

Mississippian : Van Tuyl, 8.

Missouri series: Tilton, 7.

Pennsylvanian: Noe, 13.

Ringgold County : Arey, 1.

southwestern: Smith, G. L., 1.

Stuart area: Tilton, 5.

Taylor County: Arey, 2.

Kansas: Aurin, 2 ; Cooper, 4; Keyes, 279 ; Moore, R. C., 4, 9 ; Roge $̈$ s, G. S., 7 ; Snider, 1 ; Young, C. M., 1.

Allen and Neosho counties: Moore, R. C., 5 .

Anderson County: Charles, 1.

central, Mississippian in well : Moore, R. C., 36.

central and western: Twenhofel, 19.

Cowley County : Elledge, 1.

eastern: Fath, 1.

Eldorado field: Fath, 2.

Elk City field: Boughton, 1.

Mississippi lime west of granite ridge: Ley, 5 .

Pennsylvarian west of Nemaha granite ridge: Denison, A. R., 2; Moore, R. C., 32 .

Permian unconformity: Chadwick, 13.

Salina Basin: Barwick, 1:

southeastern: Williams, D. W., 1.

Sumner County, Pennsylvanian red beds: Buchanan, 1.

Wilson County, subsurface geology : Stryker, 1.

Wilson and Montgomery counties: Moore, R. C., 6.

Wreford and Foraker limestones: . Twenhofel, W. H., 1.

Kentucky : Jillson, 13, 21, 35 ; Miller, A. M., 1.

Allen County : Miller, A. M., 5 ; Shaw, E. W., 1.

Barren County : Butts, 2. 
Carboniferous-continued.

Kentucky-Contiuued.

Berea region: Burroughs, W. G., 5. Breathitt and Innox counties: Jillson, 1.3.

Butler County : Glenn, 11.

Cave in Rock quadrangle: Weller, 16. eastern, Buckhorn region: Jillson, 37 ; Mississippian : Butts, 3 ; Pennsylvanian : Hudnall, 3.

Edmonson County: Weller, J. M., 1. Golconda quadrangle: Weller, 4.

Jackson Purchase region : Jillson, 37.

Johnson County, Paint Creek, uplift: Rhodes, 1.

Kendrick shale : Jillson, 9.

Knob region: Burroughs, W. G., 4. Magoffin County : Browning, I. B., 1.

Middlesboro Basin: Wentworth, 28.

Monticello quadrangle: Foyles, 1; MacLachlan, 1.

Morgan County: Robinson, L. C., 1.

Pottsville-flled channel in Mississippian: Burroughs, W. G., 1.

Princeton quadrangle: Weller, 7.

southeastern: Jillson, 8.

Stinking Creek region: Jillson, 3.

Warren County: Jillson, 7; St. Clair, 3.

Webster County: Glenn, 4.

western: Jillson, 102.

western coal field : Burroughs, W. G., 2.

Kinderhook group: Moore, R. C., 1.

Late Paleozoic climates: Coleman, 24. Louisian vs. Mississippian: Keyes, 8.

I,exington limestone: Keyes, 287.

Mackenzie, Kinderhook: Hume, 6.

Madison limestone: Keyes, 130.

Maine, Portsmouth Basin: Wandke, 2.

Marais des Cygnes series: Keyes, 287.

Maryland: Swartz, C. K., 4, 5.

coal measures: Swartz, C. K., 2.

Mexico, Coahuila, Permian: Böse, 5.

Peregrina Canyon: Girty, 9.

Sonora: Mitchell, G. J., 12.

Mid-Continent fields : Snider, 1.

Mississippi : Lowe, 2 ; Morse, P. F., 1 ; Morse, W. C., 4.

Tishomingo County: Bramlette, 4.

Mississippi Valley: Krey, 2.

Mississippian: Keves, 130.

Mississippian formations, early : Moore, R. C., 23.

Mississippian faunal zones: Weller, 12.

Mississippian series, synonymy and taxonomy : Keyes, 262.

Mississippian tuff, Ouachita Mountains : Miser, 3.

Missouri : Branson, 1 ; Williams, H. S., 1 ; Wilson, Mal. E., 1.

Louisiana limestone: Williams, J. S., 1.

Mississippian series: Branson, 10; Moore, 41.

Ste. Genevieve County: Weller, 19.
Carboniferous-Continued.

Missouri-Continued.

St. Louis County, Mississippian sec-

tion: Shipton, 1.

Vernon County: Greene, 8.

Montana: Bauer, C. M., 3 ; Keyes, 234.

Beartooth Mountains, Bevan, 2.

Cat Creek oil field: Lupton, 1.

central and eastern : Clapp, C. H., 2.

Crow Indian Reservation: Thom, 4.

Fergus County : Freeman, 0. W., 1.

Kevin-Sunburst oil field: F. R., 3.

Melrose phosphate field: Richards, R. W., 2.

Quadrant formation: Freeman, 0 . W., 2 ; Hammer, 2.

Soap Creek oil field: Thom, 1.

Stanford hematite district: Westgate, 1.

Sweet Grass Hills : Kemp, 8.

Muscogee shales, western interior coal field: Keyes, 51.

Nebraska, Pennsylvanian: Condra, 2

Nevada: Keyes, 128 ; Nolan, 4.

Manhattan district: Ferguson, H. G., 5 .

Muddy Mountains : Longwell, 1, 3 15.

southern: Longwell, 11.

New Brunswick: Bailey, L. W., 1; Bell, W. A., 8 ; Dyer, 8.

Burnthill Brook area: Young, G. A. 1.

Kings County, Sussex area : Hayes, A. $0 ., 7$.

Minto coal basin: Dyer, 2.

Moncton area: Wright, W. J., 2.

Newfoundland, Deer Lake district: Landell-Mills, 1.

west coast: Brunton, 3.

western: Schuchert, 16.

New Mexico: Darton, 11, 26; Keyes, 14

Artesia oil field: Rich, A., 1.

Carlsbad region: Meinzer, 16.

Chaves County: Merritt, J. W., 2.

eastern: Baker, C. L., 1; Lee, W. T., 3 ; Rich, 5.

Gallup-Zuni Basin: Sears, 6.

Manzano group: Lee, W. 'T., 2.

northeastern: Garrett, 1.

Pecos Valley: Semmes, 4.

Roswell artesian basin: Fiedler, 2.

Permian: Darton, 20 ; Keyes, 268.

Puertecito district: Wells, E. H., 2.

Rio Grande regions: Keyes, 68.

Rio Penasco Basin: Renick, 10.

Sandia Mountains: Ellis, R. W., 1 .

southeastern: Hoots, 1.

Taos Range: Gruner, 1.

New York, Allegany State Park: Lobeck, 8.

North Carolina, Permian at base of Newark: Cobb, C., 2. 
Carboniferous-Continued.

Nova Scotia: Bell, W. A., 8.

Cape Breton Island, Lake Ainslie region: Bell, W. A., 12; 'Trask, 6; North Mountain: Guernsey, 2; Sydney district: Bell, W. A., 1. coal-bearing formations: Bell, W. A., 7.

Horton-Windsor district: Bell, W. A., 2.

Minto coal horizon: Bell, W. A., 6. Northumberland Strait: Bell, W. A., 10.

Pictou County, New Glasgow, conglomerate: Bell, W. A., 9.

Sydney coal field: Hayes, A. 0., 6.

Ohio: Stout, 3.

Camp Sherman quadrangle: Hyde, 1.

Columbiana County: Stout, 5.

Delaware County: Westgate, $\overline{5}$.

Dunkard series: Stauffer, 1.

Muskingum County: Stout, 1.

Summerfield and Woodsfield quadrangles: Condit, 3.

Vinton County: Stout, 6 ; Mississippian: Hyde, 3.

Wayne County: Conrey, 1.

Oklahoma: Aurin, 2; Bloesch, 1 ; Cooper, 4; Gould, 9, 12 ; Greene, 1. Powers, 26 ; Rogers, G. S., 7 ; Ulich, 18.

Arbuckle Mountains: Taff, 7; Pontotoc series: Birk, 2 ; Morgan, G. D., 3.

Ardmore quadrangle, Glenn formation: Goldston, 1.

Beaver County: Gould, 15.

Beckham County : Gouin, 2.

Bristow quadrangle: Fath, 6.

Caddo and Grady counties : Becker, 1.

Caddo County: Clapp, F. G., 1; Cement field; Reeves, F., 1.

Carter County: Roth, 2; Tomlinson, 4: Hewitt oil field: Roark, 1.

Cleveland and McClain counties: Anderson, G. E., 4.

Coal and Pittsburg counties: Clawson, 1.

Comanche County: Gouin, 3.

Creek County: Merritt, J. W., 4.

eastern: Shannon, C. W., 4 ; Trager, 3.

Fort Scott-Wetumka correlation : Bloesch, 3.

Franks and Seminole formations, stratigraphic position: Morgan, G. D., 7 .

Garvin County: Dott, 2.

Glenn formation: Girty, $\mathbf{5}$.

Glenn oil pool: Wilson, W. B., 1.

Healdton field, Carter County: Bartram, 1.

Henryetta district: Reed, R. D., 2.

Hogshooter gas sand : Berger, 1.

Jefferson County : Robinson, H. M., 3.
Carboniferous-Continued.

Oklahoma-Continued.

Kay, Grant, Garfield, and Noble counties: Clark, G. C., 3.

Kingfisher and Canadian counties: Kite, 1.

Logan County : Bale, 1.

Love County: Bullard, 2.

McIntosh County : Clark, R. W., 4.

Mannsville area : Tomlinson, 2.

Mississippian, distribution and correlation : Buchanan, 2.

Muskogee County : Soyster, 1.

noitheastern: White, L. H., 3; Williams, D. W., 1.

northwestern : Clifton,, 1.

Nowata and Craig counties: Bloesch, 4.

Okmulgee district: Clark, R. W., 1, 2 ; White, L. H., 1.

Osage County : Beckwith, H. T., 1.

Osage Reservation: Bowen, C. F., 3 ; Goldman, 2, 3, 4; Heald, 1-4; Hopkins, O. B., 1 ; Robinson, H. M., 1, 2 ; Ross, C. S., 2 ; Roundy, 1. Ouachita Mountains : Miser, 29. paleogeography: Wilson, R. A., 8. Papoose oil field: Roark, 2.

Pawnee County : Greene, 10.

Payne County: Koschmann, 1.

Pennsylvanian : Dott, 1.

Pershing oil and gas field: Rubey, 2. Pontotoc County : Conkling, 1.

Pontotoc series: Morgan, G. D., 2.

Robberson fleld: Denison, A. R., 1.

Seminole area: Dwyer, 1.

Seminole County : Levorsen, 2. southeastern: Honess, C. W., 6.

southern: Burton, G. E., 2 ; Dunbar, 7 ; Moore, R. C., 10, 11.

southern Ouachita Mountains : Honess, C. W., 4.

southwestern.: Gould, 5 ; Sawyer, 1.

Stanley shale: Honess, C. W., 2.

Stanley-Jackfork series: Honess, C. W., 5 .

Stephens County: GJuin, 1.

Stonewall quadrangle: Greene, 6; Morgan, G. D., 5, 6 .

Sycamore limestone: Cooper, 1, 2.

Texas County: Gould, 11.

Thomas oil field, Kay County: Clark, S. K., 1.

Tonkawa field: Hosterman, 1.

upper Paleozoic rocks: Gould, C. N., 19.

Verden sandstone: Reed; 3 ; Steph. enson, C. D., 1.

Wagoner County: Boyle, 1.

Washington County: Carpenter, E., 2.

Weatherford area, Permian: Evans, N., 1.

western : Gould, 16; Patton, 7.

Wichita Mountains: Taff, 7.

Wildhorse area: Brockway, 1. 
Carboniferous-Continued.

Oklahoma-Continued.

Wreford and Foraker limestones: 'Twenhofel, W. II., 1.

Oregon: Smith, .J. E., 1. central: Packard, 6.

Paleozoic, late: Case, E. C., 2.

Pennsylvania : Miller, B. L., 4 ; Sisler, 1.

Broadtop Basin: Reger, 13.

Greensburg quadrangle: Johnson, M. E., 1.

Loyalhaina limestone: Butts, 4.

lower Allegheny-Fottsville section: Renick, 2

Permian: Keyes, 182.

Fittsburgh area: Leighton, H., 2. l'unxsutawney quadrangle: Ashley, 18.

Pennsylvanian, taxonomic rank : Keyes, 149.

Pennsylvanian unconformities: Hinds, H., 2.

Permian: Beede, 7 ; Case, 20; Keyes, 77, 268; Schuchert, 52.

Arizona and New Mexico: Darton, 20.

correlation, Kansas, Oklahoma, and Texas: Gould, 10.

in America : Keyes, 192.

investigations : Case, $6,13$.

of the Plains: Gould, 8, 14.

revolution: Finlay, 2.

Texas and Oklahoma: Anon., 50.

West Virginia : Tilton, 10.

Plattesmouth limestones: Keyes, 287.

Pottsville formation, Ohio: Morningstar, 1.

Pre-Moenkopi inconformity, Colorado Plateau: Dake, 4.

Quebec, Bonaventure formation: Clarke J. M., 26.

Red beds and faunas of the Appalachian and Kansas-'Texas sections: Beede, 7.

Red beds near base of Cherolkee shales: Tar', Rus. S., 1.

Red beds of Chester age, Mid-Continent region: Greene, 4.

Redwall limestone, Grand Canyon: Keyes, 104.

St. Iouis formation breccias: Grawe, 2.

South Dakota, central Black Hills: Darton, 14.

Black Hills region, Minnekahta limestone: O'Harra, 4.

Talladega phyllite, Clay County, Alabama, age: Prouty, 4.

Talladega slates, Alabama: Prouty, 5.

Tennessee: Nelson, 16.

Chattanooga shale: Swartz, J. H., 1. Crossville quadrangle: Butts, 6 .

Herbert Domain: Nelson, 21.

northern: Glenn, 6; Mississippian : Bassler, 17.

Overton County: Butts, 1.
Carboniferous-Continued.

Tennessee-Continued.

Iutherford County: (alloway, .I I., 1.

southern: Nelson, 20.

Sumner County : Mather, 3.

Waynesboro quadrangle: Miser, $(i$.

'J'exas : Roger's, G. S., 7 ; Udden, J. A., 3,12 .

Amarillo region: Gould, 1.

Archer County : Hubbard, W. W., 1.

Bend series: Girty, 1, 2; Moore, R. C., 2 ; and contiguous formations: Goldman, 8.

Big Lake oil field: Sellards, 21

Burkburnett: Glenn, 2.

Bissett formation, Permian : King, 4. central : Matteson, 1.

Coke County: Beede, 6; Jones, IR. A., 4.

Coke County red beds: Beede, 6, 7. Crockett County: Liddle, 2.

Culberson County: Udden, 18 ; University Block: Beede, 8 .

Diablo Plateau : Beede, 3.

Wlenburger formation: Sellards, 9.

Foard County: Beede, 10.

Fort Stockton quadrangle, Permian : Adkins, 4.

Glass Mountains: King, 2, 6 ; Gaptank-Wolfcamp problem: Keyte, 2.

Hudspeth County: Beede, 5.

Lacasa area, Ranger district: Ross, C. S., 3 .

Marathon Basin : Baker, C. L., 10.

Marathon fold: Liddle, 1.

north central: Gould, 12; Udden, Jon. A., 1 ; Pennsylvanian formations: Moore, R. C., 13 ; Plummer, F. B., 1, 4 .

nortbern : Pratt, W. E., 1.

Panhandle: Gould, 16.

Permo-Carboniferous red beds: Romer, 13.

Potter County: Patton, L. T., 2.

Ranger oil field: Eckes, 1 ; Reeves. F., 2.

San Angelo formation: Beede, 10.

Solitario uplift: Powers, 9.

Tom Green County: Henderson, G. G., 1.

western: Hoots, 1; Schuchert, 39 ; Permian: Edwards, E. C., 2.

Wiles area, Ranger district: Dobbin, 1.

Utah: Butler, 4 ; Keyes, 152.

Grand and San Juan counties : Prommel, 1.

Kaibab Gulch, Kaibab limestone : Noble, 8.

La Sal Mountains: Gould, L. M., 4.

Moab region : Baker, A. A., 1.

Ophir district: Olmstead, 1.

San Juan Canyon: Miser, 14, 17.

San Rafael Swell: Gtlluly, 4. 
Carboniferous-Continued.

Utah-Continued.

southeastern : Longwell, 6 ; Prommel, 4.

southern: Moore, R. C., 17.

southwestern: Reeside, 4.

Tintic district: Lindgren, 2.

Wasatch front: Stillman, 1.

Washington County: Bassler, H., 2.

Virginia : Giles, 10.

Dickenson County: Giles, 3.

Giles County: Hubbard, G. D., 6.

Lee County: Giles, 4.

Russell County, Wentworth, 6.

Scott County, Early Grove : Butts, 9.

soutbwestern, black shale: Stose, 22.

Valley coal fields: Campbell, M. R., 10.

Wise and northern Scott counties: Eloy, J. B., 1.

Tazewell County : Harnsberger, 1.

Washington, San Juan Islands: McLellan, 2.

West Virginia, conglomerate rocks: Reger 12.

Fayette County : Henuen, 1.

Hampshire and Hardy counties: Tilton, 15.

Mercer, Monroe, and Summers counties: Reger, 9.

Mineral and Grant counties: Reger, 7.

Nicholas County: Price, W. A., 7 ; Reger, 3.

Pendleton County: Tilton, 14.

Permian: Tilton, 10.

Tucker County : Reger, 6.

Webster County: Reger, 1.

Whitehorse sandstone, correlation, Kansas, Oklahoma, 'Texas: Clifton, $2,4$.

Wyoming: Heald, 5 .

Baxter Basin gas field: Sears, 7.

Bell Springs district, $\mathrm{C}$ a r b o n County : Dobbin, 5.

central: Lee, W. T., 19.

Lost Soldier-Ferris district: Fath, 5.

Marerick Springs: Collier, 6.

Thermopolis district: Collier, 4

- Tensleep formation: Brainerd, 2.

Wind River Mountains: Condit, 4.

Caribbean region: Vaughan, 3 .

Cariboo gold fields, British Columbia: MacKay, B. R., 1.

Carlyle-Centralia folio, Illinois (no. 216) : Shaw, 9 .

Carnotite. See also Radium.

Arizona, Aguila : Hewett, 15.

Colorado, near Denver: Wilson, J. H., 1.

southwestern: Burwell, 1.

Nevada, soutbern: Hewett, 9

Cartography.

Barometric surveying in petroleum mapping: Lahee, 3.

Canada, mapping pre-Cambrlan areas: Bruce, 6.
Cartography - Continued.

Canadian Cordillera, geological map. ping; Dunn, R., 1.

Field mapping for oil geologist: Warner, C. A., 1.

Maps, a field method of reducing to scale: Armstrong, 3.

interpretation and use: Smith, G. $0 ., 20$.

Military and geologic mapping: Bateman, A. M., 1.

Plane table: Bateman, A. M., 1.

Plane-table metbods: English, W. A., 2.

Radian measures in plane-table mapping; Palmer, H. S., 3.

Reconnaissance mapping: Fuller, M. L., 2.

Caves.

California, Samwel Cave: Merriam, 23.

Carlsbad Cavern, New Mexico: Lee, $12,14-16$.

Cavern deposits in Permian: Udden, 13.

General : Reeds, 16.

Indiana, Marengo Cave: Addington, 3 ; Speckman, 1.

Porter's Cave : Addington, 2.

Kentucky : Jillson, 66.

Edmonson County: Weller, J. M., 1.

Mammoth Cave: Lobeck, 10 ; Randolph, 1 ; Weller, J. M., 1 ; bibliography: Jillson, 40.

southern: Miller, A. M., 13

Lehman Cave, White Pine County, Nevada: Hastings, 1.

Mexico, Naica selenite caves: Foshag, 29.

Pedregal, caves in lava: Wittich, 1.

Missouri, Ozarks: Dake, 10.

New Mexico, Guadalupe Mountains: Baker, C. L., 4.

Ohio: White, G. W., 1.

Put-in-Bay, origin: Cuttingham, 1.

Oregon, Josephine County: Williams, I. A., 1.

lava river tunnel: Williams, I. A., 3.

South Dakota, Black Hills: Darton, 14 ; Johnson, J. H., 3.

Virginia, Endless Caverns: Edwards, I., 4.

Shenandoah Valley: Anon., 21.

Cayman Islands: Matley, 7, 8, 13, 14.

Celestite, Ontario, Renfrew County, Bagot township: Wilson, M. E., 2 .

Cement materials: Burchard, 1, 8, 11, 13, 19 ; Eckel, 1, 2.

Idalio, Pocatello area : Anderson, A. 1.., 3.

Indiana : Logan, 9, 10.

Kentucky : Richardson, C. H., 13.

New York, Catskill region: Jones, $\mathbb{R}$. W., 1.

Pennsylvania, Allentown quadrangle: Miller, B. L.. 5 . 
Cenozoic formations of the Pacific region: Vaugban, 28.

Cenozoic Plantae, catalog: Knowlton, 2.

Central America. See also Costa Rica, Guatemala, etc.

Mesozoic history : Stanton, 1.

Swamps, coastal: MacDonald, D. F., 3. Tectonic features: Vaughan, 26.

Economic geology.

Oil reserves: Redfield, 5 .

Petroleum: Milner, 2 ; Redfield, 9.

Ifistorical geology.

Geologic history: Ihering, 1.

Geologic mapping: Vaughan, 12.

Paleogeography : Sapper, 7.

Tertiary, correlation: Vaughan, 13.

Petrology.

Lavas: Futnam, P. C., 2.

Magma mass underiying Central America: Putnam, P. C., 2.

Physical geology.

Volcanoes: Putnam, P. C., 2 ; Sapper, $3,5$.

Physiographic geology.

General : Sapper, 6.

Cephalopoda. See also Mollusca.

Actinoceras, 'Trenton limestone, Montreal: Clark, T. H., 16.

Actinosiphonate, trochoceroid, and other cephalopods: Foerste, 21.

Adaptations: Berry, 99.

Alberta, Fernie formation, Ammonoidea : McLearn, 15.

Ammonite evolution: Trueman, 1.

Ammonite opercula, Cuba : $0^{\prime}$ Connell, 5 .

Ammonites, Cretaceous, Texas: Scott, G., 6 ; Texas and Mexico: Böse, 9.

history: Diener, 2.

Jurassic, Pacific region: Crickmay, 2.

Texas, Eagle Ford formation : Moreman, 2; Fredericksburg formation: Scott, G., 5; Weno and Pawpaw formations: Adkins, 2.

Anticosti, Ordovician : Foerste, 26.

Arctic and related forms: Foerste, 24.

Arctic Ordovician and Silurian: Foerste, 11.

Arkansas, Fayetteville, Carboniferous : Croneis, 3.

Beudanticeras breweri and Coloboceras stantoni, California: Crickmay, 4.

British Columbia, Parson Bay, Jurassic: Crickmay, 9.

Cardioceratidae: Reeside, 1.

Colorado group, Montana: Reeside, 6.

Cuba, Jurassic ammonites: O'Connell, 3.

Viñales, Jurassic: Sánchez Roig, 1., 2.

Cycloceras and associated genera : Cro neis, 2.

Devonian, Nova Scotia: Foerste, 27.

Eagle sandstone: Reeside, 12.

Eutrephoceras, Bocene, South Carolina: Reeside, 9.
Cephalopoda-Continued.

Gastrioceras, coal measures, lowa : Thomas, A. O., 6.

Gerontic ammonites, Duck Creek formation, Texas: Scott, G., 1.

Goniatites of Iowa: Thomas, 19.

Greenland, eastern, Eotriassic ammonites: Spath, 1.

northern, Ordovician: Troedsson, 2.

Habits : Raymond, 17.

Holochoanites, genetic relations: Grabau, 4 .

Hudson Bay area, Ordovician and $\mathrm{Si}$ lurian: Foerste, 22.

Jurassic Ammonoidea, Canada: McLearn, 13.

Metaplacenticeras Spath and Placenticeras Meek: Reeside, 11.

Mexico, Coahuila, Turonian ammonite fauna: Böse, 3.

Guerrero, Cretaceous: Burckhardt, 1..

Julassic: Burckhardt, 3 ; Zacatecas: Burckhardt, 1.

Lower Cretaceous : Burckhardt, 2.

Michigan, Devonian: Ehlers, 5; Alpena: Foerste, 23.

Minnesota : Sardeson, 17.

Mortoniceras : Yabe, 1.

New Mexico, Abo sandstone ammo. noids : Böse, 4.

Northwest Territories, Ordovician and Silurian: Foerste, 20.

Ochetoceras, phylogeny: O'Connell, 6.

Ontario, Timiskaming area: Foerste, 18.

'Toronto area : Parks, 9.

Ordovician and Silurian: Foerste, 17, 28.

Orthoceras, color bands: Ruedemann, R., 3.

Orthoconic, Silurian: Focrste, 30.

Ozarkian: Walcott, 8.

Perisphinctinae, costal development: O'Connell, 2.

Permo-Carboniferous ammonoids, Glass Mountains, Texas: Böse, 1.

Phases of adaptation: Dunbar, 5.

Primitive cephalopods, mode of life: Ruedemann, 4.

Prosiphon in Cretaceous ammonites: Crickmay, 1.

Rayonnoceras, Fayetteville, Arkansas: Croneis, 1.

Salterella, nature: Clark, T. H., 5, 12.

Sex distinction: Ruedemann, R., 3.

Scaphites, Upper Cretaceous: Reeside, 14.

Silurian and Ordovician : Foerste, 19.

Silurian, northern Michigan: Foerste, 16.

Spirulirostra, Mexico: Berry, 39.

Tetrabranchiate cephalopods, evolution : Raymond, 27.

Wyoming, Oregon Basin, Cody shale: Reeside, 13. 
Ceratopsia, carriage and use of head: Tait, 1.

Cerium: Watson, T. L., 2.

Cetacea. See Mammalia.

Chagrin formation, Ohio: Chadwick, 14. Chalcedony veins, south Dakota: Lawler, 1. Chalcopyrite deposits, northern Manitoba: Bluce, 5.

Chalk: Ward, 3 ; origin : Tarr, 14 ,

Cliandalar district, Alaska: Mertie, 12.

Clamplain sea, decreasing salinity southward: Goldring, 3.

Changes of level. See also Beaches; Shore lines; Terraces.

Alaska: Dall, 2.

Atlantic const: Jolınson, D. W., 18 .

Rermuda: Sayles, 14.

British Columbia, Fraser, River Delta : Johnston, W. A., 17.

Vancouver region, Pleistocene : Johnston, W. A., 4.

Chuse: Bowie, 19 ; Dutton, 1.

Causes, major: Ulrich, 3.

Champlain submergence, depth along Maine coast: Meserve, 1.

Coastal Plain, Quaternary : Vaughan, 7.

Colorado River delta: Waldorf., 1.

Columbirl Valley, l'leistocene submergince: Bretz, 1.

Coal reefs and the glacial period: Daly, 2.

General: Bowie, 21 ; Daly, 21.

Hawaii : Jaggar, 22.

Hawaiian Islands, Oahu: Pollock, 1.

Isostasy, relation of : Bowie, 4.

Lower Mississippi Valley, sinking: Sci. Serv, 6.

Maine, late Quaternary: Antevs, 16.

Manitoha, Pleistocenc: Johnston, IV. A., 2 .

Mexico, coast regions: Wittich, 21.

I.ower California: Wittich, 8 .

New England, southern, Quaternary: Antevs, 14

Newfoundland: Daly, 11 ; postglacial : Daly, 10.

New Fampshire, Quaternary: Goldthwait, 1.

New York, eastern : Fairchild, H. L., 1. Genesee River region: Fairchild, 5.

Nova Scotia: Daly, 11; Goldthwait, 5. sea coast near Wolfville: Churchill, 2 .

Paleozoic oscillations: Uilrich, 2.

Pleistocene: Daly, R. A., 1, 4, 7, 19.

Postglacial uplift of New England coastal region: Fairchild, 7 .

Post-Pleistocene: Daly, 7.

Quebec, Anticosti Island: 'Twenhofel, 9.

Recent sinking of sea level : Daly, 6, 9 .

Recent sinking of ocean level, lack of evidence of, in western Canada : Johnston, W. A., 24.

Sea-level changes due to glaciation and deglaciation: Daly, 18.
Changes of level-Continued.

Sea-level surfaces and coastal subsidcnce: Johnson, D. W., 14.

l'exas, coast region: Jones, R. A., 11.

Goose Creek oil field: Johnson, D. W., 16; Pratt, W. L., 10, 13, 15 ; Snider, 2.

Tilting in the Great Lakes region: Ireeman, J. R., 1.

Vermont, postglacial uplift: Fairchild, 2.

Vertical earth adjustments, rate of movement: Hobbs, 15.

Chapeño salt dome, Tamaulipas, Mexico: Belt, 1.

Chatcos, origin : Bryan, K., 5.

Chattınooga slale, southwestern Virginia: Swartz, J. H., 5; Tennessee, age: Swartz, J. H., 1.

Chemung group, stratigraphy in western New York: Chadwick, 10.

Chert. See also Flint.

Definition: Glock, 1.

Indiana: Bennett, L. F., 2.

Newfoundland, ferruginous chert formations: Sampson, 7.

Origin: Price, W. A., 6; Sampson, 7 ; Tarr, 14, 17 ; Twenhofel, W. H., 1.

West Virginia : Price, W. A., 6.

Wreford and Folaker limestones: 'Twenhofel, W. H., 1.

Chester series in Illinois: Weller, 2.

Chibougamau district, Quebec: Mawdsley, 2.

Chignilk region, Alaska: Martin, G. C., 14.

Chilko Lake area, British Columbia: Dolmage, 15.

Chink faceting, new process of pebble shaping: Wentworth, 20.

Chitina Valley, Alaska : Moffit, 1, 5.

Chitons, fossil, of western North America : Berry, S. S., 1.

Chlorophoenicite, Franklin, New. Jersey : Foshag, 28.

Chrome, magnetic and nonmagnetic: Lewis, J. V., 1.

Maryland: Singewald, 5.

Chrome iron ore.

Cuba, Burch, 2.

occurrences: Ross, J. G., 1.

Chromite: Diller, 1, 2.

Alaska: Mertie, 3.

Kenai Peninsula: Gill, A. C., 1, 2.

British Columbia, Clintơn district: Reinecke, 2.

Lillooet-Prince George region: Reinecke, 3.

California, Klamath Mountains: Diller, 9.

Cuba : Burch, 1 ; Burchard, 4, 10.

San Miguel de los Baños: Suárez Murias, 3.

General: Diller, 6; Sampson, 3, 6, 1:2.

Maryland: Singewald, J. T., 1,2 . northeastern: Knopf, E. B., 2. 
Chromite-Continued.

Montana, Stillwater and Sweet Grass counties: Westgate, 5.

North Carolina: Lewis, J. V., 3, 6.

Oregon, eastern: Westgate, 3.

Klamath Mountains : Diller, 9.

Pennsylvania: Pennsylvania G. S., 1. southeastern : Knopf, E. B., ¿.

Washington: Pardee, 7.

Chronology in geology: Udden, 11.

Chulitua region, Alaska: Capps, 4.

Cincinnati anticline, dimensions: Hubbard, G. D., 5.

Cirques.

Multiple level cirques: Fuller, M. B., 10.

Cirripedia.

Britislı Columbia, Sooke formation: Colruwall, 2.

Cubi, Miocene: Withers, 7.

Classification.

Cheilostomatous Bryozoa: Canu, 7 .

Coal : Ashley, 20 ; Campbell, M. R., 15; Fisher, D. J., 5; Thiessen, 13; 'I'hom, 21; use classiflcation: Ashley, 41.

Cycadophyta: Wieland, 1.

Fire clays: Parmelee, 1.

Geologic time: Wilmarth, 2.

Gypsum deposits: Wilder, 1.

Igneous rocks: Hodge, E. 'T., 2-4, 7 ; Mathews, 1 ; Pirsson, 4 ; quantitative: Hodge, E. T., 11; quant1. tative mineralogical: Johannsen, 3.

Magmatic ore deposits: Zavaritsky, 1. Mimetic crystals: Wherry, 1.

Minerals, sulpho-salt: Wherry, 13.

Oceanic islands: Davis; 23.

Ore deposits: Tovote, 2.

Peat deposits: Dachnowski, 2

Pisces: Jordan, 10.

Pre-Cambrian : Wilson, M. E., 18; Miller, W. G., 12.

Reptilia : Broom, 1; Williston, 1.

Proboscidea : Osborn, 15.

Rock classification for engineering : Pirsson, 1 ; Smith, W. D., 2.

Rocks, genetic classiflcation: Sen, 1.

Springs: Bryan, K., 2.

Clay. See also Fire clay; Kaolin.

Alberta, Athabasca River: Hume, 9.

Bauxite deposits, enrichment: Thiel, 10.

Bentonite: Davis, C. W., 2 ; mineralogy : Ross, C. S., 15.

Bibliography of clay deposits : Ries, 14.

British Columbia, Clinton district : Reinecke, 2

I.illooet-Prince George region: Reinecke, 3.

California : Boalich, 1 ; Dietrich, 1, 2. Riverside County, Alberhill: Hill, J. H., 1.

Tertiary: Linton, 1

Composition : Somers. 1.
Clay-Continued

Diaspore clay, Arkansas and Missouri : Wysor, 1.

Fire clays, northern Appalachian coal basin: Ashley, 2 ; Lovejoy, 1.

Florida: Bell, O. G., 1.

General: Ries, 5, 15, 17 ; Stout, 3.

Georgia: Ries, 5 ; Stull, 2.

High-grade American clays, occurrence : Ries, 1, 2.

Idaho: Skeels, 1.

Illinois, Union County, Mountain Glen : St. Clair, 2.

refractory clays: Parmelee, 2.

Indiana: Logan, 10, 19; Ries, 5.

Monroe County: Logan, W. N., 2.

Iowa: Galpin, 2.

Kansas, Arkansas Cily: Teetor,. 1.

Kentucky: Jillson, $\mathbf{7 6}$; Ries, 5, 6.

Louisiana: Whittemore, J. W., 2.

shreveport area: Whittemore, J. W., 1.

Manitoba, Lake Agassiz basin : Wallace, 11 ; Maynard, J. E., 1.

Michigan: Brown, G. G., 1.

Microscopic examination: Somers, 1.

Mineralegy : Ross, C. S., 24, 27.

Mineralogical examination of coal fơmation clays: McCaughey, W. J., 2.

Minnesota : Grout, 1, 11.

Mississippi : Ries, 5.

Missouri: Thornberry, 1.

diaspore and flint clays: McQueen, 1.

North Carolina: Ries, 5.

North Dakota: Budge, 1.

Ohio, coal formation clays: Stout, 3. Columbiana County: Stout, 5 .

Ontario: Keele, 8.

Abitibi and Mattagami rivers: Keele, 2.

Missinaibi River: Keele, 6,7 .

northern: Keeie, 1, 3, 4; Mesozolc: Dyer, 11.

Origin of coal formation clays: Stout, 4.

Pennsylvania: Pa. G. S., 1; Ries, 5. Monroe County, Saylorsburs, white clays : Peck, F. B., 1.

white clay : Hice, 1.

Penusylvanian flre clays, origin: Hodson, F., 2.

South Carolina: Ries, 5. white clays : Neumann, F. .R., 2.

'Tennessee : Ries, $\mathbf{5}$. western, ball clays : Schroeder, 1.

Texas, eastern: Dumble, 1.

'lexture and composition, relation: Grout, 11, 16.

United States : R!es, 5.

Vermont: Jacobs, 5.

Virginia : Ries, 3.

Washington : Burkhalter, 1 ; Glover, 1 ; Wilson, H., 2.

White clays and bauxite, origin: Woolnough, 2. 
Clay balls, formation: Haas, 2.

Cle:avge and grain of slates: Behre, 6 .

ciimate.

Factors of climatic control: Humphreys, 4.

Climate, geologic. See Paleoclimatology.

Climatic changes, nature and causes: Huntington, 1.

Climatic environment of extinct animals, determination: Case, 9.

Climatic fallacy, venerable: Chamberlin, T. C., 19.

Clinkertill : Dove, 4.

Clinton district, British Columbia : Reinecke, 2.

Clinton iron ore, origin: Galloway, J. J., 4 ; Smyth, 1.

Coal. See also Anthracite; Lignite.

Age characteristics: Stevenson, 3.

Alabama: Butts, 7.

analyses : Fieldner, 3.

Bessemer - V a n d i ver quadrangle : Butts, 13.

Alaska : Evans, G. W., 2.

Alaska Railroad region : Capps, 6.

Cold Bay-Chignik district: Smith, W. R., 1.

Matanuska field : Chapin, 8, 11 ; Martin, G. C., 3.

Nenaua field: Martin, G. C., 1.

Point Barrow region: Paige, 5 .

upper Matanuska Valley: Capps, 11.

Alberta : Allan, 17 ; Rutherford, 3.

analyses: Stansfield, E., 1.

Blackstone, Brazeau, and Pembina rivers foothills, Allan, 13.

Bow River coal basin: Dowling, 20.

Brule Lake region: MacVicar, 1.

Crowsnest area: Rose, 3.

Drumbeller district: Allan, 7 .

foothills belt between McLeod and Athabasca rivers: Rutherford, 4.

Highwood area: Rose, 1.

North Saskatchewan and McLeod river's: Rutherford, 8.

Saunders Creek and Nordegg coal basins : Allan, 9.

Smoky, Hay, and Berland rivers: MacVicar, 2.

Smoky River field: McEvoy, 1; Anon., 33.

Allegheny formation, correlation of coal beds: Thiessen, 9

Anthracite, low-temperature origin ; Roberts, J., 1.

microstructure: Kelly, S. F., 2; Turner, H. G., 3.

origin : Jeffrey, 5.

Anthracite basins, Penusylvania, structural features: Kemp, 10.

Appalachian field: Bryan, P. W., 1.

Arkansas: Branner, G. C., 4.

analyses: Fieldner, 10.

Atmospheric dust in coal: Glock, 2.

Boghead coals, origin: Thiessen, 1:
Coal-Continued.

British Columbia, Chu Chua, Eocene basin: Uglow, 7 .

Crowsnest Pass field: Strachan, 1.

Hat Creek coal area, Kamloops district: MacKay, B. R., 5; North Thompson valley: Uglow, 3.

Peace River canyon area : McLearn, 7. Vancouver Island: MacKenzie, J. D.. 5; Alberni area: MacKenzie, J D., 7 .

Canada: Gray, F. W., 2; Patton, M. J., 1 ; western: White, J., 1.

Cape Breton, Great Bras d'Or coal district: Bell, W. A., 5.

Carbon-ratio theory and Hilt's law: Reeves, F., 14.

Classification: Ashley, 15; Campbell, M. R., 15 ; Thiessen, 13 ; 'Thom, 21.

Cleat: Moore, E. S., 13.

Climatic conditions when coal beds were formed: Brown, T. C., 2.

Coalification process: Fisher, D. J. 5.

Coking coals, structure and origin: Jeffrey, 8.

Colorado, Axial and Monument Butte quadrangles: Hancock, 7.

Mancos district: Collier, 3.

Twentymile Park district of Yampa coal field, Routt County : Campbell, M. R., 5 .

Compilation and composition of bituminous coals: Thiessen, 3 .

Constitution: Jeffrey, 11 ; Stopes, 1 ; Thiessen, 2, 5, 9; Tideswell, 1 ; Anon., 43, 44

Coals, Kentucky, Illinois, and Indiana, correlation: Jillson, 108.

Environmental conditions of deposition of coal: White, D., 23.

Formation: Hackford, 1: Hixon, 1; Kendall, 2; Thiessen, 11, 13; White, D., 20 ; and origin: Thiessen, 5.

General: Jeffrey, 10; Moore, E. S., 4; Stevenson, 1, 2 ; White, D., 27.

Geology : Finlay, 1.

Idaho, eastern: Mansfield, G. R., 8.

Teton basin, Horseshoe district: Evans, G. W., 1.

Hydrocarbons, inorganic origin : Young, J. W., 6.

Identification of coals: Williams, 'T. B., 6.

Idaho, Horseshoe Basin field: Evaus, G. W., 4

Illinois : Culver, 5.

Carbondale quadrangle: Iamar, :

Avon and Canton quadrangles: Savage, 6 .

analyses: Hawley, G. W., 1.

Carlyle-Centralia district: Shaw, 9.

Colchester and Macomb quadrangles: Hinds, H., 1.

District IV: Cady, 7 
Coal-Continued.

Illinois-Continued.

Ergington-Milan area : Savage, $\cdot 5$.

Equality-Shawneetown area: Butts, 5.

Gillespie and Mount Olive quadrangles : Lee, W., 1.

Hennepin quadrangle: Cady, 3.

Herscher quadrangle: Athy, 1.

Knox County: Jelliff, 2.

La Salle quadrangle: Cady, :3

low-sulphur coal: Cady, 9.

Milan quadrangle: Savage, 5.

Morris quadrangle: Culver, 2.

New Athens-Okawville area: Shaw, 8.

I'erry County. Herrin coal: Fisher, D. J., 3.

Silline and Gallatin counties: Cady, 4.

Saline County: Cady, 12.

southern: Cady, 13.

western: Culver, 6.

Williamson and Saline counties: Cady, 11.

Indiana: Barrett, E., 8; Logan, 10. coal seams, distribution: Logan, 11. Monroe County: Logan, W. N., 1.

Vigo County : Logan, 6.

lowa: Lees, 17 ; Rice, G. S., 1.

Lucas County: Lugn, 6.

Isostatic adjustment in formation of coal beds : Kemp, 13.

Kausas: Allen, H. C., 2; Young, C. M., 1.

Kentucky : Campbell, M. R., 4 ; Jillson, $21,37,52$; Miller, A. M., 1.

asphalt coal : Jillson, 55.

bibliography: Jillson, 14.

cannel coal: Jillson, 62.

Clay County: Hodge, J. M., 3 ; Sexton Creek area: Russell, P. G., 1. eastern, Buckhorn region; Jillson, 27.

Elkhorn field: Hudnall, 1.

Goose Creek region: Hodge, J. M., :, Kentucky River, north fork: Hodge, J. M., 2.

Leslie and Harlan counties: Hodge, J. M., 1.

low-sulphur coals: Jillson, 11.

Magoffin County : Browning, I. B., 1.

Martin County : Hudnall, 2.

Middlesboro Basin: Wentworth, 28.

Morgan County : Robinson, L. C., 1.

Ohio County, Elm Lick coal bed:

Gardner, J. H., 5.

production: Jillson, 15.

Stinking Creek region: Jillson, 3.

Webster County : Glenn, 4, 5.

western coal field: Burroughs, W. G., 2.

Maryland: Swartz, C. K., 3.

Mexico: Obregon, 1.

Sonora: Paredes, 6.

Microscopic study: Thiessen, 6.
Coal-Continued.

Microscopy of anthracite: 'Lurner, H. G., 2 .

Microstructure : Seyler, 1.

Missouri : Brodie, 2; Thom, 14. analyses: Fieldner, 7 .

Vernon County: Greene, 8.

Moisture in coals: Thom, 12.

Montana: Rowe, 4.

Tullock Creek coal field: Rogers, G. S., 8.

New Brunswick: Dyer, 8.

Gloucester County: Young, G. A., 2. Minto basin: Dyer, 2.

Newfoundland: Haliburton, 1.

St. George's coal field: Baker, 11. A. 2.

New Mexico, O'Mara field : Keyes, 110. Raton field: Lee, 10.

Raton-Brilliant-Koehler area: Lee, W. T. 6.

San Juan County : Bauer, C. M., 1.

North Carolina, Triassic coal field : Pratt, J. H., 5.

North Dakota: Dove, 2 ; Leonard, 7.

Nova Scotia: Gray, 3 ; Hayes, A. O., $1,3$.

Sydney coal fleld: Hayes, A. O., 6.

Occurrence, composition, and origin : Fettke, 3.

Ohio: Camplell, M. R., 6 ; Stout, 2.

analyses: Fieldner, 1.

Columbiana County: Stout, 5.

Muskingum County : Stout, 1.

Pittsburgh coal bed: Bownocker, 8. Summerfleld and Woodsfield quadrangles: Condit, 3.

Vinton County: Stout, 6.

Wayne County: Conrey, 1.

Oil resources in coal : Fettke, 3.

Oklahoma : Cooper, 3 ; Fuller, M. L., 4. analyses: Fieldner, 9.

eastern: Shannon, C. W., 4.

Origin : Campbell, M. R., 10; Hippard, 1 ; Jeffrey, 4, 12 ; Runner, 1. and constitution : Thiessen, 8. and formation of coal: Jeffrey, 9.

Pan-Pacific region: Johnson, B. L., 6.

Pennsylvania: Ashley, 7, 26; Kuhn, 1 ; Pennsylvania G. S., 1 ; Sisler, $1,2$.

Allegheny Valley : Rayburn, 1. analyses: Fieldner, 2.

anthracite region: Parker, E. W., 1. bituminous coal fields: Sisler, 3 . cannel coal: Fettke, 4.

coal resources: Reese, 1.

'Greensburg quadrangle: Johnson, M. E., 1.

low-sulphur coals: Chance, 1 .

Pittsburgh coal bed: Ashley, 21; White, I. C., 9.

Punxsutawney quadrangle: Ashley, 18.

Resources of the Americas: Miller, B. L., 2. 
Coal-Continued.

Regional carbonization: White, D., 24. Saskatchewan, Souris field: Dowling, 11.

"Soot" in coal : Scheffel, 2.

South's coal fields: Thom, 10.

Spore exines, use in correlation: Thiessen, 4.

Structure in Paleozoic bituminous coals : Thiessen, $2,3$.

Sulphur in coal: Thiessen, 1 ; geological aspects: Ashley, 6.

Use classification: Asbley, 1.

Tennessee : Fieldner, 5 ; Forbes, 1 ; Nelson, 25.

Crossville quadrangle: Butts, 6.

Herbert Domain : Nelson, 21.

northern: Glenn, 6.

southern: Nelson, 20.

Itah: Spieker, 2.

Castlegate, Wellington, and Sunnyside quadrangles: Clark, F. R., 4.

Salina Canyon district, Sevier County : Spieker, 6.

Virginia : $\mathbf{m b y}, \mathbf{5}$.

analyses: Fieldner, 6.

Dickenson County: Giles, 3.

Lee County : Giles, 4.

Russell County: Wentworth, 6.

southwestern: Davenport, 1 .

Tazewell County : Harnsberger, 1.

Triassic: Roberts, J. K., 8.

Valley coal fields: Campbell, M. R., 10.

Wise and northern scott counties: Eby, J. B., 1.

Washington: Evans, G. W., 3 ; Shedd, 2. Skagit County : Jenkius, 8.

southwestern : Culver, 1.

West Virginia: Eby, J. B., 6 ; Reger, 11 ; White, I. C., 8.

Abram Creek-Stony River field: Ashiey, 4.

analyses: Fieldner, 8.

Cheat Mountain coal field, Randolph County : Reger, 16, 17.

Fayette County : Hennen, 1.

Farrison, Thomas bed: Campbell, M. R., 1 .

Nicholas County : Reger, 3.

Mercer and Summers counties: Reger. 9.

Mineral and Grant counties : Reger, 7. sulphur in coals: White, I. C., 3.

'Tucker County : Reger, 6.

Webster County: Reger, 1.

Wyoming, Gillette coal field: Dobbin, 3; Thom, 19; Mintutn district: Thom, 19.

Green River field: Van Lennep, 1.

Pumpkin Buttes coal field: Wegemann, 2.

Oregon Basin, Meeteetse. and Grass Creek quadrangles: Hewett, 16.

Coal balls: Feliciano, 1 ; Noé, 4.

Coal Measures. See Carboniferous.
Coalification process: Fisher, D. J., 5.

Coast erosion.

California, San Diego region : Leonard, 6.

North Carolina, Cape Hatteras: Rude, 1.

Coast line changes, Nova Scotia : Churchill, 5 .

Constal Plain terraces, origin and age: Hay, 22.

Cobalt: Drury, 1 ; Hess, 2, 7, 8, 12, 13, 16, 19,21

Idaho, Lemhi County: Hess, 5.

Ontario : Drury, 1 ; Cobalt: Whitehead, 1.

Oregon, Jackson County: Kellogg, A. E., 4.

Cobaltite.

British Columbia, North Thompson Valley : Uglow, 15.

Cobble abrasion: Wentworth, 1.

Cobble of peculiar shape: Wentworth, 14 .

Coblles, striated, southern States: Wentworth, 36 .

Coelenterata. See Anthozoa; Hydrozoa; Invertebrates (general).

Colchester-Macomb folio, Illinois (no. 208) : Hinds, H., 1

C'old Bay district, Alaska : Capps, 5 ; Smith, W. R., 4.

Cold Bay-Chignik district, Alaska: Smith, W. R., 1.

Cold Bay-Katmai district, Alaska: Smith, W. R., 3.

Colemanite, Clark County, Nevada : Noble, 2.

Colemanite deposits, origin: Foshag, 10.

Collections.

Colorado Museum, fossil mammals : Cockerell, 21.

Harvard College, Museum of Compara. tive Zoology, report on geological collections: Sayles, 5, 9, 10 ; on invertebrate paleontology: Raymond, 14, 20, 22, 25, 32, 33, 38; Stetson, 3.

U. S. National Museum : Merrill, 25, $26,27,35,44,48,51,58$.

Colloidal geology : Wallace, 9.

Colloids in geologic problems: Hubbard, G. D., 2.

Collophnne: Rogers, A. F., 9.

Color in polished sections, diagnostic value: I'almage, 1.

Color of red beds, origin: Dorsey, 2.

Color markings, Orthocelas: Ruedemann, R., 3.

Color printing of geological maps: Scnécal, 1.

Colorado.

Alkalies: Headden, 1.

Atlas of Colorado: Margerie, 2.

Bibliography, north-central Colorado: Johnson, J. H., 19.

northeastern Colorado: Johnson, .T. II., 10.

northwestern Colorado: Tohnson, J. H., $7,18$.

south-central Colorado: Johnson, J. H., 21. 
Colorado-Continued.

Bibliography-Continued. southeastern Colorado: Johnson, J. I., 14.

southwestern Colorado: Johnson, J. H., 8.

Cooperative surveying: Mendenhall, 3. Geology and natural resources: George, R. D., 6.

Geology of the Denver Basin, bibliography: Johnson, J. H., 4.

Guidebook, Denver \& Rio Grande Western route: Campbell, M. R., 3.

Maps of Colorado, list of: Johnson, J. H., 15.

Moffat 'T'unnel : Lovering, 7 .

Areas described.

Axial and Monument Butte quadrangles, Moffat County; Hancock, 7.

Big Thompson River valley: Fuller, M. B., 8.

Brilliant quadrangle: Lee, W. T., 6.

Creede district: Emmons, W. H., 4.

Cripple Creek district: Van Tuyl, 3.

Crowley and Otero counties (parts): Toepelman, 3.

Deita and Mesa counties:'Weeks, L. J., 1.

Golden area: Johnson, J. H., 12.

Grand, Jackson, and Larimer counties (parts) : Spock, 1.

La Junta area: Patton, H. B., 3.

Las Animas, Otero, and Bent counties (parts): Duce, 1.

Leadville mining district: Emmons, S. F., 1.

Moffat County : Sears, 3.

Northeastern Colorado: Mather, 12.

Platoro-Summitville district: Patton, H. B., 1.

Raton quadrangle: Lee, W. T., 6.

Red Cliff district: .Crawford, R. D., 3.

Tarryall district, Park County: Muilenburg, 2.

Twentymile Park district of Yampa coal field, Routt County: Campbell, M. R., 5 .

Twin Lakes district: Howell, J. V., 1. Wagon Wheel Gap area: Larsen, 8.

Economic geology.

Aspen district, Pitkin County: Knopf, A., 10.

Boulder County, Ward region: Worcester, 1.

Camp Bird compound veindike: Boydell, 8; Spurr, 18; Thoreau, 1.

Carnotite near Denver: Wilson, J. H., 1. Gateway district: Farnum, 1. southwestern Colorado: Burwell, 1.

Coal, Mancos district: Collier, 3.

Creede, ore deposition: Lunt, 2.

Cripple Creek district, ore at deep levels: Loughlin, 32.

Evergreen copper ores, Gilpin County : McLaughlin, D. H., 2.

Fluorspar deposits: Aurand, 1; Boulder County: Hibbs, 1.
Colorado-Continued.

Economic geology-Continued.

Gas and oil, Fort Collins : Ball, M. W., 2.

Hahns Peak region, Routt County: Lakes, 1.

Gold, Platoro-Summitville district: Patton, H. B., 1.

Gypsum : Stone, 11.

Jefferisite: Alderson, 5.

Manganese: Jones, :Ed. L., 6 ; Muilenburg, 1.

Mineral deposits, western slope: Aurand, 2 .

Mineral resources: Colorado, 1.

Mineral zones, Hinsdale County: Brown, W. H., 3.

Mining districts: Johnson, J. II., 9.

Mining in Colorado: Hender'son, 1.

Molybdenite, Climax : Haley, D. F., 1.

Natural gas, Fort Collins : Ball, M. W., 3.

Oil accumulation in Rocky Mountain region: Harrison, T. S., 2.

Oil and gas, northeastern Colorado: Anon., 39.

Oil and gas prospects, Moffat County : Sears, 3.

northeastern Colorado: Mather, 12.

Oil possibilities, Routt County: Crawford, R. D., 1 .

Oil shale: Alderson, 1, 2, 4; Chase, R. L., 1; De Beque, 1; George, R. D., 2; Hoskin 1; Jenson, 1; Lunt, 1 ; Winchester, 5 ; organic matter: Franks, 1.

De Beque: Trager, 4

Ore deposits, Leadville district: Loughlin, 31.

Petroleum: Wheeler, H. A., 7.

Outlook for ores: George, R. D., 7.

Pyrite, Leadville: Lee, H. S., 1.

Radium, uranium, and vanadium deposits: Coffin, 3 ; Hess, 15.

Secondary enrichment, Eagle mine, Bonanza: Wuensch, 2.

Silver, Aspen : Bastin, 2.

Silrer enrichment, San Juan Mountains: Bastin, 5.

Silver-bearing petrified wood, Creede : Hills, V. G., 1 ; Ring, 1.

Telluride district: Bell, C. N., 1.

Twentymile Park district of Yampa coal fleld, Routt County: Campbell, M. R., 5 .

Southwestern Colorado: Coffin, 3.

Telluride area, San Miguel County: Hurst, 2.

Historical geology.

Aspen district, Pitkin County: Knopf, A., 10.

Book Cliffs coal fleld : Forrester, J. B., 1.

Boring, Fort Collins: Ball, M. W., 2.

Boulder County, Ward region: Worcester, 1.

Browns Park formation: Peterson, 11; and Bishop conglomerate : Sears, 4.

Buried Mountain range of Permian age : Rich, J. L., 2. 
Colorado-Continued.

Historical geology-Continued.

Camp Bird district: Spurr, 18.

Carlile shale and Timpas limestone, merging in southeastern Colorado: Patton, H. B., 2.

Central City district: Hirschi, 1.

Cretaceous, northeastern Colorado: Henderson, J., 1.

Dakota group: Lee, 8.

Denver formation: Hares, 3.

Foothills formations, north central Colorado: Henderson, J., 2.

Fox Hills sandstone, Larimer County : Johnson, J. H., 20.

liront Range, physical history: Van Tuyl, 5.

Geologic formations, correlation: Lee, W. T., 19 .

Green River formation and its oll shale, origin: Bradley, W. H., 3.

Gunnison tillite of Eocene age: Atwood, 7 .

Igneous rocks, central Colorado: Crawford, R. D., 2.

Italian Mountain, Gunnison County : Cross, W., 7.

Laramie beds, absence in southern Colorado: Keyes, 79.

Laramie formation, central Weld County: Toepelman, 4.

Laramie hiatus, southern Rocky Mountains : Keyes, 147.

Mancos district: Collier, 3.

Moffat tunnel : George, R. D., 3.

Montezuma County, McElmo anticline: Coffin, 2.

Morrison formation, type section: Lee, W. T., 1.

North central Colorado, Big Thompson schist: Fuller, M. B., 6.

Northeastern Colorado: Mather, 12: Anon., 41.

Otero County, geologic map : Lupton, 6.

Pawnee Creek beds, Weld County: Loomis, F. B., 2, 7.

Permian formation: Gould, C. N., 27.

Permo-Carboniferous correlation: Melton, 3.

Pre-Cambrian, Gunnison River: Hunter, J. F., 1.

northern Colorado: Fuller, M. B., 7 .

Pre-Cambrian structure along Big Thompson River: Fuller, M. B., 2.

Red beds of Front Range, sedimentary features: Tieje, 3 .

Routt and Moffat counties, anticlines : Perini, 1.

Routt County : Crawford, R. D., 1.

Sangre de Cristo Range: Melton, 4.

San Juan region : Basin, 5 ; Reeside, 8.

South-central Colorado: Knowlton, 12.

Southwestern Colorado: Coffin, 3.

Telluride area, Sun Miguel County: Hurst, 2.

Tillite, ancient, near Gunnison: Atwood, 6 .
Colorado-Continued.

Historical geology-Continued.

Wasatch and Green River formations, relations: Sears, 5 .

Western Colorado: Harrison, T. S., 3. Mineralogy.

Anglesite, Gunnison County : Shannon, 17.

Alaskaite, San Juan region: Brown, W. H., 4.

Beidellite: Larsen, 16.

Calcites, luminescence: Headden, 7.

Carnotite and tyuyamunite: Hillebrand, 2.

Carnotite region minerals: Hess, 20.

Cancrinite, Uncompahgre quadrangle: Larsen, 19.

Creedite, Creede quadrangle: Foshag, 9.

Gilpinite, Gflpin County, identity with johannite: Lar'sen, 17.

Jefferisite : Alderson, 5 ; Waldschmidt, 6 .

Meteorite, Johnstown, Weld County: Hovey, 12.

Mesa Verde Park: Merrill, 29, 30.

Mount Ouray, Chaffee County: Palache, 17.

Wasbiugton County : Palache, 34 .

Mineral localities: Over, 1.

Phosgenite, Ilse, Custer County: Waldschmidt, 5 .

Pyrite, Bald Mountain: Whitlock, 4.

Quartz, Pikes Peak: Hawkins, A. C., 2.

Rossite and metarossite, San Miguel County : Foshag, 31.

Table Mountain zeolites: Johnson, J. H., 12.

Weissite, Gunnison County : Crawford, W. P., 1.

\section{Paleontology.}

Acanthoceras rhotomagense fauna: Reeside, 15

Amphicoelias : Osborn, 5.

Amphicyon, Pawnee Creek beds: Cook, H. J., 19.

Animas formation, flora: Knowlton; 13.

Beetles, Florissant: Cockerell, 32.

Birds, Oligocene: Wetmore, 12.

Brachyruscus, Florissant: Cockerell, 14.

Browns Park formation: Peterson, 11.

Camarasaurus : Osborn, 5, 6.

Catmint, Florissant: Cockerell, 38.

Colorado Museum, fossil mammals : Cockerell, 21.

Cretaceous, northern central Colorado: Reeside, 5.

mollusks: Reeside, 17.

northeastern Colorado: Henderson, J., 1.

Culex winchesteri, Cathedral Bluffs: Cockerell, 3.

Diatryma, plumage : Cockerell, 17.

Dinosaur tracks, Cretaceous: Peterson, W., 1.

I)inosauria: McKelvey, 1.

Diplodocus, skull : Holland, W. J., 3. 
Colorado-Continued.

Paleontology-Continued.

Jragon fy, Eocene: Cockerell, 42.

Lintelodonts : Troxell, 3.

Locene insects: Cockerell, 2.

Eocene Insecta: Cockerell, 24.

Eomyza Holoptera, Green River beds, Roan Mountains: Cockerell, 26.

Eporeodons, White River beds: Thorpe, 23.

Fiorissant fossils: Cockerell, 6 .

insects: Cockerell, 36, 41.

Footprints in Pennsylvanian sandstone: Henderson, J., 5.

Fox Hills sandstone, Larimer County: Johnson, J. H., 20.

Fulgoridae, Eocene, Roan Mountain: Cockerell, 9.

Green River flora: Knowlton, 11.

Hepatica, Florissant: Howe, M. A., 3.

Hymenoptera, Florissant: Cockerell, 23 ; parasitic: Cockerell, 4.

Hyopsodus, Eocene: Abel, 2.

Fyracodon: Troxell, 8.

Inocellia (Neuroptera), Florissant: Cockerell, 28.

Insecta, Eocene: Cockerell, 8.

Laramie flora, Denver Basin: Knowlton, 8 .

Iithospermum nutlets: Berry, 101.

Macluritella, Ordovician : Kirk, E., 8.

Mammalia, Brown's Park : Peterson, 6.

Matonidium americanum: Berry, 11.

Molrison flora: Knowlton, 4

Mosquito, Eocene: Cockerell, 3.

Moth, Hydriomena, Florissant: Cockerell 13.

Myriapod, Parajulus, Florissant: Miner, 2.

Orontium, Florissant: Cockerell, 31.

Palaeospiza bella, Florissant: Wetmore, 7 .

Paleocene mammals, new genera: Matthew, 16.

Palmoxylon cannoni, Denver: Stevens, N. E., 1.

Pennsylvanian crinoids, western Colorado: Keyte, 1.

Phenacocladus, Eocene alga: Cockerell, 34.

Plant and insect fossils, Green River Eocene: Cockerell, 27.

Pleistocene Vertebrata, Denver : Hay, 9.

Pliocene Mammalia, Yuma County : Cook, H. J., 2.

Quercus, Green River Eocene: Cockerell, 39.

Ranunculus florissantensis : Cockerell, 11.

Rhinoceros (Trigonias), oligocene: Gregory, W. K., 19.

Sauropoda, Canyon City: Osborn, 10.

Sawflies, Florissant: Cockrell, 12.

Scorpion-fly, Green River Eocene : Carpenter, F. M., 3.

Scutellaster cretaceus Cragin : Reeside, 10.
Colorado-Continued.

Paleontology-Continued.

Siphlurites, Miocene May fly, Florissant: Cockrel], 22.

Taphacris bittaciformia, Florissant: Cockerell, 30.

Teleoceras, Yuma County : Cook, H. J., 11.

Tertiary lake beds flora: Knowlton, 12

Ticholeptus rusticus: Loomis, F. B., 3.

Titanotheres, Eocene, Moffat County: Cook, H. J., 8.

Huerfano formation: Osborn, 7.

Trilophodon : Cook, H. J., 1.

Trigonias, Weld County: Gregory, W. K., 19.

Uintacolotherium, Moffat County : Cook, H. J., 7.

Wasp, Hoplisus, Green River formation : Cockrell, 15.

Petrology.

Central City district: Hirschi, 1.

Fortification dike rocks : Ross, C. S., 19.

Igneous rocks, central Colorado: Crawford, R. D., 2.

Italian Mountain, Gunnison County: Cross, W., 7.

North central Colorado, Big Thompson schist: Fuller, M. B., 6.

Pre-Cambrian, Gunnison River: Hunter, J. F., 1.

'Twin Lakes district: Howell, J. V., 1.

Zeolite beds in the Green River formation : Bradley, W. H., 8.

Physical geology.

Algal reefs in Green River formation: Bradley, W. H., 7.

Building of Rockies: Chamberlin, R.T., 1.

Carbonization of coals by igneous intrusion, Yampa field: Eby, 3.

Colorado Plateau, structural features: Moore, R. C., 21.

Contact metamorphism in Big Thompson schist, north central Colorado: Fuller, M. B., 6.

of some coals : Eby, 4.

Crustal shortening of Colorado Rockies: Chamberlin, R. T., 8.

Erosion, Mesa Verde: Haas, 1.

Faulting, Rocky Mountain region: Irwin, 2.

Horizontal compression in Rockies: Shepard, 5.

Moffat Tunnel : Lovering, 7.

Montezuma County, McElmo anticline: Coffin, 5.

Paradox Valley, origin: Powers, 18.

Northeastern Colorado, structure: Anon., 41.

Red beds of Front Range, sedimentary features: Tieje, 3.

Rocky Mountains, southern: Lee, 9.

Routt and Moffat counties, anticlines: Perini, 1.

Routt County anticlines: Crawford, R. D., 1. 
Colorado-Continued.

Physical geology-Continued.

Salt domes, western Colorado: Harrison, T. S., 3.

Sangre de Cristo Range: Melton, 4.

Southwestern Colorado: Coffin, 3.

Thrust faulting, San Luis Valley: Burbank, 2.

Williams thrust fault: Lovering, 6 .

Physiographic geology.

Ancestral Rocky.Mountains : Melton,1.

Big Thompson River valley, physiographic development: Fuller, $M$. B., 1.

Eocene glaciation: Atwood, 8 .

Fossil glacier : Brown, W. H., 1.

Front range, erosional cycles : Little, 4. northern Colorado: Mather, 8.

General: Worcester, 2.

Glacial deposits, Pine River valley: Reagan, 3, 6.

Glaciation, Front Range: Fuller, M. B., 5.

Grand Mesa, glacial geology : Henderson, J., 4.

Green and Yampa rivers, origin : Sears, 4.

Gumnison River, course: Branson, 7 .

Mesa Verde: Haas, 1.

Moraines, Estes $\mathbf{P a r k} \mathbf{r}$ egion: Wooster, 1.

Mountain front: Vestal, 1.

Multiple level cirques : Fuller, M. B., 10.

Peneplains, Front Range and Rocky Mountain National Park: Lee, W. T., 7 .

Quaternary drainage changes around Mount Olympus: Fuller, M. B., 4

Raton Mesas: Lee, W. T., 4.

Rocky Mountains: Chamberlin, R. T., 1.

San Juan Mountain region and Front Ranges, physiographic correlation: Atwood, 5.

San Juan Mountains: Atwood, 3.

San Luis Valley, physiographic history: Atwood, 4.

Unilerground water.

Crowley and Otero counties (parts): Toepelman, 3.

La Junta area: Patton, H. B., 3.

Elbert, El Paso, and Lincoln counties: Coffin, 4.

Lincoln and Crowley counties: Tieje, 1

Mineral waters: George, R. D., 1.

San Luis Valley, hydrology : Headden, 2 .

Colorado Plateau, structural features: Moore, R. C., 21.

Columnar and buttress structures : Branson, 20.

Columnar structure in lavas: James, A. V. G., 1.

Comagmatic regions: Washington, 4; distribution: Washington, 15.

Comanchean formation underlying Florida: Sellards, 6.

Commercial control of mineral resources: Spurr, 1.
Commercial geology, world atlas: U. S. G. S., 3 ; water power: U. S. G. S., 4. Composition of earth : Adams, L. H., 8. Concretions.

Calcareous concretions in streams: Roddy, 1.

California, Kettleman Hills, aragonite: Reed, 9.

southern: Haase, 1

Clay balls, formation: Haas, 2 .

Coal balls: Feliciano, 1.

Coal seams, concretions in adjoining strata : Feliciano, 1

Formation: Cook, C. W., 10 ; and distribution : Kindle, 24.

Indiana, Monroe County, Knobstone: Tucker, W. M., 2.

Iron sulphide in coal and other sedimentary rocks : Newhouse, 3.

Iron sulphide pseudomorphs of plant structure: Schwartz, 20

Labrador, Lake Melville district: Kindle, 25.

Missouri, Boone County, origin : Tarr, 5.

New York, western : Alexander, A. E., 1.

Ohio, Delaware County: Westgate, 5.

Elyria, lake deposits: Hubbard, G. D., 1.

Origin: Patton, L. T., 1.

Petroleum-bearing concretions: Binney, 1 .

Rhizocretions: Kindle, 36.

Septaria, Pennsylvanian shale, Missouri : Grawe, 2.

South Dakota, Black Hills, geode concretions : Schwartz, 14.

Syngenetic origin in shale: Tarr, 10 ; of pyrite concretions in Pennsyl.: vanian shales: Mathias, 1.

Cone-domes : Sardeson, 20.

Cone-in-cone: Tarr, 20.

Cone-in-cone structure, origin: Tarr, 10, 11 ; use in correlation: Tester, 2. Conglomerate.

British Columbia, Silurian tillite: Shepard, 1.

Chemical study: Walker, 12.

Cobalt conglomerate, origin : Coleman, 4.

Edgewise conglomerate: Clarke, J. M., 5.

Marine and terrestrial : Barrell, 19.

Pennsylvania, Nittany Valley, conglomeratic limestone: Eaton, $\mathrm{H}$. N., 2.

Congresses. See Associations.

Coniferales, anatomy and physiology: Torrey, R. E., 1.

Connecticut

Guilford quadrangle: Foye, 6.

Middletown region: Cleland, 4.

Report of survey : Britton, 1; Conn, G. S., 1 ; Gregory, H. E., 5 ; Robinson, H. H., 1.

Areas described.

Stonington region: Martin, L. H., 1.

Middletown area: Rice, W. N., 1.

New Haven area: Brown, J. S., 9. 
Connecticut-Continued.

Areas described-Continued.

Shepaug Aqueduct Tunnel area, Litchfield County: Agar, 4.

Economic geology.

Bristol copper mine : Bateman, A. M., 2.

Granite: Dale, T. N., 4 ; Gregory, H. E., 8.

Lime belt, western Connecticut: Dale, T. N., 5.

Historical geology.

Wastern Highland: Foye, 13.

Meriden area: Waring, 2.

New Haven region: Foye, 16.

Norwalk, Suffleld, and Glastonbury areas: Palmer, H. S., 4.

Quaternary, New Haven region : Ward,5.

Southington-Granby area: Palmer, $H$. S., 5.

Triassic, southern Connecticut: Longwell, 5, 18 ; Russell, W. L., 1.

Mineralogy.

Apatite, Branchville : Whitlock, 19.

Chatham : Shannon, 12, 29.

Datolite, Merfden: Shannon, 17.

Lithiophilite, Portland: Schairer, 3.

Meriden: Shannon, 7.

Middletown area: Foye, 4.

Mineral localities: Eaton, F. S., 1.

Pickeringite, Portland: Schairer, 2.

Portland, Strickland's quarry: Shannon, 11.

Rhodonite, Portland: Foye, 1.

Thulite, Haddam: Foye, 15.

Triplite, Chatham : Shannon, 17.

Trumbull, Long Hill : Shannon, 18.

Trumbull tungsten mine: Shannon, 31.

Paleontology.

Footprints, Connecticut Valley : Abel, 4.

North Branford: Lull, 19.

Petrology.

Camptonite dikes in Triassic: Russell, W. L., 2.

Pillow structure in Triassic basalts: Foye, 11.

Stonington region: Martin, L. H., 1.

Physical geology.

Camptonite dikes in Tlassic: Russell, W. L., 2.

Faulting in Triassic: Foye, 9.

Shapes of berch pebbles, New Haven: Wentworth, 10.

Triassic fault, southern Connecticut: Russell, W. L., 1.

Triassic trough, origin: Foye, 7.

Physiographic geology.

Connecticut River near Middletown, post-glacial history: Bissell, 2.

preglacial course: Bissell, 3.

Danbury region, drainage modifications and glaciation: Harvey, R. S., 1.

Eskers and crevasse fllings: Flint, 6.

Postglacial uplift : Fairchlld, 7.

Quaternary, New Haven region : Ward, 5 .

Terraces, Barrell, 6.

lower Connecticut Valley: Flint, 8. Stonington region: Martin, L. H., 1.
Connecticut-Continued.

Underground water.

Coastal ground water: Brown, J. S., 5.

Meriden area: Waring, 2.

New Haven region: Brown, J. S., 2.

Norwalk, Suffield, and Glastonbury areas: Palmer, H. S., 4.

Southington-Granby area: Palmer, H. S., 5.

Connecticut basin during the Newark epoch : Foye, 5.

Conodonts.

Bibliography: Holmes, G. B., 1.

Classification and stratigraphic use : Bassler, 16, 18.

Devonian and Mississippian: Ulrich, 13.

Genesee : Bryant, 2.

Literature: Roundy, 2.

Mississippian, Alabama ; Holmes, G. B., 1 .

New York, Portage group: Hibbard, R. R., 1 .

western : Hibbard, R. R., 2.

Texas, San Saba County, Mississippian: Roundy, 3.

Continental displacement hypothesis: Schuchert, 50, 51.

Continental drift, theory of: Van der Gracht,

Continental drifting: Ingalls, A. G., 2.

Continental fragmentation: Barrell, 11.

Continental movement and tidal forces: Taylor, 5.

Continental shelf: Shepard, 12, 13.

differential tilting: Moon, 1.

off the coast of California: Lawson, 6.

Continental shifting: Coleman, 17; Hamilton, G. H., 1.

Continents, origin : Richarz, 2.

Continents and oceans, origin: Ruedemann, 24; Wegener, 1.

Cooper limestone, central Missouri: Greger, 2.

Copley oil pool, West Virginia: Reger, 14.

Copper : Bengzon, 1 ; Butler, 5, 6.

Alaska: Brooks, 5, 12, 14 ; Martín, G. C., 4 .

Alaska Railroad region: Capps, 6.

Beatson mine: Bateman, 12.

Chichagof and Baranof islands: Buddington, 8.

Chichagof Island, western part: Overbeck, 1.

Chitina district: Birch, 1; Mofft, 5.

Jack Bay district: Johnson, B. L., 2.

Juneau and Ketchikan districts: Mertie, 5.

Kennecott: Bateman, 3, 4 ; Auon., 3.

Knik-Matanuska district: Landes, K. K., 2.

Kotsina-Kuskulana district: Mofft, 4.

Prince of Wales Island, Salt Chuck mine: Mertie, 4.

Prince William Sound: Birch, 2; Johnson, B. L., 1 ; Mofft, 6.

Arctic Canada: O'Nelll, 3. 
Copper-Continued.

Arizona: Crampton, 1 ; Tovote, 1.

Aravaipa-Stanley region : Ross, C. P., 5.

Bisbee district: Elsing, 1.

central : Ettlinger, 1.

Courtland-Gleeson region: Wilson, D. D., 2.

Globe district: Schwartz, 1.

Jerome and Bradshaw Mountains quadrangles: Lingren, 17.

Jerome district: Mitchell, W. G., 1 ; Reber, 1; Rickard, 9; Smith, A. H. D.; 1 .

Palomas Range: Keyes, 153.

Payson district: Lausen, 1.

Pima district: Ransome, 9.

Ray quadrangle: Ransome, 11.

Ray-Miami region: Ransome, 1.

Saddle Mountain and Banner districts: Ross, C. P., 14.

Superior district: Short, 1.

Warren district: Mitchell, G. J., 1, $2,4$.

Bornite and pyrrhotite, antipathy : Gilbert, G., 3.

British Columbia, Anyox: Clapp, L. R., $1,2$.

Blitannia mines: Schofield, 16.

Copper Mountain : Camsell, 4.

coast region: Dolmage, 9.

Coquihalla area: Cairnes, 4.

Hidden Creek mine: Campbell, E. E., 1.

Lasqueti Island: MacKenzie, J. D., 3. Texada Island, Marble Bay mine: Dolmage, 7.

Vancouver Island, Barkley Sound: Dolmage, 2; Sunloch district, Dolmage, 3.

California: Logan, C. A., 3.

Shasta County: Tucker, W. B., 4.

Canada: Browning, C. P., 1.

Arctic regions: O'Neill, 3.

central Arctic coast: Douglas, G. M. 1 ; O'Neill, 5.

Capping as a guide to copper deposits : Mitchell, 9.

Central States: Dunlop, 1, 4, 6, 9, 12, 16.

Chalcocite, primary, Bristol copper mine, Connecticut: Bateman, A. M., 2.

Colorado, Boulder County, Ward region: Worcester, 1.

Red Cliff district: Crawford, R. D., 3.

Cuba: Allende, 6, 7.

Pinar del Rio: Corral, 1.

Santa Clara, Malezas: Corral, 2.

Deposition from ascending solutions, chemistry: Wells, 11.

Disseminated copper ores in porphyry: Emmons, W. H., 11.

Eastern States: Dunlop, 3, 7, 11, 1.5. 18.
Copper-Continued.

General : Calkins, F. E., 1; Davis, W., 1; Siebenthal, 27.

Idaho : Gerry, 1, 3, 5, 8, 10, 13.

Adams County, I. X. L. prospect : Bell, R. N., 3.

Birch Creek district: Shenon, 2.

Mineral and Cuddy Mountain mining districts : Livingston, 4.

Salmon: Ross, C. P., 3, 7.

Seven Devils district: Livingston, 3.

Shoshone County: Umpleby, 3.

Leached outcrops: Locke, 6.

Magnetic surveying on copper-bearing rocks in Wisconsin : Aldrich, $\mathrm{H}$. R., 2.

Manitoba: Wallace, 22.

Flinfion ore body : Wallace, 5 .

Maskwa River : McCann, 1.

northern: Bruce, 5; Hanson, 1; Wallace, 2.

Oiseau and Maskwa areas: Wright, J. E., 7.

Oiseau River area: Wright, J. F., 10.

Metallferous deposits in red beds: Finch, J. W., 2.

Mexico, Cananea: Mitchell, 9; supergene enrichment: White, C. H., 3.

Nacozari district, Sonora, Pilares mine: Wade, W. R., 1.

Sonora: Tovote, 1; Carida Mine: Wandke, 5.

Zacatecas: Keyes, 153.

Michigan : Guck, 1; Lang, S. S., 1 ; Woods, 1.

Lake Superior region: Lang, S. S., 2 ; Spurr, 3 ; Winchell, A. N., 2.

geophysical methods: Broderick, 4. genesis : Singewald, 3.

Minnesota, Susie Island, Lake Su. perior: Schwartz, 26.

Montana : Gerry, 2, 4, 7, 12, 15.

Butte district: Daly, W. B., 1.

Park County : Lovering, 2.

Native copper, Nonsuch. formation, Michigan : Nishio, 1.

Nevada, Santa Fe district, Mineral County: Clark, C. W., 2.

New Hampshire, Ammonoosuc district: Ross, C. P., 2.

New Jersey, Belleville mine: Black, G. F., 2.

New Mexico: Tovote, 1. Mogollon district: Scott, D. B., 1. Santa Fe County: Berryman, 1. Tyrone district: Paige, 2.

Oklahoma, Garfield County: Reiter, 1.

Ontario, Parry Sound: Schwartz, 8.

Sudbury : Bell, J. M., 1.

Oregon, southwestern : Kellogg, A. E., 9.

Organic precipitation: Lovering, 5.

Pennsylvania : Pennsylvania G. S., 1. Adams County: Stose, 25.

Porto Rico, Barrio Pasto district: Cololiy, 9. 
Copper-Continued.

Quebec, eastern townships: Dresser, 5. Eastman, Huntingdon deposit: Hore, 2.

Gaspe Peninsula : Alcock, 16.

Horne and Aldermac mines: Cooke, H. C., 32.

Papineau County: Wilson, M. E., $11,14$.

Richardton meteorite: Quirkc, 3.

Rouyn area: Cooke, H. C., 20 ; James, 8.

western : Cooke, H. C., 26; Dufresne, 7 .

Red Bed ores: Bains, 1.

Replacement copper ore deposits in quartzite: Kato, 2.

South Atlantic States: Watson, 15.

Superficial deposits: Weed, 2.

'Tennessee, Ducktown district : Emmons, W. H., 8; Gilbert, G., 1; Nelson, $18,19$.

Utah : Butler, 4.

Bingham district: Hunt, R. N., 1.

Tintic district: Lindgren, 2.

Washington: Gerry, 1, 3, 6, 9, 11, 13.

Wyoming, Chewelah district: Armstrong, L. K., 1 ; Howard, L. O., 1.

Stevens County : Weaver, 2.

Yukon, Whitehorse belt: Cockfleld, 23.

Coprolites, Conemaugh series, West Virginla : Price, P. H., 1.

Coquihalla area, British Columbia : Cairnes, 3 ; Camsell, 6.

Coquina, Florida: Brodie, 1.

Coral islands and reefs: Vaughan, T. W., 2.

Atoll, tilted-up, beveled-off: Davis, 19.

Depth of coral-reef lagoons: Davis, 14.

Drowned coral reefs : Davis, 12.

Formation : Davis, W. M., 36 ; Vaughan, 4.

General: Davis, 17 .

Glacial control: Davis, 20.

Hawalian Islands, Oahu: Pollock, 3.

Indiana, n o r t h e r n, Silurian : Cumings, 3.

Marginal belts of coral seas: Davis, 13, 15.

Niagaran coral reefs: Cumings, 4.

Origin: Davis, W. M., 1, 35, 37 ; Hobbs, 20 ; Vaughan, T. W., 2, 32.

Reef-encircled islands, subsidence rate: Davis, 30.

Texas, Oligocene: Ellisor, 3.

Tutulla, bearing on coral reef problem : Chamberlin, R. T., 6.

Coral reefs and the glacial period: Daly, 2. Corals. See Anthoza.

Cordillera in Canada, geological record: Schofleld, 13.

Cordilleran belt, Montana and Wyoming, structural features: Thom, 2.

Cordilleran ice sheet; Read, 1.

Cordilleran shield : Lawson, 10.

Correlation.

Alaska, southern and southwestern : Mofft, 4.
Correlation-Continued.

Arizona, Fort Apache region : Reagan, 1. northeastern: Hagar, D., 6; Moole, $11,19$.

Bentonite in correlation: Sardeson, 26.

Big Stone Gap shale, Chattanoogan age : Swartz, J. H., 10.

Boring core, mineralogic analysis: Roth, 2.

California : Vander Leck, 1.

Cambrian - Ozarkian - Ordovician : Walcott, 7 .

Canadian Rockies: Burwash, 2.

Carboniferous: Beede, 7:

Carboniferous : Keyes, 275.

Kansas and Oklahoma: Goldman, 4.

Oklahoma region: Ulrich, 18.

'Texas and Oklahoma: Bullard, 2.

Caribbean region: Vaughan, 21.

Central American and West Indies, Tertiary: Vaughan, 13.

Chagrin formation: Chadwick, 14.

Chester formations: Uli:ich, 5 .

Coal measures, Maryland: Swartz, C. K., 2 .

Coastal Plain area : Brantley, 1.

Colorado, Wyoming, and Montana : Lee, W. T., 19.

Colorado River region : Longwell, 4.

Cone-in-cone structure, use in correlation: Tester, 2.

Cretaceous: Berry, 23 ; Böse, 9 ; Stanton, 5.

Alaska: Martin, G. C., 14.

basal, southeastern States: Cooke, C. W., 14.

Great Plains region: Twenhofel, 6.

Gulf region: Berry, 4.

Texas: Scott, G., 4.

Texas and Mexico: Böse, 8.

Upper: Stanton, 2; Atlantic and Gulf Coastal Plain: Stephenson, 4.

Cretaceous-Tertiary boundary, vertebrate evidence as to: Matthew, 18.

Dakota group, Colorado and $W$ yoming: Lee, 8.

Devonian : Grabau, 6.

Illinois: Bassett, 1.

Mississippi Valley: Savage, 14.

western Tennessee: Dunbar, 1.

Dundas formation: Parks, 17.

Eocene: Berry, 12.

Alabama and Mississippi: Cooke, C. W., 14.

New Jersey and Maryland: Cooke, C. W., 17.

Tennessee, Mississippi, and Alabama : Roberts, J. K., 9.

Evolutionáry changes, use in correlation : 'Thomas, N. L., 2.

General: Berry, 65; Keyes, 144, 153, 194 ; Schuchert, 13.

Geologic time classification: Wilmarth, 2.

Glaclal : Keyes, 222.

Glacial lakes, New York : Chadwick, 9. 
Correlation-Continued.

Glacial stages: Osborn, 19

Glaciation, North America and Europe : Antevs, 17.

Gulf series: Stephenson, 15 .

Hudson Bay area, Ordovician and SiInrian: Foerste, 22.

Huronian and Grenville rocks : Quirke, 12.

Illinois, Pennsylvania: Culver, 4; Savage, 11.

coal beds: Culver, 9.

Interior coal fields: Keyes, 2.

Iowa, Missouri series: Tilton, 7 .

Cambrian: Keyes, 89.

Jackson and Vicksburg deposits, Mississippi and Alabama: Cooke, C. W., 5.

Jurassic rocks, Alaska: Martin, G. C., 15.

La Plata formation in plateau country : Paige, 7.

Lebo member of Fort Union and Cannonball member of Lance: 'Thom, 7 .

Lithology, subsurface: Goldman, 5 .

Mackenzie River basin: Hume, 8.

Maquoketa and Richmond rocks, Iowa and Illinois: Savage, 13.

Maryland, coal measures: Swartz, C. K., 4.

Mesozoic, Pacific coast: Goranson, 1.

Mesozoic and late Paleozoic, Montana and adjacent States: Clapp, C. H., 2.

Michigan, Huronian formations : Allen, R. C., 2 ; Lane, 4.

Micro-fossils in correlation: Decker, 9 ; Schuchert, 24.

Minnesota, Cuyuna range: Thiel, 12. Miocene: Olsson, 1.

Mississippian: Butts, 3; Keyes, 262. Appalachian region : Reger, 13.

Rocky Mountain States and Mississippi Valley States: Branson, 11.

West Virginia: Girty, 4.

New Mexico, Texas, and Oklaboma: Gould, C. N., 18.

New York, Ordovician: Ruedemann, R., 3, 16.

pre-Cambrian : Kemp, 23.

Oklahoma, Okmulgee district: White, I. H., 1.

Ordovician : Edson, 3.

Oligocene, Pacific coast: Clark, B. L., 8.

Ontario, Credit River section :- Dyer, 4.

Ordovician: Foer'ste, 5, 15; Raymond, 18

Mississippi Valley: Dake, 6.

Organic and physical criteria: Ulrich, 16.

Pacific region, Cenozoic: Vaughan, 28. post-Cretaceous formation: Vaughan, 13.

Paleontologic, by Foraminifera: Galloway, J. J., 7.
Correlation-Continued.

Pennsylvania, lower Allegheny-Potts ville section: Renick, 2.

Pennsylvanian formations: Glenn, 4 ; McCoy, 5.

eastern Oklaboma : Levorsen, 1.

Oklahoma: Dott, 1.

Oklahoma and Texas: Goldston, 2.

Permian: Dunbar, 4 ; Schuchert, 52.

southern Great Plains: Gould, C. N., 27.

Texas, Oklahoma, and Kansas: Beede, 10; Gould, 8, 10, 14.

I'ermo-Carboniferous, Colorado and New Mexico : Melton, 3.

Pleistocene: Hay, 27.

T'orto Rico, Tertiary formations: Maury, 1, 3.

Pre-Cambrian: Collins, 11; Cooke, H. C., 19 ; Keyes, 209.

Lake Superior region : Leith, 16. northern Ontario and Quebec: Cooke, H. C., 7.

northern Quebec: Cooke; H. C., 2.

Sutton Lake area, Ontario: Hawley, J. E., 1.

Pre-Cambrian and Cambro-Ordovician :

Berkey, 3.

Representation: Keyes, 144.

Silurian: Alling, 14; Cumings, 4; Savage, 16 ; J'harp, 1 ; Ulrich, 8 , 9 ; Williams, I. A., 1.

Maryland: Swartz, C. K., 8.

Subsurface correlation by heavy minerals: Hoots, 3 ; Reed, R. D., 12.

Tertiary: Cushman, 8; Vaughan, 3 , 29,34 .

Anthozoa : Vaughan, 36.

Bighorn Basin : Hewett, 4.

Bryozoa: Canu, 5.

Echinoidea : Stefanini, 1.

Mollusca, Eocene and Oligocene: Cooke, C. W., 10.

Miocene and Pliocene: Gardner, J. A., 4 ; Woodring, 9.

Oregon-California : Howe, H. V. W., 9. pelagic mammals: Kellogg, R., 8. terrestrial plants: Berry, 62.

Triassic rocks, Alaska: Martin, G. C., 15 .

Volcanic ash beds: Keyes, 243.

Tertiary, West Coast: Clark, B. L., $4,5$.

Texas, Bend formation: Girty, 1.

Comanchean, Adkins, 2.

Hudspeth County, Carboniferous : Beede, 5.

northeastern, Cretaceous: Fohs, 2

Pennsylvanian : Plummer, 4.

Triassic, eastern North America: Roberts, J. K., 8.

Trinity group: Vanderpool, 3

Upper Cretaceous (Gulf series), Texas and Arkansas: Stephenson, 8.

Utah : Dake, 3.

San Rafael Swell: Gilluly, 4.

southeastern: Hager, D, 6. 
Correlation-Continued.

Vermont, south central, and Massachusetts, western: Hubbard, G. D., 4.

Vertebrates, use in correlation : Hay, 42.

Vicksburg group: Cooke, C. W., 7a.

West Coast Tertiary: Clark, B. L., 4,5 .

West Indies, Tertiary: Vaughan, 17.

Whitehorse sandstone, Kansas, Oklahoma, and 'lexas: Clifton, 4.

Wyoming, oil-producing areas : Morgan, G. B., 4.

Rock Springs area, Sweetwater County : Schultz, 1.

Yegua, marine, type sections: Gardner, J., 12.

Trubles.

Canada, maritime provinces, Carbon iferous: Bell, W. A., 13

Carboniferous: Keyes, 275; Schuchert, 52.

Cretaceous, basal, southeastern States: - Cooke, C. W., 14.

Mexico, northern: Cummings, 2.

Devonian: Branson, 5.

Gulf Coastal Plain: Prettyman, 1.

Gulf series: Stephenson, $\mathbf{1 5 .}$

Kansas, Oklahoma, Texas, and southeastern New Mexico: Powers, 26.

Mississippi, Paleozoic: Morse, W. C., 4.

Mississippian : Moore, 41.

Oklahoma, Mississippian, distribution and correlation: Buchanan, 2.

Paleozoic: Ulrich, 18.

northern Texas, southern Kansas: Gould, 9.

Ontario, Ordovician : Parks, 32.

Ordovician: Foerste, 15.

Paleozoic (earlier), Europe and America : Ulrich, 15.

Pennsylvania, Texas-Oklahoma : Levorsen, 1.

Iermian: Schuchert, 52.

southern Great Plains: Gould, C. N., 27.

western Texas: Schuchert, 39.

Pre-Cambrian: Cooke, H. C., 19; Wilson, M. E., 18.

Silurian, Illfnois and adjoining area: Athy, 1.

Tertiary: Berry, 51.

Oregon: Schenck, 12.

Jriassic, eastern North America : Roberts, J. K., 8 .

Upper : Smith, J. P., 3.

Triassic and Jurassic formations: Branson, 17 ; Manstield, G. R., 29.

Utuh, San Rafael Swell: Gilluly, 4.

Wyoming. Bighorn Basin: Hewett, 16. Corrosion by saline waters: Rutherford, 1

Corundum : Eardley-Wilmot, 7 .

North Carolina, Macon County: Gor. don, S. G., 8.

origin : Cobb, M. C., 1, 2.

Corundum and albitite bodies, hydrother mal origin : Larsen, 21.
Costa Rich.

General: Branson, 3; MacDonald, 4.

Middle-eastern Costa Rica: Branson, 18.

Economio geology.

Manganese: Sears, 1.

Petroleum possibilities: Redfield, 7.

Historical geology.

General: Redfield, 7 ; MacDonald, D. F., 2.

Guanacaste: Sears, 1.

Miocene, northern Costa Rica: Olsson, 1.

Paleontology.

Foraminifera and Mollusca: Palmer, K. V. W., 4.

I'lantae, Tertiary: Berry, 27.

physical geology.

Volcanoes, Irazu : Tristan, 2, 3.

Poas Volcano, eruptions: 'Jristan, 1.

Coteau des Prairies, glacial formations: Leverett, 9.

Cutton Valley oll and gas field, Webster Parish, Louisiana: McDonald, W. W., 1 ; Powers, 14.

Courtland Gleeson region, Arizona : Wilson, E. D., 2.

Craters of the Moon, Idaho: Stearns, N. D., 3.

Crazing of mountain massifs, Lower California : Keyes, 25.

Creede district, Colorado, geology and ore deposits : Emmons, W. H., 4.

Cretaceous. See ąlso Paleontology, Cretaceous.

Alabama: Jones, W. B., 13; Stephenson, 5.

Coastal Plain: Brantley, 1; Jones, W. B., 10.

eastern: Belry, 50.

Alaska : Martin, G. C., 1\%, 15.

Anvik-Andreafski region: Harrington, 1.

Cold Bay-Chignik district: Smitl, W. R., 1.

Chignik region: Martin, G. C., 1.4.

Kiwalik-Koyuk region: Halrington, 5.

Knik-Matanuska district: Landes, K. K., 2 .

Nixon Fork country: Brown, J. S., 7.

Point Barrow region: Paige, 5 .

Ruby-Kuskokwim region : Mertie, 11. upper Matanuska Valley: Capps, 11.

Alberta : Allan, 8, 12; Berry, 74; Hume, 28; McLearn, 14.

area between Athabaska and Embarras rivers: Rutherford, 5 .

Battle River: Hume, 20.

Belly River formation, conifer : Bell, W. A., 15.

Blackstone, Brazeau, and Pembini rivers foothllls belt : Allan, 13.

Bow River between Cochrane and Kananaskis : Rutherford, 6 . 
Cretaceous-Continued.

Alberta-Continued.

Bragg Crcek area : Hume, 30.

Biule Lake region: MacVicar, 1.

Crowsnest coal field, northern part: Rose, 1.

Colorado shale: Warren, P. S., 8 .

Coloradoan: McLearn, 10.

Cypress Hills: Dyer, 9.

Drumheller district: Allan, 7.

foothills belt between McLeod and Athabaska rivers : Rutherford, 4 .

Highwood area : Rose, 2.

Kananaskis Lakes-Palliser River area: Marshall, 2.

Lower Smoky River: Meluearn, 1.

North Saskatchewan and McLeod rivers: Rutherford, 8 .

Paskapoo formation: Allan, 20.

Peace and Athabaska valleys: McLear'n, 2.

Saunders Creck and Nordegg coal basins : Allan, 9.

Sheep River area: Slipper, 2. southern, artesian area: Dowling, 9. southern and central: Slipper, 1. southwestern : Stewart, J. S., 1. Swan Hills, Lesser Slave Lake district: Allan, 1.

western: Purdy, 1.

Turner Valley oil area : Hume, 22.

Walnwright - Vermilion area : Hume, 19.

Arizona : Darton, 17 ; Keyes, 83.

Aravaipa-Stanley ${ }^{\cdot}$ region : Ross, C. P., 5.

Black Mesa region: Reagan, 15, 18.

Hopi Buttes volcanic field: Reagan, 8.

Navajo country: Reagan, 20

Papago country: Bryan, 7 .

Saddle Mountain and Banner mining districts: Ross, C. P., 6.

Arkadelphia formation, Arkansas and Louisiana: Howe, H. V. W., 3, 4.

Arkansas: Miser, 4, 11.

El Dorado oil fields, Gilluly, 1.

Pike County: Miser, 12.

Smackover oil field sands : Schneider, H. G., 2.

south central: Rubey, 1.

southern : Hull, 10 ; Schneider, H. G., 1.

southwestern: Miser, 27; volcanic: Miser, 19.

White Cliffs chalk, age and colrelation: Ellisor, 2.

Basal Cretaceous, southeastern States, correlations: Cooke, C. W., 14.

British Columbia, Chilko Lake area : Dolmage, 15.

Coquihalla area Cairnes, 4; Camsell, 6.

Dease Lake area, Cassiar district: Kerr, F. A., 1.

Eutsuk Lake district. Brock. 1.
Cretaceous-Continued.

British Columbia-Continued.

Hudson Bay Mountain, Coast dis trict: Jones, R. H. B., 1.

Kitsault River to Skeena River : Hanson, 3 .

Lillooet-Prince George region: Reinecke, 3 .

northeastern: Stewart, J. S., 2.

Peace River canyon area: McLearn, 7.

Prince Rupert to Burns Lake: Hanson, 10.

Skeena River to Stewart: Hanson, 6.

southwestern: Cairnes, 2.

'Taseko Lake-French Bar Creck: MacKenzie, J. D., 2.

upper Peace River region: McLearn, 6.

Vancouver Island: Dolmage, 5; MacKenzie, J. D., 5; Barkley Sound : Dolmage, 2.

Zymoetz River area, Coast district: Hanson, 11.

California: Vander Leck, 1.

Kern County: English, W. A., 1.

La Jolla quadrangle: Hanna, M. A., 3.

Los Angeles and Ventura counties: Kew, 6.

Los Angeles Basin: Vickery, 11.

Moreno shale, age and correlation : Taff, 4.

Mount Diablo: Clark, B. L., 13.

Point Sur quadrangle: Trask, 5.

Puente Hills region: English, W. A., 3.

Sacramento Valley: Bryan, 10.

San Benito County: Kerr, P. F., 4.

San Diego County: Ellis, A. J., 1.

Santa Barbara County, Santa Ynez River district: Kew, 2; Nelson, R. N., 1.

Santa Rosa Island: Kew, 10.

Simi Valley : Kew, 1.

southern: Kew, 4.

Ventura County: Taliaferro, 1; Matilifa overturn: Kerr, 7.

Cannonball fauna: Stanton, 6.

Cavern deposits in Permian, western Texas: Udden, 13.

Cheyenne sandstone, Kansas: Berry, 37.

Colorado: Keyes, 162.

Acanthoceras rhotomagense fauna : Reeside, 15.

Axial and Monument Butte quadrangles: Hancock, 7 .

Crowley and Otero counties (parts) : Toepelman, 3.

Delta and Mesa counties: Weeks, H. J., 1.

east-central : Lee, W. T., 19.

Fort Collins : Ball, M. W., 3.

Golden area: Johnson. J. H., 13. 
Cretaceous-Continued.

Colorado-Continued.

Grand, Jackson, and Larimer counties (parts) : Spock, 1.

La Junta area: Patton, H. B., 3.

Larimer County, Fox Hills sandstone: Johnson, J. H., 20.

Las Animas, Otero, and Bent counties (parts) : Duce, 1.

Mancos district : Collier, 3.

Moffat County : Sears, 3.

Morrison formation: Lee, W. T., 1.

north central, foothills formations: Henderson, 2.

northeastern: Henderson, J., 1; Mather, 12.

Routt and Moffatt counties: Perini, 1.

Routt County: Crawford, R. D., 1.

San Juan Basin: Reeside, 8.

southeastern: Coffin, 4 ; Carlile shale and Timpas limestone, merging: Patton, H. B., 2.

southwestern : Coffin, 3; Forrester, J. B., 1.

Tarryall district: Muilenburg, 2.

Twin I.akes district: Howell, J. V., 1.

Weld County, Laramie formation:

Toepelman, 4.

Comanche series: Stanton, 14.

Comanche succession, taxonomic rank: Stanton, 7.

Correlation: Berry, 23.

Cretaceous, Upper: Stanton, 2.

Great Plains region : Twenhofel, 6.

Gulf region: Berry, 4.

Gulf series: Stephenson, 15.

Costa Rica: Redfield, 7 .

Cretaceous-Eocene boundary: Thom, 8.

Cretaceous-Tertiary boundary : Matthew, 15, 18.

Cuba : Rutten, 1.

western: Wright, A., 1.

Dakota formation: Gress, 1.

Dukota group, Colorado and Wyoming: Lee, 8.

Dakota sandstone problems: Stanton, 5.

Delaware, Wilmington quadrangle: Bascom, 2.

District of Columbia, excavation on Connecticut Avenue: Wentworth, 13.

Dominican Republic: Vaughan, 16.

Edmonton formation, Alberta: Sternberg, C. M., 7 .

Florida, Comanchean (underlying) : Sellards, 5, 6.

underlying limestones: Cushman, 2, 4 . in borings: Gunter, 4.

Georgia: McCallie, 1 ; Teas, 1.

Coastal Plain: McCallie, 7 ; Prettyman, 1.

Greenland : Böggild, 1. western: Seward, 4.

Gulf region: Berry, 4.
Cretaceous-Continued.

Gulf Coastal Plain : Brantly, 2 ; Shaw, 4 ; Spooner, 3 ; Stephensoll, 14.

Haiti : Woodring, 5.

Idaho, Bingham, Bonneville, and Caribou counties: Kirkham, 3.

southeastern: Kirkham, 1; Mansfield, G. R., 29.

Illinois, southern: Parmalee, 1.

Interior formation, stratigraphic position: Ward, 19.

Iowa, Keyes, 240, 245.

Adair County: Gow, 1.

Cass County: Tilton, 3

Cherokee County: Cable, 10.

Comanchean fossils in glacial drift: Tester, 3.

southwestern: Keyes, 68; Smith, G. L., 1 .

Jamaica: Hawkins, H. L., 3 ; Stockley, 1 ; Trechman, 1, 5, 8.

Barrettia beds : Trechman, 2.

St. Ann Parish: Matley, 11.

Kansas: Moore, R. C., 4 ; Snider, 1 ; Stanton, 8; Twenhofel, 5, 17. central, Comanchean : Twenhofel, 24. central and western: Twenhofel, 19. Comanchean and Dakota strata: Twenhofel, 6 .

Dakota sandstone: Bass, 1.

Lower Cretaceous: Bullard, 4.

Russell County: Rubey, 3.

Syracuse and Lakin quadrangles: Darton, 2.

western: Bass, 2 ; Lupton, 2 ; subsurface Comanchean: Twenhofel, 20.

Kentucky : Miller, A. M., 1.

Cave in Rock quadrangle: Weller, 16. Tuscaloosa formation: Roberts, J. K., 7.

western : Jillson, 56

Lance and Fort Union formations, age : Cross, C. W., 4; Knowlton, 5; Schuchert, 15, 19.

Lance formation, southern Saskatchewan : Sternberg, C. M., 3.

Lance-Fox Hills contact, eastern Montana and Dakotas: Dobbin, 2.

Laramie hiatus, southern Rocky Mountains: Keyes, 147.

Laramie problem: Knowiton, 8.

Late Cretaceous Gulf series: Stephenson, 13.

Lebo member of Fort Union, correlation with Cannonball member of Lance: Thom, 7.

Louisiana, Monroe gas fleld: Spooner, 1.

northern: Hull, 10 ; Spooner, 2.

northwestern : Hammill, 1.

Sabine uplift: Powers, 2.

Lower Cretaceous or Comanche series: Stanton, 14.

MacKenzie, Great Slave Lake region: Cameron, 1. 
Cretaceous-Continued.

Mackenzie River region: Camsell, 1 ; Dowling, 15; Whittaker, 2.

Mackenzie River between Norman and Beaver River: Hume, 5; Providence to Simpson: Whittaker, 5 .

Manitoba: Ells, 2; Wallace, 14.

Turtle Mountain region: Dowling, 12.

Maryland, Elkton quadrangle: Bascom, 2.

Fedelal Hill : Berry, 18.

Kent County: Miller, B. L., 6.

Mesozoic-Cenozoic boundary: Keyes, 202, 203.

Mexico, Aguascalientes, Asientos-Tepezala district: Anderson, G. E., 2.

Chapala region: Palmer, R. H., 1.

Coahuila, northern: Cummings, 2.

Coahuila and Nuevo Leon: Müllerried, 2.

eastern: Ver Wiebe, 1 ; oil flelds: Staub, 4.

easter'n const: Wittich, 24.

Guerrero, Zumpango : Burckhardt, 13.

Hidalgo, Atotonilco el Grande: Wittich, 10.

Hidalgo-Vera Cruz region: Palmer, R. H., 4.

Lower California: Darton, 10 ; Marland Oil Co., 1.

Lower Cretaceous: Burckhardt, 2. northeastern: Böse, 5 .

northern: Böse, 8; Hill, R. T., 5 : Tatum, 1.

Panuco oil field: Baker, C. L., 8. Panuco River valley: 'Trager, 5. San Felipe formation: Stanton, 4. southern: Ver Wiebe, 2.

southern Oaxaca: Palmer, R. H., 9. Tabasco: Jones, W. F., 3.

Tampico district: Belt, 2.

Vera Cruz, Idolo Island: Dumble, 6. Vera Cruz and Puebla, TecolutlaMisantla district: Hisazumi, 1.

Zacatecas, Durango, and Guerrero: Böse, 6.

Mid-Cretaceous shale de p o sition: Keyes, 198.

Minnesota : Grout, 2. northern: Allison, I. S., 4.

Mississippi : Grim, 1; Lowe, 3, 4, 13; Morse, P. F., 1; Stephenson, 10.

Missouri, Dakota sandstone : Keyes, 53.

Montana: Bauer, C. M., 3 ; Hammer, 1 ; Keyes, 234.

Beartooth Mountains: Bevan, 2.

Cat Creek oil field: Lupton, 1.

central: Bowen, C. F., 2; Reeves, F., 10.

central and eastern : Clapp, C. H., 2. Crow Indian Reservation: Thom, 4. Ekalaka field, Bauer, 4.

faulted area south of Bearpaw Mountains : Reeves, F., 8.
Cretaceous-Continued.

Montana-Continued.

Fergus County : Freeman, O. W., 1;

Winifred area: Reeves, F., 6.

Garfield County: Bauer, 6; Thom, 3.

Huntley Field: Hancock, 2.

Ingomar anticline, 'Treasure and Rosebud counties: Heald, 18.

Kevin-Sunburst oil field: Clark, F. R., 3.

Melrose phosphate field: Richards, R. W., 2.

Musselshell and Golden Valley counties: Ellis, A. J., 5.

Scobey lignite field: Collier, 9.

Soap Creek oil field: Thom, 1.

southern, Colorado group : Reeside, 6.

Sweet Grass Hills : Kemp, 8.

'Tullock Creek coal fiela: Rogers, G. S., 8 .

Mowry shale, origin: Rubey, 7 .

Nacatoch formation: Howe, H. V. W., 5.

Nebraska, Sioux County; Agute anticline: Schramm, 2.

New Jersey : Mansfield, 12.

glauconite beds: Mansfield, G. R., 2.

New Mexico: Darton, 11, 26; Keyes, 14 ; Knox, J. K., 2.

Alamosa Creek Valley: Winchester, 3. castern: Baker, C. L., 1.

Gallup-Zuni Basin: Sears, 6.

northeastern: Garrett, 1.

Pecos Valley: Semmes, 4

Puertecito district: Wells, E. H., 2.

Raton coal field: Lee, 10.

Raton-Brilliant-Koehler a r e a : Lee, W. T., 6.

Sandia Mountains: Ellis, R. W., 2.

San Juan Basin: Reeside, 8.

San Juan County: Bauer, C. M., 1 ; Reeside, 3.

North America, southern: Stanton, 1.

North Carolina: Stephenson, 4.

North Dakota: Leonard, A. G., 1, 3.

western : Stanton, 3.

Marmarth field: Hares, 5.

Oklahoma : Gould, 9.

Arbuckle Mountains: Taff, 7 .

Beaver County : Gould, 15.

Cimarron County : De Ford, 1 ; Rothrock, 4.

Love County: Bullard, 3; Comanchean : Bullard, 1.

Lower Cretaceous: Bullard, 4

Marshall County : Bullard, 3.

northwestern: Clifton, 1; Comanchean : Clifton, 3.

southeastern: Honess, C. W., 6; Miser, 27; volcanic rocks: Miser, 19.

southern (part) : Hopkins, O. B., 2.

Ontario, northern: Keele, 3, 4.

Oregon: Smith, W. D., 1.

Cascade Mountains: Hodge, E. T., 14. 
Cretaceous-Continued.

Oregon-Continued.

central : Packard, 6, 7.

eastern: Buwalda, 4.

Riddle quadrangle: Diller, 12.

western: Harrison and Eaton, 1.

Pacific coast: Goranson, 1.

Porto Rico, Coamo-Guayama district: Hodge, E. T., 1.

Humacao district: Fettke, 5.

Lares district: Hubbard, B., 3.

Ponce district: Mitchell, 7.

San Juan district: Semmes, 1.

Recedent lake shores: Wieland, 6.

Ripley formation: Berry, 63 .

Ripley greensands, Mississippi : Needham, 1.

Saskatchewan, Battle River: Hume, 20.

Eastend area: McLearn, 16.

southern: Dyer, 10.

Wapawekka and Deschambault lakes area: De Lury, 6.

South Dakota, Badlands: Ward, 8.

Black Hills: Keyes, 31 ; O'Harra, 4 ; central : Darton, 14.

Dewey County: Ward, 9.

Haakon County: Ward, 14, 16.

Lance formation: Ward, 12.

Meade County: Wilson, R. A., 6.

Newell quadrangle: Darton, 1.

Perkins County: Moulton, G. F., 1.

Ragged Butte area, Dewey County: Wilson, R. A., 7 .

western: Stanton, 3.

Ziebach County: Russell, W. L., 4, 6; Wilson, R. A., 3.

Tennessee: Wade, B., 3.

Upper Cretaceous: Wade, B., 1.

Waynesboro quadrangle: Miser, 6.

western: Schroeder, 1.

Texas: Adkins, 5 ; Böse, 2 ; Hill, R. T., 3, 5; Scott, G., 3; Stanton, 13 ; Udden, J. A., 3, 12.

Austin formation, San Antonio district: Sellards, 14.

Bexar County: Sellards, 7, 10 ; subsurface section: Jones, R. A., 7 .

Big Lake oll fleld: Sellards, 21. Butler salt dome: Powers, 3.

central: Carsey, 1 ; Matteson, 1.

Caldwell County: Sellards, 16.

Coke County: Beede, 6.

Cooke County: Bybee, 3.

correlation: Scott, G., 4.

Crockett County : Liddle, 2.

Dallas County: Shuler, 1.

Denton County: Winton, 3

Diablo Plateau: Beede, 3.

eastern: Dumble, 1 ; Renick, 12.

Fort Stockton quadrangle: Adkins, 4

Fredericksburg and Washita formations: Adkins, 1.

Gulf Coastal Plain: Powers, 17.

Johnson County: Winton, 2.

Lacasa area, Ranger district: Ross, C. S., 3 .
Cretaceous-Continued.

'Texas-Continued.

Lower Cretaceous: Bullard, 4.

Luling oll field, Caldwell County : Sellards, 19.

McLennan County: Adkins, 2; Pace, 1.

Malone formation: Kitchin, 1.

Medina County : Liddle, 3.

northeastern: Ellisor, 2; Eohs, 2; (part) : Hopkins, O: B., 2.

Panola County: Sellards, 15.

Ranger ofl fleld: Reeves, F., 2.

salt domes: Powers, 12

San Marcos quadrangle: Brucks, 2.

Solitario uplift : Powers, 9.

southern : Böse, 8 ; Tatum, 1.

Tarrant County: Winton, W. M., 1.

Taylor and Navarro formations: Dane, 1.

Terrell County : Christner, 1.

Tom Green County : Henderson, G. G., 1.

trans-Pecos Texas: Baker, C. L., 6.

Upper Cretaceous: Stephenson, 8.

Weno and Pawpaw formations: Adkins, 2.

western : Baker, C. L., 2 ; Hoots, 1.

Trinidad: Liddle, 4; Waring, 6.

southern: Callson, 2.

Trinity group: Vanderpool, 3.

Upper Cretaceous Mississippi gulf : Berry, 10.

Utah: Butler, 4 ; Keyes, 152.

Book' Cliffs region: Fisher, D. J., 4.

Carbon County, Farnham anticline: Clark, F. R., 2.

Castlegate, Wellington, and Sunnyside quadrangles: Clark, F. R., 4.

Colob Plateau : Richardson, G. B., 11. easter'n : Forrester, J. B., 1.

Green River valley: Reeside, 7.

La Sal Mountains: Gould, L. M., 4.

Moab region : Baker, A. A., 1.

Salina Canyon district, Sevier County : Spieker, 6.

San Juan Canyon: Miser, 17.

San Rafael Swell: Gilluly, 4.

southeastern: Prommel, 4.

southern: Moore, R. C., 17.

Upper Cretaceous shore line: Spieker, 5.

Wasatch Plateau: Spieker, 3.

Washington, San Juan Islands: McLellan, 2.

Whatcom County: Jenkins, 7 .

West Indies: Vaughan, 22.

Windrow formation, upper Mississippl Valley: Thwaites, 2.

Woodbine sand, Texas: Berry, 36; age : Scott, G., 3.

Wyoming, Baxter Basin gas field: Sears, 7.

Bell Springs district, Carbon County : Dobbin, 5. 
Cretaceous-Continued.

Wyoming-Continued.

Black Hills : Bradley, .T. H., jl., 1. central : Lee, W. T., 19.

Cody region: Hewett, 4.

Fremont County, Big Sand Draw: Collier, 5 ; Rae, 3.

Gillette coal field: Dobbin. 3.

Grass Creek quadrangle : Hewett, 16.

Green River valley : Reeside, $\mathbf{7}$.

Lance Creek field: Hancock, 5 .

Lost Soldier-Ferris district: Fath, 5 .

Maverick Springs: Collier, 6 .

Meeteetse quadrangle: Hewett, 16.

Mule Creek oil field: Hancock, 4.

northwestern: Dake, 5.

Oregon Basin quadrangle: Hewett, 16.

Osage oil field, Weston County : Collier, 7.

Rock Springs area, Sweetwater County: Schultz, 1.

Upton-Thornton oil field : Hancock, 3.

Wind River Mountains: Condit, 4.

Crinerville oil field, Carter County, Oklahoma : Powers, 22.

Crinoidea. See also Echinodermata.

Apiocrinus, Tehuantepec, Mexico: Springer, 10.

Balanocrinus : Springer, 6,8 .

Calceocrinidae, derivation: Sardeson, 31.

Carboniferous crinoids, parasitism : Moodie, 5.

Catillocrinidae: Springer, 7 .

Colorado, western Pennsylvanian: Keyte, 1.

Cremacrinus, Minnesota: Sardeson, 31.

Devonian, Mackenzie: Springer, 4.

New York, Goldring, 4.

Michigan : Ehlers, 9.

Dolatocrinus and allies: Springer, 3.

Flexibilia: Springer, 2; Keyes, 157.

General : Keyes, 196.

Herpetocrinus, Monticello, Iowa : Thomas, A. O., 4.

Heterocrinidae, revision : Ulrich, 10.

Indiana, Crawfordsville: Ehrenberg, 1.

Lichenocrinus, crinidal affinities: Basler, 24.

Mackenzie River valley, Devonian: Springer, 14.

Mysticocrinus : Bather, 1.

Ney̧ York, Hamilton crinoids: Goldring, 8.

Utica and Lorraine formations: Ruedemann, 17.

Pentacrinus, Alaska: Springer, 11.

Scyphocrinus roots: Ehrenberg, 2.

Silurian: Springer, 12.

Strophocrinus and Carabocrinus, Ordovician, Minnesota: Sardeson, 16.

Unusual forms: Springer, 13.

Crocodile vertebrae, mechanics: Troxell, 25. Crossville quadrangle, Tennessee: Butts, 6.
Crustacea. See also Ostracoda; Trilobita. Anguilla, Oligocene: Withers, 4.

Apus, Permian, Oklahoma: Ruedemann, 8.

Barbados, Callianassa: Withers, 6 .

Bibliography of Paleozoic Crustacea: Vogdes, 1.

Bunaia, Silurian, New York: Clarke, J. M., 4, 7 .

Calianassa and Rania, Oligocene, Washington : Withers, 3.

Carcineretes, Cretaceous, Jamaica, Withers, 1.

Caryocaris: Ruedemann, 3.

Cirripede, Niobrara, Kansas: Withers, 5.

Dominican Republic, Tertiary decapods : Ratbbun, 2.

Eobalanus, Ordovician, New York : Ruedemann, 13.

Haiti, crabs: Rathbun, 4.

Hemiaspidan crustacean, Bertie waterlime, New York: Clarke, J. M., 24.

Iowa: Walter, 3.

Jamaica, Cretaceous and Tertiary: Withers, 2.

New York, Staten Island, Cretaceous, crab : Davis, W. T., 1.

Utica and Lorraine formations : Ruedemann, 18.

North Carolina, Upper Cretaceous decapods : Rathbun, 3.

Nova Scotia, coal measures, Merostomata : Bell, W. A., 4.

Ontario, Pleistocene: Kindle, 48.

Pacific slope, stalk-eyed: Rathbun, 5.

Ranina trechmanni, Cretaceous crab, Jamaica: Withers, 8.

West Indies, Tertiary decapod: Rathbun, 1 .

Crustal shortening of Colorado Rockies: Chamberlin, R. T., 8.

Cryolite: Burchard, 5 ; Ladoo, 5.

Greenland: Gordon, S. G., 19.

Cryptogams. See Paleobotany.

Cryptozoon: Rothpletz, 2.

Crypto-volcanic regions: Bucher, 16.

Crypto-volcanic structures: Bucher, 10; Adams County, Obio: Bucher, 1.

Crystal symmetry, mathematical study: Rogers, A. F., 27.

Crystal structure, analysis by $\mathrm{X}$-rays : Bragg, 1.

Crystalline rocks of the plains: Gould, 3. Crystallography.

Addition and subtraction rule in geometrical crystallography : Rogers, A. F., 28 .

Alabandite, crystal structure: Wyckoff, 3.

Amphibole group: Winchell, 6 .

Analcite structure determined by oscillation method: Gruner, 12

Anorthite: Parsons, A. L., 1.

Apatite: Whitlock, 19. 
Crystaliography-Continued.

Apatite, epidote, and hematite from Rbode Island: Hawkins, $\Lambda$. C., 2.

Axinite, British Columbia : Poitevin, 3. Babingtonite: Washington, 26.

Barite: Whitlock, 2.

Boleite, crystal form: Gossner, 1.

Boulangerite, Idaho: Shannon, 28.

Calculations in monoclinic system : Palache, 10 .

Cerusite, British Columbia: Poitevin, 4.

Chalcopyrite, Bergen Hill, New Jersey: Wherry, 2.

Columbite, Boothwyn, Pennsylvania: Smith, I. F., 1.

Creedite, Colorado: Foshag, 9.

Crystal structure, bibliography : Morse, J. K., 1.

Crystal structure data: Wyckoff, 4.

Crystal structure model: Whitlock, 7.

Crystal structure of some metallic sulphides: Ramsdell, 1.

Crystal structures of calcites: Wyckoff, R. W. G., 1.

Crystal symmetry, mathematical study : Rogers, A. F., 27.

Crystallographic tables: Goldschmidt, V., 1.

Cyanite, Manitoba : Wallace, 12.

Datolite, Westfield, Massachusetts : Shannon, 23.

Drawing crystals: Palache, 3; Porter, M. W., 1 ; Slawson, 1.

Etch figures on crystals : Honess, A. $P$., 5.

Euhedral oligoclase, Medicine Bow Mountains, Wyoming: Crawford, A. L., 1.

Factors influencing crystal babit: Walcott, A. J., 1.

Force of crystalliaztion: Stillwell, 1.

General : Wherry, 23.

Glaucochroite, willemite, celestite, and calcite, Franklin : Gordon, S. G., 9.

Gnomonic projection: Palache, 2.

Goldschmidt two-circle method, calculations in hexagonal system : Palache, 6.

ealculations in isometric system: Palache, 4.

calculations in orthorhombic system : Palache, 8.

calculations in tetragonal system: Palache, 5.

Goniometer, two-circle: Bascom, 88; Palache, 1.

Hematite, New Mexico: Foshag, 7.

Feulandite, thermo-optical properties: Slawson, 2.

Higginsite: Palache, 9.

Hopeite: Walker, T. L., 1.

Hydromagnesite: Rogers, A. F., 1.5.

Inyoite, New Brunswick: Poitevin, 5.

Kempite, California : Rogers, A. F., 18.
Crystallography-Continued.

Magnesite erystals, Orangedale, Nova Scotia: Dobbel, 1.

Manganotantalite, Amelia, Virginia : Lee, 0. I., 1 ,

Marcasite, Racine dolomite, Wisconsin : Cook, C. W., 4.

Mimetic crystals, classification: Wherry, 1.

Model for demonstrating crystal structure: Whitlock, 7.

Monazite, Boothwyn, Pennsylvania: Wherry, 3.

Weymouth, Massachusetts: Palache, 1.0.

Natural arrangement in crystal symmetry : Sen, 2.

New crystal forms of minerals: Whitlock, 14.

Optic angle of crystal, determination : Phemister, 1.

Optical properties of minerals: Larsen, 6.

Orientite, Cuba : Hewett, 7.

Plans and elevations in study of geometrical crystallography: Rogers, A. F., 13.

Potassium fluozirconate: Kerr-Iawson, $i$.

Pucherite, pyrite, trichalcite, and wavellite: Shannon, 34.

Pyrite: Whitlock, 15.

Bald Mountain, Colorado: Whitlock, 4.

Cornwall, Pennsylvania : Hawkins, 8.

French Creek, Pennsy lva i a: Wherry, 5.

New York City: Whitlock, 3.

Tueson, Arizona: Ayres, 1.

Pyrite group: Ramsdell, 2.

Radio crystal detectors: Hawkins, 6 .

Refractive indices, determining: Win. chell, 18.

Searlesite: Rogers, A. F., 17.

Spencerite: Walker, T. L., 1.

Stephanite, epidote, and calamine: Poitevin, 2.

Stephanite, Sultepec, Mexico: Shannon, 41.

Structure of crystals: Wyckoff, 2.

Struvite: Palache, 12.

Sulphur: Bichowsky, 1.

Sundry minerals: Shannon, 17.

Surface of a crystal: Wherry, 24.

I'abulation of crystal classes: Rogers, A. F., 32.

Teaching: Fisher, D. J., 1.

Thomsonite, optical notes: Gordon, S. G., 13.

Triclinic system : Palache, 11 ; Parsons, A. L., 1.

Vivianite, Idaho: Shannon, 22.

Wavellite: Gordon, S. G., 10.

Whewellite: Wherry, 17.

X-ray analysis of crystal stiucture: Bragg, 1. 
Crystallography-Continued.

$\mathrm{X}$-ray analysis of crystals, oscillation method: Gruner, 11.

Crystule : Keyes, 187, 268.

Cuba. See also West Indies.

Oriente province: Bonazzi, 1.

Rio Almendares valley:' Allende, 5.

Santa Clara, Trinidad: Lorenzana, 1.

Santiago region: Calvache, 3, 4.

Economic geology.

Asphalt and petroleum: Allende, 15.

Bibliography of carbonaceous materials : Ortega, P., 1.

Camaguey, Caridad, and Lola mines: Allende, 4.

Canteras, finca "La Viuda"; Corral, 5.

Chrome ore: Burch, 1, 2; Burchard, 4, 10.

Chromite, San Miguel de los Baños, Matanzas: Suárez Murias, 3.

Copper : Allende, 6, 7.

Pinar del Río: Corral, 1.

Investigations concerning petroleum :

Corral, 3.

Iron ores: Kuhn, 2; Weld, 1; Santiago : Kimball, 1.

Isle of Pines: Allende, 1; Suárez Murias, 1.

Jurassic as source of oil in western Cuba: Wright, A., 1.

Manganese: Burch, 1, 2 ; Burchard, 3, 7.

Bueycito: Calvache Dorado, 1.

Mineral resources: Suárez Murias, 4.

Mineral resources: Calvache, 2.

Mina "Celia Gregoria"; Lago, 1.

Oriente, mineral resources: Aguilera, E., 1.

Petroleum investigations: Corral, 4.

Pinar del Rio: Allende, 2, 3.

Bahía Honda y La Palma: Suírez Murias, 2.

Potash, Santa Clara: Montolieu, 1.

Pyrite, Sierra de Trinidad: Allende, 10.

Santa Clara, Malezas, San Jose mine: Corral, 2.

Historical geology.

Geologic relations: Rutten, 1.

Guantanamo Basin: Darton, 18.

Granite, Habana province : Allende, 12

Jurassic: $O^{\prime}$ Connell, 4 ; western Cuba: Brown, B., 2.

Oriente province: Bonazzi, 1.

Oxfordian, western Cuba:Brown, B., 1.

Pinar del Rio, Bahia Honda y La Palma: Suárez Murias, 2.

Western Cuba: Wright, A., 1.

Mineralogy.

Cubanite: Merwin, 5.

Orientite: Hewett, 7 .

Paleontology.

Ammonite opercula : O'Connell, 5.

Cirripede, Miocene: Withers, 7.

Echinoderms: Sánchez Roig, 16.

Echinoidea : Sanchez Roig, 4.
Cuba-Continued.

Palcontology-Continuer.

Jurassic ammonite fauna: O'Connell, 3 ; Sánchez Roig, 1, 2.

Jurassic fish fauna, western Cuba: Gregory, W. K., 8.

Orthaulax, 'lertiary: Woodring, 3.

Oyster, Cretaceous: Raymond, 31.

Rudistids, central Cuba: Sanchez Rolg, 15.

Squalidae, Miocene and Pliocene, Ha vana: Sánchez Roig, 3.

Tertiary Mollusca: Cooke, C. W., 1.

Petrology.

Granite bed; Santiago de Cuba: Calvache, 5 .

Underground water.

Aguada area: Allende, 8

Meseta central : Montoulieu, 2.

Santa Clara area: Allende, 9.

Cubist method in geological correlation Keyes, 144.

Culebra Island: Vaughan, 22.

Currie oil and gas field, Navarro County, Texas: Lahee, 9.

Cuyamaca region, California: Hudson, F. S., 1.

Cyanite: Seagle, 1.

Cycadeoidea, distribution and relationships, Wieland, 3.

Cycadeoids, monocarpy: Wieland, 8.

Cycadophyta, classification: Wieland, 1.

Cycads. See Paleobotany.

Cystoidea. See also Echinodermata.

Carnyella valcourensis, Chazy limestone: Clark, 'T. H., 2.

Caryocrinites, appearance of additional arms: Foerste, 8.

Dendrocystis: Bather, 8.

Habits and structure: Bather, 6.

Holocystites: Foerste, 7.

Lipsanocystis traversensis, Devonian, Michigan : Ehlers, 6.

Michigan, Escanaba River, Trenton: Hussey, 3.

Stroma tocystites, Newfoundland : Schuchert, 3 .

Daimonhelix : Mansfield, W. C., 4.

Dakalite, North Dakota: Dove, 6.

Dakota flora, age: Berry, 22.

Dakota sandstone problems: Stanton, 5.

Dallas type of river channel: Bretz, 7 .

Damon Mound oil field, Texas: Bevier, 1.

Data of geochemistry: Clarke, F. W., 1, 5.

Decomposition of rocks. See Weathering.

Dease Lake area, Cassiar district, British Columbia: Kerr,.F. A., 1.

Deep Spring Valley, California: Miller, W. J., 35.

Deep wells. See Borings.

Defiation process : Keyes, 174.

Definitions.

Chert: Glock, 2.

Flint: Glock, 2.

Fossil : Field, 3 ; Miller, A. M., 6.

Talus and shingle: LaForge, 2. 
Delaware.

Areas described.

Wilmington quadrangle: Bascom, 2. Minerulogy.

Canbyite, Wilmington: Hawkins, A. C., 3.

Delta building: Nevin, 2.

Deltas.

Colorado River: Sykes, 1.

Fraser River, British Columbia. Xohnston, W. A., 8, 9.

age: Johnston, W. A., 7.

sandstone in delta, formation: Johnston, W. A., 6.

Mississippl River: Trowbridge, 7.

Demonstration material in geology: Cleland, 6.

Denuation. See Erosion.

Denudation of the desert: Keyes, 159.

Deposition. See Sedimentation.

Deposition of ores. See Ore deposits, origin.

Desert varnish : White, C. H., 2.

Des Moines ice lobe, map : Leverett, 10.

Deserts.

Arizona, Papago country : Bryan, 7.

Mexico, San Luis Potosi, desert phenomena: Wittich, 2.

Devonlan. See also Paleontology, Devonian.

Acadia : Bailey, L. W.. 2.

Alabama : Butts, 8, 11, 12 ; Jones, W. B., 13.

Bessemer-Vandiver q u a d r a $\mathrm{ngle}$ : Butts, 13.

Alaska, Chandalar district: Mertie, 12. Ruby-Kuskokwim region: Mertie, 11. Toklat-Tonzona River region: Capps, 12.

Wrangell district: Buddington, 4.

Albel'ta : Dowling, 5.

Banff area: Warren, P. S., 4.

Crowsnest Pass: Warren, P. S., 7.

Lake Minnewanka section: Shlmer, 6.

Arctic regions, Ellesmele Land : Holtedahl, 1.

Arizona : Darton, 17 ; Keyes, 83, 106 ; Stoyanow, 1.

Aravaipa-Stanley region : Ross, C. P., 5.

central : Ettlinger, 1.

Grand Canyon : Keyes, 94 ; Moore, R. C., 26 ; Noble, 3.

Payson district: Lausen, 1.

Pinal Creek: Stauffer, 11.

Ray quadrangle: Ransome, 11.

Ray-Miami region: Ransome, 1.

Saddle Mountain and Banner mining districts: Ross, C. P., 6.

Santa Rita limestone: Stauffer, 8, 12.

Arkansas: Miser, 4, 7, 11.

Batesville district: Miser, 8.

Hot Springs district : Purdue, 1.

Big Stone Gap shale, southwestern Virginia: Swartz, J. H., 4 ; Chaltanoogan age: Swartz, J. H., 10.
Devonian-Continued.

British Columbia, Beaverfoot-BriscoStanford Range: Walcott, 9.

Bow River" section, Banff: Kindle, 30.

Rocky Mountain trench: Shepard, 3.

Taseko Lake-French Bar Creek : MacKenzie, J. D., 2.

Windermere area, Kootenay district: Walker, J. F., 1

Chagrin formation: Chadwick, 14.

Chattanooga shale, southwestern Virginia : Swartz, J. H., 6.

Chemung group, stratigraphy in western New York: Chadwick, 10

Colorado: Keyes, 162.

Red Cliff district: Crawford, R. D., 3.

Early Devonian hiatus in Mississippi Valley: Keyes, 215.

Georgia : McCallie, 1.

Greenland: Böggild, 1. northwestern : Koch, 1.

Idaho, Fort Hall Indian Reservation: Mansfield, G. R., 3. southeastern : Mansfield, 29.

Illinois: Savage, 3.

Alto Pass quadrangle: Bassett, 1.

Calhoun County: Lamar, 6.

Equality-Shawneetown area: Butts, 5.

Edgington-Milan area : Savage, 5.

Hardin County : Weller, S., 1.

Mississippi Valley: Krey, 2.

Oriskany limestone: Savage, 10, 15. southwestern: Savage, 4.

western: Savage, 7.

Illinols and Missouri rocks compared : Savage, 14.

Indiana : Cumings, 1 ; Logan, 15.

Iowa, Jackson County: Ladd, H. S., 3. eastern : Norton, W. H., 1.

Hackberry stage: Fenton, C. L., 2, 3, 4.

Independence shale, $\quad \mathrm{Br}$ a $\mathrm{nd}$ on: Thomas, A. O., 5 .

Lake Calvin region: Schoewe, 6.

Linn and Jackson counties, outliers: Norton, W. H., 4.

Shellrock stage: Belanski, 1.

State Quarry beds: Stainbrook, 2, 3.

Kansas, Salina Basin : Barwick, 1.

Kentucky : Jillson, 35 ; Miller, A. M., 1.

Allen County : Miller, A. M., 5; Shaw, E. W., 1.

Barren County: Butts, 2.

Berea region: Burroughs, W. G., 5.

Knob region: Burroughs, W. G., 4.

Mackenzie, Franklin Mountains: Williams, M. Y., 14, 16.

Great Slave Lake region: Cameron, 1

lower Mackenzie Valley: Kindle, $\mathbf{9}$.

Mackenzie River district: Bosworth, 3 ; Hume, 3; Whittaker, 2; Wil. liams, M. Y., 13. 
Devonian-Continued.

Mackenzie-Continued.

Mackenzic River basin: Camsell, 1.

Mackenzie River between Norman and Beaver River : Hume, 5.

Providence to Simpson: Whittaker, 5 .

Maine, Moose River sandstone: Perkins, E. H. 4.

Rangeley conglomerate: Smith, E. S. C., 2.

Manitoba: Wallace, 14.

Michigan, Alpena County : Ver Wiebe, 10. southeastern: Ehlers, 12.

Minnesota: Grout, 2; Stauffer, 2, 3.

Mississippi : Lowe, 2 ; Morse, P. F., 1 ; Morse, W. C., 4.

Tishomingo County : Bramlette, 4.

Missouri: Branson, 1, 2, 5; Wilson, Mal. E., 1 .

Bailey limestone: Tansey, 1.

central: Greger, 1.

Cooper limestone: Greger, 2.

Mississippi Valley: Krey, 2.

Ozark region: Keyes, 87.

Ozark uplift, Devonian outlier : Bridge, 1.

Ste. Genevieve County: Weller, 19 ; Little Saline limestone: Stewart, G. A., 1.

Missouri, Illinois, and Iowa: Branson, 16.

Montana : Keyes, 234.

Beartooth Mountains, Bevan, 2. Melrose phosphate field: Richards, R. W., 2.

Nevada: Keyes, 128.

Muddy Mountains region: Longwell, $1,3,15$

Pioche district: Westgate, 6 .

New Brunswick: Bailey, L. W., 1. Dalhousie area : Howard, W. V., 2. Mispec group : Matthew, G. F., 3. St. John: Matthew, G. F., 2.

Newfoundland, western: Schuchert, 16.

New Hampshire, Ammonoosuc district: Ross, C. P., 2.

New Mexico: Darton, 26 ; Keyes, 14. eastern : Baker, C. L., 1.

New York, Allegany State Park: Lobeck, 8 .

Catskill region: Jones, R. W., 1.

Genesee County: Fairchild, 15.

Genesee Valley : Fairchild, 24.

Oriskany sandstone: Eaton, H. N., 3.

Portage stratigraphy: Chadwick, 3.

Sherburne sandstone: Grabau, 6 . western: Alexander, W. P., 1; Hussakof, 1 .

Ohio, Camp Sherman quadrangle: Hyde, 1.

Delaware County: Carman, 4 ; Westgate, 5 .

Lucas County, Silica shale: Stewart, G. A., 2 .

Monroe division: Carman, 2.
Devonian-Continued.

Ohio-Continued.

Olentangy shale: Lamborn, 1.

Spirifer horizons: Ireland, 1.

Oklahoma : Gould, 9; Schuchert, 21.

Arbuckle Mountains: Taff, 7 .

Carter County: Tomlinson, 4.

Mannsville area: Tomlinson, 2.

northeastern: White, L. H., 3.

southeastern: Honess, C. W., 6.

southern Ouachita Mountains: Honess, C. W., 4

Stonewall quadrangle: Morgan, G. D., 5.

Ontario, James Bay region: Savage, 2.

Mattagami and Abitibi rivers: Williams, M. Y., 7.

Moose River basin: Kindle, 26.

Pagwachuan, Kenogami, and Albany rivers: Williams, M. Y., 10.

Orcas group, Washington : McLellan, 1.

Oregon: Smith, W. D., 1.

Riddle quadrangle: Diller, 12.

Rennsylvania: Miller, B. L., 4.

Quebec, Beauceville area: MacKay, B. R., 4.

Bonaventure formation: Clarke, J. M., 26.

Gaspe: Alcock, 29.

Gaspe County, Lemieux : Alcock, 14 ; Mailhiot, 1.

Mount Albert area: Alcock, 6.

Mount Serpentine, Gaspe County : Alcock, 22.

St. George : Clark, T. H., 6, 9.

Shickshock Mountains : Alcock, 21.

Tennessee : Nelson, 16.

Cheatham County: Jillson, 49.

Overton County: Butts, 1.

Sumner County: Mather, 3.

Waynesboro quadrangle: Miser, 6.

Texas, Solitario uplift: Powers, 9.

Utah: Butler, 4 ; Keyes, 152.

Tintic district: Lindgren, 2.

Virginia: Giles, 11.

Big Stone Gap shale, age: Swartz, J. H., 7.

Giles County : Hubbard, G. D., 6.

Little North Mountain: Giles, 8.

Oriskany and Helderberg formations : Holden, R. J., 1.

Scott County, Early Grove: Butts, 9. southwestern, black shale: Stose, 22.

Valley coal fields: Camplell, M. R., 10.

western: Stose, 16.

Wise and northern Scott counties: Eby, J. B., 1.

West Virginia, conglomerate rocks: Reger, 12.

Hampshire and Hardy counties: Tilton, 15.

Mercer, Monroe, and Summers counties: Reger, 9.

Mineral and Grant counties: Reger, 7. 
Jevonian-Continued.

West Virginia-Continued.

Pendleton County: Tilton, 14.

Randolph County: Reger, 15.

Tucker County: Price, W. A., 9 ; Reger, 6.

Winters in Upper Devonian of New York and Acadia: Schuchert, 34.

Wisconsin : 'Fhwaites, 3.

Wyoming, Wind River Mountains: Condit, 4.

Yukon, Mayo district, Beaver River area; Cockfield, 15.

Whitehorse district: Cockfield, 16.

Diagenesis in sedimentation : Schuchert, 12.

Diamonds: Ball, S. H., 2 ; Eardley-Wilmot, 7.

Arkansas, Pike County : Miser, 10, 12, 18: Mitchell, 8.

Diastrophic movements, table of : Shepard,6.

Diastrophism.

Atlantic-Arctic region: Holtedahl, 2.

Cause: Chamberlin, T. C., 10.

General: Cotton, 2.

Megadiastrophism: Chamberlin, T. C., 12,17 ; Jones, W. F., 2.

Paleozoic crustal instability: Schuchert, 13.

Periodic diastrophism: Shepard, 6.

Planetary nuclei, physical phases: Chamberlin, T. C., 20.

Planetesimal growth: Chamberlin, T. C., 21.

Quebec, northern : Cooke, H. C., 2.

Selective segregation of material forwing earth: Chamberlin, T. C., 19.

Self-compression of the earth as a problem of energy: Chamberlin, T. C., 13.

Shrinkage of the earth: Chamberlin, T. C., 10.

Vertical earth adjustments, rate of movement: Hobbs, 15.

Wedge theory: Chamberlin, R. T., 11.

Diatomaceae. See also Diatomaceous earth.

Alaska, Pribilof Islands: Hanna, $2 \pi$.

Biogenesis of hydrocarbons by diatoms : Tolman, 2.

California, Cretaceous: Hanna, G. D., 33.

Monterey shales: Gaylord, 2 ; Hanna, G. D., 38.

Santa Barbara County, Lompoc: Yermoloff, 1.

Tertiary : Hanna, 31.

Canada : Eardley-Wilmot, 9 ; southern : Boyer, 1.

Collection and preparation: Mann, 1.

District of ${ }^{\circ}$ Columbia, excavation on Connecticut Avenue: Mann, 2.

General: Eardley-Wilmot, 9.

Mexico, Maria Madre Island, Miocene: Hauna, 27.

Valle de Toxi : Diaz Lozano, 1.

Nebiraska: Elmol'e, 1.

Oregon, western: Schenck, 7 .
Diatomaceae-Continued.

Washington, Copalis Beach, "epidemics": Becking, 1.

Diatomaceous earth. See also Diatomaceae. British Columbia, Lillooet-Prince George region: Reinecke, 3.

Canada: Eardley-Wilmot, 5, 9.

General : Eardley-Wilmot, 5.

Nova Scotia : Burroughs, R. W., 1 .

Oregon, eastern : Smith, W. D., 17.

Diceratheres: Peterson, 2.

Diffusion in silicate melts: Bowen, 9 .

Diffusion in vein genesis at Cobalt: Whitman, 1.

Dikes.

Alberta, sandstone dikes: Williams, M. Y., 17.

Arkansas, Scott County, peridotite dikes : Miser, 9.

Association of faulting with dike intrusion: Sheldon, 3.

Basic dike injections in magmatic vein sequences: Spurr, 20.

California, Orange County, sandstone dike, genesis indicated by heavy minerals: Meek, 2

Camptonite dikes in Connecticut Triassic: Russell, W. L., 2.

Idaho, Boise Basin: Ballard, 3.

Coeur d'Alene district: Shannon, 14.

Illinois, Hardin County: Weller, S., 1.

Kentucky, western : Currier, 2.

Maine, Ogunquit: Keeley, 2.

Portsmouth Basin: Wandke, 2.

Mechanics of dike intrusion: Billings, 1.

New Mexico, Pecos Valley: Semmes, 4.

New York, Adirondacks, Lyon Mountain region : Miller, W. J., 3.

New York, Ithaca region: Martens, 3 ; Sheldon, 1.

Lake Placid quadrangle: Miller, W. J., 1.

Lyon Mountain quadrangle: Miller, W. J., 26.

Schroon Lake quadrangle: Miller, W. J., 2 .

Ontario, Michipicoten area : Collins, 15. Oregon, Cornucopia, inclusions in porphyry dikes: Goodspeed, 1.

Pegmatite dikes, southeastern Ontario: Sine, 3.

Pennsylvania, southwestern: Honess, A. F., 3 .

South Dakota, sandstone dikes : Lawler,

Black Hills region, sandstone dikes, origin : Russell, W. L., 13.

Tennessee, Union County, mica-peridotite dike: Gordon, G. H., 4.

Texas, Bandera County: Dawson, J. M., 1.

Rockwall, sandstone dikes: Patton, 5 ; Stephenson, 7.

Vermont, Braintree : Richardson, C. H., 5.

Cuttingsville: Eggleston, 1.

southern: Bray, 1. 
Dikes-Continued.

Washington, eastern, clastic: Jenkins, 14.

southeastern, clastic: Jenkins, 11.

Dilatancy, geologic role: Mead, 4.

Dinosaur extinction: Wieland, 20.

Dinosaur National Monument: Gilmore, .23.

Dinosauria. See Reptilia.

Dip.

Apparent-dip protractor: Smith, W. S., T., 3.

Chart and protractor: Gaby, 2.

Components, determination: Higgins, 1 ; Lahee, 1 ; Palmer, H. S., 3.

Protractor for plotting dips: McKinstry, 4.

Readings on low rock dips: Filmer, 1. Dip and strike, determination : Longwell, 2 ; Smith, W. S. T., 2.

graphic determination: Crider, 1.

symbols for: Dreher, 2.

Dip needle: Stearn, 2.

Discoidal structure of the lithosphere: Willis, B., 2, 6.

Dislocation. See Faulting.

Distribution. See Geographic distribution.

Distribution of land and water on the earth : Reid, 5.

District of Columbia.

General : Palmer, E. C., 1.

Historical geology.

Excavation at Connecticut Avenue : Cuno, 1 ; LaForge, 3 ; Wentworth, 13.

Pleistocene deposits: Anon., 23.

Walker Hotel swamp deposit, age : Hay, 22.

Mineralogy.

Travertine, Rock Creek Park: Stose, 3.

Paleontology.

Diatoms, excavation on Connecticut Avenue: Mann, 2.

Pleistocene flora, excavation at ConPetroilogy. necticut Avenue: Berry, 51.

Granites: Washington, 12.

Physical geology.

Earthquakes, registration : Tondorf, 1-6. Divide silver district, Nevada: Knopf, A., 3. Dixon quadrangle, Illinois : Knappen, 1.

Dolomite.

Chemical study : Knight, N., 1.

Crystal structure: Wyckoff, 6 .

Formation: Raymond, 26.

Iowa : Smith, J. E., 11; and New York, composition : Reed, B. B., 1.

Nature and origin: Steidtmann, 5.

Occurrence : Van Tuyl, 10.

Origin: Tarr, 2, 6.

Wood, replacement by dolomite: Adams, S. F., 1.

Wisconsin : Steidtmann, 5.

Dolomitization : Walker, T. L., 55.

and ore deposition: Hewitt, 22.

in Paleozoic horizons, Manitoba : Birse, 1.
Dolomitization-Continued.

in southern Nevada: Hewett, 11

of limestones: Birse, 1.

Domes.

Gulf coast salt domes: Hills, R. T., 1.

Dominica, Island of : Earle, 8, 11.

Dominican Republic.

Geological reconnaissance: Vaughan, 16.

Historical geology.

General : Cooke, C. W., 3.

Miocene formations: Maury, 2.

Palcontology.

Barbatia patricia: Woodring, 12.

Corals: Vaughan, 37.

Crustacea, 'Tertiary: Rathbun, 2.

Mollusca, Tertiary: Pilsbry, 1.

Plantae, Tertiary: Berry, 25

Drainage changes.

Big Sandy River: Jillson, 80.

British Columbia, Cariboo district: 'Iyrrell, 2.

Rocky Mountain region: Schofield, 8.

Burled Whirlpool-St. Davids gorge, origin: Forrester, G. C., 1.

Colorado, Big 'Thompson River valley: Fuller, M. B., 1.

Mount Olympus: Fuller, M. B., 4.

Connecticut, Connecticut River near Middletown : Bissell, 2, 3.

Danbury region: Harvey, R. S., 1.

Glacial diversion of the Missouri River : Todd, J. E., 6.

Great Basin : Keyes, 116.

Great Lake region: Cook, C. W., 7.

Hudson-Champlain Valley: Stoller, 3.

Idaho, northern : Anderson, A. L., 2.

Illinois, glacial Kankakee torrent: Ekblaw, 3 .

Indiana: Malott, 6.

Bell Creek-Fall Creek Valley: Carter, 1.

Monroe County: Malott, 5.

Owen County: Addington, 1.

Raccoon Creek, Parke County : Bartle, 1.

Randolph and Delaware counties: Breeze, 1.

Iowa, Boyer River : Lees, 5.

Lee County: Wilson, B. H., 2.

Mississippi River: Schoewe, 4.

Moingona River, preglacial: Keyes, 3 .

Kentucky, Big Sandy River: Jillson, 93.

Frankfort area: Jllson, 30.

Tradewater River: Fowke, 2.

Mackenzie River Basin, postglacial lakes: Cameron, 2.

Maine, Androscoggin River: Crosby, I. B., 1.

Massachusetts, central : Alden, 2.

Minnesota, Minnesota and Mississippi rivers: Sardeson, 6.

Mississippi River: Leverett, 8; Schoewe, 4. 
Drainage changes-Continued.

Missouri, Ozark region: Tarr, 13.

Missouri River: Greene, 2.

Missouri River channel, age: Todd, J. E., 5.

Missouri Valley: Todd, J. E., 3, 4.

New Hampshire, eastern : Crosby, I. B., 1.

New York: Fairchild, 16.

Ausable quadrangle : Komp, 23. east central : Stoller, 1.

Finger Lake region: Monnett, 3.

Salmon Creek: Long, 2.

western : Fairchild, 21.

Nova Scotia, Kings County, Black and Gaspereau rivers: Churchill, 3.

Ohio, northern: Hubbard, G. D., 7. southeastern: Stout, 4.

Wayne County: Conrey, 1.

Ohio basin: Daly, 7.

Ohio River, genesis : Fowke, 1.

Ontario: Coleman, 11.

Pennsylvania : Williams, E. H., 1.

Preglacial drainage: Baker, F. C. 1.

Quebec, Gaspe : Alcock, 27.

Washington: Large, 3 .

Drift deposits. See Glacial gcology; Ice ages (ancient).

Drifting of the continents : Termier, 2.

Driftless Area, erosional history: 'Trowbridge, 1.

Driftwood Creek area, Babine Mountains, British Columbia: Hanson, 9.

Drillite: Shead, 4.

Drumlins.

New York, Lake Placid: Upham, 2.

Origin : Millis, 1.

Ducktown mining district, Tennessee: Emmons, W. H., 8.

Dufresnoy, area, Abitibi district, Quebec: Harvie, 3.

Dunes.

Indiana, northwestern : Barrett, E., 2 ; Cressey, 1-3.

Michigan: Scott, I. D., 2

Molokai, western: Wentworth, 17.

Texas, Red River valley: Sellards, 18.

Dunkard series of Ohio: Stauffer, 1.

Duparquet area, Quebec: James, W. F., 1

Dust fall, March 9, 1918: Winchell, A. N., 1; March 19, 1920: Winchell, A. N., 4.

Dynamic geology. See Physical geology.

Dynamics of the lithosphere: Jones, 0. C., 1. Earth,

Age: Bradley, J. H., 1; Bretz, 12; Clarke, J. M., 31 ; Duane, 2 ; Grant U. S., 2 ; Hess, 22 ; Joly, 1 ; Kovarik, 1; Lane, 23, 25 ; Pompeckj. 1 ; Rayleigh, 1 .

astronomical viewpoint: Brown, E. W., 1.

geologic time scale: Lane, 19.

geological viewpoint: Chamberlin,

T. C., 15 .

$4096-31-49$
Earth.-Continued.

Age-Continued.

paleontological viewpoint: Clarke, J. M., 19.

radioactive point of view : Duane, 1 . radioactive determination: Swartz J. H., 2.

uranitum minerals, age: Davis, $\mathrm{C}$. W., 1.

Amplitude of earth's motion: Sohon, 1.

Axis of rotation, changes of: Cotton. 2

Composition : Adams, L. H., 7 ; Washington, 31,34 .

Compressibllity : Woodward, R. S., 1.

Condensation, geological relations: Barrell, 10.

Constitution: Am. Geoph. Union, 1 ; Bowie, 24; Lamb, 1, 2 ; Washington, 32 .

Crust.

Antilles, fault troughs: Taber, 6 .

arcuate and lobate mountain structures: Taylor, 1.

California, Coast Ranges, mobility: Lawson, 1.

composition: Clarke, 4; Washing ton, 4.

condition : Putnam, G. R., 1 ; Reid, 9. deformation caused by waning ice caps: Daly, 16.

deformation in Pacific and Atlantic regions contrasted: Hobbs, 9 .

density of crust: Goranson, 5 .

dynamics of the lithosphere: Jones, o. C., 1.

enrly conditions: Schuchert, 14. earthquake frequency: Cotton, 1.

elastic yielding under load of sedimentary deposits: Lambert, W. D., 3.

framework of the continents, significance: Chamberlin, R. 'I., 10.

general: Coleman, 12; Longwell, 13.

isostatic adjustment: Bowie, 7 .

isostatic equilibrium: Wood, H. O., 4 lithosphere, tidal stresses: Cotton, 1. localization of major geosynclines, cause: Bucher, 4.

major features of earth's surface: Diener, 1 ; Schaffer, 1.

mobile belts, pattern: Bucher, 8 . movements of crust : Leith, 6 . outer shells of the earth: Daly, 24. resistance to change: Van Orstrand, 3 . rôle of isostatic stress: Willis, 8 . stability : Daly, 13.

Tertiary epeirogeny: Taylor, 13.

Tertiary mountain building, cause : Taylor, 2.

vertical movement of crustal material : Bowie, 28

Crust and discontinuity beneath it: Adams, L. H., 9.

Density : Heyl, 1; Washington, 25. distribution in the earth: Wil. liamson, 2. 
Earth-Continued.

Diminishing rate of rotation, effects: Keyes, 37, 71.

Discoidal structure of the lithosphere: Willis, B., 2.

Early history: Berkey, 13.

Evolution: Chamberlin, T. C., 30 ; Hobbs, 5.

Figure: Hayford, 3.

changing sphericity of the earth: Keyes, 35.

Formation : Emmet, 1.

Framework: Cumings, 2; Davis, W. M., 2.

Genesis : Chamberlin, T. C., 1, 19 ; Emmet, 2 ; Millis, $3,4$.

nebular and planetesimal hypotheses compared: Fairchild, 22; Mehl, 16.

planetesimal hypothesis: Chamberlin, T. C., $9,27$.

Gravity on earth and moon: Wright, F. E., 10.

Growth : Chamberlin, T. C., 38.

History.

control zones of earth: Chamberlin, T. C., 11

Interior: Carstarphen, 1; Cotton, 2; Cumings, 2 ; Daly, 5, 17, 21 ; Day, A. L., 1 ; Longwell, 13 ; Macelwane, 6; Sosman, 13; Washington, 4 ; Willis, 6.

chemistry of the earth's core: Barnett, 1 .

density and elasticity : Lambert, $W$. D., 1.

elastasy vs. isostasy : Chamberlin, T. C., 33.

intrageology: Chamberlin, T. C., 33. iron, distribution: Adams, S. F., 1. rigid core in earth: Macelwane, 10, 16.

seismic wave velocity and densities of crustal materials : Science Service, 1.

X-raying the earth: Daly, 26.

Magnitude of shrinkage: Chamberlin, T. C., 4

Megadiastrophism: Chamberlin, T. C., 17 ; Jones, W. F., 2.

Nature of: Adams, L. H., 1.

Ocean and atmosphere, origin: Humphreys, 5.

Origin: Chamberlin, T. C.. 41; and early stages: Chamberlin, R. T., 12.

heliokleptic theory: Sardeson, 35.

Pole wanderings: Cotton, 2.

Radial distribution of certain elements : Washington, 29.

Rate of rotation: Barrell, 10; Brown, E. W., 4.

Rigriaty: Michelson, 1.

Rotational velocity of earth and its geological effects: Daly, 14.
Earth-Continued.

Self-compression: Chamberlin, T. C., 14.

Tectonic adjustment of a rotating straticulate spheroid: Keyes, C. R., 1.

Tectonic form of the continents: Keyes, 7.

Temperature: Sàyles, 8 ; Van Orstrand, 2.

apparatus for measurement of temperatures in deep wells: Van Orstrand, 5.

deep borings: Van Orstrand, 1; White, I. C., 2 ; Anon., 5; West Virginia: White, I. C., 1 :

deepest wells: Van Orstrand, 10.

earth temperatures and structural uplifts : Thom, 13.

fluids in wells, temperature: Lahee, 7 .

geothermal data of United States: Darton, 6.

geothermal gradient, Sunset-Midway oil field, California: Rogers, G. S., 1.

Hawaii, volcanic borings: Jaggar, 23.

internal heat: Clarke, F. W., 9.

isogeothermal surfaces: Van Orstrand, 10.

Keweenaw geothermal gradients: Lane, 11.

Lake Superior region: Lane, 15.

oil field temperatmes: Washburne, 8.

Oklahoma, boring: Míser, 15.

temperature in deep mines: Lane, 14.

temperatures at moderate depths: Adams, L. H., 6.

Texas, Brazoria County, West Columbia field: Darton, 2.

variation of temperature with geologic structure in oil districts: Van Orstrand, 7 .

Variable velocity hypothesis: Spearman, 1.

Zone of flow: Hobbs, 8.

Earth and its rythms: Schuchert, 32.

Earth's crust and evolution: Daly, 12.

Earth's history, trend: Blackwelder, 4.

Larth movements. See Changes of level; Landslides.

Earth sciences as the background of history: Merriam, J. C., 3, 5 .

Earthquake insurance: Jaggar, 12.

Earthquakes. See also Seismology.

Alaska, Katmai : Fenner, 7 .

Azimuth determination in earthquakes : Urrutia, 1.

Bearing of distribution on origin : Taylor, 16.

British Columbia, December 6, 191s: Denison, F. N., 1. 
Farthquakes-Continued.

California, Calaveras Valley, April 3. 1924: Macelwane, 20.

Chittenden : Kemnitzer, w., 1.

Corralitos, September 19, 1923 : Macelwane, 4.

Crystal Springs, February 10, 1925 ; Macelwane, 19.

Eagle Lake: Kemnitzer, W., 2.

Evergreen, Juiy 19, 1925 and May 28, 1927 : Byerly, 15.

Inglewood, June 21, 1920 : Kew, 5; Taber, 3.

January 31, 1922 : Macelwane, 3.

July 19, 1925 : Byerly, 13.

Los Angeles region: Arnold, R., 1. Los Angeles, July, 1920 : Taber, 5. northern, January 22, 1923: Anon, 37.

recent: Macelwane, 9; Palmer, A. H., 3 .

registration: Bond, 1-3 ; Byerly, 6, $7,10,11,12,16-18$; Davis. E. F., 1-4; Macelwane, 2, 7, 8, $11,13,14$.

Salinas, December 27, 1924 ; Kemnitzer, L. E., 1.

San Jose: Vickery, 1.

Santa Barbara, June 29, 1925: Davis, W., 2 ; Kirkbride, 1 ; Willis. 21,22 ; intensity : Byerly, 2.

seismic force: Willis, 30 .

Sierra Nevada, March 30, 1925: Anon., 46.

southern : Hill, R. T., 8 ; Mulholland, 1 ; Taber, 4 ; early records: Carpenter, F. A., 1; earthquake conditions: Hill, R. T., 9 ; July 22, 1923 : Laughlin, 1.

1918-1921: Palmer, A. H., 1, 2, 4, 5.

Cause: Griggs, 8 ; Hobbs, 26 ; Macelwane, 15.

Causes and prediction: Bowie, 16.

Depth of focus of recent earthquakes in California: Byerly, 3.

Distribution and origin : Taylor, F. B., 19.

District of Columbia, registration : Tondorf, 1-6.

Earthquake history of United States: Heck, 12.

Earth movements in California: Day, 16.

Eastern North America: Hobbs, 26.

Elastic rebound theory: Lawson, 1.

Epicenters, determining: Hodgson, 1; Neumann, F., 1, 2.

north Paciflc: Heck, 8.

Eureka earthquake: Macelwane, 5 .

GeneraI : Chamberlín, R. T., 13 ; Daly, 21,23 ; Heck, 4 ; Hoffman, F. L., 1 ; Hovey, 9 ; Jaggar, 21 ; Jones, Er. L., 1, 3 ; Muñoz Lumbier, 5 ; Paige, 6; Reeds, 10 ; Willis, 14, 18 , 23.
Earthquakes-Continued.

Geologic theory: Montessus de Ballore, 1.

Guatemala: Mrañoz Lumbier, 3; Van de Putte, 1.

Fawaii, earthquake prediction: Finch, R. H., 4.

Kapoho, April, 1924: Finch, R. H., 5.

Kilauea, eruptions, May, 1924, and seismic sequences : Finch, R. H., 3 .

Influence of weather: Reid, 16.

Intensity of shock in alluvial areas: Vickery, 2.

Isostasy, relation to earthquakes: Bowie, 22.

Jamaica : Taber, 2.

Katmai, Alaska, 1912 : Tams, 1.

Location of earthquakes: Heck, 6.

Location of epicenters: Davis, W., 3.

Massachusetts, Boston area: Crosby, I. B., 2.

Mexico, Guadalajara, 1912: Waitz, 1. January 3, 1920 : Salazar, 2.

Orizaba : Friedlaender, 3.

Sonora, 1887 : Aguilera, 1.

Montana, June 27, 1925: Byerly, 9; Pardee, 14; Willson, 1.

Monthly reports: Humphreys, 1.

Nevada, August 21, 1925: Byerly, 13.

New England: Crosby, I. B., 4; Keith, 6; January 7, 1925: Porter, W. W., 1.

New York City : Finch, 8.

Oregon: Smith, W. D., 5.

Pacific coast: Allen, M. W., 1; Townley, 1.

Panama: Kirkpatrick, R. Z., 1.

Porto Rico: Reid, H. F., 1, 2.

October-November, 1918: Reid, H. F., 3.

Prediction: Keyes, 142, 231 ; Lawson, 4.

possibilities of prediction: Hodgson, 5.

Research work on earthquakes: Sci. Serv., 3.

St. Lawrence earthquake, February 28 , 1925 : Abbott, 1; Hodgson, S. 10, 14 ; Anon., 60.

geology: Keith, 4.

rotation effects: Hodgson, 9.

San Andreas rift: Noble, 7.

San Salvador, September 6, 1915: Larde, 1.

Seismological reports: Neumann, 4, 911.

Southern Appalachian, October 20, 1924: Neumann, F. R., 1.

Southwest earthquake, July 30,1925 : Udden, 22.

Submarine changes in configuration: Heck, 5.

Superficial factors: Sayles, 15.

Texas, Panhandle, July 30,1925 : Neumann, F., 3 ; Pratt, 12. 
Earthquakes-Continued.

Twin earthquakes: Davison, 3.

United States, 1919 : Humphreys, 2.

Utah, Elsinore: Pack, F. J., 3.

Virgin Islands: Reid, H. F., 2. 1867-68: Reid, 4.

Virginia, Warlen and Rappahannock counties, September 5, 1919 : Watson, 4.

Blue Ridge region, September 5, 1919 ; Woolard, 1.

Volcanic earthquakes, so-called: Jaggar, 15.

Washington, Dixie: Eby, G., 1.

Western North America, January 22, 1923 : Macelwane, 12.

Wyoming, Bighorn Mountains, November 17, 1925: Pardee, 17.

Jackson Hole: Blackwelder, 13.

1918: Hodgson, 3.

1925 : Heck, 2 ; Neumann, $\mathbf{F} ., 1$.

Echinodermata. See also Asteroidea ; Blastoidea ; Crinoidea ; Cystoidea ; Echinoidea; Invertebrates (general).

Cuba: Sánchez Roig, 16.

General: Springer, 9.

Iowa, Devonian: Thomas, A. O., 2, 12, 23.

Maquoketa beds: Slocom, 1 ; Thomas, A. O., 22.

Ohio, Brassfield formation: Foerste, 1.

- Cedarville: Foerste, 10.

Ontario. Toronto area : Fritz, 1.

Pelmatozoa, phylogeny and taxonomy: Jaekel, 1.

Wisconsin, Racine: Foerste, 10.

Echinoidea. See also Echinodermata.

Anguilla, Neogene : Lambert, J., 1.

California, Eocene echinoid : Schenck, 8.

Carolinas, Cretaceous: Stephenson, 9.

Cuba: Sanchez Roig, 4.

Jamaica : Arnold, B. W., 1 ; Hawkins, H. L., 2.

Cretaceous: Hawkins, H. L., 1.

Mexico, eastern, Neogene : Lambert, 2. Tampico region: Israelsky, 2.

North Carolina, Castle Hayne and Trent marls : Kellum, 2.

Pacific coast region: Kew, 3.

Scutellaster cretaceus, Colorado: Reeside, 10.

Tertiary: Stefanini, 1.

Trinidad, Tertiary : Jeannet, 1.

West coast : Israelsky, 1.

West Indies: Jackson, 2.

Wyoming, Sundance formation: Miller, A. K., 1.

Ecology in interpretation of fossil faunas: Baker, F. C., $5,7$.

Economic aspects of geology : Leith, 5.

Economic geography, source book: Colby, 1 .

Ficonomic geology (general). For areal see under the various States. See also Ore deposits, origin, and the particular products.
Economic geology (general) - Continued.

Ants as prospectors: Jobnston, W. D., 3.

Application of geology to mining: Billingsley, 1.

Applied geology, scientific by-products : Smith, G. O., 10.

Asbestos veins, origin: Stillwell, 2.

Association of ores and dikes: Crocker, 1.

Bibliography of geophysical principles applied to prospecting: Johnson, J. H., 17.

Canada, Arctic regions : Moore, E. S., 2. ore bodies in pre-Cambrian: Dougherty, 2.

Capillary relationships of oil and water : Cook, C. W., 2.

Carbon ratios: Woolnough, 1.

Coal, oil, and gas, natural resources: Johnson, C. A.; 1.

Coals, Kentucky, Illinois, and Indiana, correlation: Jillson, 108.

Colloid chemistry of minerals and ore deposits : Lindgren, 10.

Commercial control of mineral resources: Spurr, 1.

Concentration and circulation of the elements: Lindgren, 9.

Correlative value of heavy minerals: Tickell, 1.

Croppings of ole deposits : Bateman, 8.

Crystallization temperature of veins near surface: Spurr, 29.

Determination of ore minerals : Davy, 1 .

Direction of progress: Ransome, 18.

Economic aspect: Porter, C. A., 1.

Economic geologists and literature: Bateman, 6.

Economic geology : Ries, 10.

as a profession: Lindgren, 3 .

in mining: Boydell, 5.

relation to general principles of geology: Penrose, 2.

Economic limits to domestic independence in minerals: Smith, G. O., 3.

Electrical conductivity and polished mineral surfaces: Harvey, R. D., 1.

Electrical conductivity of ore minerals : Fairbanks, 8.

Electrical prospecting: Leonardon, 1, 2.

Electrical resistivity of rocks : Koenigsberger, 1 .

Eötvös torsion balance: Bateman, 11; Rybár, 1 ; Wagner, E., 1.

Fertilizer minerals, distribution : Mansfield, G. R., 34,

Filling of fissure veins : Perkins, T. A., 1 ; Young, J. W., 3.

Finding ore: Locke, 10.

Foraminifera, use in determining un. derground structure: Cushman, 15.

Formation of ore bodies Kendall, 1.

Garnet: Myers, 2.

Gels, function in formation of quartz and carbonate veins: Merritt, C. A., 2 . 
Economic geology (general)-Continued.

General: Ekblaw, W. E., 1; Leith, 5; Lewis, J. V., 16.

Geology applied to mining: Spurr, 24. Geology of prospecting: Emmons, W. H., 5 .

Geomagnetics : Stearn, 1.

Geophysical exploration: Ambronn, 1; Mason, M. S., 1.

Geophysical methods: Burton, 15: DeGolyer, 16; Jakosky, 2; in Michigan copper district: Broderick, 4.

Geophysical prospecting: Am. Inst. Min. Eng., 1; Eve, 1 ; Jakosky, 1 ; Kithil, 1; Miller, A. H., 3.

Glaciation, effects on mining: Kirkham, 6.

Ground water, relation to ore deposits : Loughlin, 22.

Gypsum and anhydrite: Wilder, 4.

Helium: Moore, R. B., 1.

International control of minerals : Leith, 1.

International mineral problems : Leith, 7 .

Internationalization of mineral resources: Leith, 2.

Intersecting fracture zones and mineral districts: Porter, C. A., 3.

Investigation of ores: Fairbanks, 12.

Leached ore capping: Morse, H. W., 1.

Leached outcrops: Blanchard, R., 3 .

Limestone contact zones, ferric oxide content: Butler, 8.

Magmatic ore deposits, classification : Zavaritsky, 1 .

Magnesite deposits, types and origin : Bain, 4

Manganese minerals: Thiel, 2.

Marcasite, paragenesis : Newhouse, 1.

Metal content, lode filling, and country rock, relations : Weston-Dunn, 1.

Metalliferous deposits: Knopf, A., 2.

Metals in intrusive magmas: Spurr, 12.

Methods for heavy mineral investigations: Reed, 4.

Mlcroscope and ore geology: Wagner, P. A., 3.

Microscopical interpretation of folded structures: Graton, 1.

Mineral deposits: Lindgren, 1, 23.

present tendencies in the study of : Lindgren, 5.

Mineral resources: U. S. Geol. Survey, 3.

of world : Spurr, 2

work of U. S. Geological Survey: Bastin, 3.

Mineral supplies, United States: McCaskey, 1.

Mineralized volcanic explosion pipes: Walker, R. T., 3.

Mineralography as an aid to milling: Thomson, E., 5

Mining geology: Geijer, 5 .

Mining geology methods at Butte, Montana: Billingsley, 1.
Economic geology (general)-Continued.

Models for determining structure of bedded rocks: Mehl, 3 .

Natural reduction of sulphates: Bastin, 15.

Nonmetallic mineral deposits: Grabau, 9 .

Nonmetallic minerals: Ladoo, 4.

Ontario, Kirkland Lake area : Tyrrell, 7.

Opaque ore minerals, determination by X-ray diffraction patterns: Kerr, P. F., 1.

Ore, examination by reflecting microscope: Schwartz, 3.

Ore deposits of the Southwest: 'Tovote, 1.

Ore finding: Rogers, A. H., 1 ; Locke, 8.

Ore hunting: Campbell, J. M., 1.

Ore-hunting geology: Locke, 2.

Ore genesis studies, flfty years' progress : Miller, B. L., 12.

Ore problems and the microscope: Uglow, 13.

Oxidation of sulphides: Carmichael, 1.

Oxidation products from chalcopyrite: Blanchard, R., 2.

Oxidation subsidence at Bisbee, Arizona: Wisser, 1.

Pegmatites and their minerals: Ellsworth, 7 .

Petroleum geology: Lahee, 14.

Phosphate rock an economic army: Stone, R. W., 1.

Physical exploration for ores: Mason, M. S., 1.

Polarized light. in the study of ores and metals: Wright, Fred. E., $1,2$.

Polished sections of ores: Short, 2.

Polishing of ores: Vanderwilt, 2.

Profession of ore-hunting: Locke, 1.

Prospector's field book : Osborn, H. S., 1.

"Pseudomorphous" quartz: Morgan, P. G., 1.

Quantitative methods in applied geology : White, C. H., 1.

Radio-aeronautic prospecting: Shaw, H., 1.

Red bed ores : Bains, 1

Relation of hardness to sequence of ore minerals: Gilbert, G., 2.

Rock prospects and the war: Loughlin, 3.

Schistose galena: Leonard, R. J., 3.

Scientiflc by-products of applied geology : Smith, G. O., 10.

Scientific ore finding: Brock, 8 .

Sections of ores, preparation: Schwartz, 19.

Seismic prospecting: Heiland, 3.

Standards for hardness of minerals : Talmage, 2.

Stone for concrete: Loughlin, 33.

Strategy of minerals: Smith, G. O., 2 .

Studying mines ${ }^{\circ}$ with a microscope: Bayley, 8. 
Economic geology (general)-Continued. Teaching economic geology: Ransome, 17.

Tellurides: Thomson, E., 8.

Tendencies in study of ore deposits: Knopf, A., 2.

Terminology of mineral deposits : Lindgren, 6.

Textbook: Fmmons, W. H., 3.

Torsional balance: Gradenwitz, 1.

Types of magnesite deposits and their origin: Bain, 4.

Vein quartz, microscopic study: Adams, S. F., 5.

Veins, origin: Taber, 14.

World view of mineral wealth: Umpleby, 1.

Zonal deposition of ores, application of theory: Anderson, T. C., 2.

Edgerly oil field, Calcasieu Parish, Louisiana: Minor, 3.

Edgewise conglomerate: Bassler, R. S., 1. Educational. See also Textbooks.

Applied paleontology: Weller, 3.

Cooperation in advanced geologic instruction : Gregory, H. E., 1.

Course in geology, outline: Glock, 4.

Crystallography, teaching: Fisher, D. J., 1.

Demonstration material in geology: Cleland, 2.

Development stages in teaching paleontology: Jackson, 1.

Dip and strike, laboratory determinations: Turner, .W. M., 2.

Field excursion, New York to Gettysburg: Johnson, D. W., 9.

Field trips: Johnson, D. W., 13; Morse, W. C., 3.

General : Buddington, 15.

Geologic teaching in mining engineering: Dake, 11.

Geology, use in education : Gregory, H. E., 3.

Geology manual : Field, 6.

Laboratory manual: Mather, 9.

Lantern slides, use in geology courses: Shepard, 9.

Mineralogic instruction, needed extension : Eakle, 8.

Mineralogical laboratory, University of Michigan : Kraus, 1.

Outline charts in teaching vertebrate paleontology: Mehl, 1.

Paleontology : Schuchert, 10.

Petroleum geology : Lahee, 14.

Practical applications of geology and physiography: Cleland, 2.

Relation of student and teacher: Mathews, 2.

Selective teaching in geology: Sardeson, 13.

Structural and petrographic geology : Kemp, 3.

Special signiflcance of geology in teaching: Merriam, 4.
Educational-Continued.

Summer school of geology and natural resources: Field, $\tau$.

Teaching economic geology: Ransome, 17.

Teaching of geology : Gregory, H. E., 4.

Teaching historical geology : Cleland, 3.

Teaching paleobotany : Berry, 19.

Ekalaka lignite field, Montana: Bauer, 4. Elaterite, Utah : Clark, A. F., 1.

Elbow Lake area, northern Manitoba : Armstrong, P., 1.

El Dorado oil field, Arkansas: Ley, 1.

Eldorado oil and gas field, Butler County, Kansas: Fath, 2.

Electrical prospecting: Crosby, I. B., 7; Rogers, A. H., 1.

Elementary and popular books.

A B C of geology : Hardy, 1.

Brief physiography: Nelson, W. B., 1.

Geology : Brewster, 1.

Man and the earth: Leighton, H., 3.

Ways of life : Lull, 17.

Clephas jeffersonii : Osborn, 20.

Elevation and subsidence. See Changes of level.

Elk Basin oil field, Wyoming: Estabrook, 1.

Elkton-Wilmington folio, Maryland-Delaware - New Jersey - Pennsylvania (no. 211) : Bascom, 2.

Ellenburger formation, north central Texas: Sellards, 7.

Emery, Virginia: Watson, 13.

Empire formation, Coos Bay, Oregon : Howe, H. V. W., 2.

En échelon and arcuate mountains : Link, 5.

Engineering geology: Ries, 4, 11.

Catskill water supply : Berkey, 6.

Illinois, Decatur dam site: Leighton, 11.

Iron Canyon, Sacramento River, California: Hamlin, 1 ; Lawson, 3.

New York, West Point quadrangle: Berkey, 3.

St. Francis dam disaster : Longwell. 17. English River valley, Ontario: Bruce, 11. Entelodonts, White River Oligocene: Sinclair, 5 .

Eocene. See Tertiary.

Eötvös torsion balance: Bateman, 11; Heiland, 2; Rybar, 1; Steiner, 1; Wagner, E., 1.

Eolation. See Wind work.

Eolian action. See Wind work.

Lozoon cunadense : Rothpletz, 2.

Epeirogeny, Tertiary : Taylor, 13.

Epi-anticlinal faults, origin and significance: Link, 1.

Epsomite.

British Columbia, Clinton district: Reinecke, 2.

Lillooet-Prince George region: Reinecke, 3 . 
Epsomite lakes, British Columbia, Ashcroft: Walker, 8.

Fquality-Shawneetown area, Illinois : Butts, 5.

Erosion. See also Glacial erosion; Sedimentation.

Arid regions: Fenneman, 2.

Arizona, Papago çountry : Bryan, 7, 15.

California, Los Angeles County : Wolff, J. E., 3.

Cape Breton, coast erosion: Gray, F. W., 1.

Changes in channel of Rio Puerco, New Mexico: Bryan, 30.

Changes in water level and flotation as forces of erosion: Walker, 50.

Channel trenching in Southwest: Bryan, 18 ; Swift, 1.

Chemical denudation of soils: Whitney, M., 1.

Cloudburst on San Gabriel Peak, Los Angeles County, California : Wolff, J. E., 3.

Coast erosion: Patton, R. S., 1.

Coast line changes, Nova Scotia: Churchill, 5.

Cobble abrasion: Wentworth, 1.

Colorado, Mesa Verde: Haas, 1.

Corrosion and corrasion, Barton Creek, Austin, Texas: King, 5.

Corrosion by saline waters: Rutherford, 1.

Desert weathering: Hobbs, 1.

Erosive processes: Malott, 10.

General: Barrell, 9; Keyes, 39.

Hawaji : Wentworth, 26.

marine and fluvial erosion: Wentworth, 29.

stream erosion: Wentworth, 37.

Indiana, Jefferson County, Clifty and Butler ravines: Culbertson, 2.

Michigan, Seul Choix Point Peninsula: Ehlers, 1.

Sulphur Island: Ehlers, 8.

New Mexico, Rio Salado: Bryan, 25. solution and fill : Lee, 13.

Nomenclature: Glock, 6.

Pedestal rocks, arid Southwest: Bryan, $13,16,17$.

Plateau region: Reagan, 9.

Red River, Texas-Oklahoma: Sellards, 17.

Red River of the North: Wallace, 15.

Sea caves, Devil's Island, Wisconsin : Edwards, I., 2.

Sierra Nevada, postglacial denudation : Muir, 1.

Soil erosion : Bennett, H. H., 1.

Solution and fill : Lee, 14.

Southwest: Bryan, 34.

Submarine denudation: Bucher; 12.

'Tennessee, elosion in clay beds : Schroeder, 2.

Terms for erosion: Allison, I. S., 5.
Erosion-Continued.

Utah : Bryan, 28.

débris of desert torrents : Pack, 6 .

San Juan Canyon: Miser, 20, 26.

Vermont, Cavendish: Jacobs, 6.

Washington, Columbia Valley: Bretz, 10.

Wave erosion: Swinnerton, 2.

Erosion cycle: Davis, 11.

Eruptive rocks. See Igneous and volcanic rocks.

Eskers.

Crevasse theory of origin: Prest, 2.

Indiana, Anderson: Reeves, J. R., 1.

Iowa, central : Smith, J. E., 5.

Minnesota : Sardeson, 8.

New York, Adirondacks: Chadwick, 21.

Nova Scotia: Prest, 1.

Digby County: McIntosh, 1.

Queen's County, Middlefield: Prest, 2.

Origin and nature: Prest, 1.

Iskers and crevasse fillings: Flint, 6

Essays. See addresses.

Estival epoch: Keyes, 224.

Etched potholes: Udden, 20.

Etching tests on pyrrhotite: Boydeil, 1.

Eurypterida.

Eurypterus, Cambrian, Iowa: Walter, 2.

Habitat: Ruedemann, 14.

New York, Utica and Lorraine formations: Ruedemann, 18.

Eutsuk Lake area, Coast district, British Columbia: Marshall, J. R., 3.

Evolution.

Acorn barnacles, phylogeny: Ruedemann, 1.3.

Air-breathing vertebrates: Pikc, F. H., 1.

Ammonite evolution: Truemann, 1.

Arrested evolution: Ruedemann, 6; paleontology of : Ruedemann, 9 .

Cephalopod adaptation: Dunbar, 5.

Cephalopoda: Berry, 99.

Dentition: Gregory, W. K., 6.

Dinosaurian climatic response : Lull, 15.

Dinosaurs: Matthew, 4.

Environment of early vertebrates: Berry, 68.

Floras: Berry, 14.

Flowering plants and warm-blooded animals: Berry, $\mathbf{1 5 .}$

Fossil plants as evidence for resistance to environment: Wieland, 14.

General: Grabau, 11; Headstrom, 1 ; Johnson, J. H., 11; Keyes, 29; Mather, 4; Moodie, 12 ; Osborn, 42 ; Parks, 25 ; Savage, 9 ; Shimer, 2.

Geologic climates: Knowlton, 3.

Geologic evidence: Berry, 42.

Geologic factors: Mathers, 6.

Geology and evolution: Nelson, 25.

Glass-sponge colonies: Clarke, r. M., 15.

Horse: Loomis, 15 ; Matthew, 34. 
Erolution-Continued.

Human dentition: Gregory, W. K., 6, 15.

Human face : Gregory, W. K., 1.

Man: Baitsell, 1; Huntington, 5 ; Matthew, 14 ; Osborn, 9.

Origin of species: Osborn, 37, 38, 40 ; speciation and mutation: Osborn, 46.

Orthogenesis: Osborn, 17.

Pre-Cambrian life: Brooks, W. K., 1.

Primitive plants: Schuchert, 14.

Proboscidea : Osborn, 34.

Rectigradations and allometrons: Osborn, 39.

Social evolution: Matthew, 12.

Stropheodonta demissa, evolution in Snyder Creek shales: Branson, 4.

Ways of life: Lull, 17 .

Excursions.

Field excursion, New York to Gettysburg: Johnson, D. W., 9.

Kansas geological fleld conference: Anon., 67.

Mississippi College field trip: Morse, W. C., 2.

Missouri-Iowa: Folger, 1.

New England intercollegiate geological excursions: Foye, 8, 12, 16-18; Anon., 22.

sixteenth annual: Cleland, 4.

New York State colleges: Eaton, H. N., 7.

Ohio geologists' field trip: Swinnerton, 3.

Exfoliation, a phase of rock weathering: Blackwelder, 10.

Experimental investigations.

Abstraction of potassium during sedimentation: Watson, J. W., 1.

Accumulation of oil in sands: Emmons, W. H., 1.

Bacteria as agents of chemical denudation: Thiel, 11.

Batholiths: Chamberlin, R. T., 16.

Bauxite deposits, enrichment: Thiel, 10.

Bornite-chalcocite intergrowths: Schwartz, 24.

Calcium carbonate, precipitation : Emmons, R. C., 8.

Capillarity and oil migration: Russell, W. L., 3.

Chalcopyrite and cubanite intergrowths: Schwartz, 17.

Chester series limestones, sedimentary analysis: Lamar, 7.

Clastic dike intrusion: Jenkins, 13.

Delta building : Nevin, 2.

Diffusion in ore genesis: Whitman, 5.

Direction of stress producing strain: Hubbert, 2.

Dolomitization: Walker, T. L., 55.

Lu echelon and arcuate mountains: Link, 5.
Experimental investigations-Continued.

Enrichment of tungsten ores: Gannett, 1.

Eolian abrasion of quartz grains : Knight, S. H., 1.

Epi-anticlinal faults: Link, 2; origin and signiflcance: Link, 1 .

Folding: Chamberlin, R. T., 9.

Folds, localization: Brown, R. W., 3.

Fractionation of petroleum during capillary migration: Cook, C. W., 6.

Fracturing of spheres: Bucher, 6, 8 .

Glacial anticyclone, mechanics: Hobus, 4.

Glaciers, model : DeLury, 7.

Horizontal faulting: Brown, R. W., 4.

Hydrothermal alteration of silicate minerals : Leonard, R. J., 1.

Ice crystal markings: Allan, 19.

Iron ores: Osborne, F. F., 2

Joint planes, formation: Wright, F. E., 3.

Lava, oxidation by steam: Ferguson, J. B., 3.

Magnetite-martite-hematite, oxidation of: Gruner, 8.

Mechanics of geologic structures : Mead, 1.

Molecular migration and mineral transformation: Wandke, 7.

Motion of glaciers: Chamberlin, R. 'T., 18.

Movements of oil and water through sands : Mills, R. V. A., 4.

Oil shale, relation to petroleum: Van Tuyl, 13.

Ore minerals, electrical conductivity: Kerr, P. F., 5.

Over- and under-thrusting: Link, 4.

Oxidation of iron in magnetite: Twen. hofel, L. H., 1.

Oxidation of sulphides and aisenides : Carmichael, 2.

Petrifaction of wood: St. John, 1.

Fetroleum, fractionation and decomposition during capillary migration: Cook, C. W., 9.

effect of pressure on migration and accumulation: Van Tuyl, 14.

migration and accumulation: Van Tuyl, 12 ; Weeks, A. W., 1.

Phosphate deposits, origin: Graham, W. A. P., 1.

Precipitation of manganese from meteoric solutions: Thlel, 3 .

Pressure, effect on migration of oil : Thomas, E. T., 2.

Pyrrbotite and pentlandite, relations: Newhouse, 4.

Rigidity of the earth: Michelson, 1.

Salt domes, origin: Torrey, P. D., 1.

Sand grains, rate of wear: Anderson, G. E., 1.

Shear-zone faulting: Kitson, 1. 
Experimental investigations-Continued.

Studies on organic nature of sediments: Trask, 8.

Subsurface relationships in oil and gas flelds, experimental studies: Mills, R. V. A., 2, 3.

Thermal stratiflcation of water in sedimentation: Kindle, 45.

Thrust faulting, process: Quirke, 5 .

Underthrusting: MacCarthy, 7.

Varves, formation: Fraser, H. J., 1.

Explorations.

Smithsonian: Smithsonian Inst., 1.

Faceted pebbles, North River, Virginia: Steidtman, 6.

Falcon Lake district, Manitoba: DeLury, 2.

Fall line, eastern United States: LaForge, 1 ; Renner, 1, 2.

Farnham anticline, Carbon County, Utah : Clark, F. R., 2.

Fault troughs: Taber, 15.

Faulting.

Alaska, Kennecott: Lasky, 1.

Alberta, Rocky Mountains: MacKenzie, J. D., 4.

Anthracite basins, Pennsylvania : Kemp, 10.

Antilles, fault troughs: Taber, 6.

Appalachians: Chamberlin, R. T., 19.

Arlzona, northwestern : Longwell, 12.

Ray quadrangle: Ransome, 11.

Ray-Miami region: Ransome, 1.

Association of faulting with dike intrusion: Sheldon, 3.

Basin Range faults: Buwalda, 16; inOquirrh Range, Utah : Gilluly, 5.

Basin Ranges: Taber, 12.

Basin Range structure: Gilbert, G. K., 1.

Block faulting, St. Croix Valley, Minnesota : Peterson, E., 1.

southeastern Minnesota : Sardeson, 28.

British Columbia, Rocky Mountain trench: Shepard, 2, 11.

California: Willis, 27.

Blackhawk Canyon, San Bernardino Mountains: Woodford, 7.

Coast Ranges: Willis, 15, 20.

fault map: Willis, 10, 13, 17.

Haywards fault: Russell, R. J., 2.

Inglewood fault zone: Taber, 10.

Livermore region: Vickery, 3.

Matilija overturn: Kerr, P. F., 7.

Mohave Desert, thrust faulting: Hewett, 18, 20.

Mount Diablo region, thiust faulting: Clark, B. L., 10, 12.

Salton Basin : Brown, J. S., 1.

Salton Sea region: Brown, J. S., 3.

San Andreas rift: Noble, 9 ; Willis, 7 .

San Benito County: Kerr, P. F., 4. San Gabriel Mountrins: Kew, 7.

San Gabriel Valley region: Johnson,

B. R., 1.

southeastern: Noble, 7 .
Filulting-Continued.

California-Continued.

southern: Davis, W. M., 33; Hill, R. 'T., 2,8 .

southwestern Sierra Nevada: Hake, 2.

Surprise Valley: Russell, R. J., 6.

Ventura County, Matilija overturn : Kerr, 7.

Warner Range: Russell, R. J., 6.

Champlain Valley, northern: Hudson, G. H., 1.

Colorado, Big Thompson River valley : Fuller, M. B., 2.

Gunnison River: Hunter, J. F., 1.

Leadville mining district: Emmons, S. F., 1.

San Luis Valley: Burbank, 2.

Williams thrust fault: Lovering, 6.

Connecticut, Triassic: Foye, 9 ; Russell, W. L., 1.

Curvature of faults: Washburne, 12. Dynamics: Reid, 17.

Elastic rebound theory: Lawson, 1.

Epi-anticlinal faults : Higgins, 2; Link, 2 ; origin and significance : Link, 1.

Experimental investigation: Mead, 1.

Fault problems, solution: Douglas, G. V., 5.

Fault surface: Geijer, 6.

Faults, active, criteria for recognizing : Taber, 8.

Faults and folds, relation: Washburn, 10.

Fissure veins, cause: Keyes, 15.

Fracturing of incompetent beds: Lovering, 8.

General: Chamberlin, R. 'T., 7, 11; Taber, 15 ; Willis, 11.

Great Basin: Louderback, 7.

Great Basin faults, age : Louderback, 2.

Great Smoky overthrust: Keith, 5 .

Greater Antilles: Taber, 11.

Horizontal faulting: Brown, R. W., 4.

Idaho, Fort Hall Indian Reservation: Mansfield, G. R., 3.

northern : Umpleby, 4.

Osburn fault; Umpleby, 5.

Pine Creek district: Jones, Ed. L., 1. southeastern : Mansfield, G. R., 4, 1.1, 29.

Illinois, Alto Pass area : Ekblaw, 2. Hardin County: Weller, S., 1.

Intersection of faults: Washburne, 9.

Iowa: Keyes, 137.

Cass County: Tilton, 3.

s o u th w es ter n, Thurman-Wilson fault: Tilton, 1 .

Isostatic compensation a cause of thrusting: Lawson, 2.

Kansas, eastern: Fath, 1.

Kentucky : Jillson, 60.

Cave in Rock quadrangle: Weller, 16.

Golconda quadrangle: Weller, 4. north central : Miller, A. M., 15. western: Currier, 2. 
Faulting-Continued.

Keystone faults: Crosby, w. O., 4.

Landslide origin of thrust faults around Bearpaw Mountains : Reeves, F., 11.

Massachusetts, Mount Toby, postglacial : Loomis, F. B., 4.

Missouri, southeasterı, thrust faulting: Flint, 3.

Mohave Desert, thrust faults : Hewett, $18,20$.

Montana Bearpaw Mountains : Reeves, F., 9.

belt of oblique faulting: Chamberlin, R. T., 2.

Billings area: Moulton, 2.

faulted area south of Bearpaw Mountains: Reeves, F., 8.

Nevada, Muddy Mountain overthrust: Longwell, 3.

southern: Keyes, 148; Longwell, 8, 12.

western : Ferguson, H. G., 7.

Newfoundland, Wabana ore deposits: Gilliatt, 1.

western, thrust faulting: Mook, 9.

New Hampshire, Ammonoosuc district: Ross, C. P., 2.

New Mexico, Sandia Mountains: Ellis, R. W., 2.

New York, Cayuga Lake region : Long, 1. Lake Placid quadrangle: Miller, W. J., 1.

Orleans County: Chadwick, 6.

Schroon Lake quadrangle: Miller, W. J., 2.

West Point quadrangle: Berkey, 3.

Normal faulting, cause: Shepard, 7 ; Washburne, 14, 15; on upthrust arches: Willis, 28.

Oklahoma, Creek and Osage counties: Foley, 1 ; Ickes, 3.

northeastern : Fath, 1.

Ontario, French River district, postglacial: Hobbs, 10.

Kirkland Lake fault: Tyrrell, 7.

Sudbury nickel district: Hitchcock, 1.

Over and under-thrusting: Link, 3, 4.

overthrusting, Green Mountains: Foye, 1.

southeastern Idaho: Mansfield, G. R., 33.

Overthrusts and underdrags: Davis, 7. Overthrusts in Appalachians: Keith, 7.

Pennsylvania, Northampton County slate belt: Behre, 6 .

Rocky Mountain region: Irwin, 2; Mansfleld, 15.

overthrust faulting: Flint, R. F., 1.

Rocky Mountain structure: Willis, 20.

Shear-zone faulting: Kitson, 1.

Tennessee, Emory River overthrust: Jillson, 43.

Terminology : Hubbert, 1.

Terrestrial and lunar faults compared : Schkarz, 1.
Faulting-Continued.

Texas, Ralcones fault zone: Sellards, $\mathbf{S}$. Balcones and Mexia faulting, mechanics: Foley, 2.

northeastern: Fohs, 2.

Thrust faulting: Keyes, 39 .

adjacent to Highwood Mountains, Montana: Reeves, F., 12.

in Basin ranges: Keyes, 228.

in Mojave Desert: Hewett, 20. process: Quirke, 4., 5.

Underthrusting: MacCarthy, 7.

Upthrust faulting: Willis, B., 1.

Utah : Butler, 4.

Bear River Range fault: Bailey, R. W., 1.

Oquirrh Range: Gilluly, 7.

Sevier Valley: Young, J. W., 2.

Wasatch fault: Pack, 7 .

Wasatch front: Stillman, 1.

Wasatch Mountains: Schneider, H. 2; Cottonwood district, thrust faulting: Calkins, F. C., 1.

Wasatch region: Butler, B. S., 1.

Veining along faults, Pennsylvanian sandstones, Oklahoma: Hoffman, M. S., 2.

Velocity of slipping of normal faults: Washburne, 13.

Vermont, western : Gordon, C. E., 1, 4.

Virginia, Appalachians, broad thrust fault: Campbell M. R., 7 .

Russell Fork fault: Wentworth, 3.

southwestern, overthrust and fen. sters: Butts, 10.

Wyoming, Elk Basin: Washburne, 11.

Heart Mountain overthrust: Hewett, 4.

northwestern: Dake, 5.

Faults, active, criteria for recognizing: Taber, 8.

Feldspar.

Canada: Eardley-Wilmot, 2; Spence, 8.

Maryland : Singewald, 5.

mineralography: Alling, 3, 5.

New York, Newland, 2.

Ontario, Ottawa district: Davis, N. B., 1.

Lanark County: Campbell, A. M., 1.

Paciflc Northwest: Wilson, H., 1.

plagioclase, determination: Goranson, 2.

Quebec, Buckingham district: Rowe, R. C., 1.

Quetachou Manicouagan Bay region : Erlenborn, 1.

Feldspar determination of metamorphic rocks : Carlson, 1.

Fensters.

Virginia, Powell Valley: Giles, 8.9. southwestern: Butts, 10.

Fiedmont and Dubuisson map areas, Quebec: James, 7.

Field geology : Lahee, 8 . 
Field work.

Airplane photographs, use in field work: Campbell, M. R., 8.

Airplanes for geologic exploration : Renick, 7 .

Canada, mapping pre-Cambrian areas: Bruce, 6.

Collecting in the bad lands: Johnston, W. D., 1.

Compass: Plummer, 3.

Dip and strike, determination: Smith, W. S. T., 2.

Dip needle, use : Aldrich, $\mathrm{H}$.R., 1.

Field mapping for oil geologist: Warner, C. A., 1.

Field methods in petroleum geology: Lahee, 6.

Kodak adapted for detail work in field: Wentworth, 7 .

Loose-leaf system for field maps and notes: Rich, 4

Magnetic methods for exploration : Hotchkiss, 5.

Measuring folded beds: Hewett, 6 .

Note book and symbols for petroleum geologists: Woodruff, 2.

Phenol red, use of: Wherry, 4.

Photography for the field geologist: Blackwelder, 12.

Reconnaissance mapping: Fuller, M. L., 2.

Recording machines: Dodge, 1.

Recording underground data: Wilson, P. D., 4.

Smithsonian Institution: Smithsonian Inst., 1 .

Stereoscopic photography in geologic field work: Wright, F. E., 6.

Subsurface contouring: Bloesch, 2.

Surveying methods: Taylor, 1.

Working plans in field operations: Keyes, 178.

Finger Lakes, origin : Fairchild, 20.

Fiords.

Alaska, Lynn Canal: Martin, L., 2.

Greenland : Koch, 2.

Fire clay.

Illinois: Parmelee, 1.

Kentucky, eastern coal field: Ries, 7. northeastern : Jillson, 75 .

Maryland: Hall, G. M., 2 ; Watts, A. S., 1.

western: Mathews, 4

Pennsylvania: Shaw, J. B., 1.

Pennsylvanian fire clays, origin: Hodson, F., 2.

Fishes. See Pisces.

Fissility of shale: Lewis, 9.

Fissures. See Faulting.

Five Islands, Louisiana: Vaughan, F. E., 2.

Flinflon area, Manitoba and Saskatchewan : Alcock, 11

Flinflon ore body, Manitoba: Wallace, 5. Flint.

Definition : Glock, 1

Origin : Tarr, 15.
Florida.

State geologist's report: Gunter, 1, 2, $5,7,9,10$; Sellards, 1.

Sea beach observations: Kemp, 2 .

Southern Florida: Harper, 3.

Economic geology.

Clays: Bell, O. G., 1.

Coquina: Brodie, 1.

Gypsum : Stone, 11

Ilmenite, zircon, and rutile beach deposits : Martens, 9 .

Limestones and marls: Mossom, 1.

Mineral production: Gunter, 1, 2, 5, 7-10.

Mineral resources: Gunter, 6.

Oil possibilities: Hill, E. A., 2 ; Sellards, 12.

Phosphate deposits: Hess, 29; Sellards, 24.

Sand and gravel deposits: Martens, 8.

Historical geology.

Basement rocks in boring: Gunter, 12.

Comanchean formations underlying Florida: Sellards, 6.

Cretaceous age of underlying limestones: Cushman, 4.

Cretaceous formations of borings : Gunter, 4.

DeLand sections: Macbride, T. H., 1.

General : Gunter, 3, 11; Mossom, 1, 2 ; Sellards, 4, 5, 12 .

Everglades, sections across: Sellards, 3.

Pleistocene deposits, stratigraphy and age : Cooke, C. W., 19.

Tertiary and Quaternary: Mansfield, W. C., 1.

Underlying rocks: Cushman, 2.

Vero deposits, age: Chamberlin, T. C., 3 ; Наy, 40

Vero and Melbourne deposits: Gidley, 9 ; age : Hay, 36

Vero, Melbourne, and St. Petersburg deposits: Cooke, C. W., 16.

Paleontology.

Alum Bluff group, molluscan fauna: Gardner, J. A., 7.

Artifacts associated with Elephas, Melbourne: Loomis, 12

Bear, Pleistocene: Gidley, 12.

Beetles; Vero: Wickham, 1.

Cetacea, phosphate beds: Allen, G. M., 3.

Corbula, Miocene: Gardner, J. A., 8.

Coskinolina and Dictyoconus?: $\mathrm{M}_{0}$ berg, 1

Foraminifera: Cushman, 12

Fresh-water mollusks: Marshall, W. B., 1.

Gavial : Mook, 1.

Gavialosuchus americana: Mook, 7 .

Human remains, Vero: Gidley, 8; Hrdlička, 1 ; Loomis, 16 ; Sellards, 2 ; Sterns, 1.

Lituonella and Coskinolina: Cushman, 31. 
Florida-Continued.

Paleontology-Continued.

Mammal faunas: Matthew, 31 .

Mammalian and fish remains: Hay, 1.

Melbourne artifacts, antiquity : Holmes, W. H., 1.

Miocene Foraminifera: Cushman, 9.

Mollusca, St. Lucie Canal: Johnson, C. W., 1.

Operculina and Discocyclina, Ocala limestone: Vaughan, 49.

Operculina and Heterostegina: Cushman, 10.

Physa, Pleistocene: Clench, 1.

Pleistocene mammals, Citrus County: Simpson, G. G., 26.

Pleistocene man, Vero: Hay, 44.

Pleistocene vertebrates, Vero, age: Hay, 36.

Sea cow, Metaxytherium floridanum: Hay, 11.

Sperm whale, Miocene( ?) : Cobb, C., 5. Tertiary and Quaternary: Mansfeld, W. C., 1.

Testudo sellardsi : Loomis, 17.

Turtles, Pleistocene: Gilmore, 30.

Physical geology.

Coquina : Brodie, 1.

Humic-acid origin of asphalt: Haseman, 1.

Physiographic geology.

Central Florida: Harper, 2.

Underground water.

Chemical character of waters: Collins, W. D., 6.

Fluorite, optical, southern Illinois: Pogue, 3.

Fluorspar.

Arizona : Allen, M. A., 4.

Canada: Eardley-Wilmot, 2.

Colorado : Aurand, 1 ; Boulder County : Hibbs, 1.

General : Allen, M. A., 4 ; Burchard, 5 ; Ladoo, 5.

Illinois, Ellzabethtown: Schwerin, 2.

Hardin County : Weller, S., 1.

Illinois-Kentucky fleld: Fay, 2; Fellman, 1; Schwerin, 1.

Kentucky : Jillson, 25; Miller, A. M., 1.

Mexico: Wittich, 13.

San Luis Potosi, Guadalcazar: Wittich, 5.

New Mexico: Johnston, W. D., 4.

Ontario, Madoc district: Wilson, M. E., $6,9$.

iolding.

Adirondacks: Buddington, 2.

Anthracite basins, Pennsylvania: Kemp, 10.

Appalachians: Chamberlin, R. T., 19.

British Columbia, Rocky Mountain trench: Shepard, 11.

California, Jivermore region: Vickery, 3.
Folding-Continued.

Canadian Rocky Mountain front ranges: Keyes, 44.

En echelon and arcuate mountains: Link, $\mathbf{5}$,

Experimental investigation: Mead, 1.

Experiments in folding: Chamberlin, R. $T$., 9.

Faults and folds, relation: Washburne, 10.

Folds from vertically acting forces: Robinson, W. I., 1.

Folds of Osage type, occurrence: Brown, R. W., 2.

General: Chamberlin, R. T., 11 ; Wil lis, 27 .

Idaho, southeastern : Mansfield, G. R., 11, 29.

Kansas, eastern : Fatb, 1.

Lake Erle region: Decker, C. E., 1.

Measuring folded beds: Hewett, 6 .

Minor folds : Decker, C. E., 1.

Montana, Bearpaw Mountains: Reeves, F., $7,9$.

Newfoundland, Wabana ore deposits: Gillatt, 1.

Oklahoma, northeastern: Fath, 1.

origin: Foley, 3.

Osage County: Millikan, 1; origin, Brown, R. W., 1 ; Kitson, 2.

Pennsylvania, Northampton County slate belt: Behre, 6 .

Plains type of folding: Powers, 25.

Pre-Cambrian: Miller, W. J., 21 ; Ruedemann, R., 1.

Rocky Mountains: Flint, R. F., 1.

Siouan fold: Keyes, 44.

Types of folding: Ickes, 1.

Utah, Wasatch front: Stillman, 1.

Wasatch Mountains: Schneider, H., 2.

Wyoming: Ball, M. W., 1.

Lost Soldier-Ferris district: Fath 3. northwestern: Dake, 5.

Foliation, New York, Lewis County: Buddington, 2.

Foliation of rocks, origin: Alling, 9.

Eootprints.

Arizona, Grand Canyon: Gilmore, 26, 27, 32, 33, 35, 36, 37.

Colorado, Pennsylvanian sandstones: Henderson, J., 5.

Connecticut, North Branford: Lull, 19.

Connecticut Valley: Abel, 4 ; Grier, 4.

Dinosaur tracks, Cretaceous, Utah and Colorado: Peterson, W., 1.

Edmonton formation, Alberta : Sternberg, C. M., 6.

Hamilton County, Texas: Wrather, 5.

Kansas, coal measures: Martin, H. T., $2,4$.

General: Adams, L. A., 3.

Mammal tracks, Paskapon heris, Alberta: Rutherford, 7.

Massachusetts, Attleboro: Lull, 5. 
Footprints-Continued.

Montana, Fort Union formation: Gilmore, 41.

Nevada, Carson footprints, origin: Stock, 4.

Ohlo, Pennsylvanian: Carmen, 3.

Onychopus, nomenclature: Keyes, 196.

Texas: Moodie, 27.

Abllene: Gould, C. N., 28.

Thinopus antiquus: Morton, 1.

Foraminifera.

Bibliography: Cushman, 22.

Biostratigraphic aspect of micropaleontology: Schenck, 11.

Bolivinita, Pliocene, C a I f o r n i a : Church, 1.

Byram marl, Mississippi : Cushman, 13.

California, Eocene, Coalinga: Cushman, 32.

Monterey shale: Hanna, G. D., $\mathbf{3 8 .}$

Palos Verdes Hills, Pleistocene: Galloway, J. J., 8.

San Diego, Eocene: Cushman, 29.

Vacaville, Eocene: Hanna, G. D., 10. Ventura County, Adams Canyon: Driver, 2.

Caribbean region: Vaughan, 21.

Change in ideas about Foraminifera: Galloway, J. J., 12.

Classification: Cushman, 28; and economic use: Cushman, 41; and nomenclature: Galloway, J. J., 6.

Climacammina, Pennsylvanian, Texas: Cushman, 42.

Contributions from Cushman Laboratory: Cushman, 22.

Correlation by Foraminifera: Decker, 9 ; Galloway, J. J., 7.

Coskinolina and Dictyoconus?, Florida : Moberg, 1.

Costa Rica, Miocene: Palmer, K. V. W., 4.

Cretaceous, Canada: Cushman, 33.

Cretaceous figured by Ehrenberg: Cush. $\operatorname{man}, 40$.

Description : Cushman, 35.

Dictyoconus, Eocene, Haiti: Wood ring, 2.

Discocyclina, California: Schenck, 10.

Ehrenberg collection: Cushman, 39.

Ehrenbergina : Cushman, 27.

Elphidiums, west coast, Tertiary anl Quaternary : Cushman, 34.

Evolutionary changes, use in correla. tion : Thomas, N. L., 2.

Nlabellammina alexanderi, Cretaceous, Texas, time range: Alexander, C. I., 3.

Florida: Cushman, 2, 9, 12.

Fort Dodge beds, Iowa, origin : Lees, 1:. Fournière area, Abitibi County, Quebec: James, 5.

Fusulina, distribution: Searight, 2.

Fusulinella, Stonefort limestone, Illinois : Henbest, 1.
Foraminifera-Continued.

Fusulinidae, Pennsylvania, Nebraska: Dunbar; 11.

General : Cushman, 22, 41.

Gulf Coastal Plain wells: Applin, E. R., 1.

Guembelina, changing $\mathrm{ch}$ a r a c te r : Thomas, N. L., 3.

Haiti, Eocene: Woodring, 6.

Hantkenina, Eocene : Cushman, 17, 19. range: Howe, H. V., 10.

Jamaica Tertiary: Vaughan; 46.

Lepidocyclina: Vaughan, 44.

Lepidocyclina, revision: Douvillé, 3.

Lepidocyclina and Carpenteria, Cayman Islands: Vaughan, 42.

Lepidocyclina c ha peri, Pan a a : Vaughan, 41.

Lepidocyclina mantelli and Nummulites floridanus: Vaughan, 48.

Lepidocycline Foraminifera, embryonic and meridional chambers: Vaughan, 30 .

Lituonella and Coskinolina: Cushman, 31.

Mexico: Cushman, 36.

Chapapote formatic $\mathbf{n}$ : Cole, W. S., 2.

Guayabal formation: Cole, W. S., 1.

Moctezuma River, Eocene: Cushman, 21.

southern, Tertiary: Nuttall, 2.

Tampico Embayment area : White, M. P., 1; Velasco shale: Cushman, 26.

Vera Cruz, Idolo Island: Dumble, 6.

Mississippi, Byram: Cushman, 6, 7.

Hiwannee, Red Bluff clay: Howe, H. V., 11.

Mint Spring marl: Cushman, 14.

Morphology and classification: Cushman, 23.

Oklahoma, Carter County, Dornick Hills formation: Waters, J. A., 1.

Glenn formation: Harlton, 2.

Pennsylvanian: Galloway, .T. J., 13 ; Harlton, 3.

Operculina and Discocyclina, Ocala limestone, Florida: Vaughan, 49.

Operculina and Heterostegina: Cushman, 10.

Orbitoidal Foraminifera, morphologic nomenclature: Schenck, 2.

structure and phylogeny: Galloway, J. J., 11.

Orbitoides: Douville, 1.

evolution in America: Douville, 2.

Orbitoididae, revision: Galloway, J. J., 10.

Oregon, Coast range: Cushman, 44.

Orthophragmina: Cushman, 11.

Orthophragmina and Lepidocyclina: Cushman, 8.

Panama, Haut Chagres: Vaughan, 41. Phylogenetic studies: Cushman, 30, 38.

Polylepidina: Galloway, J. J.; 9. 
Foraminifera-Continued.

Picking out and sectioning Foraminifera: Hudson, F., 1.

Pseudotextularia and Guenmbelina : Cushman, 20.

Quebec, Gaspé, Bonaventure cherts: Bagg, 1.

Schwagerina: Beede, 9.

Siphogenerina and Pavonina: Cushman, 25.

Siphonina and related genera: Cushman, 37.

Slide for bolding Foraminifera: Thomas, E. 'T., 3.

Stellate Orthophragmina, nomenclature : Hodson, H. K., 1.

Stratigraphic correlation value: Cushman, 5.

Tertiary: V a u g h a n, 35 ; larger : Vaughan, 51.

Texas, Canyon division: Waters, J. A., 2.

Carboniferous, Sutton County : Cushman, 45 .

central, Cretaceous : Carsey, 1.

Eagle Ford formation: Moreman, 2.

Jackson beds: Cushman, 24 ; Dumble, 7.

Midway formation: Plummer, $\mathrm{H}$. J., 1.

Pennsylvanian: Harlton, 3.

Yegua formation: Stadnichenko, $M$. M., 1.

Trinidad : Hodson, H. K., 2.

Naparima region: Nuttall, 1.

Use in correlation : Cushman, 18 ; Dumble, 3 ; Hanna, G. D., 14.

Use in determining underground structure: Cusbman, 15.

Vicksburg group: Cushman, 16.

Washington, Lewis County, Eocene: Hanna, G. D., 18.

West Indies : Cushman, 3.

Yaberinella jamaicensis, Jamaica: Vaughan, 47.

Zonal value: Vaughan, 23.

Formation thicknesses, determination : Ickes, 2.

Formations. See Geologic formations.

Fort Dodge gypsum, Iowa : Lees, 3.

Fossil, use of term: Field, 3, 4; Miller, A. M., 7,8 .

Fossil bone, mineralogy and petrography: Rogers, A. F., 19.

Fossil forests. See Petrified forests.

Fossilization.

Wood, replacement by dolomite: Adams, S. F., 1.

Wood turned to opal: Whitlock, 6 .

Fossils. See Paleontology.

Foundry sands.

Minnesota: Knapp, G. N., 1.

Fracturing of incompetent beds: Lovering, 8.

Framework of the earth : Davis, W. M., 2; Leighton, H., 1.

Franklin.

Mineralogy.

Prehnite, Admiralty Inlet, Baffinland : Simmersbach, 2.

Franklin Mountains, Mackenzie: Williams, M. Y., 16.

Frazier River Delta map area: Johnston, W. A., 17.

Fulgurites.

General: Anderson, A. E., 1.

Nebraska: Anderson, A. E., 1; Barbour, 4.

manganese: Cook, H. J., 5.

New Jersey, South Amboy: Myers, 3 . Fuller's earth.

Illinols, Pulaski County : Lamar, 10.

Fumaroles.

Alaska, Katmai region, chemical study : Allen, E. T., 2.

Fundamental problems of geology: Chamberlin, T. C., 30,42 :

Fused cores; Ross, C. S., 4.

Gabbros, Maryland, Harford County : Insley, 1.

Galena limestone: Keyes, 52.

Galena Hill, Mayo district, Yukon: Stockwell, 1.

Gallup-Zuni Basin, New Mexico: Sears, 6. Ganister.

Wisconsin, Baraboo deposits: Hotchkiss, 6.

Garnet: Eardley-Wilmot, 8 ; Myers, 2.

Mineralogy: Myers, 4.

New York: Newland, 2.

North Carolina: Katz, 1.

Gas. See Natural gas.

Grastropoda. See also Mollusca.

Bermuda, Poecilozonites : Pilsbry, 2.

Caecum, protoconchs, Miocene, Maryland: Berry, E. Will., 2.

Bathmopterus, Silurian, Alaska : Kirk, 11.

California, Etchegoin Pliocene, Scalez: Hanna, G. D., 12.

Gabb's types : Stewart, R. B., 1.

Pliocene: Carson, 2.

Rancho. La Brea, Succinea avara: Hanna, G. D., 11.

Cassididae, western America: Schenck, 3.

Conularia rugosa, Lockport limestone, Hamilton, Ontario : Dyer, 1.

Costa Rica, northern, Miocene: Olsson, 1.

Florida, fresh-water mollusks: Marshall, W. B., 1.

Helicina occulta, Iowa: Shimek, 1.

Jamaica, Bowden, Miocene : Woodring, 22.

Macluritella, Ordovician, Colorado: Kirk, E., 8.

Metaconularia : Foerste, 24.

Michigan, Devonian : Ehlers, 5.

Ohio, Guelph formation: Foerste, 14.

Olivella, California: Oldroyd, 2.

Ontario, Toronto area: Parks, 9. 
Gastropoda-Continued.

Oregon, John Day region, Miocene: Hanna, G. D., 4.

Orthaulax: Cooke, C. W., 6.

distribution: Cooke, C. W., 2.

Haiti, Porto Rico, and Cuba: Woodring, 4.

Palliseria, upper Ordovician, British Columbia: Wilson, A. E., 3.

Physa, Pleistocene, Florida: Clench, 1. Pleistocene, California : Oldroyd, 'T. S., 1; Santa Barbara: Palmer, K. V. W., 2.

Illinois: Baker, F. C., 6.

Rimella-like gastropods, west coast: Clark, B. L., 7.

San Pedro fauna, Nob Hill cut, California : Oldroyd, T. S., 3.

Scalez petrolia: Hanna, 28.

Silurian, Illinois, northeastern : Wing, 1.

'l'exas, Pleistocene fresh-water mollusks: Hanna, G. D., 9.

trails in Pennsylvanian sandstones: Powers, 10.

Trails: Raymond, 15.

Trinidad, Miocene : Mansfield, W. C., 2. Trophosycon, west const: Gale, H. R., 1. Turritella, Buda and Georgetown limestones, Texas: Ellisor, 1.

Miocene, Virginia: Garduer, J. A., 14.

Turritellas, distribution in tropical America : Woodring, 20.

Viviparus-like opercula, Pliocene, California: Woodring, 14, 15.

Geanticlines: Schuchert, 22.

Gel replacement: Lindgren, 15.

Gels, function in the formation of quartz and carbonate veins: Merritt, $\mathrm{C}$. A.. 2.

Gems : Schaller, 2.

Maine: Marble, 1.

United States National Museum collection: Merrill, 18.

Gems and gem materials: Kraus, 5.

Genesis of ores. See Ore deposits, origin.

Geneva map area, Sudbury district, Ontario: Quirke, 7.

Geochemistry.

Abstraction of potassium during sedimentation : Watson, J. W., 1.

Alaska, Katmai region, fumaroles: Allen, E. T., 2.

Alkalies in rocks and minerals, determination: Shannon, 72.

Analyses of natural waters, index: Collins, W. D., 5.

Analysis of gases from volcanoes and from rocks: Shepherd, 3.

Aragonite deposited from sea water : Wells, 4.

Bacteria as agents of chemical denudation: Thiel, 11.

Calcium carbonate, precipitation : Emmons, R. C. 8.
Geochemistry-Continued.

Calcium sulphates, physicul chemistry: Bowles, 4.

Chemical composition of the earth : Washington, 31.

Chemistry of the earth's core: Barnett, 1.

Colloid chemistry of minerals and ore deposits : Lindgren, 10.

colloids in geologic problems: Hubbard, G. D., 2.

Color of sedimentary rocks: Hagar, D. S., 3.

Concentration and circulation of the elements: Lindgren, 9.

Copper deposition from ascending solutions: Wells, 11.

Corundum, genesis: Cobb, M. C., 2.

Data of geochemistry: Clarke, 1F. W., $1,5$.

Direct synthesis of higher from lower hydrocarbons: Thom, 9.

Dolomites, chemical study: Knight, N., 1.

Earth's crust, composition: Washington, 4.

Evolution and disintegration of matter: Clarke, F. W., 6.

Humic acid origin of asphalt: Haseman, 1.

Hydrothermal alteration of silicate minerals : Leonard, R. J., 1.

Igneous rocks, average chemical composition: Clarke, F. W., 3.

Intraformational phosphate pebbles: Pettijohn, 1.

Invertebrates, inorganic constituents: Clarke, F. W., 2.

Iron protores, leaching of : Lovering, 1.

Iron sulphide in coal and other sedimentary rocks: Newhouse, 3 .

Iron-stained sands and clays: MacCarthy, 4.

Kaolin, Indiana, origin: Bucher, 5.

Kilauea, Hawaii, gases, composition: Shepherd, 1.

Killarney, magma, Sudbury, Ontario: Bain, 19.

Lava, oxidation by steam: Ferguson. J. B., 3.

Limestone, decomposition: Miller, B. L., 10.

Magnetite: Gruner, 10.

Mauna Loa, Hawail, gases : Shepherd, 2.

Metasomatic processes in silicate rocks: Goldschmidt, V. M., 1.

Metasomatism : Lindgren, 16. physico-chemical theory of: Boydell, 3.

Mineral sulphide water, analysis: Fairchild, J. G., 1.

Mineralization of the PlattevilleDecorah contact zone, Minneapolis-St. Paul region, Minnesota : Stauffer, 6. 
Geochemistry-Continued.

Natural reduction of sulphates: Bas. tin, 15 .

Observatories, need for: Jaggar, 5.

Oil, gas, and water, relations in sunset-Midway ' field, California : Rogers, G. S., 1.

Oxidation of iron in magnetite: Gilbert, G., 6.

Oxidation of sulphldes and arsenides: Carmichael, 2 .

Oxidation products from chalcopyrite: Blanchard, R., 2.

from sphalerite and galena: Boswell, 1.

Oxygen minerals and sulphur minerals in ore deposits, relations: Butler, 9.

l'acific volcanoes, chemistry: Washington, 6.

letroleum, minor constituents : Wells, 12.

Petroleum, silica, and water, geochemical relations: Nutting, 1.

l'etroleum and the filtering earths: Nutting, 4.

retroleums of Callfornia, chemical characteristics : Prutzman, 1.

Phosphorus in California petroleum : Palmer, C., 1.

Platinum at high temperatures and pressures: Shaw, 9.

Precipitation of manganese from meteoric solutions: Thiel, 3.

Problems: Sosman, 4, 5.

Pyrite and marcasite, alternating deposition : Tarr, 18.

Quality of oil, relation to structure: Ley, 1.

Reaction between ferrous and cuprous salts: Wells, 10.

Red color in sediments: Raymond, 34.

Red color of rocks, loss: Moulton, 23.

River and lake waters, composition : Clarke, F. W., 5.

Sedimentation: Steiger, 1.

Selective adsorption of water and hydrocarbons by silica and silicates: Nutting, 5.

Silica, solution and precipitation in cold water : Lovering, 1.

Silicate and carbonate rocks, analysis of : Hillebrand, 1.

Status and problems of geophysical chemistry : Sosman, 6.

Sulphide ores, genesis: Freeman, H., 1.

Syngenetic pyritization: Talr, 19.

Uranium-thorium-lead determination : Fenner, 11

Volcanism, chemical aspects: Allen, E. T., 1.

Geodes.

Origin: Van Tuyl, 8.

Geologic climate. See Paleoclimatology.

Geodetic work, value to geology : Bowie, 8 Geographic cycle : Davis, 8.
Geographic distribution.

Bear family: Merriam, 6.

Iowa, Devonian echinoderms : Thomas, 16.

Pleistocene mammals: Hay, 23, 39.

Proboscidea: Osborn, 15.

Stringocephalus: Kirk, E., 7.

ieologic climate. See Paleoclimatology.

(ieologic column; France, Britain, Germany, United States: Lane, 3.

Geologic formations, tables. See also Correlation.

Alabama: Jones, W. B., 6, 13. southern: Harper, 1.

Alaska, Jurassic: Moffit, 7 .

Matanuska Valley: Capps, 11.

northern, Canning River region: Leffingwell, 1.

Alberta : Irwin, 1.

Banff area: Warren, P. S., 4.

Bow River between Cochrane and Kananaskis : Rutherford, 6.

Cypress Hills: Dyer, 9.

foothills belt: Allan, 13; between McLeod and Athabasca rivers Rutherford, 4.

lower Smoky River: McLearn, 1.

southwestern: Stewart, J. S., 1.

Saunders Creek and Nordegg coal basins: Allan, 9.

Sheep River area: Slipper, 2.

Turner Valley oil area: Hume, 22.

Wainwright-Vermillion area : Hume, 19.

Alberta and British Columbia, foothills belt: Hopkins, O. B., 4.

Antigua : Earle, 1.

Arizona: Keyes, 83.

Grand Canyon district: Moore, R. C., 26.

northwestern: Shimer, 2 .

southwestern : Reeside, 4.

Arkansas, Batesville district: Miser, 5,8 .

Hot Springs district: Purdue, 1.

southern: Hull, 10.

Ozark region: Croneis, 5.

Britisb Columbia, Ainsworth district: Schofield, 4.

Bridge River area: McCann, 3, 4 .

Cariboo district, Barkerville area: Johnston, W. A., 22 ; Uglow, 9.

coast region: Dolmage, 9 .

Coquihalla area: Cairnes, 4.

Dease Lake area, Cassiar district: Kerr, F: A., 1.

Eutsuk Lake area, Coast district: Marshall, J, R., 3.

Fraser River Delta : Johnston, W. A., 17.

Harrison Lake district: Crickmay, 5.

Hat Creek coal area, Kamloops district: MacKay, B. R., 5.

Kamloops district, North Thompson valley: Uglow, 3. 
Geologic formations, tables-Continued.

British Columbia-Continued.

Kitsault River to Skeena River : Fanson, 3.

Lasqueti Island: MacKenzie, J. 0., 3.

Lillooet-Prince George region: Reinecke, 3.

northeastern : Stewart, J. S., 2.

Peace River district: Spieker, 1.

Purcell Range west of Brisco, Kootenay district: Walker, J. F., 2.

Rocky Mountain trench: Shepard, 11.

Rocky Mountains: Schofleld, 6.

Salmon River district: Schofield, 11.

Slocan area: Bancroft, M. F., 2.

southeastern: Schofield, 12.

Vancouver Island, Alberni area : MacKenzie, 7 ; Barkley Sound : Dolmage, 2.

Windermere area, Kootenay district: Walker, J. F., 1.

Zymoety River area, Coast district: Hanson, 11.

California: Vander Leck, 1.

Los Angeles Basin : Eaton, J. E., 3.

San Diego County: Ellis, A. J., 1. Simi Valley: Kew, 1.

southern: Kew, 4.

Tertiary : Clark, B. L., 5.

Ventura quadrangle: Cartwright, L. D. 2.

Cambrian : Secrist, 1.

Cambrian-Ozarkian-Ordovician : Walcott, 7 .

Canada, Mackenzie River basin: Camsell, 1.

Carboniferous : Beede, 7.

Central America and West Indies, Tertiary: Vaughan, 13.

Colorado: Keyes, 162. north central, foothills formations: Henderson, 2.

northeastern: Mather, 12.

Cretaceous: Gress, 1 ; Martin, G. C., 15.

Montana: Robinson, E. G., 1.

I'exas: Scott, G., 4.

Upper: Stanton, 2.

Upper, Atlantic and Gulf Coastal Flain, correlation: Stephenson, 4.

Devonlan : Bassett, 1 ; Savage, 3. Mississippi Valley: Savage, 14. western Tennessee: Dunbar, 2.

Dominican Republic: Cooke, C. W., 3; Vaughan, 16.

Enid formation: Aurin, 3.

Eocene formations, Alabama and Mississippi : Cooke, C. W., 12.

Florida : Sellards, 4, 5.

Geologic time classification of the U. S Geological Survey: Wilmarth, 1 , 2.

Geologic time scale: Ashley, 14.

$$
4096-31-50
$$

Geologic formations, tables-Continued.

Georgia : McCallie, 1, 2, 5.

Coastal Plain: McCallie, 7.

Mesozoic and Cenozoic: McCallie, 8.

Green River valley, Utah and Wyoming: Reeside; 7 .

Gulf CoastaI Plain: Sellards, 12.

Hayti : Woodring, 4.

Idaho, Boundary County: Kirkham, 7. Coeur d'Alene region: Eby, J. H., 1. eastern: Mansfield, G. R., 8.

Fort Hall Indian Reservation : Mansfleld, G. R., 3.

southeastern: Kirkham, 1; Mansfleld, G. R., 29.

Illinois, Keyes, 118.

east-central : Mylius, 7.

Equality-Shawneetown area: Butts, 5.

Galesburg quadrangle: Poor, 2.

Hardin County: Weller, S., 1.

Joliet quadrangle: Fisher, D. J., 2. northern : Thwaites, 7 .

Indiana : Cumings, 1 ; Logan, 5, 15, 24.

Iowa: Kay, 13.

Adair County : Gow, 1.

Cass County: Tilton, 3.

Mississippian: Van Tuyl, 8.

Missouri series: Tilton, 7.

north central: Fenton, G. L., 2.

Jamaica : Trechmann, 1.

Jurassic rocks, Alaska: Martin, G. C., 15.

Kansas: Moore, R. C., 9 ; Snider, 1.

Ellis County: Bass, 2.

Hamilton County: Basis, 2.

Rusisell County: Rubey, 3.

Kentucky : Miller, A. M., 1.

Allen County: Miller, A. M., 5.

Berea region: Burroughs, W. G., 5 .

Golconda quadrangle: Weller, 4.

Knob region: Burroughs, W. G., 4.

Woodford County : Miller, A. M., 22.

Louisiana, northern: Hull, 10 ; Spooner, 2.

Mackenzie, Franklin Mountains: Williams, M. Y., 14.

Great Slave Lake region: Cameron, 1 .

lower Mackenzie valley: Kindle, 9.

Mackenzie River district: Williams, M. Y., 13.

Mackenzle River basin: Hume, 8.

Mackenzie River between Norman and Beaver River: Hume, 5.

Manitoba: Wallace, 14.

Bigstone and Fox rivers area : Merritt, C. A., 4.

Oxford and Knee lakes area: Wright, J. F., 11.

Mesozoic and Cenozoic: Knowlton, 2.

Mesozoic and late Paleozoic, Montan: and adjacent States: Clapp, C. H., 2.

Mesozoic formations, Pacific coast, correlation : Goranson, 1. 
Geologit formations, tables-Continued.

Mexico, eastern, and Texas: Staub, 4. Hidalgo-Vera Cruz region: Palmer, R. H., 4.

Minnesota : Keyes, 118; Knapp, G. N. 1; Stauffer, 7.

Mississippi : Stephenson, 10. northeastern : Burchard, 20.

Missouri : Dake, 1; Wilson, Mal. E., 1. Ste. Genevieve County: Weller, 19. Vernon County: Greene, 8.

Montana: Bauer, C. M., 3 ; Keyes, 234. Beartooth Mountains, Bevan, 2. central: Bowen, C. F., 2; Reeves, F., 10.

Little Rocky Mountain region: Collier, 8.

Nebraska: Keyes, 118.

Nevada, Pioche district: Westgate, 6.

New Brunswick: Bailey, L. W.,.1.

Newfoundland, southeastern, CambrianOrdovician: Howell, 5.

New Jersey, Cretaceous and Eocene: Mansfield, G. R., 1.

New Mexico: Darton, 11, 26; Keyes, 14.

Alamosa Creek valley: Winchester, 3.

Gallup-Zuni Basin : Sears, 6.

Raton coal field: Lee, 10.

San Juan County: Bauer, C. M., 1.

New York: Keyes, 281 ; Miller, W. J., 23.

Newburgh quadrangle: Holzwasser, 1.

western, Chemung, correlation table : Chadwick, 6.

North Dakota: Leonard, A. G., 1.

Marmarth fleld: Hares, 5.

western : Stanton, 3.

Nova Scotia, Inverness County, Lake Ainslie district: Bell, W. A., 12.

Kings and Annapolis counties: Faribault, 4 .

Ohio, Camp Sherman quadrangle: Hyde, 1.

Delaware County: Westgate, 5.

Muskingum County: Stout, 1.

Vinton County, Mississippian : Hyde, 3.

Wayne County : Conrey, 1.

Oklahoma, eastern : Shannon, C. W., 4. Marshall County: Bullard, 3.

upper Paleozoic: Gould, C. N., 19.

Ontario, Batchawana area, District of Algoma: Moore, E. S., 19.

Brockville-Mallorytown area: Wright, J. F., 1, 2.

Credit River section: Dyer, 3, 4.

Dundas formation: Parks, 17.

Gunflint iron-bearing formation : Gill, J. E., 1.

Matabitchuan area: Todd, E. W., 5.

Matawin iron range, Thunder Bay district: Tanton, 15.
Geologic formations, tables-Continued.

Ontario-Continued.

north shore of Lake Huron: Collins, 11.

Pagwachuan, Kenogami, and Albany rivers: Williams, M. Y., 10.

Sault Ste. Marie, District of Algoma : McConnell, 1.

southwestern : Harkness, 4.

Sudbury district, Geneva area : Quirke, 7; Wanapitei Lake area: Quirke, 8 .

Whiskey Lake aren, District of Algoma : Douglas, G. V., 2.

Workman's Creek section: Fritz, 2. Ordovician, Mississippi Valley: Dake, 6.

Oregon: Smith, W. D., 1.

Coast Range province: Smith, W. D., 13.

southeastern: Smith, W. D., 14

southeastern lake district: Smith, W. D., 12.

western: Harrison and Eaton, 1.

Pacific region, Mesozoic and Cenozoic: Kew, 3.

Paleozolc: Keyes, 255.

Alabama and Tennessee: Butts, 8.

(earlier), Europe and America: Ulrich, 15.

lower : Ashley, 25 ; Secrist, 1.

Panama: Vaughan, 3.

Tertiary marine: Cushman, 8.

Pennsylvania : Gordon, S. G., 6 ; Miller, B. L., 4.

Greensburg quadrangle: Johnson, M. E., 1.

Pennsylvanian, Oklahoma : Dott, 1.

Permian, Arizona and New Mexico: Darton, 20.

correlation: Gould, 10.

Oklahoma and Texas: Gould, 16.

Permo-Carboniferous red beds, Colorado and New Mexico: Melton, 3.

Porto Rico, Tertiary formations: Mau$\mathrm{ry}, 2$.

Pre-Cambrian : Wilson, M. E., 18; Keyes, 209

Canada : Miller, W. G., 12.

Michigan : Allen, R. C., 2.

Pre-Cambrian and Cambro-Ordovician : Berkey, 3.

Quebec, Beauceville area: MacKay, B. R., 4.

Anticosti Island: Twenhofel, 30.

Cléricy and Kinojevis areas, Témiscamingue and Abitibi counties: James, 4.

Coleraine area: Knox, J. K., 1.

Dufresnoy area, Abitibi district: Harvie, 3.

Harricanaw-Turgeon basin: Tanton, 1.

Timiskaming County, Opasatika area : Cooke, H. C., 10.

western : Cooke, H. C., 15 . 
Cieologic formations, tables-Continued.

Rocky Mountain region: Reeves, F., 8.

Saskatchewan, Wapawekka and Deschambault Jakes area : De Lury, 6.

Silurian: Savage, 16.

correlation: Swartz, C. K., 8; Ulrich, 8.

Niagaran : Springer, 12.

Ontario southwestern : Dyer, 5; Williams, M. Y., 1.

South Dakota: Keyes, 118; Wilson, R. A., 1.

Black Hills region: O'Hara, 3 .

westeln: Stanton, 3.

South Dakota and eastern Wyoming: Wilson, R. A., 4.

Southeastern United States: Vaughan, 3.

Tennessee, Crossville $q \mathrm{u}$ a $\mathrm{dr}$ a $\mathrm{ngle}$ : Butts, 6.

lower Paleozoic formations: Gordon, C. H., 3.

middle: Lusk, 2.

southern: Nelson, 20.

western valley: Dunbar, 1.

Tertiary: Canu, 2 ; Peterson, 2.

American and European, correlation : Cooke, C. W., 10.

correlation charts: Vaughan, 34.

West Coast: Clarke, B. L., 4.

Texas, Bexar County: Sellards, 10.

Comanchean : Adkins, 2.

Cooke County: Bybee, 3.

Cretaceous : Adkins, 5 ; Böse, 2.

Crockett County : Liddle, 2.

eastern : Renick, 12.

Gulf Coastal Plain: Powers, 17.

north central, Pennsylvanian: Moore, R. C., 13.

northeastern, colrelation: Folıs, 2.

Ranger oil field: Reeves, F., 2.

Tom Green County: Henderson, G. G., 1.

Triassic: Martin, G. C., 15.

Upper: Smith, J. P., 3.

Trinidad: Waring, 6.

Utah : Dake, 3 ; Keyes, 152.

La Sal Mountains: Gould, L. M., 4.

Moab region: Baker, A. A., 1.

Salina Canyon district, Sevier County : Spieker, 6.

southeastern : Longwell, 6 ; Prommel, 4.

southwestern: Reeside, 4.

Sunnyside and Wellington quadrangles : Clark, F. R., 4.

Tintic district: Lindgren, 2.

Uinta Basin : Douglass, 2.

Wasatch Mountains : Schneider, H., 2.

Virginia: Giles, 11. western: Stose, 16.

Washington, San Juan Islands: McLellan, 2.

West Indies, Tertiary: Vaughan, 17.

West Virginia, Mercer, Monroe, and Summers countles : Reger, 9.
Geologic formations, tables-Continued.

Wisconsin: Hotchkiss, 10 ; Keyes, 118 ; Ulrich, 12.

Wyoming: Bartlett, E., 8 ; Keyes, 190 ; Morgan, G. B., 1.

Bell Springs district, Carbon County : Dobbin, 5.

Gillette coal field: Dobbin, 3.

Lance Creek field: Hancock, 5.

Lost Soldier-Ferris district: Fath, 5.

Mule Creek oil field: Hancock, 4.

Osage oil fleld, Weston County : Collier, 7.

Rock Springs area, Sweetwater County : Schultz, 1.

Thermopolis district: Collier, 4.

Upton-Thornton oil field : Hancock, 3.

Yukon, Sixtymile and Ladue rivers area : Cockfield, 5.

southern : Cockfleld, 9.

Whitehorse district: Cockfield, 16.

Geologic history. See also Paleoclimatology ; Paleogeography.

Adirondacks : Alling, H. L., 1.

Alabama, Bessemer-Vandiver quadrangle: Butts, 13.

Clay County: Prouty, 10.

Coastal Plain: Brantley, 1.

Mesozoic: Stephenson, 5.

Paleozoic: Butts, 8.

Alaska, Anvik-Andreafski region : Harrington, 1 .

Chandalar district: Mertie, 12.

Goodnews Bay region: Harrington, 6.

Iniskin-Chinitna Peninsula : Moffit, 7.

Kantishna region: Capps, 1.

Kotsina-Kuskulana district : Moffit, 4.

Mesozoic: Martin, G. C., 15.

Point Barrow region: Paige, 5.

Ruby-Kusliokwim region : Mertie, 11.

York region: Steidtman, 4.

Alberta, Lake Minnewanka section : Shimer, 6 .

Rocky Mountains : MacKenzie, J. D., 4.

southern and central : Slipper, 1.

southwestern : Stewart, J. S., 1.

Alberta and British Columbia, foothills belt : Hopkins, O. B., 4 .

Appalachians, southern : Adams, G. I., 5.

Arizona, Aravaipa-Stanley region: Ross, C. P., 5.

Bright Angel quadrangle: Noble, 1.

Courtland-Gleeson region: Wilson, E. D., 2.

Jerome district, Yavapai County : Reber, 1 ; Smith, A. H. D., 1.

lower Gila region: Ross, C. P., 1.

northeastern, Holbrook area : Hager, D., 3.

Papago country : Bryan, 7, 15.

Payson district: Lausen, 1.

Ray quadrangle: Ransome, 11.

Ray-Miaml region: Ransome, 1 . 
Geologic history-Continued.

Arizona-Continued.

Saddle Mountain and Banner mining district: Ross, C. P., 6.

San Carlos Indian Reservation: Schwennesen, 1

Arkansas Hot Springs district: Purdue, 1 .

Atlantic and Gulf Coastal Plain : Stephenson, 6.

Black Hills uplift: O'Harra, 5.

British Columbia : Brock, 4 ; Schofield, 15.

Ainsworth district: Schofield, 4 .

Bridge River area : McCann, 3 .

Cariboo district, Barkerrille area: Johnston, W. A., 22.

Coquihalla area: Cairnes, 4.

Cordillera: Brock, 13.

Fraser River canyon: Camsell, 9.

Fraser River Delta: Johnston, W. A. 17.

Harrison Lake district: Crickmay, 5

Kamloops district, North Thompson valley: Uglow, 3.

North Thompson Valley: Uglow, 11

Purcell trench: Schofield, 6.

Rocky Mountain region: Schofield, 8

Salmon River district: Schofield, 11.

Vancouver area: Schoffeld, 17.

California, Berkeley Hills: Fox, 1.

La Jolla quadrangle: Hanna, M. A., 3.

Los Angeles County, Baldwin Hills: Tieje, 6.

Paso Robles Basin : Reed, 6.

Petaluma, Point Reyes, and Santa Rosa quadrangles: Dickerson, 2

Point Sur quadrangle: Trask, 5.

Randsburg quadrangle: Hulin, 3.

Salton Sea region: Brown, J. S., 3. San Andreas rift: Noble, 9.

San Bernardino Mountains: Vaughan, F. E. 1.

San Diego County: Ellis, A. J., 1.

San Gabriel Mountains: Miller, W. J., 33.

Santa Barbara County, upper Santa Ynez River basin : Nelson, R. N., 1. southern: Hill, R. T., 8.

Warner Range: Russell, R. J., 6.

Wheeler Ridge area, Kern County: Hoots, 5.

Canada: Collins, 10.

Great Plains: Hume, 25.

maritime provinces: Bell, W. A., 13.

Canadian Cordilleras: Dowling, 16.

Canadian Rockies: Burwash, 2, 3.

Canadian shield: Collins, W. H., 22.

Caribbean region: Vaughan, 3; Woodring, 23.

Cayman Islands: Matley, 14

Central America: Sapper, 7 ; Vaughan, 3 ; and West Indies: Vaughan, 13.

Colorado, Big Thompson River valley : Fuller, M. B:; 8.

central: Crawford, R. D., 2 .
Geologic history-Continued.

Colorado-Continued.

Front Range: Van Tyul, 5.

Golden area: Johnson, J. H., 13.

Las Animas, Otero, and Bent counties (parts): Duce, 1 .

Leadville mining district: Emmons, S. F., 1.

north central, foothills formations : Henderson, 2.

northwestern : Sears, 5.

San Juan Basin: Reeside, 8.

Tarryall district: Muilenburg, 2.

Twin Lakes district: Howell, J. V., 1.

Colorado Plateau region: Willis, 9.

Connecticut: Gregory, H. E., 8.

Southington-Granby area : Palmer, H. S., 5.

Cordillera in Canada: Schofield, 13.

Cordilleran region: Beeson, 1.

Cretaceous, Oklahoma and Arkansas: Miser, 27

Utah : Spieker, 5.

Crustal deformation: Schuchert, 13.

Delaware, Wilmington quadrangle: Bascom, 2.

Dominican Republic: Vaughan, 16.

Eocene, southeastern North America : Beriy, 51.

Finger Lakes: Fairchild, 20.

Florida : Cushman, 4.

General: Bretz, 12; Keith, 8; Mer riam, 5.

Georgia, Cartersville district: Hull, 1. Macon area: Cooke, C. W., 5.

Grand Canyon of the Colorado: Darton, 3 .

Great Basin, Pleistocene history: Antevs, $5,12$.

Green River formation : Bradley, W. H., $3,4$.

Greenland: Böggild, 1, 6

Gulf Coastal Plain: Stephenson, 12, 14

Hawail, Mauna Loa and Kilauca : Stearns, 8.

Idaho, Boise Basin: Ballard, 3.

Buffalo Hump district: Beckwith, 4.

Fort Hall Indian Reservation: Mansfield, G. R., 3.

Idaho batholith region: Beckwith, R. H., 1.

Mud Lake area: Stearns, 9.

Owyhee County, Bruneau River basin : Piper, 2

St. Maries region: Anderson, A. I., 4.

Salmon River Mountains: Ross, C P., 13.

Silver City district: Piper, 7.

soutbeastern: Mansfield, G. R., 11, 29.

Illinois: Cady, 6.

Carbondale quadrangle: Lamar, 3.

Carlyle-Centralia district: Shaw, 9.

Colchester and Macomb quadrangles: Hinds, H., 1. 
Geologic history-Continued.

Illinois-Continued.

Dixon quadrangle: Knappen, 1.

east-central : Mylius, 7 .

Edgington-Milan area: Savage, 5.

Elgin region, glacial history : Leighton, 14.

Gillespie and Mount Olive quad. rangles : Lee, $W ., 1$.

Glenwood beds: Bevan, 6 .

Hennepin quadrangle: Cady, 3 .

Herscher quadrangle: Atby, 1.

Joliet quadrangle: Fisher, D. J., 2.

Kings quadrangle: Bretz, 4.

La Harpe and Good Fiope quad rangles: Savage, 8.

La Salle anticline: Mylius, 5.

La Salle quadrangle: Cady, 3.

Morris quadrangle: Culver, 2.

New Athens-Okawville area: Shaw, 8 . southern: Weller, 11, 15 ; Carboniferous: Weller, 11.

Indiana, Greene County, eastern: Malott, 1.

Iowa, Lake Calvin region: Schoewe, 6 Lucas County: Lugn, 6.

Mississippian : Van Tuyl, 8.

Kansas: Wooster, 2.

Cretaceous: Twenhofel, 17.

Hamilton County: Bass, 2.

Nemaha granite ridge: Moore, R. C., 32.

soutbeastern: Ley, 2.

Syracuse and Lakin quadrangles: Darton, 2.

western: Twenhofel, 6 .

Kentucky, Berea region: Burroughs. W. G., 5.

Edmonson County: Weller, .T. M., 1.

Knob region: Burroughs, W. G., 4.

Morgan County: Robinson, L. C., 1.

western coal field: Burroughs, W. G., 2 .

Kilauea: Stone, J. B., 1.

Lake Erie region: Decker, C. F., 1.

Lake Lahontan: Jones, J. C., 2.

Lake Superior geosyncline, Hotchkiss, 8.

Lanal: Wentworth, $\mathbf{1 5 .}$

Lesser Antilles: Earle, 8, 11.

Louisiana, Sabine uplift: Powers, 2.

Lower Cretaceous, Oklahoma and Texas: Bullard, 4.

Mackenzic River basin : Dowling, 15, 17.

Manitoba, Flinflon area: Alcock, 15.

northern: Bruce, 5.

pre-Cambrian: Alcock, 1.9.

Rice Lake and Oiseau River areas: Cooke, H. C., 9.

Maryland, Elkton quadrangle: Bascom, 2.

Kent County : Miller, B. L., 6.

Queen Annes County : Miller, B. L., 7.

Talbot County : Miller, B. L., 8.

Massachusetts, Boston area: Crosby, I. B., b.

central, glacial history: Alden, 2.
Geologic bistory-Continued.

Connecticut Valley: Miller, W. J., 10.

Essex County: Clapp, C. H., 1.

Mesozoic, Alaska: Martin, G. C., 15.

southern North America: Stanton, 1.

Mesozoic floras of North and South America : Knowlton, 1.

Mexico : Lewis, S. J., 1.

Chapala region: Falmer, R. H., 1.

Cordillera: Fletcher, 1.

EI Oro and Tlalpujahua districts: Flores, 1.

Hidalgo-Vera Cruz region: Palmer. R. H., 4.

Panuco oil field: Baker, C. L., 8.

Panuco River valley: Trager, 5.

Michigan, pre-Cambrian : Allen, R. C., 2.

Mid-Continent oil flelds: Bosworth, 1 ; McCoy, 5.

Minnesota: Grout, 2 ; Meinzer, 11.

Herman, Barrett, Chokio, and Morris quadrangles: Sardeson, 1.

St. Louis County, northern : Grout, 20.

Mississippi Gulf, Eocene: Berry, 58.

Mississippi Valley, Missouri and Illinois: Krey, 2.

Pleistocene: Leverett, 8.

upper, late Paleozoic: Van Tuyl, 1.

Missouri, Ste. Genevieve County : Weller, 19.

Vernon County: Greene, 8.

Missouri River: Greene, 2.

Montana, Bearpaw Mountains : Reeves, F., 7.

Beartooth Mountains, Bevan, 2.

central, Upper Cretaceous: Bowen, C. F., 2.

Cretaceous: Hammer, 1.

Fergus County: Freeman, o. W., 1.

front ranges, Cenozoic history: Bevan, 9 .

Quadrant folmation: Hammer, 2.

Sweet Grass Fills: Kemp, 8.

Tullock Creek coal field: Rogers, G. S., 8.

Upper Cretaceous: Rohinson, E. G., 1.

Nevada, Manhattan district: Ferguson, H. G., 5 .

Muddy Mountains: Longwell, 1, 15. Pioche district: Westgate, 6.

Rochester district: Knopf, A., 7.

Santa Fé district, Mineral County: Clark, C. W., 2.

New Brunswick, Moncton area : Wright, W. J., 2.

New Hampshire, White Mountains, North Conway quadrangle: Billings, 5.

New Mexico, Mogollon district: Ferguson, H. G., 3.

Raton-Brilliant-Koehler area : Lee, W. T., 6.

Sandia Mountains: Ellis, R. W., 2. San Juan Basin: Reeside, $\boldsymbol{S}$. 
Geologic history-Continued.

New Mexico-Continued.

Taos Range: Gruner, 1.

Tyrone district: Paige, 2.

New York: Miller, W. J., 23.

Adirondacks: Miller, W. J., 8; western: Agar, 1.

Canton quadrangle: Chadwick, 5.

Catskill region: Berkey, 6.

Genesee country: Fairchild, 15.

Genesee River region: Fairchild, 6.

Lake Clear region: Alling, H. L., 1.

Lake Placid quadrangle: Miller, W. I., 1.

Lyon Mountuin quadrangle: Miller, W. J., 26.

Newburgh quadrangle: Holzwasser, 1. physiographic history : Fairchild, 16. Pleistocene: Fail child, 9.

Schroon Lake quadrangle: Miller, W. J., 2.

Rochester, Pinnacle Hills, glacial history: Fairchild, 13.

West Point quadrangle: Berkey, 3.

North Atlantic Ocean, Tertiary history: Woodring, 8.

North Carolina: Bryson, 3.

Cretaceous: Stephenson, 4.

Nova Scotia, Northumberland Strait: Bell. W. A., 10.

Uahu: Wentworth, 22.

Ohio, Camp Sherman quadrangle: Hyde, 1.

Delaware County : Westgate, 5 .

Oklahoma : Redfield, J. S., 1.

Arbuckle Mountains: Weidman, 3.

Beckham County : Gouin, 2.

Caddo and Grady counties : Becker, 1.

Carboniferous: Powers, 26.

Cimarron County: Rothrock, 4.

Crinerville oil field, Carter County : Powers, 22.

Kay, Grant, Garfield, and Noble counties : Clark, G. C., 3.

Rogers County: Woodruff, 4. southern : Moore, R. C., 10.

southern Ouachita Mountains: Honess, C. W., 4.

Stonewall quadrangle : Morgan, G. D., $5,6$.

Thomas oil field, Kay County : Clark, S. K., 1.

Ontario, Arnprior-Quyon area: Wilson, M. E., 10.

Brocktown - Mailorytown a rea : Wright, J. F., 2.

English River valley: Bruce, 11.

Lake St. Joseph area : Bruce, 8.

Lake Timiskaming area: Hume, 14.

northeastern, physiographic history: Collins, W. H., 4.

Red Lake area, District of Patricia : Bruce, 12.

Red Lake Basin, District of Kenora : Bruce, 22.
Geologic history-Continued.

Ontario-Continued.

Sudbury district, Grassy River area : Gledhill, 5.

Sutton Lake area: Hawley, J. E., 1.

Timiskaming district, Redstone K1ver area: Bruce, 19.

Ontario-Manitoba boundary : Burwash, 6 . Ordoviciałn, Mississippi Valley: Dake, 8.

Oregon: Buwalda, 12: Smith, W. D., 9.

Cascade Plateau: Hodge, E. T., 5.

Mount Jefferson: Hodge, E. T., 6.

South Dakota, Keystone regi o n : Landes, K. K., 6.

Lead area: Hosted, 1.

Newell quadrangle: Darton, 1.

Tennessee, Ducktown district: Emmons, W. H., 9.

Rutherford County: Galloway, J. J., 1.

western valley: Dunbar, 1.

Texas, Carboniferous : Powers, 26.

central: Matteson, 1.

Dallas County : Shuler, 1.

eastern : Dumble, 1.

Gulf Coastal Plain: Powers, 13.

Hockley salt dome, Harris County : Deussen, 2.

Lacasa area, Ranger district: Ross, C. S., 3.

north central : Plummer, 4 ; Pennsylvanian: Moore, R. C., 13.

Stratton Ridge salt dome: Applin, P. L., 1.

Tarrant County : Hill, E. A., 1. trans-Pecos Texas : Baker, C. L., 6. western: Baker, C. L., 2.

Triassic, southern Connecticut : Russell, W. L., 1.

Trinidad: Milner, 1; Waring, 6. Naparima region: Illing, 1.

Uinta Mountains: Sears, 3.

Upper Cretaceous Mississippi Gulf : Berry, 10.

Utah : Schneider, H., 1.

Moab region: Baker, A. A., 1.

Tintic district: Lindgren, 2.

Wasatch Plateau: Spieker, 3.

Weber County : Pack, F. J., 2.

Vermont, Barre: Perkins, G. H., 4.

Bristol, Lincoln, and Warren townships: Gordon, C. E., 6.

central : Richardson, C. H., 1.

Green Mountain fiont: Bain, 24.

Northfield : Richardson, C. H., 2.

Pleistocene history : Fairchild, 2.

Oregon: Smith, W. D., 1.

Pleistocene: McCornack, 1.

Riddle quadrangle: Diller, 12.

southeastern: Smith, W. D., 14.

western : Harrison and Eaton, 1.

Oriskany formation: Fettke, 1.

Pacific region of Canada: Brockk, 4.

Paleozoic, Atlantic-Arctic region : Holtedahl, 2.

Pebbles: Wentworth, 4. 
Geologic history-Continued.

Pennsylvania, Cambrian aud Ordovician : Miller, B. L., 11.

Piedmont region: Smith, I. F., 3.

Permian: Schuchert, 52 ; Great Plains : Dunbar, 4.

Piedmont area, Maryland and Pennsylvania: Stose, 18.

Porto Rico: Berkey, 1.

Coamo-Guayama district: Hodge, E. T., 1.

Humacao district: Fettke, 5.

Lares district: Hubbard, B., 3.

Ponce district: Mitchell, 7 .

Pottsville formation: Fettke, 1.

Quebec, Arnprior-Quyon area: Wilson, M. E., 10.

Coleraine area: Knox, J. K., 1.

Gaspe Peninsula : Coleman, 7.

Mount Albert area : Alcock, 6 .

northern: Cooke, H. C., 2.

Percé : Clarke, J. M., 20.

Port Daniel-Gascons area : Schuchert, 29.

St. Urbain area, Charlevoix dis. trict : Mawdsley, 1.

Timiskaming County, Opasatika area: Cooke, H. C., 10.

Rocky Mountains : Keyes, 16, 132, 162.

South Dakota, Black Hills region: Fillman, 3 ; O'Harra, 3 ; Yates, 1 ; central : Darton, 14.

Vermont, Whitingham area: Hubbard, G. D., 4.

Vermont region: Keith, 1.

Virgin Islands: Vaughan, 8.

Virginia, Giles County : Hubbard, G. D., 6.

Washington: Weaver, 1.

northeastern : Jenkins, 9.

San Juan Islands: McLellan, 2.

Spokane area: Pardee, 12.

Stevens County: Weaver, 2.

West Indies: Matthew, 5; Vaughan, 10 ; (part): Vaughan, 22.

West Virginia, Hampshire and Hardy counties: Tilton, 15.

Mercer, Monroe, and Summers counties: Reger, 9.

Mineral and Grant counties : Reger, 7 .

White River beds, South Dakota: Wanless, 3 .

Wisconsin River, Pleistocene: MacClintock, 1.

Wyoming, Big Horn Basin : Hewitt, 16. southern: Sears, 5.

Yukon, southern : Cockfield, 9.

Geologic mapping, western United States: Vaughan, 12.

Geologic maps.

Alabama : Smith, E. A., 2, 5 ; (part) : Brantley, 1.

Ashland graphite area: Brown, J. S., 6.

Bessemer-Vandiver q u a drangle: Butts, 13.
Geologic maps-Continued.

Alabama-Continued.

Clay County: Prouty, 10.

northern: Semmes, 3.

Alaska, Alaska Peninsula : Martin, $G$. C., 8.

Alaska Railroad region: Capps, 6.

Anvik-Andreafski region: Harrington, 1

Canyon Creek: Overbeck, 2.

Chandalar district: Mertie, 12.

Chichagof Island, west coast: Buddington, 8; Overbeck, 1.

Chignik region: Martin, G. C., 13.

Chulitna region: Capps, 6; upper: Capps, 4.

Cold Bay district: Capps, 5 .

Cold Bay oil fleld: Martin, G. C., 8.

Cold Bay-Chignik district: Smith, W. R., 1.

Cold Bay-Katmai district: Smith, W. R., 3.

Controller Bay or Katalla oll field : Martin, G. C., 8.

Cook Inlet oil fields: Martin, G. C., 8.

Elephant Mountain : Smith, W. R., 1. Goodnews Bay region : Harrington, 6 . Hyder district: Buddington, 8.

Iniskin Bay district: Moffit, 3 .

Iniskin-Chinitna Peninsula: Moffit, 7.

Innoko-Iditarod region: Mertie, 11.

Jack Bay district: Johnson, B. I., 2.

Kahiltna Valley : Mertie, 2.

Kamishak Bay region: Mather, 7 .

Kantishna district: Capps, 6.

Kejulik Valley: Smith, W. R.. 1.

Kenai Peninsula, southwestern part: Gill, A. C., 2.

Kennecott : Bateman, 10

Kiwalik-Koyul region: Harrington, 5.

Knlk-Matanuska district: Landes, $K$. K., 2.

Kotsina-Kuskulana district: Moffit, 4.

Marshall mining district: Harrington, 1.

mineral resources: Brooks, 2.

Nenana coal fleld: Martin, G. C., $1,10$.

Nenana-Kantishna region: Capps, 1.

Nixon Fork country: Brown, J. S. 7.

Nixon Fork district, Kuskokwim basin: Martin, G. C., 9.

northwestern Arctic: Smith, P. S., 7.

Pearl Creek Dome and Mount Peulik : Smith, W. R., 1.

Porcupine district: Eakin, 1.

Ruby district: Mertie, 11.

Salmon River district: Westgate, 2. Sheenjek River district: Mertie, 16. Snug Harbor district: Moffltt, 7 . southeastern: Burchard, 6 .

Talkeetna Mountains: Capps, 6 ; western : Capps, 3. 
Geologic maps-Continued.

Alaska-Continued.

Toklat-Tonzona River region: Capps, 12.

Tolstoi district: Harrington, 2.

Tuxedni Bay area: Moffit, 2. upper Matanuska Valley: Capps, 11. Wide Bay: Smith, W. R., 1.

Wrangell district: Buddington, 4.

York region: Steidtman, 4.

Alberta : Allan, 14.

area between Athabaska and Embarras Rivers: Rutherford, 5.

Banff area: Warren, P. S., 4.

Battle River: Hume, 20.

Blackstone, Brazeau, and Pembina rivers foothills belt: Allan, 13.

Bow River bètween Cochrane and Kananaskis: Rutherford, 6.

Drumheller district: Allan, 7 .

foothills belt between McLeod and Athabaska Rivers: Rutherford, 4.

North Saskatchewan and McLeod Rivers: Rutherford, 8.

Ribstone Valley: Dowling, 5.

Saunders. Creek and Nordegg coal basins: Allan, 9.

southern: Stewart, J. S., 1; artesian area: Dowling, 19.

Turner Valley: McLearn, 14.

Turner Valley oil area : Hume, 22.

Wainwright-Vermilion area: Hume, 19.

Appalachian region: Keith, 2.

Arctic Canada, Baffin Island, Cumberland Sound area: Weeks, L. J., 3.

Arctic regions, Ellesmere Land : Holtedahl, 1.

Arizona : Arizona Bur. Mines, 1; Darton, 13.

Aravaipa-Stanley region: Ross, C. P., 5.

Banner mining district: Ross, C. P., 6.

Bisbee district: Jones, Ed. L., 6.

Black Mesa : Reagan, 15.

Bradshaw Mountains quadrangle: Lindgren, 17.

Cave Creek district: Lewis, A. S., 1. central : Ettlinger, 1.

Christmas area: Ross, C. P., 6.

Courtland-Gleeson region: 'Wilson, E. D., 2.

Glla region, lower: Ross, C. P., 1.

Globe-Ray region: Ransome, 1.

Grand Canyon: Darton, 12.

Hopi Buttes volcanic field : Reagan, 8.

Jerome district, Yavapai County: Reber, 1.

Jerome quadrangle : Lindgren, 17.

Lees Ferry region: Bryan, 11.

Mazatzal Peak region: Wilson, E. D., 1.

Miami district : Ransome, 1.

Oatman district: Ransome, 12.

Papago country: Bryan, 7.

Payson district: Lausen, 1.
Geoloyic maps-Continued.

A rizona-Continued.

Ray district: Ransome, 1.

Ray quadrangle : Ransome, 11.

San Carlos Indian Reservation: Schwennesen, 1.

Superior district: Short, 1.

Tombstone district: Jones, Ed. L., 6.

Tucson and Amole Mountains: Jenkins, 3.

Verde formation : Jenkins, 6.

Virgin Mountains: Darton, 16.

Arkansas: Branner, G. C., 3 ; Ferguson, J. G., 1.

Batesville district: Miser, 5, 8.

Hot Springs district: Purdue, 1.

Pike County, peridotite area : Miser, 10, 18; Prairie Creek area : Miser, 12.

Pike, Howard, and Hempstead counties (parts): Miser, 12.

southwestern: Ellisor, 2.

Atlantic and Gulf Coastal Plain : Stephenson, 6.

Black Fills region: O'Harra, 3.

British Columbia: Brock, 4 ; Schofield, 3.

Ainsworth district: Schofield, 4.

Atlin-Telegraph Creek, Cassiar district: Cockfield, 18.

Bridge River, Lillooet district: McCann, 3.

Cariboo district, Barkerville area: Johnston, W. A., 22.

Cassiar district, Devils Elbow Mountain : Kerr, F. A., 2.

Chillso Lake area: Dolmage, 15.

coast and islands: Dolmage, 8 ; between Campania Sound and Port Simpson; Dolmage, 9 ; between Port Simpson and Stewart; Dolmage, 9.

Copper Mountain: Camsell, 4.

Dease Lake area, Cassiar district: Kerr, F. A., 1.

Dewdney Trail: Cairnes, 2.

Driftwood Creek area, Babine Mountains: Hanson, 9.

Eutsuk Lake area, Coast district: Marshall, J. R., 3.

Finlay River district: Dolmage, 17.

Fraser River Delta: Johnston, W. A., 17.

Hazleton : O'Neill, 1

Hope Mountain : Cairnes, 2.

Hudson Bay Mountain, Coast district: Jones, R. H., 1.

Kamloops district, North Thompson valley: Uglow, 3.

Kettle Valley: Cairnes, 2.

Kitsault River to Skeena River: Hanson, 3.

Kitsault Valley: Hanson, 2.

Kootenay district (part): Walker, J. F., 2.

Lakelse Lake area : Marshall, J. R., 5. 
Geologic maps-Continued.

British Columbia-Continued.

Lasqueti Island : MacKenzie, J. D., 3. Parson Bay: Crickmay, 9.

Peace River canyon area : McLearn, 7. Peace River district: Spieker, 1 .

Pemberton area, Lillooet district: Cairnes, 8.

Purcell trench: Schofield, 6.

Rocky Mountain trench: Shepard, 11.

Salmon River district: Schofield, 14 southeastern : Walker, J. F., 1.

Taseko Lake-French Bar Creek : MacKenzie, J. D., 2.

Taseko Valley: MacKenzie, J. D., 1. Tatla-Bella Coola area : Dolmage, 16.

Vancouver Island, Alberni area : Mackenzie, 7 ; East Sooke Penin sula : Cooke, H. C., 5; Sunlocl district : Dolmage, 3.

Whitesail-Tahtsa lakes area: Marshal1, J. R., 3.

Windermere area, Kootenay district : Walker, J. F., 1.

Yale district, Silver Creek, Skagit and Similkameen rivers : Cairnes, 5 .

Tulameen area : Poitevin, 6.

Zymoetz River area, Coast district: Hanson, 11.

British Honduras: Ower, 1.

British Virgin Islands: Earle, 5.

California, Blackhawk Canyon, San Bernardino Mountains: Wo odford, 7 .

Capistrano area: Woodford, 3.

Cuyamaca region: Hudson, F. S., 1.

Deep Spring Vailey : Miller, W. J., 35.

Del Norte County : Logan, C. A., 1.

Eocene north of Mt. Diablo: Clark, B. $\mathrm{L} ., 18$.

fault map: Willis, 10 .

Humboldt County, southwestern: Hoots, 7 ; U. S. G. S., 19.

Kern County : English, W. A., 1.

La Jolla quadrangle: Hanna, M. A., 3.

Los Angeles Basin: Eaton, J. E., 3. Point Reyes quadrangle: Dickerson, 2.

Point Sur quadrangle: Trask, 4.

Puente Hills region : English, W. A., 3. Randsburg quadrangle: Hulin, 3.

Richfield oil field : Musser, 3.

Salton Basin : Brown, J. S., 1, 3.

San Bernardino County (part): Eckis, 1.

San Bernardino Mountains : Vaughan, F. E., 1.

San Diego County: Eillis, A. J., 1.

San Jacinto and Temecula basins: Waring, 1

San Onofre: Woodford, 3.

Santa Barbara County, Santa Ynez River district: Kew, 2; Nelson, R. N., 1.

Sauta Clara Valley: Reinhard, 1.
Geologic maps-Continued.

California-Continued.

Santa Rosa and Petaluma quadrangles: Dickerson, 2.

Santa Rosa Island: Kew, 10.

Simi Valley: Kew, 1.

Siskiyou County, Salmon River district: Logan, C. A., 1.

Sonora quadrangle: Benson, W. N., 2. southern coast (part): Woodford, 3 .

Sunset-Midway field : Pack, R. W., 1.

Tejon region: Anderson, F. M., 1.

Ventura Basin : Eaton, J. E., 4.

Ventura County (part); Nelsou, R. N., 2.

Warner Range: Russell, R. J., 6.

Cambrian: Schuchert, 25.

Canada: Graham, R. P. D., 2.

central Arctic coast: O'Neill, 5.

eastern : Brock, 11; Graham, R. P. D., 3.

Mackenzie River basin : Camsell, 1. mineral map: Young, G. A., 5.

platinum occurrences: O'Neill, 2.

western: Brock, 11 ; Graham, R. I. D., 3.

Canada and Newfoundland: Can. G.

S., 3; Young, G. A., 5.

Central States: Cumings, 1.

Coal fields: U. S. G. S., 1.

Colorado: George, R. D., 6; (part) : Campbell, M. R., 3.

Axial and Monument Butte quadrangles: Hancock, 7 .

Canyon City area: Osborn, 10.

Catlin quadrangle: Toepelman, 3.

Creede district: Emmons, W. H., 4.

De Beque oil field: Winchester, 5.

Delta and Mesa counties: Weeks, H. J., 1.

Grand, Jackson, and Larimer counties (parts) : Spock, 1.

Gunnison River: Hunter, J. F., 1.

Italian Mountain, Gunnison County : Cross, W., 7.

La Junta area: Patton, H. B., 3.

Las Animas, Otero, and Bent counties (parts): Duce, 1.

Leadville mining district: Emmons S. F., 1 ; Loughlin, 31.

Mancos district: Collier, $\mathbf{3}$

Moffat County : Sears, 3.

Montezuma County, McElmo anticline: Coffin, 2.

north central, foothills formations: Henderson, 2:

northeastern : Mather, 12.

northwestern: George, R. D., 2; Sears, 5 ; Winchester, 5.

Otero County: Lupton, 6.

Pitkin County, Aspen district: Knopf, A., 10

Platoro-Summitville district: Patton, H. B., 1.

Red Cliff district: Crawford, R. D., 3. 
Geologic maps-Continued.

Colorado-Continued.

Routt and Moffat counties : Perini, 1. Routt County : Crawford, R. D., 1. San Juan Basin : Reeside, 8.

Tarryall district, Park County : Muilenburg, 2.

Twin Lakes district: Howell, J. V., 1.

Connecticut: Gregory, H. E., 8.

central : Rice, W. N., 1.

Glastonbury area : Palmer, H. S., 4. Meriden area: Waring, 2.

New Haven area: Brown, J. S., 9. New Haven coast: Brown, J. S., 5. Norwalk area: Palmer, H. S., 4.

Shepaug Aqueduct Tunnel area : Agar, 4.

southern (part): Russell, W. L., 1. Southington-Grauby area: Palmer, H. S., 5.

Stonington region: Martin, L. H., 1. Suffeld area: Palmer, H. S., 4.

Cretaceous deposits, eastern Gulf region: Berry, 3.

Delaware, Wilmington quadrangle: Bascom, 2.

Dominican Republic: Vaughan, 16.

Azua and Barahona provinces: Vaughan, 16.

Florida: Gunter, 3; Sellards. 4, 5, 12.

Foxe Land, Baffin Island: Gould, $L$. M., 6,8 .

Georgia: McCallie, 1, 2; 5.

Cartersville district: Hull, 1, 3.

Coastal Plain: Prettyman, 1.

sand and gravel deposits: Teas, 1.

Tate quadrangle: Bayley, 13.

Great Lakes region: Fryxell, 1.

Greenland : Böggild, 1, 4, 6.

northern: Koch, 4.

northwestern: Koch, 1.

Peary Land: Koch, 2.

Guatemala: Redfield, 3.

Gulf Coastal Plain: Miser, 7 ; Urbina, 1.

Haiti : Woodring, 5.

central plain: Woodring, 1.

northwestern: Lutgens, 1.

Terre-Neuve region: Woodring, 5 .

Huntington-Pittsburgh Basin: Richardson, G. B., 13.

Ice recession: De Geer, 4.

Idaho: Bell, R. N., 4.

Birch Creek district: Shenon, 2.

Boise Basin :'Ballard, 3.

Boundary County: Kirkham, 7.

Buffalo Hump district: Beckwith, R. H., 1, 4.

Camas Creek Basin: Piper, 4.

Cassia County, Goose Creek basin:

Piper, 1.

Clark, Jefferson, and parts of Butte, Custer, Fremont, Lemhi, and Madison counties: Kirkham, 9.

Coeur d'Alene district: Umpleby, 3.
Geologic maps-Continued.

Idaho-Continued.

Cranes Flat, Henry, and Lanes Creek quadrangles: Mansfield, 10.

Cranes Flat quadrangle: Mansfield, G. R., 29.

De Lamar district: Piper, 6. eastern: Mansfield, G. R., 8.

Flint mining district: Piper, 6 .

Fort Hall Indian Reservation : Mansfield, G. R., 3.

Heath (Cuddy Mountain) mining district: Livingston, 4.

Hell Creek, Fall Creek, Palisade Creek, McKoy Creek, Grays Lake, and Cranes Flat quadrangles: Kirkham, 3.

Henry quadrangle: Mansfield, G. R., 29.

Lanes Creek quadrangle: Mansfield, G. R., 29.

Lapwai area: Kirkham, 11.

Lemhi County (part) : Ross, C. P., 7. Mud Lake area: Stearns, 9. north central: Thomson, F. A., 3, 4. northern, Pleistocene: Anderson, A. L., 2.

Orofino area: Kirkham, 11.

Owyhee County, Bruneau River basin: Piper, 2; South Mountain district: Sorenson, 1.

Palouse River area : Kirkham, 10.

Pend Oreille district: Sampson, 16.

Pine Creek district: Jones, Ed. L., 4.

Pocatello area: Anderson, A. L., 3.

Power and Oneida counties : Piper, 3.

Rocky Bar quadrangle: Ballard, 4.

St. Maries area : Kirkham, 8.

Seven Devils district: Livingston, 3.

Shoshone County: Umpleby, 3.

Slug Creek quadrangle: Mansfield, G. R., 29.

Snake River between Burnt River and Salt Creek: Livingston, 4.

south central: Umpleby, 2.

sontheastern : Kirkkam, 1 ; Mansfield. G. R., 29.

Vienna district: Ross, C. P., 12.

Wardner district: Rickard, 3.

War Eagle and Florida Mountains: Piper, 6.

Washington County, Mineral district: Livingston, 4.

Wood River district: Camplsell, S., 8.

Yellow Pine district: Larsen, 3.

Idabo-Wyoming, Crow Creek quadrangle: Mansfield, G. R., 29.

Freedom quadrangle: Mansfield, G. R., 29.

Montpelier quadrangle: Mansfield, G. R., 29.

Illinois: Ill. G. S., 1.

Adams County, northeastern: Currier, 1.

Alto Puss region: Poor, 1.

Ava-Campbell Hill area: Root, 1. 
Geologic maps-Continued.

Illinois-Continued.

Avon-Canton area: Savage, 6.

Carbondale quadrangle: Lamar, 3.

Carlyle-Centralia district: Shaw, 9.

Colchester and Macomb quadrangles:

Hinds, H., 1.

Chicago region, glacial: Fryxell, 1.

Dixon quadrangle: Knappen, 1.

east-central: Mylius, 7 .

Edgington-Milan area: Savage, 5.

Equality-Shawneetown area: Butts. 5.

Gillespie quadrangle: Lee, W., 1.

glacial: Hay, 16.

Hardin County and Pope County (part) : Weller, S., 1.

Hennepin quadrangle: Cady, 3.

Hennepin and La Salle quadrangles, surficial geology: Cady, 3.

Herscher quadrangle: Athy, 1.

Joliet quadrangle : Fisher, D. J., 2.

Kings quadrangle: Bretz, 4.

La Harpe and Good Hope quadrangles; Savage, 8.

La Salle quadrangle: Cady, 3.

mineral industries: Christeusen, 1 ; I11. St. G. S., 3.

Morris quadrangle: Culver, 2.

Mount Olive quadrangle: Lee, W., 1.

New Athens-Okawville area: Shaw, 8.

northeastern : Anderson, C. B., 1.

northern: Thwaites, 7.

oil and gas fields : Richardson, G. B., 1.

Pulaski County : Lamar, 10.

St. Peter sandstone: Lamar, 9.

Saline and Gallatin counties: Cady, 4 .

Saline County : Cady, 12.

Williamson and Saline counties (parts) : Cady, 11.

Indiana: Logan, 5, 10, 24; Reeves J. R., 7 .

glacial: Hay, 16.

Greene County : Logan, 4 ; eastern : Malott, 1.

Knobstone cuesta region : Malott, 4.

Law rence County : Logan, 4.

Martin County: Logan, 4.

Monroe County : Logan, 4.

Orange County : Logan, 4.

Owen County : Logan, 4

Indiana and surrounding States: Logan, 15.

Iowa : Howell, J. V., 4 ; Kay, 13; Van Tuyl, 8.

Adair County : Gow, 1.

Cass County : Tilton, 3.

Clarke County: 'Tilton, 2.

Crawford County : Lees, 18.

drift sheets: Kay, 4.

eastern : Norton, W. H., 1.

Hackberry stage : Fenton, C. L., 3.

Lake Calvin region, Pleistocene: Schoewe, 6.
Geologic maps-Continued.

Iowa-Continued:

Lucas County: Lugn, 6.

Missouri series: Tilton, 7 .

north central: Fenton, C. I., 2, 4.

Ringgold County, surface deposits: Arey, 1.

Stuart area: Tilton, $\mathbf{5}$.

Taylor County, surface deposits: Arey, 2.

Jamaica: Brunton, 2 ; Cundall, 1.

Kansas, Allen and Neosho counties: Moore, R. C., 5.

Butler County, Eldorado oil and gas field : Fath, 2.

Cowley County: Elledge, 1.

Ellis County : Bass, 2.

Hamilton County : Bass, 2.

northeastern, Pleistocene: Schoewe, 5.

oil and gas fields: U. S. G. S., 2.

Quaternary deposits : Moore, R. C., 4.

Russell County: Rubey, 3.

Syracuse and Lakin quadrangles: Darton, 2.

Wilson and Montgomery countles: Moore, R. C., 6.

Kansas and Oklahoma: Snider, 1.

Kansas and the adjolning region : Moore, R. C., 4.

Kentucky: Jillson, 20, 70, 72, 86, 87.

Adair County: Miller, A. M., 20.

Allen County: Miller, A. M., 5; Shaw, E. W., 1.

Barren County: Butts, 2.

Bath County, oil and gas: Ky. G. S., 35.

Barren County, oil and gas: Ky. G. S., 23.

Bell County : Ky. G. S., 46.

Bells Run anticline, Ohio County, structural : Ky. G. S., 36.

Bourbon County : Dunn, P. H., 1.

Boyd County, oil and gas: Ky. G. S., 25 ; structural : Ky. G. S., 11.

Bracken County, oil and gas map: Ky. G. S., 30.

Breathitt County : Jillson, 13; Ky. G. S., 1, 37 .

Butler County: Glenn, 11; Jillson, 95, 103.

Caldwell County: Weller, 17.

Carter County: Ky. G. S., 26.

Cave in Rock quadrangle: Weller, 16.

Christian County: Sutton, 2.

Clay County: Ky. G. S., 38.

Dawson Springs quadrangle: Sutton, 1 .

Edmonson County: Ky. G. S., 31.

Elliott County, oil and gas: Ky. G. S., 27.

Estill County, lower Miller Creek: Ky. G. S., 52.

Floyd County: Ky. G. S., 49 ; structural : Ky. G. S., 5.

Garrard County : McFarlan, 2. 
Geologic maps-Continued.

Kentucky-Continued.

Golconda and Cave in Rock quadirangles: Weller, 10.

Grayson County: Ky. G. S., 32.

Green County, oil and gas map: Ky. G. S., 50.

Greenup County: Ky. G. S., 33.

Hancock County, oil and gas: Ky. G. S., 13.

Harlan County: Ky. G. S., 39.

Hartford quadrangle: Gardner, J. H., 4.

Henderson County: Ky. G. S., 40.

Hopkins County: Theis, 1.

Irvine and Berea region: Ky. G. S., 14.

Isonville oil pool, Elliott County, structural : Ky. G. S., 15.

Jackson County: Eyl, 1.

Jackson Purchase region: Jillson, 28.

Jeptha Knob: Bucher, 9.

Johnson County: Ky. G. S., 3.

Knott County: Jillson, 13; structural geology: Ky. G. S., 2.

Knox County: Ky. G. S., 28.

Lawrence County: Ky. G. S., 34.

Lee County: Eyl, 2; Ky. G. S., 41.

Leslie County: Ky. G. S., 16.

Lewis County: Perry, E. S., 1.

Lincoln County: Ky. G. S., 42.

Livingston County: Weller, 14.

Lyon County: Roberts, J. K., 5.

McCready County: Murphy, 1.

McLean County, economic: Ky. G. S., 17.

Magoffin County: Ky. G. S., 4.

Martin County, structural: Ky. G. S., 6, 18.

Metcalfe County, oil and gas data: Ky. G. S., 19.

Monroe County, oil and gas data: IKy. G. S., 7.

Morgan County: Robinson, L. C., 1. Muhlenberg County: Ky. G. S., 20.

Nelson County: hy. G. S., 53.

Ohio County: Jillson, 88, 104.

Owsley County: Ky. G. S., 43.

Paint Creek uplift: Ky. G. S., 21.

Perry County: Ky. G. S., 22.

Pike County, structural: Ky. G. S., 8.

Powell County: Ky. G. S., 44.

Princeton quadrangle: Weller, 7.

Rockcastle uplift, Laurel and Clay counties: Ky. G. S., 9.

Taylor County, oil and gas: Ky. G. S., 29.

Union County: Glenn, 10.

Warren County: Shaw, E. W., 1 ; oil and gas map: Ky. G. S., 54.

Wayne County, oil and gas map: Ky. G. S., 45.

Webster County: Glenn, 5.
Geologic maps-Continued.

Kentucky-Continued.

Williamsburg anticline, Whit le y County: Ky. G. S., 10.

Woodford County: Miller, A. M., 21.

Kentucky and adjoining States: Jillson, 1, 2.

Labrador, Komaktorvik Fiord: Coleman, 6 .

Nachvak Fiord: Coleman, 6.

northeastern, and New Quebec: Coleman, 6.

Louisiana: Glenk, 1 ; Hay, 23.

norther'n, structure: Spooner, 2.

oil and gas fields: Richardson, G. B., 2.

Shreveport area : Whittemore. J. W., 1.

Mackenzie, Mackenzie basin : Cameron, 1 ; Camsell, 1.

lower Mackenzie valley: Kindle, 9.

Mackenzie River between Norman and Beaver River: Hume, 5; between Wrigley and Norman: Hume, 8.

Mackenzie River district: Whittaker, 2 ; Williams, M. Y., 13.

Maine: Smith, G. O., 15.

Belfast quadrangle: Perkins, E. H., 3.

Liberty quadrangle: Perkins, E. H., 3.

Moosehead Lake area: Perkins, E. H., 4.

Vassalboro quadrangle: Pedkins, E. H., 3.

Manitoba: Prather, 1 ; Wallace, 14, 19.

Beresford Lake area: Wright, D. G. H., 2 ; Wright, J. F., 4.

Bigstone and Fox river's area: Merritt, J. W., 4.

Flinflon area : Alcock, 15.

Island Lake area: Wright, J. F., 12.

Maskwa River nickel-copper deposits : McCann, 1.

mineral occurrences : Wallace, 14, 19.

Oiseau River area: Cooke, H. C., 9 ; Wright, J. F., 10.

Oswagan Lake-Burntwood River area : Alcock, 9.

Oxford and Knee lakes area : Wright, J. F., 11.

Rat River: Alcock, 10.

Reed and Wekusko lakes region: $\mathrm{Al}$. cock, 3 .

Rice Lake area: Cooke, H. C., 9; Wright, J. F., 3, 6 .

southern glacial geology: Wallace, 14.

Upper Whitemouth area: Johnston, W. A., 3.

WInnipegosis area : Johnston, W. A., 3.

Martinique, eastern: Barrabe, 1. 
Geologic maps-Continued.

Maryland, Cambrian and Ordorician : Bassler, R. S., 1.

coals of Georges Creek and upper Potomac basins: Swartz, C. K., 4. Elkton quadrangle: Bascom, 2.

Kent County : Miller, B. L., 6.

Pledmont Plateau: Knopf, E. B., 3. Queen Amnes County: Miller, B. I., 7.

Silurian: Swartz, C. K., 5. western Pledmont : Jonas, 4.

Massachusetts, Cape Ann, Andrew's Point: Warren, C. H., 2.

central western: Miller, W. J., 10. Essex County: Clapp, C. H., 1. eastern: Warren, C. H., 2.

Medford dike: Billings, 1.

Ware and Quinsigamond quadraugles: Alden, 2.

Massachusetts and New Yolk, Pittsfield and Becket quadrangles: Dale, T. N., $\mathbf{5}$.

Mexico: Iglesias, 1 ; Lewis, S. J., 1; Mexico, Secr. Agr., 1.

Coabuila, northern: Cummings, 2. Colima (part): Vivar, 4.

EI Oro and Tlalpujahua districts: Flores, 1.

Guanajuato mining district: Wandke, 8.

Hidalgo, Apan district: Camacho, 1.

Lower California : Marland Oil Co., 1; Distrito Sur: Bustamante, 2; La Purisima region: Heim, 1. southern: Galvez, 7.

petroleum: Ortega, G., 1.

southern: Ver Wiebe, 2.

Zacualpan district: Lewis, S. J., 1. Michigan, Alpena County: Ver Wiebe, 10.

Chippewa County : Ver Wiebe, 11.

Lower Peninsula: Phalen, 1.

Marquette and Menominee districts : Winchell, A. N., 2.

Roscommon County: Ver Wiebe, 8. Southern Peninsula, clay and shale areas : Brown, G. G., 1.

surface formations: Leverett, 14.

Mid-Continent oil fields: Bosworth, 1.

Mid-Continent and north Texas oil regions : Rogers, G. S., 7.

Minnesota: Hay, 23; Sardeson, 1; Stauffer, 7.

clay materials: Grout, 2.

eastern Mesabi range: Grout, 3.

Herman, Barrett, Chokio, and Morr'is quadrangles: Sardeson, 1.

St. Louis County, northern: Grout, 20.

surface formations: Leverett, 4.

Vermilion iron range: Schwartz, 7.

Washington County, northern: Peterson, E., 1.

Mississippi: Lowe, 2, 3, 9 ; Stephenson, 10 .

northeastern: Burchard, 20.
Geologic maps-Continued.

Missouri : Buehler, 3.

Devonian formations along the Missouri River: Branson, $\mathbf{5}$.

Ste. Genevieve County: Weller, 19.

Montana (part) : Pardee, 14.

Bearpaw Mountains: Reeves, F., 7 .

Beartooth Mountains: Bevan, 2.

Cit Creek oil field: Lupton, 1.

central and eastern : Clapp, C. H., 2.

Ekalaka field: Bauer, 4.

faulted area south of Bearpaw Mountains: Reeves, F., 8.

Fergus County, Winifred area : Reeves, F., 6.

Huntley field: Hancock, 2.

Ingomar anticline, Treasure and Rosebud counties: Heald, 18.

Jordan coal field: Bowen, C. F., 2.

Kevin-Sunburst oil field: U. S. G. S., 11.

McCarthy Mountain area: Richards, R. W., 2.

Melrose phosphate field: Richards. R. W., 2 .

Musselshell and Golden Valley countie's: Ellis, A. J., 5.

Philipsburg district: Pardee, 8.

Philipsburg phosphate field: Pardee, 6.

Rosebud County : Renick, 5.

Scobey lignite field, Valley, Daniels, and Sheridan counties: Collier, 9.

Stanford hematite district: Westgate, 1 .

Sweet Grass Hills : Kemp, 8.

'Three rorks-Yellowstone Park region: Condit, 5 .

Townsend Valley: Pardee, 10.

Nebraska, Pennsylvanian: Condra, 2.

Nevada, Divide district: Knopf, A., 3.

Elko area: Winchester, 5.

Gllbert district: Ferguson, H. G., 10.

Manhattan district: Ferguson, H. G., $2,5$.

Mills City tungsten district: Hess, 11.

Muddy Mountain overtbrust: Longwell, 3.

Muddy Mountains region : Longwell, 1, 15.

Pilot Mountains: Foshag, 32.

Pioche district: Westgate, 6.

Fleistocene lake beds: Clark, W. O., 1.

Rochester district: Knopf, A., 7 .

Santa Fe district, Mineral County: Clark, C. W., 2.

Toquima Range: Ferguson, H. G., 2,4 .

New Brunswick, Burnthill Brook area : Young., G. A., 1.

Chipman sheet, Queens County : Dyer, 8.

Kings County, Sussex area: Hayes, A. 0., 7. 
Geologic maps-Continued.

New Brunswick-Continued.

Minto sheet, Sunbury County :

Dyer, 8.

Moncton area: Wright, W. J., 2.

Newfoundland: Howley, 1 ; Snelgrove, 1., 2.

St. George's coal field: Baker, $H$. A., 2.

west coast : Brunton, 3 .

New Hampshire: Goldthwait, 6; glacial : Goldthwait, 6 .

Ammonoosuc district: Ross, C. P., 2.

Hanover district: Merritt, J. W., 3.

White Mountains, North Conway quadrangle: Billings, 5.

New Jersey, greensand beds : Mansfield, 12.

New Mexico : Darton, 25 ; Ellis, R. W., 5; (parts): Darton, 26.

Alamosa Creek valley : Winchester, 3 .

Carlsbad region: Meinzer, 16.

Gallup coal district, McKinley County: Sears, 6.

Gallup-Zuni Basin: Sears, 6.

Guadalupe group: Darton, 19.

Iron Mountain : Smythe, 2.

Jornada del Muerto: Darton, 11.

Mogollon district : Ferguson, H. G., $1,8$.

Puertecito district: Wells, E. H., 2. Raton coal field: Lee, W. T., 10.

Raton-Brilliant-Koehler area: Lee, W. T., 6.

Roswell artesian basin: Fiedler, 2.

Sandia and Manzano mountains and Sierra de los Pinos: Darton, 11.

Sandia Mountains: Ellis, R. W., 2.

San Juan County : Bauer, C. M., 1.

southeastern: Hoots, 1; Anon., 58.

Taos Range: Gruner, 1.

Tularosa Basin: Darton, 11; Powell, 1.

Tyrone district: Paige, 2.

Valencia and Socorro counties (parts) Darton, 11.

Zuni Indian Reservation: Sears, 6.

New York: Miller, W. J., 23.

Adirondacks: Newland, 2.

Canton quadrangle: Chadwick, 5.

Catskill region: Jones, R. W., 1.

Clove quadrangle: Dale, T. N., 5.

Cohoes quadrangle, glacial: Stoller, 2. eastern, Pleistocene: Fairchild, $\mathbf{H}$. L., 1.

Gouverneur quadrangle: Cushing, 1.

Lake Bonaparte quadrangle: Smyth, 2.

L a ke Bonaparte-Lowrille qu a drangles: Buddington, 2.

Lake Placid quadrangle: Miller, W. J., 1.

Lyon Mountain quadrangle: Miller, W. J., 26.

Mount Marcy quadrangle: Kemp, 7.
Geologic maps-Continued.

New York-Continued.

Newburgh quadrangle : Holzwasser, 1.

New York City : Reeds, 2.

Ordovician : Ruedemann, 16.

Plattsburg quadrangle: Hudson, G. H., 1.

Rochester district, Plelstocene : Fairchild, 6.

Rouses Point quadrangle: Hudson, G. H., 1.

St. Regis and Saranac quadrangles (parts) : Alling, H. L., 1 ; glaciation: Alling, H. L., 1.

Schroon Lake quadrangle: Miller, W. J., 2.

Skaneateles region : Monnett, 3 .

West Point quadrangle: Berkey, 3.

New York, Massachusetts, and Connecticut, Sheffield and Sandisfield quadrangles: Dale, T. N., 5.

New York, Massachusetts, and western Vermont, Greylock, Berlin, and Hoosick quadrangle: Dale, T. N., 5.

North America: Pirsson, 2, 5; Schuchert, 23.

North Carolina: Bryson, 3.

Cherokee County, Nottely and Valley River belt: Bayley, 5, 11.

Cretaceous: Stephenson, 4.

Deep River pyrophyllite deposits . Stuckey, 1.

Deep River region: Stuckey, 5 .

North Dakota: Leonard, A. G., 1; Willard, D. E., 2.

Marmarth field: Hares, 5.

New Salem lignite field: Hancock, 6 . western: Stanton, 3.

Northern Great Plains: Alden, 3.

Nova Scotia: Brunton, 6, 10; (physiographic) ; Goldthwait, 5.

Arisaig district: McLearn, 8.

Cape Breton County, Sydney : Hayes, A. $0 ., 6$.

Horton-Windsor district: Bell, W. A., 2.

Inverness County, Lake Ainslie district: Bell, W. A., 12.

Malagash Peninsula, Cumberland County : Hayes, 2.

North Mountain, Cape Breton : Guernsey, 2.

Northumberland Strait: Bell, W. A., 10.

Richmond County, Stirling area : Weeks, L. J., 1.

Ohio: Bownocker, 1 ; Westgate, 5.

Camp Sherman quadrangle: Hyde, 1.

Delaware County: Westgate, 5 ; glacial: Westgate, 5.

Dunkard series: Stauffer, 1.

glactal: Hay, 16.

northwestern, Monroe division: Carman, 2. 
Geologic maps-Continued.

Ohio-Continued.

Summerfield and Woodsfield quadrangles: Condit, 3.

Wayne County: Conrey, 1.

Oklahoma : Gould, C. N., 31; Miser, 24 ; Redfield, J. S., 1 ; Reeves, F.. 1 ; Robinson, H. M., 3.

Arbuckle Mountain region: Cooper, 1 ; Reeds, 11 ; western end : Birk, 2.

Arbuckle Mountains: Taff, 7 .

Ardmore Basin : Goldston, 2.

Ardmore quadrangle: Goldston, 1.

Beaver County : Gould, 15.

Beckham County: Gouin, 2.

Bristow quadrangle: Fath, 6 .

Caddo and Grady counties : Becker, 1.

Carter County: Tomlinson, 4; (part) ; Roth, 2; Criner Hills : Powers, 22.

Cimarron County: Rothrock, 4.

Cleveland and McClain counties : An derson, G. E., 4.

Coal and Pittsburg counties : Clawson, 1.

Comanche County: Gouin, 3.

Garvin County : Dott, 2.

Grandfield Bridge sheet: Sellards, 18

Harmon, Greer, Jackson and Tillman counties: Clifton, 5.

Jefferson County : Robinson, H. M., 3.

Kay, Grant, Garfield, and Noble counties: Clark, G. C., 3.

Kingfisher and Canadian counties: Kite, 1.

Leflore and McCurtain counties: Honess, C. W., 5.

Logan County: Bale, 1.

Love County : Bullard, 2.

Marshall County : Bullard, 3.

mineral resources: Okla. G. S., 1.

Muskogee County: Soyster, 1.

northeastern, structure map: Thom, 11 ; subsurface distribution of preChattanooga rocks: White, L. H., $2,3$.

oil and gas fields: U. S. G. S., 6.

Okmulgee district: Clark, R. W., 1.

Osage County: Beckwith, H. T., 1.

Osage Reservation: Goldman, 4;

Heald, 1-4; Hopkins, O. B., 1;

Ross, C. S., 2 ; Roundy, 1.

Ouachita Mountains: Miser, 29.

Papoose oil field: Roark, 2.

Rogers County: Woodruff, 4.

south central: Bullard, 2, 3 .

southeastern : Honess, C. W., 2.

southern : Moore, R. C., 10; (part) :

Hopkins, O. B., 2; Stonewall quadrangle: Morgan, G. D., 6 ; structural trends: Decker, L., 1. southwestern : Gould, 5; Sawyer, 1. Stephens County: Gouin, 1.

Texas County: Gould, 11.

upper Paleozoic: Gould, C. N., 19.
Geologic maps-Continued.

Oklahoma-Continued.

Washington County : Carpenter; E, 2 . western : Bullard, 4.

Wichita Mountains: Taff, 7.

Oklahoma and adjacent States (parrs): Bullard, 4.

Ontario: Canada, Dept. Mines, 1. ; Nicolas, 1.

Algoma district: Brunton, 1 ; Blind River : Collins, 11; Bruce Mines: Collins, 11; Michipicoten area : Collins, 15; Missinaibi area ; Thomson, E., 11.

Algoma and Thunder Bay districts: Canada G. S., 1.

Anima-Nipissing area : Todd, E. W., 7.

Argonaut gold mine: Knight, 6

Batchawana area, District of Algoma: Moore, E. S., 19.

Ben Nevis area : Knight, C. IV., 5.

Black River area : Wright, D. G. H.,1.

Blanche River area: Burrows, 9.

Boston-Skead area: Burrows, 8.

Brocktown - Mallorytown a r ea : Wright, J. F., 2.

Carscallen, Bristol, and Ogden townships, District of Cochrane : Hawley, J. E., 3.

Cobalt area: Knight, 11.

Contact Bay gold mines, District of Kenora : Bruce, 17.

English River valley: Bruce, 11.

Favourable Lake area, Patricia: Hurst, 5.

Gammon River area, District of Kenora: Gilbert, G., 7 .

glacial shore lines: Ledoux, A., 1.

Goudreau-Lochalsh area: Gledhill, 8.

Gowanda area: Burrows, 3, 17.

Kamiskotia area: Finley, 1.

Kenogamissi Lake area: Todd, E. W., 3

Kirkland Lake area: Burrows, 4.

Lake St. Joseph area: Bruce, 8; eastern part: Bruce, 9.

Larder Lake area: Hopkins, 8.

Leeds County : Baker, M. B., 1.

Lightning River area: Gledhill, 4.

Matabitchuan area: Todd, E. W., 6.

Matachewan district: Cooke, H. C., 1.

Matawin iron range, Thunder Bay district: Tanton, 15.

Michipicoten area: Gledhill, 7 .

Michipicoten district, Goudreau pyrite area : Collins, 15.

Mississagi Reserve and Goulais River iron ranges: Moore, E. S., 15.

Morrisburg sheet: Wilson, A. E., 2.

Murphy, Hoyle, and Matheson townships: Rose, 4.

Niagara Peninsula: Williams, $\mathbf{M}$. Y., 1.

Night Hawk Lake area: Hopkins, 9. 
Geologic maps-Continued.

Ontario-Continued.

Nipissing district, Cedar and Net Lakes : Knight, C. W., 4.

Ontario Peninsula: Williams, $\mathrm{M}$. Y., 1.

Ontario-Manitoba boundary: Burwash, 6 ; Rickaby, 1.

Patricia : Rogers, W. R., 6.

phosphate area: Spence, 2.

Porcupine gold area, District of Cochrane : Burrows, 13.

Red Lake area, District of Patricia : Bruce, 12 ; Douglas, G. V., 4 ; Rogers, W. R., 6 ; Wright, D. G. H., 4.

Red Lake gold area, District of Kenora: Bruce, 22.

Red Lake to Favourable Lake, Patricia: Douglas, G. V., 4.

Renfrew County (part); Wilson, M. E., 3.

Sahkatawich Lake section, Woman River iron range, District of Sudbury : Moore, E. S., 20.

Sault Ste. Marie area, District of Algoma : McConnell, 1.

Schreiber-Duck Lake area: Hopkins, P. E., 5.

Shiningtree silver area, District of Timiskaming: Langford, 1.

southwestern: Williams, M. Y., 2.

Sturgeon Lake gold area: Gledhill, 2. Sudbury district, Grassy River area: Gledhill, 5; Lake Panache region: Collins, 11; Moncrieff and Hess townships: Quirke, 7; Wanapitei Lake area: Quirke, 8; West Shiningtree area: Tiuley, 2: Windy Lake nickel area: Knight. C. W., 4.

Sudbury region: Bain, 5.

Sutton Lake area: Hawley, J. E., 1. Tashota-Onaman area: Gledhill, 3.

Thunder Bay district: Tanton, 3, 7 ; Bishop Lake area: Gill, J. E. 1; Little Gull Lake area: GIll, J. E. 1 ; North Lake area: Gill, J. E., 1.

Timiskaming district: Cross, J. G., 2 ; Hume, 1 ; Abitibi-Night Hawk gold area: Knight, C. W., 1; Kenogami Lake area : Cooke, H. C., 8; Larder Lake area: Cooke, $\mathrm{H}$ C. 8; McNeil township: Hopkins, 10; Redstone River area: Bruce, 19 ; Round Lake area: Cooke, $H$ C., 8.

Wakomata Lake area, Algoma district: Emmons, R. C., 3.

Waspika section, West Shiningtree area : Langford, 2.

Watabeag area: Wright, D. G. H., 2.

West Shiningtree area: Hopkins, $P$ E., 2.

Whiskey Lake area, Algoma: Doug las, G. V., 2.
Geologic maps-Continued.

Ontario-Continued.

Woman and Narrow lakes area, District of Kenora: Greig, 2.

Oregon: Smith, W. D., 9.

Astoria : Howe, H. V. W., 9.

Klamath Mountains: Kellogg, A.E., 8.

Riddle quadrangle: Diller, 12.

Panama, Canal Zone: MacDonald, D. F., 1.

Pennsylvania : Leighton, H., 2.

Adams County, mineral products : Stose, 25.

Allegheny County : Leighton, H., 2.

Allentown quadrangle: Miller, B. L., 5.

Cambro-Ordovician 1 i mest ones: Miller, B. L., 11.

Chester Valley: Stose, 18.

coal fields: Sisler, 3.

Greensburg quadrangle: Johnson, M. E., 1.

Jonestown-Lebanon region : Stose, 29. limestones: Miller, B. L., 4.

McCalls Ferry quadrangle: Jonas, 2.

New Holland quadrangle: Jonas, 5.

Northampton County, slate belt: Behre, 7.

oil and gas fields: Richardson, G. B.,

Phoenixville mining district: Miller, B. L., 3.

Piedmont Plateau : Knopf, E. B., 3.

Piedmont region, anorthosite area : Smith, I. F., 3.

Punxsutawney quadrangle: Ashley, 18.

Quarryville quadrangle: Jonas, 3. southeastern: Stose, 21.

western, oil and gas fields: Ashley, 11.

Pennsylvania and Maryland, Piedmont province: Stose, 18.

Permian, Texas-Oklahoma: Gould, 16.

Porto Rico: Berkey, 1.

Barrio Pasto district: Colony, 9.

Coamo-Guayama district: Hodge, E. T., 1.

Humacao district: Fettke, 5.

Juncos-Torre district: Fettke, 6.

Lares district: Hubbard, B., 3.

physiographic map : Lobeck, 5 .

Ponce district: Mitchell, 7.

San Juan district: Semmes, 1.

Quebec: Canada, Dept. Mines, 1.

Abitibi County, Fiedmont and Dubuisson areas: James, 7 ; Fournière sheet: James, $\mathbf{5}$.

Amberst township: Wilson, Morley E., 1.

Anticosti Island: Twenhofel, 30.

Barraute area, Abitibi County : Bain, 8.

Beauceville area: MacKay, B. R., 4.

Bonaventure County, Port-DanielGascons area: Schuchert, 29. 
Geologic maps-Continued.

Quebec-Continued.

Bristol Township: Wilson, M. E., 10.

Chatham Township: Bain, 2.

Chibougamau district, Lake David area: Mawdsley, 4.

Clericy sheet, Abitibi and Temiscamingue counties: James, 4.

Coleraine area: Knox, J. K., 1.

Dufresnoy area, Abitibi district: Harvie, 3.

Duparquet area: James, W. F., 1.

Gaspe County, Lemieux township: Alcock, 14, 29 ; Mailboit, 1.

Gaspe Peninsula (glacial) : Coleman, 10.

Harricanaw Basin: Bain, 6 .

Harricanaw and Bell river basins: Bain, 22.

Harricanaw-Turgeon region: Tanton, 1.

Hull County: Wilson, M. E., 10.

Kinojevis sheet, Temiscamingue and Abitibi counties: James, 4.

Lake David, area: Mawdsley, 5.

Lake Demontigny region: Mailhoit, 4.

Lake St. John district: Martens, 7.

La Motte sheet, Abitibi County: James, 5.

Laurentian Plateau: Dresser, 4.

Mount Albert area : Alcock, 6 .

Mount Serpentine, Gaspe County: Alcock, 22.

Onslow Township: Wilson, M. E., 10.

Percé : Clarke, J. M., 2.

Philipsburg region: Bradley, T. F., jr., 2.

phosphate area: Spence, 2.

Pontiac County, Calumet Island : Goranson, 3.

Quetachou Manicouagan Bay region: Erlenborn, 1.

Quyon area: Wilson, M. E., 10.

Rouyn area: James, W. F., 2; (part) : Cooke, H. C., 29.

St. Urbain area, Charlevoix district: Mawdsley, 1.

Timiskaming $\mathrm{Cou}$ t $\mathrm{y}$, Opasatika area: Cooke, H. C., 10.

Recession of the last ice sheet in New England: Anters, 1.

Saskatchewan, Battle River.: Hume, 20.

Cypress Hills: McLearn, 16.

Lake Athabaska : Allan, 10.

Wapawekka and Deschambault lakes area : De Lury, 6.

Saskatchewan and Manitoba: Wallace, 14.

South Dakota, Badlands: Ward, 8.

Black Hills region: O'Harra, 3 ; central: Darton, 14.

Custer State Park : O'Harra, 5.

Dewey County: Ward, 9.

Edmunds County : Rothrock, 1.

$4096-31-51$
Geologic maps-Continued.

South Dakota-Continued.

Lead district: Darton, 14 ; Paige, 3 , 4

Minnehaha County: Rothrock, 5.

Newell quadrangle: Darton, 1.

Ragged Butte area, Dewey County:

Wilson, R. A., 7 .

western : Stanton, 3.

Tennessee: Jenkins, 1; Nelson, 12.

Brushy Mountain region: Jillson, 43.

Crossville quadrangle: Butts, 6 .

Ducktown district: Emmons, W. H., 8.

east : Secrist, 1 ; Stose, 17.

Friendsville and vicinity: Gordon, C. H., 3.

Harpeth River dome: Jillson, 59.

Knoxville and ricinity: Gordon, C. H., 3.

Overton County (part), structure : Butts, 1.

Rutherford County: Galloway, J. J., 1.

State coal land (Herbert Domain): Nelson, 21.

Upper Cretaceous: Wade, B., 1, 3.

Waynesboro quadrangle: Miser, 6.

western : Roberts, J. K., 6.

western valley: Dunbar, 1.

Tennessee and Virginia (parts): Shaw, E. W., 1.

Texas: Currier \& Company, 1; Moore, R. C., 13 ; Snider, 1.

Bexar County : Sellards, 10.

central east: Dumble, 1.

Coke County: Beede, 6.

Colorado County : Bailey, T. I., 1.

Cooke County: Bybee, 3.

Crockett County : Liddle, 2.

Culberson County, University Block: Beede, 8.

Dallas County : Shuler, 1.

Denton County: Winton, 3

Diablo Plateau: Beede, 3.

Eastland and Stephens counties, structural conditions: Adams, H. H., 1.

Foard County : Beede, 11.

Fort Stockton quadrangle : Adkins, 4.

Glass Mountains : King, 4, 6.

Grandfield Bridge sheet: Sellards, 18.

Guadalupe group: Darton, 19.

Gulf Coastal Plain near Rio Grande: Trowbridge, 5.

Johnson County: Winton, 2.

Lacasa area, Ranger district: Ross, C. S., 3.

Iytton Springs : Collingwood, 8.

McLennan County: Adkins, 2; Pace, 1.

Medina County : Liddle, $\mathbf{3}$.

north central: Hager, D., 2 ; l'ennsylvanian: Moore, R. C., 11 ; Plummer, 4 . 
Geologic maps-Continued.

Texas-Continued.

northeastern: Ellisor, 2; Fohs, 2 ; Thompson, W. C., 1; (part) : Hopkins, O. B., 2.

Pecos Valley: Liddle, 2.

Petrolia field: Shaw, 6.

Potter County: Patton, L. T., 2.

San Marcos quadrangle: Brucks, 2.

Solitario uplift: Powers, 9.

southern, Gueydan and adjacent formations: Bailey, T. L., 3.

Tarrant County: Winton, W. M., 1.

Taylor marl: Dane, 1.

Terrell County: Christner, 1.

Tom Green County: Henderson, G. G., 1.

trans-Pecos Texas : Baker, C. L., 6.

west (part) : Beede, 10.

western: Hoots, 1 ; Anon., 58.

Wiles area, Stephens County: Dobbin, 1 .

Trinidad: Milner, 1; Waring, 5, 6.

Naparima region: Illing, 1.

southern: Carlson, 2.

Uinta Mountains: Sears, 4.

United States, petroleum provinces: Lilley, 1.

physiographic divisions: Fenneman, 6 .

physiographic map: Lobeck, 2; Meinzer, 6.

Utah : Butler, 4; Moore, R. C., 17 ; (part) : Campbell, M. R., 3.

Carbon County, Farnbam anticline: Clark, F. R., 2.

Castlegate, Wellington, and Sunnyside quadrangles: Clark, F. R., 4.

La Sal Mountains: Gould, I. M., 4.

Salina Canyon district, Sevier County : Spieker, 6.

San Juan Canyon: Miser, 14.

Tintic district: Lindgren, 2.

Tintic quadrangle: Lindgren, 2.

Vermont, Bethel Township: Richardson, C. H., 8.

Braintree: Richardson, C. H., 5 .

Bridport : Foyles, 3.

Cuttingsville: Eggleston, 1.

Northfleld: Richardson, C. H., 2.

Orange County, Randolph Township: Richardson, C. H., 7.

Plattsburgh quadrangle: Hudson, G. H., 1.

Rouses Point quadrangle: Hudson, G. H., 1.

Roxbury: Richardson, C. H., 3.

Shoreham : Foyles, 3.

Whitingham area : Hubbard, G. D., 4.

Woodstock quadrangle: Richardson, C. H., 11.

Virginia: Nelson, W. C., 29.

Blue Ridgé, west foot: Stose, 1.

Dinville area, Triassic: Roberts, J. K., 8.

Dickenson County: Giles, 3.
Geologic maps-Continued.

Virginia-Continued.

Giles County : Hubbard, G. D., 6.

Lee County: Giles, 4.

northeastern : Lonsdale, 2 ; Jonas, 8.

northern, Triassic: Roberts, J. K., 8.

Pittsylvania County: Watson, 13.

Richmond Basin, Triassic: Roberts, J. K., 8.

Russell County: Wentworth, 6.

Scott County, Early Grove: Butts, 9.

Scottsville area, Triassic: Roberts, J. K., 8.

Tazewell County : Harnsberger, 1.

Valley coal fields: Campbell, M. R., 10.

western : Stose, 16.

Wise and northern Scott counties: Eby, J. B., 1.

Washington, channeled scabland : Bretz, 18.

mining districts: Patty, 3.

Pasco and Prosser quadrangles : Culver, 10.

San Juan Islands: McLellan, 2.

Skagit County: Jenkins, 8.

southwestern : Culver, 1.

Spokane area: Pardee, 12.

Stevens County: Weaver, 2.

Whatcom County, coal measures: Jenkins, 7.

West Virginia, Abram Creek-Stony River field: Ashley, 4.

Cheat Mountain coal field, Randolph County : Reger, 16.

economic deposits: White, I. C., 5.

Fayette County: Hennen, 1.

Grant County : Reger, 7 .

Hampshire County: Tilton, 15.

Hardy County: Tilton, 15.

Mercer County:- Reger, 9.

Mineral County: Reger, 7.

Monroe County : Reger, 9.

Nicholas County: Reger, 3.

Pendleton County: Tilton, 14.

Summers County: Reger, 9.

Tucker County: Reger, 6.

Webster County: Reger, 1.

Wisconsin : Steidtmann, 5; Twenhofel, 15.

Wyoming: Campbell, M. R., 9 ; Morgan, G. B., 1.

Baxter Basin gas field: Sears, 7 .

Bell Springs district, Carbon County : Dobbin, 5.

Cody region: Hewett, 4.

Gillette coal field: Dobbin, 3; Thom, 19; Minturn district: Thom, 19.

Grass Creek Basin quadrangle: Hewett, 16.

Lance Creek field: Hancock, 5.

Lost Soldier-Ferris district: Fath, 5. Meeteetse quadrangle: Hewett, 16. Mule Creek oil field: Hancock, 4. 
Geologic maps-Continued.

Wyoming-Continued.

oll and gas fields: Morgan, G. B., 4; Richardson, G. B., 4.

Oregon Basin quadrangle: Hewett, 16.

Osage oil fleld, Weston County : Collier, 7.

Rawlings and Sweetwater uplifts: Fath, 3.

Rock Springs area, Sweetwater County : Schultz, 1.

Snowy Range district: Blackwelder, 14.

southeastern: Blackwelder, 14.

southern: Sears, 5.

southwestern: Winchester, 5.

Sweetwater County: Sears, 3; (part) : Bradley, W. H., 5.

Upton-Thornton oil fleld: Hancock, 3.

Wind River Mountains: Condit, 4. Yukon, Aishihik Lake area: Cockfleld, 19.

Dezadeash Lake area: Cockfield, 20. Galena Hill, Mayo district: Stockwell, 1.

Keno-Hill district: Cockfield, 6 .

Mayo district: Cockfield, 8, 15.

Sixtymile and Ladue rivers area : Cockfield, 5.

Whitehorse district: Cockfield, 16.

Geologic maps, interpretation: Dake, 12.

Geologic structures: Willis, 11.

Geologic time.

Actino-uranium and enlarged ancient halos: Wilkins, 1.

Ages of radioactive minerals: Holmes, A., 2.

Astronomical measure: Keyes, 236.

Atomic disintegration as a measure of geologic time: Ellsworth, $\overline{5}$.

Chronology in geology: Udden, 11.

General: Allison, V. C., 1; Johnson, J. H., 16; Schuchert, 35.

Geochronology as based on solar radiation: De Geer, 6.

Glacial stages, time ratios: Upham, 4

Glacial time scale: De Geer, 4.

Laminated deposits: De Geer, 1.

Iead isotopes: Piggot, 1.

Lead uranium ratios: Lane, 30 .

Measurement by atomic disintegration : Lane, 20 ; Moore, R. B., 2.

Niagara Canyon, age: De Geer, 4; Johnston, W. A., 26.

Niagara Falls, age: Taylor, 8.

Pleistocene : Leverett, 17.

California : Eaton, J. E., 6

Pleistocene clays as a chronometer: Fairchild, 11.

Postglacial time, duration : Brückner, 1. measurement: Gleason, 1; Swinnerton, 1.

Pre-Cambrian time, duration. Ellsworth, 8.
Geologic time-Continued.

Radioactive minerals as age indicators : Ellsworth, 6.

Recession of the last ice sheet in New England: Antevs, 5.

Seasonal records: Reeds, 4.

Spiral graph of geologic time: White, D., 37.

Taonurus, use in estimating geologic time: Galloway, J. J., 5 .

Time divisions of glacial periods: Osborn, 19.

Uranium-thorium-lead method: Fenner, 11

Varved clays, Little Ferry, New Jersey : Reeds, 7.

Geological climates: Scott, W. B., 4.

Geological surveys. See Surveys.

Geologists as witnesses in mining litigation: Leith, 4 ; Ransome, 5.

Geology, development of : Gregory, H. E., 7. Geology, general: Peck, C. H., 1.

Geology (popular and elementary) ; Mather, 13 ; Mills, 1.

Geology and geography in the United States: Mathews, 3.

Geology applied to mining: Spurr, 24.

Geology as a profession: Little, 2.

Geology in partnership with American industry: Smith, G. O., 11.

Geology in its relation to landscape: Henderson, J., 7 .

Geology in the law: Kemp, 4.

Geology in the World War and after: Cross, C. W., 1.

Geology in war: DeWolf, 1.

Geology of salt dome oil fields: DeGolyer, 17.

Geomagnetics: Stearn, 1.

Geomorphogeny. See Plysiographic geology.

Geomorphology. See also Physiographic geology.

Continental drift, theory of: Van der Gracht, 1.

Continental shifting: Hamilton, G. H., 1.

Continental displacement hypothesis: Schuchert, 50, 51.

Earth deformations: Quirke, 24.

Hinge zone of 'Tertiary deformation: Emmons, W. H., 7.

Major earth features: Schaffer, 1.

Trough-deeps of island ares: Hobbs, 23.

Geomorphy. See Earth, figure.

Geophysical methods: Jakosky, 2.

in Gulf Coastal Plain: Barton, 6.

in Michigan copper district: Broderick, 4.

Geophysical prospecting: Am. Inst. Min. Eng., 1; Kithil, 1.

Geophysics.

Alumina and silica: Day, A. L., 1.

Canada, western, gravity observations: Miller, A. H., 2. 
Geophysics-Continued.

Compressibility of the earth: Woodward, R. S., 1.

Density distribution in the earth: Williamson, 2.

Density of rocks from Mauna Kea and Haleakala : Washington, 25.

Diffusion in silicate melts : Bowen, N. I., 2.

Dunite, compressibility: Adams, L. H., 8.

Geophysical investigations: Day, A. L., 1.

Geophysical Laboratory, report: Day, A. L., 1 ; Sosman, 3.

Gravity anomalies and petroleum exploration: Hubbert, 3 .

Moduli of elasticity in outer earthshells: Daly, 25.

Observatories, need for: Jaggar, 5.

Pressure in magmas: Morey, 1.

Pressures in planetary atmospheres: Nutting, 2

Problems: Sosman, 4, 5

Relation of crystallization to water content and vapor pressure of water in a cooling magma : Morey, 2.

Status and problems of geophysical chemistry : Sosman, 6 .

Stone Mountain granite, radium content: Piggot, 2.

Georgia.

Geological Survey, historical sketch : Cave, 1.

Macon area : Cooke, C. W., 5.

Areas described.

Tate quadrangle: Bayley, 13.

Economic geology.

Barytes deposits: Full, 3.

Bauxite deposits: Adams, G. I., 3.

Clay : Ries, 5 ; Stull, 2.

Gold, McDuffie County : Brubl, 1.

Iron ore deposits: Haseltine, 1.

Kaolin and bauxite, Coastal Plain: Stull, 1.

Manganese: Hill, 1; Stose, 7 ; Cartersville district: Anon., 1.

Mineral resources: Cave, 1 ; McCallie, 4,5 ; Maynard, T. P., 1.

Ocher deposits, Cartersville: Haney, M., 2; Weigel, 1.

Oil prospect near Scotland, Telfair County : Hull, 2.

Petroleum and natural gas possibilities: Prettyman, 1.

Potash slates, Cartersville: Maynard, T. P., 1.

Sand and gravel deposits: Teas, 1.

Tate quadrangle: Bayley, 13.

Historical geology.

Cartersville district: Hull, 1, 3.

Coastal Plain: McCallie, 7; Prettyman, 1.

Cretaceous: Berry, 4.

General: McCallie, 1, 2.
Georgia-Continued

Historical geology-Continued.

Mesozoic and Cenozoic: McCallie, 8

Telfair County: Hull, 2

\section{Mineralogy.}

Lazulite, Graves Mountain, Lincoln County: Watson, 10.

Meteorite, Pitts, Wilcox County: McCallie, 3.

Social Circle, Walton County: McCallie, 6.

\section{Paleontology.}

Chipola fauna in Marks Head marl: Gardner, J. A., 5.

Cretaceous floras: Berry, 4.

Petrology.

Stone Mountain granite, radium content: Piggot, 2.

Physiographic geology.

Coastal Plain : McCallie, 7.

Coastal terraces: Cooke, C. W., 11.

Physical geography: LaForge, 4.

Underground water.

Thermal springs: Watson, 16.

Germanium : Papish, 2.

Geosynclines: Schuchert, 22.

Geotectonic adaptation through retardation of the earth's rotation: Keyes, 6.

Geothermal data of United States: Darton, 6 .

Geothermal gradient, Sunset-Midway oil field, California : Rogers, G. S., 1.

Geother'ms of Lake Superior copper country: Lane, 15 .

Geysers.

Yellowstone National Park: Darton, 4.

Gilbert district, Nevada: Ferguson, H. G., 10.

Gillette coal field, Wyoming: Dobbin, 3.

Gilsonite.

Utah : Bardwell, 1; Clark, A. F., 1; Douglass, 1 ; Hartzell, 1.

Glacial anticyclones: Hobbs, 4, 6, 25, and in Visher, 4.

Glacial boulders, eastern, central, and northern New York: Martens, 4.

Missouri, Columbia, sources: Wilkerson, 1.

Glacial deposits.

Connecticut, Southington-Granby area : Palmer, H. S., 5.

Correlation with Swedish time scale: De Geer, 2, 3.

Iowa, northwestern: Lees, 6.

Glacial erosion, Crosby, W. 0., 5.

General : Quirke, 16.

Gouging of valleys by glaciers: Roberts, M., 1.

New York, Ithaca: Sheldon, 2.

Glacial geology. See also Glacial lakes; Quaternary.

Alaska, Alaska $\mathrm{R}$ a il r o a d region: Capps, 6.

Chandalar district: Mertie, 12.

northern, Canning River region: Leffingwell, 1. 
Glacial geology-Continued.

Alberta, glacial boulders : Rutherford, 9 . Calgary: Burwash, 4.

structural features produced by Pleistocene glaciation: Hopkins; o. B., 3.

Altamont moraine: Leverett, 10.

American and Swedish time scales: De Geer, 4.

Astronomical theory of ice ages: Keyes, 214, 219, 221, 224, 226.

Bemis moraine: Leverett, 10.

British Columbia: Tyrrell, 1.

Cariboo district, Barkerville area: Johnston, W. A., 21 ; Tyrrell, 2.

Cariboo and Cassiar districts : Johnston, W. A., 24.

Coquihalla area: Cairnes, 4.

Fraser River Delta: Johnston, W. A. 17.

Eutsuk Lake district: Brock, 1.

Vancouver Island: Berry, 33.

Vancouver region: Johnston, W. A., 5.

California, San Bernardino Mountains: Vaughan, F. E., 1.

San Gabriel Mountains: Miller, W. J., 28.

Sierra Nevada: Matthes, 4; recurrent glaciation: Matthes, 7 .

Upper Keln Canyon: Hills, 'T. M., 2.

Yosemite region, three glaciations: Matthes, 12.

Canada : Coleman, 16.

eastern, glacial periods: Coleman, 30 ; retreat of the last ice sheet: Anters, 6.

Cause of glaciation: Keyes, 230 ; McCabe, J., 1 ; Manson, 2 ; Visher, 9.

Chronology : Allison, V. C., 2.

Climatology of the ice age: Grunsky, 1.

Colorado, Estes Park region : Wooster, 1.

Front Range : Fuller, M. B., 5.

Grand Mesa: Henderson, J., 4.

Leadville district: Emmons, S. F., 1.

Pine River valley: Reagan, 3, 6.

Twin Lakes district: Howell, J. V., 1.

Connecticut, Daubury region: Harvey, R. S., 1.

New Haven region: Ward, 5.

Stonington region: Martin, L. H., 1. Connecticut Valley: Antevs, 1.

Pleistocene terraces: Flint, 5, 8.

Continental glaciation features: Quirke, 16.

Coral reefs and the glacial period: Daly, 2.

Correlation with Europe : Antevs, 17.

Coteau des Prairies, glacial formations: Leverett, 9.

Cycles in glacial and postglacial deposits : Anters, 3.

Drift sheets: Sardeson, 34.

Drumlins, southern shore of Lake Ontario: Slater, 3.
Glacial geology-Continued.

Eskers and crevasse fillings: Flint, 6.

Estival epoch : Keyes, 224.

Factors determining direction of ice movement: Leverett, 16.

Four stage glacial cycle: Keyes, 280; Sardeson, 23.

General : Allison, V. C., 3 ; Chamberlin, T. C., 21 ; Coleman, 26 ; Hay, 16 ; Keyes, 211, 222, 282; Louis, 1; Manson, 4; Nordenskjöld, 2.

Geochronology based on solar radiation : De Geer, 6.

Glacial climate in nonglaciated regions: Bryan, 31.

Glacial climatic conditions: Anters, 11. Glacial epoch, cause : Wright, G. F., 2.

Glacial epochs, causes: Keyes, 277.

Glacial stages: Sardeson, 25; Upham, 4

Glacial sediments: Leighton, 22.

Glacial till sheets, taxonomy: Keyes, 257.

Glacial varves, Connecticut Valley, summer deposition: Sayles, 11.

Glaciation, effects on mining: Kirkham, 6.

Great Basin: Antevs, 12 ; Pleistocene history: Antevs, 5

Greenland, Peary Land: Koch, 2.

Gumbotil, origin: Kay, 4.

Ice age: Finger, 1 ; in North America : Wright, G. F., 2.

Ice ages and the drift of sontinents: Coleman, 17

Ice retreat: Antevs, 15; in North America and Europe: Antevs, 7.

Idaho: Davis, W. M., 3.

northern, Pleistocene: Anderson, A. L., 2.

Illinois, Alexis quadrangle: Wanless, 7. Alton: Leighton, M. M., 6. Carbondale quadrangle: Lamar, 3, 4. Carlyle-Centralia district: Shaw, 9. Chicago area : Fryxell, 1 ; Salisbury, 2. Decatur area: Leighton, 11.

Dixon quadrangle: Knappen, 1.

Edgington-Milan area: Savage, 5.

Elgin region: Leighton, 14.

Farm Creek section: Leighton, 17.

Gillespie and Mount Olive quadrangles: Lee, W., 1.

glacial Kankakee torrent: Ekblaw, 3. Hennepin quadrangle: Cady, 3. Herscher quadrangle: Athy, 1. Joliet district: Fisher, D. J., 6. Joliet quadrangle: Fisher, D. J., 2. Kings quadrangle: Bretz, 4.

La Harpe and Good Hope quadrangles: Savage, 8.

La Salle quadrangle: Cady, 3.

Lawrence County, Plelstocene: Cox, F. W., 1.

Morris quadrangle: Culver, 2.

New Athens-Okawville area: Shaw, 8 . 
Glacial geology-Continued.

Illinois-Continued.

northern: Leighton, M. M., 4 ; differentiation of drift sheets: Leighton, M. M., 6 .

northwestern, drift sheets : Leighton, M. M., 10 .

Oregon quadrangle: Bevan, 3.

Pleistocene: Leighton, M. M., 3.

Randolph County, pre-Illinoian till : MacClintock, 3.

Saline County: Bonnell, 3.

Sangamon River valley: Leighton, $i$.

Indiana: Malott, 6.

glacial boundary: Malott, 9 .

Hancock County: Tharp, 1.

northwestern: Barrett, E., 2 ; Cressey, 3.

Wayne County: Bushnell, 3.

Iowa: Cable, 4 ; Kay, 11; Keyes, 239.

Adair County: Gow, 1.

Algona recessional stages of Wisconsin glaciation: Smith, J. E., T, 12. Ames, glacial tills: Smith, J. E., 4. Camp Dodge region: Lees, 1.

Cass County : Tilton, 3.

Clarke County: Kay, 6 ; Tilton, 2.

Crawford County: Lees, 18.

Des Moines : Keyes, 17, 95; Pleistocene exposures: Lees, 9.

Des Moines County, glacial boulders : Lugn, 3.

eastel'n: Schoewe, 4.

Fort Dodge stages of retreating glaciers: Smith, J. E., 8.

glacial sheets: Keyes, 126.

Humboldt stages of Wisconsin glaciation : Smith, J. E., 14.

Louisa and Washington counties: Schoewe, 1.

Pleistocene : Kay, 16.

Ringgold County: Arey, 1.

southern: Schoewe, 6.

Story County: Smith, J. E., 16.

Taylor County: Arey, 2.

till sheets, taxonomy: Keyas, 246.

Union County, Aftonian gravels: Kay, 5 .

western, Pleistocene: Kay, 10.

Wisconsin and Iowan drifts: Cable, 1 .

Wisconsin till : Smith, J. E., 13.

Iowan and Illinoian drift sheets, rel ative age: Kay, 15.

Iowan drift: Leverett, 18.

Iowan till: Kay, 12.

Iowan-Wisconsin border, Iowa: Cable, $2,6$.

Juan de Fuca lobe of Cordilleran ice sheet: Bretz, 2.

Kansas, Kansas tills: Schoewe, 2. noltheastern: Schoewe, 5. till-like deposits south of Kansas River: Schoewe. 7 .
Glacial geology-Continued.

Kentucky: Jillson, 71.

eastern, glacial pebbles: Jillson, 65.

glacial boulders: Jillson, 67 .

Labrador, northeastern : Coleman, 6, 15.

Labrador ice sheet, extent and thickness: Coleman, 2.

Lake Chicago basin: Baker, F. C., 1.

Lake Erie, preglacial outlet: Wright, G. F., 3 .

Land-ice recession in New England: Anters, 2 .

Last glaciation: Antevs, 17.

Loveland loess : Kay, 14.

Maine, Kennebec River to Penobscot Bay : Perkins, E. H., 3.

Mount Desert Island: Bascom, 1. southern: Sayles, 19.

Manitoba: Wallace, 14.

Knee Lake district: Bruce, 4.

Seal-Churchill divide, terminal moraine : Alcock, 11.

Upper Whitemouth area: Johnston, W. A., 3.

Winnipegosis area: Johnston, W. A., 3.

Massachusetts, central: Alden, 2.

Nexico, glacial action: Prister, 1.

Michigan, Kalamazoo area : Leverett, 5.

Menominee County: Ver Wiebe, 9. northern peninsula : Leverett, $\boldsymbol{\tau}$.

Roscommon County: Ver Wiebe, 8.

Minnesota : Grout, 2 ; Leverett, 4.

Herman, Barrett, Chokio, and Morris quadrangles : Sardeson, 1.

Buffalo Plains : Sardeson, 10.

drift sheets: Sardeson, 3.

Mille Lacs area: Sardeson, 9.

Missouri : Leverett, 13.

northern, Nebraskan drift: Shipton, 2.

Montana: Davis, W. M., 3. Beartooth Mountains: Bevan, 7.

Bitterroot Mountains : Russell, J., 1.

Multiple glaciation theory: Thwaites, 4,6 .

Multiple glaciations: Keyes, 288.

Nebraskan and Kansan tills, Iowa : Kay, 8.

New England: Daly, 7 ; Anon., 22. southern: Fairchila, 7, 18.

Newfoundland: Coleman, 28. southeastern : Buddington, 3.

New Hampshire: Goldthwait, 2, 6. Mount Jefferson, potholes: Crosby, I. B., 6 .

New Jersey, Hackensack meadows, glacial varves: Sci. Serv., 8. postglacial laminated clays at Little Ferry : Reeds, 5.

New York: Faírchild, 16. Adirondack eskers: Chadwick, 21. Allegany State Park: Lobeck, 8. Ausable quadiangle: Kemp, 23. 
Glacial geology-Continued.

New York-Continued.

Canton quadrangle: Chadwick, 5.

Cohoes quadrangle: Stoller, 2.

eastern: Cook, J. H., 1 ; Fairchild, H. L., 1.

evacuation stages at Glens Falls: Chadwick, 20.

Genesee River region: Fairchild, 6. 15.

Glens Falls, ice evacuation stages: Chadwick, 18.

Haverstraw varved clays: Reeds, 9, 15.

Lake Clear region: Alling, H. L., 1.

Lake Placid quadrangle: Alling, 2.

Luzerne quadrangle: Miller, W. J., 19.

Lyon Mountain quadrangle: Miller, W. J., 26.

Mendon kame area : Fairchild, 19.

Mohawk-Hudson region: Stoller, 3 .

Mount Marcy quadrangle: Alling, 4.

Newburgh: Holzwasser, 1.

New York Botanical Garden, glaciation : Hollick, 9.

New York City region : Reeds, 12.

northern : Fairchild, 10.

Pleistocene: Fairchild, 9.

Rochester, Pinnacle Hills: Fairchild, 13.

Schroon Lake quadrangle: Miller, W. J., 2

Tully glacial series: Von Engeln, 1. western: Fairchild, 21; moraines : Chadwick, 11.

New York moraine, age: De Geer, 5. - Niagara Falls and recessional moraines: Taylor, 8 .

Nomenclature: Sardeson, 29.

North America: Wright, G. F., 2.

North Dakota: Leonard, A .G., 1.

Pleistocene deposits: Todd, J. E., 1.

Northern Great Plains: Alden, 3.

Nova Scotia : Goldthwait, 5; Walker, 24.

Cape Breton Island: Mather, 10.

Number of glacial stages: Keyes, 238.

ohio, Camp Sherman quadrangle: Hyde, 1.

erratic boulders: Patton, 4.

northern : Hubbard, G. D., 7.

Wayne County: Conrey, 1.

Ohio River Basin: Leverett, 19.

Ontario, Abitibi and Mattagami rivers: Keele, 2.

Brocktown-Mallorytown a r e a : Wright, J. F., 2.

Lake Huron region: Quirke, 15.

Michipicoten area: Collins, $\mathbf{1 5 .}$

Toronto region: Coleman, 19 ; Slater, 1.

Oregon: Smith, W. D., 1

Mount Jefferson: Hodge, E. T., 6

Mount Multnomah : Hodge, E. T., 5.

Pleistocene history: McCornack, 1.
Glacial geology-Continued.

Pennsylvania: Ashley, 23 ; Williams, E. H., 1 .

Susquehanna River: Stose, 33.

Pennsylvania and New Jersey: Leverett, 20.

Periodicity of glaciation: Keyes, 206.

Pitted outwash: Thwaites, 5.

Pleistricene clays as a chronometer: Fairchild, 11.

Pleistocene glacial stages : Leverett, 17.

Pleistocene ice sheet development in North America: White, D., 30.

Polar ice caps, extent: Adams, L. H., 10.

Pole wandering: Richarz, 1.

Pre-Wisconsin glaciation, northern Rocky Mountains: Alden, 4.

Prince Edward Island: Coleman, 1.

Quebec, Anticosti Island: Twenhofel, 9.

Beauceville area: MacKay, B. R., 4.

Gaspe Peninsula : Coleman, 10.

Magdalen Islands : Coleman, 1.

Mount Albert area: Alcock, 20.

Timiskaming County, Opasatika area : Cooke, H. C., 10.

Raised beaches and thickness of ice sheets : Coleman, 20.

Recession of the last ice sheet in New England: Antevs, 1.

Recessional moraines: Keyes, 232 ; between Indiana and New England: Taylor, 7.

Saskatchewan, southeastern : Stansfleld, J., 1.

Secular wasting of glacial till sbeets: Keyes, 210

Solar curve: De Geer, 4.

Solar cyclonic explanation of glaciation: Huntington, 3 ; Visher, 8.

Solar initiation of glaciation?: Keyes, 171.

Striated cobbles in southern States: Wentworth, 41.

Striations, crescentic fractures, and Iunoid furrows, relative abundance : Billings, 4.

Synchronism of American and Swedish glaciations: De Geer, 4.

Terminology : Keyes, 232.

Texas, Brazos River, boulders: Reed, L. C., 2.

Three glacial epochs in Sierra Nevada : Blackwelder, 20

Time divisions of glacial period: Osborn, 19.

Time of loess accumulation: Visher, 6

Time scale: De Geer, 4.

Usage of terms drift and till : Gregory, J. W., 7 .

Varve clay, New England: Antevs, 1. Varves, long range correlation: Coleman, 33.

Varved clays, Little Ferry, New Jersey : Reeds, 7. 
Glacial geology-Coṇtinued.

Varved glacial clay, conditions of formation: Antevs, 9.

Vermont, Braintree: Richardson, C. H., 5.

Bristol, Lincoln, and Warren townships : Gordon, C. E., 6.

Lake Willoughby region: Jacobs, 3.

Northfleld: Richardson, C. H., 2.

pre-Pleistocene beds: Antevs, 8.

Roxbury : Richardson, C. H., 3.

Whitingham area: Hubbard, G. D., 4.

Washington, central : MacMacken, 1, 2. Columbia Plateau: Bretz, 6.

east central: Bretz, 5 .

Juan de Fuca Glacier: Bretz, 2.

northern: Runner, 4.

Spokane glaciation: Bretz, 9.

Spokane region: Large, 2 ; Leverett, 11 ; Pardee, 9.

Wisconsin, Driftless Area: MacClintock, 1.

Ripon, gravel seam in limestone: Thwaites, 1.

Wisconsin ice sheet, ablation of eastern lobe: Cook, J. H., 2 ,

Wyoming, Beartooth Plateau: Dake, 2. Wind River Mountains: Alden, 5.

Glacial lakes. See also Beaches; Shore lines; Terraces.

Bowmanville stage, Lake Chicago: Baker, F. C., 10.

Illinois, Joliet quadrangle: Fisher, D. J., 2.

Indiana, northwestern: Barrett, E., 2. Iowa, Lake Calvin: Schoewe, 3, 4, 6.

Lake Agassiz: Leonard, A. G., 1.

Lake Arikaree: Todd, J. E., 5.

Lake Chicago: Baker, F. C., 1.

Lake Dawson: Fairchild, 6.

Lake Hackenșack: Reeds, 6.

Lake Iroquois: Fairchild, 6.

Lake Lewis, Washington : MacMacken, 2.

Lake Missoula: Davis, W. M., 3.

Lakes Agassiz and Wisconsin: Dachnowski, 5 .

Massachusetts, central : Alden, 2.

Michigan, Kalamazoo area : Leverett, 5.

New York: Chadwick, 5.

Cohoes quadrangle: Stoller, 2.

eastern : Fairchild, H. L., 1.

Genesee River Region: Chadwick, 11 ; Fairchild, 6.

Lake Clear region: Alling, 1.

Lake Placid quadrangle: Alling, 2.

Lyon Mountain quadrangle: Miller, W. J., 26.

Mount Marcy quadrangle: Alling, 4.

New York City region: Reeds, 12.

Schroon Lake quadrangle: Miller, W. J., 2.

Warrensburg : Miller, W. J., 25.

Onfario: Coleman, 11.

Michipicoten area : Collins, 15.

Vermont, Lake Willoughby: Jacobs, 3.

Glacial period. See Glacial geology.
Glaciation, cycle of: Hobbs, 11.

Glacier Lake section, Alberta: Walcott, 3.

Glacier motion a type of rock deformation : Chamberlin, R. T., 17.

Glacier National Park, movement of glaciers: Alden, 1 ; scenic features, origin : Campbell, M. R., 2.

Glacières.

Cocidersport ice mine, Pennsylvania: Balch, i.

Glaciers.

Alaska: Chamberlin, R. T., 4.

northern, Canning River region; Leffingwell, 1.

Kenuecott Glacier: Bateman, 5, 7.

Alberta, Freshfleld Glacier: Palmer, H., 1.

British Columbia, Bromley Glacier : Hayes in Bateman, 5.

Robson Glacier, motion: Wheeler, A. $0 ., 3$.

Yoho Glacier, movement, 1917-19: Wheeler, A. O., 2.

Canada, Rocky Mountains: Wheeler, A. $0 ., 1$.

Colorado, fossil glacier : Brown, W. H., 1.

Cycle of glaciation: Hobbs, 11.

Experiments with model glaciers: De Lury, 7.

General: Hobbs, 12 ; Reeds, 18.

Greenland: Koch, 5, 9.

eastern: Pedersen, 1.

western: Hobbs, 29.

Lyell and Freshfield glaciers, Canadian Rocky Mountains: Thorington, 1.

Mexico, Popocatepetl: Weitzberg, 1.

Motion: Chamberlin, R. T., 18.

Oregon, Mount Jefferson: Hodge,. Ii. T., 6.

Mount Multnomah: Hodge, E. T., 5.

Yukon, Klutlan Glacier: Lambart, 1. Glades, origin: Galloway, J. J., 1.

Glass sand: Richardson, C. H., 4.

Illinois, St. Peter sandstone : Lamar. 9.

Iowa : Knight, N., 2.

Kentucky: Richardson, C. H., 4.

Ohio : Bownocker, 7.

Pennsylvania: Fettke, 1.

Virginia: Watson, 3.

Glauconite: Goldman, 1; Schneider, 3.

association with unconformities: Gold$\operatorname{man}, 7$.

Missouri, southeastern : Ross, C. S., 1.

New Jersey: Mansfield, G. R., 1, 2, 7. origin : Gill, J. E., 2 ; Mansfield, G. R., 7 ; Tarr, 3.

optical properties and chemical composition : Ross, C. S., 17.

Glenn oil pool, Oklahoma: Wilson, W. B.. 1. Glossary of mining and mineral industry : Fay, 1.

Golconda quadrangle, Kentucky : Weller, 4. Gold: Dunlop, 2 ; Wuensch, 1.

Alaska: Brooks, 5, 12, 14; Martin, G. C., 4 .

Alaska Railroad region: Capps, 6. 
Gold-Continued.

Alaska-Continued.

Anvik-Andreafski region: Harring ton, 1.

Chandalar district: Mertie, 12.

Chichagof Island, western part: Overbeck, 1.

Chistochina region: Chapin, 3.

Chitina Valley: Moflit, 5.

early Tertiary placer deposit; Capps. 7.

Fairbanks district: Chapin, 4.

Goodnews: Bay region: Harrington, 6.

Hot Springs district: Chapin, 6. Hyder district: Buddington, 8. Jack Bay district: Johnson, B. I., 2.. Juneau district: Bradley, P. R., 1. Juneau and Ketchikan districts: Mertie, 5.

Kahiltna Valley: Mertie, 2.

Kantishua region: Capps, 1.

Kenal Peninsula : Johnson, B. L., :2 Kiwallk-Koyuk region: Harrington, 5.

Kodiak Island : Maddren, $\%$

Kotsina-Kuskulana district : Moffit, 4 . Kuskokwim region: Martin, G. C., '). Nixon Fork country: Brown, J. S., 7. Porcupine district: Eakin, 1.

Prince William Sound: Johnson, B. L., 1 .

Ruby-Kuskokwim region : Mertie, 11. Seward Peninsula: Catheart, 1; Harrington, 7 .

soutbeastern: Buddington, 9.

Tolovana district: Overbeck, 3 .

'Tolstoi district: Harrington, 2.

Willow Creek district: Capps, 2; Chapin, 9, 12.

Yentna district : Capps, 9.

Appalachians, southern: Frame, 1.

Arizona, Aravaipa-Stanley region : Ross, C. P., 5.

Jerome and Bradshaw Mountains quadrangles: Lindgren, 17.

Oatman district: Ransome, 12.

Payson district: Lausen, 1.

placer's: Allen, M. A., 6; Wilson, E. D., 3.

Ray quadrangle: Ransome, 11.

Tres Amigos: Keyes, 111.

Saddle Mountain and Banner mining districts: Ross, C. P., 6, 14.

Yavapai County: Staunton, 1.

British Columbia: Camsell, 8.

Atlin, Engineer mine: Weed, 3.

Bridge River area: McCann, 3, 4.

Cariboo district: MacKay, B. R., 1, 2 ; 'Tyrrell, 2; Uglow, 10 ; Barkerville area; Johnston, W. A., 11. 18, 22 ; Uglow, $6,8$.

Cedar Creek area: Johnston, W. A., 14, 18, 20.

Chu Chua, Windpass mine: Uglow, 12.
Gold-Continued.

British Columbia-Continued,

coast region: Dolmage, 9 ; and islands : Dolmage, 8.

Coquiballa area : Cairnes, 1, 4 ; Camsell, 6 .

Dease Lake area, Cassiar district: Johnston, W. A., 23.

Fraser River: Johnston, W. A., 21.

Kamloops district, North Thompson valley: Uglow, 3, 15.

Premier mine, Portland Canal district: Burton, W. D., 1.

Salmon River valley: Banks, 1; Schofleld, 14

Yale district, Hillsbar claims: Cairnes, 6.

California: Haley, 3.

ancient river-bed deposits : Alling, M. N., 1.

Carson Hill: Moss, 1.

Monterey County, Los Burros district: Hill, J. M., 4.

Nevada County: Mac Boyle, 1.

Plumas County: Mac Boyle, 2.

primary and secondary concentrations: Haley, 4.

production 1849-1923; Hill, J. M., 5.

Randsburg: Fulin, 1, 3.

Sierra County: Mac Boyle, 3.

San Bernardino Mountains: Vaughan, F. E., 1.

southern: Haley, C. S., 1.

Trinity County, East Fork district: Tucker, W. B., 2.

Wilshire district: Turner, H. W., 3.

Canada: Cole, G. E., 3; Webb, 1: Wilson, A. W. G., 2 .

Colorado, Boulder County, Ward region: Worcester, 1.

Camp Bird mine: Spurr, 18.

Creede district: Emmons, W. H., 4.

Cripple Creek district: Van Tuyl, 3.

Platoro-Summitville district: Patton, H. B., 1.

Red Cliff district: Crawford, $\mathbf{R}$. D., 3.

Twin Lakes district: Howell, J. V. 1.

Eastern States: Dunlop, 3, 7, 11, 15, 18.

General: Dunlop, 5, 8, 10, 14, 17.

Geologic distribution: Rickard, 11.

Georgia, McDuffie County : Bruhl, 1.

Idaho: Gerry, 1, 3, 5, 8, 10.

batholith: Thomson, F. A., 4.

Boise Basin district: Ballard, 1, 3. Boundary County: Kirkham, 7.

Mineral and Cuddy Mountain mining districts: Livingston, 4.

north central: Thomson, F. A., 3.

Rocky Bar quadrangle: Ballard, 4. Salmon River Mountains: Ross, C. P., 13.

Shoshone County : Umpleby, 3

Silvel City district: Piper, 6. 
Gold-Continued.

Indiana, placer gold: Hafer, 1.

Manitoba : Wallace, 22.

Beresford Lake area: Wright, D. G. H., 2 ; Wright, J. F., 4.

Copper Lake district: Wallace, 3.

Elbow Lake area: Armstrong, P.. 43; Wallace, 7 .

Flinflon area: Alcock, 15.

Herb Lake region: Alcock, 12.

northern : Gordon, J. P., 1.

Reed and Wekusko lakes region: Al. cock, 3.

Rice Lake district: Cooke, H. C., 9 ; Wright, J. F., 3, 6.

southeastern: Bruce, 3; DeLury, 4.

Mexico, Chihuahua, Yoquivo district: Hall, C. W., 1.

El Oro and Tlalpujahua districts: Flores, 1.

El Oro district, Mexico: Winchell, H. V., 1 .

San Luis Potosi, Guadalcazar: Wittich, 7.

Sonora, Lucky Tiger mine: Mishler, 2.

Zacatecas, Mezquital: De Silva, 1.

Montana: Gerry, 2, 4, 7, 12, 15.

Bannack : Shenon, 1.

Helena district: Anon., 72.

Nevada, Divide district: Carpenter, J A., 1; Knopf, A., 3 ; Sizer, 1 ; Young, G. J., 1.

Gilbert district : Ferguson, H, G., 10.

Jarbidge district: Park, J. F., 1; Schrader, 5.

Johnnie district: Labbee, 1.

Manhattan district: Ferguson, $\mathbf{H}$ G.. 5

Mineral County, Cedar Mountain : Knopf, A., 4.

Rochester district: Knopf, A., 7 .

Round Mountain district: Ferguson, H. G., 4.

Santa Fe district, Mineral County: Clark, C. W., 2.

Toquima Range: Ferguson, H. G., 2.

New Hampshire, Ammonoosuc district: Ross, C. P., 2.

New Mexico, Colfax County, Aztec nine: Chase, C. A., 1.

Mogollon district: Ferguson, H. G. 3 ; Scott, D. B., 1.

Sierra del Oro: Keyes, 59.

Nicaragua, eastern: Garbrecht, 1.

Piz Piz district: Hawxhurst, 1.

Nova Scotia: Brunton, 5, 9, 10, 11, 13; McKenzie, N., 1 ; Reid, J. A., 2.

southwestern : Faribault, 3.

Tangier: Brunton, 12.

Ontario: Hopkins, P. E., 3, 4 ; McGill, 1.

Abitibi-Night Hawk gold area, Timiskaming district: Knight, C. W., 1 ; Argonaut gold mine: Cooke, H. C., 13. Knight, 6.
Gold-Continued.

Ontario-Continued.

Beardmore: Burrows, 16.

Ben Nevis area : Knight, C. W., 5 .

Blanche River area: Burrows, 9.

Boston-Skead area: Burrows, 8.

Cochrane district: Hawley, J. E., 3.

Favourable Lake area, Patricia: Hurst, 5.

Fort Hope area: Burwash, 8.

Gammon River area, District of Kenol'a : Gilbert, G., 7.

Gauthier Township, Argonaut mine: Cooke, H. C., 23.

Goudreau area: Burrows, 5,7 ; MacLeod, 1, 2; Moore, E. S., 10.

Goudreau-Lochalsh area: Gledhill, 8.

Kamiskotia area: Finley, 1.

Kenora and Rainy River districts: Bruce, 17.

Kirkland Lake area : Burrows, 4, 12 ; Hopkins, P. E., 6, 7 ; Johnson, H. H., 1 ; Orser, 1 ; Todd, 8 ; Tyrrell, 2613.

Larder Lake area, Timiskaming district : Cooke, H. C., 8, 14; Hopkins, P. E., $1,8$.

Lightning River area: Burrows, 1; Gledhill, 4 ; Knight, C. W., 9, 12.

Matachewan district: Burrows, 2 ; Cooke, H. C., 1, 3, 4.

Michipicoten district: Collins, W. H., 1, 15 ; Gledhill, 7 ; Thomson, E., 4.

Montreal River district: Anon, 4.

Night Hawk Lake area: Hopkins, 9. northern, wide dissemination: Boydell, 13.

northwestern: Timm, 1.

Onaman area : Girvin, 1.

Pancake Lake: Hopkins, 11.

Porcupine district: Bell, J. M., 2 ; Burrows, 10, 11, 13; Dougherty, 1, 3 ; Fielding, 1 ; Hore, 8 ; Huntoon, 1; Robinson, H. S., 1; Spurr, 8.

Red Lake area, Patricia: Rogers, W. R., 6 ; Wright, D. G. H., 4.

Red Lake and Woman Lake areas: Bruce, 23.

Red Lake Basin; District of Kenora : Bruce, 22

Redstone River area, Timiskaming district: Bruce, 19.

Schreiber-Duck Lake area: Hopkins, P. E., 5 .

Sturgeon Lake area: Gledhill, 2.

Sudbury district, Makwa: Tanton, 10; Wasapika area: Hore, 1, 3, 4, 5 ; West Shiningtree area: Finley, 2 ; Goodwin, L. H., 1 ; Hopkins, P. E., 2 ; Langford. 2 ; Weed, 1.

Tashota-Onaman area: Gledhill, 3 .

Timiskaming, McNeil township : Hopkins, 10.

Watabeag area: Wright, D. G. H., 2. 
Gold-Continued.

Ontario-Continued.

Woman and Narrow lakes area, District of Kenora: Grieg, 2.

Oregon, Josephine County, Waldo district: Kellogg, A. E., 2.

Llano de Oro placers, Waldo district: Kellogg, A. E., 10.

Riddle quadrangle: Diller, 12.

southwestern, auriferous gravels : Kellogg, A. E., 8.

Pennsyivania : Pennsylvania G. S., 1. Placer gold, formation: Allison, E. L., 1.

Primary and secondary concentrations: Haley, 4.

Quebec: Goodwin, W. M., 2.

Beauceville area: MacKay, B. R., 4.

Dubuisson Township: Spearman, 2.

Lake Fortune area: Goodwin, W. M., 1.

Harricanaw and Bell river basins: Bain, 22.

Harricanaw River area: Mailhiot, 3 .

Lake Demontigny region: Mailhiot, 4. northern: Wright, D. G. H., 3.

northwestern: Brunton, 7 ; Dufresne, 3 ; prospects : Denis, 6.

Temiscamingue and Abitibi counties : Dufresne, 4.

Timiskaming County, Opasatika area : Cooke, H. C., 10; Rouyn area : James, W. F., 2.

western: Cooke, H. C., 15, 26 ; Timm, 1.

South Dakota, Black Hills, alunitic ore: Grout, 25.

central Black Hills: Darton, 14.

Homestake mine: Paige, 3.

Lead area: Paige 4.

northern Black Hills: Connolly, 4.

Southern States: Megraw, 1.

Utah: Butler, 4.

Ophir district: Olmstead, 1.

Tintic district: Lindgren, 2.

Virginia, northeastern Piedmont : Lonsdale, 7.

Washington: Gerry, 1. 3, 6, 9, 11, 14. Stevens County: Weaver, 2.

Wyoming, Atlantic City-South Pass district: Bartlett, 4 ; Runner, 5.

Yukon, Mayo area: Cockfield, 1, 4.

Sixtymile and Laduc river's area: Cockfield, 5.

Whitehorse district: Cockfield, 16. Folden area, Colorado: Johnson, J. H., 13.

Golden Lanes, Greenwood County, Kansas : Cadman, 2.

Good Hope quadrangle, Illinois: Savage, 8.

Goodnews Bay region, Alaska : Harrington, 6.

Goose Creek oil field, Harris County, Texas: Minor, 2.

Goudreau gold area, Ontario: McLeod, 2.

Goudreau-Lochalsh gold area, District of Algoma, Ontario: Gledhill, 8.
Gouverneur quadrangle, New York: Cushing, 1 .

Gowganda silver area, Ontario: Burrows, $3,17$.

Graham field, Carter County, Oklahoma : Tomlinson, 1.

Grand Canyon. See Arizona.

Granite.

Connecticut : Gregory, H. E., 8.

General: Dale, T. N., 4.

Maine : Smitb, G. O., 15.

New England: Dale, T. N., 4.

Segregation granites: Lane, 8.

Vermont, Barre: Perkins, G. H., 4.

Granite massives, primary structure: Balk, 1.

Graphic study of igneous rock scries : Grout, 8.

Graphite : Dub, 1 ; Ferguson, H. G., 1 ; Miller, B. L., 1. Redfield, 6 ; Spearman, 1 ; Spence, 1.

Alabama: Brumell, 1. Prouty, 2.

Ashland district: Brown, J. S., 6. Clay County: Prouty, 10.

Alaska, Seward Peninsula: Harrington, 4 .

Canada: Eardley-Wilmot, 2 ; Spence, 1.

Mexico : Garcia, 1.

Sonora: Honigmann, 4, 5, 6; Paredes, 6.

Ontario, Ottawa Valley : Wilson, M. E., 3.

Renfrew district: Wilson, M. E., 3.

Origin: Alling, 6; Clark, T. H., 3; Spence, 3; Winchell, 3.

Quebec: Brumell, 1 ; Spence, 6.

Amherst township: Wilson, Morley E.. 1.

Buckingham district: Brumell, 2 ; Eardley-Wilmot, 1 ; Rowe, R. C., 1. Graptolitoidea.

Beekmantown series. Levis; Quebec: Clark, T. H., 11.

British Columbia, Glenogle formation: Clark, T. H., 14.

Distribution: Ruedemann, 26.

Evolution: Elles, 1.

Glossograptus : Ruedemann, R., 3.

Indiana, Silurian : Cumings, 5 ; Shrock, 2.

Maine, Waterville: Perkins, E. H., 2.

New York, Utica and Lorraine formations: Ruedemann, 17.

Ontario, Ordovician black shales: Parks, 32.

Vermont, Northfield: Richardson, C. H., 2.

Western North America: Burling, 1.

Grassy black shales: Keyes, 56.

Gravel: Stone, 3, 7, 12 ; Teas, 1.

Florida: Martens, 8.

veorgia: Teas, 1.

Illinois : Leighton, M. M., 2.

Missouri : Dake, 1.

Mississippi River, lower: Littlefield, 4. 
Gravel-Continued.

North Dakota : Leonard, 5.

Ontario: Ledoux, A., 1.

St. Clair River: Bartlett, J., 1.

South Dakota, eastern : Rothrock, 1.

Minnehaha County: Rothrock, 5.

Yankton County: Rothrock, 3.

Texas, Trinity River district: Shaw, E., 1.

Grass Creek oil field, Wyoming: Hewett, 16.

Gravitional compaction, effect on sedimentary rocks: Rubey, 8.

Gravity observation from the standpoint of the local geology: White, 14.

Great Basin, Pleistocene history: Antevs, 12.

Great Basin ranges, origin: Davis, W. M., 5 ; Keyes, 84.

Great Basin region, physiograpbic history : Keyes, 75.

Great Lakes, changing levels : Fairchild, 17.

Great Smoky overthrust: Keith, 5.

Greater earth : Chamberlin, T. C., 11.

Greenland.

Eastern Greenland: Koch, 7.

Geology : Böggild. 1, 4.

Northwestern Greenland: Hovey, 11.

Economic geology.

Cryolite: Gordon, S. G., 19.

Mineral resources: Ball, S. H., 4, 6 .

Historical geology.

Cambrian, Ozarkian, and Canadian, northwest Greenland: Poulsen, 1.

Eastern Greenland: Koch, 8; Wordie, 1.

General : Bøggild, 6 ; Koch, 2.

Northern Greenland: Koch, 4.

Northwestern Greenland: Foerste, 24 ; Hovey, 11; Koch, 1, 6.

Peary Land: Koch, 3.

Western coast: Krueger, 1.

Mineralogy.

Arfvedsonite, riebeckite, and crocidolite: Gordon, S. G., 20.

Cohenite, Ovifak: Thomson, E., 12.

Dahllite, Kangerdluarsuk : Böggild, 2.

Leifite, Narsarsuk: Böggild, 3.

Meteorite, Savik: Böggild, 5.

Narsarsuk area: Gordon, S. G., 16.

Thomsonite in basalt, Disko: Gaertner, 1.

Paleontology.

Alalias, Cretaceous: Fritel, 1.

Cambrian, Ozarkian, and Canadian faunas, northwest Greenland: Poulsen, 1.

Cretaceous plants: Seward, 3.

Eotriassic ammonites, eastern Greenland: Spath, 1.

Rhaetic flora, Scoresby Sound, east - Greenland : Farris,. T. M., 1.

Petrology.

Enstatite-hornblendite: Machatschki, 1.

Greenland-Continued.

Physical geology.

Fault zone, northwestern Greenland:

Koch, 6.

Orography : Koch, 2.

Physiographic geology.

Ice cap: Koch, 5.

Glaciation of land ribbon surrounding inland ice: Hobbs, 30.

Glacial history, southwestern Greenland: Hobbs, 31.

Glaciers: Koch, 9 ; eastern Greenland : Pedersen, 1.

Terraces, Holstenborg district: Gould, L. M., 5 .

Western Greenland: Hobbs, $2 y$.

Green River formation, sedimentology: Hinds, 5 .

Greensand. See Glauconite.

Grenada and the Grenadines: Earle, 6, 8

Grenadines : Earle, 7.

Ground ice, northern Alaska : Leffingwell, 1.

Ground water. See Underground water.

Groundwork of diastrophism : Chamberlin, T. C., 10 .

Guadalupe group: Darton, 19.

Guatemala.

Economic geology.

Petroleum possibilities: Redfield, 3.

Saltpeter : Gale, 2.

Historical géology.

General: Redfield, 3.

Physical geology.

Acatenango: Heim, 4

Earthquake and volcanic phenomena: Van de Putte; 1.

Earthquakes : Muñoz Lumbier, 3.

Sta. Maria Volcano: Waitz, 5.

Volcanic activity, 1927 : Termer, 1.

Gueydan formation, Texas: Bailey, T. L., 3. Guidebook, Denver \& Rio Grande West. ern route: Campbell, M. R., 3.

Gulf coast salt domes: Hill, R., 'T., 1.

Gulf Coastal Plain salt domes, secondary intrusive origin: Matteson, 2.

Gumbo, Iowa: Keyes, 93.

Gumbos, correlating: Kobinson, W. I., 4.

Gumbotil, origin : Kay, 4.

Gunflint iron district, Minnesota : Broderlck, 3

Gypsum : Stone, 8, 10 ; Wilder, 2, 3.

Calcium sulphates, physical chemistry: Bowles, 4.

Calffornia, southern: Newman, 1.

Dehydration : McCormack, 1; Parsons, A. L., 13.

Geology: Newland, 3.

Gulf coast salt domes : Barton, 3.

Iowa : Wilder, 2.

age of gypsum deposits: Keyes, 166.

Fort Dodge gypsum beds : Keyes, 137.

New York: Newland, 2.

Occurrence and supply: Newland, 4.

Oklaboma: Gould, C. N., $29:$ 
Gypsum-Continued.

Ontario, Moose River: Lanning, 1. southwestern: Cole, G. E., 1, 2; Dyer, 5.

Origin of gypsum deposits: Dyer, 5 Keyes, 140 ; and classification : Wilder; 1.

Rate of solution: Lahee, 18.

United States: Stone, 11.

Hackberry stage, Devonian, Iowa: Fenton, C. L., 2.

Hackberry conglomerate, Nebraska: Bar. bour, 5 .

Haiti.

General : Woodring, 4, 5 .

Northwestern Haiti: Lütgens, 1.

Economic geology.

Oil possibilities, central plain: Woodring, 1.

Historical geology.

Miocene, central plain: Woodring, 1. Paleontology.

Cichlid fish, Las Cahobas: Cockerell, 16.

Crabs: Rathbun, 4.

Dictyoconus, Eocene foraminifer: Woodring, 2.

Eocene Foraminifera: Woodring, 6.

Miocene and Pleistocene Cirripedia: Pilsbry, 3.

Mollusca, Tertiary: Woodring, 7.

Orthaulax, Tertiary : Woodring, 3.

Tertiary plants: Berry, 31.

Physiographic geology.

Reef caps and terraces: Woodring, 11.

Underground water.

Hot Springs : Brown, J. S., 4.

Harricanaw-Turgeon basin, northern Quebec: Tanton, 1 .

Harvard summer school of geology : Crump, 1.

Hasemanite: Haseman, 1.

Hat Creek coal area, Kamloops district, British Columbia : MacKay, B. R., כ.

Hawaiian Islands.

Kaui : Hinds, N. E. A., 2.

Kaula Island: Friedlaender, 6.

Maui Volcano: Hinds, N. E. A., 12.

Mauna Kea: Jaggar, 11.

Mauna Loa, southwest rift: Finch, 7. Areas described.

Kaula, Nikon, Necker, and Gardner is. lands: : Palmer, H. S., 9.

Kilauea, products and structure : Stone, J. B., 1.

Lanai : Wentworth, 15.

Maui : Hinds, 4, 7.

Oahu, pyroclastic geology: Wentworth, 22.

Mineralogy.

Aphthitalite, Kilauea: Washington, 11.

Augite, Haleakala, Maui : Washington, 14.

Olivine: Aurousseau, 3.

Paleontology.

Marine mollusks, Oahu : Ostergaard, 1.
Hawaiian Islands-Continued.

Petrology.

Aa and pahoehoe, formation : Washington, 23.

Basalt: 'Washington, 36 .

Density of rocks from Mauna Kea and Haleakala : Washington, 25.

General: Powers, 5; Washington, 22.

Hualalai and Mauna Loa: Washington, 21.

Kilauea: Washington, 22.

Kohala and Mauna Kea: Washington, 12.

Lavas, Hawaiian volcanoes: Washington, 5, 9, 10.

Leeward Islands: Washington, 33.

Maui : Washington, 37.

Melilite and nephelite basalt: Hinds, 6 .

Oahu, pyroclastic geology : Wentworth, 22.

Physical geology.

Aa and pahoehoe, formation: Emerson, o. H., 1.

Chink faceting, new processs of pebble shaping: Wentworth, 20.

Density : Goranson, 5.

Earthquake prediction: Finch, R. H., 4.

Earthquakes, Kapoho, April, 1924 : Finch, 5.

Engulfment during explosive cruptions : Jaggar, 24.

Erosion principles: Wentworth, 26.

Halemaumau: Finch, R. H., 1 ; Jas. gar, 1.

tidal oscillations: Brown, E. W., 2. ఎeaiwa lava flow: Stearns, 10; Stone, J. B., 2.

Kilauea : Day, 14 ; Jaggar, 1.

activity: Jaggar, 8; MacCaughey, V., 1.

composition of gases: Shepherd, 1.

engulfment, chemical significance: Shepherd, 4.

eruptions: Stearns, 7 ; May, 1924 ; Friedlaender, 8; Stearns, 5; and seismic sequences: Finch, R. H., 3; July, 1927: Wilson, R. M., 1. explosions: Stearns, 11.

explosive eruptions: Jaggar, 9 ; Sherzer, 1.

heat: Sci. Serv., 2.

intrusive bodies at Kilauea: Powers, 1.

lava tube: Powers, 4.

volcano observatory: Cross, C. W., 3.

Lapies in basalts: Palmer, H. S., 13. Marine and fluvial erosion: Wentworth, 29.

Mauna Loa, eruption, April, 1926 : Friedlaender, 9.

gases: Shepherd, 2.

Mauna Loa and Kileuea, origin : Stearns, 8. 
Hawaiian Islands-Continued.

Physical geology-Continued.

Sedimentary processes on volcanic islands: Wentworth, 24.

Sediments, types of : Wentworth, 33.

Seismometric investigation of lava column : Jaggar, 2.

Strand line shift, Oabu: Pollock, 1.

Stream erosion: Wentworth, 37.

Sulphate deposits in lava tubes, Kilauea : Finch, 6.

Tectonic aspect of volcanic eruption: Wood, H. O., 1.

Temperatures of volcano borings : Jaggar, 18, 23.

Tilting and level changes at volcanoes : Jaggar, 22.

'Tuff craters, Oahu: Wentworth, 19.

Viscosity of lava: Palmer, H. S., 10.

Volcanic action: Meinzer, 4.

Volcanic investigation: Jaggar, 4.

Volcanoes: Cockburn, 1; Hawaiian Volcano Observatory, 1 ; Jaggar, $2, \cdot 10$.

Physiographic geology.

Coral reefs, Oahu: Pollock, 3.

Eustatic benches: Wentworth, 21.

Fault topography : Hinds, 9.

Fringing and fossil coral reefs, Oahu : Pollock, 2, 3.

General: Hinds, 6; Wentworth, 23.

Karren formation in basalt rocks: Palmer, H. S., 12.

Maui : Hinds, N. E. A., 3.

geomorphology : Hinds, 10 .

Mauna Kea, glaciation: Gregory, H. E., 11.

Oahu : Davis, 16.

Molokai. deselt strip: Wentworth, 17.

Underground water.

Ground-water problems : Meinzer, 3.

Honolulu district : Palmer, H. S., 8, 11.

Hazleton district, British Columbia : O'Neill, 1.

Heart Mountain overthrust, Wyoming : Hewett, 4.

Helium : Rogers, G. S., 5, 7; in natura] gases: McLennan, 1.

Canada: Elworthy, 2, 5.

General: Moore, R. B., 1.

Geology and occurrence: Kauenhowen, 1.

Hematite and magnetite, relations: Broderick, 1.

Herb Lake region, Manitoba : Alcock, 12.

Herman-Morris folio, Minnesota (no. 210) : Sardeson, 1.

Herscher quadrangle, Illinois : Athy, 1.

Heterolasma foerstei, Niagaran tetracoral, Michigan : Ehler's, 2.

Highwood coal area, Alberta: Rose, 2.

Historical (stratigraphic) geology. For areal see names of States. See also the different systems; Correlation; Geologic formations, tables; Geologic maps.
Historical geology-Continued.

Appalachian stratigraphy, variations in : Butts, 15.

Atlantic and Gulf Coastai Plain, major geological features: Stephenson, 6.

Basal glauconite aud phosphate beds: Goldman, 10.

Basal quartzites of Cordilleran region: Keyes, 199.

Biotic basis of stratigraphy : Richarz, $b$

Boring records, use of : Reed, R. D., 1.

California, geologic formation names, check list: Bailey, G. E., 1.

Canadian system: Ashley, 25.

Comanche succession, taxonomic rank Stanton, 7.

Carboniferous, early : Keyes, 123.

Coastal Plain : Cooke, C. W., 9.

Cone-in-cone in stratigraphic colrelation : 'Tester, 1.

Conodonts, stratigraphic use: Bassler, 18.

Contorted strata: Winchester, 1.

Cordilleran shield : Lawson, 10.

Correlation: Berry, 65; by micro fossils: Decker. 9.

Cretaceous-Kocone transition: Choss, C. W., 5; Keyes, 32, 33; Knowlton, 9; Matthew, 20 ; Schuchert, 19 ; Stanton, 6.

Cretaceous-Tertiary boundary: Matthew, 15; vertebrate evidence as to: Matthew, 18.

Criteria of classification: Keyes, 103.

Designation of terranes: Keyes, 286.

English terranal classification in America : Keyes, 108.

European and American sections, comparison: Ulrich, 17.

Exploration for vertebrates: Grinnell, 1.

Foraminifera, use in stratigraphy: Dumble, 3.

Fossils, relative value in stratigraphy: Cooke, C. W., .8 .

General: Bayley, 12 ; Bretz, 8; Meinzer, 6; Parks, 6; Shimer, 4; Smithsonian Inst., 1; Troedsson, 1.

Geologic classification:. Keyes, 115.

Geologic column, France, Britain, Germany, United States: Lane, 3.

Geologic column, terms, origin and significance : Lang, W. B., 1.

Geologic mapping, western United States: Vaughan, 12.

Geologic maps, interpretation: Dake, 12.

Geologic terminology : Blackwelder, 7 .

Geologic time classification: Wilmarth, $1,2$.

Geologic time scale: Ashley, 14.

Green River formation: Bradley, W. H., . 4. 
Historical geology-Continued.

Gulf Coastal Flain : Brantly, 2; Shaw, 4.

Gumbos, correlating: Robinson, W. I., 4.

Hall's work in Iowa: Keyes, 113.

Harvard summer school of geology : Crump, 1.

Homonymy : Keyes, 194.

Identification of geological formations: Udden, 3.

Identifying subsurface strata : Roberts, D. C., 1.

Initial deposits of a formation : Twenhofel, 11.

Interior coal flelds: Keyes, 2.

International stratigraphical lexicon: Keyes, 289.

Lance and Fort Union formations, age : Cross, C. W., 4 ; Knowlton, 5; Schuchert, 15.

Major subdivisions: Keyes, 164.

Michigan, surveys: Allen, R. C., 4.

Mid-Continent oll field, paleogeography and historlcal geology: McCoy, 5.

Mississippian: Keyes, 20, 123.

Modern conceptions of earth history : Bretz, 8.

Mud-crack horizons, Ordovician: Kindle, 5 .

North Atlantic Ocean, Tertiary history : Woodring, 8.

Ordovician-Silurian boundary: Jones, O. T., 1; Miller, B. L., 9 ; Ulrich, 15.

Periodic diastrophism: Shepard, 6.

Permian : Keyes, 251.

Permo-Carboniferous deposition conditions: Case, E. C., 1.

Pre-Cambrian : Keyes, 109 ; time scale : Young, G. A., 4.

Pre-Devonian deposits, Alberta and British Columbia: Walcott, 11.

Principles of correlation : Berry, 22.

Proposed stratigraphic section and code : Ashley, 16.

Rocky Mountain region: Dake, 5.

St. Louis limestone, nomenclature : Keyes, 123.

Silurian-Devonian boundary: Schuchert, 11.

Stockwellia, a basic unit of geologic time: Keyes, 256.

Stratification: Udden, 25.

Stratigraphic correlation, new methods : Swartz, J. H., 3.

Stratigraphic nomenclature: Keyes, 210.

Stratigraphic signiflcance of solution in rocks: Stockdale, 3.

Structural features of North America : Holtedahl, 4.

Taconic area, southern: Knopf, E. B., 6.

Taconic folding, Pennsylvania : Miller, B. L., 9.
Fistorical geology-Continued.

Taconic orogeny, significance: Schuchert, 26.

Taconic question: Keyes, 260.

Taconic revolution, evidence for, examined: Clark, T. H., 4.

Taconic system resurrected: Schuchert, 1.

Taxonomy : Keyes, 255.

Terranal classification: Keyes, 156.

Textbook of geology : Schuchert, 23.

Time scale: Ashley, 22.

Volcanic ash beds as key horizons: Ross, C. S., 10.

Yorkic : Keyes, 49.

History. See also Surveys.

American geology, first one hundred years: Merrill, 36.

Applied geology : Smith, G. O., 24.

Canada: Parks, 6.

Contributions of Johns Hopkins University : Bayley, 12.

Farly collecting of fossil vertebrates : Lull, 18; Matthew, 36.

General: Benjamin, 1; Fairchild, 14; McNairn, 1.

Geology : Gregory, H. E., 6.

at Johns Hopkins University : Keyes, 21.

at West Virginia University : 'Tilton, 16.

development of : Gregory, H. E., 7.

Georgia, Geological Survey: Cave, 1.

Iowa: Keyes, 18.

James Hutton, pioneer of modern geology : Hobbs, 28.

Kentucky geological survey: Jillson, $34,42$.

Michigan, surveys: Allen, R. C., 3.

New York, Adirondack region: Clarke, J. M., 15.

North Dakota, geological survey: Leohard, A. G., 10.

Ohio, geological survey: Mendenhall, T. C., 1.

Oklahoma, petroleum geology : Powers, 20.

Ore genesis studies, fifty years' progress : Miller, B. L., 12.

Paleontological research on Pacific coast : Merriam, 7.

Petrography and petrology, fifty years' progress: Bascom, 7 .

Petroleum geology: Ohern, 1.

Pre-Cambrian life medal: White, D., 38.

Seventy-five years of American geology : Chamberlin, T. C., 24.

State surveys: Merrill, 6.

Statistical study of geologists : Mathews, 3.

Stories in stone: Lee, W. T., 17.

Structural geology, progress: Mathews, 8.

Textbooks of geology : Fairchild, 12. 
History-Continued.

United States Geological Survey: Inst. Govt. Research, 1; Smith, P. S., 4.

Vermont, geological work, 1810-1923: Perkins, G. H., 7 .

Washington: Landes, H., 1.

Hockley salt dome, Harris County, Texas : Deussen, 2

Hogshooter gas sand, Oklahoma: Berger, 1.

Homonymy : Keyes, 194.

Honduras.

Economic geology.

Petroleum possibilities: Redfield, 8.

Historical geology.

General : Redfield, 8.

Petrology.

Jade, Copan: Washington, 16.

Obsidian, Copan : Washington, 13.

Hoodoos, miniature : shroeder, 2.

Hornitos: Sapper, 2.

Horse, evolution : Loomis, 15 ; Matthew, 34

Hot springs. See also Thermal waters.

Arkansas, Hot Springs district: Purdue, 1.

British Columbia : Elworthy, 6.

California, “The Geysers :" Allen, E. T., 4.

Lassen National Park: Day, 15.

Wyoming: Bartlett, 3.

Hudson Bay Mountain district, Coast district, British Columbia: Jones, R. H. B., 1 .

Hudson submarine channel : Daly, 7 .

Huntington-Pittsburgh Basin: Richardson, G. B., 13.

Huronian. See Pre-Cambrian.

Hydrated ferric oxides: Posnjak, 1.

Hydrocarbons, inorganic origin: Young, J. W., 6.

Utah : Bardwell, 1.

Hydromagnesite, British Columbia, Clinton district: Reinecke, 2.

Hydrotalcite group : Foshag, 2.

Hydrothermal alteration of silicate minerals : Leonard, R. J., 1.

Hydrozoa.

Cryptozoon: Rothpletz, 2.

Ontario, Toronto area: Fritz, 1.

Serpulites, affinities: Price, W. A., 3.

Hyracodons, Big Badlands, South Dakota : Sinclair, 6.

Ice, physical properties: Matsuyama, 1.

Ice age. See Glacial geology.

llee ages (ancient).

Alaska, southeastern, Paleozoic: Kirk, E., 1.

Arizona, Fort Apache region, Eocene: Reagan, 4, 5 .

Banded clays : Sayles, 1.

Bishop conglomerate, glacial origin: Hares, 2.

British Columbia, Silurian tillite : Shepard, 1.

Cause: McCabe, J., 1 ; Manson. 3.
Ice ages (ancient)-Continued.

Cause of periodic glaciation: Keyes, 220.

Cobalt conglomerate, origin : Coleman,

Colorado, Denver formation: Hares, 3.

Eocene: Atwood, 7, 8

Criteria for glaciation: Hobbs, 16 .

General: Coleman, 8, 17, 25, 26; Ingals, A. G., 3 ; McCabe, J., 1 ; White, D., 31 .

Maine, Silurian tillite?: Smith, E. S. C., 4.

New Brunswick, St. John, Devonian : Matthew, G. F., 2.

Oklahoma, Arbuckle and Wichita mountain regions, Pennsylvanian: Weid$\operatorname{man}, 1,2$

Ontario, Gowganda conglomerate, origin: Bain, 17.

pre-Cambrian glaciation: Coleman, $13,18$.

Ordovician, Vermont region: Keith. 1.

Pennsylvanian-Permian glaciation (?), Arbuckle and Wichita mountains: Dunbar, 7 ; Weidman, 4.

Permian, middle: Schuchert, 47, 52.

Post-Eocene - pre-Mincene glaciation, Rocky Mountains: Hares, 4.

Quebec, Levis, tillite: Sayles, 6.

Rocky Mountains, pre-Cambrian : Blackwelder, 6.

Table of glacial periods: Chamberlin, T. C., 21.

Till argillites, pre-Cambrian, Permian, and Pleistocene: Lane, 5.

Tertiary glaciation, Wyoming, Colorado, and Utah: Hares, 1.

Ice age. See Glacial geology.

Ice cave, western New Mexico: Lee, W. T., 18.

Ice crystal markings: Allan, 19.

Ice crystals, fossil: Udden, 1; growth : Plyler, 1.

Ice push on lake shores: Scott, I. D., 3.

Icebergs, Greenland, formation : Koch, 2.

Ichnology, Dartmouth College collection: Grier, 4.

Idaho.

General: Livingston, 1.

Bureau of Mines and Geology, report: Thomson, F. A., 2.

work 1919-1924: Thomson, F. A., 5.

Areas described.

Alturas quadrangle, Blaine County: Ballard, 2.

Bear Lake County, eastern : Kirkham, 2. Bingham, Bonneville, and Caribou counties: Kirkham, 3.

Birch Creek district: Shenon, 2.

Boise Basin, Boise County : Ballard, 3.

Boundary County : Kirkham, 7.

Bruneau River basin, Owyhee County: Piper, 2. 
Idaho-Continued.

Areas described-Continued.

Clal's, Jefferson, and parts of Butte, Custer, Fremont, Lemhi, and Madison counties: Kirkham, 9.

Fort Hall Indian Reservation: Mansfield, G. R., 3.

Goose Creek basin, Bassia County: Piper, 1.

Lapwai area: Kirkham, 11.

Mineral and Cuddy Mountain mining districts, Washington and Adams counties: Livingston, 4.

North central Idaho: Thomson, F. A., 3.

Orofino area: Kirkham, 11.

Pine Creek district: Jones, Ed. I., 4.

Power and Oneida counties: Piper, 3.

Rocky Bar quadrangle: Ballard, 4.

St. Maries region : Anderson, A. L., 4.

Salmon area : Ross, C. P., 7 .

Seven Devils district: Livingston, 3.

Shoshone County : Umpleby, 3.

Silver City region: Piper, 6.

Southeastern Idaho: Mansfield, G. R., 29.

South Mountain district, Owyhec County: Sorenson, 1.

Yellow Pine cinnabar district: r.ar. sen, 3.

Economic geology.

Antimony : Thomson, F. A., 1.

Antimony and quicksilver deposits, Yellow Pine district, Valley County: Schrader, 10.

Boise Basin district: Ballard, 1.

Bonneville County, coal pruspects: Kirkham, 12.

Boundary County : Kirkham, 7.

Buffalo Hump district, quartz veins: Beckwith, R. H., 2, 4.

Bunker Hill lode, Wardner : Rickard, 3.

Cement materials, Pocatello: Anderson, A. L., 3.

Cinnabar, near Black Pine: Larsen, E. S., 1.

Clark County, coal and gas possibilities: Kirkham, 12.

Clays : Skeels, 1.

Coal, eastern Idaho: Mansfield, G. R., 8. Horseshoe district, 'Teton basin: Evans, G. W., 1.

Cobalt, Lemhi County : Hess, 5.

Coeur d'Alene district: Berg, 1; Eby, J. H., 1 ; Umpleby, 3,5 ; Waldschmidt, 8.

Copper near Salmon: Ross, C. P., 3, 7. Seven Devils district: Livingston, 3 .

Disseminated lead prospect, Boise County : Ross, C. P., 10.

General: Bell, R. N., 5.

Glacially transported mine, Gilmore: Walker, R. T., 1.

Gold, Boise Basin : Ballard, 3.

Idaho batholith: Thomson, F. A., 4 . north central Idaho: Thomson, F. A., 3.

$4096-31-52$
Idaho-Continued.

Economic geology-Continued.

Gold, silver, copper, lead, and zinc: Geriy, 1, 3, 5, 8, 10, 13.

Gold veins, central Idaho: Roberts, H. M., 1.

Gypsum : Stone, 11.

Horseshoe Basin coal field: Evans, G. W., 4.

I. X. L. copper prospect, Adams County : Bell, R. N., 3.

Kaolin and feldspar: Wilson, H., 1.

Manganese : Livingston, 2.

Bannock County: Hewett, 19.

Mica deposits, Latah County: Anderson, A. L., 1.

Mineral and Cuddy Mountain mining districts, Washington and Adams counties: Livingston, 4.

Mining districts: Varley, 1.

Mining industry: Bell, R. N., 1, 2, 4; Campbell, S., 1, 3-7.

Molybdenite, Rocky Bar district: Schrader, 7.

Molybdenum : Livingston, 2.

Native lead, Halley: Shannon, 73.

Oil shale: Condit, 2 ; Winchester, 5.

Oil possibilities: Heald, 10.

Bingham, Bonneville, and Caribou Counties: Kirkham, 3.

southeastern Idaho: Kirkham, 1, 5. southwestern and south-central Idaho: Buwalda, 5.

Ore deposition, Buffalo Fump district: Beckwith, R. H., 3.

Ore deposits in Tertiary lava, Salmon River Mountains: Ross, C. P., 13.

Phosphate deposits : Kirkham, 4 ; Mansfield, G. R., 35.

Quartzburg, Gold Hill mine: McDermid, 1.

Quicksilver: Livingston, 2.

Rocky Bar quadrangle: Ballard, 4.

Salt deposits : Phalen, 1.

Shoshone County: Umpleby, 3.

Silver, Pend Oreille district: Sampson, 16.

Silver City region: Piper, 6, 7 .

South-central Idaho: Umpleby, 2.

Tin : Livingston, 2.

Tungsten : Livingston, 2.

Vienna district, Blaine County: Ross, C. P., 12.

Wood River district: Campbell, S. S.,

Yellow Pine cinnabar district: Larsen, 3.

Zonal distribution of gold, silver, lead, and copper ores: Thomson, F. A., 6.

Historical geology.

Bozeman beds: Keyes, 19.

Buffalo Hump district: Beckwith, R. $\mathrm{H}, \mathrm{1}, 4$.

Coeur d'Alene region: Eby, J. H., 1; Shannon, 14

Eastern Idaho: Mansfeld, G. R., 8. 
Idaho-Continued.

Historical geology-Continued.

Granitic rocks, age : Ross, C. P.,.16.

Igneous geology. southeastern Idaho: Mansfield, G. R., 10.

Mud Lake Basin: Stearns, 4, 6.

Paleozoic: Ross, C. P., 11.

Payette formation, age: Buwalda, 8.

Pend Oreille district: Sampson, 16.

Potlatch area : Kirkham, 10.

Richmond formation(?) : Cook, C. W., 8.

Rocky Bar district: Schrader, 7 .

St. Maries area : Kirkham, 8.

Silver City district: Piper, 7.

Snake River valley: Buwalda, 3.

South-central Idaho: Ross, C. P., 15 ; Umpleby, 2.

Southeastern Idaho: Kirkham, 5; Mansfield, G. R., 30 ; 'Triassic and Jurassic: Mansfield, G. R., 6.

Vienna district, Blaine County: Ross, C. $P ., 12$.

Wasatch and Salt Lake formations, southeastern Idaho: Mansfleld, G. R., 5.

Yellow Pine district, Valley County: Schrader, 10.

Mineralogy.

Amphibole similar to hudsonite, Custer County: Shannon, 49.

Anglesite, Coeur d'Alene district: Shannon, 2, 17.

Atlanta district: Shannon, 79.

Black sands: Shannon, 25.

Boulangerite, Blaine county: Shannon, 28 ; Mullan : Shannon, 19.

Brannerite, Stanley Basin : Hess, 6.

Calcite, Pioneerville district: Shannon, 17.

Calcite oolites of pentagonal dodecahedral form, Eagle Rock : Shannon, 69.

Ferroanthophyllite, Coeur d'Alene district: Shannon, 21.

Galenobismutite, Boise County : Shannon, 30.

Garnet: Shannon, 39.

Gersdorffite: Shannon, 47.

Gouge clays, mineralogy : Shannon, 35.

Hisingerite, Blaine County: Hewett, 14.

Jamesonite containing silver, Owyhee County : Shannon, 19.

Slate' Creek, Custer County : Shannon, 57.

Jinarite and leadhillite, Wardner : Shannon, 5.

I.udwigite, Lemhi County : Shannon, 24.

Meteorite, Oakley : Merrill, 47, 52.

Miargyrite and tetrahedrite, Flint district: Shannon, $\mathbf{7 8}$.

Minerals : Shannon, 61.

Mordenite and associated minerals, Challis, Custer County: Ross. C. S., 6.
Idaho-Continued.

Mineralogy-Continued.

Naumannite, Silver City district: Shannon, 20.

Native lead, Hailey: Shannon, 73.

Niter deposit, Dubois : Stearns, H. T., 2.

Owyheeite, Owyhee : Shannon, 27.

'Tetradymite, Hailey quadrangle : Shannon, 58; Pine Creek district: Shannon, 17.

Trichalcite, Shoshone County: Shannon, 34.

Tridymite and cristobalite in a granitic xenolith: Weymouth, 2.

Vanadinite, Lemhi County: Stearns, H. T., 1.

Vivianite, Clearwater County : Shannon, 22.

Xanthoconite, Atlanta district: Shannon, 79.

Zéophyllite, Salmon River district: Fairbanks, 9.

ZIrcon, occurrence, Pend Oreille: Gillson, 36.

Paleontology.

Carboniferous and Triassic, southeastern Idaho: Girty, 10.

Idaho formation, Snake River valley : Dall, 10.

Orygoceras, Tertiary: Dall, 7.

Payette flora: Chaney, 6.

Petrology.

Coeur d'Alene district: Shannon, 14.

Granitic rocks, age: Ross, C. P., 16.

Granodiorites, . Pend Oreille district: Gillson, 6.

Idaho batholith : Beckwith, R. H., 1.

Southeastern Idaho: Mansfield, 10.

Physical geology.

Asotin craters of Columbia River basalt : Fuller, R. E., 3.

Craters of the Moon National Monument: Stearns, H. T., 14.

Faulting, northern Idaho: Umpleby, 3.

Fissure eruption, western Idaho: Fuller, R. E., 2.

Mud Lake basin, igneous geology : Stearns, 4.

Osbuin fault: Umpleby, 5.

Rate of soil deposition, Palouse area : Peterson, P. P., 1 .

Rocky Mountain structure, southeastern Idaho: Mansfield, G. R., 4, 15.

Southeastern Idaho: Mansfield, G. R., $11,33$.

Volcanism, Mud Lake area: Stearns, 9. Physiographic geology.

Craters of the Moon: Stearns, H. 'T., 12 ; Stearns, N. D., 3.

National Monument: Stearns, H. T., $3,14$.

Drainage changes, northern Idaho: Anderson, A. L., 2.

Features of glacial origin: Davis, W. M., 3. 
Idaho--Continued.

Physiographic geology-Continued.

Idaho peneplain, age: Buwalda, 8 .

Relief map : U. S. G. S., 10.

Southeastern Idaho: Mansfield, 13, $22,23$.

Tertiary planation, central Irlaho: Mansfield, 19 ; Ross, C. P., 8.

Underground water.

Big Lost River valley : Kirkham, 12.

Camas Creek Basin : Piper, 4.

Goose Creek basin, Cassia County : I'iper, 1.

Idaho Falls : Piper, 5.

l.apwai area : Kirkham, 11.

Moscow : Laney, 1.

Mud Lake basin: Stearns, 6.

Orofino area: Kirkham, 11.

l'ahsimeroi Valley: Meinzer, 8.

Potlatch area: Kirkham, 10.

Thermal springs : Meinzer, 10.

St. Maries area : Kilkham. 8 .

Weiser area : Kirkham, 12.

Ilentification of geologicul formations : Udden, J. A., 3.

Igueous and volcanic locks. See also Intrusions; Magmas; Petrology.

Aa and pahoehoe, formation: Washing. ton, 23.

Alabama: Adams, S. F.. 2.

Ashland graphite area: Brown, J. S., 6.

Clay County: Prouty, 10.

Alaska: Martin, G. C., 15.

Alaska Railroad region: Capps, 6.

Anvik-Andreafski region : Harrington, 1.

Chandalar district: Mertie, 12.

Chicagof Island: Buddington, 8 ; western part: Overbeck, 1 .

Coast Range intrusives: Buddington, 14.

Cold Bay district: Capps, 5.

Cold Bay-Chignik district: Smith, W. R., 1.

Cold Bay-Katmai district: Smith, W. R., 3.

Goodnews Bay region: Harrington, 6.

Kahiltna Valley : Mertie, 2.

Kamishak Bay region: Mather, 7 .

Katmai region: Fenner, 8.

Kennecott: Batenran, $\mathbf{3}$.

Kiwalik-Koyuk region: Harrington, 5.

Knik-Matanuska district : Landes, K. K., 2.

Kotsina-Kuskulana district: Moffit, 4.

Nixon Fork country : Brown, J. S., 7. northern, Canning River region: Leffingwell, 1.

Porcupine district: Eakin, 1.

Ruby-Kuskokwim region: Mertie, 11.

Salmon-Unuk River region: Mertie, 6.
Igneous and volcanic rocks-Continued.

Alaska-Continued.

southeastern: Buddington, 13 ; submarine pillow lavas: Buddington, 10.

Talkeetna Mountains, western: Capps, 3.

Tolstoi district: Harrington, 2.

Toklat-Tonzona River region: Capps, 12.

Tuxedni Bay area: Moffit, 2.

upper Matanuska Valley: Mertie, 14.

Anorthosites, formation: IoewinsonLessing, 1 .

Arizona : Darton, 17.

Aravaipa-Stanley region: Ross, C. P., 5.

central: Ettlinger, 1.

Courtland-Gleeson region: Wilson, i.. D., 2 ,

Jerome and Bradshaw Mountains qundrangles: Lindgren, 17.

Jerome district, Yavapai County: Fearing, J. L., 2 ; Reber, 1.

lower Gila region: Ross, C. P., 1.

Oatman district: Ransome, 12.

Papago country: Bryan, 7, 1.5.

Payson district: Iausen, 1.

Ray quadrangle: Ransome, 11.

Ray-Miami region: Ransome, 1.

Saddle Mountain and Banner mining districts : Ross, C. P., 6.

Tucson and Amole Mountains: Jenkins, 3.

Arkansas, Hot Springs district: Lloyd, E. R., 2.

Fike County, peridotite: Miser, 12.

Assimilation and petrogenesis: Stansfield, 7 .

Average chemical composition: Clarke, F. W., 3.

Basic and uItrabasic rocks, tectonic conditions accompanying intlusion : Benson, W. N., 2.

Batholiths, laterally spreading theory : Chamberlin, R. T., 16.

problems of : Grout, 24.

Belcher Islands, Hudson Bay: Moore, E. S., 1.

British Columbia: Brock, 14

Ainsworth district: Schofield, 4.

Bridge River area: McCann, 3.

const and islands: Dolmage, 8.

Cariboo district, Barkerville area : Johnston, W. A., 22.

Chiko Lake area : Dolmage, 15.

Coquihalla area: Cairnes, 4.

Dease Lake area, Cassiar district: Kerr, F. A., 1.

Driftwood Creek area, Babine Mountains : Hanson, 9.

Emory Creek, Yale district: Cairnes, 9.

Eutsuk Lake area, Coast district: Mạrshall, J. R., 3. 
Igneous and volcanic rocks-Continued. British Columbia-Continued.

Eutsuk Lake district: Brock, 1.

Fraser River Delta : Johnston, W. A., 17.

Kamloops district, North Thompson valley: Uglow, 3.

Lasqueti Island : MacKenzie, J. D., 3.

Milbank Sound region, post-Pleistocene volcanics: Dolmage, 10.

Parson Bay : Crickmay, 1.

Pemberton area, Lillooet district: Cairnes, 8.

Prince Rupert to Burns Lake : Hanson, 10.

Salmon River district: Schofield, 11.

Texada Island: Swanson, C. 0., 2.

Vancouver area: Schofield, 17.

Vancouver Island, East Sooke Penin. sula : Cooke, H. C., 5.

Whitesail-Tahtsa lakes area : Marshall, J. R., 3.

Windermere area, Kootenay district: Walker, J. F., 1.

Yale district: Cairnes, 5.

British Honduras: Ower, 2, 3 .

British Virgin Islands : Earle, 5.

California, Blackhawk Canyon, San Bernardino Mountains : Woodford, 7 .

Deep Spring Valley : Miller, W. J., 35.

Hollywood Hills, near Los Angeles : Schürmann, 1.

La Jolla quadrangle: Hanna, M. A., 3.

Lassen Peak region: Williams, H., 1.

Los Angeles and Ventura counties: Kew, 6 .

Point Sur quadrangle: Trask, 5.

Randsburg quadrangle: Hulin, 3.

Sacramento Valley: Bryan, 10.

San Bernardino Mountains : Vaughan, F. E., 1.

San Diego County : Ellis, A. J., 1.

San Gabriel Mountain: Miller, W. J., 29.

Sierra Nevada, inclusions in granitic rocks: Pabst, 1.

Sunset-Midway fleld: Pack, R. W., 1.

Warner Range: Russell, R. J., 6.

Central America: Putnam, P. C., 2.

Classification: Hodge, E. T., 2, 3, 7, 9 ; Johannsen, 3 ; Loughlin, 33 ; Pirsson, 4.

Colorado, Boulder County, Ward region : Worcester, 1.

central : Crawford, R. D., 2.

Creede district: Emmons, W. H., 4.

Delta and Mesa counties: Weeks, H. J., 1.

Golden area: Johnson, J. H., 14.

Grand, Jackson, and Larimer counties (parts) : Spock, 1.

Gunnison River: Hunter, J. F., 1.

Las Animas, Otero, and Bent counties (parts): Duce, 1.
Igneous and volcanic rocks-Continued.

Colorado-Continued.

Leadville mining district: Emmons, S. F., 1.

Monument Butte quadrangle: Hancock, 7.

northwestern: Ross, C. S., 14.

Pitkin C o u n ty, Aspen district: Knopf, A., 10.

Platoro-Summitville district : Patton, H. B., 1.

Red Cliff district: Crawford, R. D., 3.

Routt and Moffat counties: Perini, 1.

Routt County: Crawford, R. D., 1. southwestern : Coffin, 3.

Tarryall district, Park County : Muilenburg, 2.

Twin Lakes district: Howell, J. V., 1.

Columbia River basalt, Asotin craters: Fuller, R. E., 3.

Composition, texture, classification, description, and occurrence; Iddings, 2.

Connecticut, Middletown area: Rice, W. N., 1.

Shepaug Aqueduct Tunnel area : Agar, 4.

Southampton-Granby area : Palmer, H. S., 5 .

Stonington region: Martin, L. H., 1. Triassic basalts: Foye, 11.

Constituents and distribution: Clarke, F. W., 4.

Contact metamorphism: Bain, 25.

Costa Rica: Redfield, 7 ; Sears, 1.

Density, average: Washington, 15. calculation from norm: Iddings, 3 .

in relation to isostasy: Washington, 27.

Diabase and dolerite: Johannsen, 12.

District of Columbia: Washington, 12.

Dominica: Earle, 11.

Dominican Republic: Vaughan, 16.

Evolution: Bowen, 23.

Final consolidation phenomena in the crystallization of igneous rock: Colony, 4.

General : Washington, 4.

Georgia, Tate quadrangle: Bayley, 13.

Graphic study of igneous rock series: Grout, 8.

Greenland : Böggild, 1. northwestern : Hovey, 11 ; Koch, 1.

Haiti: Woodring, 4, 5.

Hawailan Islands : Powers, 5.

Kaula, Nikoa, Necker, and Gardner islands: Palmer, H. S., 9.

Kilauea : Stone. J. B., 1.

Honduras : Redfield, 8.

Idaho, Bingham, Bonneville, and Caribou counties: Kirkham, 3.

Boundary County : Kirkham, 7.

Buffalo Hump district: Beckwith, 4. Camas Creek basin : Piper, 4. 
Igneous and volcanic rocks-Continued. Idaho-Continued.

Cassia County, Goose Creek basin: Piper, 1.

Coeur d'Alene district: Shannon, 14.

Craters of the Moon National Monument: Stearns, H. T., 14.

Fort Hall Indian Reservation : Mansfield, G. R., 3.

granitic rocks : Ross, C. P., 16.

Idaho batholith: Beckwith, R. H., 1.

Lapwai area : Kirkham, 11.

Mineral and Cuddy Mountain mining districts : Livingston, 4.

Mud Lake area: Stearns, 9. north central : Thomson, F. A., 3.

Orofino area : Kirkham, 11.

Owyhee County, South Mountain district: Sorenson, 1.

Pend Oreille district, granodiorites : Gillson, 6.

Pine Creek district: Jones, Edw. L., 4. Rocky Bar quadrangle: Ballard, 4.

Salmon River Mountains: Ross, C. P., 13 .

Seven Devils district: Livingston, 3. Shoshone County : Umpleby, 3.

Silver City region: Piper, 6. south central: Umpleby, 2.

southeastern: Mansfield, G. R., 10, 29.

Igneous intrusion, after-effects: Kemp, 12.

Illinois, Hardin County : Weller, S., 1.

Inclusions in magmas: Emmons, R. C., 1.

Intrusive Triassic diabase, Goose Creek, Loudoun County: Shannon, 46.

Kansas, Riley County : Moore, R. C., 7. Rose dome, Woodson County: Twenbofel, 23, 32.

Kentucky, Cave in Rock quadrangle: Weller, 16.

western : Currier, 2.

Lanai : Wentworth, 15.

Leeward Islands: Washington, 33.

Lesser Antilles: Lacroix, 1.

Louisiana, Cretaceous : Bramlette, 2.

Richland Parish, nepbeline basalt: Campbell, I., 1.

Magmatic differentiation: Vogt, 1, 3.

Maine, Kennebec River to Penobscot Bay : Perkins, E. H., 3.

Mount Desert Island: Bascom, 1.

Mount Kineo: Smith, E. S. C., 3.

Ogunquit: Keeley, 2.

Portsmouth Basin: Wandke, 2.

Manitoba, Beresford Lake area : Wright, D. G. H., 2 ; Wright, J. F., 4.

Bigstone and Fox Rivers area : Merritt, C. A., 4.

Cross-Pipestone area : Alcock, 4.

Flinflon area : Alcock, 15.

Island Lake area : Wịght. J. F., 12.
Igneous and volcanic rocks-Continued.

Manitoba-Continued.

Knee Lake district: Bruce, 4.

northern: Bruce, 5.

Olseau River area: Wright, J. F., 10.

Oxford and Knee Lakes area : Wright, J. F., 11.

Reed and Wekusko lakes region: Alcock, 3.

Rice Lakes aren: Wright, J. F., 3.

Maryland, Elkton quadrangle: Bascom, 2.

Harford County, serpentines; Johannsen, 14.

western Piedmont: Jonas, 4.

Massachusetts, Cape Ann: Warren, C. H., 2.

Dracut norite stock: Fairbanks, 10.

Essex County : Clapp, C. H., 1.

Westfield, gabbroid diabase: Shannon, 6.

Mexico, Aguascalientes, Asientos-Tepezala distrlct: Anderson, G. E., 2.

Chapala region: Palmer, R. H., 1.

Chihuahua, Yoquivo district: Hall. C. W., 1 .

Coahuila, northern: Cummings, 2.

Colima (part) : Vivar, 4.

El Oro and Tlalpujahua districts: Flores, 1.

Guanajuato mining district: Wandke, 8.

Guerrero: Bonillas, 1; Paredes, 1 ; Zumpango del Rio: Waitz, 2.

Hidalgo, Atotonilco el Grande: Wittich, 10; El Chico: Wittich, 9.

Hidalgo-Vera Cruz region: Palmer, R. H., 4.

Lower California: Gálvez, 2; La Purisima region: Heim, 1 ; southern : Gálvez, 7.

Michoacan, Morelia Valley: Camacho, 3.

Minillas, Cerro Prieto, Pichagua, and Sierra de Ramírez: Bonillas, 2.

northeastern: Staub, 1.

Panuco oil field: Baker, C. L., 8.

Puebla, San Juan de los Llanos: Wittich, 12.

San Quintin volcanic fleld: Woodford, 6 .

Michigan, Presque Isle, peridotite: Creveling, 1.

Minnesota, Cook County, sulphide diabase: Schwartz, 12.

Giants Range batholith: Allison, I. S., 1.

granite and gabbro intrusions of Ely greenstone: Schwartz, 7.

Gunflint district: Broderick, 3.

Kekequabic granite: Stark, 1.

Pigeon Point: Grout, 27.

St. Louis County, northern: Grout, 20.

Vermilion batholith: Grout, 18. 
Igneous and voleanic rocks-Continued. Montana, Beartooth Mountains, Bevan, 2.

faulted area south of Bearpaw Mountains: Reeves, F., 8.

Melrose phosphate field: Richards, R. W., 2.

Sweet Grass Hills: Kemp, 8 .

Mt. Pele : Shepherd, 5.

Nevada, Candelaria district: Knopf, A., 5 .

Divide district: Knopf, A., 3.

Gilbert district: Ferguson, H. G., 10. Jarbidge district: Schrader, 5.

Manhattan district: Fer ruson, H. G., $2,5$.

Miperal County, Cedar Mountain : Knopf, A., 4.

Pioche district: Westgate, 6.

Rochester district: Knopf, A., 7 .

Round Mountain district: Ferguson. H. G., 4 .

Santa Fe district, Mineral County: Clark, C. W., 2.

New Brunswick, Burnthill Brook area: Young, G. A., 1.

Dalhousie area: Howard, W. V., 2.

Newfoundland, Notre Dame Bay: Sampson, 8.

southeastern: Buddington, 3 .

west coast: Brunton. 3.

New Hampshire, Ammonoosuc district: Ross, C. P., 2.

Hanover district: Meruitt, J. W., 3. Portsmouth Basin: Wandke, 2.

White Mountains, North Conway quadrangle: Billings, 5 .

New Jersey, Beemerville: Aurousseau, 1.

New Mexico: Darton, 26.

Mogollon district: Ferguson, H. G., 3, 8 ; Scott, D. B., 1.

northeastern: Garrett, 1.

Pecos Valley: Semmes, 4.

Puertecito district: Wells, E. H., 2.

Raton-Brilliant-Koehler area : Mertie,

$\theta$.

Sandia Mountains: Ellis, R. WV., 2.

Taos Range: Gruner, 1.

Taylor Creek district: Hill, J. M., 3 .

Tyrone district: Paige, 2.

New York, Adirondack gabbros: Gill. son, 10.

Adirondacks: Alling, 3.

Ausable quadrangle: Kemp, 23.

Gouverneur quadrangle: Cushing, 1.

Ithaca: Martens, 1, 3.

Lake Bonaparte quadrangle: Smyth, 2.

Lake Clear region: Alling, H. L., 1.

Lewis County : Buddington, 2.

Luzerne quadrangle: Miller, W. J., 19.

Lyon Mountain quadrangle: Miller, W. J., 26 .

Mount Marcy quadrangle: Kemp, 7 .
Igneous and volcanic rocks-Continued.

New York-Continued.

southeastern : Colony, 3.

West Point quadrangle: Berkey, 3 .

North Carolina, Deep River region: Stuckey, 1 .

Nova Scotia, North Mountain, Cape Breton : Guernsey, 2.

Richmond County, Stirling area : Weeks, L. J., 1.

Oahu: Wentworth, 22.

Oklahoma: Gould, 9.

Arbuckle Mountains: Taff, 7 .

Cimarron County: Rothrock. 4; Black Mesa basalt: Shead, 5 .

southern Ouachita Mountains: Honess, C. W., 4.

Wichita Mountains: Taff, 7 .

Olivine bombs near Globe, Arizona : Lausen, 5.

Ontario, Batchawana area, District of Algoma: Moore, E. S., 19.

Brocktown-Mallorytown area : Wright, J. F., 2.

Cochrane district: Hawley, J. E., 3.

Kirkland Lake area : Burrows, 4, 12 ; Todd, 8 ; Lebel and Gauthier townships : Hopkins, 7.

Lake St. Joseph area: Bruce, 8.

Matabitchuan area: Todd, E. W., 5.

Matachewan district: Cooke, H. C., 1.

Michipicoten district: Collins, W. H., $1,15$.

Missinaibi area: Thomson, E., 11.

north shore of Lake Huron: Collins, 11.

Red Lake area : District of Patricia : Bruce, 12.

Red Lake gold area, District of Kenora: Bruce, 22.

Sault Ste. Marie, District of Alyoma : MeConnell. 1 .

Sudbury district: Bain, 5, 18; Fhemister, 4.

Sutton Lake area: Hawley, J. E., 1.

Timiskaming district, Abitibi-Night Hawk gold area : Knight, C. W., 1 ; Argonaut mine: Cooke, H. C., 13 ; Larder Lake area: Cooke, 11; Redstone River area : Bruce, 19.

Oregon: Smith, W. D., 1.

Cornucopia, inclusions in porphyry dikes: Goodspeed, 1.

Glass Buttes, Lake County: Waters, A, 2.

Mount Jefferson: Hodge, E. T., 6.

Riddle quadrangle: Diller, 12.

southeastern: Smith, W. D., 14.

Panama Canal Zone: MacDonald, 5.

Pennsylvania, Indiana County, peridotite dike: Honess, A. P., 4.

Lebanon County, Ordovician : Gordon, S. G., 3.

McCalls Ferry quadrangle: Jonas, 2.

New Holland quadrangle: Jonas, 5. 
Igneous and volcanic rocks-Continued.

Fennsylvania-Continued.

Ordovician: Stose, 29.

Quarryville quadrangle: Jonas, 3.

Porto Rico: Berkey, 1.

Coamo-Guayama district: Hodge, E. T., 1.

Humacao district: Fettke, 5.

Lares district: Hubbard, B., 3.

Fonce district: Mitchell, 7.

San Juan district: Semmes, 1.

Quantitative mineralogical and chemical classification: Hodge, E. T., 4, 11.

Quebec, Abitibi County, Duparquet and Destor townships: Buffam, 1.

Arnprior-Quyon area : Wilson, M. E., 10.

Beauceville area: MacKay, B. R., 4.

Coleraine area: Knox, J. K., 1.

Dufresnoy area, Abitibi district: Harvie, 3.

Duparquet area : James, W. F., 1.

Gaspe County, Lemieux 'Township: Alcock, 14; Mailhiot, 1.

Harricanaw-'I'urgeon basin: Tanton, 1.

Lake David area: Mawdsley, 5.

La Motte and Fournière areas, Abitíbi County: James, 5.

Mount Albert area : Alcock, 6 ; Mailhiot, 2.

Monteregian province extensions : Stansfield, 4.

Monteregian Hills outliers: Howard. W. V., 1.

Mount Serpentine, Gaspe County: Alcock, 22.

northern: Cooke, H. C., 2.

Pontiac County, Calumet Island: Goranson, 3.

St. Urbain area, Charlevoix district: Mawdsley, 1.

Shickshock Mountains : Alcock, 21.

Timiskaming County, Rouyn area : James, W. F., 2.

Saskatchewan, Lake Athabasca reglon, norite rocks: Alcock, 7 .

Wapawekka and Deschambault lakes area: De Lury, 6.

South Dakota, Black Hills : Paige, 4. central Black Hills: Darton, 14.

Lead area: Hosted, 1.

spodumene mine, Black Hills: Schwartz, 13.

Structure: Willis, 11.

'Texas, Amarillo district: IJarrison, T. S., 1.

Balcones fault region: Lonsdale, 10.

Fort Stockton quadrangle: Adkins, 4.

Medina County : Liddle, 3.

Solitario uplift: Powers, 9.

trans-Pecos Texas: Baker, C. L., 6.

Triangular representation: Johannsen, 5.
Igneous and volcanic rocks-Continued.

Ultra-basic rocks, origin : Bowen, 22.

Utah: Butler, 4.

Abajo Mountains : Thorpe, 1.

La Sal Mountains: Gould, L. M., 4. Ophir district: Olmstead, 1.

'Tintic district: Lindgren, 2.

Vermont, Barnard, Pomfret, and Woodstock townships: Richardson, C. H., 11.

Bethel, Barre, and Woodbury : Balk, 4.

Bethel Township : Richardson, C. H., 8.

Braintree: Richardson, C. H., 5.

central : Richardson, C. H., 1.

Cuttingsville: Eggleston, 1.

Northfield: Richardson, C. H., 2.

Plymouth and Bridgewater townships: Perry, E. L., 1.

Roxbury: Richardson, C. H., 3.

Whitingham area : Hubbard, G. D., 4.

Virginia, Jurassic? intrusives : Roberts, J. K., 3.

Louisa County, lamprophyre dike: Watson, 9.

northeastern Piedmont: Lonsdale, 2, 7.

Piedmont: Jonas, 8.

Pittsylvania County: Watson, 13.

Triassic: Roberts, J. K., 8.

Washington, Corbaley Canyon: Waters, A., 1.

San Juan Islands: McLellan, 2. southwestern: Culver, 1.

Silver Hill deposits: Anderson, A. L., 5.

Spokane area: Pardee, 12.

Stevens County: Weaver, 2.

West Indies, northeast: Vaughan, 40.

Wyoming, Lost Soldier-Ferris district: Fath, 5.

Yukon, Aishihik Lake area: Cockfeld, 19.

Mayo district, Beaver River area: Cockfield, 15.

Sixtymile and Ladue rivers area: Cockfleld, 5.

Whitehorse district: Cockfield, 16. Igneous intrusion. See Intrusions. !llinois.

Boulder, Saline County: Bonnell, 3.

Decatur area: Leighton, 11.

Geological Survey, work: Hance, 1.

Glacial geology and engíneering: Leighton, 18.

Publications on geology : Ill. G. S., 2. Soils, DeKalb County: Mosier, 1.

Survey, administrative report, 191617 : DeWolf, 2 ; 1917-19 ; DeWolf, 5.

Topographic and geologic mapping in Illinois, relation to engineering: DeWolf, 6. 
Illinois-Continued.

Areas described.

Adams County, northeastern : Currier, 1.

Ava-Campbell Hill area : Root, 1.

Avon quadrangle: Savage, 6.

Brown County : Nebel, 1.

Calhoun County: Lamar, 6.

Canton quadrangle: Savage, 6 .

Carbondale quadrangle: Lamar, 3.

Carlyle-Centralia district: Shaw, 9.

Colchester and Macomb quadrangles: Hinds, H.; 1.

Dixon quadrangle: Knappen, 1.

Edgington quadrangle: Savage, 5.

Equality-Shawneetown area, Gallatin and Saline counties: Butts, 5 .

Gillespie and Mount Olive quadrangles : Lee, W., 1.

Good Hope quadrangle: Savage, 8; and La Harpe quadrangles: Nebel, 2 .

Hardin County: Weller, S., 1.

Hennepin quadrangle: Cady, 3.

Herscher quadrangle : Athy, 1.

Joliet quadrangle: Fisher, D. J., 2.

Kings quadrangle : Bretz, 4.

La Harpe quadrangle: Nebel, 2 ; Savage, 8.

La Salle quadrangle: Cady, 3 .

Milan quadrangle: Savage, 5.

Morris quadrangle: Culver, $2,7$.

New Athens quadrangle: Shaw, 8.

Okawville quadrangle: Shaw, 8.

Oregon quadrangle: Bevan, 3.

Pike and Adams counties: Coryell, 1.

Saline County: Cady, 12; western, Cady, 11.

Williamson County, northeastern : Cady, 11.

Econornic geology.

Allendale oil field, Wabash County : Moulton, 6, 21; extension : Col lingwood, 7.

Ayer's anticline, Bond County: Bell, A. H., 4.

Bituminous shales: Barrett, 6 .

Calhoun County: Lamar, 6.

Carbon ratios and petroleum: Moulton, 4 .

Central eastern Illinois: Mylius, 1.

Centralia area : Bell, A. H., 2.

Clay, Mountain Glen, Union County: St. Clair, 2.

Coal: Culver, 5.

analyses: Hawley, G. W., 1

Carbondale quadrangle: Lamar, 3.

District III : Culver, 6.

District IV : Cady, 7.

District V (Saline and Gallatin counties) : Cady, 4.

Hennepin quadrangle: Cady, 3.

Knox County : Jelliff, 2.

La Salle quadrangle: Cady, 3.

low-sulphur: Cady, 3, 9.

Milan quadrangle: Savage, 5.

southern Illinois: Cady, 13.
Illinois--Continued.

Economic geology-Continued.

Coal beds, correlation: Culver, 8 ; Jillson, 108.

Fire clays: Parmelee, 1.

Fluorite, optical, southern Illinois: Pogue, 3.

Fluorspar : Fay, 2; Fellman, 1; Schwerin, 1, 2 ; Spurr, 30.

Fuller's earth, Pulaski County: Lamar, 10.

Gravel and limestone: DeWolf, 3.

Gravel deposits: Leighton, M. M., 2.

Herrin coal near Duquoin: Fisher, $D$. J., 3.

Hoing sand oil pools, prospecting: Moulton, 11.

JacksonvilTe area, petroleum: Bell, A. $\mathrm{H} ., 7$.

La Salle district: Ede, 1 ; mineral resources : Buzzard, 1 .

Limestone resources: Krey, 3 .

Martinsville area, Clark County : Moulton, W. H., 1.

Mineral industries, map: Christensen, 1 ; Ill. G. S., 3 .

Mineral resources: Barrett, N. O., 2, 3.

Molding sand: Littlefield, 2, 3 .

Oil and gas, east-central Illinois : Mylius, 7 .

Monroe County : Mylius, 3.

Oil and gas development, Jacksonville area : Collingwood, 3 ; and possibilities, eastern Illinois: Mylius, 6 .

Oil and gas fields, map: Richardson, G. B., 1 .

Oil and gas prospecting, central eastern Illinois: Mylius, 1.

Oil and gas resources, Ava-Campbell Hill area : Root, 1.

Oil fleld operations: Clark, C. R., 1; Moulton, 14; Spoor, 1.

Oil fields, influence of faulting: Wheeler, H. A., 4.

Oil investigations, Centralia area : Bell, A. H., 3.

oil possibilities, Alexis quadrangle, Mercer and Warren counties: Wanless, 6.

Brown County: Nebel, 1.

Galesburg quadrangle: Poor, 2.

Goodhope and La Harpe quadrangles: Nebel, 2.

Oil prospecting, western Illinois: Bell, A. H., 11.

Oil prospects, Decatur area: Collingwood, 6.

Pile County: Bell, A. H., 1.

Petroleum: Barrett, N. O., 2 ; Collingwood, 2, 4, 5; Moulton, 3, 10, 12 , 17.

Ayers anticline, Bond County : Bell, A. H., 9.

Crawford County: Hance, 2.

Flat Rock pool, Crawford County: Tough, 1. 
Illinois-Continued.

Economic geology-Continued.

Petroleun-Continued.

St. Francisville area, Lawrence County: Bell, A. H., 10.

Trenton fleld: DeWolf, 4.

Wabash County: Moulton, 19.

Potash resources: Schroyer, 1.

Potash shales : Austin, M. M., 1; Union County : Krey, 1.

Pyrite in coal beds: Cady, 5, 8.

Refractory clays: Parmelee, 2.

St. Peter sandstone: Lamar, 9.

Saline County, western: Cady, 11.

Sandoval oil fleld: Bell, A. H., 6.

Sorento dome, Madison, Montgomery, and Bond counties: Bell, A. H., 5 .

Sparta area, oil and gas possibilities: Moulton, 9.

Staunton gas pool: Mylius, 2.

Structural features suitable for oil testing: Moulton, 5.

Structural relations in western Illinois: Moulton, 13.

Wamac oil pool, Marion County : Wheeler, H. A., 5.

Waterloo anticline: Lamar, 1; Moulton, 16.

Williamson County, northeastern : Cady, 11.

Yanaway well in Siggins pool: Lamar, 13.

Zinc: Boericke, 1.

Historical geology.

Adams County, Payson anticline: Cox, B. B., 1 .

Allendale oil field: Moulton, 6.

B a s a 1 Pennsylvanian conglomerate: Poor, 1.

Bond County, Ayers anticline: Bell, $\boldsymbol{\Delta}$. H., 9.

Boring, Monmouth: Workman, 1.

Carboniferous: Culver, 3.

Centralia area: Bell, A. H., 2.

Chester series: Ulrich, 5; Weller, 2.

Clark County, eastern : Moulton, 22.

Coal beds, correlation: Culver, 9.

Crawford County: Hance, 2.

Decatur area: Collingwood, 6.

Devonian : Savage, 3, 7, 1.4.

Alto Pass quadrangle: Bassett, 1 .

Southwestern Illinois: Savage, 4.

Drift sheets of northwestern Illinois : Leighton, 10.

East-central Illinois: Myllus, 7.

Farm Creek Pleistocene section near Peoria : Leighton, 17.

Faunal horizons, Pennsylvanian rocks : Savage, 11.

Galesburg quadrangle: Poor, 2.

Geologic map : Ill. G. S., 1.

Geological section: Keyes, 118.

Glenwood limestone: Bevan, 4, 6.

Igneous pebbles and boulders in Carboniferous limestone: Savage, 18.

Jacksonville area: Bell, 4 . H., 7 ; Collingwood, 3
Illinois-Continued.

Historical geology-Continued.

Joliet district: Fisher, D. J., 6.

Kinderhook group, western Illinois : Moore, R. C., 1.

Knox County, Knox Township : Jelliff, 2.

La Salle anticline: Cady, 6; Ede, 1; Mylius, 5.

Loess deposits, Alton: Baker, F. C., 4.

Maquoketa and Richmond rocks, correlation: Savage, 13.

Martinsville area, Clark County : Moulton, 15.

Media anticline, Henderson County : Bell, A. H., 8.

Mississippi Valley: Krey, 2.

New Richmond sandstone, northern Illinois: Cady, 2.

Northeastern Illinois: Anderson, C. B., 1 ; Grant, U. S., 1.

Northern Illinois: Thurston, 1; Thwaites, 7.

Orchard Creek shale: Savage, 1.

Oriskany limestone: Savage, 10, 15.

Paleozoic rocks in deep wells : Thwaites, 3.

Pennsylvanian, northwestern lllinois : Culver, 4 ; Wanless, 5.

subdivisions: Cady, 14 ; Savage, 17. unconformities: Savage, 17.

Pleistocene: Baker, F. C., 8, 9; Leighton, M. M., 3.

Lawrence County: Cox, F. W., 1.

succession near Alton: Leighton, $M$. M., 5.

Pre-Illinoian till, Randolph County: MacClintock, 3.

Pre-Pennsylvanian surface west of Duquoin anticline: Henbesţ, 2.

Richmond beds: Savage, 12.

Ste. Genevieve formation: Lamar, 5.

St. Peter sandstone: Dake, 6; Lamar, 1, 9 ; Sardeson, 21.

Saline and Gallatin counties: Cady, 4.

Silurian: Savage, 16.

Sorento dome, Madison, Montgomery, and Bond counties: Bell, A. H., 5 .

Southern Illinois: Weller, 11.

geological history: Weller, 6, 15.

Staunton gas pool: Mylius, 2.

Thebes sandstone: Savage, 1.

Tradewater formation: Henbest, 1.

Waterloo anticline: Lamar, 1.

Western Illinois: Culver, 6.

Windrow formation: Thwaites, 2.

Yanaway well in Siggins pool: Lamar, 13.

Mineralogy.

Fluorite: Pogue, 3.

Mineral collections in State Museum : Crook, 2.

Paleontology.

Alton mammalian fauna, age: Leighton, M. M., 6.

Angiosperm, Paleozóic, in coal: Hoskins, 1. 
Illinois-Continued.

Paleontology-Continued.

Black River Brachiopoda: Fenton, C. L. 5 .

Braidwood flora: Noé, 2.

Bryozoa, Chester series: McFarlan, 1. Carboniferous, Galesburg: Jeliff, 3.

Carboniferous plants, structure: Hoskins, J. H., 4.

Coal balls: Noé, 7 .

Coal flora, Richland County: Reel. F. D., 1.

Coal measures fossils near Galesburg: Jelliff, 1.

Devonian, western Illinois: Savage, $\boldsymbol{\tau}$.

Elephas primigenius boreus, Golconda : Crook, 4, 5.

Elephas roosevelti, Cass County : Hay. 26.

Fusulina, distribution : Culver, 3.

Fusulinella, Stonefort limestone: Henbest, 1 .

Hardin County : Weller, S., 1.

Harrisburg flora: Noé, 11.

Loess deposits, Alton: Baker, F. C., 4. Mammalian faunas, shifting: Adams, L. A., 2.

Mazon Creek: Moodie, 12.

Mollusca of loess deposits : Baker, F. C., 13 .

Myeloxylon, coal measures: Seward, 1.

Orchard Creek shale: Savage, 1.

Paleozoic angiosperm, Harrisburg: Noé, 5.

Pennsylvanian flora, northern Illinois: Noé, $6,8$.

Pennsylvanian plants, structure: Hos kins, J. H., 2, 3.

Pleistocene Mollusca: Baker, 8, 11, 12. Grundy County: Baker, 6.

Joliet: Baker, 9.

Pleistocene Verteblata: Hay, 6.

Problematic fossil, Silurian: Weller, 8. Richmond fauna, northeastern Illinois :

- Evans, J. R. C., 1.

Silurian Gastropoda, northeastern Illinois: Wing, 1.

Silurian worm, Lecthaylus gregarius: Weller, 9.

Stigmarian root, Chester formation : Foerste, 14

Thebes sandstone: Savage, 1.

Petrology.

Microscopic structure of rocks : Lamar. 2.

Physical geology.

Central eastern Illinois: Mylius, 1.

Chester series limestones, sedimentary analysis: Lamar, 7.

Clark County, eastern: Moulton, 22.

Coal balls : Feliciano, 1.

Crystalline boulders in Pennsylvanian limestone: Savage, 18.

Faulting, Alto Pass area: Ekblaw, 2.

Iron sulphide pseudomorphs of plant structure: Schwartz, 20.
Illinois-Continued.

Physical geology-Continued.

La Salle anticline: Cady, 6 ; Mylius, 5.

Mississippi Valley, structure: Krey, 2.

Oolite of Ste. Genevieve formation : Lamar, 5.

Posten School structure, Monroe County : Mylius, 4.

Saline County coal field, faults and dikes: Bonnell, 2.

Sandoval oil fleld : Bell, A. H., 6.

Structural features suitable for oil testing: Moulton, 5.

Structural relations in western Illinois : Moulton, 13.

Tilden meteor: Wylie, 1

Physiographio geology.

Alexis quadrangle: Wanless, $\boldsymbol{T}$.

Cahokia mounds, origin: Crook, 3; Leighton, 8, 12.

Chicago area: Downing, 1; Fryxell, 1 ; Salisbury, 2.

Drift sheets, northern Illinois: Leighton, M. M., 4

northwestern Illinois: $\mathrm{L}$ e i g h t o n, M. M., 10

Driftless Area, erosional history : Trowbridge, 1.

Farm Creek Pleistocene section near Peoria: Leighton, 17.

Glacial drift sheets, northern Illinois : Leighton, M. M., 6.

Glacial history, Elgin region: Leighton, 14.

Glacial Kankakee torrent in northeastern Illinois: Ekblaw, 3.

Glacial phenomena, Carbondale quadrangle: Lamar, 4.

Glaciation, western Illinois: Leverett, 15.

Illinois Valley: Cady, 1.

Iowan and Illinoian drift sheets, relative age: Kay, 15.

Joliet district: Fisher, D. J., 6.

Karst topography, Alton: Lamar, 12.

Monk's Mound, St. Clair County: Crook, 1.

Northeastern Illinois : Anderson, C. B.,1.

Northern Illinois: Thwaites, 7.

Ohio River, genesis: Fowke, 1.

Paleozoic karst topography: Ekblaw, G. E., 1.

Pleistocene, northwestern I 1 li n o is : Leighton, 9.

succession near Alton: Leighton, 5.

Prairies, origin: Woodard, 1.

Pre-Illinoian till, Randolph County : MacClintock, 3.

Sangamon River at Decatur, glacial history : Leighton, 7 .

Southern Illinois: Bonnell, 1.

Underground water.

Artesian waters, northeastern Illinois: Anderson, C. B., 1.

Ground-water supplies: Habermeyer, 1.

Northern Illinois: Thwaites, 7. 
Ilmenite, Florida, beach deposits: Martens, 9.

Ilsemannite at Ouray, Utah: Hess, 17.

Immiscibility in silicate melts: Greig, 1.

Impressions on rocks : T'wenhofel, 13.

Inclusions in Igneous magmas: Bowen, 13.

Independence shale, Brandon, Iowa : Thomas, A. $0 ., 5$.

Indiana.

McCormick's Creek Canyon: Logan, 14. Paleolithic stone age : Balcom, 1.

Soil surveys: Bushnell, 1.

Soils, Benton County: Jones, G. B., 1. Carroll County: Erni, 1.

Cass County: Beals, 1.

Whitley County: Shiltz, 1.

Survey, reports : Barrett, E., 1, 6, 7; Logan, $6,7,13,16,20,26,28,29$.

\section{Areas described.}

Jasper County : Bushnell, 2.

Lawrence County : Esarey, 1.

Economic geology.

Bullding stones: Logan, 8.

Cement materials: Logan, 9.

Clay, indianaite, Monroe County : Iogan, 2-4.

Clays and shales: Logan, 19.

Coal, Monroe County : L Logan, 1.

Vigo County: Logan, 6.

Coal seams, distribution: Iogan, 11. workable: Barrètt, E., 8.

Coals, correlation: Jillson, 108.

Flints and cherts : Bennett, I. F., 2.

General : Logan, 10.

Indiana limestone: Anderegg, 1.

Indianaite: Ries, 5; origin: Logan, $3,4$.

Kaolin : Logan, 4, 6; origin: Bucher, 5.

Mineral resources: Logan, 6.

Molding sand: Hole, 1.

Natural gas: Wright, Floyd E., 2. conservation : Logan, 21.

New Albany oll shale: Reeves, J. R., $4,6$.

Oil and gas flelds: Barrett. E., 5; Wright, Floyd E., 1.

Oil fields, southwestern Indiana : Logan, 18.

Oil in middle Ordovician : Heald, 9.

Oil shales: Esarey, 3 ; Reeves, J. R., $2,3,5$.

Peat deposits: Logan, 12.

Petroleum: Bownocker, 3 ; Logan, 22 ; Reeves, J. R., 1; and natural gas: Logan, 5.

conservation: Logan, 17.

southwestern Indiana: Moulton, 20.

Placer gold: Hafer, 1.

Pyrite in coals: Barrett, E., 8.

Sullivan County oil field: Visher, 2.

Tri-County oil field, southwestern Indiana : Esarey, 2.

Historical geology.

Borden (Knobstone) rocks, southern Indiana: Stockdale, 4.

Borings : Logan, 24.
Indiana-Continued.

Historical geology-Continued.

Chester formations, Orange County : Hole, 1.

Chester. series, southern Indiana: Malott, 2.

Cincinnati anticline, dimensions : Hubbard, G. D., 5 .

structural features: Logan, W. N., 27.

General : Cumings, 1 ; Logan, 5, 1.5, 24.

Greene County, eastern : Malott, 1.

Hamburg section: Shideler, 4.

Niagaran, northern Indiana: Cumings, 5 ; Shrock, 2.

coral reefs: Cumings, 3, 4.

Ordovician, Madison: McEwan, 2.

Pennsylvanian and Mississippian, southwestern Indiana: Logan, 25.

Saluda limestone, Madison: Sulzer, 1.

Southwestern Indiana: Logan, 18.

Sub-Trenton formations: Logan, 23.

Upper Chester: Malott, 8.

Paleontology.

Brassfield limestone fauna, Jefferson County: Culbertson, J. A., 1.

Chester formations, Orange County : Hole, 1.

Crinoid occurrence at Crawfordsville: Ehrenberg, 1.

Elephas roosevelti: Hay, 26.

Niagaran, northern Indiana: Cumings, 5; Shrock, 2.

Ordovician, Madison: McEwan, 2.

Pleistocene Mollusca: Baker, F. C., 3.

Pleistocene shell, Porter County : Lyon, 1.

Scorpion, Pottsville formation, Clay County : Moore, J. I., 1.

Physical geology.

Concretions in Knobstone, Monroe County: Tucker, W. M., 2.

Erosion, Clifty and Butler ravines, Jefferson County: Culbertson, 2.

Laurel limestone, erosion forms: Sulzer, 2.

Lawrence County, structural features: Esarey, 1.

Marengo Cave: Speckman, 1.

Petroleum in a fossil cast: Reeves, J. R., 9.

Planation stream piracy : Malott, 5.

Sphalerite in coal pyrite, Bicknell: Dove, 1.

Structural features: Visher, 4.

Structural geology : Barrett, E., 5.

Stylolites, nature and origin: Stockdale, 1.

Widening of valleys by frost action : Culbertson, G., 1.

Physiographic geology.

Abandoned channels, Randolph and Delaware counties: Breeze, 1.

Anderson esker: Reeves, J. R.. 1.

Bell Creck-Fall Creek Valley: Carter, 1. 
Indiana-Continued.

Physiographic geology-Continued.

Drainage changes in Porter's Cave area : Addington, 2.

Dunes, northwestern Indiana: Barrett, E., 2.

Lake Michigan : Cressey, 3.

General : Malott, 6.

Glacial boundary: Malott, 9.

Greene County, eastern: Malott, 1.

Hancock County : Tharp, 1.

Indian Creek, Lawrence County, subterranean phenomena; Malott, 7.

Kankakee region: Bushnell, 4.

Knobstone cuesta region, southern Indiana: Malott, 3, 4.

Lakes near La Porte: Tucker, W. M., 3.

Litten natural bridges, Owen County: Addington, 4.

McCormicks Creek: Barrett, E., 4.

Marengo Cave: Addington, 3.

Miami County: Tharp, 2.

Ohio River, genesis : Fowke, 1.

Owen County, drainage changes: Addington, 1.

Porter's Cave, Morgan County: Addington, 2.

Raccoon Creek, I'arke County, change of drảinage: Bartle, 1.

Sand dunes, Lake Michigan: Cressey, 1, 2 ; Parkins, 1.

Shades: Barrett, E., 3.

Stream piracy near Greencastle: Smith, E. R., 3.

Subterranean drainage phenomena: Addington, 5 .

Terraces, Ohio River, Jefferson County : Culbertson, 3.

Wabash drainage basin: Shrock, 1.

Wayne County: Bushnell, 3.

Incompetent beds, use of thickness of: Rubey, 4.

Indianaite, Indiana : Ries, 5 ; ortgin : Logan, W. N., 3, 4.

Inequalities of sedimentation: Kindle, 3 .

Ingomar anticline, Tréasure and Rosebud counties, Montana: Heald, 18.

Iniskin Bay district, Alaska: Moffit, 3 .

Iniskin-Chinitna Peninsula, Alaska: Moffit, 7 .

Insecta.

Beetles, Fox Hills strata, South Dakota: Northrop, S. A., 1.

Caddice fly cases, Green River formation, Wyoming : Bradley, W. H., 1.

Caddis case, Eocene, Tennessee : Berry, 84.

Miocene, Washington: Berry, 9, 7.

Collecting insects : Cockerell, 33.

Colorado, Eocene: Cockerell, 8, 24.

Florissant, Miocene: Cockerell, 36 , 41 ; beetles : Cockerell, 32.

Green River : Cockerell, 27.

Culex winchesteri, Cathedral Bluffs, Colorado: Cockerell, 3.

Dragon fly, Eocene, Colorado: Cockerell, 42.
Insecta-Continued.

Description of material in United States National Museum: Cockerell, 24.

Eocene, Rocky Mountains: Cockerell, 2. Texas : Cockerell, 19.

Eomyza holoptera, Green River beds, Colorado: Cockerell, 26.

Florida, Vero, beetles: Wickham, 1.

Fulgoridae, Eocene: Cockerell, 9.

General: Brues, 1.

Hoplisus, Green River formation, Colorado: Cockerell, 15.

Hymenoptera, earliest: Cockerell, 10.

Florissant, Colorado: : Cockerell, 4, 23.

Inocellia (Neuroptera), Florissant, Colorado: Cockerell, 28.

Kansas, Permian : Carpenter, F. M., 1 ; Dunbar, 4 ; Tillyard, 1.

Copeognatha: Tillyard, 8.

Delopteridae: Tillyard, 11.

Hemiptera: Tillyard, 9.

Mecoptera: Tillyard, 7 .

Paleodictyoptera: Tillyard, 2, 4.

Protodonata and Odonata: Tillyard, 5.

Protohymenoptera: Tillyard, 3 ; and Odonata: Tillyard, 6.

Protoperlaria: Tillyard, 10.

Maryland, Carboniferous : Cockerell, 37.

Mosquitoes, oldest: Cockerell, 3.

Moth, Hydriomena, Florissant: Cockerell, 13.

Oregon, eastern, Tertiary : Cockerell, 41.

Paleozoic insects, revision : Handlirsch, 1.

Sawflies, Florissant, Colorado: Cockerell, 12.

Scorpion-fly, Green River Eocene: Carpenter, F. M., 3.

Siphlurites, Miocene May fly, Florissant, Colorado: Cockerell, 22.

Taphacris bittaciformia, Florissant: Cockerell, 30.

Termite, Eocene, Tennessee: Collins, R. L., 2.

Typus gilmorei, Grand Canyon: Carpenter, F. M., 2.

Wyoming, Eocene: Cockerell, 8.

Intercision, Pike River, Wisconsin: Ball, S. H., 4.

Interglacial periods. See Glacial geology. Internationalization of mineral resuurces: Leith, 2.

Intraformational corrugated rocks: Miller, W. J., 17.

Intrageology : Chamberlin, T. C., 33.

Intrusions. See also Dikes; Igneous and volcanic rocks; Laccoliths; Magmas.

Alaska, Coast Range: Buddington, 13. Association of faulting with dike intrusion: Sheldon, 3.

Basic dike injections in magmatic vein sequences: Spurr, 20. 
Intrusions-Continued.

Batholiths, problems of : Grout, 24.

Granitic intrusives : Kemp, 24.

Hawail, Kilauea : Powers, 1.

Idaho, western: Fuller, R. E., 2.

Igneous intrusion, after-effects : Kemp, 12.

Laccoliths and sills : Davis, 27.

New Mexico, Pecos Valley: Semmes, 4.

Mexico, southern Oaxaca: Palmer, R. H., 9.

Ontario, Michipicoten area : Collins, 15. Sudbury district: Bain, 18.

South Dakota, central Black Hills : Darton, 14.

Stresses in laccolithic intrusions : Gould, L. M., 2.

Vermont, Bethel, Barre, and Woodbury : Balk, 4.

Virginia, Louisa County, lamprophyre dike: Watson, 9.

Invertebrates (general). See also the classes of invertebrates.

Alberta, Banff area: Warren, P. S., 4. Birch Lake sandstone, marine fauna : Warren, P. S., 3.

Crowsnest Pass, Devonian and Carboniferous: Warren, P. S., 2.

Edmonton formation, Red Deer River: Warren, P. S., 2.

Lake Minnewanka section: Shimer, 6. Beekmantown series, Levis, Quebec: Clark, T. H., 11.

Baffin Island, corals, brachiopods, gastropods, and ostracodes; Hussey, 2.

British Columbia, Rocky Mountains, Ordovician: Wilson, A. E., 4.

southwestern, Pleistocene: Crickmay, 3.

Vancouver Island, Sooke formation: Clark, B. L., 8.

California, La Jolla quadrangle, Eocene: Hanna, M. A., 5.

California Academy of Sciences, report of curator: Hanna, G. D., 3.

Vacaville, Eocene: Palmer, D. B. K., 1.

Cannonball fauna: Stanton, 3.

Carboniferous, Oklahoma: Morgan, G. D., 5.

Carolinas, Cretaceous: Stephenson, 9.

Devonian, western Illinois: Savage, 7. western Tennessee: Dunbar, 2. Ellesmere Land: Tolmachoff, 2.

Harvard College, Museum of Comparative Zoology, reports on invertebrate paleontology: Raymond, 1, $20,22,25,33,38$.

Illinois, northeastern, Richmond fauna : Evans, J. R. C., 1.

Orchard Creek shale: Savage, 1.

Thebes sandstone: Savage, 1.

Idaho, southeastern, Carboniferous and Iriassic: Girty, 10.
Invertebrates (general)-Continued.

Indiana, Jefferson County, Brassfield limestone fauna: Culbertson, J. A., 1.

Inorganic constituents: Clarke, F. W., 2.

Iowa, Des Moines, Carboniferous: Thomas, 18.

Hackberry stage : Fenton, C. L., 4. Fort Dodge, Ste. Genevieve marls: Lees, 4.

Mississippian: Van Tuyl, 8.

State Quarry beds: Stainbrook, 3.

Shellrock stage: Belanski, 3.

Kansas : Twenhofel, 17.

Permian: Dunbar, 4.

Maine, Chapman sandstone : Raymond, 21.

Maryland, Silurian : Swartz, C. K., 9.

Mesozoic, bibliography: Whitney, F. L., 1.

Mexico, Coahuila, Permian: Haack, 1. Gulf of California, Pliocene : Hanna, G. D., 29.

Michigan, Richmond formation: Hussey, 1.

Mississippian : Weller, 13.

Missouri, Bailey limestone fauna : Tansey, 1.

Devonian: Branson, 5.

Kimmswick and Plattin limestones: Foerste, 9.

Mississippian : Moore, 41.

Plattin formation: Fenton, C. L., 8.

Ste. Genevieve County, Little Saline limestone: Stewart, G. A., 1.

Multilamellar invertebrates: Bassler, 11.

New Xork, Martinsburg, Trenton fauna : Clark, T. H., 1.

Vernon shale fauna: Eaton, H. N., 5 ; Ruedemann, R., 2.

North Carolina, Cretaceous: Stephenson, 4.

Northwest Territories, Great Slave Lake, Ordovician and Silurian: Hume, 18.

Ontario, Credit River section: Dyer, 3 Lake Timiskaming area: Hume, 14. Ordovician, black shales: Parks, 32 ; Ottawa region, Ontario: Wilson, A. E., 1 ; upper : Foerste, 15.

Workman's Creek section, Cincinnatian series: Fritz, 2.

Pennsylvania, Broad Top coal field, Pocono fauna: Girty, 12.

Portage fauna, Mackenzie River valley : Kindle, 4.

Pottsville fauna, Ohio: Morningstar, 1 .

Webster County, West Virginia : Price, W. A., 1.

Quebec, Anticosti Island: Twenhofel,30. upper Ordovician : Foerste, 15.

Silurian: Foerste, 14.

New York: Ruedemann, 19. 
Invertebrates (general)-Continued.

Silurian-Continued.

Ohio: Foerste, 2.

southwestern Ontario: Williams, M. Y., 1.

Tennessee, Ripley fauna: Wade, B., 3.

Texas, Cretaceous: Adkins, 5 ; Scott, G., 2.

Fredericksburg and Washita formations: Adkins, 1.

Weno and Pawpaw formations: Adkins, 2.

Trenton fauna, Ontario and Quebec: Raymond, 10.

Triassic, York County, Pennsylvania: Wanner, 1.

Upper: Smith, J. P., 3.

Trinidad: Harris, G. D., 5.

Utah, Carboniferous and Triassic: Girty, 3 .

Vermont, Fort Cassin : Foyles, 3. fossil localities: Foyles, 5.

West Virginia, Mercer, Monroe, and Summers counties, Carboniferous : Girty, 8.

Nicholas County : Price, W. A., 7.

Webster Ccunty : Price, W. A., 1.

Wisconsin, Galena limestone: Ockerman, 1.

Iowa.

Conglomerate boulders, Centerville : Wilson, B. H., 1.

History of Iowa geology: Keyes, 18.

Pleistocene clays: Graham, H., 1.

State geologist's report: Kay, G. F., 1,9 .

Areas described.

Adair County : Gow; 1.

Cass County: Tilton, 3.

Clarke County: Tilton, 2.

Crawford County: Lees, 18.

Lucas County : Lugn, 6.

Pleistocene : Cable, 4.

Ringgold County: Arey, 1.

Taylor County: Arey, 2.

Economic geology.

Coal: Lees, 17 ; Rice, G. S., 1 .

Fertilizer materials: Smith, J. E., 11.

Glass sand: Knight, N., 2, 3.

Gypsum : Stone, 11 ; Wilder, 2.

Mineral production: Kay, G. F., 2 ; Lees, $8,11,13,14,16$.

Molding sand, eastern Iowa : Smith, 15.

Petroleum and natural gas: Howell, J. V., 4.

Refractory clays and shales: Galpin, 2. Rock resources: Kay, 13.

St. Peter sandstone, oil possibilities: Osborn, W. G., 1.

\section{Historical geology.}

Adel, postglacial deposits: Lees, 15. Aftonian gravels, Union County: Kay, 5.

Ames, glacial tills: Smith, J. E., 4.

Anticlines: Dille, 2.
Iowa-Continued.

Historical geology-Continued.

Black bituminous shale near Palo, Linn County : Dille, 1.

Boring, Brighton : Lindly, 3, 4.

Davenport : Lindly, 6.

Holstein, Ida County : Lees, 10.

Laurens, Pocahontas County: Cable, 3.

Morning Sun : Lindly, 5.

Butler's Landing, Pennsylvanian outlier: Adams, J. E., 2.

Cambrian: Keyes, 89.

Comanchean fossils in glaciai. drift: Tester, 3.

Cone-in-cone in stratigraphic correlation: Tester, 1.

Cretaceous: Keyes, 240, 245.

nomenclature: Keyes, 203.

sandstone outcrop, Cherokee County : Cable, 10

southwestern Iowa: Keyes, 68.

Dakota sandstone, Cherokee County: Cable, 7.

Decorah formation: Kay, G. M., 1; divisions: Kay, G. M., 2.

Devonian : Keyes, 186; Thomas, 12. northern. Iowa: Belanski, 2.

Drift sections, Des Moines: Keyes, 95.

Fort Dodge gyspum beds: Keyes, 137 ; Lees, 3, 12 .

Gypsum deposits, age: Keyes, $166^{\circ}$.

General : Folger, 1; Howell, J. V., 4 ; Keyes, 106.

Glacial period: Kay, 7 .

Gravel deposits, Louisa and Washington counties: Schoewe, 1.

Hackberry stage, Devonian : Fenton, C. L., 2-4.

Hall's work in Iowa: Keyes, 113.

Independence shale, Brandon: Thomas, A. $0 ., 5$.

Jackson County: Ladd, H. S., 3.

Linn and Jackson Counties outliers, age: Norton, W. H., 4.

Maquoketa and Richmond rocks, correlation: Savage, 13.

Maquoketa shale: Bradley, J. H., jr., 1. Jackson County : Ladd, H. S., 1.

Mississippian formations: Van Tuyl, 8.

Mississippian-Pennsylvanian and Pennsylvanian-Pleistocene unconformities, Lucas County: Lugn, 4.

Missouri series, southwestern Iowa : Tilton, 7.

Oolitic limestone in Otis beds: Dille, 5 .

Ordovician, northeastern Iowa: Keyes, 252.

Paleozoic rocks: Keyes, 229.

Pennsylvanían system: Noe, 13.

Pleistocene, Des Moines : Isees, 9.

Preglacial Moingona River: Keyes, 3.

Richmond beds: Savage, 12.

Ste. Genevieve marls, Fort Dodge : Irees, 4. 
Iowa-Continued.

Historical geology-Continued.

St. Peter sandstone: Dake, 6; Osborn, W. G., 1 ; Sardeson, 21.

Sandstone, Linn County : Hendricks, 1. Shakopee dolomite: Sardeson, 20.

Shellrock stage of Devonian: Belanski, 1.

S i o u a Mountains, translocation : Keyes, 242.

Southwestern Iowa: Smith, G. L., 1.

State quarry beds, Devonian: Stainbrook, 3.

Stratigraphic data from deep wells: Norton, W. H., 5.

Stuart area: Tilton, 5.

Sw eetland shale: Keyes, 199. stratigraphic position: Keyes, 125.

Volcanic ash, Des Moines: Keyes, 99 ; in glacial till: Keyes, 95.

Wapsipinicon breccias : Norton, W. H., 1 ; nodules: Norton, W. H., 3.

Windfield, boring: Lindly, 2.

Wisconsin drift, relation to Iowan drift in Worth County : Cable, 1.

Windrow formation: Thwaites, 2.

Mineralogy.

Meteorites, Amana: Prior, G. T., 1. Estherville: Merrill, 9.

\section{Paleontology.}

Annelid Jaws, Devonian : Searight, 1.

Aulopora, Devonian : Fenton, M. A., 1.

Beaver tooth, Des Moines: Thomas, A. $0 ., 7$.

Black River Brachiopoda: Fenton, C. L., 5 .

Bilobites bilobus, Niagaran, Jones County : Thomas, A. O., 25.

Bone deposit, Cherokee : Cable, 9.

Brachiopoda, Maquoketa shale: Bradley, J. H., Jr., 1.

Ceraurus, McGregor: Thomus, A. O., 24.

Coal measures flora, Johnson County : Adams, J. E., 1.

Des Moines, Carboniferous: Thomas, 18.

Echinodermata, Devonian: Thomas, A. O., 2, 12, 23; geographic distribution: Thomas, A. O., 16.

Maquoketa beds : Slocom, 1; Thomas. 22.

Eurypterus, Cambrian, Lansing: Walter, 2.

Gastriceras, Mystic: Thomas, A. O., 6.

Glass sponges: Thomas, 13.

Hackberry fauna: Fenton, 1, 2, 4.

Helicina occulta: Shimek, 1.

Herpetocrinus, Monticello, I o w a : Thomas, A. O., 4.

Lime Creek shales, micropaleontology : Thomas, A. O., 9.

Minmmalian remains: Thomas, 15 .

Maquoketa depauperate fauna: Ladd, H. S., 2.
Iowa-Continued.

Paleontology-Continued.

Missouri series, southwestern lowa: Tilton, 7 .

Pentameracea, Devonian: Belanski, 2.

Pine cone from drift: Thomas, 21.

Pleistocene bone deposits, Cherokee: Cable, 8.

Pleistocene mammalian rem a ins : Thomas, 20.

Proboscidean remains, Clarke County: Kay, 6.

Henry County: Jaques, 1.

Ked Oak and Ottumwa : Thomas, 26.

Pugnoides, Devonian: Thomas, 14.

Rhynchonellid brachiopods, Devouian : Thomas, 14.

Salix : Reagan, 12.

Ste. Genevieve marls, Fort Dodge: Lees, 4.

Schizophoria, Devonian : Fenton, M. A., 3.

Shellrock stage of Devonian: Belanski, 3.

Sloth remains: Delavan, 1.

Southwestern Iowa: Smith, G. L., 1.

Stegomastodon: Osborn, 33.

State Quarry beds, Devonian: Stainbrook, 2, 3.

Stromatopora, Iowa City: Thomas, $11,17$.

Terebratulacea, Devonian: Belanski, 4.

Trilobites: Walter, 3 .

St. Lawrence limestone: Walter, 1.

Petrology.

Dolomites, composition : Reed, B. B., 1.

Physical geology.

Anticlines: Dille, 2.

Clay bank erosion, Lee County : Wilson, B. H., 2.

Devonian oolite, Linn County: Dille, 3.

Eolian sands in interglacial deposits, Des Moines: Keyes, 105.

Fort Dodge gypsum beds: Keyes, 137 ; Lees, 12.

General : Keyes, 290.

Gumbo: Keyes, 93.

Gumbotil, origin : Kay, 4.

Ice flutings on interglacial deposits: Keyes, 266.

Iron streak in the loess: Keyes, 188.

Limestone masses and septaria, origin : Lugn, 1.

Mud pebbles, origin: Lugn, 5, 9 .

Nebraskan and Kansan tills: Kay, $\mathrm{S}$.

Red Oak faulting: Keyes, 228.

Rockford geodes: Galpin, 1.

Sink hole, Pocahontas County : Cable, 5.

Siouan fold: Keyes, 44.

Status of sedimentation studies : Trowbridge, 8 .

Thurman-Wilson fault, southwestern Iowa: Tilton, 1.

Physiographic geology.

Adel, postglacial deposits: Lees, 15.

Aftonian gravels, Union County : Kay, $\mathbf{5}$. 
Iowa-Continued.

Physiographic geology-Continued.

Algona recessional stages of Wisconsin glaciation: Smith, J. E., 7, 12.

Ames, glacial tills: Smith, J. E., 4.

Boulders in Kansan drift: Kay, 3.

Boyer Valley : Lees, 5.

Camp Dodge region, Iowa: Lees, 1.

Des Moines glacial lobe, retreat: Keyes, 263.

Des Moines valley: Lees, 2.

Drainage changes, Lee County: Wilson, B. H., 2.

Drift deposits, Des Moines : Keyes, 17.

Drift sheets, relation, Clarke County : Kay, 6.

Driftless Area, erosional history : Trowbridge, 1.

Early glacial sheets: Keyes, 206.

Eskers, central Iowa: Smith, J. E.. 5.

Extinct glacial pond, Linn County : Dille, 6.

Fort Dodge stages of retreating gliciers: Smith, J. E., 8.

Glacial boulders, Des Moines Connty : Lugn, 3.

Glacial deposits : Kay, 11 ; Keyes, 23: ; Des Moines: Keyes, 92.

Glacial Lake Calvin: Schoewe, 3.

Glacial lakelet near Cedar Rapids : Dille, 4.

Glacial till sheets: Keyes, 126, 246.

Gravel deposits, Louisa and Washington counties: Schoewe, 1.

Gumbotil : Kay, 4.

Fumboldt stages of Wisconsin glaciation : Smith, J. E., 14.

Interglacial rolcanic ash, Des Moines : Keyes, 26.

Iowan till: Kay, 12.

Iowan and Illinoian drift sheets, relative age: Kay, 15.

Iowan-Wisconsin border: Cable, 2, 6.

Lake Calvin, origin and history: Schoewe, 6.

Lake Cooper, physiographic evolution: Wilson, B. H., 3, 4.

Loveland loess: Kay, 14.

Mississippi River, temporary course: Schoewe, 4.

Pleistocene : Cable, 44.

Des Moines: Lees, 9.

western Iowa: Kay, 10.

Preglacial Moingona River: Keyes, 3.

Recessional moraines: Keyes, 232; central Iowa: Smith, J. E., 17.

Stages in retreat of glaciers: Smith, J. E., 9.

Story County, glacial geology: Smith, J. E., 16.

Valley gravels of northwestern Iowa : Lees, 6.

Webster County, eolian deposits : Smith, J. E., 3.
Iowa-Continued.

Physiographic geology-Continued.

Wisconsin till: Smith, J. E., 13.

Underground water.

Clarke County: Tilton, 2.

Conservation of underground water: Lees, 7.

Water table of the loess: Keyes, 124, 241.

Iowan-Wisconsin border, Iowa : Cable, 2. Iron.

Alabama, Bessemer-Vandiver quadrangle : Butts, 13

Birmingham district : Aldrich, T. H., 2 ; Crane, W. R., 1-4.

brown iron ores: Adams, G. I., 4; Burchard, 26.

Alberta : Allan, 6.

Arizona, Eureka district, magmatic ore : Ball, S. H., 1.

Plumosa district: Keyes, 146.

Bacteria and iron deposition: Harder, $1,3$.

Belcher Islands, Hudson Bay: Moore, E. S., 1; Woodbridge, 1 ; Young, G. A., 3.

Biwabik formation, origin : Gruner, 3.

British Columbia: Ẏoung, G. A., 6.

Taseko Valley: Brewer, W. M., 1 ; MacKenzie, J. D., 1.

Texada Island, magnetites: Swanson, C. O., 2.

Vancouver Island, magnetite deposit, genesis : Uglow, 16.

California: Boalich, 2.

Madera County, magnetite: Dougherty, 6.

Canada: Moore, E. S., 11.

Arctic regions: Moore, F. S., 2.

titaniferous ores: Goodwin, W. I., 1.

Chrome iron ore, occurrences: Ross, J. G., 1.

Clinton iron ore, origin: Galloway, .J. J., 4.

Cuba : Kuhn, 2; Weld, 1; Santiago : Kimball, 1.

Distribution in meteorites and in earth : Adams, S. F., 1.

General : Burchard, 2, 9, 12, 13, 15, 16, 21, 22 ; Harder, 4.

Georgia : Haseltine, 1.

Gogebic Range: Hotchkiss, 1, 7 .

Gunflint iron formation: Gill, J. 1., 2.

Hematite in certain ore deposits: Gilbert, G., 5 .

Illinois, Hardin County: Weller, S., 1.

Indiana: Logan, 10.

Investigation of iron ores, technique: Osborne, F. F., 2.

Iron ore resources of the South: Burchard, 18

Iron protores, leaching of : Lovering, 1. Iron-depositing bacteria: Inman, 1; North, L., 1.

Keewatin iron formations: Collins, 23. Kentucky : Miller, A. M., 1. 
Iron-Continued.

Lake Superior region: Crowell \& Murray, 1 ; Royce, 1 ; Winchell, A. N., 2. manganiferous iron ores: Zapffe, 4.

Mackenzie: Kindle, 6.

Magbemite: Wagner, P. A., 5.

Magnetite: Gruner, 10 ; Newhouse, 6 ; Wagner, P. A., 5.

North Carolina, origin: Bayley, 3.

Magnetite and hematite, relations: Broderick, 1 ; Gilbert, G., 4.

Magnetite-martite-hematite, oxidation of: Gruner, 8.

Mesabi iron ores, enrichment: Allison, I. S., 2.

Mesabi magnetic ores, origin: Grout, 7 . Mexico, Bravo Valley : Paredes, 11.

Cerro de Mercado: Salazar Salinas, 3. Guanajuato, Jalisco, and Michoacan : Paredes, 10.

Hidalgo: Paredes, 2.

Minnesota, Cuyuna range: Thiel, 7,8 ; Zupffe, 1, 2, 3, 5 .

Gunfint district : Broderick, 3.

magnetite segregation in banded syenite: Grout, 18.

Mesabi range: Grout, 3 ; Gruner, 2, 5 ; Parsons, A. B., 1 ; Schwartz, 4 ; Wolff, J. F., 1.

northern, magnetites: Grout, 9.

St. Louis County, northern: Grout, 20.

Vermilion ores:Gruner, 9.

Missouri, Iron Mountain and Pilot Knob : Spurr, 33.

Montana, Stanford hematite district: Westgate, 1.

Sweet Grass Hills: Kemp, 8.

New Brunswick, Bathurst mine: Parsons, C. S., 1.

Newfoundland, Wabana: Hasebrink, 1; Hayes, $\boldsymbol{A}$. O., 9.

New Mexico, Chupadera Mesa: Keyes, 72.

Iron Mountain: Smythe, 2.

New York: Newland, 2.

Adirondack Mountains, magnetite deposits : Miller, W. J., 13, 18 ; Newland, 1 ; genesis : Alling, 10 ; magnetic ores, sedimentary phases: Nason, 1.

Ausable quadrangle: Kemp, 23.

Clinton County: Miller, W. J., 5 ; Newland, 1.

Essex County, magnetic ores: Henry, 1.

Lyon Mountain quadrangle: Miller, W. J., 26.

southeastern, magnetites: Colony, 3.

North Carolina, Lansing, magnetitemarble ore: Bayley, 4.

magnetite ores: Bayley, 2, 6 ; Pratt, J. H., 6 .

western, brown hematite ores: Bayley, $5,7,11$.

Nova Scotia, sedimentary ores: Hayes, 4.

$4096-31-53$
Iron-Continued.

Ohlo, Vinton County : Stout, 6.

Ontario : Bruce, 16 ; Collins, 7 ; Knight, C. W., $8 ; O^{\prime}$ Connor, 1 ; Ontario Iron Ore Committee, 1.

Gunflint iron-bearing formation : Gill, J. E., 1.

Lake St. Joseph area : Bruce, 8.

Leeds County, hematite: Wright, J. F., 1.

Michiplcoten district: Collins, W. FI., $1,2,16$.

Missinaibi area: Thomson, E., 11.

Mississagi Reserve and Goulais River iron ranges: Moore, E. S., 15.

northwestern: Marks, 1.

Sahkatawich Lake section, Woman River iron range, District of Sudbury : Moore, E. S., 20.

Thunder Bay district: Tanton, 12.

Ore reserves, Tennessee River basin: Burchard, 27.

Origin : Eng. and Min. Jour., 1.

Oxidation products from sphalerite and galena: Boswell, 1.

Paragenesis of martite and magnetite: Newland, 6.

Pennsylvania: Pa. G. S., 1.

Adams County: Stose, 25.

Allentown quadrangie: Miller, B. L., 5.

Forto Rico, eastern, magnetite deposits : Fettke, 6.

Humacao district: Fettke, 5.

Milyaguez, limonite : Fettke, 2.

Pre-Cambrian iron formation, origin : Moore, E. S., 21.

Quebrc, Arnprior-Quyon area: Wilson, M. E., 10.

Belcher Islands, Hudson Bay : Moore, E. S., 1.

titaniferous magnetite deposits, Chicoutimi district: Robinson, A. H. A., 3.

Saskatchewan, Lake Athabaska: Allen, 10.

Scdimentary ores, origin: Quirke, 17. Southern States: Burchard, 23.

'Tennessee, eastern: Bayley, 7 ; Smith, A. F., 2.

Waynesboro quadrangle: Miser, 6. western: Burchard, 24.

west-middle, brown ores: Burchard, 25.

Texas, eastern: Dumble, 1.

Titaniferous iron ores: Osborne, F. F., 3.

Utah, Iron Springs and Pinto districts : MacVichie, 1 .

southern: Rohlfing, 1.

Virginia, Giles County : Hubbard, G. D., 6.

Oriskany ores: Doak, 1.

Wise and northern Scott counties: Eby, J. B., 1.

Washington: Jenkins, 5. 
Iron-Continued.

West Virginia, Hampshire and Hardy counties : Tilton, 15.

Mercer, Monroe, and Summers counties : Reger, 9.

Wisconsin, Gogebic Range: Hotchkiss, 3.

Yukon: Young, G. A., 6.

Iron-stained sands and clays: MacCarthy, 4.

Island arcs, unstable middle section: Hobbs, 22.

Isocarbs, Kentucky : Russell, W. L.; 5.

Isostasy.

Abnormal densities in earth's crust : Bowie, 12

Applications in geology: Kemp, 7 .

Base for isostasy : Keyes, 112.

Basin Range faulting, Oquirrh Range, Utah : Gilluly, 6.

Bearing on geological problems : Bowie, 14

Bibliography : Knopf, A., 8.

Cause of thrusting: Lawson, 2.

Comagmatic regions, distribution: Washington, 15.

Composition of crust, data from : Washington, 4.

Density of igneous rocks: Washington, 27 .

Earth movements: Reid, 9.

Earthquakes, relation to isostasy : Bowie, 22, 25.

Elastasy vs. isostasy: Chamberlin, T. C., 33.

Equilibrium theory of earth's crust : Putnam, G. R., 2.

Fundamentals : Reid, H. F., 19.

General: Barrell; 4, 5; Bowie, 7, 11, $1.7,20,21,26,29$; Brown, C. W., 1; Dutton, 1; Foley, 4 ; Hayford, 1, 2 ; Keyes, 191, 207, 212 ; Leith, 1.0 ; Longwell, 9 ; Putnam, G. R., 3; Taylor, 9; Van Orstrand, 3; Willis, 6; Wood, 4.

Geodetic data, results: Bowie, 10.

Geological aspects : Bowie, 27 .

Geological directrix : Keyes, 39.

Geological implications: Lawson, 7.

Glaciation and deglaciation: Daly, 7 .

Gravity, western Canada : Bowle, 31.

Gravity anomalies: Bowie, 15; and petroleum exploration: Hubbert, 3 .

Gravity observations: Putnam, G. R., 1: from the standpoint of the local geology: White, D., 14.

(ravity results, Mackenzie basin : Miller, A. H., 1.

Ilerschel's view of isostatic adjustment: Longwell, 18, 19.

Isostasy as a result of earth shrinkage: Shepard, 4.

Isostatic adjustment : Daly, 19 ; Evans, J. W., 1.

Isostatic anomaly, interpletation: Melton, 2.
Isostasy - Continued.

Isostatic condition of the United States as indicated by groups of gravity stations: Bowie, 18.

Isostatic investigations: Bowie, 9.

Labrador ice sheet, relations to isostasy : Coleman, 2.

Mathematics: Chamberlin, T. C., 22; MacMillan, 1.

Minimum span of isostatic eftect: Keyes, 34.

Mountain formation: Burrard, 1.

Ocean currents and isostusy : Bowie, 1.

Orogeny: Lawson, 9.

Periodic diastrophism:..Shepard, 4.

Principle and theory : Eaton, J. E., 10.

Proof by gravity reduction method: Putnam, G. R., $\overline{5}$.

Raised beaches and thickness of ice sheets: Coleman, 20.

Regional isostatic reduction of gravity determinations: Putnam, G. R., 4.

Relation to mountain building: Swanson, C. O., 4 .

Relation to seismology: Bowie, 23.

Relation to uplift and subsidence: Bowie, 4.

Rock density : Washington, 15.

Rocky Mountains: Keyes, 16, 132.

Rôle of isostatic stress: Willis, 8.

Size of block of earth's crust independently in isostatic equilibrium. Bowie, 15.

Theory : Bowie, 6 ; Putnam, G. R., 1.

Vertical movement of crustal material : Bowie, 28.

Weight of sedimentary rocks : Lane, 10.

Yielding of the earth's crust: Bowie, 5 . Isostatic theory and applied geology : Keyes, 40.

Ivory, fossil: Stone, 18.

Jack Bay district, Prince William Sound, Alaska : Johnson, B. I., 2.

Jamaica.

Bibliography : Matley, 2.

Government geologist, report: Matley, $1,5,9$.

Liguanea plain : Matley, 3.

Areas described.

General : Brunton, 2 ; Cundall, 1.

St. Ann Parish: Matley, 11.

Wconomic geology.

Mineral resources: Brunton, 8.

Historical geology.

Barrettia beds: Trechmann, 2.

Cretaceous and Tertiary: Trechmann, 1.

Cretaceous limestones: Trechmann, $\mathbf{5}$.

Cretaceous shales: Hawkinns, H. L., 3 ; Trechmann, 8.

General: Matley, 1, 2, 6, 12 ; Stockley, 1 .

Richmond formation: Trechmann, 4.

Tertiary, marine: Woodring, 10.

Yellow limestone: 'Trechmann, 3. 
Jamaica-Continued.

Paleontology.

Barrettia : Trechmann, 2.

Cretaceous : Trechmann, 8.

Crab, Withers, 1, 8:

Cretaceous and Tertiary decapod crustaceans: Withers, 2.

Echinoidea: Arnold, B. W., 1 ; Hawkins, H, L., 1, 2.

Foraminifera, Tertiary: Vaughan, 46.

Miocene Mollusca, Bowden: Woodring, $10,21,22$.

Yaberinella famaicensis: Vaughan, 47.

Yellow limestone: Trechmann, 3.

Physical geology.

Earthquakes: Taber, 2.

Underground water.

General: Matley, 4; Stockley, 1.

Mineral spring at Windsor : Matley, 10. Jarbidge district, Nevada: Schrader, 5. Jasperoid of Joplin district: Smith, W. S. T., 1.

Jeffersite : Alderson, 5.

Jennings oil fleld, Acadia Parish: Louisiana: Barton, 12.

Jerome and Bradshaw Mountains quadrangles, Arizona, ore deposits : Lindgren, 17.

Joint systems: Barrell, 10.

Jointing: Swanson, C. 0., 3.

California, Merced Canyon: Morse, R. R., 2.

in limestones as seen from the air: Rich, J. L., 15.

Mechanical interpretation of foints : Bucher, 2.

Joliet quadrangle, Illinois : Fisher, D. J., 2. Jordan sandstone: Stauffer, 5.

Jurassic. See also Paleontology, Jurassic.

Alaska : Martin, G. C., 15.

Chignik region : Martin, G. C., 14.

Cold Bay district: Capps, 5; Smith, W. R., 4.

Cold Bay-Chignik district: Smith, W. R., 1.

Cold Bay-Katmal district: Smith, W. R., 3.

Iniskin Bay district: Moftt, 3 .

Iniskin-Chinitna Peninsula : Moffit, 7 .

Kamishaik Baý region: Mather, 7.

Kotsina-Kuskulana district: Mofft, 4.

Matanuska Valley: Capps, 11.

northern, Canning River region: Leffingwell, 1.

Point Barrow region: Paige, 5.

Snug Harbor district: Moffit, 7 .

Talkeetna Mountains, western : Capps, 3.

Tuxedni Bay area: Mofft, 2.

Alberta : Allan, 12.

Bragg Creek area : Hume, 30.

Crowsnest coal field, northern part: Rose, 1:

foothills belt between McLeod and Athabaska rivers: Rutherford, 4.

Saunders Creek and Nordegg coal basins : Allan, 9.
Jurassic-Continued.

Arizona: Darton, 17 ; Keyes, 83.

Hopi Buttes volcanic fleld: Reagan,

8.

Lees Ferry region: Bryan, 8, 11.

Navajo country: Reagan, 20.

northwestern : Reeside, 4.

British Columbia, Ainsworth district: Schofield, 4.

Brídge River area: McCann, 3.

Cariboo district, Barkerville area: Johnston, W. A., 22.

coast region : Dolmage, 9.

Coquihalla area: Cairnes, 4.

Dease Lake area, Cassiar district: Kerr, F. A., 1.

Driftwood Creek area, Babine Mountains : Hanson, 9.

Eutsuk Lake area, Coast district: Marshall, J. R., 3.

Harrison Lake district: Crickmay, 5. Hazleton: O'Neill, 1.

Hudson Bay Mountain, Coast district: Jones, R. H. B., 1.

Kitsault River to Skeena River: Hanson, 3.

Kitsault Valley: Hanson, 2.

Parson Bay : Crickmay, 9.

Prince Rupert to Burns Lake: Hanson, 10.

Salmon River district: Schofield, 7 , 11.

Selkirk Range: Schofield, 6.

Slocan area: Bancroft, M. F., 2.

Skeena River to Stewart: Hanson, 6.

Taseko Lake-French Bar Creek: MacKenzie, J. D., 2.

Taseko Valley: MacKenzie, J. D., 1.

Texada Island: Swanson, C. O., 2.

Vancouver area: Schofield, 17.

Vancouver Is l a nd: Dolmage, 5; Barkley Sound: Dolmage, 2.

Whitesail-Tahtsa Lakes area: Marshall, J. R., 3.

Yale district: Cairnes, 5.

Zymoetz River area, Coast district: Hanson, 11.

Californla, Blackhawk Canyon, Sull Bernardino Mountains : Woodford 7.

Deep Spring Valley: Miller, W. J., 35.

Kern County : English, W. A., 1.

Point Sur quadrangle: 'Trask, 5 .

Santa Barbara County, Santa Ynez River district: Kew, 2 ; Nelson, $R$. N., 1.

Colorado: Keyes, 162.

Delta and Mesa counties: Weeks, H. J., 1.

east-central : Lee, W. T., 19.

La Junta area: Patton, H. B., 3.

Moffat County : Sears, 3.

Montezuma County, McElmo anticline : Coffin, 2.

southwestern: Coffln, 3. 
Jurassic-Continued.

Cuba : O'Connell, 4.

Oxfordian, western Cuba: Brown, B., 1.

western: Brown, B., 2 ; Wright, A., 1.

Greenland: Böggild, 1.

Idaho, Bingham, Bonneville, and Caribou counties: Kirkham, 3.

Fort Hall Indian Reservation : Mansfleld, G. R., 3.

southeastern : Kirkham, 1 ; Mansfleld, G. R., 6, 29.

Mesozoic floras of North and South America : Knowlton, 1.

Mexico, Aguascalientes, Asientos-Tepezala district: Anderson, G. E., 2. eastern coast: Wittich, 24.

Hidalgo-Vera Cruz region: Palmer, R. H., 4.

northeastern : Böse, 7.

Panuco oil field, Baker, C. L., 8.

Sierra Madre Oriental, Tamazunchale: Heim, 3.

southern Oaxaca : Palmer, R. H., 9.

Vera Cruz-P u e bla, Tecolutla-Misantla: Hisazumi, 1.

Montana : Bauer, C. M., 3 ; Keyes, 234.

Beartooth Mountains, Bevan, 2.

Cat Creek oil field : Lupton, 1.

central and eastern: Clapp, C. H., 2.

Crow Indian Reservation: Thom, 4.

Ellis formation: Howe, M. A., 4.

Fergus County: Freeman, 0. W., 1.

Kevin-Sunburst oil field : Clark, F. R., 3 .

Soap Creek oil fleld: Thom, 1.

Sweet Grass Hills : Kemp, 8.

Morrison formation, age: Simpson, G. G., 7.

Nevada: Keyes, 128.

Mineral County, Cedar Mountain : Knopf, A., 4

Muddy Mountains region: Longwell, 1.

New Mexico: Darton, 11, 26 ; Keyes, 14 ; Lee, W. T., 2.

Gallup-Zuni Basin: Sears, 6.

northeastern : Garret, 1.

North America, southern: Stanton, 1.

Oklahoma, Cimarron County : De Ford, 1 ; Rothrock, 4.

Oregon: Smith, IV. D., 1.

central : Packard, 6.

Riddle quarirangle: Diller, 12.

Pacific coast: Goranson, 1.

IRed beds: Branson, 17 .

South Dakota, central Black Hills: Darton, 14

Texas. Malone formation: Kitchin, 1. trans-Pecos Texas: Baker, C. L., 6.

Ltah : Butler, 4; Dake, 3; Keyes, 152. eastern: Gilluly, 2.

Grand and San Juan counties: Prommel, 1.
Jurassic-Contimued.

Utah-Continued.

La Sal Mountains: Gould, Li. M., 4. San Juan Canyon: Miser, 14, 17.

San Rafael Swell: Gilluly, 4.

southeastern: Forrester, J. B., 2 ;

Longwell, 1 ; Prommel, 4.

southern: Moore, R. C., 17.

southwestern : Reeside, 4

Western North America: Crickmay, 5.

Wyoming, Bell Springs district: Dobbin, 5 .

central : Lee, W. T., 19.

Chugwater-Sundance contact, Bighorn district: Brainerd, 1.

Lance Creek field: Hancock, 5 .

Maverick Springs: Collier, 6.

Lost Soldier-Ferris district: Fath, 5.

Wind River Mountains: Condit, 4.

Yukon, Whitehorse district: Cockfield, 16.

Kaibab limestone, Kaibab Gulch, Utah : Noble, 8.

Kamishak Bay region, Alaska: Mather, 7. Kamiskotia gold area, District of Cochrane, Ontario: Finley, 1.

Kansas.

Geological history: Wooster, 2.

Areas described.

Anderson County: Charles, 1.

Eldorado oil and gas field, Butler County : Fath, 2.

Ellis County: Bass, 2.

Hamilton County: Bass, 2.

Kansas City district: Elledge, 1.

Russell County : Rubey, 3.

Syracuse and Lakin quadrangles: Darton, 2.

Economic geology.

Arkansas City district: Elledge, 1.

Burket-Seeley oil pool, Greenwood County : Loomis, H., 2.

Clay and shale, Arkansas City : Teetor, 1.

Coal, chemistry: Allen, H. C., 2. occurrence: Young, C. M., 1.

Eldorado oil fleld, Butler County, Stapleton oil horizon, age: Fath, 4.

Elk City gas fleld: Boughton, 1 .

Golden Lanes, Greenwood County : Cadman, 2.

Granite in oil fields: Greene, 7.

Granite ridge, burled, relation to oil fields: Moore, R. C:, 8.

Gypsum: Stone, 11.

Helium-bearing natural gas: Rogers, G. S., 7 .

Mid-Continent oil fields: Bosworth, 1.

Mid-Continent oil-field structures : Monnett, 2 ; reflected buried hills : Powers, 11.

Mineral resources: Moore, R. C., 37.

Natural gas: Snider, 1.

Eldorado fleld: Fath, 2.

chemical survey: Allen, H. C., 1. 
Ǩ́ansas-Continued.

Economic geology--Continued.

Oil and gas, Allen and Neosho countles: Moore, R. C., 5 .

Anderson County: Charles, 1.

central Kansas: Williams, D. W., 2. Russell County: Rubey, 3.

Wilson and Montgomery counties: Moore, R. C., 6 .

Oil and gas fields, map: U. S. Geol. Survey, 2 .

Oil and gas resources, 1927 : Kesler, 1.

Oil domes, central Kansas, origin: Blackwelder, 3.

Oil possibilities, western Kansas: Lupton, 2.

Oil sands, southeastern Kansas: Williams, D. W., 1.

Petroleum: Moore, R. C., 9 ; Snider, 1. Butler County: Uhrlaub, 1.

Eldorado field: Fath, 2.

flank production of Nemaha Mountains: 'Thomas, C. R., 2.

Woodson County: Moore, D. W., 1.

Rainbow Bend fleld, Cowley County: Snow, 1.

Rice County, age of petroleum-producing horizon: Ley, 7 .

Sallyards ofl field, structure: Berger, 2.

Salt deposits: Bass, 2; Darton, 8 ; Phalen, 1.

Shoestring oil pools, eastern Kansas: Rich, $6,9$.

Urschel oil pool, Marion County : Shea, 1.

Volcanic ash resources : Landes, K. K., 5.

Zinc-lead fleld: Naething, 2.

Historical geology.

Allen and Neosho counties: Moore, $R$. C., 5.

Boring, Gove County: Lupton, 3.

Bolings into granite, list: Greene, $\overline{5}$.

Buried Pennsylvanian channels and sand bars of eastern Kansas:Rich, 8.

Central and western Kansas: Twenhofel, 19.

Comanchean, central Kansas: Twenhofel, 24.

western Kansas, subsulface distribution: 'Twenhofel, 20.

Comanchean and Dakota strata: Twenhofel, 6.

Correlation of coals, Oklahoma and Kansas : Cooper, 4.

Cretaceous: Stanton, 8; Twenhofel, $5,17$.

Dakota sandstone, western Kansas: Bass, 1, 2.

Dakota formation: Gress, 1.

Eastern Kansas: Fath, 1.

Elk City gas fleld: Boughton, 1.

Ellsworth County, Sheridan well : Ley, 6.
Kansas-Continued.

Historical geology-Continued.

General : Keyes, 279 ; Moore, R. C., 4, 37 ; Snider, 1.

Granite boulders, southeastern Kansas : Twenhofel, 2.

Granite ridge buried: Fath, 1; Ley, 4 ; Moore, R. C., 8, 14.

Independence area: Reed, R. D., 1.

Intrusive granite, Rose dome, Woodson County : Twenhofel, 23.

Lower Cretaceous : Bullard, 4.

Metamorphic rocks, Woodson County : Twenhofel, 8.

Mid-Continent oil fields: Aurin, 2.

Mississippi lime west of granite ridge : Ley, 5 .

Mississippian, central Kansas well : Moore, R. C., 36.

Oil sands, southeastern Kansas: Williams, D. W., 1.

Ordovician in deep wells of western Kansas: Twenhofel, 27.

Ordovician sediments, western Kansas: Udden, Jon A., 2.

Pennsylvanian west of Nemaha granite ridge: Denison, A. R., 2 ; Moore, R. C., 32.

red beds, Sumuer County: Buchanan, 1 .

Permian : Gould, 8, 14, 27.

correlation: Gould, 10 .

Permian insects, environment: Dunbar, 4.

Permian unconformity : Chadwick, 13.

Rainbow Bend field, Cowley County: Snow, 1.

Red beds and faunas of Appalachian and Kansas-Texas sections : Beede, 7.

Red beds near base of Cherokee shales: Tarr, Rus. S., 1.

Red beds of Chester age, Mid-Continent region: Greene, 4.

Rose dome intrusive: Twenhofel, 82.

Salina Basin : Barwick, 1.

Salt beds: Bass, 2.

Southeastern Kansas, subsurface conditions: Ley, 2.

Subsurface correlation, Russell County to Marion County : Bramlette, 3.

Volcanic ash: Landes, K. K., 4.

Western Kansas: Heald, 12; Lupton, 2.

Whitehorse sandstone: Clifton, 2.

Wilson County, subsurface geology: Stryker, 1.

IVilson and Montgomery counties : Moore, R. C., 6.

Wreford and Foraker limestones: Twenbofel, W. H., 1.

\section{Mineralogy.}

Meteorite, Anthony, Harper County : Merrill, 38.

Meteorite (?), Zenith : Corbett, 3. 
Kansas-Continued.

Paleontology.

Algal deposits, Carboniferous: Twenhofel, 3 .

Amphibian, upper coal measures: Martin, H. T., 3.

Amphibian footprints: Hanna, G. D., 19.

Anguillavus hackberryensis, Niobrara beds : Martin, H. 'I., 1.

Bison, Pleistocene: Martin, H. T., 5.

Bison latifrons, Comanche County: Martin, H. T., 6.

Celtis, Philips County, Miocene: Brooks, B. W., 1.

Cheyenne sandstone flora: Berry, 37.

Cirriped, Niobrara: Withers, 5.

Cretaceous fish spine: Moodie, 25.

invertebrates: 'Twenhofel, 17.

Dakota flora: Gress, 1.

Fishes, Niobrara: Jordan, D. S., 14.

Footprints in coal measures: Martin, H. T., 2.

Fossils from wells in central Kansas: Moore, R. C., 27.

Lithospermum nutlets: Berry, 101.

Martinichthys, Cretaceous fish: McClung, 1.

Onychopus (amphibian) : Martin, H. T., 4.

Ophiacodont reptile, Permian: Romer, 4.

Paleolimulus, Permian xiphosuran : Dunbar, 3.

Permian: Dunbar, 4.

Dickinson County : Thomas, C. R., 3.

Permian Insecta: Carpenter, F. M., 1 ; Tillyard, 1, 6.

Copeognatha: Tillyard, 8.

Delopteridae : Tillyard, 11.

Hemiptera: Tillyard, 9

Mecoptera: Tillyard, 7.

Paleodictyoptera: Tillyard, 4.

Protodenata and Odonata: Tillyard, 5.

Protohymenoptera : Tillyard, 3.

Protoperlaria: Tillyard, 10.

Pleistocene Mollusca, Wallace County : Hanna, G. D., 5.

Reptilia, Niobrara group, Logan County : Wiman, 1.

Rhinoceros, Rooks County: Lane, H. H., 1.

Stigmaria, Topeka : Reagan, 12.

'Tylosaurus, western Kansas: Gilmore, 11.

Urodeles, Pliocene, western Kansas: Adams, L. A., 4.

Vertebrates, collecting: Sternberg, C. H., 4.

Petrology.

Altered volcanic ash, Cretaceous : Pinkley, 1.

Common rocks : Schmidt, 1.

Igneous rock, Riley County: Moore, R. C., 7 .
Kansas-Continued.

Petrology-Continued.

Pre-Cambrian rocks in borings: 'Landes, K. K., 3.

Volcanic ash: Landes, 4.

Physical geology.

Anticline in Benton shale area, origin : Thomas, C. R., 1.

Aqueous loess : Todd, J. E., 2.

Dakota sandstone, western Kansas, geologic structure : Bass, 1.

Dolomitic limestone, Argentine, origin : Rogers, A. F., 21.

Granite in wells: Gould, 3.

Granite ridge: Powers, 11.

Intrusive granite, Rose dome, Woodson County: Twenhofel, 23.

Metamorphic rocks, Woodson County : 'Twenhofel, 8.

Sallyards oil field, structure: Berger, 2.

Shoestring sands of eastern Kansas: Rich, 6.

Structure, relation to production of oil : Best, 1.

Subsidence near Sharon Springs, Wallace County : Moore, R. C., 33, 34.

Wamego anticline: Beede, 4.

Physiographio geology.

Asymmetrical stream valleys, origin: Bass, 3.

Kansas tills, southernmost extension : Schoewe, 2 .

Lacustrine beds near Atchison: Todd, J. E., 3.

Northeastern Kansas, glacial geology : Schoewe, 5.

'ill-like deposits, Douglas County: Schoewe, 7.

Kahiltna Valley, Alaska: Mertie, 2.

Kantishna region, Alaska: Capps, 1.

Kaolin.

Alabama : Clark, B. L., 1.

Formation: Parsons, 7.

General : Ries, 5.

Georgia, Coastal Plain: Stull, 1, 2.

Indiana: Logan, 4, 6, 10.

North Carolina : Bayley, 1, 10; Ries, 5.

Pacific Northwest: Wilson, H., 1.

Quebec, Amherst township : Wilson, Morley E., 1.

United States: Ries, $\mathbf{5}$.

Washington, Spokane: Goodspeed, 2.

Kaolinite associated with miarolitic structure: Buddington, 6.

Karst topography, Paleozolc, Illinols : Ekblaw, G. E., 1.

Karsts. See also Sink holes.

Kentucky : Jillson, 66.

United States: Danes, 1.

Kentucky.

Bibliography: Jillson, 42

Blue Grass region : Davis, D. H., 3.

Calloway County, map: Ky. G. S., 47.

Carlisle County, map: Ky. G. S., 48. 
Kentucky-Continued.

Geological Survey, recent activities : Jillson, 91

reports: Jillson, 26, 40, 69, 97 .

Geological surveys, history: Jillson, $34,42$.

Geology : Miller, A. M., 1.

Jackson Purchase : Davis, D. H., 1.

McCreary County meteorite: ,Miller, A. M., 19.

Mammalian and human remains in caves : Miller, A. M., 11.

Mammoth Cave, bibliography: Jillson, 41.

Murshall County, map: Ky. G. S., 51.

Natural resources: Jillson, 79.

Pennyroyal region: Sauer; 3.

Recent geological investigations: Jillson, 78.

Soils, geologic derivation: Jillson, 72.

State parks: Jillson, $\mathbf{5 0}$.

Webster County: Glenn, 5.

Areas described.

Allen County : Miller, A. M., 5; Shaw, E. W., 1.

Barren County: Butts, 2.

Berea region: Burroughs, W. G., 5.

Caldwell County: Weller, 7.

Cave in Rock quadrangle: Weller, 16.

Edmonson County: Weller, J. M., 1.

Frankfort area: Jillson, 30.

Jackson Purchase region: Jillson, 28.

Jeptha Knob, Shelby County: Bucher, 10.

Knob region: Burroughs, W. G., 4.

Morgan County: Robinson, L. C., 1.

Princeton quadrangle: Weller, 7.

Warren County : St. Clair, 3.

Webster County: Glenn. 4.

Western Kentucky coal field: Burroughs, W. G., 2.

Woodford County: Miller, A. M., 22.

Economic geology.

Asphalt coal (Nolin coal) : Jillson, 55

Asphalt rock: Jillson, 25.

Barren County, oil and gas map: $\mathbf{K y}$ G. S., 23 .

Bath County, oil and gas map: Ky. G. S., 35 .

Bells Run anticline, Ohio County, structural map: Ky. G. S., 36.

Bibliography of petroleum, natural gas, asphalt, and oil shale: Jillson, 6 .

Boyd County, oil and gas exploration: Jillson, 94

oil and gas map: Ky. G. S., 25.

structural map: Ky. G. S., 11, 24.

Bracken County, oil and gas map: Ky. G. S., 30.

Breathitt County, oil and gas map : Ky. G. S., 37.

Building stones : Richardson, C. H., 6. Butler County, oil and gas map: Jillson, 103.

Cannel coal: Jillson, 62 ,
Kentucky-Continued.

Economic geology-Continued.

Cement materials: Ky. G. S., 52; Richardson, C. H., 13.

Clay : Jillson, 76 ; Ries, 5, 6.

Coal : Jillson, 21, 37, 52.

bibliography : Jillson, 14

Buckhorn region, eastern Kentucky : Jillson, 27.

Clay County : Hodge, J. M., 3. Sexton Creek area: Russell, P. G., 1.

Goose Creek region: Hodge, J. M., 3.

Kentucky River, north fork: Hodge, J. M., 2.

Leslie and Harlan counties: Hodge, J. M., 1.

Magoffin County: Browning, I. B., 1.

Martin County: Hudnall, 2.

Middlesboro Basin: Wentworth, 28.

production: Jillson, 15.

Stinking Creek area: Jfllson, 3.

Webster County : Glenn, 4, 5.

Coal formations: Campbell, M. R., 4.

Coals, correlation: Jillson, 108.

low sulphur: Jillson, 11.

Cumberland County oil horizons: Beckner, 3.

Devonian black shales: Crouse, 3 .

Devonian oil shale, microscopic composition: Thiessen, 10.

Eastern Kentucky: Jillson, 17.

Edmonson County map: Ky. G. S., 31.

Elkhorn coal field: Hudnall, 1.

Elliott County, oil and gas map: Ky. G. S., 27.

Elm Lick coal bed, Ohio County : Gardner, J. H., 5.

Fire clay, eastern coal field : Ries, 7. northeastern Kentucky: Jillson, 75.

Floyd County, structural geology : Ky. G. S., 5 .

Fluorspar: Fay, 2 ; Currier, 2 ; 1ellman, 1; Jillson, 25; Schwerin, 1. Spurr, 30

General : Jillson, 98.

Geologic map: Jillson, 20, 70, 86, 87.

Glass sands : Richädson, C. H., 4.

Grayson County, map: Ky. G. S., 32.

Green County, oil and gas map: Ky. G. S., 50.

Greenup County, map: Ky. G. S., 33.

Hancock County, oil and gas map: Ky. G. S., 13.

Henderson County, map: Ky. G. S., 40

Irvine and Berea region, structural map : Ky. G. S., 14.

Irvine oil district: St. Clair, 1.

Island Creek ofl pool, Owsley County : Jillson, 84.

Isocarbs and oil and gas production: Russell, W. L., 5.

Isonville oil pool, Elliott County, structural map: Ky. G. S., 15.

McLean County, map: Ky, G. S., 17. 
Kentucky-Continued.

bconomic geology-Continued.

Martin County, structural map: Ky. G. S., 6, 18.

Metcalfe County, map, oil and gas data: Ky. G. S., 19.

Mica, eastern Kentucky: Jillson, 54.

Mineral resources: Crouse, 4 ; Jillson, $29,68,74,85$.

Molding sands: Richardson, C. H., 12.

Monroe County, map, oil and gas data : Ky. G. S., 7.

Mother plants of petroleum in Devonian black shales: White, D., 19.

Mublenberg County, map: Ky. G. S., 20.

Natural gas: Jillson, 25.

conservation: Jillson, 38.

eastern Kentucky : Jillson, 5.

Oil and gas: Jillson, 21, 23.

Allen County : Jillson, 12.

Barren County: Butts, 2.

Breathitt and Knox Counties, Jillson, 13

eastern Kentucky: Fiske, 1.

Warren County: Jillson, 18.

Oil and gas industry, development: Jillson, 4.

Oil and gas possibilities, Caldwell County : Weller, 5.

Jackson Purchase region: Jillson, 28.

Oil and gas resources: Jillson, 2.

Oil developments, central southern Kentucky : Nelson, 15.

Oll domes of Ashland, Boyd County: Jillson, 81.

Oil fields : Glenn, 1 ; Leonard, W. C., 1.

Oil horizons: Nelson, 16.

Oil pools: Jillson, 73.

Oil shale: Alderson, 3; Crouse, 5 ; Jillson, 25.

Estill County: Crouse, 1.

Paint Creek uplift, Johnson County : Jillson, 24; Rhodes, 1.

Petroleum : Galdner, J. H., 3 ; Jillson, 25.

Allen County: Miller, A. M., 5 ; Shaw; E. W., 1.

eastern Kentucky : Jillson, 17, 32.

southeastern Kentucky: Jillson, 8.

Warren County : St. Clair, 3, 4.

Wier sand horizon: Jillson, 16.

Petroleum problems : Buckner, 2.

Petroleum production: Jillson, 57.

Pike County, structural maip: Ky. G. S., 8.

Powell County, oil and gas map: Ky. G. S., 44.

Precious metal content of black Devonian shale: Crouse, 2.

Road materials: Richardson, C. H., 9.

Rock asphalt: Jillson, 64 .

Edmonson County: Weller, J. M., 1.

Rockcastle uplift, Laurel and Clay counties, structural map: Ky. G. S., 9.

Stinking Creek region: Jillson, 3.
Kentucky-Continued.

Economic geology-Continued.

Taylor County, oil and gas map: Ky. G. S., 29.

Warren County : Jillson, 18. oil and gas map: Ky. G. S., 54.

Wayne County, oil and gas map: Ky. G. S., 45 .

Williamsburg anticline, Whitley County, map: Ky. G. S., 10.

Historical geology.

Adair County, map : Miller, A. M., 20.

Allen County: Jillson, 12; Shaw, E. W., 1.

Bentonite in Ordovician: Nelson, 10.

Bourbon County, map: Dunn, P. H., 1.

Breathitt and Knox counties: Jillson, 13.

Buckhorn region, eastern Kentucky : Jillson, 27.

Butler County : Jillson, 103 map : Glenn, 11:

Caldwell County: Weller, 5. map: Weller, 17.

Carter County, map: Ky. G. S., 26.

Chester series : Ulrich; 5.

Christian County, map: Sutton, 2.

Cincinnati anticline, dimensions : Hubbard, G. D., 5.

Cretaceous sediments, western Kentucky: Jillson, 56.

Dawson Springs quadrangle, map: Sutton, 1.

Eastern Kentucky: Beckner, 1.

Estill County, lower Miller Creek: Ky. G. S., 52.

Garrard County, map: McFarlan, 1.

General : Jillson, 72, 98.

Geologic map : Jillson, 1, 20, 70, 86, 87 .

Golconda quadrangle: Weller, 4.

Haddix-Coalburg geosyncline: Jillson, 44.

Hartford quadrangle, Ohio, Butler, and Muhlenberg counties, map: Gardner, J. H., 4.

Hopkins County, map: Theis, 1.

Irvine district: St. Clair, 1.

Island Creek oil pool, Owsley County : Jillson, 84.

Jackson County, map : Eyl, 1.

Jeptha Krobs, Shelby Count : Bucher, 7.

Kendrick shale: Jillson, 9.

Lawrence County, map: Ky. G. S., 34

Lee County, map : Eyl, 2, 41.

Lewis County, map : Perry, E. S., 1.

Livingston County: Weller, 14.

Lyon County, map : Roberts, 5 .

McCready County: Murphy, 1.

Magoffin County : Browning, I. B., 1.

Marine invasions in Pennsylvanian time in eastern Kentucky: Hud. nall, 3.

Mauch Chunk, southeastern Kentucky: Jillson, 8.

Middlesboro Basin: Wentworth, 28. 
Isentucky-Continued.

Historical geology-Continued.

Mills Springs area, Monticello quaterangle: Foyles, 1.

Mississippian series, eastern Kentucky : Butts, 3.

Monticello quadrangle : MacLachlan, 1

Morgan County, map: Robinson, L. C. 1.

Nelson County: Ky. G. S., 53.

Nicholasville boring: Miller, A. M., 9.

Ohio County, map: Jillson, 88, 104.

Oil field stratigraphy: Jillson, 35.

Iant Creek uplift, Johnson County: Jillson, 24 ; Rhodes, 1.

Owsley County, map: Ky. G. S., 43.

Silurian, east central. Kentucky: Foerste, 14.

Stinking Creek region: Tillson, 3.

Trenton: Raymond, 18.

Tuscaloosa formation: Roberts, J. K., 7 .

Union County, map: Glenn, 10.

Warren County: Jillson, 18; Iaaird, 1; St. Clair, 4.

Webster County : Glenn, 5.

Woodford County, geological map: Miller, A. M., 21.

Mineralogy.

Géneral: Richardson, C. H., 10.

Marcasite in fluorite: Johnston, W. D., 2.

Meteorites, Cumberland Falls. Whitley County : Merrill, 5, 8, 13 ; Miller, A. M., 2, 4, 6 .

Eagle station : Prior, G. T., 1.

Glasgow, Barren County: Merrill, 30 ; Miller, A. M., 12.

McCreary County: Miller, A. M., 3.

Paleontology.

Anisotrypa waynensis, Warsaw formation: Deiss, 1.

Black River Brachiopoda: Fenton, C. L., 4.

Bryozon, Chester series: McFarlan, 1.

Coal measures invertebrates, eastern Kentucky: Jillson, 19.

Flora, western Kentucky coal fleld: Noe, 3.

General : Funkhouser, 1.

Kendrick shale: Jillson, 9.

Mississippian brachiopods: Ehlers, 10, 11.

Mother plants of petroleum in $\mathrm{De}$ vonian black shale: White, D., 11.

Niagaran, Jeptha Knob: Foerste, 14.

Pottsville faunas: Jillson, 53.

Terminulia, lower Eocene: Berry, $\boldsymbol{T} 6$.

Petrology.

Bentonite : Ross, C. S., 21.

Pliysical geology.

Abandoned entrenched meander, western Kentucky : Jillson, 100.

Bell County, structure map: Kentucky Geological Survey, 46.

Boyd County, structural map: Ky. G. S., 11; 24 .
Kentucky-Continued.

Physical gcology-Continued.

Breathitt County, structural geology map : Ky. G. S., 1.

Caldwell County, map: Weller, 1.7.

Carboniferous deformation, western Kentucky: Jillson, 102.

Caves, southern Kentucky: Miller, A. M., 13.

Clay County, structural geology: Ky. G. S., 38.

Creelsboro natural bridge, Russell County : Scott, I. D., 4.

Cryptovolcanic phenomena: Bucher, 11. Cumberland, Monroe, and Clinton counties (parts), structural map: Ky. G. S., 12.

Eastern Kentucky, structural deformution: Jillson, 7 .

Fault pattern: Jillson, 60 .

Faulting, Cave in Rock quadrangle: Weller, 16.

north central Kentucky: Miller, A. M., 15 .

Floyd County, map: Ky. G. S., 49. structural geology: Ky. G. S., 5.

Golconda and Cave in Rock quadrangles, map: Weller, 10.

Haddix-Conlbury geosyncline: Jillson, 44.

Harlan County, map: Ky. G. S., 39 .

Irvine and Bereft region, structural map : Ky. G. S., 14.

Irvine ofl field, structure: Miller, A. M., 18.

Isothrustic structure, Jeptha Knob: Jillson, 48.

Jeptha Knob: Bucher, 16.

Johnson County, structural geology map: 'Ky. G. S., 3.

Karst country : Jillson, 66.

Knott County, structural geology map : Ky. G. S., 2.

Knox County, map: Ky. G. S., 28.

Leslie County, structural geology : Ky. G. S., 16.

Lincoln County map, fault pattern: Ky. G. S., 42.

McCready County: Murphy, 1.

Magoffin County, structural geology : Ky. G. S., 4.

Mammoth Cave and cave region: Randolph, 1.

Martin County, structural map: Ky. G. S., 6.

Northeastern Kentucky: McFarlan, 4.

Paint Creek uplift map: Ky. G. S., 21.

Perry County, structural geology: hy. G. S., 22 .

Pike County, structural map: Ky. G. S., 8 .

Pottsville-filled channel in Mississipplan: Burroughs, W. G., 1.

Pre-Pennsylvanian deformation, westeln Kentucky: Jillson, 101.

Relief map : Jillson, 61. 
Kentucky-Continued.

Physical geology-Continued.

Rockcastle uplift, Laurel and Clay counties, structural map: Ky. G. S., 9.

Sink hole region, western Kentucky: Jillson, 45

Slate slide, Letcher County: Jillson, 46.

Stream capture, Floyd County: Jillson, 10.

Subsurface structure, eastern Kentucky : Perry, G., 1.

Western Kentucky faulting: Currier, 2.

West Hickman fault zone, Jessamine and Fayette counties: McFarlan, 3 .

Physiographic geology.

Big Sandy River, drainage changes: Jillsou, 80, 93 .

Carter caves: Jillson, 92.

Eastern Kentucky: Davis, D. H., 2.

Filled valleys, w e s t e r n Kentucky : Theis, 2.

General : Jillson, 63, 82, 98.

Glacial boulders: Jillson, 67.

Glacial pebbles, eastern Kentucky: Jillson, 65.

Glaciation : Jillson, 71.

Mammoth Cave National Park: Jillson, 106 ; Lobeck, 10.

Migration of divide, Floyd County: Jillson, 10.

Ohio River, genesis: Fowke, 1.

Peneplains: Jillson, 107.

Shawnee Hills section: Flint, 7.

State parks: Jillson, 82.

Jerraces, Ohio River, Carroll and Trimble counties: Culbertson, 3.

Tradewater River, preglacial drainage: Fowke, 2.

Valley-filled areas, western Kentucky Jillson, 90.

Western Kentucky coal field : Burroughs, W. G., 2.

Kenora and Rainy River districts, Ontario: Bruce, 17.

Kerogen: Craig, 2; Van Tuyl, 9 ; and origin of oil.: Trager, 4.

Kevin-Sunburst oil field, Montana : Clark, F. R., 3.

Keystone faults: Crosby, W. O., 4.

Kllauea, products and structure: Stone, $\mathbf{J}$. B., 1.

Kimmswick and Plattin limestones, Missouri : Foerste, 9

Kings quadrangle, Illinois : Bretz, 4.

Kirkland Lake gold area, Ontario: Burlows, 4, 12 ; Hopkins, P. E., 6.

Kiwalik-Koyuk region, Alaska : Harrington, 5 .

Knee Lake district, northeastern Manitoba: Bruce, 4.

Knik-Matanuska district, Alaska: Landes, K. K., 2.

Aodiak Island, Alaska: Maddren, 2.
Kotsina-Kuskulana district, Alaska : Moffit, 4.

Labrador: Canada, G. S., 2.

Lake Melville district: Kindle, 25. terraces: Kindle, $\mathbf{3 1}$ northeastern : Coleman, 6.

Physical geology.

Concretions : Kindle, 24.

Sand bar, unusual type: Kindle, 19.

Labridor ice sheet, extent and thickness: Coleman, 2.

La Cloche area, District of Sudbury, Ontario : Douglas, G. V., 3.

Laccoliths : Chamberlin, R. T., 16; Davis, 21, 27 ; MacCarthy, 2.

formation: Keyes, 47, 98.

Montana, Fergus County, South Mountain : Palmer, H. S., 6.

New Mexico: Keyes, 41.

South Dakota, central Black Hills: Darton, 14.

Stresses in laccolithic intrusions : Gould, L. M., 2.

Utah, La Sal Mountains: Gould, L. M., 3.

La Harpe quadrangle, Illinois : Savage, 8.

La Jolla quadrangle, Calffornia: Hanua, M. A., 3 .

Lake Athabasca, origin: Alcock, 6.

Lake Bonaparte quadrangle, New York: Smyth, 2.

Lake Chelan, origin and history : Runner, 4.

Lake David area, Chibougamau district, Quebec: Mawdsley, 5 .

Lake Lahontan, geologic history: Jones, J. C., 2

Lake Melville, district, Labrador Peninsula : Kindle, 25.

Lake ramparts: Scott, I. D., 3.

Lakelse Lake area, British Columbia: Marshall, J. R., 5.

Lakes.

Basin and Range province: Meinzer, $\overline{0}$.

Crater Lake, Oregon, origin : Diller, 11.

Finger Lakes, New Yolk: Monnett, 3 ; origin: Fairchild, 20.

Great Basin, landslide lakes: Russell, R. T., 4.

Great Basin lakes, origin : Keyes, 116.

Idaho, Mud Lake: Stearns, 4.

Indiana, La Porte area: 'Tucker, W. M., 3.

Lake Timiskaming, a Roxen lake: Davis, 25.

Michigan, inland lakes: Scott, I. D., 1.

Minnesota, Mille Lacs: Sardeson, 9.

Ohio, Berea, Lake Abram: Speckman, 2.

Reelfoot Lake, Tennessee: Nelson, 14. lakes, extinct. See also Glacial lakes.

Green River lake: Knowlton, 11.

Lake Bonneville, origin: Keyes, 116; Pack, F. J., 2 ; Lake beds, origin Keyes, 96.

Mackenzie River basin, postglacial lakes: Cameron, 2 
Lakes, glacial. See Glacial lakes.

Lamellibranchiata. See Pelecypoda.

Laminated anhydrite, Texas: Udden, 18.

La Motte area, Abitibi County, Quebec: James, 5.

Lauce and Union formations, age: Schuchert, 19 .

Lance problem: Ward, 12.

Landslides.

Alaska, Katmai district, Mageik landslide: Griggs, 3.

Canada: Nichols, D. A., 1.

Cincinnati landslides: Rogers, J. K., 1.

Colorado, Platoro-Summitville district: Patton, H. B., 1.

Great Basin ranges: Davis, 5.

Kentucky, Letcher County : Jillson, 46.

Panama. Canal slides: Nat. Acad. Sci., 1.

Quebec, Portneuf County: Wilson, . M. E., 2.

West Virginia : Ladd, G. E., 1.

Morgantown, Conemaugh formation : Scheffel, 1.

Wyoming, Gros Ventre: Alden, 6.

Land tilting in Great Lakes region : Taylor, 12.

Laramie problem: Knowlton, 8; Thom, 8.

Larder Lake gold area, Ontario: Hopkins, P. E., 1, 8.

La Sal Mountains, Utah: Gould, L. M., 4.

Laterite, origin, composition and distribution: Swanson, C. O., 1.

Lava Beds National Monument, California : Stearns, H. T., 15.

Lavas.

Alaska, southeastern, submarine pillow lavas: Buddington, 10.

Central. America : Putnam, P. C., 2.

Columbia River basalt, Asotin craters: Fuller, R. E., 3.

Columnar structure in lavas: James, A. V. G., 1.

Hawaii, Keaiwa : Stearns, 10.

Hawaiian volcanos: Washington, 5.

Hornitos: Sapper, 2.

Idaho. Craters of the Moon National Monument: Stearns, H. T., 3, 14.

Kilauea : Stone, J. B., 1:

Mexico, San Quintin field: Woodford, 6.

Mt. Pele : Shepherd, 5.

New Mexico: Lee, W. T., 4.

Oxidation by steam : Ferguson, T. B., 3. Plategu basalts: Washington, 17.

Surface fuston : Diller, 10.

Types in Pacific region: Hobbs, 19. Lead.

Viscosity of lava: Palmer, H. S., 10.

Alaska: Brooks, 5, 12, 14 ; Martin, G. C., 4 .

Fairhaven district: Ijevensaler, 1.

Ruby : Brown, J. S., 8.

Arizona, Aravaipa-Stanley region: Ross, C. P., 5.

Courtland-Gleeson region: $W$ i i s o $n$, E. D., 2.
Lead-Continued.

Arizona-Continued.

Ray quadrangle: Ransome, 11.

Saddle Mountain and Banner mining districts : Ross, C. P., 6, 14.

Arkansas, Snarp and Lawrence counties : U. S. G. S., 14.

British Columbia: Robinson, A. H. A., 2.

Ainsworth district: Schofield, 4.

Atlin district : Cockfield, 17.

Slocan district: $B$ a te ma n, 14 ; Cairnes, 10.

Windermere area, Kootenay district : Walker, J. F., 1.

Canada: Bingay, 1.

eastern : Alcock, 23; Robinson, A. H. A., 4.

Central States: Dunlop, 1, 4, 6, 9, 12, 16.

Colorado, Creede district: Emmons, W. H., 4.

Red Cliff District : Crawford, R. D., 3.

Eastern States: Dunlop, 3, 7, 11, 1.5, 18.

General : Lindgren, 19 ; Siebenthal, 3, $5,7,10,12,16,17,19,21,24$, $25,27$.

Idaho: Gerry, 1, 3, 5, 8, 10, 13.

Birch Creek district: Shenon, 2.

Boise County: Ross, C. P., 10.

Boundary County : Kirkham, 7.

Hailey, native lead: 'Shannon, 73.

Pine Creek district: Jones, Edw. L., 4.

Shoshone County : Unpleby, 3.

Vienna district: Ross, C. P., 12.

Wardner district : Richard, 3.

Mexico, Ahumada, Chihuahua : Rickard, 10.

Missouri : Keyes, 114.

Montana : Gerry, 2, 4, 7, 12, 15.

Nevada, Mineral County, Cedar Mountain : Knopf, A., 4.

Pioche district: Westgate, 6.

Oklahoma, Miami district: Netzeband, 1.

Picher district, lead and zinc: Spurr, 32.

Oklahoma-Kansas-Missouri fteld : Naething, 2.

Ontario: Alcock, 23.

Arnprior-Quyon area : Wilson, M. E., 10.

Galetta : Wilson, M. E., 12.

Sudbury mining division, Genoa township: Moore, w. S., 16.

Pennsylvania : Miller, B. L., 3 ; Pennsylvania G. S., 1.

Quebec: Alcock, 23, 29.

Gaspe Peninsula: Beidelman, 1, 2; Mailhiot, 5.

Gaspe County, Lemieux Township: Alcock, 14.

Pontiac County, Calumet Island : Goranson, 3. 
Lead-Continued.

Rapid formation of lead ore: Wheeler, H. A., 3.

South Dakota, central Black Hills: Darton, 14.

northern Black Hills : Connolly, 4.

Tri-State district: George, P. W., 1; Weidiman, 5.

Upper Mississippi Valley: Spurr, 12.

Utah : Butler, 4.

Bingham district: Hunt, R. N., 1.

East Tintic district: Goodwin, L. H., 2.

Ophir district: Olmstead, 1.

Park City district: McKay, G. R., 1.

Promontory Point mining district: Siegfus, 1.

Tintic district: Lindgren, 2.

Washington: Gerry, 1, 3, 6, 9, 11, 14. northeastern: Jenkins, 12.

Pend Oreille and Stevens counties: Jenkins, 9.

Yukon, Beaver River area: Cockfield, $12,14,15$.

Fifteenmile Creek: Cockfield, 21.

Galena Hill, Mayo district: Stockwell, 1.

Keno Hill : Cockfield, 6, 11.

Mayo district: Cockfleld, 7, 8, 13.

Rude Creek: Cockfield, 22.

Twelvemile area: Cockfield, 2.

Lead and zinc pigments and salts: Siebenthal, 21.

Leadville mining district, Colorado: Emmons, S. F., 1.

Leeward Islands.

\section{Paleontology.}

Tertiary Mollusca: Cooke, C. W., 1.

Lenses, classification : Fillman, 1.

Lesser Antilles: Davis, 18, 29, 31.

Leverrierite, schist-forming mineral: Corbett. 2.

Lightning River gold area, District of Cochrane, Ontario: Gledhill, 4 ; Knight, 12.

Liguite : Darling, 1. Sec also Coal.

Alaska, Kantishna region: Capps, 1.

Louisiana : Glenk, 1.

Montana, Ekalaka field : Bauer, 4.

Scobey field, Valley, Daniels, and Sheridan counties: Collier, 9.

North Dakota: Babcock, 1; Dove, 5 ; Hoffman, 1; Leonard, A. G., 7-9.

Fort Berthold Indian Reservation : Bauer, C. M., 2.

Marmarth field: Hares, 5.

New Salem lignite fleld: Hancock, 6 . Saskatchewan : Lee, R. J., 1 ; MacLean, 1.

South Dakota : O'Harra, 1.

Texas: Gentry, 1; eastern: Dumble, 1. Lime.

General : Lớüghlin, 4, 7, 11, 14, 27, 30.

Massachusetts, eastern New York, and western Connecticut: Dale, T. N., 5.
Limestone.

Florida : Mossom, 1:

Illinois : Krey, 3.

Indiana : Anderegg, 1.

Iowa : Smith, J. E., 11.

New Brunswick, Charlotte County, L'Etang deposits: Uglow, 17.

New York: Newland, 2.

Greene County: Jones, R. W., 2.

North Carolina: Loughlin, 9.

Ohio, Summerfleld and Woodsfleld quadrangles : Condit, 3.

Ontario: Goudge, 3.

Abitibi and Mattagami rivers: Malcolm, 6 .

Origin and utilization: Miller, B. L., 13.

Peunsylvania : Miller, B. L., 4.

Cambro-Ordovician 1 i m es t o nes: Miller, B. L., 11.

New Holland quadrangle: Tonas, 5.

Petrological selection: Loughlin, 34.

Quebec: Goudge, 3.

Red limestones, origin: Galloway, J. J., 4.

Vermont: Jacobs, 1.

Washington : Shedd, 2.

West Virginia, Mercer, Monroe, and Summers counties : Reger, 9.

Wisconsin : Steidtmann, $\mathbf{5}$.

Limestone alterations at Bingham, Utah : Winchell, 8.

Limestone conglomerates, origin: Fillman, 2.

Lingula, antiquity : Keyes, 85.

Lithium : Landes, K. K., 7.

Manitoba, Oiseau River area: Wright, J. F., 10 .

southeastern : DeLury, 8.

New Mexico, Embudo: Roos, 1.

South Dakota, Etta lithia mine: Lincoln, 4.

spodumene mine, Black Hills: Schwartz, 13.

Lithium pegmatites, genesis: Schaller, 7.

Lithology. See Petrology.

Lithosphere, dynamics of : Jones, O. C., 1. structural failure: Leith, 6 .

structure: Willis, 6.

tidal stresses: Cotton, 1.

Jiving micro-organisms in ancient rocks: Lipman, 1.

Llanoria : Miser, 7 .

Loess.

Aqueous loess: Todd, J. E., 2.

Definition : Tilton, 9 .

Illinois, Alton: Baker, F. C., 4.

Iowa : Cable, 4.

Jaundiced snow : Keyes, 227.

Origin: Keyes, 170, 224; Owen; L. A.. 1 ; and distribution: Wright, G. F., 4.

Time of loess accumulation: Visher, 6 . Washington, Palouse region: Treasher, 1.

Palouse soil: Bryan, 26.

Water table of loess: Keyes, 244. 
Loess fossils : Shimek, 1.

Logmeter: Burton, G. E.. 1.

Los Angeles Basin, California: Eaton, J. E., 3.

ILost Soldier-Ferris district, Wyoming: Fath, 5.

Louisiana.

Compilation of Louisiana-idrkansas geology: Hull, 11

Petritied wood industry : Berry, 79.

Economic geology.

Bayou Boullon salt dome, St. Martin Parish: Donoghue, 2.

Bellevue oil pool: Holman, 1 ; Hull, 6.

Clay : Whittemore, J. W., 2.

Shreveport area: Whittemore, J. W., 1.

Cotton Valley oil and gas field, Webster I'nrish : McDonald, W. W., 1 ; Powers, 14.

Last Carroll Parish, natural gais : Spooner, 5.

Edgerly oil field, Caleasieu l'arish: Minor, 8.

Five Islands: Vaughan, F. F., 2.

Gulf Coast ofl fields: Barton, 13.

Gulf Coastal Plain salt domes, second ary intrusive origin: Matteson, 2

Gypsum : Stone, 11.

Inymesville oil field, Claiborne P'arish: Hull, 4 ; Scott, W. W., 1, 2 ; Teas, $2,3$.

explanation of production of wells : Albertson, 2.

Interior salt domes: Spooner, 2.

Tennings oil field, Acadia Farish : Barton, 12.

Lignite: Glenk, 1.

Mineral resources: Howe, H. V. W., 6.

Monroe gas field: Bell, H. W., 1 ; Spooner, 1 ; Stroud, 1.

Natural gas: Snider, 1.

Natural resources: Irion, 1.

Oil and gils fields: Richardson, G. B., 2; map : U. S. G. S., 5.

Oil and gas pools, northern Louisiana: Hull, 5.

Jetroleum : Svider, 1

Red iliver field: Bates, 1.

Pine Island field gas: Crider, 4.

Iine Prairie salt dome, Evangeline Parish : Barton, 7 .

Prothro salt dome, Blenville Parish: Hull, 13.

Red River-Crichton oil field: Bates. 1.

Richland Parish gas field: Campbell, I., 1.

Sabine uplift: Powers, 2.

Salt deposits : Phalen, 1.

Salt dome structure: Lucas, A. F., 1.

Salt domes: Deussen, 1 ; Thacker, 1 ; Wolf, 1.

Spring Hill-Sarepta gas field, Webster and Bossler parishes: Ponton, 1.

Stratigraphy of oil-producing sands in northern Louisiana: HuIl, 10.
Louisiana-Continued.

Economic geology-Continued.

Structural features of oil fields, northeln Touisiana: Crider, 2.

Sulphur salt dome, Calcasieu Parish; Kelley, 1.

$\mathrm{Su}$ if a ce indications of petroleum : Steinmayer, 1 .

Trinity sand, oil and gas possibilities: Easton, 2.

Vinton oil field: Wrather, 1.

Vinton salt dome, Calcasieu Parish: Thompson, S. A., 1.

Waskom gas fleld: Grimm, 1.

Webster Parish gas flelds: Hull, i.

Welsh oil field, Jefferson Davis Parish : Reed. L. C., 1.

Historical geology.

Arkadelphia formation, stratigraphy : Howe, H. V. W., 4.

Bayou Boullon sult dome, St. Martin Parish : Donoghue, 2.

Bentonite in Upper Cretaceous: Bramlette, 1 .

Coastal Plain : Applin, E. R., 1; Spooner, 3.

Cotton Valley oil field: McDonald, W. W., 1.

Cretaceous, northwestern Louisiana : Hammill, 1.

De Soto-Red River oil. field: Bates, 1.

Edgerly oil field, Calcasieu Parish : Minor, 3.

Five Islands: Vaughan, F. E., 2.

Interior salt domes: Spooner, 2.

Jennings oil field, Acadia Parish : Barton, 12.

Lake Pontchartrain, subaqueous strata : Steinmayer, 2.

Llanoria : Miser, 7.

Many salt dome, Sabine Parish : Howe, H. V. W., 7.

Midway formation: Howe, H. V. W., s.

Monroe gas field: Spooner, 1.

Nacatoch formation: Fowe, If. V. W.. 5.

Pine Prairie salt dome, Evangeline Parish: Barton, 7 .

Port Hudson beds: Emerson, li. V., 1.

Red River-Crichton oil field: Bates, 1.

Hichland Parish gas field : Campbe]l, I., 1.

Sabine uplift: Huntley, L. G., 3 ; Pow ers. 2.

Salt domes: Powers, 12.

Section 28 salt dome, St. Martin Farish : Donoghue, 3.

Stratigraphy of ofl-producing sands in northern Louisiana: Hull, 10.

Sulphur salt dome, Calcasieu Farish : Kelley, 1.

Volcanic ash, Calcasieu Parish : Hanna, M. A., 2.

northern Louisiana: Crider, 3.

Volcanic rocks in Cretaceous: Bram. Jette, 2. 
Louisiana-Continued.

Historical geology-Continued.

Welsh oil field, Jefferson Davis Parish : Reëd, L. C., 1.

Paleontology.

Foraminifera: Cusbman, 22.

Orthophragmina: Cushman, 11.

Pliocene Mollusca: Smith, E. R., 2.

Petrology.

Nepheline basalt, Richland Parish gas field : Campbell, I., 1.

Salt dome cap rock: Goldman, 12.

Physical geology.

Differential compacting the cause of certain Claiborne dips: Teas, 5.

Salt domes: Powers, 12.

Sandstone inclusion in salt in mine on Averys Island: Heald, 14.

Structural features of oil fields, northern Louisiana: Crider, 2.

Underground water.

Salt dome waters: Minor, 1.

Sulphur waters: Henniger, 1.

I.ower Silurian. See Ordovician:

Luling oil field, Caldwell and Guadalupe counties, Texas : Brucks, 1 ; Sellards, 19.

Iunar craters, origin: Campbell, w. W., 1.

Luzerne quadrangle, New York: Miller, w. J., 19.

Lyon Mountain quadrangle, New York: Miller, W. J., 26.

Lytton Springs oil field, Caldwell County, Texas : Collingwood, 8.

McCalls Ferry quadrangle, Pennsylvania : Jonas, 2.

Mackenzie.

Areas described.

Franklin Mountains: Williams, M. Y., $14,16$.

Great Slave Lake region: Cameron, 1: Hume, 2.

Mackenzie River region between Great Slave Lake and Simpson: Whittaker, 2.

between Simpson and Wrigley: Williams, M. Y., 13.

between Wrigley and Norman : Hume, 8.

Providence to Simpson: Whittaker, 5.

Norman oil area: Hume, 5.

North Nahanni and Root Rivers area and Caribou Island: Hume, 3.

Economic geology.

Fort Norman oil area: Hume, 7.

Iron, Mackenzie River valley: Kindle, 6.

Lead-zinc deposits near Great Slave Lake: Dawson, C. B., 1.

Mackenzie River basin: Camsell, 1 ; Thompson, P., 1.

Norman oil fields: Hume, 4.

Oil flelds: Bosworth; 2, 3, 4; Kindle, 9, 15 ; Kitto, 1 ; Ness, 2 ; Redfield, 2 ; Anon., 10, 11.
Mackenzie-Continued.

Economic geology-Continued.

Oil prospecting, Mackenzle River valley : Kindle, 12 ; Ness, 1.

Historical geology.

Athabaska series: Alcock, 5.

Franklin Mountains: Williams, M. Y., 16.

Kinderhook, Liard River : Hume,' 6.

Lower Mackenzie Valley: Kindle, 9.

Mackenzie oil field: Bosworth, 3.

Mackenzie River basin: Dowling, 17 ; Kindle, 15; Ness, 1; geologic structure: Dowling, 15.

Mineralogy.

Anthraxolite: Rutherford, 10.

Paleontology.

Devonian Crinoldea: Springer, 4, 14.

Kinderhook, Llard River: Hume, 6.

Macropetalichthyids, head: Stensiö, 1.

Portage fauna, Mackenzie River valley: Kindle, 4.

Tertiary plant remains : Bell, W. A., 3.

Physiaal geology.

Gravity results, Mackenzie basin: Miller, A. H., 1.

Lower Mackenzie Valley: Kindle, 9.

Mackenzie River region, geologic structure: Dowling, 15.

Physiographic geology.

Postglacial lakes, Mackenzic River basin : Cameron, 2.

McKittrick oil field, California: English, W. A., 4.

Magmas and magmatic differentiation. See also Intrusions; Laccoliths; Lavas.

Alkaline rocks, genesis: Smyth, 3.

Angular inclusions in ore deposits: Merritt, C. A., 3.

Anorthosites, formation: LoewinsonLessing, 1.

origin : Lodochnikow, 1.

Assimilation and assimilation processes, evidence : Bain, 14 ; Phemister, 5 .

Assimilation and petrogenesis : Stansfield, 7.

Assimilation by Sudbury norite sheet: Bain, 5; Bowen, 19; Phemister, 3.

Assimilation during the Katmai eruption of 1912: Fenner, 4.

Basic dike injections in magmatic vein sequences : Spurr, 20.

British Columbia, Vancouver Island, East Sooke Peninsula : Cooke, H. C., 5.

Contact phenomena: Eskola, 1.

Corundum and albitite bodies, hydrothermal origin : Larsen, 21.

Crystallization-differentiation: Bowen, $1,7$.

Deformation of crystallizing magma: Bowen, 5.

Definition : Spurr, 21.

Diabase differentiation: Emmons, R. C., 4. 
Magmas, etc.-Continued.

Differentiation: Day, 1.

by deformation: Bowen, 6 .

of lamprophyric magma at Corbaly

Canyon, Washington: Waters, 1.

Diffusion in silicate melts: Bowen, 9 . Duluth gabbro, basal phases: Nebel, 3.

Duluth lopolith : Bowen, N. L., 1.

Emulsions of sllicates: Tanton, 18.

Final consolidation phenomena in the crystallization of igneous rock: Colony, 4.

General: Day, A. L., 1 ; Fenner, 8; Hixon, 5; Nicol, 1 ; Vogt, 4.

Granitic intrusives: Kemp, 24.

Idaho, Idaho batholith: Beckwith, R. H., 1.

Igneous ore deposits, 'genesis: Campbell, J. M., 3.

Igneous rocks: Vogt, $1,3$.

Igneous intrusion, after-effects : Kemp, 12.

Inclusions in magmas: Bowen, 13; Emmons, R. C., 1.

Killarney magma, Sudbury, Ontario : Bain, 19.

Iiquid immiscibility in silicate magmas: Bowen, 20; Greig, 3.

Magmas, dikes, and veins: Spurr, 26.

Magmatic differentiation and vein for: mation: Ross, C. S., 26.

Metallic concentrations: Spurr, 10.

Metals in intrusive magmas : Spurr, 12.

Minnesota, Giants Range batholith. Allison, I. S., 1.

Pigeon Point : Grout, 27.

Vermilion batholith: Grout, 18.

"Molten magma": Lewis, 10 ; Strauss, 1.

Movements in crystallizing magmas: Grout, 6.

Ontario, Agate Point, evidence of liqvid immiscibility in magmas: Tanton, 13.

Porcupine, syntectic poryhyry : Whitman, 4.

Sudbury district : Bain, 18.

Ore deposits, classification: Zavaritsky, 1.

formation : Lindgren, 18.

Pressure in magmas: Morey, 1.

Reaction principle in petrogenesis : Bowen, 12.

Regional metamorphism, relation to: Barrell, 7.

Relation of crystallization to water content and vapor pressure of water in a cooling magma: Morey, 2.

Roof collapse in Iate Paleozoic alkalive batholiths: Billings, 3.

Stresses in laccolithle intrusions: Gould, L. M., 2.

Tectonic conditions accompanying intrusion of basic and ultra-basic igneous rocks: Benson, W. N., 1.
Magmas, etc.-Continued.

Ultra-basic rocks : Bowen, 22.

Magmatic carbons and hydrocarbons: Lewis, 14.

Magnesite: Dolman, 1; Stone, R. W., 2.

British Columbia, Lillooet-Prince George region: Reinecke, 3.

California : Bradley, W. W., 6 ; Palmer, L. A., 3.

Nevada, southern: Anon., 20.

Origin: Turner, H. W., 4.

Quebec, Grenville: Bain, 1.

Types of magnesite deposits and their origin: Bain, 4.

United States: Phalen, 2.

Washington: Petrascheck, 1 ; Siegfus, 2 ; Whitwell, 1 ; Willis, 26.

Stevens County: Dolman, 1 ; Handy, 1 ; Weaver, 2.

Magnesium: Loughlin, 16 ; Stone, 4, 9. Magnesium salts.

Saskatchewan : Cole, L. H., 10.

Western Canada: Cole, L. H., 9. Magnesium sulphate.

British Columbia : Goudge, 1.

Magnetic methods for expioration : Hotchkiss, 5 .

Maguetic surveying on copper-bearing rocks of Wisconsin : Aldrich, H. R., 2.

Magnetite. See Iron.

Magnetite-hematite relations: Gilbert, G., 4.

Magnetite and hematite, relations: Broderick, 1.

Magnetite, fumarolic: Zies, 1.

Maine.

Turners Lake, Isle-au-Haut : Bishop, 2.

Areas described.

Mount Desert : Wood, G. M., 1.

Portsmouth Basin: Wandke, 2.

Economic geology.

Cordierite-anthophyllite mineralization, Blue Hill : Lindgren, 14.

General: Burr, 1.

Granite: Dale, T. N., 4 ; Smith, G. O., 15.

Mineral resources: Burr, 2.

Peat, Livermore quadrangle: Burr, 1. Historical geology.

Cambrian, northern Maine: Simith, E. S. C., 5,6 .

Graptolite locality, Waterville : Perkins, E. H., 2.

Kennebec River to Penobscot Bay: Perkins, E. H., 3.

Moose River sandstone: Perkins, E. H., 4.

Mount Desert Island : Bascom, 1.

Portsmouth basin: Wandke, 1.

Rangeley conglomerate: Smith, E. S. C., 2.

Silurian tillite(?) : Smith, E. S. C., 4

Waterville region, evolution of drainage : Perkins, E. H., 5.

Mineralogy.

Beryllonite, Newry : Palache, 32.

Buckfield : Hess, 28. 
Maime-Continued.

Mineralogy--Continued.

Calcium phosphate mineral, Stoneham Holden, E. F., 3.

Chrysoberyl pegmatite, Hartford: Pa' lache, 14.

Gems : Marble, 1.

(iranite pegmatites, central Maine, paragenesis: Landes, K. K., 1.

Greenwood mine: Marble, 2.

I artford chrysoberyl prospect : Marble, 4.

Olivine, Monhegan Island: Wheeler, E. F., 1.

Petalite, Peru: Marble, 5.

Pollucite, Hebron : Hess, 31.

Newry: Fairbanks, 11.

Rumford tin mine: Marble, 3.

Paleontology.

chapman sandstone: Raymond, 21.

Macroporaster nylanderi, Sil u ria n, New Sweden: Raymond, 11.

Monograptus, Waterville: Perkins, F. H., 2.

-Oldhamia, Cambrian: Smith, E. S. C., 5.

Ostracoia, Chapman sandstone: Ulrich, 1.

Petrology.

Cape Neddick gabbro, York County : Wandke, 3.

Igneous rock, Mt. Kineo: Smith, E. S. C., 3.

Ogunquit, igneous rocks: Keeley, 2.

Portsmouth Basin, intrusive rocks: Wandke, 2.

Physical geology.

Granite pegmatites, central Maine, paragenesis: Landes, K. K., 1.

Physiographic geology.

Androscoggin River, former courses: Crosby, I. B., 1.

Champlain submergence, depth along coast: Meserve, 1

Gulf of Maine, morphology: Johnson, D. W., 7.

Kennebec River to Penobscot Bay: Perkins, E. H., 3.

Mount Desert Island: Bascom, 1.

Postglacial uplift: Fairchild, 7.

Quaternary changes of level: Antevs, 16.

Submarine physiography of Gulf of Maine : Johnson, D. W., 11.

'Three Pleistocene tllls, southern Maine: Sayles, 19.

Underground water.

Flowing well, Winslow : Little, H. P., 1. Mammalia.

Agate fossil quarry, Sioux County, Nebraska: Matthew, 25.

Age of mammals, close: Osborn, 26.

Agriochoerus, John Day beds: Thorpe, 7.
Mammalia-Continued.

Alberta, Paskapoo formation : Simpson, G. G., 14 ; footprints : Rutherford, 7.

Alticamelus, Mohave Desert : Davidsou, P., 2.

Amebelodon fricki, Nebraska : Barbour, 9.

Amphicyon, Pawnee Creek beds, Colorado: Cook, H. J., 9.

Amynodontidae: Troxell, 7 .

Anchitherium agatense: Romer, 6 .

Antillean, affinities and origin : Mat-

thew, W. D., 1.

Apatemyidae: Troxell, 22.

Araeocyon : Thorpe, 10, 13.

Archidiskodon maibeni, Nebraska : Barbour, 7,8 .

Arctold carnivore, Miocene, Wyoming: Romer, 9.

Arctotherium, Pleistocene, Californin : Merriam, 17.

Texas: Matthew, 9.

Arizona, Lake Cochise area: Bryan, 23.

San Pedro Valley, Proboscidea and Edentata : Gidley, 7.

Artiodactyls : Lull, 3.

dentition: Loomis, 14.

Bassariscinae: Hall, E. R., 1.

Bear, Pleistocene, Florida: Gidley, 12.

Bear family, distribution : Merriam, 6 .

Beaver tooth, Des Moines, Iowa : Thomas, A. O., 7.

Bison remains, Cape Cod, Massachusetts: Allen, G. M., 1.

Colorado and Dawson County, Texas : Hay, 41.

Folsom, New Mexico: Hay, 41.

Minnesota : Hay. 17.

Pleistocene, Kansas: Martin, H. T.

Bison skull, Yukon Territory : Clark, T. H., 15.

Bison chaneyi, Vernon, Texas: Cook, H. J., 14.

Bison latifrons, Kansas : Martin, H. T., 6.

Bison occidentalis, occurrence in Oklahoma : Crabb, 2.

Blastomeryx : Lull, 4.

Blastomeryx marshi, restoration : Lull, 10.

Bothriodonts: Troxell, 4.

Brain of Jurassic mammals: Simpson, G. G., 20.

Bridger Carnivora: Thorpe, 17.

Brown's Park formation, Colorado: Peterson, 11

Caenopus: Troxell, 9.

California, Mohave Desert: Merriam, J. C., 1.

Pleistocene ruminant: Stock, 19.

Rancho La Brea, rodents and lagomorphs: Dice, 1.

Siestan, Hipparion: Stock, 8. 
Mammalia-Continued.

California-Continued.

southern coast ranges: Stock, 3.

'Temblor Miocene, sperm-whale: Killoge, R., 15.

Camel, Utuh : Romer, 14.

Camelidae: Lull, 7 .

Canid and proboscidean remains, Mohave Desert, California: Stōk, 25.

Canid and rhinocerotid remains, Fliocene, Callfornia: Stock, 16.

Canidae, phylogeny: Matthew, 21.

Capromeryx, Nuevo Leon, Mexico: Furlong, 1.

Chrnivora, Tertiary : Thorpe, 14.

Uinta, Utah : Thorpe, 18.

Catopsalis, Paskapoo formation, A]berta : Russell, J. S., 2.

Cats, Rancho La Brea, Califoruia : Merriam, 13.

Cetacea, phosphate beds, Florida: Allen, G. M., 3.

Archueodelphis: Allen, G. M., 2.

Xenoruphus, South Carolina: Kel$\operatorname{logg}, \mathbf{R} ., 5$.

Cetacean research : Kellogg, R. 13.

Claenodonts, Eocene, Montana: Gidley, 2.

Colorado, Brown's Park: Peterson, 6.

Yuma County, Pliocene: Cook, H. J., 2.

Colorado Museum, fossil mammals : Cockerell, 21.

Cyclopidius : 'Thorpe, 4.

Deer, phylogeny : Loomis, 19.

Desmostylus: Hay, 18.

Tertiary : Hannibal, 1.

Vancouver Island: Cornwall, 1.

Desmostylus and Cornwallius, osteology and dentition: Hay, 21.

Diabelodon edensis, southern Califor. nia : Osborn, 25.

Diceratheres: Peterson, 2.

Diceratherium : Troxell, 10.

Dolichorhinus: Peterson, 7.

Diplodocus, skull: Holland, W. J., 3.

Diplolophus, Oreodon beds, Nebraska : Troxell, 19.

Edentata, Cenozoic history : Stock, 1. gravigrade: Stock, 13.

Oligocene: Simpson, G. G., 15.

Wasatch and Wind River beds: M:Itthews, W. D., 3 .

lilephants: Hay, 13, 14; and mastodons: Osborn, 35.

California, Pleistocene: Stock: 21.

Columbia Plateau, Washington: Bryan, 26.

Mexico: Freudenberg, 23.

Minnesota: Stauffer, 4.

Michigan, Oakland County: Sher\%er, 2.

Oklahoma, Frederick: Hay, 41.

('Trilophodon), Nebraska: Cook, H. J., 16.

$4096-31-54$
Mammalia-Continued.

Fiepbas cf. jeffersoni, Fredelick, Oklahoma: Cook. H. 3, 1.7.

Elephas eellsi, Iort Williams, Washington: Hay, :3t.

Elephas jeftersonil : Osborn, 20 .

Elephas primigenius boreus, Golconda, Illinois: Crook, 4, 5.

Dlephas roosevelti : Hay, 26.

Elephas scotti, Nebraska: Barbour, 2.

Entelodonts: Troxell, 1, 3.

Badlunds, South Dakota: Sinclair, $4,5$.

Locene didelphids: Simpson, G. G., 24.

Eporeodon, John Day beds: Thorpe, $6,8$.

Equidue, Oligocene: Buwalda, 2.

Equus laurentius: Hay, 38.

Eurhinodelphis, Calvert County, Mary. land : Kellogg, R., 11.

Eusmilus, Oreodon beds, South Dakota : Sinclair, 10.

Felidae, White River beds: Thorpe, 2.

Florida, Pleistocene: Hay, 1.

Citrus County: Simpson, G. G., 26.

Fort Union beds: Matthew, W. D., 38.

General : Osborn, 13.

Giraffa nebrascensis, Nebraska : Mat. thew, 33.

Glires, Wasateh and Wind River beds: Matthew, W. D., 3.

Helaletes: Troxell, 15.

Ferpetotherium marsupium, Bridger Basin : Troxell, 23.

IIesperopithecus, Snake Creek beds : Gregory, W. K., 7, 18; Osborn, $18,21,22$; Pycraft, 1; Woodward, A. S., 1; Anon., 19.

Hipparion mohavense, Puente formation, California: Stock, 26.

Homogalax : 'Troxell, 14.

Hoplophoneus, South Dakota: Jepson, 2 ; Sinclair, 2.

Horse and elephant, evolution : Loomis, 20.

Horses : Gidley, 10.

ancestry : Matthew, 29.

evolution: Loomis, 15; Matthew, 34. history in North America: Abel, 5. remains, North Carolina : Cobb, C., 3.

Hyaenarctid bear, John Day Basin, Oregon : Merriaum, 24.

Hyaenodontidae: Thorpe, 12.

Hyopsodus, Eocene, Colorado: Abel, 1.

Hypisodus: Troxell, 2 .

Hypohippus, Fish Lake valley, Nevada : Stock, 17.

Hyrachyus : Troxell, 1.7.

Hyracodon : 'Troxell, 8.

Big Badlands, South Dakota: Sinclair,' 6.

Oligocene, Sioux County, Nebraska: Wood, H. E., 4.

Illinois; Alton, Pleistocene: Leighton, M: M., 5. 
Mammalia-Continued.

Insectivora, Wasatch and Wind River beds : Matthew, W. D., 3.

Internal mandibular groove of Jurassic mammals : Simpson, G. G., 25.

Iowa, Cherokee: Cable, 9.

Henry County, Proboscidea : Jaques, 1.

Pleistocene mammalian remains : Thomas, A. O., 20.

Ischyromys : Troxell, 11; Badlands, South Dakota : Miller, G. S., 1.

John Day Felidae: Eaton, G. F., 1.

Jurassic : Simpson, G. G., 3.

Kentriodon pernix, Miocene porpoise, Maryland : Kellogg, R., 14.

Kentucky, cave remains: Miller, A. M., 11.

Lance formation: Simpson, G: G., 19.

Lance vertebrates: Matthew, 20.

Leptauchenia : Thorpe, 4 ; and Cyclopidius : Loomis, 13.

Llama, Pleistocene, California : Merriam, 18.

Mammoths, American Pleistocene : Osborn, 20.

hairy, Utah: Hansen, 1.

Mammoth tusk, Banks Island : Kindle, 29.

Marine invertebrates associated with Mammalia : Stock, 10.

Marsupial, Jobn Day beds, Logan Butte, Oregon: Stock, 9.

Marsupialia : Wood, H. E., 2.

Maryland, Calvert Cliffs, whale: Kellogg, R., 7 .

Calvert County, Eurhinodelphis : Kellogg, R., 11.

squalodonts: Kellogg, R., 4. western, cave deposits: Gidley, 3.

Mastodons: Hay; 30 ; Osborn, 14, 16 ; and mammoths: Osborn, 45.

ancestry : Osborn, 4.

Clallam County, Washington: Culver, 11,

extinction : Russell, J. W., 1.

Gratiot County, Michigan: MacCurdy, H. M., 1.

inferior dentition: Peterson, 10

Mexico : Freudenberg, 2

New York: Clarke, J. M., 22; Osborn, 27.

Orange County: Bishop, 1.

Texas : Hay, 25.

Megalomys, Pleistocene, Barbida, West Indies: Hopwood, 1.

Megalonychinae and . Mylodontidae, Rancho La Brea: Stock, 13.

Megaptera, Lompoc, California : Kellogg, R., 3.

Merychippus, Crooked River basin, Oregon: Maxson, 1.

Merychyus, restoration: Peterson, 5.

Merycochoerus and Promerycochoerus, distinctions: Thorpe, 22.
Mammalia-Continued.

Merycodus, Mohave Desert, California : Furlong, 2.

Merycoidodon: Thorpe, 9.

hyoid apparatus: Thorpe, 19.

Merycoidodontidae: Rutherford, 1; Thorpe, 21.

Mesohippus, Protoceras beds: Sinclair, W. J., 9.

Mexico, Chihauhua, Mina Erupcion: Eaton, G. F., 2.

Tepexpan, Elephas: Draz Lozano, 4.

Micromastodon : Osborn, 25.

Miocene oreodonts: Loomis, 11.

Molars, pre-Cretaceous evolution : Simpson, G. G., 9.

Montana, Hell Creek formation : Simpson, G. G., 13.

southern, Fort Union formation, Simpson, G. G., 21.

Moropus, habits: Osborn, 3.

Multituberculates : Simpson, G. G., 4. of the Morrison, taxonomy: Simpson, G. G., 17.

Wasatch formation: Granger, 1.

Musk-ox skull, Iroquois Beach, Toronto, Ontario: Bensley, 1.

Mylodon harlani, mounted skeleton: Stock, 5.

Nebraska, Agate, rhinoceros bone bed: Cook, L. M., 1.

Miocene: Matthew, 35.

western, Pleistocene: Matthew, W. D., 2.

Neohyaenodon: Thorpe, 12.

Neomeryx finni, Dundurn, Saskatchewan : Parks, 22.

Nevada, southeastern: Stock, 7.

Thousand Creek Pliocene: Merriam, 28.

New York, Orange County, Monroe: Clarke, J. M., 11.

Pleistocene : Hartnagel, $1,4$.

Notharctus, Eocene primate: Gregory, W. K., 2.

Notharctus gracilis: Troxell, 30.

Oklahoma, elephant: Crabb, 1. Glyptodon: Gould. C. N., 30

Oligobunis, Sioux County, Nebraska: Thorpe, 5.

Oregon, Newport: Packard, 1.

Tertiary Canidae: Thorpe, 11.

Pliocene bear: Merriam, 22.

Oreodon beds faunas, South Dakota: Sinclair, 8.

Oreodonts: Loomis, F. B., 3, 9; Thorpe, 4.

geologlcal history : 'Thorpe, 26.

Oligocene, Montana: Loomis, 10.

Oreodontoides oregonensis, John Day formation, Oregon: Thorpe, 24

Origin of mammalian faunas of North and South America: Scott, W. B., 6.

Origin of species: Osborn, 37. 
Mammalia-Continued.

Palaeocastor, Miocene, Wyoming: Romer, 10.

Palaeologus: Troxell, 35.

Paleocene mammals, new genera : Matthew, 16.

Paleocene multituberculate, musculature and habits: Simpson, G. G., 27.

Paleomastodon : Osborn, 4; and Moeritherium: Màtsumoto, 1.

'Pantotheres from the Morrison: Simpson, G. G., 16 .

Parelephas: Osborn, 32.

Pauromys, Bridger formation, Wyoming : Troxell, 18.

Peccary, McKittrick Plelstocene, California : Stock, 23.

California, Rancho La Brea: Merriam, 8.

Maryland, Pleistocene: Gidley, 4.

Nebraska, Crawford: Cook, H. J., 3.

Pecora, primitive : Lull, 12.

Pelagic mammals: Kellogg, R., 8.

Pacific coast: Kellogg, R. 10.

Pennsylvania; Frankstown cave : Peterson, 9.

Perchoerus skulls, White River and John Day formations: Pearson, $\mathrm{H}$. S., 1.

Physeteroid cetacean, Santa Barbara County, California : Kellogg, R.; 9.

Pinnipeds, California : Kellogg, R. 16. Pliopedia, Pliocene : Kellogg, R., 1.

Miocene and Pliocene, Callfornia : Kellogg, R., 2.

Pleistocene: Hay, 24, 47; Romer, 14. Dallas, Texas: Iull, 8.

early : Hay, 45.

mastodons: Hay, 32.

Plesippus, Blanco formation, Texas: Matthew, 29.

Pliocene, eastern Asia and western North America : Stock, 11.

Pliocyon, John Day Valley, Oregon : Thorpe, 5.

Poebrotherium: Loomis, 18.

Porpoise, California: Gregory, W. K., 21.

Primates, Paleocene, Mon'tana : Gidley, 6.

Primitive foot: Gidley, 1.

Princeton Museum móunts. Sinclair, W. J., 1.

Proboscidea : Hay, 18 ; Ingalls, A. G., 4.

distribution and classification : Osborn, 15.

distribution in Oklahoma: Decker, 3. evolution : Osborn, 11, 29 ; and classification: Osborn, 11.

Iowa : Thomas, A. O., 26.

migrations and affinities: Osborn, 24.

new genera and species: Osborn, 44.

New York: Hay, 3.
Mammalia-Continued.

Proboscidea-Continued.

phylogeny: Osborn, 11, 34; and classification: Osborn, 11.

Promerycochoerus, John Day beds : Thorpe, 3.

Prosthennops (peccary), Oregon : Thorpe, 25.

Prosthennops xiphodonticus, Nebraska : Barbour, 3.

Radial exostosis in Daphoenus: Romer, 3.

Rattlesnake fauna, Oregon: Merriam, 19.

Reithroparamys, Bridger formation : Matthew, 11.

Reptillan characters in mammals : Wortman, 1.

Research methods, classification, etc. : Osborn, 13.

Rhinoceros: Troxell, 20.

Kansas : Lane, H. H., 1.

('Trigonias), Oligocene, Colorado : Gregory, W. K., 19.

Rhinoceroses and hydracodonts : Wood, H. E., 5, 6.

Ricardo fauna, California: Stock, 25.

Rodentia, Eocene: Troxell, 21.

Sea cow, Metaxytherium floridanum : Hay, 11.

Sloth remains, Iowa : Delavan, 1.

Smilodectes or Notharctus : Troxell, 30. Snake Creek fauna : Matthew, W. D., 2. Snake Creek fossil quarries: Matthew, 24.

South Carolina, phosphate beds: Allen, G. M., 4 .

South Dakota, Black Fills region : O'Harra, 3.

Sparassodonts: Wood, H. E., 2.

Sperm whale, Miocene (?), Florida: Cobb, C., 5.

Squalodonts: Kellogg, R., 4.

Stegomastodon, Proboscidea : Osborn, 33.

Stehlinius, Eocene insectivore: Matthew, 17.

Stenomylus, byoid arch: Peterson, 4. Suina: Barbour, 3.

Tathiodon to replace Tanaodon: Simpson, G. G., 18.

Tanupolama, Pleistocene, California: Stock, 24.

Teleoceras, Pliocene, Colorado: Cook, H. J., 11.

Tetrabelodon abeli, . Nebraska : Barbour, 6 .

Tertiary artiodactyls: Lull, 4.

Tertiary Mammalia, extinction : Cockerell, 5.

Texas, Miocene: Hay, 20.

Pleistocene : Cook, H. J., 6.

Ticholeptus Iusticus : Loomis, F. B., 3.

Tinodon and allies: Simpson, G. G., 2. 
Mammalia-Continued.

Titanotheres, Eocene, Colorado: Cook, H. J., 8.

Huerfano formation. Colorado: Osborn, 7 .

Iriassic: Simpson, G. G., 22.

Triconodonts: Simpson, G. G., 1.

Trigonias, Weld County, Colorado; Gregory, W. K., 19.

Trilophodon, Colorado: Cook, H. J., 1

Ungulates, Eocene, horned: Troxell, 16.

preorbital fossae: Gregory, W. K., 4. Uinta Basin, Eocene: Peterson, O. A., 1.

Cintacolotherium, Moffat County, Colorado: Cook, H. J., 7 .

Jintatherium molars: Wood, H. E., 1 .

Wasatch and Wind River faunas : Matthew, W. D., 3.

Whale, Monterey group, California : Hanna, G. D., 15.

Zarhachis, Calvert formation, Maryland: Kellogg, R., 1, 1.2.

Man, fossil.

Ancestry : Gregory, W. K., 22; HillTout, 2; Osborn, 49

Antiquity : Lull, 9 .

in America: Cook, H. J., 10, 12 ; Figgins, 1; Goddard, 1; Hrdlička, 2 ; Science Service, 5; Anon., 71.

in California: Merriam, $\mathbf{1 5 .}$

Artifacts, associated with Elephas, Melbourne, Florida: Loomis, 1.

California, Los Angeles : Stock, 12.

Folsom, New Mexico: Science Service, 10.

Texas Pleistocene: Cook, H. J., 6, 10.

Evidences of early man, Frederick, Oklahoma: Science Service, 9.

Evolution: Baitsell, 1; Hrdlička, 4; Huntington, 5 ; Matthew, 14 ; Osborn, $9,40$.

Florida: Cooke, C. W., 19 ; Gidley, 8; Hay, 44 ; Hrdlička, 1 ; Loomis, 1, 16 ; Sellards, 2 ; Sterns, 1.

Melbourne and Vero deposits: Gidley, 9.

Melbourne, Vero and St. Petersburg deposits: Cooke, C. W., 16.

Melbourne artifacts, antiquity : Holmes, W. H., 1.

General: Balcom, 1; Gregory, W. K., 25 ; Hay, 5; Lull, 20, 21 ; Osborn, $12,23,36,47$.

Glacial man in America: Miller, A. M., 10.

Hesperopithecus: Gregory,. W. K., 18; and Pithecanthropus molars: Gregory, W. K.. 10.

Human dentition : Gregory, W. K., 15 ; Hellman, 1; evolution: Gregory, W. K., 6.

Human origins : MacCurdy, 1.

Nebraska and Oklahoma finds: Cook, H. J., 13.
Man, fossil-Continued.

Nebraska, Pliocene pseudo-artifacts : Nelson, N. C., 1.

western, fossil implements in Pliocene deposits: Sci. Serv., 4.

Nevada: Krejci, 1.

Occurrence with Pleistocene fossils, Dallas, Texas: Shuler, 2.

Oklahoma, Frederick : Cook, H. J., 15; Hay, 43 ; Spier, 1, 2.

Origin of man: Bretz, 11; Gregory, W. K., 12, 14, 17, 23; Headstrom, 1 ; Merriam, J. C., 2.

and antiquițy: Miller, A. M., 17; Osborn, 47, 48.

and distribution: Hrdlička, 3.

from anthropold stem : Gregory, W. K., 1.6.

Paleopathology : Moodie, 18.

Phylogeny of man : Hill-Tout, 1.

Pithecanthropus molars: Gregory, W. K., 10 ; Miller, G. S., 2.

Place of origin: Gregory, W. K., 20.

Plateau habitat of pro-dawn man : Osborn, 50.

Pleistocene man : Johnson, .T. H., 6.

Social evolution: Matthew, 12.

Tertiary man: Johnson, J. H., 5.

Trenton gravels, New Jersey: Wright, G. F., 1.

Upright posture: Gregory, W. K., 24.

Manganese.

Appalachian Valley, Virginia and Tennessee: Stose, 4.

Arkansas, Batesville district : Miser, $1,5$.

Arizona : Jones, Edw. L., 6.

Bibliography : Hewett, 3 ; Wheeler, $H$. L., 1.

California, southeastern: Jones, Edw. L., 7 .

Canada: Mackenzie, G. C., 1.

Colorado: Jones, Edw. L., 6 ; Muilenburg, 1.

Red Cliff district : Crawford, R. D., :3.

Colorado River desert region: Jones, Edw. L., 9.

Costa Rica: Sears, 1.

Cuba: Burch, 1, 2 ; Burchard, 3, 7.

Bùeycito: Calvache Dorado, 1.

General: Harder, 2; Hewett, 1, 2, 3, 5 ; Leith, 15.

Georgia: Hull, 1.

Cartersville district: Anon., 1.

Idaho: Livingston, 2.

Bannock County: Hewett, 19.

Maryland: Singewald, 5.

Minnesota, Cuyuna range: Thiel, 4.

Montana: Pardee, 8.

Nevada: Pardee, 4.

New Mexico: Jones, Fdw. L., 5 ; Wells, E. H., 1.

New York, Columbia County, postglacial : Dale, N. C., 2.

Northwestern States: Pardee, $\mathbf{3}$. 
Manganese-Continued.

Nova Scotia: Hayes, A. O., 1 ; Jennison, 1.

Lunenburg County : Fearing, 2 ; Reid, J: A., 1.

western : Faribault, 2.

Oklahoma, Bromide: Hewett, 8.

Custer County : Reiter, 2.

Oregon: Pardee, 8. southwestern: Kellogg, A. E., 7.

Panama, Boqueron River : Sears, 2.

Pennsylvania: Pa. G. S., 1.

Porto Rico, Ponce district: Mitchell, 7 .

Precipitation by micro-organisms: Thiel, 8.

Southern States: Stose, $\boldsymbol{T}$.

Tennessee : Crane, W. R., 1. eastern : Stose, $\mathbf{1 7 .}$

Types of deposits: Burchard, 28.

Utah : Pardee, 8.

Virginia : Grasty, 1.

Blue Ridge, west foot: Stose, 1.

Giles County: Hubbard, G. D., 6. western : Stose, 16.

Washington: Pardee, 8, 15.

Wyoming, Laramie Mountains: Jones, W. F., 2.

Manganese minerals: Thiel, 2.

Manhattan district, Nevada: Ferguson, $\mathbf{H}$. G., 5.

Minnitoba.

Island Lake area: Wright, J. F., 12.

Areas described.

Athapapuskow Lake district: Bruce, 1.

Beresford Lake area: Wright, J. F., 4.

Bigstone and Fox rivers area, northern Manitoba : Merritt, C. A., 4.

Cross-Pipestone area: Alcock, 4.

Elbow Lake area, northern Manitoba: Armstrong, P., 3.

Flinflon area: Alcock, 15.

Knee Lake district: Bruce, 4.

Olseau River area : Cooke, H. C., 9: Wright, J. F., 10.

Ospwagan Lake-Burntwood River area : Alcock, 9.

Oxford and Knee lakes area, northern Manitoba: Wright, J. F., 11.

Rat River: Alcock, 1.0.

Reed and Wekusko lakes region : Alcock, 12.

Reed-File lakes area: Alcock, 1.

Reed Lake-Elbow Lake: Bruce, 2.

Rice Lake area: Cooke, H. C., 9; Wright, J. F, 3.

Upper Whitemouth area: Johnston, W. A., 3.

Wekusko Lake area: Alcock, 2.

Winnipegosis area: Johnston, W. A., 3. Economic geology.

Chalcopyrite deposits, northern Manitoba: Bruce, 5.

Clays, Lake Agassiz Basin: Maynard, .T. E., 1; Wallace, 11.

Copper Lake gold district: Wallace, 3.
Manitoba-Continued.

Economic geology-Continued.

Copper-zinc and gold mineralization:

Wallace, 22.

Cretaceous shale: Ells, 2.

East central Manitoba : Wright, J. F., 9.

Falcon Lake district: De Lury, 2.

Flinflon ore body: Wallace, 5 .

General: DeLury, 5 ; Frather, 1.

Gold, Elbow Lake: Wallace, 6.

northern Manitoba: Gordon, J. P., 1.

Herb Lake region: Alcock, 12.

Knee Lake district, northern Mant. toba: Anon., 7.

Maskwa River copper-nickel deposit: McCann, 1.

Maskwa River norite: Colony, 2.

Mineral resources: Wallace, 1.0, 13, 19. nonmetallic: McArthur, 1; Wallace, 18.

Mineral deposits, northwestern Manitoba: Wallace, 15 .

Northern Manitoba: Wallace, 1, 2, 4.

Oiseau and Maskwa copper and copper-nickel deposits : Wright, J. F., 7.

Pegmatites, southeastern Manitobn: DeLury, 8.

Rice Lake gold area : Wright, J. F., 6.

Sands: Wallace, 21.

Schist Lake region, Mandy mine : Hanson, 1.

Secondary processes in pre-Cambrian ore bodies: Wallace, 8 .

Southeastern Manitoba: Bruce, 3 ; DeLury, 4.

Sulphide deposits, northern Manitoba: Hanson, 4.

The Pas mineral district: Alcock, 18; Wallace, 1.

Tin, West Fawk Lake region : Delıry, 3.

Historical geology.

Borings: Dowling. $\mathrm{s}$.

Correlution: Dowling, 2.

East central Manitoba: Wright, J. T., 9.

Falcon Lake district: DeLury, 2.

General : Wallace, '1.4.

Herb Lake region: Alcock, 12.

Hudson Bay area : Foerste, 20; Savage, 2.

Maskwa River copper-nickel deposit: MeCann, 1.

Northern Manitoba: Bruce, 5; Hanson, 1.

Ordovician and Silurian, Hudson Bay area : Foerste, 22.

Pre-Cambrian : Alcock, 13. northern Manitoba: Bruce, $\boldsymbol{T}$.

Ricc Lake, Maskwa River, and Boundary districts: DeLury, 1.

Southeastern Manitoba: DeLury, 4.

Southern Manitoba: DéLury, 1.

Turtle Mountain coal measures: Dowling, 12.

Mineralogy.

Chalmersite, Cold Lake :Thomson; E., 13.

Cyanite, Reed-Wekusto area : Wallace, $\mathbf{f}$. 
Manitoba-Continued.

Mineralogy-Continued.

Heavy minerals in sand horizons : Wallace, 23.

paleontology.

Foraminifera, Cretaceous : Cushman, 33

General : Wallace, 14.

Hudson Bay area : Foerste, 22.

\section{Petrology.}

Dolomitization in Paleozolc horizons: Birse, 1.

Granite, local differentiation, Churchill River: Alcock, 8.

Maskwa River norite: Colony, 2.

Pegmatites, southeastern Manitoba: DeLury, 8 .

Physical yeology.

Dolomitization of limestones: Birse, 1.

Marlite balls : Kindle, 22.

Secondary processes in pre-Cambrian ore bodies: Wallace, 8 .

Varve materials and banded rocks: Wallace, 20.

Physiographic geology.

General : Wallace, 14.

Glaciation: Burwash, 7.

Pleistocene changes of level : Johnston, W. A., 2.

Seal-Churchill divide, terminal moraine: Alcock, 15.

Winnipegosis area, surface deposits: Johnston, W. A., 1.

Manuscript bibliographies, list: Little, 3 .

Map making. See Cartography.

Maps. See Geologic maps; Relief maps.

Maps, interpretation and use: Smith, G. O., 20.

Marble : Burchard, 6 .

Alaska, southeastern : Burchard, 6.

Constitution, characters, and history : Dale, T. N., 6.

Georgia, Tate quadrangle: Bayley, 13.

Mexico, Puebla: Wittich, 28.

Physical features: Bowles, 3.

Tennessee, east : Dale, T. N., 6; Gordon, C. H., 3.

Vermont, Roxbury : Richardson, C. H., 2. West Virginia, Pocahontas County : Price, 2.

Marcasite, paragenesis: Newhouse, 1.

Markings on rocks. Marl.

Ontario, Toronto area: Fritz, 1.

Florida: Mossom, 1.

North Carolina : Loughlin, 9.

Wisconsin: Steidtmann, 5.

Marmarth field, North Dakota: Hares, 5.

Martinique.

Economic geology.

Petroleum indications: Barrabe, 1.

Historical geology.

General: Barrabe, 1.

Physical geology.

Gases of Mt. Pele lavas: Shepherd, 5.
Maryland.

Areas described.

Kent County : Miller, B. L., 6.

Queen Annes County: Miller, B. L., 7.

Talbot County: Miller, B. L., 8.

Economio geology.

Chrome ore, northeastern Maryland: Knopf, E. B., 2.

Chromite deposits: Diller, 1 ; Gordon, S. G., 7; Lewis, J. V., 1 ; Singe. wald, J. T., $1,2$.

Coal : Swartz, C. K., 3.

Feldspar, quartz, chrome, and manganese: Singewald, 5.

Fire clay localities: Hall, G. M., 2.

Fire clays: Watts, A. S., 1.

western Maryland: Mathews, 4.

Mineral resources: Mathews, 6.

Molding sands: Trainer, 2.

Talc, Harford County : Diller, 5.

\section{Historical geology.}

Bluff sections, St. Marys County : Mansfield, W. C., 4.

Cambrian: Bassler, 13.

Carboniferous : Swartz, C. K., 5.

Clinton formations: Ulrich, 9.

Coal measures: Swartz, C. K., 2, 4.

Cretaceous, Federal Hill, Baltimore: Berry, 16.

Crystalline schists, eastern Maryland: Knopf, E. B., 3.

Elkton quadrangle: Bascom, 2.

Metamorphic rocks, eastern Maryland: Jonas, 1.

Newark system : Dorsey, 1.

Ordovician : Bassler, 13.

overlap, Piedmont province: Stose, 18

Pleistocene : Mansfield, W. C., 6.

Pre-Cambrian : Jonas, 6.

western Piedmont: Jonas, 4.

Rose Hill and McKenzie formations, sections: Prouty, 9.

Silurian : Swartz, C. K., 6.

correlation: 'Swartz, C. K., 8; Ulrich, 8.

Wills Creek and Tonoloway formations: Swartz, C. K., 7.

Mineralogy.

Almandite-spessartite garnet, Gwynns Falls, Baltimore: Shannon, 75.

Apatite, Wiant's quarry, Pilot: Shannon, 71.

Beaumontite, Baltimore: Shannon, 52.

Chrome ore, Etchison, Montgomery County: Shannon, 62.

Gahnite, cobaltifẹrous, Carroll County : Shannon, 43.

"Halloysite," Jones Falls: Shannon, 56.

Kensington mica mine, Montgomery County: Shannon, 64.

Magnesite and kammererite, Cecil County : Shannon, 60.

Margarite, Montgomery County : Shannon, 48.

Remingtonite, Carroll County: Shannon, 50. 
Maryland-Continued.

Mineralogy-Continued.

Vermiculites, Bare Hills near Baltimore: Shannon, $\mathbf{7 7}$.

Paleontology.

Arundel fauna: Gilmore, 8.

Caecum, protoconchs : Berry, E. Will., 2.

Cambrian : Bassler, 13.

Canthellophorus, Carboniferous: Bass. ler, 12.

Carboniferous insects: Cockerell, 37.

Coal measures: Swartz, C. K., 2.

Cretaceous, Federal flill, Baltimore: Berry, 17.

Dinosaur, ornithomimid, Arundel formation: Gllmore, 5.

Eurhinodelphis, Calvert County : Kellogg, R., 11.

Kentriodon pernix, Miocene porpoise: Kellogg, R, 14.

Labyrinthodont footprints: I.ull, 11.

Ordovician: Bassler, 13.

Pleistocene: Mansffeld, W. C., 6. cave deposits, western Maryland : Gidley, 3.

Mollusca, Walles Bluff : Smith, E. R. 1.

peccarles, Cumberland: Gidley, 4.

Vertebrata: Hay, 6.

Silurian: Swartz, C. K., 8.

Squalodonts, Calvert Cliff's : Kellogg, R., 4.

Terebratula, Eocene : Roberts, T. K., 1.

Upper Cretaceous Ostracoda: Berry, E. Will., 1.

Whale, Calvert Cliffs: Kellogg, R., 7 .

Xenohelix, Chesapeake Bay, St. Marys County : Mansfield, W. C., 4.

Zarhachis, Calvert formation: Kellogg, R., 6.

Zarhachis flagellator, Calvert Cliffs: Kellogg, R., 12.

\section{Petrology.}

Elkton quadrangle: Bascom, 2.

Gabbros, Harford County : Insley, 1.

Granitic pegmatites: Gordon, S. G., 2

Serpentines, Harford County : Johannsen, 14.

Plysical geology.

Black shale formation: Goldman, 11.

Ocean inlets, storm effect: Hite, 1.

Mascall flora, Oregon: Chaney, 17.

Maskwa River norite, Manitoba: Colony, 2. Massachusetts.

Boston area : Crosby, I. B., 5; Foye, 18.

Worcester area: Foye, 17.

Economic geology.

Granite: Dale, T. N., 4.

Lime belt: Dale, T. N., 5.

Silver, Newburyport: Green, F. E., 1.

Historical geology.

Connecticut Valley, geological history : Miller, W. J., 10.

Dighton conglomerate, origin : Perkins, E. H., 1.

Dracut norite stock: Fairbanks, 10.

Essex County : Clapp, C. H., 1.
Massachusetts-Continued.

Historical geology-Continued.

Scree, Triassic, Connecticut Valley: Reynolds, 1.

Silurian, Essex County : Foer'ste, 6.

Squantum tillite: Sayles, 18.

Unconformity between Berkshire schist and Stockbridge limestone, Adams: Dale, T. N., 2.

Wamsutta red beds igneous rocks: Eaton, H. N., 6.

\section{Mineralogy.}

Amesite, Chester : Shannon, 8, 16.

Bucholzite, Blandford: Shannon, 17.

Chester emery mine: Shannon, 4.

Corundophilite, Chester: Shannon, 16.

Datolite, Westfield : Shannon, 23.

Gedrite, Chesterfield: Shannon, 17.

Monazite, Weymouth : Palache, 10.

Pelbam asbestos mine: Shanuon, 3.

Pigeonite, Westfield : Gillson, 5.

Rockport, Cape Ann: McKinstry, 2.

Scapolite deposits, Bolton: Palache, 13.

Talc, Russell : Foshag, 14.

Westfleld, datolite locality : Shannon, 1.: diabantite: Shannon, 1.

Paleontology.

Aspidella-like markings, Cambridge slate : Clark, T. H., 10.

L-Bison remains, Cape Cod, Allen, G. M., 1.

$\sim$ Boston area, Cambrian : Clark, 'I. H., 10.

Footprints, Attleboro: Lull, 5.

Connecticut Valley: Abel, 4.

$\infty$ Mollusca, Boston Basin boulder clay : Morse, E. S., 1.

LOldhamia, Lower Cambrian: Howell, B. F., 2.

Petrology.

Contact plenomena, gneiss and limestone in western Massachusetts: Eskola, 1.

Essex County, igneous rocks: Clapp, C. H., 1.

Dracut norite stock: Fairbanks, 10.

Gabbroid diabase in Westield: Shunnon, 6 .

Granites and pegmatites of Cape Ann: Warren, C. H., 2.

Plyysical geology.

Boston, earthquake risk : Crosby, I. B., 2.

Earthquake, January 7, 1925 : Porter, w. W., 1.

Keystone fault, Purgatory Chașm, Sutton Crosby, W. O., 4.

Mechanics of dike intrusion : Billings, 1.

Medford dike: Jones, W. F', 4.

Postglacial faulting. Mount Toby : Loomis, F. B., 4.

Shapes of beach pebbles, Nantasket: Wentworth, 10.

Physiographic geology.

Camp Devens area : Atwood, W. W., 1.

Cape Cod region: Brigham, 1.

Mount Toby: Loomis, F. B., 4. 
Massachusetts-Continued.

Physiographic geology-Continued.

l'hysical features, central Mussachu. setts: Alden, :2.

Postylacial uplift: Fairchild, $\boldsymbol{T}$.

Till on overthrust gravels, Cambridge : Lame, 29.

Mastodontoidea. See Mammalia.

Matabitchuan area, Ontario: Todd, E. W., 5. Matachewan district, northern Ontario: Butrows, 2 ; Cooke, H. C., 1.

Matanuska coal fields, Alaska: Martin, G. C., 3.

Matanuska Valley, upper, Alaska : Capps, 11 Maverick Springs, Fremont County, Wyoming: Collier, 6.

Mayo area, Yukon: Cockfield, 1, 4, 15.

Meandering.

Colorado Plateatu country: Moore, R. C., 31

Inclosed, Colorado Plateau: Moore, R. C., 30 .

Missouri, Ozark region, intrenched and incised meanders: Tarr, 1:3.

Tidal streams: Barton, 18; Campbell, M. R., 13.

Measurement of folded beds: Hewett, 6 . Mechanics of geologic structure: Mead, 1. Mechanics of vein formation : Taber, 1.

Meetings. See Associations.

Megadiastrophism: Chamberlin, R. T., 7 ; Chamberlin, T. C., 12, 17 ; Jones, W. F., 2.

Megratectonics: Chamberlin, T. C., 30.

Melikaria: Burt, 5.

Melilite, composition : Winchell, 9 ; genesis : Bowen, 15.

Molilites, natural and synthetic: Buddington, 5.

Melrose phosphate field, Montana: Richards, R. W., 2.

Mendon kame area, New York: Fairchild, 19.

Mercury. See Quicksilver.

Mesozoic (undifferentiated).

Alaska, Alaska Railroad region: Lapps, (b.

Chichagof Island, western part: Overbeck, 1.

Goodnews Bay region : Harrington, 6. Jack Bay district: Johnson, B. L., 2. Kahiltna Valley: Mertie, 2.

Ruby-Kuskokwim region: Mertie, 11. Tolstoi district: Harrington, 2.

Arctic regions, Ellesmere Land: Holte dahl, 1.

British Columbia, Nickel Plate moun tuin: Schofield, 5.

Churwater-Sundance contact: Dobbin. 4 :

Idaho, granitic rocks: Ross, C. P., 16.

Washington, Stevens County : Weaver, (2).

Yukon, Sixtymile and raduc rivers area : Cockfiela, 5.
Metullic concentrations by mammation, ocipin : Spurr, 10.

Ietallogenetic zones: Rastall, 2 .

Metamorphic rocks, feldspar method of determining: Carlson, 1.

identificntion : Leith, 12.

Metamorphism.

Adirondacks, contact metamorphism : Agai, 1.

California, Catalina Island: Woodfiord, 1.

Riverside County, Crestmore: Eakle, 1.

Clinkertill: Dove, 4.

Colorado coals : Eby, 4.

Contact action, Etta mine: Schwart\%. 22.

C o n a c t metamorphism: Hess, 11 ; Foshag, 27.

processes: Geijer, 2.

Vermont: Bain, 25.

Corundum and albitite bodies, hydrothermal origin: Larsen, 21.

Crystalline schists, southeastern Pennsylvania and Maryland: Knopf, E. B., 3.

Dolomitization: Walker, T. L., 55

Duluth gabbro, basal phases: Nebel, 3.

Factors in rock metamorphism : White, D., 36.

General : Schaller, 7.

Granite, weathered, twice metamorphosed: Allison, I. S., 3.

Grenville limestone, Quebec: Bain, 2.

Grünerite rocks, Lake Superior region, origin : Richarz, 9.

Kansas, Woodson County: Twenhofel, 8 .

Kaolin, formation: Parsons, 7.

Killarney gneisses and migmatites, Ontario: Quirke, 22.

Lake Superior iron formations: Richarz, 11.

Limestone alterations at Bingham, Utah: Winchell, 8.

Massachusetts, Essex County : Clapp, C. H., 1 .

Metasomatic processes in silicate rocks : Goldschmidt, V. M., 1.

Meteorites: Merrill, 16.

Mineralization of the Platteville-Decorah contact zone, MinneapolisSt. Paul region, Minnesota : Stauff'er, 6.

Minnesota, Ely greenstone, contact metamorphism: Schwartz, $\boldsymbol{T}$.

Mount Royal contact metamorphic zone. Quebec: Dolan, 1.

New kind of: Winchell, 15.

New Hampshire, Hanover district: Merritt, J. W., 3.

New York, Grenville sediments: All ing, 13.

Lake Bonaparte quadrangle: Snyth, 2.

Inewis County: Buddington, 2. 
Metumorphism-Continued.

Paleozoic altered volcanic materials: Ross, C. S., 21.

Pegmatites, formation: Schaller, 10.

Pennsylvanla and Maryland, crystulline schists : Knopf, E. B., 3.

Porosity and crushing strength as indices of regional alteration: Russell, W. L., 11.

Porto Rico, Humacao district: Fettke, 5 .

Pseudo-igneous rocks, Texas: Lonsdale. 11.

Regional metamorphism: Barrell, 7 .

Secondary processes in pre-Cambrian ore bodies: Wallace, 8 .

Shale, Cretaceous, Rocky Mountain region : Wilson, J. H., 3.

Tactite: Hess, 1.

Utul, Bingham: Lindgren, 12.

Tintic district: Lindgren, 2.

Vermont, Whitingham area: Hubbard, G. D., 4.

Metasonatism : Boydell, 7, 9; Goldschmidt, V. M., 2 ; Lindgren, 16 ; Lovering, 3 ; Spencer, A. C., 1 ; Taber, 13.

and the pressure of growing crystals: Boydell, 14.

physico-chemical theory : Boydell, 3, 12 ; Goldschmidt, V. M., 3.

processes in silicate rocks: Goldschmidt, V. M., 1.

solubility and pressure: Boydell, 9 .

Meteor Crater, Arizona: Barringer, 1, 3; Boot, 1 ; Thurmond, 1.

Meteor crater, Texas: Bibbins, 1.

Meteorites.

Alpine, Brewster County, Texas : Merrill, 19 .

Amana, Iowa : Prior, G. T., 1.

Annaheim, Saskatchewan: Johnston, $\mathbf{k}$. A. A., 1.

Anthony, Harper County, Kansas : Merrill, 39.

Arkansas, western: Merrill, $\mathbf{5 3 .}$

Baldwyn, Mississippi : Glenn, 7 ; Merrill, 41.

Blithfield, Ontario: Johnston, R. A. A., 2.

Chondrules and chondritic structure: Merrill, 10.

Colby, Wisconsin: Merrill, 42.

Cold Bay, Alaska : Merrill, 19, 20.

Composition: Merrill, 46; and structure : Merrill, 1, 4.

Copper in a meteorite vein : Quirke, 3. Cumberland Falls, Kentucky : Merrill, 5. 8, 13; Meunier, 1; Miller, $\mathbf{A}$. M., 2, 4, 6 .

Cumpas, Sonora, Mexico: Palache, 17.

Deal, New Jersey : Keeley, 1.

Dungannon, Virginia: Merrill, 28.

Eagle Station, Kentucky : Prior, G. T., 1.

Ehrenberg, Yuma County, Arizona : Palache, 17.
Meteorites-Continued.

Esthelville, Iowa : Merrill, 9; Meunier, 1.

Etching, iron, meteorites: Farrington, 1.

Florence, Texas: Lonsdale. 9.

Forksville, Virginia : Merrill, 47, 50.

Four Corners, San Juan County, New Mexico: Merrill, 39.

General: Clarke, F. W., 10; Merrill, 43 ; Miller, A. M., 14.

Glasgow, Kentcky : Merrill, 30 ; Miller, A. M., 12 .

Gun Creek, Gila County, Arizona Palache, 17.

Harvard University collection ; Palache, $16,17$.

Johnstown, Colorado: Hovey, 12.

Kansas City, Missouri : Merrill, 3.

MeCreary County, Kentucky : Miller, A. M., 3, 19.

McDowell County, North Carolina Merrill, 34

Merrillite and chlorapatite in stony meteorites: Shannon, 53.

Mesa Verde Park, Colorado: Merrill, $29,31$.

Metal in meteorites: Merrill, 56, 57.

Metamorphism in meteorites: Merrill, 16.

Mount Ouray, Chaffee County, Colorado: Pálache, 17.

Navajo, Arizona : Merrill, 20.

New Baltimore, Somerset County, Pennsylvania: Merrill, 31, 32.

Nickelsville, Virginia : Merrill, 23.

Oakley, Idaho: Merrill, 47, 52.

Observations of falling meteorites : Merrill, 24 ; Miller, A. M., 12.

Odessa, Texas : Merrill, 22.

Okluhoma: Shannon, C. W., 2.

Owens Valley, California: Merrill, 1.7, $21,49$.

Oxidation of meteoric irons: Shannon, 68.

Palahatchle, Mississippi : Merrill, 40.

Pennsylvania: Stone, 16.

Percentage number of falls with reference to varying basicity : Merrill, 2.

Pitts, Georgia : McCallie, 3.

Quartz.in meteoric stones: Merrill, 37.

Richardton. North Dakota: Quirke, 1, 2 , 3.

Rose City, Michigan : Hovey, 6, 7, 8.

Savanuah, Tennessee: Merrill, 29.

Savik, Greenland: Bøggild, 5.

Sharps, Virginia: Watson, 14

Seneca Township, Michigan: Merrill, 53.

Signal Mountain, Lower California : Merrill, 19.

Smithville, Oklahoma: Shead, 1.

Social Circle, Georgia: McCallie, 6.

Sundry meteorites: Merrill, 4.

Temperature: Jones, A.T., 1, 2. 
Meteorites-Continued.

Tilden, Illlnois: Wylie, 1.

Troup, Texas: Merrill, 15 ; Udden, 10 .

Tulia, Texas: Palache, 20.

Undescribed meteorites in American Museum of Natural History collection : MacNaughton, 1.

Wallapal Indian Reservation, Arizona : Merrill, 54

Washington County, Colorado: Palache, 34.

Mexico.

Zenith, Kansas: Corbett, 3 .

Cardenas-Tampico: Diaz Lozano, 5.

Geology : Freudenberg, 1.

Glossary of: geologic terms: Muñoz Lumbier, 6.

Instituto Geológico Nacional: Paredes, 4.

Islands: Muñoz Lumbier, 2.

Lower California, southern: Gálvez, $\mathbf{7}$.

Michoacan: Barrera, 2.

Northeaster'n Mexico: Staub, 2.

Valley of Mexico: Salazar Salinas, 5.

West Mexican islands: Hanna, G. D., 32.

Areas described.

Catorce district, San. Luis Potosi : Baker, C. I., 3.

Cerro de Mercado, Durango: Salazar Calinas, 3.

Coahuila, northern: Cumming, 2.

Coahuila and Nuevo Leon: Cumming, 1 ; Carboniferous area : Müllerried, 2.

Colima (part) : vivar, 4.

El Oro district, Mexico: Flores, 1 ; Villafaña, A., 1; Winchell, H. V., 1.

Guadalcazar, San Luis Potosi : Wittich, 16.

Lower California : Gálvez, 2; Marland Oil Co., 1; Wilhelm, 2.

Morelia Valley, Michoacan: Camacho, $\ddot{8}$.

Ojinaga region, Chihuahua : Vivar, 3.

Yachuca district, Jidalgo: Winchell, H. V., 1.

Sau Juan de los Llanos, Puebla: Wittich, 11.

Southern Oaxaca: Palmer, R. H., 9.

Tlalpujahua district, Michoacan : Flores, 1 ; Villa faña, A., 1.

Vera Cruz-Puebla, Tecolutla-Misantla region : Hisazumi, 1.

Lconomic geology.

Ahumada lead mine, Chihuahua : Rickard, 10.

Asientos-Tepezala district, Aguascalientes: Anderson, G. E., 2, :.5.

Barite: Wittich, 18.

Cananea, Sonora, ore injection: Mitchell, 11.

supergene enrichment of copper : White, C. H., 3.

Caridad mine, Sonora: Wandke, 5.
Mexico-Continued. . .

Economic geology-Continued.

Chiautla, Puebla : Wittich, 25.

Coal and graphite, Sonora : Paredes, 6.

Coal and petroleum: Obregon, 1.

Colorado region, Sonora: Honigmann, 1.

Copper, Sonora: Tovote, 1.

Zacatecas: Keyes, 153.

Cuyutlan area, Colima: Paredes, 3.

Durango: Zubiría y Campa, 1.

El Chico, Hidalgo: Wittich, 9.

El Oro district, Mexico: Flores, 1.

El Tigle district, Sonora: Mishler, 1.

Feldspar-chalcopyrite rock-ore, Sonora: Spurr, 34.

Fluorite: Wittich, 13.

GuadaJcazar, San Luis Potosi: Wittich, 5 .

General: Wittich, 27.

Gold, Mezquital, Zacatecas: De Silva 1.

Gold and silver, El Oro district, Mexico: Winchell, H. V., 1.

Graphite: Garcia, 1.

Sonora: Flores, 2 ; Honigmann, 4, 5, b.

Guadalcazar, San Luis Potosi: Wittich, 4.

Guanacevi, Durango: Terrones Benitez, 1.

Guanajuato mining district: Wandke, 8.

Guerrero, central: Santillán, 1.

northern: Santillán, 2.

Hermosillo district, Sonora : Honigmann, 2 .

Huautla, Morelos: Wittich, 25.

Iron, Bravo Valley, State of Mexico: Paredes, 11.

Cerro de Mercado, Durango : Salazar Salinas, 4.

Guanajuato, Jalisco, and Michoacan : Paredes, 10.

Hidalgo: Paredes, 2.

Isthmian oil fields: Redfield, A. If., 1..

Jalisco: Navarro, 1.

Limestone replacement deposits: Prescott, 1 .

Mica: Cervantes, 2.

Mineral resources: Wittich, 23.

Durango: Rangel, 1.

Mineralized zones, Durango-Sinaloa : Santillán, 3.

Talisco-Navarit: Barrera, 1.

Sonora : Flores, 5, 6.

Nacozari district, Sonora, Pilares mine: Wade, W. R., 1.

Oil fields: Hartley, 2 ; Huntley, L. G., 1 ; Sansom, 1.

eastern Mexico: Staub, 4.

southern Mexico: Ver Wiebe, 3.

Tabasco: Ver Wiebe, 4.

Tehuantepec Isthmus: Ver Wiebe, 6 .

Oil possibilities, Lower California: Wilhelm, 2, 
Mexico-Continued.

Economic geology-Continued.

Ore deposits : Lewis, S. J., 1.

Onyx marble, Puebla: Wittich, 28.

Pachuca district: Hulin, 4.

Panuco oil fleld: Baker, C. L., 8; Tol'res, 1.

Petroliferous formations of Tampico embayment : Semmes, 5 .

Petroleum : Huntley, L. G., 1 ; Iglesias, 1 ; Ortega, G., 1 ; Shaw, 3.

bibliography : Mexico, Dept. Petrol., 1. Chiapas and Tabasco: Vivar, 1.

indications, Pacific coast: Aguilar, 1.

islands in Gulf of California : Paredes, 5.

Isthmus of Tehuantepec: Huntley, S., 1.

Lower Cálifornia : Bustamante, 1, 2. occurrence and origin: Juarez, 1.

Panuco district: Baker, C. L., 7 .

Panuco River valley: Trager, 5.

southern Tamaulipas: Ord6ñez, 1, 2. submarine deposits: Urbina, 1.

Tabasco: Jones, W. F., 3.

Tabasco and Chiapas: Lajous, 1.

Petroleum geology in Mexico: Hartley, 1.

Potash : U. S. G. S., 15.

Primary chalcocite, Cananea : Mitchell, 10.

Puerto de Nieto, Guanajuato; Gálvez, 1.

Quicksilver: Segura, 1; and gold placers, Guadalcazar, San Luis Potosi: Wittich, 7.

Guadalcazar, San Luis Potosi: Wittich, 11:

Salt, Puebla: Wittich, 28.

Salt domes, formation: Lajous, 3.

Tehuantepec Isthmus: Ver Wiebe, 7.

San Jose de Guaymas district, Sonora : Honigmann, 3.

Santa Barbara, Parral district, Chihuahua: Schmitt, 2.

Sierra Madre: Taft, 1.

Sierra Mojada district, Coahuila : Shaw, S. F., 1.

Silver: De Iongh, 1 .

Pachuca district, Hidalgo, Mexico: Winchell, H. V., 1.

Sinaloa: Pagliuchi, 1.

Sonora: Flores, 2, 4; Arizpe district, Las Chipas mine: Montijo, 1 ; Lucky Tiger mine: Mishler, 2 ; minerallzed areas: Mitchell, 3 ; ore deposits: Tovote, 2.

Sulphides, relation to water level: Lucke, 1.

Sulphur: Cervantes, 1.

San Luis Potosi : Wittich, 6.

Tecuanapa field, Vera Cruz: Allera, 1.

Tehuantepec Isthmus: Ver Wiebe, 5 .

Tepetate-Chinampa oil pool, graphic model: Huntley, L: G., 2.
Mexico-Continued.

Economic geology-Continued.

Tepezala - Asientos, Aguascalientes : Villafaña, E., 1.

Tin: Garcta, 2.

Tin placer deposits: Sampson, E. H. S., 1.

Tlalpujahua di st rict, Michoacan: Flores, 1; Villafaña, A., 1.

Yoquivo district, Chihuahua: Hall, C. W., 1.

Zacamixtle ofl pool: De Golyer, 3.

Zacatecas, Mazapil district, Santa Rosa mine: Barrera, 3.

Zimapan district, Hidalgo: Brinsmade, 1 .

Zinciferous chalcocite, Sinaloa: Eich. ler, 1.

Zona minera entre los minerales de Atotonilco el Chico y Zimapán, Hidalgo: Flores, 3.

\section{Historical geology.}

Asientos-Tepezala district, Aguascalientes: Anderson, G. E., 2.

Boring, Idolo Island, Vera Cruz: Dumble, 6.

Carboniferous, P e r e grin a Canyon: Girty, 9.

Catorce district, San Luis Potosi : Baker, C. L., 3.

Cedros Island and Turtle Bay, Lower California, Pliocene: Jordan, E. K., 3.

Chapala region : Palmer, R. H., 1.

Chapeño salt a o m e, Tamaulipas: Belt, 1.

Chiapas and Tabasco: Vivar, 1.

Cretaceous: Hill, R. T., 5.

Zacatecas, Durango, and Guerrero: Böse, 6.

Zumpango, Guerrero : Burckbardt, 1.

Cretaceous, Lower, Nazas, Durango: Burckhardt, 2.

Cretaceous and Tertiary, northern MexIco: Bose, 8; Tatum, 1.

Devonian, Coahuila: Haack, 1.

East coast: Wittich, 24.

El Chico, Hidalgo: Wittich, 9.

El Tigre district, Sonora: Mishler, 1.

General : De Iongh, 1; Lewis, S. J., 1; Wittich, 27.

Geologic map: Mexico, Secr. Agr., 1.

Geologic maps, list: Salazar Salinas, 1.

Guadalcazar, San Luis Potosi : Wittich, 4.

Guerrero: Paredes, 1.

Hidalgo, Atotonilco el Grande: Wittich, 10.

Hidalgo and Vera Cruz: Palmer, R. H., 4.

Jurassic, Tamazunchale, Slerra Madre Oriental: Heim, 3.

'Lower Callfornia: Darton, 10 ; Johnston, I. M., 1.

Distrito Sur: Bustamante, 2.

La Purisima region: Heim, 1. 
Mexico-Continued.

Historical geology-Continued.

Marine Wilcox : Dumble, 4.

Mesozoic formations: Goranson, 1.

Mesozolc history : Stanton, 1.

Nacozari district, Sonora: Wade, W. R., 1.

Northeastern Mexico: Böse, 7.

Oil fields, eastern Mexico: Staub, 4.

Panuco district: Baker, C. I., 7, 8; 'Torres, 1.

Panuco River valley: Trager, 5.

Permian, Coahuila: Böse, 5 ; Haack, 1.

Petroliferous area of eastern Mexico: Ver Wiebe, 1.

Pleistocene, Oaxaca coast: Palmer, $R$. H., 2.

Puerto de Nieto, Guanajuato: Gálvez, 1.

Salado arch, Nuevo Leon and Tamaulipas: Jones, R. A., 3.

Section along Rio de San Lorenzo, Sinaloa: Brown, W. H., 2.

Sonora: Flores, 2.

Carboniferous: Mitchell, G. J., 12.

Southern Mexico, Mesozoic: Palmer, R. H., 7 .

oil fields: Ver Wiebe, 2.

'Iabasco: Jones, W. F., 3 ; Ver Wiebe, 4.

Tajo de Andonegui, Tampico: Wittich, 19.

Tamaulipas, southern: Ordoñez, 2.

Tamaulipas and Nuevo Leon: Vivar, 2.

Tampico district: Belt, 2.

'Jehuantepec Isthmus: Huntley, S., 1. Ver Wiebe, 5 .

Tepexi, Puebla: Diaz Lozano, 2.

'lertiary, Lower California : Heim, 2.

Valle de Toxi, Ixtlahuaca: Diaz Lozano, 1.

Velasco formation, Tampico Embayment region: Cushman, 17.

Yoquivo district, Chihuahua: Hall, C. W., 1

Mineralogy.

Alabandite, Puebla: Wyckoff, 3 .

Castillite, Durango : Kalb, 1.

Catalogue of minerals: Mexico, Inst. Geol., 1.

Clinozoisite, Lower California: Rogers, A. F., 20.

Cocinerite, Ramos, San Luis Potosi : Hough, 1.

Danburite, La Sirena near Zimapan: Kupferbürger, 1.

Dumortierite, Guadalcazar : Wittich, 14,15 .

General : Foshag, 33.

Geographic distribution of minerals : Mexico, Inst. Geol., 2.

Meteorite, Cumpas, Sonora: Palache, 17.

Signal Mountain, Lower California : Merrill, 19.
Mexico-mentinued.

Mineralogy-Continued.

Minerals in granite, Guadalcazar: Kratzert, 1.

Selenite caves, Naica: Foshag, 29.

Stephanite, Sultepec: Shannon, 41.

Sundry minerals: Wittich, 22, 26.

Faleontology.

Apiocrinus, Tebuantepec: Springer, 10.

Balanocrinus, Tamaulipas: Springer, $\mathbf{5}$.

Carboniferous, Peregrina Canyon: Girty, 9.

Cedros Island and Turtle Bay, Lower California, Pliocene: Jordan, E. K., 4.

Cephalopoda, Jurassic, Oaxaca and Guerrero: Burckhardt, 3.

Chitons, Pleistocene, San Quintin Bay, Lower California : Berry, S. S., 2.

Corals, western Mexico: Palmer, R. H., 8.

Cretaceous, ammonites: Böse, 9.

Lower California: Anderson, F. M., 4.

Zacatecas, Durango, and Guerrero: Böse, 6 .

Zumpango, Guerrero: Burckhardt, 1.

Cretaceous, Lower, Nazas, Durango: Burckhardt, 2.

Devonian, Coahuila: Haack, 1.

Diatoms, Valle de Toxi, Ixtlahuaca : Diaz Lozano, 1.

Dinosaur, Coahuila: Janensch, 1.

Echinoids, Neogene, eastern Mexico: Lambert, 2.

San Rafael and Tuxpam beds, 'lampico region: Israelsky, 2.

El Consuelo, Oaxaca, cycadeoids: Wieland, 22.

Elephas, Tepexpan, Mexico: Díaz Lozano, 4.

Eocene fauna, Moctezuma River: Cushman, 21.

Foraminifera: Cusbman, 22, 36.

Chapapote formation : Cole, W. S., 2. Guayabal formation: Cole, W. S., 1. southern Mexico, Tertiary: Nuttall, $\boldsymbol{z}$. Tampico Embayment area: White, M. P., 1; Velasco shale: Cushmau, 26.

Gulf of California, Pliocene: Hanna, G. D., 29 .

Jurassic, Symon, Zacatecas: Burckhardt, 1.

Mastodons and elephants: Freudenberg, 2 .

Miocene, Lower California : Hertlein, 4. marine diatoms, Maria Madre Island: Hanna, 27.

plants, southern Mexico: Berry, 48.

Mollusca, Pleistocene, San Quintin Bay, Lower California: Dall, 4, 5; Jordan, E. K., 3.

Ochetoceras, phylogeny : O'Connell, 6.

Pectens, Tertiary, Lower California:

Hertlein, 1.

Permian, Coahuila : Haack, 1. 
Mexico-Continued.

Paleontology-Continued.

Pleistocene, Mammalia: Furlong, 1.

San Quintin Bay, Lower California : Orcutt, C. R., 1.

Pliocene, Maria Madre Island: Jordan, E. K.. 2.

Polylepidina, Cretaceous, Cardenas: Galloway, J. J., 9.

Proboscidea: Hay, 29.

Quaternary Mollusca, Lower California : Jordan, E. K., 1.

Rudistids, San Felipe formation : Stanton, 4.

southern Mexico : Palmer, R. H., 7.

Tamaulipas : Stephenson, L. W., 1.

Spirulirostra, Tehuantepec: Berry, 61.

'Iuronian ammonite fauna, Mexico: Böse, 3.

Upper Triassic: Smith, J. P., 3.

Vertebrate fossils, Mina Erupcion, Chihuahua: Eaton, G. F., 2.

Vicksburg Mollusca, Vera Cruz: Cooke, C. W., 18.

\section{Petrology.}

Eruptlve rocks, Minillas, Cerro Prieto, Pichagua, and Sierra de Ramirez: Bonillas, 2.

Guerrero: Bonfllas, 1 ; Zumpango del Rio: Waitz, 1.

Lower California: Hirschi, 2, 4. southern: Gálvez, 7.

San Martin Tuxtla volcanic area: Friedlaender, 7 .

San Quintin volcanic field, Lower California : Woodford, 6 .

Volcanic ash: Wittich, 15.

Guadalcazar, San Luis Potosi : Wittich, 20.

Volcanic sand, Popocatepetl: Martínez Quintero, 1.

Physical geology.

Callche and pseudo-anticlines: Price, 10.

Caves in lava, Pedregal: Wittich, 1.

Coast elevation: Wittich, 21; Lower California: Wittich, 8.

Cordllera, dynamics: Fletcher, 1.

Crazing of mountain massifs, Lower California: Keyes, 24.

Desert phenomena, San Luis Potosi : Wittich, 2.

Earthquakes :- Muñoz Lumbier, 1. Guadalajara, 1912 : Waitz, 1

January 3, 1920 : Salazar, S., 2. Orizaba : Friedlaender, 3.

Sonora, 1887 : Agullera, J. G., 1.

Mexico (State) : Jaeger, 1, 2.

Mountain chains: Staub, 3.

Northeastern Mexico, structure : Bisse, 7 .

Popocatepetl: Camacho, 3: Heim, 4 activity 1923-4: Mullerried, 1.

eruption: Atl, 1 ; Friedlaender, 4, 5 ; Waitz, 4.
Mexico-Continued.

physical geology-Continued.

Rhyolitic eruptions and faulting between Aguascalientes and San Luis Potosi : Waitz, 6.

Salt domes, formation : Lajous, 3.

San Martin Tuxtla volcanic area : Friedlaender, 7.

San Quintin volcanic fleld, Lower Calffornia: Woodford, 6.

Seismology in Mexico: Muñoz Lumbier, 1.

Veining, Sierra de las Cucaras, Baja Californla : Keyes, 101.

Volcanoes: Waitz, 3.

Volcanic activity, extinct, northerstern Mexico: Staub, 1.

Volcanic phenomena, Pedregal de San Angel: Wittich, 3.

Physiographic geology.

Glacier, Popocatepetl: Weitzberg, 1

Holnitos, Jorullo: Sapper, 2.

Indications of glacial action : l'rister, 1.

Ixtaccibuatl : Paredes, 7.

Lower California: Davis, W. M., 4; Nelson, E. W., 1.

La Purisima region: Heim, 1.

Sonora, island mountain topography: Waibel, 1.

Yucatan Peninsula: Huntley, T. G., 5. Underground water.

Altar district, Sonora: Blazquez, 1.

Artesian basin of Zavala, San I Juis Potosí : Paredes, 8.

Colima : Galvez, 6.

Hidalgo, Tlanalapan: Camacho, 1.

Ixtaccihuatl : Paredes, 7.

western slope: Paredes, 9.

Magdalena and Altar basins, Sonora: Alcala, 1.

Morelia Valley, Michoacan : Camacho, 3

Puebla, Valsequillo: Camacho, 2.

Queretaro, southeastern: Camacho, 5.

Saltillo, Coahulla : Gálvez, 8.

San Luis Potosi : Gálvez, 3, 4, 5; Hernández, 1, 2.

Tepexi, Puebla: Diaz Lozano, 2.

Zacatecas: Alcalá, 2.

Zacatecas and San Iuls Potosi : Blazquez, 2.

Micat.

Alabama: Clark, G. II., 1.

General: Hobson, 1 ; Schaller, 3 ; sterrett, 1.

Geology : Lewis, J. V., 7.

Idaho, Latah County: Anderson, A. L., 1.

Mexico: Cervantes, 2.

United states: Sterrett, 1.

Michigan.

General: Raasch, 1.

History of surveys: Allen, R. C., 3, 4.

Meteor, southwestern Michigan, November 26, 1919 : Hobbs, 14.

Publications relating to Michigan geology : Mich. G. S., 1. 
Michigan-Continued.

Reports of Douglas Houghton: Houghton, 1.

Areas described.

Menominee County: Ver Wiebe, 9.

Roscommon County: Ver Wiebe, 8.

Economic geology.

Clays and shales: Brown, G. G., 1.

Copper, Lake Superior region: Lang, S. S., 2 ; Spurr, 3.

native, Nonesuch formation: Nishio, 1.

Copper district: Guck, 1 ; porphyry intrusions : Lang, S. S., 1; Woods, 1. Gogebic iron rainge: Hotchkiss, 7 . Gypsum : Stone, 11.

Iron, Gogebic range: Hotchkiss, 1.

Lake Superior region: Royce, 1 ; Winchell, A. N., 2.

Mineral resources: Allen, R. C., 1; Smith, R. A., 1, 2, 4, 5.

metallic minerals: Pardee, F. G., 1. nonmetallic minerals: Poindexter, 1. Oil development: Smith, R. A., 3.

Oll and gas development: Newcombe, 1. Saginaw oil field: Carlson, 3 .

Salt deposits : Phalen, 1.

Silver, native, Nonesuch formation: Nishio, 1.

Historical geology.

Alpena County : Ver Wiebe, 10.

Cataract formation: Ehlers, 7.

Chippewa County: Ver Wiebe, 11.

Collingwood formation : Ruedemann, 15.

Drill core section, Detroit: Vanderwilt, 1.

Coral deposits: Case, 25.

General: Pohl, 1.

Gogebic Range: Hotchkiss, 1.

Huronian formation, correlation: Allen, R. C., 2 ; Lane, 4.

Huronian slate areas, Baraga County: Barrett, 1.

Lake Superior iron deposits: Royce, 1.

Niagaran, northern peninsula: Ellers, 4.

Pre-Cambrian: Cooke, H. C., 19 ; Leith, 16.

Racine formation, northern peninsula: Ehlers, 3.

Richmond formation, northern Michigan : Hussey, 1.

Salina formation: Vanderwilt, 1.

Surface formations, map: Leverett, 14.

Stonington region, northern Michigan : Hussey, 1.

Mineralogy.

Eakleite, Isle Royale: Foshag, 13.

Float copper: Kraus, 4.

Isotropic quartz, Iron River: Winchell, 10.

Keweenawan copper deposits: Palache, 15.

Meteorite, Rose City, Ogemaw County: Hovey, 6, 7, 8.
Michigan-Continued.

Mineralogy-Continued.

Seneca Township, Lenawee County: Merrill, 53.

Paleontology.

Algal deposits, Huronian: Twenhofel, 3.

Cephalopoda, Alpena: Foerste, 23.

Cystoids, Trenton, Escanaba River: Hussey, 3.

Devonian crinoids: Ehlers, 9.

Devonian gastropod and cephalopod: Ehlers, 5.

Elephant, Oakland County : Sherzer, 2.

Grand Ledge Carboniferous fauna: Kelly, W. A., 1.

Hamilton fauna, southeastern Michigan : Ehlers, 12.

Heterolasma, Silurian, $\mathbf{M}$ a $\mathrm{c}$ k i n a c County: Ehlers, 3.

Lipsanocystis traversensis, Devonian cystid : Ehlers, 6.

Mastodon, Gratiot County : MacCurdy, H.' M., 1.

Silurian Cephalopoda, northern Michigan: Foerste, 17.

Petrology.

Grünerite rocks, Lake Superior region, origin: Richarz, 9.

Peridotite, Presque Isle: Creveling, 1. Physical geology.

Erosion, Seul Choix Point Peninsula: Ehlers, 1.

Geotherms of Lake Superior copper country : Lane, 15.

Marlite balls: Kindle, 22.

Ordovician reef, Sulphur Island: Ehlers, 8.

Singing sands, Lake Michigan: Richardson, W. D., 1.

Physiographio geology.

Camp Custer area: Leverett, 1.

Dunes, Lake Michigan shore: Parkins, 1 ; Scott, I. D., 2.

Kalamazoo area: Leverett, 5.

Lakes, inland: Scott, I. D., 1.

Northern peninsula, glaciation: Leverett, 7 .

Shore lines, Elsie and Perrinton quadrangles: Leverett, 2.

Saginaw basin: Leverett, 6 .

Surface formations, map : Leverett, 14. Michipicoten district, Ontario: Collins, W. H., 1.

Michipicoten gold area, District of A'lgoma, Ontario: Gledhill, 7.

Microbarograph : Dodge, 1.

Microchemical reactions: Lindgren, 13.

Micrology, Texas, Denton County, Cretaceous: Winton, 3.

Micrometer, recording, for rock analysis : Wentworth, 12.

Microthermal observations on oil shales: Stadnichenko, 2

Microthermal study of carbonaceous rocks : Stadnichenko, 1. 
Mid-Continent oil field, paleogeography and historical geology: McCoy, 4.

Mid-Continent region, structural geology : Powers, 16.

Migration of geosynclines: Grabau, 1.

Military geology.

Wngineering geology in and after the war: Berkey, 2.

General : Bennett, L. F., 1; Brooks, A. H., 1 ; Bryan, K., 1.

Geology, use for military purposes: Vaughan, 5.

Geology in the Students' Army Training Corps: Gregory, H. E., 3.

Military and geologic mapping: Bateman, A. M., 1.

Military contribution of civilian engineers : Smith, G. O., 4.

Physiography, rôle in military operations: Bryan, 6.

United States Geological Survey, war work: Smith, G. O., 12.

War work by department of geology, University of Oregon: Smith, W. D., 4.

Mineral deposits: Lindgren, 1, 23.

Mineral industry of Utah: Lewis, J. V., 2. Mineral paints.

Georgia, Cartersville, ocher deposits: Haney, M., 2.

Mineral pipes, formation: Locke, 7.

Mineral resources (general). See also Economic geology under names of States.

Alabama: Jones, W. B., 3, 4 ; Maynard, T. B., 2 ; Smith, E. A., 4.

mineral production: Jones, W. B., 1, $2,5,11$.

Alaska: Brooks, 13 ; Smith, P. S., 6, 12.

Arizona : Rowe, J. P., 5 ; Tenuey, 1.

Navajo country: Reagan, 22.

Arkansas : Branner, G. C., 1, 3; Ferguson, J. G., 2.

British Columbia: Brewer, 3; Davis, A. W., 2 ; Nichols, H. G., 1.

Lardeau and Trout Lake mining divisions: Emmens, 2.

California : Bradley, W. W., 4, 7, 8, 9 ; Hamilton, F., 2 ; Symons, 1.

Canada: Adams, F. D., 1 ; Graham, R. P. D., 2, 3 ; Malcolm, 7, 8; Van Leckwyck, 1; Young, G. A., 5.

Hudson Bay region: Wallace, 16.

Colorado: Colorado, 1 ; George, R. D., 6.

Cuba : Calvache, 2.

Isla de Pinos: Allende, 1.

Oriente: Aguilera, E., 1.

Pinar del Rio: Allende, 2, 3.

Florida: Gunter, 6-10.

General : White, D., 21.

Georgia : McCallie, 4, 5; Maynard, T. P., 2.
Mineral resources (general)-Continued.

Greenland: Ball, S. H., 4.

Idaho, mining report for 1927 : Campbell, S., 7.

Illinois, Calhoun County : Lamar, 6.

LaSalle region: Buzzard, 1.

Iowa: Kay, 13; Lees, 8, 11, 13, 14, 16.

Kansas: Moore, R. C., 37.

Kentucky: Crouse 4; Jillson, 68, 74, 85.

Labrador: Coleman, 22.

Louisiana: Howe, H. V. W., 6.

Maine: Burr, 2.

Manitoba : Wallace, 10, 13, 18, 19.

east central : Wright, J. F., 9.

nonmetallic: Wallace, 18.

Maryland: Mathews, 6.

Mexico: Wittich, 23.

Michigan : Smith, R. A., 2, 4, 5. metallic minerals: Pardee, F. G., 1. nonmetallic minerals: Poindexter, 1.

Mississippi : Lowe, 11, 12.

Missouri : Buehler, 4, 5, 8.

Nevada : Lincoln, 1.

Newfoundland: Snelgrove, 1.

New Jersey: Twitchell, 2, 3, 4, 6.

New York: Hartnagel, 2, 6.

Nonmetallic minerals: Ladoo, 4.

North Carolina: Bryson, 1, 2 ; Drane, $1,3$.

Nova Scotia: Anon., 34.

Ohio: Bownocker, 9; Peattie, 1.

Oklahoma: Gould, 6; Redfield, J. S., $1,2$.

Ontario: Corless, 2 ; Ontario Dept. Mines, 1 ; Rogers, W. R., 3-5.

Fennsylvania, Adams County: Stose, 25.

Quebec: Dresser, 2 ; Dufresne, 5. mineral deposits: Alcock, 19.

South : Payne, 1.

South Carolina: Calhoun, 2.

South Dakota: Ward, 13.

Tennessee: Nelson, 19.

Tennessee River basin: Cudworth, 1; Smith, A. F., 1.

'lexas: Sellards, 20.

United States: Loughlin, 20, 28.

Vermont: Perkins, G. H., 8, 10, 13.

Virginia: Watson, 17.

Washington: Shedd, 4.

West Virginia: White, I. C., 6.

Wyoming, Natrona County : Hagens, 1. Platte County: Bartlett, 6.

Mineral separation, apparatus for: Fraser, F. J., 1.

Mineral supplies, United States: McCiaskey, 1.

Mineral water: Collins, W. D., 1-4; Ellis, A. J., $2-4$.

Colorado: George, R. D., 1.

West Virginia, Mercer, Monroe, and Summers counties: Reger, 9.

Mineralization along the dikes of southern Vermont: Bray, 1. 
Mineralography of the feldspars: Alling, 3. Mineralogical phase rule: Bowen, 18.

Mineralogy (general). For areal see nanjes of States. See also Crystallog. raphy ; Meteorites; Technique.

Acmite and aegirite: Washington, 28.

Acmitic pyroxenes: Washington, 35.

Agate: Farrington, 2 ; Harstad, 2.

Åkermanite-gehlinite: Ferguson, J. B., 4.

Alabandite, crystal structure: Wyckoff, 3.

Alkalies in rocks and minerals, determination: Shannon, 72.

Allanite, composition: Watson, 6 .

Almandite-spessartite garnet, Maryland: Sbannon, 75.

Aluminum sillcate minerals: Wherry, 28.

Alumogen, nontronite, and grifflthite: Lar'sen, 20.

Amblygonite-montebrasite series, properties and composition: Winchell, 20.

Amethyst and smoky quartz, pigınents : Holden, 13.

Amethyst, color: Holden, E. F., 14.

Amphibole group : Winchell, 6.

Amphiboles, monoclinic: Winchell, 13.

Analcite, Brewster County, Texas: Ionsdale, 12

sedimentary : Ross, C. S., 22.

structure determined by oscillation method : Gruner, 12.

Anisotropism in metallic minerals : Sampson, 10.

Anorthosites, origin: Lodochnikow, 1.

Anthophyllite: Shannon, 21.

optical properties: Bowen, 8.

Anthraxolite, Mackenzie: Rutherford. 10.

Apatite, crystallography : Whitlock, 19

Arfvedsonite, riebeckite, and crocidolite, Greenland : Gordon, S. G., 20.

Argentite and acanthite: Emmons. R. C., 2 ; Schneiderhöhn, 1.

Arsenides of iron, cobalt, and nickel. rate of oxidation: Walker, 43 .

Atomic volume isomorphism : Wherry. 25.

Azurite: Palache, 21.

Babingtonite: Washington, 26.

Becke reaction: McCaughey, W. J., 1.

Boidellite: Ross, C. S., 20.

Bentonite: Ross, C. S., 12.

as a one-dimensional colloid : Wherry. 27.

Beryl crystal, Black Hills: Waldschmidt, 1.

Beryllonite, Newry, Maine: Palache, 32.

Biaxial calcite : Gillson, 9.

Bindheimite as an ore mineral : Shannon, 9.

Biotite : Grout, 12.

pleochroic halos: Kerr-Lawson, 3.
Mineralogy (general)-Continued.

"Blythite" and Amelia manganese gar. net: Shannon, 70.

Boracite, chemical formula: Gruner. 13.

Bornite as a furnace product : Guild, ธ.

Bornite and pyrrotite, antipathy : Gilbert, G., 3.

Bornite-chalcopyrite intergrowth, British Columbia : Uglow, 4.

Calcites, behavior to radjum radiations: Headden, $\overline{\mathbf{a}}$.

Chester County, Pennsylvanla: Gordon, 23.

force of crystallization : Rothrock, 2.

luminescence: Headden, $6, \boldsymbol{t}$.

primary: Walker, 40.

Calcite oolites of pentagonal dodecahedral form, Idaho: Shannon, 69.

Camsellite and szaibelyite, identity : Schaller. 15.

Canfield collection: Merrill, 5i.

Carnotite, crystalline, Utah : Uess, 30.

Carrollite, identity with linnacite: Shannon, 66.

"Ceruleofibrite" is connellite: Holden, 8.

Chalcopyrite and cubanite intergrowths, significance: Schwartz, 18.

Chalmersite, occurrence: Schwartz, 2.

Chemical relationships of minerals, chart: Putnam, P. C., 1.

Chert and flint,' origin: 'Tarr, 1.7.

Chlorite: Winchell, 26 ; as a polycomponent system: Winchell, 1.6.

Chlorophoenicite, Franklin, New Jersey: Foshag, 28.

Citrine, transmission of light: Holden, 11.

C'lay minerals: Ross, C. S., 24.

Clerici solution for mineral separation by gravity : Vassar, 1.

Colloid chemistry, application to mineralogy : Fisher, L. W., I.

Color in rose quarty, cause: Holden, $9,12$.

Columbia River Plateau, chlorphaejte, sideromelane, and palasonite: Peacock, 1.

Copper deposits, Parry Sound, Ontario : Sehwartz, 8.

Creedite, Colorado: Fosbag, 9.

Crystal cleavage and crystal structure: ITurgins, 1.

Crystal structure, analysis by $\mathrm{X}$ rays : Bragg, 1.

Crystul structure of some metallic sulphides : Ramsdell, 1.

Crystal structures of calcites : Wyckoff, R. W. G., 1.

Crystal symmetry: Rogers, A. F., 23.

Crystal types, relation to modes of occurrence: Tarr, 4.

Crystallographic tables: Goldschmidt, V., 1. 
Mineralogy (general)-Continued.

Crystule: Keyes, 187.

Giubanite, identity with chalmersite: Merwin, 5.

Dachiardite: Berman, 1.

Density of minerals, measurement : Adams, L. H., 2.

Determination of common minerals and rocks, tables for: Tarr, 7 .

Determination of ore minerals: Davy. 1.

Determinative mineralogy : Lewis, 4. manual: Warren, C. H., 1.

technique : Putnam, P. C., 3.

Development of methods: Walker, 23.

Dolomite, crystal structure: Wyckoff, 6.

Double dispersion method of mineral determination : Emmons, R. $C_{m} 6$.

Doubtful mineral species: Winchell, 17.

Drawing crystals: Slawson, 1.

Dumortierite: Bowen, 21; Grawe, 5 .

Dyscrasite and the silver antimony constitution diagram: Schwartz, 25.

Economic mineralogy: Bowles, 2.

Ectropite and bementite, identity : Larsen, 19.

Elasticity of some minerals: Johannsen, 8.

Electrical conductivity of ore minerals : Fairbanks, 8.

Enstatite, hypersthene, and actinolite: Washington, 19.

Enstatite and clino-enstatite: Wyckoff, 5.

Epidote, Alaska: Matthes, 1.

Euxenite, Sabine township, Nipissing district, Ontario: Ellsworth, 21.

Feldspar group: Winchell, 14.

Feldspars, mineralography : Alling, 3.

Field book: I.oomis, 8.

Ferromagnetic ferric oxide: Sosman, 10.

"Finger prints" of minerals: Winchell, 22, 23.

Florence Pilkington Manchester collection: Wherry, 15.

Fossil bone: Rogers, A. F., 19.

Franklin minerals, phosphorescence and fluorescence: Palache, 29.

Friedelite and schallerite: Bauer, $L$. H., 3.

Friedel's law of rational symmetric intercepts: Rogers, A. F., 24.

Gageite and tephroite, probable identity: Gordon, S. G., 21.

Garnet: Myers, 2.

Garnet group, X-ray determination : Stockwell, 2.

Garnets, mineralogy : Myers, 4.

Gems and gem materials: Kraus, 5.

Gems and precious stones in U. $\mathrm{U}$. National Museum: Merrill, 18.

General: Whitlock, 16, 20.

$4096-31-55$
Mineralogy (general)-Continued.

Germanite: Thomson, E., 7.

Gilpinite and Johannite, identity : Larsen, 17.

Glauconite: Schneider, 3.

formula: Hallimond, 3.

optical properties and chemical composition : Ross, C. S., 17.

Goniometer, two-circle: Bascom, 3 ; Palache, 1.

Green color of ferrous minerals : MacCarthy, 6.

Grünerite, Lake Superior region : Richarz, 7,8 .

Gypsum, debydration : Parsons, A. L. 13.

Gypsum and anhydrite: Wilder, 4.

Hastingsite group of amphiboles : Billings, 6.

Heat, effects on properties of mineruls : Lonsdale, 1.

Heavy minerals, Mid-Continent field, criteria for recognition: Edson, 2 .

Hematite and rutile: Merwin, 2.

Hematite inclusions in Lake Superior amethyst: Holden, E. F., 14.

Heulandite, thermo-optical properties: Slawson, 2.

Hexagonal and trigonal minerals : Wherry, 8.

History and outlook: Kraus, 3.

Hornblende: Graham, W. A. P.. 2.

Humite group, optical properties : Larsen, 24

Hydrated ferric oxides: Posnjak, 1.

Hydroboracite, California : Schaller, 16.

Hydromagnesite, crystallography : Rogers, A. F., 15.

Hydrotalcite group : Foshag, 2.

Hydrous sulphates, United Verde mine, Jerome, Arizona : Lausen, 6.

Idaho, Atlanta district: Shannon, 79.

Iddingsite : Ross, C. S., 11.

Identification of minerals: Grawe, 4.

Intergrowth of certain minerals : Newhouse, 2.

Iron coloration: MacCarthy, 3.

Iron bydroxide minerals: Merwin, 1.

Isometric minerals : Wherry, 6 .

Isomorphism of albite and anorthite: Zambonini, 1.

Isomorphous siderite and calcite : Johnson, J. H., 1.

Isotropic quartz, Iron River, Michigan : Winchell, 10.

Keeleyite: Wherry, 32.

Kernite: Gale, H. S., 6; or rasorite : Palmer, L. A., 4.

Keweenawan copper deposits: Palache, 15.

Keweenawite: Thomson, E., 9.

Lead, native, Idaho: Shannon, 73.

Lead and copper sulpho-salts, isomolphic relations: Foshag, 11.

"Lehnerite" and ludlamite, identity : Berman, 2. 
Mineralogy (general)-Continued. :-

Leucoxene in Permian Mid-Continent sediments : Brown, L. S., 1.

Leverrierite, schist-forming mineral: Corbett, 2.

Lillianite and galenobismutite : Walker, 5.

Lithium pegmatites, genesis: Schaller, 7.

Louisite : Walker, T. L., 57.

Magnetite: Gruner, 10 ; Newhouse, 6 ; Wagner, P. A., 5.

Magnetite-martite-hematite, oxidation of : Gruner, 8.

Manganese minerals: Thiel, 2. identiflcation : Fairbanks, 2.

Marcasite, stalactitic forms: George, H. C., 3.

Melanterite and chalcanthite minerals : Larsen, 4.

Melilite, composition: Winchell, 9; genesis: Bowen, 15.

Melilites, natural and synthetic: Buddington, 5 .

Merrillite and chlorapatite in stony meteorites: Shannon, $\mathbf{5 3 .}$

Method for checking index of a liquid : Rutherford, 2.

Methods for heavy mineral investigations: Reed, 4.

$\mathrm{MgSiO}_{3}$ and $\mathrm{AlAlO}_{3}$, isomorphous relations: Winchell, 25.

Mica group : Hallimond, 1, 2 ; Winchell, $11,24$.

Microscopic determination of nonopaque minerals: Larsen, 6; of minerals in sections: Johannsen, 6.

Mimicry of minerals: Whitlock, 18.

Mineral names: Eakle, 10.

Mineral localities: Biernbaum, 2.

Mineral replacements in pegmatites: Schaller, 13.

Minerial separation in a finely divided state: Emmons, R. C., 7.

Mineralogic instruction, needed extension : Eakle, 8.

Mineralogical laboratory, University of Michigan : Kraus, 1.

Mineralogical Society of America, proceedings of annual meetings: Van Horn, 1-5, 8-13.

Mineralography : Thomson, E., 2. . of the feldspars: Alling, 5.

Minerals, determination: Ellis, R. W., 4.

of the rarer elements: Lee, O. I., 2.

Model cutting machine: Palache, 24.

Modern study of mineralogy : Washington, 30 .

Molecular migration and mineral transformation: Wandke, 7.

Monoclinic minerals: Wherry, 10.

Morgan memorial hall of American Mu. seum of Natural History: Whit lock, 13.
Mineralogy (general)-Continued.

Morgenthau collection: Whitlock, 10 .

Mullite, silicate of alumina: Bowen, 16.

Muscovite, composition: Winchell, 27.

Names for symmetry classes based on axes: Wherry, 31.

Natrojarosite, Arizona: Shannon, 76.

New crystal forms of minerals: Whitlock, 14

New mineral names: Ford, 1.

New minerals: Foshag, 12; Wherry, $14,16$.

New Jersey, Franklin; Palache, 30 ; and Sterling Hill: Palache, 28.

norbergite: Larsen, 23.

Niobium, tantalum, and titanium, determination: Todd, E. W., 1.

Oblique illumination in mineragraphy: Myers, 1.

Obsidian Cliff, Yellowstone National Park: Foshag, 23.

Olivine, Hawaiian Islands: Aurousseat, 3 .

Opaque minerals, examination: Thomson, E., 2.

identification : McKinstry, 5, 6.

Optic angle of crystal, determination : Phemister, 1.

new method for measuring: Johannsen, 7 .

Optical mineralogy: Winchell, N. H., $1,2$.

Ore minerals, electrical conductivity: Kerr, P. F., 5.

plastic deformation: Buerger, 3.

Orthorhombic minerals: Wherry, 9 .

Oxidation of iron in magnetite: Gilbert, G., 6 ; Twenhofel, L. H., 1.

Pearls: Wright, K. E., 5.

Pegmatites, origin: Schaller, 13.

Phlogopite, zonal, pleochroic, twinned : Walker, 41.

Phosphorescence and luminescence in calcites: Headden, 4.

1.'lagioclase feldspars, determiáation: Goranson, 2.

as a case of atomic isomorphism: wherry, 19.

Plancheite and shattuckite: Schaller, 1. Pleochroic halos: Kerr-Lawson, 2.

Pollucite: Fairbanks, 11.

Potash-soda feldspars: Alling, 11.

Preparing specimens : Levison, 1.

Preservation of mineral specimens: Parsons, 6, 12.

Pucherite, pyrite, trichalcite, and wavellite: Sbannon, 34.

Pseudo-isomorphism as illustrated in thomsonite: Wherry, 29.

“Pseudomorphous" quartz: Morgan, P. G., 1.

Pyrite, crystallography: Whitlock, 15.

Pyrite and marcasite, alternating deposition: Tarr, 18.

Pyrite group: Thompson, E., 1. 
Mineralogy (general)-Continued. l'yroxene group: Winchell, 5.

Pyroxenes, X-ray diffraction patterns: Wyckoff, 5 .

Quartz, color of three varieties: Holden, 7.

in meteoric stones: Merrill, 37.

inversion in chalcedony: White, W. P., 1.

spectograph in mineral analysis : 'Todd, E. W., 2.

Quartz-diamond intergrowth : Colony, 5. Radioactive minerals, Canada: Ellsworth, 8 ; as age indicators: Ellsworth, 6 ; Ontario : Ellsworth, 3.

Radio-detector minerals: Wherry, 26.

Recognition of minerals in crushed rocks: Johannsen, 11.

Refractive indices, determining: Winchell, 18.

measuring under the microscope: Nakashima, 1.

Relation of hardness to sequence of ore minerais: Gilbert, G., 2.

Replacement crystals, form: Fairbanks, 5 .

Rock minerals, comparative losses in crushing and sifting: Johannsen, 10.

Roebling collection: Merrill, $\mathbf{5 5}$.

Rossite and metarossite, San Miguel County, Colorado: Foshag, 31

Rotation apparatus: Kerr, P. F., 3.

Rutlle: Holden, 4.

Scapolite, properties : Winchell, 7 .

Searlesite, crystallography: Rogers, A. F., 17.

Seligmannite, Bingham, Utah: T'alache, 33.

Sequence of mineralization, Keystone pegmatites : Landes, K. K., 6.

Sorpentinization : Creveling, 1.

Shattering of minerals and rocks about inclusions: Walker, 27.

Silica, nomenclature: Hart, 2.

Silica minerals, natural history: Rogers, A. F., 30.

Silicates, alteration by Sonstadt's solution: Walker, 22.

Sillimanite: Bowen, 17.

silver minerals, microscopic features: Guild, 6.

Silver sulphide, crystal structure: Ramsdell, 3.

Skeleton quartz crystals: Bain, 7.

Soil mineralogy: Burt, 1.

Species names for mineral groups: Van Horn, 7 .

Spectroscopy applied to mineral determination: Douglas, G. V., 1.

Spencerite, dehydration: Walker, 11. Sperrylite, Sudbury, Ontario, crystal structure: Aminoff, 1.

Standards for hardness of minerals: Talmage, 2.
Mineralogy (general)-Continued.

Stannite and associated minerals: Schwartz, 5.

Strain structure in quartz, Ducktown, Tennessee: Kelr, P. F., 6.

Structure of crystals: Wyckoff, 2.

Sulphate minerals in ore deposits: Butler, B. S., 3.

Sulphide minerals, nomenclature and classification: Wherry, 11.

Sulpho-salt minerals, classification : Wherry, 13.

Sundry minerals described: Ford, 1; Gordon, S. G., 17.

Surfuce of a crystal: Wherry, 24.

Sussexite, optical data: Poiterin, 7.

Symmetry classes, arrangement : Wherry, 33.

Tables for recognition of minerals: Lane, 2.

Tabulation of crystal classes: Rogers, A. F., 32 .

Tellurides: Thomson, E., 8, 14.

Tetragonal minerals: Wherry, 7.

Tetrabedrite-tennantite system, chemical constitution: Winchell, 19.

Textbook: Dana, 2 ; Kraus, 2, 8 ; Roger's, A. F., 5 .

for beginners: Dana, 1.

Thaumasite, constitution: Holden, 5 .

Thumsonite, composition: Gordon, S. G., 15; Wherry, 21.

optical notes : Gordon, S. G., 13.

Thucholite, Parry Sound, Ontario: Ellsworth, 19.

Thucholite and uraninite, Wallingford mine, Buckingham, Quebec: Ellsworth, 20.

Time factor in artificial minerals : Peck, A. B., 3.

Topaz, etching figures: Honess, A. P., 1.

Torbenite, abnormal birefringence: Bowen, N. I., 2.

Trevorite: Walker, 29.

Triclinic minerals, list: Wherry, 12.

Triclinic pyroxenes: Winchell, 21.

Valuation of minerals: English, G. I., 1

Variscite and peganite, identity : Larsen, 13.

Vein quartz, microscopic study : Adams, S. F., 2.

Volume isomorphism in silicates: Wherry, 20.

Weissite, Colorado: Crawford, W. I'. 1.

Wentworth recording micrometer, improved: Hunt, W. F., 3.

X-ray autographs of minerals: Winchell, 22, 23.

$X$-ray determination of minerals : Mead, 3.

Xanthoconite, Atlanta district, Idaho: Shannon, 79.

Zeolites, composition: Winchell, 12.

Grant County, Oregon: Hewett, 21. 
Mineralogy (general)-Continued. Zircon, North Burgess, Ontario: Palache, 31.

Minerals, microscopical determination in section: Johannsen, 6.

Minerva oil field, Milam County, Texas: Hager, D. S., 1.

Mingan Islands: Twenhofel, 26.

Miniature hoodoos: Schroeder, 2.

Mining geology : Locke, 1.

Mhnesota.

Bibliography: Gregory, W., 1.

Mesabi ilon range: Niemi, 1.

General : Willard, D. E., 1.

Minnesota, geology of the name: Sardeson, 6.

Areas described.

Herman, Barrett, Chokio, and Morris quadrangles: Sardeson, 1.

St. Louis County, northern: Grout, 20.

Economio geology.

Biwabik iron-bearing. formation, east Mesabi district: Broderick, 2; nature and origin: Grout, 5.

Clay: Grout, 1, 11; texture and composition: Grout, 16 .

Copper veins, Susie Isḷand, Lake Superior: Schwartz, 26.

Cuyuna iron ore district: Zapffe, 2, 5 ; iron-bearing member, correlation: Zapffe, 3.

Cuyuna range: Thiel, 12.

Foundry sands: Knapp, G. N., 1.

Iron, Cuyuna range: Thiel, 9.

Gunflint district: Broderick, 3.

Mesabi range: Gruner, 5 ; Wolff, J. F., 1.

Iron sulphides in magnetic belts near the Cuyuna range: Thiel, 5.

Iake Superior region: Winchell, A. N., 2.

Magnetite deposits, East Mesabi range : Grout, 3.

Magnetite pegmatites, northern Minnesota : Grout, 9.

Magnetite segregation in banded syenite: Grout, 19.

Magnetite slates, Cuyuna range: Thiel, 7.

Manganese, Cuyuna range: Thiel, 4.

Manganiferous iron ores, Cuyuna district: Zapffe, 1.

Mesabi iron ores: Parsons, A. B., 1 ; Schwartz, 4.

enrichment: Allison, I. S., 2.

Mesabi magnetic ores, origin: Grout, 7.

Mesabi range ores: Gruner, 2.

Native silver in an iron mine, Cuyuna range, Crosby : Lane, 18.

Oil and gas possibilities: Stauffer, 7 .

Origin of Biwabik iron formation : Gruner, 3.

Peat: Soper, 1.

Portland cement materials: Sardeson, 5.
Minnesota-Continued.

Economic geology-Contiuued.

Potash in shales: Schmitt, 1.

Shale: Grout, 1.

Vermilion iron ores origin: Gruner, 0.

Historical geology.

Beloit formation and bentonite: Sardeson, 22.

Cretaceous, northern Minnesota: Allison, I. S., 4

routchiching: Grout, 15.

Cuyuna iron ore district: Zapffe, 2.

Vevonian: Stauffer, 2, 3 .

Wast Mesabi range: Grout, 3.

General: Grout, 2; Stauffer, 7.

Geologic history: Meinzer, 11.

Geologic section: Keyes, 118.

Giants Range batholith: Allison, I. S., 1.

Gunflint iron district: Broderick, 3.

Jordan sandstone: Stauffer, 5.

Lake Superior geosyncline: Hotchkiss, 8 .

Mesabi range: Gruner, 3, 5.

Ordovician, southeastern Minnesota : Sardeson, 30.

Paleozoic rocks: Keyes, 229.

Pre-Cambrian: Cooke, II. C., 19; Leith, 16.

northeastern Minnesota: Grout, 22.

Red Clastic series, age: Stauffer, 9.

Rove slate area: Grout, 23.

St. Croix Valley: Peterson, E., 1.

St. Louis County, northern: Grout, 20.

St. Peter sandstone: Dake, 6; Sardeson, 21.

Shakopee dolomite: Sardeson, 20.

Shore line of Galena seas: Sardeson, 27.

Soudan formation: Gruner, 9 .

Surface formations: Ieverett, 4 .

Type outcrops, Minnesota River valley : Sardeson, 12.

Vermilion batholith: Grout, 18.

Vermilion granite: Grout, 9.

Volcanic ash, Ordovician: Sardeson, 13.

Windrow formation: Thwaites, 2.

\section{Mincralogy.}

Mesabi range: Gruner, 5.

Stilpnomelane: Grout, 13.

Xonotlite, Mineral Center, Cook County : Schwartz, 6.

Xonotlite and pectolite in a diabase pegmatite: Schwartz, 11.

Paleontology.

Algae, Archean: Gruner, 4.

Beloit formation: Sardeson, 24.

Bison : Hays, 17.

Cremacrinus: Sardeson, 31.

Elephant remains: Stauffer, 4.

Hudsonaster: Sardeson, 33.

Ordovician : Stauffer, 10.

Ordovician clams, habit: Sardeson, 15.

Ordovician kelp, sponges, and burrows: Sardeson, 18. 
Minnesota-Continued.

Paleontology-Continued.

Organic structures, Biwabik ironbearing formation: Grout, 4.

Primitive cephalopods : Sardeson, 17.

Starfishes, Decorah shale: Sardeson, 32.

Strophocrinus and Carabocrinus: Sardeson, 16.

Petrology.

Anorthosite and granite of Pigeon Point: Grout, 27.

Diabase sill, Pigeon Point: Grout, 26.

Uuluth gabbro, basal phases: Nebel, 3.

Buluth lopolith: Bowen, N. I., 1.

East Mesabi range: Grout, 3.

Ely greenstone, granite and gabbro intrusions: Schwartz, 7.

Giants Range batholith: Allison, I. S., 1 .

Grünerite rocks, Lake Superior regiciı origin : Richarz, 9 .

Kekequabic granite, northeastern Min. nesota : Stark, 1.

Shonkinite, St. Louis County : vrout, 17.

Sulphide diabase, Cook County: Schwartz, 12.

Vermilion batholith: Grout, 1 .

Plysical geology.

Anorthosite and granite of Pigeon Point: Grout, 27.

Block faulting, St. Croix Valley : Peterson, E., 1.

southeastern Minnesota: Sardeson, 28.

Granite, weathered, twice metamorphosed: Allison, I. S., 3.

Intraformational phosphate pebbles, Twin City Ordovician: Pettijohn. 1.

Ladder veins: Grout, 10.

Mesabi range cherts, origin: Gruner, 7.

Mineralization of the Platteville-Decorah contact zone, Minneapolis-St. Paul region: Stauffer, 7 .

Physiographic geology.

Buffalo Plains, origin : Sardeson, 10.

Driftless Area, erosional history : Trowbridge, 1.

Eskers: Sardeson, 8.

Glacial drift sheets: Sardeson, 3.

Mille Lacs: Sardeson, 9.

South half of Minnesota: Leverett, 4. Minnesota and Mississippi rivers, drainage changes : Sardeson, 6.

Minto coal basin, New Brunswick: Dyer, 8. Minturn district, Wyoming: Thom, 19.

Miocene. See Tertiary.

Miscellaneous. See also Addresses.

Abstracting geologic literature: Keyes, 141.

Agricultural geology : Smith, J. E., 2.

Airplanes for geologic exploration : Renick, 7 .
Miscellaneous-Continued.

American geologists, number : Powers, 8.

Appalachian field trip : Morse, W. C., 1. Bibliographies: Lindgren, 25.

Borderland of astronomy and geology : Eddington, 1.

Colloids in geologic problems: Hubbard, G. D., 2.

Composition of geological literature: Wentworth, 30.

Continents and oceans, origin: Wegener, 1.

Contributions of geology to engineering : Ries, 16.

Cooperation in geology: DeGolyer, 6 .

Decadence of geology (?) : Bastin, 11 ; Keyes, 172.

Economic geologist: DeGolyer, 8.

Education of a geologist: Brock, 2; Lindgren, 8.

Employment of geologists: Sardeson, 2.

Engineering geology in and after the war : Berkey, 2.

Field trips in geology : Morse, W. C., 3.

Fundamental problems in geology: Chamberlin, T. C., 29.

Geodetic work, value to geology : Bowle, 8.

Geologic teaching in mining engineering: Dake, 11.

Geologists as expert witnesses: Ran. some, 5.

Geologists as witnesses in mining litigation: Leith, 4.

Geologists in the United States, geographic distribution: Sellards, 22.

Geology, U. S. National Museum : Merrill, 26.

a growing science: Bastin, 11.

and geography in the United States: Mathews, 5.

as a basis of citizenship: Pogue, 1.

as a synthetic science: Smith, iv. D., 3.

as a profession: Little, 2 .

as an aid to air navigation: Christie, 1.

at Johns Hopkins University : Keyes, 21.

in rural welfare: Smith, J. E., 6.

in the law: Kemp, 4.

in the Students' Army Trainlng Corps : Gregory, H. E., 3.

Investigation versus propagandism : Chamberlin, T. C., 3.

International geological congresses : Kemp, 27.

Marking geologicnl features: 'Troxell, 24.

Microscope and the decadence of geology: Cady, 10; Eng. and Min. Jour.-Press, 3 ; Joralemon, 1.

Microscope in geology: Waldschmidt, 7. 
Miscellaneous-Continued.

Modern geology and its contribution to engineering : Leighton, 13.

National Research Council, functions : Fenneman, 1.

division of geology and geography, work of : Lawson, 5.

Oil geology and science: Heald, 13.

Outlook for geology : DeWolf, 1.

Penrose medal : Kemp, 22.

Petroleum geology, contributions to geologic science : DeGolyer, 4.

Place of modern languages in geological research : Barrell, 3 .

Plain geology : Smith, G. O., 14.

Pre-Cambrian life, medal: White, D. 38

Preparation in geological communication : Keyes, 145.

Profession of ore-hunting : Locke, 1.

Piollication for geological abstracts: Tilley, 1.

Publisbing geological information: Geijer, 3.

Quantitative studies: Hubbard, G. D., $9,10,11$

Radium and geology : Snowden, 1.

St. Francis dam disaster: Longwell, 17 ; Iouderback, 9.

Sclentific by-products of applied geology: Smith, G. 0., 10.

Sources and tendencies in American geology : Barrell, 2.

State geological surreys and economic geology : DeGolyer, 11.

Stories in stone: Lee, W. T., 17.

Strategy of minerals: Smith, G. O., 2

'Technical papers and their presentation: Knapp, A., 2.

Training of geologists: Mathews, 5 .

United States Geological Survey as a civic institution during the war: Paige, 1.

Mispec group, New Brunswick: Mathew, G. F., 3.

Misisissippl

Geological Survey, reports: Iowe, 1, $5,6,8$.

Geology : Lowe, 2

Hconomic geology.

Amory gas fleld: Jillson, 96, 99.

Bauxite deposits: Adams, G. I., 3; Morse, P. F., 1.

northeastern Mississippi : Burchard, 20.

Bentonite : Grim, 2.

Clay : Ries, 5.

Gypsum: Stone, 11

Mineral resources: Lowe, 10, 11; 12

Oil and gas prospecting: Grim, 1; Lowe, 3, 7.

Oil possibilities, Easton, 1 .

Petroleum prospecting: Lowe, 9: Morse, P. F., 2.

Road-making materials: Lowe, 4.
Mississippi-Continued

Historical geology.

Borings : Lowe, 3, 9.

Byrain calcareous marl: Cooke, C. W., 7 .

Cretaceous : Berry, 4.

Eocene formations, correlation : Cooke, C. W., 12.

General: Easton, 1; Lowe, 3, 4, 12, 13 ; Stephenson, 10.

Paleozoic: Morse, W. C.. 4; in borings, Tishomingo County: Bram. lette, 4.

Ripley greensands: Needham, 1.

Stratigraphy : Lowe, 9.

Subsurface formations: Grim, 1.

Mineralogy.

Meteorite, Baldwin: Glenn, 7; Merrill, 41 .

Palahatchie, Rankin County: Merrill, 40.

Paleontology.

Byram calcareous marl: Cooke, C. W., 7.

Cretaceous floras: Berry, 4.

Eocene mollusks, Jackson: Cooke, C W., 15.

Foraminifera, Byram marl : Cushman, $11,13$.

Vicksburg group: Cushman, 16.

Globldens, Selma chalk, Lee County : Gilmore, 34

Mint Spring marl: Cushman, 14.

Pleistocene plants: Berry, 6 .

Red Bluff clay, Hiwannee: Howe, H. V., 11.

Physiographic geology.

General : Lowe, 12.

Underyround water.

General: Lowe, 12 ; Stephenson, 10. Mississippi River, temporary course in Iowa: Schoewe, 4.

Mississippian. See Carboniferous.

Mississippian faunal zones: Weller, 12.

Mississippian orogenic movements: Van Tuyl, 2.

Missourt.

Bureau of Geology and Mines, activities: Buehler, 7, 9.

Reports of State geologist: Buehler, $1,2,4,6,8$.

Water resources: Brckman, 1.

Areas described.

Ste. Genevieve County: Weller, 19.

Vernoll County: Greene, 8.

Economic geology.

Barite: Tarr, W. A., 1.

Clay: Thornberry, 1.

Coal : Brodie, 2.

analyses: Fieldner, 7 .

Coal areas: Thom, 14.

Cobalt-nickel-copper-lead d e p os its, Fredericktown : Tar'r, 9.

Diaspore and flint fire clays: McQucen, 1.

Diaspore clay: Wysor, 1 : 
Missouri-Continued.

Economic geology-Continued.

High-temperature vein, Madison County : Tarr, 12.

Iron ores, Iron Mountain and Pilot Knob: Spurr, 33.

lead and zinc deposits: Keyes, 114.

Mineral resources: Buehler, 1, 2, 4, $\overline{5}, 8$.

Oil and gas: Wilson, Malcolm E., 1.

Sand and gravel resources: Dake, 1.

Southeast Missouri ore magmatic listrict: Spurr, 31.

Zinc-lead field: Naething, 2.

Historical geology.

Atchison shales: Keyes, 287.

Balley limestone, Little Saline Creek area : 'Tansey, 1.

Barite areas: Tarr, W. A., 1.

Carboniferous: Williams, H. S., 1.

Chester series: Ulrich, 5.

Cooper limestone, central Missouri: Greger, 2.

Dakota sandstone: Keyes, 53.

Devonian: Branson, 2 ; Savage, 14. along the Missouri River: Branson, 5.

central Missouri ; Greger, 1.

Ozark region : Keyes, 87.

Ozark uplift, outlier : Bridge, 1.

General: Dake, 1 ; Folger, 1.

Geological map: Buehler, 3.

Geology and stratigraphy: Wilson, Malcolm E., 1.

Kimmswick limestone: Bradley, J. H., jr., 4.

Kimmswick and Plattin limestones: Foerste, 9.

Kinderhook group : Moore, R. C., 1.

Lexington limestone: Keyes, 287.

Little Saline limestone, Ste. Genevieve County : Stewart, G. A., 1.

Louisiana limestone, northeastern Missouri : Williams, J. S., 1.

Mineola dome, northeastern Missouri : Whorton, 1.

Mississippi Valley: Krey, 2.

Mississippian series: Branson, 10 ; Moore, 41.

Ordovician nomenclature: Keyes, 106.

Ozark region: Dake, 13.

Ozark uplift, age: Keyes, 86.

Paleozoic formation margins: Branson, 6.

Pennsylvanian unconformities: Hinds, I.I., 2.

Ferry and Girardeau counties: Flint, 4. Plattin formation, Ste. Genevieve County : Fenton, C. L., 8.

St. Louis formation: Grawe, 2.

St. Peter sandstone: Dake, 6; Sardeson, 21.

Section, Meramec Highlands, St. Louis County : Shipton, 1.

Warren County to Jackson County : Branson, 1.
Mollusca-Continued.

Historical geology-Continued.

Silurian, northeastern Missouri : Keyes, 42. southeastern Missouri : Flint, 2.

Mineraloyy.

Einstein silver mine, Madison County: Ross, C. S., 15.

Madison County: Tarr, 8.

Meteorite, Kansas City : Merrill, 3.

Paleontology.

Bailey limestone fauna: Tansey, 1.

Black River Brachiopoda: Fenton, C. L., 5.

Coal floras, Henry County : Round, 5.

Devonian: Branson, 5. central Missouri : Greger, 1.

Kimmswick and Plattin limestones: Foerste, 9.

Little Saline limestone fauna, Ste. Genevieve County: Stewart, G. A., 1.

Mississippian: Moore, 41.

l'ennsylvanian ostracodes, Henrietta formation : Knight, J. B., 1.

Plattin formation, Ste. Genevieve County: Fenton, C. L., 8.

Stropheodonta demissa, evolution in Snyder Creek shales: Branson, 4.

Strophomena, Black River: Fenton, C. L., 9.

Upper Devonian and lower Mississippian faunas, relationship: Branson, 8.

Physical geology.

Aqueous loess : Todd, J. E., 2.

Breccias of St. Louis formation : Grawe, 2.

Concretions, Boone County, origin: Tarr, $\mathbf{5}$.

Crystalline rocks of the plains: Gould, 3.

Mississippi Valley, structure: Krey, 2.

Septaria, Pennsylvanian shale, St. Louis: Grawe, 2.

Syngenetic origin of pyrite concretions in Pennsylvanian shales: Mathias, 1 .

Thrust faults, southeastern Missouri : Flint, 3.

Physiographic geology.

Drainage changes, Missouri Valley: Todd, J. E., 4.

General : Keyes, 183.

Glacial boulders, Columbia, source: Wilkerson, 1.

Glacial deposits : Leverett, 13.

Glaciation, southeastern Missouri : Leverett, 15.

Nebraskan drift, northern Missouri : Shipton, 2.

Ozark Highland: Sauer, 1.

Relief map: Keyes, 181.

Streams on nortbern slope of Ozark l'Iateau: Tarr, 13. 
Missouri-Continued.

Physiographic geology-Continued.

Subterranean stream piracy in the Ozarks: Dake, 10.

Underground watcr.

Ebb and flow springs, Ozarksं: Bridge, 2.

General : Beckman, 1.

Moab region, Utah: Baker, A. A., 1.

Models for determining structure of bedied rocks : Mehl, 3

Moffat Tunnel, Colorado: Lovering, 7.

Mogollon mining district, New Mexico : Ferguson, H. G., 3, 8.

Moingona River, preglacial: Keyes, 15.

Molding sand: Hole, 1.

Geology : Trainer, 1.

Illinois : Littlefield, $2,3$.

Iowa, eastern: Smith, J. E., 15.

Kentucky: Richardson, C. H., 12.

Maryland : Trainer, 2.

New York, Hudson Valley: Nevin, 1.

Ohio: Bownocker, 5, 6.

Pennsylvania : Stone, 20.

Wisconsin : Trainer, 3.

Mollusca. See also Cephalopoda; Gastropoda ; Invertebrates (general) ; Pelecypoda.

Alabama, Eocene: Aldrich, T. H., 1.

Alaska, Peard Bay region, Pleistocene : Meek, 1.

Pliocene and Pleistocene: Dall, 2.

Alberta, Coloradoan: McLearn, 10.

Paskapoo formation: Russell, L. S., 1.

Alum Bluff group : Gardner, J. A., 7.

Arctic coast, Pleistocene: Dall, 9.

Atlantic Coastal Plain, Tertiary: Palmer, K. V. W., 1 .

Barbados, Scotland beds: Trechmann, 6.

Briones fauna, California: Trask, 2.

British Columbia, Hazleton group : McLearn, 11.

Vancouver Island, Sooke formation: Clark, B. I.., 8.

California, Channel Islands: ITertlein, 6.

Coyote Mountain: Hanna, 25.

Martinez Eocene: Nelson, R. N., 2.

Meganos fauna: Clark, B. L., 18.

San Lorenzo group : Wagner, C. M., 1.

Sonoma County, Miocene lacustrine mollusks: Hanna, G. D., 7.

Trion fauna: Anderson, F. M., 1.

Vaqueros and Temblor formations: Wiedey, 1

Canada, Brock River, Tertiary: Dall, 9.

Carolinas, Cretaceous: Stephenson, 9.

Chitons, Plelstocene, San Quintin Bay, Lower California : Berry, S. S., 2.

Colorado, Cretaceous: Reeside, 17.

Costa Rica, Miocene: Palmer, K. V. W., 4.

Cretaceous, Santa Ana Mountains: Packard, 4.
Mollusca-Continued.

Cuba, Jurassic: Sánchez Roig, 2.

Dominican Republic, Tertiary : Pils bry, 1.

Eocene, southwestern Texas: Gardner, J. A., 2.

Virginia: Palmer, K. V: W., 1, 2.

Eocene and Oligocene: Cooke, C. W. 10.

Evo:ution: Grabau, 11.

Florida, St. Lucie Canal: Johnson, C. W., 1.

Tertiary and Quaternary: Mansfield, W. C., 1.

Gulf States, Pleistocene and Pliocene: Maul'y, 5.

Haiti, lertiary: Woodring, 7.

Hawaiian Islands, Oahu: Ostergaarı, 1.

Idaho formation, Snake River valley : Dall, 10.

Illinois, Joliet, Pleistocene: Baker, F. C., 9.

Ioess deposits: Baker, F. C., 13; Alton : Baker, F. C., 4.

P'eistocene: Baker, F. C., 8, 11, 12

Indiana, Pleistocene Mollusca: Baker, F. C., 3.

Jamaica, Bowden, Miocene: Woodring, $10,22$.

Cretaceous: Trechmann, $\mathbf{5}, 8$

Richmond formution, Tertiary : Trechmainn, 4.

Yellow limestone: Trechmann, 3.

Kansas, Wallace County, Pleistocene : Hanna, G. D., 5.

Louisiana, Pliocene: Smith, E. R., 3.

Maryland, Wailes Bluff, Pleistocene: Smith, E. R., 1.

Massachusetts, Boston Basin boulder clay: Morse. E. S., 1.

Mrxico, Cretaceous : Böse, 6

Lower California, Cedros Island and Turtle Bay, Pliocene: Tordan, E. K., 4; San Quintin Bay: Jordan, L. K., 3 ; Dall, 4 ; Miocene : Hertlein, 4 ; Quaternary : Jordan, E. K. 1.

Maria Madre Island, Pliocene: Jordin, E. K., 2.

Miocene and Pliocene, Coastal Plain: Gardner, J. A., 4.

Mississippi, Jackson, Eocene: Conke, C. W., 15.

New York, Utica and Lorraine formations: Ruedemann, 18.

Nomenclature: Dall, 8 ; rectifications : Hanna, G. D., 13 ; Henderson, 3.

North Carolina, Castle Hayne and Trent marls : Kellum, 2.

Miocene : Mansfield, W. C., 7.

Ohio, Logan County, Pleistocene: Baker, F. C., 2.

marl deposits: Sterki, 1.

Pleistocene Mollusca: Baker, F. C., 3. 
Mollusca-Continued.

Ontario, Ottawa district, marl deposits: Whittaker, 1.

Oregon, Coos Bay, Empire formation: Howe, H. V. W., 2.

fresh-water Mollusca: Hanna, G. D., 6.

John Day Bașin : Hanua, G. D., 2.

Orygoceras, Tertiary, Idaho: Dall, 7. Pacific region, Cretaceous : Reagan, 7 .

1'leistocene; - Goldring, 3 .

Porto Rico, Tertialy : Mary, 3.

San Pedro fauna, Nob Hill cut, California : Oldroyd, T. S., 3.

South Carolina, Miocene: Gardner, J. A., 1.

Tennessee, Ripley fauna: Wade, B., 3. 'Tertiary, Porto Rico: Hubbard, B., 1.

'Tertiary and Quaternary, California region: Smith, J. P., 1.

Texas, Bastrop County, Cook Mountain Eocene: Price, W. A., 12.

Denton County, Crateceous: Winton, 3.

Eocene: Gardner, J., 11.

San Saba County, Mississippian: Girty, 7.

Weno and Pawpaw formations: Adkins, 2.

Trinidad: Palmer, K. V. W., 1.

Miocene faunas: Maury, $\$$.

Northern Range: Trechmann, 7.

Trinitasia : Maury, 9.

Utah, Cretaceous : Reeside, 17.

Vicksburg Mollusea, Vera Cruz, Mexico: Cooke, C. W., 18.

Virginia, Miocene: Mansfield, IV. C., 7.

Washington, Big Hope Island, Pleisto. cene: Henderson, J., 9.

Eocene: Weaver, 3.

San Juan Islands, Cretaccous: MeLellan, 2.

Western North America: Hertlein, 2. West Indies 'Tertiary : Cooke, C. W., 1.

West Indian, Central American, and European Miocene and Pliocene: Woodring, 9.

Molluscoidea. See Brachiopoda; Bryozon. Molybdenum.

Alaska, Healy River : Chapin, 5.

British Columbia, Clinton district: Reinecke, 2.

Lillooet-Prince George region: Reinecke, 3.

Canada: Eardley-Wilmot, 1, 2, 4.

Colorado, Climax : Haley, D. F., 1.

I'win Lakes district: Howell, J. V., 1.

General : Eardley-Wilmot, 1 ; Hess, 2 , $7,8,12,13,16,18,19,21$; Shannon, 17.

Idaho: Livingston, 2.

Rocky Bar district: Schrader, 7.

New Mexico, Questa: Sundberg, 1.

Taos County: Larsen, 5.

Nova Scotia, New Ross : Cook, C. W., 5.
Molybdenum-Continued.

Ontario, Ottawn Valley: Wilson, $\mathbf{M}$. E., 3, 4.

Renfrew-Calabogie district: Wilson, M. E., 3.

Quebec, Abitibi : Mailhiot, 6.

Arnprior-Quyon area: Wilson, M. E., 11.

Lacorne and Malartic townships: Gerrie, 1.

Utah, Ouray : Hess, 17.

Moncton area, New Brunswick: Wright, W. J., 2.

Montana.

Areas described.

Beartooth Mountains: Bevan, 1, 2.

Butte district, Silver Bow County: Daly, W. B., 1.

Ekalaka lignite fleld: Bauer, 4.

Fergus County: DeKalb, 1 ; Freeman, 0. W., 1.

Ingomar anticline, Treasure and Rosebud counties: Heald, 18 .

Jefferson River basin: Deeds, 2.

McCarthy Mountain area: Richards, R. W, 2.

Madison River basin: Deeds, 1.

Melrose phosphate fleld: Richards, R. W., 2.

Musselshell and Golden Valley counties : Ellis, A. J., 5.

Scobey lignite field, Valley, Daniels, and Sheridan counties: Collier, 9.

Sweet Grass Hills: Kemp, 8.

Townsend Valley: Pardee, 10.

Economic geology.

Baker gas field: Moulton, 24.

Butte district, Silver Bow County : Daly, W. B., 1; Harter, 1.

Butte veins, minerals: Agar, 3.

Butte mines: Rickard, 5.

Cat Creek oil fleld, Fergus and Garfleld counties: Lupton, 1.

Cat Creek and Devils Basin oil fields: Reeves, I., 10.

Central Montana; examination for oil : Reeves, F., 4.

Chromite deposits: Diller, 1.

Stillwater and Sweet Grass counties : Westgate, 4.

Conl : Rowe, J. P., 3.

Cone domes of oil fields: Sardeson, 4. Copper near Cooke: Lovering, 5.

Crow Indian Reservation: Thom, 4.

Gold, Bannack: Shenon, 1.

Helena district: Anon, 72.

Gold, silver, copper, lead, and zinc: Gerry, 2, 4, 7, 12, 15.

Gypsum : Stone, 11.

Kevin-Sunburst oil fleld: Clark, F. R., 3; Heald, 16; Hendrickson, 1; U. S. G. S., 11.

Lake Basin oil fleld: Bauer, 5.

Magmatic chalcopyrite, Park County : Iovering. 2. 
Montaua-Continued.

Economic geology-Continued.

Manganese : Pardee, 8.

Butte und Philipsburg: Pardee, 3.

Oil and gas, central and eastern Montana: Clapp, C. H., 2.

Oil and gas possibilities: Rowe, J. P., $1,2$.

faulted area south of Bearpaw Mountains: Reeves, F., 8.

Crow Indian Reservation: Thom, 4. Garfleld County : Thom, 3.

Oil developments: Clarke, F. B., 1.

Oil fields, Sweet Grass arch : Perry, 2.

Oil possibilities: Ropes, 1.

laccolithic domes south of Little Rocky Mountains: Collier, 8.

Oil shale: Condit, 2.

Paragenesis of minerals in Butte veins : Lindgren, 22.

Petroleum, central Montana: Reeves, F., 3, 5 .

Quadrant formation : Freeman, O. W., $\therefore$.

Sweet Grass arch: Clapp, C. H., 2. Petroleum and natural gas: Rowe, J. P., 3.

Phosphate, Maxville, Granite County : Pardee, 6.

Three Forks-Yellowstone Park region : Condit, 5.

Secondary enrichment in genesis of Butte chalcocite: Locke, 4.

Soap Creek oil field, Crow Indian Reservation: Thom, 1.

Sunburst oil and gas field : Hager, D., 5 ; Sardeson, 4.

Supergene processes at Neihart: Bastin, 7 ; Hurst, 1.

Stanford hematite deposits: Westgate, 1.

Tullock Creek coal field, Rosebud and Big Horn counties: Rogers, G. S., 8.

Historical geology.

Area south of Bearpaw Mountains : Reeves, F., 8.

Bearpaw Mountains: Reeves, F., 7, 9 Belt formation, Helena: Rothpletz, 1.

Belt series: Sampson, 15; Wilson, R. A., 5.

Belt terrane, Big Snowy Mountains : Freeman, O. W., 3.

Belton district, northwestern Montana: Seashore, 1.

Cat Creek oil fleld, Fergus and Garfield counties: Lupton, 1

Central Montana: Bowen, C. F., 2; Reeves, F., 10.

and eastern Montana: Clapp, C. H., 2. Cat Creek anticline: Reeves, F., 3. Devils Basin anticline : Reeves, F., 5. examination for oil : Reeves, F., 4. Cherry Creek section Madison Valley : Runner, 9.

Colorado group, southern Montana: Reeside, 6.
Montana-Contiuued

Historical geology-Continued.

Cretaceous-Eocene transition beds : Thom, 8.

Cretaceous sedimentation and diastrophism : Hammer, 1.

Fllis formation: Howe, M. A., 4.

Fergus County : Reeves, F., 6.

Crow Indian Reservation: Thom, 4.

Front ranges, Cenozoic history : Bevan, 9.

Garfield County: Thom, 3.

General : Keyes, 234.

Geologic formations, correlation: Lee, W. 'T., 19

Glacier National Park: Fuller, M. B., 9.

Helena region: Rothpletz, 1.

Huntley field : Hancock, 2.

Jordan, Garfleld County, section: Bauer, 6.

Kevin-Sunburst oil field: Clark, F. R., 3 ; Heald, 16 ; U. S. G. S., 11.

Lance-Fox Hills contact, eastern Montana: Dobbin, 2

Little Rocky Mountain reglon: Collier, 8.

Pre-Cambrian : Keyes, 209.

Quadrant formation: Freeman, D. W. 2 ; Hammer, 2.

Quartzite pebbles at base of Lance formation: Bauer, 6 .

Rosebud County: Renick, 3, 5.

Soap Creek oil field, Crow Indian Reservation : Thom, 1.

Stanford district: Westgate, 1.

Stratigraphy, comparative: Bauer, C M., 3.

Sweet Grass arch: Perry, 2.

Tullock Creek coal field, Rosebud and Big Horn counties: Rogers, G. S., 8.

Upper Cretaceous paleogeography: Robinson, E. G., 1.

Western Montana: Condit, 2.

Mineralogy.

Aegirite, Libby : Goranson, 4.

Bismutoplagionite, Wickes, Jefferson County: Shannon, 10, 19.

Boulangerite, Superior: Shannon, 19. Butte, intermediate zone: Agar, 3.

Laumontite : Shannon, 26.

Leuchtenbergite, Phillipsburg: Shannon, 42.

Leverrierite: Ross, C. S., 5.

Sapphires: Harstad, 1.

Witherite, Altyn limestone, Mainy Glacier : Fuller, M. B., 3.

\section{Paleontology.}

Belt formation, Helena : Rothpletz, 1.

Brachyceratops : Gilmore, 14.

Claenodonts, Eocene: Gidley, 2.

Colorado group, southern Montana: Reeside, 6

Cretaceous Mollusca: Reagan, 7.

Edentate, Oligocene: Simpson, G. G., 15 .

Eporeodons, White River beds: Thorpe, 23. 
Montana-Continued.

Paleontology-Continued.

Footprints, Fort Union: Gilmore, 41. Lithothamnium, Ellis format iou: Howe, M. A., 4.

Mammalia, Fort Union formution, southern Montana: Simpson, G. G., 21.

Hell Creek formation: Simpson, $G$. G., 13.

Oreodonts, Oligocene, Three Forks: Loomis, 10.

F'lants, Missoula: Jennings, 1.

Primates, Sweet Grass County: Gidley, 6.

Tempskya knowltoni: Seward, 2.

\section{Petrology.}

Nephelite-hauynite alnoite: Ross, C. s., 9.

Sweet Grass Hills: Kemp, 8.

Physical geology.

Bearpaw Mountains, structure: Reeves, F., 7.

Belt of oblique faulting: Chamberlin, R. T., 2.

Central Montana: Reeves, F., 10.

Larthıuake, June 27, 1925: Byerly, 9; Pardee, 14 ; Willson, 1.

Ellis-Madison unconformity: Collier, 10.

Faulting south of Bearpaw Mountains : Reeves, F., 8.

south of Billings: Moulton, 2.

Folding and faulting, Bearpaw Mountains: Reeves, F., 9.

Glacier National Park, movement of glaciers: Alden, 1.

Landslicle origin of thrust faults around Bearpaw Mountains : Reeves, F., 11.

Rerl bed bleaching: Moulton, 7 .

Yocky Mountains, structure: Mansfiell, 15 .

South Mountain laccolith, Fereus County: Palmer, -H. S., 6.

Structural features, central Montana: Thom, 6.

eastern Montana: Thom, 16.

Thrust faulting adjacent to Highwood Mountains: Reeves, F., 12

rhysiographic geology.

Bitterroot Mountains, glaciation : Russell, J., 1.

Features of glacial origin: Davis, W. M., 8.

Glaciation, Beartooth Mountains : Bevan, 7.

Glacier National Park, scenic features, origin: Campbell, M. R., 2.

Multiple level cirques: Fuller, M. B., 10.

leneplains, Beartooth Mountains, southern. Montana : Bevan, 5.

Swimming Woman Canyon, Big Snowy Mountains, origin: Freemaa, 0 . w., 4.
Montana-Continued.

Underground water.

Base exchange by silicates in grounc water: Renick, 3.

Ground water and natural was, rela tions: Renick, 5.

Musselshell and Golden Valley coun. ties: Ellis, A. J., 5.

Townsend Valley : Pardee, 10.

Mouroe gas field, Louisiana: Stroud, 1.

Moon : Millis, 2

craters, formation: Wright, F. E., 11 impact origin: Beard, 1.

formation : Enmet, 2.

surface: Barrell, 11; Barringer, 2.

Terrestrial and lunar faults compared: Schwarz, 1.

Moose River basin, Ontario: Kindle, 26. Moraines.

Colorado, Estes Park region: Wooster, 1.

Illinois, Morris qualrangle: Culver, 2,7

Michigan, Roscommon County: Ver Wiebe, 8.

Minnesota : Leverott, 4.

New York. Finger Iakes region: 'J'ily lor, 6.

New York moraine, age: De Gerr.

IRochester, Pinnacle Hills : Fuirchila, 13.

St. Lawrence Valley : Taylor, 4.

western : Chadwick, 11.

Ohio, Wayne County : Conrey, 1.

Recessional moraines: Keyes, 232.

between Indiana and New England: Taylor, 7 .

Morrison formation, age: Simpson, G. G., 7 ; type section: Lee, W. T., 1.

Molrison oil field. Pawnee County, Ok!ahoma: Carpenter, E., 1.

Mosses as rock builders: Fmig. 1.

Mounds.

Illinois, Cahokia mounds, origin : Crook, 3.

St. Clair County, Monk's Mound: Crook, 1.

Scabland nrounds, eastern Washington : Freeman, O. W., 5.

Mount Albert area, Quebec: Alcock, 20.

Mount Multnomah, Oregon : Hodge, E. T., 5.

Mount St. Helens, Washington: Jillson, 33.

Nountain pediments, Arizona, Papago country : Bryan, 15.

Mountains. See Orogeny.

Mud cracks: Kindle, 20, 37; Ward, 11; forming over water: Willard, B., 1.

desert: Longwell, 14.

on steeply inclined surfaces: MacCarthy, 1.

Mud Lake basin, Idaho: Stearns, 6.

Muddy Mountains, Nevada: I,ongwell, 15.

Mud flow in semiarid mountains: Blackwèld̦er, 18. 
Mule Creek oll field, Wyoming : Hancock, 4. Museums.

New geological groups, Milwaukee, Public Museum: Edwards, I., 3.

New York State Museum, paleontological work: Ruedemann, 21.

U. S. National museum, reports : Merrill, 7, 14.

Myriapod, Parajulus, Florissant, Colorado: Minor, R. W., 2.

National Research Council, functions: Fenneman, 1.

Natural bridges.

Indiana, Shades: Barrett, E., 3. Owen County : Addington, 4.

Kentucky, Creelsboro: Scott, I. D., 4. Missouri, Ozarks: Dake, 10.

Utah : Paç, 4.

Rainbow Natural Bridge: Elwards, I., 5 ; Miser, 13.

Natural gas.

Alberta : Allan, 21; Dowling, 4 ; Elworthy, 1 ; Hume, 28 ; Ross, C. C., 1.

northern : Elworthy, 4 ; McLearn, 2. Sheep River area: Slipper, 2.

Wainwright area: Emmens, 1; Hume, 10.

Wainw right-Irma area : Hume, 13, 16. Alberta and British Columbia, foothills belt: Hopkins, O. B., 4.

Anticlinal theory: White, I. C., 10.

Appalachian oil and gas fields, greology : Mills, R. V. A., 2.

Arkansas, El Dorado: Pratt, W. E., 3. Smackover oil and gas field: Bell, H. W., 2 .

Beds of continental accumulation: Binney, 2.

Canada: Elworthy, 5, 8: Hume, 20; McLennan, 1 .

Great Plains: Hume, 25.

Colorado, Fort Collins: Ball, M. IV., $2,3$.

northeastern: Mather, 12.

Decreasing supply: Bownocker, 4.

Depletion, Appalachian field: Bownockër, 2.

Eastern United States: Moyer, 1.

Estimation of gas reserves : Versluys, 1.

Gasoline content: Dowling, 4.

General: Johnson, R. H., 7; Lilley, 4 ; McBride, R. S., 1 ; Moore, R. C., 3 ; Panyity, 1 ; Redwood, 1 ; Richardson, G. B., 6, 8; Westcott, 1 .

Helium content: Rogers, G. S., 7.

History, epochs in: White, I. C., 4.

Hydrocarbons, in or ga n i c origin: Young, J. W., 6.

Illinois, Ava-Campbell Hill área : Root, 1.

east central : Mylius, 7.

eastern: Mylius, 6.

oil and gas fields, map : Richardson,
Natural gas-Continued.

Illinois-Continued.

Pike and Adams counties: 'Coryell, 1.

Staunton gas pool : Mylius, 2.

Indiana: Barrett, E., 5; Logan, 5, 10 ; Wright, Floyd E., 1, 2.

Iowa: Howell, J. V., 4.

Kansas: Kesler, 1; Snider, 1.

Allen and Neosho counties: Moore, R. C., 5 .

Anderson County: Charles, 1.

chemical sulvey: Allen, H. C., 1.

Eldorado field: Fath, 2.

Flk City field : Boughton, 1.

map of oil and gas fields: U. S. G. S. 2.

Russell County : Rubry, 3.

Wilson and Montgoinery counties: Moore, R. C., 6.

Kentucky : Jillson, 2, 4, 21, 23, 25, $38,73$.

Allen County : Jillson, 12.

Barren County: Butts, 2.

Boyd County: Jillson, 81, 91, 94.

Breathitt and Knox counties: Jlllson, 13 .

eastern: Fiske, 1 ; Jillson; 5.

Island Creek oil pool, Owsley County : Jillson, 84.

isocarbs and oil and gas production : Russell; W. L., 5.

Warren County: Tillson, 18.

Louisiana: Snider, 1.

Carroll Parish: Spooner, 5.

Cotton Valley fleld: McDonald, W. W., 1 ; Powers, 14.

Map of oil and gas fields: U. S. G. S., 5.

Monroe field: Bell, H. W., 1; Spooner, 1 ; Stroud, 1.

northern: Hull, $\mathbf{5}$.

Pine Island field : Crider, 4.

Spring Hill-Sarepta field: Ponton, 1. Webster Parish : Hull, 7.

Louisiana-Texas, Wascom field : Grimm, 1.

Michigan : Newcombe, 1.

Mid-Continent fields: Snider, 1.

Migration and accumulation by moving underground water: Rich, 3

Migration of oil and gas: Mather, 5 .

Mississippi, Amory field: Jilîson, 99.

Missouri : Wilson, Malcolm E., 1.

Montana: Rowe, J. P., 1-3.

Baker field : Moulton, 24.

central and eastern : Clapp, C. H., 2. Kevin-Sunburst field : Hager, D., 5 ; Perry, 2.

New Brunswick : Elworthy, 7.

New Mexico: Ellis, R. WV., 3.

New York : Newland, 2.

North Dakota : Leonard, A. G., 3.

Ohio, Clinton sand: Russell, W. I., 9. Columbiana County : Stout, 5.

Vinton County: Stout, 6.

Wayne County: Conrey, 1. 
Natural gas-Continued.

Oklahoma: Powers, 20; Suannon, C. W., 1 ; Shaw, 6 ; Snider, 1.

Bristow quadrangle: Fath, 6.

Caddo and Grady counties : Becker, 1.

Carter County, Fox and Grabam fields : George, H. C., 2.

chemical survey: Allen, H. C., 1.

Coal and Pittsburg counties: Clawson, 1.

Crinerville oil fleld, Carter County : Powers. 22.

digest of oil and gas fields: MillsBullard, 2.

Fox field, Carter County, Storm, 3.

Kay, Grant, Garfleld, and Noble counties: Clark, G. C., 3.

map of oil and gas fields: U. S. G. S., 6 .

Marshall County: Bullard, 3.

Okmulgee County: Clark, R. W., 2.

Osage County: Beckwith, H. T., 1.

Osage -Reservation: Goldman, 2, 3 ;

Heald, 1, 3; Hopkins, O. B., 1 ;

Robinson, H. M., 1 ; Roundy, 1.

Pershing oil and gas field : Rubey, 2.

Pontotoc County: Conkling, 1.

Robberson field: Roth, 1.

Sayre field, Beckham County : Birk, 1.

southern (part) : Hopkins, O. B., 2.

Tonkawa field: Hosterman, 1.

Wagoner County: Boyle, 1.

Ontario: Estlin, 1; Harkness, 1-7.

future prospects: Williams, M. Y., 9.

southwestern: Williams, M. Y., 3, 4.

Oregon, eastern: Buwalda, 4.

Origin: Lewis, 9 ; Moore, R. C., 3; Wegemann, 1.

Pennsylvania : Ashley, 11, 16; Pennsylvania G. S., 1.

Greensburg quadrangle: Johnson, M. E., 1.

oil and gas fields, map: Richardson, G. B., 3.

Pore space of oil and gas sands: MeIcher, 1.

Prospecting: Panyity, 1.

Production, reserves, etc.: Arnold, 5.

Reserves, estimation: Ruedemann, P., 1.

Structure favorable for gas accumulathon: Dyer, 6.

Symbols for drilling operations: Mehl, 4. Tennessee : Nelson, 8.

Texas: Snider, 1.

Amarillo district : Harrison, T. S., 1. Currie field, Navarro County : Lahee, 9.

eastern : Dumble, 1.

Petrolia field: Shaw, 6.

Edna, Jackson County : Price, 11.

Jim Hogg County: Jones, R. A., 2.

Panhandle: Bauer, C. M., 8; Pratt, W. E., 8.

Potter County : Patton, L. T., 2.
Natural gas-Continued.

Texas-Continued.

San Patricio County, White Point fleld: Wolf, 3.

Washington County, Clay Creek dome : Labee, 20.

Webb and Zapata counties: Sellards, 13.

Underground water in migration and accumulation of oll and gas: Bonine, 1 .

Unusual natural gases: Lang, W. B., 3.

Utah, Farnham : Calvert, 1.

Waters associated with petroleum and natural gas: Mills, R. V. A., 2.

West Virginia : Reger, 2, 4.

Fayette County : Hennen, 1.

Mercer, Monroe, and Summers counties: Reger, 9.

Nicholas County: Reger, 3.

Webster County: Reger, 1.

Wyoming : Estabrook, 2.

Baxter Basin field: Sears, 7.

Bell Springs district, Carbon County : Dobbin, 5.

Fremont County, Big Sand Draw : Collier, 5 ; Rae, 3.

Golden Eagle fleld: Binney, 2.

Lance Creek field: Hancock, 5.

Laramle and Medicine Bow districts : Bartlett, A. B., 2.

Lost Soldier-Ferris district: Fath, 5. Oregon Basin, Meeteetse, and Grass Creek Basin quadrangles: Hewett, 16.

oil and gas fields, map : Richardson, G. B., 4.

Natural gas in oil migration: Mills, R. V. A., 5.

Nebraska.

Economio geology.

Alkali deposits: Barbour, 1.

Potash : Hicks, 3.

Sand: Condra, 1.

Historical geology.

Conglomerate of Black Hills: Cook, H. J., 4.

Geological section: Keyes, 118.

Granite ridge: Ruby, 1.

Pennsylvanian system: Condra, 2.

Plattesmouth limestones: Keyes, 287.

Sioux County, Agate anticline: Schramm, 2.

Paleontology.

Agate fossil quarry, Sioux County : Matthew, 25; Peterson, 3.

Agriochoerus : Thorpe, 7.

Alligator, Snake Creek beds, Agate : Mook, 5.

Amebelodon fricki, Frontier County : Barbour, 9.

Archidiskodon maibeni, Lincoln County : Barbour, 7, 8.

Avian fossils, Miocene and Pliocene: Wetmore, 4.

Birds, Sioux County : Wetmore, 13. 
Nebraska-Continued.

Paleontology-Continued.

Blastomeryx marshi : Lull, 10.

Caenopus : Troxell, 9.

Diatoms : Elmore, 1.

Diceratheres: Peterson, 2.

Diplolophus, Oreodon beds : Troxell, 19

Elephas scotti, Seward County : Barbour, 2.

Entelodonts: Troxell, 3.

Eporeodon, Scott's Bluff: Thorpe, 8 .

White River beds: Thorpe, 23.

Felidae, White River beds: Thorpe, 2.

Fossil implements in Pliocene deposits : Sci. Serv., 4

Fusulinidae, Pennsylvanian:' Dunbar, 11.

Giraffa nebrascensis, York County : Matthew, 33.

Hawk, Miocene, Agate Springs: Wetmore, $9,11$.

Hesperopithecus, Snake Creek beds: Gregory, W. K., 7 ; Osborn, 18, 21, 22 ; Pycraft, 1; Woodward, A. S., 1 ; Anon., 19.

Hickory logs and nuts, Harrison: Troxell, 29.

Hyracodon, Oligocene, Sioux County : Wood, H. E., 4

Juglans seeds, Titanotherium beds : Berry, 80.

Iongirostrine elephant, Trilophodon, Brown County: Cook, H. J., 16.

Merycoidodon, hyoid a parat us : Thorpe, 19.

Sioux County : Thorpe, 20.

Oligobunis, Sioux County: Thorpe, 5.

Oreodontidae: Thorpe, 4.

Miocene birds: Wetmore, 7 .

Miocene mammals: Matthew, 35.

Miocene oreodonts: Loomis, 11.

Jeccary, Crawford: Cook, H. J., 3.

Peltosaurus, Oligocene : Gilmore, 29.

Pleistocene, western Nebraska: Mat. thew, W. D., 2.

Prosthennops xiphodonticus, peccary, Cherry County: Barbour, 3.

Pseudo-artifacts, Pliocene: Nelson, N. C., 1.

Radial exostosis in Daphoenus : Romer, 3.

Rhinoceros bone bed, Agate: Cook, L. M., 1.

Snake Creek fauna : Matthew, W. D., 2.

Stegomastodon : Osborn, 33.

Stenomylus, hyoid arch, Sioux County : Peterson, 4.

Tertiary artiodactyls: Lull, 4.

Tetrabelodon abeli, Brown County : Barbour, 6.

\section{Petrology.}

Hackberry conglomerate: Barbour, 5.

Physical geology.

Fulgurites : Anderson, A. E., 1; Barbour, 4.

manganese: Cook, H. J., 5.

Granite in wells: Gould, 3.
Nebraska-Continued.

Physiographic geology.

Badlands : Darton. 9

Nenana coal field, Alaska: Martin, G. C., 1.

Nevada.

Areas described.

Candelaria silver district: Knopf, $\mathbf{\Lambda} ., 5$.

Charleston district: Schrader, 5.

Gilbert district: Ferguson, H. G., 1.0.

Ivanpah quadrangle: Hewett, 17.

Jarbidge district: Schrader, 5 .

Manhattan district: Ferguson, H. G., 5.

Muddy Mountains : Longwell, 15.

Pioche district: Westgate, 6.

Santa Fe district, Mineral County : Clark, C. W., 2.

Economic geology.

Borax : Foshag, 20 ; Keyes, 61.

Carnotite, southern Nevada: Hewett, 9.

Cedar Mountain, Mineral County : Knopf, A., 4.

Colemanite, Clark County : Gale, 3 ; Noble, 2

Comstock lode, bonanza ores, Virginia City: Bastin, 4.

Divide silver district: Carpenter, J. A., 1 ; Knopf, A., 3 ; Sizer, 1 ; Young, G. J., 1.

Dumortierite deposit: Jones, J. C., 3. Gilbert district: Ferguson, H. G., 10.

Gold placers, Johnnie district: Labbe, 1.

Gypsum : Stone, 11.

Halogen salts of silver, Wonder; Young, J. W., 1.

Jarbidge district: Park, J. F,, 1.

Limestone ores, Manhattan district: Ferguson, H. G., 2.

Magnesia alum near Fallon: Hewett, 13.

Magnesite, southern Nevada: Anon., 20.

Manganese: Pardee, 4.

Colorado River desert region: Joncs, Edw. L., .9.

Mineral resources: Lincoln, 1.

Nickel ores, Key West mine: Lindgren, 11.

Oil shale: Winchester, 5

Oil seep, north central Nevada: Lavington, 1.

Pioche district: Anderson, .J. C., 1. Westgate, 6.

Quicksilver deposits, Pilot Mountains, Mineral County : Foshag, 32.

Red Bed ores: Bains, 1.

Regional relations of ore deposits: Ferguson, H. G., 9.

Rochester district: Knopf, A., 7.

Round Mountain district: Ferguson, H. G., 4

Salt deposits : Phalen, 1.

Silver, Candelaria district: Knopf, A., 5.

Silver Horn district, near Pioche : Crampton, 2.

Tonopah district : Budelman; 1

Tungsten ores: Hess, 11. 
Nevada-Continued.

Economic geology-Contínued.

Virgin Valley opal deposits: Gordon, C. C., 1.

Washoe district, Storey County : Grant, W. H., 1.

Yerington district: Gaby, 1.

Historical geology.

Candelaria silver district: Knopf, A., 5.

Cedar Mountain, Mineral County : Knopf, A., 4.

Davis Creek beds: Chaney, 10

Divide silver district: Knopf, A., 3. Formation names: Keyes, 153.

General: Keyes, 128.

Geological traverse, Mohare to San Juan River: Gregory, H. E., 9.

Humboldt Range: Jones, J. C., 3.

Late Paleozolc positive area : Nolan, 4.

Manhattan district: Ferguson, H. G., 2.

Muddy Mountains region: Longwell, 1, 3 ; Noble, 2.

Pre-Triassic unconformity, southern Nevada: Longwell, 11.

Rochester district: Knopf, A., 7.

Round Mountain district: Ferguson, H. G., 4 .

Spring Mountain Range, southern $\mathrm{Ne}$ vada : Hewett, 10.

Southern Nevada: Longwell, 11, 12.

Tertiary, southeastern Nevada: Stock, 7.

Type localities of formations: Keyes, 130.

Mineralogy.

Andorite in silver ore: Shannon, 32.

Barrandite, Manhattan: Shannon, 44.

Benjaminite, Round Mountain, Nye County: Shannon, 45.

Conichalcite, Lincoln County: Gillson, 37.

Delafossite, Kimberly : Rogers, A. F., 11.

Dumortierite, Limerick Canyon, Rochester district: Peck, A. B., 4.

I.incoln Hill, Rochester district: Fairbanks, 7 .

Rochester mining district: Bowen, 21. Identification of minerals: Grawe, 4.

Pitticite, Manhattan: Foshag, 30.

Quartz, Jowa Canyon: Fisher, L. W., 3.

Rare minerals: Clinton, $\bar{T}$.

Szaibelyite, Lincoln County : Gillson, 35.

Wood tin in Tertiary rhyolites: Boydell, 6.

Puleontology.

Carson footprints, origin: Stock, 4.

Ceratopyge fauna: Raymond, $\mathbf{1 6 .}$

Cestraciont spine, Triassic: Davidson, P., 1.

Davis Creek beds flora: Chaney, 10.

Hypohippus, Fish Lake valley: Stock, 17.

Flora, Esmeralda formation: Berry, 92.
Nevada-Continued.

P'alcontology-Continued.

J.ehman Cave, White line County: Hastings, 1

Mammalia, southeastern $\mathrm{N}$ e va $\mathrm{d}$ a : Stock, 7.

Thousand Creek Pliocene: Merriam, 28.

Ordovician sponge fauna, McMonnigal Canyon: Bassler, 22.

Sculpin, Lake Lahontan: Jordan, 1:3

Triassic faunas: Stanton, 12.

Irilobites, Cambrian, Silver Peak district: Walcott, 5

Upper 'Triassic: Smith, J. P., 3.

Walnut, Miocene: Berry, 98.

Petrology.

Rochester district: Hirschi, 3.

Physical geology.

Basin Range structure in the Great Basin : Louderback, 5 .

Dolomitization in southern Nevada: Hewett, 11, 12.

Faulting, southern Nevada, Keyes : 148 ; Longwell, 8.

western Nevada: Ferguson, H. G. 7 .

Lake Lahontan sediments: Jones, J. C., 1.

Muddy Mountain overthrust : Longwell, 3.

Pedestal rock, Pershing County : Reid, J. T., 1.

Southern Nevada, structure: Longwell, 12.

Spring Mountains, structure: Longwell, 10 .

Western ranges, structural features: Ferguson, H. G., 6.

Physiographic geology.

Great Basin, morphologic features of Basin Range displacements: Louderback, 8.

Lake Lahontan : Anters, 12 ; Jones, J. C., 2.

Northwestern Nevada: Reeds, 14

Scarp production in Great Basin: Louderback, 7.

Steptoe Valley: Clark, W. O., 1.

Underground water.

Comstock lode, Virginia City: Bastin, 4.

Pahrump, Mesquite, and Ivanpah valleys: Waring, 3.

Steptoe Valley: Clark; W. O., 1.

Thermal springs: Meinzer, 10.

Nevis, geology: Earle, 6.

Newark group : Raymond, 34.

New Brunswick.

Areas described.

Burnthill Brook area: Young, G. A., 1.

Minto conl basin: Dyer, 8 .

Moncton area: Wright, W. J., 2.

Sussex area : Hayes, A. O., 7 .

Economic geolngy.

Bathurst iron district: Parsons, C. S., 1. 
New Brunswick-Continued.

Economic geology-Continued.

Coal seams, Gloucester County : Young, G. A., 2.

General: Hayes, A. O., 1 ; Wright, W. - J., 1.

L'Etang limestone deposit, Charlotte County : Uglow, 17.

Mineral deposits: Wilson, M. F., 17. Minto coal basin: Dyer, 2, 8.

Natural gas: Elsworthy, 7.

Oil and gas possibilities, Edmunston: McCann, 2.

Oil shales: Simpson, L., 1.

Albert Mines: Wright, W. J., 2.

Peat: Anrep, 1, 7, 9.

Road materials: Picher, 3.

Tungsten, Burnthill Brook area: Young, G. A., 1.

Historical geology.

Carboniferous: Bell, W. A., 13. subdivision: Bell, W. A., 8 .

Delta of Little River group: Matthew, G. F., 1.

Devonian glacial deposits, St. John : Matthew, 9.

volcanic rocks, Dalhousle area : Howard, W. V., 2.

General : Bailey, L. W., 1 ; Wright, W. J., 1.

Minto coal basin: Bell, W. H., 11; Dyer, 2, 8.

Mispec group : Matthew, G. F., 3.

Paleogeography of Acadia: Bailey, $\mathrm{L}$. W., 3.

Mineralogy.

Albertite in gypsum, Hillsboro: Parsons, 11.

Inyoite, Hillsborough, Albert County : Poitevin, 5.

Ulexite: Walker, 10.

Wolframite deposits, Burnthill Brook, York County: Swanson, W. L., 2.

\section{Paleontology.}

Cambrian faunas: Howell, B. F., 8.

Flora, Carboniferous: Round, 4; Wilson, W. J., 1.

Minto coal basin: Bell, W. H., 11.

Thelodus: Stetson, 4.

Petrology.

Devonian volcanic rocks, Dalhousie area : Howard, W. V., 2.

Physical geology.

Tidal phenomena of Bay of lindy rivers: Kindle, 42.

Newburgh quadrangle, New York: Holzwasser, 1.

Newell folio, South Dakota (no. 209): Darton, 1 .

New England, monadnock divide: Brown, R. H., 1.

Newfoundland.

Geologist's report, 1926-27 : Baker, H. A., 1.

Areas described.

Avalon Peninsula: Baker, H. A., 1.
Newfoundland-Continued.

Areas described-Continued.

Central mineral belt: Snelgrove, 2.

West coast : Biunton, 3.

Economic geology.

Central mineral belt: Snelgrove, 2.

Coal : Haliburton, 1.

General : Baker, H. A., 1 ; Davies, D. J., 1.

Iron, Wabana : Hasebrink, 1; Hayes, A. $0 ., 9$.

Mineral resources: Snelgrove, 1.

St. George's coal field : Baker, H. A., 2.

Historical geology.

Cambrian: Howell, B. F., 1.

Cambrian - Ordovician, southeastern Newfoundland: Howell, B. F., 5.

Carboniferous, Deer Lake district: Landell-Mills, 1.

Fortune Bay: Dale, N. C., 5

Geological map: Howley, 1.

Manuels Brook section: Howell, B. F., 4

J're-Cumbrian, southeastern Newfoundland: Buddington, 3.

Western New foundland : Schuchert, 16.

\section{Paleontology.}

Faradoxides faumas, Manuels Brook: Howell, B. F., 4

Stromatocystites: Schuchert, 3.

Trilobites, Ordovician : Raymond, 28.

Petrology.

Chert formations, Notre Dame Bay : Sampson, 8.

Pre-Cambrian, southeastern New foundland : Buddington, 3.

\section{Physical geology.}

Changes of level, postglacial: Daly, 10.

Thrust faulting, western Newfoundland: Mook, 9.

Wabana ore deposits, folling and faulting : Gilliatt, 1.

Physiographic geology.

Pleistocene: Coleman, 28.

terraces: Kindle, 17; Lake Melville district, Labrador: Kindle, 31.

Warping, postglacial: Daly, 11.

New Hampshire.

Soils, Coos County: Crosby, w. 0., 3.

Areas described.

Hanover district: Merritt, J. W., 3.

Fortsmouth Basin: Wandke, 2.

nconomio geology.

Ammonoosuc mining district: Ross, C. P., 2.

Granite: Dale, T. N., 4.

Road materials: Goldthwait, 3.

Historical geology.

Ammonoosuc mining district: Rrss, C. P., 2.

Glacial geology : Goldthwait, 6 .

North Conway quadrangle, White Mountains: Billings, 5

Portsmouth basin: Wandke, 1.

Stones, dispersion in the drift: Gold thwait, 2. 
Now Hampshire-Continued.

Minepralogy.

Beryl Hill, Girafton: Flint, G. M., 1.

Sarcopside, Deering: IIolden, E. F., 2.

Druse minerals in granite, Conway: Gillson, 8

Sarcopside, Deeling: Holden, 10.

Spodumene and autunite, Alstead : Megathlin, 1.

Topaz and phenacite, Raldface Mountain, Chatham: Billings, 2.

Petrology.

Granite, Conway: Gillson, 8.

Hanover district: Merritt, J. W., 3.

pawtuckaway Mountains, Rockingham County: Smith, E. S. C., 1.

Iortsmouth Basin, intrusive rocks: Wandke, 2.

North Conway quadrangle, White Mountains: Billings, 5.

Physical geology.

Glacial varves, Connecticut Valley, summer deposition: Suyles, 11.

Submergence and postglacial uplift: Goldthwalt, 1.

Piysiographic geology.

Gastern New Hampshire: Crosby, I B., 1.

Glaciation: Goldthwait, 2, 6.

Pinkham Notch, physiographic history : Crosby, I. B., 3.

Potholes, Mount Jefferson: Crosly, I. B., 6.

White Mountains: Lave, 6, 7 .

New Ilolland quadrangle, Pennsylvania: Jonas, 4.

New Jersey.

state geologist's report: Kiimmel, 1-5.

Economic geology.

Belleville copper mine: Black, G. F., 2.

Mineral industries: Twitchell, M. W., 2-6.

Mineral resources: 'Twitchell, M. W., 1.

Ore deposition, Franklin Furnace: Spurr, 17.

Potash exploration in greensands: Mansfleld, G. R., 1, 7, 9, 12.

Zinc, Franklin Furnace district: Salton, 1.

Zinc deposits, Franklin Furnace, origin: Fitch, A. A., 1 ; Ries, 8.

Historical geology.

General : Johnson, D. W., 13.

Glauconite beds: Mansfield, G. R., 2, 12.

Greensand marls, Eocene age: Cooke, C. W., 17.

Middlesex County : Hawkins, A. C., 12.

Postglacial laminated clays, Iittle Ferry : Reeds, 5 .

Shawangunk formation, age and origin : Willard, B., 3.

Sussex County: Rles, 8.

Wilmington quadrángle: Bascom, 2.
New Jersey-Continued.

Mineralogy.

Albite, Haterson : Fenner, 9

Barite, Great Notch: Wilson, E. H., 1.

Bergen Hill region: Manchester, 1.

Chalcopyrite, Bergen Hill: Wherry, 2,

Franklin Furnace: Gordon, S. G., 14; Lewis, 8 ; Palache, 28, 30.

Barysilite: Shannon, 65.

Bustamite : Larson, 9.

Epidesmine, Mercer County : Gordon, S. G., 1.

Cahnite : Palache, 23.

Chlorophoenicite: Foshag, 21, 28

Cyprine: Shannon, 38.

Friedelite and schallerite: Bauer, L. H., 3.

Ganophyllite: Larsen, 12.

Glaucochroite, wlllemite, celestite, and calcite: Gordon, S. G., 9.

Hedyphane : Foshag, 22.

Hematite, willemite, and hedy. phane: Palache, 25.

Holdenite: Palache, 22.

Hyalophane: Bauer, L. H., 1.

Larsenite and calcium-larsenite : Palache, 27.

Löllingite: Bauer, I. H., 2.

Magnetite and franklinite crystals: Van Horn, 14.

Manganiferous serpentine: Shannon. 63.

Norbergite: Larsen, 23.

Phosphorescence and fluorescence: Palache, 29.

Radiated chrysotile: Foshag, 26.

Rhodonite: Larsen, 10.

Schallerite: Gage, 1.

Sussexite: Poitevin, 6 .

Tephroite: Gordon, S. G., 11.

Zincite: Berman, 3.

Greensand: Mansfield, G. R., 7 .

Halite pseudomorphs, Triassic: Haw. kins, A. C., 10.

Meteorite, Deal, Nonmonth County : Keeley, 1.

Middlesex County : Frawkins, A. C., 9

Montville, serpentine: Shannon, Gi.

Sterling Hill : Palache, 28.

McGovernite: Palache, 26.

Stilpnomelane, Lambertville : Shannon, 17.

\section{Paleontology.}

Human remains, 'I'renton' gravels : Wright, G. F., 1

Hyposaurus : Troxell, 27.

Reptile, Triassic: Gilmore, 39.

Thoracosaurus, Cretaceous : Troxell, 28. Petrology.

Alkali gneiss, Warren County: Hinds, N. E. A., 1

Nephelite rocks, Beemerville : Aurousseau, 1.

Zinc ores, Sussex County, origin: Ries, 8. 
New Jersey-Continued.

Physical gcology.

Fulgurite, South Ambey : Myers, :3.

IIalite and glauberite cavities in Triassic rocks: Hawkins, A. C., 11.

Postglacial laminated clays, Littio Ferry : Reeds, 5.

Structure, Middlesex County: Hawkins, A. C., 12.

Physiographic geology.

Banded postglacial clay near New York City : Reeds, 3.

General: Johnson, D. W., 9.

Glacial investigations: Leverett, 20.

Glacial varves, Hackensack meadows : Sci. Serv., 8.

Varved clays, Little Ferry: Reeds, 7 .

Underground water.

Atlantic City region: Thompson, D. G., 6.

Barrier beaches, ground water : Thompsou, D. G., 5.

General : Kümmel, 5.

Ground water: Thompson, D. G., 4; Twitchell, 5.

New Mexico.

Canadian River area: Yeo, 1.

Areas described.

Brilliant quadrangle: Lee, W. T., 6.

Carlsbad irrigation project: Meinzer, 16.

Gallup-Zuni Basin: Sears, 6.

Koehler quadrangle: Lee, W. T., 6.

Mogollon mining district: Ferguson, H. G., 8.

Raton coal field, Colfax County: Lee, W. 'T., 10.

Raton quadrangle: Lee, W. T., 6.

Sandia Mountains: Ellis, R. W., 2.

Tyrone district: Paige, 2.

Tularosa Basin : Powell, 1.

Economic geology.

Artesia oil field: Rich, A., 1.

Aztec mine, Baldy, Colfax County : Chase, C. A., 1.

Black Range tin district: Naething, 1.

Brass ore in nature: Keyes, 107.

Carbon ratios, Cretaceous coals : Storm, 5.

Chupadera Mesa iron deposits, age : Keyes, 72. -

Coal, Raton field, Colfax County : Lee, W. T., 10.

San Juan County: Bauer, C. M., 1.

Copper: Tovote, 1.

San Pedro, Santa Fe County : Berryman, 1.

Tyrone district; Paige, 2.

Fierro ores: Schwartz, 2.

Fluorspar: Johnston, W. D., 4.

Gold, Sierra del Oro: Keyes, 59.

Gypsum: Stone, 11.

Hematite, Socorro County: Foshag, 7 .

Iron-ore deposit near Fatrview : Smythe, 2.

Lepidolite, Fmbudo: Rnos; 1.
New Mexico-Continued.

Economic geology-Continued.

Manganese: Jones, Edw. L., 5; IVells, E. H., 1.

Metalliferous deposits in red beds : Finch, J. W., 2.

Mining properties: Finlay, 3.

Mogollon district: Ferguson, H. G., 3, 8; Kidder, 1 ; Scott, D. B., 1 .

Molybdenite, Questa: Sundberg, 1.

Molybdenum, Taos County : Larsen, 5.

Oil and gas in 1923 : Ellis, R. W., 3.

Oil and gas possibilities, Alamos: Creek valley: Winchester, $\mathbf{3}$.

Oil resources: Knox, J. K., 2.

Oil situation: Ellis, R. W., 1.

O'Mara coal fields: Keyes, 111.

Ore deposits: Keyes, 161; Tovote, 2.

Pipe vein, Silver Hill : Keyes, 64.

Potash : U. S. G. S., 15.

southeastern New Mexico: Hoots, 1.

Red Bed ores: Bains, 1.

Salt deposits: Darton, 8 ; Phalen, 1.

San Juan County: Bauer, C. M., 1.

San-Pedro, Santa Fe County: Berryman, 1.

Santa Rita district : Rickard, 8.

Taylor Creek tin deposits, Sierra and Socorro counties : Hill, J. M., 3.

Vanadanite deposits, Elephant Butte: Keyes, 204.

Historical geology.

Abo sandstone: Böse, 4.

Alamosa Creek valley, Socorro County: Winchester, 3.

Boring, Santa Rosa : Prout, 1.

Buried mountain range of Permian age: Rich, J. L., 2.

Chaco Canyon deposits: Bryan, 21.

Chaves County: Merritt, J. W., 2.

Chupadera Mesa: Keyes, 72.

Eastern New Mexico: Baker, C. L., 1; Lee, W. T., 3 ; Rich, 5.

El Vado dam site, Rio Arriba County : Wells, E. H., 3.

Folsom, Union County : Cook, H. J., 12.

General : Keyes, 11, 14 ; Knox, J. K., 2.

Geologic map: Darton, 25; Ellis, R. W., 5.

southeastern New Mexico; Anon., 58.

Geologic structure of parts of New Mexico : Darton, 11.

Guadalupe group : Darton, 19.

Laramie hiatus, southern Rocky Mountains: Keyes, 147.

Manzano group: Lee, W. T., 2.

Mogollon district: Ferguson, H. G., 3.

Northeastern New Mexico: Baldwin, 1; Garrett, 1.

Paleozoic: Keyes, 76.

Pecos Valley: Semmes, 4.

Permian : Darton, 20.

Pre-Moenkopi unconformity, Colorarlo Plateau; Dake, 4.

Puertecito district: Wells, E. H., 2.

"Red Beds": Darton, 26. 
New Mexico--Continued.

Historical geology-Continued.

Rlo Grande region, Carboniferous: Keyes, 68.

Rio Grande Valley : Keyes, 81.

Rio Penasco Basin: Renick, 10.

Roswell artesian basin: Fiedler, 2.

San Juan Basin : Reeside, 3, 8 ; Bauer, C. M., 1 .

San Jose-Rio Puerco valley, Sandoval County : Renick, 9.

San Pedro, Santa Fe County: Berryman, 1.

Santa Fe region: Simpson, G. G., 6.

Santa Rita district: Rickard, 8.

Southeastern New Mexico: Hoots, 1; Rich, A., 1.

State line dam site: Bryan, 32.

Tros Range: Gruner, 1.

Tertiary intrusives, Pecos Valley: Semmes, 4.

Mineralogy.

Arsenopyrite, Tres Hermanas Mountains: Smythe, 1.

Chalmersite, Fierro: Schwartz, 2.

Iron-ore deposit near Fairview : Smythe, 2.

Meteorite, Four Corners, San Juan County : Merrill, 39.

Muscovite, purple, Taos County : Schaller, $\boldsymbol{9}$.

Tetradymite, Hachita : Short, 3.

Uranium minerals: Keyes, 107.

Paleontology.

Alamosaurus, Ojo Alamo formation : Gilmore, 17.

Ammonoids, Abo sandstone : Böse, 4.

Artifacts, Folsom: Science Service, 10.

Bison, Folsom : Hay, 41.

Paleocene mammals, new genera: Matthews, 16.

Pentaceratops: Osborn, 28.

Phytosaur, Triassic, $G$ u a d a $l$ o u pe County : Mehl, 9.

Reptilia, San Juan County : Gilmore, 4.

Sauropoid dinosaur, San Juan Basin : Gilmore, 12.

I'etrology.

Raton-Brilliant-Koehler area: Mertie, 9.

Physical geology.

Buttress structure, volcanic plugs: Branson, 20.

Carlsbad Cavern : Lee, W. T., 12-16.

Changes in chamnel of Rio Puerco: Bryan, 30.

Channel erosion, Rlo Salado, Socorro: Bryan, 25.

Chares County : Merritt, J. W., 2.

Colorado Plateau, structural features: Moore, R. C., 21

Elosion and sedimentation, Zuñi watershed: Bryan, 29.

Erosion by solution and fill, Pecos Valley: Lee, W. T., 14

Gencral : Keyes, 11.
New Mexico-Continued.

Physical geology-Continued.

Granite in wells : Gould, 3

Ice cave: Lee, W. T., 18.

Laccolithic structures: Keyes, 41.

Mountain structure : Darton, 7.

Niches in sandstone, Chaco Canyon: Bryan, 33.

Northeastern New Mexico, structure: Garrett, 1.

Pedestal rocks: Bryan; 13, 24.

Puertecito district: Wells, E. H., 2.

Structure features: Knox, J. K., 2.

Physiographic geology.

Ancestral Rocky Mountains: Melton, 1.

Citverns in Guadalupe Mountains: Baker, C. L., 4.

Raton mesas: Iee, W. T., 4.

San Luis Valley, physiographic history : Atwood, 4.

Underground water.

Cactus Flat reservoir site: Nye, 1.

Carlsbad irrigation project: Meinzer, 16.

De Baca County : Bryan, 20.

Ground water, Mimbres Valley, Luna County : Fiedler, 3.

Sandoval County: Renick, 6.

Rio Penasco Basin : Renick, 10.

Rosivell artesian basin: Fiedler, 1, 2.

San Jose-Rio Puerco valley, Sandoval County : Renick, 9.

Socorro County: Bryan, 1.9

Socorro and Torrance counties : Black, 1.

Tularosa Basin: Powell, 1.

Newtonite, identity with alunite: Foshag, 25.

New York.

General : Palmer, E. L., 1.

State geologist, report: Clarke, J. M., $1,17$.

State Museum, report: Clarke, J. M., 18, 23, 28, 20; Van Deloo, 1.

Areas described.

Allegany State Park: Lobeck, 8.

Ausable quadrangle: Kemp. 23.

Canton quadrangle: Chadwick, 5.

Cold Spring Harbor area, Long Island : Grier, 3 .

Genesee country, geologic history.: Fairchild, 15,24

Gouvernenr quadrangle: Cushing, 1.

Jake Bonaparte quadrangle: Smyth, 2.

lake Clear region: Alling, H. L., 1.

Lake Placid quadrangle: Miller, W. J., 1.

Iyon Mountain quadrangle: Miller, W. J., 26.

Juzerne quadrangle: Miller, W. J., 19. Mount Marcy quadrangle, Essex County: Kemp, 7.

Newburgh quadrangle: Holzwasser, 1.

Newcomb quadrangle, Essex County: Bulk, 3.

New York City : Reeds, 2. 
New York-Continued.

Areas described-Continued.

Schroon Lake quadrangle: Miller, W. J., 2.

Schunemunk region: Colony, 6, 7 .

Starks Knob, Saratoga County : Hartnagel, 7.

West Point quadrangle: Berkey, 3.

Economic geology.

Adirondack magnetic iron ores: Miller, W. J., 13,18 ; Newland, 1. genesis: Alling, 10.

sedimentary phases: Nason, 1, 2 .

Albany molding sands: Nevin, 1.

Catskill Portland-cement region : Jones, R. W., 1 .

General: Hartnagel, 5.

Gypsum : Stone, 11.

Iron ores, Clinton County: Miller, W. J., 5, 7 : Newland, 1, 6 ; Smyth, 1.

Lime belt, eastern New York: Dale, T. N., 5.

Limestone, Greene County: Jones, R. W., 2 .

Magnetic iron ores, Essex County: Henry, 1.

southeastern New York: Colony, 3.

Manganese, postglacial, Columbia County : Dale, N. C., 2.

Mineral resources: Hartnagel, 2 ; Newland, 2.

Mining and quarry industries: Hartnagel, 6 ; Newland, 8.

Oil fields: Hartnagel, 3.

Ore injection at Edwards: Spurr, 13.

Petroleum : Johnson, R. H., 3.

Pyrite deposits, St. Lawrence County, origin : Miller, W. J., 27.

Pyrite and pyrrhotite veins, Jefferson and St. Lawrence counties: Buddington, 1.

Salt deposits : Plalen, 1.

Silica materials: Colony, 1.

Silurian salt deposits: Alling, 14.

Titaniferous iron ores: Osborne, F. F., 3.

Zinc, St. Lawrence County: Wade, W. R., 2.

Historical geology.

Adirondack gabbros, age: Gillson, 10

Adirondack region: Clarke, 15.

geologic history: Miller, w. J., 8.

pre-Cambrian : Alling, 3 ; Wilson, $\mathbf{M}$. E., 15.

Anorthosite outlier near Wells: Chadwick, 17.

Canton quadrangle: Chadwick, 5.

Capitol district: Ruedemann, 27.

Catskill Portland-cement region: Jones, R. W., 1.

Catskill quadrangle: Chadwick, 15.

Catskill region: Berkey, 6.

Chemung stratigraphy, western New York: Chadwick, 8, 10.

Clinton formations; UIrich, 9.

Clinton and Little Falls : Eaton, H. N., 7.
New York-Continued.

Historical geology-Continued.

Devonian, western New York: Hussakof, 1.

Dunkirk shale, Erie County : Chadwick, 7 .

General: Keyes, 281.

Genesee River region: Fairchild, 6.

Geological history : Miller, W. J., 23.

Graptolite zones: Rueđemann, R., 3.

Grenville stratigraphy, eastern Adirondacks : Alling, 13.

Hanover shale: Chadwick, 4.

Highlands, southeastern New York: Colony, 3.

Lake Bonaparte-Lowville quadrangles: Buddington, 2 .

Marine Pleistocene fossils, New York City : Palmer, K. V. W., 3.

Oriskany sandstone: Eaton, H. N., 3.

Finnacle Hills, Rochester: Fairchild, 13.

Pleistocene history: Fairchild, 9.

Portage stratigraphy, western New York: Chadwick, 3.

Pre-Cambrian, Adirondacks : Alling, 8; Miller, W. J., 30.

Salina formation: Newland, 9.

Saratoga region: Rothpletz, 2.

Shawangunk formation, age and origin : Willard, B., 3.

Sherburne sandstone: Grabau, 6.

Silurian faunal facies in juxtaposition: Ruedemann, 20.

Silurian salt deposits: Alling, 14.

Taconic area, southern: Knopf, $\mathbf{w}$. B., 6 .

Trenton section, Martinsburgh : Clark, T. H., 1.

Utica and Lorraine formations : Ruedemann, 16.

Western New York : Alexander, W. P., 1.

Winters in Upper Devonian: Schuchert, 34.

\section{Mineralogy.}

Adirondacks, western: Agar, 1.

Barite and associated minerals in concretions in Genesee shalc Martens, 5.

Bedford, Westchester County : Brown, S. C., 1.

Calcite cave in State Museum : Gardner, H. F., 1.

Contact minerals, Edenville: Buerger, 2.

Fluorite, Rochester: Hawkins, 5.

Mahopac iron mine, Brewster: Gill son, 4.

Minerals, Lockport group, Oncida County: Monahan, 1.

Morgan memoriul hall of American Museum of Natural History : Whitlock, 13.

Niagara limestone minerals: Giles, 2 Orange County: Hoadley, 1.

Pyrite, New York City: Whitlock, 3.

Pyrite and celestite, Rochester: Hawkins, 7 . 
New York-Continued.

Mineralogy-Continued.

St. Lawrence, Jeffetson, and Lewis counties: Agar, 1.

St. Lawrence County, crystal localities: Miller, W. J., 11.

Scorodite, Putnam County : Martens, 2. Sterlingbush calcite cave: Clarke, $\mathbf{N}$. T., 1.

Sulphate minerals from weathering of shale near Ithaca: Martens, 6.

Thomsonite, Peekskill: Phillips, 1.

\section{Paleontology.}

Armstrongia, Devonian glass sponge: Clarke, J. M., 8.

Barnacles, Ordovician : Ruedemann, 13.

Bunaia woodwardi, Silurian: Clarke, J. M., 4, 7 .

Callixylon, Eighteenmile Creek: Hylander, 1.

Carnyella valcourensis, Chazy límestone : Clark, T. H., 2.

Cephalopods : Foerste, 28.

Cohoes mastodon: Clarke, J. M., 22.

Cold Spring Harbor flora: Grier, 2:

Collecting fossils: Ruedemann, 25.

Colossal Devonian glass sponge: Clarke, J. M., 25.

Conodonts, Devonian: Ulrich, 13.

Genesee: Bryant, 2.

Portage group: Hibbard, R. R., 1. western New York: Hibbard, 2.

Cretaceous, Staten Island: Davis, W. T., 1.

Cryptozoon: Rothpletz, 2.

Devonaster eucharis (Hall), six-rayed : Willard, 2.

Devonian crinoids: Goldring, 4.

Devonian forest, Gilboa: Bancroft, J. A., 2 ; Clarke, J. M., 14, 17, 18 ; Goldring, 6, 7, 9.

Devonian plant localities: Arnold, C. A., 1.

Devonian plants: Petry, 1.

Devonian seed fern forests: Berry, 55 ; Goldring, 5.

Dictyosponge, Chautauqua County: Clarke, J. M., 22.

Dolgeville fauna : Ruedemann, R., 3.

Eurypterid horizon: Chadwick, 2.

Fishes in museum of Buffalo Society of Natural Sciences: Hussakof, 1 .

Glass sponges: Clarke, J. M., 18.

Graptolite zones: Ruedemann, R., 3 .

Ilamilton erinoids: Goldring, 8.

Hemiaspidan crustacean, Bertie waterlime: Clirke, J. M., 24.

Marine Pleistocene fossils, New York City: Palmer, K. V. W., 3.

Mastodon, Cohoes, restoration: Clarke, N. T., 2.

Hudson Highlands: Osborn, 27.

Temple Hill, Orange County : Bishop, 1 ; Clarke, J. M., 22.

Mastodons, mammoths, and other Pleistocene mammals: Hartnagel, 1.
New York-Continued.

Paleontology-Continued.

New York State Museum, paleontological work: Ruedemann, 21.

Ordovician: Ruedemann, R., 3.

Oriskany fauna, Oriskany Falls: Eaton, H. N., 3.

Palaeaspis: Bryant, 4.

Pleistocene mammals: Hartnagel, 4.

Monroe, Orange County: Clarke, J. M., 11.

Proboscidea : Hay, 3.

Protobalanus, Hamilton group: Van Name, 1, 2.

Psaronius, Schoharie County: Hovey, 5.

Silurian: Ruedemann, 7, 19.

Snake Hill fauna: Ruedemann, 7.

Tree trunk, Manhattan Island: Hol. lick, 7.

Trenton fauna, Martinsburg: Clarke, T. H., 1.

Utica and Lorraine formations: Ruedemann, 17, 18, 21.

Veruon shale fauna: Eaton, H. N., 5; Ruedemann, R., 2.

\section{Petrology.}

Adirondack gabbros, age: Gillson, 10.

Adirondacks, Lyon Mountain region : Miller, W. J., 3.

western: Agar, 1.

Anorthosite gabbro, Saint Lawrence County: Miller, W. J., 9, 11.

Cortlandt norite, structure, Peekskill : Balk, 2, 5 .

Dolomites, composition : Reed, B. B., 1.

Igneous rocks, Ithaca: Martens, 1, 3.

Lake Bonaparte-Lowville quadrangles: Buddington, 2

Origin of foliation and naming of syntectic rocks: Alling, 9.

Oriskany sandstone with celestite cement: Stow, 1.

Sediments, characters: Alling, 7.

Sillimanite-schist inclusions in granite : Miller, W. J., 16

Physical geology.

Adirondacks, western : Agar, 1.

Box vein, Lyonsdale, Lewis County: Dale, N. C., 4.

Brecciation, Niagara limestone, Rochester: Giles, 1.

Concretions, western New York: Alexander, A. E., 1.

Glacial erosion, Ithaca: Sheldon, 2.

Dike near Ithaca: Sheldon, 1.

Faulting, Cayuga Lake region: Long, 1.

Orleans County: Chadwick, 6.

Foliation, Lewis County: Buddington, 2.

Grenville sediments: Alling, 13.

Highlands, southeastern New York: Colony, 3.

Niagara Falls, rate of recession: Boyd, W. H., 1. 
New York-Continued.

Physical geology-Continued.

Ningara River gorge, age: Johnston, W. A., 26.

Sedimentation conditions, middle Portage rocks: Sheldon, 5.

Sulphates in the Salina beds : Newland, 5.

Taconic folding: Milier, B. L., 9.

Physiographic geology.

Adirondack eskers: Chadwick, 16, 21.

Allegany State Park: Lobeck, 8.

Banded postglacial clay near Ner York City : Reeds, 3.

Catskill Mountains: Merwin, 3.

Cohoes quadrangle: Stoller, 2.

Dansville Valley: Fairchld, 21.

J.rainage changes, east central New York : Stoller, 1.

Drumlins, Lake Placid: Upham, 2. southern shore of Lake Ontario: Slater, 3.

Finger Lakes: Fairchild, 20 ; Monnett, 3 ; origin : Fairchild, 20.

General : Miller, W. J., 23.

Genesee glacial lakes: Challwick, 11. Genesee River region: Fairchtld, 6.

Glacial boulders, eastern, central, and northern New York: Martens, 4.

Glacial ice sheet, eastern New York, disappearance: Cook, J. H., 1.

Glacial lake, Warrensburg: Miller, W. J., 25.

Glacial lakes: Chadwick, 9 ; and clays near New York City: Reeds, 12.

Glacial striae topping Catskill Mountains: Chadwick, 19.

Glaciation in New York Botanical Garden : Hollick, 9.

northern New York: Fairchild, 10.

Hudson-Champlain Valley: Stoller, 3.

Ice evacuation stages at Glens Falls : Chadwick, 18, 20.

Ithaca region: Von Engeln, 2.

Lake Placid quadrangle, Pleistocene geology: Alling, 2.

Little Falls gorge: Miller, W. J., 6.

Mechanicsville terraces: Stoller, 1.

Mendon kame area: Fairchild, 19.

Mohawk-Hudson region, Pleistocene history : Stoller, 3.

Moraines, St. Lawrence Valley: Taylor, 4.

Mount Marcy quadrangle, glacial geology: Alling, 4.

Mouth of preglacial Salmon Creek: Long, 2.

New York moraine, age: De Geer, 5.

Niagara Canyon, age: De Geer, 4.

Niagara cuesta: Grabau, 12.

Niagara Falls : Dow, 1 ; Forrester, G. C., 2.

age: Taylor, 8.

rate of recession: Boyd, W. H., 1 .
New York-Continued.

iPhysiographic geology-Continued.

Niagara River gorge, age: Johṇston, W. A., 26.

Buried Whirlpool-St. Davids gorge, origin : Forrester, G. C., 1.

Pleistocene marine submergence of the Hudson, Champlain, and St. Lawrence valleys : Fairchild, H. L., 1.

Postglacial waters: Stoller, 1.

Recessional moraines, Finger Lakes region: Taylor, 6.

Rochester Canyon: Fairchild, 6.

Skaneateles Lake: Monnett, 3.

Susquehanna River: Fairchild, 16.

Tully glacial series: Von Engeln, 1.

Varved clays at Haverstraw: Reeds, 9 , 15.

Western New York, drainage evolution : Fairchild, 16.

Wilmington Notch, Adirondacks: Miller, W. J., 14 .

Wisconsin ice sheet, ablation of eastern lobe: Cook, J. H., 2.

Nicaragua.

Economic geology.

Eastern Nicaragua: Garbrecht, 1.

Piz Piz gold district: Hawxhurst, 1. Physical geology.

Masaya volcano: Heim, 4 ; Sapper, 4 ; Schönberg, 1.

Masaya and Momotombo: Sapper, 1.

Physiographic geology. Nickel.

General : Bengtson, 1.

Alaska: Buddington, 7.

Chichagof Island: Kerr, P. F., 2; western part: Overbeck; 1.

and Baranof islands: Buddington, 8 . Copper River valley: Overbeck, 2.

British Columbia, Emory Creek, Yale districts : Cairnes, 7, 9.

Dominican Republic, Sierra Prieta : Vaughan, 16.

General : Hess, 2, 8, 9, 12, 13, 16, 19, 21 ; Rickard, 2.

In igneous rocks: Vogt, 2.

Magnetic nickel deposits: Lindgren, 4.

Manitoba, Maskwa River: McCann, 1.

Oiseau and Maskwa areas: Wright, J. F., 7.

Oiseau River area: Wright, J. F., 9.

Nevada, Key West mine: Lindgren, 11.

Norite occurrences: Coleman, $\mathbf{5}$.

North Carolina, Webster: Ross, C. S., 25.

Ontario: Simmersbach, 1.

Cobalt: Whitehead, 1.

Shebandowan deposit: Cross, J. G., 2.

Sudbury ore deposits: Bell, J. M., 1 ; Coleman, 29 ; Primmer, 1.

Thunder Bay district, Shebandowan Lake: Tanton, 9.

Windy Lake region: Knight, C. W., 4. 
Nickel-Continued.

Oregon, Riddle quadrangle: Diller, 12.

Pennsylvania, Lancaster Gap mine: Fhemister, 2.

Night Hawk Lake gold area, Ontario : Hopkins, 9.

Nipigon-Schreiber district, Ontario : Tanton, 6.

Nitrate deposits, Amargosa region, southNitrate. eastern California : Noble, 4.

Guatemala: Gule, 2.

Nitrates: Mansfield, 16.

Nixon Fork country, Alaska : Brown, J. S., 7.

Nomenclature.

Appalachian conl measures: Ashley, 12.

Arizona formations: Keyes, 90.

Atchison shales: Keyes, 287.

Aulacera : Schuchert, 2.

Beatricea: Schuchert, 2.

Biostratigraphic terms: Fenton, C. L., 6.

Carboniferous: Keyes, 275.

Chester series: Keyes, 78.

Clastic sediments: Mackenzie, 6 ; Wentworth, 9.

Denudation, erosion, corrosion, corrasion, use of terms: Bissell, 1; Foye, 3 ; Lahee, 5.

Diabase and dolerite: Johannsen, 12.

Drift and till: Gregory, J. W., 7.

Erosional terms: Allison, I. S., 5; Glock, 6.

Flint and chert: Glock, 1.

Fossil, use of term: Field, 4; Miller, A. M., 7.

Geographic terminology: Campbell, M. R., 13.

Geologic classification : Keyes, 115.

Geologic column, terms, origin and significance: Lang, W. B., 1.

Geologic periods: Keyes, 133.

Geologic terminology: Blackwelder, 7.

Geological classiflcation: Keyes, 115.

Geosyncline, significance of term : Swinnerton, 4.

Glacial : Keyes, 222.

Glacial formations: Sardeson, 29.

Glossary of mining and mineral industry : Fay, 1.

Igneous rocks, field terms: Johannsen, 9.

Iowa chalk: Keyes, 208.

Lexington limestone: Keyes, 287.

Limestones: Kindle, 23.

Louisian vs. Mississippian : Keyes, 8.

Madison limestone: Keyes, 130.

Marais des Cygnes series: Keyes, 287.

Mineral deposits : Lindgren, 6.

Mineral names: Eakle, 10.

Minnesota, Minnesota River valley formations: Sardeson, 12.

Mississippian : Keyes, 20, 123, 262.

Missouri, Ordovician: Keyes, 106.

Mollusca : Dall, 8.
Nomenclature-Continued.

Muscogee shales, western interior conl field : Keyes, 51.

Oklahoma, obsolete formation names: Gould, C. N., 24.

Orbiculoidea : Girty, 13.

Pennsylvanian: Keyes, 80, 199, 217. Iowa: Keyes, 184.

taxonomic rank: Keyes, 149.

l'ermian: Keyes, 251.

Plattesmouth limestones: Keyes, 287 .

Post-Mesozoic: Girabau, 5.

Pre-Cambrian: Gregory, J. W., 5 ; Keyes, 109.

Pre-Paleozoic: Keyes, 278.

Proposed stratigraphic section and code : Ashley, 10.

Psychozoic: Berry, 81.

Rocks: Bowen, 15.

St: Louis limestone: Keyes, 123.

Seismological terms: Davison, 2.

Shapes of valleys, representation: Lane, 13.

Silica : Hart, 2.

Silurian: Keyes, 163, 291.

Sinian, use of term: Grabau, 14.

Spergen limestone, Missouri : Keyes, 208.

Standardization of geological terminology : Keyes, 265.

Stellate Orthophragmina: Hodson, H. K., 1.

Structure, usage of term : McLaughlin, R. P., 2.

Symbols for dip and strike: Dreher, 2 .

Syntectic rocks: Alling, 9.

Taconic question: Keyes, 260.

Tathiodon to replace Tanaodon: Simpson, G. G., 18.

Time subdivisions: Keyes, 164.

Valleys and intermont plains: Davis, W. M., 34 .

Yorkic: Keyes, 49.

North Atlantic Ocean, Tertiary history : Woodring, 8.

North Carolina.

Cretaceous sandstone, Kinston: Stuckey, 4.

Gravels on the Blue Ridge: Wright, F. J., 3.

Soils, age: Cobb, W. B., 1.

State geologist, reports: Pratt, J. II., 1., 3, 7 ; Drane, 2.

Work of State Geological Survey: Pratt., 4.

Areas described.

lort Caswell : Sten rns, N. N., 1.

Economic geology.

Brown hematite ores, western North Carolina: Bayley, $5,11$.

Chromite deposits: Diller, 1; I, J. V., 3, 6.

Clay: Ries, 5.

Copper deposits: Watson, 15.

Corundum, origin: Cobb, M. C., 1.

Garnet: Katz, 1. 
North Carolina-Continued.

Economic geology-Continued.

Hydromica : Bayley, 1.

Kaolin : Bayley, 1, 10.

Limestones and marls: Loughlin, 9.

Magnetite ores, western North Carolina: Bayley, 2, 6, 7; Pratt, J. H., 6.

Magnetite-marble ore, Lansing: Bayley, 4.

Magnetites, origin: Bayley, 3.

Mineral industry : Bryson, 1, 2 ; Drane, 3 ; Pratt, J. H., 2.

Mineral resources : Drane, 1.

Nickel silicates, Webster, origin : Ross, c. S., 25.

Oil shales, Deep River valley: Vilbrandt, 2.

Oil-bearing shale: Vilbrandt, 1.

Pyrophyllite deposits, Deep River region: Stuckey, 1, 3, 5 .

Rutile in titaniferous magnetites : Bayley, 9.

Talc, Hewitts: Diller, 5.

'Tin deposits : Haney, 4.

Triassic coal fleld: Pratt, J. H.; 5.

Historical geology.

Boring near Havelock: Mansfield, W. C., 5 .

Castle Hayne and Trent marls: Kellum, 2.

Cretaceous: Stephenson, 4.

General: Bryson, 3.

Great Smoky Mountains: Glenn, 9.

Lower Cambrian, southern Appalach. ians: Barrell, 8.

Permian at base of Newark : Cobb, 2.

Pleistocene : Berry, $\mathbf{7 5}$.

Pliocene and Pleistocene: Mansfield, W. C., 6.

Trent marl, age: Kellum, 1.

Triassic, Durham Basin : Prouty, 15, 16. Mineralogy.

Chloritoid, Deep River region: Stuckey, 1.

Corundum: Cobb, M. C., 1.

Corundum Hill (Franklin), Macon County: Gordon, S. G., 8.

Cyanite: Seagle, 1.

Genthite, so-called, Webster: Ross, C. S., 14.

Hiddenite, Alexander County : Davidson, S. C., 1.

Hydromica : Bayley, 1.

Meteorite, McDowell County: Merrill, 34.

Nickeliferous vermiculite and serpentine, Webster: Ross, C. S., 16.

Paleontology.

Castle Hayne and Trent marls: Kellum, 2.

Cretaceous : Stephenson, 4, 9.

Decapod Crustacea, Upper Cretaceous: Rathbun, 3.

Dromatherium and Micronodon : Simpson, G. G., 10 .
North Carolina-Continued.

Patcontology-Continued.

Horse remains: Cobb, C., 3 .

Mesozoic flora: Berry, 20.

Miocene Mollusca: Mansfield, W. C., 7.

Pleistocenè plants : Berry, $\mathbf{7 5}$.

Pliocene and Pleistocene: Mansfield, W. C., 6 .

Petrology.

Dunite, Jackson County: Adams, L. H., 8.

Physical geology.

Appalachian structure: Prouty, 17.

Ocean inlets, storm effect: Hite, 1.

Shore changes, Cape Hatteras : Rude, 1.

'Triassic (Deep River) basin : Prouty, 12.

Physiographic geology.

Blue Ridge: Wright, F. J., 2, 5.

Dismal Swamp : Osbon, 1.

General : Cobb, C., 4

Underground water.

Thermal springs: Watson, 16.

North Dakota.

State Geological Survey, history : Leonard, A. G., 10.

Areas described.

Edgeley guadrangle: Meinzer, 14.

Fort Berthold Indian Reservation, western part: Bauer, C. M., 2.

Marmarth fleld: Hares, 5.

Economic geology.

Clays : Budge, 1.

Coal, occurrence : Dove, 2.

Dakalite : Dove, 6.

Gravel : Leonard, 5 .

Lignite deposits: Babcock, 1 ; Dove, 5 ; Hoffmann, 1; Jeonard, A. G., 7-9.

Fort Berthold Indian Reservation: Bauer, C. M., 2.

New Salem field, Morton County : Hancock, 6.

oil and gas possibilities: Leonard, A. G., 3.

Historical geology.

Cretaceous-Eocene transition beds : Thom, 8.

General: Leonard, A. G., 1, 3, 8.

Lance-Fox Hills contact: Dobbin, 2.

Nesson anticline: Dove, 3.

New Salem lignite field, Morton County : Hancock, 6.

Western North Dakota: Stanton, 3.

White River formation: Leonard, A. G., 4 .

Mineralogy.

Leonardite: Dove, 6.

Meteorite, Richardton: Quirke, 1, 3.

l'aleontolog'y.

Cannonball fauna: Stanton, 3.

Eporeodons, White River beds: Thorpe, 23.

Fruits, Fort Union beds: Stainbrook, 1.

White River formation: Leonard, i. G., 4.

l'etrology.

Clinkertill : Dove, 4. 
North Dakota-Continued.

Physiographic geology.

Badlands of Little Missouri : Simpson, H. E., 3.

General : Leonard, $\Lambda$, G., 8; Willard, D. E., 2.

Missouri River channel, age: Todd, J. E., 5 .

1'leistocene deposits, interpretations: Todd, J. E., 1.

Southwestern North Dakota: King, 3.

Surface features: Leonard, A. G., 2.

Underground water.

Artesian water conditions: Simpson, H. E., 1, 2, 4.

Edgeley quadrangle: Meinzer, 14.

Harvey : Simpson, H. E., 5.

Report of State water geologist: Simpson, H. E., 6.

Northern Great Plains, physiographic development: Alden, 3.

Northfield, Vermont, terranes: Richardson, C. H., 2.

Northwest Territories.

paleontology.

Cephalopoda, Great Slave Lake: Foerste, 20.

Ordovician and Silurian, Great Slave Lake: Hume, 18.

Notostraca.

Ozarkian: Walcott, 8.

Nova Scotia.

Areas described.

Great Bras d'Or coal district, Victoria County, Cape Breton : Bell, W. A., 5.

Lake Ainslle district, Cape Breton Island: Bell, W. A., 12.

North Mountain, Cape Breton : Guernsey, 2.

Stirling area, Richmond County: Weeks, L. J., 1.

Sydney coal field, southern part: Hayes, A. 0., 6.

Economic geology.

Barytes: Spence, 4.

Berwick and Lakeviow areas, Kings and Annapolis counties: Faribault, 4 .

Carboniferous salt and potash deposits, Cumberland County: Hayes, 5.

Coal: Gray, 3 ; Hayes, 3.

Sydney field: Hayes, 6.

Diatomaceous earth : Burroughs, 1R. W., 1.

General : Hayes, A. O., 1 ; Wright, W. J., 1.

Gold deposits: Brunton, 5, 9, 10, 11, 13; McKenzie, N., 1; Reid, J. A., 2.

Gypsum and anhydrite: Wilder, 4.

Iron deposits of sedimentary origin: Hayes, 4.

Malagash salt deposit, potash-bearing horizon : Ellsworth, 9.

Manganese: Jennison, 1.

Lunenburg County: Fearing, 2; Reid; J. A., 1.
Nova Scotia-Continued.

Economic geology-Continued.

Mineral deposits: Wilson, M. E., 1.7.

Mineral resources: Drummond, 1; Anon., 34.

Molybdenite deposit, New Ross; Cook, C. W., 5.

Oil and gas possibilities, northern Nova Scotia: Boyd, H. E., 1.

Peat bogs: Anrep, 8.

Quartz sand and clay deposits, Melford, Cape Breton: Guernsey, 1.

Report on mines, 1926: McKenzie, N., 1, 2.

Road materials: Picher, 3.

Salt, Cumberland County: Cole, L. H., 1, 3 ; Hayes, 2.

Malagash deposits: Chambers, 1 ; Moffatt, 1.

Southwestern Nova Scotia : Faribault, 3. Tangier gold veins: Burton, 12.

Tungsten, Halifax County: Piers, 2. Wester'u Nova Scotia : Faribault, 1, 2.

Zinc, Stirling, Richmond County : Weeks, I. J., 1.

Historical geology.

Berwick and Lakeview areas, Kings and Annapolis counties; Faribault, 4 .

Carboniferous: Bell, W. A., 13.

Northumberland Strait: Bell, W. A., 10.

subdivision : Bell, W. A., 8.

Sydney district, Cape Breton: Bell, W. A., 1.

Coal-bearing formations: Bell, W. A., 7. General : Brunton, 6; Wright, W. J., 1.

Lake Ainslie region, Cape Breton Island: Trask, 6.

Malagash Peninsula, Cumberland County: Hayes, 2.

Minto, coal horizon, correlation: Bell, W. A., 6.

Mississippian, Horton-Windsor district: Bell, W. A., 2.

Now Glasgow conglomerate, Fictou County : Bell, W. A., 9.

Paleogeography of Acadia: Bailey, I. W., 2.

Silurian, Arisaig: Jones, O. T., 2; McLearn, 8.

Southwestern Nova Scotia : Faribault, 3

Western Nova Scotia: Faribault, 1.

Mineralofyy.

Forric minerals: Spencer, L. J., 1.

Loulsite: Walker, T. I., 57.

Magnesite crystals, Orangedale: Dobbel, 1 .

Mordenite and louisite: Walker, 24.

Pegmatite minerals, New Ross: Walker, 36.

Salt deposit minerals, Malagash : Rickaby, 2.

Ulexite: Walker, 10.

Zeolites: Biernbaum, 1; Walker, 17. 
Nova Scotia-Continued.

Paleontology.

Devonian, Cephalopoda : Foerste, 27.

Merostomata, coal measures: Bell, W. A., 4.

Palaeochara, coal measures: Bell, W. A., 4.

Silurian, Arisaig: McLearn, 8.

Petrology.

Amygdaloid, tubular: Walker, 16, 24.

General : Brunton, 6.

Triassic traps: Walker, 17.

Physical geology.

Coast erosion, Capt. Breton: Gray, F. W., 1.

Coast line changes, Kings County: Churchill, 5.

Drainage change, Black and Gaspereau rivers, Kings County : Churchill, 3 .

Elevation of seacoast near Wolfville: Churchill, 2.

Tidal phenomena of Bay of Fundy rivers: Kindle, 42.

Physiographic geology.

Esker excavation, Middlefield, Queens County : Prest, 2.

Eskers, nature and origin : Prest, 1.

Digby County: McIntosh, 1.

General : Goldthwait, 5 .

Glaciation : Walker, 24.

Cape Breton Island: Mather, 10.

Wolfville: Churchill, 4.

Marine sand bar, Cornwallis Valley : Churchill, 1.

Warping, postglacial: Daly, 11.

Oahu, pyroclastic geology: Wentworth, 22

Oatman district, Arizona, geology : Ransome, 12.

Ocean basins, origin: Willis, 6 .

ocean currents, climatic effects: Chamberlin, T. C., 20.

Ocean currents and geological change: Washington, 8 .

Ocean currents and isostasy: Bowie, 1.

Oceanographtc research: White, D., 16.

Oceanic islands, classification: Davis, 23.

Oceanographic investigations, projected : White, D., 25.

Oceanography: Vaughan, 33.

Deep off coast of Mexico and Central America: Heck, 1.

Ocher.

Georgla, Cartersville: Weigel, 1.

Ogilvie Range, Yukon: Cockfield, 3.

Ohio.

Geography: Peattie, 1.

Geological Survey: Mendenhall, T. C., 1

Relief map: U. S. G. S., 9.

Areas described.

Camp Sherman quadrangle: Hyde, 1.

Columbiana County: Stout, $\mathbf{5}$.

Delaware County : Westgate, 5 .

Muskingum County: Stout, 1.

Summerfleld and Woodsfield quadrangles : Condit, 3.
Ohio-Continued.

Areas described-Continuled

Vinton County: Stout, 6.

Wayne County : Conrey, 1.

Wellsville quadrangle: Hance, $\mathbf{3}$.

Economic geology.

Berea sand: Panyity, 2.

Clinton sand oil and gas accumulation: Russell, W. L., 9.

Clinton sandstone: Lockett, 1 .

Coal : Stout, 2.

Muskingum County: Stout, 1.

Pittsburgh coal bed: Bownocker, 8; White, I. C., 9.

Coal beds of Allegheny formation, onr relation: Thiessen, 9.

$\checkmark$ Coal fields: Campbell, M. .R., 6.

Coal formation clays: Stout, 3.

Coals, analyses: Fieldner, 1.

Glass sands : Bownocker, 7 .

Gypsum : Stone, 11.

Helium-bearing natural gas: Rogers, G. S., 7 .

Mineral resources: Bownocker, 9; Peattie, 1.

Molding sand: Bownocker, 5, 6.

-Oil and gas, Ordovician horizons: Panyity, 3.

Oil-producing sands, eastern ohio, structure: Lockett, 2.

Petroleum : Bownocker, 3.

Pyrite in coal: Tucker, W. M., 1.

Salt deposits: Phalen, 1.

Structural conditions, eastern Ohio: Cottingham, 4.

Summerfield-and Woodsfield quadrangles : Condit, 3.

Historical geology.

Berea sand, Panyity, 2.

Borings: Panyity, 3.

Brines of eastern Ohio: Lord, 1.

Chagrin formation: Chadwick, 12, 14.

Cincinnati anticline, dimensions : Hubbard, G. D., 5.

Devonian Spirifer horizons : Ireland, 1.

Dunkard series: Stauffer, 1.

Geologic map: Bownocker, 1 .

Huntington-Pittsburgh Basin : Richardson, G. B., 13.

Lucas County: Carman, 5.

Monongahela series: Stout, 7 .

Monroe division: Carman, 2.

Northeastern Ohio: Decker, C. E., 1

Olentangy shale: Lamborn, 1 .

o'Shaughnessy dam, Delaware County : Carman, 4.

Pottsville formation: Morningstar, 1.

Richmond faunal zones, Warren and Clinton counties : Austin, G. M., 1.

Sedimentary rocks, thickness: Hills, T. M., 1.

Silica shale, Lucas County: Stewart, (x. A., 2.

Silurian: Foerste, 2, 14

Vinton County, Mississippian : Fylle, 3. 
Olifo-Continued.

Paleontology.

Collecting fossil fishes in Cleveland shale: Hyde, 2.

Cystids and blastoids, Cedarville: Foerste, 10.

Dunkard series: Stauffer, 1.

Echinodermata, Brassfield formation: Foerste, 1.

Elephas roosevelti, Darke County: Hay, 26.

Fishes, Cleveland shale: Hyde, 4.

Footprints, Pennsylvanian: Carman, 3.

Gastropod, Guelph formation: Foerste, 14.

Marl deposits, Mollusca: Sterki, 1.

Medinan fauna: Foerste, 14.

Pleistocene Mollusca: Baker, F. C., 3; Logan County: Baker, F. C., 2.

Pottsville fauna: Morningstar, 1.

Richmond faunal zones, Warren and Clinton counties: Austin, G. M., 1.

Silica shale fauna: Stewart, G. A., 2.

Silurian: Foerste, 2, 14.

$\chi$ Type fossils in museum of Ohio State University: Morningstar, 2.

physical geology.

Caves: White, G. W., 1.

Put-in-Bay, origin: Cottingham, 1.

Cavities filled with glacial material, Silica, Lucas County: Carman, 1.

Concretions in lake deposits, Elyria: Hubbard, G. D., 1.

Cincinnati landslides: Rogers, J. K., 1.

Cryptovolcanic area, Serpent Mound: Bucher, 16.

Cryptovolcaulc phenomena: Bucher, 11.

Huntington-Pittsburgh Basin: Richa rdson, G. B., 13.

Isothrustic structure, Adams County: Jillson, 48.

Underground structure: Cottingham, 3.

Wisconsin drift, depth of leaching: Conrey, 2.

Physiographio geology.

Adams County, cryptovoleanic structure: Buchèr, 3.

Boulders outside of drift border : Patton, 4.

Islanois, western end of Lake Erie, control by foints: Cook, C. W., 7 .

Isake Abram, Berea: Speckman, 2.

Ohio River, genesis: Fowke, 1.

River valleys, northern Ohio, history: Hubbard, G. D., 7.

Underground water.

Ground waters, composition: Foulk, 1.

Sink holes and springs, Bellevue area: Hubbard, G. D., 8.

Ohio River, genesis: Fowke, 1.

Oil. See Petroleum.

Oil geology, practical : Hager, D., 8.

Oil pools, relation to ancient shore lines: Jones, W. F., 1.

Oll-field waters: Rogers, G. S., 1.
Oil shales.

Bibliography: Winchester, 5.

California, Sunta Barbara: Gore, 1, 2.

Canada : Ells, 3, 7.

Colorado: Alderson, 4 ; Chase, R. L., 1 ; George, R. D., 2.

DeBeque: DeBeque, 1.

northwestern : Lunt, 1.

Distribution in United States: Winchester, 4.

Eastern United States: Jillson, 83, 95, 96.

General: Alderson, 1, 2, 6; Dawson, J. C., 1; Fettke, 3 ; Gavin, 1 ; Hoskin, 1; Reeves, J. R., 5; Roeschlaub, 1; Trager, 2; Vilbrandt, 2 ; White, D., 4; Winchester, 2.

Genesis: Manning, 1.

Green River formation, Colorado: Sears, 5.

Green River oll shales: White, D., 4; origin: Bradley, W. H., 5.

Indiana : Esarey, 3 ; Reeves, J. R., 2-6.

Kentucky : Alderson, 3; Crouse, 5; Jillson, 25.

Devonian black shales: Crouse, 3 .

Devonian oil shale, microscopic composition: Thiessen, 10.

Estill County: Crouse, 1.

Kerogen : Craig, 2; Van Tuyl, 9.

Manitoba, Cretaceous shale: Ells, 2.

Microthermal observations on oil shales; Stadnichenko, 2.

Montana, Idaho, Wyoming, and Utah : Condit, 2.

Mother plants of petroleum in Devonian black shales: White, D., 19.

New Brunswick: Simpson, L., 1.

Albert Mines: Wright, W. J., 2.

North Carolina: Vilbrandt, 1, 2.

Ontario, Abitibi River: Williams, M. $Y$., 7.

Organic constituents: Iivingstone, 1 .

Organic content: Goodwin, R. 'T., 1 .

Organic matter: Franks, 1.

Origin : Collins, G. E., 1; Hixon, 6; Jones, J. C., 1 ; Linker, 1 ; Stadnichenko, 2; and composition: 'Thiessen, 7 ; and distribution; George, R. D., 5.

Pennsylvania: Fettke, 4.

Petroleum, relation to: Van 'Tuyl, 13. Rocky Mountain region: Winchester, 5.

Saskatchewan, Cretaceous shale: IElls, 2.

Soluble material in oil shale: McCoy, 6 .

Uinta Basin: Jensen, 1.

Wyoming: Morgan, G. B., 3.

Rock Springs area, Sweetwater County : Schultz, 1.

southwestern: Schramm, 1.

Oil supply of United States: U. S. G. S., 8. Oiseau River area, Manitoba: Wright, J. F., 10. 
Oklahoma.

Drillite: Shead, 4.

Deep-well temperature investigation: Gould, C. N., 32 .

General: Gould, C. N., 31.

Geologic problems unsolved: Gould, C. N., 20.

Oklahoma Geological Survey, seventh field conference : Gould, $\mathbf{1 7}$.

Ouachita Mountains : Honess, C. W., 3. Petroleum geology, history : Powers, 20.

Red River boundary: Glenn, 8 .

Sequoyah County, notes on: Kirk, C. T., 1.

Areas described.

Arbuckle Mountains: 'Taff, 7 .

Beaver County: Gould, 15.

Beckham County: Gouin, 2.

Bristow quadrangle, Creek County: Fath, 6.

Caddo and Grady counties: Becker, 1.

Cimarron County: Rothrock, 4.

Cleveland and McClain counties: Anderson, G. E., 4.

Gage, Ellis County: Thompson, D. G., 2.

Garvin County: Dott, 2.

Jefferson County (part) : Robinson, H. M., 3.

Kay, Grant, Garfield, and Noble counties : Clark, G. C., 3.

Kingfisher and Canadian counties: Kite, 1.

Love County : Bullard, 2.

Madill-Denison area : Hopkins, O. B., 2.

Marshall County: Bullard, 3.

Murray County, northern part: Monnett, 5 .

Southern Ouachita Mountains : Honess, C. W., 4.

Stonewall quadrangle: Morgan, G. D., 5.

Texas County: Gould, 11.

Wichita Mountains : Taff, 7.

Economic geology.

Building materials: Oakes, 1.

Burbank oil fleld, Osage County : Miller, W. Z., 1; Sands, 1, 2.

Carbon ratios of coals and relation to petroleum : Fuller, M. L., 4.

Carter County : Tomlinson, 4.

Cement oil field, Caddo County : Clapp, F. G., 1 ; Reeves, F., 1.

Coal : Shannon, C. W., 4.

Coal flelds: Cooper, 3.

Coals, analyses: Fieldner, 9.

Comanche County: Gouin, 3.

Copper, Garfield County: Reiter, 1.

Crinerville oil fleld, Carter County: Powers, 22.

Cromwell oil field, criteria of structure: Somers, 3

Dizest of oil and gas flelds: MillsBullard, 2

Ios and Graham oil and gas fields, Carter County: George, H. C., 2.
Oklahoma-Continued.

Economic geology-Continued.

Fox oil and gas field, Carter County: Storm, 3.

Garber oil field: Vanderpool, 1.

Garber ofl sands, age and correlation : Wheeler, H. C., 1.

Glenn formation: Goldston, 3.

Glenn oil pool: Rich, J. L., 13; Wilson, W. B., 1.

Graham field, Carter County : Tomlinson, 1.

Gypsum : Stone, 11.

Gypsum and salt: Gould, C. N., 29.

Harmon, Greer, Jaćkson, and 'I'illman counties: Clifton, $\mathbf{5}$.

Ifealdton oil field, Carter County: Bartram, 1.

Helium-bearing natural gas : Rogers, G. S., 7.

Hewitt oil field, Carter County : Roark, 1 ; Swigart, 1.

Hogshooter gas sand: Berger, 1.

Joplin region, lead and zinc ores: Spurr, 32.

Kay County, pre-Penusylvanian oil horizons : Aurin, 1.

Kirk gas sand, Graham district: Ley, 3.

Lead ore, rapid formation: Wheeler, H. A., 3.

Logan County: Bale, 1.

McIntosh County: Clark, R. W., 4.

Manganese, Bromide : Hewett, 8 .

Custer County : Reiter, 2.

Miami district : Netzeband, 1.

Mid-Continent oil fields: Bosworth, 1. reflected buried hills: Powers, 11. structures: Monnett, 2.

Mineral production in 1925 : Redfiell, J. S., 2.

Mineral raw materials, chemical analyses: Shead, 8.

Mineral resources: Gould, 6 ; Redfield, J. S., 1; map showing distribution: Okla. G. S., 1.

Morrison ofl field, Pawnee County : Carpenter, E., 1.

Muskogee County: Soyster, 1.

Natural gas: Shaw, 6; Snider, 1.

Natural gases, chemical survey: Allen, H. C., 1.

Nowata and Craig counties: Bloesch, 4. Oil and gas: Powers, 20.

Creek County, Merritt, J. W., 4.

Kay, Grant, Garfield, and Noble counties : Clark, G. C., 3.

Okmulgee County : Clark, R. W., 2.

Stephens County: Gouin, 1.

Wagoněr County : Boyle, 1.

Oil and gas development: Shannon, C. W., 1.

Oil and gas fields, map: U. S. G. S., 6. southern Oklahoma : Moore, R. C., 10.

Oll and gas geology, Coal and Pittsburg counties : Clawson, 1 . 
Oklahoma-Continued.

Economic geology-Contínued.

Oil and gas prospects, Jefferson County : Robinson, H. M., 3.

Oil and gas resources, Osage Reservation: Bowen, C. F., 3 ; Goldman, 2, 4 ; Heald, 1-4; Hopkins, O. B., 1 ; Robinson, H. M., 1, 2 ; Ross, C. S., 2.

Oil fields: Gould, $\mathbf{T}$.

Oil pools and red beds, relation: Burton, G. E., 2.

Oil possibilities, southeastern Oklahoma : Lockwood, 1.

Oil production: Mlls-Bullard, 1, 2.

Oil sands, northeastern Oklahoma: Williams, D. W., 1.

texture: Melcher, 3.

Oil sands and production relations: George, H. C., 5.

Oil structures, southwestern Oklahoma: Howell, J. V., 2.

Oil-field waters: Rogers, G. S., 2.

Okmulgee district: Clark, R. W., 1.

Osage Reservation: Roundy, 1.

Osage County: Beckwith, II. 'T., 1.

l'apoose oil field: Roark, 2.

lawuee County: Greene, 10.

Iayne County: Koschmann, 1.

lurshing oil and gas field, Osage County: Rubey, 2.

Petroleum : Snider, 1.

Osage Nation: Mason, S. L., 1.

Osage County: Hartley, 3.

Stephens County, "2-4" field: Storm, 1.

Velma field: Storm, 2.

Petroleum and natural gas, Bristow quadrangle: Fath, 6.

Phosphate rock, Hastings: Shead, 2.

Picher district, sub-Cherokee contour map : Siebenthal, 28.

Pontotoc County: Conkling, 1.

Robberson oil and gas field, Garvin County: Denison, A. R., 1. English, L., 1 ; Oklahoma G. S., 2.

Robberson oil field, Garvin County: Roth, 1.

Road materials, western Oklahoma: Evans, O. F., 7.

Rock distortion on local structures in oil fields : Gardner, J. H., 1.

Rogers County : Woodruff, 4.

Silt deposits: Phalen, 1 ; Darton, 8.

Sayre oil and gas field, Beckham County: Birk, 1.

Seminole County: Levorsen, 2.

Seminole uplift: Powers, 23.

Siluro-Devonian oil horizon, southern Oklahoma : Morgan, G. D., 1, 4.

Southeastern Oklahoma: Honess, C. W., 6.

Stroud oil field: McFarland, 1 ; Powers, 15.

Thomas oil field, Kay County: Clark, S. K., 1, 3.
Oklahoma-Contínued.

Economic geology-Continued.

Tonkawa ofl and gas fleld: Clark, G. C., 1 ; Hosterman, 1 ; Wilcox sand production : Clark, G. C., 2.

Turkey Mountain lime oil pools: Ruedemann, P., 2.

Unconformities, bearing on occurrence of petroleum: Bloesch, 1.

Washington County: Carpenter, E., 2.

Zinc-lead field: Naething, 2.

Il istorical geology.

Arbuckle limestone: Decker, 8.

Arbuckle Mountains: Decker, C. I., 2 ; Reeds, 11 ; geologic history : Weidman, 3.

mapping: Decker, 2.

Ardmore Basin, Pennsylvanian : Tom. linson, 3.

Blaine gypsum : Gould, C. N., 23.

Black Mesa basalt, Cimarron County : Shead, 5.

Boggy unconformity and overlap, southern Oklahoma: Morgan, G. D., 6.

Borings, Carter County: Roth, 2. central Oklahoma: Hughes, 1. into granite, list: Greene, 5 .

Bromide area: Hewett, 8.

Buried hills near Mannsvifle: Tomlin. son, 2.

Buried mountain ranges: Gould, 4.

Caddo County, Cement oil fleld : Reeves, F., 1.

Caney shale and its boulders: Ulrich, 18.

Carboniferous: Gould, 12.

Ouachita Mountains, age relations: Miser, 29.

southern Oklahoma : Burton, G. E., 2.

Carter County: Tomlinson, 4.

Cement oil field, Caddo County : Clapp, F. G., 1, 2.

Cimarron County : De Ford, 1.

Coal and Pittsburg counties: Clawson, 1.

Coals of Oklahoma and Kansas, correlation: Cooper, 4.

Comanche County: Gouin, 3.

Comanchean, Love County : Bullard, 1. northwestern Oklahoma: Clifton, 3.

Conglomerates near eastern limits of red beds : Evans, 0. F., 2.

Correlation of "Wilcox" sand, Okmulgee district, and Osage: White, L. H., 1.

Creek County: Merritt, J. W., 4.

Devonian: Schuchert, 21.

Eastern Oklahoma: Shannon, C. W., 4. underground stratigraphy: Trager, 3.

Enid formation: Aurin, 3.

Field conference: Gould, C. N., 18.

Foraker limestone, Lincoln County: Lillibridge, 1. 
Oklahoma-Continued.

Historical geology-Continued.

Formation names, obsolete: Gould, C. N., 24.

Fort Scott-Wetumka correlation: Bloesch, 3.

Franks and Seminole formations, stratigraphic position: Morgan, G. D., 7 .

Frederick, Tillman County: Cook, H. J., 12.

Garvin County, limestone occurrence: Loomis, H., 1.

General: Gould, C. N., 33; Redfield, J. S., 1 ; Snider, 1.

Geologic map: Miser, 16, 24 ; Powers, 13.

Glaciation, Pennsylvanian, Arbuckle and Wichita mountain regions: Weidman, 1, 2.

Glenn formation: Girty, 5 . Ardmore quadrangle: Goldston, 1. southern Oklahoma: Goldston, 2, 3.

Harmon, Greer, Jackson, and Tillman counties: Clifton, 5.

Hewitt oil field, Carter County : Rontk, 1 ; Swigart, 1.

Hogshooter gas saud: Berger, 1.

Human artifacts, Frederick : Cook, H. J., 15.

Furonian-Grenville relations: Qufıke 18.

Index to stratigraphy : Gould, ?

Jefferson County (part): Robinson, H. M., 3.

Kay County, pre-Pennsylvanian oil horizons: Aurin, 1.

Leflore and McCurtain counties: Honess, C. W., 5 .

Logan County : Bale, 1.

Lower Cretaceous : Bullard. 4.

southeastern Oklahoma: Miser, 27.

McIntosh County: Clark, R. W., 4.

Mid-Continent oil fields: Aurin, 2.

Mississippian, distribution and correlation: Buchanan, 2.

tuff, Ouachita Mountains: Miser, 3.

Muskogee County: Soyster, 1.

Northeastern Oklahomi: White, I. II., 3.

Nowata and Craig counties: Bloesch, 4.

Oil sands, northeastern Oklahoma: Williams, D. W., 1 .

Oklahoma Mountains, age of folding: Powers, 26

Okmulgee County : Clark, R. W., 2. Okmulgee district: Clark, R. W., 1. Ordovician correlations: Edson, 3.

Osage County: Beckwith, H. T., 1.

Osage Reservation: Bowen, C. F., 3; Goldman, 2-4 ; Heald, 1-4 ; Hopkins, O. B., 1 ; Robinson, H. M., 1 , 2 ; Ross, C. S., 2 ; Roundy, 1.

Ouachita Mountains, southern: Honess, C. W., 1.

Paleogeography : Wilson, R. A., 8.
Oklahoma-Continued.

Historical geology-Continued.

Paleozoic: Miser, 7.

Papoose oil field: Roark, 2.

Pawnee County: Greene, 10.

Payne County : Koschmann, 1.

Pennsylvanian: Wilson, R. A., 9. eastern Oklahoma: Levorsen, 1. paleogeography : Dott, 1 ; Henryetta district: Reed, R. D., 2.

sedimentation around Healdton Island: Merritt, J. W., 1.

Peunsylvanian-Fermian glaciation, Arbuckle and Wichita mountains: Dunbar, 7 ; Weidman, 4.

Permian: Gould, 8, 14, 27. correlation: Gould, 10.

red beds, southwestern Oklahoma : Gould, 55.

western OkJahoma: Gould, 16.

Pontotoc County : Conkling, 1.

Pontotoc series, Arbuckle area: Molgan, G. D., 2, 3.

western end of Arbuckle Mountains : Birk, 2.

Pre-Camblian, southeaster'n Ontario: Quirke, 13.

Pre-Chattanooga formations: White, L. H., 2.

Pre-Permian, Wichita Mountains : Howell, J. V., 3.

Problems of stratigraphy: Wilson, K. A., 10.

Red beds area: Greene, 1.

Red berls near base of Cherokee shales: Tarr, Russ. S., 1.

Rogers County: Woodruff, 4.

St. Clair limestone, Arkansas and Oklahoma: Ulrich, 14.

St. Peter sandstone : Dake, 6.

Seminole area: Dwyer, 1.

Seminole County: Levorsen, 2.

Siluro-Devonian oil horizon, southern Oklahoma : Morgan, G. D., 1, 4 .

Simpson formation: Edson, 1.

Southeastern Oklahoma: Honess, $c$. W., 6.

Southern Oklahoma: Moore, R. C., 10, 11.

Southwestern Oklahoma: Sawyer, 1. Stanley shale: Honess, C. W., 2.

Stanley-Jackfork series: Honess, C. W., 5.

Stephens County: Gouin, 1.

Stonewall quadrangle: Greene, 6.

Sycamore limestone: Cooper, 2.

Thomas oil field, Kay County: Clark, S. K., 1.

Tonkawa field : Clark, G. C., 2.

Trinity group: Vanderpool, 3.

Trinity sandstone, depth of base: Melton, 8.

Upper Paleozoic rocks: Gould, C. N.. 19.

Verden sandstone: Reed, 3; Stephenson, C. D.. 1 . 
Oklaboma-Continued.

Historical geology-Continued.

Volcanic ash, North Canadian Valley : Gardner, J. H., 2.

Volcanic rocks, Cretaceous: Miser, 19.

Volcanic tuffs, central Oklahoma: Hoffman, M. S., 1.

Wagoner County: Boyle, 1.

Washington County: Carpenter, E., 2.

Weatherford area:. Evans, N., 1; Moole, H., 1.

Western Oklahoma: Fennemann, 2 ; Patton, 7.

subsurface stratigraphy: Greene, 9.

Whitehorse sandstone: Clifton, 2. correlation: Clifton, 4.

Wichita, Arbuckle, and Ouachita mountains, age of folding: Powcrs, 21.

Wildhorse area: Brockway, 1.

Woods, Alfalfa, Harper, Major, Woodward, and Ellis counties: Clifton, 1.

Wreford and Foraker limestones: Twenhofel, W. H., 1.

\section{Mineralogy.}

Barite: Shead, 3.

Celestite ; Gould, C. N., 22.

Heavy minerals, recognition: Edson, 2.

Leucoxene in Permian Mid-Continent sediments: Brown, L. S., 1 .

Meteorites: Shannon, C. W., 2.

Sinithville: Shead, 1.

Sand barite crystals: Gould, C. N., 25. Paleontology.

Apus, Permian: Ruedemann, 8.

Artifacts, Frederick: Cook, H. J., 13, 15 ; Hay, 43 ; Sci. Serv., 9 ; Spier, $1,2$.

Beaver County, leaves: Berry, 82.

Bison occidentalis, occurrence: Crabb, 2.

Comauchean, Love County: Bullard, 1.

Cordaites showing growth rings, Bartlesville: Goldring, 2.

Cryptozoon, Arbuckle $\mathrm{M}$ o u $\mathrm{n}$ a in s : Decker, 6.

Dakota sandstone plants, Cimarron County : Noe, 9

Elephant : Crabb, 1.

Elephas, Frederick: Hay, 41.

Elephas cf. jeffersoni, juvenile lower Jaw, Frèderick: Cook, H. J., 17.

Foraminifera, Dornick Hills formation, Carter County: Waters, J. A., 1.

Glenn formation: Harlton, 2.

Pennsylvanian: Galloway, J. J., 13 ; Harlton, 3.

Glenn formation: Girty, 5.

Glyptodon : Gould, C. N., 30.

Leaf fossils, Permian: Gould : C. N., - 26.

Monoceratina, Pennsylvanian : Roth, 3.

Ostracodu, Glenn and Hoxbar formations; Harlton, 1.
Oklahoma-Continued.

Paleontology-Continued.

Ostracoda-Continued.

Pennsylvanian : Coryell, 3 ; Harlton, 4 ; Seminole County: Coryell, 4.

Pleistocene Vertebrata : Hay, 6.

Proboscidea, distribution: Decker, 3.

Stanley shale: Honess, C. W., 2.

Sycamore limestone: Cooper, 1.

Trematops thomasi, Permian: Mehl, 15.

Trinity fauna: Vanderpool, 2.

Petrology.

Volcanic rocks, Cretaceous: Miser, 19.

Physical geology.

Anticlinal folds, Custer County : Reiter, 3.

Arbuckle Mountains, structural features: Decker, 4.

"Buried hills," structural influence: Monnett, 6.

Calcite, Nussbaum formation, Cimarron County, crystallization force: Rothrock, 2.

Caliche: Lonsdale, 5, 6.

Crystalline rocks of the plains: Gould, 3.

Faulting, Creek and Osage counties, origin : Foley, 1 ; Ickes; 3.

Faulting and folding: Fath, 1.

Folding, Okmulgee County: Clark, R. W., 3.

origin : Foley, 3.

Folds of Osage County, origin : Brown, R. W., 1; Kitson, 2.

Lichens as weathering agents of limestone: Weidman, 6.

Ouachita Mountains, structure : Miser, 30, 31.

Osage County, folds: Millikan, 1.

Pershing oil and gas field, Osage County: Rubey, 2.

Rock distortion on local structures in oil fields: Gardner, J. H., 1.

Slumping previous to consolidation in Pennsylvanian : Ross, C. S., 8.

South Canadian River near Norman: Evans, O. F., 3.

Strand markings in Pennsylvanian sandstones, Osage County : Powers, 6.

Structural trends, southern Oklahoma: Decker, L., 1.

Structure map, northeastern Oklahoma: Thom, 11.

Temperature, deepest well : Miser, 15.

Thomas field, Kay County, faulting: Clark, S. K., 3.

Transverse structure in Arbuckle Mountains: Decker, 5.

Veining along faults, Pennsylvanian sandstone: Hoffman, M. S., 2.

White spots in Permian red beds : Shead, 7.

Wichita Mountain area, erosion and transportation: Evans, O. F., 1. 
Oklahoma-Continued.

Physiographic geology.

Arbuckle Mountains, physiographic history : Weidman, 3.

General: Redfield, J. S., 1; Shannon, C. W., 3.

North and South Canadian River basins: Bollinger, 1.

Parallel courses of streams : Evans, O. F., 9.

I're-Paleozoic topography: Monnett, 4.

Red River: Tex., Atty. Gen., 1.

Stream valley type: Evans, O. F., 5.

Valleys of interior plains, origin: Evans, 0. F., 6.

Western Oklahoma: Fenneman, 2.

Underground water.

Enid area: Renick, 4.

Oil-field waters: Rogers, G. S., 2.

Oldhamia, Lower Cambrian, Massachusetts : Howell, B. F., 2.

Oligocene, use of term: Berry, 86 .

Ontario.

Anthraxolite, microstructure: Kelly, S. F., 2

Borings: Ingall, 6.

Bureau of Mines reports, index: Nicolas, 1.

Department of Mines, index to reports : Ont. Dept. Mines, 2.

English River valley: Bruce, 11.

General: Raasch, 1.

Kenogamissi Lake area: Todd, E. W., 3.

Lake St. Joseph area : Johnson, J. P., 1.

Museum of Mineralogy, Ontario: Parsons, 10

Preglacial oxidation in northern Ontario: Tyrrell, 5.

Red Lake area, Patricia: Bruce, 18.

Red Lake basin, District of Patricia Bruce, 12.

Red Lake to Favourable Lake, District of Patricia : Douglas, G. V., 4

Report of Bureau of Mines : Ont. Bur Mines, 1.

Report of Department of Mines : Ont. Dept. Mines, 1.

Thunder Bay district, base and meridian lines: Swanson, W. L., 1.

base line: Green, W. F., 1.

Watabeag area, Wright, D. G. H., 1.

Areas described.

Abitibi-Night Hawk gold area, Timiskaming district: Knight, C. W., 1.

Algoma district, Deroche, Hodgins, Gaudette, and Shields townships: Brunton, 1.

Anima-Nipissing area : Todd, E. W., 7 .

Arnprior-Quyon area: Wilson, $M$. E., 10.

Batchawana area, District of Algoma : Moore, E. S., 19.

Black River area, Timiskaming : Wright, D. G. H., 1.

Blanche River area; Burrows, 9.
Ontario-Continued.

A reas described-Continued.

Boston-Skead area, Timiskaming district: Burrows, 8.

Brockville-Mallorytown area : Wright, J. F., $2,8$.

Cocbrane district, Ogden, Bristol, and Carscallen townships: Hawley, J. E., 3.

Gammon River area, District of Kenora: Gilbert, $\mathbf{G}, 7$.

Geneva map area, Sudbury district, Ontario: Quirke, 7.

Goudreau gold area, Michipicoten district: Thomson, E., 4.

Goudreau-Lochalsh gold area, District of Algoma : Gledhill, 8.

Gowganda silver area: Burrows, 3, 6.

Grassy Rivel area, south part: Gledhill, 6.

Groundhog River area: Todd, E. W., 4.

Gunflint iron-bearing formation: Gill, J. E., 1.

Kamiskotia gold area, District of Cochrane: Finley, 1.

Kenogami Lake area, Timiskaming district: Cooke, H. C., 8.

Kirkland Lake gold area: Burrows, 4, 12 ; Todd, 8; Lebel and Gauthier townships : Hopkins, 7.

La Cloche area, District of Sudbury : Douglas, G. V., 3.

Lake St. Joseph area : Bruce, 8; arca south of west end: Bruce, 10.

eastern part: Bruce, 9 .

Lake Timiskaming area : Hume, 14.

Larder Lake area, Timiskaming district: Cooke, H. C., 8; Hopkins. P. E., $1,8$.

Leeds County : Baker, M. B., 1.

Lightning River gold area, District of Cochrane: Gledhill, 4 ; Knight, 12.

Lower Missinaibi, Opazatika, and Mattagami rivers: McLearn, 12.

Madoc district: Wilson, Morley E., 5.

Matabitchuan area, districts of Timiskaming and Nipissing: Todd, E. W., 5.

Matachewan district, northern Ontario : Burrows, 2 ; Cooke, H. C., 1.

Matawin iron range, Thunder Bay district, eastern part: Tanton, 15.

Michipicoten area: Collins, 15; Gledbill, 7 .

Missinaibi area: Thomson, F., 11.

Mississagi Reserve and Goulais River iron ranges, District of Algoman : Moore, E. S., 15.

Moose River basin, northern part: Kindle, 26.

Night Hawk Lake gold area : Hopkins, 9.

Nipigon-Schreiber district: Tanton, 6

North shore of Lake Huron: Collins, 11. 
Ontario-Continued.

Areas described-Continued.

Ontario-Manitoba boundary, Bloodvein River to Twelfth base line: Rickaby, 1.

Winnipeg River to Bloodvein River: Burwash, 6.

Pearl Lake area, Porcupine district: Robinson, H. S., 1.

Porcupine gold area: Burrows, 13.

Red Lake area, District of Patricia: Rogers, W. R., 6.

Red Lake Basin, District of Kenora: Bruce, 22.

Round Lake area, Timiskaming district: Cooke, H. C., 8.

Sahkatawich (Rush) Lake section, Woman River iron range, District of Sudbury : Moore, E. S., 20.

Sault Ste. Marie area, District of Algomá: McConnell, 1.

Schreiber-Duck Lake area: Hopkins, P. E., 5.

Shiningtree silver area, District of Timiskaming : Langford, 1.

Sturgeon Lake area: Gledhill, 2.

Sudbury district, Grassy River area : Gledhill, 5.

West Shiningtree area: Finley, 2.

Sutton Lake area, District of Patricia : Hawley, J. E., 1.

Tashota-Onaman gold area, District of Thunder Bay: Gledhill, 3.

Thunder Bay district: Tanton, 5, 8 .

Timiskaming district, Redstone River area : Bruce, 19.

Wakomata Lake area, Algoma distrlct: Emmons, R. C., 3.

Wanapetel Lake area, Sudbury distrlct: Quirke, 8.

Wasapika section, West Shiningtree gold area, District of Sudbury : Langford, 2.

Watabeag area, Timiskaming and Cochrane districts: Wright, D. G. H., 2.

West Shiningtree gold area: Hopklns, P. E., 2

Whiskey Lake area, District of Algoma : Douglas, G. V., 2.

Woman and Narrow lakes area, District of Kenora: Greig, 2.

Economio geology.

Abitib1-Mattagami area : Cross, J. G., 2.

Alteration in Keeley mine, South Lorrain : Bell, J. M., 6.

Anthraxolite, Sudbury: Gibson, 2.

Apatite deposits: Spence, 2.

Argonaut gold mine, Gauthier township, Timiskaming district, Cooke, H. C., 13, 23 ; Knight, 6.

Auld and Cane townships: Burrows, 6. Brockville-Mallory area : Wright, J. F., 1.

$4096-31-57$
Ontario-Continued.

Economic geology-Continued.

Carbonaceous matter at Porcupine: Bell, J. M., 8.

Clay, Mesozoic, Mattagami and Mis. sinaibi rivers, northern Ontario: Dyer, 11.

northern Ontario: Keele, 1.

Clay and shale deposits: Keele, 8.

Abitibi and Mattagami rivers; Keele, 2.

Clays, Missinaibi River: Keele, 6, 7.

Cobalt : Drury, 1 ; Knight, C. W., 7. diffusion in vein genesis: Whitman, 1.

Cobalt and South Lorrain silver areas: Knight, 11.

Cobalt district, genesis of ores: Whit. man, 3.

Cobalt ore horizons: Shaw, J. W., 1.

Cobalt silver district: Bateman, G. C., 1 ; Cole, A. A., 1 ; Miller, W. G., 9.

Cobalt veins: Whitehead, 1.

Copper deposits, Perry Sound : Schwartz, 8.

Cretaceous sands and clays, northern Ontario: Keele, 4.

Deep-seated oxidation and secondary enrichment at Keeley silver mine near Cobalt: Bell, J. M., 4.

Favourable Lake area, Patricia : Hurst, 5.

Feldspar, Lanark County: Campbell, A. M., 1

Feldspar, Ottawa district: Davis, N. B., 1.

Fluorspar, Madoc district: Wilson, Morley E., 6, 9.

Fort Hope gold area: Burwash, 8.

Gold: Hopkins, P. E., 3, 4.

Beardmore: Burrows, 16.

Ben Nevis area : Knight, C. W., 5.

Boston-Skead area: Burrows, 8.

in quartzite, Goudreau district : Moore, E. S., 10.

Kenora and Rainy River districts: Bruce, 17.

Larder Lake, Timiskaming district: Cooke, H. C., 14.

McNeil township : Hopkins, 10.

Makwa, Sudbury district: Tanton, 10.

Matachewan area: Burrows, 2; Cooke, H. C., 1, 3.

Michipicoten district: Thomson, E., 4.

northwestern Ontario: Timm, 1.

Pancake Lake: Hopkins, 11.

Porcupine district: Dougherty, 1; Spurr, 8.

West Shiningtree area : Hopkins, $\mathbf{P}$. E., 2.

wide dissemination of gold in northern Ontario: Boydell, 13. 
Ontario-Continued.

Economic geology-Continued.

Gold and silver: McGill, 1.

Goudreau gold area: Burrows, 5, 7 ; Macleod, 1, 2.

Gowganda silver district: Brunton, 4.

Graphite, Renfrew district: Wilson, M. E., 4 .

Gravel deposits, St. Clair River : Bartlett, J., 1.

Gunflint iron formation: Gill, J. E., 2.

Gypsum, Moore River: Lanning, 1. southwestern Ontario: Cole, G. E., 1, 2 ; Dyer, 5.

Hematite, Leeds County: Wright, J. F., 1.

Iron deposits: Bruce, 16; Collins, 7 ; Knight, C .W., 8; O'Connor, 1; Ontario Iron Ore Committee, 1.

Gravel Lake, Thunder Bay district: Tanton, 12

Lake St. Joseph : Bruce, 8.

Iron oxide pigments : Fréchette, 1.

Iron ranges, northwestern Ontario: Marks, 1.

Keewatin iron formations: Collins, 23

Kirkland Lake gold area: Burrows, 4 ; Cooke, H. C., 6 ; Hopkins, P. E., 6 ; Johnson, H. H., 1 ; Orser, 1 ; Spearman, 4 ; Spurr, 9 ; Tyrrell, 9.

Lebel and Gauthier townships: Hopkins, 7.

Larder Lake: Cooke, H. C., 24 ; Hopkins, P. E., 1 ; Pearce, 2.

Lake Superior region, Port ArthurNipigon: Tanton, 3.

Lead, Galetta : Wilson, M. E., 12. and zinc: Alcock, 23.

Leeds County: Baker, M. B., 1.

Lightning River gold area : Burrows, 1; Knight, C. W., 9.

Limestones : Goudge, 3.

Abitibi and Mattagami rivers: Malcolm, 6.

Lost placers: Coleman, 3.

Mattagami and Abitibi rivers: Williams, M. Y., 6, 7 .

Mesozoic clays and sands, northern. Ontario: Keele, 3.

Michipicoten district: Collins, W. H., $1,2$.

Mine Centre district: Reagan, 2.

Mineral industry: Gibson, 1; Rogers, W. R., 1-5, 7 .

Mineral resources: Corless, 2; Ontario Dept. Mines, 1.

Mineralization, South Lorrain, Cobalt district: Bell, J. M., 6.

Mining areas, geographical relations: Miller, W. G., 7.

Molybdenite, Ottawa Valley: Wilson, Morley E., 4.

Renfrew-Calabogie district: Wilson, Morley E., 4.

Montreal River district: Anon., 4.
Ontario-Continued.

Economic geology-Continued.

Murphy, Hoyle, and Matheson townships, Porcupine gold area: Rose, 4.

Natural gas: Estlin, 1, 2.

and oil possibilities: Coste, 2 .

and petroleum: Harkness, 2-6.

Nickel : Simmersbach, 1.

Shebandowan deposit: Cross, J. G. 1.

Windy Lake and other areas Knight, C. W., 4.

Norite micropegmatite, composition, Sudbury : Knight, 10.

Northern Ontario: Tanton, 2.

Northpines pyrite mines: Hanson, 1.

Oil and gas: Harkness, $1,7$.

Oil and gas geology : Williams, M. Y., 3.

O1l and gas horizons: Dyer, 7 .

Oil and gas possibilities: Rowe, E. $P$., 1.

Oil and gas prospects: Williams, $M$ Y., 9.

Oll flelds : Estlin, 2

southwestern Ontario: Williams, $M$. $Y, .2,4$.

Oil possibilities, Manitoulin Island : Williams, M. Y., 11.

Oil in Tanton syncline, Kent County : Williams, M. Y., 5.

Onaman gold area : Girvin, 1.

Ore deposition at the Creighton mine, Sudbury : Spurr, 14.

Ore deposits, Pearl Lake area: Bain, 13.

Ottawa Valley: Wilson, M. E., 3, 4.

Palladium-bearing nickel deposit, Shebandowan Lake, Thunder Bay district: Tanton, 9

Pearl Lake area, Porcupine district: Robinson, H. S., 1.

Peat: Anrep, 2, 4, 6; Haanel, B. F., 2.

Pegmatite dikes, southeastern Ontario: Sine, 3.

Pitchblende, Butt township : Hore, 6 ; Knight, C. W., 3.

Placers in Cobalt conglomerate: Johnston, W. A., 19.

Porcupine area, porphyries: Wright, L. B., 2.

Porcupine gold field: Bell, J. M., 2; Burrows, 10, 11; Fielding, 1 Hore, 8; Huntoon, 1

extension: Goodwin, W. L., 2.

Porcupine porphyry stocks: Burrows, 15.

Porcupine quartz veins: Spurr, 25; mode of formation; Dougherty, $3,4$.

Pyrite, Calabogie district: Wilson, $\mathbf{M}$. E., 4.

Goudreau : Collins, W. H., 1. 
Ontario-Continued.

Economic geology-Continued.

Recent mining developments: Burlows, 14

Red Lake gold area, Patricia: Wright, D. G. H., 4.

Red Lake and Woman Lake gold areas: Bruce, 23.

Road materials, eastern Ontario: Picher, 2, 4.

Romney oil well: Davis, H. R., 1.

Rutter map area, Sudbury district: Quirke, 19.

Sand and gravel : Ledoux, A., 1.

Schreiber-Duck Lake area: Hopkins, P. E., 5 .

Shebandowan nickel-copper deposits : Cross, J. G., 3.

Siderite deposits, Mattagami River: Cross, J. G., 2.

Silurian, southwestern Ontario: Williams, M. Y., 1 .

Silver orcas, Cobalt, genesis: Bastin, $6,12$.

Gowganda area: Burrows, 3, 6 .

South Lorrain : Bastin, 9, 12; Bell, J. M., 3, 5 .

Silver veins, Cobalt: Knox, H. H., 1. Silver Islet ores, Thunder Bay district: 'Tanton, 4; Thomson, E., 6. paragenesis: Chadbourn, 1.

Steeprock Lake area: Tanton, 16.

Structural control of location of ore deposits : Bell, J. M., 9.

Structural materials, St. Lawrence Valley: Keele, 5.

Sudbury laccolite: Harker, 1.

Sudbury nickel deposits: Coleman, 23, 29 ; Gregory, J. W., 3 ; Park, J., 1; Phemister, 4; Roberts, H. M., 2; Wandke, 4 ; Young, J. W., 4.

assimilation and assimilation processes: Bain, 14 ; Phemister, 5.

magmatic origin : Coleman, 488.

Sudbury nickel-copper deposits: Bell, J. M., 1.

Talc, Madoc, Hastings County : Wilson, M. E., 8.

Thunder Bay district: Parsons, 5.

Timiscaming ores, structure: Schlossmacher, 1.

Wabigoon and Trap Lake soapstone deposits : Wright, J. F., 5.

Wasapika gold area, Sudbury district: Hore, 1-5.

West Shiningtree gold district: Goodwin, L. H., 1 ; Weed, 1.

Zinc and lead, Genoa township, Sudbury mining division : Moore, E. S., 16.

\section{Historical geology.}

Abitibi-Mattagami area : Cross, J. G., 2.

Alluvial fan deposits in I!pure Furonian : Bain, 3.
Ontario-Continued.

Historical geology-Continued.

Archean: Cooke, H. C., 17.

Argonaut gold mine: Knight, 6.

Ben Nevis gold area: Knight, 5 .

Borings : Estlin, 2 ; Ingall, 3.

Cobalt district: Bastin, 12.

Cobalt and South Lorrain silver areas: Knight, 11.

Cobalt conglomerate, origin : Coleman, 4.

Coutchiching: Grout, 15

Bear's Pass section, Rainy Lake: Bruce, 15.

near Steeprock Lake: Tanton, 14.

Coutchiching delta: Bruce, 21.

Cretaceous sands and clays, northern Ontario: Keele, 4.

Credit River section: Dyer, 3 .

Dundas formation: Parks, 17.

Geologic map, Algoma and Thunder Bay districts: Canada G. S., 1.

showing mineral resources: Canada, Dept. Mines, 1.

Thunder Bay district: 'Tanton, 7.

Gowganda conglomerate, origin: Bain, 17.

Grenville pre-Cambrian subprovince : Wilson, M. E., 15.

Haileyburian intrusives : Miller, W. G., $2,3$.

Hastings series: Wilson, M. E., 19.

Hudson Bay area : Foerste, 22 ; Savage, 2.

Huronian and Grenville rocks, correlation: Quirke, 12, 13.

Furonian complex near Killarney : Quirke, 11.

Huronian replacement deposits : Quirke, 20.

James Bay region: Savage, 2.

Keewatin iron formations: Collins, 23.

Keweenawan system, eastern end of Lake Superior: Moore, E. S., 18.

Klllarney gneisses and migmatites: Quirke, 22.

Kirkland Lake gold area: Todd, 8; Tyrrell, 7.

Lake Superior region, Port ArthurNipigon: Tanton, 3.

Lightning River gold area: Knight, C. W., 9.

Manitoulin Island : Williams, M. Y., 11.

Matachewan series, northeastern Ontario: Miller, W. G., 6.

Mesozoic and Pleistocene deposits of lower Missinaibi, Opazatika, and Mattagami rivers: McLearn, 12.

Michipicoten district : Collins, W. H., 1. Middle Eozoic sediments: Spearman, 3. Montreal River district: Anon., 4.

Moose and Albany rivers, northern Ontario: Williams, M. Y., 12.

North shore of Lake Furon: Collins, 11.

Northeastern Ontario: Miller, W. G., 8. 
Ontario-Continued.

Historical geology-Continued.

Oil and gas geology: Williams, $\mathbf{M}$. Y., 3.

Ordovician, Ottawa region: Wilson, A. E., 1.

Toronto: Parks, 15.

western Ontario: Parks, 28.

Ordovician black shales: Parks, 32.

Ordovician and Silurian, Hudson Bay area : Foerste, 22.

Pagwachuan, Kenogami, and Albany rivers: Williams, M. Y., 10.

Paleozoic, Mattagami and Abitibi rivers: Williams, M. Y., 6, 7.

outlier, Lake Timiskaming : Hume, 1, 14.

south of James Bay: Williams, $\mathbf{M}$. Y., 8.

Paleozoic and pre-Cambrian relationships, southern border of Laurentian Highlands, Wilson, M. E., 7.

Patricia: Burwash, 1.

Pleistocene, Toronto region: Coleman, 19.

Porcupine area: Bell, J. M., 8.

Pre-Cambrian: Cooke, H. C., 7, 19 ; Miller, W. G., 1, 4, 10; Quirke, 6 ; correlation: Cooke, H. C., 7.

northern Ontario: Bruce, 7 ; Cooke, H. C., 16.

Lake Superior region: Tanton, 17. western Patricia : Burwash, 5.

Pre-Cambrian glaciation: Coleman, 13.

Red Lake district, Patricia: Dowling, 18.

Red Lake and Woman Lake gold areas : Bruce, 23.

Romney, boring: Davis, H. R., 1.

Shebandowan nickel deposit: Cross, J. G., 1.

Silurian, southwestern Ontario: Williams : M. Y., 1.

Source of original Huronian sediments : Bain, 16.

South Lorrain district: Bastin, 12.

Steep Rock series: Rothpletz, 2.

Sudbury district, Geneva map area : Quirke, 7.

Timiskaming region: Hume, 1.

Toronto area: Credit River section : Dyer, 4.

Paleozoic: Parks, 15.

Pleistocene: Coleman, 19.

upper Ordovician: Foerste, 15; Parks, 14.

Webbwood district: Bain, 15.

West Shiningtree gold district: Goodwin, L. H., 1.

Windy Lake region: Knight, C. W., 4. Workman's Creek section: Fritz, 2. Mineralogy.

Allanite, Sequin Falls: Walker, 28. Animikite and macfarlanite, Silver Islet: Parsons, A. L.. 2.
Ontario-Continued.

Mineralogy-Continued.

Antozonite, Monteagle Township, Hastings County: Sine, 1.

Arsenates of cobalt, nickel, and iron, Cobalt: Walker, 33.

Arsenides, South Lorrain: Thomson, E., 10 ; Walker, 44.

Axinite, Hastings County: Walker, 28.

Barite, stalactitic, Madoc: Walker, T. L., 2.

Barytocelestite, Kingden lead mines, Galetta : Bruce, 20.

Beryl and associated minerals, Renfrew County: Walker, T. L., 52.

Blithfield meteorite: Johnston, R. A. A., 2.

Bytownite and huronite: Walker, 'T. L., 51.

Calciosamarskite, Hybla : Ellsworth, 17. Parry Sound : Ellsworth, 18.

Calcite, Shangoinah Island, Lake Superior: Parsons, 3.

Chalmersite, Parry Sound: Schwartz, 2.

Raglan township, Renfrew County: Thomson, E., 13.

Chapmanite, South Lorrain, Cobalt distrlct: Walker, 31.

Chert, Keeley mine, Cobalt: Walker, 34 .

Columbite: Walker, 28.

Corundum, blue, Bancroft area : Ellsworth, 4.

Cosalite: Walker, 4.

Diopside: Walker, 18.

Dumortierite, Addington County : Walker, 19.

Dyscrasite, Cobalt : Walker, 6 .

Echellite, Sextant Portage, Abitibl River: Bowen, 4.

Elaterite, Madoc: Knlght, C. W., 2.

Ellsworthite, Haliburton County : Ellsworth, 15.

Ellsworthite and associated minerals, Hybla: Walker, 25.

Epidote, Porcupine: Bruce, 14.

Euxenite, Maberly : Ellsworth, 15.

Sabine township, Nipissing district: Ellswortb, 21.

Euxenite-polycrase, Mattawan township, Nipissing district : Ellsworth, 11.

Faraday Township, Hastings County : Walker, 49.

Feldspar, Loughboro Township, Frontenac County: Sine, 2.

Ferric and ferrous vein materials, Keeley mine, Cobalt: Walker, 34.

Fluorite, optical, Madoc: Greenland, 1 ; Walker, T. L., 3.

Gowganda vein minerals: Todd, E. W., 6.

Hastingsite, Dungannon t o w $\mathbf{n} \mathbf{~ h ~} \mathbf{l}$ p. Hastings County: Walker, 38.

Hatchettolite and associated minerals, Hybla : Walker, 26. 
Ontario-Continued.

Mineralogy-Continued.

Hematite inclusions in Lake Superior amethyst: Holden, E. F., 14.

Hisingerite, Parry Sound: Schwartz, 9.

Huronite, Gowganda : Walker, 30.

Hyblite, Hybla : Ellsworth, 16.

Lyndochite, Renfrew County: Ellsworth, 14.

Mineralization, South Lorrain, Cobalt district: Bell, J. M., 6 .

Museum of Mineralogy: Parsons, 10.

Nepheline syenite area, French river: Walkel, 47.

New localities for minerals: Walker, 46.

Petzite, Hollinger mine, Timmins: Walker, 42.

Port Arthur, Cobalt, South Lorrain, and Gowganda veiu minerals, tabulation: Walker, 45.

Proustite, Cobalt: Parsons, 4.

Pseudomorphs after spinel, Bathurst, Lanark County: Graham, R. P. D., 4.

corundum after spinel, Bathurst Township : Ferrier, 2.

Radioactive minerals: Ellsworth, 2, 3.

Rammelsbergite, Cobalt: Walker, 7.

Skutterudite, Cobalt: Walker, 14. and loellingite, Cobalt: Walker, 32.

Sodalite and other minerals, Dungannon Township: Walker, 39.

Sperrylite, Sudbury, crystal structure : Aminoff, 1.

Stephanite, Coleman township: Poitevin, 2.

Sundry minerals : Poitevin, 10.

Tellurides: Thompson, E., 2.

Thucholite, Parry Sound: Ellsworth, 19.

Titanite and polycrase, crystallography : Poitevin, 1.

Toddite, Sudbury district: Ellsworth, 1.2.

Tremolite, clinohumite, and stromeyerite: Walker, T. L., 53.

Uraninite, Cardiff township: Walker, 35.

Uranium minerals, Haliburton: Miller, W. G., 11.

Uranothorite, Hybla : Ellsworth, 16.

Xanthoconite, Cobalt: Parsons, 8.

Zeolites, Lake Nipigon: Walker, 48.

Zircon, North Burgess: Palache, 31.

Paleontology.

Cephalopoda, Timiskaming a rea : Foerste, 18.

Conularia rugosa, Lockport limestone, Hamilton: Dyer, 1.

Credit River section: Dyer, 3.

Crustacean, Pleistocene : Kindle, 48.

Hudson Bay area: Foerste, 22.

Huronian stromatoporoid-like masses, Webbwood: Bain, 23.
Ontario-Continued.

Paleontology-Continued.

Mastodon, recent extinction: Russell. J. W., 1.

Mollusca, marl deposits, Ottawa district: Whittaker, 1.

Molluscoldea, Toronto area: Parks, 8.

Muskox skull, Iroquois Beach, Toronto: Bensley, 1.

Ordovician black shales: Parks, 32.

Ordovician faunas, Ottawa region: Wilson, A. E., 1.

St. Lawrence Valley: Wilson, A. E., 2.

Ottawa Trenton echinoderm faunas, distribution : Foerste, 13.

Pelecypoda, Toronto: Stewart, B. H., 1.

Plants, Mattagami series: Bell, W. A., 16.

Pleistocene and recent fossils, St. Lawrence Valley: Whittaker, $\mathbf{3}$.

Silurian, southwestern Ontario: Wil liams, M. Y., 1.

Steep Rock series: Rothpletz, 2.

Toronto area : Fritz, 1 ; Parks, 18.

Gastropoda, Cephalopoda, and Vermes: Parks, 9.

Trenton fauna: Raymond, 10.

Triarthrus canadensis, Triarth rus glaber, and Triarthrus spinosus: Parks. 4.

Upper Ordovician faunas: Foerste, 15.

Whirlpool sandstone : Foerste, 14.

Workman's Creek section : Fritz, 2.

Petrology.

Agate Point rocks: Bain, 9, 11 ; Greig, 3.

Anthraxolite, Sudbury : Coleman, 32.

Butt township, pitchblende deposits country rock: Hore, 7.

Diabase chert breccia : Emmons, R. C., 5. *

Keweenawan sill rocks, Sudbury and Cobalt: Phemister, 6.

Killarney gneisses and migmatites: Quirke, 22.

Killatney magma, Sudbury: Bain, 19.

Nepheline syenite, Port Coldwell, contact phenomena: Walker, T. L., 54.

Norite micropegmatite, composition, Sudbury : Knight, 10.

Quartz keratophyre, Porcupine gold area: Richarz, 5:

Red Lake basin, District of Patricia ; Bruce, 12.

Sill, Algoma District : Emmons, R. C., 4.

Sturgeon Lake area : Gledhill, 2.

Sudbury, igneous rocks: Bain, 18 ; Phemister, 4.

Syntectic porphyry at. Porcupine Whitman, 4. 
Ontario-Continued.

Physical geology.

Bottom deposits, Lake Ontario: Kindle, 35.

Banded argillite, Cobalt: Wallace, 20.

Changes in water level and flotation as forces of erosion: Walker, 50.

Cobalt Lake, doming: Albertson, 1.

Erosion by ice sheet: Tyrrell, 3.

Evidence of liquid immiseibility in a silicate magma, Agate Point: Tanton, 13.

Faulting, postglacial, French River district: Hobbs, 10.

Huronian replacement deposits : Quirke, 20.

Keweenawan boulder conglomerate, origin : Moore, E. S., 17.

Kirkland Lake fault: Tyriell, 7 .

Lake Huron winter beach forms : Littlefleld, 1.

McKay Lake, bottom deposits: Whittaker, 4.

Niagara Falls, rate of recession : Boyd, W. H., 1.

Niagara River gorge, age: Johnston, W. A., 26.

Pegmatite dikes, southeastern Ontario: Sine, 3.

Point Pelee, Lake Erie, shore-line changes: Kindle, 11.

Potholes, Killarney area: Quirke, 15.

Rhizocretions: Kindle, 36.

Sudbury nickel district, fault: Hitchcock, 1.

Sudbury norite sheet, assimilation: Bain, 5 ; Bowen, 19 ; Phemister, 3.

Physiographic geology.

Buried Whirlpool-St. Davids gorge, origin : Forrester, G. C., 1.

Glacial and postglacial lakes: Coleman, 11.

Glacial periods : Coleman, 30.

Glaciation: Whitman, 2.

Ice ramparts: Jarvis, G.! 1.

Lake Erie, preglacial outlet: Wright, G. F., 3 .

Lake Timiskaming, a Roxen lake: Davis, 25.

Niagara escarpment, preglacial slope and crest: Spencer, J. W., 1.

Northeastern Ontario, physiographic history: Collins, W. H., 4.

Pleistocene, Toronto region: Coleman, 19.

Pre-Cobalt glaciation: Coleman, 18.

St. Lawrence-Ottawa Valley, late glacial oscillations of level: Goldthwait, 7 .

Timiskaming region: Hume, 1.

Toronto, glacial deposits: Slater, 1.

Opasatika area, Timiskaming County, Quebec: Cook, H. C., 10.

Oolite : Hess, 25.

Iowa, Otis beds: Dille, 5 .

Of artificial origin: Twenhofel, 33.
Oolite-Continued.

Origin : Lamar, 5.

Virginia, Frederick County : Furcron, 1 Opal, Nevada, Virgin Valley: Gordon, $\mathbb{C}$. C., 1.

Opaque minerals, identification by $\mathbf{m i}$. crochemical tests: McKinstry, 5, 6.

Opisthotonos: Dean, 3 ; Moodie, 6.

Orbitoides, evolution in America: Douville, 2.。

Ordovician. See also Paleontology, Ordovician.

Acadia: Bailey, L. W., 2.

Alabama: Butts, 8 ; Jones, W. B., 13;

B e s s e m e r-Vandiver quadrangle:

Butts, 13.

northern: Semmes, 2.

Alaska, interior: Mertie, 13.

Alberta, Glacier Lake section : Walcott, 3.

pre-Devonian Paleozoic: Walcott, 18.

Arbuckle limestone, Oklahoma: Decker, 8.

Arctic regions, Ellesmere Land : Holte-. dahl, 1.

Arizona : Darton, 17; Keyes, 83.

Arkansas: Miser, 4, 7, 11.

Batesville district: Miser, 5, 8.

Hot Springs district: Purdue, 1.

Beloit formation: Sardeson, 22.

Bentonite layers: Giles, 9, 10.

British Columbia, Beaverfoot Range: Burling, 4.

Beaverfoot-Brisco-Stanford Range: -Walcott, 9.

Mount Robson area: Burling, 2, 5. pre-Devonian Paleozoic: Walcott, 18.

Rocky Mountain trench: Shepard, $3,11$.

Windermere area, Kootenay district: Walker, J. F., 1.

Ceratopyge fauna: Raymond, 16.

Collingwood formation: Ruedemann, 15.

Colorado: Keyes, 162.

Leadville mining district: Emmons, S. F., 1.

Cordilleran formations, nomenclature: Walcott, 7 .

Decorah formation, Iowa: Kay, G. M., 1; divisions : Kay, G. M., 2.

Foxe Land, Baffin Island: Gould, L. M., 8.

Galena limestone: Keyes, $\mathbf{5 2}$.

Georgia: McCallie, 1.

Greenland, northwestern: Koch, 1; Hovey, 11; Poulsen, 1.

Peary Land: Koch, 3.

Fudson Bay area: Foerste, 22, 23.

Idaho, Fort Hall Indian Reservation: Mansfield, G. R., 3. 
Ordovician-Continued.

Idaho-Continued.

Richmond formation (?) : Cook, C. W., 8.

southeastern : Mansfield, 29.

Illinois: Thwaites, 3.

Calhoun County: Lamar, 6.

Dixon quadrangle: Knappen, 1.

east-central: Mylius, 7 .

Glenwood limestone: Bevan, 4, 6.

Herscher quadrangle: Athy, 1.

'Kings quadrangle: Bretz, 4.

La Salle quadrangle: Cady, 3, 6.

Mississippi Valley: Krey, 2.

Morris quadrangle: Culver, 2.

New Richmond sandstone, northern

Illinois: Cady, 2.

northern: Thurston, 1 ; Thwaites, 7.

Oregon quadrangle: Bevan, 3.

St. Peter sandstone: Lamar, 1, 9.

Thebes sandstone: Savage, 1.

Indiana: Cumings, 1 ; Logan, 15.

Cincinnati arch, structural features:

Logan, W. N., 27.

Madison: McEwan, 2.

Saluda limestone: Sulzer, 1.

sub-Trenton formations: Logan, 23.

Iowa : Howell, J. V., 4.

Jackson County: Ladd, H. S., 3.

Maquoketa shale: Bradley, J. H., jr., 1 ; Ladd, H. S., 1.

northeastern : Keyes, 252.

St. Peter sandstone: Osborn, W. G., 1.

Kansas, Salina Basin : Barwick, 1. western: Udden, Jon A., 2 ; deep wells: Twenhofel, 27.

Tentucky : Jillson, 35 ; Miller, A. M., 1. Beren region: Burroughs, W. G., 5 . Jeptha Knob: Bucher, 9.

Monticello quadrangle: Foyles, 1 ; MacLachlan, 1.

Woodford County : Miller, A. M., 22.

KImmswick limestone. Missourl: Bradley, J. H., Jr., 4.

Manitoba: Wallace, 14.

Flinflon area : Alcock, 15.

Hudson Bay region: Savage, 2.

Reed and Wekusko lakes region: Alcock, 3.

Reed-File lakes area: Alcock, 1.

Reed Lake-Elbow Lake: Bruce, 2.

Maquoketa and Richmond rocks, Iowa and Illinois, correlation: Savage, 13

Maryland : Bassler, R. S., 1.

Michigan Cataract formation: Ehlers, 7.

Chippewa County: Ver Wiebe, 11. Richmond formation: Hussey, 1.

Minnesota: Grout, 2; Sardeson, 13. Minnesota River valley: Sardeson, 12.

St. Croix Valley: Peterson, E., 1. southeastern : Sardeson, 30.
Ordovician-Continued.

Mississippl, Tishomingo County : Bramlette, 4.

Missouri: Branson, 1, 6; Keyes, 106 ; Wilson, Malcolm E., 1.

Kimmswick and Plattin limestones: Foerste, 9.

Mississippi Valley : Krey, 2.

Plattin formation: Fenton, C. L., 8.

Ste. Genevieve County: Weller, 19.

Montana: Keyes, 234.

Beartooth Mountains, Bevan, 2.

Mud-crack horizons: Kindle, 5.

Nevada : Keyes, 128.

Candelaria district: Knopf, A., 5 .

Manhattan district: Ferguson, H. G., 5.

Round Mountain district: Ferguson, H. G., 4.

New Brunswick: Bailey, L. W., 1.

Newfoundland, Notre Dame Bay: Sampson, 8.

southeastern: Howell, 5

western: Schuchert, 16.

New Hampshire, Ammonoosnc district: Ross, C. P., 2.

New Mexico: Darton, 26; Keyes, 14. eastern: Baker, C. L., 1.

New York: Ruedemann, R., 3. Canton quadrangle: Chadwick, 5. Genesee County : Fairchild, 15, 24. graptolite zones: Ruedemann, R., 3 . Martinsburg, Trenton s e ction: Clark, T. H., 1.

Newburgh quadrangle: Holzwasser, 1. Utica and Lorraine formations: Ruedemann, 16.

West Point quadrangle : Berkey, 3.

Obio, Warren and Clinton counties: Austin, G. M., 1.

Oklahioma : Gould, 9.

Arbuckle Mountains: Taff, 7.

Carter County: Tomlinson, 4.

Comanche County : Gouin, 3.

correlations : Edson, 3.

eastern : Trager, 3.

Mannsville area: Tomlinson, 2. northeastern: White, L. H., 3.

Pontotoc County: Conkling, 1.

Seminole County: Levorsen, 2.

Simpson formation: Edson, 1.

southeastern: Honess, C. W., 6.

southern Ouachita Mountains :

Honess, C. W., 4

Stonewall quadrangle: Morgan, G. D., 5.

Thomas oil field, Kay County: Clark, S. R., 1

Wichita Mountains: Taff, 7.

Ontario: Foerste, 15 ; Wilson, M. E., 7. Arnprior-Quyon area : Wilson, M. E., 10.

black shales: Parks, 32.

Brock town-Mallorytown

Wright, J. F., 2.

Credit River section: Dyer, 3, 4. 
Ordovician-Continued.

Ontario-Continued.

Dundas formation: Parks, 17.

Brockville-Mallorytown are a : Wright, J. F., 1.

Lake Timiskaming area : Hume, 1, 14.

Leeds County : Baker, M. B., 1 .

Mattagami and Abitibi rivers: Williams, M. Y., 6.

Ottawa region: Wilson, A. E., 1.

Toronto: Parks, 14, 15.

western: Parks, 28.

Workman's Creek section: Fritz, 2.

Pennsylvania: Miller, B. L., 4.

Allentown quadrangle: Miller, B. L., 5.

central : Field, R. M., 1.

eastern, Martinsburg formation : Behre, 10.

Lebanon County : Gordon, S. G., 3.

New Holland quadrangle: Jonas, 5.

Northampton County, slate belt: Behre, 7.

southeastern : Stose, 15, 21, 29.

Pennsylvania and Maryland, Piedmont province: Stose, 18.

Peter sandstone: Sardeson, 21.

Quebec: Foerste, 15 ; Wilson, M. F., 7. Anticosti Island: Twenhofel, 30 .

Arnprior-Quyon area: Wilson, M. E., 10.

Beauceville area: MacKay, B. R., 4. Coleraine area: Knox, J. K., 1.

Levis: Clark, T. H., 8, 13.

Magog conglomerate: Dresser, 3.

Mingan Islands: Twenhofel, 26.

Mount Albert area : Alcock, 6.

Phllipsburg region: Bradley, J. H., jr., 2.

Pontiac County, Calumet Island : Goranson, 3.

St. Urbain area, Charlevoix district: Mawdsley, 1.

Quebec group: Dresser, 3.

Revision: Ulrich, 6.

Richmond beds: Savage, 12.

basal, of Cincinnati province: Shideler, 2.

"Maquoketa" formations: Shideler, 1.

St. Peter sandstone: Dake, 6, 8; complexity: Keyes, 50; derivation : Dake, 7:

Saskatchewan, Wapawekka and Deschambault lakes area: DeLury, 6.

Shakopee dolomite: Sardeson, 20.

Shore line of Galena seas : Sardeson, 27.

South Dakota, central Black Hills: Darton, 14.

Stones River limestone : Coryell, 2.

Taconic area, southern: Knopf, E. B., 6.

Taconic revolution, evidence for examined: Clark, T. H., .4.

Tennessee: Nelson, 16; Raymond, 3. central: Bassler, 8, 10.

east: Gordon, C. H., 3 ; Secrist, 1.
Ordovician-Continued.

Tennessee-Continued.

Overton County: Butts, 1.

Rutherford County: Galloway, J. J., 1.

Stones River group: Coryell, 2.

Sumner County: Mather, 3.

Waynesboro quadrangle: Miser, 6.

Texas: Udden, J. A., 3.

Marathon basin : Baker, C. L., 10.

Solitario uplift: Powers, 9.

Trenton, Tennessee and Kentucky: Raymond, 18.

Utah : Butler, 4 ; Keyes, 152.

Tintic district: Lindgren, 2.

Vermont: Foyles, 2.

Addison, Panton, and Ferrisburg townships: Foyles, 4.

Barnard, Pomfret, and Woodstock townships : Richardson, C. H., 11.

Bethel Township: Righardson, C. H., 8.

Braintree: Richardson, C. H., 5.

central : Richardson, C. H., 1.

Fort Cassin : Foyles, 3.

Grand Isle, Trenton: Perkins, G. H., 5, 9.

Green Mountains, western flank: Dale, N. C., 1.

Northffeld : Richardson, C. H., 2.

northwestern: Keith, 1; Raymond, 23.

Orange County, Randolph Township : Richardson, C. H., 7.

Plymouth and Bridgewater townships: Perry, E. L., 1.

Roxbury: Richardson, C. H., 3.

Shoreham and Bridport: Foyles, 3.

western: Gordon, C. E., 2, 4, 5.

Virginia : Giles, 10, 11; Raymond, 3. Giles County: Hubbard, G. D., 6.

Little North Mountain: Giles, 7 .

Piedmont: Jonas, 8.

southwestern: Butts, 10.

Valley coal flelds: Campbell, M. R., 10.

western: Stose, 16.

Wise and northern Scott countles: Eby, J. B., 1.

Volcanic ash bed of Tennessee, Kentucky, and Alabama: Nelson, 10.

West Virginia, Hampshire and Hardy counties: Tilton, 13.

Mercer, Monroe, and Summers counties: Reger, 9.

Mineral and Grant counties: Reger, 7.

Pendleton County: Tilton, 14.

Wisconsin: Thwaites, 3 ; Ulrich, 12.

Galena limestone: Ockerman, 1.

Tomah-Sparta quadrangles: Twenhofel, 6.

Wyoming, Wind River Mountains: Condit, 4. 
Ordovician-Silurian boundary: Jones, 0 . T., 1 ; Miller, B. L., 9 ; Schuchert, 26 ; Ulrich, 15.

Ore deposits, origin. For ore deposits in genelal see Economic geology (genera]).

Adirondack magnetic iron ores: Miller, W. J., 18.

Alaska, Chichagof Island, magmatic sulphide ore: Kerr, P. F., 2.

Salmon River district: Westgate, 2.

southeastern, Hyder district: Jewell, 1.

Alkaline sulphides as collectors of metals : Spurr, 23.

Alteration in Keeley mine, South Lorrain district, Ontario: Bell, J. M. 6.

Angular indusions and replacement deposits: Bateman, 13.

and banded structure in ore velns: Schagen van Soelen, 1.

and replacement deposits: Fairbanks, 3.

in ore deposits: Merritt, C. A., 3 ; Spurr, 22 ; Weinig, 1. Y Young, J. W., 7 .

Apatite deposits, Canada : Spence, 2.

Arizona, Aravaipa-Stanley region : Ross, C. P., Б.

Jerome and Bradshaw Mountains quadrangles: Lindgren, 17.

Jerome district: Fearing, J. L., 2; Reber, 1; Verde Central mine: Fearing, J. L., 1.

Warren mining district: Trischka, 2.

Asbestos, Sierra Ancha, Arizona: Bateman, 3.

Association of ores and dikes: Crocker, 1 .

Bacterial influence in the genesis of certain sulphide ores: Bastin, 14.

Banded structure: Boydell, 10.

Banding around rock fragments in veins: Douglas, C. B. E., 1; Spurr, 28.

Barite, magmatic origin: Lewls, J. V., 2.

Missouri : Tarr, W. A., 1.

Basic dike injections in magmatic vein sequences: Spurr, 20.

Bauxite : Burchard, 17.

Alabama: Jones, W. B., 6; Rettger, 1.

Bindheimite as an ore mineral: Shannon, 9.

Borate deposits, Kramer, California: Gale, 5.

Bornite and pyrrhotite, antipathy : Gilbert, G., 3.

In Jeune ores, Vancouver Island : Osborne, F. F., 1.

Bornite-chalcocite intergrowth s: Schwartz, 24
Ore deposits, origin-Continued.

British Columbia: Schofleld, 9.

Atlin district: McKinstry, 7 .

Bridge River district: McCann, 4.

Hazleton : O'Neill, 1.

Kitsault River district: Hanson, 4.

Portland Canal district, Premier mine: Burton, W. D., 1.

Salmon River district: Schoffeld, 11, 14.

Stewart, George gold-copper mine: Smitheringale, 2.

California, Randsburg: Hulin, 1.

Canada, metallogenesis and pre-Cam. brian : Baker, M. B., 2.

ore bodies in pre-Cambrian: Dougherty, 2.

Cananea, Sonora, Mexico, ore injection : Mitchell, 11.

Carnotite ores, Colorado: Coffin, 3.

Chalcocite, primary, origin : Bateman, 9.

Chalcopyrite deposits, northern Minnesota : Bruce, 5.

Chalcopyrite and $c$ ub a 1 te intergrowths: Schwartz, 17, 18.

Chlorine as a magmatic solvent for metals : Hixon, 7.

Chrome ore, Pennsylvania and Maryland: Knopf, E. B., 2.

Chromite deposits : Diller, 1.

Klamath Mountains: Diller, 9.

Montana : Westgate, 4.

North Carolina : Lewis, 6.

Oregon, eastern: Westgate, 3.

Climatic effect on superficial alteration : Knox, H. H., 1.

Cobalt, Ontario: Whitehead, 1 ; Whit man, 1.

Colloidal solutions, rôle in formation of mineral deposits: Boydell, 2.

Colorado, Bonanza, Eagle mine, secondary enrichment: Wuensch, 2.

central : Crawford, R. D., 2.

Creede district: Emmons, W. H., 4.

Cripple Creek district: Loughlin, 32.

Hinsdale County: Brown, W. H., 3.

Leadville district: Emmons, S. F., 1 ; Loughlin, 31.

Pitkin County, Aspen d is t r l'c t : Knopf, A., 10.

Red Cliff district: Crawford, R. D., 3.

Telluride area: Hurst, 2.

Twin Lakes district : Howell, J. V., 1.

Connecticut, Bristol copper ores: Bateman, A. M., 2.

Contact effects of gabbro and granite on ore deposition: Schwartz, 10.

Copper : Calkins, F. E., 1.

Alaska, Beatson mine: Bateman, 12 ; Kennecott: Bateman, 3; Prince William Sound: Mofflt, 6 .

Arctic Canada, central: O'Nelll, 5 .

Arizona, Ray district: Ransome, 11. Ray-Miami region: Ransome, 1. Superior district: Short, 1. Warren district: Mitchell, 4. 
Ore deposits, origin-Continued.

Copper-Continued.

deposition from ascending solutions, chemistry : Wells, 11.

Engels, California : Turner, H. W., 1.

Evergreen ores, Gilpin County, Colorado : McLaugblin, D. H., 2.

Flinflon ore deposit, Manitoba : Wallace, 5.

Idaho, Salmon : Ross, C. P., 7.

in a meteorite vein: Quirke, 3.

Lake Superior region: Lane, 12; Lang, S. S., 2 ; Spurr, 3 ; Wells, 8.

leached outcrops of copper ore; Locke, 6.

Mexico, Cananea : Mitchell, 10 ; Sonora: Wandke, 5.

Michigan: Singewald, 3.

Montana, Park County : Lovering, 2. native : Butler, 7.

Nonesuch formation, Michigan : Nishio, 1.

ores disseminated in porphyry: Emmons, W. H., 11.

Oregon, southwestern : Kellogg, A. E., 9.

organic precipitation: Lovering, 5. oxidation and enrichment at Ducktown: Gilbert, G., 1.

Quebec, Rouyn district : Cooke, H. C., 29.

Red Bed ores: Bains, 1.

secondary enrichment in genesis of Butte chalcocite: Locke, 4.

South Atlantic States: Watson, 15.

sulphides, La Fleur Mountain, British Columbia: McLaughlin, D. H., 1.

superficial : Weed, 2.

supergene enrichment, Cananea, Mexico: White, C. H., 3.

Texada Island, British Columbia: Dolmage, 7 .

Tyrone district, New Mexico: Paige, 2.

Utah, Bingham district: Hunt, R. N., 1.

Copper sulphate stalactites, rate of formation: Mitchell, 5.

Cordierite-anthophyllite mineralization : Lindgren, 14.

Corundum aplite, origin: Du Toit, 1.

Cosnical derivation of metals: Keyes, 111.

Cupriferous pyritic deposits: Kato, 1. Deep-seated ore chemistry: Hixon, 4.

Deep-seated oxidation and secondary enrichment at Kelley silver mine near Cobalt: Bell, J. M., 4.

Deformation in ores, Coeur d'Alene district: Waldschmidt, 8.

Deposition of copper carbonate from mine water: Wilson, P. D., 3.

Deposition of ores: Keyes, 62.

Depths of metallic contact mineralization : Keyes, 120.
Ore deposits, origin-Continued.

Dialytic rôle of selvages: Keyes, 107.

Diffusion in ore genesis: Smith, L. H., 1; Whitman, 1, 5.

Dolomitization and ore deposition: Hewett, 22.

Duluth gabbro, basal phases: Nebel, 3 .

Dumortierite, Nevada: Jones, J. C., 3.

Emery, Virginia: Watson, 13.

Enrichment, Cobalt district, Ontario: Bell, J. M., 6.

of tungsten ores: Gannett, 1.

Exploration for ore deposits: Locke, 3

Feldspar-chalcopyrite rock-ore : Colony, 8 ; Reid, J. A., 3 ; Spurr, 34.

Fibrous minerals, veins of : Taber, 9 .

Filling of veins: Perkins, T. A., 1; Spurr, 7 ; Young, J. W., 3.

Fluorspar deposits : Aurand, 1.

Hardin County, Illinois : Weller. S., 1.

Ontario, Madoc district: Wilson, M: E., 6.

western Kentucky : Currier, 2.

Formation of ore bodies: Kendall, 1.

Gel replacement: Lindgren, 15.

General: Andrews, 5; Grimes, 1 ; Griswold, 1; Hazlitt, 1; Hereza. y Ortuno, 1; Hixon, 8; Keyes, 153 ; Lewis, 11, 13, 15 ; Lindgren;. 23 ; Ransome, 16 ; Wagner, P. A.r 1.

Geology applied to mining: Spurr, 24:

Gold, Bitish Columbia, Atlin district : Weed, 3 ; Barkersville area, Uglow, 10.

California, Carson Hill: Moss, 1; Grass Valley: Howe, E., 1; Wilshire district: Turner, H. W., 3 .

Colorado, Camp Bird district: Spurr, 18.

Idaho, north central: Thomson, $F$. A., 3.

Manitoba, Elbow Lake area: Armstrong, 42.

Ontario, Matachewan district: Cooke, H. C., 3 ; northern : Boydell, 13; Porcupine area: Fleldt ing, 1; Huntoon, 1; Spurr, 8: Pearl Lake area: Robinson, H. S., 1; Timiskaming district: Cooke. H. C., 13.

Quebec, Lake Demontigny: Mallhiot, 4.

South Dakota, Homestake mine: Paige, 3 ; Lead : Paige, 4.

Virginia, northeastern Piedmont: Lonsdale, 7 .

Gold and silver, El Oro district, Mexico: Winchell, H. V., 1.

Graphite: Winchell, 3.

Alabama: Brown, J. S., 6.

Guanajuato district, Mexico: Wandke, 8.

Hematite in certain ore deposits: Gilbert, G., 5 . 
()re aeposits, origin-Continued.

Hinge zone of Tertiary deformation: Emmons, W. H., 7.

Hot springs and magmatic emanations : Linagren, 21.

Hypogene ore mineral deposition, time sequence: Newhouse, 8.

Ildaho, Buffalo Hump district: Beckwith, R. H., 3, 4.

'Owyhee County, South Mountain district: Sorenson, 1.

:St. Maries region: Anderson, A. L., 4.

:Silver City district: Piper, 7.

Shoshone County: Umpleby, 3.

Igneous ore deposits: Campbell, J. M., 3 ; Vogt, 4.

Intergrowth of certain minerals : Newhouse, 2.

Intimate intergrowths and mutual boundaries as proof of contemporaneous deposition: Newhouse, $\mathbf{5}$.

Investigation of ores: Falrbanks, 12.

Iron : Campbell, J. M., 2 ; Leith, 13 ; Young, G. A., 6.

Adirondack magnetites: Alling, 10 ; Miller, W. J., 13, 18, 26 ; Nason, $1,2$.

Alabama, brown ores: Adams, G. I., 4.

Allentown quadrangle, Pennsylvania : Miller, B. L., 5.

Belcher Islands, Hudson Bay: Moore, E. S., 1 ; Young, G. A., 3.

Biwabik formation: Gruner, 3.

British Columbia, Taseko Valley: Brewer, W. M., 1.

Clinton ores: Smyth, 1.

Clinton hematite ores, origin: Holden, R. J., 2 ; Stose, 24.

Cuba, Santiago: Kimball, 1.

Georgia : Haseltine, 1.

Gogebic range: Hotchkiss, 1.

Gunflint formation, Ontario: Gill, J. E., 2.

Iron Mountain and Pilot Knob, Missouri : Spurr, 33.

limonite, Mayaguez, Porto Rico: Fettke, 2 ; Taseko Valley, British Columbia: Mackenzie, J. D., 1.

magnetic ores, Clinton County, New York: Miller, W. J., 5, 7 ; Newland, 1.

magnetite segregation in banded syenite, Minnesota: Grout, 19.

magnetite-hematite relations: . Gilbert, G., 4.

magnetites, eastern Porto Rico: Fettke, 6 ; Minnesota: Grout, 3, 9; New York, southeastern: Colony, 3 ; North Carolina and Tennessee: Bayley, 2, 3, 6; Texada Island, British Columbia: Swanson, C. O., 2 ; Vancouver Island: Uglow, 16. Mesabi ores, Minnesota: Grout, 5; Gruner, 2, 5; Schwartz, 4.
Ore deposits, origin-Continued.

Iron-Continued.

Mexico, Cerro de Mercado: Salazar Salinas, $3,4$.

Minnesota, St. Louis County, mag. netite deposits: Grout, 20.

New York, Ausable quadrangle : Kemp, 23.

North Carolina, western, hematite: Bayley, 5, 11.

Ontario, Lake St. Joseph : Bruce, 8; Michipicoten area: Collins, 15.

paragenesis of martite and magnetite: Newland, 6.

protores, leaching of: Lovering, 1. sedimentary ores: Macgregor, A. M., 1 ; origin: Quirke, 17.

Tennessee, Waynesboro quadrangle: Miser, 6; western : Burchard, 25.

titaniferous magnetites, North Carolina and Tennessee: Bayley, 9 ; origin : Bayley, 2.

Vermilion ores, Minnesota: Gruner, 9.

Washington: Jenkins, 5.

Iron-depositing bacteria: Harder, 1.

Joplin region lead and zinc ores: Spurr, 32.

Kaolin, Indiana: Logan, W. N., 4 ; Bucher, 5.

Kentucky-Illinois ore magmatic district: Spurr, 30.

Leached ore capping: Morse, H. W., 1.

Leached outcrops : Blanchard, R., 3.

Lead, Ontario: Wilson, M. E., 10.

Tennessee, Ducktown district: Emmons, W. H., 8.

Wastrington, northeastern: Jenkins, 12.

Lead and zinc ore, formation: TWheeler, H. A., 3.

Joplin region : Naething, 3.

upper Mississippi Valley: Spurr, 12.

Lead-zinc ores, Promontory Point mining district, Utah: Siegfus, 1.

Lead-zinc chimneys in limestone: Spurr, 27.

Limestone contact zones, ferric oxide content: Butler, 8.

Limestone replacement deposits, Mexican province: Prescott, 1.

Localization of ore values in gouge materials : Keyes, 111.

Location of ores: Bateman, A. M., 2.

Magmas, dikes, and veins: Balliet, 3 ; Hills, V. G., 2 ; Hixon, 9 ; Jarvis, R. P., 1; Lindgren, 18 ; Spurr, 26.

Magmatic differentiation and vein formation: Ross, C. S., 26.

Magmatic ore deposits, classification : Zavaritsky, 1 .

Magmatic ores: Gregory, J. W., 1.

Magmatic sulphide oles: Wagner, P. A., 6.

Magnesite : Turner, H. W., 4. 
Ore deposits, origin-Continued.

Magnetite and hematite, relations: Broderick, 1.

Manganese: Harder, 2.

Colorado: Jones, Edw. L., 8.

Cuba : Burchard, 7.

Georgia : Hull, 1.

Idaho: Hewett, 19.

Minnesota, Cuyuna: Thiel, 4.

Nova Scotia : Fearing, 2.

Oregon, southwestern: Kellogg, A. E., 7.

postglacial, Columbia County, New York : Dale, N. C., 2.

precipitation by micro-organisms : Thiel, 8.

Virginia: Stose, 1, 16.

Washington : Pardee, 15.

Manitoba, Flinfion area: Alcock, 15. northwestern: Wallace, 15.

Oiseau and Maskwa copper and copper nickel deposits: Wright, J. F., 7.

Marcasite, paragenesis: Newhouse, 1.

Mechanics of vein formation: Taber, 1.

Mesabi iron ores, enrichment: Allison, I. S., 2 ; origin : Grout, 7.

Metal content, lode filling, and country rock, relations: Weston-Dunn, 1.

Metallic concentrations by magmation, origin: Dunn, J. A., 1; Spurr, 10.

Metallic content of ores, primary origin: Keyes, 134.

of rocks: Keyes, 114.

Metalliferous deposits in red beds: Finch, J. W., 2.

Metalliferous lode systems, relations to igneous intrusives: Emmons, W. H., 9.

Metallogenetic provinces: Emmons, W H., 6.

Metallogenetic zones: Petrascheck, 2; Rastall, 2.

Metamorphism, new kind of : Winchell, 15.

Metasomatism, physico-chemical theory: Goldschmidt, 3.

Meteoritic metals, incorporation in terrestrial ores: Keyes, 120.

Mexico: Lewis, S. J., 1.

Asientos-Tepezala district: Anderson, G. E., 5 .

El Chico, Hidalgo: Wittich, 9.

El Oro and Tlalpufahua districts: Flores, 1.

Sierra Mojada district, Coahulla : Shaw, S. F., 1.

Microscopic replacement versus injection in ores: Schwartz, 21.

Microscopical interpretation of folded structures: Graton, 1.

Mneral deposition and the circle of fire: Thompson, A. P., 1.
Ore deposits, origin-Continued.

Mineral deposits: Lindgren, 1 ; present tendencies in the study of: Lindgren, 5 .

Mineral pipes, formation: Locke, 7.

Mineralized volcanic explosion pipes: Walker, K. T., 3.

Minor crustal movements and ore deposits : Porter, C. A., 2.

Missouri, southeastern: Spurr, 31.

Molybdenite, Quebec: Wilson, M. E., 10.

Montana, Neihart, supergene processes: Bastin, 7.

Nevada, Divide district: Knopf, A., 3. Manhattan, limestone ores: Ferguson, H. G., 2 .

Mineral County, Cedar Mountain : Knopf, A., 4.

Rochester district: Knopf, A., 7.

Santa Fe district, Mineral County : Clark, C. W., 2.

New Jersey, Franklin Furnace: Spurr, 17.

New Mexico, Mogollon district: Ferguson, H. G., 8.

Santa Rita district: Rickard, 8.

Nickel, Lancaster Gap mine, Pennsylvania: Phemister, 2.

Ontario, Shebandowan Lake: Tanton, 9.

Sudbury : Coleman, 23.

Webster, North Carolina: Ross, C. S., 25.

Nickel-pyrrhotite ore, Dracut stock. Massachusetts: Falrbanks, 10.

Nickeliferous pyrrhotite, origin : Hudson, F. S., 1.

Ontario, Cobalt district: Whitman, 3.

Porcupine area: Wright, L. B., 2.

Sudbury laccolite: Harker, 1.

Sudbury nickel ores: Gregory, J. W., 3 ; Park, J., 1.; Phemister, 4 ; Roberts, H. M., 2; Wandke, 4 ; Young, J. W., 4 ; magmatic origin : Coleman, 27.

Opening as a region for ore: Dougherty, 7 ; Locke, 11.

Operative causes in ore deposition: Boydell, 11.

Ore deposit theories, development in Europe: Hummel, 2.

Ore deposition at the Creighton mine, Sudbury, Ontario ; Spurr, 14.

by circulating water: Keyes, 48.

in pre-existing limestone caves : Walker, R. T., 2.

or ore infection: Eng. M .J., 8. processes : Lindgren, 26.

Ore finding: Locke, 8.

Ore geology, primary conceptions: Locke, 9 :

Ore magma theory: Eng. M. J., 4, 5, 9.

Ore magmas: Spurr, 6; Vogt, 5. and magmatic waters: Spurr, 19. 
Ore deposits, origin-Continued.

Oxidation of iron in magnetite : Twenhofel, L. H., 1.

of sulphides: Carmichael, 1.

Oxidation products from chalcopyrite: Blanchard, R., 2; from sphalerite and galena : Boswell, 1.

Oxygen minerals and sulphur minerals in ore deposits, relations: Butler, 9.

Paragenesis of minerals in Butte veins : Lindgren, 22.

I'egmatites, natural history': Eng. M. J., 6.

Phosphates: Graham, W. A. P., 1.

Tennessee: Smith, R. W., 2.

Physico-chemical theory of metasomatism : Boydell, 12.

Pipe form of ore deposit: Wagner, P. A., 4.

Pipe vein, Silver Hill, New Mexico: Keyes, 64.

Platinum deposits: Shaw, 9 ; Vogt, 6.

Polished surfaces of ores: Thiel, 6.

Porcupine quartz velns, mode of formation : Dougherty, 3.

Pre-Cambrian veins, Kirkland Lake district, Ontario: Spurr, 8.

Precipitation of manganese from me. teoric solutions: Thiel, 3.

Primary downward changes in ore deposits : Emmons, W. H., 6.

Processes of ore deposition, research on: Lindgren, 24.

Pyrite, New York, St. Lawrence County : Miller, W. J., 27.

Virginia, northeastern Piedmont : Lonsdale, 7.

Pyritic deposits in metamorphic rocks: Hanson, 1.

Pyrophylite, North Carolina, Deep River region: Stuckey, 1.

Pyrrhotite and pentlandite, relations: Newhouse, 4.

Quartz in veins, genesis: Bancroft, $G$. J., 1.

Quebec, Horne and Aldermac mines: Cooke, H. C., 32.

Rouyn district: James, 8.

Quicksilver, Mazatzal Mountains, Arizona: Lausen, 2.

Yellow Pine district, Valley County : Ross in Schrader, 10.

Replacement: Platts, 1.

and folding: Geijer, 1.

Resorption in Grenville granite magma, Quebec: Bain, 10.

Secondary enrichment by acid waters, rate: Grout, 14.

Secondary processes in some pre-Cambrian ore bodies: Wallace, 8 .

Separation of ores from magmas: Stansfleld, 7 .

Shattering by replacement: Wandke, 6 .
Ore deposits, origin-Continued.

Bllver, Arizona, Chloride and Klngman : Bastin, 17; Wickenburg : Bastin, 6.

British Columbia, Stewart district: Dolmage, 4 ; Beaverdell : McKinstry, 8.

Colorado, Aspen, Bastin, 10.

Comstock lode, Nevada: Bastín, 4.

Idaho, Pend Oreille district: Sampson, 16.

Mexico, Pachuca district, Hidalgo : Winchell, H. V., 1.

native, Nonesuch formation, Michlgan : Nishio, 1.

Ontario, Cobalt: Bastin, 6, 12; Knight, 11; Gowganda area : Burrows, 6, 17; Silver Islet: Tanton, 4 ; South Lorrain : Bell, J. M., 3; Bastin, 12; Thunder Bay district : Parsons, 5.

Silver deposits, enrichment: Sill, 1; San Juan Mountains: Bastín, 5.

Silver Islet ores, paragenesis: Chadbourn, 1.

Silver-lead, Mayo district, Yukon : Cockfleld, 11.

Slocan district, British Columbla : Bateman, 14.

Smithsonite, formation: Watson, 7.

Solutions depositing metalliferous veins : Emmons, W. H., 12.

South Dakota, Homestake mine, mineralization : Wright, L. B., 3.

Keystone pegmatites, sequence of mineralization: Landes, K. K., 6. northern Black Hills : Connolly, 4.

Southwestern ore deposits, age and classification: Wilson, P. D., 1.

Structural control of location of ore deposits: Bell, J. M., 9.

Sulphate minerals in ore deposits : Butler, B. S., 3.

Sulphide deposits, northern Quebec: Cooke, H. C., 31

Sulphide ores: Collins, G. E., 2 ; Draper, 1 ; Freeman; H., 1-3.

Sulphides, relation to water level in Mexico : Lucke, 1.

Supergene processes, Neihart, Montana : Furst, 1.

Terminology of mineral deposits : Lindgren, 6.

Theoretical considerations: Rastall, 1. Tin, Silver Hill deposits, Washington : Anderson, A. L., 5 .

York region, Alaska: Steidtman, 4.

Titaniferous iron ores : Osborne, F. F., 3.

Tungsten ores: Hess, 11. enrichment: Gannett, 1.

Utab : Butler, 2, 4.

Bingham district: Peterson, O. P., 1. Ophir district: Olmstead, 1.

Tintic district: Crane, G. W., 1; Lindgren, 2. 
Ore deposits, origin-Continued.

Vadose ore deposition: Keyes, 55, 66.

Veln formation: Taber, 1.

Vein quartz, microscopic. study : Adams, S. F., 2.

Vein formation : Thompson, W., 1.

Veindikes, Engineer mine, Atlin, British Columbia: Boydell, 4.

Veins, origin : Taber, 14.

from intrusive magmas with contrasted contents: Kemp, 15.

of fibrous minerals: Taber, 9.

Washington: Patty, 1; Stevens County: Weaver, 2.

Zinc, Allentown quadrangle, Pennsylvania ; Miller, B. L., 5.

east Tennessee: Secrist, 1.

Edwards, New York: Spurr, 13.

Franklin Furnace, New Jersey : Fitch, A. A., 1; Ries, 8.

Tintic district, Utab: Lindgren, 2. Wisconsin district: Boericke, 1.

Zinc and lead ores, Tri-State district: Ellis, E. E., 1 ; Eng. M. J., 10 ; Netzeband, 1 ; Williams; C. F., 2.

Zonal deposition of ores: Emmons, $W$. H., 6, 10 ; Kemp, 9 ; Spurr, 5 ; Watanabe, 1 ; application of theory: Anderson, J. C., 2 ; Eng. and M. J.-Press, 2.

Zoning of mineral deposits, British Columbia: Hanson, 12.

Ore magmas: Spurr, 6.

Ore shoots. See Economic geology (general) ; Ore deposits, origin.

Ore hunting, profession of: Locke, 1. Oregon.

Bibliography: Dixon, 1.

John Day region: Jillson, 39.

Eastern Oregon: Smith, W. D., 15.

Economic geography : Smith, W. D., 6.

Geology : Smith, W. D., 1.

Report of Bureau of Mines: Parks, M., $1,2$.

Areas described.

Coast Range province: Smith, W. D., 13.

Mount Jefferson: Hodge, $\boldsymbol{E}$. T., 6.

Mount Multnomah: Hodge, E. T., 5.

Riddle quadrangle: Diller, 12.

Southeastern lake province: Smith, W. D., 12.

Willamette Valley: Smith, W. D., 11.

Economic geology.

Auriferous gravels, southwestern Oregon : Kellogg, A. E., 8.

Borax, Curry County: Gale, 4.

Chromite, eastern Oregon: Westgate, 3.

Klamath Mountains: Diller, 9.

Cobalt, Jackson County: Kellogg, A. E., 4.

Copper, southwestern Oregon : Kellogg, A. E., 9 .

Diatomaceous deposits, eastern Oregon : Smith, W. D., 17.
Oregon-Continued.

Economio geology-Continued.

Gypsum: Stone, 10.

Llano de Oro placers, Waldo district: Kellogg, A. E., 10.

Manganese : Pardee, 8.

southwestern Oregon, origin: Kellogg, A. E., 7.

Mineral resources: Swartley, 1.

Native asphalts: Hodge, E. T., 12.

Oil and gas possibilities: Buxalda, 4.

western Oregon: Harrison \& Eaton, 1.

Petroleum possibilities: Smith, W. D., 8.

Platinum, southwestern Oregon: Kel$\log$, A. E., 5.

Potassium nitrate: Nattress, 1.

Quicksilver, Gold Hill district: Kellogg, A. E., 6.

Jackson County: Kellogg, A. E., 1.

Rogue River valley: Kellogg, A. E., 3. Waldo district, Josephine County: Kellogg, A. E., 2.

Historical geology.

Astoria section: Howe, H. V. W., 9.

Cascade Mountains, central Oregon: Hodge, E. T., 8, 10, 14

Central Oregon: Chaney, 8.

Cretaceous: Packard, 7.

Columbia Valley: Bretz, 3.

Crooked River Basin: Chaney, 24.

Dalles beds and Columbia River gorge: Buwalda, 24.

Eagle Creek formation: Chaney, 1.

Eastern Oregon: Buwalda, 4; Merriam, 25 .

Empire formation, Coos Bay: Howe, H. V. W., 1, 2.

Geological history: Buwalda, 12.

John Day beds : Thorpe, 3.

John Day region: Buwalda, 15, 18, 21, 25.

John Day and Deschutes River canyons : Hodge, E. T., 13

Jurassic, Silvies Canyon, Harney County: Packard, 2.

Malheur County: Renick, 11.

Marine Oligocene: Schenck, 5 .

Marine Tertiary : Hertlein, 3.

Mesozoic formationns: Goranson, 1.

Mississippian, central Oregon: Packard, 8.

Northeastern Oregon: Livingston, 5.

Oligocene, western Oregon: Schenck, 12.

Paleozoic and Mesozoic, central Oregon : Packard, 6.

Pleistocene history: McCornack, 1.

Rattlesnake formation; Merriam, 19.

"Satsop" and Dalles formations, age Buwalda, 19.

Steens Mountains, soutbeastern ore gon : Smith, W. D., 10, 14.

Waldo district, Josephine County: Kellogg, A. E., 2. 
Oregon-Continued.

Mineralogy.

Laumontite, Grants Pass. McClellan, 1. Petzite, Cornucopia district: Shannon, 59.

Priceite, Curry County: Gale, 4.

Zeolites, Ritter Hot Spring, Grant County : Hewett, 21.

Paleontology.

Agriochoerus, John Day beds: Thorpe, 7.

Araeocyon : Thorpe, 13.

Astoria section : Howe, H. V., W., 9.

Bridge Creek flora: Chaney, 11, 16, 24.

Camelidae, John Day beds: Lull, 7.

Canidae, Tertiary : Thorpe, 11.

Cassididae: Schenck, 3.

Central Oregon: Chaney, 8.

Conifers: Mason, H. L., 1.

Cretaceous Mollusca: Reagan, 7.

Crustacea, stalk-eyed: Rathbun, 5.

Diatoms in western Oregon shales: Schenck; 7.

Eagle Creek flora: Chaney, C. A., 1, 2.

Eastern Oregon: Merriam, 25.

Echinoidea: Kew, 3.

Elphidiums, Tertiary and Quaternary: Cushman, 34.

Empire formation, Coos Bay: Howe, H. V. W., 2.

Eporeodon, John Day beds: Thorpe, 6. Foraminifera, Coast Range: Cushman, 44.

Fresh-water Mollusea : Hanna, G. D., 6. Hackberry, John Day series: Chaney, 18.

Hyaenarctid bear, John Day Basin: Merriam, 24.

Ichthyosaurian reptile, marine Cretaceous: Merriam, 27.

John Day region: Buwalda, 18.

Felidae: Eaton, G. F., 1.

Gastropoda: Hanna, G. D., 4.

Mollusca: Hanna, G. D., 2.

Jurassic Mollusca: Hertlein, 2.

Mammalia, marine, Newport: Packard, 1.

Marsupial, John Day beds, Logan Butte: Stock, 9 .

Mascall flora: Chaney, 17.

Merychippus, Crooked River basin : Maxson, 1.

Oreodontoides oregonensis, John Day formation: Thorpe, 24.

Oyster: aberrant, Eocene: Packard, 5. Payette flora: Chaney, 6.

l'elecypoda, marine Oligocene: Clark, B. L., 11.

L'erchoerus skulls, John Day formation : Pearson, H. S., 1.

P'itisburg Bluff fauna, Oligocene: Schenck, 9 .

I'leistocene mastodons: Hay, 32.

Pliocene bear: Merriam, 22.

I'liocyon, John Day Valley: 'lhorpe, 5.
Oregon-Continued.

Paleontology-Continued.

Promerycochoerus, John Day beds: Thorpe, 3, 22.

Prosthennops (peccary) : Thorpe, 25.

Rattlesnake fauna: Merriam, 19.

Reptile, Cretaceous: Gilmore, 40.

Tertiary insects, eastern Oregon : Cockerell, 40.

Terrestrial plants in marine deposits: Chaney, 13.

Trigoniae: Packard, 3.

Umbellularia, John Day series : Chaney, 19.

Upper Triassic: Smith, J. P., 3.

Petrology.

Color of varicolored obsidians, origin : Fuller, R. E., 1.

Glass Buttes, Lake County: Waters, A., 2.

Inclusions in porphyry dikes at Cornucopia : Goodspeed, 1.

Plateau basalts: Washington, 17.

Physical geology.

Caves, Josephine County: Williams, I. A., 1.

Earthquakes: Smith, W. D., 5.

Glass Buttes, Lake County: Waters, A., 2.

Inclusions in porphyry dikes at Cornucopia : Goodspeed, 1.

Klamath Lake region: Gilbert, G. K., 1.

Lava river tunnel: Williams, I. A., 3.

Owyhee project: Smith, W. D., 16.

Steen Mountains : Smith, W. D., 14.

Physiographic geology.

Crater Lake origin: Diller, 11.

Eugene quadrangle: Schenck, 1.

General: Smith, W. D., 9.

Klamath Lake region: Gilbert, G. K., 1.

Northeastern Oregon: Livingston, 5.

Ochoco erosion surface : Buwalda, 23.

Pleistocene history: McCornack, 1.

Pleistocene submergence, Columbia Valley : Bretz, 1.

Tertiary planation, eastern Oregon: Ross, C. P., 8.

Wallowa Mountains: Smith, W. D., 1S. Underground water.

Port Rock valley and Christmas Lake valley: Williams, I. A., 2.

Oregon quadrangle, Illinois: Bevan, 3.

Oreodonts, geological history: Thorp, 26.

Orogeny.

Appalachians, cross section in southern New England: Woodworth, 3. structure: Keitb, 2.

Arcuate mountains: Link, 5. evolution: Hobbs, 7.

Arizona, Jerome, Basin Range structure: Ransome, 15.

Papago country: Bryan, 15.

I3asin Range structure: Keyes, 225: I.ouderback, 5. 
Orogeny-Continued.

Basin Ranges: Keyes, 10, 34, 40, 84, 270 ; origin : Davis, W. M., 5, 26. Blue Ridge, erosional history : Wright, F. J., 5.

California, Warner Range : Russell, $\mathbf{R}$. J., 6.

Californian orogenic period: Willis, 24.

Canadian Cordilleras: Dowling, 16.

Cause: Bowie, 19.

Coast Ranges, California : Willis, R., 2.

Cordilleran shield: Lawson, 10.

Crustal shortening of Colorado Rockles : Chamberlin, R. T., 8.

Desert range tectonics, trans-Pecos Texas: Baker, C. L., 11.

Desert ranges of Mexico, origin : Spurr, 4.

Folded and fault-block mountains, relation: Woodworth, 1.

Folded mountains, origin : MacCarthy, 8.

Folding of mountain ranges : Burrard, 1

Franklin Mountains, Mackenzie: Willlams, M. Y., 16.

General: Andrews, 2, 6; Barrell, 10 ; Chamberlin, R. T., 1, 11 ; Chamberlin, T. C., 25 ; Daly, 17 ; Gillson, 11; Hobbs, 17 ; Lawson, $\theta$; Schuchert, 31 ; Stille, 1.

Horizontal compression in Colorado Rockies: Shepard, 5.

Kober's theory of orogeny: Longwell, 7

Laccolithic mountains, origin: Keyes, 29.

Mexico : Staub, 3.

Mississippian orogenic movements : Van Tuyl, 2.

Montana, central: Thom, 6.

Mountain building in the Canadian shield : Collins, W. H., 21.

without loss of isostatic equilibrium: Shepard, 8.

Mountain formation: Bowie, 6 ; Reld, 9.

Nevada, western : Ferguson, H. G., 6.

Oquilrh Range, Utah: Gilluly, 6.

Orogenic consequence of a diminishing rate of rotation: Keyes, 71 .

Orogenic forces: Reid, 7.

Paleozole mountains: Bailey, E. B., 1.

Permian revolution: Finlay, 2.

Relation to isostasy: Swanson, C. O., 4.

Rocky Mountain geosynclinal, Canada : Burwash, 3.

Rocky Mountain structure: Mansfleld, 15 ; Willis, 20.

Rocky Mountains: Chamberlin, R. T. 1, 2 ; Dake, 5 ;

southern: Lee, 9

Sierra Nevada: Muir, 3 ; Willis, 30.

Symmetric disposition of Tertiary mountain systems : Longfellow, 1 .
Orogeny-Continued.

Tertiary epeirogeny: Taylor, 13; cause : Taylor, 2.

Upthrust faulting: Willis, B., 1.

Utah, central, post-Cretaceous : Spiet. er, 4.

Volcanism and mountain-making : Chamberlin, R. T., 5.

Wyoming, northwestern : Dake, 5.

Orthaulax, Tertiary guide fossil : Cooke, C. W., 6.

Orthophragmina and Lepidocyclina: Cush man, 8.

Oscillation. See Changes of level.

Osteomyelites, Permian: Moodie, 14.

Ostracoda.

Bairdia subdeltoidea, Cretaceous, Texas: Alexander, C. I., 2.

Description : Roundy, 4.

Maine, Chapman sandstone: Ulrich, 1.

Maryland, Upper Cretaceous: Berry, E. Willard, 1.

Mexico, Moctezuma River, Eocene: Cushman, 21.

Missouri, Henrietta formation: Knight, J. B., 1.

Monoceratina, Pennsylvanian, Okla. homa: Roth, 3.

Oklahọma, Seminole County, Pennsyivanian: Coryell, 3, 4.

Paleozoic: Ulrich, 9.

Pennsylvanian, Oklahoma and Texas: Harlton, 1, 4.

Tennessee, Nashville, Trenton limestone : Kirk, S. R., 1.

Texas, San Saba County, Mississippian: Roundy, 3.

Yegua formation: Stadnichenko, M. M., 1.

Trinity fauna: Vanderpool, 2.

Overthrusts, Rocky Mountains: Mansfleld, 15.

Oxford and Knee lakes area, northern Manitoba : Wright, J. F., 11.

Oxidation of sulphides: Carmichael, 1.

Oxidation products from chalcopyrite : Blanchard, R., 2 ; from sphalerite and galena: Boswell, 1.

Oxidation subsidence at Bisbee, Arizona Wisser, 1.

Ozarkian system: Walcott, 7; Greenland, northwestern : Poulsen, 1.

Ozarkian trilobites: Walcott, 15.

Ozokerite, Utah : Clark, A. F., 1.

Pahsimeroi Valley, Idaho, ground water: Meinzer, 8.

Palangana salt dome, Duval County, Texas : Barton, 1.

Paleobotany.

$\Delta$ ge and area: Berry, 60 .

Algal remains, Unkar group, Grand Canyon: White, D., 39.

Algae, Miocene, Trinidad : Howe, M A., 2.

Alberta, Cretaccous: Berry, 74.

Paskapoo formation: Berry, 73. 
Paleobotany-Continued.

Angiosperms, origin: Kuowiton, 14. Paleozolc, in coal: Hoskins, 1.

Animas formation, Colorado: Knoriton, 13.

Annularia with Paleostachya fruit, Rhode Island: Round, 3.

Araceae, Miocene, Trinidad : Berry, 69.

Aralias, Cretaceous : Fritel, 1.

Araucarioxylon in the Cretaceous : Jeffrey, 2.

Arizona, fossil wood: Reagan, 16.

Brachyruscus, Florissant, Colorado: Cockerell, 14.

Brandon flora: Berry, 8.

Bridge Creek flora, Oregon: Chaney, 11, 16, 24; Aslatic relationships: Chaney, 14

Rritish Columbia, Cassiar district, Cretaceous : Bell, W. A., 14.

Kootenay Valley, Saint Eugene silts : Hollick, 10.

Tertiary floras: Berry, 78.

Caddis case, Eocene, Tennessee: Berry, 84.

Calamites, East Bellevue, Pennsylvania: Grier, 1.

Calatoloides, Eocene fruit, Texas: Berry, 38.

Calcareous algae in Paciflc coast linestones: Nelson, R. N., 3.

Calcified log, Pittsburgh coal, Morgantown, West Virginia : Fettke, 8, 9.

California, Carpinteria asphalt pit: Chaney, 23.

Cretaceous diatoms: Hanna, G. D., 33.

Pleistocene, Rancho La Brea : Frost, 2.

Puente flora: Chaney, 4.

southern, Plcistocene: Chaney, 26.

Tesla region, Miocene: Scott, F. M. 1.

Callixylon, New York: Hylander, 1.

Calycophysoides, cucurbitaceous fruit, Tertiary, Texas: Berry, 53.

Cantheliophorus, Carboniferous: Bassler, 12.

Carboniferous plants, Illinois, structure : Hoskins, J. H., 4.

Catmint, Florissant, Colorado: Cockerell, 38.

Celtis, Miocene, Kansas: Brooks, B. W., 1.

Celtis stones, western States: Berry, 96.

Charophyte fruits, Texas: Groves, 1.

Cheyenne sandstone flora, Kansas: Berry, 37.

Classiflcation of plants : Conard, 1.

Climate, determination by plants: Knowlton, 6.

Coal balls: Clark, F. I., 1; Noe, 7, $10,12$.

$4096-31-58$
Palcobotany-Continued.

Coal flora, Richland County, Illinols: Reed, F. D., 1.

Narragansett Basin and Henry County, Missourl: Round, 5 .

Cold Spring Harbor, Long Island, New York: Grier, 2.

Collecting fossil plants: Berry, 83 .

Colorado, Green River: Cockerell, 27.

Tertiary lake beds flora: Knowlton, 12.

Conifers, anatomy and physiology: Torrey, R. E., 1.

Cretaccous, Alberta : Bell, W. A., 15.

western America: Mason, H. L., 1.

Cornus, Converse County, Wyoming : Knowlton, 10.

Costa Rica, Tertiary: Berry, 27.

Cretaceous floras: Berry, 17.

Carroll County, Tennessee: Berry, 104.

castern Alabama : Berry, 50.

Gulf region: Berry, 4.

Cryptozoon, Arbuckle Mountains, Oklahoma: Decker, 6 .

Cupressinoxyla of the Mesozoic: Jeffrey, 3.

Cycadeoidea: Wieland, $7,15,23,24$, 26.

Alberta, Kootenay coal measures: Warren, P. S., 6.

Alberta and Texas: Wieland, 10.

distribution and relationships: Wieland, 3.

localitics, Texas: Sellards, 27.

monocarpy: Wieland, 8, 13.

origin : Chamberlain, 1.

Cycad-like leaves, Permian, Texas: Noe, 1.

Cycadophyte investigation: Wielnad, 11.

Cycadophyta, classification: Wieland, 1.

Cycads : Dablgren, 1 ; Hollick, 3 ; Wieland, 17.

Dakota flora: Gress, 1.

age : Berry, 23.

Devonian floras: Berry, 91; Wleland, 12.

Devonlan forest, Gilboa, New York: Bancroft, J. A., 2 ; Clarke, J. M., $4,17,18$; Goldring, $5,6,7,9$; Petry, 1.

Devonlan plant localities, New York: Arnold, C. A., 1.

Devonian seed ferns, New York: Berry, 55.

Devonian trees, West Virginia: Reger, 15.

Dinosaur feed: Wieland, 18.

District of Columbia, buried forest : Cuno, 1.

Dominican Republic, Tertiary: Berry, 26.

Eagle Creek flora, Oregon and WashIngton: Chaney, 1. 
Paleobotany-Continued.

El Consuelo, Oaxaca, cycadeolds : Wieland, 22.

Environmental interpretation of fossil plants : Berry, 44.

Eocene, Gulf States: Berry, 89.

Eocene floras, southeastern North America : Berry, 51.

western Canada: Berry, 70.

Eocene climate: Berry, 40.

Eucalyptus: Berry, 7.

Esmeralda formation, western Nevada : Berly, 92

Evolution of floras: Berry, 14

Fossil plants as evidence for resistance to environment: Wieland, 14.

Ganado petrified forest, Arizona: Reagan, 13.

Gener'al : Berry, 14, 105; Chaney, 22, 28 ; Guppy, 1, 2 ; Hollick, 1, 11 ; Knowlton, 3, 17 ; Wieland, 2, 16, 21.

Grand Canyon, fossil floras: White, D., $34,41$.

Great Basin, Tertiary floras: Chaney, 27.

Green River flora: Knowlton, 11.

Greenland, Cretaceous: Seward, 3, 4.

Growth rings in Carboniferous wood: Goldring, 2.

Growth rings in trees, climatic signifcance: Antevs, 10.

Hackberry, John Day beds, Oregon : Chaney, 18.

Hackberry seeds, Nebraska: Barbour, 5.

Haiti, Tertiary : Berry, 32

Hazel, history : Berry, 13.

Hepatica, Florissant, Colorado: Howe, M. A., 3.

Hermit shale flora, Grand Canyon, Arizona : White, D., 33.

Hickory logs and nuts, Nebraska : Troxell, 29.

Hydrangea, Tertiary, Alaska : Hollick,

Hymenaea, Cretaceous, Alabama : Berry, 5 .

Illinois, Braidwood flora: Noe, 2.

Chester formation, stigmarian root: Foerste, 14

Harrisburg: Noé, 11.

northern, Pennsylvanian: Noé, 6, 8 .

Pennsylvanian plants, structure: Hoskins, J. H., 3.

Inga culebrana: Berry, 21.

Iron sulphide pseudomorphs of plant structure: Schwartz, 20

John Day Basin: Chaney, 9.

Juglans seeds, Titanotherium beđs, Nebraska : Berry, 80 .

Labiatae, antiquity: Cockerell, 34 .

Kentucky, western, coal field flora: Noe, 3.

Lance-Union flora: Knowlton, 9.
Paleobotany-Continued.

Laramie flora: Cockerell, 20 ; Denver Basin : Knowlton, 8.

Latah formation, Washington and Idaho: Knowlton, 16.

Lecythidoanthus, fossil flower, Trinidad: Berry, 54.

Linden and ash, history: Berry, Edw. W., 1.

Lithospermum nutlets: Berry, 101.

Locust, geologic history: Berry, Edw. W., 2.

Mackenzie, Mackenzie River basin.. Tertiary: Bell, W. A., 3.

Marpolia, Cambrian alga, British Columbia: Walton, 1.

Maryland, Federal Hill : Berry, 16.

Mascall flora, Oregon: Chaney, 17.

Matonidium americanum, Colorado: Berry, 11.

Mesozolc and Cenozoic plants, catalog: Knowlton, 2 .

Mesozoic floras of North and South America: Knowlton, 1.

Mexico, southern, Miocene: Berry, 48

Mississippi, Pleistocene plants: Berry, 6.

Mississippi Gulf, Eocene: Berry, 58.

Mississippian floras, Ap p a $l$ a $\mathrm{c}$ h i a $\mathrm{n}$ trough: White, D., 29.

Modern plant fossil : Round, 2.

Modern plants, evolution: Sci. Serv,. 1.

Montana, Missoula region: Jennings, 1.

Morrison flora, Colorado: Knowlton, 4

Mother plants of petroleum in Devonian black shale: White, D., 11, 19.

Myeloxylon, coal measures, Illinois : Seward; 1.

Nevada, Davis Creek beds: Chaney, 10

New Brunswick: Wilson, W. J., 1.

Carboniferous flora: Round, 4.

Minto coal basin: Bell, W. A., 11

Utica and Lorraine formations : Ruedemann, 17.

Nilsonia, Steamboat, Arizona. Reagan, 12

North Carolina, Mesozoic flora: Berry, 20.

Pleistocene : Berry, 75.

North Dakota, Fort Union beds, apparent fruits: Stainbrook, 1

Nova Scotia, Minto coal horizon: Bell, W. A., 6.

Oaks, geologic history: Trelease, 2.

Oklahoma, Beaver County, leaves : Berry, 82.

Cimarron County, Dakota sandstone: Noé, 8

Permian: Gould, C. N., 26.

Oldhamia, Cambrian, northern Maine: Smith, E. S. C., 5.

Ontario, Mattagami series: Bell, IV. A.. 16 . 
Paleobotany-Continued.

Ophioglossum, Tertiary, w y o m in g : Cockerell, 25.

Ophioglossum alleni, status : Hollick, 2.

Ophioglossum hastatiforme: Cockerell, 29.

Ophioglossum hastatiforme-Danaea coloradensis : Belry, 57.

Orontium, Florissant, Colorado : Cockerell, 31.

Pacific region: Chaney, 12.

Palaeochara, coal measures, Nova Scotia : Bell, W. A., 4.

Paleozoic angiosperm: Noe, 5.

Paliurus, Miocene, Washington : Berry, 102.

Palm fruit, Miocene, Panama : Berry, 103.

Palm nut, Miocene, Canal Zone : Berry, 25.

Palmoxylon, Colorado, Denver formation : Stevens, N. E., 1.

South Dakota, Pierre formation : Stevens, N. E., 1.

Paraphyllanthoxylon arizonense, Cretaceous, Arizona : Bailey, I. W., 1.

Parichnos in gymnosperms: Jeffrey, 7.

Pathological conditions: Berry, 47.

Payette flora: Chaney, 6.

Pennsylvanian plants, Illinois, structure : Hoskins, 2.

Permian: White, D., 17.

Petrifaction of wood: St. John, 1.

Petrified wood industry: Berry, 79.

Phenacocladus, Eocene, Colorado : Cockerell, 35 .

Pine cone, Oakland, Callfornla : Metcalf, W., 1.

from drift: Thomas, 21.

Pines, Mesozoic: Jeffrey, 6.

Plant evolution and climate: Wieland, 19.

Plants erroneously referred to cycadeoids: Wieland, 25.

Plants from Stanford collection : Reagan, 16.

Platanus, geologie history: Gould, C. N., 2 .

Pleistocene : Berry, 88.

Alabama and Tennessee: Berry, 34.

District of Columbia : Berry, 52.

interglacial, British Columbia : Berry, 33.

Porto Rico: Hollick, 12

Collazo River: Hollick, $6,8$.

Potamogeton perryl, Henry County, Tennessee: Berry, 30.

Pre-Cambrian floras: Berry, 100.

Psaronius, Schoharie County, New York: Hovey, 5.

Pseudocycas, British Columbia : Berry, 31.

Psilophyton, cuticular structure: Edwards, W. N., 2.

Quercus, Green River Eocene, Colorado: Cockerell, 39.
Paleobotany-Continued.

Rancho La Brea beds, flora: Chaney, 5 .

Ranunculus florissantensis: Cockerell, 11.

Recent work: Fenneman, 3.

Redwoods, history : Hollick, 13.

Relations with Asia: Berry, 93.

Rhaetic flora, Scoresby Sound, east Greenland : Harris, T. M., 1.

Rhode Island, Carboniferous flora : Round, 4.

Ripley flora: Berry, 63.

Saccoglottis: Berry, 43.

Sagenopteris: Berry, 45.

St. John collection : Reagan, 17.

Sallx, Iowa: Reagan, 12.

Salvinia, Eocene: Berry, 71.

Sequola, ancestry: Berry, 16.

in the Mesozoic: Jeffrey, 1.

Sparganium, Eocene, Wyoming : Berry, 61 .

Standing stone forests, Yellowstone Park : Mitchell, G. E., 1.

Stigmaria, Kansas: Reagan, 12.

Sweet gum, history : Berry, 13.

Teaching paleobotany: Berry, 19.

Tempskya knowltoni, Montana: Seward, 2.

Tennessee, Cretaceous : Berry, 28.

late Cretaceous: Berry, 17.

Pleistocene: Berry, 6.

Terminalia, lower Eocene: Berry, 76.

Terrestrial plants in marine deposits: Chaney, 13.

Tertiary floras: Berry, 3.

Pacific region: Chaney, 3.

of the West : Chaney, 7.

terrestrial plants: Berry, 62.

Tetracentron, Trochodendron, and Drimys: Wieland, 4.

Texas, central, Eocene florule: Berry, 56.

trans-Pecos region, Eocene: Berry, 25.

Tree, Red Deer Valley, Alberta: Kin. dle, 14.

Tree ancestors: Berry, 46.

Tree trunk, Manhattan Island, New York : Hollick, 7.

vertical, Scranton, Pennsylvania: Davis, R. N., 1.

Trinidad, Pleistocene flora: Berry, 67. Tertiary flora: Berry, 64 .

Umbellularia, John Day beds, Oregon: Chaney, 19.

Upper Cretaceous : Berry, 10.

Utah, Shinarump conglomerate, cycads : Berry, 90.

Walnut, Miocene, Nevada: Berry, 98.

Weichselia, Cretaceous, Texas: Berry, 95.

Western floras: Chaney, 25, 28.

West Indies: Hollick, 4.

Wilcox flora: Berry, 41.

Wood, replacement by dolomite: Adams, S. F., 1. 
Paleobotany-Continued.

Wyoming, Bridger beds, Wind River Basin : Berry, 72.

Triassic: Berry, 59.

Yellowstone National Park, fossil forests : Knowlton, 18.

Paleocene, status and limits: Matthew, 8. Paleoclimatology.

Alaska : Blackwelder, 1.

Algae as limestone makers and cllmatic indicators: Glock, 3.

Ameliorations of present Arctic climates: Chamberlin, 'T. C., 20.

Ancient: Coleman, 25.

Astronomical considerations: Shapley, 1.

California, Coalinga Tertiary formations: Reed, 5.

Climate, determination by plants : Knowlton, 6.

Climatic changes: Antevs, 4.

Climatic environment of extinct animals, determination: Case, 9.

Colorado, Carboniferous: Tieje, 3.

Cretaceous climate: Seward, 4; Wieland, 11.

Eocene climate: Berry, 40.

Evolution of geologic climates: Knowlton, 3,7 ; Manson, 2.

Fossil marine faunas as indicators of climate: Kirk, E., 10.

General : Allison, V. C., 2 ; Antevs, 13 ; Chamberlin, T. C., 23 ; Coleman, 8; Huntington, 1, 2; Keyes, 219, 230 ; Knowlton, 3 ; Manson, 3 ; Ramsay, 1; Richarz, 4 ; Sayles, 8 ; Schuchert, 17 ; Scott, W. B., 4, 8; Visher, 3; White, D.; 22, 28; Wieland, 9 ; Anon., 69.

Glacial climate in non-glaciated regions: Bryan, 31.

Glacial period: Moscheles, 1.

Great Basin; Pleistocene history : Antevs, 12.

Growth rings in trees, climatic significance: Anters, 10.

Kansas, Permian : Dunbar, 4.

Lake Lahontan, geologic history: Jones, J. C., 2.

Late Paleozoic climates: Coleman, 24.

Mesozoic climate: Knowlton, 15; Stanton, 9, 10.

Mexico, Quaternary: Jaeger, 1, 2.

Mild geological climates: Huntington, 4.

Miocene climate, tropical America: Woodring, 13.

Modern climates, evolution: Sci. Serv., 1.

Ocean, effect on climate: Chamberlin, T. C., 19 .

Oceanic salinity: Visher, 5.

Ordovician: Kindle, 5.

Pacific coast States, Pleistocene changes: Buwalda, 17.
Paleoclimatology-Continued.

Paleozolc: White, D., 26; late: Cinse, E. C., 2.

Peat deposits, their evidence of climatic changes: Dachnowski, 3 .

Pennsylvanian : Savage, 18.

Permian : Hall, G. M., 1.

Physiography and past cllmates: Evans, O. F., 8.

Plant evolution and climate: Wieland, 19.

Pleistocene: Antevs, 11; Meinzer, 5. Mexico: Brückner, 2.

Polar anticyclones: Hobbs, 32.

Polar ice caps, extent: Adams, L. H., 10.

Polar temperatures and conl measures: Stefansson, 1.

Post-Tertiary changes, Alaska: Smith, P. S., 13.

Pre-Cambrian climate: Coleman, 21.

Quebec: Cooke, H. C., 2.

Quaternary climate: Grunsky, 1.

Recession of the last ice sheet in New England: Antevs, 1.

Relief hypothesis: Ramsay, 1.

Rocky Mountains, Pleistocene changes in elevation: Pardee, 16.

Seasonal records of geologic time: Reeds, 4

Silurian: Alling, 14.

Solar-cyclonic hypothesis: Visher, 8.

Tertlary: Berry, 86 .

and Quaternary, California region: Smith, J. P., 1.

Triassic climate, eastern North America : Bissell, 4.

White River beds, Soutl Dakota: Wanless, 3.

Winters in Upper Devonian of New York and Acadia: Schuchert, 34.

Paleo-ecology.

Principles and methods: Clements, 2, 3.

Wyoming, Como Bluff, Quarry 9 ;. Simpson, G. G., 11.

Paleogeographic maps.

Alabama, Paleozoic : Butts, 8.

California, Tertlary: Clark, B. L., 5.

Central States: Cummings, 1.

Cretaceous: Schuchert, 25.

Devonian: Clark, T. H., 9 ; Dunbar, 1 ; Savage, 2 .

late middle: Stauffer, 3.

Eocene: Stanton, 3.

middle : Berry, 40.

Iowa, pre-Cretaceous distribution of Paleozoic formations: Keyes, 229.

Mexico, Rio Grande dralnage basin and Gulf Coast region: Bose, 8 .

New York, Ordovician : Ruedemann, 16.

Niagaran: Cummings, 4.

North America: Schuchert, 22.

Oklahoma: Wilson, R. A., 8.

Pennsylvanian: Dott, 1.

Ordoviclan: Savage, 2. 
Paleogeographic maps-Continued.

Paleozoic, Atlantic-Arctic legion: Eoltedahl, 2.

late: Case, E. C., 2.

Paleozoic geosynclines, North America : Schuchert, 25.

Pennsylvanian: McCoy, 5 .

Oklahoma and Texas: Powers, 26.

Permian: Schuchert, 25, 52.

Phosphoria sea: Mansfield, G. R., 29.

Silurian: Savage, 2; Schuchert, 25 ; Ulrich, 8.

Texas and Oklahoma: Powers, 26.

Triassic: Branson, 17; Simpson, $G$. G., $\mathbf{5}$.

Upper Cretaceous: Stanton, 3.

Paleogeography. See also Geologic history; Paleoclimatology ; Paleogeographic maps.

Acadia : Balley, L. W., 2.

Alaska, Cretaceous: Martin, G. C., 13.

Appalachian geosyucline: Schuchert, 20.

Atlantic bridges nonexistent: Matthew, 6 .

California, central Coast Ranges, Mlocene : Reed, 7.

Tertiary : Clark, B. L., 6.

Canada, maritime provinces, Carboniferous : Bell, W. A., 13.

Canadian Rocky Mountains: Walcott, 17.

Caribbean region: Vaughan, 3 .

Central America: Sapper, 7.

Colorado, Carboniferous : Tieje, 3.

Cordilleran trough: Walcott, 13.

Cretaceous: Stanton, 5.

Utah : Spieker, $\mathbf{5}$.

Devonian: Clark, T. H., 9 ; Grabau, 6.

General: Case, E. C., 2 ; Schuchert, 13, 22 ; Keith, 8; Troedsson, 1 ; UIrich, 3.

Graptolite beds, signiflcance: Moore, R. C., 40.

Great Lake region: Grabau, 12.

Idaho, southeastern : Mansfleld, G. R., 29.

Jurassic peneplain, Oklahoma and Arkansas: Melton, 8.

Kentucky, eastern, Pennsylvanian : Hudnall, 3.

Little River group delta: Matthews, G. F., 1.

Llanoria: Miser, 7.

Marine invertebrate faunas, distribu. tion: Schuchert, 18.

Maryland, Cambrian and Ordovician : Bassler, R. S., 1.

Mid-Continent oil field: McCoy, 5.

Mississippian orogenic movements : Van Tuyl, 2.

Missouri, Paleozoic: Branson, 6.

Montana, Upper Cretaceous: Robinson, E. G., 1.

New Mexico: Keyes, 11.

New York, Ordovician : Ruedemann, 16.
Paleogeography-Continued.

Oklahoma : Wilson, R. A., 8.

Henryetta district, Pennsylvauian : Reed, R. D., 2.

Pennsylvanian: Dott, 1. western : Gould, 16.

Paciflc coast: Hanna, 23.

Pacific continent: Hanna, 24.

Pacific Odean, existence in Ordovician time: Ruedemann, 26.

Paleozoic: Schuchert, 18.

Atlantic-Arctic region: Holtedabl, 2. late: Case, E. C., 2.

Pennsylvanian, Oklahoma and Texas: Powers, 26.

Pennsylvanian sedimentation around Healdton Island, Oklahoma: Merritt, J. W., 1.

Permian: Schuchert, 25, 52.

Great Plains: Dunbar, 4.

Permo-Carboniferous: Case, E. C., 3 ; deposition conditions: Case, E. C., 1.

Physiography and past climates: Evans, O. F., 8.

Pre-Cambrian: Miller, W. J., 21 ; Ruedemann, R., 1.

Pre-Cambrian continents, existence and conflguration: Ruedemann, 11.

Pre-Cambrian land masses: Ruedemann, 10.

Quantitative criteria : Moore, R. C., 20.

Ripple marks, interpretation: Bucher, 1.

Shore line of Galena seas: Sardeson, 27.

Silurian : Ulrich, 8.

Indiana and Illinois: Tharp, 1.

Siouan Mountains: Keyes, 228.

Source of original Huronian sediments : Bain, 16.

Stones River time: Coryell, 2.

Tertiary floras: Berry, 3.

Texas, Panhandle: Gould; 16.

Triassic: Simpson, G. G., 5; Smith, J. P., 3.

and Jurassic: Schuchert, 48.

Upper Cretaceous Mississippi Gulf : Berry, 10.

West Indies: Trelease, 1.

Paleontology. For areal see names of States. See also the classes of animals; Invertebrates (general); Evolution; Paleobotany; Problematic organisms; Restorations.

Ammonite shell investing commensal Bryozoa: Dunbar, 13.

Animals of the past: Lucas, F. A., 1. Application to oil industry: Jones, R. A., 5 .

Applications of paleontology: Scott, W. B., 7.

Applied paleontology : Weller, 3 .

Archean, evidence of life in evaluated: Hawley, J. E., 2. 
Paleontology-Continued.

Arrested evolution, paleontology of : Ruedemann, 6, 9.

Bakelite for preserving fossil material : Case, 17.

Biostratigraphic aspect of micropaleontology: Schenck, 11.

Biostratigraphic terms: Fenton, C. L., 6.

Bone, fossil, mineralogy and petrography : Rogers, A. F., 19.

California Academy of Sciences, report of curator: Hanna, G. D., 3.

Canada, index to paleontology: Nicolas, 3.

Casts of invertebrate fossils: Feiss, 1.

Cephalopod adaptation: Dunbar, 5.

Climate, determination by plants : Knowlton, 6.

Climate environment of extinct animals. determination: Case, 8.

Collecting fossil fishes in Cleveland shale : Hyde, 2.

Collecting fossil plants: Berry, 83.

Collecting fossils : Ruedemann, 25 ; on Anticosti Island: Twenhofel, 25.

Collecting in Mississipian formations: Weller, 13.

Collecting in the Badlands: Johnston, W. D., 1

Collections in Boston and vicinity : Raymond, 4.

Comparison of most ancient and recent marine faunas: Clark, $\Delta$. H., 1.

Conodonts, classification and stratigraphic use: Bassler, 16.

Contributions to knowledge : Berry, 29.

Development of American paleontology : Scott, W. B., 5 .

Development stages in teaching paleontology : Jackson, 1.

Dinosaurian climatic response : Lull, 15.

Disease in extinction of races: Moodie, 1.

Early collecting of fossil vertebrates, LuIl, 18; Matthew, 36.

Ecology in interpretation of fossil faunas: Baker, F. C., 5, 7.

Evolutional paleontology in relation to the lower Paleozoic rocks : Elles, 1.

Evolutionary changes, use in correlation: Thomas, N. L., 2.

Extinction and extermination: Tolmachoff, 5 .

Extraction of fossils from refractory rocks : Hanna, G. D., 20.

Foraminifera, classification: Cushman, 28.

Fossil, use of term : Field, 3, 4 ; Miller, A. M., 7, 8 .

Fossil marine faunas as indicators of climate: Kirk, E., 10.

Fossil plants as evidence for resistance to environment: Wieland, 14.
Paleontology-Continued.

Fossils, separation by heavy liquils: Hanna, M. A., 4.

Fossils and life: Bather, 4.

Fossils as age markers: Price, G. M., 2.

Fossils from wells: Schenck, 4.

General: Bather, 3; Buwalda, 13; Diamond, 1 ; Manson, 1 ; Matthew, 19 ; Merriam, 20 ; Parks, 31 ; Peabody Mus. N. H., 1 ; Shimer, 4 ; Smithsonian Inst., 1; Stock, 18; Wieland, 21; Woodring, 16.

Great Basin and Paciflc regions: Merriam, 12.

History of life: Matthew, 39.

Invertebrates, inorganic constituents: Clarke, F. W., 2.

John Day region: Merriam, 14.

Journal of Paleontology: Hanna, M. A., 8.

Marking of type specimens: Howell, B. F., 10 .

Marine invertebrate faunas, distribution: Schuchert, 18.

Micro-fossils in correlation : Schuchert, 24.

Origin of oldest fossils : Brooks, W. K., 1.

Origin of species: Osborn, 38.

Orthogenesis: Osborn, 17.

Ozarkian system: Walcott, 7 .

Pacific region: Merriam, 10.

Paleontologic studies, practical value: Berry, 24.

Paleontological researches in Pacific region: Merriam, 16.

Paleontology and human relations: Weller, 18.

Paleozoic, late: Case, E. C., 2.

Parasitic disease: Bather, 2.

Parasitism : Clarke, J. M., 16.

Petrification of wood: St. John, 1.

Photographing fossils: Mehl, 8.

Place of paleontology among the sciences: Clark, J. M., 6.

Prehistoric evidence: Frick, 2.

Present tendencies in paleontology : Berry, 9.

Progress of life: Keyes, 28.

Progress on Pacific const: Merriam, 7.

Protypes: Troxell, 6.

Rectifications of nomenclature of Mollusca: Hanna, G. D., 13.

Repopulation of sea bottoms: Sardeson, 24.

Researches in western States: Merriam, 10.

St. John collection : Merrill, 33.

Silurian faunal facies in juxtaposition : Ruedemann, 20.

South American faunas, origin: Loomis, 5.

Species, nature of: Troxell, 6 .

Statistical identification: Frost, 1.

Symbiosis : Clarke, J. M., 16. 
Paleontology-Continued.

Type fossils in museum of Ohio State University: Morningstar, 2.

U. S. National Museum, paleontological exhfbits : Bassler, 5.

Value of paleontology: Matthew, 32.

Variations of specific distinctions: Lull, 13.

Ways of life: Lull, 17.

X-ray studies of fossils: Swartz, J. H., 13.

Cambrian.

Alabama: Butts, 8.

Alberta, trilobites: Raymond, 36.

Algae, Middle Cambrian: Walcott, 1.

Arthropods : Henriksen, 1.

Brachiopoda : Walcott, 8.

Belt fauna : Rothpletz, 1.

British Columbia, Marpolia: Walton, 1.

California, Bristol Mountain : Resser, 6.

Mohave Desert: Clark, C. W., 1.

Chordates, Vermont: Bryant, 6.

Greenland, northwestern: Poulsen, 1.

Iowa, St. Lawrence limestone, Trilobita : Walter, 1.

Maine, Oldhamia : Smitb, E. S. C., 5.

Maryland : Bassler, R. S., 1.

Massachusetts, Boston area : Clark, T. H., 10.

Montana, Helena region: Rothpletz, 1.

Nevada, Silver Peak district, trilobites: Walcott, 5.

New Brunswick: Howell, 8.

Newfoundland, Paradoxides faunas, Manuels Brook : Howell, 4.

Olenellus getzi, antennae: Dunbar, 9.

Quebec, Levis : Clark, T. H., 11.

Spongiae, British Columbia: Walcott, 2.

Stromatocystites, Newfoundland: Schu: chert, 3.

Trilobites: Walcott, 15 ,

Vermont, northwestern, trilobites : Raymond, 23.

Carboniferous.

Alabama: Butts, 8.

Mississippian conodonts: Holmes, G. B., 1.

Alberta, Banff area: Warren, P. S., 4.

Crowsnest Pass : Warren, P. S., 7.

Lake Minnewanka section : Shimer, 6.

Nordegg, Kinderhook fauna: Warren, P. S., 1.

Algal deposits: Twenhofel, 3.

Annularia with Paleostachya fruit, Rhode Island: Round, 3.

Arizona, Grand Canyon, Hermit shale flora: White, D., 34.

Permian insect: Carpenter, F. M., 2. northwestern: Shimer, 2.

Arkansas, Fayetteville formation, sharks: Croneis, 4.

Bend series, central Texas: Moore, R. C., 1.

British Columbia, Leptodus : Kindle, 38

Chester fauna: Weller, s., 1.
Paleontology-Continued.

Carboniferous-Continued.

Chester series: Ulrich, $\mathbf{5}$.

Bryozoa, Illinois and Kentucky : McFarlan, 1.

Colorado, Pennsylvanian sandstones, footprints : Henderson, J., 5.

western, Pennsylvanian Crinoidea : Keyte, 1.

Conodonts: Ulrich, 13.

Environmental conditions of Permian vertebrates: Case, 15.

Foraminifera, Pennsylvanian, Oklahoma and Texas: Harlton, 3.

Idaho, southeastern: Girty, 10.

Illinois, Galesburg: Jelliff, 1, 3.

Harrisburg, flora: Noe, 11.

northern, Pennsylvanlan flora: Noe, 6.

northwestern, Pennsylvanian: Wanless, 5.

Pennsylvanian marine faunas: Savage, 11.

Pennsylvanian plants, structure: Hoskins, 2.

plants, structure: Hoskins, 4.

Rlchland County, coal flora: Reed, F. D., 1.

Stonefort limestone, Fusulinella: Henbest, 1.

Indiana, Crawfordsville, crinold occurrence : Ehrenberg, 1.

Orange County, Chester formations: Hole, 2.

Porter County, scorpion: Moore, J. I., 1.

Iowa, Des Moines: Thomas, 18.

Fort Dodge, Ste. Genevieve maris : Lees, 4.

Mississippian : Van Tuyl, 8.

southwestern: Smith, G. L., 1.

Kansas: Moore, R. C., 4.

ophiacodont reptile, Permian : Romer, 4.

Permian Insecta: Carpenter, F. M., 1 ; Tillyard, 5-11.

Kentucky, eastern, Mississippian : Butts, 3.

Kendrick shale: Jillson, 9.

Pottsville faunas: Jillson, 53.

western, coal fleld flora: Noé, 3 .

Warsaw formation, Anisotrypa : Deiss, 1.

Wayne County, Warsaw formation, brachiopods: Ehlers, 11.

Mackenzie, Kinderhook: Hume, 6.

Maryland, Cantheliophorus: Bassler, 12.

coal measures: Swartz, C. K., 2.

insects: Cockerell, 37.

Mexico, Coahuila, Permian: Haack, 1. Peregrina Canyon: Girty, 9.

Michigan, Grand Ledge: Kelly, w. A., 1.

Mississippian faunal zones: Weller, 12. 
Paleontology-Continued.

Carboniferou 8-Continued.

Missouri, Henrietta formation, ostrncodes : Knight, J. B., 1.

Henry County, coal floras: Round, 5. Mississippian : Moore, R. C., 41.

upper Devonian and lower Mississippian faunas, relationship : Bran. son, 8.

Nebraska, Pennsylvanian, Fusulinidae: Dunbar, 11.

New Mexico, Abo sandstone, ammonoids : Böse, 4.

Nova Scotia, Horton-Windsor district: Bell, W. A., 2.

Ohio, Dunkard series: Stauffer, 1.

Oklahoma, Carter County, Dornick Hills formation, Foraminifera : Waters, J. A., 1.

Glenn formation: Girty, 5 ; Foramlnifera : Harlton, 2.

Pennsylvanian foraminifers: Galloway, J. J., 13.

Pennsylvanian ostracodes: Coryell, 3 ; Harlton, 1, 4 ; Roth, 3.

Permian amphibian: Mell, 15.

Permian Apus: Ruedemann, 8.

Seminole County ostracodes: Coryell, 4

Stanley shale: Honess, C. W., 2.

Stonewall quadrangle: Morgan, G. D., 5.

Sycamore limestone: Cooper, 1.

Ostracoda, Pennsylvanian, Oklahoma and Texas: Harlton, 1, 4.

Paleozoic, late: Case, E. C., 2.

Paleozoic anglosperm, Illinois: Noe, 5.

Pennsylvania, Broad Top coal fleld, Pocono fauna: Girty, 12.

Calamites, East Bellevue: Grier, 1. Pittsburgh : Leighton, H., 2.

Permian: Beede, 7 ; White, D., 17.

Permian tetrapods: Case, 20.

Permo-Carboniferous ammonoids, Glass Mountains, Texas : Böse, 1.

Pocono Brachiopoda: Price, W. A., 2.

Pottsville fauna, Ohio: Morningstar, 1.

Rhode Island, coal floras: Round, 5.

Schwagerina : Beede, 9.

Texas, Burkburnett: Glenn, 2.

Canyon formation, Fistulipora : Link, 6; Foraminifera : Waters, J. A., 2.

northern: Moore, R. C., 15.

Pennsylvanian foraminifers: Cushman, 42.

Pennsylvanian ostracodes: Harlton, 4.

Permo-Carboniferous red beds: Romer, 13.

San Saba County, Mississippian : Girty, 7 ; Roundy, 3

Seymouria : Romer, 11.

Sutton County, Carboniferous Foraminifera : Cushman, 45 .

Utah, Girty, 3.
Paleontology-Continued.

Carboniferous - Continued.

West Virginia, Mercer, Monroe, and Summers countles: Girty, 8.

Mineral and Grant counties: Reger, 7.

Mississippian: Girty, 4

Nicholas County : Price, W. A., 7.

Permian vertebrates: Tilton, 10.

Webster County : Price, W. A., 1.

Wyoming, Tensleep formation: Brain. erd, 2.

\section{Cretaceous.}

Alabama : Stephenson, 5.

Hymenaea : Berry, 5.

Alberta, Birch Lake sandstone marine

fauna: Warren, P. S., 3.

cichlid fish : Jordan, D. S., 18.

Colorado shale: Warren, P. S., 8.

Edmonton formation, Red Deer River : Sternberg, C. M., 7 ; Warren, P. S., 3.

dinosaur: Parks, 19, 26 ; Sternberg. C. M., 10.

Edmontosaurus: Lambe, 1.

Laosaurus : Gilmore, 20.

Paskapoo formation, Mollusca : Russell, L. S., 1 ; plants : Berry, 73, 74.

Pelecypoda: McLearn, 3, 5.

Aralias : Fritel, 1.

Arizona, Ostrea : Reagan, 18.

Steamboat, Mancos-Dakota-Tununk formation: Reagan, 19.

British Columbia, Cassiar district, plants : Bell, W. A., 14.

Callifornia, Gastropoda: Stewart, R. B., 1.

Santa Ana Mountains : Packard, 4.

Cannonball fauna: Stanton, 3, 6 ; corals: Vaughan, 9

Carolinas, invertebrates: Stephenson, 9.

Cheyenne sandstone flora, Kansas: Berry, 37.

Colorado, Mollusca : Reeside, 17. northeastern : Henderson, J., 1.

Colorado group, Montana: Reeside, 6.

Coloradoan : McLearn, 10.

Cuba, oyster: Raymond, 31. rudistids : Sánchez Roig, 15.

Daliota, so-called, Colorado and Wyoming: Reeside, 6.

Dakota flora, age: Berry, 23.

Dakota sandstone problems: Stanton, 5.

Didymotis trinldadensis, Lower Cretaceous, Trinidad: Sommermeier, 1.

Dinosaurs, Red Deer River: Stern. berg, C. H., 1.

Eagle sandstone, cephalopods : Reeside, 12.

Fish scales: Cockerell, 1.

Gulf region: Berry, 4.

Greenland, plants: Seward, 3.

westeru, plants: Seward, 4

Filiti : Woodring, $\overline{5}$. 
Paleontology-Continued.

Cretaceou 8-Continued.

Jamaica : Trechmann, 5, 8.

crab: Withers, 1, 8.

decapod crustaceans: Withers, 2.

Echinoidea : Hawlins, H. L., 1, 2.

Kansas: Moore, R. C., 4 ; Twenhofel, 17.

fishes: Jordan, D. S., 14.

Martinichthys: McClung, 1.

Niobrara beds, Anguillavus: Martin, H. 'T., 1.

Niobrara cirriped: Withers, 5.

Manitoba, Foraminifera: Cushman, 33.

Maryland, Federal Hill : Berry, 16.

Upper Cretaceous, Ostracoda : Berry, E. Willard, 1.

Mesozoic floras of North and South America : Knowlton, 1.

Mexico, Coahulla, Turonian ammonite fauna: Böse, 3.

Guerrero, Zumpango : Burckhardt, 1. Lower California: Anderson, F. M., 4.

Lower Cretaceous: Burckhardt, 2. northern, ammonites : Böse, 9.

San Felipe formation: Stanton, 4. southern, rudistids : Palmer, R. H., 7.

Tamaulipas, rudistid shells: Stephenson, L. IV., 1.

Tampico Embayment area, Foraminifera: White, M. P., 1.

Zacatecas, Durango, and Guerrero: Böse, 6.

Morrison-flora, Colorado: Knowiton, 4.

New Mexico, San Juan County, Reptilla: Gilmore, 4.

New York, Staten Island: Davis, W. T., 1.

North Carolina : Step renson, 4. decapod crustaceaus: Rathbun, 3.

Mesozoic flora: Berry, 20.

Oklahoma, Cimarron County, Dakota sandstone plants: Noe, 9.

Love County, Comanchean : Bullard, $1,2$.

Marshall County : Bullard, 3.

Oregon, Cretaceous pterosaurian: Gilmore, 40.

Ichthyosaurian: Merriam, 27.

Pacific region, Mollusca: Reagan, 7.

Plantae, catalog: Knowlton, 2.

Porto Rico, Ponce district : Mitchell, 7.

Ripley flora: Berry, 63.

Scaphites, Upper Cretaceous : Reeside, 14.

South Dakota, Badlands: Toepelmann, 1.

Fox Hills formation, beetles: Northrop, S. A., 1.

ganold fish : Gregory, W. K., 11.

Falmoxylon, Pierre formation: Stevens, N. E., 1.

Ziebach County, ',oring: Stanton, 11.
Paleontology-Continued.

Cretaceous-Continued.

Tennessee, Carroll County, plants: Berry, 104.

Cretaceous flora: Berry, 28.

late Cretaceous plants: Berry, 17.

McNairy County, Hamulus: Wade, B., 2.

Ripley fauna : Wade, 3.

Texas: Adkins, 5 ; Scott, G., 2 ; Stanton, 13.

ammonites : Scott, G., 6.

Buda and Georgetown limestones, Turritella : Ellisor, 1.

central, Foraminifera : Carsey, 1.

Denton County : Winton, 3.

Cooke County: Bybee, 3.

Duck Creek formation, ammonites: Scott, G., 1.

Exogyra: Böse, 2.

Fredericksburg formation, ammonites: Scott, G., 5.

Fredericksburg and Washita formations: Adkins, 1.

micrology : Alexander, C. I., 1 ; Carpenter, M., 1; Mahon, 1; Moreman, 1.

northern, recurrent brachiopods: Sandidge, 1.

Pectinidae: Kniker, 1.

southern, ammonites: Böse, 9.

Tarrant County: Winton, W. M., 1.

Weichselia: Berry, 95.

Weno and Pawpaw formations: Adkins, 2.

Trigoniae, Pacific coast: Packard, 3.

Trinidad: Harris, G. D., 5.

rudistids: Harris, G. D., 4.

Trinity fauna: Vanderpool, 2.

Utah, Mollusca: Reeside, 17.

Washingtou, San Juan Islands: MCLellan, 2.

Woodbine flora, Arthurs Bluff, Texas: Berry, 36.

Wyoming, Oregon Basin, Cody shale, Cephalopoda: Reeside, 13.

Devonian.

Alabama: Butts, 8.

Alberta, Banff area: Warren, P. S., 4. Brachlopoda : Kindle, 32.

Crowsnest Pass: Warren, P. S., 7.

Lake Minnewanka section: Shimer, 6 .

Peace River: Kindle, 47.

Arctic regions, Ellesmere Land: Tolmachoff, 1 .

Arizona, Pinal Creek: Stauffer, 11.

Bothriolepis, Scaumenac Bay, Quebec: Bryant, 3.

Conodonts: Ulrich, 13.

Devonaster eucharis (Hall), six-rayed : Willard, B., 2.

Dolatocrinus and allies: Springer, $\mathbf{3}$.

Ellesmere Land: KIrk, 4 ; 'Tolmachoff, 2.

Floras: Berry, 91.

Glass-sponge colonies : Clarke, J. M., 10. 
Paleontology-Continued.

Devonian-Continued.

Illinois, Oriskany : Savage, 15. western: Savage, 7.

Iowa, annelid jaws: Searight, 1. Aulopora: Fenton, M. A., 1.

Brachiopoda: Thomas, 14.

echinoderms: Thomas, 12, 23 ; geographic distribution: Thomas, 16.

Hackberry fauna : Fenton, C. L., $1,3,4$.

Lime Creek shales: Thomas, $\boldsymbol{\theta}$.

Pentameracea : Belanski, 2.

Schizophoria : Fenton, M. A., 3.

Shellrock stage: Belanski, 3.

State Quarry beds: Stainbrook, 2, 3.

Mackenzie River valley, Crinoidea ; Springer, 4, 14.

Maine, Chapman sandstone: Raymond, 21 ; Ostracoda : Ulrich, 1.

Michigan, Alpena, Cephalopoda : Foerste, 23.

Crinoidea : Ehlers, 9.

cystid, Lipsanocystis : Ehlers, 6. gastropod and cephalopod: Ehlers, 5.

southeastern, Hamilton fauna : Ehilers, 12.

Minnesota: Stauffer, 3.

Missourl: Branson, $\mathbf{5}$.

Bailey limestone fauna: Tansey, 1. central : Greger, 1.

Ste. Genevieve County, Little Saline limestone: Stewart, G. A., 1.

upper Devonian and lower Mississippian faunas, relationship : Branson, 8.

New York, Devonian crinoids : Goldring, 4.

Eighteenmile Creek, Callixylon: Hylander, 1.

Gilboa, plant material: Goldring, 7. glass sponge: Clarke, J. M., 25.

Hamilton crinoids: Goldring, 8.

Hamilton group, Protobalanus: Van Name, 2.

Oriskany fauna, Oriskany Falls, Eaton, H. N., 3.

plant localities: Arnold, C. A., 1.

plants : Petry, 1.

Portage group, conodonts: Hibbard,

R. R., 1.

seed fern forests: Goldring, 5 .

Sherburne sandstone: Grabau, 6.

Vernon shale fauna: Ruedemann, R., 2.

Nova Scotia, Cephalopoda : Foerste, 27. Ohio, Cleveland shale, fishes : Hyde, 4.

Delaware County: Westgate, 5 .

Silica shale fauna: Stewart, G. A., 2.

Ontario, James Bay region: Savage, 2.

Pisces: Hussakof, 1.

Portage fauna, Mackenzie River valley: Kindle, 4.

Quebec, St. George : Clark, T. H., 9.
Paleontology-Continued.

Devonian-Continued.

Starfish, Gaspe: Ruedemann, 23.

Stringocephalus burtoni, distribution: Kindle, 10.

Tennessee, western: Dunbar; 1, 2. Terebratulacea, Iowa : Belanski, 4.

Thread molds and bacteria: Moodie, 10.

West Virginia, Hardy County : Tilton, 13.

Mercer, Monroe, and Summers counties: Prouty, 14.

Mineral and Grant counties: Reger, 7.

Randolph County, trees: Reger, 15. Jurassic.

Alberta: McLearn, 13

Fernie formation, Ammonoidea : McLearn, 15; Pelecypoda: Mc. Learn, 9.

British Columbia: McLearn, 13.

Hazelton group: McLearn, 11.

Parson Bay: Crickmay, 9.

Cardioceratidae: Reeside, 1.

Cuba, ammonite fauna: O'Connell, 3. Viñales: Sánchez Roig, 1, 2.

western, fish fauna: Gregory, . W. K., 8.

Mammalia : Simpson, G. G., 3.

Mexico, Oaxaca and Guerrero, cephalopods : Burckhardt, 3

Zacatecas, Symon: Burckhardt, 1.

Montana, Ellis formation, Lithothamnlum : Howe, M. A., 4.

Oregon, Mollusca: Hertlein, 2.

Plantae, catalog: Knowlton, 2.

Trigoniae, Pacific coast: Packard, 3.

Trinidad, Northern Range : Trechmann, 7.

Western North America : Crickmay, 5.

Wyoming, Como Bluff, Quarry 9: Simpson, G. G., 11.

Apatodonosaurus: Mehl, 19.

Ordovician.

Alabama: Butts, 8.

Arctic Cephalopoda : Foerste, 11.

Baffin Island, cephalopoda : Foerste, 28. colals, brachiopods, gastropods, and ostracodes: Hussey, 2.

Beloit formation: Sardeson, 22. Brachiopoda : Sardeson, 24.

Black River Brachiopoda, Mississippl Valley: Fenton, C. L., 5.

British Columbia, Glenogle formation, graptolites: Clark, T. H., 14.

Rocky Mountains: Wilson, A. E., 4. upper Ordovician, Palliseria : Wilson, A. E., 3.

Cephalopoda : Foerste, 17, 28.

Ceratopyge fauna: Raymond, 16.

Cinctnnatian, recurrent faunas: Shideler, 3.

Trilobita: Foerste, 3.

Colorado, Macluritella : Kirk, E., 8.

Dolgeville fauna: Ruedemann, R., 3. 
Paleontology-Continued.

Ordovician-Continued.

Ellesmere Land: Kirk, 4.

General: Jones, O. T., 1.

Greenland, northern, C e p h a lopoda : Troedsson, 2.

northwestern: Poulsen, 1.

Hudson Bay area, Cephalopoda: Foerste, 22.

Illinois, northeastern, Richmond fauna : Evans, J. R. C., 1.

Thebes sandstone: Savage, 1

Indlana, Madison: McEwan, 2.

Iowa, Maquoketa shale: Bradley, J. H., jr., 1.

Maquoketa faunas: Ladd, H. S., 4.

Maquoketa depauperate fauna, Iowa : Ladd, H. S., 2.

Maquoketa echinoderms: Slocom, 1; Thomas, 22.

Kimmswick limestone, Missouri : Bradley, J. H., Jr., 4.

Maryland : Bassler, 13.

Michigan, Escanaba River, Trenton; cystoids : Hussey, 3.

Richmond formation: Hussey, 1.

Minnesota, cephalopods: Sardeson, 17.

Crinoidea: Sardeson, 16.

problematic fossils: Sardeson, 18.

Missouri, Kimmswick and Plattin limestones: Foerste, 9.

Plattin formation: Fenton, C. L., 8.

Nevada, sponge fauna: Bassler, 22.

New York, graptolite zones: Ruedemann, R., 3 .

Martinsburg, Trenton fauna: Clark, T. H., 1.

Newburgh quadrangle: Holzwasser, 1. Utica and Lorraine formations : Ruedemann, 16-18.

Northwest Territories, Great Slave Lake: Hume, 18.

Ohlo, Warren and Clinton counties: Austin, G. M., 1.

Ontario: Foerste, $\mathbf{1 . 5}$.

black shales: Parks, 32.

Credit River section: Dyer, 3.

Dundas formation: Parks. 17.

Lake Timiskaming area : Hume, 14.

Ottawa region: Wilson, A. E., 1.

St. Lawrence Valley: Wilson, A. E., 2.

Toronto area : Fritz, 1 ; Parks, 8,9 , 18 ; Pelecypoda : Stewart, B. H., 1.

Workman's Creek section: Fritz, 2.

Pennsylvania, central : Field, R. M., 1.

Platystrophia : McEwan, 1.

Quebec: Foerste, 15.

Anticosti Island: Twenhofel, 30 ; cephalopods : Foerste, 26.

Levis, Beekmantown series: Clark, T. H., 11.

Montreal, cephalopod: Clark, T. H., 16.

Philipsburg region, Beekmantown tijlobites: Bradley, J. H., fr., 3.
Paleontology-Continued.

Ordovician-Continued.

Salterella, nature : Clark, T. H., 12.

Snake Hill fauna : Ruedemann, R., 3.

Stones River limestone: Coryell, 2.

Strophomena, Black River and Richmond : Fenton, C. L., 8.

Tennessee, Lenoir and Athens formations, brachlopods : Raymond, $\mathbf{3 7}$.

Ottosee and Holston formations, brachiopods : Willard, B., 5.

Stones River group : Coryell, 2.

Trenton limestone, ostracodes; Kirk, S. R., 1.

Trenton echinoderm faunas, distribation : Foerste, 3.

Trenton fauna, Ontario and Quebec: Raymond, 10.

Trilobita : Raymond, 6.

Utica and Lorraine shales, faunal facies differences: Ruedemann, 22.

Vermont, central : Richardson, C. H., 1. Chazyan coral reef: Raymond, 24.

Fort Cassin : Foyles, 3.

Grand Isle : Ruedemann, 5.

Grand Isle County : Perkins, G. H., 8. northwestern, trilobites: Raymond, 23.

Shoreham and Bridport: Foyles, 3.

Vertebrata: Tieje, 4.

Virginia, Lenoir and Athens formations, brachiopods : Raymond, 37.

Ottosee and Holston formations, brachiopods: Willard, B., 5 .

West Virginia, Mineral and Grant counties: Reger, 7 .

Mercer, Monroe, and Summer's counties: Prouty, 14.

Wisconsin, Galena limestone: Ockerman, 1.

\section{Ozarkian.}

Brachiopoda, Cephalopoda, Notostraca : Walcott, 8.

Pre-Cambrian.

Algae, Archean:-Gruner, 4, 6 ; Twenhofel, 3.

Floras: Berry, 100

General : Keyes, 58.

Organic structures, Biwabik iron-bearing formation: Grout, 4.

Steep Rock series: Rothpletz, 2.

Huronian stromatoporold-like masses, Webbwood, Ontario: Bain, 23.

\section{Quaternary.}

Alaska, Peard Bay region : Meek, 1.

Pleistocene : Dall, 2.

Arctic coast, Pleistocene : Dall, 9.

Arizona, Lake Cochise area : Bryan, 23.

Atlantic Coastal Plain, Pleistocene: Hay, 2.

British Columbia, Vancouver Island: Berry, 33.

soulbwestern, PIcistocene: Crickmay, 3.

Bryozoa : Canu, 4. 
Paleontology-Continued.

Quaternary-Continued.

Callfornia, Carpinteria asphalt pit: Hoffman, R., 1 ; Stock, 20.

Los Angeles asphalt pits : Hay, 37.

Los Angeles County, Pleistocene clam : Oldroyd, I. S., 1.

Plelstocene, McKittrick asphalt deposit ; Merríam, 9 ; Ilama : Merriam, 18; peccary : Stock, 23.

Pleistocene, Arctotherium: Merriam, 17 ; Foraminifera : Galloway, J. J.. 8; Mollusca : Oldroyd, T. S., 1; ruminant : Stock, 19 ; Tanupolama : Stock, 24

Rancho-La Brea, flora: Frost, 2.

Megalonychinae and Mylodontidae. Rancho La Brea: Stock, 13.

Rancho La Brea, peccary: Merriam, 8 ; rodents and lagomorphs : Dice, 1. southern, Vertebrata : Frick, 1.

Canada, Diatomaceae: Boyer, 1.

Colorado, Yuma County, Pliocene Mammalia : Cook, H. J., 2.

Echinoidea, west coast: Israelsky, 1.

Ecology in the interpretation of fossil faunas: Baker, F. C., 7.

Florida, age of Vero vertebrates: Hay, 36.

Cltrus County, Pleistocene mammals : Simpson, G. G., 26.

Mammalia and Pisces : Hay, 1.

Mollusca : Mansfield, W. C., 1.

Pleistocene Physa: Clench, 1.

Frankstown cave vertebrates, Blair County, Pennsylvania : Peterson, 9.

Gulf States, Pelecypoda: Maury, 4.

General: Hay, 31.

Haiti, Balanus : Pilsbry, 3.

Helicina occulta, Iowa: Shimek, 1.

Illinois, loess, Alton: Baker, C. L., 2; Leighton, M. M., 5.

Grundy County, Pleistocene Mollusca: Baker, F. C., 6.

loess deposits, Mollusca: Baker, F. C., 13.

Pleistocene Mollusca: Baker, F. C., $8,9,11,12$.

Indiana, Pleistocene Mollusca: Baker, F. C., 3 ; Porter County : Lyon, 1.

Iowa, Cherokee, Pleistocene : Cable, 8. Kansas, Pleistocene Bison: Martin, H. T., 5.

Wallace County, Pleistocene Mollusca : Hanna, G. D., 5.

Mammalian faunas, shifting: Adams, L. A., 2.

Mammoth, Cheney, Washington: Freeman, 0. W., 6.

Maryland, Cumberland, Pleistocene peccaries: Gidley, 4.

Wailes Bluff, Pleistocene Mollusca : Smith, E. R., 1.

western: Gidley, 3.

Massachusetts, bison remains: Allen, G. M., 1 .
Paleontology-Continued.

Quaternary-Continued.

Mexico, Lower California, Mollusca : Jordan, E. K., 1, 3 ; San Quentín Bay, Pleistocene : Orcutt, C. R., 1. Pleistocene Mammalia: Furlong, 1.

Michigan, Oakland County, elephant: Sherzer, 2.

Minnesota, Bíson: Hay, 17.

Mississippi, Pleistocene plants : Berry, 6.

Mollusca, marl deposits, Ottawa dis. trict, Ontario: Whittaker, 1.

Pleistocene: Maury, 5.

Nebraska, Archidiskodon maibeni : Barbour, 7,8 .

Elephas scotti : Barbour, 2.

Giraffa nebrascensis : Matthew, 2.

Tetrabelodon abeli: Barbour, 33.

western, Pleistocene: Matthew, W. D., 2.

New York, Pleistocene Mammalia : Hartnagel, 1, 4.

New York City, Pleistocene: Palmer, K. V. W., 3.

North Carolina, Pleistocene plants: Berry, 75.

Ohio, Pleistocene Mollusca: Baker, F. C., 2,3 .

Ontario, Pleistocene, crustacean : Klndle, 48.

St. Lawrence Valley : Whittaker, 3.

Toronto, muskox skull: Bensley, 1.

Oregon, Pliocene bear: Merriam, 22.

Plantae, catalog: Knowlton, 2.

Pleistocene : Baker, F. C., 1.

mammals : Hay, 45.

Maryland, Virginia, and North Carolina : Mansfield, W. C., 6.

mastodons: Hay, 32.

middle region of North America : Hay, 23.

Mollusca : Goldring, 3.

plants: Berry, 88; Alabama and Tennessee: Berry, 34.

Vertebrata: Hay, $4,7,8,9,15,16$, $24,32,39$.

Pleistocene faunas, distribution: Goldring, 1 .

Quebec, St. Lawrence Valley: Whittaker, 3.

San Pedro fauna, Nob Hill cut, California : Oldroyd, T. S., 3.

Tennessee, Pleistocene plants : Berry, 6.

Texas, Dallas County : Shuler, 1 ; Mammalia : Lull, 8.

Pleistocene fresh-water Mollusca : Hanna, G. D., 9.

southwestern, Pleistocene vertebrates: Hay, 33.

Vernon, Bison : Cook, H. J., 14.

Trinidad, Pleistocene flora: Berry, 67. Utah, hairy mammoth: Hansen, 1.

Veneridae, eastern America: Palmer, K. V. W., 5.

Washington, Big Hope Island, Pleistocene: Henderson, J., 9. 
Pajeontology-Continued.

Silurian.

Alabama : Butts, 8.

Alaska, Bathmopterus: Klrk, 11.

Cymbidium : Kirk, 5.

ITarpilium : Kirk, 3.

Pycnodesma: Kirk, 6.

Antlcosti faunas: Jones, O. T., 1.

Arctic Cephalopoda: Foerste, 11.

Arkansas, St. Clair limestone: Thomas, N. L., 1., 2 ; brachiopoda: Thomas, N. I., 4 ; Trilobita : Foerste, 14.

Cephalopoda: Foerste, 19, 28.

Hudson Bay area : Foerste, 22. northern Michigan: Foerste, 16, 17. orthoconic: Foerste, 30.

Crinoidea: Springer, 12.

Echinodermata, Brassfleld formation, Ohio: Foerste, 1.

Illinois, northeastern, Gastropoda: Wing, 1.

Orchard Creek shale: Savage, 1. worm, Lectbaylus: Weller, 9.

Indiana, Jefferson County, Brassfleld : Culbertson, J. A., 1.

Niagaran : Shrock, 2. northern : Cumings, 5 .

Iowa, Herpetocrinus: Thomas, A. O., 4. Niagaran, Bilobites bilobus: Thomas, A. $0 ., 25$.

Manitoba, Hudson Bay region : Savage, 2.

Maryland: Swartz, C. K., 9.

Massachusetts, Essex County : Foerste, 6.

Michigan, Mackinac County, Heterolasma: Ehlers, 2.

New York: Ruedemann, 19. adjacent faunal facies: Ruedemann, 20.

Crustacea : Clarke, J. M., 4. new forms of life: Ruedemann, 7. salt deposits : Alling, 14.

Vernon shale fauna: Eaton, H. N., 5.

Northwest Territories, Great Slave Lake: Hume, 18.

Nova Scotia, Arisaig area: McIearn, 8:

Ohio: Focrste, 2.

Cedarville, cystids and blastoids : Foerste, 10.

Medinan fauna : Foerste, 14.

Ontario, Hudson Bay region: Savage, 2.

Lake Timiskaming area: Hume, 14.

Timiskaming area, Cephalopoda : Focr'ste, 18.

southwestern: Williams, M. Y., 1. Whirlpool sandstone: Foerste, 14.

Quebec, Anticosti Island: Twenhofel, 30.

St. Clair limestone, Arkansas and Oklalioma : Ulrich, 1.4.

Trilobita : Foelste, 3.

West Virginia, Hardy County : Tilton, 15.
Paleontology-Continued.

Silurian-Continued.

West Virginia-Continued.

Mcrcer, Monroe and Summers counties: Prouty, 14.

Mineral and Grant counties: Reger, 7,

Wisconsin, Racine, cystids and blastoids: Foerste, 10.

Tertiary.

Alabama: Cooke, C. W., 13.

Eocene, foraminifer: Cushman, 19.

Eocene Mollusca : Aldrich, T. H., 1.

Alaska, Pliocene: Dall, 2; pectens: Dall, 3.

Pribilof Islands: Dall, 1; Hanna, G. D., 1.

Albertu, Paskapoo formation, Catopsalis : Russell, L. S., 2.

Red Deer, Paskapoo beds, fish : Russell, L. S., 3.

Alum Bluff group, molluscan fauna : Gardner, J. A., 7.

Anguilla, Oligocene, decapod crustaceans: Withers, 4

Arachnida : Petrunkevitch, 1.

Arctic regions, Brock River: Dall, 9.

Arizona, Benson, bird remains : Wetmore, 5 .

San Pedro Valley, vertebrates: Gidley, 5; Proboscidea and Edentata: Gidley, 7.

Artiodactyls : Lull, 4.

Balanocrinus, West Iudies : Springer, 8.

Barbados, Callianassa, Scotland beds: Withers, 6 .

Scotland beds: Trechmann, 6.

Brandon, flora: Berry, 8.

Briones fauna, Califolnia: Trask, 2.

British Columbia, Tertiary floras: Berry, 78.

Vancouver Island, Sooke formation: Clark, B. L., 8 ; Cornwall, 1 ; Cirripedia : Cornwall, 2.

Bryozoa: Canu, 5.

later Tertiary: Canu, 4.

Byram marl, Mississippi: Cooke, C. W., 7.

Foraminifera : Cushman, 13.

California, Channel Islands : Hertlein, $\mathbf{0}$.

Coral: Vaughan, 45.

Coyote Mountain : Hanna, 25.

Desmostylus: Hannibal, 1.

diatoms: Hanna, G. D., 31.

Domengine horizon, middle Eocene: Clark, B. L., 16.

echinoid : Schenck, 8.

Foraminifera: Cushman, 29, 32. Vicksburg group : Cushman, 16

Gastropoda : Stewart, R. B., 1.

Hipparion mohavense, Puente formation: Stock, 26.

Kern County, Miocene marine vertebrates: Hanna, G. D., 20.

La Jolla quadrangle: Hanna, M. A., 5. 
Paleontology-Continued.

Tertiary-Continued.

California-Continued.

Lompoc, humpback whale: Kellogg, R., 3; Miocene birds: Miller, L. H., 3.

Los Angeles, Miocene algae: Gardner, N. L., 1.

Martinez Eocene: Nelson, R. N., 2. Meganos fauna: Clark, B. L., 2, 18. Miocene fishes: Jordan, D. S., 15.

Mohave Desert: Merriam, J. C., 1; Alticamelus: Davidson, P., 2; Merycodus : Furlong, 2.

Monterey group, whale: Hanna, G. D., 15.

Monterey shale: Hanna, G. D., 38; diatoms, Gaylord, 2.

Petaluma, Point Reyes, and Santa Rosa quađrangles, Dickerson, 2.

Pinnipeds : Kellogg, R., 2.

Pliocene, canid and rhinocerotid remains: Stock, 16; Gastropoda : Carson, 2 ; pinniped : Kellogg, R., 1.

Puente flora: Chaney, 4.

Puente formation, Hipparion: Stock, 26.

Rancho La Brea, birds: Miller, L. H., 2.

Ricardo fauna: Stock, 25.

San Lorenzo group: Wagner, C. M., 1

Santa Barbara County, Miocene flshes: Jordan, 12 ; physeteroid cetacean : Kellogg, R., 9.

Sonoma County, Miocene lacustrine mollusks : Hanna, G. D., 7.

southern, Miocene fishes: Jordan, D. S., 1, 17 ; Pliocene: Carson, 1 ; Vertebrata: Frick, 1.

southern Coast Ranges, Vertebrata: Stock, 3.

Tejon fauna: Anderson, F. M., 1.

Temblor group, sharks: Jordan, D. S., 16 ; sperm whale: Kellogg, R., 15.

Tertiary and Quaternary Foraminifera : Cushman, 34.

Tesla region, Miocene flora: Scott, F. M., 1.

Vacaville, Eocene: Paimer, D. B.K., 1.

Vaqueros and Temblor formations: Wiedey, 1.

Canada, Diatomaceae: Boyer, 1.

Cannonball fauna: Stanton, 3 ; corals: Vaughan, 9.

Caribbean region, Foraminifera : Vaughan, 21.

Cassididae, western America: Schenck, 3.

Cayman Islands, For a m in if era: Vaughan, 42.

Chipola fauna in Marks Head marl: Gardner, J. A., 5.

Chitons: Berry, S. S., 1.
Paleontology--Continued.

Tertiary-Continued.

Colorado, birds, Oligocene: Wetmore, 12.

Brown's Park formation: Peterson, 11.

Eocene alga : Cockerell, 35.

Eocene Insecta : Cockerell, 8.

Florissant, Miocene insects: Cockerell, 36; beetles: Cockerell, 32 ; Orontium : Cockerell, 31 ; parasitic Hymenoptera: C o cke rell, 4. Green River Eocene, plants and insects: Cockerell, 27.

Huerfano formation, titanotheres: Osborn, 7 .

Hyopsodus, Eocene: Abel, 2.

Insecta, Inocellia : Cockerell, 28.

Moffat County, titanotheres, Eocene : Cook, H. J., 8.

Palmoxylon, Denver formation : Stevens, N. E., 1

Pawnee Creek beds, Amphicyon : Cook, H. J., 9.

rhinoceros, Oligocene: Gregory, W. K., 19.

Costa Rica, Miocene Foraminifera and Mollusca: Palmer, K. V. W., 4.

northern, Miocene: Olsson, 1.

Plantae: Berry, 15.

Cuba, cirriped, Miocene: Withers, 7.

Miocene and Pliocene Squalidae: Sánchez Roig, 3.

Dominican Republic: Vaughan, 16.

Anthozoa: Vaughan, 37.

decapods: Rathbun, 2.

Mollusca : Pilsbry, 1.

Plantae: Berry, 26.

Early Tertiary Bryozoa: Canu, 2.

Echinoidea : Stefanini, 1.

west coast : Israelsky, 1.

Eocene, Foraminifera, California: Hanna, G. D., 10.

Eocene and Oligocene Mollusca : Cooke, C. W., 10

Eocene flora, trans-Pecos Texas: Berry, 12.

Eutrephoceras, Eocene, South Carolina: Reeside, 9.

Fishes, Eocene, Utah and Wyoming: Tanner, 1.

Miocene, California: Jordan, 5.

Florida, fresh-water mollusks: Marshall, W. B., 1.

Miocene, Corbula : Gardner, J. A., 8; Foraminifera: Cushman, 9.

Mollusca : Mansfleld, W. C., 1.

phosphate beds, Cetacea: Allen, $\mathbf{G}$. M., 3.

Foraminifera: Vaughan, 35.

Coastal Plain wells: Applin, E. R., 1.

Mint Spring marl: Cushman, 14.

Fossils dredged off the northeastern coast of North America: Dall, 11.

Groat Basin and Great Plains faunas: I'roxell, 13. 
Paleontology-Continued.

Tertiary-Continued.

Green River flora: Knowlton, 11.

Green River formation, origin: Henderson, J., 6.

Gulf States, Pelecypoda: Maury, 4.

Haiti: Woodring, 5.

Balanus : Pilsbry, 3.

cichlid flsh, Miocene: Cockerell, 16.

Eocene Foraminifera: Woodring, 6 .

Mollusca: Woodring, 7 .

plants : Berry, 32.

Hipparion, Siestan, California: Stock, 8.

Hoplophoneus, South Dakota: Jepson, 2.

Idaho, Latah flora: Knowlton, 16.

Idaho formation, Snake River valley: Dall, 10.

Insecta, Eocene: Cockerell, 3 ; Texas : Cockerell, 19.

Rocky Mountains : Cockerell, 2.

Jamaica, Bowden, Miocene mollusks: Woodring, 10, 22.

decapod crustaceans: Withers, 2.

Echinoidea : Hawkins, H. L., 2.

Foraminifera: Vaughan, 46.

Richmond formation: Trechmann, 4. Yellow limestone: Trechmann, 3.

Kansas, Miocene, Celtis: Brooks, B. W., 1.

Loutsiana, Pliocene Mollusca: Smith, E. R., 2.

Maryland, Calvert County, Eurhinodelphis : Kellogg, R., 11.

CaIvert Cliffs, Miocene whale: Kellogg, R., 7.

Zarhachis, Calvert formation: Kellogg, R., 6.

Miocene porpoise : Kellogg, R., 14.

Mexico, echinoids, Neogene: Lambert,

Guayabal formation, Foraminifera : Cole, W. S., 1.

Gulf of California, Pliocene: Hanna, G. D., 29.

Lower Californla; Cedros Island and Turtle Bay: Jordan, E. K., 4; pectens: Hertlein, 1

Miocene : Hertlein, 4.

Maria Madre Island, Miocene marine diatoms: Hanna, 27; Pllocene : Jordan, E. K., 2.

Moctezuma River, Eocene fauna : Cushman, 21.

southern, foraminifers: Nuttall, 2.

Tehuantepec, Miocene: Berry, 39.

Vera Cruz, Vicksburg Mollusca: Cooke, C. W., 18.

Miocene fishes, Californla: Jordan, 6 . Miocene plants, southern Mexico: Berry, 48.

Mississippi, Eocene mollusks, Jackson : Cooke, C. W., 15.

Mollusca, Eocene and Oligocene: Cooke, C. W., 10
Paleontology-Continued.

T'ertiary-Continued.

Mollusca-Continued.

Miocene and Pliocene: Woodring, 9 ;

Coastal Plain : Gardner, J. A., 4.

Pliocene: Maury, 5.

Montana, Eocene claenodonts : Gidley, 2.

Fort Union formation, footprints : Gilmore, 41.

Missoula region, plants : Jennings, 1.

Paleocene primates: Gidley, 6.

southern, Fort Union formation, Mammalia: Simpson, G. G., 21.

Myadesma, Paciflc coast : Clark, B. L., 6.

Nebraska, Agate Springs, Miocene hawk: Wetmore, 9.

avian Miocene and Pliocene fossils: Wetmore, 4.

Brown County, longirostrine elephant: Cook, H. J., 16.

Miocene birds : Wetmore, 7 .

Miocene Mammalia: Matthew, 35.

Peltosaurus, Oligocene: Gilmore, 29.

Prosthennops, peccary: Barbour, 3.

Sioux County, birds: Wetmore, 13; hawk : Wetmore, 11.

Nevada, Esmeralda formation, flora : Berry, 92.

Fish Lake valley, Hypohippus : Stock, 17.

Miocene walnut: Berry, 98.

Thousand Creek Pllocene, Mammalia : Merriam, 28.

New Mexico, San Juan County, Reptilia: Gilmore, 4.

North Carolina, Castle Hayne and Trent marls: Kellum, 2.

Miocene Mollusca : Mansfield, W. C., 7.

Pliocene: Mansfield, W. C., 6.

Oregon, Astoria section: Howe, H. V. W., 9.

Coast Range, Foraminifera: Cush. man, 44.

Coos Bay, Empire formation: Howe, H. V. W., 2.

Crooked River basin, Merychippus: Maxson, 1.

Eagle Creek flora: Chaney, C. A., 1. eastern, insects: Cockerell, 40.

fresh-water Mollusca : Hanna, G. D., 6.

John Day Basin, hyaenarctid bear: Merriam, 24; Mollusca : Hanna, G. D., 2 .

John Day beds, hackberry: Chaney, 18; Umbellularia : Chaney, 19.

John Day region, Miocene Gastropoda: Hanna, G. D., 4.

Merychippus isonesus, Crooked River Basin : Maxson, 1.

Rattlesnake fauna: Merriam, 19.

Orthaulax: Cooke, C. W., 6.

Orthophragmina and Lepidocyclina : Cushman, 8 
Paleontology-Continued.

T'ertiasy-Continued.

Pacific slope, sharks and rays: Jordan, 11.

stalk-ejed Crustacea: Rathbun, 5.

Panama Canal Zone: Vaughan, 3. Miocene palm nut: Berry, 25.

Payette flora: Chaney, 6.

Pelagic mammals: Kellogg, R., 8. Pacific coast: Kellogg, R., 10.

Plantae, catalog: Knowlton, 2.

Porto Rico, Lares district: Hubbard, B., 3.

Ponce district: Mitchell, 7.

Mollusca: Hubbard, B., 1 ; Maury, 3.

St. Maurice and Claiborne Pelecypoda: Harris, G. D., 1.

Snake Creek fauna: Matthew, W. D., 2. Rhinoceroses and hyracodonts, early Tertial'y: Wood, H. E., 6.

South Carolina, Mollusca, Miocene: Gardner, J. A., 1.

Oligocene sea turtles: Hay, 19.

South Dakota, badlands: Jepson, 1; Toepelmann, 1 ; Ischromys : Miller, G. S., 1.

Black Hills region: O'Harla, 3.

Tennessee, Eocene, caddis case : Berry, 4.

Terminalia, lower Eocene, southeastern North America: Berry, 76.

Terrestrial plants: Berry; 42.

Texas, Bastrop County, Cook Mountain Eocene: Price, W. A., 12.

Butler salt dome, Midway brachiopod : Gardner, J. A., 6.

central, Eocene florule: Berry, 56.

Eocene crabs: Rathbun, 6.

Eocene Mollusca : Gardner, J. A., 11.

Jackson Foraminifera : Cushman, 24.

Mlocene vertebrates: Hay, 20.

southwestern, Eocene Mollusca : Gardner, J A., 2.

Wilcox group : Gardner, J. A., 3.

Trinidad: Harris, G. D., 5.

echinoids : Jeannet, 1.

Foraminifera : Hodson, H. K., 2.

Miocene corals: Vaughan, 38.

Miocene faunas: Maury, 8.

Miocene gastropods and scaphopods: Mansfield, IV C., 2.

Tertiary flora: Berry, 64.

Uinta Basin, Eocene Mammalia : Peterson, O. A., 1.

Utah, Green River beds, Eocene birds: Wetmore, 8.

Stehlinius: Matthew, 17.

Venericardia, West Coast: Hanna, M. A., 1 .

Veneridae, eastern America: Palmer, K. V. W., 5 .

Virginia, Eocene Mollusca: Palmer. K. V. W., 1.

Miocene Mollusca: Mansfiela, W. C., 7 ; 'Turritella: Gardner, J. A., 14.
Paleontology-Continued.

I'ertiary-Continued.

Virginia-Continued.

New Castle, Miocene: Palmer, K. V. IV., 2.

Wasatch and Wind River faunas: Mattlew, W. D., 3.

Washington, Eagle Cre e k flora : Chaney, C. A., 1.

Eocene: Weaver, 3 .

Latah flora: Knowlton, 16.

Lewis County, Eocene Foraminifera : Hanna, G. D., 18.

Miocene, Paliurus: Berry, 102.

Oligocene, Crustacei: Withers, 3.

Olympic Peninsula: Dall, 6.

Western North America: Hertlein, 2 ; marine Oligocene: Clark, B. L., 11.

West Indies, Algae: Howe, M. A., 1.

Bryozoa : Canu, 1.

decapod Crustacea: Ratbbun, 1.

Foraminifera : Cushman, 3.

Mollusca : .Cooke, C. W., 1.

White River formation, Notth Dakota: Leonard, A. G., 4.

Wilcox flora: Berry, 41.

Wyoming, amiid fish, Eocene: Romer, 15.

Big Horn County, Eocene, flightless bird: Sinclair, 11.

Bridger formation, Reithroparamys: Matthew, 11.

Eocene Insecta: Cockerell, 8.

Eocene turtle: Case, 23.

Miocene, Palaeocastor: Romer, 10.

Van Tasse1, Miocene: Loomis, 6.

Triassic.

British Columbia, coral reef fauna: Shimer, 7.

Connecticut Valley: Troxell, 12.

Footprints: Abel, 4.

Continental Triassic beds: Fuene, 3.

Dromatherium and Microconodon: Simpson, G. G., 5.

Greenland, eastern, ammonites: Spath, 1.

Scoresby Sound, Rhaetic flora: Harris, T. M., 1.

Idaho, southeastern: Girty, 10.

Mammals: Simpson, G. G., 22.

Nerada : Stanton, 12.

cestraciont spine: Davidson, P., 1.

New Jersey, Hypsognathus: Gilmore, 39.

New Mexico, phytosaur: Mehl, 9.

Pennsylvania, York County: Wanner, $1,2$.

Reptilia : Huene, 1.

Plantae, catalog: Knowiton, 2.

'Texas, Coelophysis : Case, 22.

fishes: Warthin, 1.

phytosaur: Case, 24.

Reptilia: Case, 10.

vertebrates : Case, 16.

western : Case, 11, 27 ; cotylosaur: Case, 26. 
Paleontology-Continued.

Triassic-Continued.

Unionid pelecypods, Texas and Arizona : Reeside, 16.

Upper Triassic: Smith J. P., 3.

Utah : Girty, 3.

Shinarump conglomerate, cycads: Berry, 90.

Virginia : Roberts, J. K., 8.

Wyoming, Phytosaurta : Mehl, 19.

plants : Berry, 59.

vertebrates: Branson, 19.

Paleopathology.

Antiquity of disease : Moodie, 20.

Bacteria, Permian : Moodle, 16.

Disease, beginnings: Moodie, 9 .

General: Moodie, 1-4, 7, 8, 21.

Histological nature of ossifled tendons in dinosaurs: Moodie, 28.

Historical sketch: Moodie, 17.

Invertebrata : Moodle, 22.

Man : Moodie, 18.

Mesozoic : Moodle, 15.

Opisthotonos: Dean, 3 ; Moodie, 6.

Osteomyelites, Permian: Moodie, 14.

Pachyostosis : Moodie, 24.

Parasitic disease:"Bather, 2.

Phytosauria: Moodie, 19.

Pliocene pathology: Moodie, 23.

Radial exostosis indDaphoenus : Romer, 8

Trepanation: Moodfe, 13.

Tumors in Lower Carboniferous: Moodie, 26.

Paleozolc (undifferentiated).

Alaska, Alaska Rallroad region : Capps, 6. Kiwalik-Koyuk region : Harrington, 5. northern, Canning River region: Leffingwell, 1.

Tolstoi district: Harrington, 2.

Arctic coast: O'Neill, 5.

British Columbia, Ainsworth district: Schofield, 4.

Dease Lake area, Cassiar district: Kerr, F. A., 1.

Caltfornia, Randsburg quadrangle: Hulin, 3.

Idaho, Cassia County, Goose Creek basin : Piper, 1.

Nevada, Jarbldge district : Schrader, 5.

New Brunswick, Burnthill Brook area : Young, G. A., 1.

Nova Scotia, Kings and Annapolis counties: Faribault, 4.

Washington, Stevens County : Weaver, 2. Palladium.

Alaska, Prince of Wales Island: Campbell, D. G., 1 ; Mertie, 4.

Ontario, Thunder Bay district, Shebandowan Lake: Tanton, 9.

Panama (including Canal Zone).

Economic geology.

Manganese ore, Boqueron River : Sears, 2.

Historical geology.

Boqueron River: Sears, 2.

General: MacDonald, D. F., 1, 2; Vaughan, 3.
Panama (including Canal Zone)-Contd. Historical geology-Continued.

Geology with special reference to the slides: MacDonald, 5.

Haut Chagres beds, age: Vaughan, 41.

Paleontology.

Arcas, recent: Maury, 6.

General : Vaughan, 3.

Palm nut, Miocene, Canal Zone : Berry, $25,103$.

Physical geology.

Earthquakes: Kirkpatrick, R. Z., 1.

Panama Canal slides: Nat. Acad. Sci., 1. Papago country, Arizona : Bryan, 15.

Papoose oil field, Oklahoma: Roark, 2.

Paraffin dirt, Gulf coast oil fields: Brokaw, 1 ; Shaw, 2.

Faragenesis of minerals.

Arizona, Jerome district : Fearing, J. L., 2.

Bornite-chalcopyrite intergrowth, British Columbia: Uglow, 4.

British Columbia, Hazelton : O'Neill, 1. Texada Island, Marble Bay mine: Dolmage, 7 .

Butte veins, Montana: Agar, 3 ; Lindgren, 22.

Colorado, Creede district: Emmons, W. H., 4.

Hinsdale County, mineral zones: Brown, W. H., 3.

Columbia River basalt: Shannon, 40.

Copper deposits, Parry Sound, Ontario: Schwartz, 8.

Granite pegmatites, central Maine: Landes, K. K., 1.

Illinois, Hardin County: Weller, S., 1.

New Mexico, Iron Mountain: Smythe, 2.

Sudbury ore deposits, Ontario: Wandke, 4.

Timiskaming ores, structure: Schlossmacher, 1 .

Zinc ores: Secrist. 1.

Parasitic disease: Bather, 2.

Parasitism : Clarke, J. M., 16 ; Carbonlferous crinoids : Moodie, 5

Pawpaw formation, Texas Comanchean : Adkins, 2.

Payson district, Arizona: Lausen, 1.

Parajointing: Donnay, 1.

Peard Bay reyion, Arctic Alaska : Meck, 1.

Pearl Lake area, Porcupine district, Ontario: Robinson, H. S., 1.

Peat: Dachnowski, 1, 2: Soper, 1.

Bibliography : Atwood, A. C., 1.

British Columbia, sonthwestern: Anrep, 11.

Canada: Anrep, 5 ; Auer, 1.

Classification: Nachnowski, 2.

and formation: Osbon, 2.

Dismal Swamp: Osbon, 1.

Formation: White, D., 13.

General: Dachnowski, 3 ; Haanel, B. F., 1, 2 ; Odell, 1 ; Perkins, G. H., 12.

Indiana : Logan, 12. 
Peat-Continued.

Iowa: Smith, J. E., 11.

Maine, Livermore qladrangle : Burr, 1. Minnesota: Soper, 1.

New Irunswick: Anrep, 1, 7, 9.

New England: Dachnowski, 5

Nova Scotia: Anrep, 8.

Ontario: Anrep, 2-4.

Origin : Talbot, 1; Thiessen, 2.

Quebec: Anrep, 2, 3, 6, 10 .

Tropical peat bog: Wentworth, 18.

United States: Soper, 2

Pebbles.

Chink faceting, new process of pebble shaping: Wentworth, 20.

Grologic history: Wentworth, 4.

Measuring an 1 plotting shapes: Wentworth, $\&$.

kiver peblles. field study: Wentworth, 2.

Shapes: Wentworth, 8 ; of beach pebbles: Weutworth, 10.

Stream pebbles, San Juan County, shapes: Miser, 28.

Striated cobbles in southern States: Wentwortb, 41

Virginia, North River, faceted pebbles: Steidtmann, 6:

wedge work: Wentworth, 5 .

Pedestal rocks, formation : Leonard, R. J., 2 ; Bryan, 24 ; in stream channels: Bryan, 17.

Nevada, Pershing County: Reid, J. T., 1.

Southwest: Bryan, 13.

Pegmatites: Kemp, 19 ; origin : Merritt, C. A., 1 ; Schaller, 10.

Natural history : Eng. M. J., 6 ; Hess, 23.

Pelecypoda. See also Mollusca.

Alberta, Fernie formation: McLearn, 9

Peace and Smoky valleys, Coloradoan : McLearn, 5.

Arcas, Panama region: Maury, 6.

Astartella Hall : Girty, 11.

Barbatia patilicia, synonymy: Woodring, 12.

Barrettia: Trechmann, 2.

Clementia : Woodring, 17.

and Egesta, geologic history: Woodring, 18.

Corbula, Miocene, Florida: Gardner, J. A., 8.

Costa Rica, norihern, Miocene : Olsson, 1.

Crassatellites, Pleistocene, California: oldroyd, I. S., 1.

Cretaceous, Alberta: McLearn, 3.

Cuba, Cretarecus oyster : Raymond, 31 . rudistids: Sánchez Roig, 15.

Didymois trinidadensis, Lower Cretaceous, Trinidad: Sommermeier, 1.

Eocene, New Castle, Virginia: Palmer, K. V. W., 2 .

Exogyra, Cretaceous, Texas: Böse, 2.
Pelecypoda-Continued.

Iutetia and Alvcinus : Harris, G. D., 2.

Mexico, Lower California, pectens: Hertlcin, 1.

Lower California, San Quentin Bay: Dall, 4.

Tamaulipas, rudistid shells: Stephenson, L. W., 1.

Modiodesma : Ulrich, 11.

Myadesma, Pacific coast: Clark, B. L., 6.

Ontario, Toronto: Stewart, B. H., 1. Ordovician clams, habit: Sardeson, $\mathbf{1 5}$. Ostrea, Arizona : Reagan, 18.

Ostrea califolnica Marcou: Hanna, G. D., 34 .

Ostrea multilirata Conrad, occurrence: Gardner, J. A., 10.

Ostrea oregonensis, Eocene, Oregon : Packard, 5.

Pecten, Pliocene, Alaska : Dall, 3.

Pecten lohri, Pliocene, California: Hertlein, 5.

Pectens, Tertiary, West Indies, new names: Cooke, C. W., 4.

Cretaceous, Texas : Kniker, 1.

Pleistocene and Pliocene, Gulf States: Maury, 4.

Pycinodesma, new name for Pycnodesma : Kirk, E., 9.

Pycnodesma, Silurian, Alaska: Kirk, E., 6.

Rudistid, San Felipe formation, Mexico: Stanton, 4.

Rudistids, southern Mexico: Palmer, R. H., 7 .

Trinidad : Harris, G. D., 3.

St. Maurice and Claiborne stages: Harris, G. D., 1.

Triassic unionid pelecypods, Texas and Arizona: Reeside, 16.

Trigoniae, Pacific coast: Packard, 3.

Trinitasia: Maury, 9.

Venericardia, West Coast: Hanna, M. A., 1.

Veneridae, easteln America: Palmer, K. V. W., 5 .

Western North America, marine Oligocene : Clark, B. L., 11.

Pelmatozoa, phylogeny and taxonomy: Jaekel, 1.

Pemberton area, Lillooet district, Britlsh Columbia: Cairnes, 8.

Peneplains.

Appalachians: Stose, 31, 32.

northern, Piedmont region: Barrell, 6.

Blue Ridge: Wright, F. J., 5.

British Columbia, southern: Uglow, 11.

Colorado, Front Range: Little, 4.

Front Range and Rocky Mountain National Park: Lee, W. T., 7.

Driftless Area, erosional history : Trowbridge, 1 .

Erosion surfaces, eastern Appalachian highlands: Knopf, E. B., 5 . 
Peneplains-Continued.

General: Davis, 8.

Idaho: Mansfield, 19, 29.

Kentucky : Jillson, 107.

Marine peneplains: Barrell, 6 .

Mesozoic: Keyes, 202.

Montana, southern: Bevan, 5.

Northern Great Plains: Alden, 3.

Ohio, southeastern: Stout, $\mathbf{5}$.

Pennsylvania, Piedmont province: Bascom, 4.

Pleistocene peneplain in Coastal Plain : Cleland, 5.

Porto Rico: Meyerhoff, 2.

Pre-Cambrian: Du Rietz, 1.

Rocky Mountain region: Keyes, 25.

Utah: Keyes, 75, 100.

Virginia, upper James River basin: Wright, F. J., 1.

West Virginia, Mineral and Grant counties: Reger, 7 .

Peneplanation, chemical criteria of : Woolnough, 2.

Pennsylvania.

Geological Survey, work, 1919-22 : Asbley, 13.

Survey : Ashley, 5 .

Topographic and Geologic Survey, report: Pa. T. G. S., 2.

Areas iescribed

Allentown quadrangle: Miller, B. L., 5.

Elkton quadrangle: Bascom, 2.

Greensburg quadrangle: J o h n s o n, M. E., 1.

McCalls Ferry quadrangle: Jonas, 2.

New Holland quadrangle: Jonas, 5.

Pittsburgh area: Leighton, II., 2.

Punxsutawney quadrangle: Ashley, 18.

Quarryville quadrangle: Jonas, 3.

Economic geology.

Adams County, mineral resources: Stose, 25.

Anthracite: Ashmead, 1.

Anthracite region: Parker, E. W., 1.

Bituminous coal fields: Sisler, 3.

Bradford oil field: Torrey, 2.

Building stone: Stone, 19.

Cambro-Ordovician limestones: Miller, B. L., 11.

Cannel coal and carbonaceous shale deposits: Fettke, 4.

Carbonaceous shale: Fettke, 3.

Chrome ore, southeastern Pennsylvania: Knopf, E. B., 2.

Chromite deposits: Diller, 1; Gordon, S. G., 7.

Classification of cnals: Ashley, 20.

Clay: Ries, 5.

Saylorsburg, Monroe County: Peck, F. B., 1

white: Hice, 1.

Coal : Ashley, 7, 26; Kuhn, 1; Sisler, 1.

Allegheny Valley: Rayburn, 1.

low-sulphur: Chance, 1.

Coal analyses: Fieldner, 2.
Pennsylvania-Continued.

Economic geology-Continued.

Coal beds of Allegheny formation, correlation: Thiessen, 9 .

Coal resources: Reese, 1.

Copper deposits: Watson, 15.

Fire clays: Shaw, J. B., 1.

northern Appalachian coal basin : Ashley, 2; Lovejoy, 1.

Glass sand: Fettke, 1.

Lancaster Gap mine: Phemister, 2.

Lead and zinc ores: Miller, B. L., 3.

Limestones: Miller, B. L., 4.

Mineral resources: Ashley, $8 ; \mathrm{Pa} . \mathbf{G}$. S., 1.

Molding sands: Stone, 20.

Oil and gas, outlook for: Ashley, 10.

Oil and gas fields: Ashley, 11.

map : Richardson, G. B., 3.

Oil in coals and shales: Ashley, 9.

Oil resources in coal and carbonaceous shales: Fettke, 3.

Oil sands of Bradford and Allegheny fields, origin: Torrey, 5.

Petroleum: Johnson, R. H., 3 ; Maforelle, 1.

Bradford field: Umpleby, 6.

Bradford and Allegheny fields: Torrey, 3.

Pittsburgh coal bed: Ashley, 21; White, I. C., 9.

Salt deposits: Phalen, 1.

Silica refractories: Moore, E. S., 6.

Slate, Northampton County: Behre, $7,9$.

Vanport limestone, Butler and Venango counties: Fettke, 7 ; Lawrence County: Peck, F. B., 2.

Historical geology.

Allegheny formation, typical section: Swartz, C. K., 1.

Bituminous coals : Sisler, 2, 3.

Bryn Mawr glavel: Bascom, 5.

Clinton formations: Ulrich, 9.

Crystalline schists, southeastern Pennsylvania: Hawkins, A. C., 4; Knopf, E. B., 3.

General: Johnson, D. W., 9.

Honeybrook quadrangle: Smith, I. F., 3.

Huntington-Pittsburgh Basin: Richardson, G. B., 13.

Lebanon County: Gordon, S. G., 3.

Lehigh Gap, Silurian stratigrapby : Ashley, 17.

Limestones: Miller, B. L., 4.

Lower Allegheny-Pottsville section in western Pennsylvania, correlation : Renick, 2.

Lower Paleozoic, southeastern Pennsylvania : Stose, 15.

Loyalhanna limestone, southwestern Pennsylvania: Butts, 4.

Martinsburg shale: Bebre, 3, 10.

Medina, southeastern Pennsylvania : Eaton, H. N., 4. 
Pennsylvania-Continued.

IIistorical geology-Continued.

Metamorphic rocks, southeastern Pennsylvania : Jonas, 1.

Northampton County slate belt : Behre, 6.

Northwestern Pennsylvania: Decker, C. E., 1.

Ordovician, central Penusylvania : Ficld, R. M., 1.

Ordovician overlap, Piedmont province : Stose, 18.

Ordovician stale and lava, southeastern Pennsylvania: Stose, 29.

Pocono, Broadtop Basin : Reger, 13.

Pottsville and lower Allegheny formations, western Pennsylvania, correlation: Renick, 1.

Pre-Cambrian : Jonas, 6.

Shawangunk formation, age and origin: Willard, B., 3 .

Siluritu : Swartz, C. K., 10.

Southeastern Pennsylvania: Stose, 21.

Siate belt, Northampton County: Behre, 7.

Taconic uplift: Behre, 5.

Terrace gravels of Susquehanna River, correlation: Stose, 33.

Time scale: Ashley, 22.

'Triassic sediments, Gettysburg area : Stose, 2.

Triassic northwest of Lebanon: Stose, $26,27$.

Triassic outlier near Lebauon: Stose, 26.

York County : Wanner, 1.

Vanport limestone, Butler and Venango counties: Fettke, $\boldsymbol{\tau}$; Lawrence County : Peck, F. B., 2.

\section{Atineralogy.}

Calcite, Chester County: Gordom, 23.

Chester County : McKinstry, 1.

Chlorite, white: Shannon, 37.

Columbite, Boothwyn: Smith, I. F., 1.

Crocidolite, eastern Pennsylvania: Wherry, 18.

Epidesmine, Berlis County : Gordon, S. G., 1

Falls of French Creek, Chester County : Vaux, 2.

Glauberite crystal cavities in Triassic, Gettysburg area: Stose, 2.

Limonite pseudomorphous after pyrite, York County : Holden, E. F., 1.

Meteorites: Stone, 16.

New Baltimore, Somerset County: Merrill, 31, 32.

Mineralogy : Gordon, S. G., 6.

Monazite, Boothwyn : Wherry, 3.

Moore's Mill, Cumberland County : Gordon, S. G., 17.

Pyrite, Cornwall : Hawkins, S.

French Creek: Wherry, 5.

Quartz pseudomorphs, Chester County : Vaux, 1.
Pennsylvania-Continued.

Mineralogy-Continued.

Texas, Lancaster County: Gordon, S. G., 5.

Unionville corundum mines, Chester County: McKinstry, 3.

Wavellite : Gordon, S. G., 10.

York: Jandorf, 1.

Zaratite, Lancastel County : Slavik, 1.

Paleontology.

Calamites, East Bellevue: Grier, 1.

Frankstown cave vertebrates: Peterson, 9 .

Olenellus getzi, Lancaster County : Dunbar, 9.

Ordovician, central Pennsylvania: Field, R. M., 1.

Palaeaspis: Bryant, 4.

Pocono fauna, Broad Top coal field: Girty, 12.

Tree trunk, vertical, Scranton: Davis, R. N., 1.

Triassic, Reptilla : Huene, 1.

York County: Wanner, 1, 2.

Petrology.

Albitite bodies, origin: Larsen, 22.

Anorthosite, Piedmont province : Smith, I. F., 3.

genesis: Smith, I. F., 2.

Bentonite : Ross, C. S., 21.

Black granite (diabase), Bucks County: Stone, 17.

Elkton quadrangle: Bascom, 2.

Granitic pegmatites: Gordon, S. G., 4.

Huntington-Pittsburgh Basin : Rich-1 ardson, G. B., 13.

Igneous dike, southwestern Pennsylvania: Honess, A. P., 3.

Ordovician volcanics, Lebanon County, Gordon, S. G., 3.

Peridotite dike, Dixouville, Indiana County : Honess, A. P., 4.

Serpentine: Gordon, S. G.; 7.

Physical geology.

Anthracite basins, structural features: Kemp, 10.

Calcareous concretions in streams : Roddy, 1.

Conglomeratic limestone, Nittany Valley : Eaton, H. N., 2.

Coudersport ice mine : Balch, 1.

Igneous dike, southwestern Pennsylvania : Honess, A. F., 3.

Limestone decomposition, Annville: Miller, B. L., 10.

Martinsburg shale, structural features : Behre, 3 .

Post-Cretaceous faulting in Appalach. lans : Stose, 31.

Structural features, southeastern Pennsylvania: Stose, 21.

Structures in the slates, Northampton County: Behre, 6.

Taconic folding: Miller, B. L., 5.

Tectonic map, progress: Stose, 30 . 
Pennsylvania-Continued.

Physiographic geology.

Cycles of erosion, Piedmont province: Bascom, 4:

Erosion surfaces, eastern Appalachian highlauds: Knopf, E. B., 5.

General : Johnson, E. B., 4.

Glacial deposits : Williams, E. H., 1.

Glacial investigations: Leverett, 20.

Glaciation : Ashley, 23.

High gravels, Susquehanna River : Stose, 33.

Kansan pondings: Williams, E. H., 1. Peneplains, correlation: Stose, 31.

Subordinate ridges: Eaton, H. N., 1.

Susquehanna deeps: Daly, 7.

\section{Underground voater.}

Allentown quadrangle: Miller, B. L., 5. Oil-fleld waters, Bradford pool: Torrey, 2.

Pennsylvanian. See Carboniferous.

Penrose medal : Kemp, 22.

Pentremites. See Blastoidea.

Peridotite.

Arkansas, Pike County: Miser, 12; Scott County : Miser, 9.

Periodic diastrophism: Shepard, 6.

Perisphinctinae, costal development: O'Connell, 2.

Permian. See Carboniferous.

Permian ice age: Schuchert, 52.

Permian revolution: Finlay, 2.

Pershing oil and gas tleld, Osage County, Oklahoma: Rubey, 2.

Petrifled forests.

Arizona : Edwards, I., 1.

Ganado: Reagan, 13, 14.

Devonian forest, Catskill Mountains : Clarke, J. M., 19.

Sonoma, California : Dickerson, 2.

Petrifled wood industry : Berry, 79.

Petroleum. See also Oil shales.

Accumulation: Mills, R. V. A., 2; Reeves, J. R., 10; Wasbburne, 2.

by moving underground water: Blackwelder, 5 .

in sands: Emmons, W. H., 1.

in Rocky Mountain region: Harrison, T. S., 2.

of oil and gas, time factor: Johnson, R. H., 5.

Alabama, northern, oil possibilities: Semmes, 2.

Alaska : George, H. C., 1 ; Martin, G. C., 8,12 ; Smith, P. S. 10 .

Anchorage: Brooks, 10.

Chignik region: Martin, G. C., 14.

Cold Bay district: Smitb, W. R., 4.

Cold Bay-Chignik district: Smith, W. R., 1 .

Cold Bay field: Palmer, L. A., 1.

Iniskin Bay district: Mofft, 3

Iniskin-Chinitna Peninsula : Moffit, 7.

Kamishak Bay region: Mather, 7 .

northwestern Arctic: Smith, P. S., 7.

Point Barrow region: Paige, 5.
Petroleum-Continued.

Alberta : Coste, 1 ; Dowling, 6 ; Hume, 15, 17, 23, 28; Link, 3; McLearn, 14 ; Ross. C. C., 1.

northern: Elworthy, 4.

Peace River: Rutledge, 1.

southern: Williams, M. Y., 15.

Sheep River area: Slipper, 2.

Turner Valley: Davies, S. J., 1; Elworthy, 3; Hume, 22.

Wainwright fleld: Emmens, 1 ; Hume, 10, 21.

Wainwright-Irma area : Hume, 13, 16.

Wainwright-Vermilion area: Hume, 19.

western : Prudy, 1.

Alberta and British Columbia, foothills belt: Hopkins, O. B., 4.

Anticlinal theory: White, I. C., 10.

Appalachian oil and gas fields, geology : Mills, R. V. A., 2.

Appalachian ofl field: Reeder \& Com. pany, 1.

Appalachian region: Willis, 4.

Árizona, northeastern, Holbrook area : Hager; D., 3.

Arkansas, EI Dorado field: Crider, 1 ; Heald, 8 ; Hull, 9 ; Ley, 1 ; Pratt, W. E., 3 ; Teas, 4 .

age of producing sand: Stephenson, 2. Rainbow City fleld, Union County: Spooner, 4.

Smackover oil and gas fleld : Bell, $\mathbf{H}$. W., 2,3 ; Schneider, H. G., 1.

southern, oil fields, structural features: Crider, 2.

Barometric surveying in petroleum mapping: Lahee, 3.

Bedrock, role in distribution of bydrocarbons: Monte-Flores, 1.

Berea sand, Ohio, lithology : Panyity, 2.

Bibliography : Burroughs, E. H., 1-5 ; Hoyt, 1.

Biogenesis of hydrocarbons by diatoms: Tolman, 2.

Black Hills region, oil possibilities : Rubey, 5; Sinclair, E. G., 1.

Brines of oil fields: Washburne, 3, 4.

British Columbia,.Peace River district : Spieker, 1.

British West Indies: Catherall, 1.

Calcium chloride waters, connate and diagenetic: Lane, 28.

California : Collom, 1; Landero, 1 ; Legraye, 2 ; McLaughlin, R. P., 1 , 2 ; Vander Leck, 1.

Alamitos and Seal Beach fields: Cunningham, C. M., 1.

Buena Vista Hills, Midway oll fleld, Keru County: Godde, 2.

chemical characteristics: Prutzman, 1.

Ciervo field: Stalder, 1.

Coalinga field: Wilhelm, 4.

development of oil fields : Moran, 3.

Dominguez oil field: Dodd, 2. 
Petroleum-Continued.

California-Continued.

early oil development: Orcutt, W. W., 1.

Goleta district: Vickery, 6, 8, 9.

Huntington Beach field: Case, J. B., 3 ; Gester, S. H., 1 ; Grasel, 1.

Inglewood oil field: Huguenin, 2.

Keln County: English, W. A., 1; Belridge and North Belridge fields: Boezinger, 1; Devils Den field: Huguenin, 1; Hovey Hills field: Saunders, 1 ; Lost Hills field : McCabe, R. E., 1 ; Poso Creek field: Kaiser, 2; Sunset field: Copp, 1; Farnsworth, 1, 2 ; Thirty-five anticline: Godde, 3 ; Sunset Extension field : Rogers, R. G., 1; Wheeler Ridge field : Kaiser, 1.

Kern River oil field, Kern Front area: Hendrickson, 1.

Long Beach field: Case, J. B., 2; Schwennesen, 2.

Los Angeles Basin: Arnold, 3; Eaton, J. E., 1, 3 ; Milner, 4 ; Vickery, 11 ; structural features: Ferguson, R. N., 2.

Los Angeles and Ventura counties: Kew, 6.

McKittrick oil field : English, W. A., 4.

Mt. Poso oil field: Wilhelm, 3.

oil field development: Heller, 1.

oil fields: Kew, 8; Tolman, 2.

Olinda oil field: Clute, 1 .

origin: Anderson, F. M., 2, 3 ; Anderson, R., 1; Cunuingham, 1; Stipp, 1 ; and accumulation: Gester, G. C., 1, 2.

petroleum geology, development: Hamilton, W. F., 1.

production decline: McLaughlin, R. P., 2.

Potrero field: Eaton, J. E., 5.

Puente Hills region: English, W. A., 3.

Richfield field: Musser, 3.

Rincon oil field: Kotick, 1.

Rosecrans oil field: Musser, 2.

San Joaquin Valley: English, $\mathbf{W}$. A., 5 ; Stevens, J. B., 1.

Santa Clara Valley: Reinhard, 1.

Santa Fe Springs field: Case, J. B., 1 ; Templeton, 1.

Santa Maria district: Collom, 2.

Simi Valley: Kew, 1

Sonoma County: Mendenhall, 4.

southern: Eaton, J. E., 9 ; Jensen, 1.

South Mountain field, Ventura County: Hudson, F. S., 2.

Sunset-Midway field: Pack, R. W., 1.

Torrance oil field: Musser, 1.

Ventura Avenue oil field: Hertel, 3.

Ventura Basin : Eaton, J. E., 4.
Petroleum-Continued.

California-Continued.

Ventura oil fleld: Bush, 1; Craddock, 1 ; Eaton, J. E., 2 ; Hertel, 1.

Ventura County: Godde, 1: Taliaferro, 1 ; Lindero anticline: Warner, T., 2.

Ventura County and Newhall district: Hertel, 2.

West Goleta district: Sherman, 1.

Wheeler Ridge field: Cunningham, G. M., 1.

Canada : Brock, 6 ; Dowling, 8, 9, 13 ; Hume, 6, 11, 28, 29; Pearce, 1; Rigaud, 1.

Great Plains: Hume, 25; oil indications : Fisher, C. A., 2.

oil reserves: Arnold, 4.

Capillarity and oil migration : Russell, W. L., 3.

Capillary relationships of oil and water.: Cook, C. W., 2, 3 ; Washburne, 6 .

Carbon ratios: Storm, 4.

in Carboniferous coals: Price, w. A., 4.

in Oklahoma coals: Fuller, M. L., 4. western Canada: Jones, I. W., 1.

Carbon-ratio theory, present status: Dorsey, 3 ; Reeves, F., 14.

and Hilt's law : Reeves, F., 14.

proofs: Russell, W. L., 12.

Carbonaceous rocks, microthermal study: Stadnichenko, 1.

Carbonate waters: Washburne, 7.

Cementation process in sandstone: Johnson, R. H., 1.

Central America : Milner, 2; Redfield, 3.

oil reserves: Redfield, 5 .

Classification of undereloped oil land for valuation: Beal, 1 .

Classifying discovery of oll fields : Udden, Jon A., 3.

Closed contour map: DeGolyer, 18.

Coal as an aid in oil exploration: Lilley, 2.

Coal tar mistaken for oil residue: Martin, G. C., 11.

Colorado: Wheeler, H. A., 7. northeastern: Mather, 12.

Compaction as cause of migration: Beckstrom, 1.

Compendium : Ziegler, 1.

Conditions of occurrence: Harrison \& Eaton, 1.

Cone domes of oil fields: Sardeson, 4.

Correlation of oil sands by sedimentary analysis: Trowbridge, 10.

Correlative value of heavy minerals: Tickell, 1.

Costa Rica: Redfield, 7.

Cuba: Allende, 15; Corral, 4.

Decline curves of various oil pools: Johnson, R. H., 1, 4. 
Petroleum-Continued.

Deposition conditions of some Tertiary petroliferous sediments: Grabau, 2.

Detecting small quantities : Heald, 7.

Diatom oil, analysis: Becking, 1.

Diatom theoly of origin: Hanna, $G$. D., 36 ; Takahashi, $1,3$.

Diatomiferous horizons and petroleum deposits: De Landero, 1.

Diatoms as source of petroleum : Pratt, W. E., 16.

Differential compacting the cause of certain Claiborne dips: Teas, 5 .

Direct synthesis of higher from lower hydrocarbons: Thom, 9.

Distillation of oil from olganic sediments : Baker, C. L., 9.

Distribution: Van Tuyl, 4.

Domes, origin by isostatic adjustment: Albertson, 1.

Drainage areas for production. Mather, 2.

Eastern United States : Majorelle, 1.

Economics: Pogue, 2.

Estimating petroleum reserves: DeGolyer, 5 ; Veatch, A. C., 1.

Examination of well cuttings: Trager, 1.

Examining calcareous well cuttings; Claypool, 1.

Experimental petroleum geology : McCoy, 4.

Factors controlling oil accumulation: Lahee, 2.

Features of oil structures: Ziegler, 2.

Field mapping for oil geologist: Warner, C. A., 1.

Field methods in petroleum geology : Cox, G. H., 1 ; Lahee, 6.

Field work, surveying: Taylor, 1.

Fifty. years of petroleum geology : Ohern, 1.

Files of oil geologist: Dreher, 1.

Filtering earths: Nutting, 3.

Finding of oil : DeGolyer, 10.

Fishes the source of petroleum: Macfarlane, 2 .

Flooding of oil wells by fresh water: Brown, T. C., 1.

Folding, effect of stratigraphic variation on: Gardescu, 1.

Folds of Osage type, occurrence : Brown. R. W., 2.

Foraminifera, use iu determining underground structure: Cushman, 15.

Fractionation during migration: Cook, C. W., 6, 9 .

Future oil supply: White, D., 6.

Gas, factor in accumulation: Thiel, 1. General: Andros, 1 ; Arnold, 6 ; Butler, G. M., 2 ; Clapp, F. G., 5 ; Garfias, 1 ; Hager, D., 8 ; Haney, M. 3; Hartsook 1; Hummel, 1 ; Johnson, R. H., 7 ; Krey, 2 ; Lilley, 3 ; I.loyd, E. R., 1 ; Logan, 5; Mc-
Petroleum-Continued.

General-Continued.

Beth, 2 ; Moore, R. C.; 3 ; Nicolescu, 1 ; Northrop, J. D., 1 ; Panyity, 1 ; Phelps, 1 ; Prettyman, 1 ; Redwood, 1 ; Reinholt, 1 ; Richardson, G. B., 5, 7, 9, 10 ; Semmes, 2 ; Smith, G. 0., 7 ; Vander Leck, 1; Van Tuyl, 4, 6, 11; White, D., 2, 21 ; Ziegler, 1 ; Anon., 35, $45,55$.

Generation by geologic distillation: Rich, J. L., 11.

Genesis : Balliet, 1, 2; Mabery, 1.

Genetic factors of oil occurrence : White, D., 1.

Geochemical relations to siluza and water: Nutting, 1.

Geographic distribution: Mehl, 2.

Geologic aid in exploration: Ellison, 1.

Geologic distillation: Willis, 4.

Geologic exploration: Villatoro, 1.

Geologic factors in water flooding: Torrey, 4.

Geologic structure favorable for accumulation: Watts, W. L., 1.

Geological organization of an oil company : Gaylord, 1.

Geologist and petroleum induștry : DeGolyer, 10 .

Geology : Emmons, W. H., 2 ; Lilley, 4.

in finding of oil: White, D., 18.

in finding and recovery of oil : White, D., 15.

in relation to valuation: Arnold, 2.

in the petroleum industry : DeGolyer, 11.

of salt dome oil fields : DeGolyer, 17.

Geophysical methods: Barton, 1.5.

in Gulf Coastal Plain : Barton, 6. for finding oil fields: Craig, 1.

Gravitational compaction, effect on sedimentary rocks: Hedberg, 1; Rubey, 8.

Gravity anomalies and petroleum exploration: Hubbert, 3.

Gulf coist: Lucas, A. F., 1, 2; McBeth, 1 ; salt domes: Hill, R. T., 1 ; Wolf, 1.

Gulf coast oil fields : Barton, 13.

Handbook of the petroleum industry: Day, I. T., 1.

History, epochs in: White, I. C., 4.

Honduras: Redfield, 8.

Hydraulic theory of oil migration and accumulation : Rich, 7 .

Hydrocarbons, inorganic origin : Young, J. W., 6.

Idaho, oil possibilities: Heald, 10.

Illinois : Barrett, N. O., 1. Collingwood, 2, 4, 5; Moulton, 3, 12, 17 ; Spoor 1.

Allendale oil fleld: Moulton; 6, 21 ; extension: Collingwood, 7.

Ava-Camplell Hill area: Root, 1. 
Petroleum-Continued.

Illinois-Continued.

Bond County, Ayers anticline : Bell, A. H., 9.

carbon ratios: Moulton, 4 .

Carlyle-Centralia district: Shaw, 9.

Centralia area: Bell, A. H., 2, 3.

Colchester and Macomb quadrangles: Hinds, H., 1.

Crawford County: Hance, 2; Flat Rock pool: Tough; 1.

Decatur area: Collingwood, 6. eastern : Mylius, 6.

east-central: Mylius, 7 .

faulting, influence of: Wheeler, $\mathrm{H}$. A., 4.

Hoing sand oil pools, prospecting: Moulton, 11.

Jacksonville area: Bell, A. H., 7 ; Collingwood, 3.

Lawrence County, St. Francisville area : Bell, A. H., 10.

Marion County, Wamac pool : Wheeler, H. A., 5.

Martinsville pool, Clark Caunty : Moulton, 15.

Monroe County: Mylius, 3:

oil and gas fields, map - Richardson, G. B., 1.

oil field operations: Moulton, 14. petroleum developments during 1925 : Moulton, 10.

Pike County, oil prospects: Bell, A. H., 1.

Sandoval oil field: Bell, A. H., 6.

Sparta area: Moulton, 9.

Trenton fleld: De Wolf, 4.

Waterloo field: Lamar, 1; Moulton, 16.

Wabash County: Moulton, 19.

western: Bell, A. H., 11.

Yanaway well in Siggins pool: Lamar, 12, 13.

In a fossil cast: Reeves, J. R., 9.

Indiana: Barrett, E., 5; Bownocker, 3; Logan, 5, 10, 22; Reeves, J. R., 7 ; Wright, Floyd E., 1.

middle Ordovician : Heald, $\boldsymbol{9}$.

southwestern: Logan, 18; Moulton, 20 ; Tri-County field : Esarey, 2.

Sullivan County field: Visher, 2.

Indications of oil fields: Barton, 14.

Inorganic origin: Hixon, 1.

Inorganic petroleum: Lewis, 12.

Invasion of oil into a water-wet sand: Skirvin, 1.

Isocarb ratio, southwestern Virginia: Eby, 2.

Jamin action: Herold, 1.

Kansas: Kesler, 1 ; Moore, R. C., 8, 9 ; Snider, 1.

Allen and Neosho counties: Moore, R. C., 5 .

Anderson County: Charles, 1. anticline in Benton shale area : Thomas, C. R., 1.
Petroleum-Continued.

Kansas-Continued.

Burket-Seeley oil pool : Loomis, H., 2.

Butler County: Uhrlaub, 1.

central: Williams; D. W., 2.

eastern, shoestring oil pools: Rich, $6,9$.

Eldorado field: Fath, 2 ; Stapleton oil horizon, age: Fath, 4.

Golden Lanes, Greenwood County: Cadman, 2.

map of oil and gas fields: U. S. Geol. Survey, 2.

Nemaha Mountains, flank production: Thomas, C. R., 2.

oil domes, origin: Blackwelder, 3.

Rainbow Bend field, Cowley County : Snow, 1.

Rice County : Ley, 7 .

Russell County : Rubey, 3.

Sallyards field: Berger, 2.

southeasteln: Williams, D. W., 1.

Urschel oil pool, Marion County, water conditions: Shea, 1.

western, oil possibilities: Lupton, 2.

Wilson and Montgomery counties : Moore, R. C., 6.

Woodson County : Moore, D. W., 1.

Kentucky : Gardner, J. H., 3 ; Glenn, 1 ; Jillson 2, 4, 21, 23, 25, 35, 57, 73 ; Leonard, W. C., 1 ; Nelson, 16.

Allen County : Jillson, 12; Miller, A. M., 5 ; Shaw, E. W., 1.

Barren County : Butts, 2.

Boyd County : Jillson, 81.

Breathitt and Knox counties: Jillson, 13.

central southern : Nelson, 15.

Cumberland County: Beckner, 3.

eastern : Fiske, 1; Jillson, 32 ; pay ofl sands: Jillson, 17 ; Wier sand: Jillson, 16.

Irvine district: St. Clair, 1.

Island C'reek oil pool, Owsley County : Jillson, 84.

isocarbs and oil and gas production: Russell, W. L., 5.

Jóhnson County, Paint Creek uplift ; Rhodes, 1.

southeastern: Jillson, 8.

Warren County: Jillson, 18; St. Clair, 3,4

Kerogen and origin of oil : Trager, 4.

Kerogen of oil shales: Van Tuyl, 9.

Light oils in the Rocky Mountain region, origin: Geis, 1.

Limestone reservoirs, classification : Howard, W. V., 3.

Limestones as a source of oil: Trask, 9.

Localization of folds : Brown, R. W., 3.

Louisiana: Snider, 1.

Bellevue oil field: Holman, 1; Hull, 6 . 
Petroleum-Continued.

Louisiana-Continued.

Cotton Valley fleld, Webster County : McDonald, W. W., 1 ; Powers, 14.

Edgerly fleld: Minor, 3.

Haynesville fleld : Albertson, 2 ; Hull, 4 ; Scott, W. W., 1, 2 ; Teas, $2,3$. Jennings fleld: Barton, 12.

map of oil and gas flelds : U. S. G. S., 5.

nortbern: Hull, 5; oil flelds, structural features: Crider, 2.

Pine Prairie salt dome: Barton, 7.

Red River field: Bates, 1.

Sabine uplift: Powers, 2.

salt domes: Deussen, 1.

Spring Hill-Sarepta field : Ponton, 1.

Trinity sand: Easton, 2.

Vinton field: Wrather, 1.

Vinton salt dome, Calcasieu Parish: Thompson, S. A., 1.

Welsh oil field: Reed, L. C., 1.

Mackenzie River valley: Bosworth, 2, 3 , 4 ; Hume, 27 ; Kindle, 9,15 ; Kitto, 1 ; Ness, 2 ; Redfleld, 2.

between Norman and Beaver River: Hume, 5.

Norman flelds: Hume, 4.

Mexico, oil flelds : Hartley, 2 ; Huntley, L. G., 1 ; Iglesias, 1 ; Obregon, 1 ; Ortega, G., 1 ; Sansom, 1 ; Shaw, 3.

Chiapas and Tabasco: Vivar, 1.

Hidalgo-Vera Cruz region: Palmar, R. H., 4.

islands in Gulf of California : Paredes, 5.

Isthmus of Tehuantepec: Huntley, S., 1; Redfield, A. H., 1; Ver Wiebe, 5-7.

Lower California: Bustamante, 1.

Panuco district: Baker, C. L., 7, 8; Torres, 1 ; Trager; 5.

petroleum geology: Hartley, 1.

southern: Ver Wiebe, 2, 3.

Tabasco: Jones, W. F., 3 ; VerWiebe, 4 ; and Chlapas: Lajous, 1.

Tamaulipas, Ordóñez, 1, 2.

Tepetate-Chinampa pool, graphic model : Huntley, U. G., 2.

Vera Cruz fields: Semmes, 5.

Zacamixtle pool: DeGolyer, 3.

Michigan : Newcombe, 1 ; Smith, R. A., 3.

Saginaw oil field: Carlson, 3.

Microfossils and geology: Diaz, 6 .

Microscopical research: Hanna, 26.

Mid-Continent oil flelds: Bosworth, 1;

Snider, 1; and geology: Gould, C. N., 21.

origin of oil : Greene, 3.

paleogeography and historical geology: McCoy, 5; reflected burled hills: Powers, 11.

structures: Monnett, 2.
Petroleum-Continued.

Migration of oil : Dodd, 1; Mather, 5 ; and accumulation: Jones, R. A., 10 ; Rich, 3, 7; Van Tuyl, 12; Weeks, A. W., 1 ; effect of pressure on: Van Tuyl, 14.

Migration of oil and water: Parks, E. M., 1.

Minor constituents: Wells, 12.

Mississippi, oil possibilities: Easton, 1. petroleum prospecting: Morse, P. F., 2.

Missouri : Wilson, Malcolm E., 1.

Mississippi Valley: Moulton, 8.

Montana: Clarke, F. B., 1 ; Rowe, J. P., 1, 2, 3.

Cat Creek oil fleld: Lupton, 1 ; and Devils Basin flelds : Reeves, F., 10. central: Reeves, F., 3, 5 ; and easteln : Clapp, C. H., 2.

Garfleld County, oll and gas prospects: Thom, 3.

Kevin-Sunburst oil field: Clark, $\mathbf{F}$. R., 3 ; Heald, 16 ; Hendrickson, 1 ; Perry, 2 ; U. S. G. S., 11.

Lake Basin fleld: Bauer, 5 .

Quadrant formation: Freeman, 0 . W., 2.

Soap Creek oil fleld: Thom, 1.

Sunburst fleld : Hager, D., 5.

Sweet Grass arch : Clapp, F. G., 3 ; Perry, 2.

Mother plants of petroleum in Devoniam black shale: White, D., 11

Movements of oil and water througb sands : Mills, R. V. A., 4.

National Research Council and oil geology : Heald, 11.

Natural gas associated with oil deposits: Stuart; 1.

Natural gas in oil migration: Mills, R. V. A., 5 .

Natural reduction of sulphates: Bastin, 15.

Near shore conditions in locating deposits : Branson, 13.

New Mexico : Ellis, R. W., 1, 3 ; Knox, J. K., $2,3$.

Artesia oil field: Rich, A., 1.

Chaves County: Merritt, J. W., 2.

New York: Clarke, J. M., 18; Hartnagel, 3 ; Johnson, R. H., 3.

Northwest Territory: Anon., 10.

Notebook and symbols for petroleum geologists: Woodruff, 2.

Oceanography and oil deposits: Trask, 7.

Occurrence: Clapp, F. G., 2, 6 ; and origin: Juarez, 1

Ohio: Bownocker, 3.

Clinton sandstone: Lockett, 1.

Columbiana County: Stout, 5.

eastern: Lockett, 2 ; structural conditions: Cottingham, 4.

Ordovicinn horizons: Panyity, 3. 
Petroleum-Continued.

Ohio-Continued.

underground structure: Cottingham, 3.

Vinton County: Stout, 6.

Wayne County: Conrey, 1.

Oil and gas problems: Scheffel, 3.

Oil, gas, and water, relations in Sunset-Midway field, California : Rogers, G. S., 1.

Oil accumulation and periods of fold-ing: Hintze, 1.

Oil deposits, surface indications : Pearson, P. H., 1.

Oil domes, central Kansas, origin : Blackwelder, 3.

Oil geology and science: Heald, 13.

Oil in vesicular cavities of igneous intrusions: Osborne, C. B., 1.

Oil pools, relation to ancient shore lines: Jones, W. F., 1 ; Lahee, 4.

Oil reserves: Keyes, 63 ; White, D., 3. United States: White, D., 8.

Oil reservoirs and shore line deposits: Brewer, C., 1.

Oil sands and production relations: George, H. C., 5 .

Oil saturation in certain sandstones: Ruby, 2.

Oil shale, relation to petroleum: Van Tuyl, 13.

Oil structures: Hill, E. A., 1.

Oil supply: White, D., 9; Wrather, 8.

United States: U. S. G. S., 8.

Oil to carbon ratio, Alabama: Lloyd, S. J., 1.

Oil-field geology: Hager, D., 1.

Oil-field temperatures: Washburne, 8.

Oil-field waters: Palmer, C., 2; Renick, 8; Rogers, G. S., 2 ; Gulf coast : Rogers, G. S., 6.

Oklahoma: Gould, 7; Powers, 20 ; Shannon, C. W., 1 ; Snider, 1.

Beckham County: Gouin, 2.

Bristow quadrangle: Fath, 6.

Burbank field, Osage County : Sands, $1,2$.

Caddo and Grady counties: Becker, 1. Caddo County, Cement field: Clapp, F. G., 1 ; Reeves, F., 1.

Carter County: Tomlinson, 4 ; Fox field : Storm, 3; and Graham fields: George, H. C., 2 ; Tomlinson, 1; Healdton field: Bartram, 1; Merritt, J. W., 1 ; Roark, 1 ; Swigart, 1.

Coal and Pittsburg counties: Clawson, 1.

Comanche County: Gouin, 3.

Creek County: Merritt, J. W., 4.

Crinerville oil field, Carter County: Powers, 22.

digest of oil and gas fields: MillsBullard, 2.

Garber ficld: Vanderpool, 1.
Petroleum-Continued.

Oklahoma-Continued.

Garber sands, age and correlation: Wheeler, H. C., 1.

Glenn pool: Rich, J. L., 13; Wilson, W. B., 1.

Kay County: Aurin, 1.

Kay, Grant, Garfield, and Nobel counties: Clark, G. C., 3.

Logan County: Bale, 1.

Love County: Bullard, 2.

McIntosh County: Clark, R. W., 4 map of oil and gas fields: U. S. G. S., 6.

Marshall County : Bullard, 3.

Morrison field, Pawnee County: Carpenter, E., 1.

Muskogee County: Soyster, 1.

northeastern: Williams, D. W., 1.

Nowata and Craig counties : Bloesch, 4.

oil production: Mills-Bullard, 1, 2.

Okmulgee district : Clark, R. W., 1, 2.

Osage County: Beckwith, H. T., 1 ; Miller, W. Z., 1; folds: Millikan, 1 ; structural conditions: Hartley, 3.

Osage Nation: Mason, 1.

Osage Reservation: Goldman, 2, 4 ; Heald, 1-4; Hopkins, O. B., 1 ; Robinson, H. M., 1, 2 ; Ross, C. S., 2 ; Roundy, 1.

Papoose field: Roark, 2.

Pawnee County: Greene, 10.

Payne County: Koschmann, 1.

Pershing oil and gas fleld: Rubey, 2.

Pontotoc County: Conkling, 1.

Robberson field, Galvin County : Denison, A. R., 1 ; English, L., 1 ; Oklahoma G. S., 2 ; Roth, 1.

Rogers County: Woodruff, 4.

Sayre field, Beckham County: Birk, 1.

Seminole County: Levorsen, 2.

Seminole uplift: Powers, 23.

southern : Burton, G. E., 2 ; Hopkins, O. B., 2 ; Moore, R. C., 10 ; structural trends: Decker, L., 1.

southwestern: Howell, J. V., 2.

Stephens County: Gouln, 1; Storm, $1,2$.

Stroud field: McFarland, 1; Powers, 15.

Thomas field, Kay County: Clark, S. K., 1.

Tonkawa field: Clark, G. C., 1, 2; Hosterman, 1.

Turkey Mountain lime pools : Ruedemann, P., 2.

unconformities : Bloesch, 1.

Wagoner County: Boyle, 1.

Washington County: Carpenter, E., 2.

old shore lines and origin of oil : Branson, 12. 
Petroleum-Continued.

Ontario: Harkness, 1, 3-7; Williams, M. Y., 3.

future prospects: Williams, $M$. Y., 9.

Kent County : Williams, M. Y., 5.

Manitoulin County: Williams, M. Y., 11.

Romney: Davis, H, R., 1.

southwestern: Williams, M. Y., 2, 4. Oregon, possibilities: Smith, W. D., 8.

Organic material of carbonaceous shales: Rae, 2; Washburne, 5.

Origin : Burling, 6 ; Carmody, 1 ; Gurwitsch, 1 ; ilixon, 3 ; Hume, 28 ; Jones, J. C., 1 ; Jones, R. A., 8, 9 ; Lahee, 12 ; Lajous, 2 ; Landero, 1 ; Lewis, 9 ; Moore, R. C., 3 ; Rich, J. L., 12 ; Roger, 1 ; Sardeson, 7 ; Semmes, 2 ; Singewald, Q. D., 1.; Stadnichenko, 2; Stromborg, 1; Thomas, C. S., 1 ; Torres, 2 ; Van Tuyl, 7; Washburn, 1. .

and accumulation: $\mathrm{McCoy}, 7$.

Califormia: Takahashi, 2.

humus-acid : Rae, 1.

in swamp muds: MacDonald, $D$. F., 3.

migration, and accumulation: Somers, 2.

Paraffin dirt, Gulf coast oil flelds: Barton, 11; Brokaw, 1.

Pennsylvania: Ashley, 10, 11; Johnson, R. H., 3 ; $\mathrm{Pa}$. G. S., 1.

Bradford and Allegany flelds : Torrey, 3.

Bradford ofl field: Torrey, 2; Umpleby, 6.

Greensburg quadrangle: Johnson, M. E., 1.

oil and gas flelds map: Richardson, G. B., 3 .

Permeability and absorption of "sands": Melcher, 2, 4.

Petroleum geology: Lahee, 14; Van Couvering, 1.

as a profession: Woodruff, 3 .

east of the Mississippi: Richards, R. W., 1 .

past and future: Goodrich, 1, Powers, 7 .

Petroleum hydrology, Mid-Continent field: Neal, 1.

Petroleum provinces: Lilley, 1.

Petroleum-bearing concretions: Binney, 1.

Petroliferous provinces: Mehl, 6; Schuchert, 8; Woodruff, 1.

of the United States: Redfleld, 10.

Phosphorus in Californian petroleum: Palmer, C., 1.

Plant life as source of petroleum: Bartle, 2.

Pore space of oil and gas sands: Melcher, 1.
Petroleum-Continued.

Porosity and crushing strength as indices of regional alteration: Rus sell, W. L., 11.

Porosity of sands, determination: Russell, W. L., 10.

Present stage of oil geology : Clapp, 7.

Pressure, effect on migration of oil : Thomas, E. T., 2.

Principles of accumulation : McCoy, 1. Problems in oil geology : White, D., 10. Production, reserves, etc.: Arnold, 5.

Progress in petroleum geology : Plummer, 2.

Projecting structure through an angular unconformity: Corbett, 1.

Prospecting: Panyity, 1.

Quality of oil, relation to structure: Ley, 1.

Radioactivity and oil field location: White, D., 12.

Recovery of oil by flooding: Torrey, 5.

Relation to carbon values in north Texas: Fuller, M. L., 3.

Research projects: Anon., 66.

Research work: Heald, 19; Thom, 15.

Rock classification: Knapp, A.; 1.

Rock pressure: Heroy, 1.

Rocky Mountain oil flelds: Arnold, R., 7, 8; deeper drilling: Lupton, 4.

Rocky Mountain region, microscopic subsurface work: Wilson, J. H., 2.

Salt domes: Barton, 17.

Sand porosity: McCoy, 3 .

Sea beach observations: Kemp, 2.

Seismographic method for underground observations : Udden, 9.

Sericitization and dolomitization as indices in oil-bearing formations: Lahee, 10

Source and origin of salt-dome oil : Lucas, A. F., 1.

Source beds: Trask, 10.

Sources of material: Henderson, J., 8.

South Dakota, geologic features and oil possibilities: Wilson, R. A., 4 .

Spacing of wells: Uren, 1 .

Stratigraphy and paleogeography, relations to petroleum geology : Schuchert, 4.

Structurnl features for oil accumulation : Ziegler, 2.

Studies on organic nature of sediments : Trask, 8.

Submarine deposits: Urbina, 1.

Subsurface contouring: Bloesch, 2.

Subsurface correlation by heavy minerals : Hoots, 3 ; Reed, R. D., 12.

Subsurface folds and faults: Kirk, C. 'T., 2.

Subsurface relations in oil and gas fields: McCoy, 3 ; Mills, R. V. A.. $2,3$.

Sulphate-reducing bacteria in oil field water's : Bastin, 13. 
Petroleum-Continued.

Surface indications in Louisana: Steinmayer, 1.

Symbols for drilling operations: Mehl, 4.

Synclinal oil occurrence and regional uplift : Thom, 20.

Temperature of fluids in wells : Lahee, 7.

Tennessee: Glenn, 1, 3; Nelson, 8, 16. central-northern: Nelson, 15.

northern: Nelson, W. A., 1.

Overton County: Butts, 1.

structural conditions : Lusk, 2.

Willow oll fleld: Jillson, 47.

Texas: Snider, 1; Udden, 7.

Amarillo district : Harrison, T. S., 1. Archer County : Hubbard, W. B., 1.

Barbers Hill field : Bevier, 2.

Batson oil fleld, Hardin County : Sawtelle, 1.

Beaumont, Spindletop fleld: Sur, 1.

Bend series, water problems: Fuller, M. L., 1.

Bexar County: Sellards, 7, 10.

Big Lake fleld: Sellards, 21.

Blue Ridge salt dome, Fort Bend County : Hager, D. S., 2.

Brazoria County, West Columbia fleld : Barton, 2.

Caldwell County, Luling: Pratt, w. E., 6.

Central : Matteson, 1.

Coke County: Beede, 1 ; Jones, $R$. A., 4.

Cooke County : Hawtof, 1.

Currie field, Navarro County : Lahee, 9.

Damon Mound ofl fleld : Bevier, 1.

Bastern : Dumble, 1.

Eastland and Stephens countles: Adams, H. H., 1.

Edna, Jackson County: Price, 11.

Goose Creek oil field, Harris County : Minor, 2.

Gulf coastal region oil flelds: Wolf, 2.

Luling oil field, Caldwell County : Brucks, 1 ; Sellards, 19.

Lytton Springs ofl fleld: Bybee, 2 ; Collingwood, 8.

McLennan County, Adkins, 2 ; Pace, 1.

Marathon fold: Liddle, 1.

Mexia oll fleld: Lahee, 17 ; Pratt, W. E., 7 ; Whitney, R. H., 1 ; Wrather, 2; faulting and petroleum accumulation : Pratt, W. E., 9.

Minerva field, Milam County: Hager, D. S., 1.

Navarro County, Currie structure: Lahee, 19; drilling near: De Wolf, 7 .

New Richland field: Lahee, 11.

Nigger Creek pool: Hull, 14.

northeastern, salt domes: Cheney. C. A., 1 .
Petroleum-Continued.

Texas-Continued.

north-central : Hager, D., 2.

northern: Roberts, J. R., 1; Wheeler, H. A., 1, 2.

Palangana salt dome: Barton, 1.

Panhandle : Bauer, 7 ; Lockwood, 2 ; Pratt, W. E., 8.

Pecos County, Fort Stockton : Pratt, W. E., 2.

Powell oil field : Hill, H. B., 1.

Ranger fleld: Reeves, F., 2.

Reynosa Escarpment : Jones, R. A., 1. salt domes: Barton, 4; Deussen, 1 ; Jones, R. A., 6.

San Marcos quadrangle: Brucks, 2.

Saratoga ofl flelds: Suman, 1.

Sipe Springs and Deep Creek oil flelds: Wade, A., 1.

South Bend fleld, Young County, Cheney, M. G., 1.

South Dayton salt dome: Bowman, 1. southwestern oil fields: Owen W. T., 1: Stephenson, 3.

Spindletop salt dome: Barton, 5 .

Thrall fleld, Williamson County, Bybee, 1.

Val Verde County: Calvert, 2.

Webb and Zapata counties: Sellards, 13.

Westbrook field, Mitchell County : Edwards, E. C., 1.

western: Powers, 24.

Yates pool, Pecos County: Metcalf, R. J., 1.

Zapata County: Wrather, 4.

Texture of oil sands and production of oils : Melcher, 3.

Theories: Ely, 1.

Thermal currents in ofl accumulation : Pepperberg, 1.

Topographic criteria of oll fleld structure : Monett, 1.

Trinidad: Carmody, 1; Catherall, 1; Macready, 1; Milner, 1; Waring. $5,6$.

Underground conditions in oil flelds: Ambrose, 2.

Underground water in migration and accumulation or oil and gas: Bonine, 1.

United States: Rigaud, 1.

Utah, San Juan field: Miser, 17. southeastern: Prommel, 3. southern, oll possibilitles: Moore, R. C., 17,18 .

Washington County : Bassler, H., 2. Vanadium and nickel in petroleum: DeGolyer, 9.

Virginia, Powell Valley: Giles, 9.

Washington, southwestern, oil in basalt: Hudson, F. S., 5 .

Water analyses in oil production: Parks, E. M., 2.

Water displacement in oil and gas sands: Johnson, R. H., 2. 
Petroleum-Continued.

Water in oil flelds: Ambrose, 1.

Waters associated with petroleum and natural gas: Mills, R. V. A., 2.

West Indies: Milner, 2 ; Redfleld, 4, 9.

West Virginia : Reger, 2, 4.

Cabin Creek oil fleld: Wasson, 2.

carbon ratios of coals in oll flelds : Reger, 5.

Copley pool : Reger, 14.

Fayette County: Hennen, 1.

-... Mercer, Monroe, and Summers counties: Reger, 9.

Nicholas County: Reger, 3.

Webster County : Reger, 1.

Wyoming : Ball, M. W., 1 ; Bartlett; 1, 5; Estabrook, 2; Heald, 5 ; Wegemann, 1.

accumulation: Heald, 6 .

black oil: Bartram, 3.

Elk Basin oll fleld, faulting: Estabrook, 1.

Hanna Basin. and Red Desert: Krampert, 2.

Lance Creek fleld: Hancock, 5.

Laramte and Medicine Bow districts : Bartlett, A. B., 2.

Lost Soldier-Ferris district: Fath, 5.

Maverick Springs: Collier, 6.

Mule Creek oil fleld: Hancock, 4.

oil and gas flelds, map: Richardson, G. B., 4.

Oregon Basin, Meeteetse, and Grass Creek quadrangles: Hewett, 16.

Osage oil fleld, Weston County : Collfer, 7.

possibilities near Osage field: Anon., 30.

Rawlins-Lost Soldier district : Krampert, 1.

Salt Creek oil fleld: Estabrook, 4; Fisher, C. A., 1 ; water conditions in First Wall Creek sand: Nowels, 1.

southern: Bartram, 2.

Teapot Dome: Clapp, F. G., 4; Wheeler, H. A., 6.

Thermopolis district: Collier, 4.

Upton-Thornton oll fleld: Hancock, 3.

Petroleum geology, contributions to geologic science: DeGolyer, 4.

Petrollferous provinces: Schuchert, 8; Woodruff, 1.

Petrology (general). For areal see names of States. See also Igneous and volcanic rocks; Sedimentary rocks ; Technique.

Aa and pahoehoe, formation: Emerson, 0 . H., 1.

Abstracts and reviews: Behre, 2; Johannsen, 4.

Albitite bodies, origin: Larsen, 22.

Alkalles in minerals and rocks, determination: Shannon, 72.
Petrology (general)-Continued.

Alkaline rocks, origin: Gillson, 12; Smytb, 3.

Analysis of gases from volcanoes and from rocks: Shepherd, 3.

Anorthosites, origin: Lodochnikow, 1 ; Loewinson-I.essing, 1 ; Smith, I. F., 3.

Assimilation and petrogenesis: Stansfleld, 7.

Basic and ultrabasic rocks, tectonic conditions accompanying intrusion: Benson, W. N., 2.

Bend series sediments: Waite, 1.

Calculations, use of: Grout, 21.

Chalk, origin : Tarr, 14.

Chemical analysis of rocks: Washington, 1.

Chemical changes caused by shearing: Cooke, H. C., 22.

Clinkertill : Dove, 4.

Color of varicolored obsidians, origin : Fuller, R. E., 1.

Colors of American and European rocks: Johannsen, 13.

Comagmatic regions and the Wegener hypothesis: Washington, 24.

Contact phenomena, gneiss limestone in western Massachusetts: Eskola, 1.

Corundum and albitite bodies, hydrothermal origin: Larsen, 21 .

Deformation of crystallizing magma: Bowen, 5.

Demesne of petrology : Berkey, 5 .

Density of rocks from Mauna Kea and Haleakala : Washington, 25.

Determination of common minerals and rocks, tables for: Tirr, 7.

Dolomites, chemical study: Knight, N., 1.

occurrence: Van Tuyl, 10.

Dunite and basalt glass, compressibility : Adams, L. H., 8.

Feldspar determination of metamorphic rocks: Carlson, 1.

Feldspar in sandstones: Reed, R. D., 14.

Feldspars as indicators of origin : Steidtmann, 1.

Field book: Loomis, 8.

Field classification of igneous rocks: Johannsen, 9.

Fifty year's' progress: Bascom, 7 .

Final consolidation phenomena in the crystallization of igneous rock: Colony, 4.

Fossil bone: Rogers, A. F., 19.

Garnet reaction rims in anorthosite: Roesler, 1.

Gels, function in the formation of quartz and carbonate veins: Merritt, C. A., 2.

Genetic classification of rocks: Sen, 1. Grantte massives, primary structure: Balk, 1.

Granitic pegmatites: Gordon, S. G., 4. 
Petrology (general)-Continued.

Graphic study of igneous rock series: Grout, 8.

Graphs of rock analyses : Lane, 24.

Igneous intrusion, after-efiects : Kemp, 12.

Igneous rocks: Iddings, 2.

average chemical composition : Clarke, F. W., 3.

classification: Hodge, E. T., 3, 11 ; Mathews. 1.

evolution: Boweu, 23.

density determination from norm: Iddings, 3 .

quantitative mineralogical classification: Johannsen, 3.

Igneous rock textures, experiments illustrating: Wright, F. E., 4.

Inclusions in basalt : Richarz, 2 .

Iron coloration: MacCarthy, 3 .

Jades of middle America: Washington, 18.

Jaspoloid of Joplin district: Smith, W. S. T., 1.

Lamprophyres: Stansfield, 5.

Lava, surface fusion: Diller, 10.

Leverrierite, schist-forming . mineral: Corbett, 2.

Limestones: Howell, J. V., 3.

nomenclature: Kindle, 23.

Liquid immiscibility in silicate $\mathrm{mag}$ mas: Bowen, 20.

Lithium pegmatites, genesis: Schaller, 11.

Litbologic character of shale as an index to metamorphism: Wilson, J. H., 3.

Metasomatic processes in sill cate rocks: Goldschmidt, V. M., 1.

Metasomatism : Lindgren, 16.

Microscopical determination of rocks in sections: Johannsen, 6 .

Mineralogical phase rule: Bowen, 18.

Movements in crystallizing magmas: Grout, 6.

Natural glasses, relation of physical properties and chemical composition: George, W. O., 1.

New petrology : Berkey, 9.

Origin of foliation and naming of syntectic rocks: Alling, 9.

Pegmatites : Kemp, 19.

natural history: Hess, 23.

Pegmatitic growths, function of colloids in : Merritt, C. A., 1.

Petrographic unconformity: Berkey, 4.

Phenocrysts in granitic intrusions: Hess, 4.

Pillow structure in basalts: Foye, 10,11 .

Planimeter determination of percentuge composition: Johannsen, 2.

Plateau basalts: Washington, 17.

Pressure in magmas: Morey, 1.

Pyroxene group: Winchell, 5.
Fetrology (general)-Continued.

Quantitative determination of rock color : Grawe, 3.

Quantitative microscopic rock analysis : Alling, 12.

Reaction principle in petrogenesis : Bowen, 12.

Recording. micrometer for rock analysis: Wentworth, 12.

Red color of rocks, loss : Moulton, 23.

Residue from silica in rock analysis: Auroussealu, 2.

Rock classification for engineering : I'irsson, 1; Smith, W. D., 2.

Rock conditions for high dams: Ransome, 20.

Rock minerals, comparative losses in crushing and sifting: Johannsen, 10.

Rocks, determination: Ellis, R. W., 4.

Rocks and rock minerals: Pirsson, 6.

Rosiwal method for determining minerals: Johaunsen, 1.

Salt dome cap rocks, petrography : Goldman, 12.

Sectioning rocks: Keyes, M. G.. 1

Sections mounted on glass slides, labeling: Shead, 6.

Segregation granites: Lane, 8.

Silexite, Miller, W. J., 1.

Silicate and carbonate rocks, analy. sis of : Hillebrand, 1.

Stone for concrete: Loughlin, 33.

Subaerial sun cracks: Swartz, J. H., 8.

Table for determining common rocks: Lane, 1.

Tactite: Hess, 1.

Taconic area, southern: Knopf, E. B., 6.

Tectonic conditions accompanying intrusion of basic and ultra-basic igneous rocks: Benson, 1.

Till and stratified clay, microscopic sections: Sayles, 4.

Trachyte and phonolite from pyroxene andesitic magma: Brouwer, 4.

Triassic sandstones, petrographic analysis: Roberts, J. K., 4 .

Ultra-basic rocks, origin: Bowen, 22.

Verden sandstone: Reed, 3.

Volatile components of rocks: Day, A. L., 1 .

Phantograph model: Cadman, 1.

Philipsburg region, Quebec: Bradley, J. H., jr., 2.

Phosphate.

Alberta, Banff area: Warren, P. S., 4.

Canada: Spence, 2.

Florida: Hess, 29; Sellards, 24.

General: Blackwelder, 11; (urabau, 3; Mansfield, 21, 25; Stone 6, $13,15$.

Idaho: Kirḳham, 4; Mansfleld, G. R., 35 . 
Phosphate-Continued.

Idaho-Continued.

Fort Hall Indian Reservation :

Mansfield, G. R., 3.

southeastern: Mansfield, G. R., 29.

Kentucky, Woodford County: Miller, A. M., 22.

Montana, Granite County: Pardee, 6. Melrose field: Richards, R. W., 2.

Three Forks-Yellowstone Park region : Condit, $\mathbf{5}$.

Origin: Graham, W. A. P., 1.

Reserves: Mansfield, G. R., 28.

Tennessee: Rogers, A. F., 31; Smith, R. W., 1, 2.

phosphorites, nature and origin: Rogers, A. F., 29.

United States: Voskuil, 1.

Wyoming, Wind River Mountains: Condit. 4.

Phosphate rock an economic army: Stone, R. W., 1.

Phosphate practice for field geologists : Wentworth, 16.

Physical geology (general). For areal see names of States.

Alberta, structural features produced by Pleistocene glaciation : Hopkins, 0. B., 3.

Algae as limestone makers and climatic indicators: Glock, 3 .

Algal reefs in Green River formation: Bradley, W. H., 7.

Angle of cleavage fracture: sheldon, 4. Angular inclusions in ore deposits: Merritt, C. A., 3; Spurr, 22 ; Young, J. W., 7 .

and banded structure in ore veins; Schagen van Soelen, 1.

and replacement deposits: Bateman, 13; Fairbanks, 3.

Appalachian structure: Prouty, 17.

Appalachians, cross section in southern New England: Woodworth, 3.

new structural type in: Stose, 21. structure: Keith, 2.

Arcuate and lobate mountain structures: Taylor, 1.

Atlantic and Gulf Coastal Plain, struc: tural features: Stephenson, 16.

Bacteria as agents of chemical denudation : Thiel, 11.

Bacterial deposition: Breger, 1.

Banded structure: Boydell, 10.

Banding around rock fragments, in veins : Douglas, C. B. E., 1 ; Spurr, 28.

Basic dike injections in magmatic vein sequences: Spurr, 20.

Basin Range structure in the Great Basin: Gilbert, G. K., 1; Keyes. 225, 228 ; Louderback, 5.

Jerome, Arizona : Ransome, 15.

Iatholiths: Chamberlin, R. T., 14. and schistosity: Blackwelder, 9.
Physical geology (general)-Continued.

Batholiths-Continued.

laterally spreading throry: Cham. berlin, R. T., 10.

Beach cobbles: Clarke, J. M., 21.

Black shale formation: Goldman, 11.

Bleaching of red beds: Moulton, 7 .

Bottom deposits, Lake Ontario: Kindle, 35.

Breaking waves in shallow water: MacClintock, 2.

Calcareous concretions in streams: Roddy, 1.

Calcite, force of crystallization: Rothrock, 2.

Calcium carbonate, precipitation: Em. mons, R. C., 8.

Caliche and its origin: Lonsdale, 6.

Caliche and pseudo-anticlines: Price, 10.

Capillary relationships of oil and water: Washburne, 6 .

Carbon in pre-Cambrian formations: Moole, I. S., 12.

Carbonization of Colorado coals by igneous intrusion: Eby, 3.

Caribbean region, tectonic features Woodring, 23.

Cavernous weatherings in arid re. gions : Blackwelder, 25.

Chert and flint, origin : Tarr, 17.

Chink faceting, new process of pelble shaping: Wentworth, 20.

Clastic dike intrusion: Jenkins, 13.

Clay balls, formation: Haas, 2.

Cleavage and grain of slates: Behre, 6.

Coalification process: Fisher, D. J., 5.

Cobble of peculiar shape: Wentworth, 14.

Collapse of mountain summits : Young, G. J., 2.

Colloidal products of rock weathering, distribution: Wallace, 9 .

Colloidal solution: Burton, E. F., 1.

Color of red sandstone: Cartwright, L. D., 1.

Colors produced by iron in mineruls and the sediments: MacCarthy, 5.

Columnar and buttress structures: Branson, 20.

Columnar holes in wandering dunes, origin: Harshberger, 1.

Cone-in-cone: Tarr, 20.

Conglomerate, marine and telrestrial: Barrell, 9.

Contact metamorphism : Bain, 25 ; Hess, 11.

processes: Geijer, 2.

Continental drift, theory of: Van der Gracht, 1.

Continental fragmentation : Barrell, 11.

Continental movement: Evans, J. W., 2 ; Gregory, J. W., 2; and tida] forces: Taylor, 5 .

Continents, origin: Richarz, 2. 
Physical geology (general)-Continued.

Continents and oceans, origin: Ruedemann, 24; Wngener, 1.

Control zones of earth: Chamberlin, T. C., 11.

Cordilleran region: Beeson, 1.

Craters on the moon, formation : Wright, F. E., 11.

Crustal movements, California: Day, 4.

Crypto-volcanic structures : Bucher, 10.

Crystalline schists, origin : Keyes, 22.

Crystallization temperature of veins near surface: Spurr, 29.

Cycle of glaciation: Hobbs, 11.

Deflection of streams by earth rotation : Davis, 6.

Deformation in ores, Coeur d'Alene district: Waldschmidt, 8 .

Deformation of rocks : Willis, 27.

Deformative processes: Chamberiln, $\mathbf{R}$. T., 7.

Dehydration of gypsum: McCormack, 1.

Desert mud cracks: Longwell, 14.

Desert phenomena, San Luis Potosi: Wittich, 2.

Differential compacting the cause of certain Claiborne dips: Teas, 5.

Dikes and ores of Mississippi Valley: Behre, 8; Eng. M. J., 11.

Dilatancy, geologic rôle: Mead, 4.

Diminishing rate of rotation, effects: Keyes, 37.

Direction of stress producing strain: Hubbert, 2.

Discoidal structure of the lithosphere : Willis, B., 2, 6.

Dolomitization near Goodsprings, Nevada: Hewett, 12.

Domes, origin by isostatic adjustment: Albertson, 1.

Drag folding in marble : Dale, T. N., 3.

Dust fall, March 9, 1918: Winchell, A. N., 1.

Dynamies of faulting and folding : Willis, 14.

of the lithosphere: Jones, 0. C., 1.

Earth temperatures and structural uplifts: Thom, 13.

Earth's mobile belts, pattern : Bucher, 8 .

Earthquake rifts, aerial observation: Willis, 7 .

Electrical prospecting: Leonardon, 1, 2.

Llectrical resistivity of rocks : Koenigsberger, 1.

Ellis-Madison unconformity : Collier, 10.

En echelon and arcuate mountains: Link, 5 .

Eolian and subaqueous cross-bedding: Bucher, 15.

Erosion by solution and fill, Pecos Valley, New Mexico: Lee, W. T., 14.

Erosive processes : Malott, 10.

Exfoliation, a phase of rock weathering: Blackwelder, 10

Fault surface: Geijer, 6.

Fault troughs: Taber, 15
Physical geology (general)-Continued.

Faults, active, criteria for recognizing : Taber, 8.

Fire as an agency in rock weathering: Blackwelder, 15.

Fissility of shale, origin: Lewis, 9.

Folding, effect of stratigraphic variation on: Gardescu, 1.

types of: Ickes, 1.

Folding and shearing: Willis, 27.

Folds from vertically acting forces: Robinson, W. I., 1.

of Osage type, occurrence: Brown, R. W., 2.

Foraminifera, used in determining underground structure : Cushman, 15 .

Formution thicknesses, determination : Ickes, 2.

Framework of the continents, signifl. cance: Chamberlin, R. T., 10.

Fundamental lines of Nortb American geologic structure: Ruedemann, 12.

Fundamental problems of geology : Chamberlin, T. C., 4, 29, 30.

Fused sedimentary rocks in drill cores: Bowen, 14.

Gel replacement: Lindgren, 15.

Gels, function in formation of quarts and carbonate veins: Merritt, $C$. A., 2.

General: Bretz, 8; Davis, 28: Dut ton, 1; Grabau, 13; Henderson, J., 7 ; Keyes, 12 ; Mather, 14 ; Meinzer, 11; Osborn, C. S., 1 ; Scott, W. B., 1; Shimer, 4.

Geochemistry, data: Clarke, F. W., 1, 6.

Geodetic work, value to geology : Bowie, 8.

Geologic structures: Willis, 11.

Geologlc processes: Bretz, 12.

Geosyncline, significance of term : Swinnerton, 4.

Geotectonic adaptation through retardation of the earth's rotation: Keyes, 6.

Geotectonics of the Paciflc: Wills, 33.

Glacially transported mine: Walker, R. T., 1.

Glacier motion a type of rock deformation: Chamberlin, R. T., 17.

Glaciers, model, experiments with : DeLury, $_{7}$.

Graben, sốtheastern Oregon: Smith, W. D., 14.

Granite, weathered, twice metamorphosed: Allison, I. S., 3.

Granite massives, primary structure : Balk, 1.

Gravitational compaction of sedimentary rocks: Hedberg, 1, 2; Rubey, 8; Straub,. 1 . 
Physical geology (general)-Continued.

Groundwork of dlastrophism : Cham. berlin, T. C., 10.

Growing crystals, force: Taber, 13.

Gulf Constal Plain salt domes, secondary instrusive origin: Matteson, 2.

Gullies in the Great Plains, formation: Rubey, 8.

Gypsum deposits, origin : Keyes, 140.

Horizontal compression in Colorado Rockies : Shepard, 5.

Ice, physical properties: Matsuyama, 1.

Ice ages and the drift of continents : Coleman, 17.

fee crystal markings: Allan, 19.

Ice crystals, growth: Plyler, 1.

Ice push on lake shores: Scott, I. D., 3.

Imbricated structure in river gravels: Johnston, W. A., 16.

Impressions on rocks: Twenhofel, 13.

Inclosed meanders, Colorado Plateau : Moore, R. C., 30.

Intraformational corrugated rocks : Miller, W. J., 17.

Iron-depositing bacteria: North, L., 1.

Iron sulphide in coal and other sedimentary rocks: Newhouse, 3.

Island arcs, unstable middle section: Hobbs, 22.

Isostasy, bearing on geological problems: Bowle, 14.

Isothrustic structure: Jillson, 48.

Joint planes, formation: Wright, $F$. E., 3.

Keystone faults: Crosby, W. O., 4.

Laccoliths : Davis, 21.

formation : Keyes, 98.

Laccoliths and sills: Davis, 27.

Laminated structure of drill cores: Udden, 27.

Land tilting in Great Lakes region: Taylor, 12.

Llchens as weathering agents of limestone: Weidman, 6.

Limestone masses and septaria, origin : Lugn, 1.

Limestone alterations at Bingham, Utah: Winchell, 8.

Limestone conglomerates, origin : Billman, 2.

Limestone slab deformed by gravity: Kindle, 13.

Liquid silicate immiscibility : Greig, 3.

Lithologic character of shale as an index to metamorphism: Wilson, J. H., 3.

Lithosphere, structural failure: Leith, 6.

Localization of folds : Brown, R. W., 3

Meanders, inclosed, significance in the history of the Colorado Plateau country : Moore, R. C., 31.

Mechanical interpretation of joints : Bucher, 2.

$4096-31-60$
Physical geology (general)-Continued.

Mechanics of geologic structures : Mead, 1.

Mechanics of vein formation : Taber, 1.

Megadiastrophism: Chamberlin, T. C., 12.

Megatectonics: Chamberlin, T. C., 31.

Melikaria: Burt, 5.

Mesabi range cherts, origin: Gruner, 7.

Metasomatism and the pressure of growing crystals: Boydell, 14.

Microscopical interpretation of folded structures: Graton, 1.

Mid-Continent region, structural geology : Powers, 16.

Migration of geosynclines: Grabau, 1.

Minerals deposited by bacteria in mine waters: Parry, 1.

Minor folds: Decker, C. E., 1.

Mississippian orogenic movements : Van Tuyl, 2.

Mosses as rock builders: Emig, 1.

Motion of glaciers: Chamberlin, R. T., 18.

Mountain summits, collapse: Young, G. J., 2

Movements in the earth's crust : Lam. bert, W. D., 4.

Mowry shale, origin: Rubey, 7 .

Mud pebbles, origin: Lugn, 9.

Mud crack and assoclated joint struc. ture : Kindle, 21.

Mud crack and ripple mark in recent calcareous sediments: Kindle, 20.

Mud cracks : Kindle, 37 ; Ward, 11.

forming over water: Willard, B., 1. on steeply inclined surfaces: MacCarthy, 1.

Mud flow in semiarid mountains : Blackwelder, 18.

Natural waters, effects of common changes: Wells, 5.

Normal faulting on upthrust arches: Willis, 28.

North American geosyncline: Schuchert, 22

Ocean basis, origin: Willis, 6 .

Ocean Inlets, storm effects: Hite, 1.

Oolites: Hess, 25.

Origin of follation and naming of syntectic rocks: Alling, 9.

Oxidation products from chalcopyrite: Blanchard, R. 2.

Oxidation subsidence at Bisbee, Arizona: Wisser, 1.

Parajointing: Donnay, 1.

Parallel folding and boudinage: Quirke, 9.

Pebbles, wedge work: Wentworth, 5 .

Pedestal rocks in stream channels: Bryan, 17.

Pegmatites, formation: Schaller, 10. natural history: Hess, 23.

Permeability of rocks: Dahlblom, 1.

Petrifaction of wood: St Tohn, 1. 
Physical geology (general)-Continued.

Petroleum in a fossil cast: Reeves, 9.

Pitch of rock folds: Fermor, 1.

I'lanetary nuclei, physical phases: Chamberlin, T. C., 20.

Planetesimal growth: Chamberlin, T. C., 21.

Planetesimal hypothesis: Chamberlin, T. C., 9.

Pole displacement: Cotton, 2.

Polygonal weathering in igneous and sedimentary rocks: Johnston, C. S., 1.

Porosity and crushing strength as indices of regional alteration : Russell, W. L., 11.

Postglacial uplift of New England coastal region: Fairchild, 7 .

Pressure, effect on migration of oil : Thomas, E. T., 2.

Problems in physical geology: Dutton,

Quartz in veins, genesis: Bancroft, G. J., 1.

Rectilinenr shore lines, New. EnglandAcadian region, origin: Johnson, D. W., 4.

Recurrent depression and resilience in the Great Lakes region: Taylor, 11.

Red beds, origin of color: Dorsey, 2 .

Red River as an erosive agent: Wallace, 17.

Replacement and formation of concretions: Cook, C. W., 10.

Rcpiacement and recrystallization mechanism : Fairbanks, 6.

Replacement of aluminous rocks : Dougherty, 5 .

River cobbles: Lugn, 10.

River deflection due to carth's rotation: Hayes, E., 1.

Rivers, action: Hill, R. T., 7.

Rock pressure: Heroy, 1.

Rock mass movement: Leith, 8 .

Rocks, thermal conductivity and compressibility under pressure: Bridgman, 1.

Rocky Mountain geosycline, eastward extension: Keyes, 290.

Rocky Mountain structure: Flint, R. F., 1.

Rotational velocity of earth and its geological effects: Daly, 14.

Rounded sand grains, age: Anderson, G. II., 3.

Rounding of sand grains by solution: Galloway, J. J., 2.

Salina formation: Newland, 9.

Sind bar, unusual type: Kindle, 19.

Sanct grains, rounding: Anderson, G. E., 3.

rounding by sea urchins: Kindle, 2. rate of wear: Anderson, G. E., 1.

Sind holes of the strand: Palmul, $K$. II., $\mathrm{n}$.
Physical geology (general)-Continued.

Sandstone inclusion in salt in mine on Avery's Island: Heald, 14

Sea beach observations: Kemp, 2.

Sea level surfaces and coastal subsidence: Johnson, D. W., 14.

Sedimentary processes on volcanic islands: Wentworth, 24.

Selective segregation of material forming earth: Chamberlin, T. C., 19.

Self-compression of the earth: Chamberlin, T. C., 9.

Shale, fissility, and its relations to petroleum : Lewis, 9.

Shattering of mincrals and rocks about inclusions: Walker, 27.

Shifting of continents: Keyes, 210.

Shore processes: Johnson, B. L., 3.

Shrinkage cracks, origin: Twenhofel, 14.

Shrinkage of the earth: Chamberlin, T. C., 4 ; Stille, 1.

Silicification of erosion surfaces : Leith, 14 ; Tarr, 16.

Slumping in Slim Buttes region, South Dakota: Toepelman, 5 .

previous to consolidation in Pennsylvanian of Oklahoma: Ross, C. S., 8.

Solubility and pressure: Boydell, 9.

Stalagmites and stalactites, gronth : Allison, V. C., 1.

Strain ellipsoid and Appalachian structures: Chamberlin, R. T., 19.

Stratification: Udden, 25.

Stratigraphic significance of solution in rocks: Stockdale, 3.

Stress, strain, and joints: Swanson, C. $0 ., 3$.

and rupture, relations: Lovering, 4. Stresses in laccolithic intrusions: Gould, L. M., 2.

Structural features of North America : Holtedahl, 4.

Structural geology: Leith, 9.

progress: Mathews, 8 .

Structural symmetry, North America : Keith, 8.

Stylolitic structures: origin: Stockdale, 2.

Subaerial sun cracks: Swartz, J. H., 8.

Subjacent igneous invasion, relations of regional metamorphism: Barrell, 7.

Subsidence: Rice, G. S., 2.

Subsurface folds and faults: Kirk, C. T., 2.

Syngenetic origin of concretions in shale: Tarr, 10.

of pyrite concretions in Pennsylvanian shales: Mathias, 1.

Syngenetic pyritization: Tarr, 19.

Tectonic adjustment of a rotating straticulate spheroid: Keyes, C. R., 1. 
Physlcal geology (general)-Continued.

Tectonic conditions accompanying Intrusion of basic and ultra-basic. igneous rocks: Benson, 1.

Tertiary diastrophism: Taylor, 18.

Tertlary epeirogeny : Taylor, 13.

Textbook : Miller, W. J., 22.

Thermal conductivity and compressiblity of rocks under pressure: Bridgman, 1.

Thrust faulting, process: Quirke, 5 ; upthrust faulting: Willis, B., 1.

in Basin Ranges: Keyes, 228.

Tidal forces in the making of continents and mountains: Taylor, 10.

Time factor in artificial minerals: Peck, A. B., 3.

Transcontinental structural digression : Hill, R. T., 11.

Transverse faults along Rocky Mountain trench: Shepard, 10

Undertow : Lugn, 8.

Valley widening by frost action: Culbertson, G., 1.

Varve materials and banded rocks: Wallace, 20.

Varved glacial clay, conditions of formation: Anters, 9.

Vein formation: Taber, 1 ; Thompson, W., 1.

Velning along faults, Pennsylvanian sandstones, Oklahoma: Hoffman, M. S., 2.

Veins, origin : Taber, 14.

of fibrous minerals, origin: Taber, 9.

Vertical earth adjustments, rate of movement : Hobbs, 15.

Wave erosion: Swinnerton, 2.

Wedge theory of diastrophism: Chamberlin, R. T., 11.

Wedge work of roots: Thomas, A. $0 ., 3$.

White spots in Permian red beds: Shead, 7 .

Physiographic geology (general). For areal see names of States. See also Drainage changes.

Airplane photography : Lee, W. T., 5.

Allegany State Park, New York: Lobeck, 8 .

Amphitheater valley heads: Hinds, 8.

Appalachian Piedmont deformation : Campbell, M. R., 16.

Appalachian Valley: Brigham, 3.

Appalachians, southern: Adams, G. I., 5.

Arcuate mountains, evolution: Hobbs, 7.

Atlantic and Gulf Coastal Plain structural features: Stephenson, 16.

Atlantic and Pacific coastal regions, contrast: Hobbs, 13

Base level : Malott, 12.

Basin Range topography: Keyes, 293.
Physlographic geology (general)-Contd.

Basin Range structure in the Great Basin: Louderback, 5 .

Basin-and-Range province, Plelstocene lakes: Meinzer, $\overline{\mathbf{5}}$.

Block diagrams: Lobeck, 1.

Blue Ridge, erosional history : Wright, F. J., 4.

Virginia and North Carolina : Wright, F. J., 2.

"Blue Ridge" in New England: Brown, R. H., 1.

Brief physiography : Nelson, W. B., 1.

Caribbean region, tectonic features: Woodring, 23.

Channels, valleys, and intermont plains: Davis, 34.

Consequent streams: Vickery, 10.

Continental shelf: Shepard, 12.

differential tilting: Moon, 1.

Cordilleran region: Keyes, 13.

Cryptovolcanic structure, Adams County, Ohio: Bucher, 3.

Cycle of glaciation : Hobbs, 11.

Cypress Plain, Alberta: Lawson, 8.

Dalles type of river channel : Bretz, 7 .

Deflection of streams by earth's rotation: Jennings, 2.

Desert basins of Southwest, origin : Blackwelder, 19.

Desert range, genetic significance: Keyes, 155.

Distribution of land and water on the earth : Reid, 5.

Earthquake rifts, aerial observation: Willis, 7.

Erosion cycle: Davis, 11.

Erosion surfaces, eastern Appalachlan highlands: Knopf, E. B., 5.

Erosional bistory : Trowbridge, 1.

Eustatic bench of islands of north Pacific: Wentworth, 21.

Even-crested ridges: Buwalda, 7.

Evolution of earth : Hobbs, 5.

Fall line, eastern United States: La Forge, 1; Renner, 1, 2.

Fault scarps, recognition: Blackwelder, 21.

Finger Lakes, origin: Fairchild, 20.

Flood plains, head of: Tilton, 4 .

Geanticlines, horizontal movement: Brouwer, 1.

General: Daly, 21; Davis, 24, 28 ; Henderson, J., 7 ; Jones, W. D., 1 ; Millis, 2 ; Scott, W. B., 1.

Geographic terminology: Campbell, $M$ R., 13.

Geographical cycle: Davis, 8.

Geography among the earth sciences: Penck, 1.

Geologic maps, interpretation: Dake, 12.

Great Basin, morphologic features of Basin Range displacements : Lou. derback, 8.

Great Basin lakes, origin : Keyes, 116. 
Physiographic geology (general) - Contd. Great Basin ranges, origin: Keyes, 84. Gullies in the Great Plains, formation : Rubey, 9.

Hanging valleys, origin: Crosby, 5.

Harbor development by physiographic processes: Cobb, C., 1.

Hornitos: Sapper, 2.

Hudson submarine channel: Daly, 7.

- Inclination of surface, determination from contour map: Rich, J. L., 1

Inclosed meanders, Colorado Plateau : Moore, R. C., 30.

Island arcs, unstable middle section: Hobbs, 22.

Island mountain topography, Arizona and Sonora: Waibel, 1.

Islands, western end of Lake Erie, control by foints: Cook, C. W., 7.

Lake Erie, relation to land tilting: Taylor, 14.

Western end: Cook, C. W., 7.

Lateral migration of land masses: Daly, 15; Lambert, W. D., 3 ; Taylor, 3.

Localization of major geosynclines, cause : Bucher, 4.

Major features of earth's surface : Diener, 1.

Maps without culture: Wyckoff, D., 1.

Meander's in tidal streams: Campbell, M. R:, 12, 13.

Mississippi delta: Malott, 1.

Morphology of landscape: Sauer, 2.

Mountain-glacier erosion, types : Hobbs, 3.

Mountain pediments: Bryan, 4.

Multiple level cirques: Fuller, M. B., 10.

Natural boundaries in the Interior Low Plateau physiographic province: Flint, 6.

New England-Acadian shore line: Johnson, D. W., 8.

North America and Asia: Taylor, 18.

Northern Great Plains, physiographic development: Alden, 3 .

Ocean inlets, storm effects : Hite, 1.

Oceanic islands, classiflcation: Davis, 23.

Oklahoma stream valley type: Evans, O. F., 5 .

Paciflc coast States, Pleistocene changes : Buwalda, 7 .

Panorama of physiographic types : Lobeck, 7.

Peneplains and the geographical cycle: Davis, 8.

Physiographic divisions of United States: Fenneman, 6.

Piedmont plains of Great Basin, origin : Blackwelder, 23.

Pine Prairie salt dome, Evangeline Parish, Louisiana: Barton, 7.

Flateau region changes: Reagan, 9.
Physiographic geology (general)-Contd.

Pleistocene, classification and history of investigations: Kay, 16.

Pleistocene peneplain in Coastal Plain : Cleland, 5.

Pust-Cretaceous faulting in Appalachians : Stose, 32.

Prairie, origin: Jones, P. M., 1; Miller, A. M., 23; Shimek, 2.

Pre-Cambrian peneplain of North America: Du Rietz, 1.

Recessional streams of arid regions: Keyes, 168.

Relfef shading of topographic maps: Matthes, F. E., 1.

Rivers in arid regions: Keyes, 122.

Retrograding of offshore bars: Johnson, D. W., 2 .

Rocky Mountains, physiographic history: Keyes, 32.

Rôle in military operations : Bryan, 6.

Scabland, Washington: Bretz, 19.

Scenery of American rivers: Johnson, D. W., 3.

Sea level surfaces and coastal subsidence: Johnson, D. W., 14.

Shaded topographic maps: Davis, 22.

Shading of contour maps: Jillson, 89.

Shapes of valleys, representation : Lane, 13.

Stream and ocean terraces in relation to recent earth movements: Holway, 1.

Stream valleys, origin and development: Branson, 9.

Subaqueous terraces of the Great Lakes añd the Saint Lawrence embayment: Johnson, D. W., 10.

Submerged coastal plain and oldland of New England: Johnson, D. W., 6.

Submerged deltas and continental shelves: Shepard, 13.

Summit plane of Colorado Rocky Mountains : Keyes, 65.

Tennessee River : Adams, G. I., 5.

Textbook: Salisbury, 1; Tart, R. S., 1.

Tomboloes and points, formation: Johnson, R. H., 6.

Topographic criteria of oil-field structure: Monett, 1.

Topographic maps:'Davis, 9.

Trough deeps of island areas: Hobbs 23.

Unicline: Grabau, 8.

United States: Lobeck, 2, 4. age of present surface : Trowbridge, 2. north-south topographic profiles: Trowbridge, 3 .

physiographic map: Lobeck, 3 .

Utah peneplains : Keyes, 75.

Valley development: Branson, 15.

Valley form: Malott, 11.

Valley formation, interior plains region : Evans. O. F., 4, 6.

Pledmont terraces, northern Appalachians: Barrell, 6. 
Pigments. Canada : Fréchette, 2.

Pine Creek district, Idaho : Jones, Edw. L., 1. Pinkbam Notch, New Hampshire, physiographic history: Crosby, I. B., B.

Pioche district, Nevada: Westgate, 6.

Pisces.

Alberta : Raymond, 30.

Anaspida and origin of vertebrates : Raymond, 29.

Anguillavus hackberryensis, Niobrara beds, Kansas : Martín, H. T., 1.

Arizona, Devonian Arthrodira: Stoya. now, 1.

Arkansas, Fayetteville for m a $\mathrm{t} 1$ o $\mathrm{n}$ sharks: Croneis, 4.

Arthrodires : Stensiö, 1.

Bothriolepis, Scaumenac Bay, Quebec: Bryant, 3.

California : Hubbs, 1

Lompoc: Jordan, D. S., 2.

Mlocene: Jordan, 5.

Santa Barbara County: Jordan, 12 southern: Jordan, D. S., 1, 15, 17.

Cestraciont spine, Triassic, Nevada: Davidson, P., 1.

Chichlasoma, Haiti : Cockerell, 16.

Chordates in the Cambrian: Bryant, 5 ; Howell, 6.

Classification: Jordan, 10.

Collecting fossil fishes in Cleveland shale: Hyde, 2.

Cretaceous fish scales: Cockerell, 1.

Cretaceous fish spine, Kansas: Moodie, 25.

Cuba, Squalidae, Tertiary: Sánchez Roig, 3.

western, Jurassic : Gregory, W. K., 8.

Deprandus lestes: Gilbert, J. Z., 1.

Devonian: Hussakof, 1 ; Kindle, 16 .

Dinichthys pustulosus: Hussakof, 2.

Environment of early vertebrates: Berry, 68.

Eobrycon, scales: Cockerell, 18.

Eocene, Utah and Wyoming: Tanner, 1.

Eoichthys, St. Albans, Vermont: Bryant, 6.

Eusthenopteron, structure: Bryant, 1.

Evolution and distribution: Macfarlane, 1

Florida, Pleistocene: Hay, 1.

Ganoid fish, Lower Cretaceous, South Dakota : Gregory, W. K., 11.

Ganoid fishes : 'Gregory, W. K., 8.

General : Macfarlane, 2.

Historic fish remains: Miller, A. M., 16.

Kansas, Cretaceous : Jordan, D. S., 14.

Kindleia, cichlid fish, Cretaceous, Alberta: Jordan, D. S., 18.

Kindleia and Styleodon: Russell, L. S., 4.

Kindleia and Stylomyleodon, Cretaceous, Alberta : Jordan, D. S., 19

Lampris zatima, Lompoc, California : Jordan, D. S., 4.

Lasanius, reconstruction: Simpson, G. G. 8 .
Pisces-Continued.

Macropetalichtbyids, head : Stensið, 1.

Martinichthys, Cretaceous, Kansas : McClung, 1.

Miocene fishes, California: Jordan, 6. restorations: Anon., 17.

New York, western, Devonian: Hussakof, 1.

Ohio," Clevelund shale: Hyde, 4.

Pacific slope, sharks and rays: Jordan, 11.

Palaeaspls : Bryant, 4.

Paramiatus gurleyi, amild fish, Eocene, Wyoming: Romer, 15.

Quisque bakeri, Miocene herring, Texas: Jordan, 8.

St. John collection: Keyes, 176.

Sculpin, Nevada: Jordan, 13.

Sources of petroleum: Macfarlane, 2.

Shark's teeth, Pliocene, California: Jordan, 9.

Sharks, Temblor group, Kern County, California: Jordan, D. S., 16.

South Dakota, Portheus: Bump, 1.

Stylomyleodon lacus, Paskapoo beds, Alberta : Russell, L. S., 3.

Texas, Triassic: Warthin, 1.

Thelodus: Stetson, 4.

Xyne, Santa Barbara County, Callfornia : Jordan, D. S., 8.

F'itted outwash: Thwaites, 5.

Placers.

Alaska: Mertie, 7 .

British Columbia, Cariboo district: Johnston, W. A., 13

Plain geology: Smith, G. O., 14.

Plane table: Bateman, A. M., 1.

Plane-table methods: English, W. A., 2.

Planetary nuclei, physical phases: Chamberlin, T. C., 20.

Planetesimal growth: Chamberlin, T. C., 21.

I'lanetesimal hypothesis: Chamberlin, $\mathbf{T}$. C., $9,26,27,28,30,37,38,41$; Daly, 5 ; Moulton, 1 ; Reld, 12.

astronomical tests: Reid, 8.

geologic results: Chamberlin, T. C., 34.

Flunts, fossil. See Paleobotany.

Platinum.

Alaska, Chistochina region: Chapin, 3.

Kahiltna Valley: Mertie, 2.

Kiwallk-Koyuk region: Harrington, 5.

Prince of Wales Island, Salt Chuck mine : Mertie, 4.

Tolstol district : Harrington, 2.

Bibliography : Howe, J. L., 1.

British Columbia: Camsell, 5; Uglow, 2.

Tulameen district: Macaulay, 1.

Yale district, Tulameen area: Poitevin, 6.

California: Logan, C. A., 1. 
Platinum-Continued.

Canada: Mackenzie, G. C., 1; O'Neill, 2.

General: Kemp, 26; Uglow, 1.

Geology: Vogt, 6.

In quartz veins: Turner, H. W., 2. Nova Scotia, western: Faribault; 2.

Oregon, Josephine County, Waldo district: Kellogg, A. E., 2. southwestern: Kellogg, A. E., 5.

Wyoming: Duparc, 1.

Centennial : Hess, 24.

Encampment district: Finch, J. W., 1.

Playas: Foshag, 24.

Pleistocene. See Glacial geology; Quaternary.

Pleochroic halos: Kerr-Lawson, 2.

Pliocene. See Tertiary.

Point Barrow region, Alaska: Paige, 5.

Folnt Sur quadrangle, California: Trask, 5.

Polarized light in the study of ores and metals : Wright, F. E., 1.

Pole wandering, evidences $f^{\prime}, r$, in Alaska glaciation: Richarz, 1.

Political and commercial geoḷogy: Spurr, 2.

Polyzoa. See Bryozoa.

Popular and elementary: Benson, A. L., 1.

Rocks and minerals: Palmer, E. L., 2.

Rock stories : Palmer, E. L., 1.

Porosity and crushing strength as indices of regional alteration: Russell, W. L., 11.

Portland cement. See Cement materials.

Porto Rico.

Geology : Berkey, 1.

Areas described.

Coamo-Guayama district : Hodge, E. T., 1.

Humacao district: Fettke, 5.

Lares district: Hubbard, B., 3.

Ponce district: Mitchell, 7.

San Juan district: Semmes, 1.

Economic geology.

Copper prospect, Barrio Pasto : Colony, 9.

Limonite deposits, Mayaguez Mesa: Fettke, 2.

Magnetite deposits, eastern Porto Rico: Fettke, 6.

Historical geology.

Eastern Porto Rico: Vaughan, 22.

Tertiary formations: Hubbard, B., 2 ; Maury, 3 ; correlation: Maury, 1.

Paleontology.

Birds from cave deposits: Wetmore, $1,3$.

Orthaulax, Tertiary: Woodring, 3.

Paleobotany : Hollick, 12.

Plants, Collazo River: Hollick, 6.

Tertiary Mollusca: Hubbard, B., 1; Maury, 3.

Walnuts and lignite: Hollick, 8.
Porto Rico-Continued.

Physical geology.

Earthquakes : Reid, H. F., 1, 2; Octóber-November, 1918: Reid, $\mathrm{H}$. F., 3.

Physiographic geology.

General : Lobeck, 5 .

Tertiary : Meyerhoff, 2.

Potash. See also Alunite.

Bibliography : Gale, H. S., 1 ; Hicks, $1,2$.

Cuba, Santa Clara: Montolieu, 1.

General : Gale, H. S., 1 ; Hess, 26 ; Hicks, 1, 2; Mansfield, 17, 20, 24, 38 ; U. S. Senate, 1.

Georgia, Cartersville slates: Maynard, 'T. P., 1.

Illinois, potash shales : Austin, N. M., 1 ; Schroyer, 1.

Union County: Krey, 1.

Investigations, 1924 : Lang, W. B., 2.

Minnesota, content in shales: Schmitt, 1.

Nebraska: Hicks, 3.

New Jersey greensands: Mansfeld, 1, $2,7,9,12$

New Mexico: U. S. G. S., 15. southeastern: Hoots, 1 .

Nova Scotia, Cumberland County: Hayes, 5.

Oregon: Nattress, 1.

Texas: Keyes, 285 ; Udden, 26.

Midland County: Sellards, 25, 26.

Potter County: Patton, L. T., 2.

reserves: White, D., 7 .

western: Hoots, 1; Mansfield, 14; Meigs, 1 ; Udden, 14, 15

Utah, Great Salt Lake I)esert, potash brines: Nolan, 1, 2.

Marysvale district: Varley, 2.

Western United States: Mansfield, $G$. R., 31.

Potholes.

Ancient high-level potholes near the Colorado River: Rarısome, 13.

Colorado, Front Range: Fuller, M. B.,

Etched potholes: Udden, 20.

New Hampshire, Mount Jefferson: Crosby, I. B., 6

Ontario, Killarney area: Quirke, 15.

Practical oil geology: Hager, D., 8.

Prairies, origin : Jones, P. M., 1; Miller, A: M., 23 ; Shimek, :..

Illinois, origin: Woodard 1.

Washington, Olympic Peninsula, origin : Reagan, 23.

Pre-Cambrian. See also Paleontology, preCambrian.

Alabama : Adams, S. F., 2.

Alberta, Rocky Mountains: MacKenzie, J. D., 4

Arctic Canada, Baffin Island, Cumberland Sound area: Weeks, L. J., 3. Arctic coast: O'Neill, 5 . 
Yre-Cambrian-Continued.

Arctic regions, Elesmere Land : Holtedahl, 1.

Arizona : Darton, 17.

Aravaipa-Stanley region: Ross, C. P., 5.

Courtland-Gleeson region: Wilson, E. D, 2.

Grand Canyon district: Moore, R. C., 26.

Jerome district, Yavapal County: Reber, 1.

Jerome and Bradshaw Mountains quadrangles: Lindgren, 17.

Mazatzal quartzite: Wilson, E. D., 1.

Papago country: Bryan, 7, 15.

Ray quadrangle: Ransome, 11.

Ray-Miami region: Ransome, 1.

Tucson and Amole Mountains: Jenkins, 3.

Arkansas : Miser, 22.

Belt series, Montana: Sampson, 15.

Belt terrane: Keyes, 258.

British Columbia, Cariboo district, Barkerville area : Johnston, W. A., 22.

Kamloops district, North Thompson valley : Uglow, 3.

Rocky Mountain region: Schofield, 8. Rocky Mountain trench: Shepard, 3. southeastern: Schofield, 10, 12.

Windermere area, Kootenay district: Walker, J. F., 1.

California, Deep Spring Valley : Miller, W. J., 35.

Randsburg quadrangle: Hulin, 3.

Canada : Baker, M. B., 2 ; Collins, 10 ; Cooke, H. C., 19; Miller, W. G., 4, 12.

Arctic regions: Moore, E. S., 2.

Canadian Rockies: Burwash, 2.

Huronian and Grenville rocks, correlation: Quirke, 12.

Carbon in pre-Cambrian formations: Moore, E. S., 12.

Classification: Wilson, M. E., 18.

Colorado: Keyes, 162.

Big Thompson River valley: Fuller, M. B., 2.

BouIder County, Ward region: Worcester, 1.

Grand, Jackson, and Larimer coun. ties (parts): Spock, 1.

Gunnison River: Hunter, J. F., 1.

Leadville district: Emmons, S. F., 1.

Moffat Tunnel : Lovering, 7 .

north central, foothills formations:

Henderson, 2.

northern: Fuller, M. B., 7 .

southwestern: Coffln, 3.

Twin Lakes district: Howell, J. V., 1.

Correlation: Cooke, H. C., 19.

Coutchiching: Grout, 15.

Coutchiching delta: Bruce, 21.
Pre-Cambrian-Continued.

Delaware, Wilmington quadrangle: Bascom, 2.

Folding: Miller, W. J., 21.

General: Keyes, 117, 209; Lane, 22 ; Miller, W. J., 21.

Georgia : McCallie, 1.

Tate quadrangle: Bayley, 13.

Greenland, northern: Koch, 4.

northwestern: Hovey, 11: Koch, 1.

Grenville subprovince: Wilson, M. E., 13.

Huronian and Grenville rocks, correlatlon: Quirke, 12, 18.

Idaho, Boundary County: Kilkham, 7. Coeur d'Alene region: Eby, J. F., 1; Shannon, 14.

Pend Oreille district: Sampson, 16.

Pine Creek district: Jones, Edw. L., 1.

St. Maries region: Anderson, A. L., 4.

Shoshone County: Umpleby, 3.

Iowa, Ida County: Lees, 10.

Kansas, borings: Landes, K. K., 3.

Keewatin iron formations: Collins, 23. stratigraphic position: Gregory, J. W., 4.

Keweenawan at eastern end of Lake Superior: Moore, E. S., 18.

Labrador, Lake Melville district: Kindle, 25.

nortbeastern : Coleman, 6.

Lake Superior region: Leith, 16.

Laurentian problems and atomic disintegration: Lane, 21.

Literature: Steidtmann, 2, 3.

Mackenzie River basin: Camsell, 1.

Manitoba : Alcock, 13 ; Wallace, 14.

Beresford Lake area : Wright, J. F., 4.

Bigstone and Fox rivers area: Merritt, C. A., 4.

Cross-Pipestone area : Alcock, 4.

Elbow Lake area: Armstrong, P., 3.

Falcon Lake district: DeLury, 2.

Flinflon area : Alcock, 15.

Island Lake area: Wright, J. F., 12.

Knee Lake district: Bruce, 4.

Maskwa River: McCann, 1.

northern: Bruce, 5, 7 ; Hanson, 1.

Oiseau River area: Cooke, H. C., 9 ; Wright, J. F., 10.

Ospwagan Lake-Burntwood River area : Alcock, 9.

Oxford and Knee lakes area: Wright, J. F., 11.

Rat River: Alcock, 10.

Reed and Wekusko lakes region: Alcock, 3.

Reed-File lakes area: Alcock, 1.

Reed Lake-Elbow Lake: Bruce, 2.

Rice Lake area: Cooke, H. C., 9; Wright, J. F., 3.

Wekusko Lake area: Alcock, 2. 
Pre-Cambrian-Continued.

Maryland, Elkton quadrangle: Bascom, 2.

Piedmont Plateau: Knopf, E. B., 3. western Piedmont: Jonas, 4.

Matachewan series, northeastern Ontario: Miller, W. G., 6.

Mexico, Lower California : Darton, 10.

Michigan, Baraga County, Huronian slate areas: Barrett, 1.

Huronian formations: Allen, R. C., 2.

Minnesota : Grout, 2.

Cuyuna district: Thiel, 12; Zapffe, $2,3$.

east Mesabi district: Broderick, 2. eastern Mesabi range: Grout, 3.

Gunflint district: Broderick, 3.

Lake Superior geosyncline: Hotchkiss, 8.

Mesabi range: Gruner, $\mathbf{5}$.

northeastern: Grout, 22.

St. Louis County, northern : Grout, 20.

Missouri : Wilson, Malcolm E., 1.

Ste. Genevieve County: Weller, 19.

Montana: Keyes, 234.

Beartooth Mountains: Bevan, 2.

Belt series: Wilson, R. A., 5 .

Big Snowy Mountains, Belt terrane: Freeman, 0 . W., 3.

Madison Valley: Runner, 9.

Nevada : Keyes, 128.

New Brunswick: Bailey, L. W., 1.

Newfoundland, Avalon Peninsula : Baker, H. A., 1.

Fortune Bay: Dale, N. C., 5. southeastern : Buddington, 3 .

New Jersey, Sussex County: Ries, 8.

New Mexico: Darton, 26; Keyes, 14. Taos Range: Gruner, 1.

New York, Adirondacks: Alling, 3; Clarte, J. M., 15 ; Miller, W. J., 30 ; western: Agar, 1.

Ausable quadrangle: Kemp, 23.

Cortlandt norite, Peekskill : Balk, 5. Gouverneur quadrangle: Cushing, 1. Grenville sediments : Alling, 13.

Lake Bonaparte quadrangle: Smyth, 2.

Lake Clear region: Alling, H. L., 1. Lake Placid quadrangle: Miller, W. J., 1.

Luzerne quadrangle: Miller, W. T., 19.

Lyon Mountain quadrangle: Miller, W. J., 26.

Mount Marcy quadrangle: Kemp, 7. Newburgh quadrangle: Holzwăsser, 1.

Schroon Lake quadrangle: Miller, W. J., 2.

southeastern: Colony, 3.

North Dakota: Leonard, A. G., 1.

Nova Scotia, North Mountain, Cape Breton: Guernsey, 2.
Pre-Cambrian-Continued.

Nova Scotia-Continued.

Richmond County, Stixling area : Weeks, L. J., 1.

Ontario: Hopkins, P. E., 3; Miller, W. G., 1, 2, 4, 10 ; Quirke, 6 ; Wilson, M. E., 7.

Abitibi-Mattagami arra: Cross, J G., 2.

Algoma district: Brunton, 1.

Anima-Nipissing area : Todd, E. W., 7.

Archean : Cooke, H. C., 17.

Argonaut gold mine: Knight, 6 .

Arnprior-Quyon area : Wilson, M. E., 10.

Batchawana area, District of $\mathrm{Al}$ goma : Moore, E. S., :19.

Ben Nevis area: Knight, C. W., 5 .

Black River area : Wright, D. G. H., 1.

Blanche River area: Burrows, 9.

Boston-Skead area: Burrows, 8.

Brockville-M a 1 l o r y to $\mathrm{w}$ area : Wright, J. F., 1, 2, 8.

Cobalt area : Knight, 11 ; Whitehead, 1.

Cochrane district: Hawley, J. E., 3.

District of Patricia, Red Lake to Favourable Lake: Douglas, G. V., 4 ; Hurst, 5.

English River valley: Bruce, 11.

Fort Hope area: Burwasl, 8.

Gammon River area, District of Kenora : Gilbert, G., 7.

Goudreau-Lochalsh area : Gledhill, 8.

Gowganda area : Burrows, 3, 6, 17.

Grenville subprovince : Wilson, M. $\mathbf{b}$. 15.

Groundhog River area : Todd, E. W., 4.

Gunflint iron-bearing formation : Gill, J. E., 1.

Haileyburian intrusives: Miller, W. G., 3.

Hastings series: Wilson, M. E., 19.

Huronian and Grenville rocks : Quirke, 13.

Huronian complex near Killarney: Quirke, 11.

Huronian replacement deposits : Quirke, 20.

Kamiskotia area: Finley, 1.

Kenogamissi Lake area: Todd, E. W., 3.

Keweenawan system : Moorı, E.S., 18.

Kirkland Lake area: Burrows, 4, 12 ; Todd, E. W., 8; Tyrrell, 7 ; Lebel and Gauthier townships: Hopkins, 7 .

Lake St. Joseph area: Bruce, 8; eastern part : Bruce, 9 .

Lake Superior region: Tantion, 3, 17.

Larder Lake area: Hopkins, 8.

Leeds County: Baker, M. B., 1. 
Pre-Cambrian-Continued.

Ontario-Continued.

Lightning River area: Burrows, 1; Knight, 12.

Matabitchuan area: Todd, E. W., 5.

Matachewan district: Burrows, 2; Cook, H. C., 1.

Matawin iron range, Thunder Bay district: Tanton, 15.

Michipicoten district : Collins, W. H., 1,15 ; Gledhill, 7 ; Thomson, E., 4.

middle Eozoic sediments: Spearman, 3.

Missinaibi area: Thomson, E., 11.

Mississagi Reserve and Goulais River iron ranges: Moore, E. S., 15.

Murphy, Hoyle, and Matheson townships: Rose, 4.

Night Hawk Lake area : Hopkins, 9. north shore of Lake Huron : Collins, 11. northeastern: Miller, W. G., 8.

northern: Bruce, 7 ; Cooke, H. C., $7,16$.

Ontario-Manitoba boundary: Burwash, 6 ; Rickaby, 1.

Patricia: Burwash, 1.

Porcupine gold area: Burrows, 13; Robinson, H. S., 1.

Rainy Lake region, Coutchiching rocks: Bruce, 15.

Red Lake Basin, District of Patricia : Bruce, 12.

Red Lake Basin, District of Kenora : Bruce, 22.

Red Lake and Woman Lake areas: Bruce, 23.

Sahkatawich Lake section, Woman River iron range, District of Sudbury : Moore, E. S., 20.

Sault Ste. Marie, District of Algoma : McConnell, 1.

Schreiber-Duck Lake area : Hopkins, 6.

Shiningtree silver area, District of Timiskaming: Langford, 1.

southeastern: Quirke, 13.

Steeprock Lake area, Coutchiching: Tanton, 14.

Sudbury district: Quirke, 7 ; Grassy River area: Gledhill, 5; Wanapitei Lake area: Quirke, 8; West Shiningtrec area: Finley, 2.

Sutton Lake area: Hawley, J. E., 1.

Thunder Bay district: Swanson, W. L., 1 ; Tanton, 12.

Sbebandowan Lake: Tanton, 9 .

Timiskaming district, Abitibi-Night Hawk gold area: Knight, C. W., 1 ; Kenogami Lake area: Cooke, H. C., 8; Larder Lake area : Cooke, H. C., 8; Redstone River area: Bruce, 19: Round Lakn area : Cooke, H. C., 8.

Wrakomata Lake area, Algoma district: Emmons, R. C., 3 .

Wasapika section, West Shiningtree area : Langford, 2.
Pre-Cambrian-Continued.

Ontario-Continued.

Watabeag area: Wright, D. G. H., 2.

Webbwood district: Bain, 15.

western: Bain, 3; Gill, J. E., 2.

western Patricia: Burwash, 5 .

West Shiningtree area: Hopking, P. E., 2.

Whiskey Lake area, District of Algoma: Douglas, G. V., 2.

Windy Lake region: Knight, C. W.,4.

Woman and Narrow lakes area, District of Kenora: Greig, 2.

Oregon: Smith, W. D., 1.

Peneplain: Du Rietz, 1.

Pennsylvanla, Allentown quadrangle: Miller, B. L., 5 .

McCalls Ferry quadrangle: Jonas, 2.

New Holland quadrangle: Jonas, 5.

Pledmont Plateau: Knopf, E. B., 3.

Quarryville quadrangle: Jonas, 3.

southeastern: Hawkins, A. C., 4.

Pennsylvania and Maryland: Jonas, $\boldsymbol{6}$.

Quebec: Cooke, H. C., 7 ; Wilson, M. E., 7.

Abitibi County, Destor area: Buffam, 1.

Amherst township: Wilson, Morley E., 1.

Archean: Cooke, H. C., 17.

Arnprior-Quyon area: Wilson, $\mathbf{M}$. E., 10.

Chibougamau district, Quebec: Mawdsley, 2.

Cléricy and Kinojevis areas, Témls camingue and Abitibi counties: James, 4.

Coleraine area: Knox, J. K., 1 .

Dufresnoy area, Abitibl district: Harvie, 3.

Dufresnoy township : Cooke, H. C., 27.

Duparquet area: James, W. F., 1.

Grenville subprovince: Wilson, $\mathbf{M}$. E., 15.

Harricanaw Basin, pre-Keewatín sediments : Bain, 6 .

Harricanaw and Bell river basins : Bain, 22.

Harricanaw-Turgeon basin: Tanton, 1.

Lake Demontigny region : Mailhlot, 4. Lake David area: Mawdslsy, 5 .

La Motte and Fournière areas, Abitibi County: James, 5.

middle Eozoic sediments: Spearman, 3.

northern: Cooke, H. C., 2, 12.

Pontiac County, Calumet Island : Goranson, 3.

Rouyn area: James, W. F., 2.

St. Urbain area, Charlevoix district: Mawdsley, 1.

Timiskaming County, Opasatika area : Cooke, H. C., 10, 11. 
Pre-Cambrian-Continued.

Saskatchewan, Kapawekka and Deschambault lakes area : DeLury, 6.

Lake Athabaska: Allan, 10.

Sinian, use of term: Grabau, 14.

South Dakota, Black Hills: Paige, 4; Runner, 2, 3 .

cential Black Hills: Darton, 14.

Lead area: Hosted, 1.

Nemo district: Runner, 6.

Steep Rock series: Rothpletz, 2

Taconic area, southern: Knopf, E. B., 6.

Taconic question: Keyes, 129.

Taxonomic differentiation: Keyes, 109.

Tennessee, Ducktown district: Emmons, W. H., 8.

Terminology: Gregory, J. W., 5.

Texas: Udden, 12.

trans-Pecos Texas: Baker, C. L., 6.

Time scale: Young, G. A., 4.

Utah: Butler, 4; Keyes, 152.

Vermont, Northfleld: Richardson, C. H., 2.

Rochester quadrangle: Foye, 1.

Virginia: Jonas, 7.

Blue Ridge, west foot: Stose, 1.

Piedmont: Jonas, 8.

Wisconsin, Lake Supertor geosyncline: Hotchkiss, 8.

Wyoming, Medicine Bow Mountains: Blackwelder, 14 ; Runner, 8 ; north of Laramie: Kemp, 21.

Yukon, Whitehorse district: Cockfleld 16.

Sixtymile and Ladue rivers area: Cockfield, 5 .

Pre-Cambrian continents, existence and configuration: Ruedemann, 11.

Pre-Cambrian life: Keyes, 46.

Pre-Cambrian peneplain of North America : Du Rietz, 1.

Precious stones.

General: Schaller, 2.

Geologic and geographic occurrence: Ball, S. H., 5 .

United States National Museum collection: Merrill, 18.

Pribilof Islands, Alaska : Hanna, G. D., 1.

Primates. See Mammalia.

Prince Edward Island.

Glacial history: Coleman, 1.

Problematic fossils.

Illinois, Silurian: Weller, 8.

Minnesota, Ordovician: Sardeson, 18.

Xenohelix, Chesapeake Bay, St. Marys County, Maryland: Mansfield, W. C., 4 .

Proboscidea. See Mammalia.

Projecting structure through an angular unconformity : Corbett, 1.

Prothro salt dome, Bienville Parish, Louisi. ana: Hull, 13.

Protobalanus, Hamilton group, New York: Van Name, 1, 2.
Protozoa.

Silicoflagellata, Cretaceous, Callfornia : Hanna, G. D., 35.

Pseudomorphs.

Bismuthinite after molybdenite: Graham, R. P. D., 1.

Chalcedony pseudomorphs, Big Badlands, South Dakota: Honess, A. P., 2.

Colemanite after inyoite, Death Valley, Callfornia: Rogers, A. F., 1.

Corundum after spinel, Ontario: Ferrier, 2.

Hematite after goethite: Spencer, L. J., 1.

Limonite after pyrite: Holden, E. F., 1.

Iron sulphide pseudomorphs of plant structure: Schwartz, 20.

Quartz pseudomorphs, Chester County, Pennsylvania: Vaux, 1.

“Pseudomorphous" quartz: Morgan, P. G., 1.

Psllophyton, cuticular structure: Edwards, W. N., 2.

Puente Hills region, California : English, W. A., 3.

Pumpkin Buttes coal field, Wyoming: Wegemann, 2.

Punxsutawney quadrangle, Pennsylvania : Ashley, 18

Pursell trench, origin: Schoffeld, 4.

Pyrite.

Colorado, Leadville: Lee, H. S., 1.

crystallography: Whitlock, 15.

Cuba, Sierra de Trinidad: Allende, 10.

General: Smith, P. S., 1-3.

Illinois: Cady, 8 ; coal beds : Cady, 5.

In coal: Lindly, 1.

Indiana : Barrett, E., 8.

New York, Newland, 2.

Jefferson and St. Lawrence counties: Buddington, 1.

St. Lawrence County, origin: Miller, W. J., 27.

Ohio coal fields: Tucker, W. M., 1.

Ontario, Ca'abogie district: Wilson, M. E., 3.

Michipicoten district: Collins, W. H., 1.

Ottawa Valley: Wilson, M. E., 3.

South Carolina, Kershaw, Haile mine: Schrader, 1.

Tennessee, coal pyrite: Holbrook, 1.

Virginia, northeastern Piedmont: Lonsdale, 7.

Pyrophyllite.

North Carolina, Deep River region: Stuckey, $1,3,5$

Pyrrhotite.

Etching tests on: Boydell, 1.

New York, Jefferson and St. Lawrence counties: Buddington, 1.

Quantitative studies: Hubbard, G. D., 8 , $10,11$.

Quarryville quadrangle, Pennsylvania : Jonas, 3. 
Quartz.

Maryland : Singewald, $\mathbf{5}$.

microscopic study: Adams, S. F., 2.

Quaternary. Sce also Glacial geology ; Paleontology, Quaternary.

Alabama : Cooke, C. W., 13.

Alaska, Anvik-Andreafski region : Harrington, 1.

Kantishna region: Capps, 1.

Kodiak Island: Maddren, 2.

northern, Canning River region: Leffingwell, 1.

Porcupine district: Eakin, 1.

Peard Bay region: Meek, 1.

Arizona : Darton, 17.

Lake Cochise area: Bryan, 23.

lower Gila region: Ross, C. P., 1.

Papago country: Bryan, 15.

Atlantic Coastal. Plain, Pleistocene : Hay, 2.

Basin-and-Range province, Pleistocene lakes: Meinzer, $\mathbf{5}$.

British Columbia, Fraser River Delta : Johnston, W. A., 17.

Vancouver Island, Barkley Sound: Dolmage, 2.

California, Blackhawk Canyon, San Bernardino Mountains: Woodford, 7.

Los Angeles County, Baldwin Hills : Tieje, 6.

Pleistocene-Recent boundary: Matthes, 13.

Rancho La Brea: Wyman, 1.

San Benito County: Kerr, P. F., 4.

San Bernardino Mountalns: Vaughan, F. E., 1.

San Diego County: Ellis, A. J., 1.

southern, Pleistocene: Eaton, J. E. $6,7$.

Tuolumne Table Mountain : Hay, 35.

Warner Range: Russell, R. J., 6.

Champlain sea, decreasing salinity southward: Goldring, 3.

Coastal Plain terraces, origin and age : Hay, 22.

Colorado, Platoro-Summitville district : Patton, H. B., 1.

Corlelation of Pleistocene deposits : Hay, 27.

Costa Rica: Redfleld, 7.

Delaware, Wilmington quadrangle: Bascom, 2.

District of Columbia, excavation on Connecticut A venue : Wentworth, 13

Florida: Cooke, C. W., 19; Mossom, 1,2 ; Sellards, 4,5 .

Everglades section: Sellards, 3.

Melbourne, Vero, and St. Fetersburg deposits: Cooke, C. W., 16.

Vero deposits, age: Chamberlin, $\mathbf{T}$. C., 3; Hay, 40 .

Georgia : McCallie, 1 ; Teas, 1.

Coastal Plain: McCallie, 7.

Great Basin, Pleistocene history : Antevs, 12.
Quaternary-Continued.

Greenland: Böggild, 1 ; Koch, 5.

Haiti : Woodring, 5.

Idaho, Bingham, Bonneville, and Caribou counties: Kirkbam, 3.

Fort Hall Indian Reservation : Mansfield, G. R., 3.

Mud Lake basin: Stearns, 6.

Illinois, Carlyle-Centralia district: Shaw, 9.

Colchester and Macomb quadrangles: Hinds, H., 1.

Lawrence County, Pleistocene: Cox, F. W., 1.

Kansas: Moore, R. C., 4.

Syracuse and Lakin quadrangles: Darton, 2.

Kentucky : Miller, A. M., 1.

Lake Lahontan, geologic history: Jones, J. C., 2.

Louisiana, Port Hudson beds: Emerson, F. V., 1.

Maryland, Elkton quađrangle : Bascom,2.

Talbot County : Miller, B. L., 8.

Mexico, Hidalgo-Vera Cruz region: Palmer, R. H., 4.

Lower California, San Quentin Bay, Pleistocene: Orcutt, C. R., 1.

Oaxaca coast, Pleistocene: Palmer, R. H., 2.

Minnesota, Herman, Barrett, Chokio, and Morris quadrangles: Sardeson, 1.

Mississippi : Lowe, 2.

Missouri, Ste. Genevieve County: Weller, 19.

Montana : Keyes, 234.

Nevada: Keyes, 128.

Newfoundland, western: Schuchert, 16.

New Mexico: Keyes, 14.

northeastern: Garrett, 1.

Raton-Brilliant-Koehler area: Lee, W. T., 6.

New York, New York City, Pleistocene : Palmer, K. V. W., 3.

Oregon: Smith, W. D., 1.

Pleistocene history: McCornack, 1.

southeastern: Smith, W. D., 14.

Pennsylvania, Pittsburgh: Leighton, H., 2.

Pleistocene: Hay, 4, 7, 10, 15.

eastern North America: Hay, 16.

Maryland, Virignia, and North Carolina : Mansfield, W. C., 6.

middle region of North America : Hay, 23.

revision: Hay, 24.

western North America: $\mathrm{H}_{\mathrm{a}} \mathrm{y}, 39$.

Pleistocene time: Hay, 12.

Porto Rico, Coamo-Guayama district: Hodge, E. T., 1.

Quaternary and Tertiary chronology : Allison, V. C., 2.

Quebec, Lake St. John, Champlain deposits: Tolmachoff, 4. 
Quaternary-Continued.

South Dakota, Newell quadrangle: Darton, 1.

Texas, Bexar County: Sellards, 10.

Brazoria County, West Columbia fleld : Barton, 2.

Colorado County : Bailey, T. L., 1. Dallas County: Shuler, 1.

eastern : Dumble, 1.

Gulf Coastal Plain near Rio Grande : Trowbridge, 5.

McLennan County : Adkins, 2.

Potter County: Patton, L. T., 2.

Utah : Butler, 4.

Washington, Big Hope Island, Plelstocene: Henderson, J., 9.

Washington, San Juan Islands: McLellan, 2.

Quebec.

Anticosti Island: Twenhofel, 25.

Nottaway sheet: Collins, W. H., 19. Areas described.

Amherst township: Wilson, Morley E., 1.

Anticosti Island: Twenhofel, 30.

Arnprior-Quyon area: Wilson, M. E., 10.

Beauceville area: Mackay, B. R., 4.

Calumet Island, Pontiac County : Goranson, 3 .

Cléricy and Kinojevis areas, Témiscamingue and Abitibi counties: James, 4.

Coleraine sheet: Knox, J. K., 1.

Destor area, Abitibi County : Buffam, 1.

Dufresnoy area, Abitibi district: Harvie, 3.

Duparquet area: James, W. F., 1.

Eagle River area, Abitibi Territory : Mawdsley, 6.

Fiedmont and Dubuisson map areas: James, 7.

Gaspe Peninsula : Coleman, 7, 10. central: Alcock, 29.

Harricanaw-Turgeon basin, northern Quebec: Tanton, 1.

Lake David area, Chibougamau district: Mawdsley, 5 .

Lake Melville district, Labrador : Kindle, 25.

Lemieux, Gaspe County: Alcock, 14 ; Mailhiot, 1.

La Motte and Fournière areas, Abitibi County : James, 5.

Maniwaki area: Wilson, M. E., 10.

Mount Albert area : Alcock, 20 ; Mailhiot, 2.

Mount Serpentine, Gaspe: Alcock, 22.

New Quebec: Coleman, 6.

Opasatika area, Timiskaming County: Cooke, H. C., 10.

Rouyn area, Timiskaming County : James, W. F., 2.

St. Urbain area, Charlevoix Aistrict: Mawdsley, 1.
Quebec-Continued.

Areas described-Continued.

Shickshock Mountains, Gaspe: Alcock, 21.

Torngat Mountains, Labrador: Coleman, 14.

Economic geology.

Allanite, Lac a Baude, Champlain County : Harvie, 2.

Apatite deposits: Spence, 2.

Asbestos: Fisher, N. B., 1 ; Lynch, 1 ; RuKeyser, 1.

Black Lake area : Hubbard, W. D., 1. Weir township, Bonaventure County : Harie, 1.

Buckingham district: Rowe, R. C., 1. Chibougamau district: Mawdsley, 2, 4.

Copper, eastern townships: Dresser, 5. Gaspe Peninsula : Alcock, 16.

Papineau County: Wilson, M. E., $11,14$.

Rouyn area: Cooke, H. C., 20, 29.

Copper and zinc deposits, western Quebec: Dufresne, 7.

Desmeloizes and Trecesson townships: James, 6.

Dufresnoy Lake area: Harvie, 4.

Eustis mine: Hanson, 1.

Feldspar, Quetachou Manicouagan Bay : Erlenborn, 1.

Fiedmont and Dubuisson map areas: James, 7.

Gaspe Peninsula: Alcock, 19, 26, 28.

Gaspesia zinc and lead deposits: Beidelman, 1.

Gold, Dubuisson Township : Spearman,

Lake Demontigny : Mailhiot, 4.

Lake Fortune area: Goodwin, W. M., 1.

northwestern Quebec: Dufresne, 3. Temiscamingue and Abitibi counties: Dufresne, 4.

Gold belt: Goodwin, W. M., 2. northern Quebec: Wright, D. G. H., 3.

Gold fields, northwestern Quebec: Brunton, 7 ; Denis, 6.

western Quebec: Cooke, H. C., 15 ; Timm, 1.

Gold and copper, western Quebec: Cooke, H. C., 30.

Graphite: Brumell, 1 ; Spence, 6.

Buckingham district: Brumell, 2; Eardley-Wilmot, 1.

Harricanaw River gold area : Mailhiot, 3.

Harricanaw and Bell river basins : Bain, 22.

Huntingdon copper deposit, Eastman: Hore, 2.

Iron, Belcher Islands, Hudson Bay: Moore, E. S., 1.

Kaolin, Amherst township: Wilson, Morley E., 1.

Klenawisik gold district: Tanton, 1. 
Quebec-Continued.

Economic geology-Continued.

Labrador, mineral resources : Coleman, 22.

Lacorne, Abitibi, molybdenite deposits: Mailhiot, 6.

Lead and zinc: Alcock, 23.

Limestones: Goudge, 3.

Magnesite, Grenville: Bain, 1.

Maskinonge, Saint-Maurice, Champlain, Portneuf, Quebec, and Montmorency counties: Dresser, 4.

Mineral deposits, western Quebec: Dufresne, 5,6 .

Mining operations: Denis, 1-11.

Mineral resources: Drçser, 2.

Molybdenite, Lacorne and Malartic townships: Gerrie, 1.

Northern Quebec: Cooke, H. C., 12, 18 ; Opasatica area: Cooke, H. C., 11.

Northwestern Quebec: Cooke, H. C., 20.

Ore deposits, Dubuisson Township: Bain, 13.

Ore relations, Horne and Aldermac mines: Cooke, H. C., 32.

Peat bogs: Anrep, 2, 3, 6, 10.

Resorption in Grenville granite magma: Bain, 10.

Road materials, Montreal district: Gauthier, 1.

Vaudreull County : Picher, 1.

Rouyn area: James, W. F., 3, 8.

Rouyn ore bodies, structural features: MacGregor, J. G., 1.

Rouyn-Boischatel area, Temiskaming County : Hore, 9.

Serpentine belt: Knox, J. K., 1.

Structural materials, St. Lawrence Valley: Keele, 5 .

Sulphide deposits, northern Quebec: Cooke, H. C., 31.

Thetford-Black Lake district: Knox, J. K., 1.

Titaniferous magnetite deposits, Bourget township, Chicoutimi district : Robinson, A. H. A., 3.

Western Quebec: Dufresne, 10.

Wright mine, Duhamel Township : Cooke, H. C., 25.

Zinc-lead field, central Gaspe: Alcock, 29 ; Beidelman, 2 ; Mailhoit, 5.

Historical geology.

Anticosti Island: Twenhofel, 7, 12.

Archean: Cooke, H. C., 17.

Barraute area, Abitibi County, map: Bain, 8.

Bonaventure conglomerate, Gaspé : Clarke, J. M., 9.

Bonaventure formation, age: Clarke, J. M., 26.

Champlain deposits, Lake St. John : Tolmachoff, 4 .

Devonian limestone, St. George: Clark, T. H., 6,9 .

Eagle River area, Abitibi Territory: Mawdsley, 3.
Quebec-Continued.

Historical geology-Continued.

Gaspe Peninsula: Alcock, 28.

Geologic map showing mineral resources; Canada, Dept. Mines, 1.

Glacial history, Magdalen Islands : Coleman, 1.

Grenville pre-Cambrian subprovince : Wilson, M. E., 15.

Harricanaw Basin, pre-Keewatin sediments: Bain, 6.

Harricanaw and Bell river basins : Bain, 22.

Lake Demontigny region: Mailhoit, 4.

Lake Timiskaming area: Hume, 14.

Levis formation : Clark, T. H., 7, 8, 13.

Magog conglomerate : Dresser, 3.

Middle Eozoic sediments: Spearman, 3.

Mingan Islands: Twenhofel, 26.

Monteregian Hills : Howard, W. V., 1.

Northern Quebec: Cooke, H. C., 12; Opasatica area, Cooke, H. C., 11.

Original Keewatin surface, Dufresnoy township : Cooke, H. C., 27.

Paleozoic and pre-Cambrian relation. ships, southern border of Laurentian Highlands, Wilson, M. E., 7 .

Paleozoic outlier, Lake Timiskaming: Hume, 14.

Paleozoic submarine landslips near Quebec City: Balley, E. B., 2.

Percé : Clarke, J. M., 20 ; geologic map : Clarke, J. M., 2.

Philipsburg region: Bradley, J. H., Jr., 2.

Port Daniel-Gascons area, southeastern Quebec: Schuchert, 29.

Pre-Cambrian, correlation: Cooke, H. C., 7 .

northern Quebec: Cooke, H. C., 2 ; Martens, 7.

Serpentine belt: Knox, J. K., 1.

Thetford-Black Lake district: Knox, J. K., 1.

Tillite, Levis: Sayles, 6.

Upper Ordovician: Foerste, 15.

Winters in Upper Devonian of Acadia : Schuchert, 34 .

\section{Mineralogy.}

Albite, titanite, and scapolite, crystallography : Poitevin, 1.

Allanite, Labelle County : Walker, 28.

Lac a Baude, Champlain County: Harvie, 2.

Blotite, Murray Bay, pleochrolc halos: Kerr-Lawson, 2, 3.

Cacoclasite, Wakefield : Bowen, N. L., 3.

Diopside: Walker, 18.

Molybdenite, Lacorne and Malartic townships: Gerrie, 1.

Native gold in calcite, Dorchester : Dufresne, 1, 2.

Pectolite and apophyllite, Thetford mines: Parsons, 9.

Slllimanite, Romaine: Walker, 28.

Sundry minerals: Poitevin, 10. 
Quebec-Continued.

Mineralogy-Continued.

Telluride: Thomson, 14.

Thucholite and uraninite, Wallingford mine, Buckingham : Ellsworth, 20.

\section{Paleontology.}

Actinoceras, Trenton limestone, Montreal : Clark, T. H. 16.

Beekmantown series at Levis; Clark, T. H., 11.

Bothriolepis, Scaumenac Bay: Bryant, 3.

Cephalopods, Ordovician, Anticosti : Foerste, 26.

Champlain fauna, Lake St. John : Tolmachoff, 4.

Dendrocystis: Bather, 8.

Devonian starfish, Gaspe: Ruedemann, 23.

Eusthenopteron, Scaumenac Bay: Bryant, 1.

Foraminifera, Bonaventure cherts, Gaspe : Bagg, 1.

Ordovician, St. Lawrence Valley: Wilson, A. E., 2.

Pleistocene and recent fossils, St. Lawrence Valley: Whittaker, 3 .

Psilophyton, Gaspe: Edwards, W. N. 2.

Rosetted trails of worms: Clarke, J. M., 27.

Salterella, nature: Clark, T. H., 12.

Trenton fauna: Raymond, 10.

Trilobites, Beekmantown, Philipsburg region: Bradley, J. H., jr., 3.

Upper Ordovician faunas: Foerste, 15, Petrology.

Almandite, Greenville limestone, Chatham Township : Bain, 2.

Alnoite, Isle Cadieux: Bowen, 10, 11.

Essexites of Mount Royal: Bancroft, J. A., 1.

Granitic segregations in serpentine series: Dresser, 1.

Hornblendite, Cantley : Stansfield, J., 1.

Lemieux, Gaspe County: Mailhiot, 1.

Monteregian Hills, outliers: Howard, W. V., 1.

Monteregian province extensions : Stansfield, 4.

Mount Albert, Gaspe County : Mailhiot, 2.

Mount Royal contact-metamorphic zone : Dolan, 1.

Okaite: Stansfleld, J., 6.

Pre-Cambrian, northern Quebec: Martens, 7.

Syenite porphyry, Boischatel Township: Gunning, 1.

Physical geology.

Iandslide, Portneuf County: Wilson, M. E., 2

Levis formation, structure: Clark, T. H., 13.

St. Lawrence earthquake, February 28, 1925 : Abbott, 1 ; Hodgson, 8. rotation effects: Hodgson, 9.
Quebec-Continued.

Physiographic geology.

Anticosti Island, postglacial terraces: Twenhofel, 9.

Beauceville area: MacKay, B. R., 4. Gaspe driftless area: Coleman, 2.

Gaspe Peninsula ; Alcock, 17 ; Coleman, 7, 10.

Glacial periods: Coleman, 30 .

Ice conditions, northeastern Labrador : Coleman, 15.

Lake Timiskaming, a Roxen lake: Davis, 25.

Mingan Islands: Twenhofel, 26.

Plejstocene terraces: Kindle, 17.

Rivers of Gaspe: Alcock, 27.

St. Lawrence-Ottawa Valley, late glacial oscillations of level: Goldthwait, 7 .

Quebec group : Dresser, 3.

Quicksands, Brazos County, Texas : Burt 3. genesis: Burt, 2.

Quicksilver.

Anticlinal theory: Udden, J. A., 2, 6.

Arizona : Lausen, 3

Mazatzal Mountains: Hummel, 3; Lausen, 2.

Bibliography: Evans, I. P., 1, 2.

British Columbia, Kamloops Lake : Camsell, :-

Vancouver Island, Barkley Sound : Dolmage, 2.

General : Ransome, 2, 3, 7, 8, 10, 14 ; Ross, C. P., 4, 9.

Idaho: Livingston, 2.

Black Pine: Larsen, E. S., 1.

Yellow Pine district: Larsen, E. S., 3.

Mexico : Segura, 1.

San Luis Potosi, Guadalcazar : Wittich, 5, 7, 11.

Nevada, Mineral County, Pilot Moun. tains: Foshag, 32.

Oregon, Gold Hill district: Kellogg, A. E., 6.

Jackson County : Kellogg, A. E., 1.

Texas: Udden, J. A., 2.

Terlingua district: Lewis, F., 1.

Racine formation, northern peninsula, Michigan : Ehlers, 3.

Radian measures in plane-table mapping: Palmer, H. S., 3.

Radio talks; framework of the world : Leighton, H., 1 ; on oil and gas: Johnson, R. H., 7.

Radioactivity in geology: Kovarik, 1.

Radioactive minerals, calculation of ages: Holmes, A., 2.

Radium.

Carnotite ores, Colorado and Utah : Hillebrand, 2.

Colorado, Central City district, pitch. blende: Hirschi, 1.

Gateway district, carnotite ores : Farnum, 1. 
Radium-Continued.

General : Butler, G. M., 2 ; Hess, 2, 7, $8,12,13,16,19,21$; Penrose, 1. Ontario, Butt township, pitchblende: Hore, 6 ; Knight, C. W., 3.

Utah, southeastern: Williams, G. O., 1.

Radium and geology : Snowden, 1.

Ralubow Bend field, Cowley County, Kansas : Snow, 1.

Raindrops, impressions on rocks: Twenhofel, 13.

Randsburg quadrangle, California : Hulin, 3.

Rangeley conglomerate, Maine: Smith, E. S. C., 2.

Rare earths: Schaller, 4; concentration : Keyes, 267.

Rare metals: Hess, 21, 27.

Raton mesas, New Mexico and Colorado: Lee, W. T., 4.

Rawlins-Lost Soldier district, Wyoming : Krampert, $]$.

Ray quadrangle, Arizona: Ransome, 11.

Recessional streams of arid regions : Keyes, 168.

Red beds: Branson, 14; Dobbin, 4.

origin of color: Dorsey, 2.

Rocky Mountain region: Branson, 17.

Red limestones, origin : Galloway, J. J., 4.

Red Cliff district, Colorado, geology and ore deposits : Crawford, R. D., 3.

Red Lake area, Patricia, Ontario: Bruce, 18.

Red Lake Basin, District of Patricia, Ontario: Bruce, 12.

Red Rock Canyon, California : Miller, W. J., 31.

Rellef maps.

Alaska Peninsula, Aniakchak Crater: Smith, W. R., 2.

Black Hills uplift: O'Harra, 5.

California, central Coast Ranges : Dickerson, 2.

San Francisco Bay region: Dickerson, 2.

Canada, Prairie provinces: Dowling, 1.

Colorado: George, R. D., 6.

central, and New Mexico, north-central: Lee, W. T., 6.

Idaho: U. S. G. S., 10 ; Varley, 1. southeastern: Kirkham, 3.

Illinois, Chicago region: Fryxell, 1.

Lake Superior region: Winchell, A. N., 2.

Missouri : Buehler, 9 ; Keyes, 181.

Nebraska, Sioux County, Agate anticline: Schramm, 2.

New Mexico: Darton, 26.

Ohio: U. S. G. S., 9.

Oregon, western: Harrison \& Eaton, 1. Willamette Valley, Oregon: Smith, W. D., 11.

Quebec, Beauceville area: MacKay, B. R., 4.

Rocky Mountain region: Butler, 4.

South Dakota, Custer State Park: O'Harra, 5.
Relief maps-Continued.

Tennessee : U. S. G. S., 18. eastern: Stose, 17.

United States: Lobeck, 4 ; Meinzer, 6. Virginia : Stose, 16.

Washington: Leighton, 1; Patty, 3.

Wisconsin, southwestern: Blanchard, W. 0., 1.

Relief models and their construction : Reeves, J. R., 8.

Replacement and recrystallization mechanism : Fairbanks, 6.

Replacement of aluminous rocks: Dougherty, 5 .

Reptilia.

Alamosaurus, Ojo Alamo formation, New Mexico: Gilmore, 17.

Alberta : Parks, W. A., 1.

Cretaceous Dinosauria : Gilmore, 21 ; Parks, 16, 21.

Red Deer River: Sternberg, C. H., 2.

Albertosaurus arctungus, Edmonton formation, Alberta: Parks, 30.

Alligator, Snake Creek beds, Nebraska : Mook, 5.

Allognathosuchus, Wyoming: Abel, 6; Case, 19 ; Mook, 2.

Amphicoelias: Osborn, 5, 10.

Antrodemus: Gilmore, 7.

Apatodonosaurus, Jurassic, Wyoming : Mehl, 19.

Arrhinoceratops, Alberta: Parks, 20. Aspideretes, Belly River Cretaceous, Alberta : Gilmore, 19.

Barosaurus: Lull, 2 ; Wieland, 5.

Brachyccratops: Gilmore, 14.

California, Mohave Desert: Merriam, J. C., 1.

Camarasaurus : Gregory, W. K., 5 ; Osborn, $5,6,8,10$.

Dinosaur National Monument, Utah : Gilmore, 24.

Centrosaurus apertus, Belly River beds: Parks, 5.

Ceratopsia: Gilmore, 16.

carriage and use of head : Tait, 1.

skull : Sternber.', C. M., 9.

Ceratosaurus: Gilmore, $\boldsymbol{\tau}$.

Champsosaurus albertensis, Edmonton formation, Alberta: Parks, 29.

Chasmosaurus belli, integument: Sternberg, C. M., 4.

Chelys, shell : Hay, 46.

Classification: Broom, 1.

Coelophysis, Texas: Case, 21, 22.

Connecticut, North Branford, footprints : Lull, 19.

Corythosaurus, Rea Deer River, Alberta : Gilmore, 18; Parks, 10.

Cotylosaur, Triassic, western Texas: Case, 26, 27.

Crocodile, vertebrae, mechanics: Troxell, 25.

Bridger beds: Mook, 3; Troxell, 26.

Mesozoic: Mook, 8.

Wasatch beds, Wyoming: Mook, 6 . 
Reptilia-Continued.

Crocodilus acer, Manti beds, Utah: Mook, 4.

Deinodontidae, Cretaceous, Alberta : Matthew, 23, 27:

Desmatosuchus, Dockum beds, Texas: Case, 8, 12.

Dimetrodon: Romer, 8.

skull features: Case, 14.

Dimetrodon gigas: Gilmore, 3.

Dinosaur, Edmonton formation, Alberta: Sternberg, E. M., 10.

ornithomimid, Arundel formation, Maryland: Gilmore, 5.

Dinosaur feed: Wieland, 18

Dinosaur group, National Museum of Canada: Steruberg, C. M., 8.

Dinosaur National Monument, Utah: Gilmore, 23-25.

Dinosaur tracks, Cretaceous, Utah and Colorado: Peterson, W., 1.

Hamilton County, Texas: Wrather, 5.

Dinosauria : McKelvey, 1; Sternberg, C. M., 2 ; Matthew, 13 ; Alberta : Parks, 24.

Belly. River formation, Alberta : Gil. more, 18 ; Parks, 13.

carnivorous: Gilmore, 7 .

Coahuila, Mexico: Janensch, 1.

evolution: Matthew, 4.

extinction: Wieland, 20.

Red Deer region, Alberta: Sternberg, C. H., 1 ; Tyrrell, 6.

Dinosaurian climatic response: Lull, 15.

Dromaeosaurus, Alberta: Matthew, 23.

Dromatherium and Microconodon : Simpson, G. G., 5, 10.

Dromopus? woodworthi: Lull, 5.

Dyoplosaurus acutosquameus, Alberta : Parks, 12.

Edmontosaurus, Alberta : Lambe, 1.

Environmental conditions of Permian vertebrates: Case, 15.

Eosuchia, structure: Broom, 2.

Gavialosuchus americana, Florida : Mook, 1, 7 .

General: Ballou, 1.

Globidens, Mississippi : Gilmore, 34.

Histological nature of ossified tendons in dinosaurs: Moodie, 28.

Hoplosuchus, Morrison formation, Utah: Gilmore, 28.

Hyposaurus: Troxell, 27.

Hypsognathus, Triassic, New Jersey : Gilmore, 39.

Ichthyosaurian, Cretaceous, Oregon : Merriam, 27.

Ilium in dinosaurs and birds: Romer, 1.

Kansas, Niobrara group: Wiman, 1.

Kritosaurus, Belly River formation: Parks, W. A., 2, 3.

Laosnurus, Cretaceous, Alberta: Gil more, 20.
Reptilia-Continued.

Lizards, North America: Gilmore, 38.

Maryland, Arundel formation : Gilmore, 8.

New Mexico, San Juan County, Eocene and Upper Cretaceous: Gilmore, 4.

Nodosaurus textilis: Lull, 6.

Ophiacodont reptile, Permian, Kansas : Romer, 4.

Oregon, marine Cretaceous, ichthyosaurian : Merriam, 27.

Osteology: Williston, 1.

Palaeoscincus: Matthew, 22.

Paleopathology, Mesozoic: Moodie, 15.

Panoplosaurus, Belly River beds, Alberta : Lambe, 2 ; Sternberg, C. M., 1.

Parasaurolophus, Red Deer River: Parks, 7.

Pareiazauroides, West Virginia: Lull, 16.

Peltosaurus, Oligocene, Nebraska: Gilmore, 29.

Pennsylvania, Triassic: Huene, 1.

Pentaceratops, New Mexico: Osborn, 28.

Phytosauria: Moodie, 19.

brain : Mehl, 11.

Pseudopalatus pristinus, Arizona: Mehl, 18.

Triassic, New Mexico: Mehl, 9; Texas: Case, 6, 24.

secondary palate: Mehl, 12.

Primitive reptilian skull : Case, 14.

Prosaurolophus maximus, Alberta: Parks, 12.

Pterodactyls : Matthew, 7 .

Pterosaurian, Cretaceous, Oregon : Gilmore, 40.

Restorations: Gilmore, 6.

Saniwa, Bridger beds, Wyoming: Gllmore, 13 .

Saurischian dinosaurs, pelvic musculature : Romer, 2.

Sauropod dinosaur, San Juan Basin, New Mexico: Gilmore, 12.

Seymouria, Texas: Romer, 11.

South Carolina, Oligocene sea turtles: Hay, 19 .

Stelemys nebrascensis, Wyoming: Case, 18.

Stephanosaurus, crested dinosaur : Parks, 11.

Stephanospondylus: Romer, $\mathbf{5}$.

Struthiomimus, habits: Nopcsa, 1.

Struthiomimus brevetertius, Edmonton formation, Alberta : Parks, 19.

Struthiomimus samueli, Belly River formation, Alberta: Parks, 33.

Stylemys nebrascensis, South Dakota: Case, 4.

Styracosaurus, Alberta : Gilmore, 9.

Terrapene, Florida: Gilmore, 30.

Terrestrial Rhynchocephalia: Simpson, G. G., 12.

Testudo sellardsi, Florida: Loomis, 17. 
Reptilia-Continued.

Texas, Permo-Carboniferous red heds: Romer, 13.

tortolses: Hay, 18.

Triassic: Case, 16.

western, Upper Triassic: Case, 11.

Thecodontia: Huene, 2.

Thescelosaurus warreni, Edmonton formation, Alberta : Parks, 26.

Thespesius, Lance formation, Saskatchewan: Sternberg, C. M., 5.

Thoracosaurus: Troxell, 28.

Triceratops: Gllmore, 1.

Troodon validus, Belly River formation, Alberta : Gilmore, 22.

Turtles: Gilmore, 2,

Amyda nelsoni, Eocene, Wyoming: Case, 23.

armor: Hay, 46.

Kinosternon arizonense: Gilmore, 15.

Tylosaurus, western Kansas: Gilmore, 11.

Uintasaurus, Utah: Holland, W. J., 2. Utah, dinosaur footprints: Anon., 51.

West Virginia, Permian vertebrates: Tilton, 10.

Wyoming, Triassic: Branson, 19 ; Phytosauria: Meh], 19.

Resin, fossil : Steele, 1.

Restorations.

Aletomeryx : Lull, 4.

Anchitherium agatense: Romer, 6 .

Antrodemus: Gilmore, 7.

Blastomeryx marshi: Lull, 10.

Bracheosaurus: McKelvey, 1.

Brachyceratops: Gilmore, 4.

Camarasaurus: Osborn, 6, 10.

Dinosaur National Monument, Utah : Gilmore, 24.

Ceratosaurus: Gilmore, 7 .

Daphoenus, Sloux County, Nebraska: Thorpe, 20 .

Dimetrodon: Romer, 8.

Dimetrodon gigas: Gilmore, 3

Dolichorhinus : Peterson, 7 .

Elephants: Osborn, 35.

Eospermatopteris: Goldring, 5.

Eporeodon: Thorpe, 8, 16.

Eusthenopteron: Bryant, 1.

Fishes, Mlocene, California: Jordan, 5, 6, 15 ; Anon., 17.

Niobrara: Jordan, 14.

Helderberg fauna : Clarke, J. M., 5. .

Hoplosuchus, Morrison formation, Utah: Gilmore, 28.

Horses : Gidley, 10.

Hyrachyus: Troxell, 17.

Hyracodon apertus: Sinclalr, 6.

Mammalia, Black Hills region : O'Hara, 3.

Mastodion: Clarke, J. M., 23 ; Osborn, $27,35$.

Cohoes, New York: Clarke, N. T., 2.:

Merychyus, Peterson, 5 . $4096-31-61$
Restorations-Continued.

Merycoidodon, Sloux County, Nebraska : Thorpe, 20, 26.

Methods and examples: Abel, 1.

Mylodon: Stock, 13.

Nothrotherium : Stock, 13.

Palaeoscincus: Matthew, 22.

Parasaurolophus: Parks, 7.

Plants: Berry, 14.

Prosaurolophus maximus, Alberta : Parks, 12

Pterodactyls: Matthew, 7.

Quaternary vertebrates: Osborn, 9.

Reptilia: Gilmore, 6; Williston, 1.

Seymouria, Texas: Romer, 11.

Sparganium antiquum: Berry, 61.

Struthiomimus: Nopesa, 1.

Styracosaurus, Alberta: Gilmore, $\mathbf{9}$.

Triceratops: Gilmore, 1, 16.

Trilobite, ventral surface: Raymond, 8 .

'Troodon validus: Gilmore, 22.

Tylosaurus, western Kansas: Gil. more, 11.

Tyrannosaurus, pelvic musculature: Romer, 2

Vertebrates: Lucas, F. A., 1.

Reynosa formation, lower Rio Grande region : Trowbridge, 11.

Rhizocretions: Kindle, 36.

Rhode Island.

Economic geology.

General: Thomas, K., 1.

Granite: Dale, T. N., 4

Historical geology.

Dighton conglomerate, origin: Perkins, E. H., 1.

Nurragansett Basin: Round, 5 .

Mineralogy.

Apatite, South Foster: Hawkins, A C., 2.

Epidote, Pascoag: Hawkins, A. C., 2.

Hematite, Manton: Hawkins, A. C., 2.

Mineral localities: Fisher, L. W., 4

Providence County: Fisher, L. W., 2.

Veins of fibrous quartz and chlorite: Richards, G., 1.

Paleontology.

Annularia with Paleostachya fruit: Round, 3.

Coal. floras, Narragansett Basin : Round, 5.

Crossotheca, Carboniferous: Round, 1.

Flora, Carboniferous: Round, 4.

Physiographic geology.

Postglacial river changes: Brown, C. W., 2.

Postglacial uplift: Fairchild, 7.

Rice Lake area, southenstern Manitoba Wright, J. F., 3.

Richfield oil field, California: Musser, 3 . Riddle quadrangle, Oregon: Diller, 12. Rigidity of the eqrth: Michelson, 1.

Ripple marks: Bucher, 1; Kindle, 20 ; literature: Kindle, 28.

River capture. See Stream capture.

River pebbles: Wentworth, 8. 
Rivers.

Arid regions: Keyes, 122.

Colorado River: Pack, 5; Waldorf, 1. Dallas type of river channel : Bretz, 7 . Fraser River: Johnston, W. A., 8.

Glacial diversion of the Missouri River: Todd, J. E., 6.

Gunnison River, Colorado, course : Branson, 7.

Intercision, Pike River, Wisconsin: Ball, J. R., 1.

Missouri River: Greene, 2 ; channel, age: Todd, J. E., 5.

Ohio River, genesis : Fowke, 1.

Physiographic features: Hill, R. T., 7. Quebec, Gaspe: Alcock, 27.

Recessional streams of arid regions: Keyes, 168.

Red River, Oklahoma-Texas: Hin, R. T., 7 ; Sellards, 17, 18; Tex., Atty. Gen., 1.

Red River of the North: Wallace, 17. Sand rivers: Hill, R. T., 6.

Scenery, origin : Johnson, D. W., 3.

South Canadian River near Norman, Oklahoma: Evans, O. F., 3.

Susquehanna River: Fairchild, 16.

Tennessee River: Adams, G. I., 5.

Underground rivers: Reeds, 16.

Road materials.

Arkansas: Branner, J. C., 2.

General: Bean, 1.

Kentucky : Richardson, C. H., 9.

Mississippi : Lowe, 4.

New Hampshire: Goldthwait, 3.

New Brunswick: Picher, 3.

Nova Scotia: Picher, 3.

Oklahoma, western : Evans, O. F., 7.

Ontario, eastern: Picher, 2, 4.

Quebec, Montreal district: Gauthier, 1.

Vaudreuil County : Picher, 1.

Saskatchewan, Regina area: Reinecke, 1.

Texas: Nash, 1.

Washington: Leighton, M. M., 1.

Wisconsin: Bean, 2.

Robberson field, Garvin County, Oklahoma : Denison, A. R., 1.

Rochester district, Nevada, geology and ore deposits: Knopf, A., 7.

Rochester quadrangle, Vermont: Foye, 1.

Rock classification for engineering: Pirsson, 1 ; Smith, W. D., 2.

Rock distortion in oklahoma oil fields: Gardner, J. H., 1.

Rock glaciers, Utah, La Sal Mountains : Gould, L. M., 4.

Rock oil, origin : Singewald, Q. D., 1.

Rock pressure: Heroy, 1.

Rock products and the war: Loughlin, 3 .

Rock rivers: Bailey, V., 1

Rock slides. See Landslides.

Rock tanks, Arizona, Papago country : Bryan, 15.

and charcos, origin: Bryan 5.
Rock-forming minerals, microscopical determination in sections: Johannsen, 6.

Rocks, structural features. See also Igneous and volcanic rocks; Sedimen. tary rocks.

Cone-in-cone: Tarr, 11.

Coquina, Florida; Brodie, 1.

Crystalline schists, origin : Keyes, 22.

Ice crystals, fossil : Udden, J. A., 1.

Imbricated structure in river gravels: Johnston, W. A., 16.

Intraformational corrugated rocks : Miller, W. J., 17.

Mud cracks on steeply inclined sur. faces: MacCarthy, 1.

Ripple marks: Bucher, 1.

Rock distortion in Oklahoma oil fields : Gardner, J. H., 1.

Strand markings in Pennsylvania sandstones, Osage County : Powers, 6.

Zircon as a criterion of origin of metamorphosed rocks: Armstrong, P., 2.

Rocks and rock minerals : Pirsson, 6.

Rocky Bar district, Idaho: Schrader, 7.

Rocky Mountain structure: Flint, R. F., 1. Romance of geology: Mills, E. A., 1.

Rotational velocity of earth and its geological effects : Daly, 14

Rounding of sand grains by solution Galloway, J. J., 2.

Rouyn area, Timiskaming County, Quebec: James, W. F., 2.

Roxbury, Vermont, terranes : Richardson, C. H., 3.

Rubidium : Landes, K. K., 7

Rutile.

Florida, beach deposits: Martens, 9.

Sabine uplift, Louisiana : Powers, 2.

Sacramento Valley, California: Bryan, 10.

St. Bartholomew.

Tertiary calcareous Algae: Howe, M. A., 1.

St. Croix Island, geology : Vaughan, 11.

St. Kitts, geology : Earle, 6.

St. Lucia : Earle, 2, 4, 5.

St. Maries region, Idaho: Anderson, A. L., 4.

St. Peter sandstone: Dake, 6, 8.

complexity : Keyes, $\mathbf{5 0 .}$

derivation: Dake, 7.

St. Vincent: Earle, 7.

St: Vincent and neighboring Grenadines, geology : Earle, 9, 10.

Salado arch, Nuevo Leon and Tamaulipas, Mexico: Jones, R. A., 3.

Salina Canyon district, Sevier County, Utah : Spieker, 6.

Saline domes. See Salt domes.

Saline lakes, Mohave Desert: Foshag, 24.

Salmon River district, British Columbia: O'Neill, 4; Schofield, 11.

Salt.

Canada : Cole, L. H., 2, 3.

Deposition, principles: Grabau, 9.

General : Stone, 5, 14. 
Salt-Continued.

Gulf coast salt domes: Wolf, 1 ; secondary intrusive origin: Matteson, 2.

Louisiana, Five Islands: Vaughan, F. E., 2.

interior salt domes: Spooner, 2.

Mexico, Colima, Cuyutlan area: Paredes, 3 .

Puebla: Wittich, 28.

New York: Alling, 14; Newland, 2.

Nova Scotia, Malagash: Chambers, 1; Cole, L. H., 1, 3 ; Ellsworth, 9 ; Hayes, 2, 5 ; Moffatt, 1.

Oklahoma: Gould, C. N., 29.

Origin : Phalen, 1.

New York: Alling, 14.

Permian deposits, south central United States: Darton, 8.

United States: Phalen, 1.

\section{Salt domes.}

Colorado, western : Harrison, T. S., 3. Economic importance: Barton, 17.

Formation: Lajous, 3 .

General: Barton, 9; Brantley, 1; DeGolyer, 7 ; Wolf, 1.

Geology of salt dome oil fields: DeGolyer, 17.

Gulf Coastal Plain: Stephenson, 16.

Gypsum in Gulf salt domes : Barton, 3. Louisiana: Thacker, 1.

Bayou Bouillon salt dome, St. Martin Parish: Donoghue, 2.

Five Islands: Vaughan, F. E., 2. interior salt domes: Spooner, 2.

Many salt dome, Sabine Parish: Howe, H. V. W., 7.

Pine Prairie salt dome: Barton, 7.

Prothro salt dome, Bienville Parish : Hull, 13.

Section 28 salt dome, St Martin Parish : Donoghue, 3.

Sulphur salt dome: Kelley, 1.

Vinton salt dome, Calcasieu Parish : Thompson, S. A., 1.

Mexico, Tampaulipas, Chapeño salt dome : Belt, 1.

Tehuantepec Isthmus: Ver Wicbe, 2 , 5,7 .

Origin: Barton, 2, 4; DeGolyer, 14 15 ; Hixon, 1; Powers, 12; Pratt, W. E., 4 ; Rogers, G. S., 4 ; Wolf, $1,4$.

by isostatic adjustment: Albertson, 1 . secondary intrusive: Matteson, 2. cxperimental study: Torrey, P. D., 1. intrusive origin, Gulf coast: Rogers, G. S., 3.

volcanic origin theory: DeGolyer, 2. Potash salts and algae in deep boring: DeGolyer, 14.

Salt cores, origin: Washburne, 3, 4.

Salt dome waters: Minor, 1.

Stratigraphy, Gulf Coastal Plain: Shaw, 4.

Structure: Lucas, A. F., 1.
Salt domes-Continued.

Texas: Ellisor, 3 ; Jones, R. A., 6 ; Renick, 12.

Barbers Hill oil field, Chambers County : Bevier, 2.

Batson oil field, Hardin County : Sawtelle, 1.

Big Hill salt dome, Jefferson Coun. ty : Hanley, 1.

Big Fill salt dome, Matagorda County : Wolf, 5.

Blue Ridge salt dome, Fort Bend County : Hager, D. S., 2.

Bryan Heights salt dome: Kennedy, 1.

Butler salt dome: Powers, 3.

Damon Mound oil field: Bevier, 1. Fort Bend County: Fratt, W. E., 5.

Hockley dome, Harris County : Chapman, 1; Deussen, 2.

interior salt domes: Powers, 17.

Lost Lake salt dome: Wasson, 1.

Moss Bluff and Boggy Creek domes: Pratt, 14.

northeastern: Cheney, C. A., 1.

Palangana salt dome: Barton, 1 .

Saratoga oil field: Suman, 1.

South Dayton salt dome : Bowman, 1. southern: Barton, 4.

Spindletop salt dome: Barton, 5.

Stratton Ridge salt dome: Applin, P. L., 1.

West Point salt dome: DeGolyer, 1. Utah, southeastern: Harrison, T. S., 3 ; Prommel, 2.

Salt dome cap rock, petrography: Goldman, 12 .

Salterella, nature: Clark, T. H., 5, 12.

Salton Sea region, California : Brown, J. S., 3.

Salts, natural: Grabau, 9.

Salvador.

General : Larde, 3.

Physical geology.

Earthquake, September 6, 1915: Larde, 1.

Izalco Volcano: Heim, 4 ; Larde, 2, 4 ; eruption, November, 1926 : Bock, 1.

San Silvidor, eruption : Friedlander, 1. Samplograple: Gardner, J. H., 7.

Sand. See also Glass sand; Silica.

Florida : Martens, 8

General: Stone, 3, 7, 1.2; Teas, 1; Weigel, 2.

Georgia: Teas, 1.

Indiana, molding sand: Hole, 1.

Minnesota: Knapp, G. N., 1.

Missouri: Dake, 1.

Nebraska : Condra, 1.

Nova Scotia, Melford, Cape Breton Island: Guernsey, 1.

Ontario: Ledoux, A., 1. northern: Keele, $3,4$.

South Dakota, eastern: Rothrock, 1. Minnehaha County: Rothrock, 5.

Yankton County: Rothrock, 3. 
Sand-Continued.

Texas, Trinity River district: Shaw, E., 1.

Wisconsin, molding sands : Trainer, 3. Sand chrome ore, Maryland: Singewald, 2. Sand dunes, Lake Michigan: Parkins, 1.

Sand grains, measuring roundness: Cox, E. P., 1.

Rate of wear; Anderson, G. E., 1.

Rounding: Anderson, G. E., 3; by sen urchins: Kindle, 2 ; by solution: Galloway, J. J., 2.

Study of: Galloway, J. J., 3.

Sandstone.

Cementation in sandstone: Johnson, R. H., 1

Structure and origin : iGalloway, J. J., 3 Sandstone dikes, South Dakota: Lawler, 1. San Gabriel Mountains, California, southwestern, geomorphology: Miller, W. J., 33.

San Juan Canyon, southeastern Utah : Miser, 14, 17.

San Lorenzo group, San Emigdio region, California: Wagner, C. M., 1.

San Marcos quadrangle, Texas: Brucks, 2. San Onofre breccia, California: Woodford, 3. Santa Fe district, Mineral County, Nevada. Clark, C. W., 2.

Santo Domingo. See Dominican Republic. Sapphires, Montana: Harstad, 1.

Saskatchewan.

Areas described.

Eastend area, Cyress Hills: McLearn, 16.

Flinflon area : Alcock, 15.

Riverhurst district: Warren, 5 .

Wapawekka and Deschambault lakes area: DeLury, 6.

Economic geology.

Carbon ratios: Jones, I. W., 1.

Cretaceous shale: Ells, 2.

Flinflon ore body: Wallace, 5 .

Iron, Lake Athabaska: Allan, 10.

Lignites: Lee, R. J., 1; MacLean, 1. Nolthern Saskatchewan: Bruce, 13.

Oil exploration, Pasquia Hills: Wallace, 6.

Oil prospecting: Dowling, 8 ; Ness, 1. Oil prospects, Battle River: Hume, 20.

Road materials, Regina area : Reinecke, 1.

Sodium and magnesium salts: Cole, L. H., 10.

Souris coal field: Dowling, 11.

Southeastern Saskatchewan: Stansfield, J., 1.

The Pas mineral belt: Alcock, 18 .

Volcanic ash near Waldeck: Cole, L. H., 8 .

Historical geology.

Athabaska series : Alcock, 5 .

Battle River: Hume, 20.

Borings : Dowling, 3.

Correlation: Dowling, 2.
Saskatchewan-Continued.

Historical geology-Continued.

Lance formation, southern Saskatchewan : Stelnberg, C. M., 3.

Northern Cordilleran geosyncline: Fisher, C. A., 2.

Pasquia Hills: Wallace, 6.

Southern Saskatchewan: Dyer, 10: Sheppard, 1.

Surface deposits, southeastern Sas katchewan : Stansfield, J., 1.

Mineralogy.

Annaheim meteorite: Johnston, R. A. A., 1.

Heavy minerals in sand horizons: Wallace, 23.

Petrology.

Norite rocks, Lake Athabaska region: Alcock, 7 .

Eastend area, Cypress Hills: Fraser, 2. Paleontology.

Neomeryx finni, Dundurn: Parks, 22.

Thespesius, Lance formation: Steinberg, C. M., 5.

Physical geology.

Banded precipitates of vivianite in fire clay, Claybank: Stansfield, 3.

Corrosion by saline waters, Senlac Lake : Rutherford, 1.

Physiographic geology.

Lake Athabaska, origin : Alcock, 6.

Saratoga oil field, Hardin County, Texas: Suman, 1.

Sault Ste. Marie area, District of Algoma, Ontario: McConnell, 1.

Saunders Creek and Nordegg coal basins, Alberta : Allan, 9.

Sayre oil and gas field, Beckham County, Oklahoma : Birk, 1.

Scablands of Columbia Plateau, Washington: Bretz, 6 .

Scaphopoda, Trinidad, Miocene : Mansfield, W. C., 2.

Schwagerina: Beede, 9.

Scobey lignite field, Valley, Daniels, and Sheridan counties, Montana: Collier, 9.

Scree, Triassic, Connecticut Valley: Reynolds, 1.

Seasonal deposition in aqueo-glacial sediments: Sayles, 1.

Seasonal records of geologic time: Reeds, 4.

Secondary enrichment. See Ore deposits, origin.

Section 28 salt dome, St. Martin Parish, Louisiana: Donoghue, 3.

Sedimentary ripples: Bucher, 1.

Sedimentary rocks. See also Petrology.

Algonkian sediments, quantitative study: Trowbridge, 4.

Analysis of sediments : Trowbridge, 10.

Arbuckle limestone, Oklahoma: Decker, 8.

Banded clays: Sayles, 1 . 
Sedimentary rocks-Continued.

Basal glauconite and phosphate beds: Goldman, 10.

Bend and . Ellenburger limestones, Texas, microscopic characteristics : Udden, 4, 23.

Bend series sediments: Waite, 1.

Black shale formation: Goldman, 11.

Boring, Palo Pinto County, Texas: Goldman, 8.

Caliche, formation: Udden, 16.

California, Sespe formation, origin: Gianella, 1.

South Mountain, Sespe formation: Reinhar't, 1.

Ventura quadrangle, Pico formation : Cartwright, L. D., 2.

Chester series limestones, sedimentary analysis: Lamar, 7.

Classiflcation: Field, 5.

Clastic sediments, nomenclature: MacKenzie, 6.

Color chart: Goldman, 15.

Colors produced by iron in minerals and the sediments: MacCarthy, 5.

Contact of Ellenburger and Boone limestones, Texas: Goldman, 16.

Continental: Keyes, 174.

Correlative value of heavy minerals: Tickell, 1.

Description and nomenclature: Tieje, 2.

Desert sedimentary deposits: Blackwelder, 26.

Dighton conglomerate, origin : Perkins, E. H., 1.

Examination of well cuttings: Trager, 1.

Feldspars: Carlson, 1.

Glacial sediments: Leighton, 22.

Glauconite: Schneider, 3.

association with unconformities : Goldman, 7.

Gravitational compaction, effect on sedimentary rocks: Hedberg, 1, 2; Rubey, 8; Straub, 1.

Green River formation, Wyoming, shore phases: Bradley, W. H., 5 .

Green River shales: Bradley, W. H., 3. Illinois, St. Peter sandstone: Lamar, 1.

Iron sulphide in coal and other sedimentary rocks: Newhouse, 3.

Kansas, Woodson County: Twenhofel, 8.

Laminated anhydrite, Texas: Udden, 18.

Iimestones: IIowell, J. V., 3 ; nomenclature: Kindle, 23.

Lithologic correlation: Goldman, 5.

Marlite balls : Kindle, 22.

Michigan, Sulphur Island : Ehlers, 8.

Microscopic structure of rocks : Lamar, 2.

New York, middle Portage rocks, sedimentation conditions: Sheldon, 5.
Sedimentary rocks-Continued.

Oklahoma, Carter County boring: Roth, 2.

Ordovician and Mississippian limestones, petrology at their contact in Texas: Goldman, 14.

Organic material of carbonaceous shales: Rae, 2.

Oriskany sandstone with celestite ce ment: Stow, 1.

Paleozoic altered volcanic materials: Ross, C. S., 21.

Petrographic characters: Alling, $z$

Pyroclastic rocks: Wentworth, 22.

Quantitative determination of rock color: Grawe, 3.

Rancho La Brea tar beds, California, mode of accumulation: Gilbert. J. Z., 2.

Red beds of Front Range of Colorado: Tieje, 3.

Red color in sediments: Glock, 5; Raymond, 34.

St. Peter sandstone, Illinois : Lamar, 9.

Salina formation: Newland, 9.

San Onofre breccia, California: Wood ford, 3.

Saskatchewan, Cypress Hills, Eastend area: Fraser, 2.

Scale of hardness and cohesion: Kin. dle, 44.

Schedule for field description: Goldman, $6,9$.

Sedimentary materials, preparation for study: Ross, C. S., 18.

Shale, fissility, and its relations to petroleum: Lewis, 9.

Shoestring sands, origin: Rich, 6.

Siliceous shale formation: Reed, R. D., 13.

South Carolina, white clays: Neumann, F. R., 2.

Stratification and time relations: Ud. den, 11.

Study and correlation by petrographic methods: Milner, 3.

Subaerial sun cracks: Schwartz, J. H., 8.

Terms for clastic sedimens: Wentworth, 9.

Terrestrial: Keyes, 174.

Texas, characteristics: Udden, 12.

'Till and stratified clay, microscopic sections: Sayles, 4.

Triassic: Roberts, J. K., 8.

Varve materials and banded rocks: Wallace, 20.

Varved glacial clay, conditions of formation: Antevs, 9.

Varved glacial deposits: Anters, 6, 18.

Varves, formation: Fraser, H. J., 1. Verden sandstone, Oklahoma: Reed, 3.

Weight: Lane, 10.

White River beds: Wanless, 1.

Wyoming, Cambrian : Tieje, 2. 
Sedimentation. See also Conglomerate Erosion.

Abstraction of potassium during sedimentation: Watson, J. W., 1.

Algal deposits: Twenhofel, 3.

Algae as limestone makers and climatic indicators: Glock, 3.

Alberta, Lake Louise: Johnston, W. A., 15.

Arctic ice, distribution of sediments by : Kindle, 27.

Arizona, Papago country : Bryan, 7.

Atlantic coast sediments: Kindle, 34 .

Bacterial agencies: Thiel, 13.

Bacterial deposition: Breger, 1; Parry, 1.

Bahama Bank: Field, 9.

Bahamas, bottom samples : Vaughan, 19.

Barrell's work on sedimentation: Vaughan, 20.

Bay of Fundy: Kindle, 42.

California, San Francisco Bay : Louderback, 1 .

Chemical researches on sediments: Merwin, 4.

Chemical studies: Steiger, 1.

Chemical and physical researches : Wells, 6.

Chemistry: Clarke, F. W., 2.

Climatic conditions when coal beds were formed: Brown, T. C., 2.

Coarse sediments: Wentworth, 40.

Colloidal products of rock weathering, distribution: Wallace, 9

Committee on sedimentation, report; Twenhofel, 34.

work of: Vaughan, 15.

Cycles in glacial and postglacial deposits: Anters, 3.

Detrital constituents in a reef sand, Bahamas: Goldman, 17.

Diagenesis: Schuchert, 12.

Differential compression of sediments : MehI, 7.

Fraser River delta, British Columbia: Johnston, W. A., 8, 9, 12.

Gabilan Mesa, Coast Ranges, California, soil deposition: Reed, $R$. D., 10 .

General : Clements, 1 ; Louderback, 1 ; Shaw, 5, 7; Twenhofel, 16, 18, 22, 29 ; Vaughan, 10, 33.

Inequalitiss of sedimentation: Kindle, 3.

Investigation of marine sediments : Väughan, 25.

Iowa, status of sedimentation studies: Trowbridge, 8.

Jaundiced snow: Keyes, 227.

Lake Huron winter beach forms: Littlefield, 1 .

Lake Ontario, bottom deposits : Kindle, 35.

Marine sediments: Field, 8.

Marl deposition : Kindle, 45.
Sedimentation-Continued.

Mechanical analysis:- Fraser, 2; Wentworth, 27 ; accuracy : Wentworth, 32 .

Minerals deposited by bacteria in mine waters: Parry, 1.

Mississippi River, Davenport to Cairo: Lugn, 7.

Oklahoma, Red River: Evans, O. F., 1.

Ontario, Cobalt Lake: Albertson, 1.

McKay Lake, bottom deposits : Whittaker, 4.

Organic material of carbonaceous shales: Washburne, 5.

Red River of the North: Wallace, 17.

Research in sedimentation: Twenhofel, 28.

Ripple marks : Bucher, 1.

Sand grains, study of: Galloway, J. J., 3.

Sediment, collecting samples from Mississippi River: Lugn, 2.

Sedimentary processes on volcanic islands: Wentworth, 24.

Sediments and climate: Vaughan, 24.

Sediments carried out by Mississippi River: Trowbridge, 12.

Soil studies: Bennett, 2.

Source beds of petroleum: Trask, 10.

Stream aggradation through irrigation: Reagan, 10.

Studies: Posnjak, 2; in universities: Moore, E. S., 3 ; Twenbofel, 10.

on organic nature of sediments: Trask, 8.

Submarine denudation: Bucher, 12.

Thermal stratification of water in lacustrine sedimentation: Kindle, 45.

Treatise on : Twenhofel, 21.

Types of sediments, Pacific Islands : Wentworth, 33

Utah, débris of desert torrents: Pack, 6.

Variation in sediments: Twenhofel, 12.

Seismology. See also Earthquakes.

Aleutian Islands: Neumann, 7.

Apparatus for seismic measurements: Kirkpatrick, P., 2.

Azimuth determination in earthquakes: Urrutia, 1.

Berchmans seismograph : Neumann, E. M. S., 1.

Bibliography: Hodgson, 16; Seism. Soc. Am., 1.

California: Willis, 34.

Lassen Peak Observatory: Finch, R. H., 9.

seismic forces: Willis, 30.

seismological investigation: Day, 8.

Coast and Geodetic Survey, seismological work: Heck, 3.

Canada: Hodgson, 11. 
Seismology-Continued.

Committee on seismology, report: Day, 8.

Cooperation in seismology: Day, 13.

Depth and twofold character of earthquake origins: Oldham, 1.

Depth of focus of recent earthquakes in California: Byèrly, 3.

Difficulties in study of local earth movements: Day, 21.

Dispersion of energy without dispersion of frequencies in transverse elastic waves in the earth: Byerly, 9.

Earthquake frequency: Cotton, 1.

Earthquake records made by well recorder's : Stearns, H. T., 13.

Earthquake rifts, aerial observation: Wills, 7.

Earthquake shock in alluvial areas: Vickery, 2.

Earthquake waves, analysis: Klotz, 2.

Earthquake zones of the Pacific: Omori, 1.

Earthquakes and isostasy: Bowie, 25.

Epicenters: Davis, W., 4.

determining: Neumann, F., 1.

locating the epicenter of an earthquake: Makemson, 1.

location: Doxsee, 12.

Forecasting of earthquakes: Rickard, 6.

General : Day, 14, 19, 22, 24 ; Jones, E. L., 1; Macelwane, 1; Townley, 1; Vaughan, 43; Willis, 29.

Geologic theory of earthquakes: Montessus de Ballore, 1.

Greater Antilles seismic belt: Taber, 7 .

Hawaii, earthquake prediction: Finch, R. H., 4.

Hawaiian lava column, seismometric investigation: Jaggar, 2.

History: Tondorf, 9.

Impact a cause of earthquake?: Macelwane, 15.

Interior of the earth, nature: Adams, L. H., 1.

Isoseismal lines, construction and use : Davison, 1.

Isostasy, relation to earthquakes: Bowie, 22.

L waves, variable velocity: Hodgson, 2.

Measurement of time on seismograms: Byerly, 8.

Mexico: Muñoz Lumbler, 1.

Milne-Shaw seismograph : McComb, 1.

Minute cooling effect revealed by seismograph : Hodgson, 12.

Monthly reports: Humphrey, 1.

Moon's influence on earthquakes: Reid, H. F., 18.

Piezo-electrical accelerograph: Wood, H. 0., 3.

Prediction of earthquakes: Keyes, 142.

Prohlems : Heck, 7 ; Reid, 6.
Seismology-Continued.

Progress of seismological investigations: Heck, 9.

Propagation of earthquake waves: Williamson, 1.

Record of surface waves: Reid, 10.

Recording seismologic data at Ottawa: Hodgson, 6, 7 .

“Regional" and "world" seismology : Wood, H. O., 2.

Report of advisory committee on seismology: Day, 7, 14, 19.

Reports of earthquakes: Wood, H. $0 ., 5$.

Scales of seismic intensity : Davison, $\mathbf{J}$.

Seismic instruments and seismic service: Mohorovicic, 1. .

Seismic measurements by overthrow of columns: Kirkpatrick, F., 1.

Seismic waves: Sosman, 13.

Seismic waves and surface layers of the earth : Byerly, 14.

Seismograms: Tondorf, 8; interpretation: Reld, H. F., 14.

Seismograph, Chicago: Hibbard, F. N., 1.

long-period : Romberg, 1.

nontilt: Romberg, 2.

on a new principle: Morize, 1.

temperature control: Hodgson, 4 .

Seismograph and friction: Reid, 13.

Seismographic stations: Macelwane, 17.

Seismographs, influence of friction: Reid, 15.

Seismological investigation: Day, 6.

Seismological terms: Davison, 2.

Seismological Society of America, eastern section: Anon., 56 .

work: Willis, 25.

Seismological tables: Macelwane, 18. Seismological work, Canada: Hodgson, 13, 15.

Carnegie Institution of Washington: Day, 23.

Coast and Geodetic Survey: Heck, 11 ; Jones, E. L., 2.

Jesuit Seismological Association : Macelwane, 21.

Status and needs: Humphreys, 3.

Status of seismological work: Klotz, $1,3$.

Superflcial factors in seismic and volcanic activity: Sayles, 20.

Surface wave velocities in North America: Neumann, 8.

Tables of earthquake waves reflected at a discontinuity of fifty kilometers: Byerly, 4.

Torsion seismometer : Anderson, J. A., $1,2$.

United States Weather Bureau investigation: Marvin, 1.

Velocity of seismic waves: Byerly, 5 . Selenium : Cahen, 1 ; occurrence $\cdot$ Lenher, 1. 
Self-compression of the earth : Chamberlin, T. C., 9.

Seminole uplift, Oklahoma: Powers, 23.

Septaria, Pennsylvanian shale, Missouri : Grawe, 2.

origin : Lugn, 1.

Serpulites, hydrozoan affinities: Price, W. A., 3.

Shaded topographic maps: Davis, 22.

Shale.

Fissility and its relations to petroleum : Lewis, 9 ; origin : Lewis, 9.

Illinois, Colchester and Macomb quadrangles: Hinds, H., 1.

Indiana : Logan, 19.

Iowa: Galpin, 2.

Kansas, Arkansas City: Teetor, 1.

Michigan : Brown, G. G., 1.

Minnesota: Grout, 1.

Ontario: Keele, 8.

abitibi and Mattagami rivers: Keele, 2.

South Dakota, Cretaceous shales, analytical examination: Waterman, 1.

Virginia: Ries, 3.

Washington: Wilson, H., 2.

Shale oil : McKee, 1.

Shapes of pebbles: Wentworth, 8 .

Shawangunk formation, age and origin : Willard, B., 3.

Shingle: LaForge, 2.

Shiningtree silver area, District of Timiskaming, Ontario : Langford, 1.

Shore lines. See also Beaches; Terraces.

Atlantic coast, shore line investigations: Johnson, D. W., 15.

Changes affecting sea level: Johnson, D. W., 17.

Development: Johnson, D. W., 1.

General : Johnson, D. W., 1, 8.

Michigan, Elsie and Perrinton quadl'angles: Loverett, 2.

New England-Acadian shore line: Johnson, D. W., 8.

North Carolina, Cape Hatteras: Rude, 1.

Ontario, Lake Erie, Point Pelee: Kindle, 11.

Shore lines (abandoned). See also Glacial lakes; Terraces.

Indiana, northwestern: Cressey, 1.

Michigan, Saginaw basin: Leverett, 6 . Shore processes: Johnson, D. W., 1.

Shrinkage of the earth: Chamberlin, T. C., 4 ; Stille, 1.

Silica.

Canada, eastern : Cole, L. H., 5.

western : Cole, L. H., 13.

New York : Colony, 1.

Pennsylvania: Moore, E. S., 6.

Solution and precipitation in cold water : Lovering, 1.

Silicification of erosion sulfaces : Leith, 14 ; Tarr, 16.

Sillimanite-schist inclusions in granite : Miller, W. J., 16.
Silurian. See also Paleontology, Silurian. For Lower Silurian see Ordovician.

Acadia : Bailey, L. W., 2.

Alabama: Butts, 8 ; Jones, W. B., 13.

Bessemer and Vandiver quadrangles : Butts, 13.

Clinton formation: Aldrich, T. H., 2

Alaska, Chandalar district: Mertie, 12. interior: Mertie, 13.

Arctic regions, Ellesmere Land: Holtedabl, 1.

Arizona : Keyes, 83.

Arkansas: Miser, 4, 7, 11.

Batesville district: Miser, 8.

Hot Springs district: Purdue, 1.

British Columbia, Beaverfoot-BriscoStanford Range: Walcott, 9.

Silurian tillite: Shepard, 1.

Windermere area, Kootenay district: Walker, J. F. 1.

Correlation: Alling, 14.

General: Ulrich, 8 ; Weigel, 2.

Georgia: McCallie, 1.

Greenland, Böggild, 1. northwestern: Koch, 1. northern: Koch, 4.

Peary Land: Koch, 3.

Iudson Bay area: Foerste, 22.

Idabo, Fort Hall Indian Reservation: Mansfield, G. R., 3.

southeastern : Mansfield, 29.

Illinois: Savage, 16.

Calhoun County: Lamar, 6.

Herscher quadrangle: Athy, 1.

Joliet quadrangle : Fisher, D. J., 2.

Mississippi Valley : Krey, 2.

Orchard Creek shale: Savage, 1.

Indiana : Cumings, 1 ; Logan, 15.

Niagaran : Shrock, 2 ; Cumings, 3.

northern, coral reefs: Cumings, 3 .

Iowa, Lake Calvin region: Schoewe, 6.

Kansas, Salina Basin : Barwick, 1.

Kentucky : Miller, A. M., 1.

Allen County: Miller, A. M., 5; Shaw, E. W., 1.

Barren County: Butts, 2.

Berea region: Burroughs, W. G., 5 . enst central : I'oerste, 14.

Jeptha Knob: Bucher, 9.

Knob region: Burroughs, W. G., 4.

Monticello quadrangle: MacLachlan, 1.

Little River group delta: Matthew, G. F., 1.

Mackenzie, Franklin Mountains: Willians, M. Y., 14.

Great Slave Lake region: Cameron, 1 ; Hume, 2.

lower Mackenzie Valley: Kindle, 9.

Mackenzie River district: Willams, M. Y., 13.

Mackenzie River between Norman and Beaver River: Hume, 5. 
Silurian-Continued.

Maine: Perkins, E. H., 2.

Kennebec River to Penobscot Bay: Perkins, E. H., 3.

Manitoba: Wallace, 14.

Hudson Bay region: Savage, 2.

Maryland: Prouty, 9 ; Swartz, C. K., $6,7$.

Massachusetts, Essex County : Foerste, 6.

Michigan, Chippewa County: Ver Wiebe, 11.

northern peninsula, $\mathrm{N}$ i a g a $\mathrm{r}$ a $\mathrm{n}$ : Ehlers, 4 ; Racine formation: Ehlers, 3.

Middle Silurian: Grabau, 7.

Salina formation: Vanderwilt, 1.

Mississippi, T is h o m ing o County: Bramlette, 4.

Mississippi Valley : Krey, 2.

Missouri: Wilson, Malcolm E., 1. northeastern: Keyes, 42.

Ste. Genevieve County: Weller, 19. southeastern: Flint, 2.

Montana: Keyes, 234.

Nevada : Keyes, 128.

New Brunswick: Bailey, L. W., 1.

Newfoundland, Notre Dame Bay: Sampson, 8.

New Hañpshire, Ammonoosuc district: Ross, C. P., 2.

New Moxico : Darton, 26 ; Keyes, 14. eastern: Baker, C. I., 1.

New York, iadjacent faunal facies: Ruedemann, 20.

Catskill region: Jones, R. W., 1.

Clinton formations: Ulrich, 9.

Genesee country: Fairchild, 15.

Genesee Valley: Fairchild, 24.

Newburgh quadrangle: Holzwasser, 1.

Rochester : Giles, 1.

salt deposits: Alling, 14.

western : Alexander, W. P., 1.

Niagaran coral reefs: Cumings, 4.

Nova Scotia, Arisaig: Jones, O. 'T., 2 ; McLearn, 8.

Ohio: Foerste, 2.

Delaware County: Westgate, 5 .

Monroe division: Carman, 2.

Oklahoma: Gould, 9.

Arbuckle Mountains: Taff, 7 .

Carter County: Tomlinson, 4.

Mannsville area: Tomlinson, 2.

northeastern: White, L. H., 3.

southeastern: Honess, C. W., 6.

southern $\mathrm{O}$ u a $\mathrm{ch}$ it a Mountains : Honess, C. W., 4.

Stonewall quadrangle: $\mathrm{M}$ or g a u, G. D., 5 .

Ontario, Hudson Bay region: Savage, 2. Lake Timisliaming area: Hume, 1, 14. Mattagami and Abitibi rivers: Williams, M. Y., 7.

Pagwachuan, Kenogami, and Albany rivers: Williams, M. Y., 10.

southwestern: Cule, G. E., 1, 2 ; Williams, M. Y., 1.
Silurian-Continued.

Ordovician-Silurian boundary: Jones, O. T., 1; Miller, B. L., 9 ; Schuchert, 26 ; Ulrich, 15.

Pennsylvania : Swartz, C. K., 10.

Lehigh Gap : Ashley, 17.

Northampton County, slate belt: Behre, 7.

Quebec, Anticosti Island: Twenhofel, 30.

Gaspe County, Lemieux township : Alcock, 14

Mount Albert area : Alcock, 20.

Port Daniel-Gascons area: Schuchert, 29.

Shickshock Mountains, Gaspe: Alcock, 21.

St. Clair limestone, Arkansas and Oklahoma: Ulrich, 14.

Salina formation: Newland, 9 .

Shawangunk formation, age and origin : Willard, B., 3.

Tennessee : Nelson, 16.

Sumner County: Mather, 3.

Waynesboro quadrangle: Miser, 6 .

Utah: Butler, 4.

Virginia : Giles, 11.

Giles County: Hubbard, G. D., 6.

Little North Mountain: Giles, 8.

southwestern : Butts, 10.

Valley coal fields: Campbell, M. R., 10.

Wise and northern Scott counties: Eby, J. B., 1.

West Virginia, Hampshire and Hardy counties: Tilton, 15.

Mercer, Monroe, and Summers counties: Reger, 9.

Mineral and Grant counties: Reger. 7.

Pendleton County: Tilton, 14.

Wisconsin: Ulrich, 12; Thwaites, 3. sllver.

Alaska: Brooks, 5, 12, 14; Martin, G. C., 4.

Chitina Valley: Moffit, 5.

Fairhaven district: Levensaler, 1.

Hyder district: Buddington, 8.

Kotsina-Kuskulana district: Moffit, 4.

Ruby : Brown, J. S., 8.

Susitna Basin, ruby silver prospect: Capps, 10.

Arizona, Aravaipa-Stanley region: Ross, C. I., 5.

Chloride and Kingman, origin of ores: Bastin, 1.

Jerome and Bradshaw Mountains quadrangles: Lindgren, 17.

Ray quadrangle: Ransome, 11.

Saddle Mountain and Banner min ing districts: Ross, C. P., 6, 14.

Wickenburg: Bastin, 6.

British Columbia, Ainsworth district: Schofield, 4.

Atlin district: Cockfield, 17 . 
Silver-Continued.

British Columbia-Continued.

Beaverdell : McKinstry, 8.

Coquihalla area: Cairnes, 4.

Hudson Bay Mountain, Coast district: Jones, R. H. B., 1.

Kitzault Valley: Hanson, 2.

Premier mine, Portland Canal district: Burton, W. D., 1.

Salmon River district Banks, 1; O'Neill, 4 ; Prior, C. E., 1 ; Schofield, $7,14$.

Similkameen, Horn mine : Bostock, 1.

Slocan area: Bancroft, M. F., 2; Bateman, 14 ; Cairnes, 10.

Stewart district: Dolmage, 4, 14.

Stump Lake: Camsell, 7.

Windermere area, Kootenay district: Walker, J. F., 1.

California, Kern County, Randsburg: Carpenter, J. A., 2.

Randsburg quadrangle: Hulin, 1, 3.

Shasta County, South Fork district: Tucker, W. B., 3.

Canada: Cole, A. A., 2; Wilson. A. W. G., 2.

Central States: Dunlop, 1, 4, 6, 9, 12, 16.

Chemistry of enrichment: Sill, 1.

Colorado, Aspen : Bastin, 18.

Bonanza, Eagle mine, secondary enrichment: Wuensch, 2.

Boulder County, Ward region: Worcester, 1.

Creede district: Emmons, W. H., 4 ; Hills, V. G., 1 ; Ring, 1.

Hinsdale County: Brown, W. H., 3.

Pitkin County, Aspen district: Knopf, A., 10.

Platoro-Summitville district: Patton, H. B., 1 .

Red Cliff district: Crawford, R. D., 3.

Telluride area: Hurst, 2.

Easteln States: Dunlop, 3, 7, 11, 15, 18.

General : Dunlop, 2, 5, 8, 10, 14, 17 ; Wuensch, 1.

Idaho: Gerry, 1, 3, 5, 8, 10, 13.

Alturas quadrangle: Ballard, 2.

Birch Creek district: Shenon, 2.

Boundary County: Kirkham, 7.

Mineral and Cuddy Mountain mining districts: Livingston, 4.

Pend Oreille district: Sampson, 16.

Rocky Bar quadrangle: Ballard, 4.

Salmon River Mountains: Ross, C. P., 13.

Shoshone County: Umpleby, 3.

Silver City district: Piper, 6.

Vienna district: Ross, C. P., 12.

Wardner district: Rickard, 3.

Massachusetts, Newburyport: Green, $\mathrm{F}$. E., 1.
Silver-Continued.

Mexico: De Iongh, 1.

Aguascalientes, Asientos-Tepezala district: Anderson, G. E., 2.

Arizpe district, Sonora: Montijo, 1. Chibuahua, Yoquivo district: Hall, C. W., 1.

El Oro district: Winchell, H. V., 1.

Pachuca district, Hidalgo: Winchell, H. V., 1.

Sonora, Lueky Tiger mine: Mishler, 2.

Montana : Gerry, 2, 4, 7, 12, 15.

Native silver, Nonesuch formation, Michigan: Nishio, 1.

Nevada, Candelaria district: Knopf, A., 5.

Comstock lode: Bastin, 4.

Divide district: Knopf, A., 3 ; Sizer, 1 ; Young, G. J., 1.

Jarbidge district: Schrader, 5 .

Mineral County, Cedar Mountain : knopf, A., 4.

Pioche district: Westgate, 6 .

Rochester district: Knopf, A., 7.

Santa Fe district, Mineral County: Clark, C. W., 2.

Silver Horn district: Crampton, 2.

Tonopah : Budelman, 1.

Wonder, halogen salts : Young, J. W., 1.

New Mexico, Mogollon district: Ferguson, H. G., 3 ; Scott, D. B., 1.

Ontario: McGill, 1.

Blanche River area: Burrows, 9.

Cobalt district: Bastin, 6, 12 ; Bateman, G. C., 1 ; Bell. J. M., 4, 6 ; Cole, A. A., 1 ; Knight, C. W., 7 ; Whitehead, 1.

Cobalt and South Lorrain areas: Knight, 11.

Gowganda area : Burrows, 3, 6, 17.

Porcupine gold area: Burrows, 13.

Shiningtree silver area, District of Timiskaming: Langford, 1.

South Lorrain: Bastin, 12; Bell, J. M., 3, 5 .

Thunder Bay district: Parsons, 5.

Silver Islet, Lake Superior : Channing, 1 ; Tanton, 4.

South Dakota, central Black Hills: Darton, 14.

northern Black Hills: Connolly, 4.

Utah : Butler, 4.

East Tintic district: Goodwin, $\mathcal{L}$. H., 2.

Ophir district: Olmstead, 1.

Park City district: McKay, G. R., 1. Tintic district: Havenor, 1; Lindgren, 2.

Washington: Gerry, 1, 3, 6, 9, 11. Stevens County: Weaver, 2.

Yukon, Beaver River area: Cockfleld, $12,14$.

Fifteenmile Creek: Cockfield, 21. 
Silver-Continued.

Yukon-Continued.

Galena Hill, Mayo district: Stockwell, 1.

Keno-Hill district: Cockfield, 4.

Mayo district: Cockfleld, 7, 8, 11, 13, 14, 15 ; Johnson, G. F., 1.

Rude Creek: Cockfield, 22.

Twelvemile area: Cockfield, 2.

Silver City region, Idaho: Piper, 6.

Singing sands: Fairchild, 8; Fippin, 1; Ledoux, A. R.,1; Lake Michigan: Richardson, W. D., 1.

Sink holes.

Illinois, Alton : Lamar, 12.

Iowa, Pocahontas County : Cable, 5.

Kansas, Sharon Springs: Moore, R. C., 33.

Kentucky : Jillson, 66.

Allen County : Shaw, E. W., 1.

western: Jillson, 45.

Tennessee, central: Bassler, 14.

Gainesboro quadrangle, pre-Chattanooga : Lusk, 1.

Sketching case, use in geologic work: Waring, 4.

Slate.

General : Bowles, 1; Loughlin, 6, 10, 13, 17, 21, 25, 29.

Pennsylvania, Allentown quadrangle: Miller, B. L., 5.

eastern: Behre, 9.

Northampton County: Behre, 7.

Petrography : Behre, 11.

Vermont, Northfleld: Richardson, C. H., 2.

Slide-rule dip chart: Gaby, 3.

Slides. See Landslides.

Slocan area, British Columbia: Bancroft, M. F., 2 ; Cairnes, 10.

Smackover oil fleld, Arkansas: Bell H. W., 3 ; Schneider, H. G., 1.

Snake Creek fauna: Matthew, W. D., 2. Snug Harbor district, Alaska: Moffit, 7.

Soapstone.

Canada: Spence, 5 ; Wilson, M. E., 16.

General : Diller, 4, 7 ; Ladoo, 2 ; Sampson, E., 1, 4, 9.

Societies. See Associations.

Society of Economic Geologists: its sphere and its future: Penrose, 3.

Soda.

British Columbia, Clinton district : Reinecke, 2.

Lillooet-Prince George region: Reinecke, 3.

Sodium carbonate.

British Columbia : Goudge, 2.

Sodium compounds: Wells, 1, 2, 3, 7 .

Sodium salts.

Saskatchewan : Cole, L. H., 10.

Western_Canada: Cole, L. H., 9.

Sodium sulphate : Cole, L. H., 11; Wells, 8.

Soil transport through the air: Keyes, 170.
Soils.

Barbados: Harrison, J. B., 2.

Classification: Deatrick, 1; Veatch, J. $0 ., 1$.

Depletion by chemical. denudation : Whitney, M., 1.

Formation: Muir, 2.

Geology in soil classification: Veatch, J. $0 ., 1$.

Indiana, Benton County: Jones, G. B., 1.

Carroll County: Erni, 1.

Cass County: Beales, 1.

Whitley County: Shiltz, 1.

Kentucky, geologic derivation: Jillson, 72 .

New Hampshire, Coos County : Crosby, W. O., 3.

Soil surveys, development: Bushnell, 1.

Wisconsin: Whitson, 14.

Adams County: Whitson, 13.

Buffalo County: Whitson, 2.

Dane County: Whitson, 1.

Door County: Whitson, 6 .

Jackson County: Whitson, 12.

Milwaukee County: Whitson 7 .

north central : Whitson, 3.

northern: Whitson, 10.

Outagamie County: Whitson, 9.

Portage County: Whitson, 5.

Rock County: Whitson, 1.

Waupaca County: Whitson, 8.

Wood County: Whitson, 4.

Soils and geology, inter-relation: Norton, E. A., 1.

Solar cyclonic explanation of glaciation : Huntington, 3.

Solar system, origin: Jeffreys, 1.

Solifluxion.

California, Coast Ranges: Legraye, 1. Solitario uplift, Presido-Brewster counties, Texas: Powers, 9.

Sooke formation, Vancouver Island, fauna : Clark, B. L., 13.

"Soot" in coal: Scheffel, 2.

Sorento dome, Illinois: Bell, A. H., 5.

South Carolina.

Economic geology.

Clay : Ries, 5.

Cretaceous white clays: Neumann, F. R., 2.

Mineral resources: Calboun, 2.

Pyrite, Haile mine, Kershaw; Schrader, 1.

Tin deposits: Haney, 4.

Paleontology.

Capybara: Hay, 18.

Cetacean, Xenoruphus, County : Kellogg, R., 5.

Cretaceous invertebrates: Stephenson, 9 . .

Eutrephoceras, Eocene: Reeside, 9.

Mammalia, phosphate beds: Allen, G. M., 4.

Mollusca. Miocene: Gardner, J.. A.. 1. 
South Carolina-Continued.

Paleontology-Continued.

Oligocene sea turtles: Hay, 19.

Turtle, Eocene marl: Hay, 18.

South Dakota.

Badlands : O'Hara, 2.

Report of State geologist: Ward, 1, $4,7,15,18$.

Southern Black Hills: Connolly, 5. Areas described.

Badlands: Ward, 8.

Central Black Hills: Darton, 14.

Corson County, western: Russell, W. L., 7.

Custer State Park: O'Harra, 5.

Haakon and Pennington counties (parts) : Russell, W: L., 8.

Keystone district: Connolly, 1.

Lead region: Paige, 4.

Newell quadrangle: Darton, 1.

Economic geology.

Alunitic gold ore, Black Hills : Grout, 25.

Black Hills: Lincoln, 2. oil possibilities : Sinclair, E. G., 1.

Chalk: Ward, 3.

Corson County, oil possibilities: Russell, W. L., 7.

Cretaceous shales, analytical examination: Waterman, 1.

Etta lithia mine: Lincoln, 4.

Etta spodumene mine, Black Hills: Schwartz, 13.

Geologic features and oil possibilities: Wilson, R. A., 4

Gypsum: Stone, 11.

Harding County, oil and gas possibilities: Ward, 2.

Homestake ore bodies: Hosted, 1; Paige, 3, 4; age: Moore, E. S., 14.

Keystone district, Etta mine: Connolly, 2.

Lawrence County, Lead district, Homestake mine: Ross, A. J. M., 1.

Lead, geological methods: Wright, L. B., 1.

Lignite: O'Harra, 1.

Mineral resources: Ward, 13.

Mineralization of Homestake mine: Wright, L. B., 3 ; Yates, 1.

Oil and gas possibilities in northeastern Meade County: Wilson, R. A., 6.

Oil and gas prospects, southern Perkins County: Moulton, G. F., 1.

Oil possibilities: Thom, 5; Wilson, R. A., 1 .

area west of Missouri River: Lupton, 5 .

Dewey County: Ward, 9.

eastern Harding County: Toepelman, 2.

eastern Pennington County: Ward, 6.
South Dakota-Continued.

Economio geology-Continued.

Oil possibilities-Continued.

near Edgemont: U. S. G. S., 12. northern Dewey County: Wilson, R. A., 2.

southern margin of Black Hills : Morse, R., 1.

Ziebach County : Russell, W. L., 4 ; Wilson, R. A., 3.

Pegmatites, Black Hills: Lincoln, 3. Portland cement materials: O'Harra. 4.

Sand and gravel deposits, eastern South Dakota: Rothrock, 1.

Sand and gravel deposits, Minnehaha County: Rothrock, 5.

Yankton County: Rothrock, 3.

Sequence of mineralization, Keystone pegmatites : Landes, K. K., 6.

Tertiary mineralization, Black Hills: Connolly, 4.

Historical geology.

Badlands: Wanless, 1.

Black Hills: Keyes, 31; Wieland, 24. geologic history: Yates, 1.

northern Black Hills: Connolly, 4; Cenozoic history: Fillman, 3.

pre-Cambrian: Runner, 2; Nemo district: Runner, 6.

Borings: Rothrock, 6 .

northern Ziebach County: Russell, W. L., 6.

Conglomerate of Black Hills: Cook, H. J., 4.

Cretaceous-Eocene transition beds : Thom, 8.

Dewey County: Ward, 9 ; Wilson, $\mathbf{R}$. A., 2.

Fossil desert, western South Dakota: Russell, W. L., 14.

General: Thom, 5.

Geological section: Keyes, 118.

Haakon County: Ward, 16. southern, field conditions: Ward, 14.

Harding County: Toepelman, 2.

Interior formation, stratigraphic position: Ward, 19.

Lance formation: Ward, 12.

Lance-Fox Hills contact: Dobbin, 2.

Lead area: Hosted, 1; Paige, 3; Wright, L. B., 1.

Meade County, northeastern: Wilson, R. A., 6.

Minnekahta limestone: O'Harra, 4.

Northwestern South Dakota : Rowley, 1.

Oligocene section, Battle Creek Canyon, Washington County: Wood, H. E., 3.

Oreodon beds, Big Badlands: Sinclair, $7,8$.

Pennington County: Ward, 6.

Perkins County, southern part: Moulton, G. F., 1.

Ragged Butte structure, Dewey County : Wilsonon, R. A., 7. 
South Dakota-Continued.

Historical geology-Continued.

Sand and gravel deposits, Minnehaha County : Rothrock, 5.

Slim Buttes region, Harding County : Toepelman, 5.

Turtle-Oreodon layer of White River Oligocene: Sinclair, 3.

Unconformity in pre-Cambrian of Black Hills : Runner, 3.

Western South Dakota: Stanton, 3; structure: Ward, 17.

White River Badlands: O'Harra, 3.

White River beds, stratigraphy: WanIess, 3.

Ziebach County: Wilson, R. A.. 3; western: Russell, W. L., 4.

\section{Mineralogy.}

Beryl crystal, Black Hills : Waldschmidt, 1.

Black Hills: Cook, L., 2; Schwartz, 23.

Columbite crystals, Black Hills : Waldschmidt, 2.

Custer County, tantalate and columbites: Headden, 3.

Custer State Park: Waldschmidt, 4. Epsomite, Black Hills: Waldschmidt, 3. Geode concretions, Black Hills: Schwartz, 14.

Isomorphous siderite and calcite: Johnson, J. H., 1.

Keystone district: Connolly, 1.

Sequence of mineralization, Keyston: pegmatites: Landes, K. K., 6.

Sand calcite: Wanless, 2.

Spodumene, Etta mine, Black Hills, alteration: Schwartz, 15, 16.

Uranium minerals: Davis, C. W., 1.

Water pool calcite, Black Hills: Johnson, J. H., 2.

White River Badlands: O'Harra, 3. Paleontology.

Agriochoerus: Thorpe, 7.

Badlands: Jepson, 1; Toepelmann, 1.

Barosaurus, Black Hills: Lull, 2.

Beetles, Fox Hills strata: Northrop, S. A., 1.

Boring, northern Ziebach County, fossil content: Stanton, 11.

Bothriodonts: Troxell, 4.

Camelidae, Oligocene: Lull, 7.

Cannonball fauna: Stanton, 3.

Cycads, Black Hills: Wieland, 24.

Entelodonts, Badlands: Sinclair, 4, 5 ; Troxell, 3.

Eporeodons, White River beds: Thorpe, 23.

susmilus, Oreodon beds, Pennington County: Sinclair, 10.

Felidae, White River beds: Thorpe, 2.

Ganoid fish, Lower Cretaceous : Gregory, W. K., 11.

Hoplophoneus: Jepson, 2 ; Sinclair, 2.

Hyracodons, Big Badlands: Sinclair; 6 ; Troxell, 8.
South Dakota-Continued.

Paleontology-Continued.

Ischromys, Badlands: Miller, G. S., 1.

Metamynodon, Pine Ridge Agency: Troxell, 7.

Oreodon beds faunas: Sinclair, 8.

Oreodonts: Loomis, 11 ; Thorpe, 4.

Palmoxylon cheyennense: Stevens, N. E., 1.

Perchoerus skulls, White River formation: Pearson, H. S., 1.

Portheus, Hot Springs: Bump, 1.

Stylemys nebrascensis: Case, 1.

Petrology.

Lithology of the White River sediments: Wanless, 8.

Physical geology.

Caves, Black Hills: Johnson, J. H., 3.

Chalcedony pseudomorphs, Big Badlands: Honess, A. P., 2.

Contact action, Etta mine: Schwarts 22.

Dome structures: Ward, 10.

Haakon County: Ward, 16.

Mud cracks forming over water: Willard, B., 1.

Missouri River flood plain: Ward, 11.

Ragged Butte structure, Deweỳ County: Wilson, R. A., 7.

Sandstone dikes, Black Hills region, origin: Russell, W. L., 13.

and chalcedony veins in White River Oligocene: Lawler, 1.

Slumping in Slim Buttes region: Toepelman, 5.

Spodumene, Etta mine, Black Hills. alteration: Schwartz, 15, 16.

Structure, western South Dakota : Ward, 17.

Physiographic geology.

Badlands: Darton, 9 ; Anon., 53.

Fossil desert, western South Dakota: Russell, W. L., 14.

General: Visher, 1 .

Missouri River channel, age: Todd, J. E., 5 .

Physiographic features: Visher, 7.

Post-Miocene gravels, western South Dakota: Wanless, 4.

Southwestern South Dakota: King, 1. Underground water.

Artesian pressure, origin: Russell, W. L., 15.

Black Hills: Darton, 5, 14.

Newell quadrangle: Darton, 1.

South Dayton salt dome, Liberty County, Texas : Bowman, 1.

South Lorrain silver district, Ontario: Bell, J. M., 5.

South Mountain district, Idaho: Sorenson, 1.

South Mountain oil field, Ventura County, California: Hudson, F. S., 2.

Spindletop salt dome, Jefferson County, Texas: Barton, $\mathbf{5}$. 
Spiral graph of geologic time: White, D. 37.

Spodumene, South Dakota, Keystone district, Etta mine: Connolly, 2.

Spokane glaciation, Washington, age: Bretz, 9.

Spongiae.

Armstrongia, Devonian glass sponge: Clarke, J. M., 8.

Cambrian, British Columbia: Walcott, 2.

Colossal Devonian glass sponge, New York : Clarke, J. M., 25.

Dictyosponge, Chautauqua County, New York: Clarke, J. M., 22.

Glass sponges: Clarke, J. M., 10, 18.

Iowa, glass sponges: Thomas, 13.

New York, Utica and Lorraine formations: Ruedemann, 17.

Ordovician sponge fauna, Nevada: Bassler, 22.

Silicispongiae, Cretaceous : O'Connell, 1.

Spring Hill-Sarepta gas field, Webster and Bossier parishes, Louisiana: Ponton, 1.

Springs, classification : Bryan, K., 2.

Large springs of the United States: Meinzer, 17.

Missouri, Ozarks, periodic springs : Bridge, 2.

Tennessee, Rogersville, ebb and flow spring: Hall, G. M., 4.

Stalactites, copper sulphate, rate of formation : Mitchell, 5 .

Stalagmites and stalactites, growth: Allison, V. C., 1.

Stanford hematite deposits, Montana : Westgate, 1.

Stanley mining district, Arizona: Ross, C. P., 5 .

Stanley shale, Oklahoma: Honess, C. W., 3. Stikine River area, British Columbia : Kerr, F. A., 2.

Stone: Loughlin, 5, 8, 12, 15, 19, 23, 26. See also Building stone.

Monumental stones: Dale, T. N., 1.

Stories in stone : Lee, W. T., 17.

Strategy of minerals: Smith, G. O., 2.

Stratification: Udden, 25.

Determination of thickness and depth of strata: Price, W. A., 8.

Fraser River delta, British Columbia : Johnston; W. A., 12.

Strata, thickness, computation : Mertic, 8.

Structure below an unconformity : Mertie. 10

Stratigraphic geology. See Historical geology.

Stratton Ridge salt dome, Brazoria County, Texas: Applin, P. L., 1.

Stream capture.

Alaska, Tolovana and Hess River basins : Mertie, 1.

California, Coast Ranges: Willis, R., 2.

General : La Gorce, 1.
Stream capture-Continued.

Indiana, Greencastle area: Smill, E. R., 3.

Monroe County: Malott, 5.

southern, Knobstone region: Malot t, 3.

Kentucky, Floyd County: Jillsou, 10.

Missouri, Ozarks, subterranean : Dake, 10.

South Dakota: Visher, 7.

Planation stream piracy: Malott, 5

Wyoming, northeastern: Rubey, 6.

Stress, strain, and joints: Swanson, C. O, 3

Strike, determination: Higgins 1.

Stromatoporoidea.

Affnities: Twitchell, G. B., 1.

Aulacera: Schuchert, 2.

Beatricea : Schuchert, 2.

Iowa, Iowa City: Thomas, 1\%.

Strontium.

Canada: Spence, 4

General: Stose, 5, 8, 10, 13, 19, 23 .

Structural geology. See Physical geology. Structural materials. See Building stone; Clay, etc.

Study and teaching. See also Educational. Education of a geologist: Brock, 2; Lindgren, 8.

Geology in engineering training: Burt, 4.

Teaching vertebrate paleontology : Willard, B., 4.

Stylolites: Dale, T. N., 6 ; nature and origin: Stockdale, 1-3.

Submarine denudation: Bucher, 12.

Subordinate ridges, Pennsylvania: Eaton, H. N., 1.

Subsidence: Rice, G. S., 2. See also Changes of level.

By oil extraction: Thom, 18.

Kansas, Sharon Springs: Moore, R. C., 34.

Texas, Goose Creek oil field: Snider, 2. Subterranean water. See Underground water.

Sulphate minerals in ore deposits: Butler, B. S., 3.

Sulphates, natural reduction: Bastin, 15. Sulphates in the Salina beds: Newland, 5. Sulphur.

Alaska, Unalaska and Akun islands: Maddren, 1.

General: Smith, P. S., 1-3.

Geological aspects of sulphur in coal : Ashley, 6.

Gulf coast salt domes: Wolf, 1 .

Louisiana, Sulphur salt dome: Kelley, 1.

Mexico : Cervantes, 1.

San Luis Potosi, Cerritos: Wittich, 6. Tamaulipas, Chapeño salt dome: Belt, 1.

Origin: Henning, 1.

Sulphur compounds in coal, origin: Thiessen, 1. 
Sulphur-Continued.

Texas: Barton, 8.

Big Hill salt dome, Matagorda Coun. ty : Wolf, 5.

Bryan Heights salt dome: Kennedy, 1.

Volcanic sulphur, source: Papish, 1. Sulphur salt dome, Calcasieu Parish, Louisiana : Kelley, 1.

Sunburst oil and gas field, Montana : Hager, D., 5.

Sunloch copper district, British Columbia : Dolmage, 3 .

Surveys.

Activities in Southern States: Burroughs, W. G., 3.

Alabama, reports : Smith, E. A., 1, 3, 6 .

Alberta, reports of survey: Allan, 18, $21,22$.

Arkansas : Branner, J. C., 1.

State geologist's report: Branner, G. C., 5 .

California, State mineralogist's report: Bradley, 10.

Canada, reports: Collins, 3, 6, 8, 20 ; McInnes, 1-3.

Connecticut: Conn. G. S., 1 ; Gregory, H. E., 5 .

Economic value: Nelson, W. C., 28.

Florida, reports: Gunter, 2, 5, 7, 9, 10 ; Sellards, 1.

History of State surveys: Merrill, 6 .

Idaho, report: Thomson, F. A., 2.

Illinois, reports: DeWolf, 2, 5.

Indiana, reports: Barrett, E., 1, 6, 7 ; Logan. 6, 7, 13, 16, 20, 26, $28,29$.

Jamaica, Government geologist's report: Matley, 1.

Kentucky : Jillson, 34.

reports: Jillson, 26, 40, 69, 97.

Mexico: Paredes, 4.

Michigan, history of surveys: Allen, R. C., 3, 4.

Mississippi, reports: Lowe, 1, 5, 6, 8.

Missouri, reports: Buehler, 1, 4, 6, 8.

National geological survey, functions and ideals: Ransome, 4.

New Jersey, report of State geologist: Kümmel, 1, 3, 5, 7 .

North Carolina, State geologist, report: Drane, 2; Pratt, J. H., $1,3,7$.

Pennsylvania : Ashley, 5, 13.

Topographic and Geologic Survey, report: Pa. T. G. S., 2.

South Dakota, reports of State geologist: Ward, 4, 7, 15, 18.

State geological surveys: Kümmel, 7 ; Leighton, M. M., 19 ; Powers, 19.

Tennessee, reports of State geologist: Nelson, W. A., 1, 2, 11, 22.

Texas, Bureau of Economic Geology, activities : Sellards, 28.
Survejs-Continued.

United States Geological Survey: Blackwelder, 2 ; Inst. Govt. Research, 1.

annual reports: Smith, G. O., 1, $6,9,13,16,17,21,22,23,28$. as a civic institution during the war : Paige, 1.

mineral resources work : Bastin, 3.

reports: Smith, G. O., 5.

war work: Smith, G. 0., 12.

work of: Ransome, 6 ; White, D., 5 .

Vermont, State geologist, reports: Perkins, G. H., 1, 7, 11.

Virginia, reports: Watson, T. L., 1, 8.

Washington, reports: Washington, G. S., 1, 2; Culver, 12, 13; Shedd, 5.

Wisconsin, Geological and Natural History Survey, reports: Bean, 3; Hotchkiss, 2, 4.

Wyoming, report of State geologist: Bartlett, 1, 5 ; Marzel, 1; Morgan, G. B., 4 .

Susquebanna deeps: Daly, 7 .

Sutton Lake area, District of Patricia, Ontario : Hawley, J. E., 1.

Swamps.

Central America, coastal swamps : MacDonald, D. F., 3.

Dismal Swamp : Osbon, 1.

Sweetland black shales, stratigraphic position: Keyes, 125.

Symbiosis: Clarke, J. M., 16.

Symbols for drilling operations: Mehl, 4.

Syracuse-Lakin folio, Kansas (no. 212) : Darton, 2.

Tables of formations. See Geologic formations, tables.

Taconic area, southern, New York and New England: Knopf, E. B., 6.

Taconic folding, Pennsylvania: Miller, B. L., 9.

Taconic orogeny, significance: Schuchert, 26.

Taconic question: Keyes, 127, 129, 260.

Taconic revolution, evidence for, examined : Clark, T. H., 4.

Taconic system resurrected: Schuchert, 1. Tactite : Hess, 1.

Talc.

Canada: Eardley-Wilmot, 2; Spence, 5 ; Wilson, M. E., 16.

General: Diller, 4, 7 ; Ladoo, 2 ; Samp. son, E., 1, 4, 9.

High-grade talc for gas burners : Diller, 5.

New York: Newland, 2.

North Carolina and Maryland: Diller, 5.

Ontario, Hastings County : Wilson, M. E., 8.

Origin: Gillson, 7.

Vermont: Gillson, 7 ; Jacobs, 2.

Roxbury : Richardson, C. H., 3.

Talkeetna Mountains, western, Alaska : Capps, 3. 
Talus: LaForge, 2.

Tampico district, Mexico: Belt, 2.

Tampsia, Tamaulipas, Mexico: Stephenson, L. W., 1.

Tantalum: Hess, 7, 12, 13, 16, 19, 21.

Taonurus, nature: Galloway, J. J., 5.

Taos Range, New Mexico: Gruner, 1.

Tar sands, Athabasca region: Ness, 1.

Tarryall district, Fark County, Colorado: Muilenburg, 2.

Tashota-Onaman gold area, District of Thunder Bay, Ontario: Gledhill, 3.

Tatla-Bella Coola area, Coast district. British Columbia: Dolmage, 16.

Taylor-Wegener hypothesis : Daly, 15 ; Lam. bert, W. D., 3 ; Taylor, 3.

Teaching. See Educational.

Technical papers and their presentation: Knapp, A., 2.

Technique.

Acetone, use of : Ross, C. S., 23.

Aerial photography: Matthes, G. H., 1.

Airplane photographs, use in field work; Campbell, M. R., 8.

Angularity of sands, measuring: Pentland, 1.

Apparatus for measurement of temperatures in deep wells: Van Orstrand, 6.

Apparent-dip protractor: Smith, W. S. T., 3.

Attitude of concealed bedded formations, determination of: Mead, 2.

Bakelite for preserving fossil material : Case, 17.

Barometric surveying in petroleum mapping: Lahee, 3.

Binocular magnifier for determination of opaque minerals: Treasher, 2 .

Block diagrams: Lobeck, 6 .

Casts of invertebrate fossils: Feiss, 1.

Clerici solution for mineral separation by gravity: Vassar, 1.

Color chart: Goldman, 15.

Color in polished sections, diagnostic value : Talmage, 1.

Color printing of geological maps: Senécal, 1.

Compass: Plummer, 3.

Crystal structure model: Whitlock, 7 .

Determination of thickness-and depth of strata: Price, W. A., 8.

Determinative mineralogy : Putnam, $\mathrm{P}$. C., 3 .

Dip and strike, determination: Higgins, 1; Longwell, 2 ; Smith, W. S. T., 2.

laboratory determination: Turner, H. G., 1.

graphic determination: Grider, 1.

Dip chart and protractor: Gaby, 2.

Dip components, glaphic determination: Lahee, 1 ; Falmer, H. S., 2.

Dip needle: Stearn, 2. use : Aldrich, H. R., 1.
Technique-Continued.

Disintegrating samples for micro-or ganic study: Driver, 1.

Disintegrating shales by freezing and thawing: Hanna, G. D., 37.

Double dispersion method of mineral determination: Emmons, R. C., 6.

Electrical conductivity and polished mineral surfaces: Harvey, R. D., 1.

Electrical prospecting: Leonardon, 1, 2.

Electro-magnetic survey at Ducktown, Tennessee: Zuschlag, 1

Eötvös torsion balance: Heiland, 2; Steiner, 1 ; Wagner, E., 1.

Examination of well borings: Hanna, G. D., 17.

Examining calcareous well cuttings: Claypool, 1.

Extraction of fossils from refractory rocks: Fanna, 21.

Feldspars, plagioclase, determination: Goranson, 2.

Files of oil geologist : Dreher, 1.

Formation thicknesses, determination; Ickes, 2.

Geologic sections with unequal scales: Melhase, 4.

Geological features illustrated by models: Huntley, L. G., 4.

Geological hammers: Hart, 1; Walker. T. L., 56

Geomagnetics: Stearn, 1.

Geophysical prospecting: Am. Inst. Min. Eng., 1 ; Barton, 15 ; Eve, 1 ; Jakosky, 1, 2; Miller, A. H., 3.

Goniometer, two-circle: Bascom, 3; Palache, 1.

Graphic determination of projection of asymmetrical anticline: Collingwood, 1.

Graphic study of igneous rock series : Grout, 8.

Heavy liquids for separation of fossils and sediments: Hanna, M. A., 4.

Heavy mineral separation: Woodford, 2 ; apparatus: Fraser, F. J., 1.

methods for heavy mineral investigations Reed, 4.

Illustrations: Hudson, G. H., 2.

Inclination of surface, determination from contour map: Rich, J. L., 1.

Incompetent beds, use of thicknesses of : Rubey, 4

Iron ores, investigation: Osborne, F. F., 2.

Kodak adapted for detail work in field: .Wentworth, 7 .

Labeling glass slides: Shead, 6.

Lemberg's staining method, modification:- Fairbanks, 4.

Logging rotary-drilled wells : Clark, S. K., 2

Logmeter: Burton, G. E., 1. 
'Technique-Continued.

Loose-leaf system for fleld maps and notes: Rich, 4.

Magnetic field balance: Heiland, 1.

Manganese minerals, identification: Fairbanks, 2.

Mapping geologic structure, Eötvös torsion balance method: Barton, 16.

Maps, a field method of reducing. to scale: Armstrong, P., 1.

Marking of type specimens: Howell, B. F., 10.

Measuring folded beds: Hewett, 6 .

Mechanjcal analysis, accuracy: Wentworth, 32 .

Method for checking index of a liquid : Rutherford, 2.

Microchemical reactions: Lindgren, 13.

Microscope, binocular: Goldman, 13.

Microscopy of anthracite: Turner, $\mathrm{H}$. G., 2 .

Mineragraphic technique : Fairbanks, 1.

Mineral separation in a finely divided state: Emmons, R. C., 7.

Mining geology methods at Butte, Montana : Billingsley, 1.

Model for demonstrating crystal structure: Whitlock, 7 .

Model cutting machine: Palache, 24.

Models for determining structure of bedded rocks: Mehl, 3 .

Notebook and symbols for petroleum geologists: Woodruff, 2.

Oblique illumination: Buerger, 1 ; in mineragraphy: Myers, 1.

Oil-discolored bromoform, clarification : Hanna, M. A., 7.

Opaque minerals, examination: Thomson, E., 2.

identification by microchemical tests : McKinstry, 5, 6.

determination by X-ray diffraction patterns: Kerr, P. F., 1.

Optic axial angle of minerals, new method for measuring: Johannsen, 7.

Ores and metals, examination in polarized light: Wright, Fred. E., 2.

Permeability of oil sands: Melcher, 4.

Phantograph model: Cadman, 1.

Photographic practice for field geologists: Wentworth, 16 .

Photographing fossils: Mehl, 8.

Photography for the field geologist: Blackwelder, 12.

Picking out and sectioning Foraminifera : Hodson, F., 1.

Plane table: Bateman, A. M., 1.

Plane-table methods: Innglish, W. A., 2.

Plane-table survey underground: Moulton, 18.

Plotting well logs: Weeks, A. W., 2.

Polarized light in the study of ores and metals: Wright, Fred. E., 1.

Polished sections of ores: Short, 2.
Technique-Continued.

Polished surfaces of ores: Thiel, 6 .

Polishing of ores: Vanderwilt, 2.

Preparing mineral specimens: Levisun, 1.

Projecting structure through an angu lar unconformity : Corbett, 1.

Protractor for plotting dips: McKinstry, 4.

Quantitative methods in applied geology : White, C. H., 1.

Quantitative microscopic rock analysis : Alling, 12.

Quartz spectograph in mineral analysis: Todd, E. W., 2.

Radio-aeronautic prospecting: Shaw, H., 1.

Readings on low rock dips: Filmer, 1.

Reconnaissance mapping: Fuller, $M$. L., 2.

Recording machines: Dodge, 1

Recording micrometer for rock analysis: Wentworth, 12.

Recording underground data: Wilson, P. D., 4.

Reflecting microscope: Davy, 2.

Refractive indices, determining: Winchell, 18

measuring under the microscope: Nakasbima, 1 :

Relief models and their construction: Reeves, J. R., 8.

Rock minerals, comparative losses in crushing and sifting: Johamnsen, 10.

Rock thickness, calculation: Swartz, J. H., 5 .

Rotation apparatus: Kerr, P. F., 3. Roundness of sand grains, measuring: Cox, E. P., 1.

Samplograph: Gardner, J. H., 6, 7.

Sectioning rocks: Keyes, M. G., 1.

Sections, making: Weymouth, 1. of friable rock: Ross, C. S., 7. of ores, preparation: Schwartz, 19.

Sediment, collecting samples from Mississippi River: Lugn, 2.

Sedimentary materials, preparation for study: Ross, C. S., 18.

Sediments, mechanical a naly sis: Wentworth, 27.

Seismic prospecting: Heiland, 3 .

Seismograph on a new principle : Molize, 1.

Seismographic method for underground observations: Udden, 9.

Sketching case, use in geologic work: Waring, 4.

Slide for holding Foraminifera : Thomas, E. T., 3.

Slide-rule dip chart: Gaby, 3.

Spectroscopy applied to mineral determination: Douglas, G. V., 1.

Stereoscopic photography in geologic field work: Wright, F. E., 6. 
'Technique-Continued.

Strata, thickness, computation: Mertie, 8.

Subsurface contouring: Bloesch, 2.

Symbols for dip and strike: Dreher, 2.

for drilling operations: Mehl, 4 .

Telescopic alidade, manipulation: Mather, 1.

Thin-section lap: Hanna, M. A., 9.

Thin sections of friable rock: Leggette, 1.

Till and stratified clay, microscopic sections: Sayles, 4.

Torsion seismometer: Anderson, J. A., 1.

Torsional balance: Gradenwitz, 1.

Underground photography, depth of focus chart: Wentworth, 34 .

without flash light: Graton, 2.

Volumes of contoured solids, graphic computation: Wentworth, 25.

Well logs, correction: Lang, W. B., 4.

Well samples, care of : Robinson, W. I., 2.

Wentworth recording micrometer, improved: Hunt, W. F., 3.

$\mathrm{X}$-ray analysis of crystals, oscillation method: Gruner, 11.

X-ray studies of fossils: Swartz, J. H., 13.

Tectonic adjustment of a rotating straticulate spheroid: Keyes, C. R., 1.

Tectonics. See Physical geology.

Tellurium, occurrence: Lenher, 1.

T'ennessee.

Geological Survey activities: Miser, 23.

State geologist, reports: Nelson, W. A., $1,2,5,11,22$.

Relief map: U. S. G. S., 18.

Areas described.

Crossville quadrangle: Butts, 6.

Ducktown district: Emmons; W. H., 8.

Rutherford County : Galloway, J. J., 1.

Waynesboro quadrangle: Miser, 6.

Dconomic geology.

Appalachian bauxite deposits: Nelson, 13.

Ball clays, western Tennessee : Schroeder, 1.

Barite, eastern Tennessee: Gordon, C. H., 1.

Bauxite deposits: Adams, G. I., 3.

Bentonite: Nelson, 9.

Brown iron ores, west-midale Tennessee: Burchard, 25.

Clay : Ries, 5.

Coal: Forbes, 1.

analysis : Fieldner, 5.

Herbert Domain: Nelson, 21.

northern Tennessee: Glenn, 6.

southern Tennessee: Nelson, 20.

Coal fields: Nelson, 26.

Coal pyrite: Holbrook, 1.
Tennessee-Continued.

Economic geology-Continued.

Copper, Ducktown, oxidation and enrichment: Gilbert, $G ., 1$.

Ducktown copper district : Emmons, W. FI., 8 ; Nelson, 18.

Electro-magnetic survey at Ducktown: Zuschlag, 1.

Harpeth River dome, Cheatham County: Jillson, 59.

Holston marble: Dale, T. N., 6.

Iron ores, east Tennessee: Smith, A. F., 2.

Waynesboro quadrangle: Miser, 6 .

magnetic iron ores, eastern 'Tennessee: Bayley, 6, 7.

Manganese: Crane, W. R., 1; Stose, $4,7,17$.

Marbles, east Tennessee: Gordon, C. H., 3.

Mascot zinc area: Nelson, 17.

Mineral resources: Nelson, 19, 22.

Phosphate rock: Smith, R. W., 2.

Oil and gas areas: Nelson, 8.

Oil and gas resources, Sumner County : Mather, 3.

Oil developments, northern Tennessee: Nelson, 15.

Oil exploration, Sumner County: Nelson, W. A., 1.

Oil fields: Glenn, 1 ; northern Tennessee: Nelson, W. A., 1.

Oil horizons: Nelson, 16.

Oil possibilities, Overton County: Butts 1.

Oil prospects, western Tennessee: Nelson, W. A., 1.

Oxidation and enrichment at Ducktown: Gilbert, G., 1.

Petroleum : Glenn, 3.

Overton County: Butts, 1.

structural conditions: Lusk, 2.

Phosphates: Rogers, A. F., 31 ; Smith, R. W., 1, 2.

nature and origin: Rogers, A. F., 29.

Rutile in titaniferous magnetites: Bayley, 9.

Western Tennessee Valley iron region: Burchard, 24.

Willow Grove oil field: Jillson, 47.

Zinc, east Tennessee : Secrist, 1.

Historical geology.

Benton County : Nelson, 6.

Bentonite in Ordovician: Nelson, 10.

Big Stone Gap shale, Chattanoogan age: Swartz, J. H., 10.

Central Tennessee: Bassler, 10.

Chattanooga shale, age: Swartz, J. H., 1.

eastern 'Tennessee: Swartz, J. H., 11.

Cheatham County : Jillson, 49.

Cincinnati anticline, dimensions: Hubbard, G. D., 5.

Cove areas, east Tennessee: Gordon, C. H., 2 . 
Tennessee-Continued.

Historical geology-Continued.

Cove Creek Reservoir, Tennessee River: Wentworth, ' 39.

Cretaceous: Berry, 4.

Dam sites, Tennessee River: Wentworth, 38 .

Devonian, western Tennessee: Dunbar, $1,2$.

Devono-Mississippian black shales: Swartz, J. H., 12.

Eastern highland rim, Bassler, 13.

Eastern Tennessee: Secrist, 1.

General : Glenn, 3.

Geologic map: Jenkins, 1 ; Nelson, 12

Great Smoky Mountains: Glenn, 9.

Harpeth River dome, Cheathan County: Jillson, 59.

Herbert Domain : Nelson, 21.

Lower Cambrian, southern Appalachians: Barrell, 8.

Mississipian, northern Tenuessee : Bassler, 17.

Northern Tennessee coal field: Glenn, 6.

Ordovician: Raymond, 3. central Tennessee: Bassler, 8.

Overton County: Butts, 1.

Pre-Chattanooga sink hole, Gainesboro quadrangle: Lusk, 1.

Reelfoot Lake district, western Tennessee : Nelson, W. A., 1.

Silurian: Springer, 12.

Stones River group, central Tennessee : Coryell, 2.

Southern Tennessee coal fields: Nelson, 20.

Sumner County: Mather, 3.

Tertiary, western Tennessee: Roberts, J. K., $6,9$.

Trenton: Raymond, 18.

Upper Cretaceous: Wade, B., 1, 3.

Volcanic ash horizons, Stones River group: Nelson, 23.

Bedford County: Nelson, 7 .

Western Tennessee: Nelson, W. A., 1; Schroeder, 1

Mineralogy.

Meteorite, Savannah, Hardin County : Merrill, 29.

Strain structure in quartz, Ducktown: Kerr, P. F., 6.

Paleontology.

Brachiopods, Lenoir and Athens formations: Raymond, 37.

Ottosee and Holston formations: Willard, B., 5.

Caddis case, Eocene: Berry, 84.

Conodonts, Mississippian: Ulrich, 13.

Cretaceous flora: Berry, 4, 17, 28.

Carroll County: Berry, 1.04.

Devonian, western Tennessee: Dunbar, 1,2 .

Hamulus, Cretaceous, McNairy County : Wade, B., 2.

Ostracoda, Trenton limestone, Nashville: Kirk, S. R., 1.
Tennessee-Continued.

Paleontology-Continued.

Pleistocene plants: Berry, 6, 34, 88.

Pleistocene Vertebrata: Hay, 6.

Potamogeton perryi, Henry County : Berry, 30.

Ripley fauna: Wade, B., 3.

Salvinia, Hardeman and Mandy counties: Berry, 71.

Silurian Crinoidea: Springer, 12.

Stones River group, central Tennessee: Coryell, 2.

Terminalia, lower Eocene: Berry, 76.

Termite, Eocene, Hardeman County : Collins, R. L., 2

Trilobites, Ordovician: Raymond, 28.

Petrology.

Bentonite: Ross, C. S., 21.

Physical geology.

Eimory River overthrust, eastern Tennessee: Jillson, 43.

Erosion feature in western clays: Schroeder, 2.

Great Smoky overthrust: Keith, 5.

Isothrustic structure, Wells Creek Basin : Jillson, 48.

Mica peridotite dike, Union County: Gordon, C. H., 4.

Sink holes, central Tennessee: Basler, 14.

Physiographic geology.

General: Nelson, 8.

Gravel and terraces, Cumberland Val. ley : Lusk, 3.

Reelfoot Lake: Nelson, 14

Underground water.

Ebb and flow spring, Rogersville: Hall, G. M., 4.

Terminology of mineral deposits: Lind. gren, 6.

Terms for clastic sediments: Wentwortb, 9.

Terrace plains, middle Atlantic Coastal Plain: Wentworth, 11.

Terraces. See also Beaches; Shore lines

Coastal Plain terraces, origin and age: Hay, 22.

Connecticut: Flint, 8.

New Haven region: Ward, 5.

Eustatic bench of islands of north Pacific: Wentworth, 21.

Georgia, coastal terraces: Cooke, C. W., 11.

Gulf of St. Lawrence, postglacial : Kindle, 17.

Labrador, Lake Melville district: Kindle, 25, 31.

Marine terraces: Barrell, 6.

Monongahela River: Brown, S. B., 1.

New York, Colloes quadrangle: Stoller, 2.

Mechanicsvills : Stoller, 1.

Northern Great Plains: Alden, 3.

Ohio River, Indiana and Kentucky : Culbertson, 3.

Ontario, Michipicoten area : Collins, 13. 
Terraces-Continued.

Pennsylvania, Piedmont province : Bas. com, 4.

Susquehanna River: Stose, 33.

Piedmont terraces, northern Appala. chians: Barrell, 6.

Quebec, Anticosti Island, postglacial : Twenhofel, 9

Stream and ocean terraces in relation to recent earth movements: 1 Holway, 1.

Subaqueous teriaces of the Great Lakes and the St. Lawrence embay. ment: Johnson, D. W., 10.

Tennessee, Cumberland Valley : Lusk, 3.

Vermont, Connecticut Valley: Failchild, 2

West Virginia, Mineral and Grant counties: Reger, 7.

Wisconsin, Driftless Area : MacClin tock, 1 ; pre-Wisconsin: Thwaites, 8.

Tertiary. See also Palenntology, Tertiary. Alabama: Cooke, C. W., 13; Jones, W. B., 13.

Coastal Plain: Brantley, 1; Jones, W. B., 10

Alaska: Brooks, 7 ; Martin, G. C., $\delta$ Alaska Railroad region: Capps, 6. Chistochina region: Chapin, 3. Chulitra region, upper: Capps, 4. Cold Bay-Chignik district: Smith, W. R., J.

Kahiltna Valley: Mertie, 2.

Kamishak Bay region : Mather, $T$.

Kantisna region: Capps, 1.

Kiwalik-Koyuk region : Harrington, 5 .

Knik-Matanuska district: Landes, K. K., 2.

Kodiak Island: Maddren, 2.

Nenana field : Martin, G. C., 1.

northern, Canning River region: Leftingwell, 1.

Pliocene: Dall, 2.

Pribilof Islands : Hanna, G. D., 1.

Ruby-Kusliokwim region: Mertie, 11.

Salmon-Unuk River region : Mertie, 6.

Toklat-Tonzona River region: Capps, 12.

Talkeetna M o un ta ins, western; Capps, 3.

'Tolstoi district: Harrington, 2. upper Matanuska Valley: Capps, 11. Wrangell district: Buddington, 4.

Alberta, North Saskatchewan and Mc: Leod rivers: Rutherford, 8 . southern and central: Slipper, 1. southwestern : Stewart, J. S., 1.

Swan Hills, Lesser Slave Iake district: Allan, 1.

Alum Bluff group: Gardner, J. A., 7.

Anguilla: Vaughan, 40.

Intigua : Earle, 1.

Arctic regions, Ellesmere Land: Holtedahl, 1.
Tertiary-Continued.

Arizona: Darton, 17 ; Keyes, 83.

Aravaipa-Stanley region: Ross, C. I'.,

lower Gila region: Ross, C. P., 1 .

Oatman district: Ransome, 12.

Papago country: Bryan, 7, 15.

Payson district: Lausen, 1.

Saddle Mountain and Banner mining districts : Ross, C. P., 7.

Verde formation: Jenkins, 6.

Arkansas: Miser, 4, 11.

El Dorado oil field: Gilluly, 1.

south central: Rubey, 1.

southern: Schneider, H. G., 1.

southwestern, Midway formation : Hull, 12.

Atlantic and Gulf Coastal Plain : Stephenson, 6.

Barbados, Scotland beds : Trechmann, 6 .

Bozeman beds, Rocky Mountain region : Keyes, 19

Brandon liguite, age : Berry, 8 .

Briones formation, -midale California: Trask, 2.

British Columbia, Cariboo district, Barkerville area: Johnston, W. A., 22

Coquihalla area: Cairnes, 4.

Dease Lake area, Cassiar district: Kerr, F. A., 1.

Eutsuk Lake district: Brock, 1.

Fraser River Delta: Johnston, W. A., 17.

Kamloops district, North Thompson Valley: Uglow, 3.

Lillooet-Prince George regi on: Reinecke, 3.

North Thompson Valley: Uglow, 11.

Skeena River to Stewart: Hanson, 6. southwestern: Cairnes, 2.

Taseko Valley: MacKenzie, J. D., 1.

Vancouver Island, Sooke formation: Clark, B. I., 8 ; Cornwall, 1 ; Sunloch district: Dolmage, 3.

Yale district: Cairnes, 5.

British Honduras: Ower, 2.

Brown's Park formation : Feterson, 8; and Bishop conglomerate: Sears, 4.

Bryn Mawr gravel, Pennsylvania : Bascom, 5 .

California: Clark, B. I., 5, 9; Vander Leck, 1.

Amargosa Valley : Noble, 6.

Blackhawk Canyon, San Bernardino Mountains: Woodford, 7.

Briones formation: Trask, 1, 2.

central Coast Ranges, Miocene paleogeography: Reed, 7.

Coalinga district: Reed, 5.

Coyote Mountain: Hanna, 25.

Domengine horizon, middle Eocene: Clark, B. L., 16.

Eocene divisions: Clark, B. L., 1.

Kern County: English, W. A., 1; Godde, 4 ; Hanna, G. D., 20.

Kreyenhagen shale: Hanna, 22. 
Tertiary-Continued.

California-Continued.

La Jolla quadrangle: Hanna, M. A., $3,5$.

Los Angeles Basin: Arnold, 3; Eaton, 8; Vickery, 11.

Los Angeles County, Baldwin Hills: Tieje, 6.

Los Angeles and Ventura counties: Kew, 6.

Malaga Cove diatom-bearing shales; age: Hanna, G. D., 39.

Meganos group : Clark, B. L., 2, 18.

Monterey County, Pine Canyon: Stalder, 2.

Monterey shale: Hanna, G. D., 38.

Mount Diablo: Clark, B. L., 13.

Petaluma, Point Reyes, and Santa Rosa quadrangles: Dickerson, 2.

Point Sur quadrangle: 'Trask, 5.

Puente Hills region: English, W. A., 3.

Sacramento Valley: Bryan, 10.

Salinas Valley: Reed, 6.

Salton Sea region: Brown, J. S., 3.

San Benito County: Kerr, P. F.; 4.

San Bernardino Mountains : Vaughan, F. E., 1.

San Diego County: Ellis, A. J., 1. San Joaquin Valley : English, W. A., 5 ; Taff, 6.

San Lorenzo group : Wagner, C. M., 1. San Onofre breccia: Woodford, 3, 4. Santa Barbara County, Santa Ynez River district: Kew, 2; Nelson, R. N.; 1.

Santa Rosa Island: Kew, 10.

Simi Valley: Kew, 1.

southern: Jordan, D. S., 2 ; Kew, 4 ; Pliocene: Carson, 1.

Sunset-Midway field: Pack, R. W., 1 ; and Kern River oil fields : Goudkoff, 1.

Tejon region: Anderson, F. M., 1.

Vaqueros and Temblor formations: Wiedey, 1.

Ventura County: Tuliaferro, 1; Matilija overturn: Kerr, 7.

Ventura quadrangle: Cartwright, $\mathrm{L}$. D., 2.

Warner Range: Russell, R. J., 6.

Wheeler Ridge area, Kern County: Hoots, 5.

Wheeler Ridge oil field: Cunningham, G. M., 1.

Caribbean region: Vaughan, 3, 21.

Cayman Islands: Matley, 14.

Central America and West Indies, correlation: Vaughan, 13.

Chesapeake group: Mansfield, W. C., 7 . Colorado: Keyes, 162.

Axial and Monument Butte quadrangles: Hancock, 7 .

Creede district: Emmons, W. H., 4. Crowley and Otero counties (parts): Toepelman, 3.
Tertiary-Continued.

Colorado-Continued.

Delta and Mesa counties: Weoks, H. J., 1.

Golden area: Johnson, J. H., 13.

Grand, Jackson, and Larimer coun. ties (parts): Spock, 1.

La Junta area: Patton, F. B., 3.

Las Animas, Otero, and Bent. counties (parts): Duce, 1.

Moffat County: Sears, 3.

San Juan Basin: Reeside, 8.

south central: Knowlton, 12.

southeastern: Coffin, 4.

Tarryall district: Muilenburg, 2.

Twin Lakes district: Howell, J. V., 1.

Conglomerate of Black Hills: Cook, H. J., 4.

Correlation: Vaughan, T. W., 3, 29.

Caribbean region: Maury, 3.

Costa Rica: Branson, 18; MacDonald, D. I., 2 ; Redfield, 7 ; northern, Miocene: Olsson, 1.

Cretaceous-Tertiary boundary : Matthew, 15; Thom, 8.

Cuba: Rutten, 1.

Guantanamo Basin: Darton, 18.

Gulf Coastal Plain: Spooner, 3.

Dominican Republic: Cooke, C. W., 3; Vaughan, 16.

Eocene, Cordilleran: Keyes, 195.

Eocene beds in Mississippi embayment: Berry, 35.

Eocene formations, correlation, Alabama and Mississippi: Cooke, C. W., 12.

Florida: Cushman, 2 ; Mossom, 1, 2 ; Sellards, 4, 5, 12.

Everglades section: Sellards, 3.

General: Vaughan, 34.

Georgia: McCallie, 1; Teas, 1.

Coastal Plain: Prettyman, 1.

Great Basin and Great Flains formations: Troxell, 13.

Green River formation, origin: Henderson, J., 6.

sedimentology: Hinds, 5.

Green River shales: Bradley, W. H., 3.

Greenland : Böggild, 1.

Gulf Coastal Plain : Brantly, 2 ; Rogers, G. S., 6; Shaw, 4

Haiti : Woodring, 4, 5 . central plain: Woodring, 1.

Miocene: Woodring, 1.

Honduras: Redfield, 1.

Idaho, Bingham, Bonneville, and Caribou counties: Kirkham, 3.

Cassia County, Goose Creek basin: Piper, 1.

Fort Hall Indian Reservation : Mausfleld, G. R., 3.

granitic rocks: Ross, C. P., 16.

Mud Lake basin: Stearns, 6.

Owyhee County, Bruneau River basin : Piper, 2. 
Tertiary-Continued.

Idaho-Continued.

Payette formation: Buwalda, 8.

Salmon River Mountains: Ross, C. P., 13.

south central: Umpleby, 2.

southeastern: Mansfield, G. R., 5, 29.

Illinois, southern: Parmelee, 1.

Jamaica: Stockley, 1 ; 'Trechmann, 1. Bowlen, Miocene: Woodring, 22. marine: Woodring, 10.

Richmond formation: Trechmann, 4.

St. Ann Parish: Matley, 11.

Yellow limestone: Trechmann, 3.

Kansas : Moore, R. C., 4. Syracuse and Lakin quadrangles: Darton, 2.

Kentucky: Miller, A. M., 1.

Lance and Fort Union formations, age : Cross, C. W., 4 ; Knowlton, כ.

Louisiana: Glenk, 1.

Coastal Plain : Applin, E. R., 1.

Five Islands: Vaughan, F. E., 2.

Monroe gas field: Spooner, 1.

northern: Spooner, 2.

northwestern : Hammill, 1.

Pine Prairie salt dome: Barton, 7.

Sabine uplift: Powers, 2.

Mackenzie, Franklin Mountains : Williams, M. X., 16.

Mackenzie River region: Camsell, 1; Dowling, 15.

Maryland, Kent County : Miller, B. L., 6.

Queen Anne's County: Miller, B. L., 7.

Talbot County: Miller, B. L., 8.

Meganos group, Eocene, California: Dickerson, 1.

Mesozoic-Cenozoic boundary: Keyes, $202,203$.

Mexico, Chapala region: Palmer, $\mathbf{R}$. H., 1.

Coahuila, northern: Cummings, 2.

Colima (part) : Vivar, 4.

eastern: Ver Wiebe, 1; oil fields: Staub, 4.

Hidalgo, Atotonilco el Grande: Wittich, 10.

Hidalgo-Vera Cruz region: Palmer, R. H., 4.

Lower California: Darton, 10; MarIand Oil Co., 1 ; Cedros Island and Turtle Bay: Jordan, E. K., 4; La Purisima region: Heim, 1; southern Lower California: Heim, 2.

northern : Böse, 8 ; Tatum, 1.

Salado arch: Jones, R. A., 3.

southern: Ver Wiebe, 2.

Tabasco: Jones, W. F., 3 ; Ver Wiebe, 4.

Tajo de Andonegui, Tampico: Wittich, 19.
Tertiary-Continued.

Mexico-Continued.

Tampico district: Belt, 2.

Tehuantepec Isthmus: Ver Wiebe, 5.

Vera Cruz, Idolo Island: Dumble, 6.

Midway formation: Plummer, 5 ; stratigraphic position: Gardner, J. A., 9.

Midway limestone, northeastern Texas: 'Thompson, W. C., 1.

Miocene: Olsson, 1.

Mississippi : Grim, 1; Lowe, 2, 4, 13 ; Morse, P. F., 1; Stephenson, 10.

Byram marl : Cooke, C. W., 7. northeastern : Burchard, 20.

Montana : Keyes, 234.

Beartooth Mountains : Bevan, 2.

Cat Creek oil field: Lupton, 1.

central : Bowen, C. F., 2 ; Reeves, F., 10 ; and eastern : Clapp, C. H., 2.

Crow Indian Reservation: Thom, 4.

Ekalaka field: Bauer, 4.

faulted area south of Bearpaw Mountains : Reeves, F., 8.

Garfield County : Thom, 3.

Huntley field: Hancock, 2.

Melrose phosphate field: Richards, R. W., 2.

Musselshell and Golden Valley counties : Ellis, A. J., 5.

Rosebud County :-Renick, 3, 5.

Scobey lignite field: Collier, 9.

Townsend Valley: Pardee, 10.

Tullock Creek coal field: Rogers, G. S., 8.

Nebraska, Sioux County, Agate anticline: Schramm, 2.

Nevada: Keyes, 128.

Candelaria district: Knopf, A., 5.

Clark County, Callville Wash: Gale, 3.

Divide district: Knopf, A. 3.

Gilbert district: Ferguson, H. G., 10.

Jarbidge district : Schrader, 5.

Mauhattan district: Ferguson, $H$. G., 2.

Mineral County, Cedar Mountain : Knopf. A.. 4.

Muddy Mountains : Longwell, 1, 15; Noble, 2.

Round Mountain district: Ferguson, H. G., 4.

southeastern: Stock, 7 .

New Jersey, greensand marls, Eocene age: Cooke, C. W., 17.

New Mexico: Darton, 11, 26 ; Keyes, 14 ; Knox, J. K., 2.

Alamosa Creek valley: Winchester, 3.

Gallup-Zuni Basin: Sears, 6.

Mogollon district: Fergusion, H. G., $3,8$.

northeastern: Garrett, 1.

Pecos Valley: Semmes, 4.

Raton coal fleld: Lee, W. T., 10.

Raton-Brilliant-Koehler area: Lee, W. T., 6 . 
Tertiary-Continued.

New Mexico-Continued.

San Juan County: Bauer, C. M., 1. San Juan Basin: Reeside, 8 .

North Atlantic Ocean, Tertiary history: Woodring; 8 .

North Carolina, Castle Hayne and Tient marls: Kellum, 2.

North Dakota: Leonard, A. G., 1. Fort Berthold Indian Reservation: Bauer, C. M., 2.

Marmarth field: Hares, 5.

New Salem lignite field: Hancock, 6 . western: Stanton, 3.

Oklahoma: Gould, 9.

Beaver County : Gould, 15.

Texas County: Gould, 11.

oligocene, use of term: Berry, 86 .

Oregon: Smith, W. D., 1.

Astoria section: Howe, H. V. W., 9. Cascade Mountains: Hodge, E. T., 14.

Coos Bay, Empire formation: Howe, H. V. W., 2.

eastern: Buwalda, 4.

Empire formation: Howe, H. V. W., 1.

John Day region: Buwalda, 18.

marine: Hertlein, 3.

marine Oligocene: Schenck, 5 .

Mount Jeffel'son: Hodge, E. T., 6.

Mount Multnomah: Hodge, E. T., 5.

Riddle quadrangle: Diller, 12.

southeastern: Smith, W. D., 14.

western: Harrison \& Eaton, 1; Oligocene: Schenck, 12.

Oreodon beds, Big Badlands. South Dakota : Sinclair, 7.

Pacific region: Clark, B. L., 3 ; correlation: Vaughan, 28.

Paleocene, status and limits: Matthew, 8.

Panama, Canal Zone: MacDonald, I). F., 1, 2, 5.; Vaughan, 3.

Haut Chagres beds, age: Vaughan, 41.

Pliocene, North Carolina: Mansfield, W. C., 6 .

Pacific Coast and Great Basin regions: Merriam, 21.

Porto Rico: Berkey, 1 ; Hubbard, B., 2 ; Maury, 1.

Coamo-Guayama district: Hodge, E. T., 1.

Lares district: 'Hubbard, B., 3.

Ponce district: Mitchell, 7 .

San Juan district: Semmes, 1.

Rattlesnake formation, Oregon: Merriam, 19.

Santo Domingo, Miocene formations: Maury, 2.

Saskatchewan, Eastend area: McLearn, 16.

Snake Creek fossil quarries: Matthew, 24.
Tertiary-Continued.

Soldado formation, basal Eocene: Maury, 7 .

South Dakota, Badlands: Ward, 8. Black Hills: Keyes, 31; O'Harra, 3. central Black Hills: Darton, 14. Newell quadrangle: Darton, 1. Washington County, Battle Creek Canyon: Wood, H. E., 3.

western : Stanton, 3.

White River Oligocene, turtle-Oreodon layer: Sinclair, 3.

Southeastern United States: Vaugban, 3.

Tennessee, western : Roberts, J. K., 6, 9 ; Schroeder, 1.

Texas: Gardner, J., 13 ; Udden, 3, 12. Amarillo region: Gould, 1.

Bastrop County, Eocene: Price, W. A., 12.

Bexar County: Sellards, 10.

Blue Ridge salt dome, Fort Bend County : Hager, D. S., 2.

Brazoria County, West Columbia field: Barton, 2.

Butler salt dome: Powers, 3.

coast deposits: Dumble, 2.

Coastal Plain: Applin, E. R., 1.

Colorado County: Bailey, T. L., 1. Damon Mound oil fleld: Bevier, 1. eastern: Dumble, 1 ; Renick, 12.

Gulf Coastal Plain: Dumble, 3 ; near Rio Grande: Trowbridge, 5.

Hockley salt dome, Harris County: Deussen, 2.

McMullen County, Gueydan tuff : Bailey, T. L., 2, 3.

Medina County: Liddle, 3 .

Palangana salt dome: Barton, 1.

Panola County: Sellards, 15.

Potter County: Patton, L. T., 2.

Reynosa Escarpment: Jones, R. A. 1.

Reynosa formation: Trowbridge, 9 10.

salt domes: Fowers, 12.

San Marcos quadrangle: Brucks, 2.

Saratoga oil field: Suman, 1.

southern: Böse, 8 ; Tatum, 1.

Stratton Ridge salt dome: Applin, P. L., 1.

West Point salt dome: DeGolyer, 1.

Wilcox group: Gardner, J. A., 3.

Texas section: Dumble, 7 .

Trent marl, age, North Carolina: Kellum, 1 .

Trinidad: Liddle, 4; Macready, 1; Milner, 1 ; Waring, 6.

Naparima region: Illing, 1. southern: Carlson, 2.

Utah : Butler, 4 ; Keyes, 152.

Castlegate, Wellington, and Sunnyside quadrangles: Clark, F. R., 4.

Green River valley: Reeside, 7.

Salina Canyon district, Sevier County: Spieker, 6. 
Tertiary-Continued.

Utah-Continued.

southeastern: Longwell, 6 . southern: Moore, R. C., 17.

Uinta Basin: Sur, 2.

Wasatch Plateau: Spieker, 3.

Virginia, Nomini Cliffs, Choptank formation: Mansfield, W. C., 3.

Washington, Hoh formation: Palmer, R. H., 3.

marine: Hertlein, 3.

Olympic Peninsula: Palmer, R. H., 5.

Pasco and Prosser quadrangles: Culver, 10.

San Juan Islands: McLellan, 2.

Skagit County: Jenkins, 8.

southwestern: Culver, 1.

Stevens County: Weaver, 2.

Spokane area: Pardee, 11, 12.

Whatcom County : Jenkins, 7.

West Coast: Clark, B. L., 4, 5 .

West Indies: Vaughan, 17, 22.

White River folmation, North Dakota: Leonard, A. G., 4.

Wyoming, Cody region: Hewitt, 4.

Fremont County, Big Sand Draw : Collier, 5.

Gillette coal field: Dobbin, 3.

Grass Creek quadrangle: Hewett, 16.

Green River valley: Reeside, 7.

Iance Creek field: Hancock, 5.

Meeteetse quadrangle: Hewett, 16.

Oregon Basin quadrangle: Hewett, 16.

Rock Springs area, Sweetwater County : Schultz, 1.

Sweetwater County : Sears, 4 ; Green River formation: Bradley, W. H., 5.

Wind River Mountains: Condit, 4.

Yukon, Sixtymile and Ladue rivers area : Cockfield, 5 .

Zeolite beds in the Green River formation: Bradley, w. H., 8.

Texas.

Bureau of Economic Geology activities: Sellards, 28 ; Udden, 21.

Chemical analyses of rocks and minerals: Schoch, 1.

Geology of dam sites in western Texas: Patton, L. T., 3.

Identification of geological formations : Udden, 3.

Red River boundary: Glenn, 8.

A.reas described.

Bexar County : Sellards, 10.

Coke County : Beede, 6 .

Colorado County : Bailey, T. L., 1.

Cooke County : Bybee, 3.

Crockett County : Liddle, 2.

Dallas County: Shuler, 1.

Denton County : Winton, 3.

Foard County: Beede, 11.

Fort Stockton quadrangle: Adkins, 4.
Texas-Continued.

Areas described-Continued.

Gulf Coastal Plain near Rio Grande: Trowbridge, 5 .

Johnson County: Winton, 2.

Lacasa area, Ranger district: Ross, C. S., '3.

McLennan County: Adkins, 2.

Madill-Denison area : Hopkins, O. B., 2.

Potter County: Patton, L. T., 2.

Ranger oil field : Reeves, F., 2.

Solitario uplift, Presidio-Brewster Counties: Powers, 9.

Tarrant County: Winton, W. M., 1.

Terrell County: Christner, 1.

Tom Green County: Henderson, G. G., 1.

Trans-Pecos Texas, southwestern part: Baker, C. L., 6.

Wiles area, Ranger district: Dobbin, 1.

Economic geology.

Alkali lakes, western Texas: Meigs, 1.

Alunite, south central Texas: Braun, 1.

Amarillo district, oil and gas: Harrison, T. S., 1.

Asphalt, Anacacho formation: Baker, C. L., 9 .

Austin formation in San Antonio oil fields : Sellards, 14.

Balcones and Mexia faulting, mechanics : Foley, 2.

Barbers Hill oil field, Chambers County : Bevier, 2.

Batson oil field, Hardin County: Sawtelle, 1.

Bend series, water problems: Fuller, M. L., 1.

Bethany gas pool: Hull, 5 .

Bexar County oil fields: Sellards, 7.

Big Hill salt dome, Matagorda County : Wolf, 5 .

Big Lake oil field, Reagan County : Sellards, 21.

Big Lime, stratigraphic position: Edwards, E. C., 2.

Blue Ridge salt dome, Fort Bend County: Hager, D. S., 2.

Borings for potash, Midland County: Sellards, 26.

Bryan Heights salt dome, Brazoria County: Kennedy, 1.

Buried ridges, western Texas: Powers, 24.

Chemical analyses of rocks and minerals: Schoch, 1.

Clay Creek dome, Washington County: Lahee, 20.

Currie oil and gas field, Navarro County: Lahee, 10, 19

Damon Mound oil field: Bevier, 1.

Deep Creek oil field: Wade, A., 1.

Diablo Plateau : Beede, 3.

Eastern Texas: Dumble, 1.

Edua, Jackson County, gas and oil: Price, 11. 
Texas-Continued.

Economic geology-Continued.

Faulting and petroleum accumulation at Mexia: Pratt, W. E., 9.

Gas well, Jim Hogg County: Jones, R. A., 2.

Goose Creek oil fleld, Harris County: Minor, 2.

Gulf Coast oil flelds: Barton, 13; Wolf, 2 .

Gulf Coastal Plain salt domes, secondary intrusive origin: Matteson, 2.

Gypsum: Stone, 11.

Helium-bearing natural gas: Rogers, G. S., 7 .

Hockley salt dome, Harris County: Chapman, 1; Deussen, 2.

Interior salt domes: Powers. 17.

Kerens, Navarro County, drilling near: DeWolf, 7.

Lignite: Gentry, 1.

Lost Lake salt dome: Wasson, 1.

Luling oil fleld, Caldwell and Guadalupe counties: Brucks, 1, 2; Sellards, 19 .

Lytton Springs oil field, Caldwell County: Brucks, 2; Bybee, 2; Collíngwood, 8.

McLennan County: Pace, 1.

Medina County: Liddle, 3.

Mexia oil field: Lahee, 17 ; Whitney, R. H., 1; Wrather, 2.

faulting and petroleum accumulation: Pratt, W. E., 7.

Mid-Continent oil fields: Bosworth, 1. Mineral resources: Sellards, 20.

Minerva oil field, Milan County: Hager, D. S., 1.

Natural gas: Snider, 1.

Panhandle: Bauer, C. M., 8.

Natural gas resources, central north Texas: Shaw, 6

New Richland oil field, Navarro County, Lahee, 11.

Nigger Creek ofl pool, Limestone County: Hull, 14.

North Texas oil fields: Roberts, J. R., 1 ; Wheeler, H. A., 1, 2.

Northeast Texas petroleum area : Fohs, 2 .

Oil and gas in Panhandle: Pratt, W. E., 8.

Oil and gas flelds, Webb and Zapata counties: Sellards, 13.

Oil fields, Archer County : Hubbard, W. E., 1.

Oil fields, north central Texas: Hager, D., 2.

Oil fields, southwestern Texas: Owen, W. T., 1 .

Oil possibilities, Diablo Plateau : Beede, 3.

Oll-bearing formations: Udden, 7.

Palangana salt dome, Duval County: Barton, 1.
Texas-continued.

Economic geology-Continued.

Panhandle: Lockwood, 2.

Panhandle oil fields: Bauer, 7.

Petroleum: Snider, 1.

central Texas: Matteson, 1.

Coke County: Beede, 1.

Cooke County: Hawtof, 1.

Eastland and Stephens counties: Adams, H. H., 1.

Fort Stockton, Pecos County : Pratt, W. E., 2.

Luling, Caldwell County: Pratt, W. E., 6.

Ranger field: Reeves, F., 2.

relation to carbon values in north Texas: Fuller, M. I., 3.

southwestern Texas: Stephenson, 3.

Zapata County: Wrather, 4.

Potash: Keyes, 285; Udden, 26.

Midland County: Sellards, 25.

western Texas: Hoots, 1; Mansfield, 14; Udden, 14, 15; White, D., 7.

Potrish investigations: Lang, W. B., 2. Powell oil field: Hill, H. B., 1.

Quicksilver deposits, anticlinal theory : Udden, 2,6 .

Terlingua district: Lewis, F, 1.

Red Bed ores: Bains, 1.

Reynosa escarpment, oil and gas fields: Jones, R. A., 1.

Road-building materials: Nash, 1.

Salt: Darton, 8

Salt deposits : Phalen, 1.

Salt dome structure: Lucas, A. F., 1.

Salt domes: Deussen, 1; Renick, 12 ; Wolf, 1 .

Fort Bend County: Pratt, W. 14., 5 . northeastern 'lexas: Cheney, C. A., 1. southern Texas: Barton, 4 ; Jones, R. A., 6.

Sand and gravel, Trinity River district: Shaw, E., 1.

Saratoga oil fleld, Fardin County: Suman, 1 .

Seismographic method for underground observations: Udden, 9.

Sipe Springs oil field: Wade, A., 1.

South Bend oil field, Young County: Cheney, M. G., 1.

South Dayton salt dome, Liberty County: Bowman, 1.

Spindletop salt dome, Jefferson County: Barton, 5.

Spindletop oil field, Beaumont: Sur, 1.

Stratton Ridge salt dome, Brazoria County: Applin, P. L., 1.

Sulphur deposits, Gulf coast: Barton, 8.

Thrall oil field, Williamson County: Bybee, 1.

Waskom gas field: Grimnı, 1.

Westbrook oil field, Mitchell County: Edwards, E. C., 1.

West Columbia oil field, Brazolia County: Barton, 2. 
Texas-Continued.

Economic geology-Continued.

White Point gas field, San Patricio County: Wolf, 3.

Wortham and Lake Richland faults: Lahee, 16.

Yates pool, Pecos County: Metcalf, R. J., 1.

Historical geology.

Amarillo region: Gould, 1.

Archer County: Hubbard, W. E., 1. Austin formation in San Antonio oil fields : Sellards, 14.

Balcones fault region: Udden, 8 .

Barbers Hill oil field, Chambers County : Bevier, 2.

Barnett shale, age: Moore, R. C., 16. Batson oil field, Hardin County : Sawtelle, 1.

Bend formation: Girty, 1.

Bend series, age : Gilty, 2.

and contiguous formations: Goldman, 8.

Brown County: Waite, 1.

central Texas: Moore, R. C., 2.

Bexar County, subsurface Cretaceous: Jones, R. A., 7 .

oil fields : Sellards, 7 .

Big Bend area: Tex., Atty. Gen., 1.

Big Hill salt dome, Jefferson County: Henley, 1.

Big lime, western Texas, stratigraphic position : Edwards, E. C., 2.

Big salt dome, Matagorda County : ${ }^{\circ}$ Wolf, 5.

Big Lake oil field, Reagan County: Sellards, 21.

Bissett formation, Glass Mountains : King, 4.

Blanco and associated formations: Matthew, 30 .

Blue Ridge salt dome, Fort Bend County : Hager, D. S., 2.

Borings, Colorado County: Bailey, T. L., 1.

Cooke County: Hawtof, 1

Lytton Springs oil field: Bybee, 2. potash, Midland County : Sellards, 26.

Palo Pinto County: Goldman, 8.

Panola County: Sellards, 15.

Potter County: Patton, L. T., 2.

Webb and Zapata counties: Sellards, 13.

Bryan Heights salt dome, Brizoria County : Kennedy, 1.

Butler salt dome, Freestone County: Powers, 3.

Canadian River valley: Patton, 6 .

Carboniferous, north central Texas: Gould, 13.

Cavern deposits in Permian: Udden, 13. Central Texas oil fields: Matteson, 1.

Coastal Plain: Applin, E. R:, 1.

Coke County: Beede, 1, 2.

Colorado, Mitchell County: Cook, H. J., 12 .
J'exas-Continued.

Historical geology-Continued.

Coral reefs in Oligocene: Ellisor, 3.

Cretaceous: Hill, R. T., 3, 5; Scott, G., 2 ; Stanton, 13.

central Texas: Carsey, 1.

correlation: Scott, G., 4.

western Texas : Baker, C. L., 2.

Cretaceous and Tertiary, southern Texas: Böse, 8 ; Tatum, 1.

Culberson County: Udden, 18.

University Block: Beede, 8.

Currie structure, Navarro County: Lahee, 19.

Damon Mound oil field: Bevier, 1.

Diablo Plateau: Beede, 3.

Eagle Ford formation: Moreman, 2.

Eastern Texas: Dumble, 1 ; Renick, 12

Eastland and Stephens counties: Adams, H.. H., 1.

Ellenburger formation, north cential Texas: Sellards, 9, 11.

Fredericksburg and Washita formations, northern Texas: Adkins, 1.

Gaptank-Wolfcamp problem, G la s s Mountains : Keyte, 2.

General: Snider, 1; Udden, 3.

Geologic map: Currier \& Company, 1. western Texas: Anon., 58.

Glass Mountains, west Texas : King, $2,6$.

Glenn formation, north central Texas: Goldston, 2.

Goose Creek oil field, Harris County : Minor, 2.

Guadalupe group : Darton, 19.

Gueydan tuff, McMullen County: Bailey, T. L., 2, 3.

Gulf coast: Schander, 1.

Gulf Coastal Plain: Dumble, 3.

Hockley salt dome, Harris County Deussen, 2.

Hudspeth County, Carboniferous formations, correlation: Beede, 5 .

Igneous rock in wells in Panbandle: Donoghue, 1.

Interior salt domes: Powers, 17.

Lithologic correlation in "Bend" series: Goldman, 5.

Llano-Burnet and Marathon uplifts : Powers, 26.

Llanoria : Miser, 7.

Lower Cretaceous or Comanche series: Bullard, 4; Stanton, 14.

Luling oil field, Caldwell and Guadalupe counties: Brucks, 1.

Lytton Springs oil field, Caldwell County: Bybee, 2 ; Collingwood, 8.

McLennan County: Pace, 1.

Malone formation: Kitchin, 1.

Marathon basin, trans-Pecos Texas : Baker, C. I., 10.

Marathon fold, northwest Texas : Hassan, 1 : Liddle, 1.

Marine Wilcox: Dumble, 4.

Medina County : Liddle, 3. 
Texas-Continued.

Historical geology-Continued.

Midway formation: Plummer, 5 ; stratigraphic position : Gardner, J. A., 9.

Midway limestone, northeastern Texas: Thompson, W. C., 1.

Mississippian, San Saba County : Roundy 3 ; age and correlation: Girty, 7.

Moss Bluff and Boggy Creek domes: Pratt, 14.

Nacatoch formation : Howe, H. V. W., 5.

North central Texas: Hager, D., 2 ; Udden, Jon A., 1.

Northeast Texas, petroleum area: Fohs, 2.

stratigraphy and structure: Fohs, 1.

Northern Texas petroleum flelds: Pratt, W. E., 1.

Oil-bearing formations: Udden, 7.

Oil sand outcrop, Coke County : Jones, R. A., 4.

Palangana salt dome, Duval County: Barton, 1.

Panhandle: Lockwood, 2.

Pennsylvanian, Burkburnett: Glen, 2. north central Texas: Berry, 49; Moore, R. C., 13; Plummer, F. B. $1,4$.

Pennsylvanian-Permian systems, western Texas: Schuchert, 39.

Permian: Gould, 8, 14, 27; Anon., 50. correlation: Gould, 10.

Panhandle: Gould, 16.

Permo-Carboniferous, Glass Mountains : Böse, 1.

Potash salts and algae in salt dome: DeGolyer, 14.

Ranger oil field: Eckes, 1.

Red River valley: Sellards, 18.

Reynosa formation, southwestern Texas : Trowbridge, 9.

lower Rio Grande region: 'Trowbridge, 11.

Rios well, Caldwell County: Sellards, 16.

Salt domes: Powers, 12. southern Texas: Barton, 4.

San Angelo formation: Beede, 10.

San Marcos quadrangle: Brucks, 2.

Saratoga oil fields, Hardin County: Suman, 1.

Smithville, Bastrop County : Price, W. A. 12 .

South Dayton salt dome, Liberty County: Bowman, I.

Southwestern Texas: Blatchley, 1.

Spindletop salt dome, Jefferson County: Barton, 5 .

Stratton Ridge salt dume, Brazoria County : Applin, P. L., 1

'Tarrant County, geologic history : Hill, E. A., 1.

Taylor and Navarro formations in east-central Texas: Dane, 1.
'Texas-Continued.

Historical geology-Continued.

'l'ertiary : Gardner, J. A., 13

foraminiferal guides: Dumble, 2.

lower Rio Grande region: 'Ilowbridge, 6 .

Tertiary section: Dumble, 7 .

Trans-Pecos Texas: Keyes, 290.

Trinity group: Vanderpool, 3.

Upper Cretaceous: Stephenson, 8.

Upper Triassic beds: Case, 11.

Val Verde County: Calvert, 2.

Vertebrate faunal holizons, PermoCarboniferous red beds: Romer, 13.

Weno and Pawpaw formations: Adkins, 2.

West Columbia oil field, Brazoria County: Barton, 2.

West Point salt dome, Freestone Coun ty : DeGolyer, 1.

West Texas, geologic map: Beede, 10. Western Texas: Edwards', E. C., 2 ; Hoots, 1.

White Cliffs chalk, age and correlation : Ellisor, 2.

Whitehorse sandstone: Clifton, 2.

Woodbine sand, age: Scott, G., 3.

Yegua, marine, correlation: Gardner, J. A., 12.

Mineralogy.

Analcite, Brewster County: Lonsdale, 12.

Barite pisolites, Batson and Saratoga oil fields: Barton, 10.

Hauerite, Big Hill salt dome, Matagorda County: Wolf, 6.

Meteorite, Alpine, Brewster County : Merrill, 19.

Florence, Williamson County: Lonsdale, 9.

Odessa, Ector County : Merrill, 22.

Troup meteorite: Merrill, 15; Udden, 10.

Tulia, Swisher County: Palache, 20.

Niter and soda niter, Brewster County: Lonsdale, 4.

Orthoclase crystals, Sierra Blanca: Lonsdale, 8.

Puleontology.

Ammonites, Cretaceous: Scott, G., 6.

Fredericksburg formation: Scott, G., 5.

Anancus, Brazos River: Hay, 18.

Arctotherium: Matthew, 9.

Bairdia subdeltoidea, Cretaceous : Alexander, C. I., 2.

Bend series, central Texas: Moore, $\mathbf{R}$. C., 2.

Bison, Colorado and Dawson County: Hay, 41.

Bison chaneyi, Pleistocene, Vernon: Cook, H. J., 14.

Calatoloides, Eocene fruit: Berry, 38. 
Texas-Continued.

Paleontology-Continued.

Calycophysoides, cucurbitaceous fruit, Tertiary, Foard County: Berry, 53.

Carboniferous foraminifers, Sutton County : Cushman, 45.

Charophyte fruits: Groves, 1.

Climacammina, Pennsylvanian: Cushman, 42.

Coelophysis: Case, 22.

Colorado artifacts: Cook, H. J., 10.

Cook Mountain Eocene, Bastrop County : Price, W. A., 12.

Cotylysaur, Triassic, western Texas: Case, 26, 27.

Cretaceous: Adkins, 5; Scott, G., 2 ; Stanton, 13.

ammonites: Böse, 9.

Cycad localities: Sellards, 27.

Cycadeoid, Wise County: Wieland, 10.

Cycad-like leaves, Permian : Noe, 1.

Denton County: Winton, 3.

Desmatosuchia, Triassic: Case, 6, 8, 10.

Dimetrodon: Romer, 8.

Dimetrodon gigas: Gilmore, 3.

Dinosaur tracks, Hamilton County: Wrather, 5.

Diplocaulus primigenius, Baylor County: Mehl, 7.

Eagle Ford fossil zones, northern Texas: Moreman, 2.

Eocene crabs: Rathbun, 6.

Eocene Mollusca: Gardner, J. A., 11

Eocene flora, trans-Pecos Texas : Berry, 12

Eocene florule, central Texas: Berry, 56.

Exogyra, Cretaceous: Böse, 2.

Fishes, Triassic: Warthin, 1.

Fistulipora, Canyon formation, Eastland County: Link, 6.

Flabellammina alexanderi, time range: Alexander, C. I., 3

Footprints: Moodie, 27.

Foraminifera: Cushman, 22.

Cariyon division: Waters, J. A., 2. Cretaceous, central Texas: Carsey, 1. Midway formation: Plummer, II. J., 1.

Pennsylvanian: Farlton, 3

Foraminifera and Ostracoda, marine Yegua: Stadnichenko, M. M., 1.

Fort Worth area: Winton, H., 1.

Fossil footprints near Abilene: Gould, C. $N$., 28.

Fredericksburg and Washita formations, northern Texas: Adkins, 1.

Gastropod trails in Pennsylvanian sandstones: Powers, 10.

Gerontic ammonites, Duck Creek formation: Scott, G., 1.

Guembelina, changing character : Thomas, N. L., 3.

Human artifacts in Pleistocene: Cook, H. J., 6.
Texas-Continued.

Paleontology-Continued.

Human remains with Pleistocene fossils, Dallas : Shuler, 2.

Insecta, Eocene: Cockerell, 19.

Jackson, Foraminifera: Cushman, 24.

Labryinthodont thoracic shield: Case, 5.

Lutetia: Harris, G. D., 2.

Malone formation: Kitchin, 1 .

Mastodons : Hay, 25.

Micrology, Cretaceous: Alexander, C. I., 1 ; Carpenter, M. 1 ; Mahon, 1 ; Moreman, 1.

Midway brachiopod, Butler salt dome: Gardner, J. A., 6.

Miocene vertebrates: Hay, 20.

Mississippian, San Saba County : Girty, 7.

micro-fauna : Roundy, 3.

Mollusca, Eocene, southwestern Texas: Gardner, J. A., 2.

Ostracoda, Cisco formation: Harlton, 1.

Pectinidae, Cretaceous: Kniker, 1.

Pennsylvanian, Burkburnett: Glenn, 2. north-central Texas, Plummer, 4. northern Texas: Moore, R. C., 15. ostracodes: Harlton, 4.

Permo-Carboniferous ammonoids, Glass Mountains, Texas: Böse, 1.

Phytosaur, Triassic: Case, 6, 24.

Pleistocene fresh-water Mollusca, north-central Texas: Hanna, G. D., 9.

Pleistocene Mammalia, Dallas : Lull, 8.

Pleistocene mastodons: Hay, 32.

Fleistocene plants: Berry, 88.

Pleistocene Vertebrata: Hay, 6; southwestern Texas: Hay, 33 .

Plesippus, Blanco formation: Matthew, 29.

Quisque bakeri, Miocene herring: Jordan, 8.

Recurrent brachiopods, Lower Cretaceous, northern Texas: Sandidge, 1.

Seymouria, Clear Fork beds: Romer, 11.

Tarrant County: Winton, W. M., 1.

Tortoises, Brazos River : Hay, 18.

Triassic reptiles and stegocephalians, western Texas: Case, 11.

Triassic vertebrates: Case, 16.

Trinity fauna: Vanderpool, 2.

Turritella, Buda and Georgetown limestones: Ellisor, 1.

Unionid pelecypod, Dockum group, Mitchell County: Reeside, 15.

Vertebrate faunal horizons, PermoCarboniferous red beds: Romer 7,13 .

Vertebrates, collecting: Sternberg, C. H., 4.

Weichselia, Cretaceous: Berry, 95.

Weno and Pawpaw formations': Ad. kins, 2 . 
Texas-Continued.

Paleontology-Continued.

Wilcox, marine: Gardner, J. A., 3.

Woodbine flora, Arthurs Bluff: Berry, 36.

Petrology.

Bend and Ellenburger limestones, microscopic characters: Udden, 4, 23.

Contact of Ellenburger and Boone limestones: Goldman, 16.

Igneous rocks of Balcones fault region: Lonsdale, 10.

Ordovician and Mississippian limestones at their contact: Goldman, 14.

Pseudo-igneous rock and baked shale, Freestone County: Lonsdale, 11.

Salt dome cap rock: Goldman, 12.

Sedimentary rocks, characteristies : Udden, 12.

Physical geology.

Asphalt, Anacacho formation: Baker, C. L., 9 .

Balcones and Mexia faulting, mechanics : Foley, 2.

Balcones fault zone: Sellards, s.

Central Texas: Matteson, 1.

Coke County, geologic structure : Beede, 2.

Corrosion and corrasion, Barton Creek, Austin: King, 5.

Crystalline rocks of the plains : Gould, 3.

Desert range tectonics, trans-Pecos Texas: Baker, C. L., 11.

Farthquake, Panhandle, July 30, 1925 : Neumann, 3 ; Pratt, 12.

Eastland and Stephens counties, structure: Adams, H. H., 1.

Etched potholes: Udden, 20.

Glass Mountains, west Texas: King, 2.

Goose Creek oil field subsidence: Johnson, D. W., 16 ; Pratt, W. E., 10 , 11, 13, 15; Snider, 2.

Igneous dikes, Bandera County: Daw. son, J. M., 1. .

Laminated structure of anhydrite beds : Udden, 17, 18.

Laminated structure of drill cores: Udden, 27.

Marathon fold, northwest Texas : Liddle, 1.

Melikaria : Burt, 5.

North central Texas: Hager, D., 2.

Northeastern Texas fault zones: Lahee, 13.

tectonic features : Fohs, 2 ; Robinson, H. M., 4.

Pseudo-igneous rock and baked shale, Freestone County: Lonsdale 11.

Quicksands, Brazos County: Burt, 3. Red River Valley: Sellärds, 18.

Rim rock of High Plains: Udden, 16.

Salt domes: Powers, 12 ; • Renick, 12.
Texas-Continued.

Physical geology-Continued.

Sandstone dikes, Rockwall: Patton, 5; Stephenson, 7 .

Southwest earthquake, July 30, 1925 : Udden, 22.

Physiographic geology.

Boulders, Brazos River : Reed, L. C., 2.

Butler salt dome, Freestone County: Powers, 3.

Classification and nomenclature of physiographic features: Hill, $\mathbf{R}$. '1., 4.

Coast region uplift: Jones, R. A., 11.

Crater, Ector County: Sellards, 23.

Meteor crater: Bibbins, 1.

Falangana salt dome, Duval County: Barton, 1.

Red River valley: Hill, R. T., 7 ; Tex., Atty. Gen., 1.

Sand rivers: Hill, R. 'T., 6.

Trans-Pecos Texas: Baker, C. L., 11; Keyes, 290.

Underground water.

Bend series, water problems: Fuller, M. L., 1.

Bexar County: Sellards, 10.

Salt dome waters: Minor, 1.

Sulphur waters: Henninger, 1.

Textbooks.

Agricultural geology : Emerson, F. V., 3.

Chemical analysis of rocks: Washington, 1.

Determinative mineralogy: Lewis, 4.

Earth and its history: Bradley, J. H., jr., 5.

Earth history: Shimer. 4.

Economic geology : Emmons, W. H., 3 ; Ries, 10.

Elementary geology: Coleman, 9.

Elements of geology: Norton, W. H., 2 ; Quirke, 14.

Engineering geology : Ries, 4, 11.

Field geology: Lahee, 8.

Geology : Brigham, 4; Chamberlin, $\mathrm{T}$. C., 32 ; Cleland, 8 ; Emerson, F. V., 2 ; Grabau, 10, 12; Miller, W. J., 15; Pirsson, 2, 5 ; Price, G. M., 13; Schuchert, 23 .

Geology applied to mining: Spurr, 24. Geology manual: Field, 6.

Handbook for field geologists: Hayes, C. W., 1.

Introduction to geology : Miller, W. J., 24.

Mineral deposits: Lindgren, 1, 23.

Mineralogy: Dana, 1, 2 ; Kraus, 2, 8; Rogers, A. F., 5

Mineralogy determinative: Warren, C. H., 1.

Mineralogy, optical: Winchell, N. H., 1. Mineralogy and geology: Herrera, $J$ Oil field geology : Hager, D., 1.

Petroleum geology, field methods: Cox, G. H., 1.

Physical geography: Tarr, R. S., 1. 
Textbooks-Continued.

Physical geology: Miller, W. J., 22, 32.

Physiography : Salisbury, 1 ; Scott, W. B., 1.

Principles of stratigraphy: Grabau, 13. Rocks and rock minerals: Pirsson, 6. Structural geology : Leith, 9.

Thermal currents in oil accumulation: Pepperberg, 1.

Thermal waters.

Alaska, Valley of Ten Thousand Smokes: Zies, 3.

Alberta, Banff area: Warren, P. S., 4. Arkansas, Fot Springs district: Bryan, 9, 14 ; Purdue, 1.

California, Sonoma County : Day, 12.

General: Sosman, 8.

Great Basin region: Meinzer, 10.

Haiti : Brown, J. S., 4.

Heat in springs, a physical source of: Adams, I. H., 4.

Hot springs: Sosman, 7.

Relation of crystallization to water content and vapor pressure of water in a cooling magma: Morey, 2.

Southeastern Atlantic States: Watson, 16.

Utah, Wasatch fault : Pack, F. J., 8.

Virginia, Rockbridge County, Irish Creek : Haney, M., 1.

Thomas oil field, Kay County, Oklahoma: Clark, S. K., 1.

Thorium: Schaller, 4.

Thrust faulting: Lawson, 2.

Thunder Bay district, Ontario: Tanton, 5. Tidal forces in the making of continents and mountains: Taylor, 10.

Tidal waves, prediction: Finch, R. H., 2. Tin.

Alaska, Hot Springs district: Chapin, 6.

Lost River district: Fearing, F. C., 1.

Ruby district: Chapin, 7.

Seward Peninsula: Harrington, 3.

York region: Steidtman, 4

British Honduras: Jones, W. R., 1.

Gel replacement of cassiterite: Wagner, P. A., 2.

General: Johnson, B. L., 4, 5, 7, 8, 9 ; Knopf, A., 1, 6.

Idaho: Livingston, 2.

Manitoba, West Hawk Lake region: DeLury, 3

Mexico: García, 2.

placer deposits: Sampson, E. H. S., 1.

New Mexico, Black Range district: Naething, 1.

Taylor Creek district: Hill, J. M., 3.

North Carolina: Haney, 4.

South Carolina: Haney, 4.
Tin-Continued.

South Dakota, central Black Hills . Darton, 14.

Washington, Silver Hill deposits : Anderson, A. L., 5

Wood tin nodules: Newhouse, 7.

'Tintic mining district, Utah: Lindgren, 2. T'itanium.

Canada: Robinson, A. H. A., 1.

General : Hess, 2. 7, 8, 12, 13, 16, 19, 21; Robinson, A. H. A., 1.

Virginia, Amelia County: Watson, 12.

'Tomboloes and points, formation: Johnson, R. H., 6 .

Tonkawa oil field, Oklahoma: Clark, G. C., 1 ; Hosterman, 1.

'opographic and geologic mapping in Illinois, relation to engineering: $\mathrm{De}$ Wolf, 6.

Torsion seismometer: Anderson, J. A., 2.

Tortugas.

Physical geology.

Coquina, Loggerhead Key, origin: Field, 2.

J'rails.

Climacticnites : Raymond, 15.

Formation: Raymond, 15.

Gastropod trails in Pennsylvanian sandstones: Powers, 10.

Rosetted trails of worms: Clarke, J. M., 27.

Travertine: Emig, 1

Virginia, Augusta County : Collins, R. L., 1.

Tree ancestors: Berry, 46

Triassic. See also Paleontology, Triassic. Alaska: Martin, G. C., 15.

northern, Canning River region: Leffingwell, 1.

Chitina Valley: Moffit, 5.

Chulitna region, upper: Capps, 4.

Cold Bay district: Capps, 5; Smith, W. R., 4.

Cold Bay-Chignik district: Smith, W. R., 1.

Cold Bay-Katmai district: Smith, W. R., 3.

Kamishak Bay region: Mather, 7. Kotsina-Kuskulana district: Moffit, 4.

Arctic regions, Ellesmere Land: Holtedabl, 1.

Arizona: Darton, 17 ; Keyes, 83.

Grand Canyon district: Moore, R. C., 26.

Hopi Buttes volcanic field: Reagan, 8.

Navajo country: Reagan, 20

northeastern: Hager, D., 6.

Lees Ferry region: Bryan, 8.

northeastern, Holbrook area : Hager, D., 3.

northwestern: Reeside, 4; Shimer, 2 . 
Triassic-Continued.

British Columbia, Bow River section,

Banff: Kindle, 30.

Bridge River area: McCann, 3.

Chilko Lake area: Dolmage, 15.

Coquihalla area: Cairnes, 4.

Dease Lake area, Cassiar district. Kerr, F. A., 1.

Parson Bay: Crickmay, 9.

Peace River district: Spieker, 1.

Pemberton area, Lillooet district: Cairnes, 8.

southwestern: Cairnes, 2.

upper Peace River region: McLearn, 6.

Texada Island: Swanson, C. O., 2.

Vancouver Island: Dolmage, $\mathbf{5}$.

Yale district: Cairnes, 5 .

Colorado: Keyes, 162.

Delta and Mesa counties: Weeks, H. J., 1.

east-central : Lee, W. T., 19.

Las Animas, Otero, and Bent counties (parts): Duce, 1.

Moffat County: Sears, 3 .

Montezuma County, McElmo anticline: Coffin, 2.

southwestern : Coffin, 3.

Connecticut: Longwell, 18.

Meriden area: Waring, 2.

Middletown area: Rice, W. N., 1. southern: Longwell, 5; Russell, W. L., 1.

Southington-Granby area : Palmer, $\mathrm{H}$. S., 5.

Triassic trough, origin: Foye, 7.

Connecticut basin during the Newark epoch: Foye, 5.

Continental Triassic beds: Huene, 3.

Greenland : Böggild, 1.

Idaho, Bingham, Bonneville, and Caribou counties: Kirkham, 3.

Fort Hall Indian Reservation: Mansfield, . G. R., 3.

Mineral and Cuddy Mountain mining districts 4 Livingston, 4 .

southeastern : Mansfield, G. R., 6, 29.

Massachusetts, Connecticut Valley : Miller, W. J., 10; Triassic scree: Reynolds, 1.

Mesozoic of North and South America : Knowlton, 1.

Mexico, Guanajuato mining district: Wandke, 8.

Montana : Bauer, C. M., 3.

Beartooth Mountains, Bevan, 2.

central and eastern: Clapp, C. H., 2.

Melrose phosphate field: Richards, R. W., 2.

Nevada: Keyes, 128.

Mineral County, Cedar Mountain : Knopf, A., 4.

Muddy Mountains region: Longwell, $1,15$.

Rochester district: Knopf, A., 7.
Triassic-Continued.

Newark system : Dorsey, 1 ; Hobbs, 16 ; Raymond, 34 .

New Mexico: Darton, 11, 26 ; Keyes, 14 ; Lee, W. T., 2.

eastern: Baker, C. I., 1 ; Rich, 5.

Gallup-Zuni Basin: Sears, 6.

northeastern: Garrett, 1.

Puertecito district: Wells, E. H., 2.

North Carolina, Durham Basin : Prouty, 15, 16.

North America, southern: Stanton, 1.

Oklahoma, Cimarron County: Rothrock, 4.

Oregon: Smith, W. D., 1. central: Packard, 6.

Pacific coast: Goranson, 1.

Pennsylvania, Allentown quadrangle: Miller, B. L., 5.

Gettysburg area: Stose, 2.

New Holland quadrangle: Jonas, 5. northwest of Lebanon: Stose, 27. outlier near Lebanon: Stose, 26. southeastern: Stose, 21.

York County: Wanner, 1.

Red beds: Branson, 17.

Shinarump conglomerate: Case, 27.

South Dakota, central Black Hills: Darton, 14.

Texas: Udden, 3, 12.

Amarillo region: Gould, 1.

Big Lake oil field: Sellards, 21.

Crockett County: Liddle, 2.

Fort Stockton quadrangle: Adkins, 4.

Potter County: Patton, L. T., 2.

western: Case, 11, 27 ; Hoots, 1.

Upper Triassic: Smitb, J. P., 3.

Utah: Butler, 4; Keyes, 152 ; Matthews, 1.

Grand and San Juan counties: Prommel, 1.

La Sal Mountains: Gould, L. M., 4. Moab region: Baker, A. A., 1.

San Juan Canyon: Miser, 14, 17.

San Rafael Sirell: Gilluly. 4.

southeastern: Longwell, 6; Prommel, 4.

southern: Moore, R. C., 17.

southwestern: Reeside, 4.

Washington County : Bassler, H., 2.

Vertebrata, use in correlation: Mebl, 13.

Virginia : Roberts, J. K., 8. northeastern Piedmont: Lonsdale, 7. northern basins: Roberts, J. K., 2. Piedmont: Jonas, 8.

Washington, San Juan Islands: McLellan, 2.

Wyoming, Bell Springs district: Dobbin, 5.

Chugwater-Sundance contact, Bighorn district: Brainerd, 1. central : Lee, W. T., 1.9.

Maverick Springs : Collier, 6. 
Triassic-Continued.

Wyoming-Continued.

Thermopolis district: Collier, 4.

Wind River Mountains: Conduit, 4.

Triassic sandstones, petrographic analysis: Rober'ts, J. K., 4.

Tri-County oil field, southwestel'n Indiana: Esarey, 2.

Trilobita.

Anatomy: Walcott, 6.

and relationships: Raymond, 8 .

Appendages: Calman, 1 ; Clark, '1. H., 7.

Arkansas, St. Clair limestone: Foerste, 14.

Calymene, structure: Walcott, 4.

Cambrian: Raymond, 36.

and Ozarkian : Walcott, 10, 15.

earliest: Walcott, 5 .

Mohave Desert, California : Resser, 6.

Ceraurus, Iowa: Thomas, A. O., 24. structure: Walcott, 4.

Color markings: Raymond, 19.

Criteria for discrimination: Raymond, 12.

Cybele : Vogdes, 1.

Dipharus, Boston area, Massachusetts : Clark, T. H., 10.

Genera and subgenera, list: Vogdes, 1.

General: Raymond, 5.

Habits : Raymond, 17.

Iowa: Walter, 3.

St. Lawrence limestone: Walter, 1.

Lichadidae, Ordovician: Foerste, 5.

Neolenus, structure: Walcott, 4.

ventral appendages: Ulrich, 4 .

Newfoundland, Paradoxides faunas, Manuels Brook: Howell, 4.

Olenellus getzi, antennæ: Dunbar, 9 .

Olenellus with antennules: Dunbar, 8.

Ontario, Tolonto area : Fritz, 1.

Ontogenies and their significance: Raw, 1; Raymond, 35.

Ordovician: Raymond, 6.

and Silurian: Foerste, 3

lower middle: Raymond, 28.

Ordovician "hypoparian" genera: Ulrich, 7.

Phylogeny: Raymond, 7.

Pygidium: Raymond, 2.

Quebec, Philipsburg region, Beekmantown : Bradley, J. H., jr., 3.

Reversion: Ruedemann, R., 3.

Texas, San Saba County, Mississippian : Girty, 7 .

Triarthrus, structure: Walcott, 4.

Triarthrus canadensis, .Triarthrus glaber, and Triarthrus spinosus: Parks, 4.

Trinucleidae, distribution and relationships: Stetson, 2.

Vermont, northwestern: Raymond, 23.

rrinidad.

General: Liddle, 4 ; Waring, 6 .

Geology and oil resources: Milner, 1.
Trinidad-Continued.

Economic geology.

Oil resources: Waring, 5 .

Petroleum : Macready, 1; Milner, 1 origin: Carmody, 1.

Historical geology.

Brasso Miocene: Maury, 10.

Central Range: Parkinson, 2.

General: Macready, 1; Waring, 5.

Miocene and Pliocene: Maury, 8.

Naparima region: Illing, 1 ; Nuttall,

Northern Range: Trechmann, 7.

Southel'n 'Trinidad: Carlson, 2.

\section{Palcontology.}

Algae, Miocene: Howe, M. A., 2.

Araceae, Miocene: Berry, 69.

Didymotis trinidadensis, Lower Cretaceous: Sommermeier, 1.

Echinoids, Tertiary: Jeannet, 1.

Foraminifera: Hodson, H. K., 2.

Naparima region: Nuttall, 1.

General : Harris, G. D., 5.

Lecythidoanthus, fossil flower: Berry, 54

Miocene corals: Vaughan, 38 .

Miocene faunas: Maury, 8.

Miocene gastropods and scaphopods: Mansfield, W. C., 2.

Mollusca : Palmer, K. V. W., 1.

Northern Range: Trechmann, 7.

I'leistocene flora: Berry, 67.

Rudistids: Harris, G. D., 4

Tertiary flora: Berry, 64.

Petrology.

Northern Range: Parkinson, 1.

Triceratops: Gilmore, 1.

Trough deeps of island arcs: Hobbs, 23.

Tumefaction : Keyes, 207.

Tungsten.

Alaska, Fairbanks district: Chapin, 4.

British Columbia, Hazelton : Hurst, 3.

California, Randsburg quadrangle: Hulin, 1, 3.

Colorado, Boulder County, Ward region: Worcester, 1.

Enrichment of ores : Gannett, 1.

General: Hess, 2, 3, 8, 10, 12, 13, 16, 19,21 ; Shannon, 15

Idaho: Livingston, 2.

Manitoba, southeastern : Bruce, 3.

Nevada, Round Mountain district: Ferguson, H. G., 4.

New Brunswick, Burnthill Brook area: Young, G. A., 1.

Nova Scotia, Halifax County : Piers, 2.

South Dakota, central Black Hills: Darton, 14.

northern Black Hills, Connolly, 4.

United States, contact-metamorphic deposits : Hess, 11.

Yukon, Mayo area : Cockfield, 1.

Tullock Creek coal field, Montana: Rogers, G. S., 8.

Turner Valley oil area, Alberta : Hume, 22.

Turonian ammonite fauna, Mexico : Böse, 3. 
Turquoise, Arizona, Courtland-Gleeson region: Wilson, E. D., 2.

Turtles. See Reptilia.

Twentymile Park district of Yampa coal field, Routt County, Colorado: Campbell, M. R., 5.

Twin Lakes district, Colorado: Howell, J. V., 1.

Tyrone district, New Mexico, copper deposits: Paige, 2.

Unconformities.

Arizona, Grand Canyon: Noble, 3.

California, Margarita-Monterey contact : Reed, 6.

Cretaceous-Eocene transition beds: Thom, 8.

Devonian, Arizona: Keyes, 106.

Disconformities and diastems: Schuchert, 35 .

Edmonton-Paskapoo disconformity, Alberta : Allan, 16.

Ellis-Madison unconformity: Collier, 10.

Glauconite, association with unconformities : Goldman, 7.

Idaho, southeastern: Mansfield, 11.

Intraformational phosphate pebbles: Pettijohn, 1.

Iowa, Mississippian-Pennsylvanian and Penñsylvanian-Pleistocene uncon formities, Lucils County: Lugn, 4.

Massachusetts, Adams, B e r k s hire schist-Stockbridge limestone : Dale. T. N., 2.

Mesozoic-Cenozoic boundary: K e y e s, $202,203$.

Nevada, southern, pre-Triassic: Longwell, 11.

Oklahoma: Bloesch, 1.

Ordovician-Silurian: Schuchert, 26.

Paleozoic systems in Wisconsin : Ulrich, 12.

Petrographic unconformity: Berkey, 4.

Pre-Moenkopi unconformity, Colorado Plateau : Dake, 4.

Silicificätion of erosion surfaces : Leith, 14; Tarr, 16.

South Dakota, Black Hills, pre-Cambrian: Runner, 3.

Structure below an unconformity : Mertie, 10.

Tennessee, Cheatham County: Jillson, 49.

Washington, Ringold-Ellensburg formations: Jenkins, 10.

West Virginia, Mississippian disconformity : Tilton, 11.

Underdrag of Great Basin ranges: Davis, W. M., 5.

Underground water (general). For areal see names. of States. See also Hot springs; Mineral water; Thermal waters.

Analyses of natural waters, index : Collins, W. D., 5.

$4096-31-63$
Underground water (general) - Continued.

Artesian basins of United States: Imbeaux, 1.

Artesian flow, effect of earthquakes on : Taber, 17.

Artesian pressure, origin: Piper, 8; Russell, W. L., 15.

Artesian water, Honolulu type: Palmer, H. S., 7.

Artesian water supply of the Dakota sandstone: Melnzer, 15.

Association witl petroleum and natural gas : Mills, R. V. A., 2.

Basin-and-Range province: Meinzer, 5 .

Calcium chloride waters, connate and diagenetic: Lane, 27, 28.

Coastal ground water : Brown, J. S., 5.

Composition of ocean water: Lane, 16.

Compressibility and elasticity of artesian aquifers: Meinzer, 20.

Estimating ground water supplies: White, W. N., 1.

Fort Caswell : Stearns, N. D., 1.

General: Meinzer, 2, 13.

Geology of large springs: Meinzer, 19.

Ground water, relation to ore deposits: Loughlin, 22.

western United States: Meinzer, 12.

Ground-water hydrology, with definitions: Meinzer, 7.

Hot springs: Allen, E. T., 5 ; Sosman, 8.

Hydrated sulphates of magnesia in hot springs: Merwin, 7.

Hydrologic laboratory: Meinzer, 9.

Laboratory tests of water-bearing materials: Stearns, N. D., 1.

Large springs of the United States: Meinzer, 17.

Mid-Continent oil fields: Neal, 1.

Northern Great Plains, ground waters, chemical character: Riffenburg, 1.

Occurrence of yround water: Meinzer, 6.

Oil-field waters: Ambrose, 3 ; of Gulf coast: Rogers, G. S., 6.

Permeability of rocks: Dahlblom, 1; Lahee, 5.

Plants as indicators of ground water: Meinzer, 18.

Quantitative estimation: Meinzer, 1.

Sea water, relation to ground water along coasts: Brown, J. S., 2.

Springs, origin : Adams, F. D., 2.

Sulphate-reducing bacteria in oil field waters: Bastin, 13.

Texas, Brazoria County, West Columbia fleld: Barton, 2.

Water analyses, importance: Lane, 16. Water prospecting: Simpson, H. E., 5. Water table of loess: Keyes, 244.

Wyoming, Salt Creek field : Ross, J. S., 1.

Ungulata. See Mammalia.

Upper Silurian. See Silurian. 
Upton-Thornton oil field, Wyoming: Hancock, 3.

Uranium. See also Carnotite.

Colorado, southwestern : Coffin, 3.

General : Butler, G. M., 2 ; Hess, 2, 7, 8, 12, 13, 16, 19, 21; Keeney, 1, Penrose, 1.

New Mexico: Keyes, 107.

Utah, Temple Mountain: Hess, 14. Utah.

Wyoming, Lusk : Lind, 1

Coal resin, Hiawatha: Steele, 1.

Geology: Pack, F. J., 1; Schnelder, H., 1.

Guidebook, Denver \& Rio Grande Western route: Campbell, $\mathbf{M}$. R., 3.

San Juan Canyon, southeastern Utah : Miser. 14, 17

Areas described.

Castlegate, Wellington, and Sunnyside quadrangles, Carbon County: Clark, F. R., 4.

La Sal Mountains: Gould, L. M., 4.

Promontory Point mining district: Siegfus, 1.

Salina Canyon district, Sevier County: Spieker, 6.

Tintic district: Lindgren, 2.

Weber County: Pack, F. J., 2.

Economic geology.

$\rightarrow$ Alunite, Marysvale: Tingley, 1; Varley, 2.

Bingham ore deposits: Hunt, R. N., 1; Martin, G., 1 ; Peterson, O. P., 1.

Carnotite, Gateway district: Farnum, 1.

Castlegate, Wellington, and Sunnyside quadrangles, Carbon County : Clark, F. R., 4.

-Coal, analyses: Fielüner, 4.

Salina Canyon district, Sevier County : Spieker, 6.

_ Coal fields: Spieker, 2.

East Tintic district, Utah County : Crane, G. W., 2 ; Goodwin, L. H., 2.

- Economic minerals: Lewis, R. S., 1.

Farnham anticline, Carbon County: Clark, F. R., 2.

Gilsonite: Douglass, 1 : Hartzell, 1.

Gypsum : Stone, 11.

Hydrocarbons : Bardwell, 1 ; Clark, A. F., 1.

Iron, Iron Springs and Pinto districts : MacVichie, 1.

southern Utah: Rohlfing, 1.

Jurassic, southeastern Utah: Forrester, J. B., 2.

Manganese: Pardee, 8.

-Mineral industry: Lewis, R. S., 1.

Mining districts, - structural features : Beeson, 1.

Mountain Lake contact-metamorphic deposit near Salt Lake City : Rogers, A. F., 4.

Natural gas, Farnham : Calvert, 1.
Utah-Continued.

Economic geology-Continued.

Oll, southeastern Utah: U. S. G. S., 16.

Oil possibilities, Grand and San Juan counties: Prommel, 1. southerñ Utah: Moore, R. C., 18.

Oil shales: Alderson, 1; Condit, 2; Jenson, 1; Winchester, 5.

Ophir district: Olmstead, 1; Wich man, 1.

Ore deposits: Butler, B. S., 2, 4.

Wasatch region: Butler, B. S., 1.

Park City district: Hewitt, 1; Mc Kay, G. R., 1.

Petroleum, southeastern Utah: Prommel, 3.

Washington County: Bassler, H., 2.

Indications, Uinta Basin: Douglass, $1,2$.

Potash brines, Great Salt Lake Desert : Nolan, 2.

Radium-bearing silts, southeastern Utah: Williams, G. O., 1

Salt deposits: Phalen, 1.

San Juan oil field: Miser, 17; Watson, E. H., 1.

Tintic district: Crane, G. W., 1; Havenor, 1 ; Hunt, S. F., 1 ; Parsons, A. B., 2.

Uranium-bearing asphaltite sediments : Hess, 14.

Historical geology.

Abajo Mountains: Thorpe, 1.

Bingham district: Peterson, O. P., 1.

Book Cliffs coal field : Forrester, J. B., 1.

Bozeman beds: Keyes, 19.

Browns Park formation and Bishop conglomerate: Sears, 4.

Cambrian, Tintic district: Hunt, $\mathbf{S}$. F., 1.

Coal fields: Spiekcr, 2.

Colorado Plateau, southeastern Utah : Longwell, 6.

Colorado River: Longwell, 4.

Colorado River basin: Pack, 5.

Cretaceous, Book Cliffs region: Fisher, D. J., 4.

Eastern Utah : Heist, 1.

East Tintic district, Utah County: Crane, G. W., 2.

Farnham anticline, Carbon County : Clark, F. R., 2.

General: Butler, 4; Keyes, 152.

Geological traverse, Mohave to San Juan River: Gregory, H. E., 9.

Grand and Sain Juan counties: Prommel, 1.

Great Salt Lake basin: Lee, 11.

Great Salt Lake Desert: Nolan, 1.

Green River valley: Reeside, 7 .

Jurassic: Dake, 3.

eastern Utah: Gilluly, 2.

southeastern Utnh: Forrester, J. B., 2. 
Utah-Continued.

Historical geology-Continued.

Kaibab IInestone, Kaibab Gulch: Noble, 8.

Moab region: Baker, A. A., 1.

Ophir district : Olmstead, 1 ; Wichman, 1.

Prc-Moenkopi unconformity, Colorado Plateau : Dake, 4.

Salt domes, Permian and Pennsylvanian, southeastern Utah: Prom mel, 2.

San Juan area: Watson, E. H., 1.

San Rafael Swell: Gilluly, 4.

Southeastern Utah: Hager, D., 6; Harrison, T. S., 3 ; Prommel, 4 ; U. S. G. S., 16.

Southern Utah: Moore, R. C., 17.

Southwestern Utah: Reeside, 2.

Tertiary gravels, northern Utah: Keyes, 9.

Triassic, lower: Matthews, 1.

Uinta Basin: Douglass, 1, 2; Sur, 2.

Upper Cretaceous, Colob Plateau : Richardson, G. B., 11.

Upper Cretaceous shore line: Śpieker, 5.

Wasatch front: Stillman, 1.

Wasatch Mountains: Blackwelder, 8; Schneider, H., 2.

Wasatch Plateau, Cretaceous and Tertiary : Spieler, 3.

Washington County: Lassler, H., 2; Reeside, 4.

Mineralogy.

Anglesite, Tintic district: Shannon, 17.

Ammoniojarosite, southern Utah Shannon, 74

Argentojarosite, Dividend : Schaller, 6 ; Schempp, 1.

Carnotite and tyuyamunite: Hillebrand, 2.

Carnotite region minerals: Hess, 20.

Crystalline carnotite: Hess, 30

Economic minerals : Lewis, R. S., 1.

Feldspar, Salt Lake County: Field, V. W., 1.

General: Butler, 4.

Hydrocarbons: Bardwell, 1.

Ilsemannite at Ourày: Hess, 17.

Seligmannite, Bingham: Palache, 33

Tinitic Standard mine: Schaller, 14.

Uranium miuerals: Davis, C. W., 1.

\section{Paleontologu.}

Aetosaurlan reptile, Morrison formation: Gilmore, 28.

Amynodon, White River: Troxell, 7.

Birds, Green Rivel deposits : Wetmore, 8.

Camarasaurus, Dinosaur National Monument: Gilmore, 24.

Camel: Romer, 14.

Carboniferous and Triassic faunas: Girty, 3.

Ceratopyge fauna: Raymond, 16.

Cretaccous mollusks: Reeside, 17.
Utah-Continued.

Paleontology-Continued.

Crocodilus acer, Manti beds: Mook, 4.

Cycads, Shinarump conglomerate: Berry, 90.

Dinosaur footprints: Anon., 51; Cretaceous: Peterson, W., 1.

Dinosaurs, Dinosaur National Monument; Gilmore, 25.

Diplodocus, skull : Holland, W. J., 3.

Dolichorhinus: Peterson, 7.

Eocene Mammalia, Uinta Basin: Peterson, 0. A., 1.

Hairy mammoth skeleton: Hansen, 1.

Fishes, Eocene: Tanner, 1.

Stehlinius, Eocene insectivore: Matthew, 17.

Uinta Carnivora, White River: Thorpe, 18.

Uintasaurus, Uinta County: Holland, W. J., 2

Petrol,ogy.

Analcite diabase and syenite: Gilluly, 3.

General: Butler, 4.

Limestone alterations at Bingham: Winchell, 8

Sierra la Sal dikes: Gould, L. M., 1

Zeolite beds in the Green River formation: Bradley, W. H., 8.

Physical geology.

Abajo Mountains, structural fea. tures: Thorpe, 1.

Basin Range faults in Oquirrh Range Gilluly, 5, 6.

Basin Range structure: Gilbert, G. K. 1.

Bear River Range fault: Bailey, R. W., 1.

Bonneville Lake beds, origin: Keyes, 96.

Bonneville Lake deltas, faulting: Keyes, 76.

- Colorado Plateau, structural features: Moore, R. C., 21.

Contact metamorphism at Bingham: Lindgren, 12.

-Débris of desert torrents: Pack, 6.

- Elsinore eartbquakes: Pack, F. J., 3.

Erosion, San Juan Cānyon: Miser, $20,25,26$.

Grand and San Juan counties: Prommel, 1.

La Sal Mountains, laccoliths: Gould, L. M., 3, 4

Meanders, inclosed, significance in the history of the Colorado Plateau country: Moore, R. C., 30 , 31.

Mining districts, structural features: Beeson, 1.

Nequoia arch, Green River Desert: Prommel, 5.

Oquirrh Range, faulting: Gilluly, 7 . 
Utah-Continued.

Physical geology-Continued.

Post-Cretaceous progeny in central Utah: Spieker, 4.

Salt domes, southeastern Utah: Harrison, T. S., 3.

- Sevier Valley, formation: Young, J. W., 2.

Southeastern Utah: Prommel, 2, 4.

Stream pebbles, San Juan. County, shapes: Miser, 28.

Thermal springs on Wasatch fault: Pack, F. J., 8.

Thrust faulting, Cottonwood district, Wasatch $\mathrm{M}$ o u $\mathrm{n}$ a in $\mathrm{s}$ : Calkins, F. C., 1.

Wasatch region: Butler, B. S., 1.

Wasatch fault: Pack, 7 .

Wasatch front: Stillman, 1.

Wasatch Mountains: Schneider, H., 2.

Physiographic geology.

- Abajo Mountains: Thorpe, 1.

Colorado River basin : Pack, 5.

Extinct hot spring basin, western Utah: Hayes, M. 0., 1.

Great Salt Lake basin : Lee, 11.

Great Salt Lake Desert: Nolan, 1.

Green and Yampa rivers, origin: Sears, 4.

Laccolith, La Sal Mountains: Gould, L. M., 3, 4 .

Lake Bonneville: Anters, 12 ; Moscheles, 1.

origin : Keyes, 116.

physical features: Keyes, 44.

Natural bridges: Pack, 4.

Navajo Twins: Bryan, 28.

Paria River valley, southern Utah : Moore, R. C., 22.

Plateaus, peneplanal affinities: Keyes, 23.

Rainbow natural bridge: Edwards, I., 5 ; Miser, 13.

San Juan River region: Miser, 20.

Southern Utah: Burden, 1.

Terrepleins of plateaus, geological age: Keyes, 100.

Wasatch area : Pack, 7.

Zion Canyon National Park: Miller, W. J., 20

Underground water.

Green River shale water, Duchesne: Ball, M. W., 4.

Mineral waters: Fitch, W. E., 1.

Thermal springs: Meinzer, 10.

on Wasatch fault: Pack, F. J., 8. Valleys.

Development : Branson, 15.

Form and its development: Malott, 11.

Formation, interior plains region: Evans, O. F., 4.

Hanging valleys, origin: Crosby, 5.

Oklahoma stream valley type: Evans, O. F., 5 .
Valleys-Continued.

Shapes of valleys, representation : Lane, 13.

Widening by frost action: Culbertson, G., 1.

Vanadium.

Arizona: Allen, M. A., 5.

Colorado, southwestern: Coffin, 3 .

Discovery: Wittich, 17.

General: Allen, M. A., 5 ; Hess, 2, 7, $8,12,13 ; 16,19,21$; Keeney, 1 ; Shannon, 15 .

New Mexico, Elephant Butte: Keyes, 204.

Varve clay, New. England: Antevs, 1.

Varved glacial clay, conditions of formation : Anters, 9.

Vein quartz, microscopic study: Adams, S. F., 2.

Veins.

Box vein, Lyonsdale, Lewis County : Dale. N. C.. 4.

Gashed veins, Queen of Sheba, Arizona: Keyes, 204.

Ladder veins, Minnesota: Grout, 10.

Origin : Taber, 14.

South Dakota, chalcedony veins: Lawler, 1.

Ventura oil field, Ventura County, California: Craddock, 1.

Verden sandstone, Oklahoma: Reed, 3.

vermes. See also Invertebrates (general).

New York, Utica and Lolraine formations: Ruedemann, 17.

Ontario, Toronto area: Parks, 9.

Rosetted trails of worms: Clarke, J. M., 27.

Silurian worm, Lecthaylus gregarius : Weller, 9.

Vermont

Geological work in Vermont, 1810 1923 : Perkins, G. H., 7.

State geologist, reports : Perkins, G. H., $1,11$.

Areas described.

Addison, Panton, and Ferrisburg townships: Foyles, 4.

Barnard, Pomfret, and Woodstock townships: Richardson, C. H., 11.

Braintree: Richardson, C. H., 5.

Bristol, Lincoln, and Warren townships : Gordon, C. E., 6.

Essex County: Schroeder, 3.

Hanover district: Merritt, J. W., 3.

Middlebury and Burlington quadrangles: Dale, N. C., 3.

Northfleld terranes : Richardson, C. H., 2.

Orange County, Randolph Township: Richardson, C. H., 7.

Orleans County, Westmore, Browning ton, and Charleston townships: Jacobs, 4.

Rochester quadrangle: Foye, 1.

Roxbury terranes : Richardson, C. H., 3.

Western Vermont: Gordon. C. E.. 2. 
Vermont-Continued.

Economic geology.

Barre, granite: Perkins, G. H., 4.

Clay deposits: Jacobs, 5 .

Granite: Dale, T. N., 4.

Mineral resources: Perkins, G. H., 6, $8,10,13$.

Limestone: Jacobs, 1.

Talc deposits: Jacobs, 2 ; origin : Gillson, 7 .

Historical geology.

Barre, Mill Stone Hill : Perkins, G. H., 4.

Bethel Township : Richardson, C. H., 8. Black shales, Lake Champlain region, age: Ruedemann, R., 3.

Brandon lignite, age: Berry, 8.

Cambrian succession, northwestern Vermont: Keith, 1.

Chazyan coral reef: Raymond, 24.

Cuttingsville, eruptive rocks: Eggleston, 1.

Fort Cassin : Foyles, 3.

Grand Isle County: Pelkins, G. H., 9.

Green Mountain front, geologic history: Bain, 24.

Green Mountains, western flank: Dale, N. C., 1.

Irasburg conglomerate: Richardson, $\mathbf{C}$. H., 14.

Northwestern Vermont: Raymond, 23.

Ordovician formations: Foyles, 2. central Vermont: Richardson, C. H. 1.

Paradoxides beds, northwestern Vermont: Howell, 7.

Pleistocene pre-Wisconsin beds: Antevs, 8

Plymouth and Bridgewater townships: Perry, E. L., 1.

Shoreham and Bridport: Foyles, 3.

Trenton, Grand Isle: Perkins, G. H., 5.

Western Vermont: Gordon, C. E., 3, 4,5 .

Whitingham area: Hubbard, G. D., 4.

Paleontology.

- Fort Cassin: Foyles, 3.

-Eoichthys, St. Albans: Bryant, 6.

Invertebrate fossil localities : Foyles, 5.

Northfield terranes: Richardson, C. H., 2.

Ordovician, central Vermont : Richardson, C. H., 1 .

Grand Isle: Ruedemann, 5.

St. Albans "fish-plate": Howell, B. F., 9.

Trilobites, Cambrian and Ordovician: Raymond, 23.

Petrology.

Eruptive rocks, Cuttingsville: Eggleston, 1.

Granitic intrusions, Bethel, Barre and Woodbury: Balk, 4.

Mount Monadnock: Wolff, J. E., 2.

Orange County, Randolph Township: Richardson, C. H., 7 .
Vermont-Continued.

Petrology-Continued. -

Orleans phyllite: Jacobs, 4.

Whitingham area: Hubbard, G. D., 4.

Physioal geology.

Deformation, western Vermont: Gordon, C. E., 1, 3

Fault systems, northern Champlain Valley: Hudson, G. H., 1.

Faulting, western Vermont: Gordon, C. D., 4 .

Flood erosion, Cavendish: Jacobs. 6.

Granitic intrusions, Bethel, Barre and Woodbury: Balk, 4.

Mineralization along the dikes of southern Vermont: Bray, 1.

Physiographic geology.

General: Perkins, G. H., 2, 3.

Glacial varves, Connecticut Valley, summer deposition : Sayles, 11.

Lake Willoughby: Jacobs, 3.

Postglacial sea-level waters, eastern Vermont: Falrchild, 2.

Vertebrata (general). See also Amphibla; Aves; etc.

Anaspida and origin of vertebrates: Raymond, 29.

Arizona, San Pedro Valley: Gidley, 5.

California, Kern County, Miocene marine vertebrates: Hanna, G. D., 20.

Pleistocene, McKittrick asphalt deposit : Merriam, 9.

Pliocene and Pleistocene: Frick, 1.

Rancho La Brea: Wyman, 1.

Chiropterygium, primitive: Gregory, W. K., 9.

Cretaceous, Kansas: Sternberg, C. H., $3,4$.

Cretaceous-Tertiary boundary, vertebrate evidence as to: Matthew, 18.

Exploration for vertebrates: Grinnell, 1.

General : Lucas, F. A., 1; Osborn, 9 ; Scott, W. B., 5.

Grand Canyon, footprints : Gilmore, 31.

Harvard College, Museum of Comparative Zoology, report on vertebrate paleontology: Stetson, 3 .

Jaw muscles, phylogeny: Adams, L. A., 1.

Lachrymal bone, evolution: Gregory, W. K., 3.

Land vertebrates, origin: Willey, 1.

Marsh collection: Schuchert, 9.

National Museum, collection: Gilmore, 10.

Nebraska, western, Agate Spring quarries: Peterson, 3.

Notochord in fossil vertebrates: Romer, 12.

Opisthotonos: Dean, 3; Moodie, 6, 9. Ordovician : Tieje, 4.

Oregon, Pleistocene: McCormack, 1. 
Vertebrata (general)-Continued. oreodon beds faunas, South Dakota : Sinclair, 8.

Origin: Raymond, 29, 34; Stetson, 1.

Outline charts in teaching vertebrate paleontology : Mehl, 1.

Pennsylvania, Frankstown cave: Peterson, 9.

Permian, Texas: Sternberg, C. H., 3.

Pleistocene: Hay, 4, 6, 8, 9, 10. vicissitudes: Hay, 28.

Progress and trends in vertebrate paleontology : Matthew, 26.

Restorations: Abel, 1.

Snake Creek fauna: Matthew, W. D., 2. Teaching vertebrate paleontology : willard, B., 4; by outline charts : Mehl, 1.

South Dakota. badlands: Jepson, 9.

Texas: Sternberg, C. H., 4.

southwestern: Hay, 33.

Triassic: Mehl, 13.

West Indies: Matthew, 5.

Wyoming, Como Bluff, Quarry 9: Simpson, G. G., 11.

Vicksburg group, correlation; Cooke, C. W., 7a ; Foraminifera : Cusbman, 16.

Vieques Island: Vaughan, 22.

Virgin Islands.

Literature : Kemp, 28.

Historical geology.

General: Vaughan, 8, 22.

Physical geology.

Earthquakes: Reld, H. F., 2, 4.

Physiographic geology.

Physiography: Meyerhoff, 1 ; Vaughan, 11.

Tertiary : Meyerhoff, 2.

Virginia.

Geological Survey activities: Giles, 7.

Gravels on the Blue Ridge: Wright, F. J., 3.

Survey report: Watson, T, L., 1, 8.

Striated boulders on Coastal Plain: Wentworth, 31.

Areas described.

Lee County: Giles, 4.

Giles County: Hubbard, G. D., 6.

Gold-pyrite belt, northeastern Pledmont: Lonsdale, 7.

Russell County: Wentworth, 6 .

Tazewell County : Harnsberger, 1.

Triassic areas: Roberts, J. K., 8.

Wise and northern Scott counties: Eby, J. B., 1.

Economic geology.

Clays and shales west of Blue Ridge: Ries, 3.

Clinton hematite ores, origin : Holden, R. J., 2 ; Stose, 24.

Coal, analyses: Fieldner, 6.

Dickenson County: Giles, 3.

Lee County: Giles, 4.

Russell County: Wentworth, 6.
Virginia-Continued.

Economic geology-Continued.

Coal-Continued.

southwestern Virginia: Davenport,

1.

Tazewell County: Harnsberger, 1.

Coal fields: Eby, 5.

Valley coal fields: Campbell, M. R. 10.

Copper deposits: Watson, 15.

Emery deposits: Watson. 13.

Glass-sand resources: Watson, 4.

Gypsum : Stone, 11.

Manganese: Grasty, 1 ; Stose, 7.

Blue Ridge, west foot: Stose, 1.

Appalachian Valley: Stose, 4.

western Virginia: Stose, 16.

Mineral resources: Watson, 17.

Oil, Powell Valley, Lee County : Giles, 9.

Oil and gas possibilities: Giles, 11.

Early Grove, Scott County : Butts, $\boldsymbol{\theta}$. southwestern Virginia: Eby, 2.

Oriskany iron ores: Doak, 1.

Peat, dismal Swamp: Osbon, 1.

Rutile-ilmenite, Amelia County: Watson, 12.

Tin, Irish Creek, Rockbridge County: Haney, M., 1.

Historical geology.

Bentonite, so-called, Rockbridge County : Giles, 10.

Big Stone Gap shale, Chattanoogan age: Swartz, J. H., 9, 10.

southwestern Virginia : Swartz, J. H., 4 ; age: Swartz, J. H., 7.

Black shale, southwestern Virginia : Stose, 22.

Blue Ridge, west foot: Stose, 1.

Chattanooga shale, southwestern Virginia : Swartz, J. H., 6, 11.

Choptank formation in Nomini Clfffs: Mansfleld, W. C., 3.

Devono-Mississippian black shales: Swartz, J. H., 12.

Dickenson County: Giles, 3.

Fen sters, southwestern Virginia: Butts, 10.

General : Giles, 11.

Geologic map: Nelson, W. C., 20.

Jurassic (?) intrusives : Roberts, J. K., 3.

Little North Mountain: Giles, 8.

Ordovician: Raymond, 3.

volcanic ash deposit: Nelson, 27.

Oriskany and Helderberg formations: Holden, R. J., 1.

Piedmont: Jonas, 8.

Pleistocene: Mansfield, W. C., 6.

Post-Cincinnatian granites, northeastern Piedmont region: Lonsdale, 2.

Powell Valley, Lee County: Giles, 9.

Pre-Cambrian: Jonas, 7.

Scott County, Early Grove: Butts, 8.

Triassic: Roberts, J. K., 8. 
Virginia-Continued.

Historical geology-Continued.

Triassic basins of northern Virginia: Roberts, J. K., 2.

Valley coal fields: Campbell, M. R., 10.

Western Virginia: Stose, 16.

Mineralogy.

Dufrenite, Midvale, Rockbridge County: Gordon, S. G., 2.

Intrusive Triassic diabase, Goose Creek, Loudoun County: Shaunon, 46.

Hoegbomite: Watson, 18.

Manganese garuet, Amelia: Shannon, 70 .

Manganese minerals, Blue Ridge, west foot: Stose, 1.

Manganotantalite, Amelia : Lee, 0. I., 1.

Meteorite, Dungannon, Scott County: Merrill, 28.

Forksville, Mecklenburg County : Merrill, 47, 50.

Nickelsville, Scott County : Merrill, 23.

Sharps, Richmond County: Watson, 14.

Rutile-ilmenite, Amelia County: Watson, 12.

Rutile-ilmenite intergrowths, Franklin County: Watson, 11.

Rutherford mines, Amelia County: Pegau, 1 .

Triassic limestone conglomerate minerals, Leesburg: Shannon, 55.

Xonotlite, Leesburg: Shannon, 51.

Paleontology.

Brachiopods, Lenoir and Athens formations: Raymond, 37.

Ottosee and Holston formations : Willard, B., 5.

Eocene: Van Winkle, K., 1.

Mollusca, New Castle: Van Win kle, 2.

Miocene: Mansfield, W. C., 7.

Pleistocene: Mansfield, W. C., 6 ,

Turritella, Miocene: Gardner, J. A., 14.

Trilobites, Ordovician: Raymond, 28.

Petrology.

Bentonite: Ross, C. S., 21.

so-called, Rockbridge Giles, 9.

Granite, Prince William County : Lonsdale, 2.

Intrusive Triassic diabase, Goose Creek, Loudoun County: Shannon, 46.

Jurassic (?) intrusives : Roberts, J. K., 3.

Lamprophyre dike, Louisa County: Watson, 9.

Magmatic complex, Stafford County: Lonsdale, 3.

Oolite, Hayfield, Frederick County : Furcron, 1.
Virginia-Continued.

Petrology-Continued.

Triassic limestone conglomerate, Leesburg: Shannon, 55.

Triassic sandstones: Roberts, J. K., 4.

Physical geology.

Big Stone Gap area, Wise County, structure: Stose, 12.

Earthquake, Blue Ridge region, September 5, 1919; Watson, 4; Woolard, 1.

Endless Caverns, New Market: Edwards, I, 4.

Faceted sandstone pebbles, North River near Lexington: Steidtman, 6.

Russell Fork fault, southwestern Virginia: Wentworth, 3.

Shenandoah Caverns: Anon., 21.

Subterranean streams, Endless Caverns: Reeds, 8.

Thrust fault in Appalachians: Campbell, M. R., 7 .

Travertine deposits, 'Augusta County : Collins, R. L., 1.

Physiographic geology.

Blue Ridge: Wright, F. J., 2.

erosional history: Wright, F. J., 5. west foot: Stose, 1.

Dismal Swamp: Osbon, 1.

General: Giles, 11.

Upper James River basin : Wright, F. J., 1.

Underground vater.

Thermal springs: Watson, 16.

Woodstock area, in Ordovician rocks: Hall, G. M., 3

Volcanic activity, causes: Day, 17.

Volcanic ash: Smith, J. E., 1.

Cordllleran region: Wanless, 3 .

Iowa : Keyes, 95.

Des Moines: Keyes, 99 ; interglacial : Keyes, 26.

Kansas: Landes, K. K., 4, 5.

Logan County: Pinkley, 1.

Kilauea : Stone, J. B., 1.

Louisiana, Calcasieu Parish: Hanna: M. A., 2.

northern: Crider, 3

Mexico, San Lưis Potosi : Wittich, 20. Minnesota, Ordovician: Sardeson, 13.

Oahu: Wentworth, 22.

Oklahoma, central: Hoffman, M. S., 1.

Oklahoma, North Canadian Valley: Gardner, J. H., 2.

Ordovician, Tennessee, Kentucky, and Alabama: Nelson, 10.

Paleozoic: Ross, C. S., 21.

Pennsylvania, Ordovician: Stose, 29.

Saskatchewan, Waldeck: Cole, L. H., 8.

Tennessec, Bedford County : Nelson, 7.

Virginia, Ordovician: Nelson, 27.

Volcanic ash beds as key horizons: Ross, C. S., 10 . 
Volcanic rocks. See Igneous and volcanic rocks.

Volcanic gases: Butler, B. S., 3.

Volcanism. See also Volcanoes.

American Geophysical Union, section of -volcanology, meeting 1925: Sosman, 11.

Chemical aspects: Allen, E. T., 1.

Concentration of metallic constituents by volcanic emanations: Zies, 4.

Engulfment in volcanism: Jaggar, 17.

Experimental volcanology, program: Jaggar, 3.

Explosions, nature of: Sosman, 2.

Gases in volcanic activity: Day, 18.

of Mt. Pele lavas : Shepherd, 5.

General : Daly, 21 ; Day, A. L., 1 ; Soley, 1 ; Sosman, 9.

Gravity and underground lava: Wright, F. E., 7.

Lava tide, seasonal tilt, and volcanic cycle: Jaggar, 7.

Observatories, need for: Jaggar, 5.

Oxygen and volcanism: Sosman, 12.

Plus and minus volcanicity: Jaggar, 13.

Problems of volcanology: Washington, 3.

Progress: Day, 9; Jaggar, 14.

Section of volcanology of U. S. Geological Survey: Jaggar, 16.

Source of heat in volcanic activity: Adams, L. H., 3.

Tectonic aspect of volcanic eruption: Wood, H. O., 1.

Tides in lava: Brown, E. W., 3.

United States Weather Bureau investigations: Marvin, 1.

Volcanic activity, causes: Day, 17.

Volcanic research of U. S. Geological Survey: Jaggar, 20.

Volcanism and mountain-making: Chamberlin, R. $\mathbf{T}, 5$.

Volcano gas problem: Shepherd, 6.

Volcano stations of the U. S. Geological Survey: Mendenhall, 5.

Volcanological publications, current: Day, 25.

Volcanoes. See also Volcanism.

Acatenango, Guatemala: Heim, 4.

Acid gases contributed to sea during volcanic activity: Zies, 5 .

Alaska, Aleutian region: Griggs, 4.

Katmai : Griggs, 2, 6; emanations and incrustations: Shipley, 2; eruption: Griggs, 1; Fenner, 2 ; Tams, 1.

Katmai region, fumaroles: Allen, $\mathrm{E}$. T., 2.

Makushin Volcano: Maddren, 1.

Valley of Ten Thousand Smokes, floor : Cole, G. A. J., 1; Griggs, 5 ; Shipley, 1 ; fumarolic incrustations: Zies, 1 ; moving pictures: Fenner, 6; tuff deposits: Escher, 1; Fenner, 5; Griggs, 7.
Volcanoes-Continued.

Analysis of gases from volcanoes and from rocks: Shepherd, 3.

Bearing of distribution on origin : Taylor, 16.

California, Lassen Peak: Day, 15 ; Loomis, B. F., 1; eruption near: Williams, H., 1 ; volcanic activity, cause: Day, 5.

Mt. Lassen : Colburn, 1.

Central America: Heim, 4; Putnam, P. C., 2 ; Sapper, 3, 5.

Costa Rica, Irazu : Tristan, 2.

Poas Volcano, eruptions: Tristan, 1.

Distribution and origin : Taylor, F. B., 19.

Engulfment during explosive eruptions : Jaggar, 24.

Gases, rôle of : Day, 26.

General: Muñoz Lumbier, 4; Reeds, 17 ; Washington, 7.

Greater Antilles seismic belt: Taber, 7.

Guatemala: Van de Putte, 1. St. Maria Volcano: Waitz, 5. activity, 1927 : Termer, 1.

Halemaumau: Finch, R. H., 1; Jaggar, 1.

tidal oscillation in Halemaumau: Brown, E. W., 2.

Hawaii : Hawaiian Volcano Observatory, 1; Jaggar, 1, 2, 4, 10; Meinzer, 4.

Irazu, Costả Rica: Tristán, 3.

Izalco, Salvador: Heim, 4: Larde, 2, 4; eruption, November, 1926 : Bock, 1.

Keaiwa lava flow: Stearns, 10; Stone, 16.

Kilauea, Hawaiian Islands : Day, 10 ; Jaggar, 1.

activity ; Jaggar, 8; MacCaughey, V., 1.

composition of gases: Shepherd, 1. engulfment, chemical significance: Shepherd, 4.

eruption, May, 1924: Friedlaender, 8; Stearns, 5.

eruptions: Stearns, 7 ; May, 1924, and seismic sequences: Finch, R. F., 3 ; July, 1917 : Wilson, R. M., 1.

explosions: Stearns, 11

explosive eruptions: Sherzer, 1 ; 1924: Jaggar, 9.

lava tube: Powers, 4.

volcano observatory: Cross, C. W., 3.

Masaya, Nicaragua: Heim, 4 ; Sapper, 4 ; Schönberg, 1.

and Momotombo: Sapper, 1.

Mauna Loa, gases: Shepherd, 2. eruption, April, 1926: Friedlaender, 9.

and Kilauea: Stearns, 8. 
Volcanoes-Continued.

Mexico: Waitz, 3.

Pedregal de San Angel: Wittich, 3.

Popocatepetl: Atl, 1; Camacho, 4; Heim, 4; Waitz, 4; activity 1923-4 : Müllerried, 1; eruption: Friedlaender, 4, 5 .

San Martin Tuxtla area: Friedlaender, 7 .

Oahu: Wentworth, 22.

Pacific volcanoes, chemistry: Washington, 6.

Salvador, San Salvador, eruption: Friedlaender, 1.

Temperatures of volcano borings : Jaggar, 18.

Volcanic activity, present: Waslington, 38 .

Volcanoes (extinct).

Aniakchak Crater, Alaska Peninsula : Smith, W. R., 2.

Idaho, southeastern: Mansfleld, 10.

Mexico, northeastern: Staub, 1.

New Mexico: Lée, W. T., 4.

San Quintin area, Lower California : Woodford, 6.

Wainwright-Vermilion area, Alberta : Hume, 19.

Wakomata Lake area, Ontario: Emmons, R. C., 3.

Wapawekka and Deschambault lakes area, Saskatchewan : DeLury, 6.

Wapsipinicon breccias, Iowa: Norton, W. H., 1.

Wasatch Mountains, Utah: Blackwelder, 8.

Washington.

Geological Survey activities: Shedd, 6.

History of geology in State of Washington: Landes, $H ., 1$.

Palouse soil : Bryan, 26.

Reports of geological survey, 191719, 1919-21: Washington G. S., 1. 2 .

Reports of supervisor of geology, 1922-24: Shedd, 5; Culver, 12, 13.

Stevens County : Weaver, 2.

Areas described.

Whatcom County, western : Jenkins, 7 .

San Juan Islands: McLellan, 2.

Economic geology.

Antimony, Okanogan Valley : Keyes, 73.

Arsenic, Seattle district: Stoess, 1.

Chewelah and Colville districts, northeastern Washington: How a r d, L. D., 1.

Chromite deposits : Diller, 1 ; Pardee, 7.

Clays: Burkhalter, 1.

geology: Glover, 1.

and shales: Wilson, H., 2.

Coal : Evans, G. W., 3; Shedd, 2. Skagit County: Jenkins, 8.
Washington--Continued.

Economic geology-Continued.

Coal-Continued.

southwestern Washington: Culver, 1. western Whatcom County: Jenkins, 7.

Copper, Chewelah district: Armstrong, L. K., 1.

Gencral : Fischer, 1.

Gold, silver, copper, lead, and zinc: Gerry, 1, 3, 6, 9, 11, 14.

Iron ores: Jenkins 5.

Kaolin, Spokane: Goodspeed, 2. and feldspar: Wilson, H., 1.

Lead, northeastern Washington, Jenkins, 12.

Pend Oreille and Stevens counties: Jenkins, 9.

Preglacial oxidation of lead deposits : Jenkins, 16.

Limestone: Shedd, 2.

Magnesite : Petrascheck, 1; Phalen, 2; Siegfus, 2 ; Whitwell, 1 ; Willis, 26. Chewclah, Stevens County: Dolman, 1 ; Handy, 1.

Manganese : Pardee, 8, 15.

Metal mines: Patty, 3.

Mineral resources: Patty, 2; Shedd, $1,4$.

Oil in basalt, southwestern Washington: Hudson, F. S., 5.

Oil possibilities, Olympic Peninsula : Palmer, R. H., 5.

western Washington: Hager, D., 7.

Ore deposits, geologic features: Patty, 1.

Pasco and Prosser quadrangles: Culver, 10.

Pend Oreille district: Haggen, 1.

Road-building sands and gravels: Leighton, M. M., 1.

Silver Hill tin deposits, genesis : Anderson, A. L., 5.

Stevens County: Weaver, 2.

Historical geology.

Chchalis Valley: Etherington, 1.

Columbia River basalt: Shannon, 40.

Columbia Valley: Bretz, 3.

Corbaley Canyon: Waters, A., 1.

Eagle Creek formation: Chaney, 1.

Geologic history: Weaver, 1.

Hoh formation: Palmer, R. H., 3.

Latah formation, Spokane area: Pardee, 12.

Marine Tertiary: Hertlein, 3.

Mesozoic formations: Goranson, 1.

Olympic Peninsula: Palmer, R. H., 5. Orcas group, Devonlan: McLellan, 1.

Pasco and Prosser quadrangles: Culver, 10.

Pleistocene, Big Hope Island: Henderson, J., 9.

"Satsop" and Dalles formations, age : Buwalda, 19.

Skagit County: Jenkins, 8. 
Washington-Continued.

Historical geology-Continued.

Spokane region: Pardee, 11 ; Shannon, 40.

Unconformity between Ringold and Ellensburg formations: Jenkins, 10.

\section{Mineralogy.}

Bementite and neotocite: Pardee, 5.

Boulangerite, Stevens County: Shannon, 54.

Columbia River basalt: Shannon, 40

Columbia River Plateau, chlorophaelte, sideromelane, and palagonite: Peacock, 1.

Cristobalite, Columbia River basalt: Shannon, 36.

Hexahydrite, Oroville: Walker, T. L., 53.

Kaolin deposit near Spokane: Goodspeed, 2.

\section{Paleontology.}

Beetle near Spokane: Cockerell, 24.

Caddis case, Miocene: Berry, 97.

Callianassa and Ranina, Oligocene : Withers, 3.

Cassididae: Schenck, 3.

Cretaceous Mollusca: Reagan, 7.

Crustacea, stalk-eyed: Rathbun, 5.

Eagle Creek flora: Chaney, 1, 2.

Echinoidea: Kew, 3.

Elephant remains, Columbia Plateau : Bryan, 26.

Elephas eellsi, Port Williams: Hay, 34.

Eocene fauna: Weaver, 3 .

Foraminifera, Eocene, Lewis County: Hanna, G. D., 18.

Fossil remains in loess, eastern Washington: Lapham, 1.

Latah formation, flora: Knowlton, 16. Mammoth, Cheney : Freeman, O. W., 6.

Mastodon remains, Clallam County : Culver, 11.

Olympic Peninsula: Dall, 6.

Paliurus, Miocene: Berry, 102.

Pelecypoda, marine Oligocene: Clark, B. L., 11.

Pleistocene, Big Hope Island: Henderson, J., 9.

Vertebrata, Wenatchee, Chelan County : Hay, 9.

Rimella-like gastropods: Clark, B. L., 7.

Tertiary Mollusca: Hertlein, 2.

Petrology.

Clastic dikes, southeastern Washington: Jenkins, 11.

Differentiation of lamprophyric magma at Corbaley Canyon: Waters, A., 1.

Silver Hill deposits : Anderson, A. L., 5.

Physical geology.

Asotin craters of Columbia River basalt : Fuller, R. E., 3.
Washington-Continued.

Physical geology - Continued.

Clastic dikes, eastern Wishington: Jenkins, 14.

Diatom "epidemics," Copalis Beach : Becking, 1.

Dixie, earth disturbances: Eby, G., 1 .

Loess, Palouse region: Treasher, $1,3$.

Pedestal rocks: Bryan, 24.

Preglacial oxidation of lead deposits : Jenkins, 16.

Rate of soil deposition, Palouse area : Peterson, P. P., 1.

Physiographic geology.

Central Washington: MacMacken, 1.

Channeled scabland of Columbia Plateau : Bretz, 6, 10, 16-19.

and Spokane flood: Bretz, 14.

Columbia Valley: Bretz, 10.

Dalles type of river channel: Bretz, 7 .

Drainage changes: Large, 3.

Eastern Washington: Shedd, 3.

Glacial drainage on Columbia Plateau : Bretz, 5.

Glaciation, Spokane region: Large, 1 ; Leverett, 11 ; Pardee, 9.

Juan de Fuca lobe of Cordilleran ice sheet: Bretz, 2.

Lake Chelan, origin and history : Runner, 4.

Lake Lewis and Okanogan ice sheet : McMacken, 2.

Loess, Palouse region: Treasher, 3.

Mount St. Helens: Jillson, 33.

Okanogan trench and its delta terraces: Keyes, 116.

Palouse soil, Columbia Plateau : Bryan, 27.

Pleistocene submergence, Columbia Valley : Bretz, 1.

Prairies, Olympic Peninsula, origin : Reagan, 23.

Scabland mounds, eastern Washington : Freeman, 0. W., 5.

Spokane flood: Jenkins, 15; beyond channeled scablands: Bretz, 10

Spokane glaciation, age: Bretz, 9 .

Spokane region: Large, 2.

White Bluffs region: Gretz, 15; McKnight, 1.

Underground water.

White Bluffs and Hanford region: Jenkins, 4.

Waskom gas fleld, Louisiana and Texas: Grimm, 1

Watabeag area, Ontario: Wright, D. G., II., 2.

Water, underground. See Underground water.

Waves, breaking in shallow water: MacClintock, 2 .

Waynesboro quadrangle, Tennessee: Miser, 6.

Weathering.

Agricultural aspects of rock weathering: Hunt, H. A., 1. 
Weathering-Continued.

Alaska : Steidtman, 4.

Barbados soils: Farrison, J. B., 2.

Bacteria as agents of chemical denudation: Thiel, 11.

Collapse of mountain summits : Young, G. J., 2.

Colloidal products of rock weathering, distribution: Wallace, 9.

Conditions: Clelland, 4.

Desert weathering: Blackwelder, 16 ; Hobbs, 1.

Exfoliation, a phase of rock weathering: Blackwelder, 10.

Fire as an agency in rock weathering : Blackwelder, 15.

Gypsum, rate of solution: Lahee, 18.

Lichens as weathering agents of limestone: Weidman, 6 :

Mountain summits, collapse: Young, G. J., 2.

Niches in sandstone, Chaco Canyon: Bryan, 33.

Pedestal rocks, formation: Leonard, R. J., 2.

Polygonal weathering in igneous and sedimentary rocks: Johnston, C. S., 1.

Studies: Posnjak, 2.

Webbwood district, Ontario: Bain, 15.

Wedge theory of diastrophism : Chamberitn, R. 'T., 11.

Wegener hypothesis: Washington, 24.

Weight of sedimentary rocks: Lane, 10.

Wekusko Lake area, Manitoba: Alcock, 2. Well cuttings, examination: Trager, 1.

Well records. See Borings.

Well samples, care of : Robinson, W. I., 2. Wellsville quadrangle. Ohio: Hance, 3.

Welsh oil field, Jefferson Davis Parish, Louisiana : Reed, I. C., 1.

Weno formation, Texas Comanchean: Adkins, 2.

Westbrook oil field, Mitchell County, Texas : Edwards, E. C.. 1.

West Indies (general). See also names of islands.

Barbados: Wilmore, 1.

Caribbecs: Hovey, 10.

Cayman Islands: Matley, 13.

Coral reefs: Vaughan, 32 .

Gcology: Vaughan, T. W., 1, 6.

Grenadines : Earle, 7, 10 .

Martinique : Barrabe, 1.

St. Lucia : Earle, 2, 4.

St. Vincent: Earle, 7 .

Tectonic features: Vaughan, 26.

Areas described.

Anguilla: Earle, 6.

Cayman Islands: Matley, 14.

Dominica, Island of: Earle, 11.

Grenada and the Grenadines: Earle, 8.

Nevis: Earle, 6.

St. Kitts : Earle, 6.

St. Lucla : Erarle, 4.
West Indies (general)-Continued.

Areas described-Continued.

St. Vincent and neighboring Grenadines, geology: Earle, 10.

Trinidad: Waring, 6.

Economic geology.

Petroleum: Milner, 2; Redfield, 4, 9.

Petroleum developments, British West Indies : Catherall, 1.

Historical geology.

Anguilla, geology: Vaughan, 40 .

Barbados, Scotland beds: Trechmann, 6.

British Virgin Islands: Earle, 5.

Cayman Islands, geological survey: Matley, 7.

General : Earle, 9.

Geologic history: Ihering, 1.

Geologic mapping: Vaughan, 12.

Mesozoic bistory: Stanton, 1.

Soldado formation, basal Eocene: Maury, 7.

Tertiary, correlation: Vaughan, 13.

Windward and Leeward islands : Earle, $3,7$.

Mineralogy.

Pumpellyite, Haiti : Burbank, 1.

Paleontology.

Balanocrinus, Tertiary: Springer, 8.

Bryozoa : Canu, 1.

Echini : Jackson, 2. stratigraphic significance: Vaughan, 17.

Flora: Hollick, 4

Foraminifera: Cushman, 3.

Lepidocyclina and Carpenteria, Cayman Islands: Vaughan, 42.

Mammalia, affinities and origin: Matthew, W. D., 1.

Megalomys, Pleistocene, Barbuda : Hopwood, 1.

Pectens, Tertiary, new names: Cooke, C. W., 4.

Tertiary decapod Crustacea: Rathbun, 1, 2.

Vertebrate: Matthew, $\mathbf{5}$.

Petrology.

Igneous rock, northeast West Indies: Vaughan, 40.

Lesser Antilles: Lacroix, 1.

Physical geology.

Coral reefs, formation: Vaughan, 4.

Detrital constituents in a reef sand, Bahamas: Goldman, 17.

Fault troughs of the Antilles: Taber, 6.

Fault zones of Greater Antilles: Taber, 11.

Greater Antilles, seismic belt : Taber, 7.

Igneous activity: Vaughan, 27.

Lesser Antilles, origin: Davis, 18, 31.

Tectonic features: Woodring, 23.

Physiographic geology.

Antlles, fault troughs: Taber, 6 .

Bartlett trough: Taber, 2. 
West Indies (general)-Continued. Physiographic geoiogy-Continued.

Lesser Antilles: Davis, 29.

Virgin Islands, Culebra, and Vieques: Meyerhoff, 1.

West Shiningtree gold area, Ontario: Hopkins, P. E., 2

West Virginia.

Geology at West Virginia University: Tilton, 16.

Structure and scenery: Tilton, 13.

Areas described.

Fayette County: Hennen, 1.

Hampshire and Hardy counties : Tilton, 15.

Mercer, Monroe, and Summers counties : Reger, 9.

Mineral and Grant counties: Reger, 7.

Nicholas County : Reger, 3.

Pendleton County: Tilton, 14.

Randolph County, Mingo district: Reger, 1.

T'ucker County : Reger, 6.

Webster County : Reger, 1.

Economic geology.

Cabin Creek oil field: Wasson, 2.

Carbon ratios of coals in oil flelds: Reger, 5.

Cheat Mountain coal field, Randolph County : Reger, 16, 17.

Coal: White, I. C., 8.

Abram Creek-Stony River field: Ashley, 4.

analyses: Fieldner, 8.

Fayette County: Hennen, 1.

conservation: Scheffel, 4.

Pittsburgh bed: White, I. C., 9.

smokeless coals: Reger, 11.

sulphur in: White, I. C., 3.

Thomas bed, Harrison : Campbell, M. R., 1.

Coal formations: Eby, J. B., 6.

Copley oil pool : Reger, 14.

Map, coal, oil, gas, iron ore, and limestone areas: White, I. C., 5.

Marble, Pocahontas County: Price, 2.

Mineral resources: White, I. C., 6.

Natural gas: Reger. 2.

Nicholas County: Reger, 3.

Oil and gas development, 1920: Reger, 4.

Oil and gas problems: Scheffel, 3 .

Petroleum : Reger, 2.

Salt deposits: Phalen, 1.

Historical geology.

Boring, Cabell County : Reger, 8.

I. H. Lake No. 1: White, I. C., 1. Conglomerate rocks: Reger, 12.

Copley oil pool: Reger, 14.

Coprolite horizon, Conemaugh series, Morgantown: Price, P. H., 1.

Devonian : Price, W. A., 9.

Huntington-Pittsburgh Basin : Richardson, G. B., 13.

Little North Mountain: Giles, 8.

Mississippian disconformity : Tilton, 11.

Nicholas County: Price, W. A., 7.
West Virginia-Continued.

Historical geology-Continued.

Pelmian: Tilton, 8, 12.

Permian coal swamps: Tilt)n, 6 .

Randolph County :- Reger, 1.5.

Paleontology.

Calcified log, Pittsburgh coal, Morgantown: Fettke, 8, 9.

Coprolites, Conemaugh series: Price, P. H., 1.

Derbya crassa, abnormal sculpture: Price, W. A., 5.

Devonian trees, Randolph County : Reger, 15.

Faunas of Pennsylvanian and Mississippian periods: Girty, 8.

Footprints, amphibian : Lull, 16.

Mercer, Monroe, and Summers counties, Devonian, Silurian, and Ordovician faunas: Prouty, 14 ; fossil localities : Reger, 10.

Mississippian faunas: Girty, 4.

Mississippian floras, Appalachian trough: White, D., 29.

Nicholas County: Price, W. A., 7.

Permian vertebrates: Tilton, 10.

Pocono Brachiopoda, Tucker County: Price, W. A., 2.

Webster County: Price, W. A., 1.

Petrology.

Chert deposits: Price, W. A., 6.

Physical geology.

Arches Fork anticline, Roane and Calhoun counties, subsurface structural features: Cottingham, 2.

Eastern West Virginia: Prouty, 11, 13,

Huntington-Pittsburgh Basin : Richardson, G. B., 13.

Illustrations of wind action : Tilton, 18.

Landslides : Ladd, G. E., 1.

Slides in Conemaugh formation near Morgantown; Scheffel, 1.

Physiographic geology.

Morgantown area : Scheffel, 1.

Scenic geology: Tilton, 17.

Terraces on Monongahela River: Brown, S. B., 1.

Wheeler Ridge oil field, California : Cunningham, G. M., 1.

Whiskey Lake area, District of Algoma, Ontario : Douglas, G. V., 2.

White River beds. South Dakota, stratigraphy : Wanless, 3.

White River sediments, lithology: Wanless, 1.

Whitehorse district, Yukon: Cockfield, 16. Whitesail-Tahasa lakes area, British Columbia: Marshall, J. R., 3.

Whiteleyite: Merrill, 8.

Willow Creek district, Alaska: Chapin, 12, Wind gaps, northern Appalachians : Barrell, 6.

Wind work.

Atmosplieric dust in coal : Glock, 2.

California, San Joaquin and Salinas valleys: Reed, 8.

Connecticut Valley : Beaumont, 1. 
Wind work-Continued.

Denudation of the desert: Keyes, 159.

Dust fall, March 9, 1918: Winchell, A. N., 1; March 19, 1920: Winchell, 4.

Eolian abrasion of quartz grains : Knight, S. H., 1.

General: Bryan, 12 ; Keyes, 12, 82, 97, $165,170$.

Indiana, northwestern : Cressey, 3.

Locus of wind deposition: Keyes, 105.

Molokai, western : Wentworth, 17.

Pedestal rocks: Bryan, 16.

Rate of soil deposition, Palouse area: Peterson, P. P., 1.

Soil shifting and deposits: Larsen, J. A., 1.

Southwest : Blackwelder, 22.

Wind-faceted stones: Mehl, 10.

Windermere area, Kootenay district, British Columbia: Walker, J. F., 1.

Windrow formation, upper Mississippi Valley : Thwaites, 2.

Wisconsin.

General : Hotchkiss, 10.

Survey, reports : Bean, 3 ; Hotchkiss, 2,4 ; Wis. G. S., 1.

New geological groups, Milwaukee, Public Museum : Edwards, I., 3.

Solls: Whitson, 14.

Adams County: Whitson, 13.

Buffalo County: Whitson, 2.

Dane County: Whitson, 1.

Door County: Whitson, 6 .

Jackson County: Whitson, 12.

Milwaukee County: Whitson, 7.

northern Wisconsin: Whitson, 10.

north central Wisconsin: Whitson, 3.

Outagamie County: Whitson, 9.

Portage County: Whitson, 5.

Rock County : Whitson, 11.

Waupaca County: Whitson, 8.

Wood County: Whitson, 4.

Economic geology.

Baraboo ganister deposits : Hotchkiss, 6.

Iron, Gogebic range: Hotchkiss, 1, 3, 7.

Lake Superior region: Winchell, A. N., 2.

Lake Superior iron deposits: Royce, 1.

Lead and zinc ores: Spurr, 12.

Limestone and marls: Steidtmann, $\mathbf{5}$.

Magnetic surveying on copper-bearing rocks : Aldrich, H. R., 3.

Molding sands: Trainer, 3.

Road materials: Bean, 2.

Zinc: Boericke, 1; George, H. C., 4. Historical geology.

Borings : Thwaites, 3.

General : Steldtmann, 5; Twenhofel, 15.

Geological section: Keyes, 118.

Glacial gravel seam in limestone, Ripon: Thwaites, 1.

Gogebic range: Hotchkiss, 1, 3.
Wisconsin-Continued.

Historical geology-Continued.

Lake Superior geosyncline: Hotchkiss, 8.

Lake Superior iron deposits: Royce, 1.

Paleozoic: Ulrich, 3.

in deep wells: Thwaites, 3.

Paleozoic systems and breaks between them: Ulrich, 12.

St. Peter sandstone: Dake, 6 ; Sardeson, 21.

Shakopee dolomite: Sardeson, 20.

Southern Wisconsin: Thurston, 1.

Tomah-Sparta quadrangles: Twenhofel, 4.

Mineralogy.

Catlinite and quartzite quarries: Barrett, S. A., 1.

Lead region: Raasch, 2.

Marcasite, Racine dolomite: Cook, C. W., 4.

stalactitic forms: George, H. C., 3.

Meteorite, Colby: Merrill, 42.

Paleontology.

Black River Brachiopoda: Fenton, C. L., 5.

Cephalopods: Foerste, 28.

Cystids and blastoids, Racine: Foerste, 10.

Elephas roosevelti, Milwaukee: Hay, 26.

Galena limestone fauna, Appleton : Ockerman, 1.

Starfish, Galena limestone: Bagg, 2.

Physical geology.

Glacial gravel seam in limestone, Ripon: Thwaites, 1.

Sea caves, Devil's Island: Edwards, I., 2.

Windrow formation: Thwaites, 2.

Physiographic geology.

Driftless Area: MacClintock, 1 ; Martin, L., 1.

erosional history: Trowbridge, 1.

Intercision, Pike River, Kenosha: Ball, S. H., 4.

Pitted outwash: Thwaites, 5.

Pre-Wisconsin terraces, Driftless Area: Thwaites, 8.

Southeastern Wisconsin: Whitbeck, 1.

Southwestern Wisconsin: Blanchard, W. $0 ., 1$.

Wisconsin River, Pleistocene history: MacClintock, 1 .

Wolframite. See Tungsten.

Wood, replacement by dolomite: Adams, S. F., 1.

Wood tin in Tertiary rbyolites: Boydell, 6 . Wood tin nodules: Newhouse, 7.

World atlas of commercial geology: U. S. G. S., 3.

World view of mineral wealth: Umpleby, 1. Wyoming.

Report of State geologist: Bartlett, 1, 5 ; Marzel, 1; Morgan, G. B., 4. 
Wyoming-Continued.

Work of State geological survey: Morgan, G. B., 2.

Areas described.

Baxter Basin gas fleld, Sweetwater County: Sears, 7.

Bell Springs district, Carbon County: Dobbin, 5.

Gillette coal field: Dobbin, 3.

Grass Creek Basin quadrangle: Hewett, 16.

Meeteetse quadrangle: Hewett, 16.

Oregon Basin quadrangle: Hewett, 16.

Osage ofl field, Weston County: Collier, 7.

Sweetwater County: Sears, 3.

Economic geology.

Atlantic City-South Pass gold mining district: Bartlett, 4; Runner, 5 .

Bell Springs district, Carbon County, oil and gas possibilities: Dobbin, 5.

Big Sand Draw fleld, Fremont County : Rae, 3.

Black Hills, oil possibilities : Sinclair, E. G., 1.

Black oil : Bartram, 3.

Chromite deposits: Diller, 1.

Coal, Oregon Basin, Meeteetse, and Grass Creek Basin quadrangles: Hewett, 16.

Elk Basin oil field, faulting: Estabrook, 1.

Gillette coal fleld: Thom, 19.

Golden Eagle gas field: Binney, 2.

Grass Creek oil fleld: Hewett, 16.

Green River coal deposits: Van Lennep, 1.

Gypsum: Stone, 11.

Lance Creek oil and gas field, Niobrara County : Hancock, 5.

Light olls in the Rocky Mountain region, origin : Geis, 1.

Manganese, Laramie Mountains: Jones. Edw. L., 5.

Mineral resources: Morgan, G. B., 2, 4.

Natrona County: Hagens, 1.

Minturn district: Thom, 19.

Mule Creek oil field: Hancock, 4.

Oil accumulation: Ball, M. W., 1; Heald, 6.

Oil and gas, Oregon Basin, Meeteetse, and Grass Creek Basin quadrangles : Hewett, 16.

Oil and gas developments, Laramie and Medicine Bow districts: Bartlett, A. B., 2.

Oil and gas flelds, map: Morgan, G. B., 4 ; Richardson, G. B., 4.

Oil and gas occurrences: Estabrook, 2.

Oll and gas possibllitles, Bell Spring district: Dobbin, 5 .

Oil and gas prospects, Sweetwater County : Sears, 3.

Oil and gas sands, texture: Melcher, 3 .
Wyoming-Continued.

Economic geology-Continued.

Oil fields, Rawlins-I.ost Soldier district : Krampert, 1.

Oil possibilities, Baxter Basin, Sweetwatel County: Schultz, 1.

Oil saturation in certain sandstones: Ruby, 2.

Oil shale: Condit, 2; Schramm, 1; Jenson, 1; Morgan, G. B., 3; Winchester, 5 .

Oil-bearing horizons: Heald, 5.

Petroleum: Bartlett, 5 ; Lupton, 4 ; Wegemann, 1.

Hanna Basin and Red Desert: Krampert, 2.

Maverick Springs : Collier, 6.

Osage field, Weston County: Collier, 7.

possibilities near Osage field : Anon., 30.

southern Wyoming: Bartram, 2.

Thermopolis district: Coller, 4.

Upton-Thornton field: Hancock, 3.

Phosphate near Lander: Condit, 4.

Platinum : Duparc, 1.

Encampment district: Finch, J. W., 1.

Centennial : Hess, 24.

Platte County, mineral resources: Bartlett, 6 .

Pumpkin Buttes coal field: Wegemann, 2.

Salt deposits: Phalen, 1.

Salt Creek oll field: Estabrook, 4; Fisher, C. A., 1.

water conditions in First Wall Creek sand: Nowels, 1.

Teapot dome: Clapp, F. G. 5; Wheeler, H. A., 6.

Upton-Thornton oil fleld : Hancock, 3.

Uranium ore, Lusk: Lind, 1.

Historical geology.

Bell Springs district, Carbon County: Dobbin, 5.

Big Horn Basin : Binney, 2 ; Brainerd, 1.

Big Sand Draw fleld, Fremont County : Collier, 5; Rae, 3.

Bridger beds, Wind River Basin, flora and ecology: Berry, 72.

Browns Park formation and Bishop conglomerate: Sears, 4.

Centennial area: Hess, 24.

Chugwater-Sundance contact: Dobbin, 4.

Correlation table: Morgan, G. B., 1. oil areas: Morgan, G. B., 4.

Dakota group: Lee, 8.

General: Keyes, 190.

Geologic formations, correlations : Lee, W. T., 19.

Geologic map: Campbell, M. R., 9 ; Morgan, : G. B., 1.

Green River formation, Sweetwater County ; Bradley, W. H., 5.

and its oil shale, origin: Bradley. W. H. 3. 
Wyoming-Continued.

Historical geology-Continued.

Green River formation-Continued. southwestern Wyoming: Schramm, 1.

Green River valley: Reeside, 7 ; Van Lennep, 1.

Lance Creek field, Nlobrara County: Hancock, 5.

Tost Soldier-Ferris district: Fath, 3, 5. Maverick Springs, Fremont County: Collier, 6.

Mule Creek oil fteld: Hancoçk, 4.

Northwestern Wyoming: Dake, 5.

Oil-bearing horizons: Heald, 5.

Possible varves in marine Cretaceous shale: Rubey, 10.

Pre-Cambrian, Medicine Bow Mountains: Blackwelder, 14; Runner, 8.

north of Laramie: Kemp, 21.

Pre-Cambrian glaciation: Blackwelder, 6.

Pumpkin Buttes coal field : Wegemann, 2.

.Rawlins-Lost Soldier district: Krampert, 1 .

Rock Springs aren, Sweetwater County: Schultz, 1.

Teapot Dome: Clapp, F. G., 5.

Tensleep formation: Brainerd, 2.

Thermopolis district: Collier, 4.

Upton-Thornton oil field: Hancock, 3.

Wasntch and Green River formations, relations: Sears, 5 .

Wind River Mountains: Condit, 4.

Iineralogy.

Chlorite, chromiferous: Shannon, 16.

Euhedral oligoclase, Medicine Bow Mountains: Crawford, A. L., 1.

Tschermigite: Erickson, 1.

Uranium minerals, Lusk: Larsen, 18. IPaleontology.

Alga, Fuson ofl shale: Bradley, W. H., 2.

Allognathosuchus: Abel, 6 ; Mook, 2.

Allognathus, Big Horn Basin: Case, 19.

Amphibian (Ototriton), Lysite beds, Bridger Creek : Loomis, F. B., 1.

Anchitherium agatense: Romer, 6.

Apatemys, Bridger Basin: Troxell, 22.

Apatodonosaurus, Sundance formation, Fremont County : Mehl, 17.

Arctoid carnivore, Miocene: Romer, 9.

Bridger Carnivora: Thorpe, 17.

Caddice fly cases, Green River formation : Bradley, W. H., 1.

Cephalopods, Cody shale, Oregon Basin: Reeside, 13.

Cardioceratidae: Reeside, 1.

Cornus, Converse County: Knowlton, 10.

Cretaccous Mollusca: Reagan, 7. southeastern Wyoming: Reeside, 5.
Wyoming-Continued.

Paleontology-Continued.

Crocodiles, Bridger beds: Mook, 3; Troxell, 28.

Wasatch beds: Mook, 6 .

Cyclopidius: Loomis, 13.

Echinoid, Sundance formation: Miller, A. K., 1.

Eocene insects: Cockerell, 2.

Eocene didelphids: Simpson, G. G., 24.

Fishes, Eocene: Tanner, 1.

Fulgoridae, Eocene, Green River : Cockerell, 9.

Green River flora: Knowiton, 11.

Helaletes: Troxell, 15.

Herpetotherium marsupium, Bridger Basin : Troxell, 23.

Insecta, Eocene: Cockerell, 8.

Merycochoerus: Thorpe, 22.

Minerva saurodosis, Bildger formation: Wetmore, 2.

Miocene, Van Tassel : Loomis, 6.

Multituberculates, Wasatch formation: Granger, 1.

Nodosaurus textllis: Lull, 6.

Notharctus, Eocene primate: Gregory, W. K., 2.

Omorhamphus, Eocene, Big Horn County : Sinclair, 11.

Ophioglossum, Tertiary, Tipperary : Cockerell, 25.

Ophioglossum hastatiforme: Cockerell, 29 ; Danaea coloradensis: Berry, 57.

Oreodons of Lower Harrison beds : Loomis, 9 .

Oreodontidae: Thorpe, 4.

Palaeocastor, Miocene: Romer, 10.

Paramiatus gurleyi, amiid fish, Eocene: Romer, 15.

Pauromys, Bridger formation: 'Troxell, 20.

Phytosauria, Triassic: Mehl, 19.

Plants, Triassic: Berry, 59.

Poebrotherium : Loomis, 18.

Quarry 9 fauna, Morrison formation, Como Bluff: Simpson, G. G., 11.

Reithroparamys, Bridger formation : Matthew, 11.

Rhynchocephalia, Como Bluff: Simpson, G. G, 12 .

Rodentia, Eocene: Troxell, 21.

Salvinia, Fremont County: Berry, 71.

Saniwa, Bridger beds, Sweetwater County : Gilmore, 13.

Sparganium, Eocene: Berry, 61.

Standing stone forests, Yellowstone Park : Mitchell, G. E., 1.

Stelemys nebrascensis, $\mathrm{N}$ i obrara County : Case, 18.

Tensleep formation: Brainerd, 2.

Triassic vertebrates: Branson, 19.

Turtle, Amyda nelsoni, Eocene: Case, 23.

\section{Petrology:}

Cambrian sedimentary rocks: 'Tieje, 2. 
Wyoming-Continued.

Physical geology.

Columns in limestone: Branson, 20.

Deformation, northwestern Wyoming: Dake, 5.

Earthquake, Big Horn Mountains, November 17, 1925 : Pardee, 17.

Jackson Hole: Blackwelder, 13.

Elk Basin oil field, faulting: Estabrook, 1.

Epianticlinal faults, Elk Basin: Washburne, 11.

Faulting, Rocky Mountain region: Ir win, 2.

Folding, major and minor', relative ages : Ball, M. W., 1.

Fuson oil shale: Bradley, J. H., jr., 1.

Gros Ventre landslide: Alden, 6.

Heart Mountain overthrust, Cody region: Hewett, 4.

Oil field temperatures: Washburne, 8.

Lost Soldier-Ferris district, folding, age of: Fath, 3.

Salt Creek dome, temperature conditions: Thom, 17.

Variation of temperature with geologic structure in oil districts: Van Orstrand, 7.

Wind-faceted stones: Mehl, 10.

Physiographic geology.

Beartooth Plateau, glacial features: Dake, 2.

Green and Yampa rivers, origin : Sears, 4.

Laramie Range: Kemp, 25.

Pre-Wisconsin glaciation, Rocky Mountains: Alden, 4.

Stream piracy in northeastern Wyoming: Rubey, 6.

Wind River Mountains: Alden, 5.

Underground water.

Mineral hot springs : Bartlett, 3.

Oil field waters, analyses: Estabrook, 3.

Salt Creek field, analyses of underground waters: Ross, J. S., 1.

Waters from Poison Spider: Parks, E. M., 2.

Xenohelix, Chesapeake Bay, St. Marys County, Maryland: Mansfield, W. C., 4.

X-raying the earth: Daly, 26.

Yellow Pine cinnabar district, Idaho: Larsen, 3 ; Schrader, 10.

Yellowstone National Park.

Cristobalite in obsidian : Rogers, A. F', 6.

Fossil forests: Knowlton, 18.

Geysers : Darton, 4.

Hot areas, classiflcation : Allen, E. T., 7.

Obsidian Cliff: Foshag, 23.

Standing stone forests: Mitchell, G. E., 1.

Temperatures in springs and geysers: Van Orstrand, 6.

Yentna gold placer district, Alaska: Capps, 9.

Yosemite Valley, California : Matthes, 3 Yucatan.

Petrology. Yukon.

Obsidian, Chicher Itza : Washington. 13.

Dezadeash Lake area: Cockffeld, 20.

Geological mapping: Dolmage, 6.

Mayo area : Cockfield, 1, 4.

Ogilvie Range: Cockficld, 3.

Areas described.

Aishihik Lake area: Cockfield, 19.

Galena Hill, Mayo district: Stockwell, 1.

Keno Hill, Mayo district: Cockfield, 11.

Mayo district: Cockfield, 2; Beaver Rivel area : Cockfield, 15.

Whitehorse district: Cockfield, 16.

Economic geology.

Copper, Whitehorse belt: Cockfield, 23.

Iron ores: Young, G. A., 6.

Mayo district: Cockfield, 10,13 ; Williams, C. F., 1.

Mayo silver area: Johnson, G. F., 1.

Silver-lead deposits, Beaver River area : Cockfield, 12, 14.

Davidson Mountains, Mayo district: Cockfield, 8.

Fifteenmile Creek: Cockfield, 21.

Galena Hill: Stockwell, 1.

Keno Hill area, Mayo district : Cockfield, 6, 7.

Rude Creek: Cockfield, 22

Twelvemile area: Cockfield, 2.

Sixtymile and Ladue rivers area : Cockfield, $\bar{\jmath}$.

Southern Yukon: Cockfield, 9.

Historiaal geology.

Sixtymile and Ladue rivers area: Cockfleld, 5.

Southern Yukon: Cockfield, 9.

Whitehor'se district: Bell, A. H., 12.

Mineralogy.

Epidote, White Horse Rapids : Poitevin, 2.

Paleontology.

Bison skull: Clark, T. H., 15.

Equus lambel: Hay, 18.

Physical geology.

Klutlan Glacier : Lambart, 1.

Zeolite beds in the Green River formation : Bradley, W. H., 8.

Zeolites, composition: Winchell, 12.

Zinc.

Appalachian deposits, common features: Freeman, L. 1.

Arizona: Ariz. Bur. Mines, 2.

Arkansas: Sharp and Lawrence counties : U. S. G. S., 14.

British Columbia: Kobinson, A. H. A., 2.

Ainsworth district: Schofield, 4 .

East Kootenay district: Whiltemore, 1.

Slocan area: Cairnes, 10.

Windermere area: Walker, J. F., 1.

Canada : Bingay, 1.

eastern: Alcock, 23; Robinson, A. H. A., 4. 
Zinc-Continued.

Central Stites: Dunlop, 1, 4, 6, 9, $12,16$.

Colorado, Red Cliff district: Crawford, R. D., 3.

Discovery in America: Leyes, 60.

Eastern States: Dunlop, 3, 7, 11, 15. 18.

General: Siebenthal, 2, 4, 8, 11, 13, $15,20,22,27,29$.

Idaho: Gerry, 1, 3, 5, 8, 10, 13.

Pine Creek district: Jones, Edw. L., 1. Shoshone County: Umpleby 3.

Manitoba: Wallace, 22.

Missouri: Keyes, 114.

Montana: Gerry, 2, 4, 7, 12, 15.

Nevada, Pioche district: Westgate, 6.

New Jersey, Sussex County: Fitch, A. A., 1 ; Ries, 8 ; Salton, 1.

New York: Newland, 2.

Edwards: Spurr, 13.

Gouverneur quadrangle: Cushing, 1 . St. Lawrence County: Wade, W. R., 2.

Nova Scotia, Richmond County, Stirling area: Weeks, L. J., 1.

Oklahoma; Miami district: Netzeband, 1.

Picher district, lead and zinc: Spurr, 32.

Oklahoma-Kansas-Missouri field: Naething, 2.

Ontario: Alcock, 23.

Sudbury mining division, Genoa township: Moore, E. S., 16.

$4096-31-64$
Zinc-Continued.

Pennsylvania : Miller, B. L., 3; Pennsylvania $G$. S., 1.

Allentown quadrangle: Miller, B. L., 5.

Quebec: Alcock, 23.

Gaspe: Alcock, 14, 29; Beidelman, 1, 2 ; Mailhoit, 5.

Pontiac County, Calumet Island : Goranson, 3.

western: Dufresne, 7 .

Smithsonite, formation: Watson, 7 .

Tennessee, east : Secrist, 1.

Mascot area : Nelson, 17.

Tri-State district: George, P. W., 1; Weidman, 5.

Upper Mississippi Valley: Spurr, 12.

Utah : Butler, 4.

Ophir district: Olmstead, 1.

Promontory Point mining district: Siegfus, 1.

Tintic district: Lindgren, 2.

Washington: Gerry, 1, 3, 6, 9, 11, 14.

Wisconsin : George, H. C., 4.

Wisconsin district: Boericke, 1.

Zinc pigments and salts: Siebenthal, 17.

Zircon: Schaller, 4.

As a criterion of origin of metamorphosed rocks: Armstrong, P., 2.

Florida, beach deposits: Martens, 9 .

Occurrence : Meyer, 1.

Zirconium : Ries, 9.

Zymoetz River area, Coast district, British Columbia: Hanson, 11. 